GASPAR FÉLIX CALVO POBLACIÓN

\title{
LA EDUCACIÓN KUNA: \\ INTRODUCCIÓN DEL SISTEMA EDUCATIVO \\ OCCIDENTAL EN LA CULTURA KUNA DE PANAMÁ
}

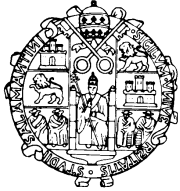

EDICIONES UNIVERSIDAD DE SALAMANCA 


\section{COLECCIÓN VITOR}

54

c

Ediciones Universidad de Salamanca

y Gaspar F. Calvo Población

$1^{\text {a }}$ edición: Octubre, 2000

I.S.B.N. : 84-7800-917-5

Depósito Legal: S. 953-2000

Ediciones Universidad de Salamanca

Apartado postal 325

E-37080 Salamanca (España)

Realizado por:

Nemática, S.L.

Impreso en España - Printed in Spain

Todos los derechos reservados. Ni la totalidad ni parte de este libro puede reproducirse ni transmitirse sin permiso escrito de Ediciones Universidad de Salamanca

$\kappa$

CEP. Servicio de Bibliotecas

CALVO POBLACIÓN, Gaspar Félix

La educación kuna: introducción del sistema educativo occidental en la cultura kuna de Panamá [Archivo de ordenador] / Gaspar F. Calvo Población-$1^{\mathrm{a}}$ ed.--Salamanca : Ediciones Universidad de Salamanca, 2000

1 disco compacto.-- (Colección Vítor ; 54)

Tesis-Universidad de Salamanca, 1992

1. Indios - América Central - Panamá - Educación.

2. Antropología y educación - Panamá.

3. Universidad de Salamanca - Tesis y disertaciones académicas.

$37(728.7)(=1-82)$

$572+37(728.7)$

378.4(460.187) Universidad de Salamanca (043) 


\section{$\underline{\text { Resumen }}$}

Hasta los inicios del siglo XX los kunas tenían un sistema de educación que perpetuaba su cultura y sus valores. Pero coincidiendo con la separación de Panamá y Colombia y, tras el nombramiento del primer presidente de la instaurada república, el indígena Róbinson se dirige a éste para pedirle que instale escuelas entre su gente a fin de que no sean engañados por los comerciantes que transitan por aquel mar. El había sido enviado junto con un hermano a los EEUU y había sido educado por el capitán de un barco. Este sería el punto de partida que iba a favorecer los anhelos de los gobernantes que deseaban civilizar a las tribus que habitaban en el territorio panameño y se podría poner en práctica los ideales de la nueva constitución.

Los medios empleados para conseguir tal fin fueron diversos. En un primer momento se envían indígenas a la ciudad de Panamá para que aprendan el modo civilizado y luego sean transmisores en sus comunidades; con esta intención se crea una escuela de indígenas en la capital y se otorgan becas para los estudiantes. A esta medida le sigue el envío de un misionero católico a las islas habitadas por los indígenas. Aunque su tarea estaba enfocada más a la evangelización, no deja de 
lado la educativa ya que ésta era un soporte imprescindible para la otra. Mientras estuvo en el poder el gobierno conservador el misionero contó con el apoyo de los mandatarios, pero en 1913 los liberales toman las riendas de la nación y se permite la entrada al territorio kuna a la misión protestante; para entonces la misión católica había abandonado las islas.

Esta nueva misión también persigue la evangelización y el hacer prosélitos, pero va a suponer un cambio muy grande para los indígenas; sus enseñanzas eran diferentes, hasta enfrentadas a las católicas, y deben aprender una nueva lengua, el inglés. Los liberales no creían que el mejor modo de civilizar a los indios fueran las misiones y con el paso del tiempo comprendieron que la misión protestante no contribuía al proceso civilizador deseado por el ejecutivo. Entre los indígenas surgieron enfrentamientos y divisiones, unas motivadas por los que aceptaban o rechazaban a los misioneros y otras por aquellos que eran partidarios de una u otra misión. Pero sus más incondicionales se vieron beneficiados con becas, algunas de ellas para realizar estudios en el extranjero.

En materia escolar el momento clave es la visita que realiza el presidente de la República a las islas en la que propone a los dirigentes la creación de escuelas. Solamente cuatro islas responden de modo afirmativo, éstas se hallan ubicadas en el sector centran y son las que habían tenido más relación con las misiones. Un año después, en 1916 se abrían las escuelas de Narganá, Corazón de Jesús, Playón Chico y Tupile. 
El malestar fue creciendo entre los indígenas y también los intentos de rebelión, incrementados en gran parte por los abusos cometidos por la policía que acompañaba a los maestros con el pretexto de defenderlos. En 1921 morían dos indios defensores de la civilización y la misión católica. Pero el paso final se dio cuatro años más tarde cuando deciden acabar con los extranjeros allí afincados, éstos en ese momento eran policías. Conseguido el propósito se declaran República Independiente Tule, bajo el protectorado de los EEUU, y este manifiesto lo dirigen a todas las naciones del mundo. El Gobierno establece conversaciones con los rebeldes y promete respetar sus derechos y no imponerles las escuelas. Solo atendería sus peticiones; de este modo se empieza abriendo las escuelas del sector central Narganá y Corazón de Jesús, y paulatinamente se reabren otras escuelas y se crean nuevas.

De modo fortuito vuelve la misión católica al sector central, esta vez compuesta por misioneros claretianos y franciscanas que se harían cargo de la educación y la dirección de las escuelas. Para poder atender a todos aquellos que son partidarios de la educación pero que no tienen escuela en las islas crean un internado para muchachos y otro para muchachas.

Por otra parte Alcibiades, indígena que había sido becado en Ios EEUU por la misión protestante, abre una escuela en Ailigandí con el apoyo de los dirigentes de aquella zona.

Con el correr de los años los alumnos que habían salido a estudiar fuera y tenían una cierta preparación fueron nombrados 
maestros en su territorio. Y en 1945 la educación de San Blas, territorio ocupado por los kunas, pasa a manos del Ministerio de Educación.

Nuestro estudio concluye en 1953 cuando se cumple medio siglo de educación o civilización y coincidiendo con la promulgación de la Carta Orgánica referida a los kunas. 


\begin{abstract}
When Panama consolidates as an independent country, the introduction of the school in the kuna community not only had the intention of educating. Although the first intention of native Robinson was to introduce the education to his natives in order not to be lied by the merchants that came to that coast, things changed enormously.

On the one hand natives thought that the education was going to change their traditional way of life. This pressure make that natives raise in rebellion with the purpose of finishing with the strange elements to his culture, however in thouse days there are only policemen in the islands. Once they finish with them, the kuna natives proclaim the Tule Independent Republic under the protectorate of the United States of America. Panama takes part in this matter and makes an agreement with indigenous people in which clarifies that the government will not commit violations of indigenous rights any more. In addition, they decide that they will open schools only in those places where natives ask for.

Education was supported by the Catholic and Protestant missions, however years later the teachers that work there were natives.

The boundary between Panama and Colombia was protected by the detachment of policemen that settled among kuna population. The intention was to defend teachers and contribute to the civilising work of the natives.
\end{abstract}


A mis padres, Juan y Felisa;

y a mi amigo panameño Dicky 


\section{INDICE GENERAL}

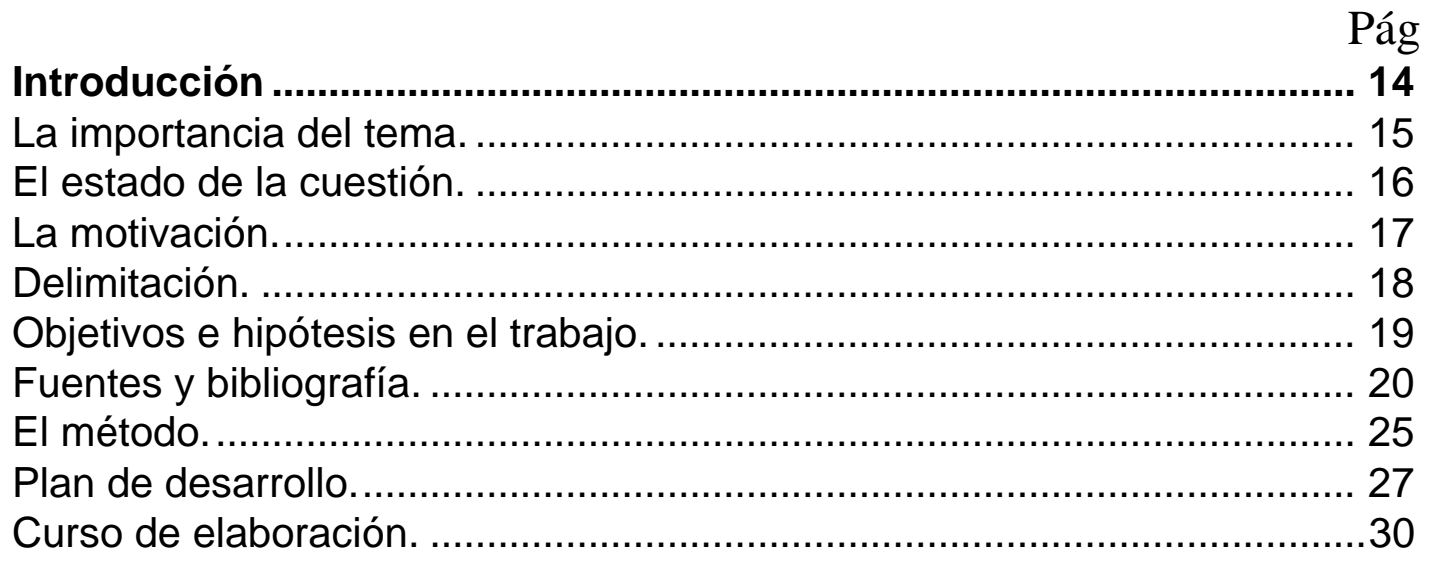

\section{LOS KUNAS EN SU MUNDO DE AYER}

1.- Aproximación al medio histórico-geográfico de los kunas ............ 33

1.1.- La situación panameña antes de la separación de Colombia ............. 34

1.1.1. Momento de la independencia de Panamá y su unión con Colombia.

1.1.2. La creación del estado federal y la inauguración del

ferrocarril transístmico.

1.1.3. Comienzo de las obras del canal interoceánico..................... 47

1.2.- El momento de la independencia. ................................................... 53

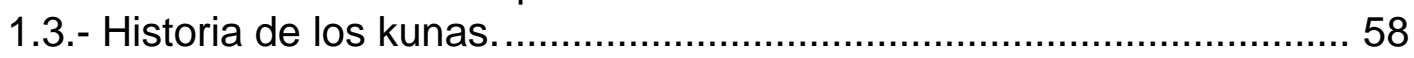

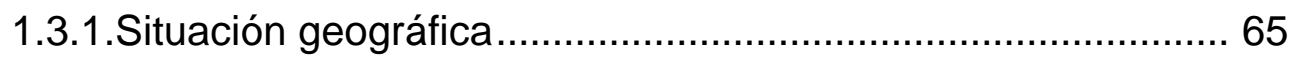

1.3.2. La familia y la sociedad........................................................ 71

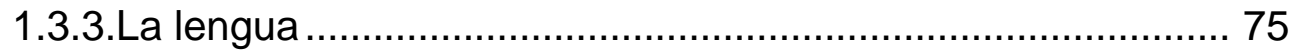

2.- El sistema educativo tribal............................................................ 79

2.1.- La educación popular. ................................................................ 80

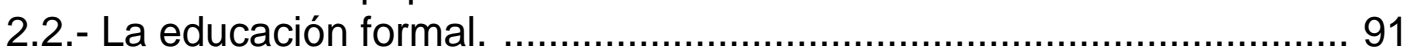

2.2.1 La educación de líderes: Nele, Kantule, Absogedi, Inatuledi,

Sahila, Argar, Masardaket, Sapin dummat..................................... 91

2.2.2 El Congreso .................................................................. 102

2.3.- Las enseñanzas de los grandes nelegan. Ibeorgun, Kikadiryai,

Olonegegiryai, Puna Nelegua, Olonadili................................................... 107

\section{LA INCORPORACION DEL SISTEMA EDUCATIVO OCCIDENTAL EN LA TRIBU KUNA}


3.1. La pedagogía europea. ............................................................. 117

3.2. Las experiencias pedagógicas españolas...................................... 125

3.3. La innovación pedagógica americana. ............................................. 128

3.4. Doctrina en materia educativa de la Iglesia Católica ......................... 132

4.- Las leyes de los cincuenta años: La acción gubernamental. ....... 139

4.1.- La primera constitución de 1904.................................................. 140

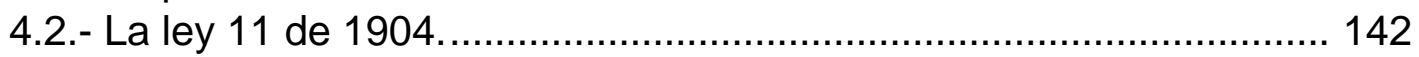

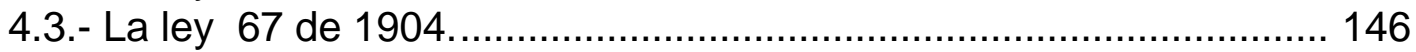

4.4.- Decreto 223 del 31 de Octubre de 1906 ...................................... 147

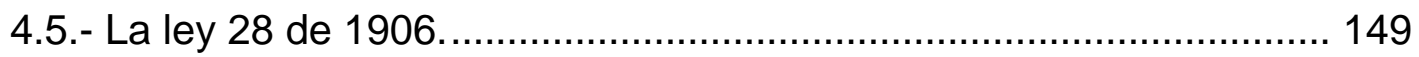

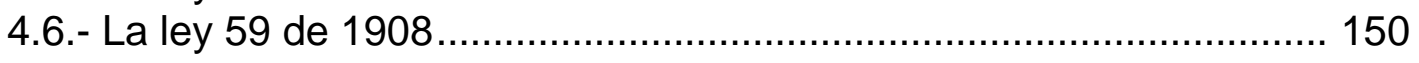

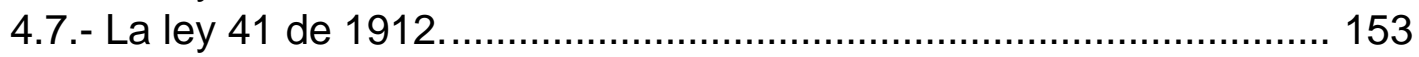

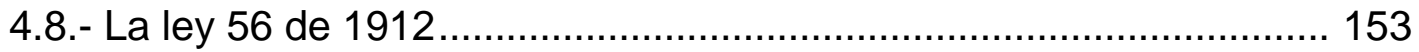

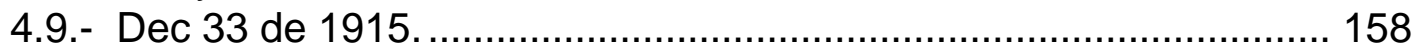

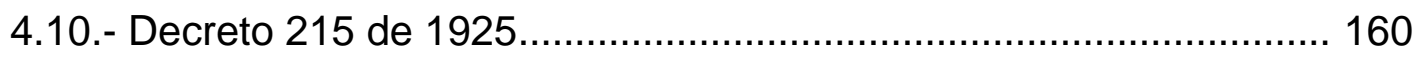

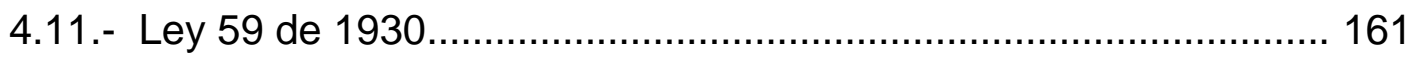

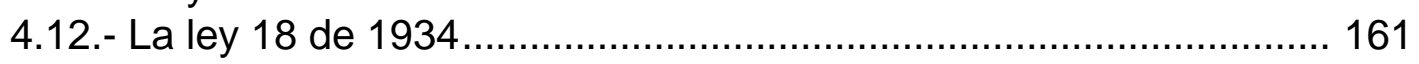

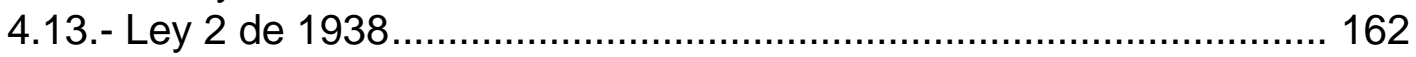

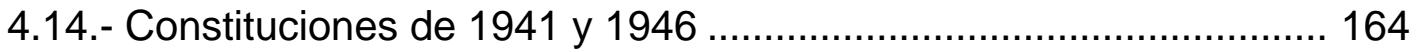

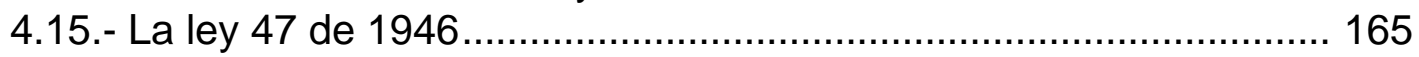

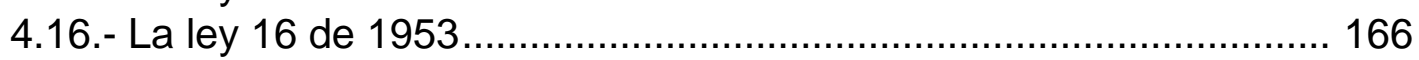

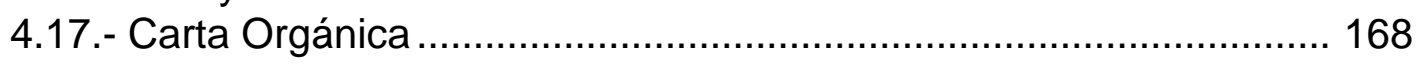

5- Inicio de la educación institucionalizada....................................... 169

5.1.- El indígena Róbinson ............................................................... 170

5.2.- La política de las becas ............................................................. 176

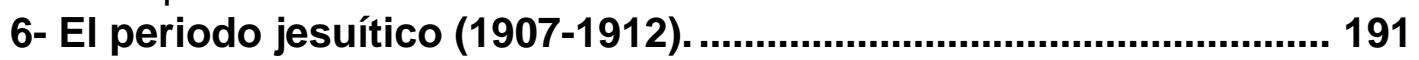

6.1. La situación que encuentra el misionero......................................... 204

6.2. La labor que realiza el P. Gassó, sus aportaciones......................... 211

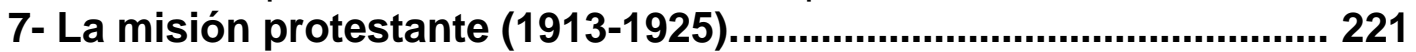

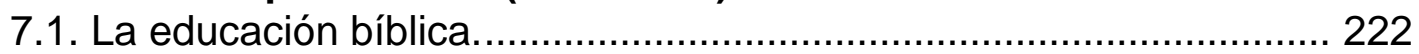

7.2. Primeras escuelas nacionales .......................................................... 241

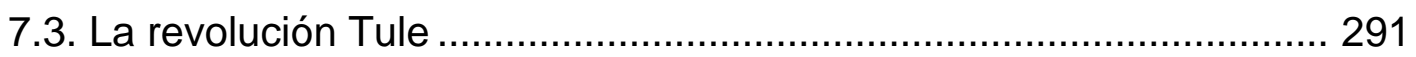

\section{RESTAURACION Y CONSOLIDACION DEL SISTEMA EDUCATIVO OCCIDENTAL ENTRE LOS KUNAS}

8.- La etapa postrevolucionaria (1928-1938) …….............................. 302

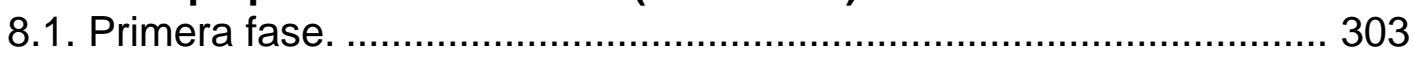

8.2. Pasos previos a la consolidación de la escuela............................... 312

9.- Bajo la dirección de los claretianos y hacia la plena

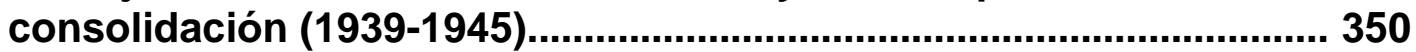

9.1. La dirección de Ricardo Velasco. .................................................. 351 
9.2. Toma el relevo M. M. Puig........................................................... 379

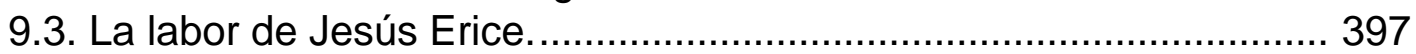

10.- La educación del archipiélago pasa al Ministerio de

Educación (1945-1953).................................................................... 435

10.1. El impulso de Estanislao López ................................................. 436

10.2. Los congresos generales ........................................................ 444

11.- Intervenciones y medios especiales para la consolidación

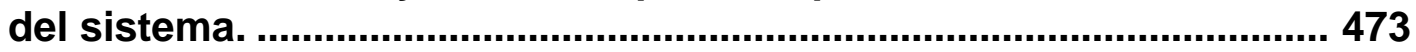

11.1. Los internados del archipiélago. ............................................... 474

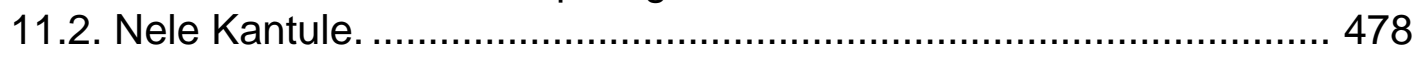

11.3. Alcibiades Iglesias ..................................................................... 496

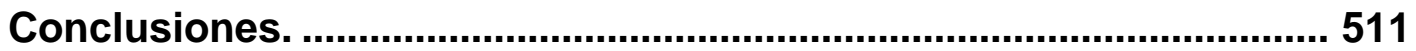

Apéndices.

I. Instrumental

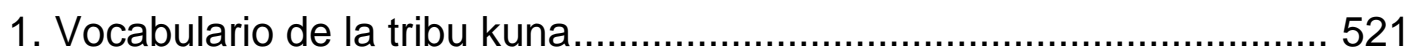

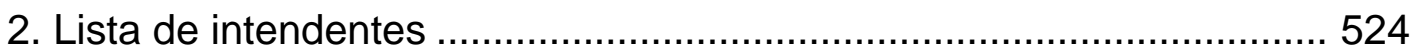

3. Lista de presidentes ……........................................................ 525

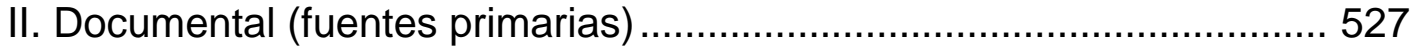

1. Regesta Documental ................................................................ 528

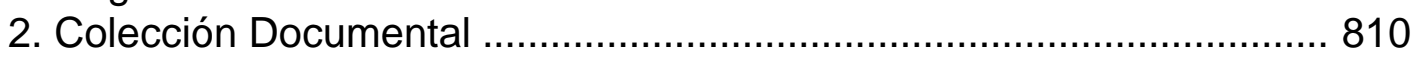

III. Bibliografía (fuentes secundarias) ................................................. 1533 


\section{TABLA DE SIGLAS Y ABREVIATURAS}

AANP: Archivo de la Asamblea Nacional de Panamá.

Ac.: Actas.

AELE: Archivo de Estanislao López en casa de su hijo Eladio López. AELI: Archivo de Estanislao López en casa de su hija lldaura López. AGH: Archivo de Guillermo Hayans en posesión de Chany Edman.

Agr: Agricultura.

Al: Archivo de la Intendencia.

ANP:Archivo Nacional de Panamá.

Arch.:Archivos.

ARPK: Archivo de Rubén Pérez Kantule en casa de su hijo Luis Pérez.

Art: Artículo.

BEN: Biblioteca de la Escuela de Narganá.

BGH:Biblioteca Guillermo Hallans.

Bib: Bibliográficos.

BN: Biblioteca pública de Narganá.

BP: Belisario Porras.

Car:Carta.

Carp: Carpeta.

CD: Colección documental.

CEBs:Comunidades Eclesiales de Base.

CFN: Crónica de las Franciscanas de Narganá.

CGK: Congreso General Kuna.

CHHS: Colegio de los Hermanos de la Salle.

CMC: Casa de la Misión Claretiana.

Col.:Colonial.

Com.: Comunidad.

Comr.:Comarca.

Cop.: Copia.

Cor.: Correspondencia.

Dat. Datos.

Diar.:Diario.

Doc: Documento.

Educ.: Educación.

Es. de P.: Estrella de Panamá.

Esc.: Escuela.

Escr.: Escritos. 
Ex.: Exteriores.

F.O.: Félix Oller.

Frag.: Fragmento.

Fran.: Franciscanas.

G. y J.: Gobierno y Justicia.

Ileg.: Ilegible.

Imp.: Importantes.

Inc.: Incompleto.

Ind.: Indígenas.

Inf.: Informe.

Ing.:Inglés.

Int:: Intendente.

Men.: Memoria.

Mis.: Misiones.

Ms.: Manuscrito.

$\mathbf{N}$.: Número.

Nom.: Nombramiento.

Not.: Notas.

Orig.: Original.

P.: Página.

Pan.: Panamá.

Per.: Personal.

Pol.: Policía.

Pr.: Primer.

Pub.: Publicado.

RPK: Rubén Pérez Kantule.

RD: Regesta Documental.

Reg.: Registro.

Rel.: Relaciones.

S.: Sobre.

SB: San Blas.

Sec.: Secretario.

Sem.: Semestre.

Soc.: Sociedades.

Ten.: Teniente.

Tic.:Ticantiquí.

Tom.: Tomo.

V. : Véase.

Val.: Valor.

Var.: Varios.

Vid.: Vida.

Vis.: Visitas.

Vol.: Volumen. 
INTRODUCCION METODOLOGICA 


\section{Introducción}

\section{La i mportancia del tema}

La educación ha sido una preocupación en todas las culturas, y los kunas han mantenido una educación válida para su pueblo y su sistema social. Pero a principios de nuestro siglo se introduce el sistema educativo europeo que fue variando sus pautas de conducta, sus estructuras y valores.

En la celebración del Quinto Centenario del encuentro de dos culturas tan diferentes como la india y la nuestra, no estará de más ver los aportes en materia educativa de nuestra sociedad occidental a ese grupo indígena de la joven nación panameña. $Y$ al mismo tiempo las enseñanzas que ellos puedan dar a la sociedad contemporánea.

La importancia del tema viene dada por la posibilidad que nos da este trabajo de analizar el modo de introducir nuestra educación en una cultura distinta, la indígena. Nos permitirá evaluar la acción desplegada y las consecuencias a las que llegó. Qué conocimientos son necesarios y pueden ayudar a sobrevivir a una cultura primitiva. Cómo se puede introducir la educación sin alterar ni destruir su sistema de vida y organización. Cómo ayudarles a incorporarse al mundo civilizado sin violar su desarrollo natural.

El tema de estudio está centrado en los primeros cincuenta años de educación sistematizada y continuada de los kunas, aunque con alguna interrupción brusca. El inicio coincide con la separación de Panamá de Colombia en 1903, los primeros pasos en pro de la escuela y la civilización, iniciados por el indio kuna Charles Róbinson, personaje de gran relevancia en los comienzos de la independencia de Panamá, en el pueblo kuna. El medio siglo culmina con un acontecimiento significativo, la promulgación de la ley 16 el 19 de Febrero de 1953, que organiza la Comarca de San Blas como reserva, territorio ocupado por los kunas. Esta ley cumple uno de los deseos más añorados por los nativos de esta región, su reserva. 
Al mismo tiempo abarca los cincuenta primeros años de andadura de la nación istmeña en materia educativa.

En este período se produce la Revolución Tule, levantamiento realizado por los indios para protestar por los abusos del gobierno y sus representantes; entre otros los maestros, que estaban realizando una labor totalmente desacertada. Este hecho supuso el cierre temporal de las escuelas y que algunas comunidades tomaran una postura más radical con respecto a todo lo procedente del gobierno. A los veinticinco años del comienzo se volvía a realizar un segundo intento reabriendo las escuelas de la zona central.

\section{El estado de la cuestión:}

Hasta la fecha podemos decir que no existe un estudio que trate este comienzo de la educación europeo occidental entre los habitantes de la costa atlántica de Panamá. Cierto es, por otra parte, que esta tribu es la más estudiada del Istmo, de los que forman el conjunto indígena nacional, bajo otros aspectos, sobre todo antropológicos.

El trabajo más destacado es la tesis doctoral del kuna Aiban Wagua, que hace un estudio de la educación en el sistema tribal.

Existen otros trabajos de los mismos indios, pero que tocan aspectos concretos de la educación y no el desarrollo histórico de la misma. Algunas referencias a periodos determinados de esta media centuria tienen las obras de los autores que han escrito algo acerca de los kunas.

Citaré a Tomás Pujadas que escribió una obra sobre el Darién; de igual modo Ricardo Falla, que ha realizado distintos estudios sobre Panamá. Los que fueron directores de las escuelas indígenas y permanecieron allí por largos años también han dejado plasmada su peculiar aportación: El Padre Gassó, Ricardo Velasco, Manuel Puig y Jesús Erice. La aportación de estos es particularmente interesante por su divulgación de la lengua kuna y sus diccionarios, así como la traducción de textos religiosos. 
Esta investigación aporta una gran cantidad de documentos como aval del proceso introductorio de este sistema educativo de occidente. Mediante su análisis se pueden ir descubriendo los pasos dados, las dificultades que se encontraron y los medios que se emplearon para establecer la escuela, que fue la principal portadora de la educación. Bajo el nombre de educación fueron ocultas acciones que distaban mucho de la cuestión pedagógica.

\section{La motivación}

La motivación personal se debe al interés sentido hacia todo lo latinoamericano, especialmente por las culturas que fueron capaces de sobrevivir superando todas las adversidades que a lo largo de los siglos se les fueron presentando, desde la época de la conquista a la colonial; demostrando una gran adaptación y resistencia. Haciendo cierta la tesis de que los pueblos que son atacados y expoliados, luchan y son capaces de buscar nuevas formas de vida adaptándose, pero procurando mantener el espíritu de su cultura.

Mi asistencia a las clases de Educación Comparada de América, impartidas por la Prof. Dra. Agueda Rodríguez Cruz, durante la carrera de Pedagogía, incrementaron los deseos de acercarme a la realidad del continente americano.

El conocimiento de los kunas llegó a mí en los primeros años de la década de los ochenta por una amistad de ese país centroamericano; y posteriormente se fue incrementando mi interés a través de diversos medios de comunicación y divulgación.

Llegó la gran oportunidad en el verano de 1986, cuando tuve ocasión de tomar un primer contacto directo con los habitantes de las costas de San Blas, tras un viaje en la lancha del Ministerio de Salud panameño, con destino a la población de Ustupu para celebrar el aniversario de la muerte de Nele Kantule ( 3 de septiembre). Las facilidades que me brindó la indígena de aquella región, Antonia de Edman junto 
con su familia, hizo que me decantara con todas mis fuerzas por aquella zona costera tan paradisíaca, pero que tristemente tiene su tiempo contado, pues su reloj marca la cuenta atrás, ya que considero que está en vías de extinción.

En un primer momento surgió alguna dificultad, pero las facilidades y colaboración de individuos relevantes del pueblo kuna, que poseían gran parte de la documentación referente al tema, compensó con creces mis esfuerzos, a pesar de no haber recibido ninguna ayuda de organismo oficial 0 institución particular.

\section{De I i mit ación del te ma}

A la hora de decidirme por el tema a tratar, opté por la introducción de la educación occidental en los kunas, ya que veía que no iba a necesitar aprender la lengua kuna, tarea que hubiera resultado muy ardua y que me hubiera llevado bastante tiempo, retrasando considerablemente $\mathrm{mi}$ investigación; de este modo tampoco sería necesaria la ayuda de un intérprete que dificultaría o podría distorsionar lo fundamental del trabajo. Los documentos existentes estaban en castellano su mayoría, y alguno en inglés; lo que me facilitaría la investigación.

Como he señalado anteriormente el trabajo se ciñe a lo que fue el proceso de introducción de la educación occidental como institución y centrado en la escuela.

La fecha de inicio la pongo en 1903, cuando el indígena Róbinson regresa a las costas de Kuna Yala, después de haber viajado en un barco americano y haber disfrutado de las ventajas de la educación en una escuela norteamericana. Pues es a partir de aquí cuando este personaje ve la necesidad de que sus paisanos sepan las nociones básicas de las matemáticas y la lengua, a fin de no ser engañados por los comerciantes. Y él mismo comienza a enseñar a un grupo de amigos. Con posterioridad iría a Panamá a pedir al presidente de la nación que cree escuelas para los kunas. 
El trabajo concluye en 1953 cuando han pasado cincuenta años de educación entre los kunas; aunque no fuera de un modo uniforme, sino con sus altibajos. En esta fecha se promulga la ley 16 que reconoce la comarca de San Blas y también se aprueba la Carta Orgánica de los kunas que ratifica su administración interna.

Las escuelas van pasando por maestros nacionales y por distintas órdenes religiosas dedicadas a la enseñanza, hasta que llega un momento que los maestros son en su mayoría del mismo grupo indígena.

\section{Objetivos e interrogantes del trabajo}

El objetivo de este trabajo es acercar la cultura kuna a la occidental y que ésta conozca un poco más aquella, mediante el análisis detallado de las sucesivas etapas. A través del estudio del fenómeno educativo, nuestro primer contacto significativo en los últimos tiempos con estos indígenas, llegar a ver cuáles fueron nuestras aportaciones positivas y nuestros errores. Analizar la introducción de la educación occidental europea como un elemento reestructurador y cambiante de la sociedad tradicional.

Al adentrarme en el análisis de las distintas etapas por las que pasó la educación kuna en sus primeros cincuenta años; me he planteado los siguientes interrogantes:

¿Se puede decir que la escuela tuvo un fin educativo en sí misma, o fue más bien un arma al servicio de lo que se llamó civilización, y que era un proceso más complejo? La educación, como creen muchos indígenas tradicionales, no fue la que introdujo los males que aquejan hoy día a su sociedad.

¿Tuvo en cuenta a los sujetos a los que iba destinada la educación, mediante la elaboración de programas específicos, adaptados a su idiosincrasia?

¿El interés despertado por los sucesivos gobiernos obedecía más a un deseo de control sobre esta zona costera, que a una preocupación por su progreso y desarrollo? 
¿La preparación del personal docente fue suficiente y ejerció una influencia positiva entre la cultura Kuna, o por el contrario realizó una acción nefasta que creó mala imagen entre los kunas?

¿Existió algún colectivo o persona que con su esfuerzo dio un empujón favorable a la educación, creando una imagen positiva que ayudara a la aceptación por parte de los indígenas?

- He querido constatar lo que la educación propiamente dicha hizo en el pueblo kuna.

- Dejar claro lo que aportaron los distintos grupos humanos dedicados a estas tareas de la enseñanza, como fueron los católicos, indígenas y protestantes.

- Lo que se fue introduciendo unido a la educación, pero que no fue labor propiamente suya; si no producto de la interacción social.

- El pueblo kuna sí deseaba la educación, pero libre del poder y de la fuerza del gobierno.

- En la actualidad muchos logros conseguidos por los kunas se deben a esta labor de la educación. De ellos han salidos legisladores, hombres de letras y ciencia que pueden seguir luchando por mantener la llama de su cultura.

\section{Fuentes y Bibliografía crítica}

Las fuentes primarias de este trabajo son básicamente las aportadas por los mismos indios. Estas fuentes son mecanografiadas o manuscritas, quedando especificado en la Regesta Documental si proceden del original o de copia.

Por fortuna dos de los grandes y más importantes indígenas fueron guardando con el paso del tiempo los papeles que llegaban hasta sus manos.

Uno de ellos, Estanislao Iguawidul López, llegó a ser cacique general de Panamá, y mantuvo siempre viva la preocupación de guardar toda la documentación referente a los indios. 
Rubén Pérez Kantule, dirigió una biblioteca que llevó su nombre, a la vez que sacó muchas copias de documentos importantes y que corrían riesgo de perderse. Su gran aportación fue como asesor de la escuela sueca de antropología dirigida por el Baron Nordenskyöld. Estos hombres que tuvieron gran visión de futuro fueron la salvaguardia de importantes datos referidos al pueblo kuna. Tras su muerte, sus hijos han recopilado todos los papeles recogidos por sus predecesores; y generosamente los pusieron en mis manos.

Un centro de vital importancia fue la isla de El Porvenir, sede de la Intendencia, donde permanecen copia de los documentos que de allí salían y los originales que eran remitidos a este destino. Su situación geográfica dificulta mucho la conservación de los papeles atacados por el salitre y la carcoma.

Los archivos del gobierno también han aportado información al trabajo; de la misma manera que lo han hecho las instituciones religiosas que durante esa época tuvieron el peso de la actividad educativa. En el archivo de la asamblea nacional tuve acceso al original de la primera constitución manuscrita de Panamá, aunque fuera en pedazos; así como a toda la legislación referida a los kunas.

En la primera incursión fue una fuente fecunda el diario del primer misionero, lo mismo que el libro parroquial de Narganá que él comenzó; regalado por el primer Presidente de la República, el Dr. Manuel Amador Guerrero y rotulado el encabezamiento por el primer obispo, Mnos. Junguito. El diario del misionero fue copiado por Rubén Pérez Kantule durante su estancia en Suecia. Del padre Gassó son destacables las cartas, muchas de las cuales se han publicado en la revista Lotería.

Poseo gran cantidad de fotocopias de la documentación existente referida al tema; así como microfilms de la documentación de la Intendencia. $Y$ he podido contar con la información oral de testigos que presenciaron los inicios de la educación y fueron los primeros sujetos educados, lo mismo 
que destacados protagonistas de importantes acontecimientos como la Revolución del 25.

Las carpetas que contienen documentación referida a la educación y que reposan en casa de la hija de Estanislao, Ildaura, en la isla de Narganá son:

- Nombramiento de Policías coloniales

- Bibliografía

- Carpeta S/N

- Cartas de 1924

- Carpeta 2

- Correspondencia de 1940 a 1950

- Carpeta de 1941

- Documentos de visitas

- Documentos y datos de D. Félix Oller

- Los años 80

- Cartas de 1945. Varias correspondencias

- Carpetas de 1947

- Diario de 1946

- Cartas de 1948

- Cartas de 1951

- Diario de 1952

- Correspondencia.

Después de revisar más de 140 carpetas, estas fueron las que me ofrecieron ayuda en mi investigación.

El monto de documentación custodiada por Eladio en el Nuevo Chorrillo también era grande; pero de las carpetas revisadas son las siguientes las que aportaron luz:

- Actas del Congreso General

- Archivos y documentos. Cartas importantes 1927 a 1930

- Archivo y documentos importantes de Estanislao López

- Archivos y documentos. Cartas 1915-1922-1933

- Octubre 25, 1949 
- Carpeta 1940-41-43-45-47-48

- De Carlos Róbinson, datos, su enfermedad y muerte - Varios documentos de memorias

- Memorias del Congreso de Tikantikí

- Varios escritos y documentos importantes

- Varios documentos.

Los documentos de la antigua biblioteca "Rubén Pérez Kantule" y que en la actualidad se encuentran en posesión de su hijo Luis Pérez, residente en Kuna Nega son:

- Atropellos cometidos con los indios

- Algunas cartas del año 1929. Historia de Ailigandí

- Becas de los indígenas kunas dadas por el gobierno nacional panameño 1921-22-23

- Cartas del Presidente de la República

- Cartas de Estanislao López

- Cartas para el Gobierno nacional

- Cartas de Humberto Vaglio al Secretario de Gobierno Justicia

- Cartas del Intendente al Presidente Belisario Porras y viceversa 1919-21

- Cartas para Nele 1931

- Cartas de 1930

- Cartas para el Gobierno Nacional por los indios de S.

Blas

- Carpeta con correspondencia de los años 20 y 30

- Congreso General Kuna de Narganá, Julio 1945

- Congreso General Kuna de Tupualá, Marzo 1945

- Correspondencias

- Correspondencias del sahila general Nele Kantule

- Datos de Narganá

- Datos sobre la vida del Sr. Rubén Pérez Kantule

-Diario de Rubén Pérez Kantule durante su permanencia en las cárceles, 1935

- Documentación de la Intendencia

- Documentos del Sr. Intendente de S. Blas 
- Documentos

- Documentos sobre el registro personal 1935

- Documentos sobre la vida de Rubén Pérez Kantule

- Documentos sobre las escuelas de San Blas

- Documentos sobre los misioneros protestantes en S.

Blas

- Documentos sobre la historia de S. Ignacio de Tupile

- Documentos sobre el pueblo de Playón Chico

- Documentos sobre el pueblo de Sasardí-Mulatupu

- Documentos sobre el pueblo de Río Azúcar

- Documentos sobre el pueblo de Río Sidra

- Ecos de S. Blas

- El caso de la expedición sueca en S. Blas

- Informe que rinde el Intendente de la Comarca de S.

Blas al Sr. Ministro de Gobierno y Justicia, por Luis Hernández, Nov. 1944

- Informe que rinde al Congreso Pablo Solís

- Informes varios de S. Blas

- Informe de las sociedades indigenistas de la comarca de S. Blas

- Leyes y decretos

- Leyes y decretos sobre indios panameños y colombianos 1826-1951

- Los sahilas en la capital

- Memoria que el Secretario de Estado en el despacho de Gobierno presenta a la Asamblea en sesión ordinaria de 1932

- Misioneros protestantes en San Blas, Misión Bautista

- Personas que tienen sus cocales en los lugares. 1933

- Publicado en la Estrella de Panamá

- Varios nombramientos de los indios de San Blas como policías indígenas 1917-1924

- Verdad sobre la Revolución de Tule. 
Los documentos del archivo de la Intendencia se encontraban agrupados en algunos casos por fechas pero no tenían nombre especial las carpetas, se estaba llevando a cabo la clasificación de toda la documentación allí depositada.

En la biblioteca de la isla de Narganá encontré algún documento en la carpeta:

- Educación, varios documentos.

Y en la biblioteca perteneciente a la escuela de la misma isla otras dos:

- Actas de los archivos de la escuela

- Memoria de la escuela.

Algún documento también recogí de la antigua biblioteca Guillermo Hayans, que guardaba correspondencia de Nele Kantule y tenía su sede en Ustupu.

Las fuentes secundarias, como expliqué anteriormente, no abundan. La obra de Aiban Wagua El indio kuna y su sistema educativo tribal, es el texto que estudia de modo más completo la educación, haciendo referencia también a la educación occidental en dos capítulos.

Pujadas se centra en Misión del Darién en la actividad realizada por los claretianos durante su periodo como directores de las escuelas kunas.

En la Regesta Documental he intentado sintetizar los documentos lo más posible, pues una gran parte de ellos se podían ver en su texto íntegro en la Colección Documental. Excepción de esta regla seguida son los documentos que aportaban una gran información y que no disponía de ellos para integrarlos en la Colección Documental, quedando más extensos para no perder la riqueza de su información.

\section{El m é todo}

En un primer momento todas mis fuerzas se dirigieron a localizar los puntos donde pudiera localizar información oral o documentación escrita. Las islas de Narganá, El Porvenir, Playón Chico, Cartí, Ustupu y Ailigandí; los archivos y bibliotecas nacionales; los caciques y sus descendientes. 
Una vez localizada la documentación disponible y posteriormente ordenada, realicé la confrontación para verificar su autenticidad y llegar a la comprensión de su contenido.

Con la ayuda de otras fuentes, como entrevistas a personas que participaron directamente en el proceso educativo y de cambio social, fui completando y relacionando la educación con toda la actividad de este grupo humano; pues la educación no es un hecho aislado, implica al grupo y a todas las facetas de la vida de éste. Con la educación se llegaron a producir acontecimientos de gran relevancia en la sociedad kuna. Por eso la educación requiere una interpretación global. Pues es una parte de la trama social.

El método de elaborar esta historia de la educación entre los kunas ha sido ante todo cualitativo; con la información aportada por los documentos he intentado reconstruir los pasos dados en la educación, pues el fenómeno educativo en sí no se puede cuantificar, aunque en ocasiones uno se pueda ayudar de este procedimiento. Sí se puede ver por las tablas el número de asistencias o de matrículas escolares, así como el número de escuelas que funcionaron, o el número de maestros indígenas que ejercieron el magisterio.

En el trabajo he intentado exponer los hechos tal como ocurrieron o por lo menos como los revelan los documentos. El desarrollo progresivo de la investigación iba dando luz a las hipótesis planteadas, sacando al final unas conclusiones que son la síntesis de todo lo acontecido.

El trabajo se entiende desde el análisis de la sociedad panameña que comienza su andadura como nación recién estrenada y que debe organizar todos los sectores integradores de un nuevo pueblo. El conjunto de esfuerzos deben entenderse desde esta perspectiva y coyuntura.

El método responde a las directrices históricas y pedagógicas, esclareciendo lo que ha supuesto la educación en esta cultura, que se ha visto modificada y alterada en su devenir, no siendo un sustituto de lo que poseían, si no un 
complemento o suplemento de lo existente, para mejorar su vida y su cultura.

Claramente se puede ver por el estudio de este medio siglo de educación cuál ha sido el cambio operado entre los indígenas; y que la educación no ha sido un proceso aislado y aséptico. En él han influido las distintas religiones, los partidos políticos, la economía, la medicina, los medios de transporte y múltiples factores más.

\section{PI an de desarrol Io}

Quiero dejar constancia de la gran ayuda que me han supuesto los medios informáticos para realizar esta investigación. La Regesta Documental requería una ordenación cronológica. La inserción de nuevos documentos que iban apareciendo fue facilitada en mi trabajo por estos medios, lo mismo que la transcripción de los documentos y las tablas estadísticas. Aunque también es cierto que en un primer momento tuve que pagar $\mathrm{mi}$ inexperiencia y falta de preparación para manejar estos aparatos.

En el análisis de documentos, en repetidas ocasiones me encontré con el problema de la ubicación de los documentos, ya que era frecuente la costumbre de poner la fecha referida al año con el último número, así si aparecía un uno podía ser de 1921, 1931, 1941 ó 1951. En estas circunstancias el contenido - algún otro dato servían de ayuda para señalar su correcta fechación.

La obra total la presento en cuatro volúmenes; comenzando con esta introducción en que expongo el tema, la importancia del mismo, con sus límites y la motivación que me llevó a elegirlo, así como reseño las personas que han tratado algún aspecto del mismo. Establezco las hipótesis y objetivos de la investigación, apoyadas por las fuentes que he empleado, señalando el método de investigación y el curso seguido en la elaboración. 
En el primer capítulo, trato de hacer una exposición que nos encuadre en los acontecimientos del país, que se separa e inicia su andadura como nación independiente.

El siguiente capítulo quiere exponer brevemente el sistema educativo tradicional seguido por el pueblo kuna, con las manifestaciones peculiares de su sociedad.

Añado unas cortas pinceladas que nos sitúan y ambientan en las corrientes pedagógicas de la épocas que pudieron tener más repercusión en la educación panameña, no olvidando la doctrina educativa de la Iglesia, ya que fue la que la dirigió más de treinta años del periodo estudiado.

Las leyes y disposiciones gubernamentales que atañen a los kunas son analizadas en el capítulo cuarto. Pudiendo verse en el transcurso de los cincuenta años la preocupación despertada en el gobierno por los indígenas, y especialmente por los habitantes de la comarca de San Blas.

La creación de la primera escuela indígena fuera del territorio kuna y las becas, junto con el afán por establecer la escuela entre los indígenas protagonizado por Charles Róbinson son los componentes del capítulo quinto.

El sexto relata la actividad de la misión jesuita entre los karibes. Iniciando allí lo que sería la primera escuela, a pesar de que su labor fuera más misional, pero siempre con el fin último de llevar la civilización a los indios, promovido esto por el Gobierno y con la colaboración de la Iglesia.

La misión protestante es el capítulo séptimo; en el cual hablo de la labor realizada por las predicadoras de lengua inglesa y de la construcción de las primeras escuelas en las islas a cargo del estado y los nombramientos de los primeros maestros nacionales; concluyendo con la revolución del 25.

El capítulo ocho desarrolla el comienzo de la educación después del cierre de la revolución y la posterior puesta en marcha de la educación en manos de los misioneros claretianos y franciscanas.

El auge de la educación está reflejado en el capítulo noveno, donde la labor intensa de los directores se ve 
recompensada con el elevado número de matrículas, y el desplazamiento de estudiantes de islas lejanas a los centros escolares de las principales islas.

En el capítulo décimo analizo la labor del indígena Estanislao López, los Congresos Generales que empiezan a tocar en sus debates los temas referentes a la educación; y el paso de ésta al Ministerio de Educación, dejando su vinculación a Gobierno y Justicia.

En el apartado undécimo expongo la acción incrementadora de la educación de Nele Kantule, luchador incansable por extender la educación entre su pueblo, lo mismo que Alcibiades, que fue un protegido suyo. Al mismo tiempo que hago una referencia a los internados establecidos en las islas para facilitar la educación a los de otras islas.

Las conclusiones nos permiten ver cual fue la labor real que se llevó a cabo entre los kunas y los cambios que produjo este fenómeno.

El primer volumen finaliza con unos apéndices que son complementarios a todo el trabajo y que pueden facilitar su comprensión.

En el segundo volumen he integrado las fuentes primarias y las secundarias compuestas por la Regesta Documental y por la bibliografía. El compendio de la Regesta alcanza casi el millar de documentos formados por cartas, actas, informes, cuadros... ordenados cronológicamente y que son el soporte de toda la investigación.

La Colección Documental está recogida en el tercer y cuarto volumen. Está integrada por las fotocopias realizadas en Panamá y por las transcripciones de los documentos que me traje fotografiados. La gran colección de documentos que está en mi poder ayudará a salvar este filón de información que se ve amenazado por la climatología y la carcoma.

La Regesta Documental tiene al final una referencia que es la localización del documento y algunas poseen una segunda llamada que indica el número de la Colección Documental donde se puede ver íntegro el documento. 
La Colección Documental aclara si las transcripciones realizadas por mí proceden de copia u original, mecanografiada o escrita; y la correspondencia con el número de la Regesta Documental.

\section{Curso de elaboración}

Para recoger documentación referente al trabajo he realizado cinco viajes hasta el lugar que habitan los kunas, conviviendo con ellos. El tiempo aproximado de estancia allí es de un año. Una primera visita de dos meses en la cual tomé un primer contacto y me informé de cuál era el estado de la cuestión en materia educativa y las posibilidades de llevar a cabo esta investigación, la realicé en el verano de 1986. Para entrar en su reserva hace falta su permiso, un aval de los caciques generales, y por su puesto que ellos estuvieran dispuestos a colaborar y facilitarme la información. Gracias a la ayuda de la kuna Antonia de Edman que tomó mis preocupaciones como suyas los caminos se fueron abriendo, y los obstáculos allanando.

Posteriormente hice dos viajes consecutivos de tres meses cada uno, separados por una semana de estancia en España. En este tiempo recopilé la mayor parte de la documentación perteneciente a los hijos de Estanislao López y Rubén Pérez Kantule. el grupo PEMASKY de los kunas me ofreció un palafito que poseían en la isla de Cartí Sugdupu a cambio de que yo les corrigiera las publicaciones que hacían en castellano. Tuve la oportunidad de visitar las islas más importantes y tomar contacto con los centros donde se hallaba alguna documentación referida a los años que pretendía estudiar. De los cuarenta enclaves isleños habitados por los indios he visitado al menos veintiocho.

Los dos últimos viajes fueron en los veranos del 88 y del 89. Completé la documentación que me faltaba del archivo de Estanislao López y la existente en la sede de la Intendencia en la isla de El Porvenir. 
A esta isla me trasladé con mi hamaca y unos pocos víveres para indagar en el archivo que allí reposa. El escaso tiempo de que disponía y el gran número de papeles que tenía que revisar para seleccionar lo que me pudiera servir, me llevó a desarrollar un trabajo poco común. Provisto de cámara fotográfica fui dejando los documentos interesantes impresos en la película, y de regreso a España revelé seis carretes en blanco y negro que utilicé como diapositivas; poco a poco fui pasando esta documentación al ordenador. En las transcripciones de la Colección Documental en la parte inmediata superior, bajo el número de la página aparece una letra y un número; o una letra, un número y una letra que es la referencia con la que las tengo clasificadas. En las copias me he ceñido al texto respetando su redacción. De igual manera que en la Regesta Documental he mantenido los términos de los documentos y por ello se puede leer Río Cidra o Río Sidra, sahila o ságuila, entre otras variaciones, pero son dos formas de designar una misma cosa. La falta de escritura de la lengua kuna y su confusión en fonemas próximos, explican estas variaciones que se verá con más detalle en el capítulo primero.

Durante mi estancia allí procuré integrarme lo más posible con los indígenas, para conocerles desde dentro. Realicé sus actividades y me acoplé a su ritmo de vida llegando a comer mono y otras especies poco comunes para un europeo.

El trabajo dio comienzo en el verano de 1986, y desde entonces he dedicado todo el tiempo que mi trabajo profesional me dejaba libre para el estudio de esta tribu.

Antes de seguir, quiero dejar constancia aquí de mi agradecimiento a todas las instituciones y personas que han contribuido a hacer posible esta investigación. Al Departamento de Historia de la Educación, a mi directora que siempre encontró tiempo para resolver mis dudas, la Dra. Agueda Rodríguez Cruz.

A los caciques generales de la comarca de Kuna Yala, especialmente a Valdés; a Rubén Pérez y su hermano Lucho, en aquellos tiempos Intendente de la comarca. A Ildaura y Eladio 
López que generosamente me ofrecieron su casa y todos los escritos que poseían; a la familia Alba de Kuebdi y a los Edman de Ustupu. A Goyo, Dora, Bernarda y Juan Pérez de Cartí.

A los Archivos y Asamblea Legislativa de Panamá, a la organización PEMASKY, a los claretianos y franciscanas que trabajan en el archipiélago. Quiero dejar también constancia de mi gratitud al departamento de Fisiología.

Mi reconocimiento a quienes contribuyeron leyendo el texto o pasando documentos, los hermanos Ampudia, Marti, Pablo y a Luis que también confeccionó el mapa de los kunas. 


\section{PARTE I. LOS KUNAS EN SU MUNDO DE AYER}

1. A P R OX I M A C I O N A L M E D I O H I S T O R I C O-G E O G R A F I C O D E LOS KU NA S. 


\section{APROXIMACION AL MEDIO HISTORICO- GEOGRAFICO DE LOS KUNAS}

1.1. La situación panameña antes de la separación de Colombia.

Para seguir el hilo histórico de la primera parte lo divido en tres puntos que van encabezados por los siguientes títulos:

1) 1821: El momento de la independencia de Panamá de España y al mismo tiempo la unión con Colombia.

2) 1855: La creación del estado federal y la inauguración del ferrocarril transístmico.

3) 1880: Comienzo de las obras del canal interoceánico.

1.1.1 El momento de Ia independencia de Panamá y su unión con Colombia.

Este hecho se veía cercano pues el pueblo panameño tenía a su alrededor ejemplos de independencia que eran un estímulo, al mismo tiempo que experimenta que el gobierno central español estaba más ocupado en asuntos de guerras que centraban su atención y descuidaban a sus colonias de ultramar. 
En 1810 cuando el gobierno español se proponía convocar cortes, pensando en sus colonias de América las había concedido representación y Tierra Firme envía dos diputados, José Joaquín Ortiz y el Pbro. Juan José Cabarcas. Este último cartagenero que llegaría a ocupar la silla episcopal de la diócesis istmeña. Con las atribuciones conferidas por sus estados elevaron unas peticiones al gobierno como fueron las franquicias comerciales y de inmigración, el restablecimiento de las ferias en la capital y el fomento de la educación. La madre patria, más preocupada por en la política interna no atendió las peticiones de los representantes. Fernando VII llegó a abrir las puertas del comercio istmeño; sintiéndose rápidamente revitalizada la economía del territorio panameño. Esta acción se hizo sentir en el comercio de Cádiz que presionó para que se derogara la franquicia ${ }^{1}$.

En 1812 Panamá es la sede del gobierno de la Nueva Granada, el virrey de Santa Fe la escoge como centro, aunque este estatus duraría poco tiempo, pues renunciaría al cargo.

Francisco de Miranda propone a Inglaterra, un quinquenio antes de la independencia, como nación de apoyo de la revolución americana, y así mismo la declara beneficiaria de la apertura del canal de Panamá cuyo proyecto se iba fraguando. Consecuencia de esto es que en 1819 llega a las costas de Portobelo una expedición inglesa, resultado de la gestión de las

1 E. CASTILlero: Historia de Panamá, Ed. Panamá América, Panamá, 19555, pp. $70-71$. 
provincias unidas de la Nueva Granada para libertar al istmo de la dominación española. Esta tentativa quedó frustrada.

Unos meses antes del esperado día de la independencia, otra expedición, en este caso mexicana, luchó por la emancipación de aquellas tierras para anexionarlas a México. Cuando llegó el momento definitivo de la independencia, Panamá optó por la anexión grancolombiana, aunque esta decisión no fue unánime. El Obispo Hijinio Durán y D. Mariano Arosemena eran partidarios de la unión a Perú. Pero la mayoría votó a favor de la unión a Venezuela, Nueva Granada y Ecuador. El manifiesto que expresaba la voluntad istmeña de separarse fue redactado por D. M. José Hurtado gran impulsor de la educación como se verá mas adelante.

La situación que tenía que afrontar la recién nacida nación es muy dura, para empezar no hay fondos y es el obispo Durán quien presta $\$ 60.000$ al gobierno republicano. Esta acción sería la que daría una mínima estabilidad a la situación gubernamental inicial.

Al año siguiente el Libertador Simón Bolívar, presidente de la Gran Colombia expresa su felicitación al Coronel Fábrega por la acertada decisión.

En 1826 tiene lugar en el Istmo la celebración del Congreso Bolivariano en el que se aprueba un tratado, un convenio y un concierto. 
Con la renuncia al poder del Libertador, el Istmo ve venir la decadencia y se separa el 26 de septiembre de 1830; más tarde pone como condición de su nueva unión que tome el mando Bolívar. Este no lo asume pero son convencidos los gobernantes y dos meses después se reincorpora a la Gran Colombia. Habían transcurrido pocos días desde la reincorporación cuando moría el gran Libertador.

A mediados del año siguiente se produce una segunda separación, pero de igual manera es breve, este desmembramiento duró cuarenta días. También Venezuela y Ecuador se separaron. En noviembre de 1831 la región central adopta el nombre de Nueva Granada. En el segundo mes de 1832 se expide la nueva Constitución y sube ese año al poder Francisco de Paula Santander que gobernaría hasta 1837. Cuando este año muere el obispo Durán sube a la sede monseñor Cabarcas, quien asistiera a las Cortes de España. Entre sus objetivos prioritarios estuvo la enseñanza. El mismo la impartía de modo gratuito para paliar las deficiencias de la escuela panameña, con anterioridad en 1823 había organizado el colegio del Istmo, de educación secundaria y profesional. Se le conoció con el nombre de "El maestro de la juventud istmeña".

Desde los comienzos de la unión de Panamá a Colombia vieron la luz diversas leyes en materia educativa, pero la puesta en práctica se iría aplazando. Comenzaron en la ley 18 de 1826 promulgada por Santander. Y el sistema de enseñanza 
lancasteriano arribó a las costas venezolanas llevado por el fundador a invitación de Bolívar en 1834. Se implanta este sistema en Panamá y se establece una escuela en Santiago de Veraguas. Con la muerte de Bolívar estalla la guerra civil y se promulgan las leyes de enseñanza laica.

Dos años después de la promulgación de la constitución se funda la Sociedad de Amigos del País, a semejanza de las existentes en la Península, que pretendían la ilustración del pueblo y el cumplimiento de las leyes que velaban por el orden. Esta sociedad publicaba una revista con el mismo nombre, donde aparecían temas relativos a la educación, con propuestas innovadoras; y velaban al mismo tiempo porque esas ideas se pusieran en práctica. Otra sociedad estudiantil que funcionó a mediados del siglo XIX fue la denominada con el sugestivo nombre de "Deseosos de instrucción"2.

Durante la presidencia de Tomás Cipriano Mosquera se produjo una revitalización de la enseñanza y en cuestión de política exterior se da un giro. Se abandona la colaboración económica con Inglaterra para dirigirla hacia los EEUU. Ratificándose con la firma del Tratado de 1846 que garantizaba la soberanía colombiana sobre el Istmo de Panamá.

A mediados de la década de los treinta el poder norteamericano se interesa por el canal interoceánico del

2 F. CÉSPEDES: La educación en Panamá. Panorama histórico y antología, Panamá, $1985^{2}$ (Biblioteca de Cultura Panameña, t.4) p. 24. 
Istmo, pero se hace cargo una sociedad granadina que no emprendería las obras.

D. Pedro Obarrio que fue gobernador de Panamá desde 1836 a 1840 creó algunas escuelas en la capital, así como en cuatro pueblos de la provincia. De igual modo el también gobernador Herrera en 1845 abrió una escuela para niñas en Panamá, su objetivo era elevar el nivel cultural de la mujer.

La nación granadina estaba en guerra civil en 1840 y el 18 de noviembre de ese año el Istmo decide por tercera vez separarse con el nombre de Estado del Istmo. Entre los partidarios de la separación predominaba la idea de la separación definitiva frente a la temporal, hasta que se solucionara el conflicto. Esta sería la mas larga de todas las separaciones. A los tres meses, el 31 de diciembre de 1841 se volvía a unir el destino de Panamá y Colombia.

En ese año los dirigentes del país llevados por sus deseos de progreso y queriendo una educación para el pueblo promulgaron la ley de transformación del colegio del Istmo en universidad. Esta sería la segunda universidad que existió en el Panamá, pero su prometedora vida se cercenó a los pocos años. La situación económica del pueblo panameño se vio prosperar entre los años cuarenta y cincuenta. Su auge se debió a que esta nación se convirtió en zona de paso de los buscadores de oro que se dirigían hacia California, en aquel entonces tierra prometida para aventureros y exploradores. Fruto de esta 
prosperidad es el desarrollo que alcanza la enseñanza a mediados de los cuarenta. Se cuentan en Panamá treinta y nueve escuelas públicas de varones que alcanzan una matrícula de 1.459 alumnos y una escuela pública con once niñas ${ }^{3}$.

En 1853 se funda el periódico "La estrella de Panamá" y con posterioridad van apareciendo otras publicaciones.

Los Estados Unidos querían controlar la navegación en el nuevo mundo y quitar poder a las naciones del viejo continente, como Gran Bretaña, y firma con nueva Granada a finales de 1846 un tratado de Paz, Amistad, Navegación y Comercio. Quedaba así clara su soberanía sobre el Istmo y menguaba la influencia y poderío francés.

Cuatro años más tarde Inglaterra y Estados Unidos firman un tratado mediante el cual, el primero se compromete a no construir canal alguno por el Istmo centroamericano sin dar participación a la otra. Y simultáneamente se firma un contrato que autorizaba a una empresa norteamericana a construir el ferrocarril a través del Istmo.

En 1852 y después del primero del año se declara la libertad absoluta de los esclavos. Pero contrariamente la iglesia se vio oprimida por las leyes dictadas por J. Hilario López.

3 A. CATON: Desenvolvimiento de las ideas pedagógicas, Imprenta Nacional, Panamá, 1955, p. 5. 
En cuanto a la preocupación mostrada por el gobierno colombiano en lo referente a los indígenas se puede reseñar la ley del 3 de agosto de 1824 que distribuía las tierras baldías entre los indios que quisieran abandonar la vida errante y formaran poblados.

La siguiente ley es dos años posterior y disponía que los indios de las costas de de la Goajira, Darién y Mosquitos, y los demás no civilizados que formaban parte de la República serían protegidos al igual que el resto de los demás ciudadanos colombianos. El gobierno adoptaría las medidas oportunas para llevarlos a la civilización.

El libertador Bolívar dictó un decreto por el que se establecía la cuantía de la contribución personal de los indígenas. Así se van sucediendo las leyes con referencia específica a las distintas zonas indígenas. Y en 1842 se ordenó el establecimiento de colegio de misiones.

La ley cuarta del año siguiente da protección a los indígenas. Se les exime del alistamiento en el ejército y guardia nacional a los que se redujeren a la vida social. La obligación de crear escuelas primarias correría por cuenta de los municipios hasta 1844. Un bienio después se promulga una ley que establece los corregidores de indígenas del Chocó, estos impondrían a los trabajadores una contribución que no excediera a los dos pesos por semestre, para pagar los sueldos de los empleados allí, entre los que figuraba el preceptor de 
escuela. La acción del gobierno iba dirigida a reunirlos en poblados y así impartirles instrucción.

Con la ley de 1848 se regula el cobro de impuestos a los indios y la distribución de los mismos.

\subsubsection{La creación del estado federal y la inauguración del ferrocarril transístmico.}

La segunda mitad del siglo XIX comenzó con dos hechos significativos para la marcha del istmo: la creación del Estado Federal y la inauguración del ferrocarril, esto ocurría en 1855.

Se produce una expansión demográfica que había comenzado en la década de los cuarenta y que en medio siglo llega a sobrepasarse en más del doble.

En 1857 el Congreso Colombiano expide la carta fundamental, en la que la nación tomaba el nombre de Confederación Granadina y la integraban ocho estados. Pero la autodeclaración de Mosquera como dictador lleva a la proclamación de los Estados Unidos de Colombia y se inicia una persecución a la iglesia.

Los dos últimos años de la década de los cincuenta ocupa el puesto de gobernador de Panamá D. José Obaldía. En ese tiempo estalla en Nueva Granada una guerra civil y el Istmo 
amenaza con la separación si se derroca al gobierno legal. Además él se mantuvo neutral en la batalla. Mosquera emprende una persecución contra el gobernador panameño que se retira a Costa Rica y se dedica a la enseñanza.

En 1861 se firma el documento conocido con el nombre de Convenio de Colón. Panamá se adhiere a la confederación de los estados o Pacto de la Unión, pero se reservaba el derecho de aprobar o rechazar la nueva constitución y se mantenía neutral en las luchas del resto de la república. Con tanta restricción, el general Mosquera molesto, invade el territorio y dicta un decreto a través del cual se confiscan los bienes a la iglesia en beneficio de la nación. Las propiedades de la iglesia se conocían con el nombre de "Bienes de manos muertas". La recaudación en el estado de Panamá alcanzó la suma de B/ 387.982.

La instrucción pública en esos años nos la detalla Catón:"Hacia 1860 Panamá estaba dividida en dos provincias: Panamá y Veraguas. El dinero gastado en instrucción pública en 1860 fue para las dos provincias de 6.681 pesos" 4 .

Es de destacar que en esos años se hace la primera impresión de billetes de la tesorería, respaldada por el estado.

La nueva constitución de 1863 ratificó el nombre de Estados Unidos de Colombia y los gobernantes de los estados

4 Ibidem, p. 5. Citando a Octavio M. Pereira en Historia de la Instrucción Pública en Panamá, Topografía Moderna, 1916, p. 22. 
recibieron el nombre de presidentes. El primero que ocupó el poder en Panamá se destacó por sus abusos en lo referente a los temas tocantes de la religión y en materia de imprenta.

Desde los tiempos coloniales Panamá se enfrentó a disputas con Costa Rica motivadas por cuestiones fronterizas. La Constitución de Rionegro intentó resolver este antiguo litigio y en 1872 se pretendió solucionar pero a costa de perder el territorio panameño, cosa que no aprobó el congreso.

En 1863 comienza un periodo de anarquía en el Istmo que se prolongaría hasta $1886^{5}$.

La creación de los Colegios Académico y del Estado en el segundo año de la década de los setenta bajo el patrocinio de D. Manuel José Hurtado, que ejerció como maestro y llegó a Director General de Instrucción Pública, hizo que la educación recibiera un impulso muy favorable. Este hombre llevado por su celo no dudó en sufragar muchos gastos públicos de la educación con su propio dinero. El crearía las escuelas públicas de Santa Ana y S. Felipe, y la Escuela Normal de Varones (1872). El personal que la dirigió fue contratada por Colombia en Alemania y sus líneas directrices seguían las enseñanzas de Pestalozzi. En Panamá estuvo Oswald Wirsing. En esta Escuela Normal se formarían los líderes que declararon la separación de la nación panameña en 1903.

5 E. CASTILlero: Historia de Panamá, Ed. Panamá América , Panamá, $1955^{5}$, p. 111. 
Tuvo también Panamá una Escuela Normal de Señoritas en 1875 que se dedicaría a preparar a las maestras de primaria, pero que se tuvo que cerrar por falta de alumnas. Tres años después de esta última fundación llegaron a Panamá cinco hermanas de la caridad que iban con destino a Nicaragua, pero fruto de las oportunas gestiones de un grupo de entusiastas del progreso, se consiguió que se quedaran en el Istmo y se instalaran definitivamente en una casa proporcionada por el Dtor. de Instrucción Pública, el Sr. Hurtado. Abrieron escuela para enseñar a un grupo de niñas a leer, escribir, la doctrina cristiana y las labores de aguja. Con el paso del tiempo las cedieron la iglesia de San Felipe y llegaron a establecer un pensionado para niñas y asilo de huérfanos; siendo también un centro de enseñanza para niños varones menores de quince años. Con posterioridad se sumaron al grupo nuevos refuerzos y ampliaron el campo de sus actividades como sería el Hospital de Extranjeros, el de Ancón y el de Santo Tomás.

La enseñanza que se impartía desde 1877 tuvo un carácter más secular, se fue perdiendo la vinculación que tenía con la religión, aunque se mantuvo ese sistema propio del tiempo colonial con la tribus del territorio. Los misioneros y la religión eran los agentes y medio de civilización de los indígenas. El estudio de la religión como asignatura quedó sujeto a la decisión de los padres. La enseñanza de la religión fue una materia que figuró en los planes de política 
conservadora y la enseñanza laica fue una peculiaridad de los gobiernos liberales.

Apareció el primero de julio de 1874 la ley 66 que trataba sobre la reducción y civilización de indígenas. Dividía el territorio colombiano en seis corregimientos de indígenas y se hacía una asignación monetaria a cada uno, para lo cual debían reunir unas condiciones entre las que figuraban la promoción de establecimientos conocidos con el nombre de colegios de misiones, donde se enseñara las lenguas o dialectos de las tribus que se iban a civilizar, y que en cada población o caserío importante que se fundara se estableciera una escuela. El presupuesto general para esta acción era de 31.000 pesos, con esto se pretendía llevar a buen término tal empresa. Panamá contaba con 5.000 pesos y el corregimiento de Cauca, en el que se encontraban los kunas del chocó con 3.000 pesos. Se autorizaba al poder ejecutivo para que contratara la impresión de gramáticas y vocabularios de las lenguas de los indios que iban a ser civilizados.

De suma importancia para Panamá era el tema del canal, cuya idea había sido preconizada por varios espíritus emprendedores y con visión futurista. Con la llegada de 1878 se celebra el primer contrato del gobierno colombiano con el francés Napoleón Bonaparte Wyse. Este traspasó la concesión que se le había hecho a la Compañía Universal del Canal Interoceánico, que era presidida por F. Lesseps, constructor del canal de Suez. 
1.1.3. Comienzo de las obras del canal interoceánico.

El uno de enero de 1880 se hacía la inauguración de las obras del canal con la presencia de Lesseps. Pero sería dos años más tarde cuando los trabajos se iniciarían en firme. Con la construcción del canal empezó otra época de esplendor para el Istmo, semejante a la del siglo XVII con las ferias de Portobelo, cuando Panamá era foco y centro de la actividad colonial, y similar así mismo, a la de mediados del XIX cuando el paso obligado de los buscadores de oro había llevado a la construcción del ferrocarril transístmico. Este hecho tendría repercusiones económicas favorables en todos los campos incluido el de la educación.

En 1883 se reunía la asamblea de maestros graduados para tratar temas de su interés: sistemas de enseñanza según Pestalozzi, clasificación de las escuelas... Se editaron dos publicaciones en materia educativa "La escuela Normal" y "La revista de instrucción pública". Los presupuestos educativos fueron sufriendo oscilaciones hasta llegar el momento de la declaración de la República. Estas variaciones estaban entre el $2 \%$ y el $15 \%$. El grueso de los presupuestos se empleaba en mantener el orden y la seguridad social. La inestabilidad era la nota dominante en el tiempo de unión a Colombia. Las guerras civiles de ésta tenían repercusión en todos los campos de la 
vida social. La última guerra civil llevó consigo la supresión de los planteles educativos 6 .

A mediados de los ochenta, ante la guerra que azotaba a Colombia, el Istmo se declara neutral. La ciudad de Colón se vio hostigada por parte de un grupo de revolucionarios y se incendió por completo, ascendiendo las pérdidas a \$8.000.000. Los autores fueron ahorcados para escarmiento público. En las costas del Pacífico también se produjeron algunos enfrentamientos y el gobierno norteamericano para salvar el orden y garantizar el libre tránsito de la vía interoceánica envió tropas a las ciudades de Colón y Panamá, haciendo uso del tratado de 1846. El gobierno central acantonó tropas con el mismo fin.

La autonomía de que había gozado Panamá llegó a su fin con la Constitución de 1886, pues se establecía en Colombia el régimen unitario, por el que se pasaba a ser un departamento nacional. Esto hacía que concluyera el progreso de la instrucción pública y de la enseñanza privada. La constitución aprobada en ese año daba un giro en el sistema político que pasaba del federalismo al centralismo, del laicismo a la estrecha alianza de estado-iglesia, de la inercia gubernamental a la máxima omnipotencia. Esto se hizo sentir muy especialmente en Panamá que sería administrada por leyes especiales, además de no reconocérsele del mismo modo que a

6 F. CÉSPEDES: La educación en Panamá. Panorama histórico y antología, Panamá, $1985^{2}$ (Biblioteca de cultura Panameña,t.4) p. 27. 
los otros departamentos. Y como remate de este agravio se nombró a dos bogotanos como delegados representantes del Istmo7. Estos hechos aumentaron el descontento de los panameños.

Este mismo año se persona el Conde Lesseps para inspeccionar la marcha de las obras del canal. Llega con la idea preconcebida de que sería la etapa final de las excavaciones del canal y comprobó con gran decepción que no era así. El cumplimiento de lo acordado y su sueño estaba aún lejos.

A pesar de toda esta serie de adversidades la educación iba haciendo progresos cuando se presentaban algunas condiciones favorables, y así en 1888 fue creado mediante decreto el Colegio Balboa, que sería dirigido por el prestigioso D. Abel Bravo. Y cuatro años más tarde se funda la biblioteca Colón, única de uso popular en la capital, pero que vería su fin en 1941.

En el mes de julio de 1889 aparece una resolución sobre misiones y colonias agrícolas de indígenas. Señala la estancia entre los indios de los misioneros jesuitas y más tarde de los agustinos. Comenta la ineficacia de este método que culpa a la inestabilidad política. Al mismo tiempo censura a los que creen que es lícito perseguir a las tribus salvajes y organizar matanzas. Aboga por la creación de colonias

7 E. CASTILlero: Historia de Panamá, Ed. Panamá América, Panamá, $1955^{5}$, p. 118. 
agrícolas donde se instruya a los indígenas al mismo tiempo que se crean escuelas.

Mientras tanto la fecha de conclusión de las obras del canal se va aplazando en diversas sesiones. A ello contribuye la malversación de fondos que retrasa las obras y termina por llevar a la bancarrota a la Compañía Universal del Canal Interoceánico.

Un nuevo estudio hace una estimación de ocho años para la conclusión. Es enviada entonces a Bogotá una comisión que solicita el aplazamiento de la inauguración. Esta comisión fue apoyada por el gobierno de Panamá entre los que se encontraban el obispo Peralta, M. Amador Guerrero, Ricardo Arango y Pedro J. Sosa. En el inicio de la década de los noventa se aprueba la prórroga y se señala como fin de las obras 1900. En 1894 había muerto ya el conde Lesseps.

Bajo el mandato quinquenal de Ricardo Arango se produjo un despliegue de la instrucción pública. Se estableció la Escuela Normal de Señoritas y se construyeron los primeros edificios oficiales para las escuelas primarias, en total unos sesenta, dotándose a las mismas de moviliario. La población urbano era minoritaria "En 1895 la población urbana del Istmo alcanza solamente el $18 \%$ de la población total (ciudades de Panamá, Bocas del Toro y Colón); el $27 \%$ se distribuye en 40 poblados y villorios y el resto, o sea 170.000 habitantes viven 
dispersos, constituyendo así una población totalmente rural y marginada según los conceptos del presente"8.

El último año del siglo XIX estalla la guerra civil más larga y ruinosa del país, que se conoció con el nombre de la guerra de los Mil Días. Costó 50.000 vidas y más de \$ 8.000.000. Provocada por el descontento de los liberales, a quienes los radicales le habían arrebatado el poder. Se inició la lucha en Bocas del Toro (Panamá) y en Santander (Colombia). Esta lucha daría al traste con el progreso alcanzado hasta entonces.

El Presidente de los Estados Unidos por ese tiempo manda una comisión que estudie la viabilidad de construcción de un canal por el Istmo. En los albores del siglo XX la comisión cree más conveniente la vía nicaragüense y así lo informa al jefe del gobierno, pero la compañía francesa había aceptado vender los derechos del canal por el precio que le habían puesto los americanos. Finalmente la comisión da preferencia a la vía panameña.

El cambio de patrocinador del canal centra ahora la atención de todos los paises. Tras esta operación los norteamericanos buscaron la manera de derogar el Tratado que les vinculaba a Inglaterra y que cohartaba sus posibilidades de trazar el canal. El Tratado Hay-Pauncefote que se firmó en

8 F. CÉSPEDES: La educación en Panamá. Panorama histórico y antología, Panamá, $1985^{2}$ (Biblioteca de cultura Panameña,t.4) p. 10. 
1901 permitía a los americanos construir el canal con dinero americano y en suelo americano.

La revolución seguía dando sus pasos y llega al Istmo una expedición compuesta en su mayoría por nicaragüenses reclutados bajo el mando del Dr. Belisario Porras, quien se declaró jefe civil y militar del Departamento de Panamá. Tomaron la ciudad de David y sometieron las provincias de Veraguas y Coclé. Pero se ve frustrado el intento de los liberales de tomar la capital, pues los conservadores habían recibido un contingente de mil hombres que engrosó su ejército. Ante estos enfrentamientos intervienen los cónsules extranjeros para que los dos ejércitos lleguen a un armisticio y capitulación. Como resultado los conservadores se mantuvieron en el gobierno del departamento.

Los problemas fronterizos que enfrentaban a panameños y costarricenses se acercaron a un final tras la mediación del Presidente de Francia, que dicto sentencia favorable al territorio istmeño.

El 28 de Junio de 1902 el congreso autoriza al presidente Roosevelt para comprar una franja de tierra de diez millas de anchura que atraviesa el Istmo y compra los derechos a la compañía francesa del canal, para la construcción del mismo. Si este no llegaba a acuerdos positivos con el gobierno colombiano se le autorizaba para tratar el mismo asunto con los dirigentes nicaragüenses. Las conversaciones tuvieron un 
final positivo y ventajoso para la nación panameña. A principios del año siguiente se estampó la firma del Tratado Herrán-Hay, por el que Colombia concedía un terreno de diez kilómetros de ancho en el Istmo para perforar la vía del canal y disfrutar por un espacio de cien años prorrogables; y a cambio el gobierno colombiano recibía 10.000 .000 de pesos de oro y una renta anual de 250.000 dólares más a partir del octavo año.

\subsection{El momento de la independencia.}

El Istmo se vio sometido a frecuentes asaltos. En el interior el cholo Victoriano Lorenzo; y por las costas, se hizo presente un barco adquirido por los revolucionarios y que tras sus hostilidades logró acorralar al gobierno en la capital. La revolución fue ganando posiciones en el interior del Departamento.

Pero mientras en Panamá se imponía el liberalismo en Colombia había desistido. Los temores surgidos en los gobernantes de esta última, tras la experiencia de 1900 llevó a solicitar la intervención de los Estados Unidos y se llegó a un acuerdo en 1902 en el que figuraban entre otras las siguientes cláusulas: cese de las hostilidades, libertad para los presos políticos y de guerra, la promesa del gobierno de realizar elecciones en el congreso, tratar las negociaciones del canal y 
la reforma del sistema monetario. Así se ponía fin a la ruina y desolación del Istmo.

A mediados del año 1903 el congreso de la república electo en ese año rechaza el Tratado firmado a primeros, por el que se cedían los derechos del canal a los Estados Unidos, después de comprobar la malversación de fondos en la compañía francesa que la había conducido a la ruina.

El cabecilla de la sublevación panameña, Victoriano Lorenzo, es fusilado para escarmiento de los revolucionarios. Al mismo tiempo que esta ejecución se llevaba a cabo; Colombia hacía lo posible por vender su imagen para que se realizara la construcción del canal por el Istmo. La publicación en el periódico liberal El Lápiz del fusilamiento de Victoriano Lorenzo desató una persecución hacia estos; tras comprobar que los tratados eran papel mojado, pues no se respetaban, y deciden entonces unirse al grupo conspirador que buscaba la separación e independencia del Istmo.

El año de la liberación fue designado gobernador de Panamá D. José Domingo Obaldía, que inicia su gestión con el descontento general por el rechazo del gobierno nacional del Tratado Herrán-Hay. Integrada por estos disidentes se formó una junta revolucionaria para estudiar la separación de Colombia. Entre los componentes se encontraba M. Amador Guerrero, que viaja al país del norte para pedir ayuda, según el tratado firmado podía intervenir en caso de conflicto para 
pacificar el Istmo. Así salía favorecida Panamá y el tratado Herrán-Hay se iba consolidando.

Colombia envía un batallón a su departamento panameño ante el falso anuncio de que se ha producido una invasión nicaragüense. Todos los mandos son encarcelados en Chiriquí y los revolucionarios seguidamente proclaman la independencia. El consejo municipal se reúne y con la firma de un acta hace pública su voluntad de ser libre y autogobernarse. Al día siguiente se celebra un cabildo en la plaza donde se redacta el documento que proclama la independencia. Tres miembros de la junta revolucionaria forman la junta de gobierno provisional.

No es del agrado esta decisión para el gobierno colombiano que envía una expedición para someter al istmo por la región del Atrato, pero la espesura de la selva imposibilitó su llegada al suelo panameño. También son enviadas dos comisiones para conferenciar y ofrecer a los nuevos dirigentes la autonomía completa, el derecho a administrar sus propias rentas y las derivadas del canal; y les ofrecen el cambio de la capital de la nación pasando de Bogotá a Panamá. Persiste el interés colombiano por mantener la anexión y solicitan ayuda para que medie el país norteamericano; pero la declaración de independencia sigue firme y los Estados Unidos sería el primer país en reconocer la República de Panamá. 
Las gestiones del canal siguen y se firma un nuevo tratado que deja en gran descontento al pueblo y gobierno de la república.

Se elige la Asamblea Constituyente y se promulga la primera constitución en 1904 y el 16 de febrero era elegido primer presidente de la república D. M. Amador Guerrero que tomaría posesión de su cargo cuatro días después.

El departamento de Panamá, mientras estuvo vinculado a Colombia, tuvo que sufrir las depresiones que mantuvo este, y en pocos momentos sintió ventajas de este vínculo. En los últimos años de su unión solo vio a dos gobernantes nacidos en su tierra que dirigieran los destinos del departamento. Era difícil que mandatarios que no conocían ni sentían el territorio tuvieran profundos deseos de mejora y progreso para la nación istmeña.

Panamá era un foco de fiebre amarilla, a esto contribuía la falta de alcantarillado y de acueductos. La situación sanitaria era deplorable, y la mortalidad alcanzaba cotas muy altas. Las obras del canal habían atraído a gran número de población antillana.

La educación recibe un primer impulso con la primera constitución de 1904, el art. 133 dice "la instrucción primaria será obligatoria y la pública será gratuita" pero la economía estaba en uno de sus peores momentos. Las guerras habían consumido todos los presupuestos, las escuelas habían estado 
cerradas en los primeros años del siglo, y el índice de analfabetismo era muy alto.

La idea matriz en materia educativa estaba en la obligatoriedad, se quería una educación para todo el pueblo.

la población rural se mueve en una economía de subsistencia en su gran mayoría, esto resalta con el hecho de que el país, en gran parte de su extensión está sin trabajar y sin explotar, sus constantes situaciones de nación de paso olvidó la explotación agropecuaria. La población urbana tiene una minoría pudiente y con gran repercusión pero sin idea de permanencia y estabilidad. La educación superior se adquiría en Colombia y en los EEUU, y una minoría en paises europeos.

La tradición educativa era muy escasa. Hasta la segunda década la educación había dependido de las innovaciones que la madre patria enviaba, en un principio basada en la catequización como modo generalizado de enseñanza popular. Y la educación más propiamente considerada era clasista, para hijos de caciques y principales. En los primeros momentos de la república la educación está en manos de instituciones religiosas y de profesores y maestros traídos del extranjero. 


\section{3.- Historia de los kunas.}

Instalado en el Urabá, el pueblo kuna, que entonces era conocido con el nombre de "urabaes", vio perturbada su tranquilidad con la llegada de los conquistadores. El empleo de los indios en las minas para extraer el precioso metal, hizo que esta tribu se viera también explotada. Al igual que los diferentes grupos étnicos que les rodeaban en la rica provincia de Castilla del Oro. Los que no eran sometidos y reducidos, no tenían otra alternativa para conservar la libertad, sino el abandono de sus tierras. De este modo, se van introduciendo poco a poco en la selva darienita. Uniendo esto a las epidemias, que aparecían con frecuencia, el número de aborígenes comenzó a menguar.

El Darién no resultaba un lugar seguro, pues su clima de pluviselva favoreció la aparición de enfermedades; además los emberá que habitaron con anterioridad estas tierras, aparecen como sus enemigos más fuertes que logran expulsarlos de esta zona.

Consecuencia de esto, es que el pueblo kuna se va ubicando a lo largo de la zona montañosa oriental de Panamá, hasta bajar a las costas atlánticas y terminar por aposentarse a finales del siglo pasado, en las islas del caribe, en el archipiélago de las mulatas. Los relatos orales de los kunas nos hablan de esta migración. Asimismo, la información de viajeros y piratas confirman estos cambios de hábitat. 
En Reverte, se recogen estos cambios de residencia: "Las dos grandes migraciones del pueblo kuna, de las que tienen memoria los actuales indios, son:

1.- su huida del Darién, donde hace cuatro siglos todavía poblaban las orillas de sus ríos, y de donde fueron empujados por las grandes epidemias y por sus enemigos naturales, los pueblos emberás;

2.- su desplazamiento según el eje ChukunakeMatungantí, desde donde fueron lentamente avanzando a través de la Cordillera de San Blas hasta la costa.

3.- a partir de Nele Pawa se puede considerar una tercera migración o movimiento migratorio por el cual los indios que habitaban en las costas de San Blas se trasladaron a las islas, después de comprobar que eran mucho más sanas"9.

Estos cambios de hábitat, supuso una variación importante en el modo de vida y de costumbres, Habituados a la pluviselva, con lo que esto significaba, pasaron a ser costeños, para más tarde adaptarse a las islas.

La antropóloga panameña Reina Torrres de Araúz, estudiosa de las culturas de su nación, también apoya estas teorías migratorias. Hace referencia a una guerra denominada del Chukunake, que tiene lugar en el siglo XIX y que motiva la

9 J.M.REVERTE: Literatura Oral de los indios kunas. Ensayo literario sobre una cultura aborigen panameña, Ed. del Ministerio de Educación, Dirección Nacional de Cultura, Panamá, 1968, p. 223. 
retirada del remanente de población kuna, siguiendo el curso del río Chukunake y de los afluentes del Tuira. Este episodio sangriento motivaría, sin lugar a duda, la migración a las islas de San Blas, donde en la actualidad vive la mayoría de los indígenas kunas ${ }^{10}$.

Los límites del Darién estarían entre el río Atrato, conocido por el nombre de Gran Río del Darién, el Golfo de Urabá y las fronteras de Nombre de Dios y Chimán ${ }^{11}$.

Entre los antiguos cronistas aparecen como habitantes del Darién los cuevas, que en ocasiones se identificaron erróneamente con los kunas. Sin embargo, es generalmente aceptado hoy día, que los kunas y los cuevas eran dos pueblos diferentes. Pascual de Andagoya y Oviedo nos han dejado descripciones claras del pueblo cueva que habitaba el Darién. Las referencias que se hacen a los llamados hombresanimales, es posible que estén indicando la presencia en aquellas regiones de caníbales, a los que dominaron los kunas y con los que se fueron mezclando, llegando al resultado final de la cultura y lengua actuales. Estos caníbales se identificarían con los cuevas.

En el siglo XVII, Fray Adrián de Santo Tomás deja constancia de la coexistencia de los kunas y los cuevas en la

10 R.TORRES ARAUZ: Etnohistoria cuna, Instituto Nacional de Cultura, Panamá, 1974, p. 40.

11 Idem: "Culturas Prehispánicas del Darién", Hombre y Cultura, t. 2, Diciembre (1971) p. 7. 
zona comprendida entre Chepo (de la provincia de Panamá) y Sambú (del Darién) ${ }^{12}$.

Este predicador, ayudado por Julián de Carrisolio, que fue criado por los kunas al ser recogido de pequeño tras un naufragio, funda poblados kunas y deja datos sobre la reducción de San Sebastián de Kapetí.

Leonel Wafer describe el fenómeno del albinismo, mutación frecuente entre los kunas, cuando realiza su travesía por el Darién. Este cirujano que iba acompañado de un grupo de piratas, es el primero en detallar la presencia de los kunas en la Costa Caribe.

En el mes de febrero de 1635, coincidiendo con el carnaval, los buguebugue atacan la ciudad de San Cristóbal de Chepo, matando entre otras personas al alcalde Simón Jurado13.

Corre el año 1774 y Andrés de Ariza escribe que la provincia de Santa María la Antigua del Darién cuenta con nueve poblados y unos doscientos vecinos que tienen nueve curatos y seis párrocos ${ }^{14}$.

Los kunas mantuvieron contacto con los misioneros desde los primeros tiempos de la conquista. Los testimonios

\section{Ibidem, p. 34.}

13 R. TORRES DE ARAUZ: "Las culturas indígenas panameñas en el momento de la conquista", Hombre y Cultura, t. 3, Abril (1977) p. 76.

14 "Compendio del actual estado de la provincia de Santa María la Antigua del Darién. Año de 1774", Hombre y Cultura, t. 2, Diciembre (1971) p. 107. 
son frecuentes. Esta presencia de los evangelizadores fue produciendo, de modo lento pero persistente, cambios que transformaron su cultura y que llegarían a asimilar con el paso del tiempo. Separar lo que era propio de la cultura primitiva indígena y lo que sería fruto del proceso de aculturación, es algo que sobrepasa las pretensiones de este trabajo. En la actualidad se pueden detectar elementos propios de la cultura occidental, que en tiempos recientes se han ido infiltrando en sus cantos tradicionales (un ejemplo es el cielo que cuentan los kunas con casas altas o rascacielos y con teléfono).

En la primera mitad de este siglo, los kunas han despertado un interés especial en los antropólogos, biólogos y genetistas. El albinismo, carácter destacado de este pueblo, es un fenómeno que se presenta en un tanto por ciento muy elevado. Esto hizo que el biólogo americano R. O. Marsh, que estuvo haciendo unos estudios en esta región del Caribe, llevará a un grupo de albinos para ser estudiados por el Instituto Smithsonian de EE. UU.

A su vez, la escuela sueca de antropología, encabezada por el Barón Nordenskyöld, también efectuó un copioso número de estudios; asesorado principalmente por el destacado indio Rubén Pérez Kantule.

Finalizando el siglo XIX comienzan a instalarse en las islas, abandonando las costas donde crece mucho manglar y proliferan los mosquitos. Las islas carecen de agua dulce, 
aunque en ocasiones se puede subsanar cavando pequeños pozos y con el agua dulce que corre en los ríos cercanos, pero la brisa que sopla suavemente las mantiene libres de insectos. Tan reducidas dimensiones del terreno isleño, les priva de la posibilidad del cultivo. Esto hace que no se independicen de modo total de la costa. Sus cultivos, sus cementerios y el suministro de agua se seguirán haciendo en el continente, además de proporcionarles caza.

Aunque la mayoría del pueblo kuna habita en la actualidad en las islas, quedan todavía poblados en la ribera del río Bayano y serranía del Darién; perteneciendo un par de comunidades a Colombia.

A través de los años, y desde los primeros días de la conquista, los kunas han mantenido relaciones con diversos pueblos europeos; unas veces como aliados y otras como enemigos. Esto también ha ido transformando su cultura. Desde los españoles hasta los escoceses, los kunas mantuvieron alianzas o relaciones hostiles, según los casos, con los franceses y los ingleses entre otros. Así se reconoce en la declaración de independencia y derechos humanos del pueblo de Tule, catalogando estos contactos con los extranjeros como perjudiciales ${ }^{15}$.

15 Declaración de independencia y derechos humanos del pueblo de Tule de S. Blas y el Darién, p. 7. 
Finalizado el sg. XVII los franceses hacen acto de presencia en el territorio indígena y traban amistad con los kunas. Llegando a usar el francés, al menos de un modo rudimentario. Se alían con los galos para enfrentarse a sus colonizadores españoles; y más tarde serían exterminados los franceses 16 .

En 1698 empiezan a recibir a los escoceses, quienes les traen las enseñanzas calvinistas y luteranas. Comienza el bombardeo de enseñanzas religiosas que se prolonga por siglos y que se acentúa en la actualidad. También se alían con ellos para derrotar a los españoles 17.

Torres de Araúz comenta la descripción del "caballero recientemente llegado" que dice que algunos niños de la principal nobleza fueron encomendados a los diputados para ser educados y para aprender la lengua escocesa18. Se refiere a los hijos de la nobleza kuna.

Los kunas rememoran en su mitología episodios comunes a otras culturas. Es el caso del mito del Arbol de la Vida, que relata el origen del agua y que aparece en varias culturas meso-americanas ${ }^{19}$. Esto nos hace ver la interrelación

16 E. NORDENSKYÖLD: An historical and ethnologiacal survey of the cuna indians, Goteborgs Museum, Suecia, 1938.

17 C. RUBEN DARIO: Doscientos años de periodo colonial en Panamá, Imprenta Nacional, Panamá, $1959^{2}$, p. 166.

18 R.TORRES ARAUZ: Etnohistoria cuna, p. 33

19 Idem: Panamá Indígena, Instituto Nacional de Cultura, Patrimonio histórico, Panamá, 1980, p. 206. 
y pertenencia a una familia indígena más grande, que abarca varios pueblos. Otro mito similar a otras culturas es el relato del Diluvio, que también aparece en el pueblo inca ente otros.

\subsubsection{Situación geográfica.}

En primer lugar aclarar que con la independencia de Panamá los kunas quedaron divididos; unos entraron a formar parte del territorio panameño y otros al colombiano. Dentro del grupo panameño, cuando se realizó la división en provincias unos quedaron formando parte de la provincia de Colón, otros de la provincia de Panamá, y finalmente un tercero pertenecía al Darién.

En la actualidad los kunas ocupan una angosta franja, situada entre los $8^{\circ}$ y $35^{\prime}$ hasta los 9 y $32^{\prime}$ de latitud norte; y desde los $77^{\circ}$ y $20^{\prime}$ hasta los $79^{\circ}$ y $8^{\prime}$ de longitud occidental, conforme al meridiano de Greenvich. La longitud de esta tierra alcanza las ciento trece millas, formadas por una zona continental y por un número superior a trescientas islas en las costa atlántica. Al oriente limita con Colombia y al occidente con la provincia de Colón, donde se encuentra la otra entrada del canal.

Las tierras continentales son montañosas. Pertenecen éstas a la cordillera andina y abundan los ríos que vierten sus aguas al Atlántico, los cuales son fuente de vida para los 
indios, ya que les abastecen de agua para su consumo, para preparar sus alimentos y para su higiene personal. En las riberas de los ríos plantan los productos de consumo habitual: plátano, guineo, caña de azúcar, yuca, maíz, arroz...

En el continente y a orillas de los ríos tienen sus cementerios, que semejan un poblado, pues sobre las tumbas levantan un chozón, con un techo cubierto, pero sin paredes; donde depositan los objetos personales del difunto.

De las más de trescientas islas de formación coralina, no llegan al medio centenar las habitadas de modo permanente, formando un poblado. El resto están dedicadas al cultivo del coco, principal fuente de ingresos de los aborígenes. Estas islas están vigiladas por una familia, dueña de los cocales, que se encarga de su cuidado y custodia. Las tareas se realizan por turnos entre los dueños de las plantaciones.

Las islas no presentan una elevación apreciable con respecto al nivel del mar. Se puede decir, que están a su mismo nivel; aunque un par de ellas tienen una formación montañosa: este es el caso de isla Pino o isla Ballena, que serían una prolongación del continente. Sus dimensiones son pequeñas. Van desde las que solo tienen un par de metros cuadrados, a las más grandes que ocupan una superficie de aproximadamente cincuenta mil metros cuadrados.

El territorio indígena está dividido en tres sectores encabezados por un cacique, que es la autoridad máxima; y, a su 
vez, todos dependen de un Intendente, que es el intermediario entre los indios y el Gobierno de Panamá, el cual tiene su sede en la primera isla occidental, El Porvenir. Esta autoridad fue un militar o miembro del Gobierno hasta el año 1976, que comienza a nombrarse para el cargo al personal indígena.

El primer sector, el occidental, es el formado por el golfo de Mandinga, al que pertenecen las islas del archipiélago de Cartí y sus alrededores. Aquí se encuentra también la isla de El Porvenir. El centro es Cartí y el cacique habita en la isla de Cartí Sugdupu.

Narganá es el centro del segundo sector, unida físicamente a Corazón de Jesús por un puente y por una trayectoria común a lo largo de los años, desde que se iniciara la empresa de la civilización, la evangelización y la educación. Estas dos islas y Kuebdi, cercana también a las dos anteriores, han perdido gran parte de sus tradiciones. Podemos decir que son las más occidentalizadas.

El sector oriental tiene como centro Ustupu. Este es el sector más próximo a Colombia. También es el que más ha mantenido sus tradiciones, pues sus contactos con los wagas se han limitado, casi exclusivamente, al de las canoas colombianas, que les suministran algunos productos de consumo habitual.

En la zona costera, en la margen de los ríos, existen algunos poblados de los kunas, que se aferran más a sus 
tradiciones y que sus escasos contactos con lo occidental les ha dado esta ventaja; apoyada por el difícil acceso a estos lugares. La educación aun en muchas comunidades de los kunas del Bayano y Darién, no es aceptada porque con ésta se perderían algunas pautas internas de conducta y sumisión. Pero esto no les impide tener relaciones con sus congéneres isleños, que les proporcionan ciertos productos de consumo diario, como la sal, conservas, telas... Los monteses han mantenido tradiciones como el tallado de madera y la caza como sus ocupaciones más habituales. Un pequeño grupo se mantiene asentado en la costa del caribe.

La actividad laboral del indio se reparte entre la pesca, la caza, la agricultura y pequeñas artesanías. Cuando no ha salido el sol, desciende su cayuco para dirigirse hacia el continente, donde se provee de agua y recolecta algunos productos, como el coco, yuca, maíz y frutas. Completa su labor cortando leña de los manglares para el fogón casero y transportando piedras y arena para los rellenos de la casa y la isla.

Suele pescar también de mañana, si el tiempo es propicio para tal actividad. Si el lugar está alejado de la isla, emplea todo el día para este menester, que si es exitoso, lo anunciará cuando se aproxime a la isla haciendo sonar la cambombia. La pesca se distribuye entre los pescadores, y los excedentes se venden. Esta zona del mar Caribe es rica en pescados y abundan las tortugas, que son apreciadas por su 
carne y por los huevos, que depositan en las playas. Los sistemas de pesca varían de una zona a otra del Archipiélago.

La caza en el continente es otra de las actividades, aunque de menor importancia para los habitantes de las islas. la carne del conejo pintado, del macho monte, del sahíno, de los venados, incluso de los monos y de las iguanas, es plato apetitoso, sobre todo en las fiestas de chicha, para las que es preciso almacenar grandes cantidades de alimento.

La actividad agrícola que desarrollan en muy primitiva. Se puede decir que es donde menos han avanzado. Los útiles empleados son casi los mismos que los del tiempo de la conquista. Para la limpieza de la selva usan el machete e incluso el hacha; y para excavar y mover la tierra la coa. Las plantaciones se hacen en el continente porque, entre otras razones, en las islas no hay espacio, ya que las casas se encuentran apiñadas. El suelo de los mismas no reúne condiciones; es básicamente arenoso y el exceso de sal hace que las plantas no lleguen a desarrollarse.

Por otro lado, los cultivos en el continente se enfrentan a multitud de dificultades: las crecidas de los ríos en la época de lluvias, las plagas y los animales. Es un hecho constatable que con el paso del tiempo la agricultura ha seguido un proceso decreciente. Sus causas pueden ser múltiples: la falta de mejora en las técnicas agrícolas, la comodidad que supone el poderlo comprar a las canoas 
colombianas que transitan continuamente por aquellas costas, o el aumento de población, fruto de las mejoras sanitarias, así como la migración de hombres, principal mano de obra, a zonas de trabajo, como Colón, Panamá capital y la zona de producción bananera de Changuinola. La tierra del continente es fértil y productiva, y el clima tropical ayuda al rápido desarrollo de los cultivos.

En la antigüedad era la mujer la encargada de las tareas agrícolas, pero paulatinamente este comportamiento ha ido cambiando, cobrando protagonismo el hombre.

El ganado que más crían es el porcino, pero no tienen animales de carga y tiro que les hagan más llevaderas sus labores agrícolas. Crían algunas aves pero se encuentran con el problema de su alimentación, que no tienen qué darles de comer. Existen tabús que no les permiten el consumo de ciertas carnes de animales; como es el caso del conejo, pues aparecería en las personas el labio leporino. Lo mismo ocurre con el pulpo, que haría que los niños naciesen débiles y sin esqueleto.

Debido al aumento de población y disminución de la producción agrícola, los casos de desnutrición son frecuentes entre la población infantil. El kuna, por lo general, realiza una comida al día; ésta se efectúa por la tarde, al regreso del trabajo. La base es el plátano cocido o asado y el pescado. Antes de comenzar la jornada acostumbra a tomar una taza de 
café. Con la entrada de las costumbres occidentales, el pan ha efectuado su aparición en la dieta del indio. Es barato y ellos mismos lo elaboran cocinándolo en hornos de gas o en los más rudimentarios de leña.

De forma esporádica consume el indio frutas recogidas en la selva. El coco entra a formar parte de sus guisos habituales, y de su comida típica, el tule masi; además de utilizarse cuando está verde, como bebida refrescante.

\subsubsection{La familia y la sociedad}

La sociedad kuna se encuentra fundamentada en la familia de estructura matrilocal; esto no es porque el gobierno corresponda a la mujer, sino porque la mujer es la que permanece en la casa de sus padres al ser desposada. El varón es quien deja la casa paterna para habitar en el hogar de los suegros. Con este hecho, el joven se somete a la autoridad del sakar, previa demostración de sus condiciones favorables para el trabajo. Sus útiles de labor y demás enseres los trasladará a la nueva vivienda.

El matrimonio entre los kunas ha sido endogámico, no solo con respecto a su raza, sino también en lo referente al lugar de vivienda de los contrayentes. La elección de esposa se efectuaba dentro de su propia isla. Por la tanto, era endogámica en cuanto a la raza y la ubicuidad. El kuna es muy celoso de sus 
mujeres y siempre temió a los wagas porque podían quitárselas 20 . No se aceptaban los hijos tenidos con extranjeros y sobre todo si era con negros.

A la raza negra, que ha estado en continuo contacto con ellos, pues es un grupo que abunda en Panamá y comercia por el Atlántico, procedente de Colombia, los ha menospreciado y considerado como seres inferiores.

Los blancos han infundido en el indio un pequeño respeto. Según sus creencias nacieron del talón del tule. Ellos se consideran tules o lo que es lo mismo personas y los demás wagas. La facilidad de movimiento en los isleños va haciendo que, por parte de los jóvenes, estas reglas pierdan vigencia.

Actúan como agentes de cambio los grupos de indios existentes en las dos grandes ciudades de Panamá y las zonas de trabajo, lo mismo que los grupos de jóvenes becados en el extranjero. Si bien es cierto que entre éstos que alteran sus costumbres, el número de los que regresan a la comarca de manera permanente, es mínimo. $Y$ en contraposición los que regresan, vuelven a sus costumbres descontentos de lo occidental.

Constata lo hasta ahora expuesto el Episodio de la Revolución de 1925, en que la población indígena decide

20 Declaración de independencia y derechos humanos del pueblo de Tule de S. Blas y el Darién, pp. 3 y 7. 
eliminar a los wagas, en su mayoría negros, y a los hijos de éstos habidos en matrimonio con kunas.

El sakar es el que organiza el trabajo de los hombres y distribuye las tareas. La mu se encarga de las faenas de la casa: encenderá el fogón, elaborará las comidas y será ayudada por las demás mujeres de la casa a la hora de ir al río a lavar la ropa y acarrear el agua. Las jóvenes cuidarán de los más pequeños.

El recinto familiar tiene dos casas independientes $y$, por lo general, separadas entre sí por un patio. Una destinada a cocina donde se enciende el fuego para cocinar los alimentos, así como para ahumar el pescado y la caza. Se quema copra que da mucho humo y los palos de mangle. La comida se realiza en silencio y por orden: en primer lugar el padre, después los hijos y por último la madre y el resto de las mujeres. Los condimentos de sal, lima limón y ají los añade el comensal a su gusto. Concluida la comida se procede al ritual del lavado de manos y enjuague de la boca.

El segundo habitáculo se destina a dormitorio y sala de estar. Durante el día las hamacas se elevan y sujetan en la parte superior de la choza; y solo se bajan en el caso de ser utilizadas para descansar. Este recinto posee también kanas, que usan las mujeres mientras cosen las molas y los hombres tejen sus cestos y abanicos. 
Las casas están fabricadas de caña brava las paredes y de palma el tejado. Las islas que mantienen más contacto con la civilización ven aumentar día a día las construcciones de concreto y cambian las hamacas por la cama. Este fenómeno, aunque parezca a primera vista un signo de progreso, suscita muchos interrogantes si se analiza minuciosamente. Pues la construcción de caña permite una continua ventilación del interior del recinto; mientras que con el cemento se acentúa el bochornoso calor tropical. Es preciso señalar que el moderno sistema de construcción favorece la desaparición de una de las virtudes de los kunas, como es la colaboración. La edificación de las casas primitivas requiere de la colaboración y ayuda de los vecinos, pues la construcción tiene una duración máxima de cinco a siete años. Mientras que las construcciones de concreto se supone que son para toda la vida, y como el que levanta esta casa no va a necesitar ya más ayuda, el tampoco ayudará a los demás. Rompiéndose esa cadena de continua colaboración.

La hamaca ocupa un espacio mínimo, se transporta con facilidad y su limpieza es más sencilla. La cama por el contrario ocupa un espacio continuamente, el colchón absorve humedad y es difícil su limpieza. No olvidemos que las islas tienen un tamaño reducido y que, por lo general, las habitaciones están superpobladas. A pesar de que las islas se van agrandando gracias a los rellenos de los que habitan la periferia, ganando así terreno al mar. 


\subsubsection{La lengua Kuna.}

Las letras del abecedario kuna según Erice son 23. Hay que tener presente que este pueblo no ha tenido una tradición escrita.

Estas letras serían $A, B, C H, D, E, G, H, I, K, L, M, N, \tilde{N}$, O, P, R, RR, S, T, TX, U, X, Y.

Consecuentemente no tendrán valor nuestras letras C, Q, F, J y LL. Los sonidos vocálicos son los mismos que los castellanos, pero se nota una mayor apertura o variación en estos sonidos dependiendo de la zona oriental u occidental. Del mismo modo que el lenguaje y la velocidad cambia según la zona. El sonido [tx] es semejante al existente en la lengua vasca.

Las letras [c,q] quedan incluidas dentro del sonido [k]. La [f, j, II] son inexistentes.

En el próximo capítulo se hablará de la lengua kuna con sus variantes, según el nivel de la persona que lo emplee. Aquí solo se hará una referencia a la lengua kuna en general para describir sus características. Son diversos los lingüistas que han mostrado algún interés por esta lengua, pero sobre todo merecen una especial mención las escuelas norteamericanas. 
Cuentan con un vocabulario amplio, siendo muestra de ello los diccionarios publicados por algunos de los misioneros que allí han trabajado21.

Carrasco y Céspedes afirman que la lengua de la provincia cueva era la chibcha, y estos eran los antecesores de los cunas 22 .

Entre las características del lenguaje kuna que ha llegado hasta nuestros días podemos reseñar:

1.- Su irregularidad: no existen reglas concretas que permitan una estructuración sencilla al estilo de las lenguas occidentales. Los plurales por ejemplo no se hacen igual, unos terminan en -gan, -mar o -mala. Las negaciones también presentan diferentes formas, mer, suli.

2.- Multiforme: es cierto que toda regla tiene su excepción, pero como es conocido la excepción confirma la regla. Aquí no ocurre esto. Se diría que las reglas son las excepciones. Las terminaciones modales presentan gran diversidad y la formación de frases es muy variada. Es muy frecuente la contracción en las frases, reduciéndolas a la mínima expresión o incluso a una palabra. La variedad de formas se puede ver en el nombre de la isla de Cartí Cangrejo Ilamada Suigtupu, Sugtupu, Sugdup, Suidup, Suitup.

21 Los más recientes son el de Puig y el de Erice.

22 CARRASCO Y CÉSPEDES: Historia de América Latina, 1 Alianza Editorial, Madrid, 1985, p. 209. 
3.- La fonética es arbitraria. Así la juzga Puig. Pero se puede decir que siguiendo la ley del mínimo esfuerzo en el lenguaje los fonemas que tienen un punto de articulación próximo, o que tienen el mismo punto de articulación con la diferencia de sorda o sonora se hacen de modo indistinto y válido para ellos. Las bilabial oclusiva sorda [p] y la bilabial fricativa sonora $[b]$ se pronuncian indistintamente. Por instinto ellos tienden a emplear los sonidos más suaves y para enfatizar usan con frecuencia el fuerte. Para designar a Dios lo mismo pueden decir Paba que Baba; o bia que pia para preguntar dónde. Esto mismo ocurre con la interdental fricativa sonora [d] y la dental oclusiva sorda [t]; la alveolar fricativa sonora lateral [I], la nasal alveolar sonora [n] y la alveolar vibrante sonora [r]; la dental fricativa sorda [s] y la palatal africada sorda [ch]; y la velar oclusiva sorda [k] y la velar fricativa sonora [g]. Para llamar a uno y mandarle venir dirán dage o tage; nele o lele designará al sabio, mola o morra hará referencia al vestido; Naidigiña o Naidikiña será el mismo nombre de persona; sui-suiga o suichuiga se refiere a un objeto puntiagudo. Se percibe al oirles hablar que en ocasiones hacen un cambio de consonante para remarcar más o dar énfasis. Así si una madre llama a su hijo y le dice dage, dage y éste no hace caso terminará diciendo tage.

Todos estos cambios tienen especial repercusión a la hora de estudiar la lengua española o cualquier otra lengua, pues cada fonema tiene su valor propio, no permitiendo 
intercambios o sustituciones. La [g] seguida de las cinco vocales siempre tiene sonido velar-fricativo sonoro. Así la palabra [dage] no se lee [daje] sino [dague]. Por ello no se usará la diéresis en los sonidos [güe, güi]; ya que cuando aparece la $u$ entre la vocal y la g se le da siempre ese sonido.

Se usa el guión para señalar que son dos palabras diferentes. Así como también se emplea el apóstrofe para unir palabras o reducirlas mediante la eliminación de alguna letra23.

23 J. ERICE: Gramática de la lengua kuna, Colón, 1980. 
2. EL SISTEMA EDUCATIVO TRADICIONAL 


\section{EL SISTEMA EDUCATIVO TRADICIONAL}

\subsection{La educación popular.}

El pueblo kuna, al igual que todos los pueblos primitivos, ha tenido su sistema propio de educación, que ha perdurado con el paso de los tiempos. Un modo particular de transmitir su cultura y sus costumbres. Por una parte, una educación informal y no institucionalizada, que se realiza en la familia, como centro principal. Esta perpetúa valores, normas y actividades propias de cada sexo. Pero también existe otro tipo de educación, que podríamos llamar institucionalizada, por tener un lugar propio, con unos conocimientos concretos, unas personas determinadas que la realizan, y por hacerse con una intencionalidad: trasmitir sus valores y conocimientos específicos diferenciadores y de minorías.

Dentro de la educación intencional podríamos distinguir dos tipos: La educación para líderes y personas con cargo específico, y la colectiva.

Los primeros son gente que tienen sus maestros que les trasmiten los conocimientos y cuyo proceso puede durar largos años. Esta educación es eminentemente memorística y solo cuenta con el apoyo de una escritura pictográfica. El alumno paga a su maestro con trabajos de ayuda en las labores cotidianas y el pueblo del alumno también da una retribución al maestro. 
El alumno ha de retener los larguísimos tratados y, una vez que esto ocurre, puede durar hasta diez o quince años, el maestro le considera apto, pero antes habrá ejercido como ayudante de su instructor.

El segundo tipo está orientada a los distintos grupos sociales: hombres, mujeres y niños, en la Casa del Congreso u Omaket Nega. Normalmente va adaptado al grupo que se dirige y su fin es ante todo transmitir conocimientos básicos de la tradición y dar ideas moralizantes. Enseña valores y virtudes que ornaron a los antepasados nelegan y que se deben imitar. Ellos vinieron con la misión de enseñar a su pueblo y servir de modelo a las generaciones venideras.

En el ámbito familiar la educación que se realiza es elemental, basada en la imitación y los consejos. Cuando el niño nace ya se le canta en la hamaca acompañado siempre por la maraca cuales serán sus tareas ${ }^{1}$ : que irá al río o al monte con su padre y traerá pescado y caza para la familia. Se le cantan también hechos mitológicos. Cumplidos los cuatro o cinco años, el niño comienza a salir con el padre, guiará el cayuco con ayuda del canalete y usará la pértiga. Será diestro con el anzuelo y con la red. En el monte, se servirá de la coa y el machete. Tejerá abanicos y cestos en su horas libres en el congreso mientras escucha las enseñanzas.

De diez a quince años se le denomina machi y ya debe

1 V. RD n. 978; V. CD, n. CDLIX. 
saber pescar y acompañar a su padre como ayudante en los trabajos y, en ocasiones, será su compañero en los largos viajes: visitas a las islas de familiares, chichas, cultivos y cuidados del campo.

Hasta los diecisiete años están recibiendo las instrucciones paternas de cómo deben realizar los trabajos. Mientras no se casen no tienen obligaciones con el pueblo. Al hombre se le valora por la capacidad de trabajo y por sus útiles para ello, requiriéndose buen instrumental agrícola, medios de transporte y la posibilidad de heredar tierras. Asiste a los congresos a escuchar a los mayores donde se forma en su cultura religiosa, política y moral. ${ }^{2}$ Mostrará su habilidad en el vaciado de troncos para la fabricación de los cayucos, vehículo indispensable para moverse por el mar y los ríos.

Es innato al temperamento kuna la serenidad y la compostura. Por eso, no soportan a las personas con mal genio. Si un muchacho da muestras de irritabilidad se consulta al nele para que vea el mal espíritu que está dañando al infante y, posteriormente, el inatuledi proporcionará la medicina que pondrá remedio a este mal3.

La educación del niño es una tarea tanto familiar como

2 J.M. PUIG: Los indios kunas de San Blas. Su origen, tradiciones, costumbres, organización social, cultural y religiosa ${ }_{2}$ Imprenta Nacional, Panamá, 1948, p. 54.

3 R.M. SOTO: La estructura de la familia en la tribu kuna, Disertación a licenciatura en misiología, Pontificia Universidad Urbaniana, Roma, 1973, p. 99. 
social. Razón suficiente para esto es que el niño pasa la mayor parte del tiempo en la calle jugando, fuera de la casa y del alcance de la familia. Cualquier miembro de la comunidad que pase a su lado puede corregirle o gratificarle su conducta 4 .

Renglón especial merece la amistad como valor fomentado y transmitido por este pueblo. Aún pequeños, los padres se encargan de iniciar la amistad entre los infantes. Se realiza entre personas de la misma isla o de otras vecinas. Los padres se intercambian regalos en nombre de los pequeños (caña de azúcar, huevos, arroz, frutas...) Cuando va adquiriendo conciencia el pequeño, los padres comienzan a hablar del amigo con el que ellos iniciaron la amistad. Esta amistad dura toda la vida. Si son de la misma isla los amigos se harán frecuentes visitas, llegando a ser varias al día. Entre las mujeres es una muestra externa de la amistad el vestir molas del mismo color y diseño ${ }^{5}$. .

En el caso de pasar por la isla del amigo será obligada la visita o incluso el pernoctar allí. Al separarse se hará entrega de los presentes al visitante como prueba de esa amistad.

Podemos decir que en la sociedad kuna el niño ocupa un

4 A. WAGUA: El indio kuna y su sistema educativo tribal. Análisis de algunos aspectos culturales y su proceso de cambio, Tesis de la Facultad de Ciencias de la Educación, Universidad salesiana, Roma, 1978. p 76.

5 En Cartí conocí dos abuelas que continuamente se visitaban para contarse sus cuitas, mantenían su amistad desde la infancia. 
lugar especial y relevante. Las prerrogativas del niño son casi ilimitadas. El respeto que se tiene por ellos es cuasi religioso. Esto lo demuestra entre otras cosas el hecho constatable de que nunca se les pega. Los padres no golpearán al niño porque Paba, en la otra vida les castigaría a ellos. El único correctivo que se puede aplicar cuando son jóvenes es frotarles con el dake, por los brazos y las piernas; pero esto se subsana porque tienen la idea de que esta planta es medicinal, por lo que el acto es más curativo que de castigo.

Goza de gran libertad el niño para jugar y moverse en la isla o en el mar, donde aprende a desenvolverse con facilidad desde temprana edad; este es un medio muy familiar para él. Al niño apenas se le imponen prohibiciones o limitaciones. Incluso en los días de chicha, cuando los mayores celebran las fiestas, el está presente como espectador en la casa en que se toma; y entra y sale sin preocuparse de más. Después se dejará la surba unos días, cuando haya finalizado la celebración, y el niño imitará allí los roles de los mayores. Los pequeños que no caminan, durante las fiestas, se mantienen en el regazo de sus madres hasta altas horas de la madrugada, o incluso toda la noche. Llegando a dormir en las hamacas de la casa de la chicha o de la comida.

La fumadera, se puede decir que es la única actividad que frena los impulsos del niño; los familiares le aleccionan para que, en esos días, no se haga alboroto y se colabore para crear un clima de reflexión y de calma, que ahuyente a los 
espíritus malignos.

El interés por el niño y su buen desarrollo llega a despertar en los padres el deseo de que adquieran o aumenten su inteligencia y su habilidad para el trabajo; lo que se logra con baños medicinales, proporcionados por el inatuledi. Puede darse el caso de que un niño sea muy difícil y necesite un tratamiento muy prolongado. En este caso, el enfermo permanecerá en casa del inatuledi haciendo la cura durante el tiempo requerido6.

En la familia se da un cierto desprendimiento de los padres hacia los niños varones, mientras que con las niñas ocurre el fenómeno contrario, tienen un mayor apego y control sobre ellas ${ }^{7}$. Esto tiene su explicación, pues llegada la hora de casarse, el muchacho dejará su casa paterna para ir a vivir en la casa de los suegros. Su familia tendrá una pérdida en los componentes del clan, siempre que estos sean varones.

Esto facilitó en los inicios de la educación occidental que los padres llegaran a ver con buenos ojos que sus hijos fueran a la escuela, mientras se mantenían reticentes a que lo hicieran sus hijas. Así los niños llegaron a desplazarse a otras islas para estudiar e incluso fueron a Panamá y al extranjero.

Recibe la misma educación la niña en la primera etapa de su vida, cantándole las ocupaciones y labores que realizará. A

6 R.M. SOTO: La estructura de la familia en la tribu kuna, p. 99.

7 Declaración de Independencia y derechos humanos del pueblo de Tule de S. Blas y el Darién, pp. 3 y 7 
la niña nunca se la castiga, ni siquiera con las ortigas que se emplean con sus hermanos.

Deben jugar dentro de la casa y por lo tanto siempre están sometidas a la mirada vigilante de su familia. Mientras que el niño puede andar desnudo o semidesnudo, la muchacha deberá ir vestida y no debe juntarse en los juegos con los niños. Desde temprana edad sabe ofrecer un asiento y bebida reconstituyente al huésped que visita su casa ${ }^{8}$.

Solamente se les da consejos, pues se tenía la creencia de que son menos inteligentes. A corta edad empiezan a usar la aguja y las tijeras para la confección de la mola; actividad que empleará la mayor parte de su vida. De esta actividad no se conoce la fecha de inicio entre los kunas, pero es algo que, con toda la probabilidad, comenzó en el siglo pasado; hay datos que atestiguan la enseñanza del uso de la aguja por parte de los misioneros franciscanos a las indias colombianas a mediados del siglo XVIII9. Antiguamente, la mujer kuna vestía con fibras vegetales y pinturas corporales, según las expediciones que visitaron el Darién. La mola podría ser una traslación de esas pinturas a la tela. Así lo constatan sus cantos tradicionales y el testimonio escrito de los viajeros de los siglos pasados.

La confección de la mola, según la tradición kuna, fue

8 A. WAGUA: o.c. pp. 67-68.

9 P. BORGES: Misión y civilización en América, Alhambra, Madrid, 1987 (Estudios, 36) p. 208. 
enseñada por Olokikadiryai enviada al poblado del río Yoo para enseñar el modo de coserla.

Labor propia de la mujer es tejer las hamacas y moldear la cerámica. Los quehaceres de la cocina los verá realizar continuamente, pero no los pondrá en práctica hasta cuando sea mayor; pues esta tarea está reservada a las mujeres de más edad.

Con responsabilidad asombrosa cuida de sus hermanos más pequeños y los cargará a horcajadas. La primera hija se considera propiedad de los abuelos, que son los encargados de su educación y sostenimiento económico ${ }^{10}$.

En el momento de casarse, la joven es valorada por la belleza física, las habilidades domésticas y la castidad. Ellas son las encargadas de la limpieza de la casa y de la isla.

A pesar de que lbeorgun les enseñó a saludar, cuando él vino a la tierra, no tienen expresiones de cortesía como "Buenos días", "Buenas tardes", o "Buenas noches". Usan las expresiones "Tegite", "Anna", "Bede" y "Nuedi", que serían el equivalente a "Hola", "Qué Tal", "Cómo vamos" y "Qué hubo"11.

La llegada de los forasteros siempre suscita las preguntas de "Cómo te llamas, "De dónde vienes", "Tienes papá y

10 R.M. SOTO: La estructura de la familia en la tribu kuna, p. 100.

11 A. PRESTAN: Ensayo monográfico sobre los karibe-cunas, Univ. San Buenaventura, p. 69. 
mamá" y "Cuándo marchas"; y siempre se le ofrece un vaso de bebida reconfortante de kokoa, chukula o café.

Los jóvenes van aprendiendo a tocar los instrumentos propios de su cultura: flautas como el kamu purgui, gulli, supe o korki-kala y las nasi; así como a ejecutar las danzas en los días festivos.

Su educación tiene como base el compartir y la generosidad; pero tristemente esto se va perdiendo con el paso de los años por la introducción de las lacras de la cultura occidental, que valoran más el tener que el ser, aproximándoles a la sociedad consumista. El kuna está acostumbrado a ser hospitalario y compartir su casa y su comida, e invita, con sinceridad, a ocupar su hamaca o su kana.

Se puede decir con el P. Gassó que los preceptos del kuna se resumen en cuatro: no ser bravo ni iracundo, no ser ladrón, no mentir y ser trabajador. Las faltas contra el primero pueden ser motivo de divorcio. $\mathrm{Y}$ las faltas contra el último lleva a las personas a pasar de una comunidad a otro, siendo rebotados por falta de aceptación social ${ }^{12}$.

El sexo es tabú. No se habla de este tema delante de los niños. Los cantos que tratan de este tema lo hacen de forma metafórica. Así para designar por ejemplo la parte genital de la mujer dicen la tinaja, por su similitud de recipiente contenedor.

12 Diario del P. Gassó, p.70. 
Al niño se le enseña lo que es ise.

La comida se efectúa en silencio y por orden. Primeramente el hombre seguido de los niños y, en último lugar, la mujer. Se bañan varias veces al día y en la estación lluviosa aprovechan los aguaceros para hacerlo mientras cae este elemento tan escaso en las islas.

Su lengua común, pues existen otros dos tipos, tiene distintos matices según el lugar geográfico. Las otras modalidades son ininteligibles para el pueblo llano, precisando un intérprete. La lengua kuna no ha tenido una escritura correspondiente a los sonidos. Su transmisión ha sido exclusivamente oral. La escritura pictográfica es usada únicamente por especialistas conocedores de los largos tratados. En un principio se imprimía en tablillas y con colores claros, o también tallada en la madera. Se continúa usando la escritura sobre la madera para las celebraciones de la chicha. Esta tabla se imprime antes de comenzar la fiesta y se coloca en la parte superior, donde se encuentran ubicadas las tinajas que contienen el líquido fermentado. Narra la asistencia de los animales que participarán en la fiesta.

Los tradicionalista continúan empleando la escritura pictográfica, aunque cada vez menos, pues el conocimiento del castellano o los medios de grabación facilitan su aprendizaje. La lectura de los textos se hace de abajo a arriba y de izquierda a derecha el primer renglón; el siguiente, de derecha a izquierda a 
y así sucesivamente alternándose. Esto se hace para evitar los saltos de la vista de uno a otro renglón ${ }^{13}$.

En lo que respecta a la actividad matemática, los kunas han desarrollado un sistema de numeración minucioso. Caracterizan la numeración según la forma del objeto al que se refieren cuando los cuentan. Para objetos con forma alargada (personas, cayucos...) usan el prefijo "war"; para elementos redondos "kwa"; y para cosas planas "mata". Pero también tienen una numeración en sentido abstracto. Esta forma de contar se está perdiendo, pues los jóvenes ya apenas la usan, dado que conocen el castellano y usan ésta.

Primeros números según la forma de los objetos a que se refieran

\begin{tabular}{|c|c|c|c|}
\hline Abstractos & redondos & alargados & planos \\
\hline 1 , wensac & kwawen & warwen & matawen \\
\hline 2, bogua & kwabo & warbo & matabo \\
\hline 3, bahagua & kwabaha & warbaha & matabaha \\
\hline 4, bahake & kwabake & warbake & matawake \\
\hline 5, atar & kwawabar & warwabar & matawabar \\
\hline 6 , ner & kwanergua & warnergua & matanergua \\
\hline 7, kuiile & kuakuiile & warkuiile & matakuiile \\
\hline 8, paabaka & kuapaabaka & warpaabaka & matapaabaka \\
\hline 9, pakebaka & kuapakebaka & warpakebaka & matapakebaka \\
\hline 10, ambegi & kuaambegi & warambegi & mataambegi \\
\hline
\end{tabular}

13 A. PRESTAN: o. c. p. 62. 


\section{2.- La educación formal.}

\subsection{1.- La educación de líderes.}

Este tipo de educación es reducida o minoritaria y presenta una serie de rasgos comunes:

a) La instrucción es individual y el aprendizaje personalizado; el maestro ejerce como preceptor. Es selectiva.

b) En esta enseñanza hay un predominio exclusivo de la memoria. Es una enseñanza memorística; la escritura pictográfica se utiliza como ayuda nemotécnica.

c) Se da un constante reforzamiento del aprendizaje (feed-back). A medida que se van superando los primeros conocimientos se va avanzando con otros nuevos.

d) La jornada tiene dos tiempos diferentes: la dedicación al aprendizaje de los tratados y su tiempo de trabajo manual. El horario es flexible, acomodándose a los interesados.

e) Los maestros llegan a serlo por aprobación de sus preceptores, pero quien tienen el último voto es el pueblo, que los confirmará como tales solicitando sus servicios.

f) Se da una limitación y oferta por parte del alumnado ${ }^{14}$. 


\section{Nele}

A continuación vamos a ver algunos casos representativos de estos líderes o maestros.

El nele se asemeja al médico occidental, pero no se puede igualar a él, ya que existen grandes diferencias. Aquél puede diagnosticar las enfermedades y llegar a descubrir sus causas. Ademas es gran conocedor de la historia kuna y posee facultades de adivino.

Según sea hombre o mujer, se le designa con el nombre de nele o nelegua. Para llegar a adquirir este status, es preciso nacer predestinado. La partera será la primera en percatarse de la excepcionalidad de la nueva criatura a través de signos externos, entre los que se pueden encontrar los remolinos del cabello. Asimismo, la precocidad sexual es un signo de predestinación a nele; y en ocasiones, se llega a creer que esto es una muestra de gran inteligencia. Los padres de la criatura tienen la última palabra para decidir si su hijo será o no nele15.

Entre las características que Aiban Wagua señala, están "dificultad del parto, la envoltura de la membrana 0 placenta en la cabeza del niño, o con la cabeza cubierta por las envolturas fetales, la posición en el momento del nacimiento, la vivacidad del niño, la rebeldía y la superioridad en la intuición e

15 R.M. SOTO: o.c. p. 96. 
inteligencia, con respecto a los niños de su edad" 16 .

La educación será diferente al resto de los muchachos. Tendrá más libertad y se le buscará pronto un maestro. Debido a la escasez de maestros, el alumno, por lo general, se traslada a casa de su maestro o preceptor y allí vive como uno más de la familia 17.

Aquel que nace con evidencias de nele y renuncia a su futura misión, debe seguir un proceso de baños que le hagan perder esa potencialidad que tenía. $Y$ con baños también se pueden aumentar los poderes del predestinado.

Los años de aprendizaje con los maestro y tradicionalistas son largos. Podríamos compararlos a nuestros estudios superiores. El tiempo de aprendizaje puede llegar a durar más de una década. Este trabajo de transmisión de conocimientos es pagado al maestro por parte de los padres y de los habitantes de la isla del alumno, en metálico y en especies.

El lenguaje de nele no es comprensible para el pueblo cuando recita oraciones, y la escritura pictográfica, empleada en distintas ocasiones, según Nele Kantule, fue enseñada por Ibeorgun.

El nele tiene poderes para viajar a otras capas de la tierra llamadas kalugan (voz plural de kalu). Las narraciones

\footnotetext{
16 A. WAGUA: o.c. p. 81.

17 R. TORRES DE ARAUZ: Panamá Indígena, p. 136.
} 
existentes de los antiguos nelegan, cuentan como encontraron otros seres en sus viajes.

Es preciso que el nele observe una conducta intachable, lo mismo que las demás personas con un cargo relevante. Su sabiduría no le hará sentirse orgulloso, sino que debe mostrarse sencillo y cercano a su pueblo ${ }^{18}$.

\section{Kantule}

También llamado Kamu tule. Este nombre le viene por el kamu que toca. Es el músico de las ceremonias o chichas. Con sus melodías repetitivas dirigirá las fiestas en las que actuará como máximo responsable.

Impone nombres a las muchachas que festejan su corte de cabello y examina las hojas de bijao para ver la historia de la joven agasajada. Examinará como ha sido su evolución desde antes del parto hasta el momento presente.

Debe saber largas listas de nombres de mujeres kunas para imponerle uno en la ico inna o fiesta de la perforación del septum nasal y, posteriormente, en la inna suit o inna uile (chicha larga o de corte del cabello), en la que se cortará el pelo

18 Quiero consignar aquí, a este respecto, el caso de un sahila sabio de C. Tupile a quien conocí, que después de su muerte, una nelegua tuvo visiones de que no se le había permitido entrar en la casa de Paba por haberse mostrado orgulloso en su vida, creyéndose por sus conocimientos superior a los demás. 
al rape para ser cubierto, a partir de entonces, con el musuar típico de la mujer kuna.

Los cantos del kantule tienen una duración de hasta cuatro o cinco días. El nombre impuesto se llega a olvidar, debido a la longitud del mismo. La economía del lenguaje lleva a que se usen nombres cortos y más familiares. Por lo general los más frecuentes son bisílabos, frente a los incluso decasílabos y mayores ${ }^{19}$.

\section{Absogedi:}

Dentro de esta categoría existen diversos títulos, según sea conocedor de unos u otros tratados. Como título más relevante podemos mencionar el de Nek Absoget. Su oficio es el de conjurar a los espíritus malignos que infectan y turban la paz de los poblados. Esta es una de las ciencias más difíciles y de más prestigio. Su aprendizaje puede llegar a durar hasta dos y tres lustros.

Como todos los tratados de la cultura kuna, tiene sus variantes, dependiendo de la región del maestro; y su extensión también es indeterminada, siendo unos más completos que otros.

Mediante la fumadera, sesión que dura cinco y hasta ocho días, en la que los hombres queman tabaco, recogiendo la trabajo fue bautizada con el nombre de Olobagindilipulibe. 
ceniza, intentan alejar los espíritus con el humo del mismo, para que no perturben a sus moradores con enfermedades y epidemias. Los asistentes a esta ceremonia se abstendrán de tener relaciones sexuales durante el tiempo que dure, no permitiéndose entrar ni salir a nadie en la isla.

El absogedi canta todos los días que dura la fumadera, sin repetirse en sus cantos. Los honorarios de un absogedi son de los más altos. En los años cincuenta, según escribe el P. Erice, podían llegar a cobrar por su trabajo hasta ciento cincuenta balboas 20 . Sin lugar a duda, esta es la carrera más lucrativa, pero también la más difícil de alcanzar.

Las facultades curativas del absogedi se centran, primordialmente, en el mundo de los espíritus, rescatando la purba de las personas a los ponigan, por mediación de los nuchus.

\section{Inatuledi:}

Se corresponde este, en algunas connotaciones, con nuestro médico occidental y también con el farmacéutico. Su conocimiento se centra en las plantas y cura por medio de estas, pero no es él quien diagnostica la enfermedad, sino el nele 21 . Elabora con sus conocimientos la medicina y la aplica. Posee grandes conocimientos de botánica. El tratado que debe

20 El Faro, (1952-53). Colón, p. 37.

21 A. WAGUA: o.c. pp. 15-16. 
aprender es el Ina Igala22, o lo que sería lo mismo camino o tratado de medicina.

El inatuledi, con su canto y baños medicinales, preparados principalmente con hierbas, exhorta a los ponigan malos, a que se vayan. Si el tratamiento requiere un tiempo prolongado, el enfermo se traslada a casa del médico. Lo frecuente es que al atardecer, el inatuledi visite la casa del enfermo, y mientras éste permanece en su hamaca acostado, él entonará su canto y aplicará la medicina.

Las plantas tienen la potencialidad de curar, pero adquieren los poderes curativos cuando se las reza al cortarlas y recolectarlas; y, posteriormente, cuando se las canta con un fin determinado23.

Entre los elementos vegetales más utilizados para curar se encuentra el sia y el kabur. Estos lo mismo que los demás elementos sanadores tienen un canto propio que les confiere los poderes curativos. El de el primero es conocido como el sia unaet o sia igala y el del segundo el kabur unaet 0 kabur igala. Por medio de estos cantos se imprime a las plantas

22 Tuve ocasión de observar su aplicación favorable en un niño con problemas en los huesos de las extremidades inferiores, que le impedían andar y que además, llevaba consigo un efecto secundario de alopecia total. Antes de dos meses, el chiquillo corría por la isla y en su cabeza nacía nuevamente el pelo.

23 En septiembre de 1986, cuando llegué a Kuna Yala por primera vez, observé en Ustupu cómo un inatuledi cantaba a unas semillas de cacao, aleccionándolas para que curasen una afección de riñón de un paciente. 
respectivas virtudes curativas, que despiertan su potencialidad.

Además de las plantas y sus respectivas partes, también se usan huesos de animales y elementos de materia muerte, como piedras o vidrios. Esta medicina es conocida comunmente como medicina de "contagio".

Los estudios de inatuledi llegan a prolongarse hasta quince años. Los tratados más conocidos son: kabur unaet, sia unaet, akualele, yank namaket, uku naibe namaket, naibe ina, punmal ina, kurgin ina, muu kurgina, nia gaet, sabdur igala, ina igala, pab igala, absoget igala y masar igar.

\section{Sahila:}

El sahila es la autoridad de la comunidad. Este poder engloba lo civil, lo político y lo religioso. Se encargará del funcionamiento de la comunidad $y$, a su vez, orienta al pueblo mediante consejos y cantos. Estos cantos, por lo general, no son comprendidos por el común del pueblo. Por esta razón, cuando concluye, se levantará el argar y expondrá el significado del canto. El requisito principal para ejercer de argar es tener facilidad de palabra para expresarse públicamente.

Debe conocer el sahila los cantos de la tradición del pueblo; y es también necesario que conozca la historia del pueblo kuna, que sepa de sus emigraciones, así como de las genealogías de los sahilas y la vida de los más sobresalientes 
personajes.

Su conocimiento se centra en el Pab Igala. De este modo, ejerce las funciones de dirigente religioso.

Aiban reconoce tres componentes del Pab Igala, serían los tipos de conocimiento que engloba:

a) En primer lugar, se encontrarían los cantos narrativos: de la creación del mundo, del mal comportamiento de los hombres, del diluvio, etc.

b) Otro apartado serían los cantos que recuerdan la vida y acción de los grandes nelegan: Kubiler, Tad Ibe, Tulilli...

c) Y finalmente se encontrarían los cantos con un cariz exhortativo.

Cuando el sahila entona estos cantos, siempre habrá otro sahila que se encargue de contestar a sus estrofas, asintiendo con una expresión similar a "así es"24.

Debe poseer conocimientos de plantas medicinales y entender de enfermedades.

Como consecuencia de sus frecuentes viajes, cada comunidad tienen más de un sahila. El primer sustituto es conocido con el nombre de sahila bipi. Entre las funciones del 
sahila está el recorrer las islas predicando. Cuando realizan esta labor, reciben una remuneración proveniente de la población visitada. Los sahilas se suelen especializar en cantos diferentes, ya que el Pab Igala es muy extenso. Su conducta ha de ser modélica para mantener su cargo, pues la elección es democrática y de lo contrario sería destituido.

\section{Argar}

Como se deduce de lo anteriormente expuesto, los conocimientos de este personaje están estrechamente relacionados con el sahila. Para poder interpretar el canto de éste, debe conocerlo, y este conocimiento hará que lo complete y amplíe en un lenguaje llano y asequible al pueblo.

\section{Masardaket}

Es este el encargado de guiar a los muertos al cielo o Paba Nega. Canta los trabajos realizados por el difunto en la tierra. Una vez producido el óbito comienza la ceremonia fúnebre. El masardaket inicia la recitación de su canto diciéndole al muerto los lugares por los que tendrá que pasar para llegar a la casa de Dios. Así como las dificultades que hallará en el camino y las personas que le precedieron y se encontrará. 
Los males cometidos en la tierra le obstaculizarán y retrasarán su llegada al cielo. Cuando llegue a éste, todo lo bueno realizado en la tierra le servirá de pago en el cielo, siendo gratificado con un paraiso donde todo es de oro. Incluso los animales cazados le servirán en el cielo. Las totumas de chicha bebidas en las fiestas se convierten en moneda celestial.

Esta ceremonia tiene sus variantes, según la categoría de la persona fallecida. El muerto en envuelto en su hamaca con sus pertenencias y así se cuelga el cadáver en una cavidad preparada en el chozón familiar del cementerio25.

\section{Sapin dummat}

Podríamos considerar estos conocimientos como un grado intermedio entre la educación del pueblo y la de los líderes. Son especialistas en labores manuales o jefes de obras, como las de construcciones, cultivos, rellenos de terrenos, pesca, químicos, encargados de preparar la chicha, etc...

Por lo expuesto hasta aquí, se podría decir que la ciencia y los conocimientos kunas están reservados, exclusivamente, al hombre, con la excepción de las nelegua, que nacen ya predestinadas y que parece que pueden acceder a

25 En la isla de Ustupu fui testigo de una ceremonia fúnebre realizada para un oferente de chicha que había muerto por el desplome de un balcón, de una casa de concreto, allí construida. La interpretación fue que Paba estaba bravo por hacer esas casas que no son tradicionales. 
conocimientos superiores. Pero existen algunos conocimientos que son patrimonio de las mujeres. Este es el caso de las comadronas, cuyo ejercicio está reservado a las ancianas, que van enseñando la práctica a las más jóvenes, mientras ejercen su oficio. Del mismo modo, el corte del cabello en las chichas es prerrogativa de la mujer.

\subsubsection{EI Congreso.}

Son diversos los nombres con los que se conoce esta casa del congreso: omaket nega, itoged'nega, lbeorgun nega. Todos ellos designan la casa donde el pueblo se reúne. Cada comunidad cuenta con la suya. Existían islas que, por su proximidad, solo tenían una para varias, pero en la actualidad se han ido independizando. Tal es el caso de Nuevo Sasardí y Mulatupu, o Concepción y Ustupu.

Construida con la colaboración de todos los hombres del pueblo, está al servicio del mismo. Es el centro de toda actividad. Es escuela para hombres, mujeres y niños, centro de noticias y acontecimientos, lo mismo que de presentación de visitantes.

La distribución interior nos permite ver, a primera vista, una jerarquización. Colgadas de los palos centrales las hamacas y orientadas hacia éstas, se encuentran las bancas, que ocupan el espacio restante. 
Se destinan las hamacas a los sahilagan $u$ otras personas relevantes de la comunidad o forasteros. Sobre ellas recitan sus cantos los sahilagan, mientras permanecen sentados. Si no están ejerciendo su cargo se recuestan en ellas. A pesar de ser jefe y organizar actividades comunales, el sahila no está eximido de los trabajos que realizan todos. El es un miembro más. Su distinción está en conocer la tradición y los cantos, y ser reconocido así por el resto de la comunidad. Su recompensa estará en la casa de Paba.

A la casa del congreso llegan los sahilagan cuando están de paso, narran los incidentes del viaje, los motivos de su visita y todos los pormenores de la misma. Y si permanecen más de un día relatarán sus sueños de la noche pasada para buscarles una interpretación. Sirve como casa de huéspedes de éstos.

Las bancas las utiliza el resto del pueblo; los más próximos a las hamacas suelen ser gente distinguida y colaboradores del sahila. Este lugar se frecuenta a diario y sólo se interrumpe si hay acontecimientos como las chichas. En las sesiones ordinarias puede tomar la palabra cualquier individuo, incluso las mujeres, aunque en un principio estuviese reservada a los hombres.

Llegan los hombres al congreso todos los días al atardecer, después de concluir la jornada de trabajo en el campo o el mar. Son convocados por los sualibedmar, que recorren la isla gritando que llegó la hora del congreso. 
Como he señalado anteriormente, el tema de la reunión en los días normales, son comentarios de trabajos comunitarios o asuntos concernientes a la comunidad; también el recordar a los maestros que les precedieron y fueron modelo y ejemplo. Se comunican noticias que han llegado de fuera y acontecimientos importantes. Pero la principal labor del sahila es cantar el Pab Igala, y la reunión se prolonga por espacio de dos a cuatro horas.

Si alguna persona o grupo ha cometido una falta, será llamado al congreso y, públicamente, será reprendido sin opción a replicar la decisión tomada por el sahila o grupo de sahilagan. El desobedecer la decisión tomada supondría rebeldía y no acatar la autoridad de quien ha sido elegido democráticamente.

En el transcurso de las reuniones, los sualibedmar son los encargados del orden y, de modo especial, de que la gente no se duerma y ponga atención a la narración del sahila. A intervalos regulares y especialmente si alguno es vencido por el sueño y por la monotonía de la entonación, el gritará: cabidameloerguesa nuenegbetimamaloerguee (despierten y escuchen).

Las mujeres pueden asistir al congreso diario, pero también tienen días señalados de un modo específico para ellas; que suelen coincidir cuando llega un sahila de otro lugar. Entonces se celebra congreso para mujeres, que se prolonga por dos días completos. Se cantan los tratados que presentan a las grandes mujeres kunas que fueron modelo y maestras de 
múltiples enseñanzas.

Escuchan el canto mientras realizan sus labores de mola y cuidan a los pequeños. Concluida la narración, el argar interpreta el mensaje del canto. No es obligatoria la asistencia, pero siempre debe concurrir a la reunión alguna de las mujeres que componen el clan familiar.

Los niños como parte integrante de la comunidad kuna, son tenidos en cuenta y asisten al congreso para recibir sus enseñanzas y exhortaciones. El objetivo principal es impartir consejos a los futuros hombres y contarles la tradición de su pueblo para que se vayan familiarizando. Se les exponen los valores que priman en su sociedad tribal. El sahila es su maestro principal.

Con el paso de los años, en las islas donde hay presencia de escuela occidental, en el congreso que se celebra para ellos, con una frecuencia de dos veces por semana, se les habla de la importancia de adquirir conocimientos y del valor que tiene el sacrificio que sus padres realizan para que ellos puedan aprender en la escuela.

La palabra congreso hace referencia, no solo a la casa de reunión sino que también designa a los distintos tipos de reuniones. El pueblo kuna, por su carácter locuaz, es capaz de pasar horas y horas hablando y escuchando. Esto posibilita que las reuniones de diverso tipo y cariz diferente se multipliquen. 
A continuación expondré los tipos más representativos de reunión, en los que se toca el tema de la educación o se transmiten enseñanzas y conocimientos.

1) El Congreso General Kuna (CGK): fue establecido, de modo permanente y periódico, después de la muerte de Nele Kantule en 1945. Se celebra por lo general dos veces al año y asisten delegados de todas las islas. Se toman acuerdos que, posteriormente, se notifican al Gobierno de Panamá por mediación del intendente.

Como este Congreso quedó establecido de modo permanente y para toda la comarca, después de la introducción de la educación occidental, siempre sale algún tema de educación para pedir mejoras, becas, ampliación y creación de planteles y otros asuntos afines 26 . Este congreso es la autoridad suprema de gobierno en la comarca.

2) Congreso Local: es el que se celebra en cada isla con una frecuencia casi diaria. Queda aclarado con lo expuesto anteriormente. Del mismo modo que las mujeres desarrollan su actividad manual mientras están en el congreso, los hombres tejen cestos y abanicos con hojas vegetales.

3) Congreso de Tradición: reunión para un gran número de especialistas (sahilagan) en el que entonan los cantos y narran su historia y el Pab Igala. La duración es de dos a cinco 
días. Las sedes de estas reuniones se van variando por toda la comarca, previo ofrecimiento de las comunidades que quieren ser sede; y la que es elegida corre con todos los gastos de manutención de los asistentes, proporcionándoles a su vez el alojamiento.

\subsection{L as enseñanzas de los grandes nele gan ${ }^{27}$.}

El propósito de este apartado es hacer una referencia, no un análisis exhaustivo, de aquellos grandes maestros que vinieron a la tierra del pueblo kuna a transmitir unas enseñanzas. Esto justifica el comportamiento y transmisión de múltiples conocimientos que el pueblo indígena mantiene. Estos relatos se han ido perpetuando a través de la conservación llevada a cabo por parte de los líderes (sahila, nele, inatuledi, absogedi...), pero siempre de un modo oral, que ha hecho que aparezcan variaciones acopladas a los tiempos.

Las historias de estos seres míticos presentan una doble modalidad: una que refieren, de modo positivo, la acción y la enseñanza, como es el caso de los relatos de lbeorgun, Kikadiryai, Olonadili y Puna Nelegua. Por otra parte, un segundo bloque que muestra la acción desacertada del nele para enseñar, qué es lo que no se debe hacer, pues es ir en contra de la misión 
de Paba; tal es el caso de Diegun28, que realizó un gobierno abusivo y despótico enfrentando a todo su pueblo.

Ante la pregunta ¿de dónde ha surgido el legado de conocimientos de los kunas? o ¿cómo han surgido las enseñanzas tradicionales?, esta es la respuesta y justificación a todo ese modo de proceder o comportarse del indio.

\section{lbeorgun 29}

Sin duda éste es el más grande de los líderes de los kunas. Llegó a la tierra acompañado de su hermana Kikadiryai y Uikudun. Su misión era enseñar a los kunas, de tal manera que mejorasen su forma de vivir. Ellos ya tenían conocimientos, pero eran escasos y pobres.

Comienza enseñando a desearse bienes desde la mañana y a saludarse. Desde el inicio enseña con la acción, no solo con la palabra. Su enseñanza es práctica, mostrándose cariñoso con los niños y con los ancianos.

Sus discípulos aprenden que los sueños tienen un significado y que Paba nos los da por algún motivo. Esta es la razón por la que no debemos olvidarlos. Se debe hacer una interpretación de ellos.

28 Boletín de las CEBs 1987, septiembre 28.

29 V. RD, n. 977; V. CD, n.. CDLVIII 
Explica como ha de ser el baño de la mañana, no como el de los pájaros, sino prolongado para así tomar fuerzas del río y poder trabajar bien. Muestra como se debe responder en los cantos que entonan en la casa del congreso. Todos los conocimientos que transmite Ibeorgun son para que se hagan extensivos. No deben quedarse solamente en la comunidad que visita.

La construcción del congreso es una aportación más de este enviado. De la misma manera que en la construcción del congreso, la edificación de las casas familiares se debe hacer con la colaboración de todo el pueblo. Establece el principio de la ayuda mutua. Enseña el nombre de los objetos y materiales, así como de las distintas partes y componentes de la casa. Debe existir una separación entre las viviendas, para que el aire circule. No deben estar hacinadas. Cada familia o clan debe tener dos viviendas para no vivir como los animales: una casa para cocinar y comer, y otra para dormir, ya que esto no se debe hacer sobre el suelo. La limpieza de la casa y de la isla corre por cuenta de las mujeres.

Imparte enseñanzas sobre los cultivos y labores de la tierra, y todo lo referente a semillas y podas. Los ancianos aprendieron el tejido de cestos, abanicos y mochilas.

Es menester tener conocimientos para defenderse de las enfermedades, mediante los recursos naturales que Paba ha puesto en la madre tierra. 
Ibeorgun conocía hasta doce tratados de kandur. El kandur de hoy día se especializa solamente en alguno de ellos, que son los que llega a conocer y dominar.

Expone todo lo referente a la chicha, las ceremonias de pasaje de las muchachas y enseña la lengua metafórica que después usarán los especialistas. Anuncia que vendrán grandes nelegan que continuarán y completarán sus enseñanzas.

Este relato está lleno de enseñanzas prácticas, pero en el fondo, intenta inculcar dos grandes valores: la ayuda mutua y el compartir. Los kunas siempre se distinguieron por esto. Entre ellos todos eran iguales y ninguno tenía más que otro; y las labores cotidianas se hacían con la cooperación de todos. La entrada de la civilización fomenta la desigualdad. Los adeptos del gobierno empezaron a tener un sueldo, o como ellos dicen, cheque; creándose una descompensación económica y mayor individualismo. Esto lo veremos a partir del capítulo quinto.

\section{Kikadirya $\mathbf{i}^{30}$}

Esta mujer, hermana de lbeorgun, instruye a las mujeres, al mismo tiempo que su hermano lo hace con los hombres. También es conocida con el nombre de Olokikadiryai.

Ella conocía las técnicas de la pintura, la decoración y

30 Boletín de las CEBs 1986. 
diseños, poseía grandes conocimientos sobre la estética femenina.

Enseña el arte de los tejidos y teñidos, así como la fabricación de los utensilios de cocina.

El modelado de barro y el tejido de la hamaca son también tareas que debe realizar la mujer. Abrió una escuela donde las ancianas aprendían todo lo referente a su condición de mujeres. Kikadiryai celebra su chicha y las mujeres aprenden todo lo concerniente a esta ceremonia.

Predica la igualdad entre los hombres y las mujeres, reconociendo sus diferencias naturales. Muestra a las ancianas cuáles son las diferentes comidas del día, y de qué deben estar compuestas. Enseñó los diseños de los guinis que adornan los brazos y piernas, confeccionados con chaquiras.

\section{Olonagegiryai 31}

Gran mujer kuna que viene a la tierra después de Ibeorgun y Kikadiryai. Sus conocimientos y enseñanzas completan la labor iniciada por los anteriores.

La principal característica de esta mujer es que viaja a diversos kalu; y así como los profetas dirigían sus enseñanzas al pueblo en general, esta enfoca sus enseñanzas en dos vertientes;

31 Boletín de las CEBs 1987. 
por una parte son conocimientos de dominio general y, por otra parte, enseña pautas y conocimientos específicos de los líderes, nelegan e inatulegan. Les enseña los tratados que pondrán en práctica en las ceremonias. Los viajes a los kalu están reservados única y exclusivamente a los nelegan.

Intenta comunicar aquello que ve en las distintas capas del mundo. Primero aprende ella, pero con la intención siempre de llevar esos conocimientos a los kunas. Su propósito es transmitir todo lo que supone progreso y perfeccionamiento para los tules. Dice asimismo las cosas malas que ve. Quiere llevar los diseños vegetales a los kunas y se encuentra con la oposición de algunos nelegan. Baja hasta el último kalu de la Madre-Tierra y aprende los diseños de los guini y de las molas.

Enseña a organizar el hogar y les habla de los sentimientos de los niños con respecto a los padres.

Los demás conocimientos que posee el pueblo kuna fueron legados por otros enviados. Una de ellos, Olonadili, que venía de las estrellas, les enseñó lo referente a los muertos, cómo llorarles y encaminarles a la casa de Paba; también les enseñó cómo deben cantar a los recién nacidos, anunciándoles cuáles serán sus tareas al crecer. 


\section{Puna Nelegua 32}

Cuando aparece esta mujer habían muerto ya Ibeorgun y Kikadiryai pero habían quedado muchas de sus enseñanzas. Se habían unido doce nelegan para enseñar; de los cuales ocho eran hombres y cuatro mujeres. Los nelegan posteriores a lbeorgun se habían reunido en la casa del congreso para exponer sus enseñanzas, y abrieron una gran escuela. Cada uno de los grandes nelegan contaron y enseñaron lo que habían profundizado por largos años.

Puna Nelegua, una de las cuatro mujeres que enseñaron a los kunas estuvo en Ukub'nega. Les anunció que la tierra era redonda, pues ella había visitado las capas y visto su forma. Mencionó las grandes mujeres que Paba había castigado por no cumplir sus mandatos. Exhortaba a los oyentes a decir siempre la verdad y no sentirse autosuficientes como Muu Iguasob, que fue castigada por ello, convirtiéndose en una rana. Otra mujer fue castigada por jactarse de sus conocimientos sobre las hamacas y reírse de las ignorantes.

Enseñó conocimientos sobre los fenómenos de la naturaleza y la posición de la mujer junto al hombre para llevar adelante los trabajos de la comunidad. Defendía la monogamia, reflejo de la igualdad del hombre y la mujer.

32 Boletín de las CEBs 1986. 


\section{Olonadili33}

Tomaba a los niños y a las niñas en sus brazos a la caída del sol y les entonaba canciones según su condición, anunciando sus trabajos futuros y las labores que tendrían que realizar cuando alcanzasen la madurez. El hombre realizaría las tareas del campo, de la pesca y la construcción. A la niña la correspondería atender a las visitas y las faenas de la casa.

Olonadili es quien enseña a cantar a las ancianas con temas referidos a los distintos sexos y a entonar tonalidades distintas. Explica como educar desde niños a los futuros hombres y mujeres. Les indica como se debe llorar a los muertos, rememorando sus buenos días y los dolores pasados. La muerte de sus dos pequeños puso de manifiesto a las gentes como había que llorarles. Les enseña a defenderse de los que vienen del más allá; así como a usar las sustancias de las plantas para curar y luchar contra la enfermedad, y no dejarse morir como animales. Con sus instrucciones perfeccionó la lengua de los kunas.

Esto expuesto hasta aquí, puede ser suficiente para tener una idea de las enseñanzas de los nelegan, creadores y transmisores de la cultura kuna. Estos personajes son el ejemplo relatado en los congresos, pero de un modo más prolijo. Con todo lo expuesto anteriormente podemos hacernos una idea de lo que es la educación tribal kuna.

33 Boletín de las CEBs 1987. 
II. LA INCORPORACION DEL SISTEMA EDUCATIVO OCCIDENTAL EN LA TRIBU KUNA 


\section{3.-LA PEDAGOGIA DE FINALES DEL XIX Y COMIENZOS DEL XX ${ }^{1}$}

En este capítulo haré un breve recorrido por las corrientes pedagógicas que circulaban e iban surgiendo cuando Panamá empezaba su andadura como nación, al mismo tiempo que se esforzaba en implantar un sistema educativo a tono con los tiempos.

Las corrientes pedagógicas que más repercusión tuvieron en Panamá fueron por un lado las alemanas y francesas; y por otro las españolas, llevadas allí principalmente por los misioneros, que fueron los encargados de la enseñanza de los indígenas durante mucho tiempo y de algún sector de la capital, en un principio con marginados. Por otra parte, las corrientes norteamericanas dejaron su huella sobre todo en los líderes nacionales que recibieron su educación en EEUU. La falta de personal preparado en materia educativa obligó pues a la nación panameña a importar personal docente del viejo continente y de Norteamérica.

Como complemento de este capítulo dedicaré la sección última a exponer las teorías educativas de la Iglesia

1 Como fuentes y bibliografía sobre este tema tan complejo pueden consultarse principalmente las obras pertinentes que recojo en la bibliografía que figura en los apéndices. A su vez estas obras suelen presentar un rico repertorio de fuentes, al menos las más importantes. 
Católica, eje central de los métodos de enseñanza de las órdenes religiosas que allí ejercieron las funciones docentes durante varias décadas.

Desde el viejo continente llegaron los movimientos pedagógicos a través de los formadores que tomaron las riendas de la educación y que además habían divulgado sus ideas por todo el eje americano, principalmente en los paises más avanzados como Chile, Argentina y Cuba.

A continuación voy a hacer una breve exposición del contenido pedagógico fundamental que se encierra en estas distintas corrientes de pensamiento, y que van a incidir de una manera más o menos intensa en la historia de la educación de Panamá en el periodo que nos ocupa.

\section{1. La pedagogía europea}

Con la aparición del método de enseñanza mutua, la educación llegó a un número mayor de ciudadanos, los pobres podían así tener acceso a la educación. A través de este procedimiento se podía llevar a un gran número de muchachos las cuestiones más elementales de la educación. Lancaster basaba su programa de educación en los monitores, que eran los alumnos más destacados, quienes a su vez iban enseñando a los muchachos en un principio las letras, dibujadas en la arena, posteriormente las sílabas, las palabra y así progresivamente 
hasta llegar a enseñarles a leer. Esta enseñanza tenía estímulos positivos, que premiaban los progresos del alumno.

Desde Colombia se importaron las ideas de Pestalozzi con profesores alemanes formados por este pedagogo. Y Panamá recibió su influencia por ser allí donde se formaban muchos maestros, debido a la integración de Panamá en la Gran Colombia.

Pestalozzi demuestra desde los primeros momentos un gran interés por las clases menos pudientes, y en su primera granja recoge a los huérfanos que empezarían el aprendizaje de las nociones matemáticas y del lenguaje. Al mismo tiempo que los muchachos desarrollaban tareas de la granja y las niñas trabajos de la casa. Su método se basaba en la observación intuitiva y profunda de los fenómenos mentales en cuanto están relacionados con el aprendizaje. La educación debía seguir a la naturaleza. Entre sus principios está la consideración de la naturaleza buena de los individuos y el potencial intelectual y moral de cada persona que requiere un cuidado especial. El mejor modo de lograr esto está en el amor de los padres y del maestro hacia el niño, y de éste hacia ellos.

La educación se debía centrar en tres apartados: El desarrollo intelectual, el crecimiento moral y la relación del alumno y el maestro. Sería el medio para que todos alcanzaran la felicidad, no solo los ricos. La moral sería el fin de la educación que deben perseguir los padres y maestros. Para él 
toda la naturaleza tiene tres dimensiones fundamentales: la forma, el número y el lenguaje. La base de la enseñanza debían ser las preguntas, ya que éstas ayudarían a crear en el niño los conceptos abstractos generalizados. Antes de nada, el niño debía aprender a hablar bien, luego se le enseñarían las vocales y a continuación se irían uniendo las consonantes a las anteriores para formar sílabas, hasta llegar a las palabras.

Las ideas de Pestalozzi tuvieron repercusión en los posteriores pensadores educativos. Froebel fue uno de ellos; y hace la distinción entre dos mundos que son el hombre y la naturaleza, el primero estaría dentro del segundo. La educación debería ser permisiva y ayudar al proceso de autorrealización. Esta educación abarcaría desde la infancia hasta la edad adulta. Da gran importancia a la niñez y trata de los primeros años de vida del niño como un periodo de gran trascendencia, acuñando el término donde el niño realiza su actividad como jardín de infancia (Kindergarten). Consideraba al lenguaje como el enlace entre el pensamiento y el mundo exterior.

La tarea educativa consistiría en crear buenas escuelas que proporcionasen una educación natural, donde el alumno llegara a tener conciencia de la naturaleza esencial de las cosas y de sí mismo.

Estas materias del curriculum deberían estar organizadas en tres categorías: lenguaje, naturaleza y matemáticas, para llegar a comprender su naturaleza y su 
contenido. Froebel pondría los pilares para realizar una educación como ciencia y hacer de la pedagogía una tecnología.

En esta época las corrientes pedagógicas que otorgaban una preponderancia a la humanidad eran acusadas de socialistas en muchas ocasiones y por ello no fueron muy bien vistas por la Iglesia Católica.

Herbart acepta la realidad como determinante y causante del yo, pero la realidad está compuesta de múltiples realidades. Según él la ciencia pedagógica deriva de la ética y de la psicología. Su objetivo material es el hombre como ser humano. El objeto formal sería la educabilidad de la voluntad. El fin de la educación debe ir más allá del gobierno y la sumisión de los niños; por ello la educación requiere dos cualidades fundamentales que son: la autoridad y el amor.

Pone el fin supremo de la educación en la moralidad. Y la educación moral tendría como objetivos el bien y la justicia. La actividad instructiva le hace al hombre crear y ordenar las ideas unificando el mundo. La instrucción debería "llenar el espíritu", entendido este llenar en sentido cualitativo y cuantitativo. Da un gran paso al establecer que se debe enseñar para la vida y no para la escuela.

El herbartismo fue adquiriendo prestigio en todas las escuelas europeas y con mayor preponderancia en las estadounidenses a finales del siglo XIX. Esta primera aceptación entusiasta se debió a que su carácter aparentemente científico 
estaba muy de acuerdo con el sentimiento tecnológico y práctico de Norteamérica, que no escatimaba esfuerzos por construir una sociedad nueva. La preparación masiva de los maestros estuvo basada en este sistema que sería desprestigiado posteriormente por Dewey.

La pedagogía de Herbart fue adoptada en la primera Escuela Normal de Varones fundada en 1872 en Panamá. En ella se seguían las llamadas gradas formales, siendo común la terminología herbartista de preparación, presentación, asociación, generalización y aplicación.

La aparición de los movimientos utópicos estuvo marcada por Owen, quien consideraba que el hombre se debe librar de los tres vicios cardinales: la competencia, la recompensa y el castigo; por el contrario, debe aspirar al valor supremo: la felicidad de toda la población. Consideraba que la clave de un buen gobierno estaba en la educación apropiada. Y la escuela sería para niños y niñas, independientemente de la clase o preparación de los individuos. La obligatoriedad era un requisito necesario, puesto que estimaba que nadie es capaz de formarse a sí mismo; y porque la educación supone una experiencia de interacción social. La escuela tendría dos niveles, uno que abarcaría de los dos a los seis años y el otro que iría de los seis a los catorce. Según su concepción no debían existir los castigos, ni las recompensas, ni la competición; y criticaba la educación memorística. El objetivo de la educación en una buena sociedad debía tender a remoralizar y conservar. 
Hace una crítica del método mutuo puesto que no persigue el cultivo de las personas íntegras. Descarta la memorización y los libros por considerarlos como una burla del estudio; y propugna el conocimiento útil apoyado por signos sensibles.

Según su teoría se debía establecer un equilibrio entre la producción y el consumo. Por tanto habría que producir aquello que razonablemente se pudiera consumir. Para ello habría que instalar a los trabajadores en comunidades cooperativas. Esta idea también era compartida por los primeros socialistas, que consideran que la educación sería una preocupación primordial de estas comunidades o falansterios, en los cuales la educación no sería represiva.

Los socialismos estuvieron cargados de una gran influencia rousseauniana. En sí no consideraban cambios básicos en la teoría del conocimiento, sino que se dirigían más a las reformas sociales y económicas. Como reacción a esto surge Marx que da al socialismo un cuerpo de teoría científica y critica a los anteriores ideólogos.

Dentro de los maestros simpatizantes del socialismo surgieron las organizaciones sindicales para luchar por el progreso y la igualdad educativa, así como para defender los intereses profesionales.

En la primera década de nuestro siglo María Montessori establecía las bases de la educación preescolar que 
posteriormente se extenderían a la enseñanza primaria y que llegarían también a influir en la secundaria. El método estaba basado en primer lugar en la consideración de la experiencia como la base de la formación del pensamiento abstracto en la vida mental del educando. La actividad educativa y por lo tanto el progreso debe estar presidido por la libertad. Se atendía a la individualidad, procurando que el niño despertase al hombre que duerme en él mediante el quehacer personal.

La casa de los niños estaba diseñada con el mobiliario a escala de los pequeños. La educación de la casa del niño estaba basada en la educación sensorial y la intelectual, cimentada esta última en la comprensión del lenguaje, la escritura y la lectura; a la primera iría asociada la expresión artística y la creatividad.

Reconoce su deuda para con Rousseau, Pestalozzi y Froebel. $Y$ en sus escritos habla del niño como un organismo que evoluciona, siguiendo las leyes naturales innatas de los procesos de transformación continua e intensa. Considera que dentro del niño existe una reserva de actividad autogeneradora que se manifiesta en corriente de energía mental y física.

El niño es un ser absorbente capaz de asimilar las experiencias del medio ambiente e incorporarlas a su personalidad. El niño recién nacido no tiene ideas innatas, solo la capacidad de comprender y llevar a buen término su potencialidad. Es tarea de la educación proporcionar las 
condiciones favorables para que esto se cumpla.

El proceso de la educación se fundamentaría en dos supuestos: el primero se basaría en que el objetivo necesario de cada niño es entrar en el reino del conocimiento, denominado comunmente como cultura; y el segundo es que la cultura humana, como mejor se adquiere es, a través de los procesos naturales de crecimiento, desarrollo y maduración biológica y psicológica.

Los materiales educativos, a diferencia de Froebel y Pestalozzi, los presenta desprovistos de misticismo, como objetos que deben ser manejados; son los medios para la comprensión y el compromiso efectivo con el mundo externo.

Su idea de integración de varios grados en una misma aula fue de provecho sobre todo para los paises que carecían de personal capacitado e infraestructura, pues los mayores podían ayudar así a los más pequeños. La lectura y la escritura iban precedidos por el manejo de letras del alfabeto recortadas, con las cuales iba tomando un primer contacto el niño. Como se puede ver más adelante este material fue empleado en la educación de San Blas por algunas maestras. Y en toda Panamá el método Montessori tuvo gran aceptación.

En fin, estas son las ideas que fueron calando en la sociedad educativa panameña. Sin duda que unas tuvieron más aceptación que otras, pero los aires renovadores también llegaron al continente americano y arribaron en el istmo, que 
mostraba gran interés por la educación del pueblo.

\subsection{L as experiencias pedagógicas}

\section{españolas}

Las ideas krausistas de la segunda mitad del siglo XIX producirían una transformación notable en la sociedad pensante española. Esta ideología de carácter burgués pero al mismo tiempo de pretensión reformista social, defendía que el hombre descubre las raíces de su ser y encuentra el verdadero sentido de su vida en lo religioso, lo moral y lo jurídico.

El último cuarto del siglo XIX español educativo estuvo presidido por el flujo renovador de la Institución Libre de Enseñanza, derivada de los pensadores krausistas, que consideraban la educación como una tarea que debe ayudar al desarrollo integral del hombre, y no centrarse solo en lo intelectual. Debe atender a lo corporal y a lo espiritual, debiéndose prolongar desde el comienzo de la vida hasta que ésta se acabe. Giner de los Ríos otorgaba gran importancia:

- a la educación física, como algo más que unos meros ejercicios gimnásticos;

- a la educación artística, sustituyendo la educación memorística por la visión directa de las obras;

- a la educación moral que debería estar dirigida al cumplimiento de los deberes. Propugnaba una enseñanza religiosa aconfesional y sin dogmas, pero creía que esto 
tardaría en llegar, y se debía realizar con una educación progresiva.

El método educativo estaba basado en el aprender haciendo, y la actividad debía sustituir a la pasividad de los alumnos. La búsqueda de la verdad ha de ser una tarea conjunta del maestro y el alumno.

Fue una constante preocupación de la Institución Libre de Enseñanza la formación y perfeccionamiento de los maestros tanto en el campo científico como en el pedagógico.

Paralela en el tiempo sería la creación de las Escuelas del Ave María dirigidas por el P. Andrés Manjón. Llevaban estas la impronta de unas escuelas cristianas que querían superar el analfabetismo la marginación y la desigualdad social. $Y$ que al mismo tiempo quería ser una réplica a la Institución Libre de Enseñanza, considerada laica y anticlerical. La primera fundación data de 1889 y estaba destinada a la instrucción de las niñas. Pero las aspiraciones del fundador llegaban más allá y creó un centro para formar a los maestros en el espíritu manjoniano.

Propugna una educación higiénica, que preferentemente se ha de impartir en el campo, al mismo tiempo que ésta ha de ser práctica, por lo que se ha de enseñar haciendo. La enseñanza popular debía llegar al mayor número posible de niños. Como consecuencia de lo anterior los pobres tendrían derecho a ella de un modo gratuito. 
Consideraba Manjón la educación como algo continuo, gradual y entero en un proceso que debe ser activo. El docente debe dejar hacer al alumno. La educación debía ayudar al hombre a ser libre y sociable.

Entre las aptitudes propias del maestro señala las morales, que deben estar presididas por la prudencia; y las pedagógicas que comprenderían desde la salud hasta la vocación.

Establece en la familia el primer centro de educación, que debe ser completada en la escuela y que a su vez proporcionaría al alumno la asistencia material, comida, vestido, libros; y la asistencia social.

Con la aparición de la segunda República se decretó la separación de la Iglesia y el Estado y se prohibió el ejercicio la enseñanza a las órdenes religiosas. Por primera vez se contemplaba la obligatoriedad de la enseñanza a los niños de siete a diez años. La educación llegó a los lugares más apartados gracias a las escuelas itinerantes conocidas como "misiones pedagógicas". Al mismo tiempo se creaba un programa para las escuelas elementales que supliera la depresión; este consistiría en repartir un desayuno entre los escolares.

En septiembre de 1933 se ponía fin al gobierno Azaña y con ello se volvía a producir un retroceso en materia educativa y social, después vendría la guerra civil y la época franquista. 
Así se configuraba lo que era el cuadro pedagógico en la España que se iba a proyectar en el Istmo americano. No cabe duda de que la educación recibida por los misioneros se mantenía como un sustrato, a pesar de que en su labor siguieran los programas marcados por el gobierno nacional.

\section{3. La innovación pedagógica}

\section{norteamericana}

En los albores del siglo XX los Estados Unidos estaban a la cabeza de los temas educativos. La proximidad con Panamá, más por temas económicos, que por cercanía geográfica -no olvidemos sus interés en el Istmo por la construcción del tren y del canal- hace que la joven nación empiece a estrechar sus lazos con la potencia norteña. En materia educativa son frecuentes los becados que reciben su formación allí. La idea de la coeducación propuesta por el Presidente Belisario y compartida también por el Inspector General era de origen norteamericano. El saludo a la bandera y las graduaciones de los ciclos son ejemplos de esta influencia. Además es justo recordar que el primer Inspector General de Enseñanza Primaria fue un ciudadano estadounidense.

En 1925 se nombraba una Comisión de Programas Educativos en el Istmo, integrada por tres personas una de las cuales tenía formación norteamericana; y de las otras dos una 
poseía una formación belga y la otra colombiana. Al año siguiente hace aparición la escuela democrática, que junto a la escuela nueva pretendería educar a las masas panameñas.

La escuela progresiva representada por Dewey establece una estrecha relación de la educación con la experiencia, marcando una continuidad y al mismo tiempo una interacción en ese proceso. La educación sería el eje de lo social, pues sería quien preparara al hombre para participar en esa vida social, adquiriendo sentido cuando se siente como una necesidad vital de la naturaleza humana; y que se desarrolla de un modo continuado, al ritmo del crecimiento. Estas ideas empiezan a calar ya en la sociedad panameña en 1918. Las ideas educativas europeas entonces inician su declive en el Istmo.

El fin de la educación estaría definido por la relación íntima del desarrollo natural, la eficacia social y la cultura. Entre los fines propios de la educación establece como inmediato los procesos educativos a través de los cuales han de formarse las disposiciones. El fin intermedio estaría definido por las disposiciones que deben cultivarse; y el remoto perseguiría desplegar las aptitudes de la persona y mejorar la vida comunitaria.

La educación desde el Kindergarten hasta los trece años la organiza en seis niveles; y los métodos educativos permitirían que el interés de cada uno se acomode a las propias aptitudes. 
A la hora de establecer el método, Dewey señala que existen métodos generales y métodos individuales, que no se contraponen, sino que más bien se complementan.

La escuela debe realizar la función de un laboratorio social donde los niños aprendan a someter toda la tradición recibida a las comprobaciones pragmáticas de la verdad. Debe ayudarle a solucionar problemas corrientes y someter a prueba planes futuros de acción. La educación debe permitir que el niño siga su tendencia natural de buscar e indagar, y realizar un aprendizaje basado en la experiencia. La educación animará al individuo a dar respuestas creativas.

Dewey establece un método de pensamiento reflexivo con cinco pasos del problema, recopilación de datos, hipótesis, comprobación y confirmación; estos serían la alternativa a los pasos propuestos por Herbart que eran un método de instrucción del maestro, y Dewey quiere que su método sea un instrumento en manos del maestro para ayudar al niño a solucionar los problemas reales que la vida le presente.

Con posterioridad aparecen la escuela del trabajo y la escuela activa orientada a la formación del carácter y con connotaciones un tanto pragmatistas en cuanto que supedita los medios a los fines. Propugnando una actividad espontánea, personal y productiva.

En el siglo XX hace aparición la Escuela Nueva que apuesta por una educación respetuosa con la individualidad del 
niño, dando cabida a los intereses innatos del escolar; y donde se debe desterrar la competencia egoísta sustituyéndola por el espíritu de cooperación. Al mismo tiempo defendía la coeducación como un modo de influencia positiva entre ambos sexos.

La Escuela Nueva sería un internado ubicado en el campo, porque es el medio natural del niño, viviendo en casas donde no superaran los quince alumnos, contando también con maestras.

La jornada escolar propiamente dicha comprendería solo las horas de la mañana. Los trabajos manuales estaban considerados de gran importancia, así como la música y el canto coral.

Según las ideas de Decroly el método de asociación de ideas o de los "centros de interés" pretendía reunir a los escolares en grupos lo más homogéneos posibles, así el programa de la clase sería más uniforme, y el número ideal de alumnos de una clase estaría entre 20 y 25 para los niños normales y 10 y 15 para los deficientes. El programa escolar ha de hacer referencia al conocimiento del niño, sus necesidades y el conocimiento de la naturaleza del medio ambiente. Todo esto estaría englobado en el programa de ideas asociadas. De esta escuela se excluyen las materias o disciplinas proponiéndose la globalización de la enseñanza.

En 1908 nacía el Plan Dalton fundamentado en el 
principio del trabajo individual que respeta el ritmo de aprendizaje del escolar. Al mismo tiempo que respeta los intereses y preferencias del niño. La educación giraba en torno al contrato individual que adquiere el alumno a largo, medio y corto plazo, denominándose respectivamente, asignación, periodo y unidad de trabajo.

El siglo $X X$ en sus inicios se caracterizó por el intento, de muchas naciones, de construir un sistema educativo aceptando la intervención del estado en dicha materia, al mismo tiempo que la legislación en cuestiones educativas iba incluyendo los estudios secundarios.

El nacimiento de la República panameña dejó constancia de esta preocupación al legislar sobre educación y considerarse al estado el principal promotor de la misma.

Como colofón, se puede decir que la vinculación de Panamá con el estado norteamericano le llevó a volcar más su atención en materia educativa hacia la nación del norte. Por ello estas corrientes pedagógicas se iban a implantar a través de los inspectores y directores que se contrataran en EEUU en las primeras décadas de este siglo.

3. 4. Doctrina en materia educativa de la lglesia católica

A pesar de que la constitución panameña declaraba la 
libre profesión de todas las religiones, reconocía sin embargo que había una mayoría de católicos entre los súbditos, y por lo mismo el gobierno proclamaba la ayuda a la Iglesia Católica en el tema de las misiones entre las tribus indígenas. Cuestión que sufrió continuos vaivenes, producto del capricho o signo de los gobernantes. Pero es de justicia reconocer que algunos mandatarios liberales y masones mantuvieron su ayuda a los misioneros porque reconocían su labor eficiente.

La diversidad de corrientes pedagógicas que iban surgiendo supuso un reto para la Iglesia. Con el fin de aclarar las ideas de los católicos el Papa Pío XI redactó la encíclica Divini illius Magistri, que dejaba asentados los principios y doctrina educativa, al mismo tiempo que condenaba las corrientes naturalistas y socialistas de la época en el campo del pensamiento. Pero también era una crítica a los gobiernos totalitaristas, que subordinaban la libertad humana y los derechos de la familia y la Iglesia a los intereses del Estado, considerando por ello la procreación como un medio de engrandecer al Estado y limitando la educación a la preparación para la guerra. En diciembre de 1929 se hacía público este documento pontificio.

Según este documento la única educación perfecta es la cristiana, tanto en el campo individual como en el familiar y social. La Iglesia tiene derecho a la educación por mandato del propio Jesucristo, convirtiéndose este derecho en un deber; derecho que está reforzado por la maternidad sobrenatural que 
ejerce la Iglesia sobre la humanidad. De esta manera no se queda solo en sus fieles, sino que debe llegar hasta los infieles. Esta acción educativa de la Iglesia se debe llevar a cabo independientemente de los poderes terrenales, abarcando la enseñanza de todos los campos del saber.

La familia debe educar a su prole, lo mismo que la Iglesia por precepto divino, derecho y obligación transmitidos por la paternidad. Este derecho inviolable dista infinitamente de ser despótico y es anterior al derecho a la educación del Estado. Para reforzar su afirmación pone el Pontífice el ejemplo de los Estado Unidos que declaran que el niño no es una mera criatura del Estado, y por lo tanto no le compete al Estado establecer un tipo uniforme de educación para la juventud. Descubría el Papa su desacuerdo con los estados totalitarios europeos. Dejaba clara esta primacía de la familia reconociendo que la Iglesia también respeta la voluntad de los padres. Por lo tanto sería injusto todo monopolio educativo establecido por el Estado.

El derecho del Estado a la educación es de orden natural, diferenciándose del de la Iglesia y la familia. Es obligación del Estado proteger y promover al individuo y a la familia, respetando el derecho sobrenatural de la Iglesia sobre la educación. Así mismo el Estado debe ayudar en materia educativa supliendo en aquellos casos donde los padres no lleguen. 
Como competencia propia del Estado estaría la educación preparatoria para desempeñar cargos de gobierno y la educación cívica, pero guardando siempre consonancia con la doctrina de la Iglesia. El Estado no puede negar el derecho y la eficacia de la educación de la Iglesia, pues esto supondría no reconocer que Cristo es el fundador de la misma. Esta eficacia redunda además en beneficio del Estado y de la ciencia.

El sujeto de la educación es todo hombre, con sus facultades naturales y sobrenaturales. Critica el naturalismo pedagógico por olvidar la formación sobrenatural, dejando que el niño actúe libremente, y por pregonar que esta criatura carece de pecado y quien le corrompe es la sociedad.

Denuncia los errores sobre la educación sexual y condena a los que creen que se podría inmunizar a los jóvenes contra los peligros de la concupiscencia con medios puramente naturales. Como equivocada es también la idea de los que apoyan la coeducación, basados en el naturalismo y la igualdad del hombre y la mujer.

Acusa a las nuevas concepciones pedagógicas de olvidarse de Dios, pensando que todo está en el hombre. Y considera a la educación católica como la única válida y perfecta; ya que tiene en cuenta los tres puntos claves del hombre en cuanto a su dimensión individual, familiar y social. Fundamenta la tarea pedagógica de la Iglesia en las palabras evangélicas: "El que reciba a un niño como éste en mi nombre, a 
mí me recibe"2.

La familia es el primer ambiente natural y necesario para la educación del niño, basada en el buen ejemplo, pero reconoce la deficiente preparación de los progenitores. Deja patente la proliferación de centros y medios educativos empleados por la Iglesia, reconociendo que la escuela es una fundación de la familia y de la Iglesia, institución que posteriormente adoptó el Estado. Extiende una condena general sobre las escuelas denominadas laica, mixta y única.

La escuela católica será aquella que esté imbuida del espíritu cristiano, y donde la enseñanza sea sana, vigilada y tradicional. Las buenas escuelas son el resultado de tener buenos maestros. $Y$ es necesario vigilar al joven en todos los ambientes para evitar que se corrompa.

El fin de la educación es cooperar con la gracia divina para formar al verdadero y perfecto cristiano, en la vida humana, sensible y espiritual, intelectual y moral, doméstica y social. Hasta aquí la síntesis de lo que era el pensamiento de la Iglesia, expuesto por su máximo responsable.

Puesto que el método de enseñanza elaborado por los jesuitas tuvo gran divulgación durante varios siglos, y como

2 Mc., 9, 37. 
ellos fueron los pioneros en la educación de San Blas aportaré algunas pinceladas.

La formación de los jesuitas que recalaron en las costas de San Blas estaba integrada por un gran conocimiento del latín, de las disciplinas integradas por el trivio de artes liberales, además de poesía, historia y nociones de matemáticas. Se completaba con la filosofía y la teología, siguiendo los textos de Aristóteles y de Santo Tomás de Aquino. Sin abandonar por otra parte el conocimiento de diversas lenguas.

En su afán por buscar una ratio los jesuitas dejaban también claro que debía acomodarse a los lugares, tiempos y personas. En el año 1599 quedaba conformada la Ratio Atque institutio studiorum Societatis Jesu, que era una exposición detallada de la parte cuarta de las Constituciones. En ellas se trataban los temas más diversos como eran la progresión de los estudios, la disciplina, los exámenes, las plegarias, y un compendio de preceptos de sentido común. Quedaba definido también el concepto de la escuela.

El contenido de la educación se basaba en el cultivo de la "pietas litterata". La dos técnicas más utilizadas por los jesuitas fueron la prelección y la concertación, posteriormente reforzadas con ejercicios escritos y repeticiones orales que perseguían cultivar y fortalecer la memoria.

Todo este programa educativo de los jesuitas 
contribuyó a añadir una nueva dimensión al concepto de educación, y fue el desarrollo de la escuela como agente de un particular credo; y en su caso concreto como agente de la Iglesia Católica. El fin supremo de la educación era inculcar y conducir a la vida cristiana. Entre las misiones estas ideas si se quiere se acentuaron más.

Como veremos en el capítulo sexto, los jesuitas destinados en la región kuna y sobre todo el P. Gassó pusieron todo su empeño en luchar contra el mal, personificado en el absogedi y la casa de los errores, que serían los representantes del demonio. Hicieron todo lo posible porque los indígenas abrazaran la fe católica.

Las órdenes religiosas que desplegaron su actividad educativa entre los kunas siguieron los programas propuestos por el gobierno nacional panameño, al mismo tiempo que difundieron el mensaje evangélico, ya que la constitución lo admitía.

Se puede decir que este período fue muy fecundo en el campo pedagógico, y que estas ideas, que acabamos de analizar, experimentaron un notable desarrollo. La formación de los educadores panameños se vio influenciada por las innovaciones que se iban produciendo. $\mathrm{Y}$ a su vez los alumnos experimentaban estos cambios en el aula. 
4. LAS LEYES DE LOS CINCUENTA AÑOS:

LA ACCION GUBERNAMENTAL 


\section{LAS LEYES DE LOS CINCUENTA AÑOS: LA ACCION GUBERNAMENTAL.}

Pretendo hacer un recorrido por la legislación de estos cincuenta años con el fin de ver los pasos dados, ya sean hacia adelante o hacia atrás, en lo tocante al progreso y civilización de los indios y especialmente de los kunas. Es un hecho constatable que este grupo fue el más privilegiado de la República, e incluso hoy día lo sigue siendo. En la actualidad todavía hay grupos que no tienen una demarcación de sus tierras; y que en consecuencia no poseen una reserva, obligándoles a la trashumancia.

Las leyes fueron apareciendo con frecuencia pero el problema fue hacer cumplir sus propuestas. Tal vez la inexperiencia de esta joven nación le llevó a promulgaciones sucesivas sin ser muy consciente de que eso que se escribía tenía que contar con unos medios que lo pusieran en práctica. Los escasos presupuestos fueron los que ahogaron las entusiastas pretensiones en muchos momentos.

\subsection{Primeraconstitución de $19044^{1}$}

Aparece en el artículo 26 el propósito del gobierno de auxiliar a la Iglesia Católica para que cree misiones para la

1 V. RD, n. 1; V. CD, n. I. 
civilización de los indígenas. Pero al mismo tiempo se permiten todos los cultos que no atenten contra la moral cristiana en la nación panameña. En lo referente a la educación queda claro en el artículo 133 que se establece la escolaridad primaria con carácter obligatorio y la pública sería gratuita. Al mismo tiempo se prevía la creación de la Escuela de Artes y Oficios y otras escuelas de enseñanza secundaria y profesional con cargo a los gastos de la nación. Y algo muy curioso, que tendría su repercusión en la comarca de San Blas; que mediante ley se podrá descentralizar la instrucción pública destinándole rentas especiales. Hubo escuelas que funcionaron bajo el auspicio del Gobierno y Justicia o de Obras Públicas.

Entre las funciones legislativas de la asamblea nacional se recoge el promover y fomentar la educación pública, las ciencias y las artes. Pero era atribución del Presidente de la República dirigir, reglamentar e inspeccionar la instrucción pública nacional.

En el artículo siguiente se expone que ningún empleado podrá recibir más de un sueldo con cargo al tesoro nacional. Algo que se cumplió con los policías destacados en la costa del caribe y que ejercieron además como maestros. Estas personas sólo cobraban el sueldo de policías, como veremos en capítulos siguientes.

En la división que se hace del territorio nacional se reconocen siete provincias, pero se ignoran las tierras de los 
indígenas; estos formarían parte de esas provincial nacionales, sin ninguna autonomía, todas las tierras son de pertenencia estatal.

\subsection{Ley 11 del 23 de marzo de $1904^{2}$}

Hacía algo más de un mes que se había promulgado la primera constitución de la República de Panamá y aparecía ahora la plasmación desarrollada del artículo 133 de la misma. Como ya establecía este artículo la ley reafirmaba el carácter obligatorio de la instrucción primaria y la gratuidad de la enseñanza pública. Exhortaba a los municipios que contaran con ingresos a invertir en educación. Es cierto que este primer gobierno dio gran relevancia a la educación. El que los ciudadanos tuvieran una mínima cultura era de suma importancia, hacía subir a la nación.

Después de los altibajos sufridos en el período de unión con Colombia, en los que la instrucción pública estuvo supeditada a las continuas guerras; se enfrentaba ahora la joven nación a un grave problema, como era la falta de formadores. No tenía gente preparada que pudiera formar a los maestros. Se habían seguido las corrientes educativas provenientes del viejo continente, como ya se vio en el capítulo segundo y tercero, teniendo que importar educadores del extranjero. Ello hizo que

2 AANP. 
los primeros años se caracterizaran por la escasez del personal en el cuerpo educativo. Había que comenzar con pocos maestros y además no tenían una formación completa. Entre los indígenas se llega a nombrar como maestros a personas que solo tienen los conocimientos del $4^{\circ}, 5^{\circ}$ y $6^{\circ}$ grado de la primaria.

Otro de los medios que acelerarían la formación del profesorado fue el envío de jóvenes becados al extranjero, que luego tendrían la obligación de impartir enseñanza entre sus conciudadanos. Las becas estaban destinadas a los niños y niñas, pero estas últimas solo tendrían derecho a una tercera parte de ellas.

Los internados, que comprendía otro campo de la instrucción, estaban sometidos a la inspección del gobierno, que vigilaba la alimentación y todo aquello que concerniera al desarrollo físico y moral del niño.

La ley liberaba a los maestros de todos los impedimentos y trabas que hicieran mermar el cuerpo docente. La escasez no permitía perder miembros del colectivo profesional. Por ello no hacían el servicio militar y estaban eximidos de contribuciones personales y de cargos onerosos.

El artículo 18 de esta ley se puede decir que hace una alusión implícita a los grupos indígenas en materia educativa.

Es competencia del gobierno el difundir la instrucción primaria en todo el territorio de la república. El presidente de la 
misma ya tenía en mente la zona costera del Atlántico, y queda plasmado en esta ley. Se quiere a sí mismo que la enseñanza tenga un predominio de lo práctico sobre lo teórico. Hay que levantar el país y para ello es preciso explotar los recursos naturales con los que cuenta la nación; como es la agricultura, un sector que estaba muy abandonado. La mano de obra en las distintas empresas del ferrocarril o el canal, dejaban de lado el cultivo del campo como algo secundario. Se quiere infundir en el niño una conciencia patriótica y cívica.

La escolaridad obligatoria estaba comprendida entre los 7 y los 15 años, siendo libre la elección de la escuela; pero quedaban disculpados aquellos que su vivienda distara más de dos kilómetros del centro escolar. Un gran número de la población vivía en caseríos desperdigados.

Como medio coercitivo para que los padres enviaran a sus hijos a la escuela aparecen las multas monetarias para quienes no cumplan con esta obligación de enviar diariamente a sus hijos. Y mayor penalización tenían aquellos que se ausentaran de los exámenes y actos públicos. El importe recolectado por los inspectores de instrucción iría a parar al ramo de instrucción pública, que lo emplearía en bibliotecas, escuelas, vestidos o material escolar.

Los municipios debían invertir una cuarta parte de sus rentas en materia educativa, y estas tenían preferencia sobre 
cualquier otro gasto. Entre las obligaciones municipales estaba la de elaborar el censo escolar.

Hacía una diferenciación de las escuelas entre urbanas y rurales. Pero no diferencia la enseñanza que en ellas se han de impartir. La educación debería tener en cuenta el alumnado al que se dirigía. Y los seis cursos de la primaria se dividían en elemental, medio y superior, comprendiendo cada uno de ellos dos cursos.

Las escuelas que no alcanzaran a sesenta alumnos estarían regentadas por un solo maestro. Aquellas que superasen dicha cifra en la asistencia diaria tendrían los maestros una media de treinta alumnos.

Las escuelas rurales contarían en su programa con los puntos más importantes de las escuelas primarias elementales. Se puede decir que eran escuelas de segunda fila, o mejor dicho de cuarta categoría como son clasificadas posteriormente. Los maestros recibirían el sueldo más bajo de toda la República B/ 40.00 mensuales, frente a los 150,00 de los de primera categoría. Por supuesto que nadie desearía ir a las escuelas rurales, y lógicamente estos puestos serían para los maestros menos preparados.

Dada la situación precaria y el deseo de formar maestros que impartieran enseñanza, el gobierno pagaría mediante becas los estudios de parte del alumnado, proporcional a cada provincia. 
Se crean las escuelas anexas a las escuelas normales que servirían de centros de prácticas para los futuros maestros. A esta escuela vendrían los kunas de San Blas a estudiar.

La enseñanza de la escuela de Artes y Oficios, creada por esta ley, sería costeada por la nación y los alumnos estarían seleccionados por las autoridades políticas de cada provincia, que podrían enviar hasta un máximo de diez alumnos por cada una.

Los gastos de instrucción pública tenían preferencia frente a cualquier otro gasto de la nación; o esto al menos dejaba reflejado la presente disposición.

A mediados de febrero se había redactado un proyecto de ley sobre las escuelas normales de varones y de mujeres. Los directores serían contratados en los EEUU y los subdirectores en Chile. Los alumnos estarían becados pero se comprometían a ejercer su actividad durante tres años en el lugar que se les designara como contraprestación de esta ayuda.

\subsection{Ley 67 del 7 de junio de $1904^{3}$}

Intenta regular el comercio por la costa atlántica, y concretamente por el Golfo de San Blas. Con esta medida se reducirán los derechos de importación que tengan como destino

3 AANP. 
el archipiélago en un $25 \%$, que sería reintegrado por la oficina de hacienda, y se prohibe la conducción de mercancías extranjeras de las costas de San Blas a cualquier otro puerto de la República.

\subsection{Decreto 223 del 31 de Octubre de} 19064

El propósito claro de este decreto es formar un grupo de indígenas que, a su vez, sean los formadores de sus conciudadanos. El medio más rápido para ello es sacar a éstos de su propio medio e introducirlos en el centro de la civilización, para que de esta manera absorban más rápidamente los nuevos conceptos y modos de vida. Allí no tendrán la presión de su cultura ni se verán distraídos por su propia gente. Todo lo que les rodea es nuevo y, como consecuencia, la presión de cambio será más grande. Lo novedoso siempre tiene un mayor atractivo en los jóvenes; por ello se esperaban resultados rápidos.

La procedencia de este decreto, el Ministerio de Justicia, nos hace pensar que la intención predominante es civilizar a los indios que se consideran salvajes, más que educarles.

La civilización requiere una copia de lo que es la vida en la ciudad, con sus modos y condiciones peculiares. Pretende 
que se imbuyan de todo lo que hay en la ciudad y que luego este grupo de jóvenes, que han conocido y vivido la civilización, hagan de civilizadores y de catalizadores de su gente. A ellos les resultará más fácil llegar a los suyos, pues conocen su modo de ser y pensar, y entre los indígenas siempre gozarán de mayor credibilidad que los extraños. Chocarán con los que quieren mantener su tradición a costa de todo, pero los más jóvenes siempre se dejarán llevar del cambio y de lo que este conlleva de novedoso.

Las personas elegidas para esta tarea deben ser aptas para recibir instrucciones. No se eligen al azar. Tienen que ser personas con disposición para el cambio; a lo que ya había contribuido Charles Róbinson, que veía la necesidad de la educación y que, personalmente, conocía los adelantos de la misma. Por ello los primeros alumnos son de Narganá y Corazón de Jesús, islas en las que el sahila Róbinson ejerce gran influencia. Para la aceptación de este cargo de sahila había puesto como condición que le permitieran introducir la educación.

Esta medida daba el primer paso al acercamiento de los habitantes de la costa atlántica al gobierno. Así se pretendía afianzar la unidad nacional, unidad que requería de esta zona estratégica de la costa y que los indios desconocían o no aceptaban. 
Es claro que una vez instruidos, o más bien civilizados, la intención es volverlos a su lugar de origen para que continúen la labor del gobierno y que sirvan al interés de los mandatarios. Para ello se les nombrará en los puestos públicos que necesitan instaurar entre ellos.

Más rápido y fácil hubiera sido separar a los recién llegados. Pero esto frena el hecho de que no saben la lengua nacional y no se les puede mandar a las distintas escuelas nacionales. En la Escuela Anexa Normal de Varones se establece un cupo de hasta treinta alumnos, pero no se llega a cubrir. La regentarían los Hermanos de la Salle, aunque por poco tiempo, provocándose después un estrepitoso fracaso.

Es de señalar que este decreto se promulga ante hechos consumados, pues los jóvenes ya están en la ciudad y surgen los problemas. En el momento de la firma del decreto son diecisiete los muchachos que se encuentran en la ciudad. La falta de conocimiento de la lengua nacional, es lo que hace que se cree una escuela de indígenas, pues de lo contrario no podrían seguir el ritmo en una clase normal.

\subsection{Ley 28 del 20 de noviembre de} $1906^{5}$

La escuela de Artes y Oficios había sido creada dos años antes, y en ella se establecía que sería una enseñanza

5 V. RD, n. 4; V. CD, n. II. 
gratuita, la impartida por este centro, poniendo un tope de diez alumnos por provincia. Pero para las costa de San Blas y el Darién se elevaba el número hasta quince becas. Con un presupuesto mensual de B/25 por alumno para cubrir todas sus necesidades.

Esta ley entraría en vigor en el siguiente curso escolar, y como los alumnos iban a encontrarse allí antes, se dispone que permanezcan en algún colegio de la ciudad hasta que diera comienzo el curso.

\subsection{Ley 59 del 31 de diciembre de}

\section{$1908^{6}$}

Es conocida esta ley con el nombre de Ley de Civilización de Indígenas.

Una vez más se une el poder ejecutivo y la Iglesia Católica en la República de Panamá para llevar adelante esta empresa. Quieren someter a la vida civilizada a las tribus salvajes. La idea de la reducción de los primeros años de la conquista y colonización aún continúa en los inicios del siglo XX.

La labor de civilización podemos decir que había comenzado en marzo de 1907 cuando llega al archipiélago el P. Gassó, con el deseo expreso del ilustre mandatario y del obispo

6 V. RD, n. 11; V. CD, n. V. 
Junguito de atraer a las tribus salvajes y rebeldes. Es sin embargo el gobierno el responsable de formar, desarrollar y llevar a cabo el plan que logre el objetivo propuesto. $Y$ se designa a la Iglesia Católica para llevar a buen fin la labor. Esta será subvencionada por la nación panameña y además nombrará maestros para las escuelas de esas regiones. ¿Por qué se sigue pensando en las misiones como intermediarios de la civilización entre las tribus? Ciertamente que hasta ese momento es la gente más preparada y con mayor experiencia en dicha actividad. Tampoco se puede dejar a un lado la situación de la nación que empieza a funcionar hace cinco años de modo independiente, y por tanto carece de experiencia.

El gobierno simpatizaba con lo católico, a quien estaba unido la tradición de siglos en materia de evangelización. Los conceptos de civilización, evangelización y educación formaban un todo y seguían unidos; siendo el principal agente el misionero.

Autoriza a la creación y formación de poblados que sean centros de la misión y enclave para la comunicación con los indígenas, como antiguamente. Así como un modo de aproximar el mundo civilizado y el no civilizado es conceder tierras a los que quieran instalarse en esos lugares recónditos. Darán aquello que sea imprescindible para comenzar la vida en las nuevas tierras; lo mismo para los indígenas que para los colonos. De esta forma comenzará un acercamiento entre las dos formas de vida, aunque solo sea por la proximidad física. 
Un nuevo reglamento regulará las relaciones de los indígenas con los civilizados. Pero no se le reconoce al pueblo indígena como un sujeto político. El estado, por su cuenta dispondrá la manera de administrar los poblados, sin contar con los indígenas; sus estructuras no son válidas para la vida civilizada y por ello no se tienen en cuenta.

En la parte central de la ley se crean quince becas para los indígenas de San Blas en la Escuela de Artes y Oficios. Estas no se llegan a cubrir en el tiempo que funcionó esta escuela. Comprenden el alimento, el vestido y las demás necesidades. Como indica su nombre, los alumnos que salgan graduados de aquí sabrán un oficio, carpintero, sastre, plomero...

Estos oficios no es que tuvieran muchas salidas en su región, pues la construcción de sus casas no requería grandes conocimientos, y la escasez de materiales tampoco permitía su uso. Se empieza a fomentar la creación y el uso de los materiales relacionados con estos oficios y ciertos usos y costumbres propios de la vida civilizada.

El gobierno tendría en cuenta estas becas a la hora de estudiar los presupuestos nacionales que eran con carácter bienal. 
4.7. Ley 41 del 13 de diciembre de

\section{$1912^{7}$}

Propone esta ley la construcción de diversos edificios de utilidad pública, entre los cuales se encuentra la edificación de una escuela de indígenas. No determina el lugar donde se ubicará, pero parece insinuar que será fuera de la capital de la república, pero de todos modos deja la decisión en manos del poder ejecutivo.

El espíritu de la ley refleja la preocupación del gobierno por el tema educativo. De los ocho edificios cinco serán escuelas, y una vez pedido el préstamo, si sobrase dinero, la intención del gobierno es emplearlo en levantar escuelas de urgente necesidad.

\subsection{Ley 56 del 28 de diciembre de $1912^{8}$}

Se produce un cambio de gobierno y suben los liberales al poder. Esta nueva ley deroga la 59 de 1908 y presenta cambios sustanciales. El encargado en este caso de llevarla a cabo es el poder ejecutivo, y pretende también por medios pacíficos la reducción a la vida civilizada. Los medios y la acción que se van a llevar a cabo parecen contradictorios, pues

\footnotetext{
7 V. RD, n. 14; V. CD, n. VI.

8 V. RD, n. $15 ;$ V. $C D, n$. VII
} 
quieren que sea por medios pacíficos, pero se pretende la reducción, término que tiene una connotación de fuerza y sometimiento. Establece una distinción de los indígenas entre tribus bárbaras, semibárbaras y salvajes de los existentes en el país.

En la presente ley no se hace mención de ningún grupo indígena específico. Se dicta la ley en general y abarca a todos los grupos del país. Pretende crear poblados que sirvan de centro de comunicación con los indígenas y nombrar personal administrativo. Instaura la policía, grupo que apoyará la acción de sometimiento. Ellos garantizarán el orden y que se mantenga la soberanía nacional. Queda sentado que todo el terreno es panameño y, consecuentemente, esto no se debe cuestionar. Tiene intención de hacer demarcaciones y nombrar personal administrativo encargado de ellas.

De nuevo está dispuesto el gobierno a hacer concesiones a aquellos que quieren cultivar las tierras que la ley determina. $Y$ a los indígenas concederles materiales y animales para que emprendan una vida civilizada. Solo hace falta estar dispuesto a abandonar el modo de vida y comenzar enrolándose en el engranaje de la civilización, con todo lo que ello supone: vida en poblados, con familias, cultivo de los campos, criar ganado y acatar las autoridades establecidas. Esto suponía la presencia de personal gubernamental que velaría en todo momento por el desarrollo de la civilización. 
La creación de puestos estratégicos que controlen la importación de mercancías es algo que afecta, de modo directo, a los indios de San Blas. Panamá había estado unida a Colombia y los indios, por estar ubicados tan cerca de esta nación que les dejaba ser y estar sin más, acrecentaba su idea de pertenecer a Colombia como anteriormente había ocurrido. Algunos mantuvieron este espíritu durante mucho tiempo. El comercio con esta nación por vía marítima se seguía manteniendo. Por lo que se quiere regular la entrada de productos en esta franja de la costa caribeña. El control de la costa se realizaría con la adquisición de naves guardacostas.

El gobierno establecería escuelas en las colonias y pueblos indígenas. Lo que verían cumplido los indios de San Blas tres años después, cuando concluye la visita del Presidente de la República y se levantan las escuelas de Narganá, Corazón de Jesús, Playón Chico y San Ignacio de Tupile.

Se instaura todo el sistema burocrático del gobierno en esta zona indígena. Lo que llegaría a ser un elemento de presión y de sometimiento de los indios.

Estas tierras panameñas tenían una organización independiente, pero con esta medida estaban sometidos al estado en todo lo administrativo, jurídico y fiscal. La comarca de San Blas dependía de la provincia de Colón. 
Punto independiente y que merece especial mención es el referido a las misiones.Ya no se dará exclusividad a la Iglesia Católica. Se hace extensivo a cualquier misión, secta o sociedad religiosa que enseñe bajo los principios y doctrinas de la moral y la civilización cristiana. Pero necesitará un permiso del gobierno para llevar adelante sus propósitos con los indios salvajes y semi-salvajes; no se menciona ya a los bárbaros. Pero estas sociedades religiosas podrían impartir enseñanzas a parte de la escuela nacional, además de hacer propaganda religiosa.

Establece una cantidad fija en los presupuestos bienales destinada al fin de la civilización de indígenas de $\$$ 75.000 .

Habían pasado dos años y el gobierno, según un memorial propio, no había podido dar cumplimiento a la ley 56 , pero afirma que tiene ya muy adelantado el plan para iniciar la civilización con los indios de San Blas, pues son los que tienen las condiciones más favorables. Pues la ley decía que el poder ejecutivo formará, desarrollará y procurará llevar a cabo un plan general con una serie de autorizaciones.

El problema que se plantea es el de la donación de los terrenos que el gobierno propone, pues pide que se lleven colonos a cambio. Solicita ayuda para llevar a buen fin la colonización, al gobierno americano, para la construcción inalámbrica de un sistema de comunicación desde el Golfo de 
San Blas. Finalizando 1915, concretamente el 22 de octubre, se establecen los límites de la comarca de San Blas. La circunscripción de San Blas había sido delimitada el 6 de Marzo del mismo año.

De la intendencia de El Porvenir, el 5 de Julio de 1919 sale una normativa con destino al destacamento de Narganá, con el propósito de orientar la acción del jefe de la misma. Se pide que use los medios pacíficos posibles para la sumisión de los indios bárbaros, semi-bárbaros y salvajes. Los agentes coloniales tienen la responsabilidad de garantizar el orden y la soberanía nacional. Las relaciones entre los jóvenes y los mayores deben ser amistosas y habrá que hacer lo posible para evitar enfrentamientos.

Asimismo el jefe del destacamento recibe el encargo de velar para que los niños y niñas indígenas asistan a las escuelas públicas creadas por el gobierno. Las faltas de asistencia motivarán una multa a los padres de un balboa; pudiendo caer en pena de arresto si la falta se repite más de tres veces. La vigilancia de las escuelas es para las dos islas gemelas, Narganá y Corazón de Jesús.

Se prohibe a las niñas, que asisten a la escuela, el uso del olazu y güines. Permiten por el contrario que lo sigan usando las casadas y se les pide que no hagan uso de procedimientos duros y ofensivos. También se solicita que se vigile a las niñas que asistan a la escuela bíblica de las misioneras protestantes, 
para que no hagan uso de los alzamuros. Pero también se requiere la colaboración de los protestantes para llevar a cabo la civilización.

Como medida civilizadora se propone la construcción de casas y el ordenamiento de estas en las islas, siguiendo los patrones de la ciudad, con espacios suficientes entre las edificaciones que permitan la ventilación y las calles anchas por donde puedan desfilar los escolares y hacer procesiones. Cuentan con el ejemplo de Róbinson, que ya había construido su casa de concreto en 1910; y cuentan con la colaboración de las personas que habían aprendido estos oficios en Panamá, y están de vuelta en su pueblo

Recomienda finalmente que tengan mucho tacto a la hora de poner en práctica estas instrucciones, pues tienen conocimiento de la belicosidad de estas tribus.

\subsection{Decreto 33 del 6 de Marzode $1915^{9}$}

Crea la circunscripción de San Blas y reglamenta su administración a través de 67 artículos. En primer lugar establece los límites del territorio conocido con este nombre, en el que está incluido el corregimiento de Puerto Obaldía. La administración estaría a cargo de la secretaría de Gobierno y Justicia, con una dotación de personal compuesta por el jefe de 
la circunscripción, un secretario, un intérprete, un jefe de destacamento, diez agentes de policía nacional, diez agentes de policía indígena, un médico y un ingeniero.

Se prevé la fundación de dos centros coloniales, uno con base en Puerto Obaldía y el otro entre el río Mandinga y la Punta de San Blas. Estaría situado en tierras de dominio público donde lo indios no estubiesen asentados con población o labranza, pero que deberían reunir una serie de condiciones de vivienda y extensión; dividiéndose en lotes rurales y urbanos. Los que tomasen esta decisión de asentarse en las colonias tenían asegurados una serie de derechos, como era la gratuidad en viajes, así como en asistencia médica y concesión de semillas.

Se regula todo lo concerniente al comercio por la vía marítima de esta franja panameña, supervisado siempre por la autoridad de la intendencia.

Es obligación del jefe de la circunscripción rendir informe semestral a la secretaría de Gobierno y Justicia, en el que hará las indicaciones que juzgue convenientes para la mejor y más rápida realización del fin que se persigue.

El médico prestaría servicio gratuito al personal del gobierno, y a los indios que reclamaran sus servicios, a la vez que detectaría las enfermedades más comunes sobre todo entre los impúberes; y les señalaría las reglas de higiene a que deben someterse. 
El cuerpo de policía colonial encargado de mantener el orden y la soberanía nacional en las regiones habitadas por las tribus indígenas, se compondrá de diez agentes y subteniente. Los diez cargos de agentes indígenas se darán a ságuilas que por su lealtad para con el gobierno sean dignos de esa recompensa. $Y$ servirán de medio de comunicación entre las autoridades administrativas y las indígenas, siendo nombrados por el jefe de la circunscripción, y sancionados por el Presidente de la República. El sueldo a percibir por la policía colonial ascendía a B/ 45,00, mientras que el de la policía indígena era B/ 15,00. Se fijaba el servicio de una nave para atender las necesidades de la circunscripción de San Blas.

\subsection{Decreto 215 del 11 de diciembre de $1925^{10}$}

Una vez pasados los acontecimientos de la revolución Tule, se pone en funcionamiento el aparato del gobierno en San Blas, que se inauguraría con el nuevo año.

Aumenta el personal y también los sueldos. La dotación de policía colonial pasa a cuarenta y dos, mientras que la policía indígena se mantiene en diez, los primeros cobrarían B/ 50,00 y los segundos $\mathrm{B} / 25,00$.

10 ANP. 
La nave guardacosta es el Panquiaco, que dispensará la comida gratuita a los jefes indígenas que viajen en él.

Se crea un juzgado municipal de la circunscripción de San Blas en la población de Nicuesa, que tendrá jurisdicción en toda la circunscripción. $Y$ tres corregidurías con sede en Nicuesa, Narganá y Puerto Obaldía.

\subsection{Ley 59 del 12 de diciembre de} $1930{ }^{11}$

Quedan establecidas como reservas indígenas las tierras baldías de la costa Atlántica pertenecientes a la costa de San Blas comprendida entre los $77^{\circ} 35^{\prime}$ y los $78^{\circ} 55^{\prime}$ de longitud occidental. Especifica que estas tierras serán poseídas en común por las tribus aborígenes que las habitan sin que puedan ser enajenadas ni arrendadas. Como se puede comprobar, la situación era distinta a la establecida en el capítulo segundo. Aquí estaban excluidos los terrenos concedidos a compañías de explotación norteamericana.

\subsection{Ley 18 del 8 de noviembre de}

$1934{ }^{12}$

Declara las reservas indígenas del país, explicitando entre ellas la del alto Bayano. Las tierras anteriormente

11 AANP.
12 AANP. 
mencionadas serán poseídas en común por las tribus aborígenes que las habitan y no podrán ser enajenadas ni arrendadas. Así mismo se compromete a declarar todas las zonas ocupadas por tribus de indios en el territorio nacional, como reservas indígenas, para que estos trabajen en ellas gratuitamente. Se da un plazo de un año para que el poder ejecutivo ateniéndose al artículo 206 del código fiscal declare las reservas indígenas de la República.

La presente ley quería mejorar y reformar la dictada en 1928 y en el borrador afloran los sentimientos humanitarios proponiendo que los poderes públicos den protección a la raza india en orden al mejoramiento de las condiciones de vida social, tomando medidas para impedir que se comentan abusos con ellos.

\subsection{Ley 2 a del 16 de septiembre de} $1938^{13}$

Por esta disposición se crea la comarca de San Blas, además de la de Barú; con la figura del intendente nombrado por el poder ejecutivo, y de quien dependerán los empleados que allí trabajen. Se establece una regiduría que tendrá su sede en Puerto Obaldía. 
El poder ejecutivo organizará la fuerza pública en la comarca y determinara el número de efectivos. En el mes de octubre se reglamenta esta normativa en la que se faculta al intendente de la comarca de San Blas para crear las comisarias que estime necesarias para la mayor eficiencia del servicio administrativo en el archipiélago, escogiendo como sedes los centros coloniales establecidos en el territorio continental e insular de la misma; y para nombrar los comisarios.

Se establecen tres secciones para vigilar y mantener el orden. En estas secciones habrá destacamentos compuestos de agentes y oficiales del cuerpo de policía nacional, y además habrá policía indígena. Concediendo estos cargos a los jefes indios que a juicio del intendente se encuentren en un grado de civilización más alto y cooperen lealmente a la labor civilizadora del gobierno.

Entre las atribuciones del intendente está la de fomentar en lo posible la instrucción pública, la agricultura, la ganadería, la industria, el comercio, el arreglo higiénico de las poblaciones, las vías públicas...

Dice que la instrucción pública en la comarca de San Blas será reglamentada por el poder ejecutivo, a través del órgano de la secretaría de Gobierno y Justicia.

Y a los sahilas investidos de cargos de policías indígenas, les pide que cooperen con la policía nacional para que los indios se sometan a las leyes nacionales, adquiriendo cada 
día un grado más alto de civilización. Solicitándoles de igual manera que presten su apoyo a los maestros de las escuelas comarcales.

Queda detallado todo lo referente a los centros coloniales en la comarca de San Blas, en los que no se deben encontrar indios asentados ni tampoco estar dedicadas a sus cultivos. Se prohibe el comercio con los extranjeros, y ellos deberán pasar control aduanero en la ciudad de Colón.

\subsection{Constituciones de 1941 y $1946{ }^{14}$}

En la primera de ellas al referirse a los indígenas dice que es obligación imperativa del estado dictar las medidas que tiendan a educar al indígena para incorporarlo a la civilización. La enseñanza primaria será obligatoria; y la normal, vocacional y secundaria se impartirán gratuitamente.

La otra constitución dice que el estado dará protección especial a las colectividades de campesinos e indígenas con el fin de integrarlas de manera efectiva en la comunidad nacional en cuanto a sus normas de vida, lo económico, lo político y lo intelectual. La acción relativa a los indígenas se efectuará conservando y desarrollando al mismo tiempo los valores de la cultura autóctona. Para lo cual dotará a los campesinos e

14 R. E. FABREGA: Constituciones de la República de Panamá de (1904 1941-1946) 1969. 
indígenas de las tierras de labor necesarias, reservará tierras para las comunidades indígenas y prohibe su adjudicación, dotándoles de un servicio de infraestructura para desarrollar las labores agrarias, y llevar a cabo el funcionamiento de cooperativas.

Como fines específicos de las escuelas indígenas estarían la creación de conciencia de deberes, derechos, dignidad y posibilidades del ciudadano panameño. Despertar el interés por una vida rural segura, saludable y decorosa. Llevar hasta sus hogares la acción de los organismos de educación y asistencia que tiendan a elevar su nivel moral, cultural y social.

\subsection{Ley 47 del 24 de septiembre de}

\section{5}

En el desarrollo de esta ley de educación los programas de enseñanza consultarán las características distintivas de la niñez y la juventud panameñas, así como las condiciones del medio físico-social.

Se hace nuevamente la diferenciación de escuelas rurales y urbanas, en las que se pondrá énfasis en la enseñanza de cuestiones de carácter urbano o rural, teniendo unos estudios base. La escuela se establecerá para un número no menor de 25 niños en un área no inferior a dos kilómetros.

15 AANP. 
Los niños menores de 15 años no podrán dedicarse a trabajo o actividad alguna que les prive del derecho de asistir a la escuela. Los padres que contravengan esta disposición serán sancionados con multa de diez centavos.

Las escuelas de adiestramiento vocacional tomarán en consideración de manera especial las necesidades de los grupos indígenas y campesinos. La misma educación primaria que se imparta a dichos grupos deberá adaptarse a sus necesidades, sin que por ello pierda su carácter y deje de capacitar al individuo para la educación secundaria. Creará cursos especiales para integrar a grupos en la cultura nacional.

\subsection{Ley 16 del 19 de febrero de}

\section{$1953{ }^{16}$}

Esta ley organiza la comarca de San Blas. Al hablar de las competencias del intendente se establece que es función suya el fomentar la instrucción pública además de otras actividades como son la ganadería, la industria y el comercio.

Las competencias educativas de la comarca habían pasado a depender del Ministerio de Educación en 1945, pero aquí se reafirma esta decisión. La voz del intendente sigue teniendo peso, en lo relativo a la enseñanza el puede hacer propuestas de creación de escuelas, pero como siempre, 
escuchando la opinión de los legítimos representantes del pueblo kuna.

La ley pide que los programas sean adaptados a las necesidades de la región. Es cierto que los programas deben tener una consonancia con la vida donde se desenvuelven los individuos; pero no se puede olvidar el plan nacional seguido en la capital, si no los estudiantes que más tarde quisieran seguir estudios en los centros de la ciudad se verían en desventaja. Esto se sumaría a las dificultades que tienen en muchas ocasiones con la lengua nacional.

Se reserva la enseñanza de los primeros grados para maestros indígenas en las escuelas donde existan más de un maestro, manteniendo la lengua materna para que la comunicación entre alumnos y profesores sea más fácil. El alumno no tendrá la sensación de encontrarse ante un mundo desconocido, por lo que no se le hará tan arduo el aprendizaje.

Las becas que desde el comienzo habían disfrutado los indígenas, a pesar de sus altos y bajos, quedan fijadas con esta ley y se reserva un número proporcional para ellos.

Se propone la creación de una granja agrícola para la capacitación de los indígenas en los métodos modernos de producción agropecuaria, y acondicionamiento de la técnica de laboreo. 


\subsection{Carta Orgánica ${ }^{17}$}

Recoge una serie de disposiciones que juzga convenientes al adelanto de la comarca y al bienestar de los comuneros. Se fijan los límites del territorio y se establece la propiedad de los indígenas, que podrá distribuir tierras particulares con autorización de los propios comuneros.

Quedan especificadas las autoridades comunales en siete categorías, detallando los diferentes congresos y las respectivas atribuciones. En sus últimas líneas se refiere al matrimonio como base de la organización comunal, y a los delitos que atentan contra la tradición y la moral kuna.

Con lo expuesto en este capítulo nos podemos dar cuenta de cuales fueron los propósitos del gobierno. En un principio comienzan con la idea de la civilización, y así aparece en la primera constitución y primeras leyes. Más tarde se pasa a considerar la educación como algo que los indios deben aceptar voluntariamente.

17 V. RD, n. 975; V. CD, n. CDLV. 
5. EL INICIO DE LA EDUCACION INSTITUCIONALIZADA 


\section{EL INICIO DE LA EDUCACION INSTITUCIONALIZADA}

\subsection{El indígena Charles Róbinson.}

A los doce años su padre lo confía al capitán de un barco, quien le coloca en una escuela inglesa de Norteamérica para que aprenda a leer. Allí estaría seis años. Después comienza a viajar en un barco donde tendría la oportunidad de conocer diversos paises y culturas.

Carlos Róbinson recibió estos nombres del capitán del barco en el que viajó a Norteamérica y de otro marinero del mismo. Volvió con un arete en la oreja, tal vez rememorando su antigua costumbre de ir adornados los hombres con aros en la orejas.

En 1902 llega a Narganá acompañado de su hermano, y entonces gobierna la isla el sahila Inakailibanler, gran conocedor de las tradiciones kunas y reconocido por todos los indígenas del atlántico.

Consciente de la situación que padecen su paisanos empieza a enseñar a sus amigos las operaciones aritméticas y la lectura. Se dedica a profundizar en sus tradiciones, lo que posteriormente le sería de gran utilidad, cuando se ganó la simpatía 
de los isleños que le nombran sucesor del sahila. El aceptó con la condición de que respetaran sus ideas en favor de la civilización y el progreso.

A finales de 1904 una comisión del gobierno realiza una gira por las costas del Atlántico para anunciar a los karibes que Panamá se ha independizado. En los inicios de 1905 hondea la bandera panameña en Narganá y Corazón de Jesús.

Acompañado de un grupo reducido de seguidores va a visitar al recién nombrado Presidente de la República para saludarle y tratar sobre la educación de los niños de San Blas. Su mayor deseo era que se implantaran las escuelas entre las tribus indígenas. Fruto de esta entrevista sería la escuela Anexa de la Normal de Indígenas, dirigida por los $\mathrm{HH}$. de las Escuelas Cristianas. Las primeras becas fueron concedidas por el Presidente Amador Guerrero, gracias a sus gestiones.

El 27 de octubre de 1906, Róbinson se presenta en la presidencia de la República con un grupo de 17 niños kunas, cumpliendo así su anterior promesa al presidente Amador, que deseaba iniciar la civilización en el archipiélago de las Mulatas. La fundación formal de la llamada Escuela de Indígenas tendría lugar tres días después. Poco más tarde se sumarían otros cinco a este colectivo. La escuela fue entregada a los Hermanos de la Salle por 
petición del Presidente, Róbinson y el P. Gassó, que se preparaba para acometer su empresa entre los kunas.

Entre los alumnos traídos se encuentra un albino, gente totalmente relegada de la vida normal de los isleños, por los problemas que tenían con el sol. Incluso eran enterrados vivos nada más nacer. Este ejercería como maestro más tarde en el Bayano, cuando Nele Kantule vino a pedir maestros a Narganá.

El $\mathrm{H}$. Venero Carlos hace un informe del funcionamiento y actividades de la escuela. Reseña que piden los muchachos internados una educación especial y esmerada, baños frecuentes y una alimentación apropiada, paseos frecuentes. La enseñanza que recibían era ante todo intuitiva y práctica, señala la dificultad que tienen para lo abstracto, por falta de práctica. Las asignaturas que estudiaban eran lectura, escritura, lengua nacional, cálculo y aritmética objetiva, geografía, dibujo, canto y religión. Considera que han alcanzado un nivel apreciable.

En la educación moral la primera meta es hacerles cristianos y en diciembre de 1907 ya habían recibido todos el bautismo. Por su carácter tímido se les debe tratar con bondad y dulzura, más que ser rígidos y severos, pues con la bondad se puede llegar mejor y acercarles a la civilización. Finaliza diciendo que civilización, educación y cristianismo es lo que necesitan por el 
momento. El aprendizaje de un oficio vendría más tarde, pues los que conocen su región dicen que de poco aprovecharía. "Inculcáseles, pues, sólidos hábitos de vida moral, a la par que conocimientos de mayor necesidad, a fin de que hagan más tarde partícipes de todos a sus semejantes, y los traigan, así al seno de la gran familia"1.

En 1907 viaja Róbinson con su esposa y el hijo, por petición del P. Gassó, hasta Panamá donde es bautizado el pequeño por el Sr. Obispo ejerciendo de padrinos el Presidente Amador y su esposa. Esta sería la primera salida de una mujer kuna, que supuso un gran reto.

Ante las agresiones sufridas por los enemigos de la civilización y el misionero, el nuevo Presidente Obaldía entrega 100 fusiles y 5.000 balas para que los dos pueblos se defiendan. Este mismo Presidente y el secretario de Gobierno y Justicia le nombran a Róbinson, Gobernador General de la tribus de la comarca de San Blas. Lo que le permitía al sahila registrar las naves de cabotaje y evitar que se introdujeran armas para los rebeldes.

El Gobierno envía al sahila Róbinson con policías para que se entreviste con Colman e Inapaquiña a fin de que reconozcan la pertenencia a Panamá pero los caciques del oriente se niegan a recibirle. Posteriormente una nueva comisión sólo consigue que

1 V. AELE. De Carlos Róbinson. 
Tupile reconozca la independencia de Colombia.

Una de las características de la civilización era la construcción de los poblados siguiendo unas normas. Carlos Róbinson estableció un trazado de calles amplias con nombres, casas con una separación adecuada y con parque, que ha permanecido hasta la actualidad.

Durante la estancia del misionero católico, Róbinson fue su apoyo y el más ferviente defensor. Dejando bien claro que quería que les enseñara el camino de Dios y les hiciera gente civilizada que no fueran engañados por los comerciantes.

Con la entrada de la misionera protestante ocurrió lo mismo. El sahila de Narganá dio su apoyo incondicional, pues además ésta les enseñaría el inglés, lengua que el conocía y que era muy útil para el trato con muchos comerciantes que arribaban a aquellas costas.

Sus frecuentes visitas a la capital, en las que se entrevistaba con los distintos presidentes, fueron gestando el deseo de construir escuelas en la comarca, que se haría realidad en 1915.

En 1917 Róbinson es nombrado sahila general con sueldo de $B / 45,00$ ante el intendente Vaglio. $Y$ en 1918 se reúne con 
Colman en El Porvenir para hacer los primeros nombramientos de policías indígenas.

Desde 1920 con la ayuda de Claudio Iglesias, primero, y después con la colaboración de Estanislao López trabaja por el cambio de vestimenta entre los kunas y por desterrar sus tradiciones e introducir la llamada civilización.

En la revolución de 1925 tiene que huir de Narganá, pues los sublevados pretenden matar a todos los wagas y kunas defensores de la civilización².

El intendente Félix Oller consiguió su jubilación en 1946, aprobada por el gobierno tras 41 años de dedicación al progreso y la educación de su pueblo. En 1959 fue condecorado con la Cruz de Vasco Núñez de Balboa, reconociendo el gobierno su gran labor en pro de la civilización y la educación. Su muerte se producía el 8 de febrero de 1966, poco después de ser traído hasta Narganá por sus amigos desde la isla donde estaba retirado.

Para el sector central de la región de Kuna Yala este hombre es el verdadero padre de la civilización, ellos así lo celebran cada año. Ciertamente fue el detonante a partir del cual surgió todo el proceso llamado civilización. $Y$ en el periodo que nos

2 V. AELI. Anotaciones. 
ocupa en este estudio estuvo siempre presente apoyando la educación de una manera o de otra.

\subsection{La política de las becas}

El primer intento de atraerse a los indígenas por parte del gobierno, se realizó con las becas; para ello otorga a 22 jóvenes de Narganá y Corazón de Jesús principalmente, la posibilidad de estudiar en la capital. Este procedimiento era generalizado en el país, pues se reconocía un tanto por ciento de becas para cada provincia. Con el transcurso de los años se mantuvo esta política, que unas veces se vio incrementada y en ocasiones sufrió los apuros de la estrechez económica de los presupuestos.

Por petición del misionero católico y Róbinson, el Presidente Carlos A. Mendoza, en 1910 concedió cuatro becas, una de las cuales era para Claudio Iglesias.

El primer graduado, fruto de estas becas, fue el joven Claudio Iglesias, que terminó sus estudios en la Escuela Hospicio en 1917 como carpintero. Y retirado en una isla propiedad de su padre, se dedicó a realizar trabajos propios de su profesión durante unos meses, con las herramientas regaladas por el director de la escuela, aprovechando para enseñar este oficio a sus hermanos. 
En 1919 la sociedad de la juventud, al frente de Claudio Iglesias visitan al Presidente de la República, previa invitación de éste, y tratan con él tres temas: las becas de los niños indígenas para la capital, la ayuda para la sociedad de la juventud y las costumbres tradicionales. Los jóvenes querían arrancar estas tradiciones, pero los métodos no eran los más adecuados, y la prisa en llevarlo a cabo puso fin a la vida de Claudio y González. Desde este año se dan nuevas becas y les promete más para los años sucesivos. Para protección de la juventud nombra a Claudio jefe de la policía con sueldo de B/ 45,00. En lo referente a quitar los alzamuros, opina el Presidente que es una cuestión muy delicada y que se debe actuar con mucha cautela.

En este año el secretario de Instrucción Pública le comenta al intendente las nuevas becas puestas a disposición de los indígenas, suspendidas las primeras ${ }^{3}$. A partir de este año se establece un sistema de pruebas para seleccionar a los becados.

Las becas no corrían con todos los gastos originados por los muchachos en la ciudad. Se debe tener en cuenta que la economía indígena era de subsistencia, por lo que si se les pedía una ayuda a las familias les causaba gran trastorno. En ocasiones algún miembro de la casa debía trasladarse a Colón o Panamá para poder

3 V. RD, n. 42. 
sacar un dinero que ayudara a mantenerse a los becados. En 1920 se pide ayuda al secretario de Gobierno y Justicia, pero también se hace constar que los padres deberían aportar algo, ya que los consideran de familias acomodadas ${ }^{4}$. El intendente se compromete a solicitar de los padres ayuda para que los alumnos se puedan pagar los gastos de vestuario y otras necesidades ${ }^{5}$.

El intendente Mojica pide al Presidente Porras en el comienzo del curso 1921-22, que otorgue cuatro becas para muchachos de San Blas, y dos para niñas 6 . Este hecho sería de gran relevancia para la comarca, pues supondría que por primera vez unas mujeres kunas salían fuera de sus islas para estudiar. La misma petición había sido hecha por escrito, y con anterioridad, verbalmente al secretario de Instrucción Pública; recordando que esta medida sería un paso más en favor de la civilización7.

La contestación llega pero denegada. En ellas se sugiere que los seis niños sean enviados a la ciudad y Gobierno y Justicia les pague lo indispensable y se haga cargo de ellos ${ }^{8}$.

Así se hace y comienzan el curso en Panamá, al mismo

\footnotetext{
4 V. RD, n. 106.

5 V. RD, n. 108.

6 V. RD, n. 142; V. CD, n. XXXIX.

7 V. RD, n. 147; V. CD, n. XLI.

8 V. RD, n. 145; V. CD, n. XL.
} 
tiempo que el intendente le agradece al Presidente Belisario y al Consejo de Gabinete su ayuda y buena acogida9

Esta acción vendría a premiar la labor y servicios prestados por el recientemente fallecido Claudio Iglesias; pues entre los agraciados se encontraban un hermano y una hermana suyos. Los jóvenes ingresan en la Escuela Normal de Institutoras, según confirmación remitida por el secretario de Instrucción Pública, que le comenta al intendente que los jóvenes se muestran muy complacidos de su nueva vida ${ }^{10}$. Luisa Iglesias sería la primera maestra graduada de la comarca.

Pero en ese entonces había otro grupo de becados que seguían estudios en la Escuela de Artes y Oficios y se pide al director de dicha escuela que guarde las plazas hasta el regreso de los muchachos que pasaban sus vacaciones en el archipiélago ${ }^{11}$.

Las dificultades acumuladas en 1921 hacen que no se puedan abrir las escuelas de San Blas, por lo que algunos toman la decisión de enviar a sus hijos a Panamá y colocarlos en familias a la vez que estudian ${ }^{12}$.

\footnotetext{
9 V. RD, ns. 149 y $150 ; V . C D, n$. XLIII.

10 V. RD, n. 157; V. CD, n. XLIX.

$11 V . R D, n s .155$ y 209; V. CD, n. XLVII.

12 V. RD, ns. 171 y 172; V. $C D$, ns. LXI y LXII.
} 
Antes de iniciarse el curso 1922-23 el intendente escribe al secretario de Gobierno y Justicia trasmitiendo la petición hecha por los habitantes de Narganá y Corazón de Jesús referente a becas $^{13}$.

Esta misma solicitud sería remitida al secretario de Instrucción Pública, pero en ella se especifica que siete becas serían para niños en el Instituto Nacional y dos para niñas en la Escuela Normal de Institutoras ${ }^{14}$. Pero la falta de presupuesto le hacen contestar al Sr. Duncan de modo negativo ${ }^{15}$.

En Junio de 1922, según carta del secretario Alfaro, son ocho las niñas que se encuentran en la Escuela Normal de Institutoras. En ella se reclama la mitad de la pensión de la niñas, que los padres se comprometieron a pagar. Por ello se pide al intendente que se haga cargo de este asunto ${ }^{16}$.

Para el siguiente curso el Presidente de la República hace un ofrecimiento de 15 becas para los indígenas, y son dos nativos los que irán a tratar con el mandatario de las condiciones de éstas. En abril se le comunica al intendente que el Gabinete aprobó la

\footnotetext{
13 V. RD, n. 213.

14 V. RD, n. 214.

15 V. RD, n. 221.

16 V. RD, n. 241; V. CD, n. LXXXIX.
} 
concesión de las 15 becas para los planteles de la capital17. Y ese mismo mes sale la propuesta de los aspirantes pero con 13 nombres, ocho de muchachos y cinco de niñas ${ }^{18}$.

En este curso se amplían los centros donde irán los becados, y cinco muchachas de Narganá ingresan en el Hospital de Santo Tomás; las primeras graduadas de comadrona saldrían en 1929.

La positiva influencia ejercida por los jóvenes educados en la ciudad, le hacen proponer al jefe del segundo destacamento la conveniencia de que se dieran becas para los estudiantes de Playón Chico y Tupile. El intendente traslada esta petición al Presidente Belisario19. A su vez el comenta a Instrucción Pública la posibilidad de aumentar las personas becadas 20 .

Nuevamente son los indígenas Estanislao López y Alcibiades Iglesias los encargados de gestionar las becas en 1924. Ellos envían la lista de los que se las merecen y piden dos más para el Hospicio 21 . Con frecuencia son ellos mismos los que acompañan a

17 V. RD, n. 285; V. CD, n. C.

18 V. RD, n. 289; V. CD, n. CIII.

19 V. RD, n. 329; V. CD, n. CXVII.

20 V. RD, n. 331; V. CD, n. CXIX.

21 V. RD, n. 337. 
los seleccionados hasta sus respectivos planteles 22.

Al iniciarse el curso escolar el Presidente escribe que se han hecho las gestiones pertinentes para conceder una beca, en las mismas condiciones de los otros muchachos, en la Escuela de Artes y Oficios a un joven indígena23.

El Presidente Belisario Porras fue el que más favoreció a los indígenas con la política de becas. Esta medida era considerada como un modo más de civilizar a los indígenas. Considerando que los que ejercieran después entre los suyos como maestros, colaborarían en gran medida a la empresa del gobierno. La idea de que los maestros fueran nativos era bastante aceptada entre los indígenas. Estaban más conformes en que fueran éstos, y no los wagas, los que les llevaran las enseñanzas.

El total de becas concedidas por el Presidente Porras durante su mandato último asciende a 60 , repartidas entre el Instituto Nacional, la Normal de Señoritas, Artes y Oficios, el Hospicio y el Hospital de Santo Tomás.

Las becas supusieron un gran lanzamiento en el tema de la civilización. Con ello los kunas aceptaban los deseos del gobierno,

\footnotetext{
22 V. RD, n. 351 .

23 V. RD, n. 352.
} 
al mismo tiempo que veían que sus tierras no eran invadidas por wagas.

Pero esta política de becas también fue cambiando el sistema económico de los indígenas. Pues las becas no cubrían todos los gastos y el nivel económico de los kunas, tan precario, les obligaba a buscar trabajos que fueran remunerados, entrando así en la cadena económica panameña. Familiares de los becados se veían obligados a buscar un trabajo en las grandes ciudades, desatendiendo sus familias, y dejando de lado las labores agrícolas y comunales. La falta de colaboración en los trabajos comunes de la isla decretados por el sahila, hizo que se impusieran multas que tenían que ser pagadas al regresar a la misma.

Con motivo de una visita de los sahilas a la capital en 1931, en la cual visitaron también las escuelas, proponen al Presidente que se restablezcan las becas 24 .

En 1934 se pone a disposición de una joven la beca vacante en la Escuela Profesional de Señoritas ${ }^{25}$. Esto es fruto de la falta de adaptación y las dificultades que surgían fuera del ambiente habitual.

\footnotetext{
24 V. RD, n. 503.

25 V. RD, n. 520; V. CD, n. CCXXVII.
} 
El director de la escuela de Narganá escribe al Presidente de la República a fin de que conceda una beca a un joven para que continúe sus estudios en la capital 26.

En un memorial de los honorables diputados se pide que atendiendo a la mejorada situación financiera se restablezcan las becas indígenas que estaban suspendidas; y que se creen nuevas escuelas, dado que las cinco existentes son insuficientes 27.

En Agosto de 1941 el intendente Constantino Villalaz conseguía cinco becas para los jóvenes de la comarca en la Escuela de Artes y Oficios, y pedía al director de San Blas que los seleccionara de entre los ex-alumnos de sexto grado de la escuela de la región 28 . Así lo hace y le envía la propuesta de cinco muchachos de diversas islas que han obtenido buenas calificaciones. Sugiere que acompañe a los jóvenes una persona mayor que les deje instalados en casas de confianza y que les solucione las posibles trabas que pudieran presentárseles ${ }^{29}$.

Con motivo del día del Indígena el Presidente de la República tiene a bien conceder cuatro becas para niños y otras

\footnotetext{
26 V. RD, n. 547.

27 V. RD, n. 682.

28 V. RD, n. 699; V. CD, n. CCCXXVI.

29 V. RD, n. 702; V. CD, n. CCCXXIX.
} 
tantas para niñas en la Escuela Normal30.

Cuando ya han transcurrido tres meses del inicio del curso de 1942 el director de la Escuela Secundaria de Colón escribe al intendente para hacerle saber que el gobierno ha otorgado tres becas para los indígenas de esa comarca en dicha escuela. Le expone las condiciones: que debe ser un joven de cada uno de los lugares más importantes de la región con conocimientos de lectura, escritura y las cuatro operaciones fundamentales, y de despierta inteligencia. La dotación de cada uno sería de B/ 20. Pero el jefe de El Porvenir delega en el director de las escuelas, que se deberá atener en lo posible a las condiciones prescritas ${ }^{31}$.

En la ciudad de Colón, la Escuela Secundaria pone a disposición del intendente tres becas para indígenas pero el director de las escuelas no quiere comprometerse por lo anteriormente expuesto y porque lo avanzado del curso hará que las familias se muestren reticentes a que salgan sus hijos ${ }^{32}$. Tras arduas gestiones el P. Puig comunica al intendente que ha enviado el niño que le pidiera para la escuela de Colón, de acuerdo con el subteniente de policía, y realiza el viaje acompañado del P. Jesús

\footnotetext{
30 V. RD, n. 731.

31 V. RD, n. 747; V. CD, n. CCCLXI.

32 V. RD, n. 667; V. CD, n. CCCII.
} 
Erice 33 .

Antes de dar comienzo al curso el Presidente de la República en conmemoración del día del indígena resolvió otorgar ocho becas para los indígenas de San Blas en la Escuela Normal de Santiago, cuatro para niñas y cuatro para niños. De las primeras, dos ya se designaron por el Ministerio de Educación. La comunicación llega la víspera del inicio de curso en la Escuela Normal, por esta razón, tras pedir permiso a la intendencia el ayudante del director de la comarca va a Panamá para disculpar el retraso de los alumnos y enterarse de los requisitos, pues la precipitación en otras ocasiones similares ha causado el fracaso de estas becas ${ }^{34}$.

Lo cierto es que después de todas las diligencias realizadas directamente por el $\mathrm{P}$. Jesús Erice se consiguió llenar todas las becas menos una, la causa pudo ser la falta de voluntad o de dinero, pues se requerían unos B/. 150, cantidad muy elevada para el nivel económico de los modestos indios. Todos los esfuerzos sirvieron de poco, o al menos no tuvieron recompensa, pues a los tres meses de estancia en la Normal los muchachos informan que el gobierno no paga ninguna beca y las familias acusan al $P$. Jesús

\footnotetext{
33 V. RD, n. 761; V. CD, n. CCCLXX.

34 V. RD, n. 729; V. CD, n. CCCXLVIII.
} 
Erice de haberse quedado con el dinero35.

Las becas fueron en muchas ocasiones una fuente de problemas, pues la falta de preparación en los elegidos y el poco esmero en la selección de los candidatos llevó a que estos fracasaran y que los indios criticaran y desconfiaran de la salida de sus hijos hacia los centros de enseñanza. En 1941 cinco becas que se habían dado para la Escuela de Artes y oficios, después de ser seleccionados los cinco muchachos y enviados con una persona de confianza, sin saber por qué se malograron. Al año siguiente, 1942, el Presidente de la República otorga ocho becas para los indígenas, cuatro para mujeres y otras cuatro para varones. La misión católica puso todo su empeño para que se cubrieran y llegaran a su destino, incluso tuvo que poner dinero para pagar los materiales exigidos en los centros.

Hay que reconocer que aunque se les pide una mínima cantidad, pero para la economía de los indígenas suponía una fortuna. Para que finalmente tras tres meses de estancia en el colegio la dirección del mismo les avise que el Gobierno no se hace cargo de los gastos de estos siete jóvenes que al final fueron, después de haber invertido sus familias cerca de doscientos

35 V. RD, ns. 667 y 729; V. CD, ns. CCCII у CCCXLVIII. 
dólares 36 .

El problema de las becas, es una vez más puesto de manifiesto por el director de las escuelas, ante el rumor de que existen ocho becas para el año próximo. Considera que en muchas ocasiones estas son concedidas a personas ineptas o carentes de condiciones que garanticen la prosecución de los estudios. Un problema grande estriba en que los becados deben ser seleccionados al final de vacaciones o al principio del año escolar, lo que se podía tener en consideración y proponerse como fechas de selección una época más propicia en que los aspirantes estuvieran metidos en el ambiente del estudio, y no dedicados a los trabajos de la zona, puestos de lucro y metidos en los vicios de sus paisanos.

Las ventajas que traería el conocer antes de terminar el curso, el número de becas disponibles, sería que la elección de los candidatos sería buena en capacidad mental, en recursos pecuniarios, en la cooperación familiar, asunto de gran importancia, en la disposición de ánimo del candidato, y facilitaría las tareas a la dirección escolar. Las circunstancias anteriores arrojan un balance mediocre en capacidad en los hasta ahora elegidos, y prueba de ello es la repetición de cursos y el consiguiente cansancio y pesimismo de los muchachos; juntándose a esto el excesivo

36 V. RD, n. 667; V. CD, n. CCCII. 
sacrificio de sus familias.

Otra circunstancia agravante de la situación expuesta, es la concesión de becas a los indios que personalmente se presentan al Ministerio solicitándolas, salvo caso de personas eminentes, pues se corre el riesgo de dar una orientación al niño a la que no tiene inclinación, deseando luego el cambio de beca. El caso más reciente era el de los dos jóvenes becados el año anterior que se les llevó a la Escuela de Artes y Oficios cuando aspiraban a ingresar en la Escuela Normal37.

Al final del año escolar Erice sugiere al gobierno la conveniencia de crear ocho becas para encauzar hacia el estudio a los alumnos más sobresalientes que finalizaron la primaria en la escuela de Narganá.

La civilización tuvo como medida auxiliar a las becas, que desde los comienzos de la relación del gobierno con los kunas se fue materializando de diversas formas. Pero en el fondo de esta acción faltó una planificación seria. Entre otras circunstancias negativas los jóvenes que se incorporaban a los estudios de la ciudad carecían de una preparación adecuada, su falta de hábitos de estudio, la poca preparación del indio para permanecer en un internado y verse privado de su libertad resultaban una traba. Pero no se debe olvidar 37 V. RD, n. 805; V. CD, n. CDVIII. 
que por otra parte mejoraban sus condiciones considerablemente, pues disponían de un lugar de estudio, contaban con personal más preparado, estaban en un ambiente más propicio de estudio.

Esto favoreció también que se fomentara la salida de las islas y que algunos indígenas dejaran sus tierras, cuando podían haber trabajado por el mejoramiento de los kunas, ya que poseían una mayor preparación que el resto de los isleños.

La economía acusó una variación notable. Los becados tenían que aportar una cierta cantidad monetaria y en ocasiones las familias se ven con dificultad para pagar estos suplementos; lo que les lleva a buscar trabajos remunerados fuera de las islas, abandonando sus tareas del campo y de la pesca; al mismo tiempo que también caía el sentido comunitario y de colaboración.

La política de las becas es algo que se debe tener muy en cuenta, pues los mandatarios panameños hicieron continuo uso de ella para ganarse a la población indígena. Los kunas como grupo organizado, se vió más favorecido que el resto de los indios nacionales, pero también es cierto que algunas becas fueron un rotundo fracaso por la falta de preparación de los candidatos, o por la mala orientación que se les dió. 
6. EL PERIODO JESUITICO 


\section{EL PERIODO JESUITICO (1907-1912)}

Tres años después de la Independencia de Panamá de la Gran Colombia, llega procedente de México y con destino a Lima ${ }^{1}$, el padre Leonardo Gassó, sacerdote jesuita, lo mismo que el prelado que ocupa la silla episcopal, en aquel entonces, monseñor Francisco Javier Junguito. El misionero nacido en Mogente (Valencia), se hospeda en la casa del señor obispo. Este, ve acercarse el fin del problema de los indios del Atlántico, pues desde el primer momento piensa que tiene en su casa a la persona idónea para mandar a evangelizar a los karibes. Así que no pierde el tiempo y comienza a hacer las diligencias con los superiores, para que dejen a este apóstol al servicio de la nueva misión.

Conseguido el propósito de retener allí al nuevo misionero, Monseñor comunica al entonces primer Presidente de la República, Don Manuel Amador Guerrero, que cuenta con la persona que haría cumplir el artículo 26 de la Constitución en esta región del Istmo.

Asume esta responsabilidad tan ardua el padre Gassó y comienza por acercarse a la lengua de los indígenas. Para ello,

1 V. RD, n. 5; V. CD, n. III. 
aprovecha la oportunidad que le brindan los hermanos de la Salle. Recordemos que entonces estaban educándose veintidós muchachos kunas en Panamá al amparo de los HH de las Escuelas Cristianas, quienes habían elaborado una rudimentaria gramática de la lengua kuna. Esta gramática era la primera brecha abierta en el lenguaje y acercamiento al grupo que iniciaba el largo camino de la civilización. Seis meses pasa estudiando la lengua kuna y tomando un primer contacto con aquellos indígenas que estudian en la capital.

Intenta embarcar el 18 de marzo de 1907 en la ciudad de Colón, rumbo a las islas del archipiélago, pero el fuerte temporal imposibilita la salida del pequeño vapor.

Este contratiempo hace que el misionero gane una baza más; en ese compás de espera hasta el día que se efectúa la salida, llegan las cartas de recomendación del Presidente de la nación. Las misivas iban dirigidas a los caciques de Nusatupu y Yantupu, especialmente a Carlos Róbinson, el cual había tenido ya conversaciones con el mandatario. En su poder estaban las cartas del señor obispo, donde se relataba la sucesión de los jefes de la Iglesia, y cómo había sido designado este padre para llevarles el mensaje evangélico.

Dos días después emprende el viaje y llega a Nusatupu el 27 a mediodía. El vapor en el que efectúa el viaje, es el correo oficial del gobierno, pero hay que señalar que este era su primer 
viaje. En esta isla, donde arriban no es aceptado. El sahila se niega a dejarle pasar la noche allí. Decide entonces trasladarse a la isla que está más próxima, Yantupu; ésta es gobernada por el sahila Róbinson, hombre que reconoce la independencia de Panamá y quiere que sus indios acepten la civilización. Dicho personaje fue clave en la labor realizada por el P. Gassó. Comienza el misionero a enseñar las letras y los números a los muchachos.

Deja constancia en su diario el P. Gassó de la labor evangélica, pero no olvida la actividad educativa: "los tripulantes del vaporcito han presenciado los adelantos de estos ocho días. Unos setenta muchachos, doce muchachas y veintiún hombres saben, Por la señal, Ave y Santa María, en su lengua; además cantan el Bendito y Santa María. Doce muchachos copian el abecedario en la pizarrilla"2. Esto lo escribe el 6 de abril de 1907. No pierde el tiempo; la escuela empieza a funcionar desde el primer momento y ya se aprecian sus frutos. En ocho días consigue que una docena de niños escriban el abecedario, y pasados dos meses de permanencia entre los indígenas el misionero demuestra sus conocimientos del kuna con un discurso que pronuncia durante una hora y cuarto, para convencer a los isleños que le dejen quedarse allí3.

2 V. RD, n. 7; V. CD, n. IV.

3 Ibidem. 
A los tres años del comienzo de su labor, el secretario de Gobierno y Justicia reconocería públicamente: "La influencia moral de los misioneros católicos es positivamente saludable a la civilización indígena... El Rev. P. Gassó, de cuya abnegación puedo dar testimonio, ha puesto al pueblo de Narganá, casi al nivel de una aldea civilizada... Pero estimo que la acción de los misioneros no basta sola para alcanzar rápidamente los fines a que tiende el Gobierno, que consisten en establecer relaciones francas y efectivas entre los indios y los demás panameños y abrir en corto plazo al comercio y a la explotación legítima esas ricas regiones, que ocupan las razas autóctonas y que ellas tienen secuestradas al progreso"4.

Cree Firmemente el Sr. Ramón M. Valdés que los indios aceptarían maestros laicos, contra los que no sienten predisposición; y previo acuerdo con los caciques, se deberían enviar hombres sobrios y circunspectos, de edad madura y casados para que las mujeres les secunden en sus tareas.

Pero las medidas deben llegar más allá. Por eso incluye la comunicación regular en vapor dos veces al mes por la región junto con el establecimiento de otro puesto de policía en las islas similar al de Puerto Obaldía.

El padre jesuita contaba con la paga del gobierno que eran B/ 80,00 , de los cuales el descontaba para pagar a los

4 El Faro (Marzo 1957), p.41. y ANP, Memorias de 1910. 
cuatro policías indígenas y dos niños kunas pensionados en el colegio de los salesianos de la ciudad; uno de los cuales estudia carpintería y el otro sastrería ${ }^{5}$. Un hijo del segundo sahila también estudiaba en el colegio y vivía en la residencia jesuita. Además los viajes que realizaba corrían por cuenta del estado. No le faltaron tampoco ayudas de distintos católicos pudientes y filántropos.

El Gobernador de Colón le proporcionó mil hojas de zinc para la escuela. A la vez que un católico húngaro le entregó otras quinientas. La comida y la mano de obra eran proporcionadas por los propios indígenas.

El Presidente Carlos A. Mendoza realiza una gira por todo el país y llega hasta San Blas, alabando las construcciones del P. Gassó6.

Reúne a los más de cien niños en la escuela por la mañana y por la tarde donde les enseña la doctrina. Se pasa lista y los no asistentes debían dar después una explicación.

Merece la pena detenernos a analizar la tarea que tiene que emprender este primer evangelizador y civilizador de los kunas, pertenecientes a esa nueva nación recién formada.

En primer lugar, tiene que acometer la tarea de

5 Uno de estos niños es Claudio Iglesias, futuro lider de la civilización.

6 Lotería, Panamá, $\mathrm{n}^{\circ}$ 66, p. 98. 
pacificar y civilizar a los indios, amén de llegarles a convencer de su pertenencia a Panamá, pues la mayoría se sienten colombianos y quieren seguir perteneciendo a Colombia. Esta es la acción encomendada por el gobierno. Además el poder nacional pone de manifiesto que los ataques contra la misión, en sus personas o enseres serán considerados ataques al gobierno y por ello defendidos por éste. Las palabra del misionero valenciano a Róbinson en 1909 son claras: "Dios está con nosotros y el Gobierno me promete armas y soldados"7.

La Iglesia Católica le asigna la otra labor: evangelizar a estas tribus. Pero la misión encomendada por unos y otros no se puede llevar a cabo de modo desintegrado, es una acción conjunta y entrelazada; que se realizará de modo simultáneo y los logros de una ayudarán a la otra. En medio de esto, va comenzando la educación, que no tendrá un fin en si misma. La educación tiene como fin la civilización, es un elemento más de ese conjunto que forma la civilización. La educación es una parte de los seres civilizados. Róbinson, en sus palabras de recibimiento, le confirma como enseñante: "Padre, esta es tu casa; vivirás entre nosotros enseñándonos y serás nuestro Padre" 8.

El gobierno tenía el convencimiento de que el mejor

7 Lotería, Panamá (Febrero 1961) p.83.

8 V. RD, n. 7; V. CD, n. IV. 
modo de civilizar a los indios era la catequización o misiones, pero en 1908 ya afloraba la idea de los liberales que creían que el comercio sería el mejor sistema de civilizar a las tribus bravas. El P. Gassó cree por el contrario que el comercio, o lo que es lo mismo la codicia, es lo que acaba con los indios; y pone el ejemplo de los norteamericanos.

Su labor se ve, con relativa frecuencia, interrumpida por los viajes a la capital para resolver los problemas que le van surgiendo. El 25 de septiembre de 1910, regresa de Panamá con un carpintero jamaicano y el P. Bernardo González ${ }^{9}$. El primero se encargaría de la construcción de la iglesia de Nusatupu, Ilamada desde la aceptación de la fe, Isla del Corazón de Jesús. El segundo, se dedicaría de lleno a la enseñanza de la lectura, escritura, cantos y catecismo. En expresión del padre Gassó, "hace vida de un perfecto maestro de escuela"10. El misionero había experimentado los difíciles desenlaces que acarreaban sus ausencias, hasta tal punto que, en ocasiones, tenía que empezar casi desde cero su labor.

Por eso en su viaje de 1910 deja al $\mathrm{H}$. Domingo González en la misión, y confía en poder extender su labor si hay más gente decidida a ir a las islas, pues ha recibido peticiones

9 El P. Gassó contó en ocasiones con la ayuda de un padre y un hermano de su Compañía. Su labor misional se extendía a toda la costa incluido el distrito de Santa Isabel.

10 V. RD, n. 7; V. CD, n. IV. 
de otros jefes.

En este viaje va acompañado por dos indígenas y el encuentro con otros misioneros, hace que el Padre les proponga como ayudantes. Uno para maestro de Narganá y el otro para otra isla. A lo que el cacique José le responde: escoge uno prudente, y que nos quiera como tú. Las cualidades que pedía el misionero para sus colaboradores eran, habilidad en los oficios, facilidad para aprender la lengua y animosos para sufrir ${ }^{11}$.

El P. Benito Pérez fue uno de sus más asiduos colaboradores. Pero los diversos documentos enumeran siete más, que estuvieron por la misión karibe en distintas temporadas y con diferentes tiempos de estancia.

El testimonio de los que le conocieron merece relevancia por la información de primera mano que proporcionan, y ellos afirman que nunca descuidó la enseñanza de las letras, siempre que le fue posible, y que ponía especial interés en la enseñanza de la niñez, en lo que concernía a los rudimentos de la lectura y escritura, para así ir introduciendo la educación y la cultura como base firme de su labor apostólica ${ }^{12}$.

Abre la primera escuela para niños en Yantupu. Esta escuela se conoció con el nombre de "ESCUELA DE CATEQUESIS",

11 Lotería, Panamá, no 66, p. 100.

12 Documentos de la Biblioteca de Cartí Sugdupu. 
lamenta el padre que por falta de medios no haya podido perfeccionarla. En su casa llega a tener internos, hasta una docena de muchachos, que él mantiene con las ayudas que le dan los habitantes de las islas que lo aceptan.

La acción evangélico-educativa se mantuvo unida en el transcurso de los años, dirigida por los padres Claretianos, y por las madres Franciscanas de María Inmaculada posteriormente. El énfasis de esta labor dual se iría cambiando con el paso del tiempo, llegando el momento en que ha predominado la evangelización como acción propia de los misioneros.

El jesuita tiene unos conocimientos elementales de la lengua karibe y esto facilita su acercamiento; pero hubiera sido contraproducente que llegara dominando su lengua, pues los karibes pensarían que al igual que les había arrebatado ésta, les quitaría a sus mujeres. Le habrían acusado de usurpador de su idioma, seguramente, sabiendo lo celosos que son de todo lo suyo. Comienza a enseñar la lengua oficial de la joven nación, que iguala a todos los habitantes y hace subir un peldaño en la escala de la civilización. Si se conseguía esto, se habría logrado uno de los objetivos del gobierno: que abandonaran las lenguas bárbaras y hablaran el idioma oficial. El presbítero valenciano hace uso de la lengua kuna, como él mismo nos cuenta en discursos que causan admiración en la concurrencia. Al mismo tiempo, enseña la lectura y escritura del castellano. 
Hay que señalar la experiencia que ya tiene en lenguas indígenas con los indios mexicanos y ecuatorianos, donde había estado trabajando; llegando a confeccionar unas gramáticas rudimentarias de esas lenguas ${ }^{13}$.

En abril de 1907, de regreso a Panamá, se entrevista con dos caciques de Tupile que allí se encuentraban. Aprovecha para ir preparando su entrada en la mencionada isla. Así mismo, es informado por el cacique Enrique, que en su primera visita lo rechazó, que el sahila del sector oriental, Inanaquiña, ha viajado a Colombia para pedir refuerzos en Bogotá y luchar contra Panamá. Es patente la división de los indios; por un lado los que aceptan a Panamá que corresponden al sector central, y de otra parte los que se consideran colombianos ubicados principalmente en el sector oriental.

La entrada en Tupile se realizaría en mayo de 1909, y les presenta una credencial del gobierno para Róbinson, nombrándole gobernador de todas las tribus indígenas de la costa atlántica, con la entrega de un bastón bendecido por el señor obispo, que simbolizaba el mando y la jurisdicción con que había sido investido. Comenta el escrito que es deseo del gobierno educarlos y fomentar la industria entre ellos a fin de que puedan gozar de las ventajas de la vida civilizada. Para el sahila de Tupile lleva otro bastón que le entregará por admitirle en la

13 En Quito permaneció desde 1895 hasta 1902; y en Chihuahua (México) desde 1902 al 1906. 
isla 14 .

Con la creación del asentamiento de Puerto Obaldía, dos años después de su llegada, se pondría frontera y freno a esta corriente que quería la soberanía colombiana. El P. Gassó está presente en la fundación que queda establecida con una dotación de dieciocho policías. Otro de los motivos de fundación del cuartel fue controlar a los sublevados que atacaron Tupile por aceptar al sacerdote.

Pasa el misionero el mes de mayo de 1907 en Panamá y da los últimos toques al catecismo y gramática kuna que, al año siguiente en enero mandaría imprimir en la editorial católica del Sr. Casals de Barcelona, en el tiempo que duró su viaje a la Península acompañado del nativo Estanislao Acosta. Comenta que el diccionario ya cuenta con veinte mil vocablos. Pujada señala, refiriéndose al catecismo karibe-kuna, que se realizaron dos ediciones ${ }^{15}$.

En julio de 1908, después de su regreso de España, sufre una grave enfermedad y es llevado por los indígenas de confianza hasta Santa Isabel, para posteriormente llegar a Panamá. En este tiempo de convalecencia expone la necesidad de un hermano carpintero y señala que José $\operatorname{Sec}^{16}$ le ha dado una

\footnotetext{
14 Lotería, Panamá (Febrero 1961) pp. 80 y 88.

15 T. PUJADAS: Misión del Darién. p. 358.

16 Este terreno conocido con el nombre de Cola de la Isla estaba pegado a Narganá y era para servicio de Dios y de la Santa Iglesia, y si el padre
} 
isla donde abundan las frutas y va a poner unas chivas y un par de vacas, que le guarda en la actualidad el Gobernador de Colón ${ }^{17}$. Las cinco chivas lecheras serían las que les proporcionarían uno de los pocos alimentos que consumían, según palabra del $\mathrm{H}$. Gurruchaga. Estas habían venido de España con él.

Les predice muertes o anuncia castigos del cielo, cuando se oponen a su labor o se le enfrentan de un modo muy director, cumpliéndose y ganando prestigio entre la indiada. Las cartas del Presidente amenazándoles con el envío de policía también les atemoriza. Teme perder el apoyo del gobierno en octubre cuando suba al poder el liberal Obaldía; ya que cuando ocupaba la vicepresidencia le manifestó que había dos métodos de entrar con los indios, uno las misiones y el catecismo; y otro moderno, con la pica y el rifle en la mano, y él era partidario de este segundo ${ }^{18}$.

En Agosto de ese año, una vez recuperado vuelve a Narganá acompañado del H. Gurruchaga, a quien presenta a los indios como su hermano y hábil en múltiples oficios.

El intento de establecimiento de la misión bautista

muriese sería para los sucesores que viniesen. Firmaron el documento Róbinson, José Sec, Oloitilikinia y el P. Gassó en fecha 2 de julio de 1908. Llegaron a permitir que las chivas se ubicaran en esta porción de tierra.

17 Cartas edificantes de la Asistencia de España, Compañía de Jesús, 1910, pp. 198 y 201.

18 Cartas edificantes de la Asistencia de España, Compañía de Jesús, 1910, pp, 201-202. 
hizo que los indios se unieran y apoyaran al sacerdote jesuita, pues temían más a los yanquis, de quien tenían noticias que destruían a los indios. Tras el intento de establecerse los protestantes en Tupile, siguen las peticiones de estos en en Ministerio de Gobierno. El misionero consigue un documento que prohibe el tránsito de extranjeros por la región, sin permiso escrito de la autoridad de Colón ${ }^{19}$.

\subsection{La situación que encuentra el}

\section{misionero.}

Los nativos de San Blas, acostumbrados a vivir en libertad y $\sin$ interferencias de elementos extraños a su cultura, ven peligrar su orden y estructura social con la llegada del nuevo waga.

El recelo a dejar allí algún extranjero, nace del temor que sienten a que éstos les quiten sus mujeres. Ya hemos dicho que la mujer en la sociedad kuna ocupa un lugar preponderante. Róbinson sentía admiración por el misionero porque, en el tiempo que estuvo hospedado en su casa, siempre miró a su mujer, de la misma manera que a las que iban a su tienda, con recato y mirada casta.

Comenta a este respecto el P. Gassó en su diario, la

19 Ibidem, pp. 288 y 290. 
buena impresión causada en los indios, de que no hubiera mujeres en casa del señor Obispo cuando el cacique y su esposa fueron a la capital a bautizar al hijo en abril de 1907: "No poco les admiró que en la casa del señor Obispo no entrase ninguna mujer, sino sólo Eva, y eso por venir con su marido y ser el caso tan raro. Esto que vieron fue muy ponderado entre los indios y ganamos así su confianza"20. Son padrinos de la criatura el Presidente de la República y su señora. Aprovechando el jefe del gobierno para prometer una partida de dinero en los presupuestos, auxiliándoles en todo lo posible y dándoles animales de cría, vacas, chivos... y lo que se criase de estos entregarlo a los casados cristianamente.

El les había dicho que no tenía mujer y que no pensaba tenerla. Esto choca con su mentalidad y les causa admiración.

Sienten rechazo hacía el extranjero que quiere quedarse también en su tierra, porque se presenta como su aliado $y$, en ocasiones, lo es. Pero llega a volverse contra ellos y les van despojando de sus tierras y posesiones. En su recuerdo estaban los contactos tenidos con los europeos. Recordemos que esta tribu estuvo aliada con varias naciones europeas, y siempre se unía a una nación para deshacerse de otra.

Otro de los motivos del rechazo es su deseo de permanecer como están y mantener su modo de vida. No son 20 V. RD, n. 7; V. CD, n. IV. 
partidarios del ritmo de la vida civilizada, que limita mucho la libertad. Ellos se sienten completamente libres y no añoran nada de la vida civilizada. Entre ellos hay individuos que conocen la civilización, algunos de forma muy variada, pues han viajado por diversos paises sirviendo en barcos. Dice el P. Leonardo que son los que más se aferran a sus tradiciones, pero que no quita que les entren algunos usos, y no los mejores de la llamada civilización 21.

Los que aceptan al misionero son los menos; casi se puede decir que se reduce a Róbinson y un número muy pequeño de colaboradores de éste, pues cuando falta el jefe, los demás no se atreven a aceptarle. Queda claro en la segunda entrada del misionero al archipiélago. Róbinson, al aceptar su elección como sahila de Narganá, ya había dejado patente sus ideas en pro de la civilización.

Los indios del sector occidental o de Kartí, igual que los del oriental, muestran su rechazo a los indios de la zona central, por aceptar al P. Gassó, más que rechazar directamente a la persona del predicador.

Unas veinte islas están contra estas dos que han admitido al padre22. En 1907 se prepara un levantamiento encabezado por los indios del oriente (Mandungandí, Mordí, Soguti

21 Ibidem, p. 58.

22 Ibidem, p. 40. 
y Arquía) para atacar a los occidentales, por favorecer y aceptar la civilización23. Róbinson, ante estas amenazas, crea dos grupos de guardias y policías para vigilar a los que llegan de fuera y a los que estaban dentro, pero inconformes. Llega a construir cuatro trincheras para la defensa del pueblo, en caso de ser atacados por los enemigos de la civilización.

Es evidente que existe un grupo que no quieren al predicador, en las islas que le aceptan digamos que de modo oficial, éste se hallaba integrado por los que ven caer su estatus y su prestigio social. Son los encargados directos de guardar, transmitir y poner en práctica sus tradiciones. El valenciano se va enfrentando paulatinamente a ellos. En el diario aparece que se resisten los absogedi y sus familias. $Y$ comenta que Corazón de Jesús cuenta con seis de estos 24 .

Con la llegada a Narganá del jesuita, se incrementa la antipatía que sienten los indios hacia la civilización que quiere cambiar su forma de vida y su cultura, que ha sido de siempre. Ellos lo argumentan así: "Dios creó al perro y hasta hoy es perro. Dios creó al tigre y hasta hoy es tigre. Dios crió la gallina y hasta hoy es gallina. Crió Dios al indio y ahora no quieren dejarnos ser indios"25. La civilización destruía lo que el indio considera esencial de su naturaleza de indio, su cultura,

\footnotetext{
23 Ibidem, p. 42.

24 Ibidem, pp. 30 y 40.

25 Ibidem, p. 15.
} 
tradición y libertad.

Constata el P. Gassó que el kuna es una persona inteligente: "Son pues estos salvajes excepcionales y me parecen los más inteligentes de los que he tratado en el Ecuador y en México"26. Este don de los indios le facilitaría su trabajo evangelizador y educativo, salvando siempre su voluntad caprichosa. La labor de los antiguos misioneros también se aprecia en sus creencias, lo que hace que la nueva religión no sea divergente de la suya tradicional ya que ha ido asimilando la predicación de anteriores evangelizadores 27.

Desde el siglo XVI tienen contacto los kunas con misioneros. Primeramente con franciscano y dominicos, y más tarde, con capuchinos y jesuitas. En varias ocasiones hace mención el padre Gassó de su hermano en religión padre Balbuguer, que les predicó en 1740.

El kuna es profundamente religioso y por esto es por lo que no se muestra contrario a la nueva religión. El cree en Paba, su dios, que les ha dado las tierras y les ha enviado profetas para que sean mejores y no vivan como animales. Ellos, después de muertos, irán a la casa de Paba. Tienen cuatro preceptos que cumplir, como ya dijimos en el capítulo segundo. Tal vez esta concepción religiosa sea el bagaje de los sucesivos años de

26 Ibidem, pp. 58-59.

27 Ibidem, p. 52. 
predicación misionera cristiana.

La lengua utilizada por los nativos del Atlántico es el kuna, pero entre ellos no faltan quienes tienen conocimiento del inglés, como Róbinson, por sus correrías en barcos norteamericanos. Así mismo, hay indios que conocen el castellano, por su relación con los colombianos; y sobre todo, por el contacto con los barcos que surcan su mar con la venta y compra de mercancías.

Una parte de los indígenas ha aceptado la educación de sus hijos, pero no en su territorio. Han permitido que sus hijos vayan a la ciudad y allí se instruyan para, de regreso, enseñar a sus paisanos lo aprendido. Por esta razón, manifiestan que no quieren a nadie en las islas. Ellos han enviado ya a sus hijos a estudiar a Panamá para que no tenga que ir allí ningún extranjero. Ante esta negativa de los indios, el Presidente de la República escribe: "Comprendo que lo que Ustedes dicen está comprobado con el envío de sus hijos a nuestras escuelas, a los que estamos educando para que sean ellos quienes lleven la enseñanza a Ustedes, y no individuos extraños a su raza".

El Gobierno respeta la postura indígena. Pero había que ver la utilidad de estos estudios y qué repercusión podían tener en la comarca de San Blas. Cierto es que este sistema elegido para educar era el más rápido, pero abarcaba un número reducido y más pequeño de muchachos. Estos, rodeados de todo lo que se 
consideraba civilización, asimilarían más rápidamente este modelo que, posteriormente, tendrían que llevar a sus hermanos de raza: "Mucho me complace saber por la lectura de sus cartas, que Ustedes están animados, por deseos de progreso y que son amantes de la enseñanza, que significa el adelanto de los pueblos"28. En este tiempo están estudiando en Panamá los muchachos becados que Róbinson llevara en 1906.

Le surgen enemigos al Padre, incluso fuera de los indios. Así, los protestantes predisponen a los nativos para que no le acepten; de igual manera, algunos comerciantes que tocan aquellas costas. Ante esto, sale en su defensa el sahila Charles, diciendo que los blancos no quieren que esté allí el padre, porque con su roce se harían muy hombres y no les podrían ya engañar29.

Cuando llega el misionero, ya existe en Narganá alguna tienda de abarrotería. Durante su estancia, él constata que hay tiendas de abarrotes y de ron. A consecuencia de esto, tuvo que cambiar la ubicación de la casa-iglesia.

Con el paso del tiempo hay indios que le aceptan por la religión que predica, aunque estos sentimientos son, en muchas ocasiones, de temor. El apela repetidas veces al texto bíblico "Initium sapientiae timor Domini", que justificaba muchas conversiones en tiempo de la conquista. El 15 de junio de 1907 el

28 Ibidem, p. 14.

29 Ibidem, p. 38. 
sahila de Kuebdi expresa su deseo de enviar niños al Padre para que aprendan el camino del cielo ${ }^{30}$, y una semana más tarde, acuden el sahila y voceros de Tupile, con las mismas intenciones. Una vez hechas las presentaciones, le comentan que algunos de su isla ya saben el Avemaría, pues Róbinson y Soo se lo habían enseñado mientras el sacerdote estaba en Panamá31.

Como argumentos de su autoridad usó los divinos y los humanos. Si no se convertían y aceptaban su presencia allí Dios les castigaría y serían presas del infierno. $Y$ en otras ocasiones la amenaza es que vendrán fuerzas de Panamá y lucharán contra ellos si atentaban contra su vida o sus enseres.

Los ejemplos que conocen los indios de los llamados civilizados, de su propia raza, es de lo más negativo a juzgar por los comentarios que refiere el P. Gassó, de dos jóvenes educados uno de ellos en Estados Unidos y el otro en Rusia32.

\subsection{Labor que realiza el padre Gassó.} sus aportaciones.

En el campo escolar vimos que el señalaba como un maestro, unos doce niños sabían escribir el abecedario en la

\footnotetext{
30 Ibidem, pp. 46, 48 у 90.

31 Ibidem, pp. 29-30.

32 Lotería, Panamá, no 63 (1961) p. 84.
} 
pizarrilla. Al poco tiempo, encarga al hermano González las tareas de la escuela y, una vez que su labor se va afianzando, encarga al padre González las labores docentes. Las actividades que desarrolla se pueden resumir en la doctrina y la escuela.

Usa métodos y materiales didácticos que faciliten la comprensión y que lleguen pronto al docente. Se hace realidad el viejo refrán "vale más una imagen que mil palabras". Las estampas, cuadros, imágenes, objetos y símbolos dan buenos frutos a la hora de enseñar. Esto iría apoyado con sus conocimientos de la lengua kuna.

Su actividad no se acaba con los que llegan a él voluntariamente. Realiza visitas por las casas: cada día recorre dos o tres casas para instruir con las estampas a los viejos que no se atreven a ir donde él33.

Cuando está retenido en Corazón de Jesús, pide permiso para ir por las casas explicando los cuadros de la doctrina.

Se sirve, para sus enseñanzas, de otras personas, como son los alumnos más adelantados. Con ellos va a enseñar la doctrina a Corazón de Jesús ${ }^{34}$. También su fiel colaborador Róbinson le ayuda en las tareas de conversión; del mismo modo que sus más directos seguidores, los sacristanes, que en cierta

33 V. RD, n. 7; V. CD, n. IV. p. 47.

34 Ibidem, p. 30. 
ocasión -dice- que están catequizando mediante los cuadros a dos ancianos, uno de setenta y ocho años, y otro de ciento treinta ${ }^{35}$. Estos alumnos aventajados serán los maestros en ausencia del sacerdote. Un capitán de barco que conoce bien el kuna, también le ayuda a explicar la doctrina católica.

Los muchachos por la mañana pronto, hacen primero los ejercicios religiosos y escolares, para emprender a continuación las tareas de pesca hasta la hora de la comida.

Funda la escuela que se conocería con el nombre de "Escuela de Catequistas". Llegó a contar con cincuenta alumnos. En su casa tuvo un grupo reducido de muchachos, de los que se encarga él personalmente. Atiende sus necesidades básicas y los educa ${ }^{36}$. Esto sería el primer internado que funciona entre los indios, aunque de un modo muy rudimentario. Más adelante hablaré del internado de los claretianos, en el último capítulo.

Enseña la lengua nacional y les motiva para que la aprendan argumentando que luego la usaran en sus viajes a la ciudad, de ese modo no les engañarán y se harán respetar cuando tengan que negociar.

$\mathrm{Su}$ actividad se despliega con todos los grupos de la población. Acomoda su tarea al ritmo de los habitantes: "A la

35 Ibidem, pp. 47-49 y 91.

36 Ibidem, p. 38. 
salida del sol, misa y rezo oficial de la doctrina, para muchachos y gente no ocupada; terminada la doctrina, los muchachos van a la pesca, hasta las doce, y las niñas a servir de niñeras (hay muchísimas criaturas) o al río,... a eso de las diez, vienen las mujeres y las niñas a la casa capilla donde, en corros, aprenden a rezar, mientras cosen algunas, y las explico las estampas de la doctrina. (Las mujeres acostumbran a coser cuando asisten a la casa del congreso a escuchar cantos de la tradición). A la hora, las dejo y siguen las que quieren allí, mientras empiezan a llegar algunos muchachos"37.

Los habitantes de las otras islas, igual que los del continente, sienten curiosidad por su labor y se acercan desde el Bayano o las islas para contemplar su misión. Algunos llegan a quedarse en Narganá como fieles seguidores.

Se acerca a la cultura a cambio de recibir los conocimientos de la cultura indígena. En septiembre de 1909, el misionero hizo un trato con un absogedi kantule. El indio le enseñaría todo lo que él sabía acerca de su oficio, y el Padre haría lo mismo. El padre escribe lo que le relataba el indio y cuando se lo lee, el indígena dice que quiere aprender a escribir así. Nos cuenta que los tratados kunas estaban escritos en caracteres jeroglíficos 38 . La escritura y la lectura despierta en

37 Ibidem, pp. 2-4 y 47.

38 Ibidem, p. 81. 
los indios, que usan tablillas, el deseo de aprender.

Ya vimos que el padre conoce la lengua kuna, pero sigue incrementando sus conocimientos y, para ello, se sirve de los muchachos que contestan a sus dificultades y le ayudan a elaborar el vocabulario karibe 39 . También prepara un mapa de la costa e islas del archipiélago de San Blas. En las islas donde entra, hace un censo de los habitantes.

Además de la actividad que él desarrolla en materia educativa, envía muchachos a educarse en los colegios de la capital, otros sirven en casas particulares, donde se hacen cargo de los niños, al mismo tiempo que les permiten asistir a la escuela.

Refuerza el valor de la autoridad. Utiliza el antiguo sistema de las reducciones, con la entrega de "vara de mando" que simboliza la autoridad. Esto da prestigio y respeto a la persona. Enseña que el sahila es representante de Dios y, como tal, se le debe obedecer y respetar. Los primeros en aceptar esto son los propios jefes, que ven aumentar su prestigio y autoridad. Quieren que el padre lo enseñe así a los indios. Esta autoridad se ve en todas las actividades de la comunidad. La actividad religiosa también está marcada por este cariz de poder. Ellos presiden las ceremonias religiosas, e incluso se llega a interrumpir cuando entran las autoridades. Estas se sirven del

39 Ibidem, p. 47. 
sacerdote para reforzar y acreditar su autoridad.

El gobierno se sirve de los regalos y los títulos para atraer a los dirigentes indígenas; efectuando nombramientos de general o gobernador.

El P. Gassó era un agente del gobierno, que es quien le autoriza la entrada allí y le paga su trabajo. Pero por otra parte tiene que disimular su pertenencia a la Compañía de Jesús; mal vista entre los liberales y masones, por ese motivo no utiliza el fajín, distintivo de la Compañía, ni se hospedaba en la residencia de los jesuitas, lo hacía en el palacio del obispo cuando viajaba a Panamá40.

Desde 1910 a 1912 ocupan la presidencia de la nación cinco mandatarios, alternando los conservadores y los liberales. Lo que perjudicó la acción civilizadora, ya que la confianza depositada en la Iglesia Católica se mantenía o disminuía según la tendencia del gobierno. Esto tuvo repercusión también en la Escuela de Indígenas regentada por los $\mathrm{HH}$ de la Salle, a quienes se les retiró del puesto, fracasando posteriormente esta misión.

El misionero pretende que se produzca un cambio en todo lo kuna, para ellos cambia los nombres de las islas, por nombres cristianizados 41 . Del mismo modo procede con el de las

40 Lotería: Panamá, nº 66, p. 100.

41 Narganá de S. José, Corazón de Jesús, Inmaculada de Río Sidra y S. Ignacio de Tupile. 
personas, asignándoles nombres del santoral católico. La casa del congreso la llama "casa de los errores" en contraposición con la iglesia que es la "casa de Dios".

El misionero les promete que no introducirá a los comerciantes blancos, ni demás extranjeros, pues algunas islas se resisten a recibirle por este motivo. La causa fue que en su visita a España con Estanislao le mostró muchos miembros de su compañía y este llegó diciendo que tenía muchos hermanos y padres y que los iba a llevar y se apoderarían de todo, mezclándose con ellos ${ }^{42}$.

Las faltas graves son castigadas en público con permiso del P. Leonardo, como ocurre con la mujer casada que comete un desliz y recibe 25 azotes $^{43}$.

Además de colocar niños en colegios de la capital, inicia la costumbre de poner indígenas en familias pudientes que se comprometían a darles educación; pero que principalmente se aprovechaban de un servicio barato en las tareas de la casa.

Por la mediación del P. Gassó se consigue del gobierno, limitar la entrada de pescadores de tortuga en la zona de los kunas. El misionero quiere que se respeten los límites históricos de mediados del sg. XIX, pero Róbinson recorta la frontera,

42 V. RD, n. 5; V. CD, n. III.

43 Lotería: Panamá no 66 (1961) p. 99. 
perdiendo de este modo los kunas 44 .

Si con la separación de Panamá se había producido una división entre los kunas, la entrada del misionero provoca más divisiones, acentuándose la separación de los que reconocen el estado panameño y los que quieren pertenecer a Colombia, o lo que es lo mismo vivir sin ingerencias de ningún tipo.

Entre las obras escritas se cuentan una doctrina cristiana en castellano y karibe, la gramática y diccionario con más de veinte mil voces, mapa de la región y censos de población de las islas.

La delicada salud del misionero y los problemas económicos y políticos hacen que en diciembre de 1912 el jesuita tenga que abandonar la misión de los kunas.

Se puede entrever que el gobierno considera la acción del misionero como un primer paso, pero cree que esto no basta y al mimo tiempo alienta unas espectativas con respecto a las tierras ocupadas por los indígenas, las cuales cataloga de ricas.

Muy acertada es la recomendación del Sr. Valdés al pedir que los maestros que para allí se nombren sean casados y maduros; los indígenas de este modo no tendrían miedo a perder sus mujeres, y las tareas educativas estarían secundadas por ambos esposos. La conducta de los maestros es algo que se debía haber tenido más en cuenta. Como veremos en los capítulos que

44 Lotería: Panamá, no 63 (1961) p. 82. 
siguen este tema quebró en muchas ocasiones los progresos. Se quiso llevar la educación sin seleccionar los agentes transmisores de ésta y el resultado en más de una ocasión fue contraproducente. Es cierto que no se contaba con suficiente personal como para elegir; pero hubiera sido más positivo restringir el número y que fueran adecuados a poner muchos pero incompetentes. Lo que es lo mismo, se debía tener más encuenta la calidad en lugar de la cantidad.

El esfuerzo del misionero llega hasta pagar los estudios a varios niños en la ciudad.

Como conclusión puedo decir que la táctica utilizada en esta primera época corresponde al sistema de las reducciones empleadas por los jesuitas. Son abundantes las directrices que se emplean tres siglos después y que recuerdan plenamente aquella empresa.

Los misioneros son los que designan la autoridad civil y ésta actúa bajo su supervisión. El gesto de entrega de la vara de mando ratificaba la autoridad indígena, a pesar de que los kunas poseían una organización social y una autoridad elegida democráticamente.

El absogedi kuna correspondería al chaman de las reducciones, el cual ve caer su prestigio y poder ganando en contraposición la figura del misionero que se siente agraciado con poderes sobrenaturales. 
En las reducciones jesuitas se usó el libro de Ordenes, donde se anotaban los principales hechos ocurridos; y el P. Gassó utilizó el libro de la parroquia de Narganá para hacer sus anotaciones, complementándolo con su diario personal.

La incursión misionera en el caribe no se lleva a término por iniciativa del obispo, al igual que en la conquista y colonización la idea surge del gobierno y es el quien subvenciona la misión.

Uno de los propósitos del sacerdote es mejorar las condiciones de vida del indio; sin una mínima calidad de vida no se podía comenzar la evangelización. El acondicionamiento material era imprescindible para emprender el espiritual.

Los términos de salvajes y bárbaros utilizados en tiempos coloniales para designar a las tribus hostiles aparecen también en la legislación de los primeros años de gobierno panameño.

Las disposiciones de Felipe II y Sixto $\mathrm{V}$ instaban a los evangelizadores a mantener las lenguas indígenas; el gobierno panameño considera la lengua kuna como un signo de barbarie. Este sería uno de los hechos más divergente del espíritu de las reducciones que hemos visto en los párrafos anteriores. Por el contrario se puede ver que el misionero desea conservar la lengua kuna y manda imprimir una gramática. 
7.- LA MISION PROTESTANTE 


\section{7.- LA MISION PROTESTANTE (1913-1925)}

\subsection{La educación bíblica}

El cambio de gobierno a los liberales en 1912 tuvo gran repercusión también en San Blas. La misión católica dejó de percibir la ayuda que recibía con el anterior régimen conservador y tuvo que marchar de Narganá por falta de medios económicos, entre otras razones.

Las ideas liberales del nuevo mandatario abrieron las puertas a la misión protestante que esperaba su oportunidad, favorecida en parte por las críticas de los políticos a la misión católica, que la consideraban anticuada e ineficaz. Los liberales consideraban que la catequización no era el medio adecuado para civilizar a los indígenas; ellos ponían más sus esperanzas en el comercio, de ahí su idea de establecer colonias que llevaran al intercambio con los nativos de San Blas.

Los principales protagonistas del grupo indígena en este periodo son Inapakiña, que lidera el sector oriental, deseoso de seguir unido a Colombia; Colman que parece aceptar la pertenencia del archipiélago a la nación panameña, y que tiene influencia en un gran número de islas; y finalmente Róbinson, defensor de la vinculación de la comarca a Panamá y colaborador del poder establecido, apoyado por las dos islas centrales.

Con la salida del P. Gassó, Róbinson aprovecha para 
escribir a Miss. Coope 1 y proponerla que venga a la isla de Narganá provista de libros de inglés y de su piano. Aprovechando tan generosa oferta se dirige al Presidente Porras para conseguir la autorización ${ }^{2}$. Los isleños ante la presencia de la misionera destapan su resentimiento contra el misionero católico.

La inglesa Miss. Coope hará su entrada en la circunscripción de San Blas el 28 de febrero de 1913. El sahila Róbinson la propone como maestra de los niños que les enseñará en inglés, al mismo tiempo que les mostrará el camino de Dios. Al año siguiente hacía su entrada en la isla de Corazón de Jesús, Martha Purdy, siendo bien recibida por Róbinson y Joe Hardy. Entre los alumnos más sobresalientes de esta misionera se pueden contar Frank Wilbur y Peter Miller, quien viajó a Estados Unidos y regresó de allí graduado en 1931.

Dos años después cuando se crearon las escuelas nacionales, la maestra Ana M. de James se queja de que las primeras cláusulas del convenio firmado por las misioneras en los comienzos de abril no se cumplen y que la labor conseguida por la escuela oficial es destruida por éstas; ya que reciben a las niñas con la argolla de la nariz ${ }^{3}$.

1 Desde su primer intento realizado en la isla Mono para predicar las ideas religiosas estaba retirada en Panamá dedicada a labores de costura.

2 M. VANDERVELDE e M. IGLESIAS: Nacido Primitivo, Traducción de Guillermo Judson, Velde Press, Emmetsburg ,p. 20.

${ }^{3}$ V. RD, n. 50 
Por otra parte la matrícula de la escuela protestante era más numerosa que la de la escuela estatal. Claudio, como presidente de la asociación de padres, emprende una campaña para que aumente la matrícula de ésta, lo que le vale la cárcel, pero las quejas ante el intendente, llevan al jefe de El Porvenir a visitar a Róbinson que promete junto con los padres que enviarán a los hijos a la escuela nacional.

Fechada en julio de 1919 una carta de Miss Coope al intendente, propone a éste, que ya que los niños corren desnudos y sin refrenamiento por la isla, debido a la falta de escuela, que ella puede impartir clases por la mañana a los niños que asisten a la escuela pública por la tarde; y los que asisten por la mañana ella los puede atender por la tarde. Argumenta que ella se sujetará a su convenio de enseñar la Biblia en español e inglés. Con su propuesta se evitaría que los niños pasen medio día ociosos; ya que la escuela pública no tiene capacidad para atender a todos de una vez 4 .

El intendente propone a la misionera, tras los incidentes de la policía, que amenacen a las jóvenes que usen alzamuros y guinis, con no ser recibidas en su escuela si se obstinan en usar esos adornos.

Se queja la misionera de que los muchachos trasnochan y tampoco le permiten a ella descansar. Comenta que

4 Al existir un grupo numeroso de escolares y tener una sola maestra la escuela recibía normalmente a los niños por la mañana y a las niñas por la tarde. 
su compañera Evans está recibiendo clases de español. Piensa que le será fácil aprenderlo ya que ha estudiado francés y latín. Reconoce que su labor de enseñar es desinteresada y sin sueldo. Que en su visita a las escuelas pudo comprobar que los muchachos estaban adelantados.

Le comenta que quiere enseñar, no por estar ocupada ella, sino por hacer algo que le gusta, educar. Esto le ayudaría a ella también en sus estudios del castellano que está haciendo5.

No se hace esperar la negativa del intendente a la propuesta de enseñanza; pues juzga que así se perdería la autonomía que el Gobierno quiere mantener en lo tocante al ramo de enseñanza. Desea que los niños asistan a la escuela nacional6.

El intendente Vaglio ordena, en julio de este año, al jefe del destacamento, que vele por el cumplimiento del convenio firmado por las misioneras protestantes. $Y$ comprobar que las niñas que asisten a su escuela-bíblica no usan alzamuro. Pone en su carta que le ha pasado una nota a la misión para que coopere con el Gobierno en la extirpación de este uso. Le llega a permitir amonestarlas buenamente si no cumplen esto7. Pero la falta de solución en este asunto hace que el intendente pida un jefe para el destacamento de Narganá donde surgen los

\footnotetext{
5 V. RD, n. 64

6 V. RD, n. 65

7 V. RD, n. 61
} 
disturbios, fomentados por Miss Coope 8 .

El intendente Vaglio solicita de la Srta. Coope un informe detallado acerca de las labores escolares. Este contesta que ha recibido su carta detallando las actividades escolares. $Y$ le pide que no se canse de enseñar a sus discípulos en el idioma español y la Biblia. Le da ánimos para que siga con su método de enseñanza y prédicas. Recuerda al mismo tiempo que la Biblia que usa tiene una parte en español y es la que debe usar para que sus alumnos progresen en el idioma oficial ${ }^{9}$.

Evans Purdy acompañada del ministro de los Estados Unidos expresa su queja ante el secretario de Instrucción Pública, por las restricciones que se les ha impuesto en la enseñanza. El jefe de policía, antes de las vacaciones ya las había amenazado con que no podrían enseñar más. Comenta que en seis años de permanencia en la comarca de San Blas ha enseñado diariamente inglés, español, lectura, escritura, aritmética, ortografía, aritmética comercial, e historia sagrada. A partir de ahora solo podrían enseñar dos horas al día y fuera del horario escolar, y una hora de estas estaría dedicado al español. Considera que esta medida no respeta los derechos de las maestras misioneras ${ }^{10}$.

Las quejas de las misioneras tienen eco en todos los

\footnotetext{
8 V. RD, n. 83; V. CD, n. XXVIII.

9 V. RD, n. 93

10 V. RD, ns. 91 y 92
} 
despachos, y el inspector de Instrucción Pública de Nombre de Dios solicita del intendente los datos que le han llevado a tomar su decisión restrictiva con la actividad de las misioneras, pues se los ha demandado el secretario de Instrucción Pública ${ }^{11 .}$

En 1921 en el mes de septiembre se reúnen los ancianos y jóvenes de Narganá para manifestar su protesta por la presencia de las misioneras evangélicas, que quieren hacer obligatorio el aprendizaje del idioma inglés para los niños y niñas de ambas islas. Comentan que durante la dominación colombiana ese gobierno no se preocupó de su instrucción y se vieron obligados a mandar a sus hijos en buques que navegaban por las costas a estudiar a Estados Unidos; pero en la actualidad la situación es muy diferente, ya que el gobierno panameño les ha proporcionado escuelas para aprender en castellano.

Proponen que se clausure la escuela protestante, o se limite a dar clases sólo los domingos por el día y por la noche. Se suman a estas las quejas de las maestras nacionales, que dicen que cuando son preguntados los escolares contestan en ingles.

Tras la revuelta de Río Azúcar y la muerte de Claudio Iglesias, Miss. Coope tiene que salir de Narganá y se retira a Panamá donde sigue sus labores de mantelerías de lino. Pero deseosa de volver con sus indios visita al Presidente Belisario para que autorice su regreso a las islas; pero el mandatario 
lamenta que no sea católica y le traiga otro grupo de mujeres como ella. Uno de los impedimentos mayores es que el obispo le dice al Presidente que deben mantener la religión católica. Le llega a insinuar que se convierta al catolicismo.

La tenacidad de Miss Coope se ve recompensada con la autorización del Presidente Porras que el 23 de febrero de 1923 transige en su deseo de volver con los kunas, pero le advierte que el gobierno ha emprendido una acción misionera entre los indios. $Y$ que para que lleguen a ser ciudadanos panameños tienen que hablar el castellano. Expone que debido a la falta de unión entre Iglesia y Estado, ella tiene libertad para enseñar cualquier fe, pero ha de hacerlo en el idioma castellano. Concluye la entrevista dejando bien claro que esa es la única restricción.

Pero este tiempo que prometía paz y progreso no duró, pues la misionera se vio envuelta en los conflictos de viejos y jóvenes, y clausurarían su escuela12.

La política de becas, usada por el gobierno y la primera misión católica, fue también empleada como medio de propagación de sus ideas religiosas, a la vez que de educación, por los miembros de la iglesia metodista. En 1916 concedían las primeras siete becas a indígenas de San Blas en una escuela de Venezuela. Seis años después eran adjudicadas otras cuatro becas a otros tantos muchachos en los Estados Unidos. La guerra mundial tuvo su repercusión, ya que alguna de estas becas se vio

12 M. VANDERVELDE e M. IGLESIAS: Nacido Primitivo, p. 36. 
suspendida por tal motivo, pues la economía sufrió un gran bajón.

Las misioneras impartían clases por las noches en inglés, pues desconocían la lengua castellana. A pesar de esto ellas se habían comprometido a dictar clases en castellano. Róbinson unido al grupo de ancianos apoya la enseñanza en inglés de las misioneras. Y la maestra nacional ve que el número de matrículas de su clase es reducido; por ello pide la colaboración de los jóvenes, presididos por Claudio Iglesias, defensor de la religión católica y todo lo que supusiera civilización y cambio.

En marzo de 1920 Duncan le hace saber al intendente que ha escrito a la Srta. Purdy exponiéndole la imposibilidad de cambiar el convenio firmado con el Gobierno porque ello supondría que los indígenas dejarían de aprender el castellano, ya que en las horas de clase oficial estarían en su clase misional13.

Otra de las quejas presentadas por el intendente se refiere a que ponen nombres en inglés a los indígenas, lo que dificulta la labor del registro a la hora de tramitar los papeles de la cedulación. Piensa el Sr. Vaglio que civilización no es enseñar idiomas y costumbres extranjeras ${ }^{14}$.

El intendente reconoce que la codificación escolar

13 V. RD, n. 98

14 V. RD, ns. 114 y 117 
obliga a impartir la enseñanza primaria en el idioma oficial, y que las otras enseñanzas pueden ser en cualquier otro idioma. Pero les recuerda que como panameños tienen la obligación de aprender el idioma nacional15.

"La Srta. Anna Coope usó como textos de clase su Biblia y algunos libros de lectura por McGuffey. Pero para comenzar, el alumno usaba lo que le quedaba más cerca, su propio cuerpo. Cada uno señalaba su oreja, ojo, nariz, pie, dedo del pie, mano, dedos de la mano identificándolos en inglés al seguir el ejemplo de la Srta. Coope"16. Y cuando se inquietaban los formaba en fila y les hacía desfilar cantando para que además de aprender música, también se hicieran con el inglés.

El intendente muestra su contrariedad a que sean expulsadas, pero ellos pueden elevar un memorial, y dada su opinión se procedería a renovar el contrato en forma que satisfaga a todas las partes ${ }^{17}$. Lo cierto es que en 1920 la escuela protestante fue cerrada temporalmente.

Sus principales enemigos han dejado de hostigarlas, pues cayeron en la revuelta de Río Azúcar, pero los jóvenes siguen persiguiéndolas. La misión protestante se queja de la labor del indio Estanislao López, que hace campaña entre los

15 A la hora de abrir su escuela las misioneras, la principal barrera que encuentran es el idioma. Por ello no tendrán más remedio que aprender kuna con sus alumnos, a la vez que estos aprenden el inglés.

16 M. VANDERVELDE e M. IGLESIAS: Nacido Primitivo, p. 22.

17 V. RD, n. 192; V. CD, n. LXXIII. 
suyos para que no asistan a las clases particulares nocturnas. Además de poner por las noches bailes frente a su casa ocasionando gran trastorno a sus labores de enseñanza. Relatan que estos bailes duran hasta las 2 ó las 3 de la mañana. Parece, por sus quejas, que el Sr. Estanislao las ha amenazado con matarlas y quemarles la casa si no salen de allí18.

En septiembre de 1921 el intendente recibe una carta remitida por Gobierno y Justicia aclarando la cuestión de las clases de las misioneras metodistas, en la cual se dice que en las escuelas particulares está permitido enseñar en cualquier idioma, por lo que no se puede obligar a las misioneras de Narganá a que dicten sus clases en castellano. Lo más que puede hacerse es aconsejarlas que den alguna clase en castellano pero nunca obligarlas a dar clase en el idioma oficial. Los indios deben saber también que no están obligados a asistir a sus clases $^{19}$.

Este cúmulo de disensiones lleva a reformar el contrato que se firmara en 1919, quedando reducida su actividad a la enseñanza en los domingos por la mañana, tarde y primeras horas de la noche, y el jueves se destinaría a los oficios religiosos. Queda claro que la asistencia es voluntaria y el intendente se compromete a darles la protección que requieran 20 .

18 V. RD, n. 193; V. CD, n. LXXIV.
19 V. RD, n. 195; V. CD, n. LXXV.
20 V. RD, n. 196; V. CD, n. LXXVI. 
La legación de los Estados Unidos demanda de Gobierno y Justicia una investigación que aclare las quejas de malos tratos presentadas por Miss Coope. $Y$ solicita que se tomen las medidas oportunas que eviten cualquier incidente desagradable 21 .

El hecho de que sea la legación americana quien se preocupe por la súbdita británica, está motivado porque ella representa a una institución americana, de la cual es miembro, y a la que representa en su labor de propagar las creencias de ésta. Pero en alguna ocasión también interviene la legación británica para esclarecer las quejas que presentan.

La falta de protección hacia las misioneras es entendida por el Gobierno, como consecuencia del desconocimiento de las leyes panameñas por parte de las protestantes. Cree el secretario de Gobierno y Justicia que Miss Coope y Mrs. Prudy ignoran lo que la constitución señala en lo referente a la religión. Así como también desconocen lo que establece Instrucción Pública referido a las escuelas privadas. No se puede apartar a los niños de su lengua oficial, enseñándoles en un idioma extranjero que les aleja de su idea de nacionalidad.

Relaciones Exteriores opina que las misiones fueron aceptables mientras el gobierno nacional no pudo cumplir con su obligación de atender a los indígenas de la costa de San Blas; 
pero una vez que el poder nacional empezó a cumplir las leyes que le obligan a atender a la civilización de indígenas, el conflicto quedó planteado de hecho. Espera que la misionera que permanece allí salga por invitación de la legación americana, aunque el gobierno nacional deba indemnizarla22.

El intendente recibe orden de trasladar al jefe del destacamento y al policía indígena Estanislao López para que no susciten mas incidentes con las misioneras protestantes ${ }^{23}$.

La religión protestante quiere también adquirir poder entre los indios y para ello nada mejor que su cacique sea un adepto. Róbinson se verá recompensado económicamente por su labor evangelizadora; y ellas estarán más seguras si cuentan con el apoyo del jefe de la isla. Róbinson rivaliza con Estanislao López temeroso de que le quite el puesto y el sueldo que recibe por dejar enseñar a las misioneras protestantes 24 .

Las quejas y los enfrentamientos se suceden y el jefe de El Porvenir considera que todo se debe al fanatismo que Coope y su compañera tienen en propagar sus creencias; considerando que lo que no favorece esto, es hostil.

Matiza el intendente Mojica que la labor del gobierno es de instrucción y que su interés es procurar que las masas adquieran el mayor grado de instrucción y civilización, dejando a

22 Memoria de Relaciones Exteriores año 1922.

23 V. RD, n. 197; V. CD, n. LXXVII

24 V. RD, ns. 200 у 204; V. CD, ns. LXXIX y LXXXI. 
un lado las creencias. Pues si se ha de apoyar algunas, en ese caso serán las católicas, dado que son las de la mayoría según reconoce la constitución 25 .

El deseo de propagación de los protestantes les lleva en noviembre a entrevistarse con el Intendente. Es el Sr. Smith quien solicita permiso de construcción en la isla de Corazón de Jesús donde reside Mrs. Purdy. La edificación sería similar a la que posee Miss Coope en Narganá. El delegado comenta que puede mandar misioneros de su secta que dicten las clases en castellano, si así lo desean. Pero el intendente le remite a Gobierno y Justicia, que es quien tiene poder para decidir en estos asuntos 26 .

La respuesta a su petición la recibe el Sr. Smith en enero del siguiente año (1922). Tras las deliberaciones oportunas del Presidente de la República y el Consejo del Gabinete. La respuesta es una negativa al permiso que solicitó y se declara cancelado el permiso revocable que se le concedió en el mes de abril. Va precedida ésta de las siguientes consideraciones:

*que la civilización de los indígenas es una cuestión esencialmente política,

*que el conducir a los indios a la vida civilizada

25 V. RD, n. 204; V. CD, n. LXXXI.

26 V. RD, n. 205; V. CD, n. LXXXII. 
implica que se identifiquen con sus conciudadanos,

*que es un hecho demostrado que lo que más une a un pueblo es la lengua, las creencias, las costumbre y sus aspiraciones,

*que la misión allí establecida les ha enseñado una lengua, una religión y unas costumbres totalmente diferentes a las nacionales,

*que la labor llevada a cabo por la misioneras ha sido ante todo de desnacionalización,

*que han provocado las disensiones entre los ancianos y los jóvenes, así como entre los que asisten a sus clases y los que estudian en las escuelas nacionales,

*que de un modo $u$ otro son responsables de disturbios que han llegado a fin tan lamentable como la muerte de Claudio Iglesias y González,

*que las rivalidades se acentuarán más en cuanto se establezcan allí los misioneros católicos que se piensan establecer con el apoyo moral y material del gobierno,

*que las misioneras han quebrantado las leyes de Instrucción Pública por no impartir su enseñanza en español, ni someterse al examen de eficiencia,

*que la libertad de religión está supeditada al orden público y este orden ha sido turbado y se mantendrá en peligro 
siempre que existan dos sistemas de enseñanza, de religión y costumbres,

*que el gobierno a pesar de mantenerse separado de la religión reconoce a la religión católica como la de la mayoría y el gobierno nacional la auxilia para el envío de misiones católicas a las tribus no civilizadas. Esta disposición limita el derecho de propaganda de cultos entre las tribus no civilizadas,

*que el gobierno vela por la conservación de todos los caracteres esenciales de la nacionalidad; y estos fines no se lograrían si se permitiera el envío de más misiones extranjeras a estas tribus de la república 27.

Las quejas no cesan, y en marzo el jefe del segundo destacamento escribe que las misioneras Coope y Purdy han continuado dictando clases en inglés a los niños de estos pueblos, a pesar de conocer la nota anterior que se remitiera al Sr Smith. $Y$ que nunca se han querido someter a lo que dispone la Codificación Escolar en el art. 42 sobre las escuelas privadas 28.

Elisa Garrido, maestra de Narganá. denuncia a las misioneras por sustraer a tres niños indígenas, de catorce y quince años, con intención de enviarlos a Estados Unidos. Los padres de los muchachos enviaron una comisión a rescatarlos, y dos volvieron desde la ciudad de Colón. Este tema lo comentaba

27 V. RD, n. 210; V. CD, n. LXXXIII.

28 V. RD, ns. 215 y 216; V. CD, n. LXXXIV. 
la maestra también con la esposa del Presidente.

Los proyectos del gobierno de mandar nuevamente misión católica se vieron cumplidos en junio, tal vez acelerados por la necesidad de contrarrestar los efectos antinacionales que acarreaba la misión protestantes. El Sr. Garrido comenta que la labor emprendida por el misionero ha dado resultados satisfactorios y que los indios han prometido no enviar a sus hijos a la misión protestante29.

No fue así cuando en 1919 apareció por las islas el jesuita Bernardo González, con recomendación del Presidente. Róbinson estaba unido a la misión protestante y manifiesta públicamente que los indios son protestantes; llegando a calificar Ana Coope al nuevo presbítero de diablo30.

Por unanimidad deciden los indígenas asistir a los oficios del padre Plácido Calella, y cesar en la asistencia a los oficios de las protestantes. Esto va unido a la decisión que tomaran Róbinson, Estanislao López y Oleluquiñe de abolir por completo el vestido de indias de las mujeres viejas, y cambiar al de gente civilizada 31 .

Pero el secretario de Gobierno pide a Mojica que le relate los actos de las misioneras que dificultaron la labor del misionero católico enviado por el ejecutivo. El jefe del

\footnotetext{
29 V. RD, n. 237; V. CD, n. LXXXVI.

${ }^{30}$ V. RD, n. 66

31 V. RD, n. 238; V. CD, n. LXXXVII.
} 
destacamento comenta la conveniencia de conseguir misión católica y la gran importancia que tiene la educación 32 .

El rechazo total que expresaron los habitantes de Narganá y Corazón de Jesús provocó en el Sr Smith y la misioneras un afán de enfrentar a viejos y jóvenes, como expresa el jefe del destacamento en carta del 24 de Junio33.

Si la nueva construcción de Corazón de Jesús no era posible, las reparaciones de la casa de Narganá y de la vivienda de Mrs. Prudy sí fueron autorizadas por el Gobierno en un primer momento y con este fin se trasladan materiales en el mes de septiembre. Quedando claro que únicamente se podrán hacer mejoras pero en ningún caso nuevas construcciones ${ }^{34}$.

Durante la construcción de la casa de Miss. Coope ya se había planteado la conveniencia de suspender dicha edificación porque se veía que la unión de esta con Róbinson hacía peligrar los planes del Gobierno35. Belisario Porras contesta con una negativa a la petición de Coope de establecerse en Narganá. Reconoce que siempre la había escuchado en lo concerniente a su labor misionera; pero su negativa es fruto de la actitud de Róbinson contraria al Gobierno, por considerar que ella tiene parte en este asunto ${ }^{36}$.

\footnotetext{
32 V. RD, ns. 244 у 245

33 V. RD, ns. 240 у 242; V. CD, ns. LXXXVIII у XC.

34 V. RD, n. 255; V. CD, n. XCI.

35 V. RD, n.34

36 V. RD, n. 37
} 
Pero esto suscita interrogantes en el intendente, los cuales son presentados a Gobierno y Justicia. La situación es que la casa que habita la miembro de la World Wide Misssionary Society en Narganá es del pueblo que la cedió temporalmente. Por lo cual si se les permite hacer mejoras adquirirían derechos sobre ella a la hora de tenerla que dejar. Cree el jefe de El Porvenir que esta cuestión, llevada adelante por el Sr. Smith tiene como única pretensión crearle dificultades al Gobierno. Dado que en la actualidad no tienen ninguna influencia entre los indios, no tiene sentido hacer mejoras en edificios que no son de su propiedad. Lo más razonable sería que abandonasen el lugar37.

Las trabas que van cayendo sobre la misión protestante hacen que en noviembre Mrs. Prudy abandone la comarca de San Blas. Y según comenta Ramón Garrido, de manera definitiva; prueba de ello es que sus pocas pertenencias son puestas a la venta por el Sr. Smith 38 .

Con la revolución de 1925 la misión protestante pone fin a su estancia en Narganá y Miss Coope ofrece su casa al Gobierno, quien la considera ventajosa por la posición que ocupa, ya que desde ella se domina toda la bahía. Se podría destinar a cuartel, puesto que en la actualidad se está usando para ello la casa de escuela 39 .

37 V. RD, n. 257; V. CD, n. XCII.

38 V. RD, n. 270; V. CD, n. XCIV.

39 V. RD, n. 378; V. CD, n. CXXXVII. 
En agosto vuelve Miss Coope para ultimar la venta de la casa y se la prohibe todo trato con los indígenas. Ella desoye las indicaciones del jefe del destacamento, lo que lleva a éste a elevar un informe acusador contra la conducta rebelde e indisciplinada de la misionera, quien iza las banderas norteamericana e inglesa, saliendo por el pueblo vestida a la manera india 40.

El gobierno se seguía considerando dueño absoluto de todo el territorio nacional, y por eso, tiene intención de crear colonias y hace concesiones de explotación a empresas norteamericanas, que extraerían productos y minerales pagando intereses al poder nacional.

Miss Coope con el apoyo de Róbinson elimina las chichas en la isla de Narganá, y la influencia de los jóvenes civilizados hacen que se vaya reduciendo el uso de guinis y argollas. Con ella se produjeron más cambios que con el P. Gassó. Impuso los vestidos norteamericanos, y lucha contra los matrimonios matrilocales.

El progreso y la civilización están más caracterizados por cosas externas, al contrario que en la época anterior, que se pretendía cambiar su mentalidad y creencias. Ahora la cuestión era que cambiasen de vestidos, adornos, bailes y construcciones; pero basado en la fuerza y el poder.

40 V. RD, n. 379; V. CD, n. CXXXVIII. 
La repuesta a las quejas de los indios por la invasión de grupos negros, son la creación de instituciones del gobierno, como son los destacamentos de policía colonial y las escuelas.

Los incondicionales de la civilización fueron gratificados con títulos militares y con sueldos especiales, como revelan los informes y las listas de cheques enviados a la intendencia.

Este periodo que fue presidido por la actividad protestante presenta cambios significativos. En primer lugar su actividad no está subvencionada por el gobierno, lo que implica una actuación más libre y guiada sobre todo por los intereses particulares de la sociedad protestante inglesa. La civilización pretendida por los gobernantes se adecuaba más a los modos colonizadores usados por las órdenes religiosas.

Las labores de la misión protestante puedo decir que se les escapó de las manos al poder panamaño, pues no contribuyó a sus intereses de civilización, o al menos a la idea que de esto se tenía entre los políticos.

\subsection{Las primeras escuelas nacionales.}

El cambio de gobierno propició la liberalización y los protestantes aprovecharon la oportunidad para introducirse en el campo indígena, donde habían hecho sus escarceos pero sin 
resultados positivos en tiempos del P. Gassó.

En memoria presentada a la Asamblea Nacional el gobierno hace pública la intención de colocar una estación inalámbrica en la cabecera de la comarca, que agilice la comunicación con la capital. Junto a esta medida se propone dotar a la circunscripción de un buque que pueda unir toda la región indígena ${ }^{41}$.

La conclusión de las obras del canal interoceánico dejó sin trabajo a un gran número de mano de obra, en su gran mayoría de raza negra. La cual intentaría ocupar tierras libres por determinadas zonas del país. Con posterioridad esto llevaría a problemas con los kunas que no les aceptarían en sus costas, cuando eligen este territorio para asentarse.

A partir de este tiempo empieza a tener repercusión la política de becas creadas por el gobierno para llevar la civilización a los indios. Los primeros frutos llegan a San Blas y aparece una nueva división en el pueblo. Los seguidores de Claudio Iglesias con la juventud de la isla y el apoyo de las maestras nacionales quieren la religión católica y todo lo que suene a civilización al estilo capitalino, incluyendo la escuela estatal. Por otra parte está Róbinson que encabeza al grupo de los viejos y reciben el apoyo de la misionera protestante que respeta parte de sus tradiciones ancestrales enseñándoles el inglés y la religión protestante.

41 V. RD, n. 16. 
Un decreto del 6 de marzo de 1915 crea la intendencia42 de San Blas; y un mes más tarde el Presidente Porras visita la zona a bordo de una lancha botada con el nombre de San Blas para escoger el lugar donde se fundaría la sede de la intendencia. Esta visita se prolonga desde El Porvenir (Coircotupu), hasta Ustupu; haciendo escala en las islas más importantes.

Propone a los sahilas la creación de escuelas; recibiendo respuesta afirmativa en Narganá y Corazón de Jesús; y posteriormente en Playón Chico y $S$. Ignacio de Tupile. Argumentan al mandatario que quieren escuela para aprender $y$ que los comerciantes no les engañen.

El Dr. Belisario Porras les asegura que enviará un carpintero que levantará las escuelas, y seguidamente les mandará a los maestros.

Efectivamente Estanislao Serrato desembarca como maestro de obras y con la colaboración de los indígenas ese mismo año deja listas las cuatro escuelas de las islas kunas.

El primer jefe de la intendencia, Enrique Hurtado, tiene el honor de presidir la inauguración de las escuelas nacionales en 1916. Las cuatro maestras designadas son: Ana Moreno James, Elisa Salazar, Manuela Frago y Guillermina Sedas,

42 Parece ser que Colman pidió al Presidente Belisario, en una vista realizada en 1912, que pusiera un puesto en la comarca, para vigilancia de los latinos y antillanos que invadían sus aguas y tierras, y de aquí surgió la idea de la Intendencia. 
que van respectivamente a Narganá, Corazón de Jesús, Playón Chico y S. Ignacio de Tupile.

Su labor será dura, la mayoría de los indios desconocen el castellano y ellas tampoco tienen conocimientos del kuna ni de las costumbre de los lugareños. Su trabajo se ve mediatizado por los intérpretes kunas, que habían sido becados en Panamá y tenían alguna noción del castellano y siguen como alumnos a la vez que ayudan a las maestras.

Como medida coadyuvante de la civilización se había propuesto el crear una colonia en San Blas. Con este fin se firma un contrato con el Sr. Fernández Hernández, que se compromete a crear una colonia agrícola en la zona de los indios kunas ${ }^{43}$.

En este periodo de trasfondo protestante se da un segundo paso civilizador que fue decisivo. Si en un primer momento el gobierno había llevado a los jóvenes hasta la ciudad para que se sintieran rodeados de la civilización, y la asimilación fuera más rápida, ahora es el gobierno quien lleva su representación hasta los indígenas. Instala a su representante en el comienzo del territorio. Desde aquí controlará a los indígenas y vigilará la actividad comercial procedente del exterior.

Al mismo tiempo quedan establecidas las escuelas en las comunidades más permeables a la civilización. $Y$ junto a éstas, los destacamentos de la policía serán los tentáculos que

43 V. RD, n. 21; V. CD, n. X. 
recuerden su pertenencia a la nación istmeña. La escuela tiene como objetivo primero la civilización. Esta Adquiere un carácter laico, después del primer intento misional con el P. Gassó, que fue considerado por el nuevo gobierno como infructuoso y anticuado. No debemos olvidar la labor protestante que realiza la misión de Narganá.

Es el intendente Vaglio quien reconoce la primacía de la escuela sobre la policía: "La policía en general, aunque no deja de influir también en esto, no puede hacer una labor como la de las maestras, comisionados como están siempre a vigilar y a hacer respetar nuestras leyes sometiendo a los indios rebeldes y hostiles. Nada hay más eficaz que las escuelas, en donde los niños adquieren el amor al estudio y luego a nuestra patria"44.

Los examinadores que evalúan la labor del primer curso comentan que se sienten orgullosos de cooperar en esta labor de nacionalización que las escuelas están llevando a cabo. La civilización consiste en crear una conciencia de pertenencia a una nación, en este caso la panameña. Este informe presenta una evaluación global de las cuatro escuelas. Puntuadas sobre cinco, Tupile alcanza esta máxima nota. La puntuación más baja la llevan Narganá y Corazón de Jesús, culpando de la merma de asistencia a la presencia de la escuela protestante.

Exponen estos dos calificadores las trabas que se han encontrado en este primer años: "La dificultad del idioma, el 
tiempo transcurrido desde la apertura de la escuela, la mayor o menor voluntad de los indios, la presencia de elementos discordantes con la uniformidad de la enseñanza nacional y la escasez de útiles escolares." 45

Las materias impartidas se han ceñido al programa oficial, salvando las distancias en lengua, que ha requerido una adaptación especial.

Era patente el empeño del gobierno en tener controlada esta zona limítrofe y costeña, y para ello pretende poner una policía fronteriza en Puerto Obaldía, que solo tendría el valor de presencia testimonial. Quiere acompañar a ésta con una escuela. La población mayoritaria de este lugar no es indígena, pero su actividad pasa por la intendencia. La lejanía y la dificultad de los medios de comunicación con la capital la unirán más al destino de la comarca de San Blas. Las poblaciones kunas próximas podrían mandar a sus niños a estudiar allí46.

Comienza el informe del primer semestre de 1919, manifestando las quejas el intendente por la poca labor hecha hasta entonces en pro de la civilización de los indígenas incluyendo aquí la labor de las escuelas de cuatro de las islas. Resalta la casi nula soberanía y autoridad nacional en la costa, poniendo su empeño en que reconozcan la autoridad del jefe de la circunscripción, pues comprobó con sorpresa que más de la

45 V. RD, n. 23; V. CD, n. XII.

46 V. RD, n. 151. 
mitad de las islas siguen en su empeño de considerarse de la nacionalidad colombiana, corriente dirigida por el general Inapaquiña.

De otro de los generales que habla es de Colman, y lo hace en tono muy crítico y despectivo, resaltando su carácter voluble. En la actualidad admite la implantación de las escuelas y la supresión de argollas y guines; llegando incluyo a pedir una beca para su hija en las escuelas de Panamá. Otro de los hijos había sido educado en la ciudad. Pide al secretario que se le deje actuar para llegar a la meta propuesta de modo pacífico pero enérgico. Cree que el temor de Colman a que se implanten escuelas, viene dado porque una vez instruidos peligraría su puesto de sahila.

Del tercer sahila importante de la región, Róbinson, también hace comentarios que le califican de inquieto, y causa de muchos trabajos de la intendencia, pero lo considera inteligente, y cree que muchos problemas han venido por dejarse guiar por la misionera Coope. El problema con Róbinson estaba centrado en que el gobierno no quería que actuara de modo independiente y autónomo, sino que todo lo que hiciera estuviera vigilado por el gobierno. El ejecutivo muestra su poder destituyendo al sahila de Corazón de Jesús y nombrando a Róbinson autoridad de las dos islas. Se intenta reconciliar al partido de los jóvenes y al de los viejos adoptando la medida de conferir al primero la jefatura a Claudio Iglesias, que tendría el título de jefe de la policía "ad-honorem" y Róbinson se quedaría 
con el poder civil, teniendo que consultar las decisiones para ser rubricadas por el jefe del destacamento. El joven estudiante había recibido el encargo del gobierno de ayudar a modernizar a los kunas en su tiempo de vacaciones y permanencia allí cuando concluye los estudios. Empieza a imponer los bailes panameños, lo que desagrada a los viejos, que habían creado las cárceles para castigar las acciones de los jóvenes. Estos habían introducido la costumbre de celebrar también los carnavales al estilo civilizado.

El gobierno se toma la libertad de poner y quitar sahilas cuando estos no actúan de acuerdo a las directrices establecidas en su acción civilizadora, pues no se deben considerar mas que empleados "ad-honorem" del gobierno.

La acción de la misionera Coope se ve limitada al convenio que se firma con ella, por lo que no instigará al sahila y estará más controlada. Estas medidas menguarían el perjuicio que estaba ejerciendo en la escuela nacional, ya que no tenía razón de ser que aprendiesen el inglés cuando todavía desconocen el castellano y lo único que hacía era favorecer la confusión entre los estudiantes. De lo establecido en el convenio todavía no se ha cumplido la cláusula $2^{\underline{a}}$ que las obligaba a dar las clases en español y en inglés, por no saber el primero, además Róbinson, amigo de ésta, gusta más de hablar el inglés. Y las maestras nacionales se ven con dificultad para conseguir productos necesarios para su subsistencia,. mientras que las inglesas gozan de todo. Propone como medida necesaria que se 
suspendan la escuelas bíblicas, ya que la misioneras no ejercen ninguna labor escolar, y sí provocan entorpecimiento.

El apartado de la instrucción pública comienza con la consideración de ser el mejor factor para conseguir la civilización, y cree de tal importancia el sostenimiento de las escuelas, que el gobierno no debería escatimar ningún esfuerzo pecuniario en construir escuelas y más escuelas. Resalta como positivo que a los indígenas les gusta y van a ella con placer, además de ser inteligentes y aprender con facilidad.

De las cuatro escuelas es notoria la sobre carga de alumnos mixtos que a ellas asisten, en Narganá son 153 alumnos y en Corazón de Jesús 101. Lamenta que se hayan suspendido las construcciones durante cuatro años, agravándose la cuestión por el mal estado que presentan los edificios existentes. Se sorprende de que Instrucción Pública en mayo le comunicara que por motivos de economía no se podían adjudicar becas a la región de San Blas y sí se otorgaran a las ocho provincias del país. Considera penoso que el presupuesto bienal no se cumpla; no pudiéndose destinar suma alguna a la instrucción pública.

El informe hace una relación de cuadros con los gastos e ingresos del último año, en el que se puede ver como dato curioso las multas de policías que van desde B/ 3,00 mensuales a B/ 75,00. El balance arrojaría un saldo de compensación entre lo que se saca de esta comarca y lo que allí se gasta. Remata estos con el presupuesto de rentas y gastos para el bienio 1919- 
21 , entre las subidas de gastas estarían las dedicadas a la policía indígena y la instrucción pública abarcaría un gasto de B/ 3.050,000.

Considera el intendente que la costa de San Blas puede ser una de las mayores fuentes de riqueza de la nación, pero cuando se produzca un mayor desarrollo en agricultura y comercio. En la actualidad solo existen dos tiendas en Narganá y otras dos en Puerto Obaldía.

Con la entrada del intendente Vaglio coincide el nombramiento del segundo destacamento, petición de aumento de la dotación policial que pasaría a ser de 29 en lugar de 19, cuatro de los cuales prestaban servicio especial a las maestras. Cinco de ellos son carpinteros y trabajan en reparaciones, pero el escaso sueldo lleva a dos de ellos a la renuncia, por lo que pide un aumento de sueldo para cuando realicen labores de carpintería.

La policía indígena está bastante lejos de ser un verdadero cuerpo de policía. Para que tengan en cuenta su responsabilidad ha sido preciso hacer cambios. Considerando como destacables a Simón Herrera, Domingo Sanguillén y Agustín González. Se les ha impartido instrucción cívica y militar.

El inspector de Nombre de Dios poco se acuerda de estas escuelas que están bajo su jurisdicción y prueba de ello son sus escasas visitas y el que la escuela de Puerto Obaldía se mantenga sin maestro y en un estado penoso, que requiere su 
cierre temporal para la puesta a punto 47.

Narganá celebra el primer carnaval dirigido por Claudio Iglesias, la reina de las fiestas sería su hermana, todo esto era parte del plan de acción de los jóvenes para introducir la civilización entre sus paisanos.

El problema de la pesca de la tortuga se zanja con un decreto de noviembre de 1919 que permite la actividad pesquera entre la punta de San Blas y el Cabo Tiburón. Al mismo tiempo que se quiere disminuir todo riesgo de levantamiento entre los indios, y para ello se prohibe el uso y venta de armas de fuego, explosivos y municiones; pero esto no afectaría a los no indígenas. A los kunas poseedores de armas de fuego que no fueran para caza les serían decomisadas 48 .

El deseo de escuela también nace en la zona oriental, pero se quería que esta escuela no fuera una introducción del gobierno, por ello se negaron a la oferta que hiciera el presidente en 1915. Ustupo comienza su andadura en 1918 con un maestro en castellano y otro en inglés. El mismo año comienza Juan Bautista Pérez su labor en el Bayano, otro lo haría en Piria y finalmente otros tres ejercerían su labor en Tiguanicua49. En 1919 los habitantes de Portogandí por iniciativa propia han improvisado una escuela y nombrado un maestro de entre los

\footnotetext{
47 ANP, Memoria de Gobierno y Justicia 1920, pp. 236-256.

48 ANP, Memoria de Gobierno y Justicia 1920, pp.14-15.

49 AELE.
} 
indios instruidos en Panamá. El intendente decide ayudarle otorgándole un sueldo de B/ 10,00 a título de agente indígena con atribuciones de maestro.

Finalmente, en marzo de 1920, el jefe de El Porvenir comunica al secretario de Instrucción Pública que las reparaciones de la escuela de Puerto Obaldía están concluyendo y le pide el equipo necesario para poder comenzar. También solicita bancas para las otras cuatro escuelas. Pero el problema queda sin resolverse al buscar maestra para aquella escuela y encontrarse con que nadie quiere ir a ese recóndito lugar. El envío de material queda supeditado a la aceptación de algún maestro para ese lugar; de tres nombrados ninguno aceptó. Las bancas que solicitara para las otras escuelas sugiere que las consiga él50.

Las primeras mesas de votaciones en las elecciones nacionales se colocan en las cuatro islas donde están las escuelas, y es para apoyar la candidatura del Dr. Belisario Porras.

Nuevamente el informe del corregimiento de Armila, al que pertenece Puerto Obaldía, comenta el mal estado en que se encuentran los edificios escolares, y que los padres están esperando que se haga realidad la oferta de la escuela. Los niños se dedican a hacer el vago por no tener escuela, ya que el número de estos crece. Sin embargo en 1922 el maestro dice que las 
asistencias son escasas, pero cuenta con la promesa de los padres de que enviarán a sus hijos. El intendente Mojica le anuncia que el gobierno tiene intención de establecer pronto la escuela formal. Pero los informes remitidos por el maestro al final de cada mes repiten que la asistencia es escasa, ya que los padres se lo toman con poco interés ${ }^{51}$.

Un decreto de febrero de este año crea una escuela en El Porvenir de carácter profesional; impartiría la rama de mecánica y de carpintería, distribuyendo en la mañana las clases técnicas y en la tarde las prácticas. Se pretendía dar una salida efectiva a esta escuela que serviría para reparar los barcos que arribaran a estas costas del Caribe. La escuela fue un proyecto del Sr. Vaglio que hizo realidad el Tercer Designado, pero que el primer problema se planteó al no contar El Porvenir con materiales de mecánica. El Intendente los solicita a Instrucción Pública, pero le contestan que es competencia de Gobierno y Justicia52.

En este mismo decreto se fijan los sueldos de los empleados de la circunscripción y a través de esta resolución se puede ver que los policías coloniales ascendían a treinta con un sueldo de B/45,00, y los policías indígenas eran diez con una gratificación de $B / 10,00$. Todo el territorio estaría dividido en tres secciones con sedes en Narganá, Portogandí y Puerto

51 V. RD, ns. 116, 258, 266 у 272.

52 V. RD, ns. 100, 101 y 113. ANP, Memoria de Gobierno y Justicia 1920, p. 33. 
Obaldía respectivamente 53.

Las escuelas creadas por el gobierno nacional se asientan en el sector central de la comarca. La parte oriental y occidental se resisten a todo indicio de civilización. Agrava más la cuestión el que el oriente sigue sin reconocer al gobierno panameño, y persisten en la idea de ser colombianos izando la enseña de del país vecino. En la visita primera del presidente nacional, los sahilas de Ailigandí y Ustupu exponen claramente que no desean escuelas. Pero lo que no quieren es la escuela nacional con todo lo que ello conlleva; porque en Ustupu en este tiempo está funcionando una escuela en un rancho de paja y sin pupitres para el maestro y los alumnos.

Lleva la escuela Juan Pérez, un alumno salido de Narganá y del Colegio de los Hermanos Cristianos, que fue pedido por Nele Kantule. No percibe sueldo, por lo que suplica al intendente que se ayude a este joven. Humberto Vaglio considera que se le debería enviar algún material, además de mandar otro maestro, dado que el censo escolar asciende a quinientos; doscientas niñas y trescientos niños. En la actualidad reciben enseñanza únicamente ochenta 54 .

Los padres de los alumnos mandan un informe del funcionamiento de la escuela de Puturgandí y hacen constar que

53 ANP, Memoria de Gobierno y Justicia 1920, p.33.

54 V. RD, n. 46; V. CD, n. XVIII. 
se le ha asignado un sueldo de diez balboas 55 .

Un decreto del mes de Julio nombra agente de policía indígena a Juan Pérez, al mismo tiempo que le concede atribuciones de maestro en la escuela de Portogandí56.

Pero estos nombramientos con el tiempo evolucionan y se hacen de policía colonial, lo que implicaba un reconocimiento de adhesión incondicional al gobierno, y suponía una paga de B./ 10. Entre estos nombramientos estuvo el del sahila Inatoiquiña, que sugiere el intendente su sobrado merecimiento por estar amenazado por otros indios 57 .

Róbinson se preocupó porque se delimitara un territorio que fuera considerado de los kunas, así lo demuestran sus conversaciones con el Presidente de la República y el secretario de Gobierno y Justicia. Llegan a establecer unos límites que al menos quedaron constatados en una carta58. Esto sería la base de la futura reserva kuna.

Atraer a los caciques hacia la voluntad del gobierno fue un objetivo que se vio acompañado de nombramientos de cargos como gobernador o policía colonial. Nele Kantule pide al intendente que su secretario sea nombrado policía indígena, de modo que así se haga respetar. Esta isla estaba dividida: una

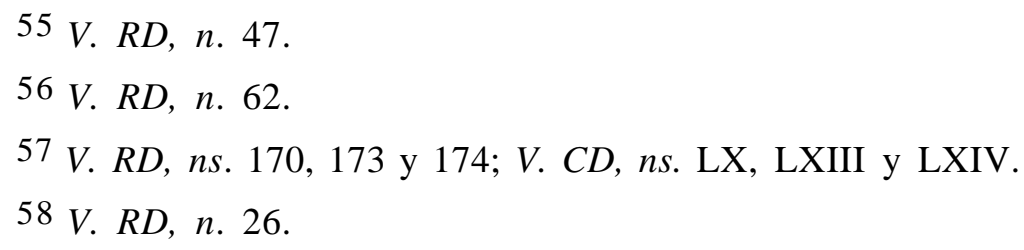


parte se consideraba colombiana y la otra panameña, ésta última es la presidida por Nele59.

En un primer momento el intendente, lo mismo que los jefes de policía hacen las funciones de inspectores de las escuelas de la costa. Ellos son quienes asisten a los exámenes finales y pasan informe del funcionamiento de las mismas 60 .

La población costera de Puerto Obaldía controlará este sector oriental que pone la mayor resistencia al poder nacional. Desde un comienzo cuajó la idea de enviar gente con una gran conciencia nacional que fuera contrarrestando la idea indígena de pertenencia a Colombia.

La escuela es considerada como una amenaza a la estabilidad y tranquilidad del pueblo kuna. El cacique Colman no la quiere porque piensa que una vez ilustrados sus paisanos ambicionarán el puesto de sahilas; lo que conducirá a las desigualdades y disputas por el poder. Esto se remediaría con la medida tomada por el intendente: los sahilas serían elegidos anualmente por él y por Colman, y así se lo dice el jefe de El Porvenir al secretario de Gobierno y Justicia61.

A pesar de todo Colman prosigue su campaña de descrédito y en Tupile consigue que diecisiete niños sean retirados de la escuela por sus padres. Los argumentos son que

\footnotetext{
59 V. RD, ns. 24 y 46; V. CD, n. XVIII.

60 V. RD, ns. 87, 88, 97, 125, 294 у 364.

61 V. RD, ns. 38 у $51 ; V . C D, n . \mathrm{XV}$.
} 
pronto se van a acabar las escuelas. Algunos indios dicen a los alumnos que ya son demasiado mayores para asistir a las clases y conseguir así que desistan de asistir a la escuela. Todo esto se vio agravado con la prohibición a un alumno que quería trasladarse a Colón, porque se acercaban los exámenes finales y no se quería que abandonara el aula. Y que Colman hizo nombramientos de policía, paralelamente a lo que hacía el gobierno de Panamá. El triunfo de Colman en el juicio contra el intendente amenazó la estabilidad de las escuelas. En Tupile y Playón Chico se proponían no mandar a los niños a las escuelas a la vez que tenían intención de atacar a la policía colonial. Lo que efectuarían tras una reunión con el opositor Olopanique62.

En carta remitida por la maestra de Tupile el intendente tiene conocimiento de que la asistencia a la escuela en esta isla ha alcanzado la cifra de sesenta y $\operatorname{tres}^{63}$.

A pesar de la oposición manifestada por Colman el intendente solicita autorización de Gobierno y Justicia para construir escuelas en Ailigandí y Cartí. La primera es residencia de Colman y la segunda es su tierra natal. La contestación viene del Presidente Belisario, ordenando que construya las dos escuelas, y que lleve adelante, aunque sea a la fuerza, la acción civilizadora64.

\footnotetext{
62 V. RD, ns. 67, 68, 69, 122 у 124.

63 V. RD, n. 74.

64 V. RD, n. 40.
} 
La paciencia parece agotarse al ver que los medios pacíficos no producen los resultados esperados por los jefes de la nación. Belisario Porras da una orden de la que luego tendría que retractarse. En el mismo tono el jefe del destacamento segundo pide a la intendencia que le den una orden para que pueda prohibir el uso de los alzamuros 65.

No pasado mucho tiempo Colman accede a que se instalen las escuelas; pero deja claro que el piensa que son la causa de todos los males de la comarca. Mientras que el intendente se los imputa a Róbinson y a la misión protestante66.

Confirma esta tesis última la postura de Róbinson, que poco después se enfrenta a la policía y se propone no mandar a los niños y niñas a la escuela nacional, porque dice que prefiere la escuela protestante. El alzamuro aparece en la nariz de las indígenas nuevamente como exteriorización de la protesta contra el gobierno67.

En 1921 se le autorizaría al intendente a que destituya a Róbinson de su cargo de policía colonial, por los enfrentamientos que tiene con el poder establecido en la región. Pero el puesto de sahila tienen que ser sus paisanos quienes lo revoquen, si están en desacuerdo con su proceder. Un nuevo giro en pro de la civilización le lleva a Róbinson a colaborar en la

\footnotetext{
65 V. RD, n. 123.

66 V. RD, ns. 52 у 53.

67 V. RD, ns. 56 у 58.
} 
extirpación de los alzamuros y guines que emprendiera el jefe del destacamento, y que resalta que se ha llevado a cabo de modo apacible 68 .

Tras esta medida la Intendencia paga los trajes de civilizadas a las indias de Narganá y Corazón de Jesús69. Esta postura se iría generalizando en las distintas islas. Sería la recompensa que pagaba el gobierno por el paso dado hacia la civilización.

Este año de 1919 se da el primer intento de revolución, pero este surge de Róbinson. Amenazan de muerte a la maestra nacional, y esta pide a la intendencia que de aviso a la misión protestante para que no reciba a las niñas que han permanecido fieles a la civilización sin ponerse la argolla ${ }^{70}$.

Los intentos de revolución concluyeron con una cierta calma y sometimiento, por ello Humberto Vaglio pide al gobierno que le envíe catorce banderas para los pueblos recientemente sometidos ${ }^{71}$. Los indios paulatinamente van aceptando su pertenencia a Panamá.

Contrario a la postura de fuerza, permitida por el Presidente Belisario y el intendente, se muestra el secretario de Gobierno y Justicia que critica al intendente sus métodos

\footnotetext{
68 V. RD, ns. 134, 136 y 137; V. CD, n. XXXIV.

69 V. RD, ns. 138 y 143.

70 V. RD, n. 57.

71 V. RD, n. 75 .
} 
violentos para romper las tradiciones kunas. Le propone que use medios pacíficos para atraerlos y derogue la orden dictada. Con posterioridad se retractaría el jefe de esta Secretaría, pues reconoce que por encima de él está el Presidente Belisario; además de que la orden hace referencia a las muchachas que asisten a la escuela72.

El Intendente Vaglio redacta nueve puntos para el jefe del destacamento de Narganá, orientando su proceder hacia una postura pacifista para con los indios, y en caso de altercado si estas medidas no dieran resultado debe ponerlo en conocimiento de la Intendencia. Prohibe los "meetings", y en caso de ser necesarios se harán en presencia de los defensores de la civilización. Esta advertencia, aunque en otros términos se la hace también el intendente al general Inapaquiña; proponiendo que los indios no asistan a los congresos porque son analfabetos. Es su obligación velar para que los niños y niñas asistan en su totalidad a la escuela pública, multando con un balboa al padre que no les mande; y el que cometa esta falta por cuarta vez será arrestado. Prohibe el uso de guines y alzamuros pero sin usar medidas duras y ofensivas. Velará el jefe de la policía para que las misioneras cumplan su contrato y no reciban a las niñas con los adornos indígenas ${ }^{73}$.

Al establecer los límites de la zona de pesca de la

$72 V . R D, n s .49$ у $55 ; V . C D, n s$. XIX у XX.

73 V. RD, ns. 29 у 81. 
tortuga para los habitantes costeros de Santa Isabel, se consideró como una medida de civilización prolongársela hasta las islas y las costas de los kunas, pero el intendente tuvo reparos para que se autorizara esta medida. La citada postura acortaba los límites tradicionales de los indios ${ }^{74}$.

Colman ve amenazada su integridad como dirigente, ante este reto inicia una campaña contra el gobierno. Recauda fondos entre su gente a fin de conseguir un abogado que les defienda de las agresiones del poder nacional. Bajo el pretexto de que se respeten las tradiciones y el vestir habitual de las indígenas, se esconden otras intenciones. $\mathrm{Y}$ les insta a los indios a que no envíen a sus hijos a las escuela; al mismo tiempo que deben rechazar a toda persona extranjera ${ }^{75}$.

Un nuevo giro se produce en la actitud de Colman que envía razón a sus partidarios para que admitan las escuelas y todo lo que quiera la policía. Manifiesta su deseo de hacer la voluntad del gobierno y perseguir al abogado que les defendía para recuperar el dinero de los indios que le prestaron ayuda 76.

Los cambios de opinión constantes de Colman hacen que el intendente y el Presidente del gobierno tomen la decisión firme de crear escuela y poner un destacamento de policía en

\footnotetext{
74 V. RD, ns. 79 y 80; V. CD, ns. XXVI y XXVII.

75 No se debe olvidar que en esta época la zona kuna estuvo muy visitada y ocupada por los caucheros que codiciaban estas tierras y satisfacían los interés personales de algún intendente.

76 V. RD, n. 109.
} 
Ailigandí77. De este modo combatirían la voluntad caprichosa del cacique.

Los exámenes finales de 1919-20 dan un resultado negativo para la maestra de Tupile. El jefe del destacamento que preside dicho acto comenta que ha encontrado mucho atraso y que la maestra no es idónea para este lugar. Ha usado un método distinto a las otras escuelas de la circunscripción y se muestra carente de paciencia, no esforzándose en aprender palabras kunas. Compara Isidro Juncan la labor realizada aquí con la de Playón Chico que sí sabían saludar, mientras que en Tupile no habían logrado ni eso78.

El intendente manda el informe completo de las cuatro escuelas a Instrucción Pública, una vez recibida la notificación de los jefes de los destacamentos sobre los exámenes. Y vuelve a resaltar que Tupile no logró las metas propuestas dada la poca experiencia y práctica pedagógica de la maestra. Pero deja ver en su informe que también se debe al abandono en que se han dejado estos planteles, ya que el inspector sólo pasó al inicio de las tareas, y sin avisar a la Intendencia; siendo mal recibido por los indios, que solo reconocen la autoridad del intendente. Aprovecha la ocasión para pedir un inspector local que se pueda trasladar hasta Puerto Obaldía, y de este modo los planteles escolares estarán más

77 V. RD, n. 220.

78 V. RD, n. 94. 
atendidos.

Entre las propuestas que presenta podemos resaltar la del aumento de sueldo para los maestro, apoyada en la carestía de la vida, que se ve incrementada en esa región apartada de todo centro económico. También es digno de reseñarse que pide que se dé la importancia que se merece a la instrucción en esa región. La tercera propuesta es la reglamentación de petición de los materiales de las escuelas; que el juzga que se deben solicitar a Instrucción Pública, aunque la Intendencia y las escuelas dependan de Gobierno y Justicia 79.

Los habitantes de Tupile, dirigidos por su sahila y en presencia del jefe del destacamento, levantan un acta de protesta por la noticia que les ha llegado de que vuelve la maestra del curso anterior. No están dispuestos a mandar a sus hijos a la escuela, dado que les maltrata y no les enseña. A esto se suma que su conducta moral ha dejado mucho que desear, ya que vivía en la escuela con un querido. Están dispuestos a enviar a sus hijos fuera de la isla si esta maestra se hace cargo nuevamente de la escuela 80 .

Esta protesta del pueblo de Tupile se ve reforzada por el jefe del destacamento segundo, que le recuerda a Humberto Vaglio que es una de las islas más sufridas y adictas a la civilización, y este hecho no se debe olvidar. Ellos han mostrado

\footnotetext{
79 V. RD, n. 97.

80 V. RD, n. 102.
} 
interés por el educación de su prole y se debe tener en cuenta. Los secretarios de Gobierno y Justicia, y de Instrucción Pública son informados también de este hecho para que obren en consecuencia81.

Llegado el momento de comenzar el nuevo curso en el mes de mayo la maestra Jacinta se presenta en Tupile. Ella misma comenta que ha tenido total oposición por parte de los indios y que no le recibieron con cariño. Reconoce que no le convenía venir a esta escuela. La matrícula presenta una notable merma. En un principio solo asisten veinte niñas y once niños, y en tres días ha ascendido a cincuenta y cuatro. Pone de manifiesto que el sahila ha mostrado preocupación por la escuela y porque su hija asista a ella82.

A pesar de todo la maestra solicita ayuda y se le envía un policía que se entrevista con el sahila. El pueblo se mantiene en la división. El sahila y un grupo son partidarios de la escuela, pero existe un sector que es liderado por Olopanique contrario a la escuela y quieren seguir con sus tradiciones y sus chichas. El jefe de la isla les aconseja que no celebren tantas chichas pues son motivo de escándalo y perjuicio de la escuela. El sahila Inatoiquiña había aceptado enviar a su hija a la escuela porque le habían prometido que cuando fuera posible se les cambiaría a la maestra83.

\footnotetext{
81 V. RD, ns. 103, 104 у 105.

82 V. RD, n. 110.

83 V. RD, ns. 111 y 118.
} 
Finalizando el año 1920 el teniente de la Intendencia pide a Gobierno y Justicia que se separe del cargo al agente de Tupile, que ha presentado mala conducta y creado problemas con la maestra de este lugar84.

El gobierno pretendía que los indios se mezclaran con los ciudadanos panameños; que convivieran juntos a la manera de los poblados nacionales. Pero llega más allá cuando se reconoce que se han mezclado las razas al nacer un hijo de waga y kuna. Comenta el teniente de Tupile que esto es una prueba patente de civilización. Al mismo tiempo que las indias han decidido cambiar sus trajes tradicionales por los de mujeres civilizadas 85 .

Si las condiciones en que comienza la educación en el resto de la república eran precarias, mucho más lo fueron en la región de San Blas. Los locales primitivos fueron poco consistentes, pues a los tres años de su edificación ya se necesitaban reparar con urgencia los edificios de Narganá y Corazón de Jesús. Y en abril de 1921 el intendente envía una nueva súplica para que se reparen las escuelas de la comarca que presentan un estado lamentable y vergonzoso para el gobierno. Propone para ello sus servicios y los del personal de la intendencia. A finales de octubre se reciben los materiales para las reparaciones de estas dos escuelas. Estas reparaciones son

84 V. RD, n. 127.
85 V. RD, ns. 135 y 154; V. CD, ns. XXXV y XLVI. 
parches que no solucionan mucho, pues son constantes las quejas por el mal estado que presentan los edificios ${ }^{86}$.

Los asuntos referidos a la educación no dependen directamente del Ministerio de Instrucción Pública, como en el resto de la República, sino que tienen que pasar por Gobierno y Justicia de quien depende la Intendencia. A través de una circular pide el intendente a las maestras de las cuatro islas que le informen de la marcha de las escuelas, así como de las asistencias y le hagan un inventario de las mismas ${ }^{87}$.

En 1919 se estudia la posibilidad de conceder título de propiedad colectivo a los indios de San Blas. El Presidente Porras es partidario de esta propuesta que hace José de la Rosa.

Las medidas civilizadoras afectaban a las construcciones y trazados de las calles. Se imponen las calles anchas que separen las viviendas, y las construcciones de estilo nacional. Róbinson sería el primero en hacer una vivienda de concreto. Quieren que las casas y las islas sean saneadas 88 .

Inapaquiña da una lista de pueblos que no quieren escuela, entre ellos se encuentran tanto del sector oriental como del occidental. Su razonamiento es que el indio no es para leer, si no para sembrar. Anteriormente el encargado de la Intendencia le había acusado de incitar a los indios para que se

\footnotetext{
86 V. RD, ns. 70, 141 у 279; V. CD, ns. XXII y XXXVIII.

87 V. RD, n. 82.

88 V. RD, ns. 77 у 347.
} 
mostraran en contra de la escuela. Pero ellos lo que quieren es vivir en paz, y se quejan de las molestias que les causa Colman89.

Inatoiquiña, sahila de Tupile, será uno de los sujetos adeptos al gobierno, que defendió la civilización y se ganó por esta causa las enemistades de los indígenas. Los de Cartí le acusan de traidor por quitar las argollas y admitir policías, pero no hacen referencia a la escuela90.

Puerto Obaldía subsana la deficiencia de maestros tras la autorización del Presidente, la aprobación de Gobierno y Justicia y el Ministerio de Instrucción Pública a que un policía destacado allí, imparta unas horas de clase. El beneficio será para la población no indígena e indígena de los alrededores. EI número de niños es superior a cuarenta. Pero se aclara que por sus servicios de maestro no recibirá ningún incremento en el salario; y su actividad se reducirá a 3 ó 4 horas sin perjudicar a las labores de agente ${ }^{91}$.

Existía el cuerpo de instructores civiles, que podría considerarse como un cuerpo auxiliar de los maestros. Belisario Porras se queja de que no existan entre la policía para que ayude a desterrar la ignorancia. Posiblemente este maestro destacado

\footnotetext{
${ }^{89}$ V. $R D, n s .81,126$ у $131 ; V . C D, n$. XXXII.

90 V. RD, n. 96.

91 V. RD, ns. 160, 166 y 168; V. CD, ns. LII, LVII y LVIII.
} 
en Puerto Obaldía perteneciese a ese colectivo92.

El problema del personal es constante. Unas veces acentuado en la escasez y otras en la idoneidad de los sujetos. El intendente pide que las personas que se nombren sean serias, ya que serán el modelo que vean los indios digno de imitarse. La escasez de presupuestos de 1919 hizo que el horario escolar fuera de jornada continua, así un mismo profesor impartiría clases a dos grupos de alumnos; uno por la mañana y otro por la tarde. Este plan ideado por el Presidente de la República contenía también el principio de la coeducación. Esta escasez de presupuesto retrasó la apertura de nuevas escuelas ${ }^{93}$.

Hasta la fecha el cuerpo docente estaba formado por mujeres; pero ahora, en 1921, el intendente pide un varón para los cursos superiores de Narganá. Los kunas celosos de sus mujeres toleraban mejor la presencia femenina, pues sus esposas e hijas se verían más protegidas.

En abril de 1921 se produce un hecho trágico que frena el camino de la civilización. Dos indígenas estudiantes en Panamá y que habían vuelto de la capital arremetiendo contra las tradiciones son asesinados por esta causa en el pueblo de Río Azúcar. El hecho se inicia cuando en las islas centrales se obliga a las mujeres a abandonar sus adornos y trajes tradicionales, ante esto una mujer deja la isla y se traslada a Río Azúcar para

\footnotetext{
92 V. RD, n. 35; V. CD, n. XIV.

$93 V . R D, n s .275,39$ y $165 ; V . C D$, ns. XVI y LVI.
} 
seguir con sus adornos. Los jóvenes Claudio y González encabezan un grupo que persigue a la fugitiva. Al llegar a Río Azúcar les esperan armados para oponerse a los atropellos que se están llevando a cabo. En este choque caen los dos estudiantes indígenas. Se decretan nueve días de luto para los empleados públicos y la juventud de las islas de Narganá y Corazón de Jesús.

Claudio Iglesias era presidente de la juventud, y jefe de la policía indígena ad-honorem, grupo que apoyaba la civilización y la educación católica, representada por las maestras nacionales; en contraposición de la escuela bíblica protestante, apoyada por Róbinson y los viejos. En la nota remitida por la intendencia se dice: "que con la pérdida de tan buenos ciudadanos sufre el gobierno en su labor de civilización de los indígenas, en la cual está vivamente interesado la de irreemplazables servidores"94.Le sustituiría Estanislao López ${ }^{95}$.

Después de este levantamiento se teme que los indios de Portogandí tengan la misma reacción y protagonicen otra revuelta, por lo que se pide al intendente que proceda a quitarles las armas con el mayor tacto posible ${ }^{96}$.

Los cambios requieren un tiempo y un proceso de adaptación, no se pueden imponer por la fuerza las costumbres

\footnotetext{
94 Orden General n 7 del 22 de abril de 1921.

95 V. RD, ns. 144 y 180.

96 V. RD, n. 183; V. CD, n. LXIX.
} 
de otras sociedades. Con frecuencia producen derramamientos de sangre. El Presidente Belisario amonesta al intendente para que los cambios se hagan por medios pacíficos, empezando por la enseñanza con los niños y niñas ${ }^{97}$. La educación sería el agente de cambio. La fuerza no daba los resultados esperados, pero de todos modos este levantamiento no fue el último.

En Octubre de 1921 recibe el teniente del despacho de Narganá los materiales para las reparaciones de las escuelas de esta isla y de Corazón de Jesús Las bancas para las escuelas fueron llegando durante el transcurso de $1922^{98}$.

La figura de Colman fue como una pesadilla para el gobierno. Siempre estuvo enfrentado a Panamá y receló de todo lo que proviniese de la nación. En este trágico acontecimiento se sospecha que esté por medio este individuo. Pero el indígena se sirve de un abogado para implicar en estos acontecimientos a la policía colonial. Se produce otro levantamiento en 1923, Colman e Inapaquiña pretenden desterrar la policía indígena y las escuelas. En este enfrentamiento murió el agente Paniza99.

La muerte de Claudio trajo como favor para la familia, que sus miembros dispusieran de becas para estudiar en Panamá. De este modo el jefe de familia Eliseo vería satisfecho su deseo

\footnotetext{
$97 V . R D, n s .148$ y $162 ; V . C D, n s$. XLII y LIII.

98 V. RD, ns. 198, 227, 230, 232, 233, 268, 271, 276 у 283; V. CD, n. LXXVIII.

99 V. RD, ns. 158 y $305 ; V . C D$, ns. L y CX.
} 
de que sus hijos superasen su propio analfabetismo ${ }^{100}$.

La muerte de Claudio Iglesias ${ }^{101}$ y González provoca un retraso en el comienzo del curso escolar en tres de los cuatro planteles existentes. Las maestras atemorizadas por estos hechos cuando llega el momento de comenzar el curso no se presentan en San Blas. El Presidente habla de tres maestras nombradas y una que tiene intención de pedir para Cartí. Pero los maestros se niegan a ocupar su puesto y el Ministerio de Educación se ve imposibilitado para resolver este caso. Para buscar una pronta solución pide al intendente que proponga a las personas competentes, que han de observar buena conducta y presentar examen de aptitud para obtener el certificado que exige la codificación escolar; y que el estime que aceptarán el cargo de maestros.

Así lo hace el intendente que en junio propone al maestro Buenaventura Garcerán para cubrir la plaza de un varón, que el solicitara para la escuela de Narganá102.

Ante la imposibilidad de abrir las escuelas algunos niños son llevados hasta la capital para que sigan sus estudios. Se les busca familias donde puedan residir, a la vez que asisten a las clases. Para ello el intendente los recomienda al

100 M. VANDERVELDE e M. IGLESIAS: Nacido Primitivo, p. 33.

101 Se puede decir que toda la familia Iglesias estuvo a favor de la civilización, por lo que se ganaron la enemistad de los kunas que no deseaban que las costumbres extranjeras se propagasen en la tribu.

102 V. RD, ns. 163, 164, 165 y 169; V. CD, ns. LIV, LV, LVI y LIX. 
Presidente de la República y a los secretarios de Instrucción Pública y de Gobierno y Justicia ${ }^{103}$.

En Julio, la maestra Carmen García va a ocupar su puesto en Narganá. Y el inspector Melo se propone visitar las escuelas; para ello el intendente requiere de Ramón Garrido la protección necesaria. Tres meses después viaja la maestra de Tupile hacia su destino. El intendente solicita del jefe del primer destacamento protección para ellas, y que le facilite a ésta el viaje hasta su destino104.

Fruto de la visita de inspección es la circular que redacta el inspector de educación de Nombre de Dios quejándose de los malos resultados del pasado semestre. Culpa de estos a la poca cooperación de los padres que no vigilan ni cuidan a sus hijos; por lo que pide que se les sancione. Seis meses después les recuerda a los alcaldes municipales que es obligatoria la asistencia puntual a la escuela para los menores de siete a quince años. Mojica, como responsable de la comarca, promete que hará todo lo posible por que se cumpla105.

Otra circular, y que atañe muy directamente a San Blas, es la que manda el inspector con el tema de los bailes, los cuales están prohibidos a los escolares, multando a los padres

\footnotetext{
103 V. RD, ns. 171 y $172 ; V . C D$, ns. LXI y LXII.

104 V. RD, ns. 182, 175 y 202; V. CD, n. LXXX.

105 V. RD, ns. 201, 223 у 228.
} 
que incurran en esta falta106.

El personal panameño destacado en San Blas se siente inseguro y sin protección ante los indígenas, que no es que sean belicosos, sino que sienten que el gobierno quiere hacerles civilizados a "magnis itineribus", usando incluso la fuerza; y el pueblo kuna al sentirse agredido responde.

El jefe de la circunscripción comenta al secretario de Instrucción Pública que "la labor administrativa en San Blas para que tenga éxito debe ser simultánea con la labor educativa pues en mi concepto la una debe ir íntimamente ligada con la otra, de suerte que, donde lleguemos a establecer nuestras oficinas y Destacamentos de Policía, debemos al mismo tiempo construir nuestras escuelas" 107.

La idea de ampliación de planteles educativos en 1921 se ve frenada por una parte por la falta de buenos maestros que quieran ir a esa región. $Y$ otra razón es que las arcas del estado no tienen presupuestada esta acción y se debe esperar a la aprobación de los nuevos presupuestos que se realizan bienalmente. Además del temor que infunde a los maestros el levantamiento de Río Azúcar.

Los ánimos de los indígenas se ven levantarse con el apoyo y propaganda realizada por extraños que frecuentan el

106 V. RD, n. 281.

107 V. RD, n. 159; V. CD, n. LI. 
lugar. En un primer momento es un alemán quien les propone que no toleren más los atropellos de los policías, y posteriormente un mejicano 108 perseguido por la justicia. Pero tal vez la nota detonante la ponga el norteamericano R. Marsh.

En Julio de 1922 el jefe del destacamento primero cree que es el momento oportuno, y así se lo manifiesta al intendente, para construir escuela en Río Azúcar y Tigre. En Corazón de Jesús existen dos maestros que atienden dos grados cada uno, mientras que la de Corazón de Jesús no ha llegado. Pide que el gobierno haga lo posible por enviar un misionero católico. La política seguida para la extensión de la enseñanza, era aprovechar edificaciones que tenían los indios, pero en Río Azúcar gastan setenta balboas en levantar la escuela109.

El tema de la educación-civilización fue motivo de división entre los indios y de emigración de las islas. En Narganá los contrarios a este cambio de la tradición se retiran en un primer momento a la isla de Tigre. En Playón Chico los reacios salen de la isla. $\mathrm{Y}$ en Cartí los partidarios de la educación por ser minoría abandonan la isla y se dirigen a Wichuwala, solicitando una maestra para que imparta clases a sus niños y niñas. El protagonista de esta acción es el agente Paniza110, que construye una casita que serviría de escuela. Llega a comentar el policía que el ramo de instrucción es al que más atención debe

108 V. RD, n. 219.

109 V. RD, ns. 245, 314 y 316.

110 Fue nombrado agente indígena de Cartí en 1919. 
prestar el gobierno. Según carta del intendente el 2 de mayo de 1922 se abre la escuela de Wichuwala con 15 niños. Ejerce las labores docentes la maestra Susana M. Cerezo ${ }^{111}$.

El intendente Mojica solicita una subida de sueldo, de B./10 a 15, para el agente Paniza por su labor en pro de la educación ${ }^{112}$.

La escuela de Wichuwala no parece estar destinada a tener mucha vida, pues en agosto el inspector de Nombre de Dios hace saber al intendente que ha sido clausurada, y le pide que se haga cargo de los materiales y traslade a la maestra a la escuela de Narganá113.

El Sr. Mojica contesta que seguirá funcionando todo el semestre y se cerrará si no alcanza el número de asistencias requerido por la ley para su permanencia en activo. Se tiene proyectado cambiar el traje de las mujeres de la isla coincidiendo con las fiestas patrias de noviembre ${ }^{114}$.

Finalmente se traslada esta escuela para Río Cidra en mayo de 1923. Y el intendente opina que se debe proceder de igual modo que en Río Azúcar: nombrando agentes coloniales que se sacarían del primer destacamento para acompañar al maestro. Crear nuevos centros de civilización requiere que se nombre más

\footnotetext{
111 V. RD, ns. 246, 212, 216, 218 y 224; V. CD, n. LXXXIV.

112 V. RD, n. 226.

113 V. RD, n. 252.

114 V. RD, ns. 253 у 259.
} 
personal para la comarca de San Blas; pues de lo contrario se van debilitando los centros establecidos ${ }^{115}$.

Río Azúcar y Río Cidra se proponían dar otro paso en noviembre, cambiando los vestidos de sus niñas y mujeres por la ropa civilizada 116 .

En los inicios de mayo, sin contar para nada con el director de la escuela, Estanislao López se lleva de madrugada a los alumnos que debían comenzar el IV grado en la escuela de la isla, para la ciudad de Colón. El director pide al jefe del destacamento, en su carácter de inspector local de esta escuela que dé parte a la Secretaría de Instrucción Pública117.

Otro revés sufre la escuela de Playón Chico al cerrarse ésta por muerte repentina de la maestra Otilia Hurtado. Pero no acabarían aquí los contratiempos, pues, corre el mes de mayo y la maestra de Narganá no se ha presentado en la escuela; y la de Tupile se encuentra gravemente enferma. Llegada la hora de dar comienzo a las clases, tres escuelas están sin maestra118.

El sahila de Playón Chico, Olopaniqui en compañía de otros isleños solicita que les envíen a la maestra Manuela Frago, de la que han quedado muy satisfechos. Pero aceptarían otra

\footnotetext{
115 V. RD, n. 301.

116 V. RD, n. 318.

117 V. RD, n. 225; V. CD, n. LXXXV.

118 V. RD, ns. 229 у 231.
} 
cualquiera con tal de no perder tiempo y que sus hijos se atrasen. Instrucción Pública nombra a Emilia Castillero que inicia su actividad el 20 de junio con una asistencia de sesenta y dos alumnos. Llegando a alcanzar a finales de mes la cifra de cien. Miguel Gordón alabaría unos meses después la labor del sahila en esta isla, por su saneamiento, cambio de vestido de las mujeres, locales de baile, y patios para juegos civilizados ${ }^{119}$. Un mes después de su llegada a la isla contrae una enfermedad ${ }^{120}$.

En Julio el intendente escribe al secretario de Gobierno y Justicia comentando la oportunidad que ya le había expresado de establecer escuelas y destacamentos de policía en Ailigandí y Portogandí. Lo apoya porque es la voluntad del gobierno ${ }^{121}$.

Una protesta mayoritaria por los que hacen campaña contraria al gobierno, se produce en Narganá encabezada por Róbinson y Estanislao y apoyada por otros noventa indígenas. Se dirige principalmente contra José de la Rosa que hace circular el comentario de que las ideas civilizadoras, las escuelas y cuarteles son disculpas para robarles, y los que apoyan estas medidas son también unos explotadores ${ }^{122}$.

Un habitante de Río Azúcar se dirige a la Presidencia,

119 V. RD, ns. 235, 236, 243, 246 у 280.

120 V. RD, ns. 248 у 250.

121 V. RD, n. 249.

122 V. RD, n. 254. 
dos años después de los luctuosos sucesos, con el propósito de solicitar la instalación de la escuela en su isla. Se considera representante de un nutrido número de jóvenes. El mismo había sido contrario, hasta hacía poco, a todo indicio de civilización.

Ese mismo año el jefe del primer destacamento recibe la notificación del nombramiento del maestro de esta isla. Es el mismo maestro quien lleva la noticia de camino a su destino. Pero quedan pendientes, para completar la estrategia seguida por el poder nacional, nombrar los agentes escolares de entre las personas más allegadas a la civilización. Servirían de ayuda y protección al maestro. Los agentes escolares suplían la escasez de policía colonial. El intendente tiene intención de trasladarse allí la siguiente semana para dejar instalados a los empleados que deben funcionar en dicho lugar ${ }^{123}$.

En octubre de 1922 reanudan las clases las escuelas de Tupile, Playón Chico, Corazón de Jesús, Wichuwala y Narganá. Esta última con dos maestros nacionales y uno indígena. Se amplían los tentáculos del poder nacional pero han de ser con una presencia representativa, y lo que no debe faltar es la representación policial, que será la presencia más directa ${ }^{124}$.

El jefe del destacamento de Narganá envía cinco nombres de jóvenes del lugar para que sean nombrados agentes escolares. Al iniciarse las tareas escolares brotan las

123 V. RD, ns. 54 у 287; V. CD, n. CI.

124 V. RD, n. 292; V. CD, n. CVI. 
disensiones, encabezadas seguramente por el grupo de los ancianos.

Andrés Mojica nombra seis policías escolares ad honorem para ayuda del maestro y policía colonial que se destaque en aquel lugar. En un primer momento los agentes nacionales debían velar por la seguridad de los maestros, más cuando la escuela estaba puesta en algunas islas sin el consentimiento mayoritario de los indígenas ${ }^{125}$.

La fama de esta policía no era muy buena entre los kunas. Su fuerza, usada en modo desmesurado, estuvo acompañada en muchos casos por una conducta libertina que se dejaba llevar por el alcohol. Lo que hizo que se acentuara en el pueblo indígena la protección por las mujeres; y que no desearan que su raza se mezclase. Consideraban a los policías gente vaga, pues solo esperaban recibir el cheque ${ }^{126}$.

El intendente reconocía en 1919 que la policía había causado problemas que atrasaban la enseñanza de los escolares indígenas en la isla de Narganá ${ }^{127}$.

Se pretendía que los alumnos matriculados asistieran a las clases, y para luchar contra el absentismo el secretario de Instrucción Pública creó este cuerpo de vigilancia que haría cumplir la obligatoriedad de la enseñanza. Esta policía escolar

125 V. RD, n. 89.

126 V. RD, n. 90.

127 V. RD, n. 31. 
fue creada en 1913 y su función era pedir una explicación en la casa de los escolares ausentes.

Las faltas a la escuela no se castigaban corporalmente, pues la ley lo prohibía, y penalizaba a quien usara estos métodos. Se adoptó la medida de imponer multas a los padres que no mandaran a sus hijos a las clases ${ }^{128}$. Así podemos comprobar que el inspector de Nombre de Dios le envía la lista de faltas al Intendente para que haga efectivas las multas de los habitantes de Tupile ${ }^{129}$.

Por toda la comarca es patente la escisión entre viejos y jóvenes. Los primeros aferrados a la tradición y que no quieren cambios. Por otra, los jóvenes que se sienten atraídos por la novedad que les liberaliza de su férreo sistema social. Los jóvenes que se han educado y siguen estudiando en Panamá son el ejemplo a imitar en la nueva vida. La fuerza de éstos entre su gente ha sido un elemento decisivo para que se opere el cambio.

La inspección de las escuelas de San Blas pertenecía al distrito escolar de Nombre de Dios, lugar de la costa situado al occidente de la región indígena. La distancia y el medio marítimo que les separa hacía difícil las visitas del inspector que tiene que contar con la lancha de la intendencia para sus desplazamientos 130 .

\footnotetext{
128 Estas multas eran recaudadas por la policía.

129 V. RD, ns. 129 y 130.

130 V. RD, ns. 263, 267 y 290; V. CD, n. CIV.
} 
Los informes escolares en este periodo son remitidos a través de los jefes de los destacamentos. Ellos serán quienes lo notifiquen al intendente y al inspector de Instrucción Pública del distrito de Nombre de Dios. En 1922 el jefe del tercer destacamento recoge las felicitaciones de Gobierno y Justicia por la buena labor llevada acabo en el tema de la educación en ese lugar ${ }^{131}$.

Los dos ejes sobre los que giran los informes, que servirán de baremo comparativo, son las asistencias y la matrícula. En 1923 ya ascienden las primeras a 113 en Narganá y a 83 en Corazón de Jesús.

Noventa y nueve de los alumnos de Narganá cursan el primer grado y 14 el $2^{\circ}$. Mientras que en Corazón de Jesús 46 son de primer grado; 14 del 2o; 21 del $3^{\circ}$ y 8 del $4^{\circ}$. No olvidemos que una maestra imparte clases a más de un grado. Aquí se ve la dificultad de los muchachos, que les cuesta superar los primeros grados, sobre todo por su desconocimiento del castellano 132.

La escuela de Río Azúcar inicia ese año el curso con una matrícula de 13 alumnos y la misma asistencia, pero se alberga la esperanza de que irá aumentando cuando vayan sintiendo los beneficios que depara la educación. La matrícula y asistencia se controlan diariamente y se informa mensualmente por lo que se espera que el panorama cambie con el paso de los

131 V. RD, n. 217.

132 V. RD, n. 297; V. CD, n. CIX. 
meses. La asistencia en la mayoría de los casos registra valores inferiores a los que presenta la matrícula; esto se debe a múltiples factores:

Entre otros podemos mencionar los trabajos. Dentro de la cultura kuna los jóvenes acostumbran a ayudar a sus padres en las tareas agrícolas y de pesca. Es costumbre también que los padres se hagan acompañar en sus traslados con motivo de visitas a otras islas o cuidar y cultivar sus cocales. Las enfermedades y epidemias que frecuentemente hacen acto de presencia en la islas también merman la asistencia escolar. Las chichas que desembocan por regla general en un estado de embriaguez paralizan la actividad de la escuela o la reducen en gran parte. El mal estado de los locales, como ocurre en Tupile, que cuando llueve el tejado deja pasar el agua y se tienen que suspender las clases ${ }^{133}$.

Una vez asegurada cierta estabilidad en el sector central, tras un número considerable de escuelas y colonias policiales; se da comienzo a la ofensiva por el sector occidental. Cartí sigue presentando resistencia, mientras que en Río Cidra, centro de una comunidad de tres islas, la apertura de un club integrado por cuarenta y ocho señoritas corona la acción emprendida por el agente Guillermo Denis, y que se inicia con la apertura de la escuela a mediados de 1923. Se pretende que los indios tomen conciencia de su nacionalidad panameña y las 
tareas de cedulación avanzan superándose el centenar de ellas. El indígena Samuel Guerrero expone al intendente en mayo que tienen setenta niños en la escuela y no cuentan con bancas suficientes para todos. A mediados de junio manifiesta que son ciento veinte los alumnos y que los indios están muy contentos. En octubre llega para el sector de Río Cidra el maestro Juan B. Cervera; y se pide al encargado que le dispense la protección necesaria ${ }^{134}$.

En la fundación de esta escuela había influido la petición presentada por el indio Sami Aguilar, que muestra su deseo de que se abra escuela en el año 1923135.

Las jóvenes se comprometen a abandonar su traje tradicional y vestir a la manera civilizada. En este grupo de islas se recogen ciento una argollas de la nariz y se destruyen para realizar otro tipo de adornos. Al mismo tiempo que las mujeres están confeccionando sus trajes de civilizadas. En la misma carta donde el intendente da conocimiento de estos hechos; evalúa la acción civilizadora y dice que se debe seguir la ofensiva por el sector de Cartí, antes de empezar con Ailigandí136.

Los isleños de Cartí hacen campaña contra el gobierno en Río Azúcar y Tigre, impidiendo que se instale la

134 V. RD, ns. 302, 303, 312, 313 y 323; V. CD, n. CXV.

135 V. RD, n. 262.

136 V. RD, ns. 310 y $311 ; V . C D, n$. CXIV. 
escuela en esta última. Parece que lo que les atemoriza a los de Cartí es que les pongan una escuela, pero sin embargo si aceptan la implantación de la policía, esta actitud es extraña pues en las demás islas es frecuente la actitud contraria137.

Otra población, Río Tigre, comienza su marcha escolar con un maestro receloso de los indígenas, a quienes considera ingratos y traidores. Piensa que el gobierno es muy blando con ellos. Miembro de una logia masónica, solo siente compasión por estos seres, y cumple con su deber porque las reglas de la masonería les exhortan a ayudar a los semejantes ${ }^{138}$.

Fue nombrado en noviembre el maestro Illueca para Río Tigre, y no transcurre mucho cuando el intendente reconoce que es difícil establecer la escuela en aquellos lugares donde no se ha establecido con anterioridad un régimen de gobierno, esta es la situación en que se encuentra dicho maestro139.

La labor de este miembro del magisterio no fue acorde con la línea del gobierno desde sus comienzos, lo que hizo que en enero de 1924 la Intendencia diera orden de que se le multara o arrestara por imponer prácticas que estaban en desuso ${ }^{140}$.

\footnotetext{
137 V. RD, n. 319.

138 V. RD, n. 324; V. CD, n. CXVI.

139 V. RD, n. 317.

140 V. RD, n. 322.
} 
El aumento considerable de alumnos en el curso de 1923, deja más a las claras las deficiencias de la educación en la región de San Blas. Las dos nuevas escuelas alojan a sus muchachos en cajones por falta de bancas. La Intendencia pide que Instrucción Pública proporcione la madera para que los indios pongan la mano de obra en su construcción ${ }^{141}$.

Los clubs se van extendiendo como un botón más de la obra civilizadora. Playón Chico ve inaugurar el suyo en marzo de 1924. Al mismo tiempo se reconoce la gran influencia que ejercen los jóvenes educados sobre su sociedad. También funcionaban desde 1922 los de Tupile, Narganá, Corazón de Jesús, Río Azúcar y este que hace su inauguración oficial ahora; al que asisten indios de las otras islas ${ }^{142}$.

En este mismo año se inaugura el de Río Tigre, siendo invitados a tal acto el intendente y su señora, nombrándoles padrinos de la ceremonia. También es invitado el secretario de la Intendencia ${ }^{143}$.

Antes de comenzar el curso de 1924 se procede a conceder nuevas placas e insignias a la policía colonial. El curso da comienzo con algún retraso en las escuelas de Tigre y Río Cidra ${ }^{144}$.

\footnotetext{
141 V. RD, n. 304.

142 V. RD, ns. 260, 326 у 329; V. CD, ns. XCIII y CXVII.

143 V. RD, ns. 339 у 340.

144 V. RD, ns. 328, 355 у 356.
} 
Los servicios del maestro de Tupile son requeridos para este nuevo curso, y el Presidente apoya la petición que realizan el jefe del destacamento y el intendente. La súplica de éste es más amplia, pues, solicita que se vuelva a nombrar el mismo personal docente para el curso 1924 en la región; y así lo confirma el Presidente Belisario, tras notificárselo el secretario de Instrucción Pública ${ }^{145}$.

Hay una excepción que se refiere al maestro de Río Tigre, así lo expone el intendente, pues le considera un personaje poco apto para ejercer su labor entre los indígenas. Los problemas surgidos con este maestro han provocado que se inicie una investigación decretada por el secretario de Gobierno y Justicia146. En abril de ese año el mandatario panameño le notifica que no ha sido nombrado el susodicho maestro ${ }^{147}$.

Las islas a la cabeza de la civilización suplican al Presidente de la República que no les cambie al intendente Mojica, gran benefactor de la región. Argumentan su propuesta señalando los pueblos atraídos a la civilización por él y mencionan: Río Cidra, Río Azúcar, Tigre, Tikantiquí y Makepgandí148.

La isla de Tikantikí parece incorporarse al carro de la

\footnotetext{
145 V. RD, ns. 331 y 333; V. CD, ns. CXIX y CXXI.

146 V. RD, n. 336; V. CD, n. CXXII.

147 V. RD, n. 344; V. CD, n. CXXIV.

148 V. RD, n. 332; V. CD, n. CXX.
} 
civilización y piden a la intendencia un maestro, pues ellos ya se han encargado de preparar el alojamiento. Esta concesión pasa por el secretario de Gobierno y Justicia, que a su vez tiene que solicitarlo a Instrucción Pública. Deseosos de instrucción los tikantiqueños mandan a sus hijos a la escuela de Tigre en espera de que el gobierno les nombre un maestro. El gesto de la destrucción de los alzamuros, es algo que enorgullece al jefe del destacamento que comunica al intendente que las ochenta y ocho mujeres esperan les envíen la tela para confeccionar su ropa de civilizadas ${ }^{149}$.

Esta labor se ve obstaculizada por los orfebres que llegan hasta esas costas y se dedican a hacer alzamuros. Es por esto que Garrido pide al intendente un decreto que les prohiba hacer este tipo de joyas. Además de que en muchas ocasiones engañan a los indios dando otros metales por oro. El mal no sólo queda aquí, sino que en ocasiones hacen de secretarios para los sahilas infundiendo en ellos sentimientos de rebeldía ${ }^{150}$.

El jefe del destacamento segundo notifica al $\mathrm{Sr}$. Mojica una nueva adhesión al plan de civilización del gobierno. El pueblo de Playón Grande da un primer paso con el abandono del vestido tradicional de dieciocho mujeres y con la creación de un "centro de recreo a la ligera". Este pueblo costero se mantenía en una completa cerrazón a las influencias exteriores desde hacía

149 V. RD, ns. 336 y 360; V. CD, ns. CXXII y CXXX.

150 V. RD, ns. 48 y 86; V. CD, n. XXXI. 
diez años ${ }^{151}$.

A finales de abril el Presidente recibía una carta remitida por el intendente que le anunciaba un nuevo logro en su empresa, se refería a Playón Grande. Así mismo le promete que pronto tendrá conocimiento de otra nueva adhesión ${ }^{152}$. $Y$ en mayo tiene conocimiento de los adelantos de Playón Grande la secretaría de Gobierno y Justicia ${ }^{153}$.

Las plazas de maestros de las escuelas del primer destacamento se cubren en abril del siguiente modo: Corazón de Jesús, Silvia E. Centello y Arturo Delvalle; Narganá, Felicidad y Río Azúcar, Evelia Salcedo. Para el segundo destacamento van: Dora Dollander en Tupile y Trinidad Pelders en Playón Chico. Requiere el Sr. Mojica del jefe del destacamento que les dispense todas las facilidades $\mathrm{y}$ atenciones necesarias ${ }^{154}$.

El empeño del jefe del segundo destacamento por extender la obra civilizadora no cesa, y así el 4 de junio de 1924 comunicaba el paso dado en Tikantikí. Tres días después añade a la lista dos nuevos lugares, Mayugandí y Airtigandí. Lo expresa así: "Solicitaron a este despacho procediera a romperles a sus mujeres los alzamuros (o argolla de la nariz) para hacer de ellos prendas modernas"155. Los trajes para las mujeres corresponden

\footnotetext{
151 V. RD, n. 342; V. CD, n. CXXIII.

152 V. RD, n. 346; V. CD, n. CXXVI

153 V. RD, n. 353; V. CD, n. CXXIX.

154 V. RD, n. 348; V. CD, n. CXXVII

155 V. RD, n. 362; V. CD, n. CXXXII.
} 
cincuenta y dos para la primera localidad y cinco para la segunda; que la caja del destacamento correrá con su coste.

La maestra de Playón Chico, durante este curso, muestra una conducta poco correcta, lo que hace que el jefe del destacamento pida que se la castigue según la ley. A mediados del curso se opta por enviar un nuevo maestro156.

Los elementos externos cambian con gran rapidez, pero las mentalidades no van al mismo ritmo, y este desfase provocará una explosión cuyo fin será la revolución de 1925. Belisario Porras pide a las maestras de Narganá y Corazón de Jesús que extirpen el uso de alzamuros y guinis; al mismo tiempo que les felicita por su labor en pro de la civilización 157.

Siguiendo el ritual, una vez dado estos pasos el gobierno deja en la comunidad un representante suyo que vigilará y se encargará de mantener y hacer progresar este cambio ${ }^{158}$.

No deja de asombrarnos la propuesta que hace el intendente en septiembre de 1924, sobre la adquisición de un cinematógrafo para San Blas, pues servirá para la instrucción de los indios. El Presidente Belisario da su aprobación pero espera que lo confirme así mismo el secretario de Gobierno y Justicia159.

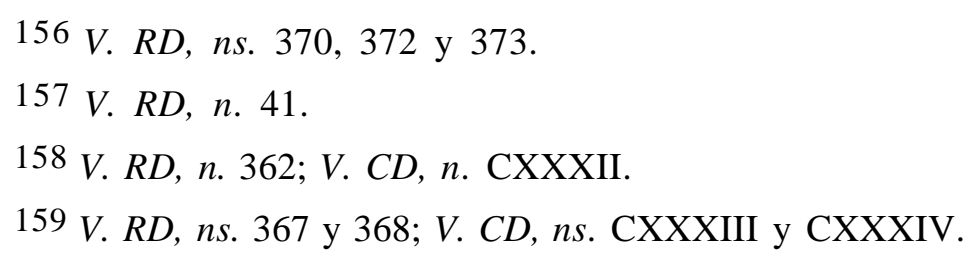


Un informe, que pudiera ser de un padre católico, relata el acto de apertura de la escuela de Río Azúcar, posiblemente la inauguración; comentando que el maestro era un policía y que estaban presentes tres policías más. Asegura el testigo que los métodos usados con los indígenas no son los mas recomendables ${ }^{160}$.

Los bailes nocturnos parece que no ayudaban a la vida escolar, pues se prolongaban hasta altas horas de la madrugada, y las mujeres eran forzadas a asistir, bajo pena de multa 0 arresto. Creían los destacados en las islas, como Narganá que para ser civilizados tenían que aprender los bailes nacionales. Pero el encargado del destacamento de Narganá reconoce que estos bailes no son nada beneficiosos para los niños, ya que perjudican sus estudios ${ }^{161}$.

En Panamá la idea que se tiene, es que estos bailes son para que las indias superen su natural timidez ${ }^{162}$. Entre otras causas, esta fue una de las que motivó que el inspector prohibiese el uso de locales para fines recreativos del personal no perteneciente a la escuela. El inspector pide la colaboración del intendente para que no se realicen bailes inmorales en la escuela para niños y padres. Así como tampoco sirva de refugio este local para la policía ${ }^{163}$.

160 V. RD, n. 377; V. CD, n. CXXXVI.

161 V. RD, ns. 277 у 278; V. CD, ns. XCVI y XCVII.

162 V. RD, ns. 193 у 211; V. CD, n. LXXIV.

163 V. RD, ns. 161 у 207. 
Finalizando 1924 los isleños de Ustupu reciben tarjetas de felicitación con nombres ingleses, lo que hace sospechar a la Intendencia que alguna organización del Canal tiene la intención de hacer a los indios de nacionalidad sajona ${ }^{164}$.

\section{3.- La Revolución Tule}

Esta etapa concluye con el levantamiento de los indios en el carnaval de 1925. Este evento se salda con la muerte de 27 personas. Su principal fin era la extirpación de la policía colonial que les oprimía y quería cambiar su inofensivo modo de vida y vestir. Si algo queda claro es que este enfrentamiento no quería atacar a la escuela y a los maestros, pues se realiza en el periodo de vacaciones.

Con posterioridad los habitantes de Tupile escriben contando los atropellos cometidos por la policía antes de la revolución. Relatan los abusos y los robos en que incurren los representantes del gobierno ${ }^{165}$.

Los indios liderados por Colman pretendían hacer una república Tule independiente de Panamá bajo el protectorado de los Estados Unidos. La declaración de independencia redactada en veinte páginas relata los atropellos que el pueblo ha sufrido en

164 V. RD, n. 376.

165 V. RD, ns. 465 y 466; V. CD, n. CLXXXVIII. 
estos años de supuesta civilización protagonizados por los policías negros que allí estaban y consentidos y estimulados en algunas ocasiones por algún intendente que quería aprovecharse de su puesto concediendo licencias a los extranjeros para explotar la región de los kunas.

El levantamiento de los indígenas hace que el gobierno dicte un decreto convirtiendo a la policía nacional en una fuerza militar que pueda enfrentarse a los rebeldes indígenas ${ }^{166}$.

Tras los luctuosos acontecimientos el gobierno resuelve decretar tres días de luto para lamentar la muerte de doce empleados suyos en la zona incluidos cuatro agentes indígenas ${ }^{167}$.

Con respecto a la educación aclaran en su comunicado que algunos jefes enviaron a sus hijos a escuelas panameñas, y algunos, incluso, llegaron a ir a escuelas americanas, y se sentían contentos por este nuevo ensanchamiento. Muchos de sus pueblos querían la escuela para provecho de sus hijos pero desconfiaban de los propósitos de Panamá y vieron que en sus islas se establecieron cuarteles de policía negroides con un maestro. Se obligó a los indios a dejar sus ocupaciones para construir escuelas y cárceles so pretexto de multas 0 encarcelamiento. Se les obligaba a derribar sus casas y construirlas alineadas y al estilo panameño. Los bailes

166 ANP, Dcto. 32 del 25 de Febrero de 1925.

167 ANP, Memoria de Gobierno y Justicia 1926, pp. 170-171. 
degeneraban en borracheras y violación a las mujeres. "Fue un alto precio que pagamos por las ventajas discutibles de la escuela. Verdad es que la escuela enseñó a nuestros niños a hablar y escribir español, y otros conocimientos superficiales, pero condujo a nuestras muchachas a una vida de vergüenza y maldad. Nuestros muchachos no aprendieron agricultura ni el desarrollo de los recursos de su tierra ni los medios de combatir las enfermedades (nuestras más grandes necesidades) sino que aprendieron a estar ociosos, a robar, a traicionar a su pueblo, a burlarse de la agricultura, a imitar a sus nuevos amos violando a las muchachas; en fin se les dijo que se les estaba enseñando a ser ciudadanos panameños"168.

La terminación del canal dejó sin empleo a un gran número de obreros de raza negra, que se aposentaron en las costas de Colón y fueron invadiendo el territorio de los kunas. Al mismo tiempo el gobierno y sus representantes en el archipiélago dieron concesiones a compañías para extraer el oro, caucho y manganeso de esta región ${ }^{169}$.

Como señal de civilización se les obligó a construir un salón de baile, para que bailasen al estilo civilizado, forzando a las mujeres para que aprendieran y asistieran bajo pena de pagar diez pesos de multa y hasta treinta días de prisión. Allí eran

168 Declaración de independencia y derechos humanos del pueblo de Tule de S. Blas y de Darién, p. 10.

169 Ibidem, p. 8. 
obligados a comprar cervezas y licores 170

Ante este modelo de civilización se fue esfumando de su cabeza todo deseo de escuela y civilización prefiriendo la carencia de ella. Después de los resultados de Narganá ningún otro pueblo quiso la escuela, pero la impusieron por la fuerza en ocho poblados más: Porvenir, Soledad, Río Cidra, Río Azúcar, Tigre, Ycantisí, Playón Chico y Tupile o Mono. La pesca de la tortuga fue gravada con un impuesto. El intendente puso una red de tiendas en las islas y los indígenas estaban obligados a comprar en ellas.

Según el Tratado Hay-Bunau Varilla171 Los norteamericanos podían intervenir en Panamá en cualquier momento para restablecer el orden constitucional; y así lo hicieron también en San Blas donde se encontraba un súbdito de este gobierno dirigiendo la revolución antigubernamental de los kunas. Pero la propia constitución panameña en el epígrafe 136 autorizaba a la intervención estadounidense cuando la paz se viera turbada o roto el orden constitucional.

Se vanaglorían los firmantes de la inteligencia de los miembros de sus pueblo reconocida por el director de la Escuela de Artes y Oficios.

Entre las resoluciones finales la número seis dice:

170 Ibidem, p. 10.

171 ERNESTO CASTILlero, Panamá y los Estados Unidos, Editora Humanidad, S. A. Panamá, 1964. p. 71. 
"La nación Tule promete aceptar y establecer, de la mejor manera que pueda un sistema moderno de escuela adaptado a las necesidades de su pueblo; a garantizar libertad de creencias, cultos y conciencias religiosas a todos los individuos dentro de sus linderos, compatible con el bien público y se adhiere a todos los usos y costumbres que se conforman con la ley internacional reconocida y establecida"172.

La precipitación de los acontecimientos llevó a desplegar un gran número de fuerzas en el golfo temiendo un enfrentamiento armado, pero el secretario de Gobierno y Justicia le comenta al Presidente Chiari que lo ve poco probable, al mismo tiempo que le explica en su carta del 2 de marzo que los indios no han sido tratados por las autoridades de la colonia en la forma que aconseja el buen sentido. Reconoce la equivocación de buena fe del Dr. Porras al disponer que se obligara a los indios a romper con sus costumbres. Se les debía haber respetado sus usos a condición de que aceptaran la autoridad y el que los indios medio civilizados se fueran acostumbrando al modo de vida nacional.

Por ello estos infelices han visto con dolor como se destruían su palmeras, se les impedía tener puercos o gallinas sueltos, se les hacía separar su viviendas y se arremetía contra sus costumbres. Que unido a la influencia de personas hostiles como Marsh, la misionera Coope y otras maestras extranjeras,

172 Declaración de independencia y derechos humanos del pueblo de Tule de S. Blas y de Darién, p. 19. 
acrecentaron su vago deseo de rebelión. Por lo cual debe tenerse en cuenta todo ello a lo hora de imponer el castigo, de modo que se vea atenuado.

Si los indios se someten el gobierno se les debe prometer un trato respetuoso con sus costumbres. Aconseja como medida necesaria, el secretario de Gobierno y Justicia, que salgan de la región la misionera y maestras que hacen propaganda subversiva entre los indios 173 .

Al día siguiente el Presidente contesta comentando que el objetivo no debe ser matar indios, sino someterlos y restablecer en esa región la autoridad y prestigio del gobierno, encauzando la acción de éste de forma más racional y acorde a las costumbres indígenas. $Y$ apunta a que tal vez la solución no sean métodos más modernos, pero sí más prácticos y de resultados más seguros. El gabinete aprueba la mediación del Dr. South, y el presidente le da las líneas directrices por las que debe discurrir el acuerdo de paz y sometimiento, al mismo tiempo que le aconseja cambiar de intendente y demás autoridades que no inspiren confianza a los indios, así como la policía colonial, ofreciéndole que se quede con sesenta de los mejores policías enviados 174 .

El 4 de marzo de 1925 se firma un acta en El Porvenir, entre trece jefes indígenas, el secretario de Gobierno y Justicia,

173 ANP, Memoria de Gobierno y Justicia, 1926. pp. 180-181.

174 Ibidem, pp. 179-180. 
y el de relaciones exteriores, junto con el juez supremo de la República y el fiscal del juzgado supremo, en presencia de un intérprete $y$ del enviado extraordinario y ministro plenipotenciario de los Estados Unidos; por el que se comprometen en nombre de su pueblo a someterse a la autoridad y leyes panameñas, devolviendo las armas y efectos robados al gobierno. Pero éste pondrá la autoridad que sea necesaria en el territorio para representarle. Y Se manifiesta que el gobierno no tiene el propósito de imponer a los indios el establecimiento de escuelas, al mismo tiempo que protegerá sus usos y costumbres, pero ellos a su vez respetarán a los que decidan optar por los beneficios de la instrucción ${ }^{175}$.

A partir de ahora el gobierno declara que los indios son sus protegidos bajo la tutela de la Iglesia Católica romana; que durante este periodo había mantenido contactos distanciados. En 1918 hubo una gira de un padre que impartió los sacramentos del bautismo y matrimonio. Durante 1922 y 1923 el P. capuchino Plácido visitó durante tres meses a los indígenas. En 1927 comienza el contacto de los claretianos con el $P$. Juan Henneman 176

En resolución número 38 del 14 de marzo de este mismo año se opta por expulsar del territorio panameño al norteamericano R. O. Marsh, y se le prohibe la entrada en el

175 Ibidem, pp. 177-179.

176 Documento preparatorio para el III Congreso de Pastoral Indígena Nacional, p.62. 
futuro en el territorio nacional, por redactar el manifiesto que declaraba independiente a la República Tule; pues se presume que fue el instigador del levantamiento indígena contra las autoridades panameñas y de los actos de barbarie que cometieron contra los agentes del gobierno177. Al año siguiente entre los responsables del gobierno se teme que este personaje vuelva a celebrar con los indios el aniversario de la revolución.

Los kunas vieron menguar sus cosechas porque no podían salir al campo o a la pesca sin pedir permiso a la policía y si llegaban después de la hora que se les ponía eran multados o castigados.

Al año siguiente de la revolución Tule, OlokintipipileleColman, uno de los cabecillas del levantamiento enfermaría gravemente, para mirir en agosto de 1929.

La falta de infraestructura en la región kuna, unido a la escasez de personal cualificado hizo que se produjeran atropellos debidos a que no existía una delimitación de competencias. Los policías ejercían de maestros, los maestros de policías, a su vez los policías eran inspectores de las escuelas; esto provocó un abuso de funciones.

Los locales escolares tenían un deficiente equipamiento y hacían la función de cuartel o de salón de baile. La escuela se vio mezclada con la represión. La falta de 
preparación y poca ética de los que en ocasiones ejercían como maestros dio una imagen falsa de lo que significaba la educación. Los kunas se negaron a recibir la escuela, en más de una ocasión, por relacionarla con la represión y los abusos. El dirigente Colman sería uno de los que calificara a la escuela como la causante de todos los males que iban germinando entre los indígenas.

Este periodo se puede decir que estuvo presidido por la obsesiva idea de la civilización. Todos los recursos y esfuerzos estuvieron dirigidos a este fin. La abundancia de veces que se repite el término civilización lo ponen de manifiesto. La escuela era un medio más para llegar a este objetivo. Incluso algunos consideraban que era la principal acción para conseguir civilizar a los kunas.

Dicha acción llevó consigo abusos protagonizados incluso por algún intendente y jefe de policía. Los aparentes progresos que reflejaban los informes obedecían a represiones que distaban mucho del voluntario cambio.

Así se fue creando un resentimiento entre los indios, que veían en todo lo exterior una amenaza a sus costumbres e integridad. De esta imagen negativa no se salvo ni la educación. Se produce en esta época un intento de demarcar la zona kuna como un territorio propio. Sería la manera de librarse de los aventureros, y los negros que se habían quedado sin trabajo en la zona del canal. 
Los maestros nombrados son mujeres porque a su vez serían mejor recibidas por los kunas, pero se llega a pedir un maestro para los cursos superiores en la zona central. Los favoritismos a la hora de las elecciones también estuvieron presentes. $Y$ en más de una ocasión las maestras y los policías llegarían a formar pareja.

De este modo la idea que el Sr. Ramón Valdés lanzara anteriormente, se lleva a cabo ahora. El proponía que se enviaran matrimonios a los kunas para que con la colaboración de ambos la acción civilizadora fuera adelante. Pero la realidad fue que no reunían las cualidades que pedía de sobrios y circunspectos. 
III RESTAURACION Y CONSOLIDACION DEL SISTEMA EDUCATIVO OCCIDENTAL ENTRE

LOS KUNAS 
8. LA ETAPA POSTREVOLUCIONARIA

$(1926-1938)$ 


\section{LA ETAPA POSTREVOLUCIONARIA}

\section{$(1926-1938)$}

\subsection{Primera fase}

Comienza este periodo, tras los acontecimientos de la revolución, con una línea suave pero en cierto modo continuista con respecto a la pasada época. Los adeptos al gobierno son premiados y recompensados y se cuenta con ellos para que la obra civilizadora siga adelante y ocupen puestos entre los policías indígenas y escolares ${ }^{1}$. El sahila Inapaquiña intenta atraer hacia los intereses del gobierno a los jefes de las comunidades más importantes y reacias a la civilización, pero con poco éxito, pues concluye pidiendo al Presidente de la República protección para sus tierras y título de propiedad de la comarca $^{2}$. El sector central sigue siendo el faro y centro de esta actividad, como lo atestiguan los diversos hechos. Los miembros del club progreso solicitan ayuda para la creación de una biblioteca y un botiquín ${ }^{3}$.

En abril de 1927 Ramón Garrido pide una recomendación para un joven que desea seguir sus estudios en

\footnotetext{
${ }^{1}$ V. RD, ns. 381 y $410 ;$ V. CD, n. CXXXIX.

2 V. RD, n. 438.

3 V. RD, n. 385; V. CD, n. CXL.
} 
la Escuela de Artes y Oficios $^{4}$. Y a su vez el intendente explica al secretario de Instrucción Pública que dicho joven fue detenido durante la sublevación en Ailigandí donde permaneció retenido hasta la fecha. Agradeciéndole que haga lo posible por satisfacer los deseos del muchacho5. En un primer intento no se consigue, ya que el padre del muchacho vuelve a solicitar una recomendación, pues su hijo está en Panamá sin haber conseguido su deseada beca. En último caso, si esto no es posible, se sugiere que se le busque una colocación. Al mismo tiempo otro indígena pide una recomendación para que su sobrino pueda seguir los estudios en la Escuela de Artes y Oficios 6 .

En materia de competencias, las escuelas de la región de San Blas al ser cambiada la dirección a los misioneros católicos, dejan también de pertenecer a Instrucción Pública y pasan a depender de Gobierno y Justicia; estando apoyados por los jóvenes indígenas educados en las escuelas capitalinas.

Hasta ahora el contingente mayor de estudiantes de esta época estaba integrado por aquellos que cursaban estudios en los centros de Colón y Panamá. Estos permanecen en sus islas, antes de dirigirse a las escuelas pues desean hablar con el Presidente de la República que va a girar visita al

\footnotetext{
${ }^{4}$ V. RD, n. 391; V. CD, n. CXLV.

5 V, RD, n. 392; V. CD, n. CXLVI.

${ }^{6} V, R D, n .396 ; V . C D, n$. CXLIX.
} 
archipiélago 7 .

El despacho de Gobierno y Justicia comenta que "dado el separatismo y exclusivismo racial muy profundo en estos indios, sobre todo desde la sangrienta revolución del año 1925, el gobierno nacional ha empleado un método de expansión civilizadora, de resultados inmejorables a juzgar por la honda penetración actual de la civilización, consistentes en colocar en el magisterio jóvenes de su misma sangre, preparados en los diversos centros de enseñanza secundaria de la capital"8.

En junio de 1926 abría nuevamente las puertas la escuela de Río Azúcar, con anterioridad Ramón Garrido informa al intendente que los locales donde debe funcionar la escuela ya están listos; se había pedido rapidez en las gestiones recurriendo a la amistad de este pueblo con el gobierno. Y según el testimonio del corregidor de Narganá este hecho se producía con gran satisfacción para los habitantes de dicha localidad. "fueron recibidos con vivas atronadoras, demostrando con esto, estar completamente satisfechos con la llegada de la maestra que tanto deseaban"9.

El informe semestral redactado por el intendente en junio de 1926 dejaba clara la existencia de tres corregimientos

\footnotetext{
7 V. RD, n. 382.

8 Documento preparatorio para el III Congreso de Pastoral Indígena Nacional, p. 68.

9 V. RD, ns. 383 y $386 ; V . C D, n$. CXLI.
} 
según se había establecido por decreto, los cuales contaban con una población aproximada de 39.000 habitantes. En lo tocante a materia educativa, refiere que las escuelas de Narganá y Corazón de Jesús, tanto los edificios construidos por el gobierno, como el comprado a la señorita Ana Coope, se encontraban en mal estado y en el periodo vacacional fueron reparados por el carpintero de la circunscripción. Ejercían la labor magisterial cinco maestros en los mencionados centros; y otro en Río Azúcar y Puerto Obaldía respectivamente. Pero el número de alumnos pr profesor era superior al reglamentado en el código escolar.

Considera que la instrucción pública es uno de los principales factores para lograr una eficaz y verdadera civilización entre los indígenas, por lo que se debe procurar por todos los medios el establecimiento de más escuelas. Pone como ejemplo a los de Río Azúcar que en este año han abierto la escuela, colaborando con su esfuerzo a la construcción escolar y vivienda del maestro. Demostrando que les agrada la escuela y concurren a ella con la mayor alegría y satisfacción. Por otra parte es de lamentar que los sublevados del año pasado destruyeran las escuelas levantadas por el gobierno en Río Azúcar, Río Sidra, Tupile y Playón Chico. Se ha comprobado que algún otro pueblo, al igual que Río Azúcar, lamenta la falta de instrucción y desean que se instaure la escuela. Estando dispuestos a colaborar en el levantamiento de los edificios 
siempre que se les garantice el envío de un maestro ${ }^{10}$.

Las becas concedidas a los indígenas parece que no se vieron interrumpidas durante los sucesos de 1925. Así dos años después el corregidor de Narganá pedía al intendente que diera un puesto de trabajo de carpintería a un joven que había terminado sus estudios en la escuela de Artes y Oficios ${ }^{11}$. A finales del curso 1926-27 dos padres de familia y Róbinson solicitan permiso para ir a recoger a sus hijos que concluyen el curso en la capital12. Del mismo modo se demanda permiso al intendente para que unas jóvenes puedan seguir su viaje camino de las escuelas de la capital. Estas son las hermanas Iglesias, pertenecientes a la familia del difunto Claudio Iglesias; que como seguidores del gobierno vieron recompensada su actitud de propagadores de las ideas civilizadoras ${ }^{13}$. Parece que la política de las becas en este época no siguió unos criterios serios y ello lo demuestra la postura tomada por los alumnos de la Escuela de Artes y Oficios que redactan una reglamentación para la concesión de becas; en ella se pide, entre otras cosas, que los aspirantes sean examinados por personal del ramo ${ }^{14}$.

El creciente número de indígenas en la ciudad de Colón

\footnotetext{
10 ANP, Memoria de Gobierno y Justicia 1926, pp.172-177.

11 V. RD, n. 388; V. CD, n. CXLII.

12 V. RD, n. 387.

13 V. RD, n. 393; V. CD, n. CXLVII.

14 V. RD, n. 411.
} 
lleva a promulgar un decreto de apertura de una escuela para los indios residentes en ese lugar. Eran atraidos por los trabajos remunerados que se podían conseguir y en ocasiones por el deseo de adquirir mayor independencia y libertad ${ }^{15}$.

Un atisbo de modernidad se deja entrever en una carta dirigida al intendente, en la cual se expone que la instrucción actual debe salir fuera de las cuatro paredes de la escuela y se debe educar a la juventud para construir una nación grande. En ella se hace patente la queja por los trabajos que realizan los niños en el relleno de la escuela. Labor que se repetía cada curso, pues no debemos olvidar que las islas aumentaban de tamaño gracias a los rellenos, labor muy unida a las escuelas; ya que estas se encontraban en los extremos de las islas con bastante frecuencia16.

En este curso las escuelas abiertas son las de Narganá, Corazón de Jesús, Río Azúcar y Puerto Obaldía, con un total de ocho maestros. Las dos primeras son reparadas nuevamente por el carpintero de la intendencia. Río Azúcar vio aumentar sus asistencias en un número superior a ochenta alumnos y se elevó el número de maestros a dos, por lo que se hizo un nuevo nombramiento. Tras la petición expresa de los padres de Nicuesa y El Porvenir se pretenden abrir estas dos

15 V. RD, n. 395; Estrella de Panamá, 1927, 8, Mayo.

16 V. RD, n. 402. 
escuelas que contarían con un mínimo de cuarenta alumnos cada una. La inspección escolar pasa a depender de Colón durante este tiempo, en lugar de ser de Nombre de Dios. El informe de este semestre expone que los padres colaboran en las tareas ayudando a los maestros en todo lo posible ${ }^{17}$.

El maestro de Puerto Obaldía llenaba así un gran vacío en la zona oriental y que al mismo tiempo era la frontera de Colombia, según las palabras del corregidor, y esta labor siempre sería agradecida por los habitantes de la población. Aunque en el segundo trimestre da comienzo a sus labores con un cierto retraso, después de su traslado a las conferencias, para las que fue avisado ${ }^{18}$.

El director de las escuelas de San Blas, Sr. Juan Valdés Jr., había ordenado la suspensión de labores, previa notificación, que decía que el pueblo de Narganá se encontraba amenazado por indios rebeldes. La población estaba exaltada y corrían peligro las vidas de los educadores castellanos ${ }^{19}$.

Vuelve a aparecer el fantasma de la mala conducta entre los representantes del gobierno. Los jefes de Narganá se quejan ante el intendente del mal comportamiento de un agente que ha seducido a una muchacha de la escuela, con lo que de mal

17 V. RD, ns. 384 y 389; V. CD, n. CXLIII.

18 V. RD, n. 404 y 406.

19 Lotería, Panamá (Marzo 1957) p. 62. 
ejemplo supone para todos los estudiantes; pues se encuentran allí todos lo alumnos de vacaciones. Por ello piden al intendente que nombre policía con sueldo a uno de los indígenas 20 .

El curso 1927-28 se abría en mayo con toda normalidad pero únicamente en las tres escuelas del sector central. Se pone de manifiesto que la matrícula es buena pero se espera que ascienda antes de finalizar la semana. Pone de manifiesto que el director de las escuelas se queja del lamentable estado que presenta la escuela de Narganá, así como del mal estado de la pintura en ésta y Corazón de Jesús ${ }^{21}$. Los habitantes de Narganá se comprometen a levantar un edificio escolar para la maestra que falta, y también a construirle una vivienda para la misma22.

En este sector se sigue defendiendo la civilización, y prueba de ello son los elogios dirigidos en la celebración de las fiestas patrias donde se ensalza el grado de civilización alcanzado y la posibilidad de asistir a la escuela. Estas ideas llevan a Estanislao y Pablo Iglesias a solicitar al partido liberal participación en la vida política, pues se consideran con un alto grado de civilización para elegir representantes ${ }^{23}$. Con la misma idea de informar de los adelantos en favor de la

\footnotetext{
20 V. RD, ns. 390 y 410; V. CD, n. CXLIV.

21 V. RD, n. 394; V. CD, n. CXLVIII.

22 V. RD, n. 399; V. CD, n. CLII.

23 V. RD, ns. 408 y 409.
} 
civilización escribe Denis sobre la isla de Río Sidra, pero apostilla que el único enemigo es el sahila y ya se sabe que sin la autorización del sahila no se puede hacer nada 24 .

En el primer trimestre, desde Puerto Obaldía, se informa de un intento de levantamiento por parte de Nele y sus seguidores 25 . Y se considera que las faltas de los indígenas deben ser castigadas con reprensiones fuertes en lugar de multas y castigos 26 .

El director de Narganá solicita un agente para el cobro de los impuestos, cosa que el corregidor ve difícil, ya que uno de los agentes indígenas está al servicio de las escuelas, otro hace de intérprete, y los otros dos se dedican a sus faenas del campo27.

La vida política va haciendo su aparición en la comarca, o al menos en el sector central, como fruto del interés mostrado por Estanislao López y algunos otros. Se crea en Narganá el Comité Indígena de Centuriones Chiaristas encabezado por Estanislao López, que pretende contribuir a la causa del Presidente Chiari28. Enseguida hacen una petición al Presidente para que sea nombrado corregidor Arturo Pérez, pues

\footnotetext{
24 V. RD, n. 413.

25 V. RD, n. 398; V. CD, n. CLI.

26 V. RD, n. 399; V. CD, n. CLII.

27 V. RD, n. 400; V. CD, n. CLIII.

28 V. RD, n. 401; V. CD, n. CLIV.
} 
sabrá defender sus intereses y luchar por la civilización que a toda costa pretenden implantar29. Estos intereses de los habitantes de Narganá responden a las aspiraciones del propio corregidor que le insiste a Estanislao para que luche en defensa de su puesto. Argumenta que el ha hecho mucho por los indios y que puede hacer más que cualquiera, pues conoce el dialecto indio 30 .

En la celebración de las fiestas patrias, acto que estaba protagonizado por la escuela, es recordada la memoria de los mártires de la civilización, cuya empresa se quiere seguir emulando con sus virtudes 31.

\subsection{Pasos previos a la consolidación de I escuela}

En el ecuador de 1928 el gobernador de Colón anuncia a la Intendencia la visita del padre Anglés y varias hermanas franciscanas que viajan para inspeccionar la zona de Narganá y donde piensan establecerse con posterioridad ${ }^{32}$. El P. Anglés sería quien hiciera el ofrecimiento a las franciscanas para que colaborasen en la educación en la región de San Blas. El inicio

\footnotetext{
29 V. RD, n. 403; V. CD, n. CLV.

30 V. RD, n. 405; V. CD, n. CLVI.

31 V. RD, n. 407; V. CD, n. CLVII.

32 V. RD, n. 412; V. CD, n. CLVIII.
} 
del curso se retrasaba, y el 28 de septiembre se hacen los nombramientos de maestros para las escuelas.

En Narganá queda como director el padre José Berengueras con cinco hermanas de las franciscanas y dos maestras más. El primero de octubre abría sus puertas la escuela encargándose del ํo la madre Valeria, del Iํ Felipa, del IVo y oo Priscila; dos señoritas se harían cargo del kinder de Narganá y Corazón de Jesús. Relatan que los niños fueron muy puntuales mostrando gran amor por el estudio de las ciencias 33. A la escuela de Río Azúcar se designan tres maestras, y dos para Puerto Obaldía34. Después de quince años de ausencia volvía la misión católica, aunque aparentemente la misión prioritaria fuese la educación.

Pero esta concesión a la iglesia católica no fue del todo libre. "En abril de 1928 se consiguió del gobierno nacional la dirección de la escuela de Narganá, pero no se firmó el decreto. En junio se dio a la prensa un avance, nada más; pero monseñor, entonces estaba fuera, y su vicario delegado luchaba para que se cumpliera lo dispuesto. En septiembre fuimos a establecer la misión y sin más nos encargamos de la escuela. El hecho parecía un desafío al gobierno. Por fin el 25 de septiembre de 1928 fue firmado y publicado el decreto. Aquello

33 Crónica de las Madres Franciscanas, p. 3.

34 V. RD, ns. 414 y 419; V. CD, ns. CLIX y CLX. 
nos sonaba más un verdadero reconocimiento de un hecho consumado que a concesiones voluntarias"35.

Con posterioridad el director debía poner todo su empeño y fuerzas en que cada año le volvieran a nombrar, lo mismo que a las madres franciscanas. Pero a pesar de todo, dos años después se cancela el nombramiento de una franciscana y en 1935 quitan el puesto de ayudante del director ${ }^{36}$. La dirección de los claretianos se inicia con una matrícula de 200 y cuando la entregan en 1945 sobrepasaba el millar.

Los representantes de Narganá manifiestan al Presidente de la República su deseo de destituir de su cargo a Róbinson y los agentes policiales porque según ellos no cumplen con su deber y dan malos ejemplos ${ }^{37}$. Posteriormente los de esta isla unidos a los de Corazón de Jesús y Río Azúcar le escriben nuevamente para pedir el puesto de intendente para Tomás E. Abello, quien ha sabido defender los derechos de los indios ${ }^{38}$.

Las desconfianzas y recelos siguen presentes entre una buena parte de los indígenas, el sahila de Tigre está dispuesto a apaciguar los ánimos de los vecinos. Por su parte

35 Documento preparatorio para el III Congreso de Pastoral Indígena Nacional p. 71.

36 Ibidem. p. 72.

37 V. RD, n. 415.

38 V. RD, n. 416. 
los gobernantes muestran su disposición a trasladarse hasta el archipiélago para discutir los problemas que creen los indígenas que traerá la civilización y que les avoca a un sentimiento de recelo hacia la educación39.

Ante los abusos de las becas y la aglomeración de alumnos poco preparados en las escuelas provinciales se redacta un nuevo reglamento por parte de un grupo para la Escuela de Artes y Oficios. En él se pide que se suspendan temporalmente las becas y que los nuevos aspirantes sean seleccionados por examen realizado por los padres de la misión. Al mismo tiempo piden que los estudios sean considerados como instrucción secundaria40.

En el último año de la década de los veinte se presentan ante el secretario de Gobierno y Justicia una delegación de los partidarios de Nele y de Colman para pedir ayuda y protección contra los negros que se adueñan de sus posesiones y de su pesca, al mismo tiempo que manifiestan sus intenciones de paz. Exponen que quieren escuelas propias con maestros indígenas, de los que ya existen con estudios ${ }^{41}$. En esta reunión estaba presente el intendente Abello que expone la manifestación hecha por los habitantes de Tigre, de querer

39 V. RD, ns. 417 y 418.

40 V. RD, n..420; V. CD, n. CLXI.

41 Esta manifestación formal de establecer un magisterio indígena, sería la iniciadora de esa realidad que a lo largo de los años se va viendo consolidar. 
mantener buenas relaciones con el gobierno. Colman ya empieza a estar minado por la enfermedad y parece dejar a un lado sus enfrentamientos con el gobierno42.

Este mismo año salían del hospital Santo Tomás con el certificado en ostetricia las alumnas Hermelinda Rodríguez y Felicidad González, tras seis años de permanencia allí43. A continuación solicitan los indígenas una plaza para un joven que quiere aprender el oficio de practicante, bien sea con beca 0 pagado con el esfuerzo de los isleños ${ }^{44}$. Para apoyar esta petición piden la recomendación del secretario de Agricultura y Obras Públicas, sugiriendo que el futuro practicante y las parteras diplomadas podrían hacer una gran labor contribuyendo a la obra civilizadora 45 . Pero la contestación trunca sus aspiraciones, ya que el hospital solamente admite mujeres alumnas en la especialidad de parteras 46 .

Estanislao López y otros dos paisanos suyos solicitan cuatro becas al Sr. Arauz para jóvenes en el Colegio de María Auxiliadora, perteneciente a las hermanas franciscanas que trabajaban en San Blas. Redactan la petición también para el

\footnotetext{
42 V. RD, ns. 417 y 422; V. CD, n. CLXII.

43 V. RD, n. 424; V. CD, n. CLXIII.

44 V. RD, n. 429; V. CD, n. CLXV.

45 V. RD, n. 430; V. CD, n. CLXVI.

46 V. RD, n. 431; V. CD, n. CLXVII.
} 
consejo municipal47.

Las mismas personas le recuerdan al Presidente de la República las becas que otorgara el Presidente Belisario para hacer obstetricia y piden que se concedan nuevamente para beneficio de los indígenas 48 .

El intendente pide al director que en su informe no haga mención del aumento de maestros. Y la necesidad de una maestra más para Corazón de Jesús cree que debe ser cubierta por una hermana franciscana 49 .

En mayo el Presidente de la República transmite la aprobación para que las cinco jóvenes con el título de ostetricia puedan prestar sus servicios en la sección de puericultura e higiene escolar con un sueldo de B/ 20 mensuales cada una. Además de prestar un servicio contribuirían a la labor del gobierno50. Y son nombradas como ayudantes puericultoras en Río Azúcar51.

En abril el intendente solicita la apertura de nuevas escuelas, pero un mes más tarde recibe contestación, en la que se le expone la imposibilidad de esta medida por falta de

\footnotetext{
47 V. RD, ns. 426 у 427; V. CD, n. CLXIV.

48 V. RD, n. 428.

49 V. RD, n. 425.

50 V. RD, n. 433; V. CD, n. CLXIX.

51 V. RD, n. 435.
} 
presupuesto. $Y$ queda relegada a un futuro, en que el tesoro lo permita52. En 1929 un maestro de Puerto Obaldía renuncia a su puesto y es nombrada una nueva maestra 53 .

Los isleños de Narganá, Corazón de Jesús y Río Azúcar interpelan al Presidente de la República si son ciertos los rumores que corren sobre la cancelación de todas las becas indígenas. Al mismo tiempo que le preguntan por su opinión con respecto a los becados que están en la Escuela de Artes y Oficios, Instituto Nacional, la Normal de Institutoras de Señoritas y la Profesional ${ }^{54}$.

Las borracheras, uno de los problemas de los indígenas y que tuvo repercusiones en la escuela, llegó a unos extremos un tanto insospechados. Ante las quejas presentadas por una maestra el intendente prohibe los alcoholes perfumados para que los indígenas no se embriaguen con ellos 55 .

En el curso 1929-30 cambia la dirección de las escuelas a manos del padre Félix Monasterio y se nombra un maestro varón para la escuela de Narganá, pero que pertenece al pueblo indígena56. Esta escuela contó con una matrícula de 204 alumnos. Además de éste se produce otro nombramiento que

\footnotetext{
52 V. RD, n. 432; V. CD, n. CLXVIII.

53 V. RD, n. 434; V. CD, n. CLXX.

54 V. RD, n. 436; V. CD, n. CLXXI.

55 V. RD, n. 437; V. CD, n. CLXXII.

56 V. RD, n. 439; V. CD, n. CLXXIII.
} 
recae en la esposa del intendente, que se hace cargo de la escuela de El Porvenir. El Presidente Arosemena es quien le hace llegar la noticia 57 . Pero los nombramientos oficiales, a los interesados no les llegan, por lo que se atrasará el cobro de su sueldo58. Por una carta posterior podemos saber que estos dos nombramientos corrían a cargo del Ministerio de Instrucción Pública59.

Una carta de septiembre hace llegar a la secretaría de Gobierno y Justicia las quejas por la falta de programa en las escuelas de la comarca de San Blas. Pero lo que realmente lamenta el intendente, es la falta de adaptación del programa de la Inspección General de Enseñanza, que no es adecuado para esta región. Conjunta a esta queje se hace saber que la inspección sólo ha realizado una visita en cinco años y los maestros entran y salen dejando su puesto de trabajo sin ningún permiso. La confusión es patente. El director de la escuela de Narganá solo actúa en dicha escuela, porque no tiene una orden expresa que le autorice a interesarse por el resto de las escuelas. El intendente aclara que según el artículo 12 del decreto 215 del año 1925 el personal de la comarca está bajo su autoridad, pero los maestros, al estar desligados del gobierno central no entrarían en su competencia, por lo que no

\footnotetext{
57 V. RD, ns. 446 y 447; V. CD, n. CLXXVII.

58 V. RD, ns. 450 y 470; V. CD, n. CLXXIX.

59 V. RD, n. 469.
} 
puede intervenir directamente en este asunto.

Río Azúcar y Puerto Obaldía funcionan según el grado de interés mostrado por sus respectivos maestros. $Y$ esta última ha visto aumentar su plantel en un grado más con la consiguiente necesidad de buscar un nuevo local que lo albergase 60 .

En septiembre es enviada una maestra desde Playón Chico para sustituir a otra de Narganá61.

La contestación no se hace esperar y tres días después la secretaría de Gobierno y Justicia hace saber que el alquiler de los locales escolares le corresponde pagarlo a Gobierno y Justicia de quien depende la comarca incluso en materia de educación. El intendente autoriza el pago del alquiler escolar que asciende a B/ 562 . Le hace saber que esa secretaría tiene el propósito de elaborar un programa educativo adecuado a las necesidades de esa zona para el curso próximo y que hasta tanto no se haga efectivo esto, se deben impartir los mismos que rigen para todo el país, dando preferencia a las asignaturas de castellano, aritmética, higiene práctica, agricultura práctica, geografía y religión.

Hace saber al intendente, que como jefe superior de la

\footnotetext{
60 V. RD, n. 443; V. CD, n. CLXXIV.

61 V. RD, n. 442.

62 V. RD, n. 440.
} 
comarca, es el inspector de las escuelas y que los directores y maestros están sometidos a lo dispuesto en el código escolar63. El intendente promete poner todo su esfuerzo para que las escuelas de este lugar alcancen todo el desarrollo y prosperidad que deben prestigiarlas 64 .

La directora de Río Azúcar hace llegar al intendente la petición de los habitantes de Tigre en la que manifiestan su deseo de reabrir la escuela; y éste promete interesar al secretario de Gobierno y Justicia para que en el nuevo curso pueda hacerse realidad 65 .

Los cheques enviados a la intendencia muestran lo que cobran los maestros y los indígenas amigos del gobierno66. Pero algunos deben ser repartidos entre más de uno como ocurre con los policías escolares de Río Azúcar y los sahilas 67 .

Los buenos ideales de Estanislao López le llevan a decir en un discurso a la federación obrera que los más civilizados deben velar por los intereses de los otros, para que respeten sus derechos 68 .

\footnotetext{
63 V. RD, n. 444; V. CD, n. CLXXV.

64 V. RD, n. 445; V. CD, n. CLXXVI.

65 V. RD, n. 451; V. CD, n. CLXXX.

66 V. RD, n. 452; V. CD, n. CLXXXI.

67 V. RD, n. 441.

68 V. RD, n. 48.
} 
El director de la escuela de Puerto Obaldía informa al intendente que el curso 1930-31 se iniciará con un censo escolar de 51 niños y que el pasado curso solo funcionaron los grados I y III, ya que los pocos que había en segundo eran repetidores y fueron pasados al tercero. Tiene esperanzas de que se pueda abrir el IV grado si los niños que pasan se quedan todos en esa población; y podrían trabajar dos maestros 69 .

La conducta que ha presentado la maestra de esa localidad ha dejado mucho que desear, computando un excesivo número de ausencias y según el director su conducta moral ha sido un mal ejemplo para la población; terminando por marcharse antes de los exámenes finales y clausurando del curso con anterioridad 70 . El intendente recibe un radio que le anuncia que la escuela de Puerto Obaldía debe seguir igual hasta el próximo año lectivo que se efectuarán los cambios ${ }^{71}$.

En este año se encontraban funcionando dos escuelas indígenas nocturnas, ubicadas respectivamente en Panamá y Colón; y a partir de ahora quedan adscritas al Reformatorio Justo Arosemena72.

El nuevo curso comienza el dos de mayo con la

69 V. RD, n. 455; V. CD, n. CLXXXII.

70 V. RD, n. 456; V. CD, n. CLXXXIII.

71 V. RD, n. 471; V. CD, n. CXCI.

72 Dcto. 102 del 15 de Mayo de 1931. 
reapertura de la escuela de Tigre a la que se designan dos maestros. En la de Río Azúcar son nombrados tres. Un padre, tres hermanas y tres maestras forman el plantel de Narganá y dos van a Puerto Obaldía73. El decreto que hacía pública esta distribución no hacía ninguna mención de la escuela de Corazón de Jesús. Pero posteriormente aparece el acta de toma de posesión de los maestros en el que se puede leer que dos de las maestras de Narganá firman su prestación de servicio en Corazón de Jesús ${ }^{74}$.

Según la nueva normativa la toma de posesión de los maestros se debía efectuar en la intendencia no ante el jefe del destacamento, como se hacía anteriormente, pero dicho jefe toma juramento para que no se retrase la fecha de inicio, que acarrearía el consiguiente descuento en sus sueldos. Se hace constar que algunos no han tomado posesión por falta de estampillas y otros por no haberse presentado 75 .

Desde ahora el personal destacado en la circunscripción de San Blas sería nombrado por el poder ejecutivo, cambiándose lo establecido en 192576 .

La secretaría de Gobierno y Justicia pide informe al

73 V. RD, n. 457; V. CD, n. CLXXXIV.

74 V. RD, n. 459; V. CD, n. CLXXXVI.

$75 V . R D, n s 460$ y $595 ; V . C D$, ns. CLXXXVII y CCLIX.

76 Deto. 81 del 12 de Mayo de 1932. 
intendente de la recomendación hecha por Estanislao López y Roberto Pérez para llenar cuatro becas vacantes de indígenas en la Escuela de Artes y Oficios ${ }^{77}$.

Una nota del secretario de Gobierno y Justicia al director $\mathrm{y}$ al intendente les hace saber que ha sido nombrada como maestra la hermana Priscila para el sexto grado de la escuela de Narganá78.

Por una carta de la maestra Micaela de Espino podemos ver el sistema de enseñanza de lectura, en el que se aprendería primero los sonidos, luego los niños manejarían los caracteres impresos para formar palabras y luego frases. Este sistema aligeraría la enseñanza además de hacerla más activa. Esto demuestra la importancia de las corrientes pedagógicas europeas ${ }^{79}$.

La maestra de Río Azúcar, Inés Córdoba comenta que se hace cargo del tercer grado pero se lamenta de que los niños carecen de los materiales más imprescindibles, como libros, cuadernos y lápices ${ }^{80}$. La otra maestra de esta localidad pide permiso al intendente para realizar algunas ventas de sus objetos que le permitan contar con un poco más de dinero, ya

\footnotetext{
77 V. RD, n. 458; V. CD, n. CLXXXV.

78 V. RD, ns. 461 у 462.

79 V. RD, n. 464.

80 V. RD, n. 467; V. CD, n. CLXXXIX.
} 
que su sueldo no la alcanza para vivir en esta región donde la vida es tan cara ${ }^{81}$. Las dos se quejan de que no disponen ni de un tanque para el agua82.

Los nombramientos de agentes indígenas siguen en pie y desde Panamá se proponen cuatro para la isla de Tigre que ha abierto una vez más las puertas de la escuela83.

Tras el envío de un informe por parte del director Félix Monasterio a la Secretaría de Gobierno y Justicia se relevan de sus puestos a las dos maestras de Río Azúcar a partir del 31 de agosto; se argumenta que este proceder es fruto de la imperioso necesidad de economía que el gobierno está haciendo84. Una acción similar se produce con una maestra de Narganá que es suspendida de su puesto y se nombra a otro maestro que pasa a ocupar la plaza de las dos maestras destituidas en Río Azúcar85. En Puerto Obaldía también se comunica la supresión de la maestra Arboleda pero el director manda un radio exponiendo la necesidad de que permanezca. Argumenta que tienen una matrícula de cincuenta y nueve alumnos distribuidos en los cuatro primeros grados. Los vecinos

\footnotetext{
81 V. RD, n. 468; V. CD, n. CXC.

82 V. RD, n. 480; V. CD, n. CXCVIII.

83 V. RD, n. 472; V. CD, n. CXCII.

84 V. RD, n. 476; V. CD, n. CXCIV.

85 V. RD, n. 479; V. CD, n. CXCVII.
} 
del lugar hacen lo mismo con otros dos radios que envían 86.

La delimitación de una zona indígena parece que se aproxima pues la Asamblea Nacional debate un proyecto de ley para resolver esta cuestión de las continuas invasiones de negros y exploradores de riquezas de la zona 87.

En octubre Róbinson pide al presidente que les provea de una caja de herramientas de carpintería para un taller que poseen y que se dedica a la enseñanza de este oficio. Hace referencia a la mala situación por la que atraviesa el país y que ellos también acusan. Este es el motivo por el que suplica se les exonere de los impuestos a la pequeña tienda que tienen para su abastecimiento. Comenta el rumor que corre de que van a quitar a las hermanas que allí trabajan y pide que no se haga esto que atrasaría la empresa de la civilización, ya que no podrían disfrutar de sus enseñanzas. Pide que se vuelva a dar el puesto de agente de policía indígena al viejo luchador Inatoiquiña y recurre para apoyar su petición a la labor prestada cuando los sucesos de 192588 .

El jefe del destacamento Anibal Watts le comunica al director de las escuelas de San Blas que en repetidas ocasiones el sahila de Tigre se ha personado en su despacho para

\footnotetext{
86 V. RD, n. 485; V. CD, n. CCII.

87 V. RD, n. 483; V. CD, n. CC.

88 V. RD, n. 484; V. CD, n. CCI.
} 
exponerle las quejas del maestro de dicho lugar por su falta de cumplimiento; pidiendo que sea reemplazado por otro cualquiera, o por uno que el propone. Pero la respuesta del director aclara que no es competencia suya el sustituir a los maestros. Esto le corresponde al intendente si así lo juzga oportuno 89 .

Los datos de las escuelas de este año son los relatados por Rubén P. Kantule en un discurso dado en la Escuela de Señoritas. La cifra de alumnos venidos a Narganá desde otras islas asciende a cincuenta y cinco; y la matrícula de las escuelas de Narganá, Corazón de Jesús, Río Azúcar y Tigre es de trescientas treinta y seis $^{90}$.

Para el curso de 1933 los indios hacen una propuesta de maestros que se pueden nombrar para los lugares que más desean la instrucción, esta solicitud estaba respaldada por los pueblos que más estimaban la educación, y se la presentan al Presidente Armodio91. El secretario de Gobierno y Justicia contesta a los habitantes de Narganá diciendo que tendrá en cuenta su petición de sustituir al maestro en su puesto por los paisanos que han terminado la escuela primaria en Narganá92.

\footnotetext{
89 V. RD, n. 500; V. CD, n. CCXV.

$90 \mathrm{~V} . R D, n .505$.

91 V. RD, n. 506; V. CD, n. CCXVII.

92 V. RD, n. 507.
} 
Si con Alcibiades había empezado el servilismo de los indios con los candidatos a Presidente; desde 1932 empieza otra división creada por los distintos partidos que buscan sus simpatizantes entre los miembros del pueblo kuna. Los principales dirigentes de los kunas fueron haciendo sus incursiones en la vida política y sacando el mayor partido posible para el archipiélago de San Blas; en la mayoría de los casos pretendían mejoras a nivel educativo. En la segunda convención del Partido Liberal Renovador Estanislao pronuncia un discurso donde recoge los temas educativos y los logros alcanzados 93 .

El intendente Aguilera en 1933 ya expone la necesidad de crear una colonia agrícola indígena en el valle de Mandinga. Esta pretensión se realizaría en varias ocasiones pero con poco éxito. Las obras de una compañía bananera, que se estaban realizando, ayudarían también a la instrucción indígena, y así se lo expresa al secretario de Gobierno y Justicia94.

Los hombres kunas destacados en este proceso cultural fueron hombres con una amplia cultura, así nos lo atestiguan sus viajes y dominio de varias lenguas. Rubén $P$. Kantule 95 viajó con los antropólogos suecos a Europa. Charles Róbinson estuvo en Estados Unidos, a Estanislao López se le

93 V. RD, n. 515.

94 V. RD, n. 511.

95 V. RD, n. 518. 
otorgó el título de cacique general de los indios de Panamá, y Nele Kantule recibió una vasta formación en Colombia.

En este curso la escuela de Río Azúcar sigue sin los materiales más imprescindibles, y así se lo comunica al intendente el maestro, señalando que no tiene ni libros de lectura para los dos primeros cursos, dieciocho de primero y veintidós de segundo. Carece de otros elementos como pueden ser reglas, y la bandera nacional exigida por la codificación escolar para presidir su labor docente ${ }^{96}$.

El intendente también pide a la secretaría de Gobierno y Justicia tres becas para que los indígenas puedan ir a aprender a la Granja Experimental de Summit en la zona del canal. $Y$ se concede una plaza para que un aprendiz pueda realizar allí sus estudios ${ }^{97}$.

El P. Berengueras siente la necesidad de trasladarse para inspeccionar las escuelas y esto hace que tome la medida de dar su cheque para la compra de una lanchita, ya que se carecía de vehículo de transporte por mar, único medio accesible para llegar a las otras islas 98 .

Tras las acusaciones al maestro de Río Cidra el intendente concluye que no son fundadas y le vuelve a enviar a

\footnotetext{
96 V. RD, n. 508; V. CD, n. CCXVIII.

97 V. RD, n. 512; V. CD, n. CCXXI.

98 V. RD, n. 522.
} 
este lugar, ordenando que los padres manden a sus hijos a la escuela99.

En el primer mes de 1934 el decreto número 8 nombra al sahila Olonibikinya, de Cartí Sugdupu, policía colonial para el sector de Cartí. Un jefe más de los indios pasa a ser colaborador del gobierno.

Por la crónica de las franciscanas sabemos que en este curso en Narganá había 10 estudiantes de Tigre, cuyos habitantes cerraron la escuela del gobierno y habían vuelto a sus tradiciones; de Tikantikí 13, de Ailigandí 6 y de Tupile y Tubalá algunos más. En Mulatupu Inapaquiña les recibe a los misioneros que está de gira con simpatía y les invita a quedarse a trabajar allí. De esta isla se apuntan algunos muchachos para ir a estudiar a Narganá. Durante la mencionada gira no son recibidos con agrado en Ailigandí donde están los protestantes 100 .

En este año de 1934 el P. Berengueras publica un libro titulado: Rudimentos de Gramática Kuna. Y un año después hace aparición el Devocionario Karibe-Kuna.

El premier Solís hace una vista a la comarca y manifiesta que allí existe una misión protestante que realiza

99 V. RD, n. 523.

100 Crónica de las Madres Franciscanas. 
actividad de catequización con la tendencia de crear animadversión al gobierno. Pero Rubén P. Kantule, desde la cárcel, argumenta que el deseo de los indios ha sido conseguir una civilización integral y así han solicitado como panameños que les dieran los medios necesarios para alcanzar esto. Cree que esos hechos desagradables no se producirían si el gobierno pusiera más instrucción pública recortando los presupuestos de representaciones y empleados innecesarias. Los sueldos de los indígenas estudiados son muy escasos para vivir, ya que no se pueden dedicar a las labores de agricultura, que ayudarían a su pobre economía que no alcanza los B/ 15 , por no tener tiempo libre ${ }^{101 .}$

En el empeño de civilizar el archipiélago de San Blas, los medios se fueron sucediendo y a veces repitiendo, comprobando el secretario de Gobierno y Justicia que el más eficaz era el de las misiones, y así se lo declara a la Asamblea Nacional en setiembre de 1934102 .

Los datos escolares son remitidos desde El Porvenir al secretario de Gobierno y Justicia, pues el intendente es el que hace de inspector de las escuelas en la comarca de San Blas ${ }^{103}$.

Una epidemia de viruela propagada en Río Azúcar ha

101 V. RD, n. 529; V. CD, n. CCXXXIV.

102 V. RD, n. 530.

103 V. RD, n. 533. 
obligado al cierre de la escuela para evitar el contagio. El director junto con los maestros y algunas madres son los encargados de atender a los enfermos ${ }^{104}$. Después de esta epidemia que afectó también a Narganá, el director pide medicamentos al intendente y le recuerda que Arnulfo Arias siempre les satisfizo estas necesidades ${ }^{105}$.

El intendente exhorta al corregidor de Puerto Obaldía para que ponga todos los medios a su alcance a fin de que los padres no dejen de mandar a sus hijos a la escuela, cumpliendo con este deber moral, y los niños asistan religiosamente. Como última sugerencia le pide que vigile la limpieza de la población ${ }^{106}$.

Otro de los maestros de Río Azúcar en este curso fue fuente de problemas y preocupación para el gobierno, que considera que su actividad más que ser educativa, pretende enfrentar a los indios y al gobierno nacional107. Al año siguiente se le trasladaría a la escuela de Río Cidra y nuevamente el intendente se ve en la necesidad de enviar a Gobierno y Justicia un memorial comprobatorio de la conducta poco deseable para alguien que dirige una escuela de niños ${ }^{108}$.

\footnotetext{
104 V. RD, n. 537.

105 V. RD, n. 548.

106 V. RD, n. 541.

107 V. RD, n. 514; V. CD, n. CCXXIII.

108 V. RD, n. 538; V. CD, n. CCXXXIX.
} 
En Naraganá y Corazón de Jesús funcionaron bajo la dirección de las franciscanas y los claretianos una escuela nocturna para las mujeres y los hombres. Entre las materias impartidas a los adultos por las misioneras franciscanas estaba la mecanografía, además de la costura y otras ${ }^{109}$.

Los nombramientos de los maestros de la región de San Blas se hacían mediante propuesta del intendente al secretario de Gobierno y Justicia, previa consulta al director de las escuelas. Y para el curso de 1934-35 se proponen para Narganá seis hermanas franciscanas; la razón es que así la educación será más uniforme. Para Río Azúcar se nombran dos maestras de las cuales una es india y la otra no, pero es esposa de un indio agente indígena. En Tigre se designa una maestra lo mismo que en Río Cidra. Para Puerto Obaldía se requiere un maestro que sea negro y esté inmunizado del paludismo. Se anota la sugerencia de nombrar los maestros con cierta antelación para poderlos reunir en Narganá a fin de conferenciar con ellos antes de que comiencen las labores y estimular a los indios a que adquieran libros en castellano ${ }^{110}$.

Finalmente los nombramientos quedan fijados con un director y un ayudante, que son misioneros, y cinco hermanas en la escuela de Narganá. En Río Cidra queda el maestro que el

109 V. RD, n. 516; V. CD, n. CCXXIV.

110 V. RD, n. 517; V. CD, n. CCXXV. 
curso pasado provocara problemas. Dos maestras para Río Azúcar, una para Tigre y otra para Puerto Obaldía. La maestra destinada a este lugar enferma, y por otras causas, además de esta, permanece cerrada la escuela durante mucho tiempo. Ello lleva a que los padres soliciten la baja en esta escuela para mandar a los hijos a la escuela particular ${ }^{111}$.

En 1934 el intendente hace ver al secretario de Gobierno y Justicia que su medida de suprimir el decreto que prohibe la venta de alcoholes va en deterioro de la labor civilizadora y en perjuicio de la escuela; pues una vez que se les permite esto hasta los niños toman, ahogando la labor que los maestros realizan. Una vez que se ponen a beber, la norma es que todos están obligados a hacerlo112.

Un grupo de indígenas pretende que se suprima la policía allí destacada así como las autoridades nacionales, ya que ellos se consideran lo suficientemente capacitados para gobernarse sin la mediación de elementos extraños a su cultura113.

En el primer año de apertura de la escuela de Cartí, el maestro presenta una denuncia ante la Intendencia por la labor realizada por un indio en contra de la escuela nacional, que da

$111 V . R D, n .525 ; V . C D, n . \mathrm{CCXXX}$.

112 V. RD, n. 527; V. CD, n. CCXXXII.

113 V. RD, n. 528; V. CD, n. CCXXXIII. 
clases en inglés y apoya a la raza norteamericana; acusando al maestro de pretender quitarles sus costumbres y que el sahila Olonibiquiña recibía un sueldo para hacer propaganda panameña 114.

Los jóvenes que salían a estudiar a Panamá y eran colocados en casas de familias acomodadas, en ocasiones no llegaban a empezar sus estudios y luego tienen problemas para volver a su tierra ${ }^{115}$.

En el curso 1935-36 el intendente pide al director de las escuelas que nombre otro maestro o maestra para la escuela de Cartí, pues el existente ha creado problemas que han levantado las quejas del sahila Olonibiquiña ${ }^{116}$. Así se nombra para este lugar a la que había sido designada para Ailigandí, pero que teme ir porque no va a ser bien recibida, con lo cual, se queda la escuela de Ailigandí sin maestra; pero cree el intendente que se subsana este mal, porque allí funciona la escuela de Alcibiades Iglesias, protegido de Nele Kantule, y que no ven con buenos ojos los misioneros católicos. Nele ya ha avisado al intendente que tiene intención de abrir la escuela particular de Alcibiades ${ }^{117}$.

114 V. RD, n. 531; V. CD, n. CCXXXV.

115 V. RD, n. 549.

116 V. RD, n. 553; V. CD, n. CCXLVII.

117 V. RD, n. 554; V. CD, n. CCXLVIII. 
En marzo de 1936 el sahila de Ailigandí, Ykuanikdipipe, comenta al Presidente de la República que la escuela del gobierno está en mal estado, y que fue levantada por el pueblo, pero que desea que el gobierno levante una nueva de material más consistente. Ellos se hallan satisfechos de la labor que hizo el maestro durante el curso pasado118. Este es de la misma opinión añadiendo la falta de bancas para los estudiantes; así se lo expresa al director para que a su vez se lo haga saber al intendente Recaredo. La situación lamentable de las escuelas Ilega hasta Suitupu y Tigre119.

Desde este año se incluyen en las listas para diputados a los propios indígenas de la región kuna. Y se gradúa el primer bachiller indígena del Instituto Nacional, lo que supondría un gran logro para la comunidad kuna.

Los dirigentes tuvieron una situación privilegiada y en todo momento buscaban que sus hijos pudiesen seguir sus estudios en Panamá. El privilegio de los hijos de los caciques se remontaba a los tiempos de la conquista 120 .

Los vecinos de Río Azúcar se lamentan ante la marcha de la maestra que impartía segundo grado, pues ahora se ha visto cargada la que enseñaba en el primero. Esta ausencia fue

118 V. RD, n. 559; V. CD, n. CCXLIX.

119 V. RD, n. 561.

120 V. RD, n. 562. 
con un permiso pero que se prolongó sin justificación, desprestigiando a la escuela121. La misma situación ha ocurrido con el maestro de Puerto Obaldía, pero éste se ausentó sin permiso. Así se acrecienta la antipatía que el pueblo sentía hacia él. El director juzga por ello que sería conveniente separarle de esta escuela ${ }^{122}$.

En agosto se produce un movimiento de maestros en la comarca y se nombra una nueva maestra para Río Azúcar. Simón Bravo tiene intención de ir a estimular a los padres una vez que se presente la maestra123. Los frutos son visibles pues la matrícula aumentará en treinta niños además de contar con la cooperación de los padres ${ }^{124}$.

La tabla estadística del mes de julio de 1936 muestran una caída en la matrícula y asistencia en la escuela de Suitupu, que según expresión del director Simón Bravo, se ha reducido a la mínima expresión. En la misma agradece al intendente el envío de materiales ${ }^{125}$. En septiembre la situación persiste sin alcanzar la matrícula el número requerido por la ley, y siendo aun peor la asistencia. Ante la esterilidad de esta

121 V. RD, ns. 564.

122 V. RD, n. 567.

123 V. RD, n. 568.

124 V. RD, n. 569.

125 V. RD, ns. 565 y 566. 
escuela el director sugiere que se traslade 126.

La visita a la escuela de Tigre realizada por el director es satisfactoria, pues los habitantes están contentos, a pesar de los pocos muebles que posee y ser el edificio una construcción típica. Sugiere que se aprovechen las maderas del antiguo cuartel para hacer bancas, pues los muchachos no tienen donde sentarse ${ }^{127}$.

La escuela de Ailigandí tiene poca matrícula debido, según el director, a la escuela particular dirigida por Alcibiades Iglesias. Hay que tener en cuenta que esta es la isla más poblada y por ello en número de infantes es muy elevado128.

Entre los intendentes que fueron desfilando por EI Porvenir fue una tónica dominante el respeto de estos hacia los misioneros católicos. Simón Bravo agradece al intendente Hernández su colaboración con la misión y con el ramo de Instrucción Pública en particular129.

En las elecciones de 1936 los estudiantes de Panamá apoyaron al Dr. Porras según Estanislao López, que estuvo cerca de la política. Los kunas se van incorporando a la vida civilizada y por ello van tomando parte en todos los sectores de la vida

\footnotetext{
126 V. RD, n. 570.

127 V. RD, n. 569.

128 V. RD, n. 571.

129 V. RD, n. 572.
} 
nacional. Los estudiantes y trabajadores kunas que se desplazan a las ciudades son los más sensibilizados con los temas políticos ${ }^{130}$.

Este año Estanislao comenta a Tomás Herrera que han pedido una escuela nueva para Playón Chico. Este maestro de Ailigandí será acusado por el director de hacer campaña contra el gobierno aprovechando su situación y la de su señora que es maestra de Tigre. Los hechos de delito consistieron en dar comida a los que votaran contra el gobierno existente. El mismo caso de oposición se dio con la maestra Ursula Roldán pedida por Nele Kantule131.

Las elecciones parece que perturbaron un poco la calma de las escuelas y que tuvieron su repercusión. El director dice que la escuela de Tigre ha cerrado sin su permiso y en Río Azúcar quieren de maestro a un hijo del pueblo que es adepto al gobierno. En este informe se aclara también que el maestro de Puerto Obaldía tuvo que abandonar el año pasado por enfermedad, poca asistencia y poca matrícula; que llegó solo a veinticuatro ${ }^{132}$.

Los destacamentos prosiguen su tarea, aunque con fuerzas muy menguadas con respecto a la primera época. Son los

130 V. RD, ns. 573 y 574.

131 V. RD, ns. 574 y 575.

132 V. RD, n. 576. 
transmisores de las órdenes del intendente ${ }^{133}$.

Las envidias de los que tenían estudios entre los indios hacen que surjan problemas a la hora de hacer los nombramientos, y esto crea la división y las rencillas. Se busca la recomendación entre el intendente o los gobernantes ${ }^{134}$. Las relaciones amistosas de las maestras con el intendente o con los otros dirigentes que consiguen sus nombramientos a costa de su incapacidad, y que dan una mala imagen en el servicio van en detrimento de la educación, como en ocasiones ocurre ${ }^{135}$.

Iguatinquipipilele pide al secretario de Obras Públicas que les ayude en la construcción del piso de la escuela con materiales, ya que la mano de obra correría por cuenta de los indígenas. Según la legislación la construcción de las escuelas debía correr a cargo del municipio, costeándose con sus presupuestos $^{136}$.

El curso 1937-38 comienza con un matrícula en Narganá que asciende a doscientos cincuenta y ocho alumnos y el director es el P. Simón Bravo, la escuela de Narganá sigue bajo la tutela de las hermanas franciscanas137. A finales de mayo se aprecia un aumento de matrícula en casi todas las

133 V. RD, n. 577.

134 V. RD, n. 583; V. CD, n. CCLII.

135 V. RD, n. 608; V. CD, n. CCLXIX.

136 V. RD, n. 590.

137 V. RD, n. 595; V. CD, n. CCLIX. 
escuelas, y la asistencia se ve caracterizada por la regularidad 138 .

Los informes mensuales del director de las escuelas nos permiten ver la marcha continuada que éstas van llevando. El, durante el año, va girando visitas a las distintas escuelas y así comprueba su funcionamiento. En junio constata que los niños de Tigre están un poco atrasados, aunque han mejorado con respecto al curso pasado, y es de destacar que el sahila tiene a sus hijos en la escuela, después de haber mostrada opsición a la implantación de la misma. La isla de Tikantikí o Niatupu es una de las más interesadas en la educación, prueba de ello es que tiene más de treinta niños en la escuela de Narganá139.

Las enfermedades generalizadas ponen freno a las asistencias, y en el mes de julio así se lo expresa el director al intendente, a pesar de que se hayan producido algunos aumentos en las matrículas. Este mes la visita de inspección a correspondido a Cartí Suitupu, que muestra una actividad floreciente ${ }^{140}$. En ocasiones estas epidemias son importadas por aquellos que salen de la región a buscar trabajo en las ciudades de la república, y vuelven con las enfermedades

138 V. RD, n. 597; V. CD, n. CCLXI.

139 V. RD, n. 599; V. CD, n. CCLXIII.

140 V. RD, n. 600; V. CD, n. CCLXIV. 
propias del mundo civilizado141. En noviembre de 1939 un doctor nuevamente hace una gira acompañado por el director de las escuelas que hace las veces de enfermero para atender esta zona desprovista de la más elemental medicina ${ }^{142}$.

En octubre la visita correspondería a Puerto Obaldía, donde la maestra desarrolla una buena labor, a pesar de que los padres no tienen interés por mandar a sus hijos a la escuela, parece casi imposible que confluyan las condiciones favorables, pues cuando hay buen maestro falta el interés y viceversa ${ }^{143}$.

Concluye el director la primera gira de visitas a las escuelas en noviembre, con la visita de Ailigandí, donde funciona la escuela pública en un local compartido con la escuela privada de Alcibiades, que durante el día da clases a los párvulos y a los jóvenes, de inglés. Su esposa la Sra. Marvel imparte clases a la niñas. Opina el director que se deberían independizar las dos escuelas, pues el local que ocupan está bien para una sola. Así mismo juzga conveniente que en la escuela privada se imparta la enseñanza en el idioma oficial, y el inglés se dé como una clase especial.

Las visitas del director llegan hasta los lugares donde no se ha implantado la escuela nacional; este es el caso de

141 V. RD, n. 621; V. CD, n. CCLXXXI.

142 V. RD, n. 649; V. CD, n. CCXCII.

143 V. RD, n. 601; V. CD, n. CCLXV. 
Tupile, pero donde funciona una escuela privada que tiene 50 niños. Los isleños piden al director que interceda para que el curso próximo les abra el gobierno la escuela pública. Su local es de madera y el interés es tan grande que obligan a los niños a que $\operatorname{asistan}^{144}$.

El maestro David Rodríguez permaneció en Ustupu desde 1937 hasta 1946, según las listas de alumnos de esta escuela que están encabezadas por dicho maestro. Esta estabilidad en el mismo centro no fue lo común entre los docentes de la comarca ${ }^{145}$.

Para el curso 1938-39 el secretario de Gobierno y Justicia pide al intendente que cumpliendo el decreto aparecido de nombramiento de maestros para la comarca avise a los mismos, ya que el desconoce las direcciones de estos. El nombramiento de Puerto Obaldía se efectuaría posteriormente ${ }^{146}$.

Los datos parecen confirmar que la economía del país ha ido mejorando y prueba de ello es que los planteles escolares han ido aumentando en el archipiélago de San Blas. Son diez los centros escolares abiertos en el curso 1938-39. Ustupu con dos maestros, El Porvenir con uno, Cartí Suitupu con uno, Narganá

144 V. RD, n. 602; V. CD, n. CCLXVI.

145 V. RD, n. 603.

146 V. RD, ns. 604 у 606. 
con cinco y el director, Corazón de Jesús con uno, Río Azúcar con dos, Wichuwala con uno, Tigre con uno, Tupile Arriba con uno y Ailigandí con otro ${ }^{147}$.

En la anterior relación falta la escuela de Puerto Obaldía a la que se nombró una maestra, pero ella lo considera insuficiente, ya que la afluencia de niños la ha hecho dividir la jornada escolar y atender a unos por la mañana y a los otros por la tarde. Por esta razón pide al intendente que se nombre una maestra más, ya que los padres no están de acuerdo con esta medida, y para que no decaiga su interés por la escuela. Ella está dispuesta a hacer todo lo posible para que no mengüe el interés por la educación ${ }^{148}$.

La carencia de los materiales escolares más imprescindibles hace que el maestro de Tigre en el mes de agosto comente al director que no poseen bancos en la escuela ${ }^{149}$.

Algunos atisbos de descontento se producen entre los indios y las alarmas se disparan rápidamente. Se teme que por cualquier motivo se produzca una revolución similar a la del 25 . En Tigre surgen unos pequeños incidentes, algo similar sucede en Ailigandí. Ante la ausencia de destacamentos de policía, los

147 V. RD, n. 605; V. CD, n. CCLXVII.

148 V. RD, ns. 607 y 610; V. CD, ns. CCLXVIII y CCLXXI.

149 V. RD, n. 609; V. CD, n. CCLXX. 
representantes del gobierno son los maestros, ellos deben informar de cualquier anomalía, de no hacerlo puede peligrar su puesto de trabajo. El director de las escuelas es quien les llama y les avisa de su responsabilidad 150.

En este curso de 1938 el único lugar que manifiesta una cierta remisión por parte de los padres ante la escuela es Cartí Suidupu. El maestro de Tigre, Andrés Iglesias, ha incurrido en falta por libar y vender alcohol. Es intención del intendente mandar personal de su oficina a presenciar los exámenes finales, para que hagan funciones de inspector ${ }^{151}$. El director quiere que la comisión nombrada para presenciar los exámenes, visite también las escuelas privadas de Ustupu al frente de Franklin y la de Ailigandí bajo la dirección del matrimonio Iglesias ${ }^{152 .}$

Los maestros pagan sus faltas con multas en metálico, al igual que los escolares ${ }^{153}$.

La circular para los maestros con el fin de ordenar los exámenes finales nos muestra el reparto de los mismos, por ella podemos ver que en Narganá se estudiaba hasta el sexto grado. $\mathrm{Y}$ cuando en el resto de escuelas terminaban los cursos

150 V. RD, ns. 612 у 635; V. CD, ns. CCLXXIII y CCLXXXVIII.

$151 V . R D, n .613 ; V . C D, n$. CCLXXIV.

152 V. RD, ns. 615 у 619; V. CD, ns. CCLXXVI y CCLXXX.

153 V. RD, n. 614; V. CD, n. CCLXXV. 
existentes podían pasar a proseguir sus estudios a la escuela central de Narganá. Después de superar el cuarto grado se entregaba un diploma acreditativo ${ }^{154}$.

Este periodo está caracterizado por la aceptación de las escuelas y la inclusión en el engranaje político. Quieren que la organización al estilo civilizado se haga con personal indígena, por lo tanto pretenden una autogestión. Pero se lucha con todos los medios por que los nombramientos de maestros recaigan en personas kunas y se buscan recomendaciones para la concesión de becas.

La misión católica mantiene también buenas relaciones con los militares norteamericanos de la Zona, que son verdaderos bienhechores ayudando tanto en los fines religiosos como de instrucción ${ }^{155}$.

Los misioneros también otorgaron becas para la ciudad de Panamá y colocaron niños y niñas, al igual que el P. Gassó en casas de familias panameñas.

El Presidente del país así como otros altos representantes se desplazaron hasta el lugar para comprobar los progresos de los indígenas, lo que servía de estímulo, y vistos los buenos resultados mantenían la ayuda a los

154 V. RD, n. 616; V. CD, n. CCLXXVII.

155 Documento preparatorio para el III Congreso de Pastoral Indígena Nacional p. 72 
misioneros y maestros. La escuela tenía por costumbre obsequiar con una velada a los distinguidos visitantes, dando así muestra de sus adelantos.

Las madres franciscanas desde los comienzos de sus labores escolares realizaban actividades que podemos llamar extraescolares, centradas sobre todo en la música, piano, cítara, violín y acordeón; tambores en las fiestas; y materias relativas a costura ${ }^{156}$. Como actividad extra realizada por las hermanas se puede mencionar todo lo referente a la cuestión sanitaria, al cargo de una especialista.

El testimonio de la actividad desplegada es claro "La escuela de las monjas no tiene nada que envidiar a las restantes del país. Esta escuela donde se da una enseñanza primaria que no tiene nada que tildar, tiene una asistencia de 350 alumnos de ambos sexos y el que llega a presenciar una velada sale sorprendido de ver esos humildes indígenas ejecutar con facilidad pasmosa difíciles piezas musicales en el piano y violín. Lo mismo sucede con los cantos que entonan en los que se nota precisión, compás y armonía y en las comedias que representan las interpretan bien"157.

El gran contingente de alumnos que fluye a las islas de la cabecera de la civilización se tienen que repartir por las

156 Crónica de las Madres Franciscanas, p. 8.

157 La Madre Caridad, apuntes para su biografía, p. 135. 
distintas casas de las islas. Cada alumno forastero debía buscarse un acudiente que era el que le proporcionaba alojamiento y comida, su familia normalmente le pagaba con alimentos.

Los indígenas reclaman una participación en la vida política, quieren elegir a sus representantes, pues consideran que ya han alcanzado un alto grado de civilización. Al mismo tiempo en las escuelas se quiere crear un programa educativo apropiado porque se ve la necisidad de que se adapte a las necesidades de la región y los individuos.

Donde se han levantado escuelas y no existe destacamento, son los maestros los representantes del gobierno y a ellos les compete toda responsabilidad para que se mantenga el orden.

Como conclusión de este periodo señalaremos la matrícula registrada en la escuela de Narganá en el transcurso de estos años: en el curso 29-30 los alumnos eran 204, en el 31-32 subió a 222; en 1933-34 llega a 234, para en el siguiente bajar a 226; en el año académico de 1935-36 nuevamente sube hasta 235, y llega a 250 en el curso 36-37; para alcanzar en el 1937-38 la cifra máxima de 288 alumnos. ${ }^{158}$

Nuevamente parecen resurgir las escuelas, y de tres

158 Cfr. MISIONEROS HIJOS DEL CORAZON DE MARIA: Memoria del Vicariato Apostólico del Darién, Imprenta acción católica, Panamá, 1939. 
que lo hacen al comienzo del periodo, cuando este concluye ya son diez. Ahora no se había usado la fuerza, más bien se puede decir que se usó la mano zurda de los misioneros y su tesón. Los indígenas son los propios peticionarios de este bien que les aporta grandes ventajas. 
9. HACIA LA PLENA CONSOLIDACION DE LA ESCUELA (1939-1945) 


\section{HACIA LA PLENA CONSOLIDACION DE LA ESCUELA (1939-1945)}

\subsection{La dirección de Ricardo Velasco}

Para el nuevo curso $1939-40$ se proponen varias innovaciones, así se lo comenta el intendente al director. Un aumento de maestros para las escuelas de la comarca, que repercutiría en Ailigandí y Tupile, que la maestra de Corazón de Jesús sea también una hermana al igual que en Narganá y la consecución de mobiliario para dotar a las escuelas. Pero la más innovadora, al menos para esta región, pues en otros lugares se hacía así, es que un decreto haga el nombramiento de los maestros para San Blas y luego la distribución de cada escuela la realicen el intendente y el director una vez evaluadas las necesidades y conveniencias ${ }^{1}$.

En Ailigandí se nombra una maestra panameña casada con un subteniente y no es aceptada por el pueblo2. Esto se vio complicado y acentuado por el retraso con que se inician las labores escolares. Ella llega una semana después de iniciarse el curso ${ }^{3}$. Los nombramientos de maestros para Ailigandí no parecen satisfacer al sahila y su pueblo. La segunda maestra

\footnotetext{
${ }^{1} V . R D$, ns. 617 y 618; V. CD, ns. CCLXXVIII y CCLXXIX.

${ }^{2} V . R D, n .624 ; V . C D, n$. CCLXXXIII.

${ }^{3}$ V. RD, n. 631; V. CD, n. CCLXXXV.
} 
nombrada es nueva y no se les notificó previamente que iba a ir esta persona que además no es indígena. Ellos quieren que sigan enseñando la civilización, indígenas capacitados en la enseñanza primaria 4 .

Para los exámenes de fin de curso el director Ricardo Velasco da unas orientaciones a los maestros en la circular que les remite. Las asignaturas objeto de evaluación son el castellano, matemáticas, geografía, historia, estudio de la naturaleza, cívica e higiene. Los cursos de tercero para arriba serán por escrito. Los maestros deben exponer en los salones los trabajos de escritura, croquis y dibujos; los ejercicios de aritmética y composición; y finalmente las apuntaciones, copias y dictados pertenecientes a los alumnos ${ }^{5}$.

La labor de progreso en la comarca se iba haciendo cada año más patente y el reconocimiento provenía de todos los sectores. Un indígena que vuelve a la comarca en abril de 1939, después de estudiar becado en el extranjero, hace un elogio muy favorable del alto grado de adelanto alcanzado por sus paisanos y apoyado por el intendente Luis Hernández 6 .

El maestro como representante del gobierno realiza campaña a favor de éste mediante conferencias, tal es el caso de

\footnotetext{
4 V. RD, n. 623.

5 V. RD, n. 454.

${ }^{6} V . R D, n .622 ; V . C D, n$. CCLXXXII.
} 
Rubén P. Kantule, maestro de Cartí Sugdupu, comenta él que las islas de los alrededores quieren que vaya también a conferenciales, pero sus tareas escolares se lo impiden. A su vez su suegro habla en el congreso de esta isla para ponderar los beneficios de la educación en la niñez, y lo bueno que el ha aprendido de la gente blanca. Rubén P. Kantule no puede abandonar su puesto de maestro pero aprovecha para hacer comprender a la gente la labor del gobierno, todo momento que le queda libre. No ha podido terminar la casa del maestro por falta de materiales. El intendente le encomienda la misión de hacer ver al sahila Olonibiquiña el mal que hace en la isla con su oposición. El atraso de la escuela lo achaca a la maestra anterior, pues los niños aun no saben el abecedario7. Finalmente arregla la mitad de la escuela, pero le faltan materiales para continuar. $Y$ acusa en esta carta a un corruptor de la moralidad que perjudica el intento de llevar a los indios a la civilización. La oposición de algún extremista termina con la destrucción de la casa del maestro8.

El maestro repetidas veces se queja de lo poco que han sacado los alumnos con la anterior maestra, dice que se puede considerar él como el primer maestro del lugar. Ante las próximas elecciones promete que los vecinos del lugar apoyarán

\footnotetext{
7 V. RD, ns. 624, 625, 626 y 627; V. CD, n. CCLXXXIII.

8 V. RD, ns. 629 y 630.
} 
la campaña política emprendida ${ }^{9}$. Las islas con escuela han empezado a tomar parte de la vida política del país como ciudadanos de pleno derecho.

En el presupuesto de materiales para las escuelas nacionales el inspector general de enseñanza incluye las escuelas de la comarca, a pesar de que los materiales se deben pedir a Gobierno y Justicia que tiene una partida para atender estas necesidades de San Blas ${ }^{10}$.

Una nueva escuela abre sus puertas una vez empezado el curso, es la de Permé, con una matrícula de 23 alumnos; y allí es trasladada la maestra que se nombrara para Ailigandí; que permanecía hasta este momento en El Porvenir. La media general de asistencias y matrículas aumentó con respecto al mes pasado y a las mismas fechas del año anterior en el primer mes del curso.

Las visitas de inspección del director tenían entre otros fines detectar las carencias y controlar la labor del maestro, al mismo tiempo que estimularle en sus funciones. En junio tras la visita de inspección, el director delata una merma en la matrícula de Río Azúcar y escasez de materiales en Puerto Obaldía11.

\footnotetext{
9 V. RD, ns. 632 y 649; V. CD, ns. CCLXXXVI y CCXCII.

10 V. RD, n. 633.

11 V. RD, n. 631; V. CD, n. CCLXXXV.
} 
Las malas comunicaciones con la comarca, por carecer de accesos, hacen que se proponga la creación de una carretera por la costa que contribuyen a sufragar los gastos los propios maestros 12 . Los maestros siguen pagando su cuota pro carretera de Colón-Portobelo que sería el trazado de la vía de comunicación ${ }^{13}$.

El número de población y el interés despertado en los habitantes del lugar, hacen de Ustupu uno de los centros de educación más importantes del archipiélago junto con Narganá. Reconoce el director que la estima que muestran por la escuela es muy superior a la que manifiestan los del distrito de Nombre de Dios. Por otra parte se lamenta de que los niños de la escuela inglesa no sepan el himno nacional, conocimiento obligatorio en las escuelas nacionales ${ }^{14}$.

Las ausencias y tardanzas de los maestros quedaron tipificadas en una ley que reformaba la existente referida a faltas. El director dice que lo tendrá en cuenta, pues éste era un problema que se presentaba con relativa frecuencia entre los maestros de la comarca ${ }^{15}$.

12 V. RD, n. 634; V. CD, n. CCLXXXVII.

13 V. RD, n. 638.

${ }^{14}$ V. RD, n. 635; V. CD, n. CCLXXXVIII.

15 V. RD, n. 636. 
El director Ricardo Velasco tuvo que pasar por la malaria como otros muchos maestros; a consecuencia de esto debe retrasar su visita a Puerto Obaldía. A esta dificultad siempre se tiene que sumar que las lanchas que faciliten viajes son escasas. Posteriormente la dirección acondiciona una lanchita para las visitas de inspección de las escuelas ${ }^{16}$.

Las fiestas patrias se celebran con toda solemnidad en la escuela, en ellas participan los empleados del gobierno destacados en las islas. Con motivo de las mismas el pueblo de Narganá consigue del intendente una comida para todos los escolares, unos trescientos veinte, consistente en un saco y medio de arroz y dos tortugas ${ }^{17}$. La labor del intendente Hernández en favor de la instrucción infantil es reconocida por todos los maestros ${ }^{18}$.

La construcción de la nueva escuela de Ustupu que se hace cada vez más necesaria se va retrasando y el local usado de la sociedad Koskuna no se vuelve a dejar al maestro; pues les parece que el tiempo ya ha sido suficiente y el gobierno no cumple su promesa ${ }^{19}$.

\footnotetext{
16 V. RD, ns. 637, 638 у 639.

17 V. RD, ns. 640, 642 у 647.

18 V. RD, n. 641.

19 V. RD, n. 643.
} 
En el informe referente al mes de octubre de 1939 Ricardo Velasco comenta que en su visita a las escuelas ha comprobado que la labor de Cartí Cangrejo no es satisfactoria; así como Puerto Obaldía y Tigre muestran mejoría con respecto al último viaje, Tikantikí ha perdido y Río Azúcar se mantiene en la normalidad20. La matrícula decae algo con respecto a la del mes anterior, y un poco más alarmante es la caída de las asistencias en las diez escuelas. Causa de esta merma es la fiebre aguda extendida por diversas islas ${ }^{21}$. Por este motivo el doctor de la intendencia viaja a Puerto Obaldía y atiende a la policía, a los niños de la escuela y a los particulares que lo solicitaron 22 .

La preocupación por la marcha de los alumnos indígenas en la Escuela Normal de Santiago es manifestada por los miembros de la Sociedad Indígenas de la Comarca de San Blas, que escriben al director para que les tenga informados de la marcha de estos becados 23 .

En noviembre el funcionamiento en las escuelas es normal, a excepción de Ustupu que por motivos de enfermedad de

\footnotetext{
20 V. RD, n. 644.

21 V. RD, n. 645; V. CD, n. CCXC.

22 V. RD, n. 648.

23 V. RD, n. 646; V. CD, n. CCXCI.
} 
la maestra de primer grado y de los alumnos ha reflejado un descenso 24 .

El sahila de Tubualá informa al intendente que el jefe de Isla Perro le manifestó su deseo de que inauguren escuela en su pueblo para el próximo curso, porque considera que es bueno para sus hijos 25 .

En las resoluciones que fijan las fechas de exámenes finales y los tribunales que los presidirán se deja claro que se evaluará el estado docente de la niñez y la labor desarrollada por los maestros. Las comisiones también supervigilarán los exámenes de las escuelas privadas 26 .

En los exámenes finales entran en juego el director, el intendente, la policía y los maestros. Aquellas pruebas que el director no puede presenciar, el intendente nombra personal del gobierno para que los presidan 27 . El resultado de las pruebas es satisfactoria para el director, que considera que ha contribuido a ello las circulares de la dirección que estimularon a los maestros 28 .

\footnotetext{
24 V. RD, n. 650.

25 V. RD, ns. 652 у 653.

26 V. RD, n. 654; V. CD, n. CCXCIII.

27 V. RD, n. 55.

28 V. RD, n. 656.
} 
Para el curso 1940-41 se programa hacer un cursillo que concluiría con un examen a los maestros un mes antes de que dé comienzo el curso y se les exigirá que tengan algún año de estudio en escuela superior. Parece que se quiere subir el nivel de los maestros, y como consecuencia mejorar la enseñanza ${ }^{29}$.

Cinco candidatas a maestras indígenas pasan un examen en abril ante el director de las escuelas. Este juzga que su conversación es buena aunque mala la gramática. Las cinco materias que son evaluadas son: castellano, aritmética, geografía, historia y cívica. Dos dan la máxima calificación en matemáticas, y una tiene la ventaja de hablar el castellano y el inglés además de sus dotes de música. Esta última es sugerida como maestra de Ustupu30.

El decreto 10 de 1940 recogía la apertura de las escuelas de Playón Chico y Río Banano, al mismo tiempo que se ampliaba la dotación de maestros en Ustupu y Ailigandí, asignando una más a cada isla y dos a Narganá. De este modo las escuelas abiertas en la comarca de los kunas eran ya 12 .

El grado de civilización de los kunas se va dejando ver por su participación en los actos culturales de la capital y colaboran en exposiciones, concursos y carnavales 31 .

\footnotetext{
29 V. RD, n. 657; V. CD, n. CCXCIV.

30 V. RD, n. 658; V. CD, n. CCXCV.

31 V. RD, n. 657; V. CD, n. CCXCIV.
} 
Este año académico se sobrepasa la cifra de 1000 alumnos en las escuelas de la comarca, correspondiendo a la cabecera, Narganá, más del tercio de ésta. Pero empieza a decaer la última escuela abierta, Permé, que solo llega a tener ocho alumnos y no alcanza el mínimo requerido por la ley32.

Algo que chocaba a los de fuera y que era un problema de mal ejemplo para los alumnos indios era la limpieza. El intendente se queja del poco aseo que presentan los maestros. Ello motiva que el director redacte circulares con este tema central33.

La escuela de Cartí cambia de maestro el último día del mes de mayo, en que toma posesión el maestro Rubén $P$. Kantule. Hasta la fecha había estado la maestra Rosario Garay. Desde ese momento ella se encargaría del kinder que comienza con cinco niñas; y el enseñará en primero y segundo34.

Desde la subinspección general de enseñanza primaria se envían útiles escolares a la intendencia. Una vez más los planteles escolares van a ver incrementado su material pedagógico35. Seguidamente el director de la escuela pide al intendente que le envíe un revólver, pues lo cree necesario para

32 V. RD, n. 659; V. CD, n. CCXCVI.

33 V. RD, n. 660; V. CD, n. CCXCVII.

34 V. RD, ns. 661 y 662; V. CD, ns. CCXCVIII y CCXCIX.

35 V. RD, n. 663. 
su actividad. Es algo chocante que un director se presente a la escuela portando un arma. El intendente se lo envía prestado; también le solicitaba una corneta, que en ese mismo envío se la manda como regalo36. No pasando mucho tiempo el director envía la lista de las necesidades de las escuelas a Luis Hernández ${ }^{37}$.

Las familias que acogían a estudiantes indígenas en Narganá tenían una cierta responsabilidad sobre ellos. Designados con el nombre de acudientes eran informados de la marcha de los estudiantes 38 .

Antes de que se produzcan los cambios del nuevo curso, Ricardo Velasco pide al jefe de El Porvenir que no cambie a su ayudante, y que si tiene intención de hacer algún nombramiento que sea el de aumentar un maestro para Playón Chico, cuya matrícula es de noventa y cinco con un solo maestro, mientras que Puerto Obaldía no tiene matrícula suficiente para ocupar a los tres maestros que allí están39.

La apertura de la escuela de Playón Chico fue una explosión que desbordó al maestro, esto hace sugerir al intendente la necesidad de nombrar un nuevo maestro. La solución se ve en quitar uno de Cartí que cuenta con un escaso

\footnotetext{
36 V. RD, n. 664; V. CD, n. CCC.

37 V. RD, n. 669.

38 V. RD, n. 666.

39 V. RD, n. 668.
} 
número de matrículas, ya que sólo llega a 50, a pesar del elevado número de niños, cerca de 20040 . La propuesta había sido hecha al intendente interino, que por falta de autoridad, y a pesar de verlo como la solución mas justa, da una respuesta negativa 41 .

Además del kinder que funcionaba en Cartí, aunque de un modo escaso, en Narganá se abre otro que cuenta con una matrícula de 60 niños. En este mes de agosto se notó un alza en la matrícula y más ascendente fue el aumento en la asistencia. Simultáneamente se imparten clases nocturnas para jóvenes en las poblaciones de Ustupu y Puerto Obaldía. Insiste una vez más el encargado de las escuelas en que los maestros os días de asueto permanezcan en sus lugares de trabajo para afianzar más los lazos de amistad entre los padres y la escuela 42 .

La construcción moderna de una escuela por parte de los habitantes de Río Tigre, lleva a un enfrentamiento con el sahila que critica la escuela y la civilización 43 .

La isla de Río Tigre considera insuficiente un maestro para desenvolverse en las labores escolares y pide al Presidente Boyd que les nombre otro; apelan a los doce años que llevan

\footnotetext{
40 V. RD, n. 672; V. CD, n.. CCCIV.

41 V. RD, n. 674; V. CD, n. CCCVI.

42 V. RD, n. 670; V. CD, n. CCCIII.

43 V. RD, n. 671.
} 
recibiendo la instrucción. Proponen una maestra que sería del agrado del pueblo porque sabría desempeñar bien su labor ${ }^{44}$.

El maestro de Puerto Obaldía presenta un informe detallado de la situación de la escuela en septiembre de 1940. Acusa como principal problema de esta localidad el cosmopolitismo del lugar fronterizo, la mayoría de los habitantes son colombianos, a pesar de que la población es panameña; además de la situación y estado poco adecuado del local destinado a la escuela. La matrícula llega a 85 y las asistencias rondan la cifra de 80 , por lo que se ve necesario nombrar un maestro más para el próximo curso. Piensa que la vigilancia de esta escuela, lo mismo que las del resto de la comarca, mejoraría la educación. Pues los maestros de estos lugares hablan la misma lengua que los educandos, pero no se debe olvidar que tienen un alto grado de inexperiencia en la enseñanza; y las visitas de inspección no pasan de dos al año. Sería conveniente, según este maestro, que se nombrara otra persona que colaborara con el director e hiciera visitas más frecuentes 45 .

En el mes de noviembre de 1940 se nota una ligera disminución en la matrícula en las escuelas de Ustupu y Ailigandí, posiblemente debido a las escuelas particulares que

\footnotetext{
${ }^{44}$ V. RD, n. 673; V. CD, n. CCCV.

45 V. RD, n. 675; V. CD, n. CCCVII.
} 
allí funcionan y merman la matrícula oficial. El que los alumnos de la escuela siguieran con las prácticas de la tradición kuna no estaba bien visto por la dirección que en alguna ocasión castiga tal práctica con la expulsión de las aulas 46 .

La escuela como local y testimonio del gobierno está supeditada en ocasiones a que los indios reciban un título de propiedad, primero se quieren sentir dueños de sus tierras, así lo expresan los habitantes de Tubualá al intendente en 1940. Ponen como condición para aceptar la escuela que el gobierno les dé un título de propiedad 47 .

La falta de asistencia a la escuela estaba motivada por múltiples causas, más o menos pintorescas, que hacen ver la escala de prioridades entre los indígenas. En esta ocasión las fiestas de carnaval son motivo para dejar de asistir a la escuela pues se deben preparar aquellas 48 . El concepto de civilización ha ido cambiando paulatinamente, y los adornos típicos de las indias no son vistos como algo salvaje e incivilizado. Ahora es algo típico y propio de una zona de la república. Para los carnavales de 1941 se propone que asista un carro alegórico de San Blas y que sea una viva representación de sus gentes y su idiosincracia 49 .

\footnotetext{
46 V. RD, n. 676; V. CD, n. CCCVIII.

47 V. RD, n. 678; V. CD, n. CCCX.

48 V. RD, n. 679; V. CD, n. CCCXI.

49 V. RD, n. 684; V. CD, n. CCCXIV.
} 
La mala conducta de los maestros presentada ante el pueblo hace que estos recelen de la educación por asociarla a los agentes que la imparten. Los escándalos morales se producen con frecuencia y son un descrédito para la educación 50 .

El propósito para el curso de 1941 es que aumente la plantilla de maestros, pero al mismo tiempo no se quiere prescindir de los existentes que han presentado un comportamiento deficiente. Se toma como solución que cambien de lugar de trabajo, estando más cerca del intendente que les tendrá estrechamente vigilados 51 .

La salida de niños hacia la capital como trabajadores en las casas de buena posición se sigue produciendo durante este periodo, aunque de un modo más restringido. Se quiere que puedan estudiar y si no los padres muestran rechazo a este modo de emplear a sus hijos como mano de obra barata. Hasta que no terminen el sexto grado los padres no quieren que los niños dejen la escuela, y de aceptar la salida del alguno pequeño sería con la condición de que allí fuese a la escuela pública52.

El ministro de Gobierno y Justicia recuerda al intendente la circular de octubre de 1940 que prohibe a los niños andar por las calles a partir de las nueve de la noche, así como

50 V. RD, ns. 681 у 685; V. CD, ns. CCCXIII y CCCXV.

${ }^{51}$ V. RD, n. 685; V. CD, n. CCCXV.

52 V. RD, ns. 686 y 696; V. CD, ns. CCCXVI y CCCXXIV. 
asistir a espectáculos que se prolonguen hasta más tarde de las siete. Tampoco se les permitía vender lotería. Para llevar a cabo esto se requería de la participación de la policía. Estas medidas parece que estaban perdiendo su eficacia por falta de celo de las autoridades. La hora de retirada de los escolares a sus casas se hace en San Blas mediante el toque de silbato53. Si algún escolar era sorprendido fuera de la casa a partir de esta hora el padre debía pagar una multa.

En 1941 los habitantes de Cartí Tupile elevan una queja al Presidente de la República por los abusos del intendente que pone multas sin oir a los acusados 54 .

Los materiales de la escuela de Ustupu siguen Ilegando, ahora será la pintura55. Aunque los indígenas corrían con la mano de obra, había bastantes dificultades a la hora de conseguir los materiales para levantar las escuelas en esta apartada región.

Cuando va a comenzar el curso 1941 el director de las escuelas solicita un carpintero para solucionar el problema de las clases insuficientes, al mismo tiempo le anuncia que la maestra de Cartí Tupile tiene intención de abandonar el puesto a finales de junio por encontrarse en estado, por lo que sería más lógico nombrar a otra ya mismo. Así mismo propone al hijo de

\footnotetext{
53 V. RD, ns. 687 y 715; V. CD, ns. CCCXVII y CCCXXXVIII.

54 V. RD, n. 688.

55 V. RD, n. 689.
} 
Charles Róbinson, que estudió algunos años en la escuela superior de la capital, para sustituir a Rubén Pérez Kantule. Una de las maestras de Narganá de volver a esta localidad, los padres no mandarían a sus hijos a la escuela, por el descontento que dejó56.

Los nombramientos para el curso los ultiman el director y Constantino Villalaz. Ricardo Velasco será quien le mande las tarjetas firmadas por los maestros, como constancia de la toma de posesión, este requisito era necesario para ejercer y cobrar el sueldo 57.

Los cuadros estadísticos que remitía el director para la intendencia y Gobierno y Justicia, a partir del curso de 194142 también irán al Ministro de Educación Pública, por expresa petición de éste 58 .

El creciente éxodo de los kunas hacia Panamá capital y Colón hace que Ricardo Velasco se dirija al gobernador de esta última provincia manifestando su preocupación por este fenómeno de gran repercusión en el archipiélago. Por un lado esto hace que disminuya la matrícula pues los niños se trasladan con las familias; y por otro lado va decreciendo la actividad agrícola. La consecuencia última de esta merma es el aumento

\footnotetext{
56 V. RD, n. 694; V. CD, n. CCCXXII.

57 V. RD, n. 698; V. CD, n. CCCXXV.

58 V. RD, n. 699; V. CD, n. CCCXXVI.
} 
de los barrios marginales en las grandes poblaciones con el consiguiente aumento de enfermedades que no pueden superar los indígenas; quienes terminan regresando en estado agónico a morir a las islas. Ante esto el ministro de Gobierno y Justicia cree que se debe emprender una campaña que haga ver a los kunas las desventajas de este éxodo y los grandes beneficios que proporciona la escuela de San Blas 59 .

La maestra de Río Cidra escribe al intendente para expresarle que está muy contenta de los niños y que la matrícula alcanza a cincuenta. Pero se lamenta de que algunos hayan salido de la escuela por no tener camisa. La obligatoriedad de uniforme escolar era un perjuicio para estas gentes que vivían con lo más imprescindible60.

Rubén P. Kantule escribe al Presidente Arnulfo Arias comentando que desea conocer las bases para formar parte del Partido Nacional Revolucionario, dada su posición influyente entre los indígenas tiene intención de fundar un club político, ya que no existe ninguno61. Siguiendo las indicaciones del mandatario renuncia a su puesto de maestro y espera que éste le recomiende, pues de lo contrario iría a trabajar a la Zona62.

\footnotetext{
59 V. RD, n. 701; V. CD, n. CCCXXVIII.

60 V. RD, n. 703; V. CD, n. CCCXXX.

61 V. RD, n. 704.

62 V. RD, n. 705.
} 
Ahora es Estanislao quien escribe al secretario del Partido Revolucionario, comentando que Nele Kantule visitó al Presidente a primeros de año y le prometió becas para los estudios secundarios en la capital para los indios de San Blas, pero no han tenido más noticias. Y Estanislao López tiene a los aspirantes 63 .

En este curso vuelve a ser tema de circular de la dirección los viajes y las separaciones del puesto de trabajo de los maestros. Juzga el director que para una buena marcha de las escuelas es preciso que se las visite una vez al mes, pero reconoce que las distancias y carencia de medios para moverse impide estas aspiraciones 64.

Finalizado el primer semestre de este curso los maestros se reúnen en Narganá para asistir a las conferencias del director que les ruega no abandonen la cumplimentación de las estadísticas, les explica la elaboración de los nuevos registros escolares; pidiendo que los maestros se mantengan unidos olvidando toda discordia. De la reunión surge un suplicatorio que solicita al intendente redacte una orden que prohiba la salida de los menores hacia las ciudades de Panamá y Colón durante el tiempo que dura el curso, ya que perjudica la matrícula y asistencia de los planteles de la comarca y principalmente al final del periodo escolar.

\footnotetext{
63 V. RD, n. 707.

64 V. RD, n. 706; V. CD, n. CCCXXXI.
} 
Los asistentes abogan por un cursillo de especialización escolar para el verano próximo en la isla de Narganá. Los maestros verían con agrado que el intendente asista a los exámenes finales. Solicitan respetuosamente un aumento del sueldo, que había disminuido en el presente año, cuando los gastos han ido en aumento. El magisterio vería con mucho agrado que se realizara la construcción de la escuela de Ailigandí, para ello se contaría con la ayuda del pueblo y la Intendencia sumados a los materiales recibidos del poder ejecutivo. Los presentes expresan su confianza al director, a quien no desean que se cambie 65 .

En octubre de 1941 el director expresa su satisfacción por el interés que muestran los maestros por la instrucción, pero destaca el celo del maestro de Ustupu. La solución para la escuela de Puerto Obaldía sería alquilar un amplio local que ha quedado en en bajo de una reciente construcción66. Un informe de este tiempo refleja que la directora de esta escuela expulsó a una niña por no saber contestar una pregunta67

Los sahilas de Tikantikí requieren un practicante para vacunar a los niños, ya que se ha extendido una epidemia de sarampión que ha provocado la muerte de algunos alumnos. Como consecuencia de estos eventos se promulga una orden para

65 V. RD, n. 710; V. CD, n. CCCXXXIII.

66 V. RD, n. 711; V. CD, n. CCCXXXIV.

67 V. RD, n. 708; V. CD, n. CCCXXXII. 
acabar con todos los animales domésticos propensos a la viruela68. En el informe del mes de noviembre se dejan ver una vez más los estragos de las enfermedades de las culturas civilizadas. En Tikantikí se ha producido una merma en la asistencia como consecuencia de una plaga de sarampión; en las demás escuelas todo ha sido normal69.

El aumento progresivo de alumnos en la escuela de Ustupu hace que esta se quede pequeña; por lo que Nele Kantule pide al Presidente del Gobierno que se amplíe esta edificación, para la que se pueden emplear materiales que sobraron de la anterior 70 .

Las fiestas del carnaval y sus preparativos levantan una polémica entre el director y los encargados de la misma por la elección de la reina de las fiestas que era una muchacha a la que perjudicaba en sus estudios. El problema es más acuciante en cuanto que estas fiestas se preparan cuando queda un mes de curso y se destina al repaso general de lo estudiado. Ello lleva a que los preparadores levanten un memorial contra el director de las escuelas, quien pone en sobreaviso al intendente de estos hechos ${ }^{71}$.

\footnotetext{
68 V. RD, n. 712; V. CD, n. CCCXXXV.

69 V. RD, n. 713; V. CD, n. CCCXXXVI.

70 V. RD, n. 714; V. CD, n. CCCXXXVII.

71 V. RD, n. 715; V. CD, n. CCCXXXVIII.
} 
Ante la proximidad de nombramiento de intendente, uno de los indígenas, Pablo Solís, se adelanta a comentar al Presidente de la República que espera que ocupe el puesto alguien que se preocupe por los indios, no gente que ya ha desempeñado el cargo anteriormente mostrando poco interés por la región 72 .

Por la circular de fin de curso se puede comprobar que funcionaron durante este curso trece escuelas incluida la de Puerto Obaldía. Presenciarían los exámenes los maestros de las escuelas próximas, o en la localidad que existe más de un maestro se reunirían y todos presenciarían los de todos. Se quiere dar solemnidad al acto y que cuenten con más elementos de juicio a la hora de efectuar las calificaciones 73 .

Este es el último año en la labor del P. Ricardo Velasco y finaliza haciendo un informe del trienio de su mandato. Este curso el plantel de profesores estaba compuesto por 30 miembros incluido el director y su ayudante. El aumento de profesorado en la región es digno de destacarse en estos cuatro últimos años. El curso 1938-39 contaba la comarca con 16 profesores; el curso 1939-40 tenía 20 maestros; en 1940-41 eran 26. Durante el curso concluido la lista era de 30 pero se vio mermada en uno, pues se suprimió la escuela de El Porvenir. El

72 V. RD, n. 716.

73 V. RD, n. 18; V. CD, n. CCCXL. 
intendente fue el encargado de designar la escuela donde cada uno debía desempeñar sus funciones.

El inconveniente de las distancias y malas comunicaciones no ha sido obstáculo para que se celebraran dos conferencias con la plantilla de los maestros y el director ha enviado siete circulares a los mismos. Se han ido aumentando los grados en diversas escuelas de la región. En este curso se abrieron las escuelas de Río Sidra y Cartí Tupile previa solicitud de las islas. En Tupile de Arriba se aumentó hasta el tercer grado, pues era el deseo de los padres de familia. La política que se sigue ahora en lo referente a las escuelas, no es ya la imposición por la fuerza, sino esperar a que las islas la soliciten cuando vean los grandes beneficios que aporta esta institución.

En el curso 1938-39 el número de escuelas eran 8; en 1939-40 subió hasta 10; en 1940-41 son 12; y este curso de 1941-42 llega hasta 13. Pero a pesar de este panorama optimista no se ha llegado a las cotas que se habían propuesto, causa de ello es que el trabajo en las ciudades de Panamá y Colón es bien remunerado lo que hace que los jóvenes se sientan atraídos por el dinero y emigren, no aumentando la matrícula en los valores deseados. Otra de las causas son las epidemias que han castigado las diversas islas provocando la muerte a alumnos de varios planteles. 
Con todo ello la matrícula y la asistencia total ha alcanzado valores máximos progresivos. El curso 1938-39 la matrícula máxima fue de 748 alumnos y la asistencia máxima de 712; el curso 1939-40 la matrícula máxima de 875 y la asistencia máxima de 809; El curso 1940-41 la matrícula máxima fue de 1100 alumnos y la asistencia máxima de 1065; El curso 1941-42 la matrícula máxima fue de 1192 alumnos y la asistencia máxima de 1090 . Un hecho notable es la instalación de una planta eléctrica donada por el suplente del Presidente, Augusto S. Boyd.

La escuela de Narganá y Corazón de Jesús ha contado con una matrícula que se aproximaba a los 350 alumnos, contando con ocho maestras, de las que alguna ha llegado a tener hasta 60 y 70 alumnos, número excesivo para una eficaz labor. El sexto grado se ha visto perjudicado por lo expuesto anteriormente de la marcha de estos muchachos para trabajar en las ciudades.

Por el cuadro de promovidos y fracasados de los diversos grados podemos observar que en los dos cursos más bajos, el kinder y el primer grado, el número de fracasados es superior al de promovidos; en el segundo curso el número de fracasados rebasa un cuarto al número de alumnos de este grado; el tercer y cuarto grado tienen un alto número de fracasados, disminuyendo progresivamente en el quinto y sexto curso. Estas escuelas que eran dirigidas por las hermanas franciscanas 
contaban con clases de instrumentos musicales. También sobresalió la enseñanza de la costura, habilidad muy desarrollada entre las indias kunas.

La escuela de Cartí Cangrejo ha visto mejorar su matrícula de los años anteriores superando el desinterés mostrado por el jefe local. En el vecino pueblo de Cartí Tupile se ha abierto la escuela atendiendo la petición de sus habitantes contando con una matrícula de 45 alumnos. Se sigue dando gran énfasis a la celebración de las fiestas patrias, como medio de identificación con la vida nacional.

La otra escuela que se inauguró fue la de Río Sidra que llegó a tener hasta 52 alumnos de matrícula aunque sus resultados no hayan sido muy positivos. En Río Azúcar el trabajo ha sido realizado por un maestro y una maestra que desarrollan una labor loable, pues tienen un número considerable de alumnas, y han alcanzado la cifra de 75 matrículas. La escuela de Río Tigre por el contrario ha contado en su matrícula con una sola niña y cincuenta niños, esta es otra de las islas un tanto recelosa de la penetración nacional, pero así todo son bastantes los niños que han cursado estudios en la escuela de la cabecera.

Tikantikí ha visto mermada la actuación de la maestra por las persistentes enfermedades que han mantenido cerrado el local escolar durante algún tiempo, además de producir bajas por mortandad en la infancia, en concreto cuatro niños. Varias 
han sido las niñas que han asistido a la escuela alcanzando la matrícula total el número de 67.

La referencia de la escuela de Playón Chico se inicia con la evaluación de los maestros de esta escuela, a uno de los cuales se considera inadecuado y poco apto para ejercer el magisterio. La matrícula ha pasado de cien. En el cuarto año de vida de la escuela de Tupile se han nombrado tres maestros para la misma, uno de ellos varón, llegando el número de matrícula a 95. La visión futurista del director le hace apuntar a este lugar como el más idóneo para fundar otra escuela similar a la de Narganá, si es deseo del gobierno favorecer la instrucción entre los indios. El considerable número de alumnos que han seguido sus estudios en la cabecera ha obtenido resultados óptimos en la escuela.

En la escuela de Ailigandí se puso un maestro más, ya que el número de alumnos era excesivo para el existente. Este hecho estaba relacionado con el deseo de que la escuela del gobierno superase a la escuela particular protestante, lo que se consiguió por el esfuerzo de los maestros; alcanzando la matrícula el centenar.

Una escuela que empezó débilmente su andadura fue la de Río Banano, en este su segundo año de existencia no se ha visto un progreso adecuado, lo que es achacado a la poca moralidad del maestro, por lo cual se cree conveniente 
cambiarle. Con esta escuela se pretendía atraer hacia la labor del gobierno en pro de la educación al cacique que dominaba en esa región, Yabiliquiña.

El gran auge de la escuela de Ustupu se debe en gran parte a la buena labor realizada por el jefe Nele Kantule. La matrícula a superado los 110 alumnos y no se debe olvidar el trabajo eficiente realizado por los maestros.

Puerto Obaldía con su lejanía y su misión fronteriza, sigue su labor enfrentándose a múltiples dificultades. El primero y más grave conseguir un maestro que aceptara desempeñar sus servicios en lugar tan recóndito con gran mayoría de población negra y un elevado número de gentes colombianas, por ser mas fácil el acceso hasta allí para los colombianos que para los panameños. Se estimuló al personal con un aumento de diez balboas en el sueldo. Pero a medio curso un maestro se vio solo haciéndose cargo de los cuatro grados. La maestra que se sumó después a las labores docentes concluyó el curso sin rendir exámenes finales. Esta escuela fue como un apéndice en la comarca, y este informe reconoce que el presupuesto de educación de la región está destinado principalmente a la civilización de indígenas.

En este informe se recoge la existencia de las dos escuelas particulares que están abiertas en la comarca. Una es la de Ustupu que emplea el inglés como lengua para enseñar y la 
otra es la de Ailigandí que fomenta el castellano. También hace referencia al internado de niños, en el que han recibido asistencia gratuita 30 muchachos. Deja aflorar su esperanza en que el próximo curso funcione otro para niñas ${ }^{74}$.

Las recomendaciones con las que concluye el director son:

a) Nombrar un maestro más para la escuela de Narganá dado que el número de alumnos es excesivo para los actuales.

b) No fundar nuevas escuelas, sino proveer a las existentes de los útiles necesarios. Por ello le envía al intendente una lista de materiales necesarios para éstas ${ }^{75}$.

c) Efectuar una subida de sueldo a los maestros, de modo que les permita enfrentarse a sus necesidades y solventar sus dificultades.

d) Reparar el edificio de Narganá y levantar más salones para satisfacer las necesidades de la demanda. Con esto termina el mandato de director de las escuelas de la comarca Ricardo Velasco, tras presentar su renuncia.El durante durante su cargo como director en San Blas adquirió la nacionalidad panameña como signo de amor a este país 76 .

\footnotetext{
74 Este tema de los internados se verá un poco más ampliado en el capítulo 11.

75 V. RD, n. 721; V. CD, n. CCCXLIII.

76 V. RD, n. 719; V. CD, n. CCCXLI.
} 
Al finalizar este curso los maestros de Ustupu mandan al intendente una carta junto con Nele Kantule comentando la decisión que han tomado de no dejar a ningún niño que marche para Colón, pues esto provoca la disminución en las matrículas. Se pretende que este aviso llegue incluso a los capitanes de los barcos, que de no contribuir con esta medida serían castigados. Esta decisión fue tomada por los indios en un congreso celebrado en Tupile, ellos son los que informan de esta medida a las autoridades. En esta misma reunión se trataron otros temas como fue la creación de nuevas escuelas y una granja agrícola, así como el establecimiento de una unidad sanitaria. El Presidente de la República muestra su satisfacción por la colaboración ofrecida por los sahilas 77 .

La maestra Elisa de Garrido en 1942 vuelve a la comarca y le expresa al intendente que lo hace con agrado. Esta había sido una de las pioneras cuando se crearon las cuatro primeras escuelas de San Blas ${ }^{78}$.

\section{2. Toma el relevo el P. M.M. Puig}

El nombramiento de los maestros para el curso 194243 sería una prerrogativa del poder ejecutivo, pero este

77 V. RD, ns. 720 y 722; V. CD, ns. CCCXLII y CCCXLIV.

78 V. RD, n. 724. 
atendería complacido las indicaciones de la intendencia. El jefe de El Porvenir no tiene claro sus competencias y preguntaba al Ministro de Gobierno y Justicia que si era competencia del intendente el nombrar los maestros según los poderes que le confería la ley de 1938 que creaba la comarca de San Blas. Por otra parte considera el Ministro que los criterios de selección del personal deben ser: la competencia, el interés y la moralidad; para que se logren los fines que persigue el gobierno, "incorporar a la vida civilizada a los indígenas mediante una labor de atracción y respeto por las instituciones y actividades de carácter social que allí se emprenden"79.

En abril de 1942 el ministerio de Gobierno y Justicia publica un decreto por el cual se nombra el personal de las escuelas de la región de San Blas. El nuevo director es el P. Manuel M. Puig y su ayudante Jesús Erice. La escuela de Narganá y Corazón de Jesús contarán con nueve maestras de las cuales siete son hermanas franciscanas. Puerto Obaldía, Río Azúcar y Playón Chico con dos maestros cada una; Cartí Sugdupu, Tupile Abajo, Tigre, Tikantikí y Río Cidra con un maestro cada isla; Tupile Arriba, Ailigandí y Ustupu con tres respectivamente80.

Los habitantes de Playón Chico desean que continúe de maestro Eduardo Filós, pero el intendente cree que esto obedece

\footnotetext{
79 V. RD, n. 723; V. CD, n. CCCXLV.

80 V. RD, ns. 726, 728 y 759; V. CD, ns. CCCXLVI, CCCXLVII y CCCLXVIII.
} 
más a los intereses del propio maestro que a los deseos del pueblo; por lo que pide al director que comunique a los maestros que en los nombramientos no se atenderán los intereses particulares 81 . Finalmente es enviado a Ailigandí por el director después de la reunión tenida en Narganá82.

Manuel Puig trasmite a los maestros una circular que le enviaran desde el Ministerio sobre la preparación de las clases. Recomienda a los maestros que la lean para que acomoden sus enseñanzas a estas directrices ${ }^{83}$.

El tema de las salidas de la isla por parte de los maestros era una falta que estaba castigada con multa, el intendente insta al director nuevamente para que vigile estas irregularidades, que luego aparecerían en una circular del Ministerio ${ }^{84}$.

El 4 de mayo se inauguraba el curso y el director exhortaba a los 310 alumnos a la aplicación en el estudio, la limpieza en el vestido, la disciplina y el interés por aprender más y mejor el castellano, que es el idioma oficial; al mismo tiempo les prohibía hablar en kuna dentro del recinto escolar. Estas mismas recomendaciones habían sido hechas a los

81 V. RD, n. 727.

82 V. RD, n. 730.

83 V. RD, n. 733.

84 V. RD, ns. 734 у 738. 
maestros a su paso por El Porvenir para firmar la toma de posesión 85 .

A mediados del mes redacta la primer circular donde se les aconseja un buen comportamiento y que no deben viajar fuera de los lugares de su destino sin permiso de la dirección. Deben tener en cuenta que son los hombres instruidos y educados; en muchos casos consejeros de los sahilas y su voz será oída en los congresos. No les está permitido tomarse libertades indebidas con las jóvenes, de igual manera que no pueden participar en las chichas 86 .

Surgió un pequeño problema en los comienzos del periodo direccional del P. Puig. Los maestros veían al Sr. Acosta, secretario de la intendencia como inspector de educación. Los continuos comentarios salidos de los maestros hicieron sentir molesto al P. Manuel M. Puig que no sabía cual era su puesto, y le ponía en un lugar conflictivo ante el magisterio de la comarca. Esto se veía agravado por los comentarios poco acertados del mismo Sr. Acosta, que ponía en entredicho la labor realizada por la dirección de las escuelas. Los formularios de control sobre las escuelas en el archipiélago eran emitidos por Gobierno y Justicia y el presunto inspector quería cambiarlos por los del Ministerio de Educación, quedando así igualadas las escuelas al

85 V. RD, n. 732; V. CD, n. CCCXLIX.

86 V. RD, n. 735; V. CD, n. CCCL. 
resto de la república; no hemos de olvidar que seguían dependiendo directamente, como todos los demás asuntos de la comarca, del Ministerio de Gobierno y Justicia87.

Durante el primer mes de este curso la matrícula de las escuelas ha sufrido una pequeña baja con respecto al curso anterior, la excepción es Narganá que ha experimentado un pequeño aumento. Para estimular a los maestros a que colaboraran en la tarea de aumentar las matrículas, es propósito del director dirigirles una circular. En la primera gira del P. Puig comprueba que los maestros de Ailigandí y Tupile de Arriba no pueden realizar su labor en el tercer grado por falta de bancas. En la visita a Río Sidra tiene conocimiento, por los muchachos, que su maestro se emborracha con frecuencia88.

Manuel Puig le remite al intendente una circular hablando a los maestros sobre su conducta, que debe ser ejemplar en el desempeño de las labores de docencia, y afirma que tiene intención de enviar otra sobre el uso del castellano en las escuelas 89 .

No se hace esperar ésta y en junio redacta la segunda circular comentando las impresiones de la visita girada a las escuelas. En ella se muestra satisfecho de los maestros porque

\footnotetext{
87 V. RD, n. 736; V. CD, n. CCCLI.

88 V. RD, n. 739; V. CD, n. CCCLIII.

89 V. RD, n. 778.
} 
asisten a la escuela bien vestidos y calzados, procurando aumentar la matrícula y mejorando el aspecto del salón de clase. Después pasa a escribir una serie de recomendaciones: como que los niños deben estar separados por grados, que deben llevar al día la lista de matrículas y asistencias, procurar que los niños hagan inflexiones con la voz ante los signos de puntuación, ejercitarlos en las frases corrientes de cortesía como el saludo, ejercitar más a los niños en la caligrafía, en las composiciones poner los datos de fecha, faltas, calificación y fecha de corrección. Finalmente exhorta a los maestros a trabajar por el aumento de matrícula, ya que en el último mes de mayo ha descendido con respecto al año pasado90.

Después del envío de esta circular el jefe de la intendencia realiza una visita a la cabecera de la comarca constatando la realidad de la escuela en ese lugar, confirmando la necesidad que tienen los niños de aprender bien el castellano. El director le comenta en una carta posterior que esta tarea es una de las principales preocupaciones en la enseñanza de los indígenas. Conjuntamente le comenta que la escuela de Ailigandí sigue $\sin$ bancas y le agradece los otros materiales enviados ${ }^{91}$. Posteriormente se puede ver que son varias más las escuelas necesitadas de bancas: Tigre, Tupile Arriba, Playón Chico, Cartí

\footnotetext{
90 V. RD, n. 740; V. CD, n. CCCLIV.

91 V. RD, n. 741; V. CD, n. CCCLV.
} 
Tupile y Narganá92. Al finalizar el primer semestre la escasez de mobiliario escolares se vería paliada un poco, aunque seguiría faltando el material escolar93.

Una nueva circular tratando el asunto de los días y horas de clase es enviada a finales de julio. El director ha comprobado, tras una visita a todas la escuelas que algunos maestros muestran "poco celo por la instrucción de la niñez y presentan un notable descuido en el cumplimiento de sus deberes como empleados del Magisterio Nacional". No le está permitido al maestro abreviar las clases, debe tener presente el reloj y ocupar bien las tres horas de la mañana y las dos de la tarde, cortadas por un descanso de un cuarto de hora en la mañana y otro en la tarde.

Tampoco es motivo suficiente para suprimir las clases el excesivo calor o las lluvias, ni las fiestas celebradas en el pueblo. Esto intenta que quede subsanado con el envío del calendario escolar que señala las fiestas o días libres. Menciona las fiestas nacionales que se deben preparar con suficiente antelación para que lleguen a ser un éxito. Nuevamente pide a los maestros que mantengan un comportamiento digno del puesto que ocupan absteniéndose del licor y las borracheras ${ }^{94}$.

\footnotetext{
92 V. RD, n. 743; V. CD, n. CCCLVII.

93 V. RD, n. 757; V. CD, n. CCCLXVI.

94 V. RD, ns. 742 y 745; V. CD, ns. CCCLVI y CCCLIX.
} 
Poco tiempo después del envío de esta circular el intendente le escribe exponiendo las quejas recibidas a causa de los maestros que se entregan a la bebida. El director reconoce que el maestro de Ailigandí ha enmendado su comportamiento con respecto a este asunto, aunque posteriormente volvería a incurrir95; y le hace saber que en su última circular trata este asunto96. La conducta del maestro de Playón Chico será motivo de censura por ausentarse de la escuela los viernes para trasladarse a Ailigandí, se le previene además que de continuar con esta conducta perdería el derecho a las vacaciones 97 .

En julio el encargado de las escuelas realiza otra visita al sector de Cartí y le comenta al intendente que el maestro de Cartí Tupile mantiene una conducta poco adecuada a su estatus, ya que está totalmente entregado al trato con mujeres. Esto provoca que los sahilas hayan tenido que llamarle la atención en el congreso. El pueblo le construyó una casa, y él no la habita prefiriendo cambiarse a vivir a las casas que celebran chichas o donde viven jóvenes. Tampoco muestra preocupación por cumplir el horario de clases mostrando los niños un gran retraso. Sugiere el director que sea el intendente quien le llame para avisarle de su mala conducta y ver si se

\footnotetext{
95 V. RD, n. 757; V. CD, n. CCCLXVI.

96 V. RD, n. 744; V. CD, n. CCCLVIII.

97 V. RD, n. 760; V. CD, n. CCCLXIX.
} 
corrige ${ }^{98}$. Pero el asunto se tiene que zanjar con la supresión de este maestro y el nombramiento de otro nuevo en agosto99. Aunque después sería llamado para hacer una sustitución por falta de maestros en la comarca; estando dispuesto el director a incorporarle al magisterio a la fuerza si fuera necesario ${ }^{100}$. Las cosas parecen tener mejor solución al final pues se encuentra otra maestra que sustituya a la de Playón Chico por encontrarse en estado, de este modo no tiene que nombrarse al ex-maestro de Tupile101.

El normal funcionamiento de las escuelas era una meta difícil de alcanzar, cuando las cosas parecían seguir un curso normal, siempre se disparaba una cuestión que entorpecía el desarrollo de la enseñanza. Ahora es desde Puerto Obaldía que llegan las quejas del regidor de policía. La maestra allí designada presenta un comportamiento irregular mofándose incluso de su compañero de tareas escolares ${ }^{102}$.

La cuarta circular del P. Puig ve la luz en agosto y es para comentar la fechas del año escolar, en ella se señalan los días de vacación y los de exámenes finales y semestrales. Finaliza haciendo pública la destitución del maestro de C.

\footnotetext{
98 V. RD, n. 746; V. CD, n. CCCLX.

99 V. RD, n. 750; V. CD, n. CCCLXIII.

100 V. RD, n. 756; V. CD, n. CCCLXV.

101 V. RD, ns. 753 y 761; V. CD, n. CCCLXX.

102 V. RD, n. 748; V. CD, n. CCCLXII.
} 
Tupile para que sirva de estímulo en lo sucesivo103. El director le comenta al intendente que le enviará un calendario con las fechas escolares, dado que es su superior inmediato en materia educativa, entre otras cosas 104 .

En este tiempo el Ministerio de Educación está trabajando en la elaboración de un mapa escolar de la nación panameña; para ello pide la colaboración al inspector de la comarca de San Blas, le sugiere que le señale los lugares donde han existido escuelas 0 donde crea conveniente edificar nuevas 105. El Ministerio pretende tener una información fidedigna de la enseñanza en el país, también quiere que se le envíe el cuadro estadístico mensual. Por la carta podemos conocer que las escuelas del país dependían de varios ministerios, del de Educación, de Gobierno y Justicia, y de Salubridad y Obras Públicas ${ }^{106}$. Otro de los puntos sobre el que se recaba información son las escuelas privadas que funcionan en la región. El director comenta que son dos, la de Ailigandí a cargo de Alcibíades Iglesias y cinco maestros más que educan a cincuenta y siete niños y trece niñas. La otra escuela existente es la de Ustupu con un único maestro que enseña el inglés a diecisiete niños. Las iglesias edificio del archipiélago se

103 V. RD, ns. 750, 751 у 752.

104 V. RD, n. 749.

105 V. RD, ns. 754 y 755; V. CD, n. CCCLXIV.

106 V. RD, n. 762; V. CD, n. CCCLXXI. 
reducen a tres, en Narganá, Corazón de Jesús y Río Azúcar que pertenecen a la Iglesia Católica; pero en las escuelas privadas se enseña la religión protestante107.

Los temores de la disminución de matrícula llegan al aproximarse las vacaciones semestrales; por lo que el director de las escuelas cree conveniente que el intendente trasmita a los capitanes de los barcos la prohibición de llevar niños en edad escolar hasta la ciudad de Colón, ya que en esta época los jóvenes desean fugarse a trabajar a Colón y abandonar así la escuela ${ }^{108 .}$

El primer secretario del Ministerio de Educación manda una carta a todos los directores haciéndoles unas recomendaciones, algunas de las cuales no son nuevas:

- Los actos culturales deben comenzar con el canto del himno del colegio y concluir con el himno nacional.

- En toda aula debe existir una bandera panameña y los escudos nacionales.

- Se debe aprovechar toda ocasión para resaltar los méritos de los hombres célebres nacionales.

- En los salones no deben faltar retratos de los hombres más destacados de la nación.

107 V. RD, n. 766; V. CD, n. CCCLXXV.

108 V. RD, n. 757; V. CD, n. CCCLXVI. 
- En los programas de actividades extracurriculares se deben incluir recitaciones, cantos y bailes con motivos nacionales 109 .

Como colofón del primer semestre el P. Puig realiza un resumen informe de las escuelas. En el comienzo del mismo resalta que la enseñanza de la comarca de San Blas está regida por las leyes y programas de la Instrucción Pública del Estado, con esta aclaración pretendía desterrar las dudas de los elementos hostiles.

Los maestros en su mayoría pertenecen al elemento indígena; la excepción son las madres franciscanas que tras largos años de dedicación se han integrado en la vida kuna llegando a dominar algunas de ellas su lenguaje. Es meritoria la labor realizada por estas en el campo de la música, para cuyo arte tienen una natural predisposición los indígenas; en costura, cuya destreza se ha podido observar incluso en Panamá en repetidas exposiciones. Y las labores de enfermería llevadas a cabo por una de las hermanas que recorre los hogares asistiendo a los necesitados. Esta medida de poner como maestros a elementos indígenas, desde la revolución de 1925 ha mostrado grandes beneficios. Los únicos lugares que no tienen maestros indígenas son Narganá y Puerto Obaldía, esta es la única población no indígena.

109 V. RD, n. 758; V. CD, n. CCCLXVII. 
La comarca cuenta con doce escuelas asistidas por treinta y un maestros y la matrícula se eleva a 1.139 alumnos. Oscilando la matricula entre los 35 alumnos de Cartí Tupile y 353 de Narganá, en cuya escuela se imparte la enseñanza primaria completa desde 1929 en que se implantó el sexto grado por primera vez. Terminando sus estudios primarios una media de 20 alumnos. No debemos olvidar que de estos algunos continúan sus estudios secundarios en la capital becados por el gobierno o la misión católica110.

Los maestros de Ustupu, Ailigandí y Tupile de Arriba, que tienen a su cargo la enseñanza del tercer grado rinden informe de los exámenes trimestrales por escrito, estos son los únicos cursos obligados a dichos exámenes. Los últimos días de las vacaciones semestrales se aprovechan para dar conferencias en Narganá a todos los maestros, corriendo estas a cargo del director, que vuelve a tratar los temas que fueron objeto de las circulares. Concluidas las mismas los maestros elevan un memorial al intendente pidiendo un aumento de sueldo, ya que la vida cada día es más cara, incluso en esta apartada región ${ }^{111}$.

El segundo semestre comienza con el cambio de maestro en Ailigandí, el intendente toma la decisión debido a

110 V. RD, n. 759; V. CD, n. CCCLXVIII.

111 V. RD, n. 764; V. CD, n. CCCLXXIII. 
que aquel se da con frecuencia a la bebida, "acto completamente ajeno a la moral de un buen enseñador"112.

El director de las escuelas traslada la petición del pueblo y el sahila de Río Perro para que el próximo curso se les tenga en cuenta y les nombren un maestro. Este deseo será nuevamente recordado por el subdirector Jesús Erice al intendente comentando que existen más de treinta niños para formar la matrícula. Esta petición también había sido elevada por el primo del sahila, el maestro Mario Porras ${ }^{113}$. Era propósito del Ministerio de Gobierno y Justicia abrir nuevas escuelas y aumentar el personal de maestros para el próximo curso. El intendente así se lo comunica al director de las escuelas. Dicho Ministerio también tiene conocimiento de las mejoras que se deben realizar en el resto de los planteles ${ }^{114}$. El local inadecuado de la escuela de Ailigandí impide que la marcha de la misma sea normal. Por ello se pretende que se separe la escuela particular de la del estado, pero son las autoridades del lugar las que deben tomar interés en el asunto115.

En esta carta se deja ver una vez más, que los habitantes de la zona de Cartí están descontentos de la gestión

112 V. RD, n. 763; V. CD, n. CCCLXXII.

113 V. RD, n. 775; V. CD, n. CCCLXXXIV.

114 V. RD, n. 768; V. CD, n. CCCLXXVII.

115 V. RD, n. 767; V. CD, n. CCCLXXVI. 
del intendente Luis Hernández, en esta ocasión es porque no les deja pasar las bebidas alcohólicas ${ }^{116}$.

A ocho asciende el número de circulares enviadas por el director durante el curso. A estas se deben añadir las instrucciones enviadas desde la inspección provincial de Colón y cinco viajes de visita efectuados por el P. Puig, en uno de los cuales contrajo la malaria. Se destaca la celebración de las fiestas de noviembre que resultaron un éxito en toda la comarca, haciendo vibrar al unísono a los indígenas de la comarca con el resto del país. Con esto se lograba una de las pretensiones del gobierno. Se consiguió el aumento de un centenar de bancas en las escuelas del archipiélago, y aunque algunos materiales escasearon, se mejoró en libros y otros útiles.

Este año ve la luz el diccionario karibe-kuna escrito por el P. Puig, tras doce años de hablar la lengua indígena, en el se encuentran más de diez mil voces. $Y$ tres años después aparece la Gramática de la lengua Karibe-Kuna del mismo autor.

Dado el aumento de matrícula en la escuela principal se requiere para el próximo año una maestra más, con lo que ascenderían a diez. El resultado de los exámenes es el siguiente: en el kinder pasan 28 y fracasan 28 , en el primer grado pasan 28 y fracasan 22, en el segundo grado pasan 22 y fracasan 22, en el tercer grado A pasan 20 y fracasan 17, en el tercer grado B 
pasan 26 y fracasan 12, en el cuarto grado pasan 34 y fracasan 22 , en el quinto grado pasan 32 y fracasan 18 y en el sexto grado pasan 26 y fracasan 2. Entre los alumnos aficionados a la música se han impartido clases de piano y violín; en las fiestas se exhibió una banda de cornetas y tambores. No se quedan atrás en las labores de costura, a las que las indias son muy aficionadas $y$ en las que muestran gran destreza.

En análisis de las labores docentes en Puerto Obaldía, le llevan a reconocer al director que los diversos cambios producidos en los maestros ha entorpecido las labores escolares con detrimento de la matrícula y asistencia. El maestro de Cartí Cangrejo ha efectuado una buena labor logrando despertar interés en la población por las fiestas patrias. Otro hecho que favorecerá en adelante a esta escuela es el cambio de sahila, ya que el nuevo es un buen patrocinador de la misma.

La escuela de Cartí Tupile, en su segundo año de funcionamiento, no ha mostrado gran adelanto con el maestro nombrado, tras la sustitución de éste se notó una gran mejoría en la asistencia y aceptación del pueblo. La escuela de Río Sidra, tras su segundo año de funcionamiento también, se puede alabar el esfuerzo del maestro, que ha conseguido del pueblo un nuevo edificio escolar de madera. Río Azúcar, donde laboran de maestros un matrimonio, ha mostrado progreso en lo referente a la educación, pero juzga el director, que esto es debido también a la presencia de un policía destacado en la isla y a la 
cooperación del sahila que han favorecido notablemente la matrícula y la asistencia. La escuela es propiedad del gobierno, siendo reparada por mediación de Luis Hernández en dos ocasiones.

Una escuela veterana, como es la de Río Tigre que tiene once años de existencia, muestra un progreso muy lento. Sus habitantes muestran mucha apatía y las frecuentes chichas contribuyen al atraso. El P. Puig cree que la maestra debe poner más interés en la enseñanza y la preparación de las fiestas patrias. Su espera descansa en que los jóvenes que siguen estudios en Narganá sean la salvación de esta situación.

Lo más destacable de la escuela de Tikantikí es que ha visto aumentar de modo considerable la matrícula de niñas, siendo esto señal de la influencia que va adquiriendo la educación. El maestro ha desarrollado una gran labor.

Los habitantes de Playón Chico han construido dos edificios escolares con piso de madera corriendo ellos con los gastos; esto muestra el interés que tienen por la educación de sus hijos. La maestra de este lugar tuvo que ser reemplazada por encontrarse en estado de gravidez.

El grupo más grande de alumnos en la escuela de Narganá correspondientes a otras islas es de Tupile de Arriba, con 24 niños; a esto ayuda la labor del sahila que no cesa de ponderar los beneficios que proporciona la instrucción a los 
pueblos. Los maestros han dejado muy satisfecho al pueblo con su trabajo. Tres niños de Tupile han sido los primeros en obtener este curso el diploma de sexto grado. El director considera un gran paso que se estableciera en esta isla un centro como el de Narganá, con todos los grados de la primaria.

De los tres maestro de Ailigandí sólo uno ha ejercido dignamente su cargo, de los otros uno presentó mala conducta, teniendo que ser sustituido y el otro por cansancio ha tenido una actuación pobre, acusándose en la matrícula un descenso considerable; por lo que la escuela oficial ha perdido con respecto a la escuela particular que funciona al lado.

Dos muchachos de Ustupu son los primeros en este curso en obtener el sexto grado. Para el director la escuela es el modo de penetrar la civilización en San Blas pero de un modo más pacífico, en muchas islas es la única representación del gobierno.

Las propuestas del director son: nombrar una maestra más para Narganá en el próximo curso y adquirir un nuevo local, nombrar un maestro para la isla de Río Perro. Comenta que los niños que han terminado la primaria con buenas calificaciones esperan que el gobierno les ayude con alguna beca para seguir sus estudios secundarios; así mismo los maestros esperan que sea atendida su petición de aumento de sueldo ${ }^{117}$.

117 V. RD, n. 771; V. CD, n. CCCLXXX. 
Como de costumbre antes de comenzar el curso 194344 se está ya mirando que personal es idóneo y con quienes se puede contar para desempeñar su labor de maestro en la comarca. El subdirector propone que se reintegre al magisterio uno de los maestros que presentó mal comportamiento, pues cree que se ha enmendado y que será bueno también porque esta persona posee el título. Queda claro, así mismo, que el sahila de Playón Chico y la isla entera no desean al maestro Colman y sí aceptan al que anteriormente propone el subdirector. La situación es que en esta escuela en segundo grado ya existen 28 alumnos por lo que se debería crear un tercer grado para que allí mismo pudieran seguir sus estudios 118 .

\subsection{La Labor de Jesús Erice}

El nuevo curso se inicia con el ascenso del P. Jesús Erice de subdirector a director. Su actividad comienza con unas conferencias en Narganá para los maestros, a las que asisten once de los mismos. Los temas tratados pretenden ampliar las disposiciones dictadas por el intendente Luis Hernández. Estas cuestiones serían:

- Que los maestros deben permanecer en sus puestos de trabajo, y los días libres dedicarlos al estudio y mejoras del edificio y jardín. Romper obstáculos para que aumente la 
matrícula y la asistencia. $\mathrm{Y}$ tratar con los padres para darles consejos.

- Que deben cultivar la amistad con los sahilas y hablarles de las ventajas de las escuelas, para que ellos sean los primeros patrocinadores de la educación.

- Que es su deber comunicar al director los problemas y dificultades, pero sin olvidar que se pueden dirigir al intendente, quien es la primera autoridad de las escuelas.

- Que el maestro debe ser el modelo de la civilización, comenzando por el vestir. La escasez del sueldo no exime el uso del calzado.

- Que no debe caer más bajo que los incivilizados dejándose llevar por el licor.

- Que los maestros deben saber comportarse con moralidad. Ellos son los primeros en conocer que los indios son celosos de sus hijas, por lo que con su comportamiento no deben contribuir a que este aumente, ya que la matrícula femenina es bastante escasa.

-Que han de mostrar su respeto a las autoridades, pues en ocasiones los maestros son los únicos representantes de él, y si no los secunda la obra civilizadora será estéril.

- Por último deben fomentar los trabajos agrícolas, y desterrar las ideas de ciertos jóvenes con estudios que creen que los trabajos de machete rebajan al hombre. Esto ayudaría a superar la crisis impuesta por la guerra y a mantener unidas las familias. 
La segunda conferencia tuvo por objeto la explicación de los objetivos escolares. Para esta conferencia se contó con la asistencia de un maestro más. Les recordó que se debe mantener muy alto el prestigio de los miembros pertenecientes al magisterio, y defenderlo contra los ataques de los indigenistas.

Se debe llevar un control de la asistencia media diaria y un promedio diario de la matrícula. Por lo tanto es necesario hacer un correcto uso del registro escolar. La nueva división territorial de provincias y distritos exige que los maestros los conozcan para poder enseñar correctamente la geografía. Una vez más se vuelve a hacer hincapié en que las escuelas se deben regir por el programa oficial, como lo han hecho siempre, al igual que el resto de las escuelas de la República.

La última conferencia trató sobre el modo de solucionar las dificultades en la enseñanza. De modo encarecido pidió a los maestros que luchasen por aumentar las matrículas, para ensanchar la acción civilizadora. Se les exhorta a trabajar por la intensificación y progreso del castellano, para ello deben recurrir a elaborar listas de nombres y expresiones. Del mismo modo el maestro debería conseguir gran número de cuadros y objetos para exponer en castellano. Esto le serviría como garante para mantener su puesto en el magisterio.

Debe el maestro preparar sus clases e intentar mejorar sus métodos de enseñanza. También se les pide que recojan 
todas la tradiciones y creencias kunas para que la cultura de su pueblo no se pierda. $\mathrm{Y}$ culminan las conferencias con la lectura de los nombramientos para las distintas escuelas 119 .

Seguidamente el P. Erice envía la lista de los maestros que asistieron a dichas conferencias, a las cuales faltaron nueve de los maestros nombrados, y el director de las escuelas se queja de los que no asistieron que pedirán luego consejo al personal ajeno al magisterio 120 .

Se propone en la primera gira, Jesús Erice, normalizar la marcha de las escuelas y trabajar por el aumento de la matrícula, ya que si esto se pospone se dificultaría su consecución. Se veía urgido a realizar esto por el mal precedente de algunas escuelas como Ailigandí, Playón Chico y Cartí. Conversa con todos los sahilas en los lugares que puede celebrar congreso para exponer los beneficios que aporta la educación. Concluye su información con un breve relato de cada una de las escuelas. Ustupu sigue su curso regular destacando el buen trabajo de los maestros.

En Ailigandí los maestros se encontraron sin escuela y sin niños, pues solo tenían matriculados treinta. Consigue el compromiso del pueblo para que construyan dos escuelas nuevas y rehabiliten una tercera. En la actualidad la matrícula alcanza

119 V. RD, n. 776; V. CD, n. CCCLXXXV.

120 V. RD, n. 777; V. CD, n. CCCLXXXVI. 
ya noventa y uno. Tupile alcanza la mayor matrícula de su historia y los maestros se sienten muy contentos. Sin embargo arroja una matrícula inferior al año pasado Playón Chico, pero espera que con sus gestiones de la primera visita las cosas cambien.

Tikantikí y Tigre llevan su marcha sin novedad. En Cartí Suitupu, Colman se presentó como hijo del pueblo, ya que su padre era de aquí, y fue bien recibido. Aquí se deja ver la atracción de los trabajos por la Zona que muestran una disminución de la matrícula con respecto al año anterior. Cartí Tupile se mantiene a pesar de haber dado esta escuela graduados en sexto grado y varios becados. Hasta la mitad ha descendido la matrícula de Rio Sidra con respecto al año anterior; es una isla muy cerrada pero la dirección espera que progrese. En Río Azúcar se ha producido un descenso debido en parte a los niños que se trasladan a Panamá y Colón, y por los niños que han subido a los grados superiores de Narganá, que han sido siete. En Narganá se ha producido un aumento en el sexto grado y el cuarto curso es excesivo en número121.

Cuando se acerca finales de mayo, el P. Erice redacta la primera circular para manifestar a los maestros las primeras impresiones de su visita a las escuelas. Alaba el interés profesional de todos los maestros y de modo especial el de

121 V. RD, n. 779; V. CD, n. CCCLXXXVII. 
aquellos que recorren todas las casas buscando niños para la escuela. Finaliza la circular con tres recomendaciones: que tomen con especial interés la enseñanza del castellano, atendiendo al programa de cada grado. En segundo lugar les insta a que cuiden los libros y los hagan cuidar, pues escasean y en el futuro será difícil conseguirlos. Y finalmente les pide que la Enseña Patria se guarde en sitio adecuado y plegada122.

Aparece la segunda circular sin intervalo de tiempo y el tema que trata es la maternidad en el magisterio, dado que aparecen varios casos en el presente año y este asunto está regulado por la ley 89. Las maestras deben cesar de su puesto tres meses antes del alumbramiento. Tampoco pueden integrarse en el magisterio las madres con hijos menores de seis meses. Por lo tanto las maestras no se pueden integrar a sus puestos hasta cumplir los plazos de los anteriores puntos. Las sustitutas serán nombradas por la superioridad.

El sueldo de las maestras en estado de gravidez será cierto sueldo de vacaciones que la dirección notificará. Por esto las que se encontraran en esta situación están obligadas a notificarlo con tiempo a la dirección de las escuelas ${ }^{123}$. En agosto la maestra de Ustupu pediría permiso para apartarse del magisterio por esta causa; y el director de las escuelas alaba su

122 V. RD, n. 780; V. CD, n. CCCLXXXVIII.

123 V. RD, n. 781; V. CD, n. CCCLXXXIX. 
labor realizada con gran dominio del castellano, y habilidad para enseñar tareas propias del sexo femenino ${ }^{124}$.

Los resultados de los estadillos del mes de mayo muestran un ascenso para algunas escuelas y descenso para otras. Río Sidra es una de las que ha visto recompensado los esfuerzos, pues la matrícula ha subido hasta sesenta, sin contar a los que asisten como oyentes. En esta misma línea ascendente están las escuelas de Tupile y Ailigandí. Entre las que acusan una baja preocupante están Río Azúcar, Playón Chico y Ustupu125.

Un problema que apunta Erice, expuesto por los maestros de Ailigandí, es la dificultad que encuentran estos a la hora de descansar, corregir los ejercicios y preparar las clases; ya que tienen que vivir con otras familias y en muchos casos familias numerosas que no les permiten realizar sus deberes. Este problema es muy generalizado y creen que una posible solución sería que el intendente solicitara a las autoridades de la comarca, con apoyo del director de las escuelas, la construcción de una casa para los maestros, y si hubiera en una isla maestros de los dos sexos que sean dos casas más reducidas; así como un escusado que podría ser usado también por los wagas que se hospedaran en las islas ${ }^{126}$.

\footnotetext{
124 V. RD, n. 785; V. CD, n. CCCXCIII.

125 V. RD, n. 782; V. CD, n. CCCXC.

126 V. RD, n. 783; V. CD, n. CCCXCI.
} 
Se busca una suplente para la escuela de Río Azúcar y las dos primeras solicitadas muestran su negativa, una de ellas por algún problema que tuvo en época anterior. Un tercer candidato en un primer momento aceptaría si su marido estuviera de acuerdo; pero una vez llegada la hora se niega a aceptar el puesto. $\mathrm{Y}$ finalmente se propone a una alumna de Narganá que terminó el curso pasado el sexto grado con buenas calificaciones ${ }^{127}$. El director manifiesta que escasea el personal femenino del magisterio porque la mayoría está en Colón y Panamá; pero aclara que los de esta isla no tienen inconveniente en que se les nombre una maestra que no sea india128.

Los ensanchamientos de las calles al estilo civilizado tenían su explicación en los desfiles conmemorativos, como es el caso de las fiestas patrias y conmemoración de la independencia de los Estados Unidos, en los que participaban plenamente los planteles escolares y los americanos del Fuerte de Mandinga, paseando las enseñas nacional y americana. La celebración según comentario del director fue un éxito ${ }^{129}$.

El mes de junio arroja un aumento en la matrícula de las escuelas de la comarca. Erice detalla la marcha de cada escuela y se lamenta de no haber podido llegar tampoco en esta segunda visita hasta Puerto Obaldía, que también refleja un

127 V. RD, n. 785; V. CD, n. CCCXCIII

128 V. RD, n. 784; V. CD, n. CCCXCII.

129 V. RD, ns. 788, 789 y 790; V. CD, ns. CCCXCV y CCCXCVI. 
aumento en su matrícula. El objetivo de esta segunda visita era la construcción de casas y excusado para los maestros, así como impulsar la enseñanza y el incremento de matrículas. Se siente satisfecho el director porque ha pernoctado en todas las islas pudiendo asistir así a los congresos y expresar en lengua kuna, sin intérprete, sus ideas. La idea de las construcciones fue muy bien acogida por los indígenas. Alaba el aumento de matrícula en Ustupu y Playón Chico, en este último lugar fue muy destacada la labor enérgica del sahila. Cartí es la escuela que no denota mejoría, la rivalidad entre los futuros sahila la perjudica.

En Tigre la maestra se halla en su casa y se pidió la construcción del escusado, están terminando la escuela nueva que ya está a medio construir. La maestra de Narganá no posee gran habilidad docente, por lo que el director le ha dado unas clases prácticas y después ha encargado a otra maestra que la ayude. La atracción seductora que provoca el dinero que se puede conseguir en la Zona está perjudicando a la educación y a las familias que se olvidan del provenir de sus hijos, pues hasta los mas pequeños son seducidos por este deslumbramiento. En honor a la verdad también se debe decir que los niños de Narganá dan gran importancia a la obtención del diploma, y aunque en tiempos de vacación trabajen en la zona regresan para proseguir sus estudios ${ }^{130}$.

130 V. RD, ns. 790 y 791; V. CD, ns. CCCXCVI y CCCXCVII. 
En esta época se está llevando a cabo la inclusión en el seguro social de los maestros. Lo que supondría una mejora para los docentes de esta apartada región ${ }^{131}$.

Una de las maestras del sector central es trasladada al interior cuando se llevan dos meses de curso, por lo que es preciso buscar una que la sustituya, se piensa en una que ha realizado sus estudios en Panamá y que domina el castellano. Además tiene la ventaja de poseer dos años de experiencia132. La misma maestra trasladada presentaría la renuncia al intendente y le manifiesta su agradecimiento por las atenciones que le prestó mientras trabajo bajo su dirección ${ }^{133}$.

La tercera circular de la dirección escolar trata sobre diversos tópicos. Comenta sus esfuerzos por conseguir casas y escusados para los maestros, así como las motivaciones despertadas para aumentar la matrícula en las escuelas que era escasa:

- Da orientaciones a la hora de entonar el himno nacional al inicio y fin de la semana de las labores escolares.

- Repite una vez más que las celebraciones de chichas y fumaderas no son motivo para suspender las clases esos días,

131 V. RD, n. 792.

132 V. RD, n. 793; V. CD, n. CCCXCVIII.

133 V. RD, n. 795; V. CD, n. CD. No olvidemos que los maestros de kuna Yala estaban considerados como los de la más baja categoría. 
y cree que el congreso debería pedir que no se interrumpan las clases por dicho motivo, al mismo tiempo que censura a los que dejan las clases para realizar sus diligencias; y piensa que los sahilas son los primeros que deben vigilar para que esto se cumpla.

- Considera que al niño se le debe mantener ocupado en la escuela y fomentar el desarrollo de su atención, pues de él depende crear este hábito.

- El maestro ha de ser enérgico con el niño, pero no mostrarse airado. Debe estar seguro de que el maestro le quiere, y que lo que hace obedece a su interés educativo. La expulsión de la escuela debe producirse cuando se hayan agotado todos los recursos.

- La actividad del maestro se debe reducir a la escuela y no sobrepasarse en sus tareas. Incluso los días de asueto se debe dedicar a su escuela y no dar normas que produzcan división en el pueblo y promuevan partidismos; pero se debe a todos de un modo desinteresado.

Para ser buen maestro más que conocimientos se requiere interés, entusiasmo y consagración total a la enseñanza, esta sería la conclusión ${ }^{134}$. Aprovecha el envío de la

134 V. RD, n. 794; V. CD, n. CCCXCIX. 
circular al intendente para solicitar que le notifique las fechas de vacaciones semestrales y de fin de curso ${ }^{135}$.

El congreso de Tupile de febrero eleva una solicitud al Ministerio de Gobierno y Justicia para la construcción de dos casas escuelas, una en Tupile y la otra en Ailigandí, pero será el intendente el que medie en esta cuestión, una vez haya pasado la crisis por la que atraviesa el país. Los sahilas contaban con la promesa de ayuda del Presidente de la República, y ahora solo falta el entendimiento entre ese Ministerio y Obras Públicas ${ }^{136 .}$

Ante la llegada de las vacaciones semestrales, el director Jesús Erice, expone al intendente que en estas vacaciones se ha prohibido a los niños de la escuela desplazarse hasta Colón por temor de que no vuelvan, y si alguno de los matriculados no vuelve a la escuela en el segundo semestre no podrá ir a Colón hasta el verano, pues si no cualquier dificultad ante el estudio les llevaría a no volver a la escuela ${ }^{137}$.

El segundo semestre comienza con una circular que hace un balance del pasado y presenta los objetivos del próximo. La calificación general sería de buena, salvando alguna que sería de regular y otras de muy buena.

135 V. RD, n. 796; V. CD, n. CDI.

136 V. RD, n. 798; V. CD, n. CDII.

137 V. RD, n. 799; V. CD, n. CDIII. 
Se propone la dirección pasar examen final personalmente a todas las escuelas acompañado de otros maestros; y una vez más exhorta a que se ponga especial interés en el castellano y sobre todo de los cursos superiores.

Los maestros no deben escatimar esfuerzos en la preparación de las fiestas patrias. $Y$ afirma el director que una de las misiones de la escuela es que los niños sientan a la patria, y que actúen el mayor número posible en los actos ${ }^{138}$.

El balance del mes de octubre, el director, lo da por normal en general. La matrícula ha descendido debido a traslados y algunas salidas. A pesar de la prohibición que se hizo a los estudiantes. Pero lo que resulta alarmante es el descenso de las asistencias, en el que ha incidido nuevamente la escuela de Río Sidra, la cual se mantiene tan solo por temor, pero aunque sea así debería continuar, para que los pocos que siguen, el día de mañana sean sus defensores. La de Tupile ha sufrido gran baja en el kinder, provocado por la enfermedad de la maestra ${ }^{139}$.

En noviembre presenta su renuncia del cargo el maestro destinado en Cartí Tupile, para ello expone como razón que le han ofrecido un buen puesto en la zona y abandona su puesto; piensa que como hay muchos pretendientes al magisterio no será problema encontrar un sustituto140.

\footnotetext{
138 V. RD, n. 800; V. CD, n. CDIV.

139 V. RD, n. 801; V. CD, n. CDV.

140 V. RD, n. 802; V. CD, n. CDVI
} 
La inspección realizada a todas las escuelas después de las fiestas patrias la resume el director en carta al jefe de la intendencia. Inicia la visita por el sector Cartí, y en Río Sidra encuentra gran desidia, por lo que reúne a los jefes en el aula y les pide expongan al pueblo el gran beneficio que supone la instrucción. Ellos así lo prometen. Los de Cartí Tupile con el cambio prefieren mujer para la escuela, y si ha de ser hombre que sea casado, ya que el anterior no dio buen ejemplo.

El maestro de Puerto Obaldía adolece de carácter para llevar una escuela, por lo que es mal visto por pequeños y grandes. Ailigandí pasa por un mal momento, ya que los padres no tienen interés porque sus hijos asistan a la escuela y estudien. En el pueblo se nota desunión y los sahilas no ejercen ninguna influencia positiva con respecto a la escuela. Uno de los maestros ha resultado un fracaso en la labor que podía haber realizado y con su comportamiento. Por el contrario merece un gran elogio la escuela de San Ignacio de Tupile, en la que pueblo y maestro compiten en dar la mejor instrucción ${ }^{141}$.

El tema de los exámenes finales es el objeto principal de la tercera circular de este curso. Es el propósito del director presenciar personalmente las pruebas finales, que recogerán los frutos sembrados durante el curso, acompañado de cuatro maestros. La conducta moral de algunos maestros ha enturbiado

141 V. RD, n. 804; V. CD, n. CDVII. 
el normal desarrollo de la instrucción, y considera que este elemento es tan importante como la preparación técnica del personal; ya que la falta de moralidad levanta murallas que impiden el avance de la civilización. No sin razón el jefe de El Porvenir al comienzo del curso encareció a los maestros un comportamiento moral ejemplar. Aparece claramente que es obligatorio el examen escrito para los cursos superiores a tercero inclusive, el resto será oral. Las pruebas se realizarán sobre aritmética, geografía, historia, religión, estudio de la naturaleza, cívica e higiene. Pero los maestros tendrán que someter al juicio de los examinadores los trabajos de escritura, dibujo, dictado y los ejercicios de aritmética de los cursos inferiores y tercero, para que se valore la labor de los discípulos y del maestro. Es responsabilidad de los examinadores redactar un informe de la labor realizada por el maestro en cada grado y entregarlo al director. Pero deja establecido unos sustitutos del grupo examinador por si alguna causa mayor impidiera llegar a estos a las islas. Con el fin de curso el maestro debe elaborar un inventario de los materiales escolares y depositarlos bajo la custodia del sahila ${ }^{142}$.

Comunica al intendente el director las fechas y horas de los exámenes finales orales, en las escuela de Narganá y Corazón de Jesús; el primero, segundo grado y kindergarden

142 V. RD, n. 806; V. CD, n. CDIX. 
tendrán también su examen escrito. Concluirá el curso con la entrega de calificaciones y diplomas ${ }^{143}$.

En la última gira del curso aprovecha nuevamente el $P$. Jesús Erice para hacer campaña en favor de la escuela, en esta ocasión es ayudado por los maestros examinadores. Como conclusión, han coincidido en todas las islas que es un gran mal el que los niños salgan hacia Colón para trabajar, llegando a ocurrir algún caso en que se han ido incluso sin permiso del padre. Esto perjudica grandemente a la escuela. Los sahilas a la cabeza de Nele Kantule deciden prohibir la salida de niños en edad escolar, si no es con permiso de la dirección de las escuelas o del intendente. Los capitanes que contravengan esta orden serán sancionados con diez balboas de multa. En Narganá se reúnen los sahilas y voceros de Playón Chico, Tikantikí, Río Tigre y Río Azúcar con los maestros examinadores y las madres franciscanas para elevar la súplica anteriormente referida a esa autoridad $^{144}$.

En los exámenes finales llevados a cabo en la isla de Cartí Tupile el sahila demanda un buen maestro para el curso próximo. No ocurre la misma situación favorable en Cartí Sugdupu, donde por segunda vez reúne congreso el director y no se presenta el sahila Olonibiquiña, siendo patente el hecho de que los indios no deciden nada sin estar presente el sahila ${ }^{145}$.

143 V. RD, n. 808; V. CD, n. CDXI.
144 V. RD, n. 809; V. CD, n. CDXII.
145 V. RD, n. 810; V. CD, n. CDXIII. 
Cumpliendo con la normativa vigente el director redacta un informe para el Ministro de Gobierno y Justicia, Camilo A. de la Guardia. En él expone que cumpliendo con la ley de estabilidad del magisterio, los nombramientos de este curso solo tuvieron por objeto llenar las vacantes, un nuevo padre entró a cubrir el puesto libre de Narganá y dos hermanas fueron sustituidas por otras. Una maestra que en junio no se había presentado en Corazón de Jesús fue reemplazada. Otra maestra indígena ocupa el puesto de la que se traslada por nombramiento fuera de la comarca. En Río Tigre se nombra al marido de la hasta entonces maestra. Por estado de gravidez son sustituidas las maestras de Río Azúcar y Ustupu.

Se restaura la escuela de El Porvenir por lo que es preciso efectuar un nuevo nombramiento. $Y$ entre las actividades llevadas a cabo por la dirección, para intensificar la instrucción, menciona cinco visitas a cada escuela convocando congresos para hablar de la educación, las conferencias al inicio del curso, cinco circulares y varias cartas personales a los maestros, estimular a los sahilas para que favorezcan la escuela, vigorizar las celebraciones patrias, que en Narganá tuvieron un espectacular lucimiento con aires militares ${ }^{146}$.

El director presenció los exámenes finales acompañado de los maestros más prestigiosos. Para el próximo curso prevé un aumento de matrícula, a lo que ayudará la medida tomada de

146 Algo muy propio del director era dar este toque miliar a la escuela, pues se consideraba un admirador y defensor de la causa aliada. 
no dejar salir niños en edad escolar a los trabajos de la zona. La escuela de Narganá y Corazón de Jesús se vio asistida por nueve maestras, sobresaliendo las labores de costura que deslumbraron a cuantos las visitaron. Las últimas maestras sustitutas mostraron poca valía para esta profesión.

El excesivo número de alumnos en el cuarto grado hizo que los repetidores pasaran al quinto con poca preparación, consiguiéndose unos malos resultados. Todo ello es producto de que las escuelas de las otras islas tienen en su mayoría sólo los tres primeros grados, por lo que se sumaron a ésta los alumnos de tres islas, existiendo ya en la de Narganá dos clases de tercer grado. Es obvio que se precisa una maestra más para Narganá. El sexto grado ha sido numeroso encontrándose niños y niñas bien preparados para proseguir estudios.

Considera el director como una medida muy acertada que el Gobierno proporcionara unas ocho becas para encauzar a estos estudiantes que concluyen la enseñanza primaria. Se puede decir que en el balance de promovidos y fracasados, de todos los cursos de Narganá, se encuentra un alto porcentaje de estos últimos

La matrícula de El Porvenir se ha mantenido en 16 alumnos en este año de reapertura. Se ha visto buena voluntad en la maestra y en los alumnos, lo cual compensa la escasa matrícula. 
Después de haber sido una de las primeras islas en acoger la escuela, Cartí Cangrejo está dando muy pobres resultados, pues ya lleva tres años sin trasladar niños a los grados superiores de Narganá. Ello se debe a los trabajos de la Zona y a las luchas levantadas por la elección de sahila. La escuela cuenta con piso de madera y suficientes bancas. El número de matrículas ha rondado los cincuenta.

La isla de Cartí Tupile ha dado muestras de interés por la instrucción, llegando la matrícula a contar con 35 alumnos. El maestro que estuvo hasta noviembre desempeñó bien su tarea, pero luego se fugó a Colón con una señorita, quedando el pueblo sin escuela. La moralidad de los kunas es muy alta y no tolera esta falta en los empleados públicos, acarreando esto que varias escuelas se pierdan por tal motivo. El congreso del pueblo pide escuela para el próximo año, cuentan con un bohío de piso de madera y poseen bancas para la misma.

Donde todavía son muchos los adversarios de la civilización es en Río Sidra, y la escuela es consentida más que deseada, la asistencia es muy irregular, a pesar de que la matrícula ha llegado a subir hasta sesenta. El maestro ha mostrado buena habilidad para cambiar a estos hombres a favor de la educación. La escuela es un bohío con piso de madera y suficientes bancas. 
Al igual que las escuelas de la cabecera, Río Azúcar ha demostrado gran empeño en la instrucción de sus hijos e hijas. Gran labor desempeñan el sahila y el policía que luchan en favor de la escuela, llegando a contar con ochenta matrículas. Fruto de ello es que han consiguiendo el diploma de sexto grado varios niños y dos niñas en la escuela de Narganá. Los dos maestros realizaron buena labor, aunque uno no vio recompensados sus esfuerzos. La escuela fue construida a expensas del gobierno, de madera y zinc, y en este momento se están efectuando nuevas reparaciones.

Río Tigre sufrió un cambio de maestro en el mes de agosto y consiguió la colaboración del pueblo en favor de la escuela. Le ayudó el tener allí mucha familia y la matrícula ascendió a sesenta, con una asistencia ejemplar, siendo los exámenes finales un éxito. Por ello se debería nombrar una maestra más en esta población para atender a la crecida matrícula y a las niñas que comienzan a ingresar en la escuela. Fruto de los consejos del maestro es la construcción por parte del pueblo de la escuela y la casa del maestro; la primera con piso de madera, pertenece la mitad al gobierno y la otra mitad al pueblo.

Otra de las escuelas que requiere una maestra para atender la demanda de las niñas que empiezan a acercarse a la escuela es Tikantikí. Si esto se llevara a efecto aumentaría la matrícula femenina y se podría atender mejor al excesivo 
número de niños. El maestro ha trabajado bien y lo prueban los resultados de los exámenes finales. El edificio escolar es un bohío con piso de madera que está suficientemente dotado de bancas.

El sahila de Playón Chico apoya decididamente la escuela de esta población que es una de las más grandes. El director consiguió que subiera la matrícula en veinte alumnos más, manteniéndose fija en ochenta y ocho, pero si ejercieran tres maestros alcanzaría los ciento diez. Uno de los maestros carece de habilidad para dirigir la escuela, pero podría mejorar con alguna instrucción que se le diera. Carece de habilidad para hablar en los congresos y cree el director que en cada escuela debería haber un maestro parlamentario. La otra maestra rindió satisfactoriamente. $Y$ el edificio escolar es un bohío de piso de madera y con suficientes bancas.

A la zaga de las escuelas de la cabecera está San Ignacio de Tupile. Este curso la matrícula superó a los anteriores llegando a ciento trece, a los que se debe sumar los treinta que estudian en Narganá, y eso que no es una población muy grande. Una de las maestra, oriunda del lugar con su gran prestigio ha hecho que la escuela adquiera un lugar relevante, y la buena labor de los otros dos maestros han colaborado en esto, más, si se tiene en cuenta que una de estas es considerada por el director como de las mejores de la comarca. Los resultados se pueden ver en que es el segundo año que los hijos de la localidad 
se gradúan de sexto grado en Narganá. Los tres edificios escolares que funcionan son bohíos y solo uno de ellos posee piso de madera costeado por el pueblo, y cuenta con bancas suficientes. Por todo lo expuesto anteriormente cree el director que se merecen la construcción de una buena escuela.

Influenciado por el poco entendimiento de los sahilas, Ailigandí muestra cierta desorganización que afecta a la educación. La matrícula es escasa a pesar de alcanzar a ochenta - noventa alumnos. Los tres maestros que desempeñan sus labores aquí se puede decir que no destacan demasiado. El que mejores cualidades didácticas mostraba se dejó llevar en ocasiones por la bebida y mostró una moral deficiente. No existe escuela del gobierno, pues se ha usado como tal un Club que los jóvenes prestan, la otra es un bohío del pueblo y la última es de madera con techo de paja en malas condiciones y también del pueblo.

Otra de las escuelas que ha dejado sentir los males de la emigración a la zona es Ustupu. Aunque la asistencia se puede considerar ejemplar, la matrícula es baja, llegando a noventa y tres. Nele Kantule emplea sus fuerzas en fomentar la instrucción. Y por segundo año los hijos del lugar se diploman de sexto grado en Narganá, y otros muchachos estudian cursos secundarios en la capital. Así mismo estudian dos becados de la isla en el Instituto de Agricultura de Divisa. 
Los tres maestros del lugar han trabajado bien. Uno de ellos ha dedicado siete años a esta escuela de modo consecutivo, y cultiva una finca escolar muy aleccionadora al mismo tiempo que dirige un gallinero modelo, que es propiedad de la escuela. Entre sus méritos se puede contar la erección de un monumento a Nele Kantule con un pequeño parque, inaugurado por el director de las escuelas. Cuentan con una escuela hermosa pero despintada, que es propiedad del gobierno, en la que se imparte clase a dos grados; y otra del pueblo, muy deteriorada en la que se alberga un grado. Están en esperan de que se les construya otra escuela similar a la primera; y juzga el director que se lo merecen, tanto el pueblo como Nele Kantule. Uno de los maestros, que posee una correcta dicción del castellano, ejerce de intérprete de este jefe.

La escuela de Puerto Obaldía, a pesar de alcanzar una matrícula de cincuenta, no da muchos frutos, por lo que se debería cambiar al maestro. El edificio de la escuela es propiedad del gobierno.

El intendente durante este curso emprendió las mejoras de las escuelas de la cabecera de la comarca, Narganá, Corazón de Jesús y Río Azúcar; cementándose el piso bajo de la escuela Belisario Porras. Sólo restaba acondicionarlo para un grado más que se necesitaba. 
Para que el progreso y la civilización avancen el $\mathrm{P}$. Jesús Erice propone cinco puntos:

1) Que se emprenda la construcción de escuelas buenas, de las que casi se carece por completo, levantando dos este años al menos y suministrar suficientes bancas a todas.

2) El incremento de matrícula y la atención de las niñas que inician su ingreso en la escuela demandan el aumento de cinco maestros más, incluyendo entre ellos al que ejercería en Río Bayano, cuya reapertura ha solicitado el pueblo con insistencia dos años consecutivos.

3) Es imprescindible adquirir cuadros murales, al menos para los grados inferiores de las escuelas de la comarca.

4) Los maestros de la comarca no pueden enfrentarse al costo de vida actual, dado el diminuto sueldo asignado para ellos, por lo que sería necesario una subida.

5) Por último, vuelve a insistir en la conveniencia de otorgar ocho becas al menos a los niños y niñas graduados de sexto grado, para que puedan proseguir sus estudios, los hay bien preparados hasta pecuniariamente. Finaliza expresando su agradecimiento al intendente por la colaboración prestada en todo momento ${ }^{147}$.

147 V. RD, n. 811; V. CD, n. CDXIV. 
Desde Ustupu le comentan a Estanislao López que esta isla necesita otra escuela y desean que Nele pida los materiales para la misma. Por ello juzgan conveniente que el gobierno mande útiles escolares para las escuelas de la comarca148.

El intendente Luis Hernández propone para maestros de Ustupu los tres recomendados de Nele Kantule, esperando que sean designados, y así se lo hace saber a un habitante de la isla a fin de que se lo trasmita al cacique ${ }^{149}$. Seguidamente hace la propuesta al Ministerio de Gobierno y Justicia de los maestros y director de la comarca para el curso 1944-45. Se descarta un maestro por su mala conducta y otros dos por presentar en el curso pasado una labor deficiente. El cuarto destituido ocupaba su puesto en interinidad 150 .

Para el nuevo curso se contará ya con dos de las maestras que estaban de baja por maternidad, y sus suplentes causarán baja. Pero está previsto que otra cese en el cargo por encontrarse en estado de gravidez. Presenta el P. Erice al intendente dos jóvenes casados que han estudiado hasta el sexto grado, uno de ellos con título de carpintero, y el otro educado en una buena familia de Panamá, que dominan bien el castellano. Se propone fijar con anterioridad la fecha de las conferencias del verano, y si el intendente lo juzga oportuno que se sancione con

\footnotetext{
148 V. RD, n. 812.

149 V. RD, n. 813; V. CD, n. CDXV.

150 V. RD, n. 814; V. CD, n. CDXVI.
} 
una multa a los que no asistan sin causa justificada. Existe una aceptación general de los maestros en todas las islas, por lo que sus jefes desean que vuelvan los mismos, excepción hecha, en Ailigandí que los sahilas no desean que vuelva un maestro, y este tampoco tiene intención de regresar.

Había quedado pendiente de resolver la cuestión de los escusados para los maestros, por lo que opina el director de las escuelas que con los materiales que se retiran de Narganá y Río Azúcar se podrían construir todos. Concluye la comunicación del $P$. Jesús Erice al intendente expresando el consejo que dio a los maestros: que busquen un trabajo o el modo de pasar las vacaciones en Panamá para no olvidar el castellano y adquirir una expresión más correcta del lenguaje ${ }^{151}$.

Antes de la apertura de curso se preparan las conferencias que se tendrán con los maestros y el intendente disculpa su no asistencia, pero propone al director que haga hincapié en los temas ya tratados más veces: la permanencia del maestro en su puesto de trabajo; que cultiven la amistad con los sahilas, para conseguir a través de ellos mejor asistencia; que comuniquen a la dirección los problemas que les surjan; que tengan buen comportamiento, respetando a las autoridades y sean ejemplo en el vestir; que aconsejen a los indios para que incrementen su labor agrícola, pues no se saben las

151 V. RD, n. 807; V. CD, n. CDX. 
repercusiones del conflicto que enfrenta a las naciones. En el final de la carta se recuerda que el programa escolar se debe ceñir al oficial152.

Un niño que ha terminado el sexto grado con buen comportamiento y notas es merecedor de una beca en el Colegio Hospicio de Panamá, es natural de Isla Pino, y el director pide al intendente que le dispense todas las atenciones hasta que pueda trasladarse a la ciudad 153 .

La apertura del curso se realiza el 2 de Mayo y el director recorre las aulas para animar a todos en las tareas que han de desempeñar. $Y$ agradece Jesús Erice que el subteniente y parte del destacamento hicieran acto de presencia en este evento. El se reunió con el mencionado destacamento para conferenciar y ver el modo de coordinar los esfuerzos en mejora de la educación, la labor más importante de la civilización. El mismo día de la inauguración de las clases, una vez concluidas estas, reúne a los muchachos en el Club "Sociedad Cultural" para arengarles con ayuda de otras personas importantes de otras islas y de los maestros todavía allí presentes ${ }^{154}$.

En el primer mes de clases los materiales solicitados al Ministerio de Gobierno aun no han llegado y urgen para las

152 V. RD, n. 815; V. CD, n. CDXVII.

153 V. RD, n. 816; V. CD, n. CDXVIII

154 V. RD, n. 817; V. CD, n. CDXIX. 
escuelas libretas, cuadernos, papel, exámenes, programas de enseñanza primaria, mapas y banderas. Otra necesidad es la expresada por el maestro de Playón Chico que demanda cinco libras de clavos para arreglar la escuela del lugar, pues su estado es muy lamentable ${ }^{155}$.

Las estadísticas de este primer mes de curso reflejan un descenso en la matrícula y donde se acusa principalmente es en las escuelas que han sufrido un cambio de maestro: Playón Chico, Tikantikí, Cartí Cangrejo, Ailigandí y Ustupu. Río Sidra se ve estimulada por el traslado de cuatro niños de tercer grado a la escuela de Narganá, dejándose notar los esfuerzos del maestro que va arrastrando al pueblo hacia el progreso ${ }^{156 .}$

En julio de 1944 una maestra y un maestro de Río Azúcar presentan la renuncia al intendente por ciertas malas circunstancias y escándalos que formó en el pueblo la primera; y el segundo porque el pueblo no gusta de él después de haber servido durante seis años como maestro157.

El lugar para la nueva escuela de Ailigandí está ya elegido y el intendente pide al jefe de la sección técnica de salubridad que se use el mismo plano que se empleo para la escuela de Ustupu, pues de este modo se evita que tenga que

155 V. RD, n. 818; V. CD, n. CDXX.

156 V. RD, n. 819; V. CD, n. CDXXI.

157 V. RD, ns. 820 y 821. 
desplazarse un arquitecto hasta San Blas. Pero en lugar de hacer un solo edificio sugiere que se hagan dos para poder dar albergue a todos los alumnos 158 .

Aparece un decreto regulador del uso y expedición de licores en la comarca de San Blas. El tema de la bebida que con frecuencia implicaba a los maestros queda restringido 159 .

El relato de los avatares que corrió una maestra de Corazón de Jesús antes de su instalación definitiva con su madre en la isla, muestra las dificultades por las que tenían que atravesar los maestros no indígenas, el cambio que suponía para ellos, ya que se trasladaban a una sociedad totalmente distinta 160 .

El interés del intendente por conocer el alcance de la matrícula femenina en la comarca le lleva al director a expresarse de modo pesimista, ya que según él un porcentaje elevado de los trastornos ocurridos en la región, que alcanza el $80 \%$, tuvieron como fundamento el sexo femenino. Como consecuencia de esto, la matrícula de las niñas ha sufrido altibajos. En Ustupu se llegó a contar con 25 niñas en la escuela y en la actualidad solo hay 12 pese a los esfuerzos de los maestros y Nele Kantule, esto es muestra de la versatilidad de

158 V. RD, n. 822; V. CD, n. CDXXII

159 V. RD, n. 823.

160 V. RD, n. 825; V. CD, n. CDXXIII. 
este pueblo indígena, pero también es cierto que en la escuela de Narganá hay cuatro muchachas estudiando y una de ellas cursa sexto grado en el internado de las madres franciscanas.

La matrícula de los niños en Ailigandí cubre la totalidad de la población existente, mientras que las niñas no pasan de veintitrés; además de las seis niñas del internado del centro de la comarca, cuatro estudian en los grados superiores y dos en los inferiores. De Tikantikí han desaparecido en este curso las niñas gracias a la insignificancia de gastos y disgustos de los maestros; pero en Narganá hay cinco niñas, una en el internado y otra salió el curso pasado con el sexto grado concluido, a la que se dio una beca que por no ser de su agrado al primer contratiempo renunció.

El grupo más numeroso de niñas del internado pertenece a Río Azúcar que alcanza un número de quince a veinte. El internado parece ser el remedio al temor que tienen los indios a que sus hijas sean perjudicadas. Para que el día de mañana las niñas de la región no carezcan de instrucción, nada mejor que las propias indígenas se preparen para ser maestras de sus conciudadanas. $Y$ se ve que esta labor avanza, siendo los frutos esperanzadores.

El único modo de ver progresar la instrucción en los niños y niñas es que el maestro adquiera prestigio y amistades, lo que no se logra de la noche a la mañana, sino con el paso del 
tiempo. El prestigio se adquiere a través de la influencia del congreso, por lo que es preciso saber hablar en público, además de presentar una moralidad intachable. $Y$ rodearse de amistades influyentes que le ayuden a aumentar la matrícula y el interés de la población por la educación. La labor del maestro ha de ser paciente y cuidadosa sin tropiezos que levanten murallas para que poco a poco puedan ir desapareciendo los prejuicios de los indígenas ${ }^{161 .}$

En el informe del intendente al Ministro de Gobierno y Justicia comenta la eficiente labor del magisterio comarcano, que ha llegado a alcanzar una matrícula de 1052 alumnos, 800 de los cuales son varones. Todavía no se ha logrado convencer a los indígenas de la conveniencia de educar a las niñas y el excesivo celo que sienten por ellas. Existen ocho becas en la actualidad; pero Luis Hernández se lamenta del frecuente fracaso de estas becas. Para ello propone dos cosas que se deben tener en cuenta:

1) que se conozcan las becas que se van a conceder antes de terminar el curso, a fin de que los seleccionados se puedan preparar bien, en lugar de retirarse a buscar trabajo los hombre, o casarse las mujeres.

2) que las becas otorgadas sirvan para cursar estudios en los planteles designados, pero en calidad de internos, ya que

161 V. RD, n. 826; V. CD, n. CDXXIV. 
sería el modo de que los estudiantes estuvieran más centrados en los estudios.

Los maestros indígenas han sido un eslabón fundamental para la labor del gobierno; pero considera necesario que se aumente el número en cinco, para satisfacer la demanda de las escuelas de Ailigandí, Tigre, Tupile y Ustupu, y las escuelas que se abrirán próximamente. Espera el intendente que las construcciones de Ailigandí y Tupile propiedad del gobierno comiencen a funcionar el próximo curso. Pero no pasado mucho tiempo el sahila Olotebiliquiña le comenta que fracasó la construcción de las escuelas de Tupile y Ailigandí. El edificio cuenta con seis aulas para el sexto grado y no tienen maestros preparados para esos puestos. Nele Kantule no había pedido maestros diplomados según parece. Afirma que los indios no tienen grandes pretensiones, pues solo quieren edificios sencillos y así se lo debe hacer saber Estanislao al Gobierno162.

Durante este curso se produjo una epidemia de sarampión que afectó a Narganá y Corazón de Jesús, muriendo algunos niños. Considera el intendente que la región de San Blas es a la que más atención se le debe prestar, por estar llamada a un próspero porvenir. La catequización religiosa ha ido perdiendo su prestigio, y se requieren nuevas condiciones. Cambiar el rumbo de la civilización pues de este modo las nuevas 
generaciones deben venir a "beber en nuestros centros educacionales pues así el frecuente trato con gentes civilizadas les harán entrar poco a poco en la corriente del progreso". Se deben crear nuevas becas para que la juventud venga a estudiar a los colegios capitalinos, ninguna suma que el gobierno invierta en esto será excesiva. Esto que afirma para los kunas lo cree igualmente propio para los otros indígenas. Se ha reparado finalmente la escuela de Narganá regentada por las madres franciscanas 163 .

En enero de 1945 el director de las escuelas se queja del comportamiento del maestro de Tigantikí, en su visita a esta escuela no le encuentra en su puesto de trabajo y además se entera de que varias veces se ha emborrachado en día de escuela, estando los niños esperándole sin que él aparezca ${ }^{164}$.

Cuando el curso 1945 finaliza, Jesús Erice informa al secretario de El Porvenir que ha concluido el curso, al que se puede considerar el más aprovechado y ordenado, destacando la escuela de Narganá. Aprovecha para recordarle la petición de los sahilas, encabezada por Nele en el curso pasado, de no dejar salir ningún niño ni niña en edad escolar, y que este año se ha tomado la misma determinación ${ }^{165}$.

163 V. RD, n. 827.

164 V. RD, n. 830; V. CD, n. CDXXV.

165 V. RD, n. 832. 
Pero también surge la protesta de un habitante de Narganá que se queja de esta medida tomada por el director de no dejara salir de la isla a ningún niño y niña hacia la capital de la república, para lo cual ha puesto bandos por el pueblo. Cree que esta medida es excesiva y que el director quiere hacer un feudo de los niños escolarizados 166.

Como síntesis del curso 1944-45 la escuela de Narganá contó con ocho maestros, siete hermanas franciscanas y un padre. Corazón de Jesús con dos. El Porvenir, Cartí Cangrejo y Cartí Tupile con una maestra cada una. Río Sidra, Río Tigre y Puerto Obaldía con un maestro respectivamente. Río Azúcar y Playón Chico con un maestro y una maestra cada isla. Ustupu y Ailigandí con dos maestros y una maestra en cada población. $Y$ San Ignacio de Tupile con dos maestras y un maestro. Pero por enfermedad de la maestra de El Porvenir desde julio quedó cerrada la escuela de este lugar. $Y$ desde septiembre se nombró una maestra más que pasó a ejercer en Puerto Obaldía. Siendo sustituida la maestra de Ustupu por encontrarse en estado de gravidez avanzada.

La labor de la dirección se puede comprobar por los más de trescientos oficios, circulares y cartas; así como cinco visitas de inspección a la mayoría de las escuelas; la asistencia a los exámenes finales de casi todas las escuelas, a pesar de las

166 V. RD, n. 833; V. CD, n. CDXXVI. 
dificultades de comunicación. También ha procurado mejorar las cualidades del magisterio corrigiendo mensualmente una composición castellana efectuada por ellos; además de dictar seis conferencias a los maestros, ha dictado conferencias a los alumnos de sexto grado sobre la vida post-escolar y la conveniencia de completar los estudios primarios. $Y$ no menor atención requiere la campaña a favor de la instrucción de las niñas llevada a cabo por Erice.

Entre las observaciones con las que finaliza el director está la referente a los edificios escolares, que se deben mejorar en su mayoría. La dirección escolar debería disponer de una lancha al menos en la época de exámenes finales, de no existir otra sería la de la intendencia, para asistir a los mismos. Propone en esta ocasión cinco alumnos que terminan el sexto grado con buenas calificaciones y con recursos económicos suficientes para que se les conceda becas. $Y$ concluye pidiendo un maestro más para Narganá, cuyo cuarto grado pasará de setenta alumnos, además también estaría bien nombrar un maestro más para Río Tigre y otro para Tikantikí167.

Una nueva queja viene a caer sobre el intendente; en esta ocasión son los habitantes de Tubualá que se quejan a una comisión del gobierno de que éste quita el dinero que los padres envían a sus hijos estudiantes en la capital ${ }^{168}$.

167 V. RD, n. 834; V. CD, n. CDXXVII.

168 V. RD, n. 835. 
Como fruto de las gestiones de las autoridades y del director se autoriza a Blanca R. de Stocel para permanecer en el Hospital Santo Tomás durante diez meses para que aprenda cosas elementales de medicina, algo que sería muy beneficioso para la comarca ${ }^{169}$.

En julio el Congreso General Kuna trata el tema de la educación, que se dice que es el más importante, en presencia del intendente de la comarca. En el se expresan los miedos y recelos que los indios han sentido a dejar que la escuela penetrara en sus islas. A partir de aquí se institucionaliza el CGK que se celebrará todos los años, al menos dos veces, y que tratará con frecuencia los temas educativos ${ }^{170}$.

La experiencia de los años anteriores en las conferencias con los maestros al inicio del curso, le llevan al director a cambiar de método, y para el curso 1945-46 él les pasará un resumen de las charlas. A ello contribuyó grandemente que no se pudieron celebrar por motivos políticos, en los cuales estaba muy enfrascada la comarca. Los tópicos tratados servirán de nexo para las futuras circulares que redacte la dirección ${ }^{171}$.

En este año se produce un cambio de gobierno y también se da un giro en las escuelas. Termina la dirección de los

169 V. RD, n. 836.

170 V. RD, n. 837; V. CD, n. CDXXVIII.

171 V. RD, n. 838; V. CD, n. CDXXIX. 
claretianos y comienza la dirección del personal nacional. El primero en esta secuencia sería Manuel Herrera, a quien sigue Plinio Ortiz. Con la salida de los misioneros de los cargos oficiales, éstos se dedicaron más a la evangelización que a la educación.

Al finalizar este capítulo se puede decir que ésta fue la época más fecunda y floreciente en cuanto al tema educativo se refiere. Por una parte se empiezan a integrar, de un modo más amplio, las niñas en la vida escolar, lo que suponía un paso gigantesco en la educación, si se tiene en cuenta el recelo de los indios para con sus mujeres. Además, la labor de estos tres directores se puede afirmar que es la más importante realizada hasta la fecha, también es cierto, y por ello no se puede olvidar, que los anteriores fueron preparando el camino para llegar aquí. La dedicación y medios empleados favorecieron el aumento de matrículas, al mismo tiempo que sirvió para vigilar y controlar más de cerca la conducta de los maestros. Se fueron mejorando los edificios escolares y aumentaron las escuelas y maestros de la comarca.

A todo esto se debe añadir que la emigración de los estudiantes hacia la Zona y Panamá, fue un reto al que tuvo que enfrentarse la escuela, ya que los sueldo eran un reclamo que atraía poderosamente a los estudiantes. Del mismo modo que las epidemias también contribuyeron a la merma de la escolaridad. 
A partir de la presente época se deja ver una mayor influencia de las ideas pedagógicas socialistas y naturalistas. Se da gran importancia a la formación agrícola y los intentos de formar colonias agrícolas son diversos, aunque con resultados similares; ya que no duraron mucho tiempo. 
10. LA EDUCACION DEL ARCHIPIELAGO PASA AL MINISTERIO DE EDUCACION (1945-1953) 


\section{LA EDUCACION DEL ARCHIPIELAGO PASA AL MINISTERIO DE EDUCACION (1945-1953)}

10. 1. El impulso de Estanislao López (IguawiduI)

Fue alumno de la escuela del P. Gassó, donde aprendió las primeras letras, hasta que en 1909 su padre lo lleva a la escuela del Perpetuo Socorro. Desde 1911 hasta 1913 estuvo en la escuela de Artes Oficios, aprendiendo todo lo referente a la imprenta. De regreso a su pueblo es nombrado secretario de Claudio Iglesias, y con posterioridad su sucesor. En 1927 es nombrado policía colonial. En 1946 es elegido tercer cacique general junto con Yabilikiña de Tubualá y Olotebilikiña de Ustupu. En 1949 junto con otro dirigentes lleva al Congreso General Kuna la idea de crear un Primer Ciclo en la comarca de San Blas, como necesidad inmediata a la respuesta masiva de la educación por parte de sus isleños.

Luchó por el fomento de becas en las distintas carreras, y su labor fue premiada por el gobierno concediéndole la Cruz de Vasco Núñez de Balboa.

Esta época se ve caracterizada por el protagonismo del mencionado indio, y creo que es justificado que se dedique un apartado a analizar la labor realizada por él. En la comarca la misión católica pierde protagonismo a partir de este momento y 
lo va ganando esta figura que luchará por el progreso y mejora de la educación del pueblo kuna.

Había sido bautizado por el P. Gassó y estudió en Panamá, donde viviría gran parte de su vida, actuando de mediador entre el gobierno y los indígenas. Llegó a ser elegido sahila de la población de Narganá y ostentó el título de cacique indígena general, que alcanzaba a los otros grupos étnicos panameños. Debido en parte a la insistencia del P. Erice para que Estanislao regrese a la comarca, que es donde le necesitan, es elegido sahila de Narganá. Un becado estudiante en California le felicita por este acontecimiento; pues está seguro que luchará por el progreso de su región y contará con la ayuda de los misioneros. Así podrá lograr la civilización de los indios. Le recuerda el estudiante que el fue bautizado por el P. Gassó1.

Los habitantes de Narganá en un congreso deciden que para ser elegido sahila la persona debe saber cantar los cantos de la tradición kuna. Esta reunión se efectúa sin el conocimiento del intendente, lo que hace que se sienta molesto y pregunte que cuál es la causa de que se exija que los sahilas sepan cantar. Pone de ejemplo contrario a Róbinson y Olotebiliquiña que no cantaban. Ciertamente que estos no cantaban en el congreso, pero tampoco era lo común, sólo aquí en el sector central donde la civilización era más avanzada ocurría esto. En este mismo congreso se pide que se defienda a la religión católica, la que es

1 V. RD, n. 847. 
reconocida como luchadora de la civilización. Algunos artículos que se habían propuesto se pedide ahora que se retiren pues lo único que demuestran es la intención de conseguir el poder los que los han redactado?

Estanislao pasa a ser el centro de referencia de los misioneros y el hombre de confianza, como lo muestran las distintas cartas que le comentan los problemas de los indígenas. Ante el lamentable panorama que encuentra Jesús Erice en la ciudad de Colón, presentado por un grupo de kunas borrachos, le comenta a Estanislao López que estos males los han introducido los que se dicen civilizados, pero esto no es la civilización. Ellos se han cogido a lo más bajo de la civilización. Esta labor de implantación de la civilización en San Blas es realmente difícil conseguirla en la comarca ${ }^{3}$.

Los cambios efectuados en el tema educativo le llevan a expresarse de modo pesimista al P. Erice ante Estanislao López, que le dice que comenzaron días tristes para la instrucción de San Blas. Pero a pesar de todo el misionero está dispuesto a seguir trabajando por Narganá y su biblioteca. Las madres franciscanas de igual modo pasan por momentos difíciles. $Y$ es el indígena quien puede, en este caso, interceder para que la situación educativa mejore ${ }^{4}$.

El centro de información sigue siendo Estanislao López

\footnotetext{
2 V. RD, n, 878.

3 V. RD, n, 844 .

4 V. RD, n. 851.
} 
y el P. Jesús le comenta que su labor se ve destruida por acontecimientos que van contra la civilización, y para muestra está el ejemplo del paso de un barco cargado de cajas de cervezas para los indios 5 .

Jesús Erice puso su confianza en Estanislao y le recuerda que su puesto está en la región de San Blas, entre su gente como lider que encauce a los jóvenes y luche por el destierro de los vicios que entorpecen la labor civilizadora6.

Desempeña una función de mediador y conseguidor para su pueblo. La labor de Estanislao como hombre preocupado por su cultura, por la educación y desarrollo de su pueblo fue reconocida por sus paisanos. Desde Panamá o Colón desempeñó siempre las funciones de mediador para resolver todos los problemas que se interpusieran a la consecución de estas metas. El fue quien trabajó por llevar a los muchachos a estudiar en las escuelas secundarias, y en la mayoría de los casos les acompañaba hasta sus destinos ${ }^{7}$. Otra prueba de lo anteriormente expuesto es que desde la escuela de Divisa un alumno, que estudió en Narganá pide a Estanislao que le informe sobre las bases de las becas para el exterior8.

Una comunicación dirigida a Estanislao López expone que las dos becas existentes para la Escuela Profesional han

\footnotetext{
5 V. RD, n. 880 .

6 V. RD, n. 884.

7 V. RD, n. 854.

8 V. RD, n. 857.
} 
sido cubiertas por dos muchachas, una de las cuales era hija de Róbinson?.

Los asuntos educativos están dirigidos en gran parte por Estanislao, como hombre de confianza elabora una lista de maestros para el intendente Félix Oller. Del mismo modo visita al inspector educativo para informar de los maestros que tienen diploma de graduados y nombrar directores en las escuelas de Ailigandí y Tupile; el sugiere a dos para estos $\operatorname{cargos}^{10}$. Una nueva recomendada por mediación de Estanislao es nombrada por el inspector para la escuela de Playón Chico a finales de octubre de 194611.

Su ejemplo fue tomado como modelo de actuación por otros padres que se desplazaron hacia las capitales para conseguir un trabajo que les proporcionara un cheque con el que pagar los estudios de los hijos en los colegios de la capital. Una recomendación más se le pide que haga al Ministro de Educación para un maestro de la comarca ${ }^{12}$.

Una delegación de indígenas encabezada por Estanislao y el intendente se dirigen al Ministerio de Educación para tratar el tema de los fracasados en la Escuela Normal y el de una beca13.

\footnotetext{
9 V. RD, n. 859.

10 V. RD, n. 864.

11 V. RD, n. 879.

12 V. RD, n. 883

13 V. RD, n. 890.
} 
Uno de los habitantes de Corazón de Jesús desea que Estanislao le informe sobre política y le recomiende para un puesto de policía colonial ${ }^{14}$. El amiguismo sigue funcionando y dos maestras de Playón Chico se quejan a Estanislao porque han sido apartadas del magisterio, una de ellas por problemas morales. Creen que un amigo del intendente quiere meter a su señora a ocupar un puesto y se lo hacen saber a Estanislao para que tome las medidas oportunas ${ }^{15}$.

Otro becado en el exterior, en este caso en Medellín, se esfuerza por alcanzar un alto nivel educativo que luego le permita servir a sus conciudadanos. Como estudios extraordinarios está haciendo los de contabilidad. La penuria económica le hace pedir ayuda, a pesar de carecer de parentesco con Estanislao; y en alguna otra ocasión piden ayuda a $D$. Félix Oller ${ }^{16}$. Tomás Herrera le pide a Estanislao que cuando asista a la convención hable de las becas para los kunas en los paises adelantados de América, y que trate con los que elaboran la ley de becas en el exterior para indígenas, puesto que estas suponen una gran garantía educativa ${ }^{17}$.

El secretario de los sahilas le comenta a Estanislao que ha sido informado por el inspector que cuando se abran las escuelas en octubre habrá dos maestras más para Narganá, pero que serán castellanas. Lo que pretende es que haga las gestiones

\footnotetext{
14 V. RD, n. 891.

15 V. RD, n. 895.

16 V. RD, ns. 897 y 930.

17 V. RD, n. 901.
} 
necesarias para que pongan maestras indígenas, pues las hay preparadas $^{18}$.

Los sahilas de Cartí Sugdupu envían un candidato a Estanislao para que haga examen, ya que lo quieren de maestro en su pueblo, y comentan que cada pueblo en su congreso busca a su maestro, esta parece ser una de las innovaciones que se implantó a partir de $1945^{19}$.

Rubén P. Kantule le comenta a Estanislao que dos niñas de Narganá podrían recibir un sueldo de maestras de B/ 30 si él se interesase en conseguirlo del Ministerio de Educación 20.

Estanislao López envía los formularios de solicitud de las becas secundarias que sirven también para niñas ${ }^{21}$. Durante los largos periodos que pasó en Panamá hizo de intermediario y de vigilante para los estudiantes kunas allí trasladados 22 .

En agosto de 1941 Estanislao comentaba a Rubén P. Kantule que sería bueno conseguir escuela para su pueblo Mulatupu, que es una de las poblaciones principales y se lo merece 23 .

El sahila de Playón Chico le pide a Estanislao que le busque un colegio a un muchacho; pero que al mismo tiempo le

\footnotetext{
18 V. RD, n. 908.

19 V. RD, n. 917.

20 V. RD, n. 925.

21 V. RD, n. 935.

22 V. RD, ns. 683 y 697.

23 V. RD, n. 709.
} 
consiga una familia para que aprenda mejor. Una vez más un miembro de la familia se trasladaría la capital para conseguir dinero a fin de pagar los estudios del joven; pero el mismo sahila, pasada una semana le suplica que mande a otro joven que lleva ocho años en Panamá y se ha dedicado a fumar marihuana y beber ron 24 .

El interés del tema educativo empieza por los de su propia familia. El deseo de que la educación siguiera hacia adelante fue un objetivo de toda la actividad del indígena Estanislao, que se extendió hasta sus hijos, a quienes dio estudios salvando todas las dificultades 25 . Así la directora de la Escuela Normal informa a Estanislao de la buena marcha de los estudios de su hija26.

En otra ocasión, Estanislao quiere saber si en la escuela de Divisa existen becas o pensiones para indígenas, pues de ser así él estaría dispuesto a pagar la pensión de su hijo. La contestación aclara que no hay cupo para mecánica, pero sí para ebanistería, siempre que se superen las pruebas. Para las becas hay que esperar la decisión del Ministerio de Educación, que es el que las concede 27 .

Para el curso 1953 es nombrada maestra de grado la hija de Estanislao en la población de Ailigandí. Le comenta al

24 V. RD, ns. 968 y 969.

25 V. RD, ns. 882 y 907.

26 V. RD, n. 877.

27 V. RD, ns. 936 у 937. 
sahila que se ha tenido que retrasar, pero que en cuanto pueda se dirigirá a ocupar su puesto28.

\section{2. Los congresos como defensores de}

\section{la educación}

El Congreso General Kuna de $1945^{29}$ acuerda pedir al gobierno que algún kuna sea empleado en las embajadas o consulados, en puestos secundarios del exterior a fin de adquirir conocimientos que más tarde sean útiles para la comarca30.

El otro Congreso de este año celebrado en Ustupu trató de nuevo el tema de la civilización y la educación, analizando los problemas que han traído a la comarca los educadores ${ }^{31}$.

A partír de ahora los congresos van a jugar un papel muy importante en todo lo concerniente a la educación. Así vemos que el punto quinto del Congreso de Ailigandí decidí pedir un aumento de sueldo para los maestros y policías de la región 32 . Estas reuniones se prodigan y con connotaciones diferentes, según Estanilao en Ailigandí celebrarían un congreso de la educación ${ }^{33}$.

28 V. RD, n. 973.

29 Este año se considera como el del inicio de los congresos generales de un modo institucionalizado. Después de la muerte de Nele Kantule se celebraría dos veces cada año.

30 V. RD, n. 841.

31 V. RD, n. 846.

32 V. RD, n. 849.

33 V. RD, n. 913. 
Los problemas educativos son tratados por un congreso de la juventud kuna en el que se comenta que un indígena ya había pedido que el magisterio de San Blas fuera trasladado al Ministerio de Educación; y pretenden crear una asociación de maestros de la comarca para mejorar el entendimiento entre estos y los padres. Al mismo tiempo que se propone solicitar más becas para la escuela de Divisa ${ }^{34}$.

El séptimo Congreso General Kuna eleva un memorandum al Ministro de Gobierno y Justicia y otro al Ministro de Educación entre cuyos temas trata la situación del problema educativo, la suspensión de becas indígenas en la Escuela Normal de Santiago y la necesidad de un inspector para el distrito escolar de San Blas; además de esto se tocan los temas de la reserva de tierras, protección para las cooperativas indígenas, la higiene de los poblados y la protección de la vida de los indios 35 .

El Congreso General de Cartí trata el tema de la cooperación de los caciques y sahilas con los maestros para la buena marcha de las escuelas. Estanislao junto con dos congresistas más elevan una petición formal al Ministerio de Educación para que cree el primer ciclo de enseñanza en San Blas. El Congreso General celebrado en Ustupu en 1952, con apoyo del intendente Félix Oller eleva la misma petición al

34 V. RD, n. 902.

35 V. RD, ns. 904 y 905; V. CD, ns. CDXLV y CDXLVI. 
Ministro de Educación 36.

En el Congreso General Kuna de 1949 celebrado en Tigre también aparecen temas relacionados con la educación, en el informe presentado por Pablo Solís sobre la administración del señor ex-intendente. Nuevamente se apunta la conveniencia de que algunos indígenas se coloquen como empleados de legaciones extranjeras, lo que les facilitaría el participar posteriormente en la vida nacional. No se abandona el tema de la creación de la reserva indígena, pues se tiene como un objetivo prioritario.

El segundo congreso educativo de sahilas y maestros de la comarca concluye recomendando a los maestros que hagan de las escuelas centros de progreso y cultivo de las tradiciones. En el final ponen unas recomendaciones para las autoridades de la región y el Ministerio de Educación 37.

El Congreso General Kuna celebrado en Ailigandí en diciembre considera indispensable combatir en la niñez kuna el analfabetismo, comenta que faltan en la región diez maestros para completar el cupo de las islas que no tienen escuelas, y que los padres deben aceptar enviar a sus hijos a la escuela; considera positivo que todos los años concluyen sus estudios de primaria más de setenta niños indígenas. Se lamentan de que los padres carecen de medios para sufragar sus gastos de

36 V. RD, ns. 926, 927 у 962.

37 V. RD, n. 954. 
despalzamiento a estudiar en la capital, que el número de becas concedidas por el órgano ejecutivo por conducto del Ministerio de Educación es insuficiente.

Por todo ello solicitan al Excmo. Presidente de la República que aumente en viente unidades el número de maestros de la comarca de San Blas, que se establezca un primer ciclo de enseñanza secundaria en la comarca de San Blas, para que los niños que finalizan la primaria tengan oportunidad de seguir sus estudios sin excesivo esfuerzo para la economía de sus padres. Relativo a la educación hay una última petición consistente en que el órgano ejecutivo establezca una unidad de fomento agrícola en la comarca de San Blas, compuesta por técnicos agrícolas a fin de que enseñen a los indígenas el trabajo agrícola. Otras de las resoluciones adoptadas se centran en pedir la anulación de creación de la provincia de San Blas, pues los kunas temen que esto llevará a una invasión de personal burocrático en la comarca. Aprueban igualmente que el intendente Oller solicite un terreno para la agricultura en la región de Mandinga ${ }^{38}$.

En julio de 1945 el decreto 1135 crea tres provincias escolares entre las cuales se encuentra la de San Blas cuya cabecera estaría en El Porvenir y contaría con las escuelas que funcionan en la circunscripción de San Blas. El traslado de la Educación Pública en la comarca al Ministerio de Educación fue

38 V. RD, n. 974; V. CD, n. CDLV. 
idea del Ministro de Gobierno y Justicia39. Es claro que los nombramientos requerían mucho tacto, conociendo la idiosincracia del pueblo kuna. Desde el primer momento está en la mente del Ministro que los nombramientos se deben hacer de acuerdo a las indicaciones del intendente, que es quien conoce de modo mejor la situación y problemática de los indígenas.

Hasta ahora los claretianos habían sido los directores de la educación y funcionaban como inspectores. En este momento pasan a ejercer de maestros, y aunque sigue como director de Narganá Erice, el nombramiento de inspector del Sr. Manuel Herrera, le hace perder poder y encontrarse bajo las directrices de este hombre que no tiene una actuación muy acertada. Una vez más la Iglesia y sus instituciones pierden poder frente a los liberales. Las madres franciscanas seguirían en sus puestos. El Ministerio de Educación se hará cargo de modo directo de todo el tema de las escuelas y los maestros. Los informes y documentación referente a esta etapa disminuyen notablemente. La intendencia ahora no es el intermediario si no el encargado de emitir los informes.

En agosto de 1945 Rubén Pérez Kantule informa al intendente de la situación de las escuelas del sector de Ustupu comentando que los maestros se están comportando bien y trabajan con gran esfuerzo para enseñar a los niños 40 .

39 V. RD, ns. 853, 887 y 931; V. CD, n. CDXLI.

40 V. RD, n. 839; V. CD, n. CDXXX. 
El cacique de Narganá se dirige al Ministro de Educación para averiguar si han nombrado al maestro de educación física de la comarca, y recomienda a un joven, esperando que satisfaga su súplica ya que él se considera un viejo luchador de la causa. Al mismo tiempo agradece el envío de libros para la biblioteca de la isla, de la que se encargaría Rubén P. Kantule y que posteriormente tuvo que ser trasladada de lugar por dar al local que la albergaba otros usos, y entonces pedir los dueños una renta 41 . Con posterioridad Rubén P. Kantule hace un llamamiento a Félix Oller para que tenga en cuenta que el pueblo de Narganá está en el camino del progreso. Por ello le agradecería el envío de libros y folletos que puedan servir para la biblioteca, de donde él era encargado42.

Los becados que estudiaban en la ciudad debían correr con ciertos gastos, que suponían un sacrificio para las familias, como hemos visto. Pero ahora además se deben pagar el servicio de la lavandería43.

Nuevamente la civilización es un argumento esgrimido por Jesús Erice al intendente para solicitar ayuda para los misioneros, pues ayudar a estos es ayudar a la civilización de los indígenas, ya que así los demuestra la historia del archipiélago 44 .

\footnotetext{
41 V. RD, ns. 840 y 920; V. CD, n. CDXXXI.

42 V. RD, ns. 869 y 870.

43 V. RD, n. 843.

44 V. RD, n. 845.
} 
Félix Oller muestra sus quejas al Presidente de la República porque el Ministro de Educación no nombra a los recomendados por la Intendencia, para ocupar los puestos del magisterio de San Blas. Los sahilas parece ser que habían acordado nombrar ayudante del inspector a Eduardo Filós y el Sr. Crespo lo había aceptado, pero no se llevó a cabo45.

La figura de este intendente deja una gran huella en la comarca, los indígenas reconocen públicamente su labor en favor del progreso de los kunas. Trabajó en la modernización de las escuelas, en aumentar las becas de los estudiantes, nombró sahilas como guardias nacionales, creó el primer ciclo en Narganá y fue autor de la Carta Orgánica de San Blas.

El recién nombrado inspector de educación primaria de la provincia escolar de San Blas remite un informe al Ministerio de Educación en noviembre para dar a conocer el estado de las obras que se realizan en las escuelas de Tupile y Ailigandí a cargo del Ministerio de Obras Públicas. En su viaje habla con los sahilas y les hace ver que la educación no trata de cambiar sus costumbres y tradiciones. Es más, los califica de representativos de un pueblo o nación mientras conserven su pureza. Todo esto parece un signo positivo para el pueblo kuna que muestra una mayor disposición a aceptar las cédulas y la civilización; pues la educación se les ofrece sin ninguna intención secundaria destructora.

45 V. RD, n. 848. 
En otra escuela se ha concluido la construcción y es Wichuwala, para ello se han aprovechado los materiales del exsitio de defensa de Mandinga conseguidos por el intendente, junto a los esfuerzos del maestro de la escuela y el sahila Tinainni. El inspector señala a éste como el segundo pueblo que ha levantado escuela con sus sacrificios y sin ningún obstáculo; el primero había sido Isla Pino que lo había hecho en las mismas condiciones 46 .

Los expresos deseos de cooperación del nuevo intendente con el inspector Herrera tuvieron pocos frutos, pues éste desoyó los consejos que D. Félix Oller le diera. Su actitud de enfrentamiento a los católicos hace que el jefe de El Porvenir muestre sus quejas al Ministro de Educación. Era un deseo de los nuevos dirigentes liberales que en la comarca se implantara de forma completa el programa de enseñanza primaria, pero lo que subyacía con esto era la idea de crear una enseñanza laica, y como ellos mismos decían desterrar el catequismo acostumbrado por las misiones religiosas. Por dos veces aparece el tema de la cedulación unido al inspector de enseñanza primaria, lo que nos demostraría que sus competencias iban más allá de los temas meramente educativos 47 .

Los desvaríos de este inspector llegaron hasta acusar

46 V. RD, ns. 850 y 928; V. CD, ns. CDXXXII y CDXLVIII.

47 Un caso curioso de la actividad de este inspector fue que le llego a quitar al P. Jesús Erice la cédula porque ponía estado civil casado. Esto produjo su escándalo, y malestar entre todos los miembros de la misión católica, que estuvieron a punto de abandonarla. 
al director de las escuelas de haberse apropiado de un cheque de la maestra de Puerto Obaldía falsificando la firma. Llegándose a demostrar posteriormente que quien había cometido tal falta era el cedulador. El director P. Jesús Erice tuvo que pasar por la vergüenza de las acusaciones de ladrón ante los alumnos y sus familias. Esta sucesión de hechos que se fueron desencadenando de modo rápido y adverso para la misión hizo que en pleno tomaran la decisión de retirarse, ante lo cual el intendente pide al Ministro de Educación que dicho inspector sea trasladado de esta provincia escolar. Félix Oller propone como nuevo inspector a un maestro graduado que ha ejercido como director en varios colegios de Colón. A pesar de todo, el nombramiento del inspector Herrera se había hecho con el consentimiento de Sr. Félix Oller, lo mismo que el resto del personal subalterno, ya que así se había acordado con el Ministro de Gobierno y Justicia, pero no habían resultado bien las cosas 48 .

La tan criticada medida por los opositores de la educación, que se tomara por iniciativa de Nele y los sahilas con el beneplácito del P. Jesús Erice, de no dejar salir a los niños de la comarca en tiempo de vacaciones, es nuevamente pedida por varios sahilas que quieren que Félix Oller revise los barcos y no deje salir a los niños que se encuentran en edad escolar, aunque no asistan a la escuela. Esto ocurría ante el comienzo de las vacaciones de 194649. Poco después tres niños son sacados de la

48 V. RD, ns. 852 y $887 ; V . C D, n s$. CDXXXIII y CDXLI.

49 V. RD, n. 855. 
isla de Río Cidra sin permiso del maestro, lo que hace que expresen su queja al intendente 50 .

El cambio producido en materia educativa en la comarca produjo grandes problemas. El intendente así se lo expresa al Ministro de Educación, ya que cree que el haber cambiado la dirección de las escuelas, destituyendo al P. Jesús Erice, ha supuesto una dificultad para la enseñanza de la región ${ }^{51}$. Esto también se refleja en las becas, y se puede comprobar que la directora de la escuela de Panamá le comunica al secretario de Gobierno y Justicia que se encuentran vacantes dos becas; una desde el curso pasado y otra desde este año52.

El aprendizaje de algunos oficios fue valorado positivamente por los sahilas; pues los consideraban útiles para sus comunidades. Yapiliquiña, sahila de Tubualá le envía dos jóvenes al jefe de El Porvenir para que aprendan construcción y carpintería, y una vez concluido se los remita, a fin de que puedan colaborar en la mejora del pueblo53.

El sahila de Ustupu, Olotebiligiña, pretende conseguir una beca para su hijo, pero teme que no se la den por su delicado estado de salud, pues esto ocurriría si le niegan el certificado médico que le exigen; en cuyo caso se la otorgarían a otro estudiante de la población. Para ver si puede hacer algo se lo

50 V. RD, n. 856.

51 V. RD, n. 858.

52 V. RD, n. 860.

53 V. RD, n. 861. 
comenta a Estanislao54.

Félix Oller consigue llevar becados al Horfelinato a siete muchachos que había mandado Yabiliquiña, y le piden a Estanislao López que los atienda55. Una queja surgida de los habitantes de la región de Tubualá expone al Ministerio de Educación que el gobierno no ha empleado un centavo en materia educativa para este sector; por lo que creen que no estaría de más que ayudase a siete muchachos ingresados en la Escuela Normal de Santiago56.

La política de las becas indígenas siguió perteneciendo a Gobierno y Justicia según lo confirman varios documentos. Una nueva beca es requerida para un muchacho que desea estudiar en el Instituto Nacional, y de no ser posible estaría dispuesto a ir a la Escuela Normal. Había cursado el sexto grado en un colegio de la capital. La petición la realiza el secretario del Ministerio y le pide al Ministro que traslade la petición a Gobierno y Justicia57.

El encargado de asuntos indígenas de Gobierno y Justicia recibe una nueva recomendación, del secretario del Ministerio de Educación, para colocar a una estudiante que posee el título de sexto grado en un colegio de la capital, pero comenta que tiene preferencia por el Liceo de Señoritas 58 .

\footnotetext{
54 V. RD, n. 862.

55 V. RD, n. 863 .

56 V. RD, n. 865 .

57 V. RD, n. 866.

58 V. RD, n. 867.
} 
Una de las becas otorgadas corre el riesgo de perderse y se propone como solución que el becado trabaje por el día y estudie en el curso nocturno de comercio en la Escuela de Artes y Oficios 59 . Los gastos de comedor ocasionados por los estudiantes en la capital en algunas ocasiones eran pagados por el club de padres de familia de la isla, solidarizándose el pueblo con la enseñanza de los jóvenes 60 .

El curso 1946-47 presenta una situación distinta, al menos eso parece reflejar la documentación, vemos que la dirección de las escuelas ha cambiado, una carta del maestro de Cartí Tupile le rinde información de la marcha de la misma a Eduardo Filós que se encuentra en Narganá. En ella le dice que se dio comienzo a la matriculación del curso el día 7 de mayo con veintiocho niños, distribuidos dieciocho en el grado $1^{\circ}$, seis en el $2^{\circ}$ y cuatro en el $3^{\circ}$. Las clases comenzaron al día siguiente con la total asistencia de los matriculados. En los estadillos enviados deja constancia de la asistencia que alcanzaba una media diaria de 23. En el mes de junio la matrícula había alcanzado ya la cifra de treinta y $\operatorname{tres}^{61}$.

El mandato del inspector Manuel Herrera solo duró un año, pero el que fue elegido posteriormente no sería el propuesto por el intendente. El cargo recaía en el Sr. Plinio Ortiz, que al comienzo del curso 1946-47 envía la primera circular. El

\footnotetext{
59 V. RD, n. 868.

60 V. RD, n. 900.

61 V. RD, n. 871; V. CD, n. CDXXXIV.
} 
maestro de Cartí Tupile le comenta que el anterior inspector fue muy bueno pero que se dejó llevar por los indios instruidos en las escuelas protestantes, lo que le llevó a enfrentarse con la misión católica. Concluye haciéndole saber que no ha recibido ningún cheque 62 .

El sahila Samuel Ros de la población de Irgandí solicita al intendente Oller un maestro para la escuela de su pueblo que ya llevan pidiendo durante dos años; y el último año el inspector les había prometido un maestro. Llegando a un acuerdo con los vecinos de Ucupa que están dispuestos a mandar a sus hijos a esta isla para que estudien. La matrícula total supondría un total de 25 ó 30 alumnos que es lo requerido por la ley63.

El 27 de junio de este año se fundaba en Cartí Tupile una escuela nocturna para adultos. Esto era fruto de la tercera circular de la inspección. La matrícula del primer día era de diez jóvenes adultos, pero se espera que el grupo crezca en una semana, ya que hombres de bastante edad desean aprender a escribir y a leer. Los problemas son los de siempre, faltan materiales, para los pequeños y para los mayores, no se cuenta con los libros de los grados respectivos, ni con lápices ni cuadernos $^{64}$. Pero cuando todavía no han transcurrido dos meses del comienzo de las clases para adultos en Cartí Tupile, el maestro escribe a Eduardo Filós comentándole que de los

62 V. RD, n. 872; V. CD, n. CDXXXV.

63 V. RD, n. 873.

64 V. RD, n. 874; V. CD, n. CDXXXVI. 
dieciséis alumnos que empezaron solo le quedan siete, ya que seis se han ido a Colón y otros tres están fuera de la isla. Y los esfuerzos del inspector han servido de poco ya que los viejos no se creen capacitados para aprender y consideran suficiente que los niños lo hagan65.

En San Ignacio de Tupile también se funda la escuela nocturna para llevar adelante la campaña de alfabetización, tras la aprobación del sahila y su pueblo, el 23 del mismo mes dan comienzo las clases con una asistencia de treinta hombres y diez mujeres. Los maestros se comprometen a emplear todas sus fuerzas para que esta labor progrese66.

La agricultura toma una mayor importancia en este periodo, y así lo demuestra la concesión por parte del Consejo de Gabinete de seis becas para que los indígenas de la comarca de San Blas estudien en la Escuela de Agricultura de Divisa. Las becas se conseguirán mediante la superación de pruebas realizadas en la intendencia y no por elección del intendente o director. Félix Oller quiere que el Ministro de Educación exprese al Presidente de la República y a su Gabinete su agradecimiento personal y el de la comarca por la forma tan acertada en que están trabajando por la región67.

Los dirigentes de la comarca siguen solicitando los favores del intendente a la hora de conceder las becas. Rubén P.

65 V. RD, n. 876; V. CD, n. CDXXXVIII.

66 V. RD, n. 875; V. CD, n. CDXXXVII.

67 V. RD, n. 881; V. CD, n. CDXXXIX. 
Kantule pide el favor para tres muchachos aspirantes en el concurso de becas. Pone en su conocimiento así mismo que una joven quiere hacer estudios de enfermería en el Hospital Santo Tomás 68 .

El agradecimiento por parte de un becado en California hacia los misioneros claretianos y franciscanas por la labor que realizan en materia educativa y de progreso de la comarca es evidente una vez más. A pesar de haber dejado la dirección siguen con su labor en Narganá y Corazón de Jesús. 69

Un decreto de noviembre de 1946 dictaba las normas para la toma de posesión de los empleados del ramo de educación. Concedía un plazo de ocho días entre el nombramiento y la toma de posesión, estableciendo como lugar para dicho acto la inspección de instrucción. Así mismo se enumeran los documentos necesarios que presentará el maestro 70 .

Los informes escolares cambiarían de formato para el curso 1947-48, en ellos aparecían nuevos conceptos complementarios de la actividad escolar, como son la biblioteca, personal auxiliar, enseñanza preescolar, el tipo de locales y pertenencia de los mismos. Finalmente se daba un plazo de una semana para iniciar las clases ${ }^{71}$.

Los habitantes de Corazón de Jesús quieren saber si las

\footnotetext{
68 V. RD, n. 896; V. CD, n. CDXLIV.

69 V. RD, n. 886.

70 V. RD, n. 885; V. CD, n. CDXL.

71 V. RD, ns. 888 y $893 ; V . C D, n$. CDXLII y CDXLIII.
} 
muchachas que estudian en la Escuela Normal continúan o han sido expulsados, pues les han llegado rumores en este sentido, también preguntan si otra de ellas repite ${ }^{72}$. En 1947 al comienzo del curso la joven interesada en la sanidad se dirige al Hospital Santo Tomás para aprender enfermería, el intendente la recomienda a uno de los médicos 73 . Poco a poco el tema sanitario iría adquiriendo relevancia, y este mismo año un doctor visita la comarca con intención de fundar la primera unidad sanitaria de la comarca 74 .

Un maestro de Playón Chico en 1950 comenta al intendente el asunto de una ayuda a un alumno que quiere estudiar ciencias médicas en el Hospital Santo Tomás ${ }^{75}$. Este es un caso más de lo anteriormente expuesto.

El movimiento político de la comarca cada vez es más intenso y lleva a elaborar, por parte de Félix Oller, una lista de indígenas representantes de los grupos de la Unión Liberal, que estaba compuesta por caciques, sahilas y gente destacada de los kunas76. También los habitantes de Río Azúcar habían pedido al intendente que se respetase el paso de botellas de licor con destino a esta isla, pues era para los días de fiesta y competición, actividades que se fueron incremetnando en las

72 V. RD, n. 889.

73 V. RD, n. 894.

74 V. RD, n. 911

75 V. RD, n. 947.

76 V. RD, n. 892. 
escuelas 77 .

Los gastos originados por los viajes de los sahilas a la capital corrieron desde un comienzo por cuenta del gobierno, cuando se trasladaban allí para tratar asuntos de importancia, lo mismo que la instancia también era proporcionada por el ejecutivo ${ }^{78}$.

Una muchacha sale de la Escuela Profesional, por requerimiento de su padre, y esto es puesto en conocimiento de los superiores para que se pueda cubrir por otra79. La enseñanza va adquiriendo tal preponderancia que en Panamá algunos jóvenes estudian además de en la escuela, cursos por correspondencia para aprovechar más el tiempo 80.

La creación de bibliotecas en la comarca empieza a ser una práctica corriente, y las islas de la cabecera son las pioneras. Ahora según un maestro de Río Azúcar se quiere reparar la escuela y la biblioteca aprovechando las maderas de una casa que el gobierno ha recibido en la comarca81.

La civilización de un paso más al comenzarse las obras del aeropuerto, de este modo se iban a facilitar las comunicaciones con esta región, cuyo único acceso se puede decir que era el marítimo. Como siempre el espíritu de

77 V. RD, ns. 924 y 906; V. CD, n. CDXLVII.

78 V. RD, n. 898.

79 V. RD, n. 909.

80 V. RD, n. 910.

81 V. RD, n. 912. 
colaboración del pueblo se extiende hasta los jóvenes de la escuela, que prestan sus servicios durante un par de horas a la semana. La idea del aeropuerto había sido propuesta por el intendente Oller82.

Los cambios de dirigentes kunas se intentan hacer de modo que sigan en una línea progresista que apoye la educación. Este es el caso de Niga Kantule que es presentado al gobierno con respaldo de los indígenas y se espera que luche por el aumento de asistencia a la escuela por parte de la niñez ${ }^{83}$.

Dentro de esta acción de los dirigentes que apoyan la educación está Olotebiliquiña, sahila de Ustupu que le envía su hijo al intendente, previa petición de éste, para que le enseñe alguna cosa que pueda ser útil a la comarca. Deja bien claro que le prohibe dormir en población que no sea kuna, si es posible que lo haga en El Porvenir; y le prohibe que tome ron o chicha.

El sahila Olomaili de la misma población le envía su hija a Estanislao para que la dé buenos consejos, como si fuera su hija, y la coloque en una buena familia que no la trate como criada y la eduquen; a fin de que luego le pueda servir a él. Le manda una aportación económica y promete enviar más. El servicio prestado por estos jóvenes era recompensado, en la mayoría de los casos, por parte de los acudientes pagando sus estudios $^{84}$. Una nieta de Nele Kantule pide que se publique una

82 V. RD, n. 914.

83 V. RD, n. 915.

84 V. RD, ns. 916, 923 y 934. 
biografía de su abuelo y comenta que ella trabaja en un colegio privado para pagarse la secundaria, pues terminó solo la primaría 85.

El aumento de maestros en la comarca hace que exista un poco más de competencia y estímulo, aquellos que no tengan buenas notas en los exámenes o presenten mala conducta serán sustituidos por los que hicieron los cursos de verano, requisito que se empieza a imponer poco a poco86.

Los informes de las escuelas en esta época sufrieron retrasos y acusaron una cierta desorganización87. Desde la escuela de Isla Pino solicitan de la inspección materiales y útiles para que la clase pueda funcionar, y del médico de Narganá medicinas que se necesitan 88 .

En 1949 llegan hasta el Ministerio de Educación las quejas de la directora de la escuela Rodolfo Chiari de Narganá y Corazón de Jesús, Sor María Otilia. En esta isla los bailes y las borracheras entorpecen la marcha de la escuela, y ello se ve agravado por la nula cooperación de quienes son miembros del gobierno que participan en dichos actos, en la actualidad los policías son indígenas. Las maestras tampoco prestan colaboración sino que muchas participan en bailes y cantan hasta altas horas de la noche. La directora se siente impotente ante

\footnotetext{
85 V. RD, n. 943.

86 V. RD, n. 918.

87 V. RD, n. 919.

88 V. RD, ns. 921 y 922.
} 
tan lamentable panorama. La única persona que se muestra dispuesta a coopera es Charles Róbinson. Esta situación penosa es puesta en conocimiento del intendente a fin de que tome las medidas oportunas.

Para este curso ya son varios los años que la dirección de las escuelas centrales están bajo las órdenes de las madres franciscanas. Se reconoce el hecho lamentable de no haberse podido aumentar el número de las escuelas por la estrechez económica que ha tenido que superar el ramo de educación, pero al mimo tiempo se alaba la labor realizada por los maestros comarcanos 89 . Los nombramientos de estos por parte del inspector se ven supeditados a la aceptación que hagan los sahilas de ellos 90 .

Los problemas de moralidad también surgen ahora entre los estudiantes desplazados en la capital. Aquí es más difícil controlarlos, y la presión social se puede decir que no es tan férrea como en las islas. Por otra parte las lacras sociales están más extendidas entre los habitantes de las ciudades ${ }^{91}$.

La escuela de Wichuwala se ve amenazada en 1950 por el descontento de este pueblo y el de Nalunega, que han decidido no mandar a sus hijos a la escuela si el Ministerio nombra nuevamente al mismo maestra para este año. Así se lo han pedido al intendente y al inspector de educación. El maestro es

89 V. RD, ns. 928 y 929; V. CD, ns. CDXLVIII y CDXLIX.

90 V. RD, n. 933.

91 V. RD, n. 932. 
motivo de preocupación para el intendente que no ve otro lugar donde mandarle porque en las localidades donde ha trabajado ha sido rechazado92.

El sahila de Río Cidra, Pipi, reclama la promesa de una ayuda que le hiciera el intendente, consistente en otorgarle cuando fuera posible una placa de policía. El se muestra dispuesto a cooperar con el gobierno y agradece cualquier ayuda que le den como contraprestación93.

En julio de 1950 el Ministro de Obras Públicas y el intendente llegan a Narganá para poner la primera piedra del Primer Ciclo de la Escuela Félix Oller. Este edificio que supondría un paso muy importante en materia educativa en San Blas sería levantado con mano indígena94. El intendente notifica al director de la escuela de Narganá que existe un cupo para cualquier señorita indígena que quiera estudiar en el Hospital Santo Tomás enfermería95.

Los maestros como presencia del gobierno todavía tienen que desempeñar algunas funciones extras como hacer de registradores, donde no les hubiera, por ello recibirían un sueldo adicional de B/ $10^{96}$.

El intendente informa de las pésimas condiciones en

\footnotetext{
92 V. RD, n. 938; V. CD, n. CDL.

93 V. RD, n. 940.

94 V. RD, n. 941.

95 V. RD, n. 939.

96 V. RD, n. 944.
} 
que se encuentra la escuela de Narganá regentada por las madres franciscanas. En un estado similar se haya la escuela de Río Azúcar que ya ha provocado daños a los alumnos. Pide al intendente que tome las medidas oportunas para que se repare cuanto antes. Con posterioridad una delegación de Narganá se habían entrevistado con varios ministros y el Presidente de la República para tratar el arreglo de la escuela, pero no servirán de nada los arreglos pues ya está en un estado muy deteriorado, y lo que se requiere es una nueva construcción ${ }^{97}$. Los sahilas de la comarca escribirían más tarde al presidente de la República por mediación del ministerio de educación para que atendiese sus súplicas de mejora de la educación tanto a nivel de reparaciones como de nuevas construcciones de escuelas 98 .

El inspector provincial da cuenta en una circular de las actividades realizadas en las distintas tiendas escolares que sirvieron de financiación al mismo tiempo que permitían la familiarización con los sistemas de pesas y medidas. Otra de las actividades llevadas por las escuelas fueron los huertos escolares que funcionaban seis en la comarca y se daba cuenta de sus actividades y los maestros que los dirigían. El inspector escolar puso especial hincapié en este modo de actividad, y ante el comienzo del curso 1953-54 dirige una circular a los maestros señalando la necesidad de preparar los huertos escolares para comenzar los cultivos del curso entrante. En este

97 V. RD, ns. 946 y 948.

98 V. RD, n. 956. 
curso la directora de la escuela de Narganá solicita el favor del inspector provincial de Colón de semillas de frijoles, zanahorias, tomates y espinacas para el huerto escolar99. Estos cultivos eran difíciles de conseguir por el suelo arenosa y salado de las islas.

En junio comienza a trabajar en Tupile, como maestro el estudiante que estuvo en Medellín y pide a Estanislao que le envíe libros de pedagogía y la guía del maestro100. Con el derrocamiento del Presidente Arnulfo en mayo se produce una pérdida en las becas del ministerio para los indígenas, según las quejas de algún usuario ${ }^{101}$.

El sector circundante a El Porvenir, encabezado por Cartí, eleva una súplica al Ministro de Educación para que se implante al menos hasta el IV grado en esta zona, a fin de que sus hijos no tengan que salir de las islas para seguir sus estudios, pues el problema es que muchas familias no pueden pagar los desplazamientos de sus hijos, como consecuencia de lo cual no pueden continuar los estudios 102 .

La introducción de la política en la región de San Blas llevó a enfrentamientos más o menos graves por parte de los indígenas. Rubén le dice a Estanislao que solamente se hayan enfrentados por sus ideas políticas, pero que él busca la libertad

99 V. RD, ns. 950, 953, 960 у 965.

100 V. RD, n. 951.

101 V. RD, n. 952.

102 V. RD, n. 955. 
de su comarca. Estas rivalidades políticas con el paso del tiempo han producido todavía, si cabe, más divisiones entre los kunas ${ }^{103}$.

El magisterio kuna realiza su labor incluso fuera de la comarca indígena. Podemos ver que un maestro indígena nombrado en Colón pide nuevamente el favor del intendente para que ahora lo envíen a la comarca, ya que tiene la familia enferma 104.

Un grupo de norteamericanos presididos por el cónsul se presenta en 1952 en el Congreso General Kuna para prometer ayuda al pueblo kuna en lo referente a la educación, salud, obras públicas y agricultura 105 .

En febrero de este año aparece la ley 18 que crea un departamento en el Ministerio de Gobierno y Justicia denominada Asuntos Indígenas de la República. Pretendía dar una mayor atención, con carácter exclusivo a todos los indios de lal República.

Las becas se fueron generalizando y ampliando a los paises extranjeros, tanto europeos como americanos. Unas becas ofrecidas por el gobierno del Brasil son el objeto de interés de Rubén P. Kantule que fue otro de los personajes relevantes de la

103 V. RD, n. 957.

104 V. RD, n. 958.

$105 V . R D, n .959 ; V . C D, n$. CDLIII. Los americanos durante años habían estado realizando explotaciones mineras y agrícolas en las costas de San Blas. 
cultura kuna, defensor incondicional de la educación ${ }^{106}$.

En el comienzo de 1953 se elabora una lista de los aspirantes a estudiar enfermería en Panamá y por primera vez aparece una referencia a otro grupo indígena, en este caso es el de los guaimíes, que también envían una lista de aspirantes ${ }^{107}$

El 19 de febrero de 1953 veía la luz la ley 16 por la que se organizaba la comarca de San Blas, creada en 1938. En ella quedan especificadas la competencias del intendente, quien viene a desempeñar las funciones de gobernador de una provincia; y a cada uno de los tres sahilas generales se les otorga los atributos de inspectores de policía con un suelto mensual de B/ 90. El resto de los sahilas de cada isla tendrá el nombramiento de comisario. Es atribución del intendente fomentar la instrucción pública, la agricultura, la ganadería, la industria, el comercio y cuidar de la higiene de las poblaciones. El estado reconocerá la Carta Orgánica tras la aprobación de esta por el órgano ejecutivo. Se reafirma nuevamente la decisión de que la educación pertenezca al Ministerio de Educación, pero la nueva creación de escuelas se hará una vez oída la voz del intendente y previo entendimiento con los sahilas y las poblaciones indígenas.

El tema de los programas parece tener una connotación avanzada, ya que se deja a un lado el programa nacional y dice 
que se adaptará a las costumbres y necesidades de la vida de los pobladores. Se reserva para los primeros grados, donde existiera más de un maestro, a los maestros indígenas. El tema de las becas también aparece, fijándose un número proporcional al de la población indígena para los concursos de becas en las escuelas secundarias y vocacionales. Se propone establecer una granja agrícola para que los indígenas aprendan los métodos modernos agropecuarios. Otro factor tenido en cuenta es el de la salud, por lo que se crean dispensarios ambulantes y casas de maternidad en las islas ${ }^{108}$.

La directora de la escuela central pide al inspector cuatro galones de pintura para su salón, por lo visto las reparaciones de los edificios siguían sin efectuarse ${ }^{109}$.

La escuela de Wichuwala es clausurada por el sahila, quien le comunica al maestro que no quieren que enseñe allí cuando éste llega de las reuniones tenidas en Colón. Donde se celebran desde el paso de la educación al Ministerio de Educación. Por ello proponía un cambio con la maestra de Playón Chico, pero no ha recibido ninguna confirmación. Este no es el único caso, pues lo mismo le ocurre al de Nalunega antes de comenzar el curso 1953-54; ya que los sahilas se oponen a que los niños se matriculen. Ante este contratiempo el intendente sugiere al inspector que no se les separe a los maestros de su

108 V. RD, n. 964; V. CD, n. CDLIV.

109 V. RD, n. 965. 
trabajo 110.

El comienzo de este curso se produce el 4 de mayo según lo atestigua la directora de Narganá, que expone que todo está preparado para dar comienzo111. Desde dicha escuela sale una petición para la UNICEF de leche y alimentos para los escolares más desnutridos ${ }^{112}$.

Los libros usados en las escuelas eran impresos en Argentina y acomodados para la nación panameña. Cuando da comienzo el curso la directora de Narganá acusa la falta de libros de lectura para los escolares ${ }^{113}$.

Las relaciones con el extranjero aumentan, contribuyendo también los misioneros que envían becados fuera de la nación istmeña. Por ello exponen al mismo tiempo al gobierno que dando más ayuda a la misión católica estos podrían garantizar mayor civilización y mayor espíritu patriótico; en resumen, más acercamiento a las leyes, a la cultura y a la vida nacional. Lo que no ocurre con los graduados en la escuela protestante de Ailigandí.

Concluyo este capítulo con un comentario del último documento que reconoce y da una gran autonomía al pueblo kuna, La Carta Orgánica. En ella se hace una explicación detallada de las autoridades kunas, sus competencias, los órganos de

110 V. RD, ns. 966 у 967.

111 V. RD, n. 970.

112 V. RD, n. 971.

113 V. RD, n. 972. 
gobierno, su patrimonio y tradición. Entre las funciones de los sahilas generales o caciques a la hora de abrir los Congresos Generales está la de relatar las tradiciones kunas, como ejemplos educativos y moralizantes. Es atribución de los congresos generales velar por la conservación de la lengua y tradición kuna. Los congresos locales se deberán celebrar con una frecuencia mínima de dos veces por semana y es competencia de ellos dictar las medidas convenientes al progreso de la localidad y bienestar de los comuneros. Esta atribución deja a las claras que de ellos depende el admitir la escuela y así ocurrirá en la realidad 114 .

Como resumen de este capítulo se puede afirmar que la educación sigue consolidándose. Los maestros tienen una mejor preparación, se fomenta la creación de bibliotecas y el número de becas se incrementa. La educación es considerada como un asunto del Ministerio de Educación y pasa a pertenecer a él, como el resto de las escuelas nacionales.

Los congresos empiezan a tener el tema educativo como un punto más a tratar, ya que la escuela ha empezado a formar parte de la actividad de las islas más importantes. Al mismo tiempo que los principales jefes son pagados por el gobierno, lo que implica que han empezado a formar parte de la nación, y por ello el gobierno tiene un cierto control sobre los mismos.

114 V. RD, n. 975; V. CD, n. CDLVI. 
La promulgación de la ley 16 y la redacción de la Carta Orgánica, que realiza Félix Oller, son la culminación de este periodo; pues aunque los kunas pertenecían a Panamá, sabían que a partir de ahora tendrían autonomía, y ellos mismos se podrían gobernar, pero vigilados siempre por la atenta mirada del intendente.

Los kunas tendrían un territorio para su explotación, que no se podría enajenar bajo ninguna forma por personas wagas, pero ellos sí podían adquirir otras tierras fuera de la comarca. 
11. INTERVENCIONES Y MEDIOS ESPECIALES PARA LA CONSOLIDACION DE LA ESCUELA 


\section{INTERVENCIONES $Y$ MEDIOS ESPECIALES PARA LA CONSOLIDACION DE LA ESCUELA}

\section{1. Los internados de Narganá y Corazón de Jesús}

Como colofón del trabajo he estructurado este capítulo que recoge tres apartados que ayudaron a desarrollar el sistema educativo. Por un lado, los internados en los que los estudiantes eran recogidos; y por otra parte la labor del más grande dirigente kuna junto con otro personaje de la tribu que implantó la escuela privada, apoyado por los protestantes.

El primer internado para jóvenes de fuera de la isla de Narganá se inaugura en el mes de octubre de 1934. Son el P. Berengueras y el P. Puig los iniciadores, para tan benéfica construcción se emplean los materiales enviados por el inspector de Colón 1 .

En este centro vivían dos tipos de alumnos: los internos y los semi-internos. A 40 llegaba el número de estos jóvenes beneficiados por la acción de los misioneros; las edades oscilaban de los 11 a los 20 años. Contaba con dos granjas agrícolas al frente de las cuales estaba el H. José Benet. En ellas se ocupaba la mayor parte del tiempo de los días de vacaciones.

\footnotetext{
1 V. RD, n. 522.
} 
Se pretendía fomentar los trabajos agrícolas entre los kunas y darles conocimientos básicos sobre los mismos. Contaba además con un trapiche y campos de deporte ${ }^{2}$. Pero el adelanto más destacable era la luz eléctrica producida por una planta de gasoil3.

Nuevamente Ricardo Velasco propone al intendente su deseo de fundar un internado de niños en diciembre de 1940, para lo cual debe contar con la aprobación y ayuda del señor obispo, quien subvencionará en su mayor parte esta obra ${ }^{4}$. la escasez de mano de obra entre los indígenas, lleva al director a traer desde Puerto Obaldía a un trabajador que dé un impulso al edificio del internado 5 . Pero se debe presentar ante el intendente para que le autorice su estancia en las islas, y antes de comenzar su labor cae enfermo6.

Por parte de la dirección de las escuelas se debe resaltar su esfuerzo en la construcción de un internado para los indígenas levantado en la isla de Corazón de Jesús. Comentando al mismo tiempo, que está previsto que el próximo año se podrá

2 Los deportes de competición fueron introducidos por los misioneros y recibieron una favorable acogida, extendiéndose rápidamente por las islas y celebrando competiciones entre ellas.

3 MISIONEROS HIJOS DEL CORAZON DE MARIA: Memoria del Vicariato Apostólico del Darién, Imprenta acción católica, Panamá, 1939, pp. 127128.

${ }^{4}$ V. RD, n. 680; V. CD, n. CCCXII.

5 V. RD, n. 711; V. CD, n. CCCXXXIV.

6 V. RD, n. 712; V. CD, n. CCCXXXV. 
contar con otro internado para las niñas que deseen seguir estudios de grados superiores a los existentes en sus islas, y que no cuenten con acudiente en la cabecera de la comarca.

El internado de jóvenes residentes en islas lejanas, ha dado asistencia gratuita a 30 alumnos. Con el internado destinado a las niñas se pretendía resolver la baja matrícula femenina, subsanando así el recelo de los padres a dejar que sus hijas salgan de casa?.

El sueño del anterior director se ve cumplido durante el mandato del P. Puig; así en el comienzo del curso 1942-43 se informa al intendente que al tiempo que se dio comienzo a las tareas escolares también quedó inaugurado un internado en Narganá para niñas de las apartadas regiones. Se estrena con quince jóvenes venidas de otras islas, que están atendidas por las madres franciscanas. El subdirector espera que este hecho contribuya al desarrollo de la civilización en San Blas. El primer internado de niños que fuera establecido de un modo precario, este curso también estrena un edificio de concreto en la isla de Corazón de Jesús donde se albergan treinta niños bajo la dirección de los padres claretianos de la misión8. Pero en julio de 1943 se pedía nuevamente permiso al asistente encargado de la intendencia para levantar una cocina nueva en el internado del

\footnotetext{
${ }^{7}$ V. RD, n. 771; V. CD, n. CCCLXXX.

${ }^{8}$ V. RD, n. 737; V. CD, n. CCCLII.
} 
colegio de Narganá9.

El director expresa su satisfacción por la inauguración del internado de concreto de Corazón de Jesús, que reúne buenas condiciones pedagógicas; y esta obra es gracia del gobierno que ha facilitado los materiales. La mayor dificultad ha residido en la alimentación, que ha escaseado. Por otro lado el internado de niñas situado en Narganá ha abierto una esperanza a la civilización, conociendo lo celosos que son los indígenas con respecto a sus hijas ${ }^{10}$.

Si la reticencia a que las niñas asistieran a la escuela fue grande, no fue menor el problema para que estuvieran en el internado. Lo que favorecía los estudios en las niñas era que concluían con más facilidad la primaría y podían incluso conseguir becas para proseguir estudios en la capital. Las religiosas gozaban de gran prestigio en la comarca y esto permitió que los padres depositaran con confianza a sus hijas ${ }^{11}$. Juzga el director que los resultados del internado de niñas es esperanzador y que ayudará a superar la repugnancia que los indígenas sienten a introducir las niñas en las escuelas ${ }^{12}$.

EI P. Isaías Riera pretende hacer mejor la construcción del internado y solicita ayuda del intendente Félix Oller para

\footnotetext{
${ }^{9}$ V. RD, n. 787; V. CD, n. CCCXCIV.

10 V. RD, n. 771; V. CD, n. CCCLXXX.

11 V. RD, n. 826; V. CD, n. CDXXIV.

12 V. RD, n. 881; V. CD, n. CDXXXIX.
} 
transportar materiales desde Colombia, que también serían para edificar una iglesia en Narganá. Dice que estas obras son públicas, de beneficio y civilización. La razón de traer los materiales de Colombia es que son más baratos ${ }^{13}$.

El internado de niños funcionó desde 1935 hasta 1943 y el de niñas desde 1943 a 1945. Según carta de H. Wassén en el internado María Claret funcionaba una biblioteca, de la cual era encargado Rubén Pérez Kantule ${ }^{14}$.

La vida de los internados fue muy desigual y corta. Las espectativas puestas en ellos no se llegaron a cumplir, por lo que se consideró un fracaso; aunque no por ello se puso la mejor intención y se emplearon todos los esfuerzos posibles ${ }^{15}$

\section{2. Nele Kantule (Iguahigbiliquiña)}

Fue éste un hombre dotado de grandes cualidades y de una amplia cultura kuna y occidental. Representó el punto medio entre la total permisividad de la civilización de Róbinson, y la intransigencia más absoluta de Inapaquiña que quería seguir

13 V. RD, n. 842.

14 Handelstidningen, WASSEN, H:, "Rubén Pérez Kantule, indio cuna en Gotemburgo, Suecia, en 1931, muerto en 1978", 22-12-78. Trad por BLANCO CALDERON, Olga.

15 Debido a este fracaso me fue difícil conseguir información sobre el tema. Pues a pesar de haber contactado con personas que trabajaron en esta empresa su conclusión era que habían existido y que no dieron buen resultado. 
perteneciendo a la nación Colombiana. Nele quería lo positivo de la civilización, como era la educación, pero sin olvidar sus valores tradiciones kunas. A pesar de ser uno de los gestores de la Revolución del 25 con Colman, lo único que pretendía con aquella acción era parar las agresiones que contra su pueblo estaba cometiendo la policía colonial.

Las buenas disposiciones de Nele hacia la civilización eran reconocidas por Adriano Robles que le pide al intendente que por este motivo le trate con las atenciones necesarias ${ }^{16}$. En materia educativa es un hombre progresista, y los nelistas presididos por el gran cacique en una reunión deciden dar libertad a los pueblos en el asunto de la educación ${ }^{17}$. En este sector oriental, que el preside, funcionaban escuelas pagadas por los propios indios y los habitantes de Ailigandí solicitan ayuda del gobierno para pagar a los maestros, pues reconocen que todos los indios están educando a sus hijos. Ellos muestran su aceptación al hecho de que los indios de Narganá estudien en Panamá, y no pasando mucho tiempo piden becas para que sus hijos también puedan ir a estudiar a la capital18.

Nele defendía la civilización pero con un ritmo impuesto por el mismo, y sin agentes extraños. En 1927 permitía el establecimiento de tres tiendas en su isla; y a partir de aquí la

\footnotetext{
16 V. RD, n. 474.

17 V. RD, n. 487.

18 V. RD, ns. 475 y 481.
} 
actividad comercial. Al año siguiente realiza un censo de todas la tiendas que funcionan en la comarca. Con la ayuda de Rubén P. Kantule redactan una circular en la que piden que se arregle el pueblo y lo mantengan limpio y de modo especial la escuela, lugar de aprendizaje de los niños ${ }^{19}$.

A partir de ahora se empieza a dejar a un lado la Revolución Tule de 1925 y Nele Kantule da un paso hacia el acercamiento al gobierno nacional. En 1930 junto con una delegación visita al Presidente para establecer relaciones amistosas y entre otras cosas le pide que se restauren las becas para los indígenas en la capital.

En septiembre de este mismo año dirige una carta a los representantes de la Asamblea Nacional de Colón con el fin de que se interesen en resguardar una porción de tierra de las costas de San Blas para reserva indígena, cosa que ya habían pedido también en la visita al Presidente. Junto con Inapaquiña se dirige en los mismos términos al Presidente Harmodio agradeciéndole a él y al secretario de Gobierno, Adriano Robles, el interés por este asunto. Corría el mes de diciembre cuando era aprobada la ley 59 sobre Reservas Indígenas y en la que aparecía la comarca de San Blas. Con posterioridad pide que se hagan modificaciones a la ley que dictasen en esta fecha 20.

\footnotetext{
19 V. RD, n. 488; V. CD, n. CCIV.

$20 \mathrm{AGH}$.
} 
Otra de las peticiones elevadas por Nele Kantule era la garantía para el goce del derecho de sufragio, ya que son ciudadanos panameños, por lo cual querían tener participación en la vida política nacional21.

Ese mismo año construyó el edificio destinado a escuela. Los maestros serían Rubén Pérez y Guillermo Hayans. Pero su deseo de extender la educación no para y funda al mismo tiempo una escuela nocturna para los casados que dirigiría el segundo de estos. Al año siguiente fundaría otra escuela de inglés dirigida por Kranky Wilbur (Francisco Díaz), y una tienda escolar cuyos ingresos ayudaban a mantener la escuela.

La falta de presupuesto para destinar a la educación por parte de la nación panameña, le llevan a Nele Kantule a buscar soluciones en el extranjero, que serán bien acogidas allí. Así los americanos le contestan que sería una excelente idea mandar a sus jóvenes a estudiar a los Estados Unidos, comentan que podrían aprender además el inglés y enseñárselo después a sus hermanos y hermanas, y los enviados a Panamá aprenderían el español y su gente podría entender además de su lengua el inglés y el español y no ser engañados cuando realizaran la venta de sus productos $^{22}$.

De sus buenas relaciones con los jefes militares

\footnotetext{
21 E. CASTILLERO y E. OBALDIA: Biografía del cacique Nele Kantule, p. 6. 22 V. RD, n. 493; V. CD, n. CCVIII.
} 
americanos de la zona surgió la posibilidad de trabajo para muchos kunas que fueron cambiando su ritmo de vida y sus costumbres, pero que al mismo tiempo les permitía pagar los estudios de los hijos que se encontraban en los colegios de la capital.

Posteriormente va una delegación mandada por Nele para entrevistarse con el Sr. Enderton y hablar sobre la enseñanza de los niños en el extranjero. Con respecto a la escuela, aclara que no quiere escuelas de misioneros, sino escuelas donde los jóvenes salgan bien preparados para la patria. Desea saber el coste que supondrá cada muchacho al año; y si no es excesivo está dispuesto a enviarlos corriendo con sus gastos. Se supone que estos estudiantes serían hijos suyos ${ }^{23}$.

El coste por niño y año oscilaría entre $\$ 500$ y $\$ 600$ según le informa el Sr. Enderton, y la estancia sería de cuatro a cinco años, aunque se podría conseguir que la estancia saliera algo más económica. La cantidad no se ajustaba a los presupuestos de los indios 24 .

Nele Kantule sigue mostrando su preocupación por la educación y progreso de los kunas. tras la legislación de la comarca le comenta al secretario de Gobierno y Justicia que su deseo es guiar a su pueblo hacia la civilización, para que las

\footnotetext{
23 V. RD, n. 495; V. CD, n. CCX.

24 V. RD, n. 498; V. CD, n. CCXIII.
} 
generaciones venideras no vivan como sus antepasados. Empieza a preocuparse por los congresos generales en los que se tratan temas relativos a la educación; y en concreto cómo preparar bien a un par de estudiantes indígenas, para que tengan título25. Llega a comentarle al secretario que quiere que sus hijos sean estudiados como él, por eso solicita becas para que puedan estudiar en la capital. Los mismos enviados a parlamentar con el americano Enderton serán los encargados de hablar con el secretario de Gobierno y Justicia quien contesta que dado que las becas son para el curso próximo tomará nota de ello26.

Con la aprobación de la comarca por la legislación panameña, Nele Kantule pretende que nadie entre allí sin su permiso, ya que el es considerado el jefe indígena, lo que le niega el secretario de Gobierno y Justicia, pues sería reducir la autoridad del intendente, anulando la autoridad del representante del Gobierno, y esto era demasiado27.

Nele se alía con todo aquel que le pueda reportar algún beneficio, por ello llega a prometer los votos de la comarca al candidato a Presidente de la República, Pacho Arias, con quien mantuvo una estrecha amistad, en las nuevas elecciones, si le asegura que se incrementará la instrucción pública y el

$25 V . R D, n .494 ; V . C D, n$. CCIX.

26 V. RD, n. 496; V. $C D$, n. CCXI.

27 V. RD, n. 497; V. CD, n. CCXII. 
magisterio indígena en los principales pueblos de la región 28 .

En abril de 1931 Nele Kantule hace una petición al Presidente de la República para establecer escuelas en Ustupu, Ailigandí, Río Cidra y Suitupu, proponiéndole los distintos maestros indígenas que pueden realizar estas labores. Pero le trasmiten la negativa de Gobierno y Justicia dado que el país pasa por una grave crisis que le ha obligado a suprimir incluso tres de los maestros de la comarca de San Blas y de la escuela indígena de Colón ${ }^{29}$. Así mismo le contesta Efraín Tejada de la Gobernación de la provincia de Colón comentando que la escasez de fondos no han permitido resolver el problema de los maestros indígenas ${ }^{30}$. Unos meses más tarde se deja ver en carta dirigida a Nele que el gobierno no ha nombrado maestros por falta de medios en el tesoro, pero que a pesar de esto ellos no desfallecerán en la obra emprendida ${ }^{31}$.

Las pretensiones de Nele son fundar a toda costa una escuela en Ustupu, y para ello pide recomendación al Sr. Arturo Pérez, que promete ayudarle en todo lo que de su parte esté. Este cree que la escuela está bien para los niños, pero estima también conveniente que aprendan algunos viejos. Esta opción de fundar

\footnotetext{
28 V. RD, n. 501.

29 V. RD, n. 491; V. CD, n. CCVI.

30 V. RD, n. 492; V. CD, n. CCVII.

31 V. RD, n. 499; V. CD, n. CCXIV.
} 
escuelas la deberían tomar todos los sahilas ${ }^{32}$. Sin pérdida de tiempo el cacique solicita a Gobierno y Justicia que le nombren un maestro para su población. Pero tristemente sale a flote de nuevo el problema económico que impide un nombramiento de tal índole ${ }^{33}$. Se aproxima el comienzo del curso siguiente y Nele recurre al Presidente Harmodio para que haga lo posible por instalar una escuela en su isla. Mas la respuesta es una nueva negativa alegando la misma causa arrastrada en años anteriores, la falta de presupuesto en Instrucción Pública. El dignatario le explica que sus recomendaciones sobre los maestros las ha remitido al secretario de Gobierno y Justicia para que atienda sus deseos 34 .

En 1933 envía a Cartagena a Rubén P. kantule y Luis Lyon con el fin de que compren libros por valor de B/ 500,00 para crear la primera biblioteca, que sería propiedad del pueblo.

Al año siguiente Nele solicita la madera para el piso de la escuela al intendente y espera que sea atendida su petición por consideración a sus buenas relaciones mantenidas con el gobierno ${ }^{35}$. Estas buenas relaciones serían recompensadas con el nombramiento de agente colonial, al igual que Estanislao y otros también recibirían este nombramiento. Por ello Nele Kantule

\footnotetext{
32 V. RD, n. 509; V. CD, n. CCXIX.

33 V. RD, n. 510; V. CD, n. CCXX.

34 V. RD, n. 519; V. CD, n. CCXXVI.

35 V. RD, n. 535.
} 
cobraba un cheque por importe de B/40,00 y el maestro de su escuela Eduardo Filós de B/35,0036.

Finalmente aparecen como novedad los nombramientos de un maestro para Ustupu y otro para Cartí en 193437. Las poblaciones anteriormente citadas eran las más importantes en sus respectivos sectores. El campo de la educación se extendía así por el oriente y el occidente.

Esto haría sospechar a los habitantes de Río Azúcar, que la suspensión de una beca a uno de sus hijos en la Escuela de Artes y Oficios sería para complacer a Nele Kantule, nombrando el maestro que solicitaba para su isla. Este hecho lo critican duramente, pues les hace perder un derecho que habían adquirido para complacer a un personaje que hasta hace muy poco se manifestaba contrario a la educación, mientras ellos llevaban muchos años siendo fieles al gobierno ${ }^{38}$. Lo que si es cierto es que Nele era contrario a ciertas formas de civilización y reacio a ciertas manifestaciones, pero era partidario de la educación de su gente, pero desligada de otras connotaciones como podía ser la religión o la policía nacional. Finalmente los isleños de Río Azúcar solicitan una beca para uno de sus hijos en la capital, aceptando el colegio que sea.

\footnotetext{
36 V. RD, n. 542.

37 V. RD, n. 521; V. CD, n. CCXXVIII.

38 V. RD, n. 524; V. CD, n. CCXXIX.
} 
El moviliario para la escuela de Ustupu debe ser solicitado por mediación del intendente, pero Nele va directamente al secretario de Gobierno y Justicia. El acostumbraba a saltarse el escalafón, ya que se consideraba el jefe de los indios, y en la mayoría de los casos era atendido por los altos estamentos, lo que demostraba que implícitamente reconocían su prestigio.

El pueblo kuna también toma como intermediario a este personaje que goza de gran prestigio en la comunidad indígena. Los habitantes de Cartí en abril de 1937 le piden que interceda ante el gobierno, pues no les han nombrado maestro para su población, además de dejarles sin cheque.

Nele Kantule preocupado por el progreso de su pueblo, quiere obtener más becas para sus conciudadanos. Las becas son para continuar los estudios posteriores al IV grado, ya que no hay posibilidad de seguirlos en la comarca, pues aún no se había implantado el primer ciclo. Se le comunica que por un decreto del 21 de Junio se nombra maestra de Ailigandí a María Quirós. Nele también había luchado por conseguir la escuela de Ailigandí. Sus mejoras no se limitan solo al campo de la educación, van más allá, así trabajará por conseguir la cedulación de sus paisanos para que sean reconocidos como unos ciudadanos más de la nación panameña39.

${ }^{39}$ V. RD, n. 552; V. CD, n. CCXLVI. 
Ante las próximas elecciones presidenciales Nele Kantule ofrece los votos del partido nelista a Belisario Porras si recomienda a unos jóvenes que han concluido sus estudios 40 . Los colaboradores del antiguo presidente reconocen que la civilización existe en San Blas gracias a este mandatario41.

En un congreso que asiste Nele tratan de la educación y éste se queja de que muchos jóvenes no se han podido educar por falta de escuelas ${ }^{42}$. La influencia del cacique en todo momento busca favorecer a los indígenas que quieren seguir sus estudios 0 pretenden trabajar en la capital43.

Nele pide al secretario de Instrucción Pública útiles para las escuelas de Ailigandí y Ustupu44. Visita al Presidente de la República y trata con él sobre la instrucción pública de la comarca. Más tarde le agradece su interés por la educación, la policía indígena y los maestros de la comarca; aprovechando la ocasión para que su secretario indígena presente las propuestas de maestros al jefe del gobierno. Con posterioridad le comentará esto al gobernador de Colón45. Los útiles escolares que solicitara Nele Kantule quiere que se los envíen por Estanislao López ${ }^{46}$. El

\footnotetext{
40 V. RD, n. 555.

41 V. RD, n. 560.

42 V. RD, n. 557.

43 V. RD, n. 563.

44 V. RD, n. 580.

45 V. RD, ns. 581 y 582.

46 V. RD, n. 592.
} 
sahila de Tigre también había pedido materiales en su visita a Panamá, por lo que quiere que el gobernador de Colón le informe si han llegado ahí47. Los útiles escolares que solicitara Nele Kantule quiere que se los envíen por Estanislao López ${ }^{48}$. El sahila de Tigre también había pedido materiales en su visita a Panamá, por lo que quiere que el gobernador de Colón le informe si han llegado ahí49.

En 1937 Nele Kantule pide al presidente Demóstenes Arosemena que le nombre otra maestra para el pueblo de Ustupu, pues la actual tiene a su cargo noventa niños. Lo mismo ocurre en la isla de Ailigandí. Comenta que en 1918, por escasez de medios, ellos tuvieron un maestro que pagaban de su bolsillo. Pide maestros para los pueblos de Playón Chico y Tupile que Ilevan cinco años solicitándolo y en la actualidad ellos están pagando uno50. En abril del mismo año le envía al presidente la lista de los noventa alumnos para hacer más fuerza en su petición de la nueva maestra, y junto a esta lista propone el nombre de la que podría ser nueva maestra51. Agradece finalmente el nombramiento de la maestra Roldán a Fabián Valverde52.

De igual modo pide que se nombren dos agentes

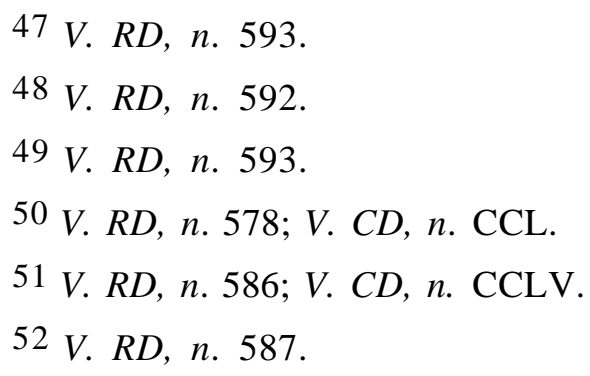


indígenas, uno en Ustupu y otro en Ailigandí, para que ayuden en el servicio escolar, pues el aumento de matrículas hace más necesario el orden. Estos nombramientos lo que llevan consigo es un sueldo y esto mismo pide para su secretario particular, una vez más 53 .

La decisión de Nele Kantule empieza a tener peso a la hora de hacer los nombramientos de los maestros. Para el curso 1937-38 pide al Presidente Demóstenes que deje a los mismos maestros, pues han sabido desempeñar su cargo de modo satisfactorio, y los pueblos donde hay escuela están contentos 54 . Pero al mismo tiempo menciona que existen tres islas que desean escuela, aquí aparece por primera vez Tigantikí, las otras dos eran Playón Chico y Tupile. El da los nombres de los que podrían ser los maestros en estos lugares 55 .

En su incansable afán de pedir llega a solicitar del secretario de Educación y Agricultura material suficiente como para equipar una escuela, pero el aclara que es para las escuelas de Ailigandí y Ustupu56. Desde Cartí el sahila pide a Nele que interceda pues les han suprimido la escuela, según le comunicó el intendente, y además han quitado el cheque a los jefes 57 . Ante la

\footnotetext{
53 V. RD, n. 579; V. CD, n. CCLI.

54 V. RD, n. 584; V. CD, n. CCLIII.

55 V. RD, n. 585; V. CD, n. CCLIV.

56 V. RD, n. 588; V. CD, n. CCLVI.

57 V. RD, n. 589; V. CD, n. CCLVII.
} 
primera contrariedad en el asunto de recomendados para maestros Nele Kantule desea abandonar en su lucha y muestra sus descontento al Presidente porque no se tienen en cuenta sus sugerencias 58 .

El plantel de Ustupu está funcionando con una matrícula de 74 alumnos. También funciona una escuela de habla inglesa que alcanza una matrícula de 40 alumnos comprendidos entre los 14 y 20 años 59 . Durante este curso se inicia la construcción de un nuevo edificio escolar en Ustupu y Nele pide materiales a El Porvenir para poder levantar el local. Los trabajos están dirigidos por el carpintero de la intendencia60.

Se mantiene la idea de Nele Kantule de mandar a unos muchachos a la capital a que saquen la carrera de abogados y después puedan ser de utilidad a su patria, desde la misma capital. Lo mismo que la idea de enviar a América del norte a otro grupo. Su deseo de que se declare una reserva indígena en esa región es uno de los objetivos a conseguir antes de que le llegue la muerte. $\mathrm{Y}$ los abogados indígenas podrían defender mejor su causa61.

Nele sigue preocupado por la educación y los becados; en

\footnotetext{
58 V. RD, n. 591.

59 V. RD, n. 602; V. CD, n. CCLXVI.

60 V. RD, ns. 628, 631, 635 y 649; V. CD, ns. CCLXXXIV, CCLXXXV, CCLXXXVIII y CCXCII.

61 V. RD, n. 665; V. CD, n. CCCI.
} 
abril de 1941 le pide a Estanislao López que termine de solucionar lo referente a las becas que prometió el Presidente de la República. El ya tiene preparados a los seis becados, con el sexto grado cursado en la escuela de Narganá. Propone el nombramiento de los dos maestros para el pueblo de Ustupu y de uno dice que ha presentado buena conducta y buena disciplina62. El 14 de abril se entrega al presidente una lista de candidatos a las becas que incluye cuatro graduados en la capital y seis graduados en Narganá, en la que al final aparece la recomendación de maestros.

La misma lista fue presentada también al Ministerio63. El 25 del mes citado son enviados cinco muchachos de los de la escuela de la comarca para que se les coloque en la Escuela de Artes y Oficios, en el Instituto Nacional o cualquier otra escuela secundaria. Así se lo pide a Estanislao López, que hace de delegado suyo en la capital64. El intendente consigue del gobierno que los jóvenes tengan una asignación de B/ 15.00 para su subsistencia, pues la habitación y otros gastos corren por cuenta del interesado; pues la instrucción también era gratuita. Pero el problema era que en la capital no existían internados. La sexta beca la propone el intendente para un sobrino de un maestro65.

\footnotetext{
62 V. RD, n. 690; V. CD, n. CCCXVIII.

63 V. RD, ns. 692 у 693; V. CD, n. CCCXX у CCCXXI.

64 V. RD, n. 695; V. CD, n. CCCXXIII.

65 V. RD, n. 698; V. CD, n. CCCXXV.
} 
Una vez más Nele insiste ante el intendente para que se hagan los nombramientos de sus recomendados. Pero el jefe de El Porvenir le aclara que el jefe supremo de la comarca es el intendente, que él es jefe de su isla y de los sahilas bajo su jurisdicción, pero nada más. En lo referente a los nombramientos de los maestros comenta el intendente que él, como maestro graduado que es, junto al director de las escuelas hará la selección de los maestros que tengan la preparación debida, y que si las propuestas por el sahila reúnen las condiciones será satisfecho en sus deseos.

La intendencia como parte del gobierno y representante de éste ante los indígenas debía funcionar como intermediaria y conducto de toda solicitud, pero en pocas ocasiones fue así, podemos decir que en las mínimas, pues la abundante correspondencia de los jefes con el gobierno nos hacen ver lo contrario. El intendente Constantino Villalaz le aclara esto a Nele Kantule; él debe ser el intermediario de sus sugerencias o peticiones ante el gobierno. Pero el cacique siempre usaba sus influencias y amistades66.

Ricardo Velasco le agradece a Nele Kantule su colaboración con la escuela, al mismo tiempo que le pide que aconseje al pueblo para que no se deje engañar por los que no representan al gobierno, y alaba a los maestros que han sufrido 
una reducción en su sueldo y no han abandonado sus puestos para coger otros más lucrativos 67 .

El funcionamiento del plantel de Ustupu ha sido ejemplar en estos años, ello se debe al esmero en el comportamiento de los tres maestros allí designados, junto con el interés que siempre ha mostrado el jefe Nele Kantule, aconsejando a chicos y grandes sobre la importancia de la educación. Con la ayuda del señor intendente se logró levantar una escuela nueva de madera. Nuevamente se comenta que la escuela particular de este lugar usa el inglés como idioma principal68.La escuela de Ustupu es modelo por la disciplina, adelanto y matrícula. Uno de los tres maestros se ha visto frecuentemente aquejado por las fiebres, por lo que sería prudente trasladarlo el próximo curso. Nele Kantule ratificará la buena labor de los maestros de este lugar con la petición al intendente de que sean nombrados para el siguiente curso69.

Como las escuelas que se levantaban eran pequeñas, ya que solo albergaban una clase o dos, la de Ustupu se queda pequeña dado el gran número de alumnos y Nele Kantule tiene el propósito de levantar una nueva escuela en el periodo de vacaciones, por lo que pide al intendente que le envíe el

\footnotetext{
67 V. RD, n. 700; V. CD, n. CCCXXVII.

68 V. RD, n. 720; V. CD, n. CCCXLII.

69 V. RD, n. 772; V. CD, n. CCCLXXXI.
} 
carpintero si éste se encuentra libre ${ }^{70}$.

En carta de Nele Kantule al Presidente de la República queda reflejado que los planteles que son propiedad del gobierno, en la comarca son tres, el de Narganá, Río Azúcar y Ustupu. Expresa su satisfacción por la labor del ejecutivo y alaba la acción del actual presidente así como la de Dr. J. D. Arosemena. Piensa que la labor del intendente L. Hernández es muy acertada y que las sucesivas reelecciones para el puesto han sido un acierto. La educación en los jóvenes ayudará a desterrar la ignorancia y el expresa que los viejos lucharán a brazo partido por la educación de los jóvenes, ya que con ello se desarraiga la ignorancia en San Blas. Es clara también la opinión con respecto a los misioneros, comenta que su caridad perdura en los corazones indígenas. No olvidemos que Nele Kantule desde un principio estuvo a favor de la educación, pero lo que no quería era a los misioneros, quería una educación secular. Muestra ahora agradecimiento por su tarea en la educación y en los internados que atienden de un modo totalmente gratuito para los escolares ${ }^{71}$.

Fruto de las gestiones de Nele Kantule fueron la apertura o reapertura de las escuelas de Tigre, Ustupu, Ailigandí, Tikantikí, Playón Chico y Tupile. A él se debió la concesión de gran número de becas y los nombramientos de muchos maestros indígenas en la comarca.

\footnotetext{
70 V. RD, n. 769; V. CD, n. CCCLXXVIII.

71 V. RD, n. 773; V. CD, n. CCCLXXXII.
} 
La vida y acción de Nele Kantule adquirió gran relevancia y su secretario redacta una pequeña biografía para presentar al Presidente de la República72. Parte de su labor en favor de la educación se vio proyectada en las conferencias que realizaba en el congreso los viernes, sábados y domingos para los niños, padres y madres de familia; donde les exhortaba a aprovechar el tiempo en la escuela.

\subsection{Alcibiades lglesias (Lonnie)}

Este apartado pretende ser un resumen de la labor de Alcibiades y la escuela misionera bautista fundada por él. $Y$ al mismo tiempo rendir un homenaje a toda la familia Iglesias, que desplegó su actividad educativa en toda la región. Su hermana Luisa fue la primera maestra indígena graduada que trabajó en la comarca; sus hermanas ejercieron también en la profesión. Claudio el mayor luchó por introducir las costumbres civilizadas, y Claudio el pequeño establecería la escuela en Mulatupu.

En el curso de 1933 vuelven a hacer aparición los protestantes en la comarca de San Blas, aunque esta vez los misioneros protestantes sean kunas, al menos el dirigente principal, que es un alumno destacado de la misión de Miss Coope enviado a estudiar a los Estados Unidos. Ante los primeros

\footnotetext{
72 V. RD, n. 824.
} 
rumores de su implantación y actividad en el archipiélago se pide al intendente que se informe de la actividad del matrimonio Iglesias 73 .

Desde la llegada de Miss. Coope en 1913, Alcibiades Iglesias fue un alumno despierto y aventajado. Prueba de su mente brillante, es el hecho de que la misionera le encomendaría la tarea de enseñar a leer a los compañeros, y le regala un Nuevo Testamento como premio.

Ante el éxito conseguido por Claudio, Anna Coope quiere que Alcibiades estudie también fuera de la isla, por lo que le manda a los Estados Unidos. Estuvo bajo la custodia del Reverendo Chester desde el 28 de febrero de 1916, pero con los avatares de la primera guerra mundial tuvo que regresar. Siendo envido posteriormente a Venezuela, donde tras una experiencia traumática vuelve a su isla natal. Estuvo matriculado en la escuela de Narganá donde cursó hasta el VI grado. Seguidamente fue a Panamá con su hermano mayor Claudio y estuvo matriculado en la Escuela de Artes y Oficios donde se graduó de electricista en 1924, sería el primero en hacerlo en esta especialidad; recibiendo los elogios del director por terminar los cinco grados en tres años. La causa de que repitiera cursos que ya había estudiado fue la falta de conocimiento del castellano, pues el dominaba el inglés.

73 V. RD, n. 513; V. CD, n. CCXXII. 
Tras la muerte de Claudio, en los acontecimientos de Río Azúcar, Alcibiades se convierte en el joven elegido por el gobierno para apoyar su labor, y le piden que enseñe a votar a su pueblo y haga campaña en favor del candidato a la presidencia, Rodolfo Chiari, en las elecciones de 1924. Como recompensa de este trabajo electoralista se le prometía una beca fuera del país. Los comicios fueron ganados por Chiari pero el joven estudiante no tuvo la beca74.

Con la revolución de 1925 la familia Iglesias tuvo dificultades con sus paisanos por considerarlos amigos del gobierno y de las ideas innovadoras.

Al regresar la calma a la región de San Blas, después del levantamiento kuna, Alcibiades intenta poner en funcionamiento una escuela misionera, pero encuentra oposición entre sus conciudadanos. Por ello se traslada hasta Ailigandí para hablar con sus sahilas y ofrecerles la creación de una escuela; ellos aceptarían pero ponen ciertas restricciones, una de las cuales es que no deben enseñar a las niñas, ni luchar contra sus costumbres. Esto se queda así, sin nada efectivo; pero con posterioridad serían los propios sahilas los que irían a entrevistarse con Alcibiades, previa autorización de Nele kantule; y le proponen que abra la escuela. También se traslada a Concepción y Ustupu, en ésta existía una escuela dirigida por

74 M. VANDERVELDE y M. IGLESIAS: Nacido primitivo, Traducción de Guillermo Judson, Velde Press, Emmetsburg. p. 37. 
Frank Wilbur, para sondear las posibilidades de extender su actividad.

Parte de los útiles de la primera escuela los recibieron de Estados Unidos. Con posterioridad siguieron Ilegando ayudas desde allí y de la Zona del canal, donde existía un nutrido número de simpatizantes norteamericanos.

Pero con la llegada de los misioneros a Ailigandí surgieron las diferencias y la división en el pueblo. En un primer momento se retiran a un extremo de la isla los opositores, y más tarde, la diferencia de ideas hace que algunos se trasladen a la orilla del continente. Tienen que empezar sus tareas en la casa de la chicha; iniciándose el edificio escolar después de la navidad de 1933. Serían 90 muchachos los primeros matriculados.

El cacique Ikwaniktipippi consideraba importante aprender inglés porque era el idioma de muchos de los comerciantes de coco, además, con posterioridad les ayudaría a conseguir trabajo en la zona del canal de Panamá. Alcibiades, conocido con el nombre de Lonnie dominaba el kuna, el castellano y el inglés, mientras que su esposa sólo sabía el inglés, ella enseñaría inglés a los niños y éstos la enseñarían el kuna75.

El problema de la disciplina, fue al primero que tuvieron que afrontar. Los kunas aman la libertad y no comprendían que si

75 Ibidem, p. 74. 
uno quería hacer otra cosa en lugar de ir a la escuela no la pudiera hacer. El sahila acuerda que sean castigados con las ortigas los desobedientes.

Se inaugura la escuela dominical en la isla y un joven va a estudiar a Costa Rica para que luego pueda ejercer de predicador. La escuela de Ailigandí seguía los métodos del Instituto Panamericano auspiciado por los metodistas de Panamá.

Comenzaron a llegar las primeras misivas del gobierno con la imposición de cerrar la escuela, y la primera reacción fue ignorarlas y buscar más ayuda para la desbordante tarea de la escuela.

El intendente Aguilera se queja, en agosto de 1934, de que el matrimonio Iglesias, establecido en Ailigandí, y otras misioneras americanas amparadas por éste, pretenden fundar en varios pueblos escuelas a base de inglés, protestantismo y americanismo. Cree que se debe cortar todo intento de reunión para que no se hagan fuertes. $Y$ considera una medida adecuada expulsar a las americanas, parte integrante de los provocadores de la revolución del 25. Además de suprimir las escuelas de Ailigandí 76 .

Una nueva prohibición cae desde la Intendencia sobre un indio que esta haciendo las funciones de religioso protestante, el

\footnotetext{
76 V. RD, n. 526; V. CD, n. CCXXXI.
} 
argumento es que no ha cumplido los requisitos que exige la ley 56 de $1912^{77}$.

Aclarando toda esta situación, escribe el intendente al secretario de Gobierno y Justicia mencionando a las dos personas arriba referidas más otra y Alcibiades Iglesias que reciben instrucciones de una agencia extranjera para enseñar a los indios el inglés y conducirlos hacia la religión protestante. Tres de los anteriores reciben sueldo por medio de cheques librados en Nueva York y que cambian en la Zona del canal.

Para completar este grupo de protestantes debemos mencionar también a la esposa de Alcibiades y a otra norteamericana que trabaja en Ailigandí con ellos; además de otro indio que actúa en Narganá y que tras la amonestación dada por el intendente ha prometido no actuar sin permiso de la policía y hasta que los indios estén más capacitados. El jefe de este grupo, Alcibiades será llamada a la Intendencia ${ }^{78}$. En ella se le hace saber que está incumpliendo las leyes vigentes, pues no tiene permiso del secretario de Gobierno y Justicia para ejercer la profesión de maestro de escuela y hacer explicaciones de la biblia, por lo que debe cesar hasta que no obtenga el citado permiso 79 .

\footnotetext{
77 V. RD, n. 532; V. CD, n. CCXXXVI.

78 V. RD, n. 534; V. CD, n. CCXXXVII

79 V. RD, n. 536; V. CD, n. CCXXXVIII.
} 
En octubre de 1934 se cierra la escuela, tras la orden de la Intendencia, y el sahila del lugar escribe al jefe de El Porvenir preguntando por las razones de esta decisión, ya que el gobierno de Panamá dio libertad a los indios de San Blas para educar a sus hijos. Acusa al intendente de hacer perder toda simiente de progreso y educación en sus hijos. Ahora es el mismo sahila Olowiquequiña quien toma el asunto en sus manos y ordena a Alcibiades que abra de nuevo la escuela. Así se lo relata el intendente al responsable de Gobierno y Justicia señalándole que ha hecho conocer al sahila los propósitos del ejecutivo de abrir una escuela oficial allí, pero se hará cuando todas las dificultades estén limadas, para no caer en errores 80 . Aclara que el motivo del cierre no es perjudicar a los niños, sino hacer saber a los esposos Iglesias que existen una leyes que deben cumplir81.

Pero la intercesión de Marvel, esposa de Lonnie, consigue del Presidente Harmodio autorización para la reapertura, pero con la condición de no traer más gente de fuera 82 .

Todos los recursos se usaron para abrir la escuela de Ailigandí. Esta vez el sahila Iguinitite (o Yguanietipipe) pide al secretario de Gobierno y Justicia permiso para que se abra la

80 V. RD, ns. 539 y 544; V. CD, ns. CCXL y CCXLIII.

81 V. RD, n. 540; V. CD, n. CCXLI.

82 M. VANDERVELDE y M. IGLESIAS : Nacido primitivo, Traducción de Guillermo Judson, Velde Press, Emmetsburg, p. 86. 
escuela del lugar que estaba a carga de Fulvia Iglesias, pero el intendente opina que es un ardid del matrimonio Iglesias, pues él es hermano de esta maestra. Cree que sería posible si saliesen del lugar los esposos Iglesias; pues de lo contrario aprovecharían este permiso para seguir realizando ellos sus actividades. Juzga competente a la maestra Fulvia que estudió en la Profesional de la ciudad de Panamá. Esta acción sí sería muy positiva y beneficiosa para los educandos de la isla83.

El maestro José Colman le hace saber al secretario de Gobierno y Justicia que le visitará Nele Kantule con una delegación de Ailigandí para exponerle que ellos quieren que siga enseñando Alcibiades Iglesias, y reconocen la labor patriótica de Nele. Además los habitantes de Ailigandí no consideran la escuela de Iglesias como extranjera pues enseña en castellano y los indios la abrieron voluntariamente ${ }^{84}$.

A finales de diciembre la Secretaría de Gobierno y Justicia autoriza al Sr. Iglesias a abrir la escuela de nuevo por el resto del periodo en curso; pero debe dictar solo clases en castellano, y apartarse de todo lo que tenga cariz norteamericano 85 .

La escuela que funcionaba en la casa de la chicha, se

\footnotetext{
83 V. RD, n. 543; V. CD, n. CCXLII.

84 V. RD, n. 556.

85 V. RD, n. 545; V. CD, n. CCXLIV.
} 
veía interrumpida con mucha frecuencia por estas celebraciones. Llegaba el momento de levantar un edificio independiente y destinado a escuela. Los domingos se realizaban varios cultos para que pudiesen asistir el mayor número posible. $Y$ fruto de la escuela aparecieron diversas tiendas, entre otras la de los muchachos de la escuela, que les permitía adquirir experiencia en conceptos aprendidos.

De modo secreto comenzó Marvel a enseñar a las niñas que solicitaban el poder aprender; y finalmente se les autorizó a que asistieran a la escuela pero no podían recibir nombres, como se había hecho con los niños. Y en 1938 el propio sahila pidió permiso para que su hija fuera a estudiar a Panamá. Salieron dos muchachas para el Instituto Panamericano Metodista, que llegarían a ser las maestras, Cristina y Fulvia.

Entre tanto la actividad de la escuela y la misión estaba echando en falta la existencia de un alfabeto kuna y la traducción de los textos sagrados a la lengua indígena.

Peter M. había intentado establecer una escuela misionera en Corazón de Jesús, pero el fuerte control del gobierno se lo impidió, lo que le llevó a escapar a Ailigandí y ponerse al servicio de Alcibiades, cobraría como ellos B/ 10,00 de sueldo.

La escuela de Ustupu, dirigida por Wilbur comenzó a enviar los alumnos más destacados, que vivirían en la casa del 
matrimonio misionero, para que pudieran proseguir sus estudios. Milton Morris sería uno de estos, obsequiado con una beca en el país norteamericano.

Lonnie comenzó a prohibir a sus alumnos que asistieran a las chichas, y con ello empezó el enfrentamiento con los mayores. Esta prohibición se refería concretamente al consumo de alcohol por parte de los estudiantes.

En 1936 fueron becados en Estados Unidos, Claudio el menor, que estaría en la escuela trece años, concluyendo su graduación de bachillerato en Artes, hermano del difunto Claudio y de Alcibiades, y otro muchacho de seis años.

A finales de la década de los treinta, con la ayuda de lingüistas norteamericanos, crean un alfabeto kuna compuesto de 17 letras. A partir de entonces empezaría la traducción de los textos de la Biblia al kuna.

Alguna de las islas de los alrededores empiezan a sentir curiosidad por la educación y desean instaurar una escuela en sus comunidades, tal es el caso de Achutupu. La escuela misionera respetaba la vestimenta y adornos de la indígena, lo que hizo que tuviera aceptación y se enviaran alumnas de las islas limítrofes para que estudiasen.

El mes de diciembre, destinado a las vacaciones, la pareja misionera se dedicaba a difundir su labor entre los 
hermanos de la ciudad de Colón y conseguir materiales escolares.

El funcionamiento de las escuelas de Alcibiades estaba limitado únicamente a los tres primeros grados, pero con el paso de la instrucción al Ministerio de Educación se amplió hasta el sexto grado. No se le había permitió más, en parte por la presión ejercida por los inspectores de la misión católica. Pero la autorización requería una ampliación de los locales que eran insuficientes. Al igual que en las escuelas oficiales de la comarca se usó la cámara de cine como medio de instrucción 86 . Por decreto 2254 del 4 de mayo de 1948 la escuela de Ailigandí es reconocida por el gobierno nacional.

La fuerza militar destacada en San Blas se retira al concluir la segunda guerra mundial. Algunos materiales de los dejados se emplean para levantar las escuelas. Ailigandí tiene una matrícula entonces de 200 alumnos. Al mismo tiempo que la escuela misionera de Achutupu iba apuntando un esperanzador crecimiento.

Claudio el menor con su esposa fundaría escuela misionera en la isla de Mulatupu en 1950. El cacique que se oponía radicalmente a ella en un principio, declaraba abiertamente que aceptaba la escuela.

Entre los problemas que se unieron a la civilización, la

86 M. VANDERVELDE y M. IGLESIAS : Nacido primitivo, pp. 116-117. 
marihuana fue uno de ellos, en 1951 ya empieza a ser motivo de preocupación entre los sahilas. Las lacras de la sociedad civilizada rompían sus esquemas ancestrales.

El senador e intendente Félix Oller, al igual que Lonnie pertenecían a una Logia Masónica. El animaría al misionero en su labor, y a que extendiese las escuelas por todas las islas de la comarca. La misión protestante ya estaba asentada en Ailigandí y su labor iba en aumento, cuando el dirigente de ésta pide permiso al intendente para que su hermano Claudio Iglesias 87 se establezca en Mulatupu, donde el sahila y su pueblo recibirían de buen agrado al matrimonio Iglesias pequeño88.

A esta escuela privada llega una partida de materiales a fines de 1950, por lo que se supone abierta para ese entonces. El encargado de hacer el reparto es Rubén P. Kantule, bibliotecario de Narganá, que le comunica al secretario de la intendencia la recepción de dichos útiles ${ }^{89}$.

La educación protestante fue introduciendo cambios de mentalidad y de costumbres, incluido su vestir; pero nunca fue de un modo violento. La construcción de una casa de concreto por parte del matrimonio Iglesias causó descontento en un principio,

87 hermano del difunto, y que recibió el mismo nombre en honor de quien dio su sangre por la civilización, pero este fue educado con los protestantes.

88 V. RD, n. 942; V. CD, n. CDLI.

89 V. RD, n. 949; V. CD, n. CDLII. 
como ocurriera en Narganá, donde estaba el centro de la acción gubernamental, ya que este tipo de construcción no era la enseñada por lbeorgun.

Alcibiades es el primer indio que se gradúa con título superior. Es miembro del ayuntamiento de Colón, y suplente de la Asamblea Nacional. Entre las labores llevadas a cabo por este personaje podemos destacar la introducción de la educación en el sector oriental, aunque existiera ya una escuela en Ustupu. La instrucción de esta zona podemos decir que estuvo dirigida por la misión bautista, y fue su propagadora. Con ella también entraron cambios que fueron variando el rumbo de este pueblo. Los kunas salieron al extranjero, agraciados con becas que en ocasiones fueron subvencionadas por el matrimonio Iglesias.

Las construcciones de concreto se hicieron habituales en el paisaje de las islas; muchos indígenas siguen creyendo que estas casas traerán desgracias a la comarca. La vestimenta original fue cediendo, al menos cuando las jóvenes salían de las islas para estudiar. La sanidad bajó el índice de mortalidad. Las celebraciones con chicha se enfrentaban a la moral predicada por la nueva religión. Los jóvenes comenzaron a cubrirse con ropas occidentales. La lengua kuna se vio dotada de un alfabeto y empezó a escribirse. Se tradujeron libros al kuna donde los niños aprenderían a leer.

En un primer momento ponen nombres a los muchachos, 
y con el paso de los años las niñas también recibirían nombres ingleses, lo que irritaría al gobierno cuando llegó la hora de conceder cédulas a los habitantes isleños.

Esta escuela dio una oportunidad a los albinos que se encontraban marginados dentro de la cultura kuna, pues se les había negado incluso el derecho a la vida en tiempos anteriores.

El motor central de la actividad de Narganá fue la ciudad de Panamá, mientras que el de Ailigandí estaba en Colón, formado por los súbditos americanos allí destacados.

Se puede decir que la acción llevada a cabo en esta parte fue muy similar a la realizada en sector central del archipiélago. El sector protestante que en los años de Miss Coope se centraba en Narganá, ahora se ve reducido en este lugar por la presencia mayoritaria de los católicos. Esto hace que se vaya creando un centro en Ailigandí, donde adquiere más fuerza con el paso del tiempo. El protestante Piter Miller de Narganá termina por trasladarse a Ailigandí tras los obstáculos que encuentra para desarrollar aquí su actividad. En aquel lugar pondrá una escuela nocturna para los ancianos a los que enseña matemáticas. Pero dado su desconocimiento del castellano tiene que enseñar en inglés. Dado que no tiene permiso para abrir escuela y además desempeña su actividad en una lengua que no es la oficial la duración de la escuela sería muy escasa90.

90 V. RD, ns. 611 y 615; V. CD, ns. CCLXXII y CCLXXVI. 
Los tres factores expuestos hasta aquí supusieron un empuje a la educación. Los internados pretendían favorecer a los que estaban más lejos de los centros escolares y contaban con pocos recursos. Nele Kantule fue una persona que luchó por el progreso de su pueblo y le dejó un legado muy rico tanto en lo referente a la tradición kuna como en lo concerniente a la cultura occidental. Y por fin, Alcibiades fue un educador y predicador que contribuyó al desarrollo educativo del sector oriental. 


\section{CONCLUSIONES}

El momento de inicio de lo que podemos llamar la educación occidental entre los kunas se puede decir que no fue el más idóneo. Los kunas habían vivido en el periodo anterior un tiempo de calma y tranquilidad. Mientras estuvieron formando parte de la nación colombiana experimentaron la autodeterminación y casi el abandono del gobierno nacional que dedicaba sus fuerzas a resolver problemas internos y librar guerras continuas por el poder. La vasta extensión de tierras que pertenecían a la nación dificultaba también las atenciones que ésta podía dispensar a los grupos indígenas diseminados por todo su territorio.

La separación de Panamá y Colombia desembocó en una excisión del colectivo indio kuna, que dejó una mayoría del grupo en el territorio panameño y un par de poblados en Colombia. Esta división no fue del agrado colombiano que por todos los medios intentó la reunificación. Panamá quiso reforzar sus fronteras; y la frontera que más problemas podía acarrear era sin duda la colombiana. Por ello desde el primer momento pone todo su énfasis en nacionalizar la frontera oriental y la costa caribeña de este sector. Los habitantes del oriente son los kunas, y es por lo que el gobierno quiere hacerles saber que pertenecen a Panamá. Se lo notifica y les envía banderas de la nueva nación para que icen la enseña nacional. 
La primera idea del gobierno es civilizar a los indios para que respondan al deseo de nacionalización que se quiere conseguir en todo el territorio. La educación era una parte de la civilización. Pero la civilización iba a suponer un cambio drástico en la sociedad kuna. El gobierno se fue buscando simpatizantes a los que correspondía con cheques. El poder nacional hizo nombramientos en un principio de policías y posteriormente de maestros indígenas.

Aquellos que recibían un sueldo abandonaban las obligaciones sociales de su pueblo. Unas veces porque los nuevos trabajos reducían en gran medida las horas libres; y otras veces por comodidad. Pues la seguridad de un salario quincenal les proporcionaba una independencia económica. Se empezaba a producir una desigualdad social. Unos pocos tenían bastante más que el resto de sus conciudadanos, y no necesitaban de la colaboración de estos.

Aparte de esta descompensación en el nivel económico, se produce un desequilibrio en lo social y educativo. Hay islas que aceptan la escuela y todo lo que esto supuso y arrastró consigo; y otras que se cierran en banda. El choque cultural supuso un impacto fuerte.

La educación provocó una movilidad en el archipiélago, y también hacia el exterior. Hubo jóvenes que se trasladaron a estudiar y residir al centro de Narganá provocando una disminución de alimentos y aumento considerable de las 
personas que habitaban en las viviendas. Del mismo modo se dio una emigración hacia Panamá y Colón para poder proseguir los estudios superiores que en las islas no existían. Estos estudios exigían unos pagos mínimos que las familias tuvieron que afrontar buscando también trabajos remunerados fuera de la comarca. Las enfermedades epidemiológicas de la civilización comenzaron a brotar y a marcar a los que quisieron participar de las ventajas de la sociedad moderna. Lo mismo que las lacras sociales se fueron apoderando de la sociedad kuna disfrazadas bajo el velo de la civilización.

A lo largo del trabajo hemos ido viendo los distintos pasos que se dieron en la educación entre los kunas. Unas veces supusieron un avance y alguna otra un retroceso. La educación es un fenómeno social que lleva consigo un gran número de implicaciones o variables. Pero en este caso se puede decir que esos factores se vieron multiplicados, ya que la educación no fue un objetivo en sí mismo; sino que entró a formar parte de una red más compleja, que era la civilización de los indios. Y por ello la educación occidental fue considerada como el medio que mejor podía ayudar a la consecución de tal fin. A causa de esto la educación ocultó en sí unos fines o medios un tanto divergentes a la esencia misma de la pedagogía.

Si la educación ha de conducir al bien y al desarrollo de la persona, y los individuos forman parte de la sociedad, también desembocará en el bien y progreso de esa sociedad. Pero se confundió el progreso y el bien con igualar a los indios con los 
ciudadanos nacionales, y no se respetaron las diferencias culturales. Se pretendía a toda costa cambiar el modo de vestir de las mujeres y de adornar su cuerpo, imponer la lengua nacional y la religión mayoritaria del país. Se quería cambiar sus bailes y manifestaciones culturales.

Los kunas experimentaron la necesidad de la educación porque comenzaron a tener una relación con el mundo exterior. Este contacto con el exterior en un principio era básicamente comercial. Róbinson propone a sus súbditos que deben aprender para no ser engañados. El gobierno se sirve de esta idea para alcanzar su meta de hacerlos ciudadanos panameños.

La época de la misión jesuita obedece más que nada a la idea estricta de la evangelización que se tenía en tiempos de la conquista. El fin principal es la conversión, acompañando a esto por el momento una instrucción mínima que se basaba en el aprendizaje de la lengua nacional y en las operaciones aritméticas elementales.

Poco contribuyó a la civilización, a los ojos del poder nacional, la misión protestante instalada en Narganá. Fue causa de continuos conflictos y enfrentamientos provocados por el desconocimiento o la mala interpretación de la ley. Lo que para Panamá resultaba válido, para esta zona de características muy específicas precisaba de una adaptación y de la creación de leyes adaptadas.

En la fundación de las primeras escuelas nacionales hay 
que resaltar la labor de las maestras que abrieron la brecha superando tantas dificultades como se presentaban en este árido campo. La falta de maestros preparados para desempeñar sus funciones, no solo en esta región, sino en todo el territorio nacional, hizo que los pasos que se daban fueran muy lentos y vacilantes, al mismo tiempo que la educación no podía presumir de calidad. Pero por ello no debemos olvidar, e incluso debemos reconocer, el esfuerzo y el interés que el gobierno nacional hizo por subir el nivel educativo de la nación. Los propios presidentes de la República y los secretarios de Gobierno y Justicia fueron quienes se encargaron directamente del tema educativo de los indios de San Blas. Así lo prueba la abundante correspondencia cruzada entre los dirigentes kunas, los directores de las escuelas y los gobernantes nacionales.

Tras la revolución parece que las cuestiones escolares toman un ritmo más lento y seguro, pero cuando las riendas pasan a manos de los claretianos la escolarización da un salto vertiginoso, pues su concienzuda dedicación es reconocida por los indígenas. La creación de los internados busca el poder atender al mayor número posible de estudiantes. Aumenta así mismo el número de alumnos que prosiguen sus estudios en los centros de la capital. $Y$ en la zona oriental Alcibiades funda una escuela protestante que cuenta con el beneplácito de Nele y que será el centro educativo de aquella región.

Los nombramientos de maestros indígenas favorecieron la propagación de las escuelas, pues los indios se fiaban más de 
sus paisanos que de los maestros nacionales. Esto no contribuyó a que mejorara el nivel de la enseñanza, pues los maestros que se nombraban contaban con unos estudios muy escasos, hasta el cuarto o sexto grado de la primaria en algunas ocasiones.

Como balance final se puede decir que la introducción de la escuela de estilo occidental entre los kunas tuvo como consecuencia una serie de aportaciones positivas muy destacables, en esta primera etapa del siglo veinte que nos ocupa:

- La formación del personal indígena les llevó a tomar parte activa en la vida política del país, teniendo derecho al voto. No quedó aquí la cosa, sino que después de declarase reserva su territorio pudieron elegir personas que les representasen en la asamblea legislativa nacional.

- El nivel sanitario mejoró al mismo tiempo que mejoraron sus condiciones de vida. Los indígenas se formaron en la rama sanitaria y la fundación de dispensarios y centros de salud ayudó a combatir las enfermedades.

- La educación fue pasando a manos de los propios indígenas, ya que la mayoría de los maestros eran kunas; y de pertenecer las competencias a Gobierno y Justicia se llegó a regularizar la situación dependiendo finalmente del Ministerio de Educación, como las demás escuelas del país.

- Ayudó a conseguir una demarcación del territorio 
indígena. Y a lograr más tarde una Reserva común de los kunas, donde viven autogobernándose.

- Colaboró en la formación de líderes y personas capacitadas para representarles y defenderles, que completaron su formación indígena con los conocimientos occidentales.

- Contribuyó a conservar sus tradiciones poniendo por escrito sus tratados y favoreciendo su transmisión y conocimiento. Además de dotar a la lengua kuna de un abecedario.

- Permitió que los indígenas consiguieran becas y pudieran continuar los estudios en la capital y en el extranjero.

- Fomentó el cooperativismo, mejorando las actividades realizadas por los habitantes de la comarca.

- Favoreció que la mujer fuera considerada al mismo nivel que el hombre, aflojando el férreo control que sobre ella se tenía, y tuvo acceso a la educación.

- La educación fue tema de preocupación de los caciques y de los congresos generales kunas, aumentando paulatinamente su importancia.

El paso dado entre los kunas puede ser una experiencia positiva para los demás grupos indígenas de la nación, e incluso del continente americano.

La educación fue un bien deseado por los principales 
núcleos de población. Sin embargo la escuela no se implantó en todas las poblaciones, ni hoy en día es aceptada en su totalidad. Algunos pueblos ni siquiera desean oir hablar de ella.

Es cierto, por otra parte, que los principales dirigentes de los kunas lucharon y apoyaron en la medida de sus fuerzas la implantación de la educación. Recordemos en primer lugar a Charles Róbinson que toma la iniciativa y propone al Presidente de la República la creación de becas y escuelas. Colman está de acuerdo con la escuela, pero lo que no desea es que las lacras sociales vayan pegadas a la educación y sean propagadas a través de ésta. Nele Kantule toma la iniciativa de nombrar maestros indígenas y son pagados por el mismo pueblo, lo que rechaza son las misiones y las ingerencias del gobierno. Olonibigiña fue el propulsor en el sector de Cartí. Rubén P. Kantule fue bibliotecario, secretario de los caciques y colaborador de la escuela sueca de antropología. Estanislao López hizo de mediador con el gobierno siendo un intermediario muy eficaz a la hora de conseguir becas para los indígenas.

Como factores negativos derivados del proceso educativo se pueden destacar:

* En muchas ocasiones se identificó a la escuela con la civilización, o al menos se quiso hacer una misma cosa de las dos.

* Las diferentes religiones crearon una mayor división entre los kunas. Al mismo tiempo que se produjo una mayor 
confusión por la lengua en que se realizaba la enseñanza, en un principio en español y con los protestantes en inglés.

* Los nombramientos de maestros indígenas con una escasa preparación, en muchas ocasiones favoreciendo el amiguismo de los intendentes o de quienes ostentaban algún poder.

* Las escuelas funcionaron con una insuficiente dotación de material, teniendo que realizar su actividad en unas condiciones muy precarias.

* La conducta de los maestros no fue un ejemplo de virtud en muchas ocasiones, haciendo que los enemigos de la escuela identificasen los vicios con la educación, responsabilizando a ésta de los males que comenzaban a pulular por la comarca de San Blas.

* La apertura hacia el mundo exterior buscando el mercado laboral que les proporcionaba unos ingresos y les liberaba del control social de la isla, con el consiguiente abandono de las actividades agrícolas y de pesca.

* La educación se vio envuelta en acciones que terminaron de un modo violento y con derramamiento de sangre.

* Las epidemias y enfermedades se propagaron de modo más drástico por las islas que tenían escuela.

* La escuela fue un elemento más de división entre los 
kunas, llegando incluso los detractores a tener que abandonar la isla.

Como punto final se puede decir que la educación fue un bien que contribuyó al progreso y mejora de la vida de los kunas. Sus principales dirigentes kunas la apoyaron y fomentaron su expansión por las islas donde ejercían una mayor influencia. Al mismo tiempo se puede afirmar que el gobierno utilizó la educación como un medio de civilización. Pero con el paso del tiempo, y a medida que los kunas fueron asimilando las costumbres nacionales, sus objetivos educativos se fueron normalizando, y se confió por fin la educación al ministerio correspondiente. 


\section{TERMINOS FRECUENTES EN LA PRESENTE OBRA}

Absoguedi: Cantor que ejerce en los sahumerios contra los malos espíritus.

Alzamuro: Olazu, aro de oro de la nariz.

Cambombia: Caracola grande.

Cayuco: Embarcación realizada mediante vaciado de un tronco.

Chicha: Bebida y nombre de la celebración indígena.

Chukula: Bebida tonificante.

Dake: Ortiga.

Fumadera: Ceremonia para auyentar los espíritus.

Gulli: Flauta de huesos de pelícano.

Iboergun: Profeta que vino a la tierra a enseñar a los kunas.

Ina igala: Tratado de medicina.

Ina: Medicina.

Inatoikiña: Ignacio Obaldía, cacique de San Ignacio de Tupile.

Inatuledi: Médico-botánico con facultades curativas.

Inna: Chicha.

Ise: Tabú.

Kabur: Ají picante.

Kalu, Kalugan: Lugar o lugares de la tierra donde puede viajar el Nele.

kamu purgui: Flauta larga de siete cañas.

Kana: Asiento macizo de madera. 
Kandur: Ceremoniante de la Chicha.

Kikadiryai: Hermana de Ibeorgun, que predicó en la tierra Kuna.

Kokoa: Bebida de cacao.

Mu: Abuela.

Musuar: Pañuelo de la cabeza.

Nasi: Maraca.

Nele : Visionario, adivino, sabio.

Nuchus: tallas antropomórficas de madera, generalmente de balso.

Nusatupu: Corazón de Jesús.

Omaket nega: Casa del congreso.

Paba: Dios.

Ponigan: Espíritus.

Portogandí: Ustupu.

Purba: Espíritu, alma.

Río Mono: Tupile.

Sahila: alcalde, jefe espiritual.

Sahino: Animal semejante al jabalí.

Sakar: Suegro.

Sia: cacao.

Suaribedi, salibedmar: Policía, policías encargados del orden. Supe: Flauta.

Tule: Indio, persona.

Tule masi: Comida india. 
Tupile: Río Mono.

Ukupseni: Playón Chico.

Urgandí: Río Sidra.

Waga: Extranjero, no indio.

Yantupu: Narganá. 


\section{LISTA DE INTENDENTES}

Enrique Hurtado

Vicento O. Cataño

Humberto Vaglio M.

Andrés Mojica

Luis Hernández R.

Tomás E. Abello

Antonio T. De Reuter

Julián F. Aguilera

Recaredo Carles

Luis Hernández R.

Vicente Calvet

Constantino Villalaz

Luis Hernández R.

Félix E. Oller

Práxedes P. Vasquez

Félix E. Oller

Alberto Arias
1915 a 1917

1917 a 1918

1918 a 1920

1920 a 1925

1925 a 1927

1928 a 1930

1931 a 1932

1933 a 1935

1935 a 1936

1936 a 1940

1940

1940 a 1941

1942 a 1945

1945 a 1948

1949

1950 a 1951

1952 a 1956 


\section{PRESIDENTES DE LA REPUBLICA DE PANAMA EN LOS}

\section{PRIMEROS AÑOS}

MANUEL AMADOR GUERRERO

20-II-1904 a 23-VI-1907

27-XII-1907 a 30-IX-1908 1 Presidente

Constitucional

JOSE DOMINGO DE OBALDIA

24-VI-1907 a 27-XII-1907 1ํ Designado Encargado

del Poder Ejecutivo

$1-X-1908$ a $1-|I|-1910$

2ำ Presidente

Constitucional

CARLOS A. MENDOZA

1-III-1910 a 30-IX-1910 2ํㅡㄹ Designado

FEDERICO BOYD

1-X-1910 a 4-X-1910 2ํㅡㄹ Designado

PABLO AROSEMENA

$5-X-1910$ a $1-I I-1912$

7-III-1912 a 30-IX-1912 1ํ Designado

RODOLFO CHIARI

1-II-1912 a 6-III-1912 3 Designado

6-VI-1923 a 10-VI-1923 1ํ. Designado

$1-X-1924$ a $7-I X-1928$

25-IX-1928 a 30-IX-1928 6o Presidente

Constitucional

\section{BELISARIO PORRAS}

1-X-1912 a 30-IX-1916 3o Presidente Constitucional

12-X-1918 a 29-I-1120 1ํ Designado

$1-\mathrm{X}-1920$ a $5-\mathrm{VI}-1923$

11-VI-1923 a 30-IX-1924 5o Presidente 
Constitucional

RAMON M. VALDES

1-X-1916 a 3-VI-1918

4ํㅜㄹesidente

Constitucional

FLORENCIO H. AROSEMENA

$1-X-1928$ a 2-II-1931

$7^{\circ}$ Presidente

Constitucional

ARMODIO ARIAS MADRID

$\begin{array}{llr}2-I-1931 & \text { a } & 15-I-1931 \\ 1-X-1932 & \text { a } & 1-X-1933 \\ 31-X-1933 & \text { a } & 30-I X-1936\end{array}$

Secretrio de Gobierno y Justicia Encargado

8ำ Presidente

Constitucional

DOMINGO DIAZ A.

2-X-1933 a 30-X-1933

1ํ. Designado

1-X-1948 a 28-VII-1949

$11^{\circ}$ Presidente

Constitucional

JUAN DEMOSTENES AROSEMENA

1-X-1936 a 16-XII-1939

9o Presidente

Constitucional

\section{ARNULFO ARIAS MADRID}

$1-\mathrm{X}-1940$ a $14-\mathrm{VII}-1941$

20-VII-1941 a $9-\mathrm{X}-1941$

24-XI-1948 a 10-V-1951

$10^{\circ}$ Presidente

Constitucional

\section{ENRIQUE A. JIMENEZ}

15-VI-1945 a 30-IX-1948 Presidente Provisional

\section{J. ANTONIO REMON C.}

$$
\begin{aligned}
& \text { 1-X-1952 a 27-IX-1953 12으 Presidente } \\
& \text { Constitucional }
\end{aligned}
$$

RICARDO ALFARO DE LA GUARDIA

$$
\text { 9-X-1941 a 15-VI-1945 }
$$

Ministro de Gobierno y Justicia Encargado 


\section{DOCUMENTAL: FUENTES PRIMARIAS}




\section{Regesta Documental}

(Fuentes primarias: manuscritas e impresas)

1904 Febrero 13 Panamá

Primera Constitución de la República de Panamá, donde se trata el tema de las misiones y de la educación. Reformada en 1941 y 1946.

AANP: Orig. ms.

V. CD, n. I.

2.

\section{Panamá}

Lista de los primeros alumnos becados en la escuela de los Hermanos de la Salle que estuvieron hasta 1912.

AELE: Carp. Var. Doc. Cop. mec.

3.

1906 Octubre 31 Panamá

Decreto de creación de una Escuela para Indígenas en la capital de la República.

AANP: Cop. mec. 
4.

1906 Noviembre 16 Panamá

Ley que propone la creación de becas para indígenas en la escuela de Artes y Oficios.

AANP: Orig. ms.

V. CD, n. II

5.

1907 Marzo $23 \quad$ Narganá

Libro de la parroquia de Narganá, relatado por el P. Gassó, que comenta las diversas actividades del misionero jesuita en el archipiélago de San Blas.

CMC: Orig. ms.

V. CD, n. III

6.

1907 Marzo $27 \quad$ Narganá

Lista de los alumnos que pertenecían a la escuela de catequistas de Narganá, fundada por el P. Leonardo Gassó.

AELE: Carp. Ocho doc. de val. Cop. mec.

7.

1907 Marzo Narganá

Diario del misionero jesuita, P. Gassó, en el cual relata su estancia entre los indios karibes.

ARPK: Cop. mec.

V. CD, n. IV 
8.

\section{Panamá}

Informe del Hermano Carlos Venero en el que comenta dónde se instalaron los alumnos y los problemas que se presentaron. Señala las materias que se estudiaban y el método usado.

ARPK: Carp.130. Cop. mec.

9.

\section{Panamá}

Informe del Sr. Lasso de la Vega en el que cuenta los progresos de los alumnos indígenas y detalla las dificultades con que se encuentran sus educadores.

ARPK: Carp.130. Cop. mec.

10.

\section{(1907) Panamá}

Informe de los $\mathrm{HH}$. de la Salle referido a la escuela de indígenas que funcionó bajo su autoridad.

CHHS: Cop. mec.

\section{1.}

\section{Diciembre 31 Panamá}

Ley 59 sobre civilización de indígenas, en la que se pide ayuda para la reducción de los indios a la Iglesia Católica; y se crean becas para los indígenas.

AANP: Ley. de 1908. Orig. ms.

V. CD, n. V 
1908 Panamá

Memoria del secretario de Gobierno y Justicia a la Asamblea Nacional en la que se queja diciendo que las misiones no han dado resultados prácticos por estar anticuadas. $\mathrm{Y}$ concluye hablando de la falta de conciencia de patria entre los indios.

AELE: Carp. Ten. Cop. mec.

13.

\section{Agosto 15 Colón}

Memoria del secretario de Gobierno y Justicia que presenta a la Asamblea Nacional en la que habla de la ineficacia de las misiones y propone poner puestos de policía en las islas.

ANP: Mem. del Sec. de G. y J. 102-105. Cop. mec.

14.

1912 Diciembre 13 Panamá

Ley 41 que habla de la construcción de un edificio para escuela de indígenas.

AANP: Ley. de 1912. Orig. ms.

V. CD, n. VI

1912 Diciembre 28 Panamá

Ley 56 que trata sobre la civilización de indígenas.

AANP: Ley. de 1912. Orig. ms.

V. CD, n. VII 


\section{Septiembre 10 Panamá}

Memoria de Gobierno y Justicia donde se habla de la civilización y de la instalación en las islas de una estación inalámbrica, al mismo tiempo que se propone establecer allí una colonia

ARPK: Carp.141. Cop. mec.

\section{Abril 18 El Porvenir}

Carta del intendente al secretario de Gobierno y Justicia, comentando el abandono en que está Puerto Obaldía en cuestión de Instrucción Pública. Le dice que interceda ante el secretario de Instrucción Pública para que se funde escuela ese año.

Al: Cop. mec.

V. CD, n. VIII

18.

\section{Mayo 14 Panamá}

Testimonio de fianza para los cargos de corregidor y de intendente en la circunscripción de San Blas de los Sres. Guillermo Cows y Andrés Mojica.

Al: Orig. mec.

V. CD, n. IX

19.

1915 Junio Panamá

Informe de la visita del Presidente de la República a la comarca de San Blas para buscar lugar donde fundar la Intendencia y poner escuelas. Pregunta a los indios si quieren escuelas y responden 
afirmativamente exponiendo sus motivos.

AELE: Carp. Var. Doc. Cop. mec.

\section{0.}

\section{Octubre 22 Panamá}

Informe del secretario de Gobierno y Justicia, describiendo la circunscripción de San Blas y señalando El Porvenir como sede de la misma.

ANP: Mem. del Sec. de G. y J. Cop. mec.

1916 Enero 27 Panamá

Contrato de la Secretaría de Gobierno y Justicia y el Sr. Fernández Hernández, para crear una colonia agrícola en la zona de los indios kunas, que se formalizó con 16 cláusulas.

Al: Orig. mec.

V. CD, n. $X$

\section{Mayo 17 El Porvenir}

Carta del jefe de la circunscripción al secretario de Estado en el despacho de Instrucción Pública, comunicándole que ha sido satisfactorio el recibimiento dado a las maestras de Narganá y Tupile.

ARPK: Carp.233 Cop. mec.

V. CD, n. XI 
Carta de los calificadores de exámenes finales Federico Gutiérrez y A. Linares al inspector de Instrucción Pública, expresando satisfacción por este nombramiento, y rinden el informe reglamentario. Comentan que los resultados han sido muy buenos a pesar de la presencia de elementos discordantes con la uniformidad de la enseñanza nacional.

Al: Carp. Esc. de agr. Orig. mec.

V. CD, n. XII

24.

\section{Marzo 7 Panamá}

Carta de Eusebio Morales al jefe de la circunscripción, enviándole dos comunicaciones para que haga averiguaciones referentes al caso, y adopte las medidas más pacíficas y benévolas para ganar la buena voluntad del cacique Charles Róbinson así como la del cacique Coman, y le diga a quién se le dará de alta como policía.

Al: Orig. mec.

\section{5.}

\section{Mayo 18 Panamá}

Carta del Sr. Morales, de la Secretaría de Gobierno y Justicia, al corregidor de Puerto Obaldía por la que le autoriza para que pueda destinar al agente Arturo R. Pérez a desempeñar las funciones de maestro de escuela de esa población, siempre que los vecinos se comprometan a pagar el local en que funciona la escuela.

Al: Orig. mec.

1918 Mayo 27 Panamá

Informe del secretario de Gobierno y Justicia, Eusebio A. 
Morales, al jefe de la circunscripción de San Blas, en el que expone que después de varias conversaciones de Róbinson con el Presidente de la República y con él, ha resuelto que en lo sucesivo se consideran como reserva, perteneciente exclusivamente a los indígenas de San Blas, todas las tierras comprendidas desde la Quebrada de la Concepción en la costa próxima a Sta. Isabel hasta el río Anachucuna, a pocas millas de Puerto Obaldía.

AELI: Carp. Biog. Cop. mec.

\section{7.}

\section{Diciembre 31 El Porvenir}

Carta del intendente a los Sres. Denis y Pérez, de Río Diablo, hablando de las buenas relaciones que se deben mantener con Róbinson para llegar a la civilización.

ARPK: Carp. 89. Cop. mec.

28.

\section{Enero 4 El Porvenir}

Carta del Sr. Vaglio a la Srta. Ana Coope, pidiéndole un informe bastante circunstanciado acerca de las labores escolares realizadas en el año transcurrido.

Al: Cop. mec.

\section{9 (Enero) 5 El Porvenir}

Notificación del intendente Vaglio, al jefe del destacamento de Narganá, en la que le expone nueve puntos que debe hacer cumplir para que siga a buen fin la obra emprendida por el Poder Nacional. El quinto trata de las escuelas públicas y multas por no asistencias. El sexto se refiere a los adornos de las mujeres y niñas. $Y$ el octavo pide que las 
misioneras cumplan con lo establecido en el convenio, ya se las a pasado un nota para que sepan a que se deben atener.

ARPK: Carp. 68 cop. mec.

30.

\section{Enero 29 El Porvenir}

Carta del intendente Vaglio al secretario de Gobierno y Justicia, comentándole los problemas de las banderas; y que han hablado con los indios de los adelantos económicos e intelectuales en la isla de Chucumbalí. El cacique ha prometido enviar a su hijo a estudiar a Panamá.

ARPK: Carp. 88. Cop. mec.

\section{1.}

1919 Febrero $16 \quad$ El Porvenir

Informe de Vaglio a Belisario Porras, comentando los sucesos que ocurrieron en Narganá, y entre otras cosas informa que la policía existente en ese pueblo venía causando diferentes problemas que fueron atrasando la enseñanza a los indígenas escolares.

ABP: Tom. XVIII. Car. 1918-1920. Orig. mec.

\section{2.}

\section{Marzo 21 Panamá}

Carta de Belisario Porras al secretario de Gobierno y Justicia, en la que le ruega que dicte un decreto nombrando agente colonial en la circunscripción de San Blas a Pablo E. Baza.

ANP: Tom. B. P. Año 1918-1920. Orig. mec. 
33.

\section{Marzo 31 Panamá}

Carta de Belisario Porras al secretario de Gobierno, comunicándole el nombramiento del corregidor de Puerto Obaldía, y en la que le pregunta si cree que sería mejor nombrarle subteniente de la policía colonial.

ANP: Tom. B. P. año 1918-1920. Orig. mec.

V. CD, n. XIII

34.

\section{Marzo $31 \quad$ Panamá}

Carta de Vaglio a Belisario Porras, en la que denuncia la rebeldía de Róbinson unido a la misionera Coope, que alienta una autoridad hostil hacia el Gobierno y compromete a Róbinson por no aceptar la jurisdicción panameña. Considera conveniente suspender la construcción de la casa de Coope.

ABP: Tomo XVIII. Orig. mec.

\section{5.}

1919 Abril 1 Panamá

Carta de Belisario Porras al secretario de Gobierno, diciéndole que entre los empleados administrativos no aparecen los instructores civiles que serían necesarios en la policía para desterrar la ignorancia.

ANP: Tom. B. P. año 1918-1920.Orig. mec.

V. CD, n. XIV 
Carta de Belisario Porras a Vaglio, informándole que tiene noticias de que en Narganá hay un edificio destinado para Iglesia Católica, concedido por D. Enrique Hurtado a la misionera evangelista.

ABP: Tomo XVIII. Cop. mec.

\section{7.}

\section{Abril 5 Panamá}

Carta de Belisario Porras a Ana Coope, comunicándole la negativa para establecerse en la isla de Narganá y le comenta que siempre la había escuchado en su labor como misionera, pero que ahora Róbinson se ha mostrado contrario al Gobierno.

ABP: Tomo XVIII. Orig. mec. Ing.

\section{8.}

\section{Abril 10 El Porvenir}

Carta del intendente al secretario de Gobierno, en la que le anuncia que la elección de sahilas será anual y la efectuarán él y Colman. Comenta la prohibición de licores, el modo de construcción de las casas y el perjuicio de los guines, las demarcaciones y necesidad de algún indio que lea. Pide una escuela para Ailigandí y otra en Cartí; y que Colman sigue en su oposición a la educación.

ARPK: Carp. 68. Cop. mec.

$$
\text { V. } C D, \text { n. XV }
$$

\section{Abril 23 Panamá}

Carta de Belisario Porras, comentando la reducción de presupuesto público que afectará lamentablemente a la Instrucción, y aclara que la educación ha sido una de sus preocupaciones. Comenta el 
plan de educación elaborado por él en su anterior legislatura y que un profesor impartirá clases por la mañana y por la tarde. Apoya la coeducación y pide la colaboración de los maestros.

ANP: Carp. Cor. B.P. 1918. Orig. mec.

V. CD, n. XVI

40.

1919 Abril 29 Panamá

Carta de Belisario Porras a Vaglio, en la que entre otras cosas le ordena construir las escuelas de Ailigandí y Cartí, y llevar adelante, aunque sea a la fuerza, la acción civilizadora del Gobierno.

ABP: Tomo XVIII. Orig. mec.

41.

\section{Mayo 9 Narganá}

Carta del jefe del destacamento, R. Garrido, al intendente comunicándole que el Presidente de la República ha enviado una carta a la maestra de Narganá y $C$. de Jesús felicitándoles por los servicios que prestan al país y a la obra civilizadora, y le pide que consigan el máximo adelanto en la civilización, y que las muchachas no usen nariguera ni guines. Le informa que hicieron una conferencia para tratar esto. $Y$ que Iglesias y Róbinson les apoyan, y los niños asisten a la escuela desde primera hora.

Al: Orig. ms.

42.

\section{Mayo 10 Panamá}

Carta del secretario de Instrucción Pública Duncan al intendente Vaglio, en la que le habla de las 15 becas del art.1756 del código administrativo y le dice que las becas puestas en concurso ahora 
corresponden a las del parágrafo 6 del art. 148 del extinguido código de Instrucción Pública. Y comenta que las primeras hace mucho que no se adjudican, pero que si es posible adjudicarlas se comunicará.

Al: Orig. mec.

43.

\section{Mayo 13 Panamá}

Carta de R.J.Alfaro al intendente, diciéndole que le envía un oficio para el general Colman y una autorización para la edificación de las escuelas referidas por él.

Al: Orig. mec.

V. CD, n. XVII

44.

\section{Mayo 13 Panamá}

Carta del secretario de Gobierno y Justicia, autorizando al intendente la construcción de las escuelas que crea conveniente, así como las de Cartí y Ailigandí.

ARPK: Carp. 68. Cop. mec.

45.

\section{Mayo 20 El Porvenir}

Carta de Vaglio al secretario de Gobierno y Justicia, anunciándole que ha recibido su notificación en la que le autoriza para usar su personal en reparar los planteles de educación de Narganá,Corazón de Jesús,Playón Chico y Tupile; y así como para construir las escuelas públicas de Ailigandí, Cartí y cualquier otra que crea conveniente.

Al: Cop. mec. 
46.

\section{Mayo 21 El Porvenir}

Carta del intendente al secretario de Gobierno, hablándole de la necesidad de marcar las rutas del mar. Le comenta que se ven izadas las banderas colombianas, y que las escuelas funcionan bien y se ven los adelantos. Dice que Ailigandí(cuyo jefe es Colman) se ve sucio y los niños salvajizados. Habla de la escuela de Portogandí cuyo maestro está sin sueldo.

ARPK: Carp. 68. Cop. mec.

V. CD, n. XVIII

47.

\section{Mayo 21 El Porvenir}

Memoria de la Intendencia en la que comenta que los padres de familia de Puturgandí Ustupu, mandaron informe del funcionamiento de la escuela y labor del maestro Juan Pérez que fue nombrado con sueldo de 10 balboas.

AELI: Carp. Nom. pol. col. Cop. mec.

48.

\section{Mayo 23 Narganá}

Carta de R.Garrido al intendente, pidiéndole que dicte un decreto prohibiendo a los orfebres hacer alzamuros, pues si no será difícil llevar a cabo los deseos del Presidente. Le informa de que éstos les venden cobre y otros metales por oro.

Al: Orig. ms. 
Carta del secretario de Gobierno y Justicia al intendente, criticando la orden de éste de romper las tradiciones de guines y narigueras. Dice que el gobierno quiere atraerlos por medios pacíficos y pide que revoque la orden.

ARPK: Carp. 68. Cop. mec.

V. CD, n. XIX

50.

\section{Junio 2 Narganá}

Carta de Ana M. de James al intendente, informándole de lo que pasa en las escuelas de indígenas y el convenio celebrado entre el intendente y la misionera bíblica el $1^{\circ}$ de Abril del mismo año. Comenta que las dos primeras cláusulas no las cumple, que levanta entre los indios una atmósfera contra las escuelas oficiales. Dice que han conseguido durante el mes de Mayo el que asistan las niñas sin argolla, pero que este mes empieza de nuevo la lucha debido a que dicha misionera dice a las niñas que las recibe en su escuela con la argolla; y con este argumento deshace la obra de civilización que el gobierno se propone.

Al: Orig. ms.

\section{1.}

\section{Junio 4 El Porvenir}

Carta del intendente al secretario de Gobierno y Justicia, en la que habla de la autorización que dio el Presidente de la República para ir quitando los guines. Y habla de la oposición de Colman a las escuelas y de la labor educativa de estas en los pueblos que las tienen. Finaliza diciendo que algunos sahilas prefieren la ignorancia en sus súbditos para que estén tranquilos, e incluye a Róbinson entre estos.

ARPK: Carp. 68. Cop. mec. 


\section{Junio 11 El Porvenir}

Carta del intendente al secretario de Gobierno y Justicia, comentándole la conversación con Colman sobre las prohibiciones, y que éste acepta la creación de escuelas en Cartí y Ailigandí pero sigue creyendo que son la consecuencia de los males de la comarca. Culpa el intendente a Róbinson de los males, y habla de las dificultades creadas por las misioneras protestantes, a las cuales se debería sacar de allí. Comenta la visita que le hizo Róbinson y transcribe una carta de Colman.

ARPK: Carp. 68. Cop. mec.

53.

1919 Junio 12 El Porvenir

Carta de Vaglio a Belisario Porras, expresándole que en la última conferencia que ha tenido con el sahilas Colman le dio el consentimiento para la construcción de las escuelas de Ailigandí y Cartí.

ABP: Tomo XVIII. Orig. mec.

54.

1919 Junio 14 El Porvenir

Carta de Vaglio a Belisario Porras, en la que le comenta que Juan Sánchez ha trabajado sin sueldo y que la maestra de Playón Chico lo solicita para su vigilancia.

ABP: Tomo XVIII. Orig. mec. 
Carta del secretario de Gobierno y Justicia al jefe de la circunscripción de San Blas, en la que se retracta de la orden anterior que anulaba el mandato de quitar los guines.

ARPK: Carp. 68. Cop. mec.

V. $C D, n . X X$

56.

\section{Junio 29 Corazón de Jesús}

Carta de Julio Carles al intendente, hablando del ataque contra la policía organizado por Róbinson; y el comentario hecho de que desde mañana no mandarán a sus hijos a las escuelas del gobierno, que ellos quieren la escuela protestante.

Al: Orig. ms.

\section{7.}

\section{Junio 29 Narganá}

Carta de Ana M. de James al intendente, diciéndole que espera que acoja de buen agrado su idea y que su resolución sea favorable a la civilización en esa región donde el deber les ha puesto como verdaderos héroes de la civilización y la conquista. Pues después del levantamiento que hubo en ese día y de la orden dada para que se pongan todas las niñas otro vez las argollas, algunas se han mantenido sin ellas, porque sus padres son amantes de la instrucción. Sugiere que ordena a la misión que no reciba a esas niñas que se han mantenido sin las argollas. Concluye comentando que teme que en cualquier momento la maten, pues la tienen amenazada.

Al: Orig. ms. 
Carta de G. Denis, policía colonial, al intendente donde le informa del levantamiento dirigido por Róbinson que está dispuesto a atacar al gobierno si mandaba aquí un piquete de policías. Le informa de la decisión tomada, que desde mañana no asistirán más los niños y niñas a las escuelas oficiales y que dieron orden de ponerlas las argollas otra vez, y dijeron que no querían más la escuela del gobierno.

Al: Orig. ms.

59.

\section{Junio 29 Narganá}

Carta para la misionera bíblica, en la que se le pide que no reciba a la niñas que se ha logrado después de mes y medio que asistan a la escuela oficial. Pues ella las recibe con la argolla, dado su fanatismo, en la escuela dominical. Se queja la que suscribe de las amenazas recibidas, pero considera que su muerte será un martirio.

Al: Orig. ms.

60.

\section{Julio 1 Playón Chico}

Carta de Benito Guilli, que escribe en nombre del sahila Olopanique, al Presidente de la República comentando que el pueblo está muy animado con la escuela, pero que los padres de familia se disgustan por querer suprimirles sus costumbres, tales como el uso de las cuentas y de alzamuros. Dice que cree que eso en lugar de atraer, distanciará; pues han dispuesto no mandar a sus hijos a la escuela y que después de que las niñas están civilizadas ellas mismas sin que las obliguen cambiarán de costumbre.

Al: Orig. ms. 
61.

\section{Julio 5 El Porvenir}

Carta de H. Vaglio a Anna Coope, comunicándole que tienen prohibido las indias educadas, mayores y menores que no estén casadas, el uso de las argollas en las narices y los guines en las extremidades superiores e inferiores. Le comenta que espera haga efectiva esta orden de modo eficaz e inofensivo previniéndoles si quiere con el argumento de que serán rechazados de la escuela bíblica a su mando dado el caso de que se opongan o se nieguen a abandonar esta costumbre salvaje.

Al: Cop. mec.

62.

1919 Julio 15 El Porvenir

Carta de Vaglio al Sr. Pérez de Portogandí, comunicándole que por decreto ํㅜ 4 del $1^{\circ}$ del presente mes se le nombró agente de policía indígena con atribuciones de maestro en la escuela de Portogandí.

Al: Cop. mec.

63.

\section{Julio 27 Narganá}

Carta de Ramón Garrido al jefe de la circunscripción, en la que le comunica que Inatoiquiña le dijo que Colman estuvo recolectando dinero para conseguir un abogado que les defienda y les permita tener sus usos, tradiciones, y finalizó hablándoles en contra de las escuelas.

Al: Orig. ms. inc.
V. CD, n. XXI 
64.

1919 Julio Narganá

Carta de Anna Coope al intendente Vaglio, pidiéndole autorización para enseñar a los niños en los tiempos que no asistan a la escuela nacional.

ARPK: Carp. 212 Cop. mec.

\section{5.}

\section{Agosto 21 El Porvenir}

Carta de Humberto Vaglio a Miss Anna Coope, donde acusa recibo de su carta de Julio contestando que no puede permitir lo que solicita sobre su proyecto nuevo de enseñanza. Argumenta que el Gobierno quiere ser autónomo en el ramo de la enseñanza, o mejor dicho, quiere que los niños y niñas no asistan a otro plantel de enseñanza que no sea la escuela pública.

Al: Orig. ms.

66.

\section{Septiembre 2 Narganá}

Carta de R. Garrido al intendente, comunicándole que el 27 del mes pasado llegó el Presbítero Bernardo González, Jesuita, con recomendación del Presidente. Cuenta que Anna Coope dijo a los niños y familia que no asistieran a sus prédicas que ese era tan malo como el diablo. Róbinson también les dijo que no asistieran que ellos eran protestantes. A pesar de todo se impartieron sacramentos. Ese día entierran a la misionera Evans Sepin Coope .

Al: Orig. ms. 
Carta de Jacinta Aguilar al intendente, en la que le comenta el desorden de la escuela pues han sido retirados 17 niños por convencer Colman a sus padres con el argumento de que se van a acabar las escuelas, y alguno no asiste porque los indios le dicen que ya está grande para asistir a la escuela. Pero relata que la causa es que ha sido nombrado policía por Colman y a otro se le prohibió ir a Colón pues se acercaban los exámenes y se fue. Pide que se dicte alguna orden.

Al: Orig. ms.

\section{8.}

\section{Septiembre 5 El Porvenir}

Carta de Humberto Vaglio a la Sra. Jacinta Aguilar, diciéndole que realizará una visita y hará que los padres que han retirado a sus hijos de la escuela vuelvan a mandarlos.

Al: Cop. mec.

\section{9.}

\section{Septiembre 6 Tupile}

Carta de Jacinta Aguilar al intendente, diciéndole que varios indios han separado a sus hijos de la escuela pues Colman les ha dicho que se va a acabar.Y que a tres niños de los ausentes él les ha dado el puesto de policías. Pide que el gobernador tome medidas.

Al: Orig. ms.

\section{0.}

\section{Septiembre 8 Panamá}

Carta de Belisario Porras a R. J. Alfaro, comentándole que las maestras que prestan servicio en $\mathrm{S}$. Blas informan que las casas donde funcionan las escuelas están muy deterioradas y es preciso 
repararlas. Expone que como la comarca pertenece directamente a la Secretaría de Gobierno y Justicia, que tome la decisión de la recuperación junto con el Sr Duncan.

ANP: Tom. B. P. año 1918-1920. Orig. mec.

V. $C D$, n. XXII

\section{1.}

\section{Septiembre 9 Panamá}

Carta a Belisario Porras, comunicando que en la mayor brevedad se ordenará las reparaciones de las casas donde funcionan las escuelas de S. Blas.

ANP: Tom. B. P. año 1918-1920. Cop. mec.

V. CD, n. XXIII

72.

\section{Septiembre 16 Panamá}

Carta de Belisario Porras a Ricardo J. Alfaro, comunicándole que le envía las bases de un decreto que concede la propiedad colectiva de las tierras de $\mathrm{S}$. Blas a los indígenas y afirma que es partidario de tal medida.

ANP: Tom. B. P. Año 1918-1920. Orig. mec.

V. CD, n. XXIV

1919 Septiembre 17 Puerto Obaldía

Carta de Juan Cerezo al corregidor de Puerto Obaldía, diciendo que la asistencia escolar es obligatoria para los padres de familia que son remisos a enviar a sus hijos a la escuela, adjunta la lista de 
padres e hijos para que, como autoridad, les haga comparecer a la escuela. Argumenta que la tolerancia resultaría en perjuicio de la Instrucción Pública.

Al: Orig. ms.

\section{4.}

\section{Octubre $31 \quad$ Tupile}

Carta de Jacinta Aguilar al intendente de la circunscripción de S. Blas, donde le informa que la asistencia a la escuela ascendió a 63.

Al: Orig. ms.

\section{Noviembre 4 El Porvenir}

Carta de Humberto Vaglio al jefe del almacén del Gobierno, pidiendo 14 banderas para poner en los pueblos sometidos buenamente al Gobierno.

Al: Cop. mec.

76.

1919 Noviembre 7 El Porvenir

Carta de Humberto Vaglio al Presidente de la República, Belisario Porras,en la que comenta el problema de la pesca de la tortuga y cree conveniente dar permiso a los costeños de Sta. Isabel pues cree que ayudaría a la civilización.

ANP: Tom. B. P. Año 1918-1920. Orig. mec.

V. CD, n. XXV 
Carta de H. Vaglio al sahila Olopanique de Playón Chico, pidiéndole que quiten los chiqueros de la orilla de la playa para mayor salubridad y para obtener el saneamiento indispensable de la escuela de allí.

Al: Cop. mec.

\section{8.}

\section{Noviembre $11 \quad$ Narganá}

Carta de Ramón Garrido al intendente, comunicándole que envió a un súbdito a detener a un indio de Ticantiquí que enterró a su nieto y que este policía fue atacado. Le pide que vaya con refuerzos.

Al: Orig. ms.

79.

\section{Noviembre 12 Panamá}

Carta de Belisario Porras a Ricardo J. Alfaro, comentándole que debe dar permiso a los de Santa Isabel para la pesca de la tortuga en la comarca de San Blas.

ANP: Tom. B. P. Año 1918-1920. Orig. mec.

$$
\text { V. } C D, \text { n. XXVI }
$$

\section{0.}

\section{Noviembre 23 Panamá}

Carta de Belisario Porras a Ricardo J. Alfaro, comentándole que el intendente se niega a hacer cumplir la orden que permite a los de Santa Isabel pescar tortuga en Santa Isabel. Pide que se recojan las armas de fuego y la dinamita de los indígenas.

ANP: Tom. B. P. Año 1918-1920. Orig. mec.

$$
\text { V. CD, n. XXVII }
$$


81.

\section{Noviembre 25 El Porvenir}

Carta del jefe de la circunscripción al general Inapaquiña de Sasardí, en la que le acusa de incitar a los indios a estar contra las escuelas, y le pide que los indios no asistan a los congresos por ser analfabetos.

ARPK: Carp.113. Cop. mec.

82.

\section{Noviembre 29 El Porvenir}

Circular del intendente Vaglio a las maestras de las escuelas de Narganá, Corazón de Jesús, Playón Chico y Tupile pidiéndoles que le envíen inventario de las escuelas y relación de las enseñanzas, asistencias y marcha de las mismas.

Al: Cop. mec.

83.

1919 Diciembre 10 El Porvenir

Carta de Belisario Porras a Ricardo J. Alfaro, en la que le comenta la insistencia del intendente para que nombre el jefe del destacamento de Narganá, lugar donde se inician los disturbios, que son fomentados por Miss Coope.

ANP: Tom. B. P. Año 1918-1920. Orig. mec.

V. CD, n. XXVIII

84.

1919 Diciembre 12 Panamá

Carta de Belisario Porras a Ricardo J. Alfaro, en la que le dice que el candidato de policía del destacamento de Narganá debe ser bien 
conocido y reconocida su valía para el cargo.

ANP: Tom. B. P. Año 1918-1920. Orig. mec.

V. CD, n. XXIX

85.

1919 Diciembre 16 Panamá

Carta de Belisario Porras a Ricardo J. Alfaro, comunicándole la existencia de una peste desconocida que está atacando a los habitantes de Portogandí y ruega que se envíe un médico. Habla también de unos hombres que padecen locura y los indígenas quieren matarlos. Concluye pidiendo que el superávit del gobierno tenga alguna repercusión en San Blas.

ANP: Tom. B. P. Año 1918-1920. Orig. mec.

V. $C D$, n. $X X X$

86.

1919 Diciembre 28 Panamá

Carta de Belisario Porras a Ricardo J. Alfaro, en la que le comunica las quejas presentadas por el intendente con respecto a ciertos joyeros que llegan a las costas y sirven de secretarios a los sahilas aprovechando para infundir sentimientos de rebeldía. Pide que estos sean expulsados.

ANP: Tom. B. P. Año 1918-1920. Orig. mec.

V. $C D$, n. $X X X I$

87.

1920 Enero 12 El Porvenir

Carta del intendente Vaglio a la maestra de Tupile, pidiéndole que le envíe la fecha de exámenes para asistir a ellos. Le ruega que se ponga de acuerdo con las maestras de Narganá, Corazón de Jesús y 
Playón Chico.

Al: Cop. mec.

88.

\section{Enero 21 Corazón de Jesús}

Carta de Garrido a las maestras, señalándoles las fechas de los exámenes finales según el decreto del presente mes, que determina los días 9 y 10 del próximo para tal fin.

Al: Orig. ms.

89.

\section{Enero 21 Narganá}

Carta de Garrido al intendente, pidiéndole refuerzos de agentes policiales pues las maestras se quedan solas, para que así las resguarden.

Al: Orig. ms.

\section{0.}

\section{Enero 28 Tupile}

Carta del jefe del segundo destacamento al intendente, comunicándole que habló con el sahila sobre el cruce de la raza y este le manifestó que estaba de acuerdo y los otros indígenas también. Que según fueran llegando wagas se irían casando, y le preguntó que si algún policía quería casarse que qué le parecía y le contestó que no quería policías, porque ellos están a expensas del cheque y no trabajan, que quieren casar a las indígenas con gente que tenga bastante dinero.Concluye diciendo que hay que seguir luchando para que los indios pierdan su idea de seres superiores.

Al: Orig. mec. 


\section{1.}

\section{Febrero 4 Panamá}

Carta de Duncan al intendente, comunicándole que se ha presentado allí E. Purdy con el ministro de los Estados Unidos para exponer sus queja por las restricciones que la Intendencia les ha puesto en sus funciones de maestras misioneras. Quiere saber el motivo y las notificaciones que el jefe de policía le hizo.

\section{Al: Orig. mec.}

\section{2.}

\section{Febrero 4 Panamá}

Comunicación de la Sra. Purdy presentada al secretario de Instrucción Pública, y que éste remite al inspector de Nombre de Dios, en la que dice que después de seis años de trabajo tras su vuelta de vacaciones no la dejaron dar clase. $Y$ que antes de marchar el jefe de policía la dijo que no podría enseñar. Aduce que ella ha estado enseñando diariamente inglés, español, lectura, escritura, aritmética, ortografía , aritmética comercial e historia sagrada. Expone que la notificación recibida decía que solo podían enseñar durante dos horas al día y fuera del horario escolar y la mitad de este tiempo lo dedicarían al español. Informa también que hay tantos niños, que los maestros del gobierno solo pueden enseñar a cada escolar media hora. Que ella fue con el objeto de civilizar y cristianizar, y no quiere hacer nada contrario a las leyes de la República, pero que cree se la ha privado de los derechos que las leyes panameñas conceden a las maestras misioneras.

Al: Cop. mec.

\section{3.}

\section{Febrero 5 El Porvenir}

Carta del intendente Vaglio a la Srta. Ana, comentándole que ha 
recibido su carta refiriendo las labores del último semestre escolar, y le pide que no se canse de enseñar a sus discípulos en el idioma español. Le anima a seguir con su método de enseñanza y prédicas, comenta que la Biblia tiene una parte en español, la cual debe usar ella para preparar sus clases y que progresen los educandos en el idioma oficial.

Al: Cop. mec.

94.

1920 Febrero 15 Tupile

Carta de Isidro Juncan al intendente, comentándole los exámenes finales presididos por la autoridad del lugar. Dice que ha notado mucho atraso en los niños y niñas y que cree que es por falta de método. Se queja del mal trato de la profesora hacia los alumnos, considerándola ineficaz para este lugar. Se refiere a los exámenes de Playón Chico que tuvieron un resultado regular, notándose la labor de la maestra en todos los sentidos.

Al: Orig. mec.

\section{5.}

\section{Febrero 23 Nombre de Dios}

Carta del inspector Pedro Campos al intendente, pidiéndole que le envíe los datos que le motivaron a tomar la actitud dicha con las misioneras para remitírselos al secretario de Instrucción Pública.

Al: Orig. mec. 
Carta de Juncan al Sr. intendente, comunicándole que el sahila Inatoiquiña en su paso por Suitupu, fue acusado de traidor por quitar las argollas y admitir policías.

Al: Orig. ms.

\section{7.}

\section{Marzo 4 El Porvenir}

Informe del intendente al secretario de Instrucción Pública, en el que dice que los jefes de los destacamentos le han referido los exámenes de las escuelas, y que los de Narganá, Corazón de Jesús y Playón Chico han sido satisfactorios. Pero los de Tupile no tuvieron el resultado deseado dada la poca experiencia y práctica pedagógica de la Srta. Jacinta Aguilar y su carácter duro con los alumnos. La labor es meritoria y no han tenido otra vigilancia que la de la Intendencia. El inspector Campos solo fue al principio una vez y sin avisar a la Intendencia, siendo mal recibido por los indios pues solo reconocen la autoridad de la Intendencia. Pide que si no se nombra un inspector local que se pueda trasladar hasta Puerto Obaldía. Ruega así mismo que se aumente el sueldo de los maestros ya que la vida es cara, y se reglamente la petición de materiales. Concluye diciendo que el material de las escuelas se debe obtener de Instrucción Pública.

Al: Cop. mec.

98.

\section{Marzo 9 Panamá}

Carta de Duncan al intendente, avisándole que le envía copia de la comunicación que le remitió a la Srta. Purdy diciéndole que no se puede alterar el convenio celebrado, pues el Gobierno no puede permitir que los indígenas dejen de aprender el castellano, cosa que ocurriría si asistieran a sus clases en las horas de la escuela oficial.

Al: Orig. mec 


\section{Marzo 27 El Porvenir}

Carta del intendente al secretario de Instrucción Pública, en la que le comunica que se están concluyendo las reparaciones de la escuela mixta de Puerto Obaldía; y le pide el equipo para que empiece a funcionar. Así mismo había solicitado 40 bancas para Narganá, Tupile, Corazón de Jesús y Playón Chico.

Al: Cop. mec.

\section{0.}

\section{Marzo 27 El Porvenir}

Carta del intendente Vaglio al secretario de Instrucción Pública, comentando que por insinuación suya el tercer Designado tuvo a bien dictar el Dto. 28 del 21 de Febrero que organiza la circunscripción de San Blas en la que se crea una escuela en El Porvenir de carácter profesional: un taller de mecánica y otro de carpintería, por la mañana serían las clases técnicas y por la tarde las prácticas. Serviría de taller de reparación para los barcos. Concluye solicitando materiales para empezar a funcionar.

Al: Cop. mec.

\section{1.}

\section{Marzo 28 El Porvenir}

Orden de petición de material necesitado para la escuela profesional del Porvenir, pedido por el intendente.

Al: Orig. mec. 
Acta de la reunión de los indios con Inatoiquiña, a la que llaman al jefe del destacamento para que presencie la misma en la escuela. El agente Denis asiste como intérprete y el sahila comenta que tiene noticias de que vuelve la maestra Jacinta Aguilar y dado su mal trato y ejemplo público muchos han resuelto enviar sus hijos fuera. Por esto desea que les envíen otra maestra.

Al: Cop. mec.

103.

1920 Mayo 1 Tupile

Carta del Sr. Junca al intendente, comunicándole que fue invitado por el sahila a una reunión donde los asistentes expresaron la disconformidad por la posible venida de la maestra Jacinta. Le recuerda que el pueblo de Tupile es uno de los más sufridos y adictos a la civilización, por lo que se debe tener en cuenta su protesta. Adjunta el acta de protesta firmada por el jefe indígena.

Al: Orig. ms

\section{4.}

\section{Mayo 6 El Porvenir}

Carta del intendente al secretario de Gobierno, comentándole la carta recibida y transcribiendo el acta que manifiesta los deseos de Inatoiquiña y sus paisanos de que no les envíen a la maestra J. Aguilar, pues el curso pasado tuvo mal comportamiento. Por esto le remite dicha acta para que obre oportunamente.

Al: Cop. mec.

\section{5.}

\section{Mayo 6 El Porvenir}

Carta del intendente al secretario de Instrucción Pública, en 
la que le informa de la reunión de los habitantes de Tupile que expresaron el deseo de que no les envíen a la maestra Aguilar, pues no vale para enseñar a los indios,

él ya lo expresó así en febrero. Han oído rumores de que vuelve para Tupile.

Al: Cop. mec.

\section{6.}

\section{Mayo 6 Panamá}

Carta de Duncan al intendente, notificándole que los indios han sido internados interinamente en la escuela de Artes y Oficios. Y que él ha pedido ayuda económica al secretario de Gobierno y Justicia. Ruega que sus padres también ayuden, pues ha sido informado que son de familias acomodadas.

Al: Orig. mec.

\section{7.}

\section{Mayo 7 Panamá}

Carta de Duncan a Humberto Vaglio, avisándole que recibió la nota de petición de material para la escuela de Puerto Obaldía. Comenta que ninguna maestra quiere ir a servir allí, y que si alguna acepta se enviará el equipo.

Al: Orig. mec.

\section{8.}

\section{Mayo 13 El Porvenir}

Carta del intendente a Duncan, anunciándole que hará las gestiones para que los padres de los alumnos cooperen en los gastos de vestuario y demás necesidades.

Al: Cop. mec. 
109.

\section{Mayo 23 Tupile}

Carta de Isidro Junca al intendente, anunciándole que Colman mandó razón a sus adictos para que admitan escuelas y todo lo que la policía quiera, que cuando saliera del cautiverio iría a Panamá a arreglarlo todo. Dice que no quiere hacer sino la voluntad del Gobierno y que pidió a Gobierno y Justicia que capturen a José de la Rosa y le quiten el dinero para devolvérselos a sus indios.

Al: Orig. ms

\section{0.}

\section{Mayo 23 Tupile}

Carta de la maestra Jacinta de Acosta al intendente, comentándole que ha tenido total oposición de parte de los indios en las tareas escolares y que tampoco le recibieron con cariño. Empezó el día 20 con treinta y un niños de asistencia, once varones y veinte niñas entre ellas la hija del sahila; y que han ido aumentando hasta llegar a cincuenta y cuatro. Dice que el sahila a mostrado interés.

Al: Orig. ms.

\section{1.}

\section{Mayo 24 Tupile}

Carta de Isidro Junca dirigida al Teniente de policía colonial, manifestándole que la maestra de ese lugar le pidió apoyo y envió a un agente a verse con el sahila y preguntar a Olopanique por qué se resistía a enviar a sus hijos a la escuela. El jefe había reunido a su gente pidiendo que se hicieran menos chichas y que manden a sus hijos a la escuela, pero se manifestó un grupo contrario a las indicaciones del sahila.

Al: Orig. ms. 


\section{2.}

\section{Mayo $28 \quad$ El Porvenir}

Carta del encargado del despacho a la Sra. Jacinta Acosta, comunicando que recibió su carta y que hace votos para que la sigan mostrando aprecio, pues esto facilita el aumento de matrículas y la civilización, que es el deseo de la autoridad.

Al: Cop. mec.

\section{3.}

\section{Junio 9 Panamá}

Carta del subsecretario de Instrucción Pública, José Crespo, al intendente, comunicándole que el material que solicitó para el taller de mecánica y carpintería de El Porvenir no le corresponde a ese departamento el proporcionarlo, sino al de Gobierno y Justicia.

Al: Orig. mec.

114.

\section{Junio 10 El Porvenir}

Carta del intendente a la Srta. Ana Coope, exponiéndole que el jefe del destacamento se queja de que no le entiendo las notificaciones que le ha hecho varias veces con respecto a los nombres ingleses que pone y que dificultan la labor del registro. Se queja de los problemas que crean al tramitar los papeles. Comenta que la civilización no es enseñar idiomas y costumbres extranjeros y la remite al convenio firmado en la Intendencia.

Al: Cop. mec. 
Carta de J. Crespo al intendente, comunicándole que recibió su notificación en la que le dice que reunidos los vecinos de Tupile el 30 de abril expresaron el deseo de remplazar a la maestra Jacinta Aguilar. Comenta que es difícil conseguir maestra para Narganá pero que intentará complacer en lo posible a los habitantes de esa región.

Al: Orig. mec.

\section{6.}

\section{Junio Armila}

Informe del primer semestre de este año del corregimiento de Armila, en el que trata el tema de la educación y expone que los edificios escolares están en mal estado, y que los padres preguntan por la oferta de la escuela. Comenta que el número de niños aumenta cada día y que por falta de local de instrucción muchos se dedican a la vagancia.

Al: Cop. mec.

\section{7.}

\section{Julio 8 Narganá}

Carta de Garrido al intendente, quejándose que la misionera Coope no atiende a las indicaciones que se le hacen, pues se le ha dicho que al Gobierno no le agrada que ponga nombres ingleses a los indígenas, pero lo sigue haciendo en perjuicio de la buena marcha del registro civil.

Al: Orig. ms.

\section{8.}

\section{Julio 16 El Porvenir}

Carta del intendente al secretario de Gobierno y Justicia, en la cual le comenta que Inatoiquiña le ha preguntado que cuándo cambian 
la maestra, y le ha respondido que no es posible por el momento, pero que cuando sea factible se hará, y esto parece que le ha dejado conforme.

Al: Cop. mec.

\section{9.}

\section{Agosto 25 Tupile}

Carta del jefe del segundo destacamento, Ezequiel, al intendente, para informarle que ha llegado a su conocimiento que en Playón Chico hicieron chicha fuerte y que algún niño de la escuela asistió a ella. Comenta que la maestra cumple con sus deberes y la asistencia a la escuela es casi completa.

Al: Orig. ms.

\section{0.}

\section{Septiembre 12 Tupile}

Carta del encargado, Ezequiel Pérez, al Sr. Isidro Junca de El Porvenir, comentando que los seguidores de Colman estuvieron allí tomando ron y que éste les dice que usen las argollas, pues ellos ganaron y deben oponerse a la policía. Reseña que ha puesto sahila en varias islas y esta actitud ha disminuido la asistencia a las escuelas.

Al: Orig. ms.

\section{1.}

\section{Septiembre 15 El Porvenir}

Carta del teniente del despacho a Isidro Duncan de Tupile, comunicándole que ha tenido noticias de que varias islas están afectadas de trancazo por lo que pide que se suspendan las clases hasta que se envíen medicinas que lo remedien.

Al: Cop. mec. 


\section{2.}

\section{Septiembre 18 Tupile}

Carta del jefe del segundo destacamento al teniente de policía colonial de El Porvenir, en la que le manifiesta que Colman se ha envalentonado por su triunfo con el intendente y están celebrando chichas, y piensan atacar a los policías. Comenta que han llegado rumores de Playón Chico que dicen que no van a mandar a sus hijos a la escuela, y que ellos van a hacer lo mismo.

Al: Orig. ms.

\section{3.}

\section{Septiembre 19 Tupile}

Carta del jefe del segundo destacamento al teniente de policía colonial de El Porvenir, pidiéndole algún escrito que le permita prohibir el uso de los alzamuros, pues él no tiene en que apoyar esta prohibición.

Al: Orig. ms.

\section{4.}

\section{Septiembre Playón Chico}

Carta del jefe del destacamento al teniente de la policía de El Porvenir, en la que transcribe el informe del subteniente que comenta la reunión que solicitó a Olopanique con los del pueblo para hablar buenamente del aseo de la población y de la eficacia de la Instrucción Pública en bien de la pequeña prole, y éste dio orden de atacar a la policía. Comenta los peligros que pasaron.

Al: Orig. ms.

\section{5.}

1920 Octubre 10 Playón Chico

Carta del subteniente destacado en esta isla, al teniente de El 
Porvenir, en la que le comunica que la tranquilidad y limpieza de esta población es buena, así como la asistencia de los alumnos a la escuela es casi completa.

Al: Orig. ms.

126.

\section{Octubre 28 Isla de Gallina}

Carta de Inapaquiña a Belisario Porras, diciéndole que en lo referente a la pregunta de la escuela, que él no quiere pues están bien como están, y los demás jefes tampoco quieren, que habló con los de Mandinga, Cartí, Río Sidra, Playón Grande, Río Banana y Ailigandí y expresaron su molestia con Colman que es de Cartí. Los de Carreto, Pino y Caledonia lo único que quieren son sus tierras y vivir en paz.

Al: Orig. ms.

\section{7.}

\section{Noviembre 20 El Porvenir}

Carta del teniente jefe Linares al secretario de Gobierno y Justicia, pidiendo que se separe de su cargo al agente Ramón Ramos que ha presentado mala conducta y que trasladado a Tupile tuvo un problema con la maestra y la ha ultrajado y calumniado delante de los indios.

Al: Cop. mec.

\section{8.}

\section{Noviembre 23 El Porvenir}

Carta del teniente Arturo Linares a Ezequiel, encargado del segundo destacamento en Tupile, recordándole que está prohibido introducir licores y celebrar chichas en esta jurisdicción. Comenta que Olopanique está de acuerdo en hacerlo cumplir.

Al: Cop. mec. 
129.

1920 Diciembre 4 Nombre de Dios

Carta del inspector P. Campos al intendente, en la que le comunica el envío de las ausencias de la escuela de Tupile en el mes de agosto para que las haga efectivas. Comenta que de estas multas tiene que dar parte a la Secretaría de Instrucción Pública.

Al: Orig. mec.

130.

1920 Diciembre 28 El Porvenir

Carta del teniente Linares a Ezequiel, del segundo destacamento de Tupile, avisándole que con cargo devolutivo le remite la planilla que representa las ausencias injustificadas de los niños de la escuela mixta de Tupile para que las haga efectivas de acuerdo al art. 1 de la ley 35 de 1919 y que remita las sumas colectadas.

Al: Cop. mec.

\section{1.}

\section{Isla de Gallina}

Carta de Inapaquiña al Dr. Alfaro, en la que comenta que el Presidente le propuso crear escuelas, pero le dijo que no quería, porque los indios no las desean y además el indio es para sembrar y no para leer.

ARPK: Carp. 89. Orig. ms.

V. CD, n. XXXII

132.

(1920) Panamá

Carta de Jenning Price, de la Legación de los Estados Unidos, al 
Secretario de Gobierno y Justicia en la que le comenta las quejas que le presentara la Srta. Coope por los malos tratos que reciben de parte de los representantes del Gobierno

ANP: Rel. Ext. Cop. mec.

\section{3.}

\section{Enero 20 Panamá}

Carta de Manuel Quintero al intendente, notificándole que se ha enterado de su nombramiento como intendente y confía en que sabrá llevar a buen término su labor, dada su experiencia; y le comenta las atribuciones que le confiere el cargo de intendente.

Al: Orig. mec.

v. CD, n. XXXIII

\section{4.}

\section{Febrero 14 Panamá}

Carta de Leo G. al intendente, comentando que la propuesta de destituir de policía colonial a Charles Róbinson la puede realizar él mismo, pero que del puesto de sahila tienen que ser los propios indios quien le destituyan.

Al: Orig. mec.

V. CD, n. XXXIV

\section{5.}

\section{Marzo 23 Tupile}

Carta del teniente Linares al Presidente Belisario, en la que le comunica que ha habido un nacimiento con júbilo, de india con waga policía y esto es prueba de una patente civilización.

ARPK: Carp. 115. Cop. mec.

$$
\text { v. CD, n. XXXV }
$$


136.

\section{Marzo $27 \quad$ Narganá}

Carta del Sr. Ramón, jefe del primer destacamento, al intendente, comunicándole que en el día de ayer procedió a la extirpación del uso de alzamuros y guines con la ayuda de Róbinson y otros indios que estaban de acuerdo en Narganá y Corazón de Jesús; que se hizo de modo apacible, lo que demuestra que están por la civilización. Le ruega que informe de ello al secretario de Gobierno y Justicia y al Presidente.

Al: Orig. ms.

\section{7.}

\section{Marzo 29 El Porvenir}

Carta de Mojica al Sr. Ramón Garrido, expresándole su felicitación por la medida tomada en la extinción de los usos indígenas y por llevarlo con feliz éxito. Le dice que su colaboración administrativa es eficaz, que no desfallezca.

Al: Cop. mec.

138.

\section{Marzo $31 \quad$ Narganá}

Carta del Sr. Garrido al intendente, en la que le envía las muestras de telas para acabar de vestir a las niñas de Narganá.

Al: Orig. mec.

\section{9.}

\section{Abril 11 El Porvenir}

Carta del intendente al secretario de Instrucción Pública, suplicándole que el personal que se designe para la circunscripción de 
San Blas sea personal serio que cumpla con sus obligaciones. También le sugiere que nombre un maestro varón para los grados superiores de Narganá.

Al: Cop. mec.

v. $C D$, n. $X X X V I$

\section{0.}

\section{Abril 11 El Porvenir}

Carta del intendente al secretario, en la que le informa a requerimiento suyo de la situación del matrimonio Garrido, y comenta que estos problemas son debidos a la rivalidad con la maestra Garrido, pero por su labor está en la lista pues basta con ver a las mujeres de Narganá y Corazón de Jesús.

Al: Cop. mec.
V. CD,
n. XXXVII

\section{1.}

\section{(1921) Abril 13 El Porvenir}

Carta del intendente al secretario de estado, pidiendo que se hagan las reparaciones de las escuelas antes de iniciarse el curso, pues de seguir así se llegarán a destruir. Comenta su interés por la instrucción pública donde más se ve la labor de civilización.

Al: Cop. mec.

V. CD, n. XXXVIII

\section{2.}

\section{Abril 13 El Porvenir}

Carta de Mojica al Presidente Belisario Porras, en el comienzo de curso en la que le pide cuatro becas para niños y dos para niñas (que serían las primeras). Estos becados harían luego su labor en la comunidad y comarca. 
ARPK: Carp. 142. Cop. mec.

V. CD, n. XXXIX

\section{3.}

\section{Abril 14 El Porvenir}

Carta del intendente a Ramón Garrido, anunciándole que no pudo comprar la tela que faltaba para los vestidos de las mujeres de Narganá y Corazón de Jesús. Y le autoriza a que lo compre con los fondos a su cargo para no perder tiempo, aunque cueste más.

Al: Cop. mec.

\section{4.}

\section{Abril 22 (Panamá)}

Orden General número 7 para lamentar la muerte de Claudio Iglesias y Agustín González, en la que se decretan nueve días de luto para todos los empleados públicos y la juventud de Narganá y Corazón de Jesús.

AELI: Cop. mec.

\section{5.}

\section{Abril 23 Panamá}

Carta de Belisario al intendente Mojica, en la que le comunica la imposibilidad de conceder las becas pedidas, que eran seis, pero le sugiere que envíe a los seis niños y que Gobierno y Justicia les pague lo indispensable y se haga cargo de ellos.

ARPK: Carp. 142. Orig. mec.

V. $C D$, n. $X L$

\section{6.}

\section{Abril 25 Panamá}

Carta de Jeptha Duncan al intendente, expresándole las gracias 
por el informe referente a los presuntos problemas del matrimonio Garrido.

Al: Orig. mec.

\section{7.}

\section{(1921) El Porvenir}

Carta del intendente al Sr. secretario de Instrucción Pública, recordándole su petición verbal de becas para los jóvenes y las jóvenes indígenas, pues esto es un paso más en favor de la civilización.

Al: Cop. mec.

V. CD, n. XLI

148.

1921 Abril 26 Panamá

Carta del Presidente Belisario al intendente, lamentando la muerte de Claudio Iglesias y Agustín González que eran tan útiles para la civilización.

ARPK: Carp. 112. Orig. mec.

$$
\text { V. CD, n. XLII }
$$

\section{9.}

\section{Abril 29 Narganá}

Carta del intendente al Presidente Belisario, en la que le agradece la acogida de las becas propuestas para los seis jóvenes, y le avisa que ya han salido con destino a la capital los agraciados.

ARPK: Carp. 142. Cop. mec.

V. CD, n. XLIII 
Carta del jefe del destacamento al secretario de Gobierno y Justicia, para comunicarle que en esa fecha siguen para ingresar en los planteles de enseñanza los jóvenes Pablo Iglesias,Rubén Pérez, Oscar Padilla, Ignacio Jake y las niñas Esther Jake y Luisa Iglesias.

Al: Cop. mec.

\section{1.}

\section{Abril 30 Puerto Obaldía}

Informe del corregidor Cabeza, de Armila, correspondiente al primer trimestre del año, en el que se queja de la falta de la atención de la región debido a su situación alejada; por lo que los padres tienen que salir con sus hijos para buscar trabajo a otros lugares y se les niega la instrucción.

Al: Orig. mec.

\section{2.}

(1921) Mayo 2 El Porvenir

Carta del intendente al secretario de Instrucción Pública, contándole su visita a las escuelas de Tupile y Playón Chico y el mal estado en que las encontró; y que de no repararse, la maestra de Tupile solo podrá dictar clases los días que haga buen tiempo.

Al: Cop. mec. inc.
V. CD, n. XLIV

\section{3.}

\section{Mayo 3 Panamá}

Carta de Belisario Porras a Mojica, en la que le dice que ha dado aviso al señor secretario para que reciba a los jóvenes que vienen a estudiar a la capital.

ARPK: Carp. 112. Orig. mec.

$$
\text { V. CD, n. XLV }
$$




\section{4.}

\section{Mayo 6 Panamá}

Carta del Presidente Belisario Porras al intendente, en la que le habla de que las indias de Tupile han decidido cambiar sus costumbres y esto ya es signo de la civilización.

ARPK: Carp. 115. Cop. mec.

$$
\text { V. CD, n. XLVI }
$$

\section{5.}

\section{Mayo 7 Panamá}

Carta de Jeptha Duncan al intendente, notificándole que ya avisó al director de la escuela de Artes y Oficios para que reserve la plaza de los indígenas.

Al: Orig. mec.

$$
\text { V. CD, n. XLVII }
$$

156.

\section{Mayo 9 Panamá}

Carta del Presidente Belisario Porras al intendente, notificándole el recibo de sus cartas contando los sucesos de Río Azúcar y la decisión de enviar la lancha Estrella para servicio de San Blas.

ARPK: Carp. 112. Orig. mec.

V. CD, n. XLVIII

1921 Mayo 10 Panamá

Carta de Jeptha Duncan al intendente, comunicándole la imposibilidad de reparar las escuelas por falta de presupuesto y 
continúa diciendo que los becados han ingresado en la escuela Normal de Institutoras.

Al: Orig. mec.

V. CD, n. XLIX

158.

1921 Mayo 12 Panamá

Carta de Belisario Porras a Mojica, en la que le habla de un abogado que defenderá a Colman, y teme que pueda destruir la obra de civilización. Termina diciéndole cómo hay que tratar a los indios.

ARPK: Carp. 112. Orig. mec.

V. CD, n. L

\section{9.}

(1921) Mayo 14 El Porvenir

Carta del intendente al secretario de Instrucción Pública, comunicándole que hasta la fecha sólo empezó las labores escolares la maestra de Corazón de Jesús y no conoce los motivos por los que los otros maestros no se han presentado, supone que los pasados acontecimientos pueden ser la causa.

Al: Cop. mec.

V. CD, n. LI

160.

(1921) Mayo 14 El Porvenir.

Carta del intendente al secretario de Gobierno y Justicia, exponiéndole la petición que le hicieron los moradores de Puerto Obaldía de construir una escuela, y comenta que el número de niños es superior a cuarenta. Propone que imparta las clases un agente de policía acantonado en el lugar, si lo permite Gobierno y Justicia. 
Al: Cop. mec.

V. CD, n. LII

\section{1.}

\section{Mayo 16 Nombre de Dios}

Circular del inspector Víctor Melo, prohibiendo el alquiler de locales escolares para fines recreativos de individuos que no dependan de las instituciones escolares.

Al:Carp. Not. del pr. sem. 1922. Orig. mec.

\section{2.}

1921 Mayo 20 Panamá

Carta de Belisario Porras a Mojica, en la que le dice que los cambios deben ser por medios pacíficos y que los cambios deben empezar por la enseñanza con los niños y niñas.

ARPK: Carp. Cor. de los int. de 1920 a 1930. Cop. mec. V. CD, n. LIII

\section{3.}

\section{Mayo 21 Panamá}

Carta de Belisario Porras a Mojica, hablando de las tres maestras nombradas y de una que piensa pedir para Cartí. Comenta que en Puerto Obaldía puede seguir dando clase un policía, y que los padres de allí pidan la escuela y el maestro.

ARPK: Carp. 134. Orig. mec.

V. CD, n. LIV

\section{4.}

\section{Mayo 23 Panamá}

Carta de Jeptha Duncan al intendente, comunicándole que no ha sido posible conseguir maestros para esa circunscripción debido a los 
recientes acontecimientos allí ocurridos y le ruega que busque candidatos, pues tal vez le sea más fácil.

Al: Orig. mec.

V. CD, n. LV

\section{5.}

\section{Mayo 28 Panamá}

Carta de Belisario Porras a Mojica, en la que le trascribe una carta que recibió del secretario de Instrucción Pública en la que anota las dificultades que tiene para nombrar maestros en aquella región. Comenta la falta de dinero para las nuevas creaciones.

ARPK: Carp. 134. Orig. mec.

V. CD, n. LVI

\section{6.}

\section{Mayo 30 El Porvenir}

Carta de Mojica al Presidente Belisario Porras, manifestándole su agradecimiento por haber conseguido que el policía de Puerto Obaldía dedique unas horas a la enseñanza. Le promete el censo y la petición formal de los padres, de la escuela y el maestro. Concluye comentando su deseo de crear escuelas y el problema de la falta del dinero.

ARPK: Carp. 85. Cop. mec.

V. CD, n. LVII

\section{7.}

\section{Mayo 31 El Porvenir}

Carta de Andrés Mojica al Sr. Juan Cabezas, jefe del tercer destacamento en Puerto Obaldía, en la que informa que ha recibido instrucciones del Sr. Presidente de la República y del secretario de 
Gobierno y Justicia a fin de permitir que el agente colonial Santiago Cabarcas dicte clases de enseñanza primaria durante 3 ó 4 horas diarias mientras se construye el local conveniente para escuela y se nombra maestro en propiedad conforme lo solicitaron los padres de familia. Da instrucciones para levantar un censo de población que muestre los niños y niñas que están en edad escolar.

Al: Cop. mec.

168.

\section{Junio 1 Panamá}

Carta de Jeptha Duncan al intendente, accediendo a su petición de que el Sr. Cabarcas, agente de policía, imparta clases en Puerto Obaldía hasta que se nombre un maestro, pero sin remuneración especial.

Al: Orig. mec.

V. CD, n. LVIII

\section{9.}

(1921) Junio 8 El Porvenir

Carta de Mojica al secretario de Gobierno y Justicia, manifestándole su apoyo en la búsqueda de maestros para la comarca y le hace la recomendación de un maestro que podría ejercer en la escuela de Narganá.

Al: Cop. mec.

V. CD, n. LIX

170.

\section{Junio 8 Panamá}

Carta del Presidente Belisario Porras al intendente, comentando que ha recibido a sus recomendados y que hará lo posible para que se 
les de unas placas de agentes coloniales.

ARPK: Carp. 85. Orig. mec.

$$
\text { V. CD, n. LX }
$$

\section{1.}

\section{Junio 18 El Porvenir}

Carta de Mojica al Presidente Belisario Porras, en la que le recomienda a un indio que viaja para colocar a dos niños en los planteles de enseñanza primaria y buscarles familia. Comenta que no ha sido posible abrir las escuelas en San Blas.

ARPK: Carp. 85. Cop. mec.

V. CD, n. LXI

\section{2.}

(1921) Junio 18 El Porvenir

Carta de Mojica al secretario de Gobierno y Justicia, recomendándole a un indígena que se dirige a Panamá a colocar a dos niños en aquellos planteles, y le pide ayuda y protección para la misión que le lleva al joven.

Al: Cop. mec.

v. CD, n. LXII

\section{3.}

1921 Junio 20 El Porvenir

Carta de Mojica al Presidente Belisario Porras, en la que le envía la lista de personas que han dejado el saburreti, en la cual ha colaborado el sahila Inatoiquiña, que ha sido amenazado y pide un sueldo para él.

ARPK: Carp. 115. Cop. mec.

$$
\text { V. CD, n. LXIII }
$$




\section{4.}

\section{Julio 5 Panamá}

Carta del Presidente Porras al intendente, en la que le manifiesta la aprobación de cargo del agente policial Inatoiquiña, una vez que se produzca una vacante, así se lo ha expresado R.J. Alfaro.

Al: Orig. mec.

V. CD, n. LXIV

\section{5.}

1921 Julio 6 El Porvenir

Carta de Andrés Mojica a Ramón Garrido comunicándole que la Sra. Carmen J. García ha sido nombrada maestra de ese lugar y ruega que la dé el apoyo necesario y la instale.

Al: Cop. mec.

176.

192 Julio 9 El Porvenir

Carta de Mojica al jefe del segundo destacamento, Santiago Castillo, felicitándole por los logros en pro de la civilización.

ARPK: Carp. pub. en la "Es. de P." Cop. mec.

V. CD, n. LXV

\section{7.}

\section{Julio 12 Puerto Obaldía}

Carta de Juan Cabezas, jefe del destacamento y corregidor, al intendente refiriéndose a la ordenación del censo escolar de esa población. Le comunica que el agente Santiago Cabarcas ha sido designado para impartir clases durate cuatro horas cada día y que le envía el censo y útiles necesarios para primaria, así mismo le remite 
las firmas de los interesados del lugar.

Al: Orig. mec.

\section{8.}

(1921)

Lista de niños capaces de recibir instrucción en la población de Puerto Obaldía.

Al: Orig. mec

V. CD, n. LXVI

179.

(1921)

Relación de útiles y moviliario para equipar la escuela de Puerto Obaldía.

Al: Orig. mec.

V. CD, n. LXVII

180.

1921 Julio $13 \quad$ Narganá

Nombramiento de Estanislao López como jefe de la juventud, que se hace ante el destacamento de policía en Corazón de Jesús, siendo reconocido por setenta y dos de Narganá y treinta de Corazón de Jesús.

AELI: Carp. s/n. Cop. mec.

181.

1921 Julio 18 El Porvenir

Carta de Mojica al Presidente de la República, en la que adjunta la lista de las mujeres que han abandonado sus costumbres, y dice que 
los nuevos trajes han corrido por cuenta del gobierno.

ARPK: Carp. 115. Cop. mec.

V. CD, n. LXVIII

182.

1921 Julio 22 El Porvenir

Carta del intendente Mojica a Ramón Garrido, comunicándole que se dirige para allí a fin de realizar la inspección escolar, el Sr. Víctor Melo, a quien debe prestar la protección y ayuda necesaria.

Al: Cop. mec.

\section{3.}

\section{Julio 23 Panamá}

Carta de Ricardo Alfaro al intendente, en la que le indica que proceda con el mayor tacto para quitar las armas a los indios de Portogandí y que las guarde en el arsenal de la circunscripción.

Al: Orig. mec.

v. CD, n. LXIX

\section{4.}

1921 Julio 26 El Porvenir

Carta del intendente Mojica al secretario de Instrucción, comunicándole que el Sr. Cabarcas dicta clases a los niños de Puerto Obaldía y solo recibe sueldo de policía colonial, y que la escuela carece de útiles por lo que suplica le envíe la lista solicitada.

Al: Cop. mec.

\section{5.}

1921 Julio 26 El Porvenir 
Carta del intendente Mojica al secretario de Instrucción Pública, diciéndole que ha recibido de los moradores de Puerto Obaldía la lista de niños que pueden recibir instrucción, en total cuarenta y dos.

Al: Cop. mec.

186.

\section{Agosto 1 Panamá}

Carta de Ossa al intendente, solicitando que le envíe copia del decreto que autoriza a quitar violentamente sus argollas y guines a los indios, como prueba en el caso que se sigue a algunos indios.

ARPK: Carp. 18. Orig. mec.

V. CD, n. LXX

187.

\section{Agosto 4 Panamá}

Carta de Leo G. al intendente, comunicando que se ha aumentado el número de agentes indígenas de la policía colonial a quince.

Al: Orig. mec.

V. CD, n. LXXI

188.

1921 Agosto 16 Panamá

Carta del secretario Duncan al intendente, pidiendo que le mande la lista de útiles que considere necesarios para el funcionamiento de las escuelas de la circunscripción.

Al: Orig. mec.

\section{9.}

\section{Agosto 29 Narganá}

Carta del jefe del primer destacamento al intendente, en la que le envía las copias de la autorización para quitar aros y guines a los indios, para que sirva de prueba en el sumario contra unos indios. 
ARPK: Carp. 104. Orig. mec.

V. CD, n. LXXII

190.

\section{Agosto 3 Panamá}

Carta de Duncan al intendente, acusándole recibo de su notificación del comienzo de la actividad escolar de la Srta. Carmen J. García en Narganá, el día 11 de Julio. Comenta las necesidades de reparación de las escuelas de Narganá, Tupile, Playón Chico y Puerto Obaldía.

Al: Orig. mec.

191.

1921 Septiembre 1 Panamá

Carta de la Legación de los Estados Unidos al secretario de Gobierno encargado de la Secretaría de Relaciones Exteriores, Ricardo J. Alfaro, en la que comenta los malos tratos recibidos por las misioneras de parte de los funcionarios del Gobierno. Solicita le comunique las medidas tomadas para evitar esto.

ANP: Mem. rel. ex. año 1922. Cop. mec.

\section{2.}

\section{Septiembre 5 El Porvenir}

Carta del intendente Mojica al secretario de Gobierno y Justicia en la que comenta la reunión tenida por los indios en Narganá quejándose de las misioneras protestantes y pidiendo que se clausuren las escuelas protestantes. Expone las quejas de las maestras que al preguntar a sus alumnos contestan en inglés en lugar de hacerlo en castellano. El intendente les manifestó su opinión que era la de la ley vigente. 
Al: Cop. mec.

V. CD, n. LXXIII

\section{3.}

\section{Septiembre 12 El Porvenir}

Carta de Mojica al jefe del primer destacamento, en la que le transcribe una carta de la misión protestante que se queja de que no la permiten dar clase, y que Estanislao López se opone, trayendo como consecuencia el que los mayores dejan de asistir a las clases, aunque lo siguen haciendo los niños.

ARPK: Carp. Cor. de los int. 1920-30. Cop. mec.

V. CD, n. LXXIV

\section{4.}

\section{Septiembre 16 Panamá}

Carta del secretario de Relaciones Exteriores al Sr. J.Price, enviado Extraordinario y Ministro Plenipotenciario de los Estados Unidos, en la que le comunica que ha enviado una traducción de su nota y de la carta de la Srta. Coope al secretario de Gobierno y Justicia pidiéndole una investigación. Le manifiesta que le hará partícipe de los resultados cuando tenga notificación de ello.

ANP: Men. rel. ex. año 1922. Cop. mec.

\section{5.}

\section{Septiembre 16 Panamá}

Carta de Gobierno y Justicia al intendente, en la cual comenta que las clases de las escuelas particulares no es obligatorio que se dicten en español.

Al: Orig. mec. inc.

V. CD, n. LXXV 
196.

1921 Septiembre $17 \quad$ Narganá

Convenio celebrado entre las misioneras protestantes y la Intendencia reformando el anterior, en el que se restringe la enseñanza de las misioneras a una hora concreta y día de la semana. Se establece que la asistencia será voluntaria. El intendente promete protección a las misioneras.

Al: Orig. mec.

V. CD, n. LXXVI

\section{7.}

\section{Septiembre 19 Panamá}

Carta de Ricardo Alfaro al intendente, comentando las quejas que se han presentado contra Ramón Garrido por las misioneras protestantes, y le dice que por petición del Presidente de la República cambie al Sr. Garrido, así como al agente Estanislao López.

Al: Orig. mec.

V. CD, n. LXXVII

\section{8.}

\section{Octubre 3 Narganá}

Carta de Arturo R. Pérez al intendente Mojica, con la que le envía una lista de materiales necesarios para las escuelas de Narganá y Corazón de Jesús.

Al: Orig. mec.

V. CD, n. LXXVIII

199.

1921 Octubre 4 El Porvenir 
Carta de Andrés Mojica a Arturo R. Pérez, subteniente encargado del primer destacamento, avisándole del envío del material escolar para que entregue a las respectivas maestras de Narganá y Corazón de Jesús.

Al: Cop. mec.

\section{0.}

\section{Octubre 6 El Porvenir}

Carta de Andrés Mojica al Jefe del primer destacamento, comentando las averiguaciones sobre el asunto de pago de la misionera Ana Coope a Charles Róbinson. Y concluye comentando que ha solicitado ayuda para combatir la epidemia de viruela.

Al: Cop. mec.

V. CD, n. LXXIX

\section{1.}

\section{Octubre 10 Nombre de Dios}

Circular del inspector de educación comentando los malos resultados del pasado semestre, en parte culpa de la poca cooperación de los padres, que no les vigilan ni cuidan ,y pide que se sancione a estos padres.

Al: Carp. Not. del pr. sem. 1922. Cop. mec.

\section{2.}

\section{Octubre 14 El Porvenir}

Carta de Andrés Mojica al Jefe del primer destacamento, comunicándole que la maestra de Tupile se dirige hacia allí y le pide que le proporcione los medios necesarios para que prosiga su viaje hacia su destino.

Al: Cop. mec.

V. CD, n. LXXX 
203.

1921 Octubre 21 Panamá

Carta del Sr. Wn. Jennings Price al secretario de Relaciones Exteriores, Narciso Garay, en la que expone que las misioneras protestantes no gozan de garantías de seguridad, y hace referencia a los acuerdos tenidos en 1914 por los encargados de aquel entonces.

ANP: Men. rel. ex. año 1922. Cop. mec.

\section{4.}

\section{Noviembre 10 El Porvenir}

Carta de Mojica al secretario de Gobierno y Justicia, afirmando que las misioneras protestantes gozan de todas las garantías propias de su situación y comenta que la labor de éstas es más de fanatismo que de otras cosas. desmiente ciertos comentarios falsos que le han dado al secretario.

Al: Cop. mec.

V. CD, n. LXXXI

\section{5.}

\section{Noviembre El Porvenir}

Carta del intendente al secretario de Gobierno y Justicia, comentando la visita que le hizo el Sr. Smith de la sociedad de misioneros americanos y su intención de hacer un edificio análogo al de Narganá en Corazón de Jesús. El citado señor ofreció enviar misioneras de su secta que enseñaran en castellano.

Al: Cop. mec.

V. CD, n. LXXXII

206.

\section{Diciembre 6 Panamá}

Carta del secretario de Relaciones Exteriores al Sr. Willian J. Price, en la que expone que las misioneras gozan de toda protección, 
pero que tal vez ellas no conocen la constitución, ya que esta dispensa protección a la religión Católica, pero se la niega a las otras. También le informa que Instrucción Pública exige la enseñanza en el idioma nacional. $Y$ concluye comentando el pago de un tributo al jefe indio.

ANP: Men. rel. ex. año 1922. Cop. mec.

\section{7.}

\section{Diciembre 13 Nombre de Dios}

Carta del inspector Melo al intendente, comunicándole que ha tenido noticias de que en las escuelas se asilan policías y se realizan bailes inmorales para padres y niños. Le pide su colaboración.

Al: Carp. Not. del pr. sem. 1922. Orig. mec.

\section{8.}

\section{Diciembre 23 Panamá}

Carta de Duncan al intendente Mojica diciéndole que recibió copia del convenio celebrado con las misiones residentes en Narganá, que es reforma del anterior, así como la copia del oficio número 177/B del 21 del presente mes.

Al: Orig. mec.

\section{9.}

(1921) Abril 28 El Porvenir

Carta del intendente al secretario de Gobierno y Justicia, pidiéndole que reserve las becas pues los alumnos no han podido ir a la escuela de Artes y Oficios debido a la muerte de Claudio Iglesias.

Al: Cop. mec.

210.

1922 Enero 5 Panamá

Carta del Sr. Alfaro al Sr. Smith de Cristóbal, negándole un permiso de construcción en Narganá para la iglesia protestante. 
Expone dieciséis puntos que critican la acción de las protestantes allí, entre otros los perjuicios acarreados por las dos religiosas y los dos sistemas de enseñanza.

ARPK: Carp. 212. Cop. mec.

V. CD, n. LXXXIII

\section{1.}

\section{Enero 17 (Panamá)}

Carta del secretario Julio Pezet al inspector V. Melo, diciéndole que él no ha tenido conocimiento de que en la escuela se lleven a cabo bailes inmorales, sino para que las mujeres superen su natural timidez.

Al: Carp. Not. del pr. sem. 1922. Cop. mec.

\section{2.}

\section{Marzo 11 El Porvenir}

Carta del intendente Mojica al secretario de Instrucción Pública, comunicándole que algunas familias de Cartí se han venido a Wichuwala y en reunión decidieron solicitar una maestra para que imparta clases a sus niños y niñas. El agente Paniza, promotor de la idea, construyó una casa que podría servir para la escuela. $Y$ concluye diciendo que el ramo de Instrucción es al que el gobierno debe prestar más atención.

Al: Carp. Not. del pr. sem. 1922. Cop. mec.

\section{3.}

\section{Marzo 18 El Porvenir}

Carta del intendente Mojica al secretario de Gobierno y Justicia, notificándole que le han pedido en Narganá y Corazón de Jesús becas para el Instituto Nacional, Escuela Normal de Institutoras y Escuela 
de Obstetricia; y que estas últimas serían muy convenientes ya que mueren muchos niños al nacer.

Al: Cop. mec.

\section{4.}

\section{Marzo 18 El Porvenir}

Carta del intendente Mojica al secretario de Instrucción Pública, solicitando por petición expresa de los habitantes de Narganá y Corazón de Jesús becas para los niños. Pide siete para niños en el Instituto Nacional, y dos para niñas en la Escuela Normal de Institutoras.

Al: Carp. Not. del pr. sem. 1922. Cop. mec.

\section{5.}

\section{Marzo 18 El Porvenir}

Carta del jefe del primer destacamento, Ramón Garrido, al intendente, para comentarle la situación de las misioneras de Narganá que siguen dictando clases de inglés a pesar de la prohibición, y no se someten a lo dispuesto en los ordinales 1 al 9 del art. 42 de la codificación escolar de enseñanza primaria sobre escuelas privadas.

Al: Orig. mec.

\section{6.}

\section{Marzo 18 El Porvenir}

Carta del jefe del segundo destacamento al secretario de Gobierno, en la que transcribe una carta que ya envió al intendente para contarle que las misioneras se han negado a dejar de enseñar y lo hacen en inglés, y que no se han sometido a la codificación escolar de enseñanza privada.

ARPK: Carp. Mis. prot. en S.B. Cop. mec.

\section{CD, n. LXXXIV}




\section{7.}

\section{Marzo 20 El Porvenir}

Carta del Encargado del Despacho de la secretaría de Gobierno y Justicia a Juan Francisco Cabeza, jefe del tercer destacamento y corregidor de Puerto Obaldía, acusando recibo del informe de la labor escolar llevada a cabo en ese lugar, y felicitándole calurosamente por el buen éxito alcanzado en esa labor.

Al: Orig. mec.

\section{8.}

\section{Marzo 20 Panamá}

Carta del secretario Duncan al intendente Mojica, aprobando la solicitud que requería de una maestra para Wichuwala; y le dice que ha elegido a la Srta. Susana M. Cerezo.

Al: Carp. Not. del pr. sem. 1922. Orig. mec.

219.

1922 Abril 4 Narganá

Carta del jefe del primer destacamento, Ramón Garrido, al intendente, informándole que el mexicano que buscan está en Ailigandí con Colman.

ARPK: Carp. 104. Orig. mec.

\section{0.}

\section{Abril 10 El Porvenir}

Carta de Mojica al secretario de Gobierno y Justicia, para comunicarle que es propósito del Presidente y suyo crear destacamento de policía y escuela en Ailigandí, residencia de Colman.

Al: Cop. mec. 


\section{1.}

1922 Abril 12 Panamá

Carta del secretario Jeptha Duncan al intendente Mojica, exponiéndole la imposibilidad de las becas que solicita por falta de presupuesto.

Al: Carp. Not. del pr. sem. 1922. Orig. mec.

\section{2.}

\section{Abril 19 Nombre de Dios}

Carta del inspector de Instrucción Pública V. Melo al intendente, avisándole que está en su poder el material escolar de las escuelas de Wichuwala y Corazón de Jesús.

Al: Carp. Not. del pr. sem. 1922. Orig. mec.

\section{3.}

1922 Abril 22 Nombre de Dios

Circular de V. Melo a los alcaldes municipales, recordando el art. 10 de la ley 35 de 1919 que obliga a todos los niños de siete a quince años a asistir puntualmente a la escuela.

Al: Carp. Not. del pr. sem. 1922 Cop. mec.

\section{4.}

\section{Mayo 2 El Porvenir}

Carta del Encargado del Despacho al inspector Melo, notificándole que comenzó sus labores de maestra Susana M. Cerezo en este día en Wichuwala y que las dimensiones del local escolar son 30 por 14,4 pies y dos metros de alto.

Al: Carp. Not. del pr. sem. 1922. Cop. mec. 


\section{5.}

\section{Mayo 3 Narganá}

Carta del jefe del primer destacamento a Mojica, en la que transcribe una carta del director de la escuela de Corazón de Jesús quejándose de que Estanislao López se ha llevado a Colón a los niños que debían empezar el cuarto grado.

ARPK: Carp. 29. Orig. mec.

$$
\text { V. CD, n. LXXXV }
$$

\section{6.}

\section{Mayo 6 El Porvenir}

Carta del intendente Mojica al secretario de Gobierno y Justicia, solicitando una subida de sueldo(10 a 15 balboas) por la labor en pro de la educación del agente Paniza.

Al: Cop. mec.

\section{7.}

\section{Mayo 8 Panamá}

Carta de Duncan al intendente Mojica, comentando la posibilidad de cambiar el local de la escuela por el de la oficina del destacamento.

Al: Carp. Not. del pr. sem. 1922. Orig. mec.

\section{8.}

\section{Mayo 10 El Porvenir}

Carta del intendente Mojica al inspector V. Melo, prometiéndole que hará lo posible porque se cumpla la circular segunda del 22 de Abril que le envió.

Al: Carp. Not. del pr. sem. 1922. Cop. mec. 
229.

\section{Mayo 15 El Porvenir}

Carta del intendente Mojica al secretario de Instrucción Pública, anunciando la repentina muerte de la maestra de Playón Chico, Otilia Hurtado de Sánchez, por lo que la escuela se ha cerrado. Pide que se nombre otra lo más pronto posible para evitar atraso en los educandos.

Al: Carp. Not. del pr. sem. 1922. Cop. mec.

\section{0.}

\section{Mayo $16 \quad$ Narganá}

Carta de Ramón Garrido al intendente, pidiéndole que se sirva enviarle tablones para terminar las escaleras para las escuelas de Narganá y Corazón de Jesús.

Al: Orig. mec.

\section{1.}

\section{Mayo 20 El Porvenir}

Carta del intendente Mojica al secretario de Instrucción, poniéndole en conocimiento que no funcionan tres escuelas de la comarca: la de Narganá por no haber llegado la maestra, la de Playón Chico por defunción y la de Tupile por encontrarse con grave enfermedad la maestra.

Al: Carp. Not. del pr. sem. 1922. Cop. mec.

\section{2.}

\section{Mayo 24 Nombre de Dios}

Carta del inspector Melo al intendente Mojica, notificándole el envío del tablero de la escuela de Corazón de Jesús y tres cajas de 
útiles para las escuelas de Narganá, Playón Chico y Tupile.

Al: Carp. Not. del pr. sem. 1922. Cop. mec.

\section{3.}

\section{Mayo $26 \quad$ Narganá}

Carta del jefe del primer destacamento al intendente Mojica, reiterando su petición de material para reparar escaleras y goteras de las escuelas de Narganá y Corazón de Jesús.

Al: Orig. mec.

\section{4.}

\section{Mayo $26 \quad$ Narganá}

Denuncia de la maestra Elisa G. de Garrido ante el juez del circuito de Colón, para acusar a las misioneras Purdy y Coope por sustraer tres niños de la isla para mandarlos a los Estados Unidos. Dice que dos fueron recuperados en la ciudad de Colón. Con anterioridad la maestra había comunicado esto a la esposa del Presidente de la República.

ANP: Men. rel. ex. año 1922. Cop. mec.

\section{5.}

\section{Junio 3 Playón Chico}

Carta del sahila Olopaniqui y otros, redactada por su intérprete Benito Guillen, al secretario de Instrucción Pública pidiéndole que les envíen a la maestra Manuela Fraguo de la que están muy contentos, y sino se encuentra, otra, pues no quieren perder tiempo.

Al: Carp. Not. del pr. sem. 1922. Orig. ms. 
236.

\section{Junio 8 Panamá}

Carta del secretario de Instrucción Pública al intendente Mojica, participándole el nombramiento de la maestra de Playón Chico, Emilia Castillero.

Al: Carp. Not. del pr. sem. 1922. Orig. mec.

\section{7.}

\section{Junio 11 Narganá}

Carta del jefe del destacamento a Francisco Cabeza, teniente encargado de la Intendencia, comentándole la buena marcha de la labor católica y de la mala que lleva la protestante, y la decisión tomada por los isleños de no asistir a los actos protestantes.

ARPK: Carp. 21. Cop. mec.

$$
\text { V. CD, n. LXXXVI }
$$

\section{8.}

\section{Junio 19 Narganá}

Carta de Garrido, jefe del destacamento, a Mojica, comentando la marcha de la civilización en Narganá y Corazón de Jesús dirigida por Róbinson, Estanislao y Ololuquiñe. Comenta que asisten a la misión católica y han dejado la protestante.

ARPK: Carp. Cor. de los int. de 1920-1930. Cop. mec.

$$
\text { V. CD, n. LXXXVII }
$$

\section{9.}

\section{Junio 21 Santa Isabel}

Carta del Sr. Paulino Garibaldi al intendente, expresándole que hizo un trato con el Sr. Juan B. de León por el que llevaba a su hijo de 
16 años para $\mathrm{S}$. Blas hasta que dieran comienzo las clases y que ya han pasado tres meses y no han empezado las clases ni regresado el muchacho. Que ellos sólo aspiran ver a sus hijos asistir a la escuela todos los días.

Al: Orig. ms.

\section{0.}

\section{Junio 24 Narganá}

Carta de Garrido a Mojica, comentándole que los protestantes quieren crear división y disturbios por no permitirles permanecer allí y para esto intentan crear división entre jóvenes y viejos.

ARPK: Carp. 212. Cop. mec.

V. CD, n. LXXXVIII

\section{1.}

\section{Junio 24 Panamá}

Carta de Alfaro al intendente, hablándole del pago a la Escuela Normal de Institutoras por la estancia de unas niñas, y le ruega que se reclame a los padres la mitad del pago según lo acordado.

ARPK: Carp. 29. Orig. mec.

V. CD, n. LXXXIX

\section{2.}

\section{Junio 26 El Porvenir}

Carta de Mojica al secretario de Gobierno y Justicia, comunicándole la acción obstaculizadora de los protestantes que le comentó el jefe del destacamento. $Y$ ha pedido que se haga una investigación lo más rigurosa posible.

ARPK: Carp. 212. cop. mec.

v. $C D$, n. $X C$ 


\section{3.}

\section{Junio 27 El Porvenir}

Carta del intendente Mojica al secretario de Instrucción Pública, comunicándole que dieron comienzo las clases en Playón Chico el 20 de los corrientes y asisten 62 alumnos.

Al: Carp. Not. del pr. sem. 1922. Cop. mec.

\section{4.}

\section{Junio 28 Panamá}

Carta de Alfaro al intendente Mojica, pidiendo le relate los actos realizados por las misioneras protestantes que obstaculizaban la labor del misionero católico enviado por el Gobierno.

Al: Cop. mec.

\section{5.}

\section{Junio (Narganá)}

Informe del jefe del primer destacamento a la Intendencia, hablando de la importancia de la instrucción pública, comenta que hay dos maestros que atienden cuatro grados en Corazón de Jesús. La maestra de Narganá no ha llegado. Describe el estado de los edificios y habla de la estancia del misionero Plácido Calella y de la conveniencia de conseguir misioneros católicos.

Al: Carp. Puerto Obaldía 1922. Orig. mec.

\section{6.}

\section{Junio (Tupile)}

Informe del jefe del segundo destacamento al intendente, diciendo que en Playón Chico hay no menos de 100 alumnos y que los reacios han salido de la isla.

Al: Carp. Puerto Obaldía 1922. Orig. mec. 


\section{7.}

\section{Junio (Tupile)}

Informe del jefe del segundo destacamento Francisco Lombardo a la Intendencia, comentando el tema de la Instrucción Pública y se refiere al edificio escolar que está en mal estado teniendo que suspenderse las clases cuando llueve pues el tejado deja pasar el agua.

Al: Carp. Puerto Obaldía 1922. Orig. mec.

\section{8.}

\section{Julio 9 Tupile}

Carta de Miguel Gordón al intendente Mojica, notificándole la enfermedad de la maestra de Playón Chico.

Al: Carp. Leg. del 2o sem. 1922. Orig. mec.

\section{9.}

\section{Julio 12 El Porvenir}

Carta del intendente al secretario de Gobierno y Justicia, mencionándole la oportunidad que ya le había expresado anteriormente de establecer escuelas y destacamentos policiales en Ailigandí y Portogandí. Comenta que esta es la voluntad del Gobierno.

Al: Cop. mec.

\section{0.}

\section{Julio 15 El Porvenir}

Carta del secretario Ubaldo Barría al encargado del segundo destacamento de Tupile, comunicándole que la maestra Emilia Castillero de Playón Chico sigue sin novedad recibiendo la atención médica.

Al: Carp. Leg. del 2o sem. 1922. Cop. mec. 


\section{1.}

\section{Julio 25 Panamá}

Carta del secretario de Gobierno y Justicia al intendente Mojica, pidiendo que le aclare la prohibición de tocar la comparsa en la escuela e Iglesia.

Al: Orig. ms.

\section{2.}

\section{Agosto 5 Nombre de Dios}

Carta del inspector Melo al intendente, informándole que en reciente fecha ha sido clausurada la escuela de Wichuwala. Le pide que se haga cargo de los muebles y que la Srta. Cerezo se traslade a Narganá.

Al: Carp. Not. del 2o sem. 1922. Orig. mec.

\section{3.}

\section{Agosto 22 El Porvenir}

Carta del intendente Mojica al inspector escolar, notificándole que la escuela de Wichuwala seguirá funcionando todo el semestre, pero se cerrará si no existe la asistencia reglamentaria para su funcionamiento.

Al: Carp. Not. del 2o sem. 1922. Cop. mec.

\section{4.}

\section{Agosto 23 Narganá}

Carta de Estanislao López, Róbinson y otros noventa al Presidente de la República, exponiéndole que el Sr. José de la Rosa solo hace que instigar a los indios y que ellos no lo quieren pues va diciendo que las medidas civilizadoras tales como las escuelas, los 
cuarteles de policía, etc. no son medios mas que para robarles, y los que apoyan esto también son unos explotadores.

AANP: Orig. mec.

\section{5.}

\section{Septiembre 9 Panamá}

Carta de R. Chiari al intendente, en la que le comenta la acción del Sr. Smith de llevar material para reparar el edificio de las protestantes y dice que no se le puede impedir, pues no es para nuevas construcciones sino para reparaciones y mejoras.

ARPK: Carp. 212. Cop. mec.

V. CD, n. XCl

\section{6.}

\section{Septiembre 23 Nombre de Dios}

Carta del inspector Melo al intendente, pidiéndole que le informe de si han comenzado las clases los maestros.

Al: Carp. Not. del 2o sem. 1922. Orig. mec.

\section{7.}

\section{Septiembre 29 El Porvenir}

Carta de Mojica al secretario de Gobierno y Justicia, comentándole que la casa de los protestantes había sido cedida por el jefe del destacamento para clases y servicios religiosos, pero ahora era la religión católica la abrazada y los otros no tendrían intervención y en caso de que hicieran mejoras adquirirían derechos en el edificio.

ARPK: Carp. 212. Cop. mec.

$$
\text { V. } C D, \text { n. XCII }
$$


258.

1922 Septiembre 30 Puerto Obaldía

Carta del maestro Santiago Cabarcas al intendente, comunicándole el envío de las asistencias, le comenta que han sido escasas pero que los padres han prometido que los enviarán cuando regresen.

Al: Orig. ms.

\section{9.}

\section{Octubre 10 El Porvenir}

Carta del intendente Mojica al secretario de Gobierno y Justicia, anunciando que el 3 de Noviembre es la fecha designada para el cambio de vestido de las mujeres de Wichuwala.

Al: Cop. mec.

\section{0.}

\section{Octubre 11 El Porvenir}

Carta de Mojica al secretario de Gobierno y Justicia, en la que le informa de los adelantos de la civilización en Tupile, Playón Chico, Narganá, Corazón de Jesús y Río Azúcar. Se han creado clubs que cooperan con la civilización del Gobierno y han realizado la alineación de las casas.

ARPK: Carp. 104. Cop. mec.

v. CD, n. XCIII

\section{1.}

\section{Octubre 17 El Porvenir}

Carta del intendente Mojica al inspector, comunicándole que se han reanudado las clases de las escuelas de Tupile, Playón Chico, 
Corazón de Jesús, Wichuwala y la de los maestros Cabrera, Filós y Delvalle de Narganá.

Al: Cop. mec.

\section{2.}

1922 Octubre 20 EI Porvenir

Carta del intendente Mojica al secretario de Gobierno y Justicia, diciéndole que el indígena Sami Aguilar quiere que se abra escuela el próximo curso en su isla de Río Cidra.

Al: Cop. mec.

\section{3.}

\section{Octubre 20 Nombre de Dios}

Carta del inspector Melo al intendente, notificándole que el 9 de Noviembre empezará una inspección a las escuelas de la comarca. Pide que le dejen la lancha para viajar.

Al: Orig. mec.

\section{4.}

\section{Octubre 25 Nombre de Dios}

Carta del inspector Melo al intendente, en la que le comunica que recibió el certificado médico del maestro de Narganá, Cabrera. Le dice así mismo que envía los materiales de la escuela de Wichuwala que le solicitó la maestra.

Al: Carp. Not. del 2o sem. 1922. Orig. mec.

\section{5.}

1922 Octubre 28 El Porvenir 
Carta del intendente al inspector Melo, confirmándole el recibo de su nota y que ya ha avisado a los jefes de los destacamentos para que notifiquen a las maestras su visita de inspección.

Al: Cop. mec.

\section{6.}

\section{Octubre 28 El Porvenir}

Carta del intendente Mojica a Santiago Cabarcas de Puerto Obaldía, confirmándole el recibo del informe de asistencias de los alumnos y le comenta que es muy bajo el correspondiente a Septiembre. Le anuncia que el Gobierno tiene intención de establecer escuela formal.

Al: Cop. mec.

\section{7.}

\section{Octubre 31 Puerto Obaldía}

Carta de Santiago Cabarcas al intendente, notificándole el envío del formulario de asistencias de ese mes.

Al: Orig. ms.

\section{8.}

\section{Octubre 31 Tupile}

Carta de Miguel Gordón al intendente Mojica, diciéndole que ha recibido las bancas de las escuelas de Tupile y Playón Chico.

Al: Carp. Leg. del 2o sem. 1922. Orig. mec.

\section{9.}


Carta del inspector Melo al intendente, avisándole que no podrá hacer la visita de inspección debido al mal tiempo, y le pide que le avise cuando sea propicio, pero que no avise a los maestros para encontrarlos desapercibidos.

Al: Orig. mec.

\section{0.}

\section{Noviembre 9 Narganá}

Carta de Ramón Garrido, jefe del destacamento, al intendente, comunicándole que la Srta. Purdy ha dejado la misión y no regresará, y que el Sr. Smith ha puesto en venta los enseres allí dejados.

ARPK: Carp. 212. Cop. mec.

V. CD, n. XCIV

\section{1.}

\section{Noviembre 16 Nombre de Dios}

Carta del inspector Melo al intendente, notificándole que ha enviado una mercancía para la escuela mixta de Narganá que es de urgente necesidad.

Al: Orig. mec.

\section{2.}

\section{Noviembre 30 Puerto Obaldía}

Carta del maestro Santiago Cabarcas al intendente, para enviarle el formulario de asistencias, que es escaso. Comenta que él sigue exhortando a los padres que son indiferentes y que ellos aprecian muy poco la instrucción. Concluye diciendo que hay niños y niñas que no han asistido ni una sola vez.

Al: Orig. ms. 


\section{3.}

\section{Diciembre 1 Wichuwala}

Carta de la maestra Susana Marta Cerezo al intendente, agradeciéndole la felicitación de él y la de la Secretaría de Gobierno y Justicia.

Al: Orig. ms.

\section{4.}

\section{Diciembre 3 El Porvenir}

Carta de Mojica al secretario de Gobierno y Justicia, avisándole que van hacia la capital Estanislao López y Alicio Iglesias para tratar con él y el Presidente asuntos de la civilización.

ARPK: Carp. Cor. Cop. mec.

v. CD, n. XCV

\section{5.}

\section{Diciembre 10 Nombre de Dios}

Carta de Melo al intendente, pidiéndole que averigüe sobre la conducta de los maestros de Corazón de Jesús y le pide que no se informe con el jefe del destacamento pues está su mujer implicada.

Al: Orig. mec.

\section{6.}

\section{Diciembre 15 Nombre de Dios}

Carta del inspector Melo al intendente, notificándole el envío de bancas para las escuelas de Wichuwala, Corazón de Jesús y Playón Chico.

Al: Orig. mec. 


\section{7.}

\section{Diciembre 18 Narganá}

Carta del encargado del destacamento, Horacio Méndez, a Mojica, en la que le manifiesta su aprobación por la resolución sobre los bailes de los niños de las escuelas de Narganá y Corazón de Jesús, que se celebraban hasta altas horas y perjudicaban a los niños en sus estudios.

ARPK: Carp. Cor. Cop. mec.

\section{CD, n. XCVI}

\section{8.}

\section{Diciembre 28 Panamá}

Carta de Arístides Arroyo al intendente, con la cual le adjunta el oficio dictado por el jefe del primer destacamento de la circunscripción sobre la organización de bailes dados a los educandos en la escuela de Narganá y Corazón de Jesús.

Al: Orig. mec.

V. CD, n. XCVII

\section{9.}

\section{Diciembre Narganá}

Informe del segundo semestre del encargado del primer destacamento tratando de la instrucción pública. Comenta que es urgente la reparación de las escuelas de Corazón de Jesús y Narganá ya que presentan falta de pintura y es una amenaza para los educandos.

Al: Orig. mec.

\section{0.}

\section{Diciembre Tupile}

Informe de Miguel Gordón al intendente correspondiente al segundo semestre de 1922, en el que expone las mejoras entre las que 
cuentan el saneamiento de Tupile y Playón Chico. Comenta que el sahila de este último lugar merece un aplauso por su adhesión al Gobierno, y señala el hecho de que las mujeres han cambiado sus vestidos por los de la gente civilizada. Concluye haciendo alusión a la instalación de locales para bailes, y que se han hecho patios para juegos civilizados.

Al: Cop. mec.

\section{1.}

\section{2}

Circular del inspector de Instrucción Pública señalando la prohibición de asistir los niños que van a la escuela a los bailes, bajo pena de multa a los padres; y se pide que aleje a los varones de las tabernas y los juegos públicos.

Al: Carp. Not. del pr. sem. 1922. Orig. mec.

\section{2.}

\section{Abril 8 El Porvenir}

Carta de Mojica al secretario de Gobierno y Justicia, avisándole que Alicio Iglesias y Estanislao López van a la capital para resolver las quince becas ofrecidas por el Presidente. El sahila de Río Azúcar, Manuel Muñoz, quiere conseguir la escuela.

ARPK: Carp. 29. Cop. mec.

V. CD, n. XCVIII

\section{3.}

\section{Abril 13 El Porvenir}

Carta del intendente al Jefe del primer destacamento, solicitando las medidas de las escuelas de Narganá Corazón de Tupile y Playón Chico para solicitar la pintura a la Secretaría de Instrucción Pública.

Al. Cop. mec. 


\section{4.}

\section{Abril 18 Narganá}

Carta de Miguel Gordón al intendente, en la que le remite las medidas de las escuelas de Narganá, Corazón de Jesús, Playón Chico y Tupile, que previamente le había solicitado con el fin de satisfacer las necesidades de materiales.

Al: Orig. mec.

V. CD, n. XCIX

\section{5.}

\section{Abril 20 Panamá}

Carta del secretario Chiari al intendente, comunicándole que las quince becas han sido adjudicadas. El asunto de la escuela lo ha enviado al secretario de Instrucción Pública para ver si es posible.

ARPK: Carp. 29. Cop. mec.

V. CD, n. C

\section{6.}

\section{Abril 22 Narganá}

Carta del Jefe del primer destacamento al intendente, anunciándole que se hizo una peregrinación a las tumbas de los mártires nunca bien llorados Claudio Iglesias y González en el segundo aniversario de la muerte de estos mártires de la civilización.

Al. Orig. mec.

\section{7.}

\section{Abril 26 El Porvenir}

Carta de Andrés Mojica al jefe del primer destacamento, solicitándole que aloje al maestro de Río Azúcar y le proporcione 
alimento hasta que pueda seguir su viaje. Le pide la lista de indígenas de esta isla que deben ser nombrados agentes escolares. Finalmente le comunica su intención de ir a instalar a los empleados que deben funcionar allí.

Al: Cop. mec.

V. CD, n. Cl

288.

\section{Abril 28 Narganá}

Carta de Horacio Méndez al intendente Mojica, comunicándole la lista de elegidos para desempeñar las funciones de agentes escolares en Río Azúcar. Comenta que tras una entrevista con Nele Kantule sacó en conclusión que éste se opondrá a la apertura de la escuela en ese lugar.

Al: Orig. mec.

v. CD, n. CII

\section{9.}

1923 Abril 30 Narganá

Carta de Mojica al secretario de Gobierno y Justicia, en la que envía la lista de los aspirantes a las becas ofrecidas.

ARPK: Carp. 29. Orig. mec.

V. CD, n. CIII

290.

\section{Abril 30 Panamá}

Carta al intendente de San Blas, en la que se requiere la lancha para el inspector escolar del distrito, afín de que pueda hacer la visita reglamentaria a las escuelas que se encuentran en el Golfo de San Blas. 
Al: Orig. mec.

V. CD, n. CIV

\section{1.}

\section{Abril $30 \quad$ Narganá}

Carta de Mojica al secretario del despacho de El Porvenir, en la que le comunica que avise al secretario de Gobierno y Justicia que ha decretado el nombramiento de agentes escolares ad honorem para ayudar al maestro y la policía destacada allí.

Al: Orig. mec.

V. CD, n. CV

\section{2.}

\section{Mayo 2 El Porvenir}

Carta de Ubaldo Barría, secretario del despacho de Intendencia, al secretario de Estado, informándole que con motivo de la apertura de la escuela de Río Azúcar ha tenido que nombrar policía indígena para ayuda del maestro y de la policía colonial.

ARPK: Carp. 112. Cop. mec.

V. CD, n. CVI

\section{3.}

\section{Mayo 4 El Porvenir}

Carta de Ubaldo Barría al secretario de Gobierno y Justicia, comunicándole que no podrá hacer la inspección de las escuela el inspector de Nombre de Dios, pues no hay combustible para la lancha; a no ser que Instrucción Pública o Gobierno suministren el combustible. Comenta que la Intendencia está dispuesta a cooperar siempre con el ramo de Instrucción Pública, el más eficiente en las tareas civilizadoras.

Al: Cop. mec. 


\section{4.}

\section{Mayo 4 El Porvenir}

Carta del secretario del despacho, Ubaldo Barría, al jefe del primer destacamento, pidiéndole que le notifique cuándo se presentaron los maestros y cuándo dieron comienzo a las clases.

Al: Cop. mec.

\section{5.}

\section{Mayo 6 Narganá}

Carta de Horacio Méndez al secretario de la Intendencia, comunicándole que se abrieron las escuelas, al mismo tiempo le transcribe el número de matrículas y los grados que se imparten en cada una. Le notifica que ya informó de esto al inspector de Instrucción Pública del Distrito.

Al: Orig. mec.

V. CD, n. CVII

\section{6.}

\section{Mayo 9 Narganá}

Carta de Horacio Méndez al secretario del despacho de El Porvenir, comunicándole que el 7 del presente se abrió la escuela de Río Azúcar con una matrícula de 13 alumnos, y expresa sus esperanzas en que este número aumentará cuando vean el beneficio de la escuela.

Al: Orig. mec.
v. CD,
n. CVIII

\section{7.}

\section{Mayo 11 Narganá}

Carta de Horacio Méndez al Jefe del despacho de la Intendencia 
de El Porvenir, en la que le avisa de que la maestra de $1^{\circ}$ y $2^{\circ}$ grado de Corazón de Jesús comenzó sus labores escolares el 2 del presente mes.

Al: Orig. mec.

V. CD, n. CIX

298.

\section{Mayo 13 Narganá}

Carta de Horacio Menéndez al Sr. Ubaldo Barría, anunciándole que no han llegado los útiles de Institución Pública, pero que tuvo noticia de que están en Nombre de Dios. Afirma que se repartirán entre los respectivos maestros.

Al: Orig. mec.

\section{9.}

1923 Mayo 14 El Porvenir

Carta de Ubaldo Barría al jefe de primer destacamento, comunicándole que recibió la caja de útiles escolares de Narganá y Corazón de Jesús.

Al: Cop. mec.

300.

\section{Mayo 15 Narganá}

Carta del secretario del despacho, Arturo Pérez, al Sr. Mojica, notificándole que recibió los útiles de las escuelas de Narganá y Corazón de Jesús.

Al: Orig. mec.

\section{1.}

\section{Mayo 28 El Porvenir}

Carta del intendente Mojica al secretario de Gobierno y Justicia, diciéndole que según notificación del oficio 193 que informa del 
traslado de la escuela de Wichuwala para el pueblo de Río Sidra, para ello se debe proceder de igual modo que en Río Azúcar, nombrando tres agentes coloniales que se quitarían al primer destacamento, por lo que cada paso que se da crea la necesidad de aumentar el cuerpo de agentes de San Blas.

Al: Cop. mec.

\section{2.}

\section{Mayo 28 Río Sidra}

Carta de Samuel Guerrero al intendente Mojica, quejándose de que tienen setenta niños en la escuela y no tienen suficientes bancas, y que le habían dicho que no le podían poner la escuela en la isla.

Al: Orig. mec.

\section{3.}

\section{Junio 14 Río Sidra}

Carta de Samuel Guerrero al intendente Mojica, comentando entre otras cosas que los indios están contentos con la escuela y que hay ciento veinte alumnos.

Al: Orig. mec.

\section{4.}

\section{Junio 16 El Porvenir}

Carta de Andrés Mojica al secretario de Gobierno y Justicia, diciéndole que es preciso la construcción de veinte bancas para acomodar a los niños y niñas. Este año ha excedido en mucho el número de escolares y las existentes son viejas y deterioradas. Dice que las dos nuevas establecidas están funcionando con cajones. La Secretaría de Instrucción Pública proporcionaría el material y los indígenas pondrían la mano de obra.

Al: Cop. mec. 


\section{5 .}

\section{Junio 29 El Porvenir}

Carta de Mojica al secretario de Gobierno y Justicia, en la que le dice que después del levantamiento de los indios hay una agitación bélica para exterminar la policía indígena y las escuelas; promovida por Colman e Inapaquiña.

ARPK: Carp. 111. Cop. mec. inc.

V. CD, n. CX

\section{6.}

\section{Julio 3 Panamá}

Carta de Belisario Porras al secretario de Gobierno, Rodolfo Chiari, comentando la nota que recibió con las medidas a tomar para restablecer la normalidad en San Blas.

ANP: Carp. Cor. B. P. Orig. mec.

V. CD, n. CXI

\section{7.}

\section{Julio 30 Panamá}

Carta del Presidente Belisario Porras al Secretario de Gobierno, R. Chiari, comunicando que le llegó el decreto que hacía los nombramientos de San Blas siguiendo las indicaciones del intendente Mojica.

ANP: Carp. Cor. B. P. Orig. mec.

$$
\text { v. CD, n. CXII }
$$

\section{8.}

\section{Septiembre 13 Tupile}

Carta de Miguel Gordón al secretario de Intendencia, Ubaldo 
Barría, comunicándole el envío de dos objetos pertenecientes a la señorita Silvia Elena Centella, maestra de la escuela mixta de Playón Chico.

Al: Orig. mec.

\section{9.}

\section{Septiembre 15 Narganá}

Carta de Horacio Méndez al secretario de El Porvenir, Ubaldo Barría, en la que transcribe la carta que le remitió el director de la escuela de Corazón de Jesús en la que le anuncia que se terminaron las labores escolares, y que hasta ese momento todos permanecieron en sus puestos.

Al: Orig. mec.

v. CD, n. CXIII

\section{0.}

\section{Septiembre 22 Río Cidra}

Carta del jefe de sección, Guillermo Denis, al intendente, en la que le envía la lista de las señoritas que han aceptado vestir de modo civilizado, y el gobierno se encargará de pagar sus primeros trajes.

ARPK: Carp. 111. Cop. mec.

v. CD, n. CXIV

\section{1.}

\section{Octubre 4 El Porvenir}

Carta del intendente Mojica al secretario de Gobierno y Justicia, comunicándole que se instaló el alumbrado público en Río Sidra e Isla Ratón y en los últimos días consiguió que de manera espontánea y con colaboración de la población colonial se efectuara el cambio de vestido y adornos. El día 1 de Septiembre eran ciento una las argollas 
quitadas y depositadas en la oficina de policía. Se decidió destruirlas y cambiar su forma para ser devueltas, y más de cincuenta jóvenes se encuentran confeccionando sus trajes que estrenarán con la inauguración del club social, el estado proporciona los trajes. Comenta que sólo queda por civilizar el sector de Cartí y se debe emprender la labor civilizadora aquí antes de seguir por Ailigandí.

Al: Cop. mec.

\section{2.}

\section{Octubre 15 El Porvenir}

Carta de Ubaldo Barría al encargado de la sección de Río Sidra, comunicándole que Juan $B$. Cervera ha sido nombrado maestro de la escuela de esa sección y ruega que le dispense la protección necesaria.

Al: Cop. mec.

\section{3.}

\section{Octubre 15 Río Sidra}

Carta de Juan Serracín al intendente Mojica, notificándole la llegada del maestro Juan B. Cervera, diciéndole que reunió a los indios para hablarles de la escuela y quedaron contentos.

Al: Orig. mec.

\section{4.}

\section{Octubre $17 \quad$ (EI Porvenir)}

Carta de F. J. Aguilera, intendente, al secretario de Gobierno y Justicia, enviándole la cuenta de setenta balboas de los materiales que trasladó para edificar la escuela de Río Azúcar.

Al: Cop. mec. 


\section{5.}

\section{Octubre 17 (EI Porvenir)}

Carta de Julián F. Aguilera a la maestra de Puerto Obaldía, Narcisa Navas, comunicándole que recibió su oficio y que la bandera la tendrá antes del 3; de los útiles hará la reclamación debida.

Al: Cop. mec.

\section{6.}

\section{Octubre 23 (EI Porvenir)}

Carta al secretario de Gobierno y Justicia, anunciando que ha sido enviada la factura de los sacos de cemento para la escuela de Río Azúcar, pero que el cemento no ha llegado.

Al: Cop. mec.

\section{7.}

\section{Noviembre 14 El Porvenir}

Carta del intendente al secretario de Gobierno y Justicia, en la que le comunica que fue nombrado maestro de isla Tigre, Gilberto Illueca. Le comenta los inconvenientes que tiene nombrar maestros en lugares donde no se ha establecido un régimen de gobierno, y las dificultades que encuentra el maestro de Tigre por hallarse en esta situación. Concluye exponiendo que la circunscripción de San Blas depende en todo del despacho de Gobierno y Justicia incluido el establecimiento de escuelas.

Al: Cop. mec.

\section{8.}

\section{Noviembre 14 El Porvenir}

Carta del secretario de Gobierno y Justicia a Mojica, 
comunicando que el día 3 de los corrientes fue escogido por los indígenas de Río Sidra y Río Azúcar para llevar a cabo el cambio de vestido en niñas,jóvenes y mayoría de señoras, y que se realizó en armonía según las indicaciones del Presidente de la República.

Al: Cop. mec.

\section{9.}

\section{Noviembre 24 El Porvenir}

Carta de Andrés Mojica al secretario de Gobierno y Justicia, comunicándole que los indios de Cartí, llevados en contra de la acción alentadora del Gobierno, se dedican a levantar los ánimos de los de Tigre y Río Azúcar con el fin de eliminar las labores escolares en este y no permitir establecer dichas labores en el primero, pues cuando les hablan de maestros ellos dicen que no. Y que la implantación de la policía en Cartí es fácil y sin peligro, que lo que les atemoriza es el establecimiento de la escuela y ahora no se puede por estar terminando el curso. Lo que se podría hacer es ir preparándoles

Al: Cop. mec.

320.

\section{Río Sidra}

Informe del jefe de la sección de Río Sidra al intendente, comentando las labores realizadas en los meses del último trimestre del año. Trata de la construcción de casas y escuela así como del "Club Belisario Porras" y parque "Pedro Paniza" víctima de la civilización.

Al: Orig. mec.

321.

\section{Enero 14 Narganá}

Carta de Horacio Méndez a Ubaldino Barría, en la que pide doce 
libras de clavos para la construcción del nuevo club que en pro de la civilización se está construyendo en Corazón de Jesús.

AELI: Carp. Car. 1924. Cop. mec.

\section{2.}

\section{Enero 24 El Porvenir}

Carta de Ubaldo Barría, secretario, al jefe del primer destacamento de Narganá, Antón Zandole, para que aplique la pena de arresto o multa que considere conveniente al señor Gilberto Illueca por su labor obstruccionista en la población de Tigre, donde desempeña el cargo de maestro de escuela, el cual impone prácticas distintas a la que de cierto tiempo para acá ha venido empleando

AELI: Carp. Car. 1924. Cop. mec.

\section{3.}

\section{Enero 29 El Porvenir}

Carta de Ubaldo Barría, en la que dice que desde hace seis meses en Río Cidra se implantó la escuela y la policía, y que ya se ha adelantado mucho.

AELE: Car. 1921-24-25-26. Cop. mec.

v. CD, n. CXV

\section{4.}

\section{Febrero 8 Tigre}

Carta del director de la escuela de esta isla, Gilberto Illueca, al intendente, en la que tratando a los indios de salvajes e hipócritas comenta que la policía indígena no presta servicios. Así mismo acusa al gobierno de debilidad y habla del abandono de los que estudiaban en la Capital.

AELE: Car. 1921-24-25-26. Cop. mec.

$$
\text { V. CD, n. CXVI }
$$




\section{5.}

\section{Febrero $14 \quad$ Narganá}

Carta del jefe del destacamento Horacio Méndez en la que pide al encargado de la Intendencia, Ubaldo Barría, doce libras de clavos para la construcción del nuevo club que en pro de la civilización se está construyendo en Corazón de Jesús

AELI: Carp. Car. 1924. Cop. mec.

326.

\section{Febrero 14 Tupile}

Lista de indígenas, confeccionada por Miguel Gordón, que asistirán a la inauguración del Club Claudio Iglesias procedentes de Tupile, Narganá y Corazón de Jesús.

Al: Orig. mec.

\section{7.}

1924 Febrero 16 El Porvenir

Carta del intendente a Horacio Méndez, enviándole solamente seis libras de los clavos pedidos.

AELI: Carp. Car. 1924. Cop. mec.

\section{8.}

1924 Febrero 21 El Porvenir

Informe del intendente comentando la imposición de placas e insignias a la policía colonial.

AELI: Carp. Car. 1924. Cop. mec.

\section{9.}

\section{Marzo 7 El Porvenir}

Carta del intendente Mojica al Presidente de la República Belisario, comentando el informe del jefe del segundo destacamento 
Miguel Gordón sobre los adelantos de Playón Chico. El intendente opina que se podía dar becas a jóvenes de aquí y Tupile. Comenta la buena labor de las dos maestras en esta escuela.

ARPK: Carp. 29. Cop. mec.

v. CD, n. CXVII

\section{0.}

\section{Marzo 12 El Porvenir}

Carta de Mojica al Jefe del segundo destacamento, notificándole que recibió su carta y la lista de los indígenas que asistirán a la inauguración del centro social de Playón Chico. Le felicita por su labor y ofrece su apoyo para que la maestra siga en ese puesto, pues la considera un elemento importante en la tarea de instrucción.

Al: Cop. mec.

V. CD, n. CXVIII

\section{1.}

\section{Marzo 13 Panamá}

Carta del Presidente al intendente, para agradecerle el informe de la inauguración del "Club Claudio Iglesias". Y comenta la vuelta a sus islas de los alumnos en vacaciones. Propone las becas para Tupile y Playón a Instrucción Pública; y que se deje a los mismos maestros.

AELE: Car. de 1921-24-25-26. Orig. mec. v. CD, n. CXIX

\section{2.}

\section{Marzo $14 \quad$ Narganá}

Carta de varios indios al Presidente de la República, pidiendo que no quiten al intendente Mojica que tanto ha hecho en pro de la civilización. 
ARPK: Carp. 88. Cop. mec.

V. CD, n. CXX

333.

\section{Marzo 15 Panamá}

Carta del Presidente de la República al intendente, asegurándole que no habrá cambios en los maestros de la comarca de San Blas, pues ya había hablado con el secretario de Instrucción Pública que se lo ha asegurado. Comenta finalmente el tema de la becas.

ARPK: Carp. 29. Cop. mec.

V. CD, n. CXXI

334.

1924 Marzo 24 (Panamá)

Carta a Belisario Porras en la que habla de los indios de San Blas y de los progresos que se hacen para llegar a la civilización. Argumenta que estas mejoras sirven para aumentar la moral

ANP: Tom. B.P. año 1920-1924. Cop. mec.

\section{5.}

\section{Abril 1 Narganá}

Carta del jefe del destacamento, en la que comenta que los agentes coloniales cobran 2,25 balboas al mes como sueldo.

AELI: Carp. Car. 1924. Cop. mec.

\section{6.}

\section{Abril 4 El Porvenir}

Carta del intendente Mojica a Belisario Porras, en la que dice 
que está conforme con el secretario de Instrucción Pública en no cambiar el plantel educativo de San Blas, pero sí el de una persona que no cree apta para la labor civilizadora.

AELE: Carp. Car. 1921-24-25-26. Cop. mec. v. CD, n. CXXII

\section{7.}

\section{Abril 4 Narganá}

Carta de Estanislao López y Alcibiades Iglesias a Mojica, mandando la relación de niños que merecen las becas para la capital. Al mismo tiempo que demandan para dos muchachos plazas para el Hospicio.

AELI: Carp. Car. 1924. Orig. mec.

\section{8.}

\section{Abril 6 Narganá}

Carta de M. J. Herrera en la que envía a Mojica dos alzamuros pertenecientes al indígena Tomás Arias, que se encontraban depositados en ese despacho.

AELI: Carp. Car. 1924. Orig. mec.

\section{9.}

\section{Abril 10 Isla Tigre}

Carta de Raimundo González invitando a Mojica y su señora a la inauguración del Club Social, que será el 15 del presente y al mismo tiempo les nombran padrinos.

AELI: Carp. Car. 1924. Orig. mec.

\section{0.}

\section{Abril 10 Isla Tigre}

Carta de Raimundo González en la que invita a Ubaldo Barría y su señora a la inauguración del Club Social,que será el 15 de abril. 
AELI: Carp. Car. 1924. Orig. mec.

\section{1.}

\section{Abril 13 Narganá}

Carta del jefe del destacamento al intendente, comentando que se está llevando a cabo el trabajo de cedulación en esta isla y la de alrededor.

AELI: Carp. Car. 1924. Orig. mec.

\section{2.}

\section{Abril 13 Narganá}

Carta de Miguel Gordón al intendente Mojica, anunciándole que el pueblo de Playón Grande ha abandonado sus costumbres tradicionales por las de la gente civilizada y han construido un centro de recreo. Dice que las mujeres están interesadas en las costumbres implantadas en Tupile y Playón Chico.

Al: Orig. mec.

V. CD, n. CXXIII

\section{3.}

\section{Abril 19 El Porvenir}

Orden de Mojica en la que se autoriza la movilización del cuerpo de policía colonial por lo que queda del segundo semestre del año en curso.

AELI: Carp. Car. 1924. Cop. mec.

\section{4.}

1924 Abril 21 Panamá 
Carta del Presidente Belisario al intendente Mojica, en la que le informa que el secretario de Instrucción Pública le ha comunicado que el señor Gilberto Illueca no ha sido nombrado para el próximo año como maestro.

AELE: Carp. Car. 1921-24-25-26. Orig. mec.

v. CD, n. CXXIV

\section{5.}

\section{Abril 22 Panamá}

Carta dirigida a Belisario Porras, en la cual le comentan que se ha suspendido la orden de traslado de un policía, ya que ha prometido observar buena conducta.

ANP: Tomo 1924. Cop. mec.

V. CD, n. CXXV

346.

\section{Abril 24 El Porvenir}

Carta del intendente Mojica al Presidente Belisario, en la que le trascribe la carta que ha recibido de Miguel Gordón comunicándole que se ha producido un nuevo paso en la civilización en la isla de Playón Grande y que ha sido voluntario.

ARPK: Carp. 116. Cop. mec.

$$
\text { V. CD, n. CXXVI }
$$

\section{7.}

\section{Abril 25 El Porvenir}

Carta de la Intendencia, en la que se exige que la nuevas construcciones sean sometidas a la consideración de los destacamentos, para que guarden la distancia de las casas civilizadas.

AELI: Carp. Car. 1924. Cop. mec. 
348.

1924 Abril 30 El Porvenir

Carta del intendente al jefe de sección de policía en Río Azúcar, anunciando que va con ese destino Evelia Salcedo y pide que le preste las atenciones necesarias y le dé protección para que no sufra interrupción en el desempeño de sus funciones. Le ruega que sea respetada en todas sus tareas por los moradores de ese lugar.

AELI: Carp. Car. 1924. Cop. mec.

v. CD, n. CXXVII

349.

1924 (Abril)

Informe que comenta los atropellos de los policías. Expresa la conformidad de los sahilas con la escuela pero no con los bailes a los que les obligan a las muchachas, y sus consecuencias posteriores que llegan a los embarazos.

ARPK: Carp. Cor. de los int. 1920-1930. Cop. mec. v. CD, n. CXXVIII

\section{0.}

\section{Abril 30 El Porvenir}

Carta del intendente Mojica anunciando que van Silvia E. Centella, Felicidad Ruiz, y Evelia Salcedo a ocupar sus puestos en la escuela de Corazón de Jesús, Narganá y Río Azúcar. El Sr. Arturo Delvalle, Dora Dollander y Trinidad Hilders para Corazón de Jesús y Playón Chico, en el segundo destacamento.

AELI: Carp. Car. 1924. Cop. mec.

\section{1.}

\section{Mayo 2 Narganá}

Carta de Luis E. Alemán al intendente Mojica, en la que le comunica que va a solicitarle permiso para dirigirse a la capital el 
agente Alicio Iglesias que acompaña a los estudiantes a sus respectivos planteles.

AELI: Carp. Car. 1924. Cop. mec.

\section{2.}

\section{Mayo 3 Panamá}

Carta a Belisario Porras, notificándole que se han hecho las gestiones para conceder la beca al joven indígena Demetrio Paredes en la escuela de Artes y Oficios en las mismas condiciones que otros que se encuentran allí.

ANP: Tom. B. P. Año 1920-1924. Cop. mec.

\section{3.}

\section{Mayo 12 Panamá}

Carta del secretario de Gobierno y Justicia al intendente, comentándole que recibió la notificación de que los moradores de Playón Grande han entrado a formar parte del movimiento de civilización impulsado por el Gobierno.

Al: Orig. mec.

v. CD, n. CXXIX

\section{4.}

\section{Mayo 13 El Porvenir}

Oficio de Andrés Mojica dirigido al jefe de la sección de policía en Río Sidra, informando que ha sido nombrada la Srta. Soledad Velásquez, directora de la Escuela Mixta de Río Sidra, con el fin de reanudar la labores escolares del presente año. Solicita se las presten toda clase de atenciones y protección o ayuda que ella necesiten para el buen desempeño de su labor y comodidades personales.

Al: Cop. mec. 


\section{5.}

\section{Mayo 19 Río Cidra}

Carta de José Samuel García, jefe de la sección, informando al intendente de que en la mañana del día 14 la señorita directora dio inicio a las labores escolares; comenta el número de alumnos de los dos grados, y considera que son insuficientes los bancos y los útiles escolares escasos.

Al: Orig. ms.

\section{6.}

\section{Mayo 26 El Porvenir}

Carta del intendente Mojica al jefe del primer destacamento de Narganá, comunicando que sigue para ese lugar el Sr. Antonio Moscoso nombrado maestro para Tigre, a quien dará todas las facilidades del caso para mejor cumplimiento de su cometido.

AELI: Carp. Nom. de pol. col. Cop. mec.

\section{7.}

\section{Mayo 30 Panamá}

Carta del secretario de Gobierno y Justicia al intendente, trasmitiéndole las quejas del Sr. Bartolomé Martínez por los abusos cometidos por el corregidor de Puerto Obaldía. Le pide que investigue este asunto pues estas quejas se han repetido.

Al: Orig. mec.

\section{8.}

\section{Mayo $31 \quad$ Narganá}

Carta del jefe del primer destacamento al intendente, comentando que el director de la escuela de Río Azúcar le había 
mandado un oficio referente a la peste de alfombrilla.

AELI: Carp. Car. 1924. Cop. mec.

\section{9.}

\section{Junio 1 Río Azúcar}

Carta de Luis E. Alemán al intendente, notificándole que se dirigen hacia ahí para solicitar permiso unos indios que van a Colón para vender pailas y poder comprar madera para el piso del club que lleva el nombre de Mojica.

AELI: Carp. Car. 1924. Orig. mec.

360.

\section{Junio 3 Narganá}

Carta del Jefe del destacamento al intendente, anunciándole que los habitantes de Ticantiquí han destruido sus alzamuros y las mujeres suplican que se les envíe tela para hacerse trajes como la gente civilizada. Finalizan pidiendo que cuanto antes se les mande el maestro de escuela.

Al: Orig. mec.

v. CD, n. $\operatorname{CXXX}$

\section{1.}

\section{Junio 3 Narganá}

Lista de las indígenas del pueblo de Ticantiquí que desean trajes de gente civilizada, enviada por el jefe del destacamento.

Al: Orig. mec.

v. CD, n. CXXXI

\section{2.}

1924 Junio $10 \quad$ Narganá

Carta del Jefe del destacamento al intendente, notificándole que los habitantes de Mayugandí y Airtigandí decidieron deshacerse de los 
alzamuros, y le solicita permiso para regalar los trajes para las mujeres.

Al: Orig. mec.

V. CD, n. CXXXII

\section{3.}

\section{Junio 25 Narganá}

Carta de Marcelo J. Herrera en la que informa al intendente Mojica de su actividad visitando los pueblos y atendiendo a los enfermos; termina solicitando medicinas.

AELI: Carp. Car. de 1924. Orig. mec.

\section{4.}

\section{Septiembre 1 Tupile}

Carta de Miguel Gordón al Sr. Mojica, avisándole del envío de una planilla de la maestra de Playón Chico.

Al: Orig. mec.

\section{5.}

\section{Septiembre 4 Tupile}

Carta de Miguel Gordón a Andrés Mojica, en la que le informa de que ha sido recibido en ese despacho la planilla correspondiente a los objetos solicitados, y que los de la Srta. Dollanders, directora de Narganá, no se han recibido y el resto se entregará a la Srta. Trinidad Hilders.

Al: Cop. mec.

\section{6 .}

\section{Septiembre 8 Tupile}

Carta de Juan Berracín al Sr. Mojica, adjuntándole una relación de objetos enviados por la Srta. Trinidad Helders, maestra de la escuela de Playón Chico. 
Al: Orig. mec.

\section{7.}

\section{Septiembre 9 Porvenir}

Carta de Mojica al Presidente de la República, comentándole la conveniencia de adquirir un cinematógrafo que han ofrecido para la instrucción de los indios.

AELE: Carp. Car. 1921-24-25-26. Cop. mec.

$$
\text { v. CD, n. CXXXIII }
$$

\section{8.}

\section{Septiembre 16 Panamá}

Carta del Presidente Belisario Porras al intendente Mojica, en la que comenta que ha recibido su carta del 9 con la propuesta de adquirir un cinematógrafo y que dicha oferta la ha pasado a Gobierno y Justicia con su aprobación.

AELE: Carp. Car. 1921-24-25-26. Orig. mec V. CD, n. CXXXIV

\section{9.}

\section{Septiembre 17 Panamá}

Carta del inspector general de Enseñanza Primaria al intendente Mojica, comentando el caso del cheque del maestro de Tupile.

Al: Orig. mec.
V. CD, n. CXXXV

\section{0.}


Carta de Miguel Gordón al intendente, en la que le comunica que cuando llegó a Playón Chico encontró algunas irregularidades de personal, y que como se trata de la maestra, pide que resuelva el caso pues ya se hacen acreedores de un castigo serio según la ley. Le anuncia que envía testigos y el Sr. Docroz hará la acusación.

Al: Orig. mec.

\section{1.}

\section{Septiembre 28 Tupile}

Carta de Juan Serracín al intendente, comunicándole el envío de la planilla firmada por la maestra Srta. Trinidad Hilders, maestra de Playón Chico.

Al: Orig. mec.

\section{2.}

\section{Octubre 19 El Porvenir}

Carta de Mojica al Jefe del segundo destacamento de Tupile, en la que explica que el portador de la presente es T. R. Navia, nombrado maestro de escuela en Playón Chico; se lo recomienda y ruega que le preste toda la atención y ayuda en el desempeño de sus funciones.

Al: Cop. mec.

\section{3.}

\section{Octubre 21 Tupile}

Carta de Miguel Gordón al intendente, poniéndole al corriente de que ayer comenzó las labores escolares el joven T.R. Navia en la escuela de Playón Chico y que le prestará su ayuda para el buen desempeño de su cometido.

Al: Orig. mec. 
374.

\section{Noviembre $20 \quad$ Narganá}

Carta del jefe del destacamento Horacio Méndez al intendente, comunicándole que va hacia el Hospital Santo Tomás el alumno Moisés Barsalló, alumno de la escuela mixta de Corazón de Jesús, pues está enfermo y le acompaña Estanislao López.

Al: Orig. mec.

\section{5 .}

\section{Diciembre 13 Tupile}

Carta del jefe del segundo destacamento al intendente, pidiéndole como obra de caridad que el joven Enrique siga a Panamá a que le vea la vista un facultativo, pues casi la ha perdido. Argumenta que es uno de los primeros que cogió el rumbo de la civilización que se le dio a este pueblo, y es justo que por su lealtad al gobierno se haga todo lo posible por su salud.

Al: Orig. mec.

\section{6.}

\section{Diciembre 31 El Porvenir}

Carta de Julián Aguilera al secretario de Gobierno y Justicia, poniendo en su conocimiento que los habitantes de Ustupu han recibido felicitaciones que tenían nombres en inglés, lo que demuestra que alguna organización del Canal tiene interés en que nuestros indios piensen en hacerse de nacionalidad sajona; y esto no conviene a la labor del Gobierno.

Al: Cop. mec.

\section{7.}

\section{4}

Informe posterior a la apertura de la escuela de Río Azúcar, en el que se comenta que el maestro era de la policía nacional de Panamá. 
Refiere los incidentes del acto de inauguración de la escuela y los medios coercitivos que se emplean con los indios y el tema de la propiedad de la tierra.

ANP: Tom. B. P. año 1920-1924. Cop. mec.

V. CD, n. CXXXVI

\section{8.}

\section{Abril 21 El Porvenir}

Carta del intendente de San Blas al secretario de Gobierno y Justicia, sugiriendo que ahora que se establecieron los destacamentos se pueden nombrar los maestros para las escuelas. Habla de la venta de la casa de Ms. Coope que se podrían usar para cuartel.

Al: Cop. mec.

v. CD, n. CXXXVII

379.

\section{Agosto 3 Narganá}

Informe del jefe del destacamento Ramón Garrido al intendente, en el que expone la conducta de Miss Coope y su acompañante después de la venta de su casa y útiles. Se queja de la falta de respeto y mal comportamiento de éstas.

Al: Orig. ms.

V. CD, n. CXXXVIII

\section{0.}

\section{5}

Discurso de conmemoración de los primeros luchadores por la civilización, comenta los que cayeron muertos y trata de la petición de las maestras y las defensas de la policía indígena.

AELE: Carp. Car. 1915-22-23. Cop. mec. 
381.

1926 Abril 3 El Porvenir

Carta de Luis Hernández a Rodolfo Chiari, recomendándole a un joven indio que se dirige hacia Panamá y que es gran defensor del gobierno y la civilización.

AELE: Arch. y doc. 1915-22-33. Orig. mec.

V. CD, n. CXXXIX

382.

\section{Abril $15 \quad$ Narganá}

Carta de Ramón Garrido al intendente, rogándole que haga saber al inspector de educación que los estudiantes que están allí no viajarán para sus escuelas, sino cuando venga el Sr. Presidente, pues quieren hablar con él.

Al: Orig. mec.

\section{3.}

\section{Abril 18 Narganá}

Carta de Ramón Garrido al intendente, en la que le comenta que los indios de Río Azúcar tienen terminadas las casas donde deben funcionar las escuelas, por lo que pide que tome interés en el asunto para que manden los maestros, pues esto es de interés general y a la vez que se ayuda al ramo de Instrucción Pública se mantendría satisfecho a un buen amigo del Gobierno.

Al: Orig. mec.

\section{4.}

1926 Junio 12 Narganá

Carta del jefe del destacamento al intendente, en la que le 
comunica que sigue para allí el carpintero, después de haber reparado las escuelas de Narganá y Corazón de Jesús.

Al: Orig. mec.

\section{5.}

1926 Junio (10) Narganá

Carta de un grupo de indígenas, socios del club progreso de Narganá, al Presidente de la República pidiendo un botiquín y una biblioteca.

AELE: Carp. Car. 1921-24-25-26. Cop. mec.

V. CD, n. CXL

386.

1926 Junio 13 Narganá

Carta de Ramón Garrido al intendente, en la que comenta el buen recibimiento dispensado a la maestra de Río Azúcar a quien fueron a buscar a su despacho; y en su pueblo posteriormente la recibieron con vivas atronadoras.

Al: Orig. mec.

v. CD, n. CXLI

\section{7.}

\section{Enero 20 Narganá}

Carta del corregidor de Narganá al secretario del despacho, en la que le avisa que dos agentes indígenas van para Panamá a recoger a sus hijos que están en el colegio, y comenta que Róbinson también ha solicitado en este despacho permiso para el mismo fin que los anteriores.

Al: Orig. mec. 
388.

\section{Febrero 12 Narganá}

Carta de Ramón Garrido al intendente, en la que le recomienda a un indígena para carpintero de la Intendencia, pues ha salido diplomado de la escuela de Artes y Oficios.

Al: Orig. mec.

V. CD, n. CXLII

\section{9.}

\section{7 (Febrero) El Porvenir}

Informe del intendente al secretario de Gobierno y Justicia. En lo referente a Instrucción Pública dice que marcha perfectamente bien y que cada año toma más auge, y los niños concurren con puntualidad y entusiasmo a las clases y se les nota el deseo de aprender; le han tomado amor al estudio y cariño a sus maestros. Pone los lugares donde hay escuela: Narganá, Corazón de Jesús, Río Azúcar y Puerto Obaldía. Atribuye el aumento de la civilización al celo manifestado por los maestros.

Al: Cop. mec. inc.

V. CD, n. CXLIII

\section{0.}

\section{Febrero 23 Narganá}

Carta de Charles Róbinson, Alicio Iglesias y Estanislao López al intendente, confesando que están dispuestos a poner orden y disciplina en su pueblo, y se quejan del comportamiento de un policía que está corrompiendo a una hija del pueblo, por lo que quieren que le quiten del lugar.

Al: Orig. ms. inc.
v. CD,
n. CXLIV 


\section{1.}

\section{Abril 19 Narganá}

Carta de Ramón Garrido al intendente, comentando que acompañado de los estudiantes del Instituto Nacional va un joven que desea que lo recomiende para continuar sus estudios en la escuela de Artes y Oficios.

Al: Orig. mec.

v. CD, n. CXLV

\section{2.}

\section{Abril 20 EL Porvenir}

Carta del intendente al secretario de Estado en el despacho de Instrucción Pública, pidiéndole recomendación para un joven que desea seguir estudios en la Escuela de Artes y Oficios.

Al: Cop. mec.

V. CD, n. CXLVI

\section{3.}

\section{Abril $27 \quad$ Narganá}

Carta de Ramón Garrido al intendente, en la que le suplica que autorice el paso a las hermanas Iglesias que deben presentarse en el colegio y van acompañadas de su hermano.

Al: Orig. mec.

V. CD, n. CXLVII

\section{4.}

\section{Mayo 3 Narganá}

Carta de Ramón Garrido al intendente, notificándole que abrieron sus puertas las escuelas, y la matrícula es bastante buena pero 
espera que mejore en el transcurso de la semana, así lo ha manifestado el director. Comenta que el director le pidió ayuda para reparar las escuelas.

Al: Orig. mec.

V. CD, n. CXLVIII

\section{5.}

\section{Mayo 5 Panamá}

Decreto dado en la ciudad de Colón para abrir una escuela para los indios de este lugar.

ARPK: Carp.135. Cop. mec.

\section{6.}

\section{Mayo 7 Narganá}

Carta de Ramón Garrido al intendente, recomendando a un joven que fue a Panamá con intención de conseguir una beca y no lo ha logrado; y ahora se dirige hacia allí su padre. También le pide ayuda para que otro joven pueda terminar sus estudios en Artes y Oficios.

Al: Orig. mec.

v. CD, n. CXLIX

\section{7.}

\section{Mayo Panamá}

Carta del general Inapaquiña al Presidente de la República, solicitando un título para poder apaciguar a los indios. Esta resolución se había tomado en el congreso de mayo. Dice que él conoce lo que es la civilización y así mismo se considera un hombre educado. Finaliza comentando el problema de los negros.

AELE: Carp. Arch. y doc. Car. imp. 1920-30. Cop. mec.

$$
\text { v. } C D, \text { n. } C L
$$


398.

\section{Junio 10 Narganá}

Carta del corregidor de Narganá, Garrido, al intendente, en la que le comunica el paso de una lancha de extranjeros, que dicen ser suizos.

ARPK: Carp. 145a. Cop. mec.

$$
\text { V. CD, n. CLI }
$$

\section{9.}

\section{Julio 17 Narganá}

Carta del sub-teniente Hipólito Guevara al intendente, prometiéndole que reprenderá fuertemente a los indígenas que cometan faltas. Comenta el compromiso de los ságuilas de Narganá de construir escuela para la maestra que falta.

Al: Orig. mec.

v. CD, n. CLII

\section{0.}

\section{Julio 17 Narganá}

Carta del jefe del destacamento al intendente, comentando que el director de las escuelas le ha pedido un policía para que le secunde en sus labores de cobro de impuestos, y pretexta que todos tienen recargado el servicio. $Y$ aclara que ahora presta los útiles de la oficina al director ya que éste carece de ellos.

Al: Orig. mec. inc.
v. CD, n. CLIII 
Carta de Estanislao López al Presidente Chiari, en la que le comunica que ha quedado formado el " Comité Indígena de Centuriones Chiaristas" del cual es presidente.

AELE: Carp. Arch. y doc. Orig. mec.

$$
\text { V. CD, n. CLIV }
$$

\section{2.}

\section{Agosto 29}

Carta al intendente, sin firma, transmitiendo el malestar de los indios por los trabajos que realizan de relleno en la escuela, como todos los años. Algunos se quejaban de que esos trabajos eran malos y más para los niños. Argumenta que la instrucción moderna debe salir fuera de las cuatro paredes de la escuela, y transcribe las palabras de José Crespo que piensa que hay que educar a la juventud para hacer una nación grande.

Al: Cop. mec.

\section{3.}

\section{Agosto Panamá}

Carta de los narganeses al Presidente R. Chiari, pidiendo que nombre a Arturo R. Pérez corregidor, puesto que es promotor de la civilización y esto ayudará a mantener el orden y adelanto.

AELE: Carp. Arch. y doc. Cop. mec. inc.

$$
\text { v. CD, n. CLV }
$$

\section{4.}

\section{Septiembre 1 Puerto Obaldía}

Informe del Sr. Plutarco al intendente, en el que escribe en lo referente a la Instrucción Pública, que el maestro ha llenado un gran vacío y que siempre lo agradecerán. Y habla de otras mejoras que 
redundarán en bien de la comarca.

Al: Orig. mec.

\section{5.}

\section{Septiembre 9 El Porvenir}

Carta de Arturo R. Pérez a Estanislao López, en la que solicita que pida su nombramiento de corregidor ya que él ha luchado por el adelanto de Narganá. Comenta que ha progresado la civilización desde que él está allí.

AELE: Carp. Arch. y doc. Orig. mec.

\section{v. CD, n. CLVI}

\section{6.}

\section{Octubre 1 Puerto Obaldía}

Informe de Plutarco Batista al intendente, expresándole que en las escuelas públicas las funciones escolares se han suspendido a mediados pues el maestro no fue hasta entonces que recibió un radio para presentarse a conferencia del magisterio, pero que llegará pronto a reanudar sus labores.

Al: Orig. mec.

\section{7.}

\section{Noviembre 2 Narganá}

Discurso del joven Enrique Morales conmemorativo de la muerte de Claudio Iglesias y Agustín González, en el que se relata que fueron mártires por sus ideas civilizadoras.

AELE: Carp. Arch. y doc. Cop. mec.

v. CD, n. CLVII

408.

\section{Noviembre 3 Narganá}

Discurso del joven Estanislao G. López en las fiestas del 3 de 
Noviembre, en el que se elogia el grado de civilización alcanzado y la posibilidad de ir a la escuela en San Blas.

AELE: Carp. Arch. y doc. Cop. mec.

\section{9.}

\section{Noviembre 29 Narganá}

Carta de Estanislao López y Pablo Iglesias al partido liberal, exponiendo su deseo de elegir sus representantes y para ello aducen el grado de civilización que han alcanzado.

AELE: Carp. Arch. y doc. Orig. mec.

\section{0.}

\section{Diciembre 20 Panamá}

Carta del Sr. López al intendente, para decirle que dé de alta como policía indígena, incluido en la planilla de sueldos desde enero, al indígena Nicolás Herrera, quien debe seguir prestando servicios de policía escolar en San Blas, como ha venido haciendo hasta ahora.

Al: Orig. mec.

\section{1.}

\section{Mayo}

Informe de los alumnos de la Escuela de Artes y Oficios, haciendo una reglamentación para que la becas de los que terminan o se retiran se den a gente que sea examinada por personal del ramo.

AELE: Carp. Arch. y doc. Car. imp. 1927-1930. Cop. mec.

\section{2.}


Carta del Gobernador Inocencio Galindo al intendente, en la que le anuncia que próximamente irán para ese lugar el $P$. Anglé y varias hermanas para inspección de la escuela y posteriormente posesionarse de ellas.

Al: Orig. mec.

V. CD, n. CLVIII

\section{3.}

\section{Septiembre 27 Río Sidra}

Carta de Denis al intendente Andrés Mojica, en la que comenta el tema de la civilización y dice que va para adelante y el amor de los indios hacia ella crece. Comenta que el único enemigo es el sahila Soo.

Al: Orig. mec.

\section{4.}

\section{Septiembre 28 Panamá}

Carta al intendente, trascribiéndole el decreto de nombramiento de maestros para la comarca de San Blas.

Al: Orig. mec.

V. CD, n. CLIX

\section{5.}

\section{Octubre 1 Narganá}

Carta de los representantes de Narganá al Presidente Florencio, pidiendo que sean destituidos de su cargo Charles Róbinson y los agentes de policía, porque no cumplen con su deber y dan malos ejemplos.

AELE: Carp. Arch. y doc. Car. imp. 1927-30. Cop. mec. 
416.

\section{Octubre 5 Narganá}

Carta de los representantes de Narganá, Corazón de Jesús y Río Azúcar al Presidente Florencio, pidiendo que ponga de intendente a Tomás Emilio Abello, persona que ha defendido los intereses de los indios.

AELE: Carp. Arch. y doc. Car. imp.1927-30. Cop. mec.

\section{7.}

\section{Noviembre 13 El Porvenir}

Carta del intendente al secretario de Gobierno y Justicia, comentándole una visita del Obispo en la que llegaron hasta la isla de Tigre, en la cual el sahila expresó el deseo de tener una entrevista, pues desea su adhesión al Gobierno para lo que deben emplear regalos; él por su parte procurará apaciguar a los indios de los alrededores.

Al: Cop. mec.

\section{8.}

\section{Noviembre $17 \quad$ Narganá}

Carta que relata los problemas que traerá la civilización a la comarca. Comenta que lo irán a estudiar los gobernantes a la región misma.

AELE: Carp. Arch. y doc. Car. imp. 1927-1930. Cop. mec.

\section{9.}

\section{Diciembre 11 Panamá}

Carta del subsecretario de Gobierno y Justicia al intendente Abello, comunicándole los nombramientos de maestros para Narganá y 
la circunscripción.

Al: Orig. mec.
v. CD, n. CLX

420.

1928

Carta de Abel Ortiz, Alfredo Brenes y Ernesto Peña a la escuela de Artes y Oficios, remitiendo los nuevos reglamentos sobre becas y exámenes de selección. Comentan los problemas que presentan los becados.

AELE: Carp. Arch. y doc. Car. imp. 1927-30. Cop. mec. v. CD, n. CLXI

\section{1.}

\section{Narganá}

Crónica de las Franciscanas de Panamá en el que se detalla el transcurso de las actividades escolares en Narganá, donde imparten la enseñanza.

CFN: Com. de las Fran. de Pan. Orig. mec.

\section{2.}

\section{Enero 1 Panamá}

Informe de los indios Manuel González, Machi Jorge, Manuel Roldán y Carlos Rey, comentando la visita al secretario de Gobierno y Justicia y expresando su deseo de cesar en las hostilidades a la acción civilizadora del Gobierno. Piden escuelas y maestros indígenas.

ARPK: Carp. 21. Cop. mec.

v. CD, n. CLXII 


\section{3.}

\section{Enero 19 Narganá}

Carta de Félix Monasterio al intendente, notificándole que las maestras de Río Azúcar, las más sacrificadas de la región por las condiciones en que tienen que vivir, desean adelantar los exámenes y él no considera que sea problema, le ruega que se lo conceda.

Al: Orig. mec.

\section{4.}

\section{Enero 26 Panamá}

Certificado de las alumnas Hermelinda Rodríguez y Felicidad González, por los estudios realizados en el Hospital Santo Tomás en la especialidad de Ostetricia.

AELE: Carp. Arch. y doc. Car. imp. 1927-30. Cop. mec. v. CD, n. CLXIII

\section{5.}

\section{Febrero 10 El Porvenir}

Carta del intendente al director Simón Bravo, notificando que recibió los datos estadísticos y comenta que los resultados son satisfactorios y le ruega que en el informe anual no haga mención del aumento de maestros. Expone su opinión en el asunto de la maestra de Corazón de Jesús que el cree que debe ser una hermana franciscana, y señala que el nombramiento de maestra se hará por decreto.

Al: Cop. mec.

\section{6.}

1929 Marzo 19 Panamá

Carta de Estanislao y E. Morales al Presidente del Consejo 
Municipal, escriben en nombre de los indígenas de San Blas residentes en la capital solicitando cuatro becas para el colegio María Auxiliadora, y proponen los nombres de los seleccionados. Consideran que esto contribuirá a la civilización.

AELE: Carp. Arch. y doc. Car. imp. 1927-30. Cop. mec. v. CD, n. CLXIV

\section{7.}

\section{Marzo Panamá}

Carta de Estanislao. Morales y Herrera al señor Tomás Arauz, en la que solicitan las cuatro becas para los jóvenes en el colegio de Maria Auxiliadora.

AELE: Carp. Arch. y doc. Car. imp. 1927-30. Cop. mec.

428.

\section{Abril 9 Panamá}

Carta de Estanislao López, Tomás Herrera y Enrique Morales al Presidente Florencio Harmodio, en la que recuerdan las becas que en su tiempo dio el Presidente Belisario para hacer obstetricia. Piden que éstas tengan nombramiento en San Blas, para beneficio de los indigenas.

ARPK: Carp. 88. Cop. mec. 
Carta de Estanislao y Morales al Dr. Prieto del Hospital, hablando de un joven que quiere ser practicante. Piden una ayuda y ellos harían un esfuerzo para que se lleve a cabo.

AELE: Carp. Arch. y doc. Car. imp. 1927-30. Cop. mec. V. CD, n. CLXV

430.

\section{Abril 16 Panamá}

Carta de Estanislao L. y el segundo representante E. Morales al Sr. Felipe Clement, secretario de Agricultura y Obras Públicas, en la que proponen un joven para las becas del Hospital.

AELE: Carp. Arch. y doc. Car. imp. 1927-30. Cop. mec. V. CD. n. CLXVI

431.

\section{Abril 22 Panamá}

Carta de Clement al Sr. Estanislao L. y E. Morales, diciendo que en el Hospital Sto. Tomás sólo admiten mujeres para estudiar la especialidad parteras.

AELE: Carp. Arch. y doc. Car. imp. 1927-30. Cop. mec. V. CD, n. CLXVII

\section{2.}

\section{Mayo 4 Narganá}

Carta de Adriano Robles al intendente de la circunscripción de 
San Blas, en la que le comunica la imposibilidad por el momento de establecer más escuelas en esa región, por motivo de no estar incluido en el presupuesto.

Al: Orig. mec.

V. CD-, n. CLXVIII

433.

1929 Mayo 6 Panamá

Carta del Presidente Florencio a Estanislao, Enrique Morales y Tomás Herrera, en la que les comunica que han sido nombradas, como trabajadoras con 20 Balboas de sueldo en la Sección de Puericultura e Higiene Escolar, las Srtas. Teresa González L., Teresa Garrido, Hermelinda Rodriguez, Felicidad Rivera e Inés Garrido.

ARPK: Carp. 88. Orig. mec.

V. CD, n. CLXIX

434.

\section{Mayo 8 Panamá}

Carta del subsecretario Adámez al intendente de El Porvenir, transmitiéndole el contenido del decreto quo nombra a la maestra de la escuela de Puerto Obaldia, L.D. NeWistrator.

Al: Orig. mec.

V. CD. n. CLXX

\section{5.}

\section{Mayo 20 Panamá}

Nombramiento de las tres jóvenes que vinieron de Panamá con 
destino a Rio Azúcar como ayudantes puericultoras.

AELE: Carp. Arch. y doc. Car. imp. 1927-30. Cop. mec.

436.

\section{Junio 11 Panamá}

Carta de una representación de Narganá, Corazón de Jesús y Rio Azúcar al Presidente de la República, en la que piden que les informe sobre los estudiantes de Panamá becados por el Gobierno, y si se han suspendido estas becas en los cuatro planteles de la capital.

AELE: Carp. Arch. y doc. Car. imp. 1927-30. Cop. mec. V. CD, n. CLXXI

437.

\section{Junio 14 Panamá}

Carta de Adriano Robles al intendente, en la cual comenta el caso de un indigena que molesta a la maestra. Señala las medidas tomadas para evitar que los indios se emborrachen con alcoholes perfumados.

All: Orig. mec.

V. CD. n. CLXXII

438.

\section{Junio 17 Panamá}

Carta de Inapaquiña al Presidente del Gobierno, en la que dice que, tras una reunión con los sahilas de las comunidades más importantes, ha intentado atraer a las tribus más reacias a la 
civilización. Pide protección para sus tierras y titulo de propiedad de la comarca.

AELE: Carp. Arch. y doc. Car. imp. 1927-30. Cop. mec.

439.

\section{Agosto 22 Panamá}

Comunicado para el Sr. Francisco Ossa, anunciándole su designación como maestro para la escuela de Nargani en el curso 1929-1930. Lleva adjunto el certificado de toma de posesión firmado por el director de las escuelas.

Al: Orig. mec.

V. CD, n. CLXXIII

\section{0.}

\section{Agosto 26 El Porvenir}

Carta del intendente Abello al corregidor de policia de Puerto Obaldia, autorizándole a que haga el pago del local alquilado de la escuela que importa 5 balboas.

Al: Cop. mec.

441.

\section{Septiembre 10 El Porvenir}

Carta de Abello al subteniente jefe del destacamento de Nargank 
comunicándole que desde el primero se han nombrado policías escolares, de Rio Azúcar a Miguel Aranda y Nicolás Herrera, y que el cheque de estos sueldos va a nombre del policla escolar Nicolás Herrera; debe repartirlo con Aranda de la misma forma que lo hacen los sahilas.

Al: Cop. mec.

\section{2.}

\section{Septiembre 11 Playón Chico}

Carta del intendente Abello a Félix Monasterio, informándole que se dirige hacia esa la Srta. Ruby Smith, nombrada maestra de ese lugar en reemplazo de Cristina G. de Valdés; se la recomienda y espera que sea acogida con complacencia.

Al: Cop. mec.

\section{3.}

\section{Septiembre 13 El Porvenir}

Carta del intendente al secretario de Gobierno y Justicia, en la que le comenta que se ha abierto un grado más en Puerto Obaldía y le especifica el costo del alquiler de la escuela. Se queja de que el programa oficial de las escuelas no es el adecuado para la región y que los maestros se ausentan de sus puestos sin causa justificada. Comenta que no ha querido inmiscuirse en el régimen interno de las escuelas de la Comarca.

Al: Cop. mec. inc. V. CD, n. CLXXIV

444. 
Carta del intendente a Félix Monasterio en la que le transcribe un oficio recibido de Panamá, que dice que la educación de San Blas depende en todo de la Secretaria de Gobiemo y Justicia y que este despacho se propone crear programas especiales para las escuelas de la comarca, pero mientras esto sucede deben seguir los programas oficiales, haciendo preferencia a la enseñanza del castellano y otras materias básicas.

Al: Cop. mec.

V. CD, n. CLXXV

\section{5.}

\section{Septiembre 21 El Porvenir}

Carta del intendente al secretario de Gobiemo y Justicia, comunicando que recibió su oficio en el que se le da el cargo de inspector de las Escuelas Púiblicas de San Blas. Se propone dar a las escuelas la prosperidad que debe prestigiarlas.

Al: Cop. mec.

V. CD, n. CLXXVI

446.

\section{Septiembre, 26 El Porvenir}

Carta del intendente al inspector general de enseñanza, transcribiéndole la carta que el Presidente de la República dirigió a su sefiora, en la que le comunica su nombramiento de maestra en El Porvenir. $Y$ pide que le envie los nombramientos de su esposa y otro maestro para que puedan comenzar sus labores una vez tomada posesión del cargo.

Al: Cop. mec. inc. V. CD, n. CLXXVI I 


\section{5.}

\section{Septiembre 21 El Porvenir}

Carta del intendente al secretario de Gobierno y Justicia, comunicando que recibió su oficio en el que se le da el cargo de inspector de las Escuelas Públicas de San Blas. Se propone dar a las escuelas la prosperidad que debe prestigiarlas.

Al: Cop. mec.

V. CD, n. CLXXVI

\section{6.}

\section{Septiembre 26 El Porvenir}

Carta del intendente al inspector general de enseñanza, transcribiéndole la carta que el Presidente de la República dirigió a su señora, en la que le comunica su nombramiento de maestra en El Porvenir. $Y$ pide que le envíe los nombramientos de su esposa y otro maestro para que puedan comenzar sus labores una vez tomada posesión del cargo.

Al: Cop. mec. inc.

V. CD, n. CLXXVII

\section{7.}

\section{Octubre 17 El Porvenir}

Carta del intendente Abello a Félix Monasterio, avisándole del envío de la nota que se remitió a $P$. Anglé notificándole los nombramientos de Angelina de Abello y Francisco Ossa. Le ruega que firme la notificación y haga constar que comenzaron sus labores el día 1.

Al: Cop. mec.

\section{8.}

1929 Octubre 19 (Panamá)

Discurso de Estanislao López ante la Federación Obrera. Dice que 
los que van más adelantados en la civilización tienen el deber de velar por los compañeros para que sean respetados sus derechos.

AELE: Carp. Arch. y doc. Car. 1915-22-33. Cop. mec.

\section{9.}

1929 Diciembre 11 Río Azúcar

Carta de Inés de Córdoba al secretario de Instrucción Pública, relatando la situación que se ha producido con un maestro que está ejerciendo sus funciones y no ha devengado sueldo todavía.

Al: Orig. ms.

V. CD, n. CLXXVIII

\section{0.}

\section{Diciembre 12 Narganá}

Carta de Félix Monasterio al intendente Abello, adjuntándole la petición de la maestra de Río Azúcar de un sueldo devengado, que aún no se ha cobrado. Dice que la señora del intendente puede estar en esta situación, por lo que deberá cursar las instancias.

Al: Orig. mec.

V. CD, n. CLXXIX

\section{1.}

\section{Diciembre 23 El Porvenir}

Carta del intendente Abello a la maestra Inés V. de Córdoba, respondiéndole que enterado por ella del deseo de los habitantes de Tigre de fundar escuela, hablará con el secretario de Gobierno para estudiar el caso en el curso próximo, ya que este está al concluir.

Al: Cop. mec.
V. CD, n. CLXXX 


\section{2.}

\section{9}

Lista de los cheques enviados al personal de la comarca de San Blas.

Al: Orig. mec.

V. CD, n. CLXXXI

\section{3.}

\section{Enero 18 Narganá}

Carta de Félix Monasterio al intendente, en la que le comunica que recibió una carta de la Secretaría de Gobierno anunciándole que los exámenes finales de la comarca comenzarán el 3 de Febrero, y se clausurarán los mismos el sábado 8 de ese mes; pero dice que esto se referirá a la escuela de El Porvenir regentada por su señora, y que cree que a Puerto Obaldía avisarán de Instrucción Pública.

Al: Orig. mec.

\section{4.}

\section{(1930) Enero Narganá}

Circular de Ricardo Velasco a los maestros, comentando el tema de los exámenes finales y la forma de desarrollarlos. Pide que se expongan los trabajos de los alumnos para inspección del público y examinadores; así como que publiquen las listas de promovidos y fracasados.

Al: Orig. mec.

\section{5.}

\section{Febrero 3 Puerto Obaldía}

Oficio de Diógenes lbáñez al intendente, enviándole el inventario 
general de la escuela, y el censo escolar con los cursos que funcionan. Opina que podrían trabajar dos maestros en ese lugar y finaliza comentando los exámenes.

Al: Orig. mec.

V. CD, n. CLXXXII

456.

\section{Febrero 3 Puerto Obaldía}

Oficio del Sr. Diógenes lbáñez al intendente, en el que informa de la actuación de la Srta. maestra a su cargo, quejándose de su comportamiento y sus pocas habilidades para la docencia; apostilla que ha registrado 38 ausencias escolares.

Al: Orig. mec.

V. CD, n. CLXXXIII

\section{7.}

\section{Abril 25 Panamá}

Decreto de nombramiento del personal docente de las escuelas de la comarca de San Blas, en el que pone el inicio y fin de las tareas escolares, así como el tiempo de vacaciones semestrales.

Al: Orig. mec.

V. CD, n. CLXXXIV

458.

1930 Abril 28 Panamá

Carta del secretario de Gobierno y Justicia al intendente, adjuntándole las recomendaciones hechas por Estanislao López y Roberto Pérez para cubrir cuatro becas indígenas que quedaron vacantes en la escuela de Artes y Oficios. Le pide su opinión.

Al: Orig. mec.

v. CD, n. CLXXXV 


\section{9.}

\section{Mayo 1 Narganá}

Actas de la toma de posesión de los maestros de la comarca de San Blas.

Al: Orig. mec.

v. CD, n. CLXXXVI

\section{0.}

\section{Mayo 5 Narganá}

Carta del jefe del destacamento al intendente, en la que le comenta que anteriormente la posesión de los maestros se efectuaba en el despacho del destacamento, aunque sabe que ahora se hace en la Intendencia, pero él se ha visto obligado a dar posesión a los maestros en esta ocasión.

Al: Orig. mec.

V. CD, n. CLXXXVII

\section{1.}

\section{Mayo 27 Panamá}

Carta del secretario de Gobierno y Justicia al director de las escuelas de la comarca, comunicándole que por Dto. 69 se nombró a la Hermana Priscila, de sexto grado, en la escuela de Narganá.

Al: Cop. mec.

\section{2.}

\section{Mayo 27 Panamá}

Carta del secretario de Gobierno y Justicia al intendente, comunicándole que por Dto. 69, del día de ayer, ha sido nombrado maestra la Hermana $M$. Priscila de sexto grado en la escuela indígena 
de Narganá; y pide que se lo comunique a la agraciada.

Al: Orig. mec.

\section{3.}

(1930) Mayo 29 El Porvenir

Carta del intendente al Ministro de Gobierno y Justicia, comentando que la maestra designada para Puerto Obaldía no se ha presentado a tomar posesión de su cargo.

Al: Orig. mec.

\section{4.}

\section{Junio 16 Panamá}

Carta de la maestra de grado Micaela G. de Espino, en la que solicita 2 reales de plata para un juego de letras impresas para la enseñanza de la lectura. El sistema es que aprendan los sonidos, luego manejarán los caracteres impresos para formar palabras, y luego frases. Dice que aligera la enseñanza y la hace más activa.

BN: Carp. Educ. var. doc. Orig. mec.

\section{5.}

\section{Junio 20 Tupile}

Informe de los habitantes de Tupile hablando de los intendentes y las presiones ejercidas para quitar las costumbres y usos indígenas. ARPK: Carp. 98. Cop. mec.
V. CD, n. CLXXXVIII

\section{6.}

1930 Junio 20 Tupile 
Informe que narra los atropellos de la policía colonial; contiene los nombres de los jefes de los destacamentos. Y concluye mencionando la revolución de 1925.

ARPK: Carp. 98. Cop. mec.

\section{7.}

\section{Junio 27 Río Azúcar}

Carta de la maestra Inés $V$. de Córdoba al intendente, anunciándole que se ha hecho cargo del tercer grado, pero que los niños no tienen útiles. También dice que está sin tanque de agua.

Al: Orig. ms.

v. CD, n. CLXXXIX

\section{8.}

\section{Junio 27 Río Azúcar}

Carta de la maestra Ruby de Escala al intendente, solicitando permiso para vender unas cosas de la casa, pues la vida en esa zona es muy cara y quiere ayudarse de esto.

Al: Orig. ms.

v. CD, n. CXC

\section{9.}

\section{Julio 1 Panamá}

Carta de José $\mathrm{D}$. Crespo al intendente, en la que le comunica que no se ha recibido la notificación de comienzo de labores de los maestros Francisco Ossa y Angélica de Abello, quienes prestan servicio por cuenta de la Secretaría de Instrucción Pública, y que ha retenido los cheques hasta que le llegue la confirmación.

Al: Orig. mec. 
470.

\section{Julio $14 \quad$ Narganá}

Carta de Félix Monasterio al intendente, diciendo que le ha llegado la comunicación del extravío de la toma de posesión de Angélica y Ossa, y le pide que envíe las cartas certificadas.

Al: Orig. mec.

\section{1.}

\section{Julio 20 Puerto Obaldía}

Carta de Diógenes lbáñez al intendente, en la que le comunica un radio recibido, y que le piden que le trasmita al intendente, para que la organización de las escuelas de esa comarca se mantenga como está hasta el próximo año lectivo, pues los cambios se efectuarán entonces.

Al: Orig. ms.

v. CD, n. $\mathrm{CXCl}$

\section{2.}

\section{Agosto 3 Panamá}

Carta de Adriano Robles al intendente, recomendándole a cuatro indígenas para que sean designados como agentes indígenas, en el caso de que fuera posible tales nombramientos.

Al: Orig. mec.

v. CD, n. CXCII

\section{3.}

\section{Agosto 9 Panamá}

Carta para el intendente, adjuntándole los cheques de dos maestros que ejercen labores en esa región. 
Al: Orig. mec.

v. CD, n. CXCIII

\section{4.}

\section{Agosto 16 Panamá}

Carta de Adriano Robles al intendente, comentándole que Nele Kantule es un cacique caracterizado por muy buenas ideas civilizadoras, y que coopera con el gobierno en la patriótica labor de civilización y progreso de los hijos de San Blas, le pide que tenga con el las atenciones necesarias.

Al: Orig. mec.

\section{5.}

\section{Agosto $20 \quad$ Ailigandí}

Carta de los asistentes a la reunión, al Sr. Adriano Robles, diciendo que todos los indios están educando a sus hijos y quieren a los indios de Narganá que están estudiando en Panamá y desean darles empleo. Piden ayuda para pagar a los maestros.

ARPK: Carp. 98. Cop. mec.

\section{6.}

\section{Agosto 29 Panamá}

Carta del secretario de Gobierno y Justicia al intendente, avisando recibo del informe del director de las escuelas, junto con el comunicado de la Intendencia, y en conformidad con ambos escritos la Secretaría resuelve que dos maestros ejerzan tan solo hasta el 31 de Agosto.

Al: Orig. mec.
v. CD, n. CXCIV 


\section{7.}

\section{Septiembre 1 Panamá}

Lista de los cheques del personal de la comarca de San Blas remitido por el subsecretario José C. de Obaldía.

Al: Orig. mec.

v. CD, n. CXCV

478.

1930 Septiembre 1 Panamá

Lista de los cheques remitidos al intendente, del personal que labora en la comarca de San Blas.

Al: Orig. mec.

v. CD, n. CXCVI

479.

1930 Septiembre 26 Panamá

Carta del subsecretario de Gobierno y Justicia al intendente, comunicándole que por decreto ejecutivo se ha declarado insubsistente el nombramiento de la maestra de Narganá y se ha nombrado a otro maestro.

Al: Orig. mec.

V. CD, n. CXCVII

480.

193020 Río Azúcar

Carta de la maestra Ruby S. de Escala al intendente, solicitándole un tanque para el agua, una mesa para el salón y un tablero.

Al: Orig. ms.

v. CD, n. CXCVIII 


\section{1.}

\section{Octubre 4 Panamá}

Carta de Enrique Morales a la Dra. de la escuela República de Chile en la que le pide permiso para sacar a su hija porque su esposa está mal y la va a enviar a San Blas y desea que la acompañe.

AELI: Carp. 2 Cop. mec.

\section{2.}

\section{Octubre 6 Panamá}

Carta del jefe de la sección de contabilidad al intendente, enviándole los cheques de dos maestros que prestan servicios en la comarca, y le suplica que comunique su recibo.

Al: Orig. mec.

v. CD, n. CXCIX

483.

\section{Octubre 8 Panamá}

Carta a los señores Inapaquiña y Nele Kantule, comentando que ya se están dando los primeros pasos para el señalamiento de una zona indígena en San Blas, y que será presentado en la Asamblea Nacional y él hará todo lo posible porque el proyecto sea aprobado.

Al: Orig. mec.

V. CD, n. CC

484.

\section{Octubre 14 Panamá}

Carta de Róbinson al Presidente F. H. Arosemena, en la pide una caja de herramientas de carpintería para la enseñanza de ese oficio y ruega no se suspendan las labores civilizadoras de las hermanas de la 
Caridad. El por su parte cooperará en las tareas de la civilización. AELE: Carp. Arch. y doc. car. imp. 1927-30.Cop. mec. V. CD, n. CCl

\section{5.}

\section{Octubre 21 Puerto Obaldía}

Carta de Diógenes lbáñez al intendente, en la que le dice que tienen los cuatro primeros grados y un total de matrícula de cincuenta y nueve. Comenta que su labor se ve interrumpida por las reparticiones.

Al: Orig. ms.

$$
\text { v. CD, n. CCII }
$$

\section{6.}

\section{Octubre 25 Narganá}

Carta de Rubén Pérez Kantule a Estanislao López, diciendo que Inapaquiña se ha inventado que el Presidente les dijo que no establecieran escuelas en sus dominios.

ARPK: Carp. 98. Orig. ms.

$$
\text { v. CD, n. CCIII }
$$

\section{7.}

$1930 \quad$ Noviembre 25

Actas del congreso general de los nelistas presidido por Nele Kantule, entre otra resolución da libertad a los pueblos de la comarca en materia de educación.

AELI: Carp. 2. Cop. mec.

488.

\section{Diciembre 14 Ustupu}

Circular de Nele y Rubén Pérez Kantule, en la que piden que arreglen el pueblo y sobre todo que limpien las escuelas que es muy 
importante para nuestros hijos. Asimismo hablan del empleo dado a un dinero.

ARPK: Carp. 98. Orig. mec.

V. CD, n. CCIV

\section{9.}

(1930) Narganá

Circular del director Ricardo Velasco a los maestros de la comarca de San Blas, comentando el tema de los exámenes finales.

Al: Cop. mec.

\section{0.}

(1931) Mayo 17 El Porvenir

Carta del intendente Mojica al secretario de Gobierno y Justicia, en la que le anuncia que el jefe del destacamento de Tupile se ha visto en la necesidad de trasladar su oficina a la escuela por las malas condiciones del lugar en que funcionaba.

Al: Cop. mec.

V. CD, n. CCV

\section{1.}

\section{Mayo $18 \quad$ Panamá}

Carta del Presidente Alfaro a Nele Kantule, denunciando que la falta de dinero imposibilita el crear nuevas escuelas y hacer los nombramientos de maestros indígenas de Ustupu, Ailigandí, Río Cidra y Suitupu; y que ha tenido que suprimir tres maestros.

ARPK: Carp. 95. Cop. mec.

v. CD, n. CCVI 


\section{2.}

\section{Junio 12 Colón}

Carta de Efraín Tejada a Nele Kantule, en la que comenta el problema de los maestros y dice que la falta de dinero le imposibilita estos nombramientos.

ARPK: Carp. 95. Cop. mec.

v. CD, n. CCVII

\section{3.}

1931 Junio 23 (Colón)

Carta de J. J. Enderton a Nele, en la cual señala que le parece bien mandar a EEUU a algunos alumnos para estudiar y aprender inglés; y estos a su vuelta que enseñen a los suyos. También habla de mandar a Panamá a estudiantes.

ARPK: Carp. 94. Cop. mec. ing.

\section{v. CD, n. CCVIII}

\section{4.}

\section{Junio 30 Ustupu}

Carta de Nele al secretario de Gobierno y Justicia, hablando de la civilización y de los maestros, comenta que desea preparar a tres indios (que tengan título ). Quiere que la comarca que acaba de legislarse sea una antorcha para la República.

ARPK: Carp. 94. Cop. mec.

$$
\text { v. CD, n. CCIX }
$$

\section{5.}

1931 Julio 10 Ustupu

Carta de Nele al Sr. Enderton, dice que no quiere escuela 
misionera, si no donde los niños se puedan preparar bien. Quiere saber el costo que originan los estudios en el extranjero.

ARPK: Carp. 94 y 95. Cop. mec.

V. CD, n. CCX

496.

1931 Julio 10 Ustupu

Carta de Nele al secretario de Gobierno y Justicia, en la que muestra su satisfacción por la creación de la reserva indígena, y comenta que él lucha en pro de la civilización y que quiere que uno o dos de sus hijos estudien en la capital.

ARPK: Carp. 95. Cop. mec.

v. CD, n. CCXI

\section{7.}

\section{Julio 16 Panamá}

Carta de F. Arias P. a Nele, en la que dice haber tomado nota del asunto de las becas para el próximo año; y que del asunto de los permisos de pesca es competencia del intendente.

ARPK: Carp. 95. Cop. mec.

V. CD, n. CCXII

\section{8.}

\section{Julio 20 Colón}

Carta de Enderton a Nele, en la que le señala lo que podría costar el viaje y la estancia de los estudiantes en EEUU: $\$ 125$ de viaje y la estancia de $\$ 500$ a 600 .

ARPK: Carp. 94. Cop. mec.

V. CD, n. CCXIII 


\section{9}

\section{Agosto 23 Panamá}

Carta dirigida a Nele Kantule y Guillermo Hayans, en la que se trata de la publicación de la biografía de Nele. Termina diciendo que siente que no se hayan nombrado maestros para San Blas.

ARPK: Carp. 95. Cop. mec.

v. CD, n. CCXIV

\section{0.}

\section{Septiembre $8 \quad$ Narganá}

Carta de Anibal Watts, jefe del destacamento, a la Intendencia de El Porvenir, trascribiendo la carta enviada al director de las escuelas de la comarca, y la contestación de éste, que comenta las quejas del ságuila de Tigre por falta de cumplimiento del maestro. Contesta que él no tiene atribuciones para cambiar a los maestros, pues es competencia del intendente.

Al: Orig. mec.

v. CD, n. CCXV

\section{1.}

\section{Noviembre 20 Ustup}

Carta de Nele Kantule y Samuel Morris a D. Pancho Arias, futuro candidato a Presidente de la República, en la que le prometen los votos en las elecciones a cambio de ciertas concesiones que debe prometer, como son el ensanchamiento de la instrucción de San Blas y magisterio indígena en los principales pueblos de la comarca.

ARPK: Carp. 95. Cop. mec.

502.

1931 Diciembre 9 Gotemburgo

Carta del Barón Nordenskiold a Rubén Pérez Kantule, en la que le habla del interés despertado en París por la cultura kuna. Le pide 
ayuda para continuar sus investigaciones de antropología.

ARPK: Carp. 142. Orig. mec.

V. CD, n. CCXVI

503.

1932 Junio 23 Ustupu

Informe de una alumna de tercero de comercio, Marina Iglesias, en el que cuenta la visita de los sahilas a la capital y a la escuela. Refiere la propuesta que hicieron al presidente de la República de restablecer las becas. Habla de la civilización y de los que se han negado a ella.

ARPK: Carp. 199. Orig. mec.

\section{4.}

\section{Septiembre 1 Panamá}

Memoria del secretario de Gobierno y Justicia, comentando los pocos adelantos realizados con los indios, y reconoce su modo de organización. Habla de las escuelas de indígenas, que son dos, y las escuelas de la comarca de San Blas que ya suman doce. Cree que de seguir así se llegará a corromper a los indios.

ARPK: Carp. 216. Cop. mec.

\section{5.}

\section{Octubre 13 Panamá}

Discurso de Rubén Pérez Kantule en la escuela de Señoritas, en el que señala que concurren más de cincuenta y cinco alumnos de distintas islas de la región a Narganá. Y que son 336 el número de alumnos matriculados en las escuelas oficiales establecidas en Tigre, Río Azúcar, Corazón de Jesús y Narganá.

BN: Carp. Educ. var. doc. Orig. mec. 
506.

\section{Marzo 7 Colón}

Carta de los indígenas al Presidente Harmodio, en la que se habla de la delegación que envían para que se nombren maestros en los pueblos que estiman la educación y la instrucción.

ARPK: Carp. 88. Orig. mec.

V. CD, n. CCXVII

\section{7.}

\section{Abril 17 Panamá}

Carta del secretario de Gobierno y Justicia, Juan A. Jiménez, al pueblo de Narganá, en la que manifiesta que tendrá en cuenta su petición de sustituir al maestro en su puesto por sus paisanos que han terminado la escuela primaria en Narganá.

AELI: Carp. Cor. de 1940 a 1950. Orig. mec.

\section{8.}

\section{Mayo 16 Río Azúcar}

Carta del director Luis Méndez al intendente, comunicándole que dio comienzo a sus labores en ese lugar desde el momento de su llegada y que la escuela carece de útiles indispensables para realizar su labor, como libros de lectura, reglas y la bandera, sin la cual no se puede trabajar.

Al: Orig. mec.

V. CD, n. CCXVIII

\section{9.}

\section{Junio 8 Colón}

Carta de Arturo R. Pérez a Nele Kantule, en la que le felicita por 
la idea de querer poner una escuela en su isla; y le dice que si los otros jefes quisieran lo mismo sería una gran cosa para San Blas.

BGH: Carp. s/n. Orig. mec.

\author{
v. CD, n. CCXIX
}

510.

\title{
1933 Junio 8 Panamá
}

Carta de Juan A. Jiménez a Nele Kantule, en la que le comunica que es imposible nombrar un maestro con cargo al fisco para su población debido a la mala situación que atraviesa el mismo.

BGH: Carp. s/n. Orig. mec.

v. CD, n. CCXX

\section{1.}

\section{Julio 6 El Porvenir}

Carta del intendente Julián F. Aguilera al secretario de Gobierno y Justicia en Panamá, donde habla sobre la bondad, extensión y mejoras que el valle Mandinga comprende, y las obras de la San Blas Banana Corporation. Esto sirve para el mayor afianzamiento de la tranquilidad entre los indios y un mejor aportamiento para la instrucción indígena; así mismo comenta que sería altamente beneficioso que en dicho valle de Mandinga se estableciera una gran colonia agrícola india.

Al: Cop. mec.

\section{2.}

\section{Noviembre 8 Panamá}

Carta de J. A. Jiménez al intendente de El Porvenir, anunciándole que ha sido admitido un indígena en la Granja de Summit como aprendiz. 
Al: Orig. mec.

v. CD, n. CCXXI

\section{3.}

\section{Diciembre 14 Panamá}

Carta del Subsecretario de Gobierno y Justicia al intendente, pidiéndole de modo confidencial que se entere de las actividades del matrimonio Iglesias, y que informe a esa secretaría.

Al: Orig. mec.

v. CD, n. CCXXII

\section{4.}

\section{Diciembre 15 Panamá}

Carta de Juan A. Jiménez al intendente de la comarca, pidiéndole información sobre el maestro Peña, que según parece está haciendo una labor obstaculizadora entre el Gobierno y los indios.

Al: Orig. mec.
V. CD
n. CCXXIII

\section{5.}

\section{3}

Discurso de Estanislao López en la segunda convención extraordinaria del Partido Liberal Renovador, en el que habla de la educación, de las primeras becas y del testamento de Nele Kantule.

AELE: Carp. Arch. y doc. Car. 1915-22-33. Cop. mec.

\section{6.}

\section{Enero $10 \quad$ Narganá}

Carta de J. M. Berengueras a Rubén Pérez Kantule, que se 
encuentra en la cárcel, en la que anuncia que su esposa Olimpia empezará a estudiar mecanografía.

ARPK: Carp. 142. Orig. mec.

v. CD, n. CCXXIV

\section{7.}

\section{Marzo 19 El Porvenir}

Carta de Julián Aguilera al secretario de Gobierno y Justicia, haciendo recomendaciones de maestros para las distintas escuelas de la comarca y explicando la situación de éstas. Termina diciendo que las recomendaciones las hace de acuerdo con el director de las escuelas de San Blas.

Al: Cop. mec.

v. CD, n. CCXXV

\section{8.}

\section{Abril 1 Colón}

Carta de Rubén Pérez Kantule a su esposa y familia, desde la cárcel de Colón, en la que afirma que cuando salga la enseñará lenguas e instrumentos musicales.

ARPK: Carp. 122. Cop. mec. Inc.

\section{9.}

\section{Abril 7 Panamá}

Carta del Presidente Harmodio Arias a Nele Kantule, en la que detalla las gestiones para que las escuelas de San Blas pertenezcan a Instrucción Pública, pero por el momento no es posible. Hace también referencia a las recomendaciones de los maestros.

BGH: Carp. s/n. Orig. mec.

$$
\text { v. CD, n. CCXXVI }
$$


520.

1934 Abril 24 Panamá

Carta del subteniente, Roberto Royo, al intendente de la comarca, en la que le comunica que la beca que había quedado vacante se entrega a otra señorita.

Al: Cop. mec.

V. CD, n. CCXXVII

521.

1934 Mayo 11 Panamá

Decreto 56 por el que se nombra el personal docente de las escuelas públicas de la comarca de San Blas.

Al: Cop. mec.

V. CD, n. CCXXVIII

\section{2.}

\section{Julio 5 Narganá}

Carta de Berengueras al intendente Aguilera, en la que le comunica que recibió los cheques del pasado mes de los maestros de Narganá, Río Azúcar, Tigre y Río Cidra; y envía los datos mensuales de las escuelas de la comarca. Dice que recibió del inspector de Colón los materiales del Internado. Le envía su cheque de Junio para la compra de la lanchita que le es indispensable.

Al: Orig. mec.

\section{3.}

\section{Julio 7 El Porvenir}

Carta del intendente Aguilera a los señores Aguila, Sapín, Olo y Soo de Río Cidra, comunicándoles que sigue para hacerse cargo de esa 
escuela el maestro Ernesto Peña, pues no se encontraron pruebas de la acusación formulada, y que ordena a los padres de familia que envíen a sus hijos a la escuela de la que es maestro el Sr.Peña.

Al: Cop. mec.

\section{4.}

\section{Julio $13 \quad$ Narganá}

Carta del jefe del destacamento al intendente, exponiéndole la queja que le hicieron los vecinos de Río Azúcar por quitarles la beca que tenían concedida al pueblo, para complacer a Nele Kantule, y esperan que les sea concedida una beca en un colegio de la capital.

Al: Cop. mec.

v. CD, n. CCXXIX

\section{5.}

\section{Julio 17 El Porvenir}

Carta de Julián F. Aguilera al secretario de Gobierno y Justicia, en la que le transcribe los oficios del corregidor de Puerto Obaldía que comentan la situación de la escuela de este lugar; que no se abre y la maestra está en estado de gravidez. Refiere que los padres quieren mandar a los hijos a una escuela particular.

Al: Cop. mec.

v. CD, n. CCXXX

\section{6.}

\section{Agosto 13 El Porvenir}

Carta de Julián F. Aguilera al secretario de Gobierno y Justicia, notificándole una reunión de los protestantes. Recomienda el cierre de la escuela bajo el patrocinio norteamericano y la expulsión de las misioneras extranjeras. 
Al: Cop. mec.

V. CD, n. CCXXXI

\section{7.}

\section{Agosto 18 El Porvenir}

Carta del intendente al secretario de Gobierno y Justicia, comentando la prohibición que se ha hecho de introducir licores. Dice que esta prohibición ha evitado desórdenes en Narganá y Corazón de Jesús, y se queja de la contraorden dada verbalmente por el secretario de Gobierno y Justicia en Narganá.

Al: Cop. mec. inc.

v. CD, n. CCXXXII

\section{8.}

\section{Agosto $21 \quad$ Narganá}

Carta de Berengueras a Julián F. Aguilera, en la que le cuenta la celebración de un matrimonio, y los memoriales que va a presentar un indígena en Panamá, parece que pidiendo la supresión de la policía, pues se consideran capaces de autogobernarse.

Al: Orig. mec.

v. CD, n. CCXXXIII

\section{9.}

\section{Agosto 21 Colón}

Carta desde la cárcel, de Rubén Pérez Kantule, al director del periódico Panamá-América para que se la publique. En ella comenta las declaraciones del secretario Solís sobre la misión protestante que cree que está contra el gobierno. $\mathrm{Y}$ habla de los que se están educando en el instituto de Panamá.

ARPK: Carp. 139. Cop. mec.

v. CD, n. CCXXXIV 
530.

\section{Septiembre 1 Panamá}

Memoria del secretario de Gobierno y Justicia a la Asamblea Nacional en su sesión ordinaria, comentando la civilización de indígenas y los medios más apropiados. Pone las misiones como agente más eficaz.

AELE: Carp. Var. escr. y doc. imp. Cop. mec.

\section{1.}

\section{Septiembre 13 El Porvenir}

Denuncia presentada por el maestro de Cartí contra un indio que da clases en inglés y habla mal del gobierno.

Al: Orig. mec. inc.

v. CD, n. CCXXXV

\section{2.}

\section{Octubre 1 El Porvenir}

Carta de Julián F. Aguilera a Federico Filós, anunciándole que debe cesar en sus labores de religioso protestante por no haber llenado los requisitos que exige la ley, de lo contrario se consideraría conducta violatoria de la ley con insistencia.

Al: Cop. mec.

v. CD, n. CCXXXVI

533.

1934 Octubre 4 El Porvenir

Carta de Joaquín Otolla al secretario de Gobierno y Justicia, en la que le envía los datos escolares proporcionados por el director de San Blas, y comenta que los de Puerto Obaldía se han solicitado y una vez los reciba se los remitirá.

Al: Cop. mec. 


\section{4.}

1934 Octubre 6 El Porvenir

Carta de Julián F. Aguilera al secretario de Gobierno y Justicia, comentando que los indios que imparten propaganda protestante reciben instrucciones de agencias extranjeras que también les envían cheques. Uno de ellos prometió que no reuniría a la gente sin permiso de la policía.

Al: Cop. mec.

v. CD, n. CCXXXVII

\section{5.}

\section{Octubre 10 Ustupu}

Carta de Nele Kantule a Julián Aguilera, en la que le solicita la madera para el piso de la escuela que funciona actualmente, y comenta las buenas relaciones mantenidas con el Gobierno y por eso espera su favor. Concluye diciendo que los rumores oídos sobre las escuelas de San Blas no los considera serios.

Al: Orig. mec.

\section{6.}

\section{Octubre 13 El Porvenir}

Carta de Julián F. Aguilera al señor Alcibiades Iglesias, comentando que según la legislación vigente, debe cesar en su labor de maestro y predicador hasta que no tenga el permiso del secretario de Gobierno y Justicia.

Al: Cop. mec.

v. CD, n. CCXXXVIII

\section{7.}

\section{Noviembre 3 El Porvenir}

Carta del Sr. Aguilera al secretario de Gobierno y Justicia, comunicándole que se ha extendido una epidemia de viruela en Río 
Azúcar, y el director de las escuelas y algunas madres se encargan de atender a los enfermos, por lo que se ha decretado el cierre inmediato de esa escuela para evitar el contagio de los niños.

Al: Cop. mec.

538.

1934 Noviembre 15 El Porvenir

Carta de Julián Aguilera al secretario de Gobierno y Justicia, comentando que le ha enviado un informe sobre el maestro de Río Cidra quien lleva una conducta no acorde a su posición y cargo. Pide que le comunique si se ha hecho merecedor de una sanción.

Al: Cop. mec.

V. CD, n. CCXXXIX

539.

1934 Noviembre 16 El Porvenir

Carta del intendente al secretario de Gobierno y Justicia, en la que le trascribe la carta que recibió del ságuila de Ailigandí, que expresa su desconformidad por el cierre de la escuela. $Y$ dice que ya informó al ságuila de que Alcibiades conoce la orden de prohibición.

Al: Cop. mec.

v. CD, n. CCXL

540.

1934 Noviembre 16 El Porvenir

Carta de Julián F. Aguilera al ságuila Olowiquequiña, comentando el motivo del cierre de la escuela del señor Alcibiades. Expone que el Gobierno tiene intención de establecer allí escuela y que los señores Iglesias necesitan permiso de la Secretaría de Gobierno y Justicia.

Al: Cop. mec.

v. CD, n. CCXLI 


\section{1.}

\section{Noviembre 24 El Porvenir}

Carta del intendente Aguilera a Bernabé Cerezo de Puerto Obaldía, en la que le comunica que debe tomar las mediadas oportunas para que los niños no dejen de asistir religiosamente a la escuela, y obligue a los padres a que cumplan con ese deber moral. Finaliza pidiéndole que vigile la limpieza de la población.

Al: Cop. mec.

\section{2.}

\section{Diciembre 2 El Porvenir}

Carta del Sr. Aguilera a Nele Kantule de Ustupu, en la que le hace saber que le envía los cheques de él y del maestro de escuela Eduardo Filós, de 40 y 35 balboas respectivamente, correspondientes al mes de noviembre.

Al: Cop. mec.

\section{3.}

\section{Diciembre 9 El Porvenir}

Carta del intendente al secretario de Gobierno y Justicia, detallándole los reparos que siente a que se abra la escuela de Ailigandí, pues cree que es una artimaña para que vuelvan a impartir sus enseñanzas los esposos Iglesias. $Y$ concluye diciendo que él ha pedido la creación oficial de la escuela de Ailigandí para acabar con esto.

Al: Cop. mec.

v. CD, n. CCXLII

\section{4.}

1934 Diciembre 10 Ailigandí

Carta del ságuila de Ailigandí al intendente, expresándole su 
descontento por haber mandado cerrar la escuela. Dice que los niños que estaban adelantados y ahora están perdiendo. Concluye comentando que ha dado orden a Alcibiades para que abra la escuela.

Al: Orig. ms. inc.

V. CD, n. CCXLIII

545.

1934 Diciembre 21 (EI Porvenir)

Carta del intendente al secretario de Gobierno y Justicia, en la que le notifica el recibo de su oficio en el cual expresa su consentimiento a que se abra la escuela de Ailigandí y se dicten clases en castellano.

Al: Cop. mec.

V. CD, n. CCXLIV

546.

(1934)

Informe, posiblemente de un congreso, que trata de los problemas que se derivan de la mala conducta de los maestros, y acusa a estos de los males y no a la escuela. Dice que la instrucción es buena para recibir sus beneficios y que en su trato habitual no les engañen.

Al: Cop. mec. inc.

v. CD, n. CCXLV

\section{7.}

\section{Marzo 7 Panamá}

Carta de la dirección escolar de Narganá al Presidente de la República Harmodio Arias, solicitando una beca para que un joven siga sus estudios en la Capital.

ARPK: Carp. 88. Cop. mec. 
548.

\section{Abril 17 Narganá}

Carta de Berengueras a Recaredo Carles, pidiéndole que le envíe material para el botiquín, que quedó vacío después de la epidemia que hubo en Río Azúcar y en Narganá. Comenta que Arnulfo Arias les favorecía con medicamentos.

Al: Orig. mec.

\section{9.}

\section{Mayo 27 Panamá}

Carta al Presidente Harmodio, en la que los autores se quejan de que los niños que son llevados a Panamá bajo el pretexto de tutelaje no los ponen en la escuela y luego se niegan a entregarlos a sus padres.

ARPK: Carp. 88. Cop. mec. inc.

\section{0.}

\section{Junio 2 Narganá}

Carta de Manuel M. Puig a Recaredo Carles, agradeciéndole el envío de medicinas, ya que tienen en la escuela varios casos de niños con problemas de vista, catarro y fiebre.

Al: Orig. mec.

\section{1.}

\section{Junio 14 Ustupu}

Carta de Nele Kantule, escrita por Eduardo Filós, a Recaredo Carles, intendente de San Blas anunciándole que han recibido una carta del secretario de Gobierno y Justicia diciéndole que las bancas de la escuela hay que solicitarlas a la Intendencia.

Al: Orig. mec. 
552.

\section{Junio 21 Panamá}

Carta de Galileo Solís al Sr. Nele Kantule, en la que le comenta el tema de la becas, y le dice que por el momento no hay más presupuesto al mismo tiempo que le anuncia también que se nombró maestra para Ailigandí.

Al: Cop. mec.

V. CD, n. CCXLVI

\section{3.}

(1935) Julio 8 El Porvenir

Carta de Recaredo Carles al director de las escuelas de la comarca, en la que le pide que envíe cuanto antes un maestro a la escuela de Cartí Cangrejo, pues el sahila así se lo ha pedido y desea que se solucione el problema del maestro anterior. Le avisa también del envío de los útiles escolares.

Al: Orig. mec.

v. CD, n. CCXLVII

\section{4.}

\section{Julio 10 El Porvenir}

Carta del intendente al secretario de Gobierno y Justicia, remitiéndole la carta que le enviara el director de las escuelas de la comarca en la que comenta que un maestro tomó posesión del cargo pero se encuentra sin escuela. Dice que se nombró también maestra en la escuela de Suitupo. Comenta el problema suscitado por la escuela protestante de Ailigandí a la que se oponen los misioneros católicos.

Al: Cop. mec.
V. CD, n. CCXLVIII

\section{5.}

\section{Septiembre 20 Ustupu}


Carta de Nele Kantule a Belisario Porras, en la que dice que el partido nelista le apoyará en la campaña presidencial, y solicita recomendación para unos jóvenes que han concluido sus estudios.

ARPK: Carp. 88. Cop. mec.

\section{6.}

\section{(1935) 2 Panamá}

Carta de José Colman al secretario de Gobierno y Justicia, que la escribe en nombre del pueblo de Ailigandí, en la que dice que va una comisión compuesta por Nele Kantule y otros que quieren que Alcibiades Iglesias siga de maestro en Ailigandí, pues en una reunión todos declararon que estaban contentos con la labor patriótica de Nele Kantule. Dice que no hay una escuela extranjera, pues se enseña en castellano, y la escuela fue creada voluntariamente por los indios del pueblo.

AELI: Carp. Cor. de 1940 a 1950. Orig. mec.

\section{7.}

\section{Ustupu}

Carta de Nele Kantule en la que informa, posiblemente al intendente, de los puntos tratados en el congreso. $Y$ en el punto tercero hace referencia a la educación, y comenta que muchos jóvenes no se han podido educar por falta de escuelas.

ARPK: Carp. Doc. reg. per. 1935. Orig. mec. inc.

\section{8.}

\section{Febrero 6 Narganá}

Carta de Félix Monasterio al intendente Recaredo Carles, enviándole los datos estadísticos de Enero y anunciando la conclusión de los exámenes así como la clausura del curso.

Al: Orig. ms. 
559.

1936 Marzo 22 Ailigandí

Carta de Ikuanikdipipi al Presidente Harmodio, en la que le dice que la escuela del Gobierno fue hecha por el pueblo a base de relleno y ahora se encuentra en mal estado; por lo que demanda una escuela de material más consistente.

ARPK: Carp. 88. Orig. ms.

$$
\text { V. CD, n. CCXLIX }
$$

560.

\section{Mayo 12 Panamá}

Carta de un colaborador a Belisario, en la que trata de los diputados y del apoyo en la próximas elecciones. Le da las gracias por que la civilización existe en San Blas gracias a él.

ARPK: Carp. 88. Cop. mec.

\section{1.}

\section{Mayo $20 \quad$ Narganá}

Carta de Simón Bravo al intendente Recaredo Carles, comentando que el maestro de Ailigandí se queja de que no tiene bancas y el pueblo se lamenta del mal estado. Los maestros de Suitupo y Río Tigre también se han quejado del mal estado de las bancas y el local.

Al: Orig. mec.

\section{2.}

\section{Mayo 24 Panamá}

Carta de Estanislao López a Rubén Pérez Kantule, en la que dice que su hija no ha ido a Panamá a buscar marido sino a estudiar, y que su deseo es que llegue a maestra.

AELI: Carp. 2. Cop. mec. 


\section{3.}

\section{Mayo 27 Ustupu}

Carta de Nele Kantule a Manuel Alba, en la que le recomienda a una señora que se educó en la escuela profesional y quiere que le den un trabajo.

AELI: Carp. 2. Cop. mec.

\section{4.}

\section{Junio 20 Narganá}

Carta de Simón Bravo al intendente Luis Hernández, comunicando que la maestra de Río Azúcar, Ana de Espinosa, se ausentó con permiso de 15 días por motivos de salud y hacer cambios de escuela, y han pasado 25 días y no sabe nada de ella. Se ha encargado del $2^{\circ}$ grado la maestra Josefa Salazar, que tiene el primer grado también. Comenta que es difícil cumplir con los dos grados y los vecinos empiezan a quejarse.

\section{Al: orig. mec.}

\section{5.}

\section{Julio 4 Narganá}

Carta de Simón Bravo al intendente Luis Hernández, comunicándole el envío de la tabla mensual de asistencias. Dice que la escuela de Suitupu se ha reducido a la mínima expresión en cuanto a matrícula y asistencias.

Al: Orig. mec.

\section{6.}

\section{Julio 4 Narganá}

Carta de Simón Bravo al intendente Luis Hernández, remitiéndole 
adjunto la estadística escolar mensual, y agradeciendo el envío de materiales que muestran su generosidad.

Al: Orig. mec.

\section{7.}

\section{Julio $30 \quad$ Narganá}

Carta de Simón Bravo al intendente Luis Hernández, en la que le hace saber que la titular del 2 grado de Río Azúcar, Ana de Espinosa, lleva dos meses ausente, y que esto desprestigia a la escuela. Lo mismo ocurre con el maestro de Puerto Obaldía que lleva fuera de la escuela sin permiso mucho tiempo, y el pueblo siente antipatía por él, por lo que pide que se le separe de esta escuela.

Al: Orig. mec.

\section{8.}

\section{Agosto 10 Narganá}

Carta de Simón Bravo al intendente Luis Hernández, comunicándole que recibió la lista de movimiento de maestros de la comarca de San Blas, y que tan pronto llegue la maestra Ruby Smith a la escuela de Río Azúcar irá a estimular a los padres.

Al: Orig. mec.

\section{9.}

\section{Agosto $24 \quad$ Narganá}

Carta de Simón Bravo al intendente Luis Hernández, diciendo que recibió el comunicado de la caja escolar que le envió; y escribe que la visita a la escuela de Tigre le causó buena impresión pues estaban contentos con la escuela. Comenta que tiene pocos muebles y es de construcción del país. En Río Azúcar con la llegada de la nueva maestra se han recogido 30 niños más, y los padres han prometido 
defender y cooperar con la instrucción. Pide que se aprovechen maderas del antiguo cuartel para bancas.

Al: Orig. mec.

\section{0.}

\section{Septiembre 1 Narganá}

Carta de Simón Bravo al intendente Luis Hernández, diciéndole que la matrícula de Suitupu sigue igual y que el número no llega al marcado por la ley, y la asistencia media es peor. Comenta que es estéril esa escuela y sugiere que se traslade. Concluye diciendo que los datos de Puerto Obaldía no los recibe.

Al: Orig. mec.

\section{1.}

\section{Septiembre 5 Narganá}

Carta de Simón Bravo al intendente Hernández, notificándole que en Ailigandí funciona una escuela dirigida por Alcibiades y su señora y esta es la causa de que la escuela pública tenga poca matrícula, comenta que es la isla más poblada. Despliega sus quejas en varios puntos.

\section{Al: Orig. mec.}

\section{2.}

\section{Septiembre $17 \quad$ Narganá}

Carta de Simón Bravo al intendente Luis Hernández, para manifestarle su agradecimiento por la colaboración prestada con la misión y con el ramo de Instrucción Pública.

Al: Orig. mec. 


\section{3.}

\section{6}

Carta de Estanislao López a Rubén Pérez Kantule, en la que comenta que los estudiantes apoyarán en las elecciones presidenciales al Dr. Porras.

AELE: Carp. Arch. y doc. 1915-22-33. Cop. mec. inc.

\section{4.}

\section{6}

Carta de Estanislao López a Tomás Herrera, comentando las elecciones y las posibilidades de los candidatos a Presidente. Luego habla del maestro de la escuela de Ailigandí, que le ha propuesto a él. Así mismo que ha pedido una escuela nueva para Playón Chico.

ARPK: Carp. 89. Cop. mec. inc.

\section{5.}

\section{$1936 \quad$ Narganá}

Informe de Simón Bravo al intendente, en el que le expone el caso del maestro Tomás Herrera que ejerce en Ailigandí, que por sus ideas políticas ha hecho campaña contra el Gobierno y que aprovechó la situación de su señora, maestra de Tigre, para que votaran contra el Gobierno, dándoles comida. Dice que la maestra Ursula Roldán de Solís pedida por Nele Kantule y Estanislao, Presidente del Club de Narganá es un instrumento que maneja la oposición del gobierno.

Al: Orig. mec.

\section{6.}

\section{$1936 \quad$ Narganá}

Informe de Simón Bravo al intendente Luis Hernández, 
comentando el estado de las escuelas a su cargo. La de Tigre dice que cerró sin su permiso y en Río Azúcar quieren de maestro a David Díaz que es hijo del pueblo y adepto al Gobierno. El maestro de Puerto Obaldía tuvo que abandonar el año pasado por enfermedad, poca asistencia y poca matrícula, sólo tenía 24.

Al: Orig. mec.

\section{7.}

\section{(1936) Agosto 25 El Porvenir}

Carta del intendente al subteniente jefe del destacamento de policía de Narganá, exhortándole a que siga cumpliendo sus órdenes, le pide que comunique a la maestra de Río Azúcar que lo que necesite tiene que pedírselo al director de las escuelas.

Al: Cop. mec.

\section{8.}

\section{Febrero 3 Panamá}

Carta de Nele Kantule al Presidente Arosemena, pidiendo una maestra más pues hay una matrícula de 90 y pide también que los maestros de Playón Chico y Tupile sean pagados por el Gobierno.

ARPK: Carp. 93. Cop. mec.

V. CD, n. CCL

\section{9.}

\section{Febrero 3 Panamá}

Carta de Nele Kantule al Presidente Demóstenes, pidiendo que le nombre agentes indígenas de Ustupu y Ailigandí, y a su secretario. Comenta que estos agentes son para servicios escolares debido al aumento de matrículas.

ARPK: Carp. 93. Cop. mec.

$$
\text { v. CD, n. CCLI }
$$


580.

\section{Febrero 5 Panamá}

Carta de Nele Kantule al secretario de Instrucción Pública, Anibal Ríos, en la que demanda útiles para las escuelas de Ailigandí y Ustupu.

ARPK: Carp. 93. Cop. mec.

\section{1.}

\section{Febrero 10 Colón}

Carta de Nele Kantule al Gobernador de la provincia de Colón, en la que le comunica los asuntos que trató en Panamá en la visita al Presidente y la charla sobre la Instrucción Pública de la comarca.

ARPK: Carp. 93. Cop. mec.

\section{2.}

\section{Febrero 10 Panamá}

Carta de Nele Kantule al Presidente Demóstenes, en la que le agradece su acogida y el interés que tiene por la instrucción, los maestros y la policía indígena de San Blas. Finaliza comentando que su secretario le llevará las propuestas de maestros.

ARPK: Carp. 93. Cop. mec.

\section{3.}

\section{Mayo 20 Colón}

Carta de Humberto Ossa a Estanislao López, pidiéndole que favorezca a su hermana para el nombramiento de maestra, pues tiene diploma; y hace alusión a las rencillas entre las rivales.

ARPK: Carp. de cor. Año 20 y 30. Orig. ms.

v. CD, n. CCLII 


\section{4.}

\section{Abril 27 Panamá}

Carta de Nele Kantule al Presidente Demóstenes, agradeciéndole el haber nombrado los mismos maestros, en los lugares de San Blas donde están funcionando bien.

ARPK: Carp. Doc. reg. per. Educ. 1935. Cop. mec. V. CD, n. CCLIII

\section{5.}

\section{Abril 27 Panamá}

Carta de Nele Kantule a Demóstenes, diciendo que es su deseo fundar tres escuelas ese año, que serían la de Playón Chico, Tupile y Ticantiquí, y que hay otros pueblos que también quieren. Le propone tres maestros para estos pueblos.

ARPK: Doc. reg. per. Educ. 1935. Cop. mec.

$$
\text { V. CD, n. CCLIV }
$$

\section{6.}

\section{Abril 27 Panamá}

Carta de Nele Kantule a Demóstenes, para pedirle el nombramiento de la otra maestra de Ustupu, y le manda la relación de las matrículas que son noventa. Recomienda para este puesto a Evangelina Ossa.

ARPK: Carp.93. Cop. mec.

$$
\text { V. CD, n. CCLV }
$$

\section{7.}

\section{Abril 27 Panamá}

Carta de Nele Kantule a Fabián Valverde, para agradecerle que nombrase a la maestra Ursula Roldán.

ARPK: Carp. 93.Cop. mec. 
588.

1937 Abril 27 Panamá

Carta de Nele Kantule a Anibal Ríos, secretario de Educación y Agricultura, en la que le recuerda la petición de materiales y le comenta que si es posible que se lo dé para llevar él personalmente. Estos materiales son para las escuelas de Ailigandí y Ustupu.

ARPK: Carp. 93. Cop. mec.

V. CD, n. CCLVI

589.

\section{Abril $28 \quad$ Cartí Sugdup}

Carta de Olotebiliguiña y representantes del pueblo de Cartí a Nele Kantule, en la que le comunican que les cancelaron la escuela y pide que se solucione esto, también se quejan de que les quitaron el cheque. Dicen que Olonibiquiña está insoportable y que la suspensión se la comunicó el intendente.

ARPK: Carp. 300. Orig. ms.

V. CD, n. CCLVII

590.

1937 Abril $28 \quad$ Panamá

Carta de Iguatinquipipilele al secretario de Obras Públicas, Leopoldo Arosemena, en la que pide ayuda al Gobierno para la construcción del piso de la escuela. La mano de obra la pondría el pueblo.

ARPK: Carp. 93. Cop. mec. 
Carta de Nele Kantule al Presidente Demóstenes, manifestándole su ofensa por no haber nombrado a su recomendada para maestra, y dice que se retira del asunto.

ARPK: Carp. 93. Cop. mec.

592.

1937 Mayo 2 Panamá

Carta de Nele Kantule a Anibal Ríos, secretario de Educación y Agricultura, para decirle que los útiles escolares que pidió el 29 se los entregue a Estanislao López.

ARPK: Carp. 93. Cop. mec.

593.

1937 Mayo 15 Panamá

Carta del sahila de Tigre a Humberto Lenadiger, Gobernador de la provincia de Colón, en la que le dice que en su anterior visita a Panamá hizo una petición de maderas y clavos y quiere saber si ha llegado esta a la oficina pertinente.

ARPK: Carp. 93. Cop. mec.

\section{4.}

1937 Mayo $18 \quad$ Narganá

Carta de Ursula Roldán al secretario de Gobierno y Justicia, comentando que después de haber sido nombrada para Ustupu como maestra, al ir a firmar a la Intendencia se encontró con que habían puesto a David Rodríguez, y quiere saber si es un capricho del intendente.

ARPK: Carp. Cor. de los años 20 y 30. Orig. mec. V. CD, n. CCLVIII 


\section{5.}

\section{Mayo $21 \quad$ Narganá}

Carta de Simón Bravo al intendente Hernández, comentando la distribución de alguna maestra y las hermanas franciscana. Señala que la matrícula ya llega a 258, lo que da un porcentaje alto para cada maestra.

Al: Orig. mec.

V. CD, n. CCLIX

596.

\section{Mayo 22 Panamá}

Carta del secretario de Gobierno y Justicia al intendente, en la que dice que fue nombrada maestra de Ustupu la señora Ursula Roldán y que no ha tomado posesión por estar otro en su lugar. Le pide que le dé posesión de la escuela a la maestra Roldán.

ARPK: Carp.93. Cop. mec.

$$
\text { V. CD, n. CCLX }
$$

\section{7.}

\section{Mayo $29 \quad$ Narganá}

Carta de Simón Bravo al intendente Hernández, remitiéndole los datos estadísticos en los que se aprecia el aumento de matrícula y la regularidad en la asistencia.

Al: Orig. mec.

v. CD, n. CCLXI

\section{8.}

1937 Junio 18 Narganá

Acta de una sesión de reunión de vecinos de Narganá, en la que se 
trata entre otras cosas de las construcciones de las casas y puente, comentando que el gobierno emplea mucho en la educación y existen personas que actúan mal, por lo que piden policía para que vigilen.

Al: Orig. mec.

v. CD, n. CCLXII

599.

1937 Junio $30 \quad$ Narganá

Carta de Simón Bravo al intendente, remitiendo los datos estadísticos y comentando que la escuela de Tigre ha aumentado con relación a años anteriores. Ha visitado Tigantiquí que está muy interesada por la escuela.

Al: Orig. mec.

v. CD, n. CCLXIII

600.

\section{Julio $28 \quad$ Narganá}

Carta de Simón Bravo al intendente Hernández, remitiendo los datos estadísticos, y comenta que las enfermedades han hecho decrecer la asistencia, pero la matrícula se ha mantenido. Señala la buena labor del médico de la Intendencia y el fracaso de la visita a Tigantiquí.

Al: Orig. mec.

V. CD, n. CCLXIV

\section{1.}

\section{Noviembre 1 Narganá}

Carta de Simón Bravo al intendente Hernández, enviando los datos estadísticos y manifestando su buena impresión de la visita a la escuela de Puerto Obaldía, a pesar de la apatía de las gentes del lugar. 
Al: Orig. mec.

V. CD, n. CCLXV

602.

\section{Noviembre $22 \quad$ Narganá}

Carta del director de las escuelas al intendente Hernández, comentando su última visita a las escuelas y dice que en Ailigandí fue bien recibido, lo mismo que el doctor que vacunó a varios centenares de niños y niñas. Especifica que el local es propiedad del pueblo y que funciona la escuela privada de Alcibiades que enseña a niños y jóvenes y su señora a niñas, y termina reseñando la visita a las escuelas de Ustupu y Tupile.

Al: Orig. mec. inc.

V. CD, n. CCLXVI

\section{3.}

\section{Ustupu}

Lista de los alumnos que estuvieron en la escuela de Ustupu desde el año 37 al 46. Está encabezada por el maestro David Rodríguez.

AELE: Carp. Var. escr. y doc. imp. Cop. mec.

\section{4.}

\section{Abril 21 Panamá}

Carta de Daniel Pinilla, subsecretario de Gobierno y Justicia, al intendente, avisándole del envío con el presente oficio de copia autenticada del Dto. Ejecutivo no 33 por el que se nombran los maestros de escuela de esa circunscripción para el año escolar 193839, y le ruega que envíe a cada uno la notificación de su nombramiento, pues desconoce las residencias habituales de los maestros.

Al: Orig. mec. 


\section{5.}

\section{Abril 21 Panamá}

Decreto que nombra los maestros de escuela de la comarca de San Blas para el curso 1938-39.

Al: Cop. mec.

V. CD, n. CCLXVII

\section{6.}

\section{Mayo 6 Panamá}

Carta de Daniel Pinilla al intendente, notificándole que según decreto ejecutivo no 35 de esta fecha se nombra maestra de Puerto Obaldía a la Sra. Esther de Rivas para el curso 1938-39.

Al: Orig. mec.

\section{7.}

\section{Mayo 28 Puerto Obaldía}

Carta de Esther de Rivas al intendente Hernández, en la que solicita un nuevo maestro o maestra para la escuela, pues ha crecido el número de alumnos y ella tiene que dar clase en dos turnos, uno por la mañana y otro por la tarde.

\section{Al: Orig. ms.}

V. CD, n. CCLXVIII

\section{8.}

\section{Julio 1 Narganá}

Carta de Simón Bravo al intendente, Luis Hernández, comentando el caso de una maestra que solicitó un permiso y se lo concedió en atención al intendente, pero aclara que esto cargará el trabajo de las madres franciscanas y se refiere a la poca eficacia en la labor de la 
maestra mencionada.

Al: Orig. mec.

V. CD, n. CCLXIX

609.

1938 Agosto $30 \quad$ Narganá

Carta de Simón Bravo al intendente Hernández, adjuntando los datos de asistencia y matrícula de las escuelas de la comarca y le cuenta también que ha visitado varias escuelas y su estado es satisfactorio.

Al: Orig. mec.

v. CD, n. CCLXX

610.

1938 Noviembre 27 Puerto Obaldía

Carta de Esther de Rivas al intendente Hernández, avisándole que recibió su oficio sobre la asistencia de los niños a la escuela y que tendrán en cuenta estas disposiciones.

Al: Orig. ms.

V. CD, n. CCLXXI

\section{1.}

\section{Diciembre 3 Narganá}

Carta de Simón Bravo al intendente Hernández, comunicando que tuvo conocimiento de la apertura de la escuela privada de Ailigandí por Peter Muller y que cree que no tiene permiso para abrirla. Señala que no podrá enseñar el castellano porque no lo sabe.

Al: Orig. mec.

v. CD, n. CCLXXII 


\section{2.}

\section{Diciembre 3 Narganá}

Carta de Simón Bravo al intendente, comunicándole las investigaciones realizadas sobre el maestro de Tigre y el de Ailigandí. Expone que como representantes del gobierno en las islas tienen obligación de comunicar lo que allí acontezca.

Al: Orig. mec.

v. CD, n. CCLXXIII

\section{3.}

\section{Diciembre Narganá}

Carta de Simón Bravo al intendente, enviándole los datos estadísticos escolares que tienen un buen promedio y dice que los planteles marchan bien. Le pregunta que cómo organiza los exámenes finales y comenta la situación de un maestro que ha presentado mala conducta.

Al: Orig. mec.
v. CD, n. CCLXXIV

\section{4.}

\section{Enero 1 Narganá}

Carta de Simón Bravo al intendente, en la que le agradece el envío de la prensa y le comenta la buena impresión que le ocasionó el pueblo de Ustupu y el buen funcionamiento de su escuela. Escribe al final que recibió información sobre la escuela de Ailigandí.

Al: Orig. mec.
v. CD, n. CCLXXV

\section{5.}

\section{Enero 4 Narganá}

Carta de Simón Bravo al intendente, adjuntándole una circular enviada a los maestros en la que se señalan las fechas de los 
exámenes finales en las distintas escuelas, y habla de la escuela nocturna de Ailigandí y las escuelas privadas de ésta y Ustupu.

Al: Orig. mec.

V. CD, n. CCLXXVI

616.

1939 Enero 4 Narganá

Circular de Simón Bravo a los maestros, en la que expone los días de exámenes orales y escritos de acuerdo con lo dispuesto por el poder ejecutivo, y en la que les señala que ellos son los responsables del material escolar y lo deben dejar en lugar seguro.

Al: Cop. mec.

V. CD, n. CCLXXVII

\section{7.}

\section{Febrero $10 \quad$ (El Porvenir)}

Carta del intendente a Simón Bravo, comentándole las cuestiones escolares y recordando que el envío del informe escolar se lo debe dirigir a él. Propone que sean ellos los que den destino a los maestros.

Al: Cop. mec. inc.

v. CD, n. CCLXXVIII

618.

\section{Febrero $10 \quad$ Narganá}

Carta de Simón Bravo al intendente, comunicándole los nombres de los miembros que formarán los grupos examinadores. Dice que visitará las escuelas privadas para estimularles en la cooperación con el gobierno, y propondrá el aumento de maestros para Tupile y Playón Chico. 
Al: Orig. mec.

V. CD, n. CCLXXIX

\section{9.}

\section{Febrero 10 Narganá}

Resolución de Simón Bravo, director de las Escuelas, para nombrar los maestros examinadores en las distintas escuelas comarcales por delegación de la autoridad comarcal.

Al: Cop. mec.

v. CD, n. CCLXXX

\section{0.}

\section{Marzo 1 Panamá}

Carta de Amadeo Vicente, subdirector del Departamento de Beneficencia, al intendente, en la que le avisa del envío de cheques por valor de 19,50 balboas, sueldo de dos personas por los servicios prestados a ese departamento en el mes de Febrero.

Al: Orig. mec.

\section{1.}

\section{Marzo 7 Panamá}

Carta al director del Departamento de Beneficencia e Higiene, tras una inspección a las islas en la que denuncia unos casos de tuberculosis que acabaron con la vida de los indígenas, pero comenta que se originaron fuera de la comarca. Concluye comentando que la enseñanza impartida por las madres es equiparable a la de las mejores escuelas de la capital.

Al: Orig. mec.

v. CD, n. CCLXXXI 


\section{2.}

\section{Abril Narganá}

Impresiones de Pablo Solís a su regreso a la comarca, alabando la actuación del intendente Hernández y constata el progreso de la región y los adelantos en la educación, la visita del Intendente a las escuelas y la reunión con los maestros.

ARPK: Carp. Cor. Orig. ms.

V. CD, n. CCLXXXII

\section{3.}

\section{Mayo 9 Ailigandí}

Carta del sahila Olowigueguina y del secretario Juan Colman, diciendo que con el subteniente Santiago le envió una carta en la que le expone los motivos por los que su pueblo y voceros no están de acuerdo con el nombramiento de la segunda maestra, pues no se les remitió ninguna nota anticipada. Ellos quieren que siga enseñando la civilización, indígenas capacitados en la enseñanza primaria.

Al: Orig. ms.

\section{4.}

1939 Mayo $16 \quad$ Cartí-Cangrejo

Carta de Rubén Pérez Kantule al encargado del despacho de El Porvenir, comentando su labor en pro del Gobierno nacional y el entorpecimiento de algunos jóvenes bochinchosos.

Al: Orig. mec.

v. CD, n. CCLXXXIII

\section{5.}

\section{Mayo 22 Cartí Sugdupu}


Carta de Rubén Pérez Kantule al Encargado de la Intendencia, en la que comenta que estuvo su suegro Pedro Filós hablando sobre la educación de los niños y dándoles a entender el basto conocimiento que él ha adquirido de las costumbres buenas de la gente blanca, por medio de sus hijos educados.

Al: Orig. mec.

\section{6.}

\section{Mayo 23 Cartí Sugdupu}

Carta de Rubén Pérez Kantule al encargado de la Intendencia, exponiéndole que estuvo hablando con el pueblo de Cartí y les explicó que no podía dejar sus servicios de maestro para tratar los asuntos internos del pueblo, pero puede explicar cuando no entiendan la labor que está haciendo el Gobierno. Finaliza diciendo que se necesitan materiales para terminar la casa del maestro.

Al: Orig. mec.

\section{7.}

\section{Mayo 26 Cartí Sugdupu}

Carta de Rubén Pérez Kantule al encargado de la Intendencia Vicente Calvet, avisándole que recibió la carta que le pide haga ver al sahila Olonibiquiña el mal que está haciendo en su pueblo. Como maestro achaca la mala labor realizada a la maestra Juana G. de Haya, pues los niños no han aprovechado en nada, no comenzaron a aprender ni el abecedario.

Al: Orig. mec.

\section{8.}

\section{Mayo $31 \quad$ Ustupu}

Carta de Nele Kantule al secretario de El Porvenir, pidiendo que 
le envíe materiales para la escuela que se construye en el pueblo.

Al: Orig. mec.
V. CD, n. CCLXXXIV

\section{9.}

\section{Junio 18 Cartí Cangrejo}

Carta de Rubén Pérez Kantule al Sr. Vicente Calvet, encargado de la Intendencia, expresándole que ha arreglado la mitad de las escuelas pero le faltan tablas, por lo que pide que si le es posible se las envíe. Acusa al Sr. José García de corruptor de la moralidad, lo que puede ser perjudicial para los que intentan que los indios lleguen a ser civilizados.

Al: Orig. mec.

\section{0.}

\section{Junio $30 \quad$ Cartí-Cangrejo}

Carta de Rubén Pérez Kantule al intendente, quejándose de los daños ocasionados por un indio que destruyó su casa.

Al: Orig. mec. lleg.

\section{1.}

\section{Junio Narganá}

Informe de Ricardo Velasco al intendente, sobre la situación escolar de la comarca en estos meses. Trata del inicio del curso y pequeños problemas que tuvo que enfrentar, y que el intendente desconoce por haber estado ausente.

Al: Cop. mec.
v. CD,
n. CCLXXXV 


\section{2.}

\section{Julio 7 Cartí-Cangrejo}

Carta de Rubén Pérez Kantule al intendente de la comarca, en la que le comunica que los indios están con el Gobierno nacional en la campaña actual y se quejan de la pésima situación de la escuela y la mala labor de la maestra anterior.

Al: Orig. mec. inc.

v. CD, n. CCLXXXVI

633.

1939 Julio 11 Panamá

Carta de E. J. Castillero, inspector general de enseñanza, al intendente Luis Hernández, notificando la llegada de petición de materiales para el buen funcionamiento de las escuelas de la comarca, y expone que se incluyó a las escuelas de San Blas en el cuadro de distribución de materiales. Concluye refiriendo que los materiales deben pedirse a la Secretaría de Gobierno que tienen un presupuesto para atender estas necesidades de la comarca de San Blas.

Al: Orig. mec.

\section{4.}

\section{Julio $25 \quad$ Narganá}

Carta de Ricardo Velasco al intendente Hernández, comentando el oficio que le mandó solicitando la colaboración de los maestros para la construcción de la carretera de Portobelo-Colón.

Al: Orig. mec.

V. CD, n. CCLXXXVII

\section{5.}

\section{Agosto $10 \quad$ Narganá}

Carta de Ricardo Velasco al intendente Hernández relatando las impresiones de su visita, entre las favorables reseña Ustupu, donde la 
escuela ha alcanzado casi el nivel de la cabecera, y el maestro de Ailigandí que hace gran labor de atracción. Los de Ustupu piden que se termine pronto la escuela.

Al: Orig. mec.

V. CD, n. CCLXXXVIII

\section{6.}

\section{Octubre 3 Narganá}

Carta de Ricardo Velasco a Luis Hernández, comunicándole que recibió la ley reformatoria referente a las ausencias y tardanzas de los profesores de segunda enseñanza, comenta que la tendrá presente en sus determinaciones del ramo.

Al: Orig. mec.

\section{7.}

\section{Octubre 9 Narganá}

Carta de Ricardo Velasco a Luis Hernández, en la que le avisa del envío del programa de fiestas patrias que celebrará el plantel escolar y los demás elementos oficiales, y que el viaje a Puerto Obaldía lo hará una vez recuperado de la malaria.

Al: Orig. mec.

\section{8.}

\section{Octubre $15 \quad$ Narganá}

Carta de Ricardo Velasco al intendente, en la que le avisa del recibo del paquete escolar con las banderas nacionales. Le comunica que su gira por las escuelas estará supeditada a lo que le permita el Clodire y le remite las cuotas pro carretera Colón-Portobelo de los maestros de Narganá.

Al: Orig. mec. 
639.

\section{Octubre $18 \quad$ Narganá}

Carta de Ricardo Velasco a Luis Hernández, avisándole que le enviará su lanchita, pues ya le ha comentado su intención de trasformarla para sus viajes de inspección escolar.

Al: Orig. mec.

\section{0.}

\section{Octubre $18 \quad$ Narganá}

Carta de Ricardo Velasco al intendente, comunicándole que en las fiesta la junta de hornato ha incluido una comida para todos los niños que asisten a la escuela. Dice que la matrícula asciende a 320 alumnos y se calcula el gasto en un saco y medio de arroz y dos tortugas de regular tamaño.

Al: Orig. mec.

\section{1.}

\section{Octubre 19 Narganá}

Carta de Ricardo Velasco, director de las escuelas, a Luis Hernández, anunciándole que los maestros de la comarca tienen intención de hacerle un obsequio, por sus esfuerzos en mejorar la instrucción entre los indígenas, pero que no se lo han podido enviar.

Al: Orig. mec.

\section{2.}

\section{Octubre 26 El Porvenir}

Carta del intendente al presidente y secretario de la "Junta de Ornato", aprobando la decisión de dar una comida a los niños de la escuela como parte del programa de fiestas patrias. 
Al: Cop. mec.

v. CD, n. CCLXXXIX

\section{3.}

\section{Noviembre 1 Narganá}

Carta de Ricardo Velasco al intendente, comunicándole que recibió de David Rodríguez, maestro de Ustupu, una carta en la que le anuncia que la sociedad koskuna le ha prohibido que use su centro para escuela, y que están contrariados los habitantes porque ven que la escuela del Gobierno no se termina.

Al: Orig. mec.

\section{4.}

\section{Noviembre 1 Narganá}

Carta de Ricardo Velasco al intendente, en la que le comunica que en este mes que acaba se ha podido hacer cargo de la marcha de las escuelas de Cartí Cangrejo, Tigre, Ticantiquí, Puerto Obaldía y Río Azúcar, y la impresión de Cartí no es satisfactoria, la de Tigre y Puerto Obaldía ha mejorado con respecto al último viaje, Ticantiquí ha perdido y Río Azúcar progresa normalmente.

Al: Orig. mec.

\section{5.}

\section{Noviembre 1 Narganá}

Carta de Ricardo Velasco al intendente Hernández, cumplimentando los datos mensuales con respecto a la marcha de las escuelas, y resalta la merma en la matrícula y en las asistencias; atribuye ésta a la fiebre extendida por toda la comarca.

Al: Orig. mec.

v. CD, n. CCXC 
646.

\section{Noviembre 7 Santiago}

Carta del Director de la escuela, Alvarez, a la Sociedad Indígena de la comarca de San Blas, diciendo que les tendrá informados de la marcha de los empleados allí en la escuela y que desea que todo funcione bien.

ARPK: Carp. Cor. Orig. mec.

v. CD, n. CCXCl

\section{7.}

\section{Noviembre $15 \quad$ Narganá}

Carta de Ricardo Velasco al intendente, diciendo que se celebraron las fiestas patrias con toda normalidad y solo hubo que retrasar la parada debido al mal tiempo. En Cartí Cangrejo no se celebró debido a la muerte de una hija de Rubén Pérez Kantule, maestro nacional en ese lugar, quien tuvo que trasladarse por tal motivo.

Al: Orig. mec.

\section{8.}

\section{Noviembre 16 Puerto Obaldía}

Carta de Guillermo Denis, regidor de policía, al intendente, diciendo que llegó a ese lugar el doctor y comenzó por examinar a los miembros de la policía y siguió con los niños y varios particulares que solicitaron su servicio.

Al: Orig. mec.

\section{9.}

\section{Noviembre $24 \quad$ Narganá}


Carta de Ricardo Velasco al intendente Hernández, notificándole que siguiendo sus órdenes acompañó al doctor y que en Ustupu encontró una casita construida como escuela pero sin condiciones. Relata la situación de varias escuelas.

Al: Orig. mec.

v. CD, n. CCXCII

\section{0.}

\section{Noviembre $28 \quad$ Narganá}

Carta de Ricardo Velasco al intendente, comunicándole que una vez revisados los datos de la comarca es regular su funcionamiento si exceptúa a Ustupu por motivos de enfermedad, tanto de los alumnos como de la maestra del primer grado. Concluye diciendo que confía que se remediará esta falta con las medidas tomadas por el intendente.

Al: Orig. mec.

\section{1.}

\section{Diciembre 19 Puerto Obaldía}

Carta de Esther de Rivas al intendente, mostrando su extrañeza porque el pueda pensar que ella llegue a hacer cambios en el plantel de educación; pues ella cree que ésta es cuestión que corresponde al Gobierno.

Al: Orig. mec.

\section{2.}

\section{Diciembre 20 Tubualá}

Carta del sahila general Yabiliquiña al intendente, comunicándole que este mes se presentó ante él el sahila de Isla Perro con delegados, a fin de pedir escuela del Gobierno para otro año, pues cree que es bueno para sus hijos.

Al: Orig. mec. 


\section{3.}

\section{Enero 12 Narganá}

Carta de Ricardo Velasco, director de las escuelas, al Sr. Vicente Calvé, encargado de la Intendencia, a la que adjunta las notas remitidas a la dirección de las escuelas de la comarca por el secretario Yapiliquiña, en relación con la escuela solicitada para Isla Perro.

Al: Orig. mec.

\section{4.}

\section{Enero $16 \quad$ Narganá}

Resoluciones adoptadas por Ricardo Velasco para los exámenes de fin de curso en la comarca, en las que se tiene en cuenta las distancias de las islas.

Al: Orig. mec.

V. CD, n. CCXCIII

\section{5.}

\section{Enero 18 Puerto Obaldía}

Carta de Guillermo Denis, regidor de policía, al intendente, en la que le comunica el recibo de un oficio donde le enumera los agraciados para supervigiladores de los exámenes de fin de año en la escuela de este lugar, pues el director le había expresado su imposibilidad de asistir a dichas pruebas.

Al: Orig. mec.

\section{6.}

1940 Enero 28 Narganá

Carta de Ricardo Velasco al intendente Luis Hernández, 
comentando su impresión favorable de los exámenes, y señala que los maestros han trabajado estimulados por las circulares de la dirección.

Al: Orig. mec.

\section{7.}

\section{Febrero 2 Narganá}

Carta de Ricardo Velasco al intendente Villalaz, enviándole el informe final del curso, y sugiere que los maestros del año próximo deberían ser examinados previamente. Propone las personas que irán a participar en el carnaval.

Al: Orig. mec.

v. CD, n. CCXCIV

\section{8.}

1940 Abril 1 Narganá

Carta de Ricardo Velasco al intendente Hernández, en la que le comunica el resultado de los exámenes al que sometió a las maestras por indicación suya. Recomienda a una para la escuela de Ustupu.

Al: Orig. mec.

v. CD, n. CCXCV

\section{9.}

\section{Mayo 22 Narganá}

Carta de Ricardo Velasco al intendente Luis Hernández, comunicándole que le envía las tarjetas de identificación de firmas, y anuncia que se ha alcanzado el número 1.000 en la matrícula. Comenta que en Narganá se ha llegado a 335 y que Permé solo tiene 8 niños.

Al: Orig. mec.

v. CD, n. CCXCVI 
660.

\section{Mayo $22 \quad$ Narganá}

Carta de Ricardo Velasco al intendente Luis Hernández, afirmando que prepara una circular para los maestros que tratará del aseo. Confía que mejore cuando reciban el primer cheque. Destaca la pulcritud del maestro Francisco Soo.

Al: Orig. mec.

v. CD, n. CCXCVII

\section{1.}

1940 Mayo $31 \quad$ El Porvenir

Nombramiento del Sr. Rubén Pérez Kantule como maestro de Cartí Suigdup desde la Intendencia de San Blas.

ARPK: Carp. Dat. s. la vid. de R. P. K. Orig. mec.

v. CD, n. CCXCVIII

662.

1940 Julio 23 Cartí Cangrejo

Carta de Rubén Pérez Kantule al intendente, felicitándole por su nueva reelección para este cargo y comenta la buena labor de la maestra y las obras que está llevando a cabo en la escuela. Le anuncia que cinco niñas asisten a la escuela de la maestra.

Al: Orig. mec.

v. CD, n. $\operatorname{CcxcIX}$

\section{3.}

\section{Agosto 7 Panamá}

Carta de Rubén D. Carles, subinspector general de enseñanza primaria, al intendente, comunicándole que la ha enviado útiles 
escolares y solicita le comunique cuando los reciba.

Al: Orig. mec.

\section{4.}

\section{Agosto 8 El Porvenir}

Carta del intendente Hernández a Ricardo Velasco, comentando el envío de un revolver y una corneta. Dice que lo primero es necesario por sus visitas y le felicita por la labor en pro de la instrucción cuyos frutos se están ya cosechando.

Al: Cop. mec.

v. CD, n. CCC

\section{5.}

\section{Agosto 12 Ustupu}

Carta de Nele Kantule a Estanislao López, en la que le comunica su propósito de enviar a estudiar a unos muchachos a la capital y otros a Norteamérica para que luego luchen por su región.

ARPK: Carp. 300. Cop. mec. inc.

$$
\text { V. CD, n. } \mathrm{CCCl}
$$

\section{6.}

\section{Agosto 13 Panamá}

Aviso enviado por la directora de la Escuela Profesional, Isabel Herrera, a una familia para que asista a la reunión que tratará asuntos de calificaciones y promoción de su acudiente.

BN: Carp. Educ. var. doc. Orig. mec. 


\section{7.}

\section{Agosto $20 \quad$ Narganá}

Carta de Manuel M. Puig al intendente, agradeciendo que delegara en él para escoger los becados con destino a Colón, pero expone todas las dificultades que han sufrido los becados en los últimos años. Le ruega que haga conocer estas dificultades al Presidente de la República.

Al: Orig. mec.

V. CD, n. CCCII

\section{8.}

\section{Agosto $27 \quad$ Narganá}

Carta de Ricardo Velasco a Luis Hernández, suplicándole que no cambie a su ayudante, que si va a hacer un nombramiento, que sea un maestro para Playón Chico, pues hay una matrícula de 95 niños con un solo maestros, y que Puerto Obaldía no cuenta con suficiente matrícula para tres maestros.

Al: Orig. mec.

\section{9.}

\section{Agosto $27 \quad$ Narganá}

Carta de Ricardo Velasco a Luis Hernández, enumerándole la lista de necesidades de las escuelas que le había solicitado

Al: Orig. mec.

\section{0.}

\section{Septiembre 6 Narganá}

Carta de Ricardo Velasco al intendente Calvet, remitiéndole los datos mensuales de las escuelas y señala que la matrícula ha 
aumentado; y se abrió el kinder en Narganá. Concluye haciéndole saber que envió una circular sobre los exámenes semestrales.

Al: Orig. mec.

V. CD, n. CCCIII

\section{1.}

\section{Septiembre 9 Narganá}

Carta de Ricardo Velasco a Vicente Calvet, transmitiéndole que por información recibida del Sr. Francisco Soo se ha enterado de que los habitantes de Río Tigre intentan levantar una escuela moderna, cooperando sus habitantes a la acción del Gobierno, pero el sahila ha expresado críticas contra la escuela y la civilización.

Al: Orig. mec.

\section{2.}

\section{Septiembre 19 Narganá}

Carta del director de las escuelas al intendente Calvet, pidiéndole un nuevo maestro para Playón Chico y recomendando suprimir un maestro de Cartí, pues estos han demostrado poco interés por la instrucción.

Al: Orig. mec. inc.

v. CD, n. CCCIV

\section{3.}

\section{Septiembre 19 Río Tigre}

Carta de los habitantes de la isla al Sr. Presidente de la República, pidiendo un maestro más para el pueblo y aprovechan la oportunidad para proponer a la Srta. Adelaida Calvo.

AELE: Carp. 1940-41-43-46-47-48. Cop. mec. inc.

$$
\text { v. CD, n. CCCV }
$$




\section{4.}

\section{Septiembre 21 El Porvenir}

Carta del intendente interino al director de la escuelas, lamentando no poder ayudarle a organizar las escuelas de Playón Chico y Cartí. Dice que eso es competencia del intendente titular.

Al: Cop. mec. mec.

V. CD, n. CCCVI

\section{5.}

\section{Noviembre 8 Puerto Obaldía}

Informe de la escuela rendido por Simón Salazar al intendente, en el que expone el deficiente estado en que encontró la escuela y las dificultades que se presentan agravadas por su lejanía. Propone las mejoras que se deben hacer para impulsar la educación.

Al: Orig. mec.

V. CD, n. CCCVII

\section{6.}

\section{Diciembre 2 Narganá}

Carta de Ricardo Velasco al intendente Villalaz, comentando el tema del plebiscito constitucional y los útiles solicitados para la escuela de Puerto Obaldía. Al mismo tiempo le envía los datos estadísticos reseñando que la merma se ha producido en Ailigandí y Ustupu. Concluye relatando la expulsión de un niño, y la situación de una mujer que corrompe a los escolares.

Al: Orig. mec.

v. CD, n. CCCVIII

\section{7.}

\section{Diciembre 14 Narganá}

Carta del subteniente del $2^{\circ}$ destacamento, Julio A. Núñez al intendente, comunicando que hizo comparecer a la señora que se 
acusaba de corruptora y negó las acusaciones. También ha pedido que comparezcan los padres de un niño expulsado de la escuela, pero no han podido por enfermedad.

Al: Orig. mec.

v. CD, n. CCCIX

\section{8.}

\section{Diciembre 15 Tubalá}

Carta del ságuila Yabiliquiña al intendente, comentándole que el director de las escuelas le escribió para ver si quería una escuela en su jurisdicción y dice que no le moleste más, que el pueblo primero quiere un título de propiedad.

Al: Orig. ms.

v. CD, n. CCCX

\section{9.}

\section{Diciembre 20 Narganá}

Carta de Julio A. Núñez al intendente Villalaz, exponiendo las malas contestaciones que recibió el director al preguntar a los padres de una joven por qué no enviaban a su hija a la escuela. Comenta que todo era porque había sido elegida reina de los carnavales del club.

Al: Orig. mec.

v. CD, n. CCCXI

\section{0.}

\section{Diciembre $27 \quad$ Narganá}

Carta de Ricardo Velasco al intendente Villalaz, pidiendo permiso para desplazarse a Colón. Manifiesta su intención de crear un internado para niñas y dice que espera cooperación del Gobierno del mismo modo que lo hizo con el internado de niños.

Al: Orig. mec.

v. CD, n. CCCXII 


\section{1.}

\section{Diciembre $31 \quad$ Narganá}

Carta de Ricardo Velasco al intendente, enviándole los datos estadísticos de las escuelas y comentando el mal comportamiento de un maestro. Dice que esto no se puede permitir.

Al: Orig. mec.

V. CD, n. CCCXIII

\section{2.}

\section{(1940)}

Memorial a los honorables diputados de parte de los representantes del pueblo kuna, en el que se pide que se tenga en cuenta la situación financiera actual y que por ello se restablezcan las becas indígenas que estaban suspendidas. También piden la creación de nuevas escuelas pues las existentes son insuficientes, que según el informe son cinco.

ARPK: Carp. Inf. de las soc. ind. de la comr. de SB. Cop. mec.

\section{3.}

\section{Enero 26 Ustupo}

Carta de Francisco Soo a Estanislao López, en la que le pide que cuide a un joven que se ha trasladado a la ciudad y que le mande libros pues él desea estudiar.

AELI: Carp.1941. Orig. mec.

\section{4.}

1941 Febrero 1 El Porvenir

Carta del intendente Villalaz al director Ricardo Velasco, 
enumerando las características que deben presentar los que asistan como representantes de los kunas al carnaval de Panamá.

Al: Cop. mec.

v. CD, n. CCCXIV

\section{5.}

\section{Febrero 10 El Porvenir}

Carta del intendente Villalaz al Ministro de Gobierno y Justicia, adjuntándole el informe escolar anual recibido del director en el que dice que dada la escasez de personal para esta región los maestros de los que se ha recibido queja deben cambiarse en lugar de cesarlos, pues quedarían bajo una vigilancia directa del intendente. Concluye exponiendo que está de acuerdo con el aumento de maestros.

Al: Cop. mec.

v. CD, n. CCCXV

\section{6.}

\section{Marzo 12 Panamá}

Carta de Agustín Fermara, primer secretario del Ministerio, al intendente Constantino, pidiéndole que haga gestiones para conseguir un muchacho indígena que desee trabajar en casa de una familia honorable y tenga conocimientos del castellano.

Al: Orig. mec.

v. CD, n. CCCXVI

\section{7.}

\section{Marzo 19 Panamá}

Circular del Ministro de Gobierno y Justicia, Alfaro de la Guardia, al intendente, hablando de la moralidad pública y de la protección de la niñez, en la que señala la hora de retirada de los 
niños de las calles para dedicarse a las tareas escolares.

Al: Orig. mec.

v. CD, n. CCCXVII

\section{8.}

\section{Marzo 22 Cartí Tupile}

Carta de los isleños al Presidente de la República, quejándose de los atropellos del intendente que detiene y pone multas sin oir a los acusados. Comentan que al parecer hubo bebidas en las fiestas de Narganá y que fue con policías a detenerlos.

AELI: Carp. 1941. Orig. mec.

\section{9.}

$1941 \quad$ Marzo 30

Carta comentando la entrega de tres galones de pintura blanca a Nele Kantule para la escuela de Ustupu.

AELI: Carp. 1941. Cop. mec.

\section{0.}

\section{Abril 3 Ustup}

Carta de Nele Kantule a Estanislao López, en la que le pregunta si le manda a seis muchachos becados según se acordó con el Presidente de la República; y pide que le remita al Presidente los nombramientos propuestos por él para el magisterio.

ARPK: Carp. 300. Orig. mec.

$$
\text { v. CD, n. CCCXVIII }
$$

\section{1.}

\section{Abril 4 El Porvenir}

Carta de Constantino Villalaz a Nele Kantule, en la que le recuerda que el único jefe de la comarca es el intendente, y que está 
trabajando con el padre director para seleccionar a los maestros de la comarca. Concluye afirmando que si las personas que recomienda reúnen las condiciones serán elegidas.

Al: Cop. mec.

v. CD, n. CCCXIX

\section{2.}

\section{Abril 14 Panamá}

Lista enviada por Nele Kantule con los nombres de los graduandos de la capital y de Narganá para que se les conceda becas. $Y$ la propuesta de maestros para que se entregue al Presidente.

ARPK: Carp. 300. Cop. mec.

v. $C D$, n. $\operatorname{CCCXX}$

\section{3.}

\section{Abril 16 Panamá}

Carta de Estanislao López al sahila y Ceferino Villalaz, en la que le dice cuales son los maestros propuestos para Tigre, les sugiere que pidan estos mismos al intendente. Acompaña a la lista una propuesta de beca.

ARPK: Carp. 300. Cop. mec.

V. CD, n. CCCXXI

\section{4.}

\section{Abril 25 Narganá}

Carta del director Ricardo Velasco al intendente, pidiendo un carpintero para solucionar el problema de las aulas antes de que comience el curso. Le comunica el estado de gravidez de una maestra nombrada y otros asuntos de varios maestros.

Al: Orig. mec.
V. CD, n. CCCXXII 
695.

\section{Abril 25 Ustupo}

Carta de Nele Kantule a Estanislao López, en la que le comunica que va una comisión y lleva a los muchachos becados para que los coloquen en algún instituto o escuela. Le pide que haga una carta y firme por él, para el Presidente de la República.

ARPK: Carp. 300. Orig. mec.

v. CD, n. CCCXXIII

\section{6.}

\section{Abril $26 \quad$ Narganá}

Carta de Ricardo Velasco al intendente, suplicándole que debido al retraso en los nombramientos le indique dónde deben reunirse. Referente a la petición del Ministro de Gobierno dice que nadie quiere que su hijo salga de la escuela para ir a servir, y que debería ser uno que hubiese cursado el sexto grado.

Al: Orig. mec.

v. CD, n. CCCXXIV

\section{7.}

\section{Mayo 14 Panamá}

Carta de Estanislao López a Tomás Herrera, en la que le comenta el caso de una estudiante embarazada de siete meses.

AELI: Carp.1941. Cop. mec.

\section{8.}

\section{Mayo 20 El Porvenir}

Carta del intendente Villalaz a Ricardo Velasco, haciéndole saber que recibió las tarjetas de identificación de firmas y le indica 
la asignación de los becados. Le comenta que no existe internado en Panamá y propone a uno de los jóvenes para disfrutar de beca. Le pide que elija a los becados de entre los que están en la comarca.

Al: Cop. mec.

v. CD, n. CCCXXV

\section{9.}

\section{Mayo 23 El Porvenir}

Carta de Villalaz a Ricardo Velasco, comunicándole que ha conseguido cinco becas para los indígenas y propone que haga un concurso para los exalumnos de sexto grado. Finaliza diciendo que le envíe tres copias de los cuadros estadísticos ya que le ha solicitado uno el Ministro de Educación Pública.

Al: Cop. mec.

v. CD, n. CCCXXVI

700.

\section{Mayo $23 \quad$ Narganá}

Carta del director de las escuelas de la comarca, Ricardo Velasco, a Nele Kantule, diciéndole que comunique a su pueblo que huya de los engañadores y que sepa que el magisterio de allí ha sufrido un descuento y a pesar de esto no se ha ido a otros lugares mejor retribuidos.

ARPK: Carp. 88. Orig. mec.

v. CD, n. CCCXXVII

\section{1.}

\section{Mayo 29 Panamá}

Carta del Ministro de Gobierno y Justicia, Alfaro de la Guardia, al intendente, en la que le comenta una carta que le envió al señor 
director de las escuelas, Ricardo Velasco, al Gobernador de Colón, expresando su preocupación por el éxodo de indígenas a las capitales del país con lo que supone de detrimento para la agricultura y las escuelas de la comarca.

Al: Orig. mec.

V. CD, n. CCCXXVIII

702.

\section{Mayo $30 \quad$ Narganá}

Carta de Ricardo Velasco al intendente Villalaz, trascribiendo el nombre de los cinco becados y pide que sean acompañados por un agente hasta la escuela de Artes y Oficios, así éste verá el modo de dejarlos colocados en casas de confianza.

Al: Orig. mec.

v. CD, n. CCCXXIX

\section{3.}

\section{Junio 6 Río Cidra}

Carta de Rosario G. de Herrera al intendente Villalaz, expresando su satisfacción por el trabajo en la escuela y notificándole que la matrícula es de 50 y que los que no asisten es porque no tienen camisa.

Al: Orig. ms.

v. CD, n. CCCXXX

\section{4.}

\section{Junio $26 \quad$ Narganá}

Carta de Rubén Pérez Kantule al Sr. Presidente de la República, Arnulfo Arias M., en la que le solicita las bases para ser miembro del partido Nacional Revolucionario, y comenta que él es una persona 
influyente y tiene la intención de fundar un club político en la comarca, ya que no existe ninguno.

AELI: Carp.1941. Orig. mec.

\section{5.}

\section{Junio $26 \quad$ Narganá}

Carta de Rubén Pérez Kantule al Presidente Arnulfo Arias, en la que le comunica que renunció a su puesto de maestro para obedecerle a él, y que espera que ahora le recomiende pues de lo contrario irá a trabajar a la Zona.

AELI: Carp. 1941. Orig. mec.

\section{6.}

\section{Julio $15 \quad$ Narganá}

Carta de Ricardo Velasco al intendente, agradeciéndole el envío que le hizo de los registros escolares para las escuelas de la república. Comenta que mandará una circular a los maestros para su mayor comprensión. $Y$ concluye diciendo que hará en cuanto pueda una inspección, pues cree que se deben visitar todos los meses.

Al: Orig. mec.

v. CD, n. CCCXXXI

\section{7.}

\section{Julio $30 \quad$ Panamá}

Carta de Estanislao López a Víctor M. Villalobos, secretario general del Partido Nacional Revolucionario, expresándole que Nele Kantule hizo una visita al Presidente de la República a comienzos del año y le prometió becas para estudios secundarios en la capital para los indios de San Blas. Le pide que mire a ver que ha pasado pues el tiene a los aspirantes.

AELI: Carp.1941. Cop. mec. 
708.

\section{Agosto 19 Puerto Obaldía}

Carta de Antonio Arias al director de las escuelas de la comarca, quejándose por la actuación de la directora de su escuela que ha expulsado a una de sus niñas sin motivo, después de reprenderla con palabras indebidas.

Al: Orig. mec.

v. CD, n. CCCXXXII

\section{9.}

\section{Agosto 27 Panamá}

Carta de Estanislao López a Rubén Pérez Kantule, en la que le habla de conseguir escuela para su pueblo, Mulatupu, ya que es de los principales y cree que se lo merece.

AELI: Carp.1941. Orig. mec.

710.

1941 Septiembre 28 Narganá

Acta de la conferencia del Director Ricardo Velasco a los maestros, exhortándoles a la unidad entre ellos y a seguir haciendo las estadísticas mensuales. En ella explica los nuevos registros y concluye con una serie de peticiones al intendente para la mejor marcha del magisterio.

Al: Orig. mec.

v. CD, n. CCCXXXIII

\section{1.}

1941 Octubre $27 \quad$ Narganá

Carta de Ricardo Velasco al intendente, comentando que finalizó 
su viaje de inspección y ha notado mayor interés por la instrucción. Dice que la escuela de Puerto Obaldía se debería instalar en un local amplio y concluye comentando que se trajo un hombre para trabajar en el internado.

Al: Orig. mec.

v. CD, n. CCCXXXIV

\section{2.}

\section{Octubre 29 Narganá}

Carta de Ricardo Velasco al intendente, en la que entre otras cosas expone que algunos ságuilas piden un practicante para vacunar a los niños pues ya se han producido varias muertes.

Al: Orig. mec.

v. CD, n. CCcxxxv

\section{3.}

\section{Diciembre $10 \quad$ Narganá}

Carta de Ricardo Velasco al intendente, en la que le remite los datos estadísticos y comunica que el sarampión ha producido notable descuento en las asistencias, lamentando algunas muertes de alumnos matriculados.

Al: Orig. mec.

v. CD, n. CCCXXXVI

\section{4.}

\section{Diciembre 11 Panamá}

Carta de Nele Kantule al Presidente De La Guardia, en la que dice que el Gobierno construyó una escuela en Ustupu y se ha quedado pequeña, por lo que convendría hacer otra, ya que allí quedó material de la anterior.

ARPK: Carp. 88. Cop. mec.

$$
\text { v. CD, n. CCCXXXVII }
$$




\section{5.}

\section{Diciembre $31 \quad$ Narganá}

Carta de Ricardo Velasco al intendente, comentando los problemas surgidos con motivo de la celebración de los carnavales, pues han elegido para reina a una de las alumnas de la escuela, y esto se agrava más por celebrarse el último mes del curso, cuando hay que dedicarse a repasar.

Al: Orig. mec.
V. $C D$,
n. $\operatorname{CCCXXXVIII~}$

\section{6.}

\section{1}

Carta de Pablo Solís al Presidente, en la que expresa que algunos que han sido intendentes quieren volver a serlo, pero aclara que no se han interesado mucho por los indios; que existe gente en Panamá que se ha preocupado y que espera que vaya a la Intendencia alguien que colabore.

AELE: Carp.1941. Orig. ms.

\section{7.}

\section{Enero 2 Narganá}

Carta de Ricardo Velasco al intendente, defendiéndose de las acusaciones propagadas por los indígenas. Comenta que tiene derecho a defender a la niñez y a que su nombre permanezca intacto.

Al: Orig. mec.
v. CD, n. CCCXXXIX

718.

\section{Enero 3 Narganá}


Circular de Ricardo Velasco a los maestros de la comarca, tratando el tema de los exámenes finales y nombra a los examinadores de cada escuela, que deben informar por escrito de los resultados. Exhorta a los maestros a que no se muevan del puesto hasta después del 31 de ese mes.

Al: Orig. mec.

v. CD, n. CCCXL

719.

1942 Febrero 10 Narganá

Informe escolar de la comarca de San Blas, rendido por el director Ricardo Velasco al intendente, en el que le menciona los nombramientos de maestros y una estadística de la asistencia y matrícula de los últimos años. Hace después una descripción detallada de las escuelas en particular. $Y$ concluye proponiendo unas indicaciones para la mejora de la educación en la comarca.

Al: Orig. mec.

v. CD, n. CCCXLI

720.

\section{Febrero 17 Ustupu}

Carta de Nele Kantule y los maestros al intendente, expresando la aprobación de Nele en lo acordado en el Congreso de Tupile, entre las resoluciones figura el control de niños que van para Colón. Piden que comunique a los capitanes la prohibición de llevar niños sin los permisos correspondientes.

Al: Orig. mec.

v. CD, n. CCCXLII

\section{1.}

\section{Febrero 19 Narganá}

Lista de los útiles escolares necesarios para las escuelas y pedidos por el director de las mismas. 
Al: Orig. mec.

V. CD, n. CCCXLIII

\section{2.}

\section{Marzo 18 El Porvenir}

Carta del intendente a Nele Kantule, transcribiéndole la carta que le remitiera el Presidente de la República comentando las actas del congreso indígena, y su buena disposición para los temas de educación y civilización.

Al: Cop. mec.

v. CD, n. CCCXLIV

\section{3.}

1942 Abril 11 Panamá

Carta del Ministro de Gobierno y Justicia al intendente, contestándole a su pregunta sobre si es competencia del intendente nombrar maestros y director de la comarca. Dice que el Ministro oirá gustoso sus sugerencias.

Al: Orig. mec.

v. CD, n. CCCXLV

\section{4.}

1942 Abril 18 Colón

Carta de Elisa de Garrido al intendente de la comarca, manifestándole que recibió la comunicación de su nombramiento y que acepta el cargo de maestra con mucho agrado.

Al: Orig. mec.

\section{5.}

(1942) Abril 22 Panamá

Carta dirigida al Presidente Belisario Porras, comunicándole que ya pidió al intendente derogue el decreto de traslado del jefe del 
destacamento, pues ha prometido observar buena conducta y no molestar a la maestra de Narganá.

ANP: Carp. Cor. B.P. Orig. mec.

\section{6.}

\section{Abril 23 Panamá}

Decreto número 375 por el que se nombra el personal de las escuelas de la comarca de San Blas, firmado por el Ministro de Gobierno y Justicia.

Al: Cop. mec.

V. CD, n. CCCXLVI

\section{7.}

\section{Mayo 1 El Porvenir}

Carta del intendente a Manuel M. Puig, comunicándole que recibió carta de los vecinos de Playón Chico, en la que le exponen la conveniencia de que siga el maestro Eduardo Filós. Comenta que el memorial enviado por estos vecinos está guiado por los intereses particulares del maestro. Dice que debe anunciar a todos los maestros que la Intendencia no atenderá a intereses personales.

Al: Cop. mec.

\section{8.}

\section{Mayo 2 Narganá}

Carta de Manuel M. Puig al intendente Hernández, notificando el recibo del decreto de nombramiento de maestros, y le agradece su nombramiento como director.

Al: Orig. mec.

v. $C D$, n. CCCXLVII 
729.

\section{Mayo 3 Narganá}

Carta de Manuel M. Puig al intendente, comunicándole que han tomado posesión los maestro de la comarca, a excepción de Domitilo Garibaldi y José Colman, los cuales no se han presentado.

Al: Orig. mec.

v. CD, n. CCCXLVIII

730.

\section{Mayo 3 Narganá}

Carta de Manuel M. Puig al intendente Hernández, comentándole la petición de los habitantes de Playón Chico para que siga allí el maestro Eduardo Filós, pero comenta que ya le había dado la orden de que fuera a Ailigandí y así lo aceptó el maestro, y concluye con la noticia de que todos han partido para su destino.

Al: Orig. mec.

\section{1.}

\section{Mayo 3 Narganá}

Carta de Manuel Puig al intendente Hernández, comunicándole que el Presidente de la República en conmemoración del día del Indígena resolvió otorgar cuatro becas para niños y cuatro para niñas en la Escuela Normal.

Al: Orig. mec.

\section{2.}

\section{Mayo $6 \quad$ Narganá}

Carta de Manuel M. Puig al intendente Hernández, notificando el comienzo de curso en las escuela de la comarca, y habla de las 
exhortaciones hechas a los alumnos de Narganá, así como de las recomendaciones propuestas a los maestros por indicación de la Intendencia.

Al: Orig. mec.

V. CD, n. CCCXLIX

\section{3.}

\section{Mayo $14 \quad$ Narganá}

Carta de Manuel M. Puig al intendente, anunciándole que recibió una circular de gran importancia que trata del tema pedagógico tan polémico, referido a la preparación de clases. Recomendará su lectura a los maestros para que acomoden su proceder a estas enseñanzas.

Al: Orig. mec.

\section{4.}

\section{Mayo $15 \quad$ Narganá}

Carta de Manuel M. Puig al intendente, en la que le comunica que recibió la nota en la cual se insta para que se vigile a los maestros a fin de que no hagan viajes a lugares distintos a donde deben estar radicados, y que en caso de necesitarlo, deben pedir permiso en esta dirección. A los transgresores se les debe poner multas para evitar irregularidades en las funciones que desempeñan.

Al: Orig. mec.

\section{5.}

\section{Mayo $15 \quad$ (Narganá)}

Circular de Manuel M. Puig sobre la conducta del maestro, en la cual señala que el maestro es el elemento instruido de la isla, en muchas ocasiones consejero del ságuila, por lo que debe de ser modelo de moralidad. Les recuerda la prohibición de hacer viajes fuera del 
lugar de residencia.

Al: Orig. mec.

V. CD, n. CCCL

736.

1942 Mayo $18 \quad$ Narganá

Carta de Manuel M. Puig al intendente Hernández, quejándose del Sr. Acosta, a quien se tiene por inspector de Educación en la comarca y critica los métodos usados por los maestros en las escuelas de San Blas, por considerarlos anticuados.

Al: Orig. mec.

v. CD, n. CCCLI

\section{7.}

\section{Mayo 19 Narganá}

Carta de Jesús Erice al intendente Hernández, comunicando que coincidiendo con la apertura del curso escolar se inauguró un internado para niñas y que también se inauguró un nuevo edificio para el internado de niños.

Al: Orig. mec.

V. CD, n. CCCLII

\section{8.}

\section{$1942 \quad$ Mayo $31 \quad$ Narganá}

Carta de Manuel M. Puig al intendente, acusándole recibo de la llegada de la circular enviada por el inspector tratando el tema de las ausencias, tan oportunamente redactado.

Al: Orig. mec. 
739.

\section{Junio 2 Narganá}

Carta de Manuel M. Puig al intendente, remitiéndole los datos estadísticos de las escuelas y se queja de la disminución de matrícula en algunas escuelas. Comenta que en su visita observó el regular funcionamiento de las escuelas de la comarca. Termina diciendo que ha oído a los niños de Río Cidra que su maestro se embriaga.

Al: Orig. mec.
V. CD,
n. CCCLIII

740.

\section{Junio 5 (Narganá)}

Circular de Manuel M. Puig que comenta las impresiones de la última visita a las escuelas. Alaba el esfuerzo de los maestros por ir bien presentados a clase e intentar el aumento de matrículas; hace unas recomendaciones para mejorar el castellano y la marcha de la escuelas.

Al: Orig. mec.

v. CD, n. CCCLIV

\section{1.}

\section{Junio $30 \quad$ Narganá}

Carta de Manuel M. Puig al intendente, en la que le comunica que envió una circular a los maestros de la comarca y habla de la campaña que él hace en favor del castellano. Agradece los materiales escolares enviados por la Intendencia y le pide bancos para la escuela de Ailigandí.

Al: Orig. mec.
v. CD,
n. CCCLV

742.

1942 Julio 25 Narganá 
Circular de Manuel M. Puig a los maestros, tratando el tema de las horas de clase. Pide a los mismos que pongan especial interés en lo concerniente a la lengua castellana; y finaliza diciendo que existe la prohibición de que los maestros se entreguen al licor.

Al: Orig. mec.

V. CD, n. CCCLVI

\section{3.}

\section{Julio 28 Narganá}

Carta del director de las escuelas al intendente, comunicándole que recibió su envío de bancas; y a continuación pone una relación de pueblos que necesitan más.

Al: Orig. mec.

V. CD, n. CCCLVII

\section{4.}

\section{Julio $28 \quad$ Narganá}

Carta de Manuel M. Puig al intendente, en la que le notifica que recibió su oficio en el cual expone que varios maestros de la comarca se dedican a la bebida. Comenta que trata este tema en su última circular.

Al: Orig. mec.

v. CD, n. CCCLVIII

\section{5.}

\section{Julio 28 Narganá}

Carta de Manuel M. Puig al intendente, avisándole del envío de la copia de una circular remitida a los maestros después de la visita. El tema es los días festivos y las horas de clase, que algunos se permiten acortar o suprimir.

Al: Orig. mec.

v. CD, n. CCCLIX 
746.

\section{Julio 29 Narganá}

Carta de Manuel M. Puig al intendente, denunciando el mal comportamiento del maestro de Cartí-Tupile. Se le ha presentado el sahila para exponer su queja. $Y$ ha sabido que con frecuencia acorta las clases; además llevó mala impresión de los niños que no acertaban a responder bien.

Al: Orig. mec.
v. CD, n. CCCLX

\section{7.}

\section{Agosto 17 El Porvenir}

Carta del intendente a Manuel Puig, trascribiéndole la carta del director de la escuela secundaria de Colón, que expone la decisión del Gobierno de conceder tres becas a los indígenas de esa comarca. Le dice el intendente que delega en él para que elija a los que han de disfrutar de esas becas.

Al: Cop. mec.

V. CD, n. CCCLXI

\section{8.}

\section{Agosto 19 Puerto Obaldía}

Carta de Guillermo Denis al director de las escuelas Manuel Puig, notificando que la maestra ha tenido una actuación desacertada con errores graves, y se mofa públicamente de su colega. Le pide que tome las medidas necesarias para que estos males no sigan.

Al: Orig. mec.

v. CD, n. CCCLXII

749.

1942 Agosto 20 Narganá 
Carta de Manuel M. Puig al intendente, acusándole recibo de la nota 916 que hace insubsistente el nombramiento de Ismael Róbinson para maestro de la escuela de Tupile, y se nombra en su lugar a Pablo Solís. Le dice que lo haga saber a los maestros para que les sirva de estímulo de buen comportamiento. Le anuncia que le enviará un calendario escolar sobre las fechas escolares.

Al: Orig. mec.

\section{0.}

\section{Agosto $20 \quad$ Narganá}

Circular de Manuel M. Puig a los maestros de la comarca, comentando el calendario escolar decretado por el Presidente de la República. En ella exhorta a los maestros a preparar con esmero a los alumnos para los exámenes finales, y trasmite la nota de la Intendencia que pide a los maestros que mantengan un buen comportamiento.

Al: Orig. mec.

v. CD, n. CCCLXIII

\section{1.}

\section{Agosto $21 \quad$ Narganá}

Carta de Manuel M. Puig al intendente, adjuntándole el envío de la circular sobre fechas escolares en la que exhorta a los maestros a que preparen con tiempo a los niños para los exámenes semestrales, a fin de que obtengan brillantes resultados.

Al: Orig. mec.

\section{2.}

\section{Agosto 23 El Porvenir}

Carta del intendente a Manuel M. Puig, en la que le anuncia que 
recibió su carta y la circular que había pasado a los maestros en la que exhortaba a estos a preparar con tiempo a los niños para los exámenes semestrales, a fin de que obtengan brillantes resultados.

Al: Cop. mec.

\section{3.}

\section{Agosto 25 El Porvenir}

Carta del intendente a Manuel M. Puig, comentándole que recibió un informe de la maestra de Playón Chico diciendo que se encuentra en estado de gravidez avanzado, y pide que le confirme si es cierto para tomar la medidas oportunas. Le hace saber que el exmaestro de Tupile Abajo, Ismael Róbinson se encuentra allí.

Al: Cop. mec.

\section{4.}

\section{Agosto 25 Panamá}

Carta de Alberto Méndez, segundo secretario del Ministerio de Educación, al intendente, para comunicarle que ha enviado un mapa de la comarca en el cual deben señalar los lugares donde hay escuela pública.

Al: Orig. mec.

\section{5.}

\section{Agosto 25 Panamá}

Circular del Ministerio de Educación solicitando colaboración para el mapa escolar que se quiere tener de la zona, en el que se pide que se señalen otros puntos importantes de referencia.

Al: Cop. mec.
v. CD, n. CCCLXIV 
756.

\section{Agosto $28 \quad$ Narganá}

Carta de Manuel M. Puig al intendente Hernández, comentándole que es cierto que la maestra Rosario se encuentra en estado y que pedirá al maestro destituido de Tupile que se persone en la Intendencia.

Al: Orig. mec.

v. CD, n. CCCLXV

\section{7.}

\section{Septiembre 3 Narganá}

Carta de Manuel Puig al intendente Hernández, adjuntando los datos estadísticos y comunicando que envió las bancas a las escuelas; y que los maestros solicitan cuadernos y papel. Comenta que un maestro se ha embriagado en la última temporada varias veces. Le pide que dé la orden a los capitanes para que no lleven a ningún niño en edad escolar en las lanchas.

Al: Orig. mec.

v. CD, n. CCCLXVI

\section{8.}

\section{Septiembre 5 El Porvenir}

Carta de la Intendencia al P. Manuel Puig, transcribiéndole una carta del Primer secretario del Ministerio de Educación con sugerencias para las escuelas, entre las que comenta el modo de realizar actos culturales y las actividades extracurriculares que no se deben olvidar.

Al: Cop. mec. inc.

V. CD, n. CCCLXVII

\section{9.}

\section{Septiembre 5 Narganá}


Resumen de la Legislación Escolar de la comarca de San Blas, que ha seguido las directrices de Instrucción Pública del Estado. Comenta la preparación del personal docente y los programas desarrollados.

Al: Orig. mec.

V. CD, n. CCCLXVIII

760.

\section{Septiembre 5 Narganá}

Carta de Manuel M. Puig al intendente, diciendo que ha mandado aviso al maestro de Playón Chico para que abandone su costumbre de trasladarse los viernes a Ailigandí dejando su puesto.

Al: Orig. mec.

V. CD, n. CCCLXIX

\section{1.}

\section{Septiembre 8 Narganá}

Carta de Manuel Puig al Intendente Hernández, contestando a su petición de enviar un niño a la escuela secundaria de Colón. Y aprueba la sugerencia de cambio de maestra de Playón Chico, que le hiciera el intendente.

Al: Orig. mec.

v. CD, n. CCCLXX

762.

\section{Septiembre 12 Panamá}

Carta a Luis Hernández, del Ministerio de Educación, en la que le piden el cuadro estadístico y datos de las escuelas que funcionan en la comarca así como de las iglesias y religiones que existen en ese lugar. 
Al: Orig. mec. inc.

v. CD, n. CCCLXXI

\section{3.}

\section{Septiembre 15 El Porvenir}

Carta de Luis Hernández a Manuel M. Puig, comentando que ha recibido información fidedigna que denuncia al maestro de Ailigandí como bebedor por lo que muestra una conducta moral ajena a un buen enseñador; y pide que sea reemplazado por el Sr. Avila a quien considera competente.

Al: Cop. mec.

v. CD, n. CCCLXXII

\section{4.}

\section{Octubre 1 Narganá}

Carta de Manuel Puig al intendente Hernández, remitiendo los datos estadísticos y manifestando la satisfacción que siente por la buena actuación de los maestros de Ustupu, Ailigandí y Tupile. Dice que ha dado conferencias a los maestros recomendándoles una conducta irreprochable y que los maestros elaboren un memorial pidiendo aumento de sueldo.

Al: Orig. mec.

v. CD, n. CCCLXXIII

\section{5.}

\section{Octubre 7 Narganá}

Carta de Juan Vasquez al intendente, informándole de su actividad en el tiempo que lleva de sub-teniente. Relata su actividad de administración de justicia y comenta la labor educativa en la escuela de Narganá y la matrícula de este plantel. 
Al: Orig. mec.

v. CD, n. CCCLXXIV

766.

1942 Octubre 19 Narganá

Carta de Manuel María Puig al intendente Hernández, respondiendo a sus preguntas sobre las escuelas privadas que funcionan con sus profesores y matrículas, y las religiones que existen en la comarca.

Al: Orig. mec.

v. CD, n. CCCLXXV

767.

\section{Noviembre 4 Narganá}

Carta de Manuel Puig al intendente Hernández, enviándole los datos estadísticos de las escuelas así como la felicitación en su onomástica. Le recuerda la petición de maestro solicitada por Río Perro y comenta el mal estado de la escuela de Ailigandí, que obliga a los tres cursos a estar en el mismo salón.

Al: Orig. mec.

v. CD, n. CCCLXXVI

\section{8.}

\section{Noviembre 6 El Porvenir}

Carta de Luis Hernández a Manuel M. Puig, en la que dice que recibió los datos estadísticos y que pidió al Ministerio de Gobierno aumento de maestros y nuevas aperturas de escuelas. Le avisa del envío de bancas para la escuela de Tupile.

Al: Cop. mec.

V. CD, n. CCCLXXVII 
769.

1942 Diciembre 17 Ustupo

Carta de Nele Kantule al intendente, elogiando su labor de progreso en la comarca, que es generalmente aceptada a excepción de la zona de Cartí; y le pide ayuda para subir el precio del coco. Manifiesta su intención de construir una escuela nueva en Ustupu.

Al: Orig. mec.

V. CD, n. CCCLXXVIII

770.

\section{2}

Informe escolar del último bienio, donde se expone la labor encomiable realizada, que se ve en el aumento de escuela y matrícula. Señala también el aumento de maestros y el incremento de becas destacado sobre todo en los dos últimos años lectivos.

Al: Orig. mec. inc.

v. CD, n. CCCLXXIX

\section{1.}

\section{Febrero 10 Narganá}

Informe del año escolar, rendido por Manuel M. Puig al intendente Hernández, en el que comenta los nombramientos de maestros en ese curso así como la labor realizada en cada una de las escuelas. habla de los internados de niños y niñas; y concluye con unas indicaciones relacionadas con la educación.

Al: Orig. mec.

v. CD, n. CCCLXXX

772.

\section{Febrero 13 Ustupu}


Carta de Nele Kantule al Coronel Hernández, pidiendo que tenga en cuenta el deseo expresado en el Congreso de nombrar a los mismos maestros para el nuevo curso. Argumenta para ello la buena conducta de estos maestros.

Al: Orig. mec.

v. CD, n. CCCLXXXI

\section{3.}

\section{Marzo 16 Ustupu}

Carta de Nele Kantule al Presidente de la República, titulada satisfacción indígena, en la que reconoce la labor educativa y el deseo de que todos adquieran conocimientos. Reconoce la labor de los misioneros que es desinteresada.

ARPK: Carp.300. Orig. ms.

v. CD, n. CCCLXXXII

774.

\section{$1943 \quad$ Marzo $18 \quad$ Narganá}

Carta de Jesús Erice, subdirector, al intendente Hernández, comentando el caso de un maestro a quien se recomienda para mejorar el cuadro del personal docente. El pueblo de Playón Chico ha expresado su descontento con el maestro y ha descendido la matrícula. Añade que se puede establecer un tercer grado.

Al: Orig. mec.

v. CD, n. CCCLXXXIII

\section{5.}

\section{Abril 5 Narganá}

Carta de Jesús Erice al intendente Hernández, manifestando su satisfacción por la solicitud de escuela de la Isla Irgandí, presentada 
por el ságuila del lugar. Comenta que hay más de 30 niños para matricularse.

Al: Orig. mec.

v. CD, n. CCCLXXXIV

776.

\section{Abril 23 Narganá}

Resumen de las Conferencias dadas a los maestros de la comarca por el director de las escuelas, en las que se tratan las normas de la Intendencia, y se hace también una explicación de los objetivos escolares. Concluyen con una orientación para que el maestro pueda solucionar los problemas que se le planteen.

Al: Orig. mec.

v. CD, n. CCCLXXXV

777.

1943 Abril 29 Narganá

Carta de Jesús Erice al intendente, transcribiéndole la lista de los maestros asistentes a las conferencias. $Y$ se lamenta de que luego algunos acudan a pedir consejo a personas ajenas al magisterio.

Al: Orig. mec.

v. CD, n. CCCLXXXVI

778.

(1943) Mayo $18 \quad$ Narganá

Carta de Manuel M. Puig al intendente, adjuntándole una circular mandada a los maestros de la circunscripción recomendándoles una conducta ejemplar en el desempeño de las labores de la enseñanza, y añade que próximamente enviará otra sobre el uso del castellano en las escuelas, pues la juzga muy conveniente. 
Al: Orig. mec.

\section{9.}

\section{Mayo $22 \quad$ Narganá}

Informe de Jesús Erice tras la inspección de las escuelas, al intendente Hernández, manifestando su objetivo de que incrementaran las matrículas. Hace una descripción detallada de cada una de las escuelas de la comarca.

Al: Orig. mec. inc.

V. CD, n. CCCLXXXVII

780.

1943 Mayo 24 Narganá

Circular de Jesús Erice a los maestros de la comarca, comentando las impresiones de su primera visita de inspección; y concluye haciéndoles tres recomendaciones.

Al: Orig. mec.

V. CD, n. CCCLXXXVIII

781.

1943 Mayo 24 Narganá

Circular de Jesús Erice a los maestros de la comarca, exponiendo el tema de la maternidad en el magisterio. Trata este tema porque en la comarca existen varios casos afectados por la ley 89 que regula este asunto.

Al: Orig. mec.

v. CD, n. CCCLXXXIX

782.

1943 Junio 2 Narganá

Carta de Jesús Erice al intendente Hernández, adjuntándole los datos estadísticos, y comenta que se han producido cambios en las 
matrículas; señala las subidas y explica las causas de los descensos. Dice que hará un viaje nuevamente para lograr el aumento de matrícula.

Al: Orig. mec.

v. CD, n. CCCXC

\section{3.}

\section{Junio 3 Narganá}

Carta de Jesús Erice al intendente Hernández, exponiendo los problemas surgidos en su visita a Ailigandí referente a la vivienda de los maestros de la comarca con las familias indígenas, pues no les dejan descansar y dificulta su preparación de las clases. Dice que la posible solución sería que cada isla levante una casita para el maestro o maestra.

Al: Orig. mec.

v. $\mathrm{CD}$, n. $\operatorname{CCCXCI}$

\section{4.}

\section{Junio 17 Narganá}

Carta de Jesús Erice al intendente de la comarca, comentando las gestiones realizadas para encontrar suplente para la escuela de Río Azúcar y manifiesta la negativa de varios. Apostilla comentando que en esta isla no tienen problemas en recibir maestra no india.

Al: Orig. mec.
v. CD, n. CCCXCII

\section{5.}

\section{Junio 23 Narganá}

Carta de Jesús Erice al intendente Hernández, comunicándole que la maestra de Ustupu, Carolina P. de Alfaro, ha pedido la separación 
del magisterio por razones de maternidad y expone sus cualidades como maestra. Reseña otras cuestiones varias.

Al: Orig. mec.

v. CD, n. CCCXCIII

\section{6.}

\section{Julio 2 Narganá}

Carta de Jesús Erice al asistente encargado, Efraín Briceño, acusando recibo de los cheques de sueldo de los maestros de la comarca correspondientes a la segunda quincena de junio con un total de 26 maestros.

Al: Orig. mec.

\section{7.}

\section{Julio 2 Narganá}

Carta del jefe del destacamento Francisco Nsar a Efraín Briceño, pidiendo la aprobación para que el $P$. Muñoz levante una cocina nueva en el internado del colegio de Narganá.

Al: Orig. mec.

v. CD, n. CCCXCIV

\section{8.}

\section{Julio 3 Narganá}

Carta de Jesús Erice a Efraín Briceño, asistente encargado de El Porvenir, anunciándole que le envía el programa de fiestas escolares con motivo de la independencia de los EEUU. Le da las gracias por el envío de las banderas americanas y panameñas.

Al: Orig. mec. 
789

1943 Julio 3 Narganá

Programa de festejos para desarrollar en las escuelas de Narganá y Corazón de Jesús con motivo de la independencia de los EEUU.

Al: Cop. mec.

v. CD, n. CCCXCV

790.

1943 Julio 3 Narganá

Carta de Jesús Erice a Efraín Briceño, remitiéndole los datos estadísticos de la comarca y comentando que la matrícula ha aumentado. Dice que el próximo informe le detallará los cambios.

Al: Orig. mec.

v. CD, n. CCCXCVI

791.

1943 Julio 8 Narganá

Carta de Jesús Erice al intendente Hernández, comentando la segunda inspección de las escuelas, cuyo objeto era la construcción de casa y excusado para los maestro. Comenta la matrícula de las mismas, así como la labor de los profesores. Habla de los problemas que causa la Zona donde van a trabajar los indios.

Al: Orig. mec.

v. CD, n. CCCXCVII

\section{2.}

1943 Julio 9 Narganá

Carta de Jesús Erice al asistente encargado, Efraín Briceño, 
remitiéndole los formularios de la caja de seguros para solicitar la expedición de carnets.

Al: Orig. mec.

793.

\section{Julio 14 Narganá}

Carta de Jesús Erice al asistente encargado, Efraín Briceño, comunicándole que la maestra Elisa, viuda de Garrido, ha sido trasladada al interior, lo que supone una gran pérdida para el magisterio de la comarca, y propone como sustituta a Aurora G. de Esquivel que es india y ha expresado que aceptaría el cargo. Conoce el uso del castellano y ha estudiado en Panamá, además de tener dos años de experiencia como maestra; pero deja la elección al intendente.

Al: Orig. mec.

v. CD, n. CCCXCVIII

\section{4.}

\section{Julio $15 \quad$ Narganá}

Circular de Jesús Erice, tratando el tema de los sanitarios y el aumento de matrículas, y habla también del tema del himno nacional y de las clases que se suprimen por fiestas. Dice que el niño no debe estar ocioso, sino ocupado siempre y el maestro se mostrará enérgico, limitando su actividad a lo escolar.

Al: Orig. mec.

v. CD, n. CCCXCIX

\section{5.}

\section{Julio 17 El Porvenir}

Carta de Elisa V. de Garrido al intendente, presentando la renuncia de su puesto para aceptar otro cargo en educación, y le 
agradece sus atenciones.

Al: Orig. mec.

v. $C D$, n. CD

796.

\section{Julio 22 Narganá}

Carta de Jesús Erice a Efraín Briceño, asistente encargado de El Porvenir, acompañándole el envío de la circular no 3 enviada a los maestros de la comarca, y le pide las fechas de fin de curso y comienzo así como de las vacaciones de septiembre, pues no se ha podido enterar por la prensa ya que es escasa.

Al: Orig. mec.

V. CD, n. CDI

\section{7.}

\section{Julio 23 Narganá}

Carta de Jesús Erice al intendente, comentándole que la maestra de Ustupu, Carolina P. de Alfaro ha pedido permiso por maternidad y tiene dos años de servicio, y diploma de sexto grado de la Profesional, conociendo el castellano perfectamente. Le expone la negativa de la maestra Blanca González a ser maestra de Río Azúcar, a pesar de haberlo confirmado anteriormente, por lo que propone a Adelaida de Bonilla que también tiene diploma de sexto grado.

Al: Orig. mec.

\section{8.}

\section{Julio 27 El Porvenir}

Carta del intendente Hernández al Ministro de Gobierno y Justicia, pidiendo que se construyan dos casas escuelas en Tupile y 
Ailigandí, dice que se lo pide ahora porque estima que ha mejorado la situación y aconseja la construcción de edificios por cuenta del gobierno.

Al: Cop. mec.

V. CD, n. CDII

\section{9.}

\section{Septiembre 3 Narganá}

Carta de Jesús Erice al intendente Hernández, en la que le solicita permiso para poder viajar a Colón en las vacaciones de Septiembre. Le comunica que ha advertido a los niños que no pueden viajar a Colón, por temor a que no vuelvan a la escuela.

Al: Orig. mec.

v. CD, n. CDIII

\section{0.}

\section{Octubre 8 Narganá}

Circular de Jesús Erice a los maestros, comentando la labor realizada por el magisterio en la comarca, y tratando el tema de los exámenes finales y los examinadores. Concluye hablando de las fiestas patrias y de su preparación que no debe escatimar esfuerzos.

Al: Cop. mec.

V. CD, n. CDIV

\section{1.}

\section{Noviembre 1 Narganá}

Carta de Jesús Erice al intendente Hernández, adjuntando los datos estadísticos escolares y comentando la normal disminución de matrícula a medida que pasan los meses y que algunos mantienen la escuela sólo por temor. 
Al: Orig. mec.

v. CD, n. CDV

\section{2 .}

\section{$1943 \quad$ Noviembre $17 \quad$ Narganá}

Carta de Jesús Erice al intendente, comunicándole que el maestro de Cartí Tupile ha presentado su renuncia al cargo, pues le han ofrecido un puesto de trabajo en la Zona, y le comenta que si no tiene suplente él lo buscará.

Al: Orig. mec.

V. CD, n. CDVI

\section{3.}

\section{Noviembre 27 Corazón de Jesús}

Informe sobre edificios escolares en construcción en la comarca que habla de las escuelas de Ailigandí y Wichuwala. En la inspección a Ailigandí se habla al pueblo diciéndoles que el gobierno no quiere la destrucción de las costumbres indígenas. Las escuelas se levantan con la colaboración del pueblo.

Al: Cop. mec.

\section{4.}

\section{Diciembre 11 Narganá}

Carta de Jesús Erice al intendente Hernández, en la que le rinde informe de la inspección realizada a las escuelas de la comarca, y se queja de la falta de interés en Río Sidra. Dice que en Cartí prefieren mujer, y si no hombre casado. En Ailigandí y Puerto Obaldía se nota el mal funcionamiento por diversas causas.

Al: Orig. mec.

v. CD, n. CDVII 


\section{5.}

\section{Diciembre 23 Narganá}

Carta de Jesús Erice al intendente Hernández, comentando los problemas de las becas que se dan a gente poco preparada y dice que se deben escoger a los candidatos con tiempo. Expone que los seleccionados son mediocres y los que hacen peticiones personales de becas, con frecuencia son encaminados hacia estudios que no les interesan.

Al: Orig. mec.

v. CD, n. CDVIII

\section{6.}

\section{Enero 12 Narganá}

Circular no 3 de Jesús Erice a los maestros, tratando el tema de los exámenes finales; comenta que el tribunal examinador estará compuesto por cuatro maestros y el director. Se queja de la conducta moral de sus subordinados que retrasa la instrucción e implantación de escuelas. El Coronel ha recomendado encarecidamente mayor moralidad. Los exámenes en los cursos superiores serán escritos y detalla las asignaturas sobre las que versarán. El tribunal valorará el trabajo de alumnos y profesores.

Al: Orig. mec.

v. CD, n. CDIX

807.

\section{Enero 15 Narganá}

Carta de Jesús Erice al intendente, en la que realiza anotaciones al cuadro del personal docente por si las creyera convenientes tener en cuenta, y hace presentación de posibles sustitutos que pueden ser buenos para la comarca. Concluye hablando de la higiene de los maestros. 
Al: Orig. mec.

v. CD, n. CDX

\section{8.}

\section{Enero 20 Narganá}

Carta de Jesús Erice al intendente, comunicándole que recibió sus oficios y se queja de la ineficacia del correo. Comenta que aprovechará la lancha para visitar las escuelas y presenciar los exámenes; y termina haciendo referencia las fechas de exámenes en Narganá y Corazón de Jesús.

Al: Orig. mec.

v. CD, n. CDXI

\section{9.}

\section{Enero 29 Narganá}

Carta de Jesús Erice al intendente, comentándole que aprovechó la presencia de los maestros examinadores para reunir a los isleños y abrir caminos en favor de la escuela. Se queja de los niños que se escapan a Colón incluso sin permiso paterno con perjuicio de la escuela. Reseña que Nele Kantule y los sahilas han decidido que no se deje salir a ningún niño de edad escolar sin permiso de la dirección escolar. Sugiere al intendente que ponga multas.

Al: Orig. mec.

v. CD, n. CDXII

\section{0.}

\section{Febrero 2 Narganá}

Carta de Jesús Erice al intendente, remitiendo los datos estadísticos del último curso, en la que comenta que el ságuila de Cartí-Tupile pidió con interés un buen maestro. Así mismo señala la 
lamentable situación de la escuela de Cartí-Cangrejo.

Al: Orig. mec.

v. CD, n. CDXIII

\section{1.}

\section{4 (Febrero) Narganá}

Informe del año lectivo 1943-44 de la comarca de San Blas, en el que se hace una exposición detallada de cada escuela, así como de los internados indígenas que funcionan. Finalizando con la propuesta de las reparaciones y reformas convenientes.

Al: Orig. mec.

v. CD, n. CDXIV

\section{2.}

\section{Marzo $17 \quad$ Ustupu}

Carta de Ricardo M. Martínez a Estanislao López, que se encuentra en Panamá, diciendo que el pueblo de Ustupu necesita otra escuela y que desea que pida Nele Kantule materiales para la misma. Cree que el Gobierno debe mandar útiles escolares para la comarca.

AELI: Carp. Doc. de vis. Orig. mec.

\section{3.}

\section{Marzo $20 \quad$ El Porvenir}

Carta de Luis Hernández a Ricardo Martínez, secretario de Nele Kantule, en la que le avisa que tiene la lista de recomendados para maestros de Ustupu según los deseos de Nele y su pueblo.

ARPK: Carp. 300. Orig. mec.

$$
\text { V. CD, n. CDXV }
$$

\section{4.}

\section{Marzo $31 \quad$ El Porvenir}

Carta del intendente al Ministro de Gobierno y Justicia, 
adjuntando la propuesta del director y los maestros de la comarca para el curso 1944-45. Se descartan los maestros que presentaron mala conducta o deficiente labor.

Al: Cop. mec.

v. CD, n. CDXVI

\section{5.}

\section{Abril 19 El Porvenir}

Carta de Luis Hernández al director de las escuelas, disculpando su asistencia a las conferencias de los maestros de la comarca, pero sugiere que haga hincapié en cuestiones como la permanencia de los maestros en su puesto, que cultiven la amistad con los sahilas. Les pide que den buen ejemplo en la población que estén; recordando que el programa educativo se debe ajustar al oficial.

Al: Cop. mec.

V. CD, n. CDXVII

\section{6.}

\section{Mayo 2 Narganá}

Carta de Jesús Erice al intendente Hernández, presentándole a un niño graduado de sexto grado que se dirige hacia el Hospicio de Panamá; comenta que es el mejor de su grado en ciencia y comportamiento.

Al: Orig. mec.

v. CD, n. CDXVIII

\section{7.}

\section{Mayo 2 Narganá}

Carta de Jesús Erice al intendente L. Hernández, comunicando que dio comienzo a las tareas escolares, y recorrió todas las aulas 
manteniendo una charla con los miembros del destacamento para aunar los esfuerzos de todos en pro de de la civilización y de la educación.

Al: Orig. mec.

V. CD, n. CDXIX

\section{8.}

\section{Mayo $28 \quad$ Narganá}

Carta de Jesús Erice al intendente, quejándose de que muchos materiales escolares aún no han llegado y los que tenía los ha repartido. Señala que el maestro de Puerto Obaldía ha solicitado materiales en exceso, así mismo el de Playón Chico solicita clavos para arreglar la escuela.

Al: Orig. mec.

\section{v. CD, n. CDXX}

\section{9.}

\section{Junio 8 Narganá}

Carta de Jesús Erice al intendente Hernández, enviándole los datos estadísticos del mes de Mayo. Aclara que los descensos de matrícula se acusan en las escuelas donde ha habido cambio de maestro, y que en Río Sidra se nota la mejoría como fruto del esfuerzo del maestro.

Al: Orig. mec.
v. CD, n. CDXXI

\section{0.}

\section{Julio 26 Río Azúcar}

Carta de Berta Alicia López al intendente Hernández, presentando la renuncia de su cargo por ciertas malas circunstancias 
y escándalos que formó en el pueblo.

Al: Orig. ms.

\section{1.}

\section{Julio 27 Río Azúcar}

Carta de Roberto P. Díez al intendente Hernández, presentando la renuncia de su cargo de maestro, y expone que el pueblo no gusta de él después de haber servido seis años como maestro.

Al: Orig. ms.

\section{2.}

\section{Agosto 1 El Porvenir}

Carta de Luis Hernández al señor Guillermo de St. Melo, en la que le comunica que tiene escogido el terreno donde se construirá la escuela de Ailigandí, y para evitar dificultades le sugiere que se use el plano que se hizo para la escuela de Ustupu, pero haciendo dos edificios en lugar de uno.

Al: Cop. mec.

V. CD, n. CDXXII

\section{3.}

1944 Agosto 1 Panamá

Decreto número 3 que reglamenta el uso y expedición de licores en la comarca de San Blas.

AELI: Carp. Doc. y dat. de D. FO. Cop. mec.

\section{4.}

\section{Septiembre 6 Ustupu}


Pequeña biografía para presentar al Presidente de la República sobre la figura de Nele Kantule, redactada por su secretario.

ARPK: Carp. 89. Orig. mec.

\section{5.}

\section{Octubre 8 Narganá}

Carta de Jesús Erice al intendente Hernández, comentando todos los pormenores hasta llegar a colocar en una casa a la maestra Méndez y su madre. Le cuenta esto para que vea las dificultades que se encuentran en estos casos.

Al: Orig. mec.

V. CD, n. CDXXIII

\section{6.}

\section{Octubre 12 Narganá}

Carta de Jesús Erice al intendente Hernández, detallando la situación de la instrucción femenina en la comarca. Comenta que el internado de las madres franciscanas ha ayudado mucho a la educación y persistencia de las muchachas en la escuela, y expone la labor que debe realizar el maestro en su comunidad.

Al: Orig. mec.

V. CD, n. CDXXIV

\section{7.}

\section{Noviembre 14 El Porvenir}

Informe del intendente en el que se habla de las escuelas, del número de matrículas, del aumento de plantilla y de las becas de la dirección. Concluye tratando el asunto de reparación de las escuelas y del tema de las misiones.

ARPK: Carp.183. Cop. mec. 


\section{8.}

\section{Diciembre 23 Ustupu}

Carta de Olotebiliquiña a Estanislao López, en la que le dice que fracasó la construcción que se iba a hacer para Tupile y Ailigandí. Comenta que el edificio tiene seis aulas para el sexto grado y que ellos no tienen maestros competentes para esos puestos, pues carecen de maestros diplomados, ya que no los pidió Nele Kantule. Aclara que los indios quieren edificios sencillos, y ruega que trasmita esta opinión al Gobierno.

AELI: Carp. 1941. Orig. mec.

\section{9.}

\section{$1944 \quad$ Narganá}

Circular de Jesús Erice a los maestros de la comarca, exhortando a los maestros indígenas a ser ejemplo de moralidad. Trata también de los exámenes finales y los miembros que compondrán el tribunal con los sustitutos. Pide a los maestros que hagan inventario del material de la escuela y se lo den a custodiar al ságuila.

Al: Orig. mec.

\section{0.}

\section{Enero 9 Narganá}

Carta de Jesús Erice al intendente Hernández, comentándole su visita a Tigantikí en la que no encontró al maestro, y comenta el comportamiento poco correcto del mismo. Dice que volverá para comprobar la labor y comportamiento de éste.

Al: Orig. mec.
V. CD, n. CDXXV 


\section{1.}

\section{Enero 15 El Bayano, Pirga}

Carta de Estanislao López a D. Pancho Arias, comentando su visita al Bayano, la cual hizo por encargo personal de él.

AELI: Carp. Doc. y dat. de D. FO. Orig. mec.

\section{2.}

\section{Febrero 8 Narganá}

Carta de Jesús Erice al secretario encargado de El Porvenir, anunciándole que el día de ayer terminó el curso y que ha sido el año más aprovechado y ordenado en la escuela de Narganá. Recuerda la petición de los sahilas del año pasado encabezados por Nele Kantule para que ningún niño ni niña en edad escolar sea autorizado a salir de la comarca; y comenta que se ha tomado la misma decisión este año.

Al: Cop. mec.

\section{3.}

\section{Febrero 9 Narganá}

Carta de Raúl Caicedo al secretario encargado de la Intendencia, quejándose de las medidas tomadas por el director de las escuelas de impedir que en tiempo de vacaciones los niños viajen a Colón sin su permiso.

Al: Orig. mec.

v. CD, n. CDXXVI

\section{4.}

\section{Febrero El Porvenir}

Informe escolar de la comarca de San Blas rendido por el director al Ministro de Gobierno y Justicia. Señala los nombramientos 
de maestros para las escuelas y relata las actividades realizadas por la dirección.

Al: Cop. mec. inc.

V. CD, n. CDXXVII

\section{5.}

1945 Marzo 5 Tubualá

Informe de los indios ante una comisión del Gobierno, quejándose del mal proceder del intendente que quita el dinero que envían los padres de los indios a sus hijos estudiantes en la ciudad.

ARPK: Carp. 54. Cop. mec.

\section{6.}

\section{Abril 14 Panamá}

Autorización otorgada a la Sra. Blanca Rosa de Stocel para permanecer en el Hospital Santo Tomás durante diez meses, con el fin de que aprenda cosas elementales de medicina.

AELI: Carp. Los años 80. Cop. mec.

\section{7.}

\section{Julio 5 y 6 Narganá}

Actas del Congreso General Kuna, que trata entre otras cuestiones de la educación y se habla de que hay gente que aun es contraria a la escuela entre los indios de la comarca.

ARPK: Carp. 44. Orig. ms.

$$
\text { V. CD, n. CDXXVIII }
$$

\section{8.}

\section{Julio 18 Narganá}

Circular de Jesús Erice a los maestros, comentando que las conferencias del verano ha querido que fueran escritas para subsanar los fallos anteriores y que quiere que sirvan de nexo para futuras 
conferencias.

Al: Orig. mec.

V. CD, n. CDXXIX

839.

\section{Agosto 1 Ustupu}

Carta de Rubén Pérez Kantule al intendente, en la que le informa de su visita a las islas bajo el mando de Nele Kantule, y dice que los maestros están trabajando bien y su comportamiento es bueno. Concluye anunciando que informará nuevamente después de su viaje al lado del sahila Yabiliquiña.

Al: Orig. mec.

v. CD, n. CDXXX

\section{0.}

1945 Septiembre $10 \quad$ Narganá

Carta del Cacique de Narganá al Ministro de Educación, en la que recomienda a Stocel para profesor de educación física, y le agradece los libros enviados para la biblioteca.

AELE: Carp.1940-41-43-45-47-48. Orig. ms.

$$
\text { v. CD, n. CDXXXI }
$$

\section{1.}

\section{Septiembre 18 (Narganá)}

Resoluciones del Congreso General Kuna, que acuerda pedir al gobierno que algún kuna sea empleado en puestos secundarios en embajadas o consulados en el exterior con el fin de adquirir conocimientos que más tarde serán útiles para la comarca.

AELI: Carp. Car. de 1945. Var. cor. Cop. mec. 


\section{2.}

\section{Septiembre $21 \quad$ Narganá}

Carta de Isaías Riera a Félix Oller, en la que le pide ayuda para transportar tejas desde Colombia para la construcción de Iglesia y un internado de niñas en Narganá; argumentando que son obras públicas de beneficio y civilización.

AELI: Carp. Doc. y dat. de D. FO. Cop. mec.

\section{3.}

\section{Octubre 8 Santiago}

Carta de Ildaura a Estanislao, en la que le comunica que han acordado que incluso los becados deben pagar el servicio de lavandería, que asciende a B/2.25. Comenta sus problemas de la vista que la impiden estudiar de noche.

AELI: Carp. Car. de 1945. Var. cor. Orig. mec.

\section{4.}

\section{Noviembre 5 Colón}

Carta de Jesús Erice a Estanislao López, en la que le cuenta cómo encontró en Colón a un grupo de kunas embriagados y dice que se han vestido con la podredumbre de la civilización, pero que esa no es la verdadera civilización. Comenta que estos males los han traído los que se dicen civilizados. Concluye reconociendo que la civilización completa en San Blas es difícil.

AELI: Carp. Car. de 1945. Var. cor. Cop. mec.

\section{5.}

\section{Noviembre 5 Colón}

Carta de Jesús Erice al intendente Félix Oller, en la que le pide 
ayuda y argumenta que ayudar a los misioneros es ayudar a la civilización indígena, y concluye que así lo atestigua la historia de San Blas.

AELI: Carp. Doc. y dat. de D. FO. Cop. mec.

\section{6.}

\section{Noviembre 12 Ustupu}

Informe de un congreso en el que se habla de la civilización y la educación, y de los problemas que traen los educadores a la comarca.

AELE: Carp. Dat. bib. Cop. mec.

\section{7.}

\section{Noviembre 18 California}

Carta de Aquilino Díaz a Estanislao López en la que le felicita por su nombramiento de sahila y le dice que el va a favorecer el progreso de San Blas y contará con el apoyo del catolicismo. Comenta que el fue educado y bautizado por el P. Gassó y que con la ayuda de los misioneros y las franciscanas logrará civilizar a los indios de la comarca.

AELI: Carp. Car. de 1945. Var. Cor. Orig. mec.

\section{8.}

\section{Noviembre 25 (El Porvenir)}

Memorandum que hace Félix Oller para el Presidente de la República, en el que se queja de que el Ministerio de Educación no nombre los recomendados por la Intendencia para San Blas. Comenta que el Dr. Crespo acordó nombrar a Eduardo Filós como asistente del inspector de educación y esto parece que ya había sido acordado por los sahilas.

AELI: Carp. Doc. y dat. de D. FO. Cop. mec. 


\section{9.}

\section{$1945 \quad$ Noviembre $27 \quad$ Ailigandí}

Resoluciones adoptadas por el Congreso, que en el punto quinto solicita un aumento de sueldo para los maestros y policías.

AELI: Carp.1947. Orig. mec.

\section{0.}

1945 Noviembre 27 Corazón de Jesús

Informe, posiblemente del director escolar, al Ministerio de Educación sobre las obras de las nuevas escuelas de la comarca de San Blas.

Al: Cop. mec. inc.

V. CD, n. CDXXXII

\section{1.}

\section{Diciembre 22 Colón}

Carta de Jesús Erice a Estanislao López, comentando que comenzaron días tristes para la instrucción de San Blas, pero que él trabajará todo lo posible pues ha demostrado su interés por Narganá y su biblioteca. También comenta las dificultades por las que atraviesan las madres franciscanas y solicita su ayuda para que mejore la instrucción.

AELI: Carp. .Car. de 1945. Var. cor. Cop. mec.

\section{2.}

\section{Diciembre 28 El Porvenir}

Carta de Félix Oller al Ministro de Educación J. D. Crespo, exponiéndole la mala actuación del inspector escolar de la comarca que no quiso atender a las indicaciones del intendente para mantener 
buenas relaciones con los miembros de la misión católica.

Al: Cop. mec.

V. CD, n. CDXXXIII

\section{3.}

\section{5}

Escrito tratando de la visita al despacho del intendente, del inspector de educación de la comarca. Transcribe el Dcto. 1135 que crea la nueva provincia escolar de San Blas.

Al: Cop. mec.

\section{4.}

\section{Enero 13 Corazón de Jesús}

Carta de Mario Porras a Estanislao López, en la que le dice que él comenzó a llevar a los muchachos a la escuela secundaria y le felicita por su gran labor.

AELI: Carp. Diar. 1946. Orig. mec.

\section{5.}

\section{Enero $16 \quad$ Cartí Tupile}

Carta de los sahilas Miguel Palacios, John Smith y Luis Estocel a Félix Oller en la que piden que no deje salir a ningún niño de la escuela, menores de edad, hacia Colón, aunque no estén matriculados en la escuela, pues los pueblos que no tienen escuela les critican y llaman pendejos. Ahora que se acercan las vacaciones piden que revise los barcos.

AELI: Carp. Doc. y dat. de D. FO. Cop. mec. 
856.

\section{Enero 20 Narganá}

Carta de Samuel Morris al intendente, en la que se queja de que Luis Alemán se llevó a tres alumnos de Río Cidra sin permiso del maestro.

AELI: Carp. Doc. y dat. de D. FO. Cop. mec.

\section{7.}

\section{Enero 27 Divisa}

Carta de Horacio Filós a Estanislao López, pidiéndole que le informe sobre las bases de las becas para el exterior, y comenta que el ha estudiado en Narganá aunque no es de esa población.

AELI: Carp. Doc. de vis. Orig. mec.

\section{8.}

1946 Febrero 9 El Porvenir

Informe del intendente al Ministro de Educación José D. Crespo, comentando el problema surgido al no restablecer al director de escuelas Jesús Erice.

AELI: Carp. Doc. de vis. Orig. mec.

\section{9.}

\section{Abril 2}

Comunicación dirigida a Estanislao López, para avisarle que hay dos becas para la Profesional, y son llenadas por Bilma Gloria y Rosalinda Róbinson.

AELI: Carp. Diar. 1946. Cop. mec. 
860.

\section{Abril 2 Panamá}

Carta de la directora Isabel Herrera $O$. que escribe al secretario de Gobierno y Justicia, comunicando que están vacantes las becas de Lastenia Filós, desde el año pasado, y la de Eloisa Ferrer desde este año.

AELI:Carp. Doc. de vis. Orig. mec.

\section{1.}

\section{Abril 3 Tubalá}

Carta de Yapiliquiña al intendente, anunciándole que le envía dos jóvenes para que aprendan de construcción y carpintería, y una vez concluidos los estudios se los remita.

AELI: Carp. Doc. y dat. de D. FO. Cop. mec.

\section{2.}

\section{Abril 5 Ustupu}

Carta de Olotebiliguiña, cacique de San Blas, que le comenta a Estanislao López el delicado estado de salud de su hijo. Dice que el quería una beca para su hijo, pero teme que con esa salud no le den el certificado médico y se lo otorguen a otro de Ustupu.

AELI: Carp. Doc. de vis. Orig. mec.

\section{3.}

\section{Abril 7}

Carta en la que se comenta que Félix Oller había traído siete niños para becar en la escuela Horfelinato, y le pide a Estanislao López que atienda a los siete muchachos que había mandado Yabiliquiña. 
AELI: Carp. Diar. 1946. Cop. mec.

\section{4.}

\section{Abril 8}

Escribe Estanislao López que fue a visitar al inspector, y éste le pregunta que quiénes tienen diploma de graduados, para nombrar directores en las escuelas de Ailigandí y Tupile. El da una serie de nombres y recomienda a dos. Oller le había pedido que le confeccionara una lista de maestros.

AELI: Carp. Diar. 1946. Orig. mec.

\section{5.}

\section{Abril 9 Panamá}

Carta dirigida al Ministerio de Educación, en la que se queja el que suscribe de que en los pueblos de la jurisdicción de Yabiliquiña, el gobierno no ha empleado un centavo en materia de educación; y pide que ayude a siete muchachos que ingresaron en la Escuela Normal de Santiago.

AELI: Carp. Doc. y dat. de D. FO. Cop. mec.

\section{6.}

\section{Abril 11 Panamá}

Carta de César A. Quintero primer secretario del Ministerio, pidiendo al Ministro una beca para Ofilio Linares, y sugiere que a ser posible se la den para el Instituto Nacional; y de no ser posible esto para la escuela Normal de Santiago. Comenta que cursó el sexto grado en el Simón Bolívar de la capital. El secretario pide que transmita la solicitud a Gobierno y Justicia encargado de las becas.

AELI: Carp. Doc. de vis. Orig. mec. 


\section{7.}

\section{Abril 23 Panamá}

Carta de César A. Quintero al Sr. Alejandro Cajar, encargado de Asuntos Indígenas en el Ministerio de Gobierno y Justicia, recomendando a la Srta. Felicia Alvarado Díaz que terminó el sexto grado en la Escuela República de Argentina, comenta que tiene preferencia por ingresar en el Liceo de Señoritas.

AELI: Carp. Doc. de vis. Orig. mec.

\section{8.}

\section{Mayo $20 \quad$ Narganá}

Carta de Tomás Herrera a Estanislao López, en la que comenta el caso de un joven que no ha ido a la escuela en la ciudad de Panamá y que ha perdido el puesto. Señala que se ha buscado como solución que trabaje y estudie en la escuela de Artes y Oficios en el curso nocturno de comercio.

AELI: Carp. Doc. de vis. Orig. mec.

\section{9.}

\section{Mayo 22 Narganá}

Carta de Rubén Pérez Kantule a Félix Oller en la que le dice que tenga presente que el pueblo de Narganá está en marcha en el camino del progreso.

AELI: Carp. Doc. y dat. de D. FO. Cop. mec.

\section{0.}

\section{Mayo $28 \quad$ Narganá}

Carta de Rubén Pérez Kantule al intendente Félix Oller, en la que le pide que le mande folletos y libros que no le sirvan para la 
biblioteca.

AELI: Carp. Doc. y dat. de D. FO. Cop. mec.

\section{1.}

\section{Junio 5 Cartí Tupile}

Carta de Antonio López a Eduardo Filós, reseñándole la matrícula habida y la distribución de grados. Señala que comenzó el curso el siete de Mayo y que este mes ya subió la matrícula.

Al: Cop. mec.

v. CD, n. CDXXXIV

\section{2.}

\section{Junio 11 Cartí Tupile}

Carta de Antonio Pérez al inspector de educación Plinio Ortiz, felicitándole por su nombramiento de inspector; y se queja de los que han estudiado con los protestantes.

Al: Orig. mec.

v. CD, n. CDXXXV

\section{3.}

\section{Junio $17 \quad$ Irgandí}

Carta del sahila Samuel Ros al intendente Félix Oller, en la que le pide que nombre un maestro para la escuela, pues están de acuerdo con los habitantes de Ucupa y estos mandarán a sus hijos a Irgandí para que estudien allí. Se queja de que lleva dos años pidiendo esto y el último año se lo pidió al inspector de la Escuela y le prometió que se lo mandaría. Finaliza diciendo que tienen 25 ó 30 posibles matrículas que es lo que exige la ley.

AELI: Carp. Doc. de vis. Orig. mec. 


\section{4.}

\section{Junio 28 Cartí Tupile}

Carta del maestro Antonio López al inspector Plinio, anunciándole que recibió su circular no 3 en la que le habla de la fundación de la escuela nocturna de Tupile. $Y$ pide material para sus niños.

Al: Orig. mec.

v. CD, n. CDXXXVI

\section{5.}

\section{Junio 28 San Ignacio de Tupile}

Carta de Blanca de Porras al inspector de Educación, hablando de la fundación de la escuela y del número de niñas que asiste. Escribe también sobre la escuela nocturna.

Al: Orig. mec.

V. CD, n. CDXXXVII

\section{6.}

\section{Agosto 10 Cartí Tupile}

Carta de Antonio López al Sr. Eduardo Filós, comentando que la matrícula nocturna es de 16 jóvenes y comenta que con los ancianos no se puede contar.

Al: Orig. ms.

v. CD, n. CDXXXVIII

\section{7.}

\section{Septiembre 6 Santiago}

Carta de una profesora de la Normal de Santiago a Estanislao López, en la que le dice que su hija va muy bien en las clases. 
AELI: Carp. Doc. de vis. Orig. mec.

\section{8.}

\section{Septiembre $20 \quad$ (El Porvenir)}

Escrito que manifiesta las quejas del intendente por haber hecho un Congreso a escondidas, en el cual se pedía que el sahila sepa cantar; y pregunta que cuántas veces ha cantado Róbinson y Olotebiliquiña. Se pide que se defienda la religión católica que es la que ha luchado por la civilización. Finaliza pidiendo que se retiren los artículos 4 y 49 íntegramente pues se deja ver que los que hicieron esto pretenden conseguir el poder.

AELI: Carp.1947. Orig. mec. inc.

\section{9.}

\section{Octubre 30 El Porvenir}

Carta de Plinio Ortiz a Estanislao López, en la que le dice que tuvo mucho gusto en hacer nombrar a su recomendada para maestra, la Sra. Adelaida Calvo para la isla de Playón Chico.

AELI: Carp. Doc. de vis. Orig. mec.

\section{0.}

\section{Octubre $30 \quad$ Narganá}

Carta de Jesús Erice a Estanislao López, en la que le comenta lo lamentable que es que el barco lleve cien cajas de cerveza para los indios y que lo que ellos tratan de hacer por la civilización se lo destruyen.

AELI: Carp. Doc. de vis. Orig. mec.

\section{1.}

\section{Noviembre 2 El Porvenir}

Carta de Félix Oller al Ministro de Educación, expresando 
satisfacción por su comunicado en el cual le hace sabedor de las seis becas otorgadas a los indígenas de la comarca, y le pide que le comunique las condiciones de estas becas.

Al: Cop. mec.

V. CD, n. CDXXXIX

\section{2.}

\section{Noviembre 9 Panamá}

Carta de Estanislao López a Ernesto de la Guardia Jr., en la que le demanda treinta balboas prestados para pagar gastos de sus hijas, una en quinto año y la otra en tercer año en la Normal de Santiago; así como de los varones que están en el sexto y quinto grado respectivamente. Comenta que empieza ese mismo día a trabajar en el Jardín Balboa y se lo devolverá.

AELI: Carp. Doc. de vis. Orig. mec.

\section{3.}

\section{Noviembre $17 \quad$ Narganá}

Carta de Enrique Morales a Estanislao López, comentando que su yerno ha ido a Panamá para que su hija siga estudiando, ella está en el Colegio Santa Familia, y le pide ayuda para conseguir un buen trabajo. Así mismo ruega que recomiende a su primo Luis González para maestro en San Blas cuando hable con el Ministro José Daniel Crespo.

AELI: Carp. Doc. de vis. Orig. mec.

\section{4.}

\section{Noviembre 22 Narganá}

Carta de Jesús Erice a Estanislao López, en la cual le comenta que su puesto está entre su gente para encauzar a los jóvenes y desterrar los vicios, pero le pide que solucione antes sus asuntos 
personales.

AELI: Carp. Doc. de vis. Orig. mec.

\section{5 .}

\section{Noviembre 29 Panamá}

Decreto 1691 por el que se establecen normas para tomar posesión del cargo los empleados del ramo de educación.

Al: Cop. mec.

v. $C D$, n. $C D X L$

\section{6.}

\section{Diciembre 15 California, Los Angeles}

Carta de Aquilino Díaz agradeciendo a los Padres Claretianos y a las Madres Franciscanas lo que hacen por la educación y el progreso de San Blas.

AELI: Carp. Doc. de vis. Orig. mec.

\section{7.}

\section{El Porvenir}

Carta del Intendente Félix Oller al inspector de Educación, manifestándole sus intenciones de que existieran buenas relaciones entre él y el director de las escuelas; comenta que el había aceptado el nombramiento del inspector por recomendación de un Delegado.

Al: Cop. mec. inc.
V. CD, n. CDXLI

\section{8.}

\section{Enero Panamá}


Informe del Departamento de Estadística, Personal y Archivos comunicando que se ha confeccionado un cuadro de matrículas y asistencias en el que se incluye la enseñanza pre-escolar y las bibliotecas.

Al: Cop. mec.

v. CD, n. CDXLII

\section{9.}

\section{Marzo 1 Corazón de Jesús}

Carta dirigida a Estanislao López, que se encuentra en Panamá, para preguntarle que si las alumnas que estudian en la Escuela Normal, Priscila Dalys y Eladia han sido expulsadas; pues han Ilegado rumores que la única que se salvó fue María González. Piden también confirmación si Bertilda ha repetido.

AELI: Carp. 1947. Orig. mec.

890.

\section{Marzo 13 Panamá}

Visita de los Sres. Félix Oller, Mauricio Correa, Nidipipi y Estanislao López al Ministerio de Educación para entrevistarse con él, pero por ausencia de éste lo hacen con los inspectores de San Blas. Comentan la lista de fracasados enviada por el director de la Escuela Normal y el tema de una beca.

AELI: Carp. 1947. Orig. mec.

\section{1.}

\section{Abril 1 Corazón de Jesús}

Carta de Enrique Morales a Estanislao López, en la que le solicita información sobre política y una recomendación para un puesto de policía colonial. 
AELI: Carp. 1947. Orig. mec.

\section{2.}

\section{Abril 9 Panamá}

Carta del intendente Félix Oller a Domingo Díaz, en la que le envía nombres de indígenas para representantes de los grupos de la Unión Liberal. Todos son caciques, sahilas y gente destacada.

AELI: Carp. Doc. y dat. de D. FO. Cop. mec.

\section{3.}

\section{Abril 29 Panamá}

Circular del Director General de Educación a los inspectores de Educación Primaria, explicándoles el impreso-modelo para informar del inicio del curso y diciendo cómo se debe rellenar.

Al: Orig. mec.

V. CD, n. CDXLIII

\section{4.}

\section{Mayo 6 El Porvenir}

Carta del secretario general de los sahilas, Francisco Soo, que escribe a Estanislao López comunicándole que Juan Díaz lleva a su hija al Hospital Santo Tomás para que aprenda enfermería, y dice que Félix Oller la recomienda al Dr. Mendoza.

AELI: Carp. 1947. Orig. mec.

\section{5.}

\section{Mayo 13 Playón Chico}

Carta de dos jóvenes mujeres a Estanislao López, en la que 
expresan su queja, pues recibieron un telegrama del Ministerio diciéndoles que están fuera del magisterio, una porque no hizo su nuevo nombramiento y la otra por quitar el marido a otra señora. Acusan a un indígena de que quiere meter a su señora pues es amigo de Félix Oller.

AELI: Carp. 1947. Orig. mec.

\section{6.}

\section{Mayo $27 \quad$ Narganá}

Carta de Rubén Pérez Kantule al intendente, hablando de los científicos suecos que allí se encuentran y de los aspirantes a las becas y comenta el caso de una muchacha que quiere hacer enfermería en el Hospital Santo Tomás.

AELE: Carp. 1940-41-43-45-47-48. Orig. ms. V. CD, n. CDXLIV

897.

\section{Mayo $28 \quad$ Medellín}

Carta de Tomás Herrera a Estanislao López, en la que cuenta que él no estudió más que hasta sexto grado y que hace veinte años, pero que ahora estudia bastante y también hace contabilidad de 7 a 9 . Reconoce que no es su pariente cercano pero le dice que si puede le mande cincuenta pesos de plata, pues está haciendo un esfuerzo para luego servir mejor a su comarca.

AELI: Carp. 1947. Orig. mec.

\section{8.}

\section{Junio 2 Colón}

Carta de Félix Oller al Gobernador de la provincia de Colón, Víctor Navas, en la que pide que tenga a bien suministrar alimentos y 
alojamiento a los sahilas y secretarios que se dirigen hacia ahí.

AELI: Carp. Doc. y dat. de D. FO. Cop. mec.

\section{9.}

\section{Junio 10 Panamá}

Carta de los sahilas de Corazón de Jesús, Narganá y Río Azúcar al Presidente de la República, notificándole que depositan los documentos de los años 1904 a 1947 en poder del Sr. Estanislao López. Comentan los buenos consejos recibidos del Dr. Belisario Porras.

AELI: Carp.1947. Orig. mec.

\section{0.}

\section{Julio 4 Panamá}

Nota de cobro firmada por la maestra Arnulfa del sexto grado, por importe de 0,25 balboas correspondiente al comedor del mes de Julio de la Escuela República de Argentina, y que la paga el Club de Padres de Familia.

AELI: Carp.1947. Orig. mec.

\section{1.}

\section{Julio 23 Medellín}

Carta de Tomás Herrera a Estanislao López, en la cual le dice que cuando asista a la convención nacional hable de la becas para los kunas en los paises adelantados como Chile, Colombia, Argentina, México y Cuba; y pide que hable con el Sr. Felipe $O$. Pérez o con Diógenes de la Rosa sobre la ley de becas al exterior para los indios, y las garantías que dan.

AELI: Carp. 1947. Orig. mec. 


\section{2.}

\section{Julio Panamá}

Decisiones del Congreso de la Juventud kuna presentadas en un informe en Panamá con los acuerdos tomados, en el que Pablo Solís había pedido que el magisterio de San Blas fuera trasladado al Ministerio de Educación, y Anibal Llibre pedía que se creara una asociación de maestros de San Blas para mejorar el entendimiento entre ellos y los padres. Juan Colman proponía que se crearan más becas en la escuela de Divisa.

AELI: Carp. 1947. Cop. mec.

\section{3.}

\section{Agosto $6 \quad$ Medellín}

Carta de Tomás Herrera a Estanislao López, en la que le comenta las disposiciones que existían en tiempos de la conquista referentes a la educación de los indios y de los hijos de los caciques.

AELI: Carp. 1947. Orig. mec.

\section{4.}

\section{Agosto $14 \quad$ Ailigandí}

Carta del Presidente del Congreso Indígena Kuna, Francisco Soo, al Ministro de Gobierno y Justicia avisándole del envío de una delegación para comunicarle los temas del último congreso, que entre los puntos tratados cuenta con uno referente a la situación del problema educativo.

ARPK: Carp. 88. Cop. mec.

v. CD, n. CDXLV

\section{5.}

\section{Agosto $14 \quad$ Ailigandí}

Carta del Presidente del Congreso Indígena Kuna, Francisco Soo, al Ministro de Educación avisándole del envío de una delegación para 
comunicarle los temas del último congreso, que entre los puntos tratados cuenta con uno referente a la situación del problema educativo.

ARPK: Carp. 88. Cop. mec.

v. CD, n. CDXLVI

906.

\section{Agosto 22 Río Azúcar}

Carta de los isleños pidiendo que las botellas de licor y cerveza que tienen que pasar por la Intendencia sean respetadas, y dé su autorización pues las quieren para los días de fiestas y competiciones.

AELI: Carp. Doc. y dat. de D. FO. Orig. mec.

\section{7.}

\section{Agosto 27 Colón}

Carta de Alfredo López a Estanislao López, en la cual le recuerda que le prometió ayudar cuando necesitase plata.

AELI: Carp. 1947. Orig. mec.

\section{8.}

\section{Septiembre 16 Colón}

Carta de Francisco Soo, secretario de los sahilas, a Estanislao López en la cual comenta que se encontró con el inspector de Educación y le comentó que cuando se abra la escuela de Narganá en Octubre tendrá dos maestras más que serán castellanas. Al mismo tiempo pide que haga las gestiones oportunas para que pongan indias, pues las hay preparadas.

AELI: Carp. 1947. Orig. mec. 


\section{9.}

\section{Octubre 11 Panamá}

Carta de un padre que saca a su hija de la Escuela Profesional y anuncia que queda libre la beca que disfrutaba. Se la proponen a otra persona para que quede cubierta.

AELI: Carp. 1947. Orig. mec.

\section{0.}

\section{Octubre 25 Panamá}

Carta de un alumno indígena que comenta que está estudiando en la escuela y hace por correspondencia unos cursos, comenta que no volverá en un tiempo por San Blas, pues se quedará para trabajar y ayudar a la escuela.

AELI: Carp. 1947. Orig. mec.

\section{1.}

\section{Octubre 27 El Porvenir}

Carta de José E. Huerta que escribe a Estanislao López, que se encuentra en Narganá, para comunicarle que el Dr. Birmanys se dirige para allá con el fin de fundar la primera Unidad Sanitaria de la comarca.

AELI: Carp. 1947. Orig. mec.

\section{2.}

\section{Noviembre 6 Río Azúcar}

Carta de David Díaz a Félix Oller pidiendo permiso para ir a tirar una casa que el Gobierno ha recibido en la comarca, y así poder recoger la madera para reparar la biblioteca y la escuela.

AELI: Carp. 1947. Orig. mec. 


\section{3.}

\section{Diciembre 7 Narganá}

Carta de Estanislao López al Sr. José E. Huerta en la que le hace saber que se celebró en Ailigandí un Congreso de la Educación.

AELI: Carp. 1947. Cop. mec.

\section{4.}

\section{Enero 7 Narganá}

Carta de Estanislao López a Félix Oller, en la que le comenta que están trabajando en el aeropuerto y la Madre Otilia, directora, ha puesto 120 alumnos que han trabajado dos horas para colaborar en la obra.

AELI: Carp. Doc. y dat. de D. FO. Orig. mec.

\section{5.}

1948 Enero $26 \quad$ El Porvenir

Carta de Juan Colman al sahila de Narganá, en la que respalda a Niga Kantule ante el gobierno y espera que éste a su vez luche por aumentar la asistencia de la niñez a la escuela.

AELI: Carp. Car. de 1948. Cop. mec.

\section{6.}

\section{Febrero 19 Ustupu}

Carta de Olotebiliquiña a Félix Oller, quien le ha pedido que le mande a su hijo, dice que lo enviará pero que le prohibe dormir en población que no sea kuna y que tome ron o chicha. $\mathrm{Y}$ a poder ser que duerma en El Porvenir, y ruega que le enseñe cualquier cosa para bien de San Blas y del pueblo de Ustupu.

AELI: Carp. Doc. y dat. de D. FO. Orig. mec. 


\section{7.}

\section{Abril 7 Cartí Sugdupu}

Carta de Olonibiguiña, Niga Kantule e Iguawiguiguiña a Estanislao López en la que le anuncian que le mandan a David Abad para hacer examen porque le quieren para maestro de su pueblo, y comentan que cada pueblo en su congreso busca su maestro.

AELI: Carp. Car. de 1948 Cop. mec.

918.

1948 Mayo $24 \quad$ Tupile

Carta de Mario Porras a Estanislao López, en la cual le habla de que los maestros que tengan malas notas o conducta deficiente serán sustituidos por los que han ido al curso de verano.

AELI: Carp. Car. de 1948. Cop. mec.

\section{9.}

\section{Junio 14 Colón}

Telegrama enviado al intendente de El Porvenir, para que comunique a los directores de las escuelas de Playón Chico, Nusatupu y Ustupu que remitan los informes de las matrículas y asistencias del mes de Mayo.

AELI: Carp. Car. de 1948. Orig. mec.

\section{0.}

\section{Julio $30 \quad$ Narganá}

Carta de Rubén Pérez Kantule a Estanislao López, en la que le comunica que la biblioteca ha sido cerrada desde el 24 del presente, ya que los dueños piden 1.500 balboas porque la casa ha sido usada como salón de música sin el consentimiento de los dueños, y ahora 
está mudando los libros para su casa. Comenta que está dispuesto a levantar una biblioteca si la gente le ayuda.

AELI: Carp. Car. de 1948. Cop. mec.

\section{1.}

\section{Agosto 14 Isla Pino}

Carta del maestro de la escuela a la Inspección de Educación para que le envíen material y utensilios para su aula.

AELI: Carp. Cart. de 1948 Cop. mec.

\section{2.}

\section{Agosto 14 Isla Pino}

Carta del maestro Federico Smith al médico de Narganá pidiendo que le envíe medicinas para los padres de familia y para la escuela, pues las necesitan.

AELI: Carp. Car. de 1948. Cop. mec.

\section{3.}

\section{Febrero 11 Ustupu}

Carta del sahila Olomaili a Estanislao López, anunciando que le envía a su hija Elena Morales y le ruega que la dé la educación como si fuera su propia hija. Le envía 10 balboas y dice que posteriormente le mandará otros cinco, le dice que le avise cuando salga para Panamá y que allí la ponga con una buena familia que no la trate como sirvienta, y que la eduque para que luego le sirva a él, por último le sugiere que la adoctrine con buenos consejos.

AELI: Carp. Cor. de 1940-1950. Orig. mec.

\section{4.}

\section{Febrero 25 Panamá}

Carta de Eligio Crespo, segundo secretario, al intendente, en la que le habla de la campaña de la moralidad y comenta la carta que 
envió la directora de la escuela de Narganá y Corazón de Jesús, quejándose de los obstáculos que encuentran en la policía indígena. Así mismo se queja del ejemplo de los maestros que asisten a los bailes.

Al: Cop. mec.

V. CD, n. CDXLVII

\section{5.}

\section{Agosto 27 Narganá}

Carta de Rubén Pérez Kantule a Estanislao López, en Panamá, en la cual habla de dos niñas que podían tener los sueldos de maestras, si él se interesara en conseguirlos en el Ministerio de Educación, ellas podrían gozar cada una de 30 balboas.

AELI: Carp. Cor. de 1940 a 1950. Cop. mec.

\section{6.}

\section{Octubre 25 Cartí}

Acta del Congreso General Kuna celebrado en Cartí en el que se trata de la cooperación de los caciques y sahilas con los maestros para la buena marcha de las escuelas.

AELE: Carp. 25 octubre 1945. Cop. mec.

\section{7.}

\section{Octubre 25 Cartí Sugdupu}

Informe del Congreso General Kuna de Cartí en el que los congresistas de Narganá Tomás Herrera, Estanislao López y Samuel Morris hacen la petición formal al Ministerio de Educación de la creación del Primer Ciclo de San Blas.

BN: Carp. Educ. var. doc. Cop. mec. 


\section{8.}

\section{Octubre 25 Tigre}

Informe que se presenta en el Congreso General Kuna; y en el que aparece el tema de la educación y la construcción de las escuelas de Wichuwala y Tigre.

ARPK: Carp. 184. Cop. mec.

V. CD, n. CDXLVIII

929.

1949 Diciembre 24 El Porvenir

Carta de Pablo Solís al Sr. Estanislao López en la que le expone el informe que rindió en el congreso, y comentando que el quiere ser reelegido en su puesto.

Al: Orig. mec.

v. CD, n. CDXLIX

\section{0.}

\section{Enero 3 Narganá}

Carta de Enrique Morales a Estanislao López, en la cual le comenta que su yerno está estudiando en Medellín y el le ayuda, pero que debido al bajo precio del coco no le alcanza, suplica que le comente a Félix Oller si puede ayudarle.

AELI: Carp. Car. de 1948. Cop. mec.

\section{1.}

\section{Enero 5 (El Porvenir)}

Escrito de Félix Oller en el que comenta que por petición suya se han cambiado los asuntos de Educación, que pertenecían a Gobierno y Justicia, al Ministerio de Educación. Sugiere que los nombramientos de inspectores de educación se hagan de acuerdo con el intendente. 
AELI: Carp. Doc. y dat. de D. FO. Cop. mec.

\section{2.}

\section{Enero 6 Narganá}

Carta de Tomás Herrera a Estanislao López, en la que le comunica que una joven de San Blas que estudia en el colegio Dumbar de Colón ha quedado embarazada por un joven del pueblo de Ticantiquí.

AELI: Carp. Car. de 1948. Cop. mec.

\section{3.}

\section{Enero 15 Narganá}

Carta de la hija de Estanislao López a éste en la cual le explica que Enrique Morales, sahila de Río Azúcar, la quiere a ella para maestra de su pueblo, y que los sahilas no habían aceptado a María Quirós que era la propuesta por el inspector.

AELI: Carp. Car. de 1948. Cop. mec.

\section{4.}

\section{Febrero 16 Panamá}

Carta de Jesús Erice a Tomás Herrera, en la cual le sugiere que deje a la muchacha en casa de su acudiente para que continúe los estudios secundarios, y que su acudiente pagará los estudios.

AELI: Carp. 1. Cop. mec.

\section{5.}

\section{Febrero 27 Panamá}

Carta de Estanislao López a Leonardo Miselis, para enviarle los formularios de petición de concurso de becas secundarias; le aclara 
que también sirven para niñas.

AELI: Carp. 1. Cop. mec.

\section{6.}

\section{Marzo 2 Panamá}

Carta de Estanislao López al Director de Mecánica Divisa, en la que le pregunta si hay becas o pensiones para indígenas, pues si existen becas el está dispuesto a pagar la pensión de su hijo Eladio.

AELI: Carp. 1. Cop. mec.

\section{7.}

\section{Marzo 4 Divisa Herrera}

Carta de Temístocles a Estanislao López, en la que le dice que no hay cupo para mecánica, pero sí para el que quiera estudiar ebanistería, si supera las pruebas. Comenta que para el asunto de las becas hay que esperar la decisión del Ministerio de Educación.

AELI: Carp. 1. Cop. mec.

\section{8.}

\section{Abril 29 El Porvenir}

Carta de Félix Oller a Rubén Pérez Kantule, comentando diversos asuntos, entre ellos el tema del maestro de Wichuwala y Nalunega que tiene descontentos a sus moradores y han pedido su cambio, amenazando con no enviar a los niños a la escuela.

Al: Cop. mec.

v. $C D$, n. CDL

939.

1950 Abril 30 El Porvenir

Carta del intendente Félix Oller al director de la escuela de Narganá, adjuntándole el oficio que le remitiera la escuela de 
Enfermería del Santo Tomás, en el que le informa de la reserva de un cupo para cualquier señorita indígena que tenga interés en aprender enfermería.

Al: Cop. mec.

\section{0.}

\section{Junio 3 Río Cidra}

Carta del sahila Pipi al intendente Félix Oller, recordándole la promesa que le hizo, que una vez que pudiera le colocaría una placa de policía, y que ha habido oportunidades y no lo ha hecho. Comenta que él necesita una ayuda del gobierno pues sabe su situación. Le recuerda su amistad con él y está dispuesto a cooperar y respaldar a su Gobierno. Concluye diciendo que le agradecerá cualquier ayuda que le dé.

Al: Orig. mec.

\section{1.}

\section{Julio 5 Narganá}

Relato de la llegada del intendente y del Ministro de Obras Pública, Roberto López Fábregas, para poner la primera piedra del Primer Ciclo Félix Oller. Comenta que la mano de obra será indígena.

AELE: Carp. Var. Doc. Cop. mec.

\section{2.}

1950 Agosto 7 Ailigandí

Carta de Alcibiades Iglesias al intendente Félix Oller, exponiendo la posibilidad de que su hermano se establezca en Mulatuppu, pues en su última visita allí así se lo manifestaron.

Al: Orig. mec.

v. CD, n. CDLI 


\section{3.}

\section{Septiembre 1 Ustupu}

Carta de Beatriz Kantule a Félix Oller, pidiéndole publique en prensa un artículo sobre su abuelo; dice que está trabajando en un colegio privado para sacar y pagarse la secundaria, pues terminó solo la primaria.

AELI: Carp. Doc. y dat. de D. FO. Orig. mec.

\section{4.}

\section{Octubre 6 Panamá}

Carta del subdirector general del registro civil, García Monge, a Félix Oller, intendente, diciéndole que deben actuar como registradores oficiales, donde no los hubiera, los maestros 0 directores de escuela y que recibirán un sueldo adicional de 10 balboas.

Al: Orig. mec.

\section{5.}

\section{Octubre 24 El Porvenir}

Carta de Héctor Castillo, encargado de la Intendencia, a la Sra. Adelaida Calvo, transcribiéndola el telegrama recibido, enviado por Delvalle, que la permite reanudar su actividad de maestra en la escuela de Ticantiquí a partir del 30 de octubre. Pide que comunique su inicio de actividad.

Al: Orig. mec.

\section{6.}

1950 Noviembre 4 El Porvenir

Carta de Félix Oller a Arturo Delvalle, inspector de Educación, 
informándole que la escuela de Narganá, que funciona en un edificio muy viejo regentado por las madres franciscanas, está en pésimas condiciones. También dice que la escuela de Río Azúcar se encuentra en mal estado produciendo daños a dos niños. Le pide que tome empeño porque se reparen lo mas pronto posible.

Al: Cop. mec.

\section{7.}

\section{Noviembre 6 Playón Chico}

Carta de un maestro de la escuela a Félix Oller, en la que le habla de una ayuda a Figuigte que desea recibir ciencias médicas en el Hospital Santo Tomás y que ahora se encuentra enfermo de la vista.

AELI: Carp. Doc. y dat. de D. FO. Orig. mec.

\section{8.}

\section{Noviembre $24 \quad$ Narganá}

Carta de Francisco Garrido y Alejandro Paniza a Estanislao López, comunicándole que han estado con varios ministros y con el Presidente de la República, y habían prometido el arreglo de la escuela de Narganá, pero que no servirá esto de nada dado el lamentable estado en que se encuentra.

AELI: Carp. 1947. Orig. mec.

\section{9.}

\section{Diciembre $15 \quad$ Narganá}

Carta de Rubén Pérez Kantule al secretario de la Intendencia, en la que le comunica que recibió la nota de los materiales con los mismos, y promete que los repartirá honradamente.

Al: Orig. mec.

v. CD, n. CDLII 
950.

\section{Febrero 3 Colón}

Circular del inspector de Educación Provincial, Arturo Delvalle, a los maestros, en donde da cuenta de de las actividades realizadas por "mi tienda".

AELI: Carp. Doc. y dat. de D. FO. Cop. mec.

\section{1.}

\section{Julio 5 Tupile}

Carta de Tomás Herrera a Estanislao López, en la que le solicita libros para él, de pedagogía y una guía del maestro. Le comenta que empezó a trabajar a finales de Junio.

AELI: Carp. 1947. Cop. mec.

\section{2.}

\section{Octubre 7 Tigre}

Carta de Martín Luter a Estanislao López, en la cual le dice que antes de empezar las clases fue al Ministerio de Educación por el asunto de su hijo Marcelino Luter para conseguirle beca en la escuela de Divisa, pero le dijeron que era muy chico y le recomendaron uno de Panamá. Comenta que desde el derrocamiento de Arnulfo el Ministerio cerró el asunto de becas.

AELI: Carp. Car. de 1951. Cop. mec.

\section{3.}

\section{Octubre 16 Cartí Sugdup}

Resumen del debate presentado sobre los huertos escolares en el que se reseñan los seis que están funcionando en la comarca y los maestros que están a su cargo.

AELI: Carp. Doc. y dat. de D. FO. Cop. mec. 


\section{4.}

\section{Octubre 17 Cartí Sugdup}

Resoluciones del segundo Congreso Educativo de sahilas y maestros de la comarca haciendo recomendaciones a los maestros para que hagan de las escuelas centros de progreso y cultiven las tradiciones, concluye con unas recomendaciones para el Ministerio de Educación y para las autoridades de la región.

BEN: Carp. Act. de los arch. de la esc. Orig. mec.

\section{5.}

\section{Octubre 24 Cartí}

Carta de los sahilas de los pueblos circundantes a El Porvenir al Sr. Ministro de Educación, D. Ricardo Bermúdez, para exponerle la situación de la educación en San Blas y manifestarle el deseo de que se implante al menos el IV grado para que sus hijos puedan seguir estudiando sin salir de las islas.

AELI: Carp. Car. de 1951. Cop. mec.

\section{6.}

\section{Octubre 25 Panamá}

Carta de los sahilas de la comarca al Presidente de la República, para que por su mediación el Ministro de Educación atienda a sus peticiones para mejorar la educación en la región; en ella trascriben la lista de mejoras y nuevas construcciones de escuelas.

AELI: Carp. Car. de 1951. Cop. mec.

\section{7.}

\section{Diciembre $16 \quad$ Narganá}

Carta de Rubén Pérez Kantule a Estanislao López, del Partido 
Renovador, en la cual le dice que son enemigos porque pertenecen a distintos partidos políticos, pero le invita a establecer conversaciones, y comenta que el busca la libertad para la comarca de San Blas.

AELI: Carp. Car. de 1951. Orig. mec.

\section{8.}

\section{Septiembre 3 Colón}

Carta de Humberto Ossa a Félix Oller, en la que le pide como favor que intervenga para que le envíen a San Blas, ya que tiene su familia enferma, y con anterioridad también intervino para que lo enviaran a Colón.

AELI: Carp. Diar. de 1952. Orig. mec.

\section{9.}

\section{Septiembre 8 (Ustupu)}

Acta del Congreso en el que se habla de la cooperación de americanos y panameños en cuatro temas, uno de los cuales es la educación.

AELE: Carp. Mem. del C G K de Tic. Orig. ms.

$$
\text { v. CD, n. CDLIII }
$$

\section{0.}

\section{Diciembre 2 Colón}

Circular de la Inspección a los maestros, en la que se indica la necesidad de preparar huertos escolares para comenzar los cultivos del próximo año.

BEN: Carp. Mem. de la Educ. Orig. mec. 


\section{1.}

\section{Diciembre $16 \quad$ Narganá}

Carta de Rubén Pérez Kantule a Francisco Garrido, en la que le comenta que existen unas becas ofrecidas por el gobierno de Brasil, y le pide que se informe sobre ello con el Sr. Fernando González Díaz, secretario de Ministerio de Educación.

AELI: Carp. Diar. de 1952. Cop. mec.

\section{2.}

\section{Ustupu}

Informe del Congreso General Kuna haciendo la petición al Ministro de Educación de la creación del Primer Ciclo en San Blas, apoyados por el intendente Félix Oller.

BN: Carp. Educ. var. doc. Cop. mec.

\section{3.}

\section{Enero 2}

Carta de Juan Colman a Estanislao López, en la cual le dice que tiene la lista de los aspirantes a estudiar enfermería en Panamá. Comenta que el grupo Guaimí ya la han enviado.

AELI: Carp. Cor. Cop. mec.

\section{4.}

\section{Febrero 19 Panamá}

Ley número 16 por la que se organiza la comarca de San Blas. Trata de la educación y las becas, y entre las funciones del intendente también se encuentra el fomentar la Instrucción Pública.

AALP: 1953. Orig. mec.

V. CD, n. CDLIV 


\section{5.}

\section{Marzo 24 Narganá y Corazón de Jesús}

Carta de la directora al inspector provincial de Colón en la que le recuerda que prometió enviar cuatro galones de pintura para su salón; y pide por favor semillas de frijoles, zanahoria, tomates, espinacas y lechugas para el huerto escolar.

BEN: Cop. mec.

\section{6.}

\section{Marzo 28 Colón}

Carta del maestro Roberto Pérez al inspector, para informar de que al regreso de una reunión a su escuela de Wichuwala se encuentra que está precintada, y le llama el sahila para comunicarle que no quieren que enseñe allí. Propone un cambio con la maestra de Playón Chico, Carolina de Alfaro, pero no ha recibido confirmación.

AELI: Carp. Cor. Orig. mec.

\section{7.}

\section{Abril 1 Panamá}

Carta de Félix Oller al inspector y director de primaria, Arturo Delvalle, diciéndole que los maestros Roberto Pérez y Daniel Crespo de Wichuwala y Nalunega se tuvieron que retirar porque los respectivos sahilas se opusieron a que los niños se matriculasen, pero afirma que no se les debe separar de su trabajo.

AELI: Carp. Cor. Orig. mec.

\section{8.}

1953 Abril 1 Playón Chico

Carta del sahila Manuel González a Estanislao López en la que le 
pide que busque un colegio para Eduardo Lombardo donde pueda estudiar; también le sugiere que le busque una familia para que aprenda mejor, y que su cuñado Liberto López va para trabajar por él.

AELI: Carp. Cor. Orig. mec.

\section{9.}

\section{Abril 7 Playón Chico}

Carta del sahila Manuel González a Estanislao López en la cual le suplica que vea a un joven, de esta isla, que lleva ocho años en Panamá y está fumando marihuana y bebiendo ron, le suplica que si puede se lo mande.

AELI: Carp. Cor. Orig. mec.

\section{0.}

\section{Abril 27 Narganá y Corazón de Jesús}

Carta de la directora de la escuela a la inspección, comunicándole que ya están preparadas las maestras y tienen los materiales listos para comenzar el curso el 4 de Mayo; y envía adjunta la lista del profesorado.

BEN: Orig. mec.

\section{1.}

1953 Abril 27 Narganá y Corazón de Jesús

Petición de ayuda de alimentos, de leche y mantequilla a la UNICEF para dar a los escolares más desnutridos.

BEN: Cop. mec.

\section{2.}

\section{Mayo 5 Narganá}

Carta de la directora pidiendo libros a la editorial Argentina Capeluz, ya que han comenzado el curso y se encuentra sin libros de lectura. Sugiere que la envíen la edición acomodada para Panamá. 
BEN: Cop. mec.

\section{3.}

\section{Mayo 5 Panamá}

Carta de Estanislao López al sahila de San Ignacio de Tupile comunicándole que su hija Ildaura ha sido nombrada maestra de grado para ese pueblo, pero que se ha tenido que retrasar.

AELI: Carp. Cor. orig. mec.

\section{4.}

\section{Diciembre 1 Ailigandí}

Resoluciones del Congreso General Kuna realizado en esta localidad, pidiendo maestros y solicitando también un primer ciclo de secundaria; y manifiestan su desconformidad por el proyecto de ley de la comarca y quieren establecer una unidad de fomento agrícola.

ARPK: Carp. 245. Cop. mec.

$$
\text { v. CD, n. CDLV }
$$

\section{5.}

\section{3}

Carta Orgánica de los indios kunas aprobada al amparo de la ley 16 de este mismo año.

ARPK: Dat. de Narganá. Cop. mec

V. CD, n. CDLVI

\section{6.}

\section{6 a 1946}

Listas de alumnos, notas de exámenes y tablas estadísticas con los datos de las escuelas, reflejando las bajas y alzas en la matrícula 
y asistencia, comparados con el mes anterior y el año precedente; así como visitas giradas por el director de las escuelas. Junto con los porcentajes de hombres y mujeres que se encontraban matriculados y asistían a la escuela.

Al: Orig. Mec.

V. CD, n. CDLVII

\section{7.}

\section{Octubre $15 \quad$ Sasardí}

Relato de Ibeorgun cantado por el sahila Iguanibiginia, y traducido al castellano por Aiban Wagua, donde se recogen algunas de la enseñanzas que realizó este profeta a los kunas.

v. CD, n. CDLVIII

\section{8.}

\section{Agosto 19 Cartí Sugdup}

Transcripción del canto de hamaca realizado por una niña de diez años, y traducido al castellano por Melania; en el que relata las tareas que tendrá que realizar cuando sea mayor la hermana pequeña.

v. CD, n. CDLIX 
COLECCIÓN DOCUMENTAL 


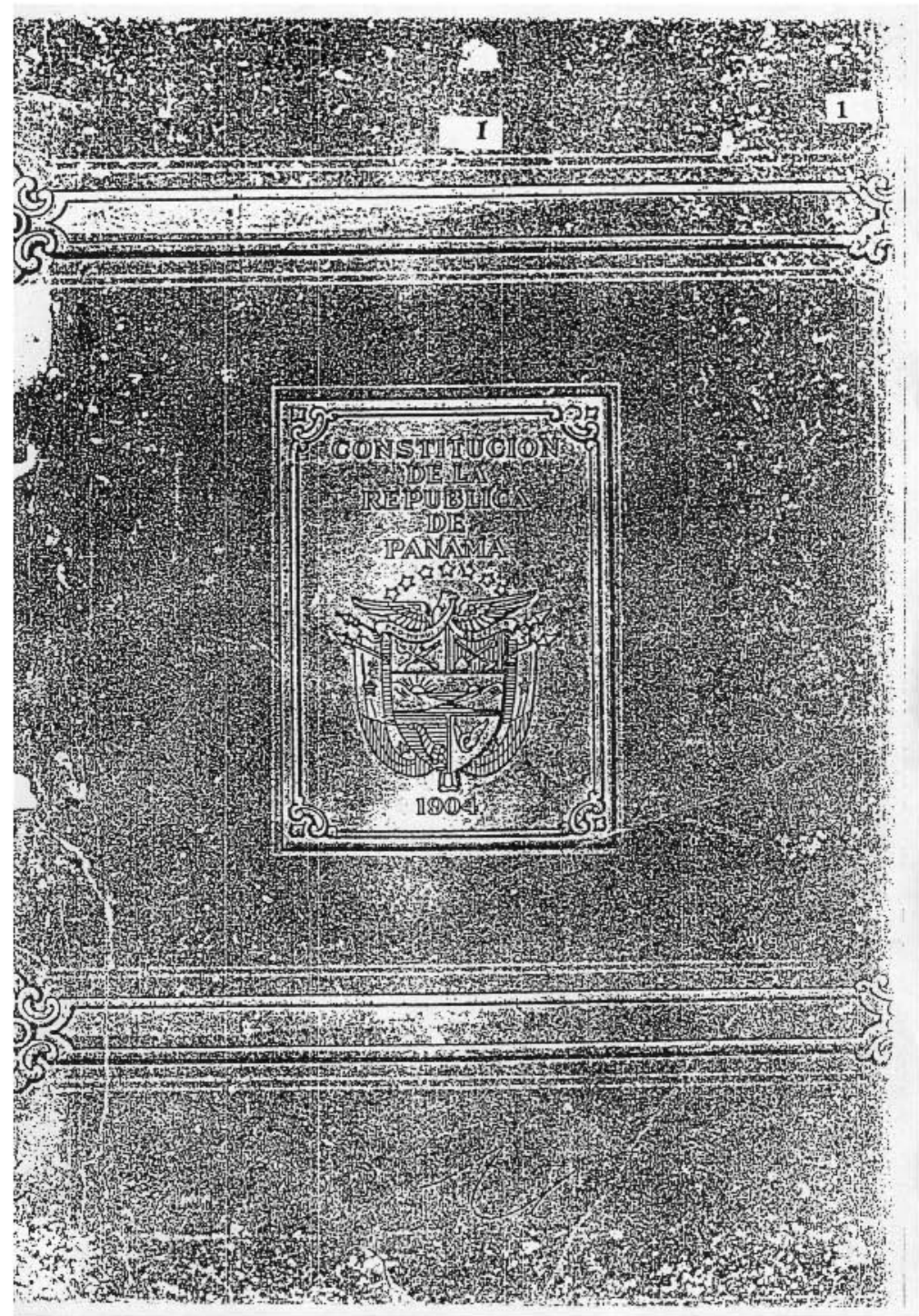




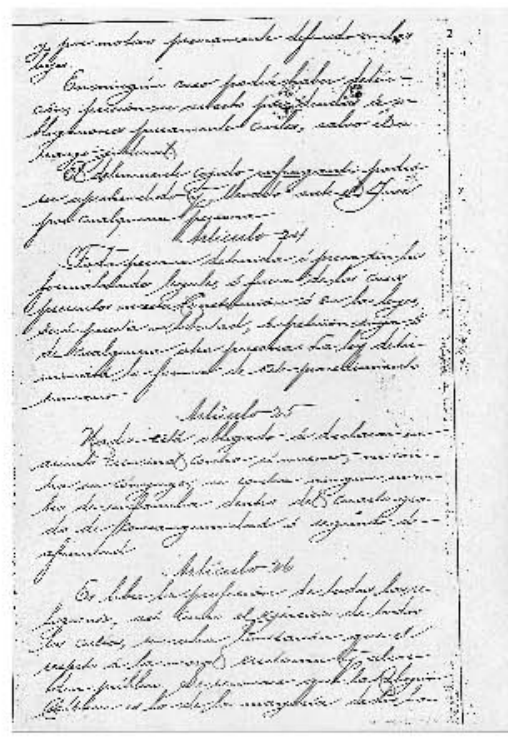




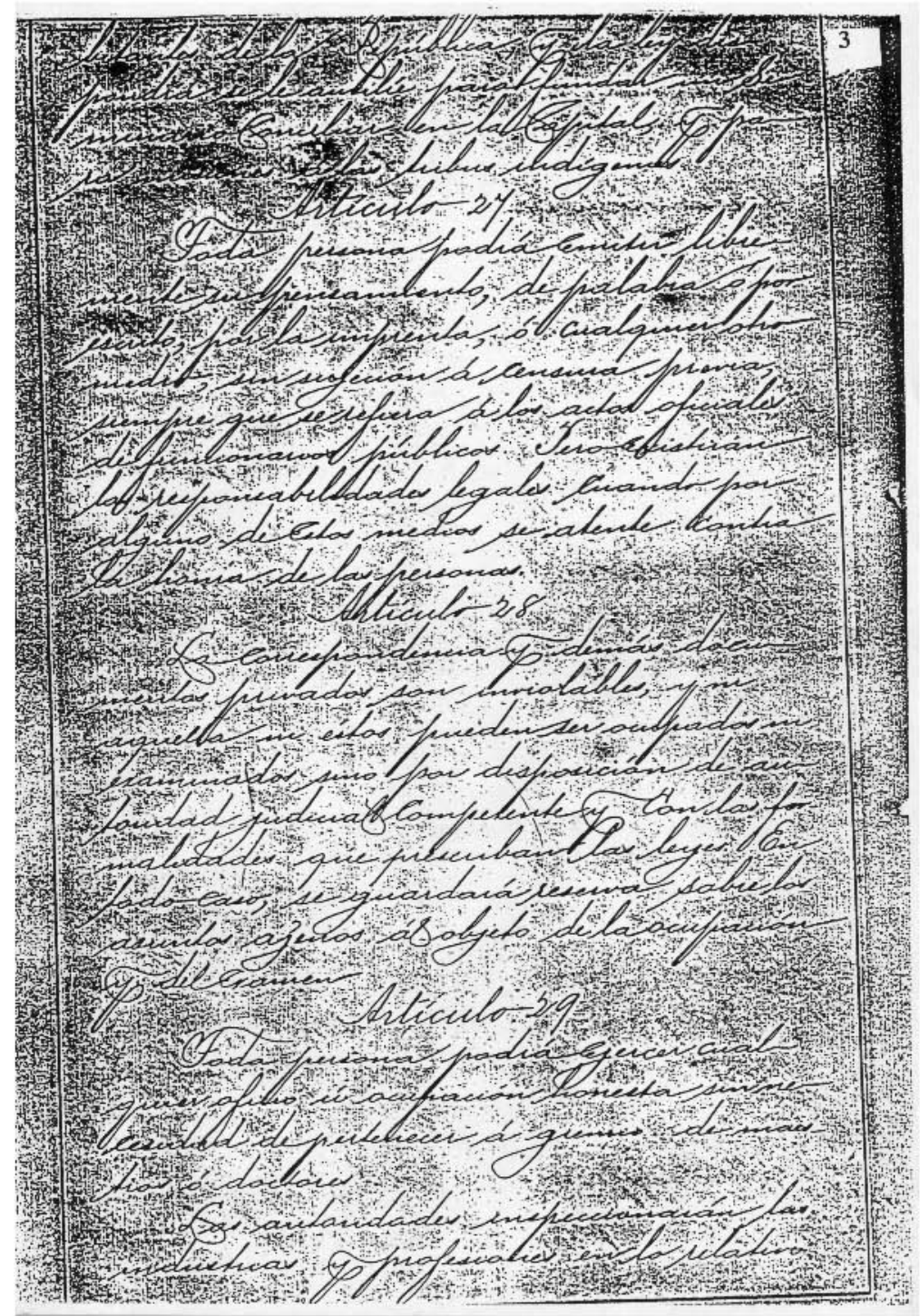




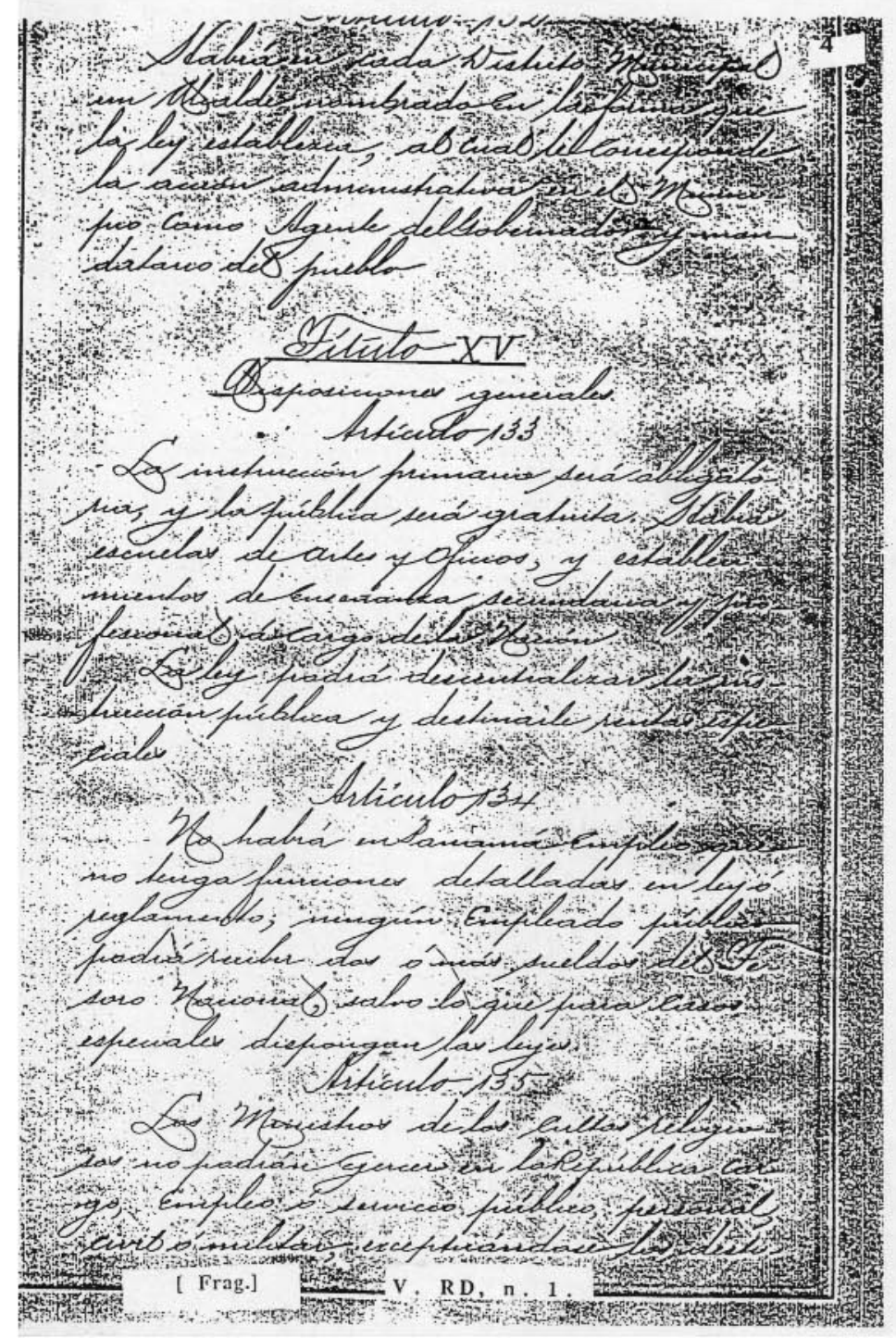




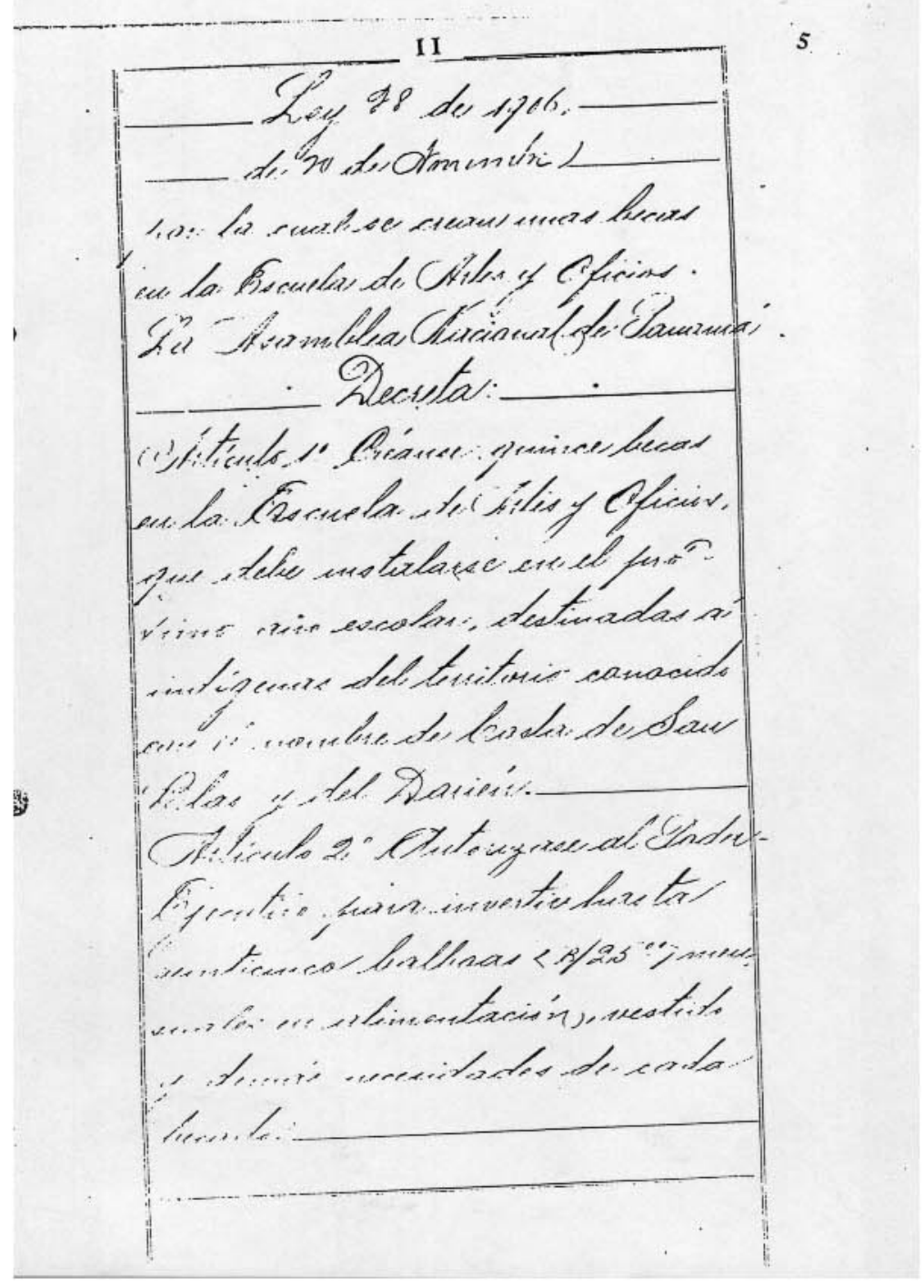




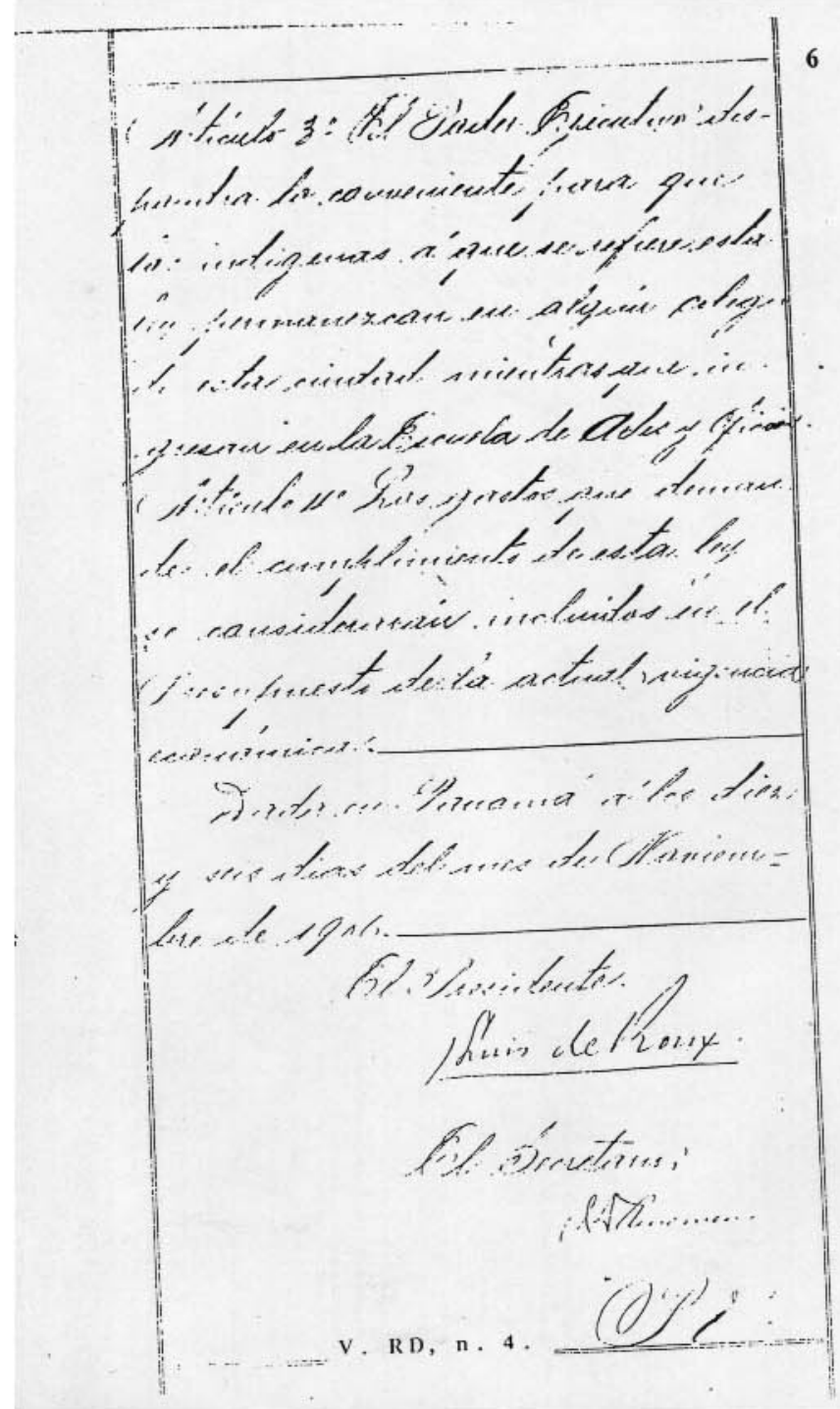




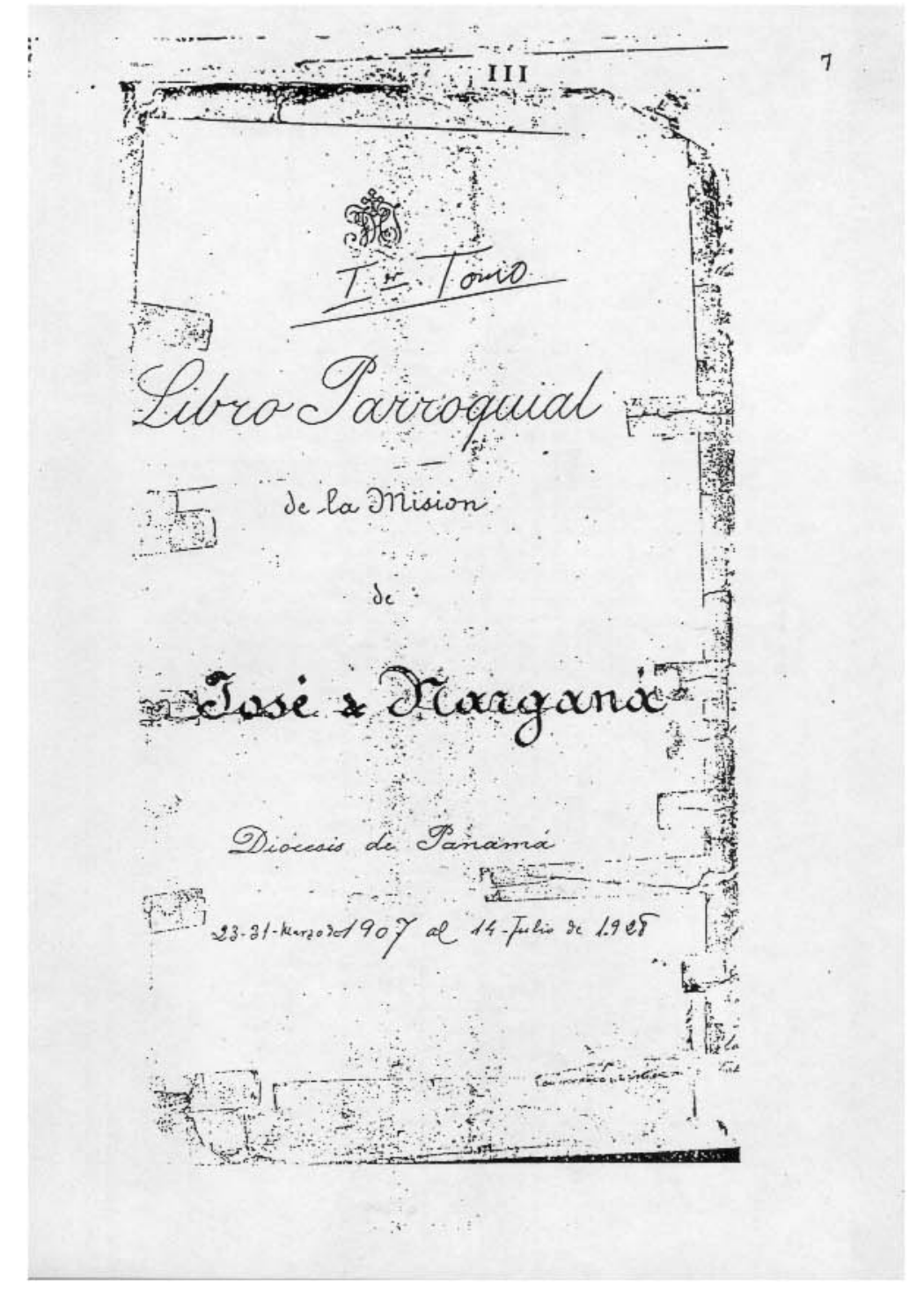




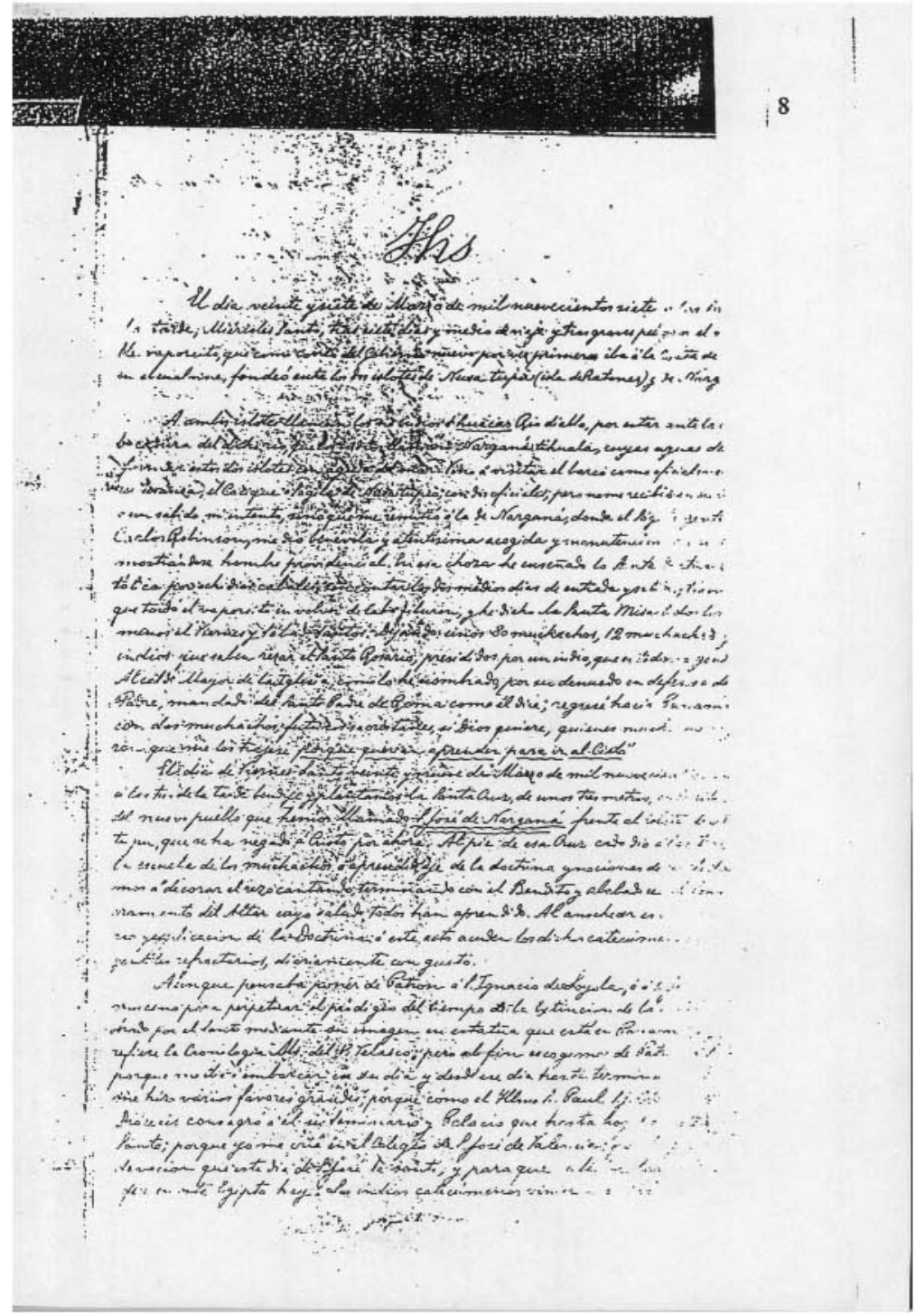




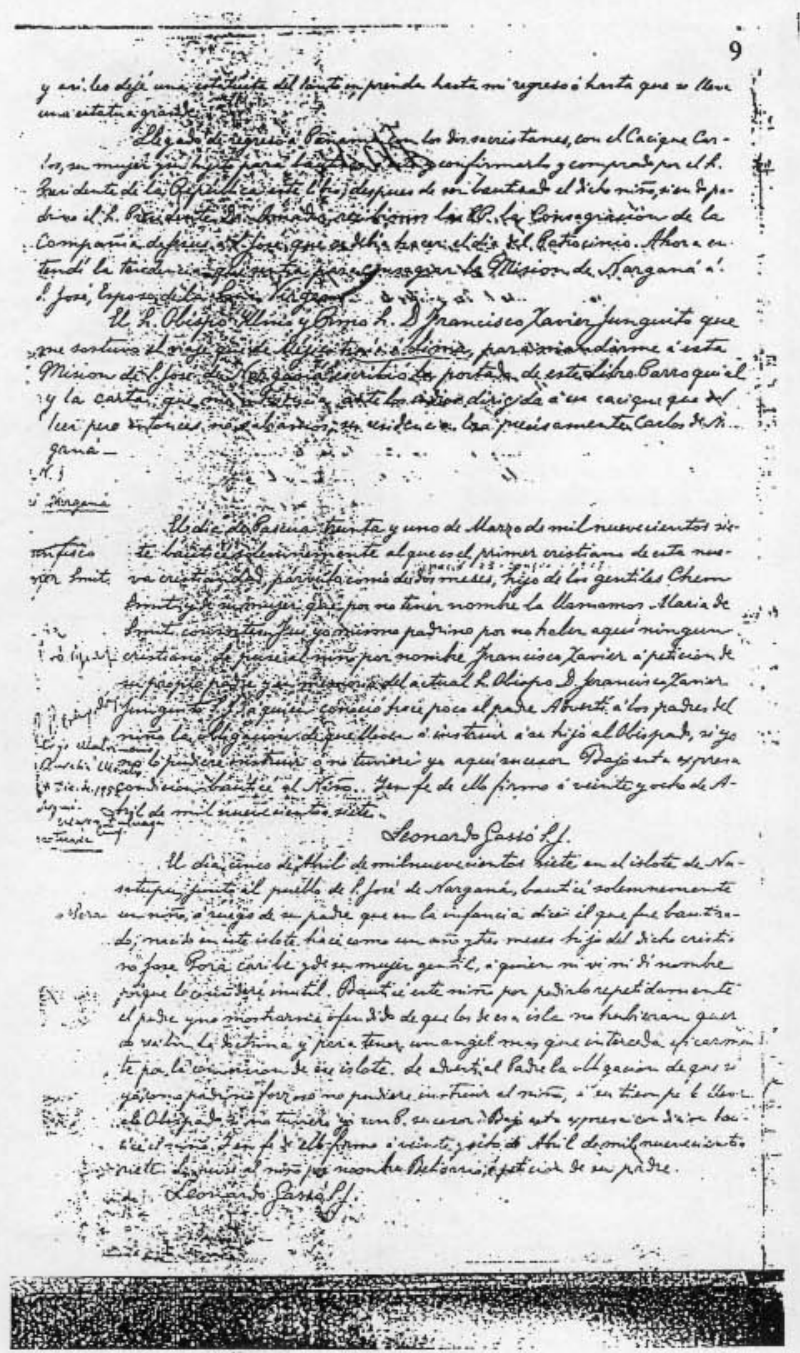




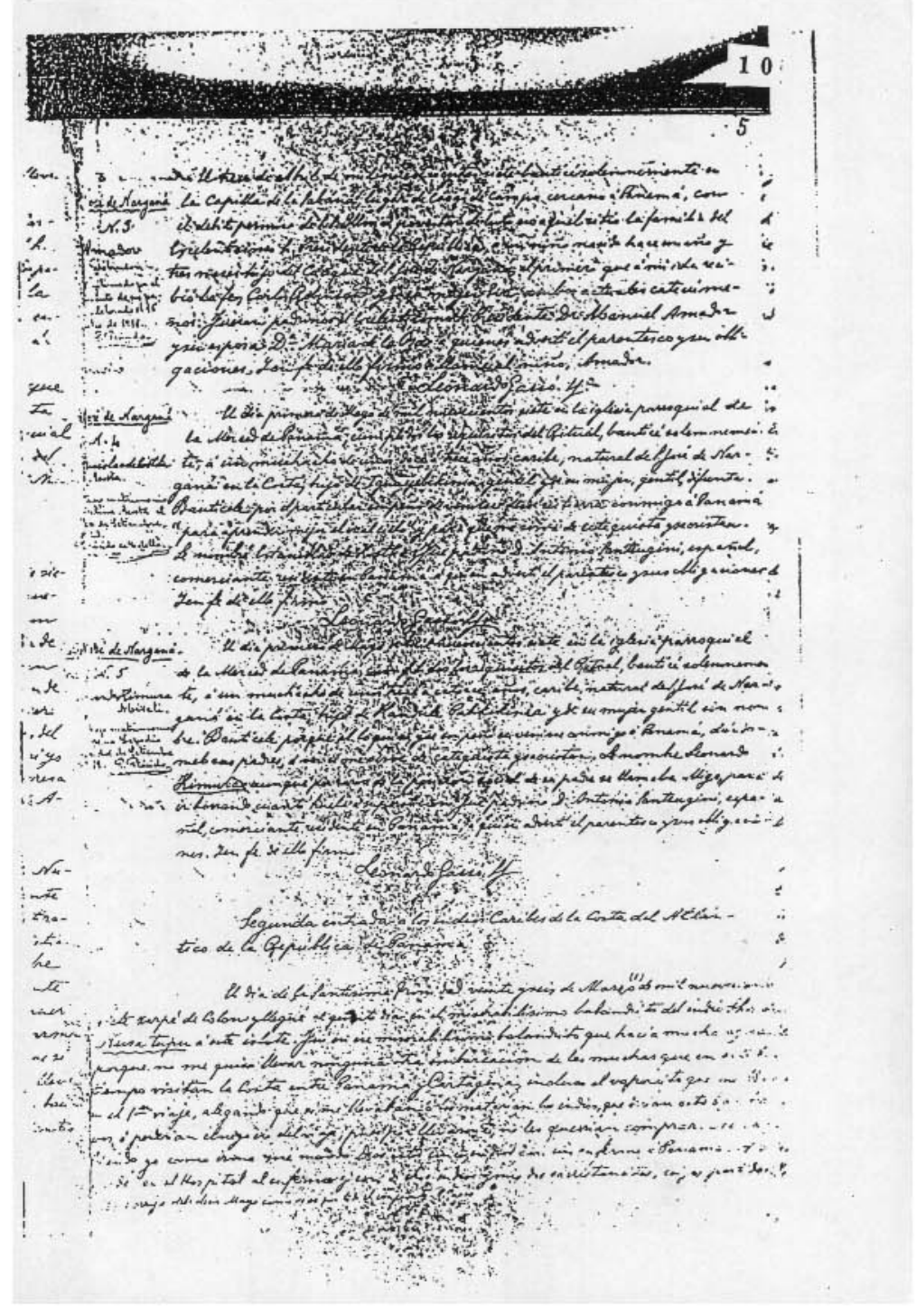




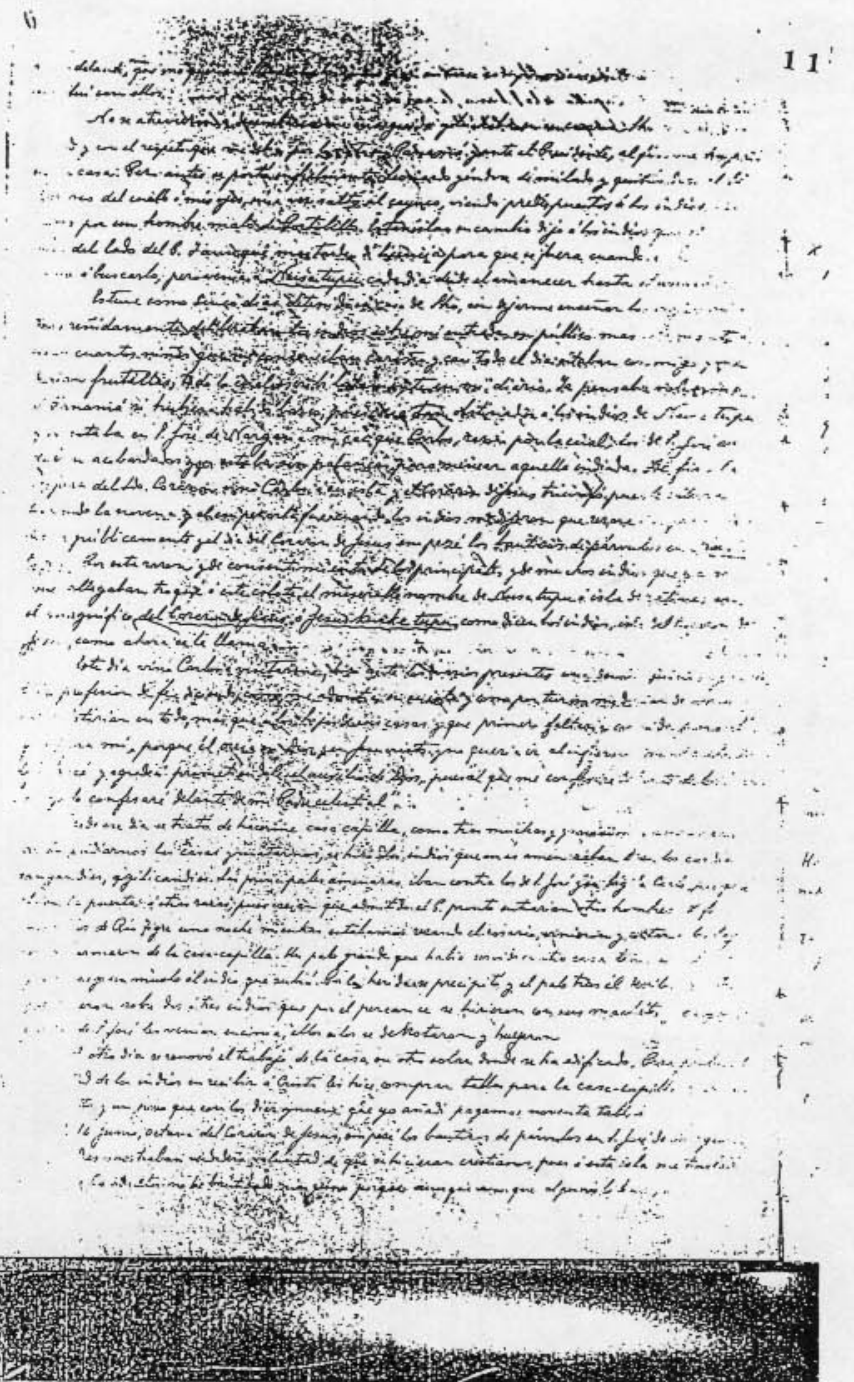




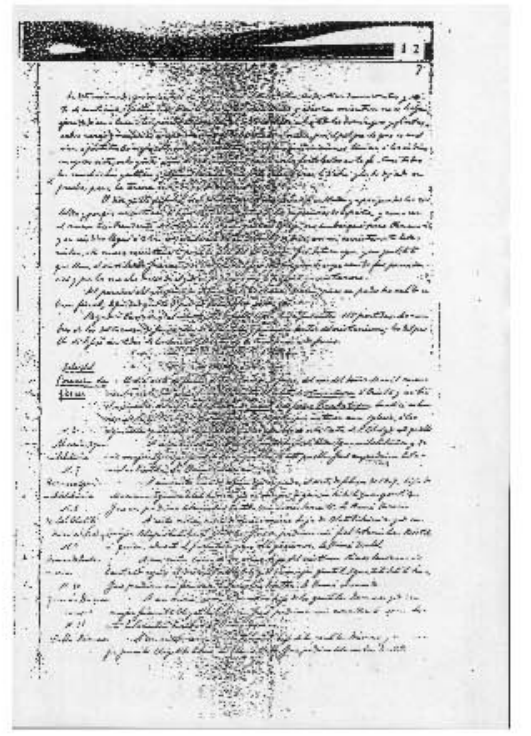




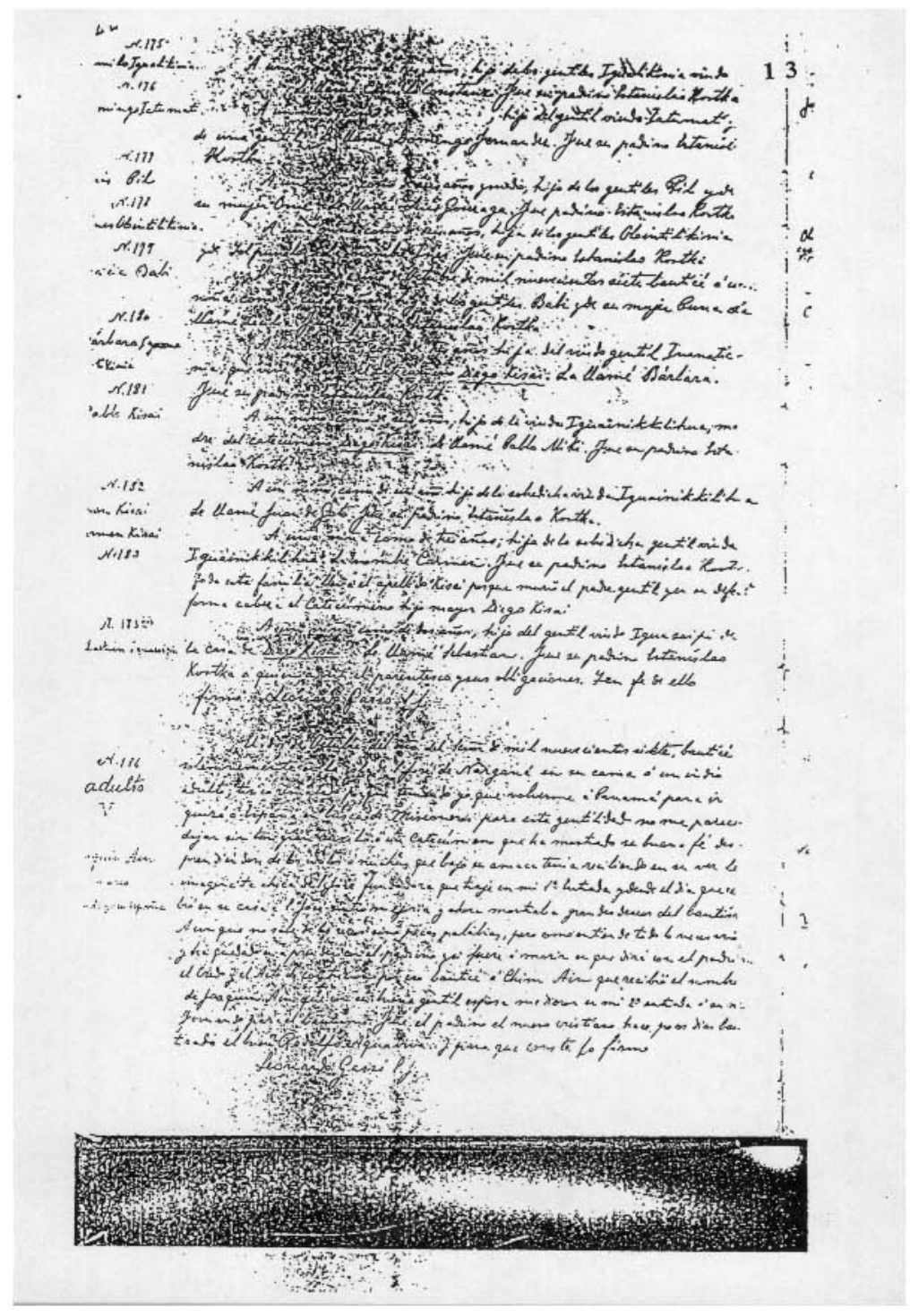




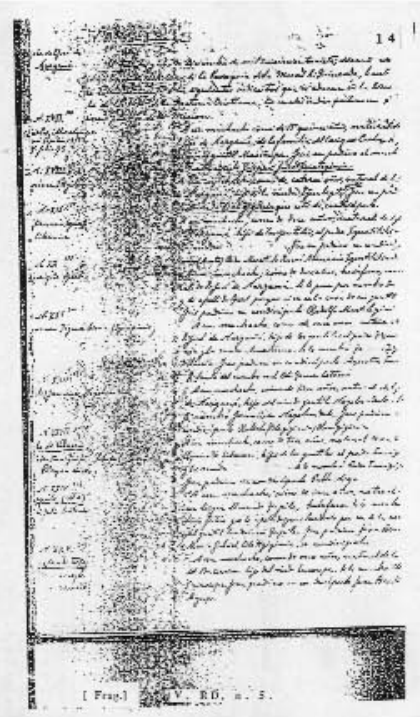




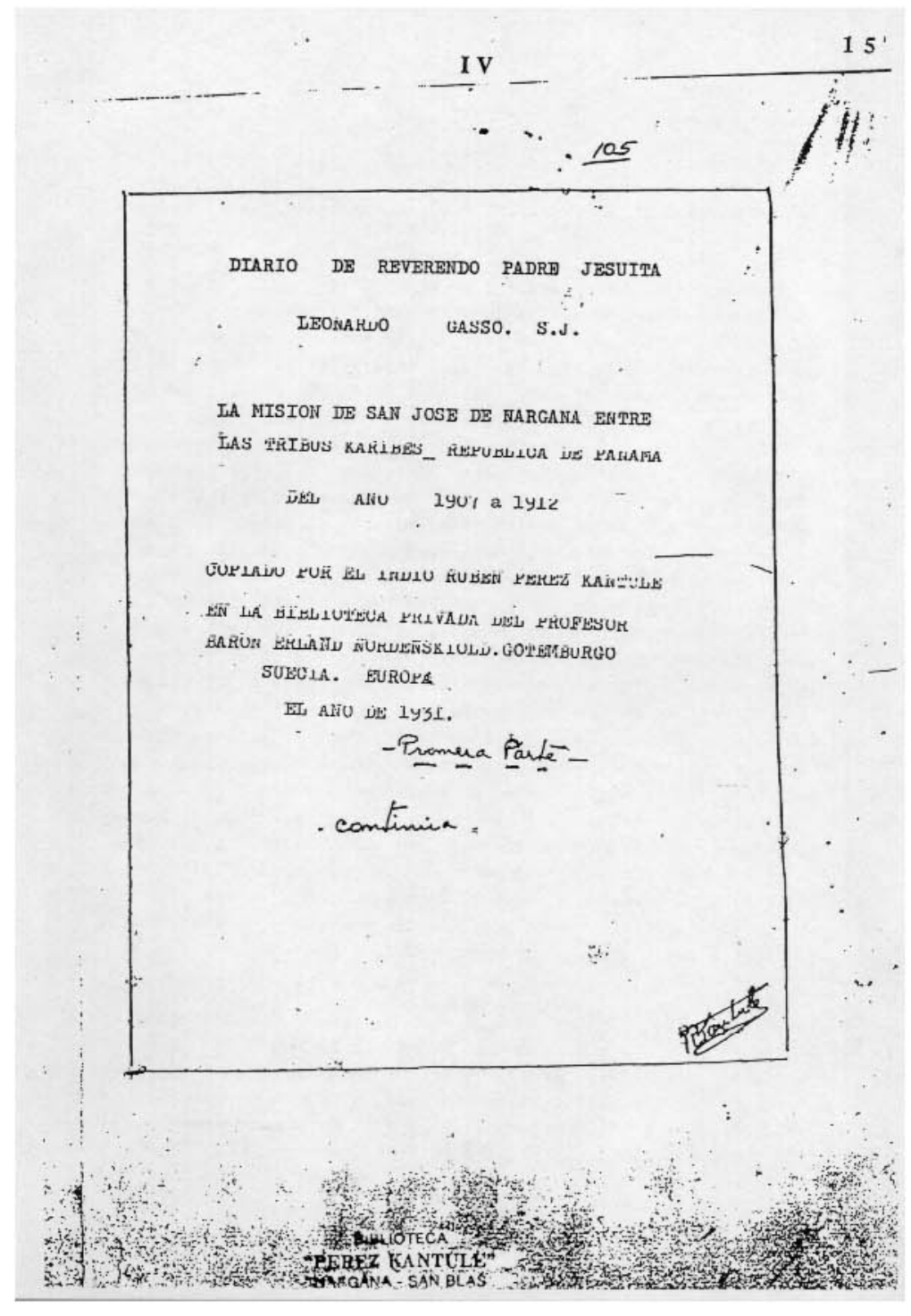




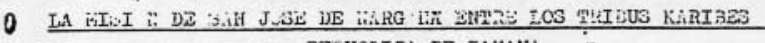
REIUSLICA DE TAHAR

CCHPIIUACICA

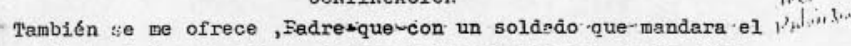
Fresidente, todos-tenârian-miedowy’asi"ventrarian־en-razón. Ilas dado en el quicl, hijo, norque Initium sapientiae timor Domini, y éstos noesonshombres, sina bestias, $y$ asin rezan las historias de nuestras antiguas misiones.- Asf,pues ahora que vayas a Panamá le dices esto al Fresidente. ?Pero tú, Carlos y lds buenos no me hariais una chozai- Si, Fadre- II no te parece que entonces poco a poco, ayudando a Dios, los conquistariamos? Padre, los muchachos $y$ zente joven $y$ bastonte indios de edad media ya los tienes Eanados, peto los denás ¿quíén sabe? No sabe el poüre Carlos que yo tenso miedo de tener soldados, pues sungue la conquista por el solo sacerdote, humanamente hablando, sea insuficiente pora formar cristiandades de indiós solidemente edificados, dando mas que era adagio comf́n de los antiguos misioneros que para cabeza "in"

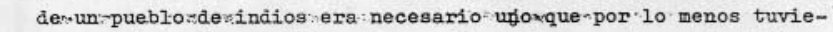
ra un quinto de-español, estoses, de europeo; pero en la alternat tiva de caer en manos degente apóstata y descreida $\circ$ de solo salvar a parte de la indiade, prefiero esto a aquello. Ahbra seria ruina, cierta parte despues, aunque por ahora y temporalmente adelentesen más, según está el mundo de perdido.

Lo cierto es que cuando vine no tenía ni un conocido, ni ge vinieron a recibir en la isila de enfrente, y aquil el pueblo tuvo dificultad, y San José ine ha traido algunos de las 1slas enemiga, toda la juventud y varios hombres decididos de esta śla con el cacique. Varios otros hombres si no son amigos, son aficionado: admíradores. Veremos como completa San José el favor.

Vida del misionero de indios fentiles- El primer bautizo en la futura Isla del Segrada Corazón. Firme resolución de los llargonas on adnitir misionerosv. Friner fiscal de doctrina en esta cristianidađ- Se declara el Fatriarca :jan José, titular de esta misión.Adellando de los indios presenciado por la tripulación del vaporcito que regresa- Ea familia del Cacique Carlos y dos futuros sa- 


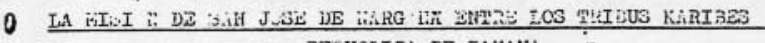
REIUSLICA DE TAHAR

CCHPIIUACICA

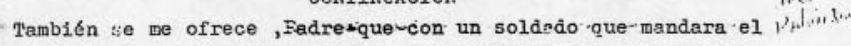
Fresidente, todos-tenârian-miedowy’asi"ventrarian־en-razón. Ilas dado en el quicl, hijo, norque Initium sapientiae timor Domini, y éstos noesonshombres, sina bestias, $y$ asin rezan las historias de nuestras antiguas misiones.- Asf,pues ahora que vayas a Panamá le dices esto al Fresidente. ?Pero tú, Carlos y lds buenos no me hariais una chozai- Si, Fadre- II no te parece que entonces poco a poco, ayudando a Dios, los conquistariamos? Padre, los muchachos $y$ zente joven $y$ bastonte indios de edad media ya los tienes Eanados, peto los denás ¿quíén sabe? No sabe el poüre Carlos que yo tenso miedo de tener soldados, pues sungue la conquista por el solo sacerdote, humanamente hablando, sea insuficiente pora formar cristiandades de indiós solidemente edificados, dando mas que era adagio comf́n de los antiguos misioneros que para cabeza "in"

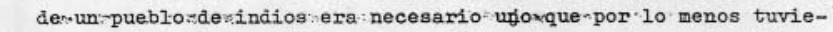
ra un quinto de-español, estoses, de europeo; pero en la alternat tiva de caer en manos degente apóstata y descreida $\circ$ de solo salvar a parte de la indiade, prefiero esto a aquello. Ahbra seria ruina, cierta parte despues, aunque por ahora y temporalmente adelentesen más, según está el mundo de perdido.

Lo cierto es que cuando vine no tenía ni un conocido, ni ge vinieron a recibir en la isila de enfrente, y aquil el pueblo tuvo dificultad, y San José ine ha traido algunos de las 1slas enemiga, toda la juventud y varios hombres decididos de esta śla con el cacique. Varios otros hombres si no son amigos, son aficionado: admíradores. Veremos como completa San José el favor.

Vida del misionero de indios fentiles- El primer bautizo en la futura Isla del Segrada Corazón. Firme resolución de los llargonas on adnitir misionerosv. Friner fiscal de doctrina en esta cristianidađ- Se declara el Fatriarca :jan José, titular de esta misión.Adellando de los indios presenciado por la tripulación del vaporcito que regresa- Ea familia del Cacique Carlos y dos futuros sa- 


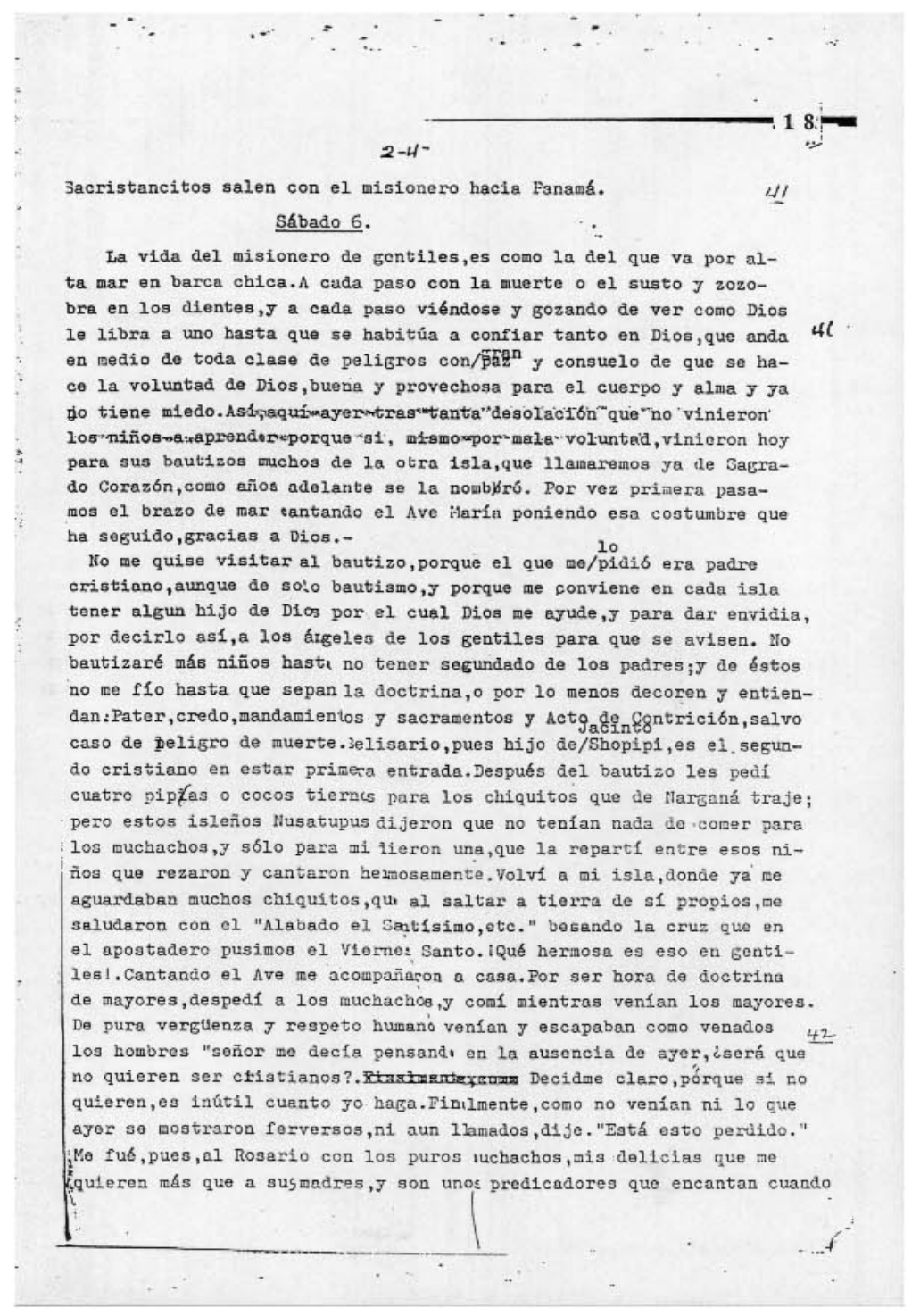


hablan del infierno $y$ de 10 que padeci6/ Jesucristo por nosotros $y$ de que han de venir conmigo al cielo. Handé a llamar a mi cacique Carlos dos veces, y no 10 encontraba, Ya la tenemos, So me volvỏrán atrás los pobres cences, y no lo están aquí cantando con todos tiles,pues solo los fervorosos catecúmenos ostan aqui cantando con todos sus pulmones.Señor, eres el unico que puedes con los Gentiles;si tu no lo arreglas, nadie puede arreglarlo.Fensando esto.Ecce Deus!viene el Cacique j con 61 un porrazo de hombres.Es que hablan estado tratando el gran negocio que luego diré.

Acabado el Rosario rezamos le Doctrina,se enseño y explicó lo de necesit te, como todos los dias. Be consiguib hoy que se pusieran de rodillas, $\mathrm{y}$ no en cuclillas, como suelen para cantar el Bendito $\mathrm{y}$ alabado, etc. "\$610 el pue blo cristiano sabe arrodillarse, me hizo notar tiempo atrás el señor Obispc j es asi gue a estos indios les están difícil eso como casi a nosotros ponernos de codo en el suelo.

Fúme con el caciague a casa,siguínáose cuatro principales. "Padre, me dic el providencial Carlos,estos cuatro son del todo buenos,"y les empleza a hablar con tal energía $¥$ tan clésicamente, como ellos suelen el tratar de hablar con tal energía $t$ tan clásicamente, como ellos sue no entendía ní una palabra.Cuando yo veía que les impresionabar la noción de Carlos y que co fervor todos a uha hablaban,le pedia explicacín a Carlos. Dntonfes él en fervor todos a uha hablaban, le pe latín de sacristía,me decía: Pues dicen a estarnos como bestías. Tu nos dices que Jesucristo, verda. dero Dios $y$ hombre, dejó a su vicario San Fedro y Pio $x$ y que éstele ha di dero Dios $y$ hombre, dejo a su vicario san Fedro hios de Dios, $\vec{y}$ que así cho al señor Cbispo que te mandase para hacernos hijos de Dios, $j$ que as vayamos contió al cieio; pero esǿs viejos endemoniados tienen la cabeza $d$ ra $\mathrm{J}$ no entienden $\mathrm{y}$ no quieren hacerte caso,y añaden que para que quieren Padre, pues en cada islote hay dos, cuatro, seis sacerdotes gentiles o hbsofe pueden comparar ellos contigo?.Tú eres enviado de Dios

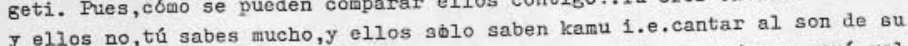
J ellos no, tú sabes mucho,y ellos sølo saben kamu tienes mujer y aquí vol flautas sus creencias. Además: tu eres santo que no tienes anjer v aqui vol vi6 a hablarles con eran fervor, diciendo: "Yo estoj da y noche viviendo c este Padre, $y$ a mi mujer ni la mira, sino cono si fuere un nibo.Aquin nenen toudaskias-mujeres ac sus comprasey con ser tan recelosas con otros ya se 1 todaskes muestran cariño, pero creo acercan $y$ le traen sus hijitos y aunque a todos aue no conoce si son mujeres. Este Padre es bueno, hijo de Dios. siguí6 Carlos,el nismo padre me contaba que cuando venfa de Colbn estando

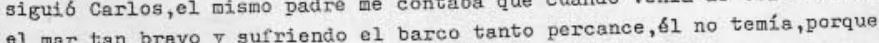
ol mar tan bravo y sufriendo el barco tanto percance, no nos tuvo miedo como arbia que $\mathrm{Dios}$ le ayudaba;y venidos sin conocernos, corazon para recibirle otros huahikas, porque sabia que Dios nos daria duen nada le falta. Más el oL. 
tro día se le perdio el Fadre un gemelo de la camisa, $j$ la buscamos en este arenal $z$ casa $y$ no 10 encontramos por un día.Al fin Padre con los muchachos rezaron a San Antonio, se levant6 el Padre a..buscarlo y en seguida 10 chos rezaron a Sen Antonio, se levanto el Padre albucalo 10

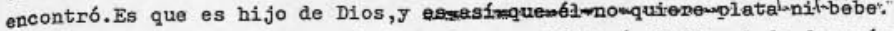
y...di Padre,algún día tendrás mujer? pregunto José,el fiscal de después diré.- Dios me libre,porque yo quiero vivir como Jesucristo, sin mujer. ¿qué os parece?dijo mirando a los otros.-Pues le hacemoserasax casa porque este es de Dios y que viva con nosotros,y si-esos viejos hijos del demonio no quieren poco-importa, nos juntamos veinte hombres hechos $\mathrm{y}$ la hacemos aquí junto a la de Cacique.Ys:tú-Padre,poco-a-poco nos enseñerás, pues tanta-

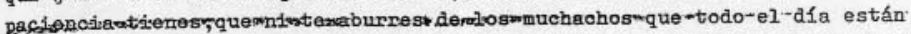
encima-de-tf.Dicen que los inonteses quieren bajar a matar al Cacique que te admiti6 y a t1.ivo bajarḱn, porque nos temen ja.Pero si bajan jo, dijo el orador, con mi machete te defenderé." Le abracé en señal de agradecimiento,j le dije: Pues tú serás desde hoy mi vicario 6 abarkinete $\circ$ fiscal,y dirigirás el rezo cuando yo no esté en el pueblo.Te nombro,pues,el primer fiscal" Al otro día en la funcion o Doctrina, celremoniosamente lerentreguémin-cruz, comc

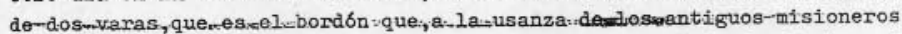
del tarañón, llevo fabricados de un palo o hueso de la hoja de cierta palme. ra que en el Ecuador se llama chonta, duro y pesado con brillo.Esta-es la ir gi-gni-axdewfi-scal-de-doctrina, a la antigua usanza en las misiones. Dncargué gele se hiciers otra como esa, $y$ que en mi ausencia me concervara esa.Lueso hice donación a pueblo en su persona, de una estatua del Fatriarca San José de menos de palmo,regalo del $\mathrm{D}$. Ipiña a mi salida de méjico, que en la naleta impensadamente vino acá, 7 ante la cual,clavada en el asta de la cruz-bo dón, rezábamos la joctrina,por todo altar, en el gran chozón. Luejo de rodillas todos y de común consentimiento nombramos a Sen José, Fatrón y lítular de esta mision, y nos consagramos a 61 por las razones que el principio de esta historia, dije. Al mes v1 10 oportuno de esta consagración,pues, vuelto a Pananá, recibimos la cabta de nuestro muy reverendo Padre General en que consagraba la Compañía al Santo Patratitca y mandaba la formula que cada ca sa habfa de decirle en el dia del Patrocinio.

Tras todo eso,para que no se olvideran del nombre de Santo Patriarca" 1.lamé a ese indio Shec, tul decidido defensor y primer fiscal, con el nonbre do José quien hasta stror hoy,1912, se ha conservado primer catecímeno y it go el más fervoroso cristiano, a pesar de las prueosa por donde ha pasado la Misión y adelante se dirán.

Entonces José dijo:Nosotros te queremos Padre, Tía nos herás hijo de Dios 7 nos libraŕs de la casa de los demorios nia-neka 6 infierno y Dios quer que poco a poco nuestro pueblo sea la cabeza de esta tierra.-S1, hijos;y vo 
sotros me ayudareis para hacer cristianos a toda la nac16n"-

S1, Padre, todo lo hemos de hacer.- Dios os conserve vuestro buen deseo.Dejemos al Fadre ya para que se vaya a descansar."

Al poco de estar acostado aunque tenco una cortina que con el rincón forma una alcoba, venía el Cacique como que ne quería hablar;pero como es

if $\tan$ considerado,ni se atrevib a entrar y yo me hice el dormido. Luego entendi a la madrugada que se quería despedir de mi,pues se había olvidado ente En efecto, al poco, serían como las diez, oigo un largo cántico,parecído a la tonadas que en Cuba dicen ser indícenas.Parece dice esa tonada que estos karibes fueran de la misma raza de los de las Antillas venidos de la Flori. da, cono con otras razones se prueba. 11 fin de cada estrofa hacía el canto une cadencia larga, que equivale al pozosde Homero $\sigma$ a la que dice Ir. Luis " de iebn en el hebreo de los Lalmos, i.e.considerady massinemat $j$ sentid 10 f que dígo,Itogolooooé i.e.entenderemos i.e., saboteceemos en 10 dicho.h qué vendrá este cántico?,me decía;será como que me está exorcezanỏo este abso geti, $₫ i$ vecino?.Al minuto de callar 61 , empezaron a cantar los gallos.Holá, dije,es que el absoseti anunciaba el cambio de tiempo.Es as 1 que a las 4 tres de la madrugada, oí gren alboroto que todos los varones se iban a la pesca de la tortuga,incluso mi buen Cacique y hoy amanecido el mar más liso que una balsa de aceite.

Cuanõo me levanté ya había dos indios a la puerta encargados por el Caci que para que me asistieran en la Misa tocando la campanilla, oficio del Caf. cique. Ellos se encargaron de servirme la comida,y a cada rato venien hace me la corte si bien yo les dejaba ahí sentaços $z$ seguía nis ocupaciones, mientras los muchachos en dos carros a los dos extrenos de la wese, rezan el Rosario que me sé yo cuantas veces, yendo unos y viniendo otros, $z$ aientras un niño de siete años enseriaba "Santa Haría"a un viejecito de más de 130 años(1).Los extremos se tocan. Dice el viejecito que quiere ir al ciels conmigo, y por eso viene a verme todos los días.

(1). "Bste tiempo andando se bautiz6; se llam6 Pablo Olopibia

muy puntual a la Hisa los Doningos. Este nos dará datos

histo

ria."
Zsta tarde lleg6 de regreso mi famoso vaporcito que ha gastacio diez dí para correr cosa de tres. Dios 10 ha hecho para darme tiempo 7 poder sali para correz de aquí cuando jo quería,para ni ser molesto ni quedar poco instruido é estał gente. Al-Cacique Carlos desde $s$ tercer día de mi estancia le noté que tenía una baránda de ideas en su cabeza, que produjeron su efecto a fines de 1911, cuendo se presentaron circunstancias oportunos on ai ausencia.For no poder yo explicarle por falta de lengua tantos perfiles como $s$ necesarios y por no hacerle daño con mi impropiedad en la lenguaje karibe 
1e propuse que se viniera a Pananá,donde el jeñor Obispo en inglés le dirí 10 que jo quería.Accedí́ y luego me dijo: "Ywno podrá venir conmigo mi mujer?.Muy bien, dije y entonces bautizapms a tu hijito en Panamá. - I sería su pacirino el señor Presidente?.Pues, díselo a su mujer". Mucho. trabajo costo convencerla que salfera de su tierra,alegando que se había de norir,que se le había de reir por su traje que ninguna mujer salía de su tierra.Al fin la conquist6. Más hoy me vine Carlos con que ya de ninguna manera verix. quiere venirse.

Los tripulantes, del vaporcito ha presenciado los edelantos de estos ocho dfas. Unos -70 muchachos, 12 muchachas. y 21 hombres saben "Dor la señal", Ave y. Santa María en su lengua además cantan el "Benäito" g "Santa Haría". Doce muchachos copian el abecedario en la pizarilla.Todos saludan ya con el "Aladodo el Santisimo Sacramento"besan la mano y se quitan el sombrero ante el Dadre y.el Cacique; éste alcunos besan la mano. Estas diferencias han h chorque el Cacique me respete mucho,porque 10 hago respetar. Iso, la castida en el trato, que ellos admiran, el hablar únicamente de Dios o su ley $\mathrm{y}$ el despreciarmel dinero eso lo que me ha dado este ascendiente en 10 humano. Lo aprendi del V.P. Ferrer,primer misionero del fiarañon, en su historia por el P. Velasco.

A mi vicario José Shec le he entregado, tras el rezo, esta noche mi cruz 6 baston 7 la estatuita de dicha de San José,para que se quede cautivo el Santo en este Eripto,para que logre de Dios derrocar los ídolos z conservarne la iïsibn. pueca pues el riscal encargado de dirigir el Rosario cada noche, según me 10 han visto hacer.

\section{Día 7.}

Vista la negativa de la mujer del Cacique le pregunte la verciadera $J$ fuerte razón de volverse atrás. "Padre, que los indios son tontos;que los pa dres de la mujer dicen que los van a murmurar, porque salib una mujer de su tierra,que quieren por eso reñir conmigo,que se va a dorir la-mujer, etc." Entonces me fuí a la madre, $J$ tanto ae hablé en castellano, que ella no entendía, que se asust $6, y$ luego en karibe, $y$ al fin dijo:Pues que vayaz,porque va con su aarido y contigot:Sairtmos, pues, hoy de San José de llarganá el Cac1que, su mujer e hijo $\mathrm{J}$ mis dos futuros sacristancitos, el candoroso Estanislao $y$ el aventajado Leonardo, $y$ fuimos a dorair a orillas de un islote, pasandó mala noche.-

$$
\text { Día } 8 .
$$

Tras inc6modo día en el vaporcitoZapato, venimos a dornir en un rancho 1lamedo Escribano, donde las tres pobres familias de negros(Nieves Camargo) que all1 habfa, me trataron nuy bion $y$ rezado el Rosario juntos, quedaron 
edfficacos e inclinaron a los de Santa Isabel, a donde pertenecian para que más tarde se me afioionarán los del caserío de Santa Isabel, hoy parroquia nuestra, como lueco se dirá.: otro día dijeles misa,quizá la primera que alli nunca se ha dicho.

\section{D1a 9.}

Pasamos sin beber todo el día hasta llifamar, donde el maligno capitán ne1 gro protestante $y$ demás tripulacion religiosa 6 protestante no quisieron pernoctar,porque piadosos negros de ese pueblecito,salieron a recibirme 4 pidiendo les dijera Hisa. He hicieron estos muchos regalos en la media hora que saltamos a tierra. Tuimos a dar a Plajadamas.

En señada la maliona tripulación on que no fuera al vecino pueblo de Nor bre de Dios, dijeron que iban a zapár de madrugada,para que no tuviera alls posibilidad de decir iisa doncie mucho la deseaban. lablé al protestante masón dueño del islote Playadamas y aijo: No tenga miedo, Fadrc, que le dejen. Vaya al pueblo, que yo sostenaré a estos mal educados hasta que v. vuelva. ic6mo se hizo!.El tal mason se hizo tal, porque ell ser masón no es ir contra Dios, sino entrar efuna sociedad buena de mutuos socorros, amen de que cựantas más relífiones tiene uno más honra a Dios. De esta honradote hombre 10 civil se hablará más tarde.Ctro día ne dijo: Usted sabe lo que ha hechc trayendo esa mujer india?.Mire $V$.que los indios le van a matar a $V ., y$ aun lla corre peligro de regreso, porque no quieren que ninguna mujer salga de sustierras. (llago notar esto, para que se vea la desaertade intención que últimamente se tuvo de sacar muchachas inãias, cosa muchísinas gús grave entre estos ināios, aun para oaucarlas religiosamente.) Le expliquá todo, $J$ dijo:" Đues, dispense, Fadre que the haya atentado a indicarle todo esto, porqu yo, aunque extranjero, cono vine joven a estas costas y a estos indios, debo cuando fioy (era riquísimo) J les he cobrado cariño, sentiria que V.no les pudiese hacer el bien que pretende civilizarlos,por eso me adelanté.El đaclque Carlos (esa noche con su Iamilia se hosped6 en Playadamas muj amigo del tal Mister Hol) the ha preguntado que pensaba jo del Padre,pera que vea Ustee si son desconfiados, aunque se muestra,y lo es tan amigo de usted. Ie he contestado que el Padre es bueno $y$ quiere el bien de los indios. For eso Carlos se cetermina a seguir el viaje con su mujer a Fanamá".Grandes bienes, cono se pretendia, resultaron de la venida del matrinonio. En liomore de plos, se reuní mucha gento al Rosario de la noche $y$ sermón $y$ ala Nisa de las cuatro de la madrugada, y hos regalaron mucho. 


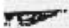

$-10$.

dfa.Felicisimo mar,insolentisimo tripulación ni comida nos ofrecieron.Ferpoctamos en Portobello mis indios $\mathrm{y}$ yo en el vacio cuarto.

$$
\text { Dia } 11 .
$$$$
\because
$$

i Llegamos a Colbn. Como la india anda en ese traje, aunque su marido le ha estirado la pampanilla hasta cerca del tobillo con la tela larga 6 samurru que le ha puesto,todavía al andar se le ven los dibujos de abalorios con que se tornean las pantorrillas $J$ tobillo, el anillo de oro pendiente de la nariz no 10 puede ocultar, ni quitarse nada de eso ni de su abigarrada chanoia y variados collares, so pena de que la maten a la vuelta como renegó de sus costumbres.Asi es que les dije en el vaporcito $y$ fuf por un coche para desde el buque llevarlos al coche $y$ a lał casa de los Hermanos de la canadada para que les vean menos pssibles $y$ no les avergúencen con usos $\exists$ admiraciones. (1).

Les Hermanss nos trataron muy bien, plátano abundante, mucho arroz, nade de sal, $\mathrm{ni}$ adobes, ni carne,pues a las indias les da asco todo eso; los hombres todavia se aplican algo a todo.

(1).-En ese tiempo por maravilla venía algún indio a poblato; hoy vienen muchos varones, pero no mujeres. 
एक्ष:-

$-11-$

VI.

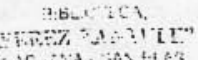
$\therefore \quad$ ch nut A ta Llegada del Cacique a Panamá.-El Sr. Presidente es padrino del hijo del Cacique.- Noticias consoladoras que traen otros caciques.- Reembarque de los huéspedes.cios originalísimos de unos indios.-Cristo

\section{Dia 12.}

E1 sobre aaltos que cada golpe del coche producía en la india, crecí cunndo sentida en el tren empezo a andar. lliraba a todas partes agarrándose moviendo la causa de tanto correr.

Ilevé a mis indios en coche,1legados a Panamá,al Palacio del 3r. Obispo, donde me hospedi. Recíămos con gratisima sorpresa.Su Señoria Ilustrísima, pues en los veinticinco dias que de aquí faltaba no sabia de mi nada, J me pues en los veic 6 muerto. Exominibus liberavit me Dominus. Favores todos ćrelan naufraf́6 6 muerto. Exominibus indios, j se les agasajó mucho destinán de Sen Jose poner las hamacas, pues no sabian dormir de otra manera $y$ se les preparaba comida a su susto para que no enfermasen.

D1a 13.

Tuf con el Cacique al Beñor Presidente de la República, Dr-Amedor Guerre

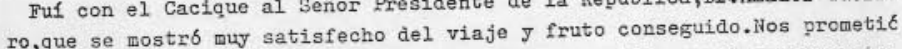
ro,que se mostro muy satisfecho del viaje J fruto conseguide. pros propuesto, quedarianimales de cria, chivas, vacas, etc.,para nuestro uso,y de lo que

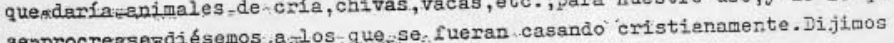

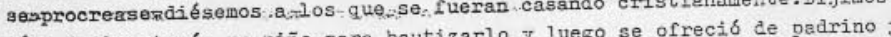
cómo Carlos trala un niño para bautizarlo j luego se ofrecio de padrino añađio que su señora sería mađrina. IFas que como estaban la fanilia de luañadio que su seña señoría Ilustrísima no tenía into en la Sábanad, habriamos do ir allá si señor a flú se hizo, quedándome ne conveniente pera becer el bautizo en su capilla.ksl se bino, auedándone nc poco edificado de que Su Excelencia contestara tan exactamente el interic gatorio del Ritual y aun dijera el Credo en latin.Hicieron luego sus reg: gatorio del Ritual y aun dijera 1 amb Amado

- los los padrinos a su ahijado y a los padres del niño,que se llamb hrados f. Vueltos a casa del señor Obispo también hizo sus regalos a los tres.Qued Carlos tan satisfecho, que pidio retratasen a la familia luciendo los $v$. âtidos que los dieron, Eqa, que así llama la mujer de Carlos estaba bue

ya con el chal que la madrina Da.María de la Osa le habia rejala.

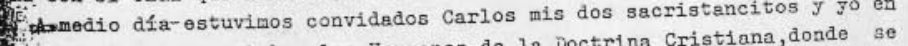
1 20 Hormal, que regentaban los Eermanos de la Doctrina Cristiana, donde se Psta 
.12 -

fo de esos muchachos al vernos $J$ que les traiamos tres grandes sacos de buenas frutas mandadas por sus padres. In la mesa nos obsequiaron mucho $10 \mathrm{~s}$ hermanos.Cozaba Carlos de ver sus mehrehras ensuéz̃os cumplidos $y$ me recordoba la diferencia de esta gran junta, aquella en que se determinb matar a las mujeres, cono arriba dije All $\neq$ Gacique, acabada la mesa como es gran predicadorţresmpredicó-lango-a-10s educandos sobre que se portasen bien, aprendtesencrespetasenva-sus-maestros . J.. olvidasen las enseñanzas de sus gentiles padres, porquewios habia de querrer que mediante su educacion se tranformasemarkaribexianóntierra de San Blas. I Gnoraba Carlos lo que més tarde habla de suceder y a su tiempo se dirá.

Dia t 14 de Abril (1902)

Hoy, Jr.Señoria IIustrisima confirm6 al chiquitin imador, tan ङracioso. Es el primer confirmado de la tribu.. Ya la madre empieza a salir de su cuarto por los corredores, haciéndose de casa,pues la alegría del corredorcito indiecito, hackécuscass le da a entender que ésta es casa de confianza pues todos los miman a tales huéspedes, desde el señor Obispo hasta el cocinero.Les lievápor-les-iglesias y al hospital grandioso del Cerro y el cementerio, paramentodas partes explicarles lo que se ha de hacer en su pueblo.Todo eso $\rightarrow$ pratendíamos conseguir del viaje.

\section{Dra 15 (de Abril)}

Thegaron a Panemá dos caciques de otras islas. Venían ellos a ver un 50brino,que al fin no vieron,pero Dios lo traia para afianzar á́s a Carlos J al Señor Presidente. İn efecto, con aquellos ful a la Iresidencia,j contaronrcbro el dfa que selimos de San José de Narganá los gentiles de Playon Chatcomóntoun-seni enemigos del Padres, fueron a Río Mono, hoy San İnacio de Tupile, pueblo amigo del Fadre,y los insultaron a los tupiles, porque querían Padre. Istos se fifefendieron,, , estando una $y$ otra parcielidad en sus cayucos, fue una como batalla naval. $A 1$ fin, el Cacique de Tupile enpeź el cayuco 0 barco del Cacique viejo del playon,quien viendo a los nuestros con sus machetes tan dispuestos a cerrar con ellos, tomaron la huida $j$ persesuicos se fueron escapando en sus cayucos.

if Dicen estos" caciques; a los cuales se ha gñedido un enviado de los gentilos del Pacífico, que éste viene a averiguar la novedad ocurrida en la en. trada del. Padre a le gentilidad que hasta allá repercutio.No es, pues, un puntico sin tracendencia la entrada y conversión de tlarganá como se verá.

chn el relato se aninaron Carlos y el señor Presidente viendo que ja teneotros que sienten con nosotros cuando hace un mes nadie nos queriar 7. nadie de los huacas 6 extranjeros se podrá apear en sus islas. Añaden eof caciques que ayudarfan a Carlos para hacerme una casa-iglesia 6 chozon Nit. 


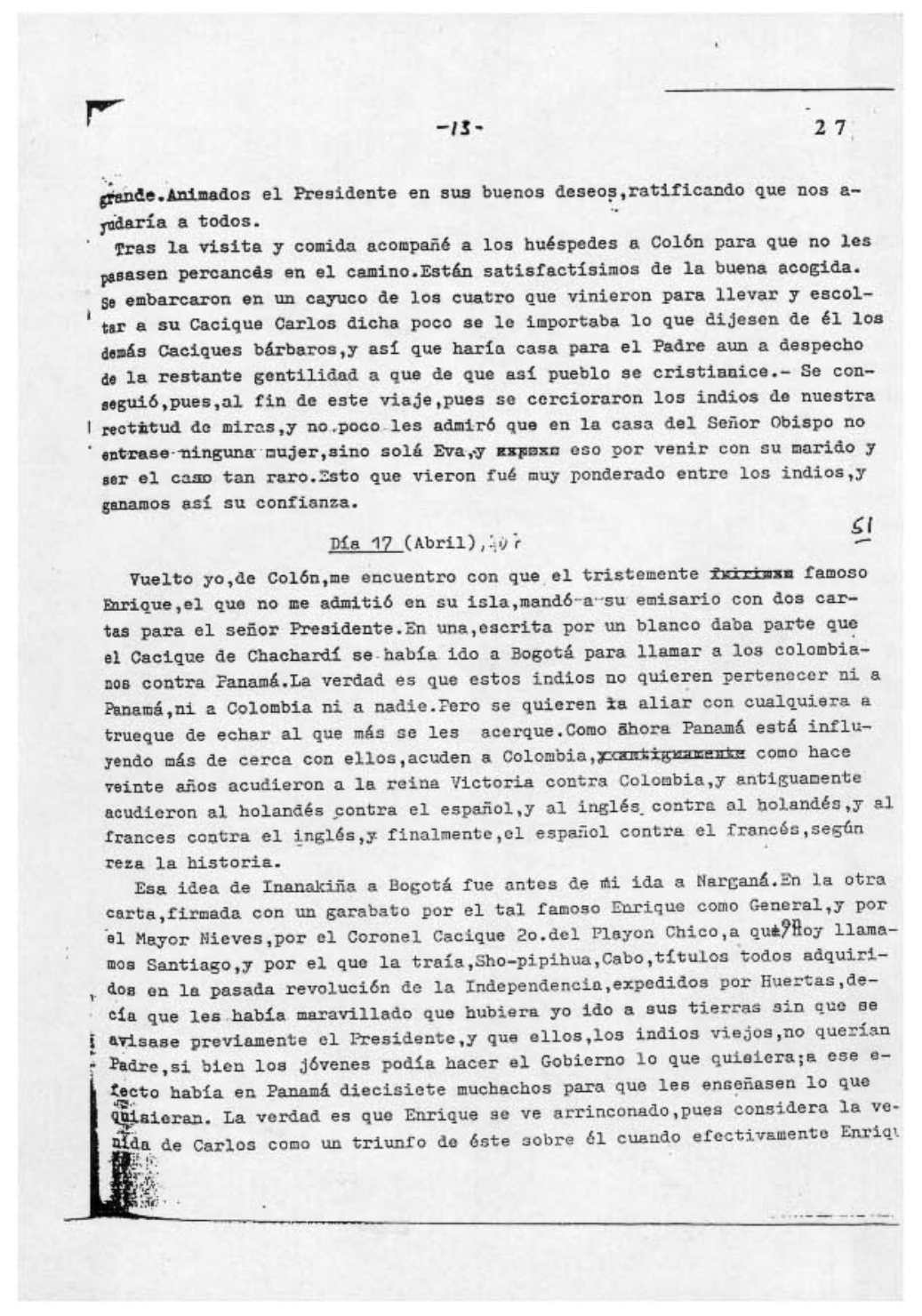


F.14-

siempre ba sido considerado entre los indios y por los revolucionarios de siempre ba sido considerado entre los indios yo tione la culpa. Porque no me admitió en su isla,

prestigios que Carlos. $\mathrm{kr}$ se tione la culpa. Forque
que es edonde fui primero.

Calva Para que se vea la tontera del tío indio $y$ su salvajismo.Trae el tal sho- pipi las cartas contra mí, no me dío las pipas cuando bauticé su hijo, cartodo me viene ahora a que le llevé al Iresidente para entregarlas las cartas 3 me pide de comer. Żse es el nundo.

Me dice que mi fiscal José todos los días preside el orifinal íosario, que en Narganá les enseñé. No se perdíb la jornada, pues los gentiles hacen oracibn.

Tras la entrevista que hemos tenido con el Fresidente, en que f́ste nos ha Tras la entrevista que hi ha dicho que el Padre es muy bueno,pues que 105 viejos no quieren tadre por que sin 61 ha vivido sieepre, el rresidente ha contestado con la siguiente carta:

$$
\text { "Panamá, } 18 \text { Abril } 1907 .
$$

Sr.D. Enrique Clay y demás amigos.-San José de Nargań. Estimados señores y buenos amigos : Mucho me complacef saber por la lectura de 0 - cue - son amantes de la enseñenza pordeseos-de progradelanto de los pueblos.

"Aprovecho la oportunidad para hacerles saber que el $\mathrm{Pa}-$ dre Gass 6 no piensa establecer en la tribu de ustedes(es decir,en su isla sino en la de Carlos, por ahora) visitado a Narganá. Tampoco tiene el Gobierno de la República regiones personas extrañas, pue de Vds.sin valerse de ninguna influencia extraña, salvo la misma protección del Gobierno, pero no tiene otro objeto que la tranquilidad de vds. Conor do-quem-oeque-vis.dicen-está corprobado con el envio para que híjoskennuestras escuelas, los que entan a ustedes, $\mathrm{J}$ no indivi

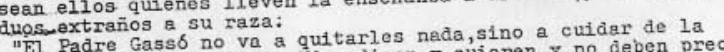
"El Padre Gasso no va a quitaricen y quieren, y no deben preocuparse crejendo que kl $_{1}$ busca otra cosa sino el bien a poner y no va a cambiarles $10 \mathrm{~s}$ nombra

les.nombre a loser qua de $1 \mathrm{a}$ Mision de Inanakiña (a Bog̣tít porque no tendrá ningún resultado. El buque que dicen piensan traer (esos indios llamados colomblanos) pueden tener seguridad de que no hacerles algan daño avisen enseguida a Panamé. Crean que pueredundar en mal de Vas.

p.D amigo. Manuel Am mucho hicieran casa psra el Tadre,

quien construcción de ella." 
$-15=$

Dia 18 (abri1) $1 \div r^{2}$

Th palenkerio encontro ajer en Colbn/ un indio racional de 모o Sidra,y le pregunt $6: \dot{i}$ Qué dicen los indios acerca del Padre?.Muy buen Fadre;le querremos mucho,por 10 que nos cuentan los narganas aunque no ha venido a nuestro pueblo, le querremos hacer una gran casa con alfombras,porque jo soy caballero y-he visto hasta España y nos gusta a los buenos que nos renga Padre! A eso repuso-otro indio viefo encarándose con el huaka palenkeño:"iQué te parece!. Đios:crib-el-perro $y$-hasta hoy es perro;Dios crí alrtigre, y hasta hoy es tigre; Dios crib la gallina, $y$ hasta hoy es gallipa;crib. Dios al indio,y ahora no quieren dejarnos ser indios.- Eso no se puede aguantar. Que nos dejen per indios.

Es que aldunos huakas les ha/netido la idea que han de entrar los indios por el sistema os aro moderno/qृ de justisimamento detestan, pues hace desGracladas a les naciones, como-jes vicuentan los indios corredores que van a muchas naciones, como dije; quienes por desgracia solo ven en esa atmósfera pudredumbre $y$ maldad:El pobre indio cree el Padre va a meterles ese espíritu egoista irreligiose, soberbio J deshonesto mediante la karta como ellos dicen, 0 letra. Ilienen estos indios karibe cosas muy buenas en las cuales se vo la huella de un gran apostol 6 misionero, que según la historia de-je ser ve la huella de un gran aṕstol 6 misionero, que segun la historia de.to suerte y no querer ootar a lo que no se ha hecho para fl, que el año ha de pensar nucho en Dios 7 se as 1 se saludan. ¿En qué piensas?"Mienso en Dios" pensar mucho en Dios 7 se as 1 se saludan. que el indio no he de ambicionar dinero,y al que 10 ambicione 10 igualan quitándoselo y echanaoselo al mar, etc, etc. Se ven cosas muy admirables en quitándoselo y echandoselo al mar, etc., etc. sacerdotes, que deben ser los antiguos fiscales del wisioneros;en el Guardar la honestidad de las muchachas, en el recato conyugal, y eso que viven on chozones de veinte y tres almas sin cuartos, ni tabiques, ni lienzos, eteon chozones de veinte y tres almas sin cuartos, nis borracheras con s $\delta 10$ explicarles 7 hacerles rezar la Doctrina, quedarían muy buenos cristianos. Por eso-en.las.enseñanzas de la Ioctrina no repugnan, sino el modo de ser moderesa,bi..las.enseñanzas de la Lue hay un grupo pequeño de educados entre jankis 6 janitizados., que,teniena una sran confusión de ideas, por detestar de algunas cosas de los viejos, detestan de todas, s610 porque están encarnadas en los viejos,, admiten por el contrario todo 10 moderno, a carga cerrada, bueno y malo, sobre toco malo, 3610 porque esa a la moderna, 6 que 10 han visto en elguna parte por donde han corrido, sin fljarse si eso les conviene $\delta$ es para ellos Gín pocer bien a los más y no Gran discreción necesitará el misionero para hacer bor hoy gerán los que ás tequitar a los de ese pequeño grupo,quienes hoy por hoy serán Lajayuderán. 


$$
-16 .
$$

Hasta hacer la segunda entrada a los indios me entretuve en arreglar mis spuntes y preparar al bautiano mis dos secristancitos, quienes también aprendieron a ayudar la misa.

$== \pm=-=$

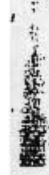


$-17-$

PUNDACION DEL PUEBLO SAGRADO CORAZON DE JESUS.-

SEGURIDA ENTRADA A LAS INDIAS KARIBES DEL PAKAMA.

1 "PEREZ KLNTLL:" $\therefore$

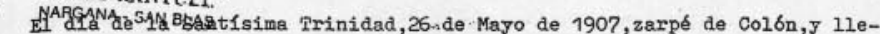
gué al quinto dia, en un miserablilsimo balandrito de los indios del Tigre, capiteando por el indio Sho al islote de éste, iTusatupu. Fui en ese misera-

blelisimo barquito, que hacia mucha agua,porque no me quiso llevar ninguna otra embarcacion de las varias de comerciantes, que van a la tal costa karibe,1ncluso el vaporcito que me llevb el primer viaje,alegando,que si me 11 e raban 6 los matarian los indios,pues decían estaba toda la indiada fuera de gran parte de los narganás bravísima por haber aportado un desconocido a sus tierras,era yo; 6 perderian el negocio, pues por llevarme no les comprarian los indios las mercancías.

F No sabiendo yo c6mo irme a 103 karibes, me mand6 Dios cinco indios, quienes habla venido trajendo un enfermo a Fanamá. Acomodé en el hospital al enfermo, y luego me fú al Presidente, que tan enpeñaco estaba en la civilizac16n de estoa indios, $y$ le dije cop8 no encontraba la embarcación y como hablan venido esos cinco;que yo se/traeria,pues querían pedirle no sé que cosa, $\mathrm{y}$ que entonces Su Excelencia les mandase que me llevaran.

Ilevélos,pues al Presidente.Le dijeron que ellos no querían Padre,porque nunca hablan tenido Padre. Les pregunto si ellos tenían aleuna queja del $\mathrm{Pa}$ dre.Dijeron que no, antes veían que era buen huaka o extranjero."Pues enton ces dejenlo, que él les hará a ustedes muchos bienes y-que vaya enseñando a los muchachos. Asf-Vãs:pođrán-observar lo que enseña, $\mathrm{y}$ verán que enseña cosàs-buenas." No pudo escapar Sho, sobre todo que se ví comprometido, pues ó venía a pedir exfencion del peso que como derecho de Fuerto les pedín por su embarcación en cada viaje en Colon,y el señor Fresidente había concedido is exencion a trueque de que me llevaran.

A pesar del compromiso de Sho usé de varias industrias para que no se me escabullera. En efecto, me lo llevé a comer conmigo en Colón, j lo hice dormir en 11 habitacion, pues querian irse de noche.Al otro día ise dijo": "Padre,S1 vienes connigo vas a morir, pues el barco hace mucha agua " No illporta, dife,por donde paseís vosotros paso jo. ¿Sabes nadar, me dijeron ?. Fo. "Pues entonces te ahogas". Como ellos vieron que yo no les creía, dijeron, Bho y $10 s$ indios.Que habian vonido a decir que estaba el barco lleno de gína, que fuera con ellos para cerciorarme. Fui y efectivamente emplezan potral tras pozal a desaguar. LEstuve ya a punto de desistir del viaje, viendo 1 Inmimente peligro,pero me di.je:ai muero por ir a predicar el Evangelio 17. mejor oportunidad,Que le vamos a hacer, les dije, no hay otro barco, al 4. Voj con vosotros.Después conocl que todo eso lo hicieron para asustarme 案. 
$-18-$

pues si habla tanta agua era porque en cinco dpas no habla dado a la bomba, yo que en el viaje no cogí el barco tanta agua. He embargú, pues, con mis dos oscristancitos que arriba dije sEstanislao y Leonardó a quienes en la iflesia de la Herced bauticé, bien instruido el 10,de liayo de 1907. IIegados a Portobello;pretendió dejarme en t1erra Sho,y visto que jo no 10 perdia de vista tomb aun blanco para disuadirme del viaje, diciendo que 108 Indios estaban bravísimos y me matarian. Ho 10 consiguib, $\mathrm{y}$ tras trế días $y$ dos noches del miserable barquito, amanecimos a vista de Narganá.lleno jo de gozo empecé a ponderar que era a propósito aquel día del Corpus pars la segunda entrada 30 de liayo. Bnpez 6 Sho a hablar en alto $y$ sincopado karibe, con 10 que jo no podía entender, pero a pesar de las muchas muestras de cariño que jo les daba a mis indiecitos y ellos me habian dado, noté en Leonardo cierto retraimiento y más afianzamiento en żtanislao. wué será eso? me decía pespús supe que Sho me los estaba pervirtiendo para que me abandonaran. Me puse on proa cuando ya nos acorcábamos, como anhelando conocer a los indiecitos que salieron a la playa, y que tan cariñosos habfa dejado en San José, cuando Sho íperiosamente dijo: "Ponte a popa,que los indios están bravos". fio me quería yo convencer, pues sabrosos me los habla dejado. "Donde está carhos?,pregunté a unos niños que con un cayuco estaban pescanão. "B̊ casa"lle consolé, pero Sho, queriendo corregir a los niños, dijo:Carlos se fué a pescara otra isla". Entonces supe que Sho era la isla donde no me habían recibido la primera vez. $\mathrm{Ya}_{\mathrm{a}}$ lo tenemos. No atracamos, pues, a mi isla, sino a ka enemiga. Balieron multitud de hombres que empezaron a gritar, que por que me habla sho traldo, $y$ me amenazaban con los puños cerrados $\mathrm{y}$ uno con un cuchillo. Luchaba Sho en su corazón y no se atrevía a desembarcarme. De una parte su gentilidad, fo otra el mandato del Fresidente Dr.Amador. Y Qué hacemos, dijo?.Llévame a Carjos.- No está , ni vendrá en muchos días quizá un nes.¿Quereis volverte a Panama? En tal caso dije, contigo. "Tení él la responsabilidad, y dijo.Conmigo ho nl hay barco, que éste es del Blo hi bre. Fues entonces me hospedo en tu Pajan , No había remedio, $y$ asi se hizo!Metete aquí,dijo, era un cuartito sobre 1. pallecito bamboleante, que tendría unos tres metros. Nñadi6:"No salgas de Qu que te matan. "Durante todo ese tiempo vino la hermana de Leonardo, y él 17 guardar razones se ech6 al agua, subio al cayuco de la hermana, quitóse 57 1.trario que desde el día del bautizo llevaba al cuello, y lo echó al mar.

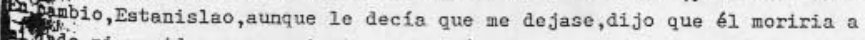
1. da $\mathrm{d}$, nenidos sus parientes, me dijb, hasta que al tercer día que vivia nhision, vino una niria, su tia por 61. Pntonces Estanislao dijo:Padre 20. Hempreno venía de la otra isla a ayudarme la misa que decia yo en mi to, yo pasaba Estanislao el día conmigo, enseñando la doctrina a los ni-

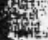




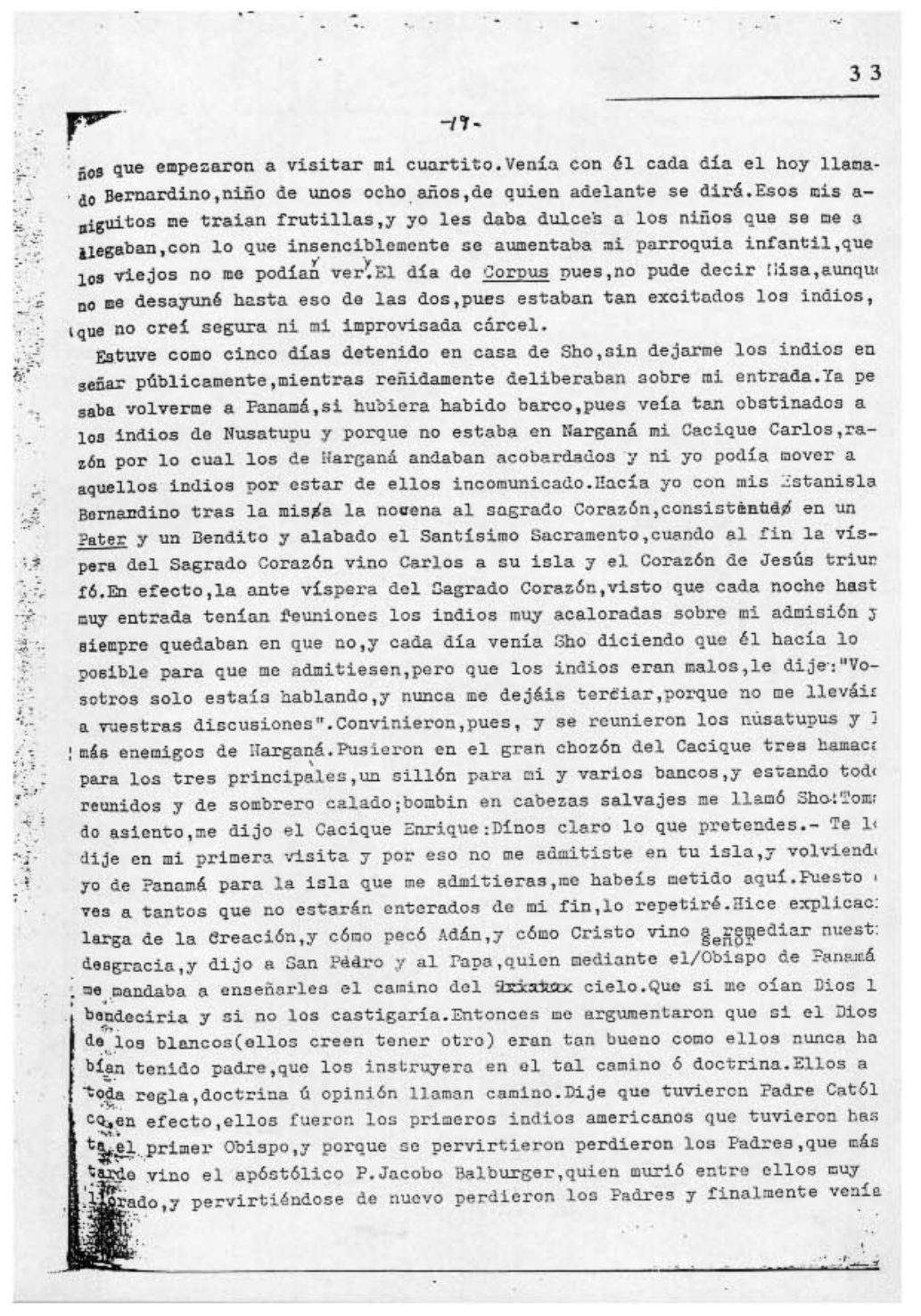




$$
-20-
$$

pora yo.Se desbocaron tres diciendo que yo era un mentiroso,y que fuere rdad o no 10 que jo decía, no querían admitir ningun Paäre,primero por ser tranjero,y ellos no admitían extranjero; segundo porque ellos tenían su le: 511 Padres o absoseti y estaban con ellos bien avenidos.Como os veo tan fu iosos, dije, no quiero ahora decidir, y asi os doy un dfa de tiempo para deli erar. Mañana a estas horas vuelvo,y si la asamblea,ó el cacique en su nombr osos tres sin juicio (estaban esos fuirosos, uno era absogeti principal,o ro un brujo (1), otro un curandero), me dice que me vaya, entonces yo sacaré is zapatos, sacudirélos para no llevarme ni una arenilla de nuestra playa,y is zapatos, sacudirélos para no lios sobre vosotros;os vendrán enfermedades, torracias,moriréis en vuestra infidelidad y bajaréis a quemaros.Tras ese yabrupto me ful sin deppedirme.Se quedaron asustados $y$ gूo admirado de que ublese hablado con tal energla y soltura casi por cinco cuartos de hora er caribe, de modo que jo les entendi por sus interpelaciones y ellos me entenIfin. Duró su reunión,ido yo, hasta las dos de la madrugada.

(1).Este murió a fuego lento, bien embreado, a los dos años, sacrificado asf por los dos pueblos de Nusatupu 7 Nargań, setenciado por todo as pue asistieron a su quema,, $\mathrm{y}$ parece que el juez, que tal dict6, fue Enrique, su adlátere Sho, en una dè mís idas al Fanamé.*

4. la mañana, cuando me levente, vino Sho $\mathrm{y}$ me dice:Padre, sabes que el cacíque stro Inrique está con mucho miedo por 10 que ajer disjiste de los casti: de Dios. Sí,señor, dije, apretando más, os acabaria Dios, si no recibis su ley Enrique, pues dice que quiere hablar contico.- Traelo, pues" Vino j dije:Cuá

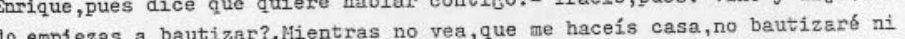
es por eso, dijeron él y el cacique de Ukunseni (a) que par

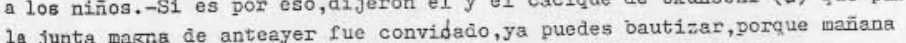
1a junta magna de anteayer fue convidado, ya puedes bautizar, porque wanana se empieza la casa". En eso,1leś Carlos a verme. Hizo ante los presentes un
devota juiciosa espléndida profesion de fé.Dijo que toe quecase en su isla, y como por turno me derían de comàr $y$ me asistirían en todo, nás que a los h1jos de sus casas, $y$ que primero faltaría comida para ellos que para af,pc vo or creía en Jesucristo y no quería ir al infierno, sino al cielo, Yo,1lc

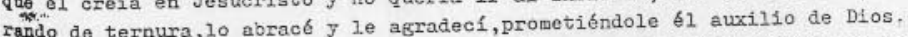
rand de ter hombres, yo lo confesaré delante de pues el que me confesare delante de los hombres, yo lo confesaré delante del T. Pedre celestial. Todo eso fue tras la lisa y novena de la vispera del orazón de Jesús 6 de Junio de 1907, a eso de las ocho de la do comul garia

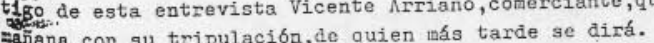

(2). A este cacique, que ahora se llama Santiago, se debe en gran parte W que los indios hayan admitido al misionero, á santiago, y le pregun1hisus buenos servicios a los dos anos le la virgen del plar que la. Carmen regalo a la Misibn. 
$-21-$

A otro dfa,fiesta del Sagrado corazón, empecé a bautizar infantes y ca- 60 de đía bautizaba diez a doce o más, convirtiendo en capilla otra choza más da dia bautizaba de ala del corazón de s propósito. Por Jeś́s y durante su novena, de acuerdo con los principales indios le llamé ISTA DEL SAGRADO CORAZOH DE JESUS "Kuaketupu".

7. Me trasladé a otro día a Narganá de donde venia al Sagrado Corazón,y bau4. tizaba y enseñaba la doctrina, diciéndoles ilisa algunos días.

Por este tiempo vinieron los indios de Río Tigre, 7 una noche,mientras ent otra casa estábamos rezando, rompieron y desbarataron mi casa.Dios castiǵ el jefe,murí comido de un tigre.

- el jefe,murib con cuadro del Sagrado Corazón de Jesús

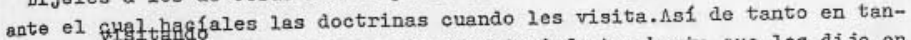
ante el frsttaldo a los indios y bautizando infantes, hasta que les dije,en

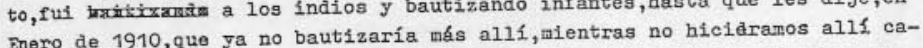
sa-i lesia, cosa que los indios se huian.hlegahdn que ja había iflesia en San José de Narganá, cono si eso bastara tanto más que por neda querlan ir al vecino pueblo pues 10 miraban como ajena.

al vinceros notabbes en esta isla.El 24 de febrero de 1910, en el lecho del dolor, bauticé al moribundo Maninikinia, quien

i) ro de 1lamarme para que lo bautizara antes del norir. Haturo el buen acuerco dan afligido $y$ bla sido valentbr jueria la salud. "Si, Pacore.Pues si te bautizas con toda fó,como testimonio de que nuestra Religión es Pues si te bautizas con toda fó, como testimonio de que nuede, Dios te curarállo le puede hacer rezar las tres veces el Pater I Credo de rúbrica porque daba lástima y así sólo rezb fielmente dos veces, pero con tan buena fé que al decirle Forribce idola, hizo quitar los que bs jo la hamaca le habían puesto. En su lugar pusimos frente al enfermo la imagen que dije del Sagrado Corazón,que traje a América hace unos veinte $\beta$ fion

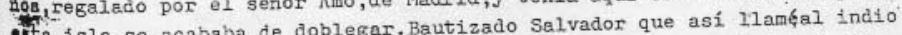
- tha isla se acababa de doblegar. 7y rolvi a Marganá.A los dos días, visto que no me traian nottciak do sal-

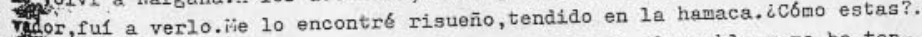
1. I. todo bien a cabo de venir de dar un paseo por el pueblo, y me he tend1.

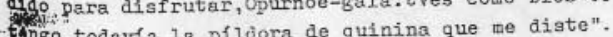

To tovía la piliora de quinina que me dista. Afmbui la curaxión. Yo le había dado la quinina a suegros de la esposa. ixteriví, pues, la oblea.

(n) ntes de este caso, tamoín, antes esta jugen del sagrado corez cha la mujer de éste ge 
Tó estaba furiosa contra nuestra parecer de hacerlo cristiajuício.sluadre estaba furiosa cone 10 bautizara. Le no, $\mathrm{J}$ sobre toco contra mi.El enfermo quiso de pue a la vista la dicha imagen. La mache quit la imagen. Volvi a ponerla en la hamaca del enfermo. Bautizado Nieves, los la imagen. parientes incitados por la vieja,se pueieron como energumenos contra ti. diciendo que mis medicinas esto, es los santos oleoşlos habla matado, pordiciendo que mis que tras el bautis la honra del Santo Beutla reconocen la safud venida por el bautismo. Desde entonces ban tenido en reneracion a 10 indio,esa inagen que estaba on rehenes hasta que el pueblo recibiese la estatua que diré.

lo recibiose la estatua que dis. La gran remora para la evancelacion de este lstote ha sido elaba segun haque Enrique, que en fuerza de mis razones $y$ constancia,me d aba segun haciendo 10 poco que podia; $y$ en fuerza de su pertinaz gentilidad impedia haciendo lo pocos a punto de hacer le cer la casa $\mathrm{y}$ asentarme en el islote. Tres veces astuve a pun al solar con ocasa,j tres veces se desdijeron los indios $y$ me ocuparon al solar con otras casas. Tinalmente a fines de 1909 murí gentil Enrique, después de sen depuesto por sus mismos subditos, justo castigo de Dios,J entró sho, qu1, 16 di 6 muestras de conversión. Por eso el dia del Dulce Nombre de Jesta, 16 de Enero de 1910, recibi6 el nombre de Francisco Xavier, y se alist6 como catecúmeno. Hacía días venía diciendo que siendo 61 cacique, de él depenás hacer casa é ílesia. En tal fiesta, pues,le conviaé a comer junto con el eacique Carlos y su ajudante José. In la mesa descubríó como hasta ahora 2. iba a dos caras para dar susto a Enfrique, $\mathrm{j}$ porque tenía que yo introduci iba a cos caras para dar fur otra parte me ayuaba, porque, veía ser bueno cu ria a kuakue tupu,pero por otra parte me ajuándole su coraź́n doble. Promet to yo enseñaba.Carlos le dio gran carga, afeándole su corazón doble. Sho tener ya une sola palabra, J para nostrarlo "vanos, dijo, a empezar la sa,y quiero Padre que tu estojas el terreno", No había que elegir, pues soj quedaba un pedazo de arrecifre que batía mucho el mar del liorte, habia 2. rellenar un pedazo de playa del tá, dijo el indio Luis, tocándole Dios e cunstancias, Vistas las dificultades dijo Pade vive junto a mi otra casa corazón "cúdo mi terreno,y quiero que el Padre vive junto a mi obra do dío Despej6,pues el solar donde actualmente está la casa-iglesia j mo lo dio 2. Entonces se dis traza para hacer la estatua del Sagrado corazon que

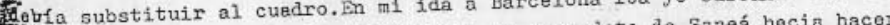
Te aljeron que un sacerdoto de it. 
18 estatua, se hiciera una flesta al Sagrado Coraaon. Ocultan quien paga tales estatuas. Me di6 una tarjeta dicho sacerdote, $y$ con el Hernano Peñalba m les estatuas. Me dib una tarjeta dicho sacerdote ge nos entregaría la estatua.Agradecí al señor sacerdote su regalo para qu 10 hiciera constar á los dadores, diciéndole que procuraría llegar a to de la fiesta,j por eso escribo esto.

Traje la estatua con los demás regalos que buenos catblicos de Barcelona, Valencia, Tortosa, Torragona, Gandía, Zaragoza, Nanresa, Bilbao y. Loyola, me d na, ron para este misio con otras cosas, desde 1907 a Agosto Marqués de Camillas. Estuvo la estatua con otras cosas, desce porque ahí par 1ncidentalmente el barco que la traia a los karibes.Dios castíǵ al dueño lncidentalm a se le ofreció brillante ocasión para dejar de dicho alna pur de que lloranio su protestantísł́mo masónico no quiso convertirse a pesar de que llorando $\mathrm{J}$ era un holandés robustote, me decía que estaba conunicado de la verãad de nuestra Religion, y había visto mi-legros en Iourdes. Murió mas6n a los dos meses de dicha entrevista. Después no me quisieron traer los barcos de esa casa la estatua, porque como protestante, decian,tenían miedo de llevar san- Al fin,los indios determinaroñ.irla a traer en un urkagolo, tronco vacio El actual dueño de Playadamas, que por ser tambíén protestante, no hacía es El actual dueno de lactitud de los gentiles, nos la mandó fuerza por traerla, vergonzado de la actitud decha dicha en un balandro grande que hacía ać venia.jl cacique Sh fue al belandro a recibirla,y aunque el Hermano, mi compañero, desde Narga que dista dos minutos de fondeađero, 1 a reclamb, Sho, no quiso entregarla, al gando que el Fadre les había dicho que era de su pueblo que se iba a conv tir.

Te Septiembre de 1910 con un carpintero negroxpx llegue de naná, elón la csas-igle jamalcano protestante por no encontrar vino también el P.González, porque I Ila , como se hiz由 el 27 de Septiembro. Vino también el p. conzález, porque 1 capitanes protestantes de los barcos que acá vienen, como buenos emisarios ies está con esta diria cancion a los indios. Wois unos ciegos y por esc Nobres, porque no aprendeis letras(el protestante, mientras no hay letra ac (i. la Biblia,y las catumias no pueden entrar). Las letras dqu de coner Za sabían ellos contestar que según a qui W xas 3.

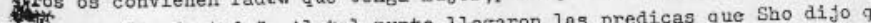
Hos ensenan de todo". Al-tel- punto llegaron las predicas Hoira solo-escuelasy no iflesia.Tube, pues, que traer un Fadre que exclu tha 畒: 
$-24$

- iglesia. $\mathrm{A} l$ fin apes al indio y a los demás de liarganá,que con más respeto decían 10 mismo. Tatal hunos 8.610 indios, peîo cabeza, porque los demás ranfegan de escueles de jankis J. de cuanto diga otro nodo de ser àverso de. 10 que ellos han usado. Al fin,todos se me sujetaron mejor que antes apeándolos de aquellas iajeas de los protestantes, que en naca pegan con el 1 pobre indio,que no ha nacido para bellos ideales, porque han topaco con quien conoce lo que son indios. $A y$ de los pobres indios cuando catblicos, les patrocinan aquellas ideas para ellos!. Serán victimas, como 10 han sido todos los demás en donde han ofotradi.

- Se trabajo,pues,con arajor en la fábrica de casa e íflesia y en el calor de la obra, aijeron los indios que en premio, quierien ver la estatua. Como aqui no hay cuartos donde suardar cosas, $y$ en el ca,jon venían tras cosas, a610 pretendimos destapar el rostro, Cuando vieron la dulce mirada rodeada del envoltura se quedaron sobrecogidos. "A, 7 ", gritaron, si estál vivo, pues nunca ellos habían visto un rostro de estatua.Hincados hicimos una consagracín y rezamos un Credo luego un Padre nuestro por el bienhechor. Esta fies ta, aunque sencilla,debi6 ser muy acertada al sagrado Coraźn, oyendo las roces de estos gentiles $\mathrm{J}$ catecúmenos.Luego cuando más tarde descubrímos la estatua, hallamos junto a la orla del vestido,esta inscripción en lápiz. s.Adria de Lleida, que deberá ser del artífice.Deseo conservar el nombre de tan buen acreador a nuestro recuerdo.

E1 4 de Hoviembre nos volvimos,el carpintero,el Padre y yo á Fanamá, dejando ja cerrada y teclada casa é ílesia si bien se acabó a primeros de Enero de $1911 \mathrm{y}$ en 15 de Enero hicinos la prometida fiesta en la nueva cristianidad, exhibiendo el Sagrado Corazón, haciéndole el pueblo el besamanos, celebrando una Hisa, 10 más solemne que pudimos,j haciendio nueve bautizos de infantes, dos ce ellos gemelos hijos del cacique Francisco sho. Por la tarde en la procesión, el Corazón de Jesús recorríb el pueblo para tonar posesi6n. Se dejo en la nueva iglesia tædo lo necesario para Higa 5 bautizos de 108 regalos traidos de Barcelona, Tarragona, 31 no es un hermoso cáliz que el señor obispo de Panamá, P.Francisco Xavler Junguito, conagrob.

Aunque ya qued 6 como establecido este pueblo, con todo hasta el 31 de Jplio no se hizo la inauguración siemne de la f́glesia,pues para eso día Be le habia de dar la vara de autoridad de Cacique a Francisco Xavier Sho nombrándole los ayudantes y demás empleados del pueblo. La procesión ese Tia fue en honor de San Ignacio. (a). (a). Contínua en la página 143 . 


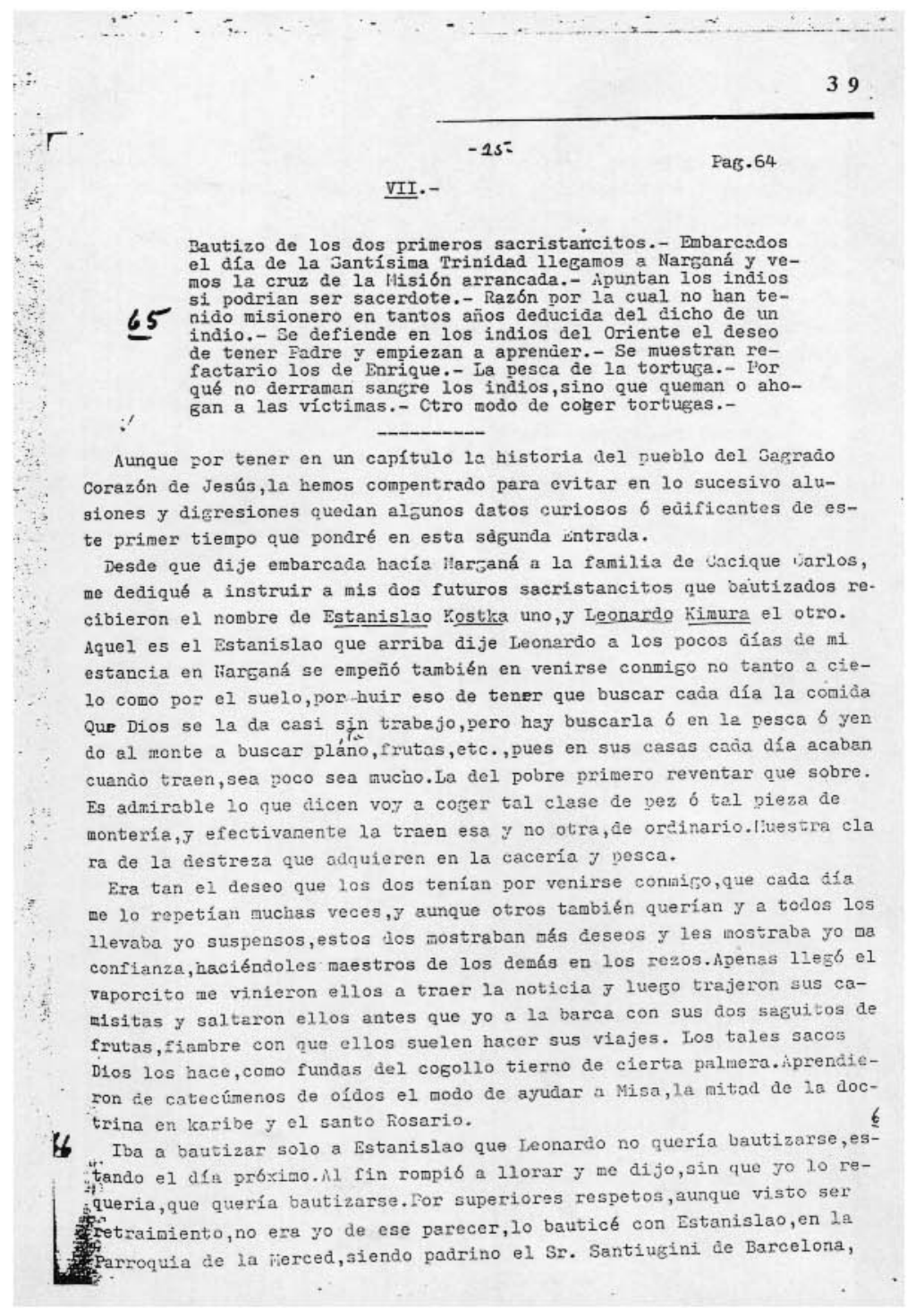


$-26$.

recino nuestro en Panamá.El mismo día comulgaron todos en la Plisa que les dije en la capilla de la virgen que está al pie y fuera de la larroquia, ínico santuario por desirle naf ce est, civdad.

Entretanto iba yo buscando bareo para volver"a la Misión,concluidos ais apuntes de lengua Karibe y diario,pero naciie me queria llevar. En efecto, supe que él que nos había llevado de práctico en el vaporcito famoso, había hecho correr, $1 a$ especie que on un pueblo más allá de tlarganá,los indíos habían querido matar a la tripulación,porque me habían aportado a Narganá,tierra de indios.Por eso tambłén el aueño del vaporcito no quería que to me embarcara.Dios los cestiź, pues el taf "vaporcito fue declarado por el Gobierno inútil, aun para el astillero, $\mathrm{y}^{\prime}$ el tạl práctico pasó poco después a un barco de vela,y se ahogó, beodo, precisamente prackxtespurús entre mis dos islas de Karganá y iafrado Corazón. Hlay que ayudar en las empresas de la salvación de las almas.

El día 26 de Haj̧o,pues,fiesta de la jantísima irinidad, nos embarcanos ais dos sacristancitos yo no en el haxzm miserable barco de Sho, como dije animado con el Ecce, volviacum sum, unţes docete de la lisa de hoy, acordándome que tamooco a San Ifnacio le quisieron llevar en el barco bueno a do de llez6 con el barco medio descalafateado.ion qué calmas $y$ soles sin agua en el día y con lluvia de noche sobre cubierta,porque no habia cámara

El 30 día de Corpus aportamos a llusatupu,donde a las injuries $\mathrm{y}$ amenazas que los indios me hacían por mi venida,se añadí la pena de ver a Leonardo que, arrancándose de mi iả̦oşaltó de un urkarjolo 6 barquicuelo y sacéndose del cuello el hermoso tosario del día del bautisno, lo echó al mar $y$ se fue sin hacerme caso.

En eso reparé que en mi isla de enfrente, llarganá, no estabe en fiesta, la fran cruz que el dia de "Viernes Santo" habianos plantado.iQque he hecho?.El cacique grande i.e.Enrique, dijeron unos niños la liizo arrancar y F echar por manos de los niños (muchachos)en elfiar bien lejos.-iYa la teneF zos! , Iuego ciertos son los toros me dije, hoy me matan,pues los viejos 6 . estaban tan furiroses, Sho, quiso disimular $y$ dijo que los hombres no se $6 i$ babian metido en eso,sino que fue un juego de los suchachos $y$ que eso le: dijo que hicieran un janici(de los protestantes masones sería) que por acá vienen a comprar ó cambiar cocos por géneros.iQué niradas de odio satánico me dirifian alfunos indíost.Ml fin, Sho no sabiendo que hacerse co vigo,pues me había traido por encergo del Presidente como arriba se dijo 3 vienco que yo le decía que me hospedaria en su casa, me enñaló un cuartito de unos cuatro metros cuadrados de tablas cuchillado que tenía sobr el bamboleante ruellecito que se había hecho para cargar $y$ descargar sus cocos al urikarrolo añadiondo: No salgas de aquí porque to matan. Ese miedo fue el centinela que me puso $y$ entorno la puerta. Afortunalamente alsuna 密 
tablas del piso sobre el mar estaban mal clavadas $y$ me alegré por tener alli un desaglle.A poco que hayan leido estos viejos se les había ocurrido la dificultad de los tales desar;les; $y$ cierto que es un punto dirícil en tales barquichuelitos a veces mismm por uno $\exists$ dos días sobre todo on los primeros viajes que hice que debía ir con tanta cautela por ser la Gente tan orífinal como se irá viendo $y$ aun en tierra es difícil porque todo el tan oríginal como se irá viendo y aú ecupado de casas hasta la misma orilla del mar. For eso los medios para el efecto se meten on el mar.

Dolíame, nues, mucho la cabeza por falta de desagles en los uías de narega cibn y por falta de agua para beber que me repugnaba la poca que había,y falta de dormir $z$ de alimento, pues ya era tarce y estaba on ayunas.Tensé que me llevaría a mi isla de San José donde diria la piisa en día tan grande. 'rodas egas circunstancias,y la falta de saguridad entro jontiles,y la sobra de amenazas me determinaron de dejar la Misa en día tan clásico.lí fiel Estanislao, que ní invitado quiso irse a su casa,fue mi companero en esta original prisibn.Al poco vino Sho,trayéndome tres plátanos asados, un par de huevos $j$ un pedacito de tocino asado on las brasas. Fos repartimos la comida mi Estanislao y yo.El cuartito dicho tenía otra ventaja $y$ es

que estaba solo,si bien sobre el manso mar del arrecife,pues Sho vivia en su gran choza dentro de la isla.En ese cuartito, pues di.je Misa,estos días y recibí las visitas prinero de los niños y después de los mozos, que con entusiafios empezaron a cantar Ave Karía $j$ el Rosario en karibe $y$ luego entusiafos empezaron a cantar Ave Varía j el Rosario en karibe y luego el cuartito quedaba enfrente de la actual casa que hoy tenenos en San Jost de Narganá y había como dos 6 tres minutos de distancia.

\section{Día 31.}

A pesar de tan mal recibimiento, observóse la costumbre de los indios de presentarse el viajero 6 presentarlo a la asamblea/que cuente lo ocurrido en el viaje.si el viaje es de poca monta, la asamblea $1 s^{\prime}$ constituyen los nayores de la familia del viajero y algunos curiosos,péro si el viaje es de trascendencia como este de Sho, se reunen casi todos los hombres del pueblo en casa del cacique $y$ colsando tres hamacas en el centro de la ca8a para los tres principales $J$ luego tablones 6 bancos burdos al alrededo: de las hamacas para los asistentes se da cuenta por el jefe del viaje, lacbaja hente pero sin dejar el más mínimo suceso y todo eso con cierto rit cobicamente pero sin dejar el más mínímo suceso y todo eso con cierto rit no a cuyo fin de estrofa el cacique $\delta$ el que recibe la cuesta contesta con el itosolooor dentar en la hatacion, ja obscurecido, a casa del Earó tal prenda allá,quizá de algún buque que teaca sino en sillón. Me extrañó tal prenda allá,quizá de algún buque que 


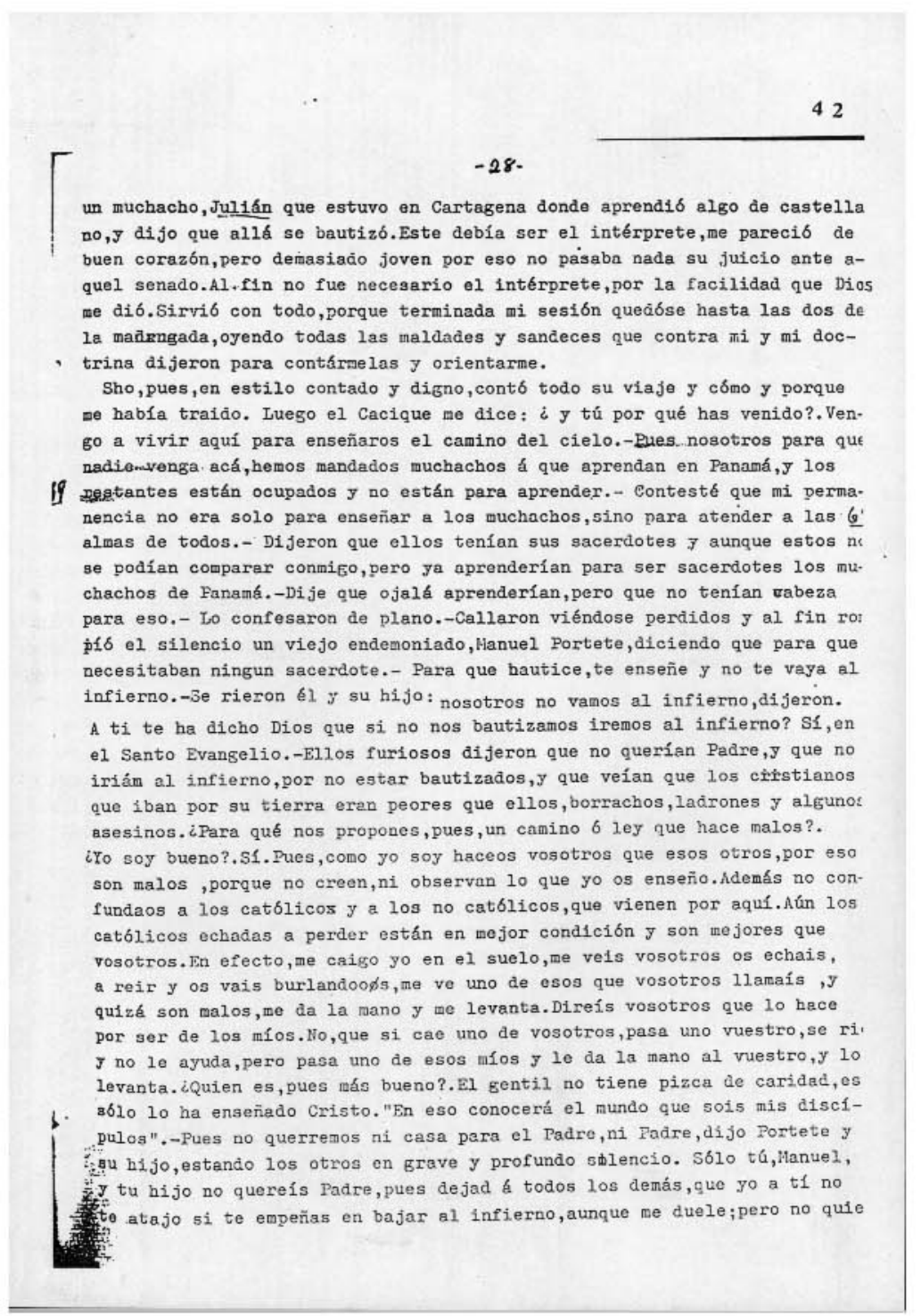


ras que estos otros y tantos niños se priven de Dios por tu culpa.- No so? yo solo, sino todos los hombres $y$ mujeres dicen 10 mismo, $y$ sino que hablen

19 I Atemorizados a media voz,dieron a entender bastantes que no querian Pad I menos la casa en sus tierras. Finalmente tras unas dos horas en que repi. tí eso de varias maneras dije, que jo me quedaba aqui, aunque me mataran,p: ra salvar los que quieran salvarse. Diferon que no querían matarme, sino q. 1 no querían huacas 6 extranjeros [Parece le hizo efecto al dicho de Sho, qu interpelado antes por uno por qué no me mataba, contest6:Y después vendrá Gobierno de Panamé y nos matará con fusiles a todos.

70 Olvidábame,que el bijo del Portete el f́ltimo argumento gue me sac6 para admitir Padre fue que ellos nunca habían tenido Padre $\mathrm{y} / \mathrm{si}$ el Padre fuera necesario para ir al cielo. ¿Como Dios los habia dejado hasta ahora sin $\mathrm{Pa}$ dre?.iOh justicia de Dios! porque vuestros mayores no se aprovecharon de los que Dios mando,por eso los perlisteis en la extincion.- En efecto,es sa digna de meditación la justicia y providencia de Dios en lo que me dij hace veinte dias en Panamá un indio de estos karibes del Atlántico,aunque vive entre los de la parte del Pacifico,el cual sabiendo que yo habla hecho la primera entrada á los karibes, vino a conocerme teniendo por milagr mi 1da $\mathrm{g}$ regreso, Dijo. Hire, Padre, de mi region del Facffico todos los indios son bestias que no piensan nás que comer.S610 jo, otro Rafael cristia nos,, un gentil bueno pensamos en Dios. De la otra región del Atlántico só 1o en Harganá, en Rfo Azúcar y Tupile (hoy San Ignacio de Tupile) piensan bastantes en Dios.Los demás no piensan, sino en ser bestias. Con Justicia Dios me ha traido a esos pueblos tan sin pensęrlo yo.- ¿For qué, pues, deja Dios a los demás gentiles?,-Porque se niegan a las inspiraciones, $\mathrm{y}$ Dios e justo y los castiga terriblemente dejándolos como bestias gordas por esos bosques.

$$
\text { Dia 10. de Junio. }
$$

Tras la Misa me vino Sho con el cacique, por efecto de las amenazas de a yer de 10 del Gobierno,está atemorizado. Inttium,Sapienti timor Domini. Aprovechando esta buena disposicion antes que se empenvasen las circunate cias le d1je.a Sho que me llevasen un pato a la otra 1ala a ver á mis ami ifos. s610 ví á algunos,me dijeron que ellos estaban fieles $\mathrm{y}$ me hariar. ce sax, que solo aguardaban viniera Carlos de su pesca de tortuga dentro unos dias. He resolví pues a estar en mi cuartito, aguardanão la hora de Dios.

1. Vino a visitarme en mi cuartito un negro comerciantillo. vuenta que vier 3adel Oriente de alrededor de los indios de Tupile.Están esos indios quejo(a) porque no he ido a su tierra y los muchachos van en sus pescas cantar - Co:Viva Santa María.Durante mi estancia en Panemá fueron algunos a aprenis: 
aabde-tosade-largań y llevaron a ofúle- la semilla que Carlos y el fiscal José hablan fomentado.

Dia 3 de Junio.

Cada día comulga mi eacristancito en la lisa que a puerta cerrada dig - pmpiezan los mozos á aficionarsenos y nos atisban por los rendijas.Así, pues, dije las estampas de doctrina.Habido el permiso, un rabo les enseño a rezar $\mathbf{t}$ otro les explico cuadros a los curiosos. Me ofrecieron dos niños para bau tizar,pero como veo que los viejosho quieren ser crístianos esperaré.

Dia 4 de Junio de 1907.

Todas estas noches tienen sus juntas liablolicas los viejos,y de todas resulta; "fuera el Padre y sobre no se haga casa para el ladre". Sho cada día se vende por mi amigo y cada día dice:Yo te ayudo lo posible,pero lc indios son malos.iloy, pues, le dije:Claro,estaís vosotros solos hablendo, no hay quien conteste a las dificultades,por eso no resolvemos wada favc rable. Dejadme ir a vuestras juntas y veréis. Convino Enrique $y$ me prepare ron la casa como el día 31. Endemoniado sanefium. Convocaron mas indios ? absogetis $\delta$ sacerdotes. 1 blanco de la cuestión es si se ha de hacer ca: a. Fadre.-Se resisten, porque eso es tener un Fadre de asiento en el pu blo, $\mathrm{y}$ eso le duele al demonio.- Al fin terció en la cuestión el cacique joven de Ukuseni al que hoy llamamos Santiago) el viejo es otro,j me d: jo que él queria bautizarso:parece de fino corazón y apacigú á los vie. jos furibundos. Hoy estaba la gente más exaltada que el otro día. Sobrepo. ní́ndose, pues, Santiago resolví́ que iria una comisión a Pananá a pregun tar al Tresidente si me habian de hacer choza. El negocio era dar la togas Dije : iPara qué ha de ir la tal comisión a preguntar 10 que gidente dice en la carta a Dnrique?Volvamos a leerla. Iba Inrique a baja la del entabladito que como piso en su choza tiene, y le gritó Shó. No la bajes, que está demasiado claro. Lo que Sho,queria era ver como raciocion

72 do podrían encontrar alguna interpretación por donde escapar. Luego en a to karibe,para que yo no entendiera, dijo me dijeran que yo no hacian $c a$ sa,porque habian de oir antes $\mathbf{a}$ los monteses.iVaya unas bestias endemon das los monteses.Se descubrí, pues la perfidia de Sho, dije cómo eran ta infelices,que querian servir al demonio,que no les había dado nada,y en cambio se resistian a Dios que les habia dado todo $\mathrm{y}$ les queria dar más Les duele a los viejos que les arranque el demonio como se les arrancar 
$-31-$

las muelas.Asi, pues, como les he dicho tantas verdades $\mathrm{y}$ tan vehementement están los viejos cono jadeanco de la batalla,y así como postrados ja no se atreven acontestar. 3610 el sacerdote de más prestigio dijo,tapándose 1 cara con el bombín (muchos usan sombreros bombín, cosa que cia risa en un salvaje) que jo era un mentiroso al enseriar que si no se bautizaba iban a infierno. Que êl también sabía para poderme contra decir. ¿ọuién eres tú?.

't le di.je.Se tapó más la cara y dijo:el Gran cacique de Nargená"(1). Fues au

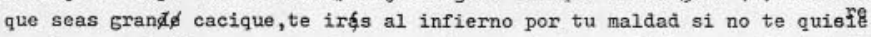
ras hacer cristiano a quemarte para siempre." $y$ les volví a repetir toda I doctrina como el otro día,para que no dejase ignorancia,ja que hoz parece se desdecían de los buenos sentimientos de días atrás.Quedaron taciturnos y se les veia la tempestad de su corazón.isí, pues, teruiné dicienão que si efectivamento él era sran cacique $z$ a nombre de todos, $j$ la junta tacla, me echaban y yo me iria de la isla, pero que al quitarno yo los zapatos para sacuairlos y ni un granctle arena de ellos llevarme. Dios les castigaria co enfermedades, etc., que les daba un día de tienpo para deliberar y exabrupt fuí:

Como yo entonces no sabfa si había alguno sobre el cacique Larlos,
no se pude entonces echar en cara la Gran mentira que acababa de deno se

Dia 5 de Junio de 1907.

Todavía ni viene Carlos ger mas que se le llama,único que podria contra rrestar la influencia de/zax viejos.Los mozoz sí se portan bien rezan y cantan con fruición.

Hoy trajéron un tobugón espantoso. La pesca de la tortuga tiene a los nás de los indios entretenido.Ponen una red rectangular de unos 20 retros de largo por tres 6 cuatro de ancho:un ángulo atánlo a un palo dẹ balse muy liviano, el ángulo corresponaiente on la uisma línea, atánlo/una tortu 73 ga hecha también de palo de balsa que se llama tortuguilla, que representa la hembra. Ese lado de la red queda pues, a flor de agua, suspendido de la tortuguilla, por un extremo y del palo de balsa por el otro,al lado opuest recala dentro del mar. Viene el macho $y$ aun hembras a jugar con la fingida hembra 6 tortuguilla con 10 que se enreda por poco que se descuía la ver dadera tortuga en las zambulladas que da con la tortugilla.Al principio no se da por entendida, siguiendo el juego, sigue el enredo hasta que le es imposible el menearse.

Cada mañana vista el indio sus redes hasta que ve las dos tortugas enr dadas flotan junto al palo que como barca está fijo en el peso que por el ́́ngulo de bajo del palo a modo de ́́bcora lo tiene sujeto.As1, ya el punto esta en subir al cayuco patas arriba al animal, chmo una caldera quítándol 
$-32-$

1a acción de sus remos.- Llevada a tierra de alguna isla vecina, la desnudan, le amarran las patas $\delta$ remos,,$y$ a casa, tocando de alegria por la presa una gran caracol.Si el indio tiene necesidad de carne,tiene que ir a una islita a como a diez minutos de la casa,donde destroza el animal sofocado 6 muerto de hambre, pues las mujeres no han de ver sangre,porque si la ven dicen se les alborota a ellas, $\mathrm{y}$ ademṕs les da asco de comerla tal carne ( Pero si el indio no necesita carne, ante su casa enciende mechones de heno que aplica a cada escama, J va así con el calor 7 con el cuchillo desconchando el carey,teniendo al animal amarrado.Este, durante la dotorosa oper ción, de tatho en tanto fatigosamente y sorbiendo el aire con sordo ruido, levanta la cabeza $y$ ojos abiertos al cielo y abre la boca para respirar fuertemente, de.jando de nuevo crer la cabeza de colpe en ol suelo.iTipo de paciente sufrimiento!. Descascarado asi el animal lo suelta el indio $y$ fatígosamente se dirige con sus remos hacía el aqua,parece huelan el agua aunque no la vean,llegado al mar, como una flecha se desliza para ordinaria mente ser pasto de otros peces, pues va ya sin defensa..115unas veces vienen $($ pues se vuelven a pescer tortugas descascaradas.

(1)

Hoy ya matan las tortugas y otros animales, pues en estos cinco años tanto viaje de los indios a poblado se ha dado dudn más a comer y se es ha pegado de apetito a las mujeres aunque a las veces se muestran esa comida.

Lo gracioso es que quienes tan cruel operacion hacen, tienen horror V.E de matar un cerdo,y dicen que los huacas son unos sanguinarios $y$ bárbaros que derreman y sacan santrre de los aniunales al matarlos.Cierto día andandc el tiempo,me trajeron de rezalo un pedazo de cerdoiolá! y ieste cerdo quie lo mató?.Nadie. Tues, cómo traes este pedazo?. Lo hemos ahogaco, pero no matado.Es que por horror a la sangre que dije ataban en esos tiempos el cerco a la popa del urkarolo $\mathrm{y}$ arreaban por el mar, hasta que al infeliz le entraba el afua por donde los naturalistas saben y fehecía ahogado. For el he rror a ver sangref,quemando a fuero lento a las misinas mayores o sepultan vivos a los infantes, como se dirá.

Volviendo a las tortuças, el modo dicho es uno para cogerlas.otro, es que los aninalitos van a las islitas arenosas a buscar sitio para su desove. zocontrado, cavan y se sientan cabeza recta arriba,y inientras ponen sus cuarenta 6 más huevos,bien pueden venir a cogerlas que no se han de menear de la operación.Si felizmente nadie las inconodo, sepultan los huevos con aus remos,y después de pasearse en todas direcciones para despistar las huellas $\mathrm{y}$ después de entrar $y$ salir varias veces del mar para señelar varios y confusos derroteros se va para volver en día fijo,creo que son quir $c e$, mientras el cazador que logro ver v.gr. la flitima operación vuelve en

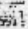




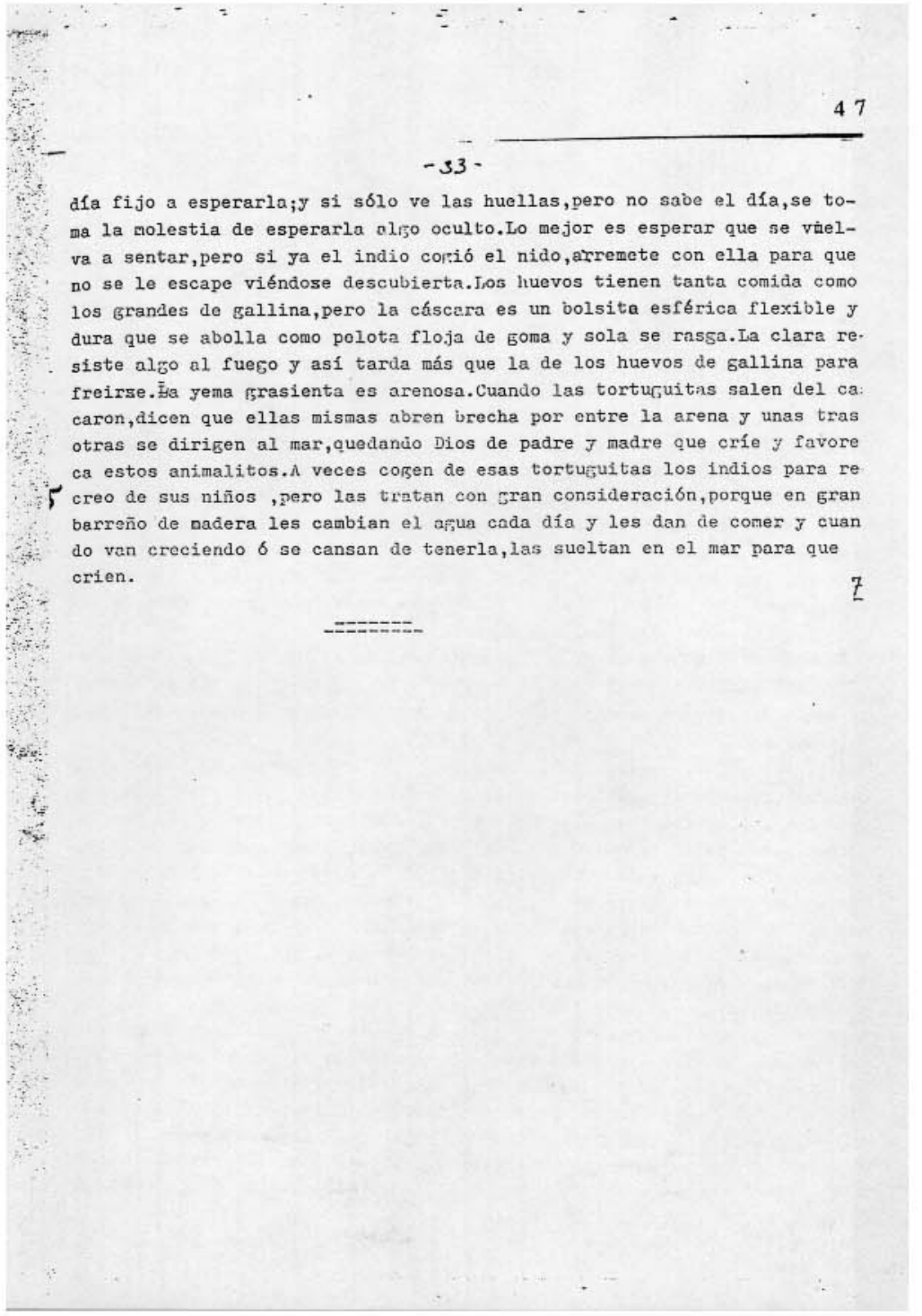




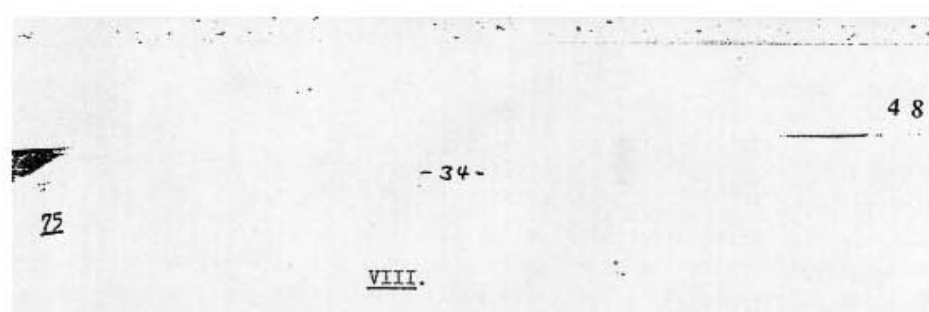

Este territorio se llama por los españoles Costa De San Blás, como trae ol regio cronista Oviedo; todavía se conserva ese nombre en Fanamá.Se lla- mó también Tierra Firme a toda la vastísima costa,por contraposicion a la islas fronterizas de las Antillas. Fernando el Catblico dividio Tierre Fir 留 con dos provineias pasando la línea divisoria por el Golfo de Urabá, de Norte, sur al extreno casi de nuestra actual fiisión. La parte de levante se llamá Nueva Andalucía, la de poniente, Castillo de Oro.Apenas se fundó la Capital "Santa María La Antigua",ya luefo encontramos a Castillo de Cro dívidida en otros como Departanentos.

6 Por 10 que a nosotros toca, se llamó Darién o Jariel Garién se divias 6 luego en tres provincias:Darién del ilorte 6 Costa de San Blas,propiamente dicha;Darién medio 6 sea La Cordillera, Darién del Jur, o sean los que hoy se comprende en los territorios de Chepo, Bayano y Canas por levante $y$ poniente de cara al mar $\mathbb{P a c}$ fifico.

El archipiélago que al pié de la costa del Norte hoy se llamb "de liulates", pues como dije Wo.I mula en karibe dice gallinazo(especte de cuervo: de donde los espanoles, españolizando la voz,deritaron el nombre de Islas Mulatapd.

Este mapa,pues representa la Costa de San Blas, lo único que he corrido desde Playa Chiquita, anejo de Santa Isabelpor el Ceste, morricrestr hasta Cabo Tíburón, extreno de la República de Panamá por el Este.

Los grados están pintados desigualmente, porque hice pasar las líneas pt donde en los mapas suelen hacerlos pasar, ya que no tuve oportunidad de $\mathrm{cr}$ parar, no porque no lleve el terreno la configuración que pongo.Parece qu los autores de los maped que he tenido á la vista no hayen tenido la pro. phruat ligidad de tomar con exactitud el dibujo de esa Costa, ni la postcion de varios islotes. De donde han venido descripancias que hoy ja son percept1les.ᄉa1 v.gr. Las Islas de Ratones están pintadas en los mapas a. chos en sitio distante de donde en realidad están y hoy nombres de terr: torios que son de alfunos conocídos por el nombre de otros.Conjeturo gue estrecharon en los nombres el terreno entre $78^{\circ}, y 30^{\prime}$ y $79^{\prime \prime}$, por ser el m nos poblado,si no es en su extremo Deste.mi objeto ha sico dęr idea del territorio de la actual Misión. Debo el traslado $\mathrm{y}$ arreglo de este dibujo a un Hernano de la Doctrina Eristiana en Col6n.

Como no era posible apearse en los poblados, pues entonces los indios n 10 peraitian, como $n 1$ aún 10 permiten on varios partes, tuve que averiguar t: 
1 número de habitantes por el número dả casas, $\mathrm{y}$ por eso pongo a cada pueblito el número de casas que desde el nar pude contar.Cada casa supone por término medio, véńtite almas.

Los puntos asf ..... dicen el camino que siguí la fasolina.Las rayas sí l,perpendicular a los puntos, dicen la distancia del números de las millas gue vapuntadas en el mapa sobre los puntos. Las islas habitadas, laras pequeñas son distan puras habitaciones 6 doraitorios, por decirlo as del continente de 8 a 18 minutos comunmente. otros muchísimos islotes inhabitados 7 muchos ríos sin interés hoy pare

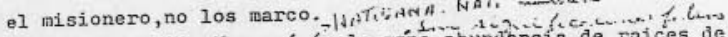

Por haber silo karganá (nalo géna, abundancía de raices de cañas bambue te rio donde hay abundancia de raices bambues) el primer pueblo que the admitió,se le hace el honor de que dé nombre a toda la iisión.

Ios islotes habitados suelen tomar el nombre del río vecino del contiLos islotes habitados es el camino oblisado pere ix nente que parte a los indios de agua $y$ que es el camino oblisalo para 1 a las rozas y cacerias.Asi la isla Kardi (kala tí, río de log huesos) to el nopre del río vecino y Hiatupu (nia tupu,isla del Diabo) del río vec no a unas seis horas gús el Este de Narganá,etc.etc. no a unas seis horas más el iste de Narganá, tc.etc. del Darién del Harte.

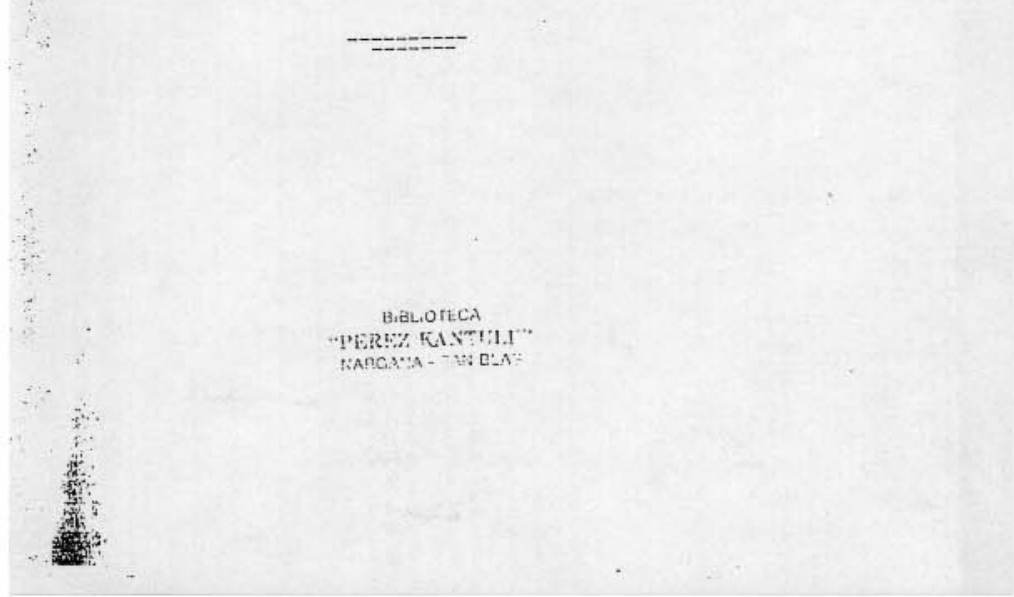




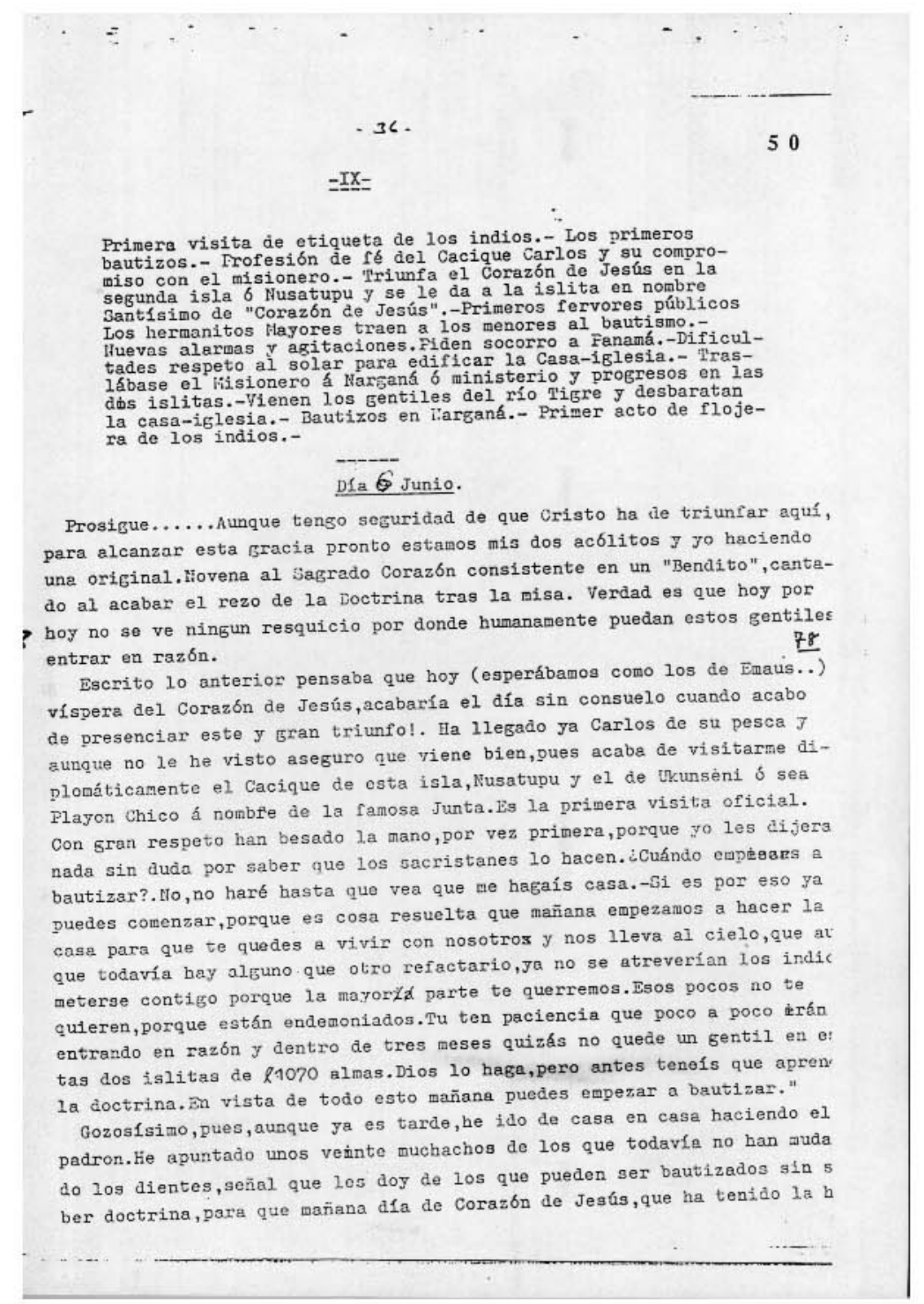


billad de vencer a estas gentes tan suavemente, Be hagan alganos niños bifos de Dios, a gusto y peticion de sus padres.Tarea tienen las madres, pues les he dicho hagan una camisita blanca para vestir a sua hif1tog al tiempo aceipe vestum candidamquem immaculatum perferas ante tribunal Domini nostri Jesucrite, etc. Andan en ello con girande fervor.Por fortuna , tienen costumbre de pasar hasta bien entrada la noche largas horas embastando fuertemente sua adorndisimas chambras, que esa lo que se reduce su cosia.

Dia del Corazb́n de Jeś́s.Tras la Misa traido los chiquitos por su padre 6 madre operacion larga, sentados los padres 6 sus representantes en hilere para que no se me trabuquen, por el orden en que la vispera se escribierc estando los chiquitos desniditos como suelen,j los padres con la camisita al brazo, les explique las ćremonias y eficacia del bautismo. Aoabado el bautizo, les puse une medallita, con encargo no se la suelten para que huya de ellos el demonio,idea que les cuadra mucho $y$ para que al encontrarme con ellos los reconozca y les haga fiestas con lo que cobran gran cariño al misionero, cosa necesaria en cristianos nuevos.

Dl Ságila o Cacique a falta de fiscal de Doctrina, sostenfa la cruz durante la ceremonia, obligándole as 1 á venir, para que vea 61 quienes son 10 : bautizados,y me descubra los que faltan y explique 10 que jo con pocas pa. labras 6 impropiamente digo. Como al Cacique le doy mucho honor en eso,y en el tomar el desayuno juntos, $y$ en hacer que todos le saluden como a mí con ól."Álabado sea el Santisimo Sacramento", $\mathrm{y}$ aín algunos por descuidop le besan la mano, está êl muy sabroso.

Hoy ha habido seis comuniones la de mi fielísino sacristancito Estanislao,que comulga cada día.ioh que angelicall la del sacristancito arrepentido,que eyer vino con su madre rogando que le admitiera de nuevo coma a hijo,y la de unos blancos.El capitán de éstos, Vicente Arreano, el més bueno:de los huakas cono-dicen los indios se ha confesado a vista de los gen tiles para-edificarlos.El, miełntras se confesaban sus dependientes, explicaba lo de la confesion y comunion a los indios, pues habla bien el karibe Ha venido tras eso Carlos a visitarme diciendo que no había veniâo al principio de esta mi segunda entrada, porque estaba pescando lejos, 3 f́l sblo tíene que atender a a ramilia,y como Dios le ayudaba en la pesca de tortugas, 11 eg 6 a coger once, quiso aprovechar el lance para de paso $y$ con su tardanza ponerse encima de los habladurlas de los contrarios que susurat 
d1jo, que venfa cuando querla"(Esta 1 dea es de ciudadano libre yankl. Ba una de las 1deas que trajo de Estados Unidos de Amérlea). Añadí que 61 hoy empezaba la casa con su gente para mi,porque me 10 habia prometido cuando fue a bautizar y confirmar a su hijlto en Panamé, y tambí́n lo habla prometido al Presidente ante $m 1$, que él pasaba por encịma de 10 que dijeran en contra los indios viejos y los monteses bravos que todos en su isla de Sen José de Nargqná, me querían como a Padre suyo,y no temiese nada porque todos los muchos fieles me rodearian, que no me faltaria la comida,pues cada semana se encargaría una familia por turno (1) de toda mi manutencion, $y$ que primero las faltaria á ellos comida que á mí;que él sabia que mi misín era enseñerles y encaminarles al cielo, aun a costa de mi vida, y que porque 61 sabía eso,por eso me quería más que 61 crela en Dios uno $\mathrm{y}$ en Jesucristo y le querla amar y temia condenarse $y$ por eso quería ser buen cristiano $y$ deseaba que su gente pensara como $f 1$.

He levanté llorando, comparando mí entrada, dia de Corpus con esta salida de la novena del Corazbn de Jesús; icomo Dios cambia los panoramesl y ante los á́gilas del Sagrado Corazón y de Ukunsent que a la llegada de Carlos habian ocurridi y ante Vicente Arriano, que presencí $\mathrm{y}$ comentó tódo,abracé a Carlos y lo dije como Dios providencialmente lo había escogido para ayudar a la salvacion de sus nacionales, y que Dios en este mundo lo bendeceria con la pesca de tortugas, que ellos tanto aprecían, $y$ con el respeto de todos,y en el cielo como aṕstol, porque ajudaba al Padre,representante de Dios, en la salvación de las almas que advirtiéra como el otro ságile de de Dios, en la salvacín de las almas que advirtiera como co las virueChachardi, Inanakiña que me quiso venir a matar, Dios lo mató con las virue-
las.
Dijo que todo era asi $\mathrm{y}$ que,porque 61 conocía eso queria llevar a su $\frac{81}{8 e n}$ Dijo que todo era así $\mathrm{y}$ que,porque él conocía eso queria llevar a su ge 作 mandar lo bueno aunque se le opusieran 1.03 malos, y por eso pasaba por cique mientras no estuviese hecha la casa no se despegaria de mi lado,pero que me abandonaría sino que pondrfa quien en todo asiatiera y êl we vendría a visitar a menudo; que deseaba que su pueblo fuese modelo de toda la gentilldad, y aporeso les enseñase b1en a sus gentes, que los blancos no querian que yo dstuviese con ellos, porque creen que con mi roce se harían los indios muy hombres y ja no les podrian engañar pero que él conocie los indios muj hombres y ya no les podrlan engañar pero que él conocie elucinar que finalmente él hacia todo eso porque crefa que debía hacerlo para para poder ser hijo de .No regults oso prón a saber:que cada dia, 6 cuando querian me traia cada un also $y$ guardando yo las cosas de eso me sustentaba y aun se sustentaban 103 va-

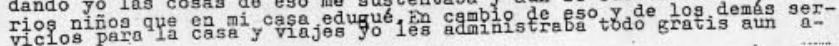


$-39-$

atendíndoles en su negocios $\mathrm{y}$ enfermedades con medicinas.

Tras tanta diablura de los dias pasados, ¿c6mo no me desharia de gusto al o1r eso?.Dfjeles que los ságilas 6 gobernantes son representantes de Dios $\mathrm{y}$ yo harfa que el pueblo los respetase ya que en ellos, como decia Vicente no hay ninglin respeto, ni aun el de hijos para con sus padres. Andando el t1empo v1 cuanto les encanta ese respeto a los mayores que les he procurado meter.

Pensaba yo que en este mes de Junio debla haber almas fervorosas por Ea. paña que pidiendo al Sagrado Corazbn la conversión de los gentiles aplico el Señor los ruegos at en beneficio de estos pobres; de otra suerte no sé como se convirtio este 1slote.Por ser hoy día del Corazon de Jestis antes que se levantase la sesion y se folviese Carlos á su isla de común consen timiento, nombramos a esta Isla del Sagrado Corazon 6 sea Jesús Huaketupu. Hoy, pues, ha cambiado por completo el panorama. IOh que harmoso eso de que vayan en sus bautizos á toda hora cantando el "Ave Marla" y el Bendito" y saludando con el "Alabado", etc.los que aln no son cristianos.Los tuchechos parecen me quieren más que a sus madres.Hasta los borrachos que eren temibles dias atrás, in vino veritas, al verme ahora empiezan a canter, aunque malı el "Ave" $y$ a quererme besar la mano mientras que los otros de sus parientes, avergonzados de ellos los quieren esconder para que no los conozca borrachos.iQué pronto $\mathrm{g}$ eflcazmente cambia Dios los corazones cuando quíere.El único negocio que hoy preocupa a los muchos convertido,lástima no sean todos es hablar de Dios.Aun de los muchbchos se les oye al

1) ir a pescar 6 a echar la barca al agua.Jesus Huake taja pentake, Coraźn de Jesus ayúdame" y si son de Narganá,San José pan pentake. Es une romeri: a mi choza a ver los cuadros de la Doctrina. No poco les consuela cuando les dijo que en esos bosques donde antes sus abuelos vivian, hubo jesuitas (1) que enseñaron a sus mayores $y$ que al fin muriendo entre ellos el apo: tb́lico P.Balburger y saliendo para el Marañon su sucesor y venida al poca la Extinción de casi todo se olvidaron los indios $y$ se hicieron de nuevo gentiles hasta ahora.

(1).-Los Padres Agustinos Candilarios se encargaron de la parte de
allende de Urabá y los jesuitas de aguende del Golfo Urabá $\delta$

Atratos. Aquellos pertenecia a Cartagena estos a Panamá. Est

Loado sea Dios.Hoy fue dfa de guatazos preparemonos para sinsabores.

$$
\text { Dia } 8 .
$$

Por más que he aconsejado que no vayan a Pananá para tratar sobre 10 ye resuelto acerca de edificar la casa, hoy el Cacique de Ukunseni y un indio que creo pérfido del pueblo de Sagrado Corazón se ha ido. Las be dado u- 
na carta para el Presidente.Veremos s1 con ella deshago sus nuevos enrena carta para tres en la distribucion para ir de casa en dos.He puesto la hora diños cada día para los bautizos,pues veo que la co casa a la recluta de ninos cada des cueste un triunfo salir de sus esconari tedad de las madres hace que les cueste un triunfo sallr de sus esconanten pajos para inscribir a sus hijos de v1spera. Vea. que los mas se apares, para el bautismo. Déjoles de apellido al nombre tentil de sus padres, jar que $\mathrm{ya}$ tengo experiencia de otras partes, porque los indios camino hasta de domicilio, 8 no s 610 se olvidan de los nombres cristianos, síno hasta
si están ellos 6 sus hijos bautizados,por eso hay que apuntar a qué chozon pertenecen, bautizar juntos a todos los hermanitos para desús a tinguir sus nombres por las edades, etc.Hay algunos indios taciturnos $y$ tinguir sus nombres por las el bautismo. como endemoniados que no contesta hijo y tá estáis siendo hijos del diablc Les digo: "Tengo pena porque tu hijo y tú estás siendo hijos la tontería de unot y lleváis camino del infierno." a veces lloro al ver la ton muchos acom6 la maldad de otros,y algunos les hace efecto,y dicen los muchos acomo panantes. "Mira que compasion tiene de nosotros. 2 como nos quiere!"Pero noté que no se bautizan los de parentelas de absogetis 6 saceráotes. mos por el barrio donde hay tres absogetis de los seis de este pueblo, mos por el barmo donantes:" Nh1 hay otros Padres como tú no vajas que es dijeron los acompanantes: cantan sus tonadas". lQué miradas tan coléricos no tán bravos, y por eso cantan sus tonadas 


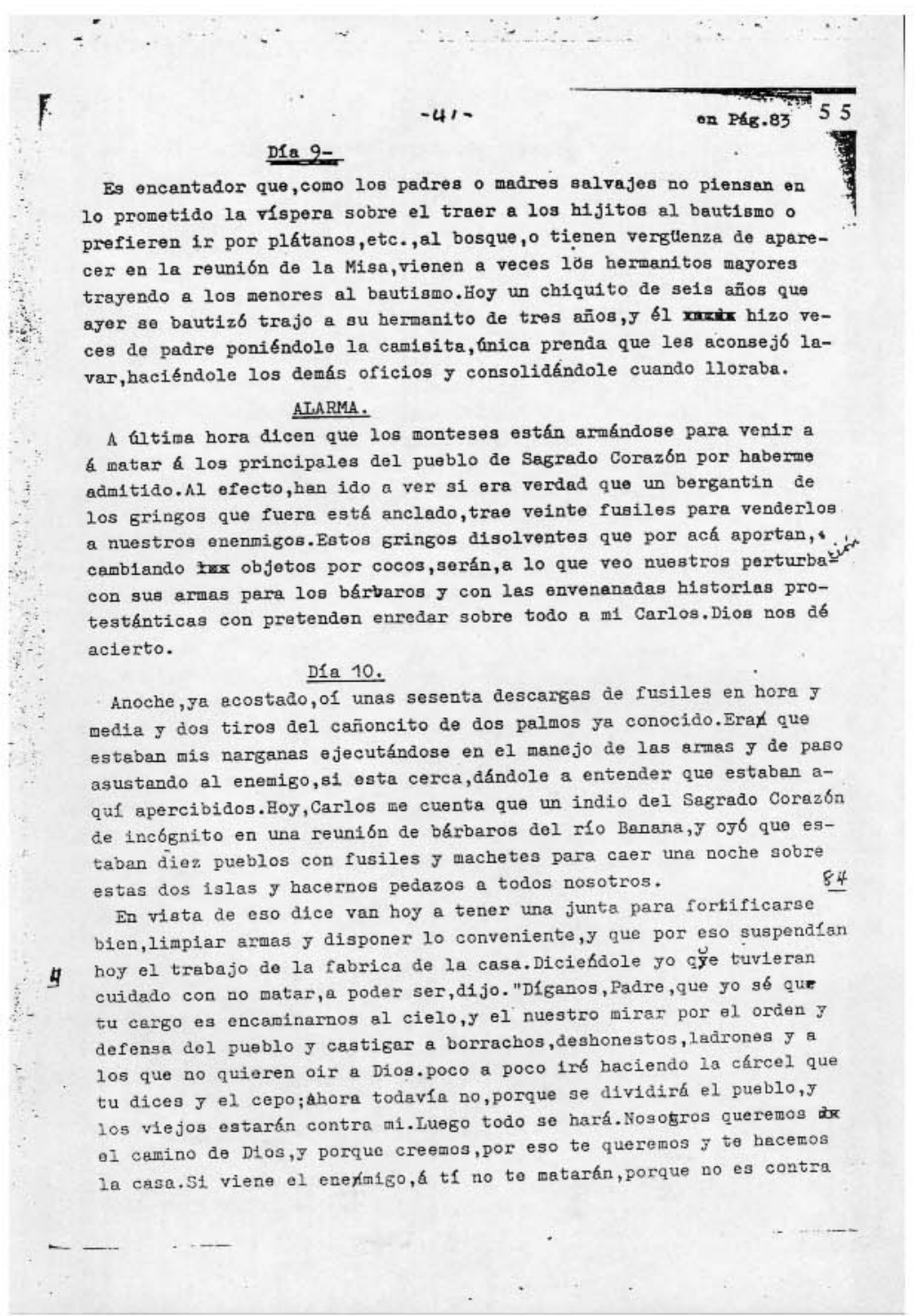


t1 el enojo, sino contra nosotros porque te hemos admitido.Mas qué importa nos maten por esa causa? creo que D10s nos llevaŕa al c1elo, aunque todavía no estemos bautizados.Esos bérbaros dicen burlándose que nos han de matar para que vayamos a ver a Dios,ya que ellos no creen en Dios.Para que veas lo bárbaros que son, ahora matan a sus niños si sueñan, porque 10 tienen por mal agllero, sin pensar que son sus propios hijos.Ojalá se haga la guerra,porque s1 morimos vamos al cie$10, y$ sino, ya que no quieren entrar en razbn degrado, entrarán-por fuer za.Tu escribenos una carta al Presidente que nos mande Wincheres,y nosotros solos hacemos la suerra. Ya ves que todos $10 s$ pueblecitos, unos veinte,están contra estos dos islíbas,situadas en medio de todos los gentiles,y por todas partes nos atacaran, paracur pero ni yo ni mi gen. te teme.El finico mal es que aquí todos son de hecho ságilas o Cac1que: I todos quieren mandar; voy a ver si los sujeto a todos,porque como ger tiles no saben obedecer, como tá quieres que aprendamos."

Mira, hijo, veo en este negocio mano extraño, y lo que quieren es divi diros para que haya una intervencion de interesados.-Yo iré a consejar a los bárbaros,y les ezplicaré eso,y evitaremos la guerra.- No irás, Padre porque nadie te acompanará, por saber cierto que si a tí no te matan, $a$ ellos s1.- Pues yo s 610 me 1 ró con niños." Carḷos y varios otros que lban a todo eso concurriendo, se rieron $y$ dijeron. "El Fadre cree que esos bárbaros son como nosotros. Ya sé que no son como vosotros, pero si los pobres piensan una cosa por otra,y no hay quien les eseñe, $i$ C6mo quereis que se mejoren?.No conviene que siendo humanos peleéis. Por otra parte,este alboroto es traza del denonio para inpedir que se haga la casa.- No, Padre, la casa se hace, $f$ mañana iremos al

T5 trabajo; como somos muchos, en un día la plantamos y en otro la cobijamos, teniendo traidos del bosque los elementos.Tablas es 10 que no tenemos pare hacer piso.-El Presidente de Panamé pondrá su parte,jo a- \{ ñadiré 10 que pueda,, $\mathrm{y}$ cada uno de rosotros un peso 0 lo que quiera,, el que no qulera que 10 deje,que luego se vergonzará de no haber dado Hi. deseo es conocer vuestra buena voluntađ y que entre todos se haga la casa para que sea de todos la csas del Padre, ́́ donde vaýás con toda confianza".A todos agradó la idea.Determinaron hoy cambiar de so lar,diciendo que donde íbamos a edificar está cerca una tienda,y no es conveniente que el Padre olga borrachos.- A su tiempo diré el origen de estas tiendas. No les quise atacar las borracheras por no $1 \mathrm{r}$ de nasiado aprisa. Hagamos la casa, aunque sea sobre el agua; venaré tfenpo más oportuno para aquello.Los 1ndios me ban hecho escribir esta carta la cual fue en el balandrito aludido en la carta.

"Narganá, Jun1o 10 de 1907.- Exceléntisimo Señor Presidente :Tengo 


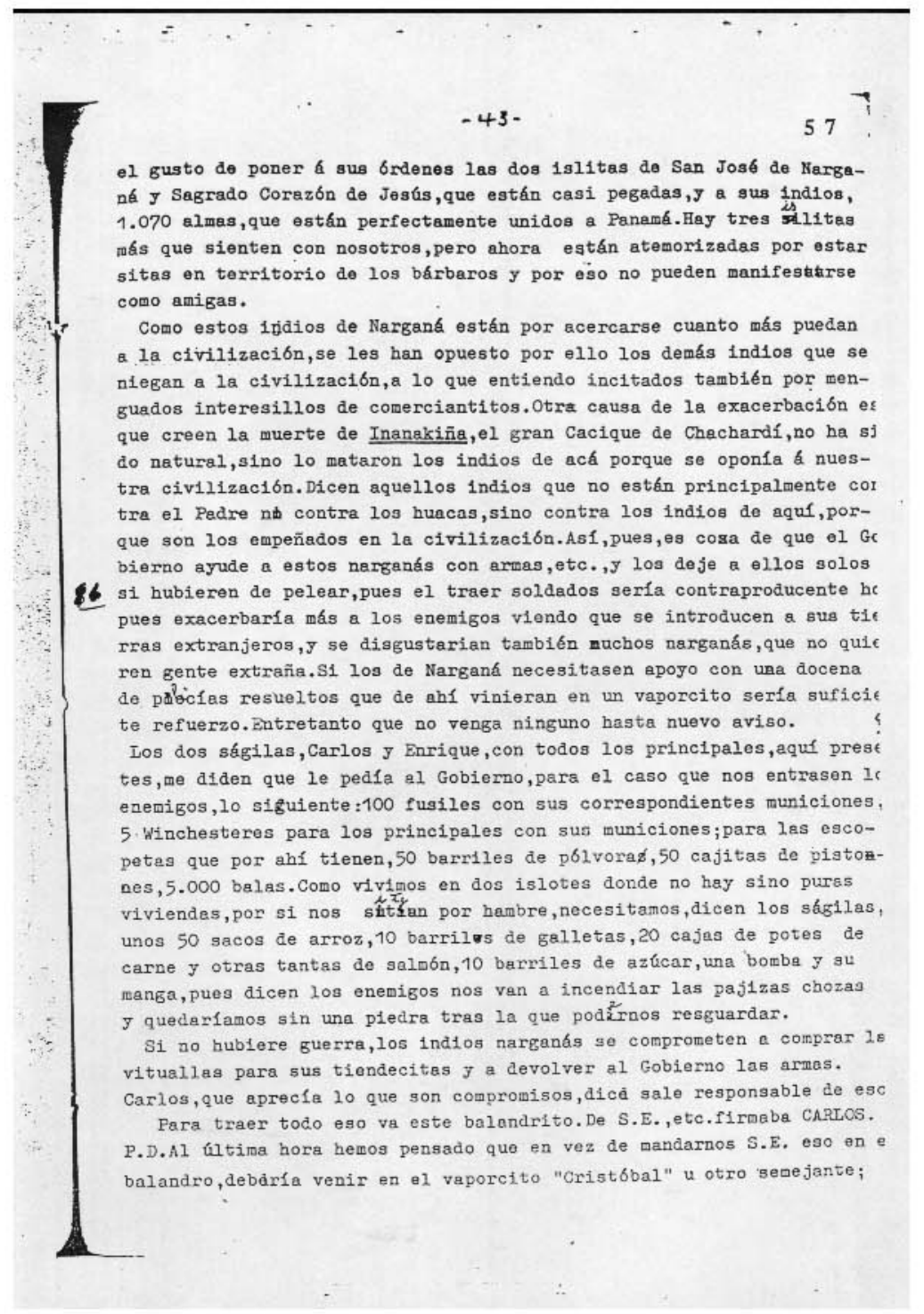


mas no en el de Ami, que para esta celeridad no sirve. Entonces on a quel bardo pasaría jo solo a visitar a los rebeldes para evitar el choque $y$ hacer las paces.Si vienen en el tal vapor cuatro o cinco policias, vengan de paisanos, ocultas las armas $y$ con encargo que no se mantfiesten, a no ser que aqui se lo indicáramos.

$$
\text { Dia } 11 .
$$

Por lo que toca a la casa-iglesia, han cambiado ya cuatro veces on dos $1 f$ días de solar. De los dos primeros solares me han sacado sucesivamente porque cerca hay dos tienditas de abarrotes y ron; $\mathrm{Y}$ sus dueños se sthtirían perjudicados en la venta de ron con $m 1$ presencia 6 cercanfa. Ia piensan en ello, eso que aún no les hablo contra la borrachera, pues 10 que trato ahora es de afirmar el pié solamente. so mi casa cerca,porque se le aminoraba el desembarcadero 6 plaja 6 donde suben $y$ guardan sus cayucos o urkagolo. El cuarto ha callado $y$ en Fista de eso han empezado a preparar $y$ parar el armazón de la casa. Esta queda reducida, después de echados grandes planos.Es que el prudentiaimo Carlos gur ve que no está el horno para bollos,j por eso, aunque jo reclame a la espñola,que debia ser grende y asi y asá me dice: "S1,Padre, ja está ahora bueno, después te haremos btra mejor." I es de notar que Carlos, muy hueco, me dice: "Tanta gente como ves que hoy han traico materiales de palos,hojas de palma ja cosidas, carrizos y beju$\cos 6$ cuerdas silvestres (que son los clavos del país), se debe a qud anoche, cuando te peds permiso para ir a la reunion que en karibe 1laaan lafeo o leleo 6 tumati chun make, les hablé mucho, j ja tengo a todos los de esta isla conformes." Verdad es que por fas 6 por nefas con tales juntas $y$ trabajos en esta segunda entrada no me ha venído Carlos a ningún Rosario,ni a Misa,pero creo que es por entrar con la de ellos los gentiles, a quienes casi cada dfa reune y salir con Cristo. Dios 10 hage. Esta noche,viniendo yo del Rosario,al pasar por el lareo, he tido que dos sacerdotes estaban como salmodiando en medio de buena concurrencia.Algunas mujeres mientras oyen van cosiendo, faena eterna, sus adornadisimas, a manera de caracoles 6 laberintos,y abigarradímas chambres o camisolas, que les llegan más abajo de la cintura, sobre $10 a$ pañetes azules que a modo de sayas les llegan a medio auslo.No me he querido acercar por no introducirae demasiado aprisa.Tras esos cultos fú́ la discusión sobre la casa.Todo lo ofk desde el rincón de mi improvisada choza. 
Dia 12.

Hace pocos dias me trasladé 6 esta 1sla de San José, pera cada día voy de tarde á la del Sagrado Corazon a la Doctrina y a Rosario,pues 64 me han rogado que cada dí les rece para que no se atrasen. En Sen Joo 86 es mucho el adelanto; habrá como ochenta muchaches que saben "Por 1a señal, Pater, Ave," J algunos el Credo.

Van apareciendo ciertos los toros. Mientras hoj estábamos en el Rosario, de seis a siete de la noche, con sin lgual fervor, demástrado on los indios, porque a voz en cuello centaban y rezaban, vino una turba de indios del rfo Tigre, verdaderos tigrest, a pelear con los de este pueblo. Ho encontrando a nadie en el pueblo,porque Carlos y unos ve1nto de $10 s$ principales se habian 1do al Sagrado Corazon a convertir to de los principales se hablan conmigo en el rezo,j no atroví́ndose a venir al gran choza donde las numerosas $\mathrm{J}$ grandes voces del Rosario que cantábamos les hicieron pensar que estaba la gente armada; $s 1$ contestaron con encarimarse en ml ohosar que estaba la gente armacion cortaron todos los bejucos que hacen za en construccín y a machetazos cortaron todos los bejucos que hacen b́ndolo todo.Ellos mismos se derrotaron. Ocasiono su hulda que uno de ellos al descolgarse se enganch6 el muslo en el único clavo viejo que por chiripa habfa en una viga, trayéndola on pos al brincar al suelo, $\mathrm{y}$ so rasgo ol muslo hacléndose una herida con el machete on la caida.A sus propios gritos $\mathrm{y}$ ruido de las vigas que calan, arrancaron a correr hacia sus barcos, creyendo que el mundo se les vonfa encima. A tales voces salí algón gentil viejo de agét los que no venf́en al Rogario, $y$ pudo presenciar lo dicho.

Fn eso par6 el ataque que espeŕ́bamos.Gracias a Dios los monteses dejaron solo a los del Tigre,porque haciendo la noticia de las peticiones que hicimos al Presidente, $y$ vinieron miedo.

$$
\text { D1: } 13 .
$$

Dista de 10 ocurrido anoche, $y$ sabiendo que la razón que en el vecino rfo Thgre han dado sus moradores dé la fazeña ha gido que el terreno donde se 1 ba $b$ ediricar ora de uno del Tigre, hemos quedador en buscar otro solar. Va, pues, la quinta traslacion. de la casa.(1) Barrunta el demonio que la tal choza-igleaja lo va a dar que rascar.

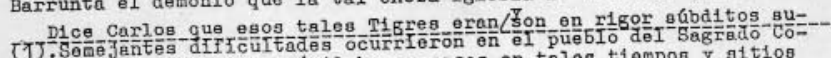
1). como se ba podido imaginar. 
yos,pero hace unos d1ez años empezaron a 1rse allá por mot1vo de ans - rozes, J los t1ene que vivir ack, 81 bien entretanto más vale diaimuas porque no están ahora para entrar en raźn.

En cambio,es un consuelo este pueblo de Sen José.A mi venida las muferes y n1ี̃as, que son la gente más diffoll entre gentiles, hufan de verme,hoy se han presentado a examen de la doctrina en más quince mujeres, de las cuales cinco hasta saben cantar solas el "Ave" y el "Pater" , J han quedado constitúdas maestras de las demás. De las mozas hay unas quince que a voz en cuello puedan dirigir el Rosario cantando, no afinadamente; pero eso poco nos da ni a Dlos ni a mi.Lo que queremos es que su corazbr se cristanice, $y$ eso Dios lo está haciendo j ellas van cooperando.

Farece que esto no sea pueblo.gentil. A las custro de la madurgada ja es un ruido, y golpear de remos y cayucos que no se peade dormir. Es que los hombres se van a sus rozas lejenas.Las mujeres que tienen que lavar ćntaros del pais á esta hora.Al salir el sol es la Misa j rezo oficial Ge la doctrina para muchachos $\mathrm{y}$ gente no ochpada.Terminada la Doctrina, los muchachos van a la pesca hasta las doce $\mathrm{y}$ las niñas a ponerse de niñeras (hey muchlsimas críturas) 6 al río.Dejánme en paz para hacerme mi desayuno,rezar, etc.A eso de las diez vienen las mujeres $\mathrm{j}$ niñax a la casa-capilla, donde en corros aprenden a rezar mientras van cosiendo elsunss, les explico las estampas de la Doctrina.A la hora las dejo y biguen las que quieren allf, mientras emplezan a venir algunos quchay biguen las palotes, contestan a mis dificultades, chos, que, entreteniendose en hace pabe, etc. A eso de la una y gedia, cuanão

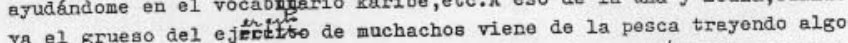
ya el srueso del ejo de fruto de slina, a que asiste toda la gente menuda con su alacridad propia. ca a Doctrina, a que asiste toda la gente menuda con su alacridad propia. recorriendo cada dia dos 6 tres chozas para que los viejos y viejas que recors hora de descanso j rezo en casa, me voy con 108 más adelantados de la 90 Doctrina al Saprado Corazbn, donde, enseñade un rato la Doctrine y rezado el Rosario, visitamos enfermos, etecétera. Vueltos a San José, ja esté do ol liscal ose punta en blanco, pues 11 egados En eso ya van apareciendo los hombrea de punta en biān, luego comen de sus trabajos, a eso de las tres, lo primero se bañan, luego comen y tomada su ropa $11 m p 1 a$ j el bomb1n se disponen como para una recepolon. Esto les ha enseñado Carlos. 


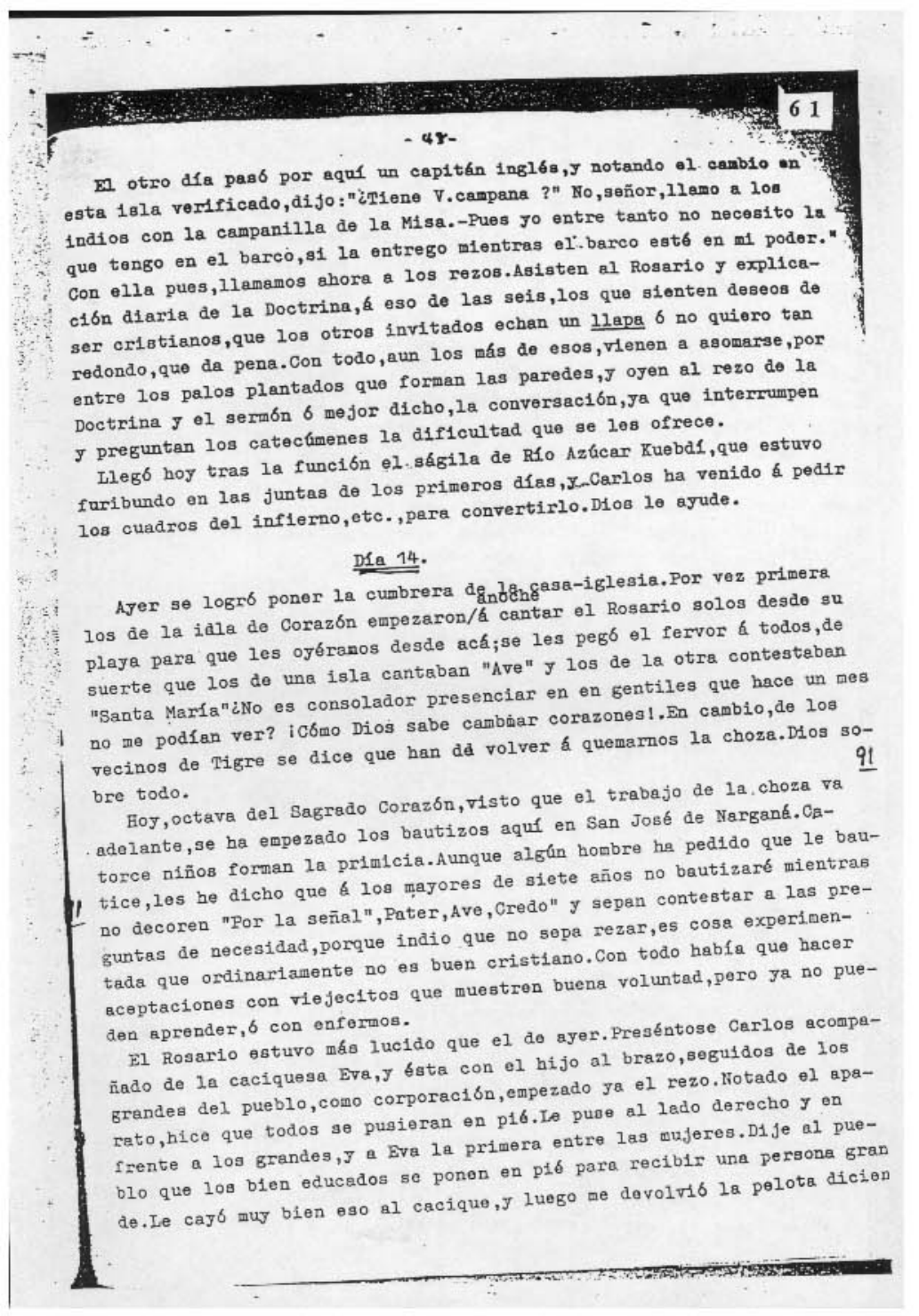




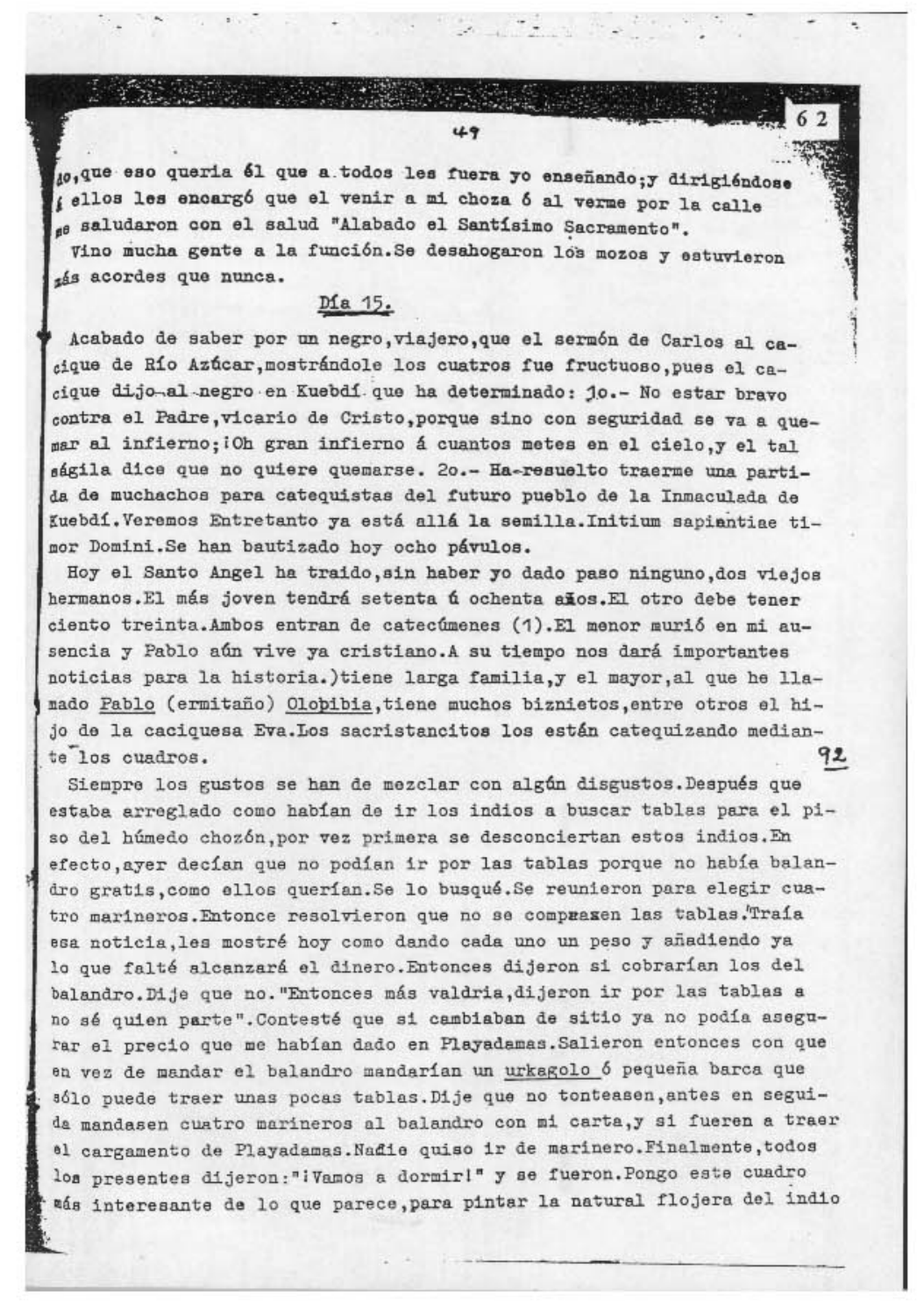




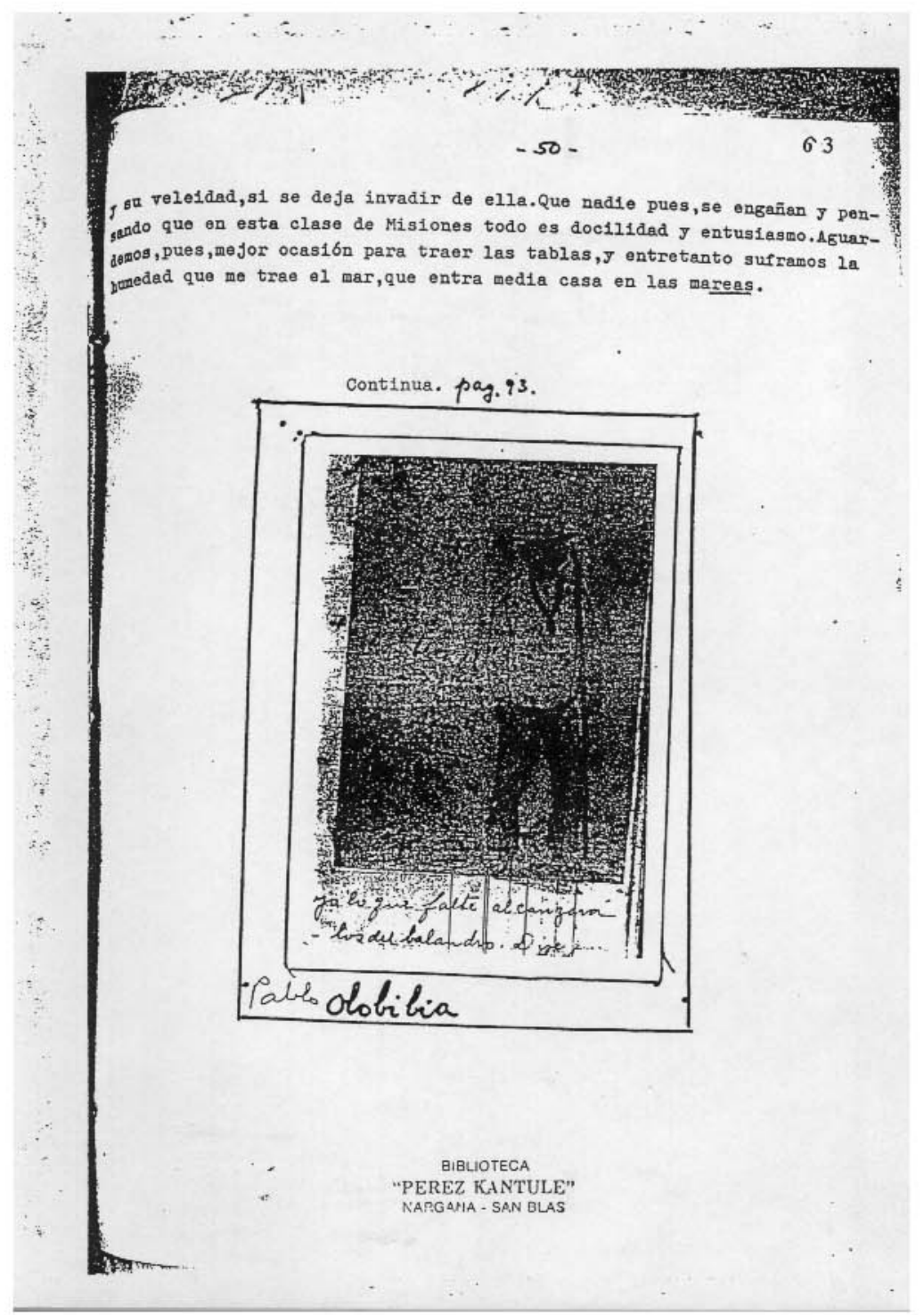




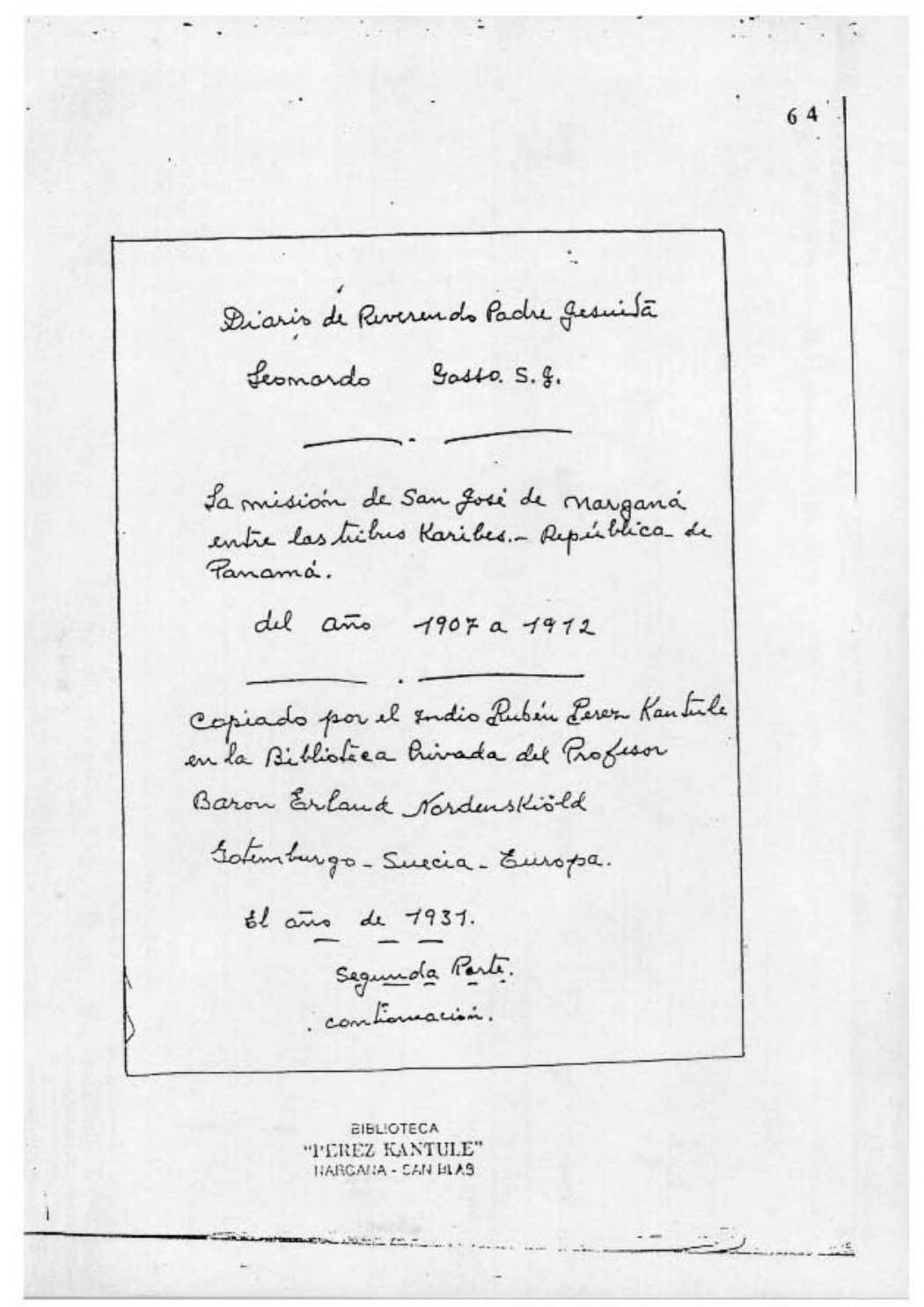




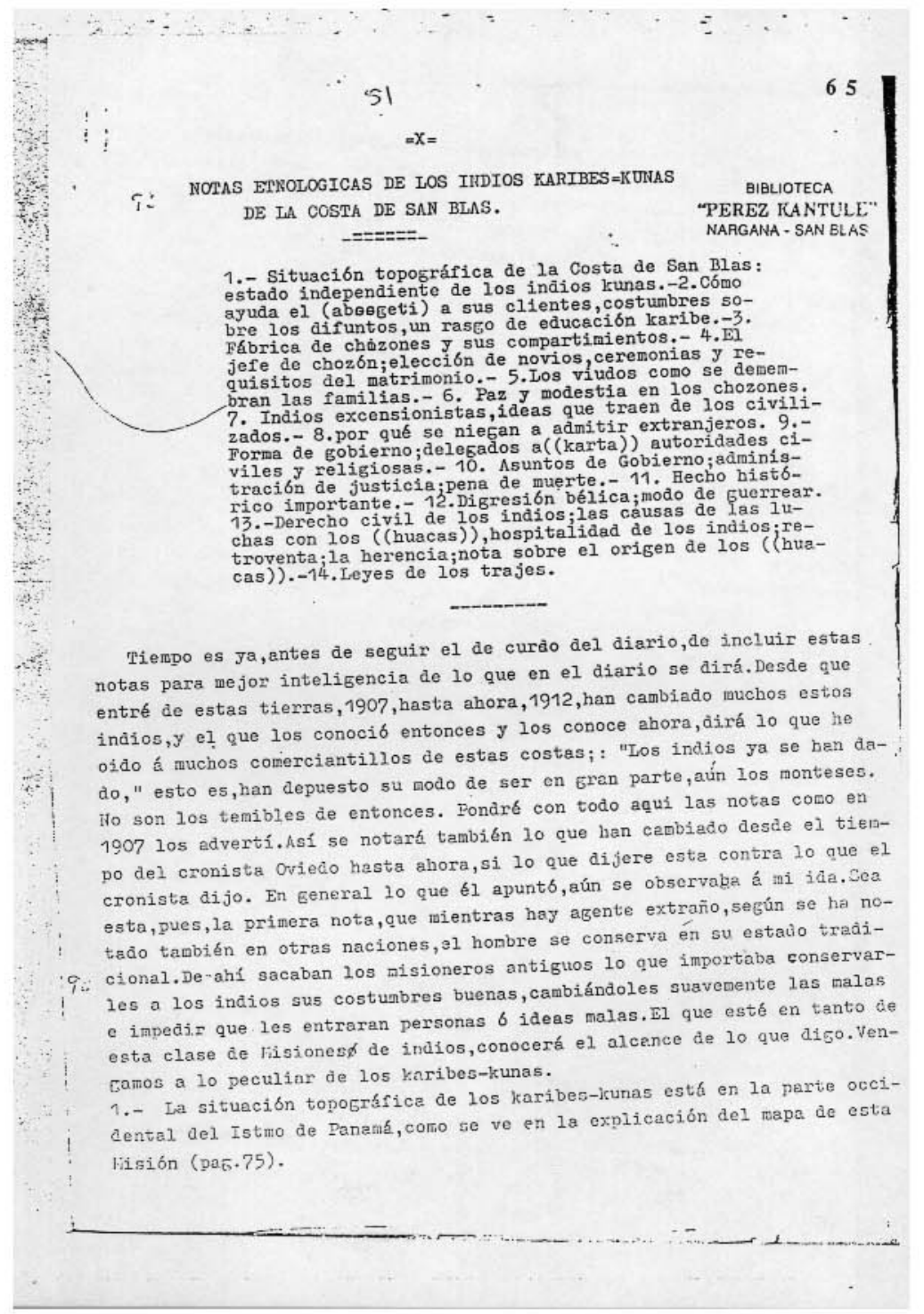




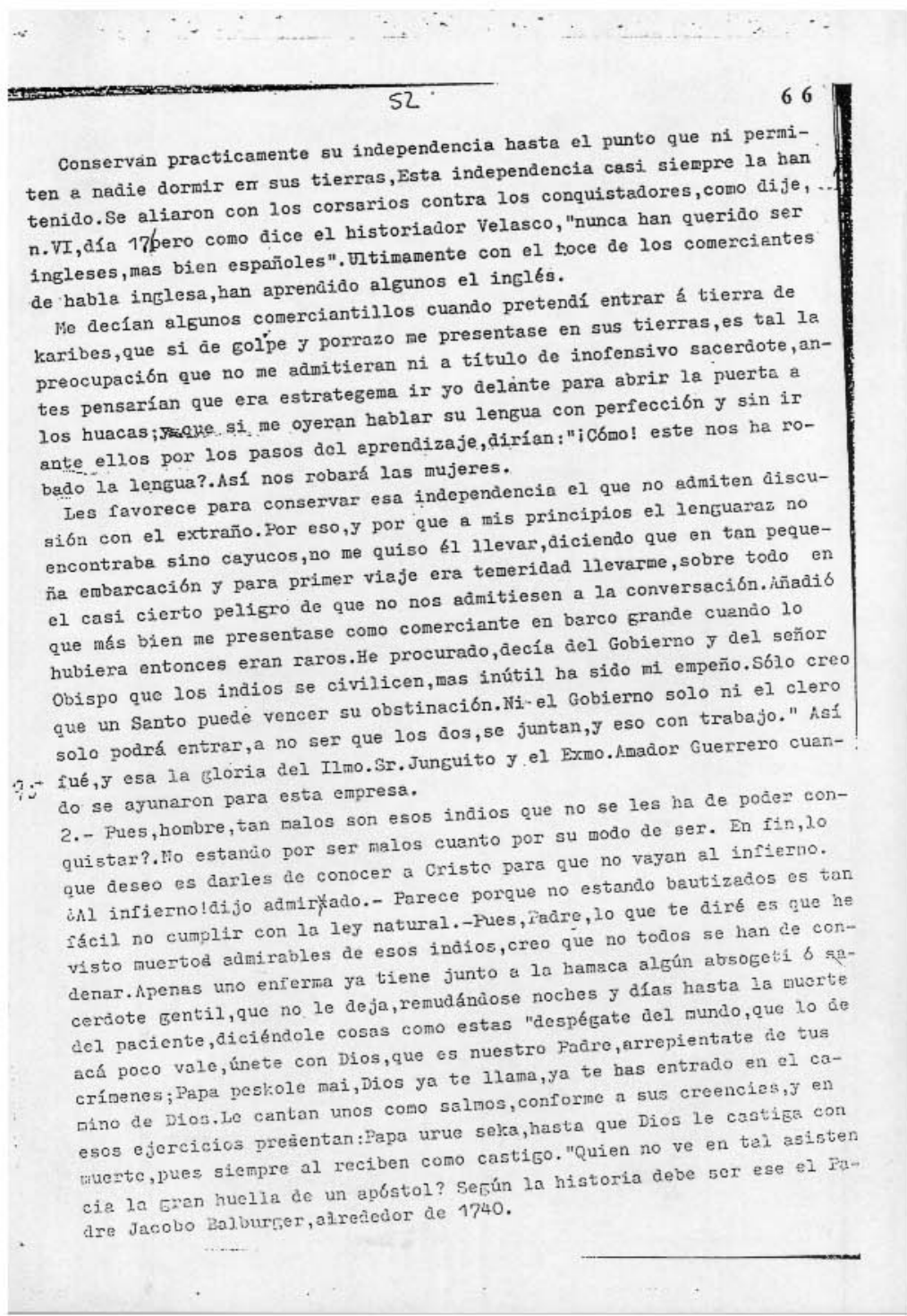


Lo que hace el aboogeti es el oficio del fiscal de Doctrina en las antiguas Misiones americanas cuando estaban ausente el misionero. Los absogetis cumplen, pero las muertes, como dirá en su tiempo,en muchos gentiles suelen ser honorosas. Las costumbres de los inâios en tal trance van descritas en la carta de 14 septiempre 1910. All1 me dejé que apenas expiro el enfermo lo lavan con celeridad y rompan en llanto ritmico.En el n.VI dije sobre los cenenterios.

4. Lloran, aunque no sea por difuntos, ordinariamente hablando 6 mejor dicho cantando 6 cofi rítmo, aunque pocas veces se ve llorar ni a muchachos ni a mayores $s 1$ no es por los difuntos.Cuando están hondamente afligidos, sobre todo los hombres muestran su dolor con una estupenda seriedad. Con esa seriedad, sin ademanes, ha habido quien se ha ahorcado para ir a verse $\mathrm{y}$ es$\operatorname{tar}$ cin su madre poco ha difunta. De difunto no se hable,que es gravísimos ralta de educacion en karibe. Ahora, a fuerza de hablar de las almas del purgatorio,si corre hablar de elgún pariente nunca dicen muri6, sino por motáfora:fulano se perdib:́́ fulano Dios le cestigó:zuteno ha sido arrebatado.se fué, etc.. Pias sucede, v.gr.que murí el padre $y$ en el padron 11 am6 a su hijo 6 ahijado v.gr. Estanislao Pitaso que lleva de apellido el nombre gentil del Padre. Luego hay un murmullo, aun en la iglesia, que si el misionero sigue llamando así el niño,tendrá éste que dejer de venix, que más valiera que se le cambie el nombre, etecetera, pues Pi,tas6 ya se $t$ perdio.

3.- Febrican grandes chozones de hasta cincuenta pies de largo por hasta veinte pies âe ancho por otros veinte pies de alto.El armazon de gruesos e incorruptibles palos y larzos, pasan de generación a generación. $\Lambda$ las ocho 6 diez columnas emparejades las suelen atar con un grueso travesaño que forna el tabique imaginario que separa las familias $\mathrm{y}$ enseres de caáa una. De travesaño a travesaño cuelgan las hanacas. Palos hay que es imposíble meter los clavos. Sírvense para el empate de bejucos, que también duran una eternidad si no están a la imṕtemperie. Hay bejucos de todo calibre; desde para atar un pajarito, hasta pera atar un tóro. Rumboso, como siempre nuestro Dios en sus dones, di6 a estas criaturas en el bosque cuanto apatecen.Dios les libre del espíritu močerna descontentadizo que hacen el hombre infeliz. Conbcenlo esos pobres indios,y por eso también se cierran hombre infeliz. Conbcenlo esos pobres indios,y por eso también se clerran zón de cualquier vecíno según la disócsicion del cacique. Reunidos los pes el orden y activičac

iz que desplázan, cuídándose cada uno de lo suyo.Las paredes son palos plantados, que de-cimos jiras que duran muchos a propósito ese sisteme. 
Sujetan las jires unas con otras atados con bejuoos 10 más junto posible a los palos traversaños, despues de clavados en el suelo. El techo formando a los palos trave cañabravas nuy largas apoyadas $y$ atadas en la cumbrera con una especie de cañabre 6 caballete en los lareueros y en las solorgue unos queríendose librar de los de ciertas palmeras, a eusto del ducio. lorgue unos queriendose librur de mucbos ratones que del bosque vienen a laf, islat, cabaljeros en los palos cn las frecuentes riadas cubir con osa pazmia, pero no anidan en ellas los Auncue cuesta mbs trabjo ratones, porque diz que se pinchan los ojos, dsos pichos al quererse intró cen entro la palma. Las íslas habitadas de este archifiélaco están cerca de la desembocadura de los ríos. Dura veinte $y$ treinta años esa palma. Otros ínáios, si lo que quieren es' salir pronto del paso usan otra palma que les dura ocho otrá diez, otra quince años. Loq que de una vez se quíeren, desentender pera toda su vida buscan otra palma más difícil de traer por su ratender para toda su vida buscan otra pal arriba, que pueda durar cuarenta 6 cincuenta años. ra y estar lejana monte arriba, que pueda durar cuarenta o dercer parte del primero, que es para cocine. cocina.Las casas están de ese cono círculo están las que no cupieron en el forma de por 10 que no calles, $y$ a veces hay tal redondel,sin orden ni concierto, por lo gue no hay calto que pasar por dentro las casas de unos para llegar a otres. Dn esas servidumbres no reparan sino los que se van entrando por el nuevo mo, do de ser. Ijo tiene las casas por 10 común puertas. A 10 más una tabla con aleún puntal Ho tiene las casas por lo como a los perros.Cada familia tiene a su rope 6 bejuco para iapedir el paso de a çl gada sobre una larga caña brava suspendida horizontalmente por bejucos on el lugar de la tal familia y á públíce subasta, En dicho lugar arriman sus repos, velas, cuerdas y herramientas. Con estar toca trim tan pablico sin puertas, pasando la gente a cualquier hora, $y$ siendo tres y cinco familiar en un solo chozón, anedie se le desaparece nada. LPodrá llegar a eso la civilizacion moderna?.

4.- En cada choź́n bay un patriacea.Este hecho el rape de la bija, ceremonía sobre la cual después se hablará trata de casaría si es que no la casa ria sobre la cual doßjo el rape y la madre saben con quien se va a casar la hija pues aćá no busca el novio a la novia, síno el padre de la novia es la hija, pues acá no busca juzga oportuno para que ontra a ser hijo y siervo quien busca al que juzga més oportuno para que dichoso el peöre que tiene musujo. El patriarca 6 suegro se llana saka. Fs dichoso el pedre que tiene nu chas hijas, porque eń su vejez tendrá muchos giervos e hijos que le bagan servicios, $y$ desgraciado el que tenga todos 6 casi todos sus hijos carones, poroue se le han de ir a casfajena. En efecto el novio pasa a ser wiembro le la casa de la esposa y alli ha de vivix.Y nótese que contra el wajda 


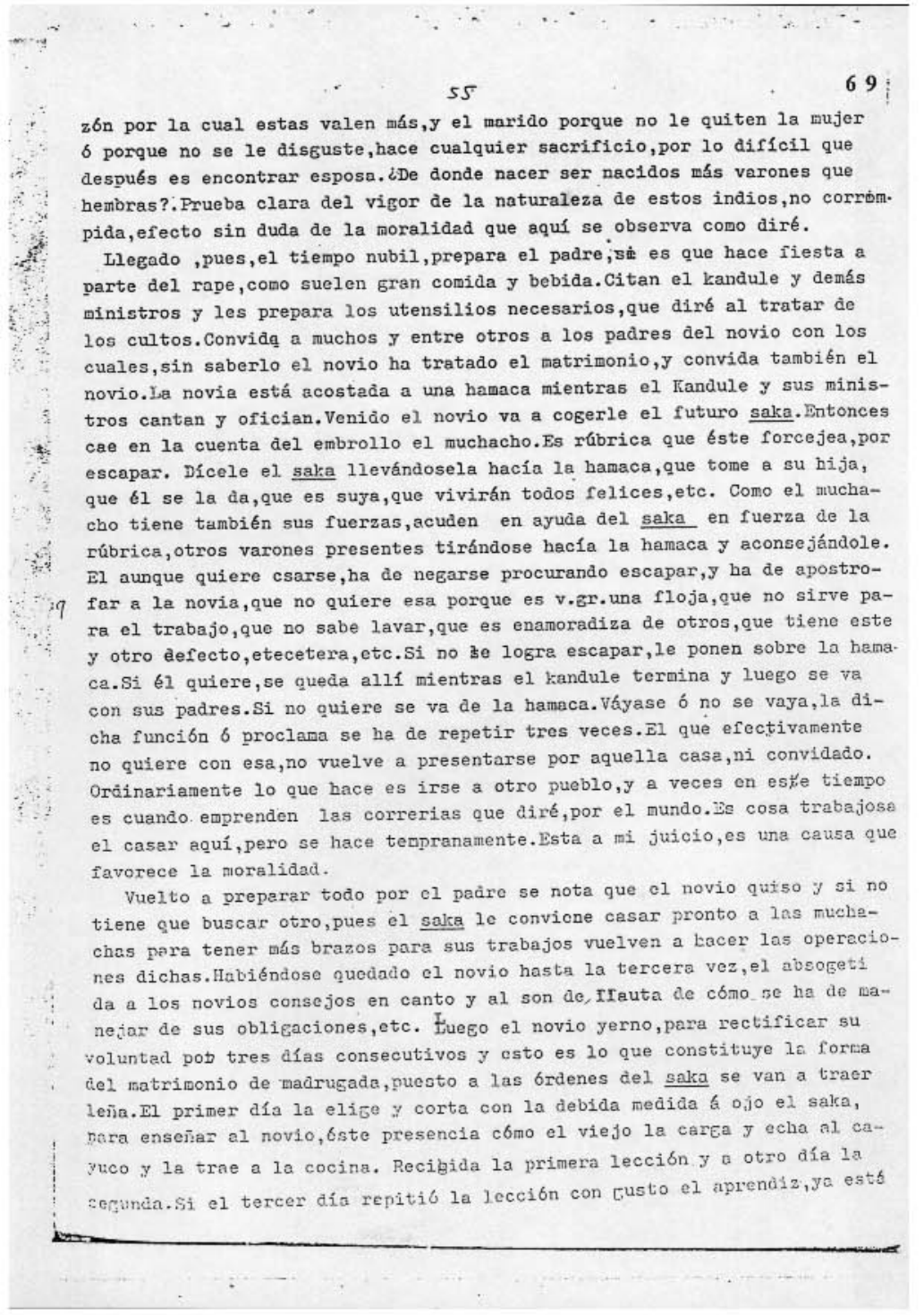


heche el matrimonio. EI traer leña para la cocina es casi la única obligación a la casa junto al tramo del salka.Llamo travo novio y se le da un tramo de media entre atravesaño $y$ atravesaño del chozon el espacio sin paredes que mecia entre atravesar casarse debe tener urque âjje, donde cuelgan las hatacas. El novio para casarse debe tener urkagolo 6 barco propio, remos, vela, anzuelo, arpon barra para cavar y machete, deber ser trabajador y no corrompido.Si no tiene ese dote con dificul I tad encuentra saka, si no es para alguna muchacha desflorada,pues aqui siempre se casan mozos con mozas $\mathrm{y}$ en aquel caso,no a la otra se la casa hace la fiesta del rape, ni con el ßovio se gasta en esas comilonas $\mathrm{j}$ culhace la llesta del rape hi importuna algo que toma a tal hija. El y ella tos, sino que lisamente se le inportuna algo que toma a tal hija. El y ella por la necesidad de vivir emparejados, pues ni hombre, ni ga vivir ać acomodamente, se junten después después de la ceremonia de la levía y los obvios consejos del saka, de que se amen, de que no sean bravos, de ña y los obvios consejos del

Co su imaginario departamento 6 cuarto, cologan la haColocada la puya.Junto a la pared la de la mujer al lamaca paralelanente, caro hay nino chiouito su hamaca, ente la pared y la mado la del marido, cuando hay niño cbiguito su dre.Cuando hay dos, el más chiquito siempre junto a la mate dre to al lado de fuera del pad el pared y el hermanito major $y$ así sucesivanensiempre,el segundo entre el pared y elia la otra pared.Así se van casahdo te echando siempre a los mayores hacia la otra pared.Así se van casada todas las hijas $y$ se van colocando en la casa. De donde a veces si hay cinco hijas,resultan cínco hileras $\delta$ cinco familias puestas paralelamente. co hijas, resultan cinco hasła ocho ó diez. Entonces cada tramo A veces hay más de cinco fanilias hasja ocho onteriores, se diviōe en ãos como inaginariamente, pues nunca hay paredes interiores, se diviäe en dos como inaginariamente, extremos una $y$ otra familia hacía el centro del trano.

viudos de cssen puidas, más nunca con solteras, aunque el viu.- Los viudos de casen con vuidas, és hunca con solte pero yerno, es' do sea cacique tias, el caka. Esto fue lo que le bizo equivocar a Cviedo curntá a las brienes del saka. Esto fue lo que lak poran unos nobles. do dijo que los sakes (errata de imprenta?) por sakas eran unos. nue si és:lo tiunen tanta autoridad por ser nobles, sino por tener hijas.que si éstas se mueren, queda el saka cono otro cualquier vulgar, pues ontonces los tas se mueren, queda elígados, y 6 se quedan ahi si sus hijos, nietos y bizniejernos guedan desligados, 6 se quda anciano, 6 si no cs muy antos del saka, ya son mayores y el tal ycrno muy anciano, socos tienen, aunque ciano, se vuelve a casar y a pesar de sus canue sal:a.

sean carcavales) para el servicio do otro nuevo salias y cada padre hace

1/. Fuerto el saka, entonces, si, se destajan las ramilias y cada padre haca casa nueva con sus hijos y nietos si los tiene. Por la tal a jomerectón 


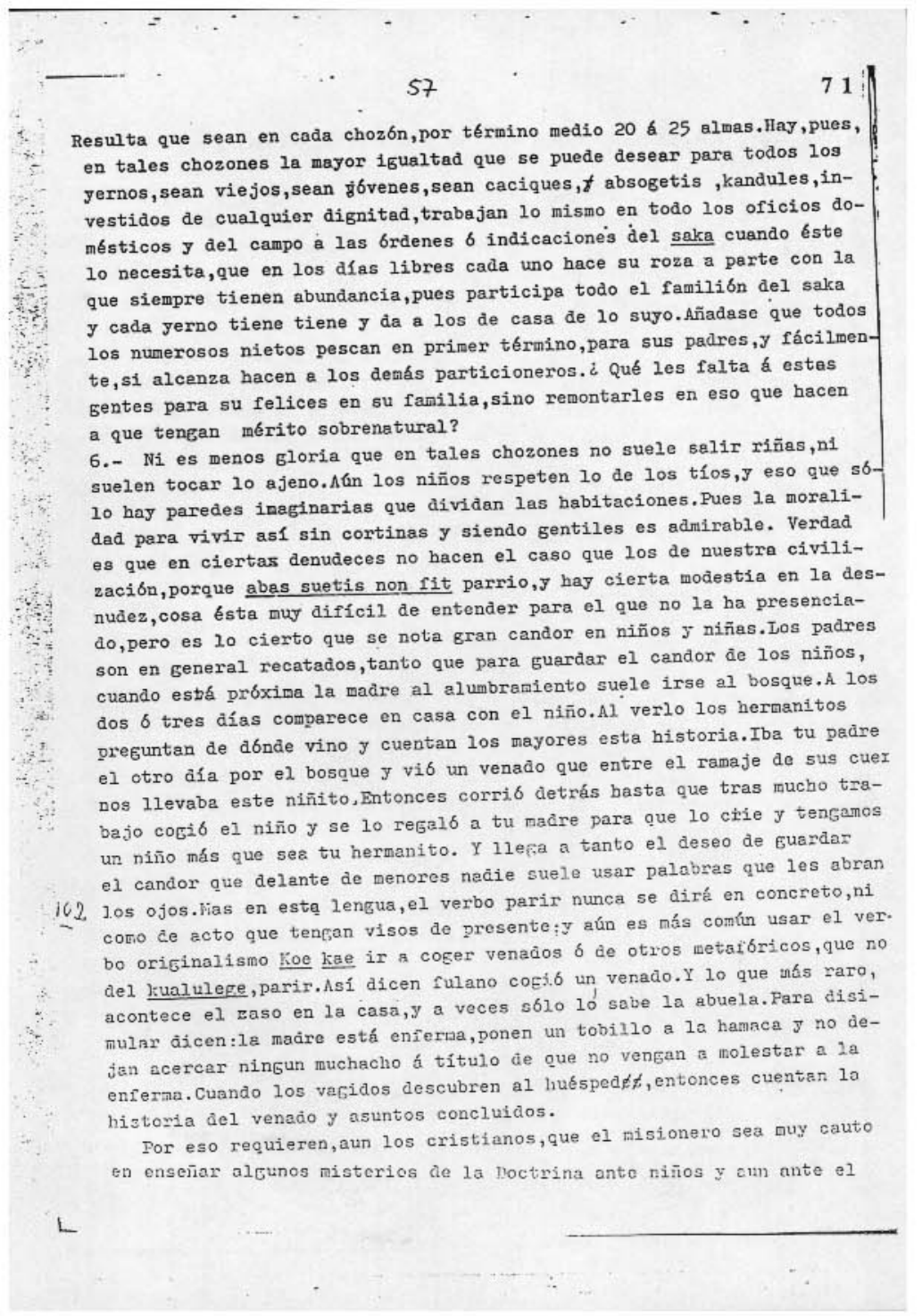


público.ls1 se explica el recato de las niñas y de las mujeres.I罗tima que el demonio les haya metido el lavatorio del rape pero maravilla que a pesąr de pare eso recobren el hábito de modestia natural. El deshonesto es muy mal visto,y aunque hombres entre hombres de alguna tribu especialmente sean libre pero cada vez me persuaào más que eso es importado. Aún entre los muchachos se ve que son más libres y atrevidos,los que se han asomado a los pueblos llamados civilizados que los que se han quededo siem pre en sus lares.

AJuda a conservar ese recato, la resistencia de los indios a que no entre en sus tierras extraṕéco por miedo que les importe ese libertinaje. in efecto,dicen ellos llevanào la cosa al extreno de la exageracín.si dejamos entrar buakas nos quitarian las mujeres con su desenvolvimiento y hasta ellas nos dejarían a nosotros $y$ se irían ellos aunque sean negros. For eso no admiten discusion ni distingos si los huakas son buenos 6 malos sino que en tratóndose de entrar huakas se cierran en seguida.

En los pleitos que pueden ocurrir entre casados es juez nato el absogeti Este oido las partes castiga al culpante, halando con el cacique.

7.- Dije que tienpo de la juventud es cuando estos indios haceh sus grandes excursiones a veces por ent:ee evitar un compromiso matrimonial. Tan es así, que no son pocos lo que han corrido las Antillas, 6 los puertos de Istados Unidosis. Indios hay que conocen los puertos de toda América anbos ma res y aún los puertos principales de Oceanía y Europa.Así se explica como algunos indios saben el inglés $y$ el castellano que aprendieron yendo de grumetes en los buques. Encontré uno que babía pasados unos 20 años corrien do por el mundo pasando doce años de sirviente en casa de un capitán de barco en la Rambla Barcelona. Lo admirable es que cuando vuelven con uno 6 dos cofres de ropa( eso han de ostentar al venir 6 sino son despreciados como guien hizo bancarrota) y al parecer canbiados vuelven a entrar en el Dolcie de indios; $y$ aún suelen ser son los más tenaces conservadores de las antiguas usanzas. En efecto cono suelen traer muy bajo concepto del munco, en 10 tocante a honradez $J$ moralidad, afianzan ellos las ideas que los deaás tienen de la paldad de los hualcas. Eso no quita que se les vajen entran do algunos usos, pero no ciertapente los mejores. $\Lambda$ eso les ayuda continuos barcos que ultinamente llegan a sus costas trajéndoles objetos, cono fonbsrafos, caleodoskopios $\mathrm{y}$ otros instrumentos de uso y entreteníiento a true que de cocos. funque el huaka no salte a tierra, la curiosidad lleva al inaio al barco.Son, ṕues, estos salvajes excepcionales y me parecen los más if teligentes de los que he tratado en el Ecuador y on México,y si es cierto lo que aseguran las historias que los incios americanos casi todos son de 


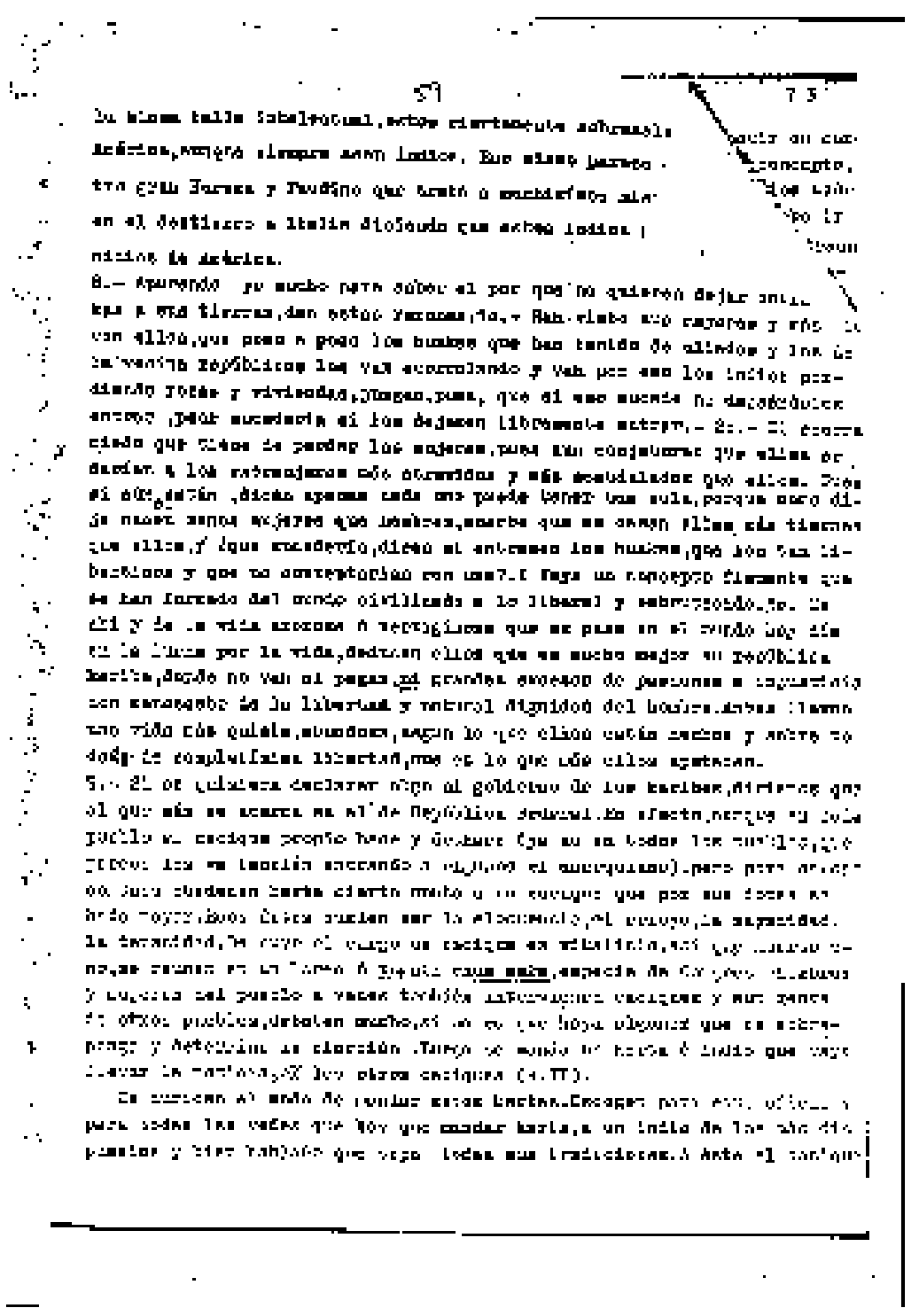




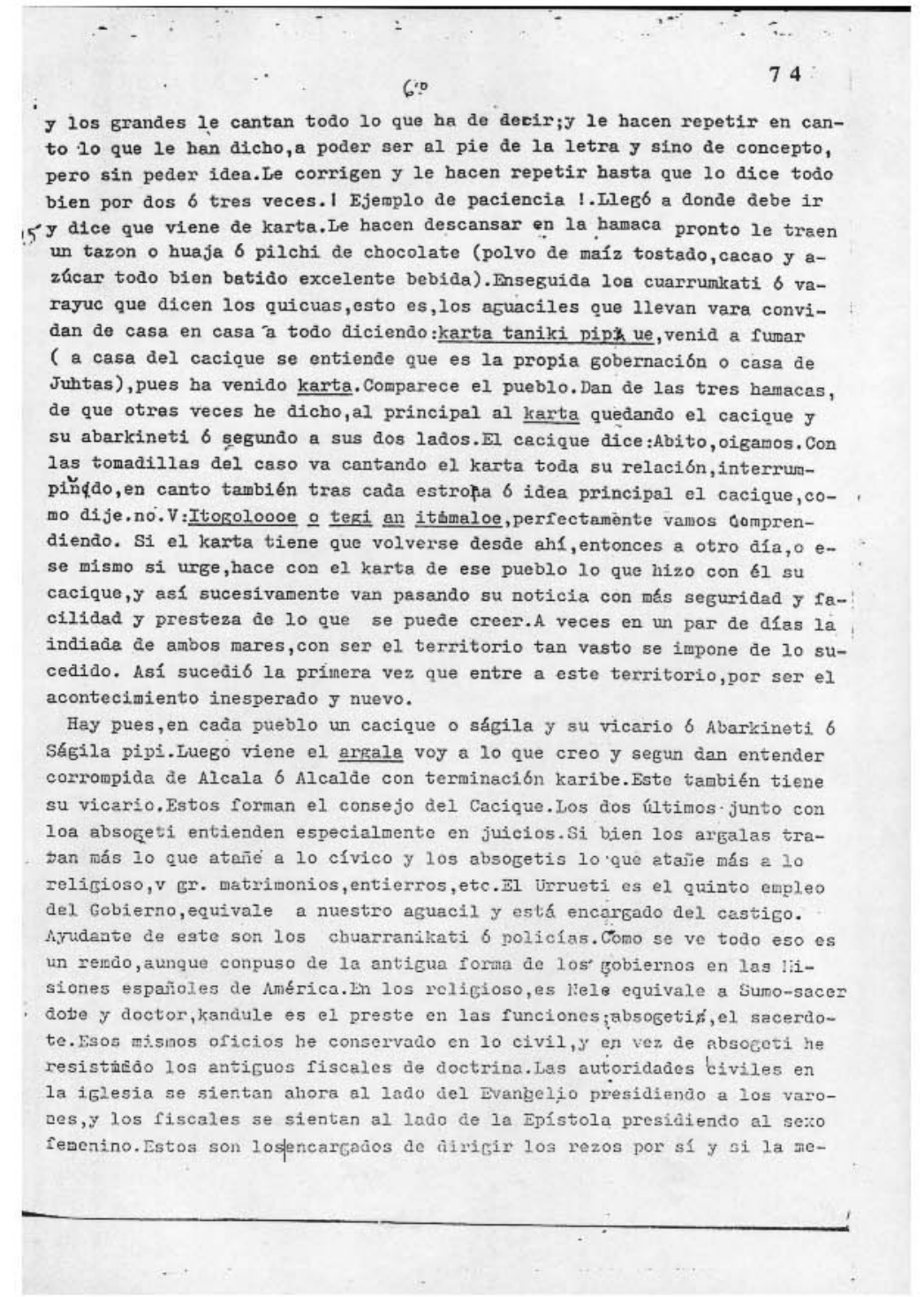




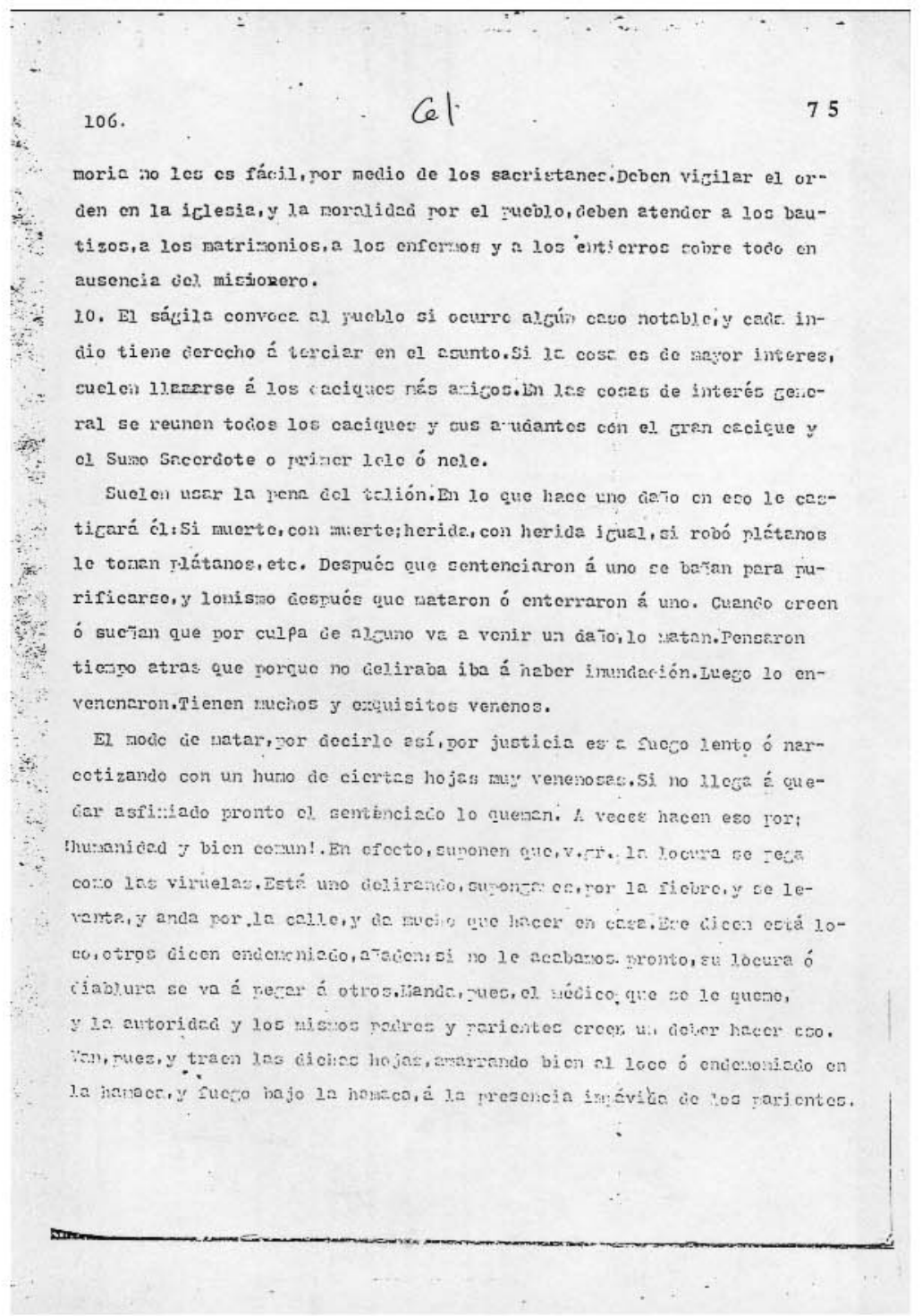


Arcüi yo al padre de uino de los deçacizcios, por que había hecho eso,y díjo: Peùre, yo no lo neté, vólo 20 r.resencié. Il cioctor fue quien orcienó

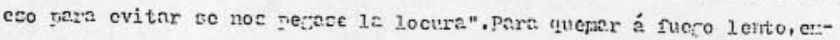

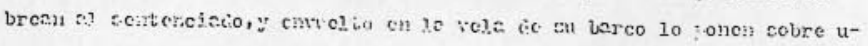

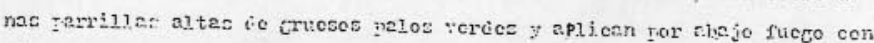

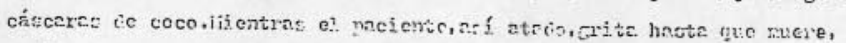

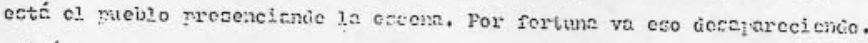

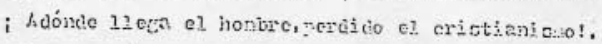

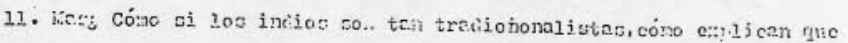

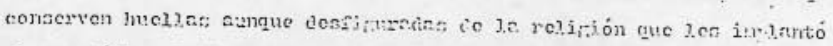

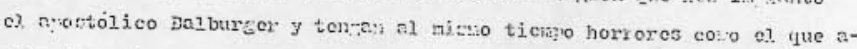

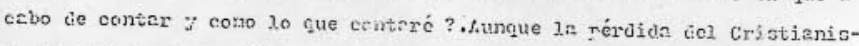
tho es suriciente ra:ón yara c:nlicar cse bajo nivel ce huranidednos de

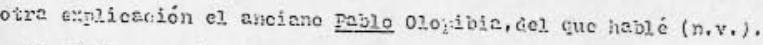

En erecto, cuenta el ancianito (I) que cuencio ćl cre soro cie mos 50

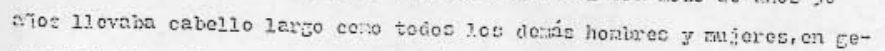

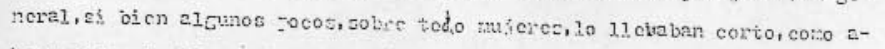

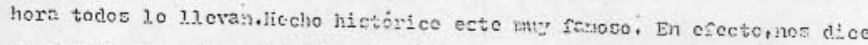

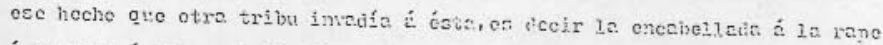

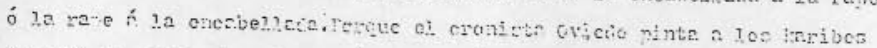

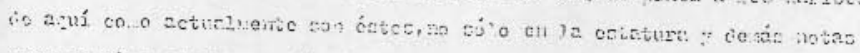

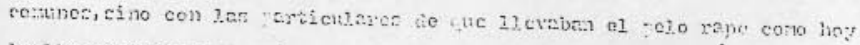

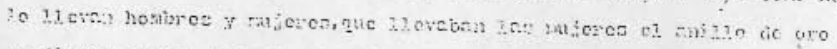

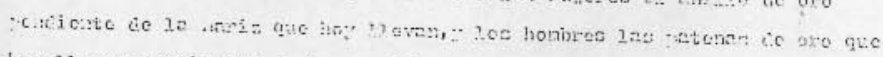

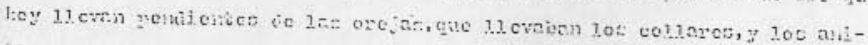

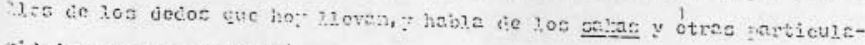
Acices que how netenos.

(1) 70íne los

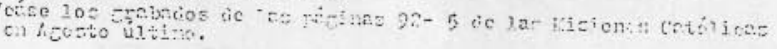

[ Frag.]

V. RD, n, 7 


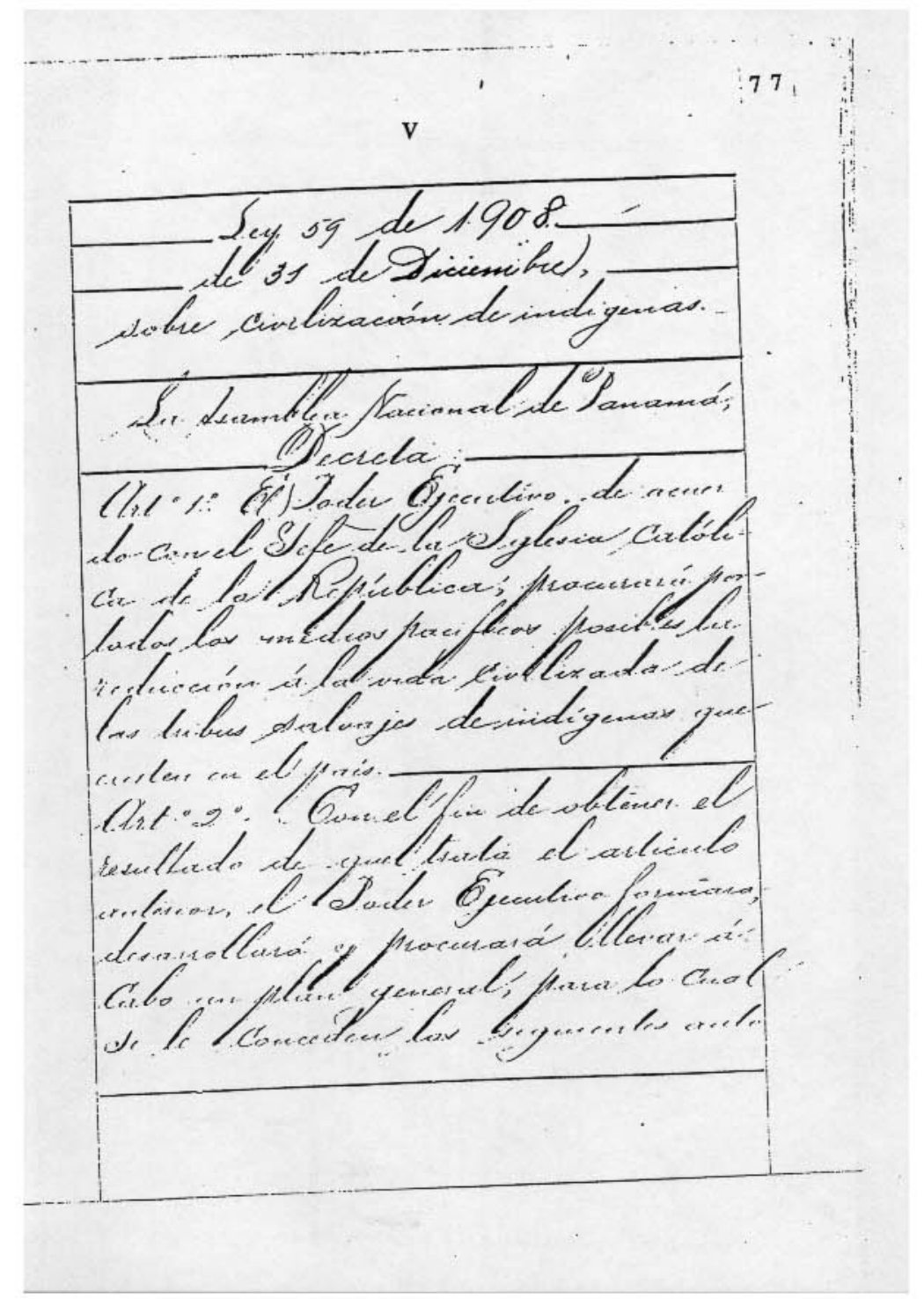




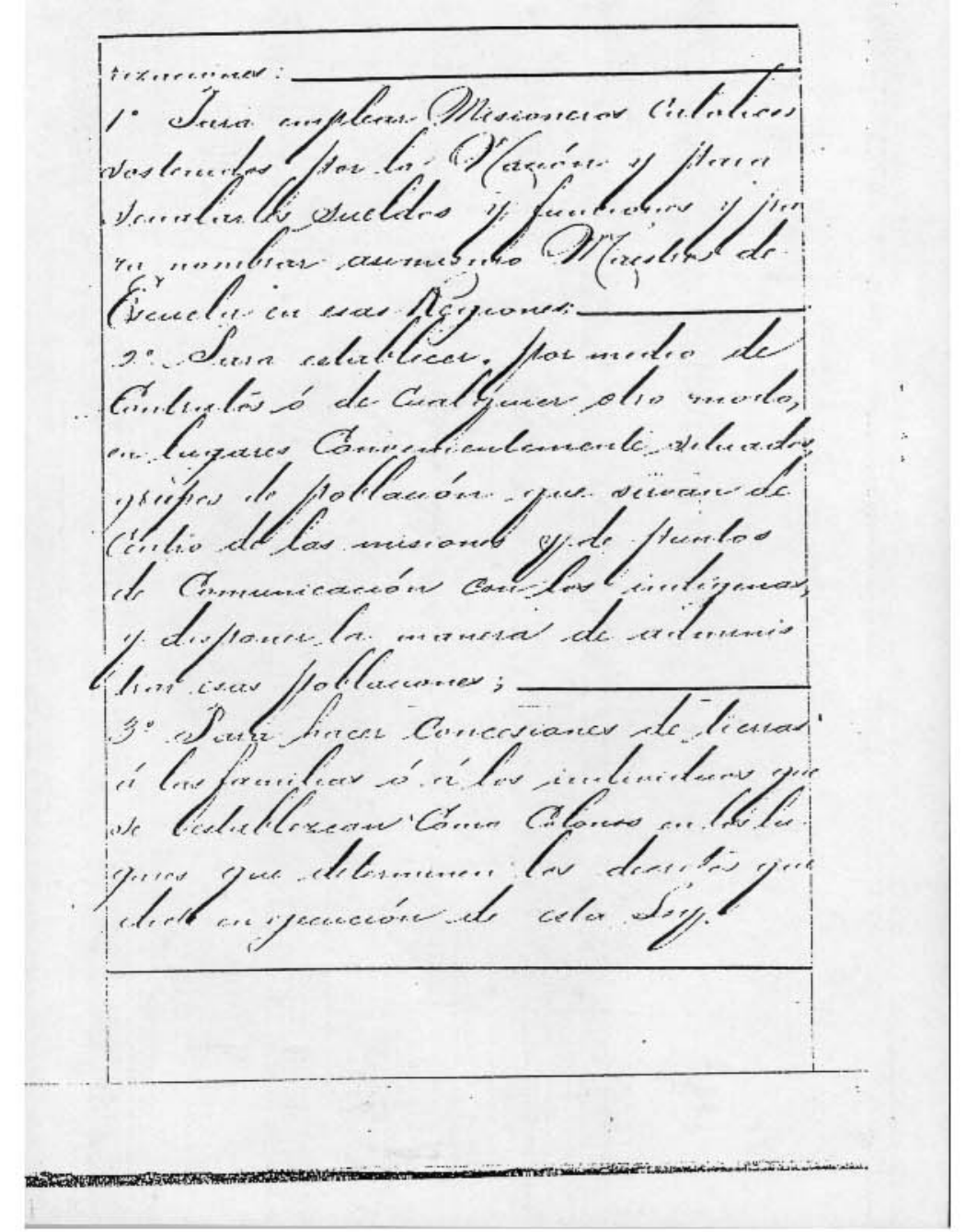




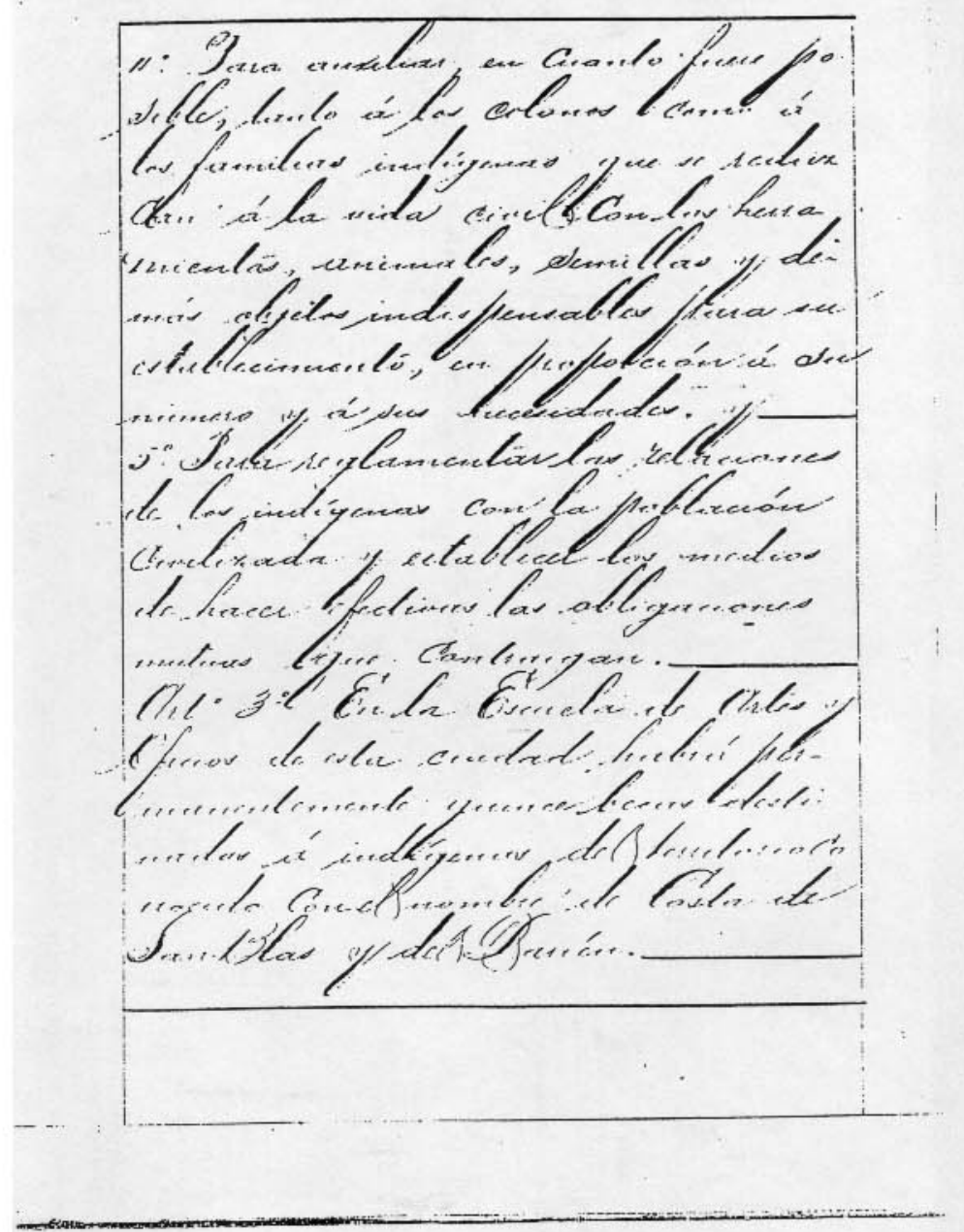




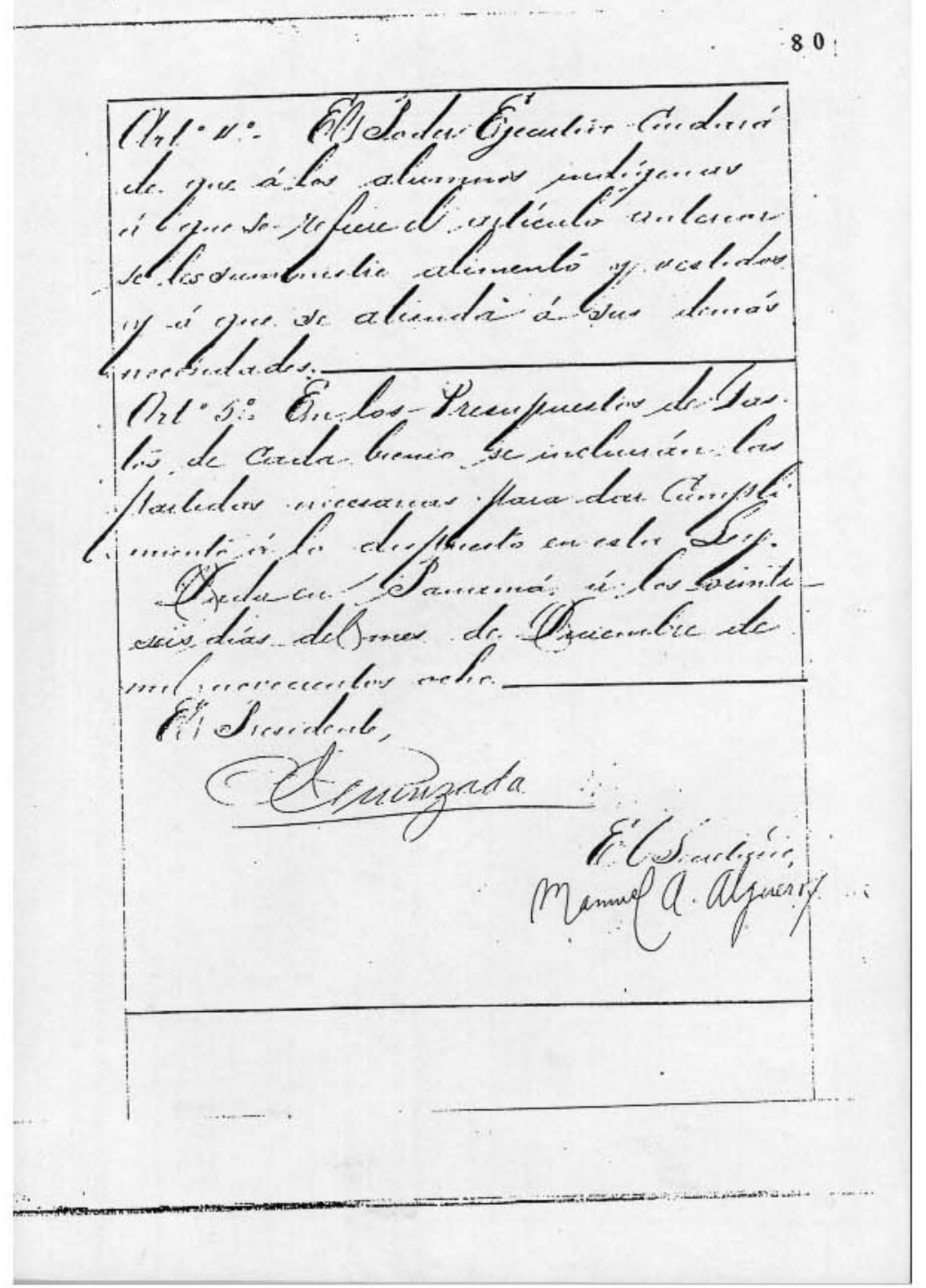




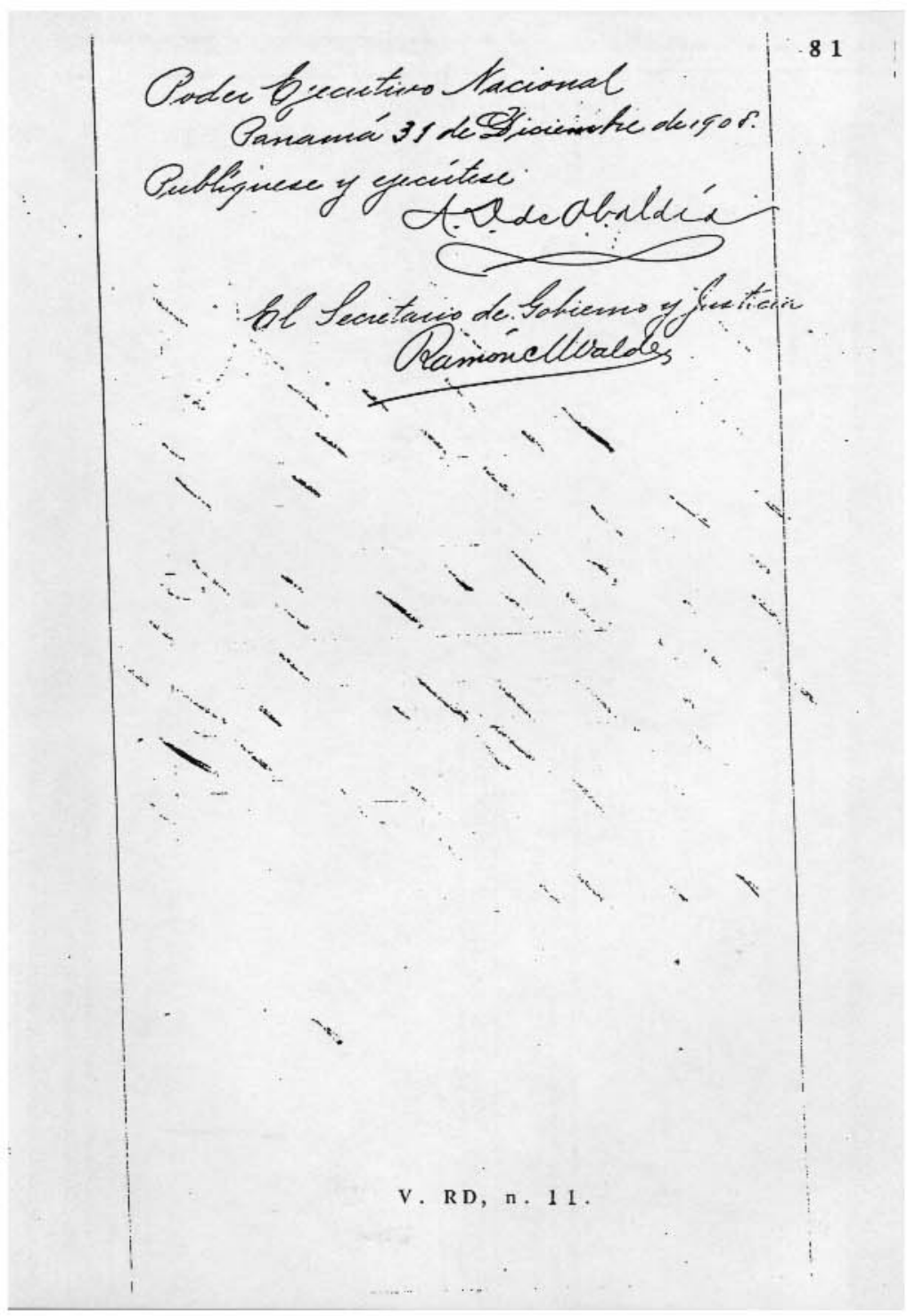




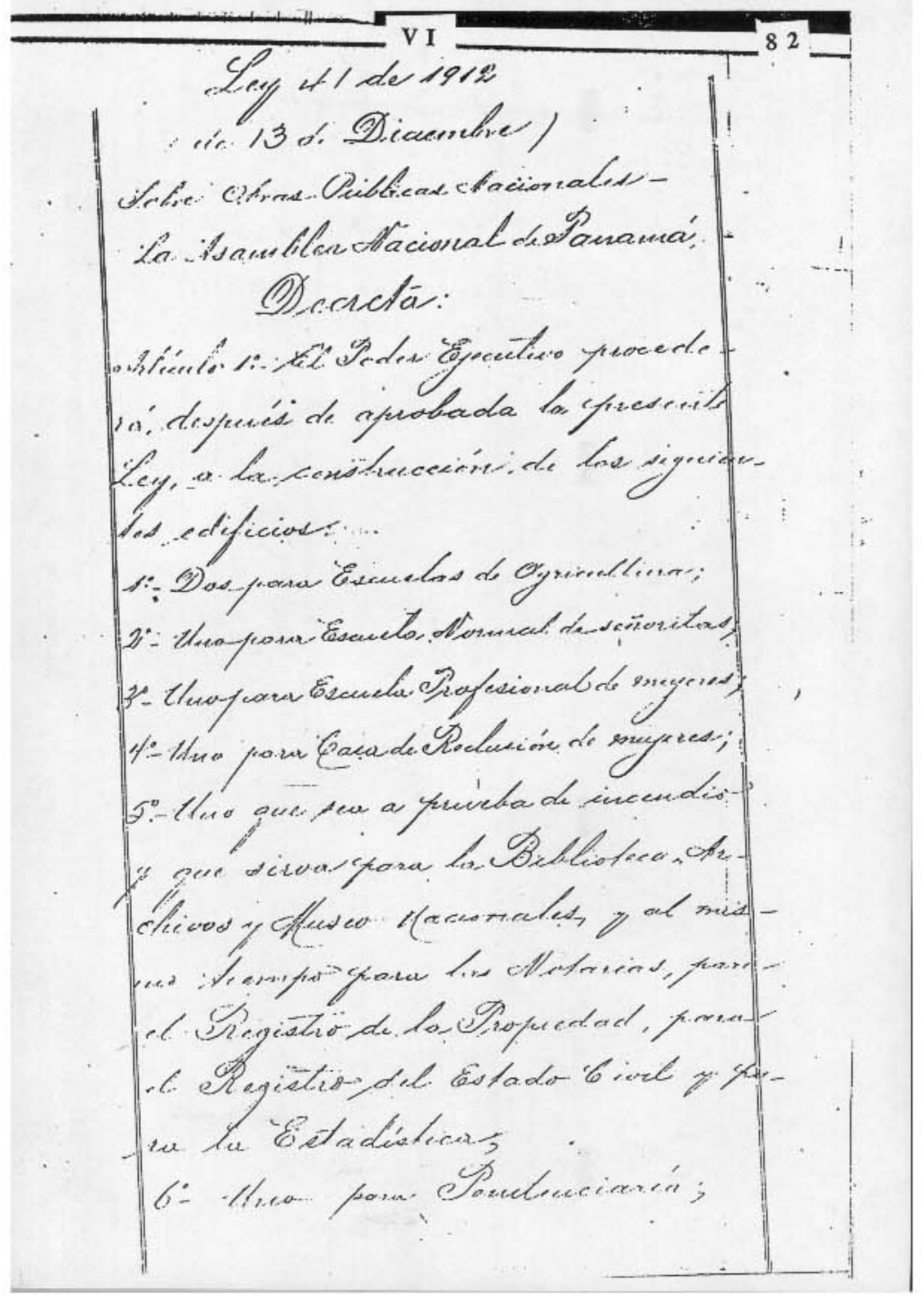




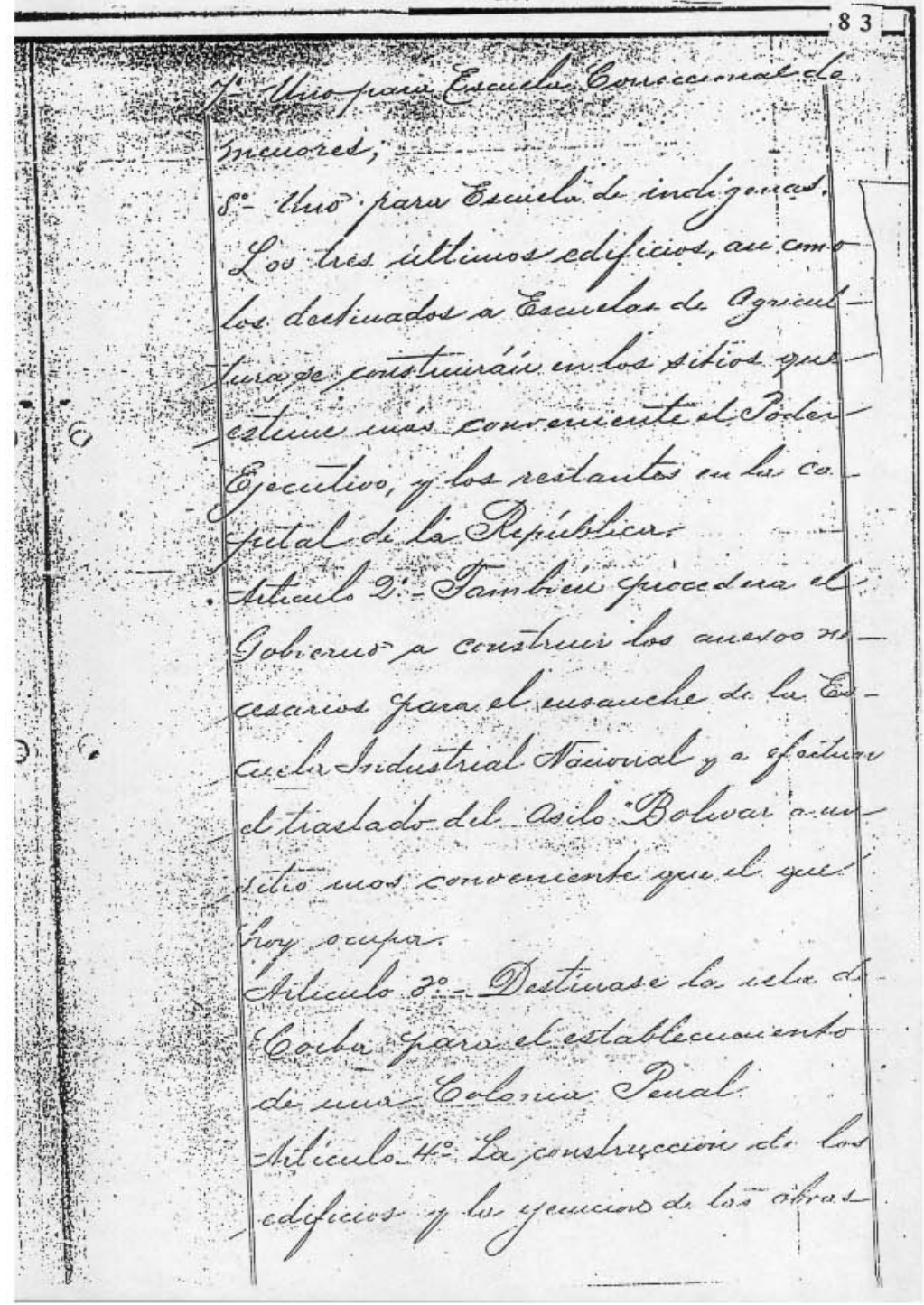




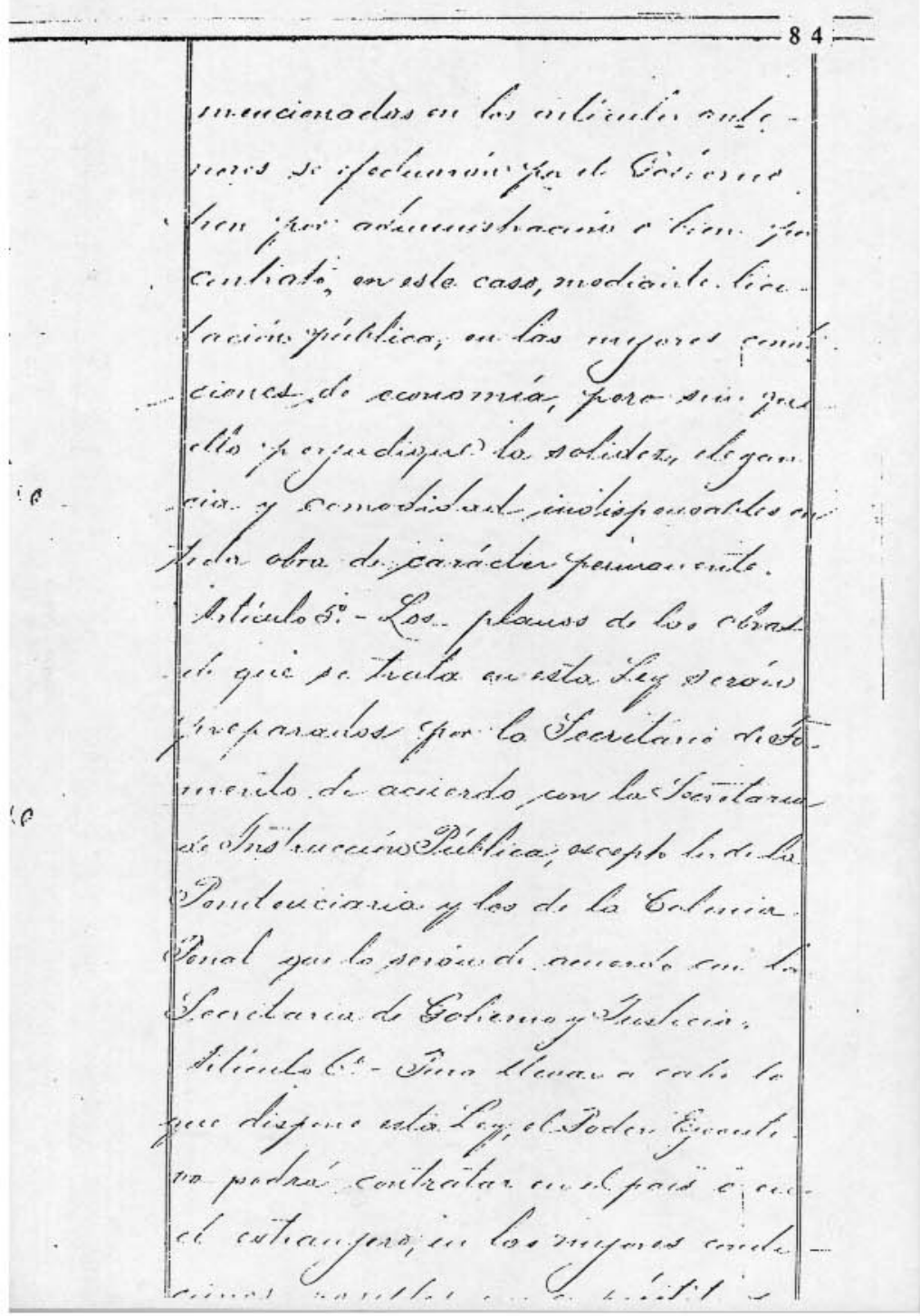




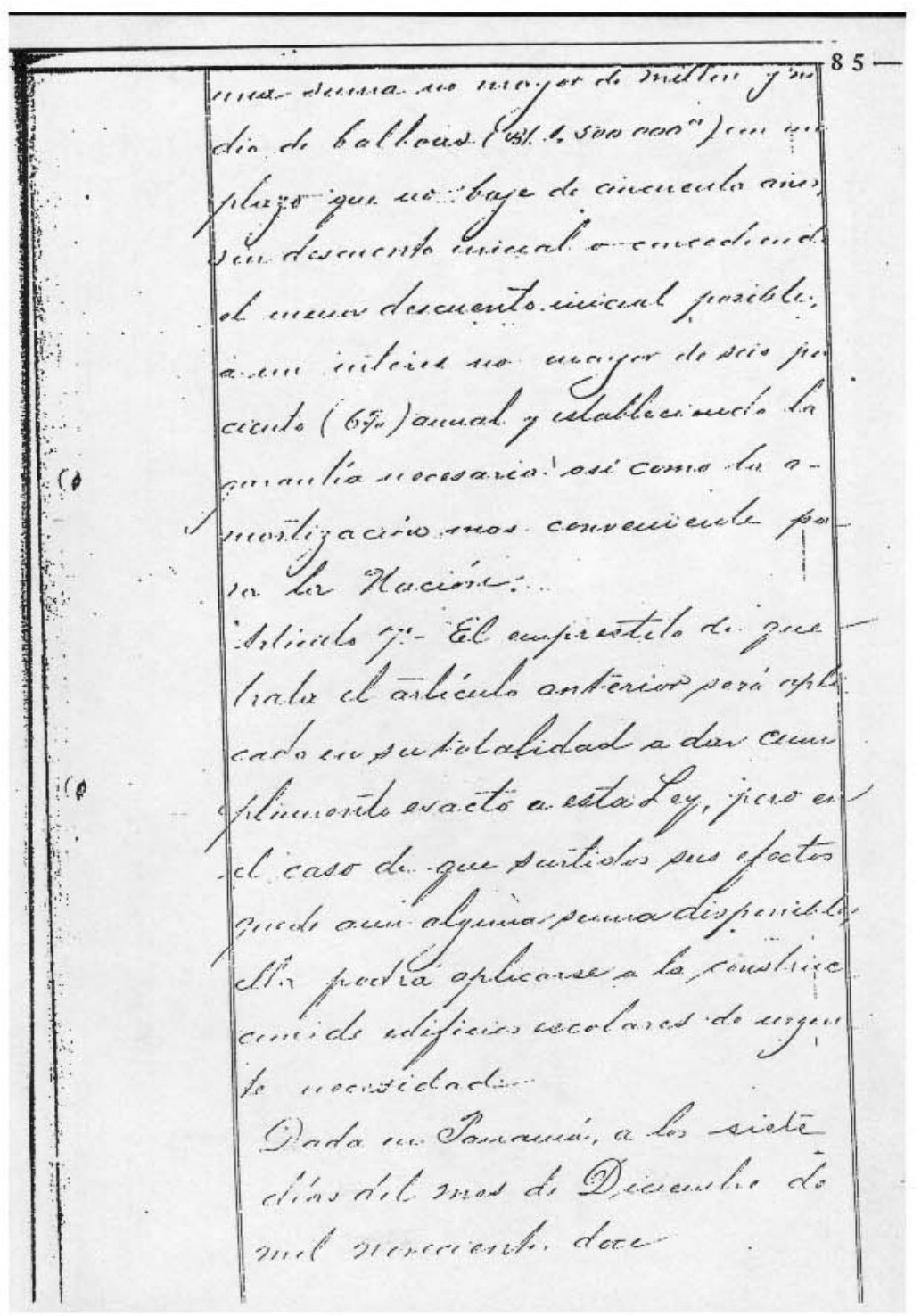




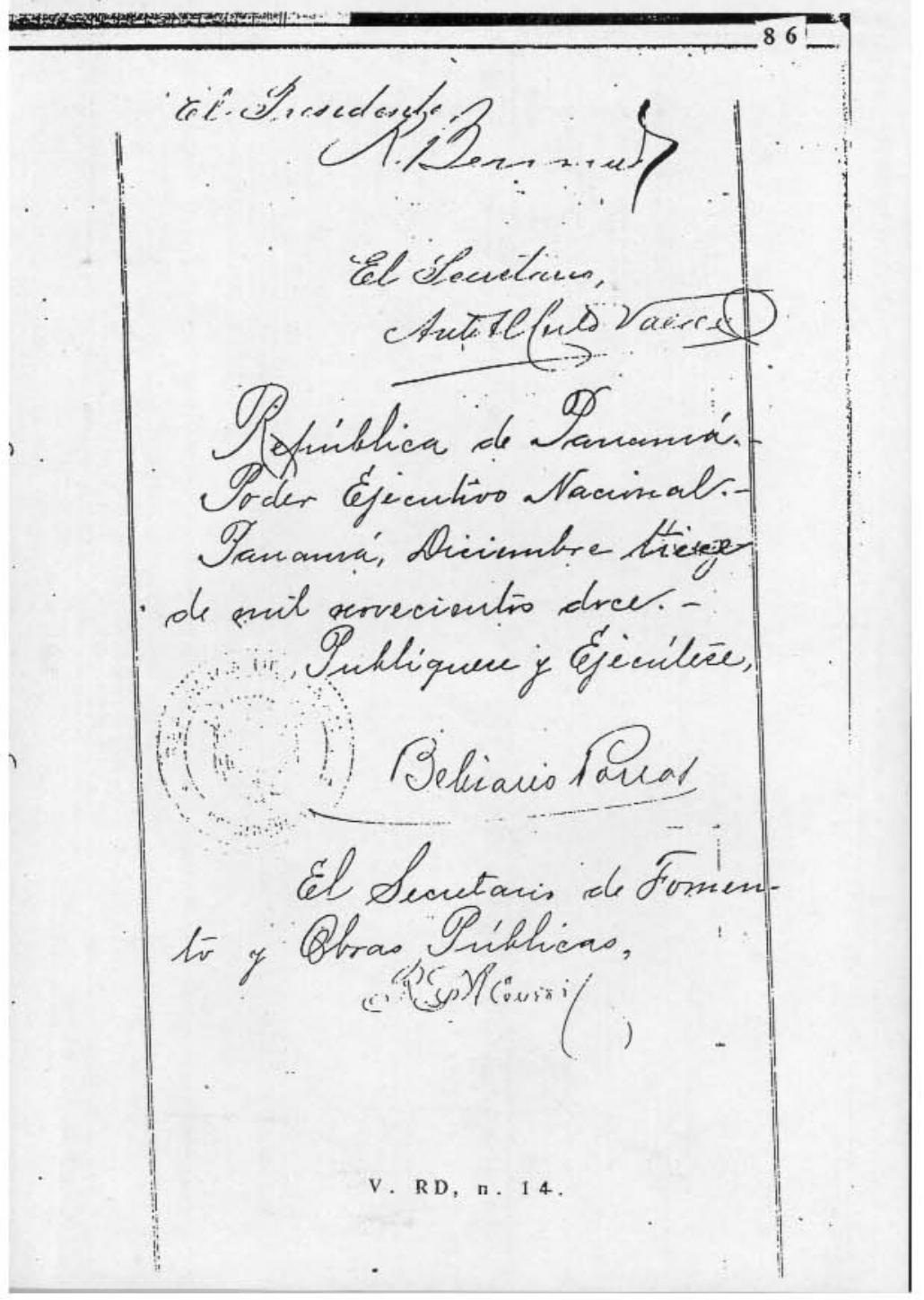




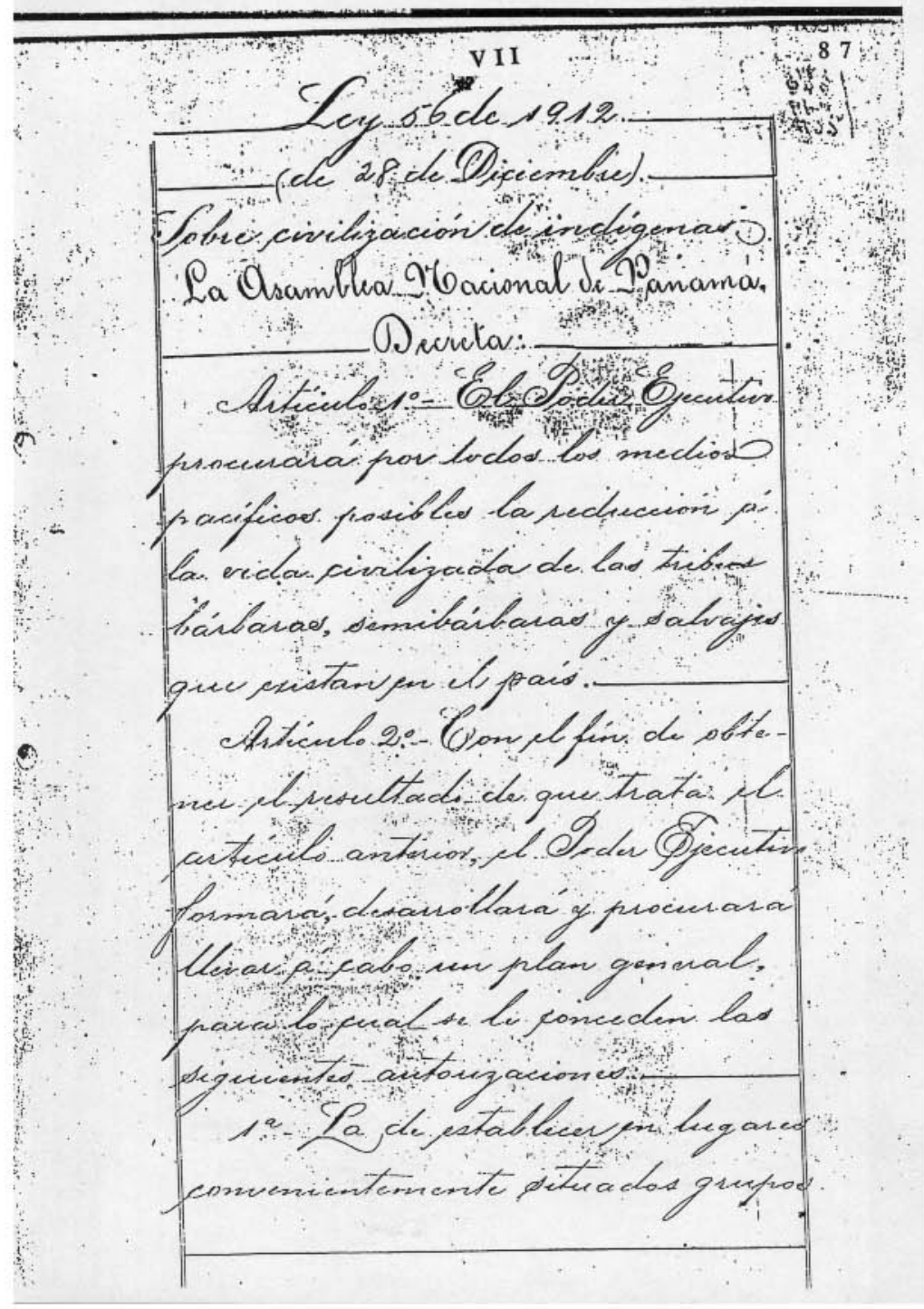




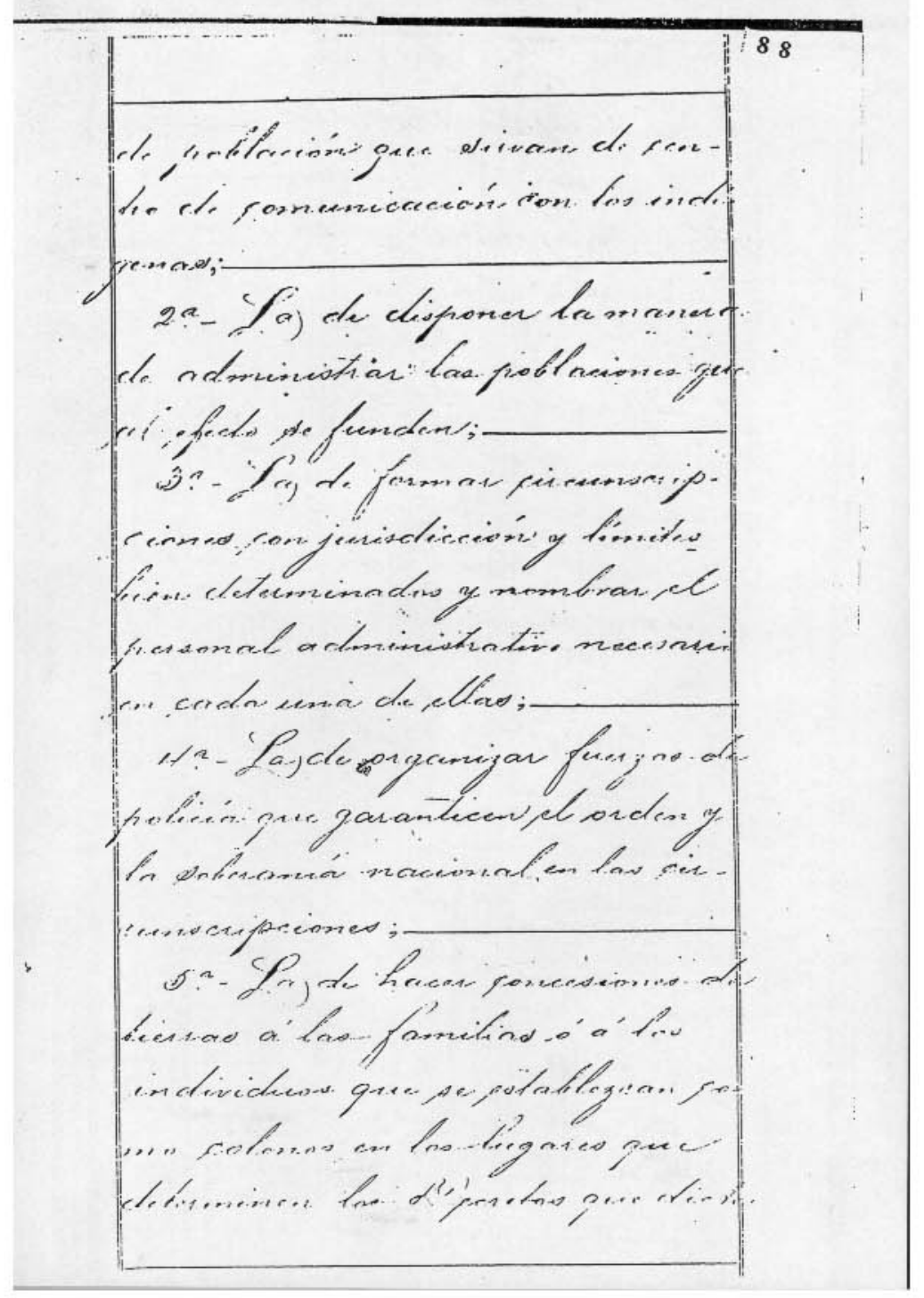




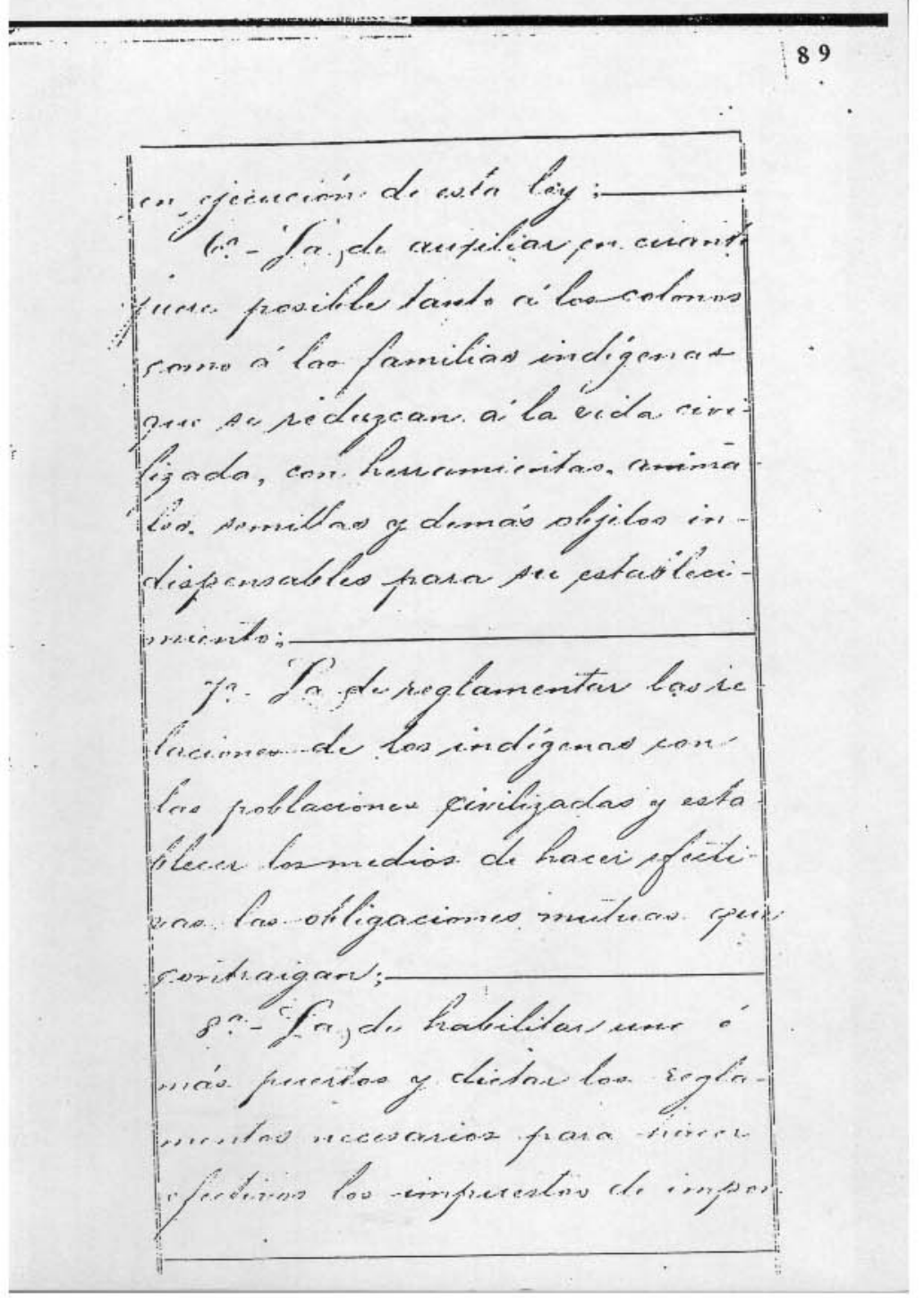




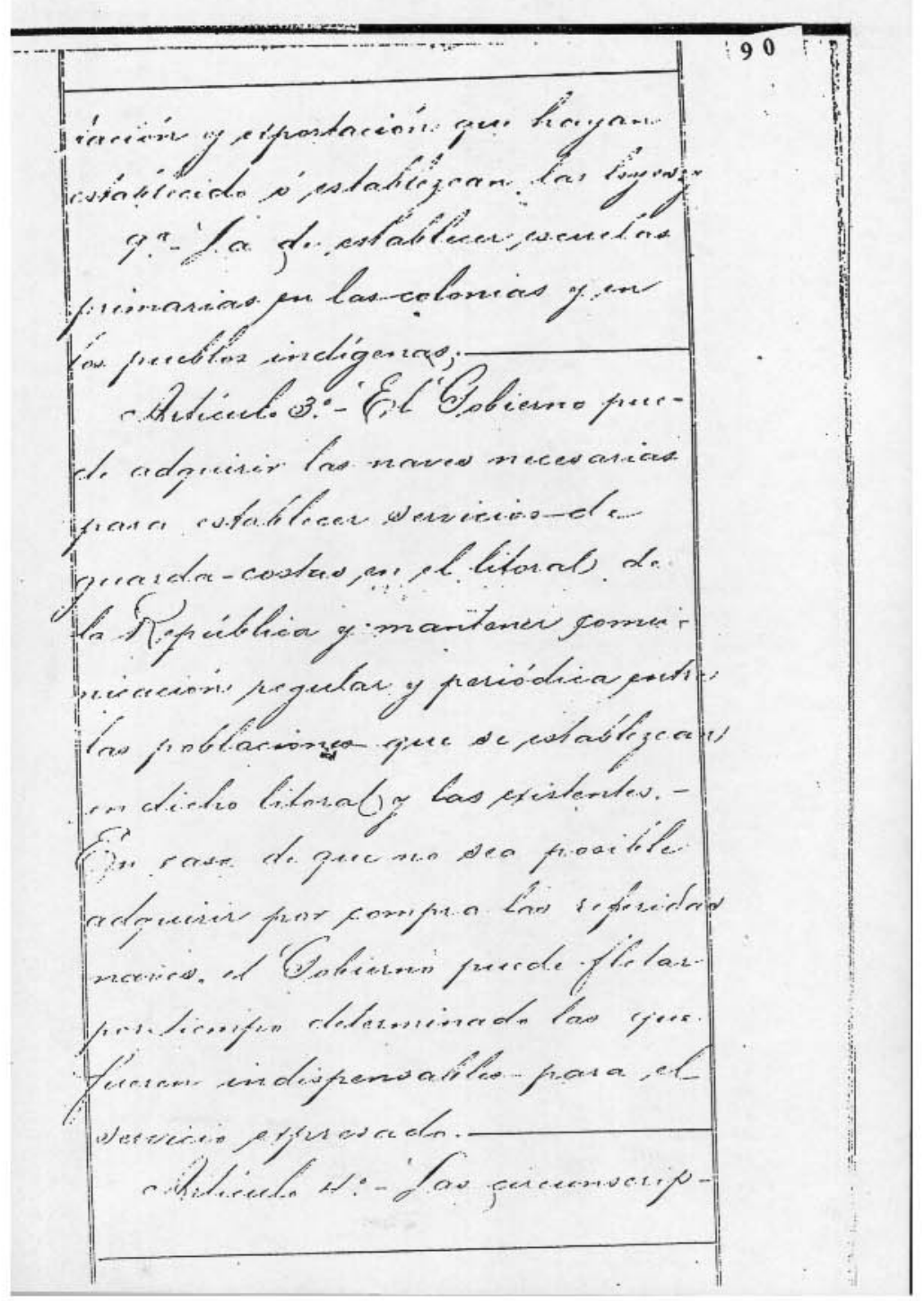




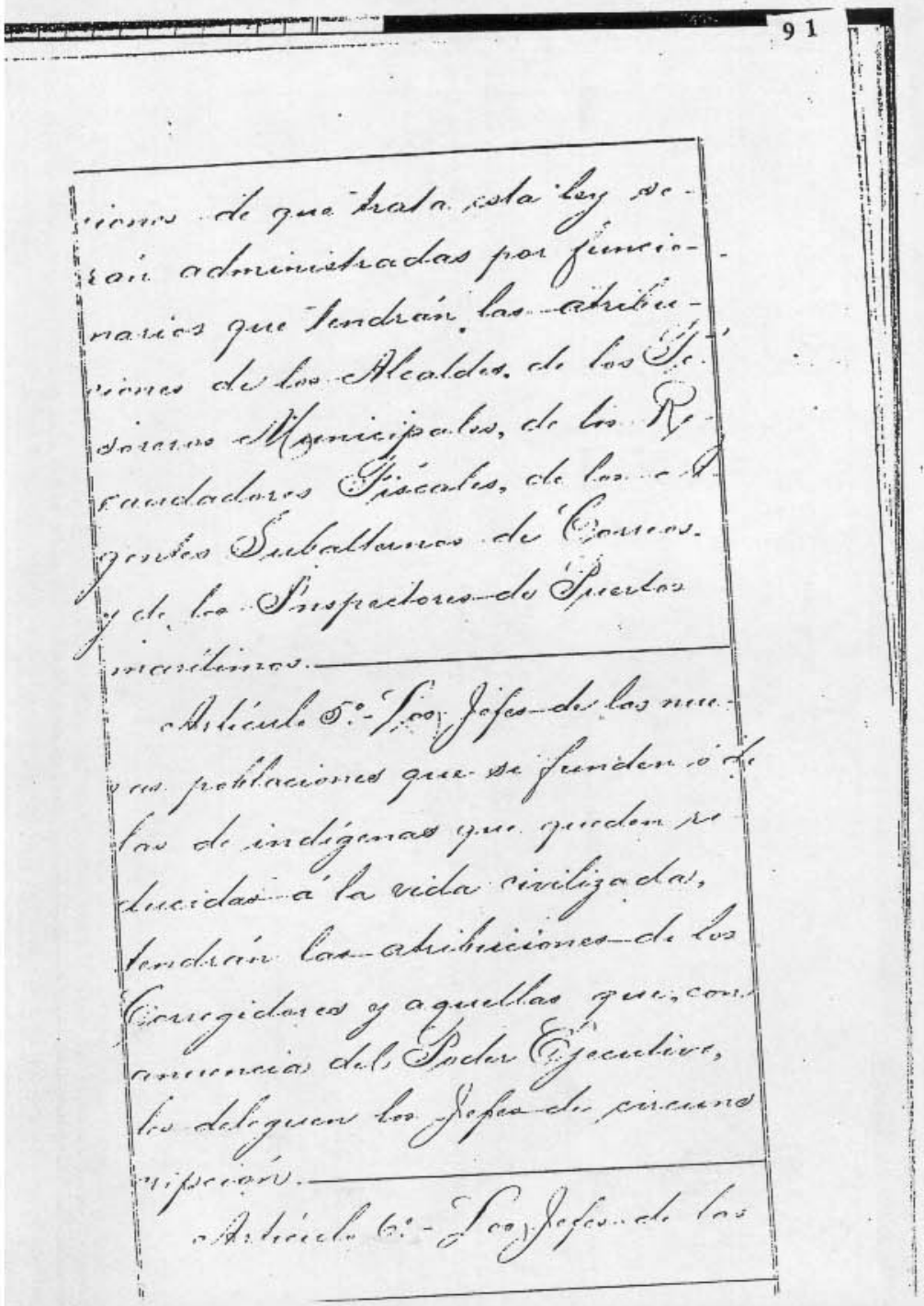




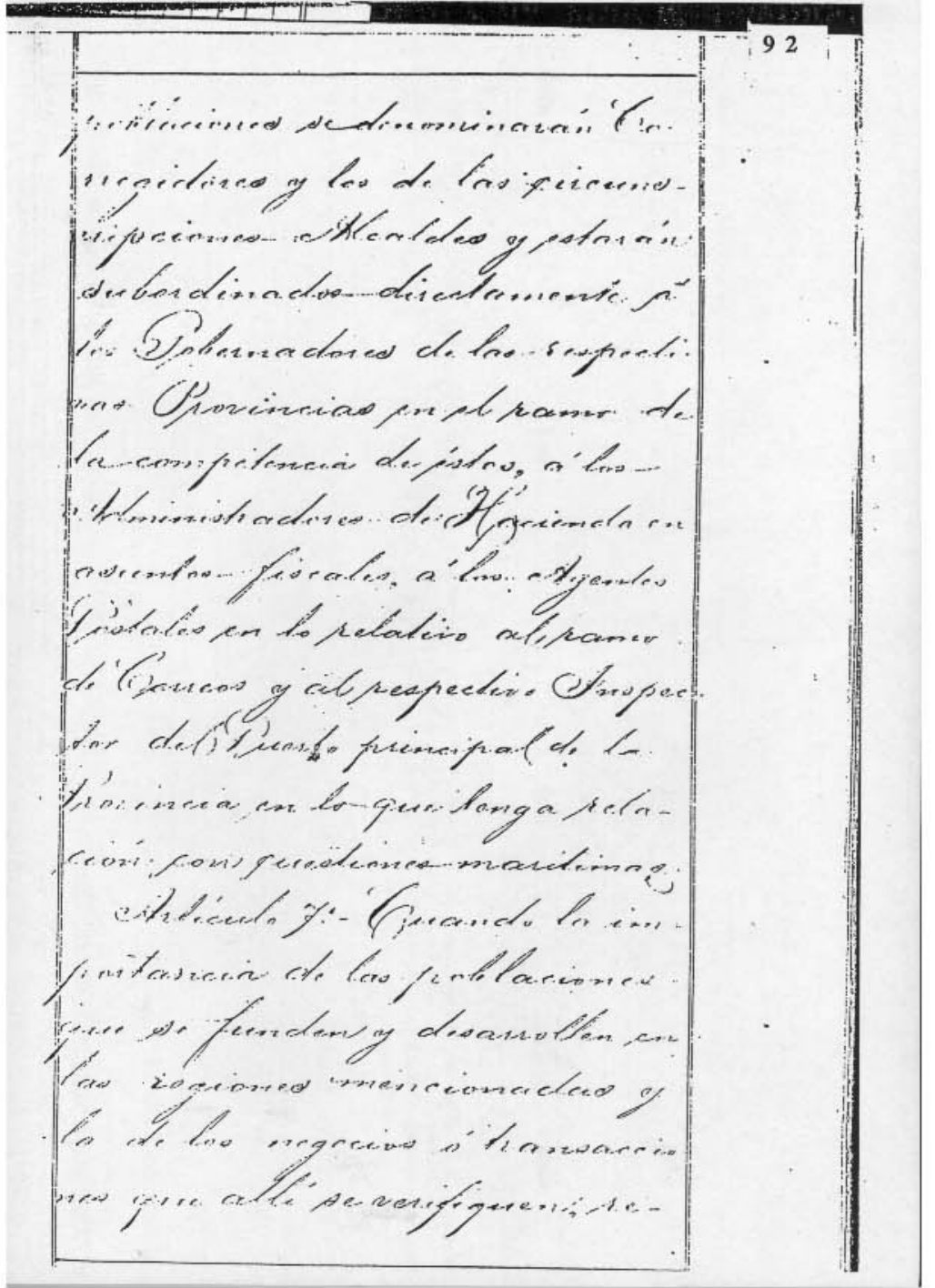




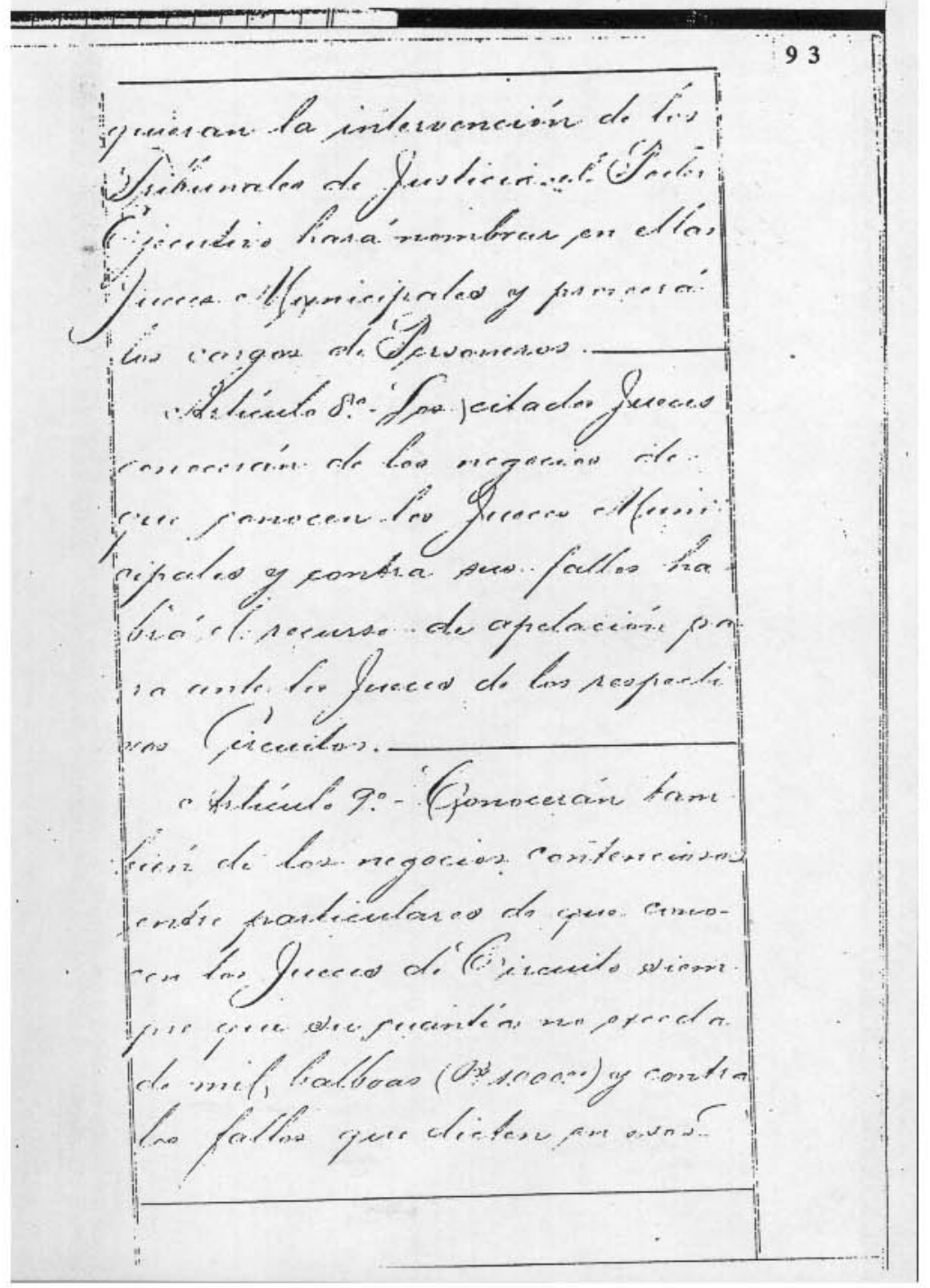




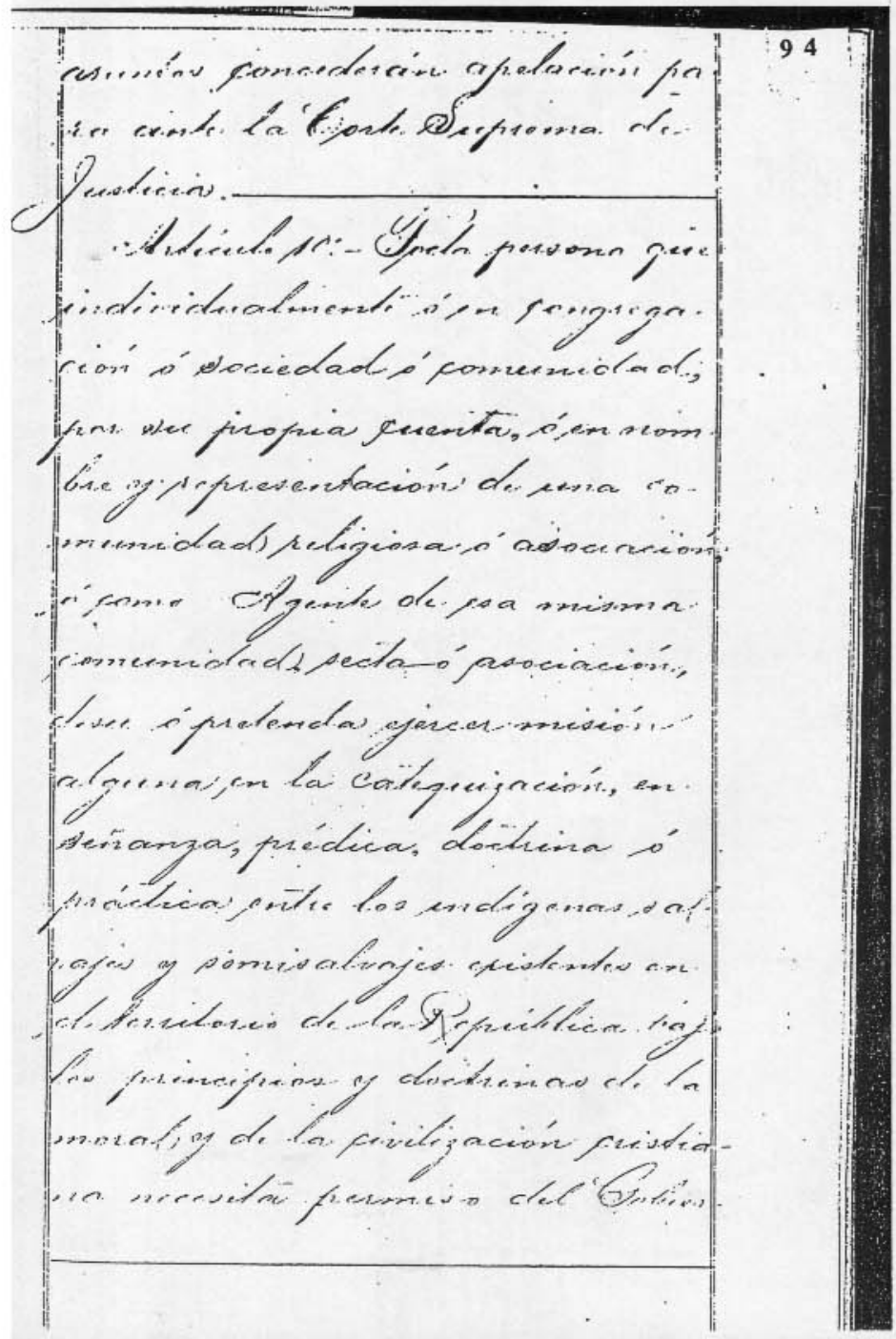




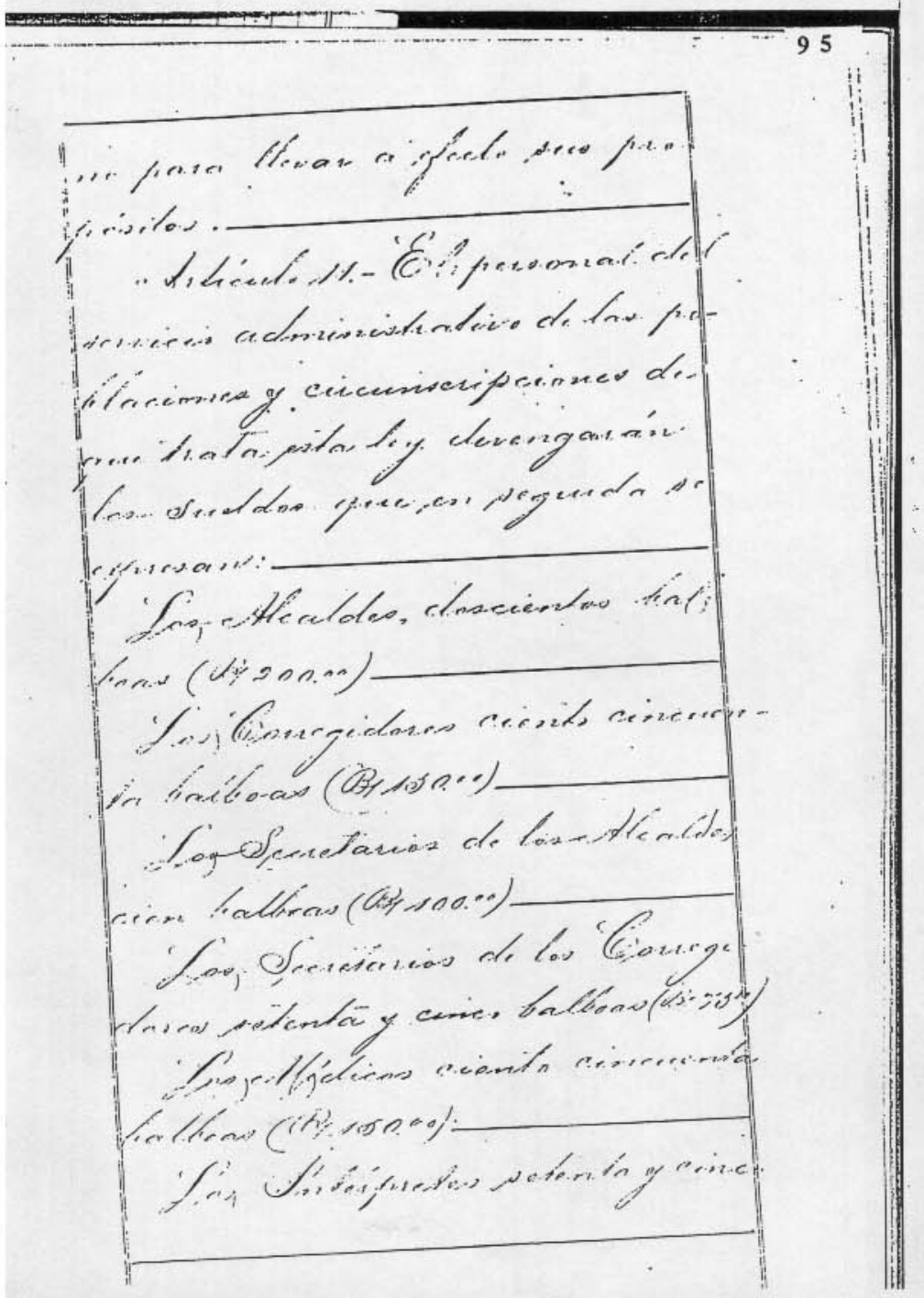




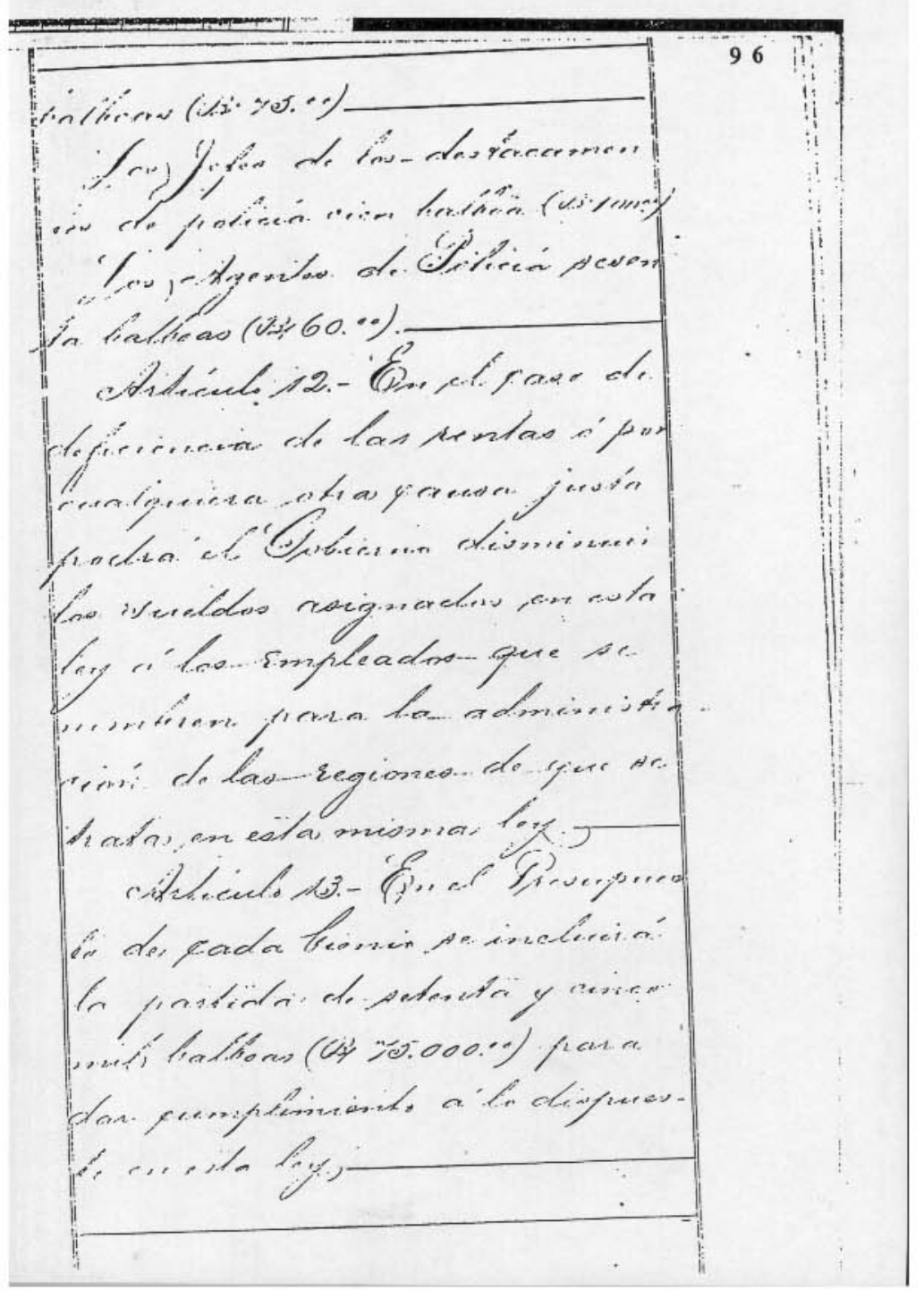




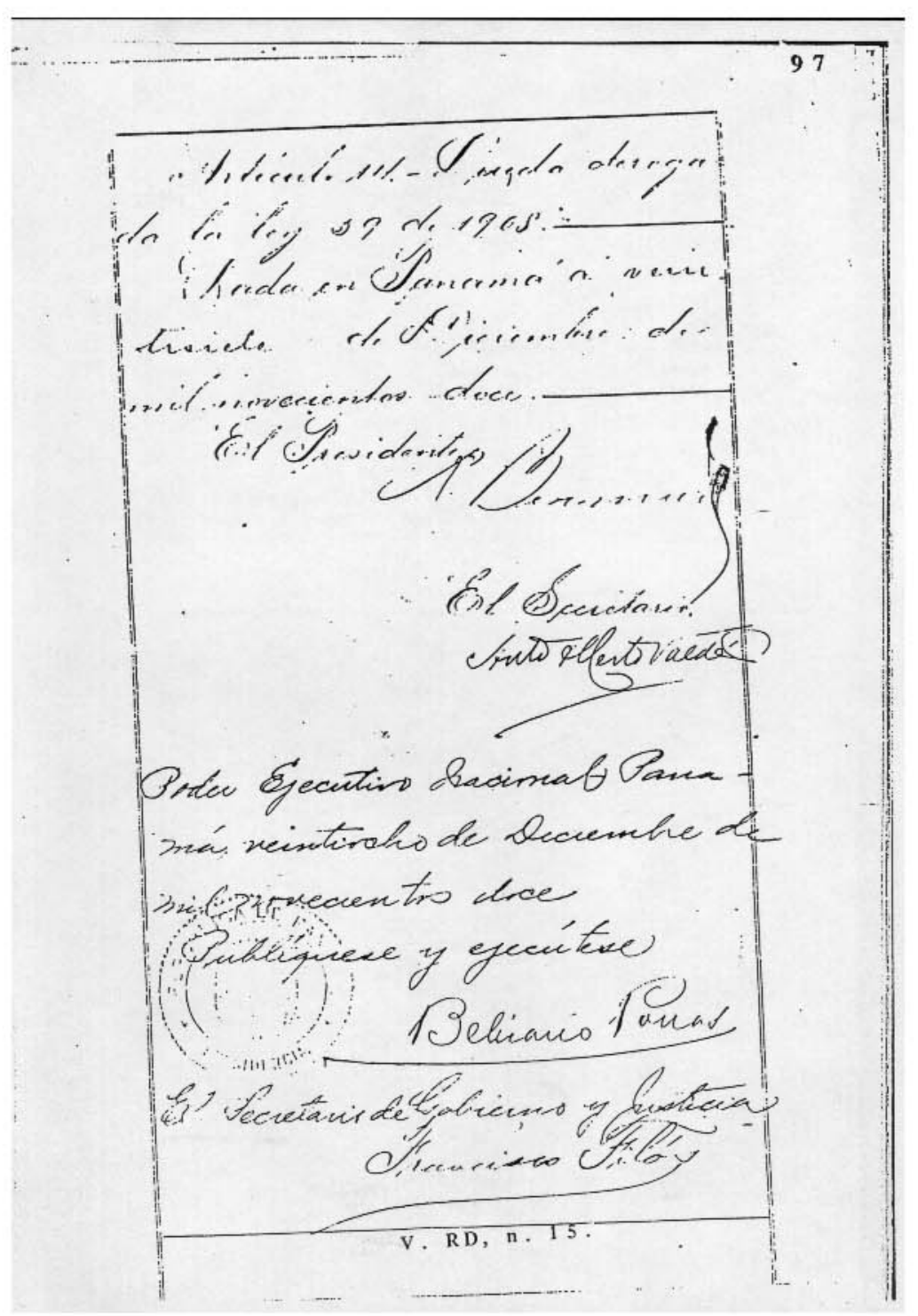




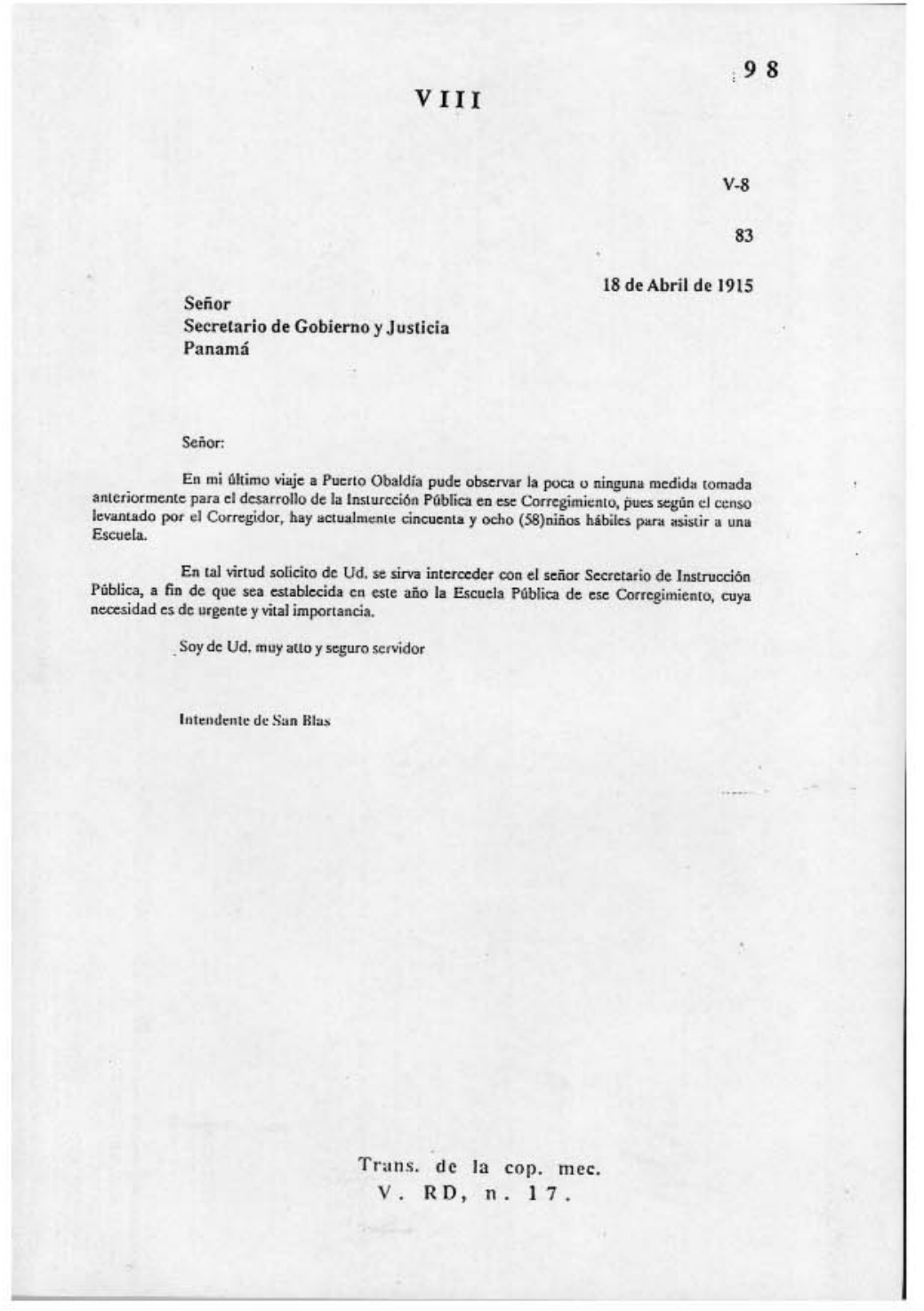


Panamá, 14 de mayo de 1915. Señor JEFE DE LA CIRCUNSCRIPCION DE SAN BLAS, E.S.D.

Para responder por el buen manejo en el desempeño de las funciunes del cargo de Corregidor en la Circunscripicon de San Blas, presento como fiador al señur Dun, (juillerrmo A. Cowes, quicen en prucba de que accpta firma al pie.

Soy de Ud. atto. seguro servidor.

Andrés Mojica

Acepto,

Guillermo A. Cowes

INTENDENCIA DE LA CIRCUNSCRIPCION DE SAN BLAS.

Panamá, 14 de Mayo de 1915.-

Acêplese al señor Guillermo A. Cowes como fiador personal del señur Andrés Mujica Acéplese al señor Guillermo A. Cowes como fiador personal del señor A A
al

Conuniquese.

El Jefe de la Cirrcunscripción

Enrique Hurtado

En Panama , a los quince dias del mes de Mayo de mil nuvecientos quince, proséntósc en el Despacho de la Secretaria de Gobierno el Señor Guillermo A. Cowes y por utra del scîu Enrique Hurtado fiadores del Señor Andrés Mojica, para responder del buen mancju

de éste en el desempeño de las funciones de Corregidor

de la Circunscripción en referencia, puesto para que ha sido

nombrado.

Para constancia se firma la presente diligencia.

El Jefo de ta Circunscripción

Enrique

EI Fiador

Guillermo A. Lemes

Trans. del orig. mec.

V. RD, n. 18 . 
CONTRATO NUMERO 2

Entre los suscritos, Juan B. Sosa, Secretario de Gubierno y Justicia, tn representación del Gobierno Nacional, por una parte, y Manuel Fernández, en su propio numbre, por tas oraza se b celebrado el contrato contenido en las siguientes cláusulas:

12- Manuel Fernández se obliga a establecer una Colonia Agrícola de cien familias, por lo menos, en el sitio que sea más conveniente entre la desembocadura de los rios Anachucuna y Navagandí y desde el Mar hasta la cima de los Montes del Darién. El área de la población será de veinte hectáreas y adyacente a esa área destinará Fernández un globo de terreno de cinco mil hectáreas que será dividio en lotes de diez hectáreas cada uno;

24. Manuel Fernández se obliga a nivelar las veinte hectáreas de terreno destinadas para población señalando las calles, plazas y lotes de edificación de acuerdo con el plano de que trata te nivelacion en el pina

39. Manuel Fenández se obliga a vender a cada una de las familias llevadas para bu Colonización un lote de terreno sufficiente para edificar habitaciones y sus accesorios en el terrento urbanizado. El precio de estos lotes será fijado en tarifa que deberá tener la aprobación del Gobierno. Las condiciones de venta de lotes a los colonos serản las establecidas en el Decreto № 33 de 1915, dietado por el Poder Ejecutivo, ramo de Gobierno, pero no tendrá aplicatéön el arliculo 23 de este Decreto:

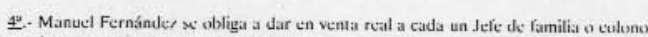
a de hectâreas deatro de las 5 .1000 do qué trata ta cláusuia $1 \%$, en las condicioaes del Decruto mencionado;

59- Manuel Fernaindez se obliga a establecer, dentro del término de ocho años ca el sitio que sea mais conveniente y apropiado del terreno que solicita, cultivos agricolas y llorestaltes en extensión no menor de cuantro mil hectáreas:

64. En compensación de las obligaciones impuestas por este contrato a Manue Fernánder, el Gobierno cede en plena propiedad a esie señor veinticinco mil hectír eas de tiurra to

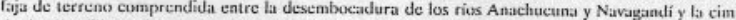

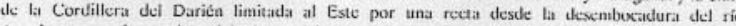
Aniachucana a la cambre del Cerro det mismo nombre, y al Oeste, por ufra recta desde i. descmbocadura det ro Navagandi hasta la cumbre del Pico del mismo nombre. No se cufiprenden en is que están fremte o cerca de esa cost

Esta cscritura de cesiôn serái inscrita cuando el Concesiunario presente al (iobiernı para su aprobacioion el plino de que trata la cliusula $12^{\circ}$ del presente contrattu.

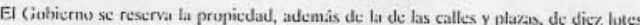

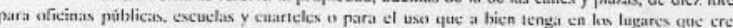
curvenientes; 
72-El Gobierno se obliga a exonerar de toda clase de impuestus o cuntribuciones en el término de quince años contados desde la fecha de este contrato los terrenos rurules mencionados término de quince años contados desde la fecha de este
aquí, lo mismo que las fincas que en ellos se establezcan;

82. El Gobierno se obliga a habilitar un puerto tan pronto como en El haya una población de cincuenta familias por lo menos;

29. El Gobierno concede a Manuel Fernández el derecho de organizar Compañias para explotar los terrenos que por este contrato se ceden;

10.- El Gobierno cuncede a Manuel Fernández el derecho de construir caminus carreteros, ferrocarriles y lineas telefónicas de uso privado dentro del término de que se trata y de ejecutar sin necesidad de permisos especiales toda clase de trabajos que tiendan al desarrollo y

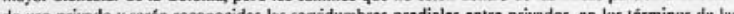
Leyes civiles vigentes, oque rijian can al monento de su aplicación;

11.- El Gobierno concede a Manuel Fernández el derecho de construir un muelle y de explotarlo durante quince años contados desde la fecha de la construcción, si ésta se verificase antes de diez años contados desde la fecha de este contrato. Vencido el plazo de la explotación el Gobierno entrará en posesión o propiedad plena del muelle que será entregado en essado de servicio con todos sus accesorios:

12:- Manuel fernández se obliga a ejecutar y presentar para su aprobación al Gobierno, seis meses después de celebrado este cuntrato un plano del terreno que se le cede y a depositar comb

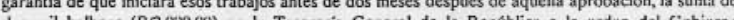

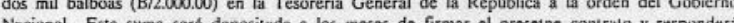
también de la obligación a que se refiere el artículo siguiente;

139- Manuel Fernaindez se obliga a organizar en el término de cuatro mesuss a partir de La aprobación de este contrato, una Compañia con Capital y elementos suficientes a satisfiacciòn dé Ciobicrno que puede llevar a cabo la empressi de colunizaciơn y desarrolio de la region que se le cede. Lat omisión de esta obligatión en el plazo estipulato será causa para que cl tiobierno declare sin valitez este contrato y para que perciba ta suma que tn concepto de garantia depusite of Cuncesionario en ta Tesareria General;

14\%. - Los indigenas no podrản ser considerados cumo colonos y reconocerá y respelará cl señor Matnuel Fernindez la propiedad de los cultivos:

15*. El Gobierno se compromete a dar de manera efectiva toda la protección qut aceesite el scrior Fernánder para llevar a efecto esa empresa y caso de que pur algún motivo de prorrogar los términos mencionados en este contrato por un tiempo igual a aquel en que haysan sides suspendidos.

República.

16e- Este contrato necesita para su valider de la aprobación del señor Presidente de lat

Panamí. Encro veintisitte de 1916

ES Secretario de (jobistrno y Justicia

Juan B.Sinsa

El Contratista

Manuel Fernaindez Hernaindez 
República de Panamai.- Poder Ejecutiwo Nacional.- Secretaría de Gobierno y Justicia.Sección Segunda.- Panamá,27 de Enero de 1916

Aprobado

Registrese, comuníquese y publíquese.

\section{BELISARIO PORRAS}

El Secretario de Gobierno y Justicia

Juan F. Sosa

Es copia auténtica.

El Subsecretario de Gubicrno y Justicia

(firma ilcgible)

Trans, del orig. mec.

V. RD, n. 21 . 
El Porvenir,17 de fayo de 1916.

Señor Secretario:

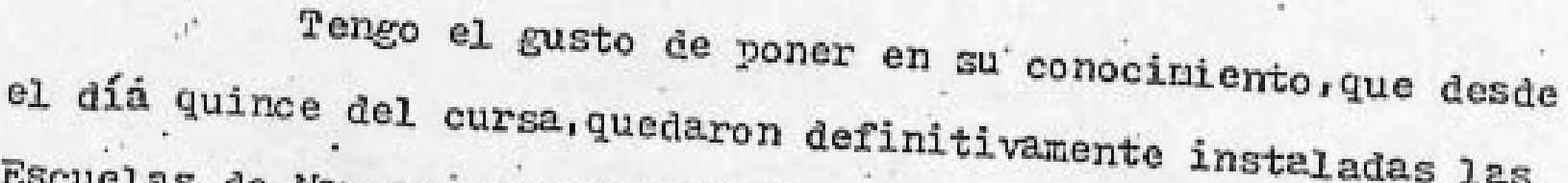
Escuelas de largana y Tupile, habiendo sido satisfactorio el recibiendo que a las respectivas mestras, hicieron los indios de esos lugares:

Con toâa consioleracion, me suscribo su affrn.

Jefe de la círcunscripcion de S.B.

Señor Secretario de istaco en el Despacho de lintruccion Publica. Panamá. 


\section{REPUBLICA DE PANAMA \\ CIRCUNSCRIPCION DE SAN BLAS \\ Porvenir, Enero 16 de 1917 \\ Señor Inspector de Instrucción Pública, Colón.}

Nos referimos a su atenta nota No, 435 , del 28 de Diciembre, recibida el 11 de los corrientes, en la cual nos comunica que hemos sido nombrados para formar el Jurado de Calificación que actuará durante los Exámenes de fin de curso en las escuelas de la Circunscripción de Sản Blas.

Es un motivo de satisfacción personal cooperar en esta forma a la obra eficiz de nacionalización que las escuelas están ejecutando entre los indios de San Blas; y al rendir el Informe reglamentario y las correspondientes calificaciones nos atenemos, no sólo a los resultados obteridos durante los exámenes, sino tambien a la tarea que cada maestra ha llevado a cabo en su caso particular, dadas las circunstancias del medio ambiente: ta dificultad del idioma, el titmpo transucrrido desde la apertura de la escuela, la mayor o menor voluntad de los indios, la presencia de elementos discordantes con la uniformidad de la enseñanza nacional, y la escasez de útiles tscolares. Nosotros, que estamos unifieados con la vida, que pudiera llamarse nacional, de San Blas, que hemus asistido al nacimiento y desarrollo de las escuelas, no podemos prescindir de ciertos detalles al rendir un Informe de la naturaleza del presente.

En nuestro criterio, el resultado de los exámenes ha sido muy bueno, como ejnslan ta las respectivas actas, a las cuales referimos al señor Inspector.

El promedio de cada escuela es el siguiente:-

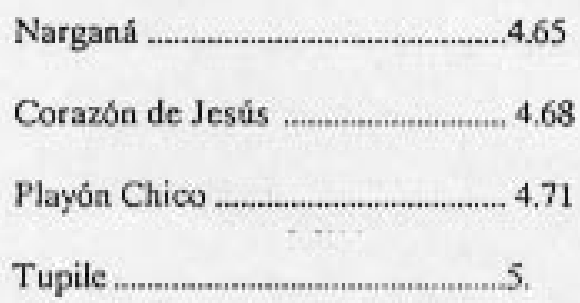

La enseñanza impartidat ea las clases se ciñe mís o menos estrictamente a los programas oliciales para el primer grado, con la salvedad de que a los Ejercicios de Lenguaje ha sido necesario darles un desarrollo especial, objetivo, como Método de easeñanza dél idiuma.

En las escuelas de Narganá y Corazön de Jesüs, ta asistencia hat sido felativanacnec menor que en las dos restantes, debido a la presencia de las dos misioneras americanas, establecifias hace cuatro años y apoyadals por les jelies indigenas.

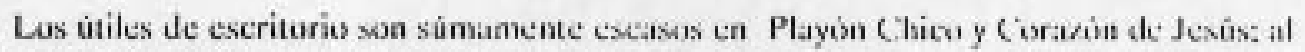
seảalatr esta deficienciat abrigames la esperamza de que el próximo dàu escenlar se inatugurarti, en ese particular, bajo mejures basts.

Sumus del Inspector cen tada consideración ateatus y seguru servidures.

El Canificador 1 El Calificador

Fed. Gutierrez A. Linares

Trans. del orig. mec.

V. RD, n. 23 . 


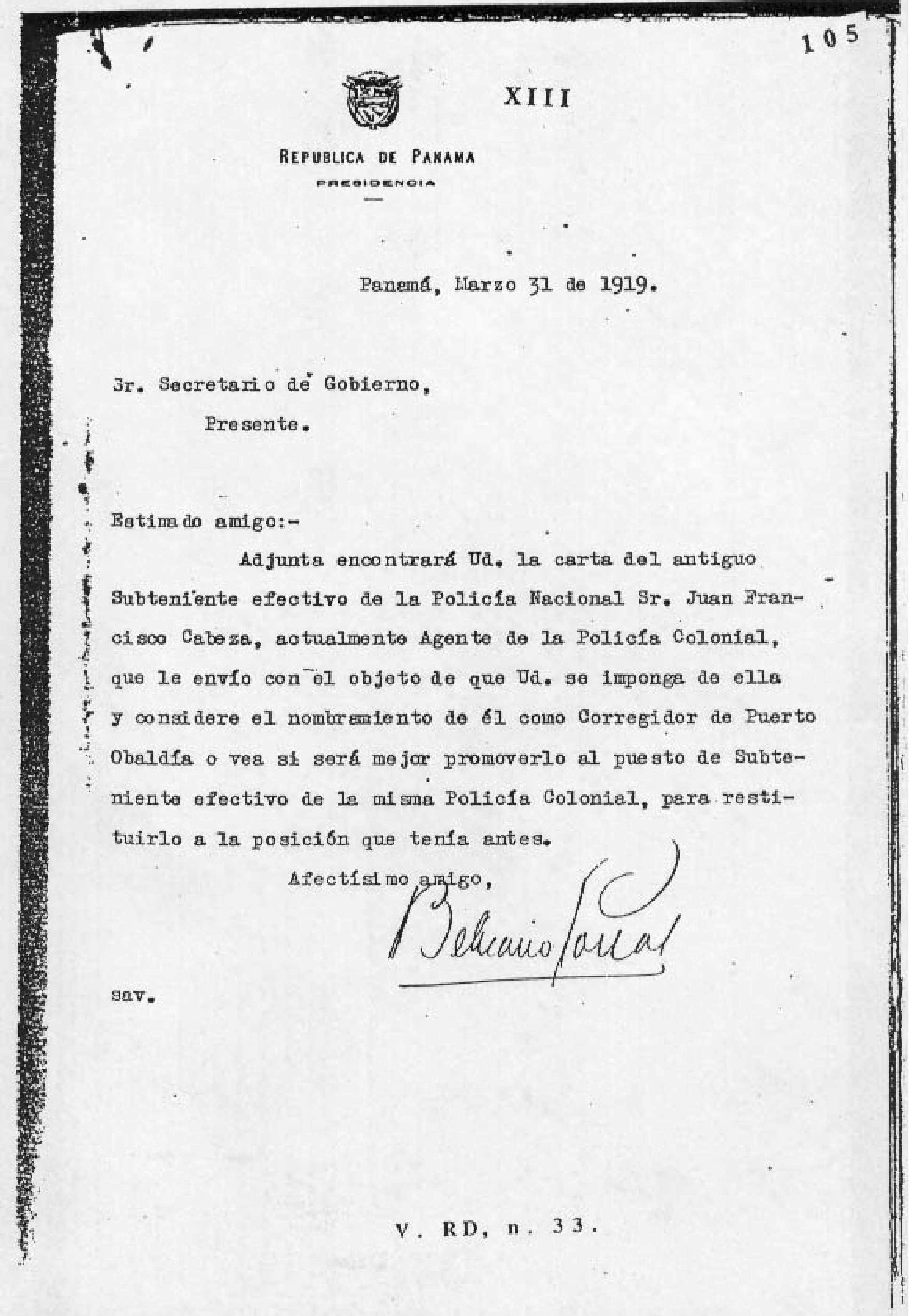




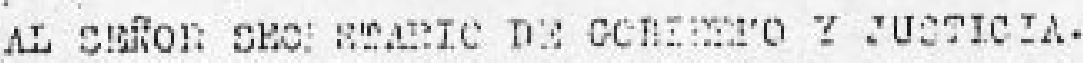

$$
\text { V. RD, n. } 38 \text {. }
$$




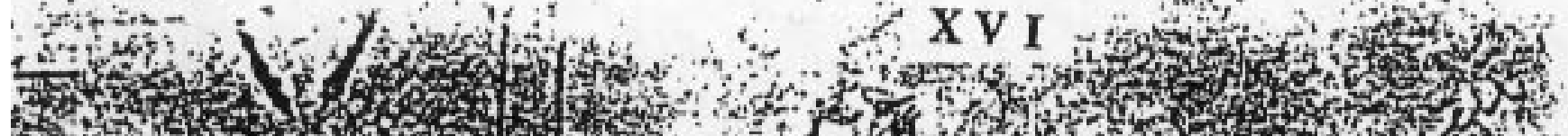

T.5. (3)

Fj: 136.

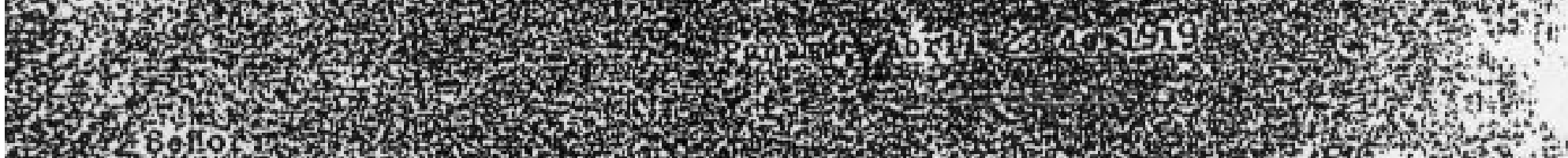

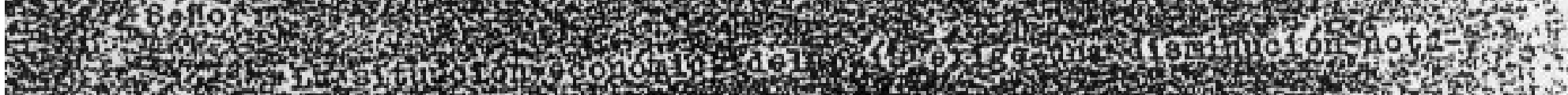
W.

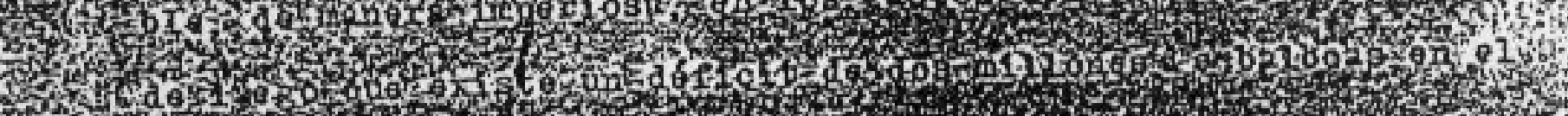
F.

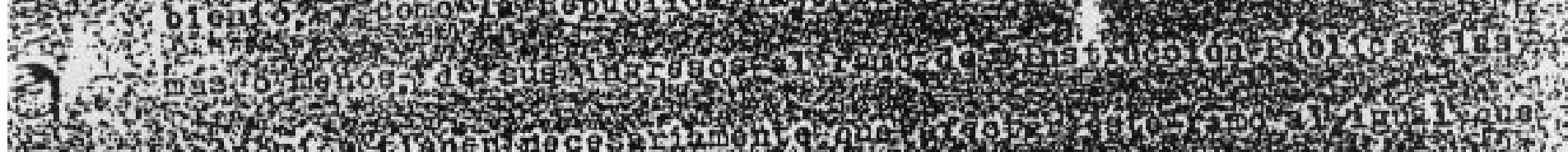
F. s.r.

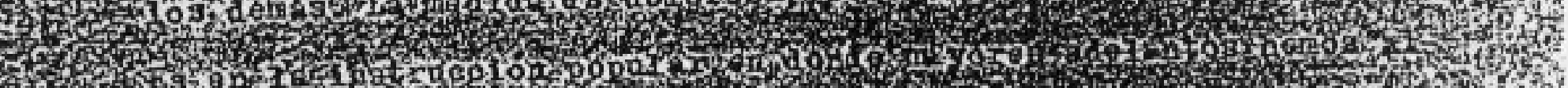

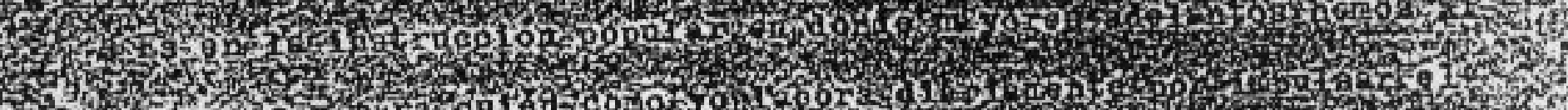

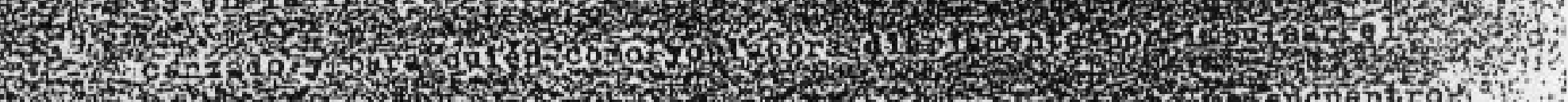

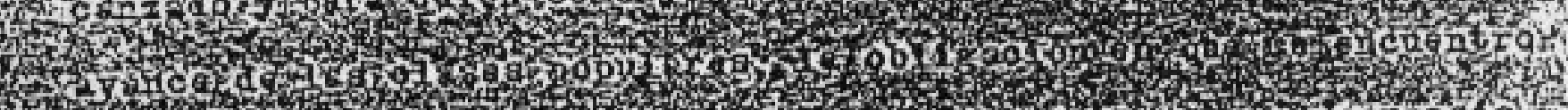

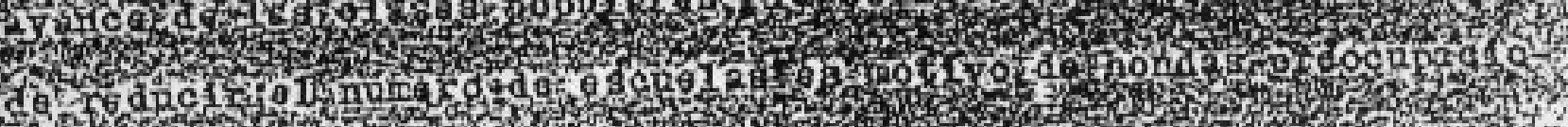

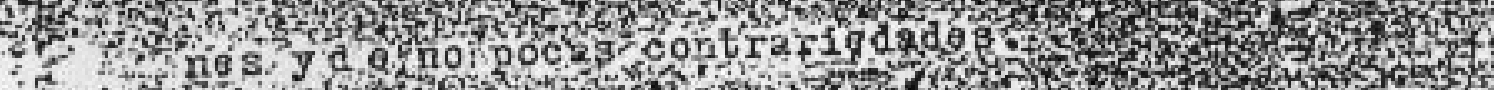

(3)

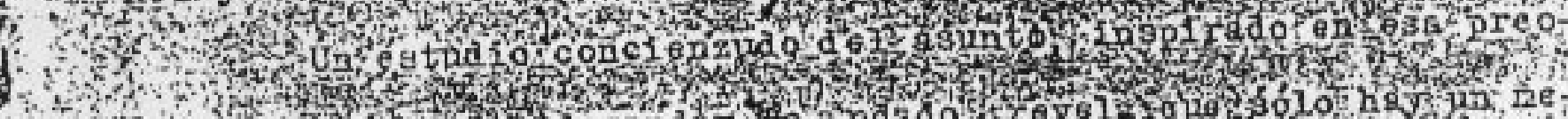

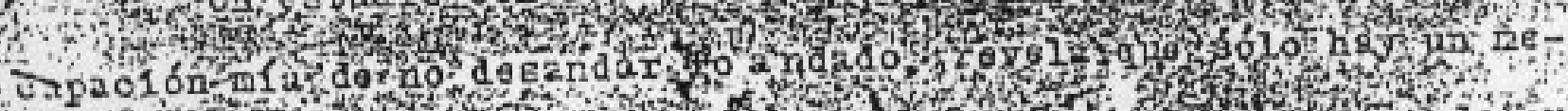

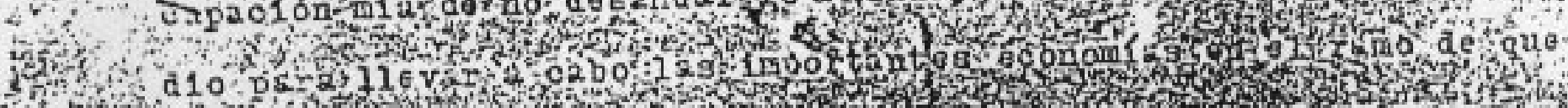

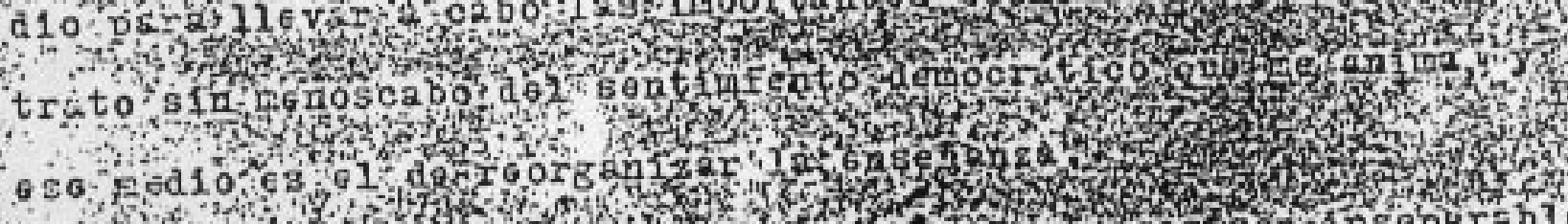

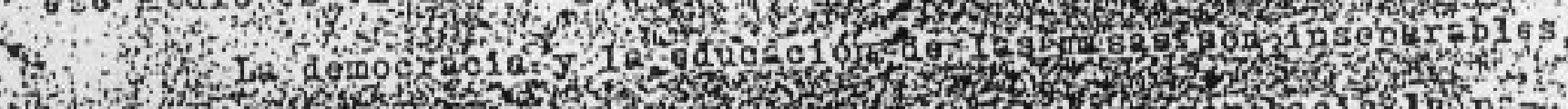

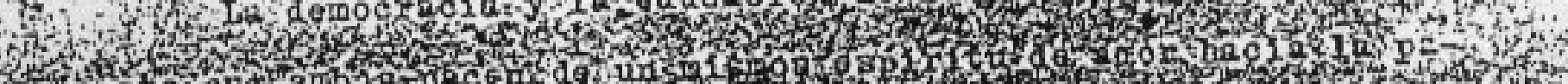

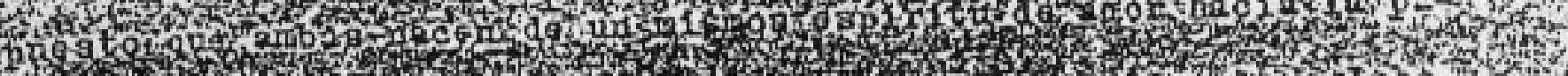
A37.

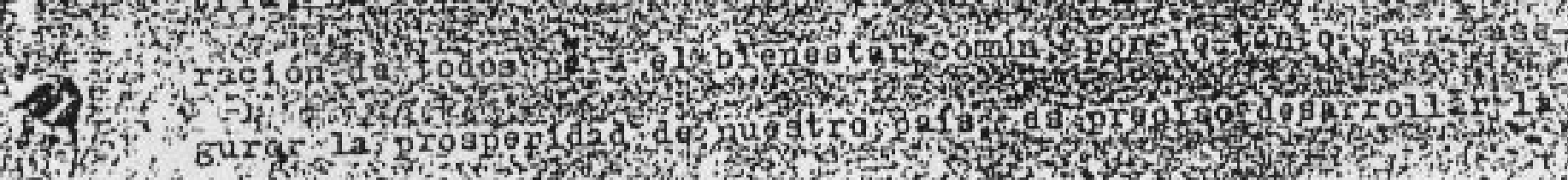

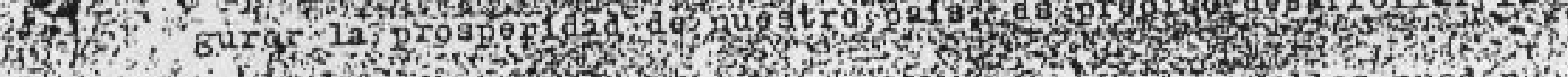

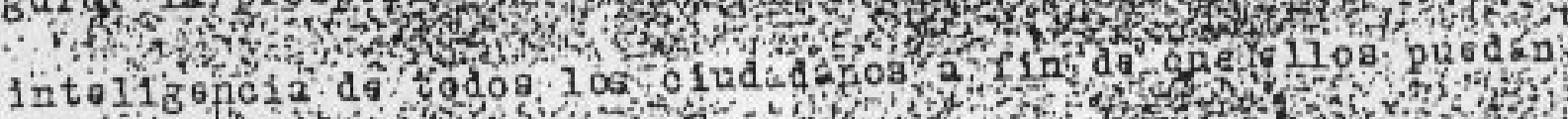


(1)

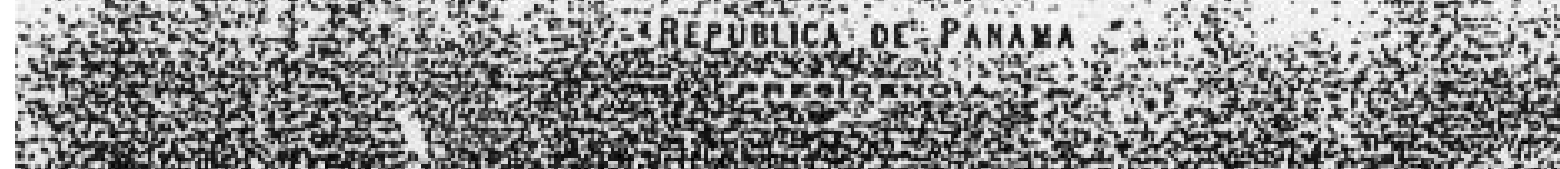

H.

N 3tr.

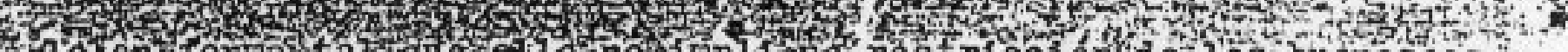

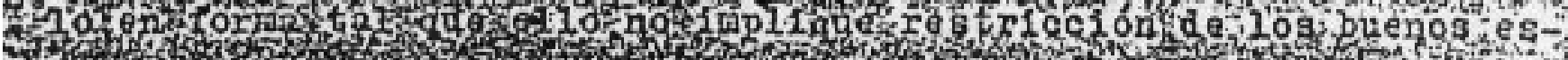

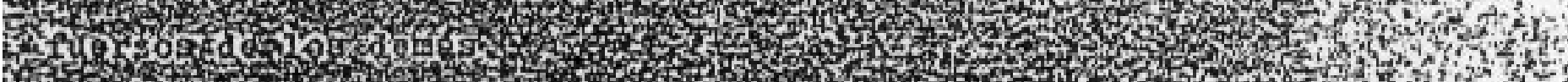
a

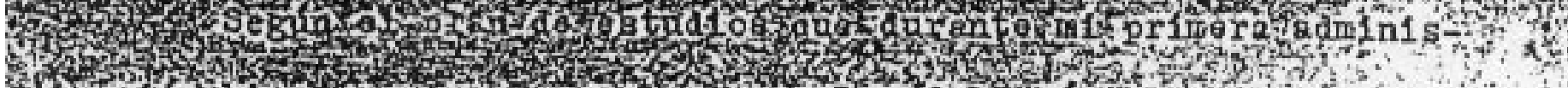

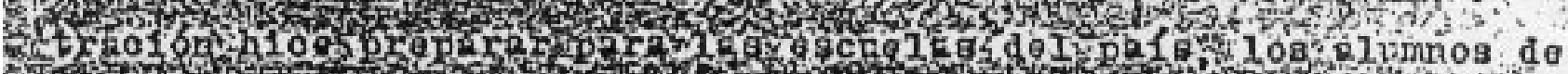

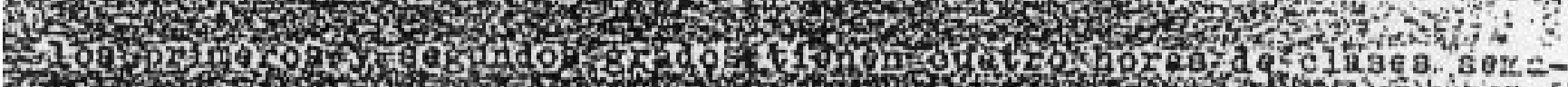
Y 4.

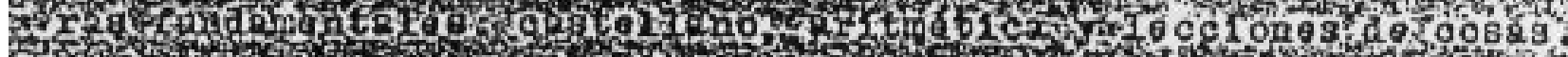

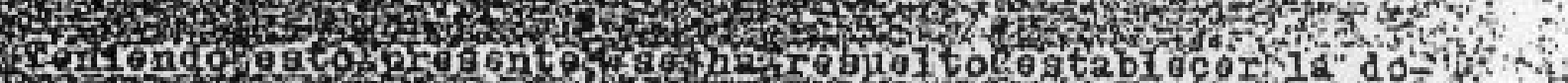

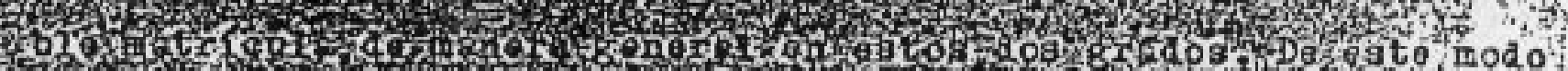

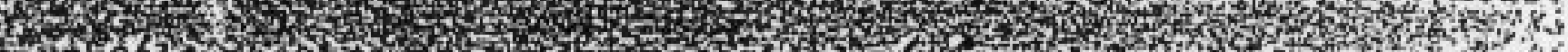
3.

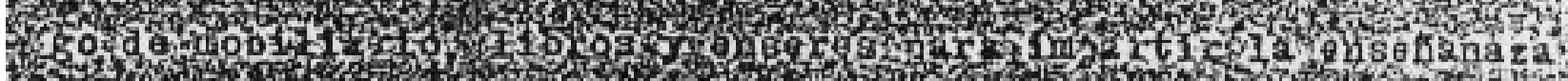
Wo

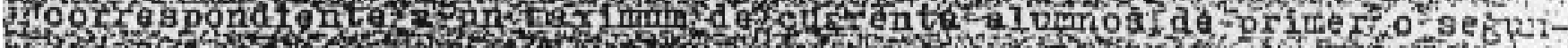

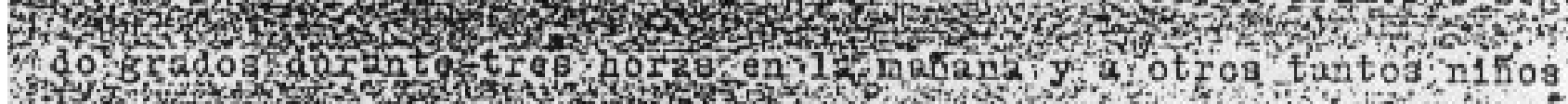

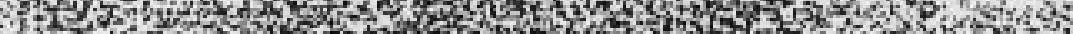

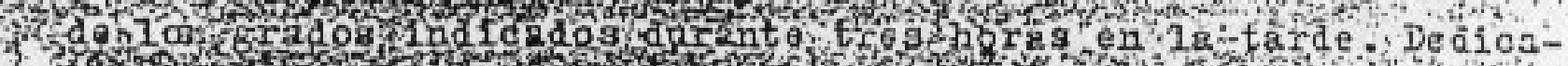
4.

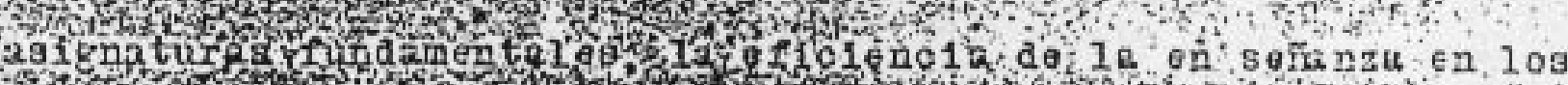
H.

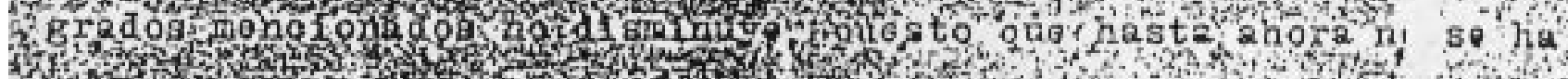

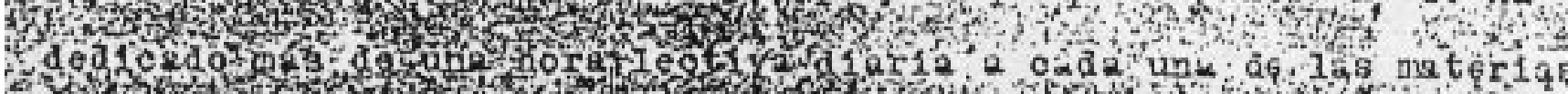

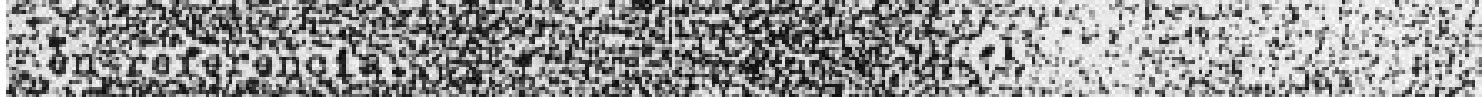
$\begin{array}{lll}3 & 0\end{array}$ 3.

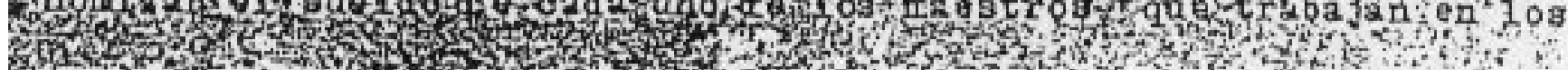

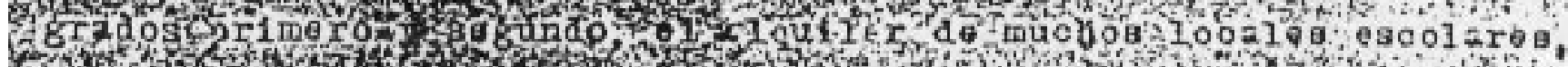

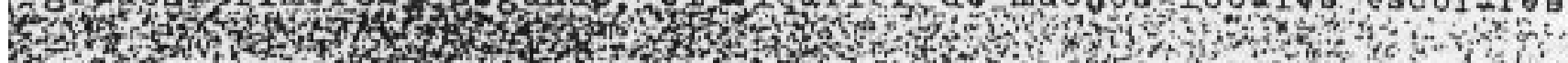

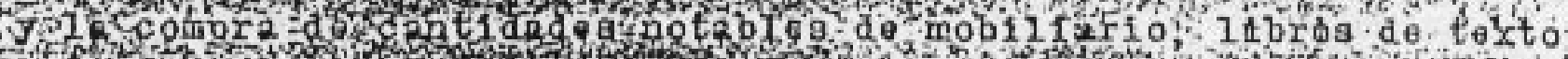

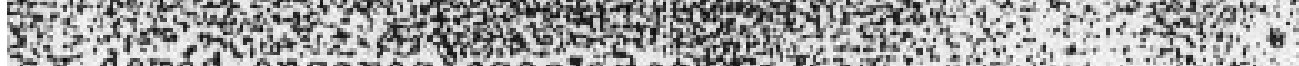

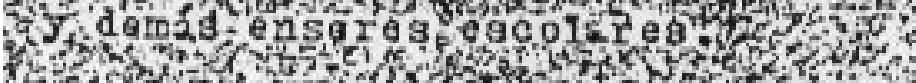


F.

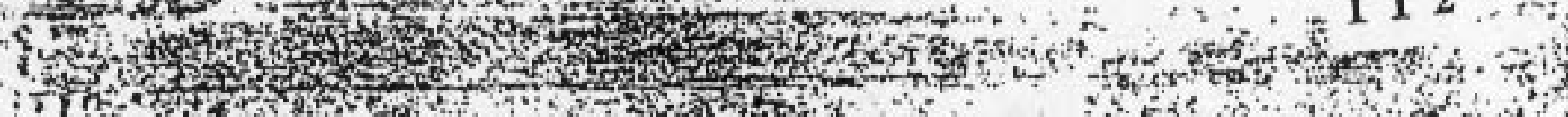

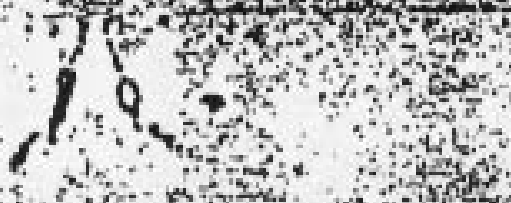

as

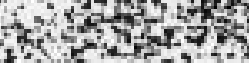

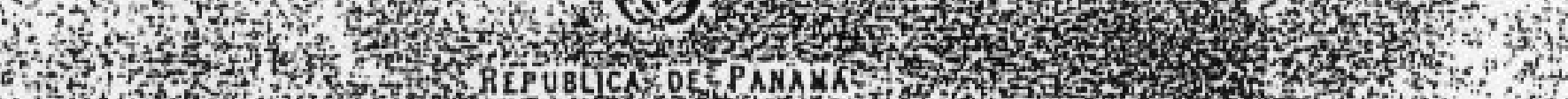

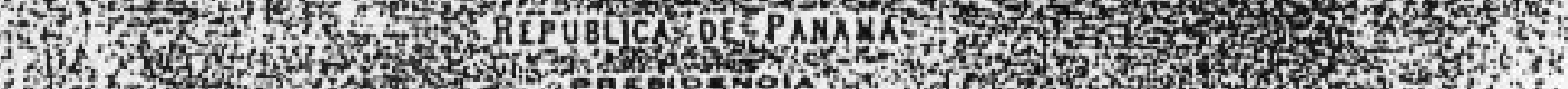

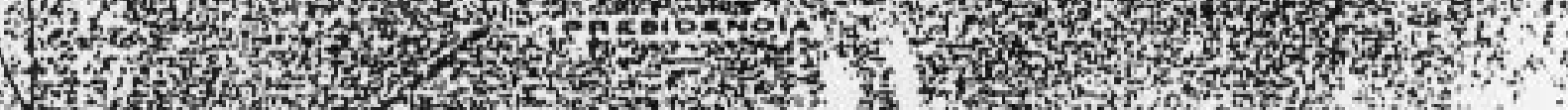

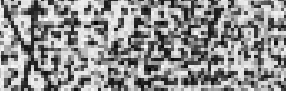

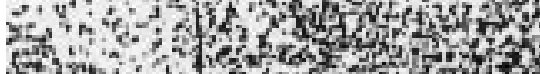

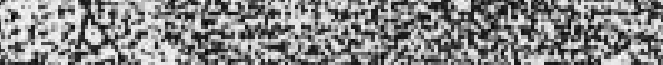

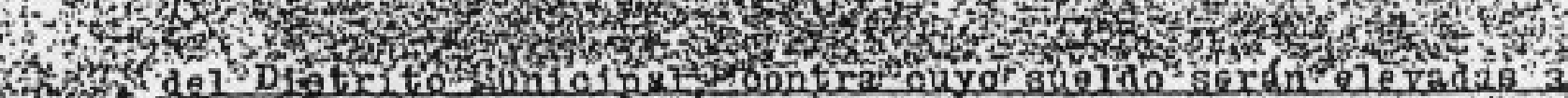

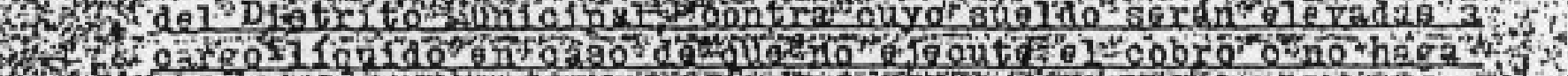

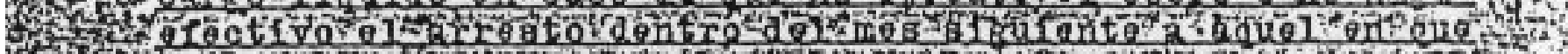

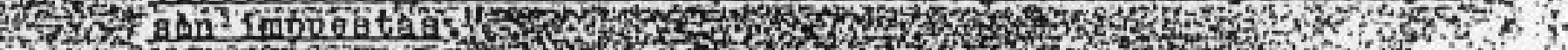

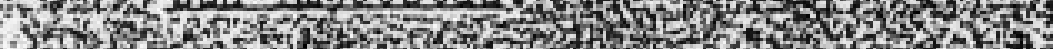

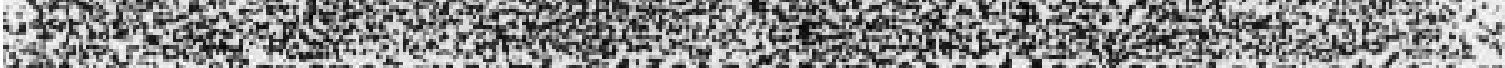

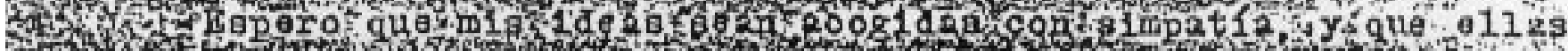

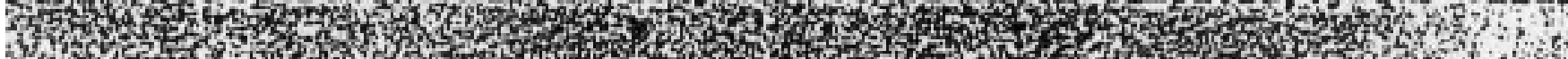

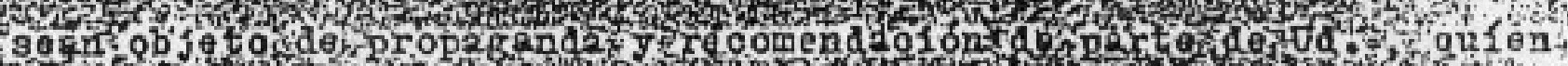
1.7.

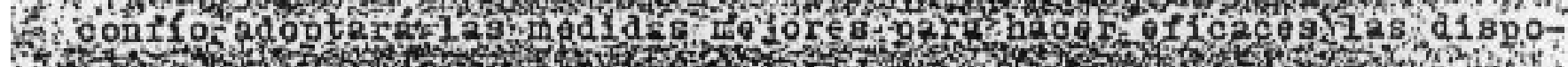

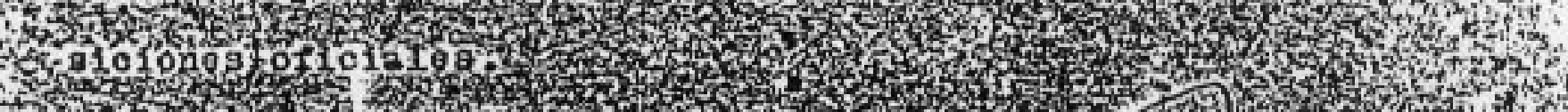

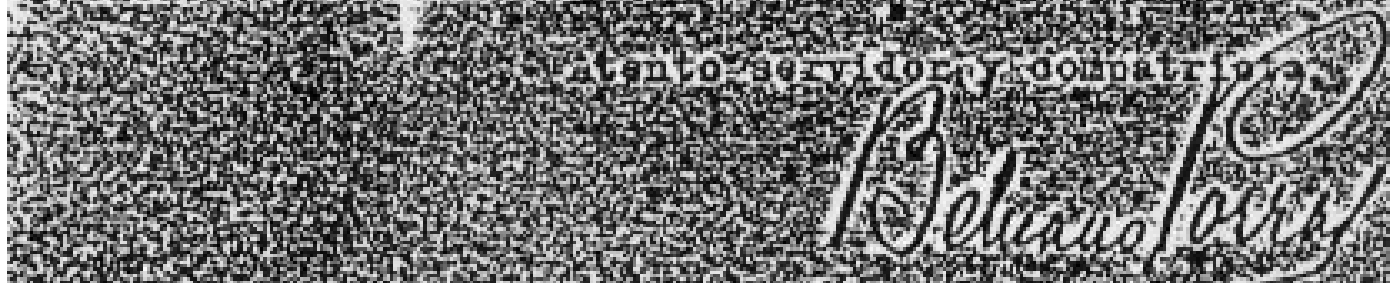

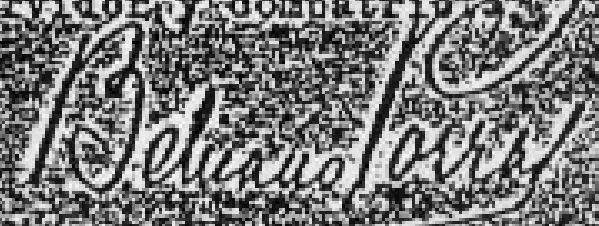

(5)
$12+2 \times 1 \times 2=2$ 


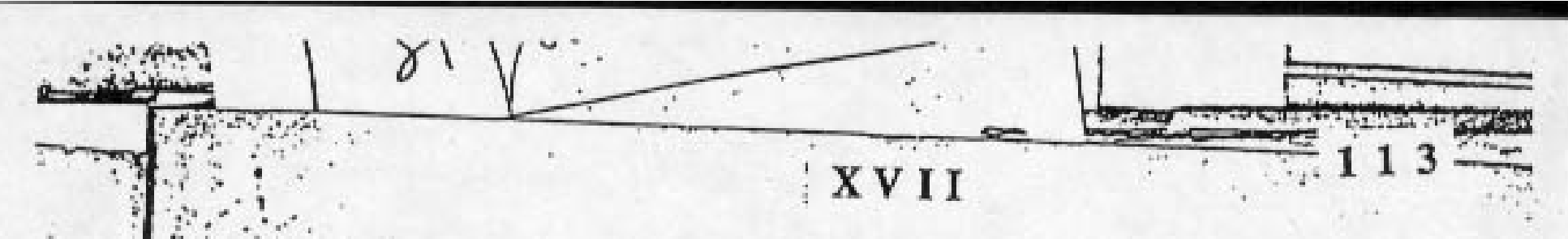

NÜMERO 5 OL.

Panamá Mayo 13 de 1919.

- Soñor ( Humbih Vagliom, )
Jofo do la cirounsoripoion do \$: Blas, El Porvonir:

El Ejocutivo autoriza a Ud. para la construoofón do las osouolas públ1oas on las poblao1onos: de Aligand, Carti y cuslquiora otrai que va. oroa oonvonionto.

Para ostas oonatruooiones se utilizarán Ios serviolos dol personal a su mando. Soy. do Ud. etento y S. S.

J. M. G. 


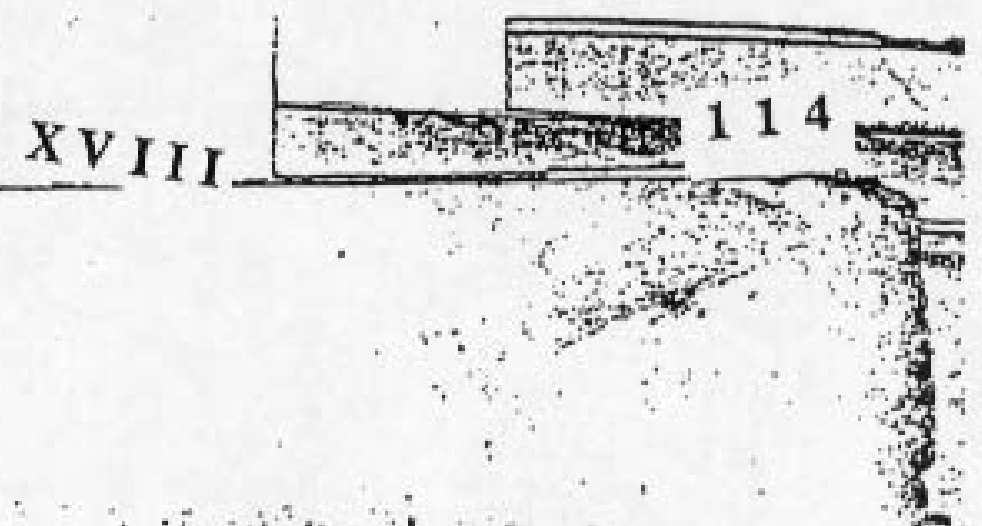

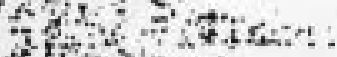

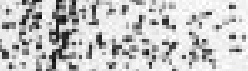

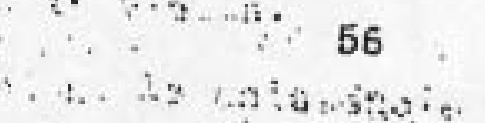

Soñor Soorotario do Góblorno y Justicia.

\section{E. S.D.}

Para su oonocinisinto no e日 grato informarle que 7lajo de esta foohe quo hizo ol vapor "San Blas" tuvo la opontrni

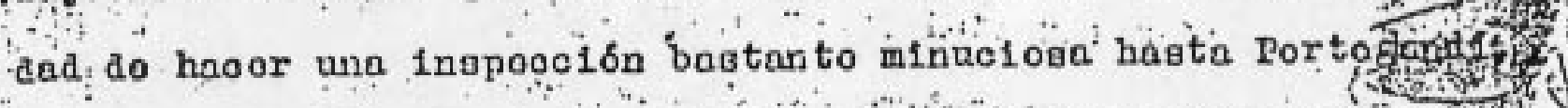

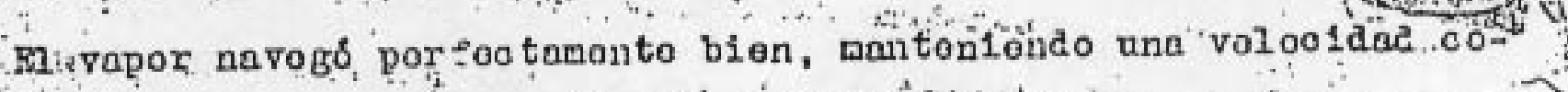

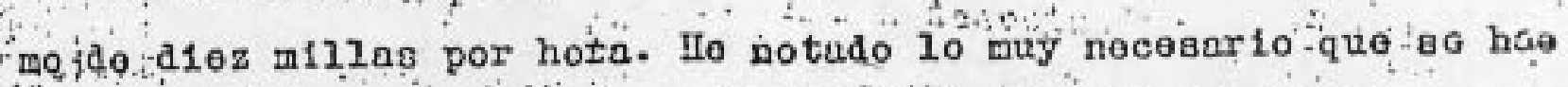

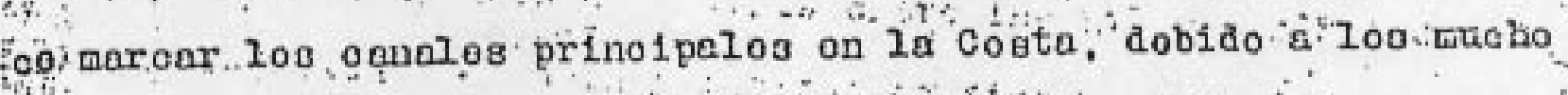
errooffoa g: bajos quo hay.

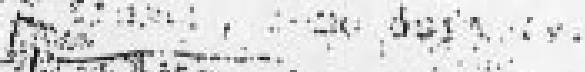

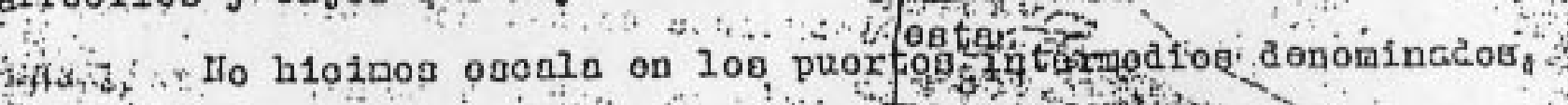

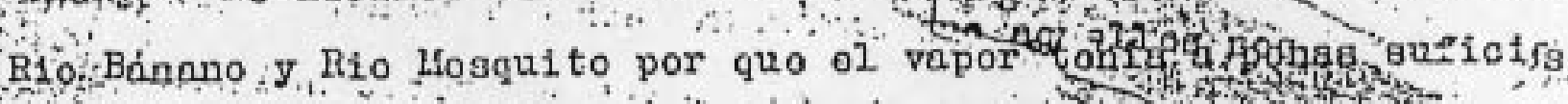
to oop1 to para hacar ol viajo airocto y répido. of hoptilos. y roboldos: a gran distancia nots aon los antoojoc de larga viata quo no tonfón lzada bandora do ningana nacional1dé, y eof quo nos divisaron. Ilowaron les astas de bandarsis oolcmbiainag. Katao tribus dopondon dol roboldo Inapaquíia desas haoo tion po; se jaotan do aus proosas on contics la nuestro Gobiorno $y$ gon considarados cono los incios más nalos à osta orĝ́on. Hublers quorido orrevar a ostos puortos; desooso oomo ostoy por 1mplente all1 muostian loyos $\mathrm{y}$ gobiorno, poro como ol, vapor no $1 \mathrm{ba}$ a $\mathrm{F}-$ oocala on dichos puortos, a mís do quo ol poraonal quo mo acos ñaba no oo componf́a ąs g̨ue do un Jo:o co Destacemonto, St. Kí

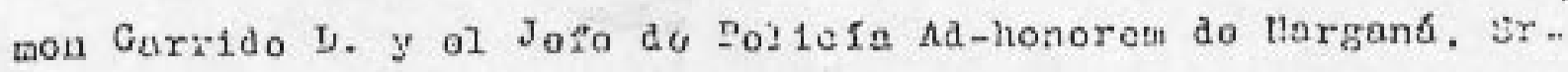


Claudio Iglosias, doold mejor aplazarlos la vialta.

$L_{a s}$ escuelas marohan porfootamonte bion. La asiatonofa de If ota al adelanto que tienen, por el asoo, dnepejo Josoltura con que si. tratan a Ias personas quo saludan. Wi las roparaciones que EQ1. Coostion 208 plantolos de onseñanza y s 810 oopero quo me mandon ol I. material para ounplimontar lo ordenado por Ua.

H. Fl puoblo de Al1gend, on dondo resido ol Saguila piraral at Colman, os un lagar suo10, asquoroso, intransitablo y aus habitin letes ostán aún nuy salvajizados. Las mujores so osoondon cuardo s nos voon y 1 os hombros $\mathrm{y}$ n1fios andan doopeinados $\mathrm{y}$ puy mal ves-. tidos. La deoropanoia que oxisto ontro las niñas y niños de las tribus que tionon oscuola y las que no tionon. como ósta (v.g.), os oone1dorablo. Los 1ndios educandos estan mas despiortos; gon an mos listos y nonos timidos, miontias quo aquolios nos huyon unos J. óáa de la pubortua.

6.i. Arr1vamos a Portogana y ol Ságuila, Nolo, no estaba aht pero vino pronto. Muvo con ól una conforonoía larga aobro al conduota y ilrmo achosión a nuestro Cobiorno, oxponiśndolo que no dososba ga no hioloso man1fostacionos falsas quo no ougpl1

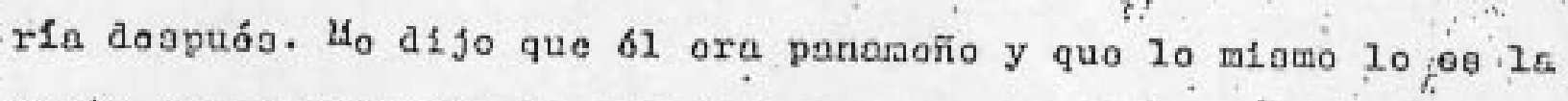
parto quo roprosonto do ose tribu; que an problo ootá dividido on dos parton: une do ojtas os panarneña y os a la quo 81 ropiosonta oono Sógulla: la otra parto es oolonbiana, cuyo safulile of distinto. Esta division do purtico on una miama 1sla, originen d1oguotos y dosordonos constantoconto Xen le partor do oste tribu quo oawanda ol Skgulla llolo. habla unes ovautas bendorag pe.- 
namofac 1zadas $\mathrm{y}$ on la otra flamoaban cinoo bandoras jolomblanas, las cualos fuoron arriadas on soguida por nosotros. Ho so las mande. por quo ostan on muy anl ostado. Eato saguila.colomb1ano preo1b16:1: a) Vodo do Destacamento quo mo acompañaba, con maohd\&on mano 'so its trats do convonoorlo y atraerlo oon buonos modos, y. nos oxpuso quo 6I no ronøofa mostras loyos n1 goblorno $y$ se fub: onsogulą. Ho fus a oogorlo por quo ol Nepitan y Lfaquiniata dol vapor no advirtieron : quo no tonfan sufioionto acoito para osporar más.t irb on ol pno. via

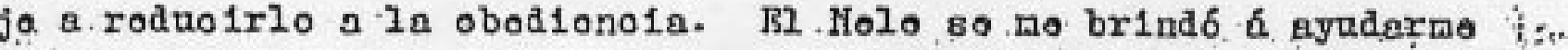

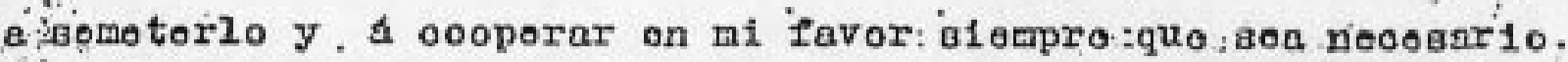
A Ia voz mo applioó quo lo nombrara do Pollofa Iudfgone a Bu Soorecar miguive tario, Ilamazo Cuarquina, para implantar al autoridad on tode la.

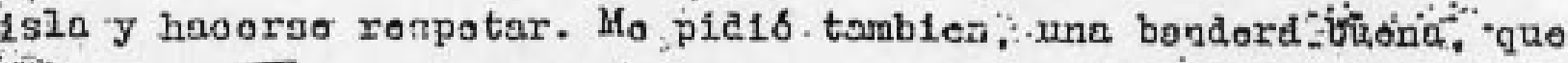
notionon. Croo convoniente quo so 10 concoda tanto por ser ol Sá-

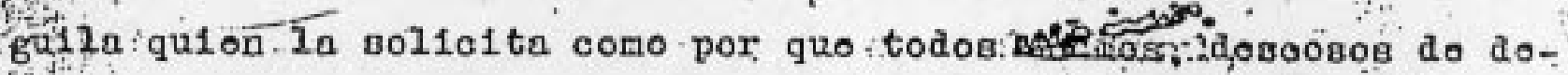

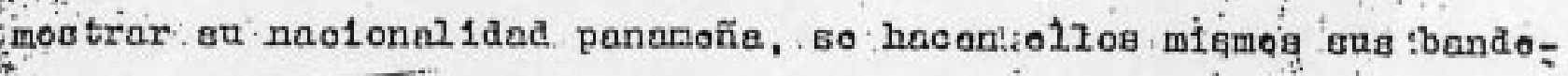
ras, rosultando todes nalhochas, con 20 coloros mel colocados y s. duras pones 5o puodo idontificar que clese do bandera os Ia quo fzen En osta 1ola, Portogand, tionen une escuola on una de 108 ranohos do paja, sin un pupitro para ol mastro, ni baros pas n1ños, sontóndoso todos on unos tueos do netorn; $n$ s tionon útizea y ostá a oargo do un ind1o llanado Juan Proroz, quion ostudis primeramonto on Hargene y despube on Panar é con log Hormonos Cristisnos. rosultando und do log dífpulos nas adolantados do au olaso . filx outá osto 1ndígona Peóroz, osforzándoso por ol, Adelanto do guc $+1$ 



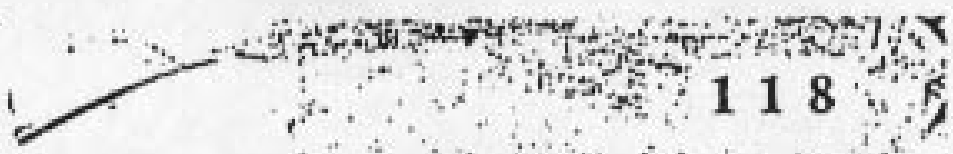

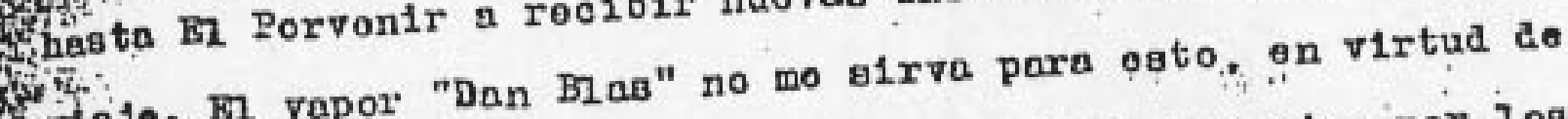

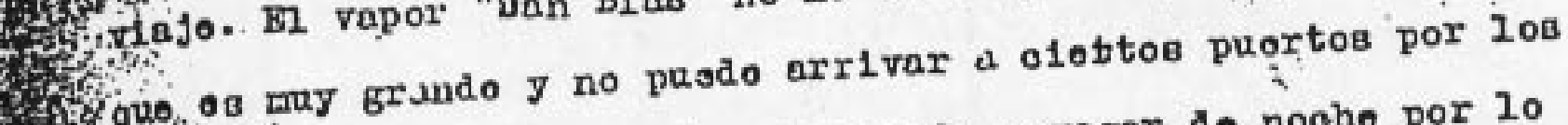

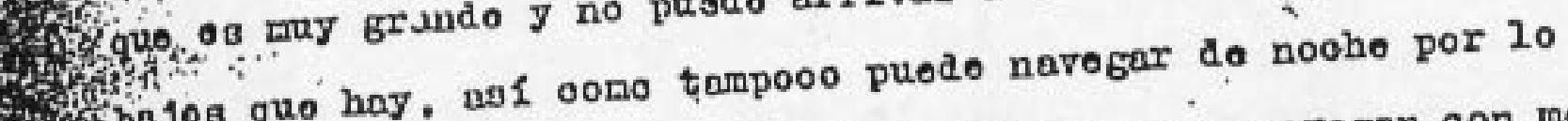

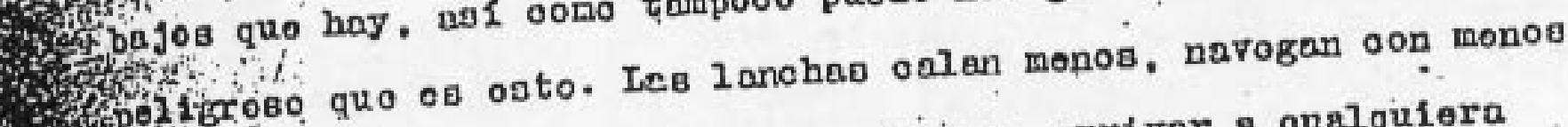
pe 2 broso quo oв osto. pol1g:o ninguno, arrivar a oualquiera 8 Hoja, a oualquior puorto.

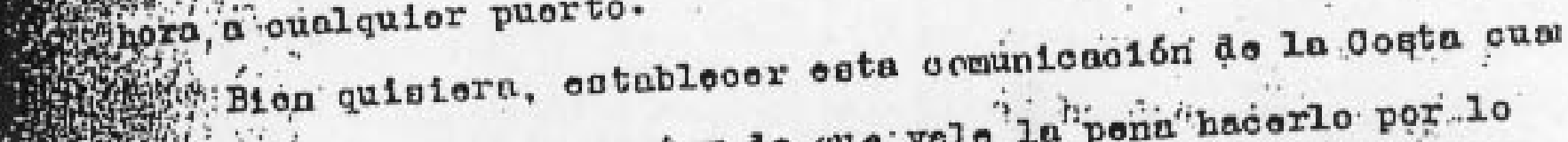

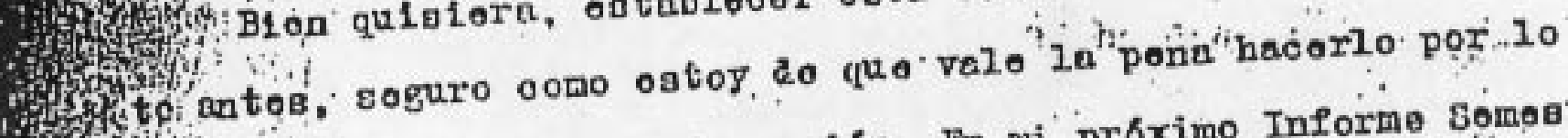

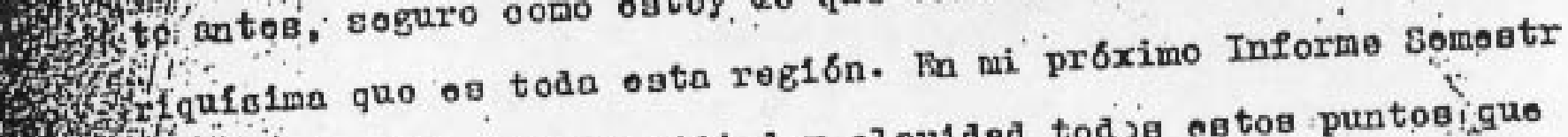

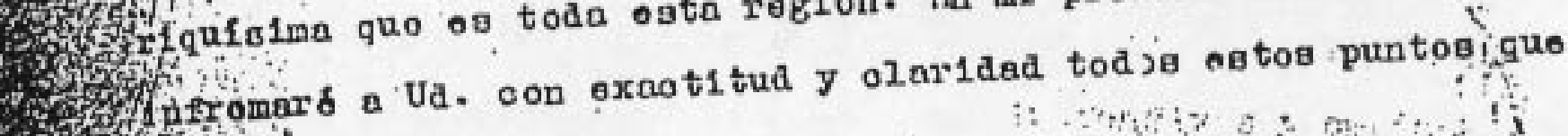
Fos

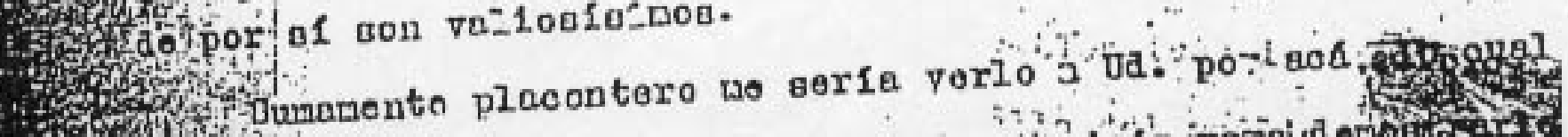

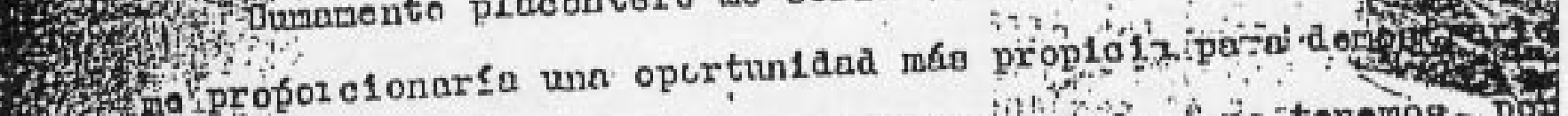
(4)

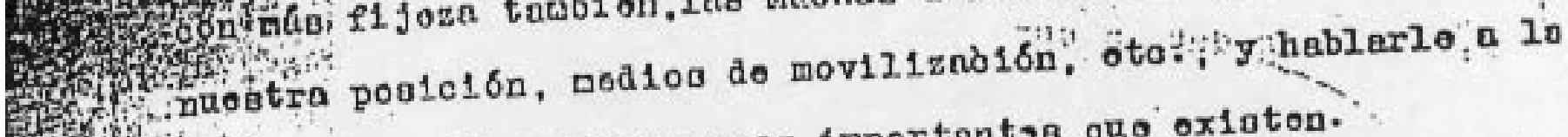
Q7. pobro wuches otras o onas importants quo oxiston.

Con todn ooveideración. orbano su my ntento sorvidor.

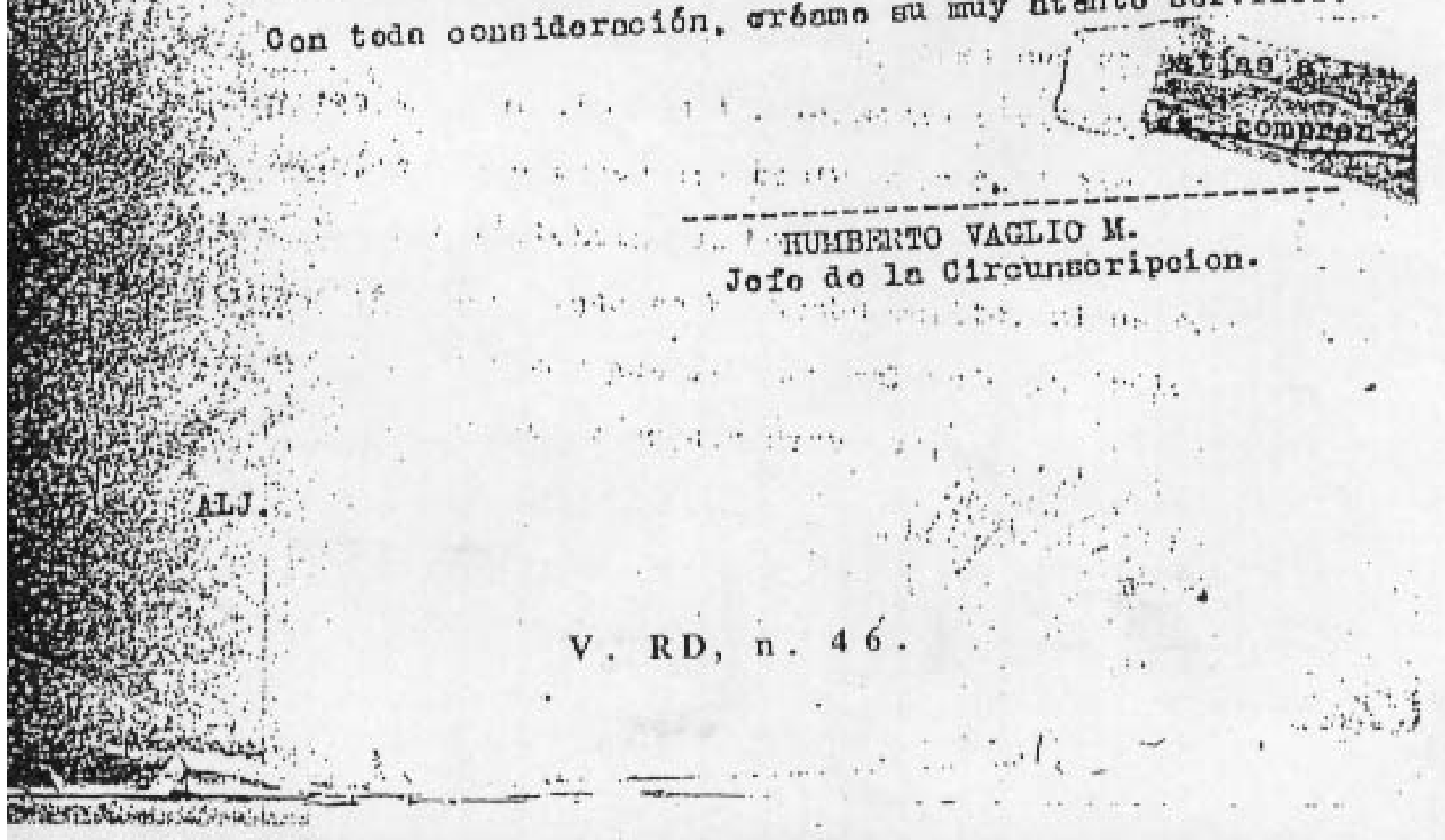


quejado a este Despacho de Comandante de le usted ha dado instrucoio7.2

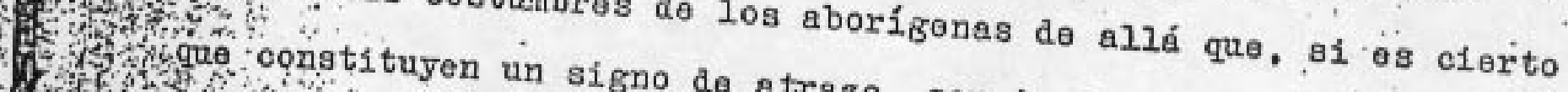

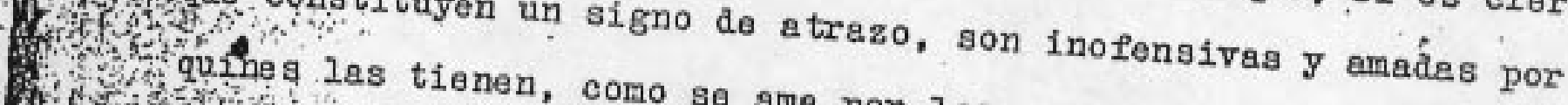
quine

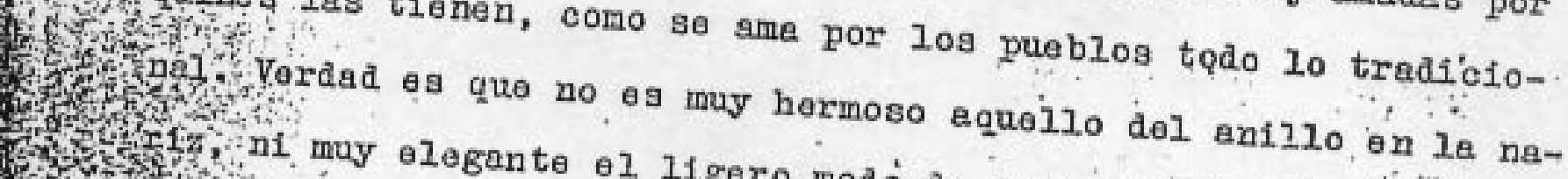

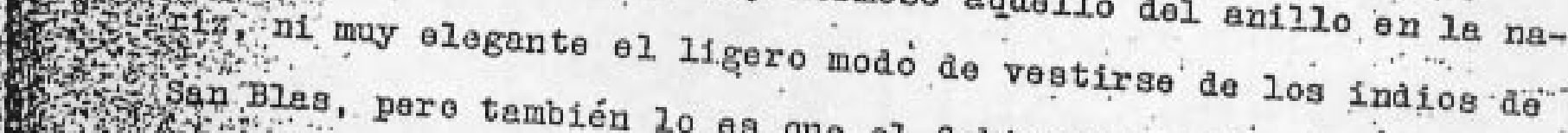
San Blas, pero tembién 20 es que el Goblerno ho desea epartarse. entun ípico der la línea de conducta F. Ia civilización a de por lo que respeta a 4h. (4. Ios por todos 10 medios pacíficos y captarse sus simpatias a fin de que una vez en contacto con las personas civilizadas, comprendan las ventajas que ofrecen las costumbres de éstas y terminen por edoptarlas sin violencias do ninguna clase. En tal virtud, sirvęge revocar la orden a que se ha hecho mérito, si es verdad que la ha dado, a instruir a sus subalternos del modo yo indicado. Soy do usted atento y sebuor servidor.

V. R D, n. 49.

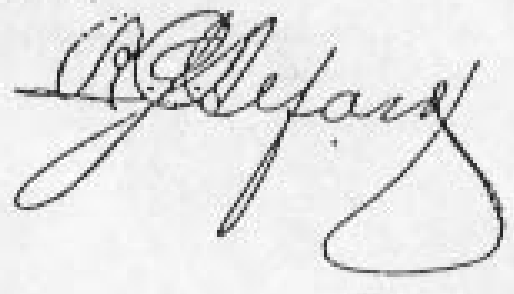



te. los corriontes, debo informarle que la nota nóme-

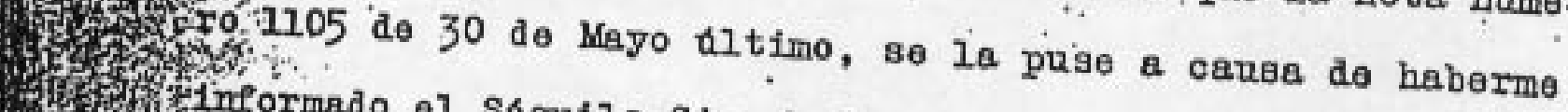
Ho 17 . Iog guines y alzamuros por las Indas de la costa de 3.

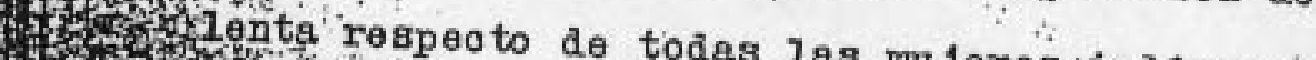
3 H.

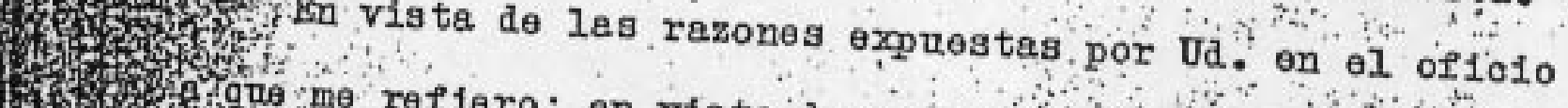
135 (2)

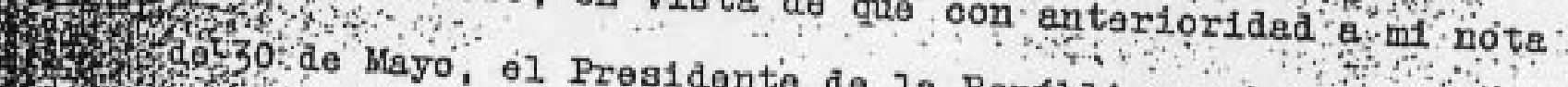
73 fopablica ya habia comuni-

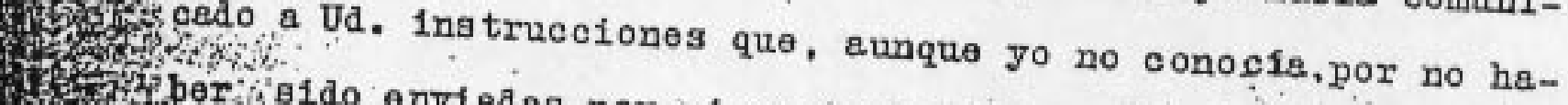
12 ber efdo enviedas por m1 oonducto, deben cumplirse y mante2.

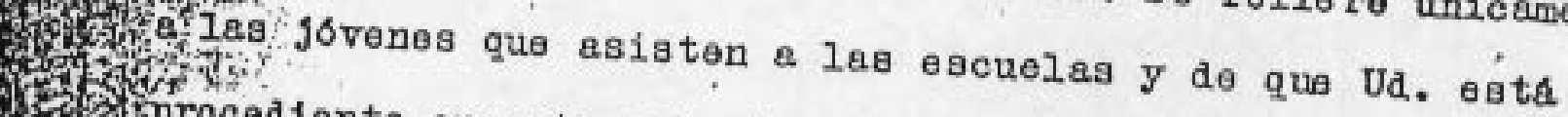
tos oves.

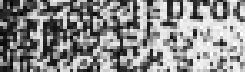
for

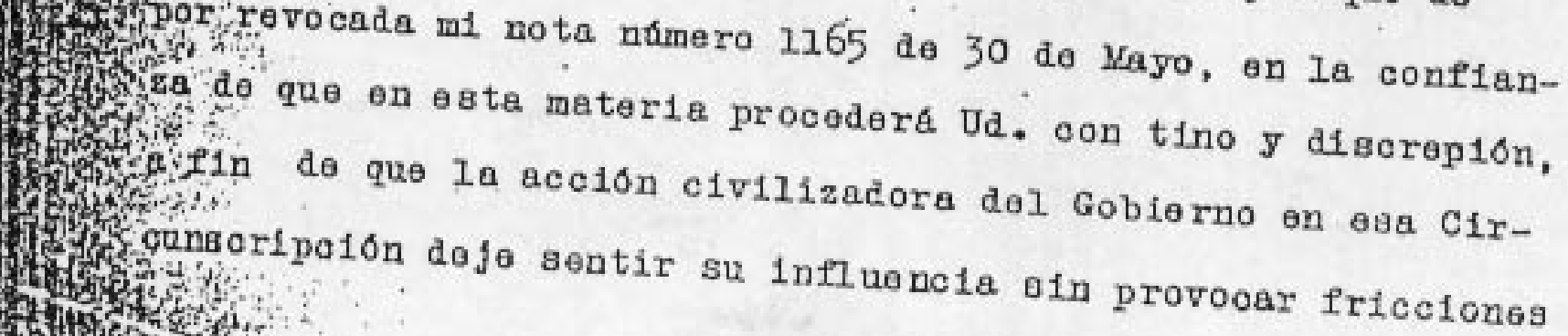




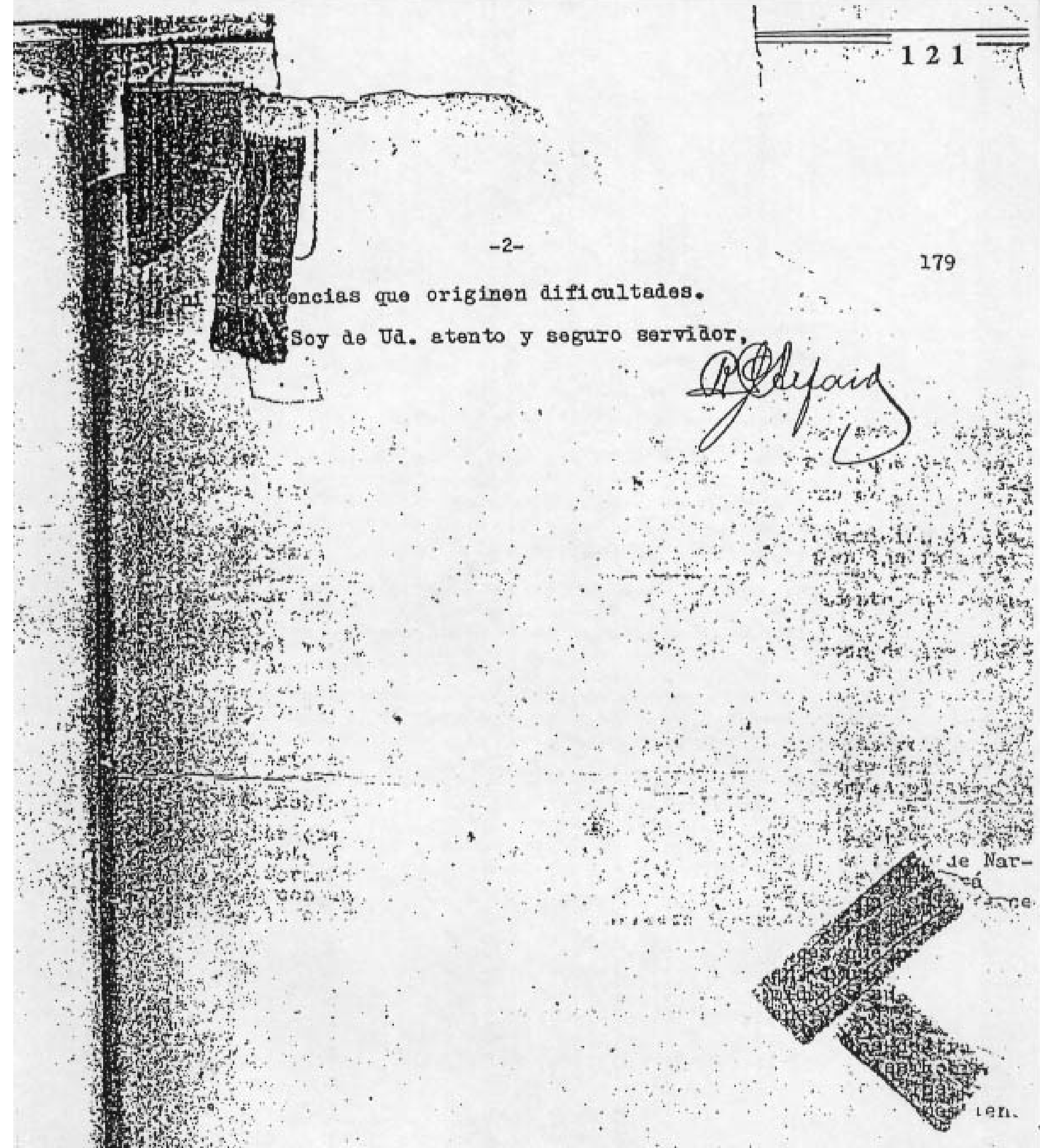

$+7$

V. RD, n. 55 . 
Narganá, Julio 27 de 1919

\section{Señor \\ Jefe de la Circunscripción \\ Panamá}

Atendiendo a lo ordenado por Ud, le informo de lo siguiente:

Hoy llegó a esta el Ságuila Inatoiquiña y me comunico, que Colman ha visitado los pueblos de Tupile, Playón Chico, Ticantiqut, Tigre, Rio de Azúcar y Cartí con el propósito de colectar dinero para buscar un abogado, que consiga con el Gobierno permiso para la libre introducción de licores, y asf mismo consiga que las niñas vuelvan a usar los alzamuros y gûines. Todo esto lo ba conseguido comentar a los pueblos antes referidos contra el Gobierno.

En Tupile llegó a insultar al Ságuila que es buen amigo del Gobierno. Les habló a los indios diciéndoles que no mandaran a sus bijos e hijas a la escuela; que el iba para Panamá y que allí haría con el Señor Presidente lo que hizo con Ud. sobre la misma. Y que según manda el Presidente cogería miedo y orederase enseguida

En Carti les dijo a los indios que no recibieran más los caucheros: y una cooperativa y una compañia que la mismo día les mandé todas la agua;hecho que no llegó a consecuencias porque el indio que las lanzo si ellos hacian eso porque eran individuos pagaron sus promesas al Gobierno.

Con todo esto como Ud. comprenderá hizo mucho daño a los pueblos que hay escuelas, ya que están sometidos al Gobierno de la República.

También se comenta al Señor Inspector de Instrucción Pública para visitar a Las Escuelas, Este para el Señor Presidente... se ha pronunciado.

Acompáñole dos cartas una del Ságuila Colman en Tupile y otra de la Compañía que

escribe

De usted atento y seguro servidor

Jefe del Destacamento

Ramón Garrido

Trans. del orig. ms. inc.

V. R D ; n. 6.3. 


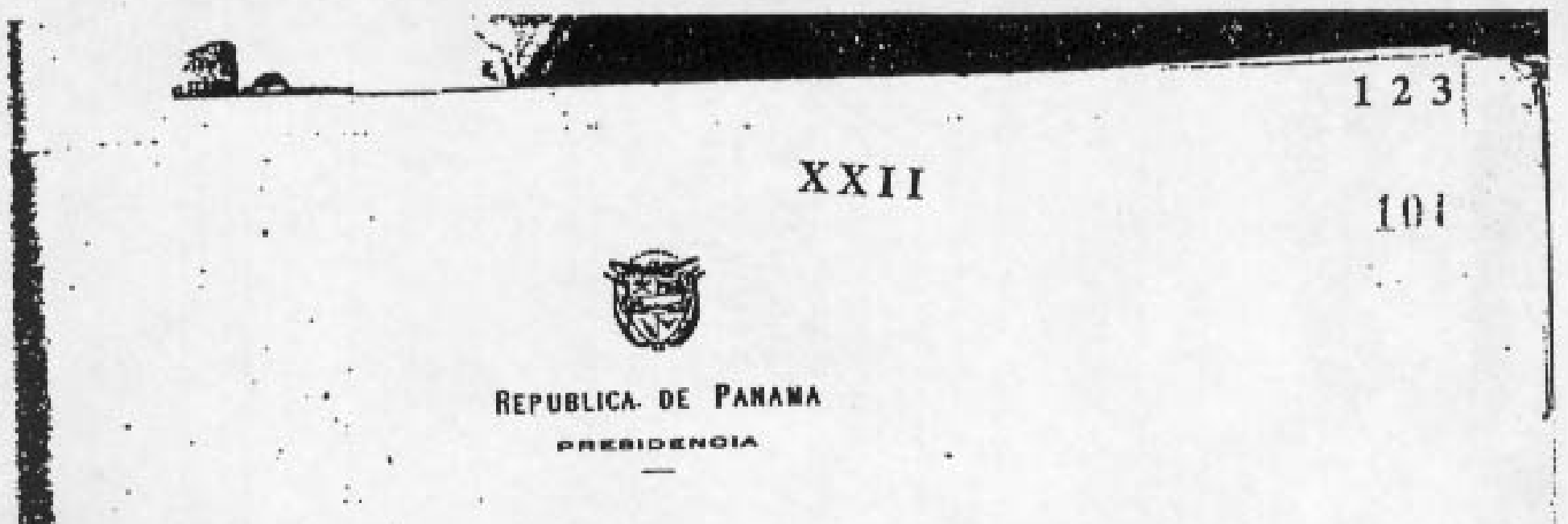

Panamá, Sept1embre 8 de 1919.

Sx. Dr. R1 cardo J. Alfaro,

Seoretario de Goblerno,

Presento.

M1 estimado aml go:

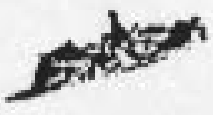

Las maestras que prestan eexviclos on la Circunscripoion de San Blas, especielmente las de Narganá y Corazon de Jesus, me inform que las casas donde funclonan dichas escuele so encuentran sumamente deterloradas y quo eв do Imper1os a necesidad el repararlas cuanto antes.

Como la C1roungcripoión de San Blas Be goblerna por leyes өөpeolalos, las oages de esouela de alla dependen direotamente de la Secretaría a tu cargo y por tento te auplioo encareciamente te pongas de acuerdo con el señor Duncan para que acue rdon qué. $r$ eparaciones deben ef́e tuere $\theta$ on ellas, pare que procedas a ordensrias ou anto éntes.

вav.

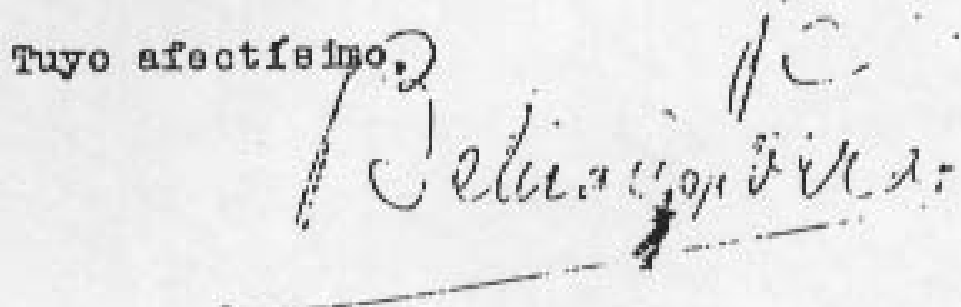

$$
\text { V. RD, n. } 70 \text {. }
$$




\section{XXIV}

Republica de Pakama

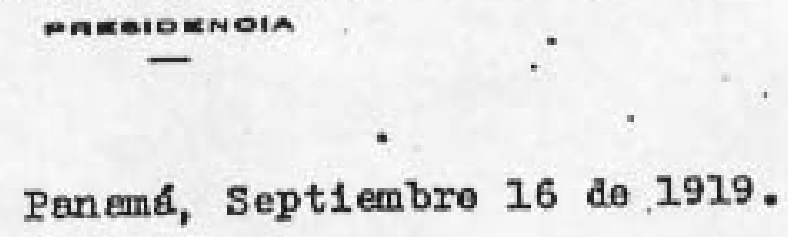

Sr. Dr. R1cardo J. Alfaro,

Seoretario de Gobiemo,

Presente.

M1 estimado. amigo:

Te envio un memoriel que he reolbido del se-".

for José de la Rosa funto $\infty$ n las beses para nn Deoreto.

quo pide on ol referldo memorial. Se trata de concederle titụio a los indiog de San BleB, coleotivamente, gobre

las tierras quo ocupan. Soy on principlopartidar io de ов media para resgurar a esas gentés de la rapaciana de 208 extraños, $\dot{y}$ por ello te ruego estadies la proposiolón de de la Rosa y me dés tú oplnión...

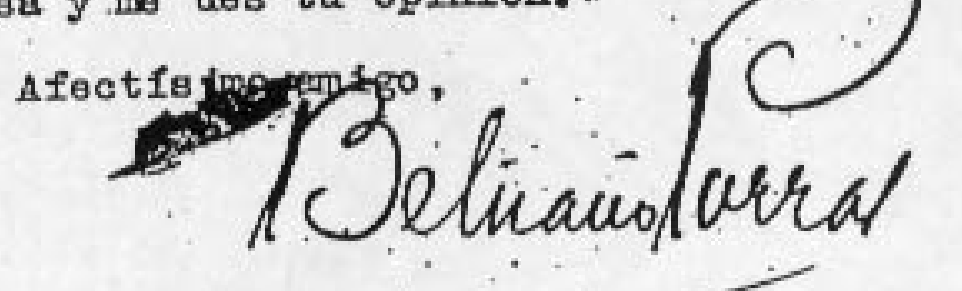

19

$$
\text { V. RD, n. } 72 \text {. }
$$




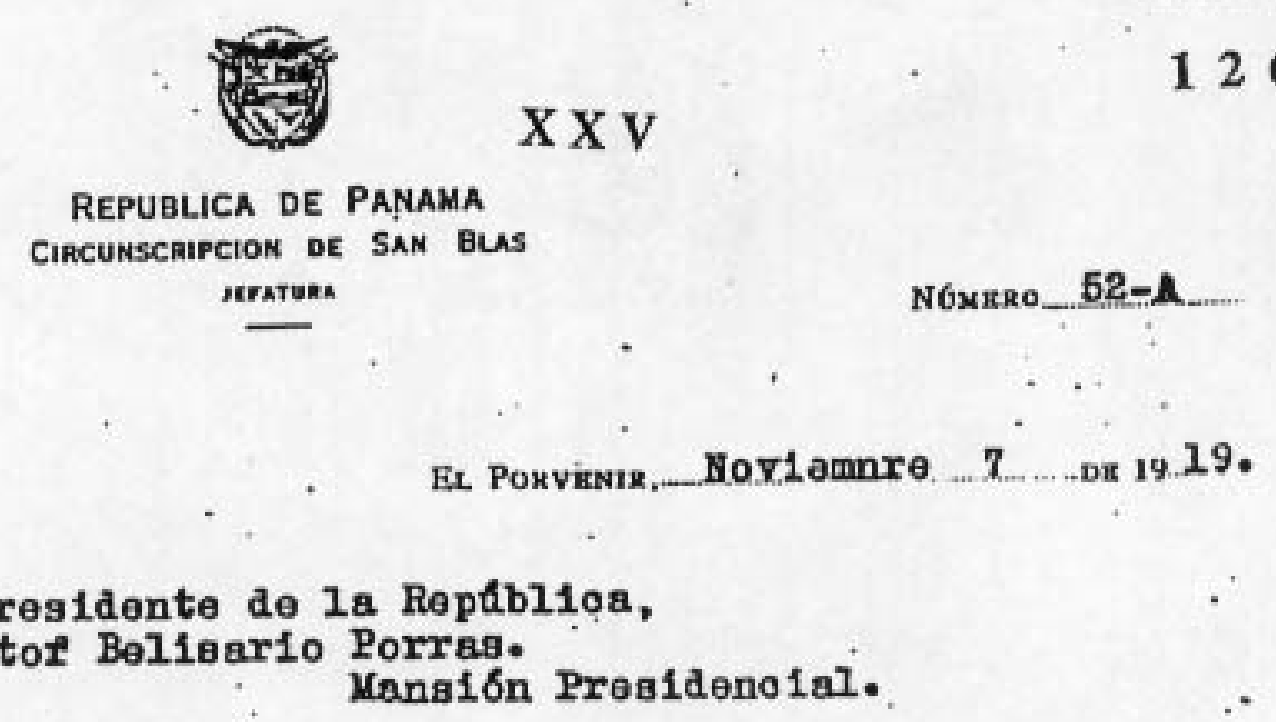

Frmo. geñor Presidente de la Repábliọ,

Dootor Belleario Porras.

Kangion Presideno1al.

U1 may diatinguido Dootor:

Desde ml llegadá á éste no ho dejado de reo1bir las repet1aì súplios de 108 gantalsabeleros, que ja no me suenan propiamente como la solioltad de un permiso gino oomo el grito plañidero de la neoesidad que los obliga a 1mplorarme que les conoeda el perm1so de la pesos de tortuga on la olrounsoripoion do. San Blas. .

il efecto he estudiado con detenimiento 1a disoropano1a que fluotia entro la necesidad de-2a mayoria do 108 pobres pesoadores do Santa Iasel y el oarkotés frivolo y ogoista de 108 Ind1os de esta Costa, que se oreen 108 in10os oon dereoho 4 la menolonada pesoa por Dereoho Divino y no por el que el Goblerno Ies ha reservado hasta la feohs, $y$ he saoado oomo oonolusion que af deberfamos otorgar el permiso de la pesos. de tortuga on San Blas, desde lnego que los ind1os, por una parte, no pesosn este anfiblo sino oon muy poos frecuenola; por otra, es muy probsble que esta ooncesion venga \& estiblecer las releoiones intimas $y$ oomero1ales entre santaibabeleros 6 indios, ouja medida oosdyuvaré un tanto on $1 \mathrm{a}$ ofvillseolsin de ́́stos on el trato que lloguen a oonnatar.

Queds \& fulo1o de Tuestra. Broelenola resolver eata petioion on definitiva, agradeolóndole que la resolviera favorablemente:

Con sent1m1 entos de m1 más distinguida oon-

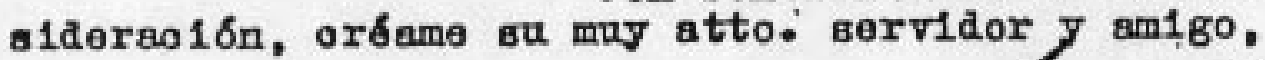

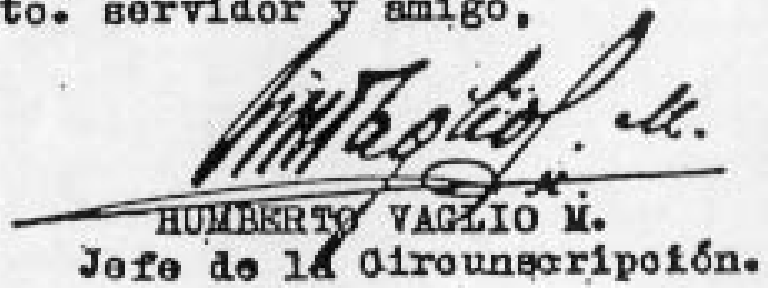

ALJ. V. RD, n. 76 . 
Penamá, noviembre 23 de 1919

Sr. Dn

Ricardo J. Alfaro,

Presente.

Batimudo amigo:

Degae hace algún tiempo los vecinos del D18trito de sti. Irabel se vienen agitando on el sentido de que se les porfelta pesoar tortugas on la costa de San Blas. Por ia Secretarla do faciende ee ha dietado la disposición pertinónte,péro perece

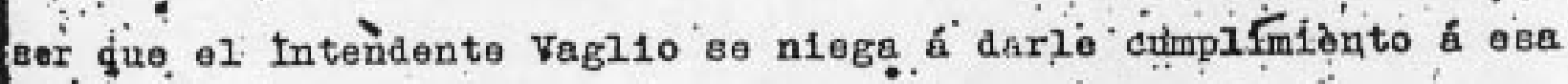

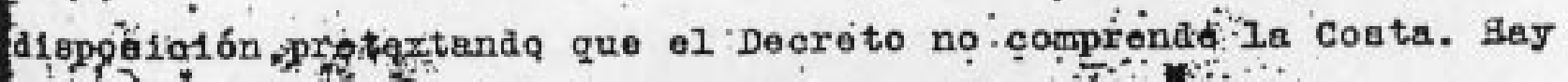

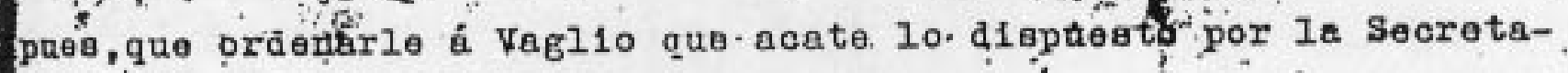
ría de fraglende.

También se hace prec18o, en vi-sta de los recientes sucefos qourridos en $1 \mathrm{a}$ isla de lioantiqui, qúe Is intendencia haga recoger todes las armas de fuego en poder de los indios, gsí como la dinamita uue posean $\delta$ cyaluuier otro explosivo, disponiéndose que, para que un 1nd1o pueda portar arma de íuego de las deatineda á cacerla, obtenga primero ún permiso especial de la Intendencia:
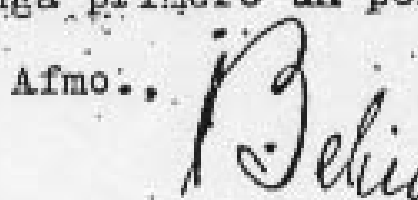

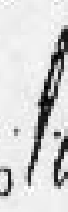

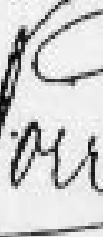
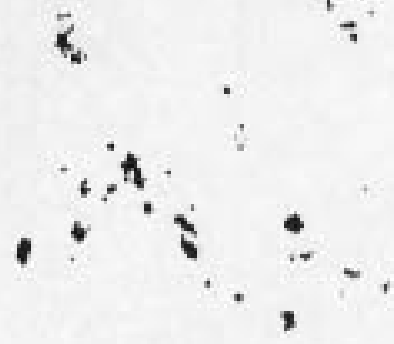


\section{V I I I}

\section{Republica de Panama}

PAKEIOENOLA

Funare, Dicienore 10 de 1919.

Sr. Dr. Picand? J. Alfaro,

Secretario de fobtemo,

nisaad.

:1 querido Picerdo:

tace tiempo que viene él Tefe de la Circunsoripción de San Blas, Sr. Dn. Iumberto Taglio, Interessao en que se le proporcione el Jele. de destacmento que nècesita para esfacionarlo en. I'ergana, en donde so inician cesi tbáos 10 aisturbios que ocurren entre los 1ndios en ese oosta, sesuramente por Ie rebelala que viene Ie alsionera iliss Coopa Iomentando. Zs probable que el ser̈or Vagl 1o te escribe sobre este mismo tema y ojals consideres el ssunto como de uizente necesided y dirponges. el exvío de
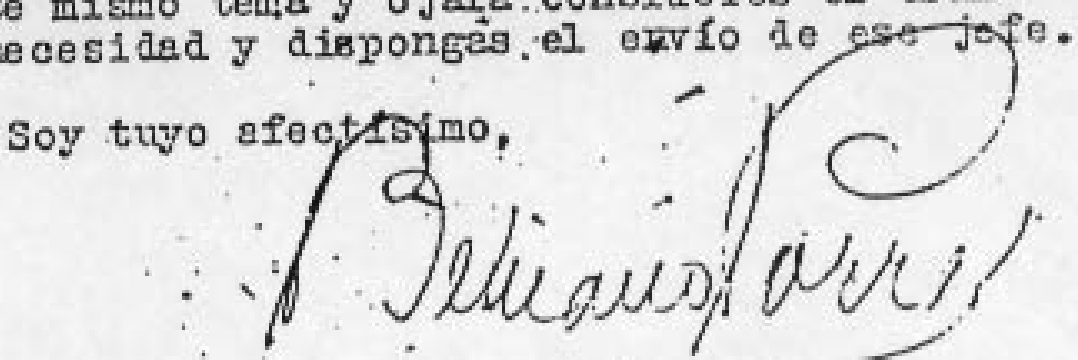

งอง.

.681 


\section{XXIX}

\section{Republica de Pakaha}

PRERELERTIA

Panomá, D1oliombro I2 đo 1919.

- Soñor àootor don

Ricerdo J. Alforo,

PRESENTWE.

Batimado amigo:-i.

In contestación a to atenta carta do ayer daseo manffostarto quo, rne vez quo ol Intendento Vegl10 to ha dado candidato para -I Desteormento de Pollole de Nergane, 61 dobe conocerto bien, J deb. ester seguro do la eficecia de aus cepacidedes y a Puedes nombrarlo, paes.

do 


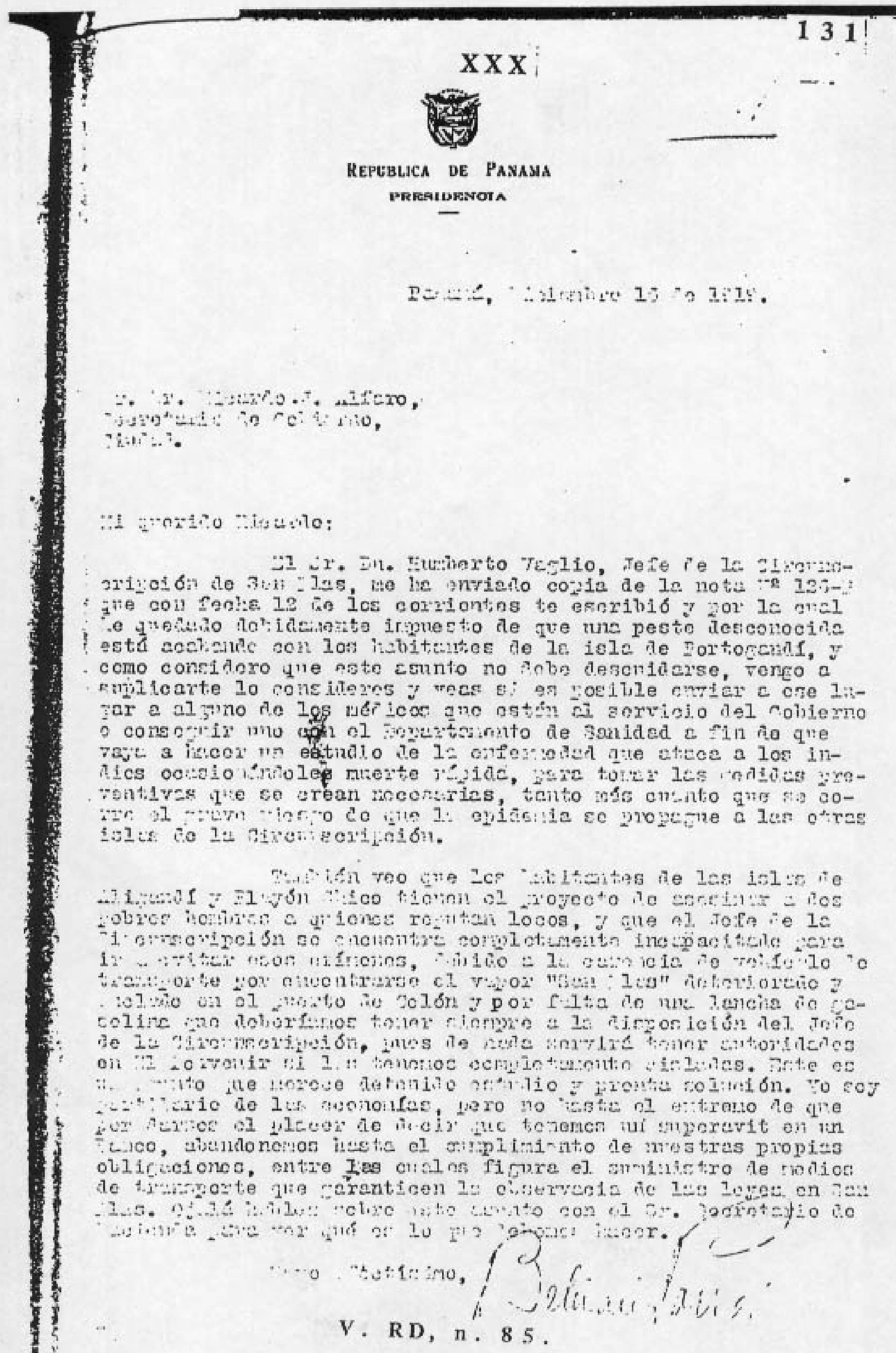




\section{(ris}

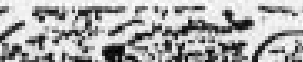

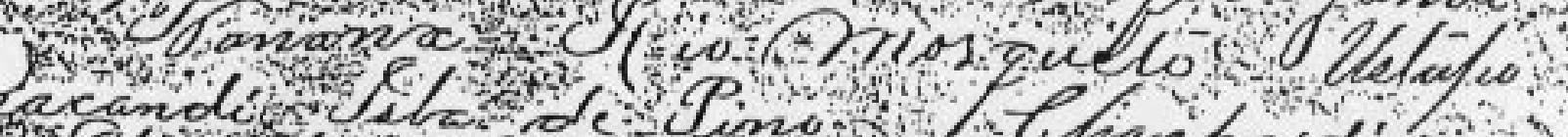

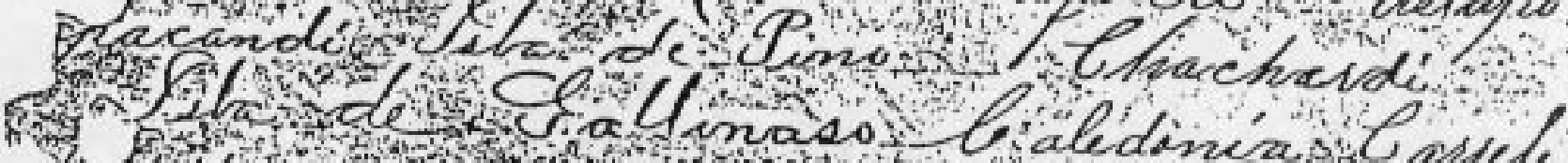

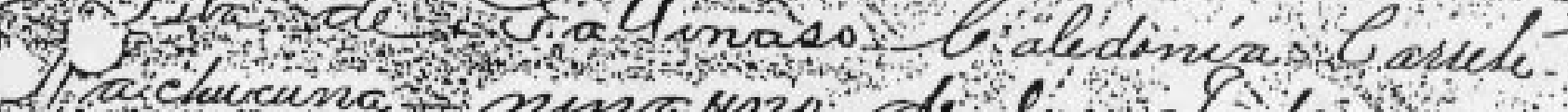

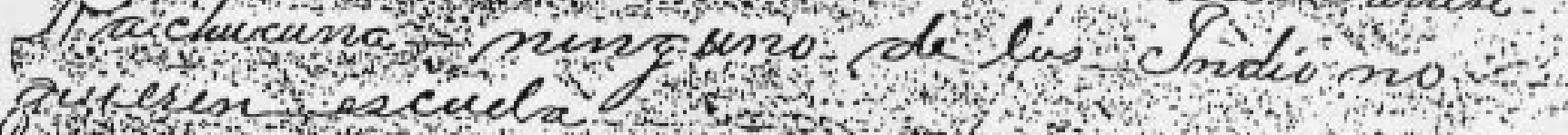

\section{(1)}

at

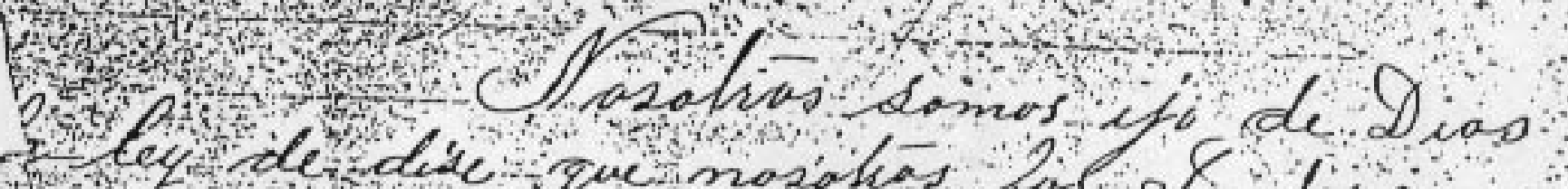

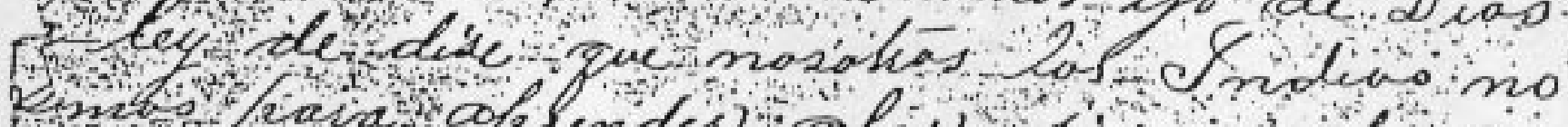

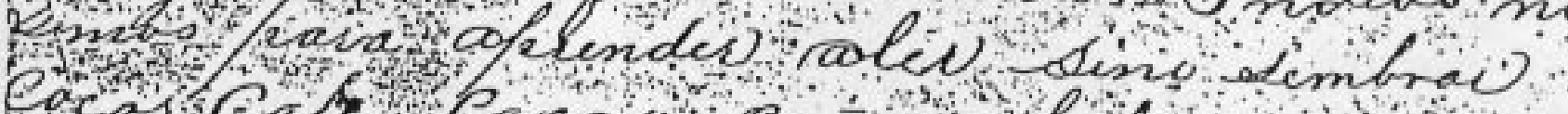

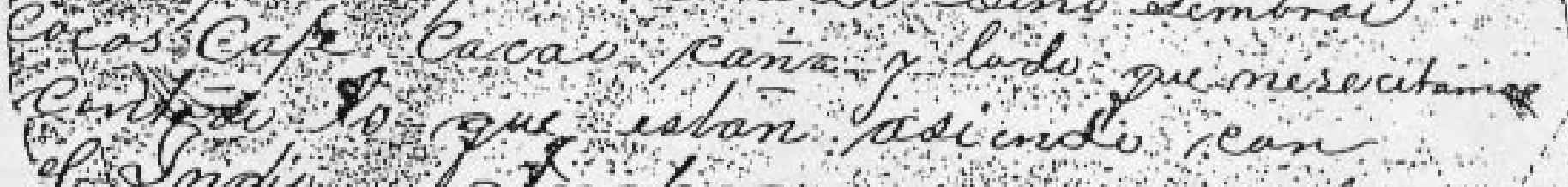

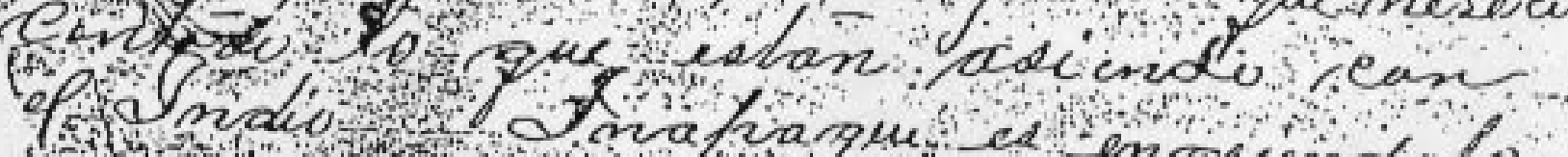
(5)
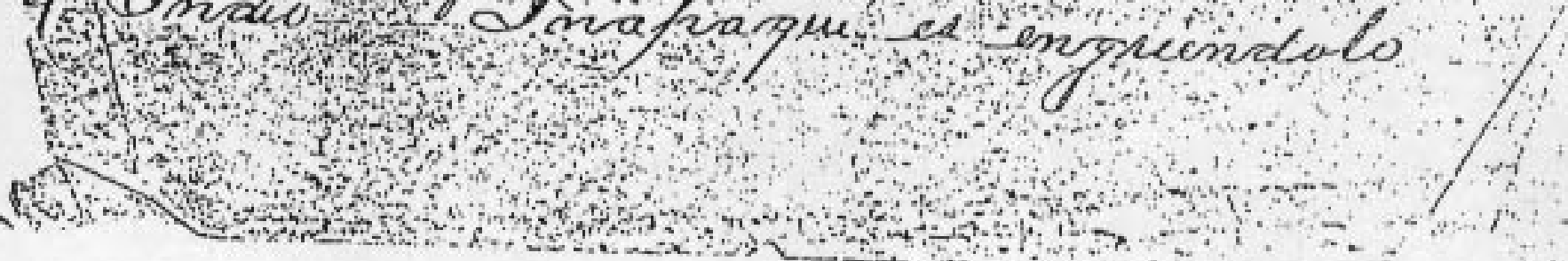


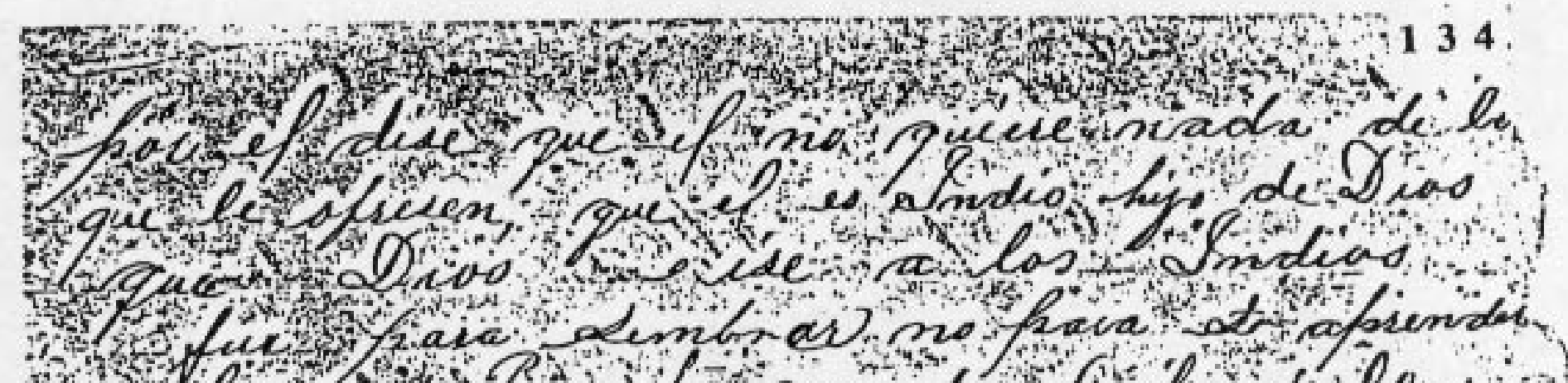

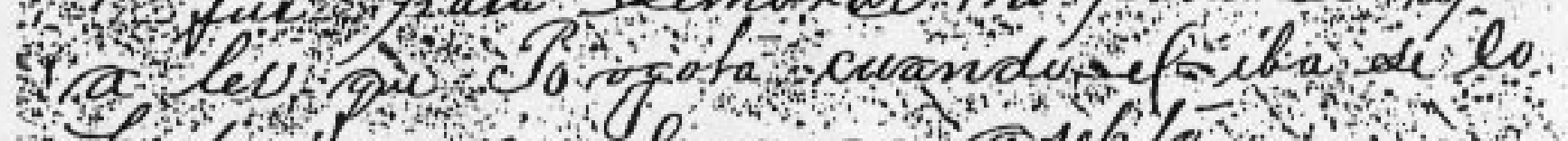

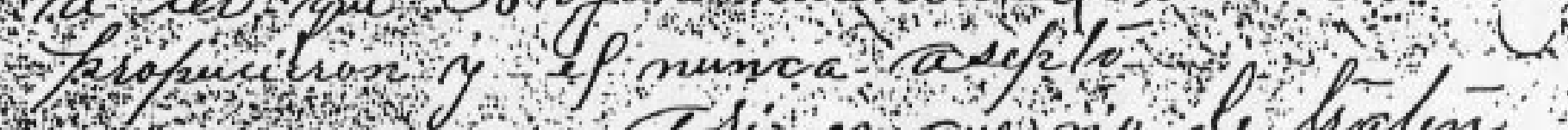

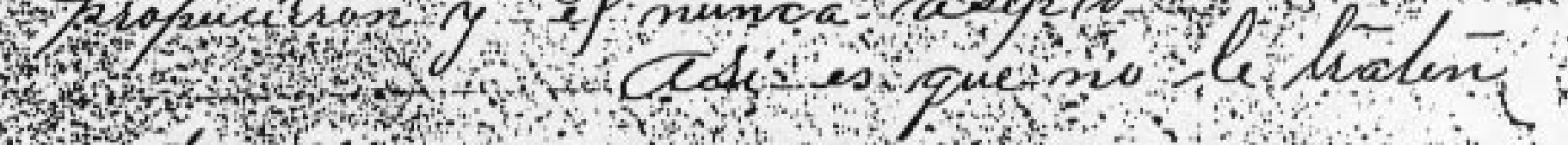
Q

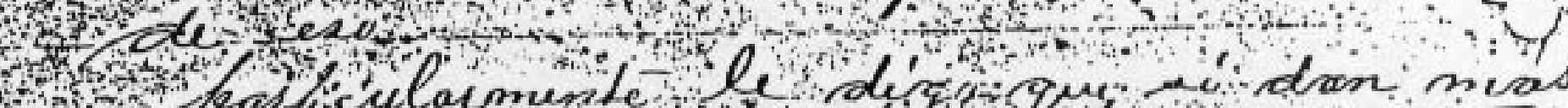

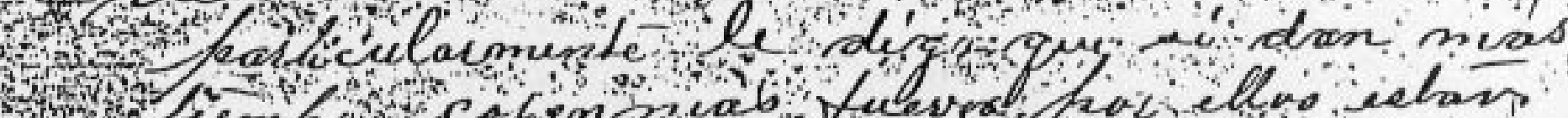

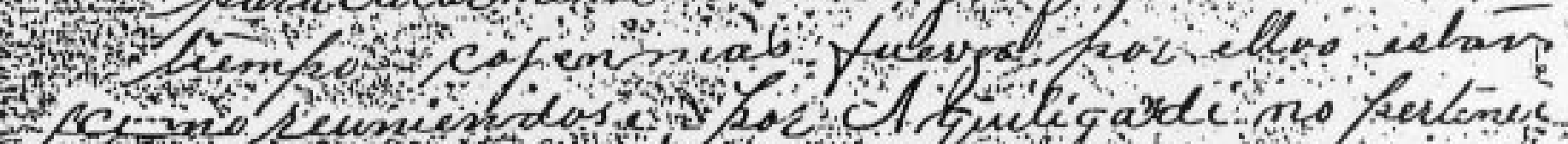
5.

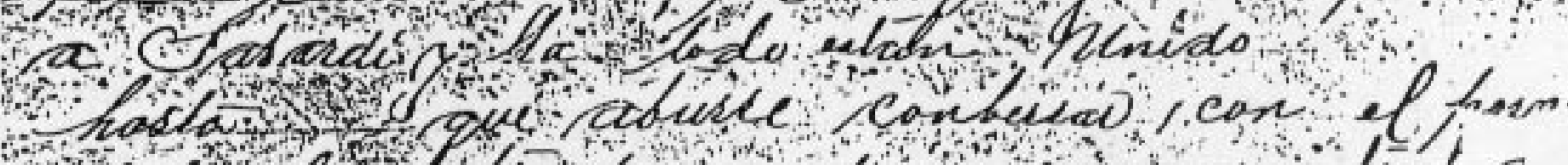

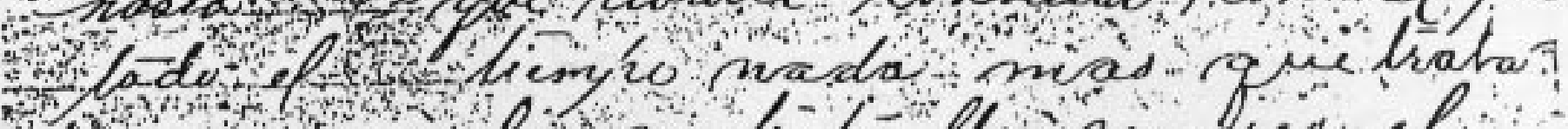

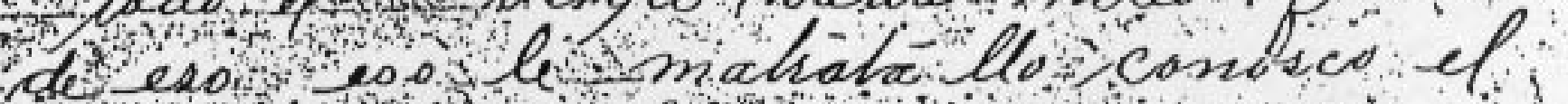
cos

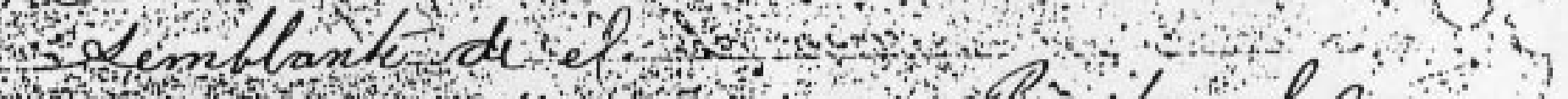

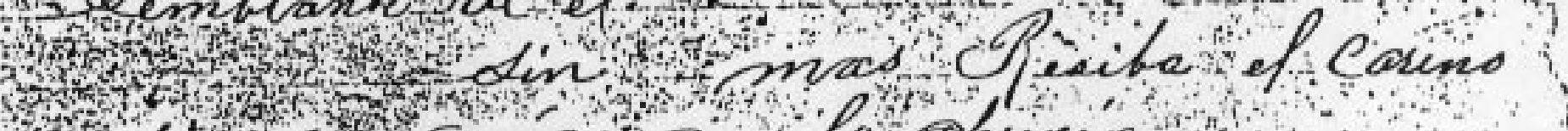

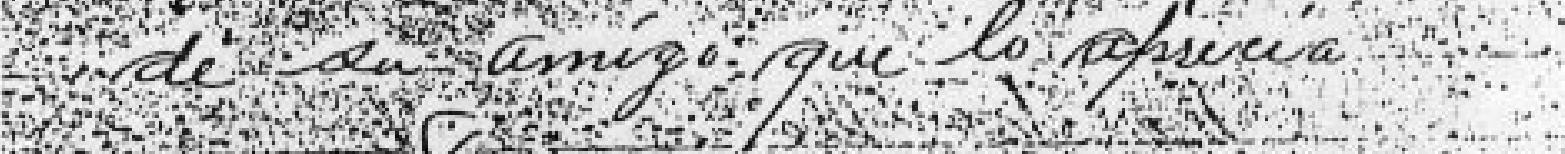

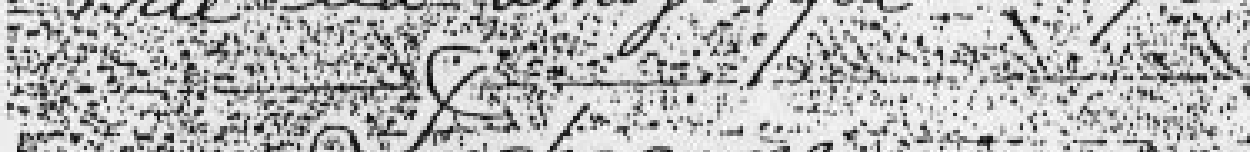

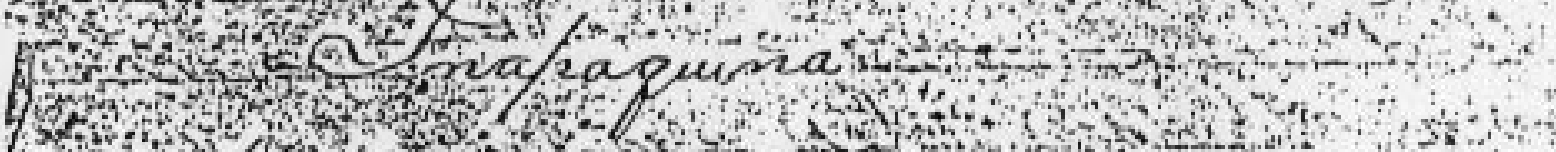

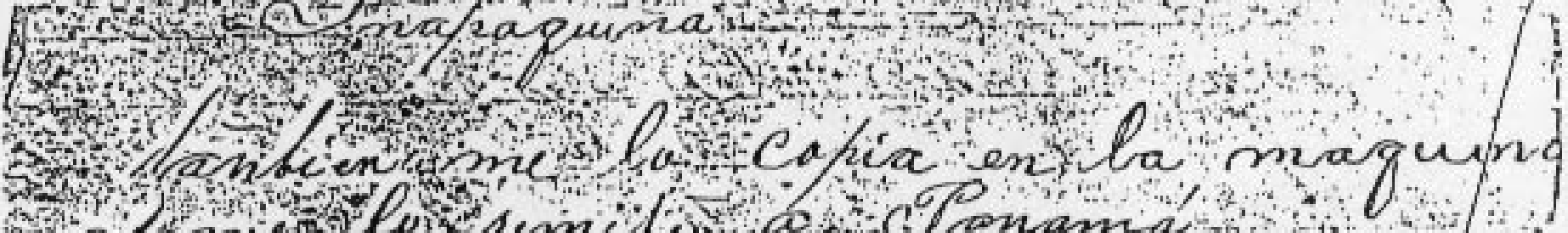

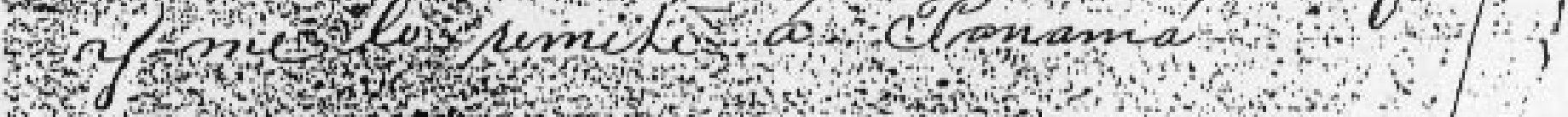

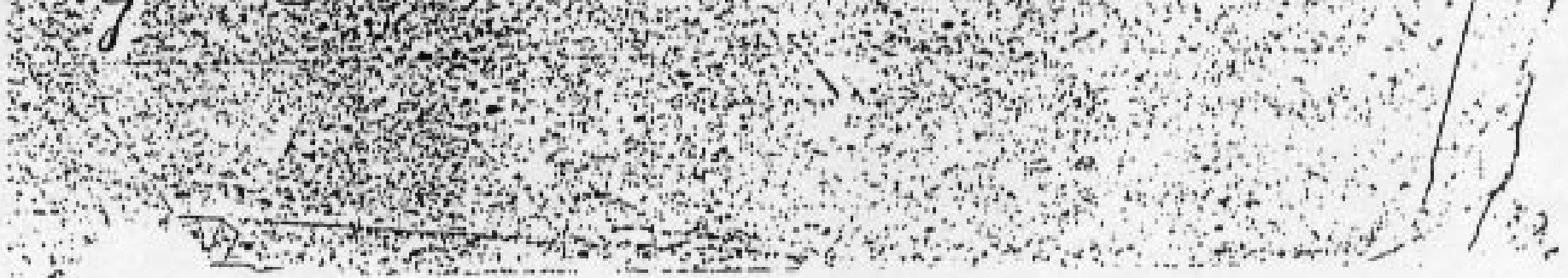




\section{XXXIII}

Número 153

Panamá, Enero 20 de 1921.

\section{Señor Don}

\section{Andrés Mojica.}

Intendente de la Circunscripción de San Blas.

\section{El Porvenir.}

\section{Estimado Señor:}

He recibido su atenta Circular $N^{2} 1$ de 10 de los corrientes, por medio de la cual se sirve Ud, comunicarme que por Decreto Ejecutivo $\mathrm{N}^{*} 186 \mathrm{de} 15$ de Diciembre del año pasado, el Excelentísimo Señor Presidente de ta República ba tenido a bien nombrar a Ud. Intendente de esa Circunscripción, y que ha tomado ya posesión del cargo.

Sus relevantes dotes civicos y su larga prác-tica to los asuntus administratinus, me hacen esperar fundadamente que sabrá Ud. encauzar y dirigir con acierto todas lexs asuntos fclaciunados con la adminsitración de esa importantisima zona del Pás.

A esa merituria labor concurre la cincunstancia nuoy apreciable por cierto de que lat Ley 56 de 1912, sobre Civilización de Indigenas, concede a Ud. las atribuciones de les Alcaldes, de los Tesoreros Municipales, de los Recaudadores Fiscales, de los Agentes Subalternos de Correus y de ios Inspectores de Puertos Maritimos. Este sistema brinda a Ud. la menera de llevar a cabo un plan general de administración, que bien organizado y mejor dirigido le pone en condiçones de controlar debidaemuat todos los asuntos relacionados con su cargo.

Me congratulo con Ud., pues, por la alta prueba de confianza de que ha sido objeto y le deseo el mejor éxito en sus delicadas labores.

De Ud. muy atto y S.S.

Manuel Quintero.

Trans, del orig. mec.

V. HD, n. 133 . 
Número 191-b

PANAMA, Febrero 14 de 1921.

\section{Señor}

\section{Intendente de la Circunscripción de San Blas,} El Porvenir.

\section{Señor:}

Se ha recibido en este despacho su oficio número 25-B, del 31 de Enero último, con tl cual remitió usted a esta Secretaria el memorial dirigido a esa lntendencia por los indios de Narganá y Corazón de Jesús, en el que solicitan que se destituya del puesto de Policia Colonial al indiu Charles Robinson. A este respecto manifiesto a usted que esa Intendencia puede destituirlo directamente; y lo que se refiere a su destitución del puesto de Ságuila de esas tribus, debe usted indicar a los indios que son ellos los que, en una reunión o asamblea general, deben reemplazarlo por otro que sea de su agrado, puesto que el Gobierno no puede intervenir en el nombramiento o en la remoción de los Ságuilas, que son autoridades puramente indigenas.

Soy de usted muy atento servidor,

Por el Secretario de Ciobicrno y Justicia,

Leo $($ :

Trans. del orig. mec.

V. RD, n. 134 . 
Excmo. вeగor Preaidente de la Kepública.

Doctor Balisario Porras.

PANAMA.

\section{Diatinguido Boctor:}

Permiteme llevar a conocimiento de usted la satiafactoria noticia de que en el pueblo de Tupila ae ba regiatrado, con fecha 18 de. Loa corrientea, el nacimiento de un nifo que tuvo la inda Magdathena Pallares con el Agente de Policia Colonial Guillermo Denis.Concoptuo de satiafactoria esta noticia por ser la primera vez que tal cosa ancede con toda la voluntad y agrado de los familiares indios, a la vez 'que dicho entrogamlento de indígena con "guaca" nos asevera en cierto modo que los indios eatán cediendo y que dí por día va resultando más efectiva la civilización,y mís rápido y aficaz el scercamiento de una raza con la otra por medio de la mezcla.

Con aentimientos de mi más diatinguida consideración, créame V.E. au muy atto.в.y amigo, 


\section{$X X X \vee I$}

EL PORVENIR, 11 de Abril de 1921

\section{Señor Secretario:}

He tenido oportunidad de ver publicados los nombraminetos del personal decente de Las Escuelas de la República, así como la autorización que se dá a la Secretaría a su digno cargo para determinar el personal que ba de servir en los distintos planteles de educación en la República y me permito reiterar a Ud. mi solieitud de que el personal que se designe para la Círcunscripción de San blas, sea personal serio, que no piense en frivolidades y que en su afán de "vivir la vida" descuiden la obligación de guardar el comedimiento y la circunspección a que están obligados como educadures de una generación que, ávidos de saber, ven en todos los maestros un modelo vivi-uente cuyos actos imitan o tratan de imitar por deber.

Igualmente hago presente a Ud. la necesidad de nombrar un Maestro varón para lus grados superiores en Narganá y Corazón de Jesús, pues el grado de civilización y el adelanto de los educandos indigenas, hace imperativo la designación del tal matstro, aparte de que es un deseo vehemente de los moradores de esas islas.

Espero que el senoor Secretario no descuidarả esta solicitud que le hago ea bien de la administración pública,y me suscribo atento y seguro servidor.

Intendente de San Blas

Señor secretario de Instrucción Pública,

Panamá.

Trans. de la cop. mec.

$$
\text { V. R D, n. } 139 \text {. }
$$




\section{V I I}

M-39

Número 48-B

11 de Abril de 1921.

Señor Secretario:

De conformidad con sus instrucciones tengo a bien informar a Ud. que me he entrevistado con el Señor Ramón Garrido, Jefe del Primer destacamento en esta Circunseripción y he profundizado, mediante minucioso: examen, el asunto de los disgustos que dicho señor tuviera con su señora, Maestra de Escuela en Corazón de Jesús y he llegado al conocimiento de lo siguiente:

Que el señor Garrido ha unido disgustos con su señora, como ucurre en ludu matrimonio, y que si éstos han sido del conocimiento de alguna persona no hat sido con el ánimo de que sirviera pura la exportación y mucho menos para que sirviera de arma contra su señora y yuien aûn en las presentes difícies circunstancias porque atraviesa el pais guarda la măs absoluta moderación y el acatamiento debido a quien la presenta.

En mi sentir parece que se trata de rivalidades por el cargo de Matestra que la señora de Garrido desempeña y considero de mi deber manifestar que la labor de la señora mencionada está a la vista con admirar hoy a las indias de Narganá y Corazón de Jesús, vistiendo el traje regular de las ciudades civilizadas, pues dicha señora los ha confeccionado casi en su totalidad y ha influido en el ánimo de esas indias a lin de conseguir el cambio de vestuario, contribuyendo así de inancral elitaz a la labor en cuyo éxitu estả el Gobierno prolundamente interesado. sergures servider.

Esperande laber cumplides can el señor Scefetarie, me es grato suxcribirme atcato y

Trans. de la cop. mec.

V. RD, n. 140 . 


\section{XXXVIII}

$M-41$

13 abril 1.-

\section{Señor Secretario:}

Próximas a reanudarse las tareas escolares considero del caso insistir en que ol señor Secretario pruvea lo conducente a fin de realizar las reparacioegs que necesitan las Excuclas de csta Circunscripción y cuyo detalle y presupuesto informé a ese Despacho y agregar a ta wer, que ya las reparaciones han adquirido mayores proporciones y no será extraño que, al demorar más tiempo el despacho de los materiales solicitados, tenga que anunciar ta destrucción total de alguno de dichos edificios.

Verdaderamente que la responsabilidad de este descuido no podemos atribuirla a falta de gestión por parte de esta Intendencia, ni de buena woluntad por el senor Secretario, pero el caso es que el aspecto de dichos locales actuidmente nos hace aparecer como descuidadus, negligentes y pocos apreciadores de las propiedades del Gobierno, especialmente en materia de Jnstrucción Pública, en donde se debe, en mi humilde concepto, tener el mayor esmero posible, toda vez que ese ramo es donde reside la labor más eficaz en materia de civilización.

Considero demás reiterarle la señor Secretario el ofrecimiento de mis servictius y los del personal a mis inmediatas órdenes para realizar las reparaciones o constucciones que las exigencias del servicio asi lo requieran.

\section{Al señor}

Secretario de Estado en el Despacho de 1. Pública.

Panamá

Trans. de la cop. mec.

$$
\text { V. RD, n. } 141 \text {. }
$$




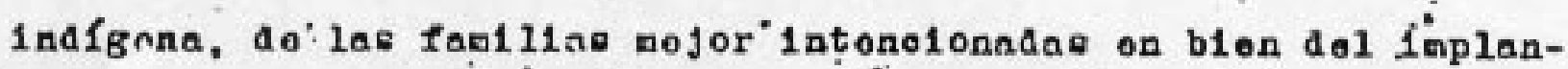
tamionto de la o1vilizaeion, quienes han manifestado do la manora

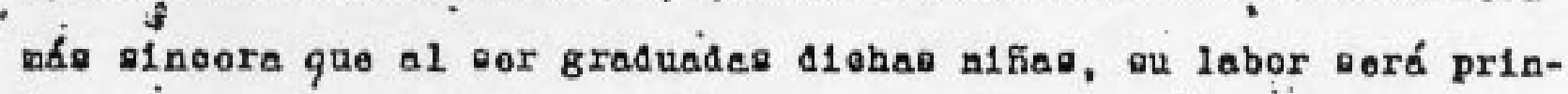
olpalnente haoer oxtenolyo aus conoolalontos y las aostumbres ad-

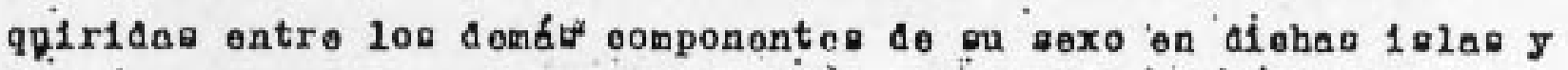
- Aenás adyaentes:o

Segun me 1nforno el vefior Seerrtario do Instruesión Púb11ea, la áneasión de laha beeas dopende do qua ol do toblerno y Just1 ela ordene 208 gastor que elias osaalonen, que pon relat1* ranentio pequefioa, para quo puedan aer adalt14os, puos pór perto dol prinero no hay 1neonrenionté alguno toda vos quo hay ospoeso sufiaionto para roelbiriog on 100 rnspoetivos plantolog. * ojala, puos. Dd. eotinado Dootor, logro obtioner do am-

boo Boóretarios un entondmiento siue perastl a ostos jóvenes, os-

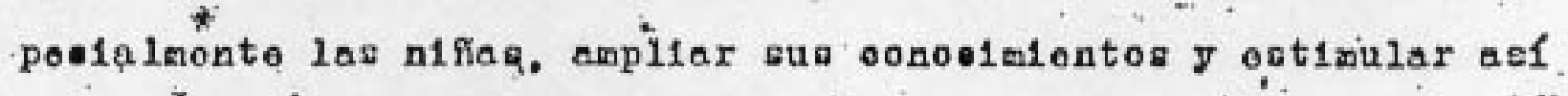

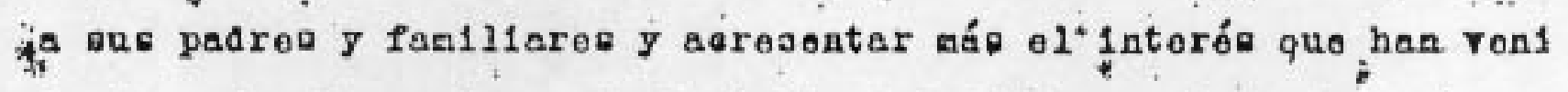
do domotrando en Lavor do la*labor deI-Goblerno. Sienpre suyo afmo. amigo y gorvidor.

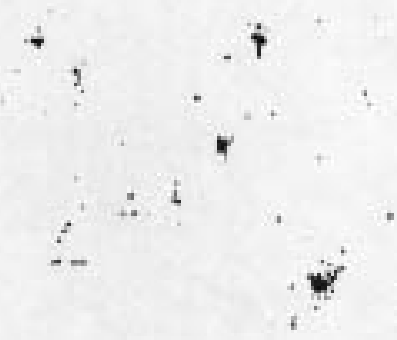




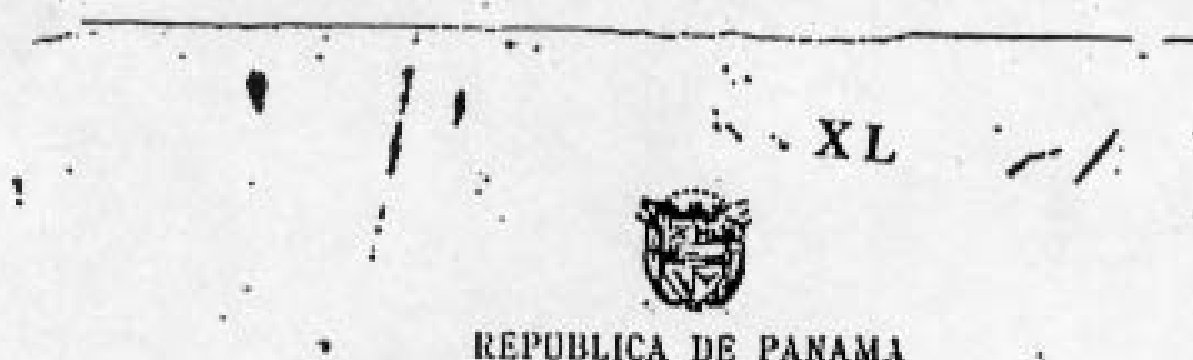

\section{3}

\section{REPUBLICA DE PANAMA}

PREGLENCIA
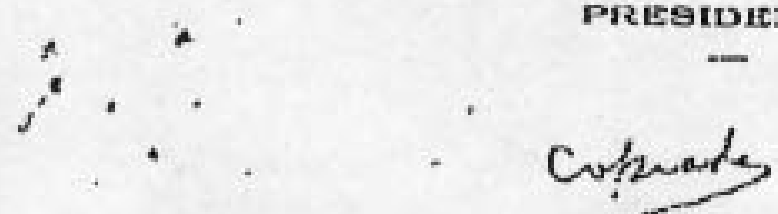

Pafiniar, Abril 23 do 1921.

3r. Dn. Andrés Mojica,

Intendente de la

C1rcunsotipoión de San Blas,

PORVEIIR.

Mi estimado emigo:

Ito reflero a su atenta carta del 13 de los corrlenter para mantestarlo quo en Consojo de Gebinete se-resolvio dyer quo en la in- .

vosiblildad en que nos cncontremos para conceder las sels becas a quet Ud. haco referencia en ella, a 4 ind fonas $\mathrm{y}$ a dos nifias do la misa raza, $10^{\circ}$ prifetico ea que el Sr: Secrotario de Goblemo los proporciono 10. suma indispensablo para el poco àe su pensión aque en la escueis, esi como tarnbién pare todos sue detufe gastos, pues todo consideranos

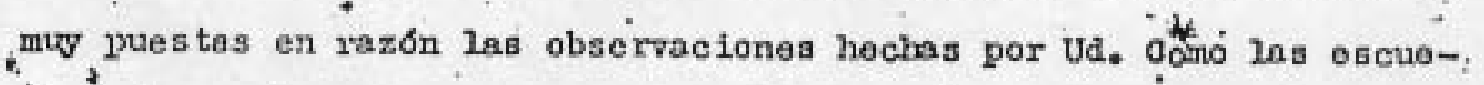
las estón ya paral abrirse, puede td. enviar inmediatanente, a los oola jovenas que ha seleceionado. 'en la segurtad te quo ol Secretario do Goblerno los acogerá y vors la manora de oolocarlos en las respeotivas. esouelas. .

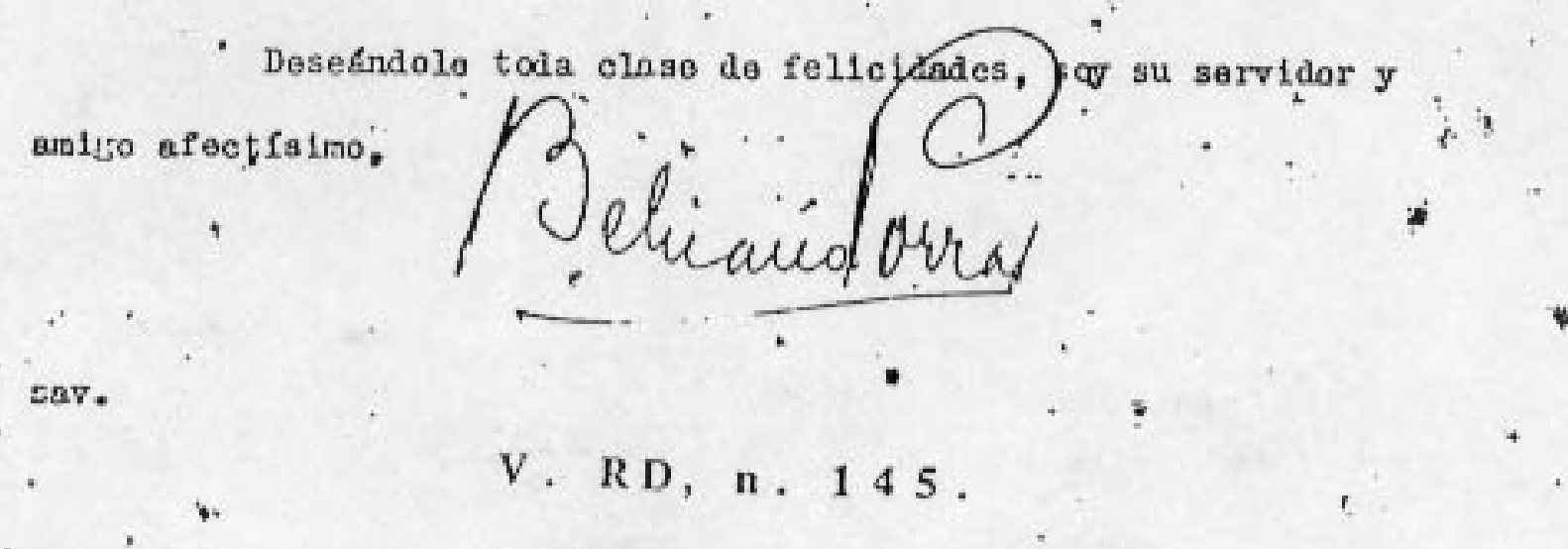




\section{LI}

\section{Secretario de I. Pública.-2-}

Igualmente me permito solicitar del señor Secretario la concesión de las becas para los jóvenes y las jôvenes indígenas, cuya petición hice verbalmente. Es la primera vez que niñas indigenas se disponen con el consétimiento de sus familiares a venir a la Capital a ingresar en un plantel de enseñanza y no deja de representar este becho un gigantesco paso hacia la completa civilización de estas tribus.

Confio en la buena voluntad del señor Secretario y su interés en el desarrollo de la Instrucción Pública en toda la República, su muy atento seguro servidor,

\section{ANDRES MOJICA,}

Intendente Jefe de San Blas,

Al señor

Secretariu de Instrucción Pública,

Pànamá.

Trans. de la cop. mec.

V. RD, n. 147 . 


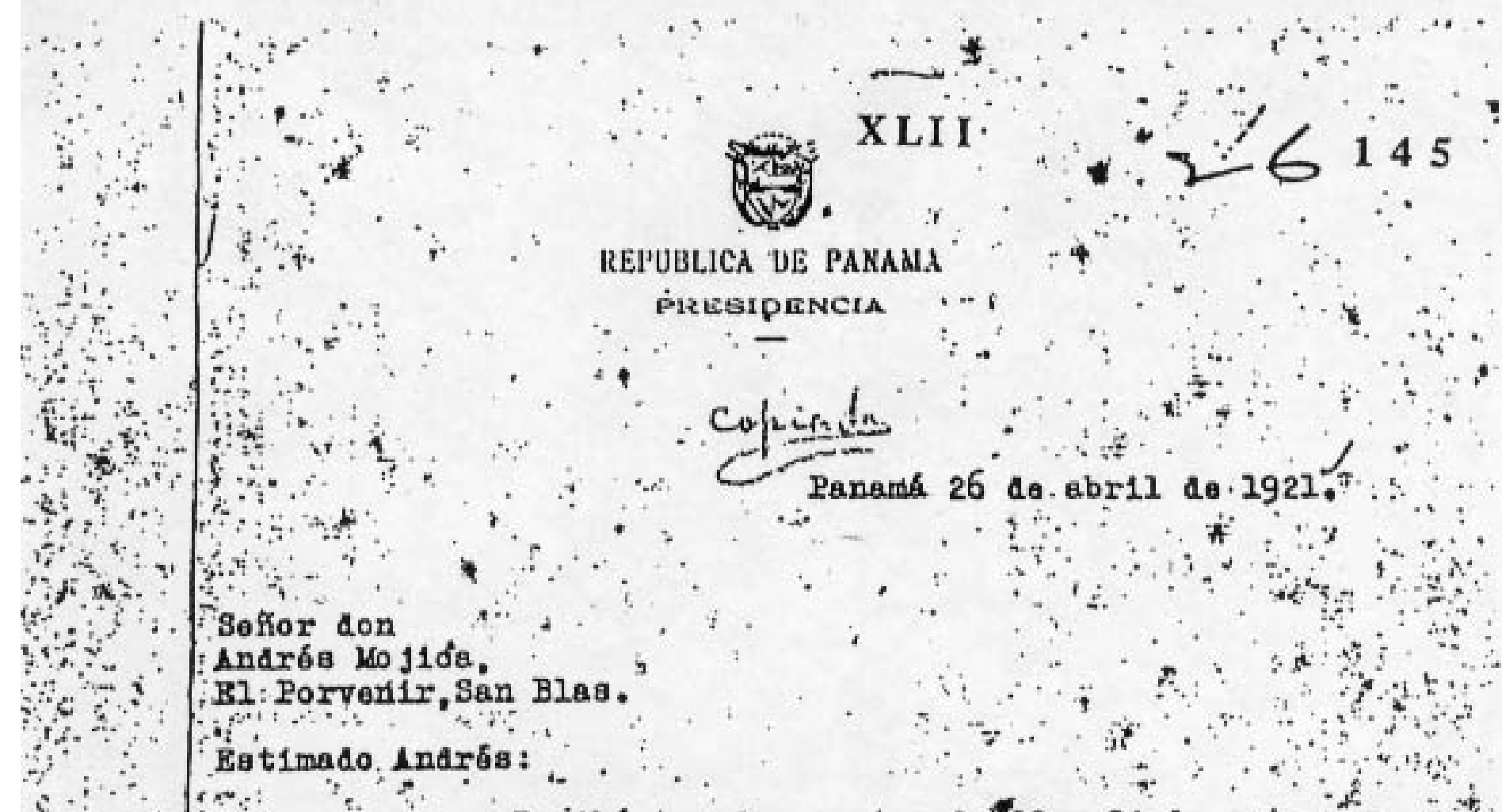
Redib1 tus dos artas de?22,y. 24 de osto mes, y con mache pena me he 1mplasto del agesinato do Iglesias y Gon-:-

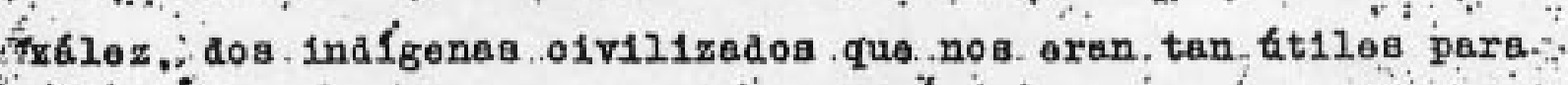

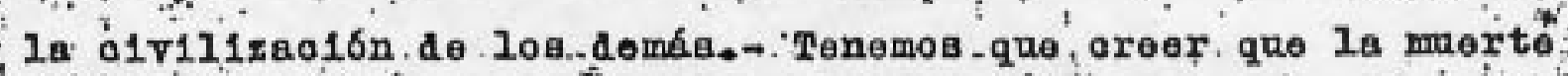
de ellos tue Iraguada y qu ha aido obre de Sagujles oomo log que indiose. Probablementé colman até met1dó on ol complot. I-

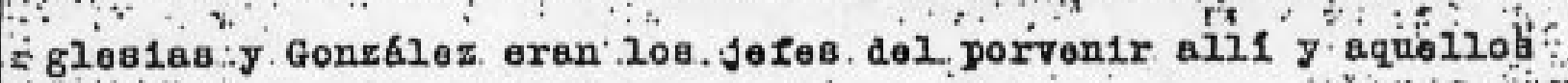

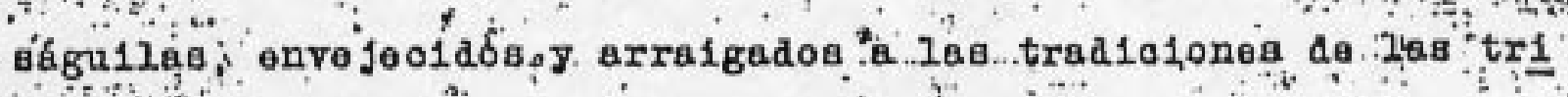

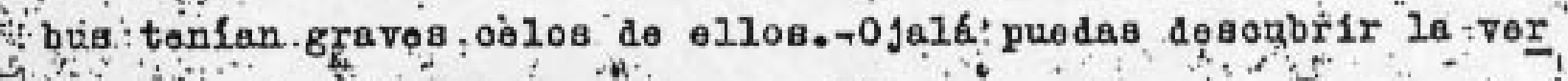
dad.y.que, 1 están oompromet1aos los fralgab para ger juzgados.

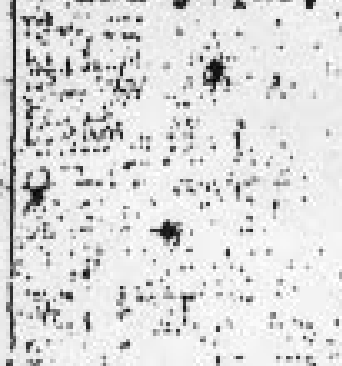
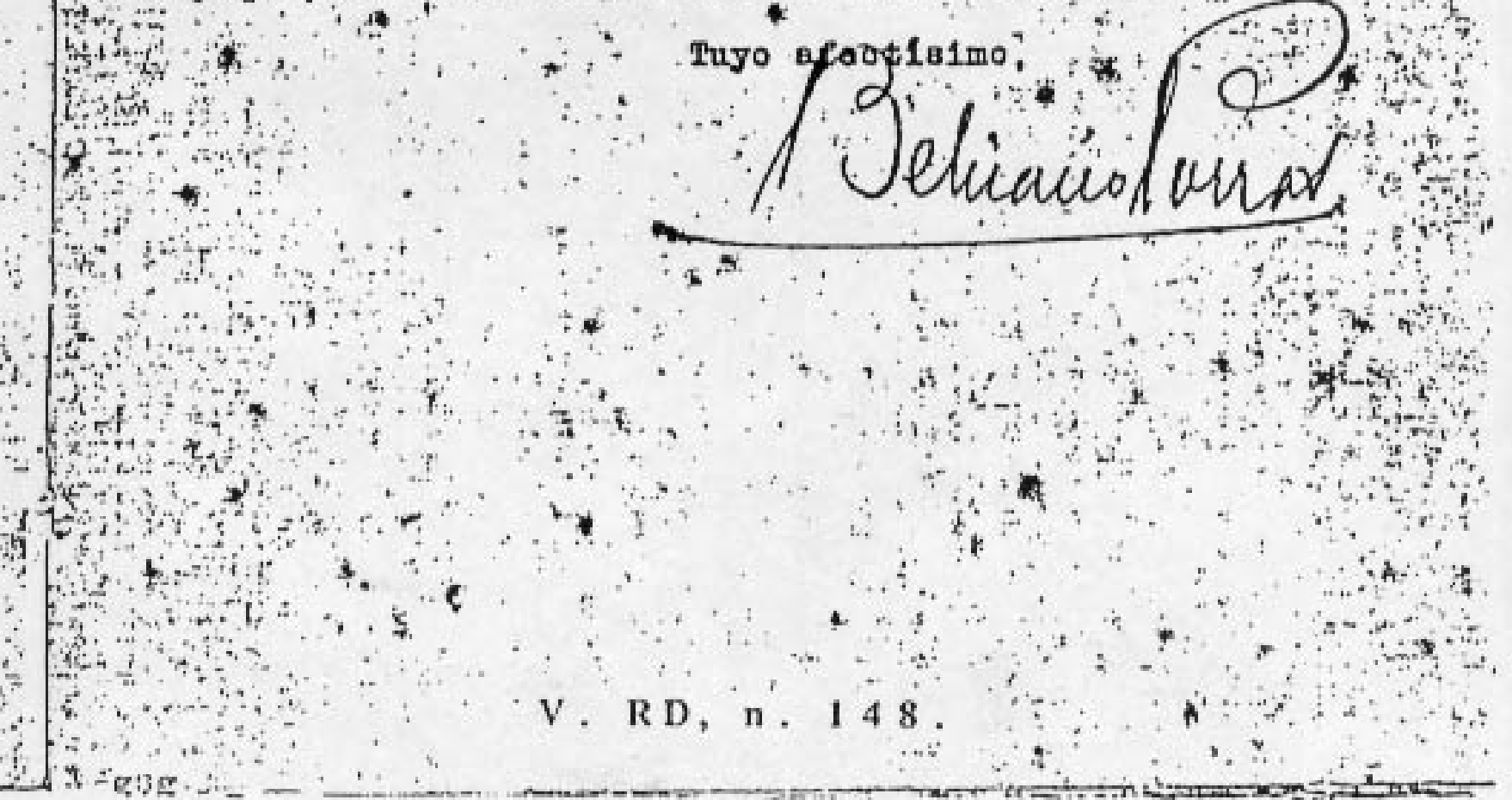
Exomo. Yoft or

Dootior Don Bollearlo Porras.

Panama.

Intiando Dootor y amigot

Ho os erato nviser a Ud. reolbo de ou itenta ooreunioaolon

+ doi 23 do los k. bondodosa abogla que dio va. y. ol Conrejo de Gablnote a la solloltud que tie permltiera haoes on feror de lod Jovenea indigenas, raronea Pablo Iglooins, Rabón Parer, Oncar Pad111a I I paol (Seafo) (Seyp)

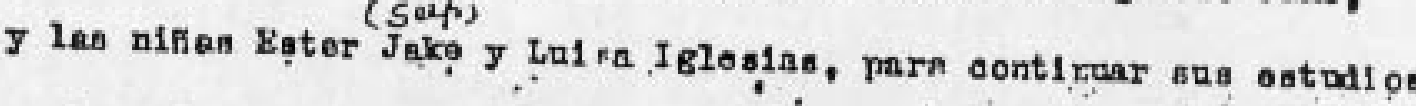
on les plantoloe de onsefanrs do la'Capital.

4

a la rex me "imito informarlo que al galonto mas inatruo- olonea lea ho ordonado fogulr hoy miamo pora panima a ponerso a las ordene dẹl sefor Seoretarlo de Goblerno fara 10 delicnso.

La lmprosion que tal acort ecimlonto ha cauado ontre Ias

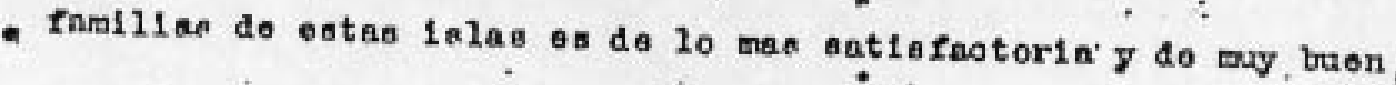
augur10.

Que oo connerve biez oon 100 denoos do au armo. amlgo y leal" sorridar.

$\cdots \quad \therefore \quad \therefore$ ALDERS veJICA, 


\section{XLIV}

$M-45$

Número 212

\section{Señor}

2 Mayo

1.

\section{Secretario de Instrucción Pública}

PANAMA

\section{Señor:}

Con motivo de estar próximo a reanudarse las tareas escolares, estuve visitando las planteles de enseñanza de Tupile y Playón Chico, las cuales permanecen en un abosiluto abaudıno, especialmente la escuela de Tupile que necesita una refracción total pues de ura manera se perderá por completo el edificio, cumu ya he manifestadu varias ucasiones en notas anteriores.

Principalmente tiene el techo completamente adeñado y debido a tas crudez del invierno es estos lugares, la matstra no podrá dictar sus clases sino solamente lus dia secus es decir cuando no llueve, y por esta razón será imposible comenzar las tareas escolares este año, sin llevar a cabo su completa refracción.

La escuela de Playón Chico se encuentra en mejores condiciones pero es necesario cambiar cuanto antes las visagras y cerraduras de hierro que actualmente tiene por otras de cubre, pues las primeras debido al salitre que despide el mar, están en muy mal estado. También es de imperiosa necesidad darle un baño de pintura y repasar varias columnas de las que sosticnen to edificio que sinó están quebradas de un tơdo estân bastante rajadas.

Con el fin de evitar mayores gastos en lo futuro, me permito recomendar el cambio del zinc, en los techos e esos edificios por otro...

Trans. de la cop. mec. inc.

$$
\text { V. RD, n. } 152 \text {. }
$$




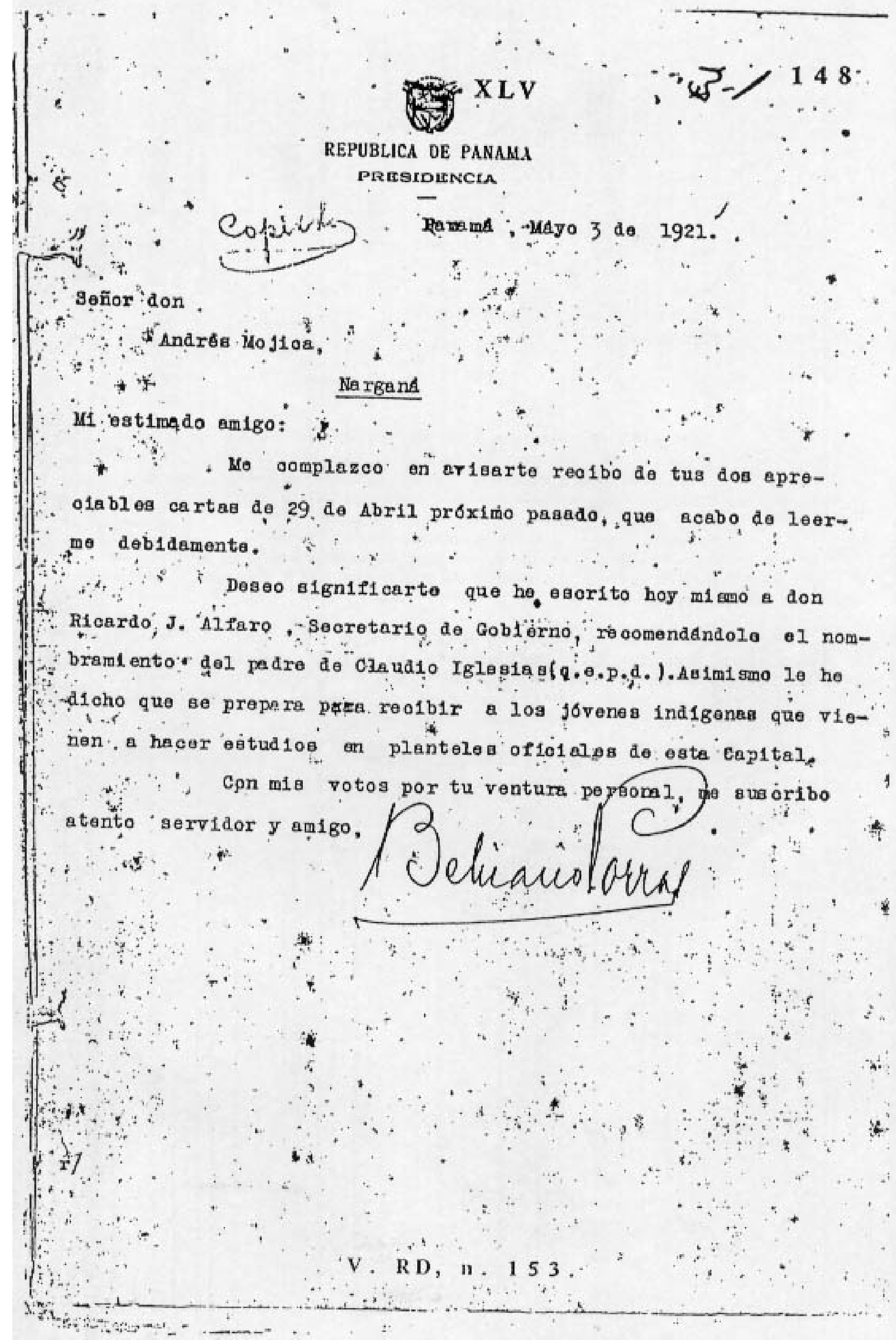




\title{
- Sello XLVI, lcon amorla
}

REPUBLICA DE PANAMA

Preaidencia

Pananá, mayo 6 de 19az.

\author{
Sr.An.Andréa Mojics, \\ Intendente de la \\ Circunacripción de San Blas, \\ E1 Porveinir.
}

Ui querido amigo:

Tengo para contentarte tus notas 20,21 y, 22 de 2 y 3 de ate mes; con las dos primeras he recibldo copias que ma anuncias de notas dirigidas al Sr. Secretario de Gobierno,y con la "ultima ae viniaron los cundros demostrativos del movimiento de Caja de la Circunacripción.

Mucho me alegro que las indias de Tupile bayan decidido cambiar aua vestidos por 208 que uasn nuestros mujerea,pues allo implica el que la civilización eatá introduciéndose definitivamenta en la Circunacripción.

Respecto a Ior alzamuros a que bace reserencia en ung de sus notas, he de manifestarle que a la Preaidencia no loa trajo el Sr.Va- ' glio, quien wólo we dí on una ocasión una argollita pequefia, que ni eiguiera es de oro eino de plaqué.

Eepero que me aeguirá informando aobre el movimiento de $\mathrm{Ca}$ ja y que el efectivo de Éta volveró a quedar an aumento. ..

Tuyo afectíaimo.

BELISARDO PORRAS.

anv, 


\section{XLVII}

M-44

Número 270

Panamá 7 de Mayo de 1921.

Señor Intendente de la Circunscripción

de San Blas

El Povenir.

Señor:

En atención a lo expuesto por usted en su atenta nota número 200, de fecha 28 de abril último, con relación al regreso de los indigenas de esa región que estudian en la Escuela de Artes y Oficios, me complazco manifestarle que he dado el aviso correspondiente al señor Director del citado establecimiento para que aguarde el regreso de los citados indigenas.

De usted atento servidor,

Jeptha B. Duncan

Trans. del orig. mec.

V. RD, n. 155 . 


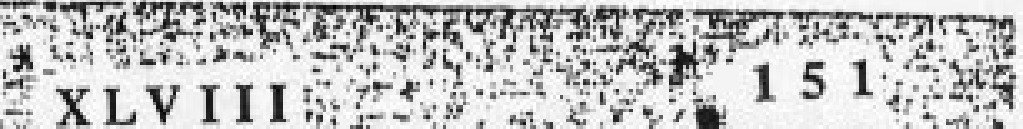

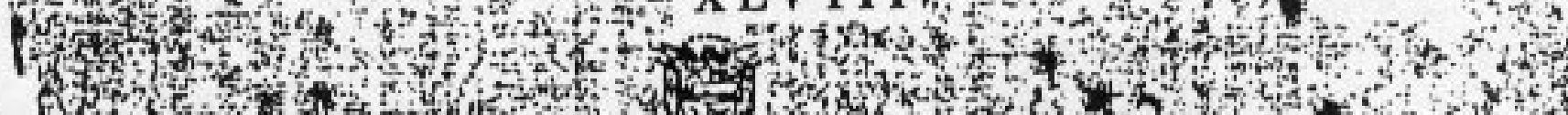

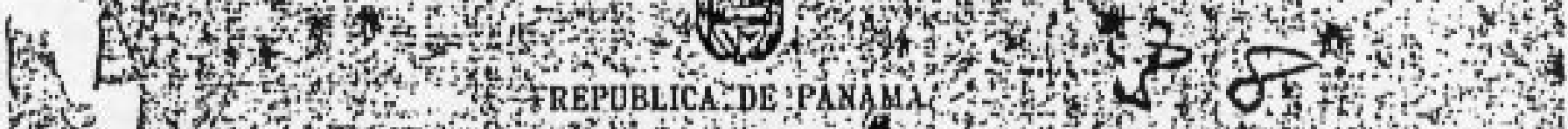

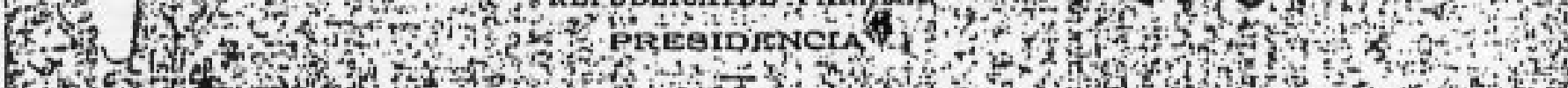

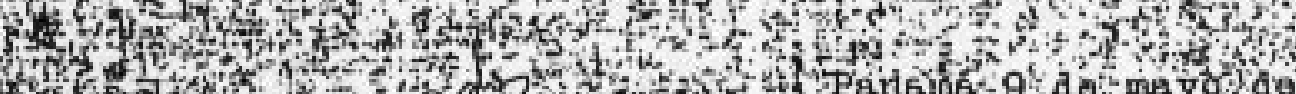

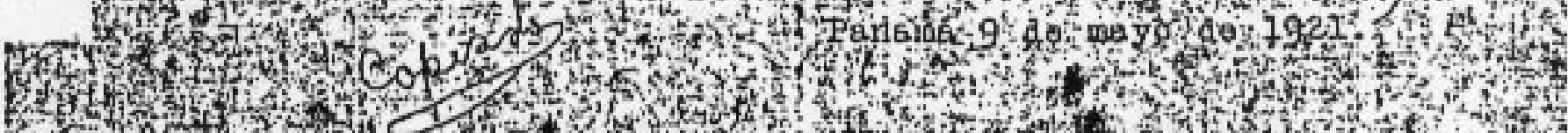

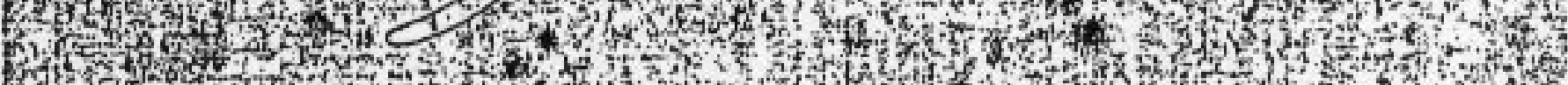
10.

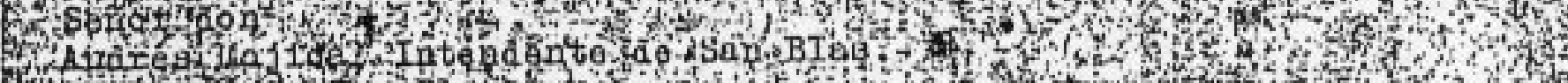
Hot

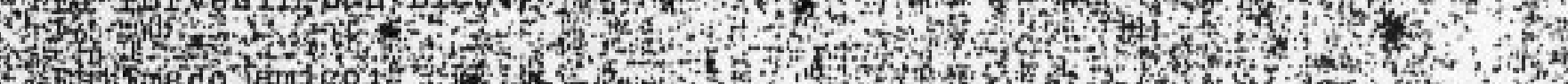

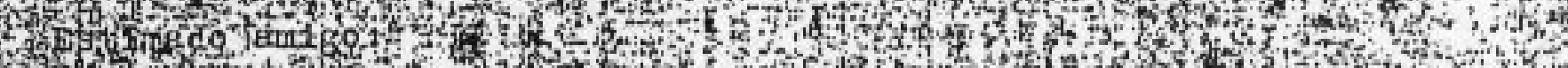

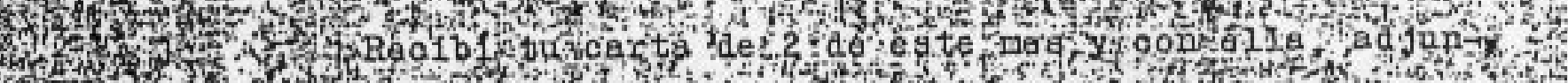

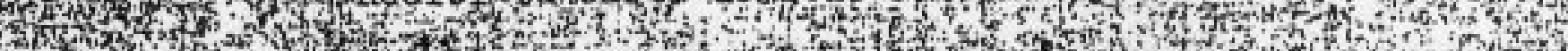

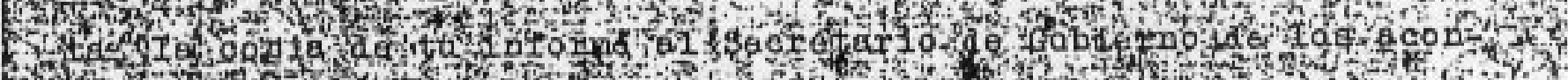

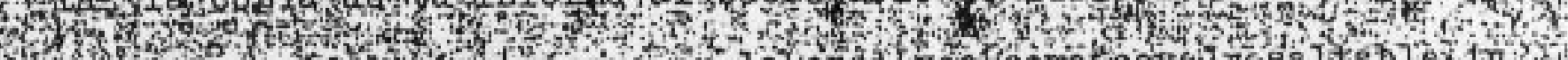

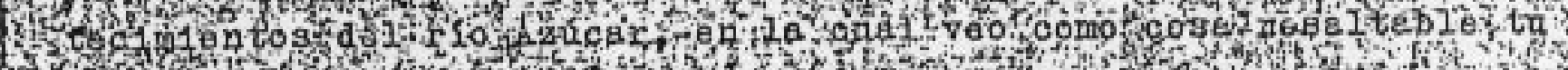
Fon.

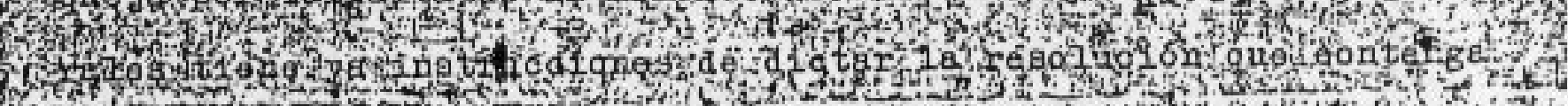

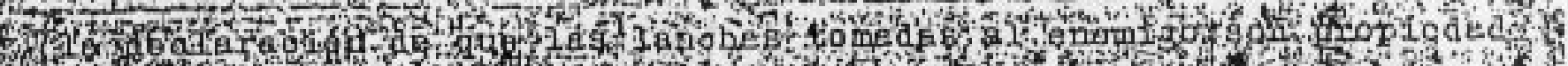
-

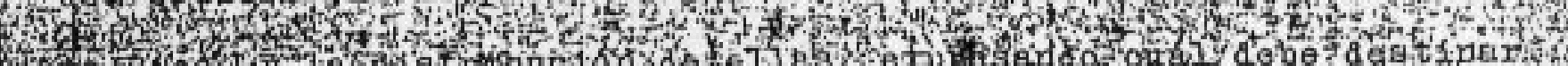

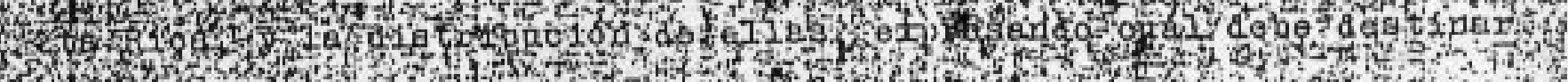

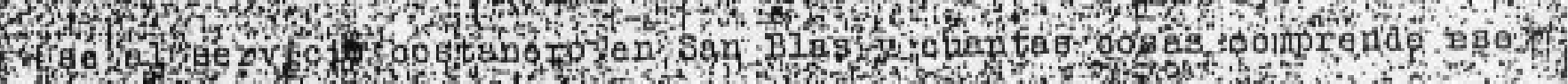
mof

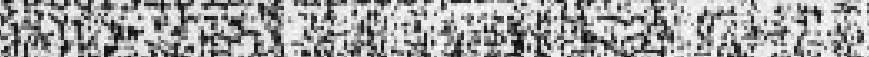
4 H.

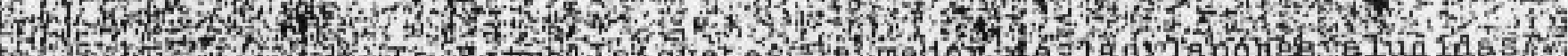

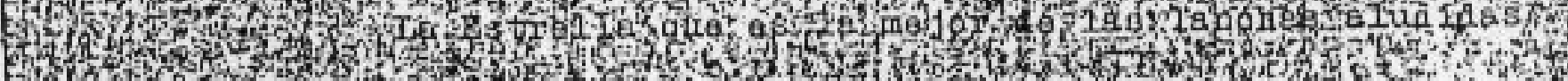
240,5 .

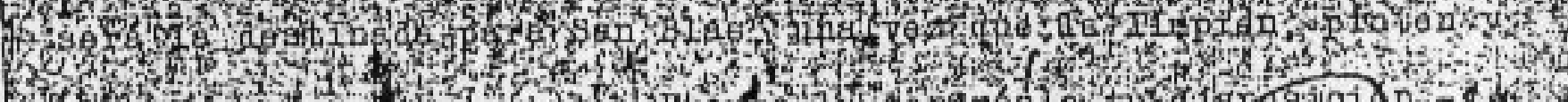
$J_{2}{ }^{2}$ क

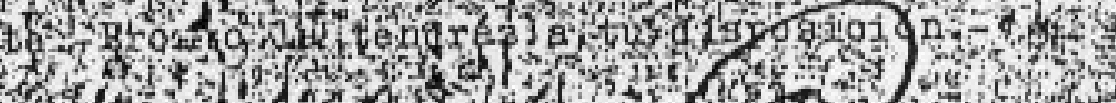

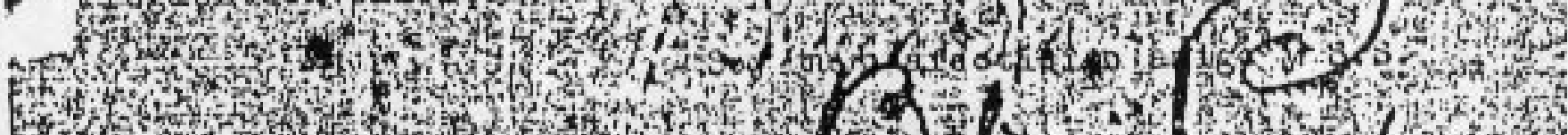

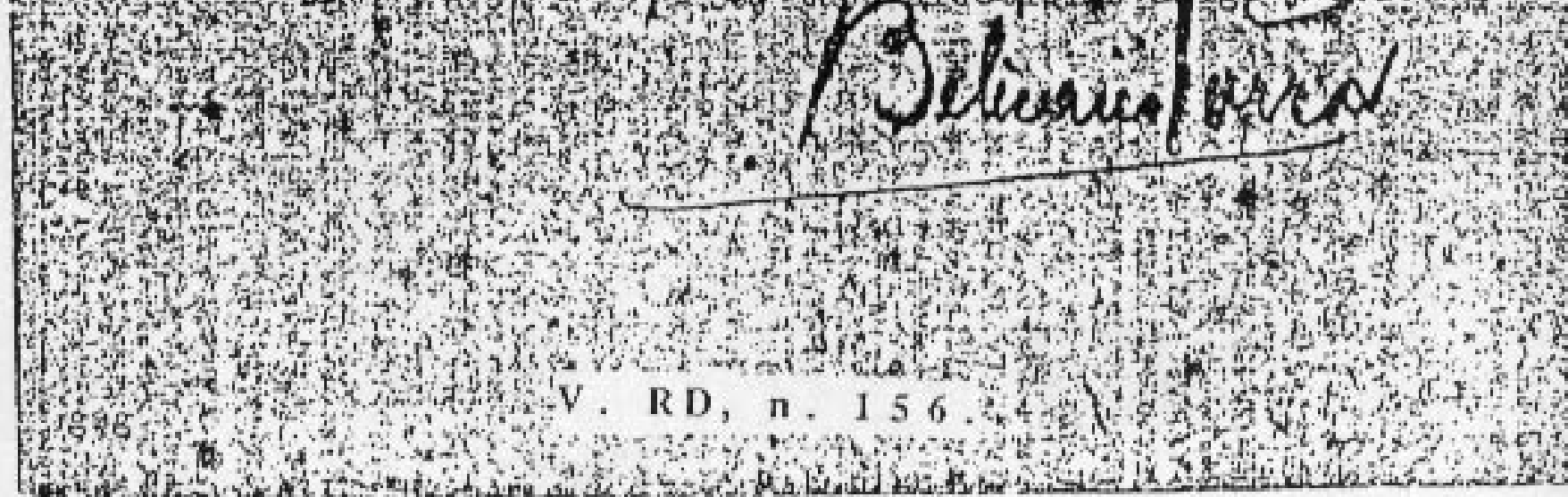




\section{$\dot{X} \operatorname{LIX}$}

\section{Sección Primera}

Número 245.

\section{Señor Intendente de la Circunscripción de SAN BLAS.-}

Panamá, 10 de Mayo de 1921

\section{Señor:}

Refiérome a sus comunicaciones Nos. 162 y 212 de 13 del mes pasido y del actual, respectivamente, por la que me solicita provea lo conducente para evitar la desfucción de los edificios ocupados por las escuelas de esa Circunscripción especialmente los de Tupile y Playón Chico y me notifica, además, en la primera de sus citadas comunicaciones, el envio de algunas jóvenés indigenas con el objeto de que ingresen a las escuelas de esta Capital.

En contestación, paso por la pena de reiterarle una vez más el pessar yue mé causa no poder ordenar las reparaciones de los edificios-escuelas de esa Circunscripción pues al ello me veo impedido por carecer el presupueslo de partidas a tal fin. Sin embargo, haré las gestiones del caso para ver si es posible salvar esos edificios y evitarle el Tesoro Nacional una erogación bastante crecida más tarde.

Con respecto a las indigenas, permitame felicitarlo por este nuevo paso en pro de la civilización de esa importante región del pais, el cual será sin duda de provechosas resultados. Las indigenas en cuestión han ingresado a la Escuela Normal de Institutoras y hasta la lecha se muestran muy complacidas de su nuevo género de vida.

De usted muy atento y S. S.,

Jeptha B. Dunean

Trans. del orig. mec.

$$
\text { V. RD, n. } 157 \text {. }
$$


OFW gitor

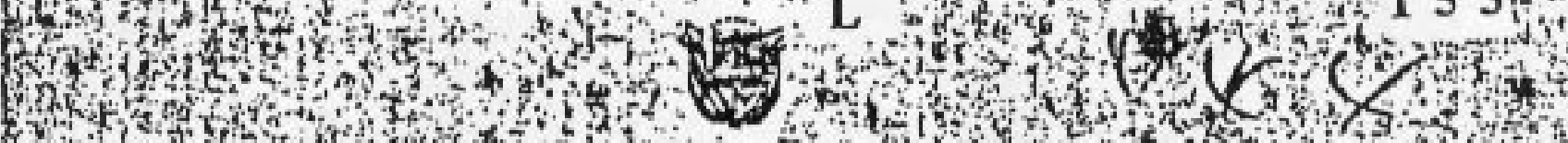

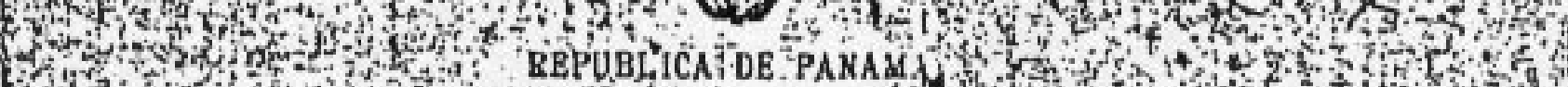

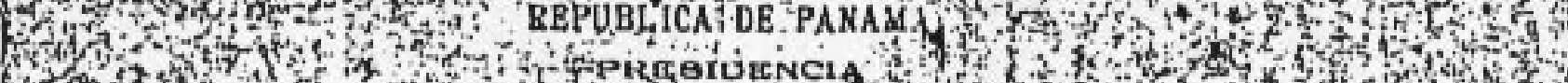

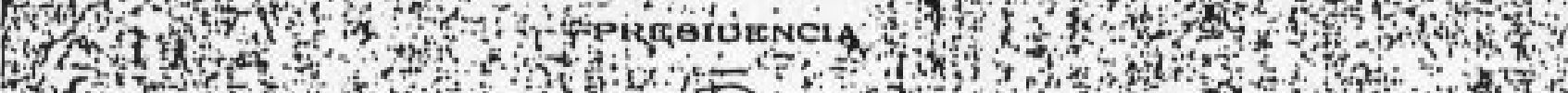
-

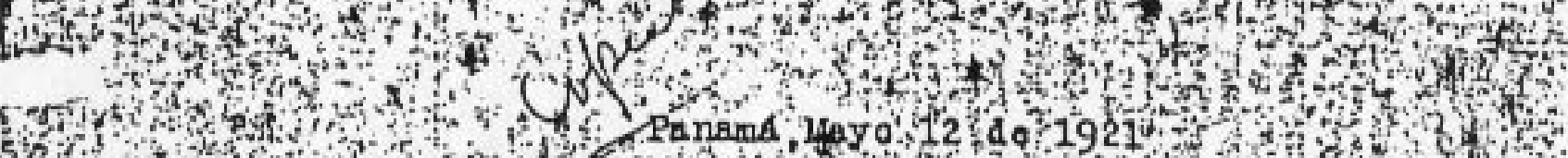

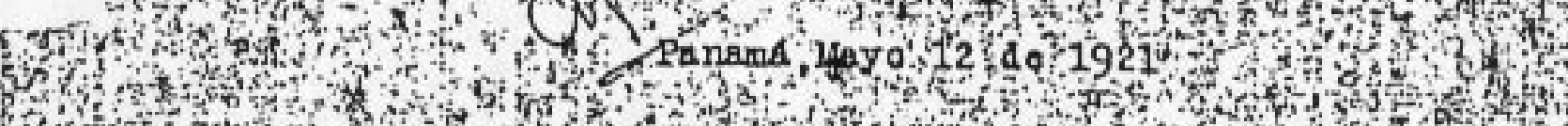

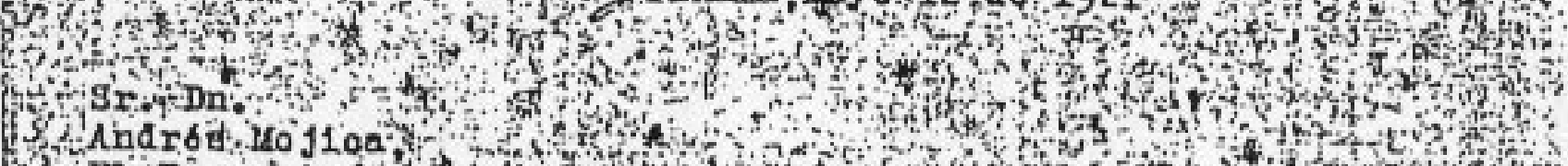

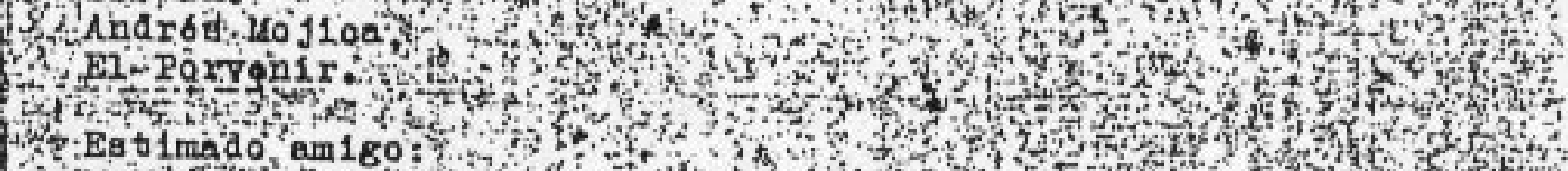

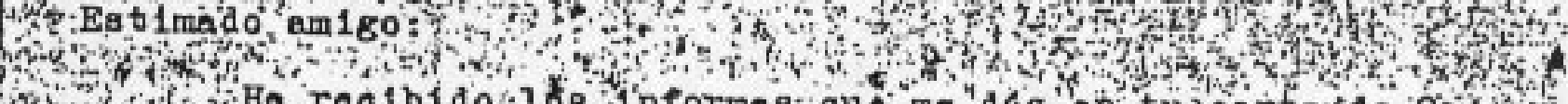

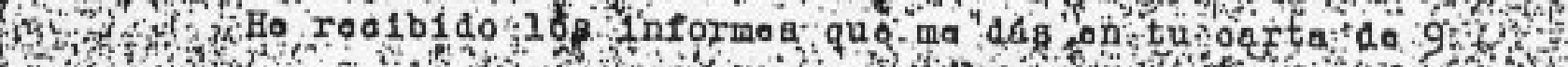

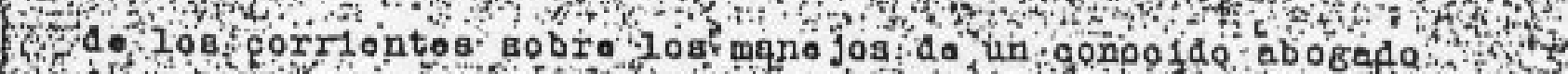

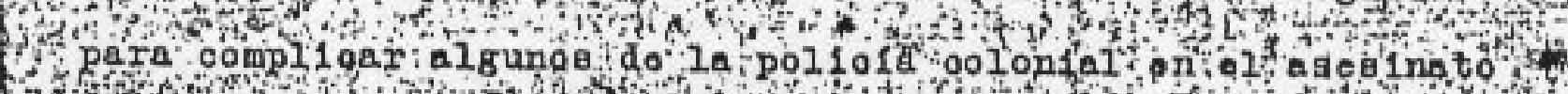

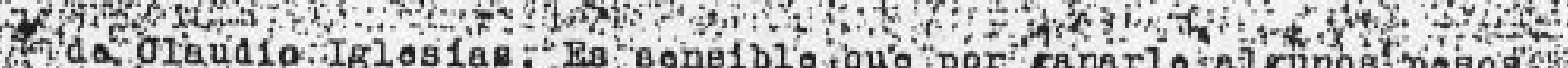

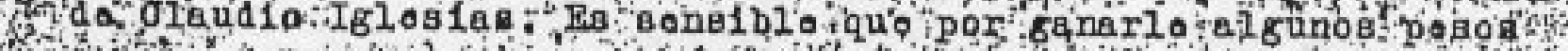

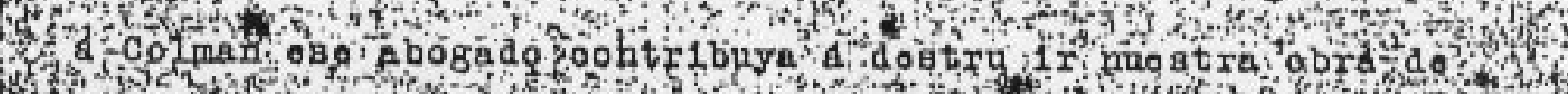
(1)

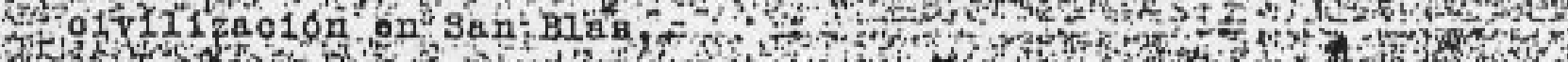

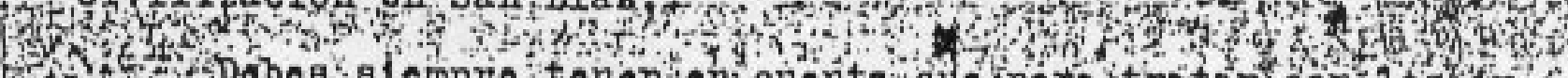

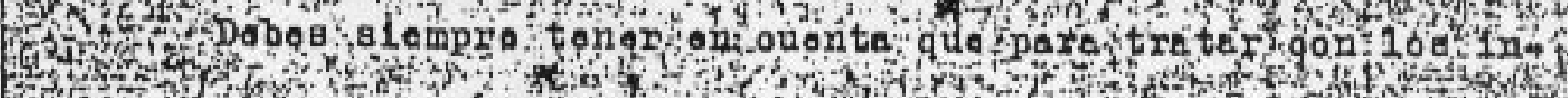

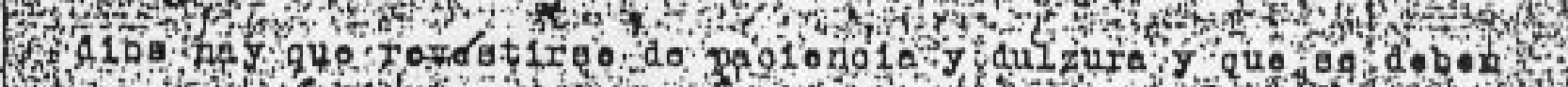

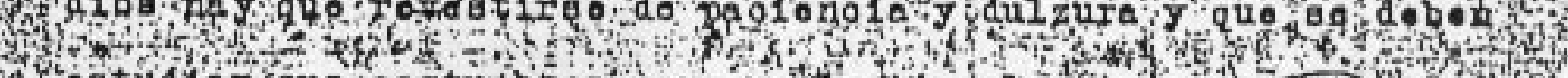

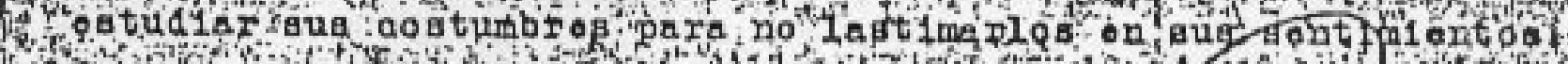

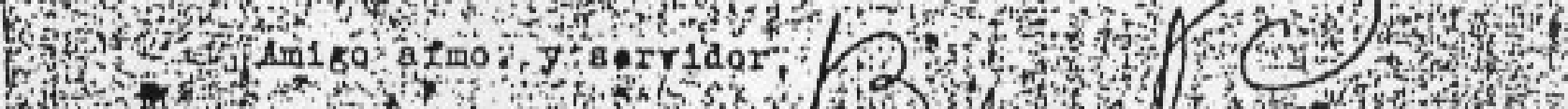

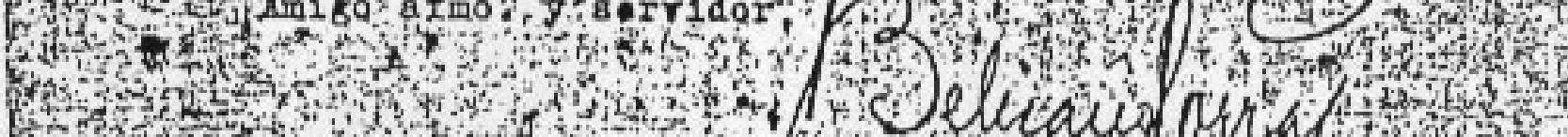

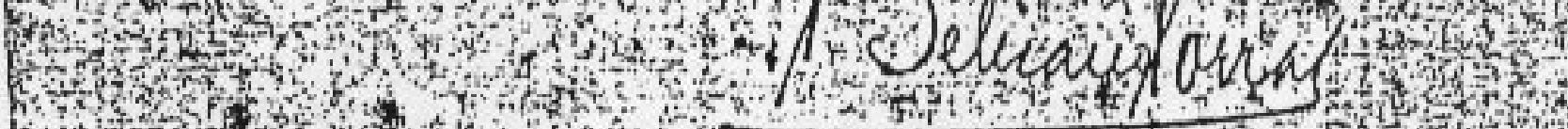

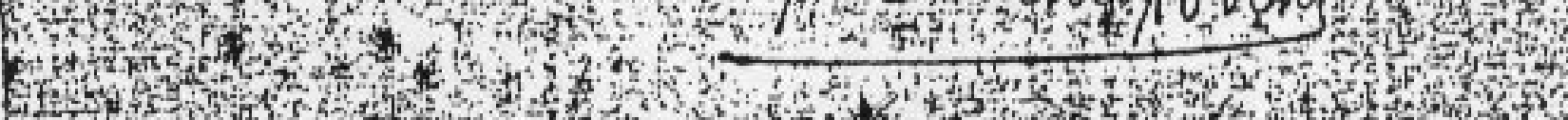

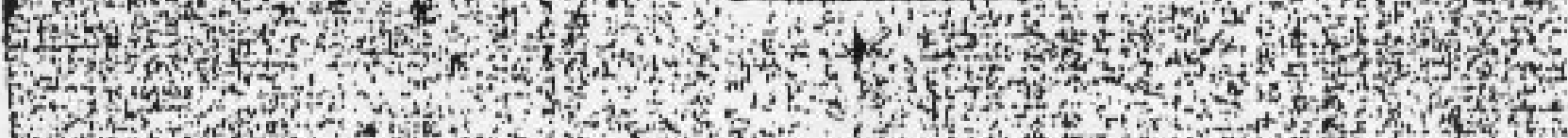

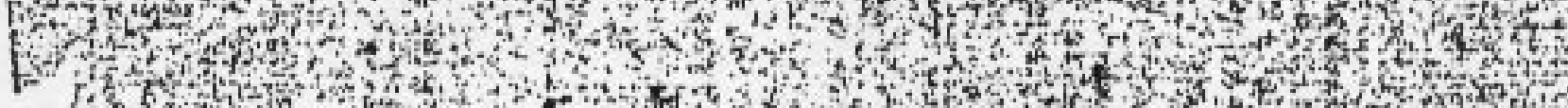
Bow 


\section{LI}

M-47 y 48

Número 261

14 Mayo 1.

\section{Scñor Secrctario:}

Me tomo la tibertad de informar a usted que hasta la fecha sólo ha comenzado a funcionar la Escuela que regenta la señora Elisa de Garrido en Corazón de Jesús y por consiguiente se encuentran sin reanudar las tareas escolares las escuelas de Narganá, Tupile y Playón Chico.

Desconozco las causas por las cuales las maestras nombradas para estos planteles no bay-tan venido a ocupar sus respectivos puestos, pero presumiendo que los últimos acontecimitntos que se desarrollaron en esta región en el mes próximo pasado sea una de las causas por las cuales no se atrevan a venir, deseo significarle señor Secretario que esta Intendencia tendrá especial interés en prestar toda garantía y seguridades a los o las maestras que vengan. Verdaderamente yue estus acontecimientos no pueden menos que causar mala impresión, pero son hechus que nu deben impedirnos por ningún motivo el continuar en el cumplimiento de nuestas misión. Son cassos aistiados.

Además el suscrito tiene la firme convicción de que el Gobierno nos rodeará en lo sucesivo de mejores elementos para nuestra conservación personal.

Creo del caso recordarle la solicitud que le hice de un maestro varón para la Escuela de Narganáa fin de mejorar la condición de los educandos, sin perjuicio, de que continúen funcionando las maestras como han venido funcionando basta el presentc.

El nủmero de alumnus $y$ el adelanto gue ya han adgairide muchex de clltex hace imperiuso el que la Secretaria a su digne carges, con ol lin de aprowecha mejor su hatudable tahor relizada hasta la fecha haga el numbramicnto que solicito del maestro varón. Prucbat de ello es, yue de Narganá, seggún enticndo, ha salido el mayor número de júvenes indigenass patra la (apital y de lew más aprovechatus.

Convendrá conmigo el señor Secretario y le repito mis palabras "Lat labor Administ: rativa en San Blas para que tenga éxito debe ser simultánea con la labor educativa pues en mi concepto la una debe ir intimamente ligada con la otra, de suerte que, donde lleguemos at estabalecer nuestras oficinas y Destacamentos de Policía, debemos al mismo titmpo consaruir nuestras Escuelas.:-

En espera de que usted aecedia a mi solicitud me es grato suscribirme su muy ateutes ys.

s.

\section{ANDRES MOJICA}

Intendente de San Bliks.

Al stenor

Secretario de lnstruccioin Pühlicit.

PANAMIA.-

Trans. de la cop. mec.

V. RD, n. 159 . 


\section{I}

$\mathrm{M}-49$ y 50

Número 263

14 Mayo 1.

\section{Señor Secretario:}

En mi última visita a Puerto Obaldia me solicitaron los moradores de ese lugar el que gestionara con el Poder Ejecutivo la construcción de una pequeña esc uela, tada vez que el edificio que antiguamente servia como tal, se habia destruido totalmente, y el envio de un maestro con tel fin de que sus hijos que son netamente panameños no se vieran privados del pan de la enseñanza.

Verdaderamente existen más de cuarenta niños de ambos sexus nacidus y criadus en Puerto Obaldia, es decir netamente panamenos aunque de padres columbianos, que están desarrollándose sin ninguna clase de instrucción. A esta solicitud me permiti ofrecerles que haria todo lo posible por conseguir que el Gobierno atendiera a sus necesidades pero que la situación actual tal vez no permitiria realizar ambas cosas la construcción de la escuela y el envio del macsaro.

A esta manifestación contestaron que conprendian que el Gobierno no prodría hacer ambas cosas ahora pero que crefan que si podia permitir que uno de los Agentes de Policia acantonados en Puerto Obaldia, a quien ellos consideraban competentes y de su confianza enseñara las primeras letras a sus bijos y fueran preparándose de este modo basta que el Gobierno puediera formalizar la escuela y las clases. El Jefe del Destacamento señor Juan Francisco Cabezas igualmente me recomendó a uno de sus agentes señor Santiago Cabarcas, persona de alguna edad y apropiado para el caso.

En mi concepto salvo mejor opinión del señor Secretario, creo que prevía intcligencia con su honorabie colega de Gobierno y Justicia pordria accederse a esta solicitud y autorizar usted al Agente Cabarcas para que putdat dietar dichas clases y el doctor Alfaro autorizarme para pxrmitir que dicho Agente dedique tres o cuatro horas diarias parra impartir alguna instrucción a leghanines que: estän en eondiciones de recibirlas. Bien entendido que estas autorizaciones sérin dé earácter transitorio mientras el Gobierno provea lo que crea conveniente.

Dada las condiciones del servicio actualmente en Puerto Obaldia cre, que éste no se perjudicaria y mucho menes cuando abrigo la esperanza de que el Gobierno Nacional autorizara cl aumento de Agentes que he solicitado.

En espera de que usted atendiendo estas razones gestiune el asuate an el sébur Secretario de Gobicrnes y Justicia y de vir pronto sus gratas nuevas me suscribu su atentu y s.s.

\section{ANDRES MIOJICA}

Intendente de San Blas.-

Al schnor

Secretario de Instrucción Pública.

PANAMA.

Trans. de la cop. mec.

$$
\text { V. RD, n. } 160 \text {. }
$$




\section{abufilen}

Sello

REPUBLICE DE PANAMA

LI I I

Presidencia

Panamb́l Mayo 20 de 1921.

Sefor Don

Infiréa Mojica.

El Porvenir.

Estimado amigo:

He reftero a au apreciable carta de 14 de 10 corrientes; avisandome el nombramiento de 108 sefiorea Enrique Morales y Abraham Garrido para Agentes de Policia Indígena aggún la recomendación que le hize; rgradecido por la atención.

Yo no we he referido eapecialmente a usted cuando indiqué que no debía procederse de manera violenta con $10 s$ indios tratando de despojarlos de aus güines y alzamuros; hablando en términos generalea decia $y$ abora le repito que en mi opinión.lo miamo que la do los miembros de mi Gabinate, se debe adoptar con loa indígenas los procedimientos pacíficos, no violentarlos en sus costumbres, no obligarlos a despojarse de 108 atributos que ellos consideran sagrados, y solamente empezar la labor de bacerlos cambiar de costumbrea por medio de las ensetianzas en las, escuelas como tos nifos y niflas que a日iatan a las clases.

Tanto uated como los emplandog de eas Circunscripción debe seguir una línea de conducta de acuerdo con las ideaa que on términos generales le dejo expresadas,y tengo la seguridad de que no $B \in$ repitirán hechos de sangre, como los que desgraciadamente hemos tenido que lamentar.

Soy au afectísimo amigo,

BELISARIO PORRAS.

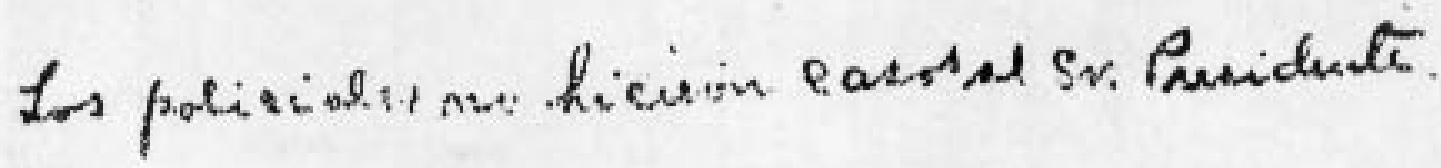

$$
\text { V. RD, n. } 162 \text {. }
$$


Fis

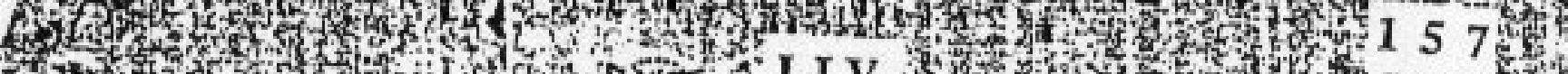

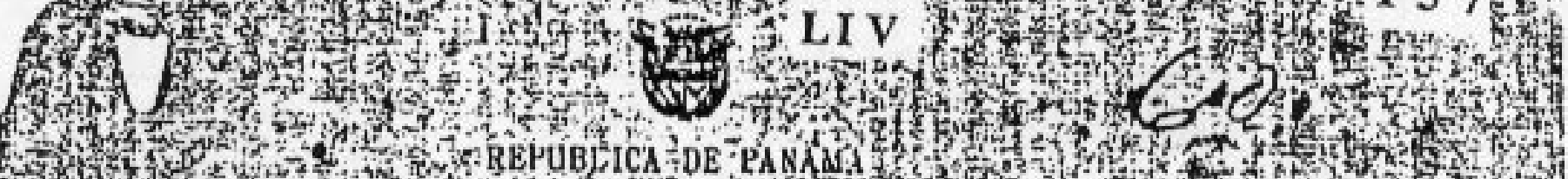

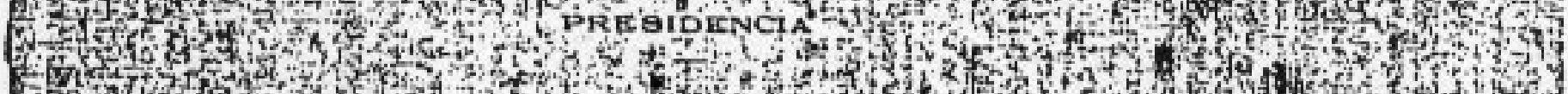

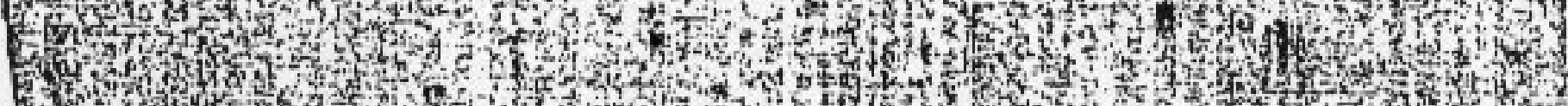
5.

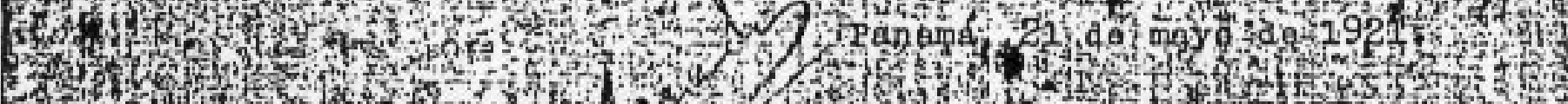

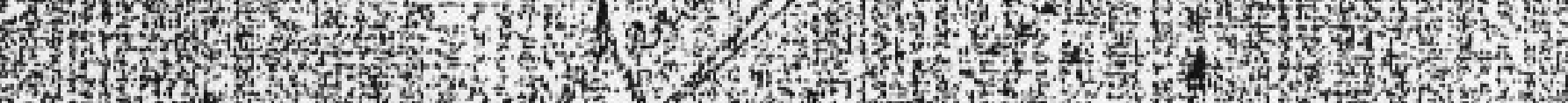
Befozation

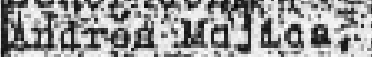

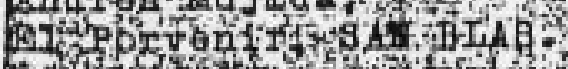

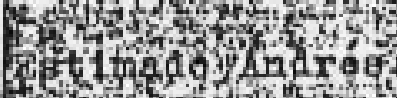

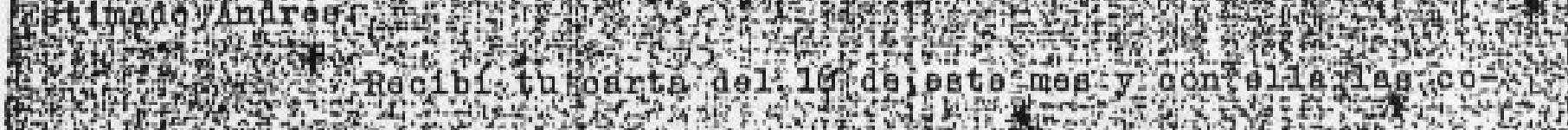

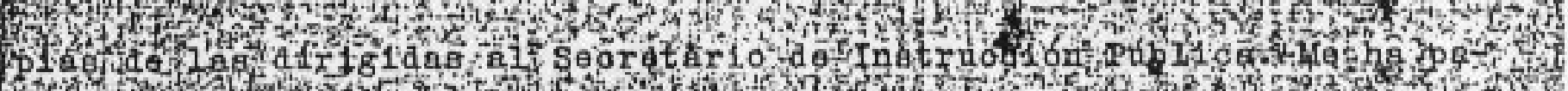
Hedo

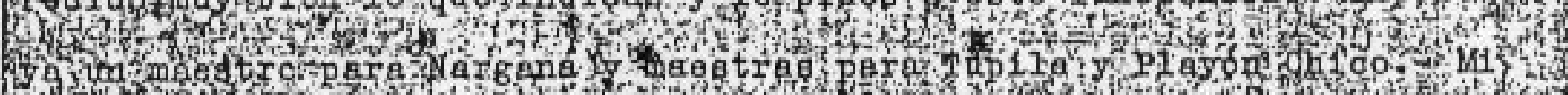

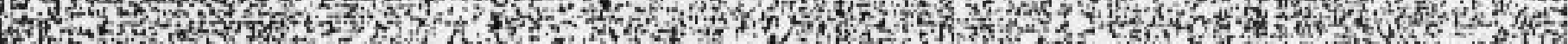

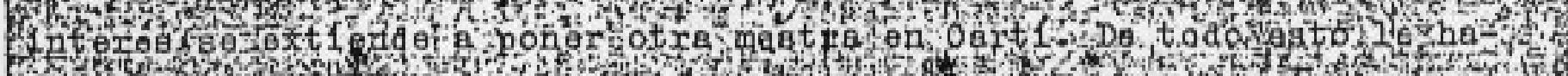

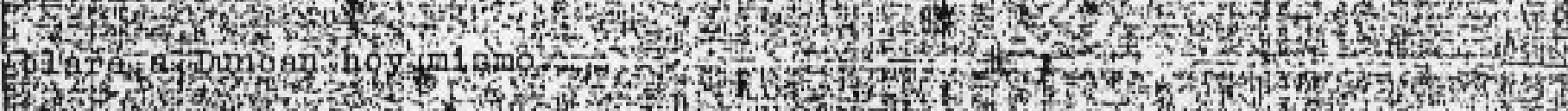

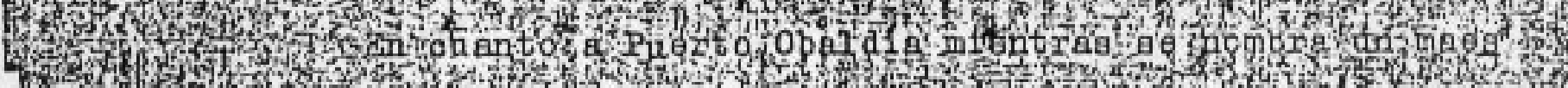

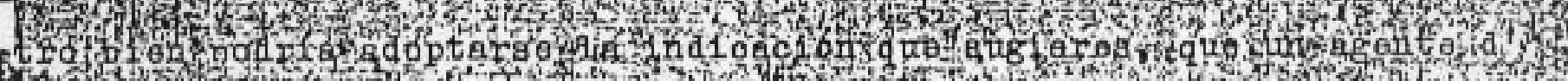

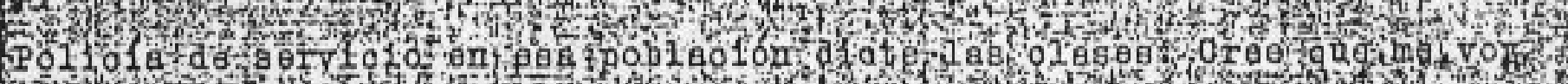
Q

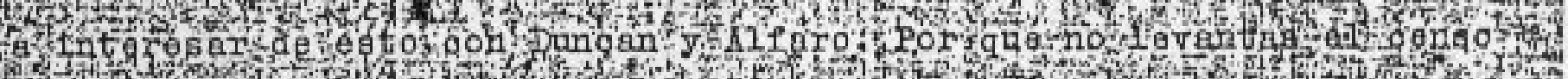

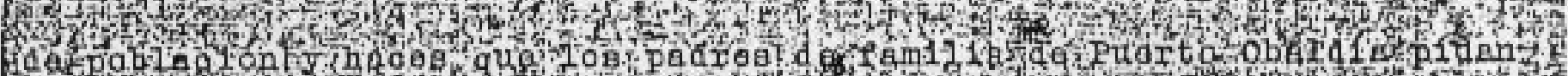

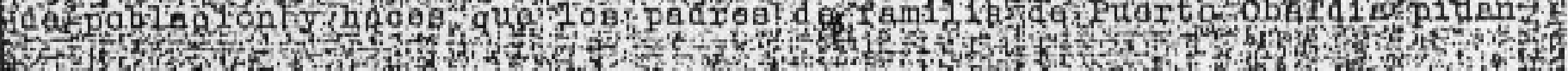

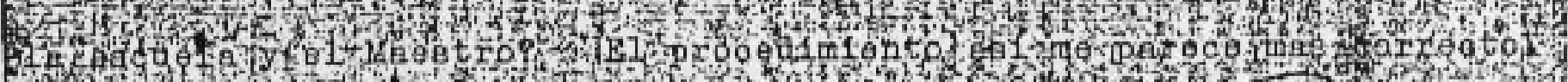

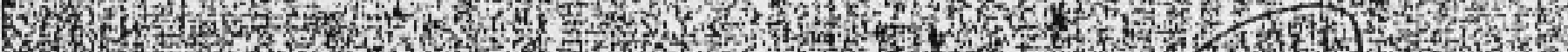

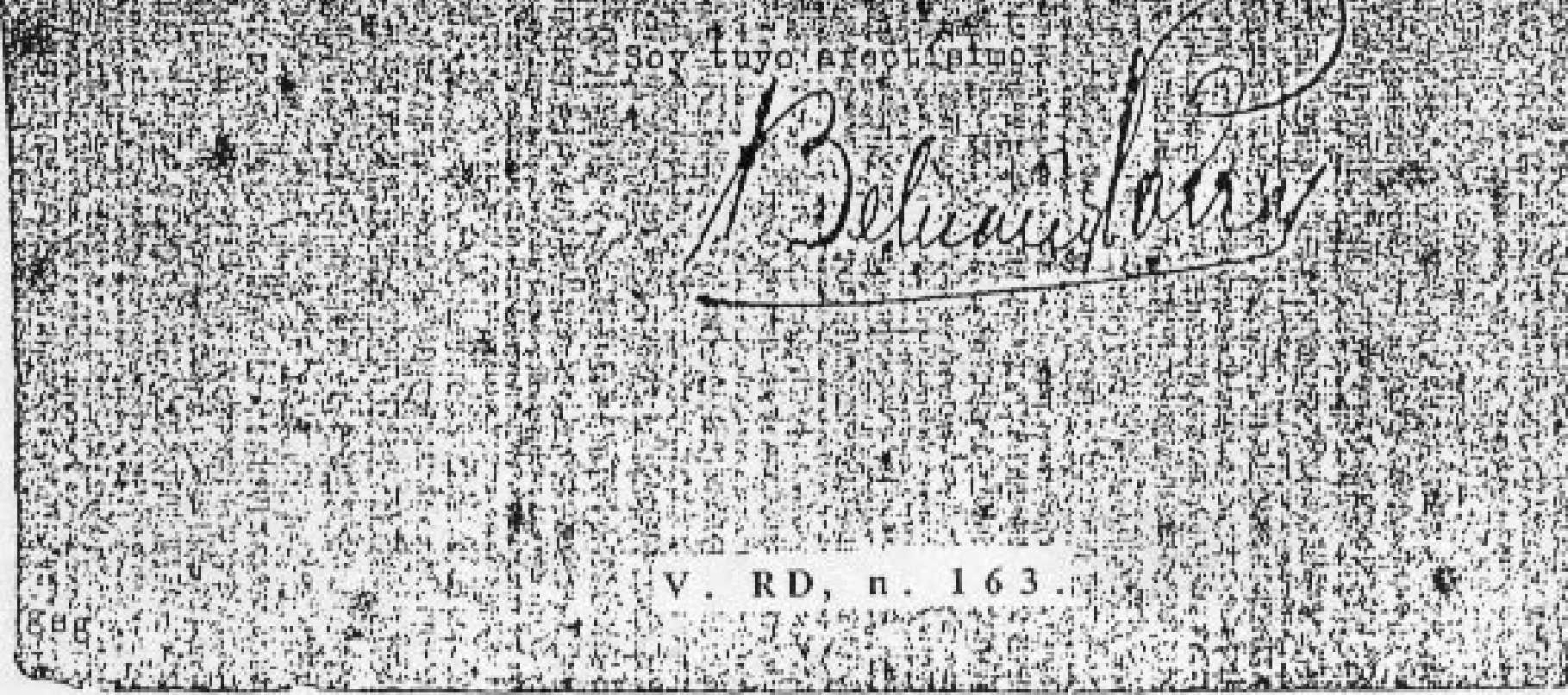




\section{$L V$}

M-38

Sección Primera

Número 281

\section{Sr. Intendente de la \\ Circunscripción de San Blas' \\ El Porvenir.}

\section{Señor Intendente:}

Se ha recibido en este Despacho su atento oficio número 46 B, relacionado con el nombramiento de maestros para tas escuelas de esa Circunscripción.

En contestación, siento manifestarle que debido a las acontecimientos ocurridos recientemente en San Blas, no me ha sido posible conseguir maestros que açpten puestus alli,

y por esta razón, a pesar del vivo interés que tiene la Secretaría en que comiencen a funcionar las escuelas cuanto antes, no ha sido posible hacer los nombramientos.

En vista de lo expuesto, le estimaré a usted en alto grado que se sirva buscar candidatos para las escuelas de San Blas, pues tal vez a usted le sea fácil convencer a algunas perso-nas que desten ejercer el magisterio alli de que no bay motivo para tener temores o receles de lus indigenas. Los ánicos requisitos necesarios para optar puestos en escuelas rurales, como sun las de esat Circunscripeión, son observar buena conducta y presentar examen de aptitud para abtener et Certificado que cxige la Codificación Escular.

Dé usted atento y S.S.,

Jeptha B. Duncan

Trans. del orig. mec.

V. RD, n. 164 . 


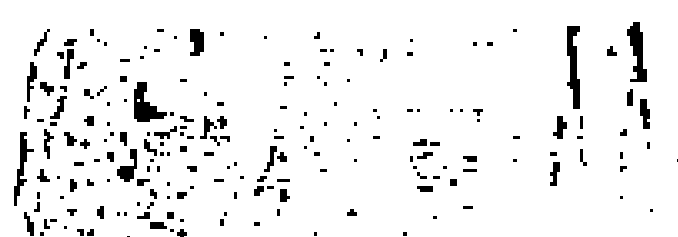

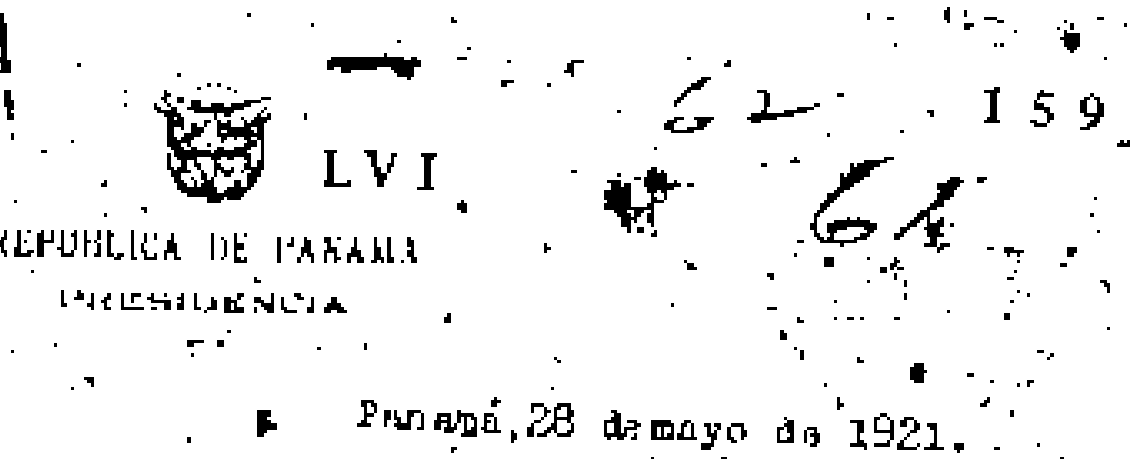

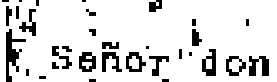

Mridróe Hajlea.

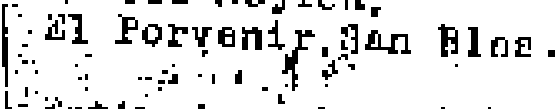

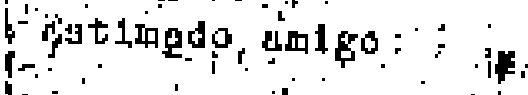

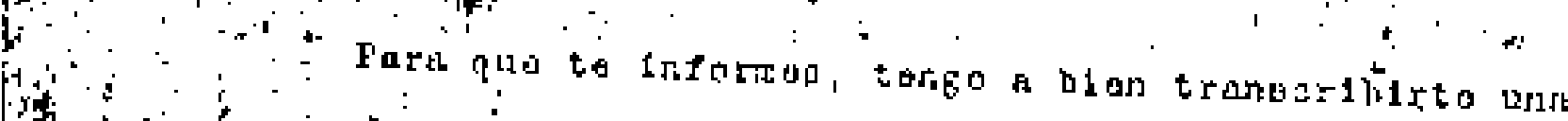

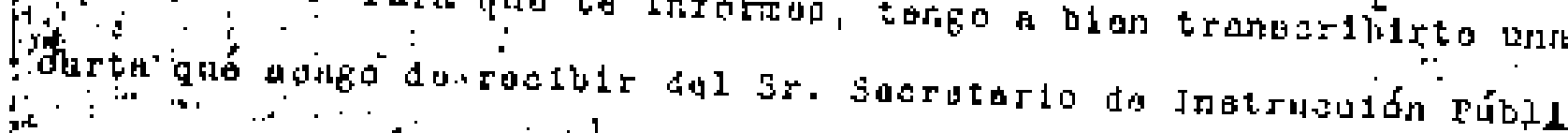

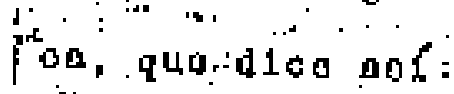

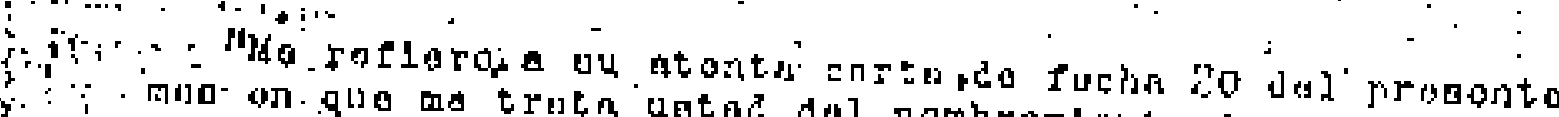

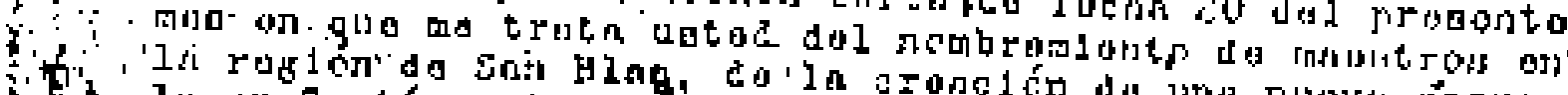

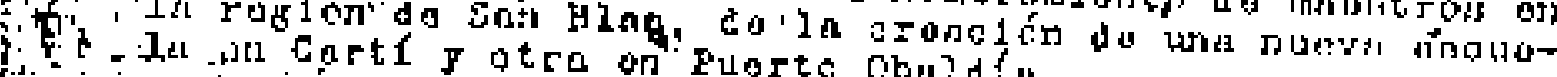

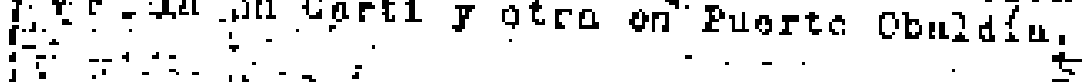

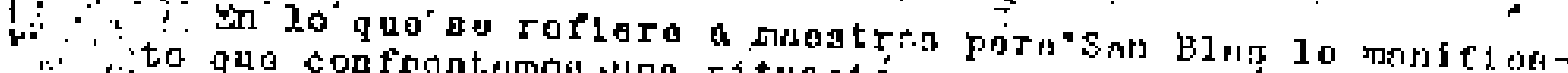

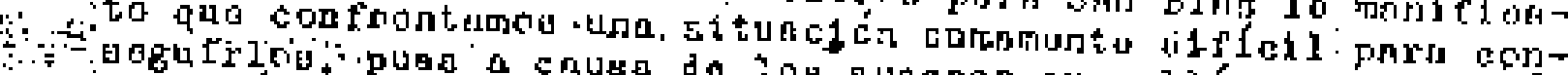

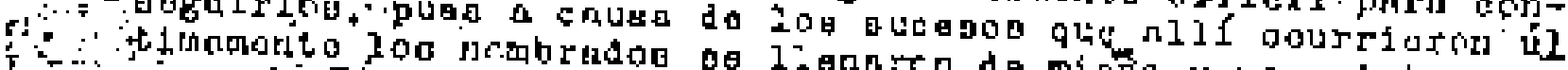

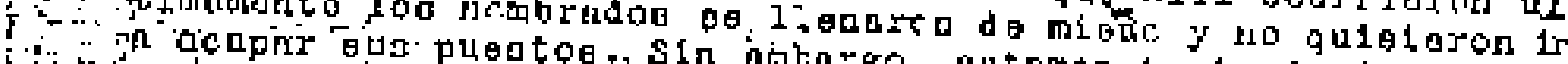

i. : :

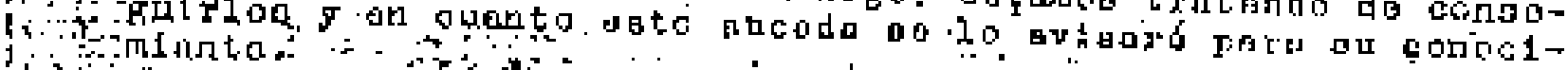

1 i

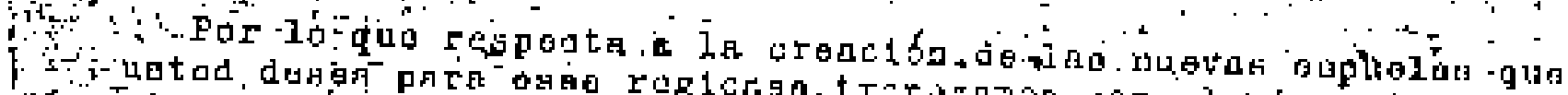

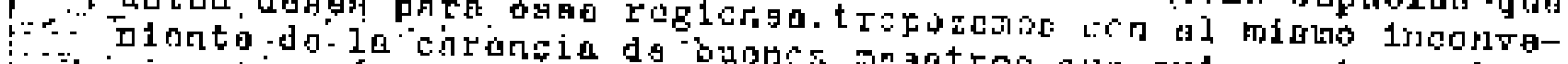

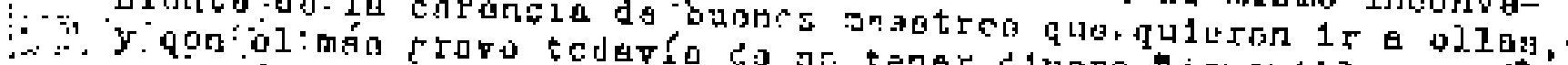

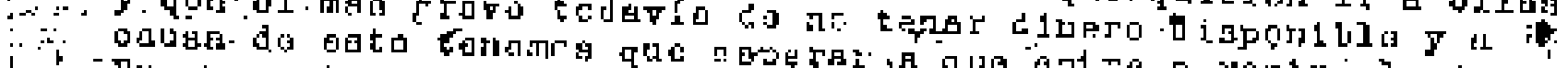

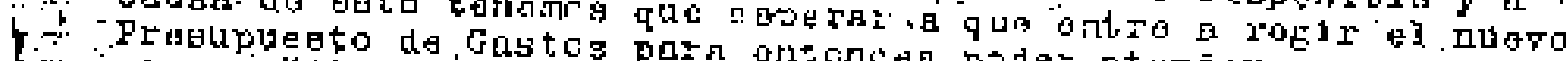

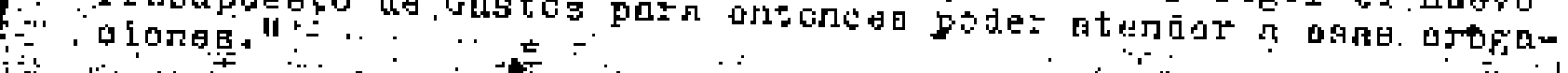

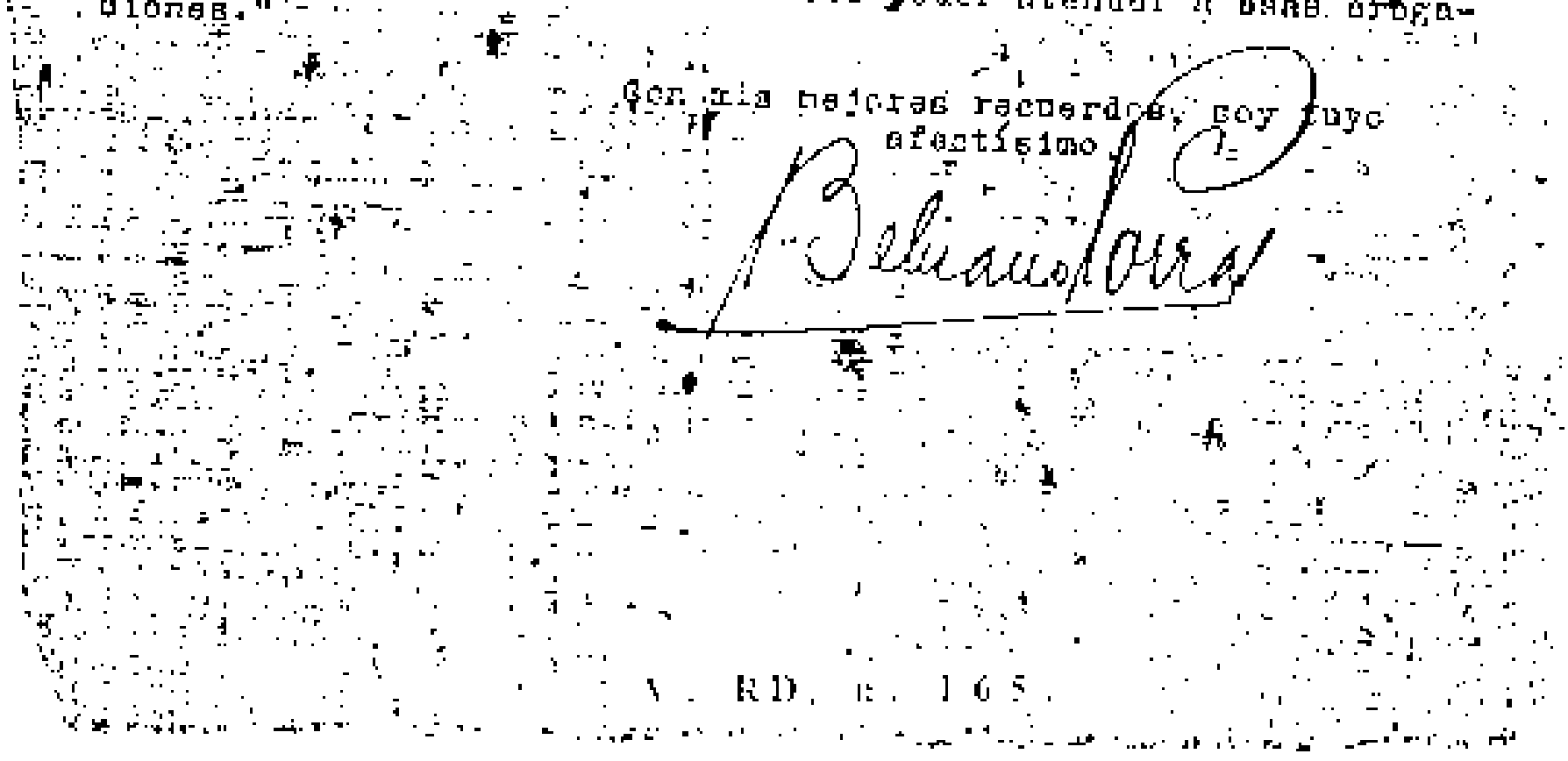




\title{
LV I I
}

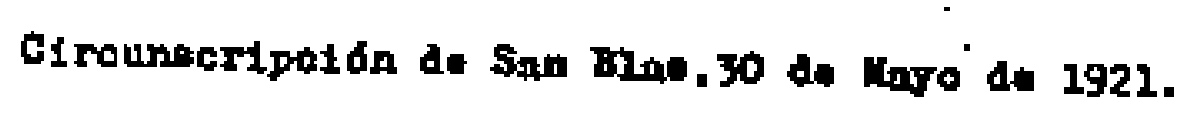

\begin{abstract}
Sottar Dootor
Dan Baliesio Partat.

Presidante do lo Fepiblica.

Parnta.
\end{abstract}

Patifindo Doctor y ango:

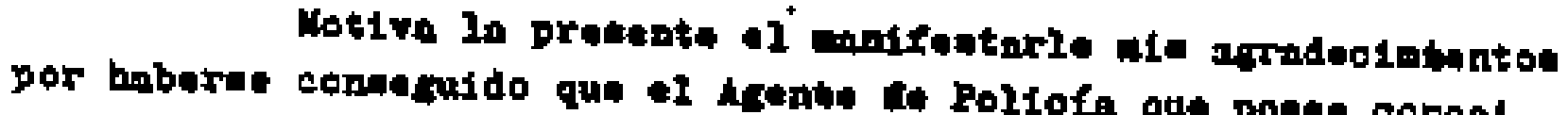

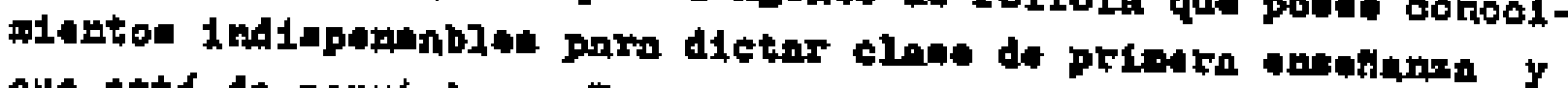

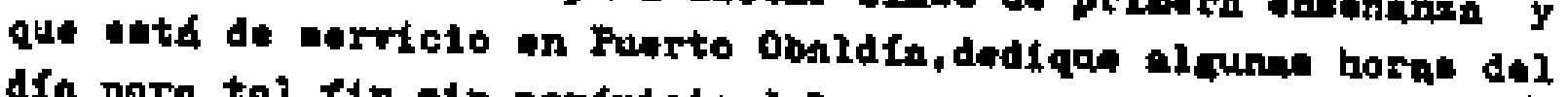

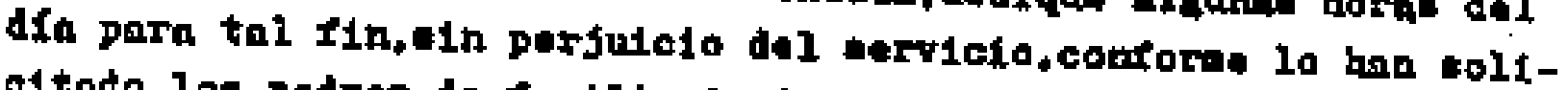
oftado lon padren de tranilio de archo lucer.

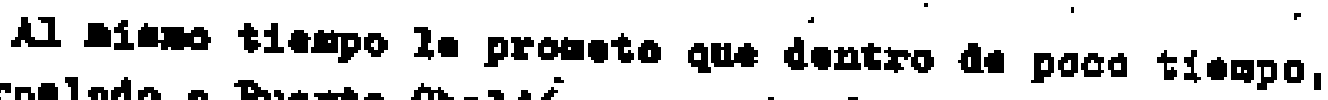

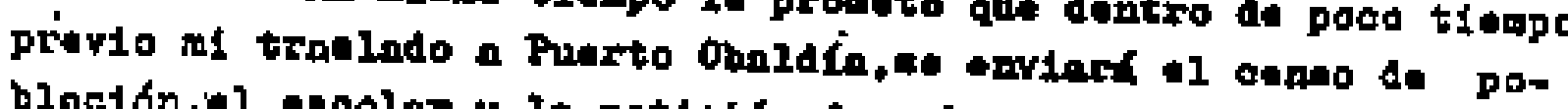

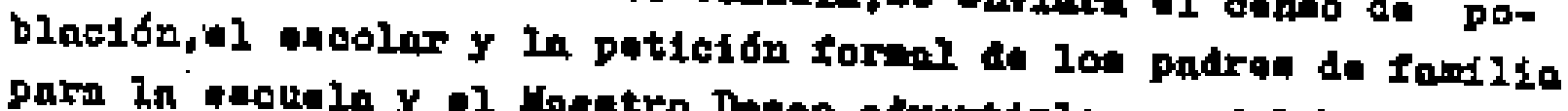

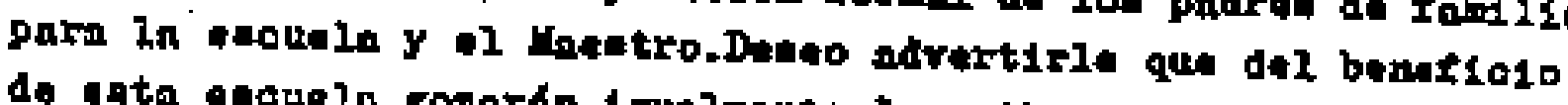

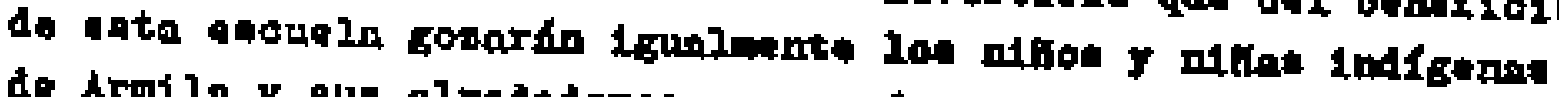

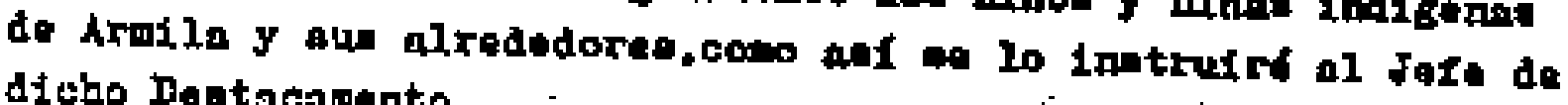
dicho Bentacarinto.

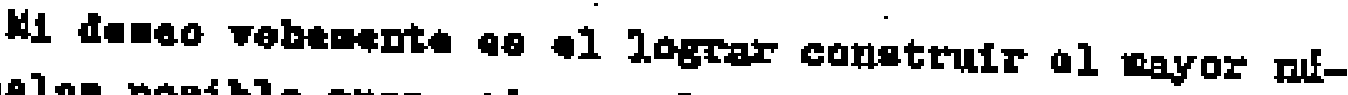
mero de cecuala posible pure ente en el madio nín eticaz y agara

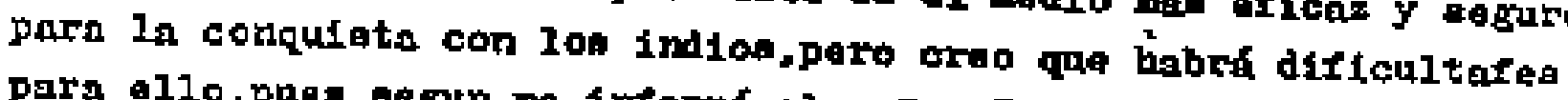

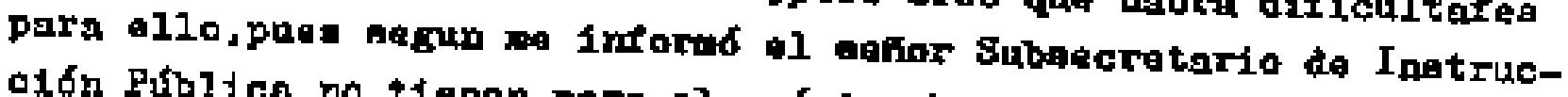

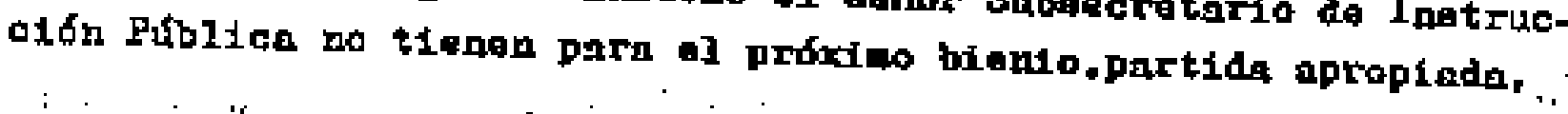

Soy de W. atoo. amigo y lalal servidor.

ATDRES MOJICA

Interiente de San Blno.

V. RD, I, I66. 


\section{I I I}

Seceión primera

Número 307.

Punaras, I0 de Junlo de 1921 .

Sefor Intendente de lo Circunseripeton

de Son Bla:

EL PORVENIR

\section{Selpor}

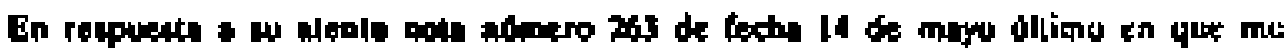

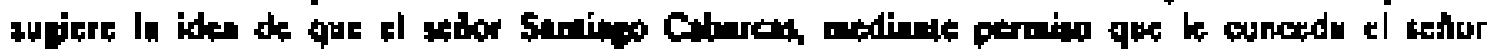

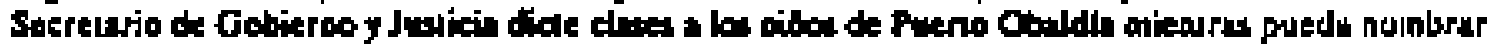

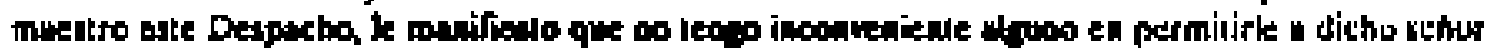

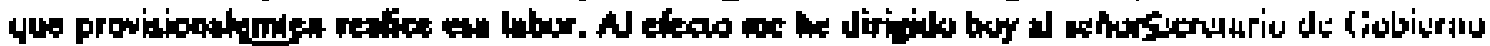

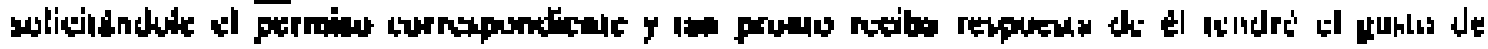

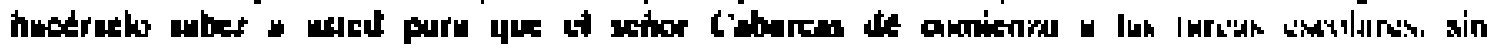

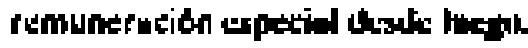

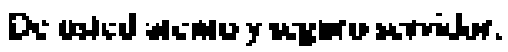

Jepihy L. Donen

Trans. del orig- mec.

V. AD, D. I 68 . 


\section{X}

M.52

Número 319.

- junfol.

\section{Secins Secrelesinx}

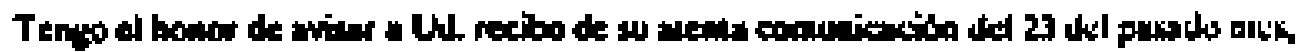

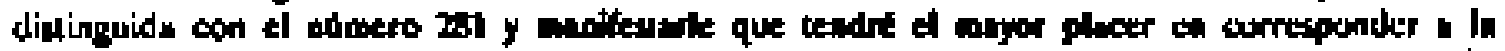

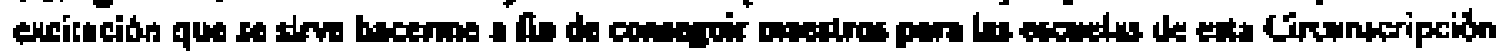

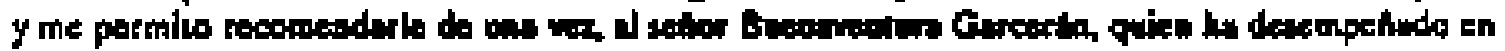

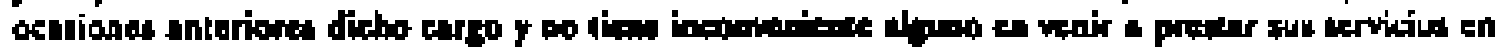

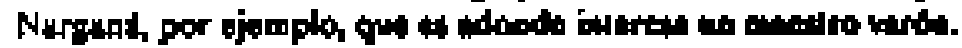

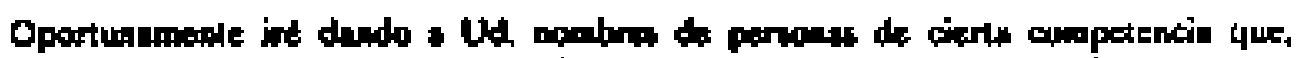

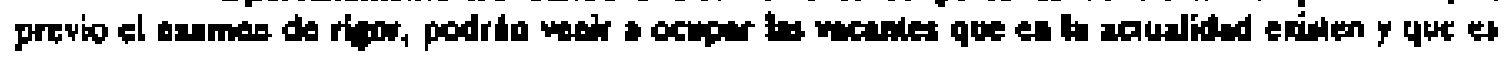
urgente lenter.

Soy de Ud. Wlealo semidor.

NDRTS MOJICA,

Intendeale de Sun Bing.

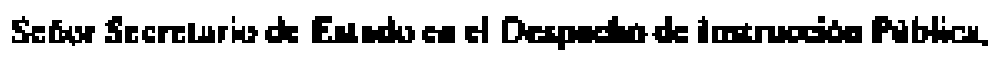

$$
\text { Paosuth }
$$

Trans, de la cop. mec

V. RD, t. I69. 


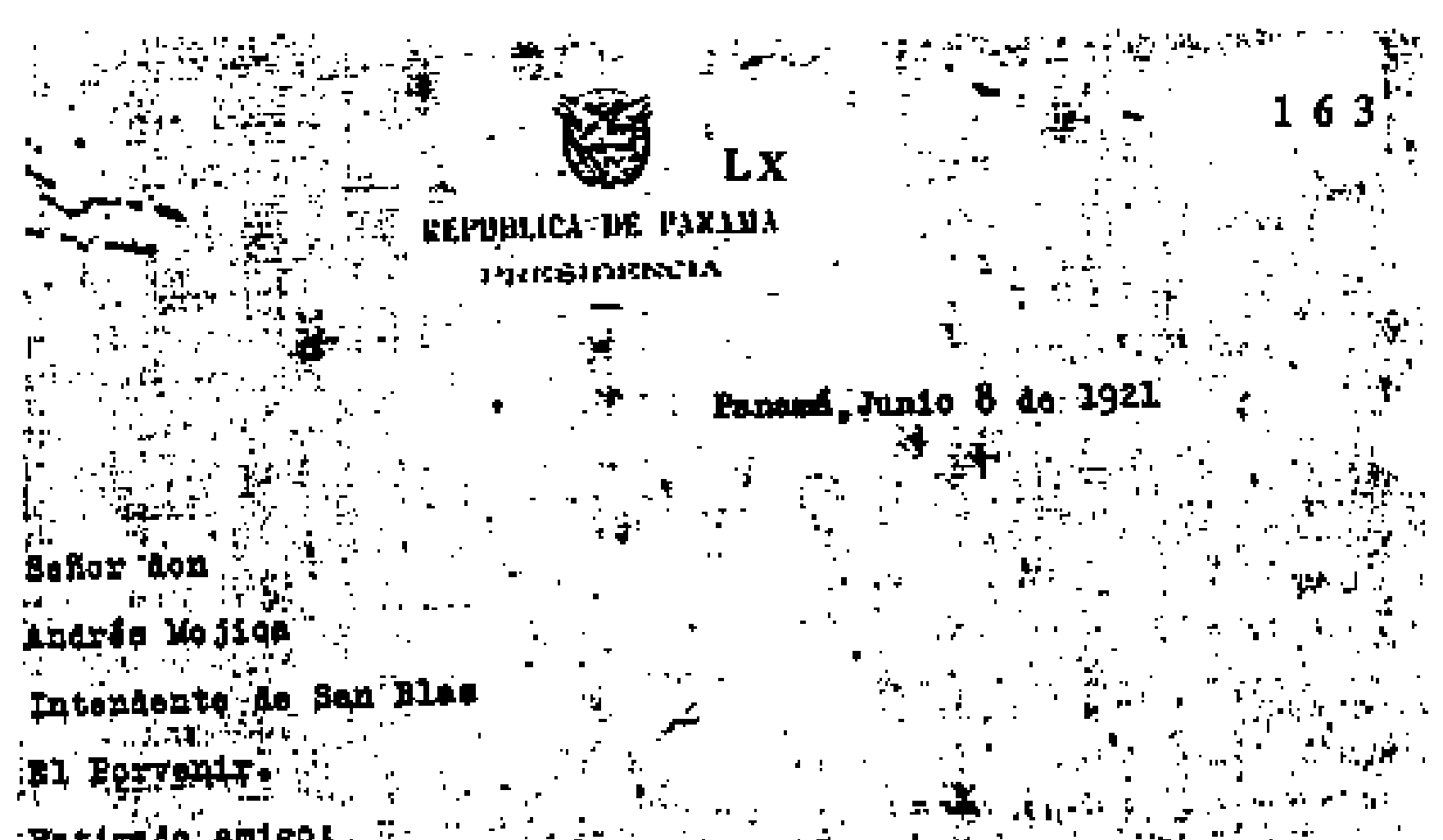

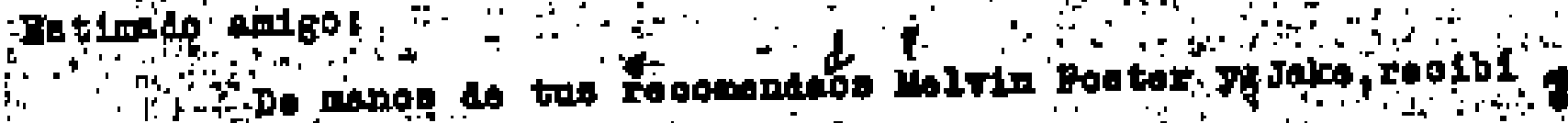

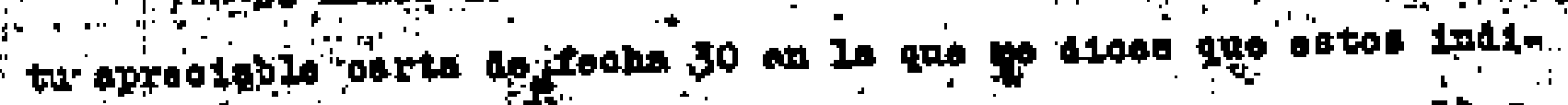

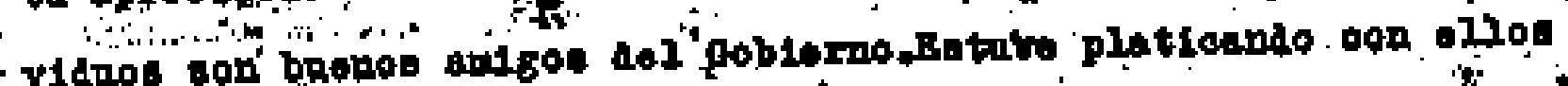

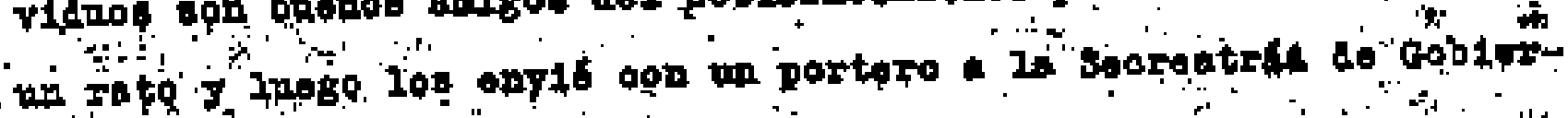

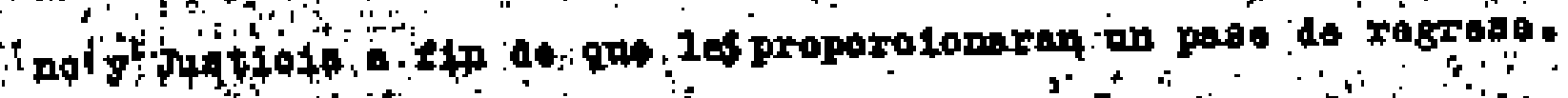

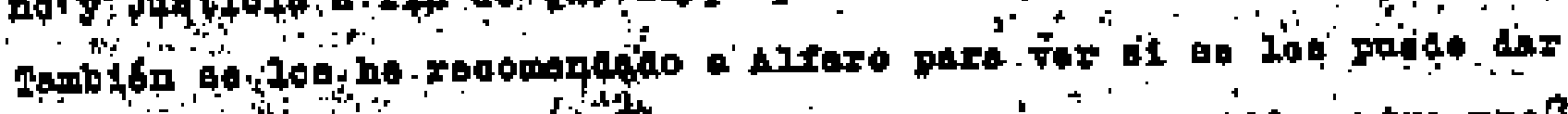

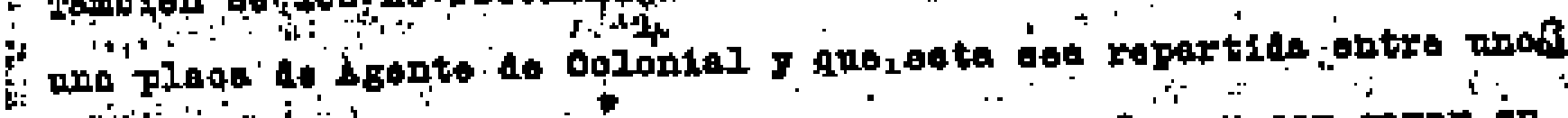

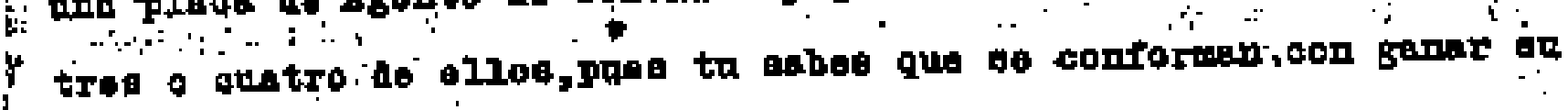
B/.30,00 y de ate tapere deo ostimuln.

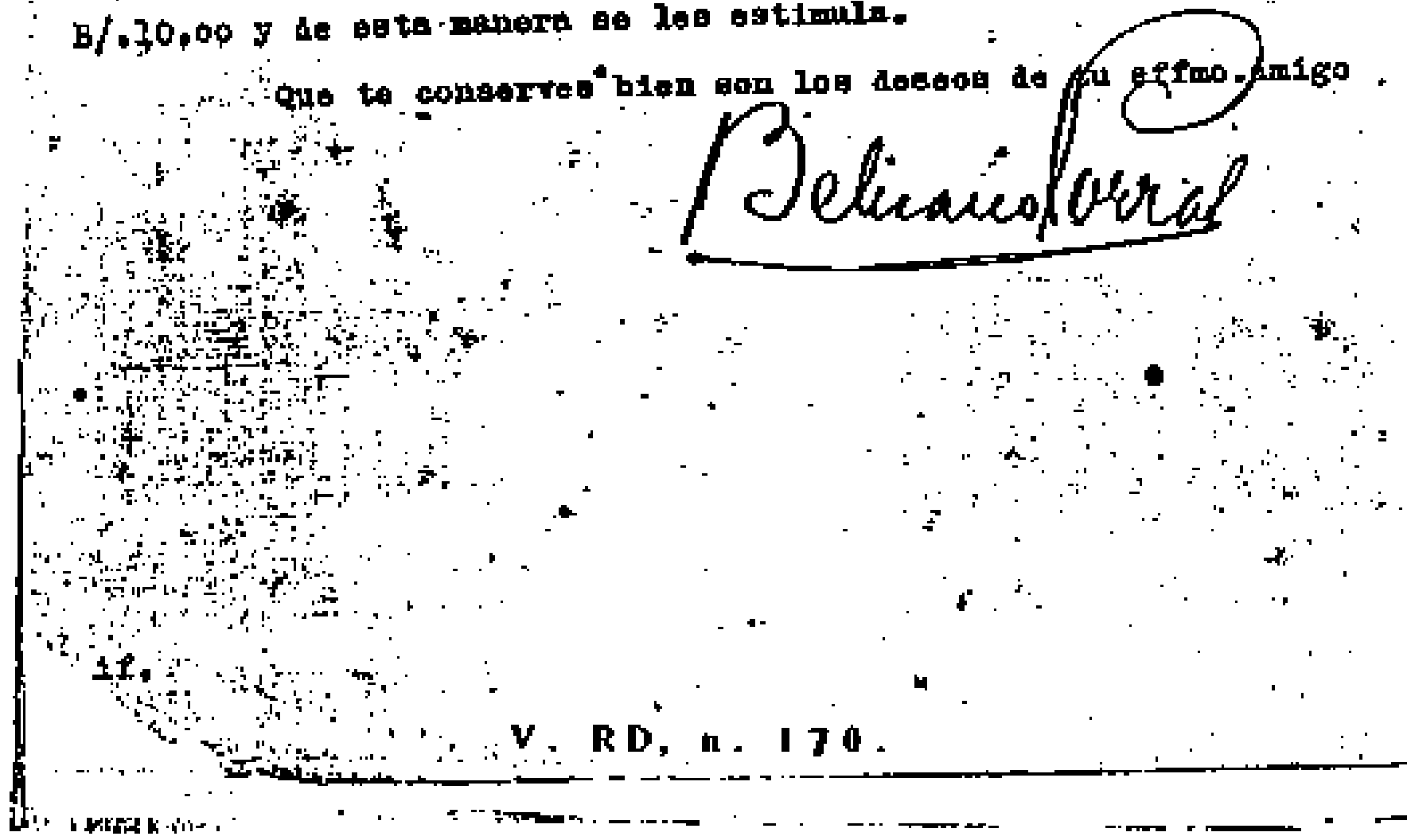




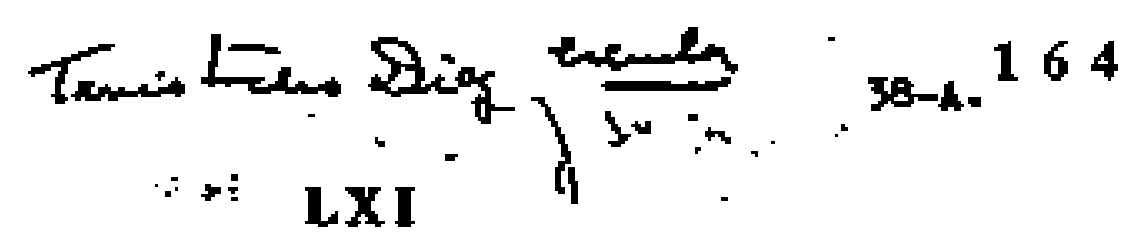

C1rounecripeión de San Blne, 18 de Junio de 1921.

Sahor Dantor

Dof Pel1encib YorTaE,

Previdarto de lin Replibisea,

Paringh.

Entiando Dostbe y onfor

Tergo al placor de recoumarle al portador, wetor Jung

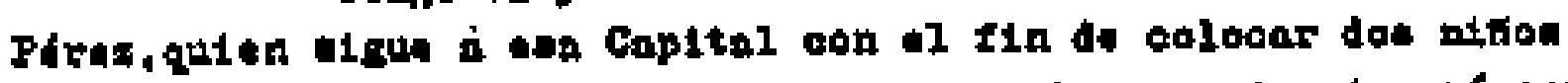

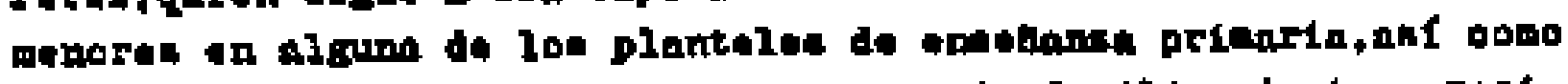

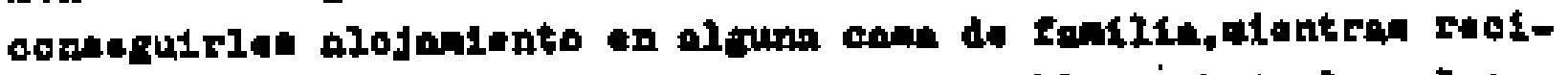

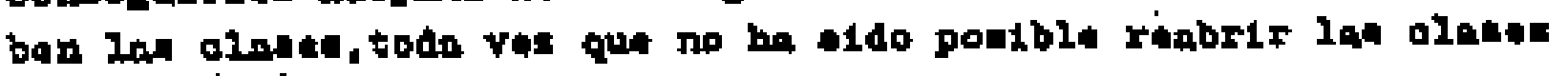

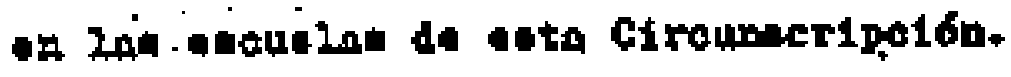

Igualonate on he porfitido teconandarlos a lot ronpeotivol Seoretamion do Gobierno y Justicia a Inetrucoín Pública.

Iexatactinado tode ouento un au favor cea dable bectr qua do Ud.an olaspra leal earridor y nolgo.

AHDEES DOJICA

Intendente de Sin Blos"

V. RD, n. I7 I. 
Nómero 323.

18 junios.

\section{Seluor Secteiniox}

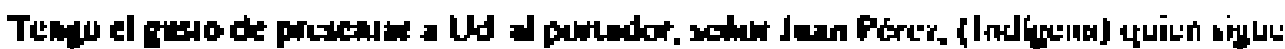

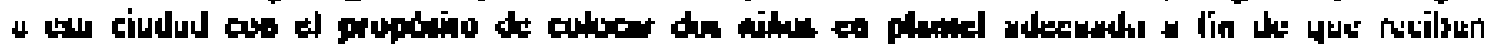

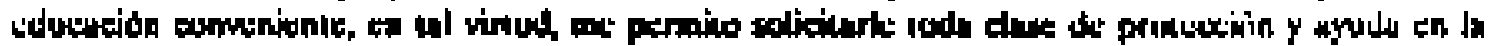
nuble minion \&w lkems.

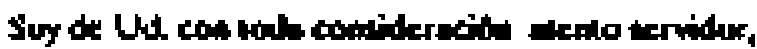

\section{ANDris mojich}

Initnokalt de Sta Bine

Sehor

Scorcturio de Eapdu en el Despacto de

Indruccion Pubtion.

Pantint

Trans. de da cop. mec.

V. RD, n. J $7 \mathbf{2}$ : 


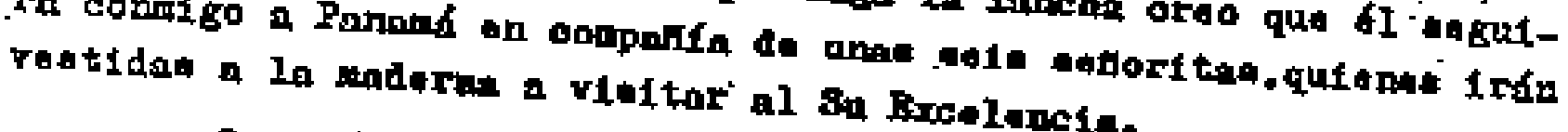

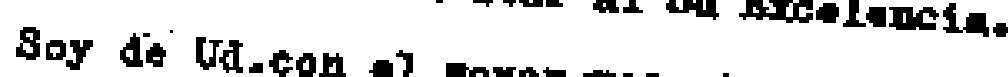
Y lanl ar1go.

Banor Dootor

Doz Adicario Portan

Partang ata da la Roplblica. recibir andao dizlito. batante pobre $y$ para 


\section{LXIV}

RPPUBLICA DE PANAMA PRESIDENCIA

Panama, Julio 5 de 1921

\section{Señor don}

Andrts Mojtes

El Porvenit, Sen Blas

\section{Oudrido maipox}

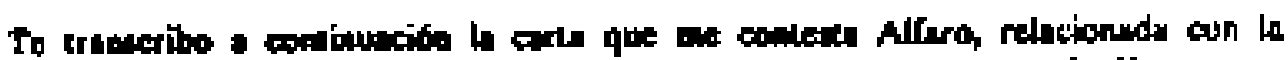

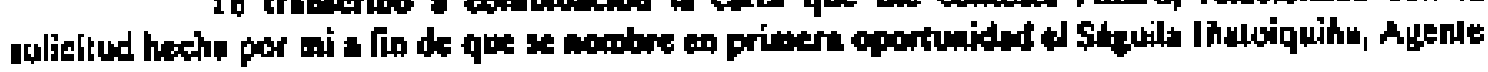
It Poliels. Dict ad:

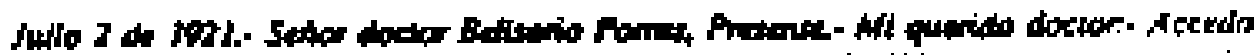

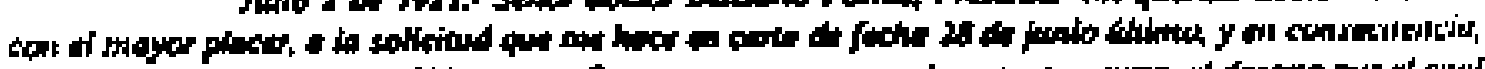

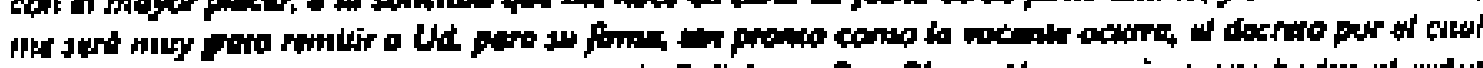

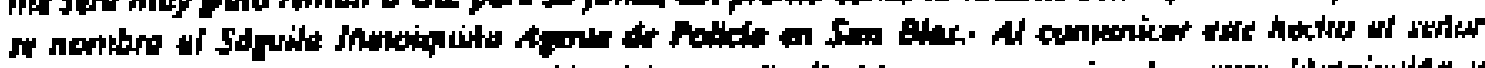

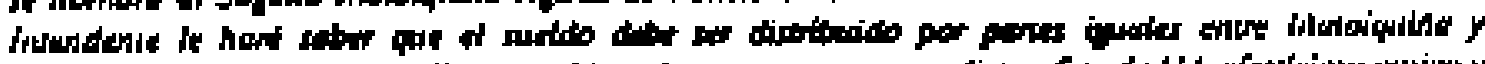

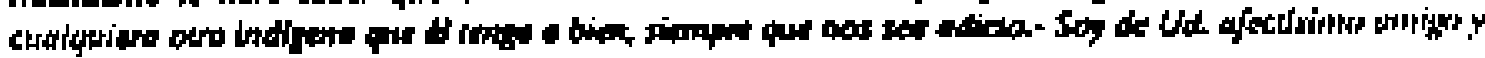

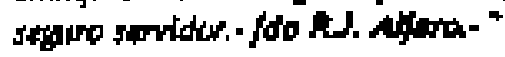

Soy tuyo wha. anigo

Belisurite Porrta

Trans. del orig. mec.

V. R D. n. I T4. 


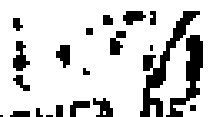

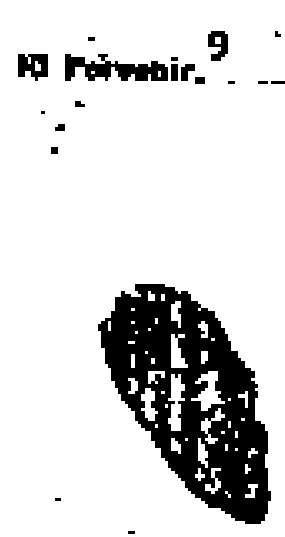

1. 㭧

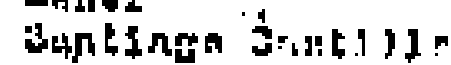

Jofo dol ge jut trateraln. MUNIJy.-

- $\Delta$ เी

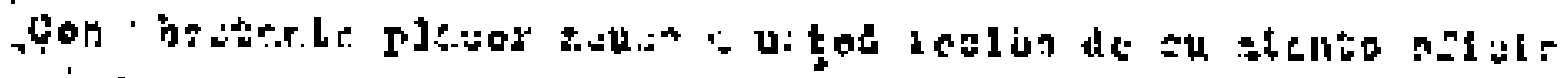
ligusnguiln.

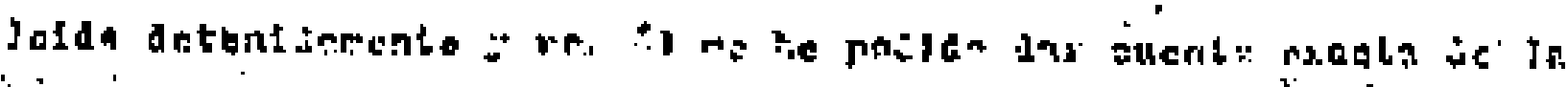

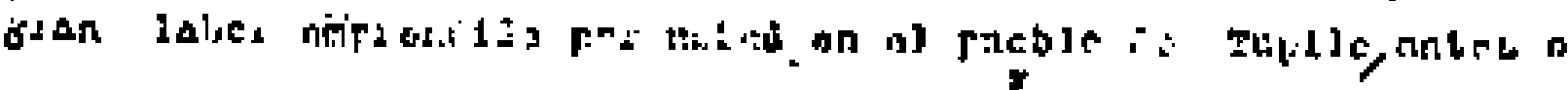

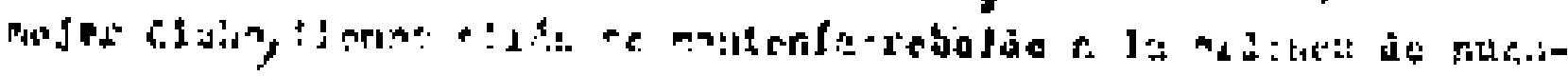

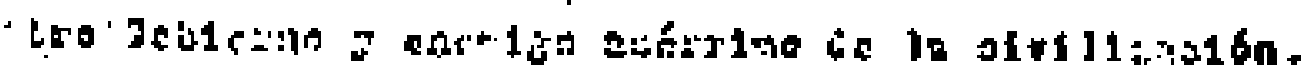

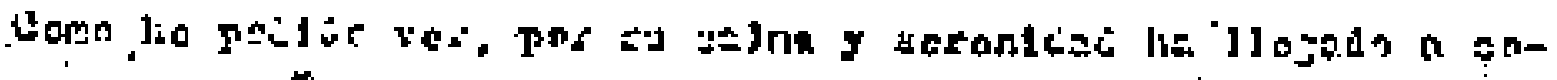

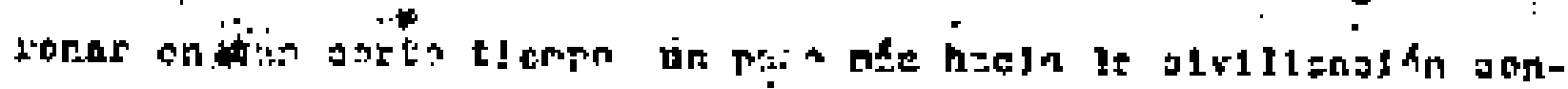

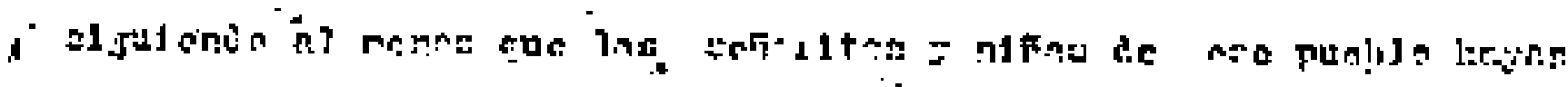

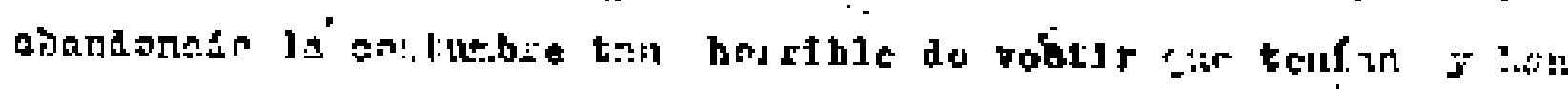

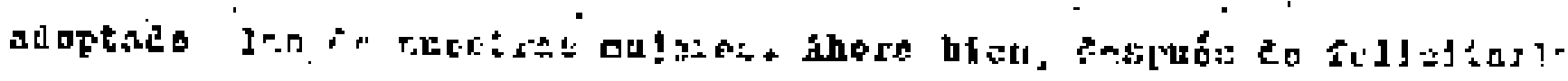

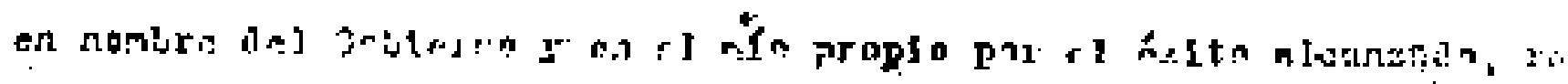

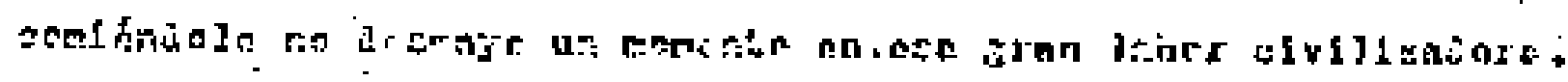

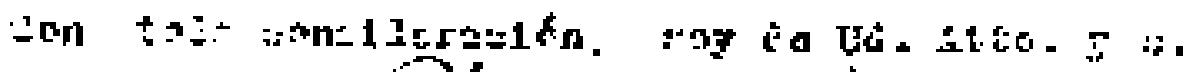

Ir: $:$

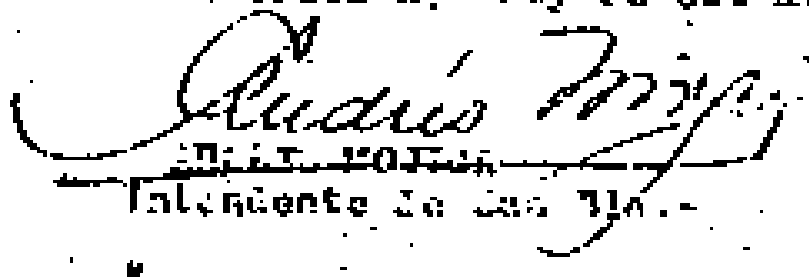

V.RD, n+176. 


\section{LXVI}

M.56

\section{LISTA DE NIÑOS CAPACES \\ PARA INSTRUCCION \\ EN LA POBLACIONDE \\ PUERTO OBALDIA}

\begin{tabular}{|c|c|c|c|c|}
\hline Nas: & NOḾnes: & EDAD: & SEXO: & NOMBRE DEL PADRE U CURADUR \\
\hline 1 & Minach Stutim & 8 & F. & Mipul A Suatizo \\
\hline 2 & Toonts Suaizeo & 6 & M. & $\cdot \quad+$ \\
\hline 3 & Matuc| Jinkturex & 7 & M. & kuse Jindenct \\
\hline 4 & Loonitas Num: & 9 & M. & Fulel Torin \\
\hline 3 & Juliw Burrera & 14 & M. & Frexa is P. Burretu \\
\hline 0 & Mumal Bim & II & M. & $\cdot$ \\
\hline 7 & Euer Cerrerro & $\mathbf{y}$ & F. & $-\quad=$ \\
\hline $\mathbf{s}$ & Grexois Myllings & 16 & F. & Beriokone Mnninet \\
\hline 9 & Narciso Marlingr. & 12 & $\mathbf{F}$. & $\cdot$ \\
\hline 1ㅏㅏ & 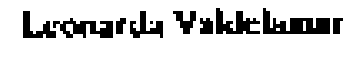 & II II & F. & Macix de bo, Gunzdez \\
\hline 11 & Eul'cmis Vuldklangr & $\mathbf{3}$ & F. & $\cdot$ \\
\hline 52 & Joae I, Guerreru & $\mathbf{w}$ & M. & Jose Goertera \\
\hline 13 & Fhorencis Gactetro & $\boldsymbol{\gamma}$ & M. & $=$ \\
\hline 14 & Alejeodro Medrana & $\mathbf{s}$ & M. & Alrjandru Medramu \\
\hline 15 & Angto Futal: & 3 & $\mathbf{F}$ & 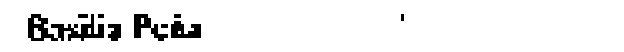 \\
\hline
\end{tabular}




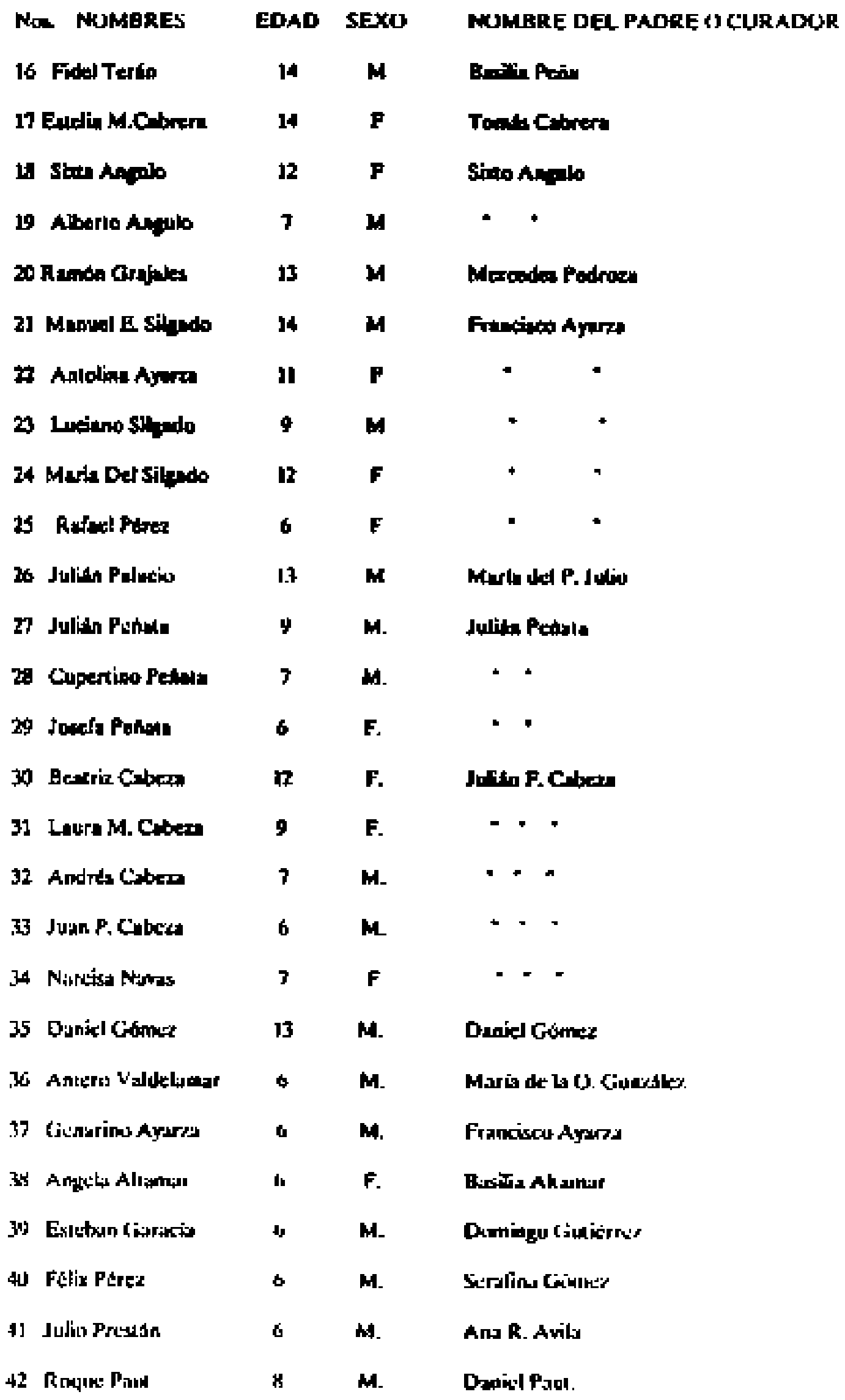

Trans. del orig. mec.

V. RD, n. 178 . 


\section{LJSTA DE TEXTOS, UTILES Y MOBILARJO PARA LA ESCUELA \\ DE \\ PUERTO ORALDIA: \\ TEXTOS:}

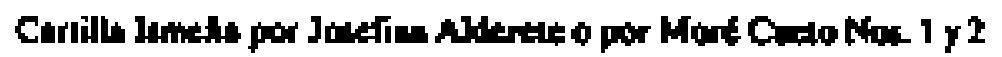

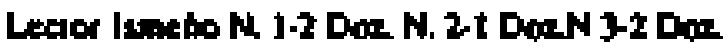

Compendio de Grombica por Rueda, 3

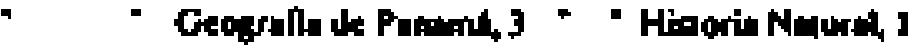

- Lexciones de Curos 1

- Hisorit Suguth 3

- Ejorcicion de Cafiedenin I

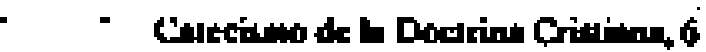

- Veuncinis, I

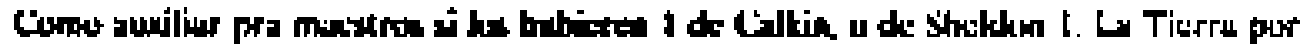

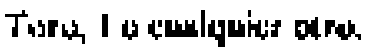

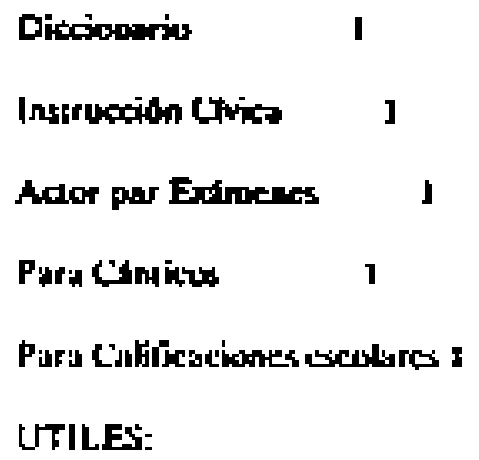

Pizarra 24 y jijes I cajia- Parta jex 1 tim, i cyjikn.- Cuswernos de Escrilura,

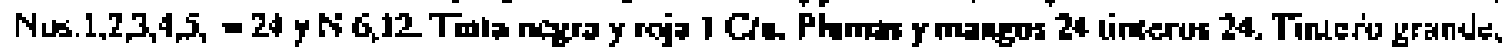
I pupel secipnic y para dibujo.

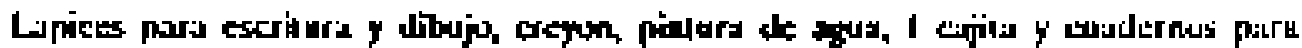

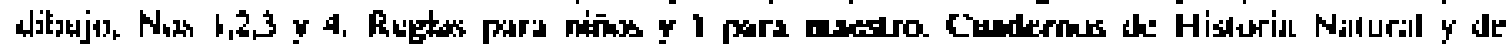
(ieıngeallis. Lialidturia grimalc I

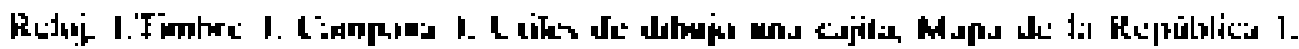

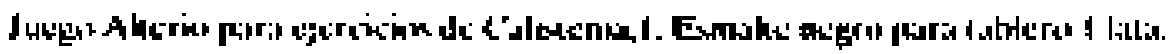

MI IBLLIARIS J:

Mesil $k$ :Tiahlefo I: silkes 1

Trans, del orig. nec.

V. R D, n. I 79 . 


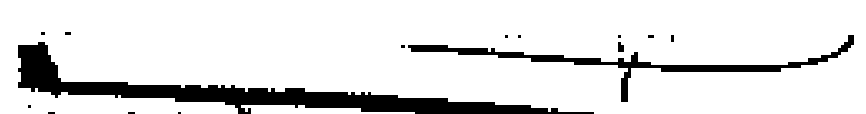

\section{ofieng Lxvil I}

172

$41 \mathrm{~A}$.

\section{lt julia 2921.}

Excio. eafor P'residenté de lo Hepéblica, Doctor Beilsario Porros,

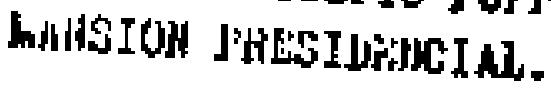

Hatioludo doctar y anibo:

al conucintento una listungo el honor de adjuntarlo pura de Pupllo, que han contonido los indias caublas del pueblo zamuros y sulios y han adpoten ubundonar el uso dé los al-

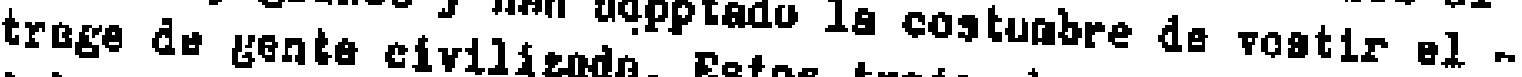
del gobferno.

slerpre servidor y anjón toda considerución, quedo cono-

(PDO.) MNDRES HOJICA

Intenden te de Jan Blas.

LS FIEL COrIA Le Li COl'IA

V. RD, M, 181 . 


\section{X}

$\mathbf{M}-\mathbf{5 8}$

Número 626-b

\section{Senor}

PANAMA, 23 de Jajlo do 1921.

Inleadrente do in Clreunseripeiden de San Blas,

DJ Porvenir.*

Setor:

Coms quiera que la introduccion de armas de fuego en la Circunseripción est. prohibida espero gue usted proceda, onn el_mpar tyclo

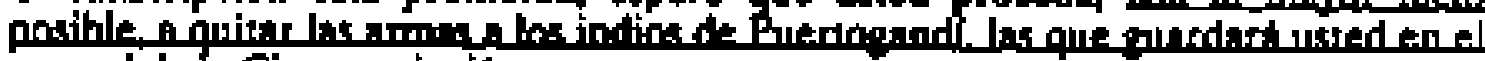

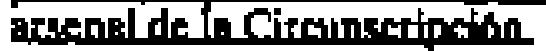

Me reઈiero a su siento oficio nómero 113-B, det 16 de los corrienles.

Soy de usted muy atento servidor,

R. Allaro

Trans. del orig. mec.

V. RD, n. I8 $\mathbf{3}$. 
ictions

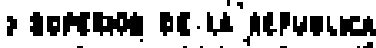

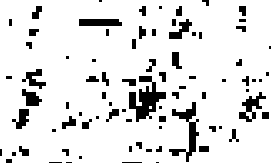

mon shrox.

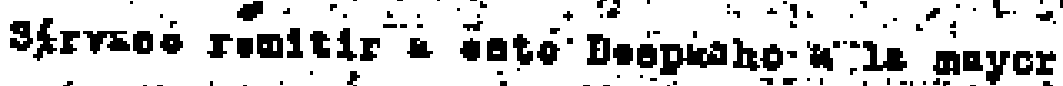

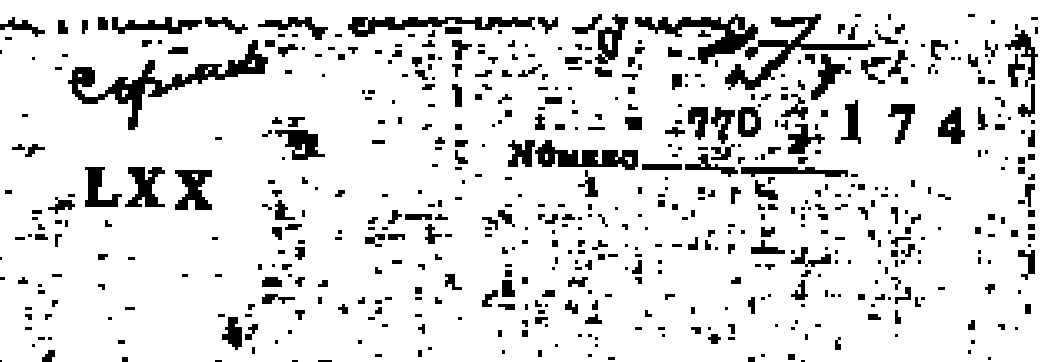

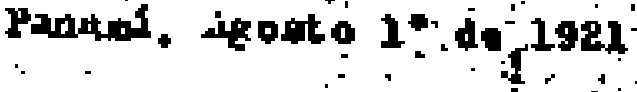

5े

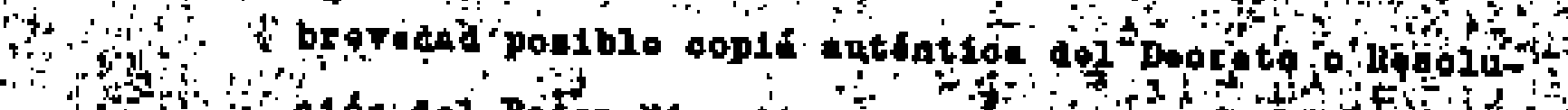

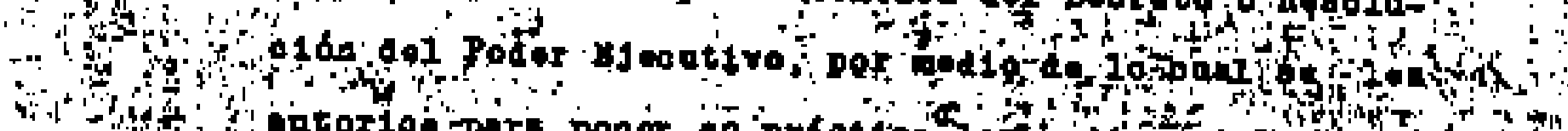

in

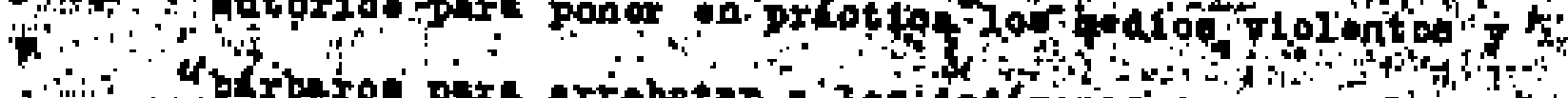

g. i

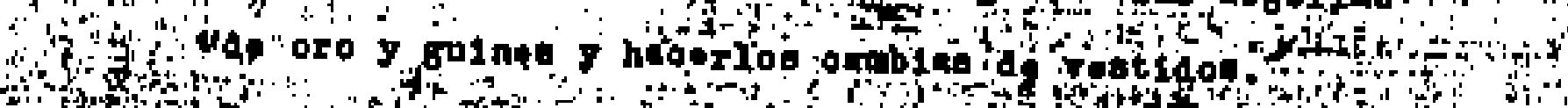
:

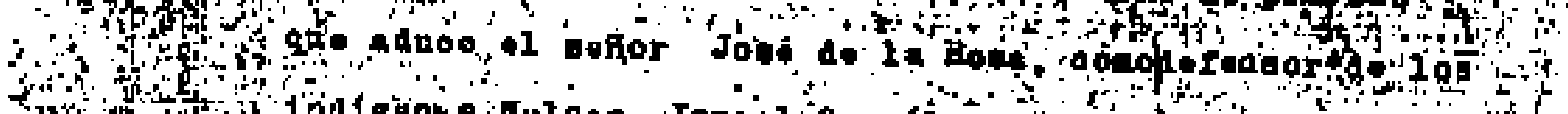

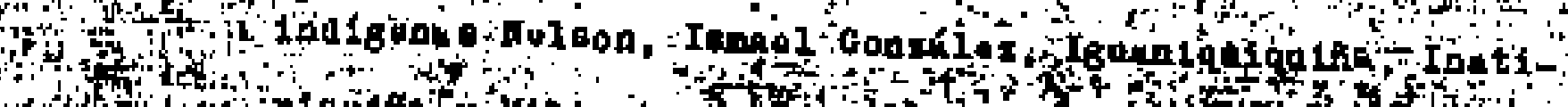

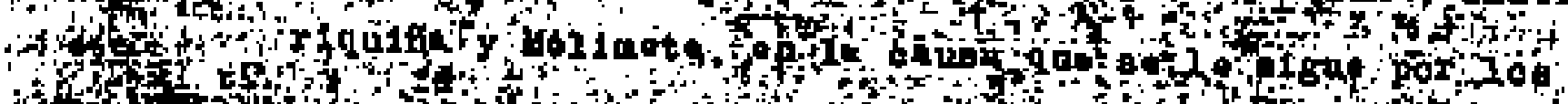
Wholy

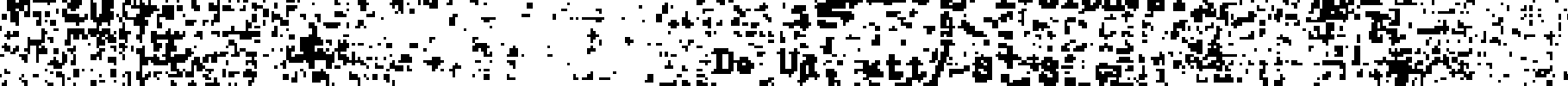
L 年4

40

E

r.

-

ond

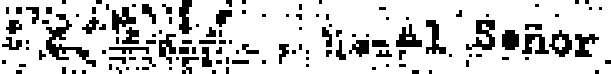

a

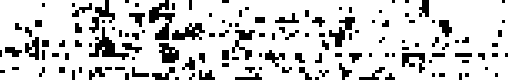

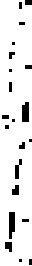

in

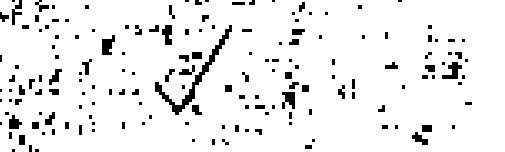

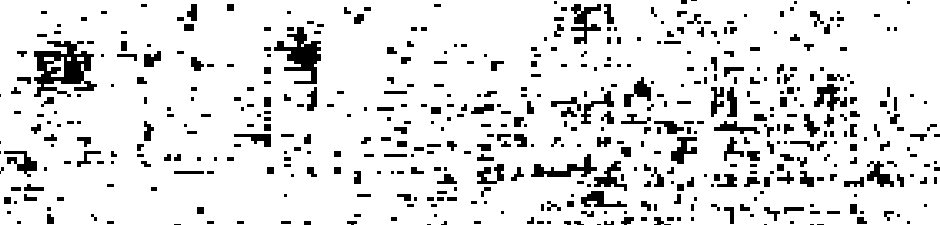

$\therefore$ ity

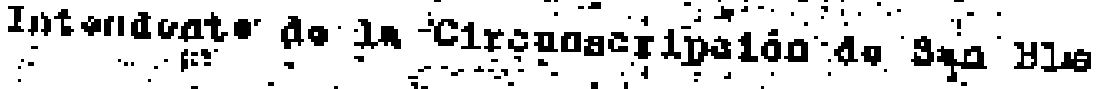

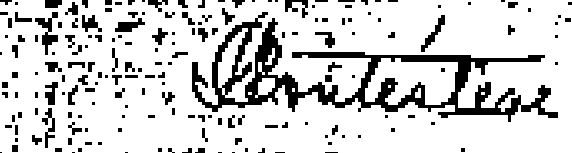

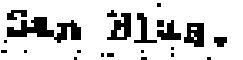

$-\because \frac{1}{2}$

oret,

A 


\section{$\mathbf{L X X I}$}

Número 672-b

Sef́or

PANAMA, 4 de Agotin de 1921.

Interidalo of lo Circunseripeifon de Sop Blas,

Ed Porvendr.-

Sehor:

Parre su conocimienio y para los fines a que bya luzar, le remito con el presente oficio copila del Decreto Nomero 153, de 30 de Julio ultimo, por el cuil se aumenta el nomero de Agentes Indfgenas de la Polidi Colonisl de esa Circunscripción a 15 a partir del primero de los cirrientes.

Soy de uted muy teienio servidor,

Por el Secresarto de Gobierno y Justicti

Leo G.

Trans. del orig. mec.

V. RD, 1. I 87 . 


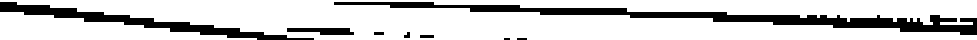

Sallow

$\therefore$.

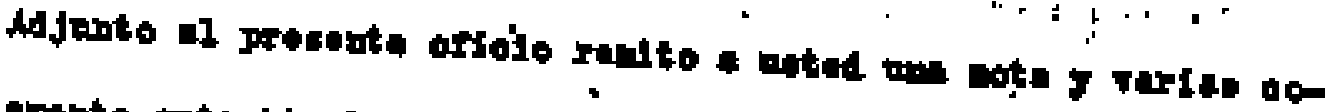

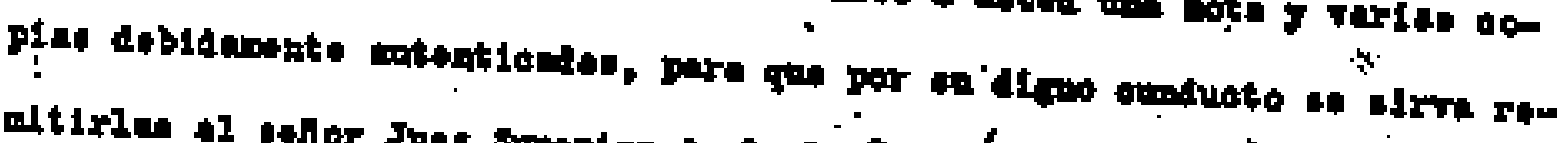

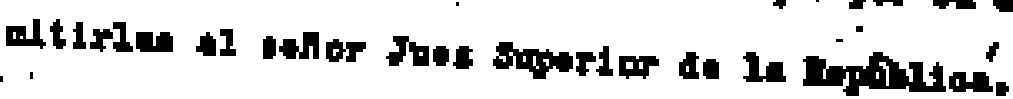

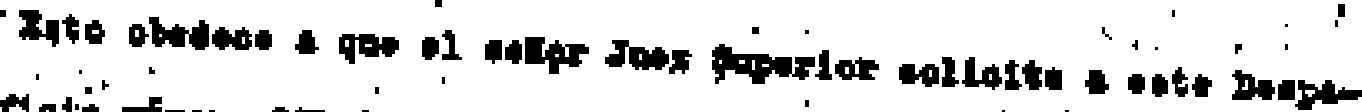

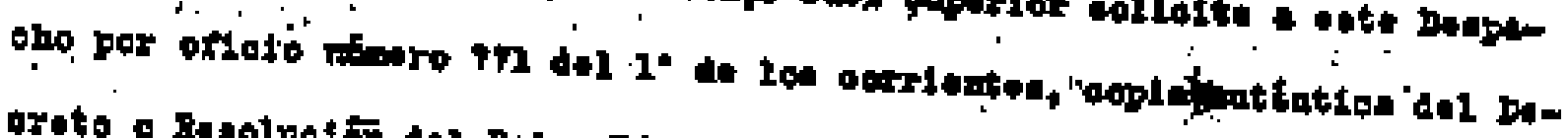

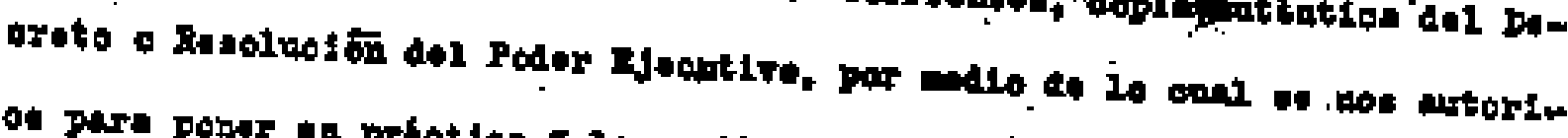

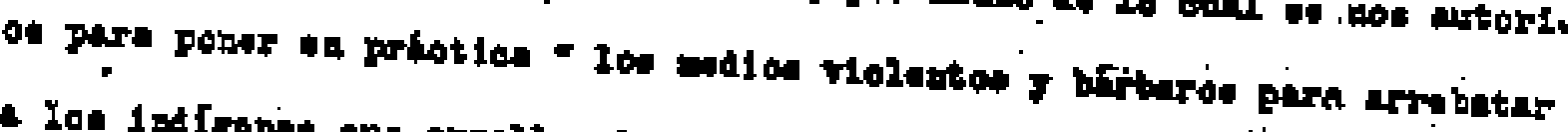

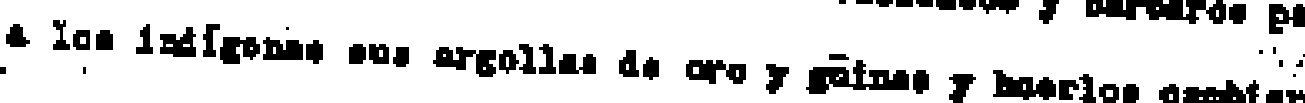
do in

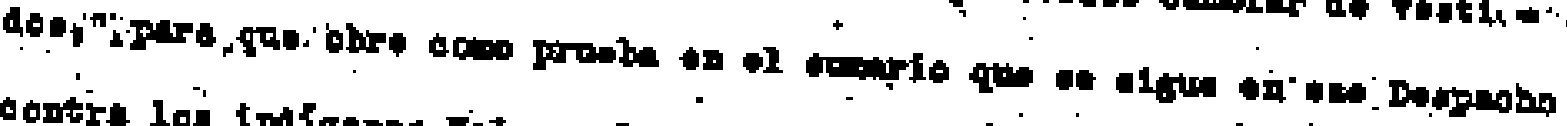

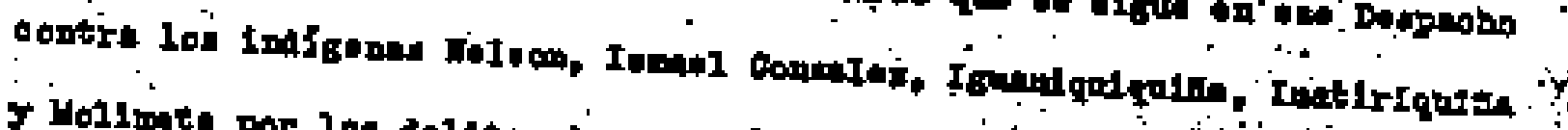

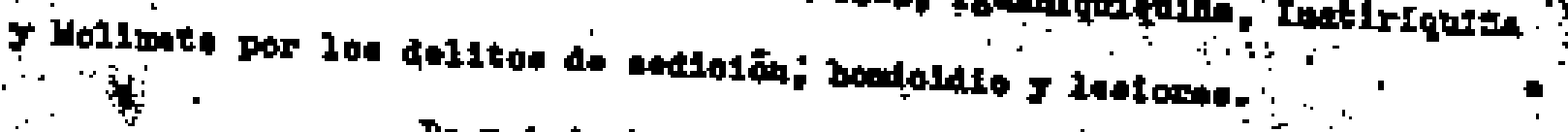

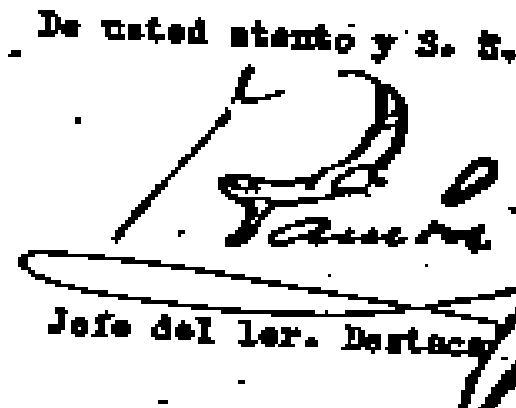

41 sanor

Int*ilente de $\operatorname{san} \min$. 
M-59,60 Y 61

Númera 159 B

El Porvenir, Septlembre 5 de 1921.

\section{Sehor Secreluinox}

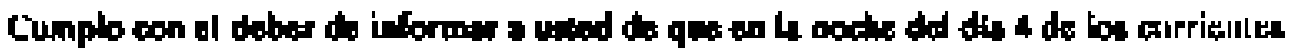

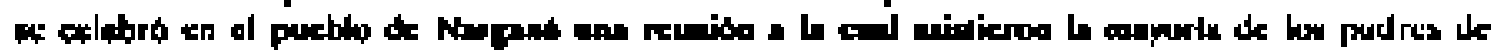

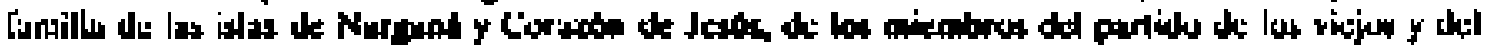

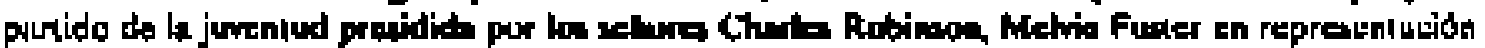

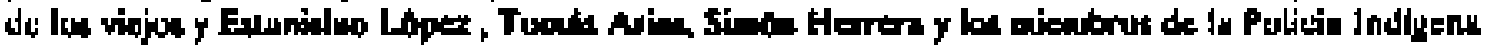

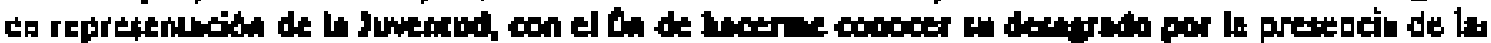

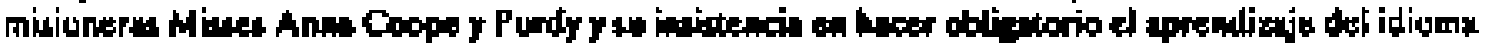

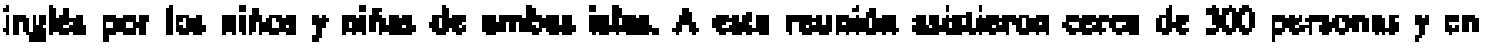

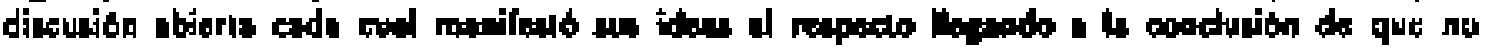

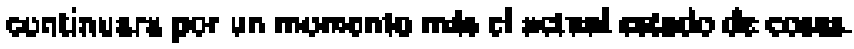

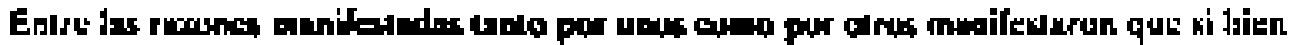

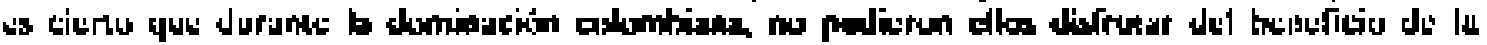

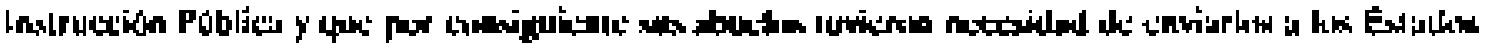

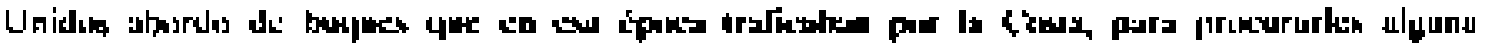

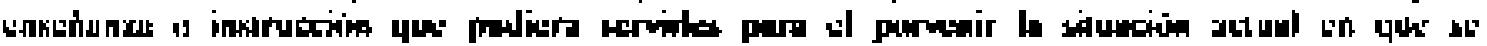

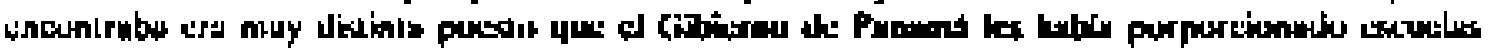

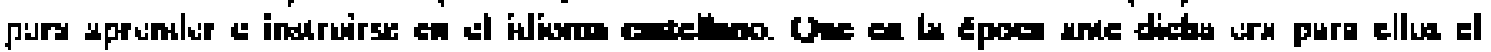

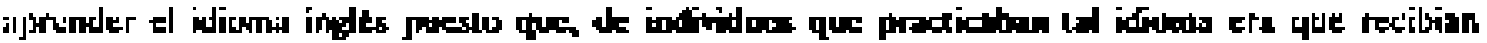

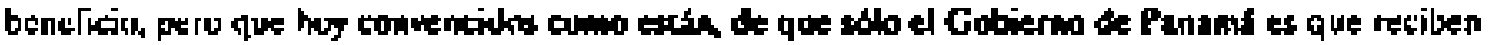

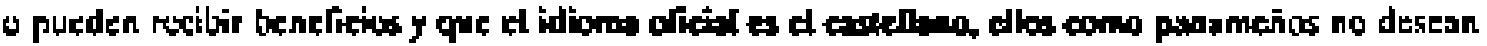

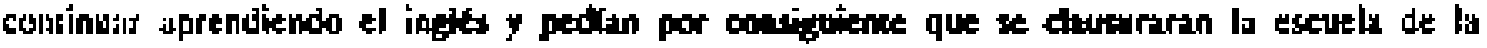

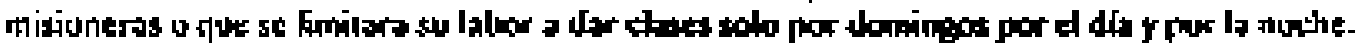

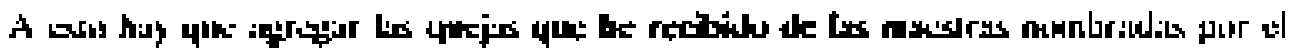

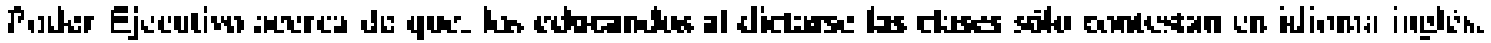

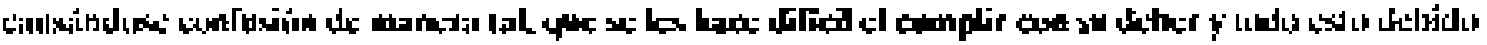

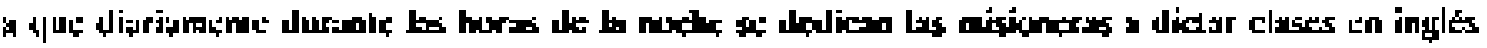

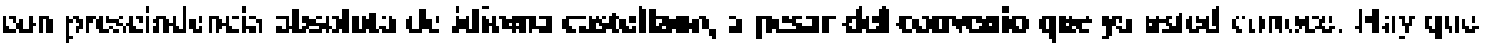

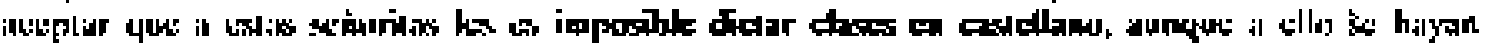

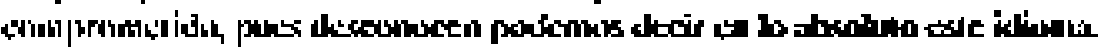

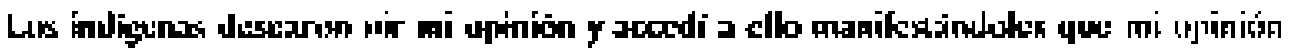

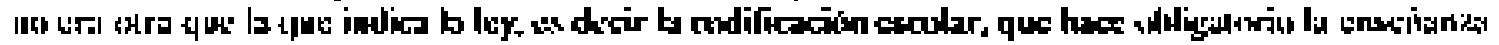

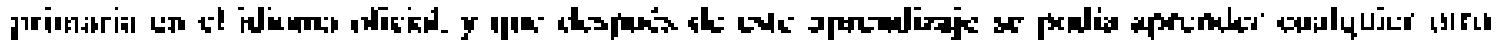

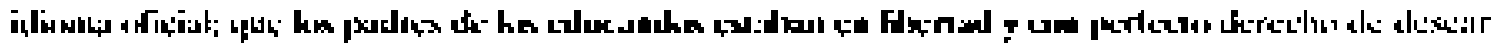

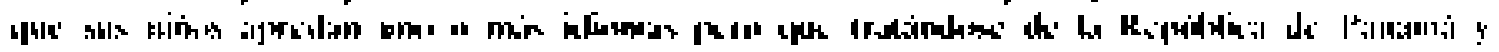

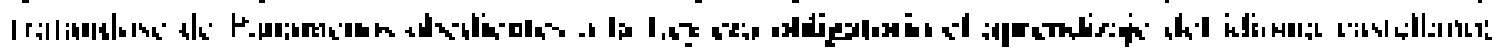

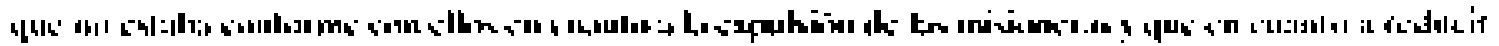

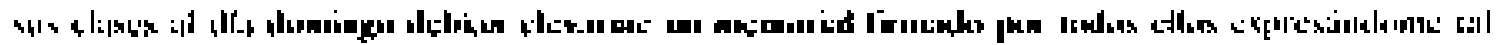

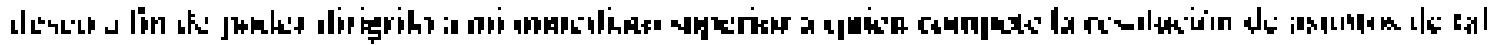

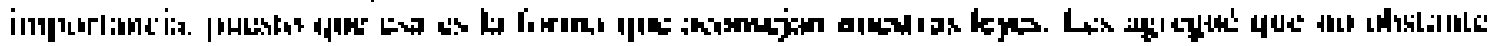

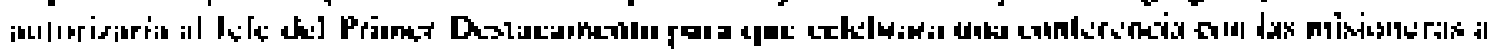




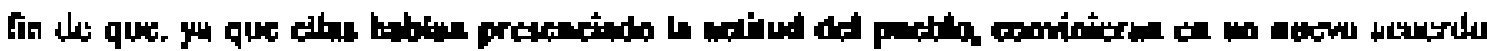

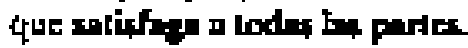

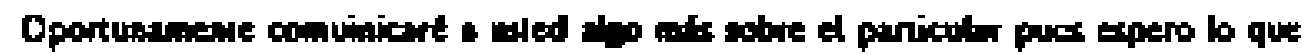
contualque el Jef́a de ler. Detrucaniata.

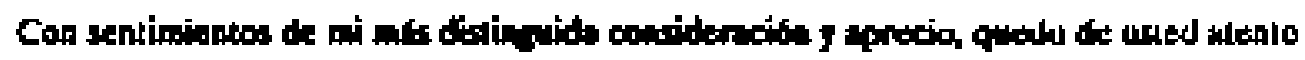
y.6.

\section{ANDRES MLNICYA}

Intenckentw de Sin Bha

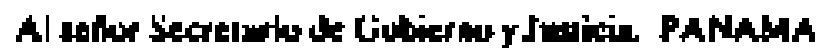

Trins. de la cop. mec.

v. $k 1, n+192$. 
Fofiors

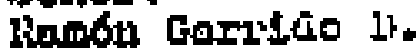

tofo dol ies.lieatncemonto

IHLAGSH:

Pointor:-

A fl to quo kd.Inforno a le ncyor brovedna poolblo lo trang ortbo a convinupetón 10 alcuionte:-

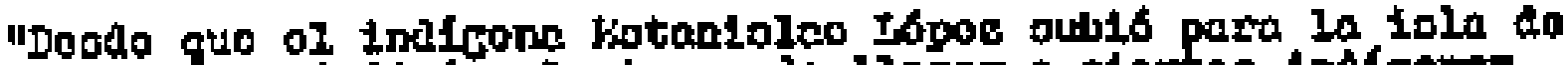

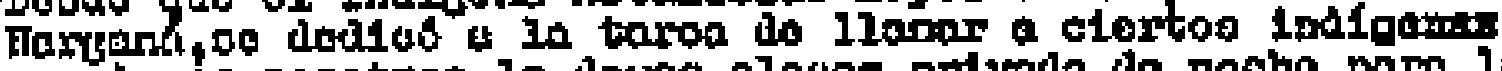

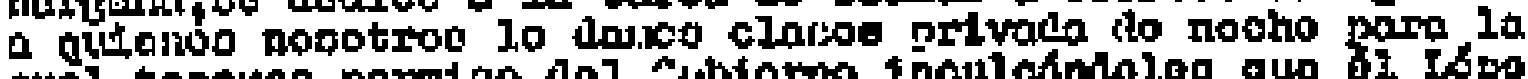

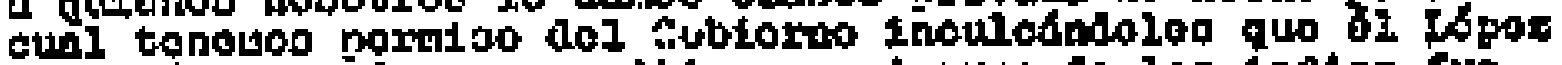

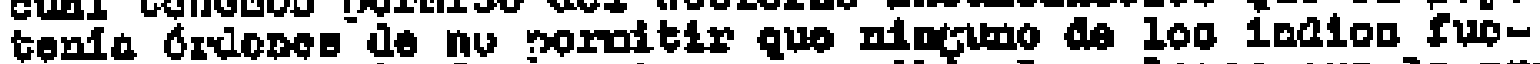

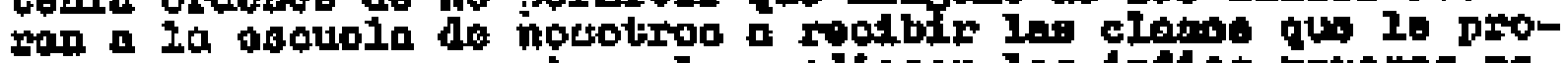

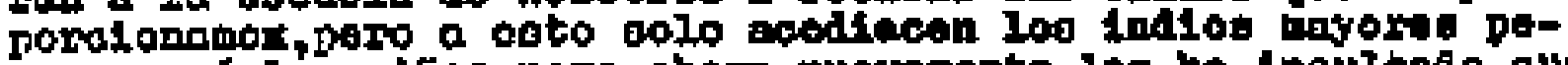
To no aol los affios, pero ahorn movenato les ba inouldado que

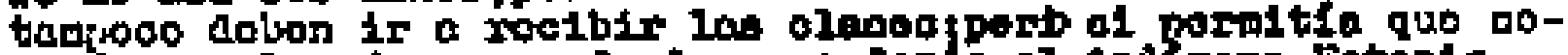

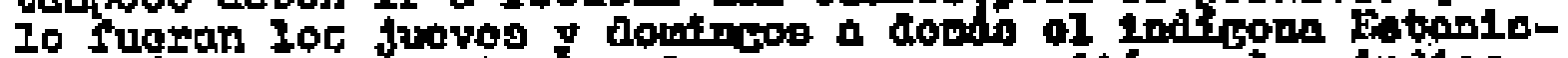

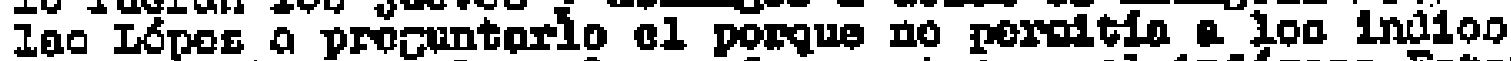

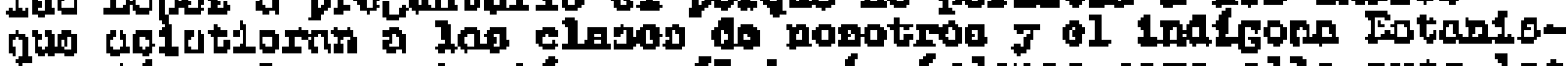

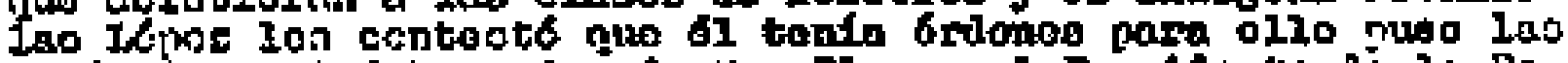

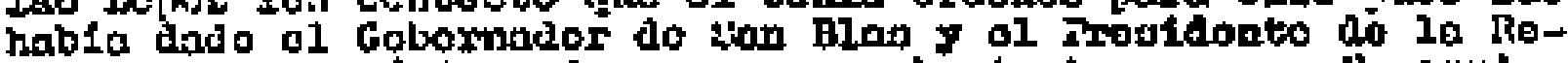

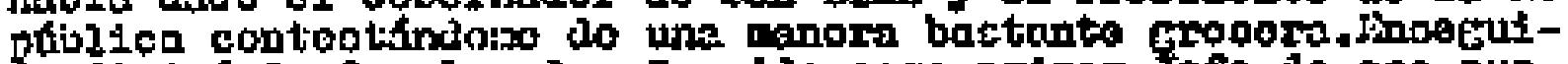

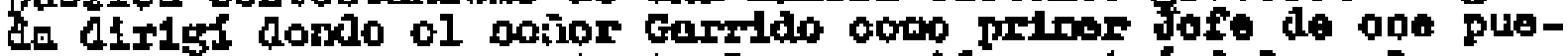
blo a puner on conocintento 10 ocumblo nodtefinalo a la vez

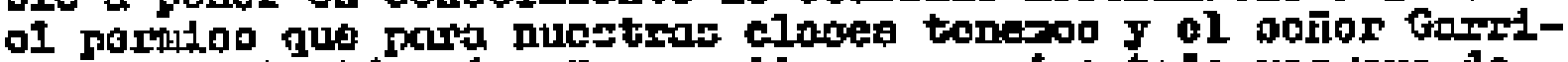

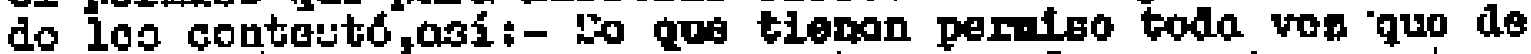

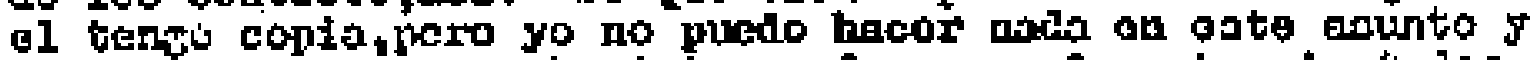

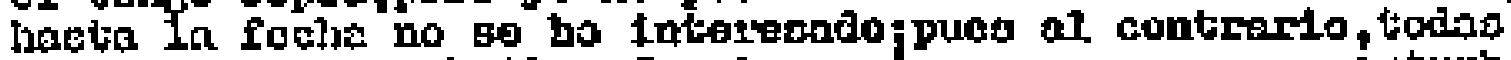
la nochos ponch lailos Frente a pi cona coco para yorturbar. wo pues eatos durst hasta las 205 ke le mallana, oblicgondo

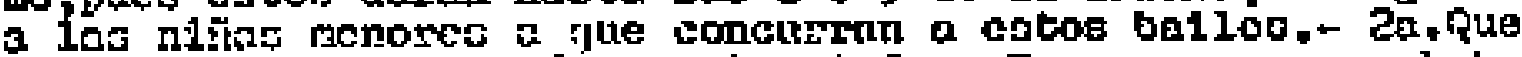

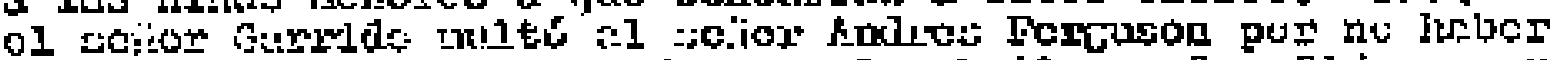

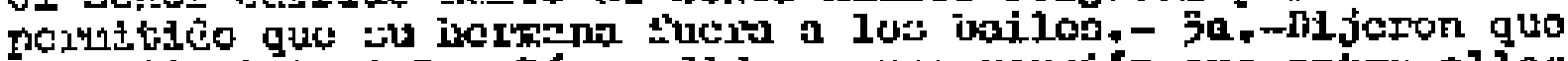

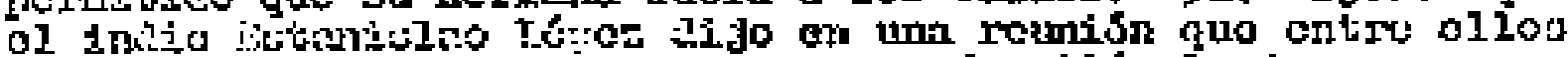

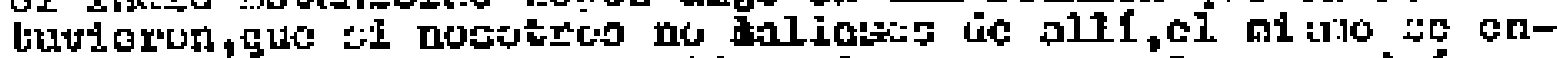

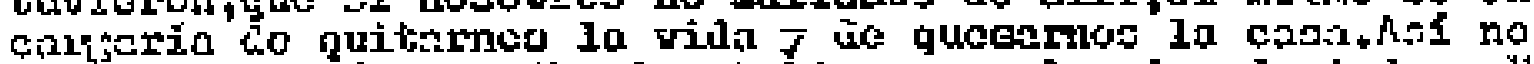

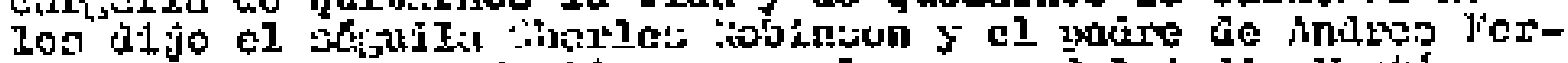
cuisun gue so 11 rev

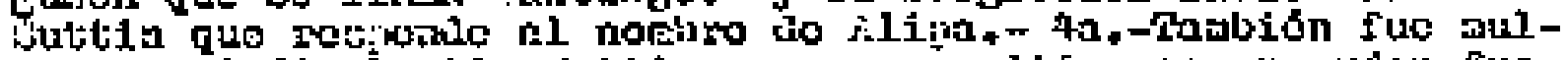

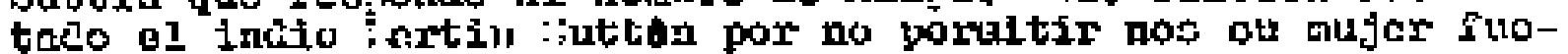
ra a balar,-

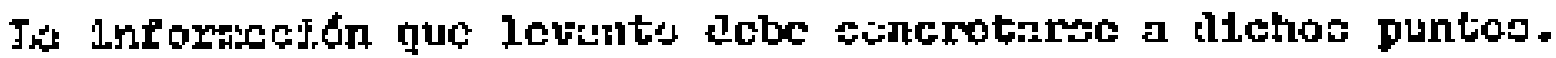

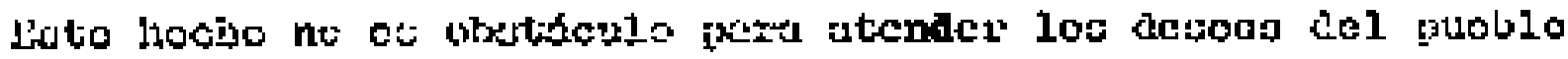

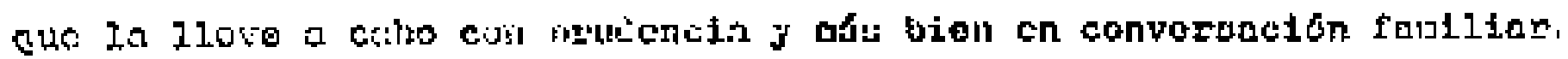

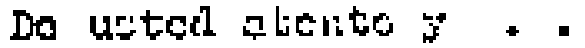
$\cos 10$.

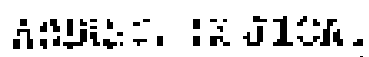

Trtendence le :in milen.

$$
\text { V. RI, n. } 193 \text {. }
$$




\section{$\operatorname{LXXV}$}

SECCION DE JUSTIC1A

Nänero $956-b$

PANAMA, Sepilembro 16 de 1921.

Sefior

lntendeste de la Clrtunseripción do Sun Blas.

E] Forveblr.

Solkor:

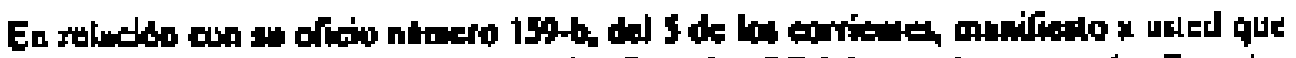

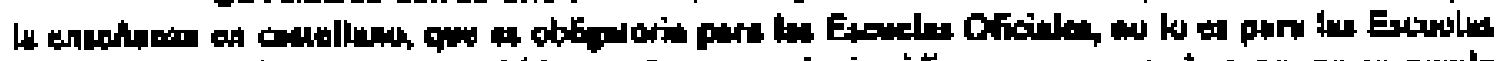

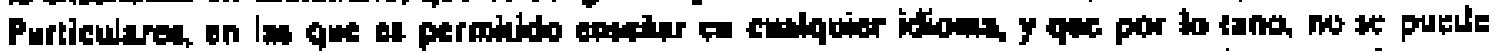

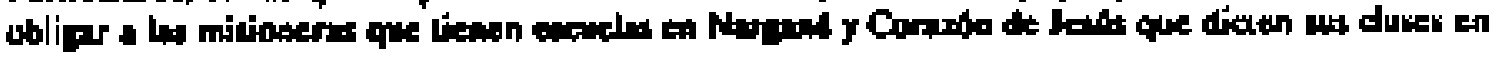
curelloning.

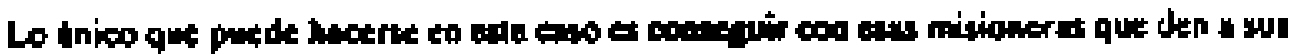

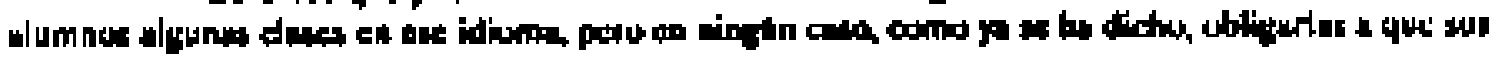

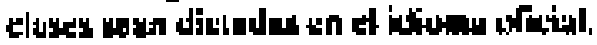

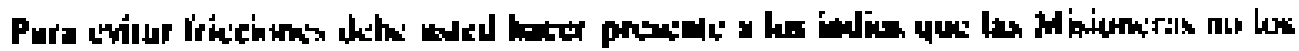

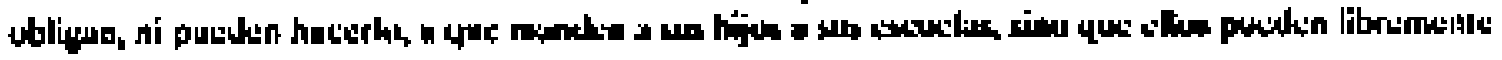

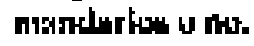

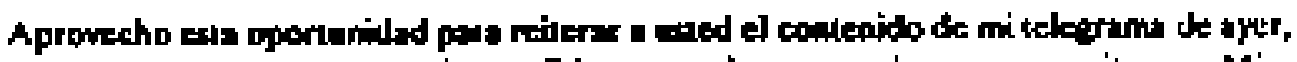

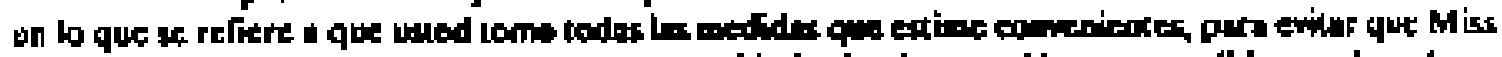

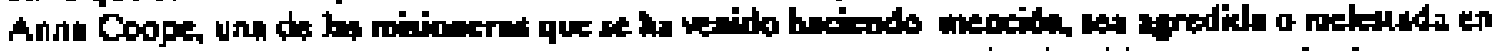

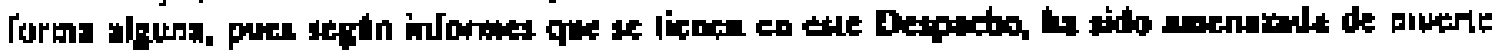
por Ẽduridas Lopez.

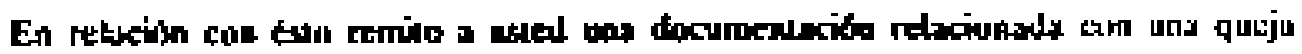
prestududu pur tol Minisucrikz..

'Trans. del oritg. mec.,inc.

V. RD, n. 195 . 


\section{V I}

$M-62$

\section{CONVENIO}

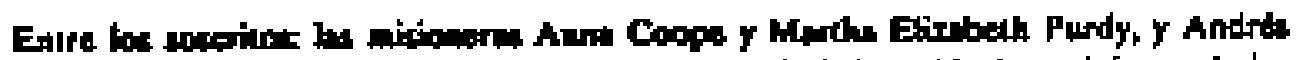

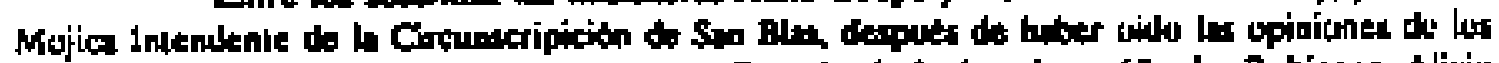

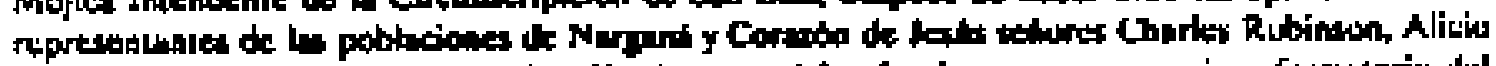

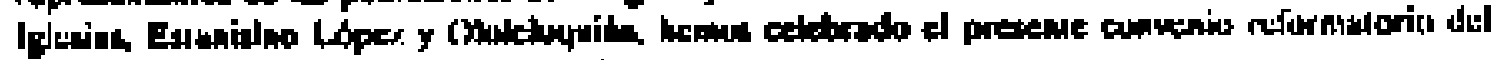
celebrado of din J" de Abril de 1919 a siber.

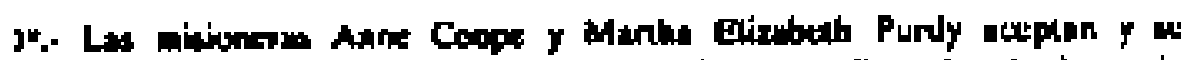

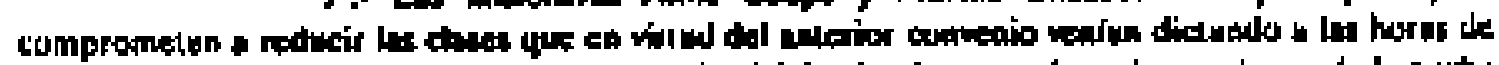

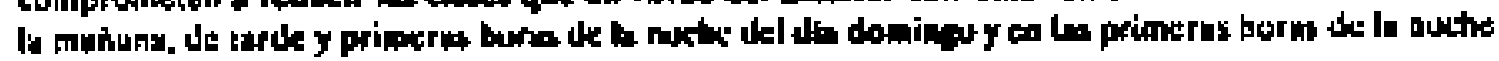

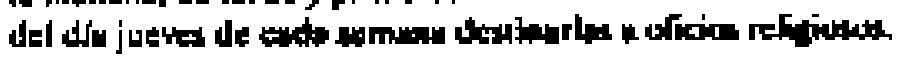

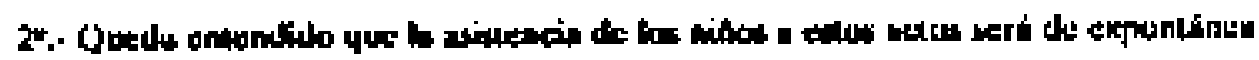
wolunind de las inditenum.

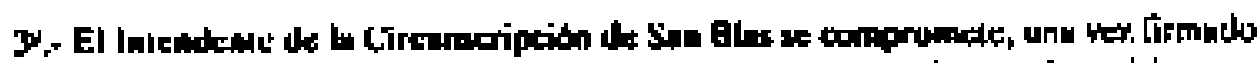

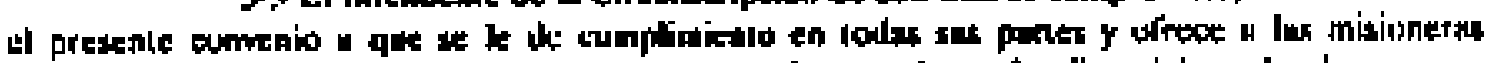

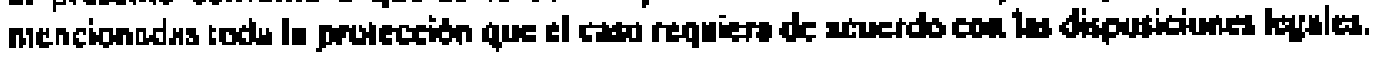

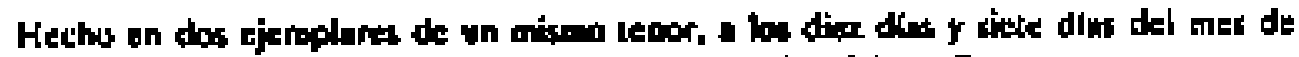

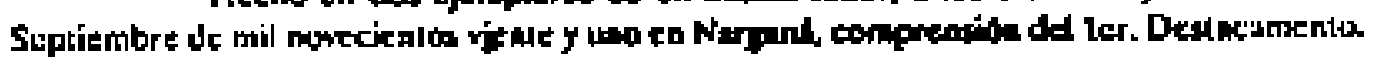

El Inlendewke. Andrís Midjke

ta mlstencer, Anoo Croik

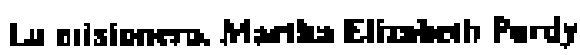

E1 Sicreturab. Jolin Peat

Trans. del orig. mec.

$$
\text { V. R D, n. } 196 \text {. }
$$


Núnecro B74-B

\section{Sefior}

PaNAMA I9 de Septiembre de 1921.

lnterdente de be Cirewnseripetion de Sin Blas, E] Porvenls.

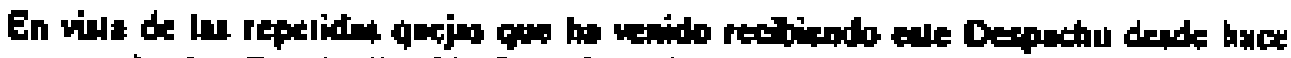

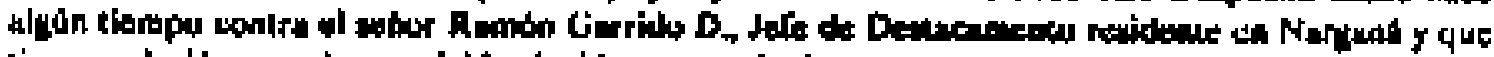

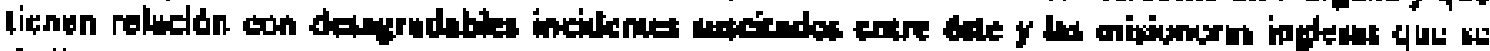

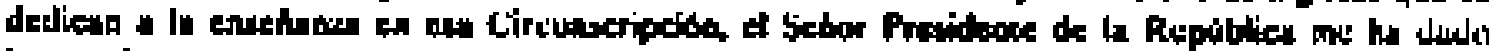

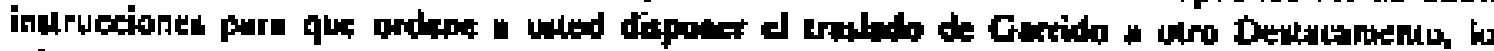

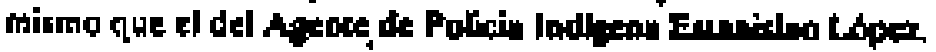

Soy da wed oury arenio wrivilor.

h. Alinery.

Trans. tel orig. mec.

V. RD, n, 197 . 


\section{Setór}

\section{Andrts Mojicm}

Intendeple de San Blas

El Porvenlr.

Sthor:

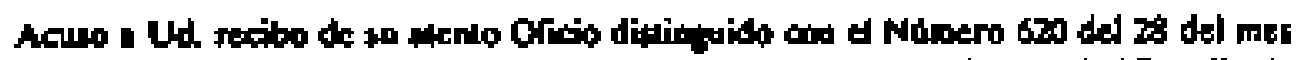

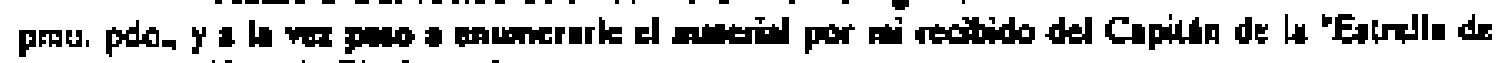
Coto', whor Hortio Bbekwood:

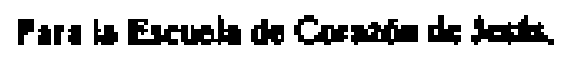

5 cqrredurat de besdo

6 Lablones de $1 \times 17$

5 piexted de 40

6 pieres de 2 x 4

4 liras de $1 \times 3$

I harril uk thanb

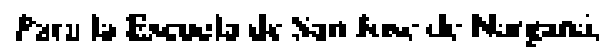

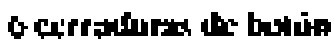

12 ablons de 1 x 12

8 Baradas para bakdo

3 pirces de $4 \times 4$

25 liriss 1 s 3

I) Ijbling ate 1 an

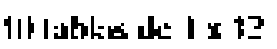

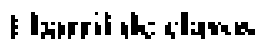

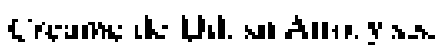

Mrlario h. Meines

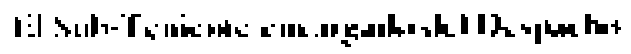

Trans. del orie mec.

V. R D, n+ 198 , 


\section{$\boldsymbol{L X X I X}$}

$N-48$

Nümero 637

Señor

Porvenir 6 Odubre I.

\section{Jefin del lo Destacamenta.}

NARGANA

Sthor:

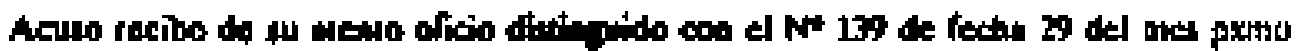

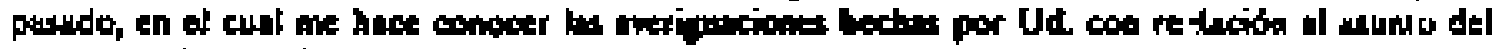

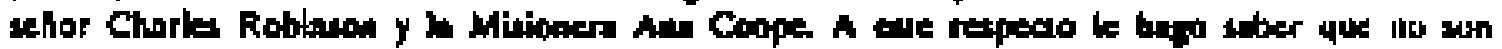

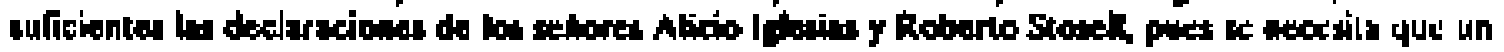

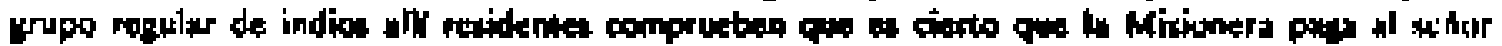

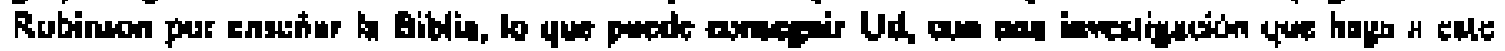

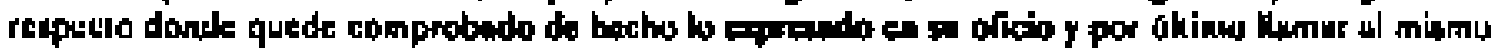

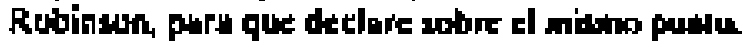

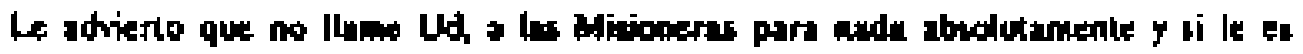

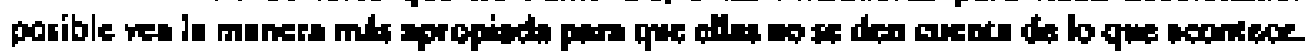

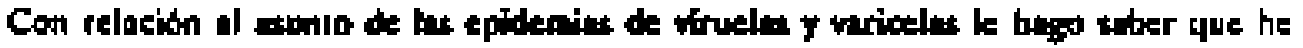

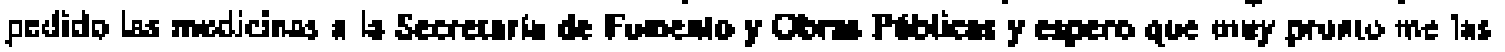

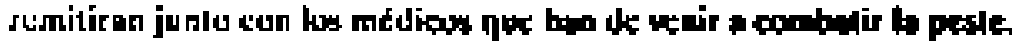

Sing Uل Alliry ar.

Andrein Minjer

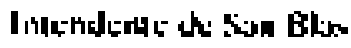

Trans, de la cop. mec.

V. RD, n. 200 . 


\section{$\operatorname{LXXX}$}

N-49

Número 665

El Porveatr, ld Oclubre 1.

\section{Sehtor}

' Jelo ded Jer. Desincommia.

NARGANA

\section{Senor.}

Cornunico a usled que para esa sigue a bordo del batandro "RESULT" la matstra de la escuelo de Tupile con el lín de que usted le preste ius comodidades que sean necesarios para trasladarse al lugar de su destino pues el balandro que hasta Nergens to lleva no sigue viaje disecto hoste Tupile.

En tal virtud, si hay slguna mo que lleque a Tupile zarpando de ese puerio sirvase trasladarla en El o si no proporcionarle los medics de yue a la mayor brevedad posible y con les mayures camodidades que se puedan conseguir llegue a su destino.

Suy de usted atenuo y s.s.

\section{ANDRES MOJTCA}

Intendente de San Blas.

Trins. de la conp. mec.

V. RD, n. 202 . 


\section{$\mathbf{L X X X I}$}

M-68 y 69

Nốnero 19: B

\section{Selor Secrotaring}

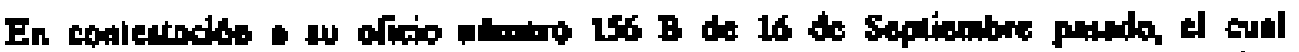

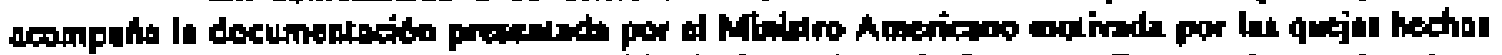

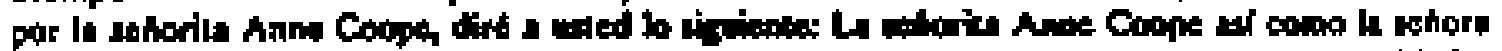

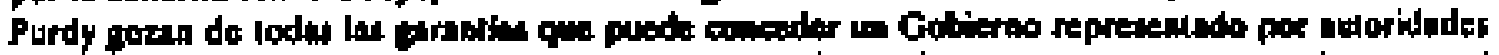

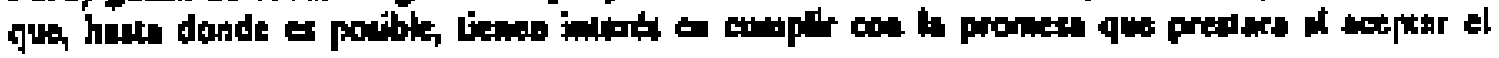
corter.

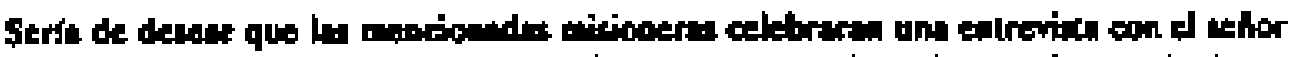

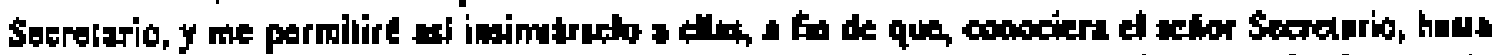

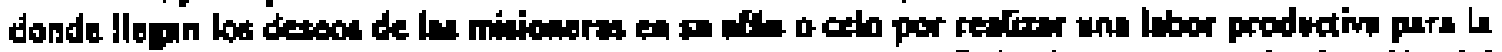

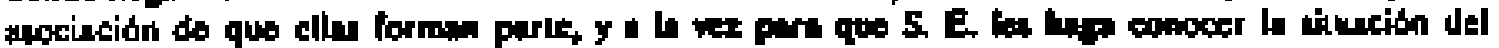
Gobierno en materin de relipion.

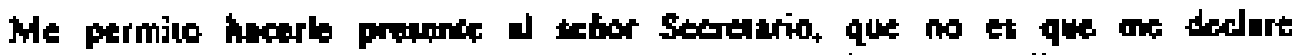

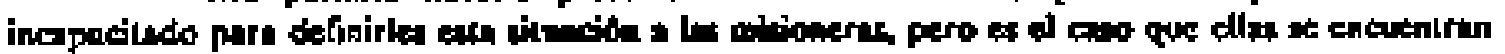

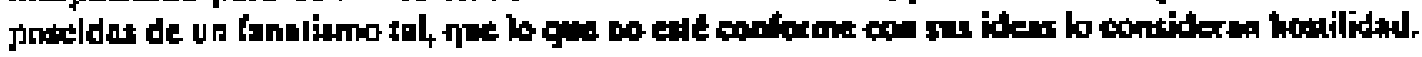

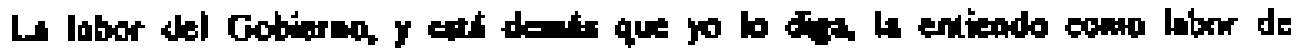

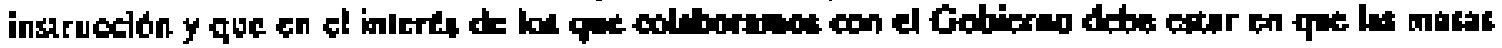

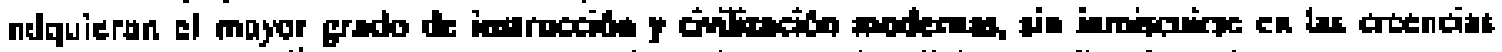

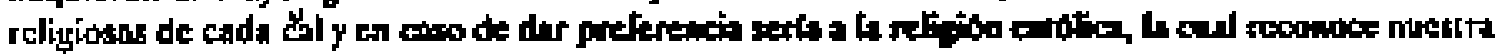

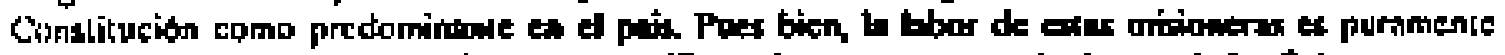

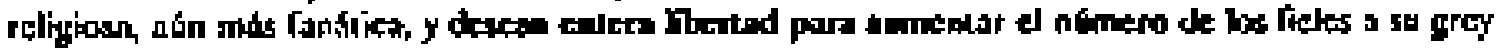

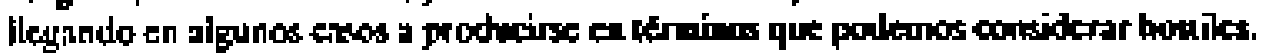

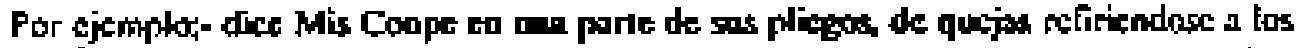

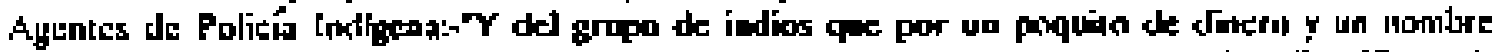

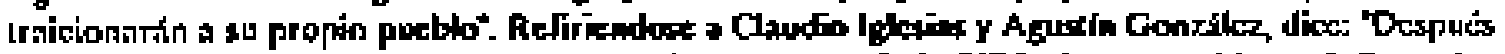

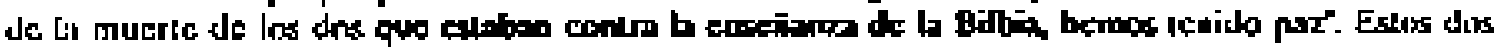

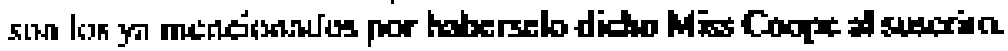

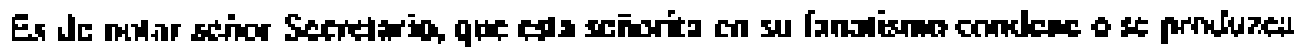

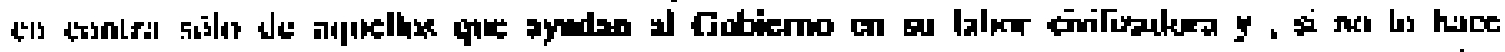

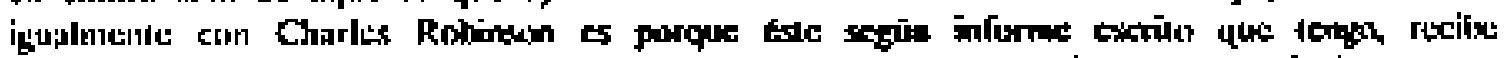

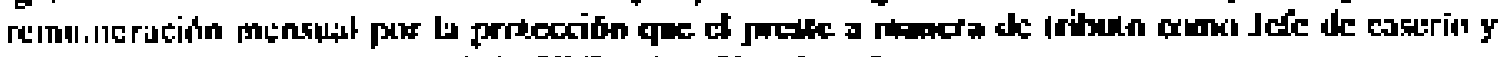

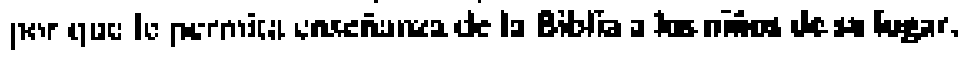

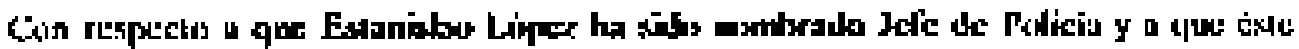

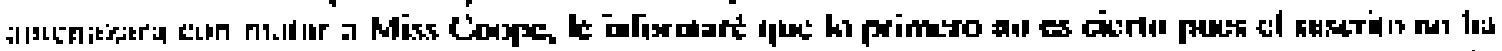

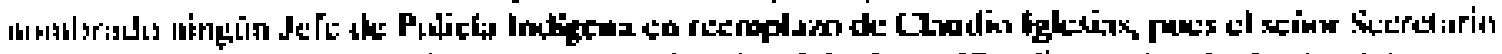

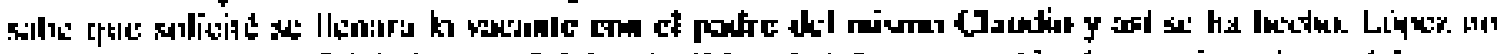

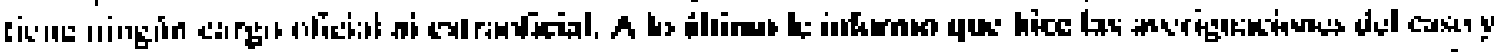

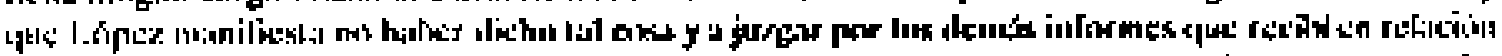

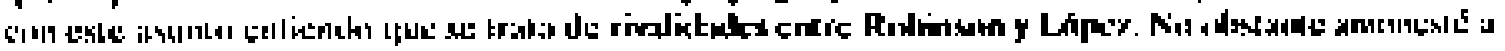




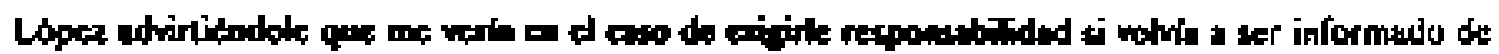

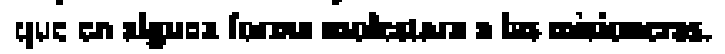

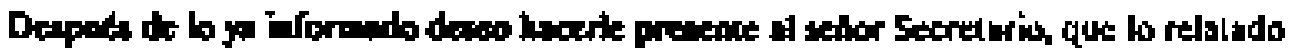

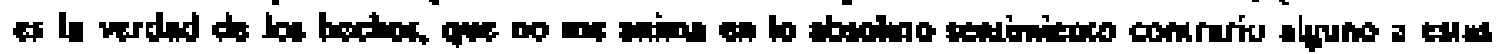

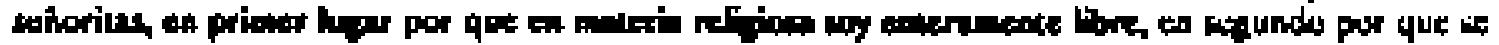

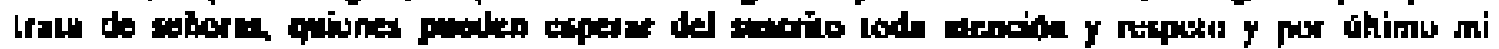

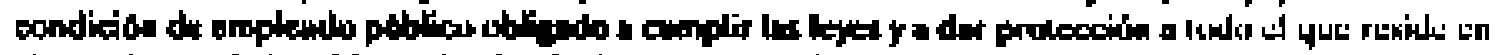

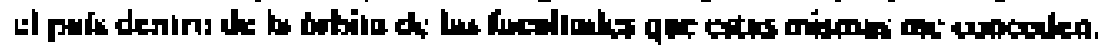

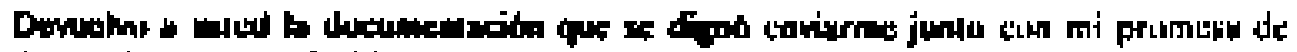

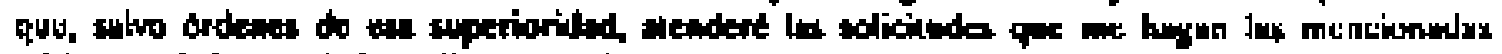

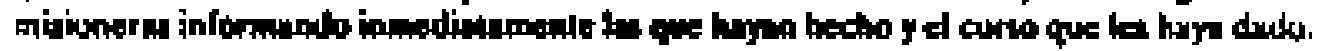

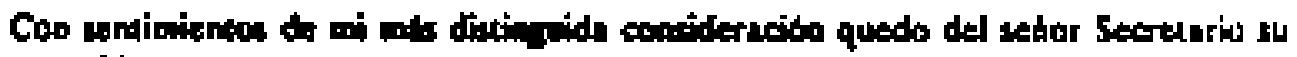
uento y togure uervidor.

\author{
ANDRES MOJICA \\ Inlendiewe de Sen Bter.

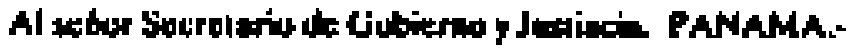

Trans. de la cep. inec.

V. RO, n, 204 . 


\section{$\mathbf{L X X X I I}$}

$M-63$

NOVIEMBRE ].

\section{Seltor Socretario:}

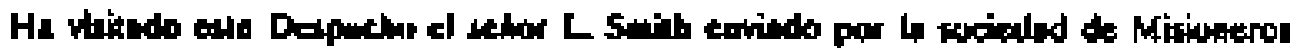

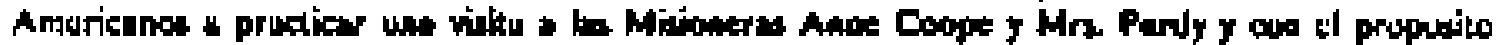

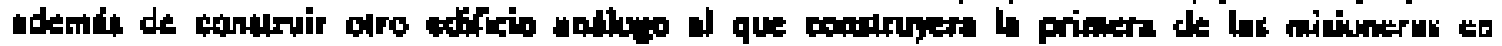

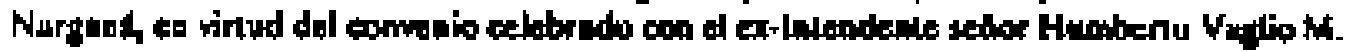

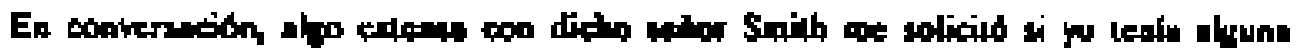

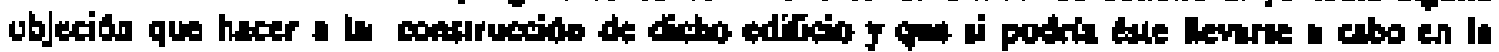

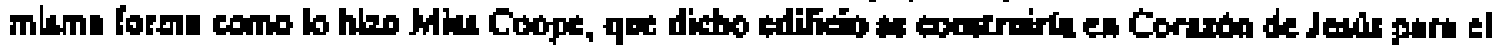
morvicis dr Mru. Purdy.

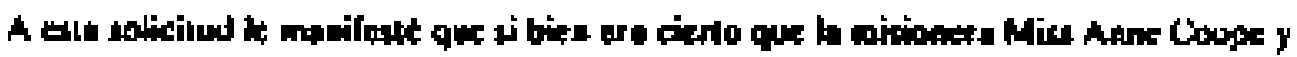

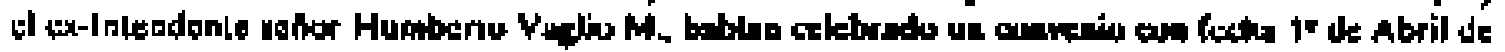

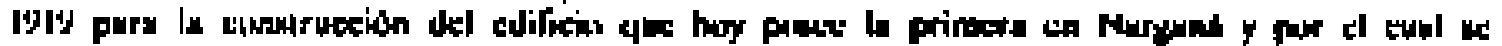

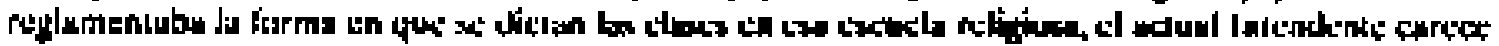

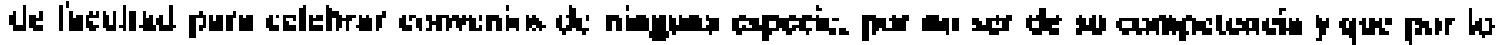

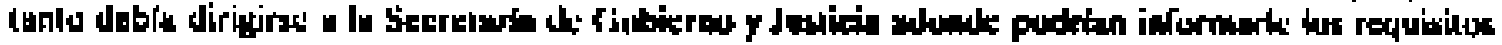

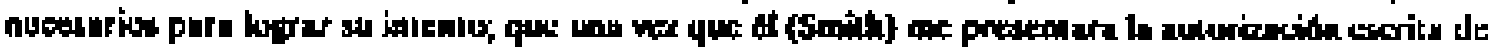

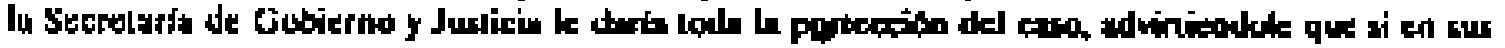

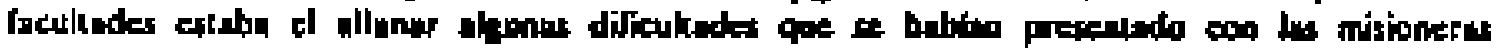

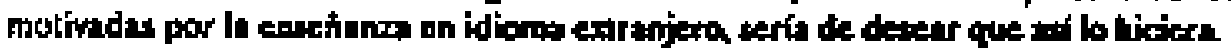

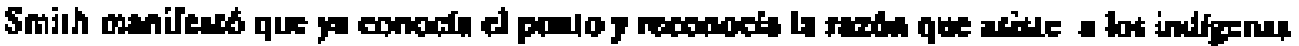

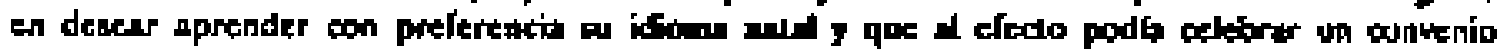

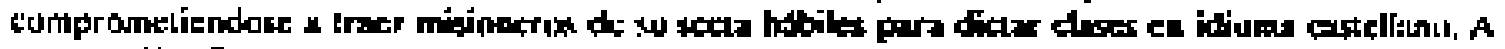

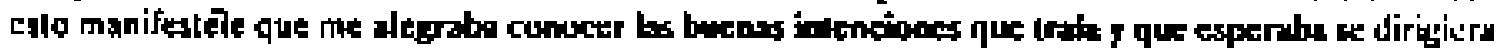

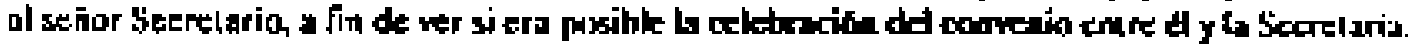

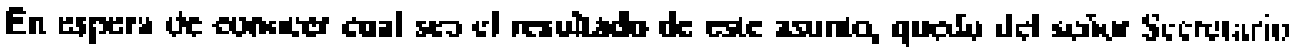

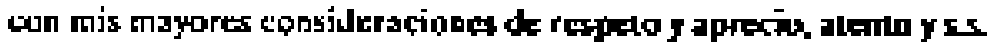

ANDRES MOJICA, IUIEMIOnIE de Sor Bta.

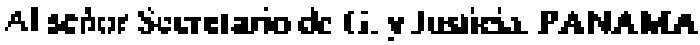

Trans. de ba cop. Hec.

V. RD, n. 205 . 
Betax

I.G.SmLth.

F.0.가 rox

Criatóbel, Canai zone.

Seilor:

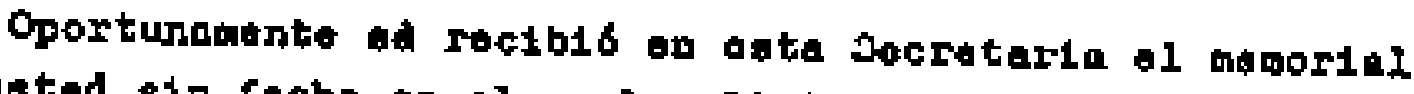
do heted sin fechn en ol cual oolicita un pamiso irrevocable para construlr un editicio en la lela di rargana en la Circungaripción de Son Blas para dedicerle la mioton que

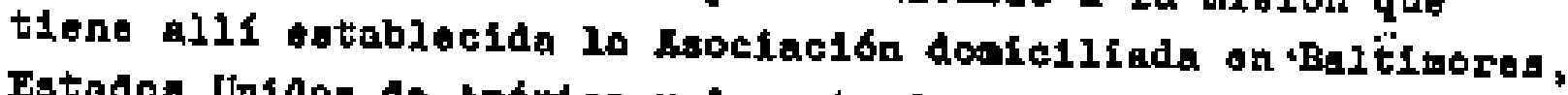

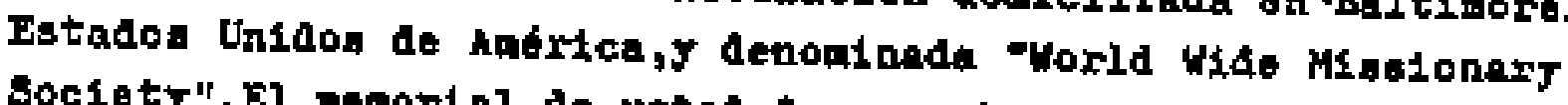
Society".El menorial de usted tue pusato on conocialento del Ixcelantieimo señor Preaidonte de la Repóblica quien a a vaz

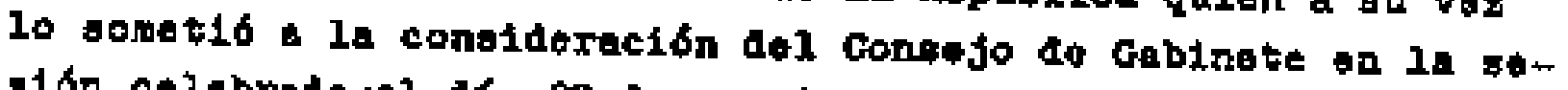

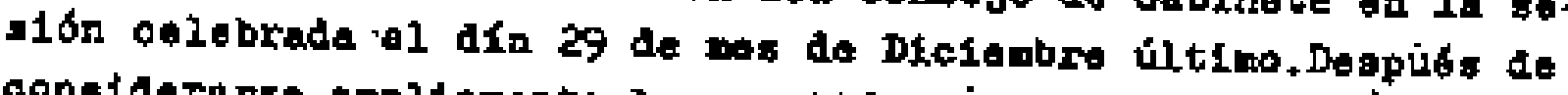
conelderarse anpliemente la cuestion cón viota de todos los informea of 1 ciales $J$ extraorsciales suninistrados al gobierno a como tamblon los entecedentes de esta paticion e historia do lo ocurrido all1 durante el tiampo en que han perwanecido en tarsarḱ como misionera s las sej̣oritas Coope 5 RurkJ,el Conoto do Gabinete Ma llegado a las siguientes conclusiones:

1a. Qug la civiziración de log Indrgenas de San bias es una cuestion exericialeente polfticn en que el Gobierno de la Mepubl1ca tiene ur interts naclornl; zaa. Gus al atraer a los lndigenas de $\operatorname{San}$ Blas a la vida ctilizada,el Gobiorno tiene que velar ante todo porque osos 1ndios so Identiriquen en ta todo como el. regto de sus conciudadanos; 3a. Que un becho deasatrado ampliamente por la citacia 5 por la iligtorla polftica de todas las nacionsg que lan lazos wás Evertes quo unen artre si a los que

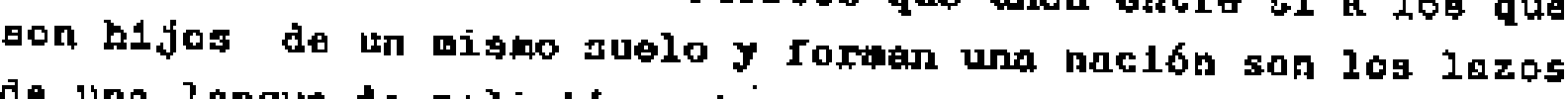
de una longro, do roligion $y$ de jdentidad de contubbres $r$ da aspiraciones; 40 . Que la mision eatablecida en jun glas no be he-. cho hecto ahora m\$s que enzeñarle a los indfconas ura lengua Que no ea la(10п्ठus) castollana, una religion que no ag 20 de majorio do 103 hobjtarton y costumbres cnteromente direrentes a las cos- 
'

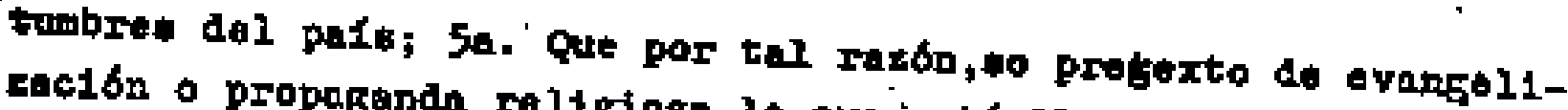
zacion o propaganda religjose, 10 quo ajta llofando a cabo on San

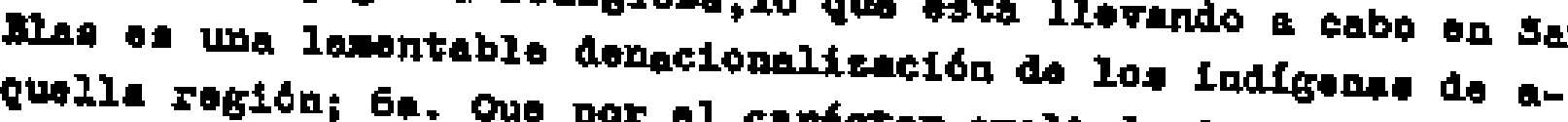

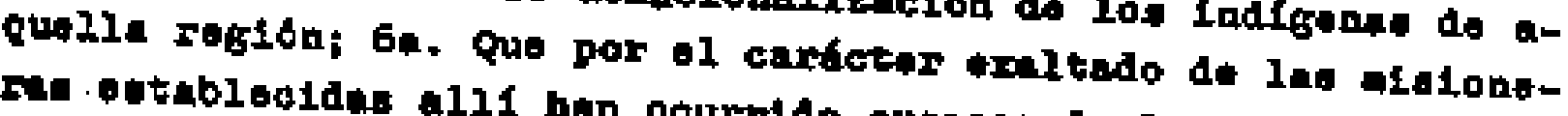

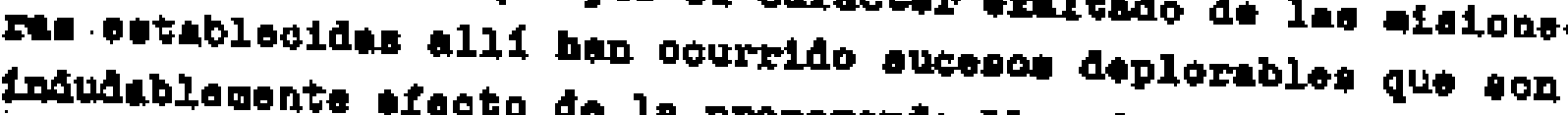
Indudublewente weoto de la propaganda lierada cabo par olla que on algunos capor ban tereinado de anare tan trigtce como

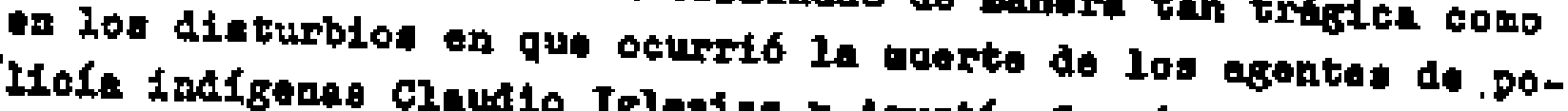

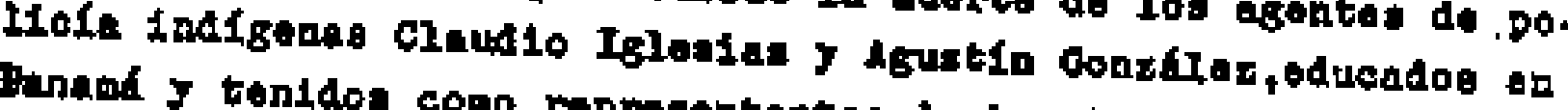

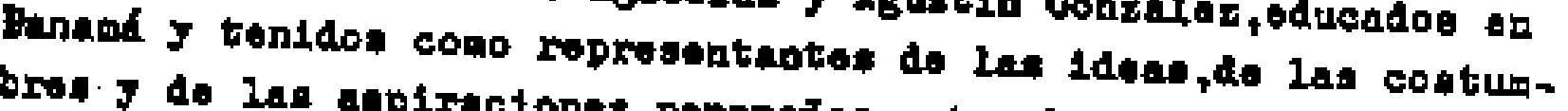

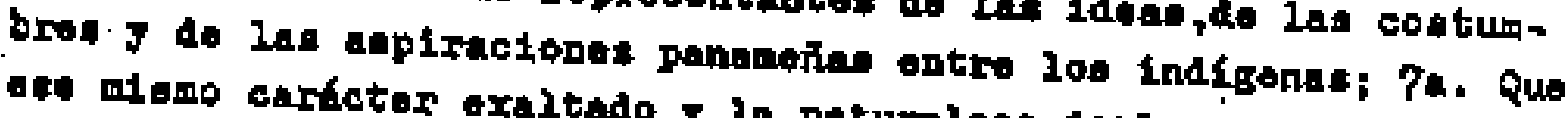

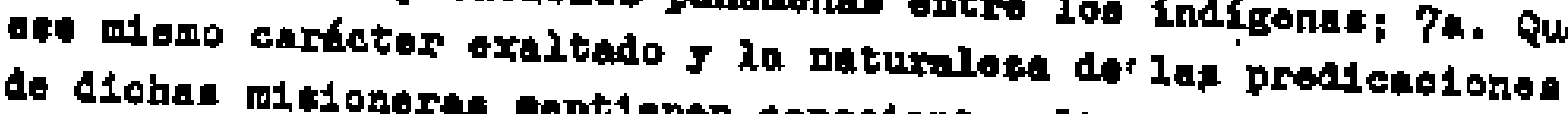

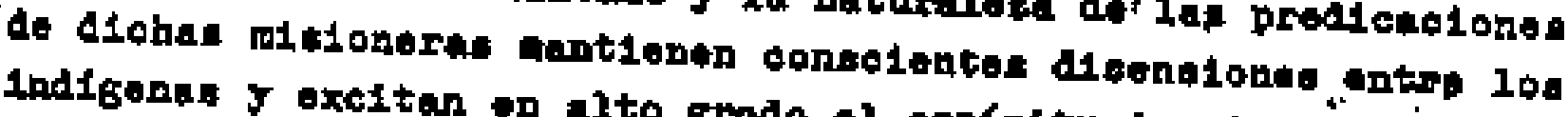
Indigenag $J$ exciton on alto grado ol explritu do rivalidad $J$ do

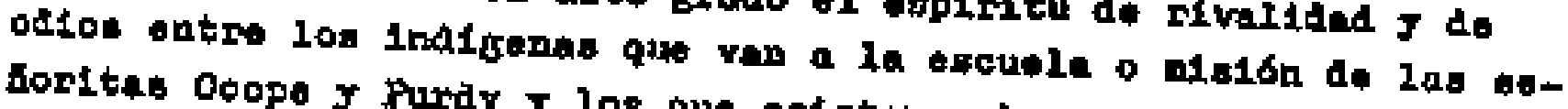
Sortteb Coopo y Purdy $\mathrm{y}$ los que astoton la escuela póblica tata-

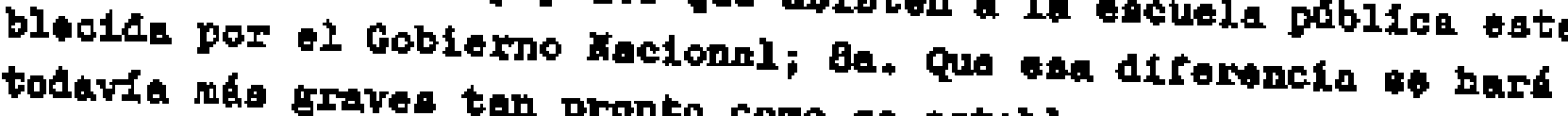
toduvia més graves tan pronto cono se eatublescan al21 200 mI-

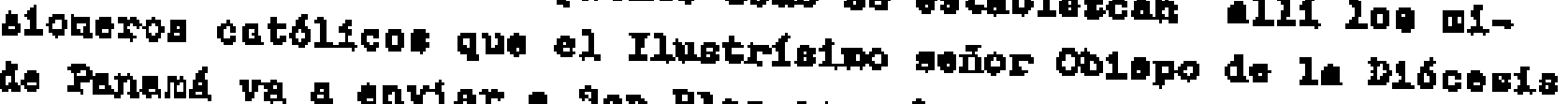
de Panamá va a enviar a Jar Blas con ol apoyo noral 5 matartal del Goblerno de la Repáblice; 9a. Que In malón de la socledad que da. repregenta eftablectan en San Blas, ha ventalo quebrendando les leJos sobre Instrucokon PGblica por no dar aseñanca an español na

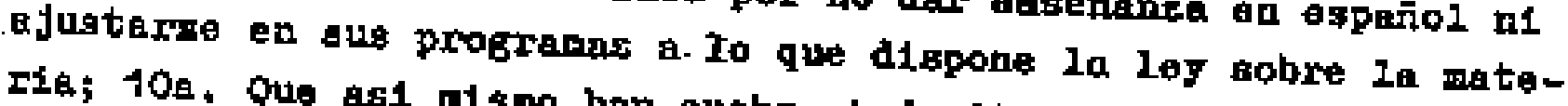
ria; 10a. Que asi nismo ban quebrantado dichas qiajoneraa las leyea adbre Instrucción Pública al no haberse sonetido al examen de efiolencia se requiere la les para toda persona que abra ura eqcuele privada para enseñanza general; 11a. Que aundu la Constitución establece que la profeafón de todas las rellelones sera $11-$ bre, la wisma constituctón establece que la libertad de cuelquier

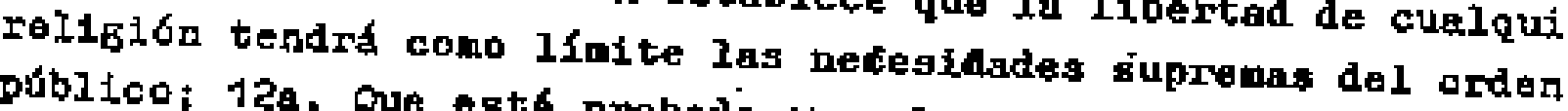
público; 12a. Que estif probado quo el orden píblica ba aldo turbado $y$ an constante peligro de ser turbado aleatras existan a1rultineanente antre los indfenis de relifioses, dos sisteans de ensefionze y dos ordenes de costumbras no mision protestante pue se producen con al eatiabocialento do unal, oo ougtonte rantoner oxtranjere; 13o. Qive la Constitución Macio- 
copla

\$o. $20-n$.

\section{3}

retonoce que la folletón catbliog os la to la moyork do lon hison dol pafs $y$ autorise al toblerno Kaclonkl pars aurlilar ol

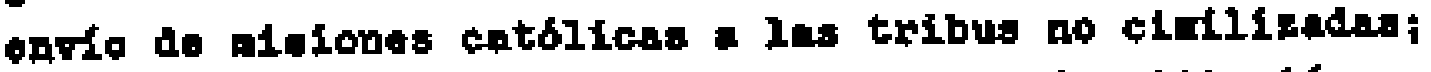

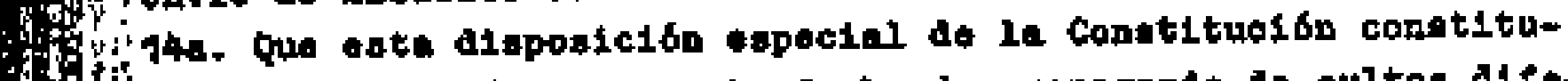

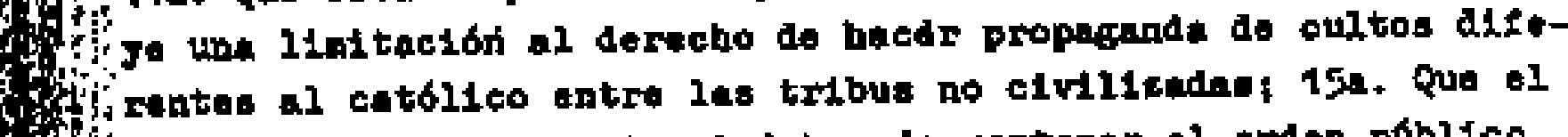

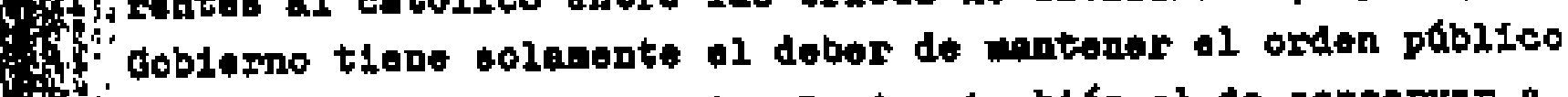
on todo ol territoxio nacional okno tambín al do contervar a todo trano 100 ceractora y reosos osenciales do la nacionilim

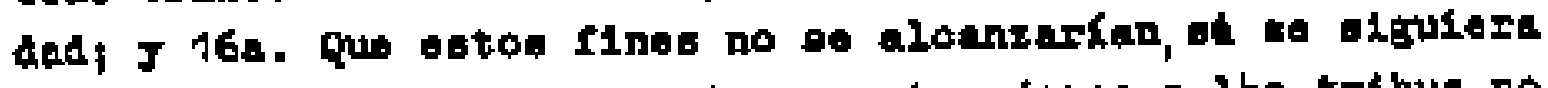

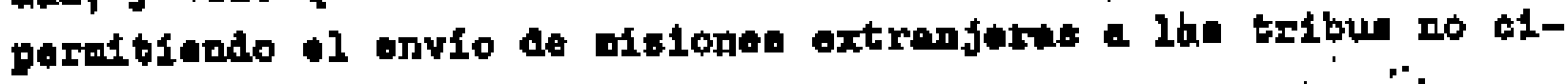
pllizudes do lo Ropublica.

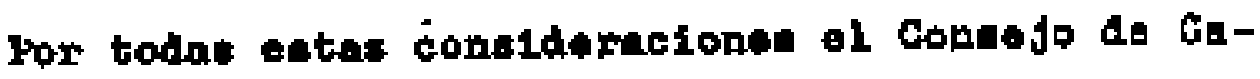

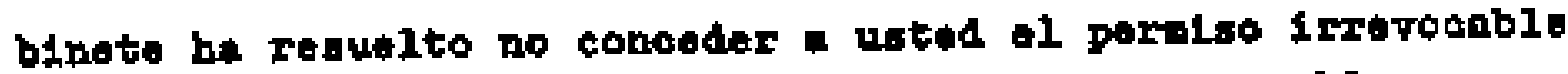

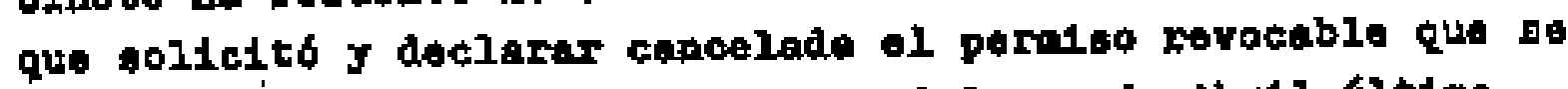
concedso uated por note de focha dol mos do Abr1l bltito. soy de td.atto y S.3. (tdo.) .A.J,Alfaro.

copia: 


\section{V \\ $192:$ \\ El Porventr 18 de Harzo de 1922'.}

Sofios swozatario:

Para que ol secretamo so do cuonte eructe do Eatatuk

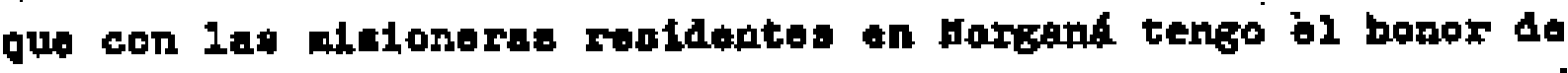
traneribirlo in elguiente hota:

"Kargand 15 de threo de 1922.- Ho.52.- Solior, Andr6e Moj1ca, -Interuente do San blas.-El Poxweair. Soffort Pare 108 flnes condigulentes intorno * usted, que las aekoras mi-

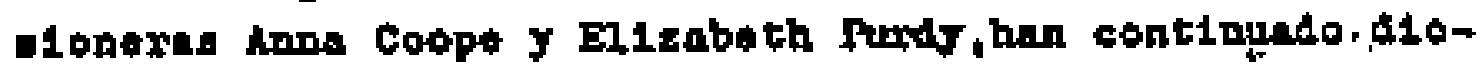
tando clator de 1 nplos a loo niños de entos pueblos, pe-

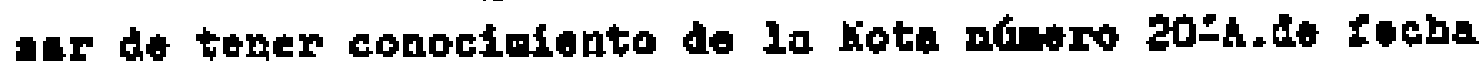
5 do Inero del ofio en curso,j atctada por le jecroterie 40 Goblemo $g$ Justicin on contestacion a un arsontal prosentade a tas boppacbo por ol sofior L.0.Salth oono ropre-

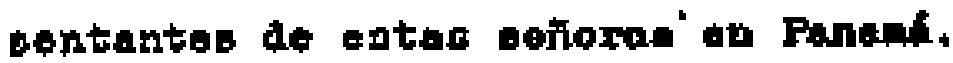

hemde dichas seitoreg nunce ban querido soecterse a lo dispuesto en 100 ordinules $1,2,3,4,5,6,7,6$ y 9 del Axtsculo 42 de la codifleación Eucolar de Enafthanes prinarite cobro oscuelar privades, vigented y requiritos. Eir consecunncle, este Dexpacho smplica a used sol sirva ordenarle que debe bacer al respecto.

De ud atto.y i.s.

(rdo.) Ranón Garrido D.

Jofe del 2da Deatecomento"

motyada la lanche "La Estrella de Coto" ol ines de Abril 1922 en arrecifre de Ulnaicus.

En U1chup-uale abrio prinera ves la escuela on Mayo de 1922 , el dia 2 con 15 niños.

copir.

V. RD, D. 216 . 


\title{
derizana, 3 de Hayo de 1922.
}

\author{
Astrox \\ Andres Mojica \\ Intondente do yan Blas \\ POAVEYIR.
}

Soflor:-

Pare su conociolento y para que lo bega conpcer do $2 \mathrm{a} \mathrm{Sh-}$ crotirle do Instrucción Pública, coto lo desea ol sefior M1rector de las Esculas de este lugar, tengo bien trangcribis a . usted,el siguicnte oficio qu dicho athox as ba pasado:

morazba de soate, ilayo 3 de 1922

Señox

Ramón Gerrido D.

Pto.

Señor:-

Esta Pireción para loa tines consigutertes, comunlca a usted, que el señor Estranislao Lopez, residente on KaIganá, Yiunze, partif doblerno Kacional ba depositado pierta con2 jej prosente on la madrtigadra la ciudac de colón ol dfe alumpos del juturo IV grado que llevándose consijo todos los cuela.

Bste proceder del señor Lopez ha echabo por tierra las aspiraciones de la secretaría de Instruccion piblica a la vez que ba cansado una pequeña desorientación en el proDirección. para el proximo año lectivo traía trazado osta

- Este Tespecho os pido wuy encrecidasente que jara evitarse resoonsabilidad, oficios en vuestro caracter de InsPóbica, las razones bicuela a la Becretaria de Instruccion tran of oquella ciudad. las chales dichos jovenes se encueacon tentimiento de alta consideración créame 30 atto.i.s.

Director de la beucla."

soy de usted otento y $5 . s$.

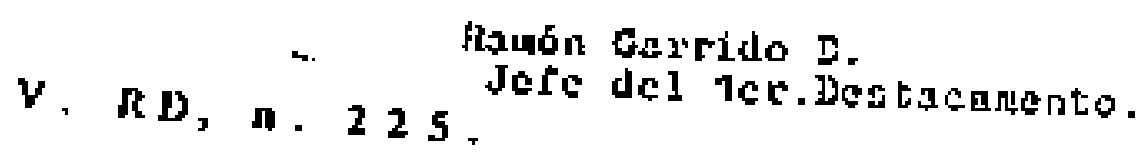




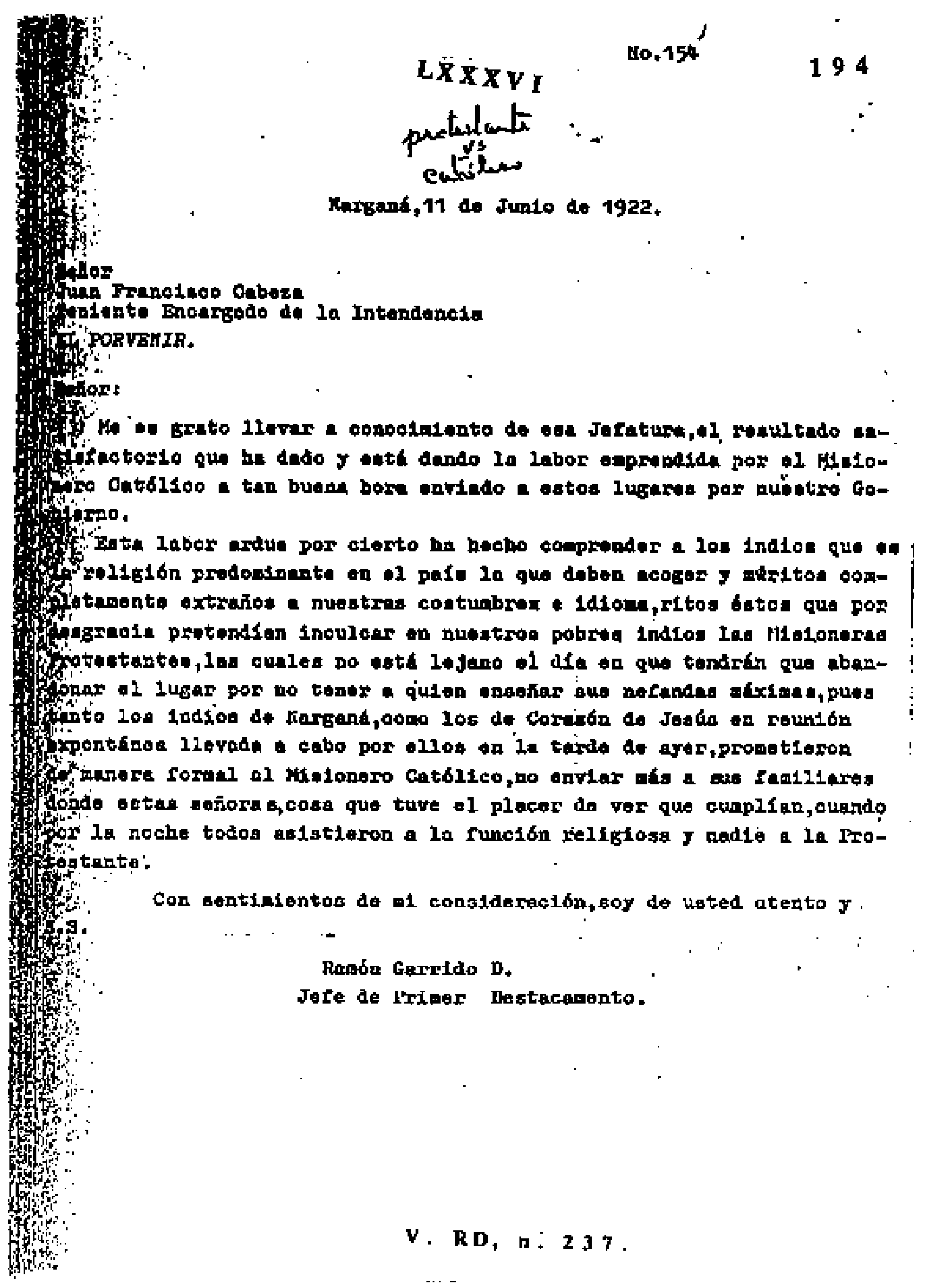




\section{LXXXVII \\ Nargana, 19 de : Tunto de 1922.}

geñon

hadras Hojtca

Interdente de san bles

EL Fortinza.

\section{SeItor:}

Con placer inform a usted, la labor civiliadora llevada a ca.

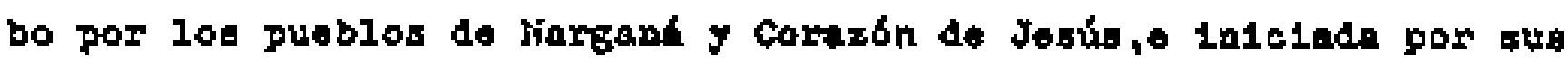
Jefes Pollticoa geñores Charles iobinson, Eqtanisleo Iópez J CleluQutive.

Eatoa nohorea con lo vense do ett* Dexpacbo, reunteron on Congreco pleno a aichos pueblos, con el fin de ayudar a mustro Goblern.

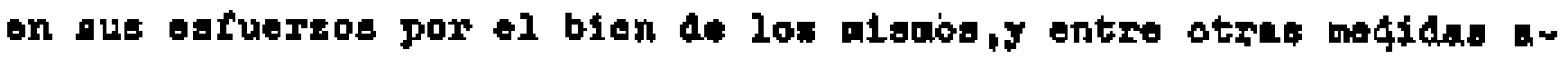
conderon les aigujentes: Abolir por conpleto el veetido que in la actualidad llevap las matros rtejes, (o sea el do indias) $\mathrm{J}$ camblar este por ol de genters civilizadas, como lo lievar las jovenes de ertos dos pueblos.

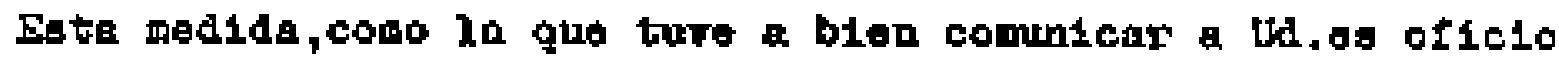
antorjor,y que consiste en no dejax quo gus tanizlares agiatan la ceremonias de les Migionerns Frotpatantes 5 si a las orlctos Cat6li cos que diasiapente celebre el Padre Plácido de cazelln,fuorion apro badas IPO unaninided, coaprometiendoge todos a cuaplirles ftelmente.

El-sugcrito en su caracter de representante del Gojierno en e te lupar,felicito a estos señores, $y$ par sus coniuctos a los inciog

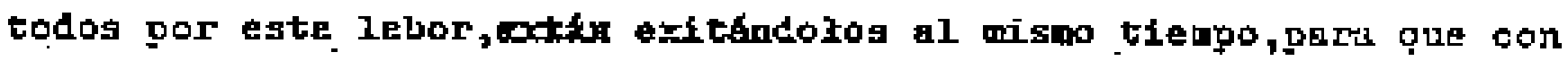
tinuea trabajando con ahiaco, cono baste ahore lo han becho.

Soy äe usted, atento y is.

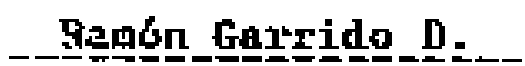

Jefe del Initer Desatacamento.

$\cos s a$.

V. RD, n. 238 . 


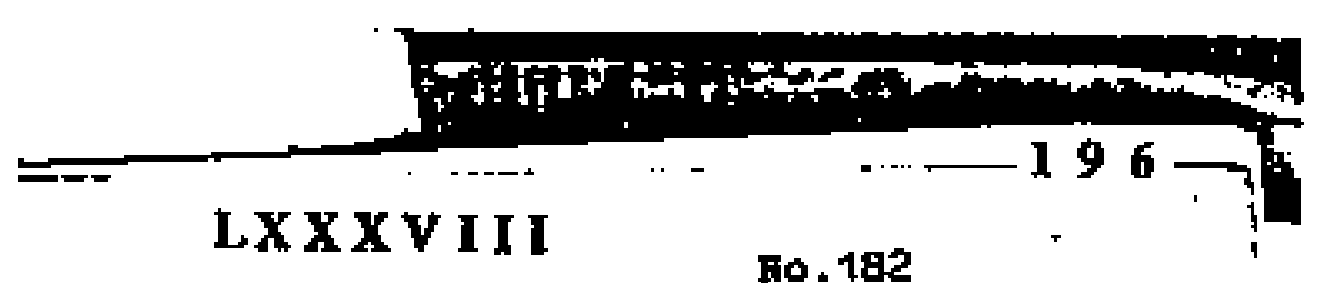

nargont, 24 de Junio do 1922.

Boftox

andre. Hojica

Intendente do jan vlas

EI PUITEtill.

Seflor:-

Con notivo de in ectitud de $200 \cdot$ pueblos de Hergane y Corazbn

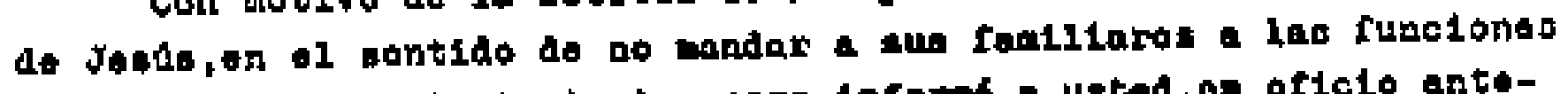
de las Midoionerag 1rotestantes, cono infored usted, on oficlo anterior,por no quesur atí que peranescan equi, el soñor t.f.3mith,quion

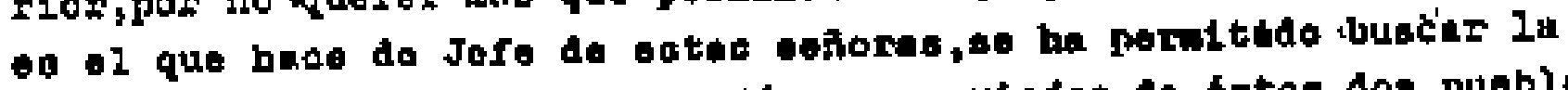
manera de que hayan entre los jovenes $y$ riejos de bitos dos pueblon,

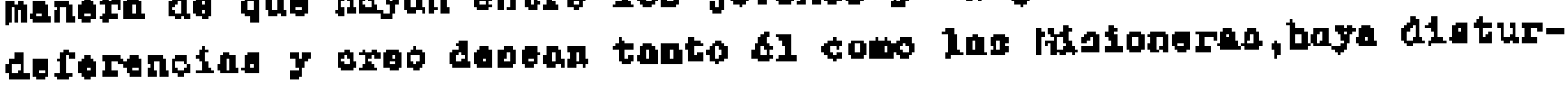
blo ontro $20 s$ mienos indios.

Como on al camcter de Jefe ragpongable de este textacamento, i

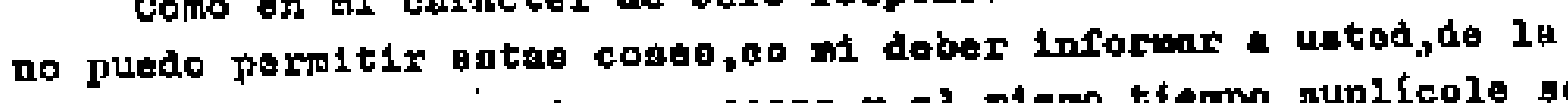
actitud asumidu por ontas persoass, $y$ al nisa tismpo auplicole ne sirve dara instrucciones para proceder de acuerdo con elias.

Ios señored Ianiel ispoz 7 Estanislao Lopex,portadores de este of 1cio, nodrán informar a usted, de el modo de proceder de los lizaioneres antea dichot.

Sờ de usted;atentu J.A.s.

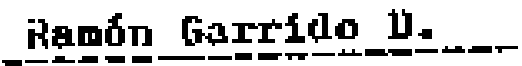

Jefo del Irimer Lestacanento.

copia. 
Panama , 24 d* juglo d* ig22,

ingor

fut

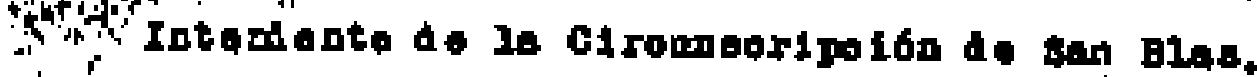

i: Porpendr;

in,

a sonor.

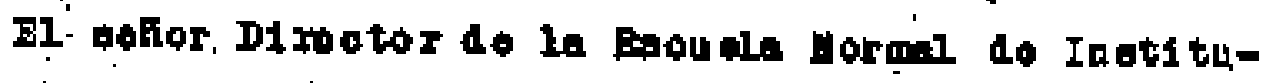

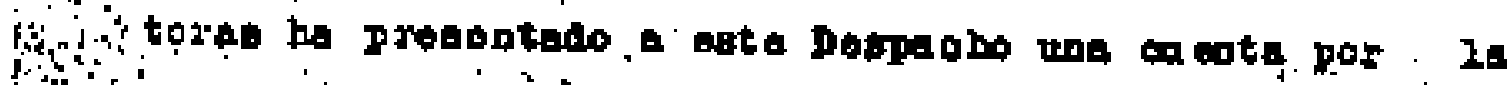

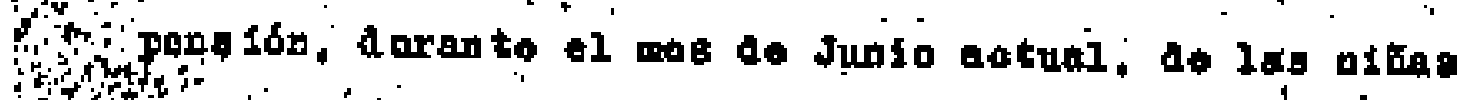

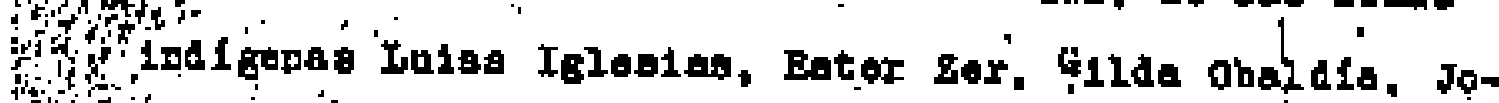

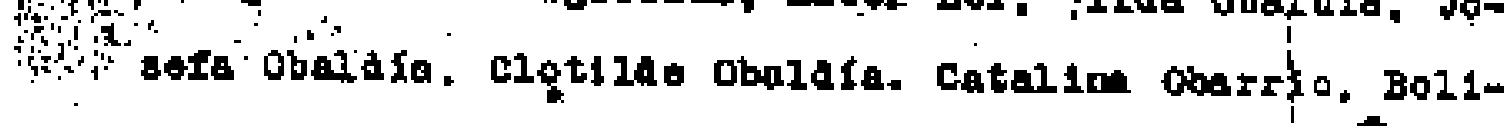
Yie Solfo y Blopon Ilibre. Eota sooretarle ha probudo ys a pago da 29 coenta an apation, pero comojlog pa-

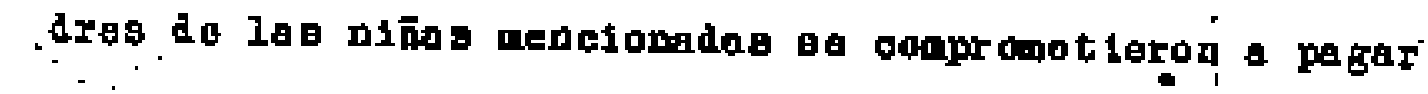

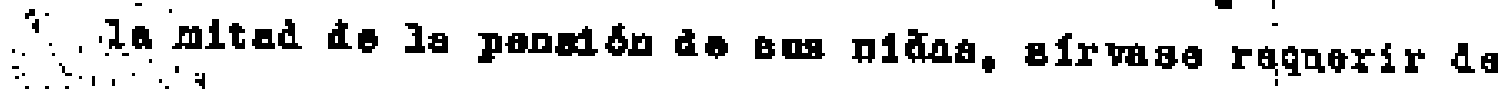

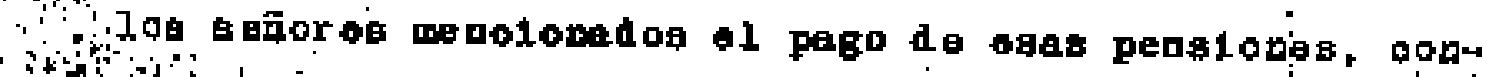

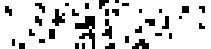
- forme a lo etetipniado. $\therefore$ ing $y$
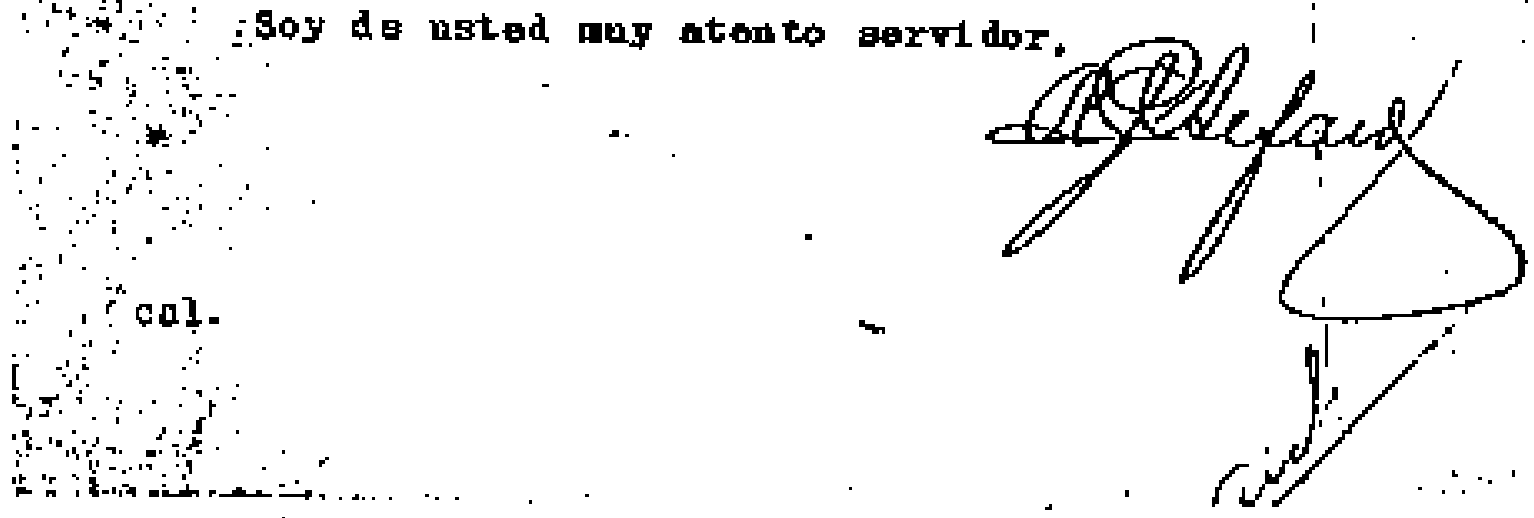


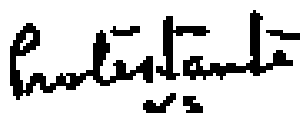 $\checkmark 5$ \\ Ceristos}

El Porvedr, 26 de Junso de 1922.

10.77-B

Boner tecretanto:

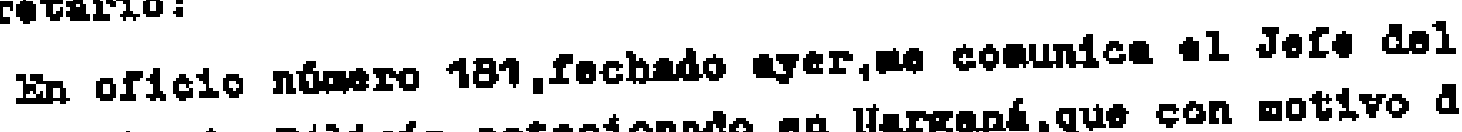

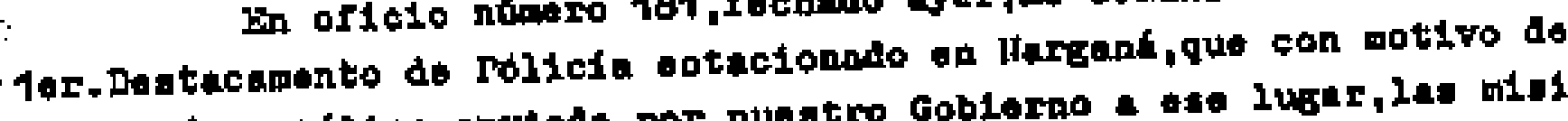

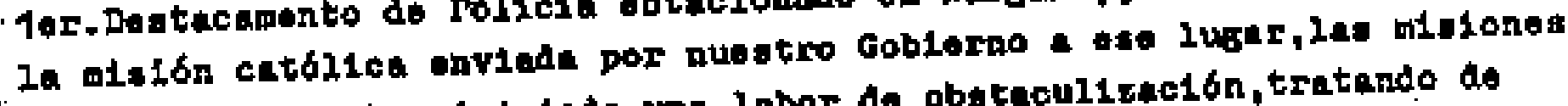

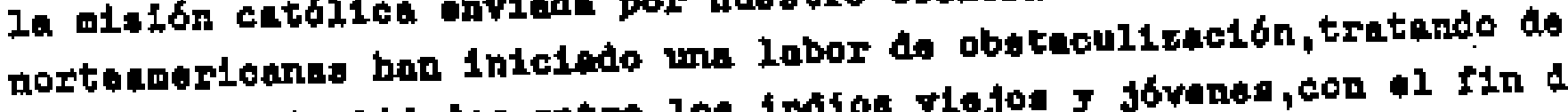

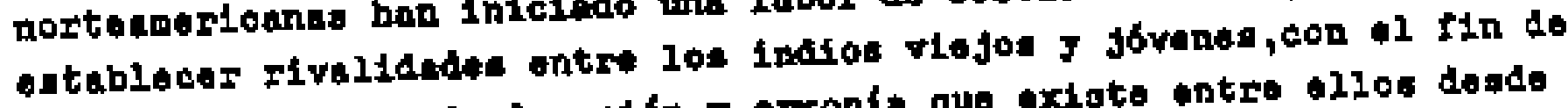

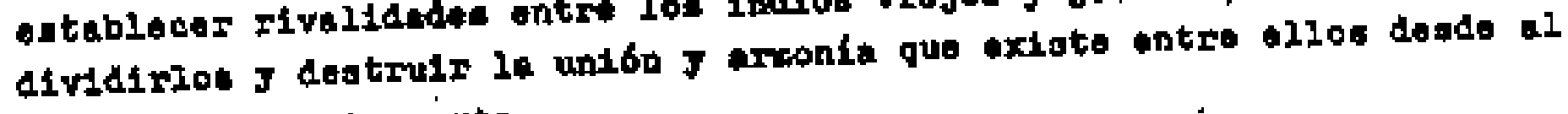
Gir t1ompo a cate parte.

on vieta de este infores he ordenado al Jofe de dioho Destroune

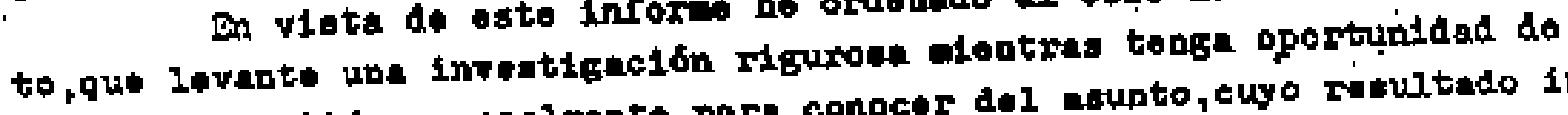
tracladorme alle permonalente pora conocer del asupto, cuyo ribultado ir formar al añor secretario. Mentras tanto, po aucriba ruy atento $J$ ioguso sarvidor;

Andres lojict

Intendente de San Blas."

hl señor
Secretarda de igtado en el Despacho da G-J Juaticia

Panamá.

$\operatorname{copia.~}$

V. RD, n, 242 
(Trascribir al Mer.bto.esta tiota para que cueplanos la ordon 199 dol auperior.)

. Ja21o

Phkilth, septlembre 9 de 1922.

\section{Sornor}

Intendente de 1a Cixcunscripción de san Blas.

\section{El Forrans}

Enflor:

So he recibido en oste Dapacho su oficlo núpero 101-b. del

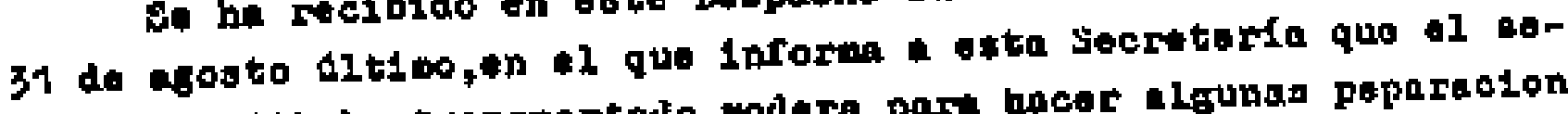

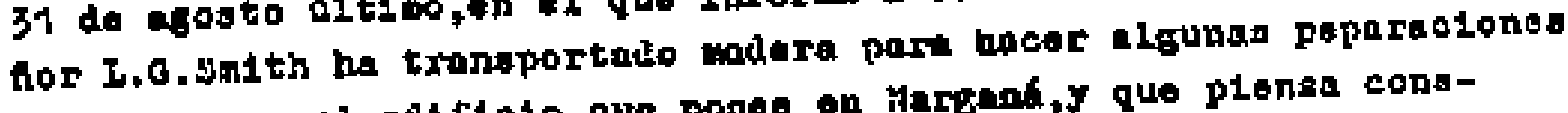

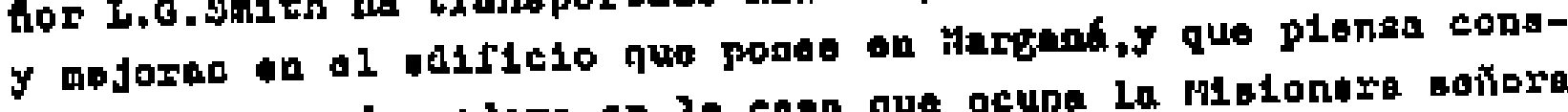
truir un piso de madera on la casa que acupa la Misiontra soñora lhurdy a corazon de Jeable.

El glerto que on Conalo do Gablpete se resolvio dancelar. ol pernias rovocable quo hobla aldo concedido al boñor Binlth pura

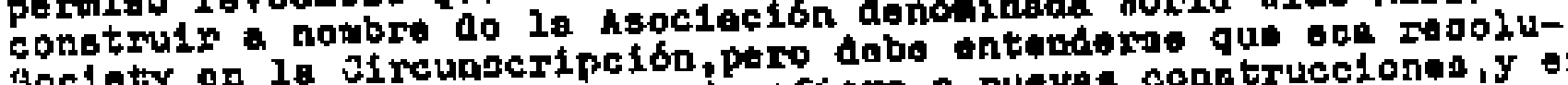

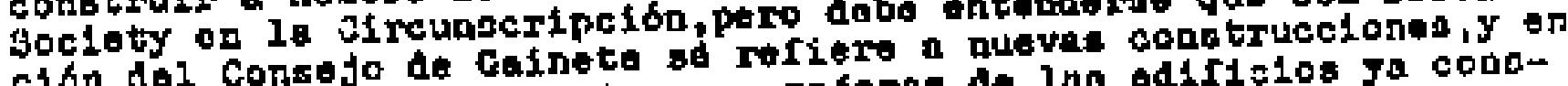
cibn dol consojo ae calnotones I mejoras do lao odifisios ja cona-

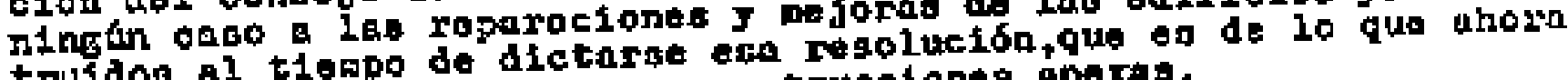
trukdos al tiowp que no seas construeciones anexas.

In consecuesc1e, ette bospacho entima que no to puado negar al señor jintith el perniso que solicite pare reparar y mojorar el idjflc1o que poses la Worla wide Missionary Society en Corazon de Jesús. construla un piso en la case de la señora

Goy de usted auy atento seryidor,

li. Chlari -

copia 


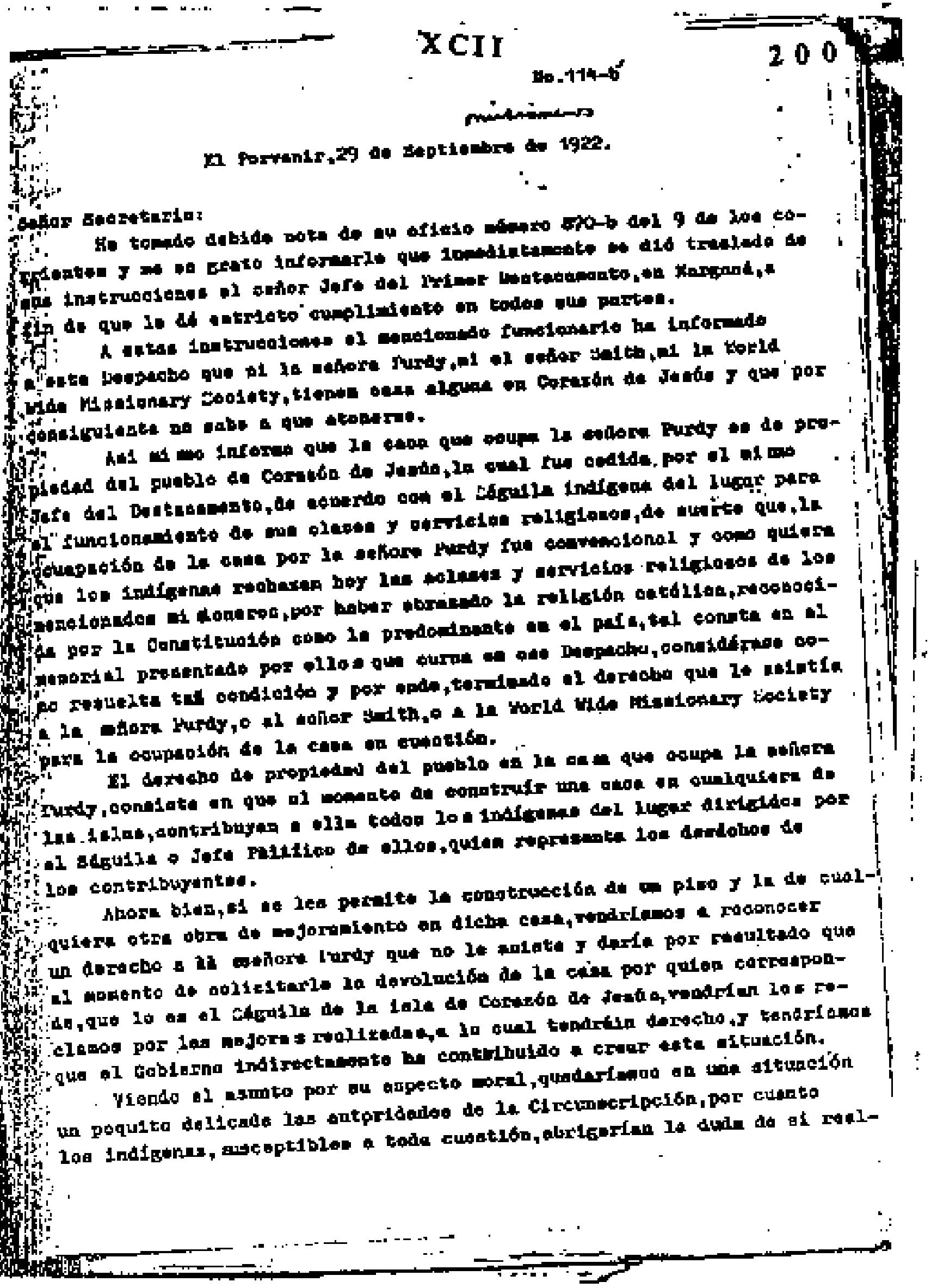




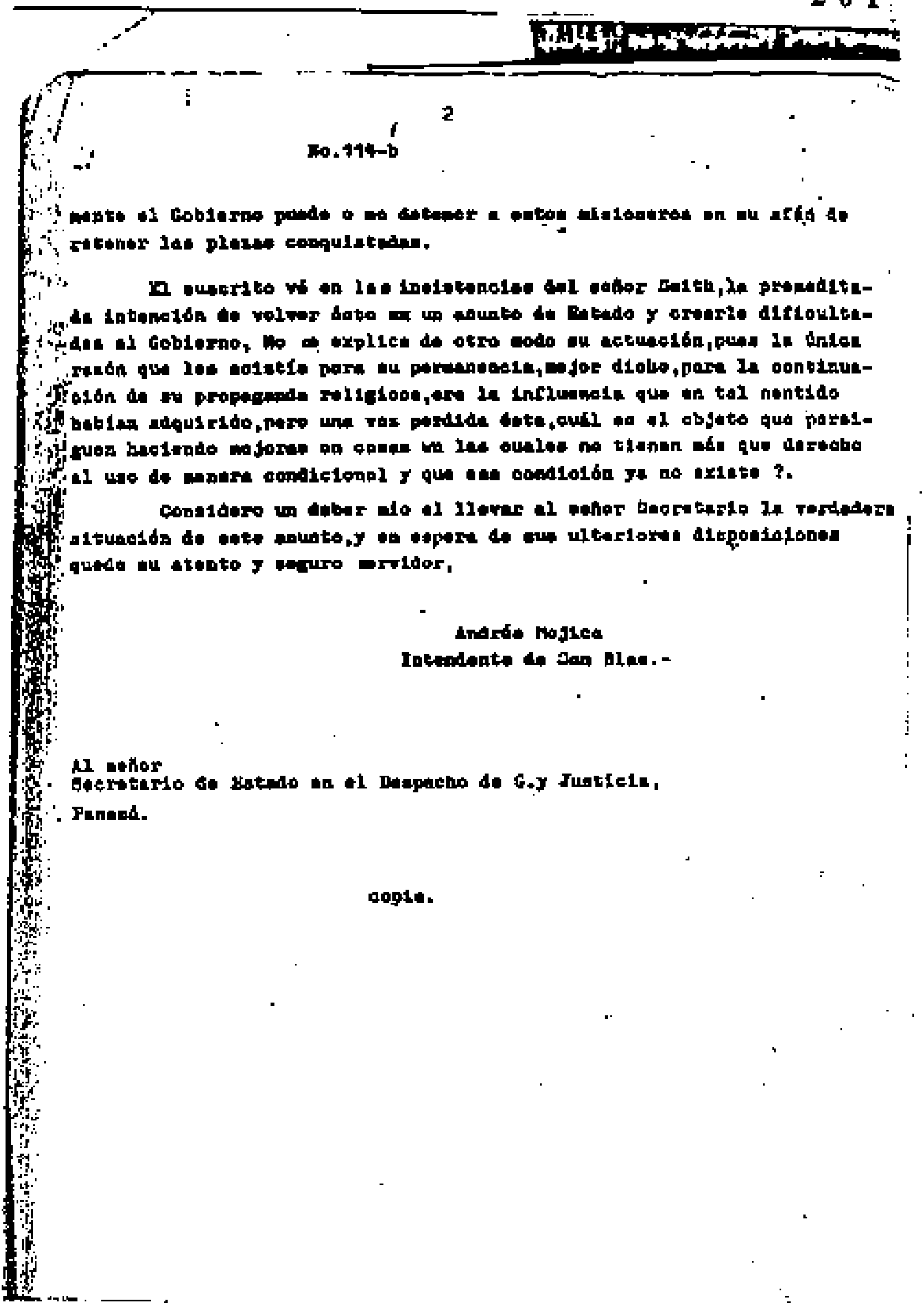

V. AD, n. 257 . 
E1 Porvenir, 11 de Oetubre de 1922.

Señor secretar10:

Fn la btilsa visite practicada a los Deatecasontos de POlicla, se pudo apreciar el adelanto alcenzado on la labor de civiliseoion do los ladigenax por los bochos siguientes que con la mayor oatiaracaion pusanos intortar:

En al puoblo de Tupile se be organizado un club do membrot do le juventud indigenes qu lleve por titulo "Club CLviliza-

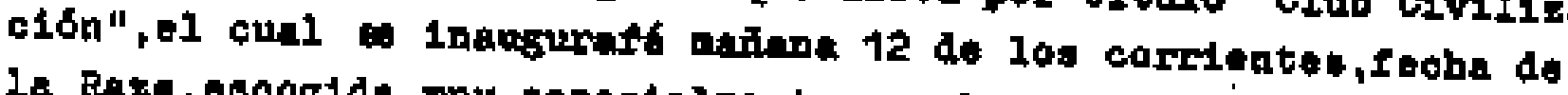

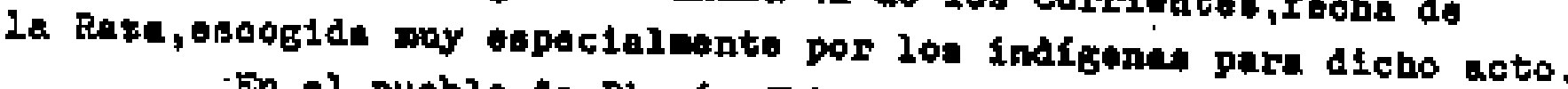

En ol puoblo do Pleyón Ghico wo llovo a cabo iguelmento, - 16 del mes pasado, la tpauguración do otro club organizado por $2 \mathrm{~s}$ juvantud y llave por titulo "Club Progrwo".

In estos doe pueblos te he llovado la elinesctón do las

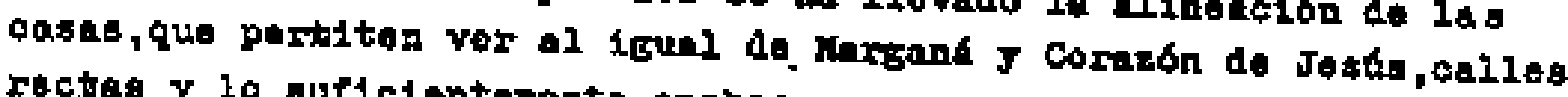

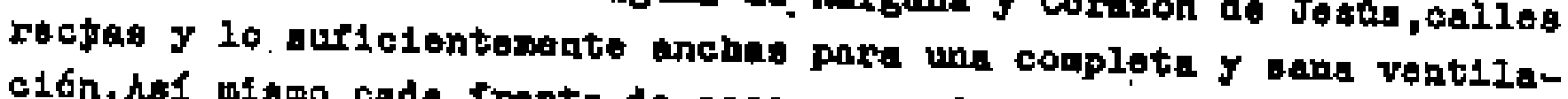

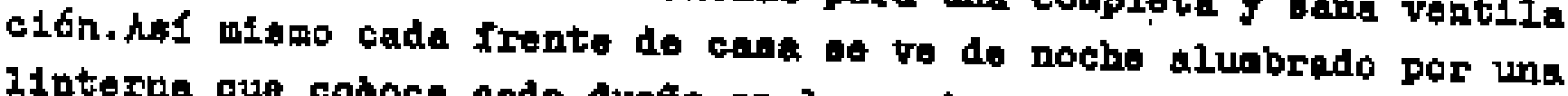

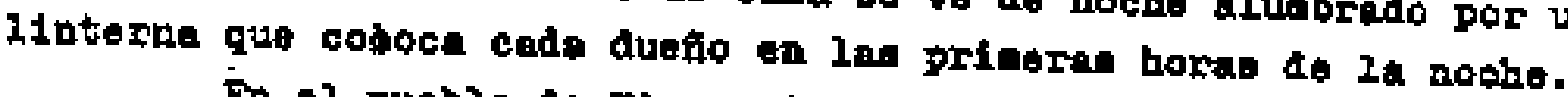

in el pueblo at Migre, si bien no se be oatablecido ningln oeatro, so nota la influenaia que von adquirtendo los niombros da. In

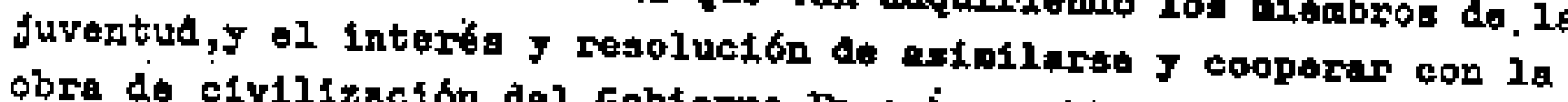
obra do civilización del tobierno. B este pueblo turinon la oportu-

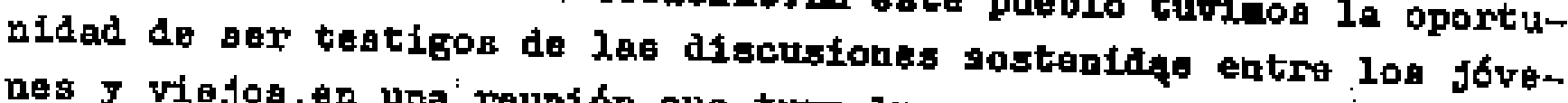
nes $z$ viejoa, tn una reunión que two lngar a nuestra l2ejade, siendo notoria ia preponderencia de los primeros sobre los últimos,y es mug probable que a principio de uño estó instalado el club en dicho pusblo.

in Karganá y Corazón đe Jesús están casi terminados los edificlog donde tuncionsrón centroa abálogos a los anteriores y es prou bablo tanbién que el dia 28 de íovieabre proxino, fecba de nuestra primera independencia $;$ del natalicio de su Excedencia Docobr 2el1onrio porran, lireglaente do la flepública, se inauguraré el centro del primero de estos pueblos.

En Río axúsar so ha crganizedo el pertido de la juventud, el cual cuente ga con 72 mienbros gue han comenzado a construir ia caaa pura el funcionariento del club, no obstante la tenez oposición 
do los rejos, eneofgos do la civilizecion y de lag asenazas do que vieren aiondo objeto.

Aprovecho la pportunidad para edjutiorlo, cono nuestre, ung inviteción que be dirigido a este Dospacho ol Fronidente del club de Tupile.

Todos eatoa centros tienen por objeto in celobractón do baf-

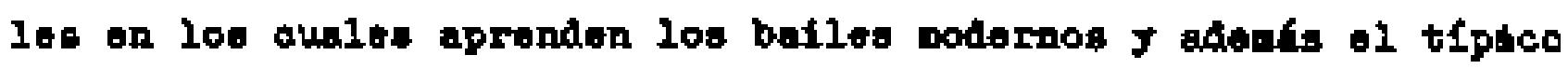
nactonal (tamborto);al alsmo tieapo ol Prosidente do olloa alre de órgeno de conunicecion entre lae autoridides $y$ habitarton del lugar para el efecto de $2 a$ trasolskón $\mathrm{y}$ cuppliniento de la brdeneo que te ingerten con el IIn de atplier y aflanzar las modidne de alvilfación nue no viened adoptendo.

En nueatro proxino lafores careses a conucer ol atado do coene en los dentes buebtos que no honos valtado,J esperando o1s la opinion dol teños secrotario sobre ostan bechos, as auscribo wuy ntento y 8.s.,

Andro: Hofice

Intendente de San Blas ,-

\section{A1 Syffor}

Eecretario Ae Eatado en cl Despecho de G.J Justicia

Fhtalta, -

copite. 


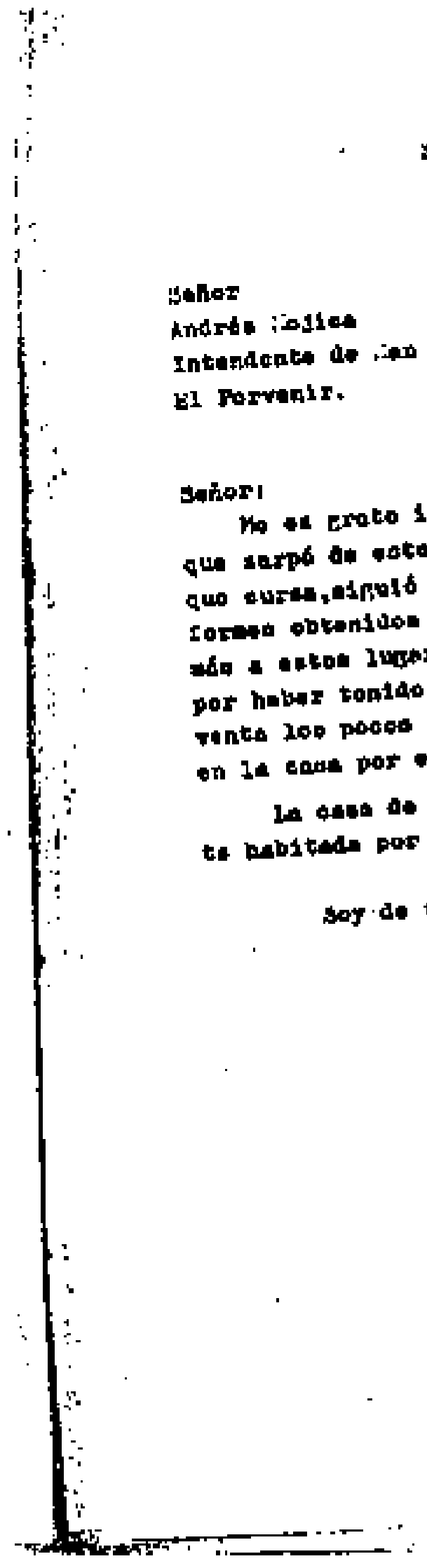

\subsection{3\%? \\ XCIV abeth minimann 204 ;}

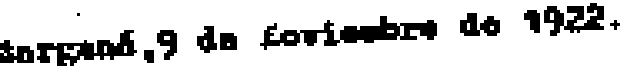

Wher

Andrato iestes

Intugdente of ing slat,

gl porvanis.

in

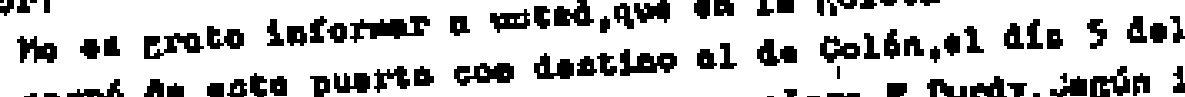

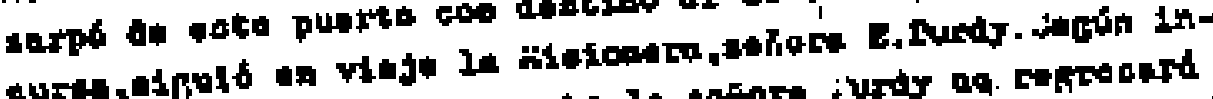

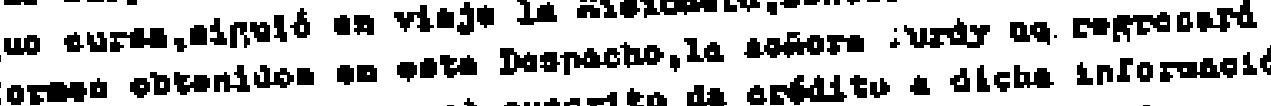

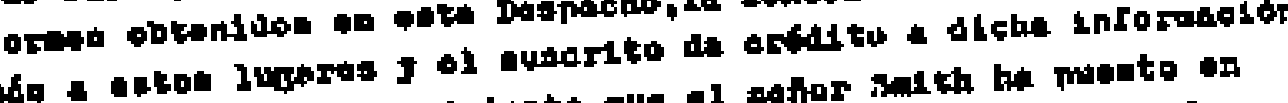

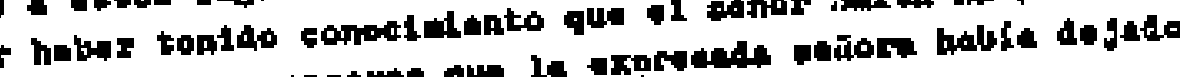

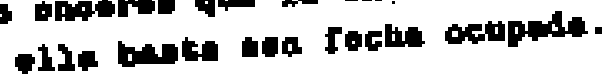

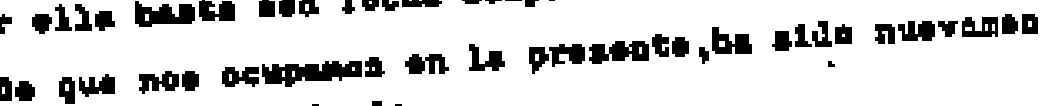

un Garcida D.

Jera del postectento.

V. KD. n. 270. 
$151-3$.

\section{Mangana $\mathrm{XCV}$ \\ 3 de Dleledbre de 1922.}

señor Secretario:

portadores señores Etantsiao G.ISpee y Allalo Igla-

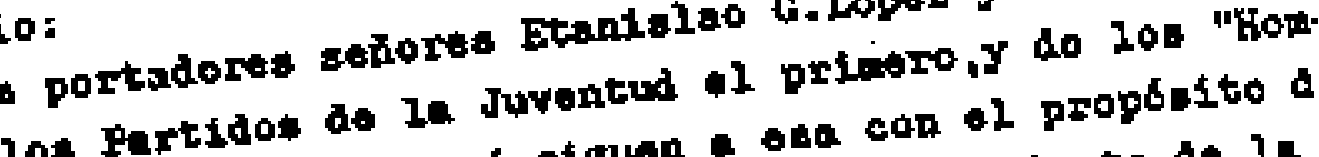

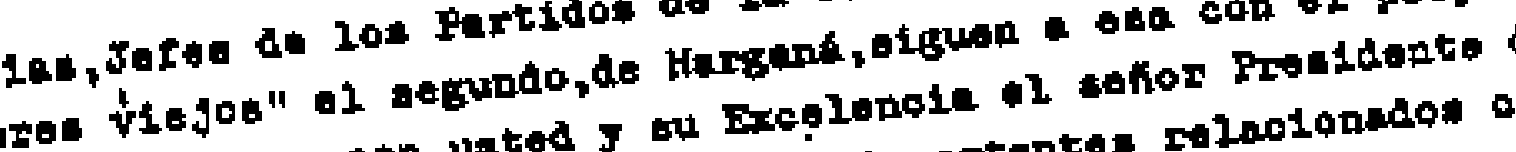

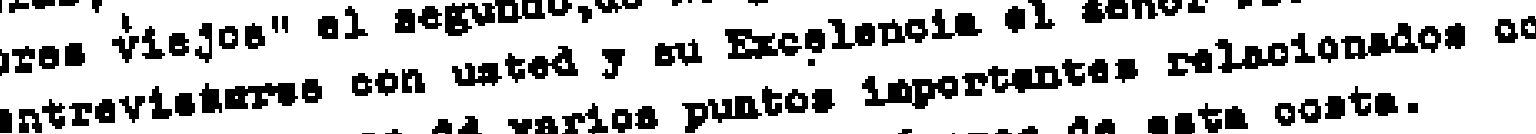
Bepublica, acerce da varios puntos alvilizection on les poblectonat

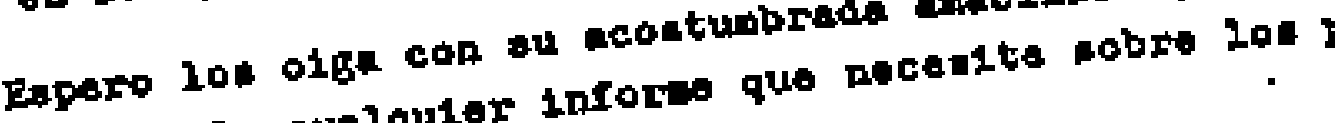
pFonto a audinitiarle cuelquier inforto quo toa que trater.

Soy del gahor secretario muy etanto y B.S.,

\section{Andrts tajices}

Intenderte de San Blas.-

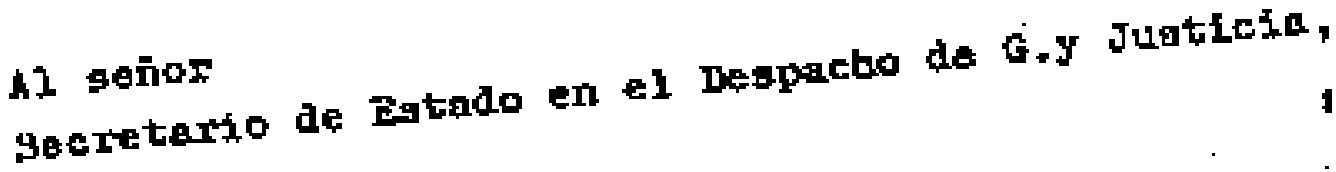

Panana.-

V. RD, n. 274 . 


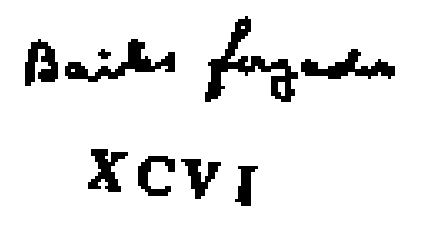

inargand, 18 de melambre de 1922

Sottor

Mntro Kojtoa

Interdente do gan blos

Ex IORVhaIJ.

\section{Detlor:-}

Faxa on aprobación as as lo eatima convoniente, tengo a bien adr

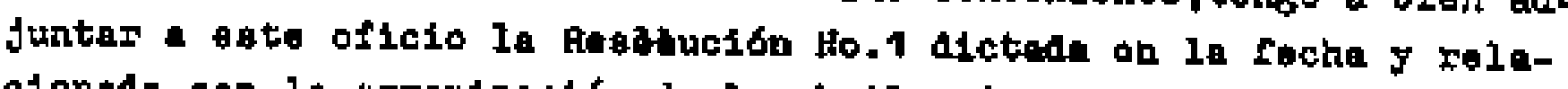

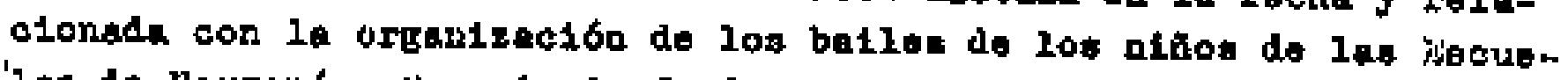
'Ias de bargata $y$ corazon de Jeeba.

For creerlo conveniente para la buena areba de le Inetrucolon d. dichos nitios mo he visto on el caso de tonar eata medias, puss los menciongdos bajles que sin excepción se dan todas lat noched bata muj taxle creo so son mug necosariog a estog ninos y s1 prejudican notablemente ous estulios.

Con sentilnilentos de consideración, soj de usted auy atento $g$ 4.s.

Foracio fónder

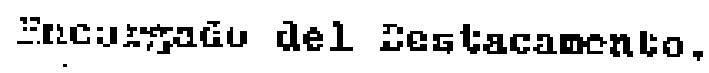

copia.

V. RD. n. 277 . 


\section{CVII}

$N-39$

Numero 1]52-6

PANAMA, 25 de diclembre de 1922

Sekior

Intendente de la Cireunscripción de San BNas

EJ Porwinir

Sehor;

Con el presente oficio devuelvo - Ud. debidamente aprobado. la resulución N' 1 , dicloble por el Jele del Prímer Desiecamento de le Palicia Colonial de ess Circunscripción, por ly aral se diecan medidas tendientes y la urgunizacion de los bailes dados a los educinulos en las Escuelas del Gobierno esublecidas en los pueblas de Nargan't y Corznón de Jesus.

Soy de usied muy atento servidor.

Arfolldes Royo

Trans. del orig. nuec.

V.RD, n. 278 . 
Reces indigener 6-b'.

Bl Porvenir, 8 de Abril 1923.

Sethor secreter10:

Iod Indfgenos Alficio Iglesias y Etanlalao 0.I6pez se d1rigep a oad Capitul con ol 14n do geationar con ol Propidente de la kapública, ol ofrectadeato que para oste aho los fun bocho do

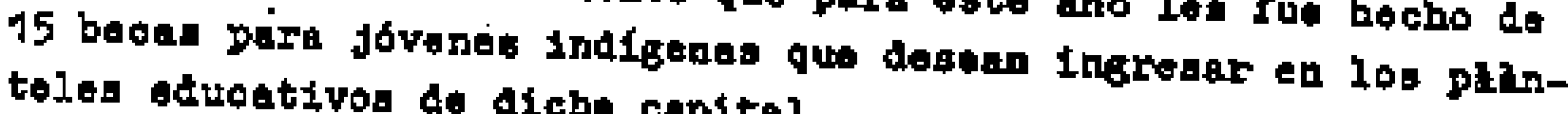
toles oducativor do dichn capitol.

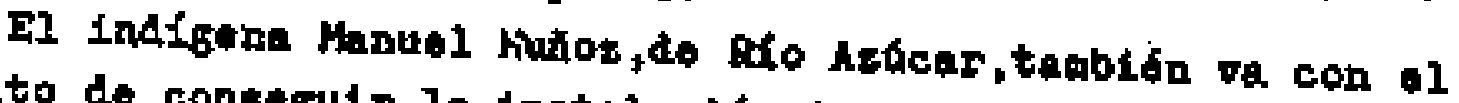
proposito de conseguir la Inatalectón do une, oscuela on ou pueblo,hesta bace pocos weans contrerto do toda obra de civilizaatón y progrego,j siondo voero do arecido ndeero do la juventiud de ose pueblo, ruego al sejor secretario se alrve bestionar con su cologa 4 . Inetrucción Prblica en ol sentido te que anbas mision nes obtengan al fin que desean,pase avenzadiatoo on la civilizacion do esta rogs $16 \mathrm{n}$.

3oy del sefior secretario nuy atentio $y$ s.s.

Andrés ت̈ojica

Intendente de san blas.

Al señor

Becretario de istado en el Despacho de F.y Jutticia I’anadí.

$$
\operatorname{copsa}
$$

v. HD, n. 282 . 


\section{CI X}

\section{Sthor}

Andris Mojich

Intendeate Jefe de la Circonsctipcion de Sin Blas, EL. PORVENIR.

Sehor.

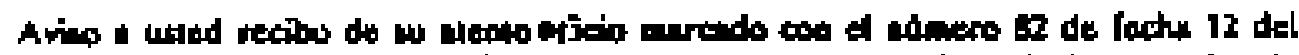

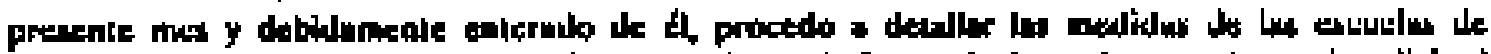

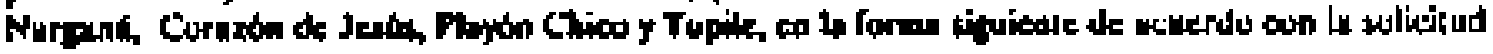
que se me huser.

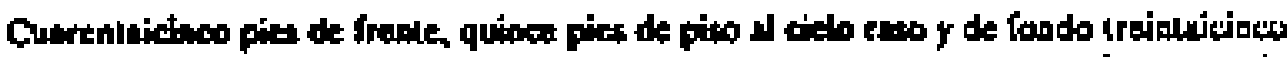

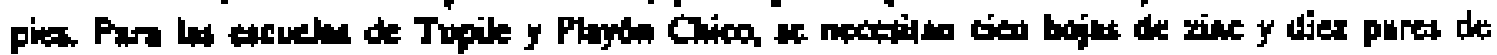

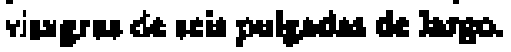

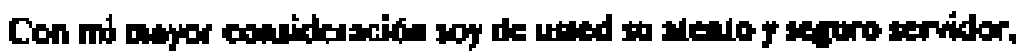

Migun Gortan H.

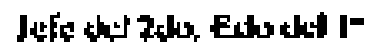

Trans. del orig. Inec.

V.R D. n. 284 
80210

Húnero 232-B!

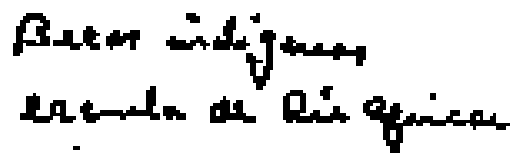

Panand, Abril 20 do :1923.

\section{Sořon}

Intendents to le clrcunscripeion at san Bles.

Promente,

\section{gefor:}

En respuenta a su oficio fechado ol 8 de lon corrientea, distinguido cọn el mbinoro 6-b,inforao a usted quo on conseja de Gabinete se aordo adjudicar 15 becas para jovenes indicjenge qua han do Ingresar on planteles educativos de esta capitaz. Ba cuapto a Ia instelación de una escuela en fío Arúcar, ne he dirigido en esta fecha al seitor Secretario de Instrucción Pablica en tal sentico,a fin de ver si es posible conplacer en sus apiraciones a log moradores del pueblo referido.

Soy de usted muy atento servidor,

R.Chism. 
Námero l09.

\section{Sthor}

Jefe del ler Deglacomento.

Nargená.-

\section{Sehor:}

El poriedor del presenle oficia, sefor Victar M. Siln, ha sido nombrado Meestro de Escuela en Rlo Arofer, y como scordamos et este Despucho, permanecerá en ese desracomenra, donde usled le procurará alojamiento y alimentación hasta tanto sea el momento de sezuir al lugar de su destino.

Slrvase enviar la lissa de indigenas de Rlo Azucar que deben Ser nombrados Agenles Escolares, pues solo se espera dichn lisus pury diclar te] Decrelo respectivo y ussladarine al referido lugar con el tan de instalar los emplesdos que deben luncionar alli, to cual pretendo hacer la semena proxima.

Soy de usied muy alento y seguro servidor.

Andrés Mojtical

Inkendenie de San Blas

Trans. de la cop. nuec.

V. RD, th. 287 . 
Número 88

\section{Sethor}

NARGANA, 28 de Abril de 1973.

\section{Andrts Mojles}

Intendente de Son Blas '.

\section{EL PORVENIR.}

Sotor:

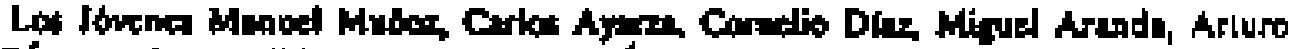

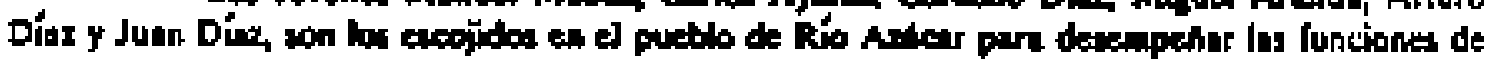

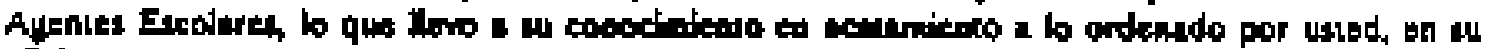

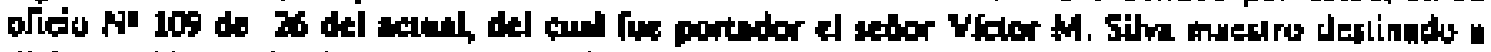

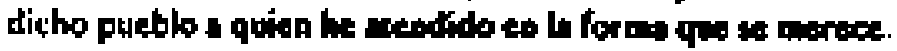

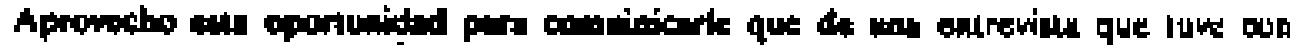

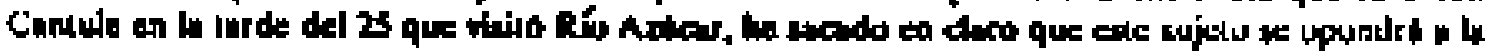

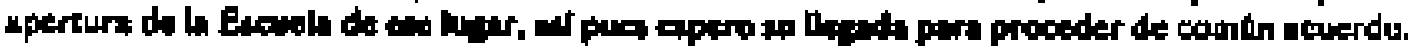

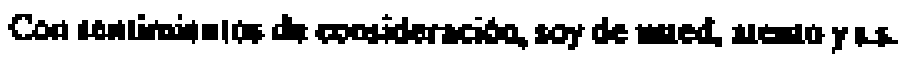

Horecle Minder

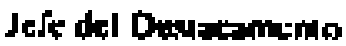

Trans. del arig. mec.

V , RD, n. $28 \mathrm{~s}$. 


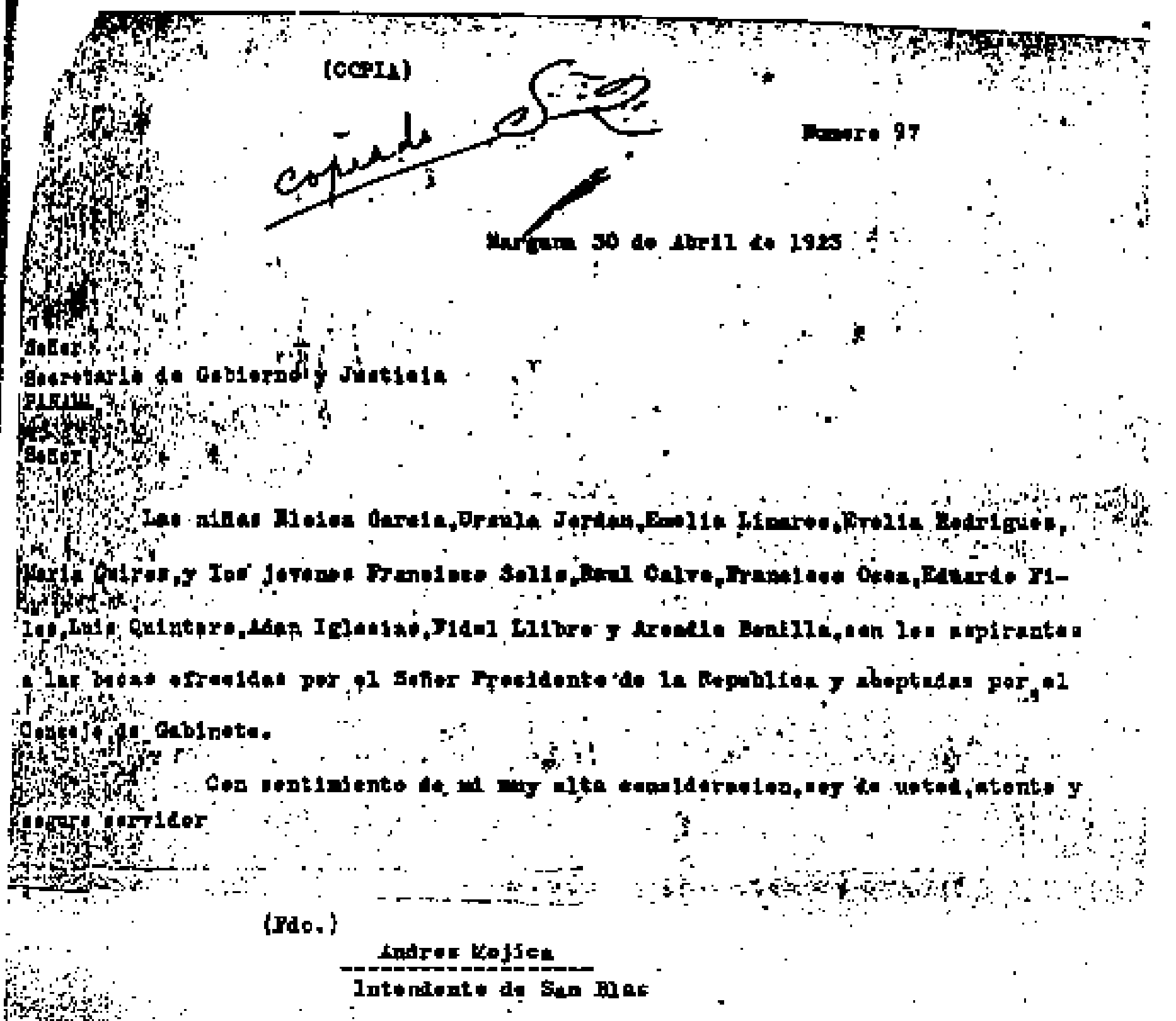

10

m

th

sis

0

,

ris 


\section{CIV}

$\mathbf{N} \mathbf{4 0}$

Númeró 257-b

PANAMA, 10 de Abrl de 1923.

Srior

Intandente de In Circenscripaion de San Blas,

El Porvenitir.

\section{Sebor:}

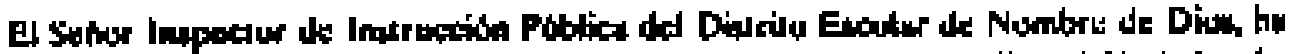

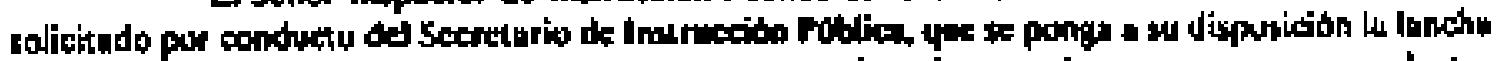

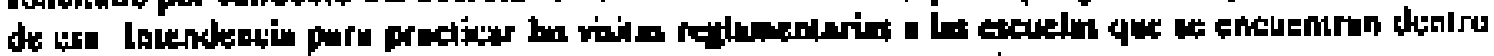

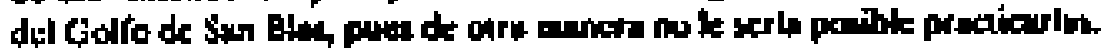

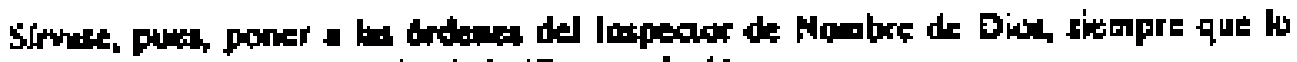

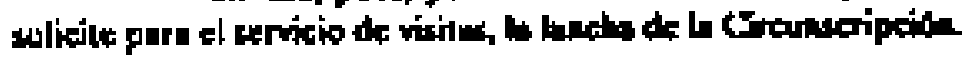

Soy de uned mur wento servidor.

(lisma ilegibus)

Trans. del orig, mec.

V. AD. n. 290 . 
CV

$\mathrm{N}-44$

Nómero 95

NARGANA, 30 de Abrit de 1923

\section{Sehor}

Uboldo Barria

Seeretario Encurpado del Despacho

El Porvenlr.

\section{Sehor:}

Sirvese de prdemy uns comisión para copturar il indigena de nombre Sirt Boy, residtente en el pueblo de Chuqumbili y deienerto con las seguridades del cuso hasta inj regreso.

Ast raismo se sarvirs de comupicar a It Secretarla de Gobierno y Justicia la necesidad que be tenido de nombrar los indlgenas del pueblo de Río Azucar sehores: Manuel Muboe Carlos Ayarza, Cornelio Diaz, Migued Arundu, Arturo Diax y Juan Diaz, Agentes de Policia Fscolar ad hunorem para que les sirvan de ayuda al maesiro como a la policía que quede desiucada alli,

Creame de usied su atento y seguro servidor

Andriss Mojles

intendente de San Blas

Trans, del orig. nice.

V.RD, I. 291 . 
M Forvonir, 2 de fiajo de tajz.

\section{( Señor تecrotarlo:}

El netior Intendento be neguldo a pasar viskte a 200 bestace-

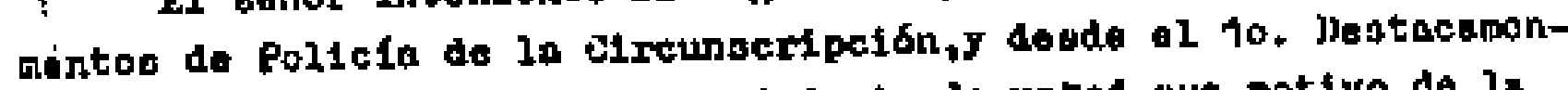
to me reconionda llevar a conbeimiento de uated que motivo de la

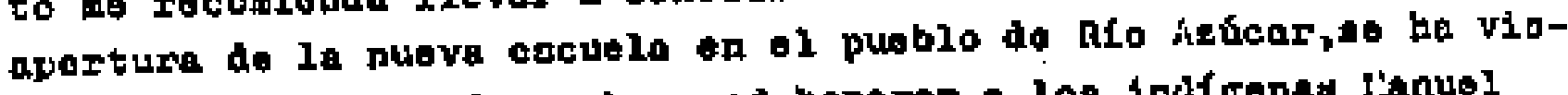
to on la naceoldad de nowbrar admonoren, a log ind geped lanuel

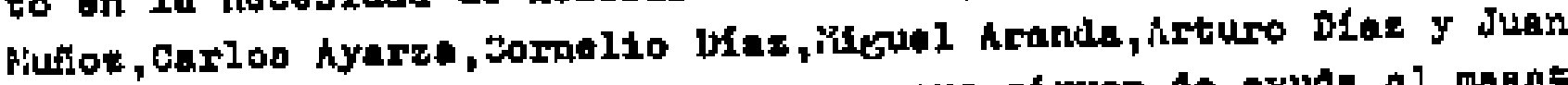

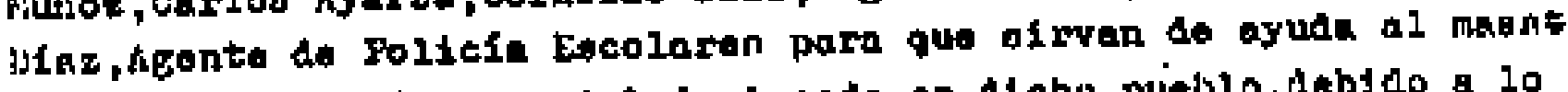

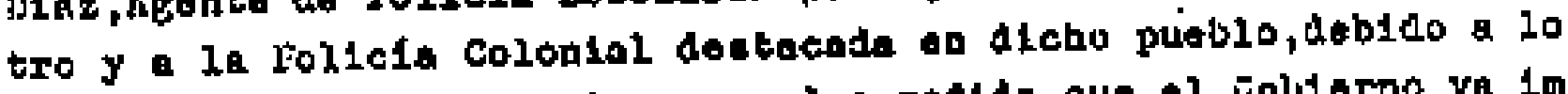
roulucido que va aiendo ol personal a modide que ol voljorno va 1m-

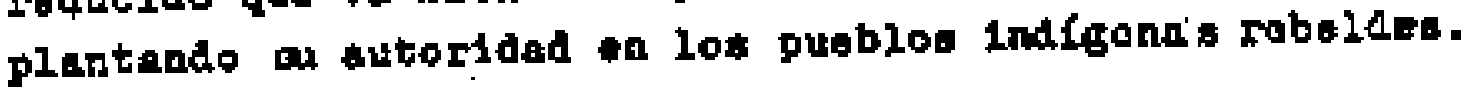

Nprovectio 1a op̣ortuniagd parn exprosar al sorior tobretarlo on estideción y aprecio porsonel conque we suacribs

In my atento $\mathrm{J}$ seguro sarvidor,

Ubaldo Barria

irio. theargado del Degpacho.-

\section{Al seinor}

Jecretarto de Fatado en el Deapacho de G.y Justicla,

l'enadtá. -

$\cos 1 \mathbf{a}^{-}$

V. RD, n. 292 . 


\section{CVII}

Número 1$] 4$

\section{Sefor}

NARGANA, 6 de Mayo de 1923

\section{Ubalda Barrita \\ Srio. Edo. del Despecho EL PORVENIR.}

Setior:

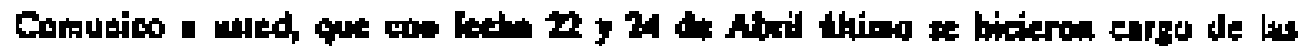

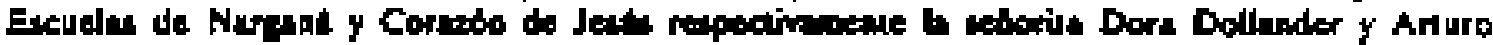

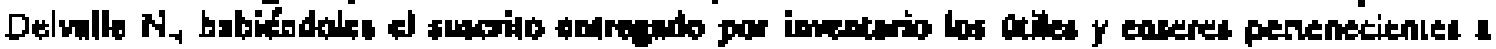
dichate planieles.

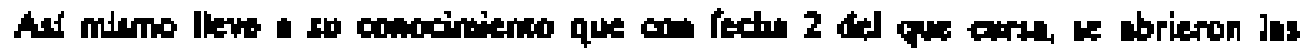

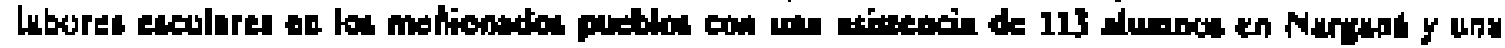

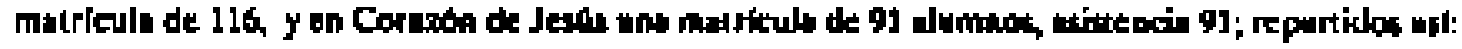

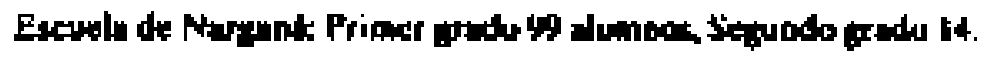

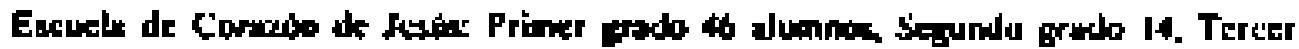
urado 21 y Cluurte Gíndos atuminus.

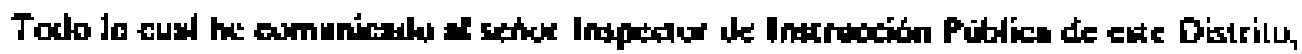

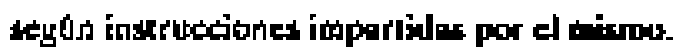

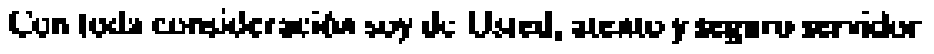

Horucia Mendkz

JeTe dei Destacamenlus.

Trans. del orig. mec.

I.R D, n. 295 . 


\section{I I I}

Nómero II9

NARCANA, 9 de Mayo de 1923.

Sehor

Lbaldo Barifo

Sria. Eda. del Despacho

EL. PORYENIR.

\section{Sehor:}

Placerne llevar a su conotimienio, que con lecha 7 del que eutst, se comenzarun las burees tscolares en el puseblo de Río Azicar, con una asjsienciu de 13 aluminos, e iguld número de malricula pero espero que este número alumentute a medida que los indios vean el beneficio que trac consigo la Escuelw.

Con loda conside ración soy de usied atenta y seguro servidar.

Hortcio Mender

Jefe del Destacamenio

Trans. del orig. mec. 
Nuimero 123

\section{Sefior}

NARGANA, II de Mnyo de 1923

Ubalds Burris

Srlo. Eda de] Despacko

EL POR VENIR,

\section{Senor:}

La sehora Ant R. de Trevis, maestra det $1^{0}$ y $2^{\circ}$ grado de la Escuela de Corazón de Jesús, se presen1ó este Despacho el dí 27 de Abril ôltimo y dió cortienzo u sus labores escoiares el dia 2 del que curst. de dar a esa Jefatura.

Dejo asl subsanada la omisión de este dato que invotunimriamente dejé servidor

Con sentimienlos de mi considerución, soy de usced, atento y seguro

Horacio Méndez

Jele de] Deslaçamento

Trans. del orig. mec.

V.R D, N. 297 . 


\section{CX atrouen}

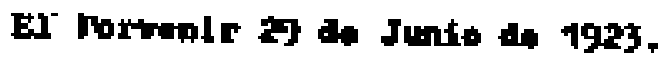

Moilor inerotarlo:

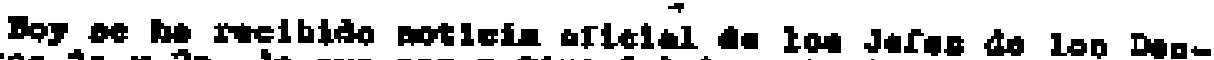

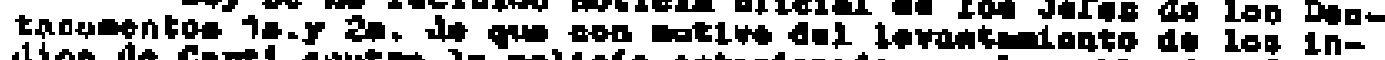

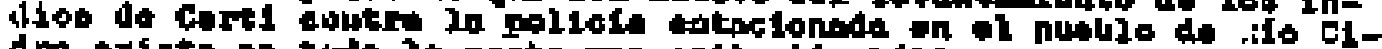

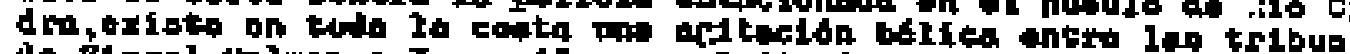

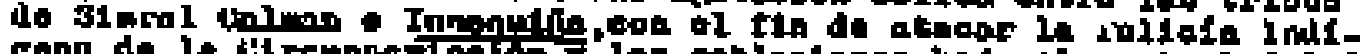

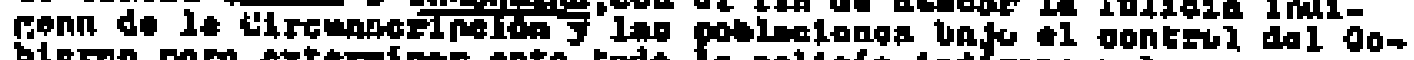

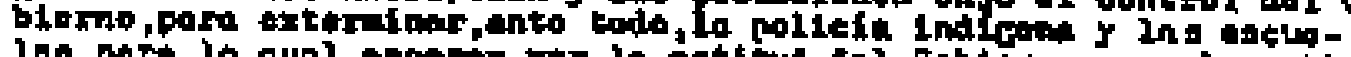

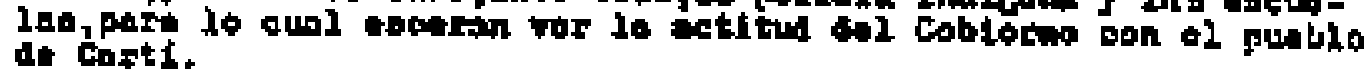

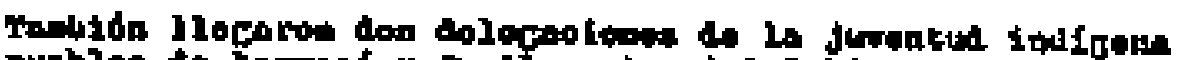

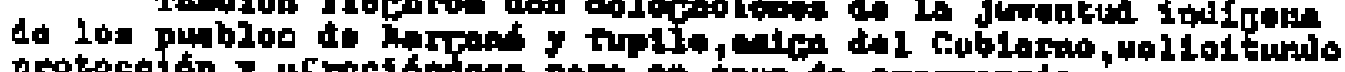

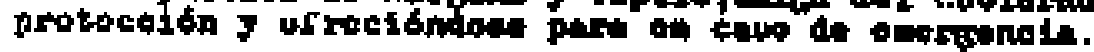

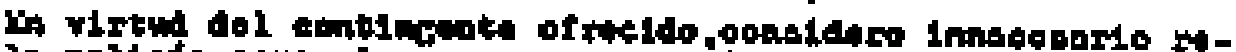

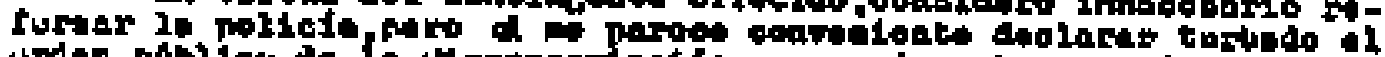

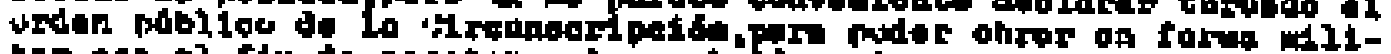

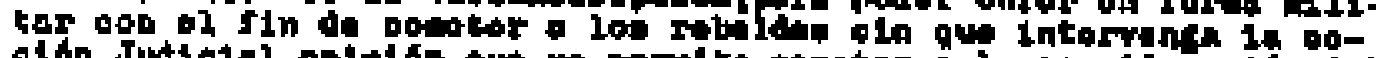

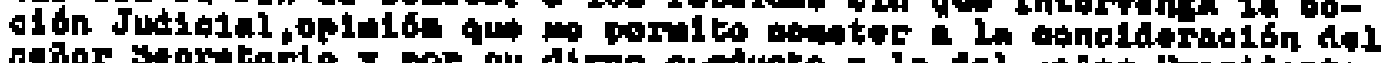

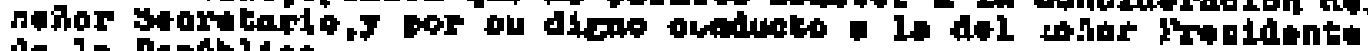
in In Repbiles.

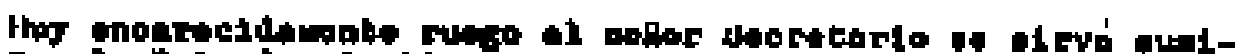

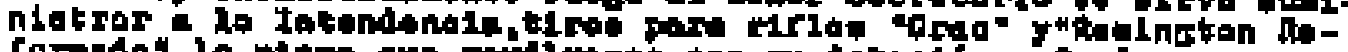

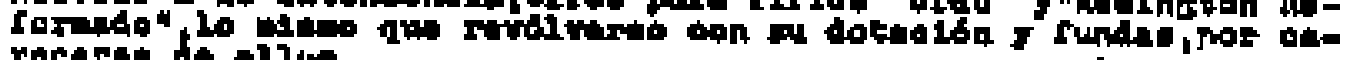
rectest di tlive.

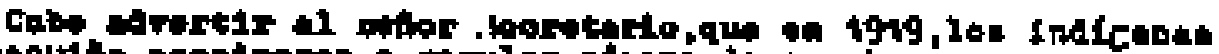

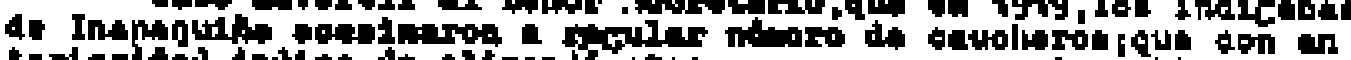

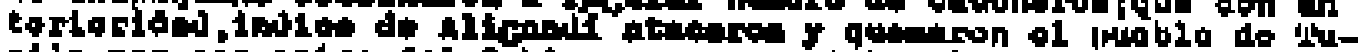

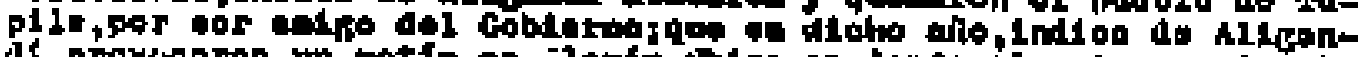

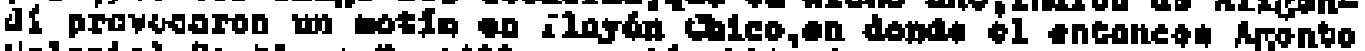

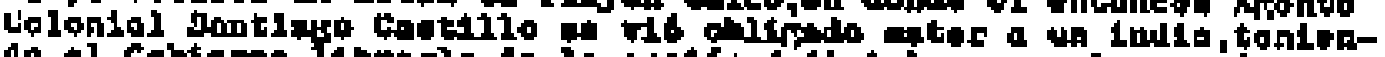

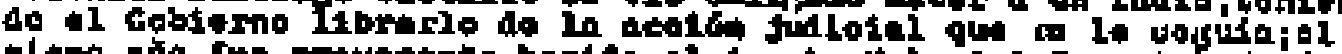

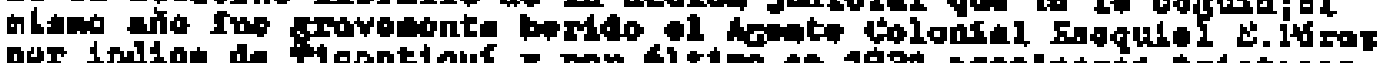

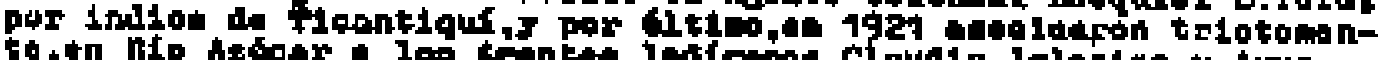

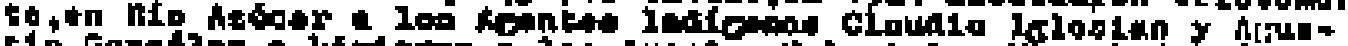

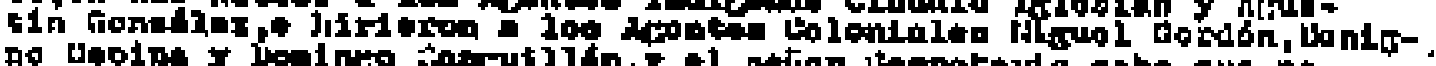

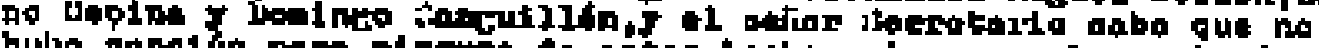

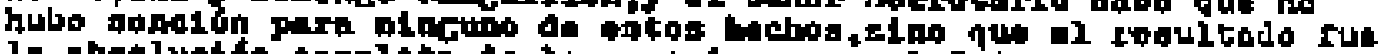

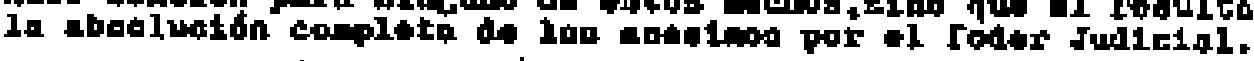

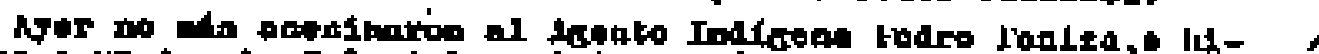

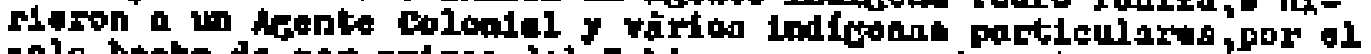

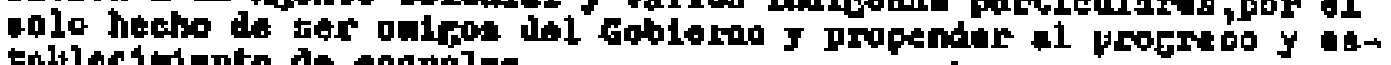

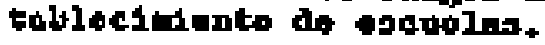

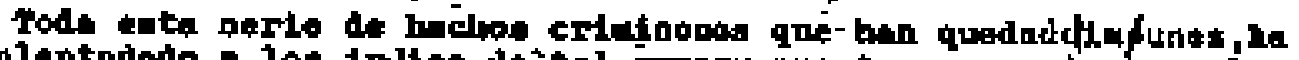

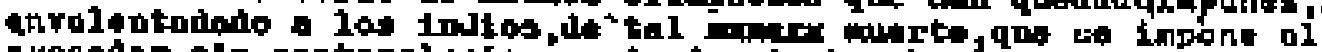

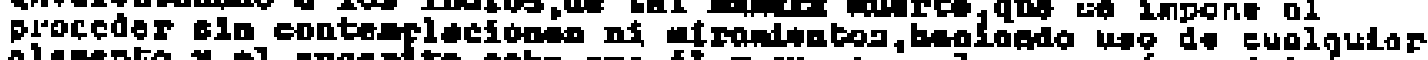

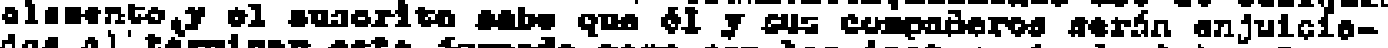

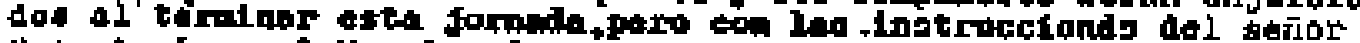

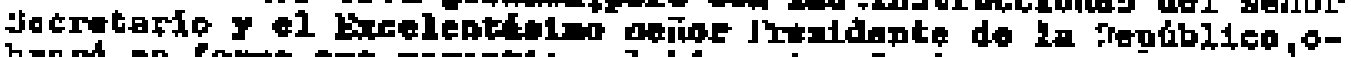

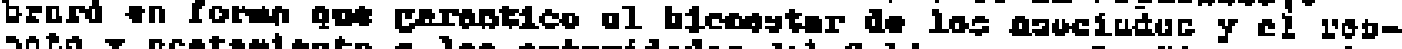

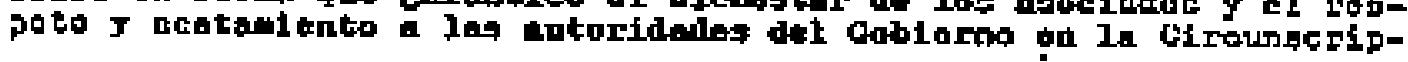




\section{1 (1)} P. atoming

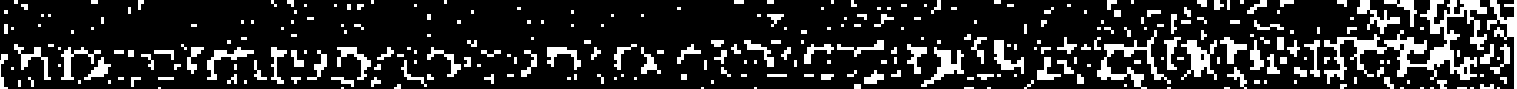

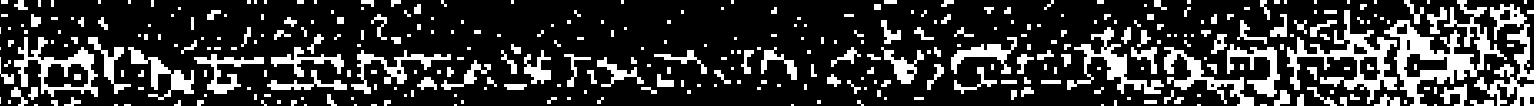

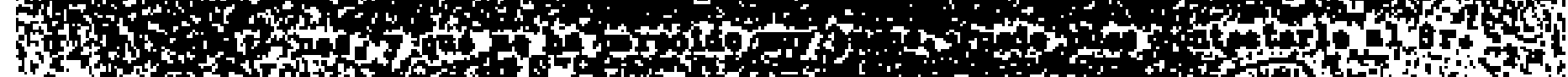

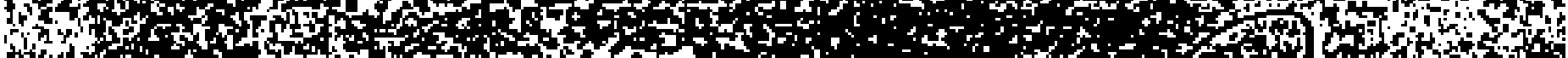

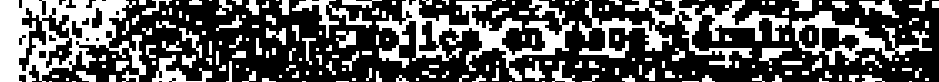
(5)

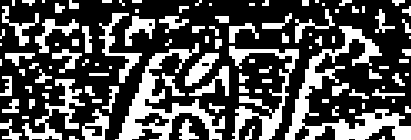

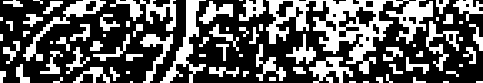

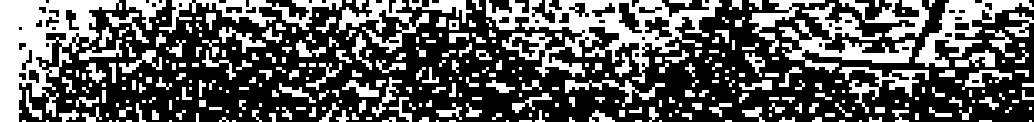

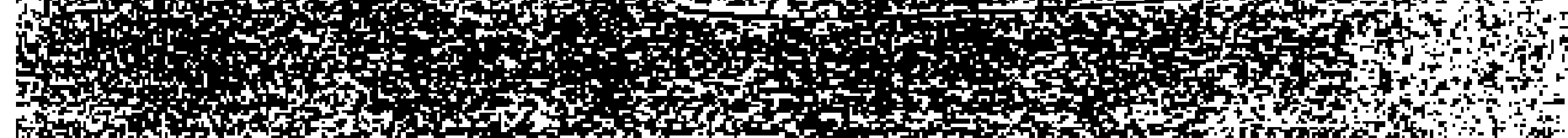

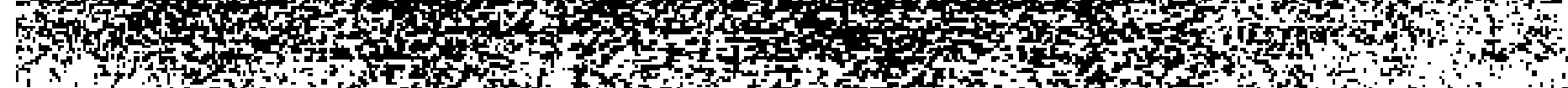
19.

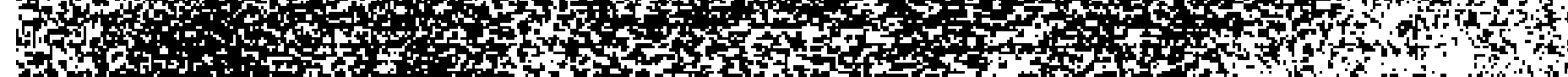

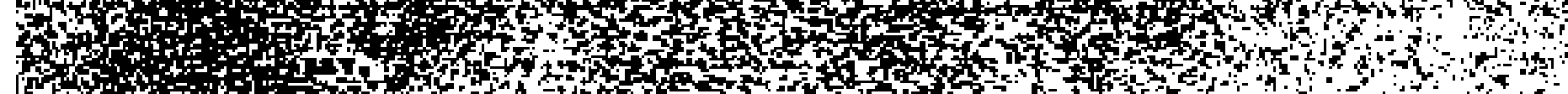

$$
\text { H. }
$$




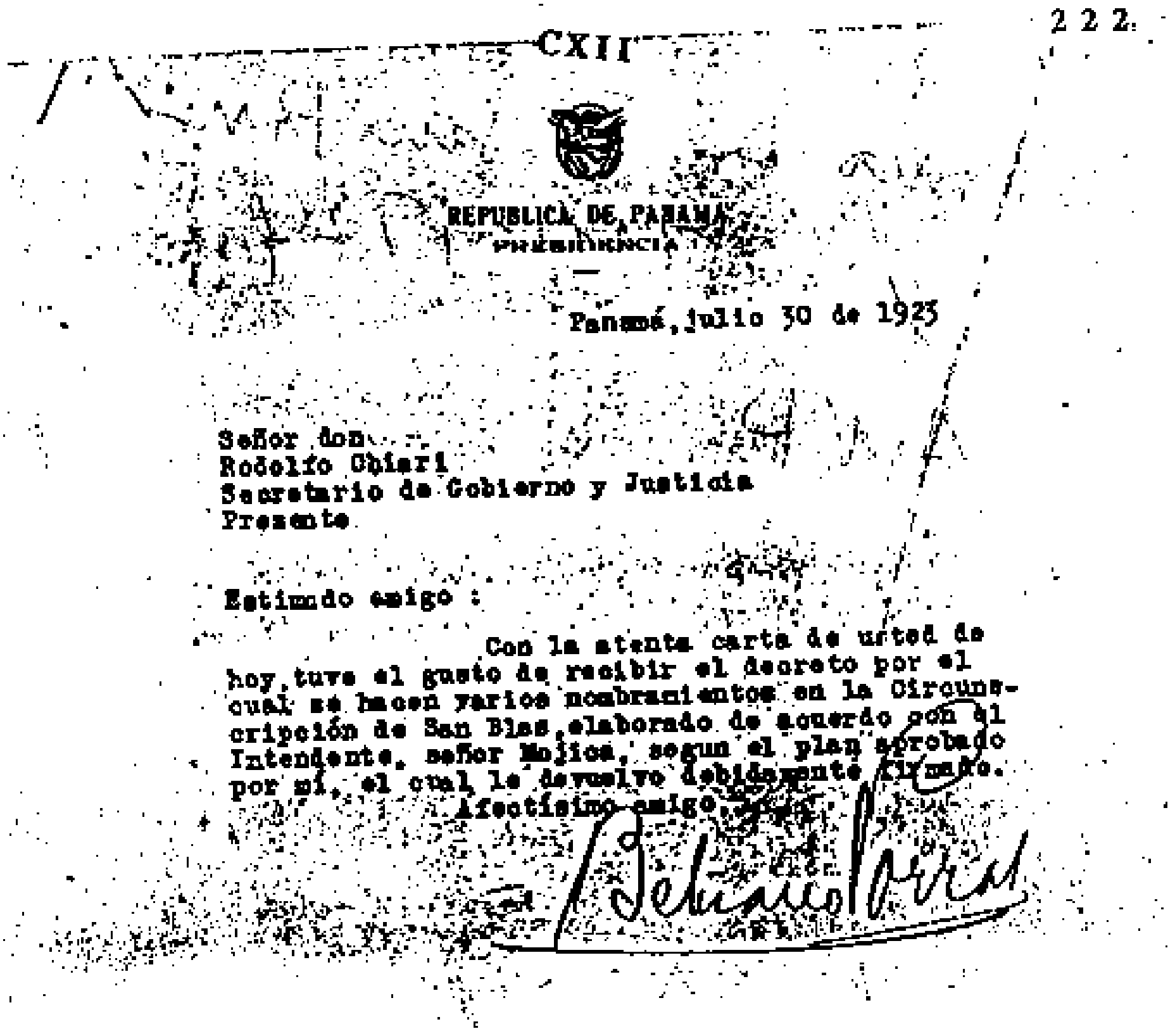

sonor dob to

Sototerio do Goblerio y Juatlate Presente

Rotimdo asigo

Con Ie etiente certio de witod do hoy, tare 2 gaato at reokbr el georoto por ol

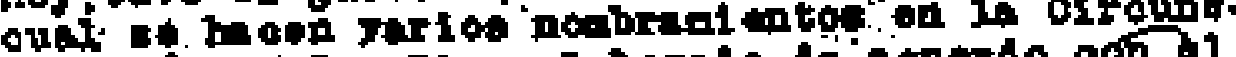

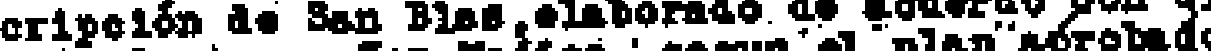




\section{CXIII}

$\mathrm{N}+54$

Número 284

NARGANA, 15 de Sepdiengre de 197J.

\section{Señor}

Ubaldo Bnrrits

Secretario E. del Detpacho

Q. Porvenlr.

Serkor:

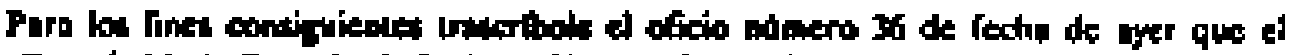

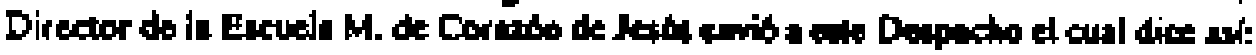

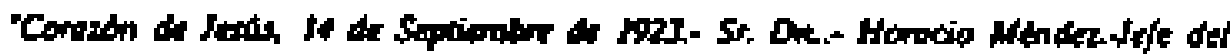

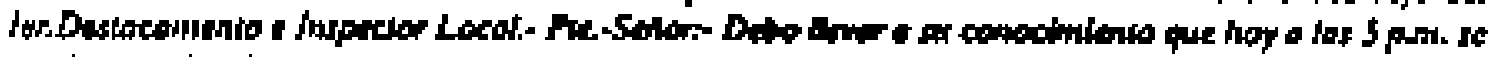

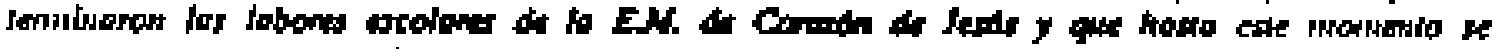

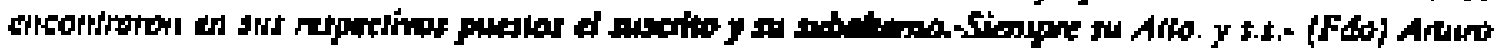

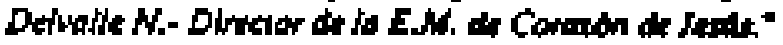

De usted su ntento seguro secvidor.

Morucin Metates

Jefe del Destacamenta.

Trans. del orig. mec.

V.RD, n, 309 . 


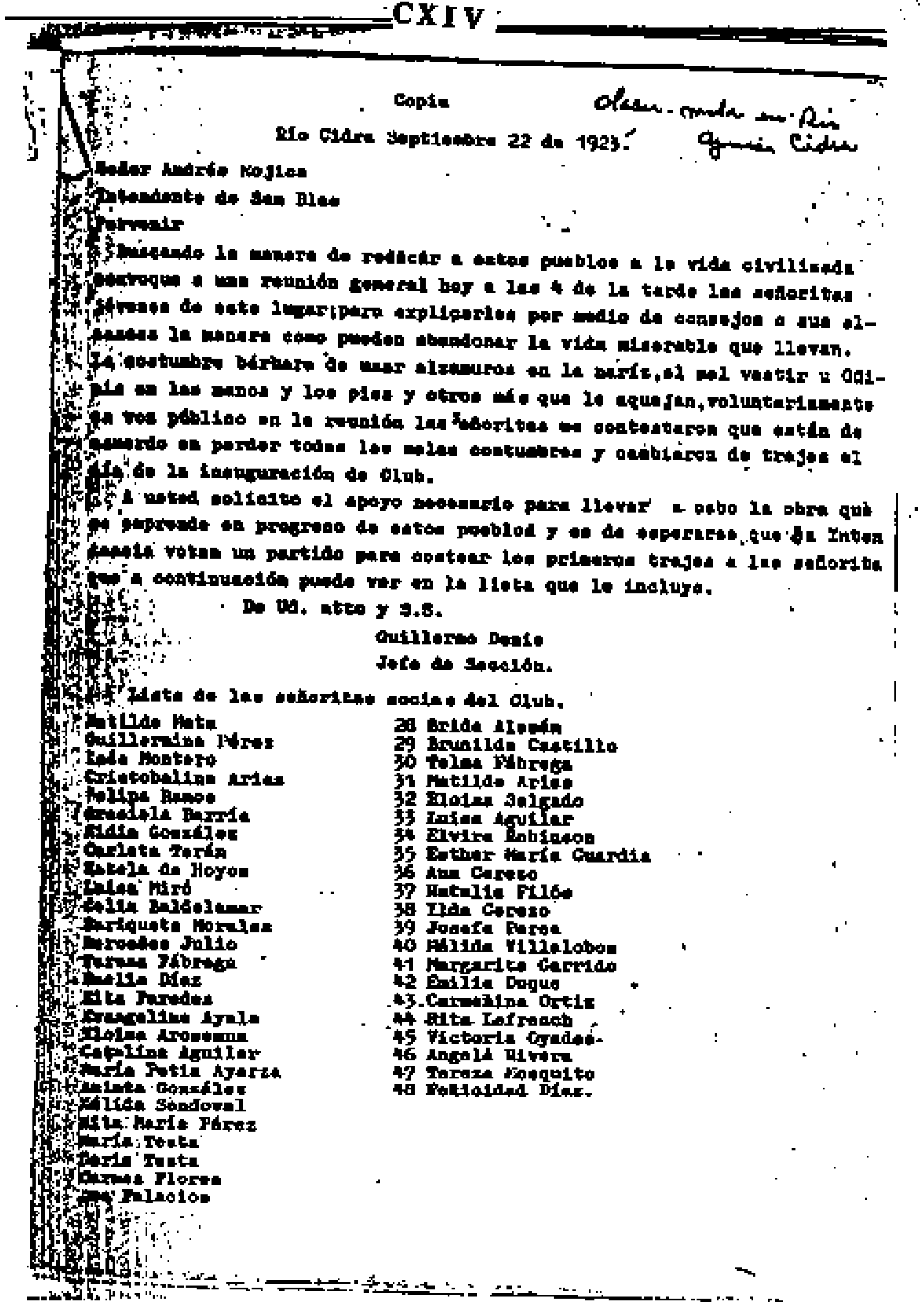

V. RD, n. 310 . 


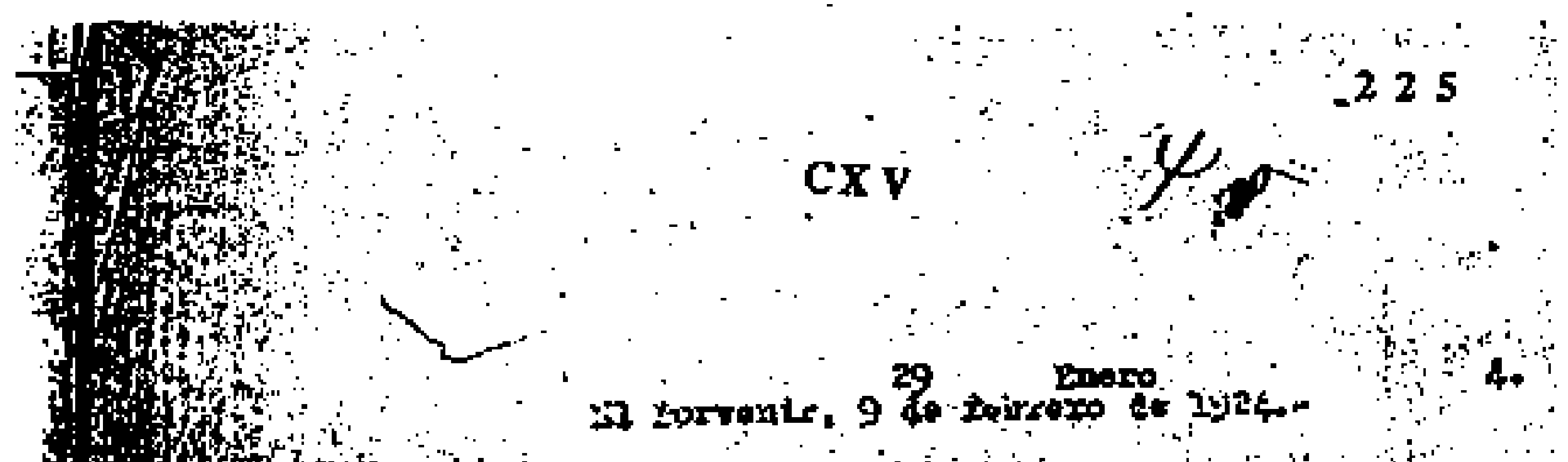

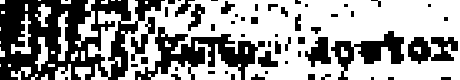

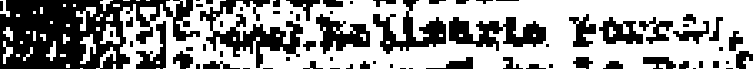

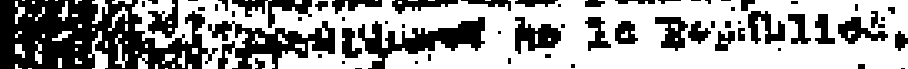

15

is

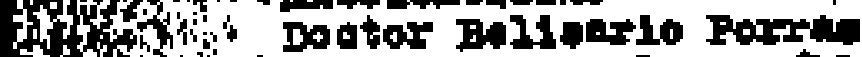

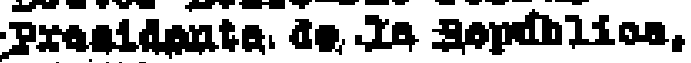

74istra

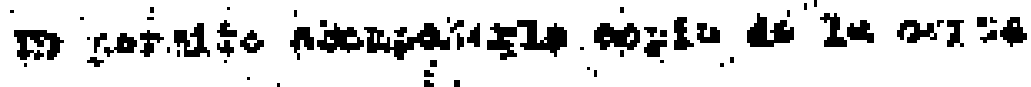
i. .

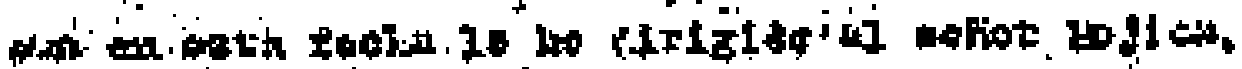
Iatinato Dootor:

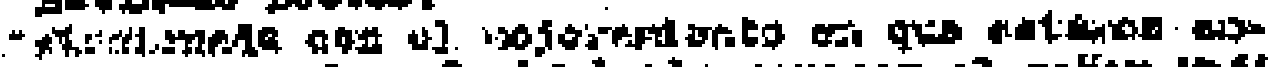

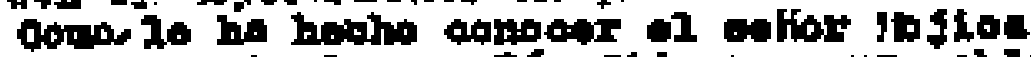

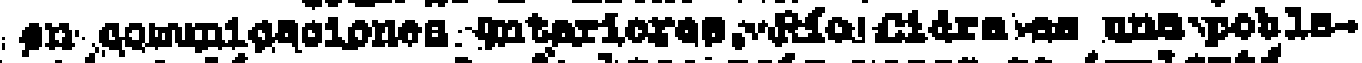

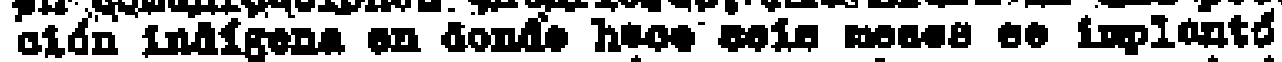

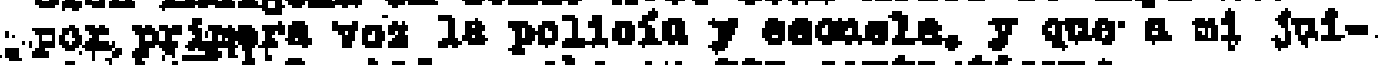

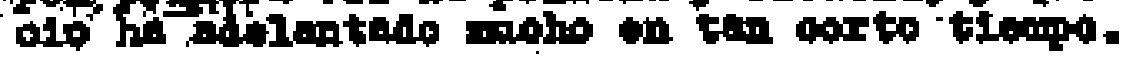

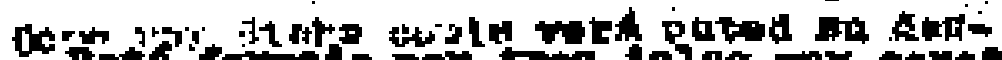

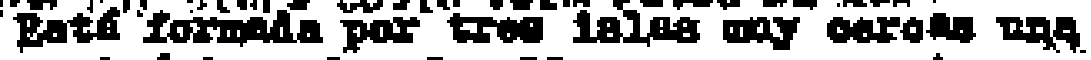

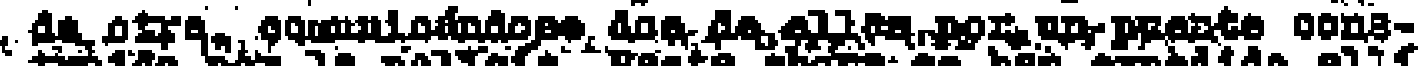

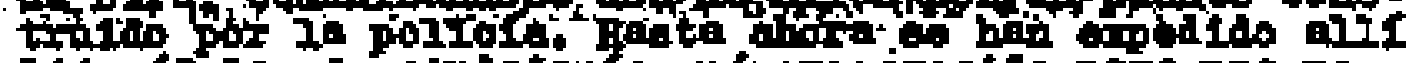

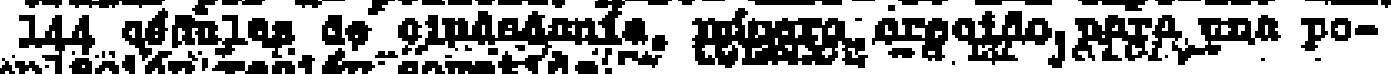

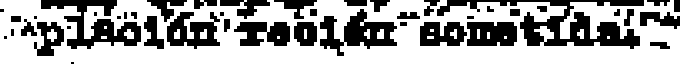

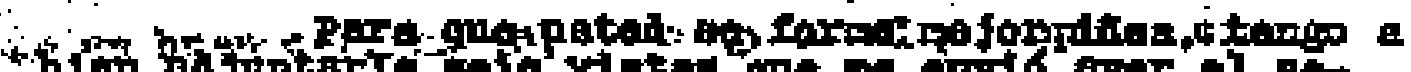

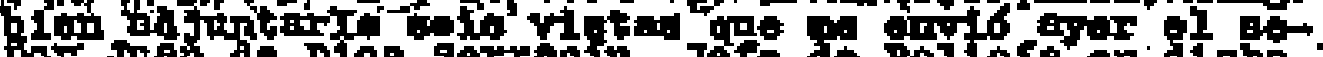

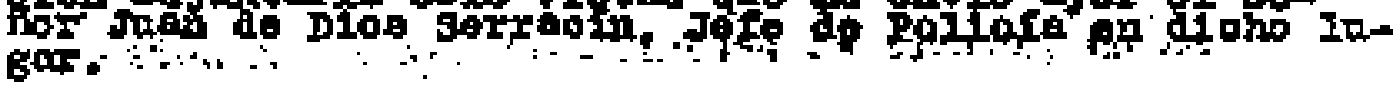

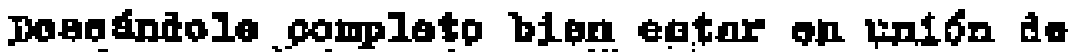

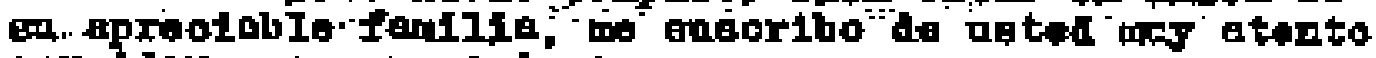

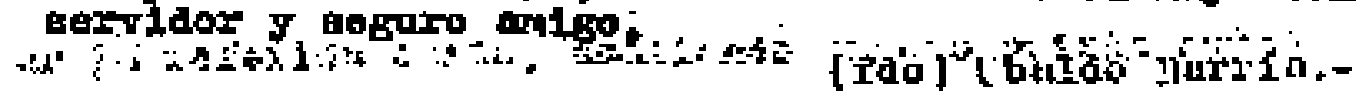

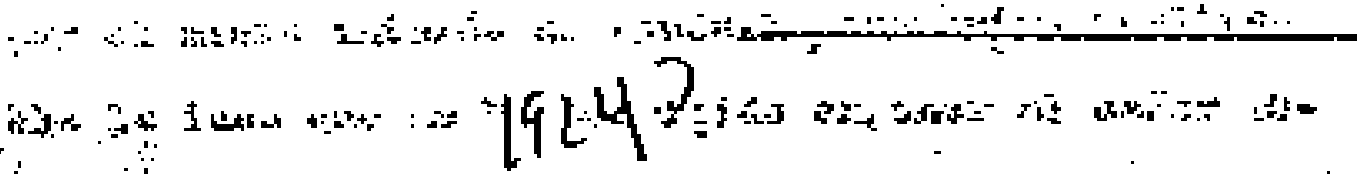
thatin:

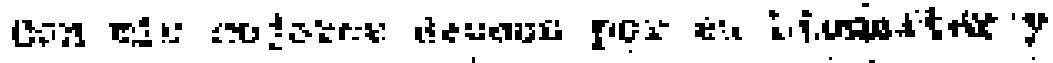

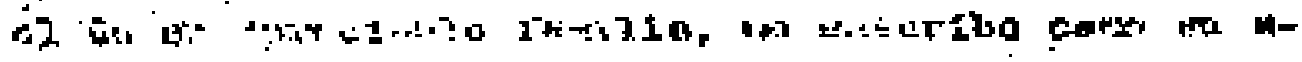

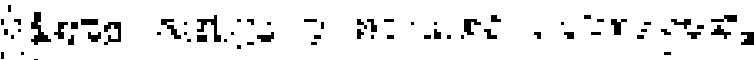

$$
\text { V. RD, D. } 323 \text {. }
$$




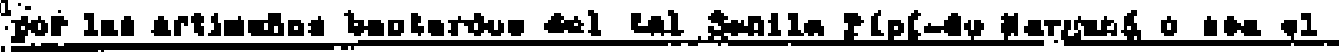

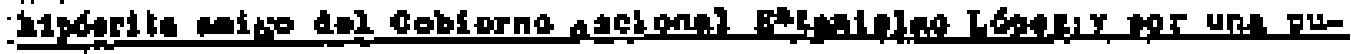

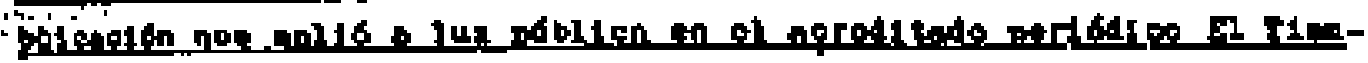

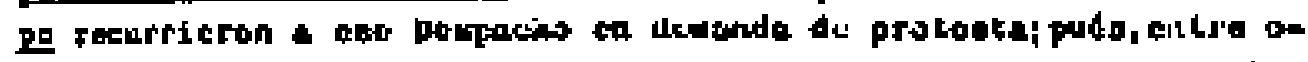

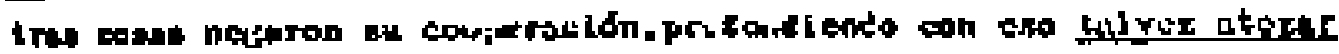

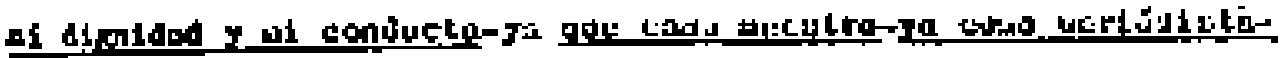

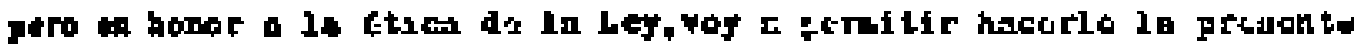

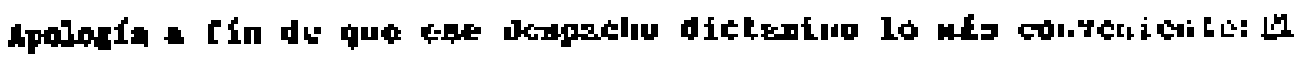

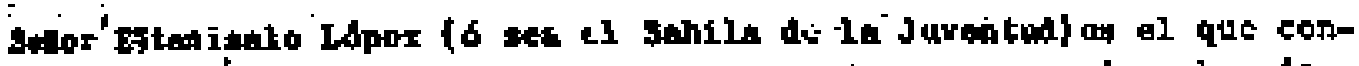

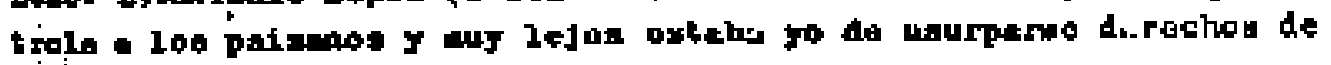

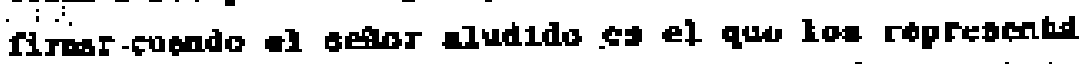

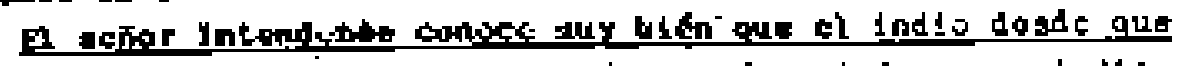

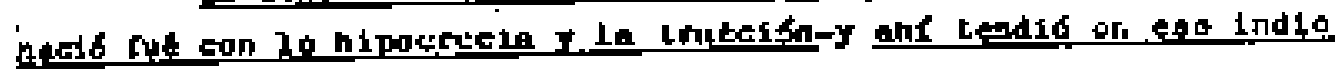

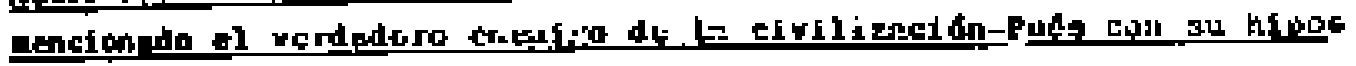

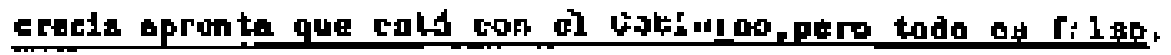


:

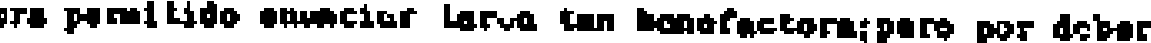

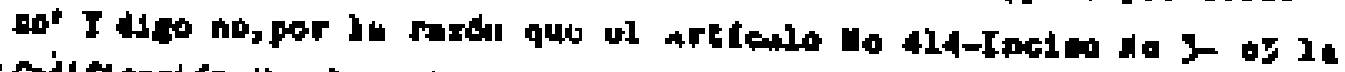

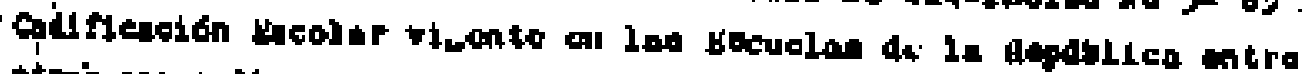

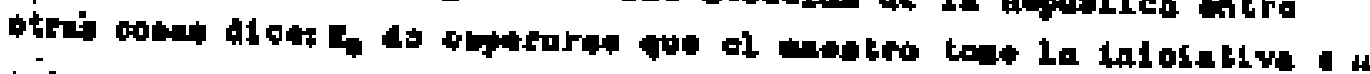

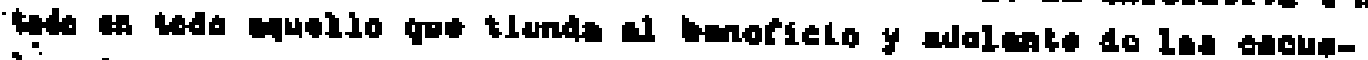

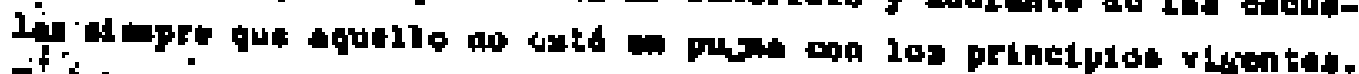

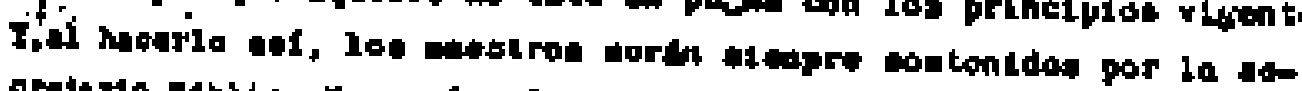

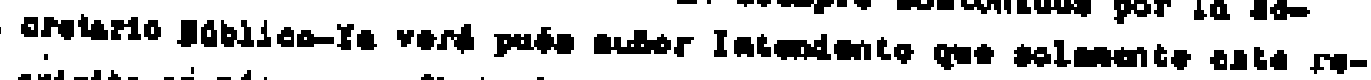

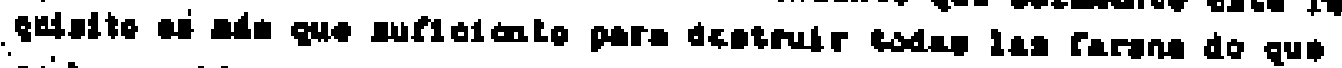

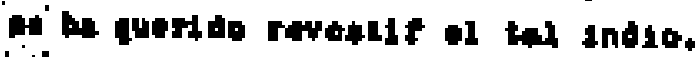
a

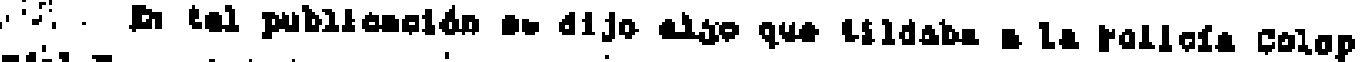

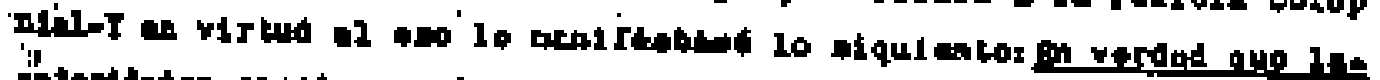

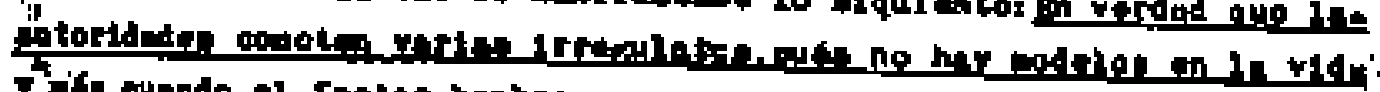

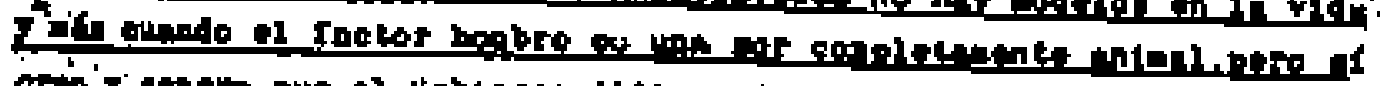

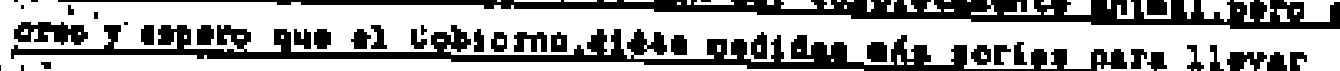

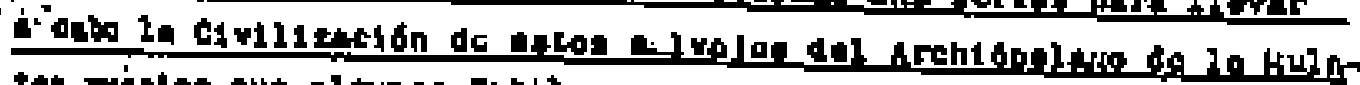

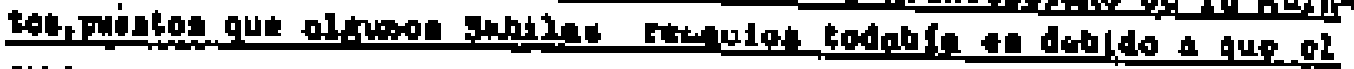

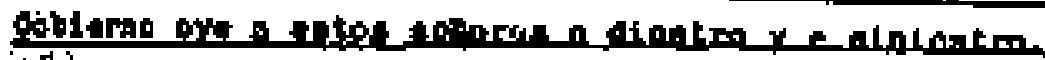

-j'

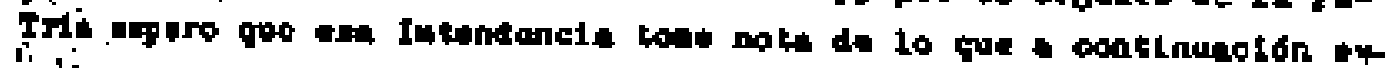

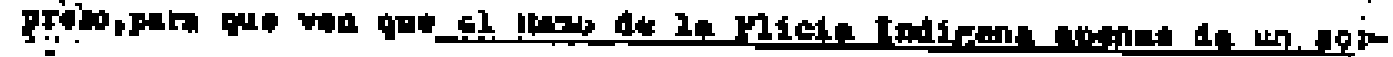

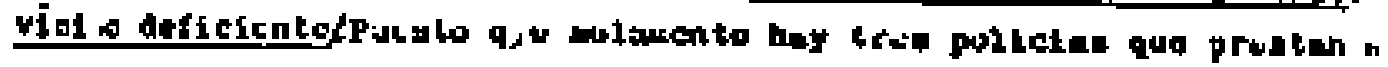

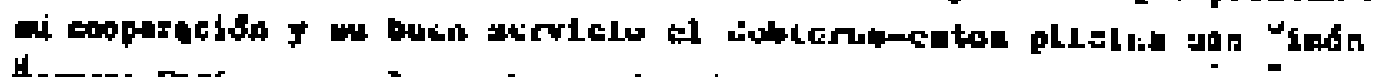

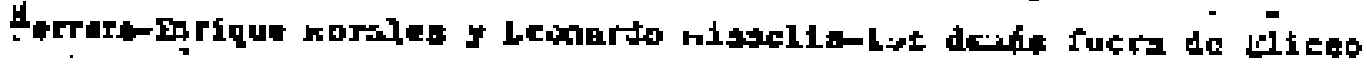

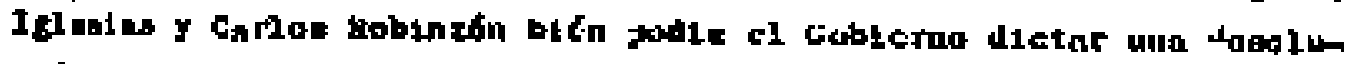

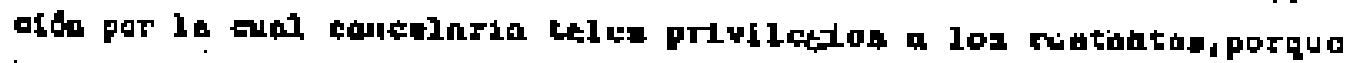

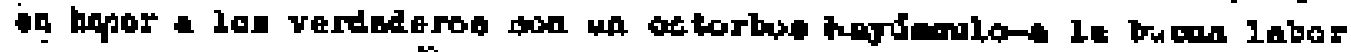

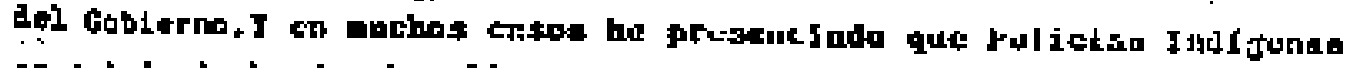

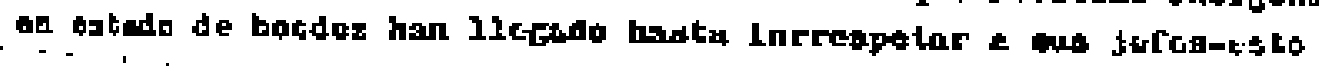

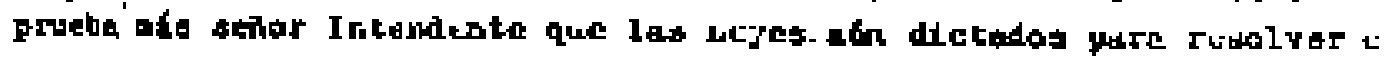

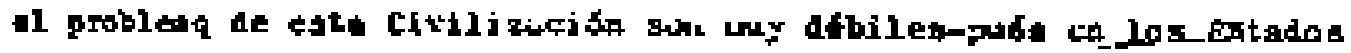

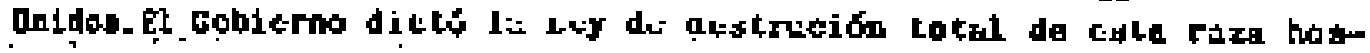

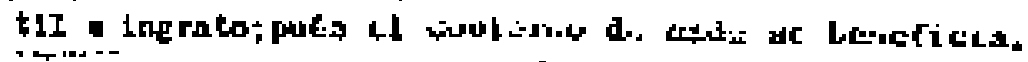

$\therefore$

: :

• 


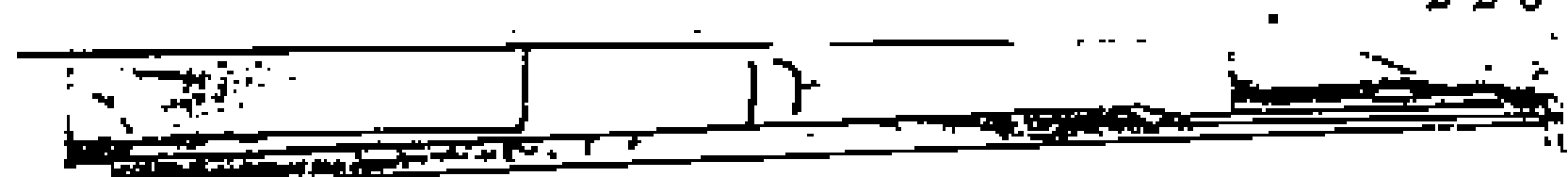

1

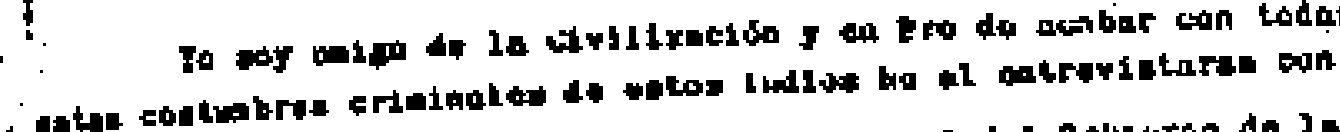

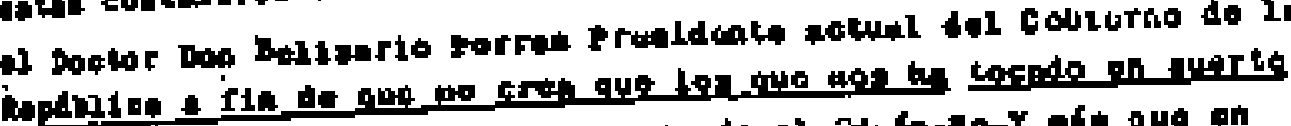

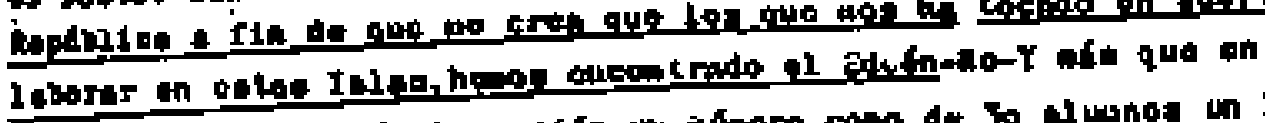

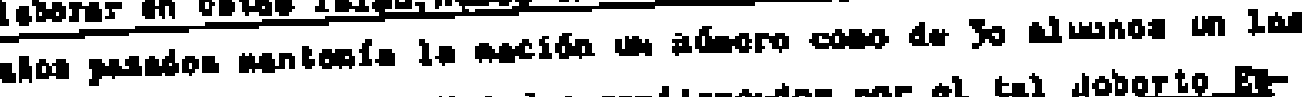

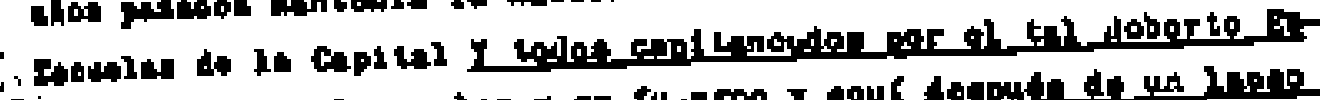

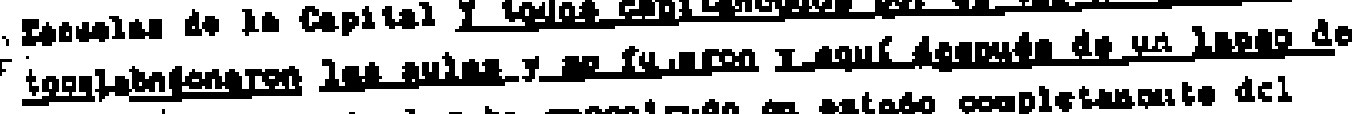

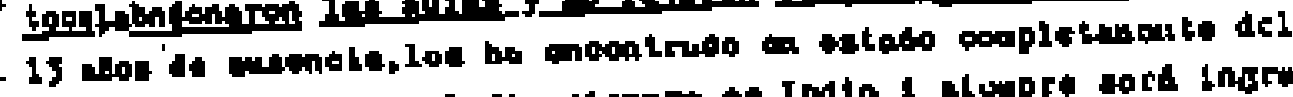

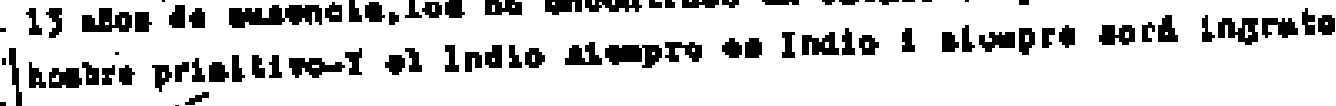

1 lt tratder.

艛:

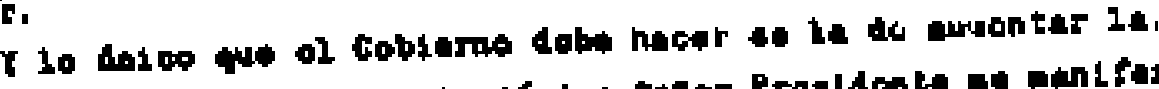

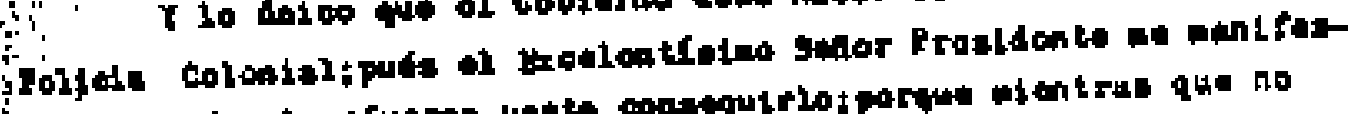

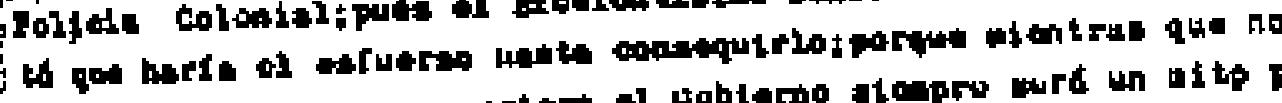

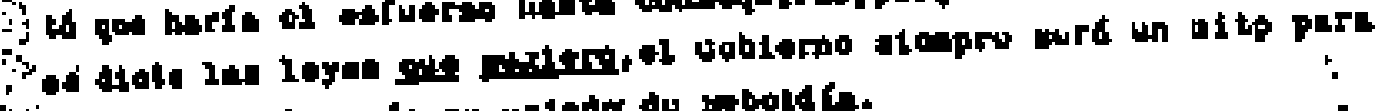

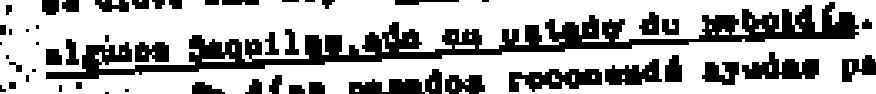

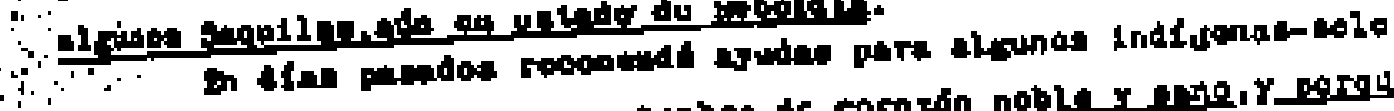

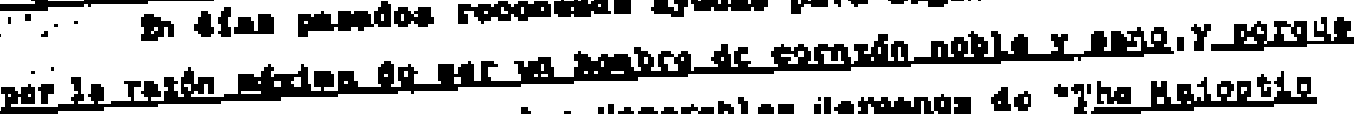

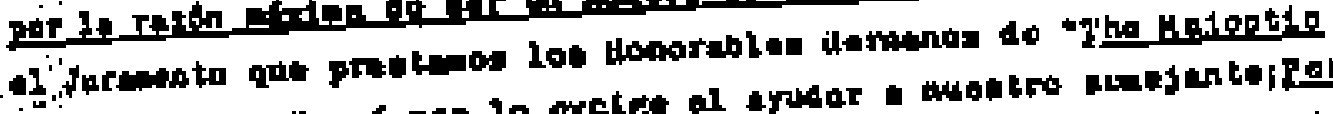

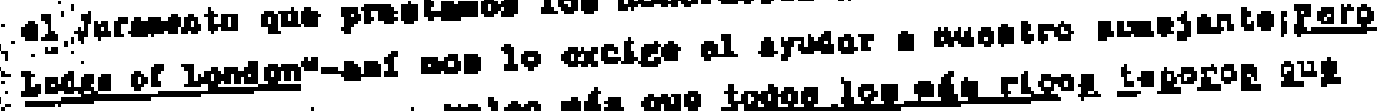

势

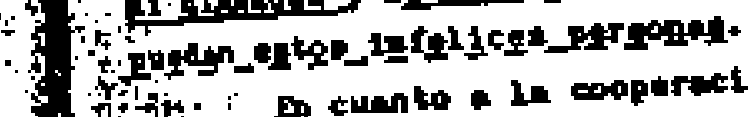

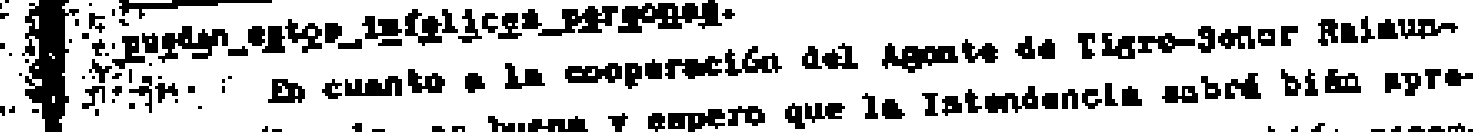

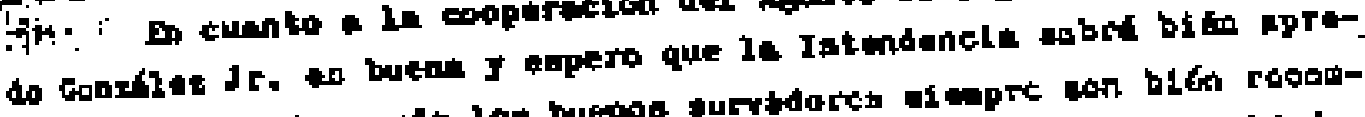

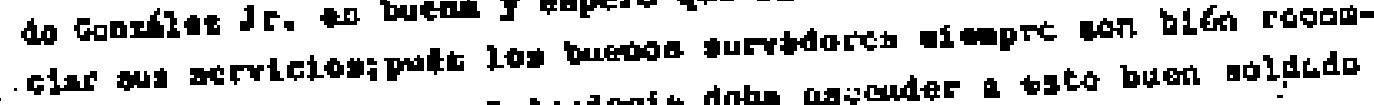

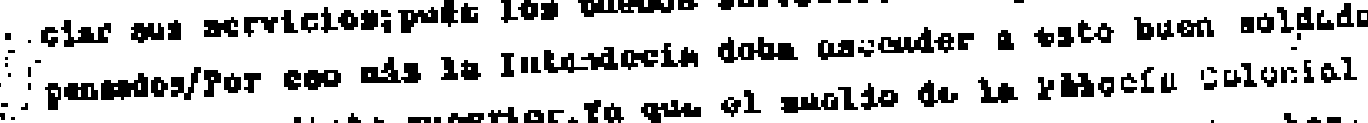

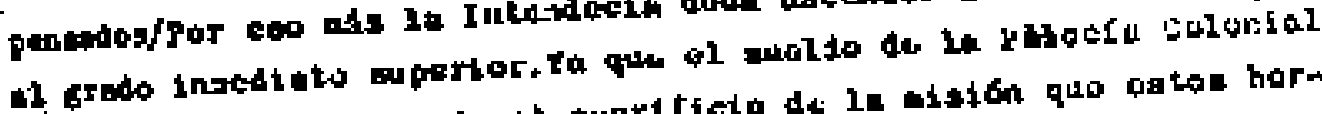

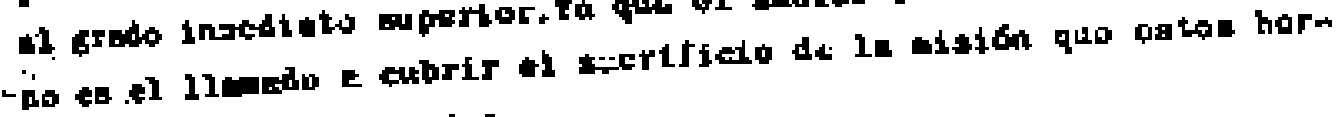

ipoos en 10 knch FTinten.

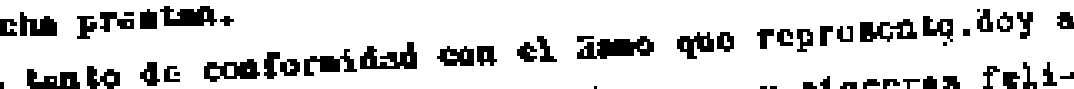

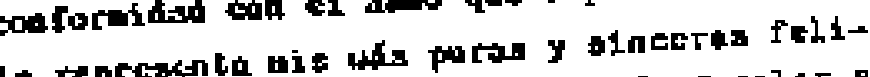

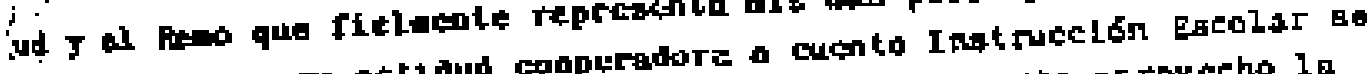

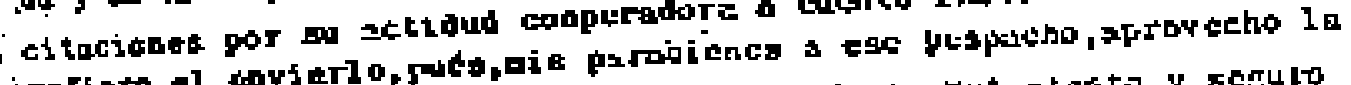

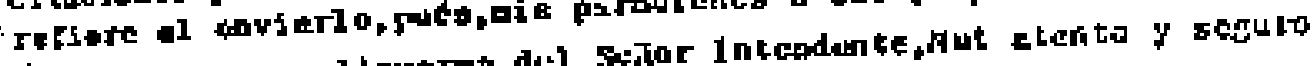

$\therefore 970$

ierridor.

:

senlitago gilberts Illuect J5.

H.D. dc la Egcue. H. do İGre.

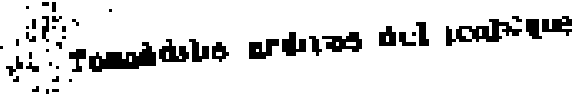

Y.RD, n+324. 


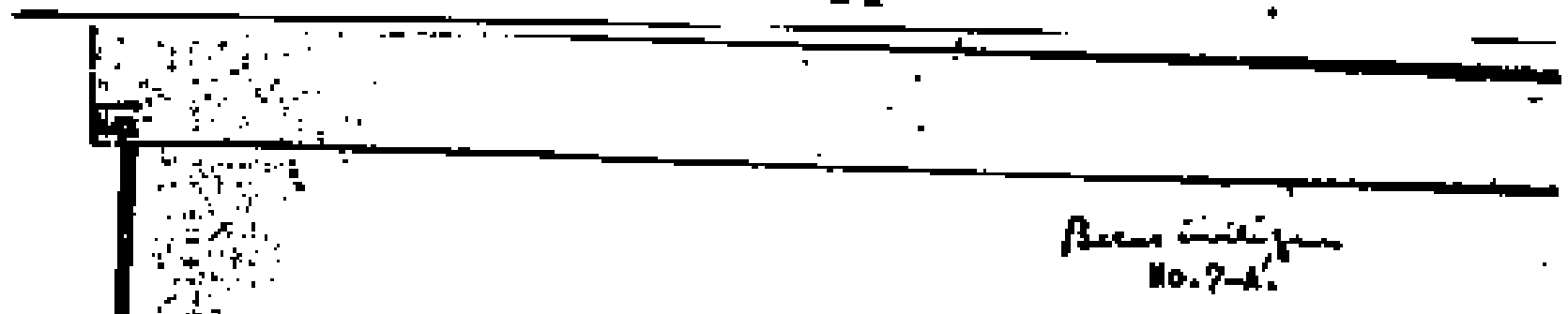

m Porvinit 7 de Hero do 19at.

Sudor Doctor

Don Foligar-10 Jorros,

$\because$ Honl6r Jrtulderesal

: Traned.

Tytsendo boctor y inigo:

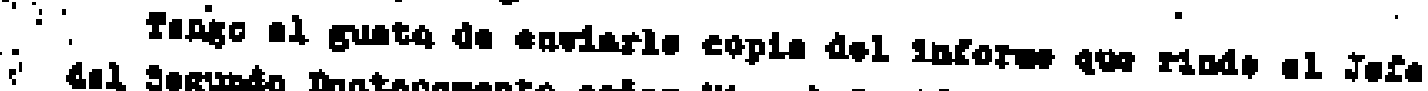

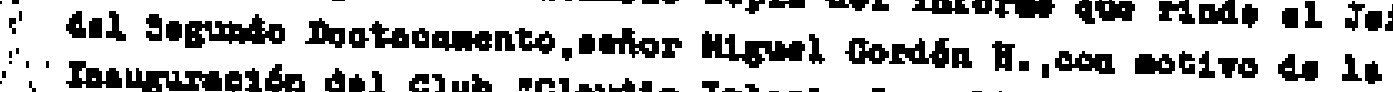

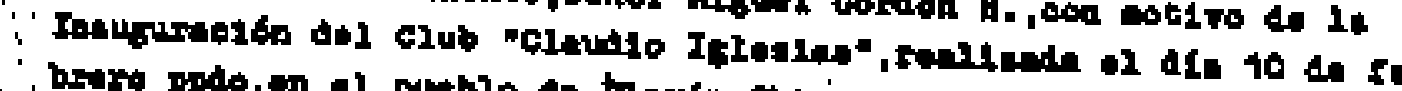

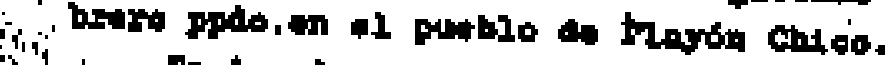

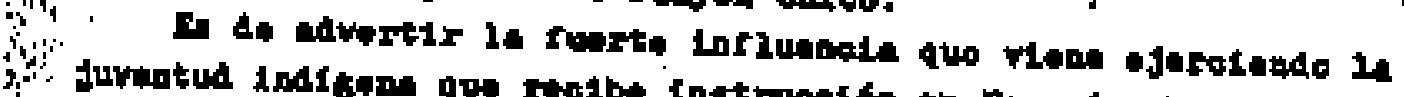

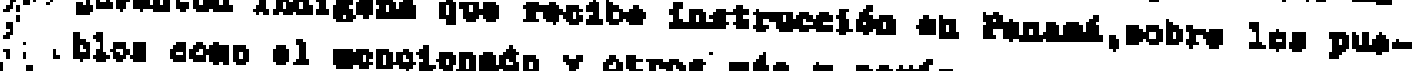

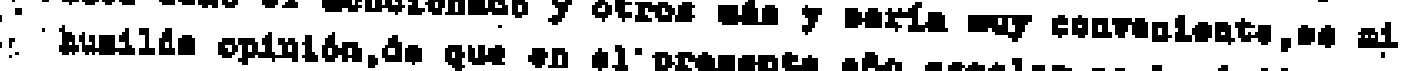

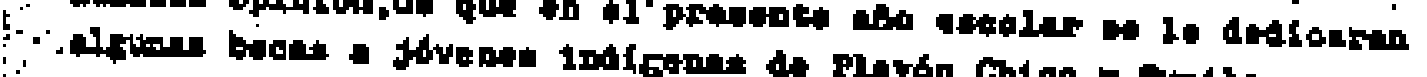

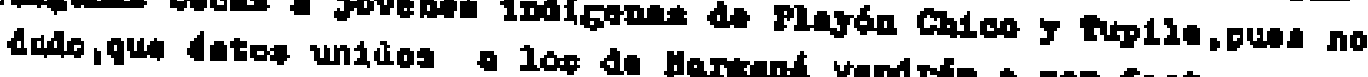
Hartand vandril a wer factocos do

mercon laborag.

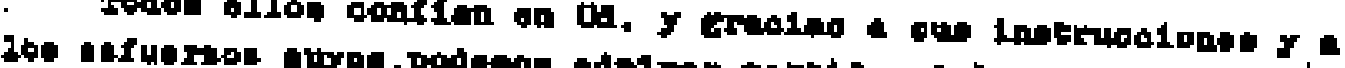

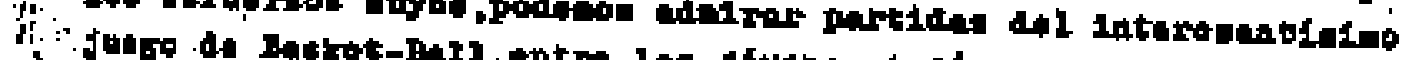

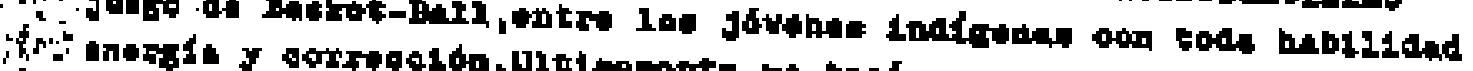

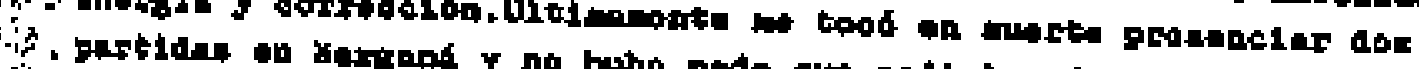

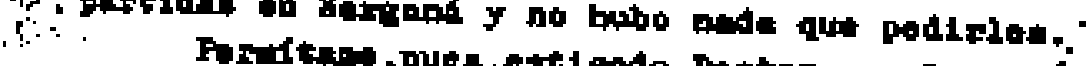

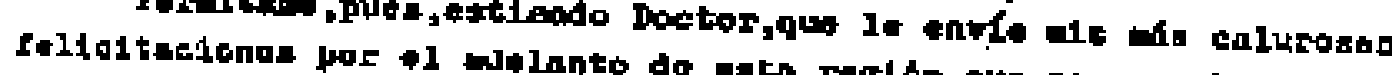

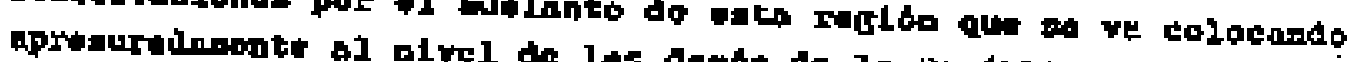

1 in a

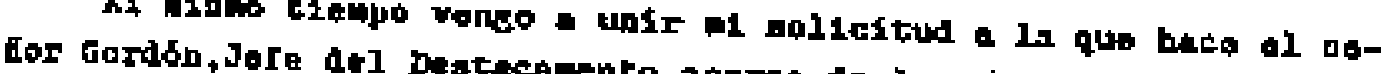

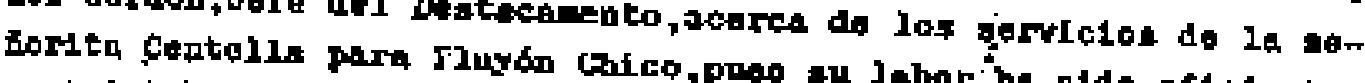
on todo sont1do, muy tane to ospocigno su lebor ha sido ar1e1ento

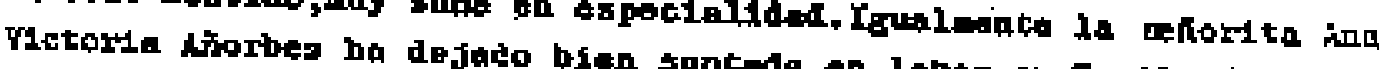
soacada an labor en Tupile.En otra mitzbron del perroual docenta.

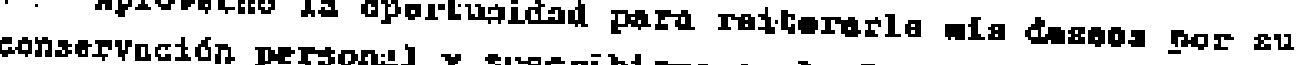

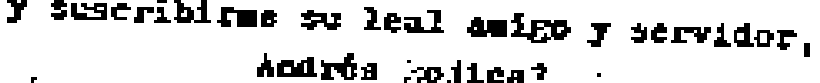

$=$ copia.

V. RD, D. 329 . 


\section{V I I I}

Número 150

\section{Sehor Jath dil 2* Destucammito.}

12 Mirzo 4 TUPILE.

\section{Sekor:}

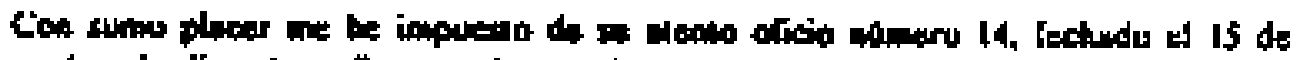

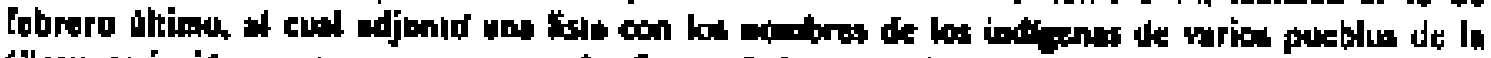

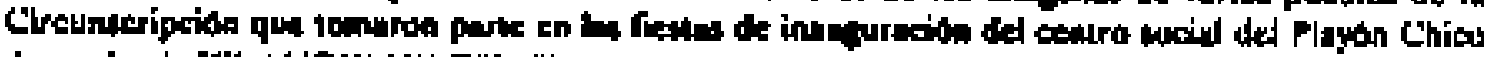
denutainady "CLAUDIO MLEESIAS".

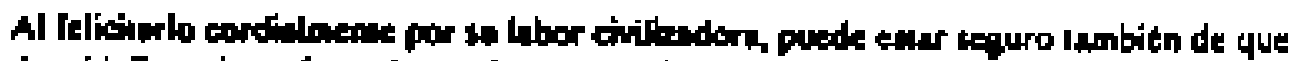

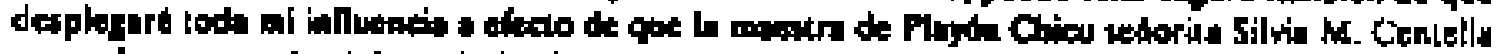

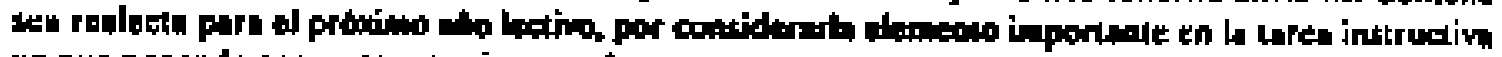

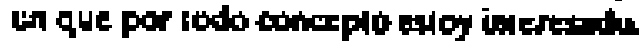

$D \in$ Ud. muy eleale y crpuro senidor.

\section{AFdrt Moulso}

Intendesilt de San Blat.

Trans. de la cop. riec.

$$
\text { V. RD, n. } 3 \mathbf{3 0} \text {. }
$$




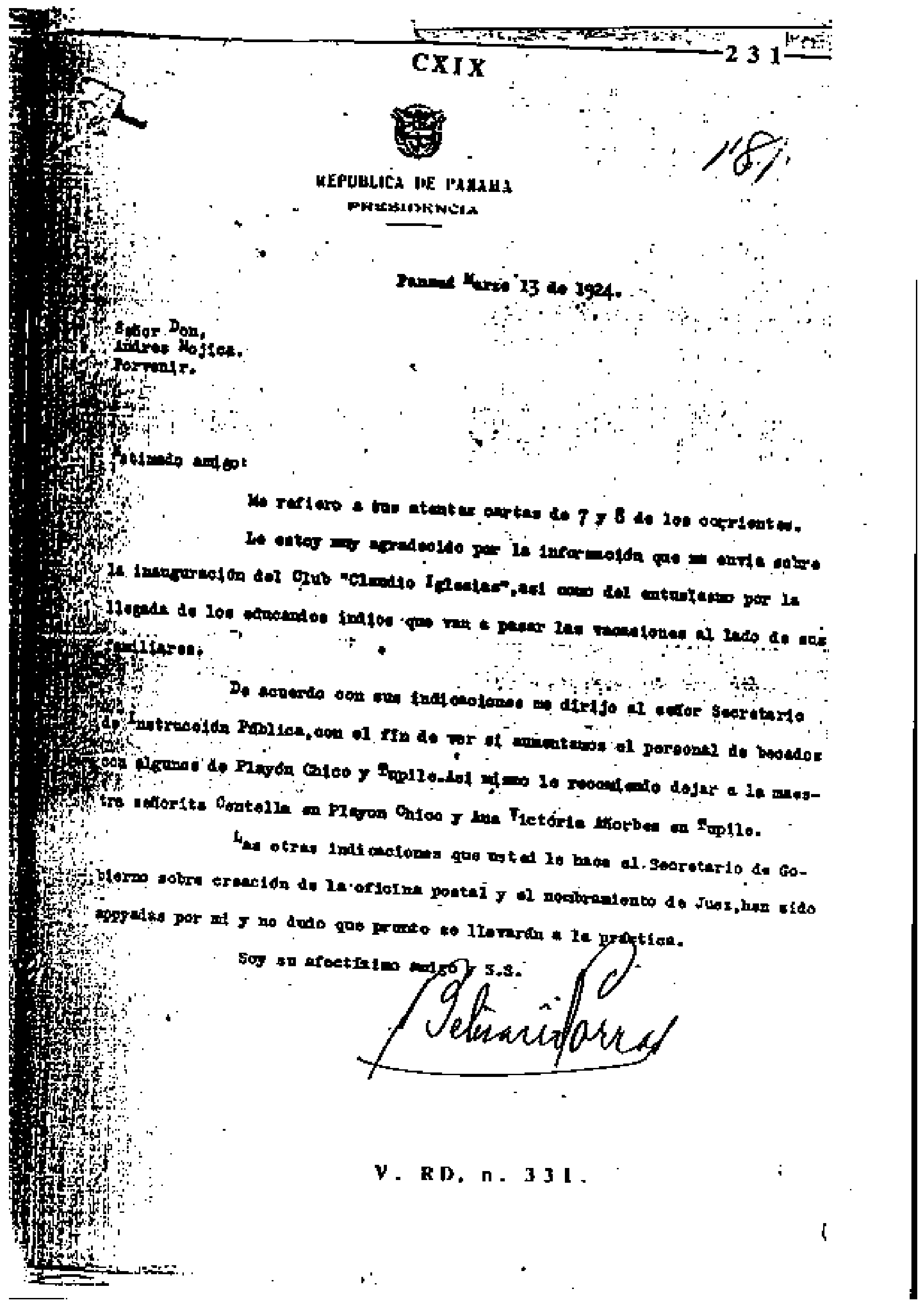


Gefior Dotpr Don

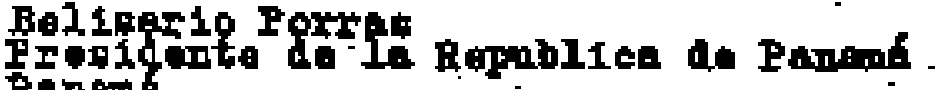
Penneng

Bimo Sestor.

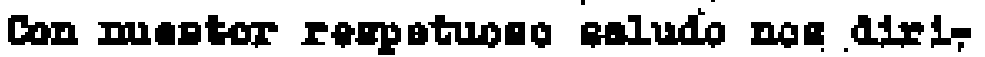

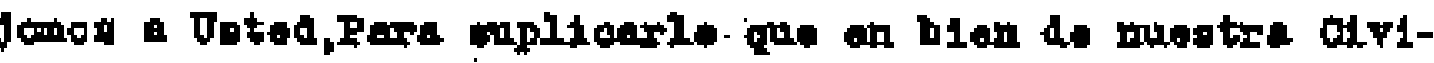

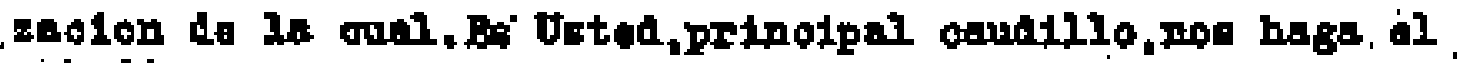

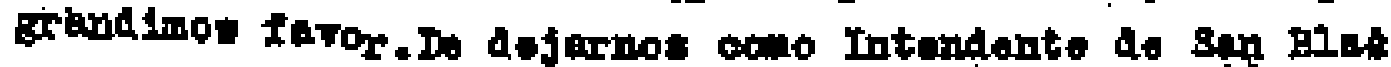

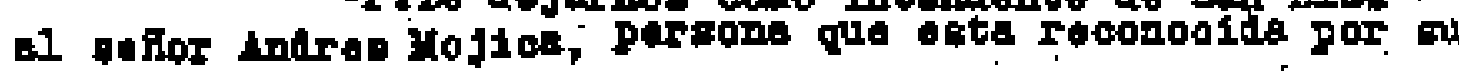

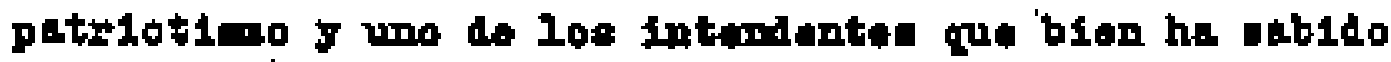

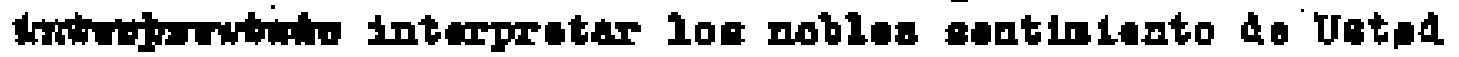
pera don nocotror lon indios do' asta pronetedora rogth.

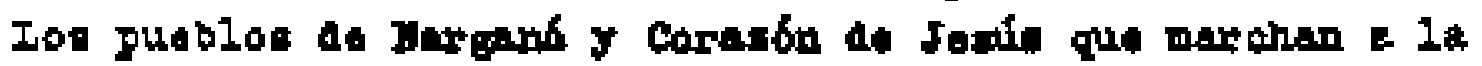

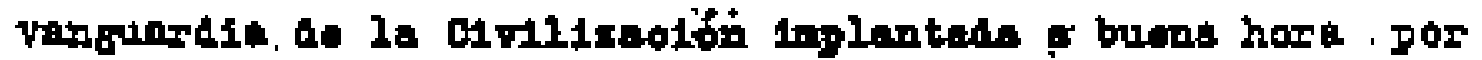

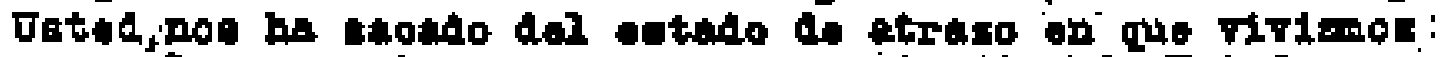

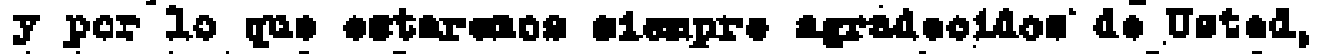

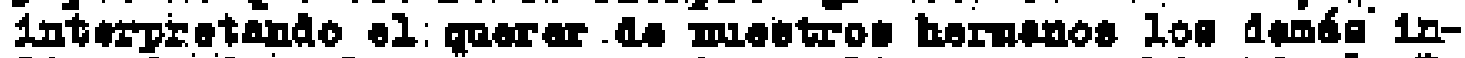

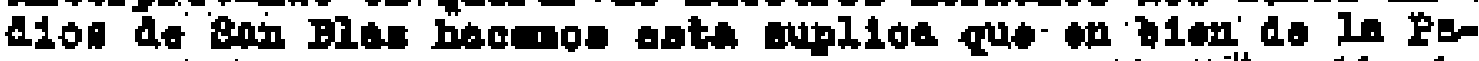

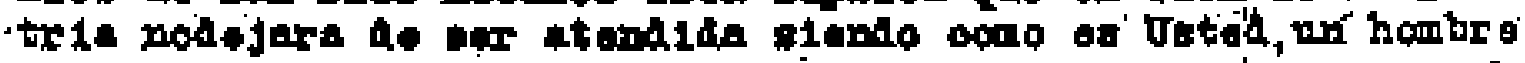

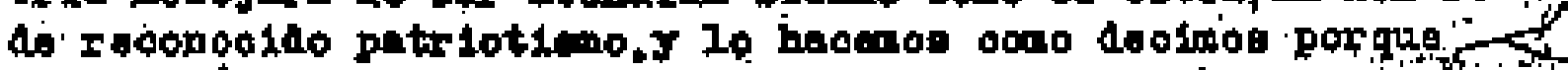

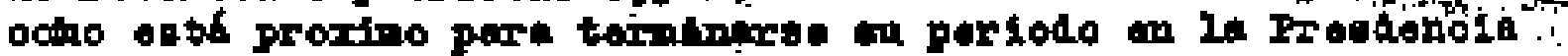

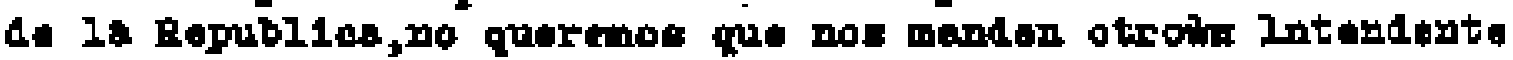

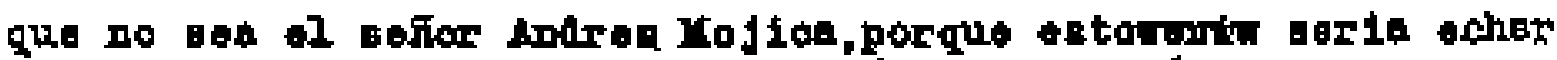

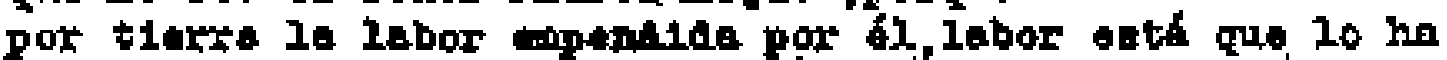

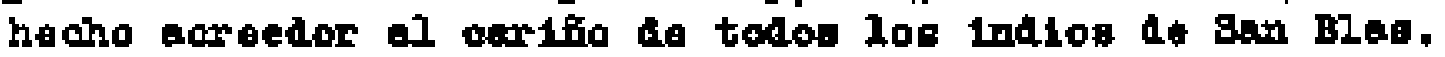

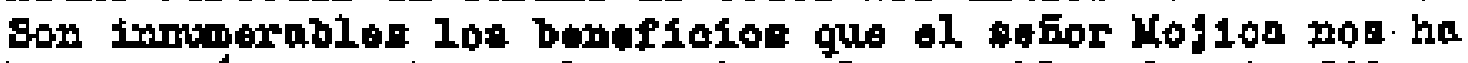

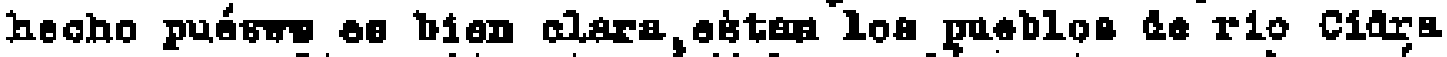

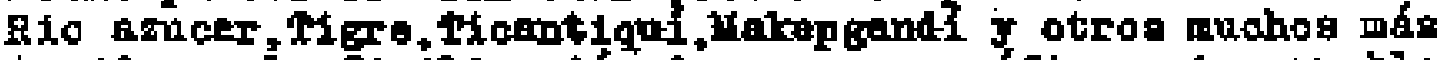

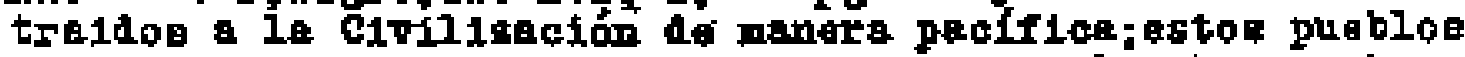
antion complotinente rebaciog atode lebor del Goblerno han

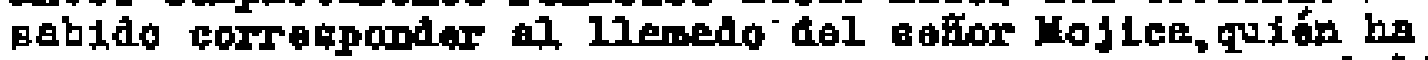

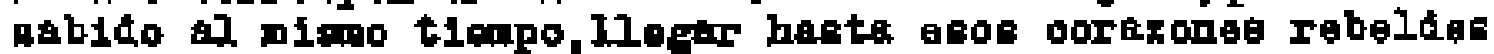

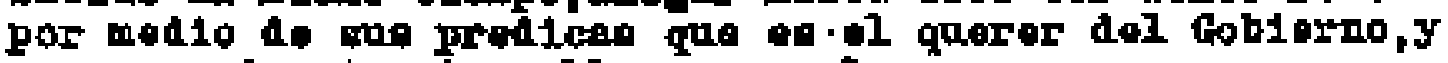
no por medio de atropolyo gue a loque no quaramon.

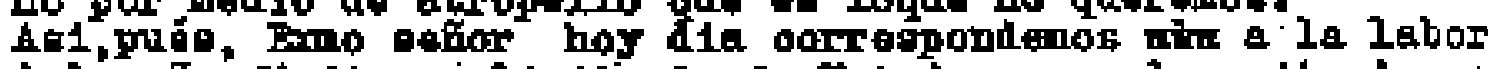

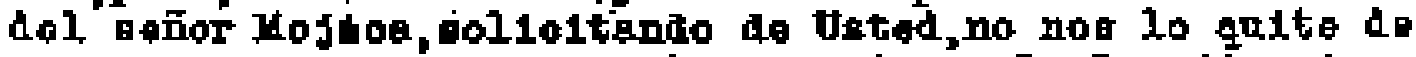

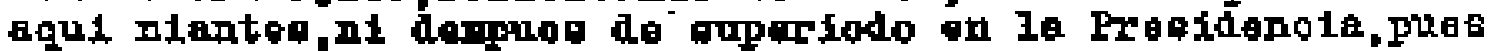

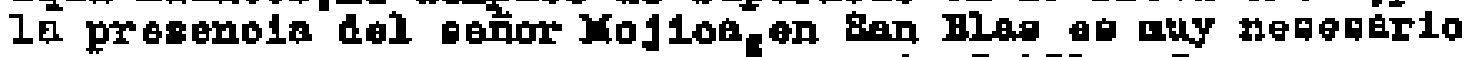

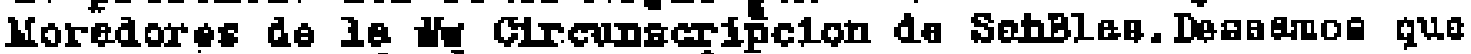
nueatro petición bes stepdidis.s.s.s. y anigos

Alopladea leleolaejpar Harganá. gimón Herr oréleontrdo jisbeli.

Bstanfelao.G.Iopez is:

For C. daJ Hamol mus̆g

Ee copte por butoralog 


\section{sello \\ REFUBITCA WE inthet \\ Prosidencia}

\section{مren :}

\section{Pontun, tharzo 15 do 1924.}

gr.t. Andres tojtca,

El. Forvonir san Blas.

\section{Mi quarido anigon}

the cooplazco en coutuitarle que al sx.tecretario de Instrucción Pfiplica so hado la seguridat do que no harf cambioa on ol personal de mastros de san Ilaa on el próximo año, For 10 que bace las becas para los Indios de cupile(Tupile) y Majón Chlco, le avisazó próximamente lo que al respecto acuerde-con el ir. Iscretario del Gobiemo.

soy suyo arectisino,

Nelfsario porrag.

couts. 


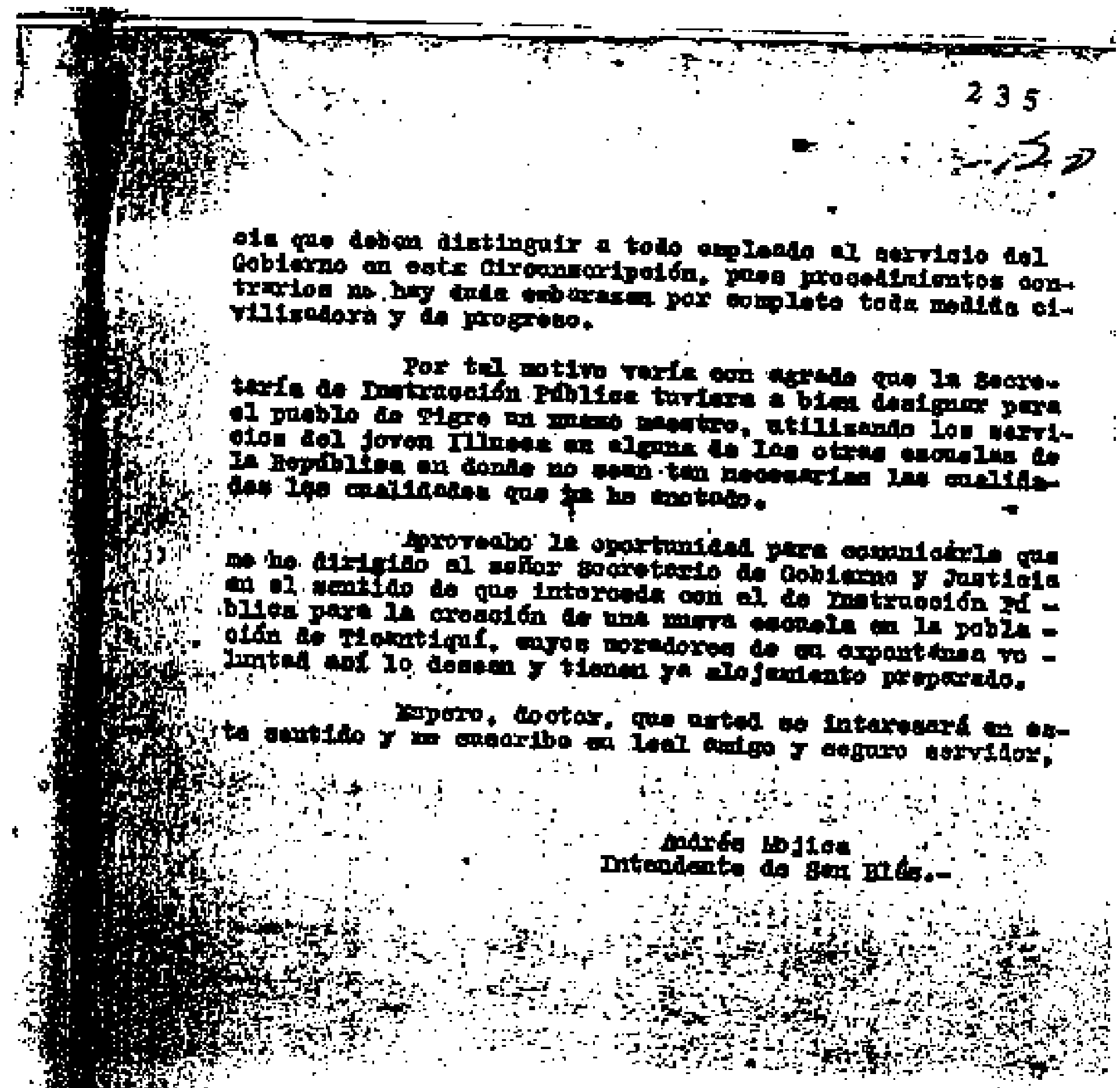

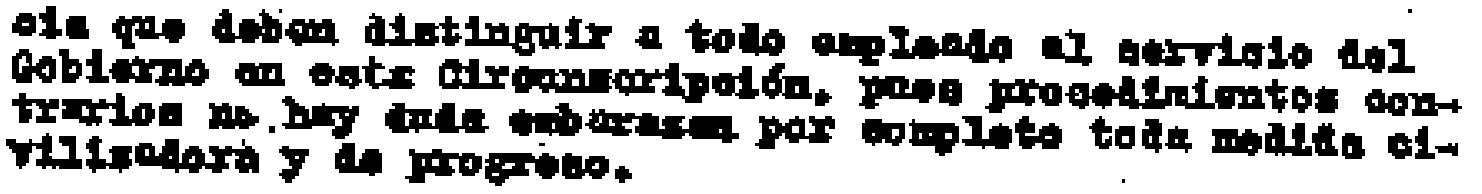

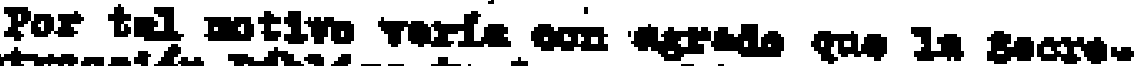

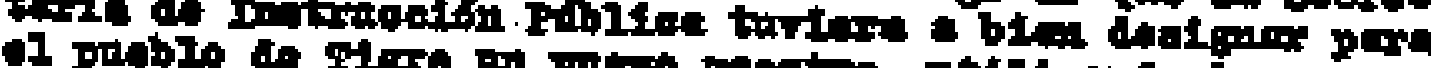

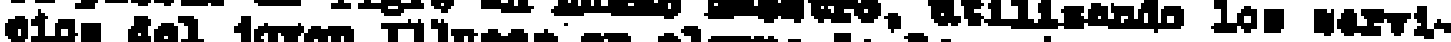

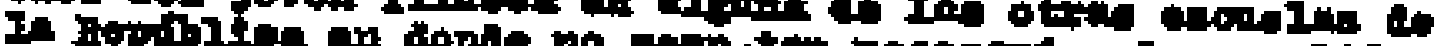

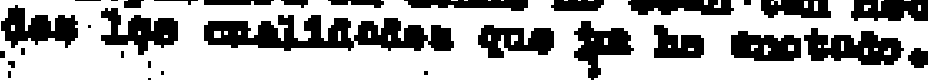

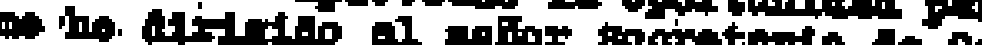

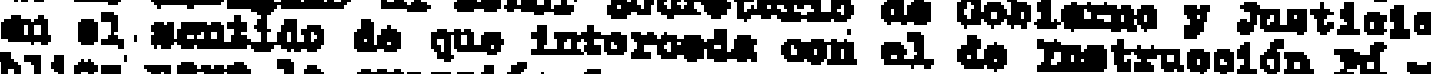

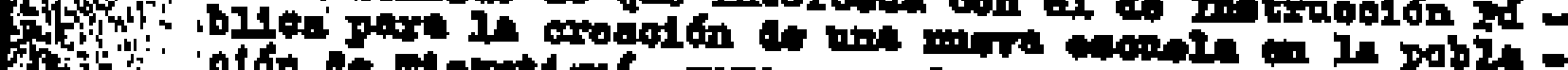

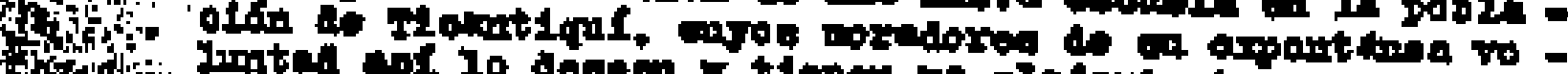
7 on

.

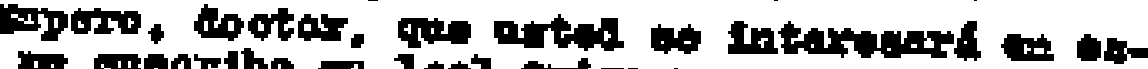
tristes 


\section{CXXIII}

Número 33

TUPLLE, 13 de kbril de 1924

\section{Sahor}

Ardrts Mojison.

Intendeple Jeft de bic Circunscripelón de Sen Bins,

EL PORVENJR.

Solkor Inesadentes-

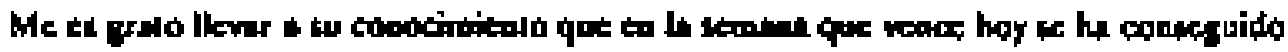

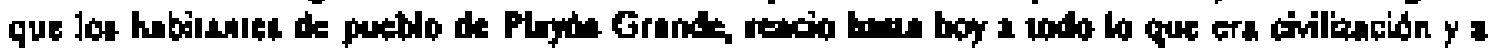

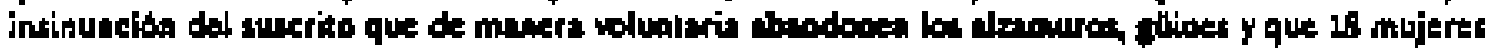
se muden sul velides por lou de gente ciniliande.

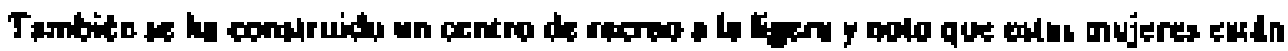

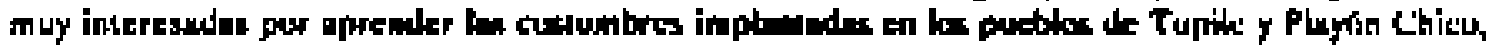

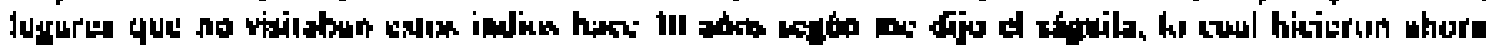

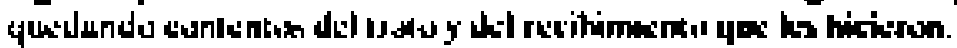

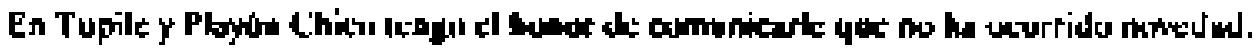

De uswed atento y stgarp serwidar,

Mkgrel Gordion $H$.

Jele del 2 do. Desacrimealo.

Trans. del orig. Hec.

$V, R D, n, 342$ 


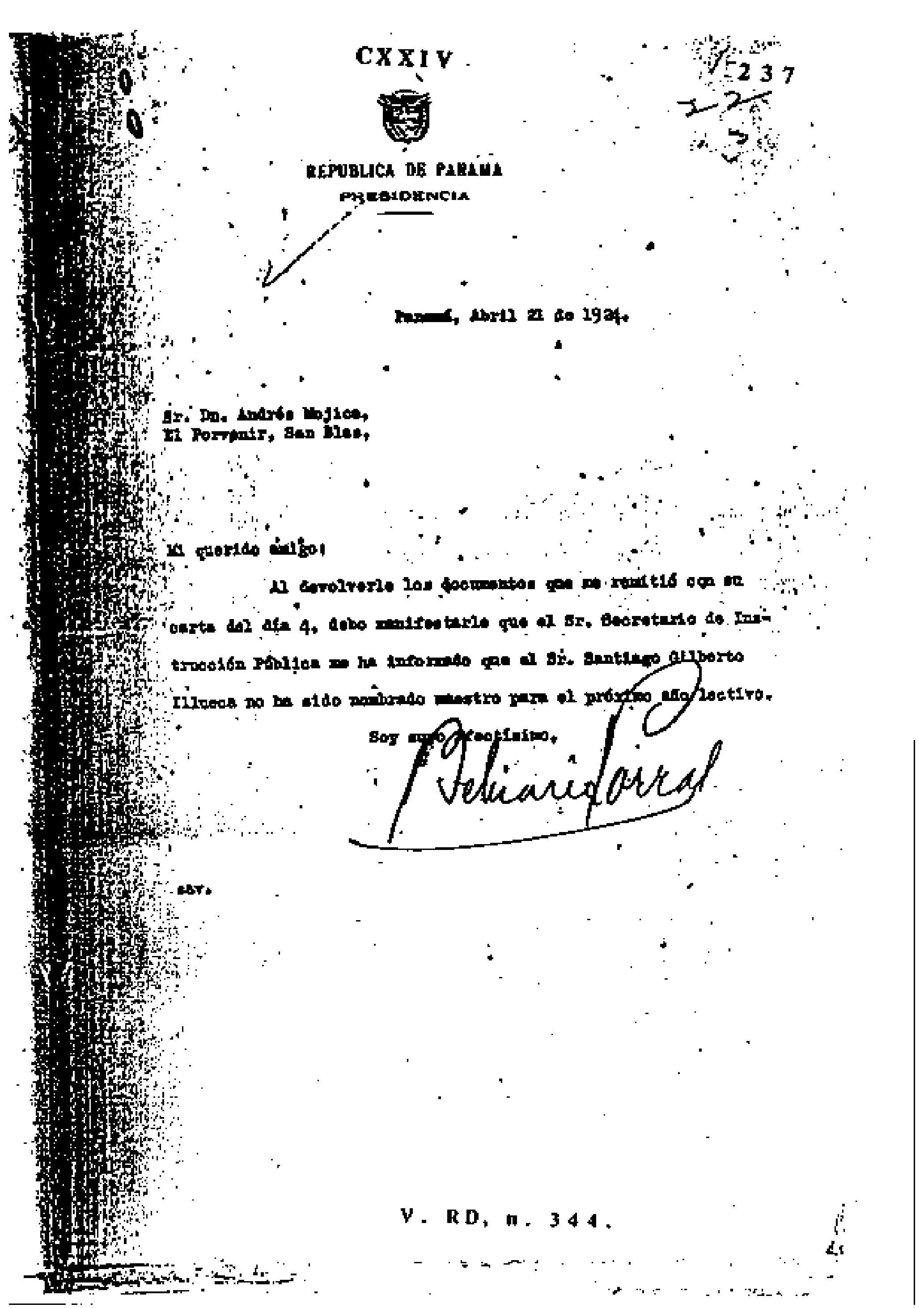




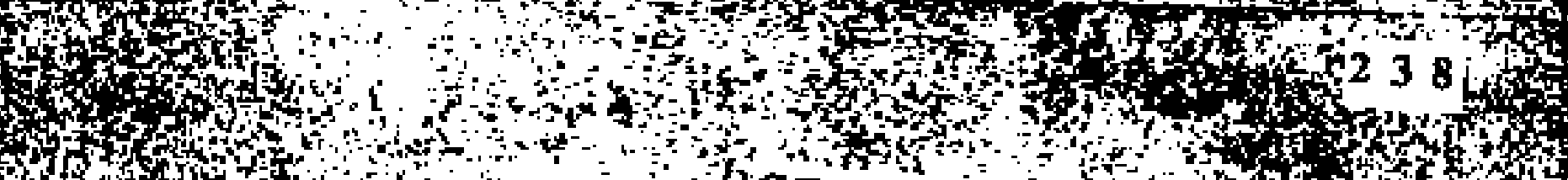

1.

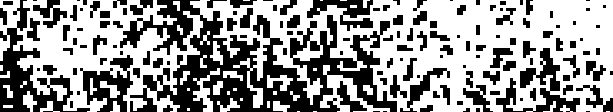

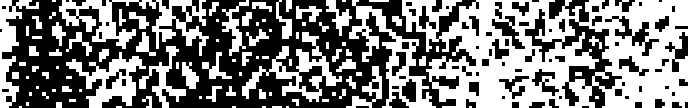

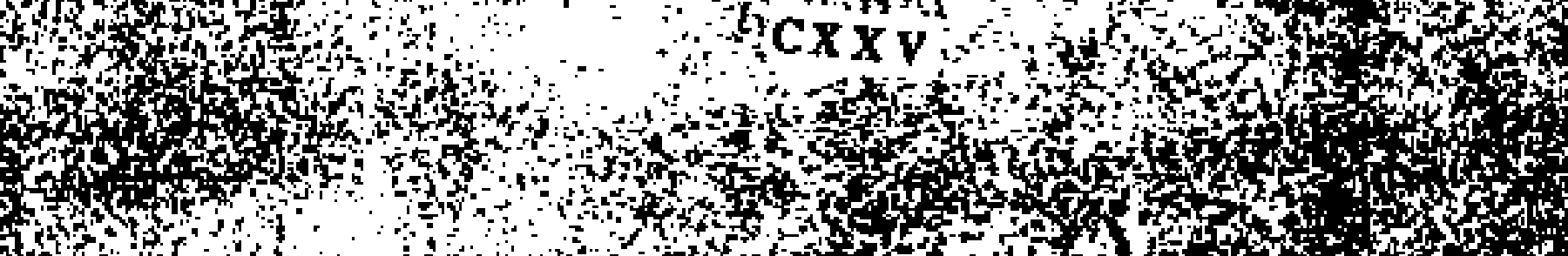

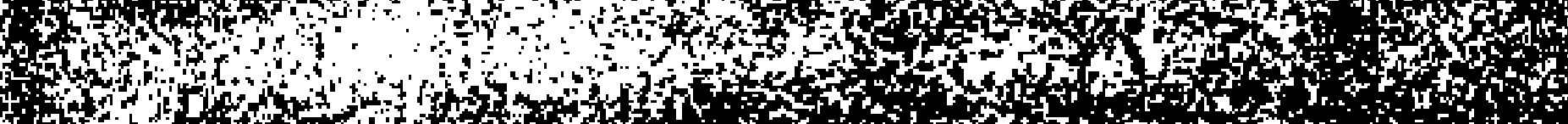

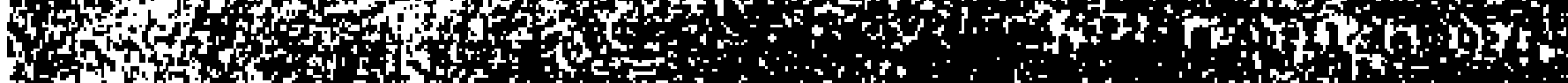

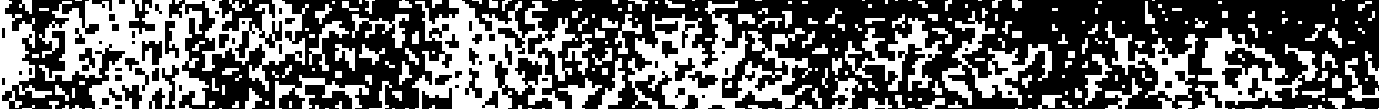
of

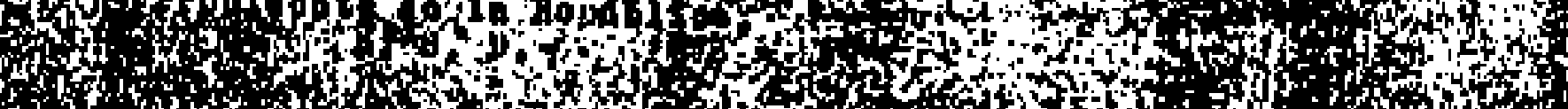

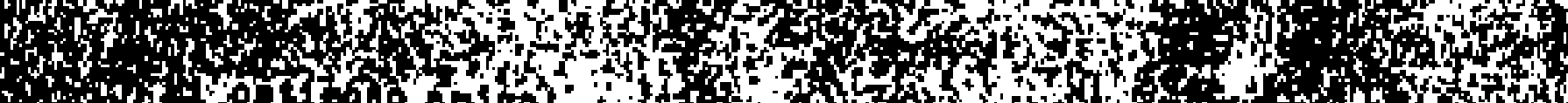

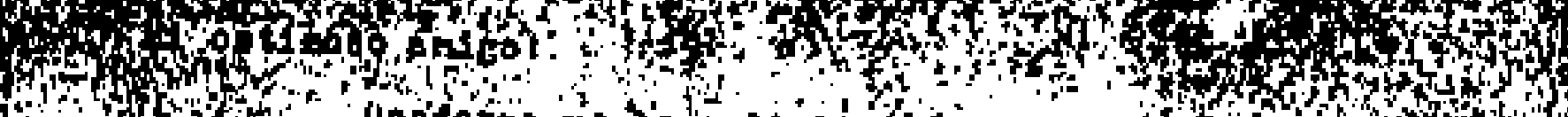

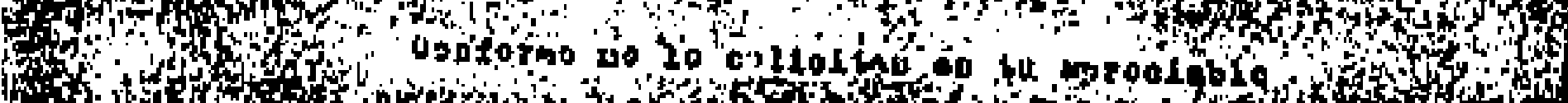

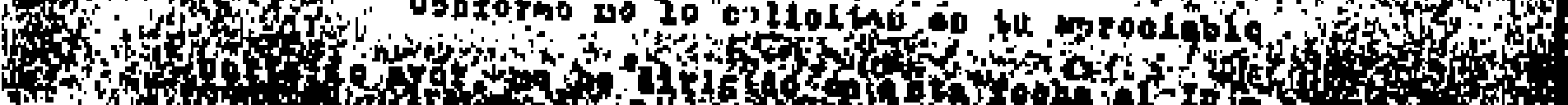

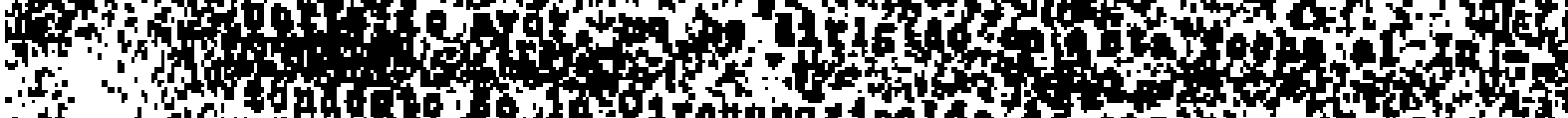

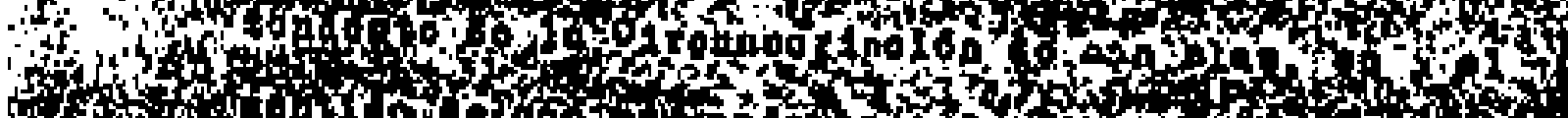

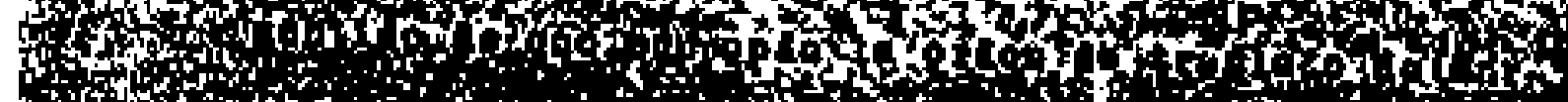

is $\mathrm{r}$

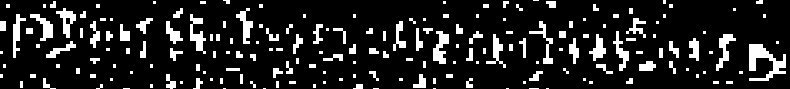

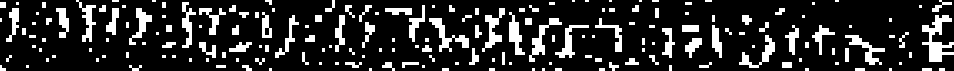

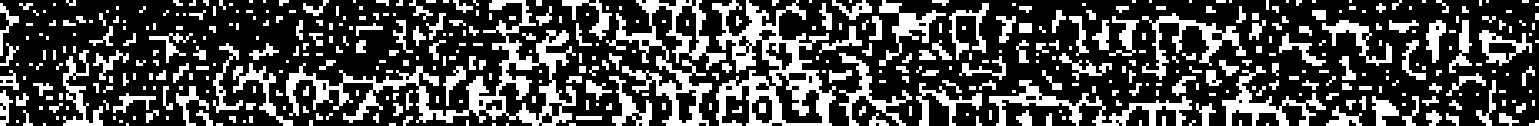

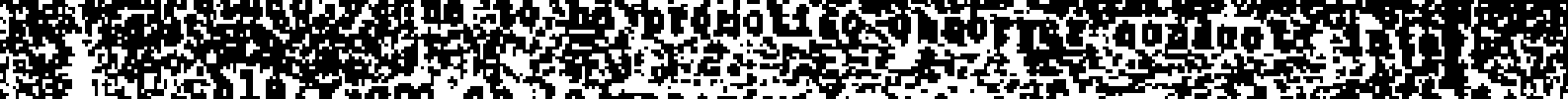

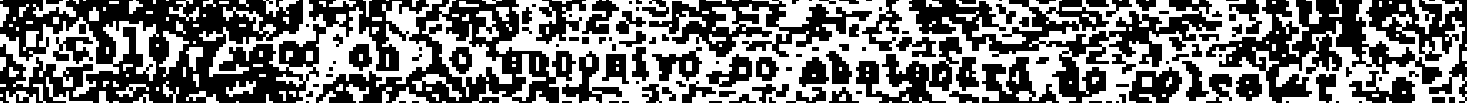

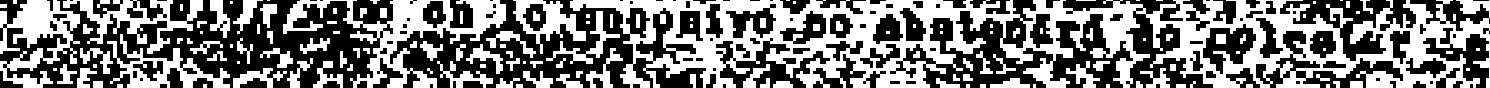

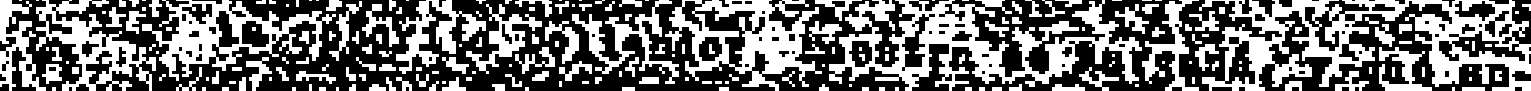

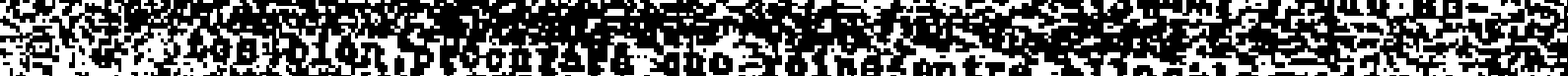

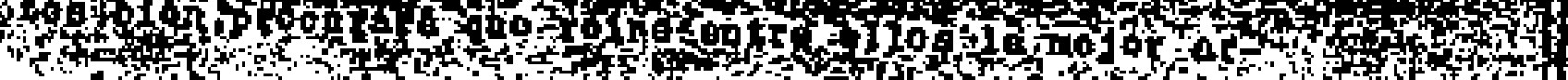

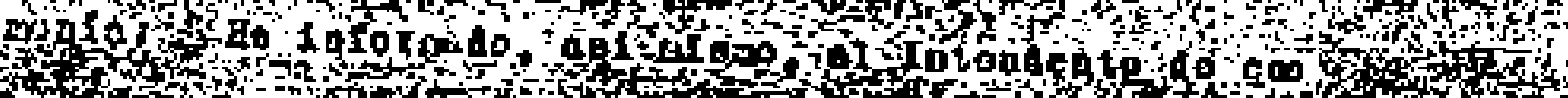

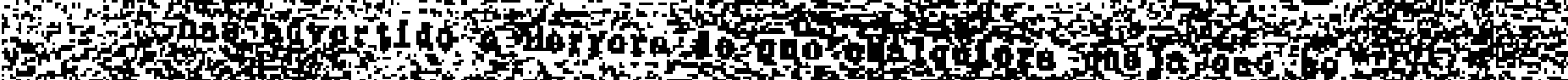

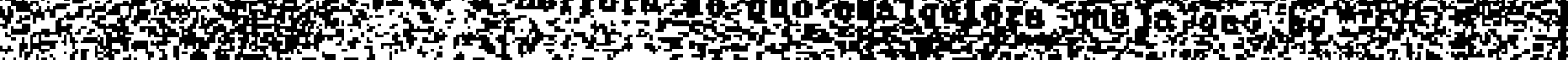

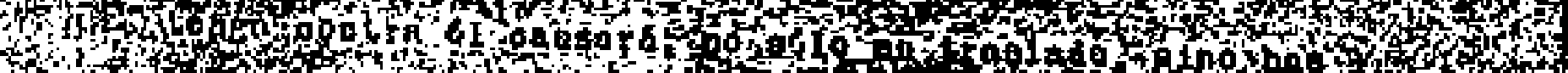

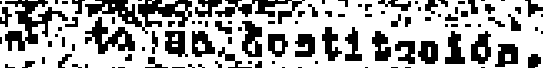

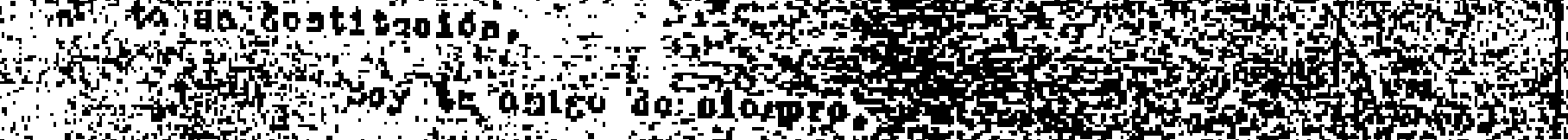

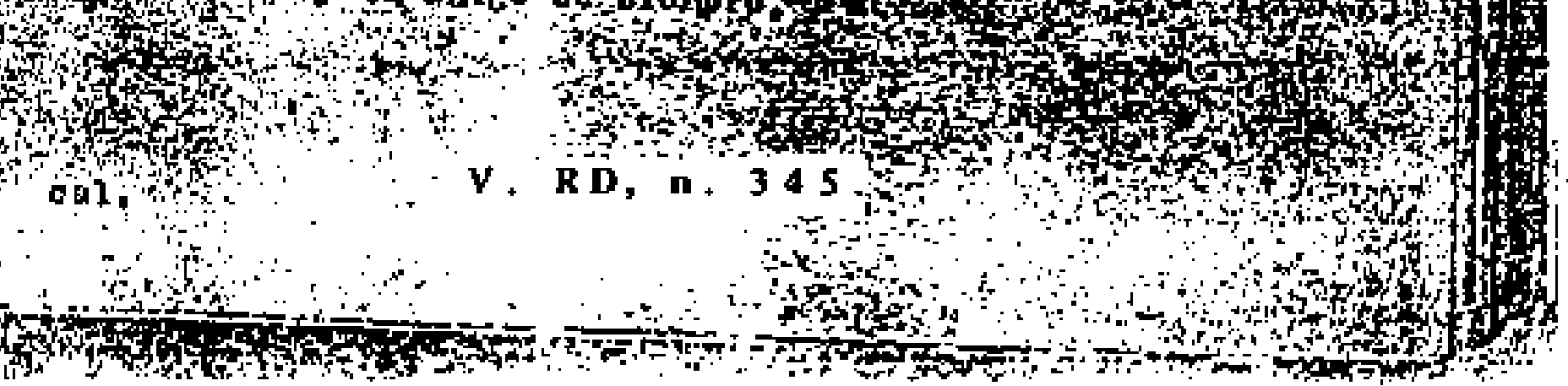




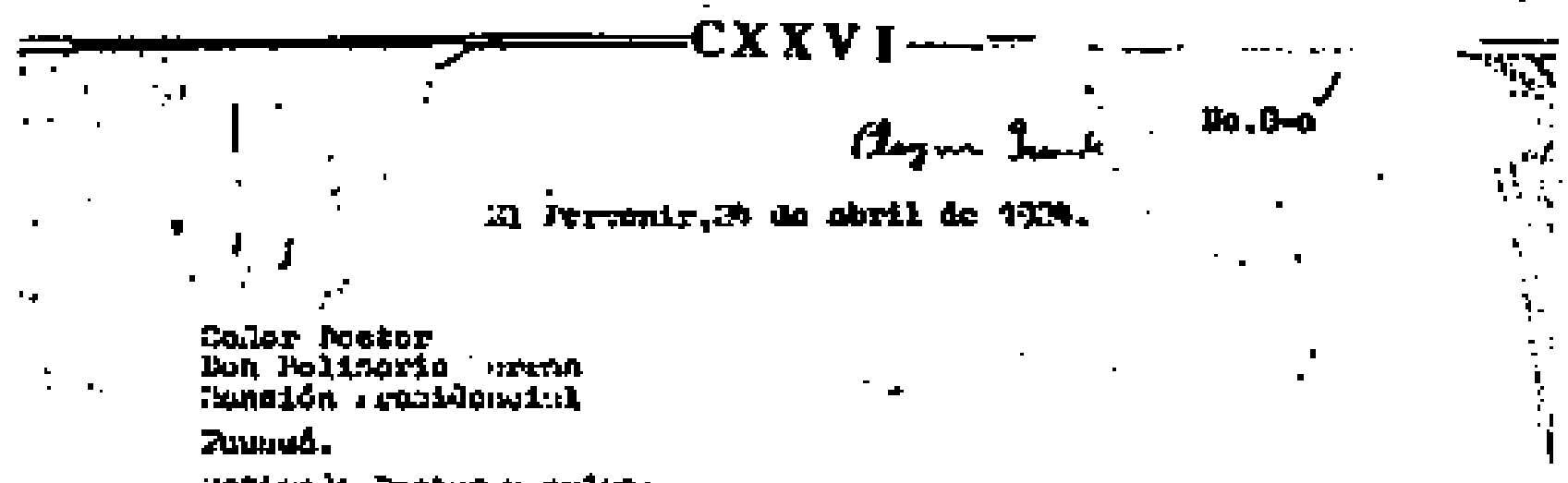

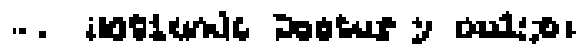

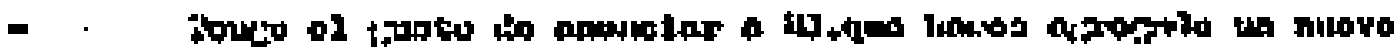

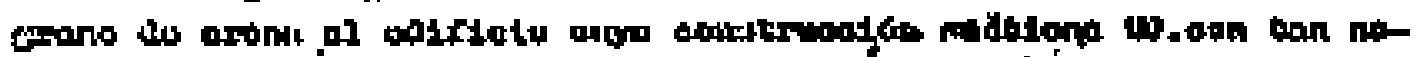

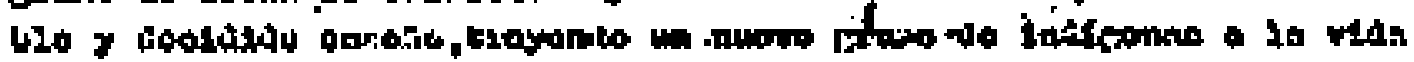

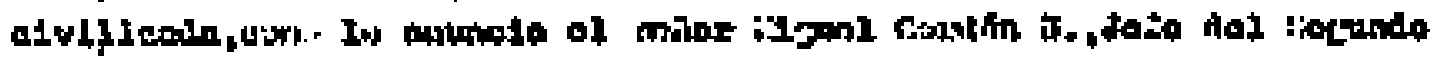

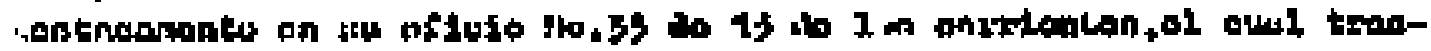

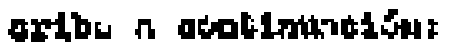

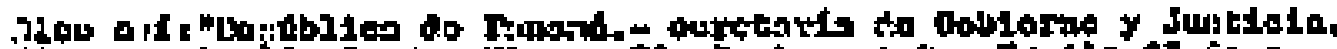

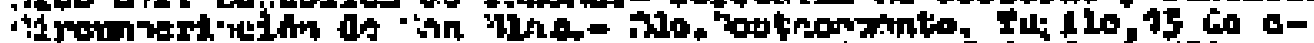

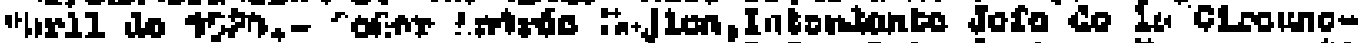

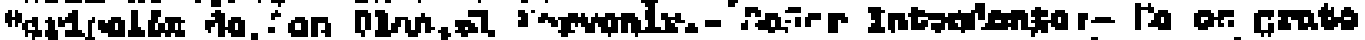

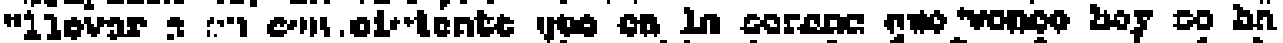

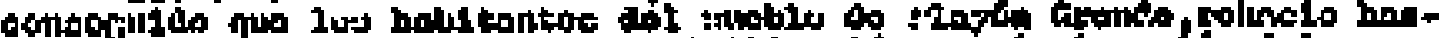

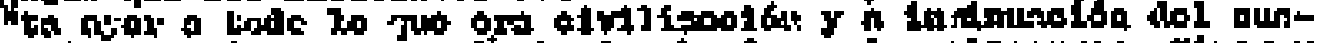

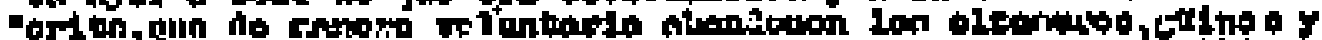

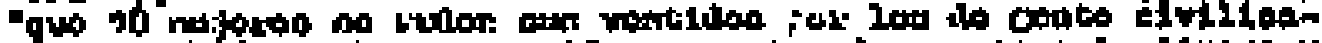

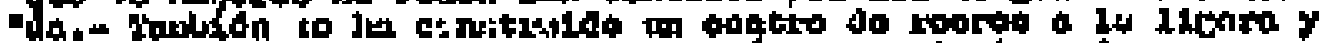

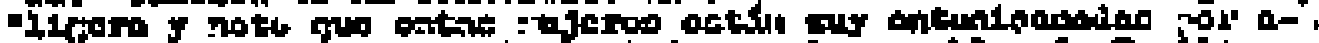

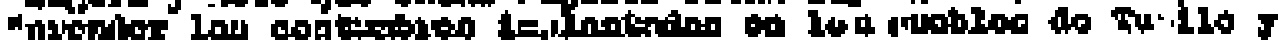

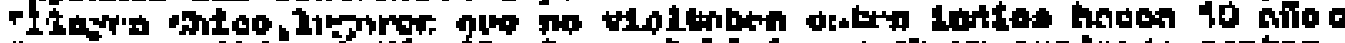

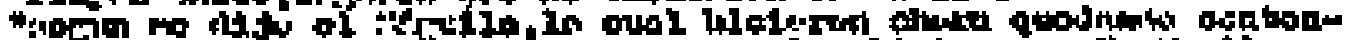

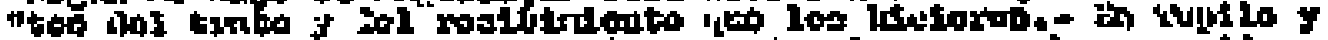

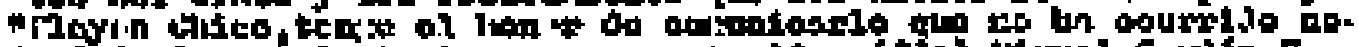

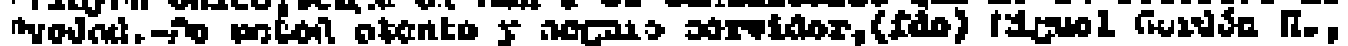

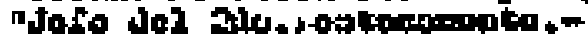

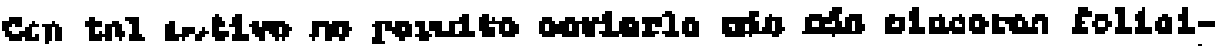

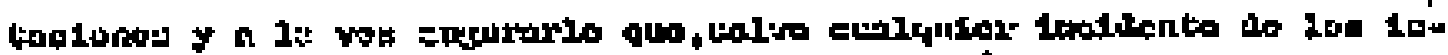

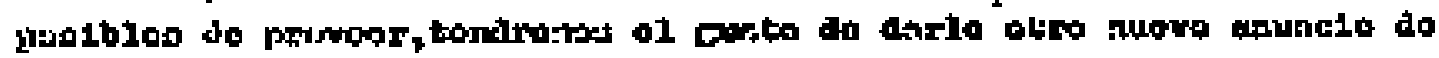

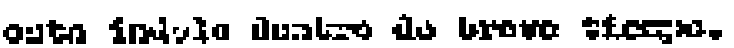

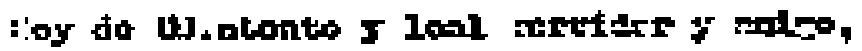

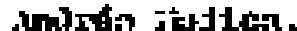

Intoriasto do tor ning.

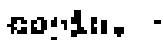

V.R D, n+346. 


\section{CXXVII}

Ocden Mantro 273

Porvandr 30 de $A$ bril de 1924 .

Safloz

Bncurgudo and Primer Doat:ieninato:

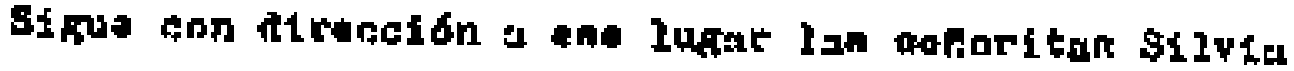

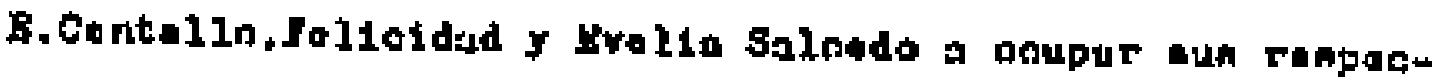

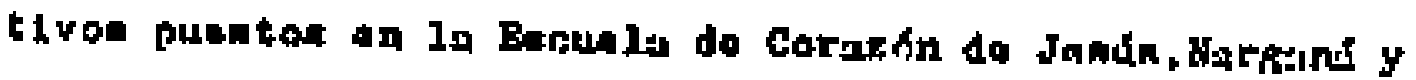
Fín Aaurar ratpoctivnente.

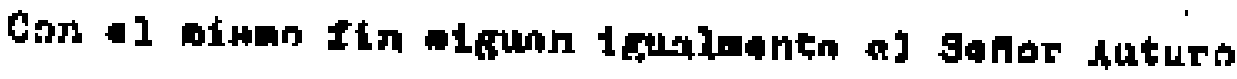

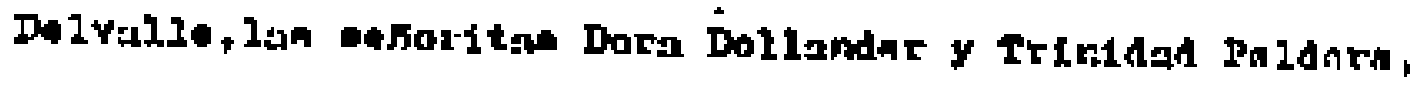

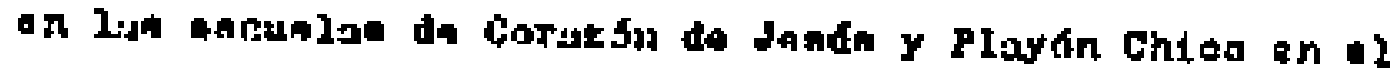
Sagundo Dentocananto.

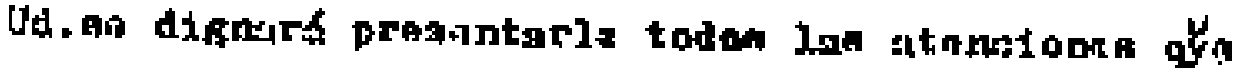

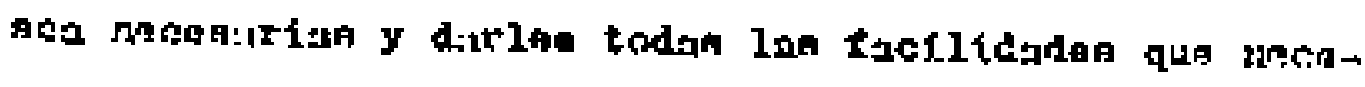
a 1.tin.

Soy do Ud.atanto y naguco șividar

Androt 46jica.

Intantenta.

V. RD, n. 348 . 


\section{CXXVIII}

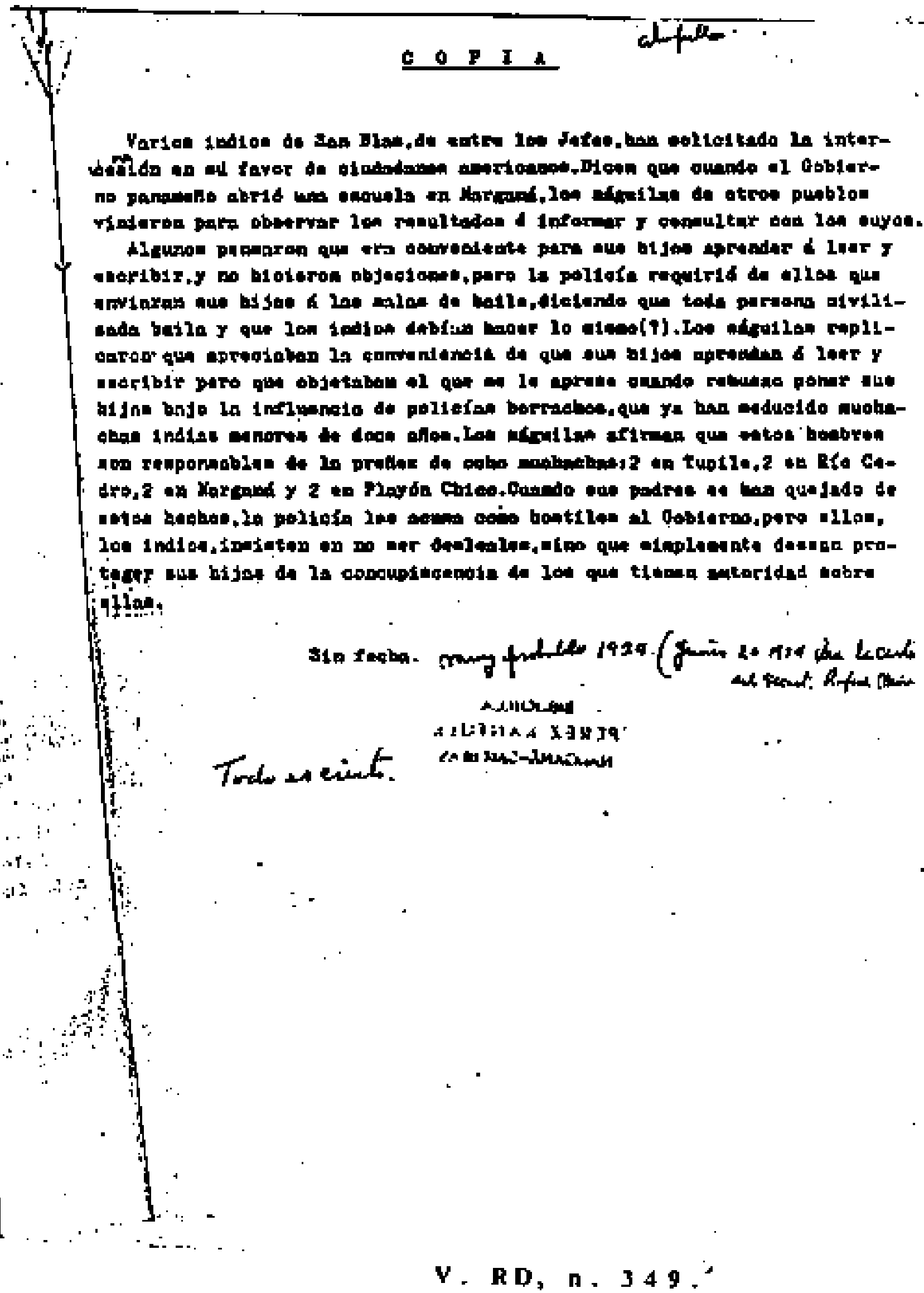




\section{$\operatorname{CXXIX}$}

$\mathbf{Y}+9$

Nŏ́nera 848

Seinor Intendenle de San Blas.

Pananí, 12 de Mayo de 1924.

El Porvenir.

Sefox Intendeale:

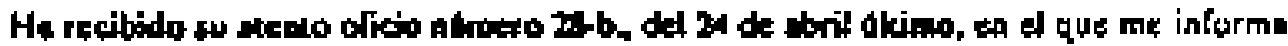

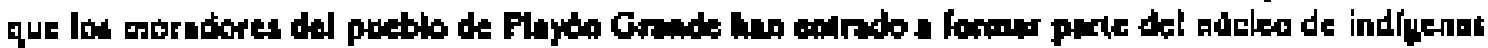

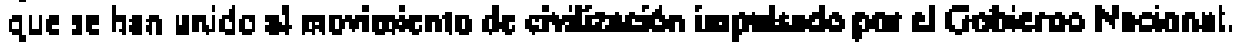

Soy de whed, to tode contiderecits,

Rotord

Setrelasio de Gobierno y lusaticin.

'Trans, del orig. mec.

V. R D, n. 353. 


\section{$\operatorname{CXXX}$}

Númerr 93

Nargant 3 de Jenio de 1924

\section{Sabar}

Andr4 Mojlea

Intondente de Sap Blas

EJ PORVRNIR

Sedor:

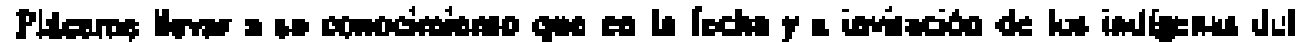

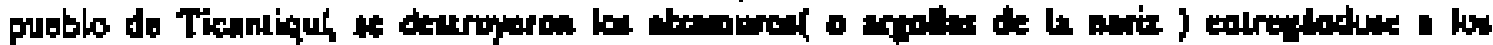

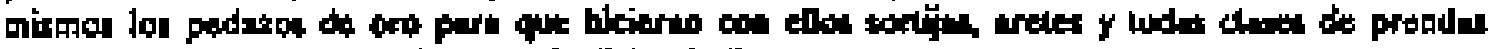

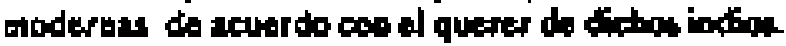

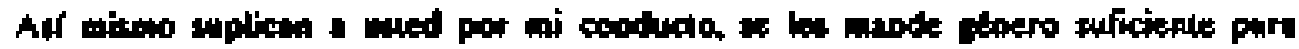

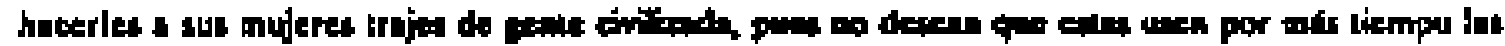

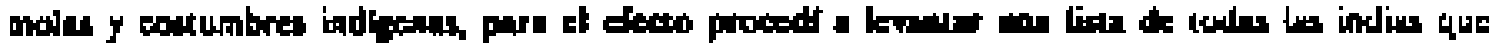

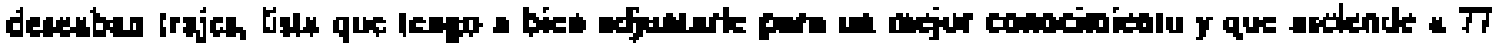
Irnj:

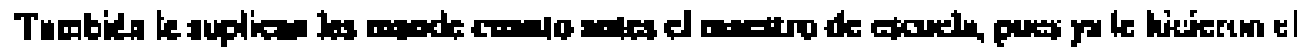

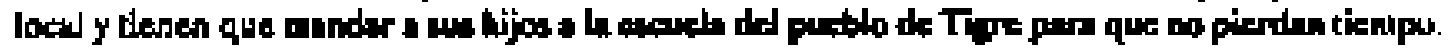

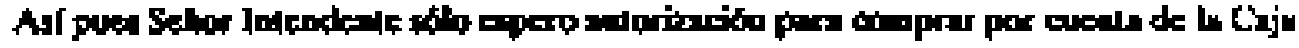

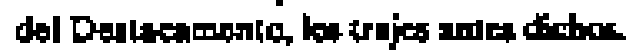

De trued alonco y wequro servidox.

M. J. Fermirs

Jefe del Desuatumentur.

! Trans. del orig. mec.

V. RD, n, 360. 


\section{LISTA DE LAS INDIAS DEL PUERLO DE TICANTTQUI QUE DESEAN TRAJES DE GENTECTVLUZADA}

\begin{tabular}{|c|c|}
\hline 1.-10ipipi & 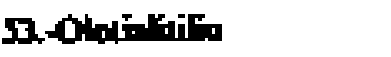 \\
\hline 2-Barte Hore & SA,Cenita Diax \\
\hline 3.-Olubna & 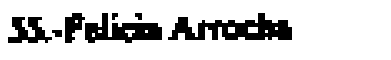 \\
\hline 4.-Olegvitiputh & 56-Siptorgut \\
\hline 5.Amapipl & 57.stepipo \\
\hline 6.-Slepipi & 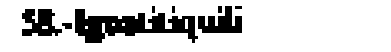 \\
\hline 7.-Yoluase & 97.tarbets Conrdin \\
\hline 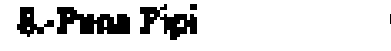 & 60.5egula Hone \\
\hline 9.Ololipiquili & 6). Alyin Pestre \\
\hline 10.Amayo & 6-Anntips \\
\hline 11. Himd & 6.Y.Yolo \\
\hline 12-Eusban Home & 64,-5imapiqu \\
\hline 13.-Marí Pomrieda & 65.-Chopui \\
\hline 14. -Olohipiquilis Strau & G6-Ama Ppi \\
\hline 15. Okpingeiquifí & 67. Igranguiquili \\
\hline 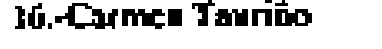 & 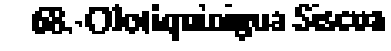 \\
\hline 17.-Igna & 69.-1guariquati \\
\hline 13.-Olaipaili & M-Amagm \\
\hline 17.-Amo & 7I_-Sinticquik \\
\hline 20.510 & 72. Tganlintiali \\
\hline 21.-POar & 73.thos Varcla \\
\hline 22-Juan Ehrman Hotat & T4.-Manuch Varts \\
\hline 23. Igaspipicquili & 75, Estoill \\
\hline 24,-1, Hninily & 76.,Amspipi Үзори \\
\hline 25. - Heken Rimer; & D.-Curmen Diter \\
\hline 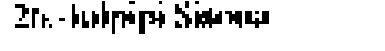 & \\
\hline
\end{tabular}


27.trobel Gonthe

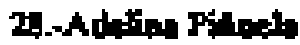

29.-Mrit Caburta

30.-Mrat Coherat Dolore:

31.-Elase Forrm

32-Berte Fince:

3.-Cun Row

34-Metide A rovernend

35.-Marth [orbed ]

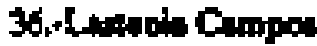

37.-Doiores Murbar

34-Elan Stackes

39. Jonefian PArez

49,-Durio Buita

4L-Ragaed Rodrisper.

42,-Erraglangle Mindex

43. Gillermin: Möa

44.-Elbing tivetnes

45-Amelin Herrem

46.Iohunat.

17.-Otoxipiquali Yaran

48.-Okxipiqualucat

49. Olointipuinticus

S0.Igualiquiquir

\$1.-Amnpipi Siscu.

52. Oiniste
TOTAL TI Iris

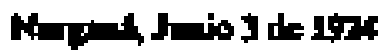

E Jeic del Deatucane to

M. Herver: 


\section{$\operatorname{CXXXII}$}

V.15

Nưmero 97

Setior

Narzanif, 10 de Junio de 1924

Andrif Mojlew

Intendante de Sor Blas

EL POR VENIR

\section{Sthor:}

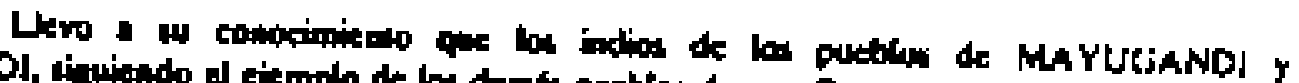

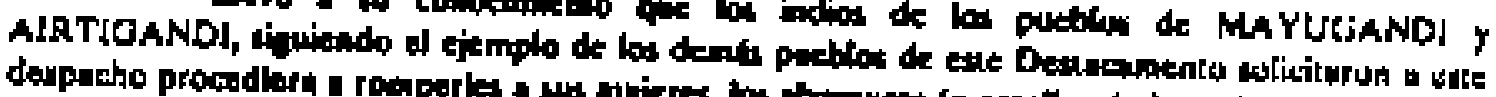

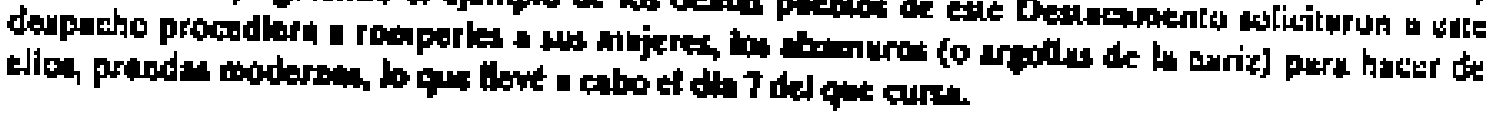

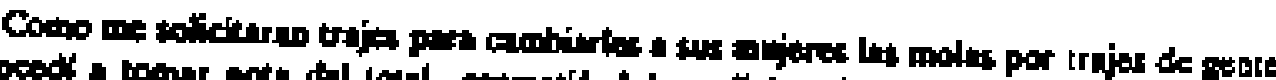

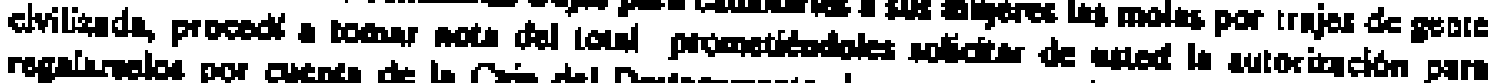

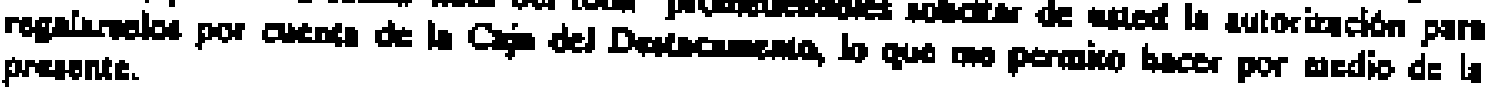

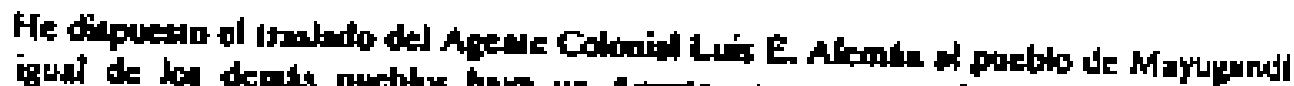

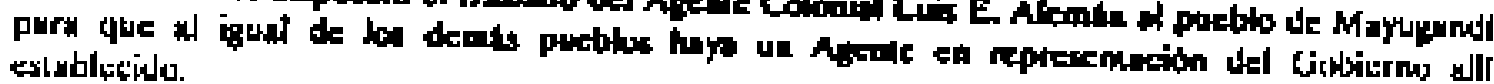

El siguiente as at? tutul de injoc:

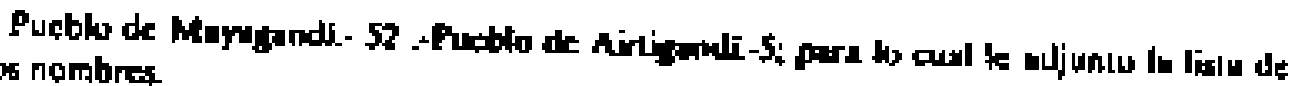
los respectinus nombres.

De tored atento y seguto servidor.

M.J.Haterg

lefe del Desuaganento

Trans. del orig. mec.

v. RD, n. 362 . 


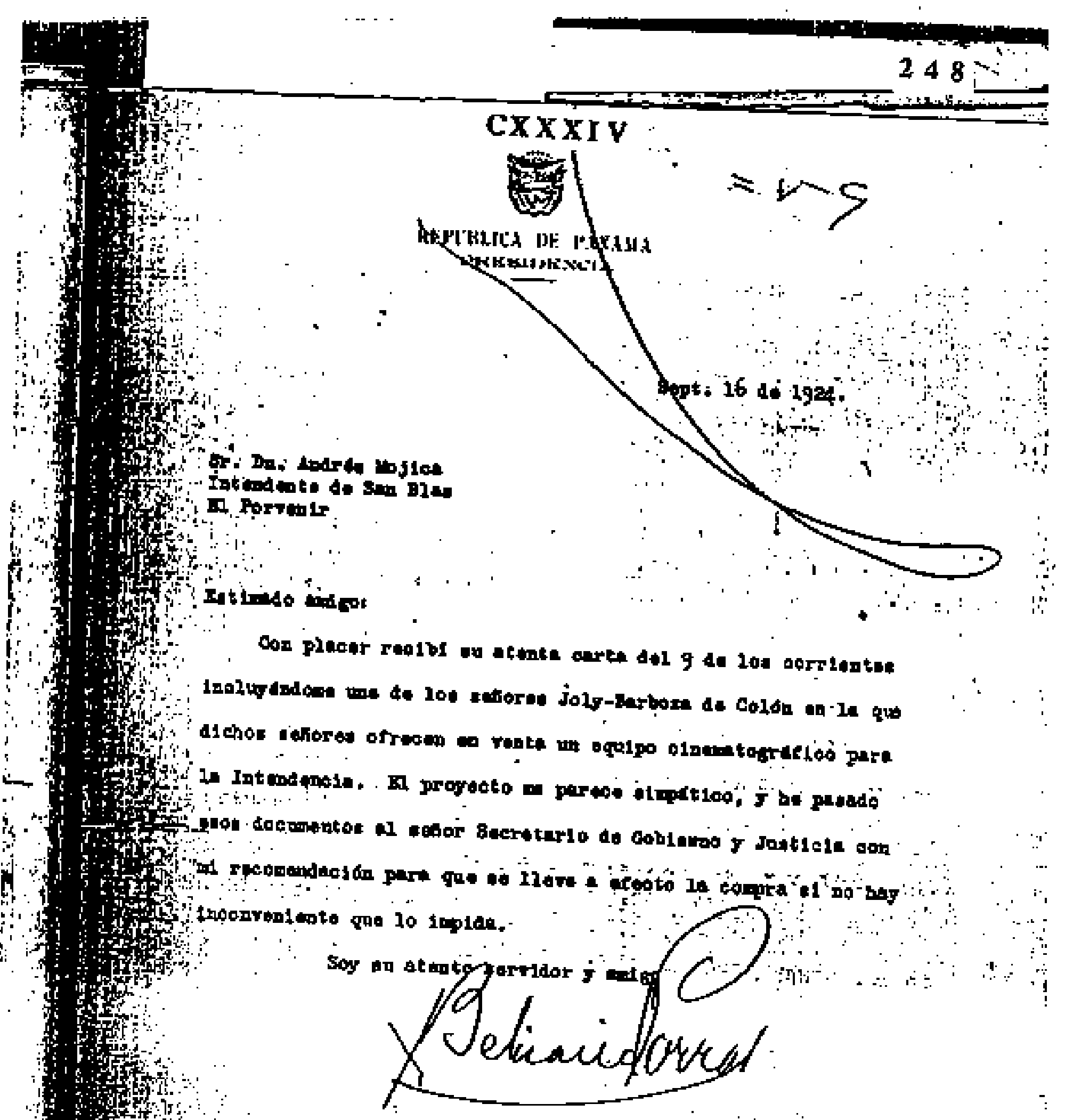

V. RD, ก. 36y. 


\section{$\operatorname{CXXXV}$}

V.12

Nónero 4152

PANAMA, 17 de Septiqunbe de 1924.

\section{Sef́nor \\ Andrif Mojlea \\ EI PORVENIR (Sen BIns)}

Sethor:

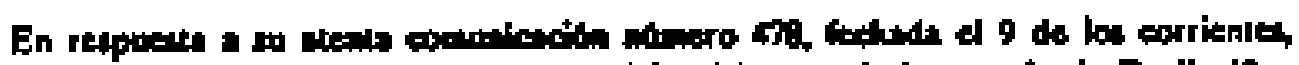

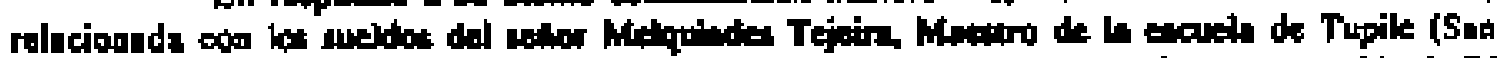

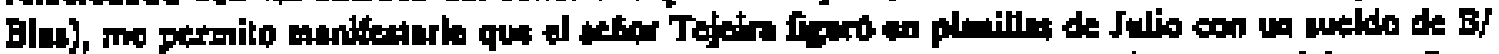

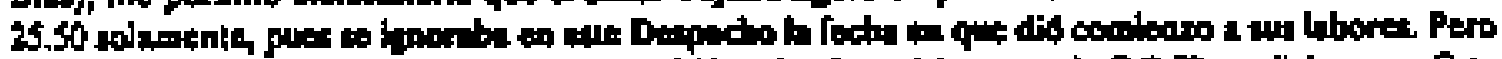

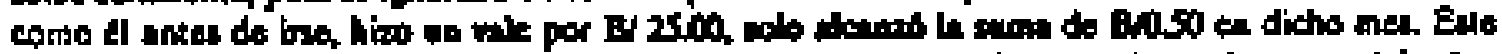

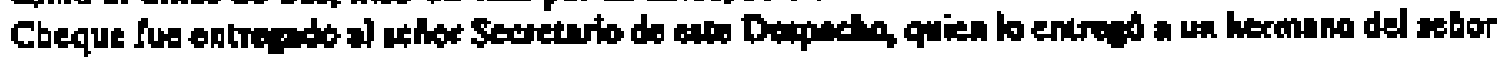
Tejejrs, mediunte recibo.

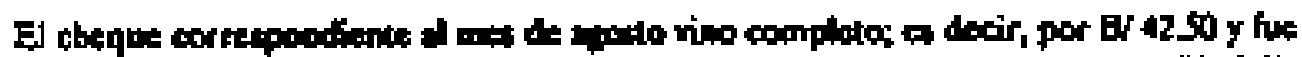

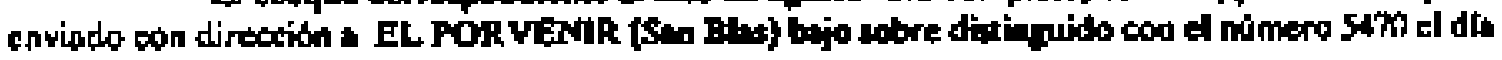
$30 \mathrm{dt}$ agoto sltimo.

De usted atento servidor.

Intpector Genneral de Endiena

Primaria.

(iirma ikgible)

Trans. del orig. mec.

V. RD, n. 369 . 


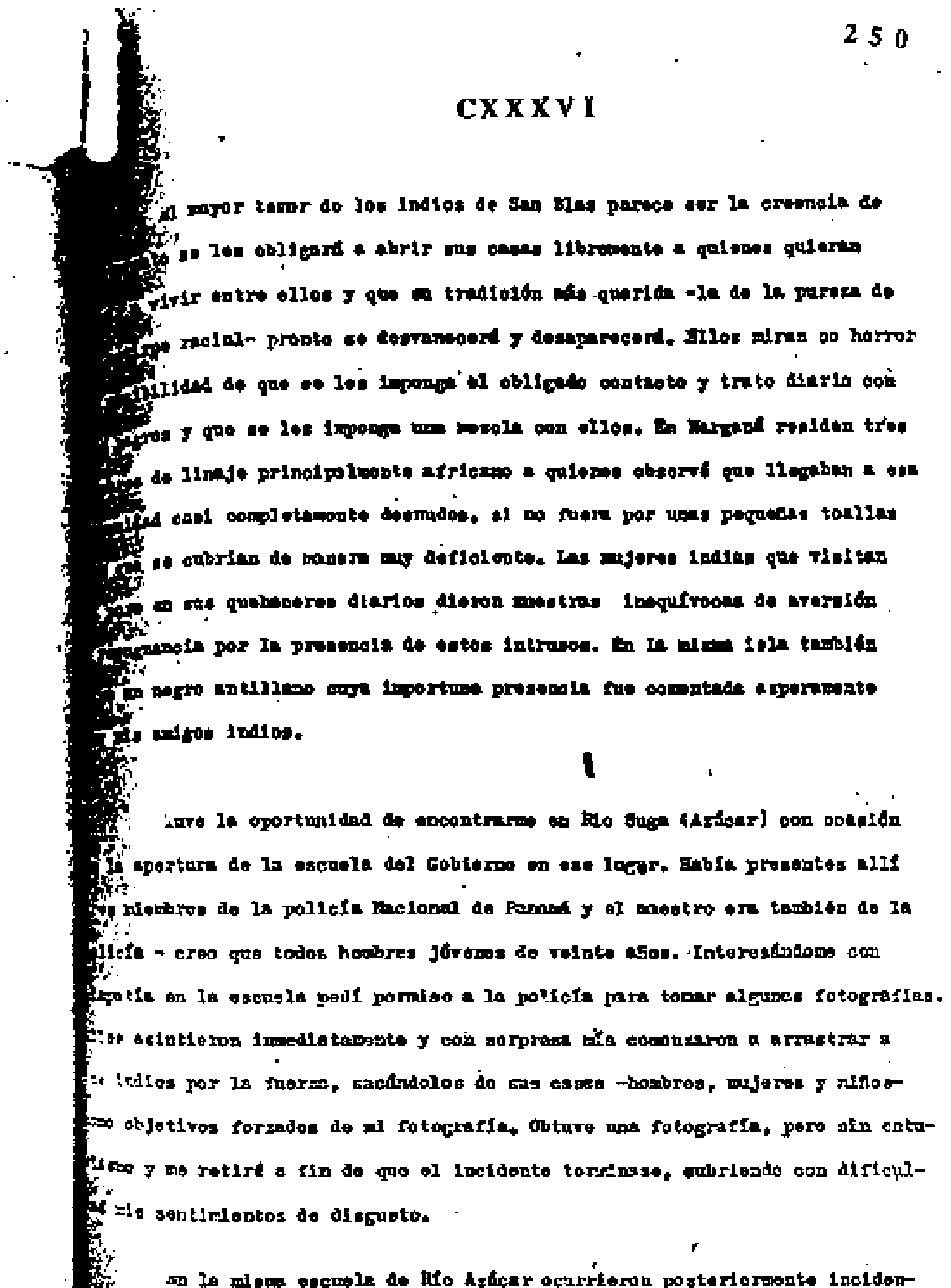




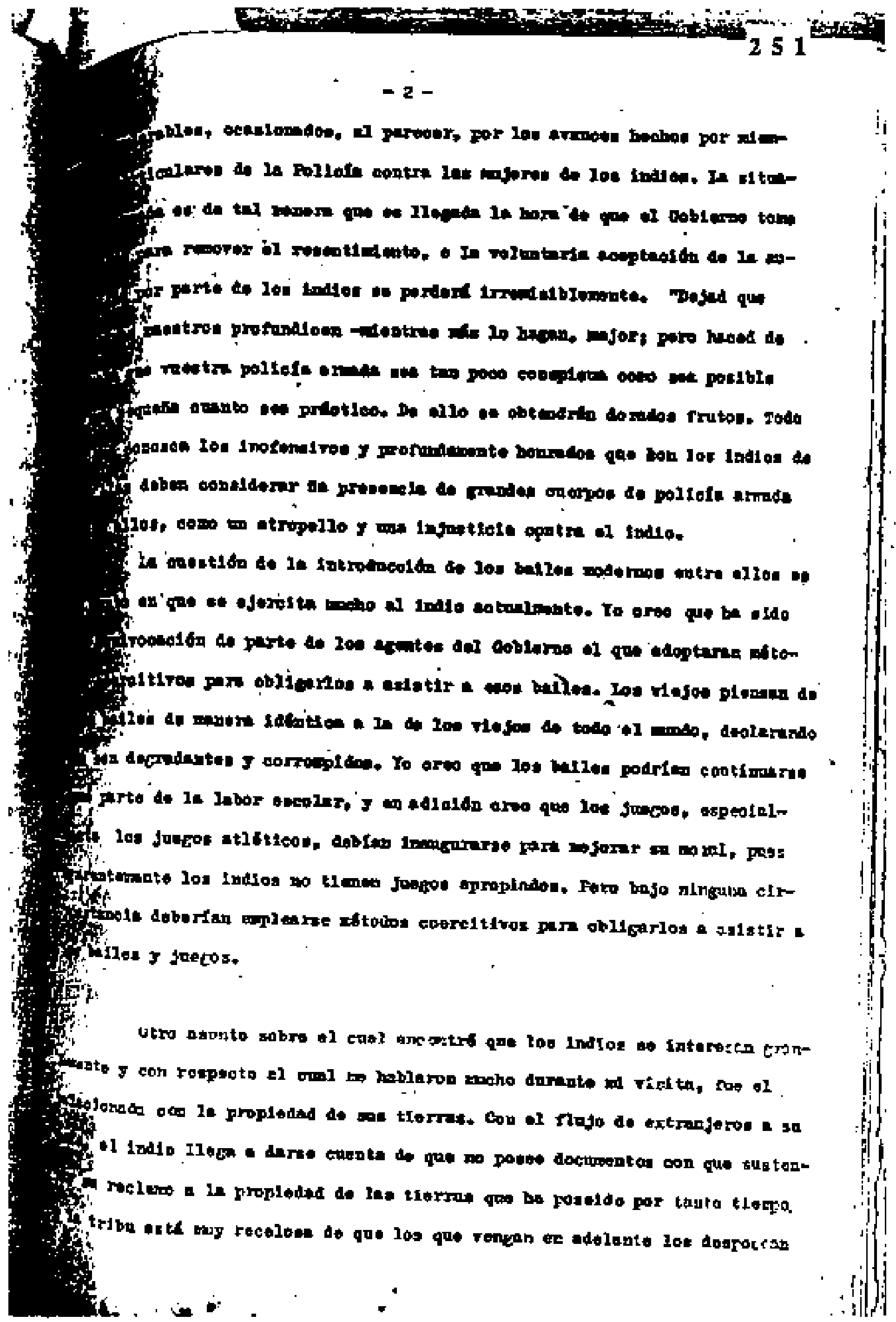




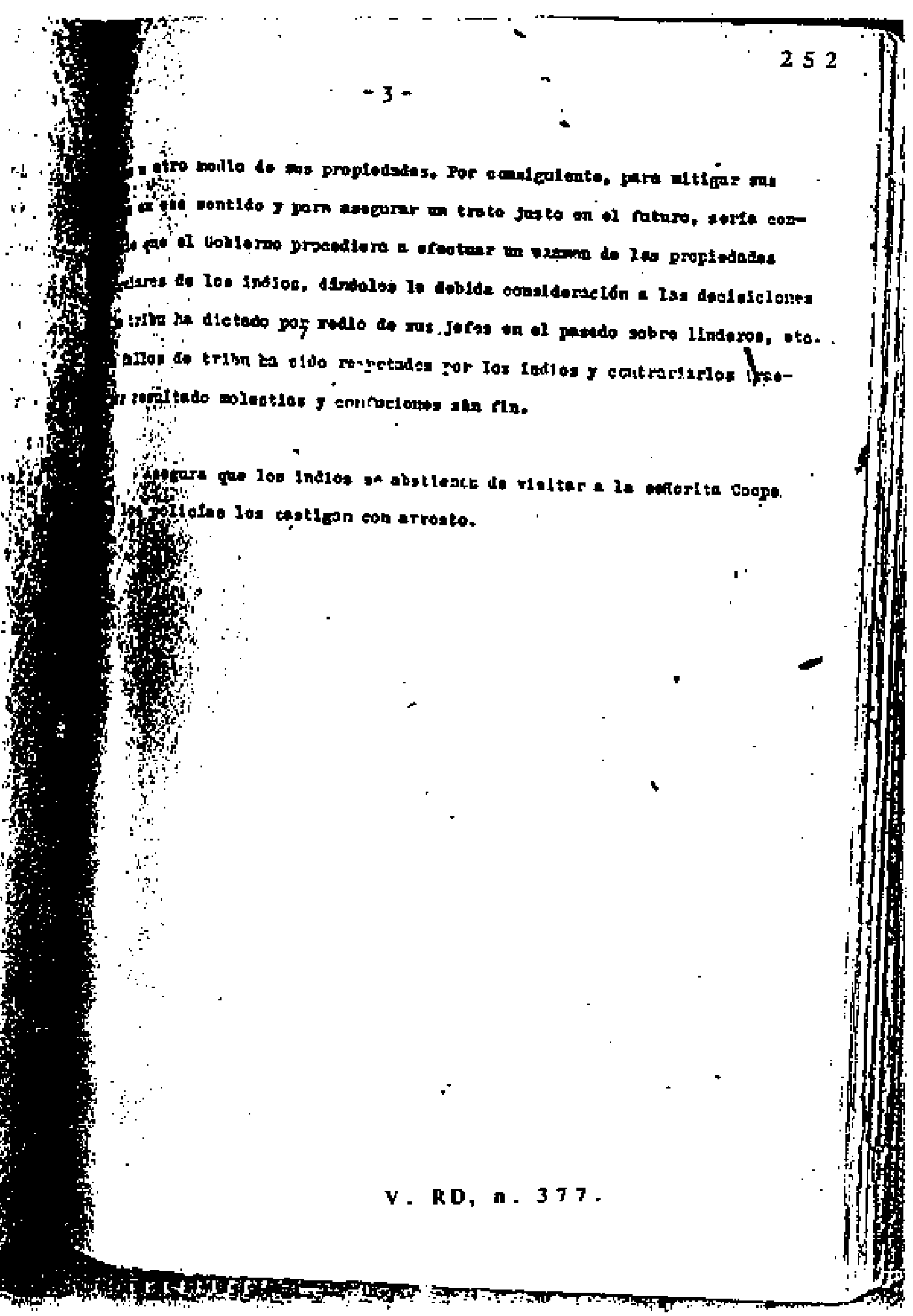




\title{
$\operatorname{cXXXVII}$
}

sg

21 Abril dis 1925

Seltor

Secredarto de Gobiermo y Jutida

Panemí

\section{Suptor;}

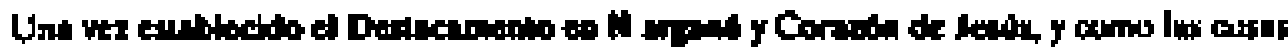

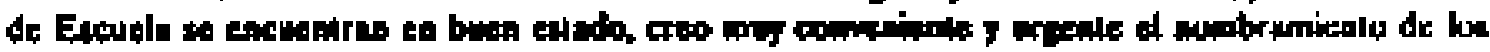

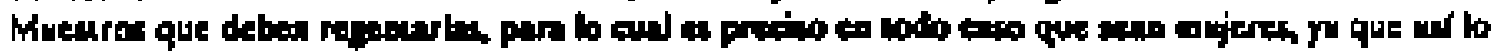

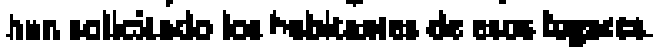

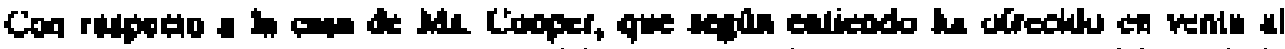

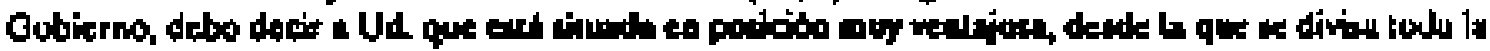

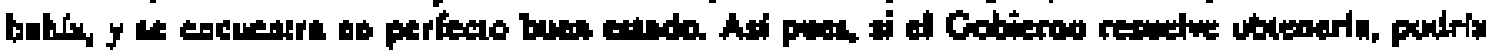

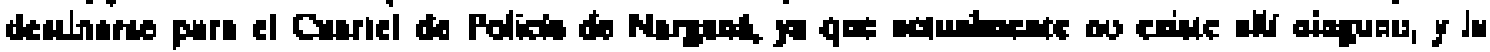

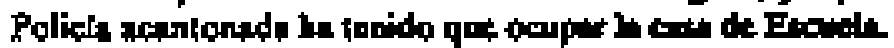

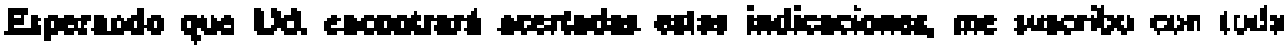

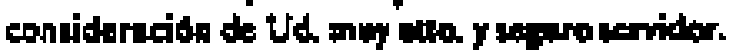

\author{
Intendente de Sag Dlas
}

Trans, de ti cop. mec.

V. RD, n. 378 . 


\title{
CXXXYII I
}

V.2] $* 27$

Nónero 61

\author{
Sefor

\begin{abstract}
Intendente da San Blat:
El Porrenir.-
\end{abstract}

Naryenf, 3 da Agosto de 1925

\section{Subor.}

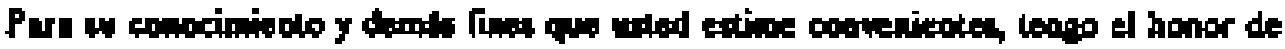

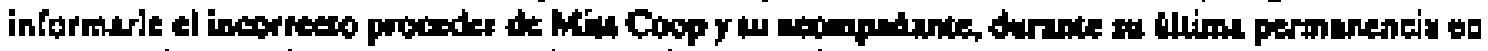

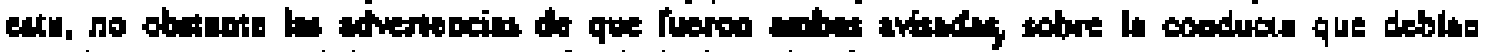

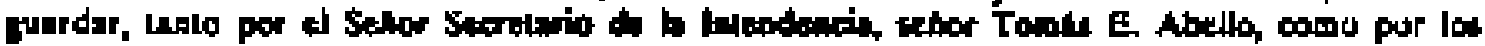

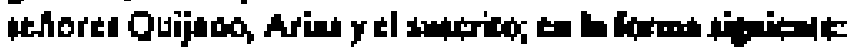

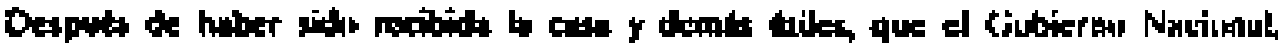

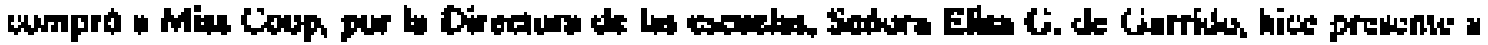

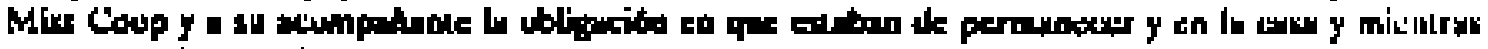

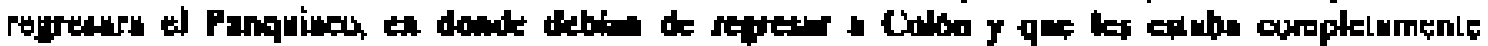

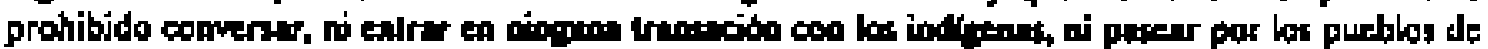

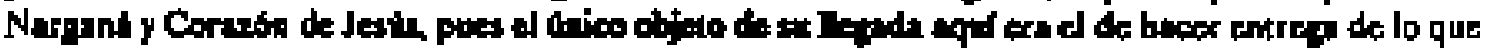

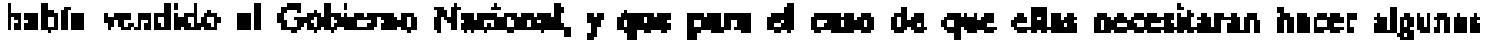

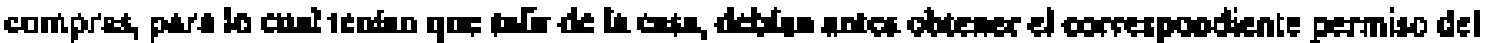

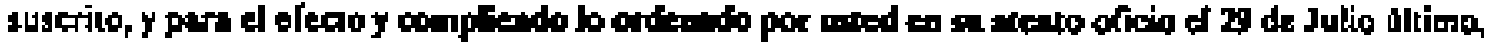

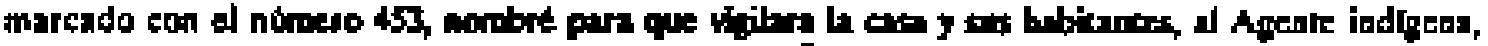

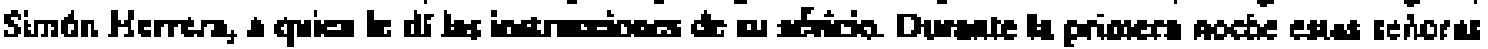

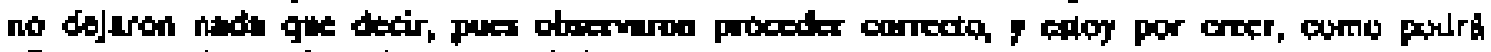

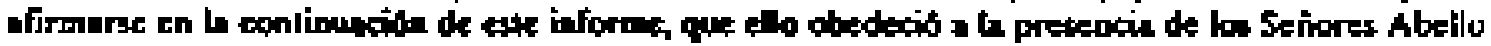

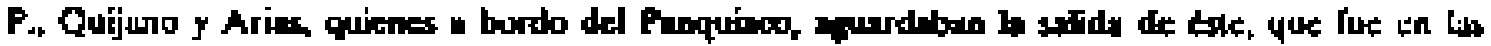

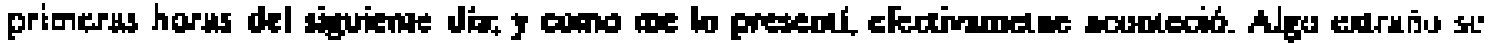

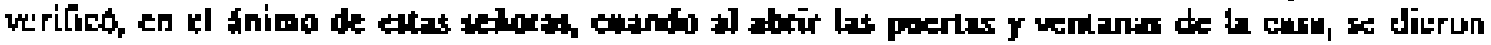

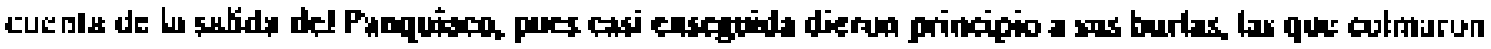

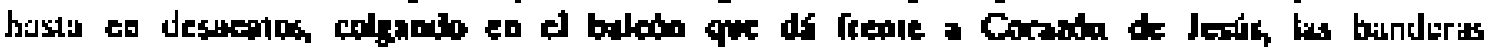

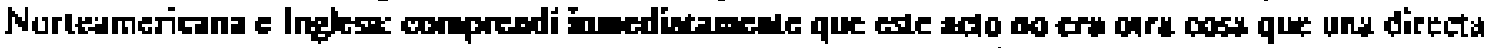

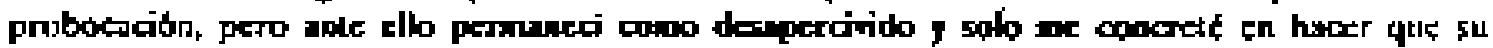

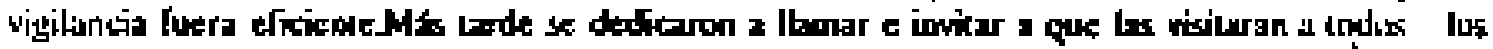

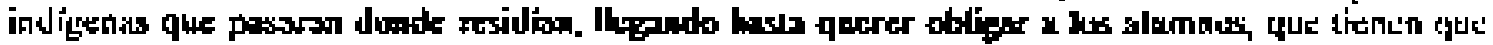

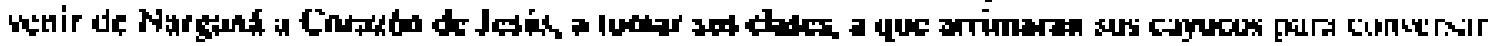

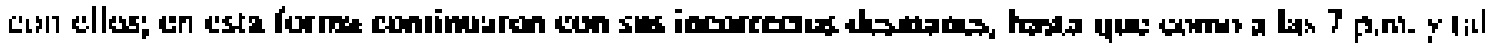

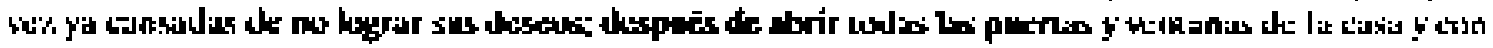

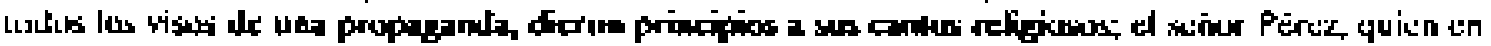

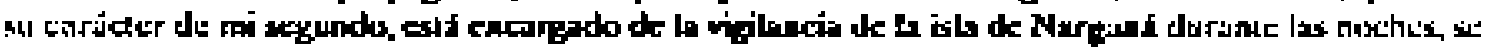

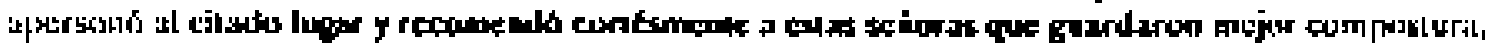

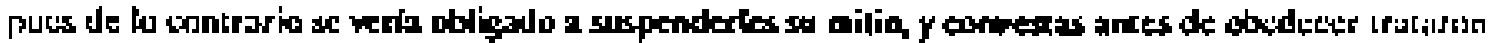

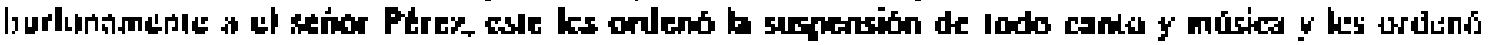

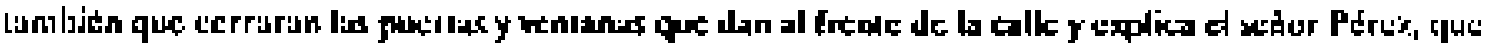

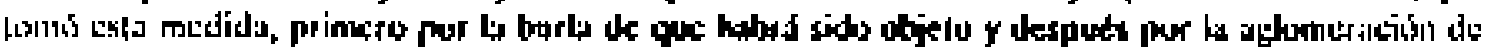

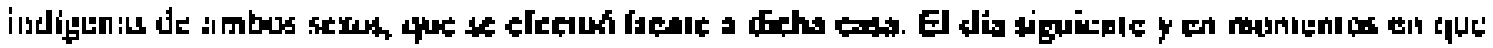

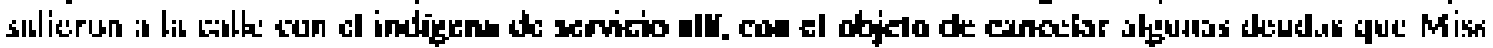

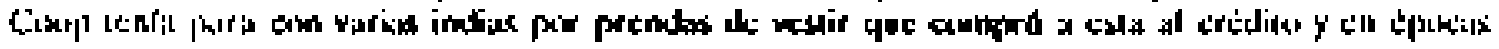

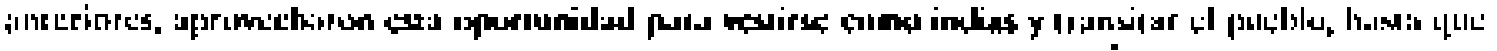




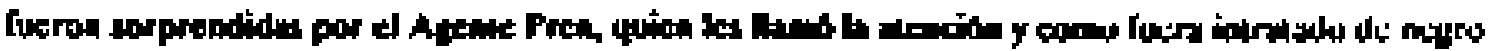

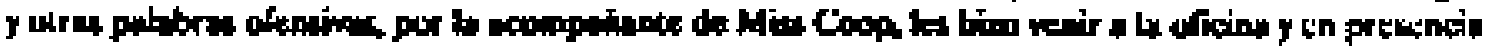

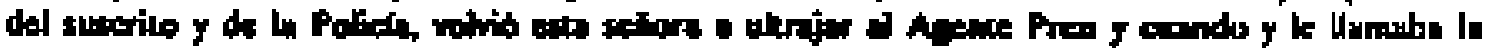

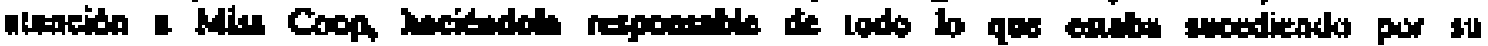

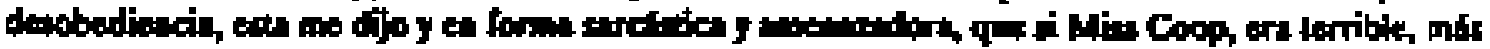

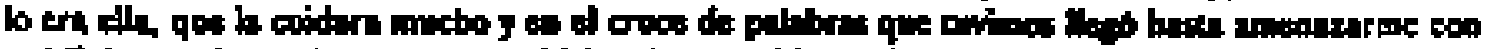

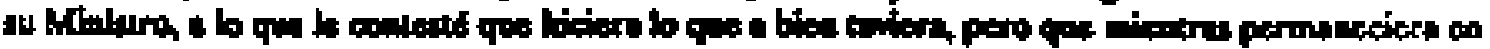

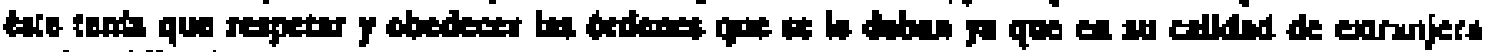

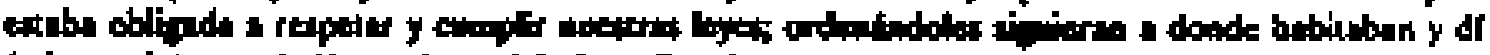

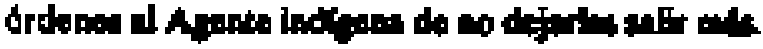

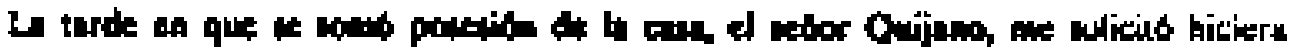

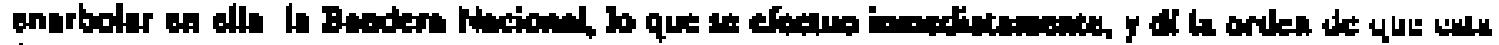

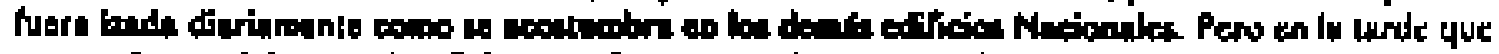

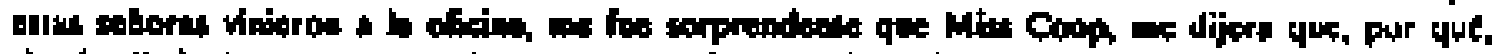

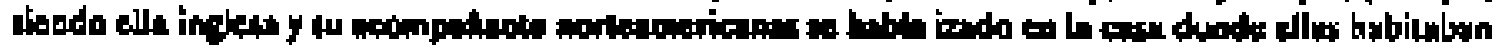

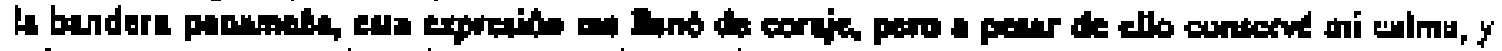

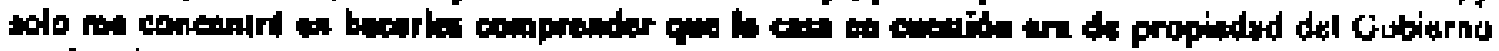

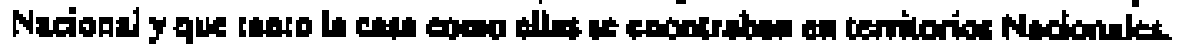

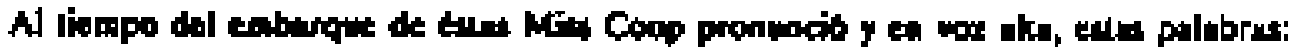

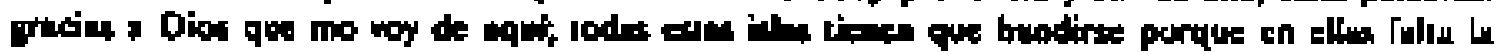
prtestnkia do Dixa.

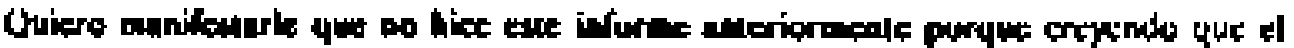

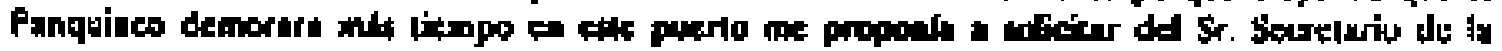

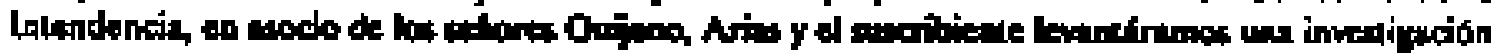

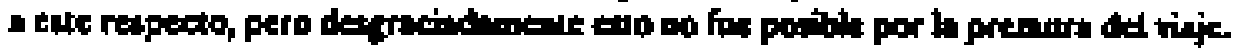

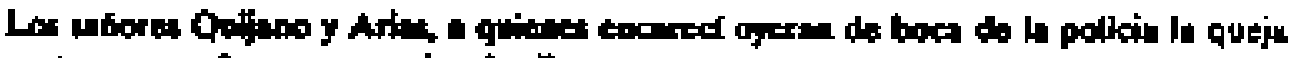

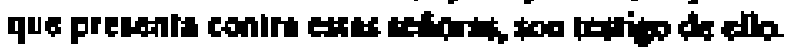

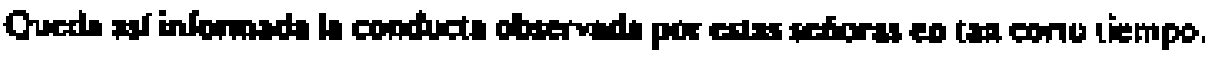

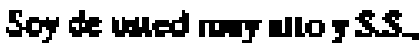

Rumain Corride D.

Jote del Dexacamentu.

Trans, del orig. ms.

V. RD, n. 379 . 


\section{CXXXIX}

El Fortanix 3 de Abril at 1926

Bromo, Sr, Don,

. Fodolto Gh10r1.,

Frestidente do 10 kopdulice,

Fendund , -

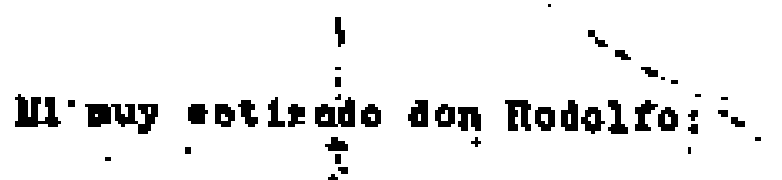

安

Mlgue para oen el Jovan"

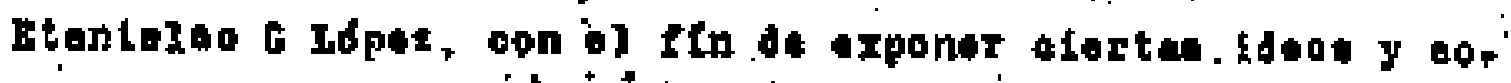

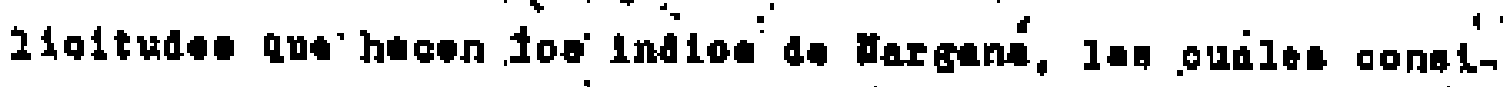

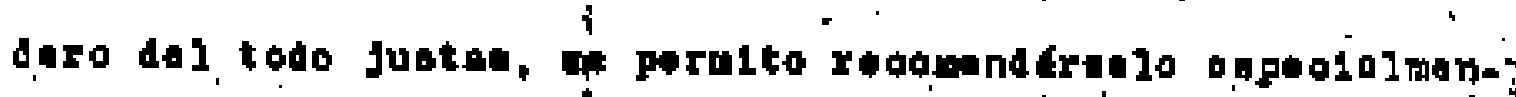

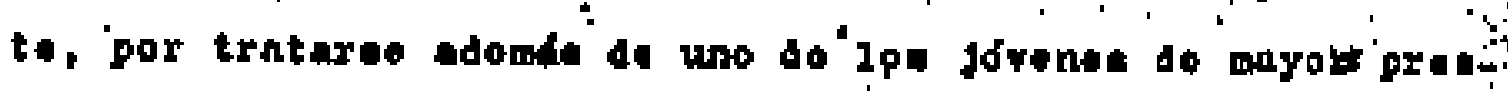

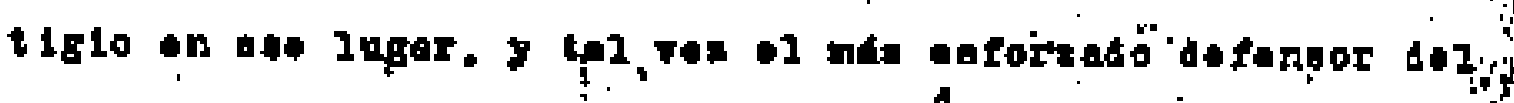

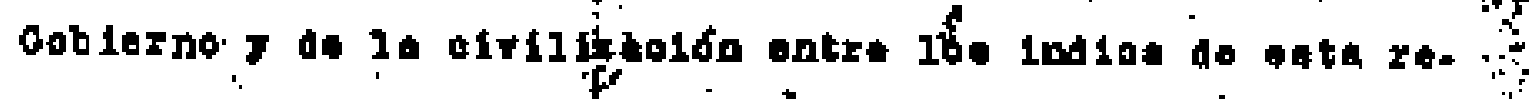
gton.

Ant lelpind ole at agr adacimieñ:

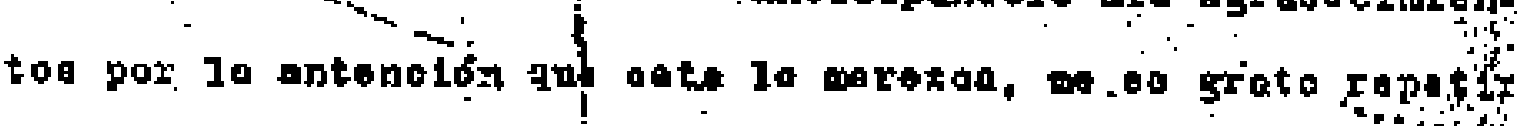
ton

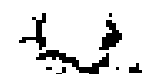

8

Exo.

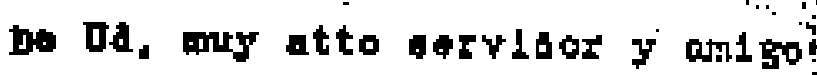
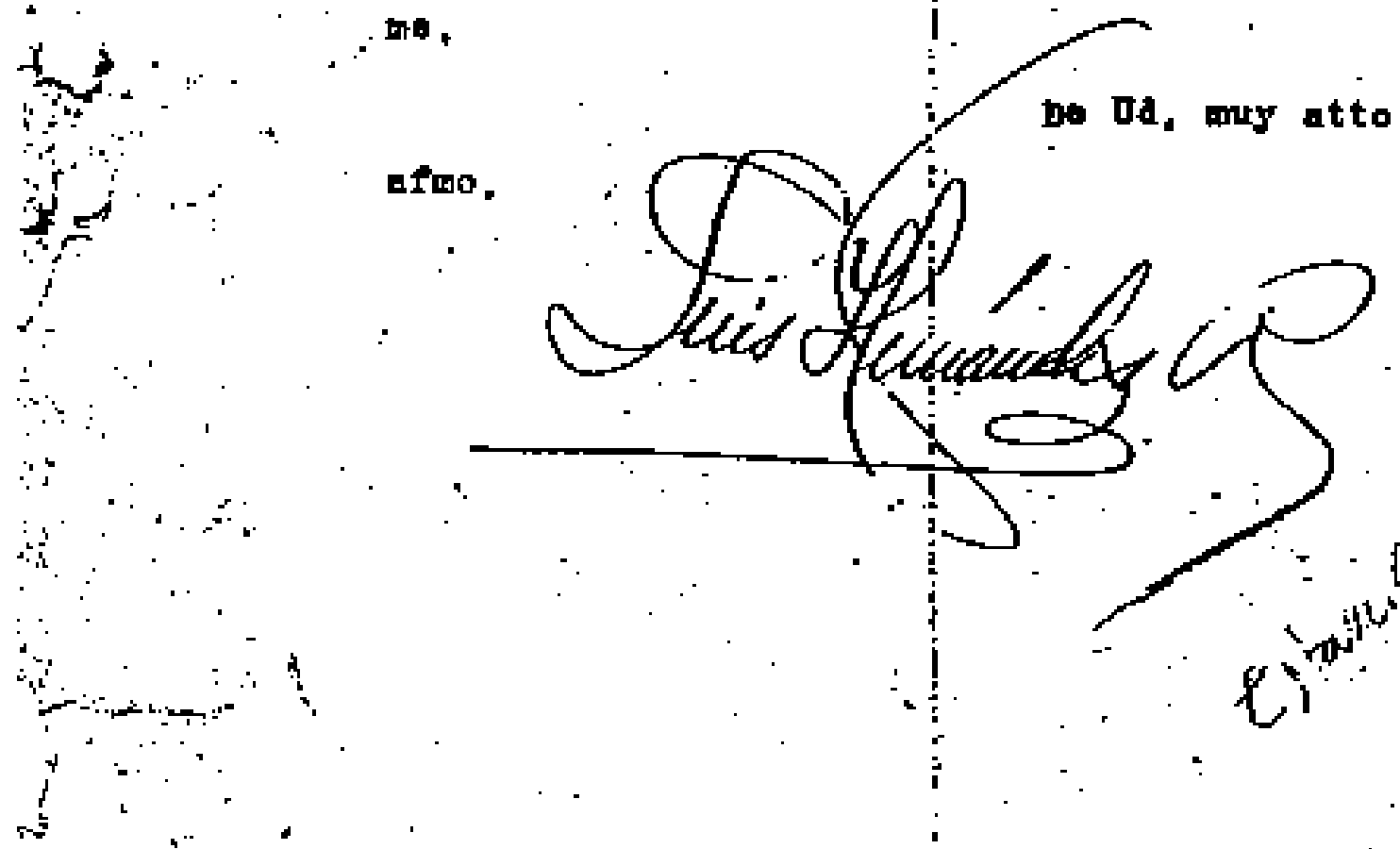

V.RD, I. 381 . 


\section{CXL}

\section{Whand If de Jurro De 2986}

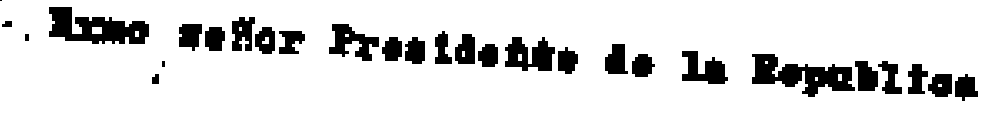

Aatior Prostront*

$$
5,0 .
$$

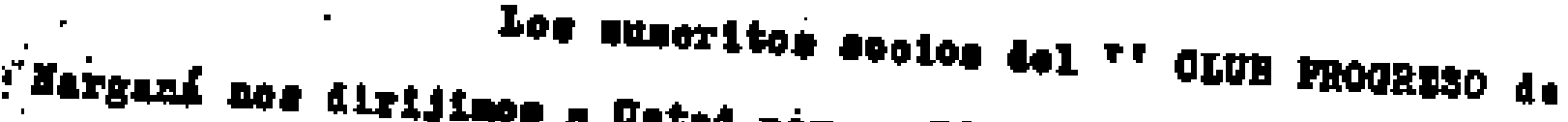

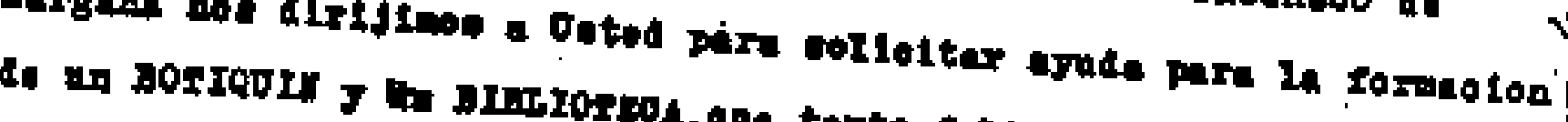

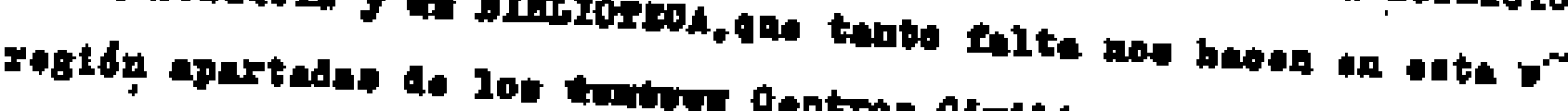

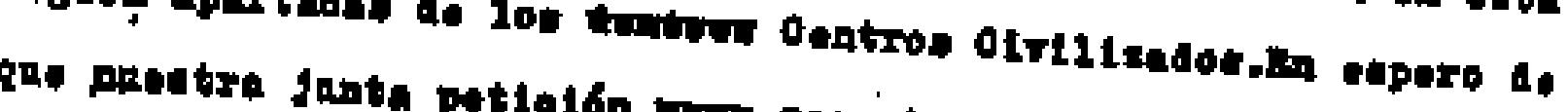

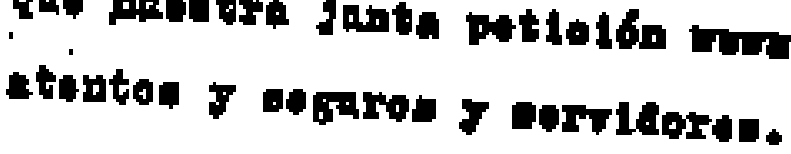

Bationteleo G.topes

Hanel Albs

Eapas towonto

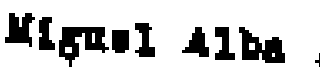

\section{Altolo Igloctes}

$$
\text { tam D, Paren }
$$

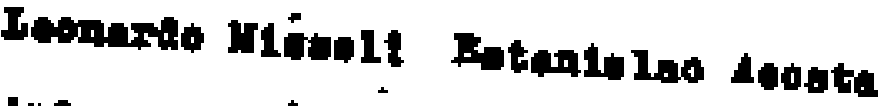

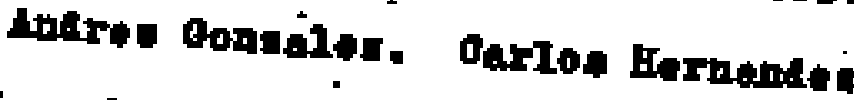

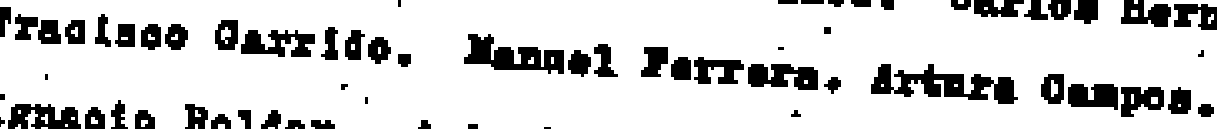

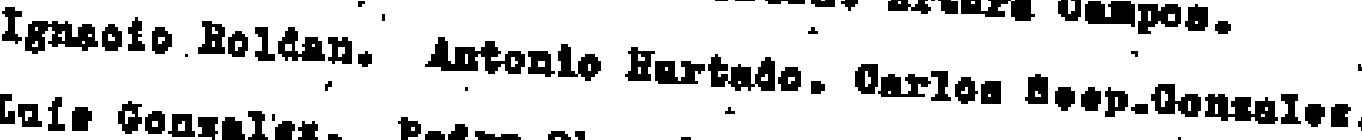

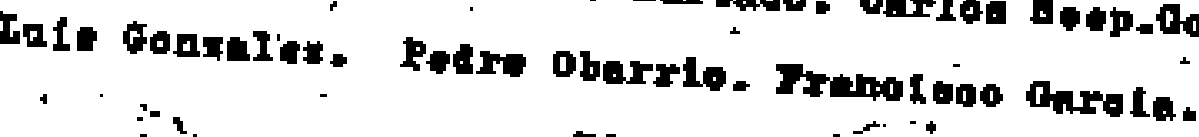

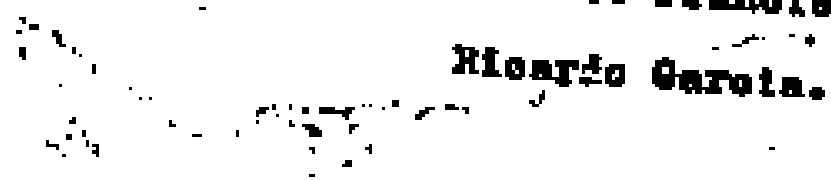

V. RD, n, 385 .

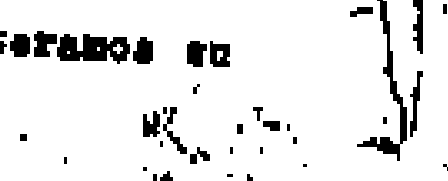




\section{CXLI}

NARGANA, 13 de Junio de 1926

Sentor

Intendeate de Sen Bas

Et Parvenir.

\section{Sodor}

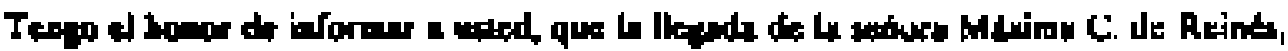

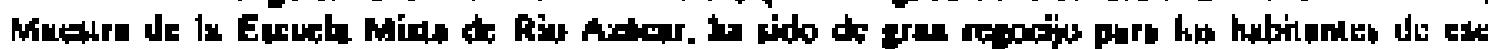

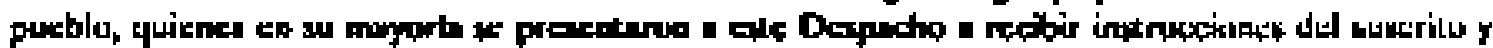
.

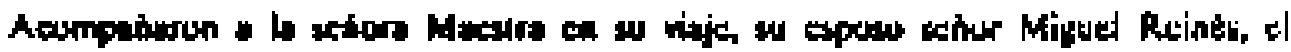

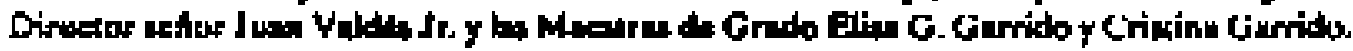

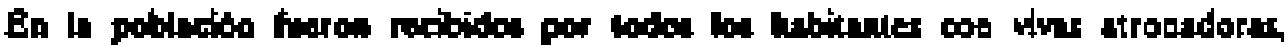

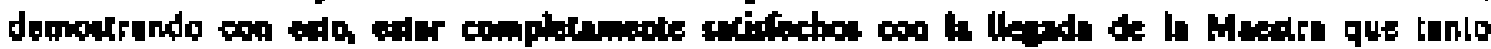
dreutumn.

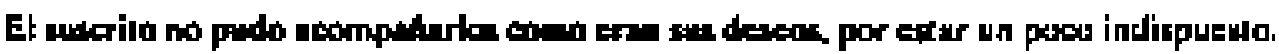

Soy de byed, may aleolo y sefulo semidow.

Rambn Garrito D.

Corregidtex de Napgon

Trans. del orig. inec.

V. RD, n. 386 . 


\section{CXLII}

Número 23

Seitior

Nartant, 12 de Pebrevo de 1927.

Intandente de Sta Blas,

El Porwiolir.

\section{Solort-}

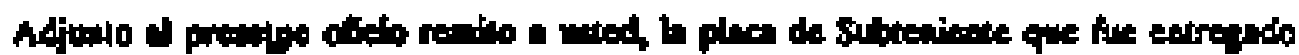

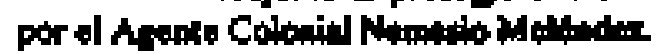

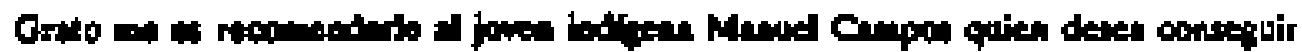

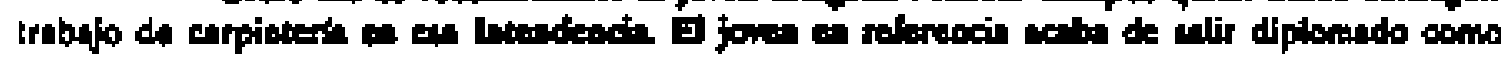

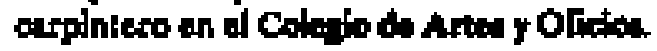

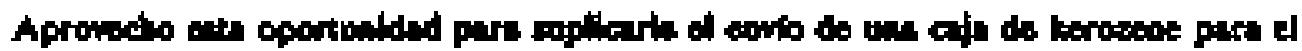

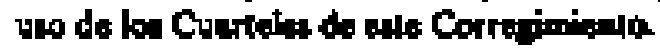

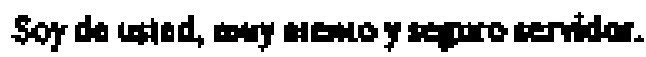

Rendin Gerrite

Correjdor de Nopolat

Trans. del orie- mex:

V.RD, 0,388 : 


\section{CXLIII}

\section{INSTRUCCION PUDIJCA}

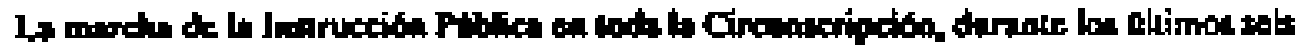

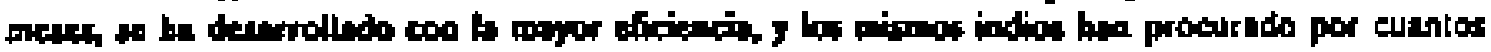

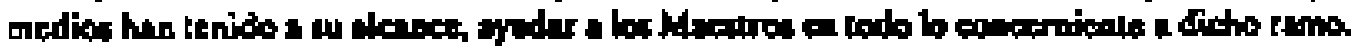

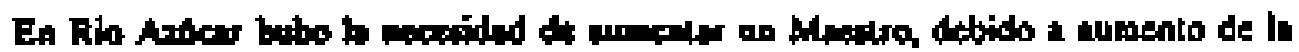

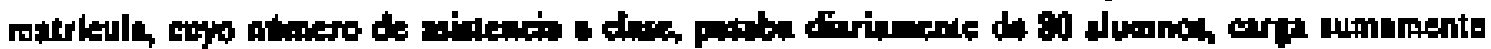
painde pars us esto medro.

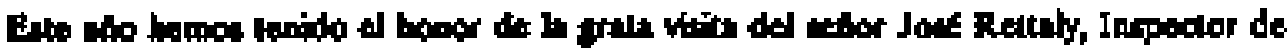

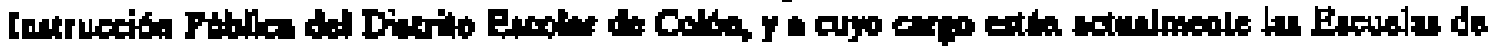

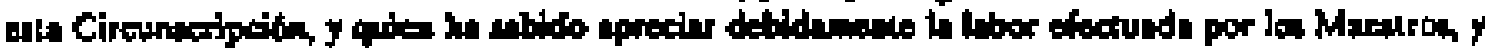

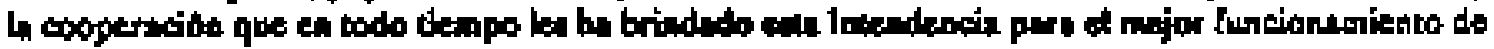
Ie Euevelus.

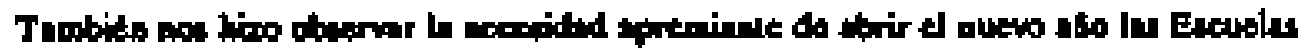

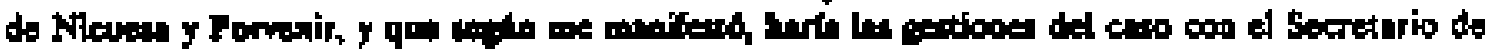

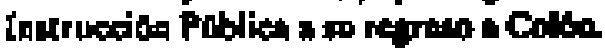

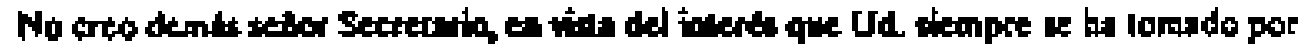

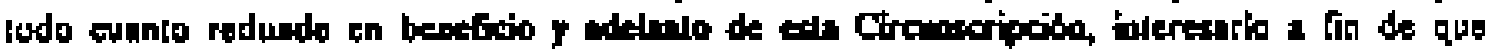

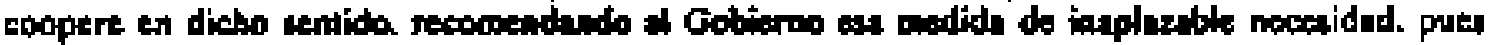

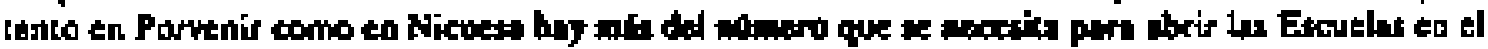

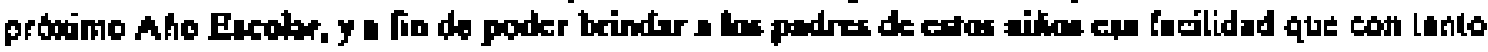
inhelo desenn,

\section{INSTRUCCION PUELICA}

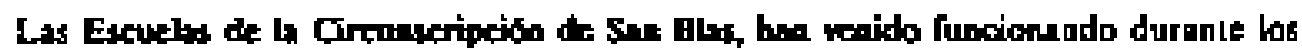

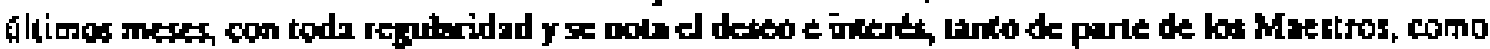
de los indion, de convilbir por todos lo mefios a ts aleace al mejoraniento de estor centres de

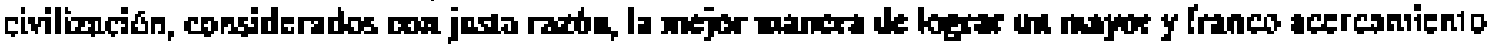

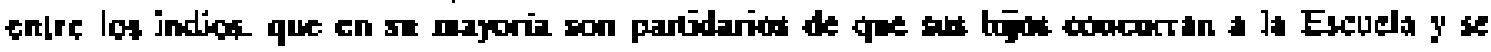
instruyas.

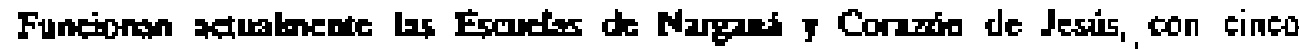

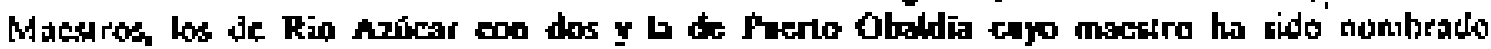
ręcienicmente.

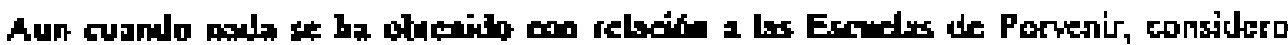

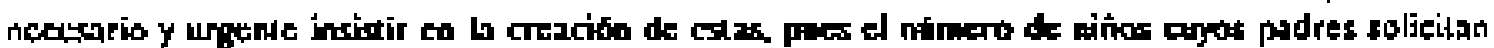

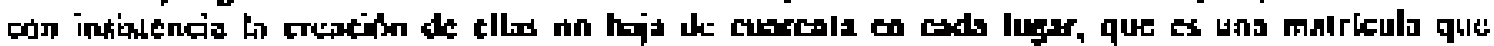

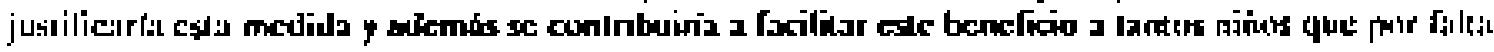

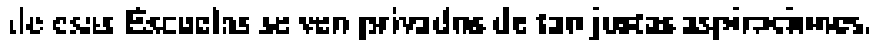

Trans. de la cop. mee. inc.

$$
\text { v. RD. n. } 389 \text {. }
$$




\section{CXLIV}

A.IA

Sefior

Nargens 23 de Febrero de 1927

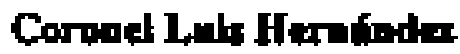

Inlandente dis Sing Blas

Porveis

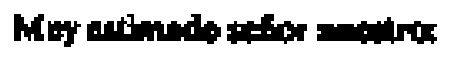

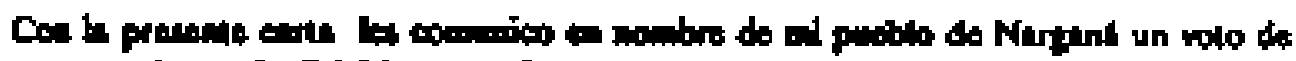

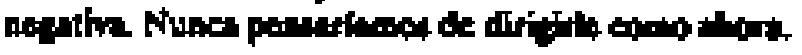

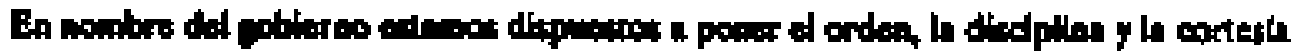

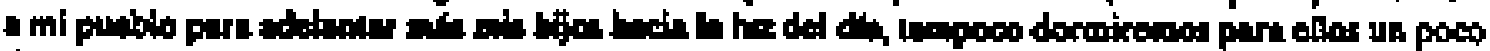

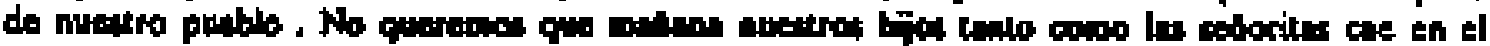

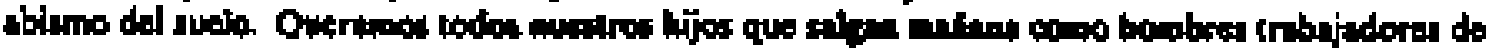

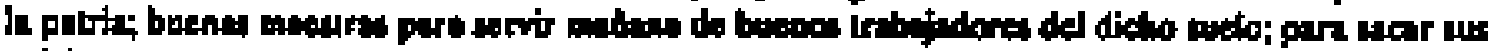

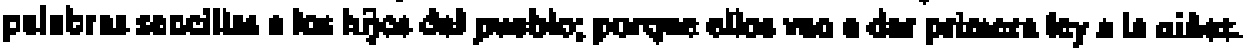

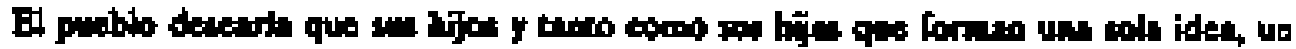

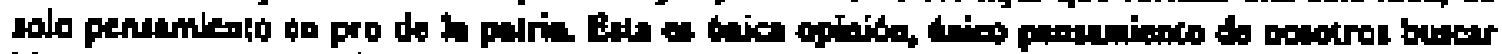
biton y propresar la pairl.

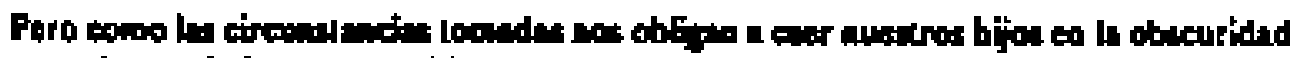

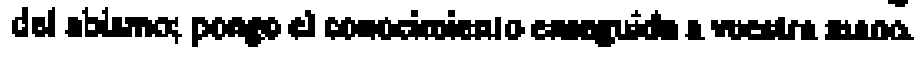
fintu tit pueblo.

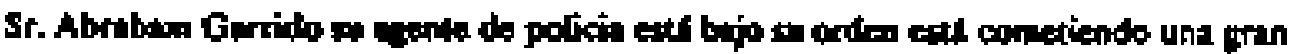

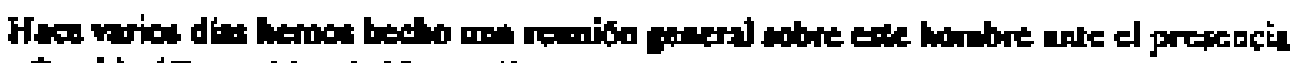

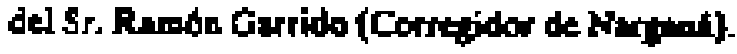

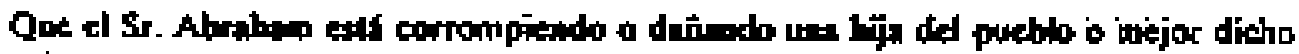

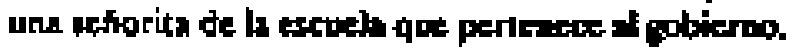

Tada el pretblo end ofigusado de el.

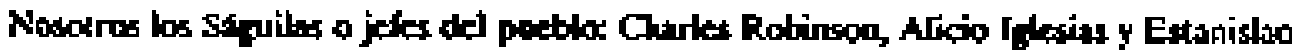

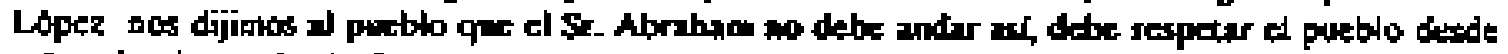
mis pobre tasels el inds rice.

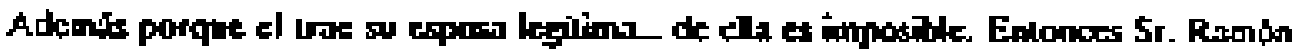

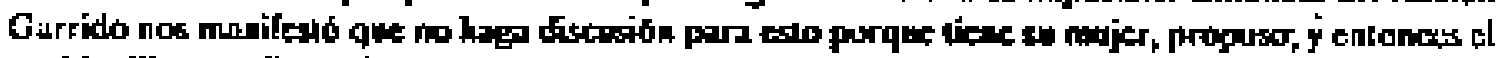

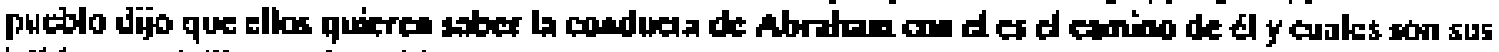

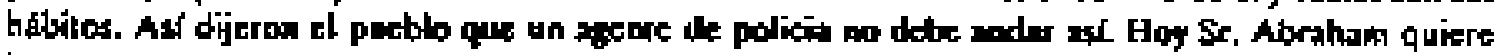

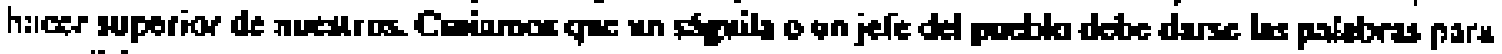
cumplirla

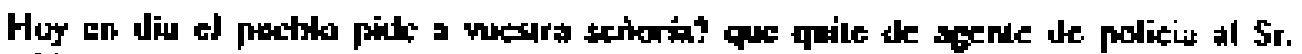

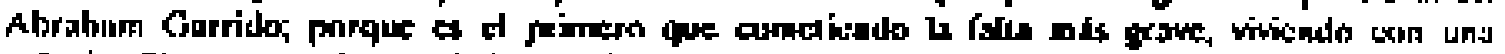

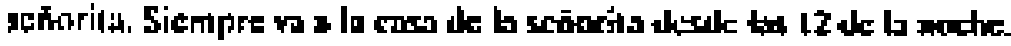

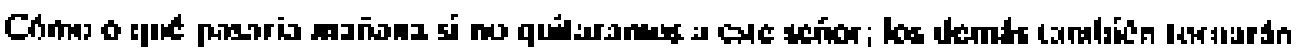

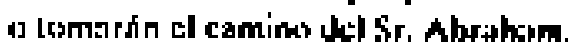




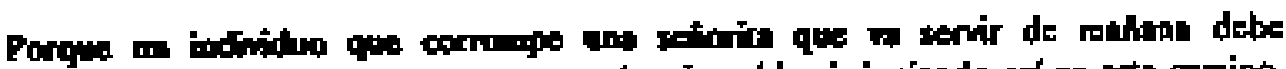

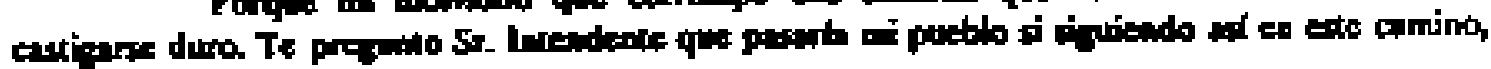

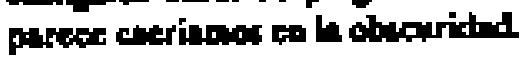

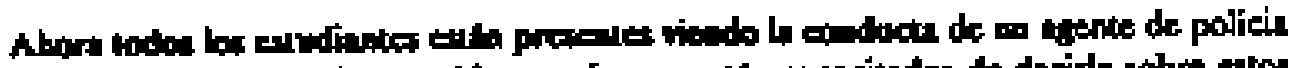

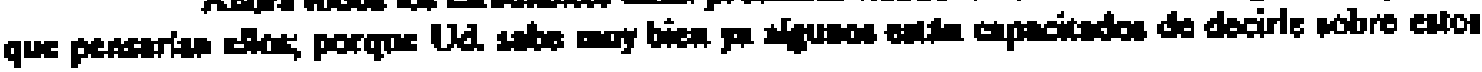
tovplos

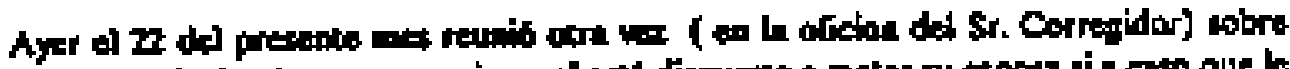

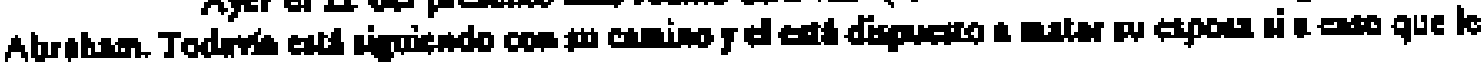
porfit en prono.

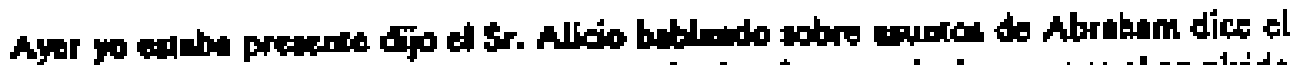

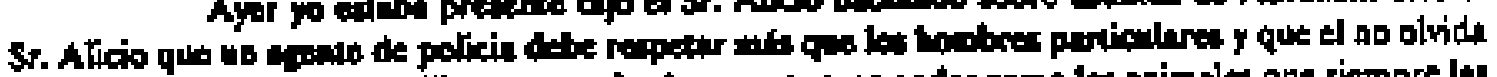

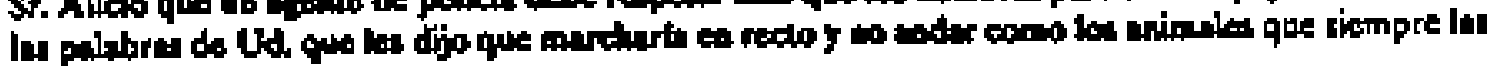

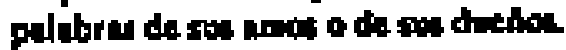

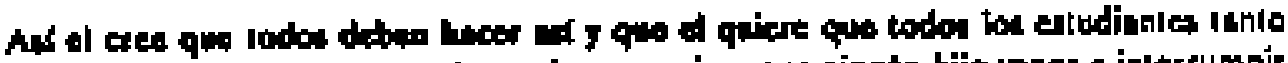

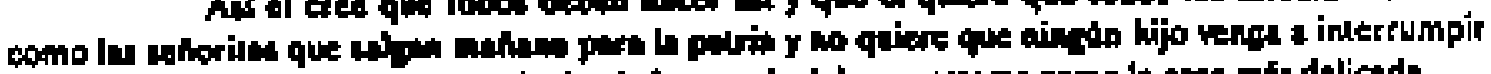

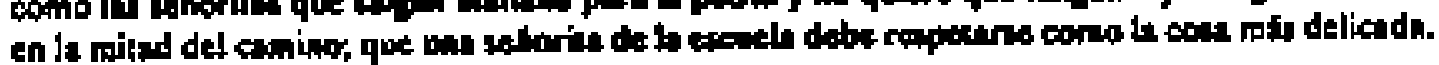

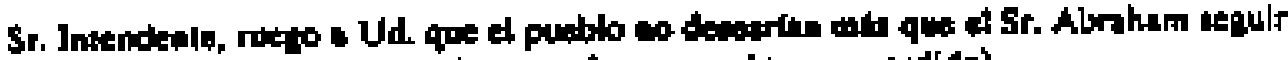

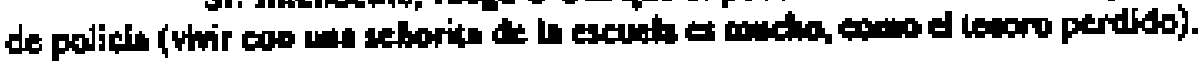

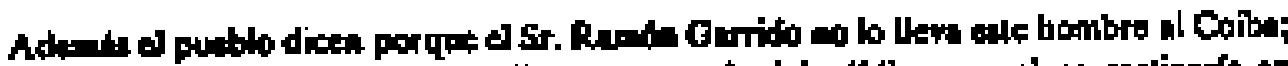

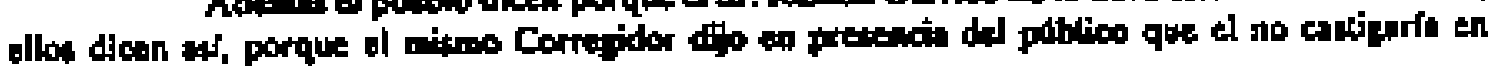
Porvenif siro al Coibe

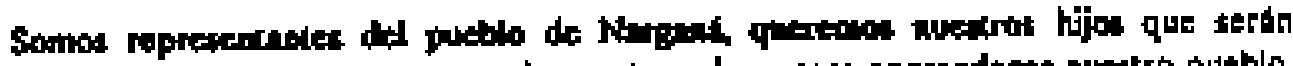

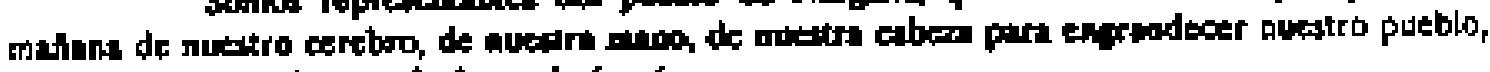
que harte á un homber particular aderfa af, les avisaris a Ud.

Ademis Ud. bes inkemb que si cunlpuier acence a ba uperior de policla que conste

Sin mats deciste

Somos sus segures gervidates y leates unigos

Charles Rotinson

Alicio lakrims

Eslanistore Loper

Trans, del orig. ms. inc,

$$
\text { v. RD, n. } 390 \text {. }
$$




\section{CXLV}

Número 31

\section{Snb̄or}

Intondente de San Bin:

EJ Porvenir.

Setor:

NARGANA, I9 de alril de J927

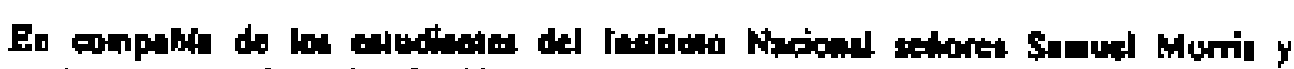

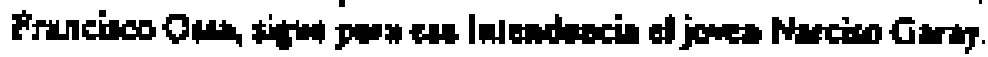

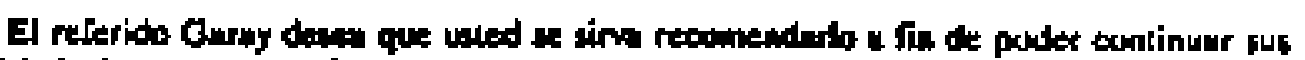

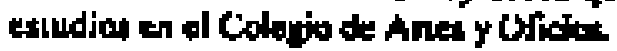

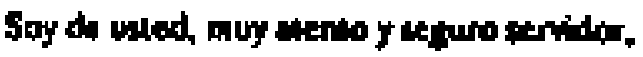

Ruraon Garride D.

Correytider de Narpant.

Trans. del orig. arec.

V. RD, n. $39 \mathrm{I}$. 


\section{CXLVI}

V.16

Número 194

30 Abril

7

\section{Setior}

Seertataio do Eslado en el Despacho de Instrucción Públiea,

Paramb.-

\section{Solkor apturitiox.}

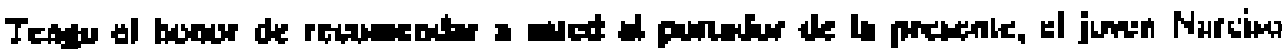

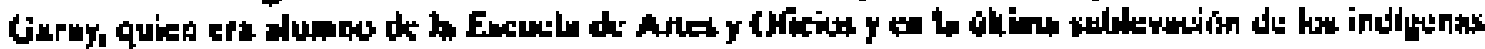

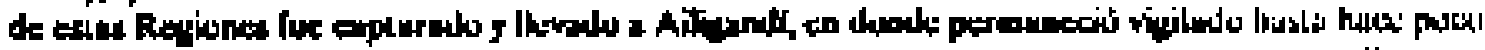

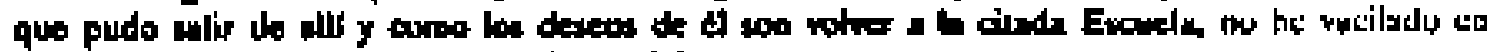

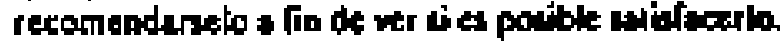

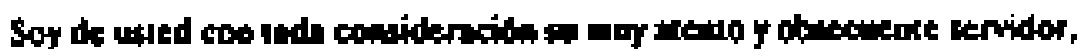

Intandenie.

Trans. de la cop. mec.

V. RD, n. 3\$2. 


\section{CXLVII}

Número 35

NARGANA, 27 de Abri] de 1927.

\section{Selior}

Intendente de Son Btos,

it Porvantr.

\section{Sethor:}

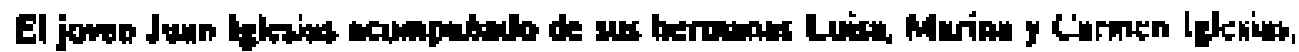

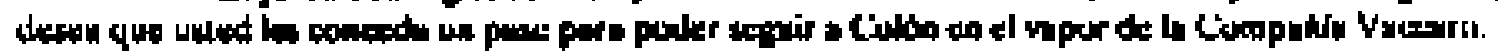

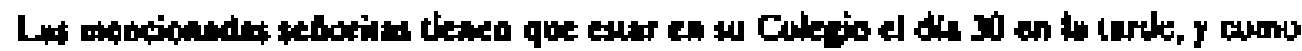

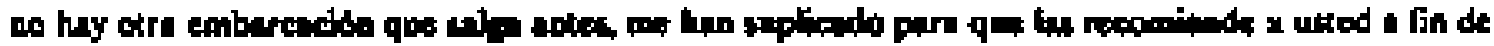
no perder in opoctunded que ne les prosianla.

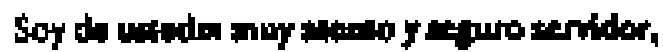

Randin Garrido $D$.

Correpidor de Nater

rrans. del orig- mec.

V. RD, n. 393. 


\section{CXLYIII}

Número 38

NARGANA, 3 de Mayo de 1927.

Sehor

loterdente da San Bles,

El Porvenit.

\section{Sobor:-}

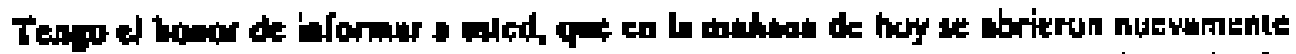

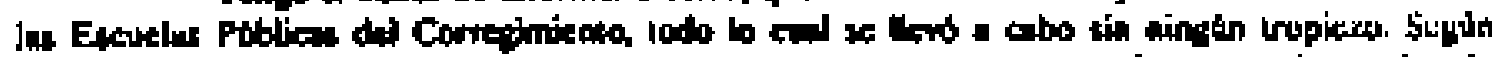

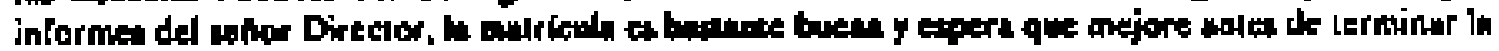
segran.

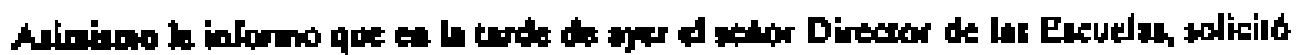

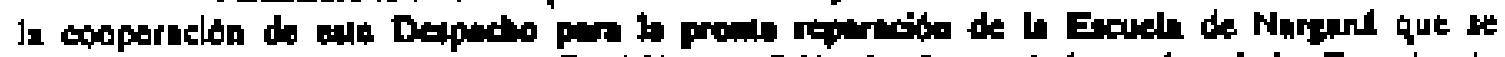

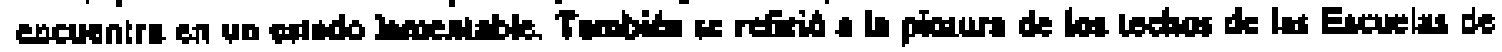
*ablun is

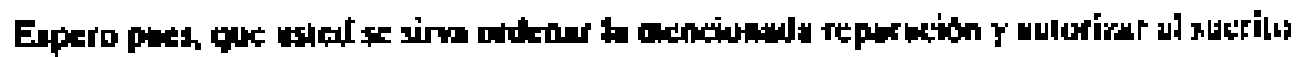

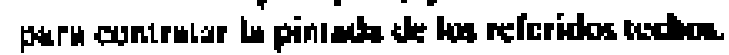

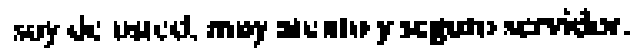

Rmá́s Gorridu L.

Correpidor de Nagat

Trans. del orig. mec.

$$
\text { V. RD, n. } 394 \text {. }
$$




\section{CXLIX}

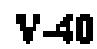

Número 40

NARGANA, 7 de Mayo de 1927

Sehor

Initendente do Sin Blas

El Forrunir.

Sohor:-

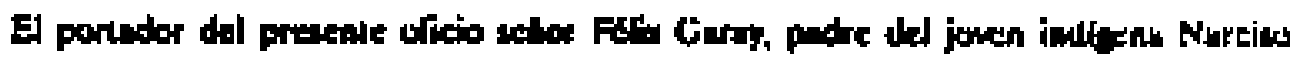

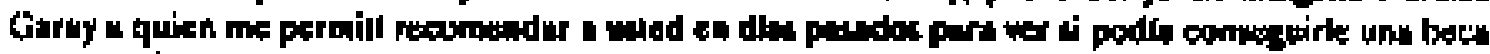

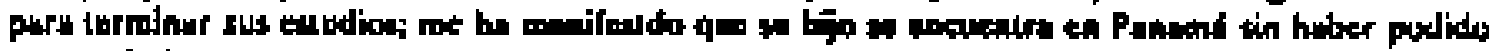

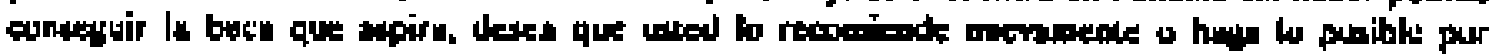
colocurlo.

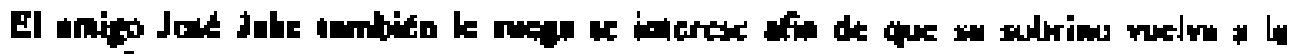
Eacueln de Arter y Uivion

Soy de tasted, moy wemo, kefuro setvidor.

Ramin Cenrmin D.

Cortegidar de Norpans.

Trans, del orig- nec.

V. RD, I. 396 . 
CL

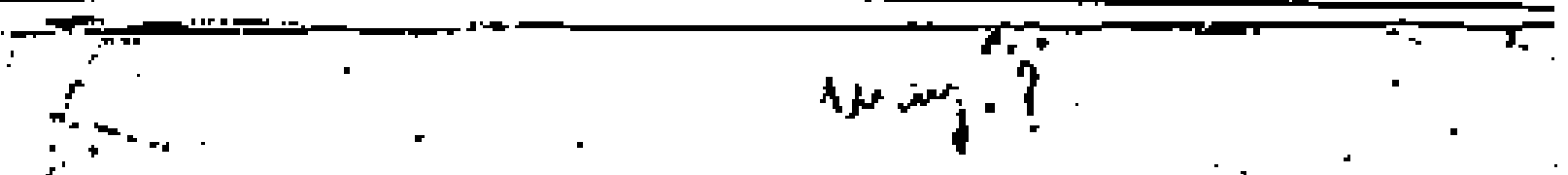

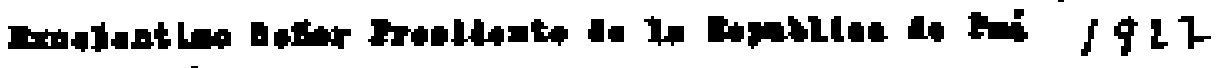

$\because$ ing tobrinte

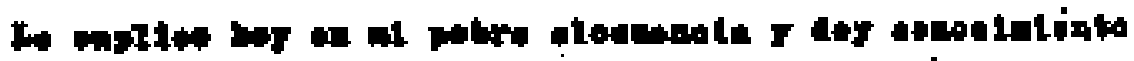

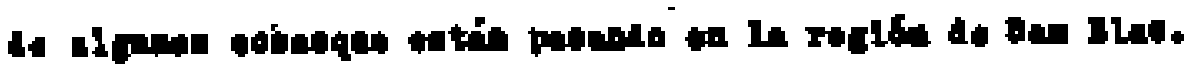

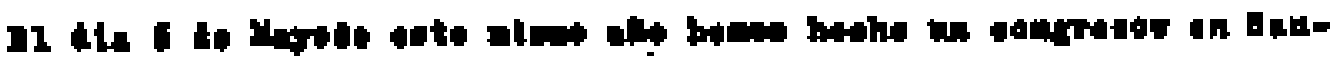

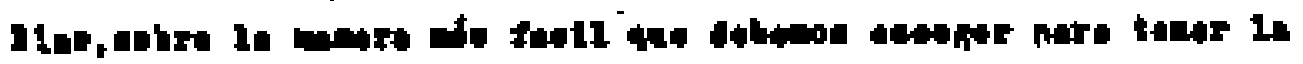

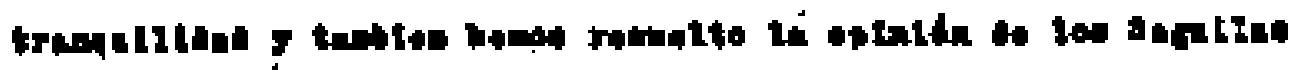

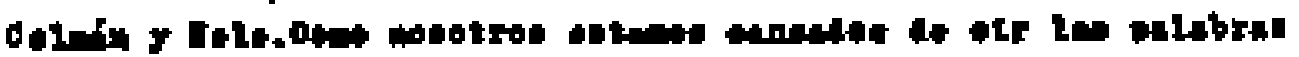

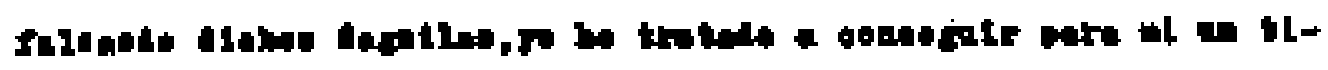

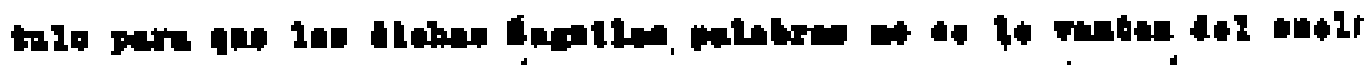

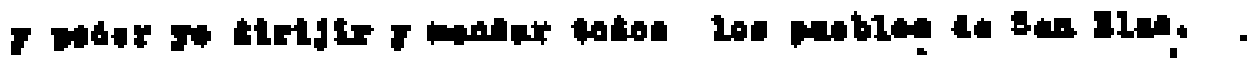

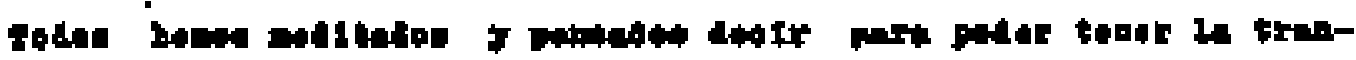

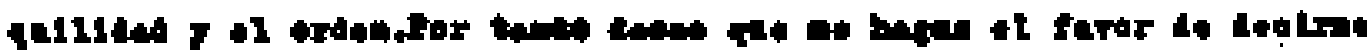

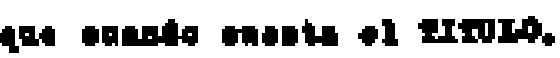

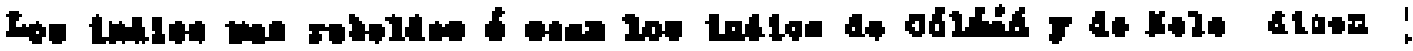

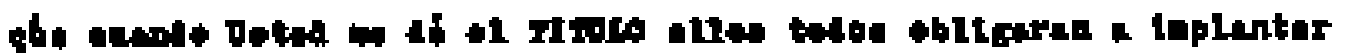

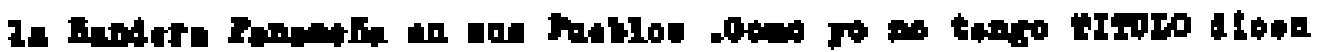

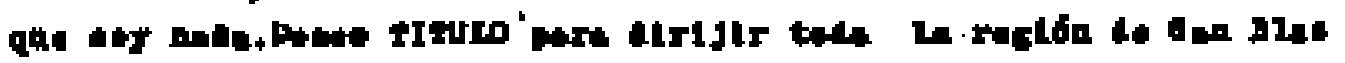

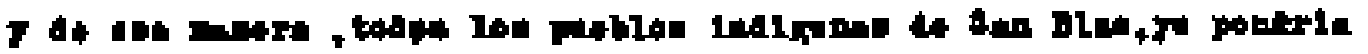

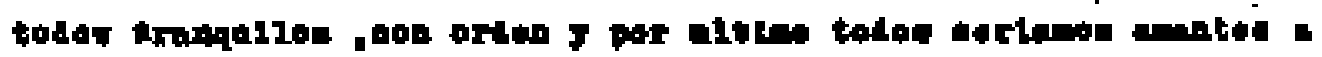

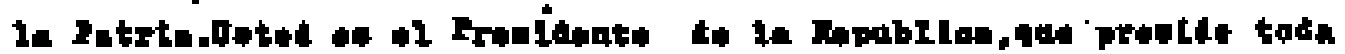

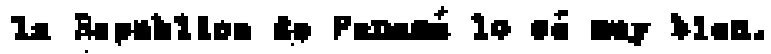

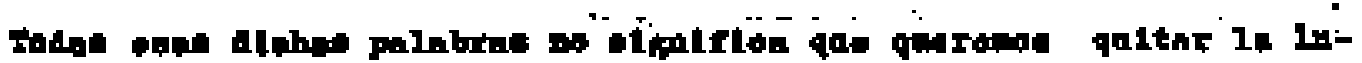

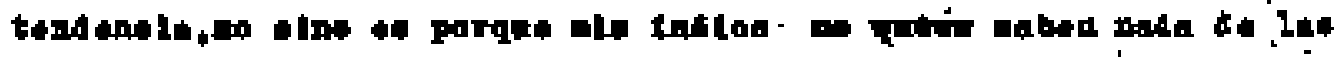

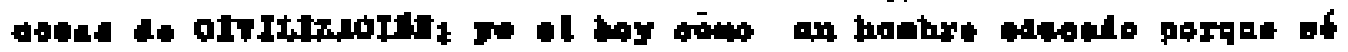

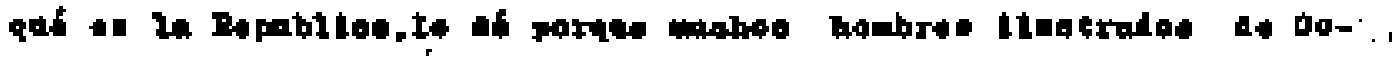

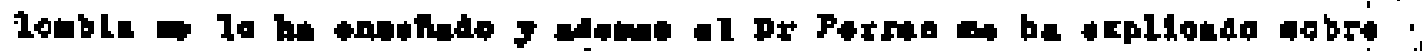

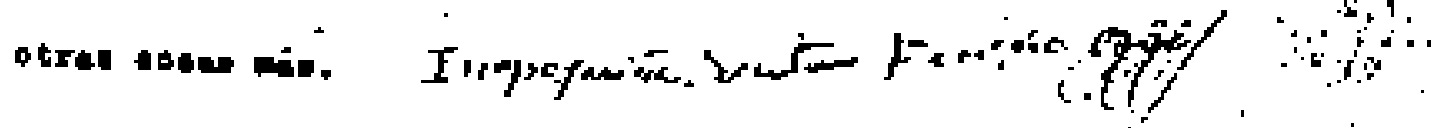




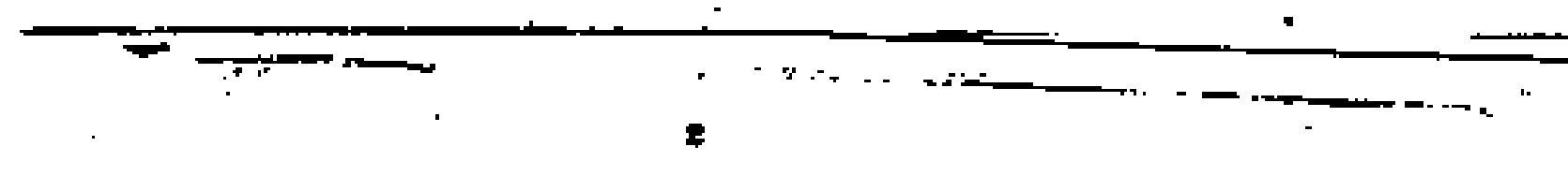

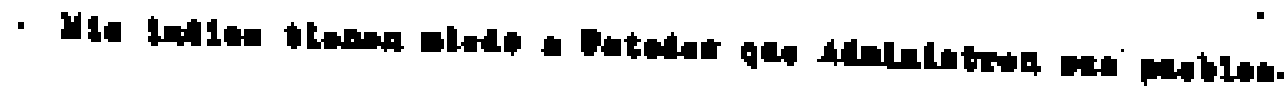

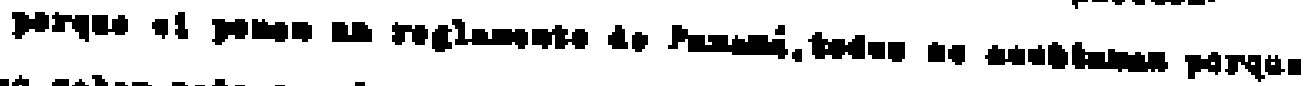

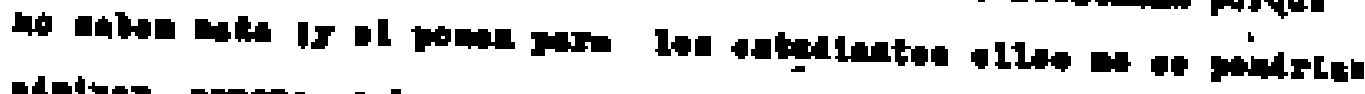

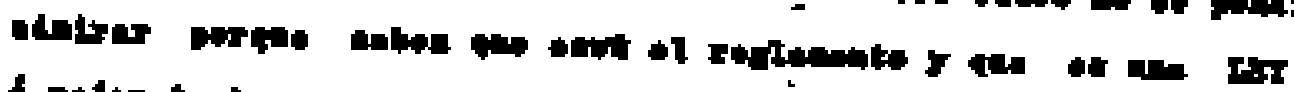

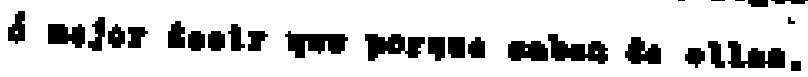

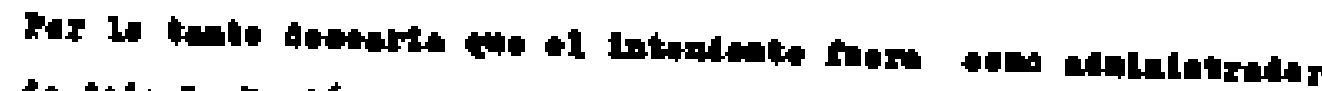

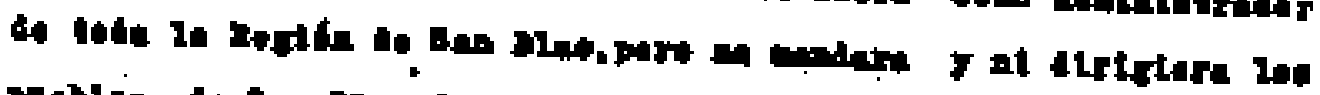

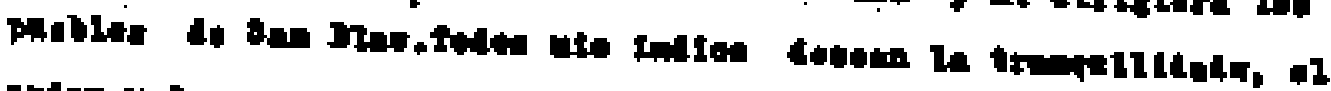

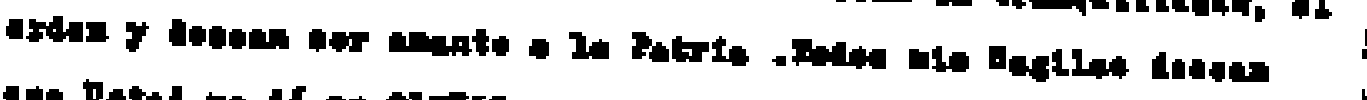

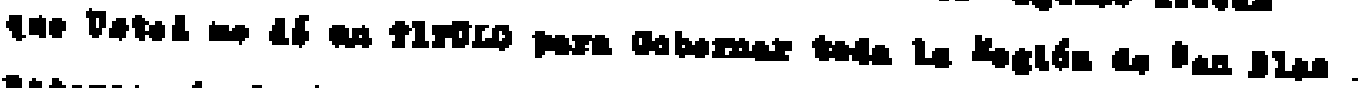

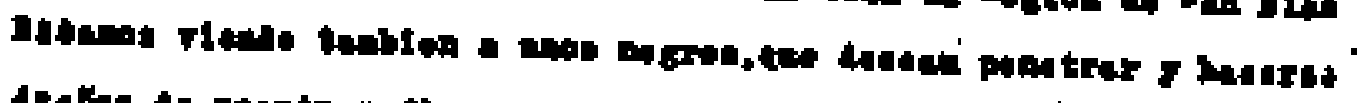

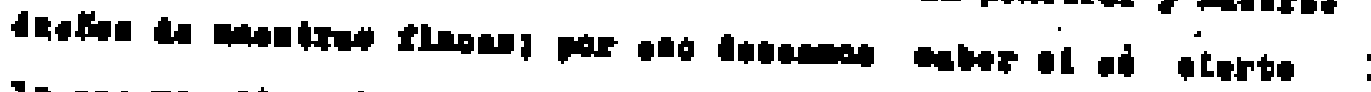

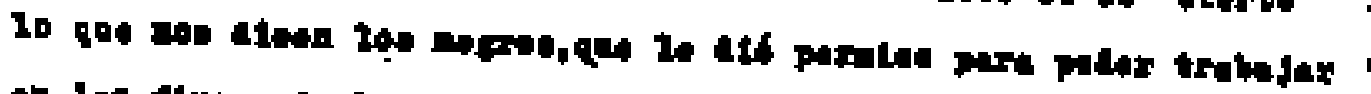

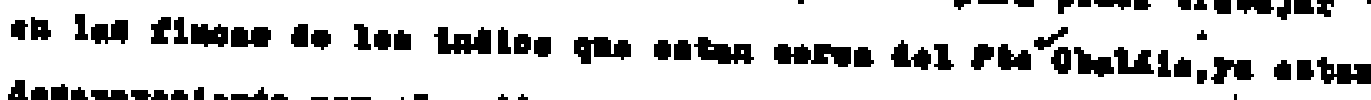

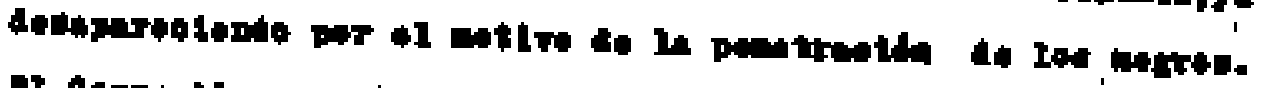

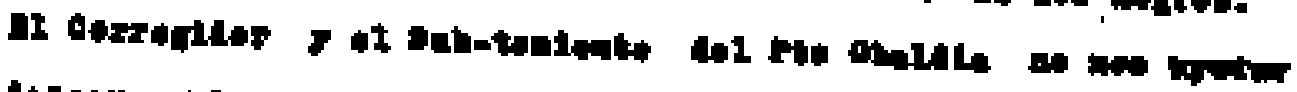

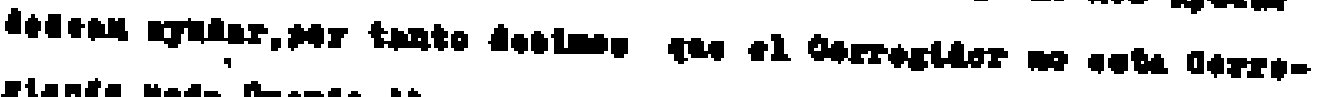

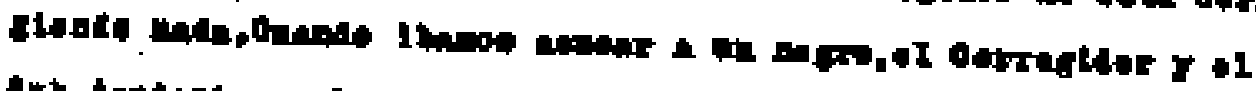

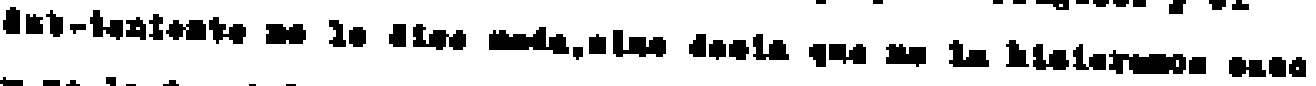

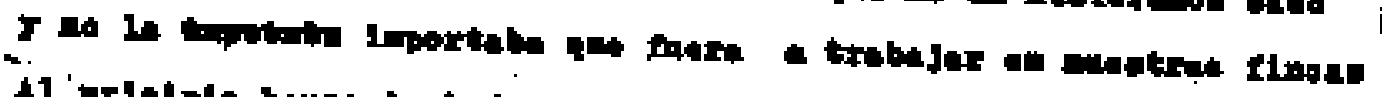

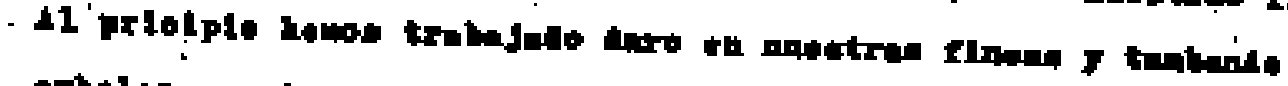

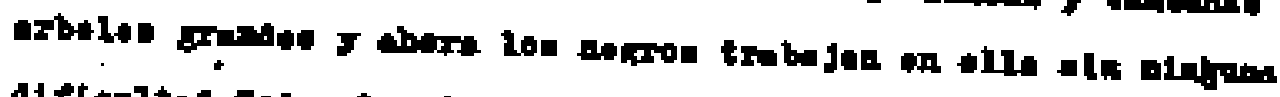

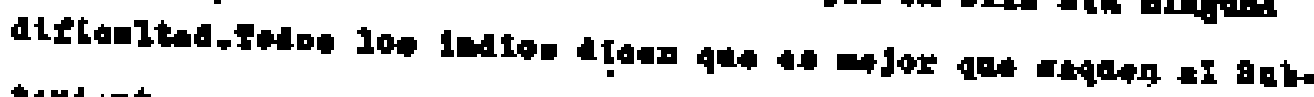

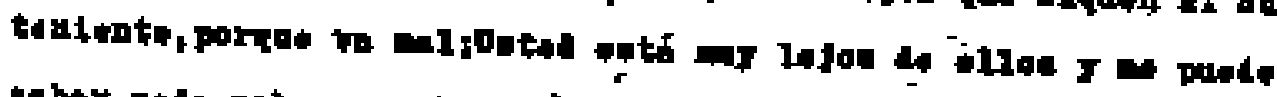

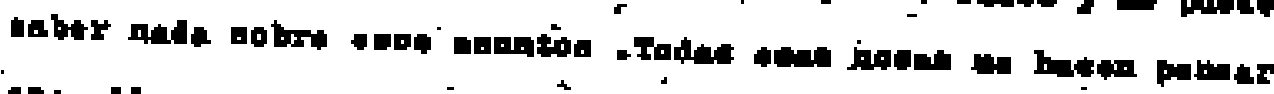

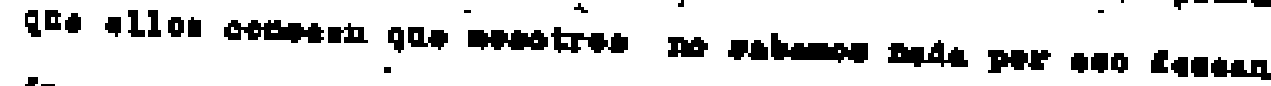

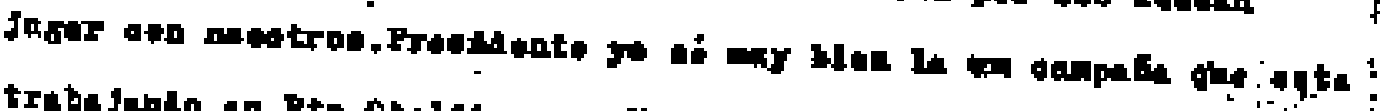

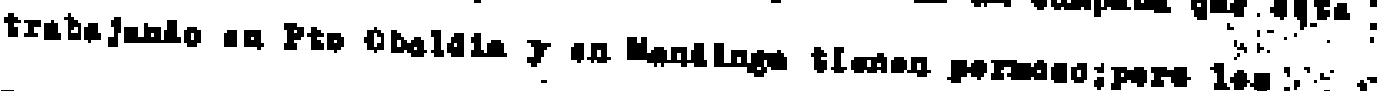

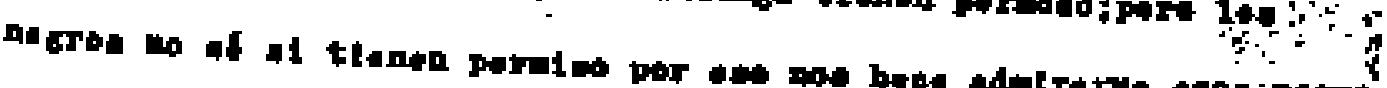

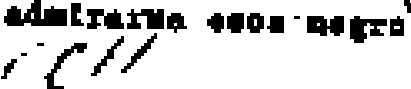




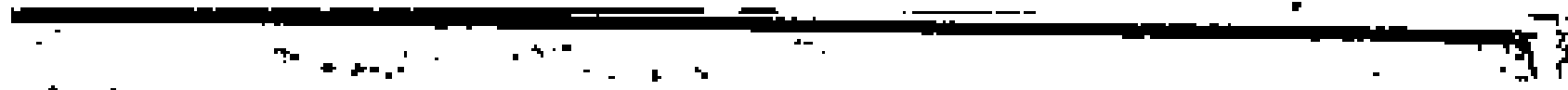

$=1$

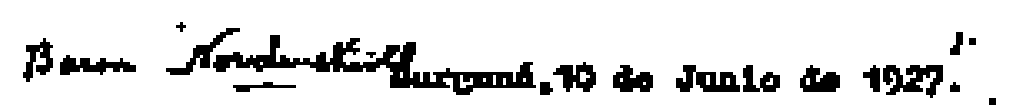

1.

$4 \underbrace{}_{\text {SOL }}$

=-r.

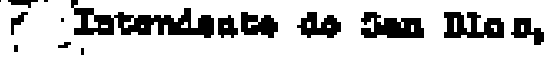

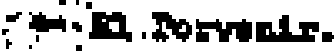

in

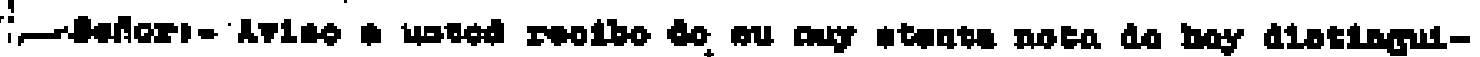

':

ic

, 4 "

$\because$

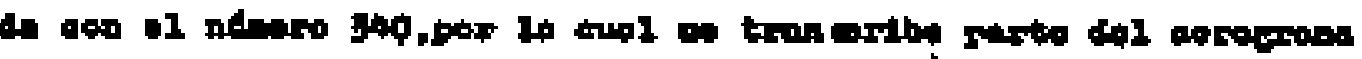

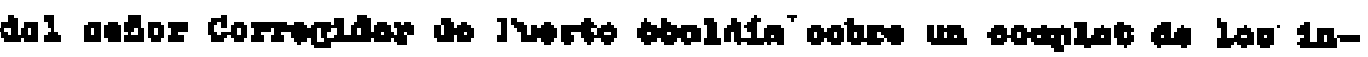

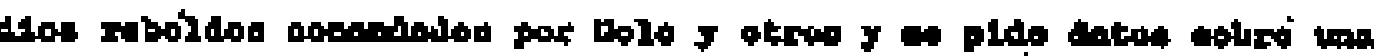

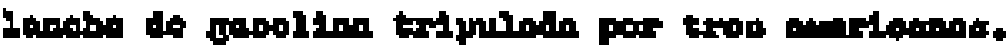

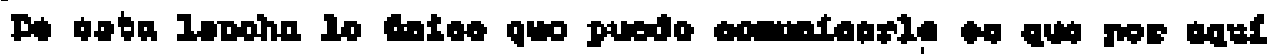

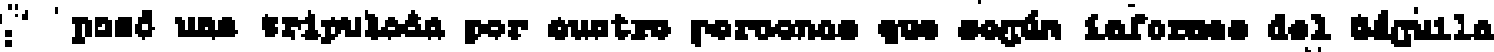

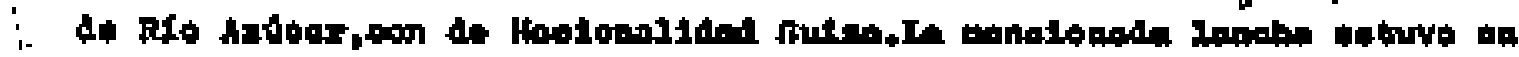
"i.:-

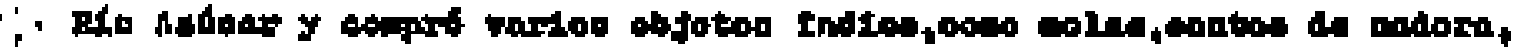

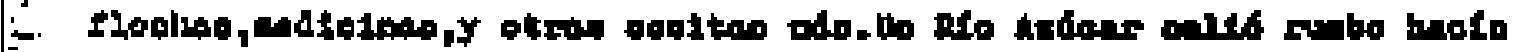

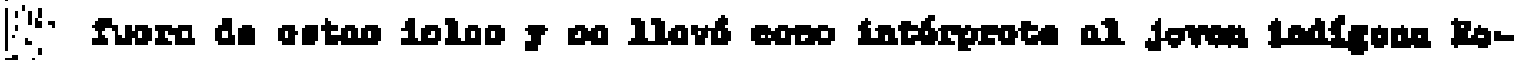

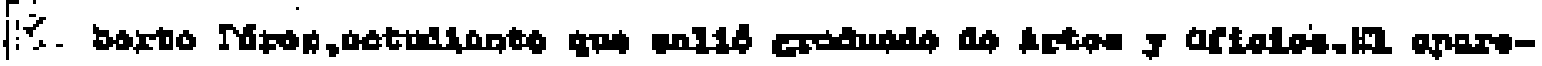

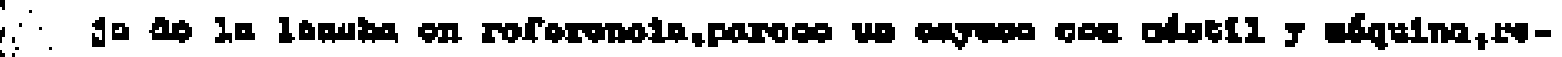

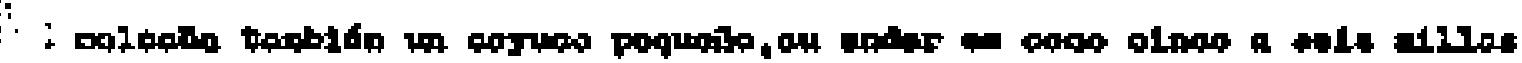
ir pos mow,

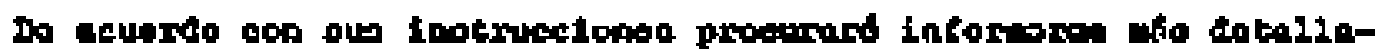

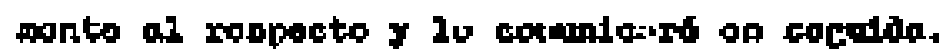

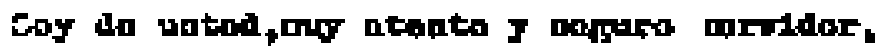

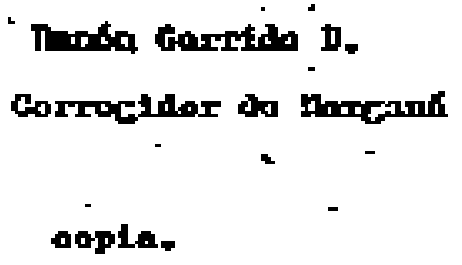

$\therefore$

n' - $\therefore:$

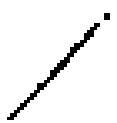

v, RD, n, 398 . 


\section{CLII}

NARGANA, 17 de Juljo de 1927

\section{Sefor}

Iniendente de b Cireanscripetion de San Blos

EH Porveair.

Selior.-

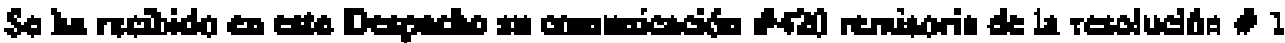
dletude el 3 de Jullo de 1927 aprobada por est mperiontided.

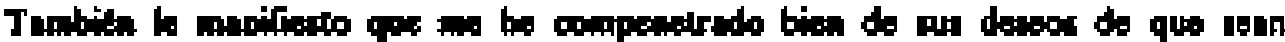

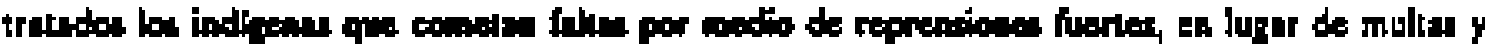
cartipon.

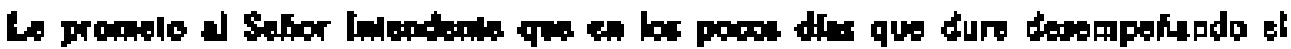

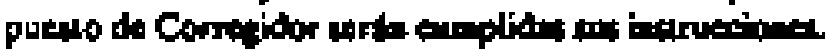

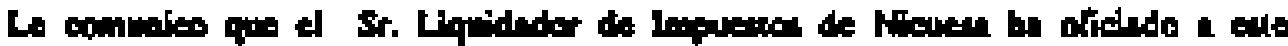

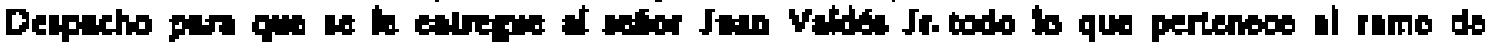

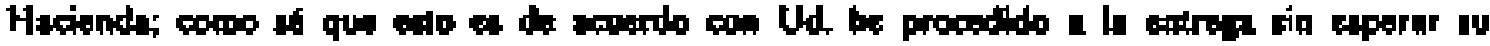
Altoritucion.

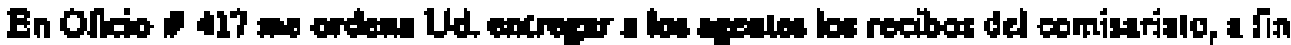

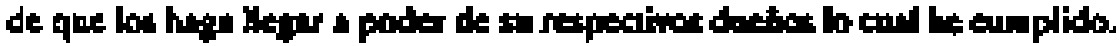

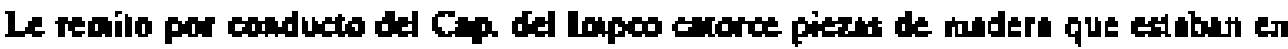
Correbon de Jente.

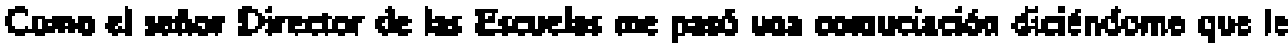

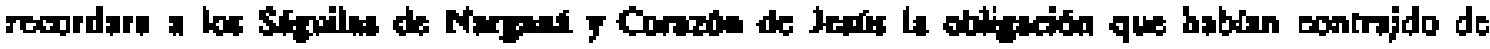

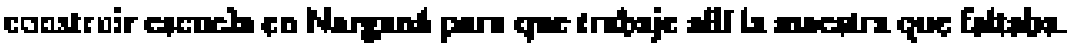

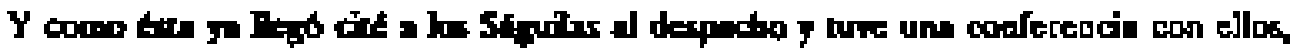

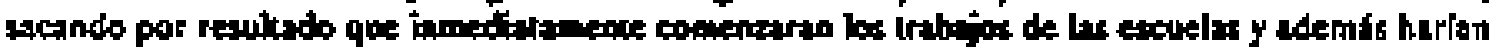

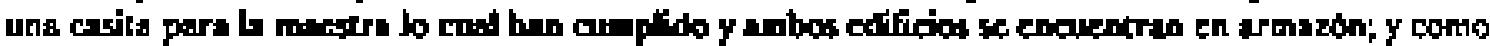

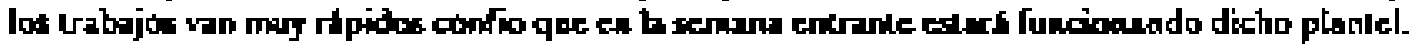

Tambita le comunica que are he lonado la salorikation de darle permiso para dos

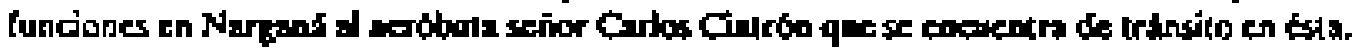

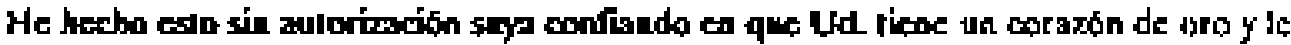

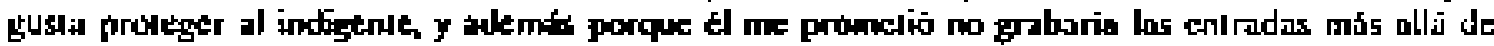

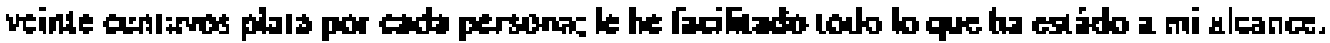

Alcalo y sejuro servidor

Hipililo Curvara

Sub-ienicale encsrgatu

Trabs. del orig. mec?

$$
\text { V.RD, n. 399. }
$$




\section{CLIII}

A.SA

\section{Sefior}

Narzant, 17 de Julio de 1927

\section{Intandente de la Cirtunseripekon de San Blat} El Porvenir

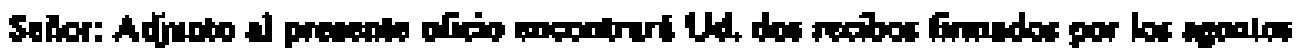

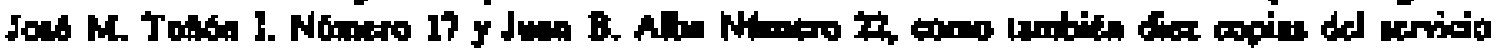

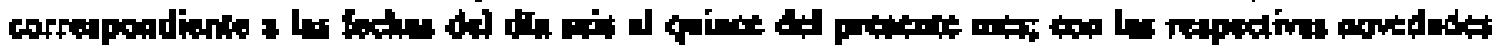
unotadu al roupaldo.

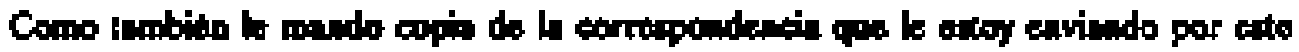

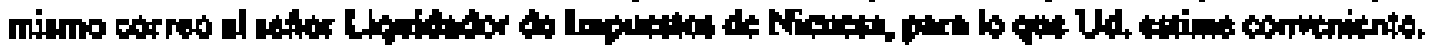

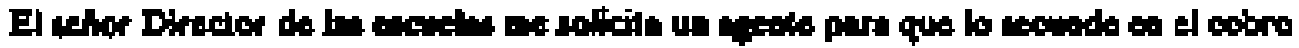

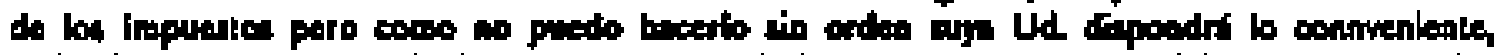

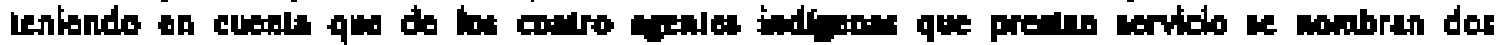

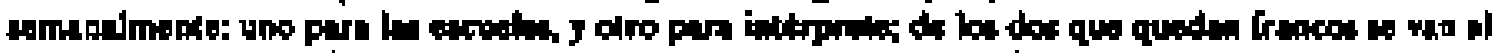

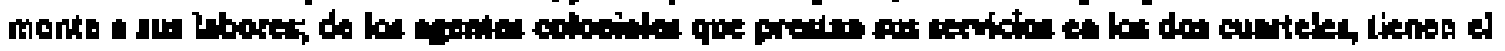
corvito muy recargado.

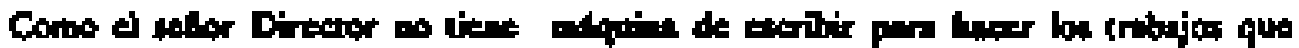

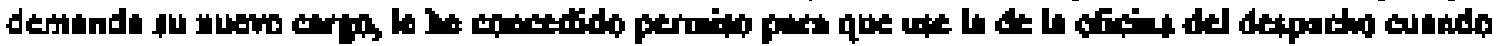

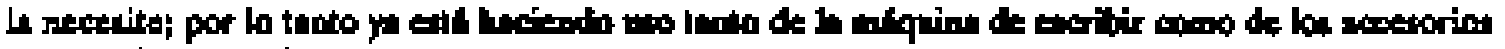
pertenecionted a olle, exp.

Trans. del orig. mec. ine.

$$
\text { v. RD, n. } 400 \text {. }
$$




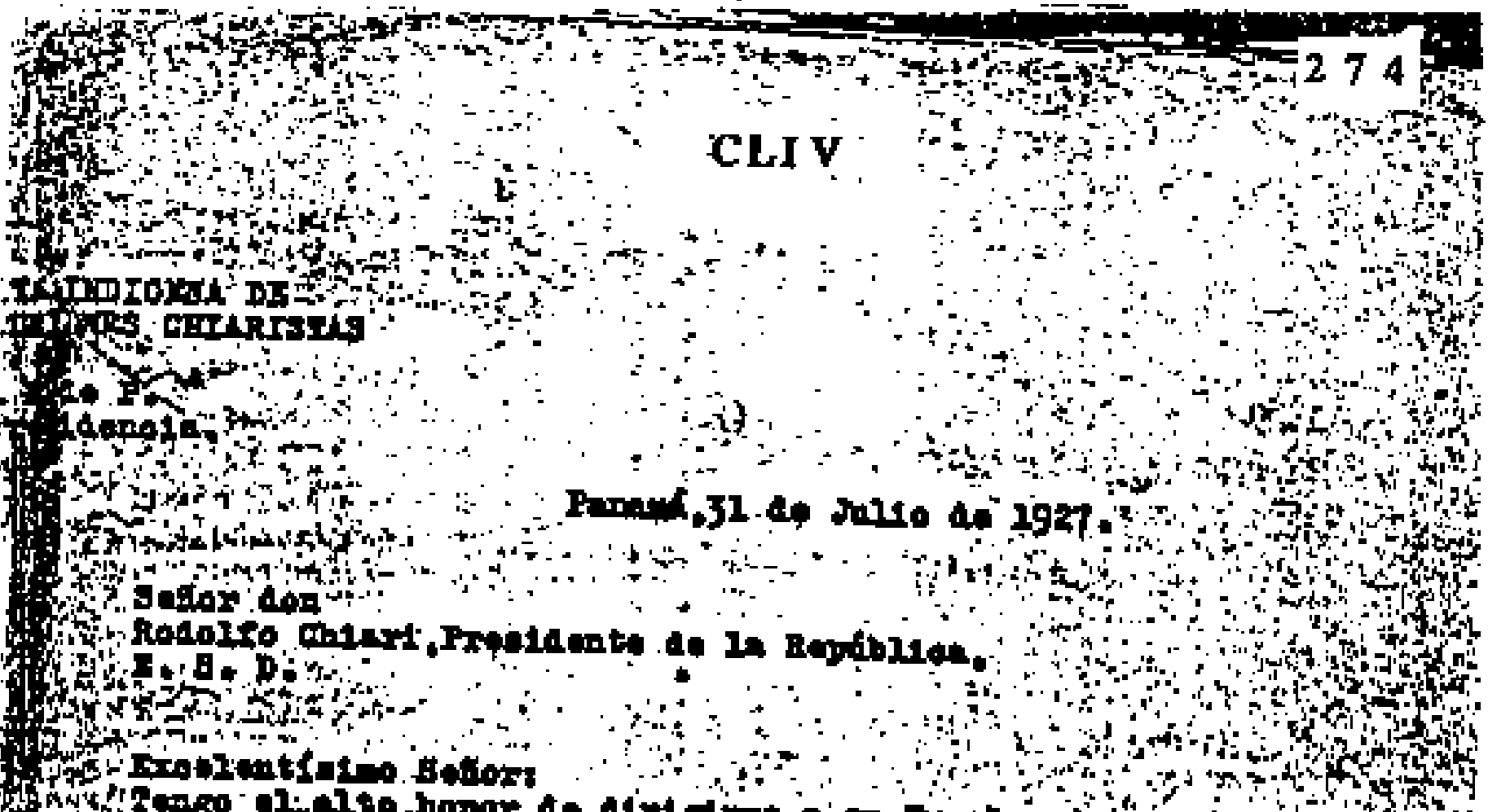

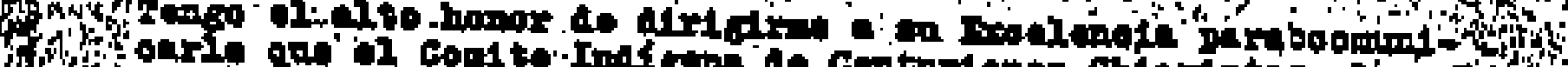

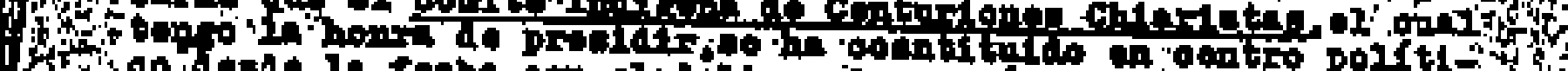

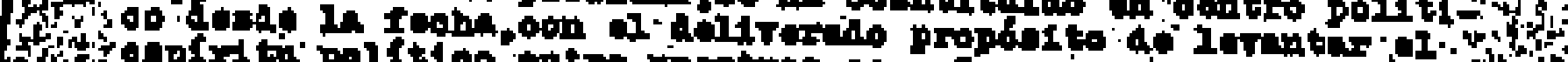

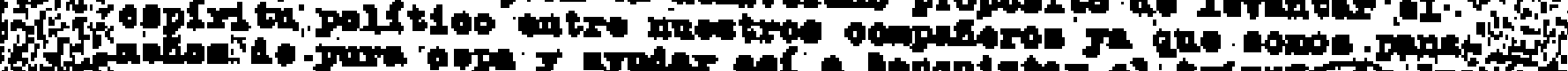

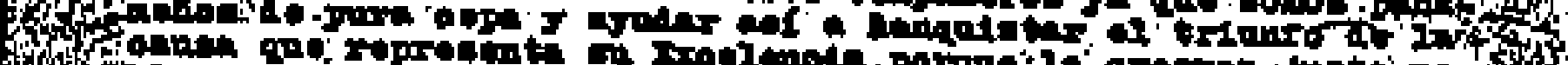

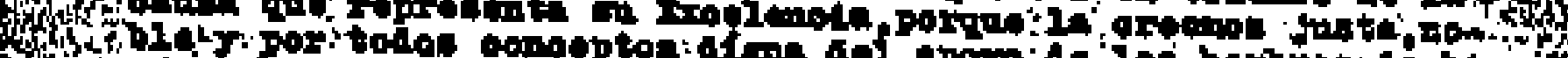

(1)

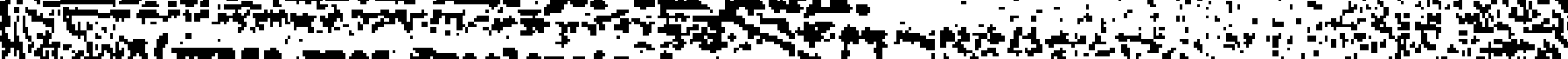
M

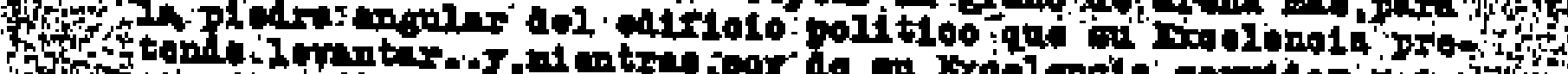

A

(j)

1.

Fin

1920

औis 4 ,

10

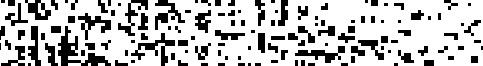

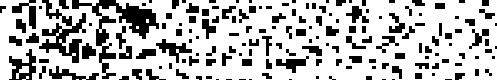

194

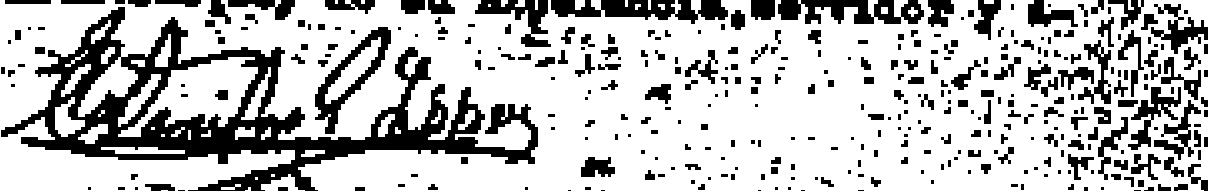

metident:-

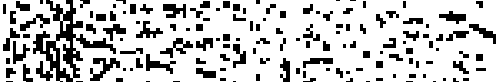

Hex

a

Thand

if

i

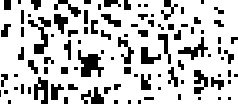

O

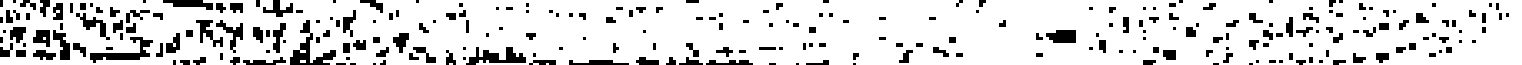




\section{CLV}

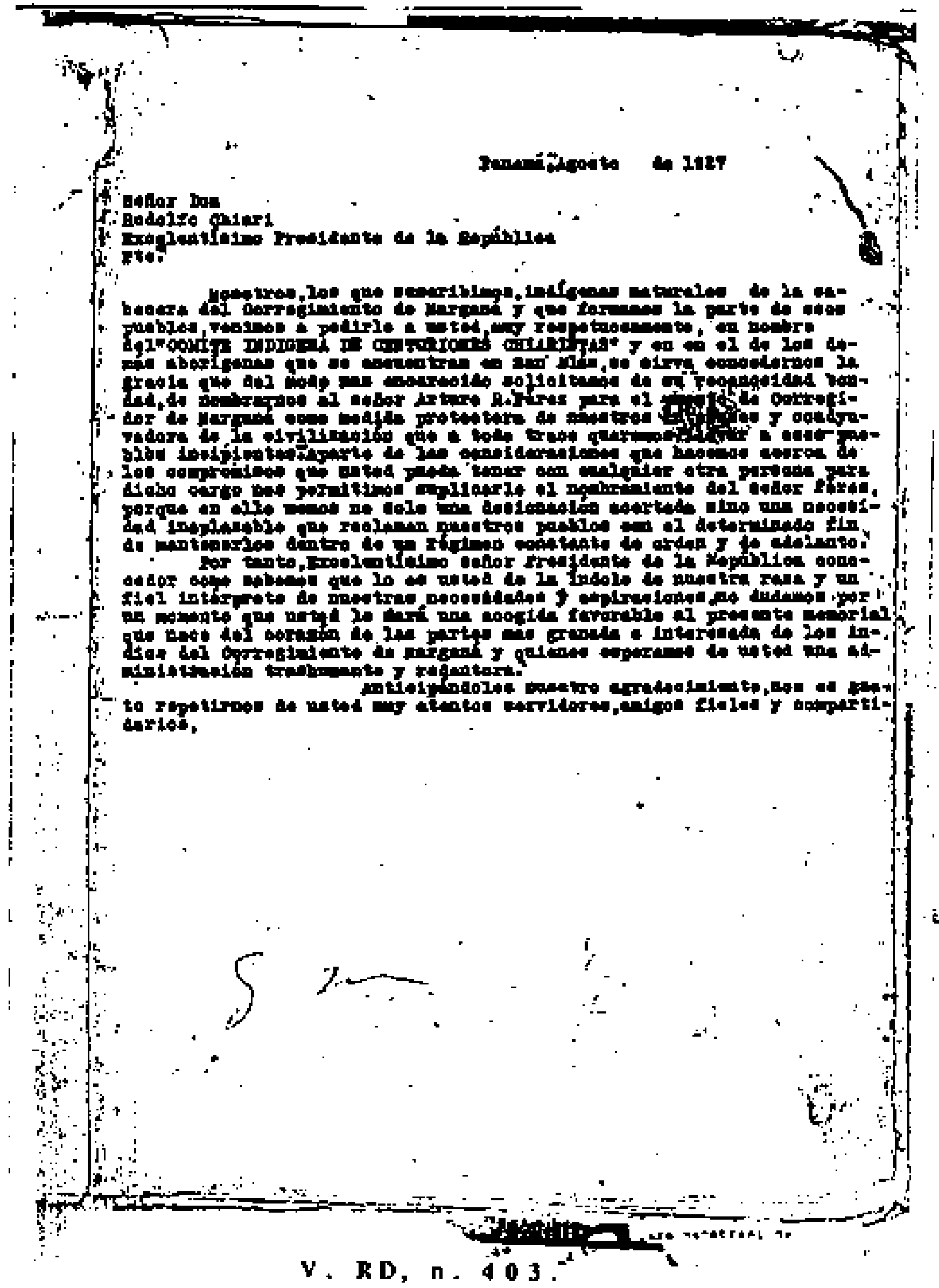




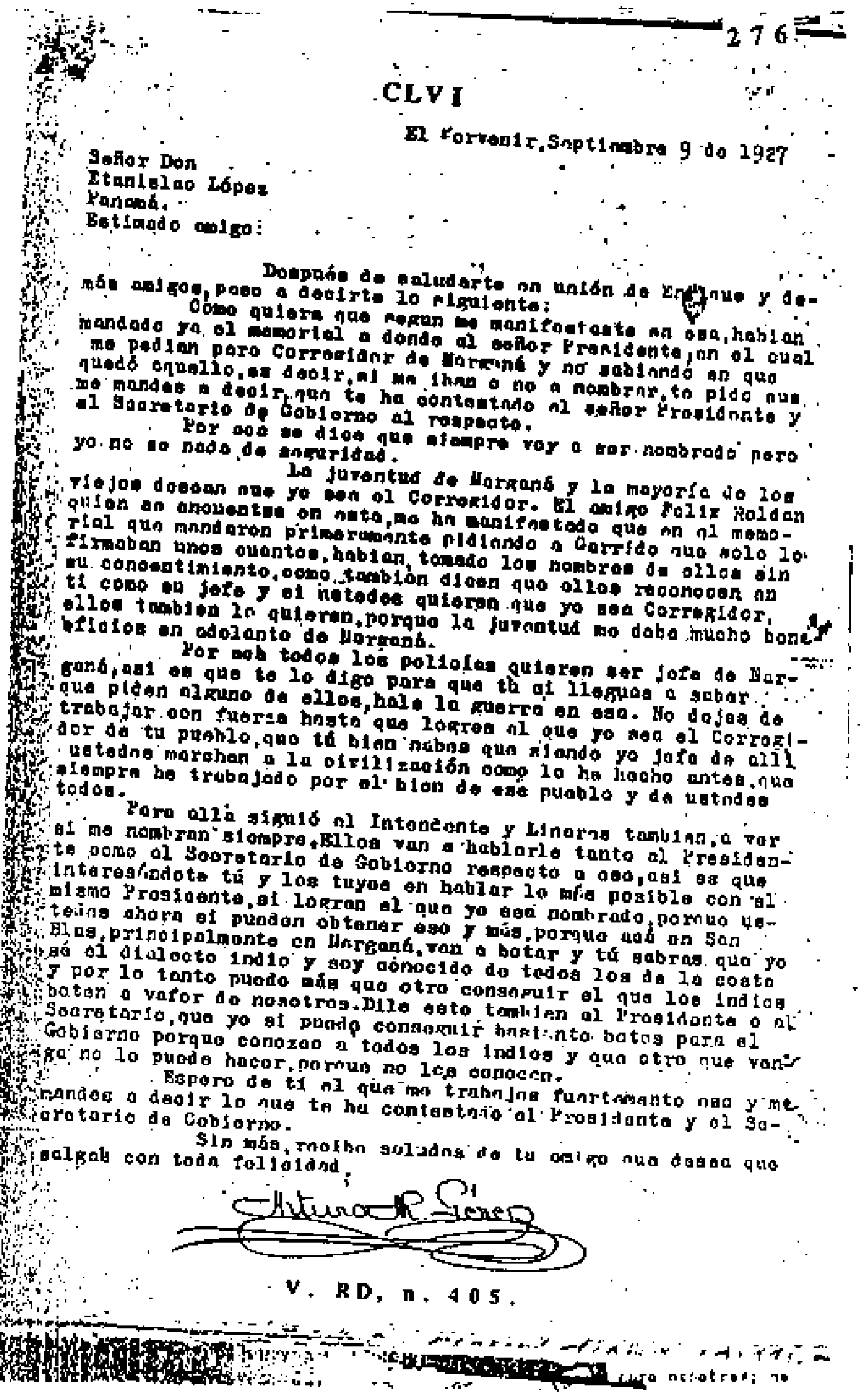




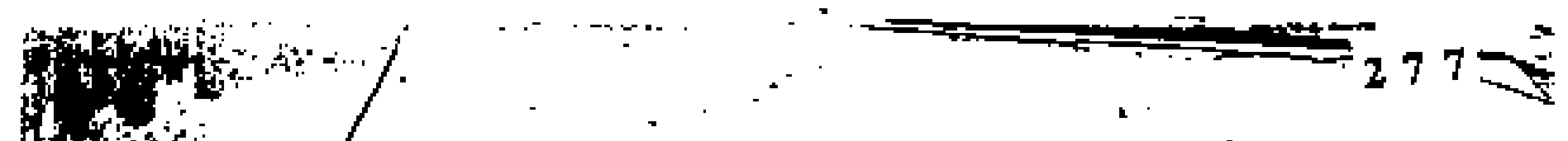

\section{II}

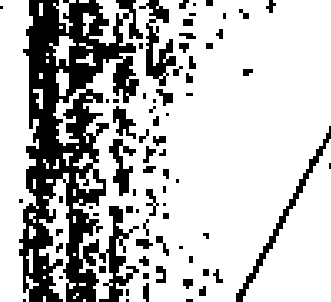

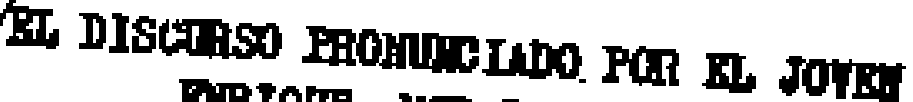

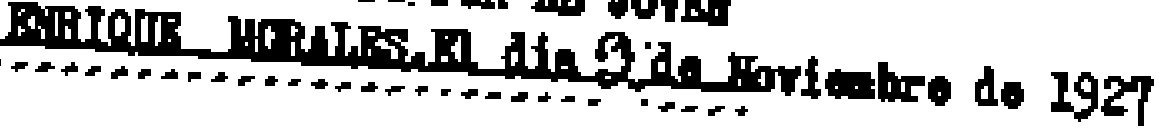

Alororot.

sta nato

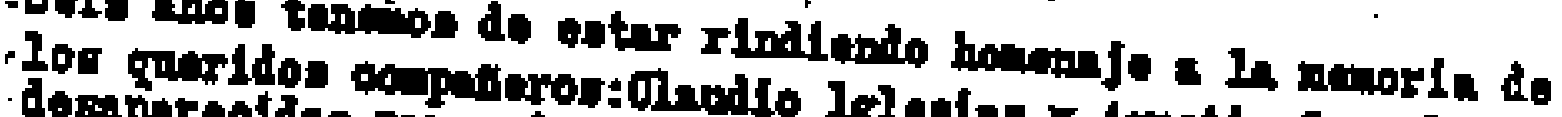

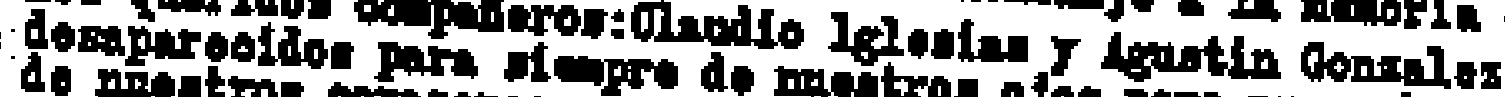
In pos ctrationg.

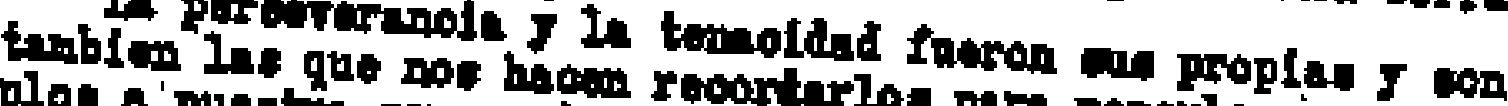
ploo a meatra gongraoton.

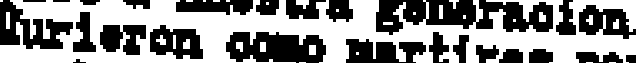

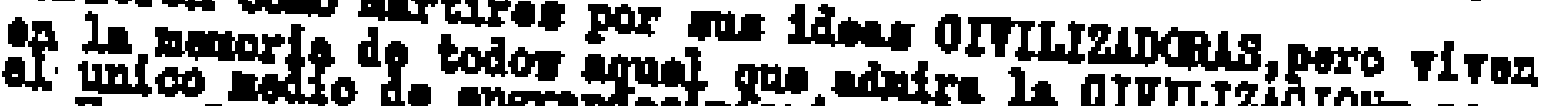

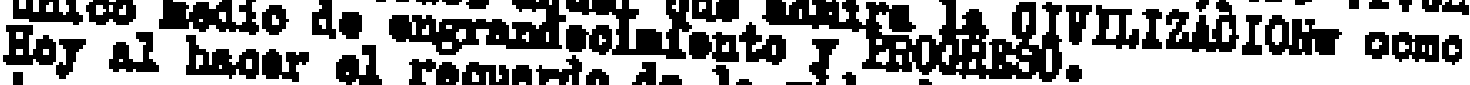

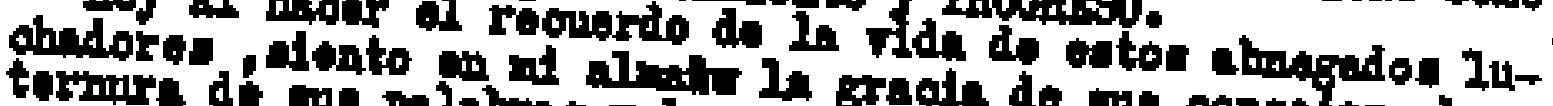

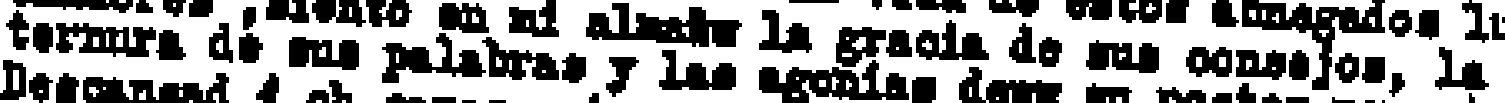

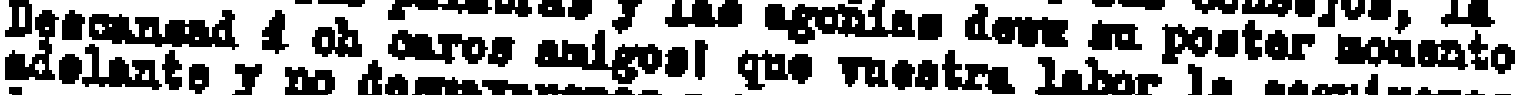

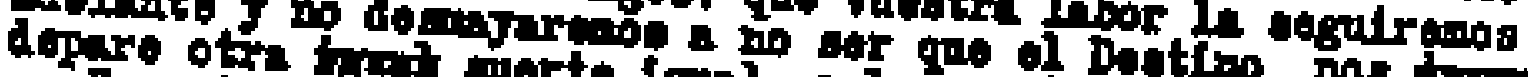

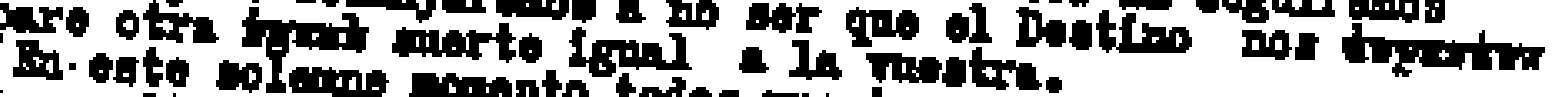

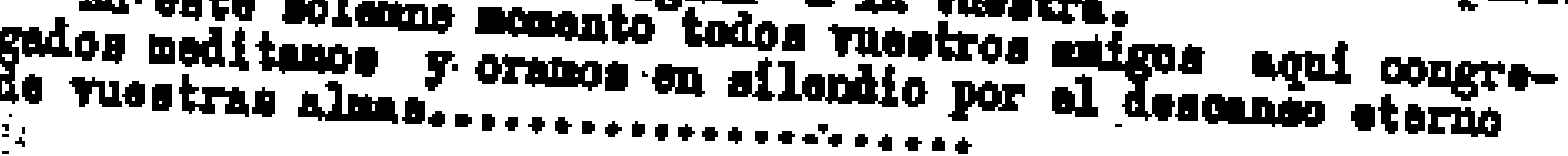




\section{III}

A-3

Sefor Coronet Lois Hmoindz R,

Coĺ́n, Julio 7 de 1938. Interudente de San Bhas.

Porvealy.

MF eqiondo unimax

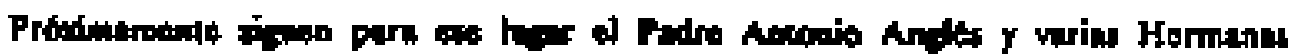

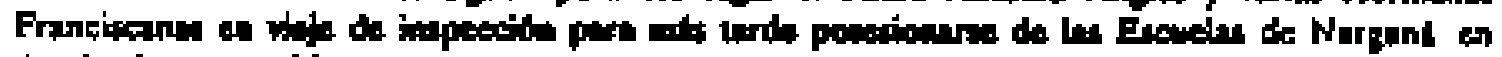
tonde pienuta nablecerse.

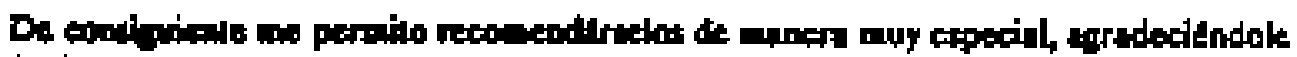

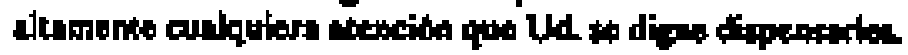

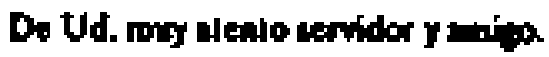

Ineroxlo Gollade Jr.

Gobernudior.

Trans. del orig. mex.

$v+R D, n+412$. 


\section{CLIX}

A-2

Númera 1\$ I

Panamu, Septiembre 28 de 1920

Seȟor

Intendente de lin Cireunseripelón

de Sinn Blas

Porventr

Sehur:

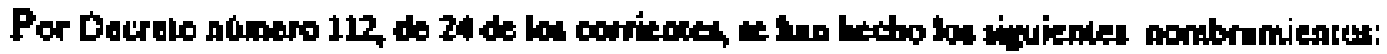

Pura Meantros en NARGANA:

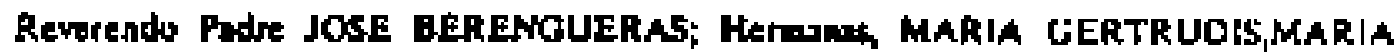
CRESCENCIA MARIA PRISCILA;MARIA FEUPA Y MARIA VALERIA;sEMUT' JULIA DE HERAZO Y keilorilH CRISTIMA DE VALDES.

Purn la Eucueda de RIO AZUCAR.

Sohoras JUANA A DE TUNOON, JUDTH DE CERALLOS E INES VAC CORDOBA.

Para la Ewodu de PUERTO OHALDA:

Sefigres Turibio R. Bertio y Stbina Aberole

De usded alening y sx.

(Firntia ilcuitik')

Trans. del orig. mec

V. RD, n. 414. 


\section{CLX -}

A-1

Número 97.C

Sr. Tohít E Abella.

Paname, 11 de Dieiembre de 1928

Intendente de la Clreunscripeión de San Blus.

El Porrenir.

Sebor:

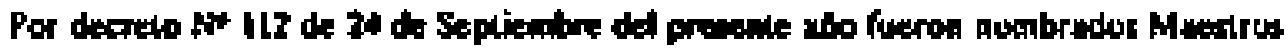

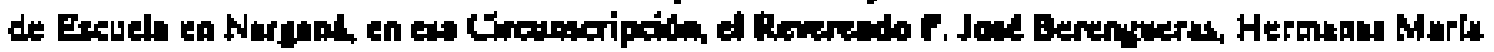

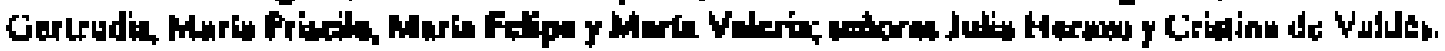

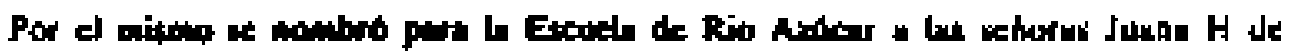

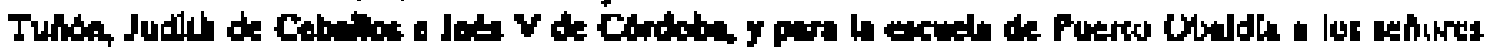
Toribio Berric y sebim Alverole.

Septionbre okima.

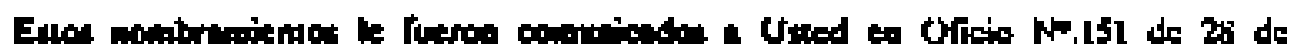

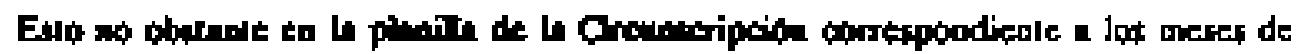

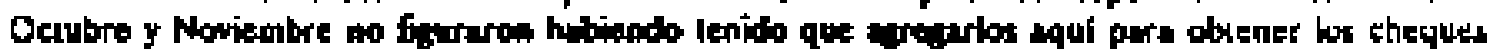
correspondienses.

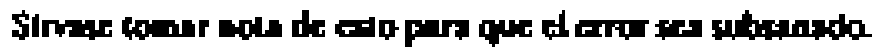

Soy de Ud Ano y SS.

Sub-uaretartio de Gutieren y Joativiz.

Trans. del orig. mee

V. RD, n, 419 . 
Mrodo Droun

Tramol gat boo

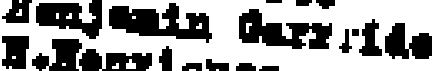

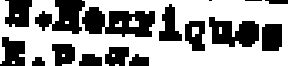

Angore

Mel orter

A.verienter

4.르는

Arinditin

2. Rerese

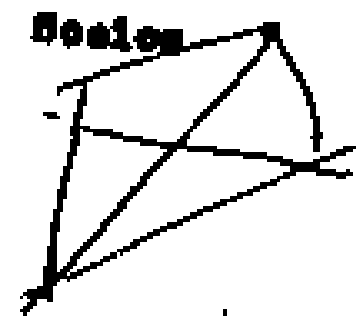

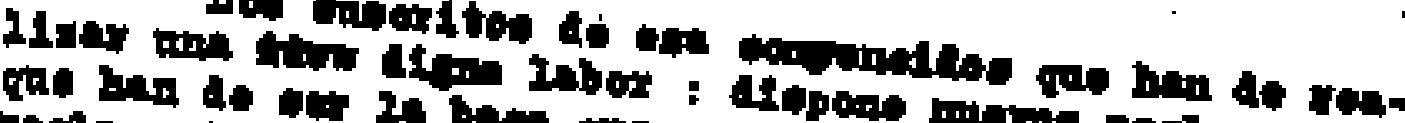

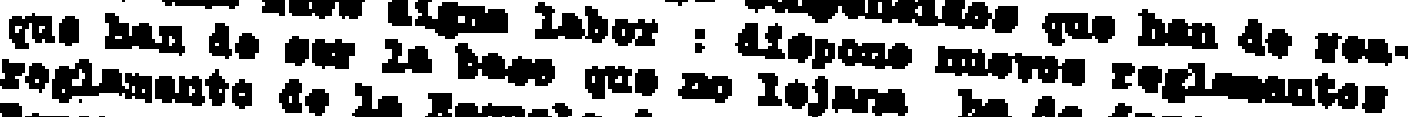

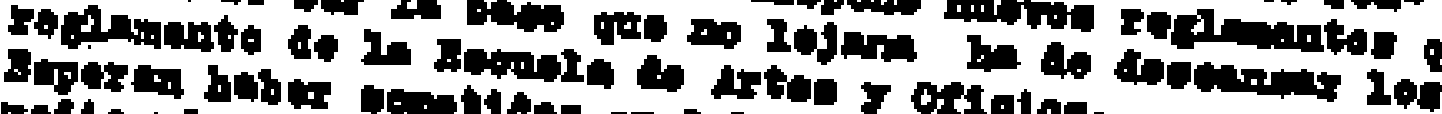

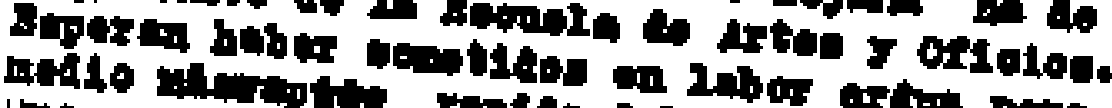

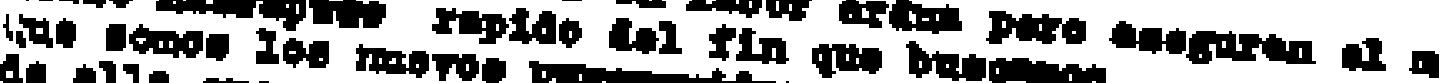

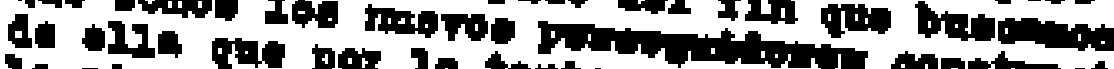

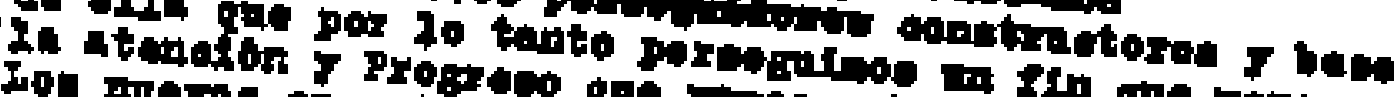

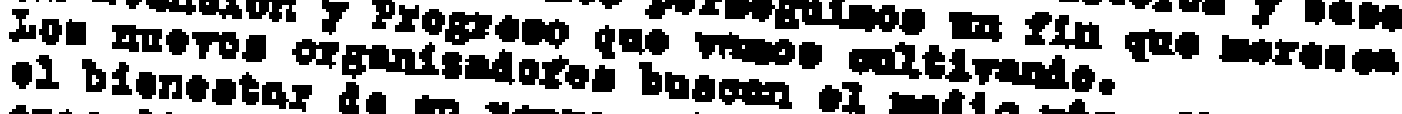

ore difin.

Tonter

algan ify

1. $\mathrm{Ba}$

EDon 1

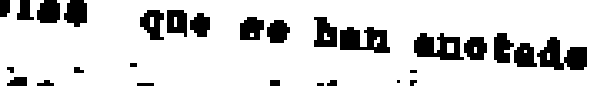

B

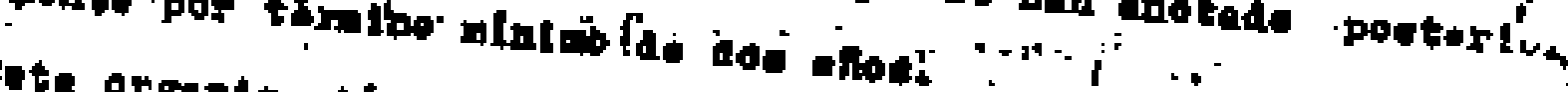

4

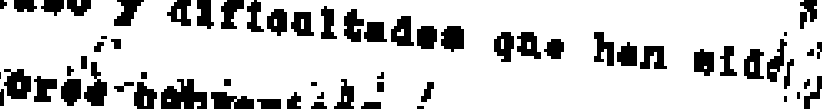

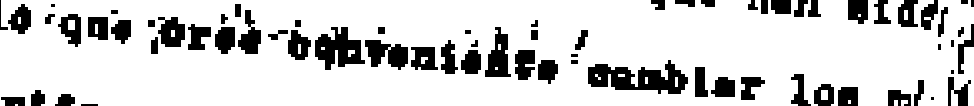

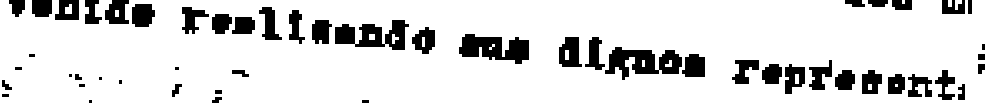

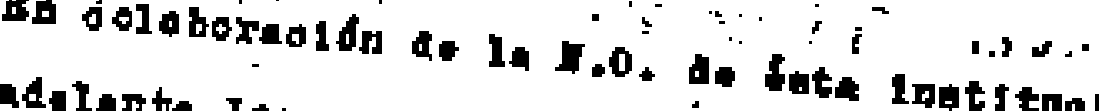

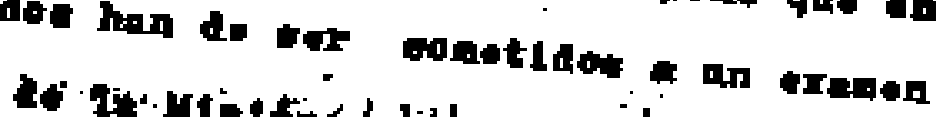

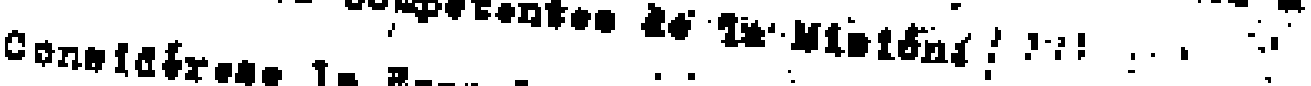

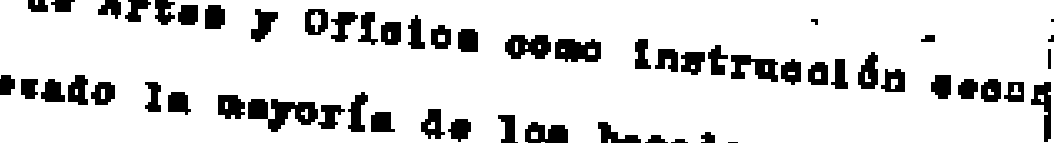

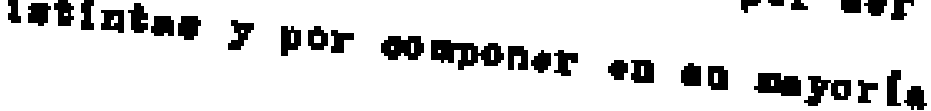




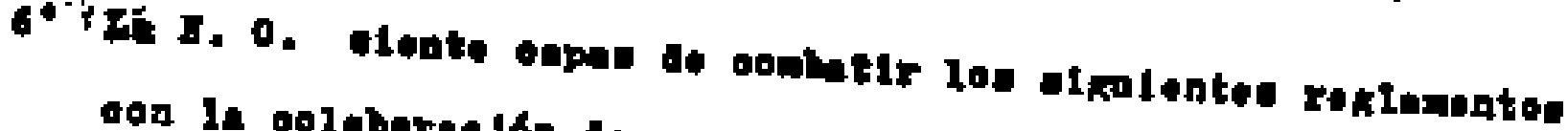

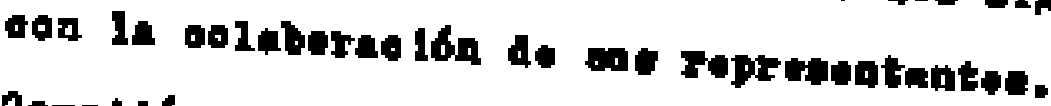

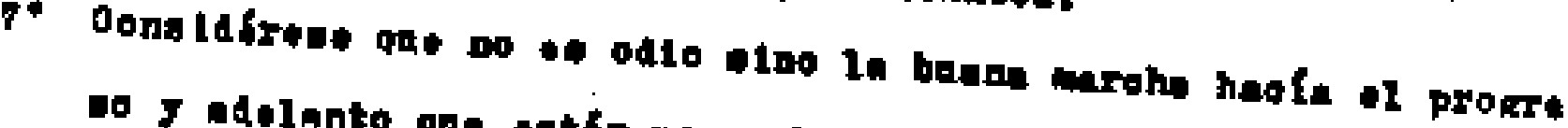
do J adolanto qa etón por cobrecelit.

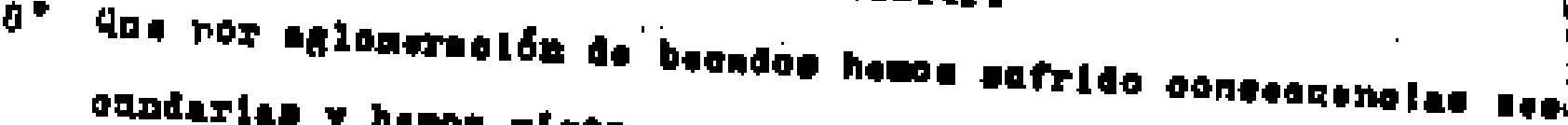

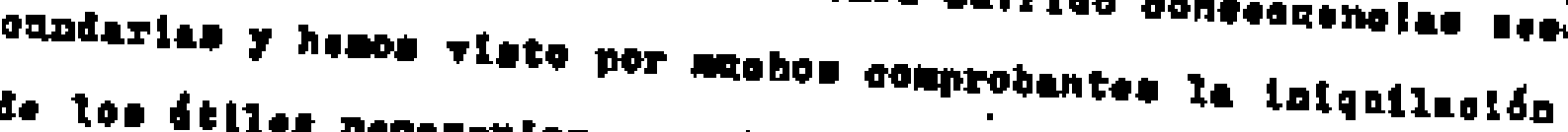

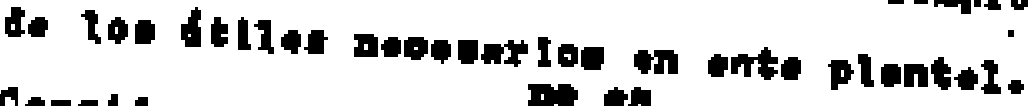

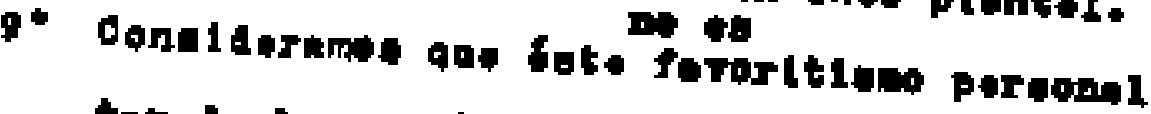
tar de le blatha que oovredponde.

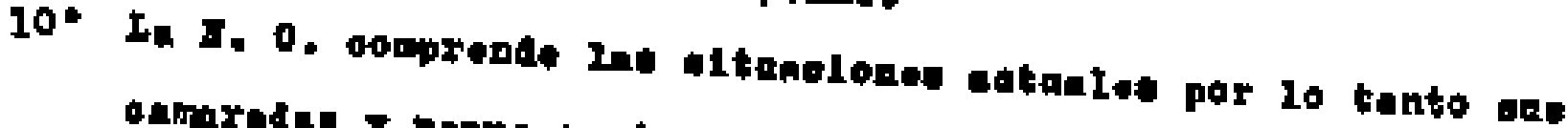

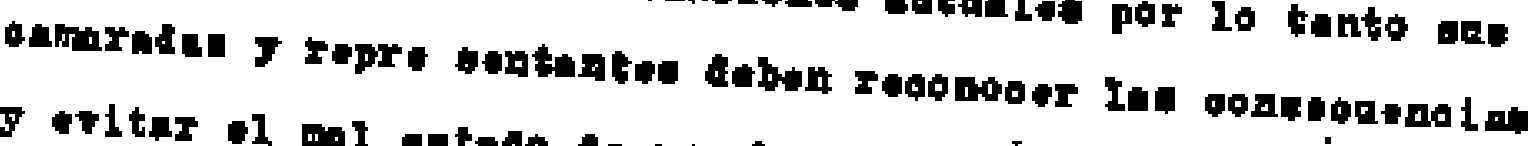

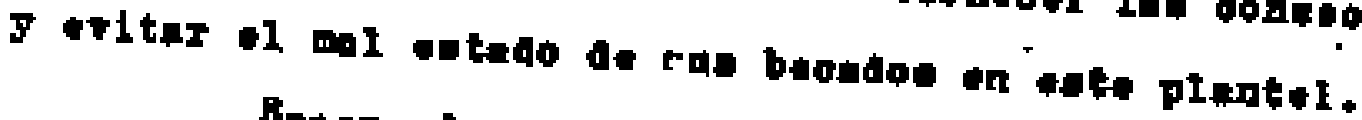

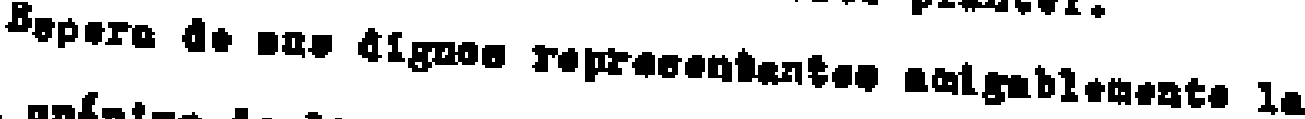

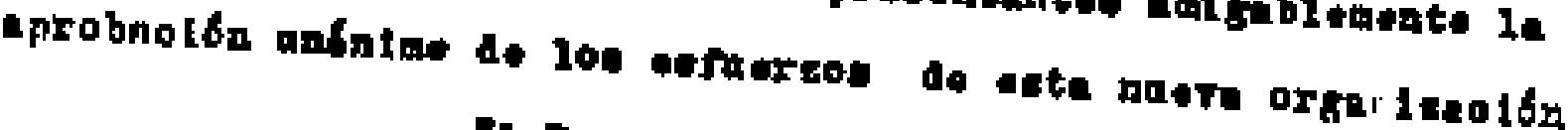
81 Probiante

$$
\text { (rado) abel Ortte }
$$

81 Beoretarlo

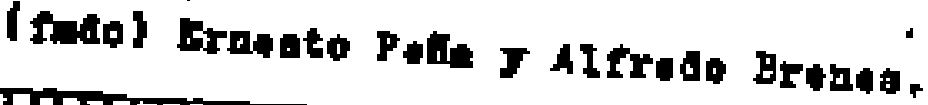

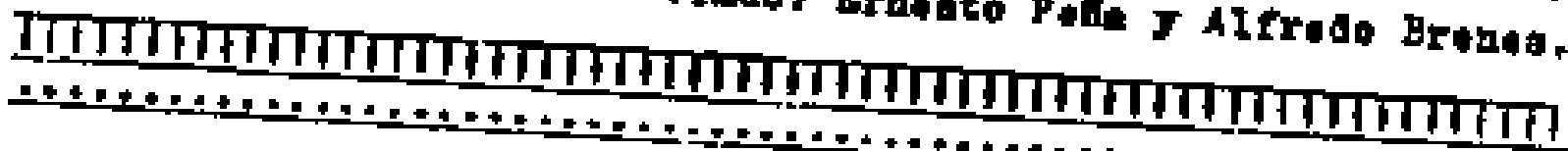




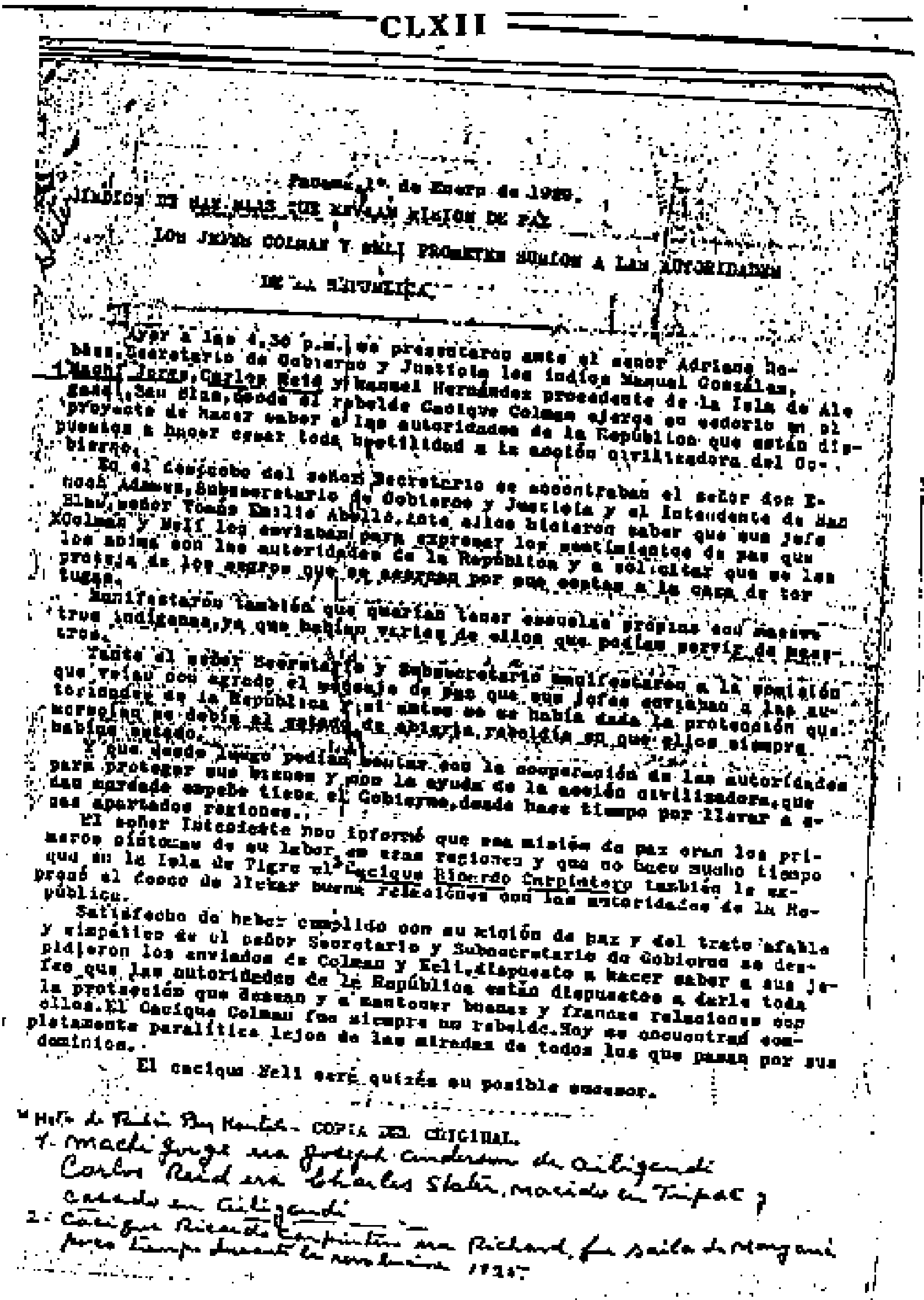

$$
\text { Y R D, n. } 422
$$




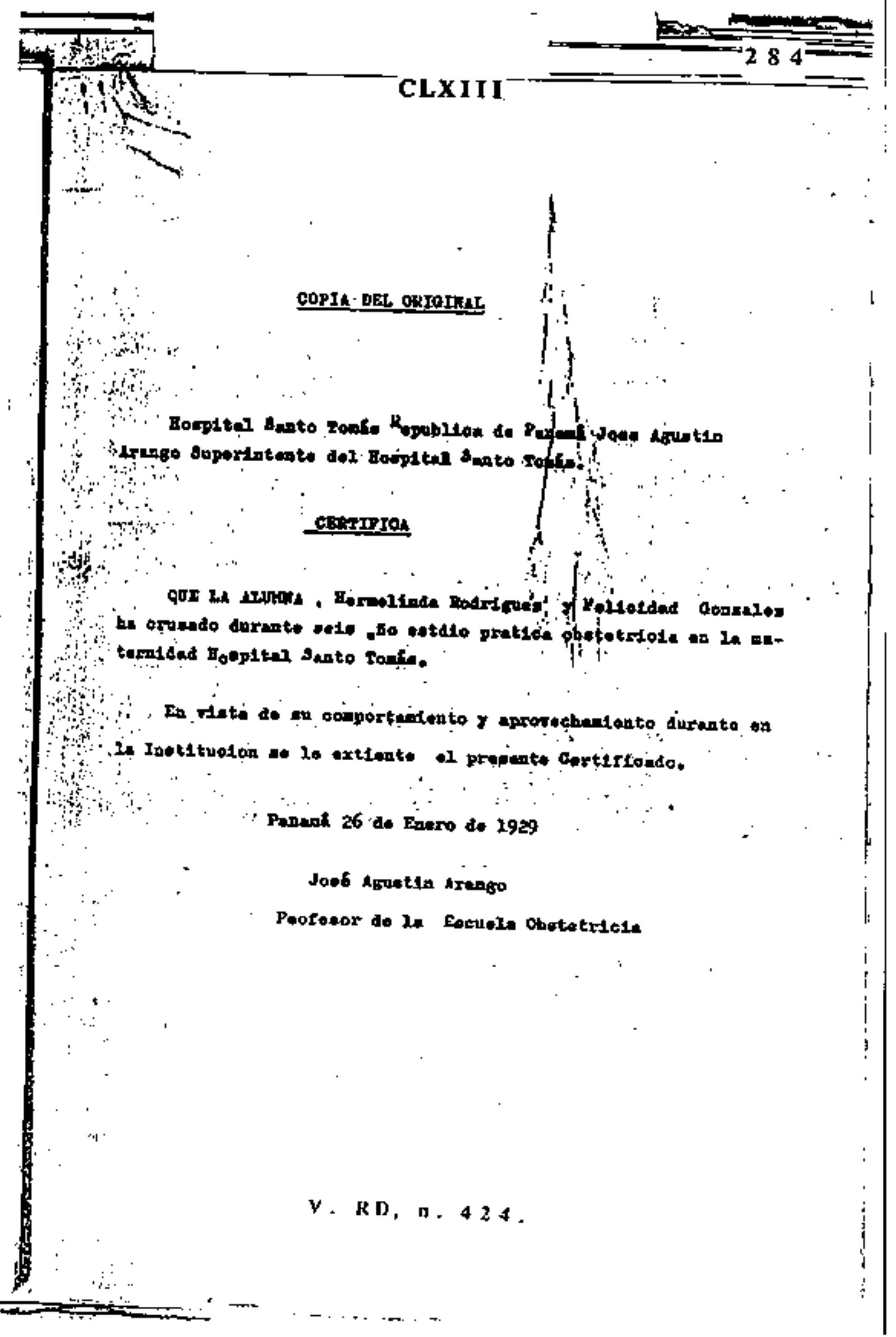




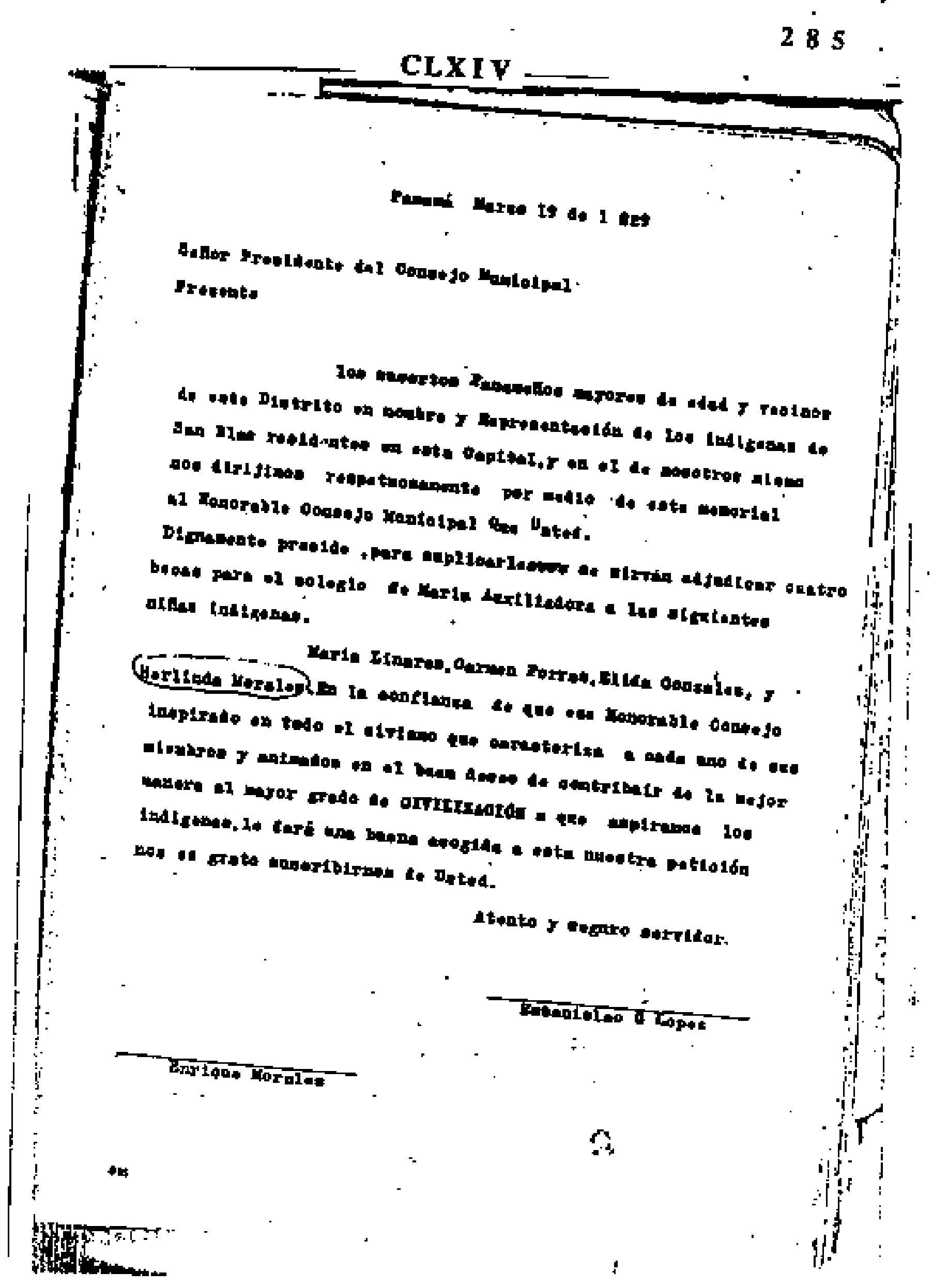

V. RD, n. 426 . 
ClXV

- 286

Funarif 14 de Abril de 1920

S. Fior.Dootor.pon

rrito.

Rogpltal gnnto tonát.

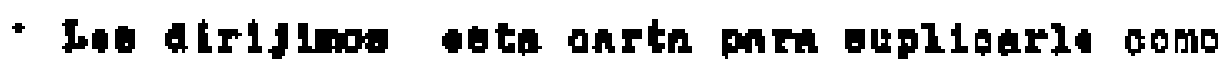

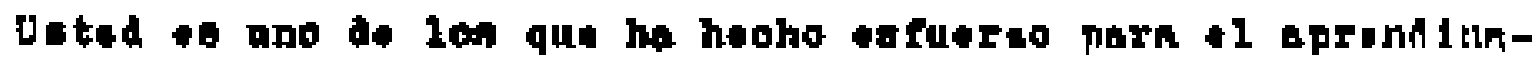

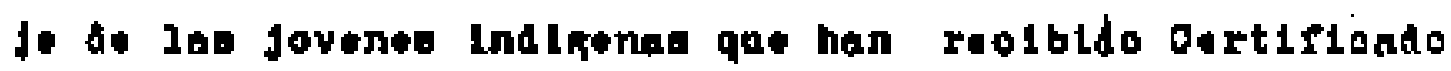

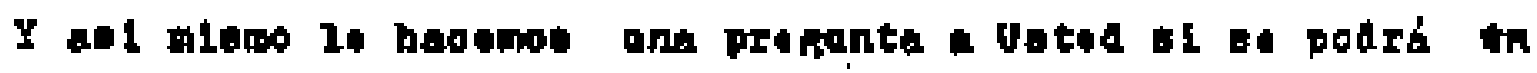

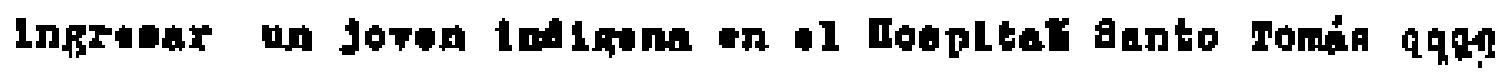

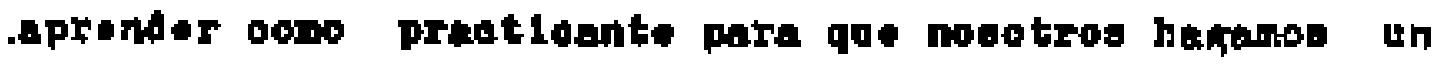

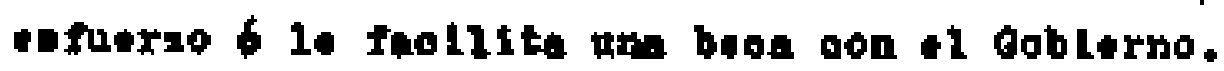

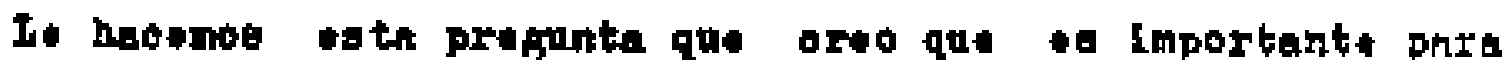

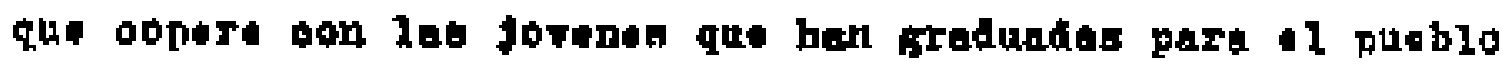

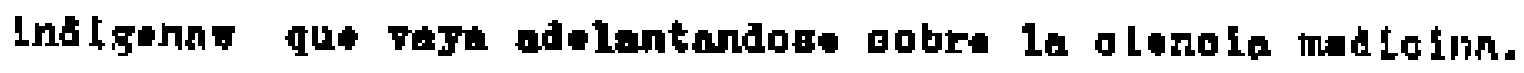
Y 1* wejeragon nu Contertacloń.S.S.S.

Ropresentante.

Retanta100. *. Irópes

Sa gundo Rapregentinte

Bnrlque Hornieg.

$\mathrm{B}, \mathrm{M}$.

$$
\text { V. RD. D. } 429 .
$$




\section{CLXVI \\ Fana ź 26 d* Abr11 de 19gg}

G. hor.110

Iu10.F*11p*-016nent

\$oretarto dorloultara $y$ Obras Fubrloas.

DLetinguldo attior $y$ anlgo.

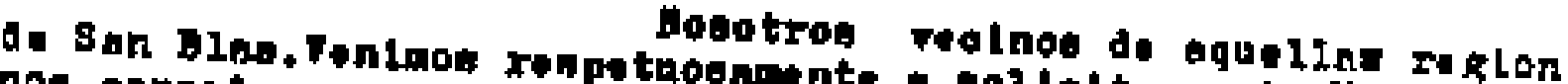

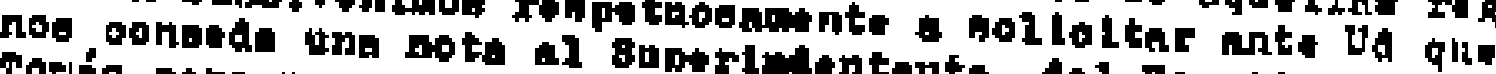

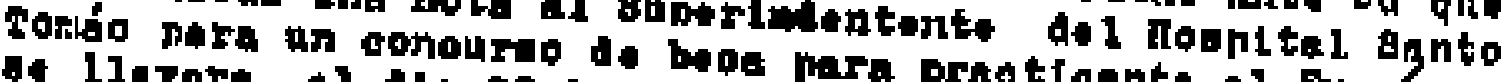

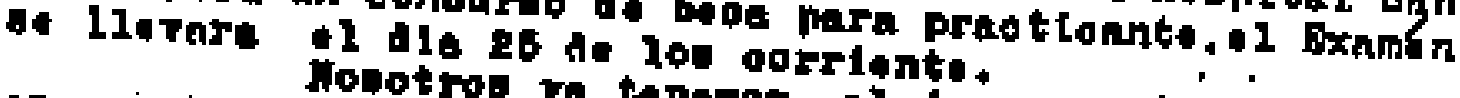

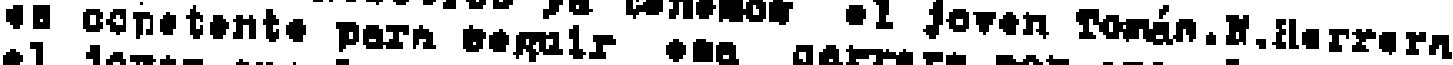

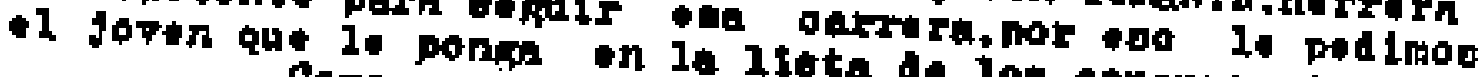

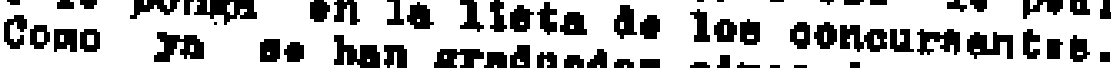

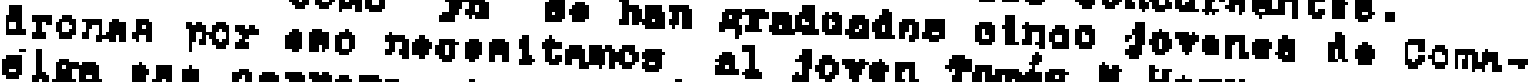

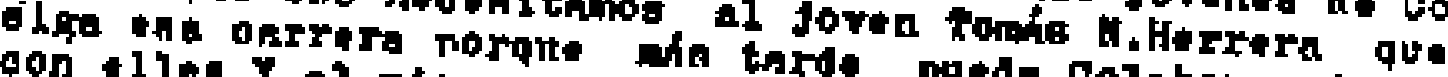

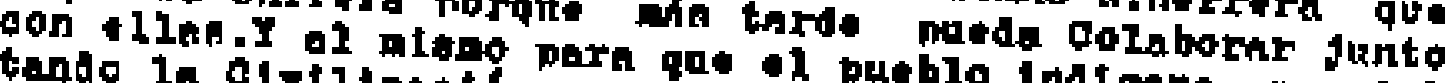
tando 1a olvtilneoton $z$ oogtumbrea. quderemog los que poderesetarlo que con eto geato mugo

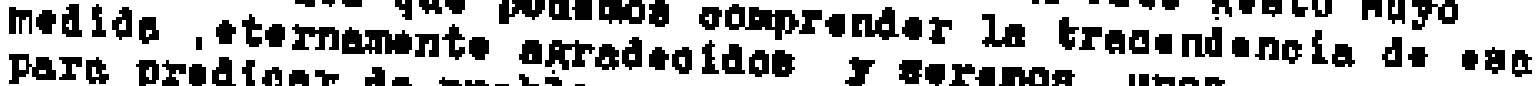

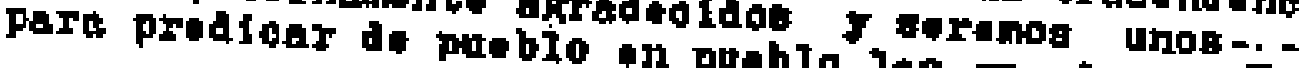

$$
\$ . \$ .8 .5 .
$$

- I a gúfo Roprenentanto Eatanialao o Iopis

Enrighe Nork1

:

B, $\mathbf{1}$.

$$
\text { V. } \mathbf{R D}, \pi .4,30 .
$$

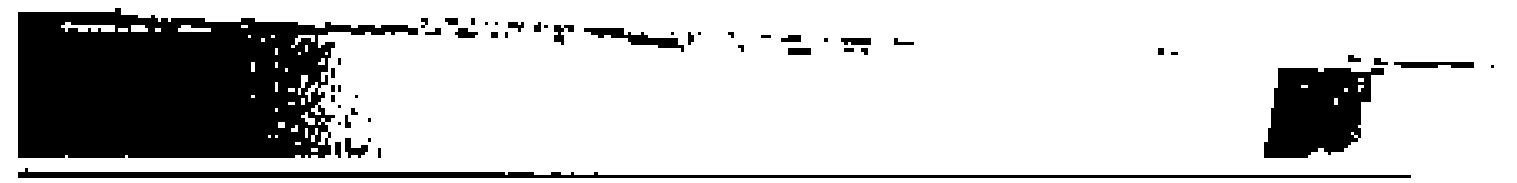




\section{V I I}

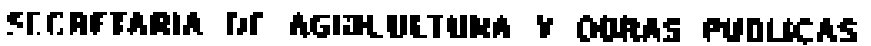

Panod, Abr11 22 do 1929.

sosarat

Botantaluo Ibpex y E. Horalae

Frobenter.

Segoran:

In renpuete 18 etenta onrte de antades do 26 de

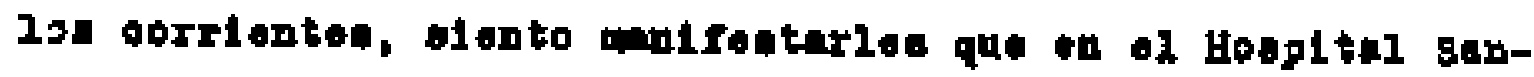

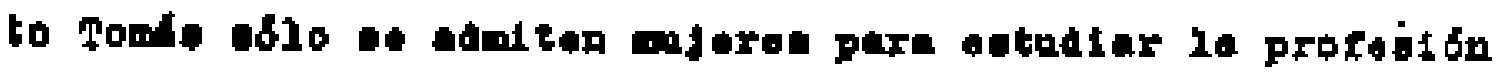
do perterse.

be netedee way atento eartidor.

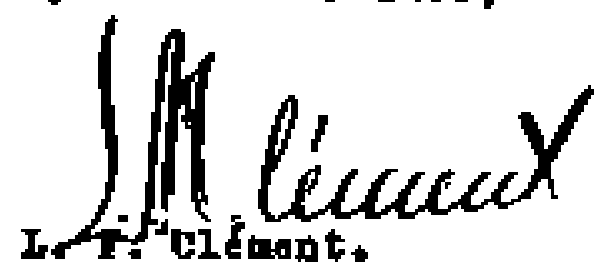

mos.

V. H D, n, $4 \mathbf{3} 1$. 


\section{V II I}

N-56

Nómeroz17.4

NARGANA, 4 de Mayo de 1929.

\section{Seริơr \\ Intendente do In Cirtunserlpetón de San Blas, \\ El Porvenir.}

\section{Setion::}

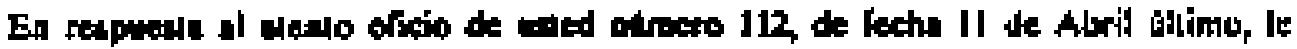

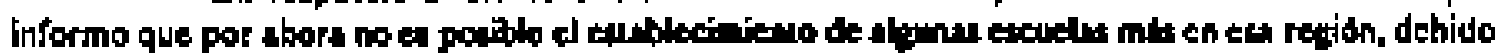

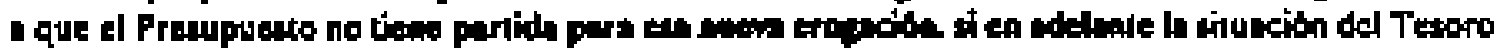

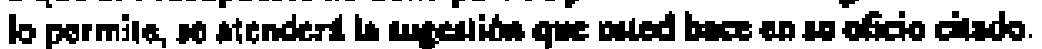

Soy de usted my tlealo servidor.

Adriane Robles

'Trans. del orig, mec

V. R D, N. 4 32 , 
Núntęro 2?6-1

PANAMA, 8 de Mayo de 1929.

\section{Señor}

Intendente de la Curcunseripción de San Bian,

EI PoryenIr.

\section{Sehor:}

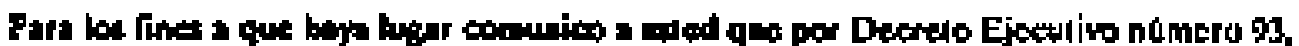

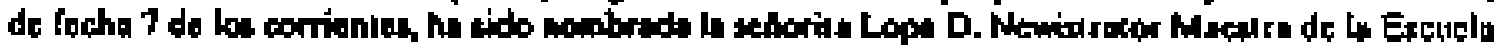

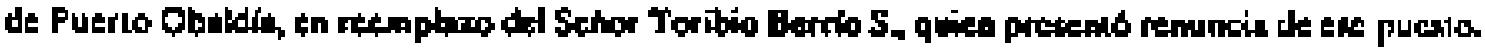

soy de wed bour wewo tervidor.

For el Secrelerio de Gobieros yonticin

Adumer

Subcerrelario

Prans, del orig. nuce

V. KD, n. 434 . 
Sebor Don

Panead Il de Junfo de 1929

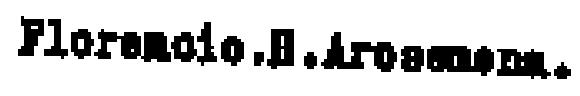

Prealdante de in Poptblio

Provanto

Loe dirifinoe onte oarte on noobro dol $F$

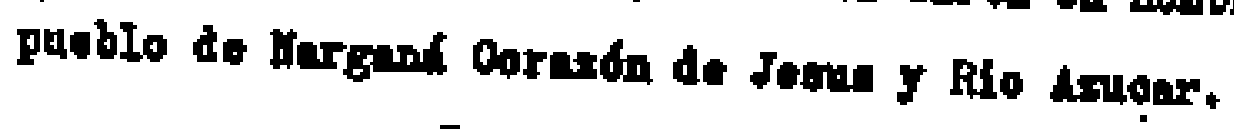

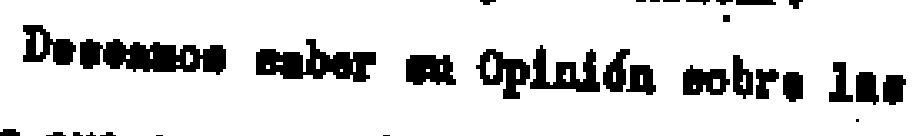

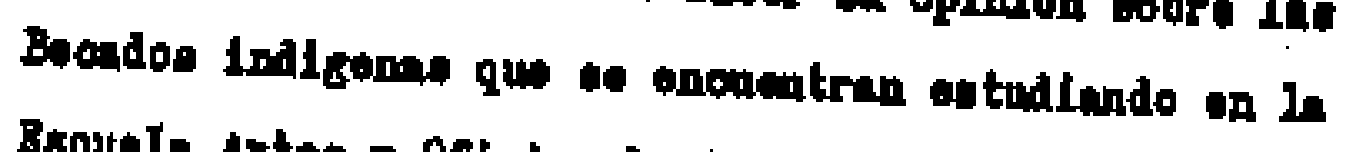
Bsoutele Irtee $\mathrm{J}$ Ofiolos, inetituto biaclonel, Ia Mornal do Inatitutoras do eatioritue $J$ la Profosional .

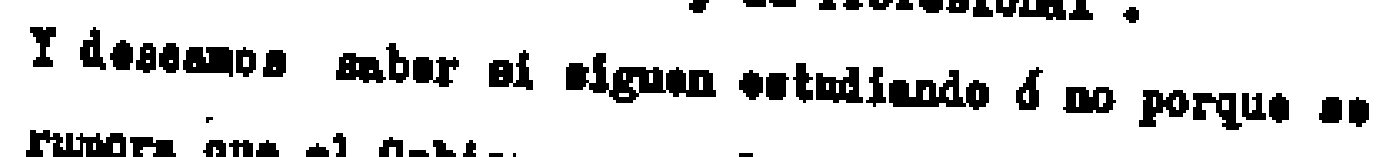

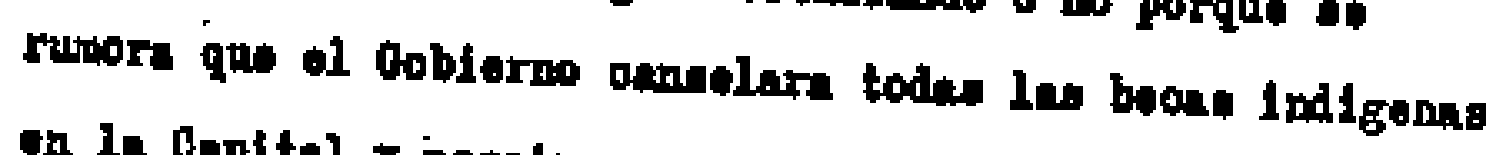

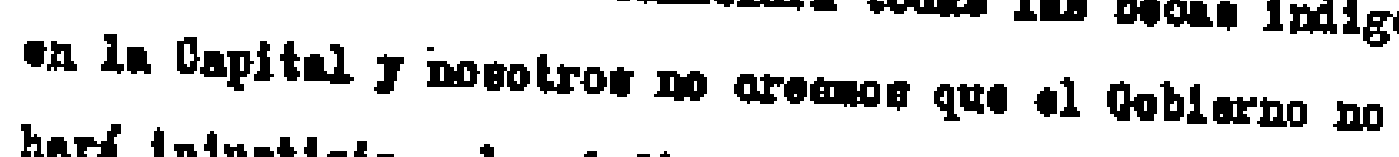
hard Iajụtioia a los Indlgunae de san Blac qultarlo todas lal bucas, oppermion on oontegtaoín por ol correo do ln cluied.

$$
\begin{aligned}
& \text { bapodinos do Uated nefior trealdente } y \text { momas } \\
& \text { enígos } \mathrm{J} \text { buenos enervidores }
\end{aligned}
$$

$292 \operatorname{lin}$

CLXXI 


\section{CLXXII}

Número 288-b

PANAMA, 14 de Junio de 1939.

\section{Sefor Intendente de la Conera de San Btat,} El Porverir.*

\section{Solior:}

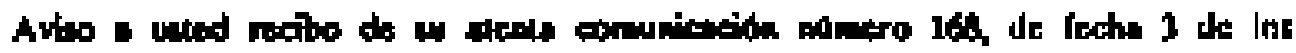

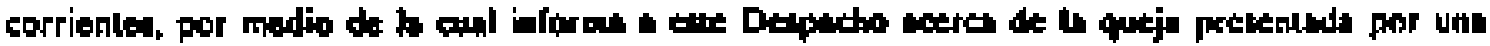

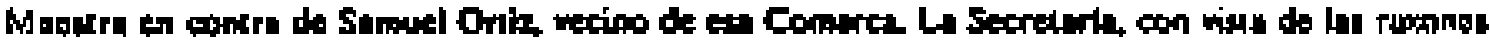

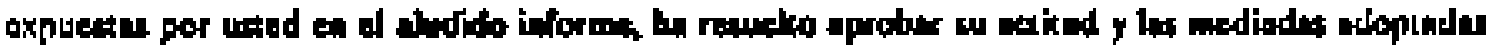

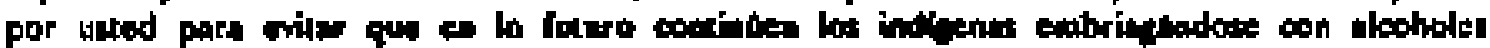
perromation.

Soy de utred mory alento mervider.

Adrano Roble:

Trans. det orig. mee.

V. RD, $=437$ 
Pangach, 22 de igosto de 1929

\section{Sefior Frencisco de la Osso}

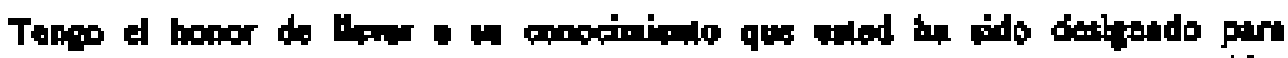

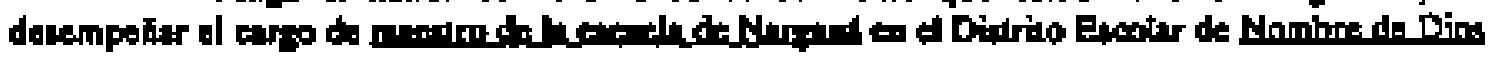

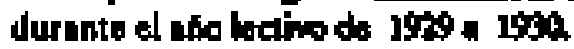

De usted clento atridim.

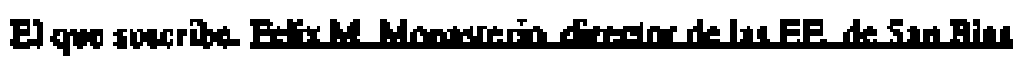

$$
\text { CERTIEICA: }
$$

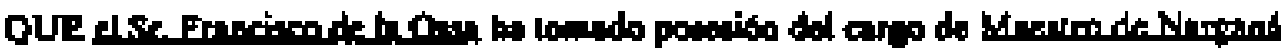

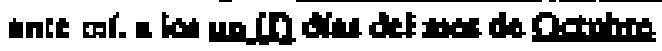

THir M. Monniserlo

Director de las Escueles de S. Blas:

Trans. tel orig. met.

V. R D, \#, 439 . 


\section{$\operatorname{CLXXIV}$}

A-10A Y $11 \mathrm{~A}$

13 Sepiletritse 29

Sefior

Secrets do de Goblerno y Justicia. Panamá,.

\section{Selor Secretario:}

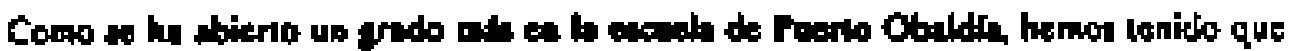

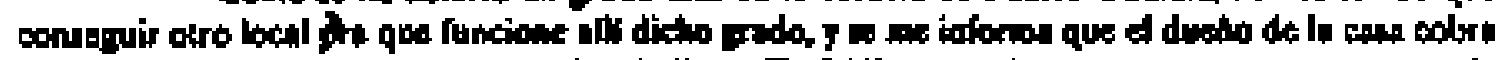

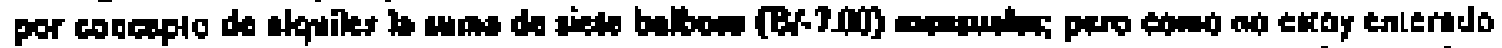

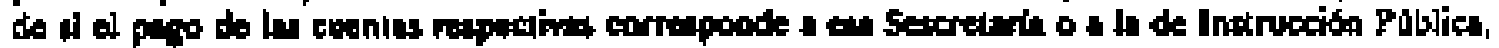

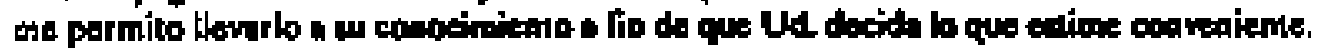

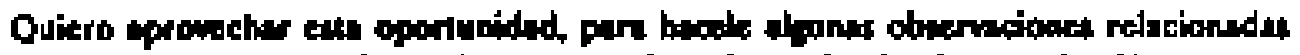

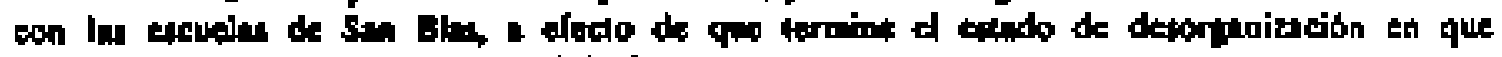

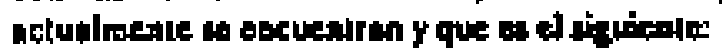

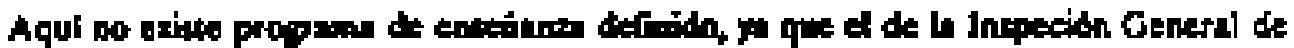

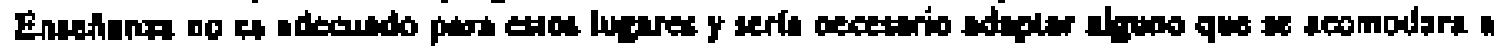

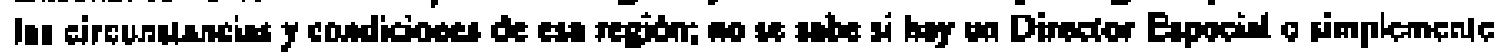

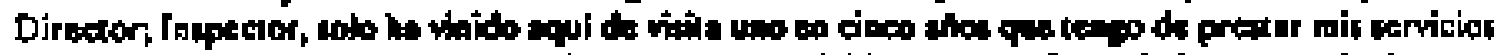

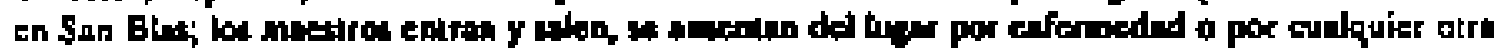

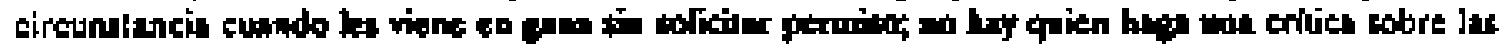

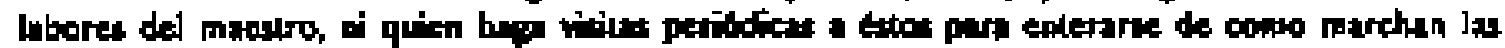

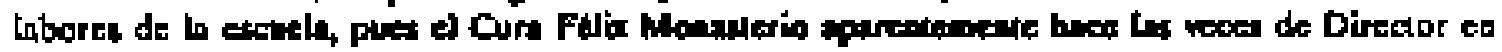

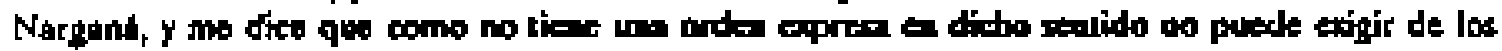
magstros lales requitilios.

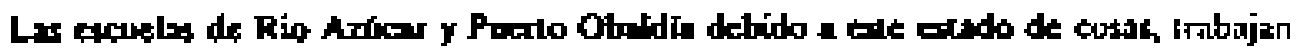

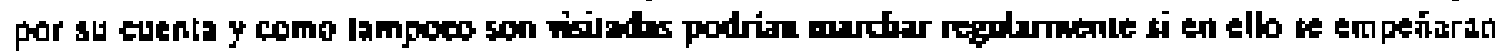

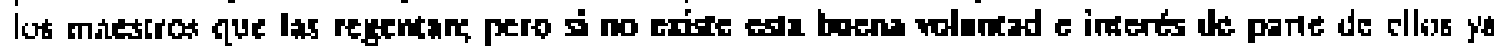
puede Ud. imaginatsc como smarían exas escorlas

Yo por mi purle, aun cendo we intereso el que toda maxhbe de la mejur milnera

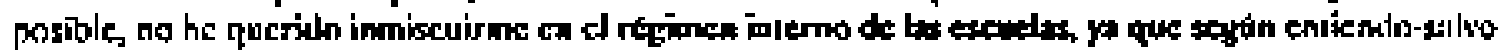

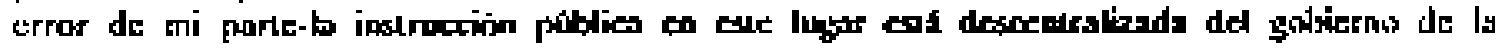

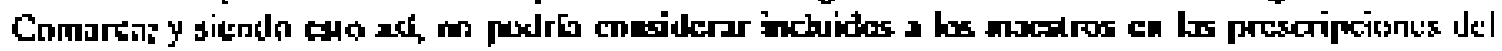

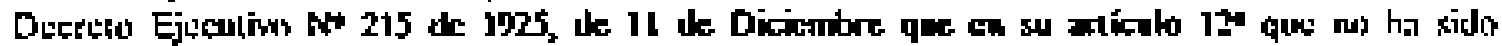

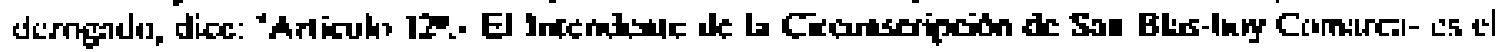

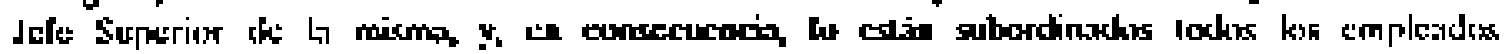

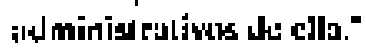

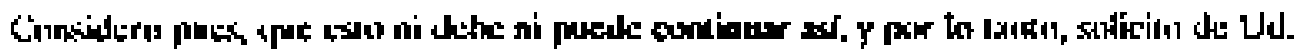

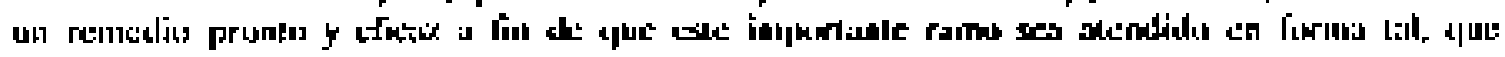

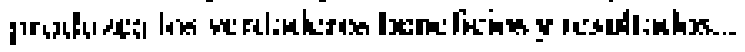

Trans. te la cop. mec. inc. V. k D, n. 443. 


\section{CLXXV}

A-9A

I8 Septiembre 29

\section{Sefior Curt}

Palix M. Monasterio,

Nortand.-

\section{Sylom Orite}

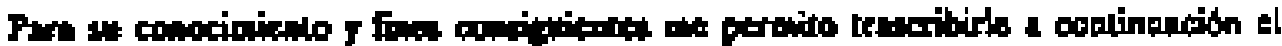

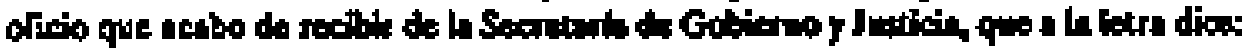

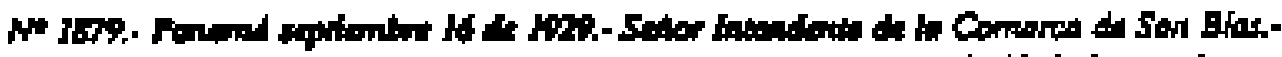

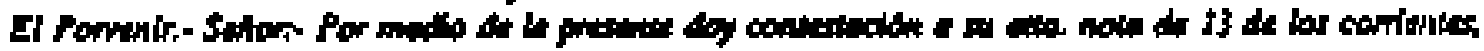

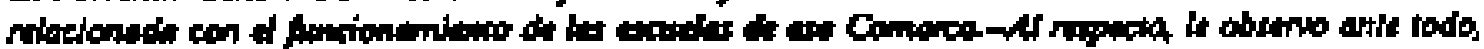

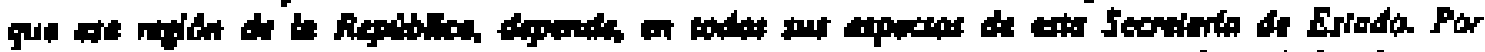

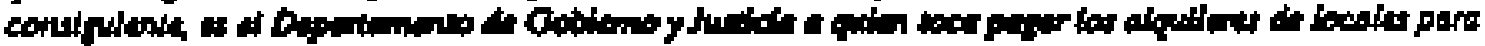

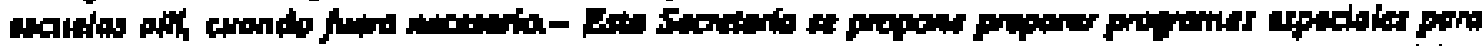

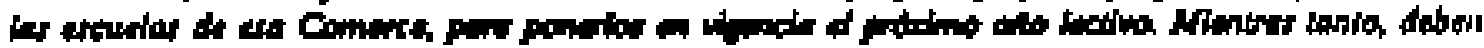

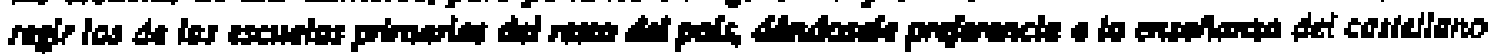

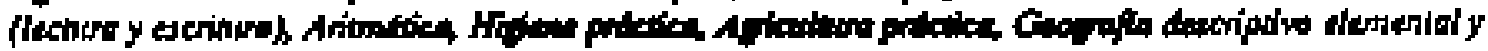

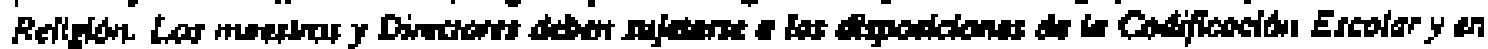

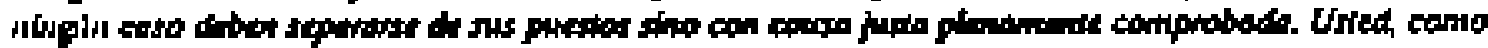

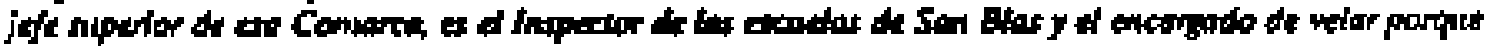

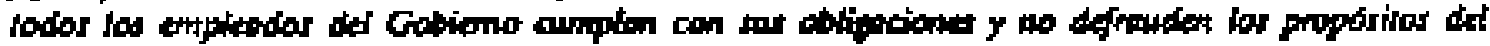

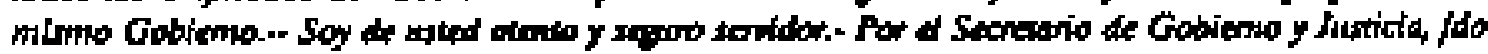
Jort C de Oblalla. Swbeerentia"

Soy dk wated misy alento y segwo servidar,

Tanis E Abelle P.

InIendende

Trans. de la cop. mẹc.

v. RD, n. 444 . 


\section{CLXXVI}

A-8.

21 de Septiambre de 1929

Sefior

Serreterio de Gobterno y Justleia,

Panturk.-

Sedor Seareacrix

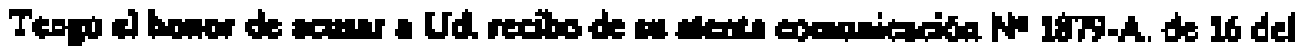

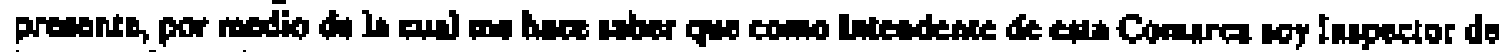

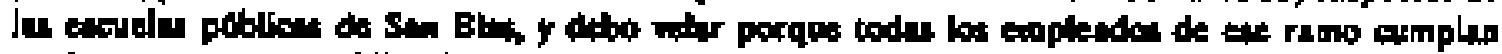

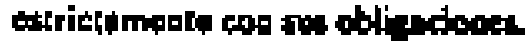

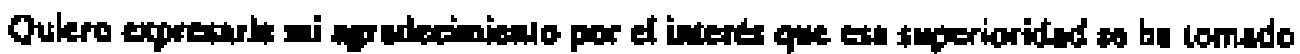

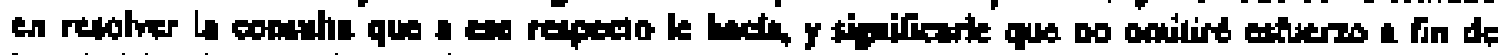

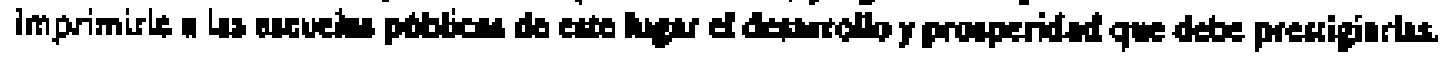

Soy de Ud. moy ato y ceppro servita.

Inlyodenis

Trans. de la cop. mec.

V. R D, N. 445 . 


\section{Sulior}

Inspector General de Betefintrits, Panderif.-

Sollor

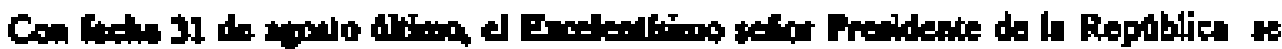

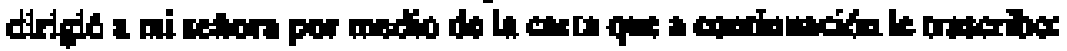

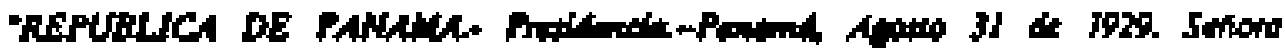

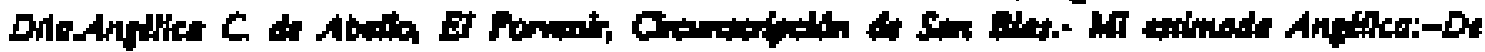

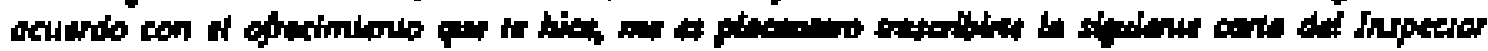

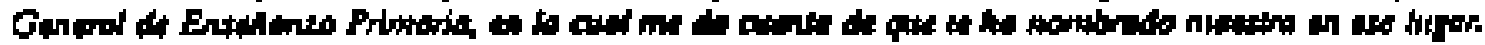

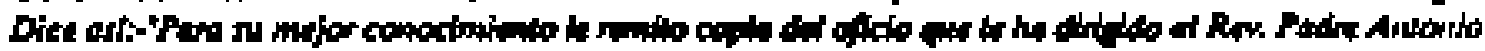

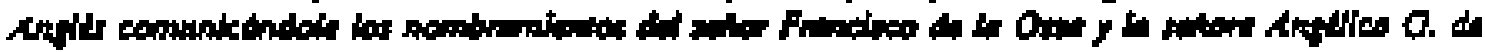

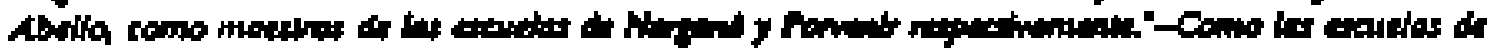

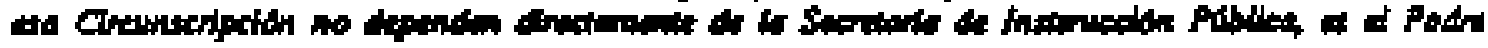

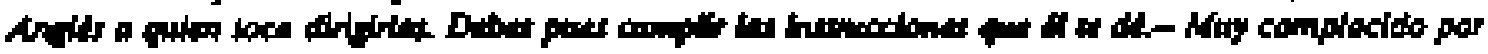

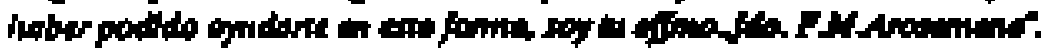

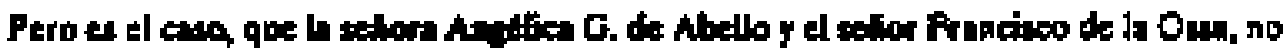

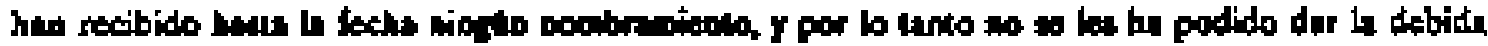

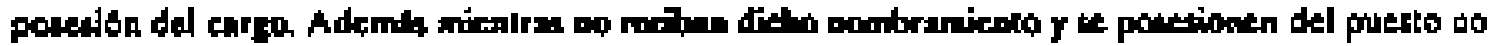

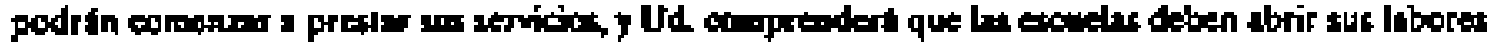

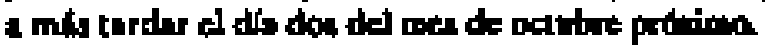

Cono lmendese de la Conerca de Sa Blat, b Secrelarla de Gobiemo y Juaticia mo

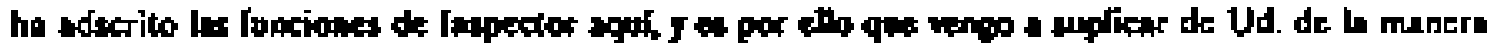

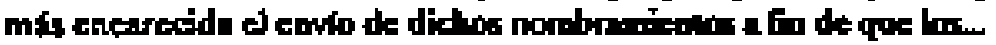

Trans. de la cop. biac. inc. V.RD, n. 446 . 


\section{CLXXY I I I}

A-13A

Shĭor

Rít Artiear, Dlefembre 11/29

Secratarlo do Instrucetion Póblles.

Ponsand.

Moy Eximado Solvor.

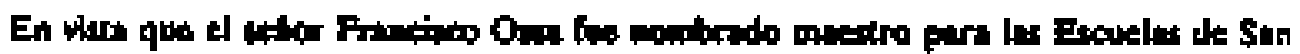

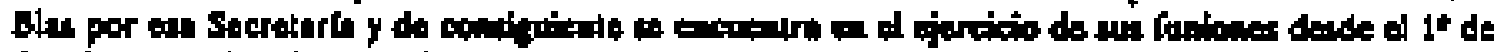

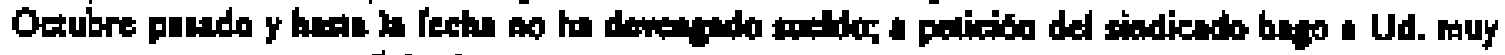
respetuocingnte ents nobcilud

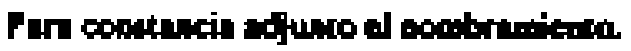

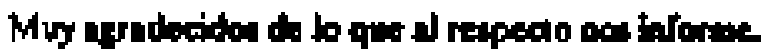

Inla de Carisbm

Trans. del orig. ans.

V. RD, I + 449. 


\section{$\operatorname{CLXX1X}$}

Narguts, 12 de Dielembre de 1929

\section{Sefior Don}

TOMAS E. ABELLO

Intendente de Sinn Blas

Ev Porverior.

\section{Mry Sebor ming}

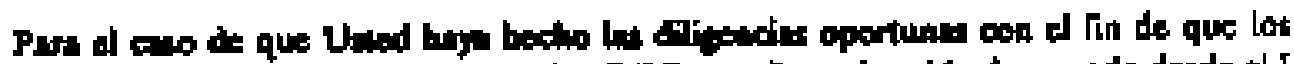

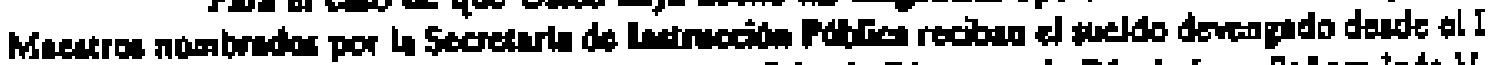

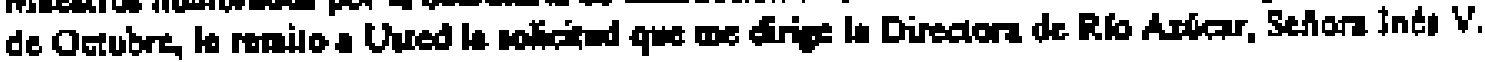

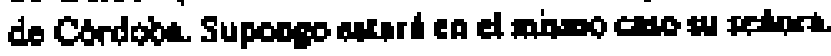

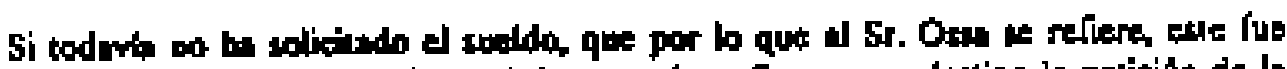

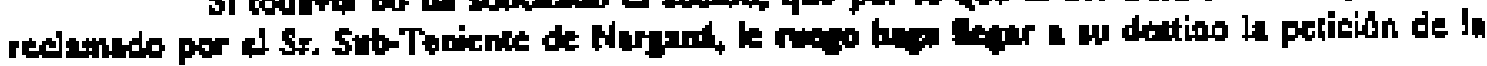
Sehors Inda que edjunil le embo.

De Unled nlta envidor , tiona saing

Ftllx M. Moanitula, CMS.

Trans. del arig. mec.

V. R D, n. 450 . 


\section{$\operatorname{CLXXX}$}

5

Nómero 460

\section{Sthore Dohe}

23 Dielentre 1929

Ines Y, de Córdobe.

Rlo Axtear.

\section{Sethort;}

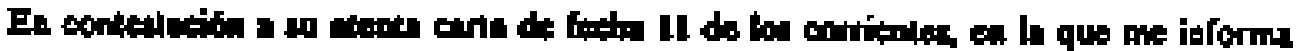

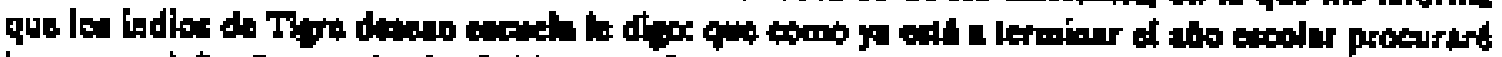

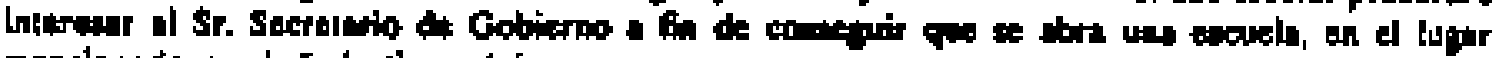

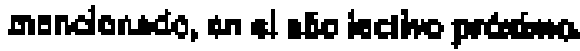

Soy de Ud mento y S.S.

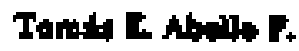

Intendeste

Trans. de la cop. mec.

$v+R D, n+451$. 
Sr. Intendente de Sin Bles Ylenen

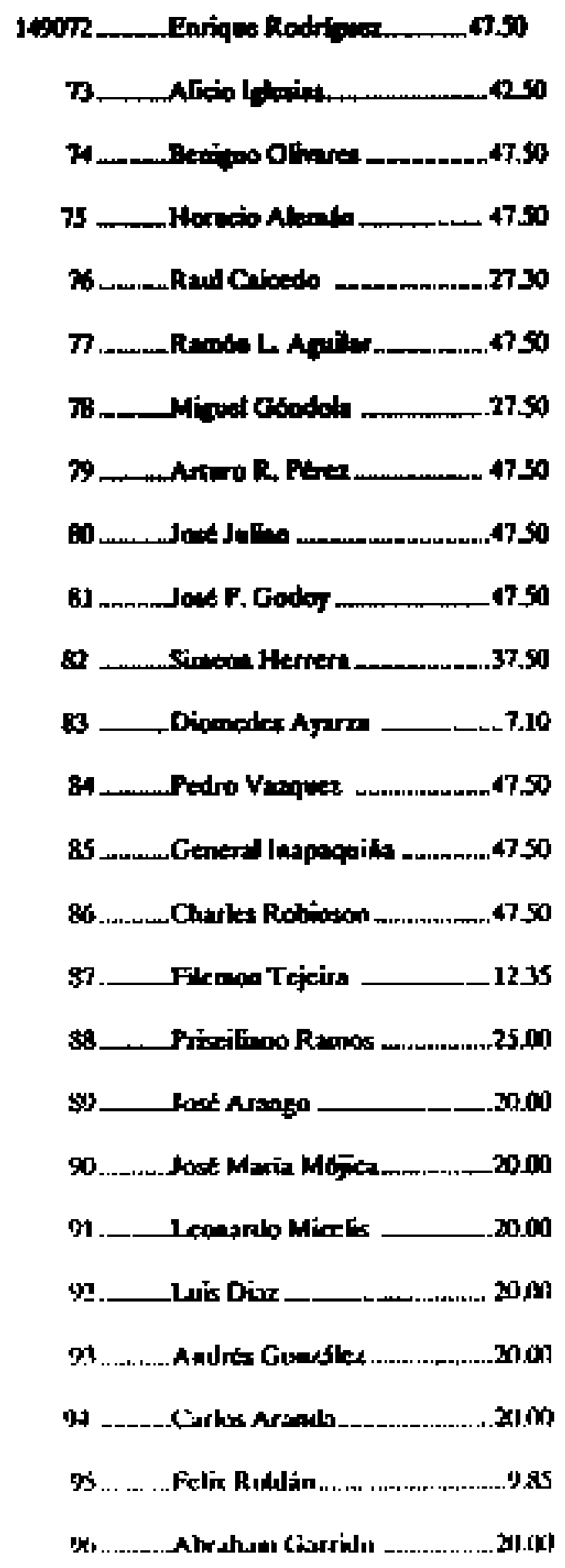




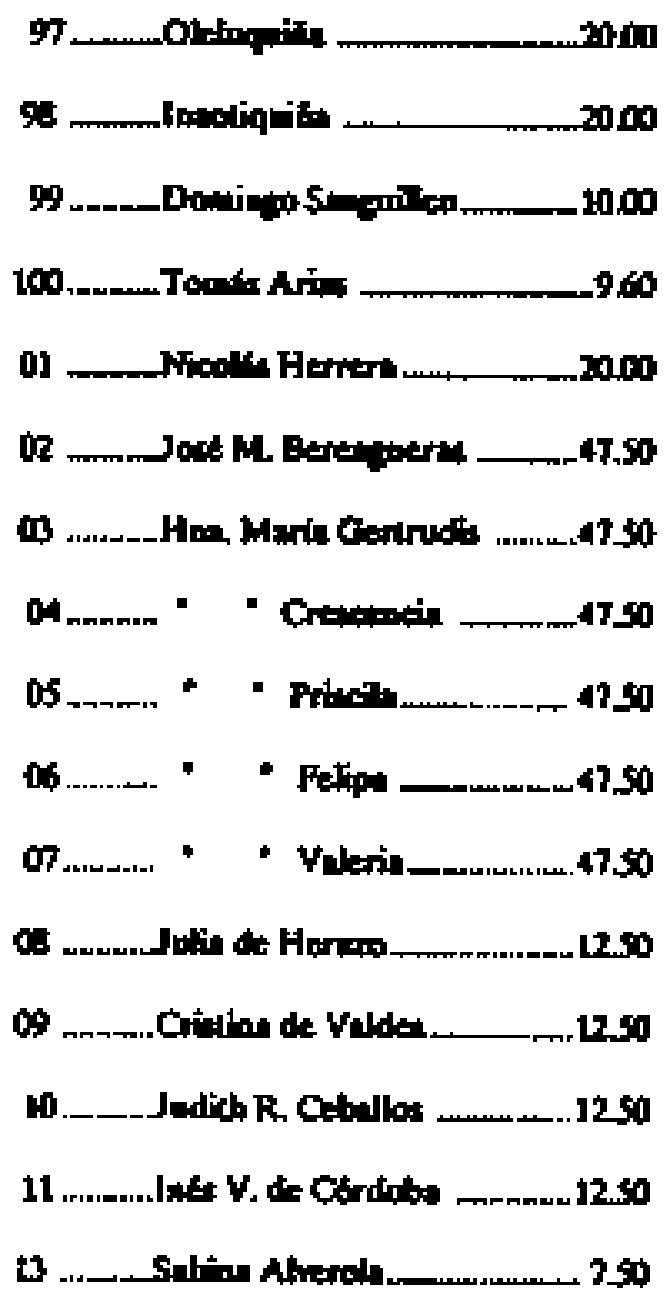

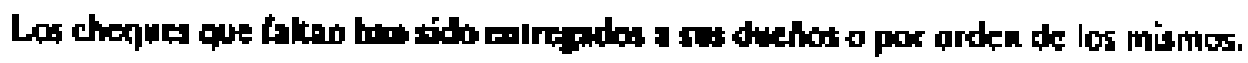
Lo etsimare me anise recibo.

De Ud, altato SS.

Por el Secretario de Gobiena y Jupricia.

1929

Suburetario.

Trans. del orige inec.

V. RD, n. 452 . 


\section{$\operatorname{CLXXXI}$}

A-34A

Setor

Paerto Obaldia, 3 de Febrero de 1930.

Intendente de In Comaren de San Blas,

Porvatir,

\section{Enimado Sabor:-}

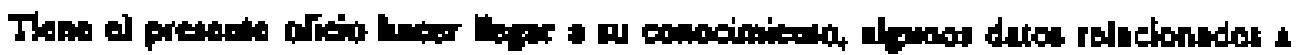
ete pientil que ropida.

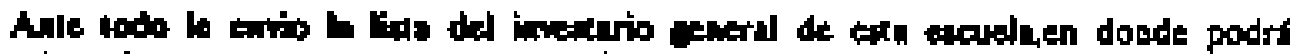

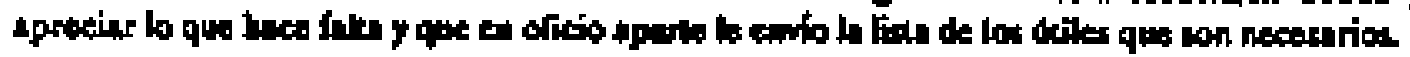

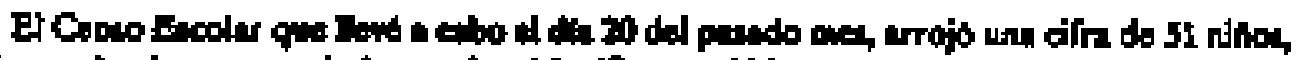

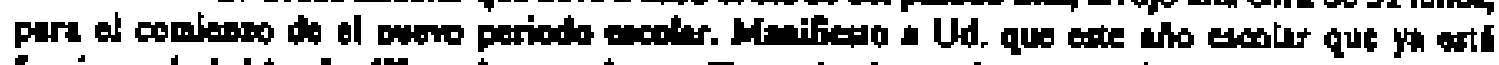

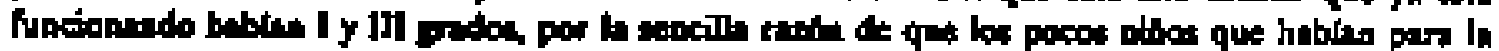

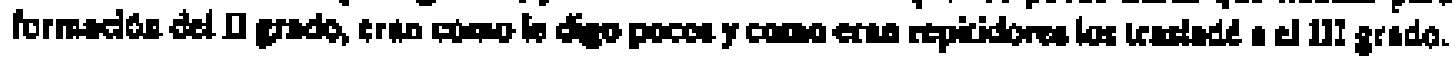

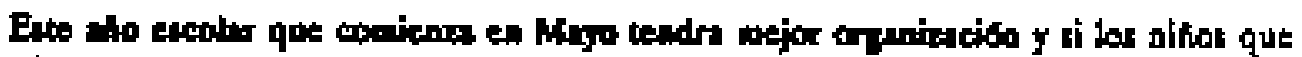

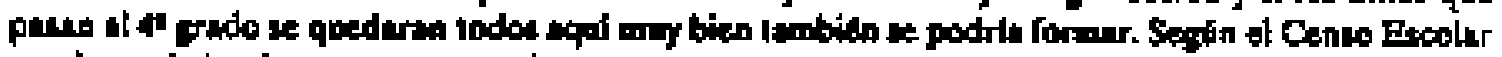

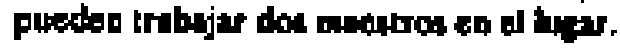

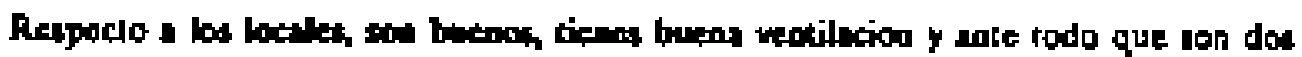

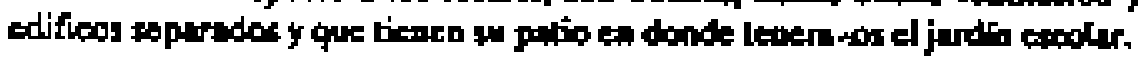

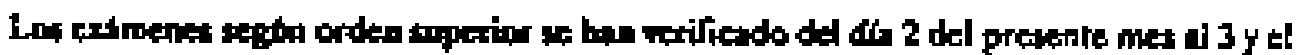

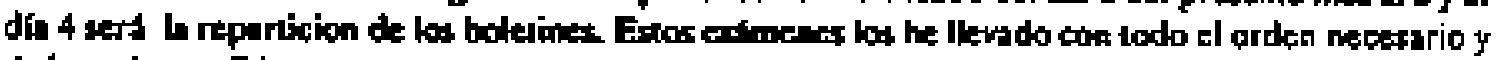
do lo mejor powibte.

De Ud Arto y 5.5 .

Ditgenes las

Dirccior.

Trans. del orit. mec.

Y. RD, n. 455. 


\section{CLXXXIII}

A-35A y 36A

Puarto Obaldfa, 3 de Pebrero de 1930.

\section{Sehor}

Intendente de ta C de San Blas,

Porvenitr,

Selopr:

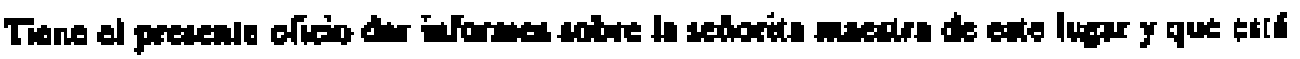
bajo mi dirwets.

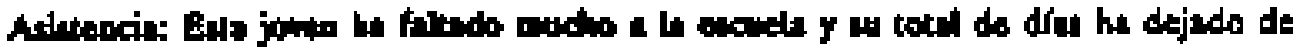

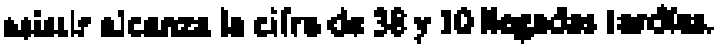

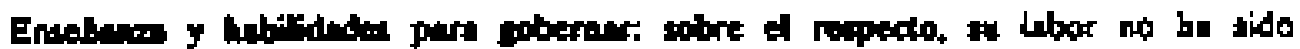

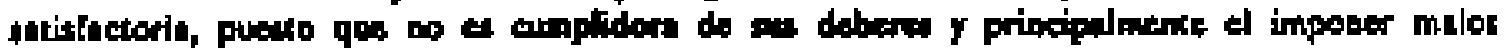

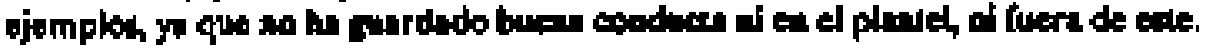

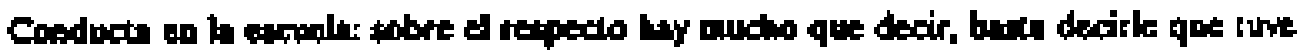

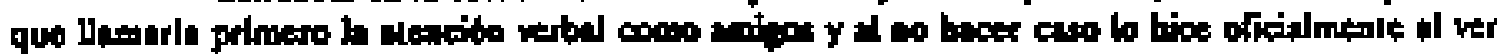

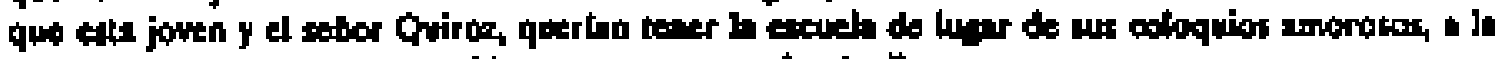

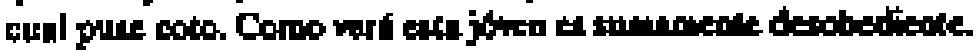

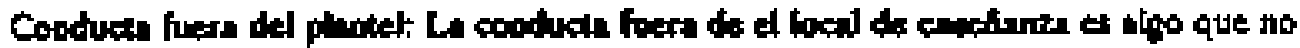

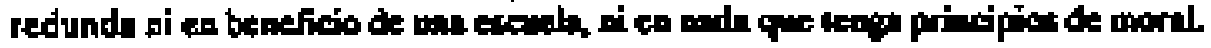

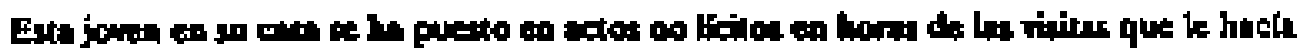

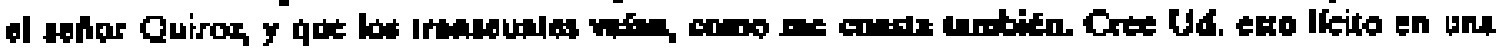

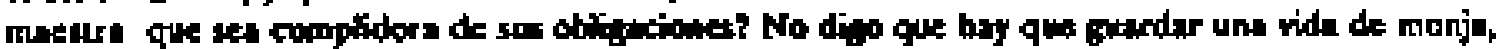

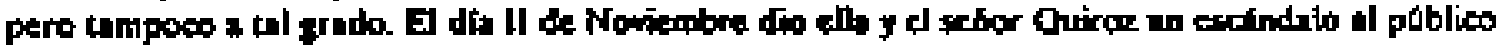

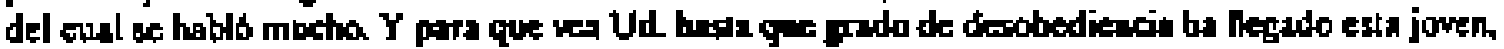

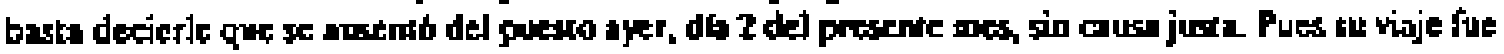

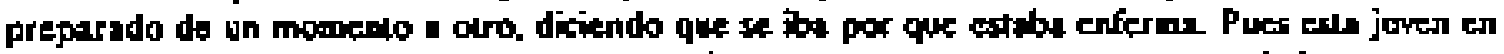

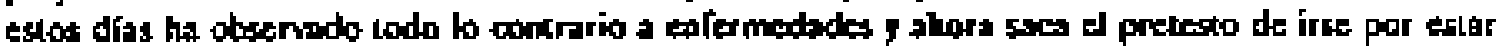

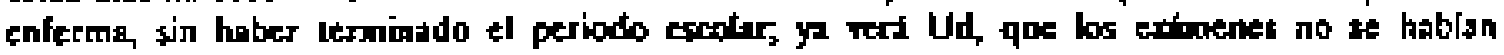

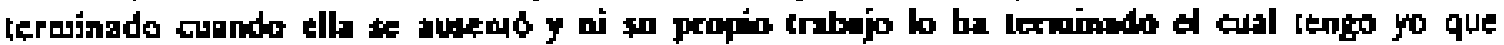

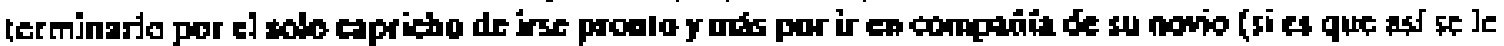

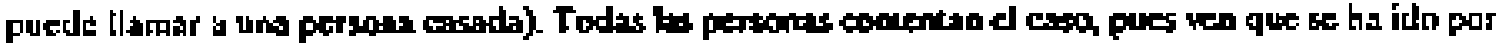

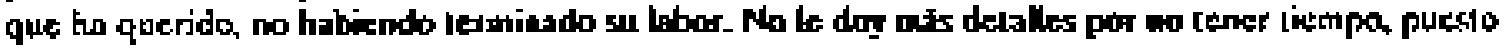

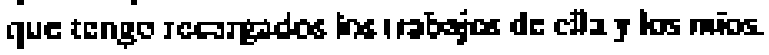

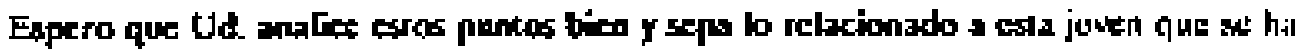

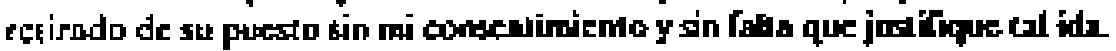

De Ud. Alemo y S.S.

Dilipterex lbainex

El Directis.

Trans. lel orig. mec.

V. RD, n. 456 . 


\section{CLXXXIV}

DBCRETO NUMERO SS DE 1930

(de 25 de Awril)

por el coel se nombre el personal docewte de las Escuelas do In

Conerta de San Bint

KL. PRRSIDENTE DE LA REPUELUCh,

en aso de ins theultades logeles,

DECRETA:

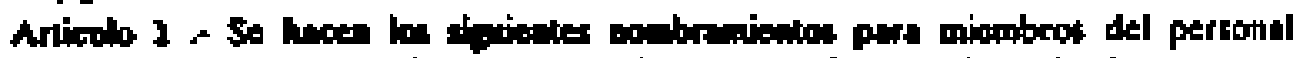

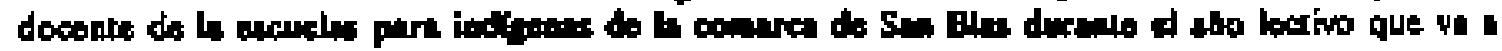
inicianes

\section{EROUEA DERIOAZAUCAR}

Direttorn- Int, V. de Cordoba

Merevas. 5obion Aberola

Ruby W. Sinith

BSTIGIARNARGANA

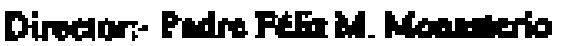

Medros- Hennase M. Gentrudis

Herand M. Felipt

Hetmang M. Clamoming

Julin Naring

Mertu de los R Guitiste

Eneror M. Salocido

ESCIJULA PUERTOOHALIA

Macdrox- Ditogens I. Iboinez

Berilanda Anbolech

\section{ESCUELA DETHRE}

Mocstros: Mario Ponfes glanct Lifre

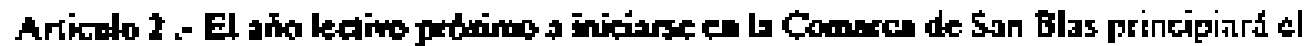

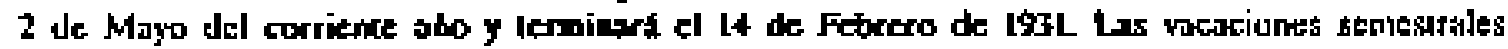

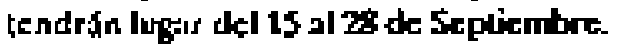

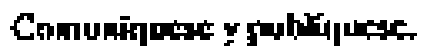

Lruinty.

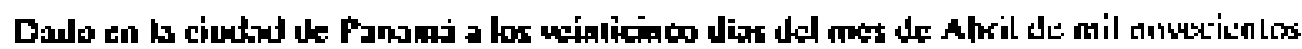

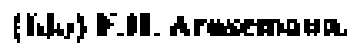

Trans. Uel origh. utec.

V. RD, n. $45 \%$. 


\section{$\operatorname{CLXXXV}$}

- -334

Numero $951-\lambda$

\section{Stefitir}

Intendenie de la Conaree de Son Bles, El Porventr.

\section{Setwo:}

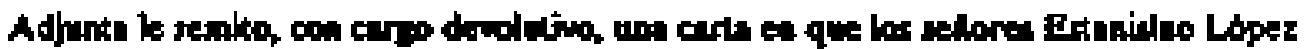

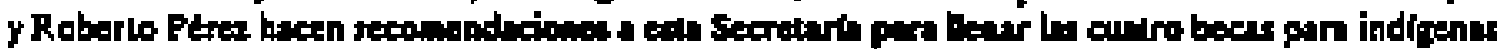

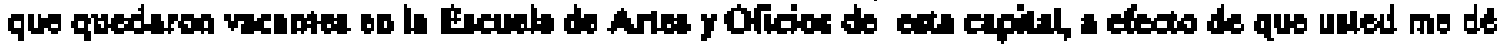

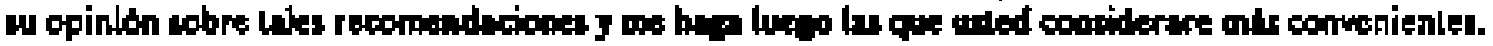

Soy de uadod wewo y reparo nervidor.

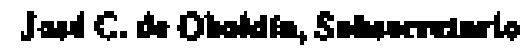

Pot el Secreturio de Gobierno y Jutitio

Trans. del orig. mec.

V. RD, n+ 458 . 


\section{CLXXXVI}

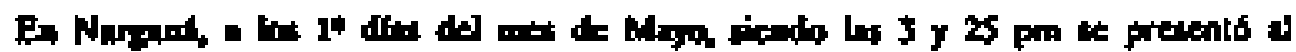

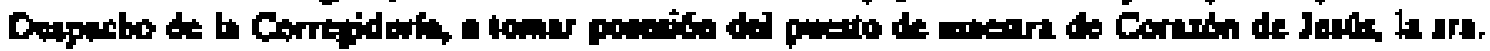

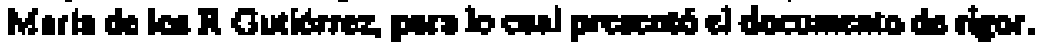

en thle

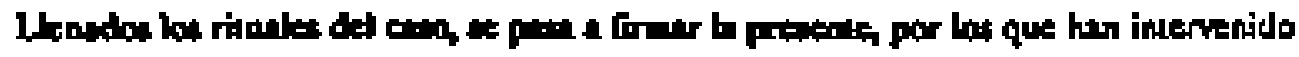

\section{L pocesioneds}

\section{Marts de las R Goldmes}

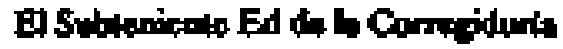

\section{Berabd Cerem}

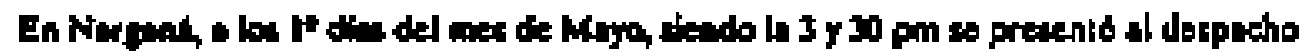

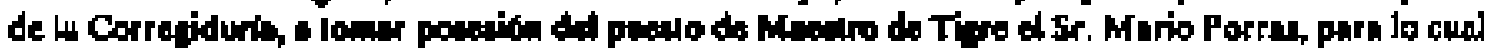
prenantio el dowereanto de ripor.

ella.

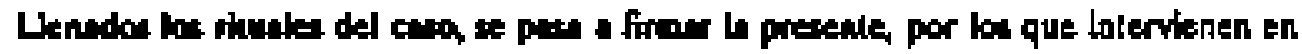

\section{El posesionado}

\section{Mario Porrs}

\section{El Subrenieme Ed de la Corregiduri}

\section{Bernebf Cerman}

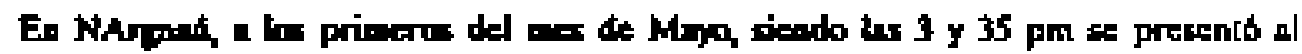

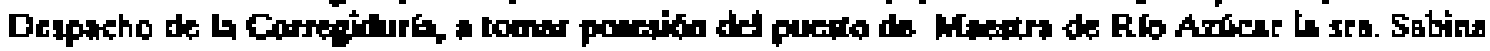
Ester, pars ko and preseale th documento de ripac.

An eilis.

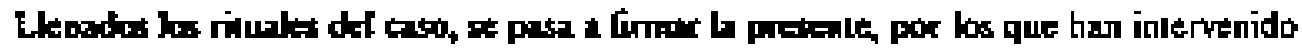

$$
\text { Lastionads }
$$

Stlina Esler

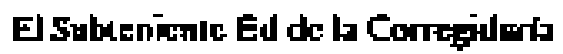

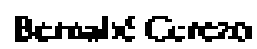

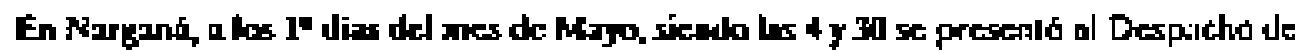

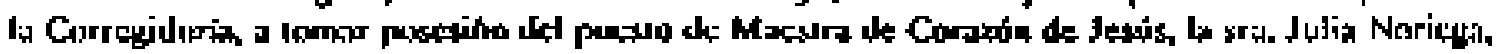

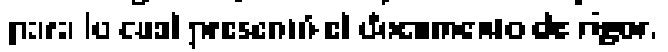

เillit.

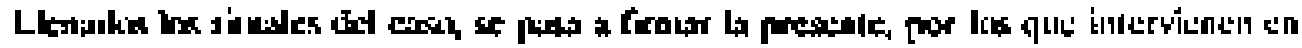




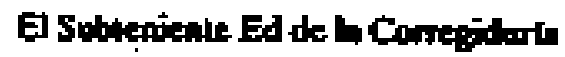

\section{Bernate Cercon}

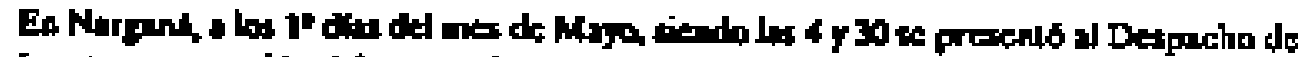

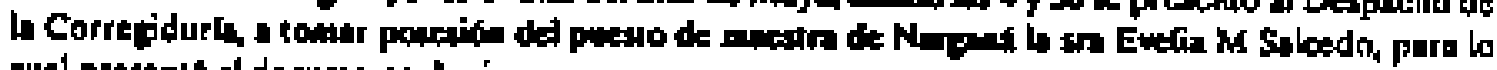
eual pratentc al documedo de rípor.

en elli.

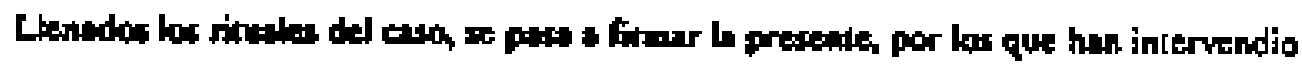

\section{Lo poresionends}

\section{Crelle M Sulotilo}

El Sublamiante Ed de b Corregidues

Beroubs cereso

Trans. तel nrig. mec.

V. RD, n. 459. 


\title{
$\operatorname{CLXXXVII}$
}

Número 32

Nergand 5 de Mayo de 1930

\author{
Solior \\ Inlendente de b C de San Bing, \\ Ed Pornoir.
}

\section{Selnar:-}

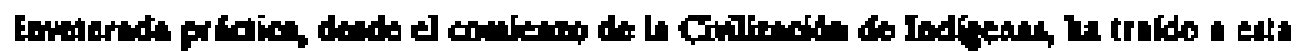

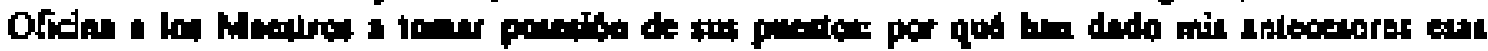

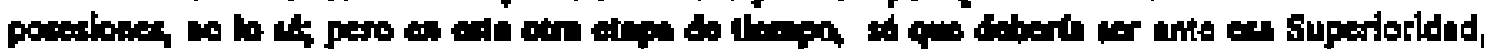

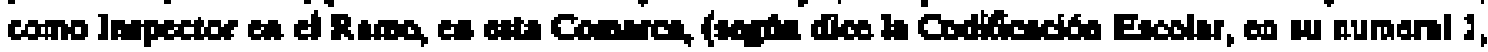

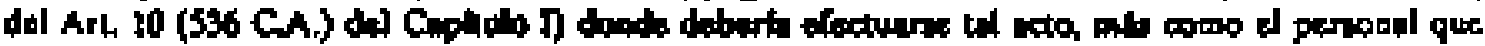

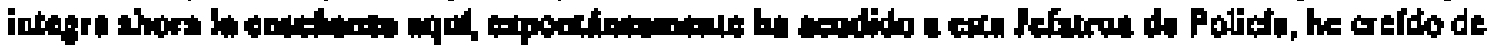

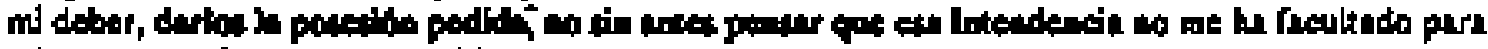

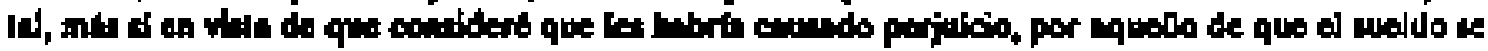

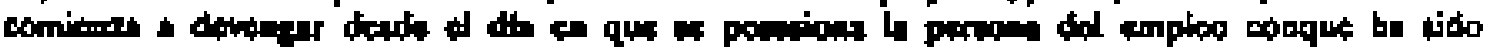
agraciaso.

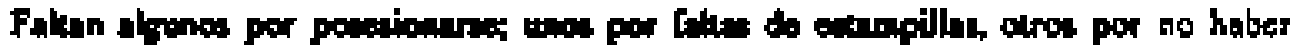

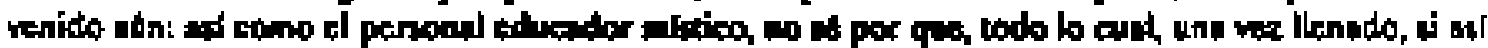

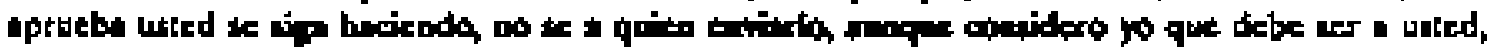

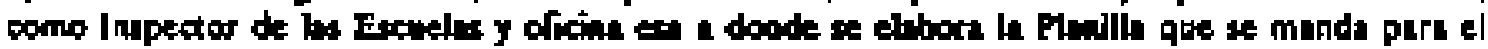

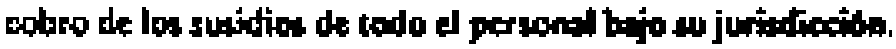

sobulterno,

Experando us Ipcrs y al mandy, quedo, como steopre, gl atento servidor y reIpetwoso

Bernabe Cerero

Subteniegle Jete ded Deutacanento.

Trans. del orig. mec.

V. RD, n. 460 . 


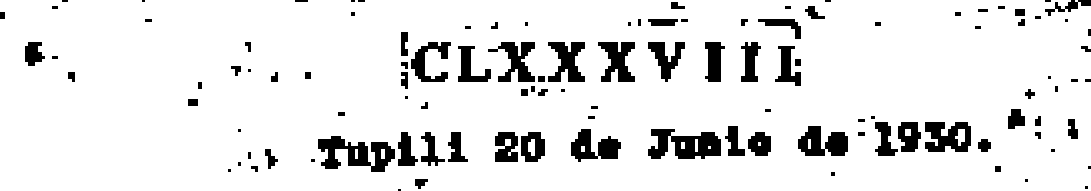

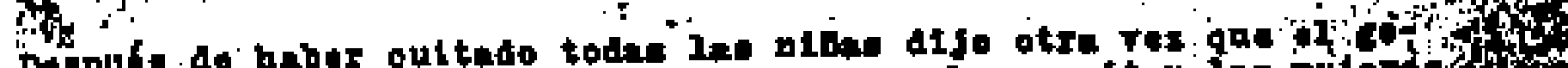

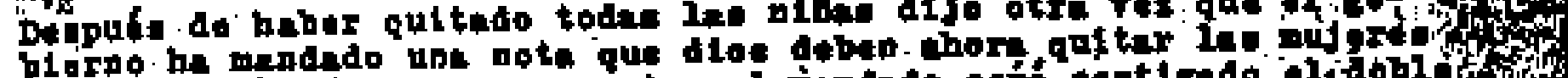

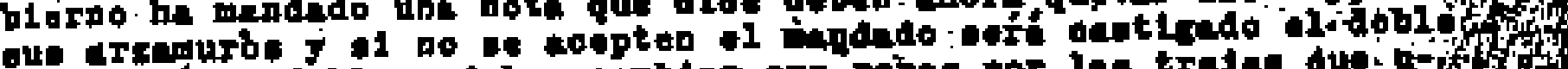

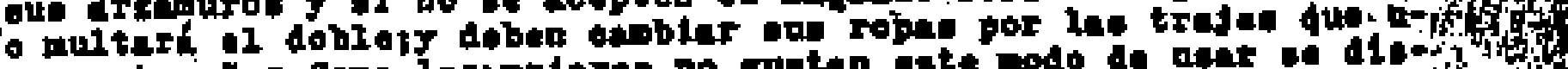

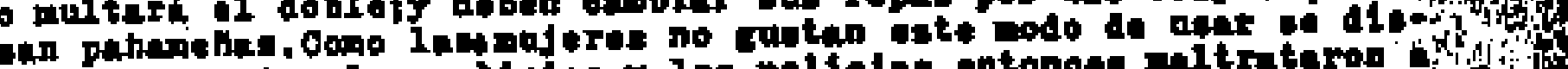

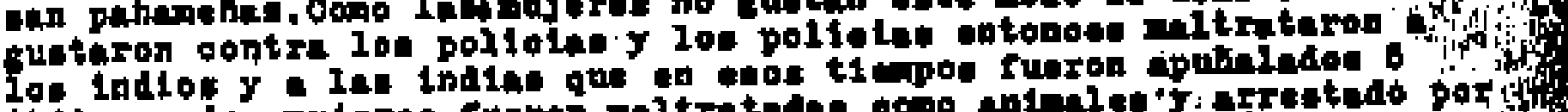

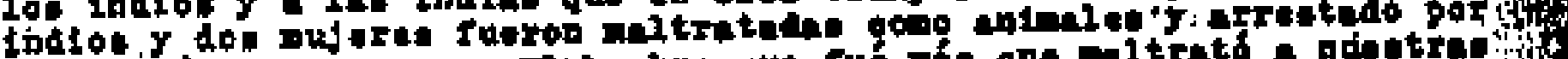

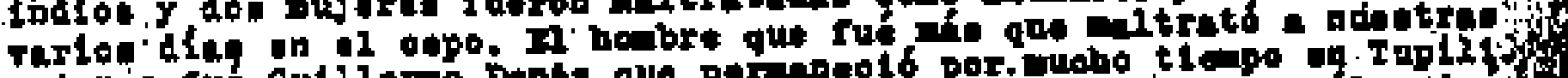

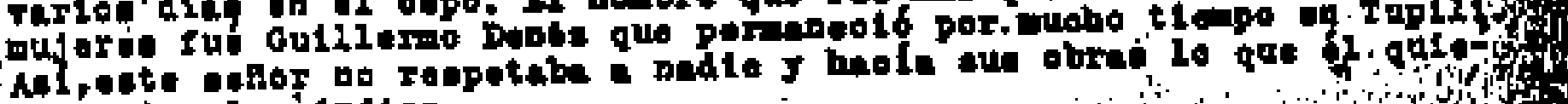
re oodiza 108 Indios.

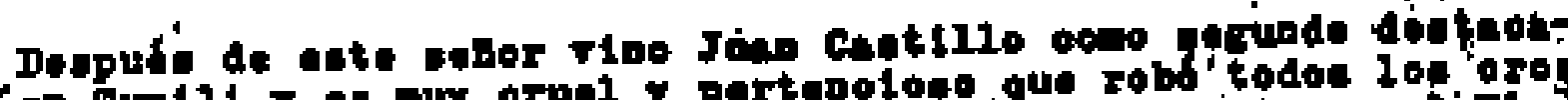

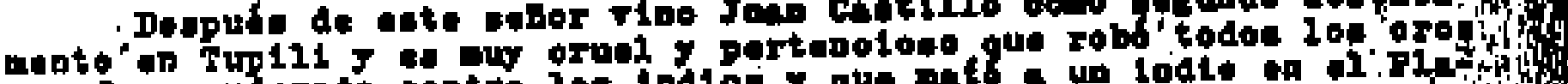

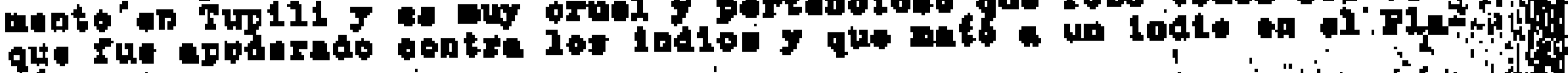
Yob oh100.

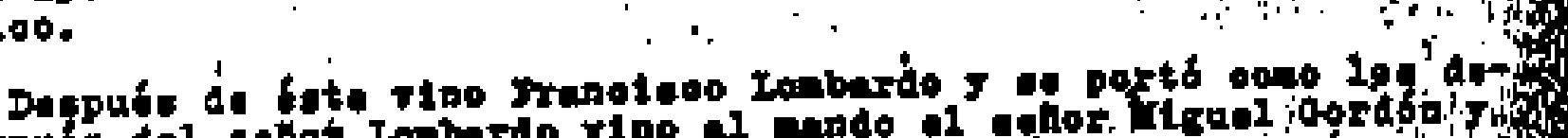

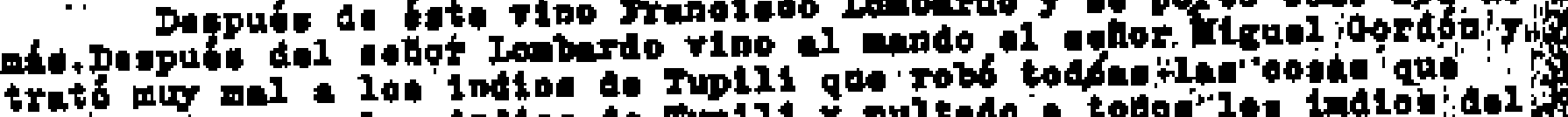

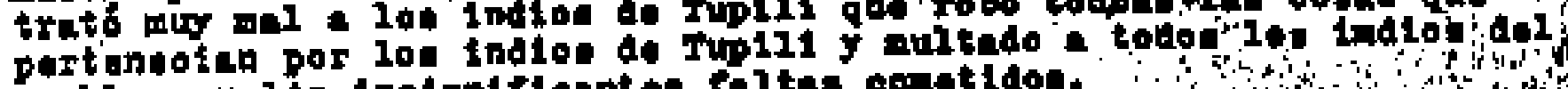

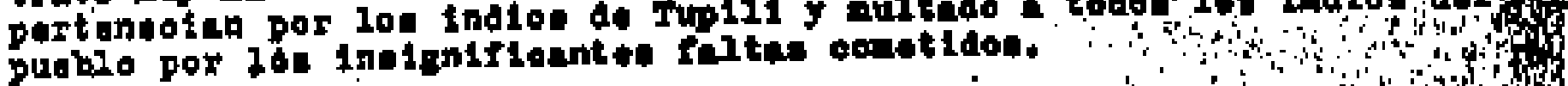

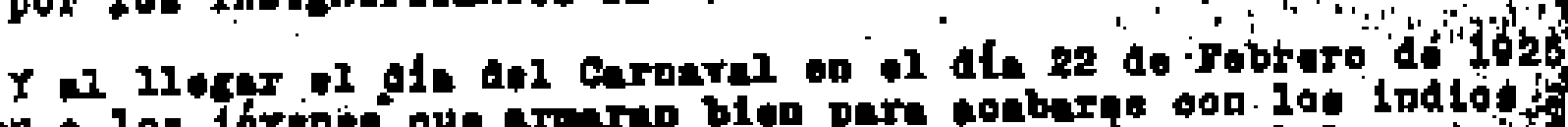

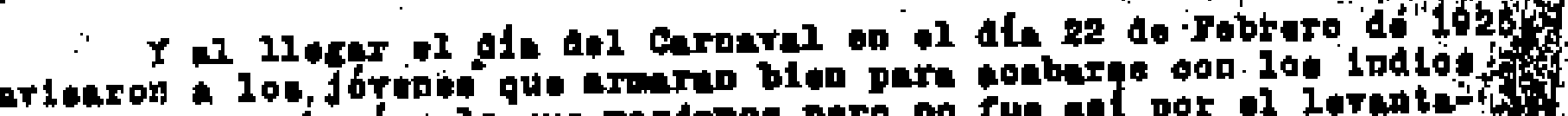

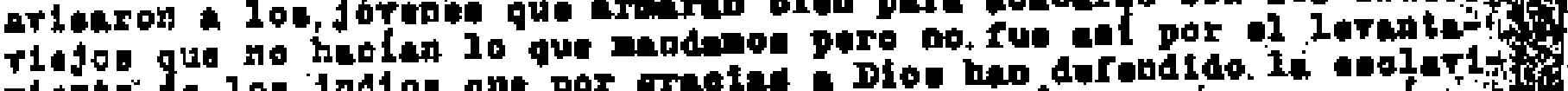

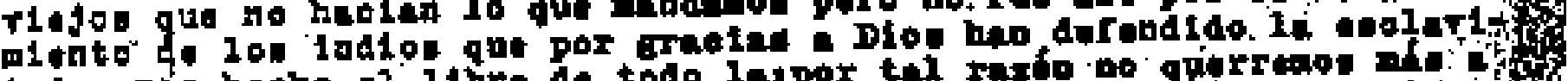

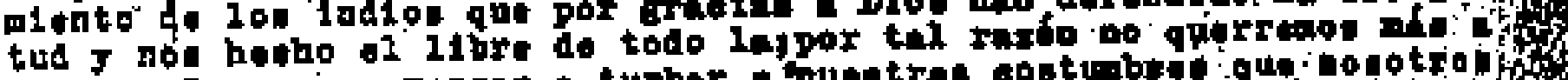

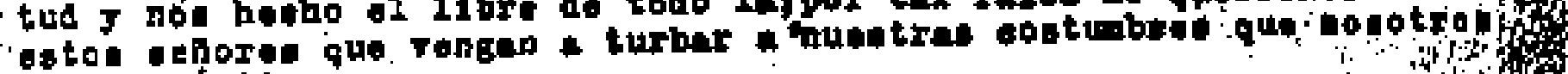
Putme rigtimes.

Las, palebres de low habitanted de Tupil1.

eopla ortginel. 


\section{$\operatorname{CLXXXIX}$}

A.25A

Rro Axícur 27 de Junio de 1930

\section{Seifor Don}

Tomsts E. Abrilo

Inspector de las Escuelas de San Blas

Porvenitr

Muy apinudo wator:

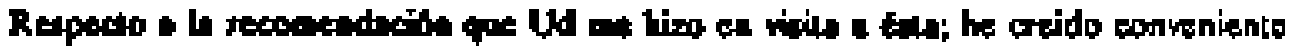

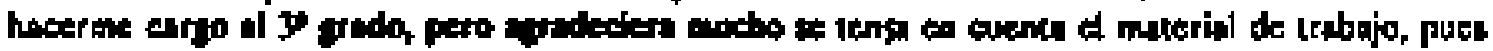

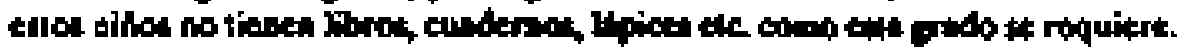

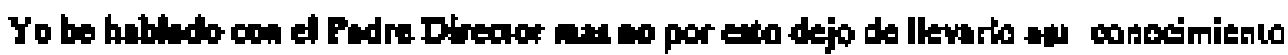
como nutaridad meperior. destonds.

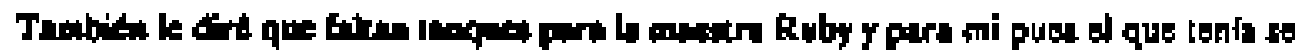

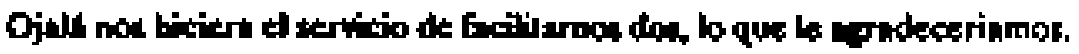

De Ud. Alg"

In: V. \& Cb́tebo

Trans. del arie. ms.

V. RD, n. 467 . 
Río Azúcar Junio 27 de 1930

\section{Sthor Don.}

\section{Toming E Abello}

Intendente de San Blas

Narganf

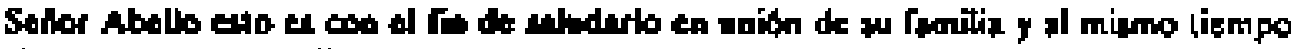

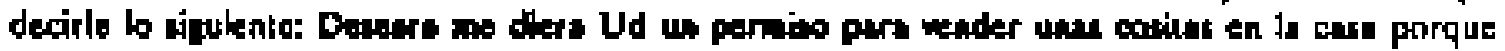

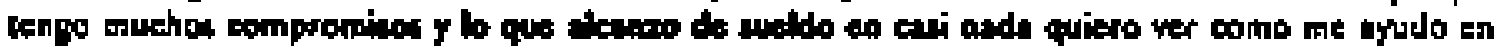

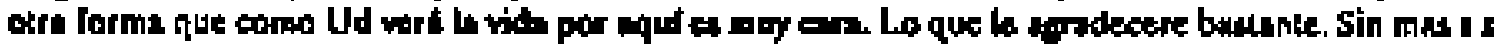
เy

Ruby M S de Eucilo

Trans. del orig. uts.

V.RD, n+468. 


\section{$\mathrm{CXCI}$}

A-15A

Plo, Otaldfa, 20 de Julia 1930

Senior Intendente de la C. de

San Blas:

Porvenir.

Selior.

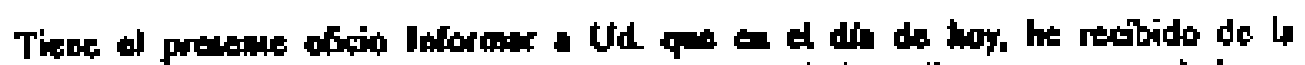

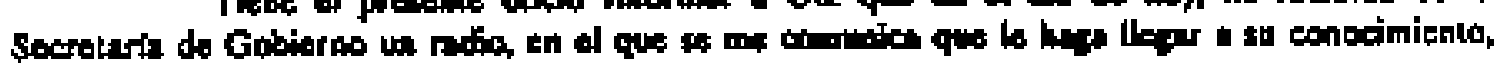
como lo irunteriba.

Derelo Encouls Pto. Obudin

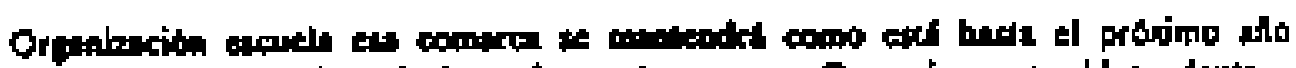

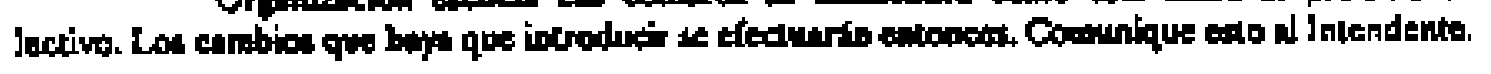

Servidor

Gobictrab

De Ud Axlo, y S. $\mathbf{S}$.

Dibenes 1hober

Trans. del orig. ms.

v. RD, I. $47 \mathrm{I}$. 


\section{CXCII}

Número 1555-A

Sehior

Pantiofic, 3 de Agasto de 1930

Intendente de In Conarea de Sea Blas.

El Porvenit.

\section{Selor:}

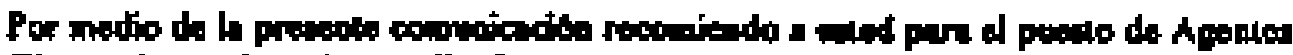

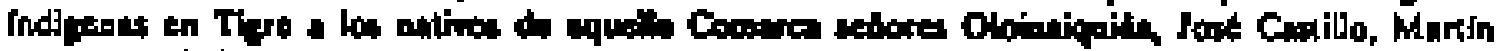

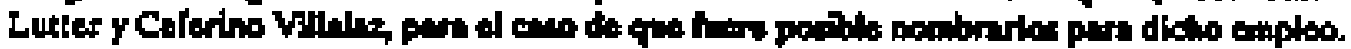

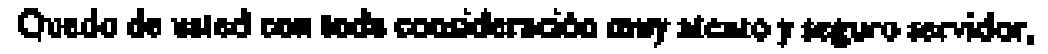

Adripos Robles.

Trans. del orig, inec.

V. R D, n, 472. 
Número క21B-A

PANAML, 9 de agasto do 1930.

Sefior

Intendeate de la Ch-

Cuaseripción de San BAns,

Fl. PORVENIR, San Blos

RSPUBLICA DE PANAMA

INSPECCION GENERAL DE ENSENANZA FNIMARA

\section{Sedor:-}

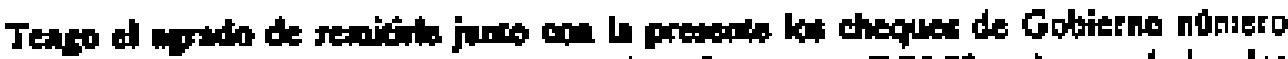

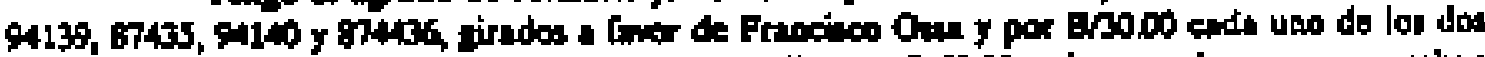

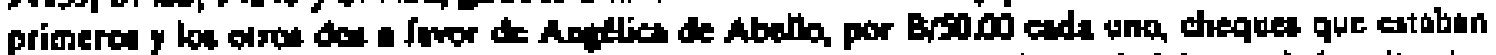

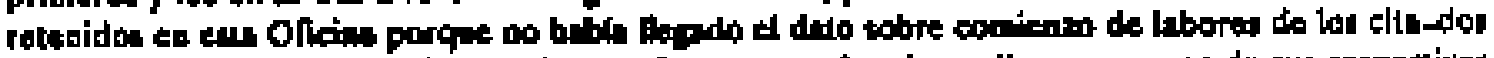

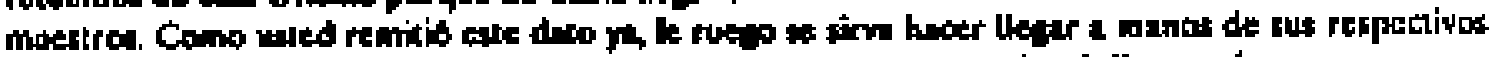

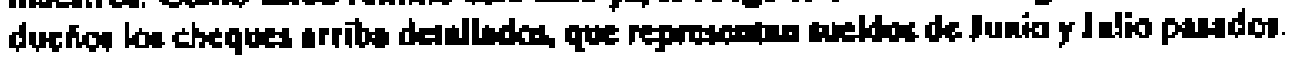

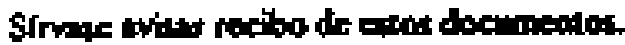

De miled alento scridiox,

(firma iefible)

Trans. del orig. Inec.

v. RD, n. 473 . 


\section{CXCIV}

Núnero 845-C

Sentar Iatondente

Panami, 29 de Ayosto de I930

del a Comara de San Blas

El Porvenir

\section{Soltor:}

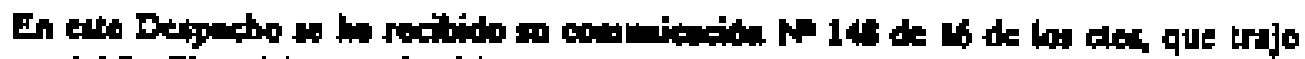

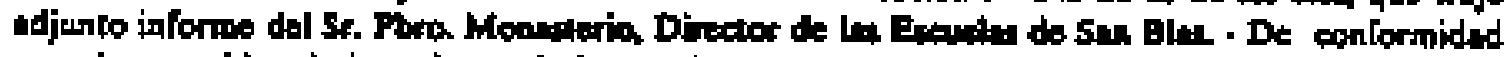

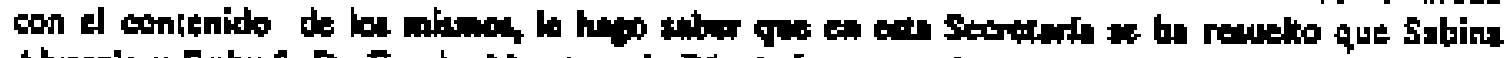

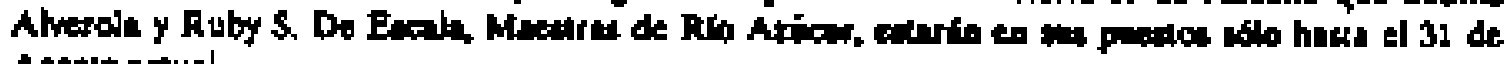
Aposto actual.

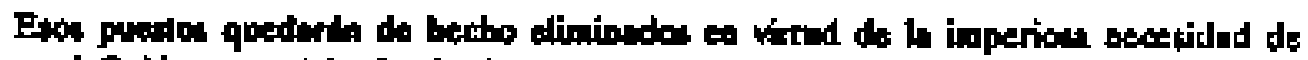

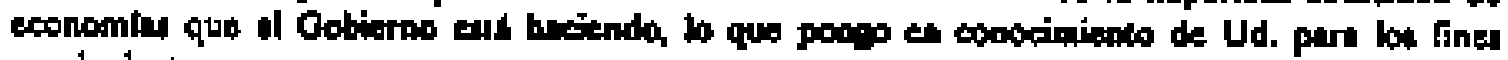
constritenter

De Ud. Allo.S.S.

El Socreturio de Gobiarno J Juticis

Trans. del orie. mec.

v. RD, n. 476 . 


\section{$\operatorname{cxcv}$}

A.181

Nơnero 850-C

Sefior

PaNAMA, I de Septiembre de 1930

Intendengle de la Comarte de San Blas

EL PORVENIR

Selvor.

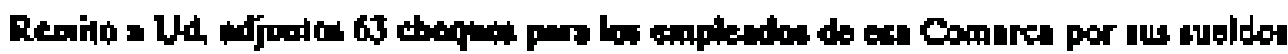
deveapeder durate ol mes de Apowo det Fie. ala

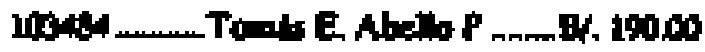

$$
\begin{aligned}
& \text { 5 - } \\
& 99.25
\end{aligned}
$$

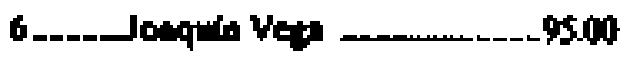

$$
\begin{aligned}
& 7 \text { - } 7 \text { Nilinedo Rebero }
\end{aligned}
$$

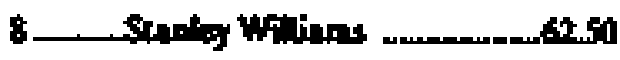

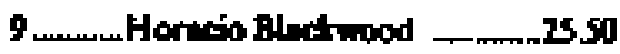

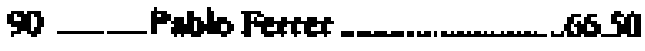

$$
\begin{aligned}
& 1 \text { 61.7S }
\end{aligned}
$$

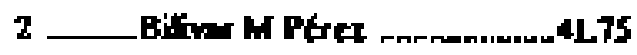

$$
\begin{aligned}
& 3 \text { _. Migud A, Moraks n.m-....36.75 }
\end{aligned}
$$

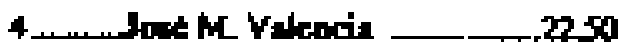

$$
\begin{aligned}
& \text { 5...n....Jom Chere _ 2750 }
\end{aligned}
$$

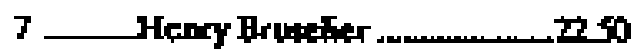

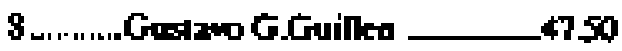

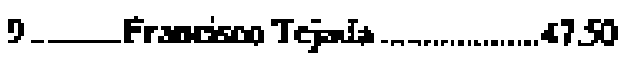

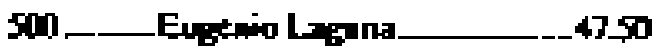

$$
\begin{aligned}
& \text { 1 ---_Mantín Lesuma _c-...-------_\$600 }
\end{aligned}
$$

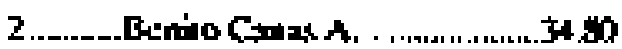

$$
\begin{aligned}
& \text { J ..........Leopitho Pemar...-........7750 } \\
& 4 \ldots . . . . . . R: \text {. } \\
& \text { (1 . ....... Alupudin Afapd .....................17.50 }
\end{aligned}
$$




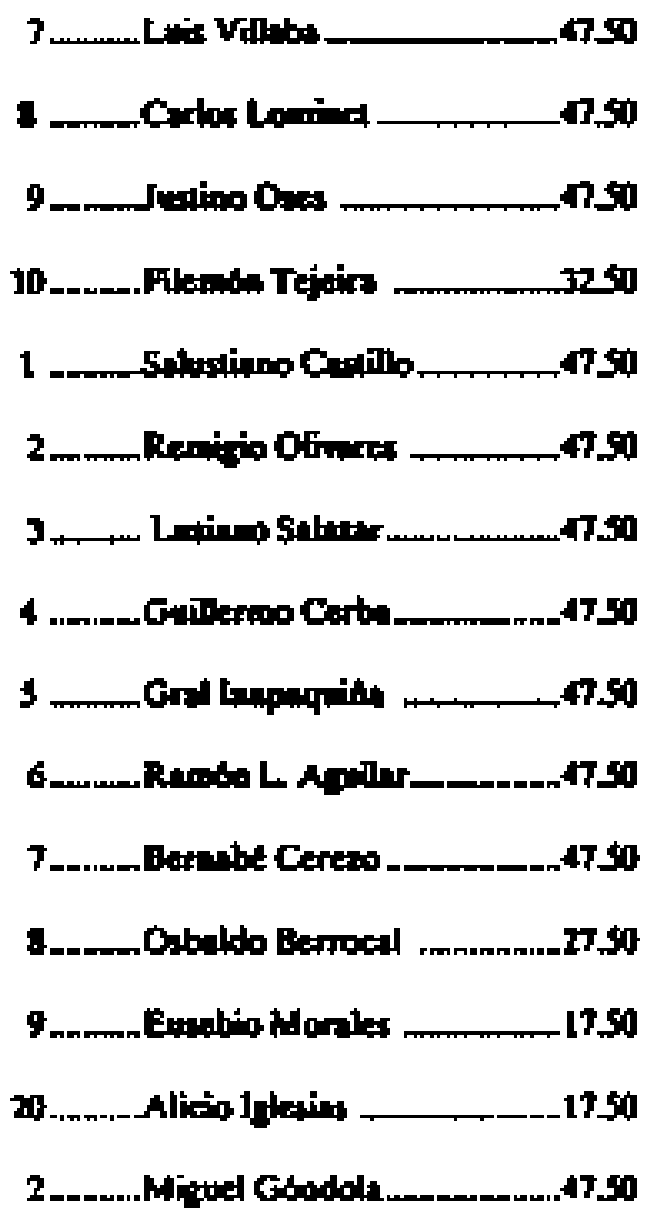

Trans. del orig- mec.

v. RD, n. 477 . 


\section{CXCVI}

PaNAMA, I de Septiembre do 1930

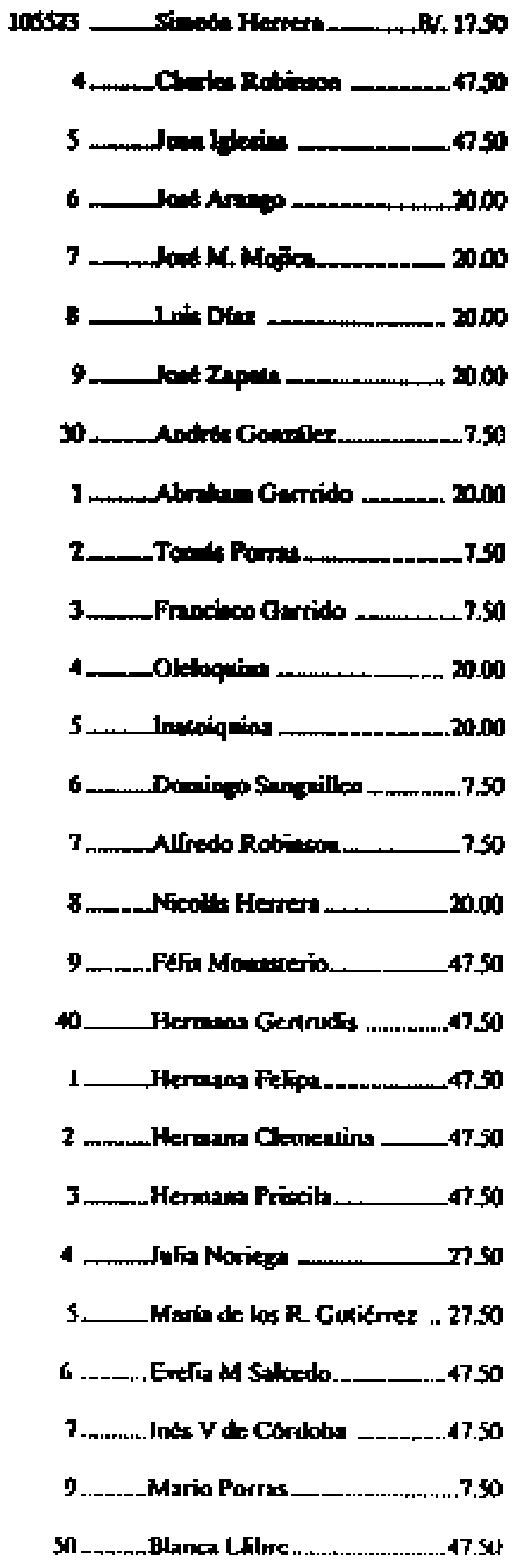


2__Eetide Atbolled 350

Sivas mistate rectio

De Ud. alonso SS.

Joef C de Otheth

Sobuecederio

Trans. del orig. mec.

V.RD. n. 478 . 


\section{CVII}

Númpro J642A

\section{Salior}

PANAML, 26 de Septiembre do 1930

\section{Intendeale de la Connree de Sag Blat,}

Bl Portenir.

\section{Selon:}

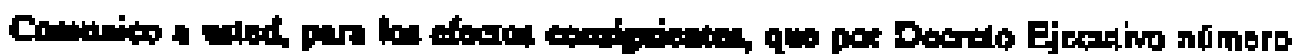

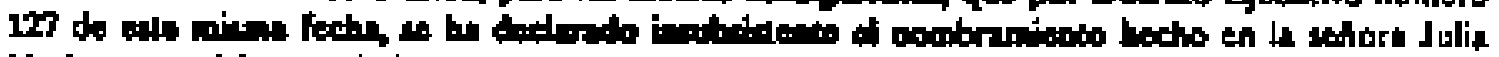

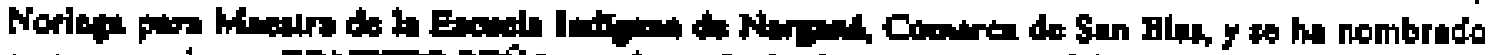

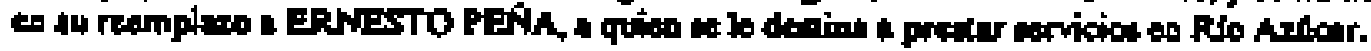

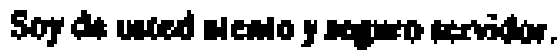

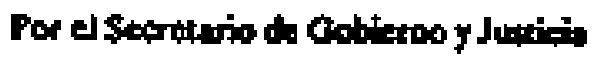

Jat C. do Otalkm

Subectersio

Trans. del origt mec.

Y.RD. D. 479 . 
Río Azúear 20 de 1930

\section{Stikr Don \\ T. Abello \\ Porvenlr}

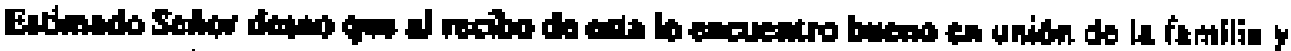

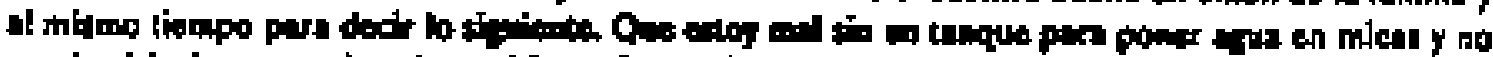

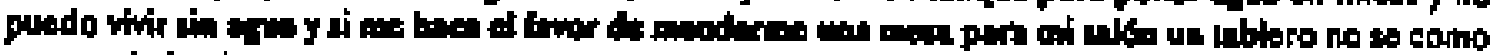

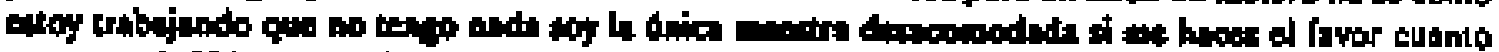

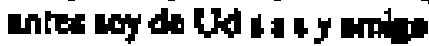

Rubs $\mathbf{S}$ da Ixim

Trans. del orig. ms.

V, RD, n. 480 . 


\section{REPUBLICA DE PANAMA INSPDCCION GENERAL DE ENSWNANZA PRMMARA}

PANAMA, 6 de Octubre de 1930 .

\section{Selivor}

Jalundente do la Cireatiscripatom

de Sen Bitss,

EL PORVSNIR, Snn Blas

Sthoc:

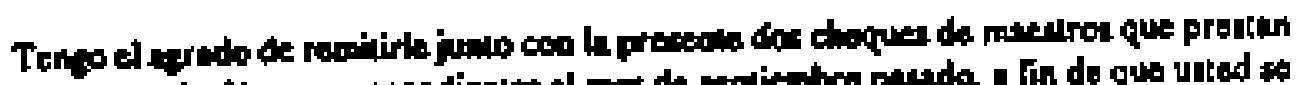

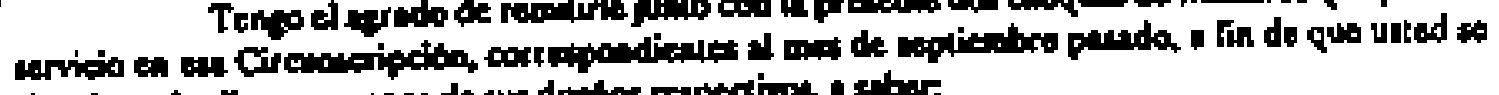

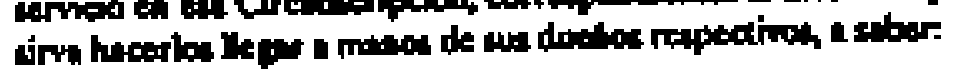

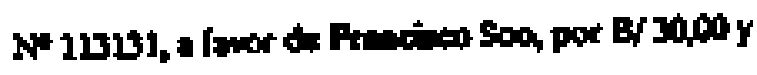

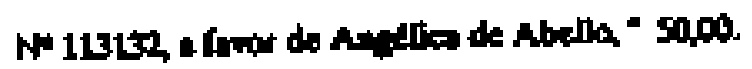

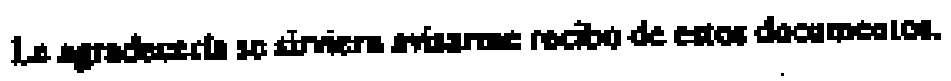

De wated atepto tervidot,

Jelo at in Secrión de Contabikdad

(firnd ilejible)

'Trans. del orig. niec.

V. RD, n. 482 . 


\section{Soforms Cedignos}

Pangari, Otubre 8 de 1930.

\section{Ifapagulfis y Nals,}

Comares do San Blex.

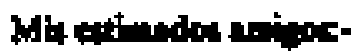

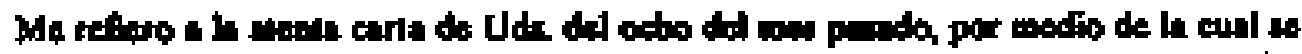

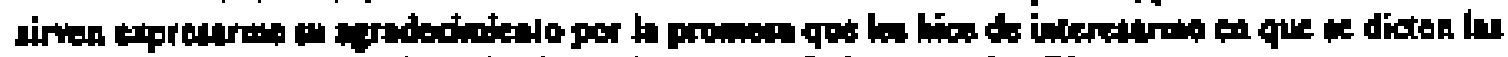

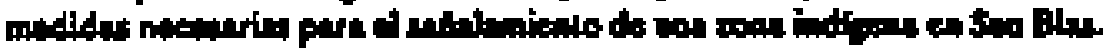

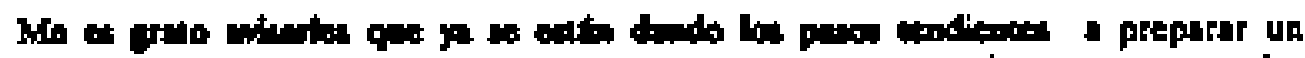

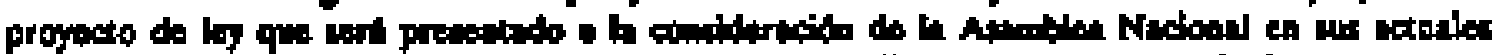

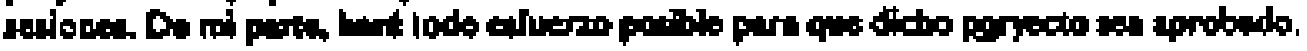

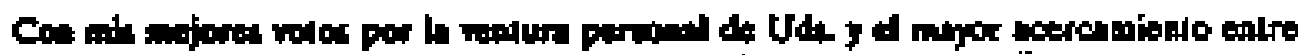

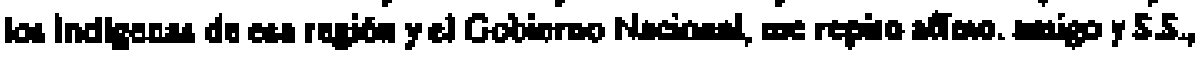

Trans. del orig. inec.

V. RD, n. 483 . 


\section{CCI}

Sellor con.

Plorwodo il Arovidiona.

Prosidonte de la Ropública.

r r o a a t o.- :

Bxaro, Befior:-

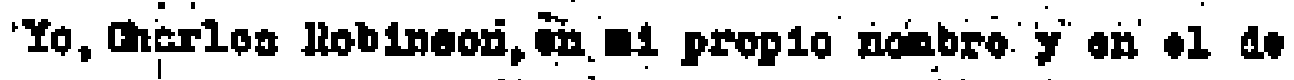

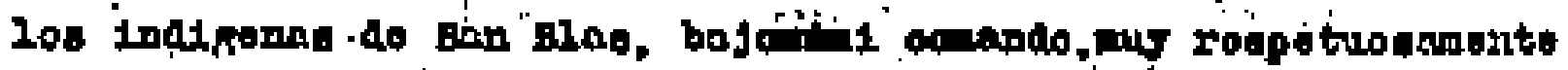

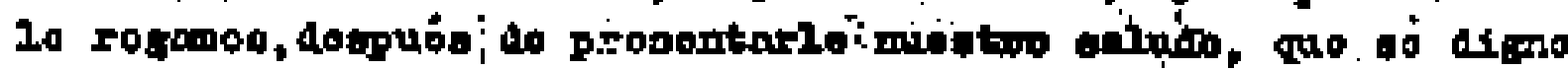

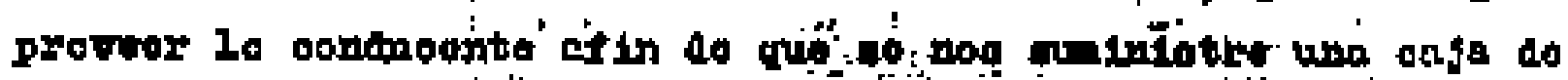
horromiente do eastritoria pard in tullor exibtaito an mestro

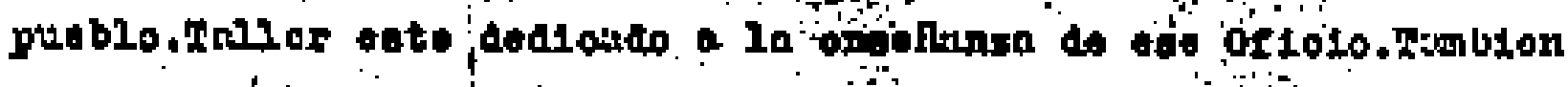

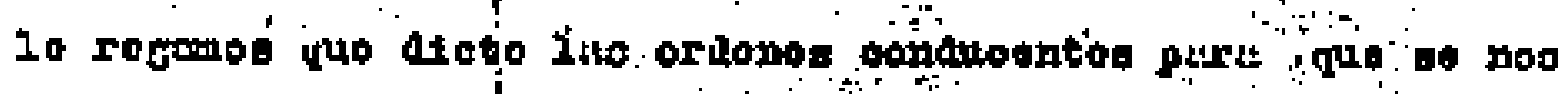

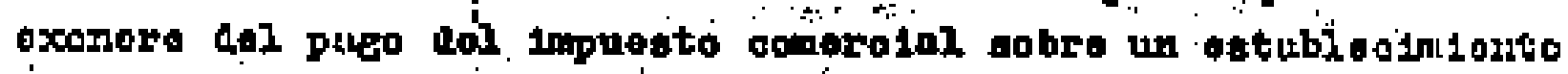

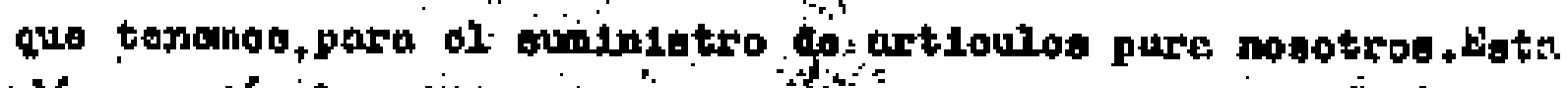

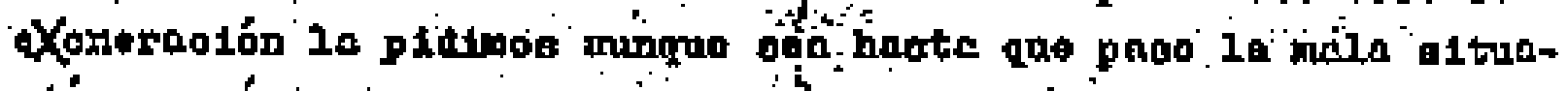
olón económias "porque atriviesó "il pals.

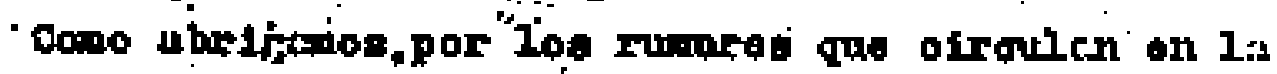

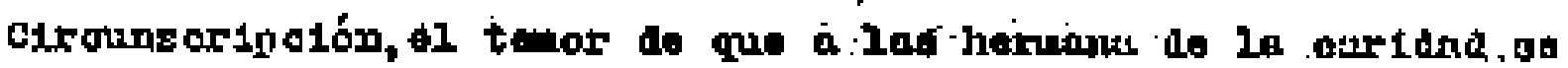
loeguppenderan 10 leboras ton oflotiontes quo vionon prestendo on nuogtra región, ló robano que de eer olerto eatos rumores

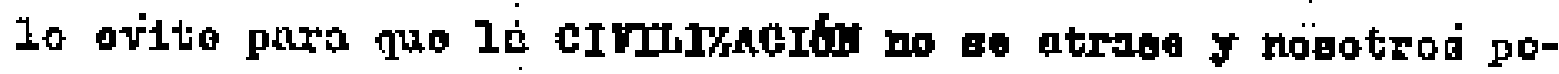

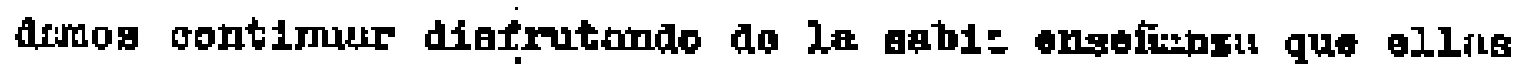
Impartion.

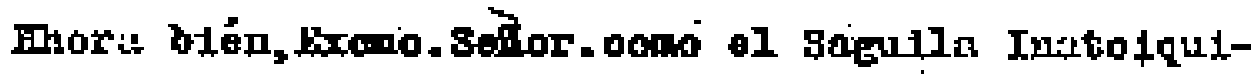
Iie ha gldo dado de buja del puesto de agente do poliala indige-

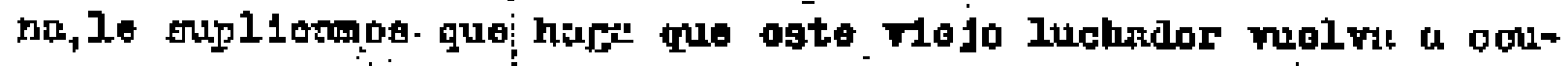
par ogo puegto,yit qui os de tonor suevita que diono sagulla fuo uno de 109 que presto nejor gerrioto on rator del Goblorno Ha-

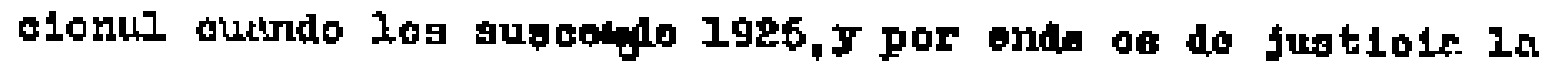

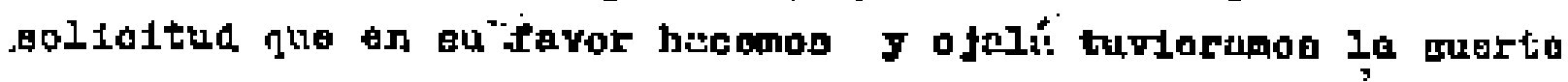




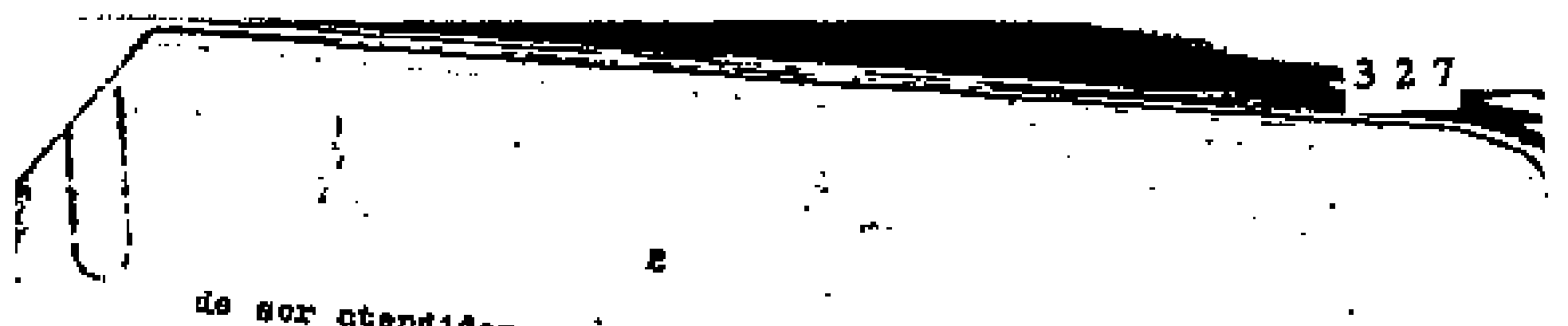

de arr atentidoo on olla.

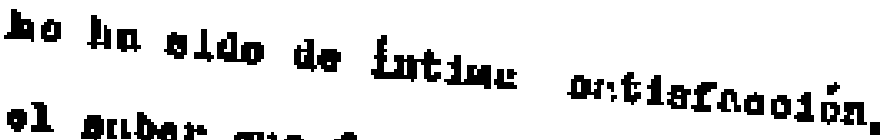

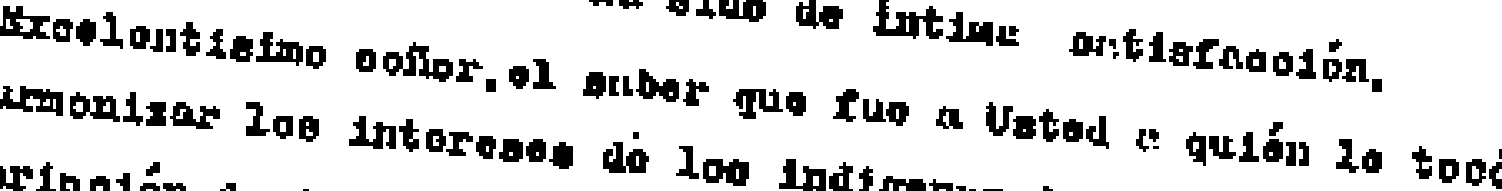

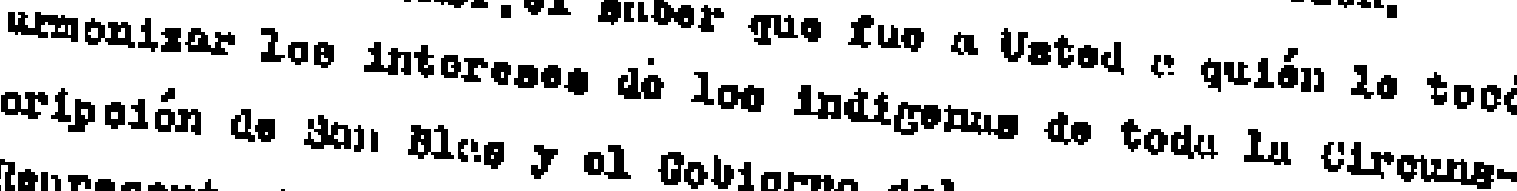

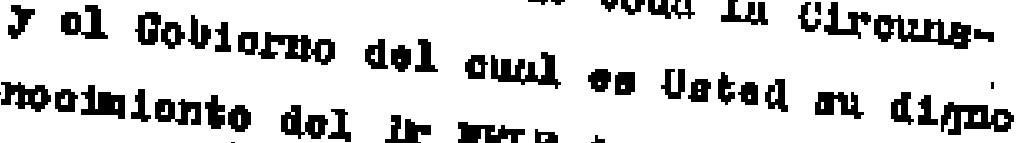

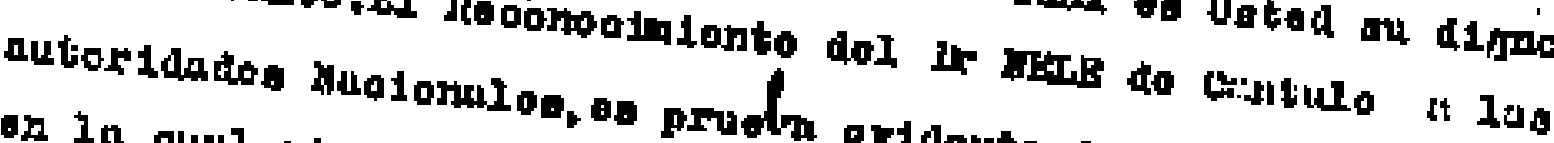
on in ouvd osompro

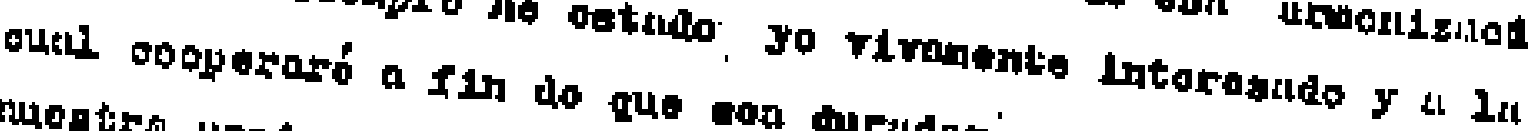

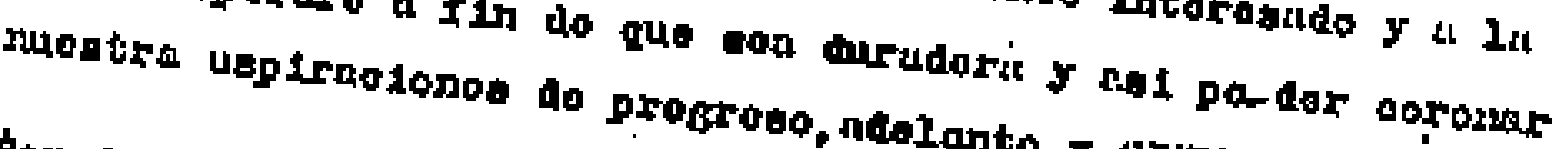

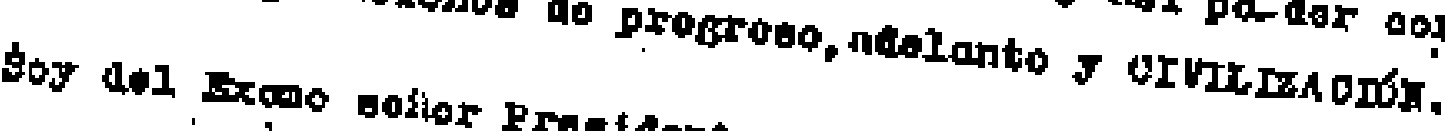
duy obsecuente gerridor.-

Gherlos Roulnson. 
Pta. Abaldía, 21 de Oelubre de 1930

\section{Sr. Intendenie de la C a Sen Blas, El Porvenir.}

\section{Sebor:}

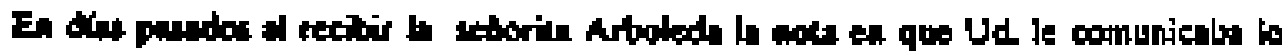

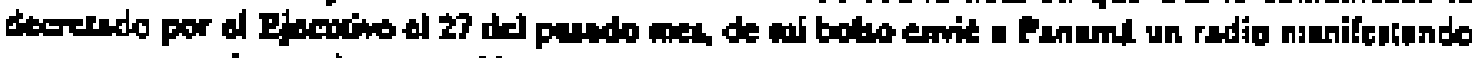

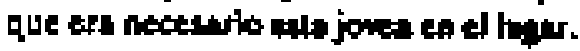

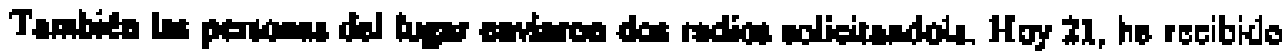

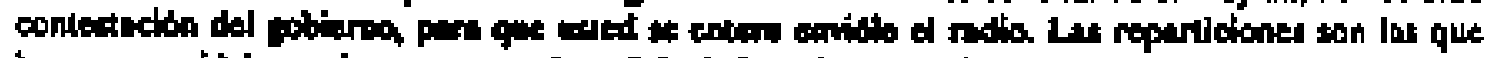

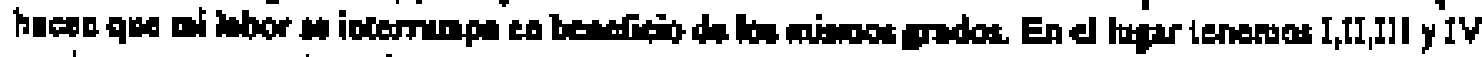

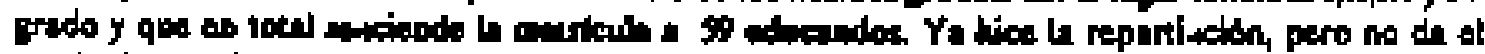

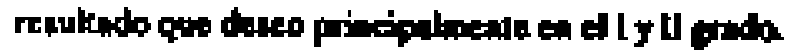

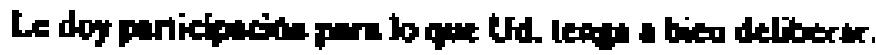

Do Ud Ano. SS.

Dibtinat Ibika

rrans. del oríg. ms.

V. RD, n, 485 . 
$329 \div$

CCIII

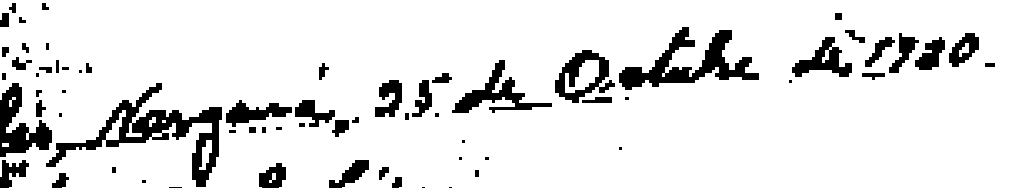

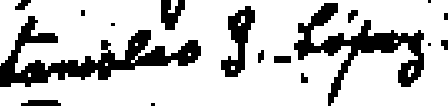

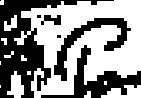

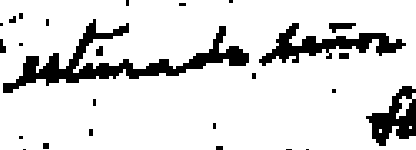

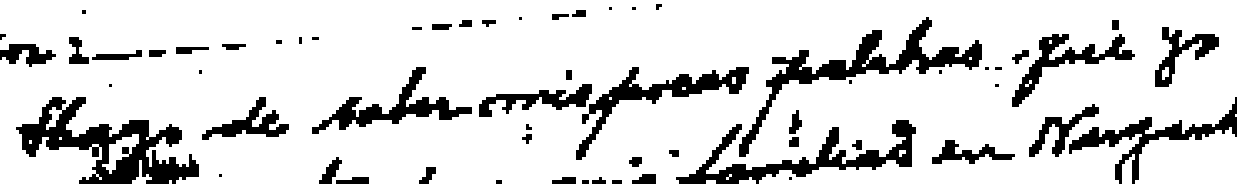

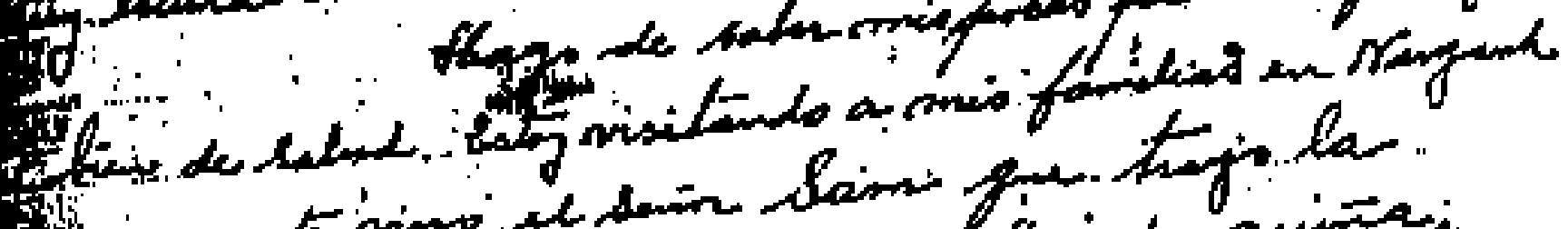

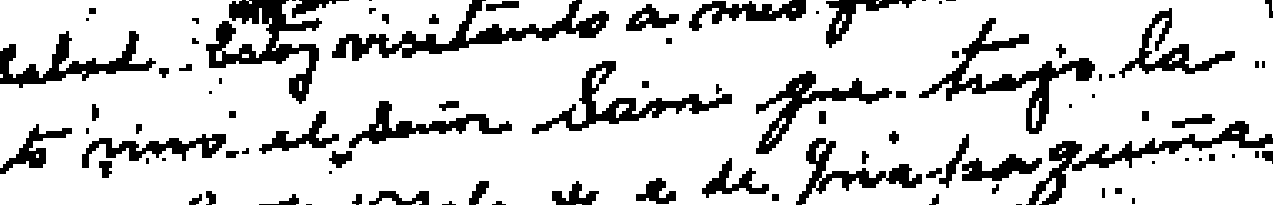

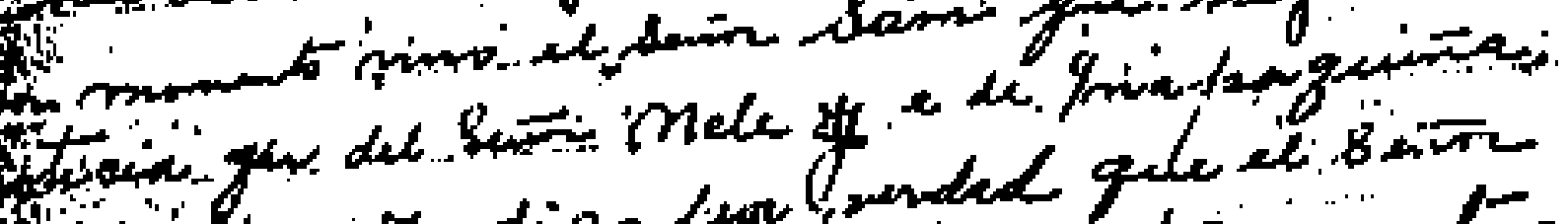

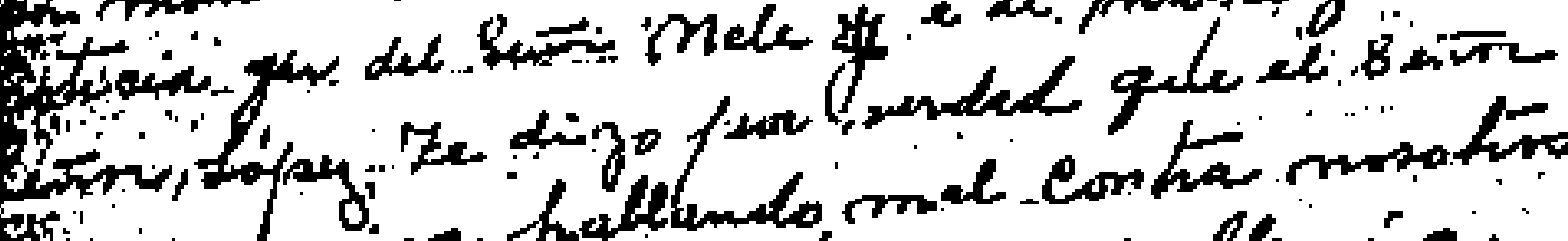

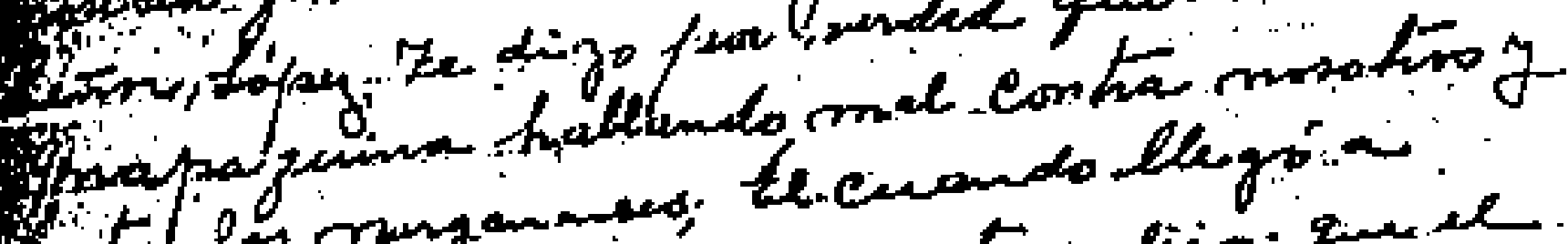

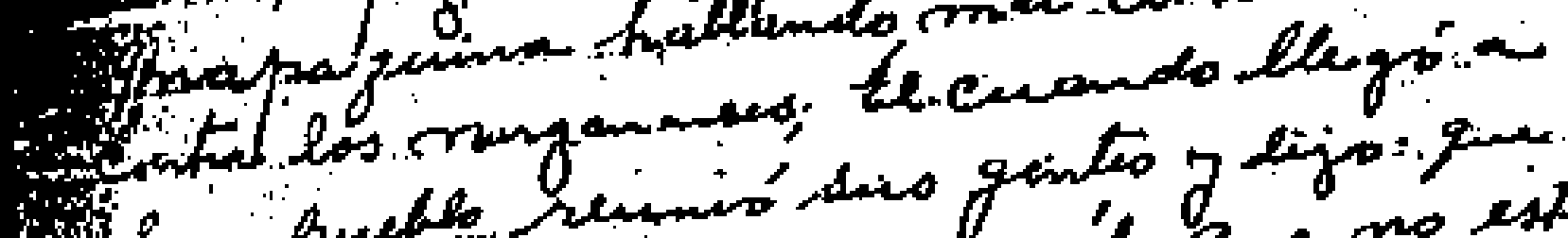

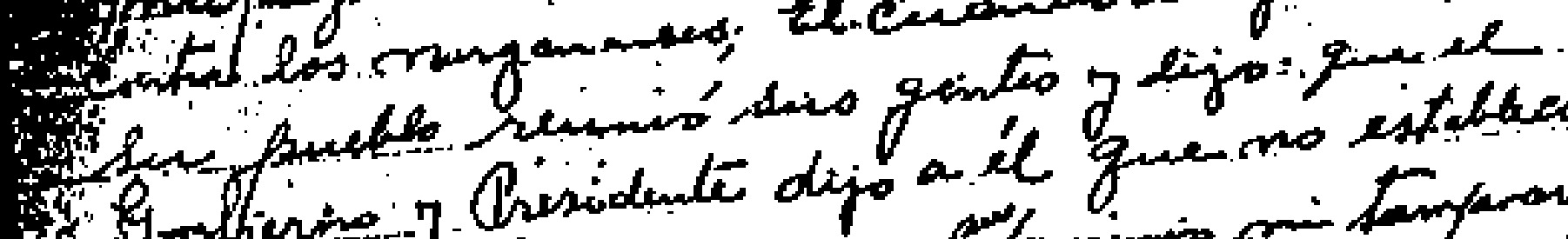

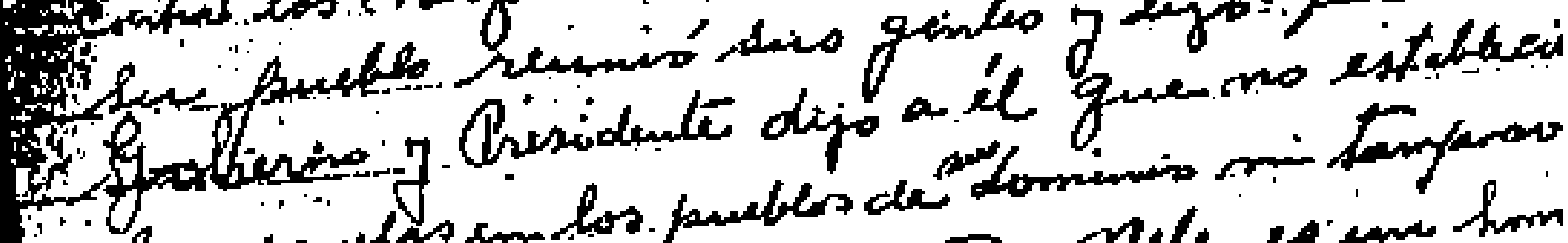

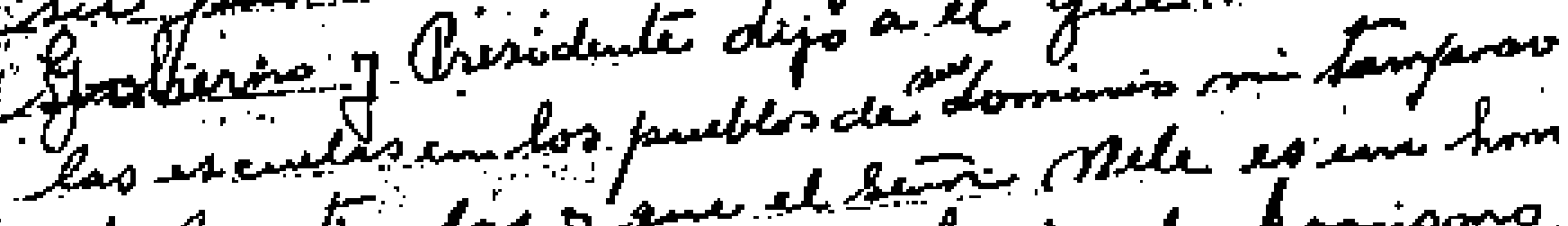

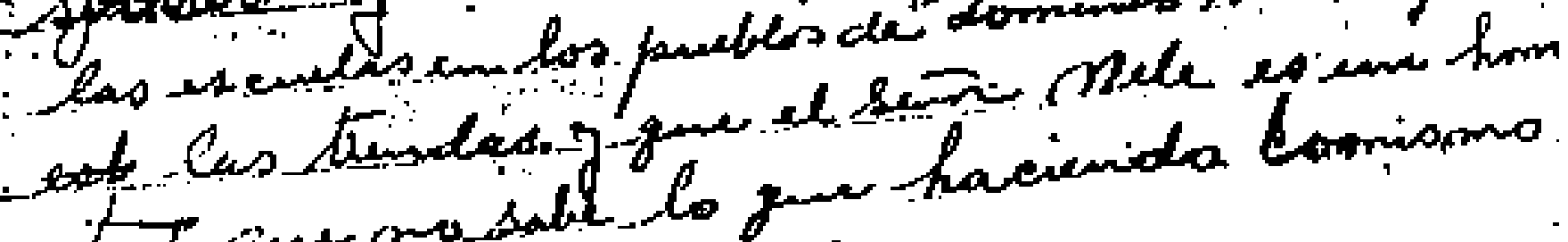

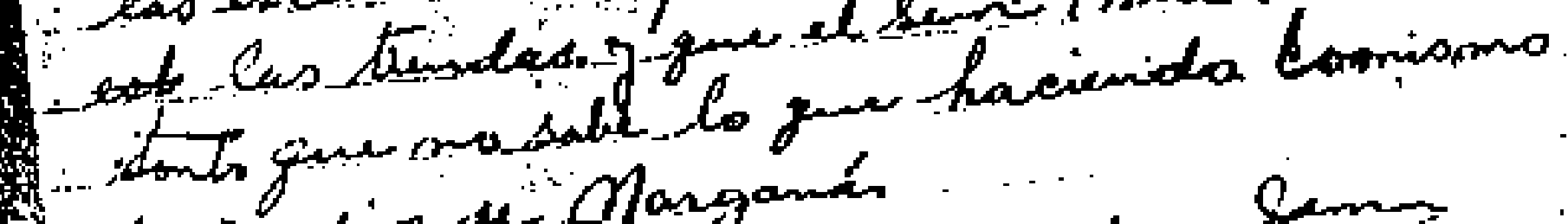
los indiva Mangana

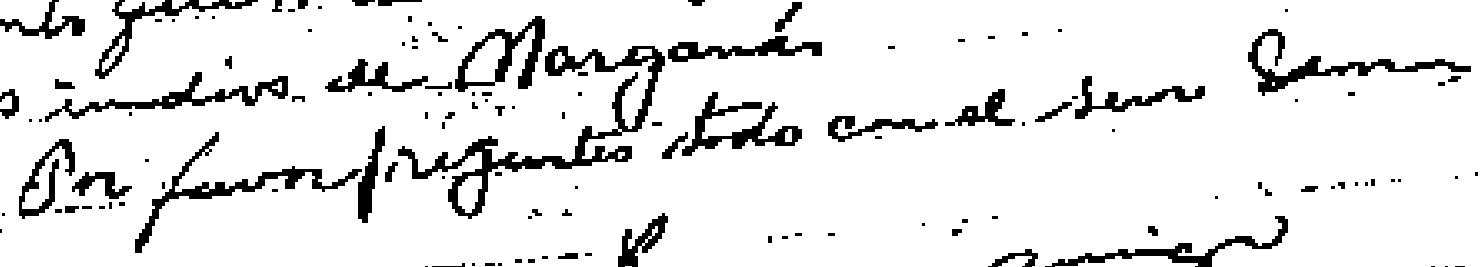

Bry 


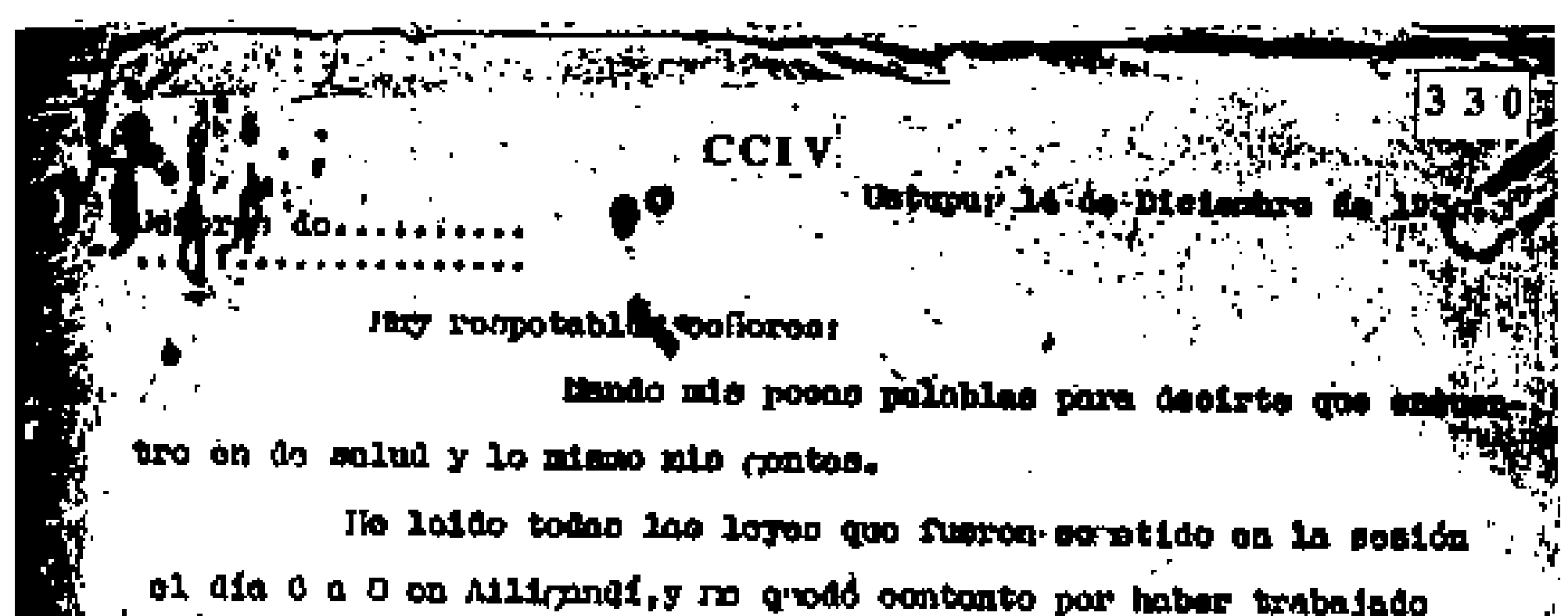

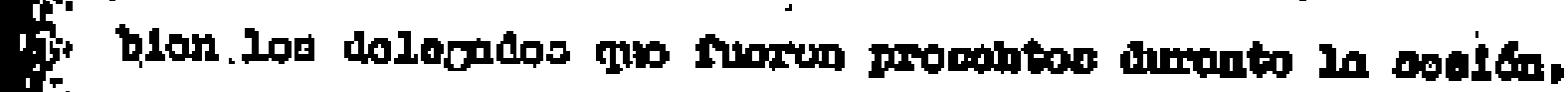

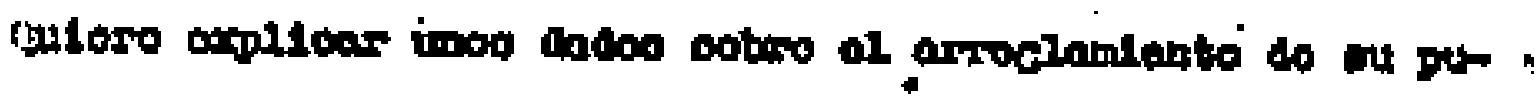

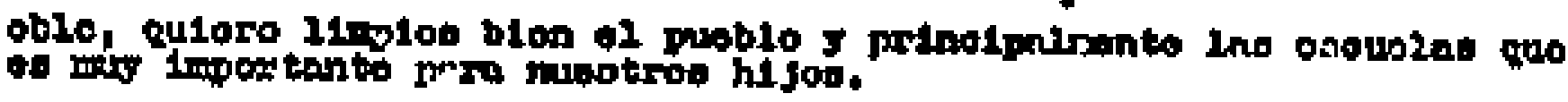

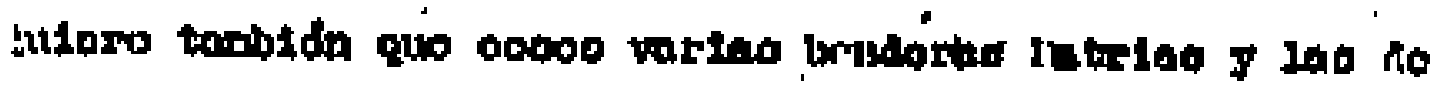

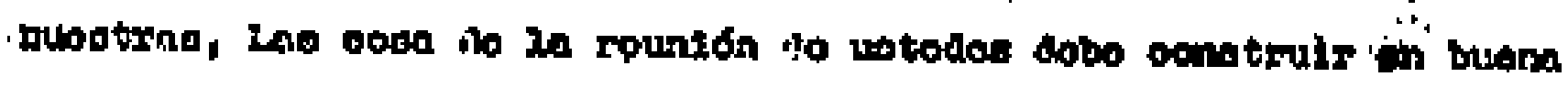

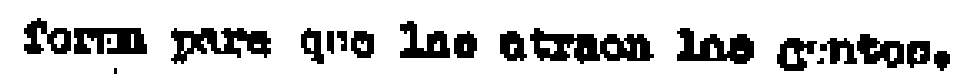

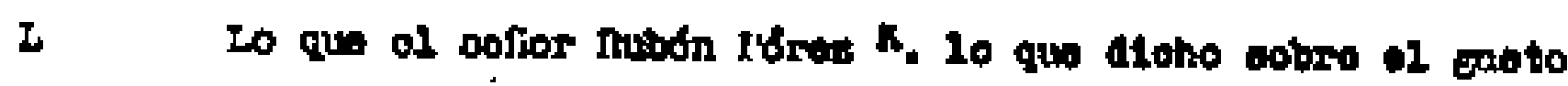

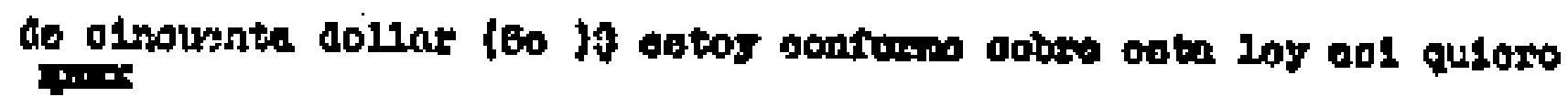

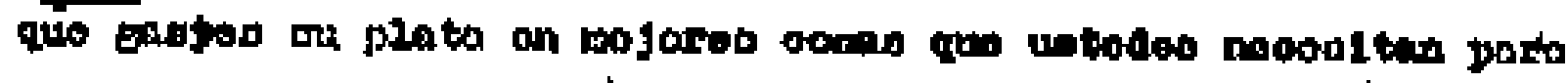
indornar ou problo.

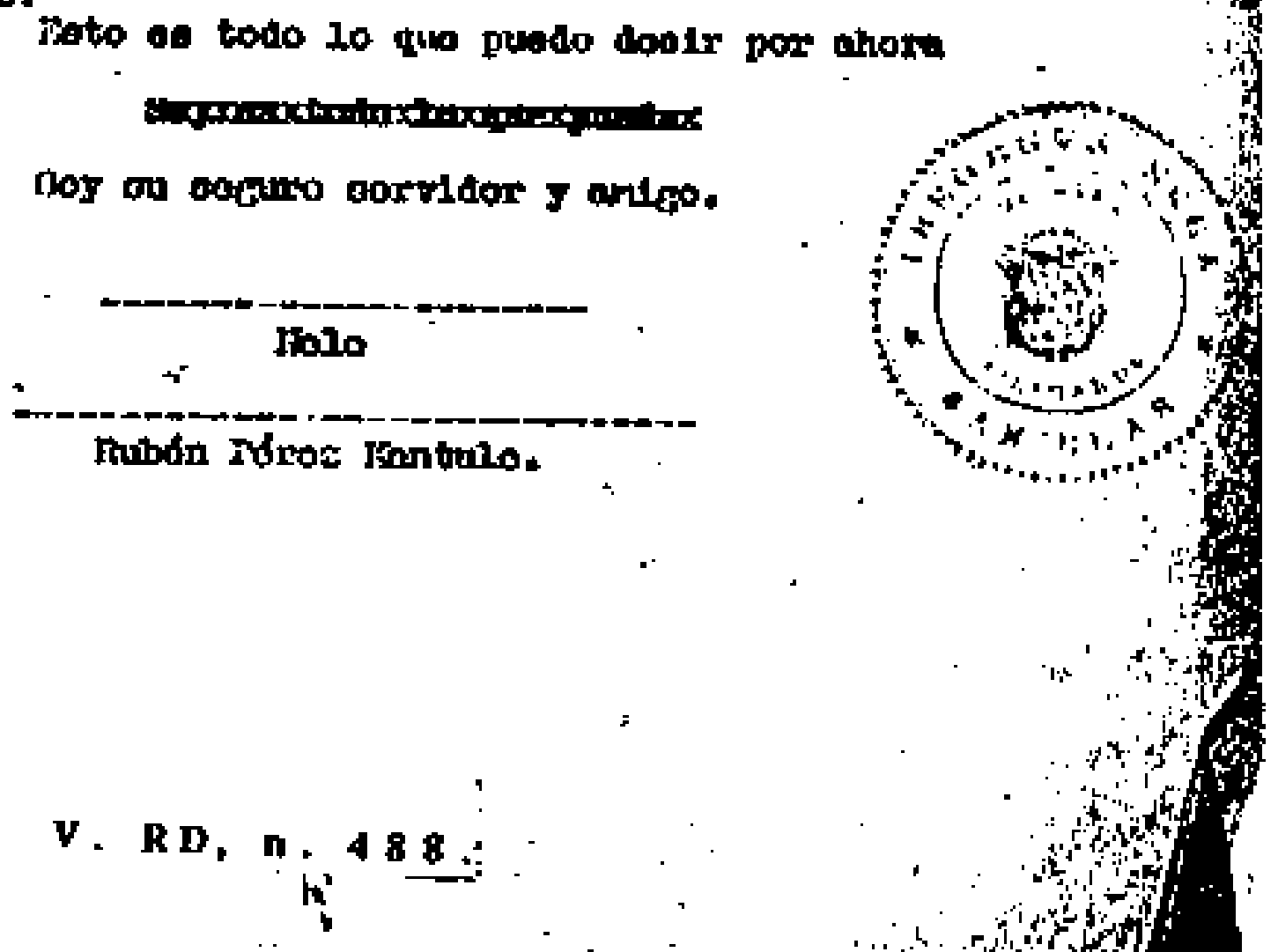

An 


\section{CCV}

$\mathbf{Y - 2 0}$

17 Mayo

1.

\section{Setion Secrotutia}

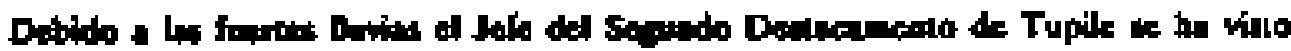

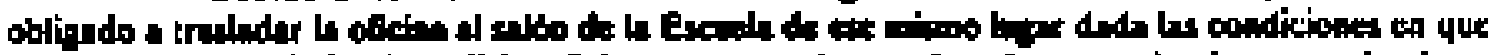

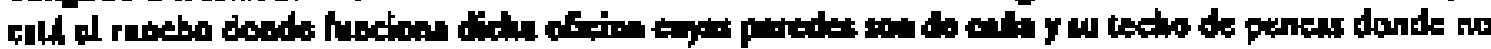

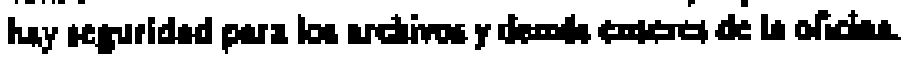

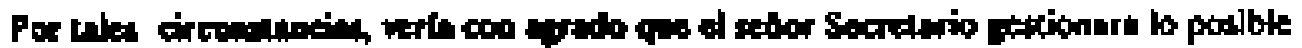

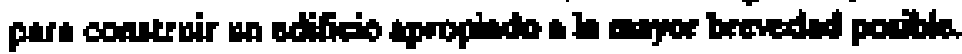

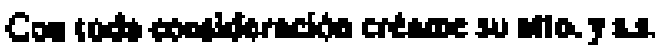

ANDRES MOIICA

Iacenkeure de

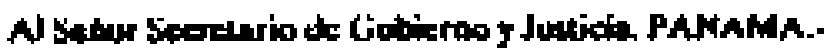

Trans, de la cop. mec.

V. RD, n. 490 . 
.

יר:

$\therefore$

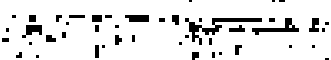

- CCVI.

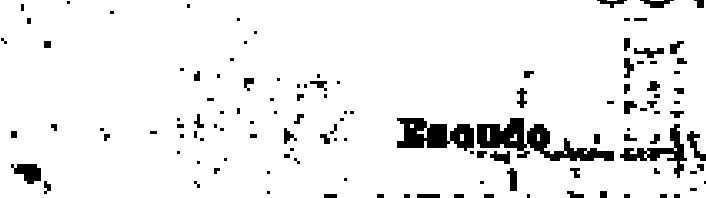

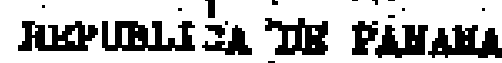

Preptacügli

a.

1.:

Al istito

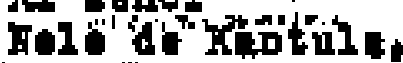

Votwiputio

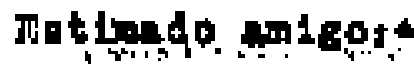

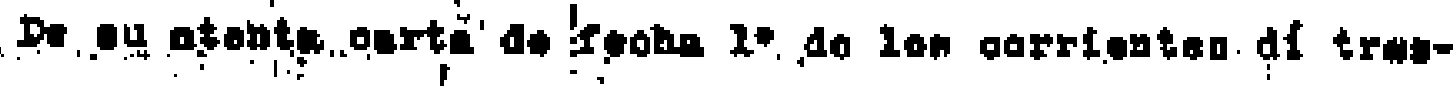

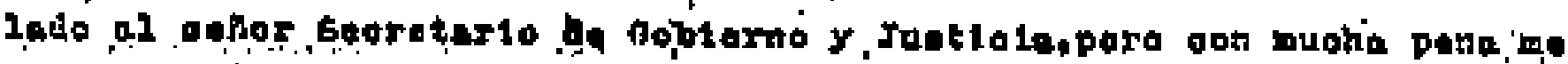

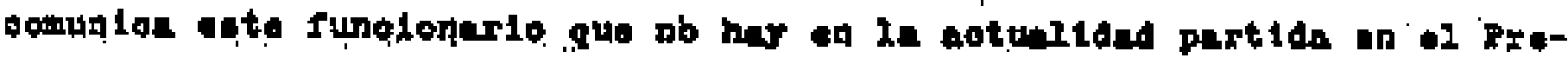

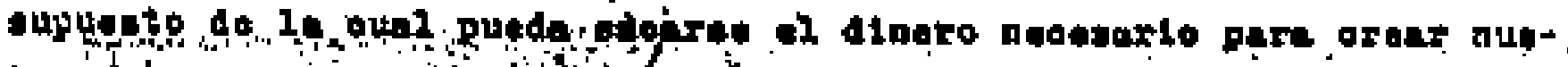

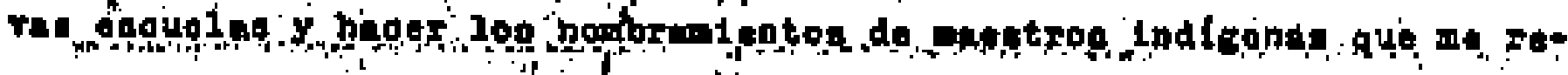

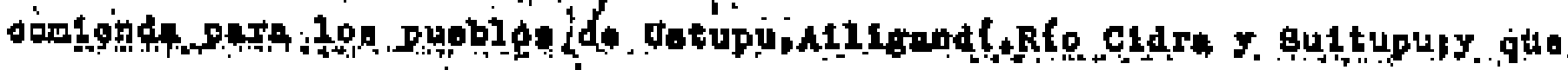

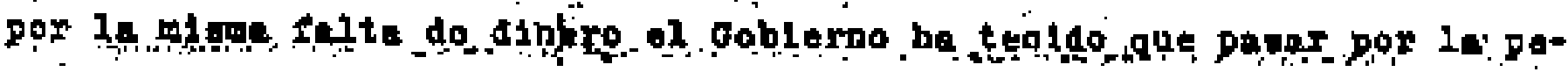

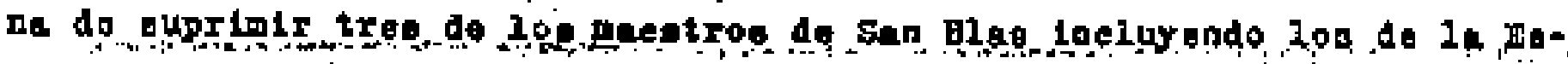

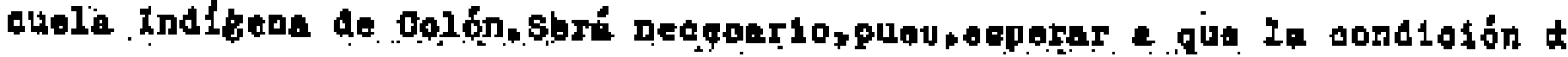
dol Prosupuesto peré rer at ags poplble ocoplacorio.

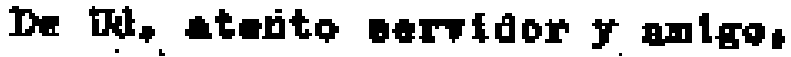

R.j. Nuroro.

mans.

Zn copis dal briginal. 
40

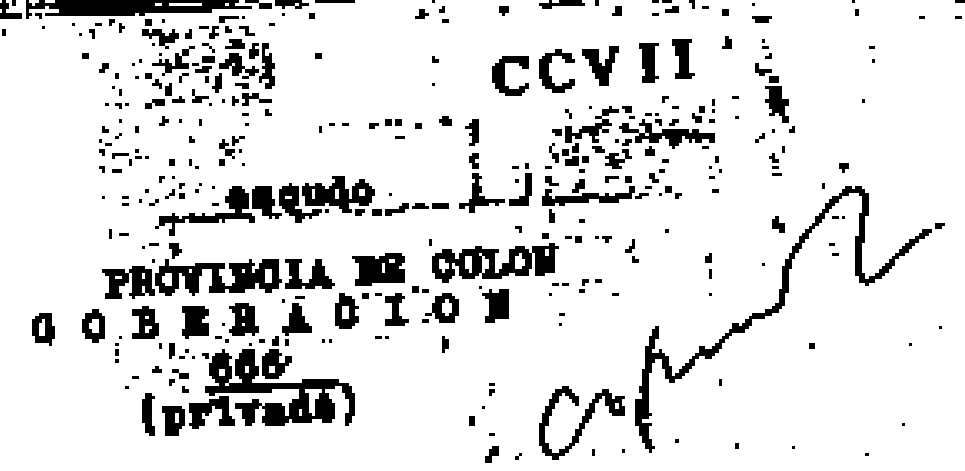

: . Colón 28 de Juato de 1931

$\therefore$

genor dor pole de Contuleb

Onol que de Bar B2ale

diatup.

That 1matho nollori-

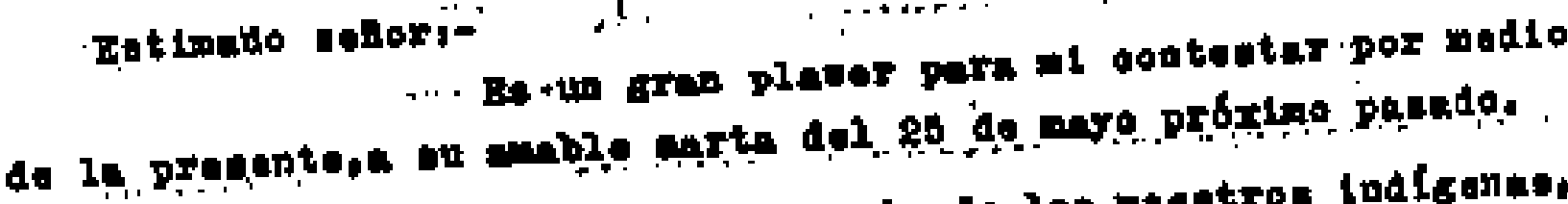

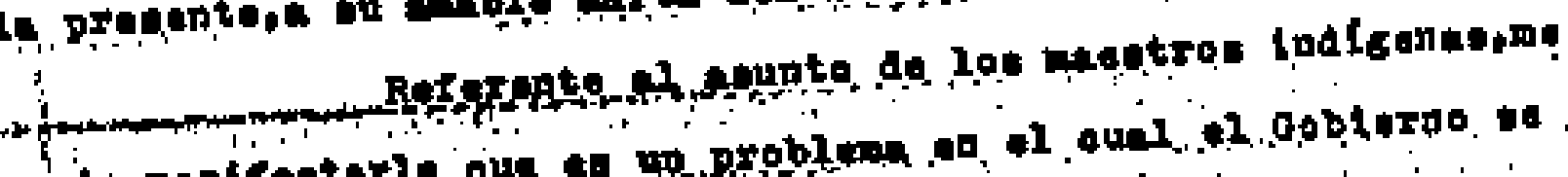

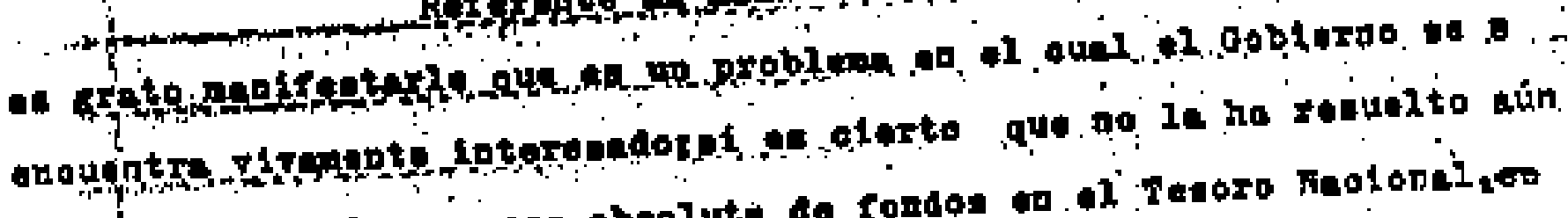

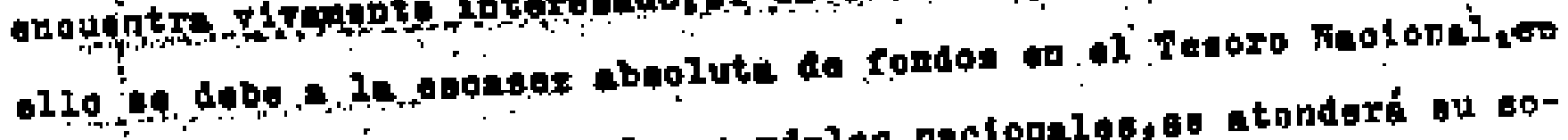

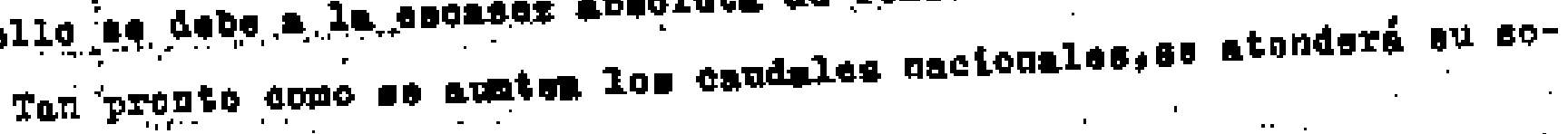
11attud.

Yuy pronto ganeré unos dias por Jatup,don de tendxó al pla-

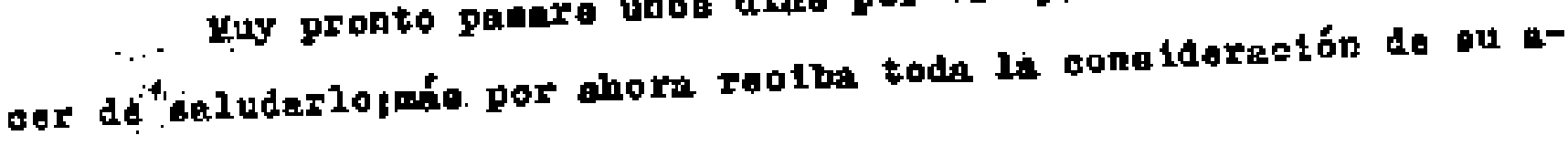
tento acrudidor $y$ anigo.

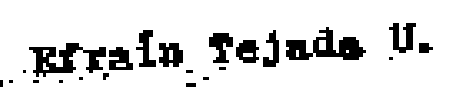

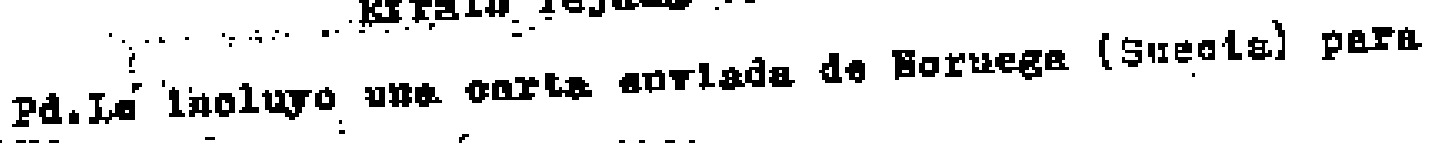
tJd.

opple dẹtoriginal.

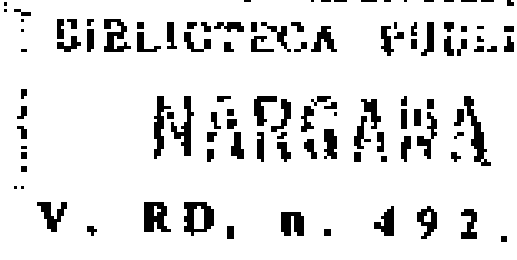


ints

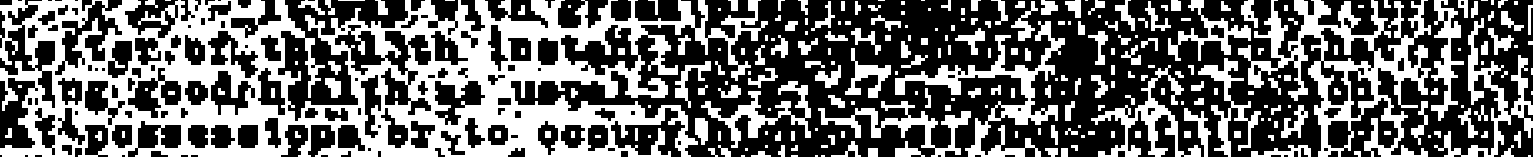

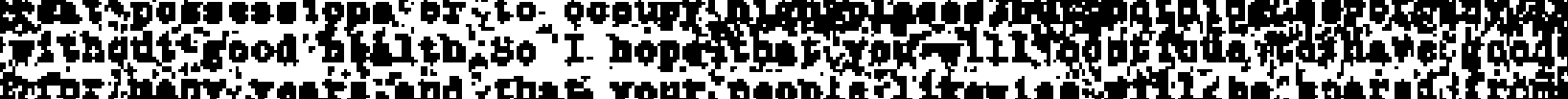
(1) Q

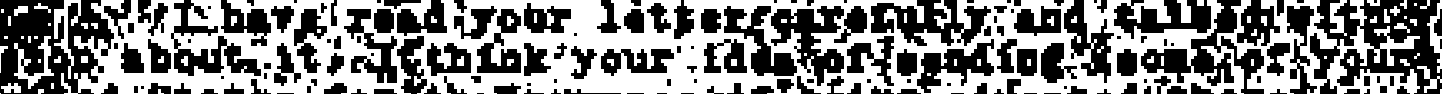

th

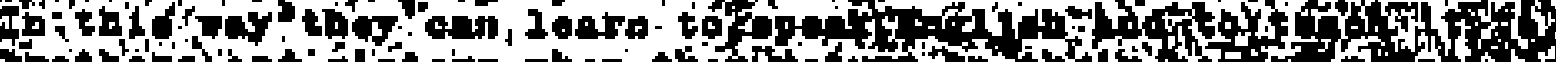

4 ofh 1 2140 of

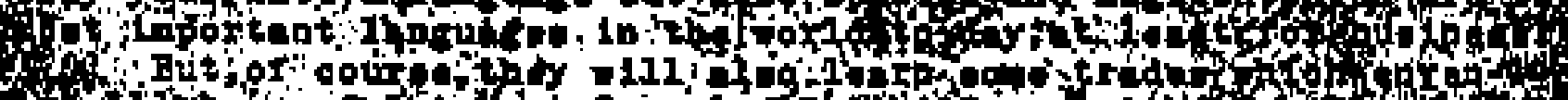

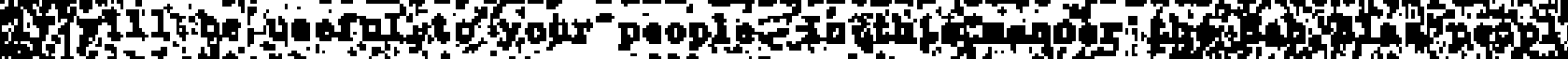

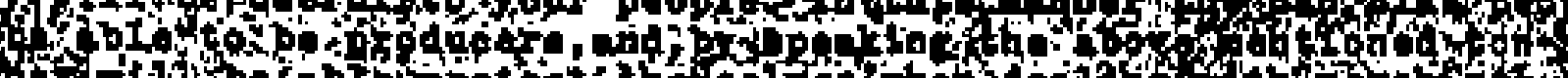

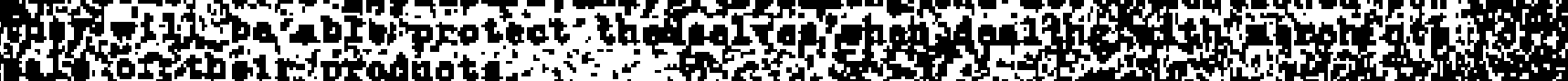

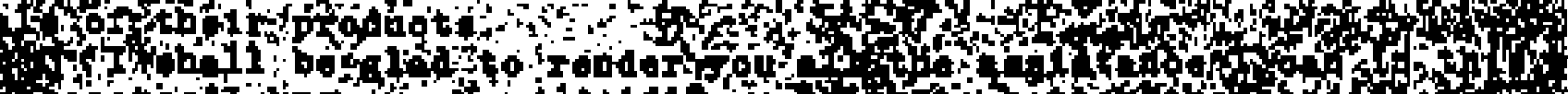

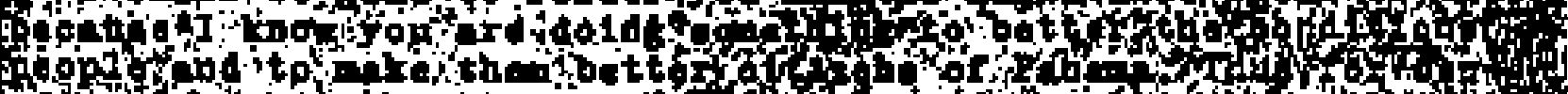

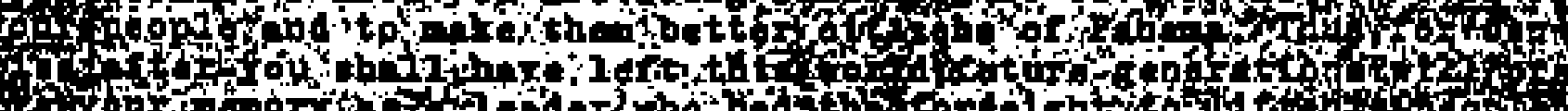

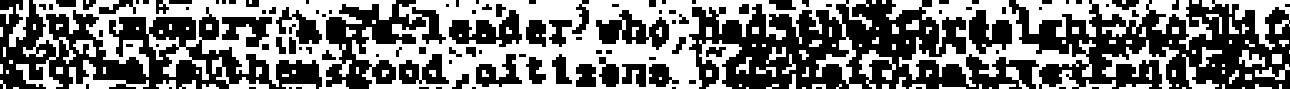

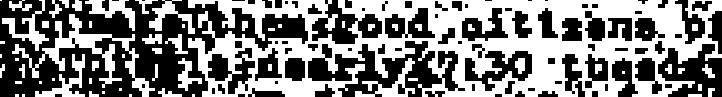

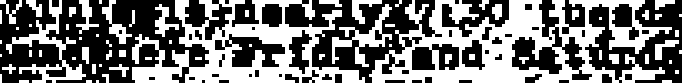
if

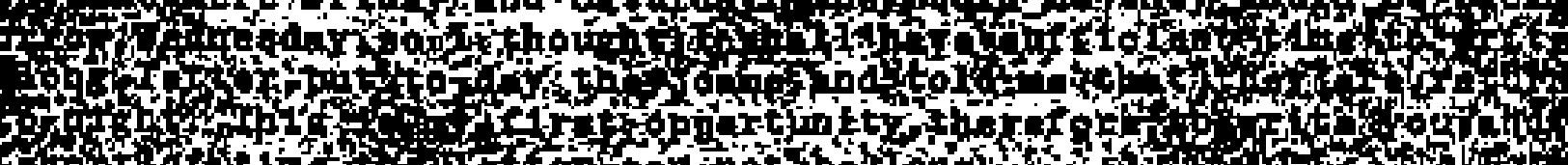

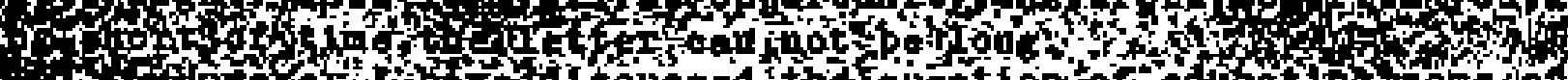

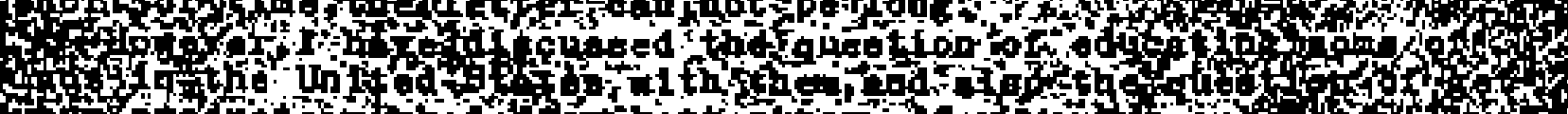

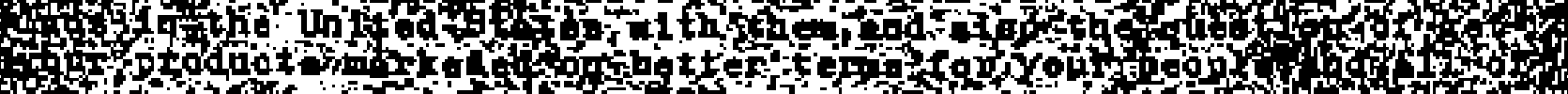

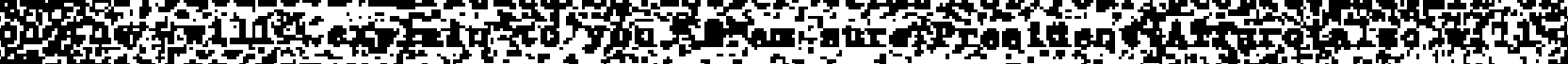

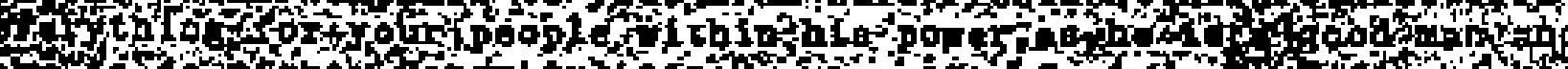

40 of

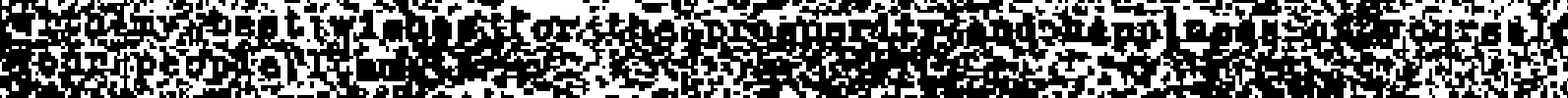

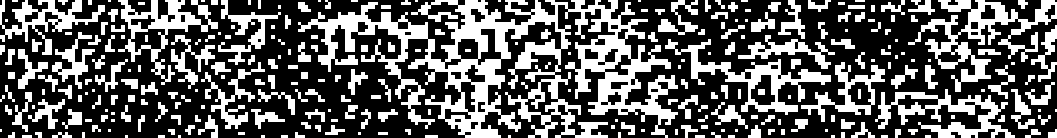

(1) (3) R D, $1+493$ 


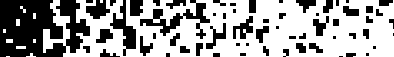

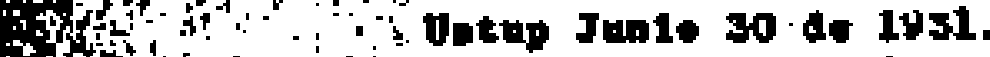

Thy

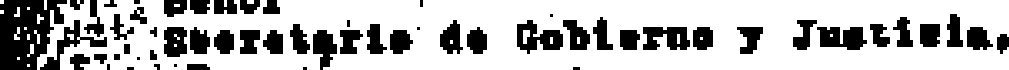

(1) Paper.

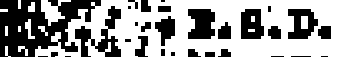

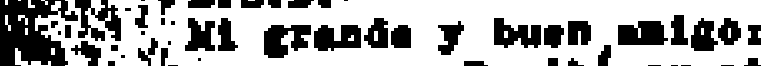

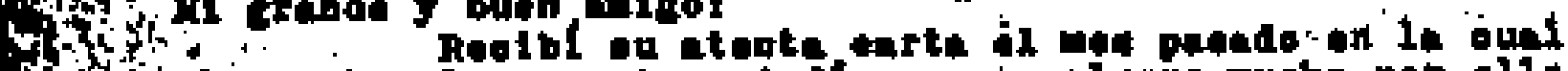

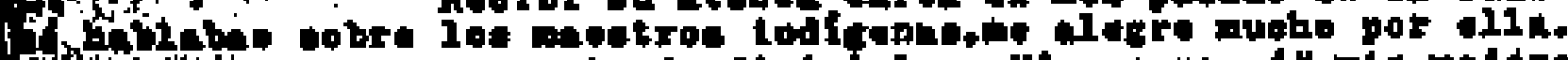

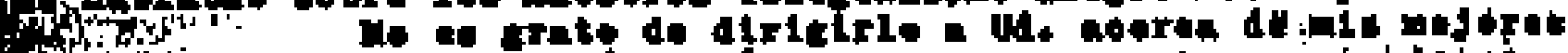

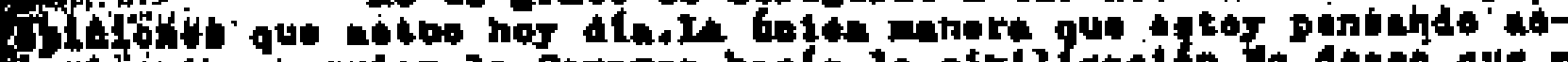

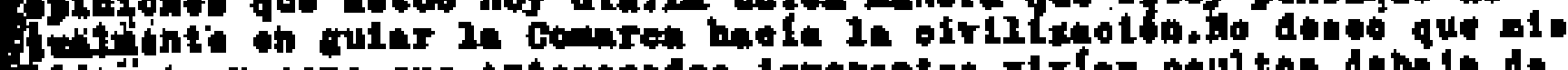

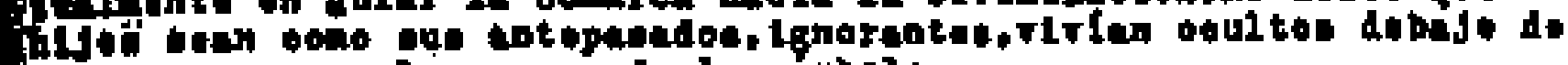

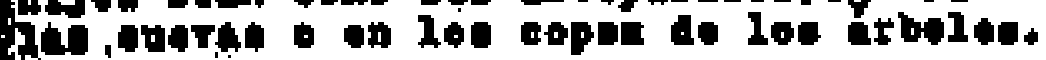

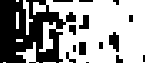

(4)

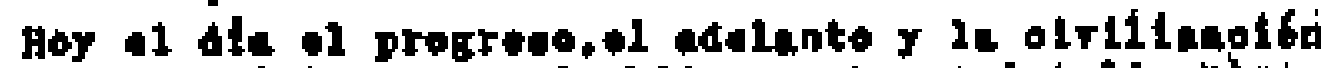

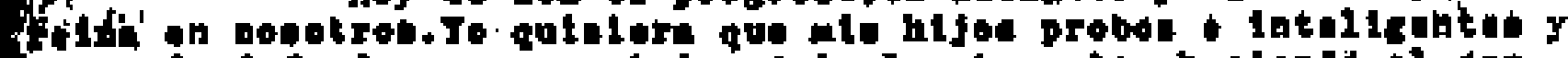

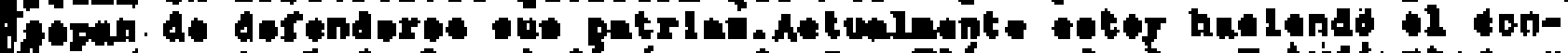

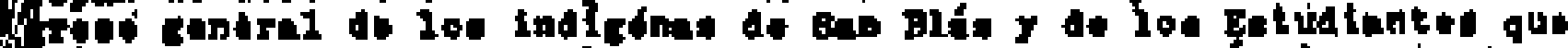

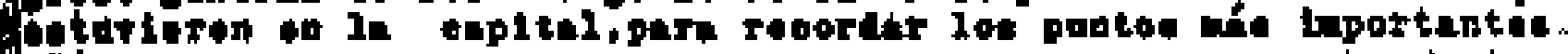
(1)

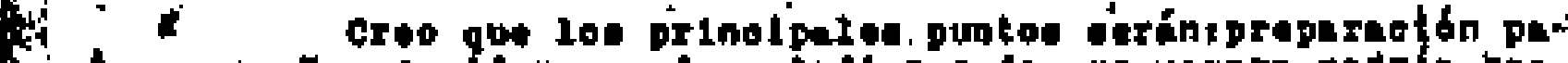

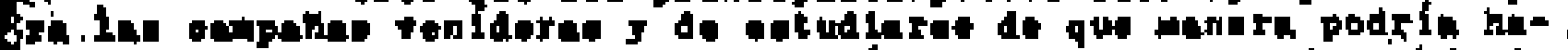

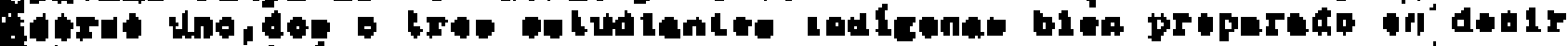

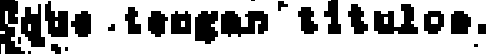

ing

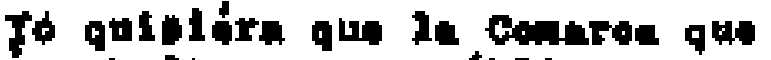

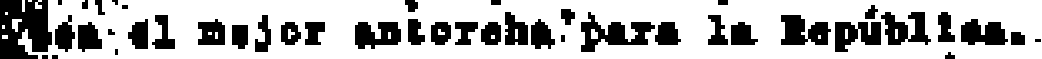

Fyj

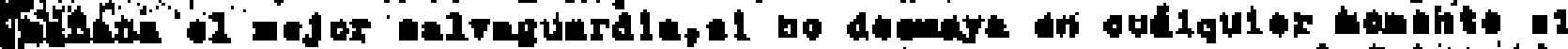

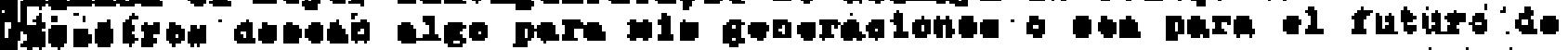
thotet rod d

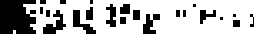

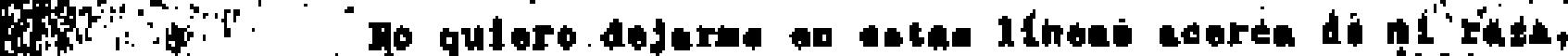

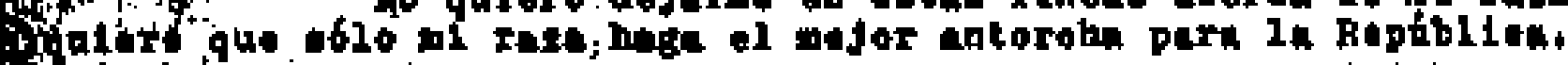

$\operatorname{lin}_{1}^{3}$

: 6e deptopldo at mejor andgo.

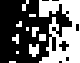

ints

4

ith

iele de Kantule

(Seatiprivato) genuel Morrie.

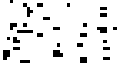

13

is

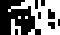

14:10

mopite orloldal.

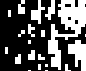

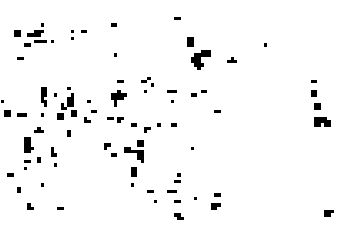

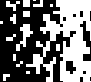

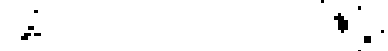

v. RD, $\mathrm{n}, 49 \mathrm{~d}$

. 49

?

$\therefore)^{2}$ $+1$ 


\section{CCX \\ UEtup Jultu de 1931 .}

gehor

Indarton

Colbn

E. S. D.

, 41 gren $Y$ buen entgot

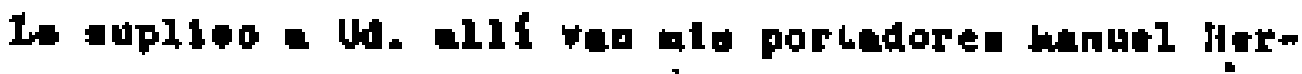

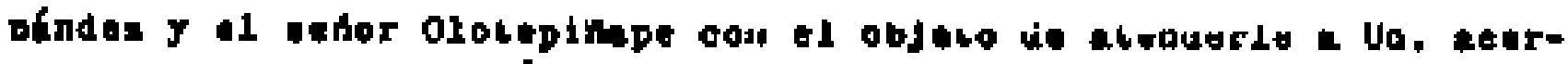

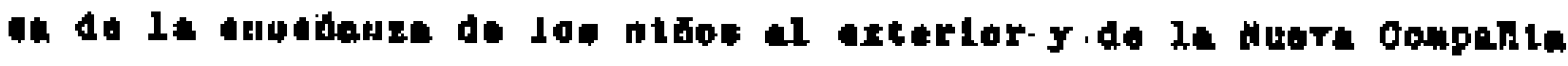
de 2000000.

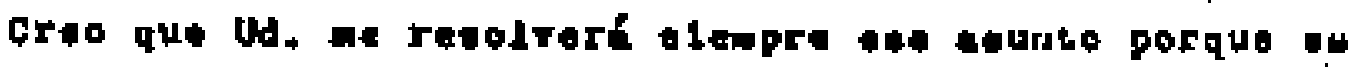

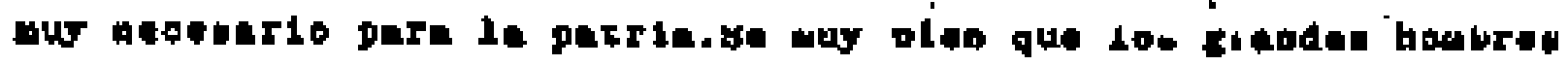

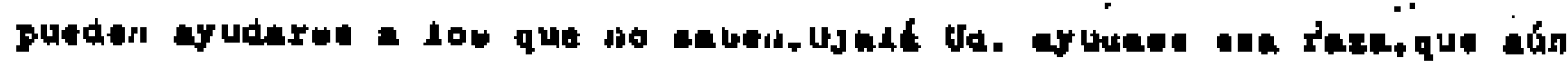
no ve he wetolado.

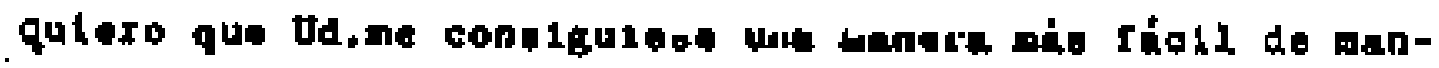

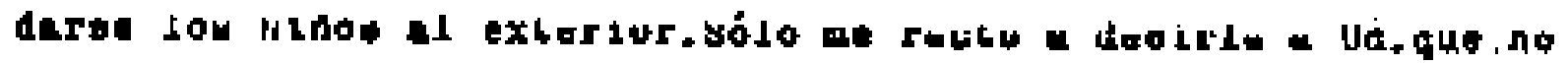

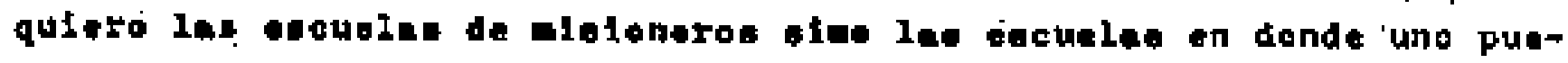

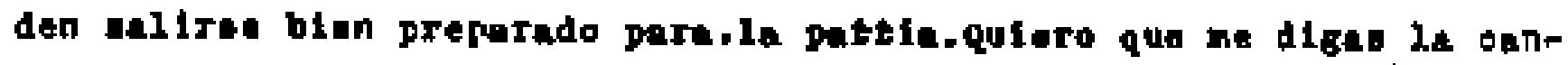

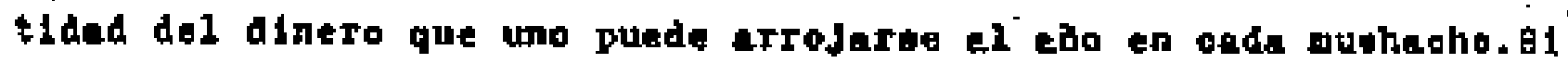

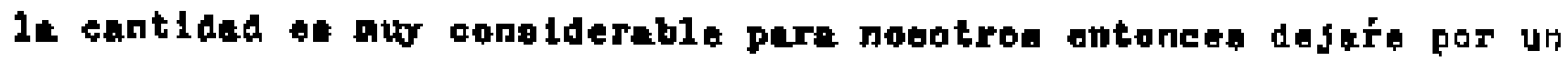

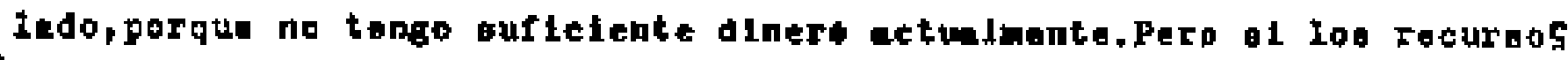

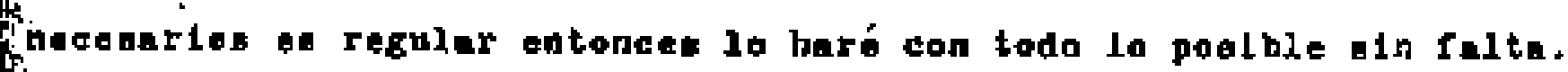

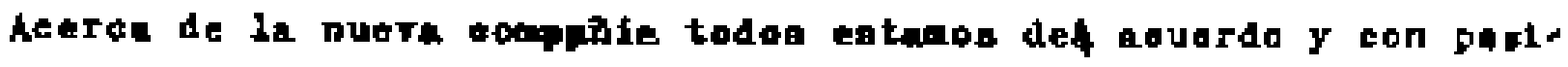

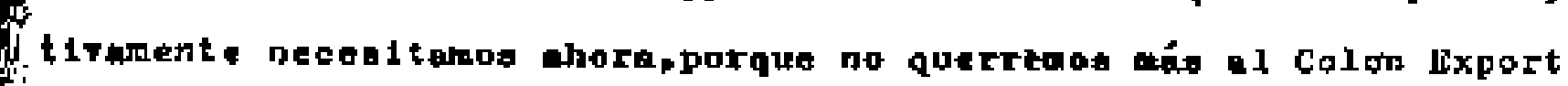
njotra opraparia rieja alno nueve.

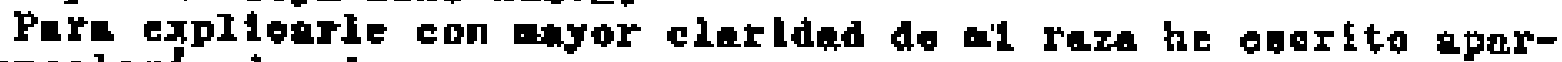
ta la genteologla de mi raxa.

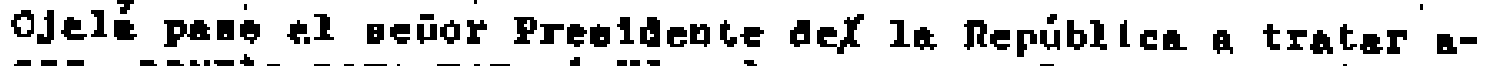

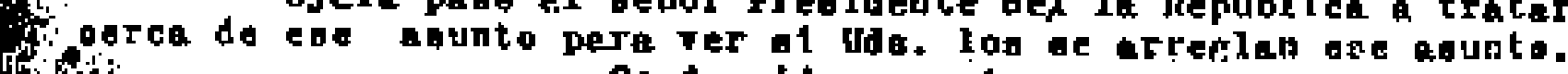
ind

Se Aeopido ou pinlat

Mele de Kancule

Sect.pritedo samuel morrte

Ouple or rg 1he 1

UELLO.

$$
\text { V. IR D, n+ } 495
$$




\section{CCXI}

Uetip Iulto 10 de 1931

Gon้อร

Gaorabgrlo da Goblutno $g$ Jubticin.

Jenpria,

13. $8 . \Omega$.

21 buon y gran esteo?.

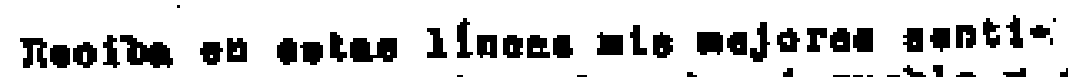

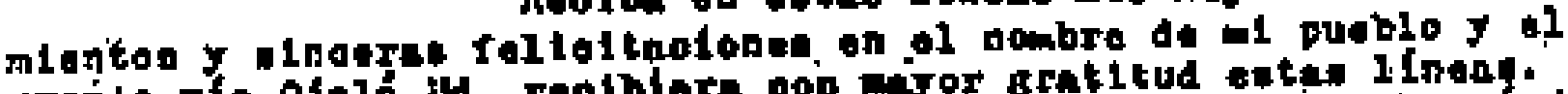

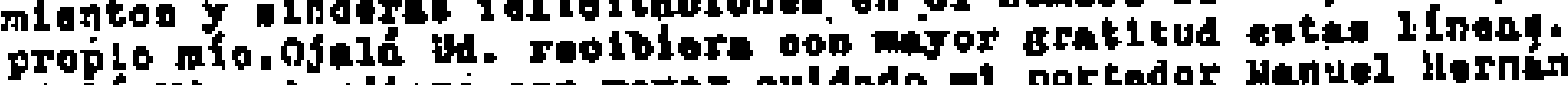

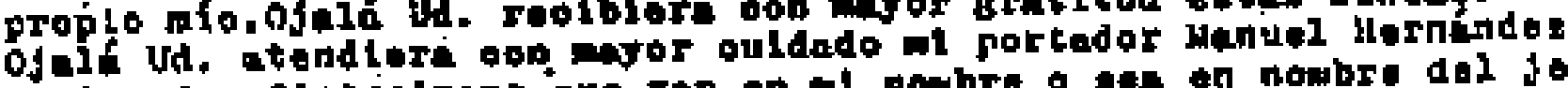

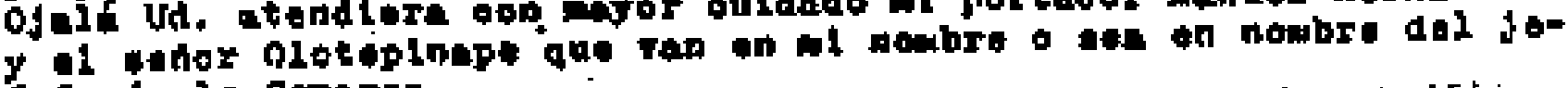

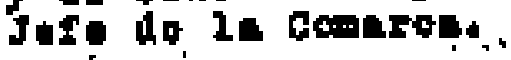

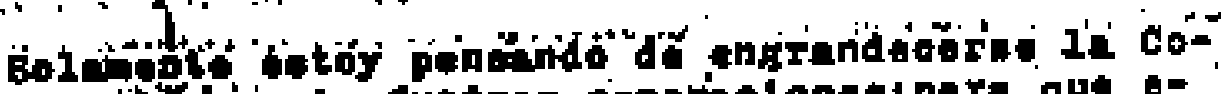

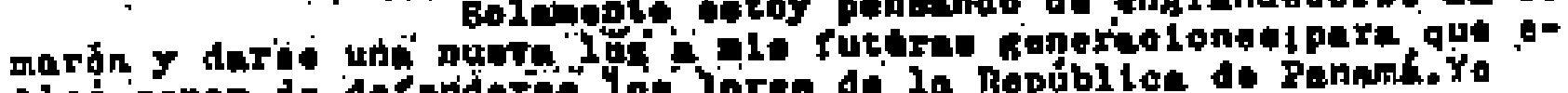

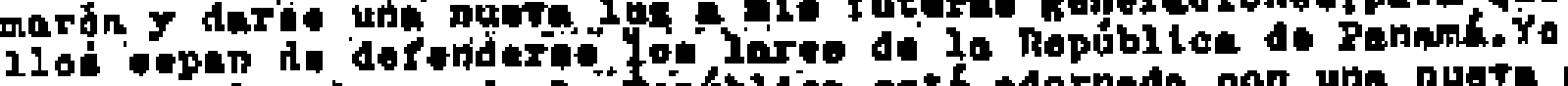

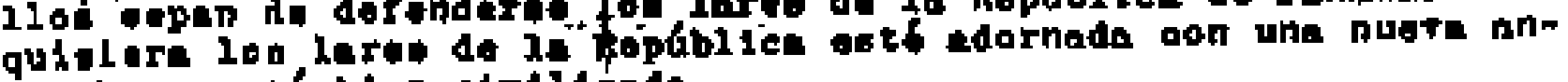
torahe $y$ gote blon olfilipede.

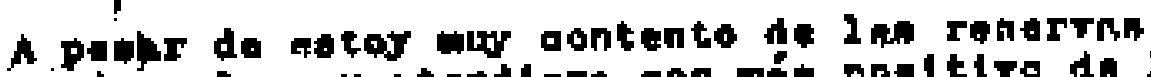

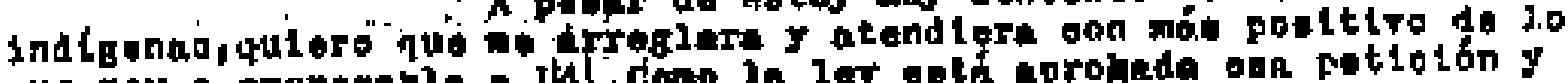

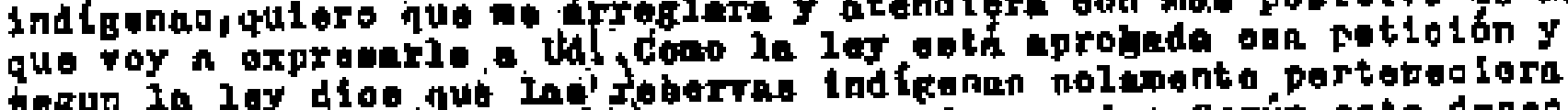

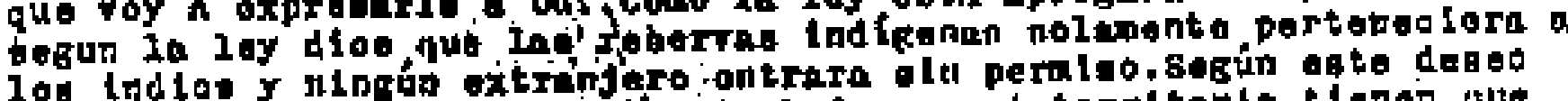

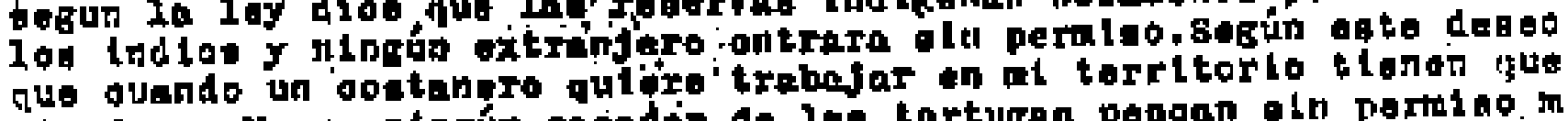

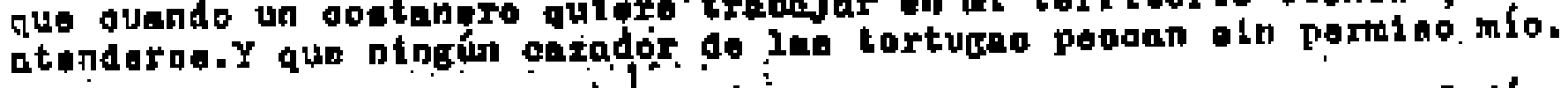

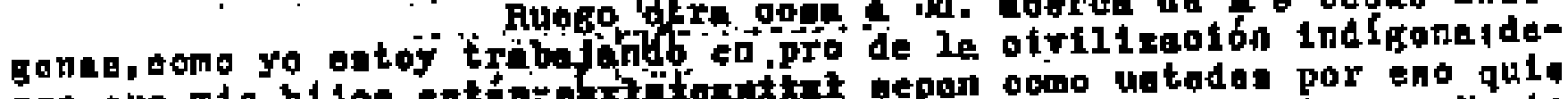

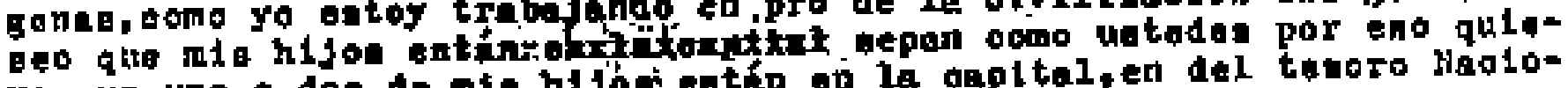

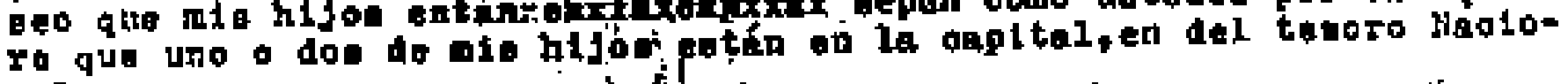
nal;

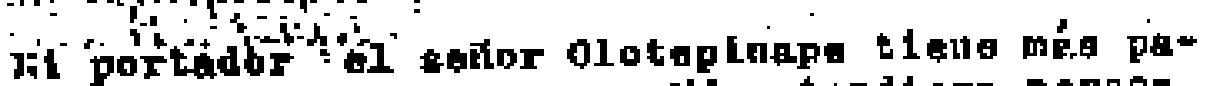

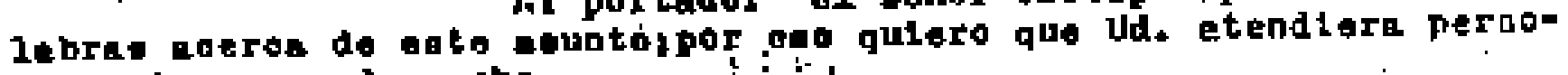
nalmente on de degaotio.

!: : :

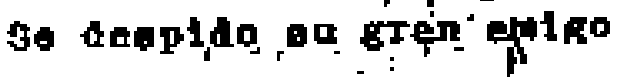

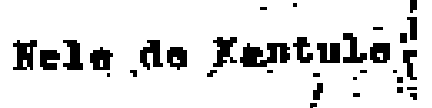

(aect.pritado).Semed varple

copla origingl.

00210 


\section{CCXII}

tallo ortola

\section{iforo 6en-1}

i

\section{Sahox}

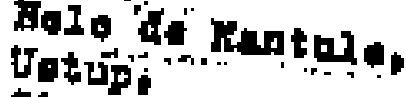

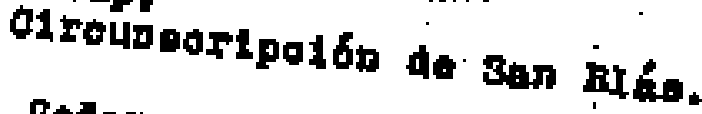

getor.

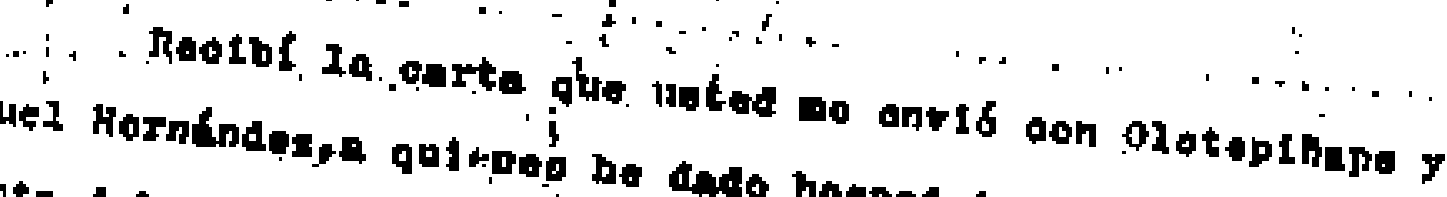

Vantel horninderga quitpog be ando howpedase on un hoted pow ouente del teppro neotopepi.

To tou apointble

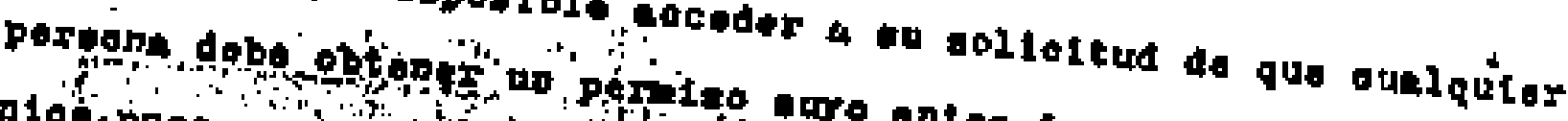

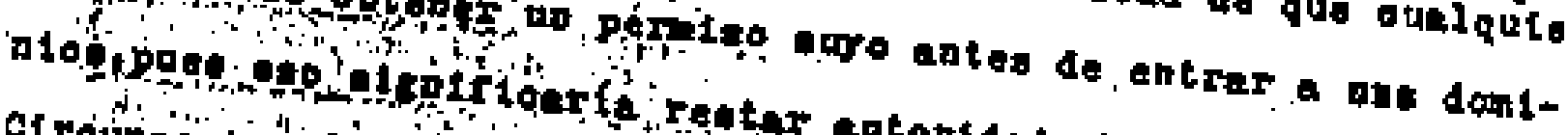

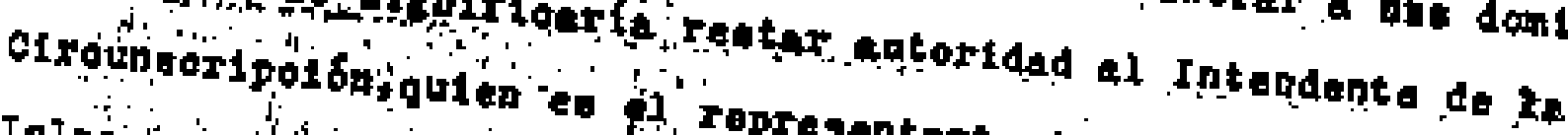

a. Con repecto

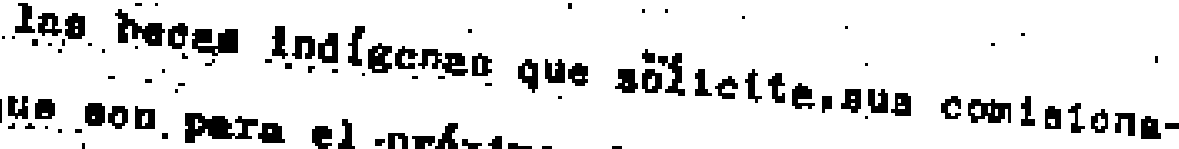

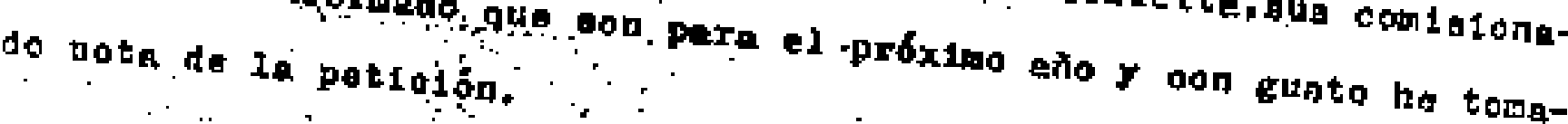

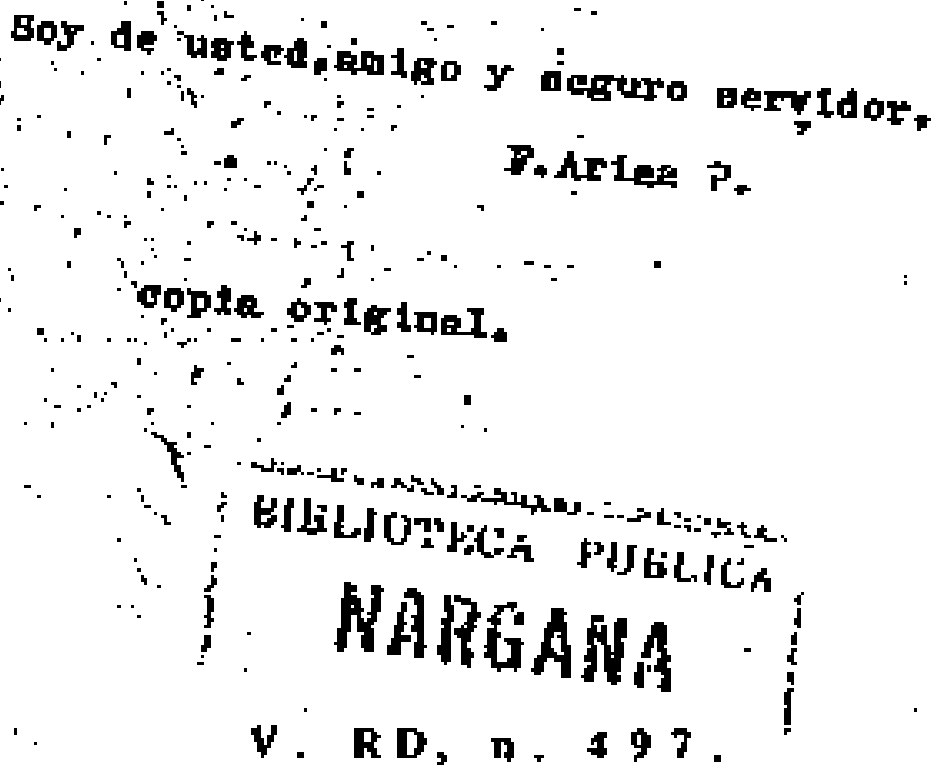


ic.

Carlar Bele.

Aligind1,R.P.

My grant and goad friend:

Your co-1Eat onat, Oleteptnapo, eccompented by

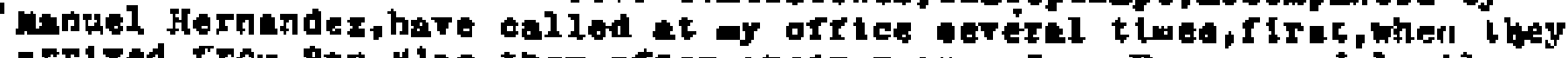

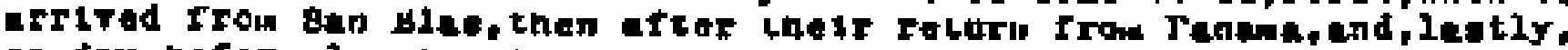
condny, before learing to report to joü

It epptere that ther called upot the forkrn-

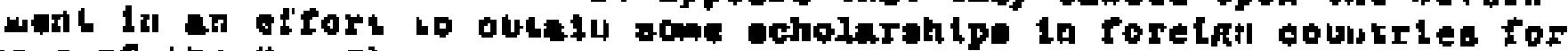

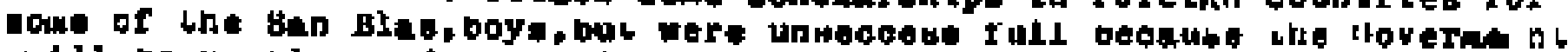

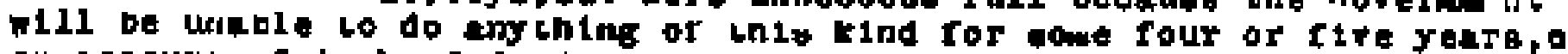
ot soours of liak of funde.

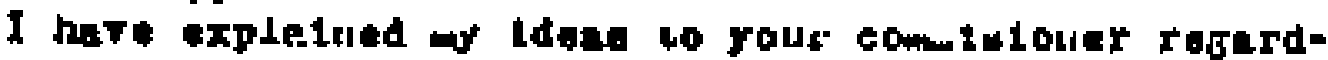

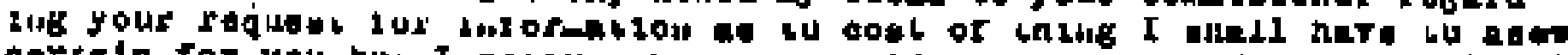

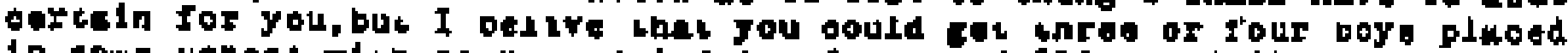

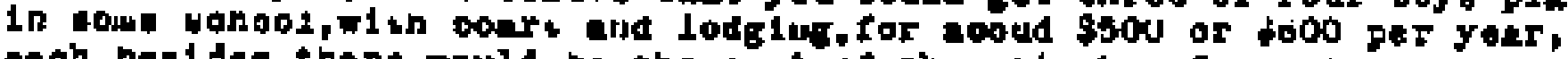

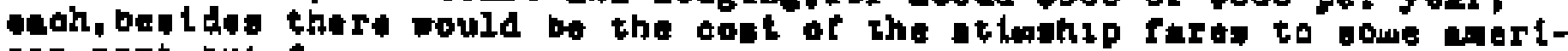

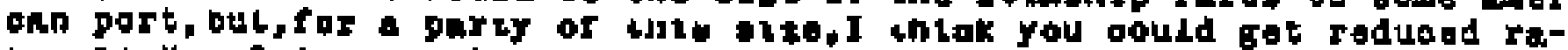

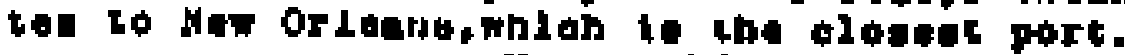

You would probebly here to end waw one along with

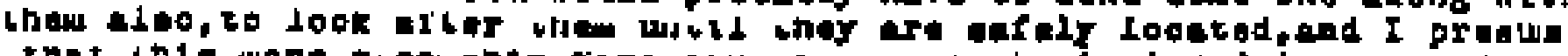

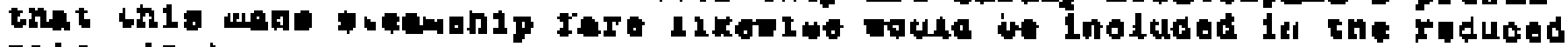

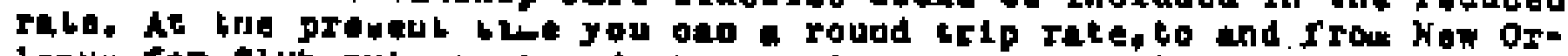

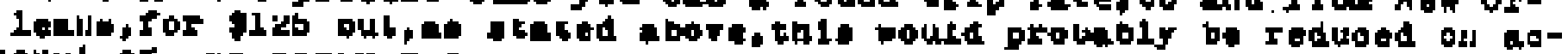
ookit or the pariy rete.

Buppose you uend four boyt La tag Jithed btetes and,

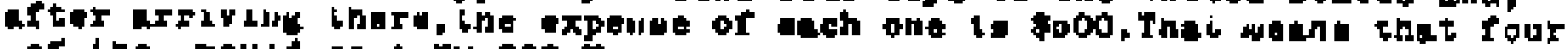

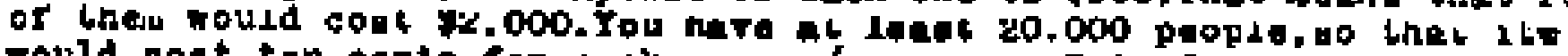

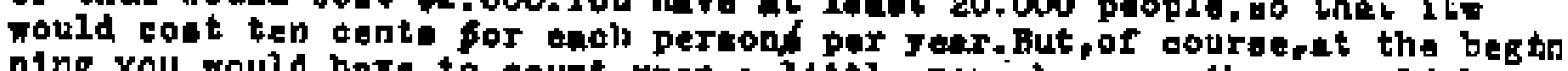

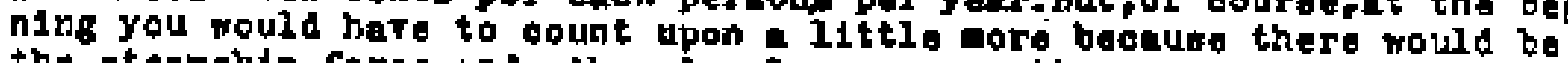

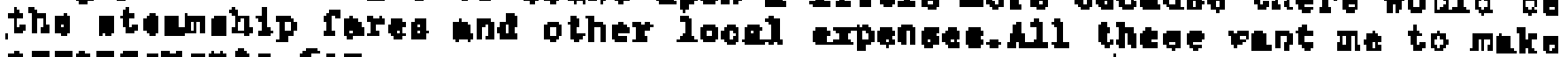
errugements for you.

At to the change in bandling your coooaruta, that ig metter that w12l take coneidereble tine work and energy, it mi1 not eapy to iet a ner company in the merket right aray, os they till hare to bo continced that the busipeas ls large enough to be worth ohile, That, howet arer, te can work on also, and I om aure that finaliy come cood errengement can be wade thet ilil be benerielel to your people in the wey ofgetting batter profits out of their producte.

A soon te you are ready for me to rake...

perdió le perte.

Fe copla ded víganal.

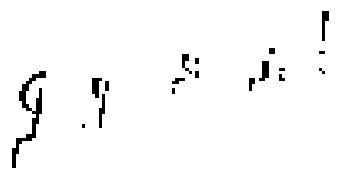

BDOLOTECA

PERE T. KANTLLE"

AARBANA-5AN BLAS

V.RD, n. $49 \mathrm{~g}$. 


\section{CCXIV}

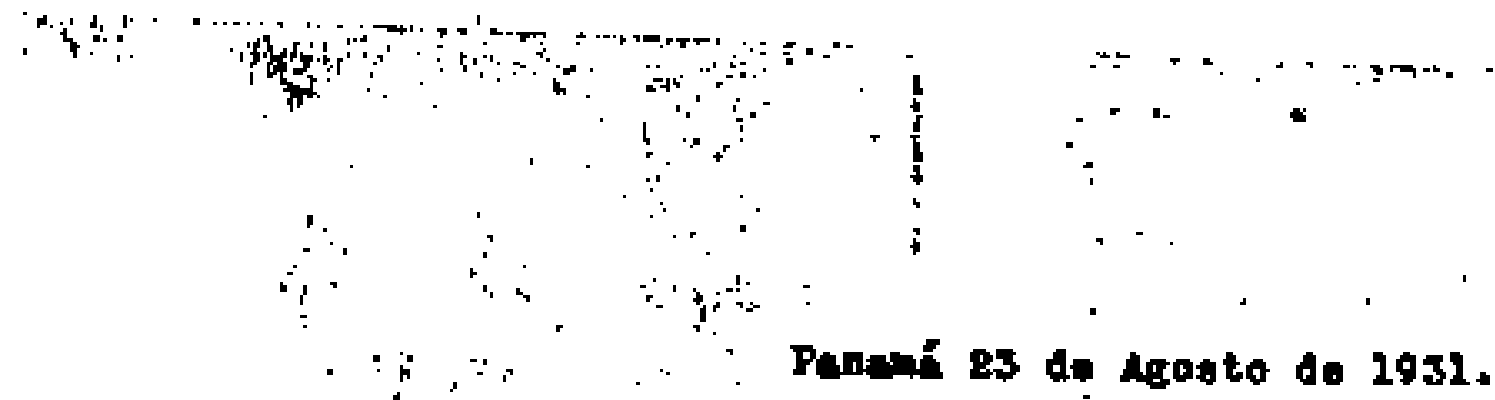

Gothow dof Degtort

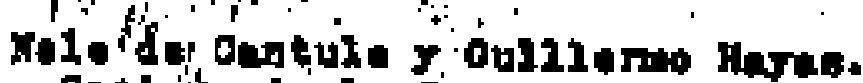

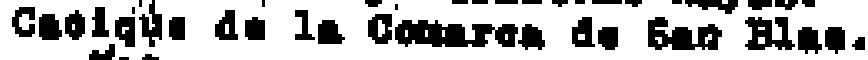

$\therefore$ totis.

A1 'Ly distigguldo Dootort

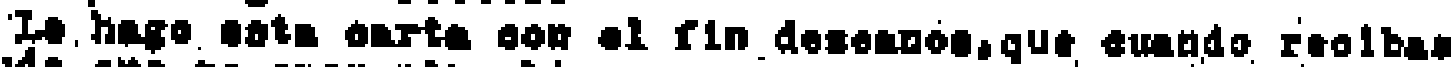

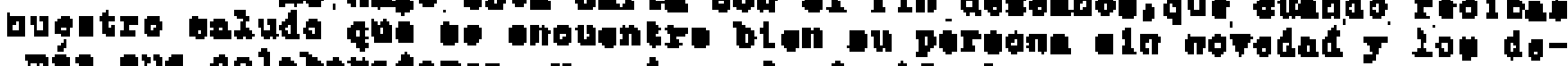

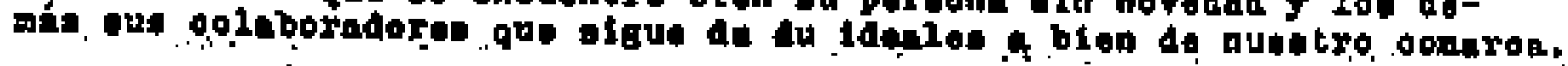

16 тар"

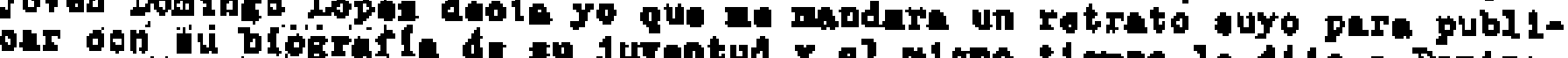

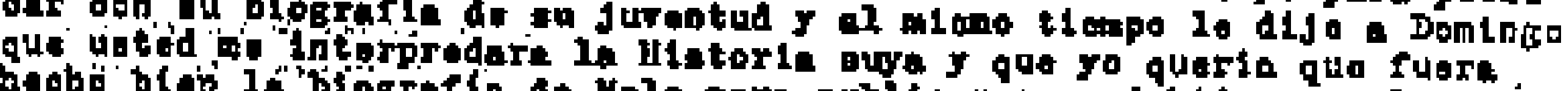
gerio para publteat oune debido nomo loa

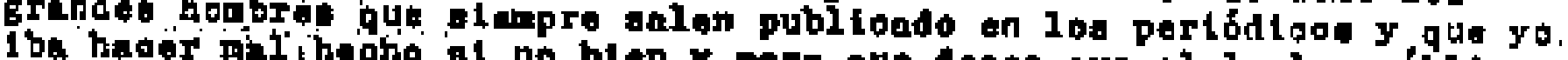

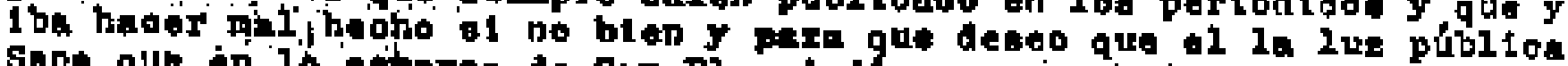

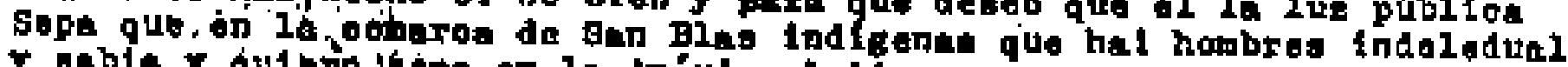

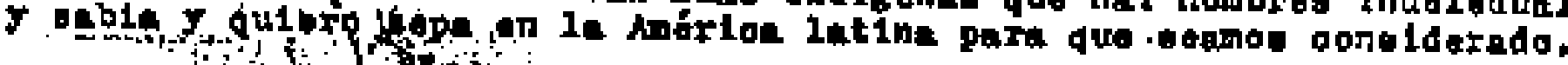

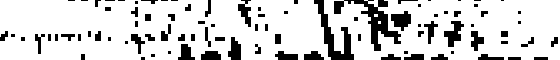

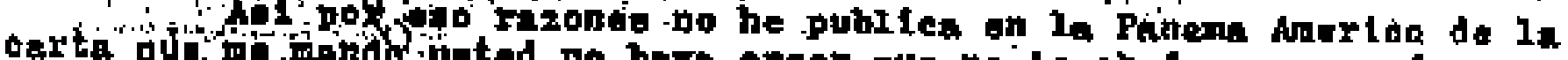

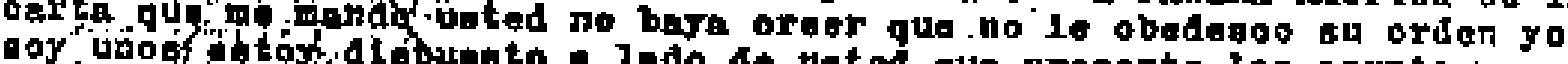

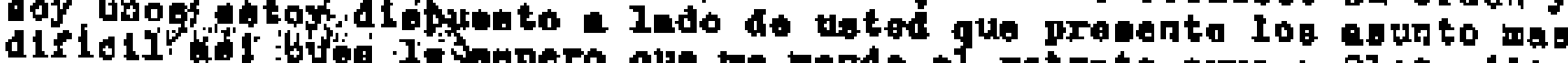
o veri thejd

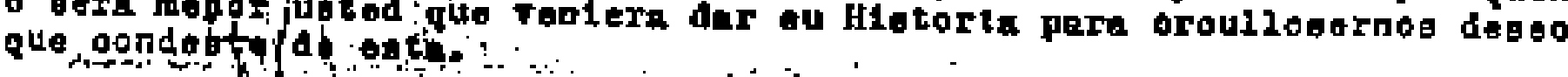

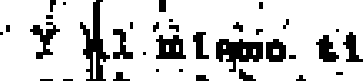

Teatbl la

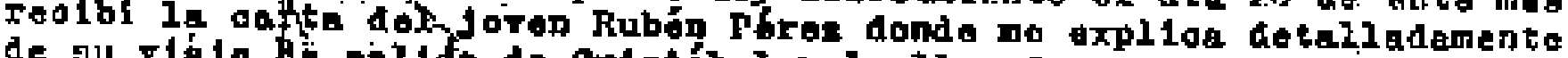

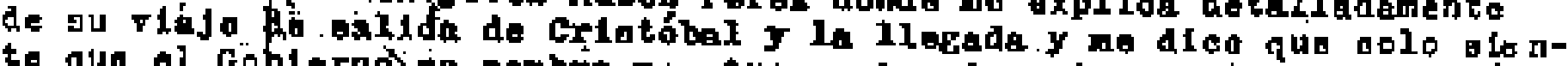
te qua ol Gaplernojio nowbro matroo $y$ tabplon gle eonoldara altacín

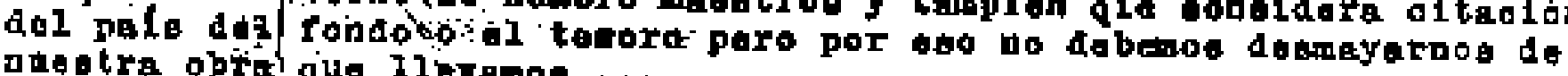
ade otra gbitis que Ilibereos

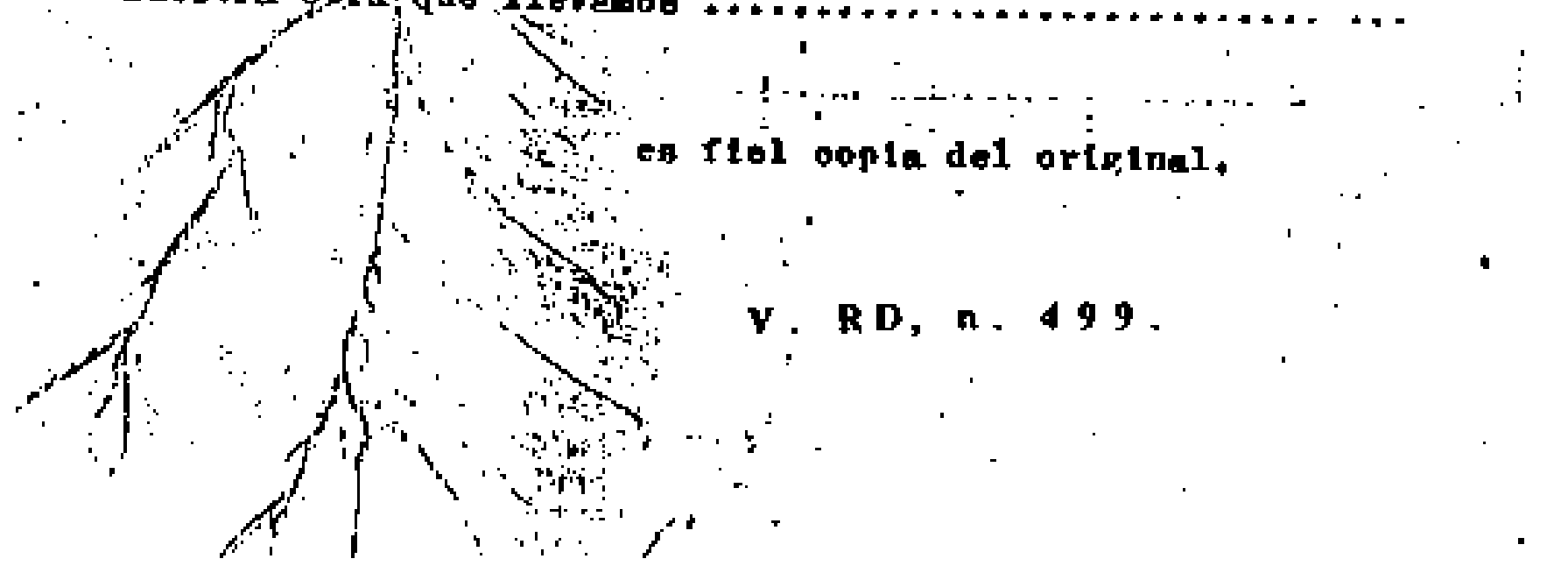




\section{$\operatorname{ccxv}$}

$\mathbf{N}+\mathbf{1}$

Nómera 26w

Narpanf, 8 de Septienbre de 1931

Stiór

Intindeate de do Comarea de Sap Bas

El Porventr.

Sohor:

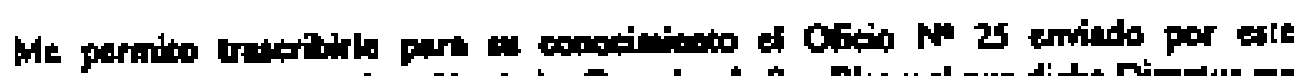

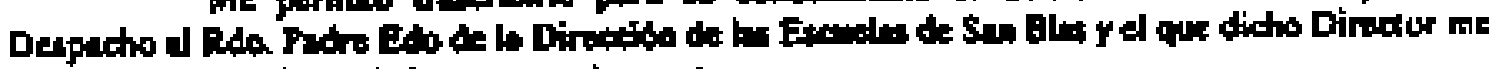

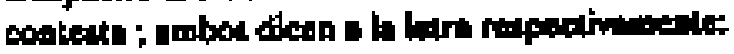

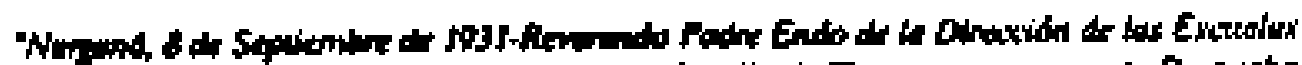

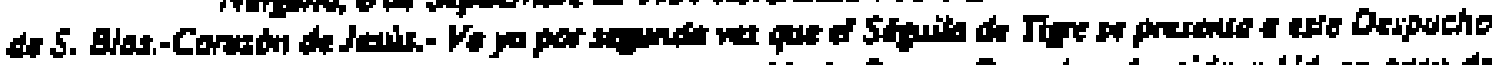

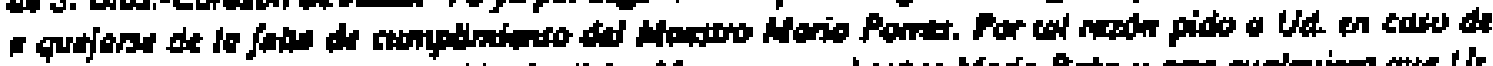

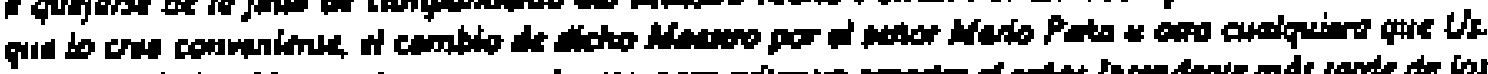

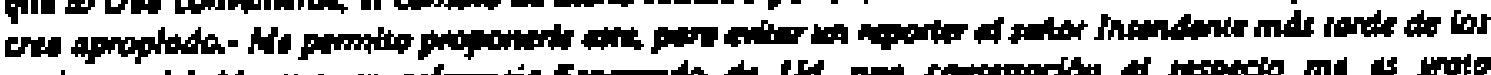

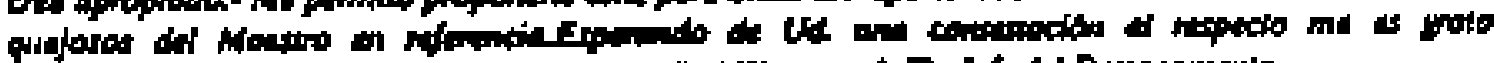

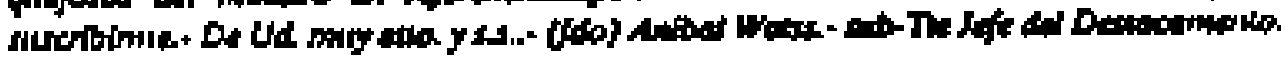

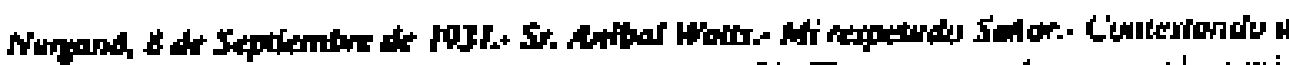

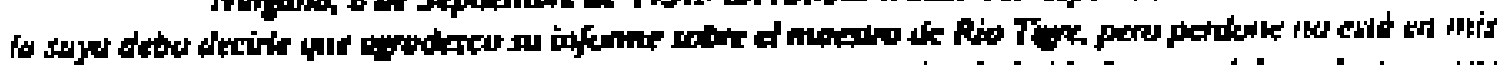

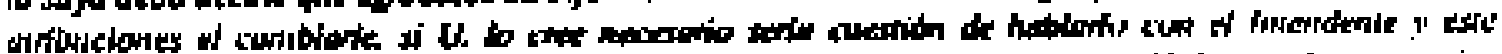

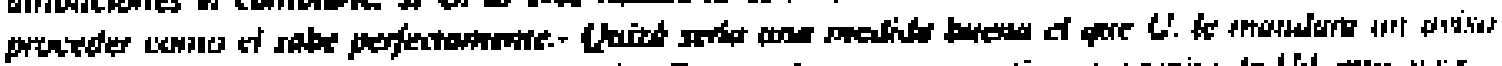

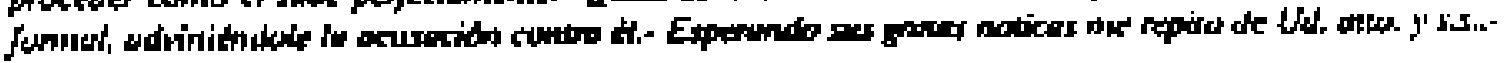

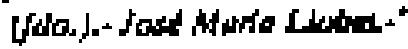

Soy de Ud. atto. y s.s

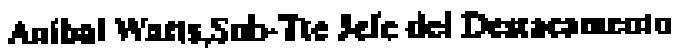

Trans, del orig. mec.

V. RD, n. 500 . 
eor

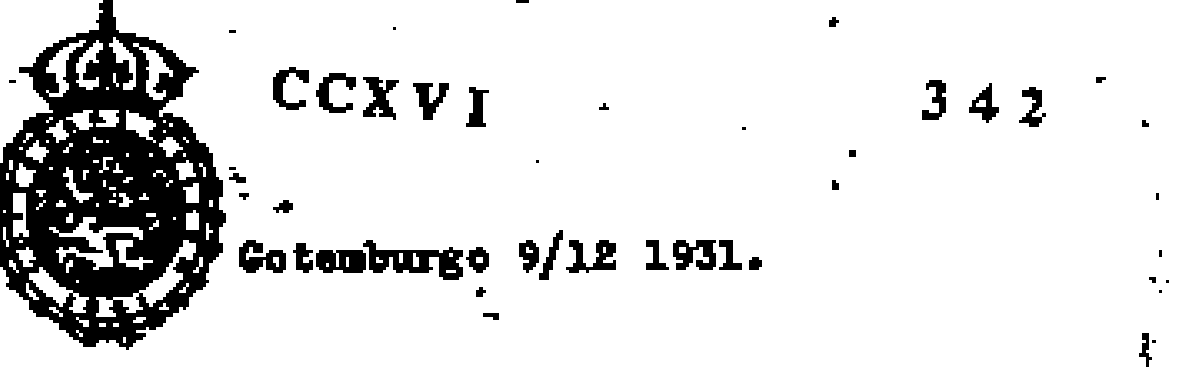

ar.D. Ruber phes Kming

Paturgandi:

( $\operatorname{son}$ Blat)

arerido unigo:

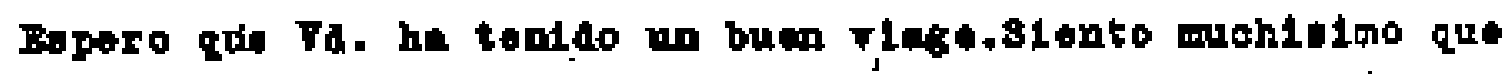

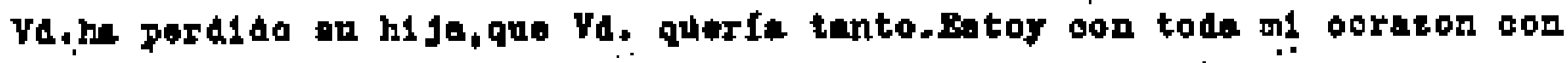
Va.

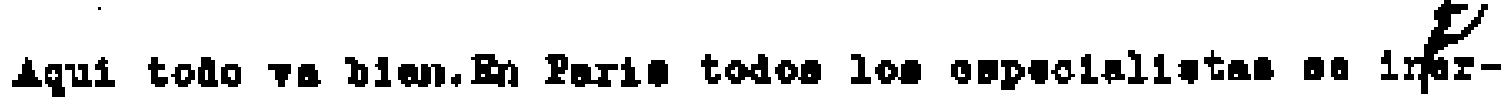

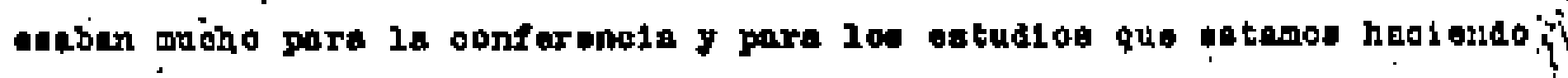

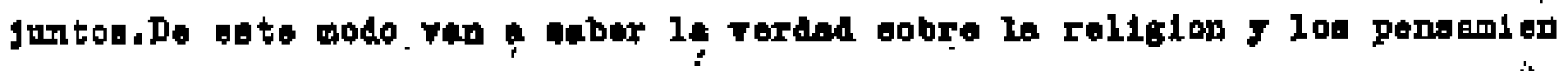

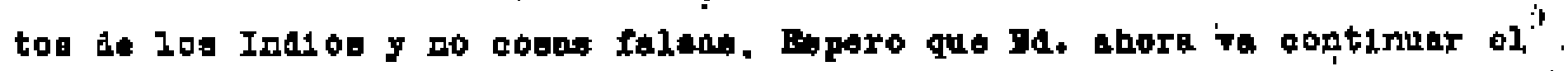

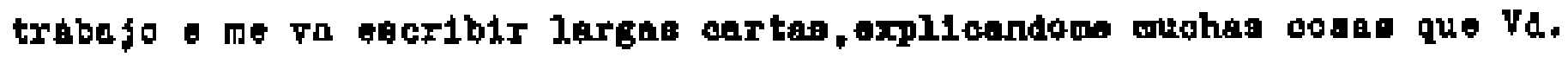

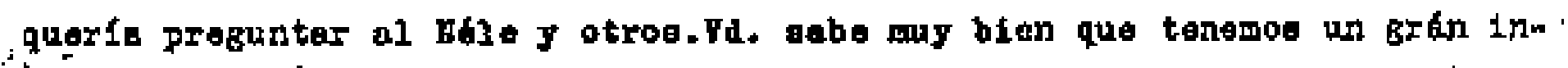

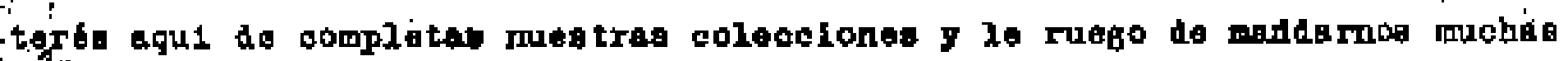
$\therefore 4$.

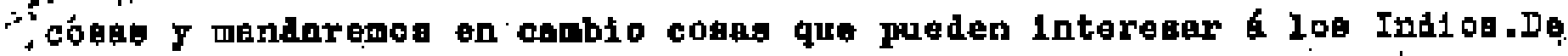
gumigente gran 1mportama bera de congegair las tablas con plotograrles or Arquis.

'Salude mohiatno de mi parte al Sefior K6le, que edoiro mucho poc su Intelligencia $f$ ou aeracter, Stenta wahialuo que ol ha perdido su gefiors

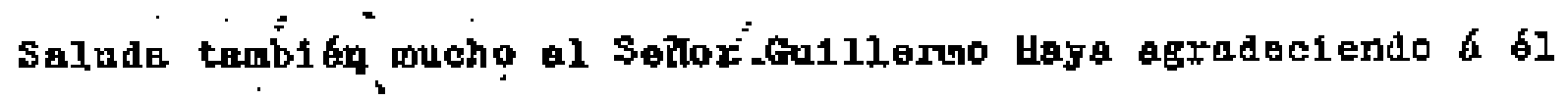
log antog $y$ ouentab que el woe ha mandedo.to nanders 108 cantoe para qua

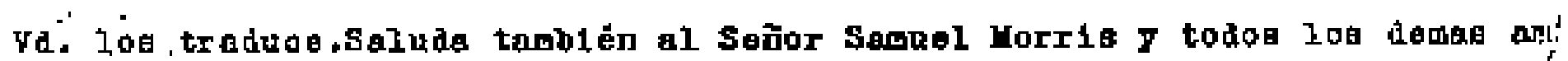
gog. 


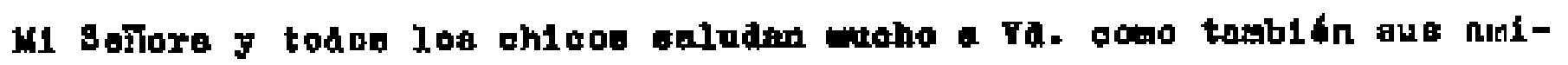
Bor on al Mnero.

galuda muoho ol ontor strom.

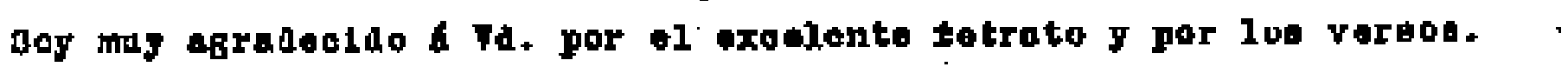
su afeotitsino inleo

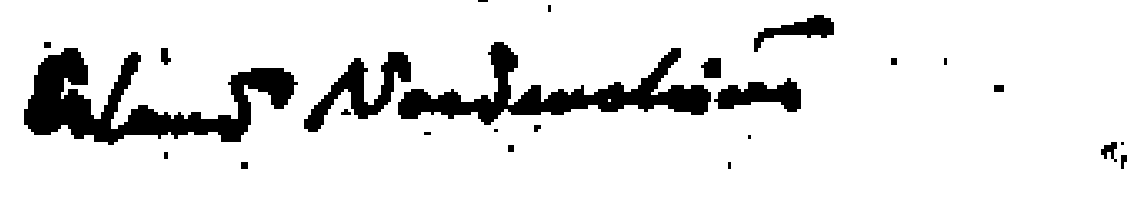

l<smiles></smiles>

V. R D, 1. 502 . 


\section{VII}

tow<smiles>[Y5][As]</smiles>

1

boldenikerzo 7 at 1933.

dafox 1.1

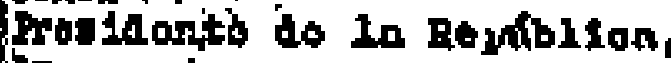

ins.

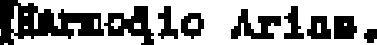

tiunear.

1. 8. b.

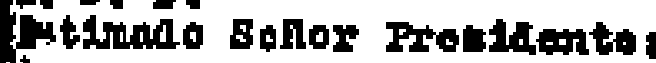

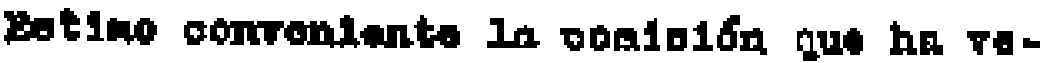

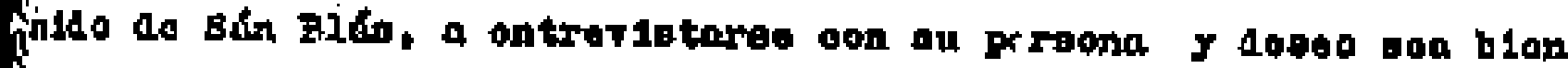
"wootian $y$ towbien por la seoretarta do at $y$ Justiota.

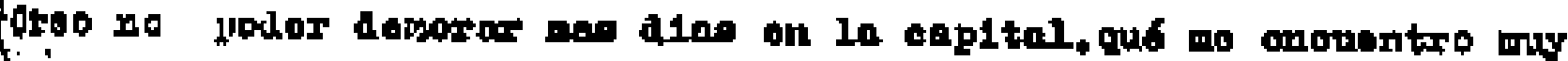

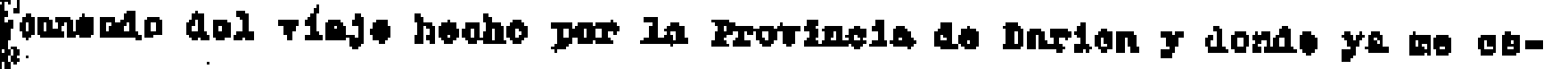
i. pora mi fumi11e.

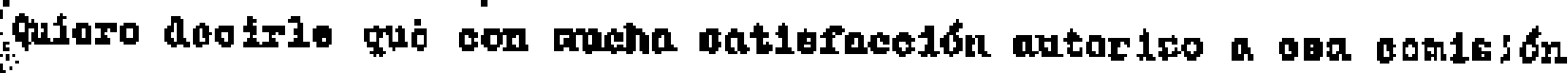

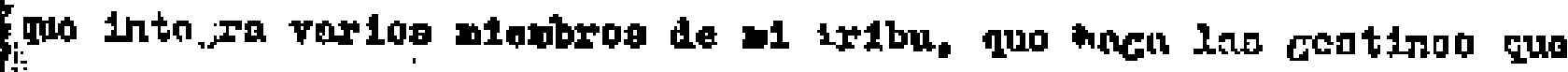

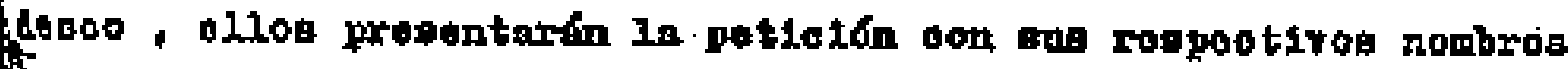

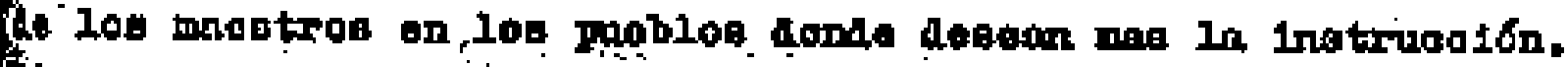

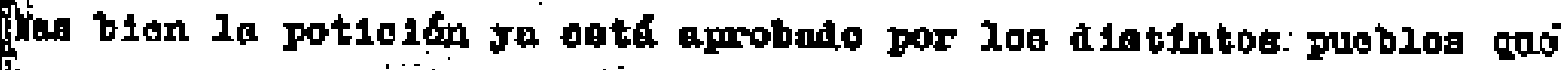
त.

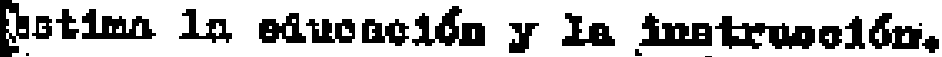

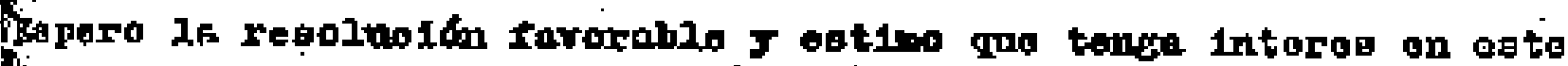
t: foaso.

i.

En Pefuro soridior.

.4

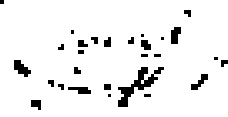

V. RD, n. 506. 


\section{$\operatorname{CCXVIII}$}

N-10

Nưmtro. 2

Río Arincar Mayo 16 de 1933

Seftor dow

Jullón Apoilere

Di Porvealt.

Selion

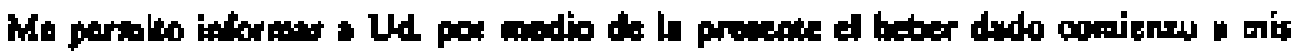

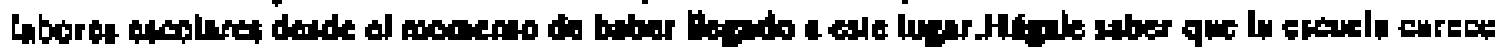

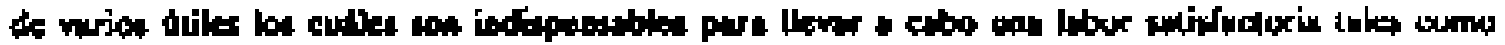

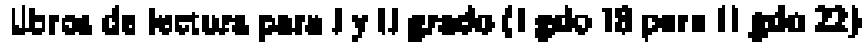

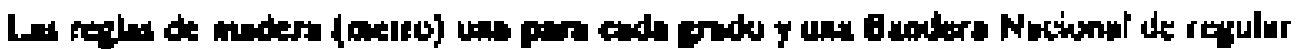

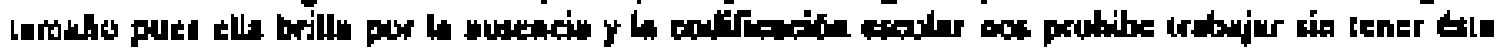
landu.

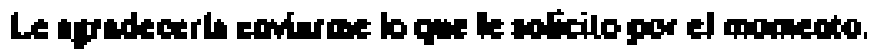

De Ud. alealerpenie segwo sorvidor

Luls E. Mindkr C.

Director

Trans. del orig. mec.

V. RD, n, 508 . 


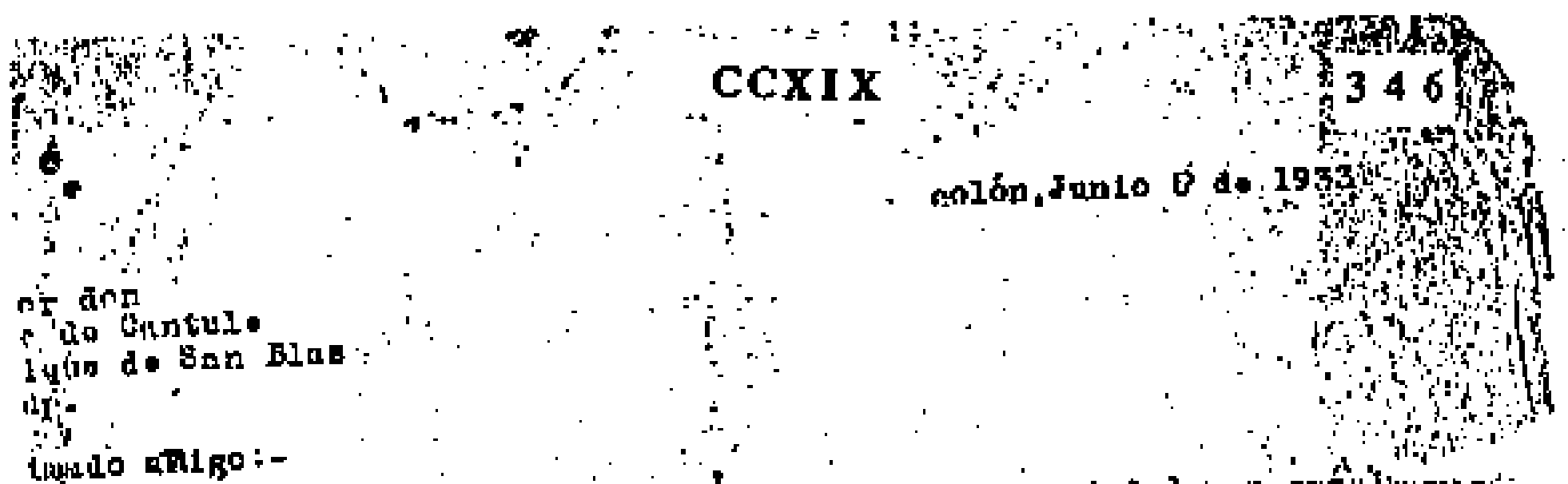

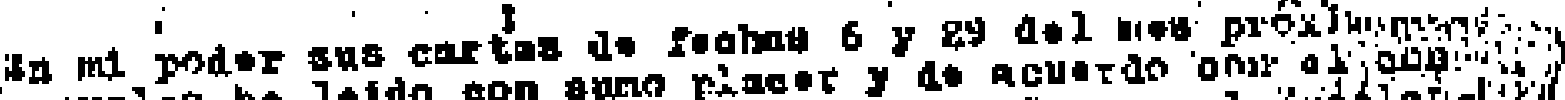

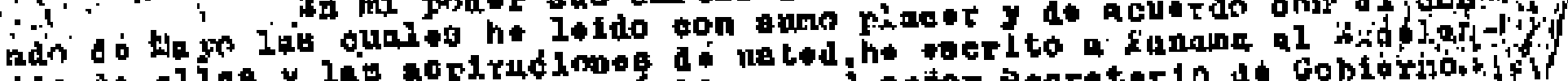

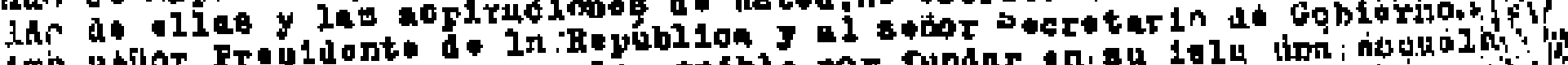

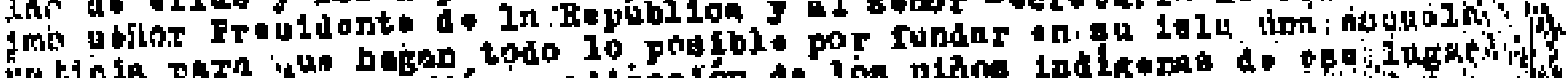

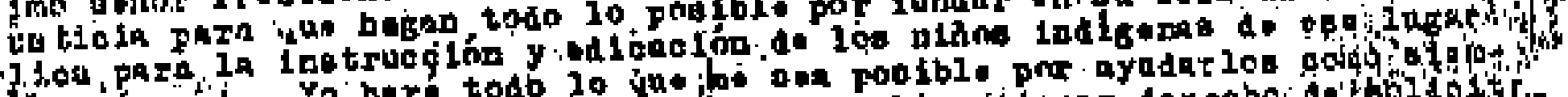

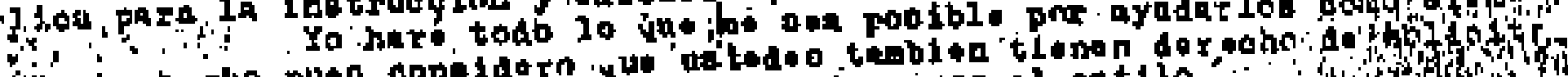

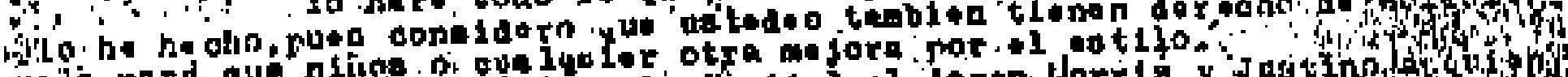

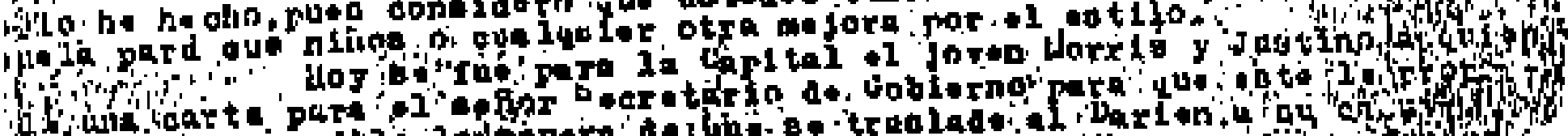

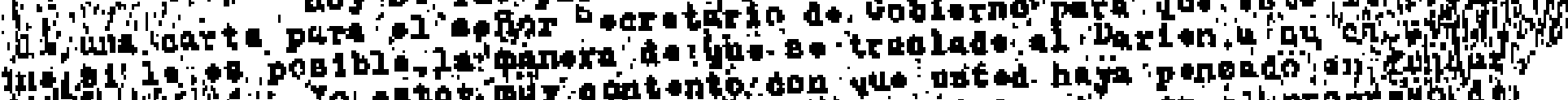

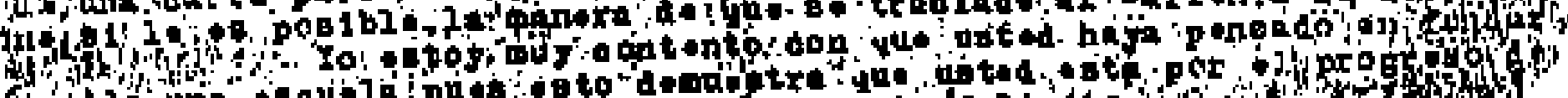

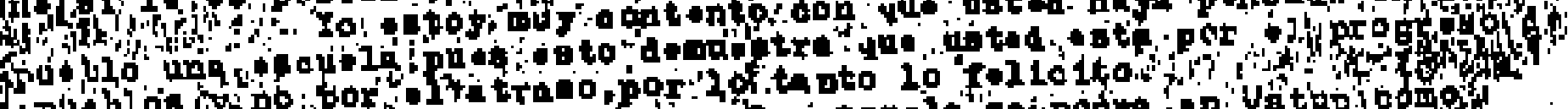

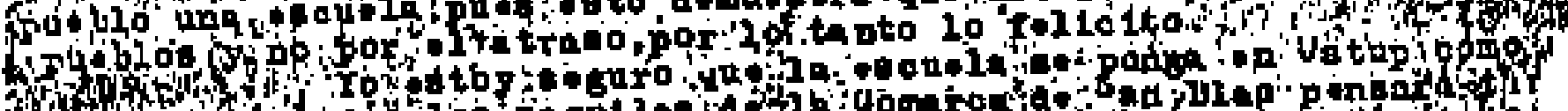

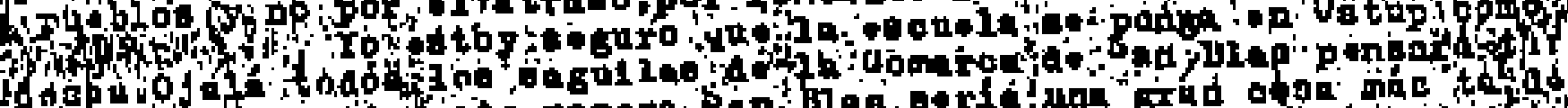

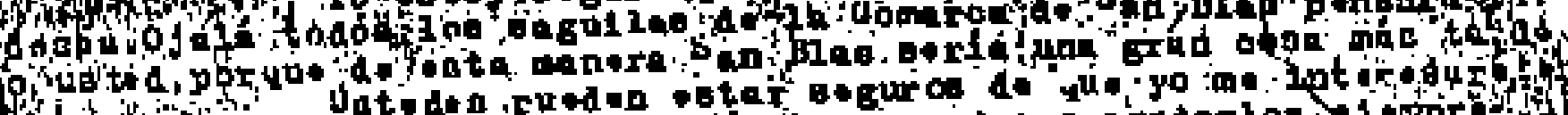
A.

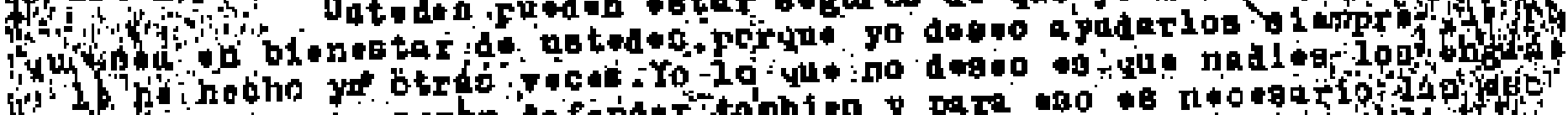

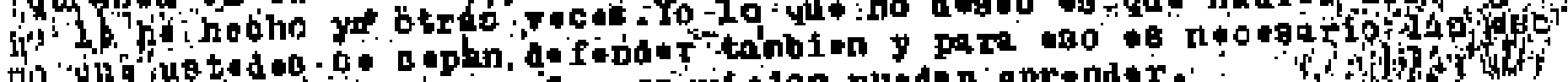

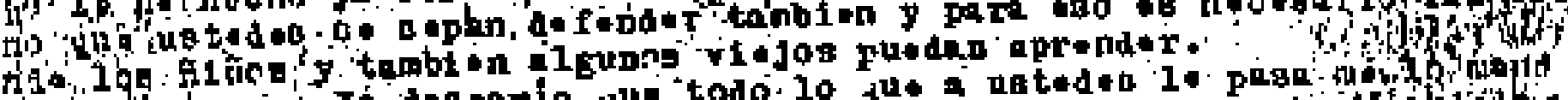

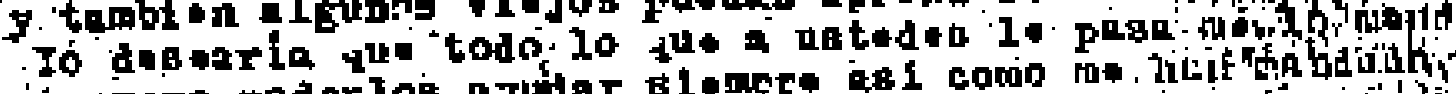

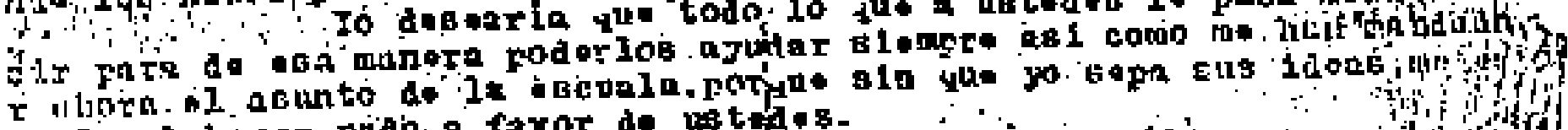

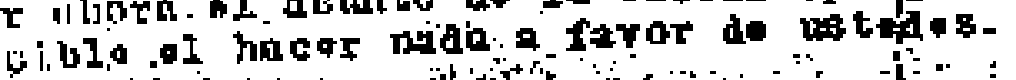
A

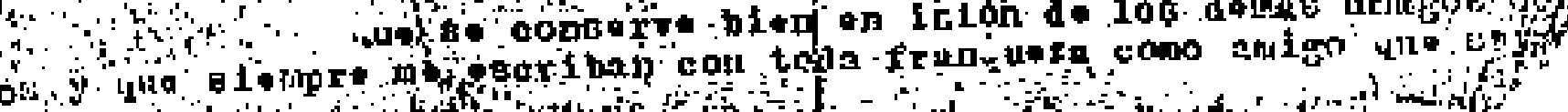

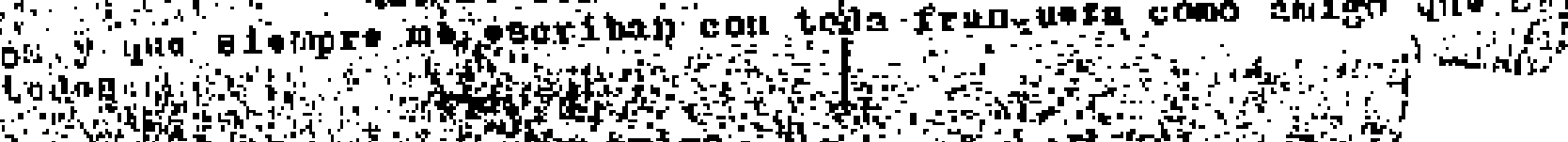
for 6 . 1.

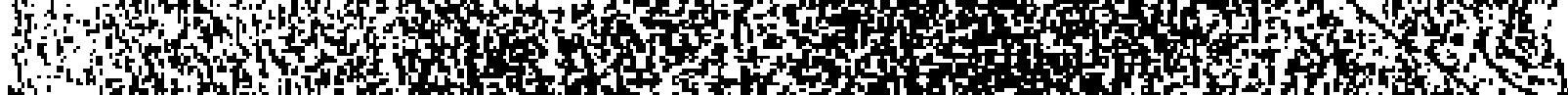
(4)

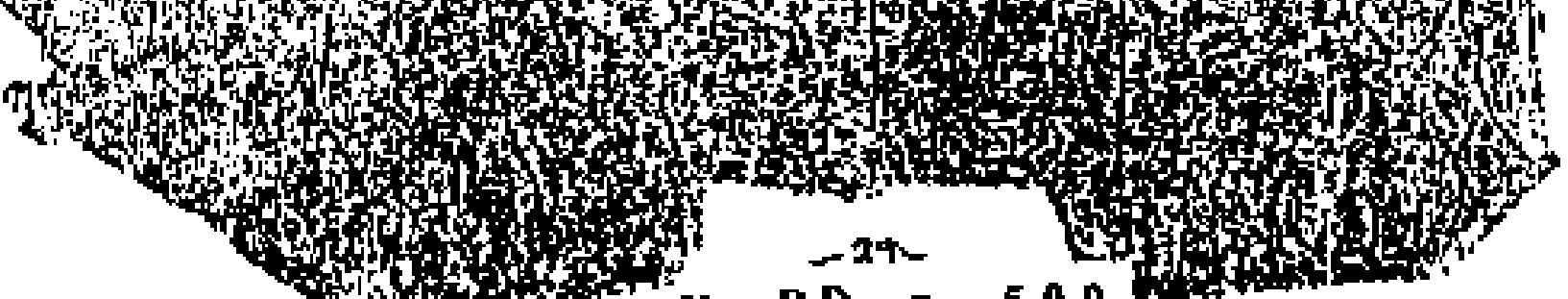

RD. n. 509 


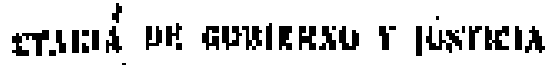

Panami. Junio 8 do 1935 :"

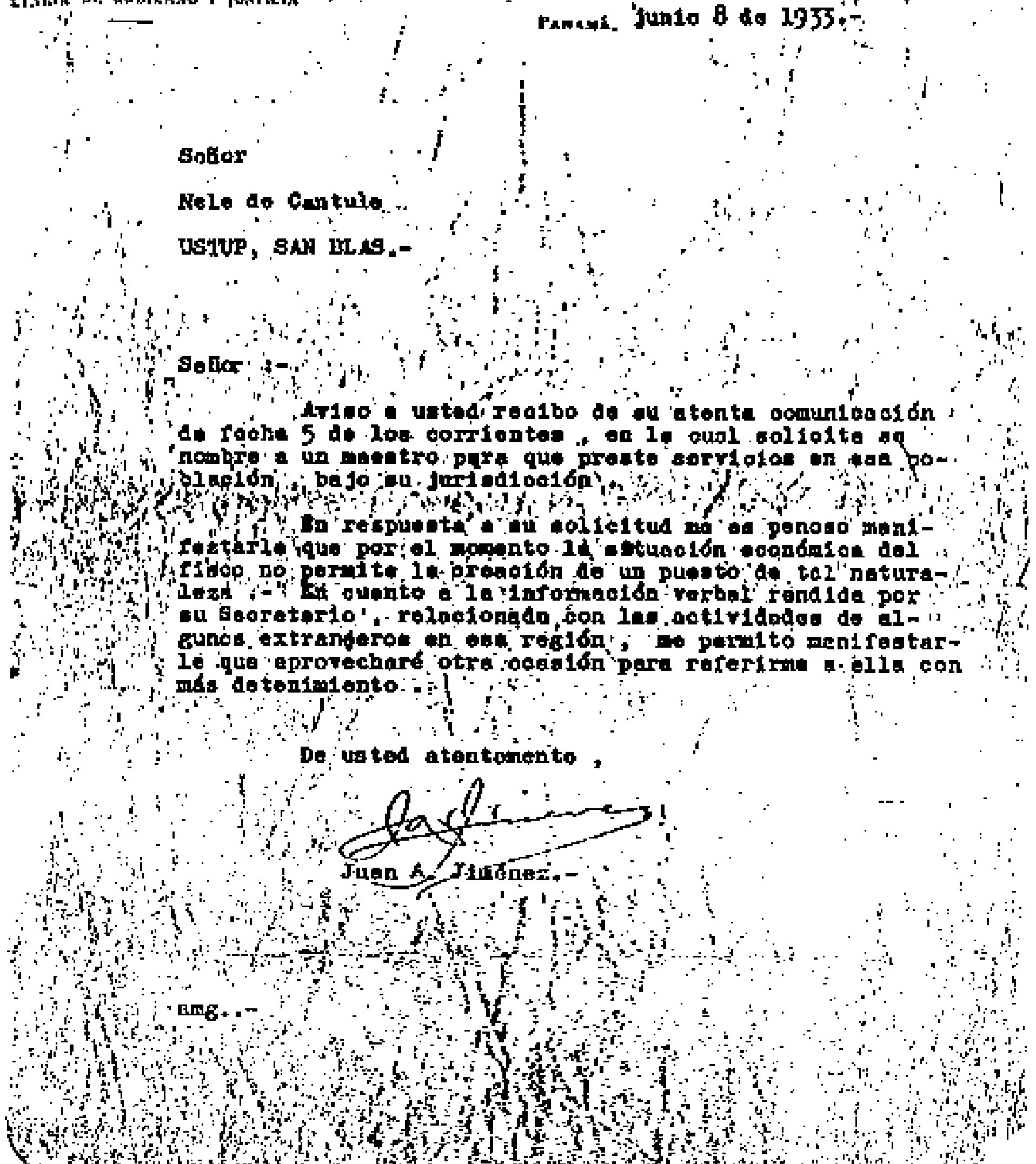




\section{$\operatorname{CCXXI}$}

Námero 3731-C

\section{Sefor}

Panamf, Noviembre 8 de 1933

Intendente de ta Comarea de San Blas. LL PORYENIR.

Sehor:

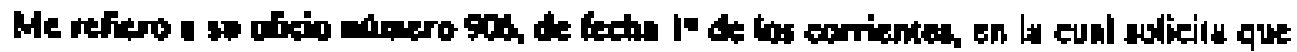

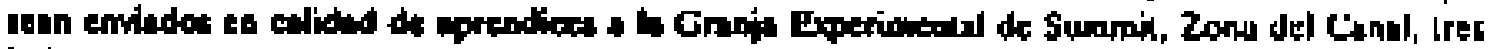
indlivens.

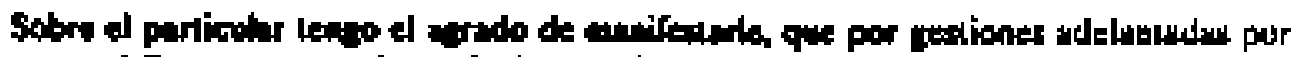

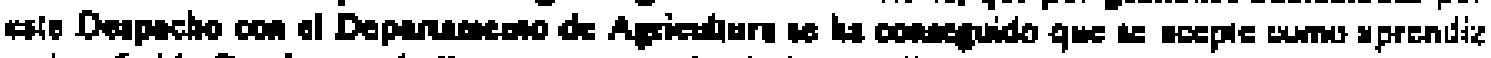

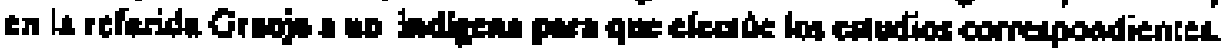

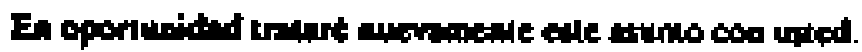

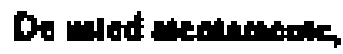

Juso h Jintere-

Trans. del orig. mec.

V. RD, n. S I 2 . 


\section{$\operatorname{CXXII}$}

V.18

Número 841-B

Sefor

Panami, 14 de Diciembre de 1933.

Intendenle de la Circunscripción de San Blas, EL PORVENIR.

Saltor lalendeale:

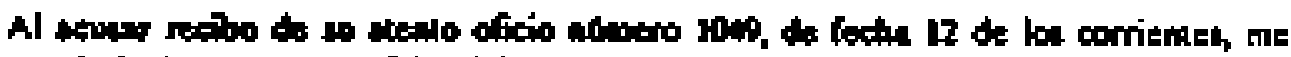

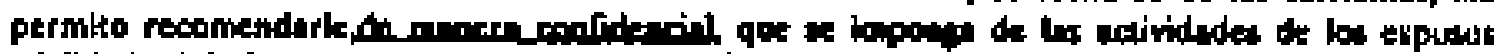

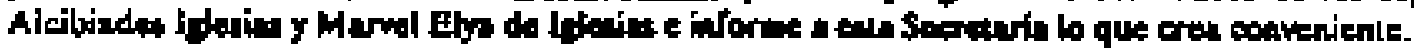

Soy de wed atedmenlt,

Pur tel Serveturio de Cobicrou y Jariai

Roberto R, Roy

Sub-Secreterio

Trans. del orig. mec.

V. RI, I. 5 I 3 . 


\title{
Repúbllè de Panimin
} SECRETARIA DE COBIDRNO Y JUSTICA

\author{
Sefior \\ Inteindente de le Comnro de Sen Bta: \\ EL PORVNNIR-
}

\section{Sebor:-}

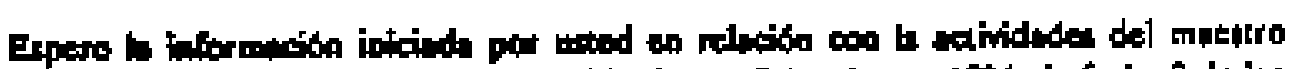

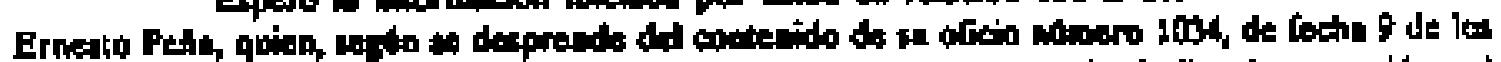

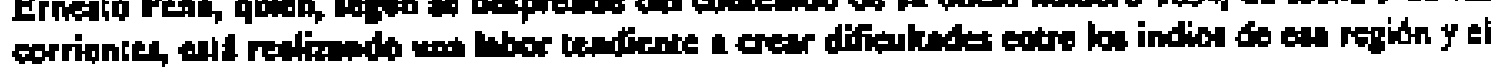
gobierno.

De uated aloalannere,

Jusu A. Jimetaxa

ants.

Trans. del orlg. mec.

V. RD, n-514. 


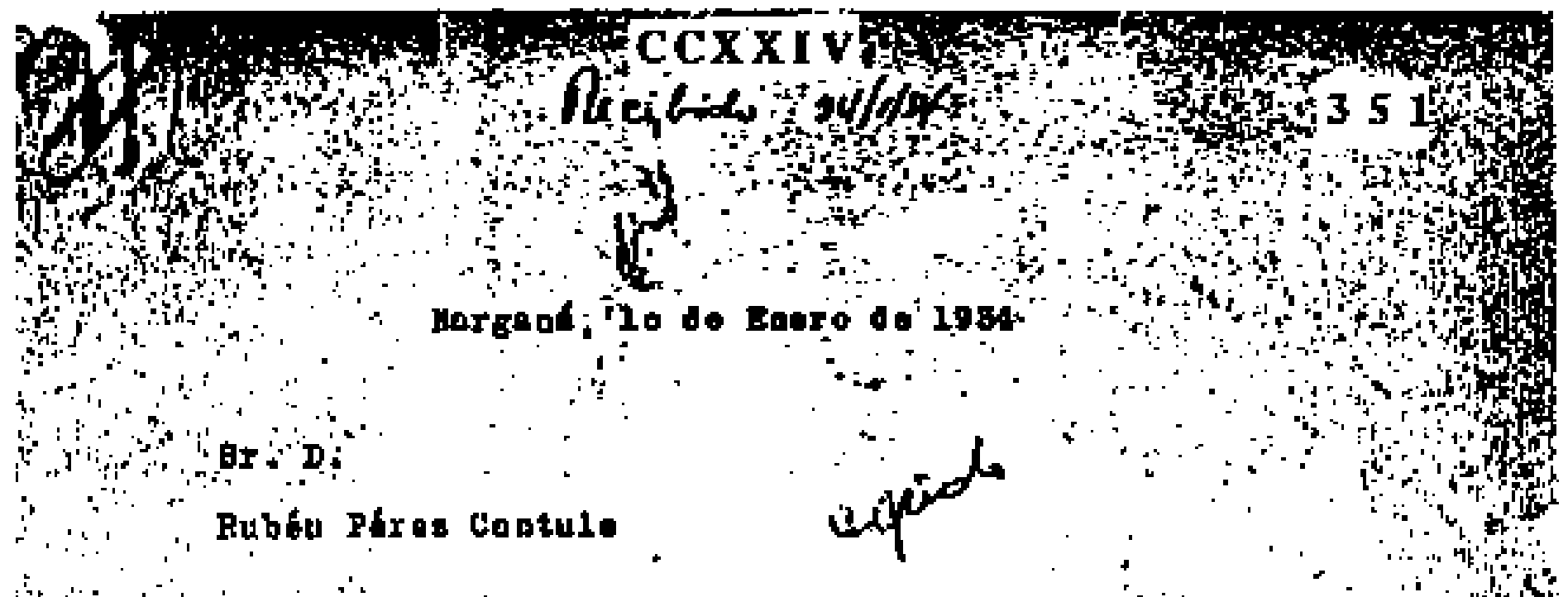

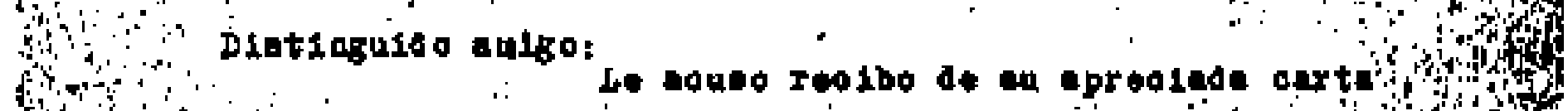

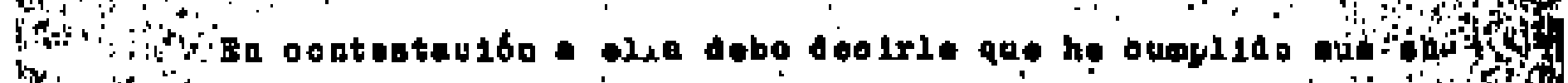

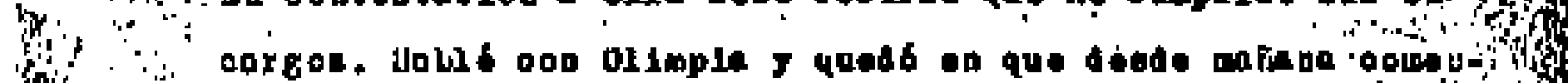
'sit :

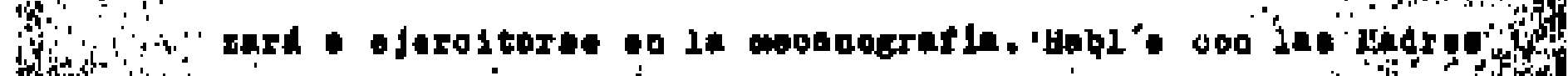
y tado qued 6 arregledo.

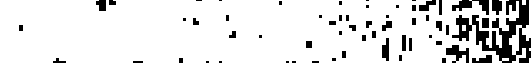
S.

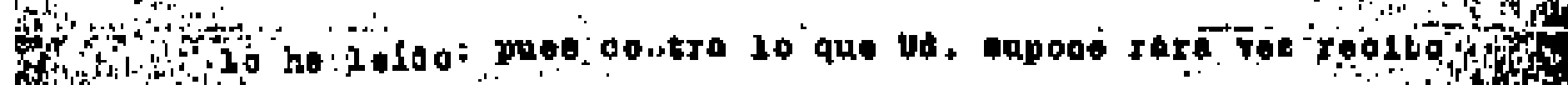
P.

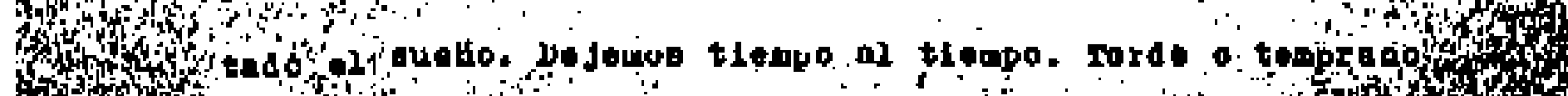
ofoly

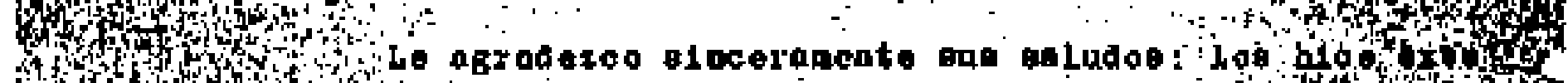
Elaty if
Y
An

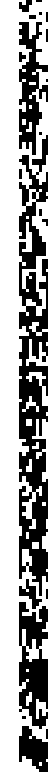

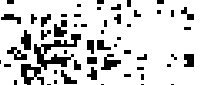
Fon 40 


\title{
Saivor
}

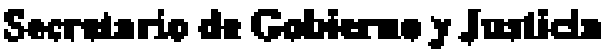 \\ PANAMLL
}

\section{Selor Secteturiox}

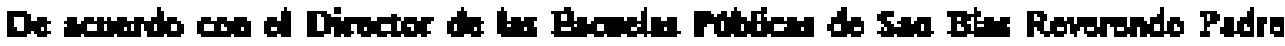

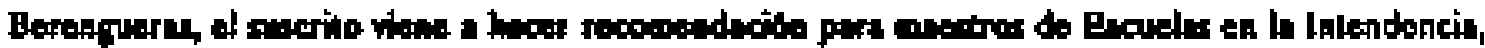
modlatie wopliercioner.

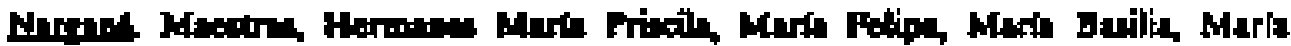

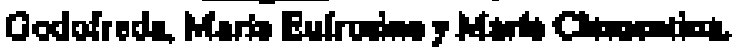

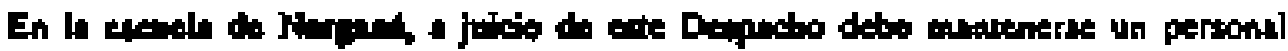

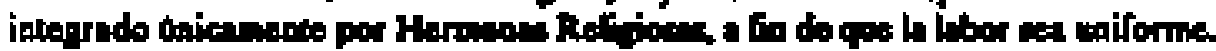

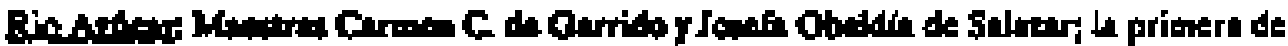

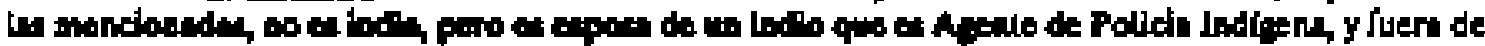

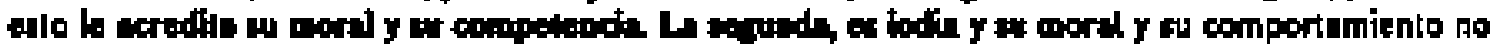

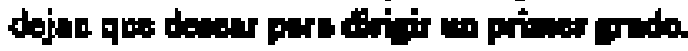

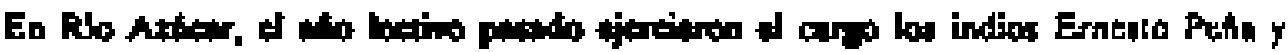

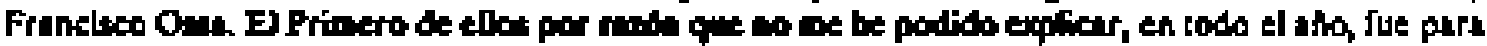

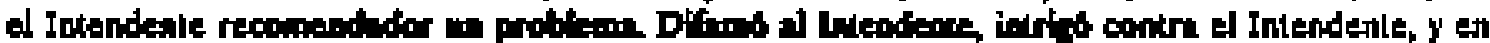

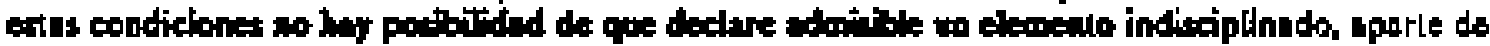

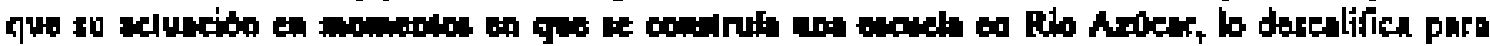

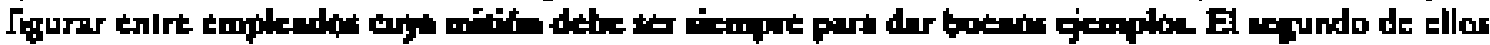

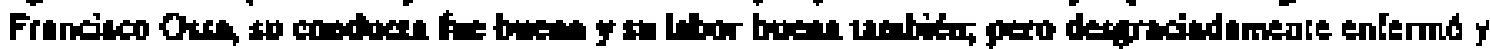

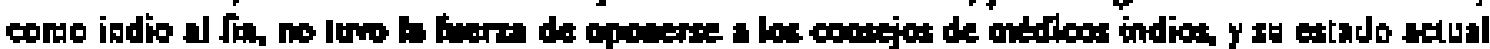

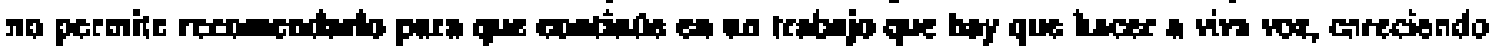
de lueras para empleark.

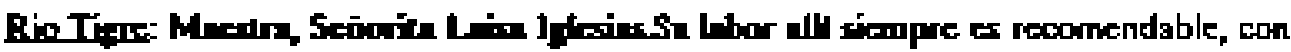

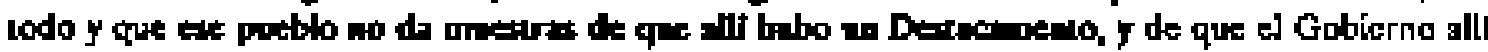

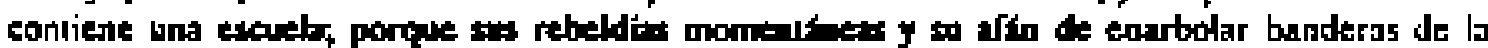

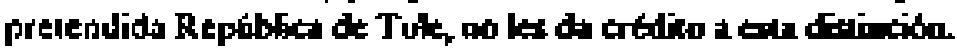

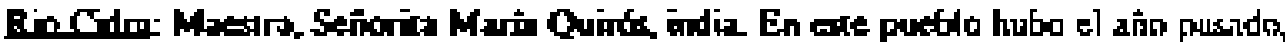

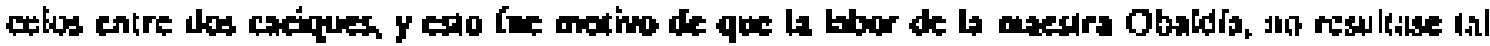

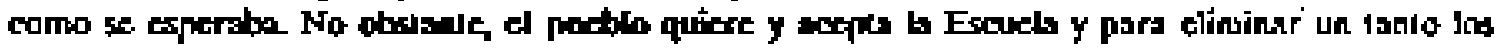

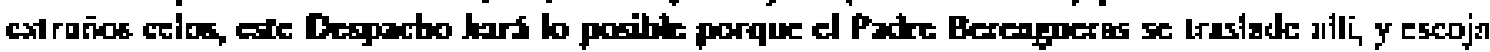

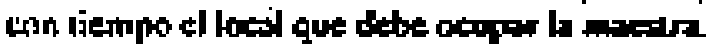

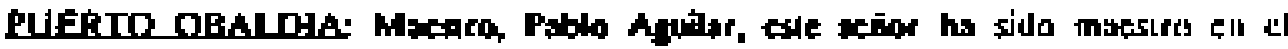

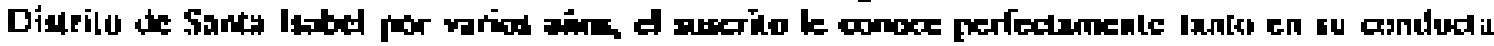

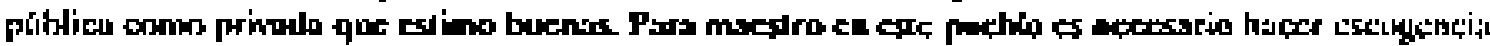

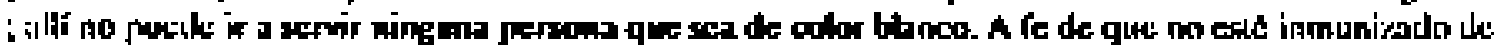
pultudismir.

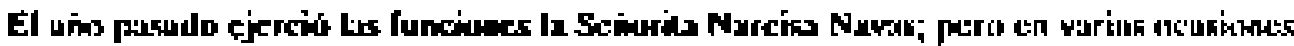

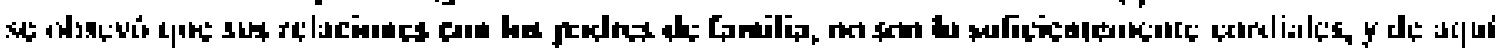




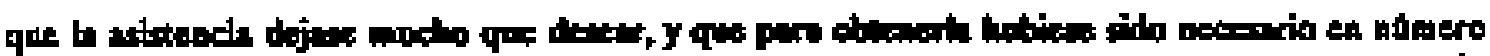

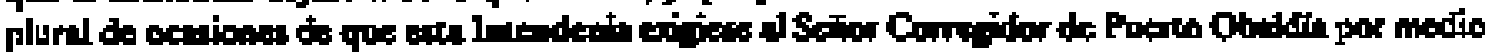

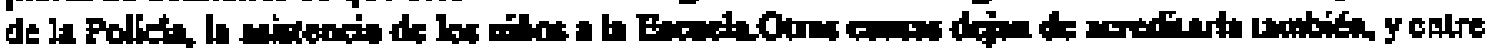

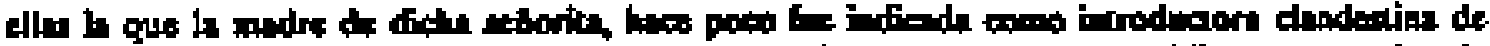

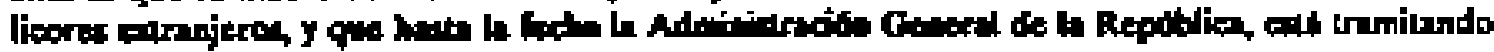

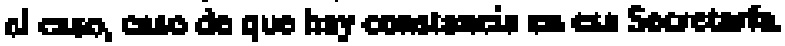

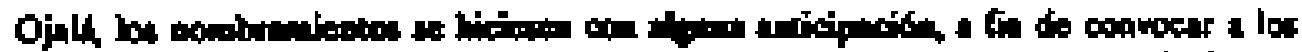

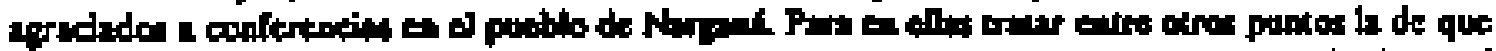

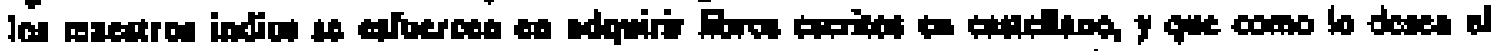

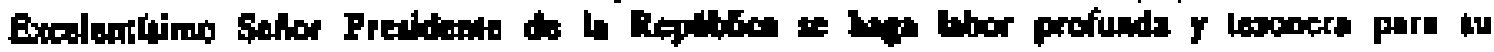
encothinar.

De Ud. ato. y k1.

Jullas t, Apollora,

Intenderue

Trans. de Ia cop. nec.

V.RD, N +517 . 
Panant, Abril 24 de 1934

\section{Sefior}

\section{Intendento de lo Comarea de Sen Blen}

EL PORVENIR.-

\section{Sthor Indundonicis.}

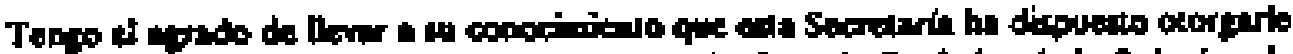

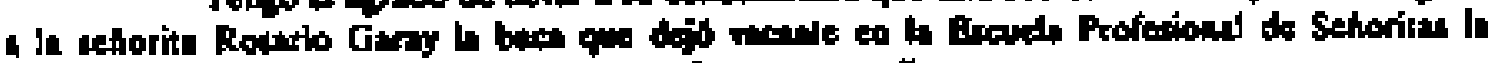

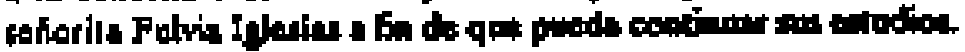

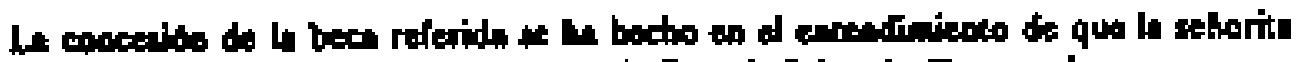

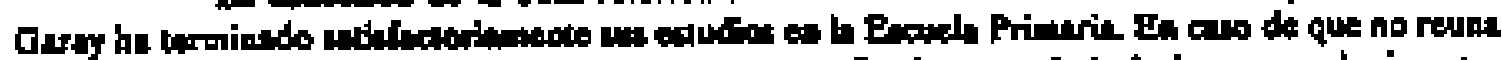

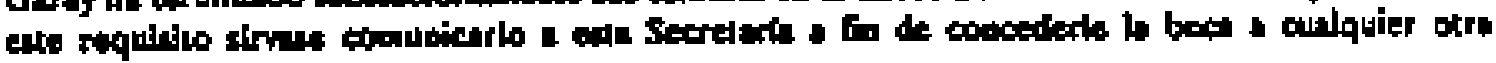
intertandn.

De unitd tentemeale.

Rabeito R Royp

Sub-Sext험o

Trans. de la cop. mec.

V. RD, n. 520 . 


\section{$\operatorname{CeXXVIII}$}

R-13

DECRETO NUMTER 56 DE 1934

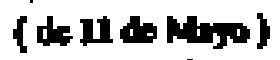

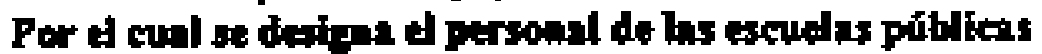

da to Counara de San Bloct.

Fl PRSSIDENTE DE LA RPPUBLCh

an aso de sus facpliades lecales,

DECRETA

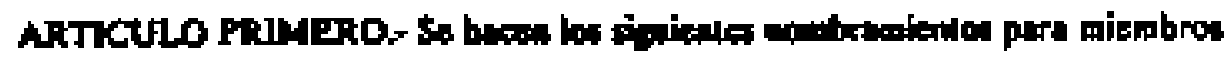

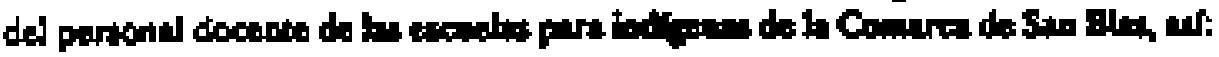

ESCUELA DE NARGANA;

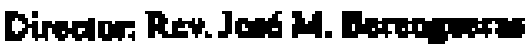

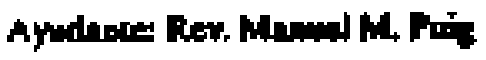

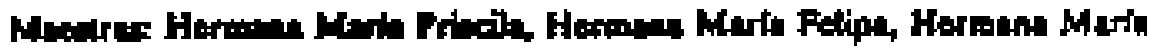

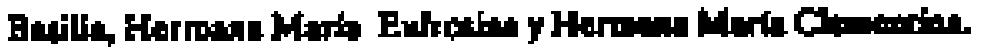

ESCUELA DE R1O SIDRA

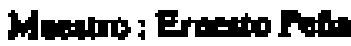

ESCUEL_A DE RIO AZUCAR:

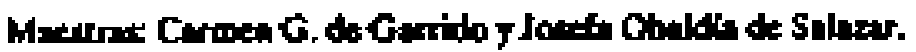

ESCUELA DE RKO THGRE-

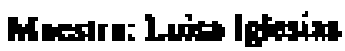

ESCUELA DE PUERTO OAAIDHA:

Marsire Nucia Mass

ESCUELA DE USTUPO:

Maestrox Eduardo Fits

ESCUELA DE CARTt:

Mesorox Rodento PERez

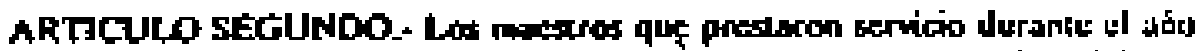
lediro pasado y cuyas nombres no aparcesa con el prosente dectio, quedea separados del servicio.

Cometaiquese y puliniques.

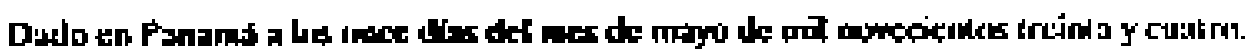

Trans. de la cop. mec.

V. RD. n. SZ1. 


\section{$\operatorname{CCXXIX}$}

Stinor

Narpanf,13 de Junio de 1934

Intendenie da la Comare de Son Blas.

El Porventr

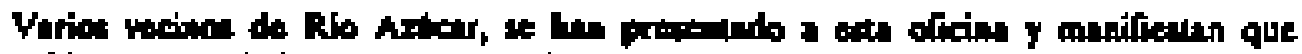

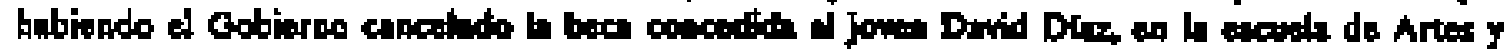

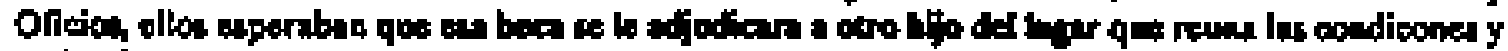

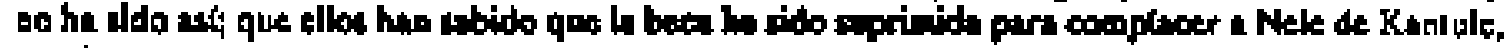

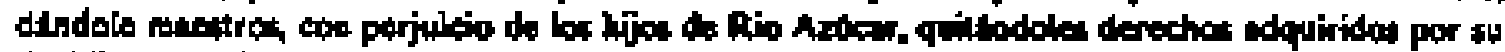

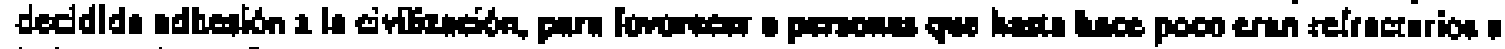

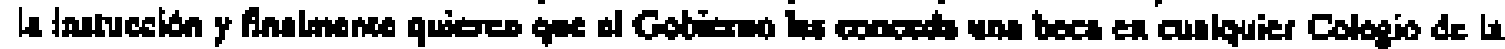
Conpital an hijo de Rlo Arases.

Do unted alto. y 4 .

M.G.Rkon

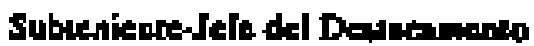

Trans. de la cop. mec.

V. RD, I. 524 . 
Selior

Setretnrto de Gobitrmo J Justletin.

PANAML

\section{Seber Sompintix}

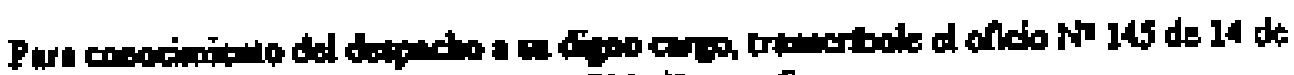

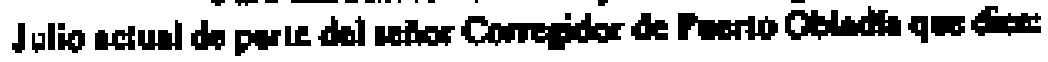

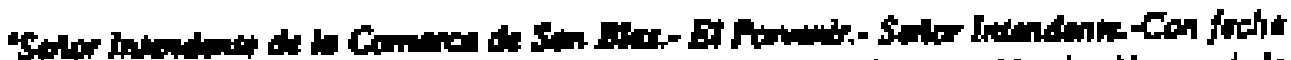

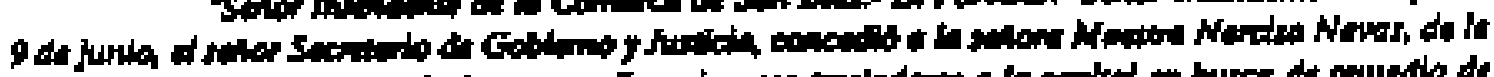

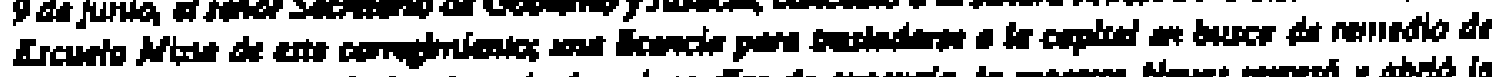

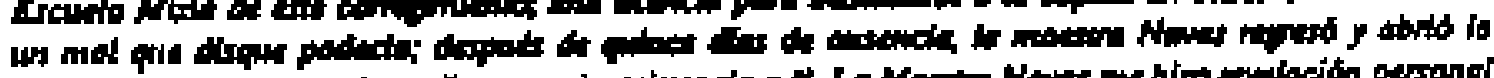

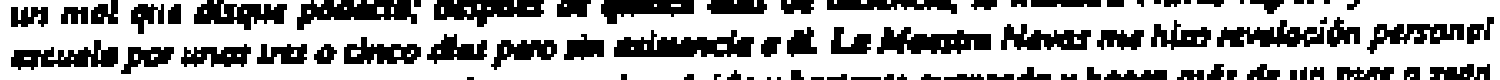

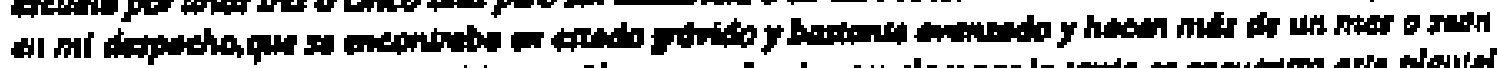

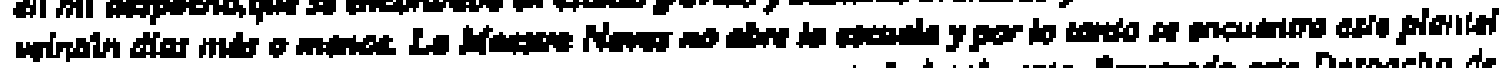

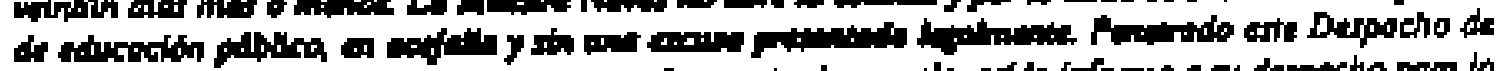

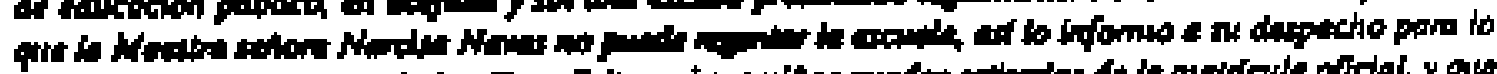

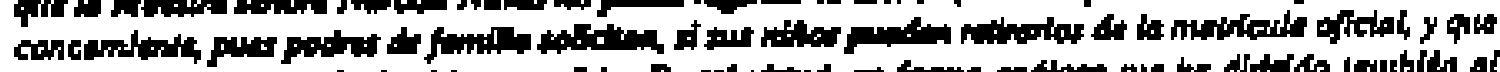

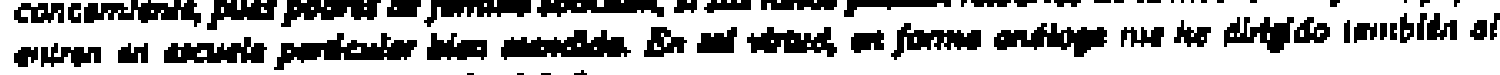

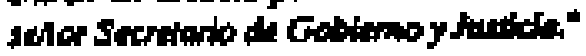

De UA mloy

Jofida F, Apelikern.

Intendente.

Trans. de la cop. mec.

v. RD, n. 525 . 
D Porvenir, Agosto 13 de 1934

Spinor

Secritario de Goliterno y Justicil

Panami

\section{Sollor Sendurice}

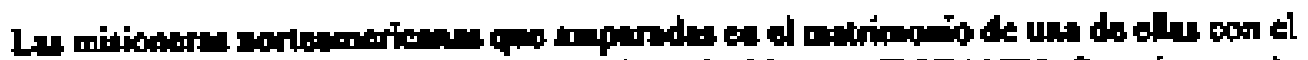

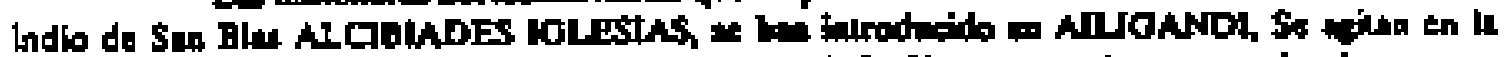

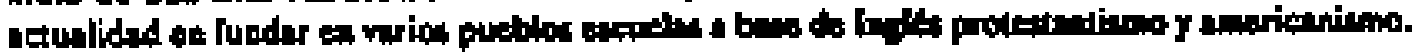

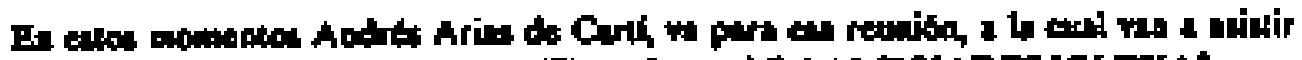

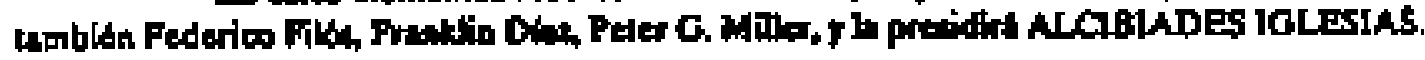

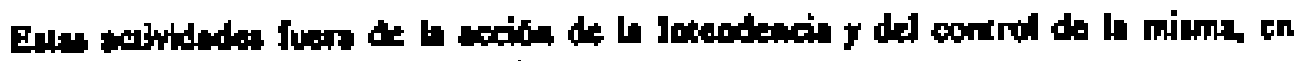

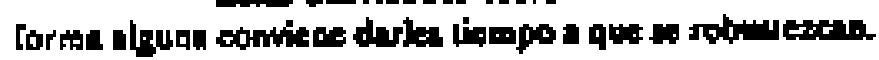

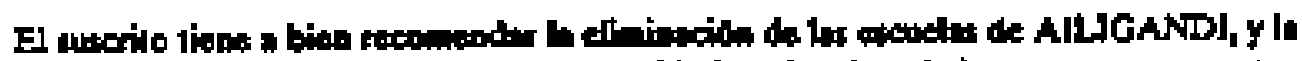

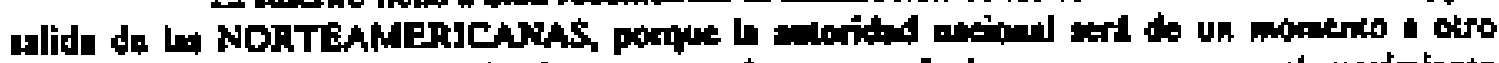

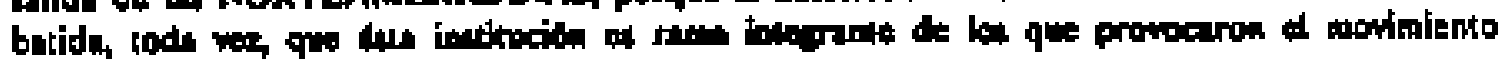

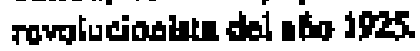

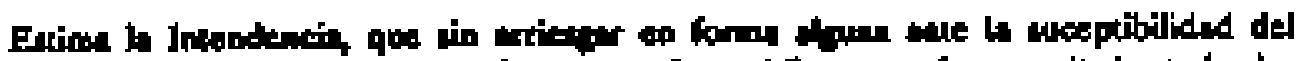

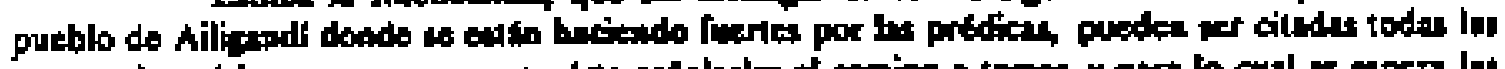

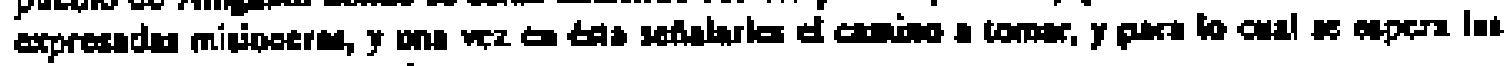
ordenes detl genor Secrelario.

De Ud atia y s.s.

Jullds B. Agdilkra

Trans. de la cop. mec.

V, RD, n. S26. 


\section{$\operatorname{ccx} \times \times I$}

El Perveidr, Ayosto 18 do 1934.

\section{Sthar}

\section{Setreturlo de Gobierae y Justicta.} Ed Porvenitr.

\section{Selor Secreiniax}

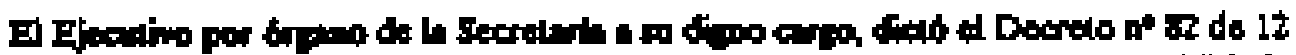

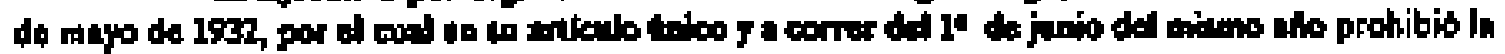

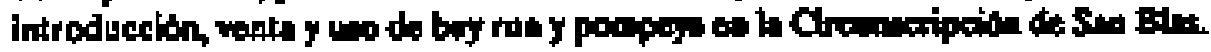

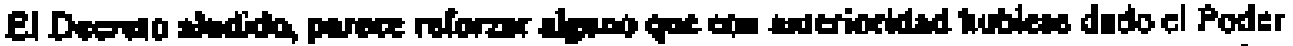

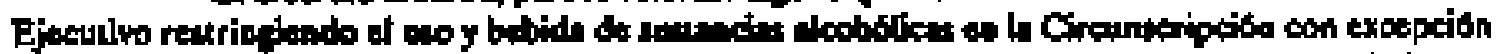

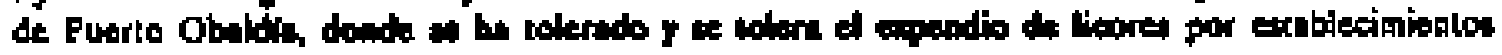
patentudos.

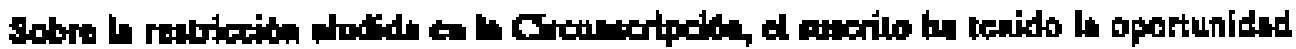

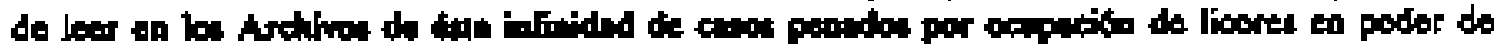

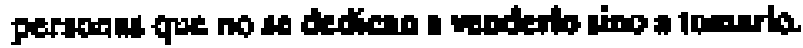

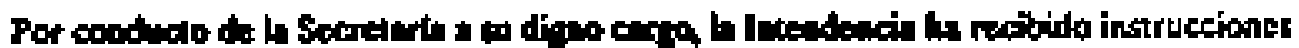

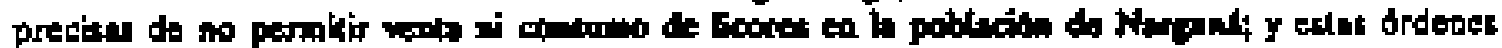

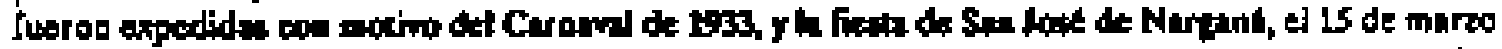

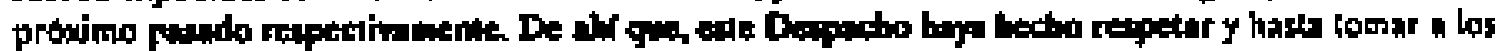

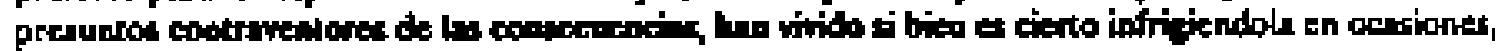

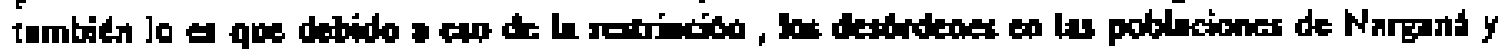
Curazon de Jescis, wo hap podido kener by

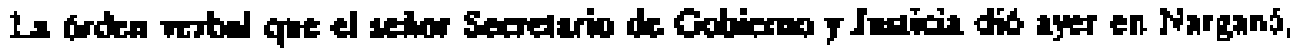

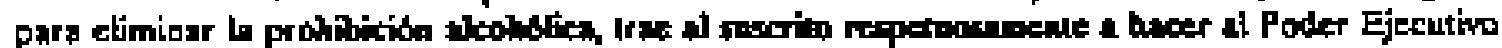

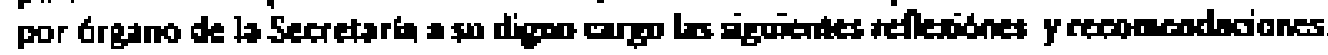

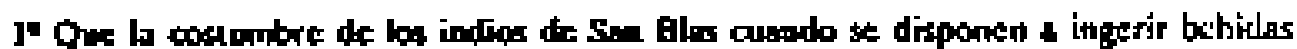

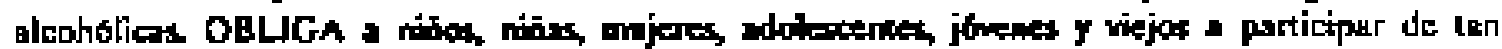

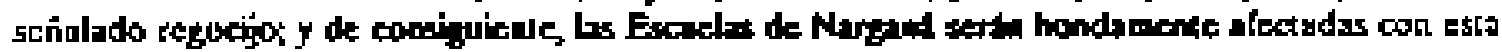

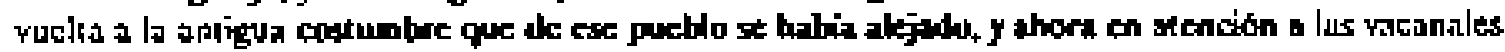

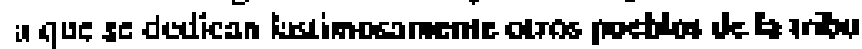

de San Blas donde mo ha silpigatablecido d prixcipio de Juloridzal

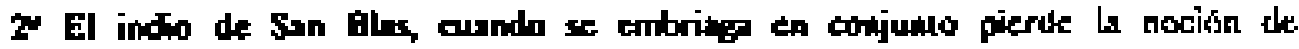

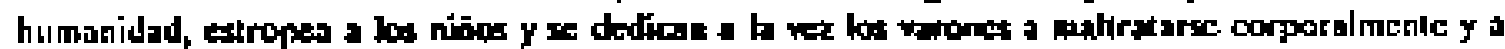

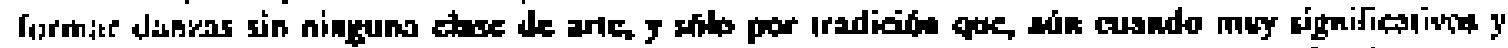

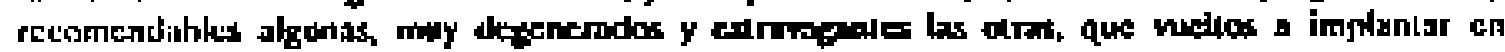

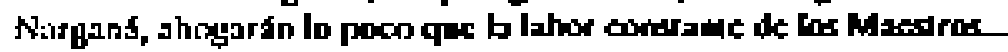

Trans. de la cop. mec. inc.

$$
\text { V. RD, n. 527. }
$$


Sr. D.

Nargant, 21- Vill- 1934.

Jullín Felipe Aguilere

Intendente de San Blus

\section{Sr, Loboodene:}

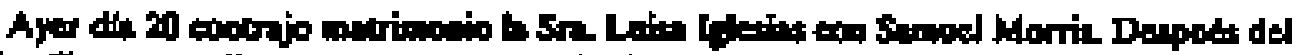

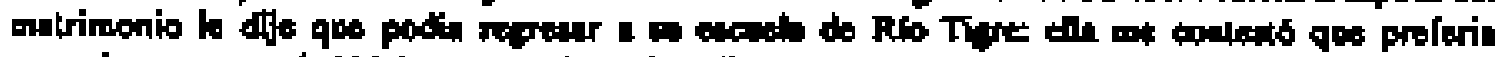

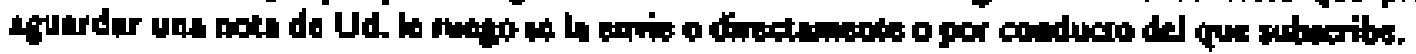

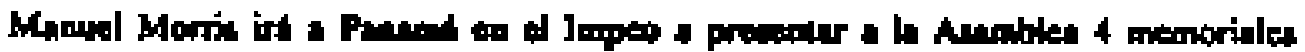

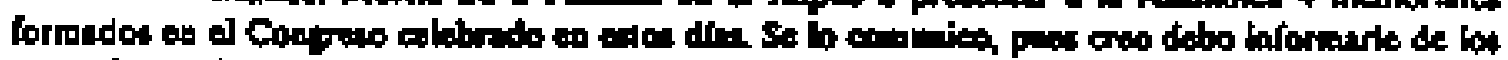

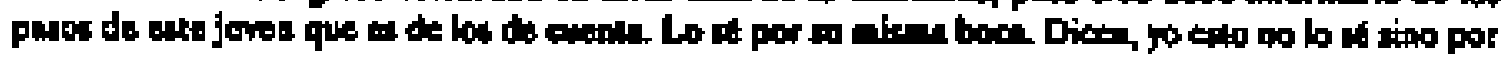

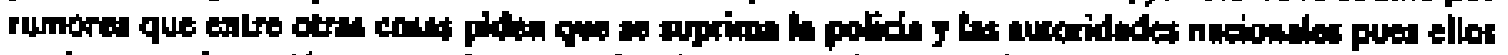

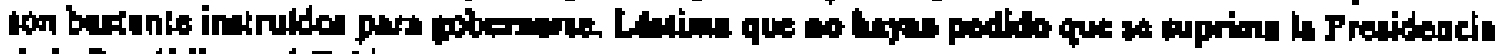
de la Repatbliea y el Gablacie.

Aleslo y segtro servidor.

Jow M, Baranguerat ems.

Director.

Trans. del orig. mec.

V. R D, a. 528 . 
Pta.

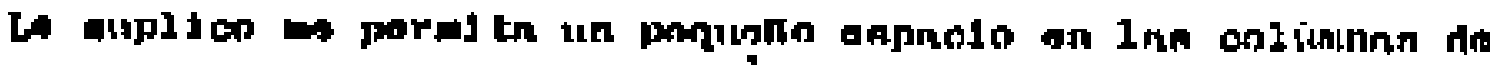

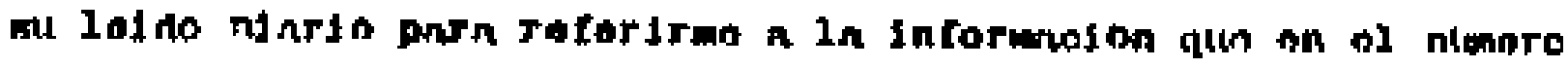

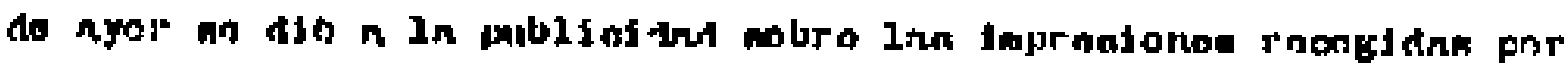

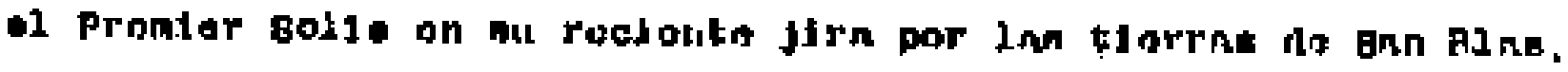

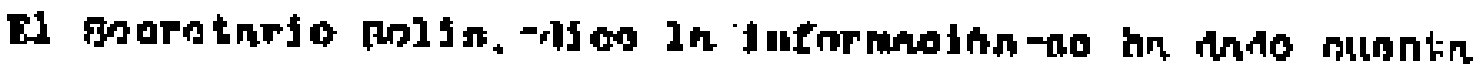

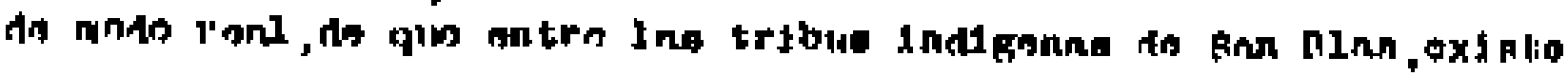

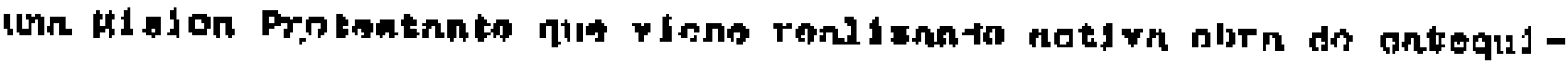

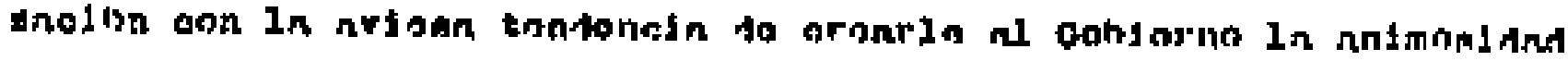

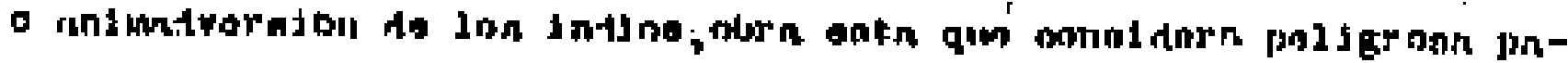

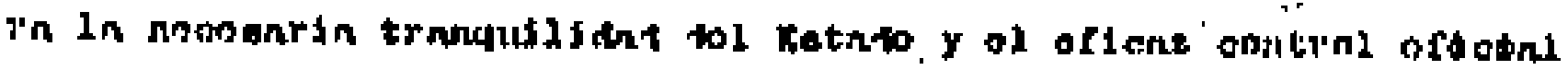

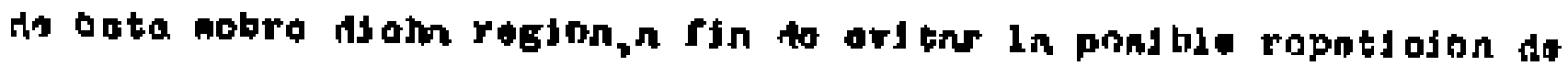

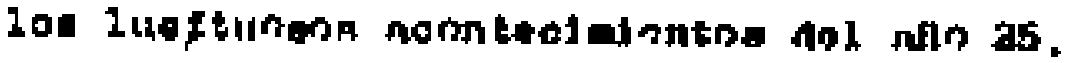

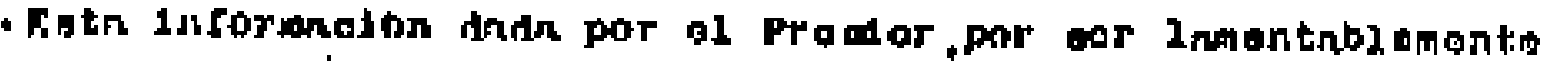

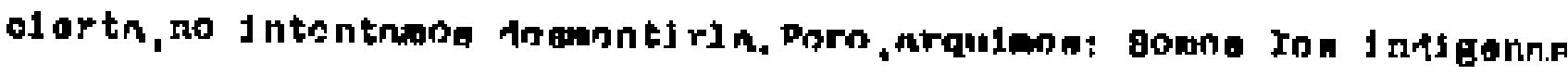

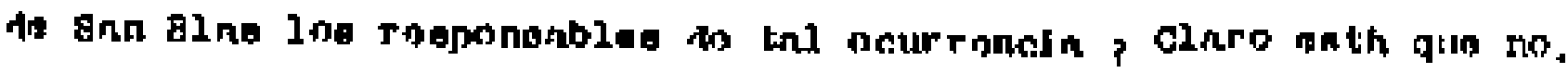

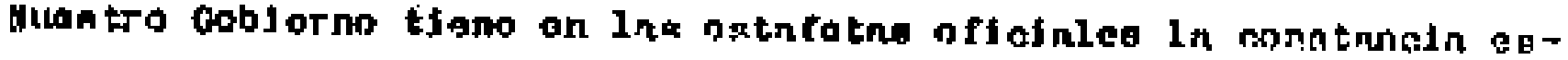

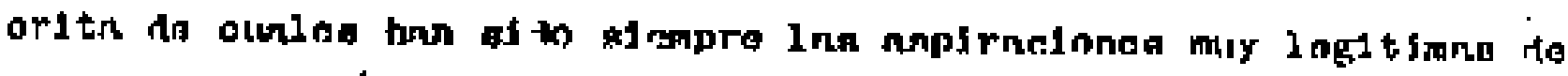

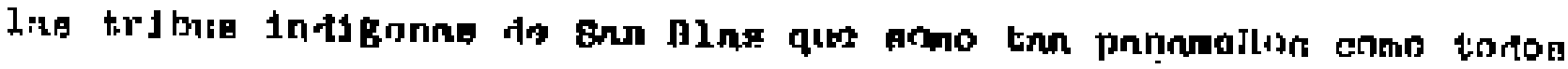

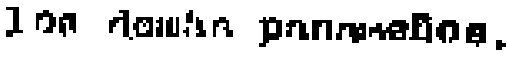

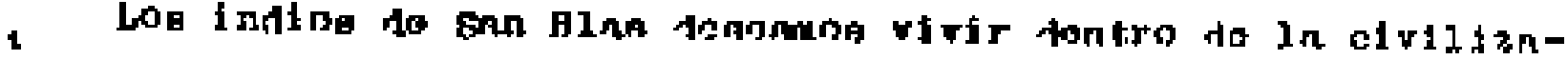

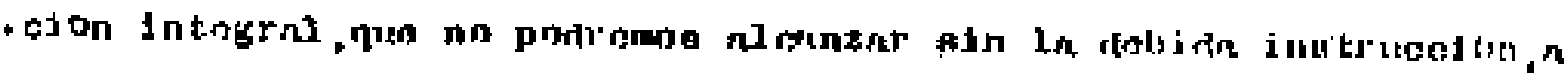

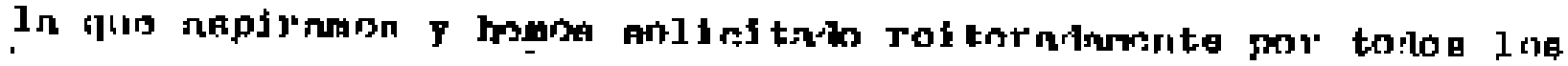
matiog.

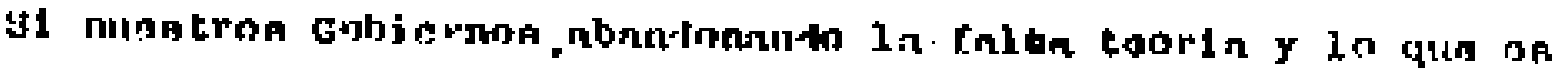

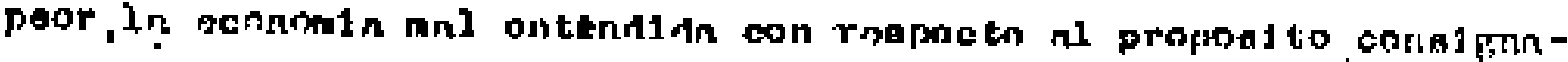



Geltor d1 roctor...

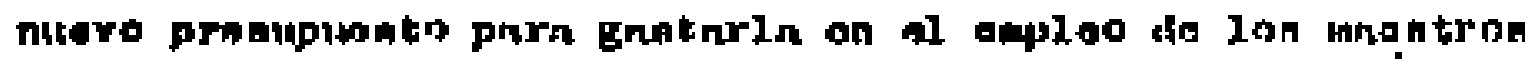

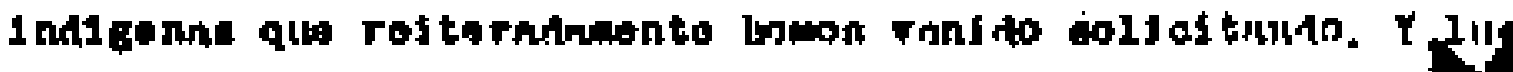

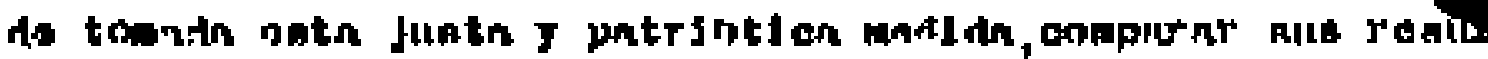
egnoten, at An 1934.

Pubon Phrse Knntuls.

Ginrool Modoln.

MT: :

$\operatorname{ten}$.

meriserp

จ

P!I

nining

$[8] \cdot \mathrm{res}$

IrT

טרו

ril

'so

ri

.

in 


\section{$\operatorname{ccx} \times x \mathrm{v}$}

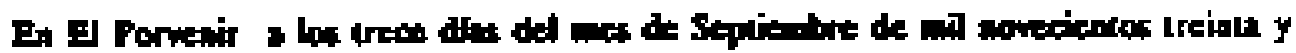

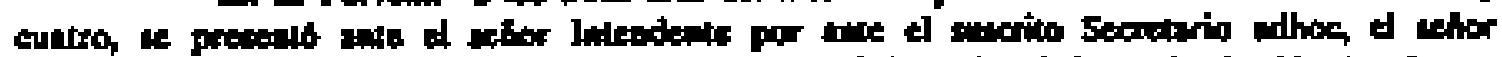

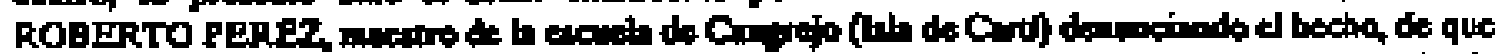

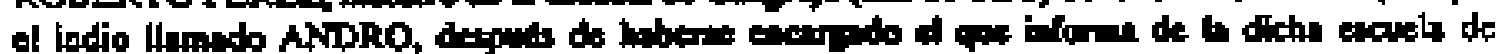

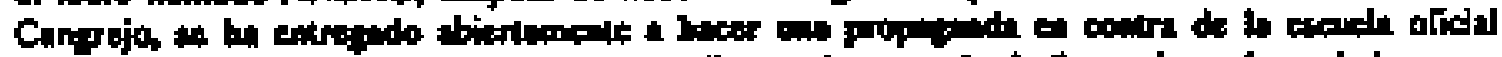

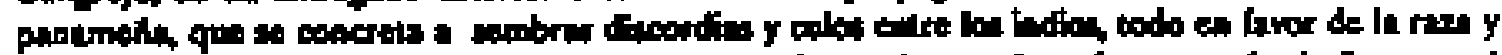

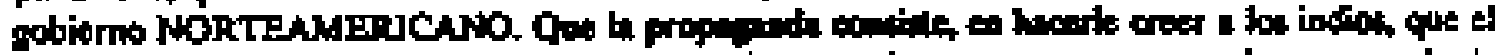

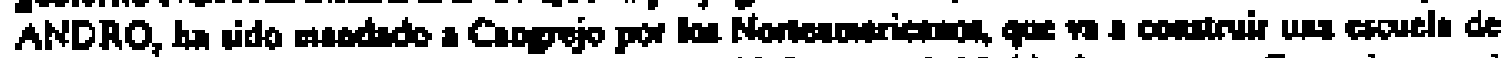

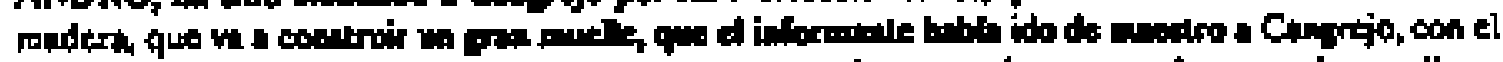

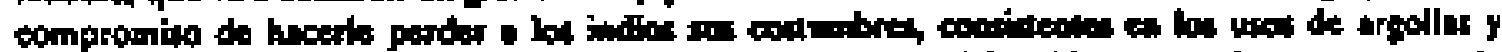

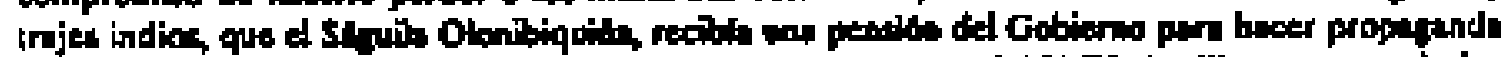

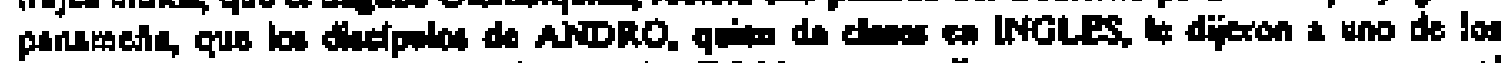

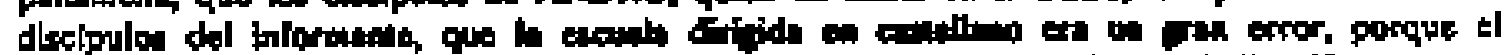

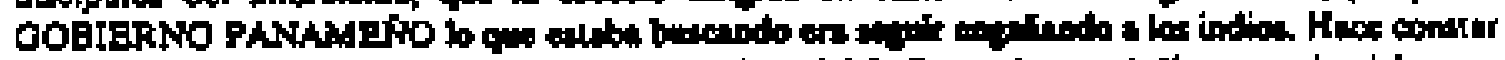

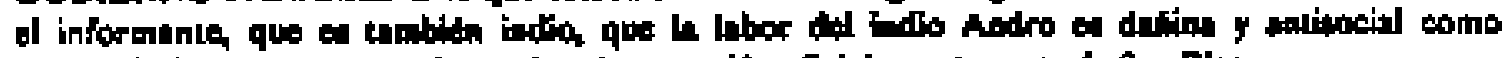

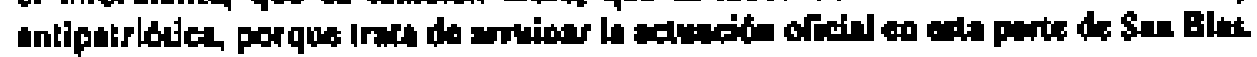

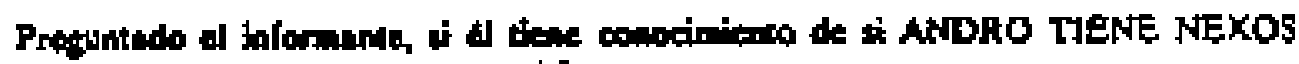
CON LAS ACTIVIDADESDESPLEGADAS FOR

Trans. del orig. nec. inc.

$$
\text { V. RD, D, 531. }
$$




\section{$\operatorname{CCXXX\vee I}$}

1 Oelubre 4

\section{Sefior}

Foderico Filds

Presente

Selor:

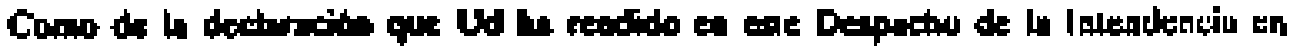

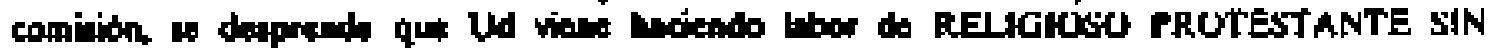
HAGER ILENADO LOS REQUETOS OUE EXIGE LA LEY 36 OE I9L2, EL SUSCRITU SE

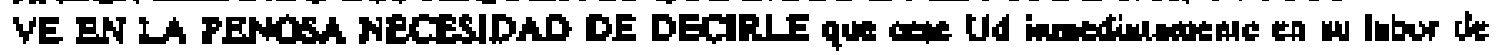

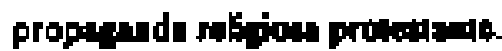

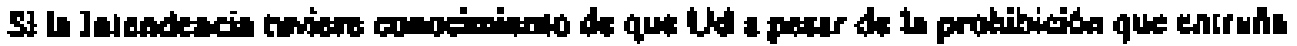

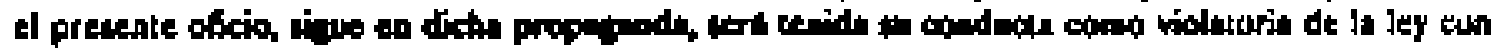
insilutencis.

De Ud nillo. th

Iullin F. Alptithe

Isutendence

Trans. de la cop. mec.

v. RD, n. 532 . 


\section{$\operatorname{CCXXX}$ I I}

6 Oetubres 4.

Señor

Secrelarlo de Gobiterao y Justicit,

PANAMA.

\section{Sefier Secreanio:}

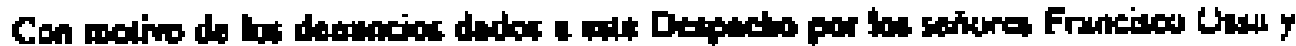

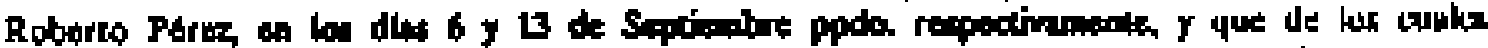

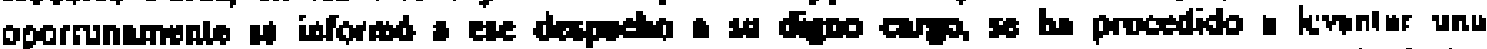

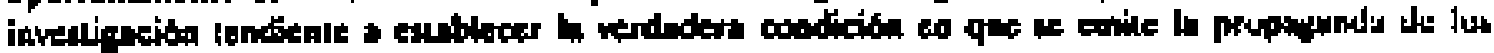

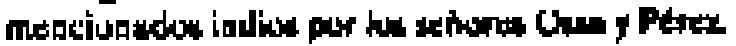

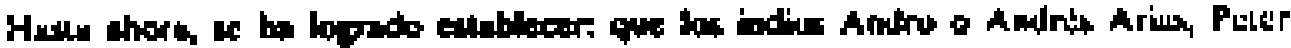

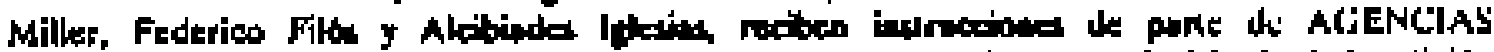

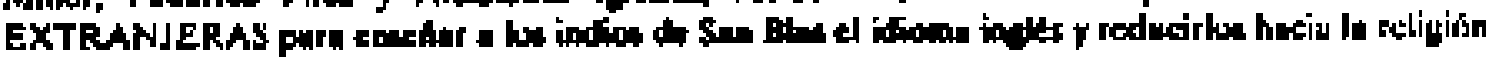
protesinnte.

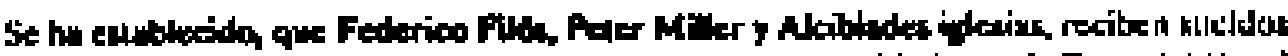

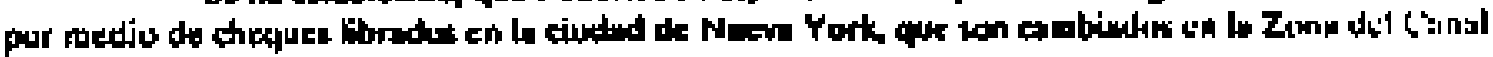

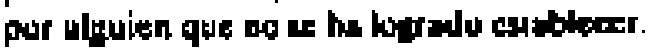

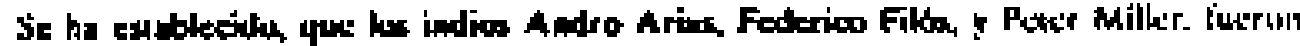

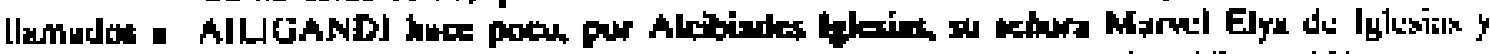

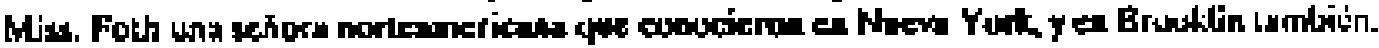

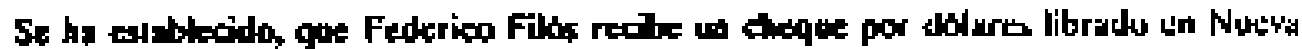
York por Mr. J. Peler Buemio.

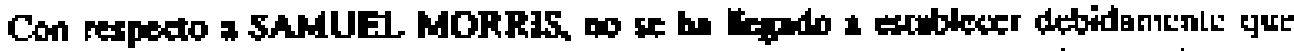

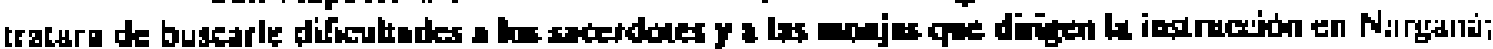

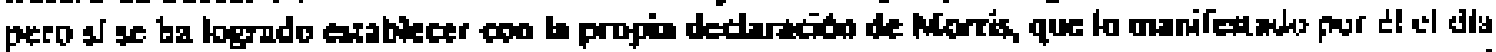

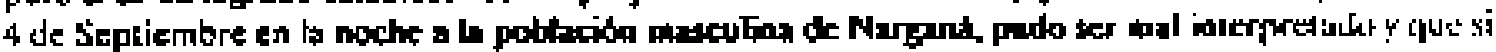

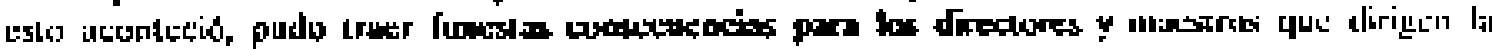

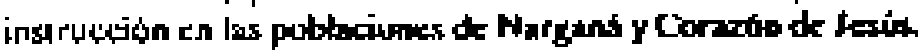

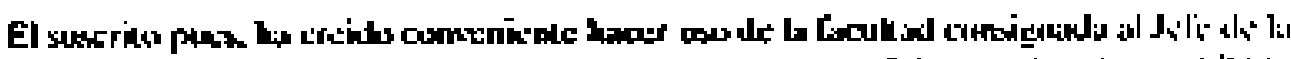

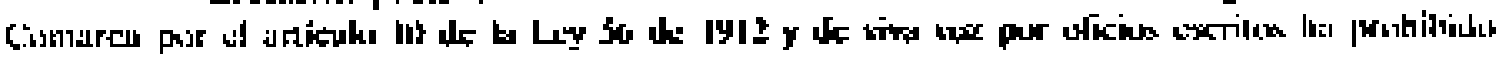

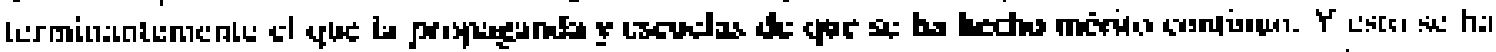

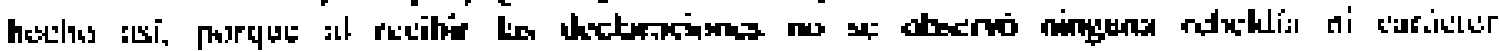

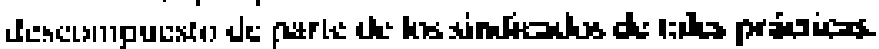

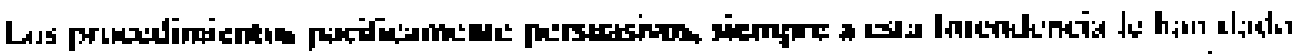

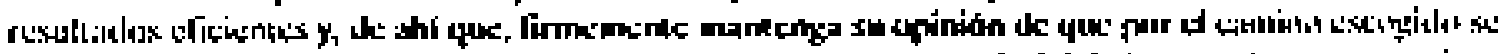

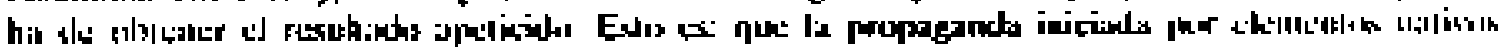

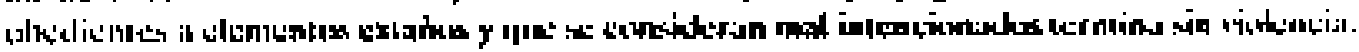

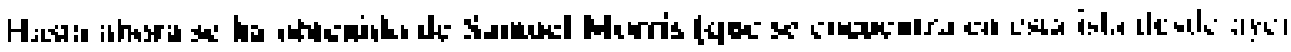

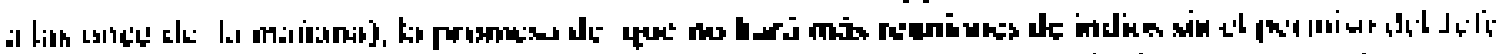

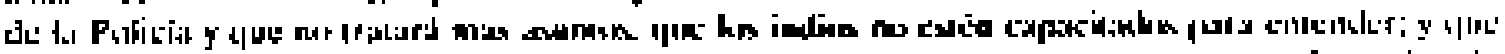

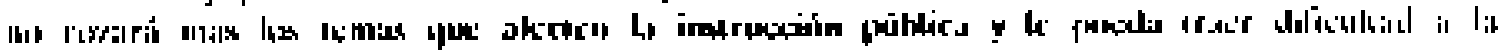

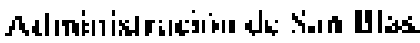




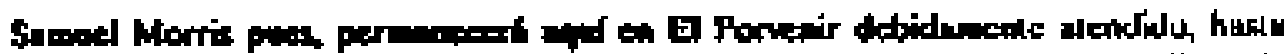

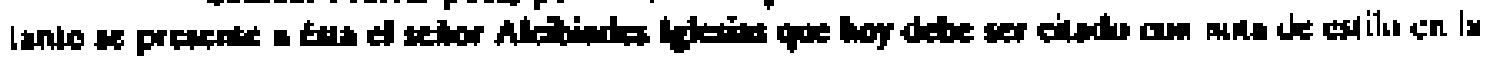
poblacido de AllJGavDl.

De Ud efedurents.

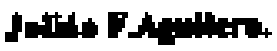

Inendewe.

Trans. de la cop. mec.

$\checkmark . R D, \pi .534$. 


\section{$\operatorname{CCXXXYIII}$}

I3 Oclubre 4.

\section{Sehor}

Atdbiades bflesias.

\section{PRESRNTR.}

\section{Schort:}

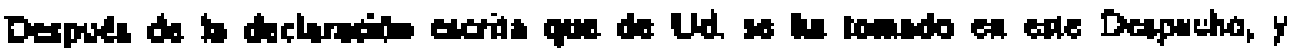

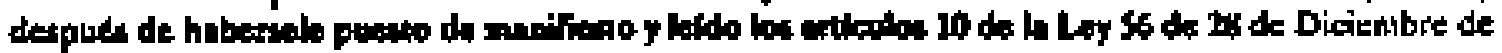

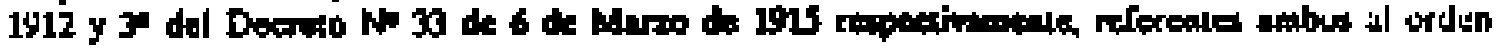

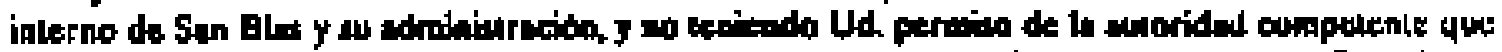

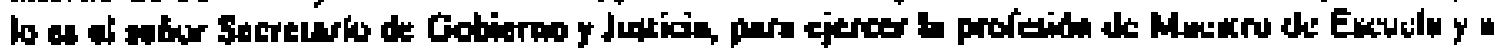

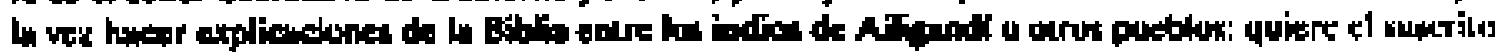

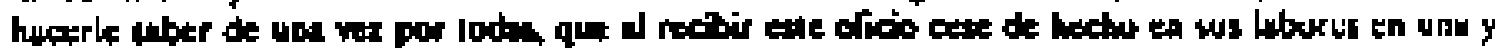

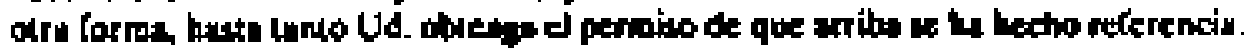

Do Ud. sta. y.1.

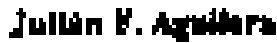

Jutendenito.

Trans. de la cop. mec.

V. R B, n. 536 . 


\section{$\operatorname{ccx} \times \mathbf{I X}$}

Sefor Sacrapario de Cobierno y Justicta.

\section{PANAMA*}

\section{Seinor Sefreduix}

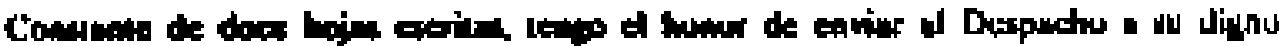

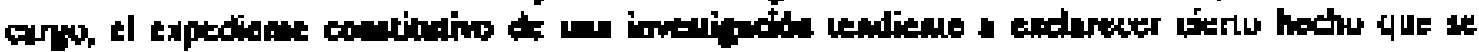

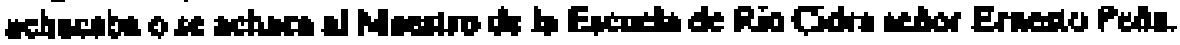

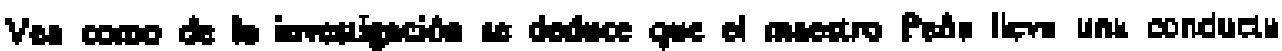

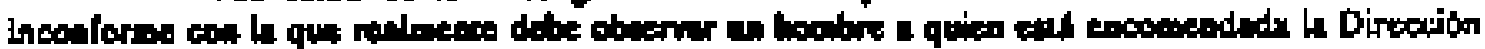

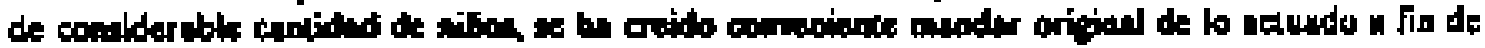

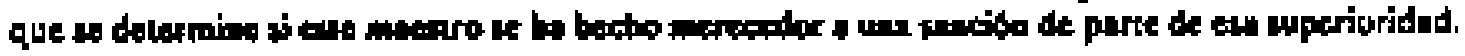

De Ud. ata y 4 .

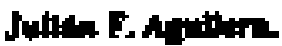

Jatepolante.

Trans. de la cop. nucc.

V. RD, n+ 538 . 


\section{$\operatorname{CCX}_{L}$}

V-30

Sethor

16 Noviembre 4

\section{Secretario de Gobiemo y Jualici.}

Panamd

\section{Seter Sotredurite.}

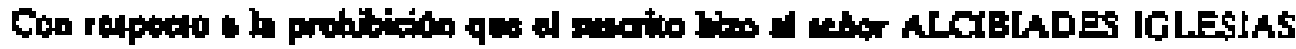

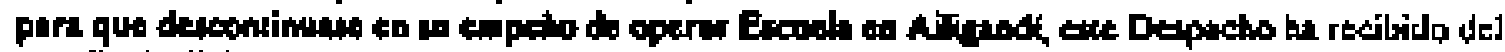

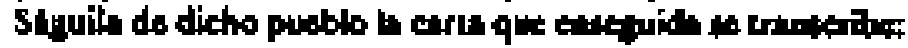

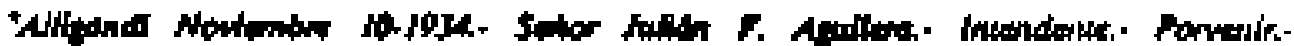

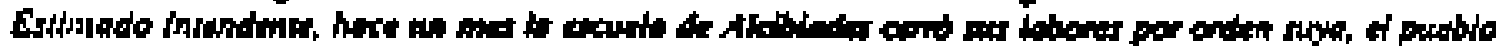

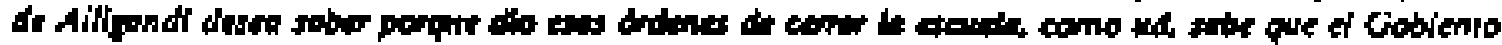

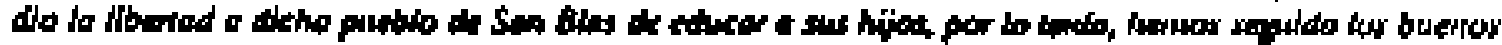

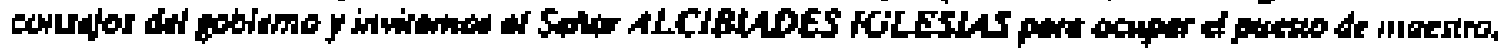

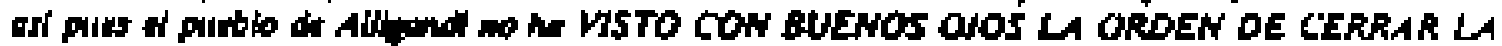

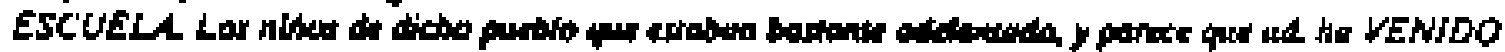
A PERDER TODA SWIENTE DEL PROGRESO Y LA EOUCACION OE LOS HUOS. GWOT

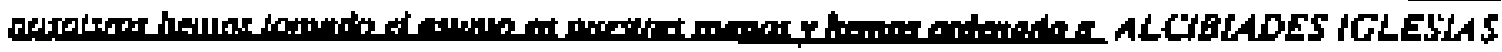

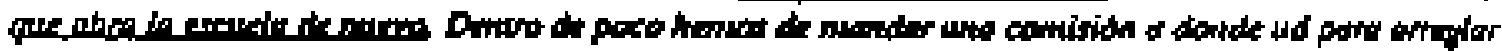

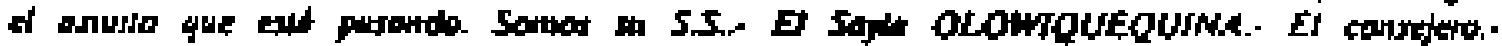
ICUANITIPIPI:

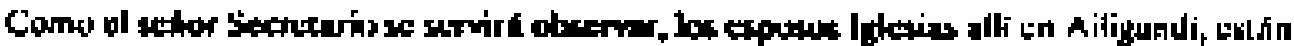

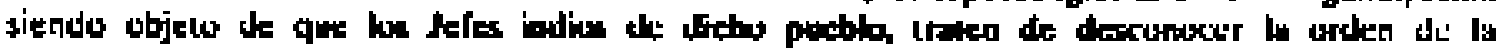

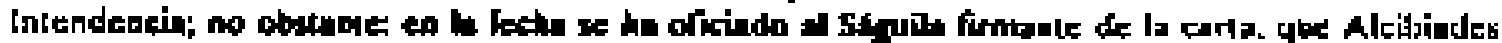

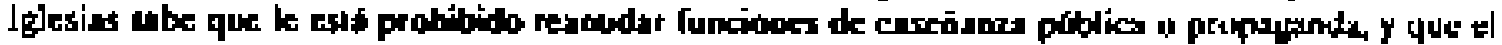

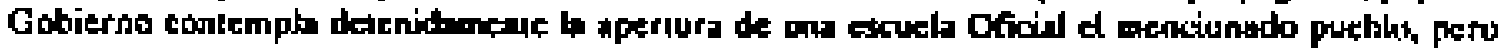

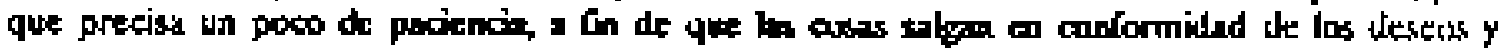
nectesidad de los edluciendos de alli.

De Ud atenamente.

Julist F. Agpillers

Intende'sle

Trans. de lan cop. inec.

V.R D, n+539. 


\section{Selior}

OLOMQUZQUIẌA

Sutoilin do Allifondt

Niltegndf

\section{Sefor scipite}

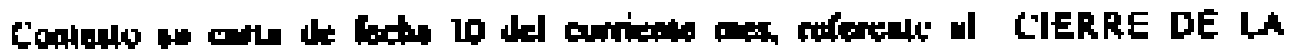
ESCUELA OE ESE PUEBLO.

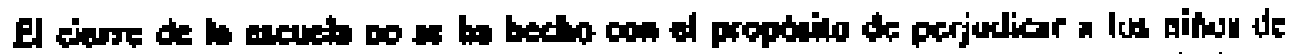

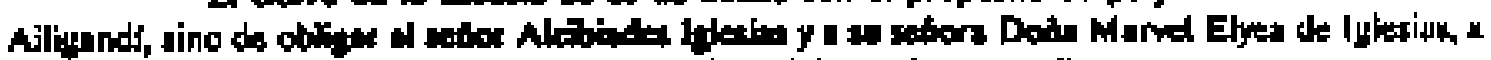

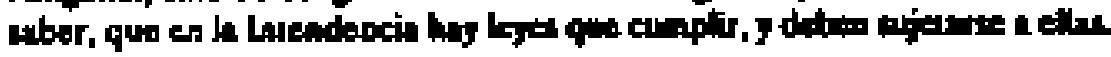

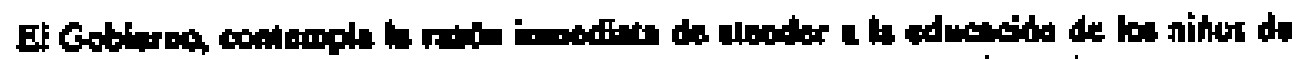

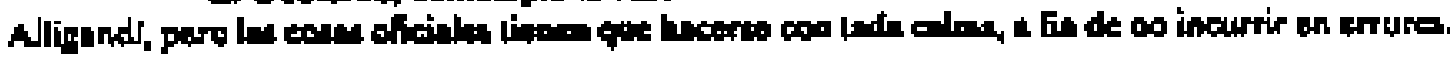

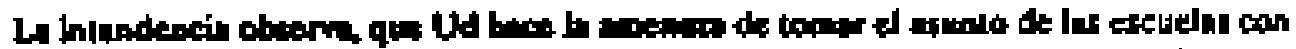

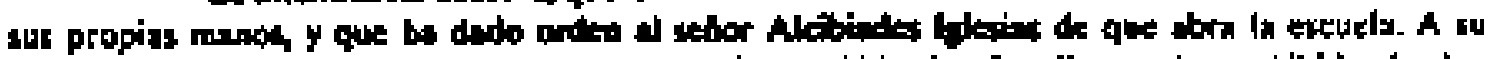

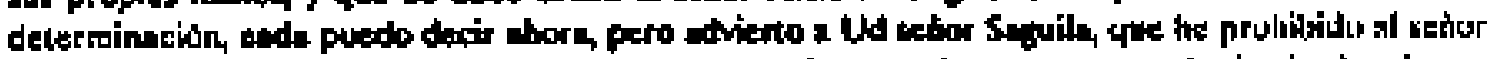

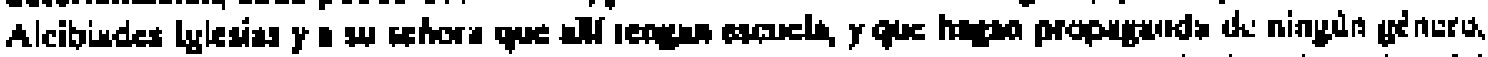

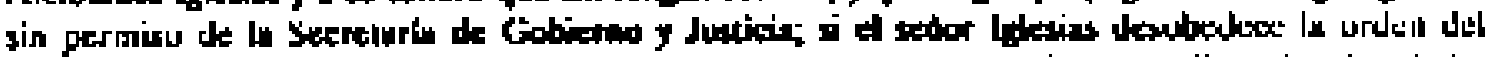

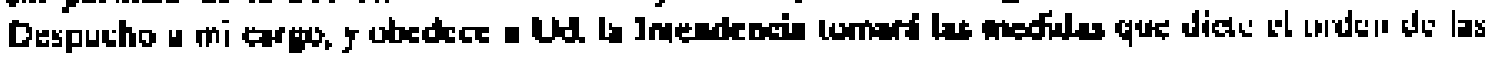
Leycus.

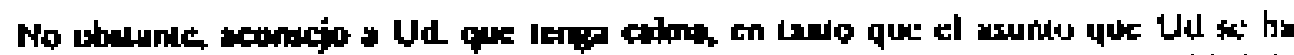

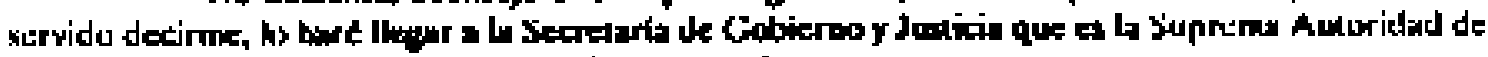
Ч४

De Uư alchtaminur.

Julión F'. Atginers

tnesndent:

Trans. de la cop. mec.

V. BD, n. S40. 


\section{I}

Sefor

Secretario da Gobierno y Justidia.

PNNAMA.

\section{Sofion Socrelariar}

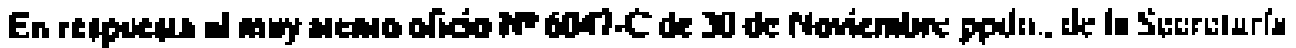

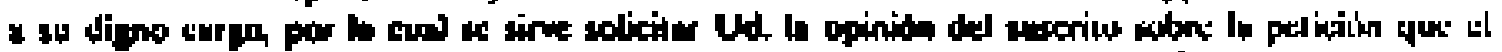

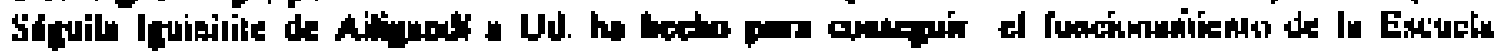

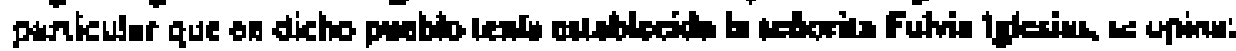

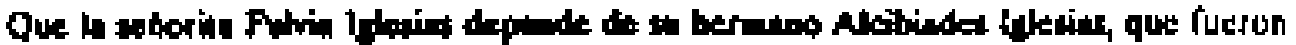

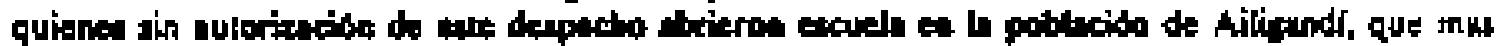

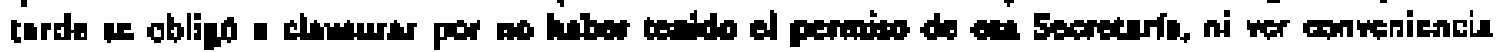

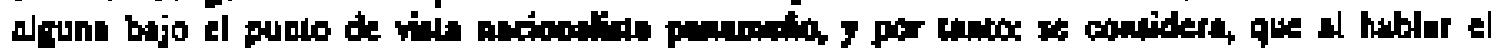

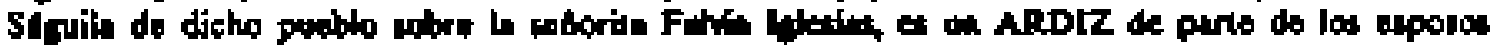

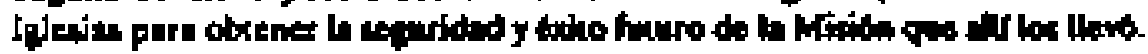

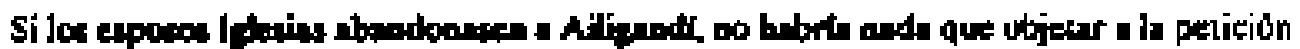

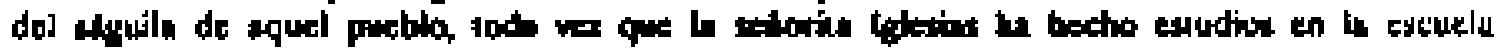

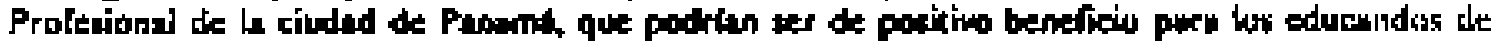
Ajliyendi.

No es dents hacer conatar, que b Intedencia he pedida que la excueln de Ailjgentit

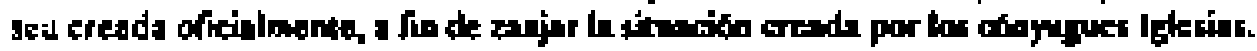

De Ud etentuneate.

Jultiłn F. Agolikets.

J nie ndende

Trans. de la copl atec.

V.RD, n, 543. 
Ailigand $10-12-34$

\section{Sefior \\ Julkin Asullerm \\ Intendence \\ Porvanle}

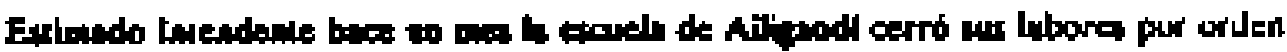

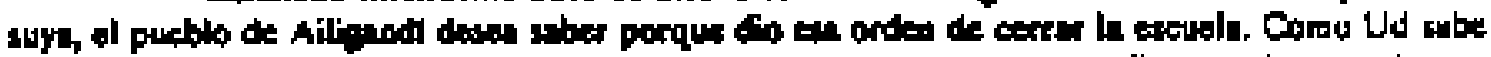

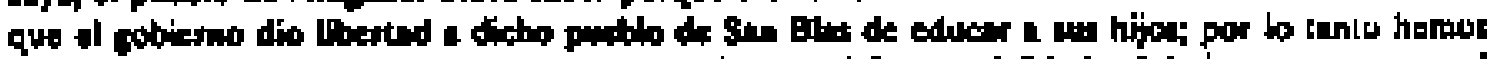

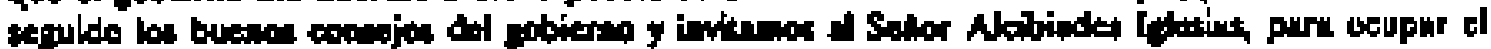

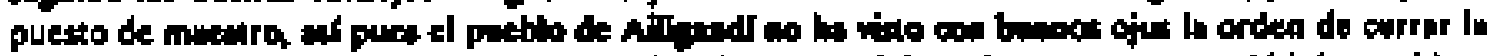

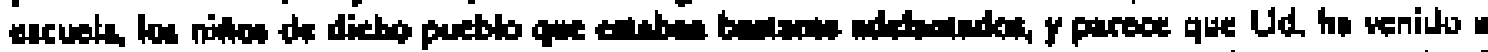

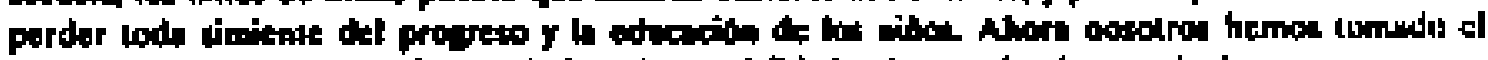

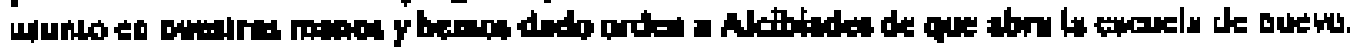

Trans. def orig; mec. inc.'

$$
\text { V. R D, n. } 544 \text {. }
$$




\section{CCXLIV}

21 Diciensbre

4

Siffor

Sieratario de Gobiermo y Justiein

Pannmí.

\section{Sehor Secreturio:}

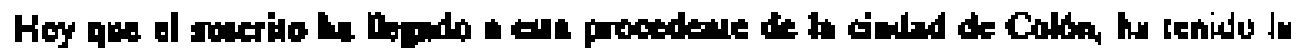

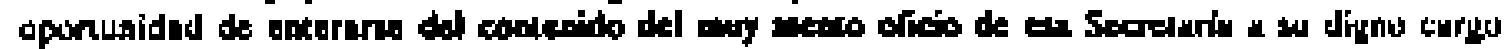

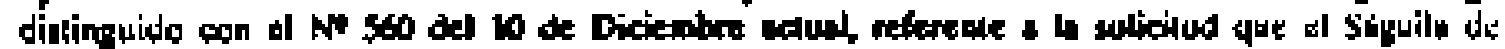

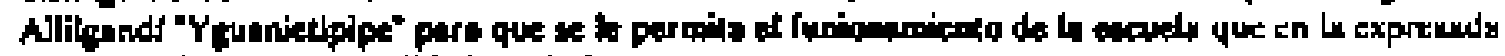

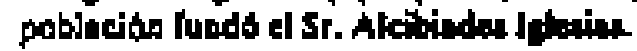

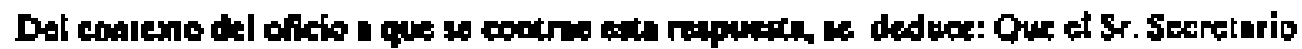

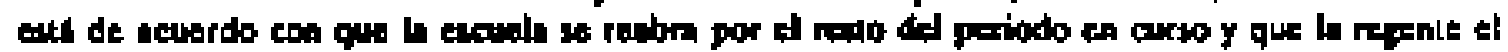

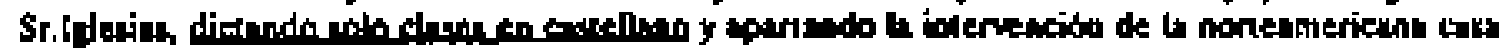
an Aleibindes toptein.

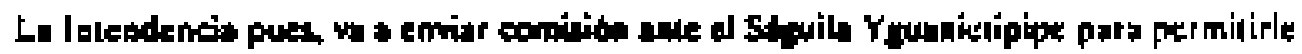

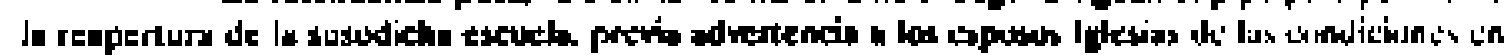

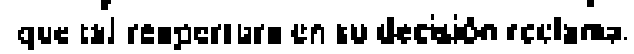

Sidy du Ud, muy alin y ax

Jullán R. Azuilers

Intendenie.

Trans, de la cop. niec.

v. RD, n. 545 . 


\section{$\operatorname{CCXLV}$}

R-6 Y $T$

1934 ?

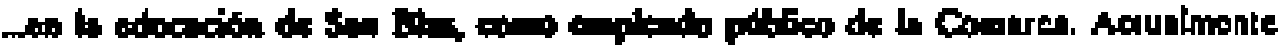

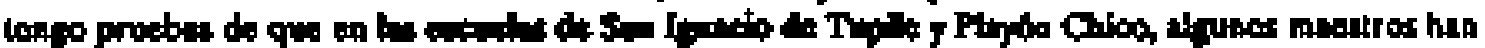

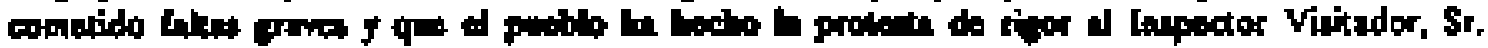

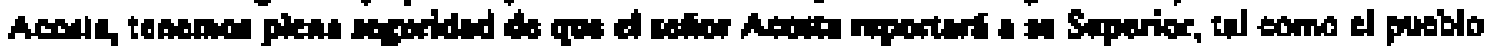

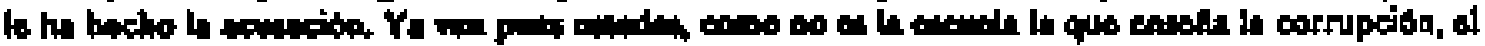

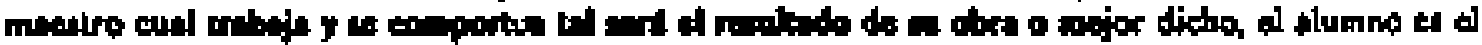

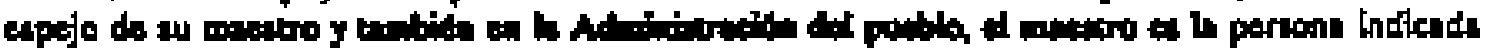

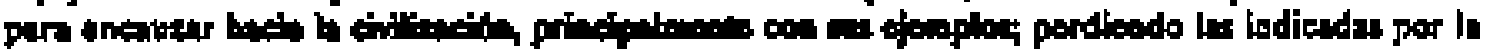

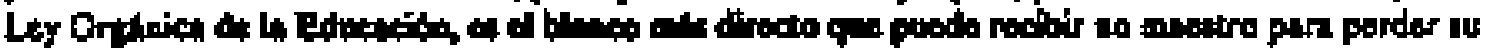

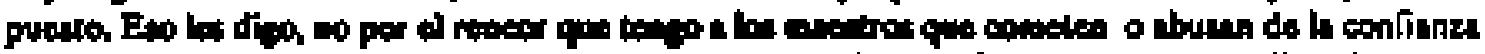

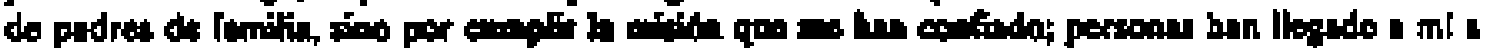

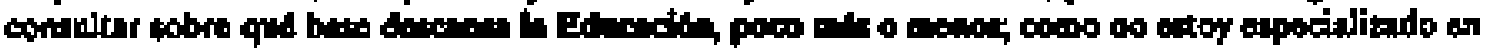

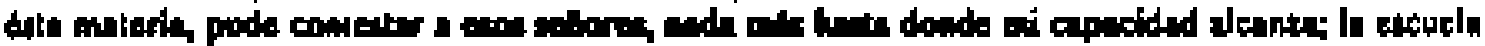

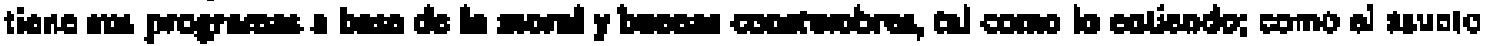

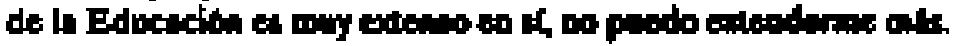

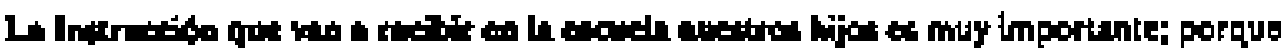

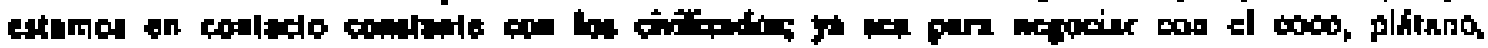

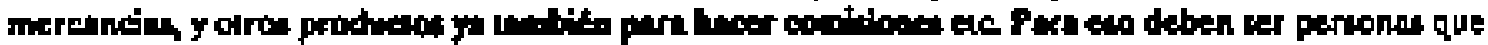

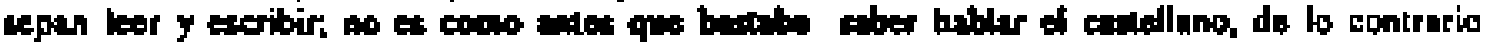

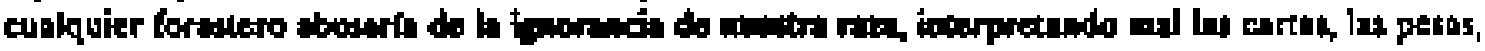

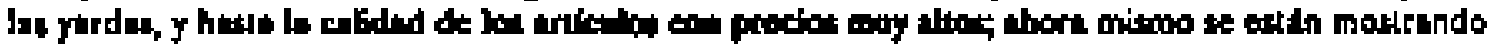

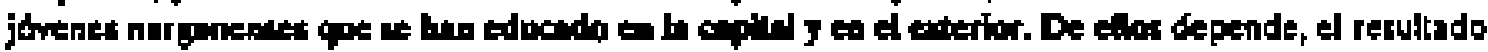

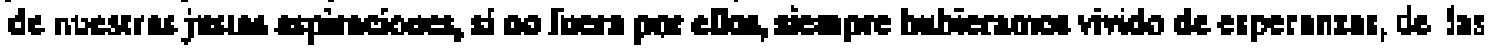

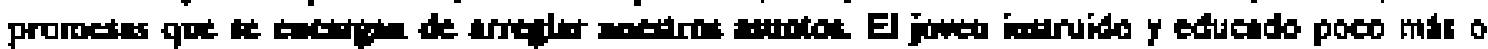

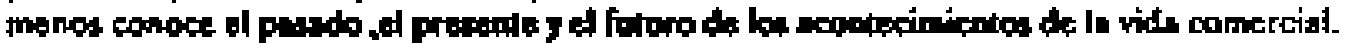

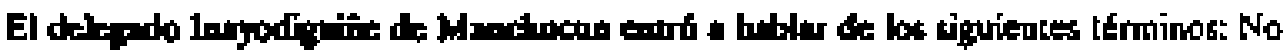

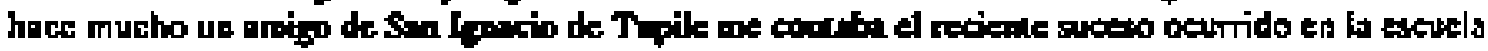

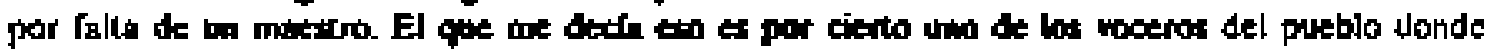

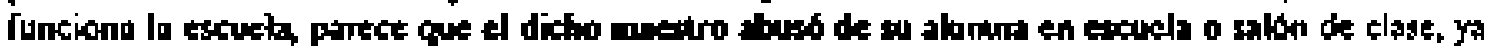

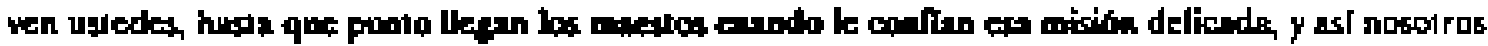

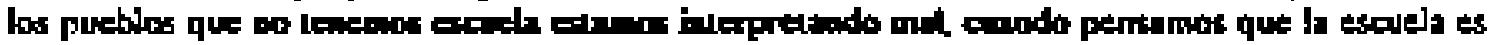

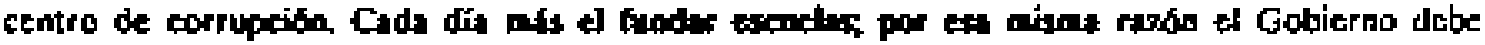

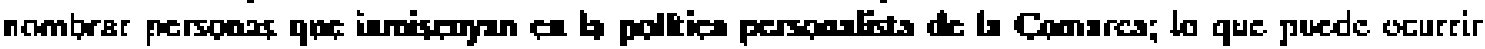

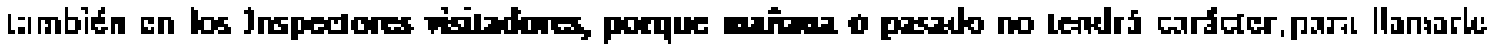

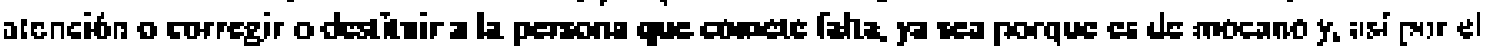

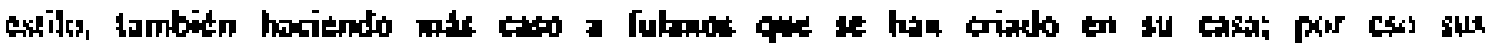

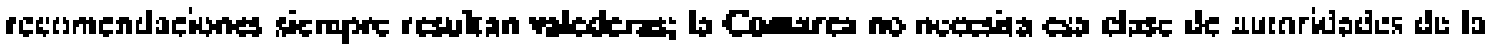

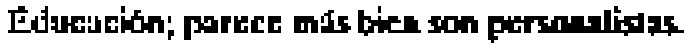

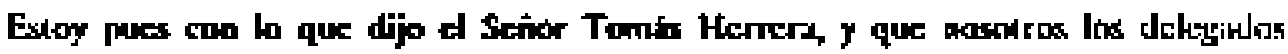

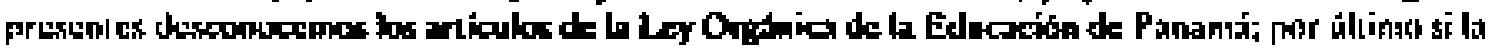

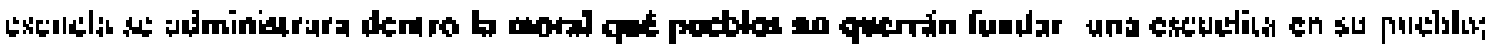

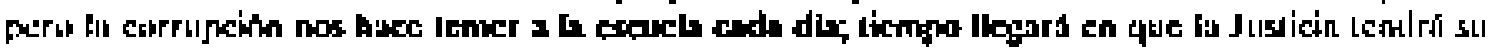

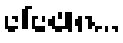

Trans. de la cop. mec. inc.

$$
v, R D, n+546 \text {. }
$$




\section{I}

21 de Junio de 1935

\section{Sthor}

Nele de Kaniolo

USTUPU. Son Blas

Sutor

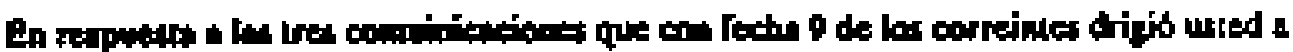

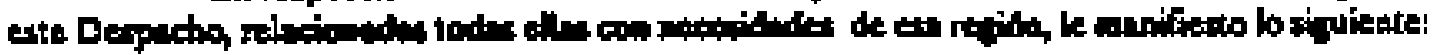

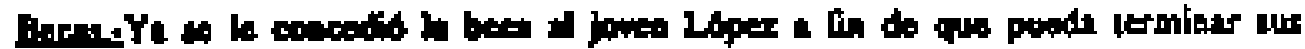

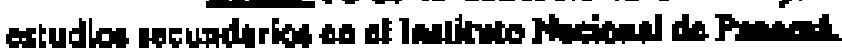

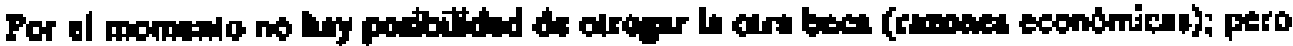

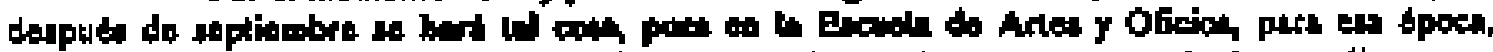

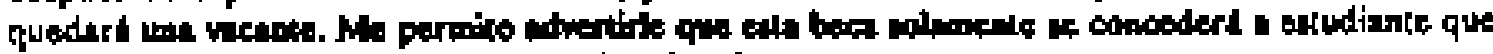

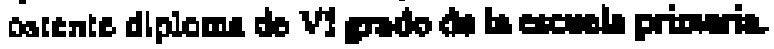

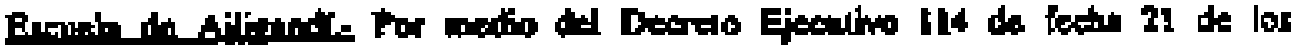

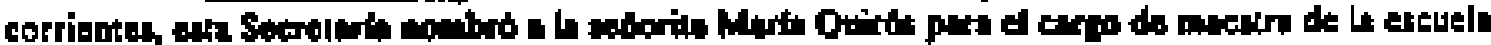

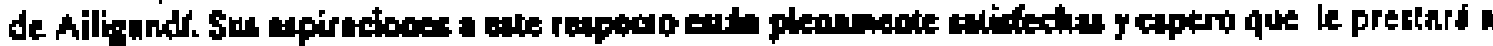

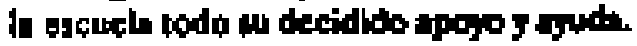

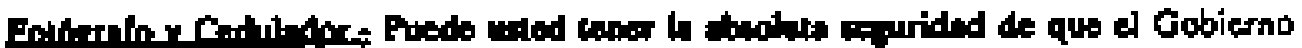

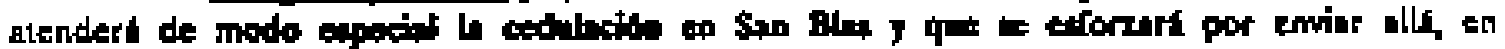

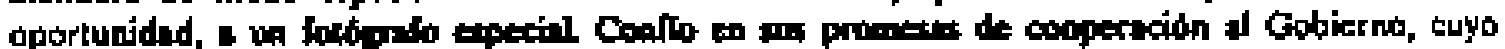

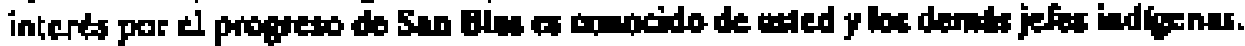

De nated alestrente.

Golileo Solis.

Trans. de la cop. mec.

Y. RD, n. 552 . 


\section{CCXLVII}

R-21

B Julio 5.

Sefior

Director de les Escuelas de Sin Bans.

NARGANA-

\section{Sellor Dirocidor:}

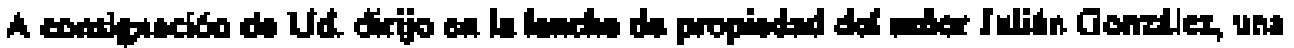

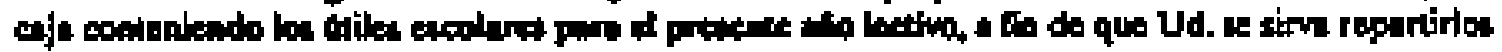

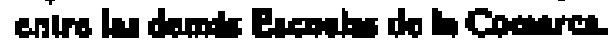

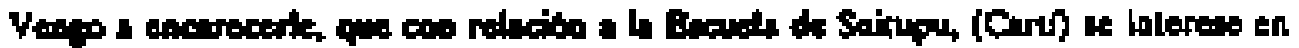

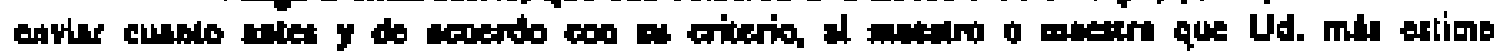

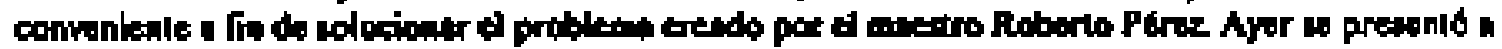

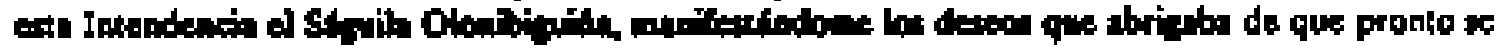

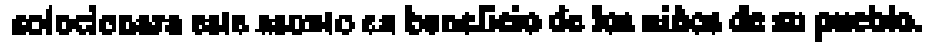

Da Ud alis yas

Ruenrido Carka.

Inoodeale.

Trans. del orig. mec.

V. RD, n. $5 \mathbf{5 3}$. 
Nún. 430

10. Julio 5 .

\author{
Sefior \\ Sickringrio de Goblemo y Justidin. \\ PANAMA.
}

Seltor Secretarior.

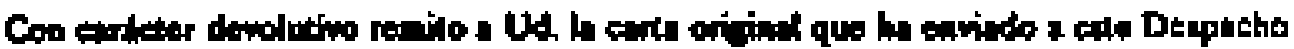

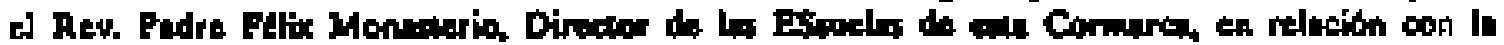

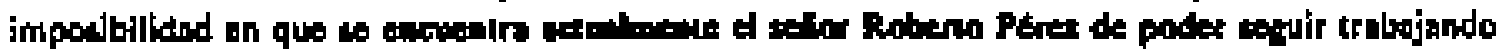
como Mreuro do Everoln to este hap.

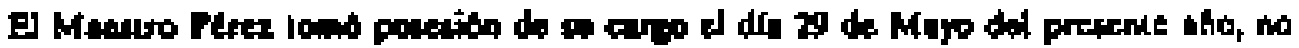

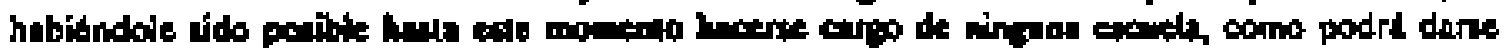

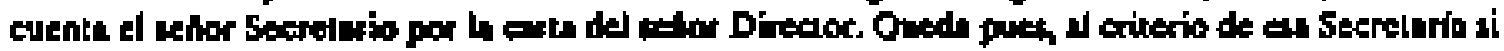

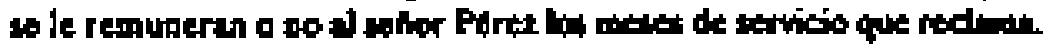

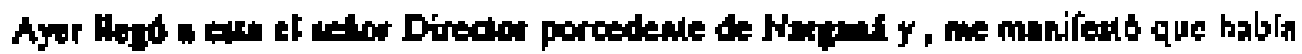

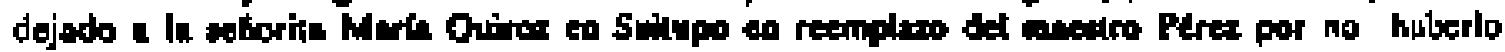

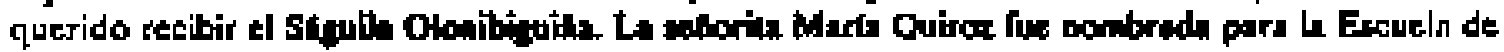

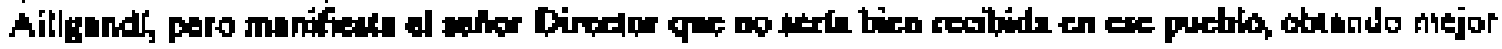

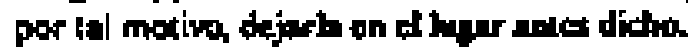

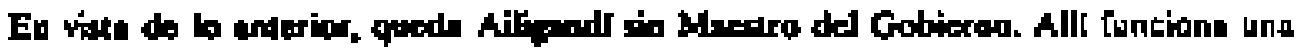

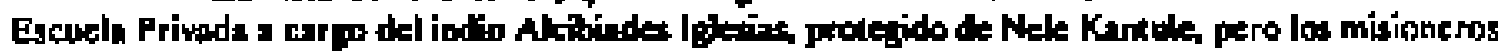

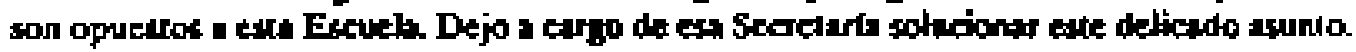

Le acompsino deats ung earla que he recibido tankifo del Ssguill Neke Kantule,

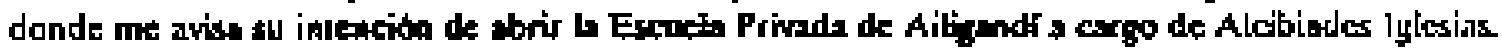

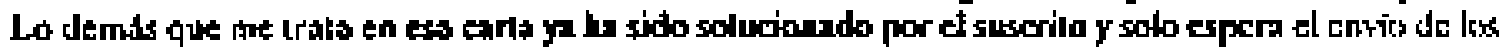
mil pitss de mindert para el poso de la Escuela.

De US. alta-y \&s.

Trans. Je la coo. niec.

V. RD, M. 554 . 


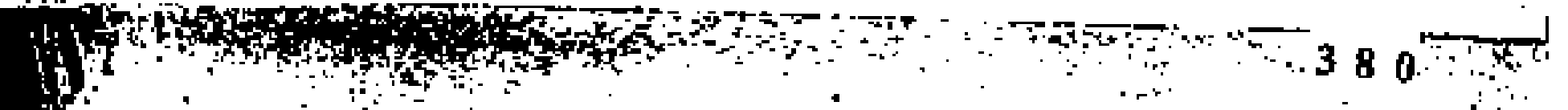

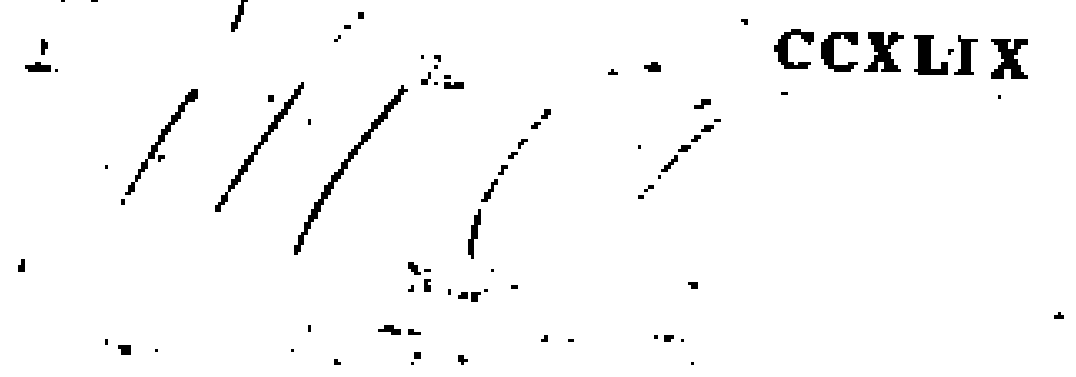

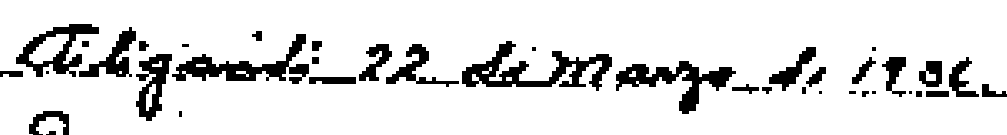
5.94

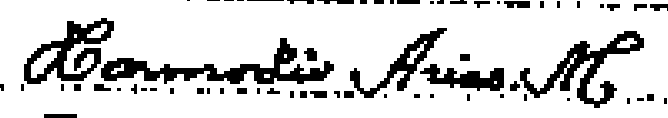

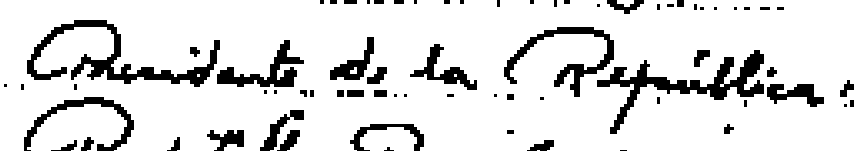

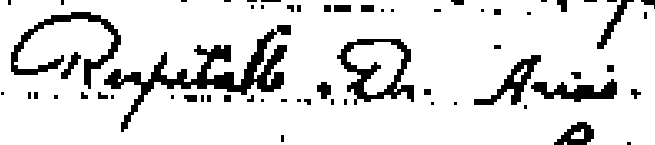

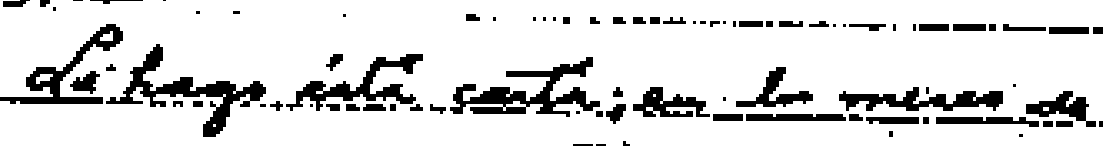

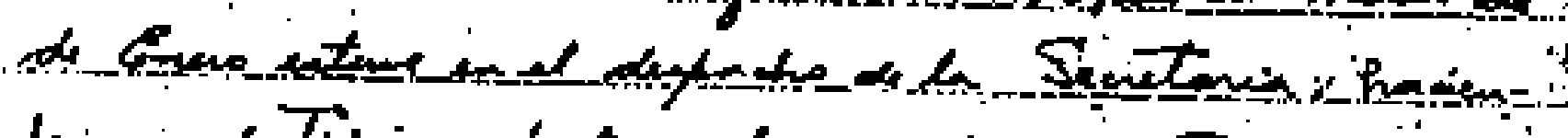

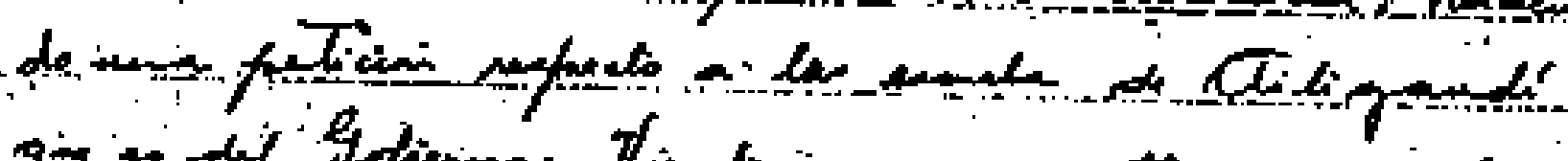

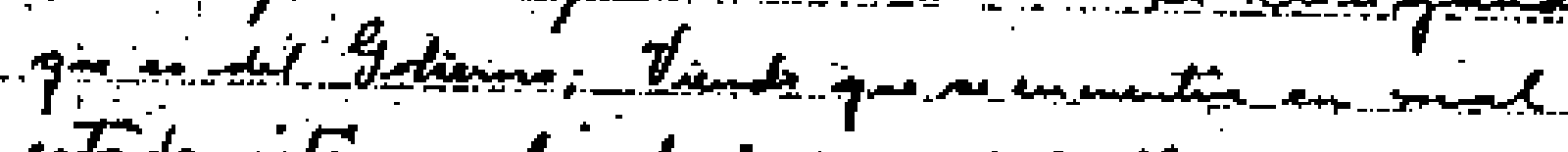

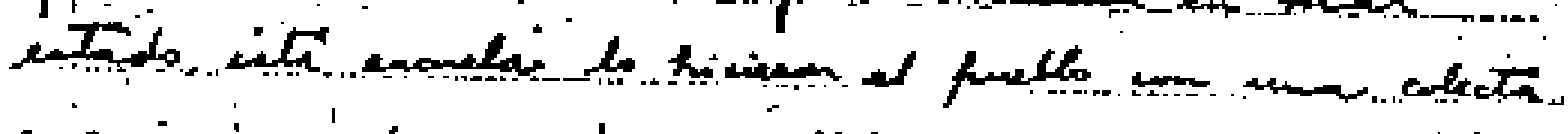

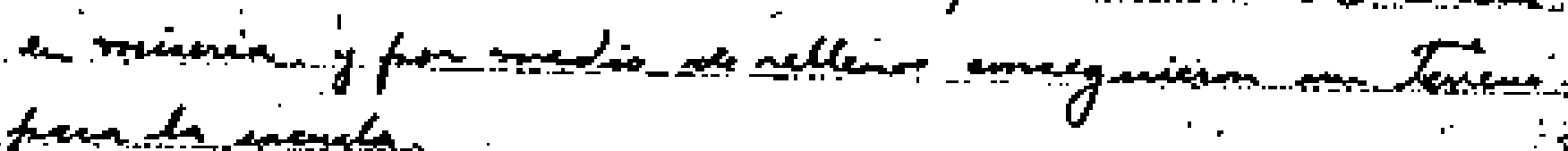
frem h semas.

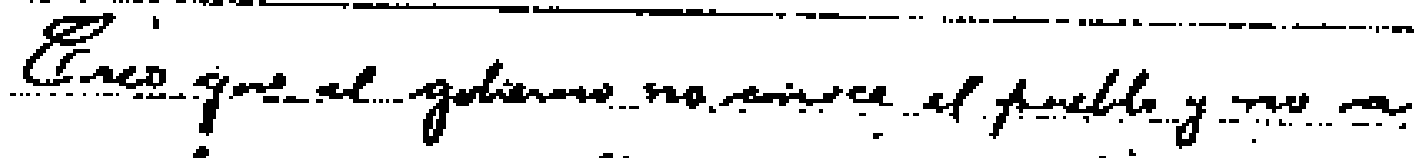

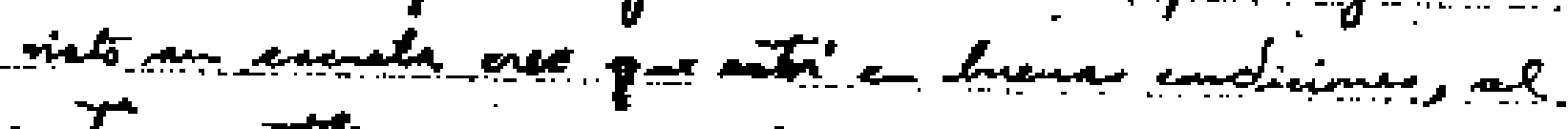

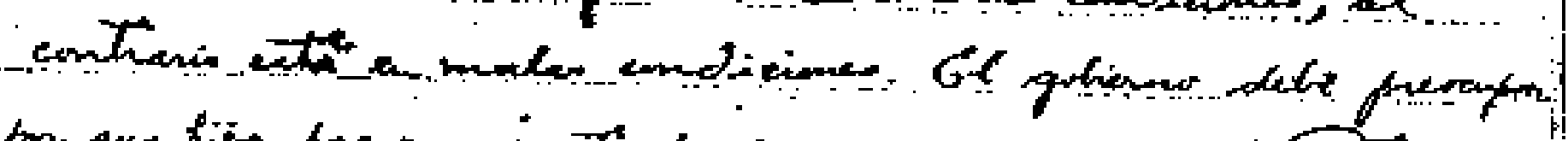

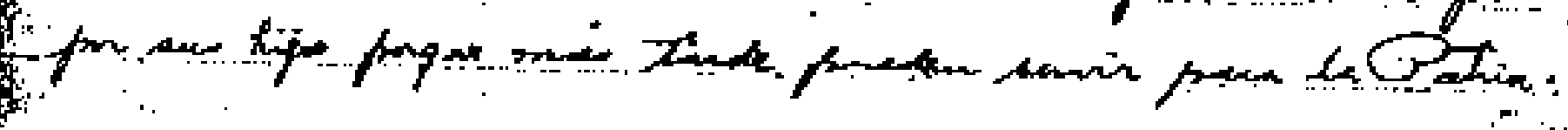


381

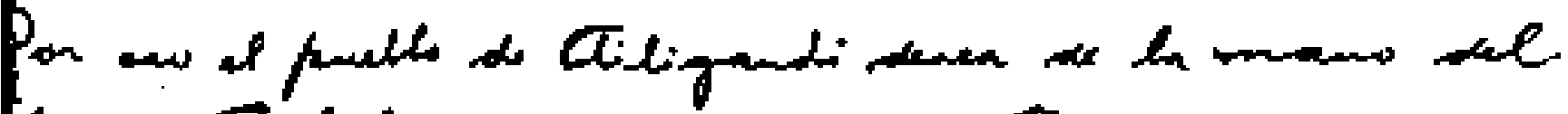

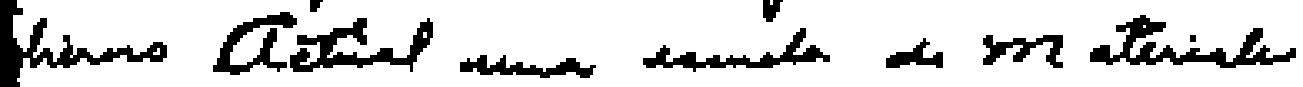

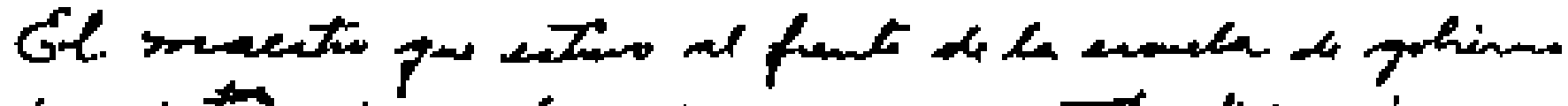

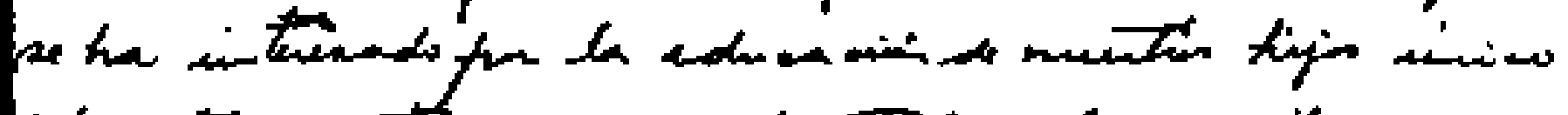

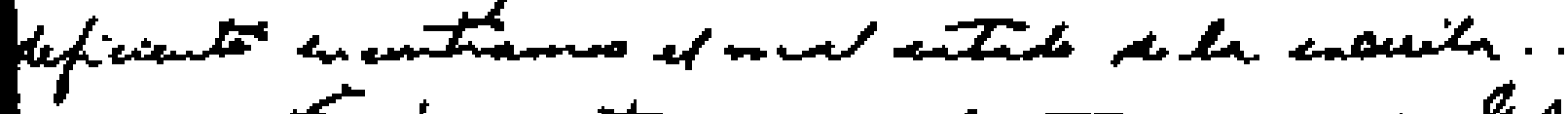

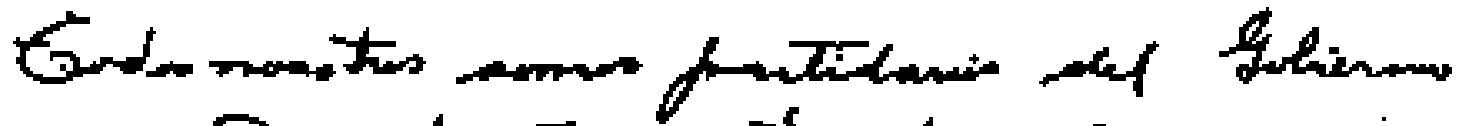
S. itt Segem tomiden gamp-

Ythamithapiper

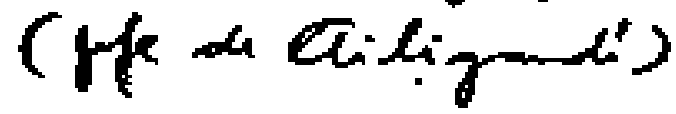

$$
\because \ldots \ldots \text {, KD, n. } 559 .
$$




\section{CCL}

\section{Pana' a 3 de Febrero de 1937}

\section{Eathor Dootor}

Dearotened J. Arodereng

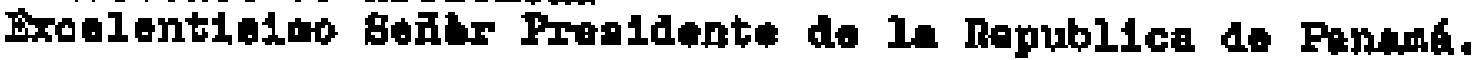

geñor Preglante, este poticlón ap core la 1nstrupolor

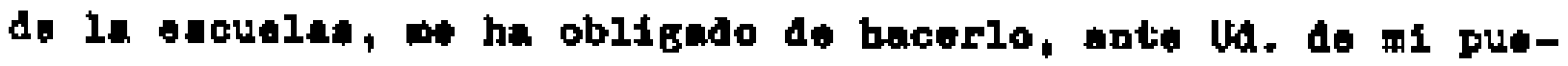
blo, en 1910, enturiack por muentro ounter, $y$ no podion reot.

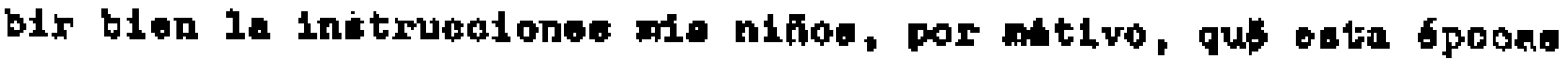
no liabien jovenes copetentes, de dar lecoloned coso do abork que liey, en $193 \dot{z}$ en cuando es fundo orlotalanke, el goblorro hlfaro.

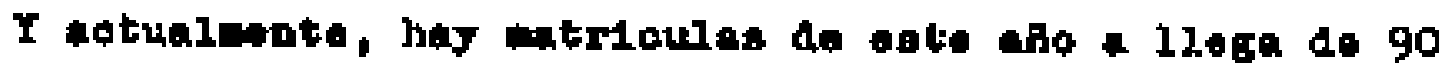

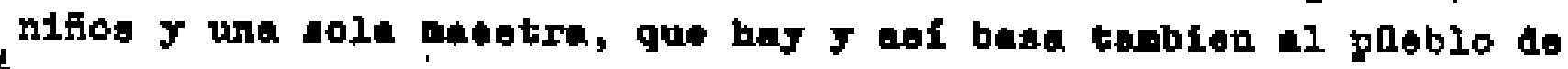

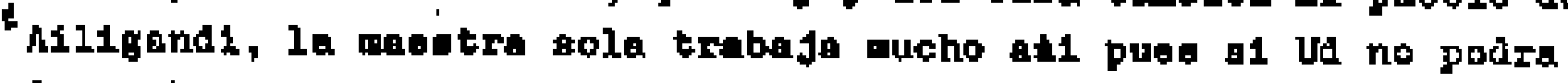
- da nombrarma, otra mestra para que tenga en su poder del 1 grado, miemtra ln maestra que esta puede tener el segundo grado.

Y tumbien ol podiade funder dos nuevas encuplas en $10 \mathrm{E}$ puoblos de Tupil1 J Plejón Gbico, eatog pueblog aon grandes $\mathrm{J}$ ye tienen cowo ci nco afios que luchan para que el bobterno se lo nontre, maestras, Jo creo, que el boblerto swo lo hara nombra,

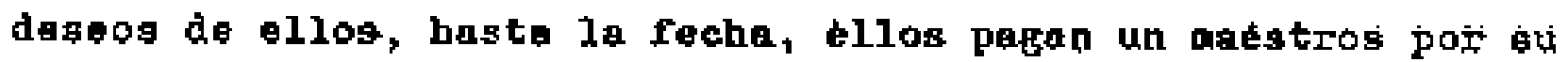
cuentas, aj pues creo sera atodaldo de su petielon en favor de ellog, sin mas por ahora.

Su seguro servidor.

cacique rele do Cantula

Secretar1o, Rtcardo Fartinez

$$
\text { V. RD, n. } 578 \text {. }
$$




\section{CCLI}

\section{Panena 3 te Fobraro 1937}

\section{BeHor Dootor}

Domos tenef J. Arouebear

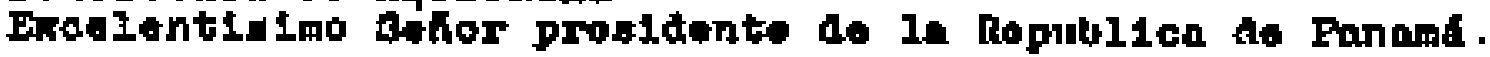

Venso to w. de petirlog un gren ravor al nodzan

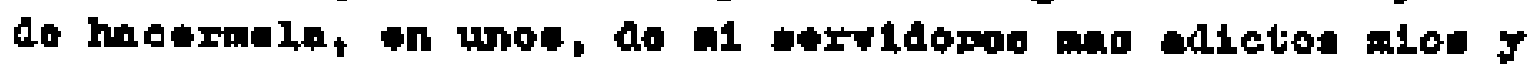
para byon de loe pueblos.

Belor proptento oe lon alguiented, potiolon, ud paxa

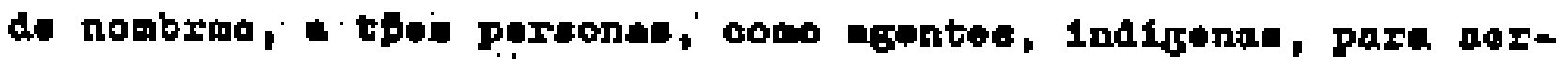

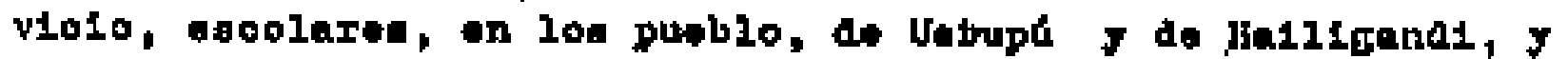

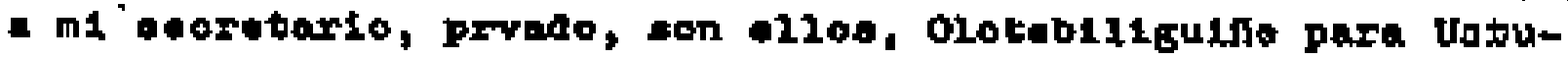

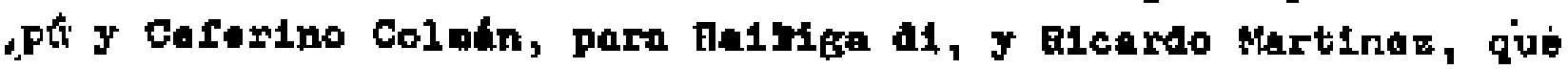
- mx Becroterio.

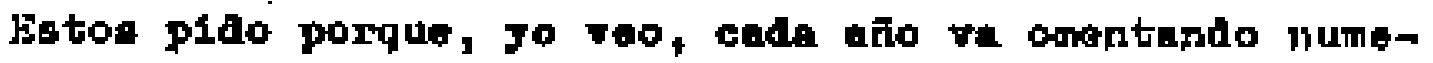
ro do inñon, y para poner en orten, y doofplinas a log ndffog

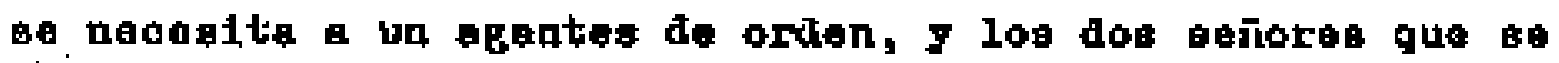

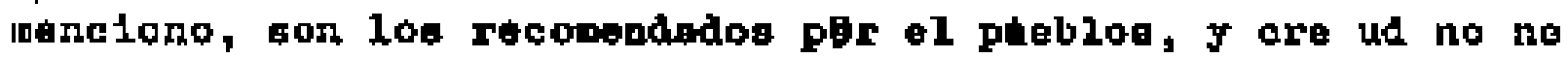

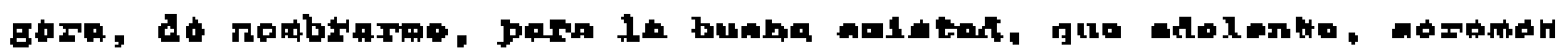
y a mi secretarto ficrado Hartinoz, y tento fo on ud. Is aspiractor, del pueplo de su degeso, anticipando la gracioa.

su seguro servidor.

Gacigue Hede de Candula

l

secretarjo. Ajcaido la16j.nne

V. RD, n. S79. 


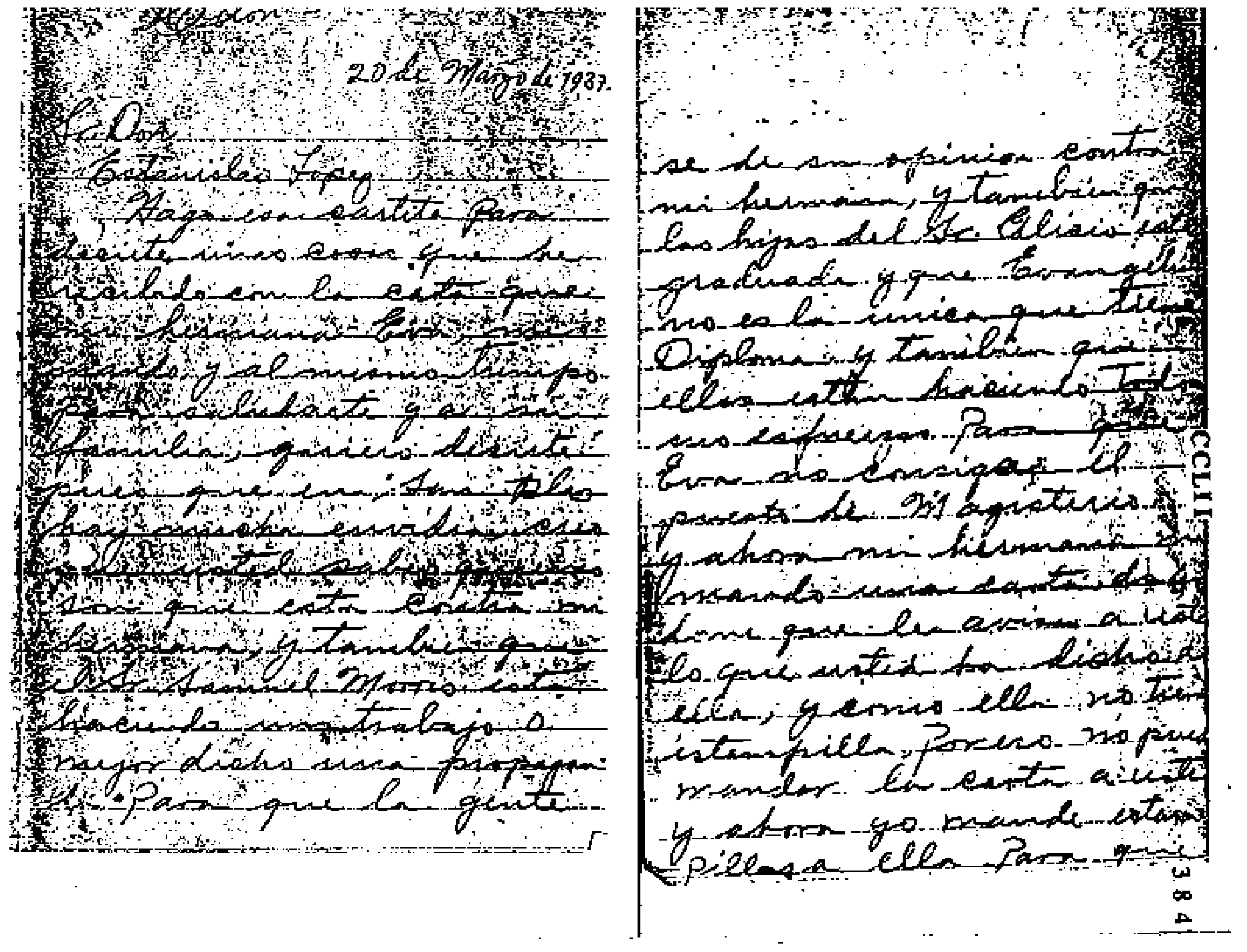




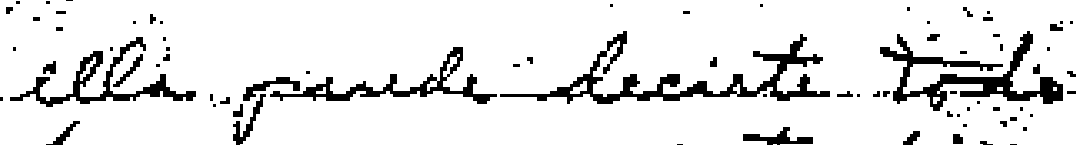
Dri yor por partedinoa.

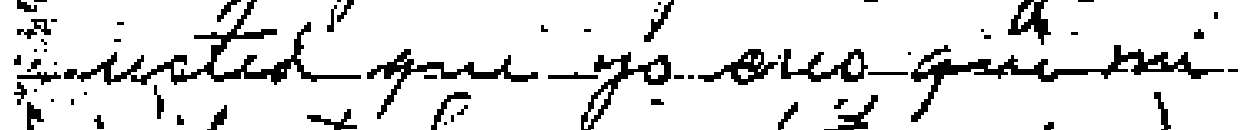
wifunto fermono (fromaines)

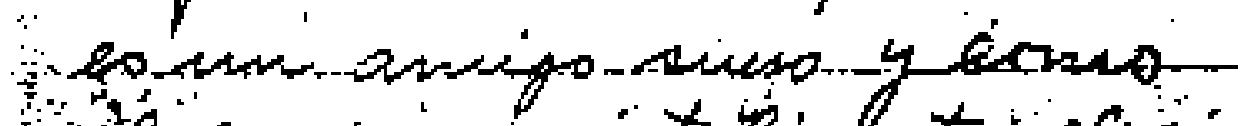
Leses tom interighterisi. opich haver toto lo quin.

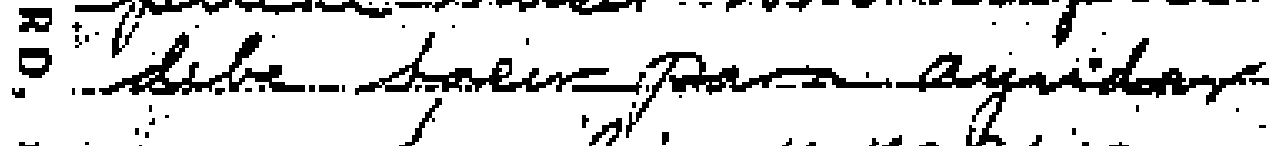
- $\therefore$ ina tamilia y ye buso in gre ganopuldenemple. - Gir a el Brin aysuria

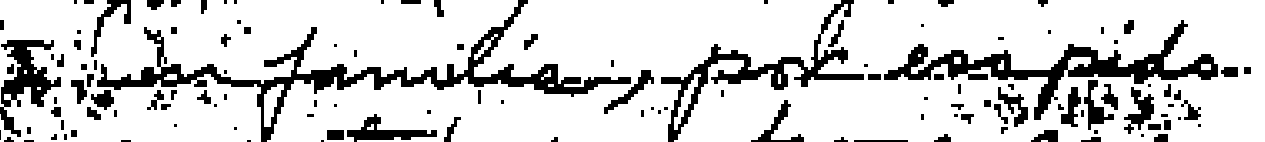

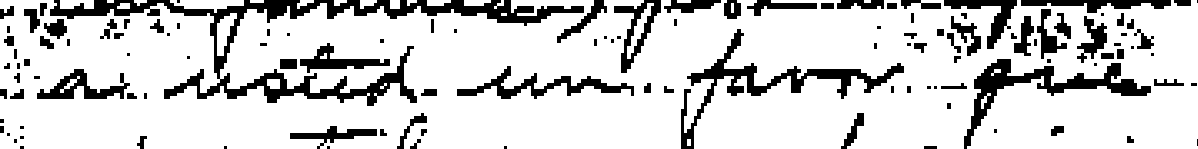

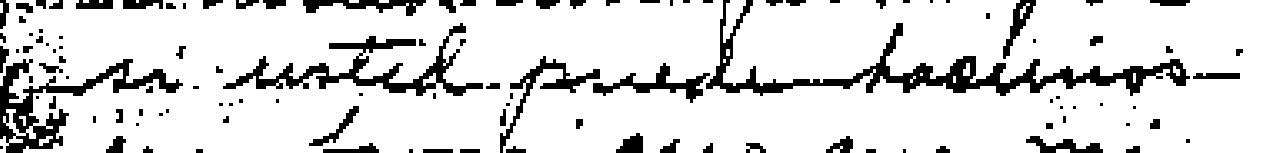

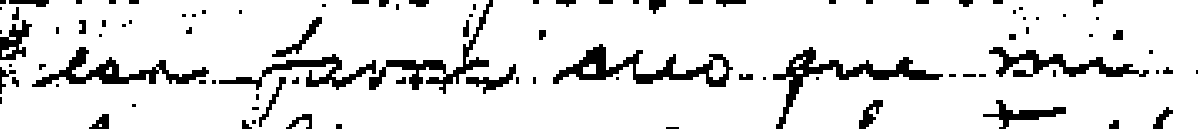

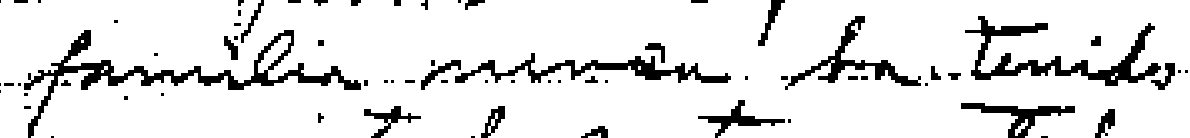
einemistad sont whed pirde stiw tarmilin

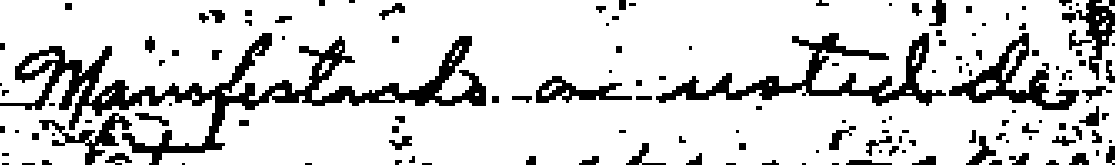

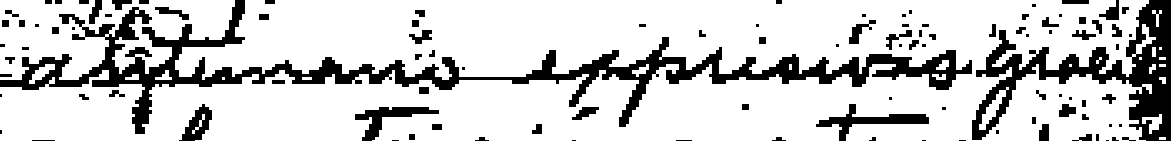
por le ativain quinting

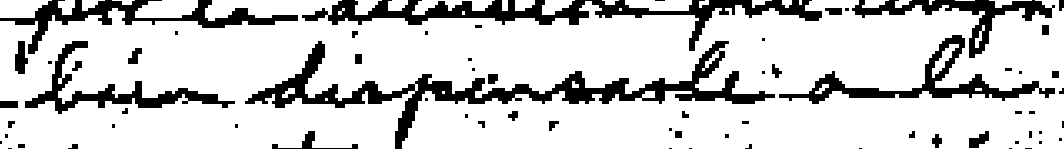

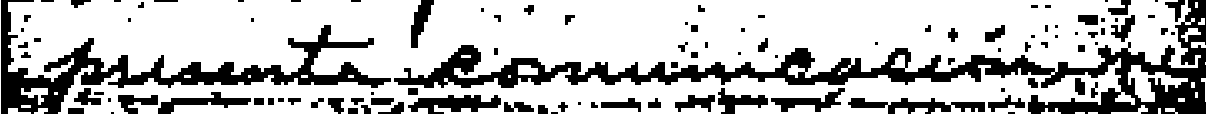

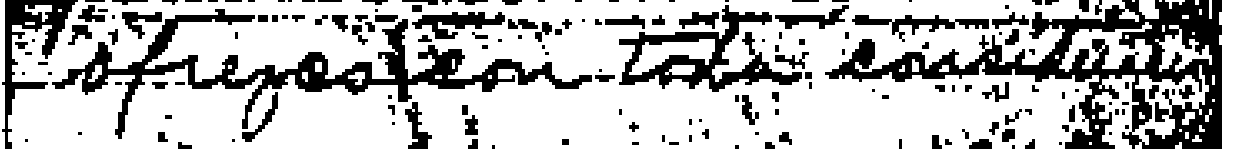
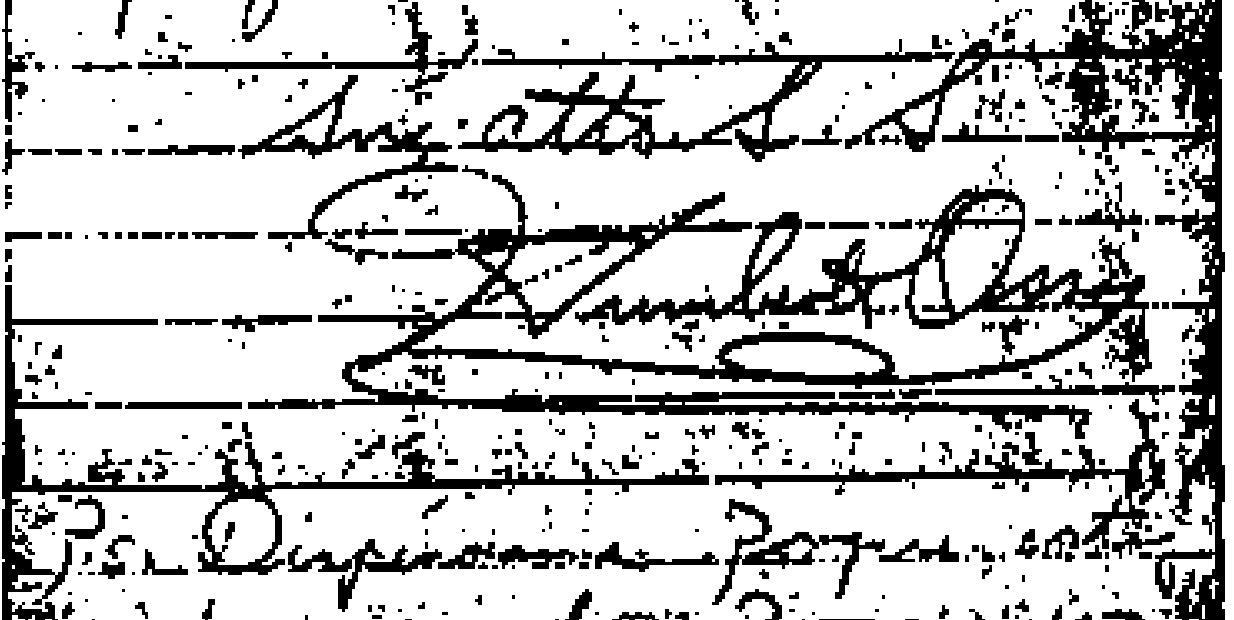

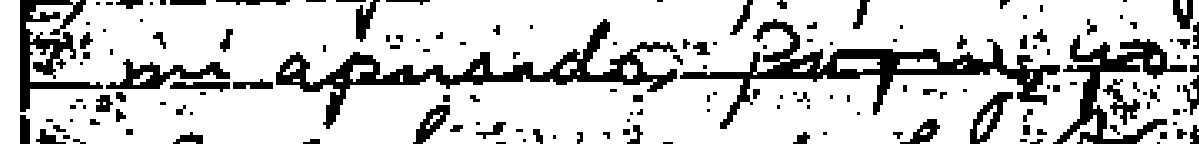

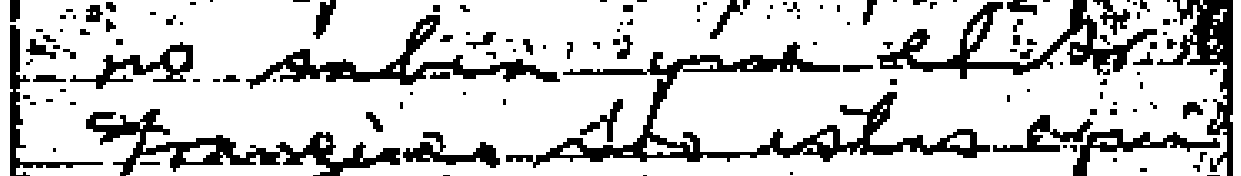
Hanginat 1

$H: 0$

1 


\section{CLI I I}

\section{$t^{+}$}

Panamé 27 de Mbril de 1937

\section{Señor Doctor}

Demostenes J. Arosंemena

Excelentisimo Beñor Presidente de la $k$, de l'ananá.

I'ox medio de In presontie venfso dar mi. agrallocimdento y saludnrle, nl. mismo bfempo,

Señor presidente, que es verlad ud, se anostrado, bien de la amistad, hacin, nas de los pueblos, que esta funclonato Escuelas, de nombrar, el mismo personal, maestros para el periodo de 1937, que se bien los ptreblos, estan de acuerdo, con ellos porque estos maestros, supleron de cumplir, con la obra de ensefianse.

As1 ftes señor presidente, su goblerno, eera aplaudido, en la comarca de san Blad, por saber hacer justicia, bien de los pueblos de su deseos.

$$
\text { Su seguro servidor. }
$$

\section{Nle de Cantule.}

Se cretario, Ricarclo Martinez

$$
\text { V. RD, n. } 584 \text {. }
$$




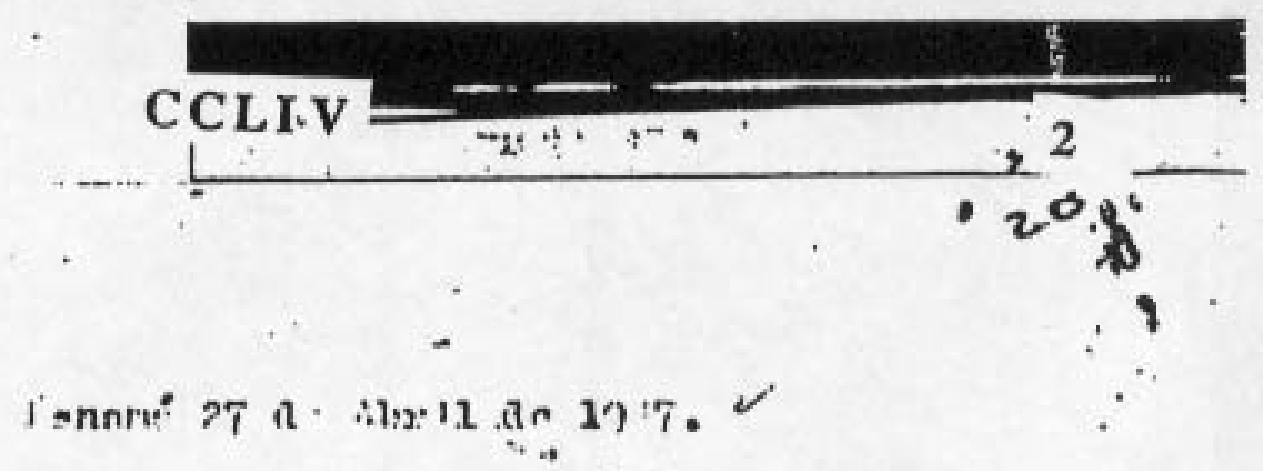

Ie" or voetor

dusn D. 'rosamin'.

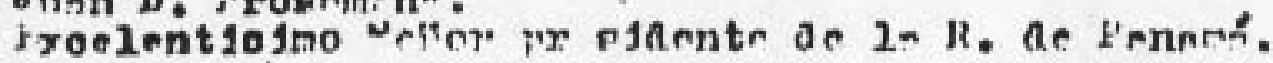

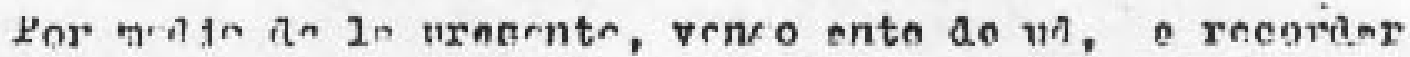

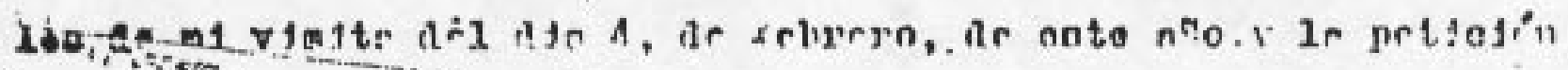
rue hise en xan ali vinile:

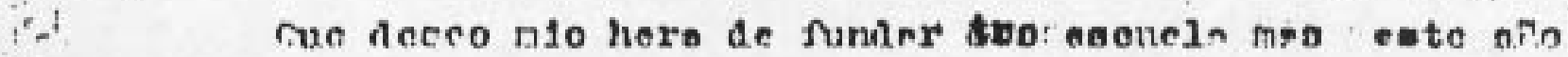

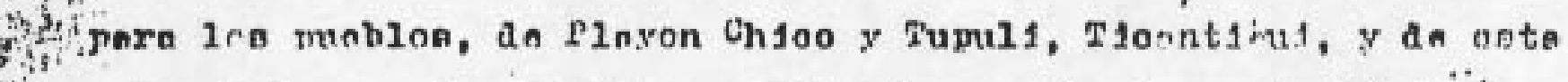

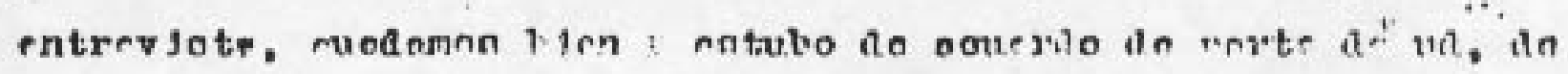

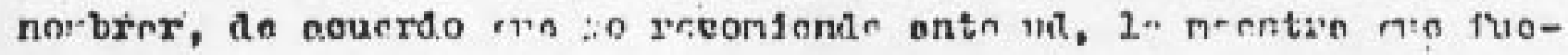
de oerlo.

seflor, prendante notes tres meblue mer manojono tiena

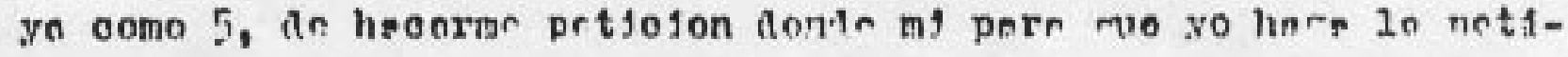

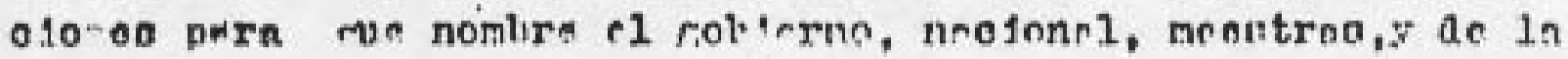

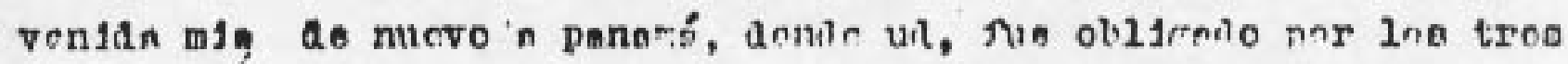

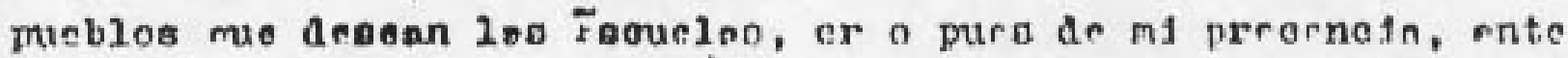

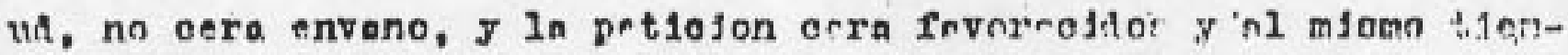
po rnoonsendo a las mosetra rur puoilo dosenpañor cl fucoton do

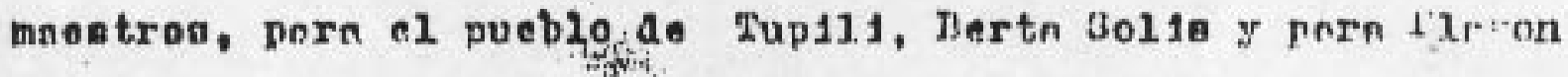

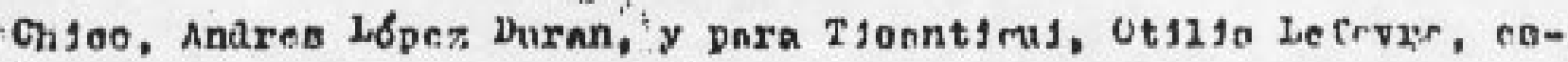

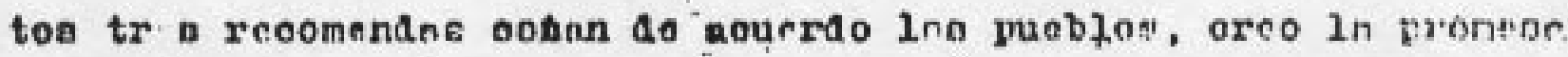

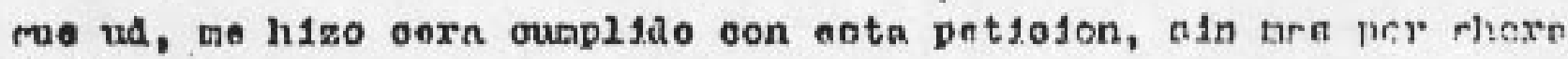
cu temuro servjar.

गता० da Contale.
V. RD, n. 585.




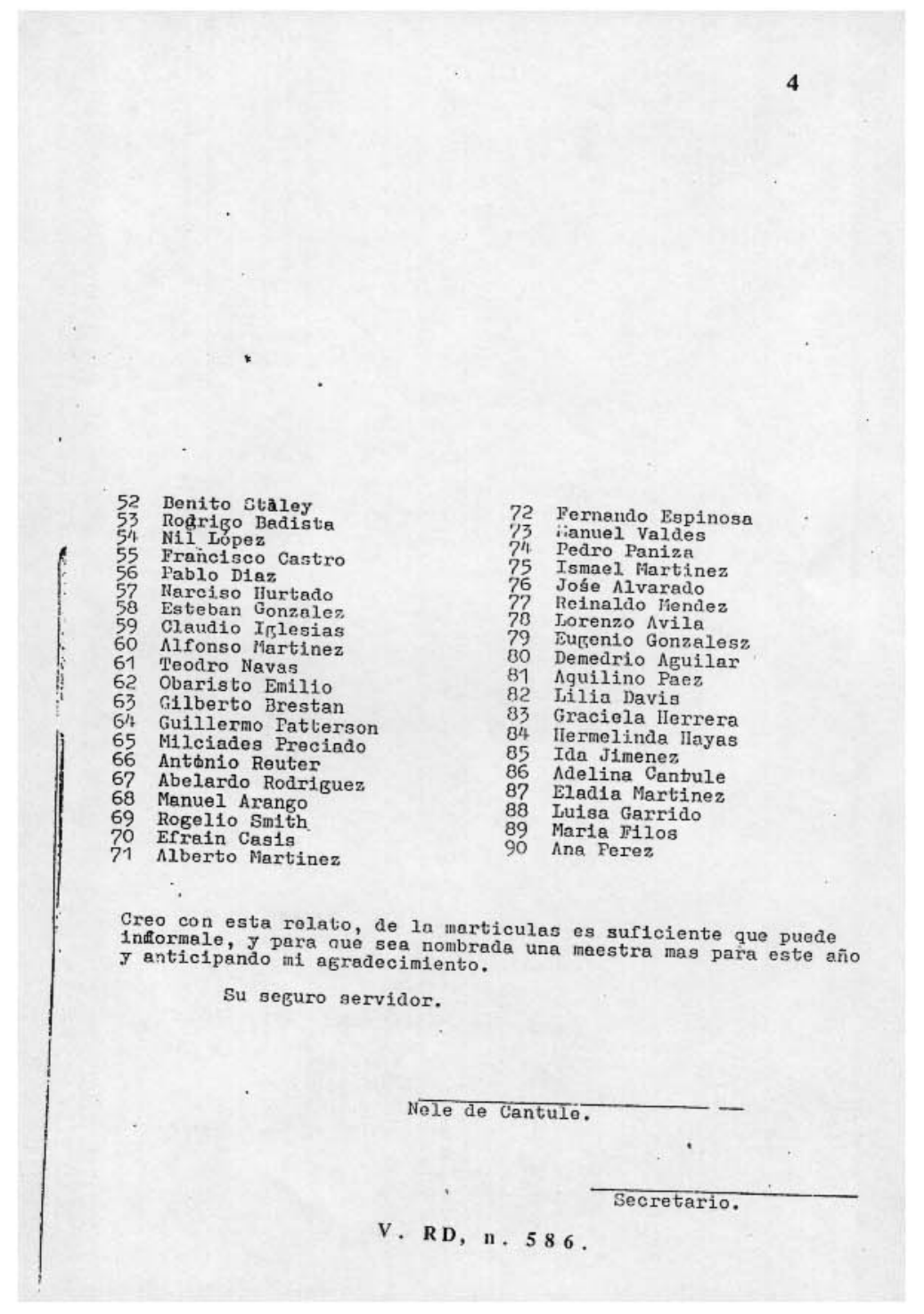



52 Benito Staley
5il Roo Badisti
55 Frañcisco
Pablo Dlaz
Marciso Hurtado
Lsteban Gonzalez
clatalo irlesias
61 Teonso Nartine
2 Obario Navas
63 Gilberto Emilio
Guillermo
5 Milciades Preciado
Antinio Reuter
Abelardo Rodriguez
8 Manue1 Arango
Rogelio Snith
Efrain Casis
N1berto Martinez

72 Fernando Espinosa

73 ianuel Valdes

5 Pedro Paniza

Ismael piartine

Roinaldo

Jorenzo tyila

Eugenío Gonzal

Demedrio Aruilar

Aquilino

Lilia Davis

Graciela llerrera

Ida Jimenez

Ndelina Cantul

Eladia Martine

Luisa Garrido

Maria Jilos

Creo con esta relato, de la marticulas es surtciente que puede 1nfformale, J para aue sea nombrada una maestra mas para este año
y anticipando mf agradecimfento.

su seguro servidor.

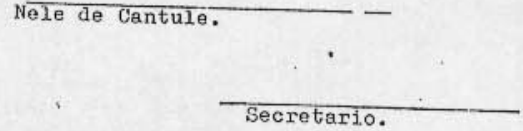

V. Rn . 
Señor Don

Antbel Rios D.

Secretario Educacion y Agricultura. $_{\text {. }}$

pte.

3oñor Gecrotintio, hacgo racofilarles, de esta peticion, Boñor Becrotnxio, hağ rocoflarles, de egla peticion, que le hize de this ultina viaje, que estaube en el mes de el de 5, ante ud, y ud me prometio de enviarme, en el mes de yo mismo; en los sigulentes ultiles.

12, Docenas de cadernos.

12, Docenas de palael de dibujos.

12 Docenos de Lapiz.

6, Docenas de I,ibros de Grados I. II. III.

6 Laminas

4, Resmas de papel practicas.

4, Cajas de tizas.

3, Mapas de panamá.

3, Libros de Geograria Universal.

3, Historia de parjamá.

3 , Instrucion Clvioas.

3, Dicimnario Enciclopedico Iltstrado.

Señor Secretario, esta peticion son para los dos pueblos, Ustupu y Altgandi, su seguro servidor, $y$ atilgo.

Nele de $C_{\mathrm{n}}$ ntule

V. RD, n. 588 .

Gorrotiario. 


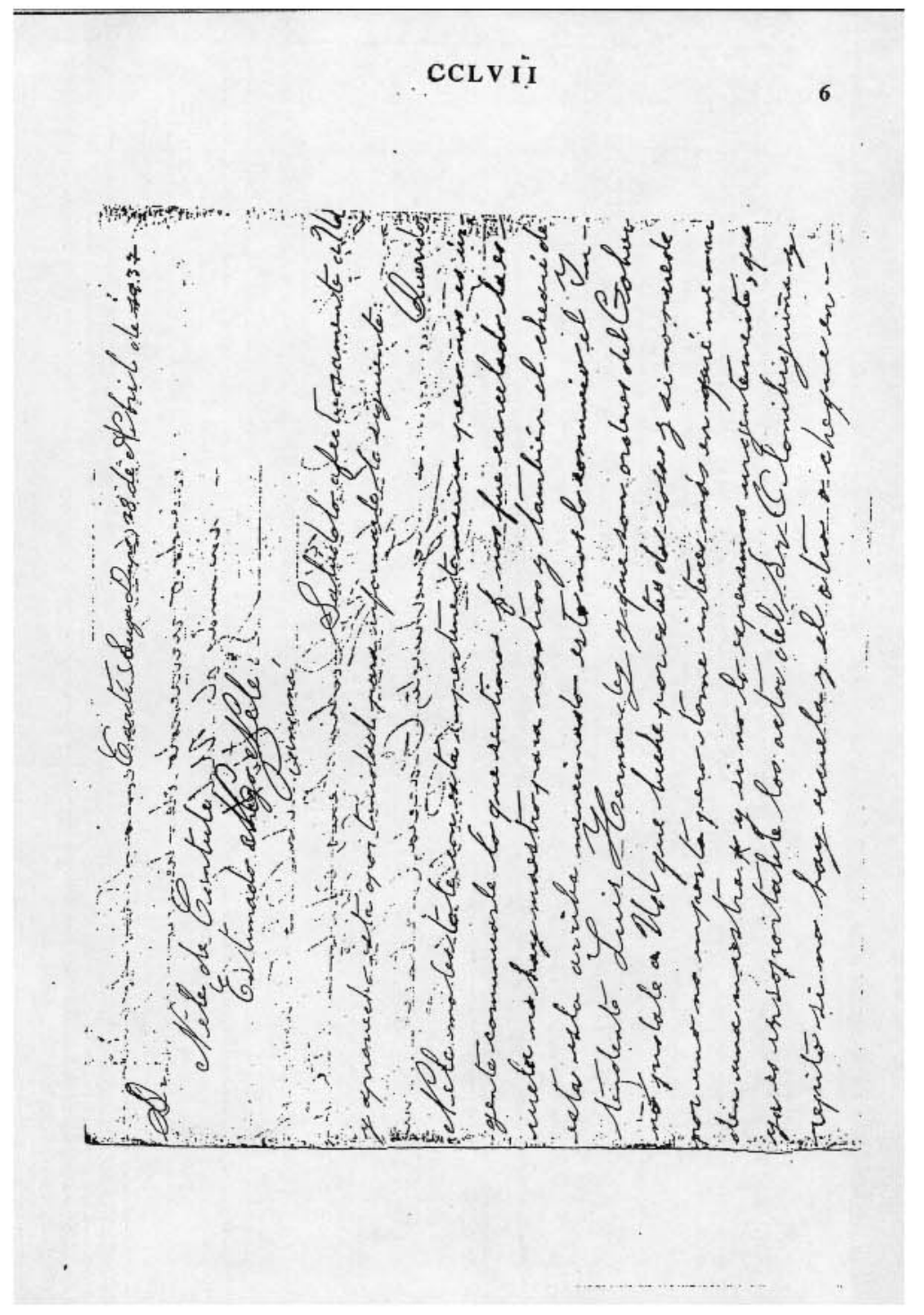




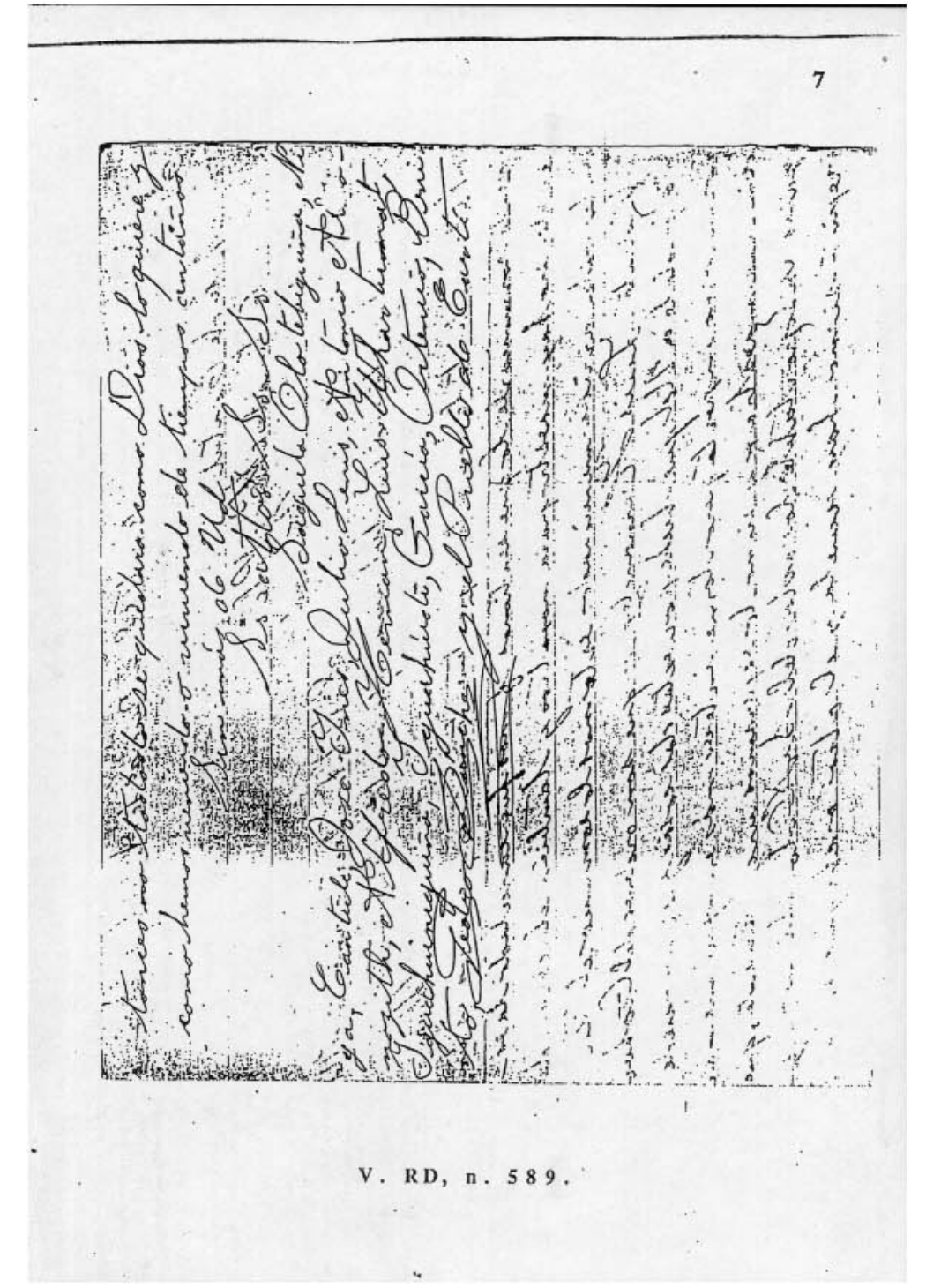




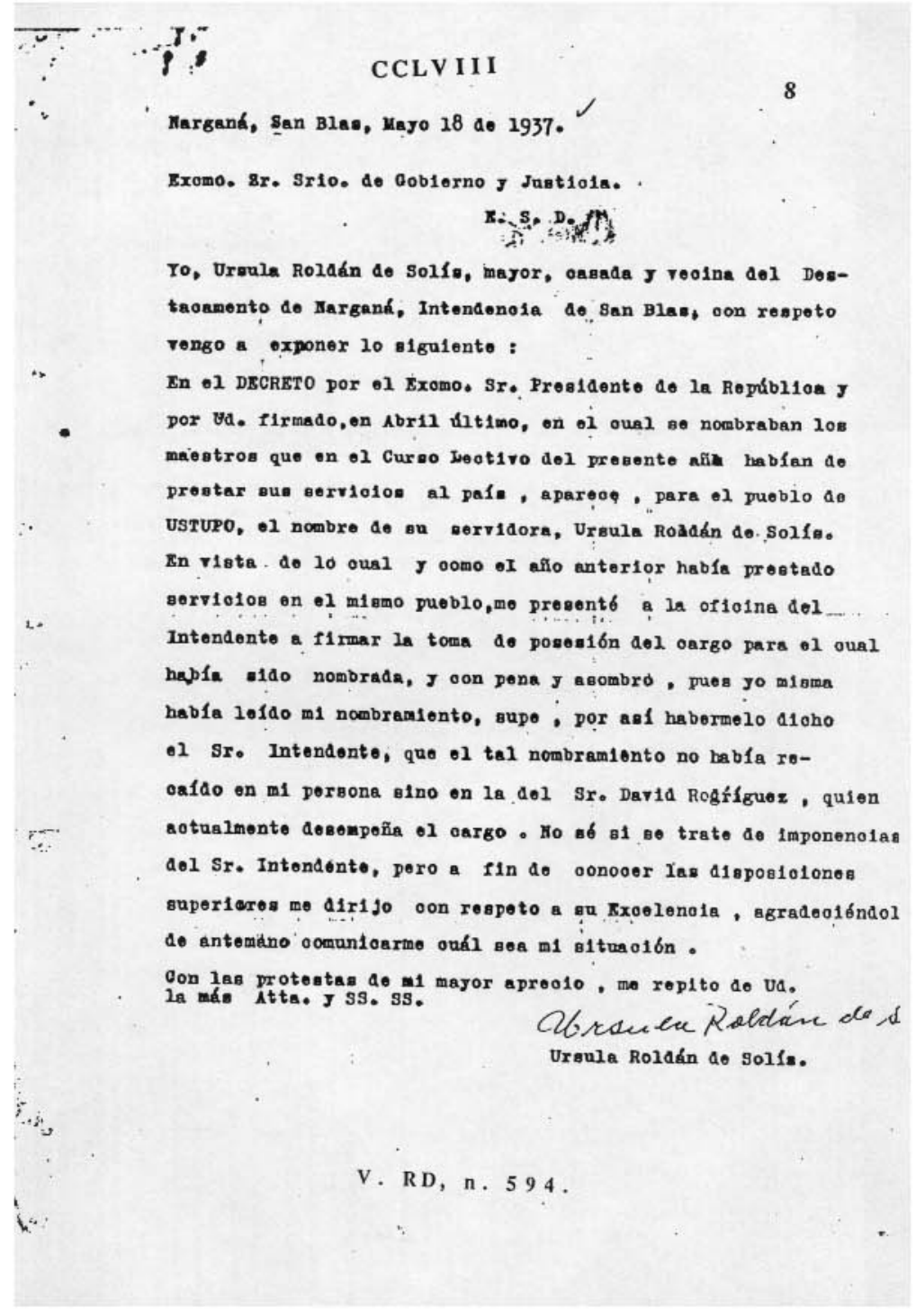




\section{$\operatorname{CCLIX}$}

R-65

Número 12

SEÑOR CORONEL

Narganá, 21 de Mayo de 1937.

LUIS HERNANDEZ $R$.

INTENDENTE DE SAN BLAS

EL PORVENIR.

SEÑOR INTENDENTE:

He recibido sus dos últimos comunicadus, uno de ellus privado, por el que neo sus sentimicntos y buena voluntad en todo, a la que sabremos corresponder debidamente.

La Hermana Belarmina ya ha tomado posesión y con este mismo correo kt manclo tl libro Como no tengo sello de posesión le mando su importe de 0,10 .

La Sra. de Arancla se queda de macsira en Corizón de Jesús y en Narganá lass cinco Hermanas. La matricula es ya de 258 alunnos, to que da un porcentaje grande de alumanos para eada maestro.

Las Madres, en mi nombre, le agradecen su intervención en el asunto y su rápida soluciủn. Soy del Señor Intendente, atto. y s.s.

Simón Bravo. Director.

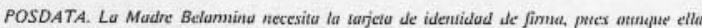

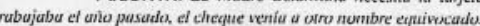

Vale.

Trans. del orig, mec.

V. RD, n. 595 . 


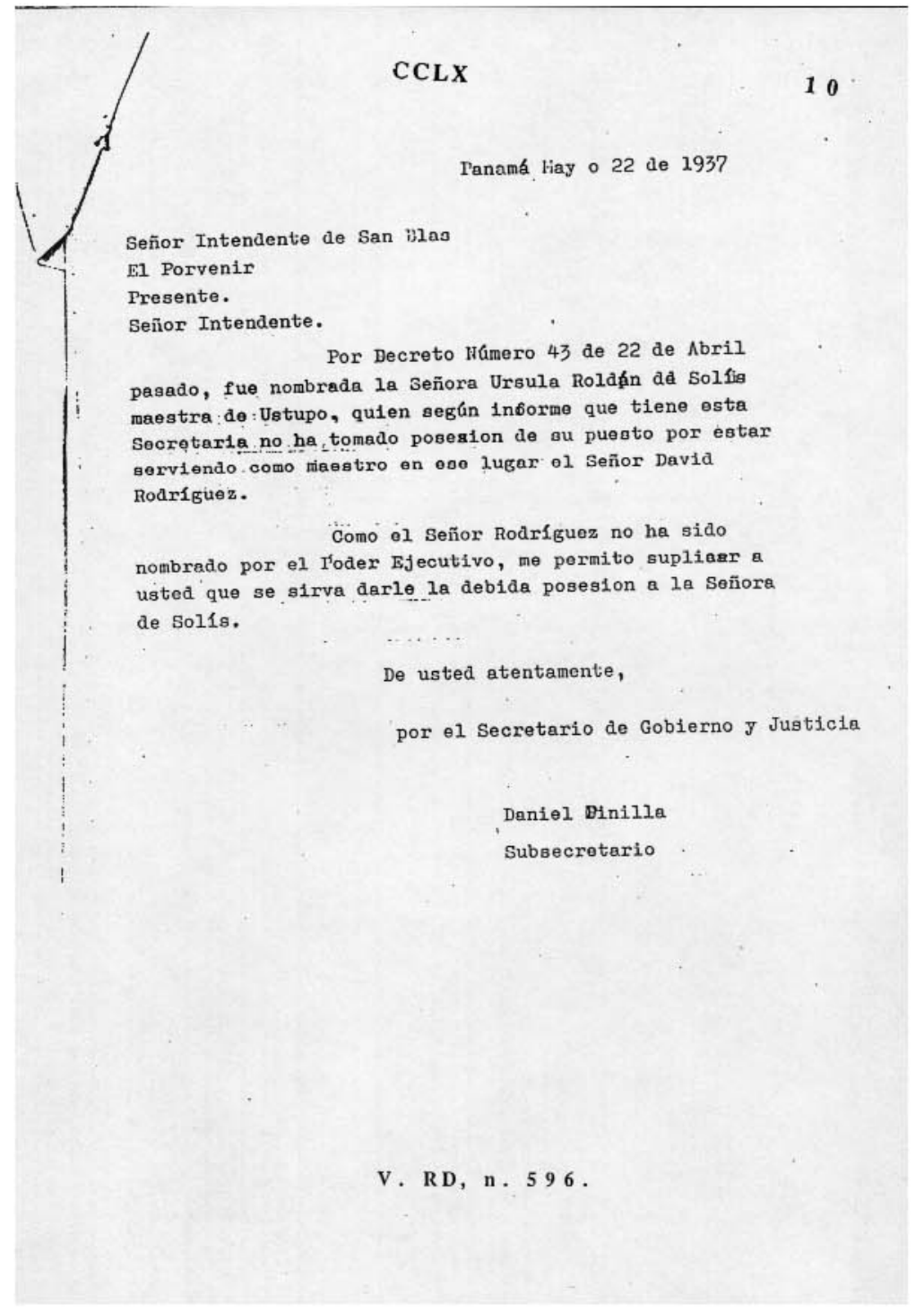


SENTOR CORONEL

LUIS HERNADEZ $R$

INTENDENTE DE SAN BLAS.

EL PORVENIR.

SENOUR INTENITENTT:

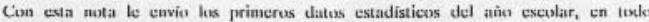
conformes a lus informes que ne han girado lus seiores macstros.

Se puede apreciar el aumento de matricula en casi todas las escuelas y la regularidad en la asistencia, lo que supone un paso aslelante en esta región, bajo su buen gobierno.

Los dalos de Puerto Obaldia no los he recibido en esta fecha aủn.

Sin otra cusa que comunicark, soy de Ud, atto, ys.s.

Simén Bravo. Diretur 
SESION XIII

En esie cuartel de policía de Narganá, hoy día 16 de Junio y a las 3 p.m. se reunierun para sesionar los sig can Brenesy Napoleón Haya.

Haya.

No asistieron los Señores Samuel Morris y Luis Diaz, sf el fiscal, interpretando Nupoleón

1. La Presidencia recuerda que hace ya un mes entero no se ha sesionado la Junta y uhora se reanudan las sesiones ordinarias.

El Sr. Luis Diax, que trabaja en una compañia conocreial de la región, no pundrá asistir en

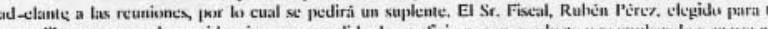

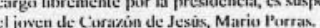

Hace saber también la presidencia que durante el mes pasado ta manklide commprar un lablones para el arreglo completo del muelle de Corazón de Jesús, invirtiendo para tal fin una cantidad da csoro de ta Junta. Ya estín colocados los tablones, cuyo trabajo lo ejecutó Guillermo Rivera, pagando as su trabajo subsidiario.

2. Las cabezeras del pucnte que une a las dos islas hermanas se encuentran en mal estado y el Presidente vela, com ces so deber, por la conserva a de esta imporunas para la conservación del puente. sobre todo, ahora que empiezan las fuertes lluvias y crecientes del río.

el miembro Charkes Robinson cree que hay ya muchos palos daniadus que necesitan su reposición. Anteriormente el pueblo componía el puente cada dos meses: ahora que cl Gobierno lo hiro nuevo nace muchos meses que no se ha renovado un solo palo.

El Ságuila de Corazón de Jesús conferenció ayer en su isla: las casas que van a levantar no jenen aún material preparado, por lo cual hasta otro mes no las empezarán. El piensa arreglar su puente lunes próximo.

El Secretario dice que es buena la idea del Sr. Brences, El terminal del pucate de Cirazón de

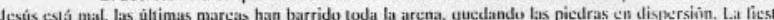

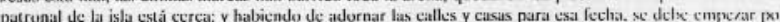
lo mís necessario y lo mís pronto posiblh.

Anatade que ha visto con estrañeza que en las islas se escoge el domingo como el día ma upropósitu para derribar y construir las casas, siendo este trabajo público y como vecinal, Las leyes civile de todos los paiscs oficinas y trabajos públicus los domingos: aqui conviene suspender tanbién en tesos días la construcción de casas.

La presidencia lee el C.A. sobre el día de la fiesta patronal que se permite y que todus lus

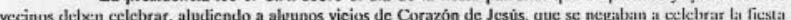
patronal de su isla. se han de tener.

Añade que está de suyo prohibido esos trabajos públicus los domingos y yue a sect pusible nu

Charles Robinson dice que él no trabaja esos dias y que algunos ke critican. Pero el deficunde to dicho sobre el particular y pide a la Presidencia que ponga un agente por el pueblo para que no se 

construyan casas los domingos. El Sr. Presidente reunirá al pueblo para esle lin y señalará un agente que vigile el cumplimiento del descanso de los domingos, prohibiendo hacer casas.

3. El Ságuila de Narganá diec que el Gobierno gasta mucho por la educakiün de su puchblo y está viendo cosas que no le gustan. El ha visto que hay madres de fanilia que curiosean ho que pasa cn lus
clubs, llevan a sus hijjos pequeños y muchachos que están aûn en la escuela, que se punga policia para impedirlo.

La presidencia dice que ya ha dado orden a la policía para que vigilen y prohiban la entrada de menores en el Club y que las señoras no deben enviar a sus hijos a esos lugares.

Narganá, 18 de Junio de 1937

Simón Bravo (fdo.)

Fa Secretarie $\quad$ kal Presidente

Trans. del orig. mec.

V. RD, n. 598 . 


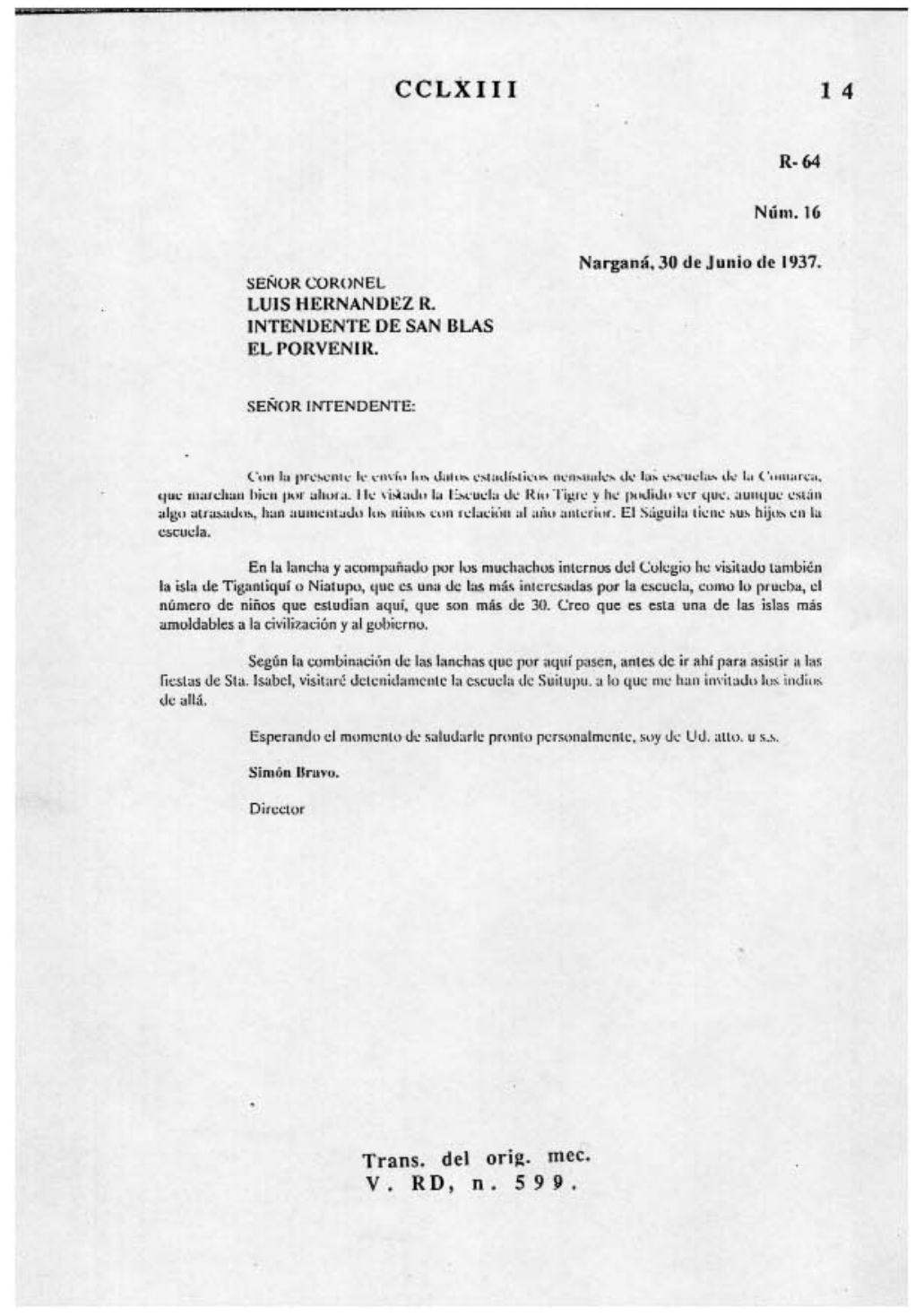


Número 18

SEÑOR CORONEL

LUIS HERNANDEZ $R$

INTENDENTE DE SAN BLAS.

EL PORYENIR.

SEÑOR INTENDENTE:

Con la presente te remito hus tados estadísticos escolares de la Comarca del anes de Julion.

Las cnfermedades rcinantes han hecho decrecer algo la asitencia media diaria: la matricula hat seguido muy bien, hasta con aumento $\mathrm{cn}$ algunos planteles.

Durante el mes he hecho una visita detenida de inspección a la escucla de Suitupu, (Carti). yue se encuentra foreciente hasta la fechia.

el Médico Practicante de la Intendencia durante su estancia aquif ha hecho gran labor, $\mathrm{H}_{\mathrm{a}}$ salvado a alyunos adultos de trances difíciles, a causa de sus inyecciones; ha medicinado uncinariais; ha

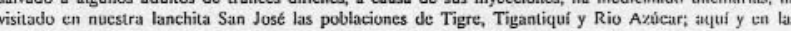
predichas islas ha vacunado a los niños que todavia no lo habian hecho, que pasan de varios centenares.

En Tigantiquuí, en donde no hay escuela, no diố resultado la visita.

Terminu acusando recibo de su última, referente al viaje del Señor Calivet y notificíndoke que le envio para su Señora c hijo un paquetito, conteniendo objettos religiosos

Suy del Sceñur Intendente allmos. s.s

Simoin Bravo, Director.

Trans. del orig. mec.

v. RD, n. 600 . 


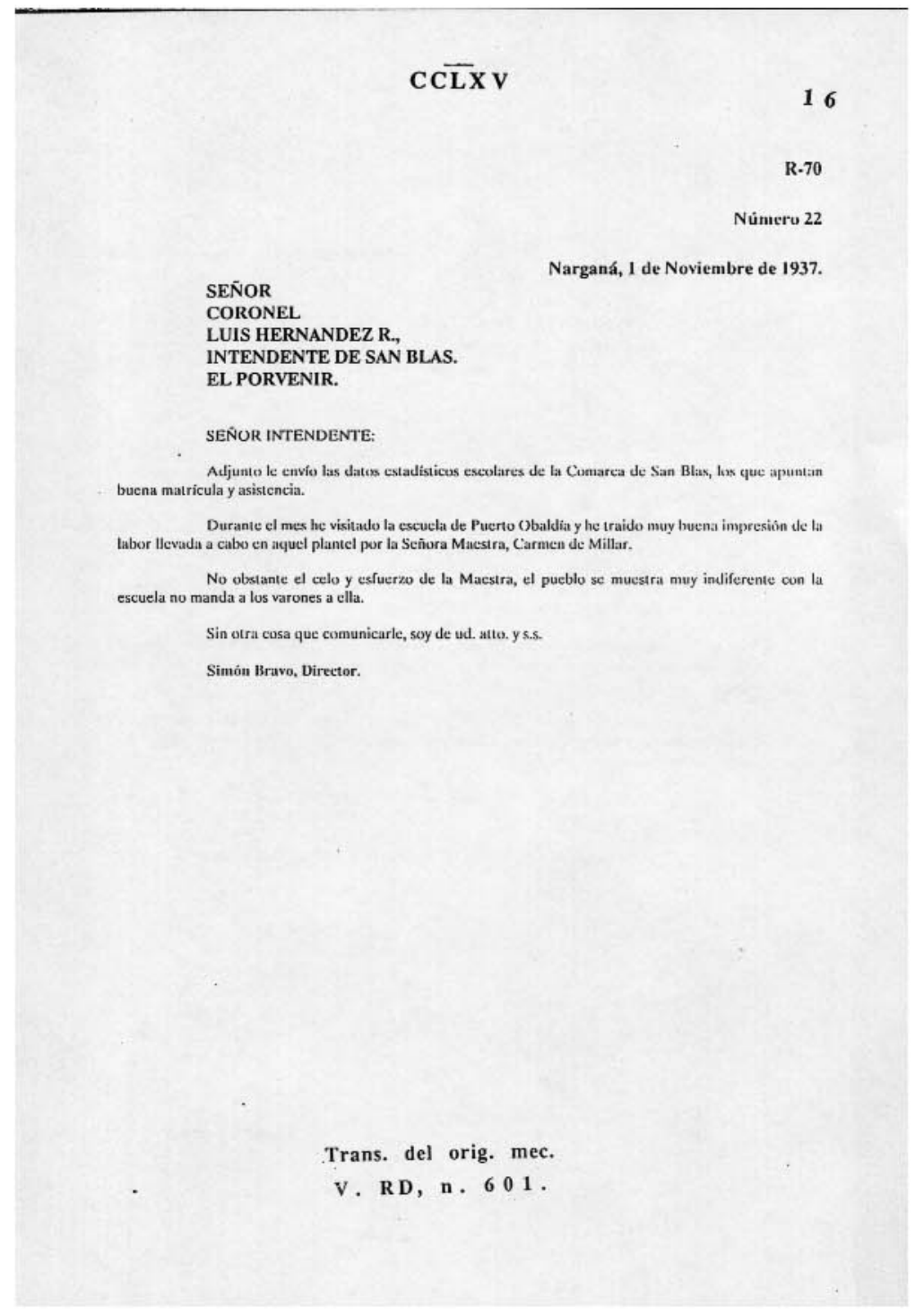




\section{CLX V I}

Núm. 25.

SEÑOR CORONEL

LUIS HERNADEZ R.

INTENDENTE DE SAN BLAS

EL PORVENIR.

Narganá, 22 de Noviembre de 1937. algunas impresiones.

Terminada mi última visita oficial a todas las escuelas, tengo cl gusto de comunicar

Visité la escuela de Ailigandí Jirigida por cl Señor Maestro Tumás Herrera. Tantı los Ságuilas como el pueblo me recibió muy bien, lo mismo que al doctor, quien vacunó a varios centenares de niños $\mathrm{y}$ niñas. la escucla del Gobierno funciona en un edificio de madera bastante bie escuela privada del Señur Alcibiades y Señora Marvel.

El Senior Matestro trabaja bicn con una matricula de 45 alumnos y sebre todo, habla cn las reuniones de los indios, deshaciendo sus prejuicios contra la escuela. Este año ha hecho buen labor.

Lescuela privada del Señur Alcibiaucs se compone de niños o párvulos a quienes da clase de dia y de jóvenes a quienes enseña inglés. La Scñora Marvel tiene clase de nitias, aujuonta a li clase del Gobiern

Habiè a todo ol pucblo sobre la excucla pública y la necesidad de cnsancharla n independizarla, ya que estia ahora confundida con la escucla privada.

El Scñor Alcibiades y Scñora me recibieron bien y hasta me obsequiaron.

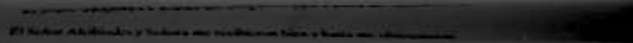


Me parece oportuno apuntar des resoluciunes para que Ud. las estunlie.

1.- Independizar completamente la escuela privada de la escuela pública, construyendo edificios distintos. El actual edificio es bueno, pero dividido es muy pequeño.

2.- En la escuela privada se ha de enseñar el idioma de la nación, tanto a los párvulos como a los adultos y el inglés sc ha de enseñar, como clase especial.

Visité también la escucla pública de Ustupo. El edificio es ampliu, bíca pintado conn dis aulas capaces para unos 90 alumnos.

La matricula actual es de 74 alumnos. En mi presencia ejecutaron el programa de lis

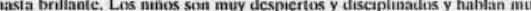
bien el castellano en las recilaciones. El maestro, David Rodrigucz, cjeree muy bien y es estimado por Nele Kantule, quicn estuwo presente en la visita.

Nele Kantule me dijo que descaba la escucla y estaba alcgre cun mi visita y que fuera dos veous al ańo allí. Terminó diciendo que cscribiti
civilizados, subre su voluntaul de esair con cl (iobierno.

En Ustupos hay una escuela excluavianente de habla inglesia, con una matricula de wit alumnos de 14 a 20 años, con un cufificio de madera.

El masstro es el indiu Franklin.

Visité también Tupile, en donde funciona una escucla privada de 50 niños. Hablé a todo el pucblo reunido y me dijeron que querian escuela del Gobierno para otro año y que lo pidiera. buenas condiciones. Oiro año se dechería pedir cseucla para esta simpática isla de Tupile.

El doctor Auilera ha vacunado a 4(X), incluyendo el clemento escolar

Soy del Señur Intendente atto, y s.:.

Simón Bravo

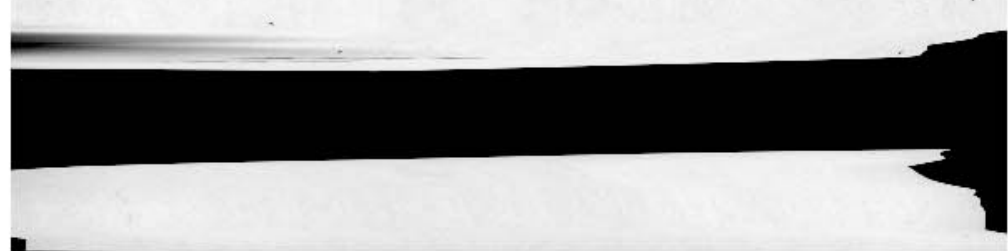




\section{DECRETO NUMERO 33 DE 1938}

(de 21 de Abril)

Por el cual se nomran los maestros de escuela de la Comarca de San Blas para el ańo escolar de 1938 a 1939.

EL PRESIDENTE DE LA REPUBLICA,

en uso de sus facultades legales,

DECRETA:

ARTICULO UNICO:Se nombran maestros de escuela de la Comarca de San Blas para el año escolar de 1938 a 1939 a los señores que se mencionan a continuación:

\section{EL PORVENIR.J. de la Rosa A.}

USTUPQ- David Rodriguez. y Evangelina Ossa

SUITUPUDE CARTI. Juana do Hayans.

NARGANA.- Director Pro. Simón Bravo

Maestras Hermanas:Priscila, Felipa, Basilia, Clementina y Baleriana.

CORAZON DEJESUS: Inés María R. de Santiago.

RIOAZUCAB: Luisa de Morris y Carmen de Muller.

WICHUWALA. Carmen Bonilla.

RIOTIGRE- Andrís Iglesias.

TUPILE ARRIBA- Josefa O. de Salazar.

AlliGANDI-Tomás Herrera

COMUNIQUESE Y PUBLIQUESE.

Dado en Panamá, a los 21 dlas del mes de Abril de mil novecientos treinta y ocho.

Trans. de la cop. mec.

V. RD, n. 605 . 


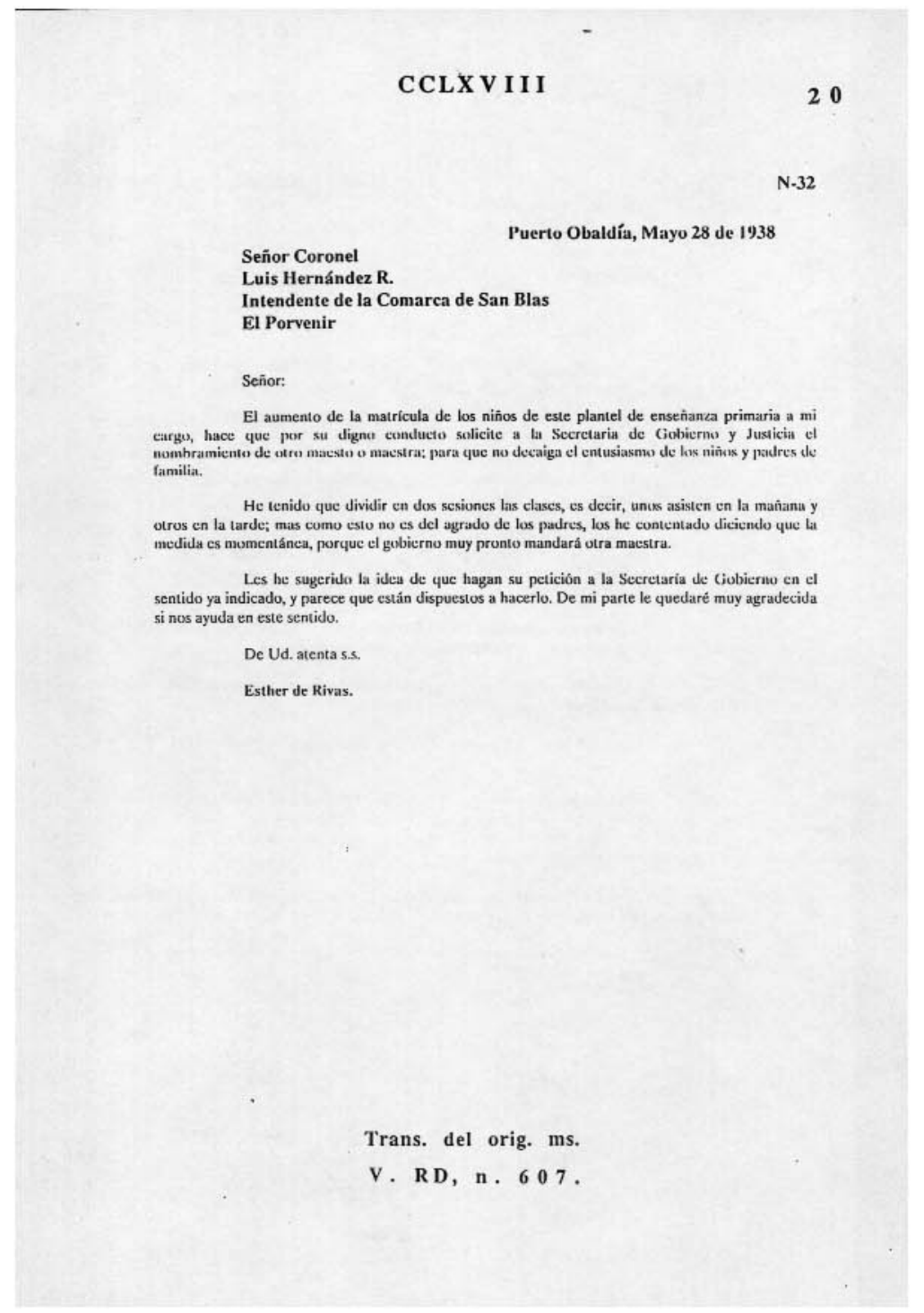


Señor Coronel

Narganá, 1 de Julio de 1938.

Luis Hernández R.

Intendente de San Blas.

El Porvenir.

Señor Coruncl:

Ayer recibí la suya, fechada el 29 de Junio en la que me comunica el caso de su comadre Inés de Santiago, maestra de Corazón de Jesús

Aunque el caso de que se trata, está bien determinado en el cócligo escolar, como incouppatible con el magisteriur atcndiendo a la petición que Ud. me hace en favor de ellia y las momento y ta lusspitalidad que ha tributado a todos los que han pasado por ahí, aceedo a conceder ese permiso por un mes.

Las Madres, aún haciendo un gran sacrificio personal, que justo es reconocerlo, se encargarán del plantel du-rante ese lapso de tiempo y yo me encargaré de coordinar las distintas secciones, de modo que los alumnos del Jardín Infantil pascn a Corazon de Jesús y alif una Madre se encargue de unos 100 alumnos.

Mucho trabajo será para la Madre Clementina esa clase, pero ella tiene cualidades para educar a los pequeños y mantener la disciplina de un modo admirable.

La actual titular, que se ausenta ahora por algún tiempo, tiene unos cuarenta alumnos y no ordena bien la clase, habiendo notado yo merma en la disciplina.

amistad.

Este asunto pues, queda canjeado del modo dicho, accediendo a su solilititud y a su

El Sr. Obispo a los pocos días de llegar a Nombre de Dios le sorprendió la malaria y ha tenido que regresar a Colón para mirar por su salud. El P. Manuel irá a predicar a Bocas y cstará aquí a fines del corricnte. Por esta razón, no me será posible acompanarle a las fiestas de Sta. Isabel, que se las desco muy felices.

Con el Hermano José llegó todo el material para la capilla que va para adelante. iQué bien nos vendría el Carpintero por 15 días para arreglar los marcos de las muchas puertas y ventanas!

Sin otra cosa que comunicar, soy de Ud. atto. y seguro servidor y amigo.

Simón Bravo

Trans. del orig. mec.

V. RD, n. 608 . 


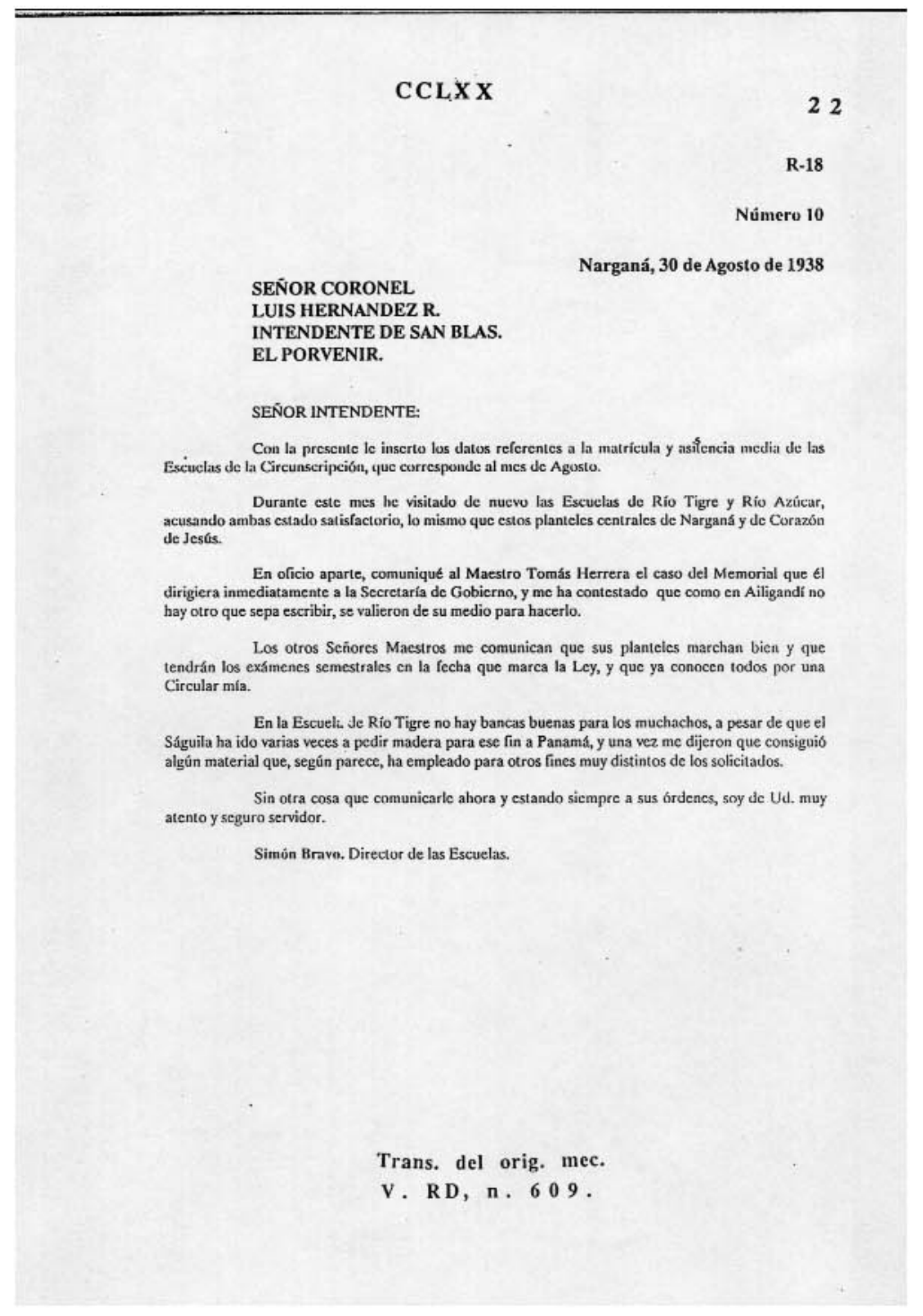




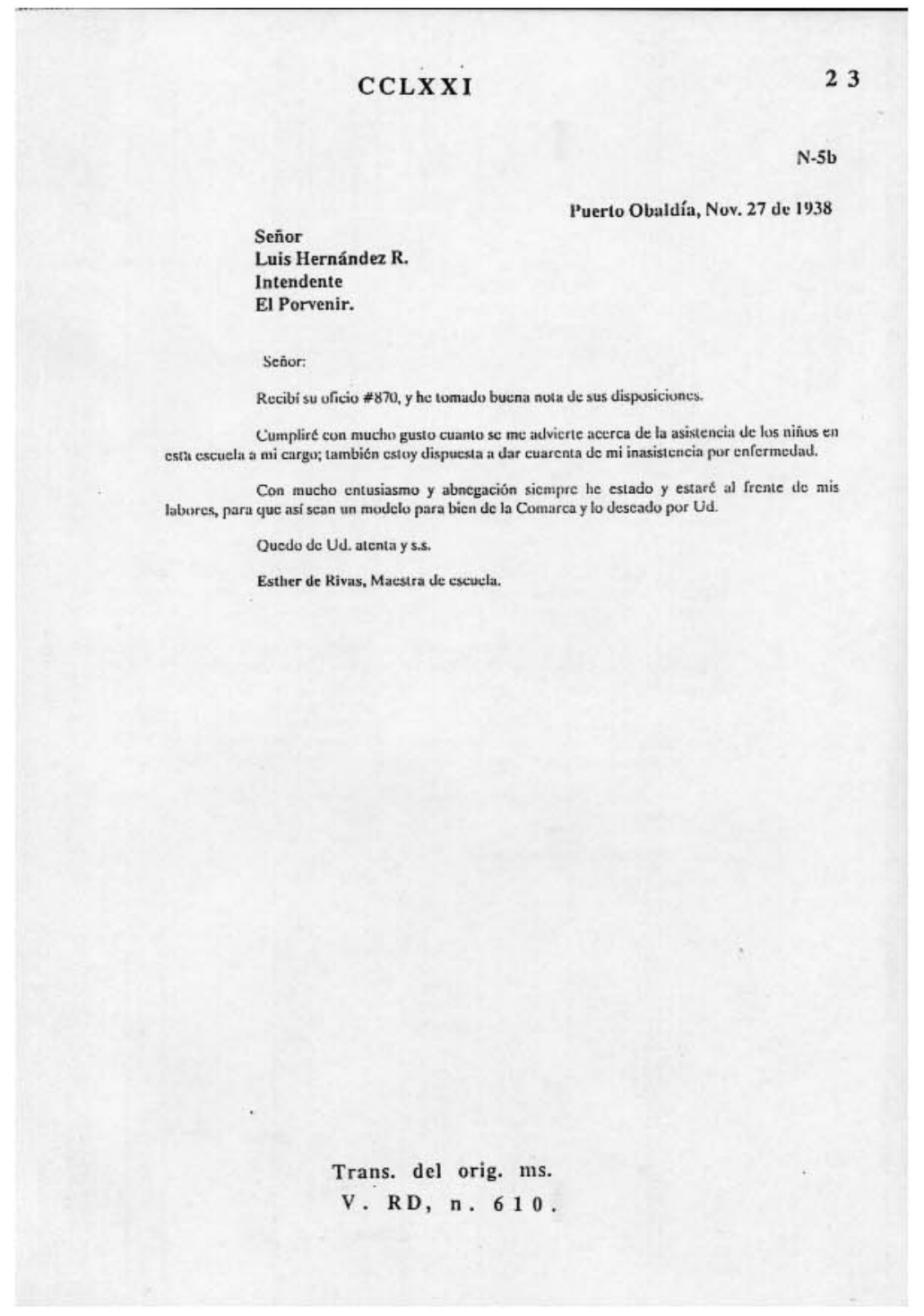




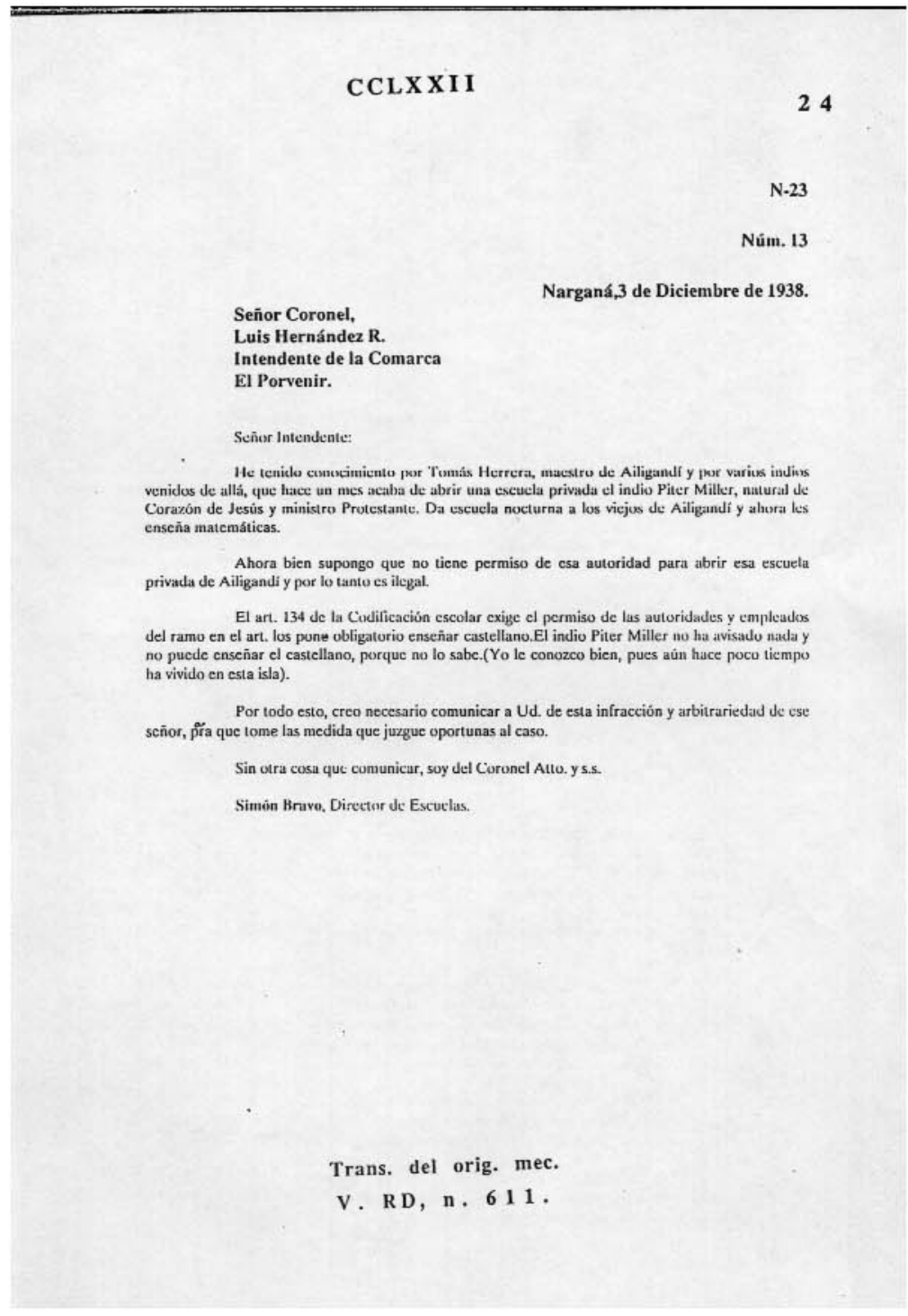




\section{CCLXXIII}

$\mathrm{N}-21$ y 22

Num.16

Narganá, 3 de Diciembre de 1938

Señor Coronel,

Intendente de la Comarca

El Porvenir.

Señur Coronel:

En atención a su comunicado le he de antuciar el resultado de las investigationes.

Andrés Iglesias, masstro de Tigre fue citado en esta Dirección a una confercutia y

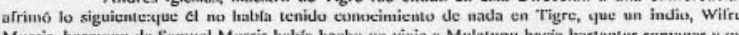

Añadió yue una comisión de policias, mandada por el Sr. Subleniente de Nurganj, llegó a Tigre para tratar de los impuesios y algunus jóvenes al ver al policía Gióndola que cargalba tel revólver dlijeron:"vamos a quitárscle y le disparames at abdomen" pero el ságuila de ta isla les reprendió par ta neckéc.

El Señor Santiago dijo al Señor matestro que debiu avisar de tude y yue no laath

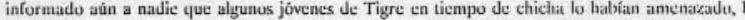
que fue cierto y no negó. Posteriormente yo hable de nuevo al Señor maestro y le recalyué sus deberes, como unico repressentante del Gobierno en la isla, y la obligación que lenia de informar en cualquier movimiento, oral o real,en contra del gobierno, de la civilización y de la escuela, cusa que

Prometió cumplirlo en adelante con fídelidad.

Asi mismo, habiendo sido citado el macstro de Ailigandí, Tomás Herrera, cumparareció en esta dirección de Escuelas y declaro lo siguiente: que en Ailigandi no habian hablado de levantarse contra el gubierno y la civilización, pero algunos indius se había cxpresado co cuntra de las impuestos de las tiendas y que un joven venido de Panamai traia la noticia de que el impuesto er injusto, según lo habian manifestado los indius ilustrados de Panamá. Además que las istis de Yabli iguiña, próxinas a Ailigandí no pagan el impuesto, y las islas de Nele lo paituan en cécetivo, to que les cuesta mucho porque los barcos que comercian no les pagain el coco con plata simo con mercancia.

También asceguró el referido maestro que el asunto de las maderas ya estaba

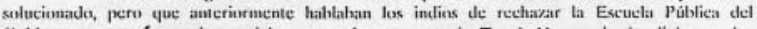

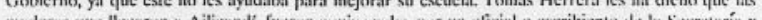

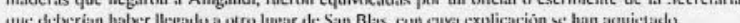

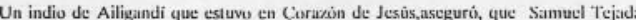

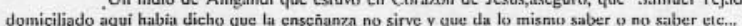
esta noticia la oyó Tomás Herrera en Ailigandi de labios del mismo indígena que la escuchó.

Oido esto, que parece real, le hice ver sus obligaciones, como el único representanie dut Gubierno en la isla y la obligación que tenía de informar de todos los asuntos a las autoridades, bajo la pena de peligrar su puesto si descuidaba en hacerlo. 
Prometió hacerlo y eumplir todos sus deberes. Posteriurnente habtó con el scñor Subteniente, quien le hizo parecidas aseveraciones.

Creyendo haber satisfecho sus deberes al respecto y quedando a sus órdenes.

Soy de Ud. atto.y s.s.

Simán Brave, Dircetor de Escuclas

Trans. del orig. mec.

V. RD, n. 612 
Señor Coronel,

Luis Hernández $\mathrm{R}$.

Intendente de la Comarca.

EI Porvenir.

Señur Intendente:

Con esta le envio hos datos estadisticos escolares del mes, yue apentan un buen pronedio de asistencia.

Durante el mes fueron llamados a este despacho los macstrus de Ailigandi y Ris Tigre, Tomais Herrera y Andrés Iglesias, pur munivus que Ud. ya conoce.

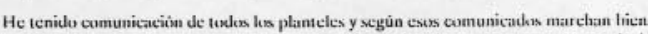

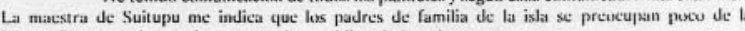
instrucción y son algo remistos en mandar sus hijos al plantét.

Ya conoce, porque fue remitido a su despacho, la falta de Andrés Iglesias, maesiro de Tigre, que contravino las leyes que prohiben libar $y$ vender licor $y$ que vienen a confirmar mis sospechas que el referido maestro ha caido ya varias veces en esa falta en la poblaciôn donde enseña.

Me indico Usted en su última visita que este año mandaría algunos empleados de esa para presenciar los exámenes de lodas las escuelas de la Comarca y como las Escuelas se cierran el 10 de Febrero, me indicară Ud. el modo de poder coordinar los exámenes en las distintis escuelas de lit Comarca, ya que las comunicaciones son tan difíciles en la mayor parte de los planteles.

Yo por mi parte desco que me presencien los exámenes de todas las Escuelas para poder estimular más a las macstrus $y$ alumno

Con tocla consideración me suscribe de Ud. atto. y s.s.

Simón Bravı

Trans. del orig. mec.

V. RD, n. 613 . 


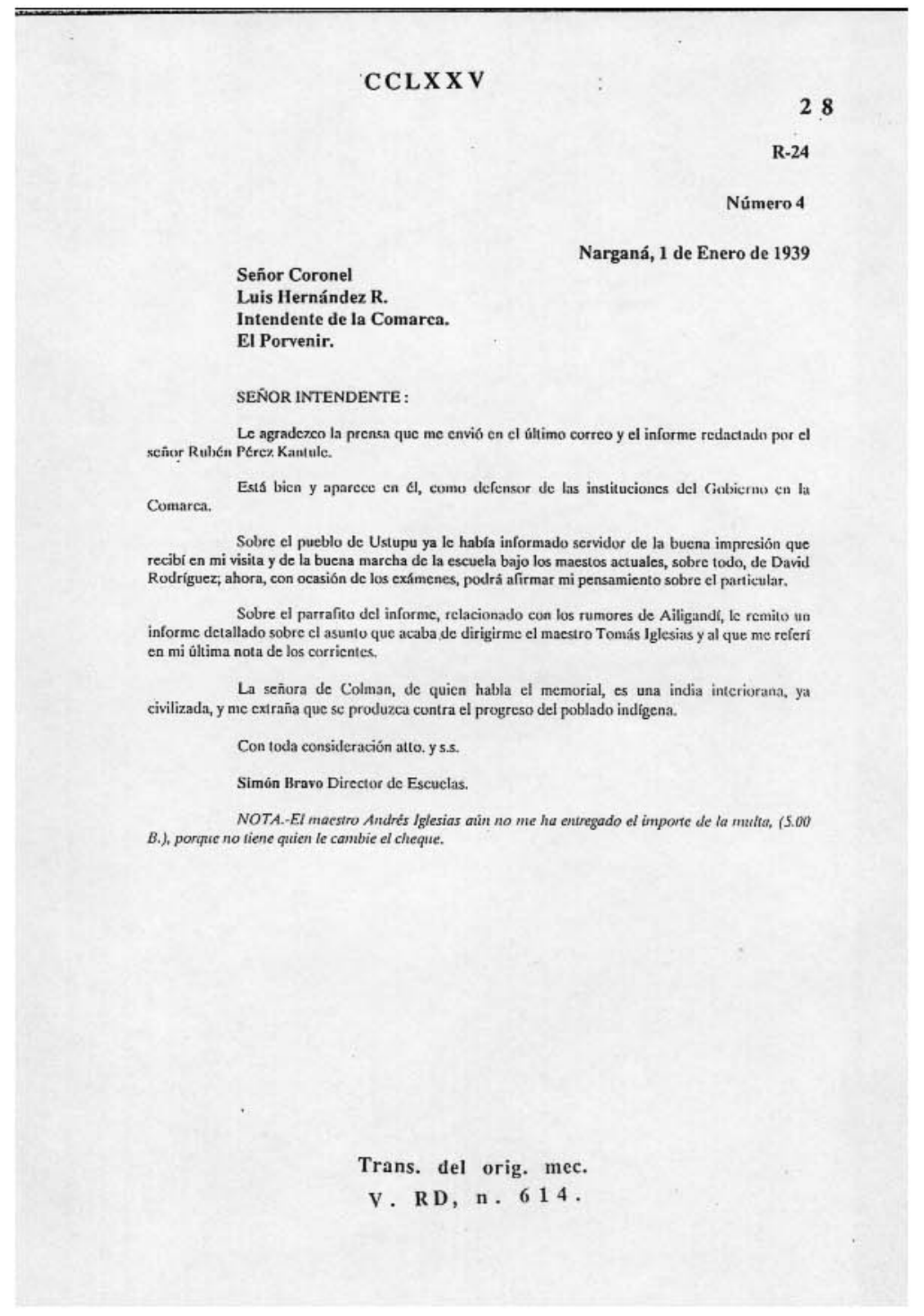




\section{$\operatorname{cclXXV}$}

Senior Coronel

Luis Hernández R.

Intendente de la Comarca.

El Porvenir.

SEÑOR INTENDENTE:

Adjunto a la presente nota va una Circular, dirigida a todos los Maestros de la Cornarca y cspero su aprobación

En ella se determinan las fochas y el modedo de theer los exímenes finales en las distint escuelas de la comarca de San Blis.

Por la distancia y mala combinación de barcos, yo creo que se podrá asistir a los exámenes de la escuela de Ustupu, pero la Comisión, nombrada por Ud., puede hacerlo facilinente.

Desearfia conocer, si no lo cree Ud. inoportuno, el resultado de la conferencia que tuvo Ud. con Piter Miller, que está ahora dando clases nocturnas privadas en Ailigandi,

Asímismo, me permito insinuarle que la Comisión que presencie los exámenes de las escuelas públicas, pase también una visita a las escuclas privadas de la Comarca, que son las siguientes: la escuela inglesa de Franclin en Ustupu y la escuela de Alcibiades Iglesias y Ms. Marvel en Ailigandf.

Soy de Ud. muy atento y seguro servidor.

Simòn Bravo, Director de Escuelas

Trans. del orig. mec.

V. RD, n. 615 


\section{$\operatorname{CCLXXVII}$}

Número. 4

CIRCULARA LOS MAESTROS DE LA COMARCA DE SAN BLAS Año escolar 1938-1939

ASUNTO: Exámenes finales.

\section{SEÑORES MAESTROS:}

Por conducto de la presente Circular, llevo a su conocimiento las fechas de calendario escolar, relacionadas con los exámenes y clausura del ańo escolar 1938-1939.

Con el único fin de que estos actos se realiocn con mís solemnidad, disciplina efcetividad; para que se pueda apreciar más y mejor la labor desarrollada a lo largo del año escolar,

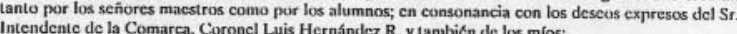

HE DISPUESTO COORDINAR LOS EXAMENES FINALES AL TENOR SIGUIENTE:

A) Una Comisión inparcial se personará cn las distinjas escuelas de la Comarca, para diclar su respectivo juicio sobre el resultado de los trabajos de instrucción y educación de cada

B) Los Grados III,IV,V,VI, de la Escuela de Narganá empezarán los exámenes de escrito el dỉa 6 de Febrero próximo y terminarán el día 9 del mismo mes.

C) Los exámenes orales que han de ser presenciados por la Comision, nombrada para el caso, se repartirán en esta forma:

El día 3 en Suitupu de Carlí; el día 6 en Narganá y Corazón de Jesús; el dia 7 en Rí Azúcar y Río Tigre; el día 8 en Tupile; el día 9 en Ustupu y Ailigandi.

D) Una Comisión especial presenciará los exàmenes de la escuela de Plo, Obaldía el dia 9 y publicará las notas el día 10 .

E) El día 10 de Febrero, en conformidad con el Decreto del Ejecutivo, se clausurars solemnemente en Narganá el curso escolar 1938-1939 con la entrega de los Diplomus de VI Grado lectura pública de la lista de alumnos promovidos $\mathrm{y}$ fracasados.

Los señores maestros recuerden fielmente sus obligaciones respecto al archivo escoler inventario general de muchles $\mathrm{e}$ inmuebles, reseńa histórica de la escuela, lista de promovidas Iracasadtex cle..., axi como el depositar en lugar adecuado y seguro el material escolar del plantel cue regentan, Los maestros son respouscalles de la conservación de tales átiles de enseñanza.

us.s.

Deseándoles cxito brillante ca sus trabajjos, quedo de uds. con toda consideraciün atto.

Simón Brave, Director de Escuelas.

Narganá, 4 de Enero de 1939.

Trans. de la cop. mec.

V. RD, n. 616 . 
10 FEBRERO 9

\section{REF.: SU ATENTO OFICIO № 8 DEL 6 DEL PRESENTE MES SEÑOR PRESBITERO: SIMON BRAVO, DIRECTOR DE LAS ESCUELAS. \\ NARGANA}

SENCR:

EN ATEN(ION $A$ SU ATENTO) OFICIO (TTADO EN REFEREN(IA, ME PERMITO AVISARLE RECTOU DE LUS DAOS ESTADISTSICOS MENSUALES DE LAS DEL PROGRESO DE TUDOS ESTUS PLANTELES.

EL INFORME ANUAL DE LAS ESCUELAS AL CUMPLIR CON SUS LABURES FINALES, ESPERO ME L() DIRIJA A MI, A FIN DE TRASCRIBIRLO) A LA SE('RETARIA LAADMINISTRACION. NO) HAGAA MEN(IIIN EN SU INF()ME DE AUMENT() DE MAESTR(OS; PUES ESTO) ESTA PREVIST() P(OR DECRETO EJE(UTIVO). Y SERIA INADMISIBLE HACER HINCAPIE SUBRE ESTE TUPICU)

LO ESPERO A SU PASO PARA PANAMA QUE, COMO BIEN LO MERECE DISFRUTAR DE SUS VACACIOANES YA QUE SU LUCHA HA SIDO TENAZ EN ESTE ANNO Y NECESITA DESCANSO PARA QUE VUELVA CON NUEVOS BRIOS - PARA QUE DISCUTAMOS LA ORGANIZACION PARA EL ANO LECTVO ENTRANTE DE OPICION OUE LA MAESTRA DE CORAZUN DE JESUS DEBESER UNA HERMANA.

UNA VEZ OUE TERMINE TODO LO OUE TENGA OUE HACER $Y$ ESTE LIST() PARA VIAJAR A PANAMA, A SU PASO) HABLAREMOS DETENIDAMENTE: Y(I) LE DARE UNA NOTA ARZA UUE A REPRESENTACIUN MIA HAGAA LAS (iESTIIJNES DE LOS UTILES NECESARIOS (O)MO MOBILIARIO).

PARA EL NUEV() AÑ() HE PENSADU) UUE SE HAGIA PUR UN DE(RETU EL NUMBRAMIENTO DEL PERSONAL DE MAESTRUS, QUEDANDO A JUCIO DE OUE UNA VEZ CONOCIENDUSE EL PERSO: NAL DE MAESTROS, LOS INSPECTURES

EL AUMENTO UUE HACE EL DECRETU EJECUTIVO N* 78 DEL 8 DE N()VIEMBRE PASAD(), Y LA VAC(ANTE P(IR LA PROMOCIION DE USTED

Trans, de la cop. mec. inc. V. RD, n. 617 . 


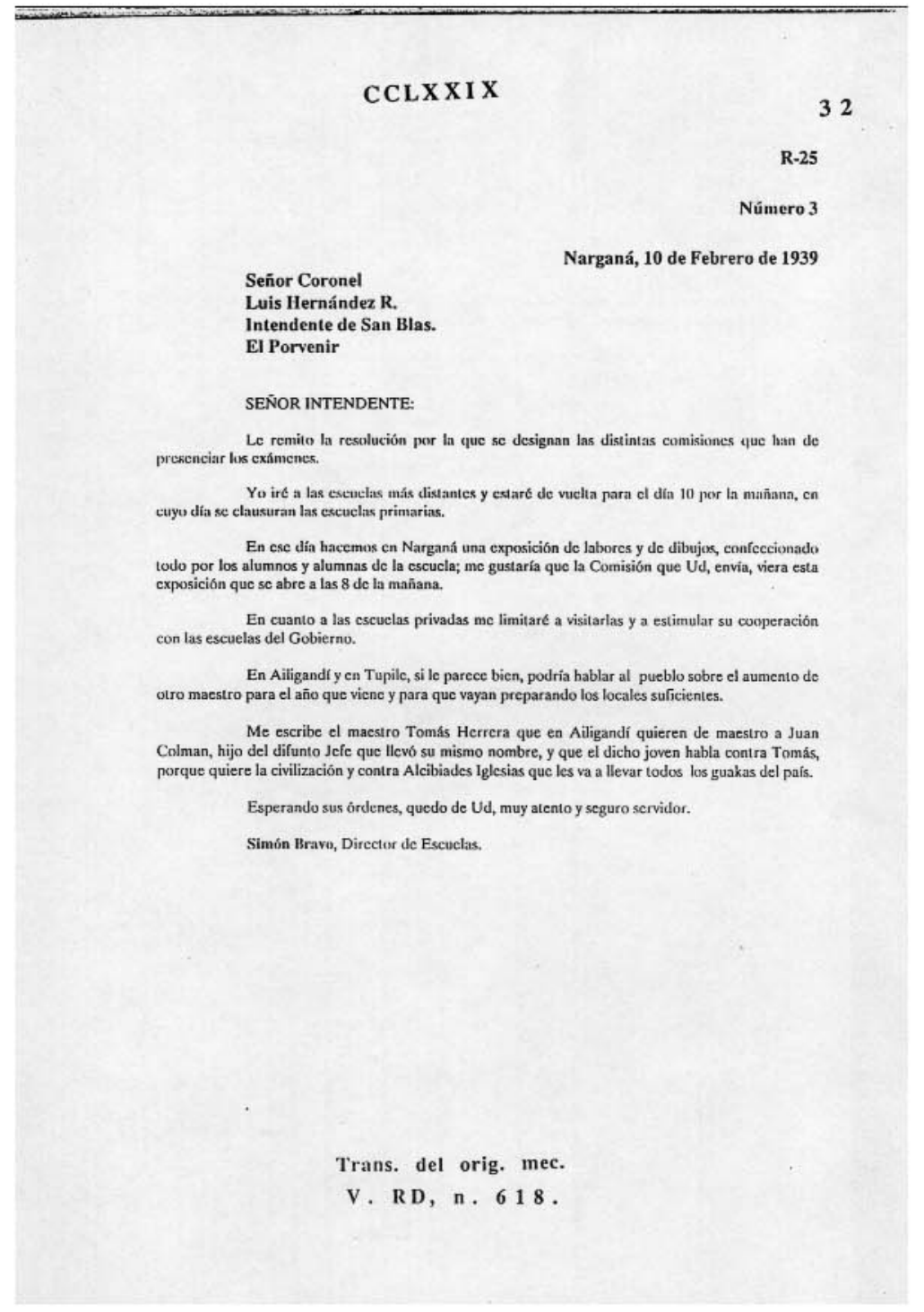




\section{$\operatorname{CCLXXX}$}

CONSIDERANDOS

$1^{\circ}$ Que la suprema Autoridad de la Comarca me ha delagado los poderes para designar el tribunal o comisión de examinadores en todas las escuelas de este distrito escolar de San Blas;

${ }^{2}$ Que, dado la distancis que separa a unos planteles de otros y la escasez de tiempo de que se dispone, una sola comisión no puede llevar a efecto la supervisión de todos los exámenes orales:

RESUELVO

1* Nombrar tres enmisiones de examinadores, integradas por les siguicntes schiores:

A). Para la escucla de Suitupu-Cartf a los scinores Ramiro Walker y Juvito de la Rusa A. (Día 3 de Febrero). Para las Escuelas de Narganá, Río Azúcar y Tigre a los mismos señores, juntamente con el Rev. Manuel M. Puig.

B). Para las escuclas de Tupile, Ailigandí y Ustupu a los señores Tomás Herrera, David Rodriguez, Evangelina Ossa, Josefa de Salazar y el subscrito, cunforme al método de rolaciôn.

9 de Febrero).

C). Para la escuela de Pto, Oballía a los Señores Juan Vázquez y Guillermo Denis. (Día

2. Supervigilar los cxámenes de las escuclas privadas de Ailigandi y Ustupu por medio de la Comisión de examinadores.

Narganá, 10 de Febrero de 1939

Simún Bravo, Director de Escuclas.

Trans. de la cop. mec.

V. RD, n. 619 


\section{$\operatorname{CCLXXXI}$}

Panamá, Marzo 7 de 1939. Señor Director del Dpto. de Beneficencia e Higiene Panamá.

Señor Director,

Por medio de la presente me permito reportar sobre el viaje a las islas de San Blas, efectuado de acuerdo con sus órdenes entre los dias 25 de Febrero y 4 de Marzo de 1939.

Primeramente hay que decir las gracias al Scĥor Intendente de la Comarca, Coronel

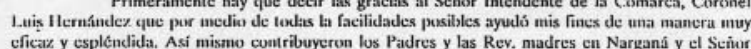
Pérez Kantule.

Efectivamente era cierto el reporte sobre varias defunciunes debidas a tuberculosis, enviado al Señor Secretario de Gedhierno.

Estas defunciones ocurricron en las islas de Narganá y la isla de Ayócar, Se trata en todo de cinco casos que muricron áltimanente con un termino de casi ires mesces. Averiguando indios que en busca de trabajo han emigrado de sus islas a Colón y uno a Panumi on buse trabajo.Me informarun los Rev. Padres y el Padre Manucl Puig en esp, que lus indigenas en Colôn viven en condiciunes higiétricas muy malas. Hasta 10 están durmiendo en un solo cuarto y tambiêtn lo alimentación parece yue es deficiente,Bajo de estas endiciunes una infeccioin de llhe. iseurre naturalmente con facilidad.

En ningun caso el foco de la infección parece haber sido en las islas sinu tudus sc infectaron en Colón y Panamá y regresaron enfermos a sus islas nativas.

Con el fin de informarme si en las mismas islas hay focus de infección de lbe, visite en compañia del Rev. Padre Puig todas las casas en las islas de Azúcar y Narganá donde se encuntraron Anfermus de cualquier clase. Mas o menos 50 casos. Solamente en un solu casso-primipara, Diagn Amebiana, raquitismo, avitaminosis, etc.

Para evitar contacto con los enfermos que tal vez en el futuro pueden venir en las ınismas circunstancias como las anterieres me comunique con los Rev. Padres y las Rev. Madres.

Ambas ... Jeclararan que por el próximo futuro irian supervisando la lleganda potencial de nuevos easus de ltsis, y que tomaran las medidas necesarias para separar los enfermus de sus familiares o otras agrupaciones para evitar nuevas infeceiones.

Las demás enfermedades fueron atendidas taista dunde cra pusible bajo de lex medius primitivus que cran a la disposicion.

Me aprovecho de las experiencias de esia expediciôn para dar unas sugestiones que me parecen necesarias e utiles.

La Publación de las islas de Narganá y Corazón de Jesús (: 1000 Personas aproximadanente) muestra un espiritu de cooperación y civismo que es verdaderamente inusual. Se han construido por ejenplo iltimamente una iglesia moderna con un salón de cunferencia en ta part 
de abajo, todo de concreto, 2 centros de la juventud indigena, construcciones de maderah, parques con plantas y flores y más instituciones para el bien común.

La enseñamar que dan las Madres me pareece similar a las nejores excuelas de la (:aptital ( clase de gimnastico, higienc, dibujo, etc.) la misma población es descosa de emprender e inteligente. Las calles son de una limpieza ejcmiplaria, encargandose cada uno de las habitantes con la parte que

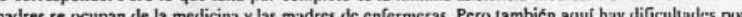
falla delos medicamentos necesarios

Encontrandose Narganá más o menus en el Centro de la distancia entre Culón y la frontera de Colombia me parece que la colocación de una enfermera visitadora en Narqaná seria de una utilidad grande.

Adjunto una lista de les medicamemntos más nceesarios que fue cenfeccionadus scgún

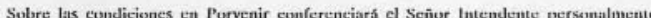

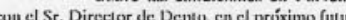

Soy del Sr. Director muy atento y seguro servidor.

(firma ilegible)

Trans. del orig. mec.

V. RD, n. 621 . 


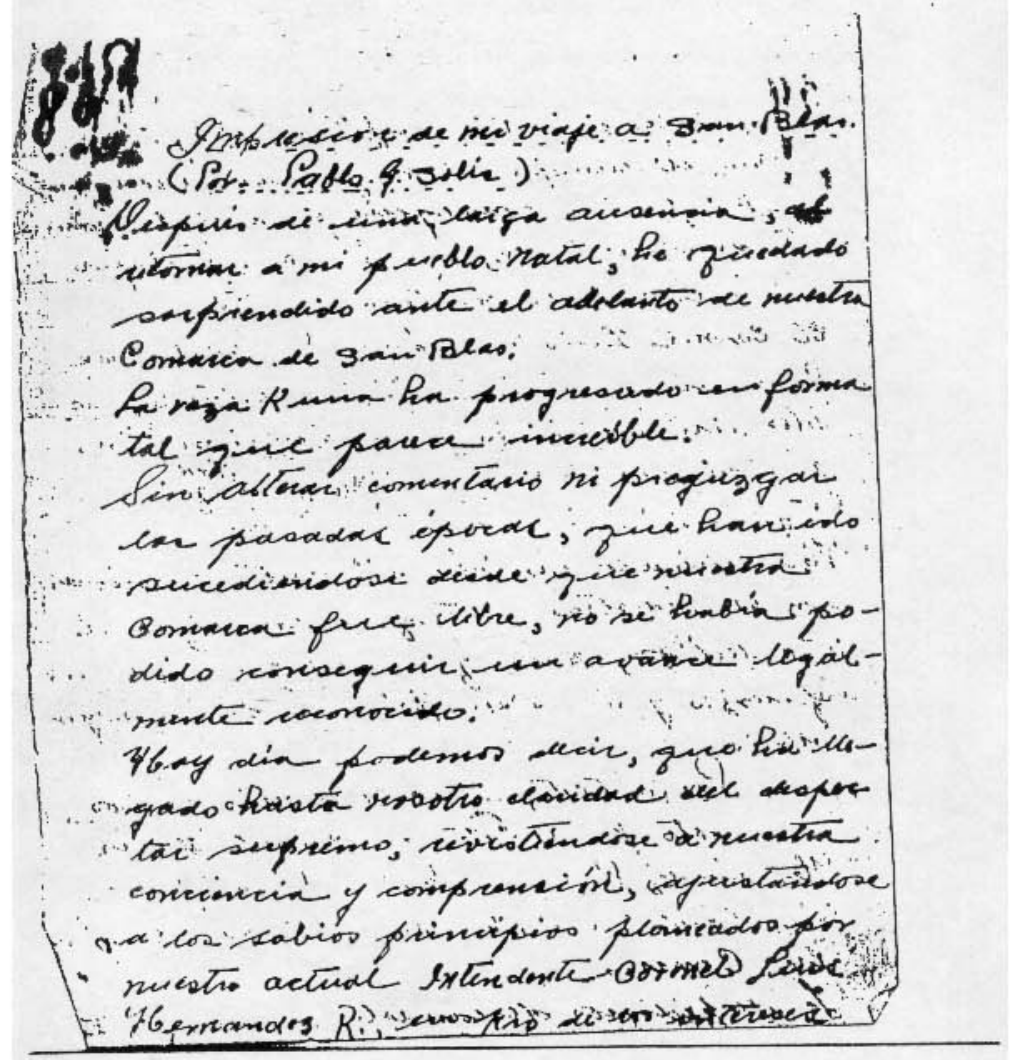




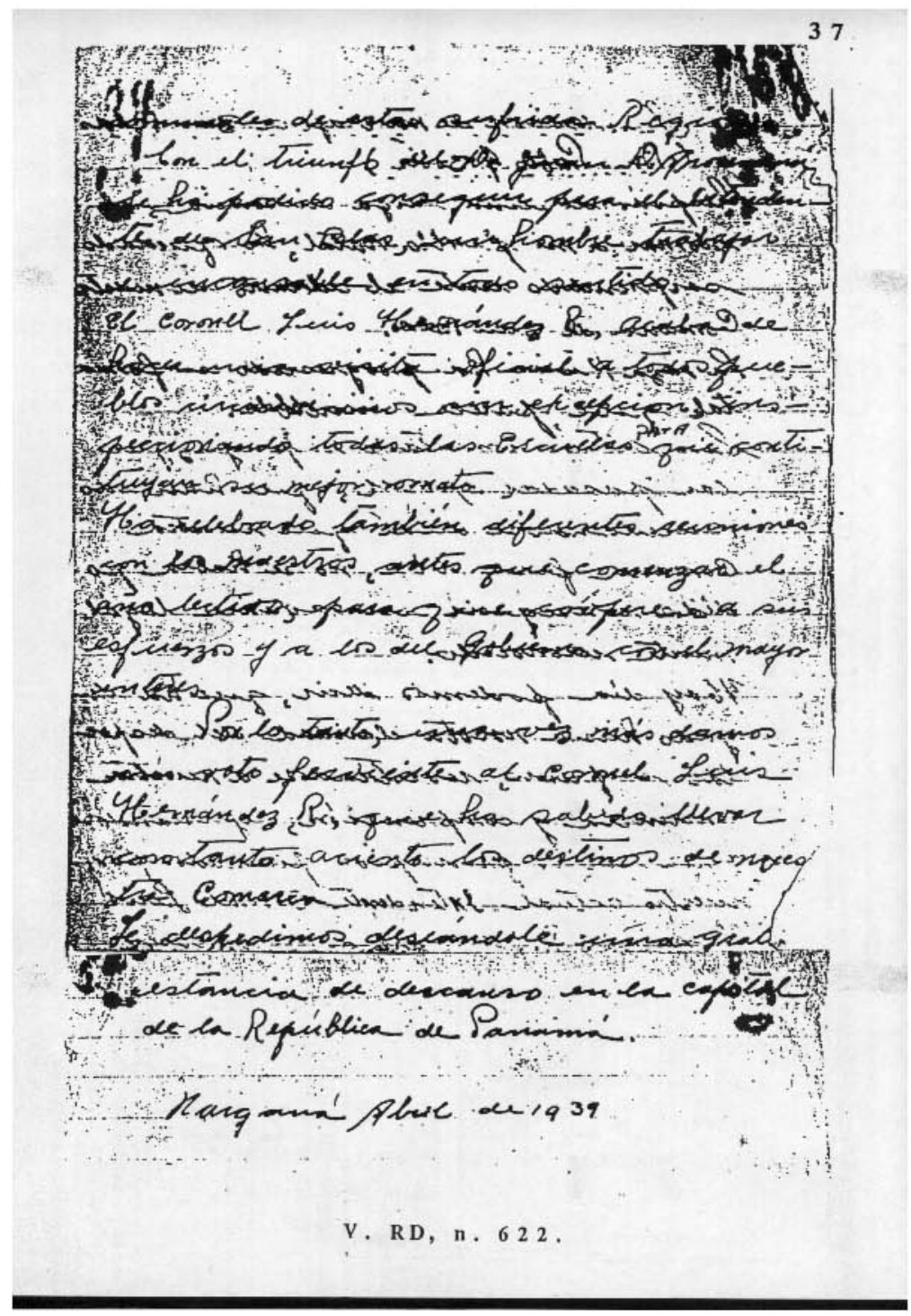




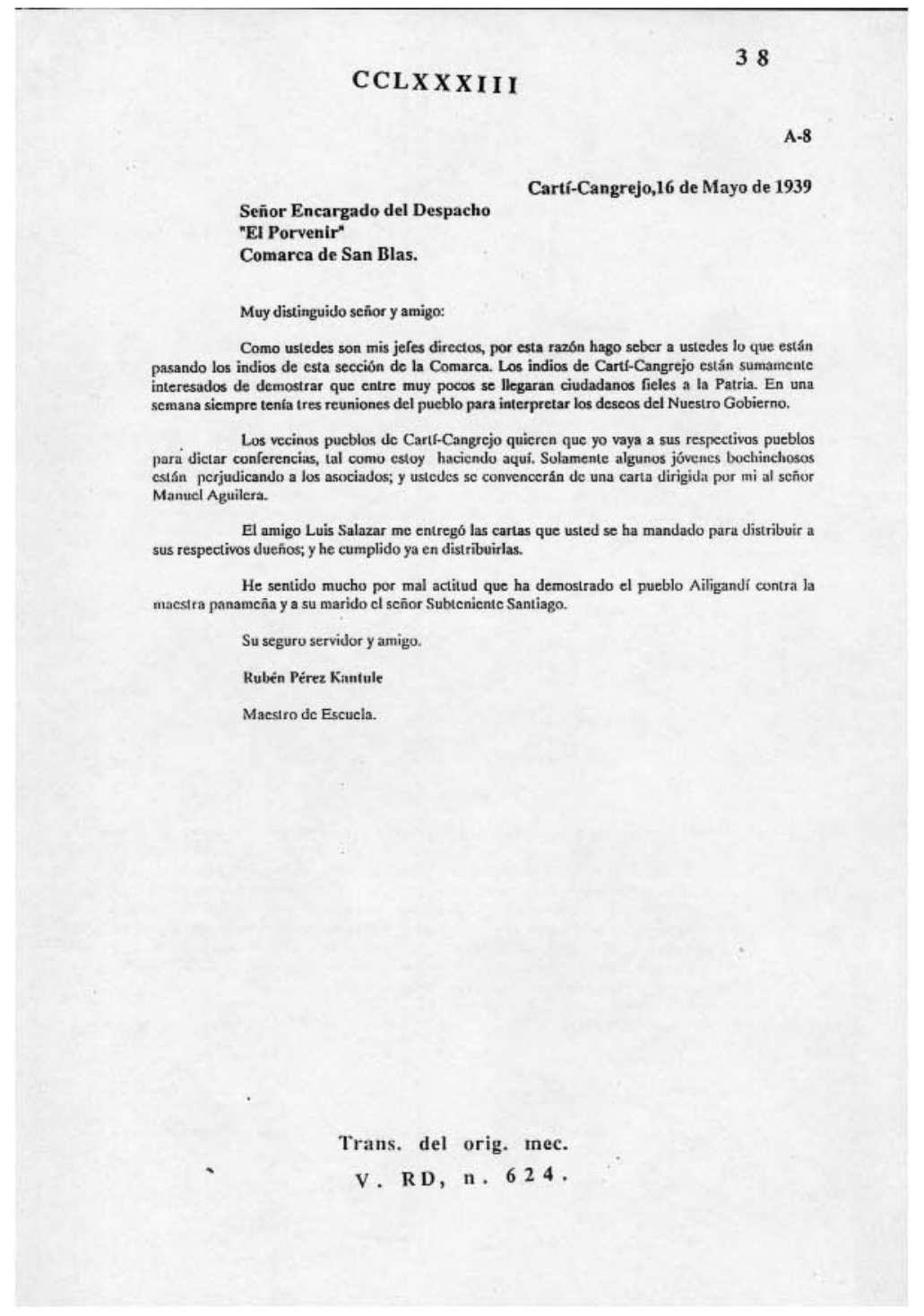


Ustupu San Blas 31 de Mayo de 1939

Señor don

Ovito. Secretario del Porvenir

Muy estimado señor Secretario.

Desen comunicarle estas cortas linens para saludarlo y al mismo tieanyo de que usted recilar mi carta cute se cncuentre de bucna silud y deso de manifestarle por medio de estas líncas para gue usted nos haga ese servicio pues senior Secretario como en el pucblo de Ustupu se está construyendo un cuificio Escolar para cl pucblo de Ustupo ya que veo que nos hace falta materiales para cl culificio Señor Secretario uquif le envio una lista de los manteriales para el edificio que son las
siguientes que se hace falta

\section{5. $4 \times 6 \times 16$ pies \\ $10-2 \times 4 \times 16$ pies \\ $10-4 \times 4 \times 16$ pies \\ $10-2 \times 12 \times 16$ pies \\ $50 \times 2 \times 6 \times 16$ pic}

10 libras de claves de 2 pulgadas

3 libras de clavos de 4 pulgadas

Pucs scîor Secrelario csas son las listas que le pido urgente como me dice el carpintero que el tiene mucho trabajo aquí en el Porvenir desea de hacer ligero el edificio pues entonees yo me lo envie ented me envic los materiales que yo le he pedido en esta lista, pues deseo de que usled lo más pronto posible que el carpincro lo necesita y también le manda la lista cl carpintero de los 政 sted secrelario del anigo Luis Ifenandez R. y cnearga del despacho del pues yo le cnvio por molivo de que se necesita los materiales usied. No se le olvide de mandarlo en la lancha la ESFERA y desco que usted me contesic su atenta carta. usted perdone.

S.S. ATro.S. amiger

Nele de Kantule

Cacique de San Blas.

Trans. del orig. mec.

V. RD, n. 628 . 
R-11,12 y 13

INFORMEESCOLAR DELA COMARCA DE SAN BLAS Mayo y Junio de 1939.

Señor,

Coronel LUIS HERNANDEZ $R$.

Intenidente de la Comarca.

El Porvenir.

Señur Intenlente:

Cumplichdo un deber de esta Direstón, voy a rendirle un sencillo informe neerca de los acontecimicntos, que durante su ausencia de la Comarea han roto la monotonta del tiempo.

Comicnzas de año escolar.

Todus los seîures macsiros dieron principio a las labores escolares con puntualidad, si exceptuanus a la sen̂ura Inés de Santiago, la eual por diferentes motivos perdio mís de ocho días cual todo claras fué rechazada por los indios del lugar. del todo claras fuerechazada por los indios del lugar.

Hubo de regresar a El Porvenir en donde cjerció hasta el 13 de junio fecha en que se abrió la cscucla de Permé, en donde está actualmente con unaio hasta cl 13 de junio fecha en quue sc DeAlliGiandL solicitan Macstro.

Después de lo ocurrido, Roberto Pérez maestro de Ailigandí, solicitó un socio con que poder hacer frente a la matricula cn aumento. Dicha solicitud fue cursada por esta Dirección a la Intendencia, recibiendo contestación desfavorable y comunicandola al propio tiempo al interesalo.

Ein de Mayo.

A su Jebido ticmpo remitió esta Dirección a la Intendencia los datos estadisticos Ilegando al conocimiento de haber mejorado la situación escolar en la Comaręa.

La matricula gencral aument6 en 23 alumnos la asistencia media cscular se clewó en 25 puntus sobre el mes anteriur. Si complarames el mes con el identico de 1938, vemos que in mentin 2.5 sc clewo 44 alumunss; y has asistencia media, 46 .

Las couferencias y visitits a los padres de fanilia asciende a 15 (quince)

MesuleJunie

Obaldia.

A primeros de Junivo, me traslade en visita de inspección a Rlo Azícir y Puento

Ambas escuelas marchan normalmente, si bien la primera ha perdido matrícula y la scgunda esta desprovista de átiles cscolares 
A mi regreso a Narganá, me encontré con una solicitud de parte de los maesirus y pueblo de Ustupu, solicitándome matcriales para levantar una escuela de regulares dimensiones Como estos indios manifiestan gran interés por la instrucción de sus hijos, la remiti a El Porvenir.

Asunto de Río Azicare.

Por voces callcjeras, que no por otras, vine a enterarme de una trifulca habida por celo entre la maestra Carmen y la mujer de uno de los indios de dicho pucblo.

Cuando lleguo a mi conocimiento, la autoridad del Destacamento se había trasladado a Río Azúcar en donde se encontró con el Secretario de esa Intendencia, quien actuó en la liquidación del asunto.

De regreso de Rio Azúcar me comunicaron que nada había sucedido y por lo mismo nada quise gestionar, esperando lines de mes para comunicar a dicha maestra (ademas de otras cosas) un aviso de alerta para lo sucesivo.

Yinica c colin.

Por motivo de las Fiestas y bien a pesar mío, hube de solicitar de esa Intendencia un permiso para trastadarme a Colón con la finalidad de ultimar el programo a seguir.

Nada pude arreglar al tener conocimiento de que Usted no podia asistir, obligado por compromisos más serios, $y$ que los turistas no ofrecian seguridad.

No fue inútil sin cmbarago mi viaje, ya que proporcioné además de alegría para los indios (con un novillo); una bena máquina de escribir pars esta escuela júntamente con olyunos libros.

Esta es a grandes rasgos la actuación del Director de las Escuelas de la Comarca, que Usted gobierna con el tino y disposición que todos palpamos.

Repitiendome de Usted siempre scrvidor,

Ricardo Velasco

Director.

Trans. de la cop. mec.

V. RD, n. 631 . 
Carti-Cangrejo, 7 de Julio de 1939.

Coronel Luis Ilernandez R.

Intendente de la Comarca de San Blas

El Porvenir.

Muy distinguido señor Intendente:

Acuso que he recibido su muy atenta carta fechada del día 4 de este mes.

Siento mucho que no pude venir personalmente como ya anuncié en mi carta anterior; para que usted sepa de la situación actual de

Carti, cnvío al saila del lugar.

Quicro manifestarle anticipadamente que en cuanto del asunto de la política todos los indios estan jurados de ser ficles al Gobicrno Nacional para luchar por la compuña actual. El ex-saila del lugar a hecho un trabajo muy lindo al favor de la politica que usted va a presidir. El estuvo visisando a los pucblos vecinos por su propia voluntad de hacer propaganda ya que el todavia posec una in huencia prante cotre los paisanos suys por tener una csperiencio en cste caso.

En cuanto de la Escuela quiero informarle que he encontrado la escuela en pésima situación, Los niños que estuvicron con la mestra Juana de Hayans no han aprovechado en nada. Muy estrañado fui cuando encontré a los pobre niños sin conocimiento alguno sobre las materias del programa de la escuela. Asi, he quedado como el primer naestro que ha estado en este pueblo en este año;veo pues que ha sido inhábil la maestra durante los periodos de tiempo de las cscaclits comareales.

Me quedaria sumamente agradecido, si usted me mandara algunas libras de clavos de 3 pulgadas. Necisito para terminar la casa del maestro que el..

Rubén Perez Kantule.

Trans. del orig. mec. inc.

V. RD, n. 632 . 
Número 78

Señor Coronel,

Narganá, 25 de Julio de 1939

LUIS HERNANDEZ R.

Intendente de la Comar

EL PORVENIR.

Señor Coronel:

En respuesta a su atcnto oficio número 798 del 22 de los cofientes, en el que solicila de os macsirus de la Comarca la cuoperación personal a la obra patriótica y provincial de ln carrecter de Colon-Portobelo, debo responderle:

unc atendiendo a los cuatro años de servicio que me ha tocado pernanceer en cl Distrito de Portoble scré parn ni una satisfacción colahorar lo más que pueda a csa obra tan Distrito de Portobclo scrá para mir una satistacción colaborar lo más que pueda a csa obra tan
deseada por los cosieños.

Inmediatamente pondre manos al asunto con el fin de que todos los macstros se preocupen y ayuden económicamente a la realización de tan bella obra nacional y regional.

De usted atento y s.s.

Ricardo Velasco

Director.

Trans. del orig. thec.

V. RD, n. 634 . 
Señor Coronel,

NARGANA, 10 de Agosto de 1939

LUIS HERNADEZ $R$.

Intendente de la Comarea de San Blas.

EI PORVENIR.

Senor Coronel:

Terminada mi gira de inspecciôn por las escuelas de Ustupu, Ailigandi y Tupile, lókame darte alguata idea de mis impresiones.

Ustupu es la escucla mís adelautada en conjunto, después de la Cabrecra.

Los Jefes del pueblo estín ansiusus de civilizaciốn, y su interés porçue los niñus aprendan es muy superior al interés quue manifiestaun los padres de familia en el Distrito escolir de Nombre de Dios.

Además de cnterarme de la marcha de la escuela en todas las asignaturas, presencie una velada de los niños, admirindente su despejo y soltura.

Una cusa djojo de agradarme y fue di ver que has alumnas de la cscucla de inglés, no subian el himno nacional, siendo algumus de cllos de màs yue mediana estatura.

Rubertu destmpeña en Ailigandi un buen papel de atracción hacia el gubierno.

En Tupilc, Jusefa lleva perfectamente su escucla.

Siempre a sus ördenes de Usted,

Ricardo Velasco.

Director

P.D. MAcho me insisticrun en Ustumut

para que agenciarn la rápida temuinación

de la escueta.

Los locales actuales, reulmente no son aptos.

Trans. del orig. mec.

V. RD, n. 635 . 
SEÑORES

26 OCTUBRE

CARLOS B. SANCHEZ Y RICARDO VELASCO,

PRESIDENTE Y SECRETARIO DE LA "JUNTA DE ORNATO",

NARGANA.

SEÑORES:

EN ATENCION AL CONTENIDO DEL ATENTO OFICIO DE ESA JUNTA DISTINGUIDO CON EL N*239 DEL 18 DE LOS CORRIENTES, LE DOY MI VOTO DE APLAUSO AL DESEO DE UDS., DE QUE, COMO PARTE DEL PROGRAMA DE CELEBRACION DE LAS FIESTAS PATRIAS SE ENCUENTRE UNA COMIDA PARA ENCUENTRO MUY BUENA Y OUE MERECE MI APROBACION.

CON RELACION A LA EXIGENCIA POR PARTE DE LAS AUTURIDADES DE LA SECCION DE RENTAS INTERNAS DE COLON PARA EL PAGO DEL IMPUESTO PERSONAL, ESPERO OUE EL SENOR SUBTENIENTE JEFE DEL $2^{\circ}$ DESTACAMENTO DE ALLI, LE EXPIDA UN REACIBO A LOS VECINOS EN QUE CONSTE QUE DE ACUERDO CONIVALETE A UN DIA DE TRABAJO CON ESE COMPROBANTE QUEDAN

DE UDS. MUY ATENTAMENTE,

LUIS HERNANDEZ $\mathrm{R}$,

-INTENDENTE.

Trans. de la cop. mec.

V. RD, n. 642 . 
Número 234

Narganá, 1 de Noviembre de 1939.

Señor

Coronel LUIS HERNANDEZ R.,

Intendente de la Comarca.

El Porvenir.

Señor Coroncl:

Después de mi regreso de Puerto Obaldia, le remito las cuentas

mensuales con respecto a la marcha de has escuelas de la Comaree

Por los datos apuntados se deduce una merma en la matricula de 8 (ocho) alummus en

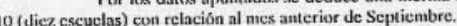

Mayor resulta la falta de asistencia, que se eleva a 15 alumnos en idéntico número de planteles escolares. aguda y general que se ha extendido en varias localidades de la Comarca.

Soy de Usted atto. y s

Micardo Velasco, Director.

Trans. del orig. mec.

V. RD, n. 645 . 


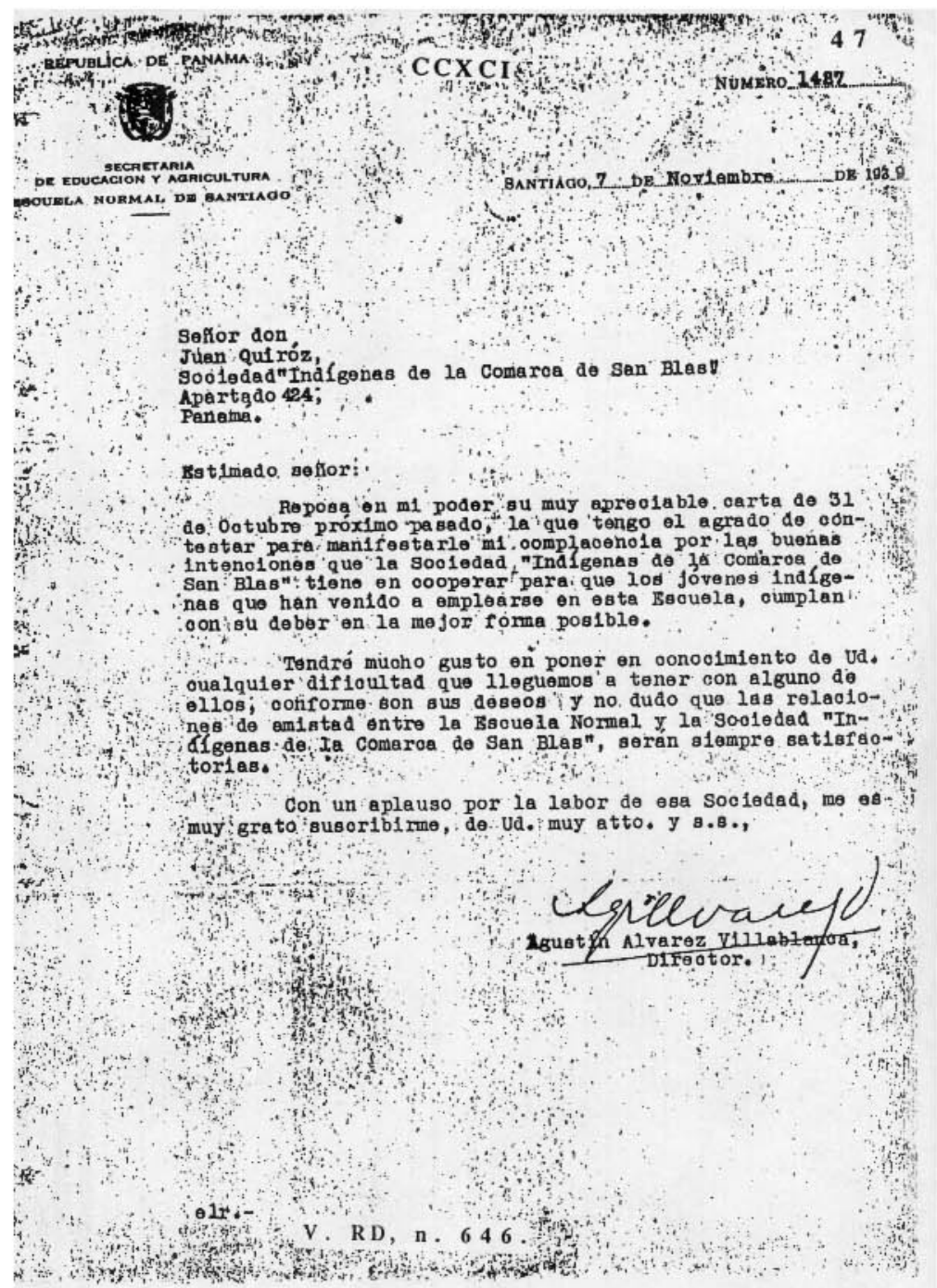


Número 267

Señor

Coronel LUIS HERNANDEZ $R$.

Intendente de la Comarca.

El Porvenir.

Scñor Coronel:

Cumpliendo sus instrucciones acompañe al Doctor visitando las escuelas de Ustupu Cumpliendo sus instrucciones acompañé al Doctor visitando las escuelas de
Ailigạandí y Tupile además de servir como verdadero ayuulante a los enfermos en Tuhalí cte.

Creo que tanto Usted como el Gobierno han adquirido más aprecio de parte de los
nativos de la Comarca por esta gira humanitaria, la cual quedará bien grabada en ellos y dará los mejores resultados.

ninguna clase.

En Ustupu encontré construida una casita para escuela, pero sin luzz ni condiciones de

El ambiente que existe acerca de la construcción de la nueva es enteramente de desconfianza y por lo mismo fue inútil proponer a los interesados cedieran el local anterior hasta la
terminación del presente curso escolar.

En Ailigandi me fue imposible visitar la escuela por haberse trasladado el maestro a Tupile cn un día de Trabajo.

Adjúntole a esta la comunicación del Macstro Rubén para que conozca la situación por la que atraviesa la escuela de Carti.

Con ta más alta consideración para Usted soy su atto. y s.s.

Ricardo Velasco, Director

Trans. del orig. mec.

V. RD, n. 649 . 


\section{CX CIII}

\section{RESOLUCION}

Considerando:

a) Que ha llegado la hora definitiva en la formación de las Comisiones de Examinadorcs para las escuelas de la Comarća.

tribunal calificador,

b) Que es mucha la distancia que separa una planteles de otros para confiarlos a un solo

RESUELVO

$1^{\circ}$. Sceñalar las fechas del cealendario en las cuales deberín Ienerse les exímencs y

$2^{\circ}$. Nombrar el personal que debe presenciar las prucbas finales tanto de alumus cono Je profesores al tenor siguiente:

Ustupu; (Día 20 y 21) Director, Roberto Pérez, Josefa de S. y Juana de Haya.

Ailigandí; (Dia 22 y 23) Director, David Rodriguez, Evangelina Ossa, Josefa O. do Salazar $y$ Juana de Haya.

Tupilc; (24) Director, David Rodriguez, Roberto Pérez y Evangelina Ossa.

Ticantiquí; (Dia 25) Director, Luisa de Morris, Roberto Preciado y Julio Göndola.

Tigre; (Día 25) Director, Julio Góndola y Tomás Herrera.

Rio-Azúcar; (Dia 26) Dircctor, Julio Góndola, Tomás Herrera.

Narganá; (Día 29 y 30) Director, Luisa de Morris, Evangelina Ossa, Carmen de Millar. Suigtupu; (Día 30) Jovito de la Rosa

P. Barrera.

Puerto Obaldia; (Dia 28 y 29) Scñores Juan Vázquez, Benigno Ramírez y Francisco de

Perné; (Día 29) A escogencia de la Macstra siempre y cuando no sean familiares suyus.

La Comisión examinadora de Ailigandr supervigilará los exámenes de las escuclas privadas alli existentes, lo mismo que hará en Ustupu la correspondiente nombrada para el lugar.

Estas comisiones dictarán un fallo calificador del estado docente de la niñę, de la labor desarrollada por los maestrox.

Narganá, 16 de Enero de 1940.

Rieardo Velaseo,

Dircctor.

Trans. del orig. mec.

V. RD, n. 654 


\section{$\operatorname{CCXCIV}$}

Número 328

Señor Don

Narganá 2 de Febrero de 1940

Constantino Villalaz

Intendente de la Comarca.

El Porvenir.

Señor Intendente:

Le incluyo en la presente nota el informe final del curso, esperando que yo mismo cntrẹgaré un cjemplar a la Sccretaŕa de Gebierno a mi llegada a Panamá

Tocante a los macstros que pucdan scr nombrados para cl aîu entrante creo seria mejor someterlos a un examen a mediados o principios de Abril, supuestos desde lucgo algunos ańos de cotsulio en escuela superior.

Como le indiqué anteriormente pienso regresar para tener un cursillo con todos los maestros de la Comarca antes de principiar el curso, Cualquiera cosa que ocurra puede comunicarso conmigo en el apartado 1002 de Panamá. Usted podrá indicarme si prefiere que adelante mi venida y la fecha de la misma.

Para el carro de carnaval irán Samucl Morris, Francisco Sóo y un fulito entre los varones, De las mujercs irän Evangclina, Rosariv, Aurora, Juana, Jusefa y Luisa, En total 9.

Del señor Intendente muy atento. s.s

Ricardo Velasco.

Director

Trans. del orig. mec.

V. RD, n. 657 . 


\section{$\operatorname{CexCV}$}

Número 382

Señor Coronel

Abril de 1940

Luis Hernández R.,

Intendente de la Comarca

El Porvenir.

Señor Coroncl:

En cumplimicnto a sus indicaciones sometí a previo examen en esta Direcciôn a Juana de !layans, Rosario Garay, Carolina Paniza, Adetaida Calvo y Aurora Garrido,

El examen del idiuna resulto bueno para todas en lo que respecta a la conversación y malo tocante a la gramática.

En matemáticas solo Juana de Hayans y Aurora Garrido resultaron perfectamente bien.

En resumen las calificaciones obtenidas son del tenor siguiente:

Luana de Hayans:Castsellano 4, Arimética S, Geografia S, Historia 4, Civica 5.

Aurora Garrida Castellano 3;Aritmética S;Geografía S; Historia S;Clivica 4.

Bosario GaraxyCastellano 4; Arituética 3; Geografía 4;Historia 3;Civica 4.

Carolina Pamiza:Castellano 2;Aritmética 2;Geografia 4; Historia 4; Civica 5

Adelaide Calve-Castellano 2; Aritmética 2; Geografía 3;Historia 3;Civica 4.

Aurora Garrido habla bien el castellano y el ingles; es buena cantora y tiene una presencia bastante atracativa. Esta será la más indicada para la escuela de Ustupu en vez de Carolina
Paniza.

En espera de nuevas órdenes soy de Ud. atto. ys.s.

Ricardo Velasco, Director.

Trans. del orig. mec.

V. RD, n. 658 . 
Número 31

Señor Coronel

NARGANA, 22 de Mayo de 1940

LUIS HERNANDEZ R.,

Intendente de la Comarea.

EI Porvenir

Señur Coronel:

Le testoy reminiendo con la presente la mayor parte de las tarjetas de identificación de lirmas, confiando mandarle muy lucgo las restantes.

Aprovecho la presente oporttunidad para hacerle sabedor que en las escuclas de ta inicus en histeria de estos phanteles.

Aqquí cn la cabecera, la matrícula ha subido hasta 335 alumnos. Quiero sin embargo lamentar la escasisima matricula de Permé (8) niños del todo insuficiente para una maessra.

Del senur Curonel muy atto. y s.s.

Ricardo Velasco,

Director.

Trans. del orig. mec.

V. RD, n. 659 
Señor Coronel

NARGANA, 22 de mayo de 1940

LUIS HERNANDEZ R.,

Intendente de la Comarea.

El Porvenir.

Scnior Coroncl:

En contestación a sus quejas a cerea del pecen aseo observado por algunos maestrus en las aulas de la Comarea, estuy preparando la sce gunda circular en la cual vuclvo a insistir una tez más solore asuntos tan impontantc para ta clucación del niños.

cheque.

Conflio que te remediara bastante la falta al recibir los nueves matestros su prime

Me llamó la atenciủn per su pulcritud, orden y buena distribuciôn de útiles esculares,

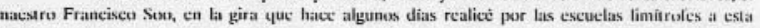
mancing

En espera de sus gratas írdenes me repito de Ud. su atto, ys

Ricardo Velasco.

Director

P.D. El Señor Obispo de Colón nos visitará en la primera semana del mes entrante

Trans. del orig. mec.

V. RD, n. 660 
En El Poevenir, a los treinta $y$ un dias del mes de mago de mil novecientos cuarenta, comparecio al Despacho del Señor Intendentẹ de la Comarca el Señor Rubén Pórez Kantule, coṇ el fin de tomar posesión del cargo de maestro de la Escuela de Cangrejo-Carti en ésta Comarca nombra do por Decreto No. 15 de fecha de hoy.

Juramentado en forma legal ofrecis cumplir bien y fielmente el cargo que se le confia.

Asi terminb la presente diligencia que se firma para constancia.

E1 Intendente: (fdo.)

Luis Hernandez $P$.

El Posesionado: (rdo.)

Rubén Pérez Kantule

E1 Secretario: (fdo.)

J.de la Rosa A.

ES FIEL COPIA DE'SU ORIGINAL

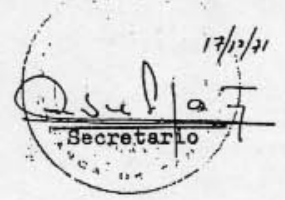

V. RD, n. 661 . 
Coronel Luis Hernández R. Intendente de la Comarca de San Blas

El Porvenir

Comarca de San Blas

República de Panamá

Muy distinguido Coronel e Intendente:

El pucblo de Cirtr Cangrejo por conducto nucstro le cnvía su cordial felicitación para usied por su regreso a la Cornarca y esperando que conserve bien de su salud.

La scenorita Rosario Garay no ha perdido su tiempo de clases en la escuela, gracias por el esfuerzo del Señor Vicente Calvet E. que cumplío enseguida de mandar las maderas; y yo encargue Je construir olra a la, micntras clla dando sus clases cn mi casa. Rosario está enseñando a los kinder bancas para los nuevos alumnos que se encuentran sin bancas. Señorita Garay es de cunstruir cjemplar para mi sabe muy bien de enseñar y tratar con sus alumnos y ella es muy querida por parte del pueblo. Ya ella tiene consigo cinco niñas en su grado.

Felicitando a usied en nombre de la cscuela de esta Isla.

Rubén Pérez Kantule?

Trans. del orig. mec.

V. RD, n. 662 
Señor

8 agosto 40 .-

Pbro: Ricardo Velasco,

Director de las Escuelas.

$\mathrm{N}$ a rg a ná.

Señor:-

En atención a su nota № 76 del 4 de los corrientes me permito decirle yue no he aciariciado la idea de un husto para mí, si los puebles que clirecta o indirectamente han recihido mis

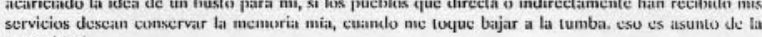
pesteridad.

Con relación a la cornela y al revílver la primera se la estoy enviando comes un regalts

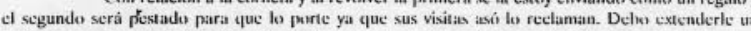
recilor que entrgará al subteniente haciendo comstar el nümero del arma y la SERIE a que pertenece.

Acabo de recihir lus dattes estadisticas mensuales $y$ aprowecho la oportunidad para felicitarlo por la noble tarea yue viene realizando en la Cimarca en pro de la instrucción, pues los felicitarlo por la noble tarea yue viene realizand
frutos se están ya cosechando de manera ruidosa.

Sin otro particular soy de usied muy atento y scguro servidor.

Luis Hernández $\mathbf{R}$.

Intendente

Trans. de la cop. mec.

V. RD, n. 664 


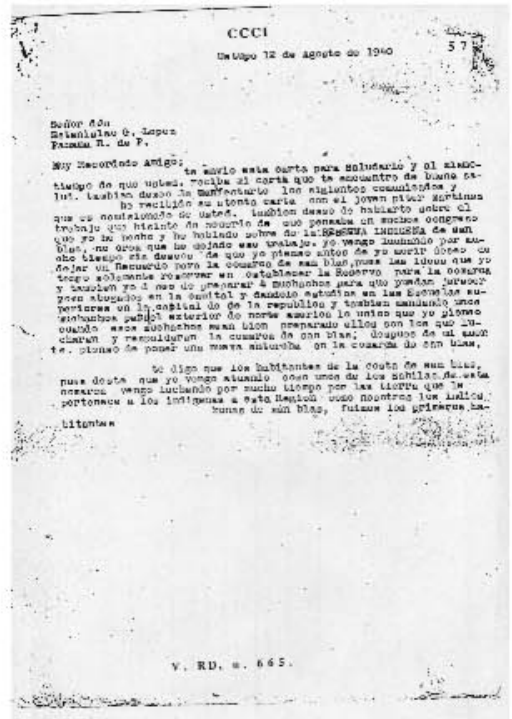




\section{I}

\section{Sr. Coronel}

Narganá, 20 de Agosto de 1940

Luis Hernández $\mathbf{R}$.

Intendente de la

Comarca de San Blas

El Porvenir.

Stềor Coruncl:

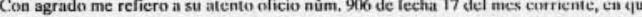
me remite copia de la nota dirigida a usied por ie Director de la Escucla Secundaria de Conlón, solicitándole los nombres de tres niños indigenas para llenar las tres becas para indius cuncedidas pur el Gubierno a ese Colegio.

Agradezco mucho la delegación hecha cn mi persona para la escogencia de los niñus que deben gozar de este benefício, pero, sin detrimento de la debida sumisión y en virtud de la franca inteligencia que siempre ha reinado entre nosotros, me atrevo a manifestarle lus grandes disgustios

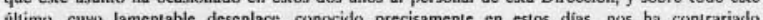

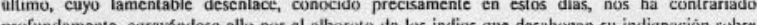
profundamente, agravandose cllo por cl aboroto de los indios que desahogan su indignación sobre correspundencin cosechady precisamente en la aplicaciôn de las becis, en que cun gusto nus imponemus no poces trahajos $y$ aün gastos pecuniarios.

Concretándome a la alusión hecha arriba sobre lo ucurrido con las becas de estos dos últimos años, le expongo: 10 Por oficio núm.463 correspondiente al 23 de Mayo de 1941, comunicó a esta Dirección, ef entonces Iniendene de la Comarca Sr. Vilalaz, la consecucion de cinco becas para los indigenas de la Comarca de San Blas en la escuela de Artes y Oficios, cuya escogencia encargó al Director de estas escevelas, llevandota a cabo tras numerosas dinigencias. Fueron agraciados los ninius: David Abad, Manuel Herman, Manuel Gutierrez, Rogelio Smith y Efrain Martinez. Por designaciön Intendencial se encomendó al policia indigena Emilio Yanes la presentación de los becados al centro docente; pero por diversas causas que todavia no se han precisado, fracasaron por completo las cinco juriass hubo de sopurtar el entonees Padre Directir.

II0 El Sr. Jusé Danicl Crespou, Asesor Pedagógico de Educaciòn, por nota núm.583 recthada el 28 de Abril de 1942 remite a esta Dirección la resolución del Exmo. Sr. Presideate de la
República de otorgar ocho becas a las indigenas de San Blas, cuatro para niñas y cuatro para varones en la Escuela Normal de Santiago. El Ministerio de Educación habia escogido yáa Blanca Llibre y Bertilda Lopez, dejando los demás al criterio del Director de las escuelas de San Blas. De todo informé a usted inmediatamentc. Con el entusiasmo que tan grata nueva nus produjera y a fin de que no fracasaran como el año anterior, resolvimos realizar por nosotros mismos hasta la uiltima

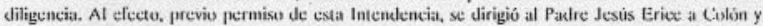

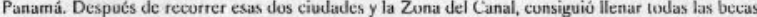
menus una, pues no cra facil o pour falta de voluniad o de dincro requerido (a lo ments Bls. LSOJ)

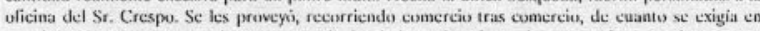
aquet Centro Decente y solamente cuando lis hubo colicado en lus respectivis autobuses para Santiago, pagando el pasaje de algunos, emprendió cl Padre el regreso a Nargana. 
El Sr. Crespo, por oficio número 640 del 14 de Mayo del año en cursu, informa a esta Dirección haber sido favorecido con las becas para la Normal de Santiago, los siguientes niñus: Efrrai Martinez, Guillermo Andrevc, Francisco Díaz, Bertilda Lopez, Blanca Llibre, Marfí Giunzález y Adilia Porras. Pasan de una docena las cartas de encumiendas, peticiones, efe. $y$ al caho de tres meses $y$ medio de estar estudiando, nos connunican los becados, que han recibido aviso de la Dirección de la Normal, que el Gobierno no paga ninguna beca para los ninos Je alli. Enteradas las familias, han lanzado al Padre duras increpaciones de indignación ( ue esto no hace tres dias) y hasta calumnia, como la de que la plata de his becas la ticne ce padre. Es que les es mas scnsible cate cerca de duscientus dốlares.

Señor Coronel: En presencia de la precaria situación en que cstos hechos nus colocan ante los indios comprenderá nuestra gran dificultad para proceder a escuger niîos para las becas de Colón. Además, habiendo mediado ya el año escolar, la oposición de los papás será cierta; a lo cual se an̂ade ta incertidumbre de la beca, a juzgar por los hechos anteriores, que se han hecho del doụinio públicu. Por otra parte nu hay garautfa en los que están fucra de la escuela por ta razón que arriba aduje.

Sienpre ha side nerma nuestra indefectiblemente observada, ta cooperaciòn con ol

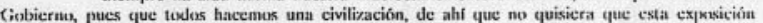
(iobiermu, pues que tudes hacemos una civilización, de ath cor

Serria muy de nucstsro agradto, Scenor Corronet, hiciera sabedor de estas nuestrus dificultades al Excmo. Sr. Presidente de la República, quien concedió generusamente las ocho becas de Santiago en el Día del Indio. Ojalá pudicra salvar usıed con su intervención, esas uchu becas de la Normal de Santiago, que parece vienen al fracaso, antes de pasar a otras nuevas menos importantes. No dudo que su gestión obıendria feliz éxito, dada la amistad personal de que usted goza ante el Excmo. Sr. Presidente de la República.

\section{Anticipándole las gracias, se repite su atento y seguro servidor,}

Manuel M2. Puig

Director de las escuclas.

NB: Aunque el documento parecia estar fechado en el 1940, yo creo que corresponde a 1942, pues es cuando Puig está como director de las escuelas de San Blas.

Trans. del orig. mec.

V. RD, n. 667 


\section{C CI I I}

Número 121

Señor Don

Vicente Calvet E.,

Intendente Interino.

El Porvenir.

Señor Intendente:

Adjunto encontrará los datos mensuales de las escuelas de la comarca, que podrá apreciar en las sumas totalcs.

La matricula ha ido cn aumento durante el mes que finalizó, siendo todavia mayor la diferencia favorable respecto a la asistencia.

En las estadísticas no hago constar la matricula de kinder abierta en las escuelas de Nargana (no menos de 60 ).

Tampoco hago mención de tas horas nocturnas durante las cuales se instruyen los jóvenes en Ustupu y Puerto Obladia.

Esta Dirección ha polido apreciar la cficiencia del maestro Sr. Simón Salazar residente en Pucrto Obaldia; debiendo hacer constar la poca salud de su señora y el correspondiente atraso de los niños menores.

Por medio de una circular se ha comunicado a todos los señores maestros de esta circunscripción las lechas de exámenes semestrales conforme el Decreto emanado del Poder Ejecutivo al comenzar las labores escolares, como tambien su abligacion de permancer en sus puestos en días de asueto ordinario en orden a afianzar más y más los lazos entre los padres de familia y la escuela.

Soy del señor Intendente muy atto. ys.s.

Rieardo Velasco,

Director.

Trans. del orig. mec

V. RD, n. 670 . 


\section{$\operatorname{ccciv}$}

Número 130

Señor Don

Narganá, 19 de Septiembre de 1940

Vicente Calvet E

Intendente de la Comarca.

El Porvenir.

Señor Intendente:

Dudando mucho de que Ud. se resuelva a tomar disposiciones al respecto, quiero ne tstantc hacele excesivia matricula con que cuenta la escucla del lugar.

Mucho nos ba cestado entrar en la mencionada isla y creo sería muy conveniente complacerles en sus deseus afianzando de este modo nuestra posición actual.

El medio más correcto sería suprimir un maestro en Cartí exponiendo a sus habitantes que debido a no haberse notado mayor interés entre ellos por la instrucción de sus hijos la maestra Rosario pasará a desempcñar sus funciones en otra parte donde se le necesite.

Carlí cuenta con un censo escolar de más de 200 niños de los que tan solo asisten 50 Playón-Chico tiene una matrícula de 95 nin̂os.

Para los 50 primeros tenemos dos macstros nacionales, micntras quc para los 95 segundos disponemos tan solo de un maesiro.

El nombramiento de Rosario para Carti fue en...

Trans. del orig. mec. inc

V. RD, n. 672 . 


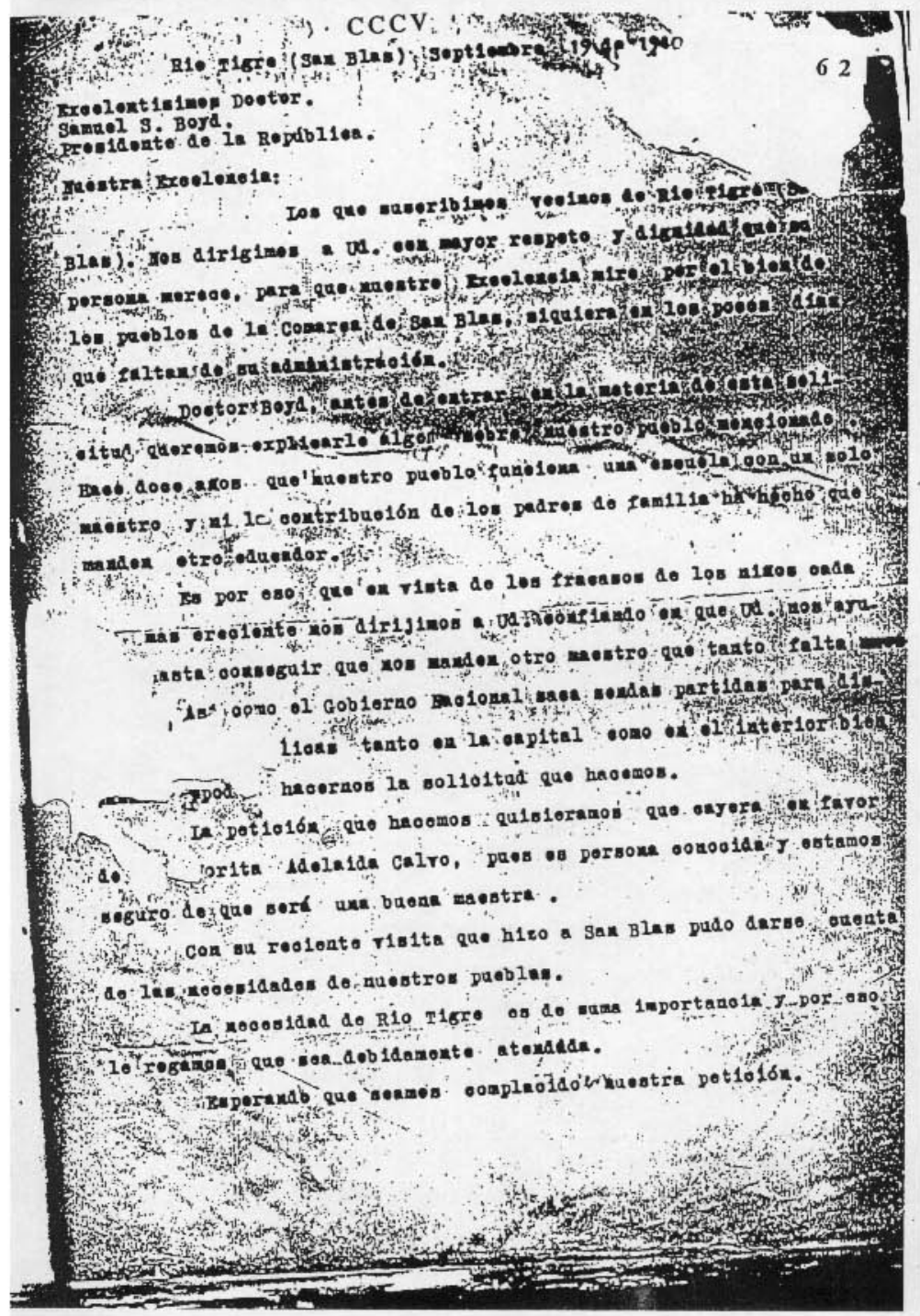




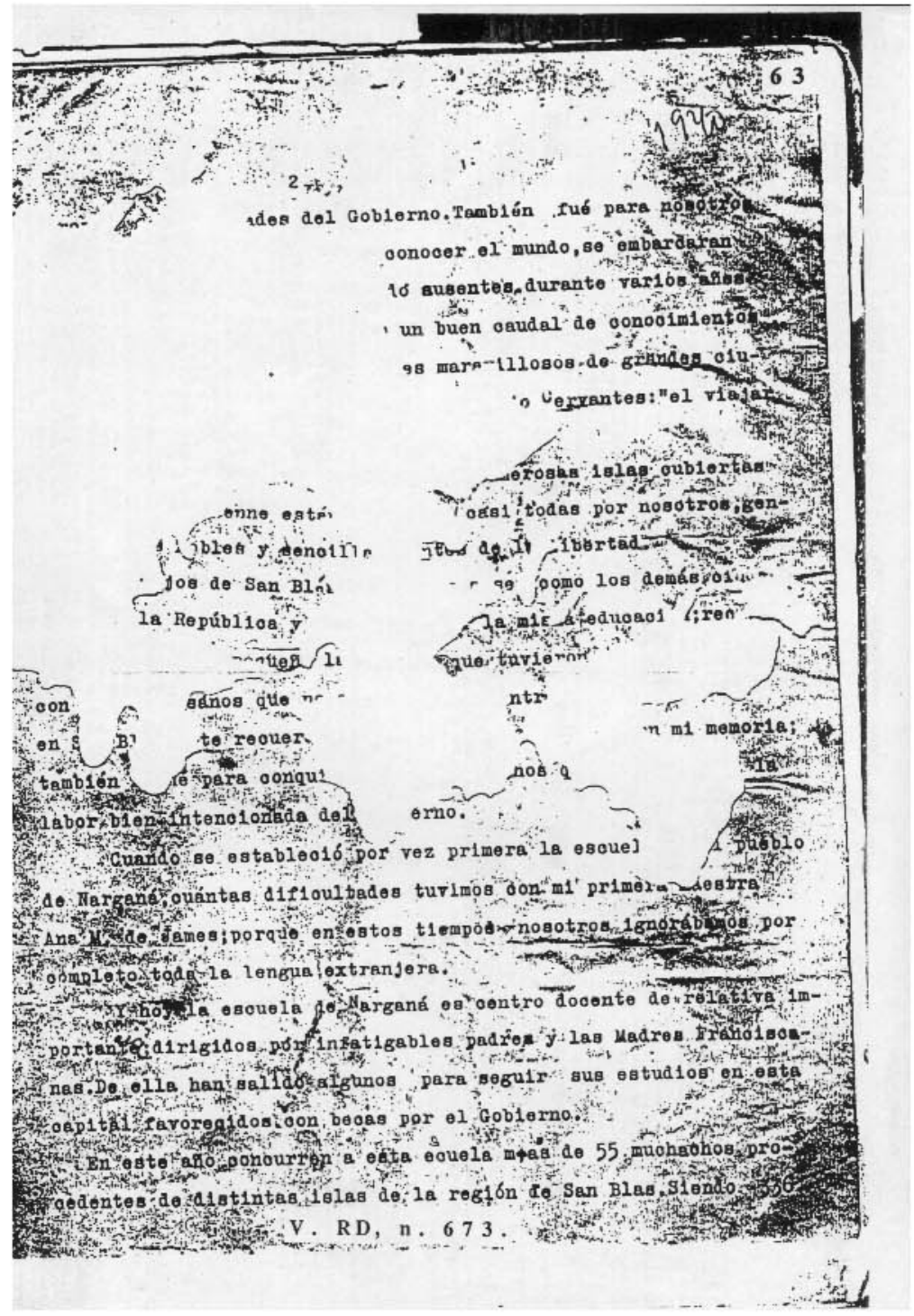


Señor

Director de las Escuelas de la Comarca,

Narganá

21 Septiembre

Señor:-

(iustuse doy contestación a su muy atento oficio $n^{\circ} 1.30$ de 19 de las que cursin, en el

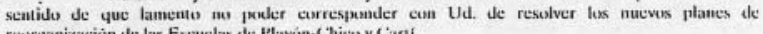
reorganizaciòn de las Escuelas de Playón-Chico y Canti.

Como Ud. comprendera esta es una diespusición del señor Intendente titular la yue el suscrito en su carácter de Interinidad, jamás podria deshacer aunque a las claras se vé que ese puatto en su nuevo programa de adminisración de las Escuelas, es el mejor que podría adajpharse si sc
quierc contribuir al mejoramiento de la instrucción püblica de la Comarca.

Sinembargo, yo pasaré este asunto en consulta con el sen̂or Intendente de cuyo resultado le daré cuenta oportunamente y así podremos resolver satisfactoriamente este asunto de vital importancia.

Soy de Ud, muy Alto s.s.

Vicente Calvet $\mathrm{E}$.

Intendente Interino,

Trans. de la cop. mec.

V. RD, n. 674 . 
Señor:- Intendente de la Comarca de San Blas:

M-25 y 26 El Porvenir:

Señor:

Cumpliendo un deber que me imponen mis obligaciones docentes, pretendo acercarme a Ud. por este medio para hacerle unat información minuciosa y fiel sobe el estado de cusis cxistente en esta localidad, en cuanto a Instrucción se refiere.

ESTADO EN OUE RECIBL LA ESCUELA. aprecio que muchos han sidu los servidures que han pasado por esta frontera, revcstidos del cargo de maestru, sin que a la verdatl se

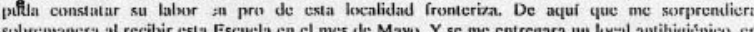

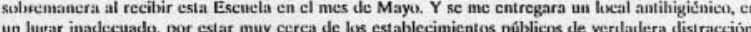

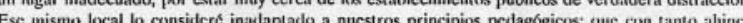
venimos deféndiendo la apóstoles de la Enscrianza.

La Escuela yue me tucó recibir, carecia de todo documento fiel que acreditara su existencia, y de clio solamente hacian fiel testimonio; las miscras banquitas por donde partece haber pasado más de dos generaciones.

EL PRUBLEMA EDUCACIONAL EN PUERTU UBALDIA: Dado el aspecto de ta Escuela he puesto en jucgo mis habilidades, a fin de hacer una investigación juiciosa y acertuda, yue me ponga más en relación con los itereses de la Escuela y de ta comunidad.

Por esta investigación, pucdo decir que uno de los problemas que ha venido afectando los intereses de esta Escuela y de la juventud Panameńa que ha crecido en esta frontera, ha sido el
Cosmopolismo existente en este apartado rincún de la República. Y Enseñanza en este pucblo es más dificil, que cn cualquier otro pucblo del pais.

Los ciudadanos Colombianos que aquí habitan, ajenos a nuestras custumbres, imponen la de ellos al encontrarse en mayuría en la población. De aqui que esta Escuela, tenya que hacer una labor netamente "Panameniista" con la amplia cooperación que le brinden las autoridates adrninistrativas.

IMPULSO OUE DEBE DARSELE A LA ENSENAANZA EN PUERTU OBALDIA. Obladia, por el hecho de ser frontera, es el pueblo visitado por excelencia, por altos personajes que llegan de uno $y$ otro pais, cuyo primer deseo es el de medir el progreso de nuestro pais, por lo que alcanzan a ver en nuestros planteles cducativos de primera enseñanza. Y lastimosa ha sido tia impresión que se ha llevadr en monos anterioses, cando csta Escucta estaba regentada pur un

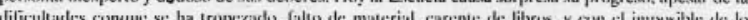

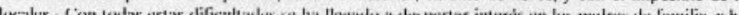

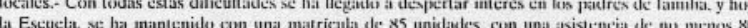

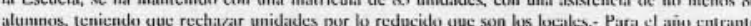
Factible es pensarlo la poblaciòn infantil que concurra a las aulas reclamará de por si, una unidad mís en las filas del personal docente.

Otras investigationes han hecho de mi conocimiento, que el problema clucacional de Puerto Obaldia, es el mismo por el que atraviesa la mayoria de las Escuelas de la Comarca, por falı de vigilancia a cstas últimas.

En ctantu a estas últimas Escuelas, a que me permito informar brindando una cooperación más a la administraciún, es Jecir que cstản a cargo de maesirus completamentı 

incxpertus en la Enseñanza y aunque hábiles están dentro de la circunstancia de que sun dé misisto
dialecto de los educandos, y casi nunca se les visitan más de dos veces por ańo. De aqui yoe sugiriera al señor Intendente la creación de una nucva Dirección, que coopere hombro a humbru centel el Padre Directer residente en Narganá. (jjala que esta sugerencia que hago, se estudiara y se tomara en cucnta de entre las mejoras que se le picnsin hacer a la Comarca, pues solamente dindole impulso a la Instrucción, podriamos terminar con el tradicional gobierno indigena, yuc tanto obstaculiza t prugreso de tantos hombres útiles en todo sentido a la Patria.

MEJORAS OUE SE NECESITAN PARA La ESCUELA DE UBALDIA. En primer lugar necesitamos, equipar a la escuela, de los materiales y aties que complenenten el mastro. De estos

El aumento de una unidad más, para vernos en la obligación de accptar a toda la población infantil, que tanto nccesita del pan espiritual, y como más necesario todivia, es preciso conseguir un salón que reuna las condiciones que hoy por hoy vienen exigiento nuestrus métoulos modernos.

Esperando del señor Intendente, su estudio a esta información fiel que le hago y yue sus conclusiones nos beneficien, suscribo con toda consideratión cumo su más atento y sceguro scrvilur.

Simoón Salazar A.

Director de la Escucla Eduardo Navas.

Puertes (Mhaldia, Nuvicmbre \& de 1940.

Trans, del orig, mec.

V. RD, n. 675 . 
Señor Don

Constantino Villalaz C.

Intendente de la Comarca.

El Porvenir.

Señor :-

Acísole recibo de sus atentas nolas del 29 y 30 del pasado mes de noviembre clasificadas con lus námerus 1441 y 1449 respectivamente, relacionadas con el Plobiscito cumstitucional, Reunión de ságuilas y lista de útiles solicitachs por el nacstro de Puerto (Obaldia-Sir. Simón Salazar.

Tocante a la suspensión de clases por parte de los macstros de la eomarea, así como también referente a la campaña que deben desarrollar en pro de la nueva constitución ya he cursado las primeras órdecos a los puestos cercanos, esperando la llegada de algún bote con destino a las demás isles para remitir las restantes. Crề que mañana saldrá cl lmpeo,

Con respecto a ciertos útiles escolares a que hace mención, no cré factible para cl gobicrno dotarnos inmediatametne de ellos y por ende no los solicite. Sin embarge siguicnde su gobicrno dotarnos inmediatametne de cllos y
indicación le traseribo en plicgo aparte la lista.

Aprovecho tambien la oprotunidad para remitir a ese Despecho las tablas de estadística mensual. Por ellas apreciará como se lucha en cstos últimos meses por que los niños scan constantes en la asistencia y en la matricula apesar de haber disminuido en algunas escuelas como en Ustupu y Ailigadí.

Durante el presente mes lo único digno de mención es el que apesar de mi prohibición expresa sacaron de esta escuela de Narganá a un niño de quinto año para bañarlo en medicina y hacerle fumar etc. por lo cual ha sido expulsado.

Así mismo quiuro manifestarle que muy cerca de la escuela de Narganá esti domicitiada una tal Juliana, a la cual muy bic se le pulring

Esta joven es nacida en Pucrto Obaldía y no creo que sus padres scan panameĩus.

Del Señor Intendeten muy atto. s.s.

Rieardo Velasco,

Dircetor.

Trans. del orig. mec.

V. RD, n. 676 . 


\section{$\operatorname{CCCIX}$}

Nümero 32

NARGANA, 14 de Diciembre de 1940

Seño

Intendente de la Comarea de San Blas.

EI Porvenir.

Señor Intendente:

Tengo el huaur de referirme a sus atentas conunicaciones números 1486 y 1488 de 6 de los corricates, relacionadas con un denuncio pressentaklo contra una scîura de nombre Juliana sobre cienos hechos imputados por el stinur ue fue sometido a procedimicntos de hechiceria.

A este respecto me permito informar a usted que hice comparecer a este Despacho a be

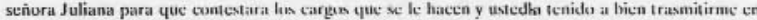

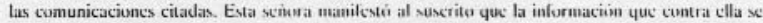

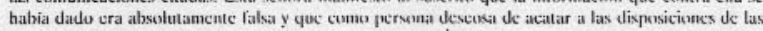
autoridades constituidas, procuraria en lo sucesivo smdarto más correctannente pesible para evitar ctmentario alguno.

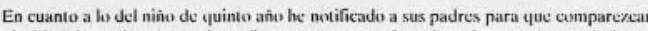
ante esia Superioridad, to cual no hacen inmediatamente por motivis de enfermedad, pero to harả tan pronto les sea posibic.

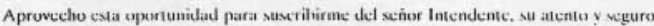

Julio A. Núnez

Sub-lenicnte Encargado del

Destacamento $\mathrm{N}^{\circ} 2$.

Trans. del orig. mec.

V. RD, n. 677 
Señor Don

Constantino Villalaz

Intendente de la Comarca de San Blas

El Porvenir.-

Hago csta carta con el fin de decirle que he recibido una carta del Scriur Directur de la Escuela de Narganá, diciéndome que si yo deseo una escuela para el próximo año en mi jurisdicciôn.

Eso te lo avisu, para que no me molesta tanto en eso, yo por mi parte no te puedo decir

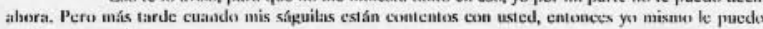
pedir una escucla.

Pero mis ságuilas uhora nada más cstán pensando en conseguir una vida tranquila sin molesto antes de sus hijos. Es que por eso mis ságuilas desean que el Gobierno le den un Título de propicdad despues Je Lso cntonecs tic pido al establecer una escucla de mis pucblus.

\section{Sin más le aviso a usted.}

Soy de usted un atento y seguro servidor.

Siguila tabiliquuiña.

Tubalâ.

Trans. del orig. ms.

V. RD, n. 678 . 
Nümero 35

Señor Don

Narganí, 20 de Diciembre de 1940

Constantino Villalaz C:

Intendente de la Comarea de Sin Blas

El Porvenir.

Señor:-

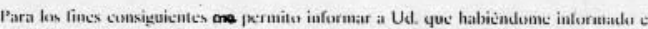

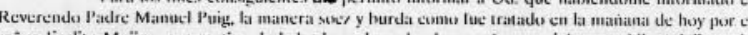
scinor Jischito Mojica, com modive de halkerle reclaunado el porqué no enviaha a su hija Adelina a I

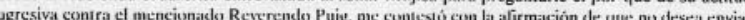

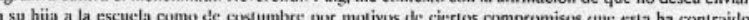

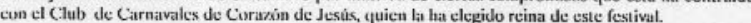

suy de Ud, muy alte. s.s.

Julio A. Nüitez

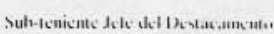

Trans. del orig. mec. V. RD, n. 679 . 


\section{Señor Dun}

Constantino Villalaz C.

Intendente de la Comarca.

El Porvenir.

NARGANA, 27 de Diciembre de 1940.

Señor:-

Mucho le agraaleceria a Ud. ki tuvierra a bién concederme perrmiso para ir a Colón en los Jias.jpóximes, con el fin de aggenciar cun el Excemo. Sr. Obispo que está para llegar de lus Estadus Unidus, algunos usuntos intinamente vinculadtus a estas escuelas

Es mi propisisto formar ctuanto antes un internado para niñas y para ello debo contar mismu mudo cun que cooperaron a la construcción del internado de nin̂us.

Del señor Intendente muy atta. ss.

Ricardo Velasseo,

Director.

Trans. del orig. inec.

V. RD, n. 680 . 


\section{CCCXIII}

Número 313 NARGANA, 31 de Diciembre de 1940.

Señur Don

Constantino Villalaz $(\mathrm{C}$

Intendente de la Comarca.

El Porvenir.

Señor:

Aprovector ba copertunidad de remitir a Ud. los datos mensuales de las escuclas para

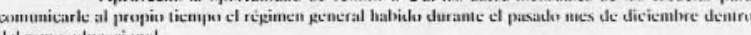
det ramos celueacional.

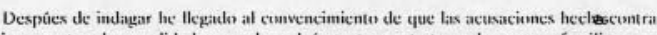

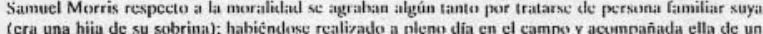
nin̂́o. Como el suceso se ha corrido es un descrédito para cl magisterio en pleno que no puedo tolerar.

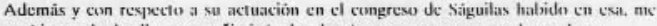

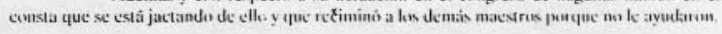

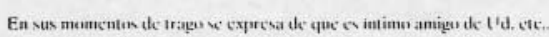

Con respecte a Fiduarde Filin pude asi mismo conformar to que ke manifesté

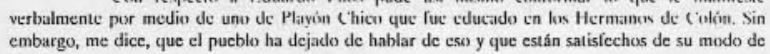
cmbargo,

Agradezco su interés por las escuclas, remitiendo cuantas ba-ncas estàn a su manoo.

Sin otro particular me es grats suscribirme de Ud. atto. ys.s.

Ricard» Velaseo,

Directur

Trans. del orig. mec.

V. RD, n. 681 . 


\section{$\operatorname{CCCXIV}$}

Señor Pbro.

Don Ricardo Velasco

Director de las Escuelas de la Comarea

Narganá.-

Señor:

Válgome de este medio para dirigirme a usted en relación con el grupo de indlgenas que será enviado a Panamá para los próximos carnavales, haciéndole la observación de que ese grupo preferencia a las personas que tengan el tipo caractersitico de los indios de San Blas, y por eso me parcece que las macstras, por sus lá́litos de civilización se han apartado un poco del tipo a que me refiero, pues con los masajes y demás peculiaridades de la moda han dado a su rostro una apariencia muy distinta a la de las indias. Además, su manera de conducirse en público difiere mucho de las indigenas.

En virtud de lo que manifiesto anteriormente, yo cstimo que las muchachas que se escojan deben reunir las condiciones que lo detallo, eso si prefiriendo siempre a las más simpáticas, las que deberán ir ataviadas con unas vestimentas típicas, y con sus argollas, arates, sortijas, collares y dem lo do do ánimo a los del grupo.

Yo no recuerdo bien el tipo de todas las maestras, pero considero que la señora de Mứris es la que menos tipo tiene de indigena.

Como es la primera vez que en Panamá se va a representar un carro alegórico de San Blas, debemos esmerarnos para que todo resulte lo mejor posible para bien de nosotros.

servidor.

Sin más que decirle sobre el particular, me es grato suscribirme muy atento y seguro

Constantino Villalaz $\mathrm{C}$.

Intendente.

Trans. de la cop. mec.

V. RD, n. 684 
Núm. 130

El Porvenir, 10 Febrero 4

Señor

Ministro de Gobierno y Justicia

Panamá.-

Seńor Ministro:-

Adjunto al presente oficio tengo el honor de remitir a usted copia debidamente autenticada del informe anual que rimde el Director de las Escuelas de la Comarca, Presbitter

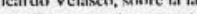
31 dé Encro próxime pasadk.

Cimo usied podrai ver, en el infurme cn mención hay varias olsservacivones en relaciôn

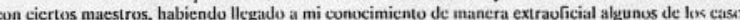
que el Presbilero refierc, que per la furma como me ha sido suministrados, no be querido precider en cunsecuencia por falta de prucbais suficientes, no obstante de que los habitantes de los lugares en donde sirven los mencionadus maessros me han enviado peticiones escritas para que sean reelegidos en el próximo año lectivo. Ademais, soy de opinión quec, por la escasez de personal docente apropiado para esta region, no debcr destituirse ctos scñock, sing

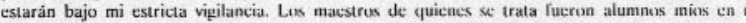
Instituto Nacional, y en cas. de que hulhicran cometido amieriurmente la falta de que se les actosn,

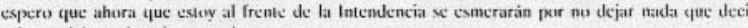
sobre su labor cducativa y counduct:

Yo estoy de acuerdu cun el aumento de maestros, por ser de urgente necesidad para ta Conarca, cosa esta que se la hice conocer en el informe general que le remití a cumienzos del mes considere de importancia.

Quedo de usted muy atento y scguro servilor,

Constantino Villalaz C:

Intenicnte

Trans. de la cop. mec

V. RD, n. 685 
REPUBLICA DE PANAMA

A-21 MINISTERIO DE GOBIERNO Y JUSTICIA

\section{Señor Dun}

Constantino Villalaz,

Intendente de la Comara de San Blas

El Porvenir.

\section{Amigo Villalaz:}

Por instrucciones recibidas del scīor Ministro, me permito solicitarle que haga las gestiones necesarias para conseguir entre los muchachos indigenas de 8 a 10 años de edad, uno que

Con mis saludes y gracias anticipadas, soy de usted, atentamente:

Agustin Veruara

Primer secretario del Ministerio 
$\operatorname{CCCXVII}$

Seccion: Segunda.

Panamá 19 de Marzo de 1941

Señor:

En circular de fecha 16 de octubre de 1940, este Ministerio impartio ordenes a las autoridades de policia sobre moralidad páblica y protección a la niñez. En ella se prohibio el tránsito de niños e impúberes por las calles de las ciudades y demás poblaciones despues de las nueve de la noche, a menos que estuvieran acompańados de personas adultas responsables. Se prohibio asímismo a los empresarios de espectáculos páblicos que admitiesen a tales menores en las funciones que debiescn prolongarse despues ge las siete de la noche, aun cuando estos estuviesen acompañados de

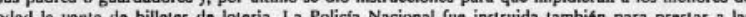
autoridades la cooperación necesaria para el cumplimiento de tales disposiciones.

Las Grdenes impartidas en esa circular no se han cumplido estrictamente, segün informes que este Ministerio ha recibido.

Las autoridades administrativas dieron al principio muestras del más vivo interés en relación con estas medidas de protección social y por algunos dias los menores se vieron obligados retirarse temprano a sus hogares para dedicarse al cstudio de sus tareas escolares en vez de perder el tiempo lastimosamente en ocupaciones que no corresponden a su edad, pero en la actualidad esi práctica ha sido olvidada, siendo en gran parte responsables de esta omisión las autoridades, parecen haber perdido sue entusiasmo por el cumblimiento de tan importantes dispesiciones.

En consecuencia, estimaré a usted que se sirva dictar las medidas eficaces para que se cumplan estrictamente las disposiciones de la mencionada circular.

De usted atento servidor.

Ricardo Adolfo de la Guardia,

Ministro de Gobierno y Justicia.

Al señor Intendente de la Comarca de S. Blas

El Porvenir.

Trans, del orig. mec.

V. RD, n. 687 . 


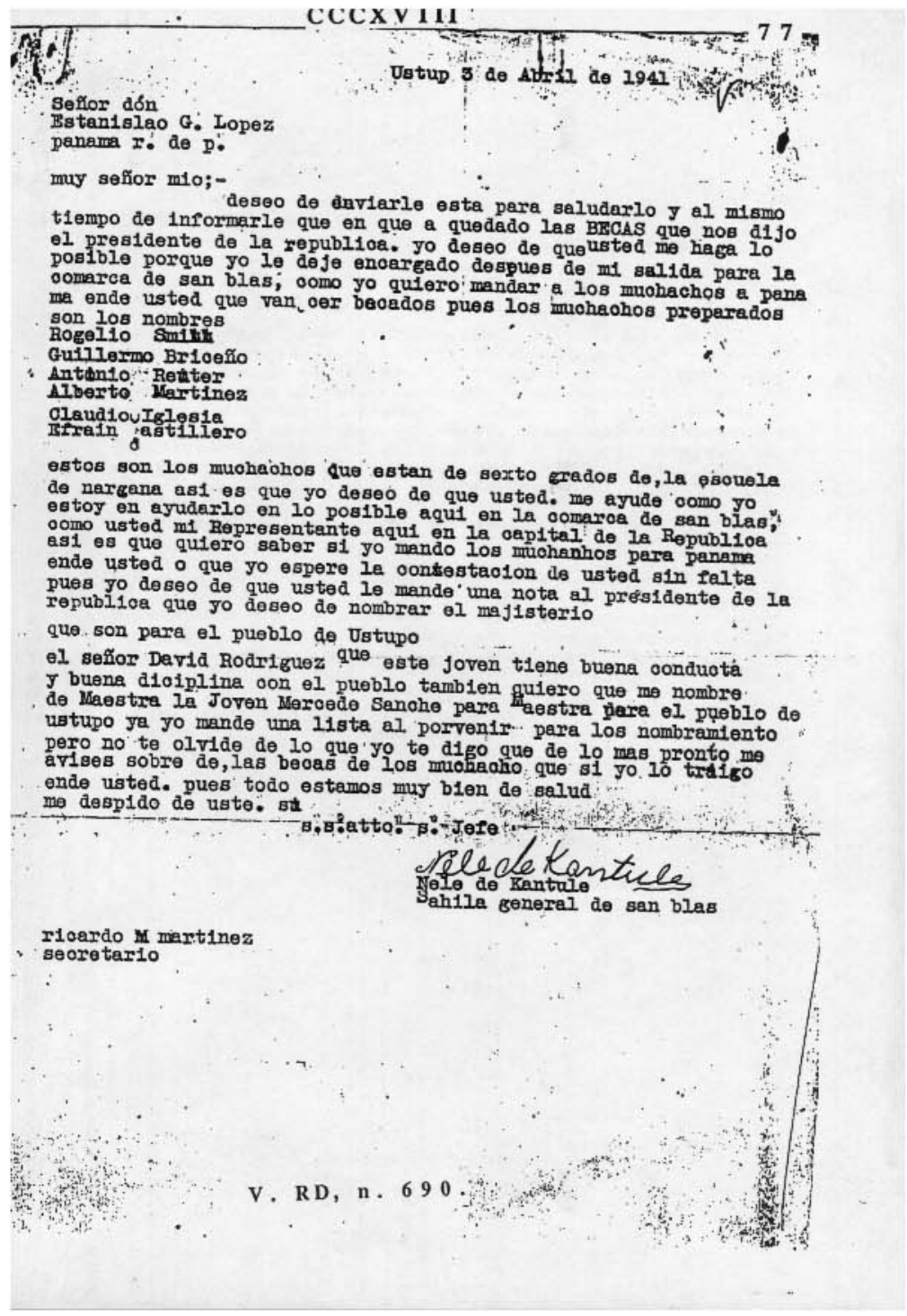


Señor

Nele de Kantule

Us tupo

Señor:

Me dedico a contestar su atenta carta del 31 de Marzo último, en la que me recomienda odo, que está en un error al considerar, como me lo hace ver el comienzo de su carta, que usted es el Jefe Supremo de la Comarca, puesto que tal cosa únicamente lo es el suscrito, y tanto usted como el Señor Yapiliquiña son Sánilas Generales, jele cada uno de los sáhilas de su jurisdicción, y subordinados ambos a las ordenes de esta Intendencia.

En relación con lo que me solicita sobre los nombramientos de maestos, le pongo de manifiesto que corno soy atestro graduado, en cooperación con el Presbítero Ricardo Velosco, manifiesto que como soy maestro graduado, en cooperación con el Presbitero Ricardo Velasco, competentes del lugar, afin de que en esta ocasión el personal docente que integre estas escuelas tenga la preparación debida.

Aprovecho la oportunidad para hacerle la observación de que es deseo del Excelentísimo Señor Presidente de la República que cuando algún funcionario público tenga que solicitarle algo, se dirija a el por el conducto regular. En su caso debe usted dirigirse primero a este Despacho cuando tenga que hacer alguna solicitud en asunto oficial, con el proposito de darle el curso correspondiente.

Cuente usted que si las personas que me recomienda reunen las condiciones requeridas, será satisfecha su solicitud.

Deseando que se conserve bien, me es grato suscribirme su atento seguro servidor $y$ amigos

Constantino Villalaz.

Intendente.

Trans, de la cop. mec.

V. RD, n. 691 . 


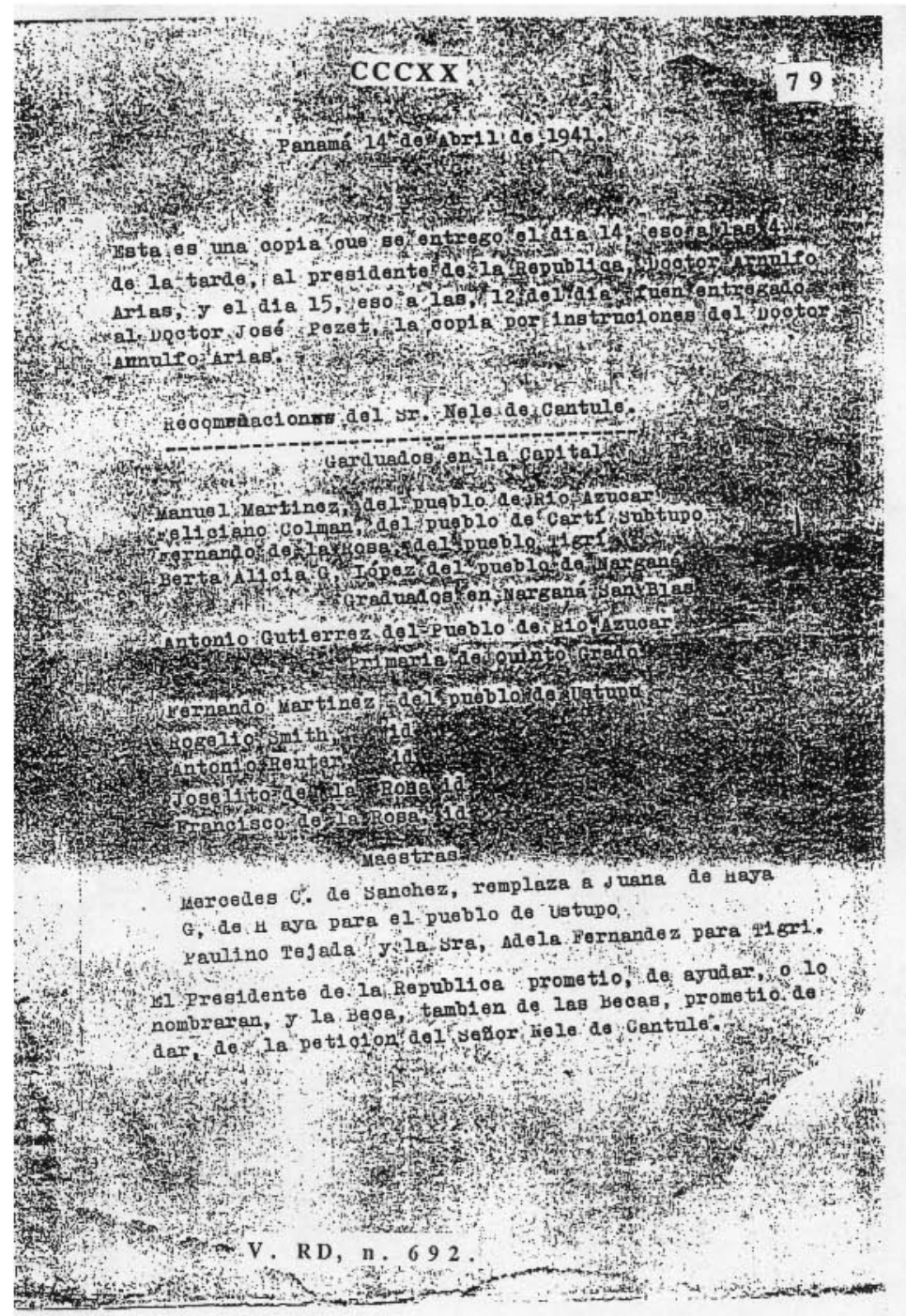




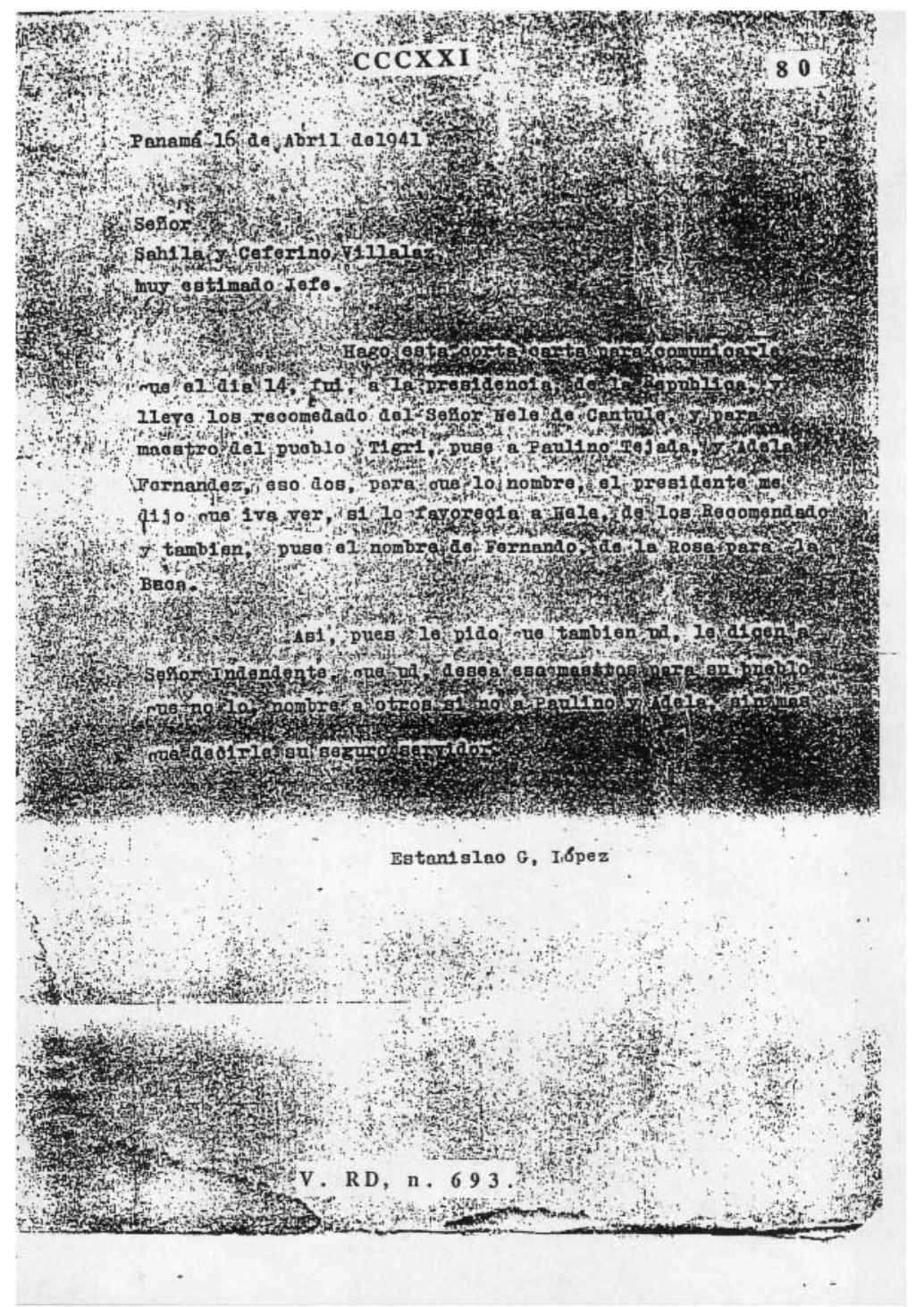


Número 1

Señor Don

Constantino Villalaz,

Intendente de la Comarca.

El Porvenir.

Señor Intendente:

Siendo inminente la apertura del curso escolar y no disponiendo de las elases necesarias para los gradus aqui cstablecides, me apresuro a solicitar de Usted un carpintero con el fin de que pudamus solucionar esic problem:

Veré de coupcrar una vez más prestando los materiales que scan necesarios.

En relación con el nombramiento de Blanca Llivre para macstra de Carti-Tupile, tengo la obligación de comunicarle que piensa separarse del puesto a fines de Junio debido a su estado de gravidez. Creo serfa mejor nombrar uno nuevo.

Para reemplazar a Rubén Pérez Kantule se me ha presentado Ismael Robinson, hijo del Ságuila de Narganá, quien se educo algunos años en escuela superior de la Capital.

Sobre la maestra Celedonia Molinar debo comunicarle que de regresar a Narganá los padres no mandarán a sus hijos a la escuela. Además me entero de que ha intentado malvistarme an

Siendo esto áltimo un asunto muy serio por ser injusto y tratarse de mi persona rúgole que la deje en El Porvenir.

Del Señor Intendente muy atento seguro servidor,

Ricardo Velasco,

Dircetor.

Trans. del orig. mec.

V. RD, n. 694 . 
$\therefore \rightarrow$

CCCXXIII

Uatupo 25 de Abril de 1941

вอบ็ำ dón

stanislao G. Lopez

Panama R. de P.

oumunioarle que esta comision lleva a los muohaoh

capitel de la republica esta oom1sion liava a los

muohaohos siguientes que so buenos alumno de nargana'

Gutllermo Brioefio.

claudio Ielesia

Antonio neuter.

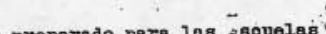

estos son los muohahos que ye ostan proparado
la oap1tal o por las osouelas de Arto Oriolo y

nal $\mathrm{y}$ en otras osouelas seoundarlas de la oap1 tal.

pues sinas becas :

y oomo deseo de saber en que ha quedado el memordal para el presicento

de estos. trabajos. oomo yo lo deje enoargado de esto edelante del presidente

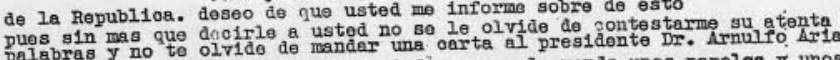
sobre esta de lo que le digo a usted. poreso le mando unos papeles y.

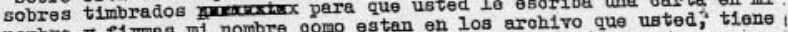
nombre y 11 rmas mi nombre

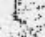

s.s. atto. s. jefo:
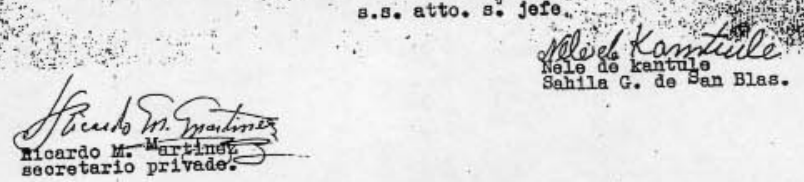

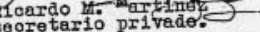

V. RD, n. 695 . 
Número 2

Señor Don

Constantino Villalaz

Intendente de la Comarca,

El Porvenir.-

Señor Intendente:

Como se van retrasando demasiado los nombramientos de la Comarca, espero de su generosidad que nos facilitará lo más posible la toma de posesión.

Ud.dirá si es mejor que nus reunamos en El Porvenir o bien en Narganá con el fin de tener alguna cunferencia y ultimar algunus destinus todavia pendientes de solución.

En cste caso deberiamos aprowechar la ida de alguna de las lanchas o bien esperar la de esa Intendencia con las cunsiguientes difícultades en el alojamiento de los maestrus.

En relación al muchacho que solicita su Excia. el Ministro de Gobierno para dedicarle a servicios domésticos, lengo que decire que nadie desea que su hijo salga de la escuela para servir en Panamá sino es despues de sexio año. Algunos lo mandarian si en Panamá pudiera ir a la escuela pública, pero el caso tal como se presenta no parece ser así.

Yo pudiera conseguirle un muchacho de los que han salido este año de sexto grado, que sabe bien el castellano y todavia tiene las facciones de niño.

Ud. me dirá si lo aceptarian o no. Tiene 15 años.

Del Señor Intendente muy atento y seguro servidor.

Ricardo Velasco,

Director.

Trans. del orig. mec.

V. RD, n. 696 . 


\section{$\operatorname{CCCXXV}$}

Núm. 480

Señor Pbro.

Don Ricardo Velasco

Director de las Escuelas de la Comarea

El Porvenir, 20 Mayo 41

Señor:-

Tengo el agrado de avisar recibo de sus atentos oficios, № 22,23 y 24 , de fecha 28 de lus que han llegado a mi poder las larjelas de identificacion de lirmal de que me hace referencia, lo mismu que las de los maestrus Andrés Iglesias y Blanca Llibre.

Con relación a las cinco beeas para indigenas de que me habla en su nota 23, llewo a 5 connecimicnto que he cunstguido det Gobierno Nacional que le asignen a cada uno de los becados to

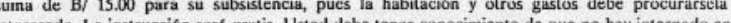

Respecto al asunto de las becas le sugiero al sobrino del maestro Andres Iglesias, si usicel lo encuentra preparado. No espere a los de Panamá. Busque entre los que se encuentran en la Comarca.

De la noticia que me da en su oficio $\mathrm{N}^{0} 24, \mathrm{me}$ apresuro a felicitarlo, puesto que cs orgullo para tener como ciudadano panameño a un caballero de las cualidades suyas.

Aprovecho la oportunidad para solicitarle el servicio de que mande inmediatamente csta al carpintero Ignacio González, aunque no haya terminado el trabajo, porque lo necesito con urgencia.

Quedo de Usted atento y seguro servidor,

Constantino Villulaz C.

Intendente.

Trans. de la cop. mec

V. RD, n. 698 
$\operatorname{CCCXXVI}$

R-40

Num. 463

EI Porvenir, 23 Mayo 4|

Señor Pbro.

Don Ricardo Velasco

Director de las Escuelas de la Comarca

Narganá.

Señor:-

Tengo el agrado de informar a usled que he conseguido cinco (5) becas, para indigcnas de la Comareza, en lu Escuela de Aries y Oficius, prara lo cual le agradeceré mucho que llame a concurso a los ex-alumnos del VI grado de las Escuclas de la región, con el fin de escoger los cinco jóvenes más aprovechados y que observen buena conducta, y enviármelos en la primera oportunidad.

Aprovecho la ocasión para solicitarle se sirva remitirme tres copias, en vez de dos, cuando envie los cuadros estadistsicos mensuales, con el objeto de suministrarle una ul sễor Ministro cuando envie los cuadros estadisticos mensuales
de Educación Pública, quien me la ha pedido.

También deseo qu tenga la bondad de decirle al carpintero Ignacio Gonzálcz que termine lo más pronto posibic su trabujo para que se traslade a esta.

Quedo de usited muy attento y seguro scrvidor.

Constantine Villalaz C:

Intendente.

de cop. mec. 


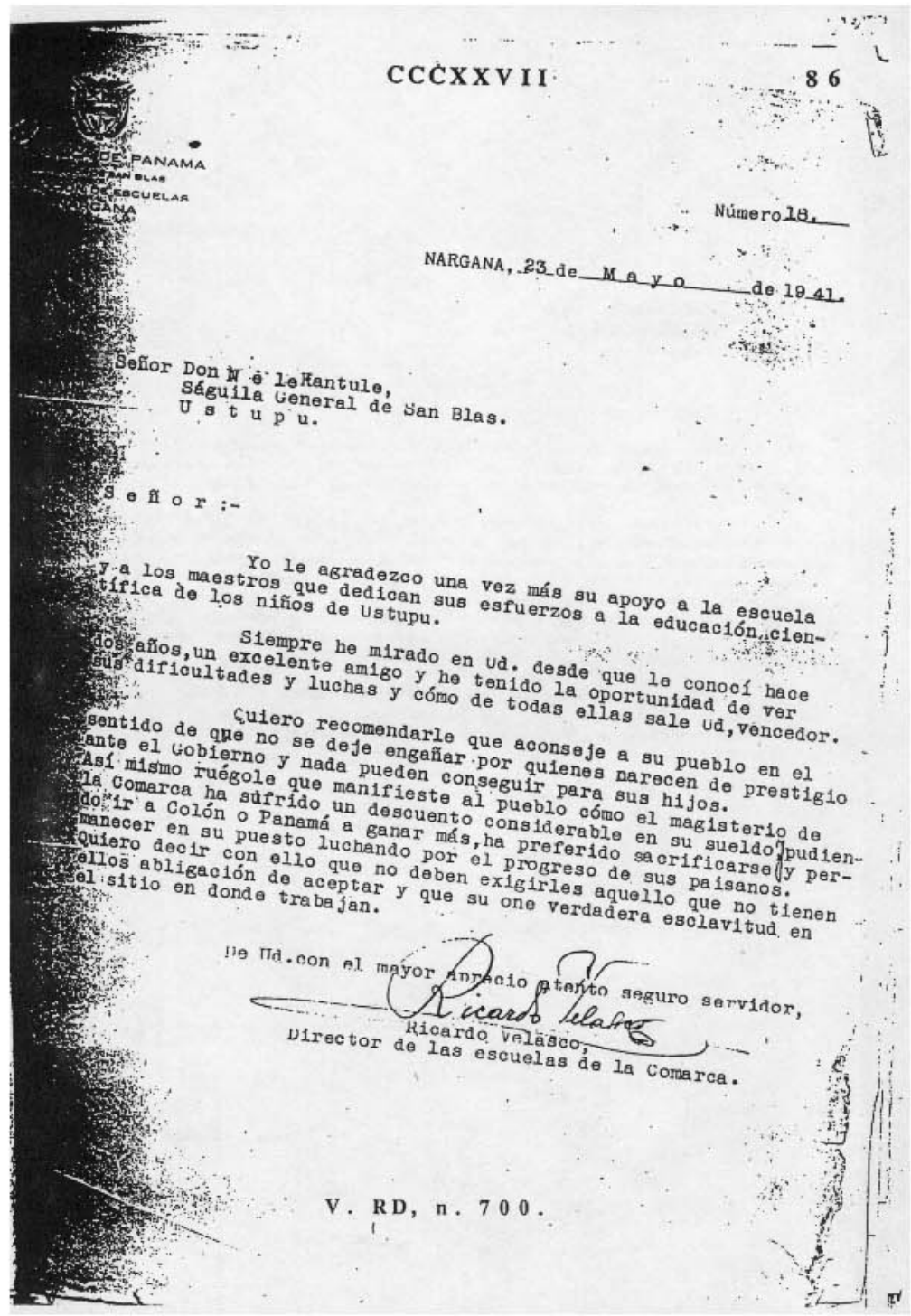


Señor Intendente de la

EL PORVENIR.

Panamá, 29 de Mayo de 1941

Señor Intendente:

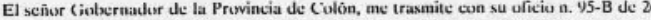
de los corricntes, una nuta que le dirigió el señor Ricardo Velascu, Dircetur de las Escuclas de es: Comarca, cuyo contenido considera de impurtancia someter a la consideración del Ministerio.

En su comunicación el señor Velasco, expresa aprehensión por el exodo cada an̂o mayor de los indios Cunas hacia las ciudades de Panamá y Colón, donde se decican a trabajos superiores a sus fuerzas, abandonando las labores agricolas lo cual perjudica notoriamente nu solo al desarrollo agricola de la region sino la labor colosizadora y cilizadora emprende con tanto interts por ef Gobierno, que con esas miras ha dotado la Comarca de un buen némero de Escuelas, sino que

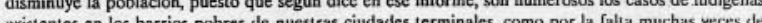
alimentación adecuada, regresan a sus hogares a morir victimas de la tuberculusis.

La situación expuesta requierc la intervención del Gobierno y los méludos indicadus para evitar ese estado de cosas son los de la persuasión, haciendo resaltar a los Cunas las desventajas que ese constante éxodo trae consigo $y$ una inteligente $y$ activa propaganda en favor de las Escuelas alli establecidas.

No dudo que con el interés que caracteriza sus gestiones en el desempeño de tan importante cargo, logrará un apreciable éxito en la campaña que se le ba indicado.

Soy de usted atento servidor,

Rieardo Adolfo de la (iuardia,

Ministro de Gobierno y Justicia 


\section{$\operatorname{CCCXXIX}$}

Número 30

Señor Don

Constantino Villalaz C

Intendente de la Comarca

El Porvenir.

NARGANA, 30 de Mayo de 194

Señor:-

Despues de haber teldo su contestación a mi nota sobre el asunto de las cinco becas creo acertado connunicarle los membleses de los agraciadus y yue sun asi.

Rugelio Smuth, de Ustupu, con muy bucnas calific

Manuel Herman, de Curazén de Jesús, con idem.

David Abad, de Carti-Cangrejo, con idem.

Efrain Martinez, de Rio Azúcar, con buenas calif.

Manuel Gutierrez, de Corazón de Jesủs, con buenas calif.

Creo sería muy conveniente que el agente Emilio, tío de Efraín Martinez, fuera quien acompañe hasta la escueis de Artes y Oficios a los cinco muchachos con el fin de que no surgen tropiezos en el camino.

El mismo tratará de ver colocados en casas de confianza a los interesados.

De usted muy atento y seguro servidor.

Ricardo Vel.ssco,

Director de las cscuelas de la Cimmarca.

Trans. del orig. mec.

V. RD, n. 702 . 


\section{$\operatorname{CCCXX}$}

Señor

Constantino Villalaz

Intendente de la C. de San Blas

Porvenir

\section{Estimado Señor}

Con mucho placer te dirijo estas pequeñas frases.

Aquif me hallo muy bicn y estoy contenta de los niños, la matricula tutal es 50 han salide unos porque dicen que mo tienen eamisas, de essos asuntes quiero que hables con ol saila, perque ahora êl va personalmente.

Ouicro que me hagas el favor de conseguirme dus candaos y unos clavess para la puerta de la escuela.

s.s.s.s

Rosario G. de Herrera

Trans. del orig. ms.

V. RD, n. 703 . 


\section{$\operatorname{CCCXXXI}$}

M-24

Número 102

NARGANA, 15 de Julio de 1941.

\section{Señor Don}

Constantino Villalaz C.,

Intendente de la Comarca.

El Porvenir.

Señor Intendente:

Agradezco el interés de Ud. por el recato funcionamiento y ejemplar organizaciún de las escuelas a mi cargo confiadas, remitiendome un apreciable número de ejemplares de "Registro escolar para las escuelas de la República:.

Aunque el librito en cuestion cuenta con dos páginas aclaratorias pienso que no van a entenderlo los maestros, por lo cual preparo una scgunda cicular con este objeto.

Lo antes que me sea posible inspeccionaré de nuevo las eseuelas de arriba de cuyo funcionamiento no he quedado satisfecho en la primera gira.

Esta impresión motivo la primera circular en la que he dado algunas normas severas sobre viajes y separación del puesto.

En los tres años que llevo al frente de las escuelas de la Cumarca he apreciado ta absoluta necesidad de visitar a los planteles todos los meses, ánico medio para impulsar a los maestros al recto desempeño de sus funciones. Lástima que no pueda contar con los medius al efecto.

De las 250 hojas de zinc consignadas a mi favor por la Orden de Compra Ne 9278 han llegado a mi poder 243. Espero que Ud. notificará el error al Señor Wilcox, aunque con anterioridad ya se to comunico esta Dirección.

Del Señor Intendentc atento y seguro servidor,

Ricardo Velasco

Director de las escuelas de la Comarca.

Septiembre.

P.D.Espero de su generosidad una elegante fotografía con destino a la exposición de

Trans. del orig. mec.

V. RD, n. 706 . 
Señor Director de la Comarca

de San Blas

Narganá

Reverendo Padre:

Lo saludo y mis respetos para Ud. Esta es para clevar una queja de la Directiora de la Escucla de este lugar, pues me ha expulsado una de mis niñas de la escuela sin motivo alguno, más que porr que no respondió a una pregunta. Lucgo empezó a reprenderla y terminó con palabras indevidas, tal como alzada, que fue
la áltima que le dijo: Ud me dirá si estas son palabras de una maestra para una alumna.

Siendo Ud. su superiur me quejo a Ud, para que tome las medidas que le corresponden pues esto me duele por que es tronchar la voluntad de la niña.

Me suscribo de Ud como su atta, y s.s.

Antonia Arias

Trans. del orig. mec.

V. RD, n. 708 . 
ACTA DE LA CONEERENCLA

Que el Magisterio de la Comarca celebró en Narganá el 28 de Septiembre 1941.

El día 28 de Septiembre del año de 1941, en las primeras horas de la mañana, tuvo lugar la conferencia semestral del Magisterio de la comarca en el salón escolar de Corazón de Jesús.

El personal que acudió a la cita se componia del siguiente modo:

Director, Rdo. Ricardo Velascos; Macsstrus, Francisco Soo, Eduardo Filós, David Dias,

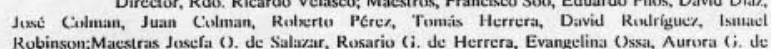
Esquivel y Juana de Haya.

Los tópicus que se tralaron fucron los siguientes:

El Director dio por abierta la sesión dirigiendo acto seguido la palabra a lus circunstantes, recomendándoles la fidelidad a la estadística mensual, explicó ademas los cuadrus del unidad y al destierro de discordias entre los maestros.

Por unanimidad se convino en exponer a la Intendencia los puntes siguientes:

1)- El maragisterio solicita del Sr. Intendente un decreto probibiendo la salida de menores hacia las ciudades de Colón y Panamá durante el periodo escolar, pur perjudicar la matricula y asistencia en los planteles comarcales principalmente hacia el fin de curso.

2)- Todos los presentes abogan por un cursillo de especializaciòn escolar para el verano próximo en la isla de Narganá. 3)- Todos los presente verian con agrado ta asistencia del Sr. Intendente a los
exámenes finales.

4)- Todos los presentes solicitan respetuosameate el aumento de suckdo, disminuido $\mathrm{cn}$ el presente aîu cuando los gastus han aumentado.

5). El magisterio vería con la mayor simpatía se llevara a términu la cunstrucción de la escuela en Ailigandí, mediante la ayuda del pucblo y de la Intendencia sumados a los materiales recibidos del Poder Ejecutivo.

6)- Por unanimidad se le da un voto de confianza al Director y se expresa que no descan cambios.

Leyóse por último la Circular № 25 de la Intendencia referente al orden de cscalafón que debe guardarse en todo asunto con el Gobierno.

útiles.

Acto seguido, el personal se dirigió a ta Direcciòn en donde se distribuyeron algunos

Por lus presentes.

Kicardo Velasce, Directur

Trans, del orig. mec.

V. RD, n. 710 . 
Número 200

Señor Don

Constantino Villalaz C.

Intendente de la Comarca.

El Porvenir.

Señor

Aycr, Jía 2to del corriente mes de octubre finalieć mi viaje de inspección por todlas las escuelas de to Comurea inctuyendo las de Puerio Obaldfa y exceptuando las de Canti

En la mayor parte he observado mayor interés por la instrucción de los niños llevando ba preferencia el abnegado maesro de Ustupu Señor David Rodríguez.

Pude darme cuenta que uno de los invíos de material escolar remitido a Puerto ()baldia dcbida forma consiguiendo el local amplio que existe en los bajos de la casa recientemente construitia por el Ruso como por alli se le llama.

En relación a los libros de texto que tanto me pide el Sr. Felipe Camargo, me es imposible complacerle y le indiqué que seria mejor que él mismo los comprara para los años venideros ya que en distint: 5 Épocas ha trabajado en las escuelas.

No quiero omitir el que cun anuencia del Señor Regidor de Puertu Obailín y cumtand con la licencia presumpta de Usted y por tratarse de un trabujo páblice cual es el interneste on construcción presumpta de Usted y por tratarse de un trabajo publico cual es cl internaklo o un hombre en la idea de remitirle después al lugar de su procedencia y comunicirsclo a Ud... El Señor Subteniente, siguiendo las ídenes establecidas le remite ante ese despacho con el fin de que resuctv subre él.

Nunca créi que fucra tan estricto connigo en csta ocasión, pero él cumple con su déber

Espero favorable acugida en este asunto de parte de la primera autoridad de la

cos

Del Señor Int andente sepuro servidor,

Ricardo Veluss:o

Director.

Trans. del orig. mec.

V. RD, n. 711 . 
Nümero 106

NARGANA, 29 de Octubre de 1941

Señor Don

Constantino Villalaz C

Intendente de la Comarea.

El Porvenir.

Señor:

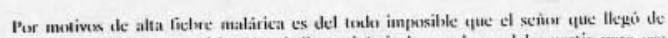

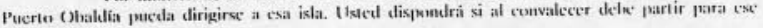
Dexpactho.

Aprovecluo la opportunidad para enmunicarle que algunos sigguilas de Tupile solictitan un practicante para vacunar a los niñus, pur cuantu la cpidemia del sarampión es gencralisima habicndo

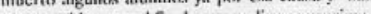

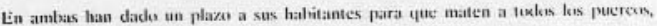
gallinas y urrus animales propensos a la virucla.

Del señor Intendente muy atento y seguro servidor,

Ricarilo Velasce,

Director de las escuelas de la Comarca.

Trans, del orig. mec

V. RD, n. 712 . 
$\operatorname{CCCXXXVI}$

Señor Coronel
Don Luis Ilernaindez, $\mathrm{R}$

Intendente de la Comarea.

EI Porvenir

NARGANA, 10 de Diciembre de 1941.

Scinn Intcut: ntc:

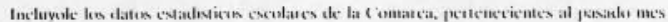
de nuviemlue.

No lus remití antes por esperar su llegada a la Intendencia y suponerle algún tamto ocupalo durante les primeros días de ta nueva administración en San Blas.

La enfermedad del sarampioín ha producido notable descuentu en la asistencia durante el mes en referencia, deb condo tamentar la muerte de algunos alumnos matriculades en la ista de

Del Señor Intendente muy altento y scguro servidor,

Ricardo Velasco,

Director de l..- escuelias de la ciomarca.

Trans. del orig. mec.

V. RD, n. 713 . 


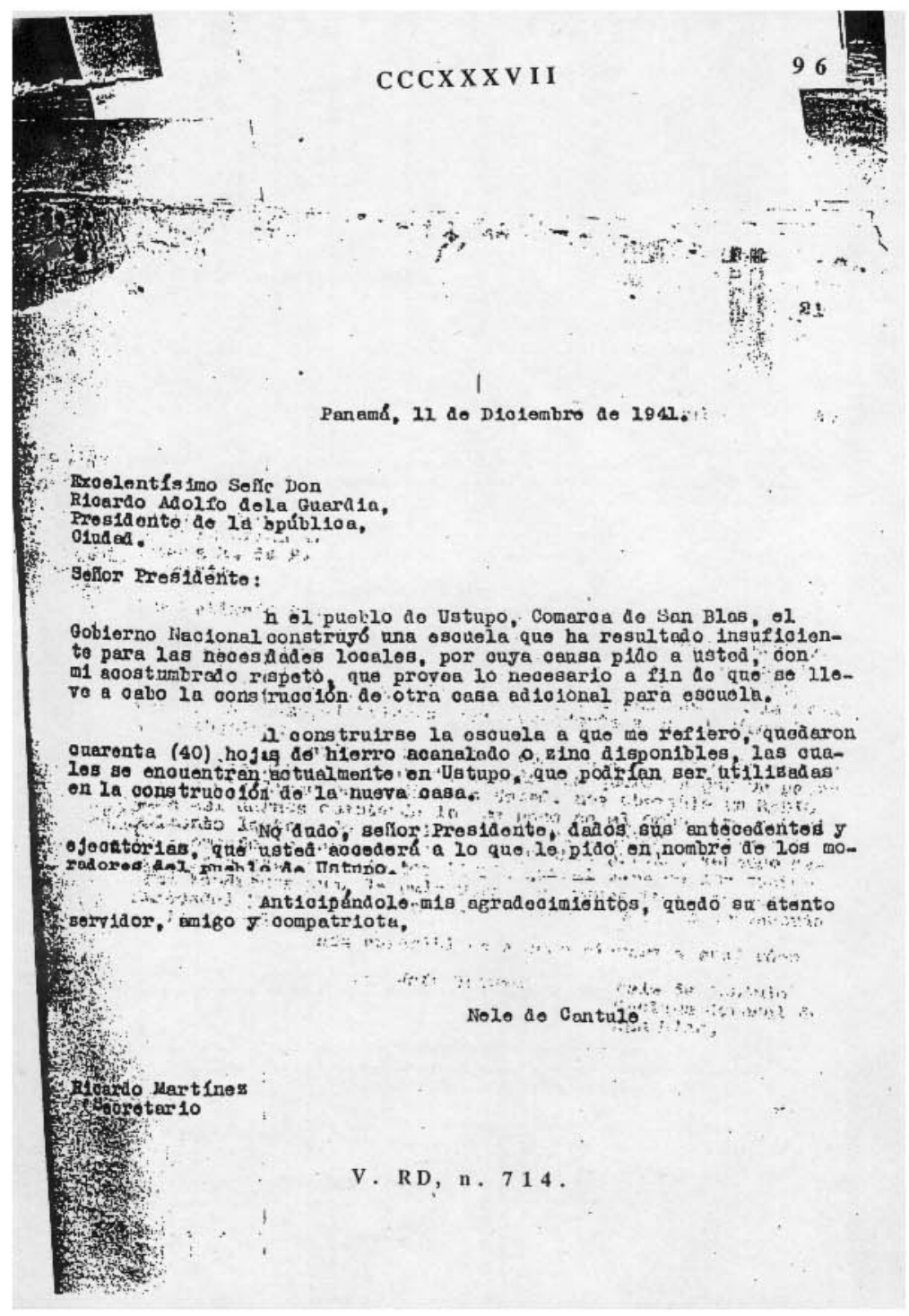


Señor Coronel

Don Luis Hernández $\mathrm{R}$

Intendente de la Comarca

El Porvenir.

Steñor Corruncl:-

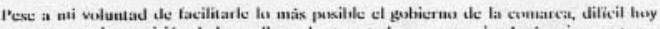
mas yoe nunce, tie veo en la precisión de hacer llegar hasta usted cumo superior Jerairyuica, un tema que espero ressolverá satisfiactorianiente.

La Junta de carnaval organizada ca Corazón de Jesús celebró un congreso en el cual se me atacó por impedirles la celebración de las fiestas. Oué motivo tienen para ello?

Cumpliendo mis deberes de inspector de la disciplina escolar, he debido suspender el año a la niña Laura Pérez conocida de usted, por actos inmorales realizados en públioo con varios jóvenes y con el fin de evitar que recaigan sobre este plantel lo que todavia no ha sucedido en mi
periodo escolar y puede suceder fácilmente en el caso presente. Es una niña de mucho histurial.

Esta resolución ha coinceidido con la clección para Reina del carnaval recaida subre ctlla, así como la escugencia de otras niñas de ta escuela para llenar el cortcjo, alguna de has cuales cursà normalmente el tercer grado (es una niñita pues).

Estas niñas se encargan de colectar todos los dias las cuotas, empleando para tillu el tiempo libre de la escuela.

Varius dias a ta semana asisten a bailes nocturnus de personas mayores yendo a sus casas rendidas de sucño y cansancio que les impide estudiar las lecciones de clase.

A esto se añade que principian a celcbrar esalas reuniones en el último mes de escuela, didicado al repaso de las materias vistas durante el año.

On uisté (no sé) sucle ser la respuesta en las aulas.

Sólo quien vive las difícultades escolares exisentes entre el elcanentu indigena, comprende ta paciencia y sacrificio de las maestras en tiempo ordinarios, cuanto más en tiempo como el presentel

Considerando todas estas razones recomendé a las niñas que si les cra posible se desligaran de tales compromisos y que si sus padres les mandaban, obedecicran. Fucron cunsujus que como educalor, mo como mandatario dirigi a la niñez en sus aulas.

Esto se llama impedirles los carnavales Señor Intendente? Estu se llama mandar o querer mandar en la isla cumo dice la matestra Calcelonia Molinar?

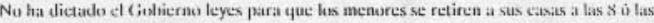
9 p.m. y yo no reclamo semejantes medidas? 
hechos?

En que localidad civilizada se escogen niñas de la escuela para tratar cun humbres

Y si no hay en la localidad niñas jóvenes qué culpa tiene la disciplina de la escucla?

A nadie prohibo los carnavales y sería una tontería que yo me pusiera en asumtos semi-oficiales como son estas fiestas, sin autoridad ninguna para ello. Sólo y únicamente deliendo por medio del consejo la buena marcha de mi escuela.

Si los festejos se celebraran en las vacaciones no les hubiera dicho una palabra $y$, si uscogicra la Junta niñas salidas de la cscucla callaria igualmente.

No me opongo tampoco a una fiesta digna y provechosa que la junta central de carnaval organizada el año pasado en la ciudad capital es testigo de mis esfuerzus pur llevar hasta allá un carro upico comalch ton ayuda del magisteri

Uno de los que hablarou fue Simón Herrera, cl cual por otros asuntus deberia ser

Como pienso que los indios quieren levantar un memorial y setgùn un agente de pulici. harain to posible por sacarme del lugar le pongo al tanto de cuanto ha sucedido para los fines de su gubierno. Lus ticmpos son malus y conviene estar al tanto de acusaciones inlundiadis.

Soy de Usted atento seguro servidor,

Ricardo Velasco, Dircctor

Trans. del orig. mec.

V. RD, n. 715 . 


\section{$\operatorname{CCCXXXIX}$}

Número 363

Señor Don

Luis Hernández R.,

Intendente.

El Porvenir.

Sccũor:

Han Ilegalu rumores a esta Directión en el sentido de que los indios están descuntentos de los servicios del Director, asi como tambien de ser propagandista anti-nacional.

Lamento se haga caso a quienes han obrado por un espiritu de venganza rastrera; pero sobre esses puntos y entonees, ta verdad arrojari al suelo las caretas de los facciusos.

Como Sacerdote, me es imposible accplar la doctirna naxa, perseguidura y cundenada como estã por la suprema autoridad eclesiástica: como nacionalizado panameño deseo el triunfo de la causa nacional en favor de la cual he laborado no poco.

No tengo aspiraciones al scguir en el puesto que ocupo mayorincente ctuindo no sces aprecian mis sacrificios y cedo el lugar a cualquiera otro de mayores simpatias; pero si creo tencr derecho a defender la niniez y a que mi nombre permanceca intacte.

No he dirigido guerra subterránea contra ninguna autoridad, como tal vez se ha propalado en las islas de Tupile y Ailigandi, llegando ese rumor hasta esa Intendencia.

Sirvan estas lfacas dentro del mayor respeto, para expresar mi scmair del cual se hacen sulidarios cuantus desapasionadamente me conocen,

Por ültimu, y con respecto a otras acusaciones, deberán andarse con mucho cuicladn. pucs cierto de mi inocencia, las cosas puteden llevarse por otrus caminos y por quicn ticne abligaciöe de defenderme.

Del Señor Intendente atento seguro servidor,

Ricardo Velaseo, Director.

Trans. del orig. mec

V. RD, n. 717 . 
Circular $n^{2} 3$

REPUBLICA DE PANAMA.

Dirección de escuelas de

la Comarca de San Blas.

ASUNTO: EXAMENES FINALES.

Narganá,3 de Enero 1942.

Señores Macstros de la Comarcax-

Por Decreto No 15 de 1941 de 20 de marzo, el EXMO. SR. PRESIDENTE de la República en uso de sus facultades legales 'DECRETO: QUE'

'Los exámenes de fin de año tendrán lugar en la óltima semana de labures, y las vacaciones comenzarín cl lo de febrero de 1942 .

En atenciún al presente Beeretee, esta Direccioin viene por la prescente circular a scinalar

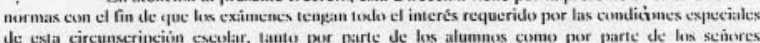

1) Examinadures:-(Tucdan nombrades del mode siguiente.

Pto. Obaldia El Sr. Regider se juntará a los señores Felipe Cam. y matestra.

Ustupu; para texlas las escuclas scgün costumbre. Los tres Matestros alli existentes: senores David Rodriguez, David Diaz y Juana de Haya

Ailizandi-Rio Bananư; para todlas las escuclas scgún costumbre, señores Ruberto Pérez José Colman y Juan Colman.

Tupilc, señor Tomis Herrera, Jesefa O. de Salazar y Aurora G. de Esquivel.

Playón-Chico, Tomäs Herrera. Eduardo Filös e Ismael Robinson.

de Morris.

Ticantiquí. Tiere. Rlo Azúcac, Francisco Soo, Evangelina Ossa, Fulvia de Stro y Luisa

Rlu Sidra. Carti-Suiztupu, Carti-Tupilc. Andrés Iglesias, Mario Porras, Blancat Llitre y Rusario Garay de R.

Narganí-Curazin de desus. Examinarán las auturidades locales.

Ubscrvactiontes.

a) Tuxlos deberán informar por escrito y scparadamente acerca del resultado de lis exämenes que hubieren presenciades.

b) Todos deben remitir a csta Dirceciòn el REGISTRO ESCOLAR Jebidamente

Ninguno de los señores minstros podrán moverse de sus puestos antes del śbud 31 de enero, no sicado razón para cllo ta convinación de lanchas que se ofrecierc.

J) Las fechas particulares de eximenes quedan a escogencia do los exanuinadores. Deseando para todos un feliz resultado en sus labores finales me suscribo como su atento servidor,

Rieardo Velasee, Dircettors.

Trans. del orig. mec.

V. RD, n. 718 
INFORME ESCOLAR DE LA COMARCADE SAN BLAS

(Año lectivo 1941-1942)

R.P.RICARDO VELASCO ORDOÑEZ

DIRECTOR DE LAS ESCUELAS

Señor Don

Narganá, 10 de febrero de 1942

Luis Hernández E.

Intendente de la Comarca.

El Porvenir.

Señur Intcendente

Con el mayor placer de mi parte, rimdole un sencillo informe de la bathor celtueativa Illevada a cabo por el personal docente comarcano, cumplicndo a la vez cum la obligenciôn prescrita co

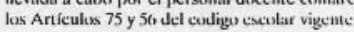

Próxima a finalizar mi situación, estamparé en estas páginas algunos datos tricnales con cl tin de hacer descollar una labur comparativa y dar valur al mérito.

NUMBRAMIENTOS

El Poder Ejecutivo, por Decreto № 82 de 30 de abril de 1941, tuvo a bien extender lus numbramientos del personal que debia regentar las clases entre estos indigenis de San Blas y en
puesto fronterizo de Puerto Obaldia.

Durante los dos años precedentes, la autoridad intendencial basada en el Articulu 70 de

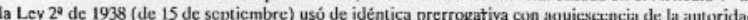
superior. Esta interpretación de la ley fue rechazada a su vez, por el nuevo lntendente Sr. Constiantine Villalaz $\mathrm{C}$.

He aquí ta lista del personal nombrado por Ministerio de Gobicrno y Justicia:

DIRECTOR, Rudo. Padre Ricardo Velasco

AYUDANTE, Rvdu, Padre Manuel Me. Puig

MAESTROS, Andrés Iglesias, Blanca LLibre, Rosario Garay, Francisco Soos, Fulvia de Sov, Pia, Adolfina, Brigida, Ulrica, Eufrosina, Clementina, Cayclana, Luisa de Murris, Evangelina

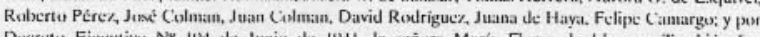
Decreto Ejectutivo $\mathrm{N}^{0} 104$ de Junio de I941. la señura Maria Flores de Llerena. También fue

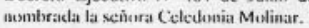

Al señor Intendente de la Comarca, como jefe inmediato del magisterio, te correspondió la tarea de asignar la plaza en donde debía cjercer canda uno de los nombrados.

Todo el personal arriba indicado ocupó sus puestos a ta mayor brevedad, si exceptuamos a la señora de Ltercan, quien se personó el 25 de Septiembre, abandonando Puerte

Si tenemos presente la lista del magisterio de San Blas aparecida en añus anteriures deduciremus yue desde el año 1938- 39 hasta el presente 1941.42, ha aumentado en la proporciứn 
siguiente: Año 19338-39, 16 macsuros. Año 1939-40, 20 maestros. Año 1941)-41, 20 macstros. Atitu $1941-42,30$ maestros.

Debo consignar no obstantc, que la lista propiamente tal aparecida en el Minsiterio ascendía a 30 maestros, pero que debido a la supresión de la escuela de El Porvenir, quedó insubsistente el oportuno nombramiento.

DIRECCION DE LAS ESCUELAS.

Esta Dirección ha trabajado callada pero cjemplarmente en cuantus asuntos se hat relacionado con la celucación y civilización de los indios, apoyando en todo momento las dispusiciones superiores y haciendolas llegar hasta los puntos más apartados y desapercibiduss de Sar Blas.

El personal que la integra, Dircetor y Ayudante, sc han esforzado por cumplir a

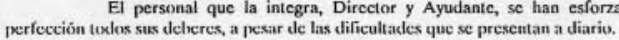

2) Ha rcinade ta mayor armenia cntre la Dirceciôn y cl persunal deccntc, complaciende

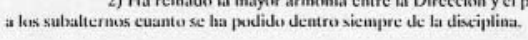

Gracias a estas relaciones de mutus comfian/a ha sido pesible la formseción de un Musco Indigena en la isla de Curzazón de Jesús, el cual fue exhibido al públicu en la Ciudad Capital mereciendo el aplauso de cuantos colcgius superiores y personas instruidas lo visitaron.

No obstante las distancias y escasez de comunicaciones, hemos celebrado slos conferencias comarcales con resultados positivos.

Se ha expedido 7 Circulares sobre distintos túpicos; se han repartido diversas comunicaciones del Ministerio de Educación siendo la principal la Revista que lleva el misma nombre.

La actaación de todu el personal docente se ha reflejado de un modo particular en las liestas Patrias, para cuyo esplendor se han sacrificado su modesto sueldo baciendo sentir el umor al pás en los puntos más escondidos de esta región inculta.

3) Como producto especial de este año en la tarea civilizadura de los indius, podemus asignar la función de DOS CENTROS y el aumento de grado en otros planteles.

Siguiendo la táctica de dejar al convencimiento $\mathrm{e}$ iniciativa indigenas la fundación de muevas cscuelas, Las islas de Rio-Sidra y Carti-Tupile representadas por un clenesto juven y de uspiración, sulicitaron la apertura de la carta aspiración,
resultados.

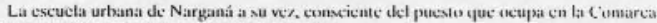
solictito y le fuc comexdida una makstra especial de costura.

En Tupile (de arriba) y complaciendo igualmente el deseo de lus padres de faunilia, se aumentó una plaza más cun el fin de enseñar el tercer año de escuela.

Quiero finalizar el presente párrrafo anotando algunos datos de años anteriures referentes al número de escuelas y a su desarrollo:

Año 1938-39, número de escuelæ8, Año 1939-40, número de escuelas 10. Añu 1941-41, número de escuelas 12. Año 1941-42, número de escuclas 13 . 
4) El aumento en el personal y en los plameles escolares ha dado como consecuenciat lingica el auge en la matricula, si bien es verdad que no se ha conseguido lo que se esperaha. Dus ham sido las causas yue han contribuido a cllor; a) el trabajo bicn retribuido en Las ciudades terminales del

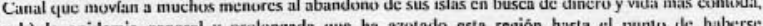
y b) la epidemia general y prolongada que ha azotado esta región

Ambas causas se expusieron a su debido tiempo a la autoridad competente.

Como dato curioso c interesante a la vez aduciré aquí los datos de matícula y asistencia máxima en los distintos años:

Año 1938-39, matricula máxima -745: asistencia máxima 7/2.

Año 1939-40, marrcuta máxima -875; asistenciu máxima 890

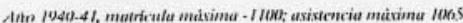

Tho 1941-42, matricula maximu - 1192; asistencia maxima 10\%0

5) Labor malcrial.

Mereed al interés desplegado por el actual Secretario Gencral de ta Presidencia y en ayuel entunees Primer Secretario en el Ministerio de (iobierno y Justicia, Licenciado Dun Agustin Ferrari, obtwieronse materiales para tar consactiocion de dha escucta en Ailigandi, la cual sin embargo y por difetentes motivos nu pudo llevarse a féliz término.

Merece también una mención especial en estas líncas, la ayuda prestada a los trabajos de instalación de una hermosia planta cléctrica donada por el Dr. Augusto $S$. Boyd Juramte su Bhes

Pero lo que ha absorvido gran parte de las energias del personal de la Dirección, hai sido a no dudarlo la edificación de un elegante Internado para indigenas en la isla de Corazón de Jesús.

Para el año prixime, esla calsecera de las escuclas contará con dos cdificies-internaches para los niñus de aubos sexin que descean seguir los grados superiores de la tnecianza primaria y me cuenten cun acudientes en este lugar

ESCUELAS EN PARTICULAR

1). Narpana-Corazoin de Jesuis

que se aproxima a lus 350 .

Todas clltas ham traltajakto con regularidad y sacrificio cjemplares.

Algunos han contado en sus grados, matrículas que han sobrepasado los $60 \mathrm{y}$ hasta 70 alumnos, hecho que deberá corregirse en lo sucesivo mediante el nombramiento de un nuevo puesto.

El sexto grado ha sito profundamente afectado por los trabajos de la zona a la cual se han trasladado no pocos de los que deberian laber finalizado sus estudius primarios.

Este ha sido el resultado final de eximenes: 
Grado. Matricula. Promovidos. Fracasados.

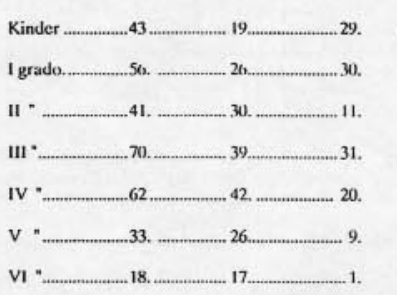

Nota peculiar para ese plantel la siclo la exposición de cossłuras verilicada en P'anamá

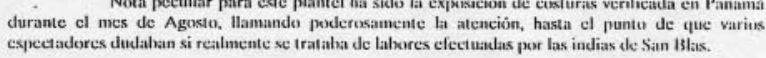

Con ello se ha visto la efectividad del mumbramiento de nueva maestra para esac ramo.

Al igual que en anios anteriores ha funcionado tambićn un cursillo de instrumentación, lo que además de prestigiar la escuclas, engrandece los actos literarios.

También ha estado abierto el Internado para niños pertenecientes a las islas apartadtas, recibiendo la conveniente asistencia gratuita 30 de cllos aproximadamente. Para el próximo año escolar tenetnos planeado dundatencionamincto de un nucvo lucal para niñas, esperando muy por falta de confianza on los padres de familiat

\section{2).Carti-Cangrcio}

El señor Andrés Iglesias fue nombrado para regentar las clases de esta escuela, dificil para cualquiera segun sc puede observar en todos los informes anteriores. Ello es debido al desinterés del jefe local y no al espiritu refractario del pueblo.

Asi y todo, gracias al interés desplegado por el magisterio se consiguc nu despreciable número de alumnos para la escucla central de Narganá, lo cual dará muy en breve resultadus admirables.

El maestro Andrés Iglesiass ha trabajado bicn ha conseguido mantener hastu el fin del año una matricula superior a la que obtuvieron dos macstros en cl año pasado.

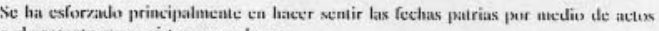
literarius hasta cl presente nunca vistes en ese lugar.

3) Ciarti-Tupile

Fue abierto este plantel nacional a solicitud de sus habitantes siendo numbrada cumo maestra del mismo la señora Blanca Llibre de Porras, La matricula ha sido de 45 alumnus.

Por motivos de gravider fue reemplazala por su señor esposo Mario Purras el cual puede decirse que ha sido efectivimente el macstru durante todo el año

Está Carti-Tupile a pocas yardas de Carti-Canyrejo, bo que ha facilitetolo a los maesstrus de ambas partes la unión de los planteles en las fiestas principales y que el estimulo entre los diss pueblos haya comenzado a sentirse. 
Los esposos Porras, merecen bien de esta Dircección y de la Intendencia,

Algunas yucjas sin cmblargo llegaron en relación a varius excesus cn cl licur de parte de cstes macsiros; pero bay que ser justus en decir que ta causa radieaba ta la propia calhecera de b. Intendencia

4) Riv-Sidta

Por vez primera ha funcionado esta cscucla con resultados yue todiavia no pucden apreciarse. Rosario G. de Herrera ha sabido dejar satisfechos a los habitantes, esperando para un futuro no muy lejano resultados más lúcidos. Matriculas máxima subió hassa.5). Rio-Azúcar

Francisco Soo y Fulvia de Soo quedaron señalados para esta escuela, una de las mas antiguas.

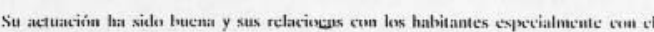
ságuila, digna déc cncomico.

La matricula general del aỉo ha alcanzadu la cifra de 75 alumnes, comtánclose bastantes

6)Rio-Tierc

Una matricula de SO niños y una niña ha sido el fruto principal alcanzado por Luisu de Morris, maestra india graduadi.

Tigre es una de las islas más refractarias a la penetración naciunal y mucho es paraher masesirus peder seguir haciendo lo que se pueda y dejanto para los veniderese el reconger ta eviscecha Sun bastantes sin cembargo low ninios que han cursialo grades superiores en la escucla cercana de

\section{7)Ticantiqui}

en la Profesional.

causa principul Irabajo ha estado bueno aunque no ba igualado a su actuación del primer año. La caatro, y le impidió abrir la escuela durante algunas scmanas.

la matricula obnenida asciende a 67 alumnas entre los cuales se cuentan varias ninīis.

Esta maesstra puede ser una candidata para la escuela ecntral de Narganá, por Esta maestra puede ser una
manifestar preparación y dominio de los niños.

\section{8) Pliyún-Chico}

Eduardo Filćs, indio graduado, $\mathrm{c}$ Ismatel Rotinsun han regentado lus grades de exta

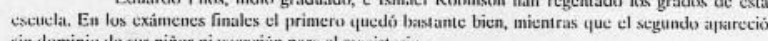
sin dominio de sus niños ni wocación para el magisterio.

Entre ambus han existido cuestivnes personales, cuya raiz era les celes, La maltricula obienida ha pasado del (lou) certenar.

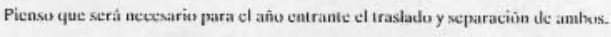

9) runile 
Al cuarto año de funcionar este plantel, ha merccilu se le asignaran 3 macstrus; Tumias Herrera, Josefa O. de Salazar y Aurora G. Je Esquivel. los tres han dado buenos resultados, rabajando con una matricula de 95 aluminos.

Este es el punto mas acomodado para la fundación de oura cscucla similar a la de Narganá y que deberá instalarse dentro de pocos ańus si el Gobierno desea favorecer la instrucción completa de los indios.

Un número considerable de alumnos de esta isla han seguide su instrueción en la escucla central con óptimos resultadex.

10) $\Delta$ ilizandi

Por tres años consecutivus ha regentado esta escuela el señor Roberto Pérę, al cual se unió el maesıro jose Colman oriundo de esta misma polblación.

Debido a la existencia en este mismo lugar de una escaula particular patrexinada por to

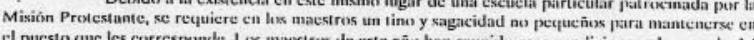
el pucsto que les corresponde. Los maestros de este añu han reunido esas condiciones y la escuela del Gubierno por ellos representada ha superado ampliamente en matricula a la particular. Ha pasaido del centenar ordinarianiente. Sin embargo Roberto Pérez se encuentra algún tantu cansado de ese puesto y creu será bueno trasladarlo.

\section{1)Riv-Banane}

Colman

Esta isla de la jurisdicción de Yabiliquinia, lleva dos años de recibir al maestro Jual

Su actuación a jurgar por el descenso en la matricula mo ha hoorado al Gobierno y les qucjas sobre su moralidad han persistido al igual que durante el aîu precedente.

Por tratarse de conquistar al cacique mencionado en pro de la escuela nacional, creo una necesidad sustituir al mencionado maestro por otro.

\section{2)Usupu}

Ustupu ha sido siempre uno de hos puntus céntricos de la comarca a ha ver de ser uno de lus mayores en publaciin.

Debido a estas causas y a la inteligencia de sus habitantes ba funciunode una werem

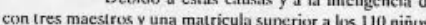

los macsıłros David Rexlrigucr, David Díaz y Juana de Haya, hau trabajadu coun esmero y sacrificio, aguantando la malignidad de aquel clima. Se han tomado grande interés en aconscejar a lus padres de familia para que manden sus hijes a la escucla central de Narganá y ham sido ejemplares en su vida, constituyendo ello la mejor propaganda de la civilización entre estus indigenas.

Gran parte en el desarrollo escolar de esta isla le corresponde al jefe local Nele Kantule pur lus conscjos admirables que imparte a chicos y grandes, $\mathrm{y}$ al señor Luis Hernández, quien obtuve resortes para levantar una moderna escucla de madera.

Son varios los alummos de esta isla que han terminado su sexto grado dando el mejor resultado en inteligencia, no en sumisión y moratidet

13)Puertu Obaldia

Ha funcionado esta escueta froseriza en medie de grandes dilicullades ya por parte det

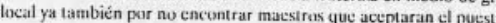



produjo el resultado apetecido.

Hasta el mes de septiembre un sulo macstro, Felipe Camargo, regentaba las clases de primero, segundo, tercero y cuarto año, cn espera del cambio en la situación.

El macstro Felipe Camargo ha trabajado con interćs, pero ha querido abarcar demasiado. La señora Maria Flores de Llerena presentỏ muchas dificultades para acexplar el puestu y finalizó sin rendir examen. La matrícula ha llegado a los 65 alumnos, notándose un descenso en comparación de la matricula obtenida durante el año precedente, - 85. El maestro Felipe Carnargo, después de haber cohabitado con una joven del lugar, ocasionando el escándalo que se supone, legitimó su estado por medio del correspondiente acto matrimonial.

La presencia del señor Mario Julio corresponsal de una periódico de la capital en cșc puesto fronterizo, le movió a escribir algunos suchtos mediante los cuales aparecia cn cumpletto

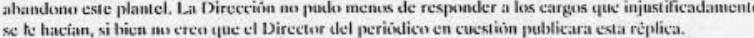

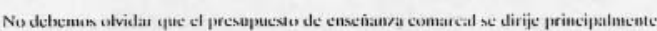

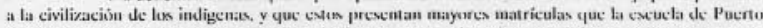
Obaldia. Tiene razón no ubstante el Sr. Felipe Camargo al yucjarse de falta de triles pero no de

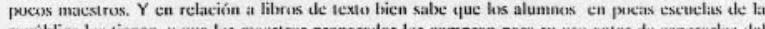
república los tienen, y que los matstrus preparados los compran para su uso antes de esperarlos det Gobierno

\section{Escuelas Privadas}

Existen en la Comarea dos planteles sujetus a dirección particular depcndiente de una misión protestante. Están radicadas en las islas de Ustupu y Ailigandí. La primera cuenta cun un plantel cuyo idioma usual no es ef nacional, mientras que en la segunda se fomenta el castellanco.

INDICACIONES DELA DIRECCION Como final de este informe, quiero scñalar aquí algunos puntos en orden al mejor
funciouamicnto de cstas escuclas.

1). Ante el exceso de matricula en la escuela central de Nargania, se hace imprescindible cl nombhramiento de una plaza más para cl ańo entrante.

2)-. Nu deben fundarse nuevas escuclas, sino mis bien proveer de úriles a las existentes. pacas dificultade.

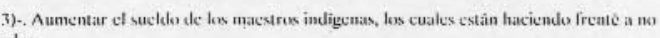

4). Urge la reparación de la escuela central de Narganá y el aumento de salones.

Finalizo el presente informe, agradeciendo a las autoridades superiores toda ta cooperación que se me ha prestado durante el tricnio de mi permanencia en el pucsto, y me retire teniendo la conciencia tranquila y satisfecha por haber cumplido mi deber.

Como nacionalizado panameño, desco que para muy pronto csta Cumarta de San Blas se incorpore definitivanente al carro de ta civilización nacional.

Narganá, 10 de Febrero de 1942

Trans. del orig. mec. inc.

V. RD, n. 719 . 
Ustupu, 17 de Febrero de 1942

stimado Corone

El Porvenir

Al regreso de nucstro viajc le comuinicamos al sefior Nele Kantule todos los proyectos aprobados por el congreso indigenista celebrado en la Isla de Tupile, de la cual el señor Kantule como es uno de los primeros organizadores ha quedado muy satisfecho.

Deseamos tanto como nosotros y cl scñor Kantulc, que nos haga cse favor de no dejar passar para Colón a los niñok jóvenes escenlares solanente que lleven permises de sus mackstros y Jefes

También comunique a los capitanes de las lanchas que tengan cuidado de no llevar

Le avisamos eso por la razón de que unos tres niños de esta población han salito por mala conducta y puedan ser que algún día vayan a Colón.

\section{Somos sus seguros servidores.}

Nele Kantule

Davil Diaz

Juana de Haya

David Redriguez

Trans. del orig. mec.

V. RD, n. 720 . 
Lista de útiles escolares 
Número 376

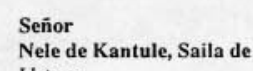

Para conocimicnto de usted me es grato transcribirle a continuación la carta que , con fecha 3 del presente mes, me ha dirigido el Exeelentísimo Señor Presidente de la República y que dice asi:

\section{"Schor Don}

Luis Hemández $R$.

El Porvenir, San Blas.

Mi estimado amigo:

Con algin retraso, explicable por los dias que estuve en jira por la Provincia de Chiriqut, por el cxceso de trabajo que trve que despachar a mi regreso, te acuso necibo de tu carta del tg de febre átimo, por la cual me comunicas el érito del Congreso Indígena que se llevó a cabo en los dius 14 y 15 en las Isla de Tupile.

He leido con interés las actas de csas sesiones, y te felicito por el ćxito obtenido. Veo con placer que poco a poco mutestras indigenas de San Blas se incorporan a la vida civilizada y se preocupan por oblener locales escolares, el establecimiento de una Unidad Sanitaria y la creación de Granjas Agricolas.

Te niego agradezas en mi nombre la cooperación que prometen al Gobiemo los Sähilas con motivo de la actual emeryencia y puedes asegunarles que serún complacidos en lus solicitudes que han hecho, annque algunas de esas obras demorarün por la dificultad de obtener las materiales

\section{Tu afectsimo.}

(Udo) RICARDO ADOLFFO DE LA GUARDLA"

Soy de usted muy atento y seguro servidor,

Intendente 
Número 228-B

Coronel Luis Hernández R.

Intendente de la Comarca de San Blas.

EL PORVENIR.

\section{Señor Intendente:}

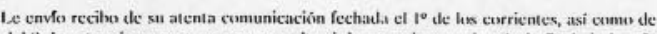

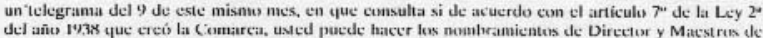
Escucla de ese C'unarea.

Aunque anteriormente se han hecho esus nombramicatus por conducto de esa Intendencia, la Ley de que se trata se refiere solo a una parte del personal de servicio en otrus ramos de la Aúminisiración y además es una facultad expresal del Ponder Ejecutivo el nomber lus conpleados nacionales, que le confiere la Constitucion nacional, en su articulo 10y) ordinal $3^{*}$ lo cual priva sobre cualquier otra disposición legal.

Tales numbramientos se harán pucs, por el órgano de este Ministerio, cal su oportunidad, pero oirá con el mayor agrado cualquier sugestión que en la Organización Escolar

Este Ministerio está interesado en que para la escangencia de los candidatas a macsinus sc tenga cn cuenta ante todo, ta cumpetencia, interés y la mayur moralidad en cata cisu, a lin de su labur cultural responda al propósito del Gobierno, que no es otro que el de incorpurar a ta vista civilizada a los indigenas de la región, mediante una labor de atracción y respeto por woths lis inslituciones y actividades de caracter secial que alli se emprenden.

De usted atento servidor,

C: de la Guardia Jr.

Ministro de (inhicrno y Justicia.

Trans. del orig. mec.

V.RD, n. 723 . 
DECRETO NUMERO 375

A-66 y 67 (de 23 de Abril de 1942)

por el cual se nombra el personal de las Escuelas de la Comarca de

San Blas.

EL PRESIDENTE DE LA REPUBLICA

en uso de sus facultades legales,

DECRETA:

ARTICULO 10.-Sc nombra al Rvdo, Padre MANUEL M. PUIG, Direcer de Is Escuclas de la Comarca de San Blas, en recmplazo del Rvelo. Padre Ricardo Vclasco quicn renunciós

ARTICULO $2^{\circ}$ - - Se numbra al Rvdo, Padre JESUS ERICE ayudante del Dircctor.

siguicntes:

ARTICULO 3․- Se numalran Macsiros de las Escuelas de ta Comarca, a las personas

NARGANA Y CORAZUN DE JESUS:

Hermanas: María Clementina

- Brigida

- María Adolina

- Eufrosina

" Ulrica

PFa

- Cayclana

Matesıras: Elisa Vda. de Garrido y Sara Méndez.

PUERTO OBALDIA

Maestros: Domitilo Garibaldi y Manucla Aguilar

CARTI (CANGREJO)

Macstro; Andrés Iglesias

TURILEABAJO

Macstro: Ismacl Rubinsun

RLOCIDRA

Maestro: Roberto Preciado.

RIO AZUCAB 
Macstros: Franciseo Soo y Fulvia dc Son.

TIGRE

Macstra: Luisa I. de Merris

TIGANTIOUI

Macstro: Mario Porras

PLAYONCHICQ

Macsiros: José Colman y Rosario de Herrera.

TUPILE (ARRIBA)

Macstrux: Jesefa (), de llerrera, Carolina P. de Alfaro y Temás lierrera

AlliciANDI

Macstros: Juana de Hayans, Roherto Pérez, y Eduardo Filís.

USTUPO

Macstros: David Rodriguer, David Diaz y Cristina Lónec.

COMUNIOUESE Y PUBLIQUESE.

Dado en la cuidad de Panamá, a los veintitrés dias del mes de abril de mil novecientos cuarenta y dos.

El Minisiro de Gobierno y Justicia,

C. de la Guardia Jr.

Trans. de la cop. mec

. RD, n. 726 . 


\section{CCCXLVII}

Señor Coronel

Luis Hernández $\mathbf{R}$

Intendente de San Blas

EI Porvenir

Narganá, 2 de Mayo de 1942

Scĩor Coroncl:

Me es grate acusar recilos de la copia autenticada del Decreto Ejecutins nümero 375 de fecha 23 de Alriil, por el que se nombra el perssonal doecente de las Escuelas de Sam Blas.

Le agradezen vivamente, Scîur Coronel, ta distinción con que me ha henrade nonbrándome Director de las Escuclas de la Comarea,

Procuraré trabajar con todo el empeño posible para promover incesantemente of The dirección.

De usted muy atento y seguro servidor.

Manuel M.Puig

Director de las Escuelas

Trans. del orig. mec.

V. RD, n. 728 . 


\section{I}

Señor Coronel

NARGANA 3 de Mayo de 1942

Luis Hernández R.

Intendente de San Blas

El Porvenir.

Scn̄or Cironcl;

Acabo de recibir una nota del Ministerio de Educaciồn, con fecha 28 de Abril, en la que el Señer Danicl Crespo me dice textualmente: "En commemoración del día del indiginal, el Señur Presidente de la República resolvio otorgarles a los indligenas de San Blas, cuatro becas para niñass y cuatro para varones, en la Escucla Normal de Santiago. Aqui se han escogido los nombres de Blanca Llibre de Porras y Bertilda Lopez para dos de dichas becas. Ruego a usted tenga la bondad de escoger dos niñas más y cuatro varones que hayan cursado el sexto grado con las mejores calificaciones, para adjudicarles las becas restantes.

El curso lectivo comenzará en la Normal el 4 del próximo mes de Mayo, fecha en que deberán cstar acá para comenzar sus estudius."

La premura del tiempo y la escasez de transportes impiden a los niños presentarse en la fecha indicada por el Señor Crespo, por lo cual hemos creido conveniente que fuera el Padre Jesús a fecha indicada por el Señor Crespo, por lo cual hemos creido conveniente que fuera el
Panamá y le dé al Señor Crespo explicaciones de la tardanza de los niños, verbalmente.

Además se han de averiguar muchos pormenores o requisitos para el ingreso de los niños en la Normal, lo cual es imposible desde San Blas.

En dos ocasiones anteriores sc han frustado las becas ofrecidas generusantente por el Gobierno, por pequeñas dificultades de última hora, y sentirianus que esto se repitiera.

Tratándose pues de un asunto tan importante para el bien de la instrucción en la Comarca, y no habiéndonos sido posible pedirle permiso con anticipacion, erecmos que usted no tendrá inconvenięc en permitir al Padre Jesús que vaya a Panamá, arregle este asunto y se regrese inmediatamente.

Agradeciéndole tal fincza, sc repite de usted atento y seguro servidor.

Manuel Maria Puig

Director de las Escuclas

Trans. del orig. mec.

V. RD, n. 729 . 
$\operatorname{CCCXLIX~}$

Número 9

Señor Corenel

NARGANA 6 de Mayo de 1942

Luis Hernández R.

Intendente de San Blas

El Porvenir.

Scîn Coroncl:

El día 4 de Mayo se dio comienzo on todan Ins escuelas de la Comarca $n$ las laboro escollares, dand a as curn fechas del curso escolar.

La escuela de Narganá también abrí el curso lectivo en la forma reglamentaria; ante los 310 niños parados en correcta formación, dirigi una ferviente alocución, exhortándoles a la
aplicación al estudio, limpicza en el vestido, disciplina en la escuela e interés por aprender más y mejor cada día el castellano que es el idioma oficial; les prohibí hablar una sola palabra en indio dentro del recinto escolar.

Parecidas recomendaciones habia hecho a los maestros según indicaciones suyas al pasar por El Porvenir; que aparecieran siempre bien vestidos $\mathrm{y}$ calzados ante los alumnos de la escuela; que no hablaran ni hicieran las explicaciones sino en castellano; que respaldaran ante los pueblos y sus autoridades las órdenes emanadas de la Intendencia que son las del Gobierno de la República.

Con el fin de que las indicaciones suyas, muy atinadas por cierto, se cumplan mcjor pienso insistir en futuras circulares a todos los maestros y poner además especial atención sobre sus inflacciones, en las visitas que muy pronto vamos a comenzar por las escuelas de la Cumarca.

\section{De usted muy atento y seguro servidor.}

Manuel María Puig.

Director de las Escuclas.

Trans. del orig. mec.

V. RD, n. 732 . 
CCCL

A.29

Circular número 1

15 de Mayo de 1942

Asunto: Conducta del Maestro.

Señores:

Al comunicarme por vez, primera con vusotros en el presente año lectivo, me es placentero cnviaros un atento y cordial saludo.

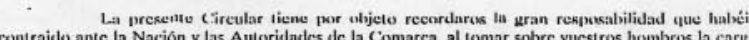
contraido ante Jel magisterio.

El Maestro en esta comarca tiene el honor de ser considerado como el hombre instruido y cducado que ef́́ por cncima de todos los demás que lo rodean. El Maestro es, en muchas ocasiones, el consejero obligado del sahila en los asuntos difíiiles; su voz es escuchada con singular atención en los congresos y reuniones populares; el dietamen del Maestro merece siempre especial atención a solucionar los diferentes asunto de las islas en que trabaja.

Pero el aprecio y consideración con que lo distinguen los pueblos, exige del maestro una conducta intachable; más no será asi, si no pone especial cuidado en la moralidad, en la abstención de bebidas alcohólicas y en el cxacto cumplimiento de los deberes escolares. El Maestro que se permite liberlades indebidas con las sef́oritas o las mujeres de la isla donde reside; cl que toma parte activa en las chichas o bebidas alcohólicas; el que deja de abrir la escuela a las horas determinadas, o, lo que es peor, omite la clase por fútil pretesto, falta notablemente a los deberes sagrados del magisterio que
se ha comprometido a guardar ficlmentc.

Esta direceión ha recibido instrucciones de la Intendencia en el sentido de que se llame la atención de todos los Macstros sobre el exacto cumplimiento de los puntos arriba indicados, con el

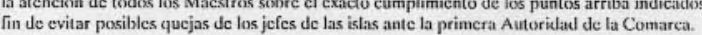

Aprovecho la ocasión para recordarles que está prohibido a los Macsirus hacer viajes fucra del lugar en que residen habitualmente, sin el permiso de esta Dirección. Dicho permiso le será concedido siempre que exista causa justificada para cllo.

Los buenos descos que mostraron todos los Maestros en la Conferencia habida en Narganí, de trahajar activamente cn la instrucción y educación de los niños, me dan esperanza cierta de que el presente año lectivo sera de positivos resulados en el hien de la ninere en ta Comarcat y que cada inatestro liará honor a la alta y delicada profesión que ejerce con una conducta irreprensible y cjemplar.

De todos atento y scguro servidor

Manuel María Puig.

Director de las Escuelas.

Trans. del orig. mec.

V. RD, n. 735 . 


\section{CCCLI}

Sr.D.

Luis Ilerníndez R.

Intendente de la Comarca

ElPorvenir

Señor Coroncl:

La confianza, que me inspiran la amistad y buena inteligencia que siempre ha existide

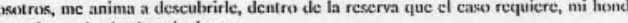
prencupación causada por hos heclus signientes:

Entre las primeras palabras de saludo que escuchamos de las dos maestras, Sara Méndez, y Elisa Garrido, apenas descembarcadas en csia isla, podemos presentar a usted estas:" Ahora

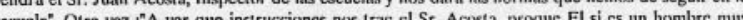
competente y preparado en la Direceión de escuclas".

El P. Jesús Ericc, viajando de Porvenir a Narganí, en compañia del|kr. Acosta, oyó de sus labios:"Hemos de hacer "que dejen estos Maessitros los sistemas viejos de escaso resultado e imponerles ofros nuevos con que salgan de su rutina".

Los dos Padres, en distintos días, con ocasión de ir al cuartel en busca del Sr. Acosta para invitarle a comer, oimos alli estas palabras:"Busca usted al Sr Inspector de las Escuelas ?". Y otra vez:"Nadie nos ha presentado al Sr.Secretario de la Intendencia e Inspector de las Escuelas de San Blas".

El Sr. Acostia, en conversación con cl Macstro de Tigantiquí Sr. Mario Porras, ulijo a este:"Oue pediria a usted la tancha de la Intendencia para visitar El periódicamente las Escuelas de cste:" Oue pediria a usted la tancha de la Intendencia para visitar Ee perróoticimente las Escuelas de

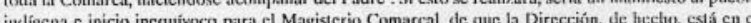

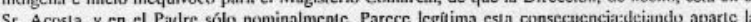
posición poco airosa que usted pucde adivinar en le caso.

Finalmente,dijome el $\mathrm{Sr}$. Acosta que descaba pedir al Ministerio de Instruecció Pública Jos formularios para el informe mensual, retirando los impresos porr el Ministerio de Gobierno, Esta imnovación, odemás de extraña, no la entiendo bajo el aspecto de la actual asignación de competencins.

Sr.Coroncl, los hechos arriba apuntados y los repetidos eneomios verificados a ta extraordinaria competencia del Sr.Acosta en presencia nuestra, aquí en Narganá, arrojjan, en lógica

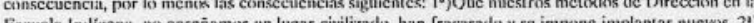

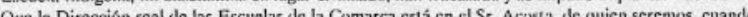

En presencia de este estado de cosas, ignoro a qué tendrain que cenirrse mis actividades en el puesto que el Gebierno de la República, previa la benevolencia de usted, me ha inspirado y cn 
el que deseo colaborar con el cntusiasmo que me inspira el cariño a los indios por quienes llevo laborando más de 11 (once) años.

Por Coroncl, si algo desagradable hallara para usted en estas líneas, sepa que es

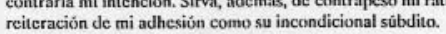

Soy de usted atento y seguro servidor,

Manuel M. Puig

Director de las Escuelas de San Blas

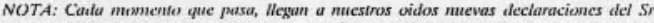
Acosala. A punto de mandiar esta carta al correo, se nos notifica que dicho Sentor dijo que no segulamos ningrin programa. Esu calumnia no es menos sensible que lo amiha indicado; siendo, por ofro parte, digna de fe la persona de quien procede la injormación. Bien sabe ustsed, Senor Commel, que segnimos el Progrnnedel Estado crm toda exuctitud y hasta se ha repartido a cada Macsiro un resumen de ese Progruma Oficial para más facilidad del Maestro

Trans. del orig. mec.

V. RD, n. 736 . 
Sr. D.

Narganá, 19 de Mayo de 1942

Luis Hernández $\mathrm{R}$

Intendente de la Comarca,

ElPorvenir.

Scĩor Corroncl

Por la presente tengo el gusto de anunciarle que, simultanceamente cun ta apertura del curso escelar, tuwo lugar en la ista de Narganá y en el edificio contiguo a la cscuela püblica, o estableciniento de un internado para niñas indigenas de apartadas regioncs. Desle el primer momento ingresaron 15 (quince) ninitas.

Este hecho, primero en la historia de San Blas, augura grandes esperanzas para ef desarrollo de la civiliziación en la Comarca.Las niñas estarán totalmente bajo el cuidado de las

Otro hecho, consolador también, me es grato notilicarle la inauguración de un nuevo edificio, todo él de concreto, en la isla de Corazón de Jesús, destinado a internado de niños de lejanas islas; este fue estrenado por treinta niños, el día 10 de los corrientes. Funcionará hajo la dirección de los Reverendos Padres de la Misión.

Celebro que estos dos hechos, de halagüeño porvenir para la Comarca, pueda usted insertar en la brillante historia de su administración cn la Comarca de San Blas

Debo también hacerle saber que el Rdo. Padre Manuel Puig, Director de las Escuelas de la Comarca, acaba de salir a inspeccionar las Escuelas de jurisdieción.

Soy de usted atento y s,s.

Jesús Erice.

Subdirector de las Escuelas de San Blas

Trans. del orig. mec.

V. RD, n. 737 . 
Luis Hernández $\mathbf{R}$.

Intendente de la Comarca

El Porvenir.

Señor Coroncl:

Me es grato remitirle con ta presente los datos estadisticas de las Escuelas de I

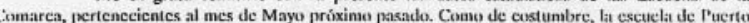
Ubaldia no manda lus datos, a pesar de repetides avis.

La matricula de algunas Escuclas ha disminuido algo respecto al añu pasado, scerú pockrá usted observar; pienso llamar la atención de los macsiros sobre el particualr a fin de que trabajen en aumentarla; en Narganá, en cambio, ha aumentado notablemente.

En la visita of-icial que he girado a las Escuelas de la Comarca, he poclido observar que odlas funcionan regularmente, Para su mayor adelanto he creido conveniente laber alguna buservaciones a los maestros en circular que muy pronto voy a remitirles.

Juzgo de inaplazable necesidad el proveer de unas 20 bancas el salón del toroer gado Ic las Escuclas de Ailiondf $y$ Tupile de Arriba, respectivasenter pues les os impusible a diados

No he recibido quejas de ningún Sahila respecto a la conducta de los maestros. Los niños de Río Sidra me dijeron espontáncamente que su maestro bebía y se emborrachaba mucho; el cstar los jefes de la isla ocupados en un gran congreso, me impidió averiguar la verdad de tales alirmaciones.

Convenimos con dicho maesto, que el cheque seria mejor se lo mandaran directamente desde el Porvenir, con la lancha de Río Sidra; pues desde Narganá rarísima vez hay oportunidad para ello.

Finalmente, le agrad-ezco mucho, Señor Coroncl, la cooperación que para guardar $e$ orden de las Escuela nos presta el cuerpo de policía de Narganá.

De usted nuy atento servidor.

Manuel M. Puig

Director de las Escuelas

Trans. del orig. mec.

V. RD, n. 739 
Después de girar la Visita Oficial a las Escuelas de la Comarca, deseo hacerics algunas observaciones prácticas encaminadas al mejor funcionamiento de los planteles pucslos bajo su celo y

Me ha complacido ver la atención prestada a la recomendación de ta primera Autoridad de la Comarcat. solre presentarse en la Escucla bien vestidos y calzallos lus Maesiros; ef morustos en ir a la escueda; y por fin el intercs eun que procuran mejorar el aspecto del salón essentur, ya proveyendolo de bancas y mesitas, ya adornándolo con cuadros de paisajes $y$ figuras de colores de que gustan mucho los niños. Ahora desco advertirles: $1^{\circ}$ En todo salón de escuela debe haber separaciön entre los
niños de kinder, primero y segundo grado; lo contrario trae pésimos resultadus a la instrucción.

$2^{\circ}$ Todos los macsiros deben llevar al día y con fidelidad la lista de Matricula y Asistencia, con el fin de que sean exactos lo datos estadísticos mensuales.

$3^{2}$ He observado que muchos nińos al leer no hacen distinción en la inflexión de voz de la coma, punto final y signo de interrogación. El Maestro debe poner especial cuidado en corregir estos defectos.

$4^{\circ}$ Conviene ejercitar a los niños de todos los grados en las frases corricntes de saludo, despido, petición de permisos, etc. de suerte que cualquier visitante se dé cuenta de que los niños poseen bien cstas frases del castellano.

$5 \circ$ Deben ejercitar más a los niños en la escritura, sería de descar que todos los dias se dedicara algón rato a la misma; así los niños mejorarian la caligraffa, adquiririan más facilidad de expresarse por escrito y aprenderian las reglas fundamentales de ortografía. En el primer grado deben hacer cjercicios de irases cortas: a) Uso del punto al final de la frase. b) Conpesiciones do fr eses cerritos ha de ser de media página más o menos. Donde no sea posible hacer estos cjercicios con tinta pueden hacerlos con lípiz,
pero en ningún caso pueden omitirlos.

Al registrar los cuadernos durante la Visita, observé con extrañeza que algunos solo habian dictado tres o cuatro páginas solamente. $6^{\circ}$ El Macstro en cada compusición debe poner: $1^{\circ}$ El número de
faltas. $2^{\circ} \mathrm{La}$ calificación. $3^{\circ} \mathrm{Fecha}$ de La corrección. $4^{\circ}$ Su nombre o iniciales. 70 Finalmente ruego muy cncarecidamente a todos los Maestros continúen la campaña en pro del aumento de la Matricula Escolar, pues las cuentas del mes de Mayo áltimo arrojan un descenso en varias Escuelas respecto al mes de Mayo del año pasado.

Aprovecho la ocasión para agradecerics muy de veras las atenciones de que fuí objeto durante la Visita. Esperando que todos prestarán la mayor atención a las observaciones anteriores para darlas exacto cumplimiento, se repite de todos atento y seguro servidor.
paras

Manuel M. Puig Director de las Escuelas de San Blas

Trans. del orig. mec.

V. RD, n: 740 . 
Número 66

Sr. Coronel

Narganá, 30 de Junio de 1942

Luis Hernández $\mathrm{R}$

Intendente de la Comarca

de San Blas.

Señor Coroncl:

Le remito hes datus estadisticus del mes de Junio que acaba de transcurrir.

El día 5 de dicho mes, se cursô una Circular a todos los Macsirus de la Comarea

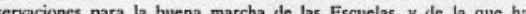
acusado recibo muy complacidos.

He pasado visita repetidas veces y muy detenidamente a todos los grados de las Escuelas de Narganá y Corazón de Jesús, fomentando la práctica del castellano, que es una de nuestras principales preocupaciones en la enseñanza de estos indigenas.

Fue muy oportuna la visita oficial que el dia 10 de dicho mes, hizo a estas Escuelas, el principal Jefe de las mismas, Sr. Coronel Luis Hernández R. y que confirmó en todos los niños la necesidad imprescindihle de aprender bien el castellano que es la lengua oficial y popular de la Nación.

No puedo menos de registrar complacido el solemne recibimiento que los planteles escolares de aquí rindieron a la primera autoridad comarcal, como prueba de afecto, respeto gratitud a quien tanto se interesa por su progreso y adelanto.

También debo consignar agradecido, las mesas, tableros, eajas de tinta ete, que se han recibido de esa Intendencia durante el pasado mes, para la buena marcha de las Escuclas.

Finalmente me permito recordarle la urgente necesidad de bancas en que se halla escuela de Ailiganti, regentada por el Maestro Roberto Pérez, el cual, repetidas veces se ha dirigido a csla Direccion en solicitud de las mismas.

De usted muy atento y seguro servidor.

Manuel M. Puig

Director de las Escuclas.

Trans. del orig. mec.

V. RD, n. 741 . 
Circular número 3

25 de Julio de 1942

Dirección de las Escuelas

de San Blas.

N A R G A N A.

Asunto:Sobre los dias y horus de clase.

Señores Maestrus:

Suficientemente informado acerea de la marcha de las escuelas lajin mi direcciôn. delho,

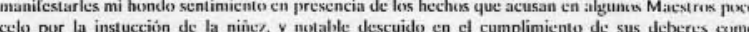
celo por la instucción de la niñe,
cmpleados del Magisterio Nacional.

Todo Macsiro debe llenar hien las horas de clase, sin que ke stea permitidu abreviarlis per fútiles pretextos. El huen Macstro cumple exactanente bas huras reglanemtarias de class.

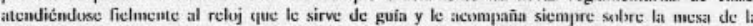
escuela. Ningún Maestro ignora que la clase por la maniana dehe durar tres horas y por la tarcle oteras des; y que el reereo en ambas casis mo deloc pasair de un cuarto de hor

Mucho menos deben suprimir sin causa justificada las días de clase; sobre esto llamo la tención de toxdas, reprobando exon toda la energia de mi cargo la facilidad con que oniten la clase por

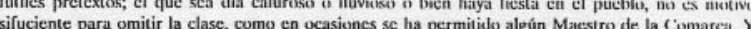
para que nadie pueda alegar ignorancia de los dias de vacación, utiunta les remito una listit oficial de los dlas en que durante el curso sc omitc o no la clase. Procuren leerla con atención y Gijarla en luger visible de la escucla.

Les decia en la Circular anterier que procuraran ajercitar más a los ninios en la escritura para que aprendieran las reglas de urtugrafia y a la vez mejuraran la caliegrafía. He vistu con agrado que todos los Macstros han cumplido fielmente la recumendación de la Circular. Deseo que

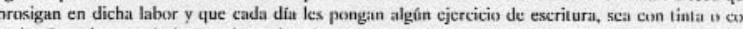

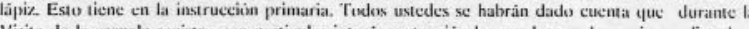
Visita de la escecla registro con particular interés y atenciōn les cuadernus de cscrilura, dictaklo y dibuju

Deseo advertir a tudes las Macstros que procuren preparar con suficicnte anticipacium la gran fiesta del 3 de Noviembre. En texlas las escuelas han de celebrar una gran velada con pocsias,

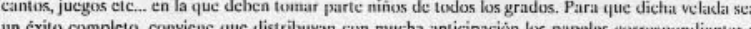
caula niño, pues sólo asi se obtendrá el yuc solgan airosos en su cometide.

Finalmente, atumue me da pena ef repetirlo, tengo que insistir en to de ta primera Circular acerca del licor. Está terminantemente prohibido a lus Maestros entregarsie a lecthidias

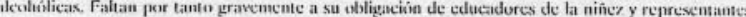
de la civilizatción cn csaa Cemnarcat aquectlos Maesiros que se dejan deminar por el degradante vício de

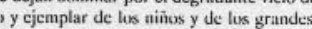
政 tanto muy contraria al cstado y profesión de Macstro y muy mal vista por todus los indios, el que un instructor de la niñez aparczea manchiado por este vicio. Por fortuna son muy pocos los Maestrus gue adolecen de este defecto pero dencer que no haya ung a Intendencia de reportar a aquellos Masstus uve se desminden en esto.

Agradeciénd.ses muy de veras las atenciones que me dispensarson durame la Visita a las escuelas, me repito de todus alento y seguru scrvidur.

Manuel M. Puig Dircetor de las Escuetias de la Cimarea

V. RD, n. 742 . Trans. del orig. mec. 


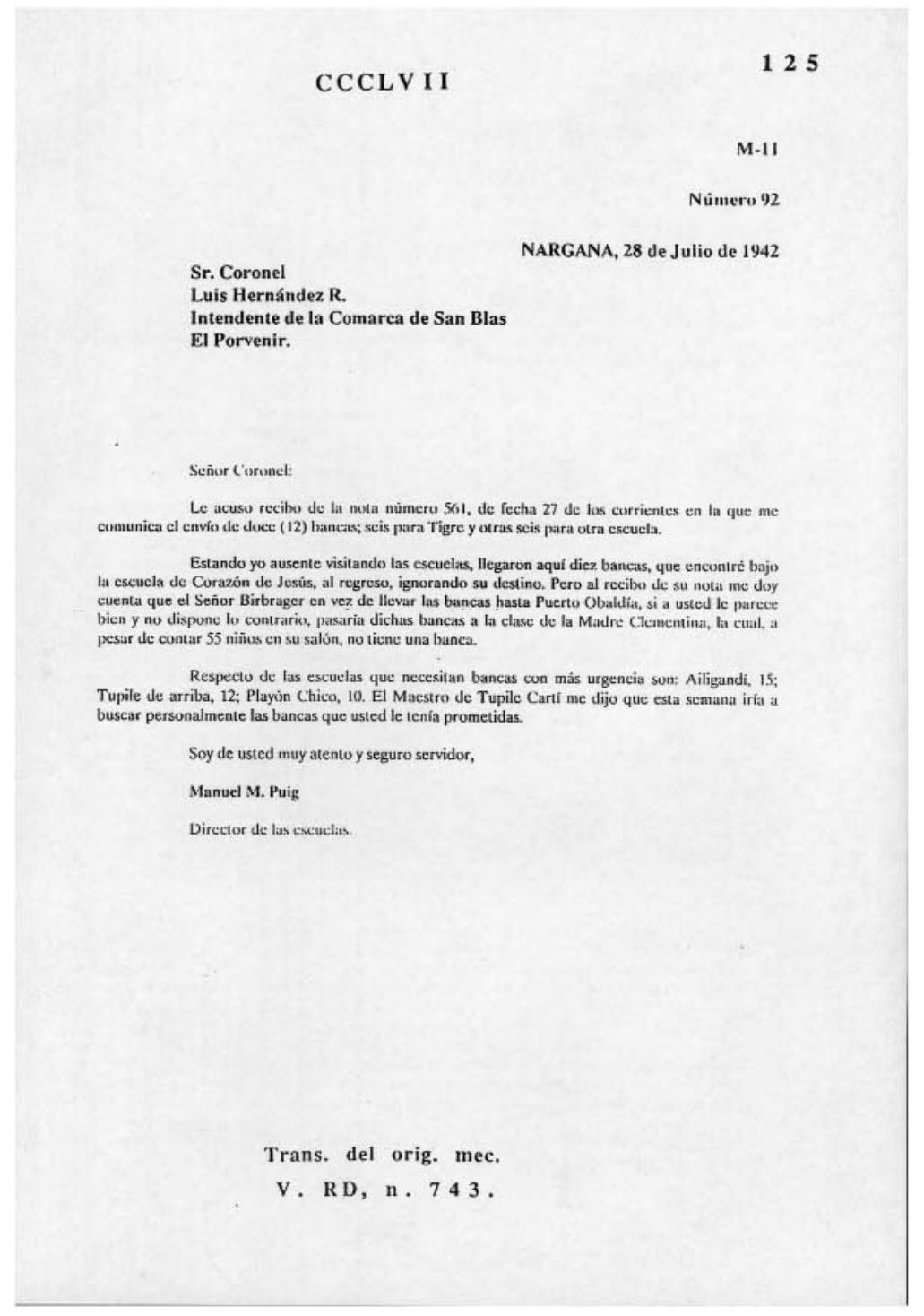


Número 95 Sr. Coronel

NARGANA, 28 de Julio de 1942

Luis Hernández R.

Intendente de la Comarca

de San Blas

El Porvenir.

Señur Cirronel:

Me es grate acusarle reciho de la nota número $\$ 57$ de fecha 25 de hos corricntes tn bi

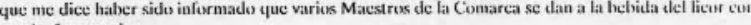
mucha frecuencia.

Lamento haber recibido la nota con retraso, pues al recibo de la misma, accabilba de regresar de la visita a las Islas de Rio Sidra, Carti-Cangrejo y Tupile que efectué en cayuco.

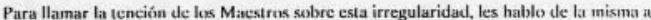

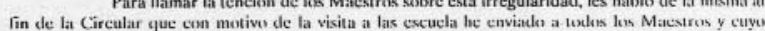
ejemplar le remito en carta aparte.

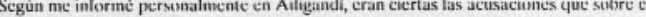
Maestro Filós formularun los Sáhilias de aquella isła. Dicho Maestro no hat repetido tal acto y en tia actualidad observa buena conducta.

Se usted muy atento y seguro servidor,

Manuel M. Puig

Director de las escuelas

Trans. del orig. mec.

V. RD, n. 744 
Número 96

NARGANA, 28 de Julio de 1942

Sr. Coronel

Luis Hernández R.

Intendente de la

Comarca de San Blas

El Porvenir.

Striur Curnecl:

Me complatace en remitirle unia copia de ba Circular que con montiwe de lat Visita a las

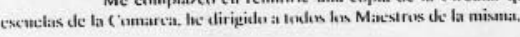

Tambrićn le incluys una copia de hos días nacionales feriathes y évicos durante cl curses,

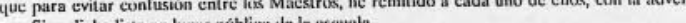
que fijen dicha lista en lugar público de la escuela.

Durante la Visita me informe que algunos Maestros se permitian acortar las horas de clase y aún alguna vez dejaban de darla, sin causa verdaderamente grave. Por esto les he dirigido la niñez en la Comarca.

Por lo general las escuelas marchan bien y los Maestrus trabajan con interés por la instrucción y educación de los niñox.

De usted muy atento servidor,

Manuel M. Puig

Director de la escuclas.

Trans. del orig. mec.

V. RD, n, 745 . 
$\operatorname{CCCLX}$

Deseo informarle con la presemte solhe ta conducta del Maesiro Ismael Robinson yue ejerce el magisterio en la Isla de Tupile-Carti.

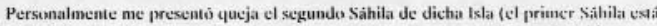

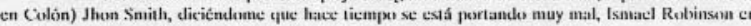
materia de moralidad, pues vive entrcgado completamente al trato con las mujeres.

El pucblo le hizo una casa nueva para que viviera allf tranquilo con su esposa; nunca t has yuerido babitar; hizo șiltir la esposa para Narganá, quedañndose solo y cambiándose de casa cn casa sobre todo donde hay señoritas o $5 \mathrm{e}$ va a celcbrar una chicha. En público congreso le avisaron de su mala conducta, y el respondio que no ic importaba nada que lo sacaran de macstro, pues el no vive del cheque del Gubierno sino de los cocales que tiene muchos.

La segunda noche que yo dormí $\mathrm{en}$ Carti-Cangrejo, pasó a las 9 de la noche tn un cayuco con varias mujeres, de paseo, lo cual me dijeron los indios tenía por costumbre...

También me dijo dicho Sáhila que acortaba muchas veces las horas de clase pur esarse hablando con las mujeres. Y el Maestro Andrés Iglesias me dijo que esto cra verdad, pues vía deste su lsla tocar el caracol para entrar en clase, cuando él hacía mucho tiempo que la eslaba dando.

La impresión que yo me llevé de la Visita a dicha cscuela fue muy mala pues less niños nu acertaban a responder bien minguna pregunta.

Creo que seria muy conveniente que usted lo llamara a la Intendencia, y le avisara de su mala conducta, para ver si se currijc.

De usted muy atento servidur,

Manuel M. Puig

Director de las escuebiss.

Trans. del orig. mec. inc.

V. RD, n. 746 . 
CCCLXI

129

V.44

17 Agosto 2

Rvdo. Padre Manuel M. Puig

Director de las Escuelas

de la Comarca,

NARGANA.

Rvdo. Padre Director:-

Para conocimiento de usted le transcribo a continuación la nota que con fecha 10 de los corrientes me ha dirigido el seńor Director de la Escuela Secundaria de Colọn y que dice asi:

Serior Imendente:

El Gobiemo Nacional ha dispnesto conceder tres becus para indifenas de esa Cumarcu. con el fin de que vengan a hacer estudios en este Colegio. Giozarán de un mensualielad de veinte balboes $(B / 20,00)$

Esta dirección desea que usted escoja a los indigenas que han de disfnutar de exas becas. Debe ser uno de cada uno de los lugares más importantes de la comarca, y ellos deben saber leer, escribir $y$ las cuatro operaciones fundamentales. Ademós es preciso que se hayan distingtido ent la escuela primaria por lo despierto de su inteligencia."

El suscrito delega en usted la fucultad de escoger a los indigenas que han de disfrutrat de esas becas, teniendo en cuenta los requisitos y forma indicados por el Director de la Escucla Secundaria de Colón y, a no ser posible llenar estrictamente tales requisitos, le autorizo para que busque, de acuerdo con su criterio,la forma que considere mas conveniente para el hin indicado, a electo de que cuanto antes pueda suministrar a esta intendencia los nomberes de los indigenas que usted estime merecedores de dichas becas, para hacerlos conocer oportunamente del Directur de la
Escuela arriba expresada.

Soy de usted atento y seguro servidor,

Intendente.

Trans. de la cop. mec.

V. RD, n. 747 , 


\section{$\operatorname{CCCLXII}$}

Número 207 Señor

Manuel María Pui

Director de las Escuelas de la Comarca de San Blas Narganá.

Seño

Para que esa dirección essé devidamente informada, llevo a su conocimicnto que la alassira de grado Manuela Aguilar de servicio en esta escuela, se ha venido interesando vivaniente en representa. Se ha dado a la tarea de expulsar Jel seno de la escuela a niñas honestas, yue de un modo $y$ otro hacen honesta a la misma, con palabras injuriosas $y$ desderosas para ellas $y$ para sus representantes legales.- Según el decir de ella, no tiene aquí más jeffe que Ud. y tanto la vez del señor intendente como la mia carecen de importancia(1). La indicada maestra no desperdicia ocasión par mofar e irrespetar pabicamente por asi deciric a su colcga de labures y de secguir esta tn el sentid que va, puede en un momento dado agotare la cilma y golerancia que hasta aqui ha soportado masestro y producirse un Jescenlace desagradable para la labor escolar y Ud. Ujalá esa Dirceción prevea los medios y cuanto antes posible de ajustar las cosas y poner curtapisa al mal yue se acelere

Soy de Ud. muy atento y seguro servidor

Guillermo Denis

Regidor de policla

(F) es una locura de la maestra P. Puig

Trans. del orig. mec.

V. RD, n. 748 . 
Dirección de las escuelas

de San Blas

NAR G A N A

Circular $\mathbb{N}^{\mathbb{2}} 4$.

Asunto: Fechas del presente año escolac.

20 de Agosto de 1942. Señores Maestros:

El Excmo. Sr. Presidente de la República con fecha anterior a la presente, determinó por decreto especial el calendario escolar del modo que sigue:

Para las cscuclas primarias y secundarias públicas del país, el semestre esceolar empeczará el custro de Mayo y lerminará el síbado 12 de Septicmbre de este atho. Lus exímentes del del 13 al 27 de septiembre.

El segundo semestre principiará el lunes 28 de septiembre y terminará el sábado 6 de febrero de 1943. Los exámenes de fin de año tendrán lugar en la uultima semana de labores y las vacaciones comenzarán el 7 de Fehrero de 1943.

Asueto para Navidad

La semana comprendida entre et 24 y 31 de Diciembre será de asueto escular. Las La semana comprendida entre et 24 y 31 de Diciembre será de asuelo escelar. Las
clases por lo tanto se reanudarán el 3 de Encro, por ser el primeru, Año Nuevo, y cl dos de Enero, dia de la Constitución.

Aprovecho La veasión para recumendar a lodos los Maestros que preparen con gran diligencia y cuidado a todos los niños para los exámenes del primer semestre.

De todos es bien sabido que según fuere la preparación de los alumnos, asi será también el resultado feliz o desgraciado que se obtendrá de los mismos en los exámenes.

Espero pues del celo de los Señores Maestros, que se esmerarán en que todos los niños puestos bajo su cuidado, rindan unos exámenes semestrales lo más brillante que sea posible, lo cual constituirá a no dudario una gloria y una corona de méritos para el propio Maestro.

Voy a terminar esta Circular trascribiendoles ta nota que esta Dirección acaba de recibir de la Intendencia, la cual, es una voz de alerta a t-odo el Magislerio de la Comarca para que observe una conducta ejemplar e irreprensible, scgún les ha aconsejado en diferentes ocasiones. La referida nota dice assi textualmente:

"Llevo a conocimiento de usted, para que lo dép conocer de lus Maestros de ta Comarca y para que sirva de estimulo en el futuro para el buen comportamiento de estes, que por Decreto Ejecutivo N0485, de fecha 12 de los corrientes, se declaró insubsistente el numbramiento hecho en el señor Ismael Robinson para Maestro de escuela en Tupile Abajo y se numbró en su reemplazo al sch̃or Pablo G. Solis"

Me repito de tedas his sciubres Maestros atento y seguro servidor.

Manuel M. Puig

Director de las escuclas.

Trans. del orig. mec.

V. RD, n. 750 . 


\section{CCCLXIV}

REPUBLICA DE PANAMA

MINISTERIO DE EDUCACION

Segunda Secretaría

ASUNTO:Información para un Mapa Escolar.

25 de Agosto de 1942

Señor Inspector:

Envío a Ud. en esta misma fecha, certificado, un mapa con el proposito especial de que Ud. sitúe, de una manera más precisa, los lugares donde actualmente funcionan las escuelas de la Provincia Escolar a su cargo- - También puede Ud. indicar $\mathrm{cn}$ cl, lo que ic será altamente agradecido, cl.curso de algún rio importante. lagumas, cerros, caminos, ctc. Sería conveniente que, cun signos donde debiera abriso otras - Por escrito Ud, puede hacer cualquiera sugerencia o indicaciones en atención al conocimiento que pucde ya tener de esos lugares.

Cuanto Ud. haga en este mapa será utilizado en un mapa general que confecciona e Ministerio con la cooperacion de expertos de la República de Panamá y la Zona del Canal, por lo que por el cuidado pront y la reserpa Ud. ponga en el arreglo de estos informes. Una vez terminada la labor que a Ud. se le solicita, le ruego regresar este mapa, por paquete certificado, a esta Secretaria.

Tenga la bondad de avisarme recibo de este mapa-

De Ud. muy atentamente,

Alberto Méndez P.

Segundo Secretario del Ministerio.

Trans. de la cop. mec.

V. RD, n. 755 
$\operatorname{CCCLXV}$

Número 186

NARGANA, 28 de Agosto de 1942

Sr. Coronel

Luis Hernández $\mathbf{R}$.

Intendente de la

Comarca de San Blas

El Porvenir.

Señor Coroncl:

Me es grato acusarle recibo de su atento oficio núm. 955 del presente mes.

Respecto al informe solicitado sobre la gravidez de la Maestra Rosario de Herrera, en

Respecto al informe solicitado sobre la gravidez de la Ma conversar al respecto con s stado bastante adelantado, he de decirle que es cicro. He Playón Chico de hacerle una visita.

En la primera oportunidad mandaré una nota al ex-Maestro de Tupile-Abajo, Ismael En la primera oportunidad manadure una nersone en esa Intendencia lo antes posible. De Robinson, que se halla en Playón Chico, para que se persone en esa Intendencia lo antets posible. De
no querer ir, pasaré comunicación al Encargado del Deslacamento de Policia, para que lo conduecan ahi a la fuerza.

De usted muy atento y scguro servidor,

Manuel M?. Puig

Director de las escuelas.

Trans. del orig. mec.

V. RD, n. 756 . 
Número 187 Sr. Coronel

NARGANA, 3 de Septiembre de 1942 Luis Hernández R

Intendente de la

Comarca de San Blas

EI Porvenir.

Stenur Curonct:

Le incluyo con la presente lis datos estadisticus de las escuclas de la Cimarea correspondientes al mes de Agustu proximo pasado.

El 20 de dicho mes mandé una Circular sobre fechas del calendario escolar, cuya copia remití a usted oportunamente.

En el último viaje del "Esfuerzo" mandé 10 bancas a Tupile y 10 a Ailigandí; $y$ además un tablero nue

Muchos maestros solicitaban cuadernos y papel para tarea, pero les digo que no es posible debido a las actuales circunstancias.

El Maestro Eduardo Filós creo que se ha embriagado algunas veces durante la última temporada, según se me ba informado.

Respecto a los maestros de Puerto Obaldía le mando informe aparte.

Creo que sería una medida muy buena y eficaz para impedir que disminuya la matrícula en las escuelas de la Cumarca, el yue usted diera la orden a todş los capitanes de lancha para que no
lleven a Colón a ningún niño de edad escolar durante las vacaciones de Septiembre. Cumos tovdus los añus hay algunes niños que descan fugarse a trabajar a Culón y abandunar la escuelia.

De usted muy atento y seguro servidor,

Manuel M?.Puig

Trans. del orig. mec.

V. R D, n. 757 . 


\section{CCCLXVII}

Rvdo. Padre

Septiembre 2.

\section{Rvdo. Padre}

Director de las Escuelas,

Narganá.

Señor Director:

Con la presente le trascribo, para que usted a su vez la remita a los macstros bajo su dirección, una circular que el Primer Secretario del Ministerio de Educación, señor Eligio Ocaña V., de carácter civico, y que dice ast:

"Seniores Director:

Pur purecerme profundamente educutivo y de grun truscendencia paru lu fornación del carácter moral de la juventud estudiosa, presento algunas sugestiones a pesar de que no son nuevas ni originales por ser ya algunas recomendaciones de estas nomas establecidas en alyunos colegios:

a) Todos los actos culturales deben comenzar con el himno del colegio y conchiar con el Himno Nacional: estos himnos deben ser cantados por todos los alumnos y maestros y el Himno Nacional además, por el público asistente al acto.

b) En las aulas debe haber banderas panamerias y escudos nacionales.

c) En los salones de clases no deben faltar retratos, de maestros próceres, cumpuriotas ilustres, ex-presidentes y estadistas célebres, educadores consagrados e intelectuales notables.

d) Se debe aprovechar toda ocasión de exaltar los méritos y obras materiales y culturales de muestros hombres representativos.

e) En los programas de actividades extracurriculares deben incluirse nummeros de recitaciones, cantos y bailes de morivos nacionales.

Estas cinco sugestiones, como claramente se comprende..

Trans. de la cop. mec.inc.

V. RD, n. 758 . 


\section{I}

\section{Legislación Escolar de la Comarca de San Blas}

La enseñanza pública de la Comarca se ha regido por las leyes y programas de ta Instrucción Pública del Estado, a ella se han ajustado, en lo posible todos los reglamentos
disposiciones impartidas por esta Dirección a las Escuelas a nuestro cargo, para el mejor régimen de las mismas.

\section{Preparación e indole del personal docente.}

El personal docente de las Escuelas Indigenas de San Blas, expresảndome con precisión puedo decir que es especial y adecuado a la tribu, cuya instrucción se lleva a cabo.

El magisterio comarcal está constituido por elementos indigenas y no indigenas. Este úlitimo personal se cumpone casi en su totalidad, de los miembros de la orden Religiosa de las

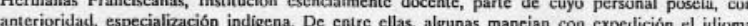
kuna, merced a los muchos an̂os de labor docente en este lugar y la perfecta comprension de la idiosincracia de esta tribu las capacita para la trascendental labor de atracción.

En la actualidad se educan bajo la dirección de las Hermanas Misioneras niñus de lass apartadas y reacias islas, exito de los acernados iesortes de atracción, empleados desde los primeros an̂os de su establecimiento en este centro, madre de la civilizaciōn de esta Cumarca.

De lus predichus resortes, uno es la censenanana de la música instrumental, en que hat demostrado los indios buena dispusición, luciendo sus habilidades en las numerosas veladas artisticobiterarias, incluso en la misma capialal de la República. Otra lo es sin duda, el aprendizaje de custura, en que se han registrado extraordinarios progresos. Finisimos boradados de mano india fueron

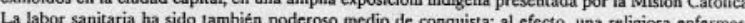
especializada, recorre sin descanso los hogares, repartiendo al chas, wa religiosa enfermer cspecializada, recors
supercherías indias.

En la escuela primaria de Narganá ha colaborado ordinariamente alguna maestra no Misionera. En ta actualidad ejercen el magisterio dos de reconocida competencia. Es que Narganà, familiarizado

con el elemento extraño, por el constante roce con el gobierno, nu repugana en tant grado al personal ajeno a su raza.

Dado el separatismo y exclusivismo racial muy profundo en estos indios, sobre tudo desde la sangrienta revolución del año 1925, el Gobierno Nacional ha empleado un método de expansión civilizadora de resultados inmejorables, a juzgar por la honda penetración actual de la

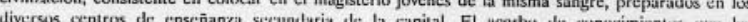

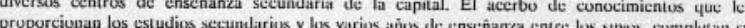

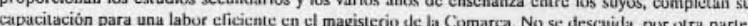
que se ballen animados para defender en todo momento los intereses del gobierno.

Exceptuada esta cabecera de Narganá y la población no indigena de Puerio Obaldia b enseñanza de los indios kunas etstá en manos de Maestros indigenas, insustiuibles toduvía si quiere conservar y acrecentar la expansión adquirida por la civilización Comarcal.

Directiva de la Comarca. 
La Autoridad Intendencial de la Comarca se halla radicada en la isla de "El Porvenir", primera de las del archipielago de San Blas.

En la actualidad desempeña la dirección suprema cl Sr. Curoncl Dn. Luis Hernándé R. en su tercer periodo, cuya competencia y acierto viene suficientemente acreditado pur esa triple designación.

La Dirección y Sub-Dirección de las Escuelas de la Comarca curre a cargo de los Padres Misioneros Catolicos, Manuel Me. Puig y Jesús Erice, repectivamente.

ESTADISTICA ESCOLAR

DE LA COMARCA DE SAN BLAS (AÑO LECTIVO 1942-43)

Actualmente funcionan en la Comarca 12 escuelas, todas indigenas, menos la de Puerto Obaldiá. Un total de 31 (treinta y un) maestros ejercen el magisterio. la matricula asciende a la

Una presentación más detallada de los macstros, alumnos y escuelıs, será el mcjor informe que cl lector pucda recibir, hela aquuf;

Cant-Cangrejo: 57 atumnos. Maestro: Andres Iglesias.

Cant-Tupile: 35 alumnos. Maestro: Pablo Iglesias.

Rio Sidru: 45 atumnos. Mastro: Robeno Preciado.

Rlo Azúcar: 72 uhumnos, Maestrus: Francisco Soo y Fulvia de Suo

Narganä: 353 alumnos. Maestrus: Hemanas Franciscanas siguientes: Maria Clementina, Brigida, Maria Adolfina, Eufrosina, Ulicia, Pia y Cayetana. Además las Maestras: Elisa vda. de Garrido y Sara Méndez.

Rio Tigre: 57 alumnos. Maestra: Luisa I. de Morris.

Tigantiki: 52 alumnos. Maestro: Mario Pormas.

Playón Chico: 93 alumnos. Maestros:José Colman y Rosario de Herreru.

Aifuro.

Tupile; 91 alumnos. Maesiros: Tomás Herrera, Josefa $O$. de Salazar y Carolina p. de

Ailigandif: 100 atumuos. Maestros: Robeno Pérez, Eduardo Filos y Juana de Haya.

Ustupo: 104 Alumnos. Maestros: David Rodríguez, David Diaz y Cristina López.

Pueno Obaldta: 80 atumnos. Maestros: Manuela Aguilar y Enesto Acosta C.

En Narganá se imparte la enseñanza primaria completa desde el aâu 192y, un yue se implanto el sexto grado, por vez primera. Un promedio anual de 20 alumnos terminan sus estudios primarios. Adcmas, cn la mayor parte de los centros de la ciudad capital cursan estudius sectundarius crecido nủmero de indígenas favorecidos con becas del gobierno y de la Misión Caúblíca.

Narganá a 5 de Septiembre de 1942.

Manuel M. Puig

Dircctor de las Escuelas de San Blas

Trans. del orig. mec.

V. RD, n. 759 . 
$\operatorname{CCCLXIX}$

Número 195

$$
\begin{aligned}
& \text { Sr. Coronel } \\
& \text { Luis Hernández R., }
\end{aligned}
$$

Intendente de la

Comarca de San Blas

El Porvenir.

Señor Coronel:

Quedo enterado del contenido de la nota número 1017 del 2 de lus currientes, en la que mé comunica que el Macstro de Playón Chico, Scñor José Colman sc retira a Ailigandí desde cl inernes de cada seen menos que sea con permiso de ese Despacho o con su asentimiento.

Le he mandado inmediatamente una nota en términos fuertes advirtiendole que no debe abandonar su puesto sin permiso previo o se verá en peligro de perder el derecho a vacaciones.

Me es grato reiterarme su atento y seguro servidor,

Manuel M. Puig

Director de las escuclas.

Trans. del orig. mec.

V. RD, n. 760 . 


\section{$\operatorname{CCCLXX}$}

Sr. Dn.

Luis Hernández R

Intendente de la

Comarca de San Blas

El Porvenir.

Señor Coroncl:

Con agrado me refiero a ta nota, privada que me remitió con fecha 31 de Agosto diciéndome que de acuerdo con el Subteniente de Polić́a, le remitiera un niño para la Escuela

Fue escogido el niño Leonidas Obaldia, el cual fue con el Padre Jesús, despuets de varios titubeos de la familia.

Respecto a lo que me indica en la misma nota de si considero apto para el puesto de Maestra de Playón Chico a Evangelina Ossa, en reemplazo de la maestra Rosario de Herrera me parece muy bien el cambio, pues la considero como una de las mejores Matestrats.

Suy de usted muy atento y seguro servidor,

Manuel Mי. Puig

Director de las escuelas

Trans. del orig. mec.

V. RD, n. 761 . 


\section{$\operatorname{CCCLXXI}$}

Señor

Panamá, Sept. 12 de 1942

Luis Hernández

Intendente de la Comarca de

San Blas, El Porvenir.

Mi estimado amigo:

Acá he recibido el Mapa que Ud. con la diligencia que acostumbra, devolvió al Ministerio de Educación. Estoy al frente de ese trabajo y le agradezco esc gesto con magnificas observaciones.

Una molestia más que podria Ud enviar, sea directamente o por conducto del Mínisterio de Gobierno y Justicia, a este Ministerio de Educación, el Cuadro Estadístico sobre Malsreula y A sistencia Mensual.

El Año pasado yo envie el formulario y lo estuve recibiendo durante scis meses. Esta información ha sido de gran valor porque el Ministerio de Educación es siempre la fuente de información para el extranjero, sobre el movimiento educativo de un pais; y, naturalmente, solo se está en condiciones de serlo cuando se tienen los informes. Ahora mismo estamos recíbiendo los informes de las escuelas que dependen del Ministerio de Salubridad y Obras Públicas.

No se que haya escuelas privadas en la Comarca de San Blas, pero, si las hay, sería de gran valor la información acerca del personal docente y educando de cllas.

También me interesaría el informe ( $y$ ya le estoy pidiendo demasiado) del número de iglesias que hay en la Comarca y la clase de religión que imparten.

En este mismo correo le enví́ unos 20 Cuadernos Estadísticos y también una copia de uno de los que recibí el año pasado, con el objeto de que, si ud. pone en función su proverbial bondad y va a cooperar con el Ministerio de Educacón enviando estos datos, le sirva este cuadro de modelo

Trans. del orig. mec. inc.

V. RD, n. 762 . 
Rvdo. Padre

Manuel M. Puig

Director de las Escuelas

Narganá.

Scĩor:

Este Despacho ha recibido informes fidelignos que comprueban que el maestro Eduardo Filos, de Ailigandi, se dedica con frecuencia a la bebida, lo cual constituye un acto completamente ajeno a la moral de un buen enscĩador.

Por lo tanto este Despacho ha dispuesto que el maestro Filós sea reemplazado en su puesto por el señor Victor Avila, maestro competente, a partir del 27 de los corrientes, o sea, durante el segundo semestre de este año escolar.

Soy de usted con consideración, atento seguro servidor,

Luis Hernández R.,

Intendente.

Trans. de la cop. mec.

V. RD, n. 763 . 
CCCLXXIII

Número 210

Sr. Dn.

NARGANA, 1 de Octubre de 1942

Luis Hernández R.,

Intendencia de la

Comarca de San Blas

El Porvenir.

Señor Coroncl:

transcurrir.

Le remito con la presente los datus estadísticus del mes de Septiernbre que acaba de

Los maestros de Ustupo, Ailigandí y Tupile de arriba, que tienen a su cargo ta rado, presentaron a esta Dirección los exámenes semestrales por escrito, de sus respectivos alumnos

He quedado satisfecho de la labor de dichos maestros, pues según se ve en dichos exámenes se esmeraron en la instucción de los nin̂os y en su preparación para rendir exámenes.

Los dias 23 y 24 dí conferencias a los maestros en la oficina de la Dirección de Escuclas. Por motivos de las fiebres que con frecuencia me molestan, no me fue posible fijar fecha cierta y anticipada a dichas conferencias, lo que ha ocasionado la falta de asistencia involuntaria de algún mactro.

En dichas conferencias, además de tratar de varios tópicos relativus a la escuela, Ies recomendé nuevamente la necesidad absoluta de la conducta irreprochable de todo maestro; $L$ fidelidad exacta $y$ puntual $\mathrm{en}$ los dias $\mathrm{y}$ horas de clase; $\mathrm{y}$ la prohibición absoluta de las bebidas alcohólicas. También les recomendé que todos los meses, al mandar los datos mensuales, informen a esta Direccion cualquier novedad que les haya ocurrido durante el mes, a fin de que pueda yo Instrucción Póblica, señor Eligio Ocana V.

Al final de las conferencias, todos los maestros por unanimidad, convinieron en presentarle a la Primera Autoridad Comarcal, un Memorial pidiendo aumento de sueldo, por motive de que la vida se está poniendo cada dia más cara. Se lo remito en sobre aparte. También le remito en otro sobre los datos de Instrucción Pública.

De usted atento y seguro servidor,

Manuel Mי Puig

Director de las escuclas.

Trans. del orig. mec.

V. RD, n. 764 . 
CCCLXXIV

$V-46,47$ y 48

Número 203

NARGANA, 7 de Octubre de 1942

Señor Coronel

Luis Hernández R.

Intendente de la Comarca

El Porvenir

Scñor:

En atención al contenido de su muy atento oficio \# 1197 de 5 de los corrientes, me es placentero cumplir con el mandato del apartado (g) del Decreto Ejecutivo número 70 de 1938 de 22 de. Octubre, reglamentario de la Ley $2^{4}$ de 16 de Septiembre del mismo año, de rendir a esa Superioridad el informe que cada Jefe subalterno de Despacho en la Comarca, debe hacer al final de cada año de administración, de consiguicnte aunque someramente le expondré mis actividades desarrolladas en este Despacho, y mis puntos de vista sobre las necesidades más urgentes.

Administración de Justicia

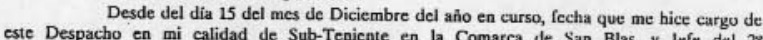
este Despacho en mi calidad de Sub-Teniente en la Comarca de San Blas, y Jefe del $2^{2}$ Destacamento, pude darme cuenta inmediatamente de lo complicado que son los asuntos a resolver no obstante de que el Gobiende de civilización en que se encuentran los nativos de esta región, ello primarias a caro del competente Rudo. Padre Manucl Puacter buenos planteles de enseñanzas regentados por 8 maestras de ellas 6 Rdas. Madres Francicenas y 2 birctor, un Sub-Director, $y$ con ahinco en sus tareas de civilización y enseñar a un nímero de 358 ables seíoras que trabajan matricula actualmente en este lugar.

Aunque se nota que me he apartado un poco del sentido de este capítulo, ello precisaba ya que para ilustrar más a esa Superioridad, de mis actividades desarrolladas en lo que va del año de 1942, se necesita abarcar todas las dependencias del gobicrno eslablecidas en este. Destacamento.

Los indios de las islas de Río Azúcar, Tigre, Ticantiquí y Mayugandi vienen tudos a soluciunar sus diferencias ante las autoridades de este Destacamento, pero siempre con la tendenciu de elevarse en quejas ante el superior (La parte perdedora como es natural tiene que resultar uno entre dus se discuten un derecho) y con el sentido de apelacion como debe ser. De allí pues ha dependido mi mayor actividad en haber evitado con mis calculos los anteriores. A los indios según he sacado en conclusion se les ha hecho ver de que todo cuanto la naturaleza ha decado a la Comarca de San Blas, les pertenece y que las autoridades hasta cierto punto tienen que diferenciar la aplicación indios $y$ eston en periodo

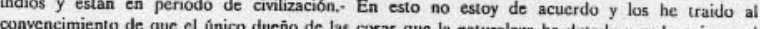
Gobierno Nacional y por lo tanto pucde disponer de ellas euando lo dutado a cada pais, cts el circunstancias asi lo exijan. Mejoras

si se tiene en cuenta la actividad que hay que despleagr para cunsugir ume los hi.jes det lugar presten su cooperación al emprender una mejora, el periodo de crisis por que los hijus del universo y el ningún recurso de que disponer, se puededecir quritraviesa el plataforma o malecón que queda frente a la estación de Polića, se le ha colocado ha separado la Cuartel, se ha blanqueado.

Juan Vasque

Sub-Tenicnte Jefo

Trans. del orig. mec. inc.

V. RD, n, 765 . 


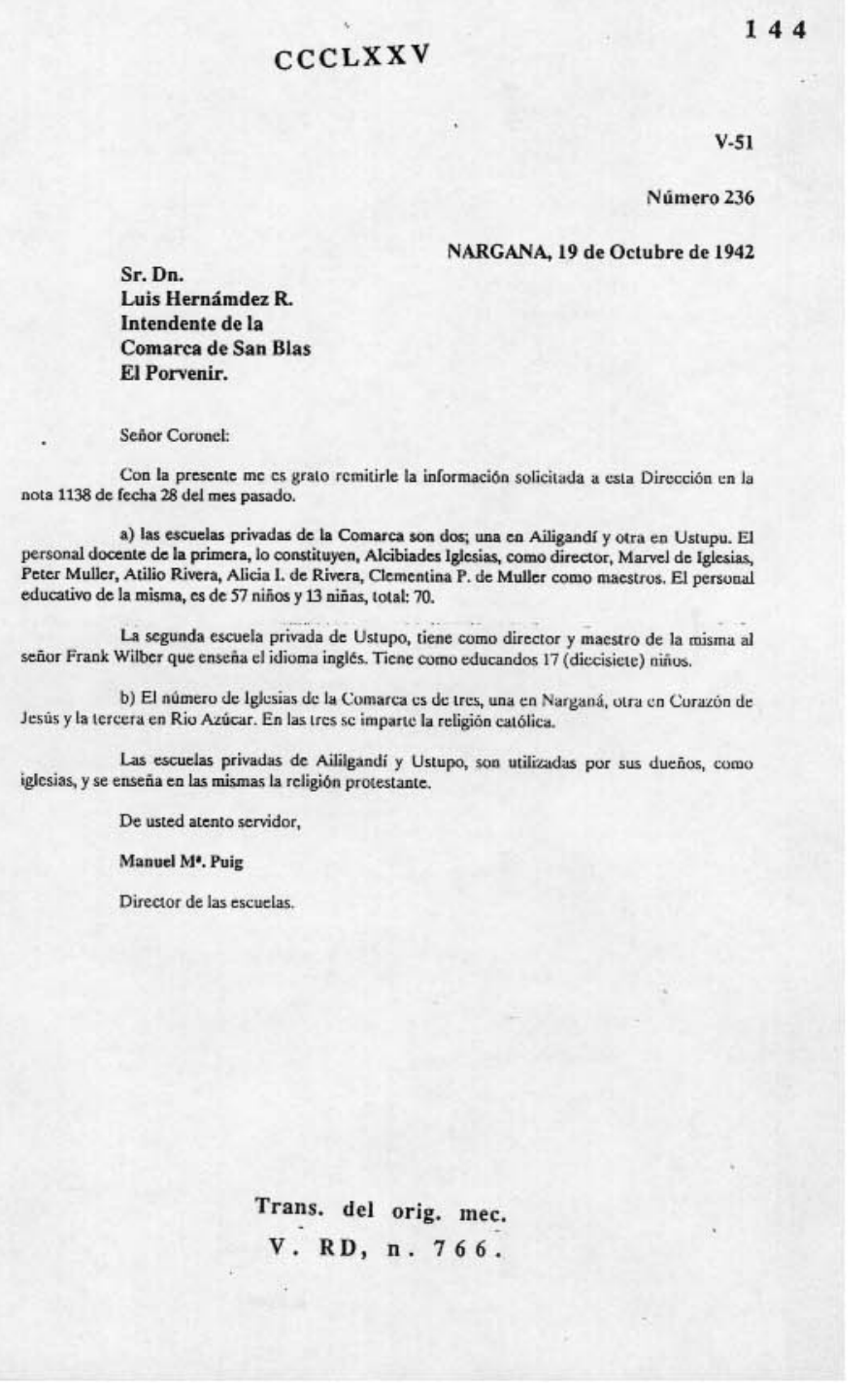


Número 246

Sr.Dn.

NARGANA, 4 de Noviembre de 1942

Luis Hernández R

Intendente de la

Comarca de San Blas

El Porvenir.

Señor Coronel:

Le remito con la presente los datos estadisticos del mes de Octubre proximo pusado. También van en sobre aparte los datos estadísticos para Instrucción Pública.

He de anotar complacido la espontaneidad con que todo el magisterio de la Comarca se

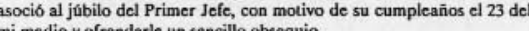
mi medio $y$ ofrendarle un sencillo obsequio.

En la visita por las escuelas de la Comarca, pude ver los interesantes programas aue en todos los plantelas se iban a desarrollar durante las ficstas patrias. Todos los maestros estaban nuy animados a celebrarlas con gran esplendor.

Como le indiqué en nuestra última entrevista, el sáhila y pueblo de Rio Perro le piden desde ahora con gran interés les tenga presentes para porporcionarles un maestro el próximo año escolar.

La escuela que en la actualidad no funciona bien por falta de local adecuado es la de Ailigandi. Los tres grados se ven precisados a laborar en un solo salón, baciendo puco menos que imposible labor de los maestrus. Llamé la atención de los principales del pueblo para que arreglen cuanto antes los otros dos edificios a fin de que puedan funcionar por separadu.

El "Esfuerzo" descarg6 aquí 10 (diez) bancas que supongo usted mandarin a una Isla determinada. Haga el favor de indicarme a qué isla se han de mandar y las enviaré en la primera oportunidad.

Respecto de la madera que usted regalo para la escuela de Rio Tigre, todavía no la han colocado. Después de las fiestas patrias piensan hacer el trabajo.

\section{De usted atento servidor,}

Manuel Mי. Puig

Director de las escuelas.

Trans. del orig. mec.

V. RD, n. 767 . 
Rvdo. Padre
Manuel M". Puig,

6 noviembre 2

Director de las Escuelas,

Narganá.

Señor:

Acuso recibo de su atento oficio número 246 , de fecha 4 de los corrientes, con el cual remitio los datos estadísticos de las Escuelas de la Comarca.

Ma ha complacido que las Escuelas de la Comarca hayan celebrado el dia máximo de la programas especiales

Con relación a las necesidades de las Escuelas le manifiesto que ya en el informe que presenté al Ministerio de Gobierno a fines de octubre las hice presente y es muy posible que se abran nuevas escuelas y se aumente el personal de maestros.

Las dicz bancas que mandé en el Esfucrzo son para la escuela de Tupile y le agradecer que las mande alls en la primera oportunidad.

De usted atento servidor,

Luis Hernández $\mathbf{R}$.

Intendente.

Trans. de la cop. mec.

V. RD, n. 768 . 


\section{CCCLXXVIII}

Número 667

Señor Coronel

USTUPO 17 de Diciembre de 1942

Luis Hernández $\mathbf{R}$

Intendente de San Blas,

Muy recordado amigo:-

Deso de enviarle csta para saludarlo y al mismo tiempo de que usted reciba mi carta que se encuentre de buen estado de salud.

Veo señor Intendente que administración en la Comarca de san blas, va en buena Disciplina ya que en la Comarca han visto su buena labor y progreso para la comarca de san blas asf es que todos le tenemos una buena simpatía por su progreso que lleva para los indos de esta y ya que los indios sc han convencido en usted, pues tambien le informo pero yo veo que solamente los indios
de Cartí no se han convencido todavia de usted por el progreso que usted, lleva en esta Región porque los indios de Cartí se quejan de usted por no dejar pasar el Licor a Cartí y a otros pueblos yo se que eso sería mejor de no dejar pasar el Ron pues en mi nombre deseo de que usted no administro permiso para comprar Licor, pues sobre de esto que yo le digo por eso se quejan de usted pues yo veo que usted to hace mejor eso es un buen progreso de usted.

Señor Intendente por aca arriba no tenemos queja de usted $y$ le linformo que no hay novedad solamente entran enbarcaciones que hacen sus transitos de comprar Cocos veo que compran en buen precio pero yo desearia de que usted me ayudar de subir el precio de la compra por litha as as ge por the pere deseo de pertreviste a presidente el mes pasado.

Pues señor Intendente creo que usted me haga el favor de enviarme unas maderas crucza también le informo que yo pienso construir una escuela nueva aqui en Ustup despues de las vacaciones pues si usted en las vacaciones sus carpinteros lo tiene desocupado desearia de que usted me lo mande para poder hacer lo mas pronto posible la escuela que menciono eso se lo pido después de las vacaciones. Así es que en mi nombre será favorecido. Pues sin mas

Quedo de Usted S.S. Atto. S. Amigo;

Nele de Kantule

Sahila General de san blas.

Trans. del orig. mec.

V. RD, n. 769 . 


\section{Informe Escolar}

I) la labor escolar realizada por el Magisterio Comarcal en el áltimo bienio lectivo, es digna de todo encomio por su cficiencia. Para apreciar esta, nada mejor que los númerus estadísticus, se ha notado un incremento notable en escuelas, maestros y matricula, elementos tres, que arrojan el nive escolar 1939-1940 ascendian a veinte (20); el año siguiente se aumentó seis más, 26 y al subsiguiente la
Lisla era de 30 (treinta).

Las escuelas del año lectivo 1939.40
hasta 12: progresando en otra.... hasta 13 (trece).

$$
\begin{aligned}
& \text { La matricula del año 1939-1940 era } 896 \\
& \text { " * 1940-1941 * } 1108 \\
& \text { * } \quad{ }_{1941-1942}{ }_{1192}
\end{aligned}
$$

II) Un beneficio positivo, digno de consignarse, que la instrucción indigena de San Blas ha recibido en el periodo de los dos años lectivos precedentes, lo constituyen las becas del Gubierno-

Trans. del orig. mec. inc.

V. RD, n. 770 
INFORME ESCOLAR DE LA COMARCA DE SAN BLAS Año lectivo 1942-19443.

SR. DN.

LUIS HERNANDEZ $R$

INTENDENTE DE LA

COMARCA DE SAN BLAS

EL PORVENIR

SEÑ (IR CORONEL:

En cumplimicnto de los Articulas 75 y 50 de ba Codificación Escular vigente, paso rendirle un sencillo informe de la bahor educativa lievada a cabo por el personal doeente de este Comarca.

NOMBRAMIENTOS

El Poder Ejecutivo, por Decreto nûmero 375 de fecha 23 de Abril de 1942, hizo el nombramiento de maestros para la Comarca de San Blas en la forma siguiente:

Director, Rndo. Padre Manucl M. Puig, en recmplazo del Rndo. Padre Ricardo Velascu quicn renunció

Ayudante del Director, Rndo. Padre Jesús Erice

Narganá y Corazón de Jesús

Hermanas: Clementina, Brigida, Adolfina, Eufrosina, Ulrica, Pia, Cayetana, Matestras: Elisa vda de Garrido y Sara Méndez.

Puerı Obaldiu: Dumitilo (iaribaldi y Manucla Aguilar

Carti-Cangreju: Andrès Iglesias

Tupile-Abajo: Ismacl Rubinms

Rio Sidra: Roberto Preciade

Rio Azúcar: Francisto Soo y Fulvia de Soo

Riu Tigre: Luisa de Murris

Tigantiki: Mario Porras

Playón Chiex: Jusst Ciolman y Rusario de Herrrere

Tupile-Arriba: Josefa de Salazar, Carolina de Alfaro y Tomás Herrera

Ailigandi: Juana de Haya, Roberto Pčrez y Eduardo Filós

Ustupo: David Rodrigucz, David Diaz y Cristina Lopez. 
Domitilo Garibaldi, quien no accpló el cargo, fue suplido pur Ernesto Acusta C. Manuela Aguilar, fue reemplazada en el scegundo semestre por Alejandrina Vargas.

Rosario de Herrera, debido al estado de gravidez, fue sustituida por Evangelina Ossa.

Fueron destituidos de sus cargos: Ismacl Robinson a quicn suplió Pablo Solis, y Eduardo Filós, reemplaźndole Víctor Avila.

\section{DIRECCION DE ESCUELAS.}

Esta Direccion ha trabajado con eficiencia y sacrificio en el ramo de la instrucción y civilización de los indios; siempre en coordinación y dentro de la más perfecta armonía con el lntendente de la Comarca, Coronel Luis Hernández $\mathrm{R}$.

He tenido comunicación constante con las masstrus de la Comarea, resulviendo sus dilịcultades, atendiendo a las peticiones de material escolar, y urgiendoles en todo tiempo el cumpliento exauto de sus deberes escolares.

Se han expedida ucho circulares sobre distintos túpicus educatives; hanse repartido diversas comunicaciones del Minislerie de Educaciỏn y se ha dado curso a varias instrucciones de la Colin, yue se ha crédo de utilidad e interés para los maesarus de la

Cinco veces consecutivas se ha girado la Visita de Inspección por todas las escuelas de la Comarca diseminadas entre el Porvenir y la frontera de Colombia. En una de estas visitas, el yue suscribe, contrajo una fuerte malaria que le ha molestado varios meses.

A Pesar de la dificultid de comunicaciones, hemos eclebrado varias confurencias con el magisterio de la Cornarca, con resultados positivos. De común acuerdo, en la última de dichas conferencias se elevó un Memorial al Coronel Luis Hernández R. pidiendo el aumento de sueldus, que confiamos será alendido.

Becas:

En conmernoración del "Dia del Indigena" el Excmo. Sr. Presidente de la Repúblice, resolvió otrogar ocho becas a los indigenas de San Blas, cuatro para niñas y cuaturo para varoncs en la Escuela Normal de Santiago.

Resultarun farurecides lus varunes; Efrain Martinc\% (iuillerma Andresce. Franciseos Diaš y de las niñas: Bertilla Lipus, Blunca Llihre y Adelina Porras.

Esta Direcciòn prestó tedo su apuyo y cooperaciòn para la aplicaciún de dichas becas. El Subdirector de las esceclas, hizo viaje expreso a Conlón y Panama en busca de los favèrecídes, a tin de prestartes la conveniente ayuda, poniéndolos en condiciones de emprender el viaje para la Normal de Santiago.

\section{Eiestas palrias:} No puedo omitir el gran entusiasmo con que se celebraron en tudas las escuelas de la
Cumarca las fiestas patrias. Se desarrollaron muy interesantes y variados programas, Ellos hicieron de la atnada patria.

\section{Gralimet:} En nombre de todo $\mathrm{el} \mathrm{magisterio,} \mathrm{me} \mathrm{place} \mathrm{hacer} \mathrm{constar} \mathrm{nuestra} \mathrm{profunda} \mathrm{grataitud} \mathrm{al}$
Gubierno de la República, por el envio de libros de lectura, tiza, tinta y lápices, de todo lo cual hemus 


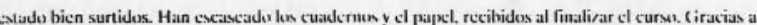
la actividad del Coronel Luis Hernaindey, se ha conscguido un aumento aproximado de ciento eincuenta bancas nuevas en las esceuclas de la Comarea.

\section{Diccionario Karibc Kuna:}

Después de varios años de trabajo y vencidas no pequeñas dificultades, puedo ofrecer al Gobierno un diccionario de la lengua karibe kuna, con más de diez mil voces traducidas del espanhul al indio. en un volumen de 215 páginas. los doce largos ańos que llevo de hablar dicha lengua, me han facilitado hacer este trabajo.

Creo que la obra será de interés para los cmpleados públicus yue han de actuar en là Comarca, para los turistas que ansian conseguir esta clase de trabajos y para los mismws indigenas a

\section{ESCUELLAS PARTICULARES}

\section{Nargana-Ciorezón de Jesüs}

Nucve maestras han irabajado en esta escucla, la principal de la Comarcea, con una matricula de 355 alumnıs.

Todas han trabujado con cjemplaridad y consagración dignas de ludo encomio. El nutable aumente de la matricula, requicre para el curso próximo, el nombramicnto de otra maestra.

La corriente de atracción y confianza que la escuela de Narganá va irradiando hasta las mas remotas islas, es cada día mayor, aumentando por consiguiente el número de niños que afluyen de todas ellas.

Este fue el resultado de los exảmenes finales:

Grado

Matricula Promovidos Frucasados

$\begin{array}{llll}\text { Kinder } & 56 & 28 & 28\end{array}$

$\begin{array}{llll}\text { I grudo } & 50 & 2 s & 22\end{array}$

11 grado $\quad 44 \quad 22 \quad 22$

$\begin{array}{lll}I I \text { grado } A & 37 \quad 20 \quad 17\end{array}$

III grado B $\quad 38 \quad 26 \quad 12$

$\begin{array}{llll}I V \text { grade } & 56 & 34 & 22\end{array}$

$\begin{array}{llll}V \text { grado } & 32 \quad \text { si } & 32\end{array}$

$\begin{array}{llll}V & \text { graule } \quad 25 \quad 26 \quad 2\end{array}$

También en el presente curso se han dado con regularidad clases de piano y violín a los alumnos aficionados a la música. Estos, lucieron sus habilidades artísticas en los actos literarios de las alumnos aficionados a la música. Estos, lucieron sus habilidades artísticas en los actos literarios de las
fiestus nacionales y locales, pero de un modo especial en la grandiosa velada del tres de Nuviembre.

Fue una nota muy interesante para el público, en dicha fiesta, la pequeña banda de cornetas y tambores, organizada y dirigida por el Subdirector de las escuelas.

La profesora de costura, ha presentado al finalizar el curso, una interesante expesicion de labores de toda clase. Trajes, Tupices, Tapetes, sobrecamas, almohadunes, encajes, burdados de 
lus mas finus y curiusus, llamaban la atenciỏn de cuantess la visitaron. La profécura recibió calurobas Felicilaciunes

\section{Internado de niños}

La nota principal en el prescnte año, ha sido a no dudarlo, la inauguración de un magnífico edificio de concreto, destinado a Colegio Internado de nifíos indígenas de Iejanas islas.

Se halla situado en la isla de Corazón de Jesús. Mide 12 metros de ancho por 18 de largo y 7 de alto. Artistica fachada de forma de un gran baldaquino hermosea la calle principal de la isla. Llama la atención de los indios y demás visitantes el masaico del piso bajo.

Las condiciones pedagógicas de luz y ventilación en todos sus departamentus hacen de el un buen centro de educación. Faworcec la higience un tancuevedeposito de aguat, cuya capacidas asciende a 15.000 litros.

Otro pequeño edificio de concteto, algo apartado, sirve de cocina y despensa del Ciscegiu, para perder salvar ta higicie escolar.

La obra se ha podido hacer gracias a la generosidad del (jobierno que facilitó todo c material necesurio. Han recibido alención gratuita en el nuevo edifício, 30 niñoss de las más remotis islas. Debido a la esceastz gencral de alimentos, hemus tenido dificultad en la manutenciỏn de los

Intcrnado de niñas

Con la inauguración del año escolar, comenzó a funcionar un nuevu internado para ninass en la isla de Naryaná. 18 niñas han estado al cuidado de las Madres Franciscanas en el presente curso.

Insignificante parecerá dicho número, para quien ignore lo celosos que son los indios en desprenderse de sus hijas. Nosotros vemos en este internado, el principio de una nueva civilización, en la que comienzan a entrar las niñas indigenas en la carrera de la civilización.

\section{Puerto Obaldia}

Ha cjercido el scenor Ernesto Acosta Ci. Ficl a su cargo a pessar us la dificultades con

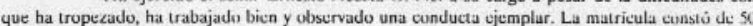
alumnos.

Manuela Aguilar, enstenó el tercuro y cuarto grado con gran acierto y aceptación det pueblo, pero debido a su caricter un lanto raro, cumenzó a disgustarse cun lus pudres le funition terminando per $n$

Alcjandrina Vargas, suplente de la anterior, realizó muy bucna labor durante tres messes, La nuti cia de la muerte de su mamá la impulsó a retirarse del lugar pucu untes de terminar el curso y sin presentar exámenes.

El cambio de Irabajo y trabajadores de Puerto Oballia a Permé, ha tenido a lus niñus y familias en constante movimiento, entorpeciendo las labores cseculares con detrinentu de la matricula

\section{Carti-Cangrejo}

Al frente de este plantel estuvo de nuevo el maestro Andrés Iglesias. Dutado de bủenas cualidades para la enseñanza, a la que da siempre gran interes, ha logrado mantener sin notable alteración la matricula y asistencia todo el curso. La matricula alcanzó a 60 alumnos. 
Personalmente pude presenciar cl progreso del alumnado en las visitas de inspecciön causándome agradable sorpresa.

Ha sabide despertar tatre les discipules y cn todlo cl pucblo, gran interís por las liestas patrias, que celcbró con esplendor nunca visto cn aquellu isia.

El cambio de jefe upcrado en el lugar, ha mejorado la situación de la cscucla, ta cual contará en adelante con un bucn patrocinador de la misma

Carti-Tupile

Es el segundo año que funciona esta escuela, teniendo matriculados 35 alumnos. Ismael Robinson, designado para regentarla, no logro despertar entusiasmo en el pueblo en pró de la instrucción, debido a su carácter apático y a su conducta inmoral. Por Decreto Ejecutivo nưmero 455 de fecha 12 de Agosto, fue destituido, nombrándose en su recmplazo a Pablu Sulis.

Este, logro muy pronto captarse las simpatías del pueblo, formando mejor ambiente a favor de la escuela y mejorando la asistencia. Ha trabajado bien en la cnscñanza de los niños y mechenido bucnas relaciones con cl vecino matestro de Cangrejo. Las dos escuelas se han juntidu con frecuencia pa

\section{Río Sidra}

Roberto Preciado ha regentado este plantel con resultados muy apreciables. Hasta 50 alumnos logro hacer subir la matricula.

No sin yran esfucran, cunsiguió del puchlo ta construcción de un nueve edificio escolar. cua piso altu de madera que costearun hax vecinos del lugar. El propio macsiso tomó purlé muy actives
en la construcción de la obra.

Esta escucla cn el stgundo año de funcionar, ha mcjorado mucho cun respecto al año anterior $y$ ofrece un porvenir más risueño.

\section{RloAzúcar}

Nuevamente Francisco Soo y Fulvia de Soo estuvieron a cargo de esta escuela. Han hecho buena labor en el plantel y los niños están bastante adelantados.

La presencia de un agente de polića en la isla y la cooperación decidida de su jefe, han lavorecido notablemenic bematricula y asistencia. Después de Narganá es ol centro que cuctuta cun mäs niñas en el alumnado y donde la escuela ejerce mayor inlluencia civilizadora. La matricula general ha sido de 75 alumnos.

El edificio escolar, propiedad del Gobierno, ha sido reparado en dos ocasiones por el El edificio escolar, propiedad de
Intendente de la Comarca, Luis Hernández R.

\section{Rio Tigre}

Esta uscucla después de once anios de exissencia, progresa muy despacio. Es características la apatía de sus habitantes por todo lo yue significa cultura y civilización. Las freceuvotes chichas la manticnen en el atrasi.

Luisa de Morris, maestra graduada, que desde muchus anos viene actuando al frente de este plantel, ha conseguido muy poco cn orden al progreso del mismo. Creo deberia poner más interés en la enseñunza y en La.preparación de las fiestias patrias. Ha trabajado con 57 allumnus.

Un grupo considerable de niños tigreños que cursan en la escuela de Nargană, sỏn una halagũeña esperanza de mejor porvenir par la instrucción pública en esta isla. 
Tigantiki

Mario Porras, encargado de esta escuela, ha hecho muy buena labor y se ha interesado en hacerla progresar. La matricula alcanz 6 la cifra de 54 alumnos.

El jefé de la isla y sus moradores están satisfechos de la actuación y cunducta de este maestro. $\mathrm{Ha}$ mantenido el piantel disciplinado y en buena marcha. En las visitis de inspecciön, presenta los cuadernos limpios $y$ en debida forma.

Se ha contado entre los alumnos un número considerable de niñas, lo cual prueba ta influencia que va adquiriendo la escucla en este poblado indigena.

Playon Chice

Jost Colman y Rosario de Herrera, se hicieron cargo de esta escuela. Ambus han trabajado con eficiencia y excelente resultado, en la instrucción de los niñus encumendados.

Rosariv, por su estado de gravidez, fue reemplazada en el scgurndo semestre por Evangelina Ossa. La preparación pedagogica y el carácter enérgico de esta maestra, hacen que su labor sea excelente en todos los lugares en que actua.

La matricula ba excedido siempre la cifra de 90 alumaos. Los habitantes de esta población, dieron una prueba del intertes que les merece la instruccion de sus hijos, construyendo do poblacion, dieron una prueba del interts que les merece la instruccion de sus hijos,
edificios eseolars que han dotado de piso de madera costeado por ellos mismos.

\section{Tupile de Arriba.}

Un grupo de 24 niños de esta isla han cursado grado superior en la escuela de Narganá; número no igualado hasta el presente por ninguna otra. El aprecio, que de la escuela bacen estus indigenas, se debe al jefe Manucl Hernảndec, quien no cesa de ponderarles los grandes bienes que la instrucción proporciona a los pueblos.

Los tres maestros que han ejercido, Josefa de Salazar, Carolina de Alfaro y Tomás Herrera, con su fidelidad al trabajo y cjemplar conducta, han dejado plenamente satifechus al pueblo y a su jefe. La matricula ha sobrepasado la cifra de 90 alumnos.

Avelino Ortiz, Florentino Núnez: y Tcodoro Chiari han sido los primeros niños quc han obtenido diploma de sexio grado en el presente curso.

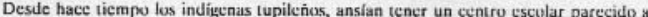
de Narganá. A mi juicio ello constituiria un paso de gigante en la marcha de la instrucción püblica de la Comarca.

Ailigands

Tres fueron los maetros asignados a esta escuela

Roberto Pérez, Eduardo Filos y Juana de Haya.

El primero, por estar cansado de trabajar varios años en el mismo lugar, ba uctuadu muy pobremente $y$ con escaso fruto.

El scgundo, con su conducta puco cjécmplar tambičn perjudicô ta bucna marctha dẹ plantel. Fue remuvido de su puesto y sustitutido por Víctur Avila, el cual ha terminato felizemente con buen resultado.

escolares.

Juana de Haya ha permanecido ficl a su cargo, cumpliendo en todo tiempo sus déberes 
Las irregularidades de los dirigentes de la escuela, dejäronse sentir muy pronto en la matricula, marcando un descenso de 100 a 80 alumnos.

Entiendo que el macstro Roberto Pérę debe ser trasladado en el próximo curso.

La escuela oficial, que tiene a su lado ta escucla particular patrocinada por ta misión protestante, no ha quedado muy airosa ante los indios en el presentc cursu. Un persunal bien escogido, para el año proximo, le devolvería el prestigio habido en años anteriures.

Ustupe

Esta escuela es a no dudarlo, una de las primeras de la Comarca, por su disciplina, adelanto $y$ matricula.

Parte principal en la bucna marcha de la misma, se debe al prestigio y consejos de Nele Kantule, espiritu progresista y amigo de la civilización.

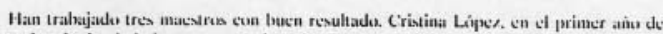
actuar en el magisteris, ha dado truena cuenta de sf. La paca expresión y encrgia al dar la clasc, le ha restado simpatias cutre aypuclles indiom.

David Diaz, como cen anus anteriures, ha cumplida con los Jeberes que $k$ impune $1 \mathrm{~s}$ escuela, teniendo además buena aceptación entre la gente de Ustupo. Las liebres que con frecucncia aquejan a este macsiro, aconscjan un trislado para cl año próximo.

David Rodríguez, en el sexto año de cjercer en el mismo lugar, ha dado nuevamente prueba de competencia, consagración al trabajo y conducta intachable. Una buena cualidad de este maestro es la frecuente exhibición de recitaciones escolares, variados cantos, y ejercicios gimnásticus
bien preparados. Tanto cl jeflc cumo cl pucblu descan que siga trabajando alli,

Daniel Crespo y Elrain Castillero, son los dos primeros niños. de Ustupo que han obtenido diploma de sexlo grado en el presente curso.

No hay duda que las escuelas de San Blas desempeñan una misión cficaz y patriótica. Ellas han irradiado la luz de la civilización a 1139 niños indigenas esparcidos por tuda la Comarça.

En muchas islas, la csecucla es la única institución del Gobierno y el ủnico medio de progreso para los indigenas.

Cion cllia, se legera hacer penetrar la civilización en la forma más suave y pacifica.

Del cambio notable clectuado en muchas islas mereed a la escuela. pudrả darsec cuenta quien las visitó años atrás y las visita ahora.

\section{Indicacioncs de la Dirccciôn}

las escuelas:

Antes de terminar, descu hacer algunas indicaciones para el mejor funcionaminteto de

1) La escuela de Narganá, necesita el nombramiento de otra maestra para el curso próximo.

II) Es de urgente necesidad para el buen funcionamiento de dicha escuela, la adquisición de un nuevo local. 
III) El jefe y los habitantes de Rio Perro descan se les nombre un maestro.

IV) Los nih̉os que han terminado los estudios primarius cun las mcjores calificaciunes, esperan del (jobierno les ayude cun algunis becas para proseguir lus estudius secundarios.

v) Lus maesirus de la Cómarca, cunfian será atendido fasurablenente ol Memorial presentado, pidiendo cl aumento de sucldo.

Dejo constancia de mi profundo agradecimicnto al sctíor Intendente de la Cumarca, por la franca y decidida cooperación prestada en todo mumento a csla Dirección de Escuelas. servidor,

Del señor Intendente de la Comarca, Coronel Luis Hernández R. atento y seguro

Manuel Mo Pulg

Director de las Escuclas.

Narganá 10 de Febrero de 1943

Trans, del orig. mec.

V. RD, n. 771 . 
Número 6732

\section{Señor Coronel}

Luis Hernández R.

Intendente de San Blas,

presente.

Señor Coroncl:

Deseo de cnviarle esta para informarle ya que llegarun las vacaciones asi es que le hago una petición ancicipadamente, ya que usted ha tenido la bondad de interesarse $y$ ha cumplido $y$ th progresado la Comarca de San Blas, y la comarca sigue en un buen Sñdero de una nueva Civilización en esta comarca, asi es que yo le hago saber anticipadamente a usted, para que usted, se recuerde ya que el pueblo de ustup ha aprobado en el cong. ireso ya que han estudiado pues le pide el favor y en David Díaz como de maestros otra vez para el pueblo de ustup.

Señor Coronel como el señor David Rodriguez y David Díaz ellos estuvierun una buena disciplina y han cumplido sus deberes como de Maesto en el pueblo de ustup asi es que no se le También le informo que la Maestra Cristina López también deseo de que usted me la nombre también a la Joven Berta López o unas de ellas me lo nombra yo se lo pido en mi nombre y del pueblo que como el pueblo de ustup le ha tenido una buena simpatía a los maestros mencionados en esta carta.

Scīor Coronel no se le olvide de nombrar otra vez a los maestros que yo deseo para este pueblo yo he visto a estos jovense que han cumplido su deber ya que yo nunca he visto otros maestros que ha cumpli el deber de maestrus, asi es que yo le pido ese favor antes de los nombramientus de magisterio se to pido a usted para cire asied me lo designe a csios scinores para maestros para pueblo de ustup.

Acepte usted scĥ̉or la sçuridad de mi más distinguida consideración. su amigo;-

Nele Kantule

Sabila general de san blas.

Trans. del orig. mec.

V. RD, n. 772 . 


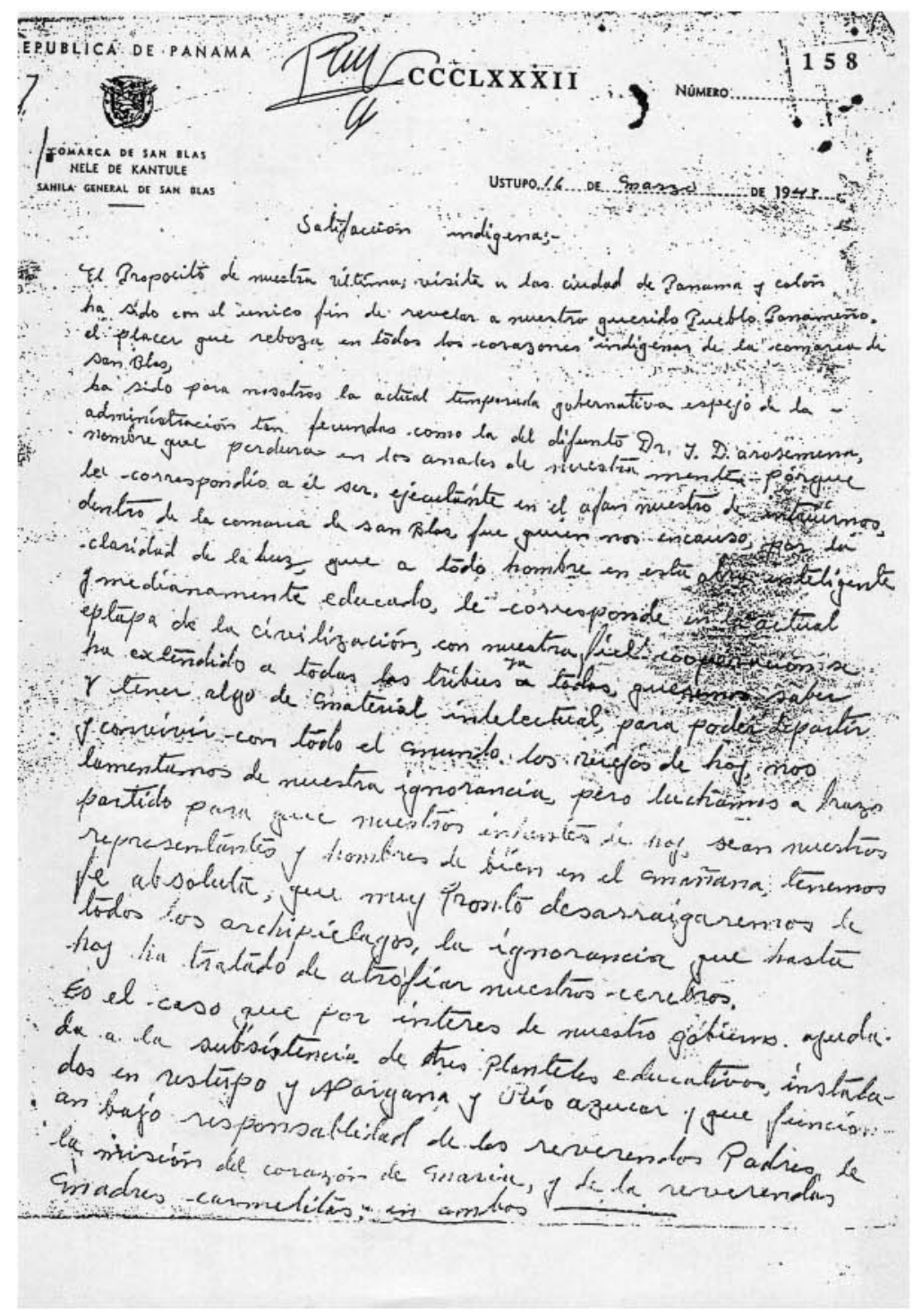




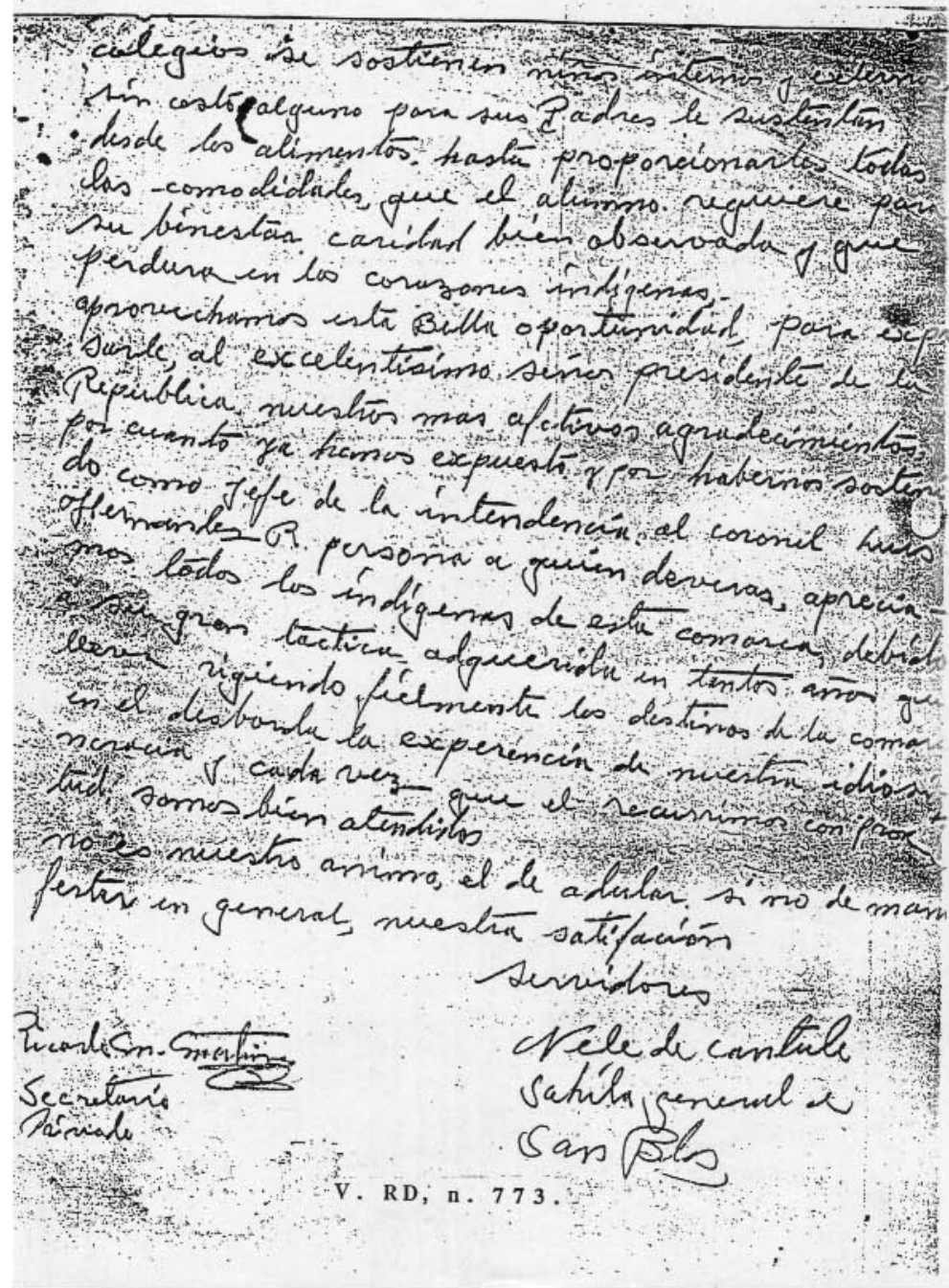


Sr. Coronel

Narganá, 18 de MArzo de 1943

Luis Hernández R.

Intendente de la Comarca,

El Porvenir.-

Señor Coronet:

En entrevista habida con el Sr. Filós, después de haber sido llamado a ese despachus, ane enteré de que se le habf́a delatado de contrariar a su persona. Lamento semejante delación de que ni

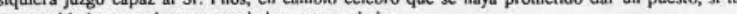
upurtunidad, como alguna vez se to he recuinendado.

Creo reflejar el sentir de esta Dirección al manifestarle que es muy conveniente para mejorar el cuadro del personal docente de la Comarca, que el Sr. Eduardo Filós pueda entrar a formar parte activa en el magisterio Comarcal.

Habiéndome prometido una correción efectiva de la falta en que uncurriera, siempre será de buen tono para el magisterio que un titulado entre a ejercerlo.

El ságuila de Playón Chico, en conversación con el que suscribe, expresó su descontento y el del pueblo con el Macsiro Colman, mientrus ponderaba su accptactión a lavor del Sir. Eduardo Filos. Ultimamente se ha registrado alli un descenso notable de matricula. Los datos csiadisticus arrojan la existencia de 28 niños de segundo grado en el mes de septiembre lo que prueha la urgencia

Soy de usted attnto y segurus scrvidor,

Jesús Erice I.

Sub-Director de las EE,

Trans. del orig. mec.

V. RD, n. 774 . 
Sr. Coronel

Luis Hernández $\mathbf{R}$.

Intendente de la Comarca

El Porvenir.

\section{Señor Coronel:}

Siento honda satisfacción al poder comunicarle tan grata nueva como la solicitud de una Escuela en Irgandi (Rio Perro) efectuada en csta Dirección por el Sr.Samuel Ros, Ságuila de alli en numbre de su pueblo, con encargo especial de que se la trasmita a Usted, como era natural. Al cécclo comunícame que existen más de treinta niños para formar matrícula escolar.
Me informa asi mismo que esta petición fue elevada arriba por conducto de su primo el Sr. Maestro

Soy de Usted atento y seguro servidor.,

Jesús Erice

Sub-Director de las Es.

Trans. del orig. mec.

V. RD, n. 775 . 

COMARCA.

BREVE RESUMEN DE LAS CONFERENCIAS A LOS MAESTROS DE LA

CONFERENCIA 1 TEMA: Normas de la Intendencia En la isla de Corazón de Jesús, a las 3.30 p.m. del día 20 de Abril tuvo lugar la primera conferencia del magisterio Comarcal, dictad por el Padre Director, Jesuls Erice i. Concurricron a la misma los maestros siguientes:Luisa I. de Rodriger Francisco Soo, Jose Co Soo, Cristina Lopez, Roberto Perez, Tomas Herrera, David Ernesto Acosta. Los demás no pudiero asistir por encontrarse ausentes.

Una vez reunidos procediose a la elección de secretario, obteniendo la mayoría por volación oral el Sr. Acosta.

El Padre Director diserto previamente sobre la armonia que debe reinar entre Autoridad y los subordinados, la que se conseguirá acatando sus brdenes y escudando su prestigio.

El plan a desarrollar en esta sesion constituyeron las disposiciones impartidas por el Sr. Intendente de la comarca, Luis hernandez $R$,encaminadas a la buena marcha de la escuela, las cuales foeron leidas o incrpretes anpliancnte, advciendo las muchas razones que asisten a tan

a) Permanencia estricta del Maestro en su puesto, solo una urgencia suma le exime de su observancia. En los dias libres, el Maestro estudie y realice las pequeñas mejoras del edifici escolar y jardin; discurra el modo de remover los obstáculos que se oponen al incremento de matrícula y asistencia diaria; cultive el trato con los padres de familia, aconsejandolos individual y colectivamente; sobre todo anote las causas de la poca eficiencia en el aprovechamiento de algún alumno o de todos, buscando sus remedios.

b) El cultivo de la amistad de los Ságuilas. Es conocido de todos el acatamiento de indigena a las órdenes del Ságuila, aprovéchelo el maestro ; entable relaciones anisho adoctrinándole sobre las ventajas de la instruecion y excitando la emulación de los pueblos para una ayior importancia pue un daa adquirirann merced a la capacitación de sus hijos y otras razones que el avisa

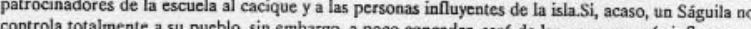
por lo que no se excusa el macsiro de segri a poco conceder, será de las personas más influyentes. Cocomenación superio

c) Comunicar al Director los problemas educativos y sociales de la escuela. El es el superior inmediato, guardemos el orden jerárquico. El Director debe enterarse de las lifich cuestiones de la escuela como asunto de su competencia y que tiene mayor proporción de resolverlos en las giras de inspección. En cl Director está dar curso a los problemas de mayor cuantía olen que necesite consejo; sin embargo no deben olvidar que el Intendente es la primera Autoridad de Escuela, a quien pueden acudir directamente sin caer en la embarazosa nimiedad.

d) El Macstro sea modelo de civilización en el vestir, primeramente. En particular, ta exigua remuneración no es motivo suficiente de no calzarse. Opinó el Director que el maestro que descle el principio fomara esa nor a como justa por razones de economía, es mejor presente su

2) En el comportamiento social, el maestro no debe descender más abajo que los sin civilizar, víctima del licor.3) En la moralidad. Esta reviste mayor importancia, porque nadie desconoce el cuidado de los nativos en salvaguardar sus hijas, $y$ la escuela por esa exagerada prevención lamenta la ausencia del elemento femenino. Es tan notoria la transcendencia de este punto y tantas veces recordado que me libra de extenderme. 
4) En el respeto a las Autoridades Hizose especial hincapié en este aspecto. El Gobierno Nacinal y las Autoridades, de especial competencia en las distintas escalas de ella, están empenados, sin escatimar sacrificios, en la civilización Comarcal; presentemoslos al indigena revecunda esos desvelos y sacrificios, la obra civilizadora será esterililla unificación de hermandad nacional no se llevará a cabo. La Autoridad para influenciar necesita prestigio, no se lo quitemos.

5) Aconsejar el incremento de la Agricultura. A ello nos obliga la dificultad de importación, la carestía o elevación de precios de los géneros aún de los primera necesidad, el desconocimiento de la terminación del conflicto armado, siendo una verdad que de la guerra solo se conocen los principios. Debe censurarse la ideologia de ciertos jovenes que propugnan de palabra y con hechos que el trabajo de machete, de monte, etc. rebaja a la persona, no sea que los indios lleguen a juzgar que ello es un postulado de la civilizacion, por ser tal joven graduado o diplomado. Todo trabajo

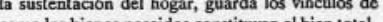
nes poseidos constituyen el bien total.

- CONFERENCIA IIITEMA: Explicación de objetivos escolares.Se notó aumento de concurrencia en esta sesion con la llegada de la Maestra Josefa O. de Salazar. Antes de entrar en el desarrollo del tema el Director creyón necesario recordar a los maestros la dignidad y excelencias de: Magisterio, a fin de que sepan defender tan alto organismo social frente a probables detractores, asi como el honor de las personas a el pertenecientes, las cuales, casi en su totalidad, poseen cualidades que tienen y dan no poca competencia en el ramo: veterania, efíciencia, material didáctico propio, moralidad y prestigio ante el pueblo indigena. El ser miembro de esta abnegada Institución pese a la precaria situación economica, no oira cosa argue sino que los informa un alto ideal regenerador de su raza, un espiritu por encice de la plata, que ojals existiera en los pretendidos defensores del indigena. El Maestrost hombre es lo

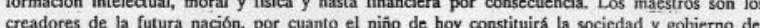
mañana. Fs cierto que la Institución del magisterio honra a sus miembros, pero tambien los ano del maestros de la Comarca honran a la Institución. Terminada esta advertencia paso el Director a la explicacion de los ternas siguientes:

1) Asistencia media diaria y Promedio diario de la Matrícula. Una vez expuestos dos métodos de verificar esas operaciones, se presentaron dos cjemplos que convenientemente desarrollados se entregaron a cada maestro en tarjeta aparte.

uso.

2) Del Registro Escolar se hicieron, igualmente, algunas observaciones para su recto

3) Mapa de la República: Este fue objeto de explicación conforme a la novisima Division Territorial de Provincias y Distritos, llevada a cabo por la Ley 103 del 12 de Jutio de 1941 habido también en cuenta el Tratado de límites aprobado por medio de la Ley 51 del 20 de Mayo de 1941. De esta suerte los maestros podrán enrseñar rectamente la Geografía Nacional, mientras vienen los nuevos mapas anunciados para las Escuelas.

4) El Programa. Se insistió en la fidelidad al Programa Oficial. Las Escuelas de la Comarca se han regido siempre por el Programa Oficial aprobado para las demás Escuelas de la República. En la enseñanza deben acomodarse a cl con estricto rigor. Para mayor claridad y más fácil
manejo lo tienen extractado en hojas aparte. Deben enseñarlo fntegramente lo correspondiente a cada grado, pero sin sobrepasarse.

CONFERENCIA WI TEMA: Solución de dificultades en la enseñanza.

a) Insistióse encarecidamente a los maestros el incrementar la matrícula escolar, sin omitir medio alguno, a fin de ensanchar la acción civilizadora. Arriba se enunciaron algunos medios como influenciar sobre los Ságuilas, personas influyentes, padres de familia, hablando en los congresos con ese objeto etc. Sea manifiesto al pueblo el interés del maestro por la educación 
mediante el esfuerzo en su ejercicio que no escaparáa a la perspicacia indígena, con ello conseguirá la mediante el esfuerzo en su ejercicio que nadres de familia que con gusto mandarán sus hijos a la escuela.

b) Intensificación del castellano. Propusieronse medios:1) Conseguir acopio grande de términos, frases y corrección de formas gramaticales, sin salirse un ápice del limite senalado a cada grado. Para ello escriban listas de palabras traducidas al indio, aprendiéndolas, repasándolas,introduciendo emulación con desafíos o premios; este cjercicio deben practicar todos los grados. Escriba variedad de frases y recilaciones acomodadas al grado, aprendiendo previamente sus términos $\mathrm{y}$ de tal modo redactadas que no se repitan los mismo vocablos. Ejercite las formas gramaticales estudiadas, siempre a base de palabras conocidas, no deberia ennsenarse cosa alguna sin antes aprender su traduccion e.d. de las palabras que entran en la asignas. Eros leminos, frases y formas gramaticales repita $y$ repase constates metodo por necesidad, al cabo de pocos ans, ace que habra soluciondo las do en ese del habla ordad te pre nunias matos, advertencias mantenga rigido encuadrado en ese marco. Infinidad de preguntas, mandatos, advertencias y explicaciones lloverán durante
giros y modismos insensiblemente.

2) Ponga cl macstro ante los ojos del niño toda su enseñanza, lleve a clase los más objetos posibles; ojalá portasen consigo los maestros una coleccion de cuadros plásticos de toda la cnseñanza, ello equivaldri actuación, siendo también una recomendación para su estabilidad en el magisterio.

c) Exámen de su eficiencia. Los dias de asueto de el maestro una mirada retrospectiva la labor realizada, corrija las deficiencias, estudic la manera de realizar su trabajo más efectivo prepare las materias de la semana y antes de la clase debe discrencias se saben, pero enseñar no todos saben.

d) Disertose sobre la conveniencia de que el magisterio recoja en toda su extensión ta interpretación que los indios kunas dan a todos los aspectos naturales y sobrenaturales e.d. es conjunto de tradiciones, creencias, supersticiones que constituye la civilización indigena. De esta suerte se conseguirá conservar la cultura kuna a punto de desaparcoer.

c) Se dí́ a la conferencia un carácter de amplia libertad para exponer las experiencias de los macstros y sus dificultades lo que se verificó en buena harmonía.

f) Finalmente dio lectura de los nombramientos para las distintas escuelas, no sin previa observación del Director acerca del modo de recibirlos, guardando sumisión ejemplar y sin detrimento de la nutua harmonia.

NARGANA 23 Abril de 1943

Trans. del orig. mec.

V. RD, n. 776 


\section{$\operatorname{CCCLXXVI}$}

Número 12

Sr. Coronel

Luis Hernández R.

Intendente de la Comarca,

El Porvenir.-

Señor Coroncl: Acuso recibo de su atento oficio № 416 relativo al envio de la lista de los maestros que a las conferencias celcbradas lus dias 20, 21 y 22 acudieron. Sun lus siguientes:

- Luisa de Morris, Juana de Hayons, Fulvia de Sou, Cristina Lúpez, Rubertu Pérez, Tomás Herrera, David Rodriguez, Francisco Soo, Jose Gulman, Victor Avila y Ernestu Acusta. A lus anteriores debe agregarse la Maestra Josefa 0 . de Salazar a partir desde la segunda conferencia, asi como lalio a la tercera el Sr. Ernesio Acosta que, según reterencias, debio embarcarse en alguno de los barcos de

Faltaron por consiguiente los Maestros: Andrés Iglesias, Pablo G. Solís, Roberto Preciado, Sara Méndez, Elisa Vda. de Garrido, Evangelina Ossa, Mario Porras, Carolina de Alfaro y Preciado, Sar
David Diaz.

Tristemente posible será que haya quien acuda a personas ajenas al magisterio Comarcal enpusca de soluciôn a temas reiteradamente explicados por esta Dirección en conferencias tanto semestrales como anuales, a causa de la inasistencia a las mismas.

Soy de usted muy atento y seguro servidor.

Jesús Erice,

Director de las Escuelas de la Comarca.

Trans. del orig. mec.

V. RD, n. 777 . 


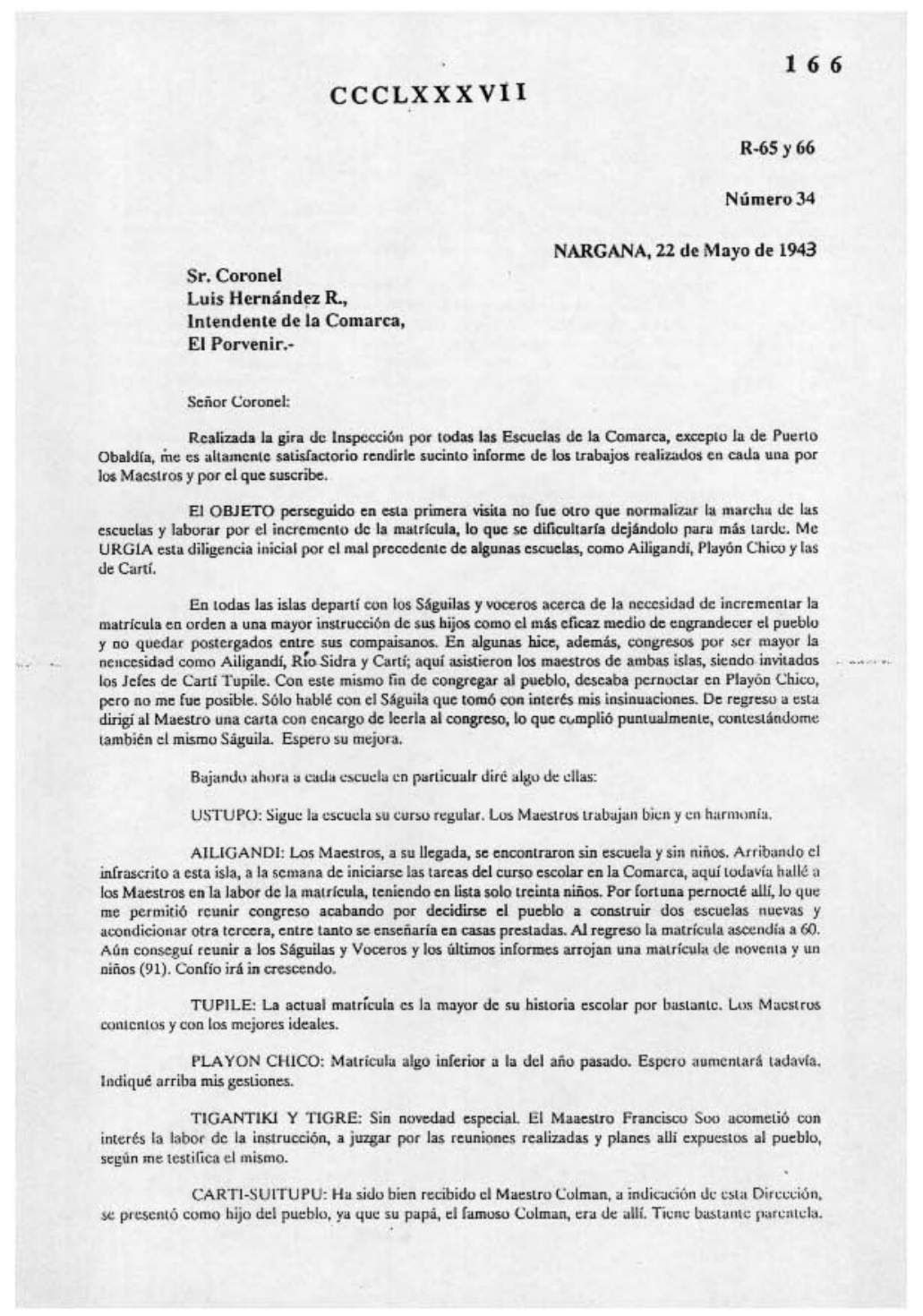


Parece que la influencia de los trabajos de la zona se dejan sentir en la matrícula escular que, por athura, es algo inferior a la del año pasado. Creo ascenderá. El Maestro trabaja con interés.

CARTI-TUPILE: Tiene igual matricula que el año anterior. Hirzese ver a estas islas con escuela que están qurt hijos, ya que son muchos los diplomados de sexto grado y varios los becados por el Gobierno.

RIO SIDRA: Disminuyo la matrícula. De sesenta descendió a (30) treinta. Después de conversar en particular con los ságuilas y Voceros, reunl congreso, en el que defendieron nuestra causa costumbres, que sun cultivadas por personajes. partidarios de Yabilikina. Hay ycún infurme del Mawsirv, un buen grupo que hace campania en conira. Sin embargo abrigo cunfianza de que alcansaria par lo menus a la matrícula del año anterior. El Maestro me produjo óptima impresión por su interés y manera de cunducir la enseñanza.

RIO AZUCAR: Bajó bastante la matricula debido en parte a traslados de niños a Panamá y Colón; asf'como también han subido a los grados superiores de Narganá en número de sieté.

NARGANA: Aumentó la matrícula sobre el año anterior. En sexto en particular creció en cuatro más. La Madre de $4^{\circ}$ grado tiene excesivo número, 57 ; en rigor le correspondian más o menus.... a subir a $5^{\circ}$ grado a los fracasados de $4^{\circ}$ el curso anterior, con proposito de que repitan el $5^{\circ}$ grado el proximo año escolar.

Soy de usted muy atento y seguro servidor,

Jesús Erice

Director de las Escuelas de la Comarca.

Trans. del orig. mec. inc.

V. RD, n. 779 . 
CCCLXXXVII

\author{
DIRECCION DE LAS ESCUELAS \\ COMARCA DE SAN BLAS \\ NAR G A N A. \\ TEMA: Impresiones de mi primera inspección.
}

24-Mayo-1943

Señorcs Maestros:

Legue a vosotros, por este medio, mi cordial saludo, simbolo de unidad de ideales y cuncordia de sentimicntus, cual cunviene a colczas empeñadus en un mismo ufán.

He recorrido todas y cada una de las escuelas, excepto la de Plo. Obaldia. Cun ello he conseguido aliviarme de una fuerte preocupación que me agobiaba por la incierta perspectiva de algunas Escuelas; los hechos han confirraiso que no eran vanos mis presentimientos. La solución de las primeras
dificultades del Macstro, en varias partes nuevo, y, sobre todo, el incremento de la matricula constituyeron el OBJETO de esta mi prematura visita, en la convicción de que más tarde se imposibilitiaria la consecución de este segundo objetivo, estabilizándese la escuela; porque nadie ignora que ta contribución de las Escuelas a la acción civilizadora está en razón directa de su matrícula.

En mi gira inspeccional pude observar con satisfacción que existía un gran interés profesional por parte de todos los Maestros sin excepción. Bien por todos y adelante! Abrigo la confianza de que aú mejorarán las Escuelas su matrícula merced al entusiasmo del masgisterio en unión con las actividades desarrolladas por nos en esta visita ante los Ságuilas y pueblos reunidos en Congreso, siempre con vuestra entusiasta cooperación. A plaudo además, el procedimiento empleado con optimos resulados por algunos Maestros, de correr casa por casa buscando niños para la escuela; opino que ello es factible en. todas lis

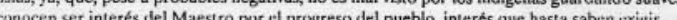

No era posible que pretendieramos en esta primera inspección aquilatar la eficiencia de vuestra labor apenas iniciada todavia; en la siguiente este será uno de los objetivos principales. Canien los
hechus, que son mas elucuentes que las palabras; el viajero, que contempla un campo bicn cultivajdo y limpio, con plantaciones de copioso fruto, no ba menester elogios para su agricultor, la realidad te hable más que a voocs. Hacer honor al mérito es confortante para el interesado, estimulante para los cumpañerous y siempre justo; se lo haremos pues. Estudiaré la manera de que la siguiente gira sea más reposada.

RECOMENDACIONES: $1^{\circ}$ Tomen con especial empeño la enseñanza del castellano dentr de los limites del progreso de cada grado. Esmérense $\mathrm{en}$ la redacción del vocabulario mais completo que les sta dado, conforme a instucciones recibidas. 29) Traten bien los libros y hagan que lus traten, purque cscasean y no se podran conseguir en un fituro proximo. 3) Así mismo la Esnsena Partir debe gaaruarse bien plegada y clocada en sitio decente, no se de el caso de vérsela no de otro modo que el trapo de limpiar

seguro servidor,

Muy agradecido a sus muchas atenciones en la visita, se despide de Ustedes muy atento y

Jesús Erice 1 .

Director de las Escuelas de la Comarca

Trans, del orig. mec.

V. RD, n. 780 


\section{$\operatorname{CCCLXXXIX}$}

DIRECCION DE LAS ESCUELAS

24-Mayo-1943.

DE LA

COMARCA DE SAN BLAS.

N A R G A N A.

TEMA: La Maternidad en el Magisterio.

Señures:

Presentánduse en este año casos de aplicación de la ley 89 (art.94 y Siguientes), concerniente al estado de gravidez de las Maestras en el ejecreicio, conceptué propicia la ucasion para proporcionarles a predicha Ley son del tenor siguiente:

1) El estado grávido avanzado de las Maestras es incompatible con el cargo que desempeñan y deben, en consecuencia, cesar en sus puestos tres meses antes del alumbramiento.

meses

20) No puede entrar al cjercicio del magisterio la madre de familia con hijos menores de seis

32) Las maestras cesantes por gravidez siguen perteneciendo al Cuerpo del Magisterio, debiendo reintegrarse a sus puestos una vez trascurridos los plazos indicados en las dos normas anteriores,

44) Las Maestras comprendidas en estas disposiciones serán temporalmente nombradas por la Superioridaut correspondiente por mientras dure el impedimento de aquellas.

5*) Las Maestras salientes por estado de gravidez avanzada percibirán cicrto sucldo de vacaciones, Esła Dirección se encargará de notificar a las interesadas qué cantidad propurcional les corresponda.

Finalmente, las Maestras afectadas por las precedentes normas pundrán cuanto antes en conocimiento de esta Dirección los datos necesarios sobre el particular, a fin de realizar a tiempo, todas las

\section{Soy de Ustedes atento y seguro servidor,}

Jesús Erice l.

Director de las Escuelas de la Comarca.

Trans. del orig. mec.

V. RD, n. 781 . 


\section{$\operatorname{CCCXC}$}

uis Hernández R.,

Intendente de la Comarca.

EI Porvenir.-

Señor Coronel:

Por la prescute ie remito los datos estadísticos del mes de Mayo de 1943, registadis ch las Escuclas dé la Comarca bajo mi Dirección.

A punto lijo no recuerdo cuántos cjechplares debo proporcionar a ese Despacho, pues no hallo constancia de ello, por lo cual le agradecere me lo indique cuando Usted guste.

Como verá Usted se ha notado en las Escuelas cambios apreciables de matricula, algunas ascendiendo y otras en notable descenso. Despues de no pocas diligencias y apremius se ha conseguido buen resultado en ciertos planteles. $Y$ así por ejemplo en Río Sidra se ha conseguido el número de (60) sesenta además de otros muchos oyentes que cuenta en su aula sin incluirlos en la matrícula; no obstante su desastroso estado inicial que era de treinta alumnos. Tupiec registra una matricula superior a lodos los años (91) muy bien dichos maestros.

Pero debemos tomar nota de las lamentables bajas en otras escuelas como Rio Azúcar, obedeciendo a traslados a las ciudades de la República y a ascensos a cursos superiores. Hechas las averiguaciones convenientes sobre posibles inasistencias culpables, parece no existir. Playón Chico es otra de las islas en que no pude actuar el tiempo suficiente para obtener un mayor resultado, debido a la mala combinación de las lanchas. Aún espero hallar remedio. Ustupo es otra de las notablemente deficientes. Veré de realizar gestiones en orden a mejorar su situación, la cual creía que obedecia a la ausencia de los nunos de vacación en utras islas, según ane indicaron los Maestros, pero parece haber alguna causa mayur. Si no encontraramus el modo de superar las dificultades que se oponen a una mayor matricula, tal ve\%, si asi it pareee a Usted podriamos pensar en aliviar el peso de otros Maesiros con traslade de alguna Maesira de Ustupo

Estoy estudiando el modo de realizar otro viajc, pero las comunicaciones en verdad son malas; espero, sin embargo hallaré alguna proporción.

Soy de Usted muy atento y seguro servidor,

Jesủs Erice, Director.

Trans. del orig. mec.

V. RD, n. 782 . 
Número 64

\section{Sr. Coronel}

unio de 1943

Luis Hernández R.

Intendente de la Comarca

El Porvenir.-

Señor Coronet:

Me complazco en informarle acerca de un problema a resulver presentudo pur los Maestrus de Ailigandr a mi paso por esa isla y que, propuesto a los demás maesirus en particulas, hicieron suya todos dicha proposición.

Sc reconocib por todos la necesidad de remediar los inconvenientes que presenta para los Maestros de la Comarca la cohabitación con otras familias, a veces numerosas. Estas no les deja descansar ni al mododa ai por la noche, carecen del aistamiento que requieren el estudio y no pueden poner reparos ni encuentran modo de hallar solución. Esto, naturalmente, reviste más inconvenientes en unas islas que en otras.

En Ustupu, por ej. tiencn una costumbre óptima por la buena voluntad que supone co el puebio, pero no así para los maesirus que no la quieren; y es que al Macstro se le señala una casa tija para todo el año, sin que tenga opción a escugerla.

La solución que aprobaron los Maestrus todos, sin excepción, cunsistió en que se exigiera o, al menos, se pidiera en forma de ruego, a los pucblos por la Autoridad de la Comarca con la cooperacion de la Dirección de las Eserelas, que cada isla levante una casita para el Maestro 0 Maestros; y donde hubiere

Igualmente que levantan un excusado, que, además de servir para el Maestro, puedon utilizar los Uagas forasteros que eventualmente se hospeden en las islas.

Soy de Usted muy atento y seguro servidor,

Jesús Erice

Director de las Escuelas de la Comarca

Trans. del orig. mec.

V. RD, n. 783 


\section{$\operatorname{CCCPCII}$}

Número 63

Señor Coronel

Luis Hernández R

Intendente de la Comarca,

El Porvenir.-

Señor Coroncl:

Me es grato retaciuatarme con Usted cun ocasion de enterarle de las diligencius llevadas a cabo para hallar suplente al puesto próximarnente vacante de la Escucla de Riv Azúcear.

Habiendome entrevistado con la Señora María Quiross, esposa de Eduardo Filós, recibí una negativa categorica a iniciativa y motivos personales, sin que en ello interviniera para nada su consorte.

La Señorita Berta López rechazo, igualmente, el puesto de Rio Azúcar por ciertas prevenciones contra personas de aquella isla con quienes tuviera relaciones anteriormente; pero le Azúcar con tal que así piense su esposo que actualmente está en Colón y no tardará en venir. Al pasar por esa puede cerciorarse de su pensamiento.

Ya no hay a quien recurrir para ofrecer puestos de magisterio entre las del sexo femenino, pues la mayoria se encuentran en las ciudades de Colón y Panamá.

Soy de Usted atento y seguro servidor,

Jesús Erice

Director de las Escuelas de la Comarca

P.D. En Rio Azicar no hay inconvertiente en poner Maessras no indias.

Trans. del orig. mec.

V. RD, n. 784 . 
Número 66

\section{Sr. Coronel}

Luis Hernández R.

Intendente de la Comarca,

El Porvenir.-

Narganá, 23 de Junio de 1943.-

Me es grato participarle quc, obedeciendo a instrucciones de esta Dirección, la Maesıra de Ústupu, Carolina P. de Alfaro, ha solicitado permiso de separación de su pucsto de Maestra, ya a partir del primero de Agosto próxings
Julio de 1941 sobre la Maternidad.

La antedicha Macstra lleva dus años de ejercicio en el Magisterio Comarcal. Pusce diploma de sexlo grado adquirido en la Profesional, habiendo cursadu alli toda la enseñanza

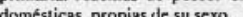

Se me ha informado de que la Señora Blanca González de Estocel, esposa de Ricardo Estocel, no quiere ser Maestra de Rio Azúcar

.......... contra-lo que anteriormente me dijera en particular.

En úttimo caso, podriase presentar para ese lugar la Señora Adelina M. de Bunilla, esposa del Sr. Victor Bonilla de Corazon de Jesús, la cual posee diploma de sexto grado en la Escuela de Narganá. Hace un año que terminó sus estudios primarios con óptimas calificaciones.

Soy de Usted muy atento y seguro servidor.

Jesus Erice

Director de las Escuelas de la Comarca.

Trans, del orig. mec.

V. RD, n. 785 


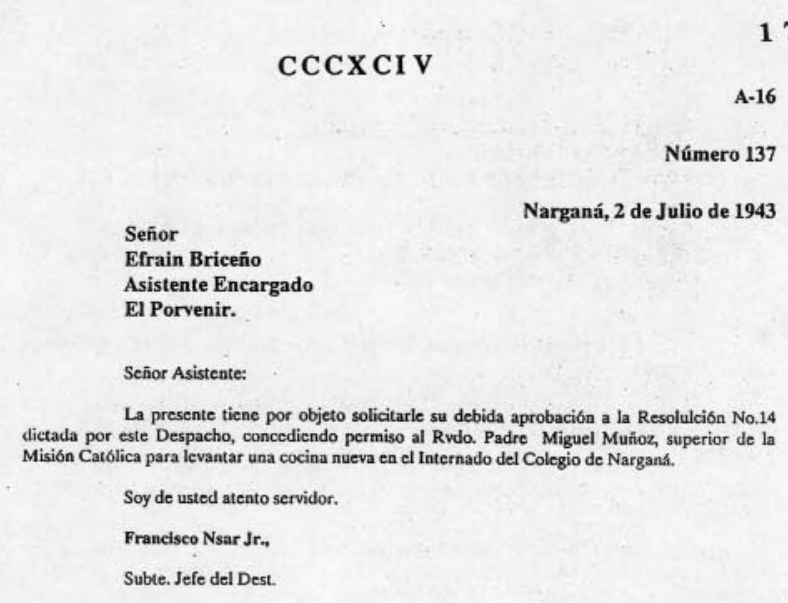

Trans. del orig. mec.

V. RD, n. 787 . 
PROGRAMA DE EESTEJOS

QUE DESARROILARA

LA ESCUELA CENTRAL DE NARGANA Y CORAZON DE JESUS,

$$
\text { ELDIA }
$$

4 DE JULIO,FIESTA DE LA INDEPENDENCIA DE LOS EE.UU.

(En prueba de admiración y carińo

hacia la Gran Nación Norteña).

Las 5 a.m. Descarga cerrada por la Policia, salvas de cañon, repique de campanas y alegres pasacalles

las 8 a.m. SOLELMNE MISA por los Caidos Americanos de la Independencia y de la actual guerra y por la rápida Victoria Final de la causa aliada.

Las 8 y media: Desfile marcial del Gran Centro Escolar de Narganá y Corazón de Jesưs, al toque de tambores y cornetas por las calles de ambas islas, paseando las banderas Americana $y$ Panameña cn estrecha unión.

FORMACION: La formación arrancará de la Escuela de Rodolfo Chiari de Narganá y, de Jesús, donde se pronunciarán discursos y poesías alusivos a la memorable fecha del día.

Se cantarán los himnos de ambas naciones amigas, al principio y término del desfile.

INVITACION: Por este medio quedan invitados a tomar parte activa todos los habitantes de ambas islas con las Autoridades, Clubs y demás Sociedades Juveniles.

Asi mismo se han pasado invitación a los Jefes Americanos de los Fuertes de Mandinga y Porvenir, para presidir dichos actos.

ADVERTENCIA: Los Centros y Sociedades conviene lleven, en cuanto les sea posible, las banderas de las dos nacionalidades. No estará mal que acompańe también la bandera propia.

Trans. del orig. mec.

V. RD, n. 789 . 


\section{$\operatorname{CCCXCVI}$}

Número: 00

Narganá 3 de Julio de 1943.

Efraín Briceño.

Asistente Encargado.

El Porvenir.-

Estimado Señor:

Por la presente me satisface remitirle los datos estadsfticos de las Escuelas de la

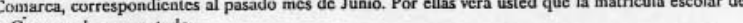
aumentado.

En el proximo informe de la segunda inspección llevada a cabo a las Escuelas detallert los cambios favorables que se han operado en cada Escuelas junto con las reseñas de las gestiones llevadas a efecto bajo otros puntos de vista importantes.

Ya me dispensará Usted que estos datos no hayan sido remitidos con la puntualidad debida. Toda semana que antecede he estado de lleno consagrado a la preparación del Programa de festejos del dia 4 de Julio, que resultó magnifico y entusiasta, con buena cooperación de las autoridades y pueblo.

Soy de Usted muy atento y seguro servidor.

Jesús Erice.

Director de las Escuelas de la Comarca.

Trans. del orig. mec.

V. RD, n. 790 . 
Sr. Coronel

Luis Hernández R.,

Narganá, 8 de Julio de 1943

Intnedente de la Comarca,

El Porvenir.

Señor Coroncl:

Ya alibiado de las abrumadoras atenciones requeridas por la celebración del los fcsțtejos del día 4, pasu a redactar un breve informe de la segunda inspecciòn llevada a las Escuclas de dos veces por no poder combinar bien los viajes, ya que las ouras escuelas urgian atenderse.

EL QBJETO que me propuse esta vez, lo constituyeron la construcción de casa y excusado para los Maestros, impulsar la ensenianza y orientarla donde hubiera menester $y$, por fin, $c$ incremento de la matricula de algunas Escuelas algo deficiente. Era mi propósito como MEDIO para alcanzar esos fines, pernoctar en todas y cada una de las islas, para reunir congresos, aunque tuviera que emplear no poco el vehiculo indigena del cayuco. Asi lo realicé puntualmente. En todas las islas luve la satislaction de exponer mis ideas al congreso sin intermediario o iaterprete, en su lengu indigenas. $\sim \cdots$

Todos los pucblos acogieron la idea de esas dos construcciones como muy acertada y

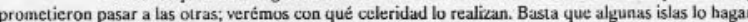
para que, más o menos tarde, las imiten las restantes.

En Ustupu la matrícula (la matrícula) anterior, 84 alumnos, era deficiente; a raiz de esta visita ha llegado a los 95 niños; no desdice mucho del número de Macstros, hicieron méritos par conservarlus. En Playón Chicu ocurría lo mismo, 68 alumnos asistian a las aulas. Por acción inmediala (5eláguila se matricularon en mi presencia 96 niños, pero de Castante buena matrícula.

En Cartí noté mucha apatía por la Escuela y ninguna cooperación con el Maestro, tal vez debido a la división existente respecio del saguilato, ya que nadie mueve pié ni mano, entre los por Olonibikina que no compareció, actuando sin embargo el contendor suyo con su gente. Dieron promesas; verćmus los resultados.

En Tigantiki y Tigre no reuni congreso, En la primera el Saguila estaba auscnte, pero Jejé para El una carta en que exponía todos los objetivos perseguidos en esta inspección. No me cabe Juda de que, en puebio tan de escuela, se llevarán a cabo todas esas mejoras. En Tigre la maestra se haya en su casa. Hay tiempo de urgirles la erección del escusado y, cuando ocur
otro maestro también se le pedirála casa. Por ahora nos contentaremos con que... 
Número 83 (bis)

Narganá, 8 de Julio de 1943

terminen la Escuela nueva que está mediada. Se han decidido a ello, cuntando con les propios recursos, que no son pocos. Hoy día, bien cabe entre los indios la frase:"Querer es poder.

Hallé en Narganá a la Maestra Concepción algo deficiente en la manera de llevar la clase, no obstante las instrucciones previas que le diera al inicar sus tareas, por lo que decidi dictarle ocupaciones, la Muestra Elisa Vda. Je Garrido ha estado adiestrando practicamente ton tirts dias de se nota en Ella mucha mejuria subre el particular

Ahora si podemos decir que la matricula de las Escuelas de la Curnarea es muy buena en general. Incluso en Puerto Obaldia hase incrementado. El afán de las lanchas y el plantel yue va corriendo en las ciudades de la República por causa de los trabajos de la Zona, tienen at los indius en una división perenne, sin advertir en la necesidad de atender a sus hijos para el día de mañana. Los niños, aún pequeños, van seducidos por esa misma ilusión de la Plata. Es sin embargo consolador la estima de la instrucción e importancia que, con razón, atribuyen al diploma los niños de Narganá; merced a ello no se dejan cegar por el brillo del oro, prefiriendo regresar a proseguir sus estudios aunque por ventura estuvieran en los trabajos de la zona, en tiempo de vacaciones.

\section{Soy de Usted muy atento y seguro servidor,}

Jesús Erice, Direcior de las Escuelas.

Trans. del orig. mec.

V. R D, n. 791 . 
Sr.D.

Narganá, 14 de Julio de 1943

Efrain Briceño

Asistente Encargado,

EI Porvenir.-

Señor

Con sentimiento debo manifestarle, por si todavia no llegó a su conocimiento, 니 trastado a otra eseucla del Interior de un miembro del Magisterio Comarcal tan relevante cumu la

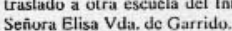

Al lamentar tan sensible pérdida y buscando alguna persona que pudiera sustituir a ta cesante, juzgo como buena la Señora Aurora G. de Esquivel, que actualmente se encuenta aquí en Narganá y que gustosa aceptará el cargo conforme ella misma manifiesta.Por de pronto es india.

Acerea de su idoncidad puedo decirle que sus estudios han sido realizados en la ciudad Je Panarań la mayoria, poseyendo bien el uso del castelleno. Ha sido durante dos años connsiecutivo Maestra de Ailigandi y Tupile respectivamente, y cun aceptación.

Dejo a su prudencia si cunvendra avisar de ello al Sr. Coronel que actualmente tiene buena proporción para hallar una maesira no india en alguna de las ciudades, en caso de yue no nombramiento de la anterior.

Soy de Usted muy atento y seguro servidor,

Jesús Erice

Director de las escuelas de la Comarca.

Trans. del orig. mec

V. RD, n. 793 . 
$\operatorname{CCCX\dot {CIX}}$

DIRECCION DE LAS ESCUELAS

DE LA COMARCA

NARGANA

TEMA:Diversos tópicos.

15-Julio-1943.

Señores Maestros:

Unificar vuestrus esfuerzos hacia la consecución de un buen éxito en la enseñanza total de la Comarca y elevar hasta su corvación las otras iniciadas en pro del Magisterio, es el fin de la presente, al par que rectifico las deficiencias que nuncas han de faltar.

Determinado a resolver un importante problema que constituía anhelo legítimo del personal docente, a saber; la casa del Maestro y su servicio sanitario, partí por segunda vez para las encuentran una persona esta obra, salvaguarda su prestigio ante los ferasteros que, al ilegranito ista honrará a la hospitalidad oficial y nac ics atiende en sus necesidades y hospedaje de trainsio que necesidades y hospedaje de tránsito que honrará a la hospitalidad oficial y nacional. No bemos
omitido diligencia que pudiera contribuir ul exito de nuestras gestiones ante los puchless, reuniendo congreso en todas las islas y comunicando nuestro pensamicato por el cunducto más atractivo de su nativo idioma, como de cllo sois testigus.

Todaviá, pasando a otro punto, martillamos et tema del incremento de la matrícula alli donde era deficiente, en la convioción de que la insturcción guarda proporción directa con ella. Y más. Velad por veestro prestigio, Maestros, por medio de la matricula, sosterviéndola al menos.

Quiero servirme de este medio para enunciar algunos defectos por ser comunes a varias Escuelas; a las que no tengan aplicación, sus remidos servirán de preservativos o normas de conducta.

A) Himno Nacional: Es claro, primeramente, que el Himno Nacional, y cualquier otro, debe cantarse unisono y en idéntica entonación por todos No es posible que una ayrupación de aiños coincida en un mismo tono cun solu decir el Matestro: Canten, uno, dos y tres. Si el Maestru carece de diapasón que le señale la primera nota, recoja de la experiencia el tono fijo y acumodado a cada canto, y entonees con voz suave pero incligible las primeras palabras. Camte con lus ninus todo el tiempo, dingiendo con los gestas de la mano los diversos movimieatos del canto, para eso ensiyese lo suficiente. Cuán desagadable impresion produce enlos oyentes las voces y tonos desafinados de un

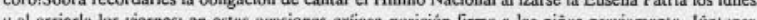
$y$ al abre

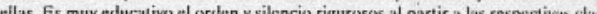

B) Suspensión de clascis: La celcloración de chichas y de las fumas de tubacis nor sisn razón justificativa para suspender la clase en tales dfiss; ninguna isla debe umitirla. Esta suspensiòn no es requerida por la naturaleza de dichos actos, purque de hecho, nu obstante realizarsc, Tuncionan las clases en la mayoria de las islas. Además,porqué cn los congresos nu se pude al pueblu el respeto a la Escuela y se armonesta en lus mismos a los trasgresores de tal disposición? Por ventura nu haly tambien entre los indios policias? Nadie objetará que ello no perjucida grandemente a lainstructión, dada la frecuencia con que tienen lugar, y que no desdice del interts que todos los pueblos tienen pur la ensenanza de sus hijos. Por fortuna es raro este caso, cpera alli donde ocurra cumuniquen estas
irregularidades al saila. 
Aqui es...de censurar el proveder de aquellos que, sin dificultad, dejan los niñis de tia escucla para acudir a alguna cita o realizar diligencias, ctc. Las causas que justilican las predichas salidas deben ser raras y notables, como... del personal oficial, seta del Gobicrnu, Ue lia intendencial o permitan la tibertad de llamar el Maestro en dicha hora, pues convive con ellos y les sobran oportunidades para hablar largo y tendido; en cualquier eventualidad bien pueden acudir a la misma Escuela.

C) Actividad del niñoen la Escucla Por ningán momento debe estar el niño ocioso o sin tarea concreta en la clase;todos a la vez deben estar actuando, trabajando en algu; el maestro que tiene dos o tres secciones busque la manera de hacerlo así; ya dimos en nuestra visita las nurmas particulares y concretas a los deficientes en este aspecto. Para ello, primero despues y sicmpre, disciplina fuerte, pero suave a la vez, es decir, sin palo, con su insinuación, interés, actividad y viginciancia ininternumpida; sepa caplarse la atencion del nimo y que la recuncentre en la tarea selala los àcucie, ni sueras exerior y reacios hasta a las insinuantes llamadas del mismo Director, lo que arguye falta de hábito de atender.

D) ElMaestro energico a veces, nunca airado: El niño debe tener pruebas, hasta ta habitual convicción, de que el Matestro le quiere y que estả muy inleresado en su aprovechamientu, en su total educación y que caanto hace y dice bocdece a ese interés educative; pero tris procbas

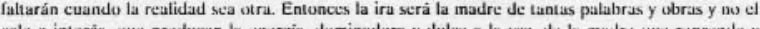
celo o interés, que producen la cinergia, dominadora y dulee a la ve', de la madre que reprende y castiga, porque ama. El Maestro nunca diga al discipulo palabras que rencen aversion o desestima. presencis bu presencio Escucia debe obedecer a causa habitual y nociva la comunidad de los niños y despoús de apotudos todos los recuros de enmienda pevio aviso a sus padres y llam de lo se habrá obtenido que el niño no lleve rencor a la Escuela ni animadversión al Maestro. Es evidente que no es este el procedimiento de los airados.

E) El Muestro es solo para la Escuela:Por fuentes fidelignas tengu nuticias de que hay quienes se sobrepasan en sus actividades o se extralimitan. El Maestro tiene un camipo acotado del que no le es lícito salir; su mision exclusiva es la Escuela y los niños; aún los dias de asueto debe comportarse como lal. Nada de dar normas de buen partidismos que hacer odicsos al Maestro y a la Escuela; lejos de aceptar comisiones politicas y redactar notas o solicitudes por cualificada que sea la persona demandante; ni deben pertenecer a agrupaciones parciales del pueblo. El Maestro es para todos, enseña y quiere a todos por igual. ENTIENDASE, empero que, siendo la persona mas ilustrada del pueblo y acudiendo a él las gentes en dernanda de consejo, solución de dificultades, escribir cartas a familiares ausentes, estampar direcciones en los bullos, te., Gie. no deben negar estos favores de amigo. En fin, el asunto no ts tan nuevo y desconocido para los Maestros que debamos extendernos en más explicaciunes-

FINALMENTE, me hahćis oido muchas vecex y tal vez hassa ba sacicdald yue para ser bucn buen Macsiro no tanto se requictra conocimicntus y titulus, cuanto cstar animado de entusiasmo, interés, consagraciuin total de sus energias a la enscỉanza, ser bient intcrcionado cn la ensenianza, autrentar la matricula y prestigiar $y$ hacer atractiva a la Escuela ante lus niños $y$ ante el pueblo?

Jesús Erice, Director de las Escuelas de la Comarca.

Trans. del orig. mec.

V. RD, n. 794 . 
Coronel

Luis Hernández $\mathbf{R}$.

Intendente dez $\mathrm{R}$.,

Stendenter

Porvenir, 17 de Julio de 1943.

Señor: Ruego a usted se sirva aceptar mi renuncia del puesto de Maestra de Escuela en
Narganá, que hasta la fecha he venido desempeñando.

Al presentar mi renuncia, para poder aceptar otro puesto en Educación, le expreso mis sentidos agradecimicntos por las atenciones que he recibido de usted mientras trabajé bajo su dirección.

Soy de usted muy atenta y segura servidora,

Elisa Vda, de Garrido.

Trans. del orig. mec.

V. RD, n. 795 . 


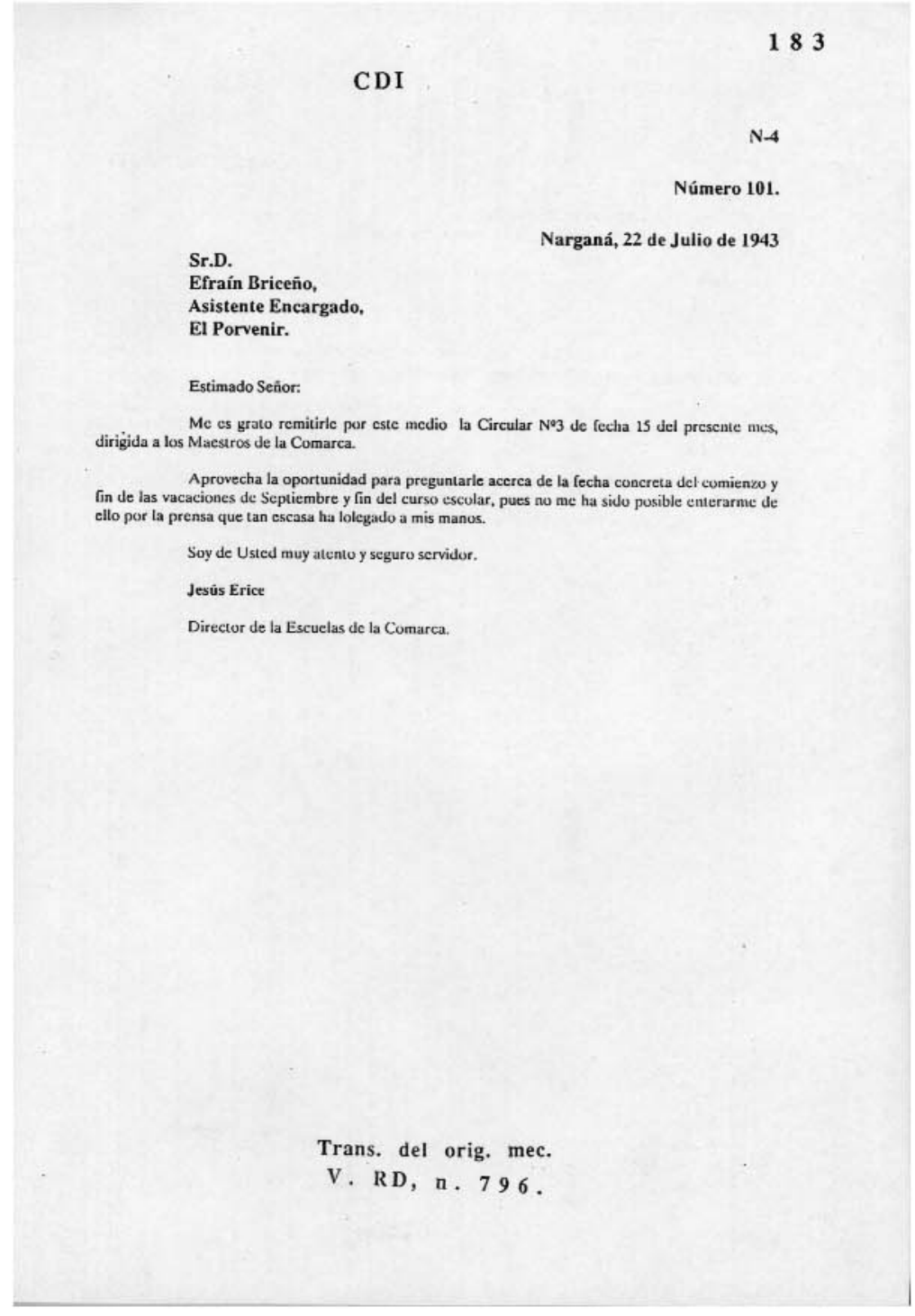




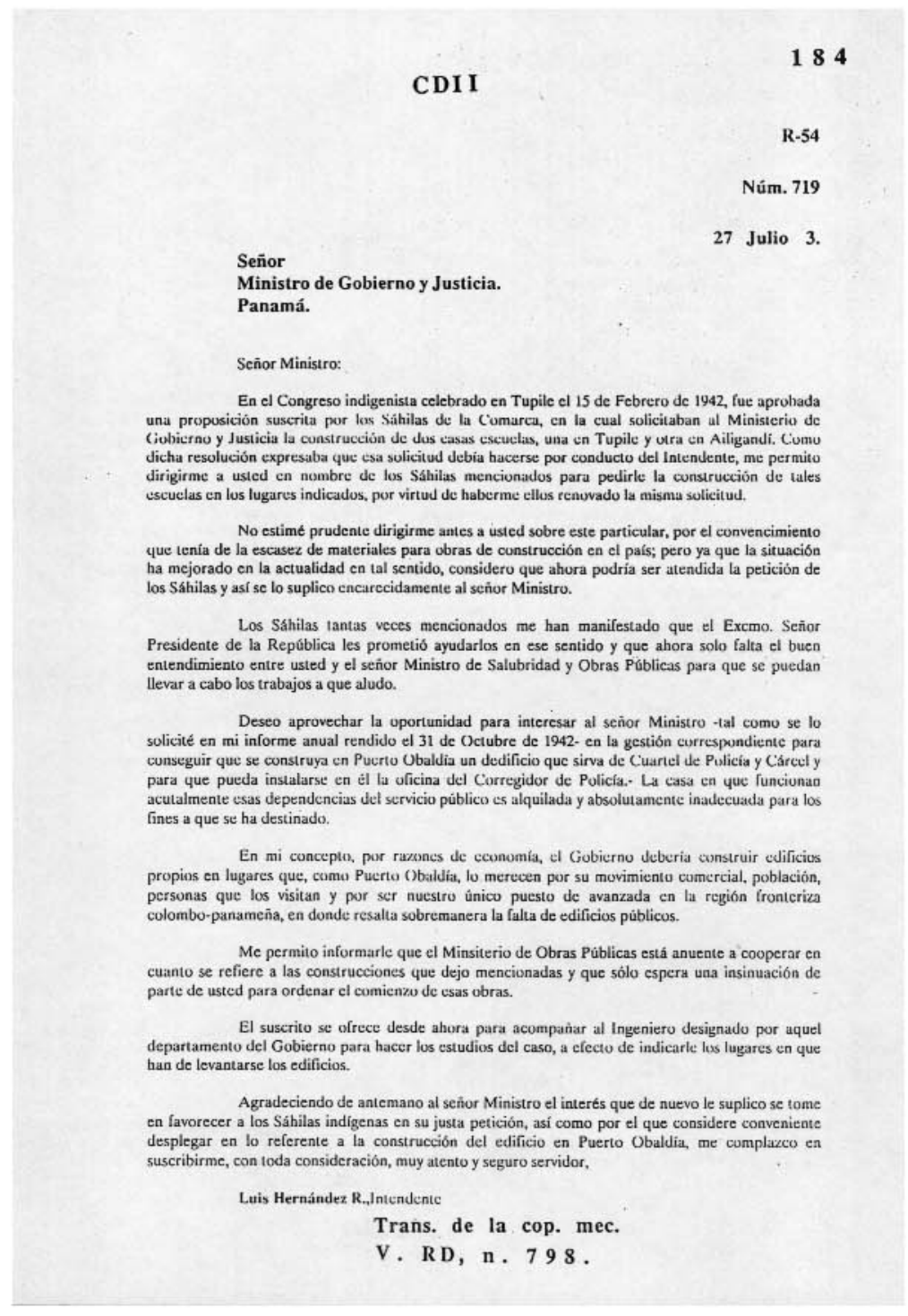




\section{Señor Coronel}

Luis Hernandez $\mathrm{R}$,

Intendente de la Comarca.

El Porvenir.-

Señor Coronel;

Estando próximas las vacaciones de Septiembre, me convendria realizar un viaje a Colón si me permilen ta circulacion de lanchas y otras circunstancias. Agradeceriale me avisase anticipadancne si algun incerts escolar se opone a este mi proyectado viaje a fin de yuc, suspendiéndolo, pueda atenderlo.

Así mismo, he advertido a los niños de la escuela que en estas vacaciones no pueden ir a Colón, por el mal cjempo propendiendo a dejar focilonte sus estudios al sentir que, de lo contrario, cundiría mal cjemplo, propendendo a dejar facirifice

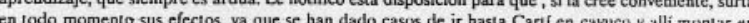

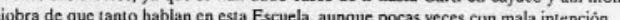

Soy de Usted atento y seguro servidor,

Jesús Erice

Director de las Escuclas.

Trans. del orig. mec.

V. RD, n. 799 


\section{DIRECCION DE LAS ESCUELAS DE LA COMARCA DE SAN BLAS}

Circular $\mathrm{N}^{2} 4$ N A R G A N A 8-0ctubre-1943.

\section{Señores Maestros:}

Iniciada felizmente la última etapa del curso escolar 1943-44, estimo conveniente dirigir una doble miradar una retrospectiva que abarque el panorama pasado y otra que nos presente el camino por andar.

En general, califico de buena la labor realizada por el Magisterio Comarcal en el período escolar que antecede, lo que no obsta a que existan anotaciones de regular en algunos y de muy buena en otros. No siempre es el exito la norma justipreciadora del mayor mérito, porque este es producto también de otros factores. Para nadic es desconocido que hay terrenos estériles y terrenos rértiles, debido a obstáculos de diversa findole, no guardando infalible proproción la labor con el exito. Sirvales esto, apreciados Maestros, como de informe de las inspecciones realizadas. La
preparación de las fiestas patrias no me permite llenar mi deseo de emprender una gira este mes de octubre, pero es mi proposito realizarla inmediatamente después de colcbradas.

EXAMENES FINALES: Con antelación suficiente anuncio mi determinación de verificar personalmente, en companía de varios Maestros, los exámenes finales, Haciendo pasar por el tamiz de tribunal único a todas las escuelas y exigiendo de cada Maestro examinador juicio inmediato por escrito del resultado observado en todos y cada uno de los grados. Con ello pretendo serán avisados por lo menos con un mes de anticipación, a fin de que preparen sus preguntas. Vuelvo a insistir en que pongan especial empeño en la enseñanza del castellano, máxime en los grados superiores.

EIESTAS PATRIAS: Está demás advertirles, por harto sabido, que deben afanarse con todas sus disponibilidades en la preparacion de las fiestas patrias, empleando para ello todo el tiempo requerido por un escogido programa, sin temor de restar algo a las materias de clase, ya que ello constituye verdadero estudio $y$ no pequena instrucción, al par que se ejerce así una de las rrascendentales misiones de la escuela, a saber: hacer que los ninos sientan a la Patria en su tierno corazón, sin olvidar a los demás elementos del pueblo, toda vez que el maestro es el único instrumento de civilización y portador de las caricias de la común Madre Patria. Como sugerencia me permito indicarles que es altamente grato a los padres de familia que su niño actúe en público,

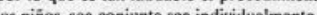
los nitios, ese conjunta sea individualmente.

Saliendo al paso de una objeción derrotista en el sentido de que el auditorio no es capaz de comprender todo el mérito de una actuacion brillante del miestro, afirmo que algo de rangin an falta, sin embargo sería falso negar al pucblo aquella psicologia por a la que que algificar recto tes el valor de las actividades desarrolladas por el maestro y discipulos en la prepapración y ejecución de los múttiples actos del programa de festejos, psicología que se manifiesta en las frases populares como estas: "Las fiestas prometen ser grandes o resultaron muy interesantes', si es a p parte post.

Jesús Erice

Director de las Escuelas

Trans. de la cop. mec.

V. RD, n. 800 
Número 192 Sr. Coronel

Luis Hernández R

Intendente de la Comarca.

El Porvenir--

Señor Coronel:

Por la presente me es grato remitirle los datos estadisticus de las Escuelas Comareales currespondicntes al mes de Octubre próximo pasade.

Su funcionamiento en general, es normal. Como siempre, a medida que adclantan los meses disminuye algo la matrícula debido a traslados, que este año han sido numerosos, y aủn ù salidas. Pequeñia es la diferencia de la matricula sobre el mes anterior, menos seis; pero respecto de la asistencia ha sido notable; menos setenta y siete (72)menus setenta y dos. Este descenso es debido solu a las escuelas de Ric Sidra y Tupile. Rio Sidra solo mantienc la escuela por temor, así opino con el macstro. El Director debe realizar mas visitas, al menos mensualmente, a esa escuela para que sostenga la malricula y usistencia, pues ninguna voluntad tienen de instruir a sus hijos. Sin embargo me inclino a pensar que es mejor continuar la escuela, porque los hijos que salgan sabiendo leer y escribir y conociendo algo de la lengua castellana algün día llegarán a querer la escuela, tenicndo autoridad en el pueblo. Ahora estoy en mejor condición de visitar esa escuela, con la ayuda de mi panguita. Lastima que hayallegado tan tarde, al iniciarse la brisa, pues no es para dehido a la cnfermedad de la macsira Evangeclina. Averiguarí

Los datos de Puerto Obaldia son buenos, pero ta realidad, seguin infurmes, debe ser ruinosa. Espero rectificar esa situación en Breve.

Soy de Usted muy atento y seguro servidor,

Jesús Erice

Director de las Escuelas de la Comarca.

Trans. del orig, mec.

V. RD, n. 801 . 


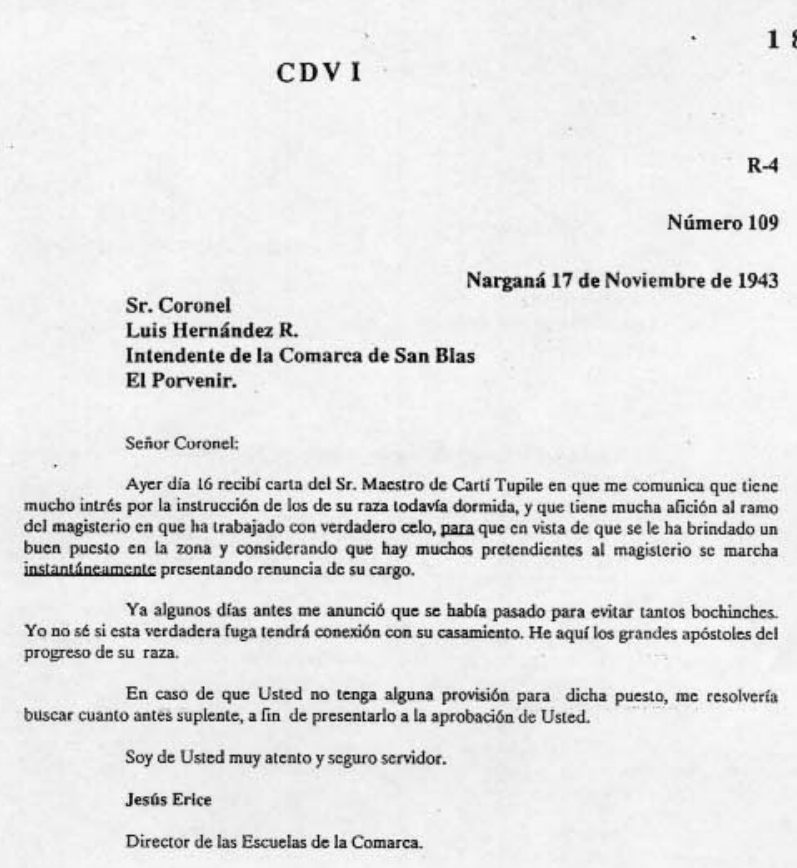

Trans. del orig. mec.

V. RD, n. 802 . 
Número 117

Sr. Coronel

Diciembre de 1943

uis Hernández R.

Intendente de la Comarca,

El Porvenir.-

Señor Coronel:

Me us grato rendirle un pequenio informe acerca la inspección realizada a las Escuelas

En primer lugar recorrí las situadas hacia Canti, las de El Porvenir y Riu Sidra inclusive. En esta ûltima isla encontré bastante desidia en el pucblo para mandar los niñus a la cscuela. Reuní il Ságuila y a todos los principales del pueblo dentro de la misma aula, en que exhortarun a los niños a que estimen la instrucción y que asistan puntualmentc. Ellos por su parte me prometieron acunscjar al pueblo en ese sentido.

El Maestro parece trabaja bien tanto dentro de la clase como haciendo congresos en el pucblo.Lástima que no haya podido pasar visita mensualmente; necesita ese pueblo removérsele de su estancamiento racial y de mil otros prejuicios que aún fomentan propios y extraños. Sin embargo he conseguido efectuar cuatro giras.

En Cartí Tupile preficren mujer, a lo menus humbre que lleve su mujer. En públicu congreso me indicaron tenia relationes el Muestro, pero se guardarun bien de avisarmelo antes. Ellus congreso ine indicaron tenia relacions
tienen no poca culpa de lo icurrido.

En Puertu Obaldia es una lástima lo que ocurre en aquella escucla. El Maestro sin inters. abandonado: por ende mal visto por pequenios y grandes. Consecuencia de ello muy pubre asistencia; una clase desordenada, Пloja o relajada, un etcétera, para aclararlo con frase vulgar; carece de carácter para conducir una escuela.

En Ailigandi el pueblo apenas si le importa la escuela. a juzz̨ar por la ninguna presión que los padres hacen a sus hijos para que asistan o estudien. Este fenómeno opino que se base,en el foado, en la desunion y desorganizacion del pueblo, en que lus Saguilas no trabajan al pueblo ni ejercen influ demasiado interés, por ta enfermecad que le obligó a ausentarse, pur el pesimismu yue le infundió el estado amorlo del pueblo y por olros excesus en que ha escandalizado. Por ahora será mejor no remover nada cstimos terninundo las tareas.

Las demás estuclis llevan buen record, sobresaliendo entre todias Tupilte (Sim Ignacio), en que pucblo y Maestro compiten en dar la mejor instrucción.

Sin mas, se suscribe de Ud. atto. y s.s

Jesús Erice, Director

Trans. del orig. mec.

V. RD, n. 804 . 


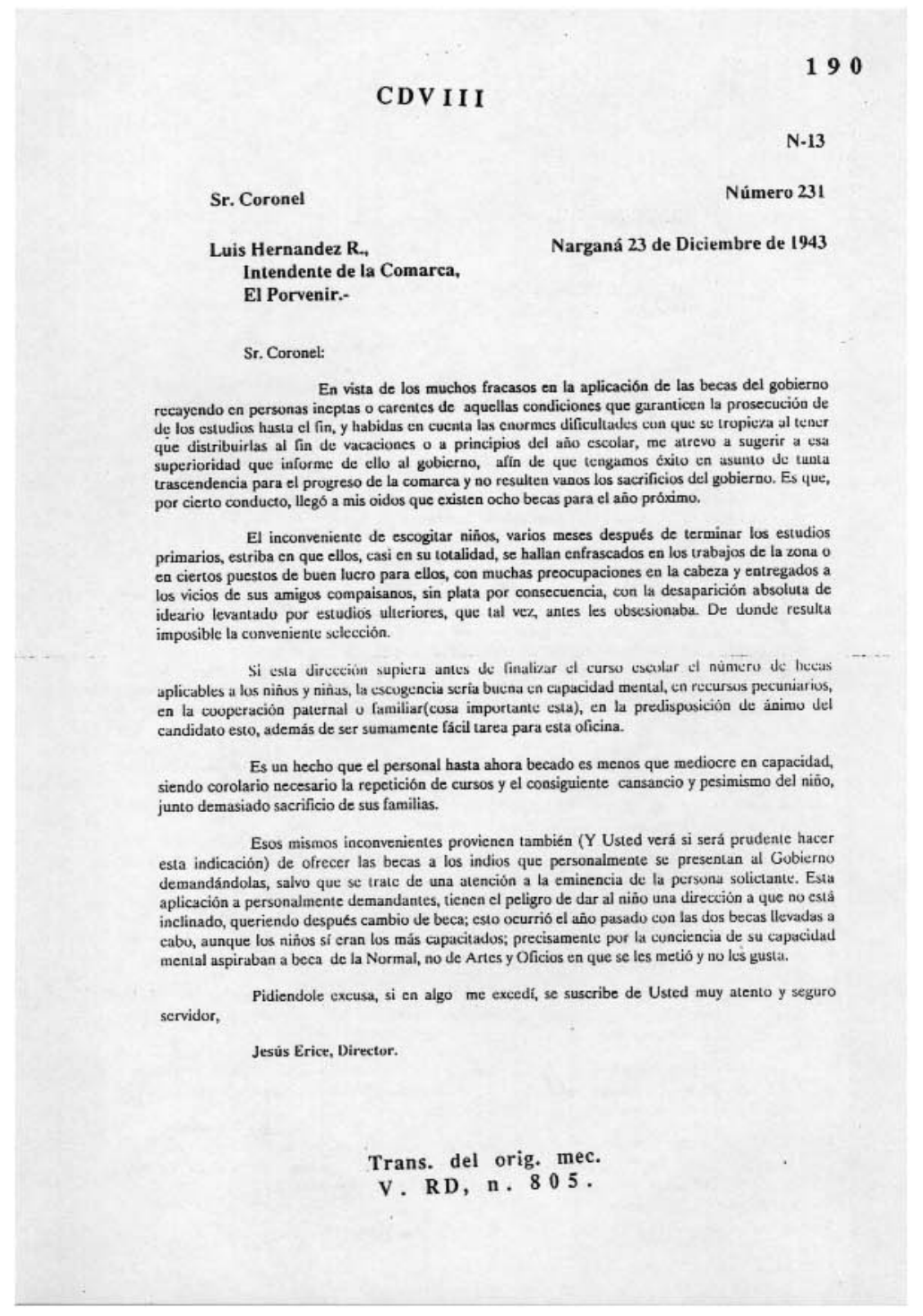


Próximo a finalizar el año escolar 1943-44, precisa fijar los dias de exámenes y comienzo de las vacaciones; no otro objeto ticnen las presentes lineas.

Lleg6 la hora de la recolcecion; toca recoger el fruto de la siembra y cultivo de la instruccion llevados acabo por cada maestro durante los largos meses del año, lo que verificari un tribunal examinador, compuesto por cuatro maestros y presididos por el Director, que recurrerá todias las escuelas de la Comarca. así el mérito tendrá su recompensa.

Dirigiendo una mirada desde la cumbre del curso que finaliza, a la labor ducente $y$ a la cunducta moral de mis subordinados, aquella generalmente es satisfacturia, mientras con bondo pesar veo lunares en la última. NO puede escapar a la perspicacia de los macstros indígenas de San

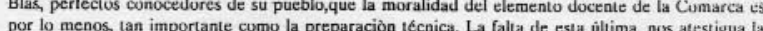
esperiencis, retar a la instruccion y la expansiòn de la secuelay; pero las deficiencias es atestigua la levantan murallas al avance de la civilizaciòn y hasta causa potables retrasos Muy ficil us será estimados Maestros, comprobar mis aseveraciones con cjemplos. Cun cuin profundo us será, de la realidad indigena encareció el $\mathrm{Sr}$, Coronel la moralidad de los Maestros,al iniciarse las larwo del presente año.

E X A M E N E S: Están sujetos a exámenes escritus los gradus superiores deste ef tercer grado inclusive. Los demás sufrirán la prueba de palabra. El últumo dia de clase para lus pequeños y el postrer examen para los mayores será el 4 de Febrero, viernes. El año escolar terminará el día 6 con el reparto de diplomas y promociones en dicha fecha.

Los exámenes versarán sobre aritmética, geografia, historia, religión, estudio de ta naturaleza, civica e higiene.

Los maestros pondrán a disposición del tribunal examinador los trasbajos de escritura y dibujo, ejercicios de aritmética, dictado, etc. de los grados inferiores y del terceru, a fin de que sea dibujo, ejercicios de aritmética, dictado, ctc. de
justipreciada la labor de discipulos y macstros.

Los mismus del tribunal examinador deberan redactar, inmediatumenas despuis det

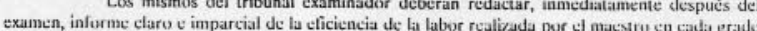
y entregarlo al Director.

El tribunal trabajará sin discriminaciōn de dias de clases o festivos. Cun esto prevengu a los Maestros para que tengan dispuestus a sus alumnos. Sabido el dia en que los examinadores se dirigen a su cometido, pueden prever el turno de examen de cado escuela.

POSIBILIDAD:Si, por cualquier causa, no pudiera examinar el tribunal designado, procedo a nombrar sustitutos en la forma siguiente: en Ustupu y Ailigandí examinarian los maestros de la propia localidad. Las escuelas de Tupile y Playón Chico serán probadas pur los Maestros de ambas islas conjuntamentc. Para las esuelas de Tigantiki, Rio Tigre y Rio Azúcar es fácil provecr a
última hora. 
I N V E N T A R I O : Los maestros, al cerrarse el año escolar, confeccionen un completo y bien detallado inventario de todo el material de la escuela y depositenlo co puder del sab a custodia y dejändole, al mismo tiempo, una copia de dictho inventario, con cle cacargo seis de febrero. No hay ninguna razón suficiente para que los Maestros salgan de su puesto hasta tel dia Mientras llega nuestra proxima entrevista se suscribe de ustedes muy atento y seguro servidor Jesús Erice

Directur de las Escuelas.

Trans. del orig. mec.

V. RD, n. 806 
Sr. Coronel

Luis Hernández R.

Intendente de la Comarca,

El Porvenir.-

Narganá, 15 de Enero de 1944

Señor Coronet:

Mirando el cuadro del personal docente del siguiente año escolar, le anticipo algunas indicaciones por si le pueden ser útiles:

Primeramente están comprendidas en el Parágrafo del art. 97 de la Ley 89, las Señorus Fulvia de Soo y Carolina P. de Alfaro, las cuales deben reintegrarse, ya desde el principio del curso, a las tabores de la escuela; mientras las scrioritas Carmen Obarrio y Berta A. López, como suplentes deben cesar de pertenecer al grupo docente.

La Maestra Juana de Hayans aviso ya a este Despacho que le corresponde dar a luz ten el mes de Junio, por lo que no podrá reingresar en el trabajo hasta Diciembre cunforme el art.96 de la
misma ley citada.

Presentu cumu buenos candidatos para el magisterio dos jóvenes casados, diplomadus con sexto grado, preparados y de probada moralidad, además de ser de buena indule. Uno es Rafael Bonilla, carpinteru y Horacio Ouintero cl otró éste se educó tn una buena fanilia dé Panamá.Ambus dominan correctamente el casıeilano y con gusto han recibido la proposición hecha al respecto.

Aprovecho la oportunidad para sugerirle ta conveniencia de avisar a los Maestos anticipadamente la fecha en que han de tener lugar las conferencias de verano a fin de obrener de ellos mejor asistencia y para que sean fructiferas. Tal vez no seria desacertado fijar alguna sanción a los ausentes por falta culpable.

Inclúyole también una indicación general de los pueblos con escuela, hecha a este Despacho en el sentido de que no quieren cambio de Maestros para el año próximo.Solo Ailigandi inanifesto que no desea al maestro Mario Porras y El mismo ha pasado nota en que manifiesta que de Y pensando, todavia, en el año siguiente, es urgente necesidad resolver de una vez para
siempre la cuestión de los excusados para los macstros de la Comarca. Todas lis diligencias realizadas en ese sentido durante este ańo no han dado resusltado casi en parto alguna Opino cue el material, que se retira de las reparaciones de Narganá y Rio Azúcar, alcanza para todos. Solo ello constituiria una gran mejora escolar.

Aconsejé a los Masestros que Jeberian buscar algún trabajo o un muxlo de pasar las vacaciones en Panmá para no olvidar cl castellano o adquirir una más correcta cxpresiôn det
lenguaje.

Soy de Usted muy atcnto y seguro servidoe.

Jesús Erice

Director de las Escuelas

Trans. del orig. mec.

V. RD, n. 807 . 
Número 264 Sr. Coronel

Narganá, 29 de Enero de 1944 Luis Hernández R.

Intendente de la Comarca,

El Porvenir.

Scenor Corsunct:

En la gira llevada felizmente a cabo por todas las escuelas de la Comarca realicé

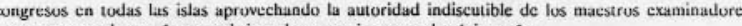
para promover la enseñanza y abrir un buen camino para el próximo año.

Un gran mal se ha notado en todas las islas:el escaparse los niños a Colón, hasta sin permiso de los mismos papás, cumo ocurrió en Playón Chico, con enorme perjuicio de la buena fija para todos los niños de la Comarca el que ningún niño de edad escolar se deje marchar a Colón sin permiso de esta Dirección, que no lo dará sino en casos bien probados o de esa Intendencia. Hoy mismo tuvo lugar un congreso en Narganá con asistencia de los Ságuilas y voceros de Playön Chico, Tigantiki, Rio Tigre, Rio Azúcar y Nargana, junto con los maestros examinadores mas lus de las islas vecinas $y$ las Rdas.-Madres $y$ reordaron subir suplica a esa Autoridad a tin de conseguir" sit consentimiento a esa determinación, imponiendo diez balboas de multa a los capitanes que de cualquier manera encubrieran un niño escolar en su lancha.

En carta aparte le informo de las impresiones particulares.

Soy de Usted muy atento y seguro servidor.

Jesús Erice, Dircetor.

Trans, del orig. mec.

V. RD, n. 809 . 
Número 269

Sr. Coronel

Narganá 2 de Febrero de 1944

Luis Hernández $\mathrm{R}$

Intendente de la Comarca

El Porvenir.-

Señur Coronel:

Me complanto en remitirle lus datos estadisticus del útimo mes del curso escular 1943-44. Ocupaciunes urgentes me impidieron recopilarlos con la puntualidad debida.

Aprovecho la ocasion para referirme a algunos hechos acaecidos en lus exáments llevados a cabo los dias pasados. En Carti-Tupile realizamos congreso con nutrida asistencia; el Ságuila requirió con mucho interés un buen Maestro para el pueblo en el año próximo.

En Carti-Cangrejo es lamentable la situación de la escuela; en dos ocasiones me he llevado la desagradable surpresa de reunir congreso y no comparecer el Sagmila Olonibiquiña, y es sabido que nada se decide entre los indios sin el Saguila. En exámenes lampoco compareció en el congreso convocado al efectu. El estaba algo enfermo, hablamos con êl un rato en su casa, peru se le vio paseando por las calles, pudiendo por lo mismo haber ido a hacer acto de presencia ul menus, to que no efectuo no ubstante habérocke pasade aviso. Cion lo que nada se pudo hucete.

Sin más se suscribe de usted muy atento y seguru servidor.

Jesús Erice.

Director de las escuelas.

Trans. del orig. mec

V. RD, n. 810 . 
M-32 a 36

\section{NFORME ESCOLAR DE LA COMARCA DE SAN BLAS}

(Año lectivo 1943-44)

EXCMO. SEÑOR DON

CAMILO A. DE LA GUARDIA,

MINISTRO DE GOBIERNO Y JUSTICIA

PANAMA.

EXCELENTISIMO SEÑOR:

En cumplimiento de las normas que el Codigo Escolar impone al Director de Escuelas en sus art. 75 y 76 , me propongu rendirle un informe completo dentro de la mayur cuncisión.

NOMBRAMIENTOS: Vigiendo ya ta hey de la estabilidad del magissuriu naciunal, lus numbramientos de este año solo tuvieron por objeto llenar vacantes. El Poder Ejecutivu, pur Decreto reemplazo del Rvdo. Padre Manuel M*. Puig, cesante por enfermedad; y maestro de Narganá al Rvdo. Padre Miguel Gómez supliendo al primero. Asi mismo maestras de Narganá a lus Hermanas Demetria y Oilia en sustitución de las Hnas. Adolfina y Eufrosina, relevadas por enfermeadad.

A principios de Junio fue nombrada maestra de Corazón de Jesús la Sta. Cuncepción Tapage en lugar de lal Srta. Sara Méndez que no se presentó. Desde el primero de agustu entró a ejercer en Cor. de Jesús la maesira indigena graduada Luisa de Morris succediendo en el puesto a Elisa vda. de Garrido, nombrada maestra fuera de la Comarca; sucedió en Rio Tigre a Luisa de

Por gravidez avanzada cesaron las macstras Fulvia de Soo en Rio a partir de Julio, reemplazándola Berla A. López; y en Ustupu Carolina de Alfaro desde Agoslo, a quien suplió là Srta. Carmen Obarrio. Restaurada la escuela de El Porvenir se nesde Agusto, a quiten suplío lá Orlega.

DURECCION DE ESCUELAS. La Dirección Escolar ha desarrollado mútiples actividades en orden a intensificar la instruccion, y asi, con incesante afán ha estado influenciando sobre los pueblos y escuelas, visitándolas cinco veces y relizando en ellas otros tintos conuresos. Dictó tres conferencias a los maestros antes de iniciarse las tareas escolares. Ha mantenido constantea comunicación epistolar con ellos, dirigiendoles, ademas, cincu circulartus sobre diversos tópicos. A los Saguilis se pasaron varias proclamas de alictento. Se ha esforzato en esplendorar las fiestas patrias, destacando las celebradas en Narganai, en cuya preparación y desarrollo to correspondió pare inportante, mereciendo mencionarse cl magnitico destite con fusiles, turnetals y tambores en correclo paso mifitar. Este desfilic, aunque con menus clementos, se repitió en Ustupu, el dia ochu de este mes con or esión de inaugurarse un parque en honor de Nele Kantule, Hevando a tan

El que suscriber llevó a cabo personalmente el examen final de todas las escuelas en compañia de los maestros mis prestigiosos, aprovechando tan propicia oportunidad para hacer cungreso en cada isla; de tllos se esperan óptimos resultados para el próximo año escolar; haré resaltar, por su importancia, la reunión verifiacada en Nargana el día 30 de Enero, con asistencia de los Ságuilas y Voceros de mis de seis islas, de los maestros de las escuelas vecinas y de los examinadores, en presencia de la escuela de Narganá en pleno. 
También se ha cuoperado desde esta oficina con Sección Indigenista de Panamá, remitiendo a la misma cuantos datos y trabajos se ban solicitado en relación con estos indigenas.

La amplia cooperación prestada por el Sr.Intendente, Coronel Luis Hernández R., en cuanta iniciativas y problemas se han presentado a esta Dirección.

Hecho esperanzador. En virtud de los acuerdos tomados por los maestros y ságuilas de la Comarca bajo la dirección de este Despacho, en perfecta harmonia con la primera Autoridad de Comarca. Se espera para el año próximo una matricula que sobrepasará a las añus anteriures. Ellos se refieren a conseguir que ningún niño de cdad escolar deje la instrucción escular por cnfrascarse en los trabajos de la Zona.

\section{ESCUELLAS PARTICULARES}

- NARGANA Y COR. DEJESUS. En este plantel central de la Comarca han trabajado nueve maestras; una se encarga de la costura. La disciplina, competencia y sasacrificio carncterizan visitantes profesionales.

La labor de la Srta. Concepción Tapago ha sido muy deficiente; es tel primer añu que trabaja, pero promete un futuro puco halagüeño. No debiera seguir en su puesto de encuntrat

La maestra graduada indigena, Luisa de Morris, adolece de falta de interés y celo La maestra graduada indigena, Luisa de Morris, adolece de faita
prefesional con las inevilables consecuencias de la indisciplina y escasa eficiencic

No quiero omitit aquí la forzosa irregularidad ocurrida este ańo, subiendo a quinto grado los niños que debinn repetir el cuarto por haber excesivu número de ellos en este gender los malos efectos consiguientes. No debe perderse de vista que de tres escuelas vieper al cuarto grado, además de funcionar aquí tercero A y tercero B. Urge pues el aumento de una maesira ch Narganá.

El sexto grado ha sido numeroso. Hay niños y niñas de buenas condiciones para el estudio y económicamente bien preparadas a seguir estudios superiores. Ojala propinara cl Gobierno unas ucho becas al menos.

\begin{tabular}{|c|c|c|c|}
\hline Grado & Matrícula & Promovidos & Fracasados \\
\hline Kinder & 55 & 31 & 24 \\
\hline Iv & 45 & 27 & 18 \\
\hline $11{ }^{\circ}$ & 42 & 20 & 22 \\
\hline$I I N^{*} A$ & 35 & 23 & 12 \\
\hline $11 l^{\circ} B$ & 39 & 15 & 24 \\
\hline$N^{\circ}$ & 50 & 29 & $2 l$ \\
\hline ve & 45 & 19 & 26 \\
\hline$V^{\theta}$ & 30 & 26 & 4 \\
\hline
\end{tabular}


NUEVO HORIZONTE: Pláceme consignar aquí el prestigio que el Colegio-lnternado para niñas de apartadas islas, a cargo de las Hermanas Franciscanas, va adquiriendo entre los indigenas. Hay fundamento para esperar que desaparezca por este medio la tradicional repugnancia
indigena a introducir niñas en la escucla.

EL PORVENIR. Este ańo se restauró esta escuela. La ha regentadu la Maestra Isaura V. de Ortega, quien ha sabido mantener hasta el fin la matricula inicial: 16 alunmus. Ha demostrado tener excelente habilidad y sostener creciente interes. Presentö brillante examen final. Este centro ofrece mejores esperanzas para el año que viene.

CARTI-CONGREIO. Triste sucrte corre la escuela de este lugar. Siendo de las primeras escuelas en acoger la insirucción, estos años languidece su ideal eductivo. Tres añus ha que no son trasladados los niños a los grados superiores de nargana. Ejercen perniciusa influencia los trabajos de la Zona. Es de peores consecuencias aún la lucha del saguilato, frustrando tudas las actuaciones del maestro y Director.

El edificio escolar es un bohío, con piso de madera suministrada por el Gubiernu; puseo suficientes bancas. La matrícula oscilo al rededor de los 50 alumnos. El muesstro olrece regular mérito
en habilidade interés.

CARTI-TUPLE, pueblo interesado en la instrucción. La matricula alcanzó a 35 alumnos. El maestro Pablo G. Solis trabajó hasta noviembre realizando buena labor. Enredado con una señorila se fugo a Colon, quedando desue entonces el pueblo sin escucla La moralidad del indigena de San Blas es muy alta, y no perdona al empleado público, aún indio, lunares en este particular. Son demasiados los casos de perderse la escuela por esta razón.

Este pueblo merece cscucla y ta pidió para el próximo añu, en congreso celebradu pur el que suscribe y las maestros examinadures, el 28 de Encro pasado. El edificio essevlar es un buthio,
con piso de madera; posee bancas.

RIOSIDRA. Publación muy cultivada por los adversarios de la civilización. La escuela es consentida. Varios congresos celebrados por esta Dirección tuvieron éxito, uscendiendo la matricual hasta 60 alunos por el momento, pero descendió a 50 , siendo my irregular la asistencia. Hay esperanzas de transformar a esta gente a fovor de la civilización en las campañas ya planeadas para habilidad y regular Roberto Preciado ha dado buena cuenta este año, demostrando bastante bancas.

RIO AZUCAB. Pueblo empenado de por vida en la instrucción de sus hijus e hijas no menos que el mismo Narganí. El ságuila y el policia sostinene la escuelá en la maxoms altura de interks. Subió la Narganá,ademas de varios orros niâns, eficiencia, por diversas causas no correspondió a $\mathrm{el}$, ni el exito del examen final. La maestra Berta A. López ha realizado buena labor, posee buenas cualidades para la enscñanza. El edificio escolar de madera y cine se consthyb a expensas del Gobierno. En la actualidad se realizan notables mejoras y

RIO TIGRE El maestro Samuel Murris ha laborado desde principius de agusto,

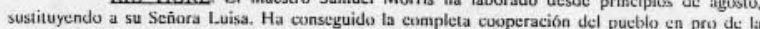
escucla, Le han favorecido las circunstancias de ser buen parlamentario y iener radienda alli nucha farmilia. La matricula ascendió hasta 60 alumnos, con una asistencia cjemplar, pressenianio lucidus exámenes linales. Aqui debe coloctarse una maestra más; la crecida matricula y las varius niñas que han comenzada a ingresar la demandan. Otro mérito no pequeño del maestro es haber ubtenidu del pueblo la construcción de escuela y casa del maestro. El Edificio escolar es un bohio, con pisu de madera, siendo de esta la mitad del Gobierno. 
TIGANTIKL. Pueblo dedicado a la instrucción. Ha comenzado a matricular a las niñas, las que aủn asisten en escaso número por falta de una maestra. si se quiere la prosperidad de esta escuela debe nombrarse maestra tambien; asi lo requieren la excesiva matricula y la atención al sexi

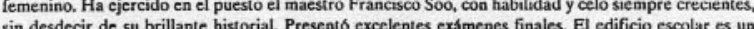
bohío, con piso de madera; contiene suficientes bancas.

PLAYON-CHICQ Es uno de los pueblos mayores de la Comarca, el Ságuila, verdadero líder, apoya resueltamente la escuela; por su intervencion el que suscribe consiguio subir ta maltricula a 20 alumnos mas sobre la existente al iniciarse las tareas del año. Se ha mantenido fija en el Dedra ascender sobre 110 por lo menos cjerciendo tres maestros. E maestro Victor Avila, habiendo desempenado el magisterio durante año y mediu no es capaz de

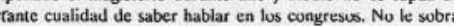
tampoco cumpetencia en el ramo, dando su cxamen tinal reglar, sin embargo cuenta con buen record en la conducta y con algunas instrucciones que se le darán puede ser buen elementu. En cado escuela de la Comarca debe haber un macstro parlamentario.

La señorita Cristina López arrojó bưena eficiencia, habiénduscle ubservado bustante interés durante el año; rindió un buen examen final. El edificio eseolar de cste plantel es un bohio. con piso de madera. Posee suficientes bancas.

SAN IGNACIO DE TUPLLE. Después de Narganá y Rio Azúcar, sin duda el pueblo que mejor trabaja en la instrucción de sus hijos. Este año superó la matricula a todos los años anteriores, ascendió hasta 113 alumnos, no obstante de no ser muy grande el pueblo y tener cerca de 30 niños en la escuela superior de Narganá. Ello es debido, en parte, al prestigio profesional de la maestra Josefa O. de Salazar, hija del pueblo. Con ella han colaborado Evangelina Ossa y Andres iglesias. los tres compiticron en habilidad, interés sacrificado y exito final. Sin embargo Evangelina, a

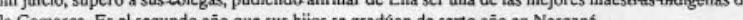
la Comarca. Es el segundo año que sus hijos se gradúan de sexto año en Narganá.

Los tres edificios escolares son bohíos. Solo uno de ellos tiene piso de madera costeada por el pucblo y bancas suficientes. Merece que se le construya una bucna escuela.

AlliGANDL. Pueblo desorganizado por falta de inteligencia mutua entre los Sàguilas; devidido en banderias no existe acuerdo en la obra de la educación. Escasa matricula, oscilando cntre 80 y 90 alumnos. Hay tres macsirus: Tumis Herrera. Mario Porras y Juana de Hayans, sin descollar demasiado en cosa alguna, actuó bastante bien. Mario Porras, dejảndose arrastrar, tal vec, del pesimismo que infundia ol cstado amorfo de la población, se condujo harto deficiente en la
moralidad, excediéndose tambièn tn la bebida. Lástima que sus buenas cualidades didácticas sean anuladas tantas veces por su comportamicnto.

El Gobierno aquí tampoco tiene escuela. La una es un Club que los jóvenes han prestado; la otra es un bohio que el pueblo edificó no con buena fortuna; y la última es de madera con techo de paja, construida por el pueblo, pero que ya está en muy malas condiciones.

USTUPC Esta escuela sintió los efectos de la emigración a la Zona; la matricula estuvo baja: 93 alumnos; sin embargo la asistencia ha sido cjemplar, Las auturidades, especialmente Nele de Kantule se afman por la instrucción. Es el segundo año que sus hijos se diploman en ul sento gra de Narganá. otros varios cursan estudios secundarios en la capital. Los dos ninios indigenas becados en el Instituto de Agricultura de Divisa son de Ustupu.

Han trabajado tres macstros: David Rodríguez, David Diaz y Carmen Ubarrio. Lus tres han trabajado bien. David Rodrigucz, alma de aquella escuela durante siete años consecutivos, por entero es de la escuela y para la escuela. Años ha que viene cultivando una finca escolar mu con cerco de cemento dedicado a Nele de Kantule, cuya inauguración efectuó el que suscribe el día 8 del acutal, constituyendo un acontecimiento que formará tpoca en Ustupo. 
Existe una hermosa escuela del Gobierno, pero despintada ya; en ella funcionan dos erados yen ora muy deteriorada del pueblo se alojan los niños de otro grado. El espera otra escuela grados y en otra muy deteriorada del pueblo se alojan los nings
similar a la primera; el pucblo y Nele de Kantule lo merecen.

El maestro David es benemérito en su labor, sin llamar poderusamente la atenciún. Pur su correcta dicción castellana es un buen intérprete de Nele de Kantule, de quien es estimado. La seniorita Carmen sustituyó a Carolina, cesante por embarazo. Trabajó cun regular méritu.

PUERTO OBALDIA. Esta escuela debicra correr mejor suerte. El maestro Ernesto Acosta carece de capacidad para gobernarla. De pobres habilidades didácticas rinde medivcre eficiencia; tampoco le aumpania excesivamente el interés por hacer labor en sus niños. La matrícula anduvo por los 50 , con ligeras alternaativas. Sicndo mucho del elemento advenedizo se dificulta la regularidad en la

REPARACIONES Y REEORMAS La primera autoridad de la Comarca ha emprendido decididamente importantes mejoras y reparaciones en las escuelas de Narganá. Corazzón poce estos tres importantes edificius. Se ecmentó el piso bajo de la escuela Belisario Purras; solo resta cercarlo y acondicionarlo para un grado más que se secesita. 
แ $\%$

-

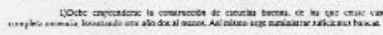

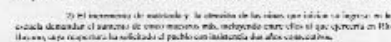

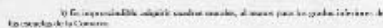

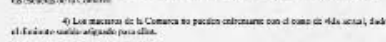

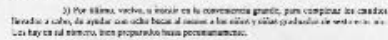

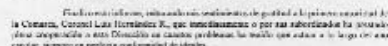

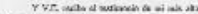
mancio.

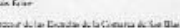

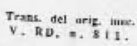




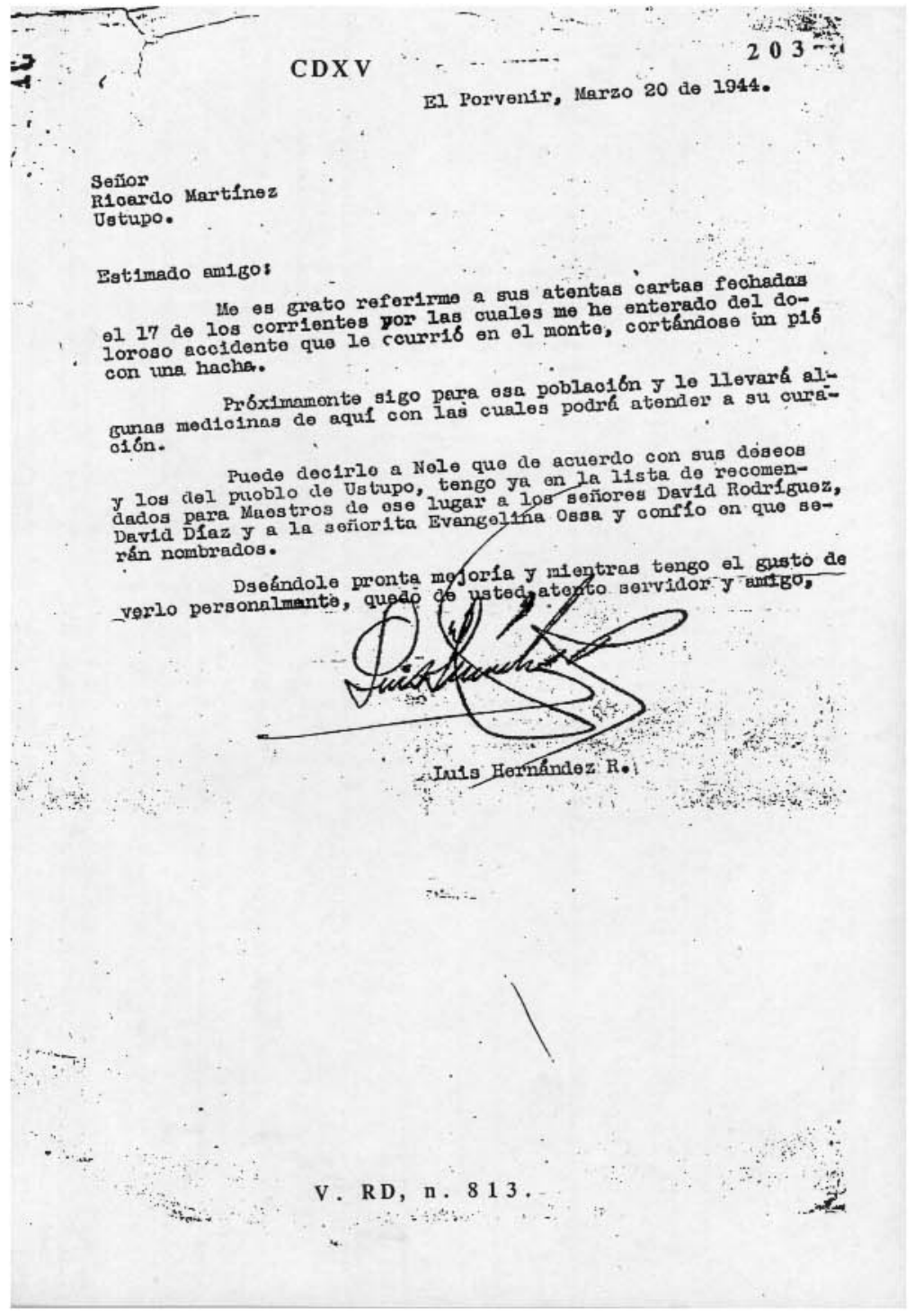


Señor don

Camilo de la Guardia Jr.

Ministro de Gobierno y Justicia,

Panamá

Señor Ministro:

Con el presente oficio le adjunto la lista de candidatos que este Despacho presenta a ese Ministerio, para Director y maestros de las escuelas de la Comarca para el año escolar 1944-1945.

Han sido descartados los maestros Mario Porras por observar mala conducta y ser mu dạdo a la bebida, según el informe del Director de las Escuelas; Concepción Tapago por considerarse

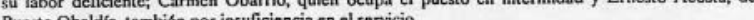

Soy del señor Ministro con toda consideración, su aleno y seguro servidor,

Luis Hernández R.

Intendente.

Trans. de la cop. mec.

V. RD, n. 814 . 
Rvdo. Padre

Jesús Erice

Director de las Escuelas

Narganá.

19 abril 4.

\section{Señor Director:}

Por la presente le informo que, muy apesar de mis deseos, nu me será pusible asistir a las conferencias de los maestros de la Cumarea que-se celebrarán en esa durante los dias 20,21 y 22 Jel corriente mes. No me es posible asistir porque en estos monentos tengo aquí una visita oficial que
demorara varius dias, ni cl Sereteario tampoco podrá asistir porque el señor Asistente se encuentra en estos mumentus en Panamá y el tiene que reemplazarlo.

En los temas a tratar en las Conferencias son mis descos que haga hincapié en los siguientes asusntos:

a) Que los maestros permanezcan en sus puestos estrictamente; salvo casos de causa b) Que los macstros cultiven la amistad de los sahilas y tengan cun ellus perfecta armonía a fin de conseguir por su medio mejor asistencia a clase,

c) Que comuniquen a esa Dirección todos los problemas de indole educativa o sucial que se les presente.

d) Que deben dar períccto ejemplo en el buen vestir, y su comportamiento social, sobre todo en lo que se relaciona a la parte moral. El maestro debe ser un ejemplo por demostrar un profundo respeto a las autoridades.

e) Que los maestros den cunscjos a los indios con relaciön al incrementu de la agricultura, no sabemos cuanto tiempo ha de durar cl actual comflicto, ni las consecuencias agricultura, no sabemos cuanto tempo ha de durar el actual comflicto, ni las consecutncias
economicas que tracrá consige. Antes de termianr descu recordarles que la Instrucción en las Escuelas de la Comarca debe ceñirse estrictamentc al programa oficial que rige $\mathrm{en}$ las demás escuelas del pais.

De usted atentu servidor,

Luis Hernández $\mathbf{R}$.

Trans. de la cop. mec.

V. RD, n. 815 . 


\section{CDXVIII}

Número 20 Sr. Coronel

Luis Hernández $\mathbf{R}$

Intendente de la Comarca de S.B.

EI Porvenir.-

Narganá, 2 de Mayo de 1944

Por la presente precento a su fenevolkncia al niño diplomado de sexao grado este at̃o en Narganá, natural de Isla Pino y huérfiano de Padre; el mejor niño de su grado en ciencia

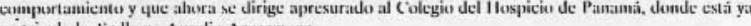
matriculado. Se llama Aurclio Artsemena

A rradeceriale proweyese de alguna mancra la altención en esa micntrass aguarda manera de trasladarse a la ciudad de Colón. Dispense la petición de este servidor que tanto agradecerá, mientras tanto se suscribe
de Usted muy atento y seguro servidor.

Jesús Erice, Dircctor de las Escuelas de la Comarca.

Trans. del orig. mec.

V. RD, n. 816 . 
Número 22

Sr.Coronel

Luis Hernández $\mathbf{R}$.

Intendente de la Comarca

El Porvenir.-

Señor Coronel:

Me complazco en comunicarle que hey, a lass 8 a.m., se diố comienteo a las tareas Me complazco en comunicaric
esciolatares del curso 14:44.45, aqui en Narganá.

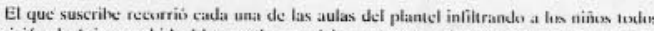

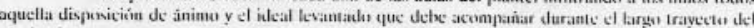
año leclive.

Hicieron también acato de presencia el Subteniente y otro nủmero colonial de Destacamento , por lo que agradecido, participo este hecho a esa Autoridad.

Asi mismo tuvo lugar en la oficina del Destacamento de Policia un intercambio de ideas c impresiones entre los agentes del orden público y el que suscribe, con el fin de coordinar nuestros enisma labor civilizadora

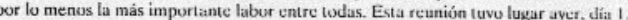

Al terminar las horas de clase de cste dia 2, las 4 p.m., lus niñus todos de la Escucla de

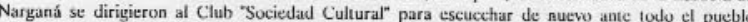
reunido, con numerosas personas de otras islas, la palabra del Directur de las Escuelas y de alumes maestros autorizados que aún estaban presentes, tomando así mismo la palabra representanjes de lejanas islas, cuyos hijos estudian aqui en crecido múmero.

Soy de Usted muy atento y seguro scrvidor.

Jesús Erice, Dircetur de lus Escuclas.

Trans. del orig. mec.

V. RD, n. 817 . 
Sr. Corone

Luis Hernández R.,

Intendente de la Comarca

El Porvenir.-

Señur Coronel: Llevo a su conocimiento que muchos de los materiales solicitadus a Gohierno aún no han llegado y urge suministrarlos a las escuclas, así como:Libretas, o cuadernos del

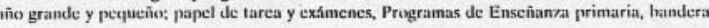
map̣as.

La tiza reparti tuda, correspondiendo dos cajitas a cada macsiro. Los borradores igualmente, wando to

Me encuentro en la imposibilidad de atender al Maestro de Pucrto Obaldía quec, a juzzar por la diversidad de libros de enseñanza que solicita y por el material o conseres de limpiés

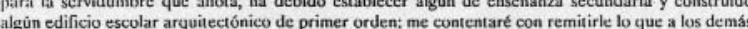
o lo que aquf hay, más tarde podremos pensar en presentar presupuestos de ello al Controlador de th República.

Aprowecho la oportunidad para retrasmitirle la solicitud une of matsotro de. Playón Chicu ha hecho a esta Dirección, expresando la necesidad de unas cinco libras de clavos para arregla la tsccuela de aquel lugar.

Soy de Usted muy atento y seguro servidor,

Jesús Erice, Director de las Escuelas.

Trans. del orig. mec.

V. RD, n. 818 
Sr. Coronel

Luis Hernández R.,

Intendente de la Comarca,

EI Porvenir.-

Señor Coronet:

Me us grato remitirle hos dattes estadísticus correspondientes at mes de mayo de presente curso escolar.

Lat matricula ha descecendide notablemente; fijändonos en los cuadrus de cada escucha, nos es fácil observar que to que dan el tono funamental de desecnso son las Escuelas que han side afectadas por cambius de maestros:Playón Chicu, Tigantiki, Carti Cangrejo, Ailigandi y Ustupu.

Sin embargo Rio Sidra comienza a dar frutos con el traslado de niñus de tercer grado a La cscuela superior de Narganá en número de cuatro. Esperamos que otro año duplicará esta cifra. Es alguna, al cabo de bastantes años ha conseguido cultivar la ideologia haciéndola inclinarse hacia ef progreso.

Finalmente ruégule me dispense la demora en enviarle estos datos, pues jurgué mejor esperar a que tudhos los macsires lus remitiesen a esta oficina, pues faltaban varios; asi no hay lagunas que dificulten las uperaciones relacionadas de dichos datus.

Soy de Usted muy atento y seguro servidor,

Jesús Erice, Director

Trans. del orig. mec.

V. RD, n. 819 . 


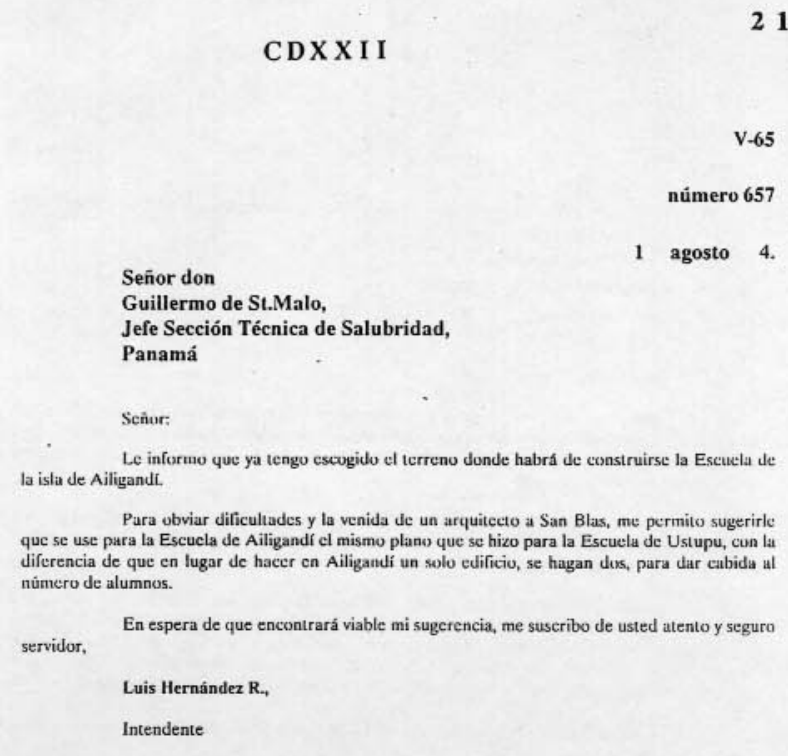

Trans. de la cop. mec.

V. RD, n. 822 . 
CDXXIII

Señor Coronel

Luis Hernández R.

Intendente de la Comarca

El Porvenir.-

Señor Coronet:

Jưgando que tal vez algún dia le pueda ser átil, le presento la siguiente información, relacionada con la llegada y atenciones de la Señorita Sara Méndez y su mamá a la isla de Corazón de maestra por segundo periodo aqui.

Aunque ignoraba su llegada coincidio que en aquel momento me encontraba en et pueblo, pudiendo prestarla desie el mismo instante toda la ayuda que una persona en tales circunstancias es capaz de sugerir; venía con su anciana mamá.

El Padre Director organizó toda una brigada de niños para desembarcar y trasladar sus muebles, abriendo el bajo de la escuela y después a la casa que el mismo tras muchas diligencias

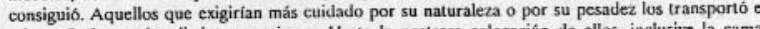
realizo el que suscribe. Usted sabe bien lo que cuesta mover a esta gente para tales ayudas.

Llegadas las horas de comer, al mediodia y tarde, fueron atendidas en casa de las Rdas. Madres a iniciativa del que suscribe.

Lo más difficil fue la búsqueda definitiva de casa durante toda aquella semana Lerminando por lin por optar por la primera que se encontró el primer día, a saber. la casa de biblioteca de los jóvenes que se consiguió a precio módico. Los libros se llevaron a un local del colegio internado donde aún funcionan bajo la dirección de los Padres.

Es cierto que no tardamos en hallar viviendas varias, pero no acomodadas al alquilerque se quería y a las condicones requeridas por el estado de salud de la anciana mamá de la Srta. maestra. Consuitado con ese Despacho, obtuve del pueblo el que se decidiera cerrar cl bajo de I escucla, pero al ciectuarlo cllos opinaron que no le convenia. Ya no supe qué haecer mas y se han Soo

Esto us lu que se rcalizó a favor de la macsira Sria. Méndez a fines de Abril de 1944, poquito antes de inicarse las clases.

De ninuruna manera inienté redactar respuestas a una presunta queja, sí opiné que puede serle útil alguna vez a ese Despacho.

Soy do Usted suyo atento y seguro servidor,

Jesús Erice, Dircetor

Trans, del orig. mec.

V. RD, n. 825 . 


\section{CDXXIV}

R-17 y 18

Número 199.

Narganá, 12 de Octubre de 1944.

\section{Sr. Coronel}

Luis Hernández R.

Intendente de la Comarca,

El Porvenir.-

\section{Señor Coroncl:}

Con gusto respondo a su atento oficio $\mathrm{N}^{\mathrm{e}} 824$ referente a la matrícula de las niñas. Entro de una vez en la cuestión.

No debe olvidarse que el sexo débil entre los indigenas tha dado fundamento por menos al ochenta por ciento de los transtornos y dificultades de cierto alcance; aún aquellos a parecer muy ajenos al fenomicno seguidose hallaria que tienen relación con el. Si deben extrañarnos pues, los altibajos en los números de la csiadistica que no reheja bien la verdadera situación de Instrucción femenina, que en realidad y respecto de los años anteriores, ha mejorado como abajo diré y probaré. Las cifras claramente bajas son de lamentar, pero solo obedecen a frioleras pasajeras

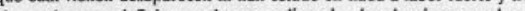

No quiero fundar la solución en mi opinión, sino que aduciré todos los hechus para el examen de cualquiera, sin que deje de analizarlos aquí.

En Ustupo la matrícula alguna vez alcanzó el número 25 en niñas y ahora es de doce, nô obstante los esfuerzos unificados de los prestigiosos y veteranos maestros y Nele de Kantule con sus ayudantes. Adrniraremos aquí la versatilidad del pucblo indigena. pere en Narganá hay cualro niñas de Ustupo,y una de ellas en sexto grado en el internado de las Reverendas Madres.

En San Ignacio de Tupile los niños de edad escolar están matriculados totalmente Maestros y jefes del pueblo llevan con fervor la cosa escolar, sin embargo las niñas no pasan

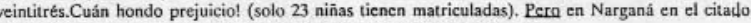
Internado hay cuatro niñas en los grados superiores y dos en los inferiores.

De Tigantiki desaparecieron las niñas este año mereed a la insignificancia de gastos y dispustos de maestros. Tan débilmente estaban ingresados en la escuela o tan fácilmente mudaron de graduada de sexto grado el año pasado. Lústima que habiéndosele dado una beca que no queria, at menor contraticmpo la abandonó.

De Rio Azúcar hay en el predicho internado de las Religiosas de quince a veinte niña Hay experiencia de en general las de la escuela de Narganá. Es grande la confianza y aprecio de todos los indios de la Comarca en dichas Religiosas. Ellas con su Internado resolverán sin duda el problema de las niñas que, según sus prejuicios, corran peligros de ser perjudicadas,

Teniendo en cuanta que ningün otro fundamento cabe colvcar mejor en un pucblo para la instrucción de sus niñas que hijas del mismo pueblo bien instruidas y graduadas de sexto grado y en ustas islas en que parece disminuir, camina firme hacia adelante. 
220-B.

Aún no he contestado directamente a lo que se inquiere en la nota del Ministerio $N^{0}$

No se puede tomar otra medida que la que puede tracr el maestro en un pucblo, es decir la oportuna actuación del maestro dentro y fucra de la escuela que debe ser en San Blas la saber; Rodearse de prestigio y de amistades, lo cual es privilegio de bastantes años de ejercicio.

Primero aquel prestigio que todo indio necesite para influir en un pueblo desde el Pristerien a uno buen parlamentario ystar adornalo de interts por al progreso $y$ bien del pueblo.

En segundo lugar rodearse de amistades influyentes para que seaacuerpado en sus actuaciones parlamentarias $y$ para poder reducir a la práctica las decisioses $y$ depis ideas de progreso que vaya infiltrando en la gente.

Esa doble labor difícil y larga siempre puede tener sus exitos y fracasos por cualquier intervención de algán descontento. En donde si no se obtienc lo que puede esperarse de un maestro, bien puede disculparselo alguna vez.

Por áltimo digo que el camino a seguir en toda instrucción es una labor paciente y cuidadosa, sin tropiezos que levanten murallas. Algân día, cuando menos se piense, todos los delicado asunto se levantan murallats que perdurarán muchos lustros. Sr. Coronel: esta es la solución que me ha parecido mejor a la pregunta, $y$ no veo otro camino por hoy en que todavía estamos empezando a entrar por esta senda virgen.

Soy de usted muy atento y scguro servidor.

Jesùs Erice.

Directur de las Escuelas de la Comarca.

Trans. del orig. mec.

V. RD, n. 826 . 


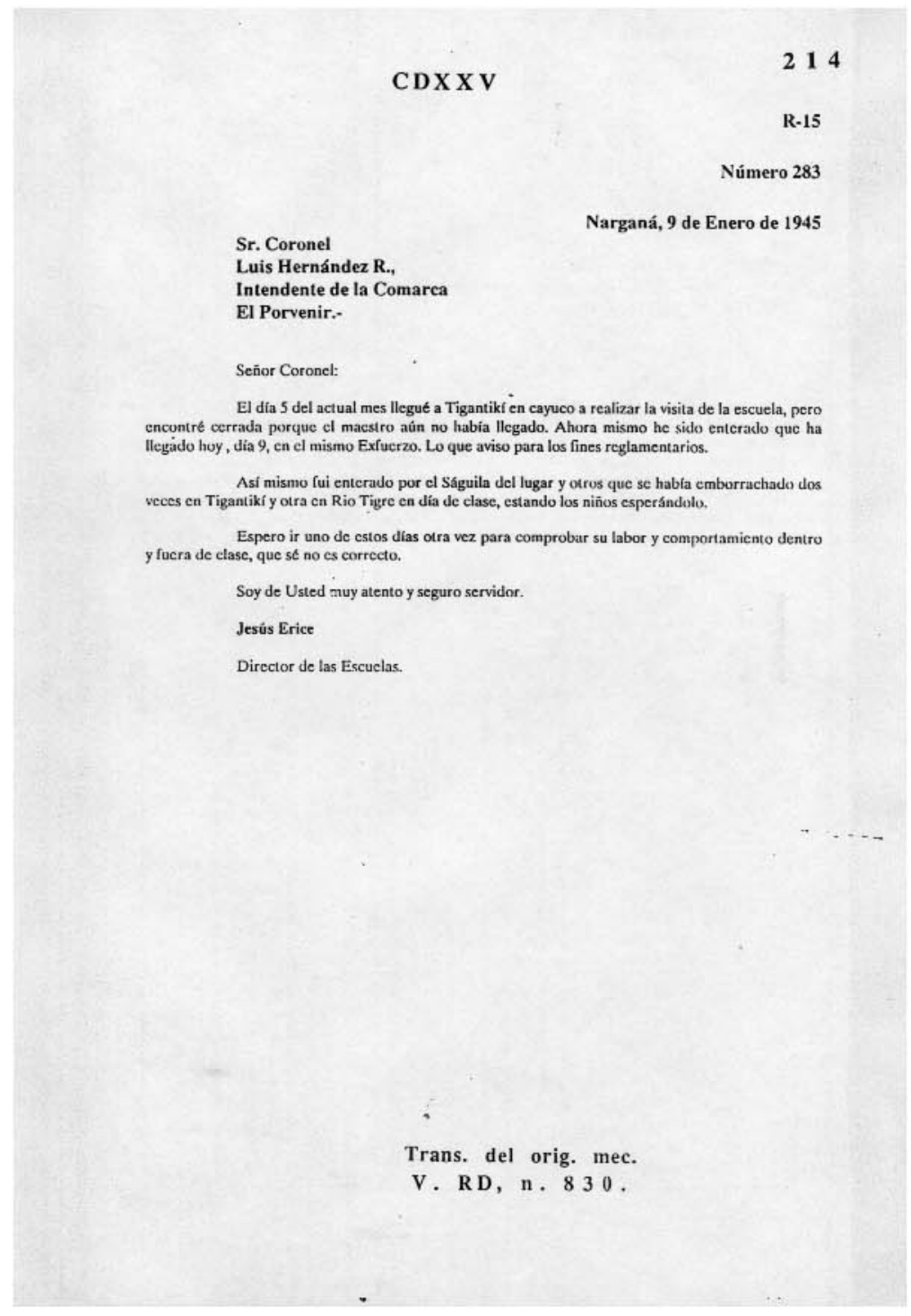




$$
\text { Señor }
$$

Guillermo Escudero

Secretario Encargado de la Intendencia EI Porvenir.

Señur:

Informo que aqui cl Reberendo Padre jesús quiere tener un imperio con los niños que Yas salieren de la cscuela que no quieren que los niñes vayan a la capital ni nińas y las madres y padres

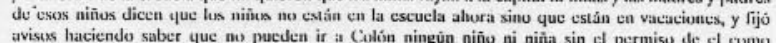

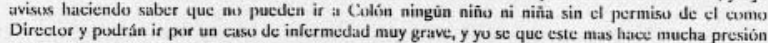

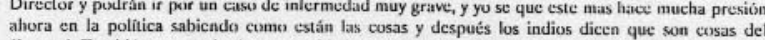
ahora en la politica sabicndo cumo están las cosas y después los indios dicen que son consas del
Curonel. También aprovecho ta oportunidad para decirle que llame al carpintero lgnascio Guncález Curonel. También aprovecho la oportunidad para decirle que llame al carpintero Ignacio Gunzález
para que se fuera en el motor Velero pájaro a csa cabecera y me contestó que el se iba en el Esfuerzo. Raul Caicedo

Soy de usted atento y scguro scrvidur. 


\section{CDXXVII}

INFORME ESCOLARDE LA COMARCADE SAN BLAS

(Año lectivo 1944-45)

MINISTRO DE GOBIERNO Y JUSTICIA

PANAMA

EXCELENTISIMO SEÑOR:

Cumpliendo las normas que el código escolar prescribe en sus art. 75 y 76 acerca del informe que se debe rendir al fin de cada curso escolas, me propongo hacerlo con la mayur brevedad informe que se do

NOMBRAMIENTUS: El Poder Ejecutivo, por conducto del Ministerio de (iebicrno y

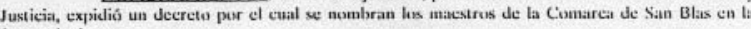
forma siguiente:

DIRECTUR DE LAS ESCUELAS:Rvdo. Padre Jesús Erice.

NARGiNA:Rvdo Padre Isaias Riera; Hermanas Pia, Brigida, Clementina, Ulrica, Casilda, Demetria y Otili

CORAZON DE.JESUS: Maestras: Sara C. MEndez y Luisa de Morris.

El Porvenir Isaura de Ortega.

Carti-Canerejo: Cristina Lòpez.

Carti-Tupile: Lastenia Filós.

Riu Sidra: Ruberto Preciado.

Rí Azuicac Roberto Pớrę y Berta A. Lúpcz

Riu Tigre: Manuel Morris.

Playin Chicu: Francisco Soo y Fulvia de Sivo

San lenacio de Tupile:J tescfa O. de Salazar, Evangelina de Linares y Andrés Iylesias.

Ailigandi: Tomás Herrera, Carolina P, de Alfaro y Francisco Avila.

Uslupu: David Redrigucy, David Diaz y Blanca Llibre.

Puerio Ohaldia: Felipe Canargo.

La Maestra Isaura de Ortega hubo de retirarse en Julio por enfermedad, dejando ,de funcionar la escuela de El Porvenir desde aquel momento. En su lugar se nombró a la sefíviti Leonora Villaroel que pasỏ a ejercer en Puerto Obaldia desde el principio de Septiembre.

La Schiora Blanca Llibre de Porras ecsó en su puesto por gravidę avanzada, siends sustituida por la Señura Juana de Hayans a primeros Dicicmbre 
DIRECCION DE ESCUELAS: La Direcció Escolar, aparte de la labor de oficina, cuyas notas oficioc y circulares cuentan un número superior a los 300 ha desarrolado las siguientes actividades:

10 Ha realizado cinco giras de inspección a la mayoría de las escuelas.

$2^{\circ} \mathrm{Ha}$ presenciado, presidiendo tribunal de cuatro maestros, los examenes finales de casi todas las escuelas, a cayuco generalmente. $3^{\circ} \mathrm{Ha}$ reunido varios congresos generales, fomentand el ideal de la instrucción escolar, principalmente en Ustupo y Nargana.4. $4^{\circ} \mathrm{Ha}$ procurado mejorar capacitación del Magisterio dictando seis conferencias, corrigiendo a cada matstro mensculmente una composición castellana redactada por elios para cjecricio del ienguaje y adiestraindolos, por fin, en el empleo del registro escolar, cuyo perfecto manejo han conscguido. los ninios del sexto grado sobre la vida posi-escolar, trabajando adernals pur la coloctaction de los mismos para completar sus estudios primarios. $6^{2}$ Ha realizado campaña a fivor de lus niñas mereciendo... 


\section{OBSERVACIONES DE LA DIRECCION ESCOLAR}

1) En el informe final del año anterior se dejo constancia del estado de los edificios escolares y otros muebles; por enterado nada he anotado sobre ello, pero subsanaré la omisión diciendo que solo hay escuela (edificio) en Narganá, Cor. de Jesús, Rio Azúcar y Ustupo. La de Narganá, que cuenta... está ya acabada, urge construirse cuanto antes otra de ocho salones por lo menos. ...del Gobierno el hecho de que los indios vayan delante en construcciones modernas, pues se repite el hecho de levantar ellos cdricios... con mader bohio.

II) Descaria esta Direceión disponer algunas veces durante el ańo escolar, al menos para exímenes finales, de la lancha de la Intendencia, porque no es fácil encontrar en la Comarca persona que por mas trabajos pase que el Director de las Escuelas. A no ser que se haya de omitir persona que por mas trabaje.
una labor que debe hacerse.

III) El Magiseterio de la Comarea de San Blas inquiere desazonado la razón de porqqué el gobierno lo tiene en olvido o postergado, cuando los demás maestros de la República son agraciados con aumento de sueldo en dos años consecutivos, no obstante memoriales elevados macomuna

IV) Este Despacho presenta a ese Ministerio cinco alumnos de Narganá, diplomados este año de sexto grado con buenas calificaciones y con recursos pecuniarios sulficientes para (Ustupo), Florindo García (Nargana), Arturo Goazález (Ailigandí), Francisco Jiménez (Tupile) y Julio Benitez (Ailigandi).

v) Con todo encarecimiento pide csta Dirección el nombramiento de un macsiro más para Narganá, cuyo cuarto grado pasará de sctchta alumanos el próximo

Finalizo este informe agradeciendo a las Autoridades cuanta cooperación han prestadoal magisterio de la Comarca durante cl año lectivo que acabamos de clausurar el día secho de febreto
de 1945 .

Del Excmo. Sr. Ministro de Gobierno y Justicia, atento servidor,

Jesús Erice 1.

Director de las Escuelas de la Comarea.

Trans, de la cop. mec. inc. V. RD, n. 834 . 


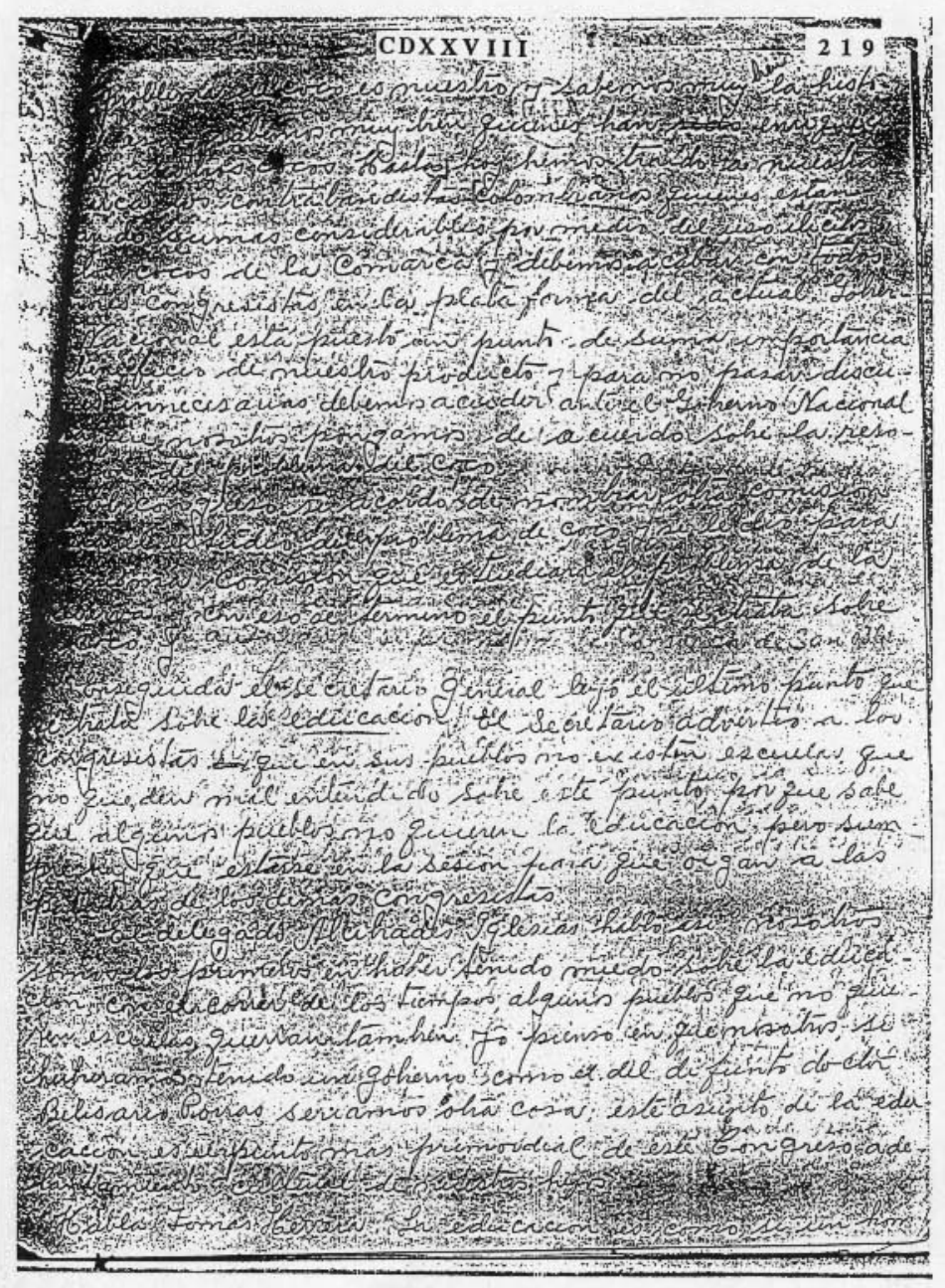




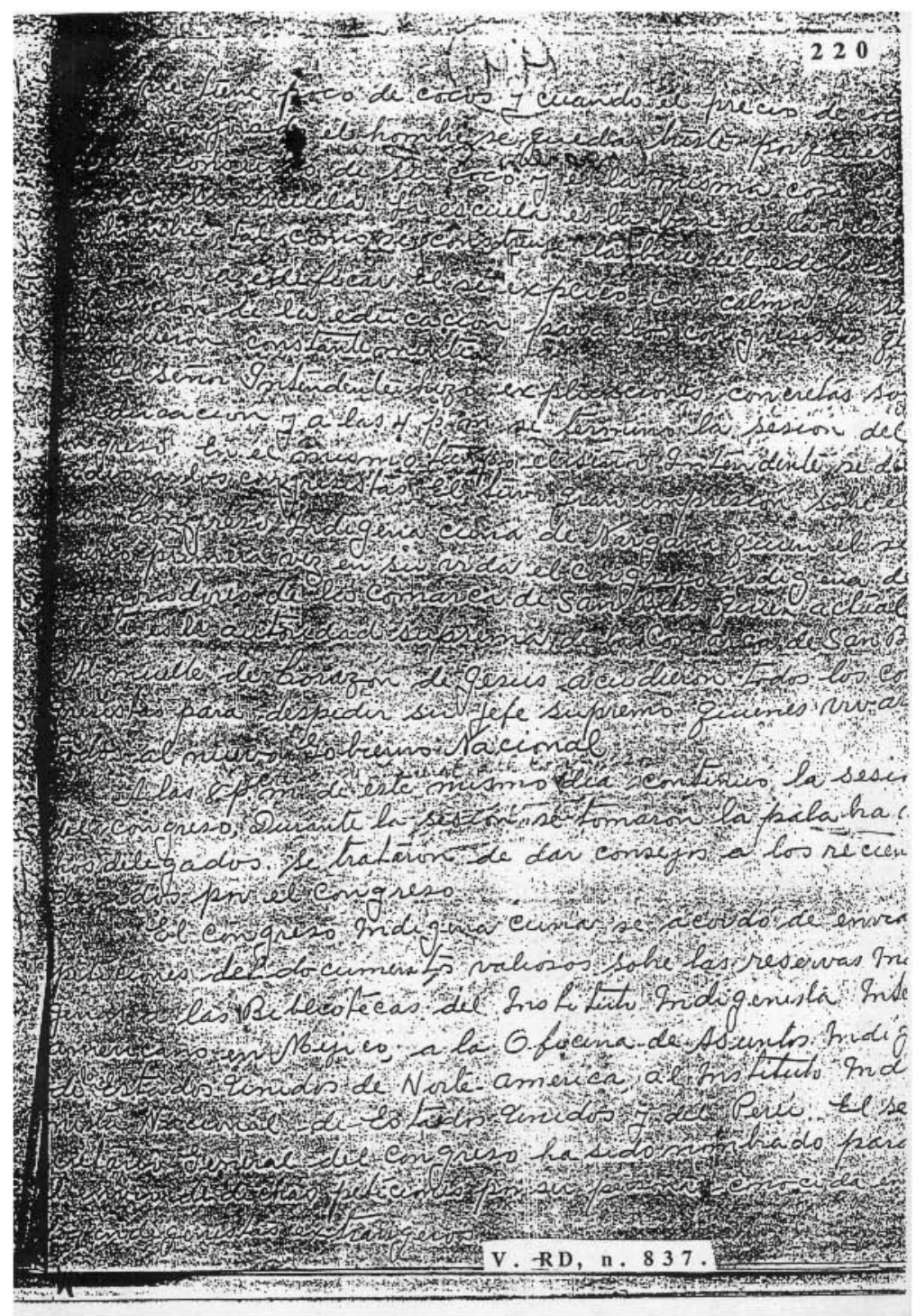




\section{Sres. Maestras y maestros \\ DE LA}

COMARCA DE SAN BLAS

Muy apreciados:

Este verano propúseme dictar las conferencias anuales prescritas, dándolas distinta forma que en años anteriores, es decir: brindándoos por escrito y en estilo breve y condensado los diversos topicos que habian de ser objeto de nuestras explicaciones, ahorrándoos asi el trabajo de tener que anotarlos.

El principal móvil que nos determinó a dar esta nueva orientación a dichas conferencias fue la experiencia-de otros años en que observé no se tomaban notas y-si se tomaban no-con la exactitud conveniente $y$ en lodo caso obse llevaban a la pratica diffcilmente sanable de la falta de asistencia justificada o no justificada.

$\mathrm{Y}$, como habcis podido observar, somos de aquellos a quienes gusta dar normas prácticas para realizarlas, no por puro cumplimiento. Lo que os ofrecemos, pues, ahora son las 作 politica que aquellos se desarrollaba en la Comarca.

Como os indiqué, la finalidad de ellas es servir de lazo para las explicaciones-y - . . orientaciones de nuestras visilas de inspección y de futuras conferencias, toda vez, que dichas normas generales vienen sin la suficiente explicación y desarrollo. Esto no puede constituir objeto de solo circulares, que abarcaría libros enteros, sino más bien de explicaciones.

Esta manera de adiestramiento conceptúo el más provechoso para vosolros y pensamos seguir esta misma dirección respecto de otras formas importantes de la Pedagogía que no debe ignorar los macstros, a fin de que su labor sea mís eficiente.

Soy de ustedes muy atto. y scguro scrvidor,

Jesús Erice 1.

Director de las Escuelas de la Comarca de San Blas.

Trans. del orig. mec.

V. RD, n. 838 
Señor don Constantino Villalaz C Intendente de la Comarca

El Porvenir,

Muy distinguido sen̂or Intendente $y$ amigo:

Hago una información acerca de mis observaciones que he recibilo durante los diez

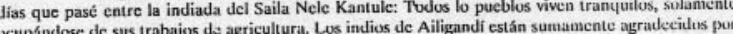
la buena labur que ha hecho el Gobicrao Nacional sobre el caso de la lancha "Adelina:"

En cuanto de las escuelas, sus maestros están comportando bien y están trabajandu con

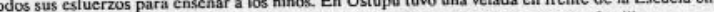
dia aniversario del libertador Simón Bolivar con la sissencia de todos los padres de familia.

El maestro David Díaz todavia sigue con las enfermedades. Como la escuela no pusee en debida forma las medicinas. El tiene dolor de cabeza cun fiebre y dolor agudo del estömago.

\section{En estus dias ya me encuntraré al ludo del Saila Yabiliquuina}

Los indios de Ustupu estản contentus por el recibiniento que estuy haciendo de lis nuticias por medio de la radio; poryue tengo conmigo la mia

Después de mi régreso de mí viaje del arriba informaré de nuevo.

Su seguro servidor $y$ amigo indigena

Rubén Pérez Kantule

Trans. del orig. mec.

V. RD, n. 839 . 


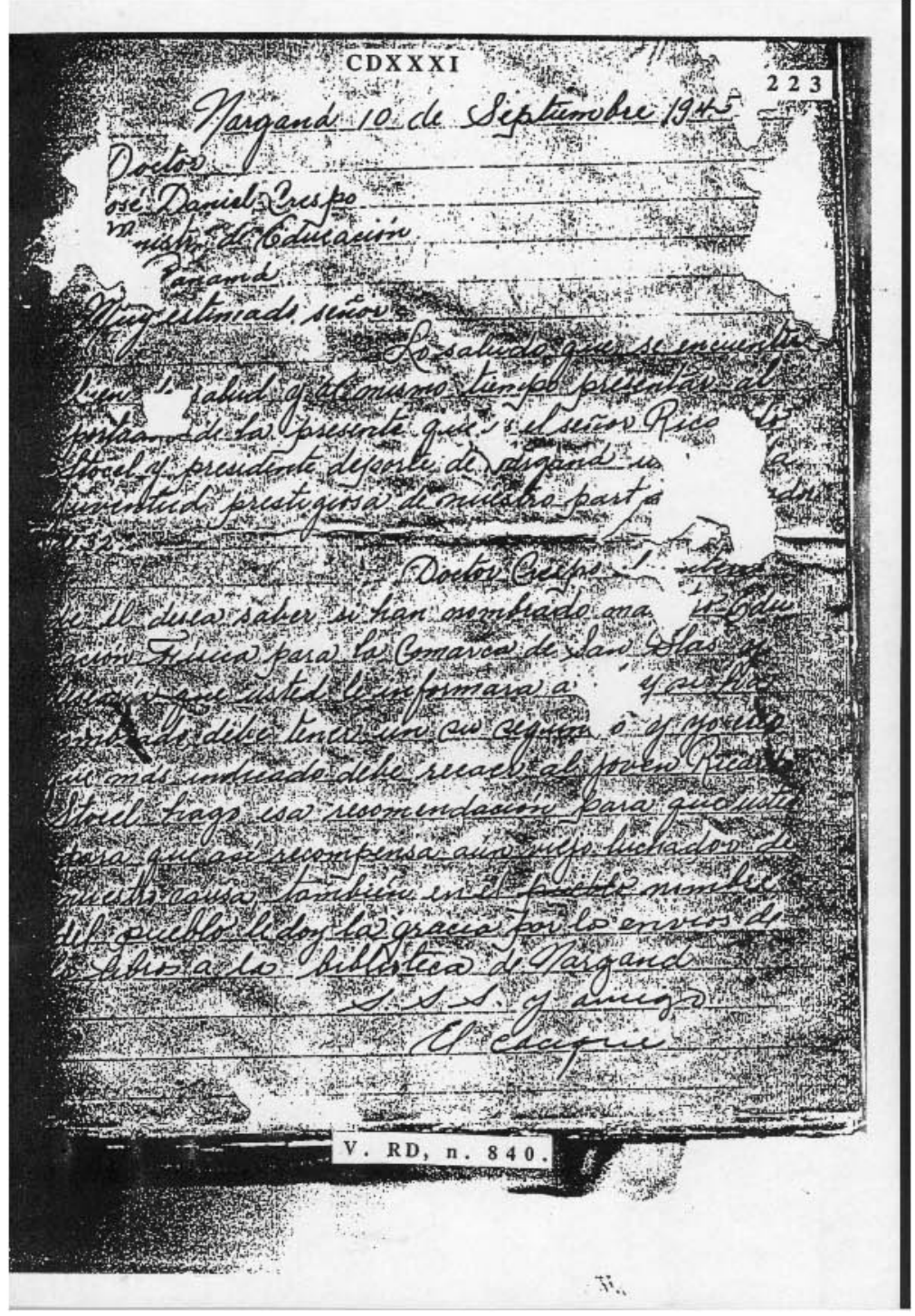


Informe sobre edificios

escolares en construcción

San Blas Corazón de Jesús, 27 de Noviembre de 1945

Señor

Segundo Secretario del

Ministerio de Educación,

P a n a má.

Señor:

Cumpliendo órdenes que el scñor Ministro me impartiò en mi óltima visita a su Despacho, practique visita de inspección ocular a los cuificios que para escuclas cstá constrayende respectivamente, rindo por el digno cunducto de Ud. el informe correspondiente.

El día 19 de lus corrientes a las 2 p.m. se trasladó en lancha, aprovechando una oportunidad despues de haber tratado de efectuar con jira varias veces sin logrario, hasta haber tenido que regresar de medio camino por daño de la enbaracacion que lo conducia. el suscrito Inspector de Educación Primaria de la Provincia Escolar de San Blas, en viaje directo hasta Ailigand, a donde llegó a las 7 p.m. Esa misma noche se dedicó el suscrito a cruzar ideas con los macstros de la Escucla Pablica y la privada y lambicn cun el Safhila y varios padres de lamilia, quienes informo, en nombre del Ministerio y por condacto de este Despachio, la idea de que la

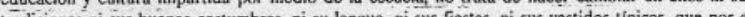

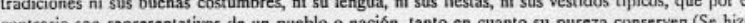

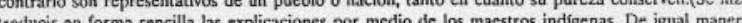
tuvo oportunidad el suscrito de expresarse ante los caciques más poderosos de la Comarca, señores Yabiliguina y Olotebiliguina, al tener el honor de conocerlos.

A provecho la oportunidad para informarles que estas ideas han sido bien recibidas por aquellos jefes $y$ han producido buen efecto, pues ellos a su vez manifestaron que ahora que educación se ofrece a sus pucblos sin tocarlos sus más caros sentimientos y costumbres, cstán dispucstos a aceptar las cédulas y la civilización.

ESCUELA DE AILIGANDI EN CONSTRUCCION. Copio a continuación el act que extendi, firmada por el suscrito y el capataz que está al frente de la obra.- "Noviembre 20 1945. Tiempo que dura la visita de 7 a 8 a.m... Proposito de la visita: Observar la obra que se construye por contrato con el Gobierno.-Objetivo de las activis

CONSTRUCCION-DE ESCUELADE WICHUWALA. Otra obra importante que se ha realizado es la construcción de la escuela de la Isla de Wichuwala, materiales extraidos del desmantelamiento ex-sitio de defensa de Mandinga, con los materiales conseguidos por el Señid Intendente, se ha llegado a completar la construcción de dicha escucla junto con la cooperación del SŚhila Tinainni y el macstro de escuela. El pucblo de Wichuwala ha aliviado sus necesidades que taato anhelaba de tener una pequeña Escuela, para que sus hijos reciban enseñanza del saber. Esice el segundo pueblo que ha levantado una escuéla con sus sacrificios sin obstáculo de ninguna especic,
primero fue en la Isla de Pinos, en la misma condiéón y en la misma forma se llevó a cabo la construcción de la escuela,y por lo tanto el Seńor Intendente, aplaude al Sahila

Gebierno.

Je la Isla de Pinos y al Sahila de Wichuwala en la forma como se ha cooperado con el 
Considerando que un pais el nuestro, de recursos limitados, como tantas cosas importantes faltan por hacer y son esenciales para el desarrollo y progreso, precisa planificar estos, resulten gastos inútil del Tesoro Nacional.

Trans. de la cop. mec. inc.

V. RD, n. 850 . 
CDXXXI I I

Señor Doctor

Don J.D. Crespo

Ministro de Educación,

Panamá

Señor Ministro:
226

R-19

Núnmero 855

Diciembre 5

Desde Panamá pedf al Señor Inspector Escolar de esta Comarca, don Manuel Herrera O., luego que me cnicre de su nombramicnto que actuara de acuerdo con la política de la Intendencia, a lo cual accedió gustuso el Señor Herrera y que, consecuentemente, tendria de mi parte toda la cooperación y cl apoyo necesarius en lo que personal y administrativamente me fucra dable
para el mejor desarrollo de sus tabores.

En forma muy especial solicite al señor Herrera que procediera con la mayor delicadeza y atención al tratar como inspector o Jcfe a las Reverendas Madres Franciscanas y el Gobierno de Don Rodolfo Chiari, después de los desgraciados sucesos de 1925, por haber posta Misión educado varias generaciones indigenas y contribuido en todo momento, con el aporte de sus luces, al desarrollo moral, material e intelectual de la Comarea, con el beneplácito de sus superiores y el de los moradores de esta región.

Advertí al Inspector Herrera que no podiamos perder de vista nuestro ideario polltico de obligar a dicha Misión a aceptar en forma completa el desarrollo del programa de enseñanza primaria, para combatir de eso modo, caso que lo hubiera,el catequismo acostumbrado por misiones de las de las ciude recomendiones $y$, más aun, no ha seguido las prácticas estabiecidas por mi de colaboración y los habitantes de esta Intendenciz, quenes por cl ben tre

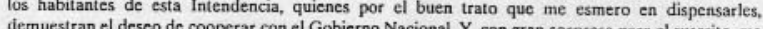
ha manifestado el Señor Herrera que no coth de acierdo con co debe dispensársele a estos viejos servidores católicos, debido a ene tiricamente se trau yo creo simples extranjeros y que él cilará y hará comparecer a dichas Madres y educodores a st inspección..., que la Inspección es también residencia del Señor Inspector, y aunque asi no lo fuera dicho señor tiene el derecho a que se le dispensen las finezas y cortesias a que son acreeduras tanto ellas como los Sacerdotes que actuan en la Comarca como profesores, ya que han sabido graniearse la admiración y el respeto no sólo de los padres de familia que les confian sus hijos en los internados sino de los habitantes en general.

Además, el Inspector Herrera, ha llevado sus actuaciones oficiaies hasta retener la Cédula de identidad personal del Sacerdote Director de las Escuelas de la Comarea, Don Jesús Erce, porque dicha cedila decta que el estado civil dec aludido Director era el de casado. Esto causó para reclamar de ese error en la ofica consiguiente el seior Director trajoy acos a que es soltero. El hecho de que el Sacerulote era casado fue motivo de fascinoció y del constar consizuienle dentro de los habitantes indigenas de Nargan y se hubiera obrio plazo prudencial al Director para desvanecer tal cargo infundalo. Al visior aner bute un Narganá me pidió dicho Director hablara con el Inspector en el sentido equivocada y que ic retuviera, si queria, la que habia traido rectificada y, el Inspector, se 7 
Jevolver o hacer el cambio de cédulas, a pesar de habérselo solicitado el suscrito en forma sulplicatoria.

Otra acusación desagradable del señor Inspector Herrera contra el Director fue la de hacerle el cargo de haberse apropiado un cheque de una Macstra de Puerto Obaldila y cl de falsifica la firma de dicha maestra y haber cobrado el aludido cheque. La decharación que obligó el señor Inspector a rendir al Director fue con el carácter de INDAGATORLA y después pudimos constatar que el autor del delito fue el Cedulador nombrado por el Gobierno pasado que todavia presta servicios como tal en la Comarca y que se nombra Jovito de la Rosa. Y el señor Director fuc nuevamente avergonzado ante los alumnos y padres de familia al saberse que se le acusaba de
falsificador y ladrón del cheque de-una Maestra.

Al tener conocimiento de que la Misión en pleno descaba retirarse de la Comarca por encontrarse sus componentes profundamente disgustados con la conducta del Inspector Herrera para con ellos, les manifesté que me dieran la oportunidad de inteligenciarme con usted, como cn efecto lo hago por medio de la presente, a fin de solicitar de su benevolencia se sirva trasladar a otra Provincia Escolar al Inspector Herrera, y me permito recumendar a usted, en forma muy especial al Maestro Graduado, ex-miembro del Magisterio Nacional, don José E. Huerta, quien ha sido director Especial de las Escuelas de Chitré y República de Bolivia, en Colón.

Me permito enviarle copia de la atenta comunicacion que me ha dirigito Su Señoria Ilustrisima, J.M. Preciado, Obispo de Colón, relacionada con este asunto.

Dándole gracias anticipadas por la atención que le merezca la prescntc, me cumplazco en suscribirme de usted,

Félix E.Oller,

Intendente. 


\section{$\operatorname{CDXXXIV}$}

Señor Eduardo Filós

Narganá

Con mucho gusto envio la contestación.

El dỉa 7 de Mayo hice matricular a los niños, total fue 28 nin̂os. Así: 18 de I gdo., 6 de II gdo., 4 de III gado, y el día 8 comencé la classe asistieron todos, 28 completos.

Has recibido los datos estadisticos mensuales que le mande?.

Alli le he puesto total de la matricula y total de asistencia media diaria 23.

Ahora para cl mes de Junio ya la matrícula alcanzó a 33 niños total.

Soy de Ud, S.S.S.

Antonio López

Macstro.

Trans. de la cop. mec.

V. RD, n. 871 . 


\section{$\operatorname{CDXXXV}$}

Señor

Plinio Ortiz

Inspector de Educación

Mi muy estimable Scñor

He recibido la circular $N^{0} 1$.

He escuchado con mucho gusto su atenta palabra Scíor: Me alegro muchos nor rectonocer su nombre y por su ocupación del honroso cargo de Inspector de Educación de Snn Blas.

El Señor Manuel Herrera el Inspector del año pasado ha sido muy bucno, pero por los indios instruidos que han cursado con los protestantes estos lo ha puesto indiganción, por completo,

Inspector: todo el mes de Mayo no he recibido cheques.Quiera que Dios pase muy felicidades vida.

De Ud.S. atto S.

Antonio Pérez

Macstro. 


\section{$\operatorname{CDXXXVI}$}

Señor

Cartí Tupile, Junio 28 de 1946

Plinio Ortiz

Inspector de Educación de San Blas

Señor

He recibido circular \# 3.

Donde me informas de fundar la escuela nocturna para adultos.

Pues bien: La escucla nocturna de C. Tupile fuc fundada el 27 de Junio de 1946 con 10 matriculas todos son jovenes adultos. Lef para ellos circular y ellos quedaron conformados así que leer y erscribir. Yo por mi parte para mis niños estoy pidienulo cuasiernos, lśpices, tinta, libros de 1 gdo y de tercero, como ya están acostumbrados de esperar materiales de Goberno.

Ahora que se halla fundado la escuela nocturna pidole al Inspector cuadernos, lápices, Lizas, libros de I gdo porque ya dentro de dos meses ellos sabrán leer y eseribir.

Pidiendo a ud, que disculpe la molestia le saludo respetuosamente como S.S.S.

Antonio López

Maestro.

Trans. del orig. mec.

V. RD, n. 874 . 
CDX XXVI I

R-30

Señor

Inspector de Educación

Provincia Escolar de San Blas

Señor

Recibida la circular número 3 de esta Inspección me permito informarle que en resencia de los maestros, de los Ságuilas en Congreso fue leida la circular $N^{2} 6$ del Magisterio de

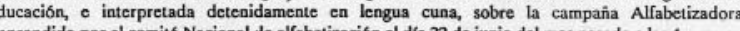
emprendida por el comité Nacional de alfabetización el día 22 de junio del mes pasado a las 4 p.m.

Con el interes de la comunidad en general; muy bien voy a dar y esta dirección permite of fundar la escuela nocturna para adultos.

femeninos

El lunes 23 se fundó la escuela con la matricula de 30 alumnos masculinos y de 10

Esta dirección se cmpeña en aumentar la matrícula tanto de masculino y de femenino dentro de pocos dias más.

Me suscribo de Ud. muy atto s. ys.

Blanca M. de Porras

Trans. del orig. mec.

v. RD; n. 875 


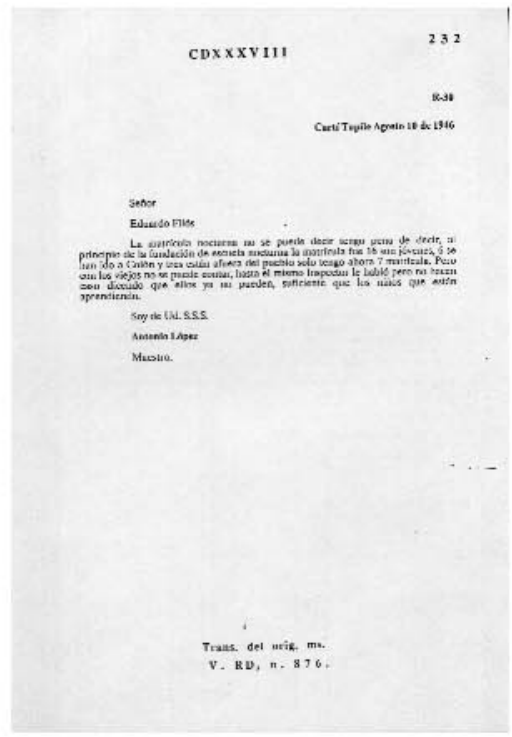




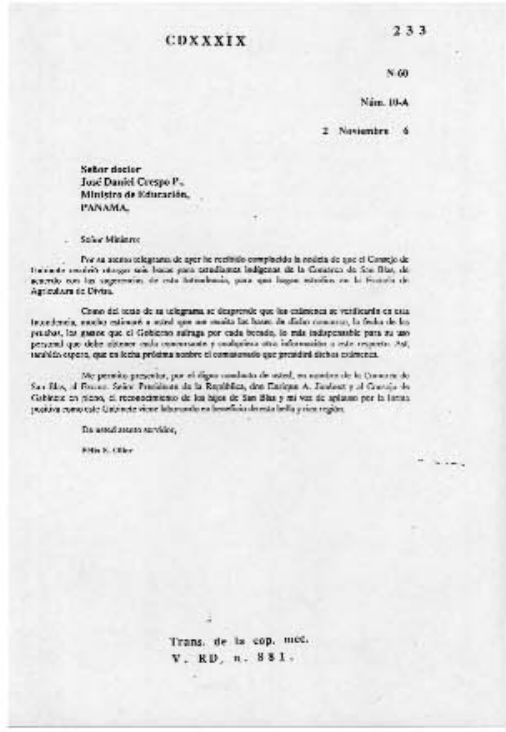




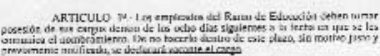

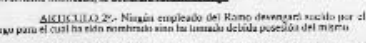
and

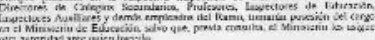

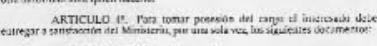

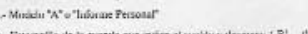

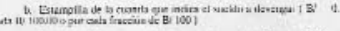

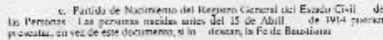
the -

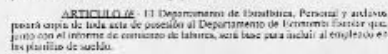

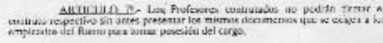




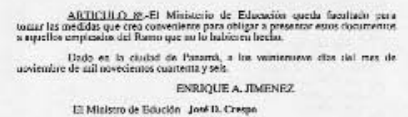

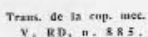




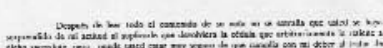

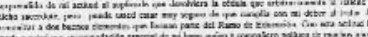

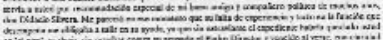

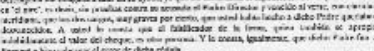

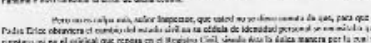

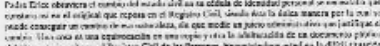

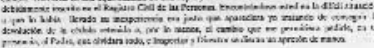

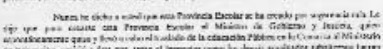

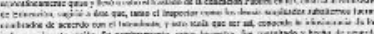

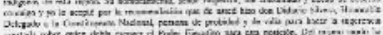

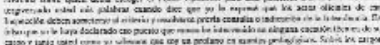

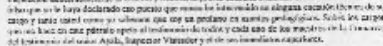

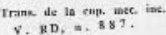


$\because 7$

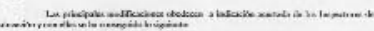

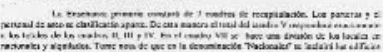

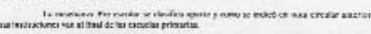

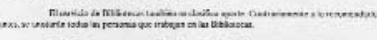

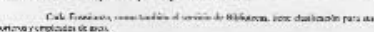

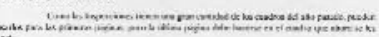

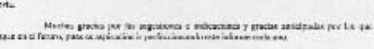

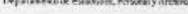

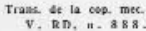




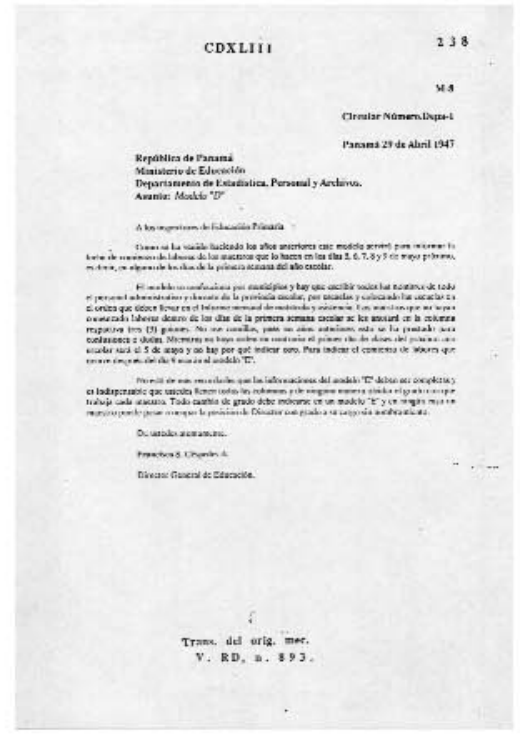




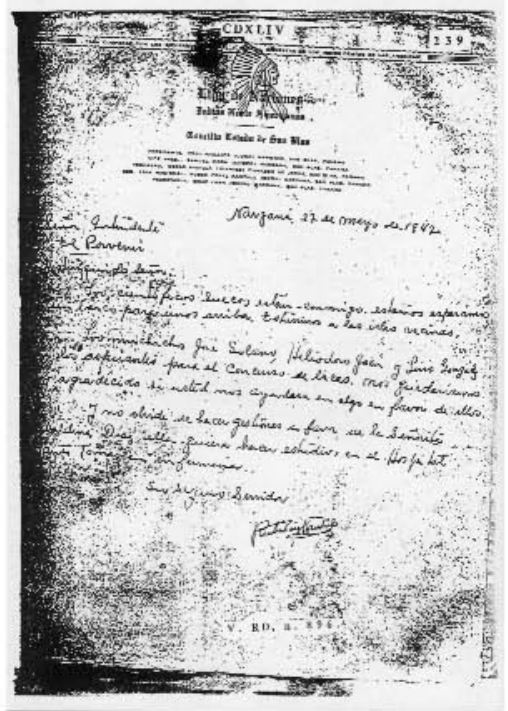




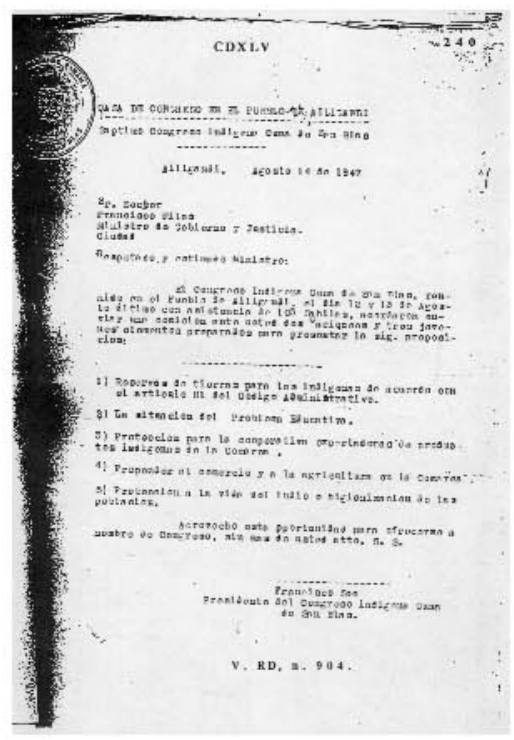




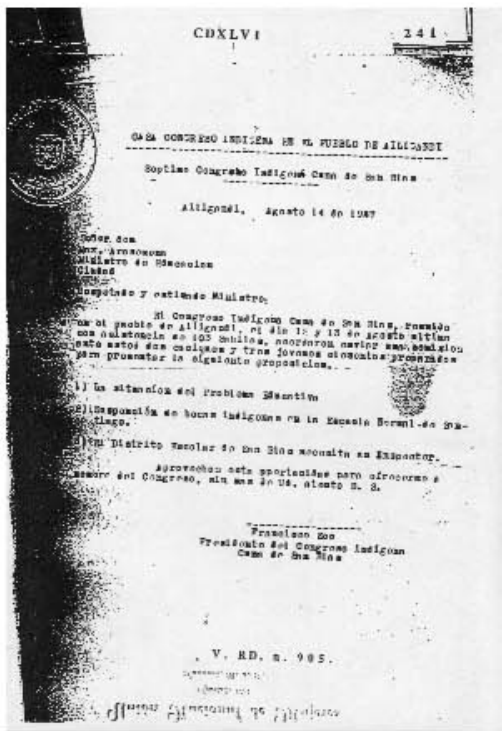




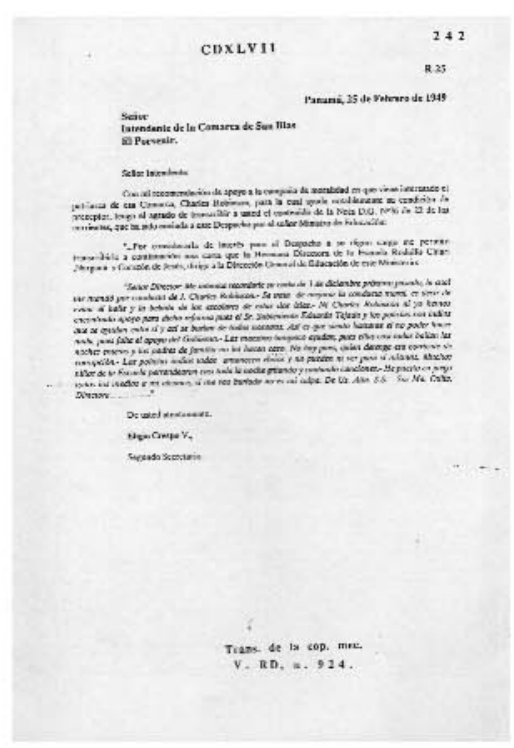




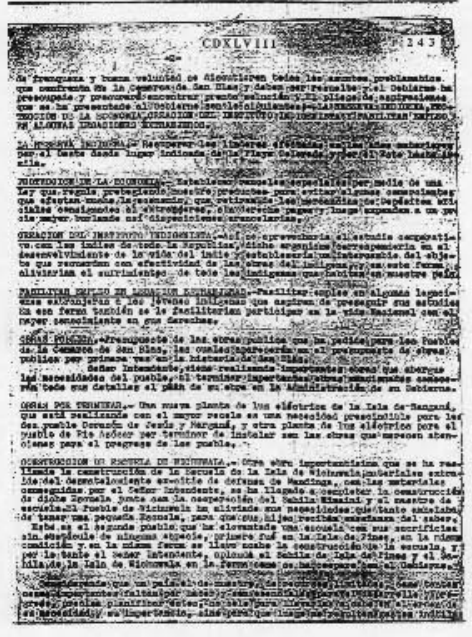




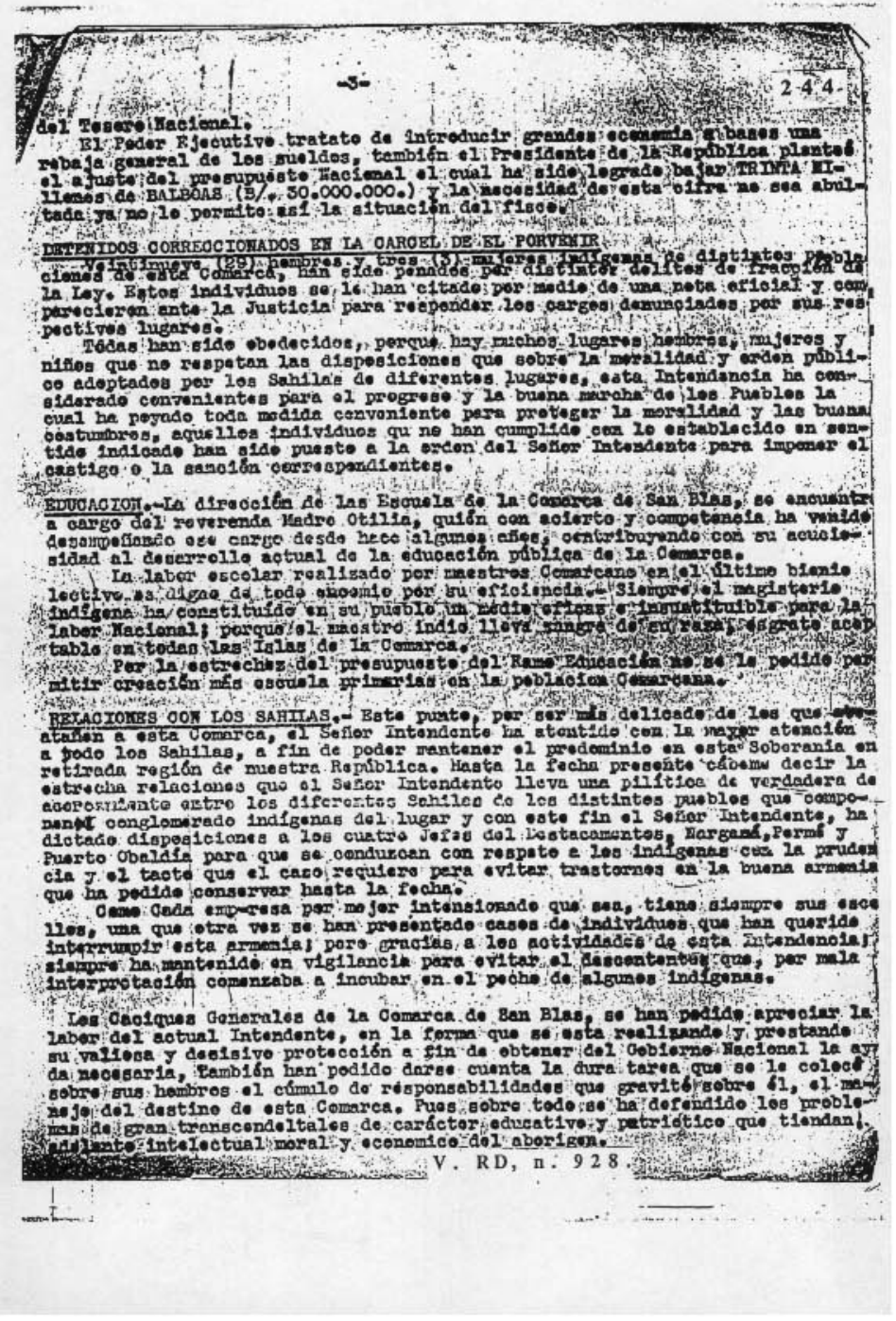


Señor

El Porvenir, 24 Diciembre de 1949

\section{Panamá.}

\section{Estimado Amigo:}

Por medio de esta me permito escribirie a usted, a fin de que reciba el informe que rendi en el Congreso celebrado en el 25, de Octubre, sobre la Adminstracionn del Señor ex-Intendente informe que bice cuando el Gobierno era Doctor Daniel Chanis Jr.

Usted lea este informe para ver cómo te paraece, enseñaselo a Felix Oller el trabajo que he podido presentar, como los Caciques Generales están en Panana para ver usted con su polfitica lt pudo conveneer a los Caciques que me recligan de mi puesto.

Hace dos dias le hable con amigo Tomás el esta dispuesto a defenderme en el Congreso. En este momento estoy solo en la Intendencia y por eso no puedo separarme de la Intendencia.

Saludos a Ildaura y Acladio.

Pablo Solis

Trans. del orig. mec.

V. RD, n. 929. 


\author{
- Personal \\ Señor don \\ Rubén Pérez Kantule \\ Narganá.
}

Estimado amigo:

Debido a mi larga estadia en la Capital haciendo frente a la campana para que no se protibiera la entrada de naces de la costa colombiana a la Comarca, no habia podido dar antes contestación a sus cartas fechadas el 29 de marzo, 31-del mismo mes y cuatro de los corrientes.

Lamento mucho que usted no hubiera podido llevar los trabajos de la Cultura Kuna a la Expusición que se celebró en el Instituto Nacional. Considero que el Fracaso nu es de usted, sino de amigu Bunifacio quicen ha dechido comprender yue csos indigenas icnian que abandonar sus trabajos para ir a perder licho a Pand y yec cso Departamento do cipu a P Tigre. Asf lo hice saber al señor Percira que usted me lo pidió y creo que el viaje de Pereira a Narganá en la semana próxima pasada debe haber sido para remunerarle siquiera parte de lo que usled tuvo que invertir.

Con respecto a su queja sobre el mal trato que le había el señor Catillo, Encargado de la Intendencia, dado al Sátila de Carti, señor Niga Cantule, ya este asunto ba sido arreglado satisfactoriamente y dicho Sáhila y el señor Castillo son ahora dos buenos amigos.

Referente a lo que me dice del maestro Roberto Pérez, su situación mumentáncta ts dificil, porque a perdido la simpatia y aprecio de los moradores de Wichiwala y Nalunega, quienes han hecho Congreso para pedir a esta intendencia y al huspector de Educacion Devalle que nombre ute Eu como mostro, porque las otras isles donde ha trabajado a teriormente le ha pasado lo mismo.

Esperaba verlo a usted ayer sábado en el Congreso de Carti, pero la falta de laneha-y _.. una fuerte tempestad que ha agitado durante todo el día, me ha impedido asistir a dicho Congreso.

Mañana dumingo 30, visitarć a Mandinga donde permaneceré tudo el tienpo que sta necesario con el grupo de indigenas yue trabajarain en la trocha hacia Cerro Azul.

Al irformarme Esaanislao que usted le habia escrito que lo habia suspendido en su puesto de Bibliotecario Jefe de las Bibliotecas de la Comarca, fui donde nuestro amigo Galileo quien me informó que no era cierto su separación de dicho cargo y que usted permaneceria en su puesto en dicho cargo

Como campaña nueva le anuncio que estamos exigiendo que se obliguen a la Compañá de Aceites Urraca a comprar cocos y copra hecha en Panamá. Ellos venian produciendo copra de Oceanios to indigenas que son los mayores prosible, el precio del coco para mayor bienestar de las familias indigenas. cununicación.

Sin más por el mumento, me suscribo su amigo y servidor, quicn veo nuevamente su

Félix E. Oller. Intendente de la Comarca de Sạn Blas

Trans. de la cop. mec.

-V. RD, n. 938 . 
Ailigandí, Comarca de San Blas

Señor Don Félix Oller

7 de Agosto de 1950. Intendente de la Comarca de San Blas,

Porvenir, Comarca de San Blas

Estimado amigo:

Acabo de visitar la Isla de Mulatuppu por la invitación de Saikla Nipakinye y sus voceros. El pueblo de Mulatuppu me recibí con manos abiertas y me consulto acerca de la posibilidad que mi hermano Claudio y su señora se establezcan entre ellos.Mi hermano y su señora hemos hecho den Ailinadi Yo se que Usted como lntendento do lo Comarca de San Blas y como 政

Tan pronto que mi hermano y su esposa termina sus diligencias en Colón, como Usted sabe que ella está en estado, descan ir a la Isla de Mulatuppu. Creo que estarán listos durante el mes de Diciembre.

Por medio de esta carta deseo comuinicarte los deseos del Pueblo de Mulatuppu, los deseos de mi hermano y su esposa y los deseos de Usted.

Acepte las consideraciones especiales con que me suscribo de Usted.

Soy su amigo y seguro servidor,

Alcibiades Iglesias.

Trans. del orig. mec.

V. RD, n. 942 . 
CDLII

Señor Don Alonso Velarde

Narganá, 15 de Diciembre de 1950 Secretario de la Intendencia de la Comarca de San Blas El Porvenir.

Estimado Señor Secretario:

Quiero acusarle de que yo recibí su nota 520 en que me manifestaba sobre el envio de materiales de las escuelas.

Tales materiales de las escuclas han sido recibidos por el suscrito con las mismas cantidades que me dice en su Nota.

Ya estoy enviando preguntas a los maesros activos sobre el anuncio de dichos materiales. Envie dos cajas de tizas a la Escucla Privada de Sasardi Mulatupu y algunas copias de los libros. de la escuela

Hare todo lo pósible de cumplirme sobre la repartición hunradamente a lus materiales

Su scguru servidor,

Rubén Pérez Kantule

Blibiotecario Jefe

P.D. Las dos bolsas de caucho las entregué al señor Francisco Soo.

Trans, del orig. mec.

V. RD, n. 949 . 
- Deta des le saion del bonguas bo lhate el dir $8 d_{e}$ suptisy be de1952.

At las. 9. de la mañisex se vermio ex ef selore

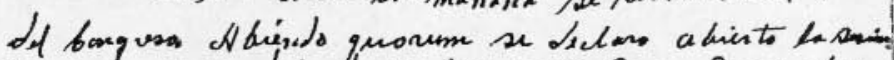

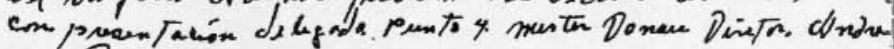

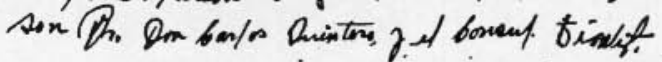

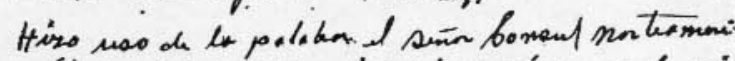

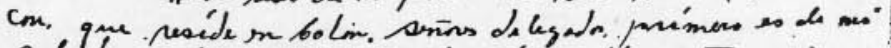

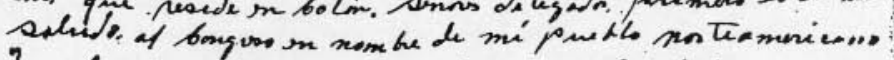

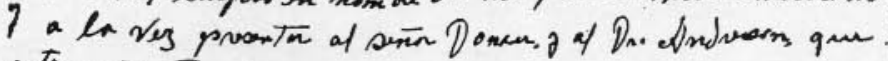

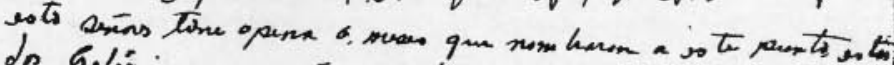

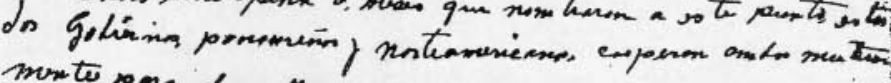

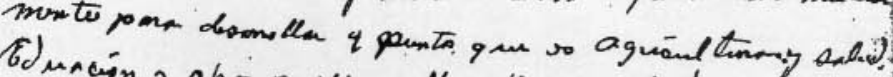

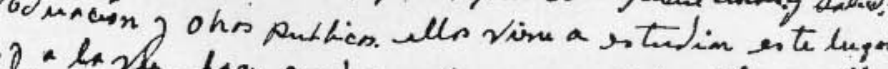

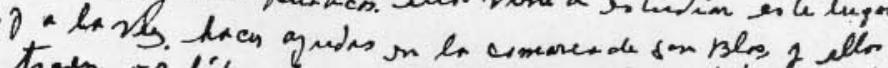

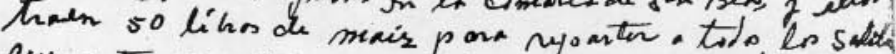

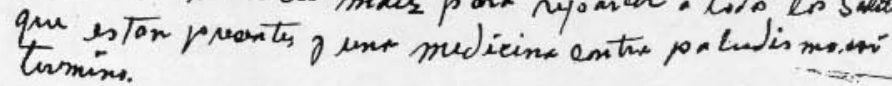

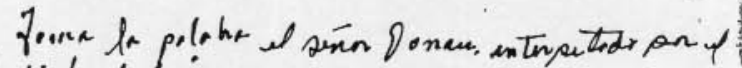

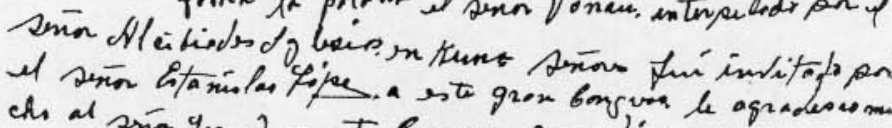

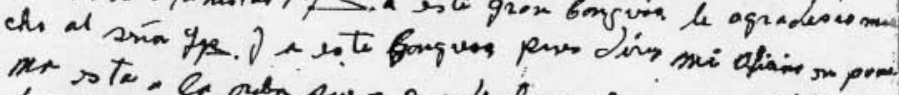

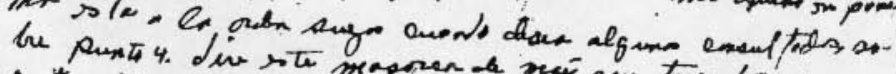

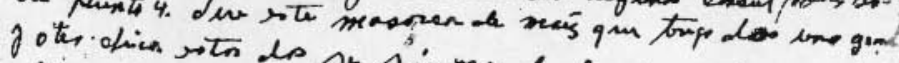

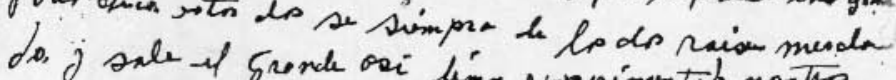

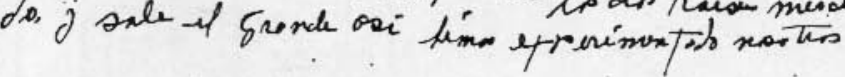




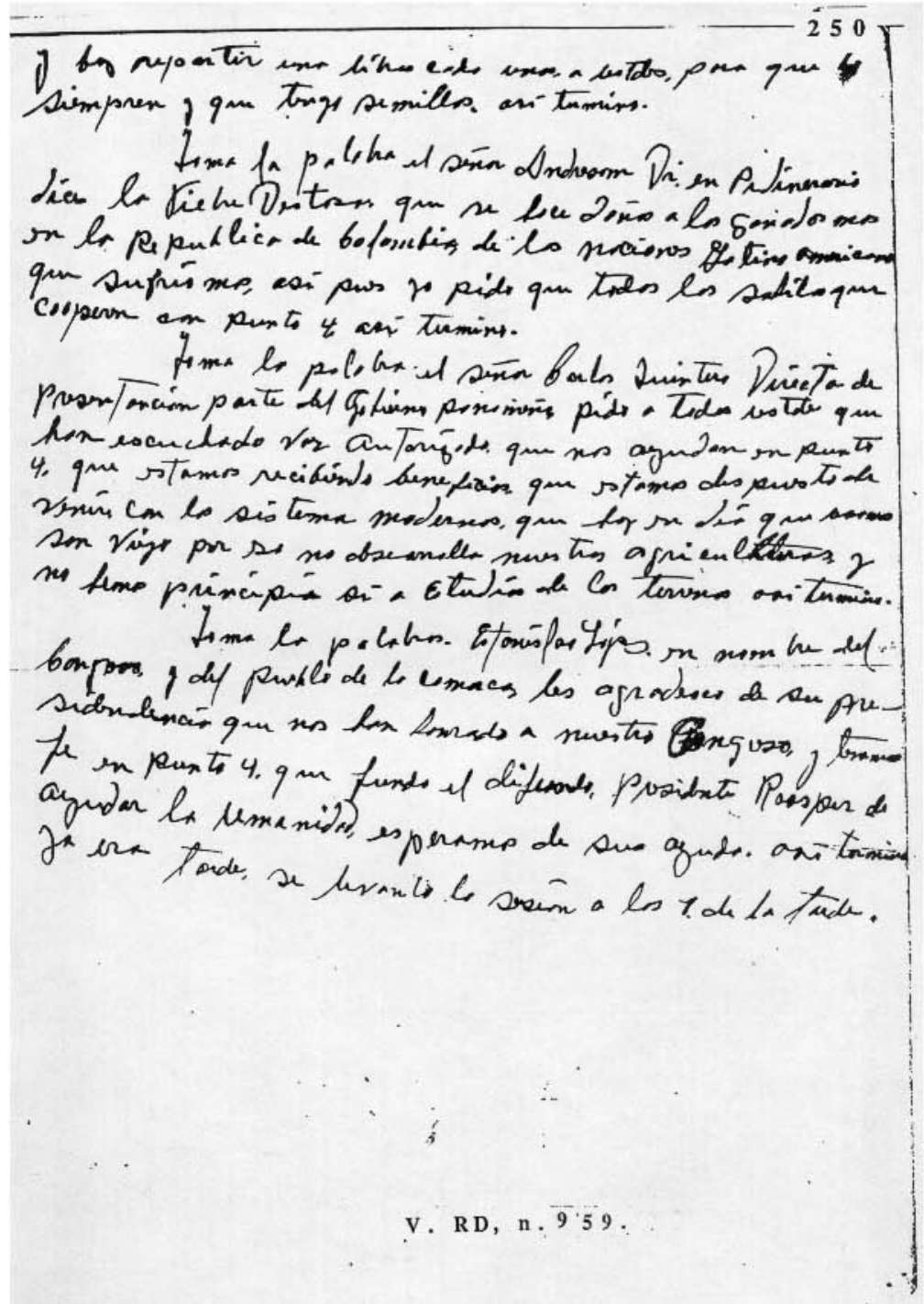




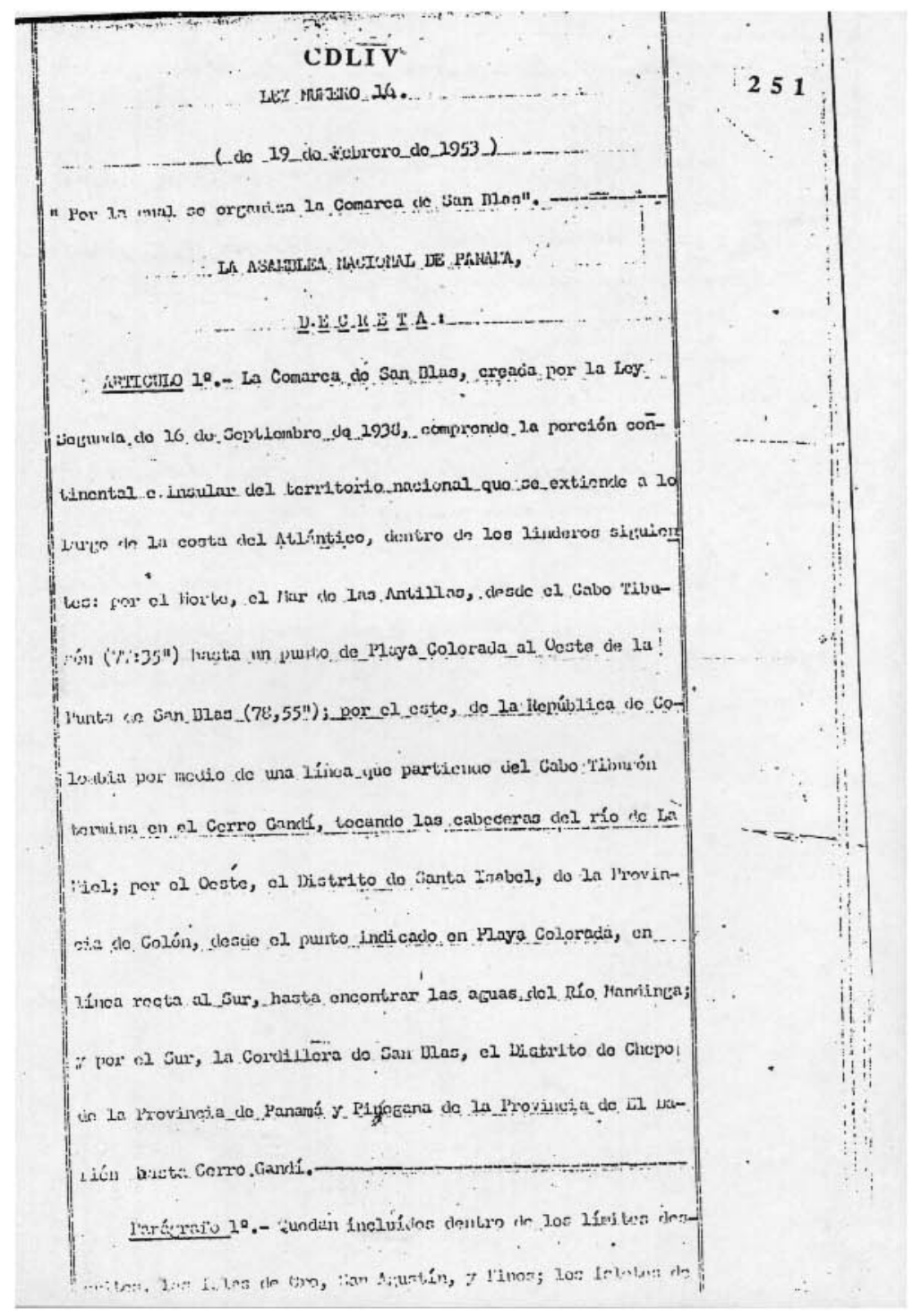




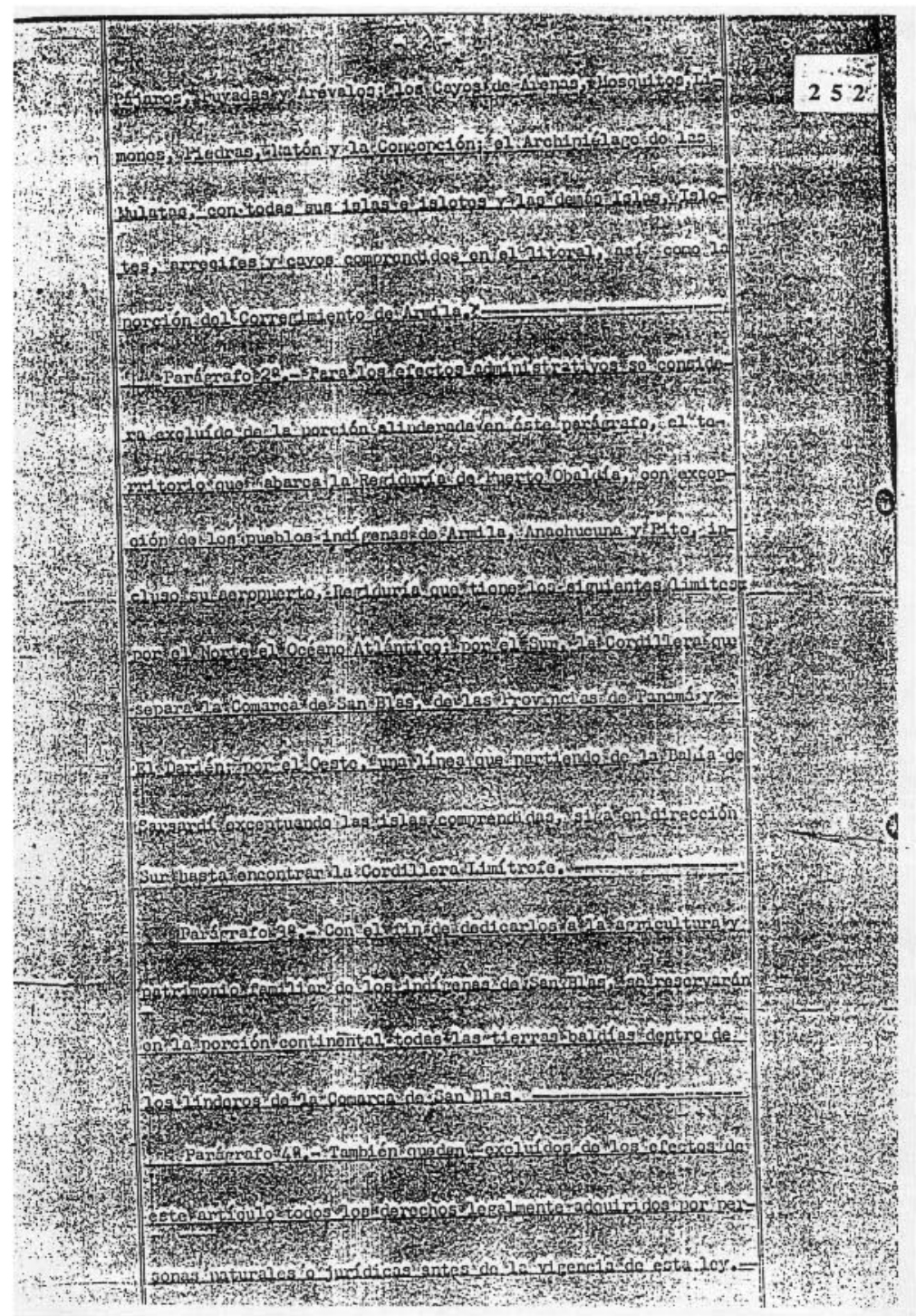




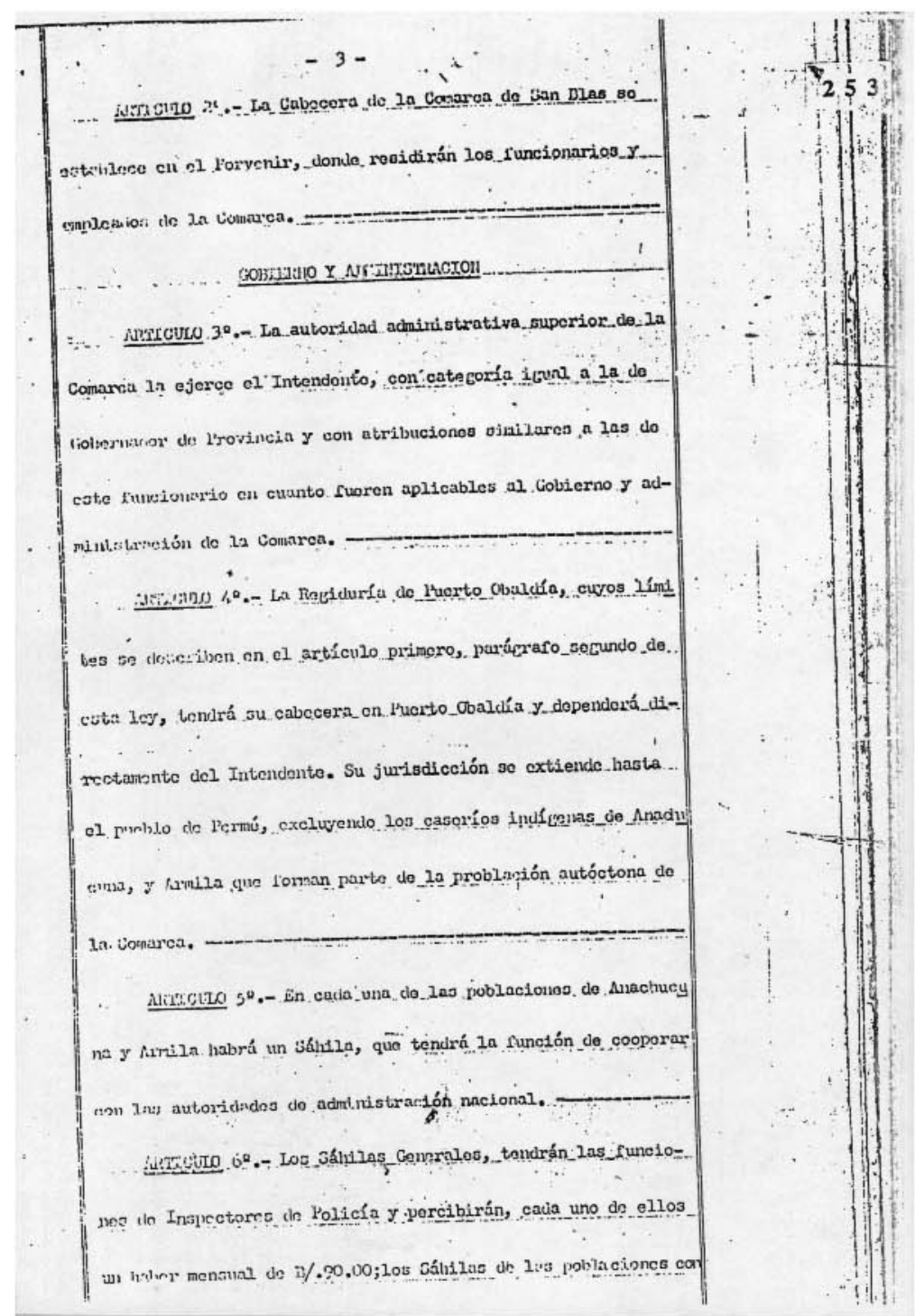




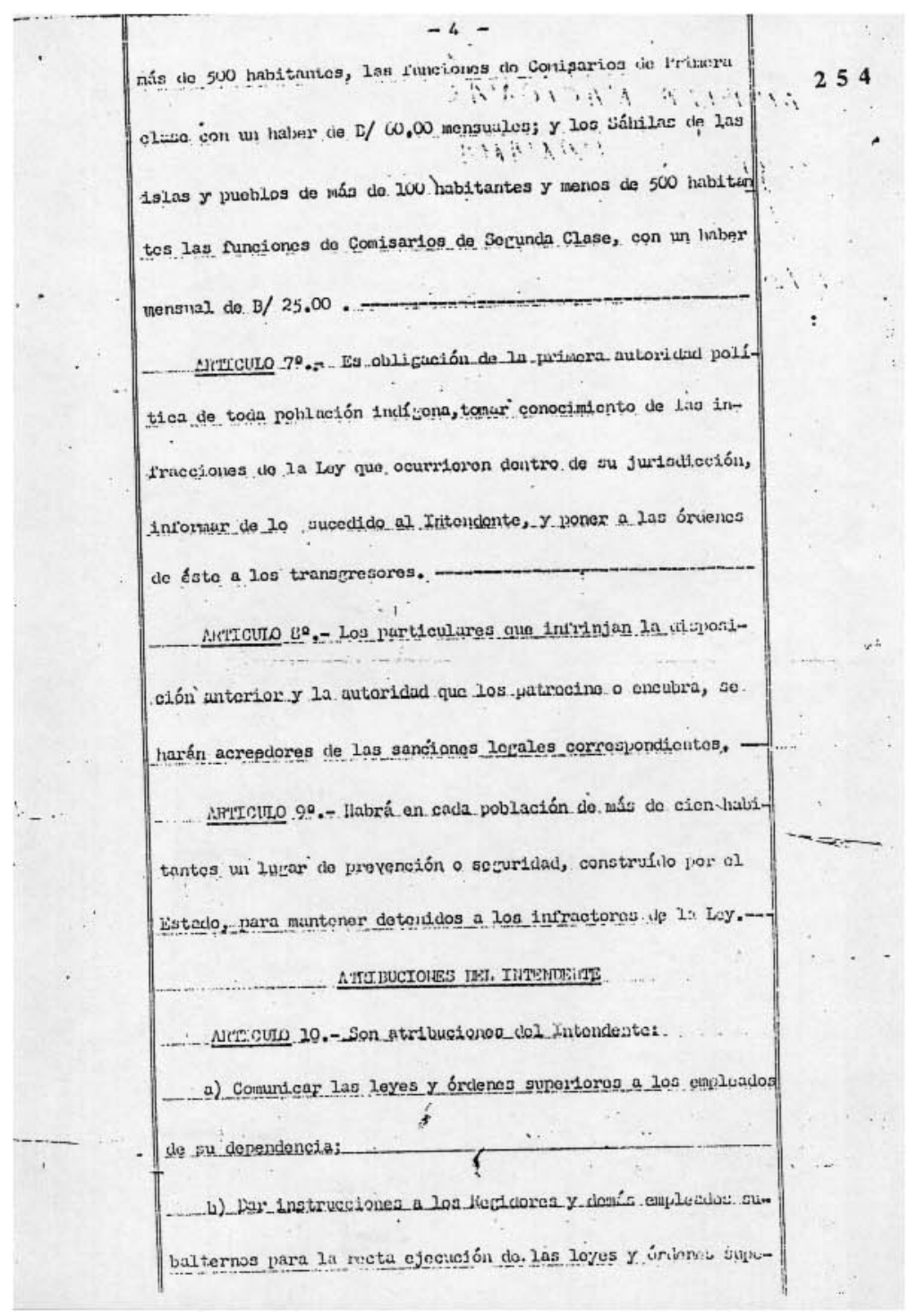




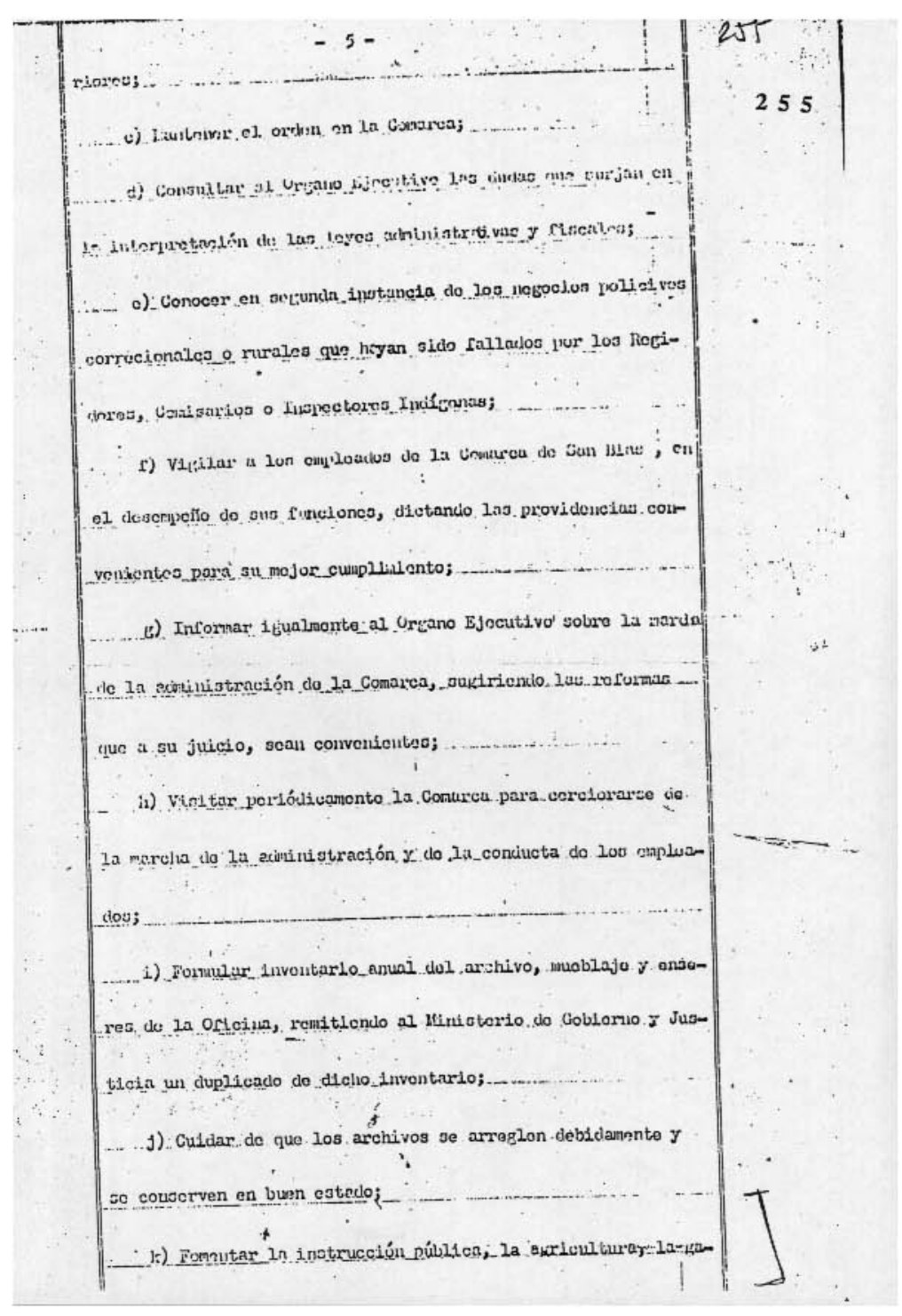




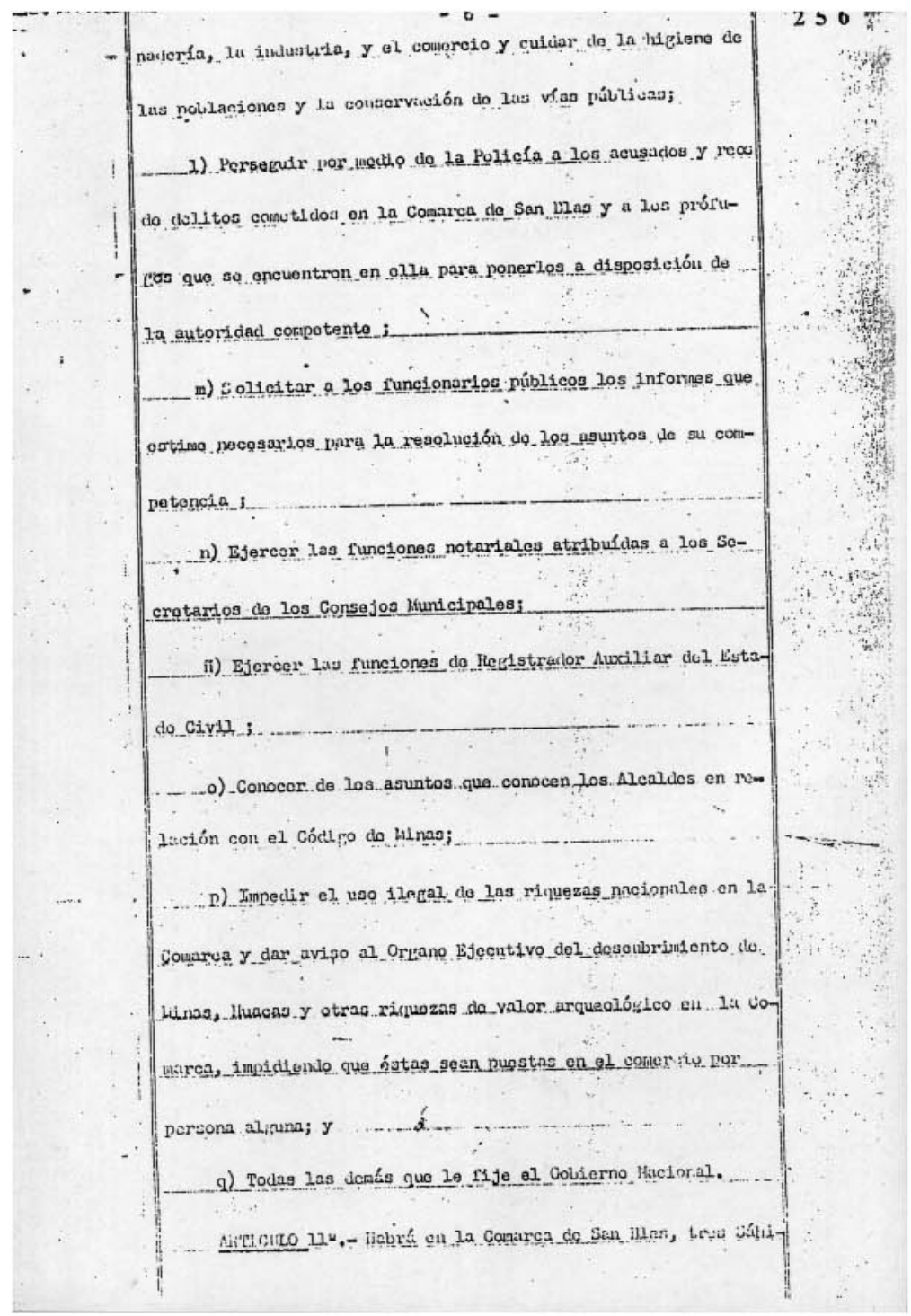




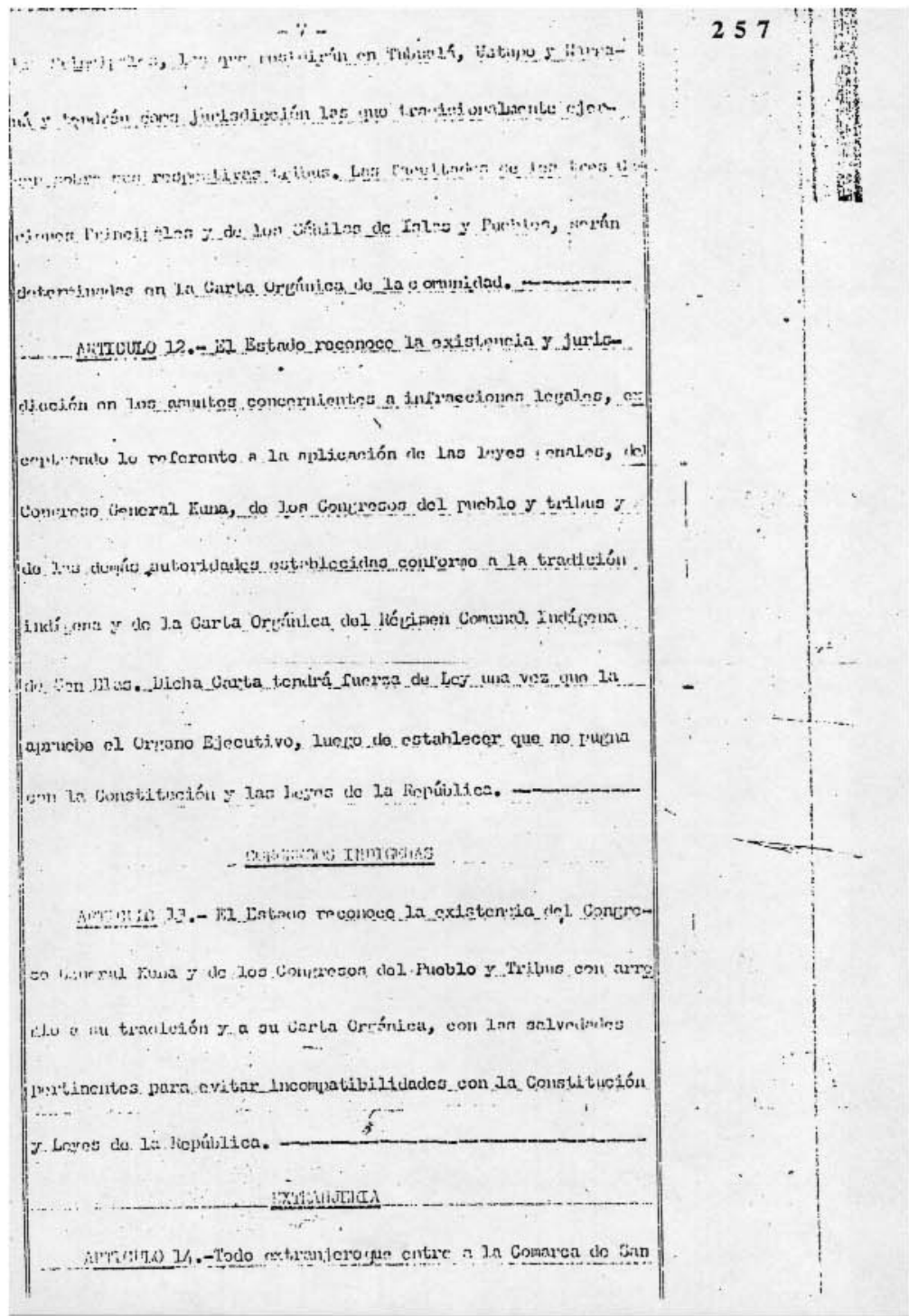




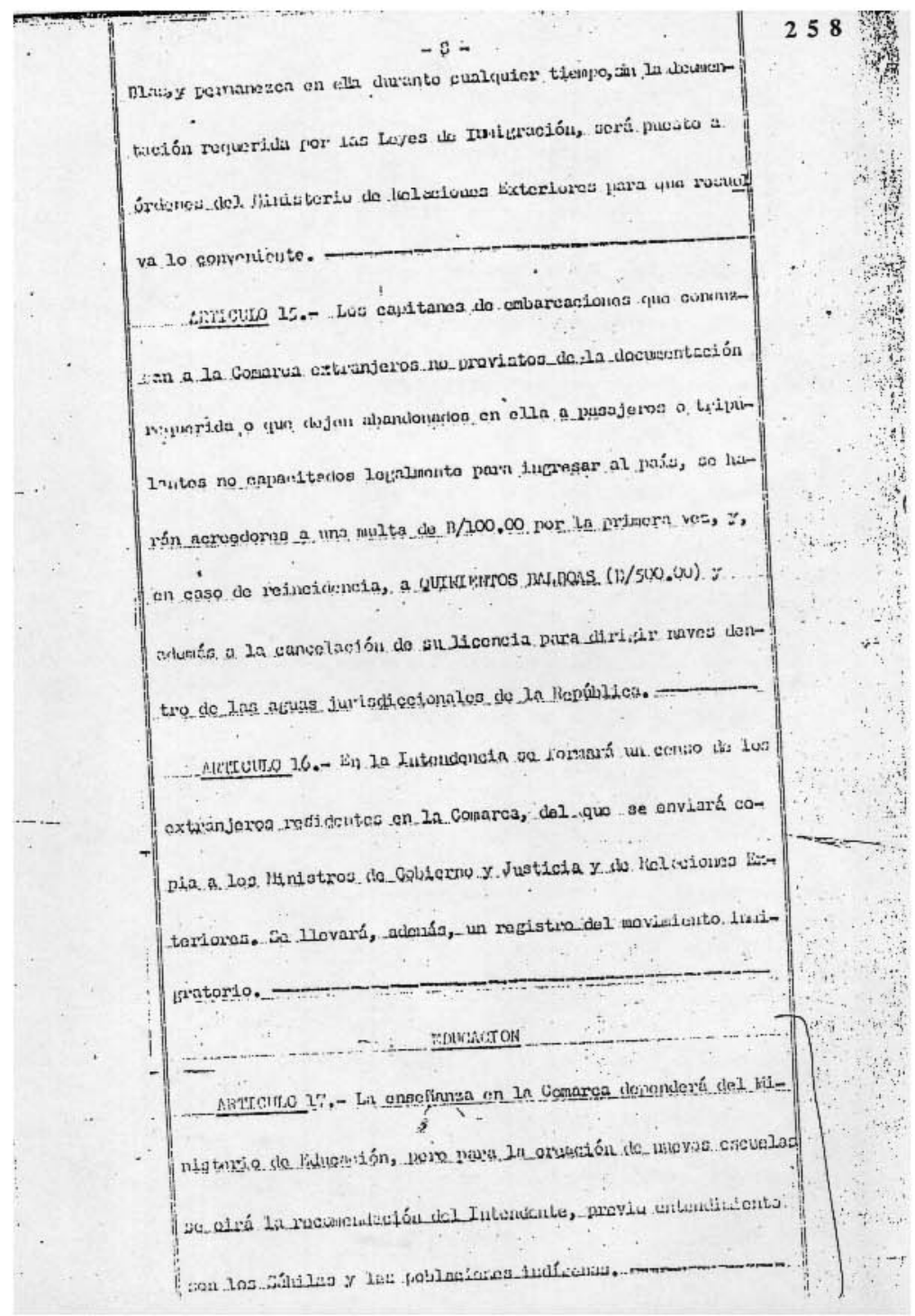




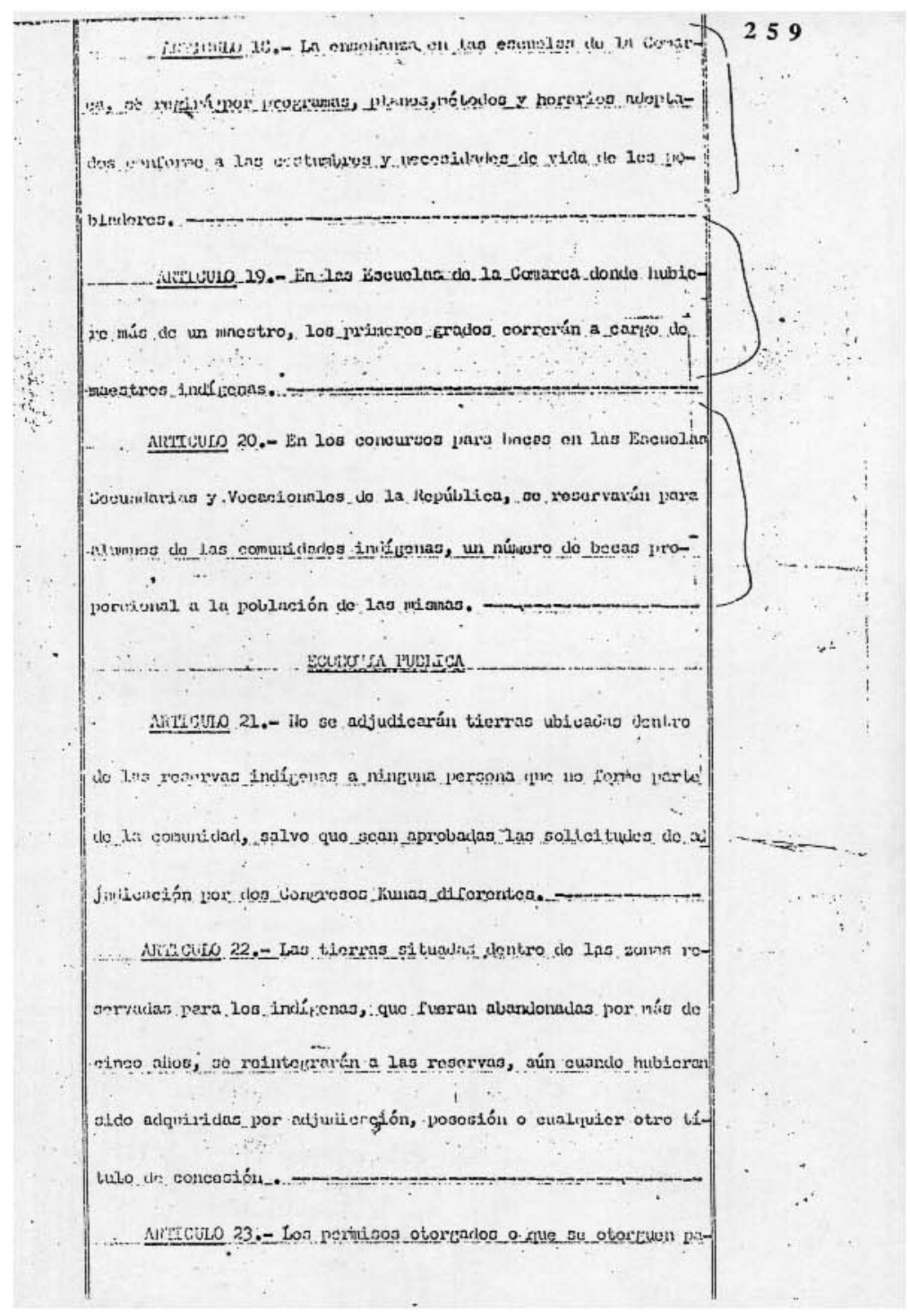




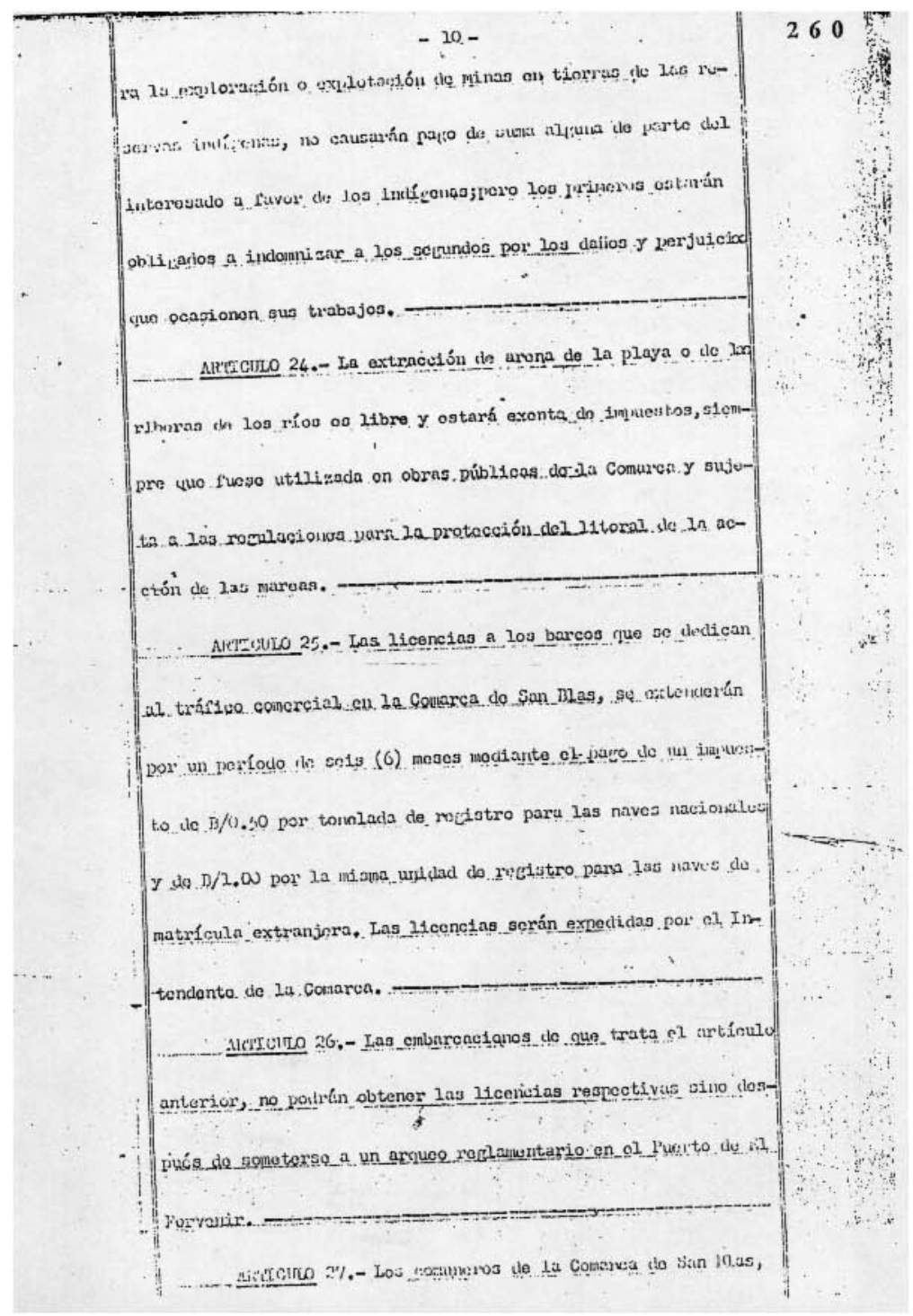




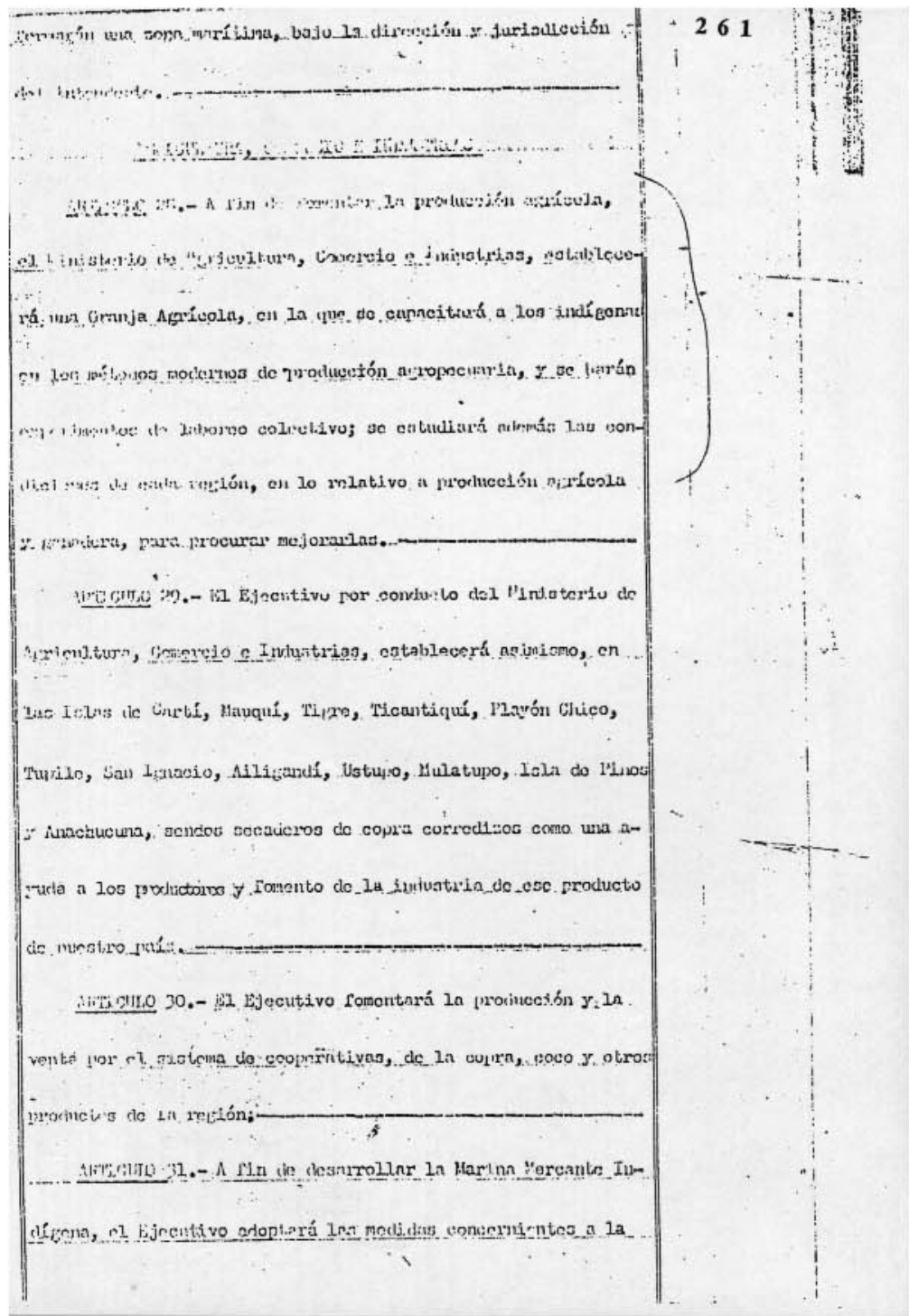




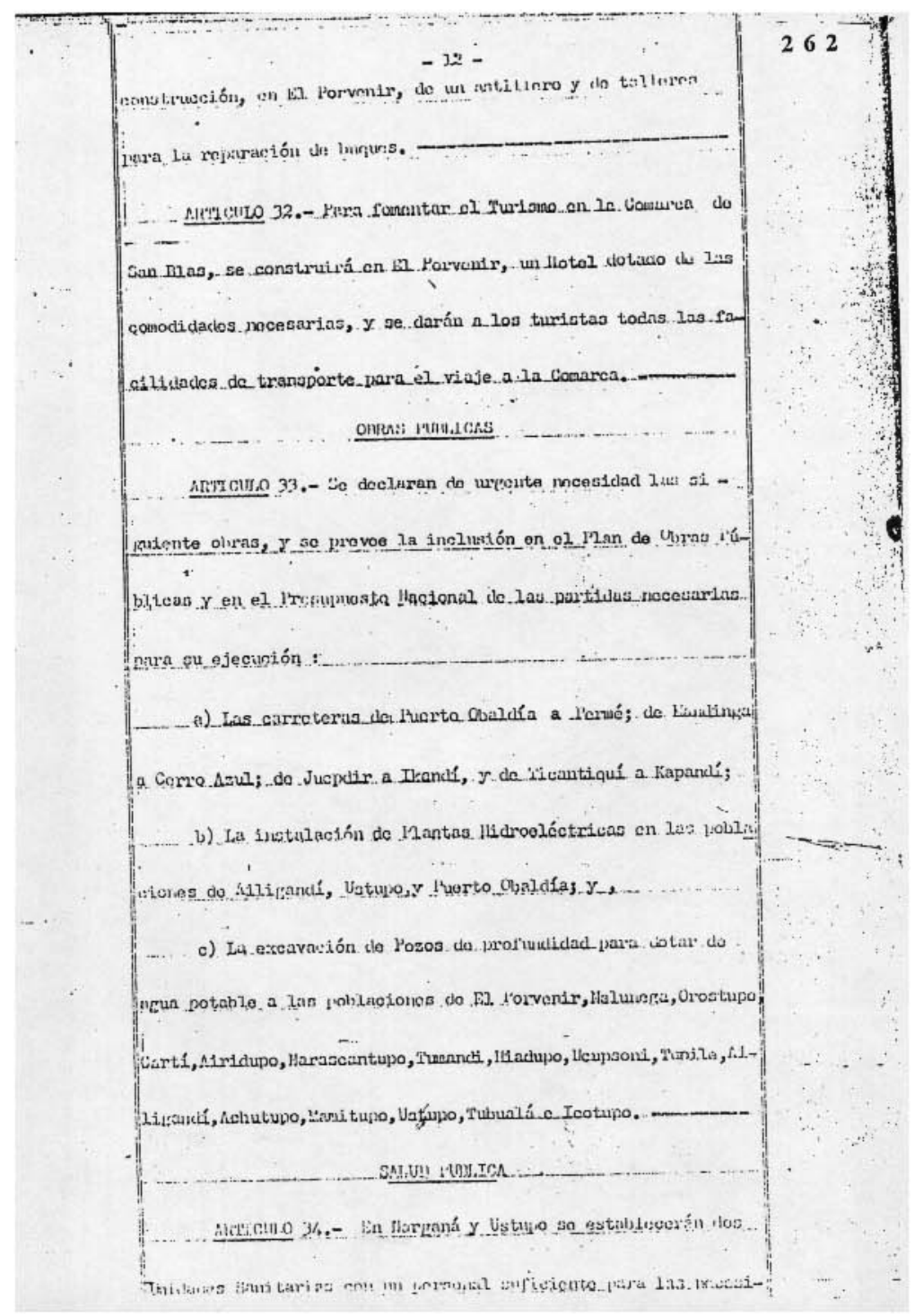




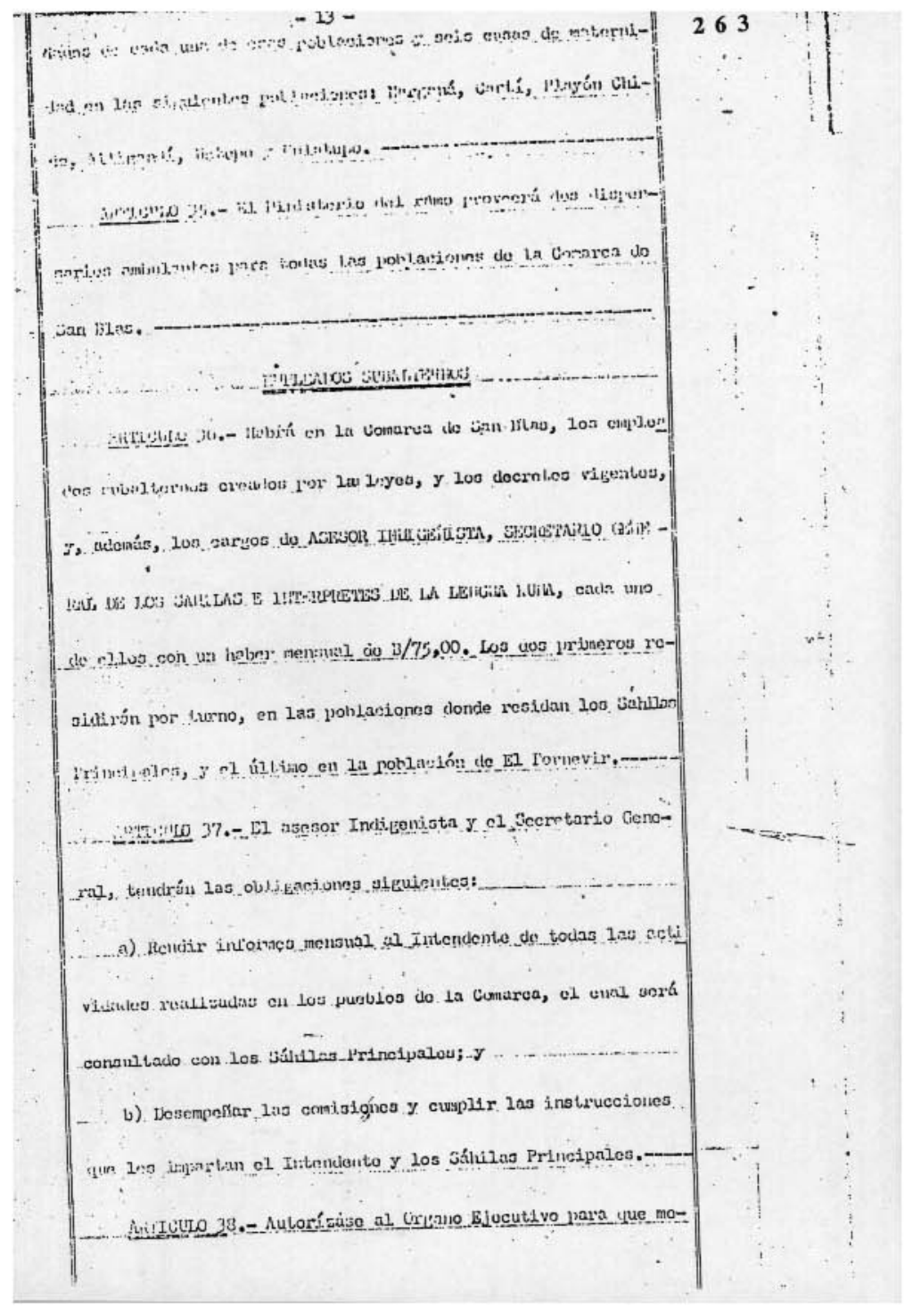




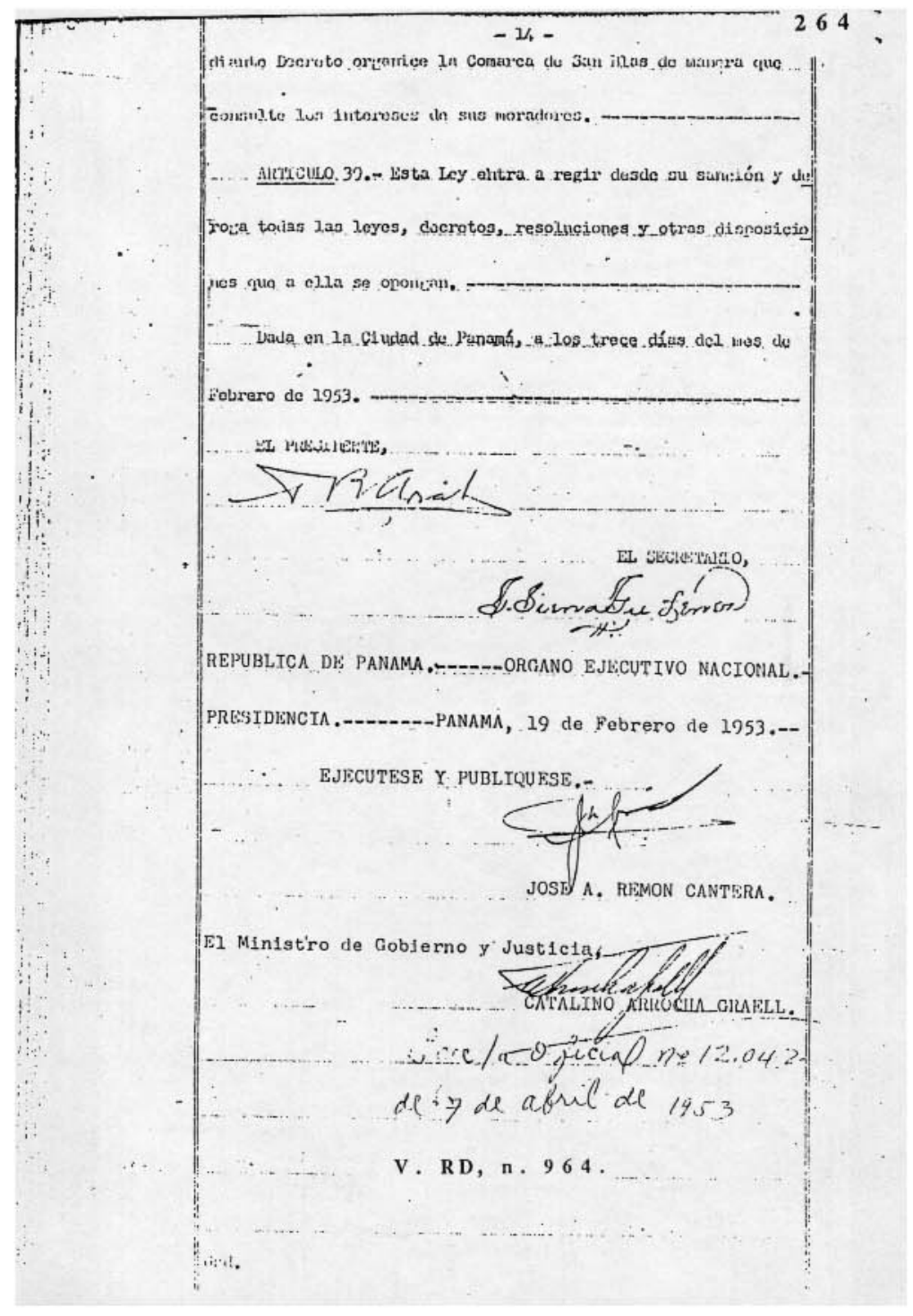




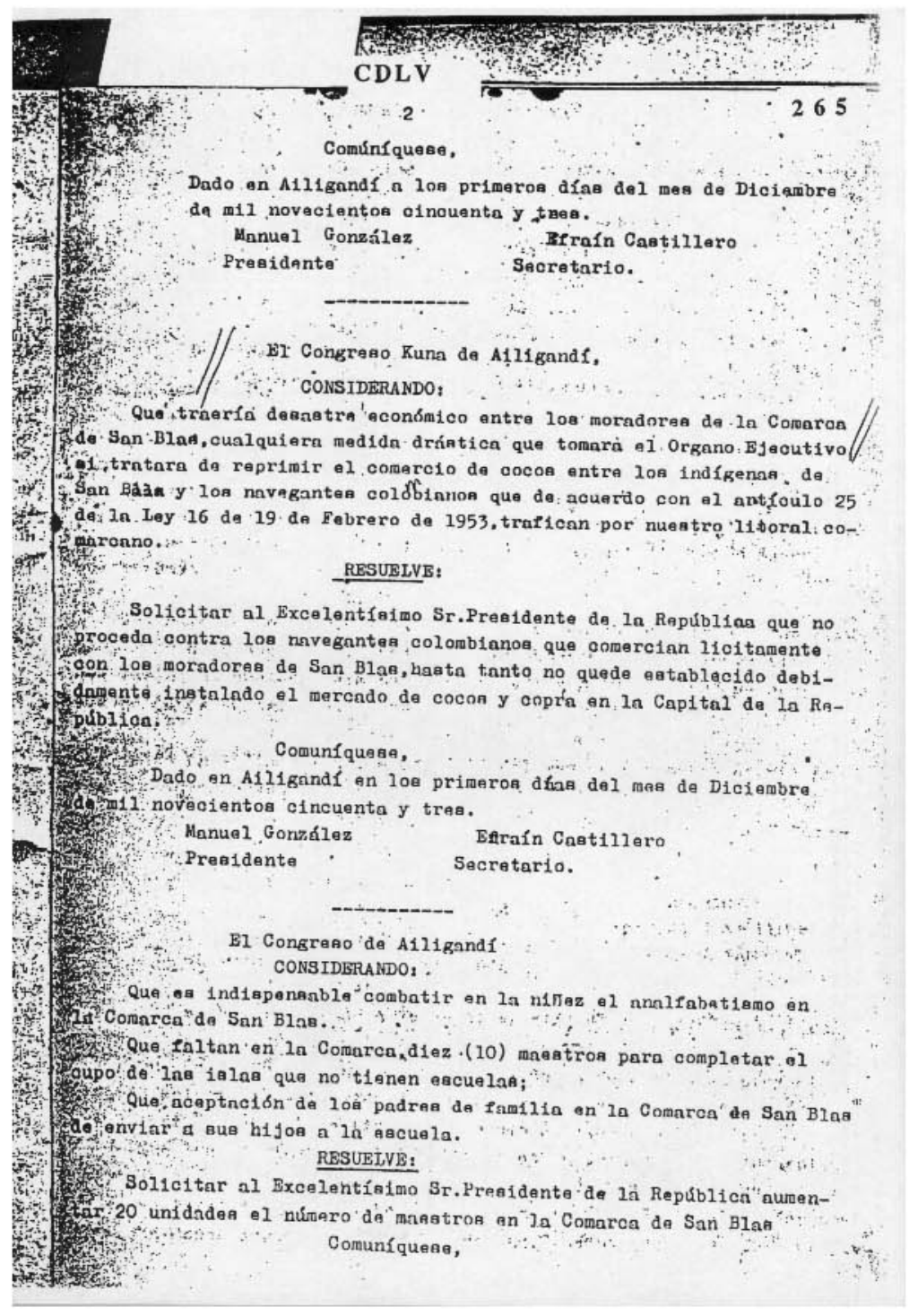




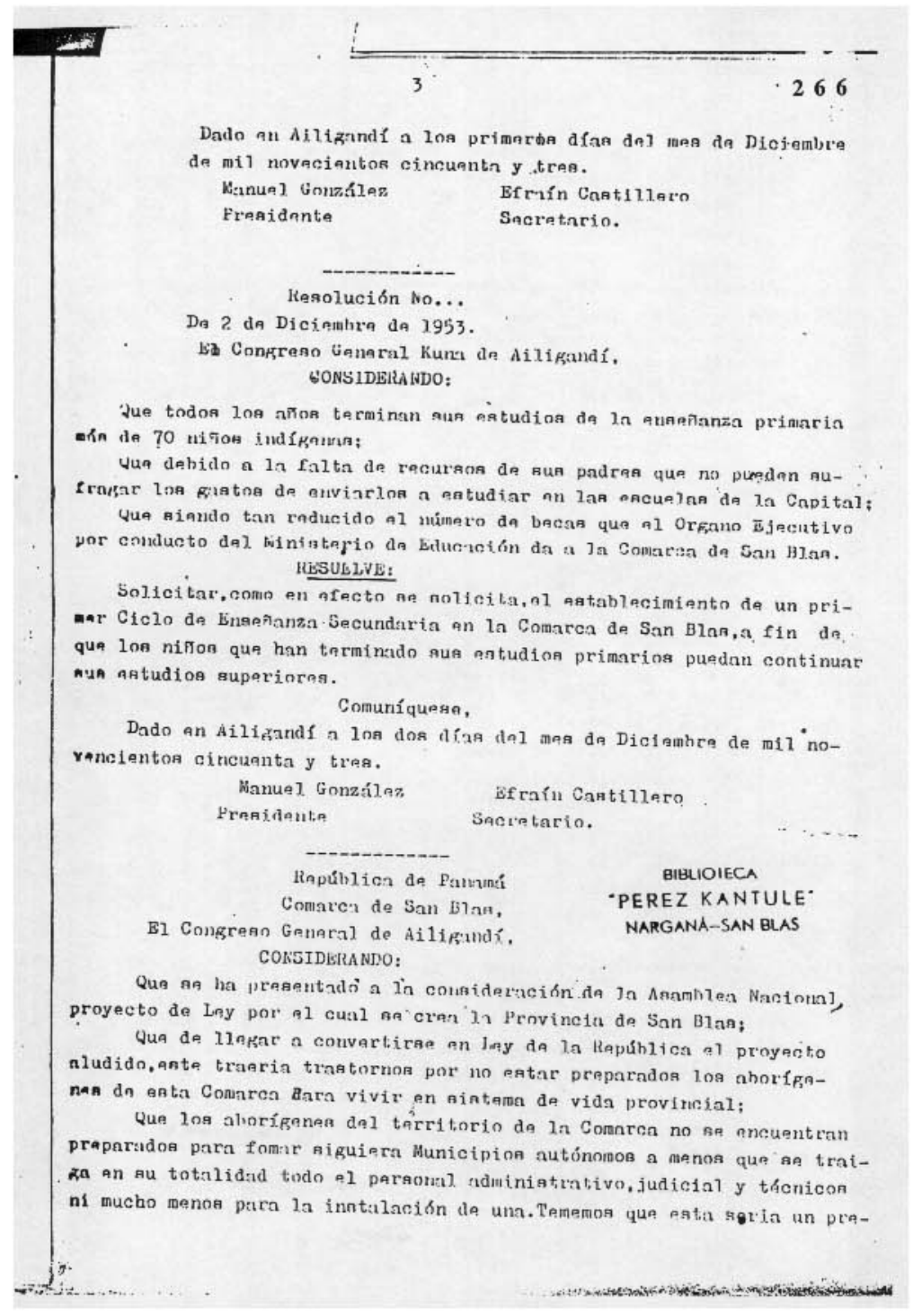




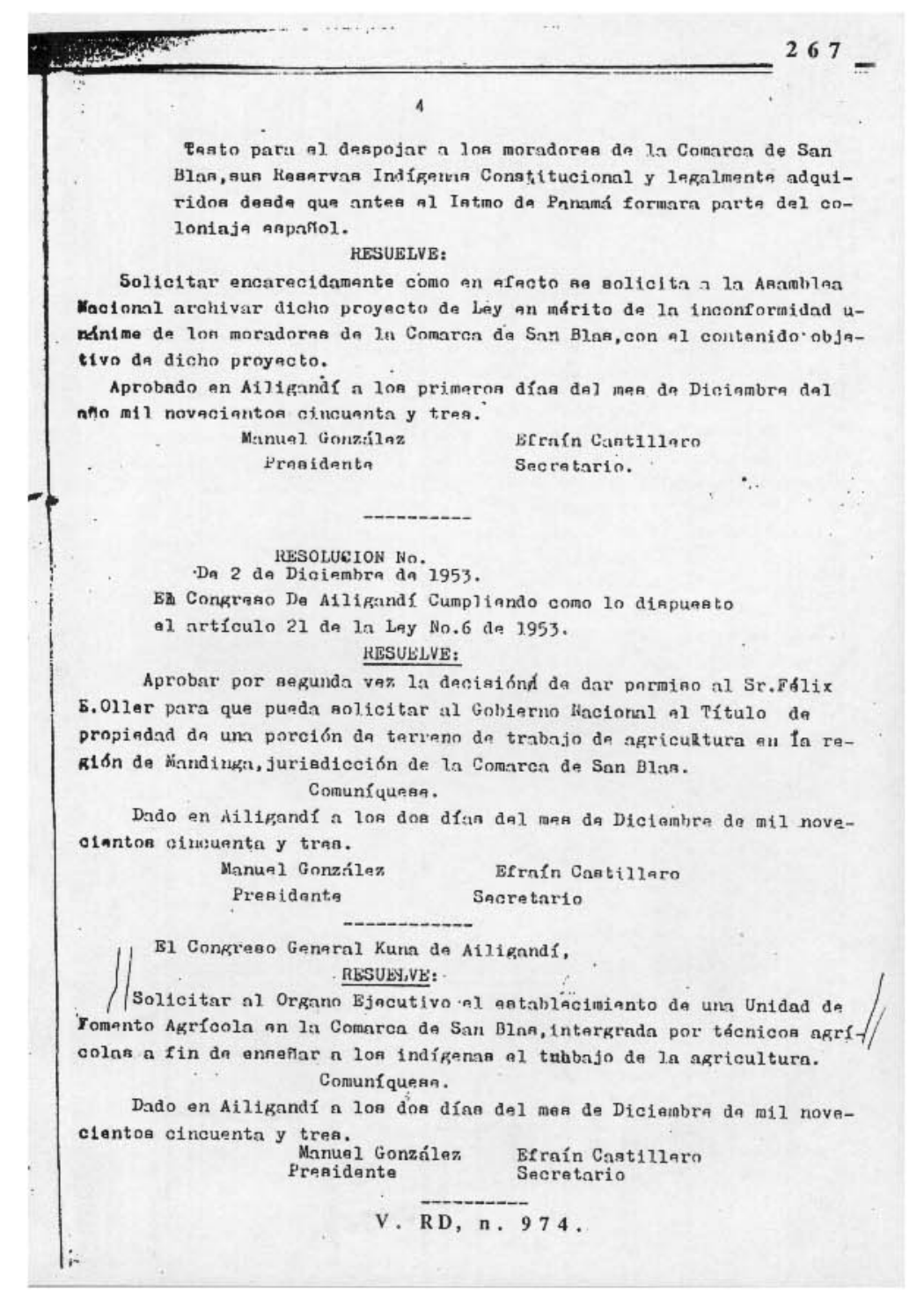


ARTICULO 1: La Comarca de San Blas, comprende el territorio de la Costa Atlántica: entre los linderos siguientes: por Norte, con el Mar de las Antillas; por el Sur, con Puerto Obaldía; y por la Cordiliera de San Rlas; por el Este, con Puerto Obaldia; el Ceste, con la línea que partiendo de playa Colora. ta comprendidas dentro de la delimi$\triangle$ RTICULO 2: Las tierras artículo anterior, son de propiedad de la comunidad de San Blas, y de toda adjudicación a indín

CAPITULO II

AUTORIDADES COMUNALES

RTICULO 3: Las comunidades indígenas de San Blas, para su Gobier ARTICULO 3: Las local, están sujetas a sus autoridades propias, elegidas por los comuneros. Dichas autoridades se desempenan y demás Lemás limitación

ARTICULO 4: Las autoridades comunales son:

a) El Congreso General Kuna

les

b) Los Congresos locales

c) Los tres Caciques Generales (sânila de más de qui-

los Sahilas para las poblaciont)

) nientos comuneros labar pien

Los Sáhilas para las poblaciones de más

f) $\mathrm{y}$ men Argarganas (voceros)

f) Los Argarganas (voceros

\section{CAPITULOC III}

CONGPESOS

ARTICULO 5: Los Congresos son Generales y Locales.

APTTCULO 6: Los Congresos Generales se reunirán por 10 menos,

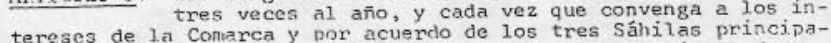
tereses de la comarca te comorca. Las sesiones durarán ocho (8) días útiles.

ARTIrULO 7: Será scde del Congreso General, el escogido por los tres Sáhilas principales de acuerdo con el Intendente, con 30 días de anticipación por lo menos.

ARTICULO B: El Sáhila General, quien preside el Congreso en sesión inaugural, rendirá informe verbal, dará cuent de las obras ejecutadas, expondrá los problemas vitales y de actualidad y expondra la rralizacion de las obras que considere como ejemplos educativos y morelizadores; rendirán culto a la rejigión y a los antenasados, todo. 10 cual se hará en cl centro del recinto y con ceminonial de estilo. 
ARTICULO 9: Enseguida se pondrá en dabate las cuestiones de inte-.

rés general. El debate será amplio, sin limitación alpuna, a fin de que puedan producirse los Sáhilas locales, los delegados acreditados $y$, en general, todos los comuneros que concurran a la sesión, con toda la libertad, formulando reparos y $\operatorname{cr} \frac{1}{2}$ ticas, sugerencias, formulas o procedimientos. Despues de agotado el debate, se procederá a tomar los acuerdos o resoluciones perti-
nentes por mayoría de votos.

ARTICULO 10: El Congreso General se constituirá con los Sáhilas gidos y con los argarganas, también elegidos. Pueden intervenir en la deliberación, todos los voceros comuneros e invitados presentes en la sesión.

ARTICULO 11: Son atribuciones de los Congresos Generales:

a) Dictar las medidas necesarias para el progreso de la Comarca y

b) Cuidar la conservación de la tradición, de las costumbres, de la xeligín, de la lengua y de la música. d) Dictar disposiciones defendiendo la pureza y la legitimidad de

e) Acordar la ejecución de obras que sean útiles a los habitantes

f) Cautelar los fondos de la comunidad, tomando en cuenta los gas tos de la recaudación.

g) Velar por la conservación de los bienes comunales. Dictar todas las disposiciones que juzgeen conveniente

ARTICULO 12: De las sanciones del Congreso General se llevará acestará bajo la dirección y dependencia de los tres Sáhilas Genera-

ARTICULO 13: Los debates del Congreso serán dirigidos por el Sáhí

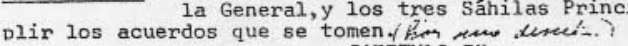

$$
\text { CAPITULO IV }
$$

DE LOS CONGPESOS LOCALES

ARTICULO 14: La realización de los Congresos locales serán obliga vez que lo convenga el sáhila del pueblo. APTTCULO 15: El Sáhila del pueblo preside el Congreso; rinde ei gresistas los acuerdos y las disposiciones del congreso los congresistas los acuerdos y las disposiciones del Congreso General; y somete a debate las cuestiones de interés local, las que deben APTICULO 16: Son atribuciones de los Congresos Locales:

a) Dictar las medidas convenientes al progreso de la localidad y bienestar de los comuneros.

b) Acordar la ejecución de las obras de utilidad y ornato para la localidád.

c) Examinar el manejo de los fondos de la comunidad.

Tomar nota de los acuerdos y resoluciones del Congreso General para su debido cumplimiento. 
e) Vigilar y controlar el funcionamiento de las tiendas del comercio que operan en el pueblo.

ATICULO 17: Los acuerdos del Congreso General y de los CongreRTICULO 17: Los locales, serán comunicados al Intendente de la comarca, para su aprobación o improbación.

ARTICULO 18: El Intendente de la Comarca de San Blas, puede con currir al Congreso General y a los congre opinión y represen les, y tomar parte en los debates llevando la op

ARTICULO 19: Para la organización y funcionamiento del Congreso pectivo dispondrá de sus colaboradores.

ARTICULO 20: LOS acuerdos y disposiciones que adopten los ConARTICULO 20: Los acuerdos y disposiciones que adopten a la tr dición y a las buenas costumbres de la comunidad, ni estar en pugna con la Constitucion Nacional y

ARTICULO 21: Los Sáhilas principales tienen jurisdicción en toda ARTICULO 21: la Comarca; son los depositarios de la tradición Ku na; $10 s$ predicadores de la religión y de la Doctrina Kuna, los go bernantes y conductores de la comunidad.

ARTICULO 22: La autoridad de los Sáhilas es paternal, procura so lucionar las necesidades de la comunidad, dando pre ferencia a los intereses generales sobre los particulares, a 105 permanentes sobre los transitán obligados a observar conducta intachable en sus actos públicos y privados.

ARTICULO 23: Por impedjento del Primer Sáhila (ausencia o enfer medad), le sucederá en el gobierno local, el segundo Sáhila y éste, por las mismas causas, sucedido por el tercero. mente a la tradición y a las prácticas del gobierno.

APTrCULO 24: Los Sáhilas locales son las legítimas autoridades los susilas locales son las desempeñándose conforme a la tradición y buenas costumbres.

APTICULO 25: Para todo informe al Intendente o acuerdos con él u otras autoridades nacionales; y para casos de que del Conpreso Kuna o de los Locales serín los casos de que se trate.

$$
\text { CAPITULO } \mathrm{V}
$$

\section{DE LOS SUAPIBCAMAS}

A.FTICULO 26: Los Suaribganas son elegidos por los comuneros, en número na menor de 20 no mayor de 50 , segín

ARTICILA 27: Sus funciones:

a) Convocar a los delegados y a los comuneros cada vez que haya Congreso.

b) Cuidar en las sesiones del Congreso, el orden, estimulando a los debates que se produzcan.

c) Atender a los visitantes $v$ a los turistas (extrafios) 
ARTICULO 28: Los Argarganas son elegidos por los comuneros según el número de habitantes del pueblo, teniendo en cuenta sus limpios antecedentes, su capacidad y sus condicio los Ritos.

ARTICULO 29: Sus funciones son:

a) Interpretar y explicar los informes que rinde el Sâhila.

a) Interpretar y explicar los informes que rinde el

DEL PATRIMONIO COMUNAL

ARTICULO 30: El patrimonio comunal está formado:

a) Por las tierras de sembradíos y de estos naturales de dominio

y posesión.

Pros fonclos provenientes de cuotas, de trabajos comunales,

c) Los bienes dejados por los que mueren, sin dejar herederos re conocidos.

ARTICULO 31: Las tierras comunales son imprescriptibles, inajena utilidad pública o de necesidad social y previa indemnización, además, inembargables.

ARTICULO 32: Los bienes comunales no son responsables por deudas u otras obligaciones de los comuneros, adquiridas individualmente.

ARTICULO 33: Habrá un administrador y tesorero de bienes y foncomunidad, teniendo en cuenta su solvencia económica y su honorabilidad. 'Y podrán ser reelegidos hasta por dos veces.

ARTICULO 34: Es fuente principal de la economía de la Comarca la producción de los cocos y la elaboración y ventạ de la copra. Por consiguiente, es obligación de las autoridades co:munales y de los comuneros individualmente, mantener en el mercado el más alto precio posible, apelando a todos los medios lícitos.

ARTICULO 35: Para alcanzar y conservar el meior precio de los coducción y de venta. Dicha Juntá constará de cinco miembros elegi dos por los comuneros; y sus funciones serán las de cuidar la produccín y costo de las mercancías y diversos artículos que se ven-

\section{DE LA FAMILIA Y DE LA TPADICION KUNA}

ARTICULO 36: La familia es la base de la organización comunal; como tal es respetada y defendida. La bigania y el concubinato son delitos graves, penados severamente para defender la pureza y santidad de la descendencia. ARTICULO 37: En el matrimonio, la mujer lleva al varón, el que
está obligado a trabajar al servicio de la familia de su esposa. 


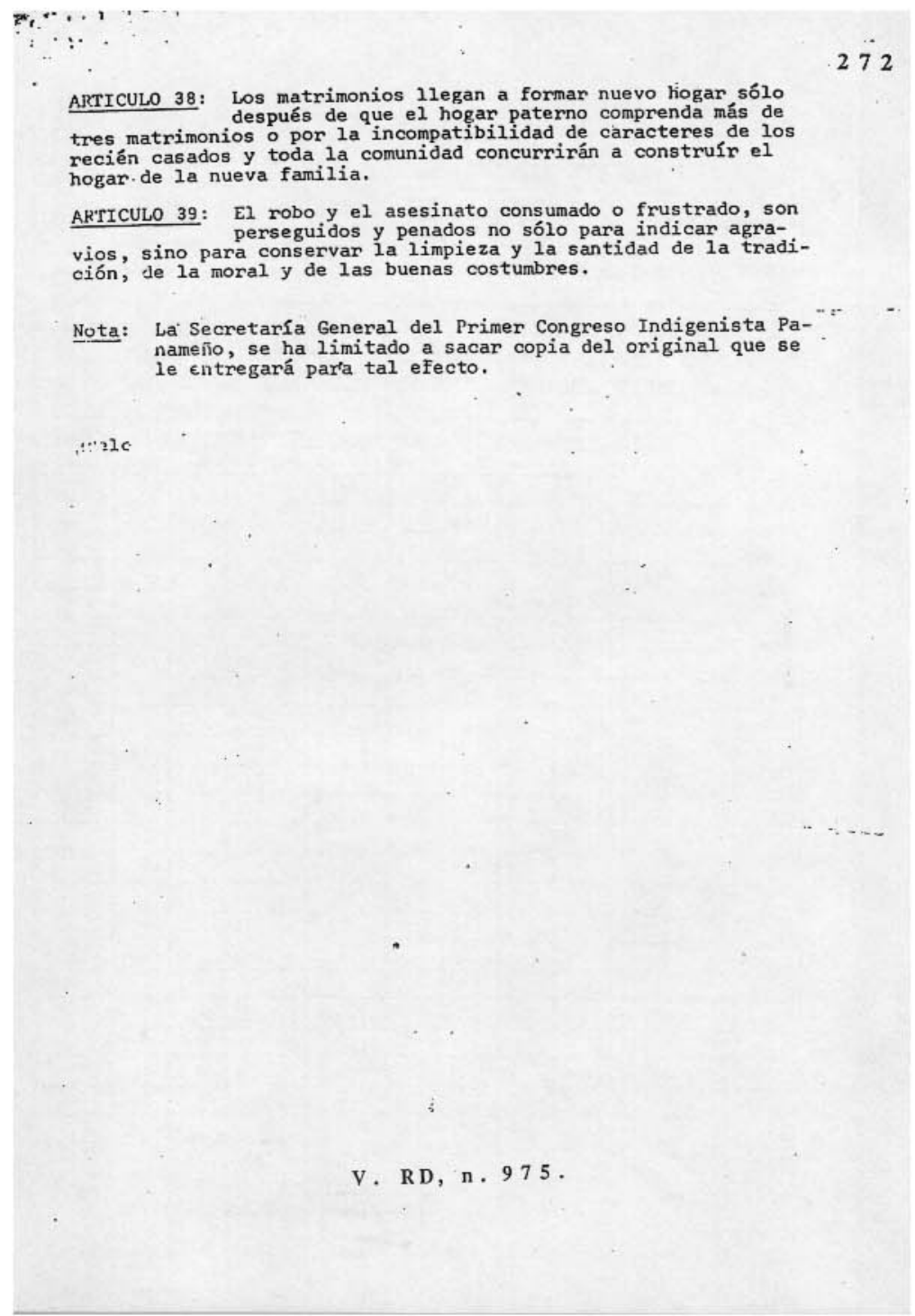


CDLVII

273

\begin{tabular}{|l|l|l|l|l|l|l|}
\hline & TABLA ESTADISTICA MENSUAL & & & & & N-71 \\
\hline & COMARCA DE SAN BLAS & & & & \\
\hline \multicolumn{5}{|l|}{} \\
\hline INTENDENTE DE LA COMABCA DE SAN BLAS
\end{tabular}

INTENDENTE DE LA COMARCA DE SAN BLAS

Señor:

A continuación encontrará usted $\propto$ dato de la Matricula y Asitencia de su escuela en el mes de la fecha Comparado con el mes útimoy con le correspondiente, del curso pasado

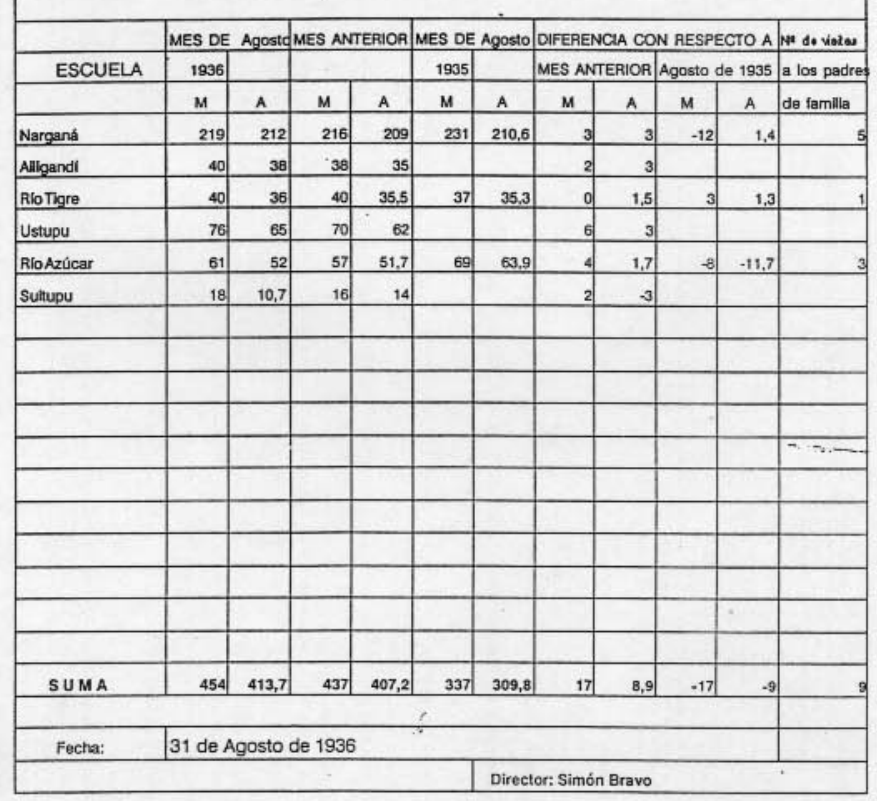




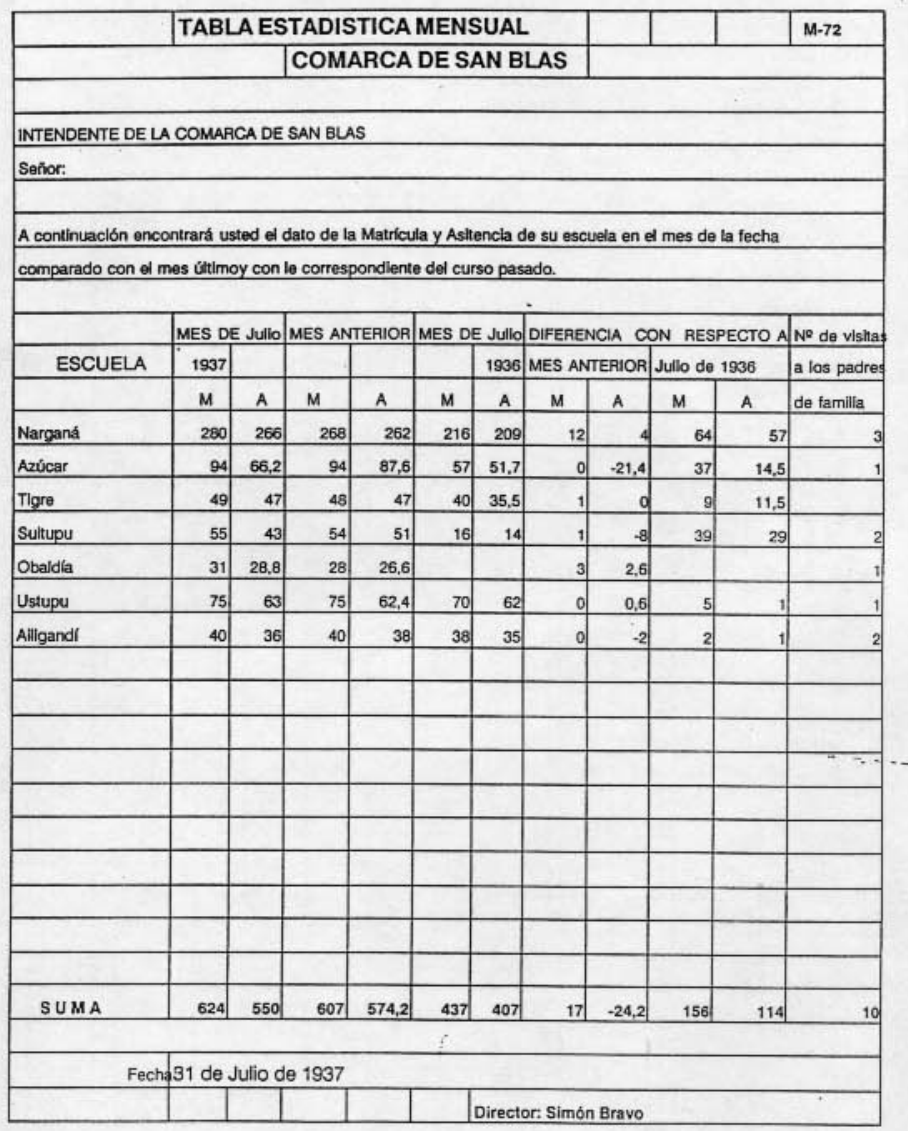




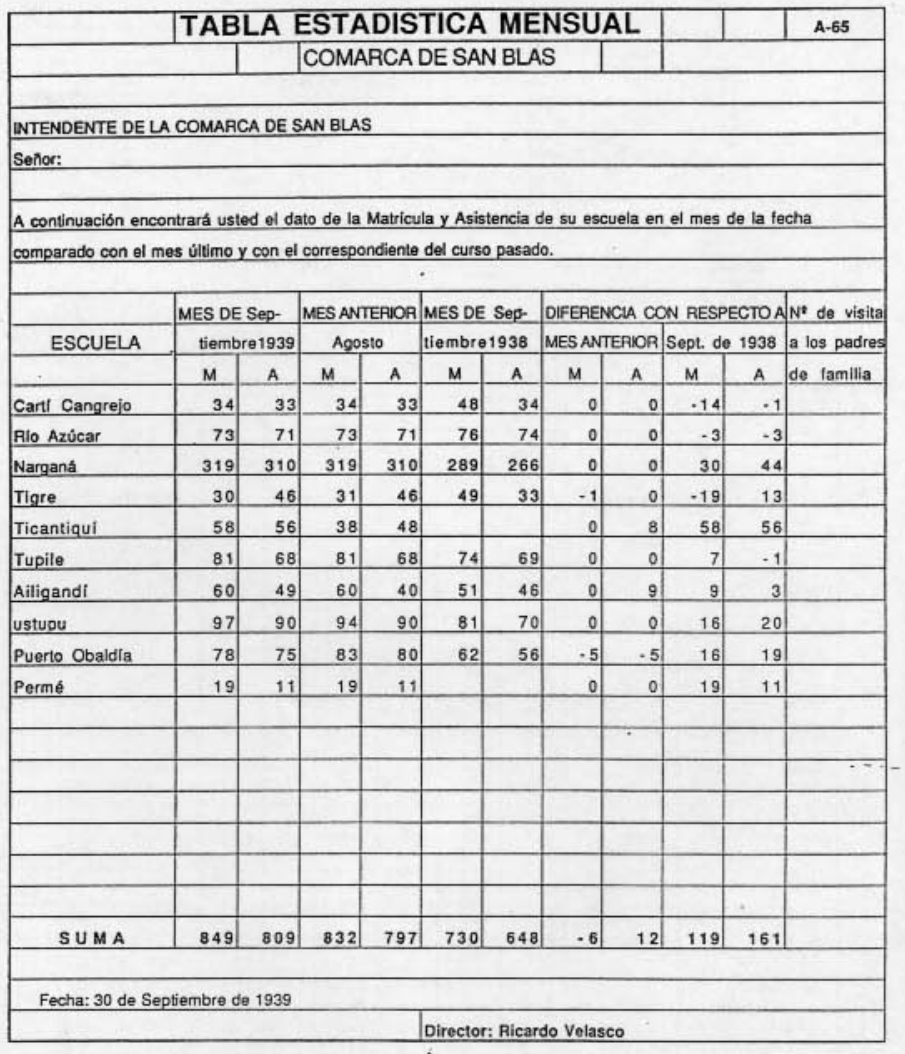




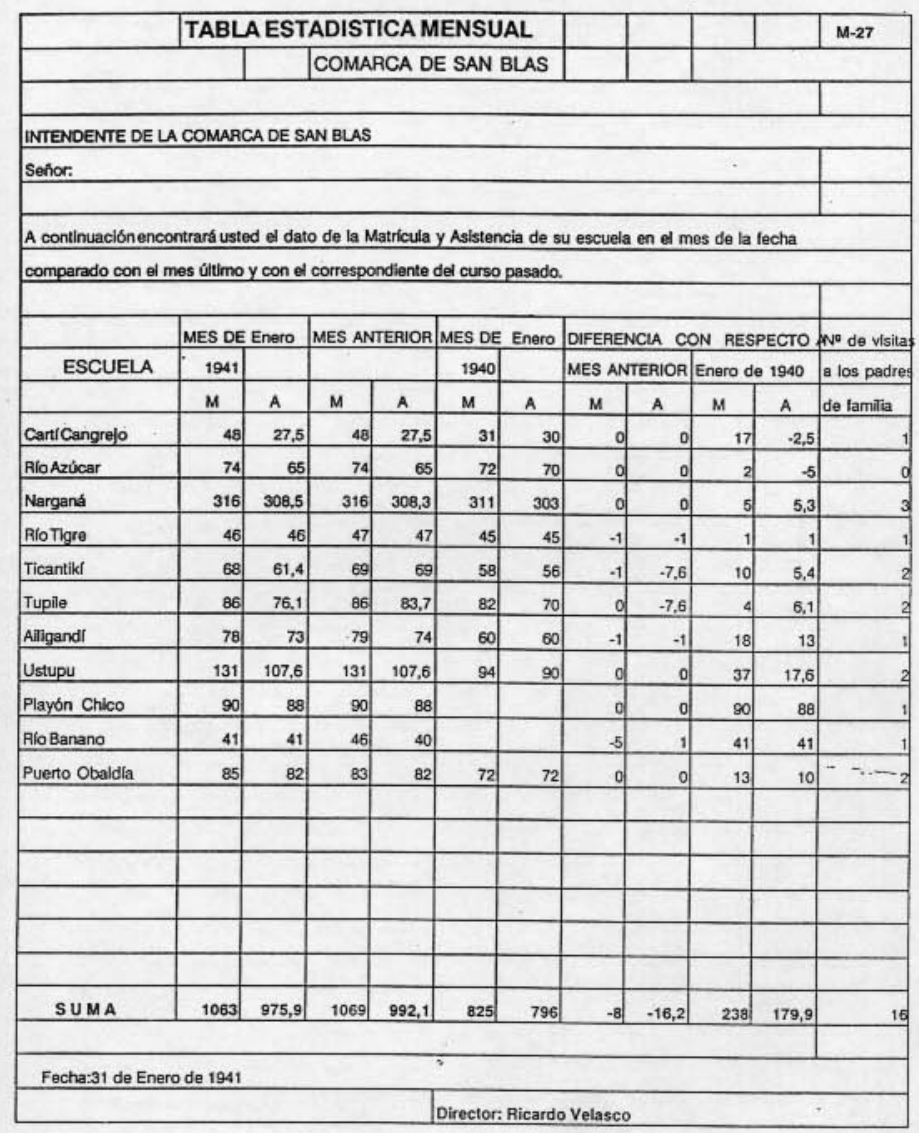




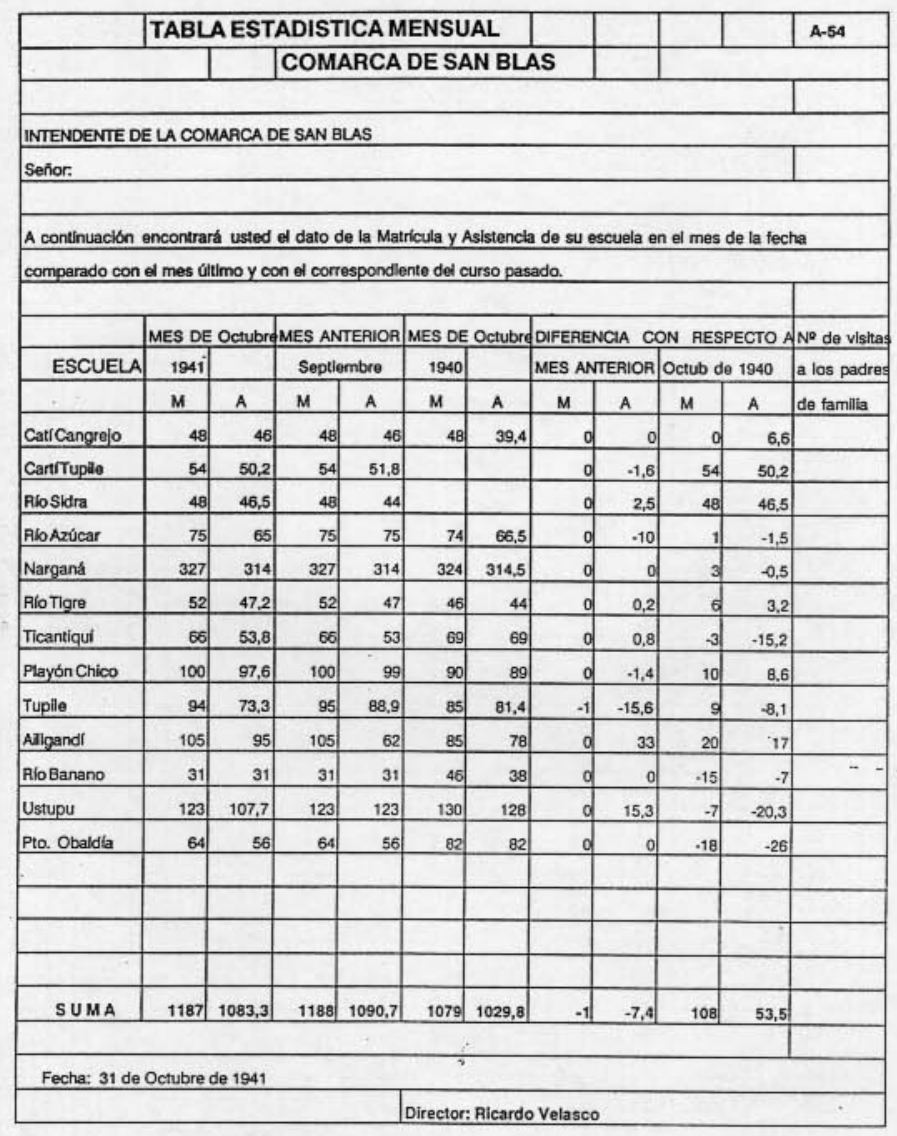




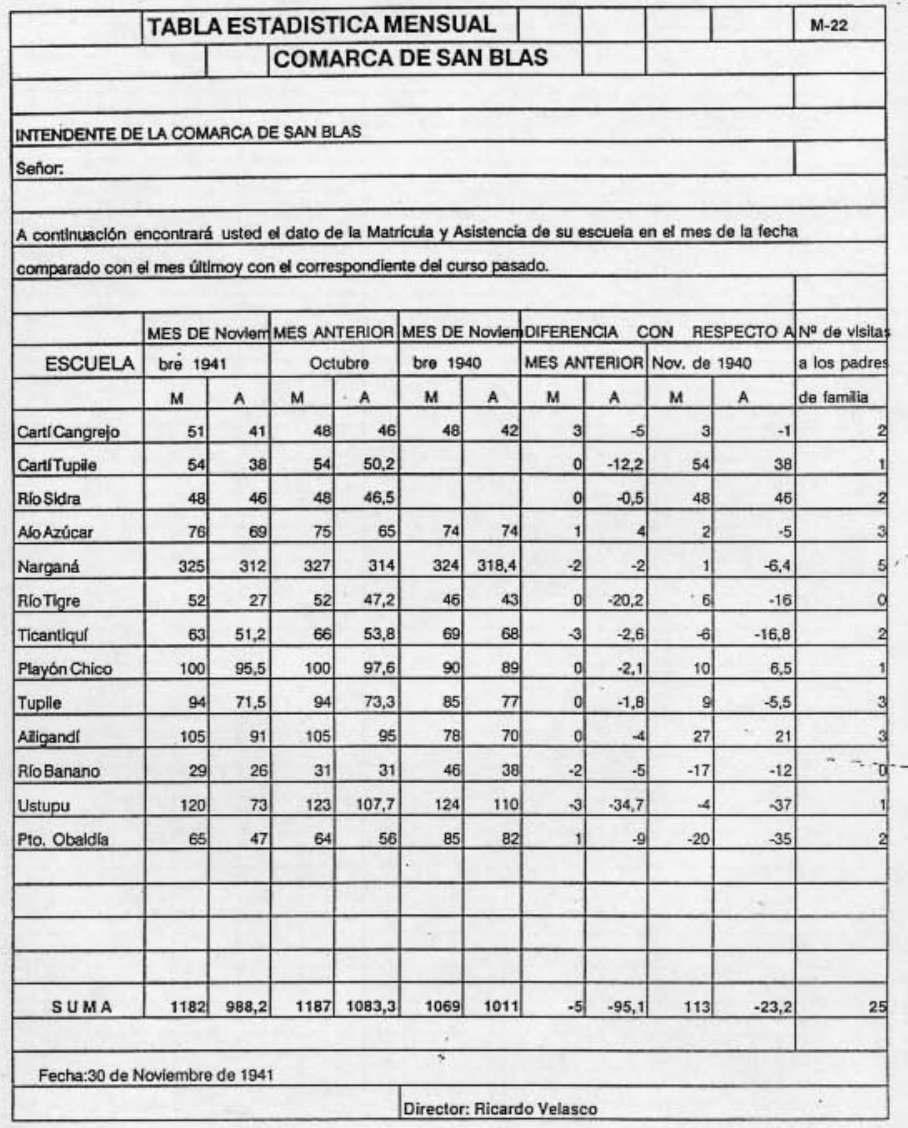




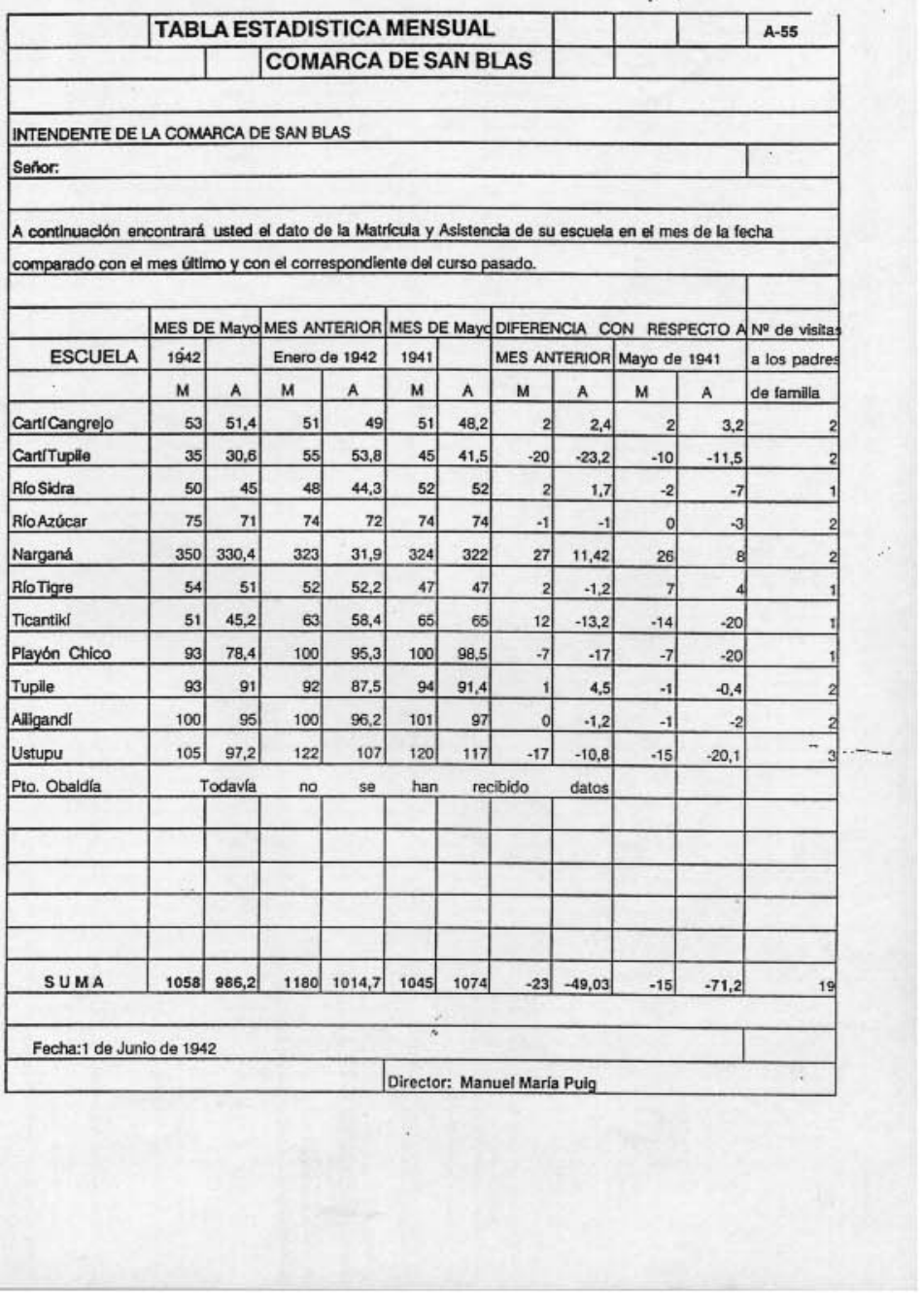




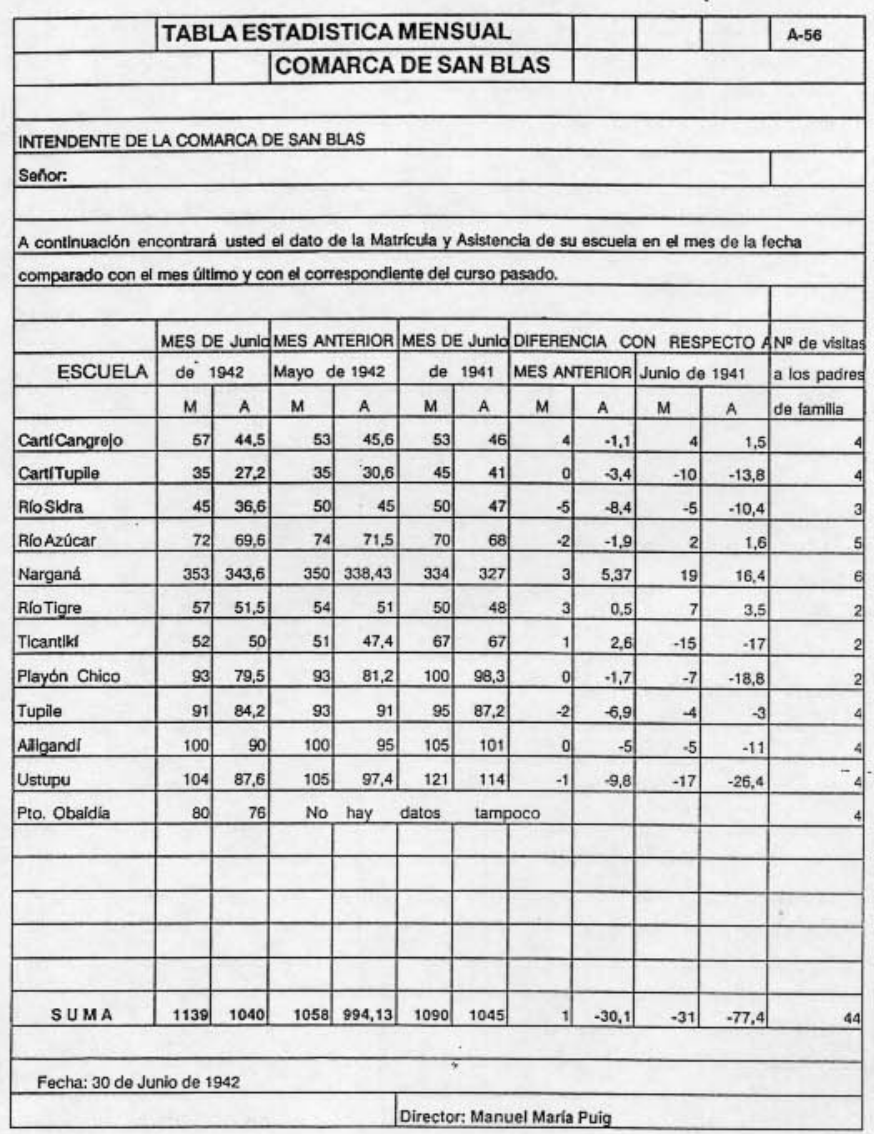




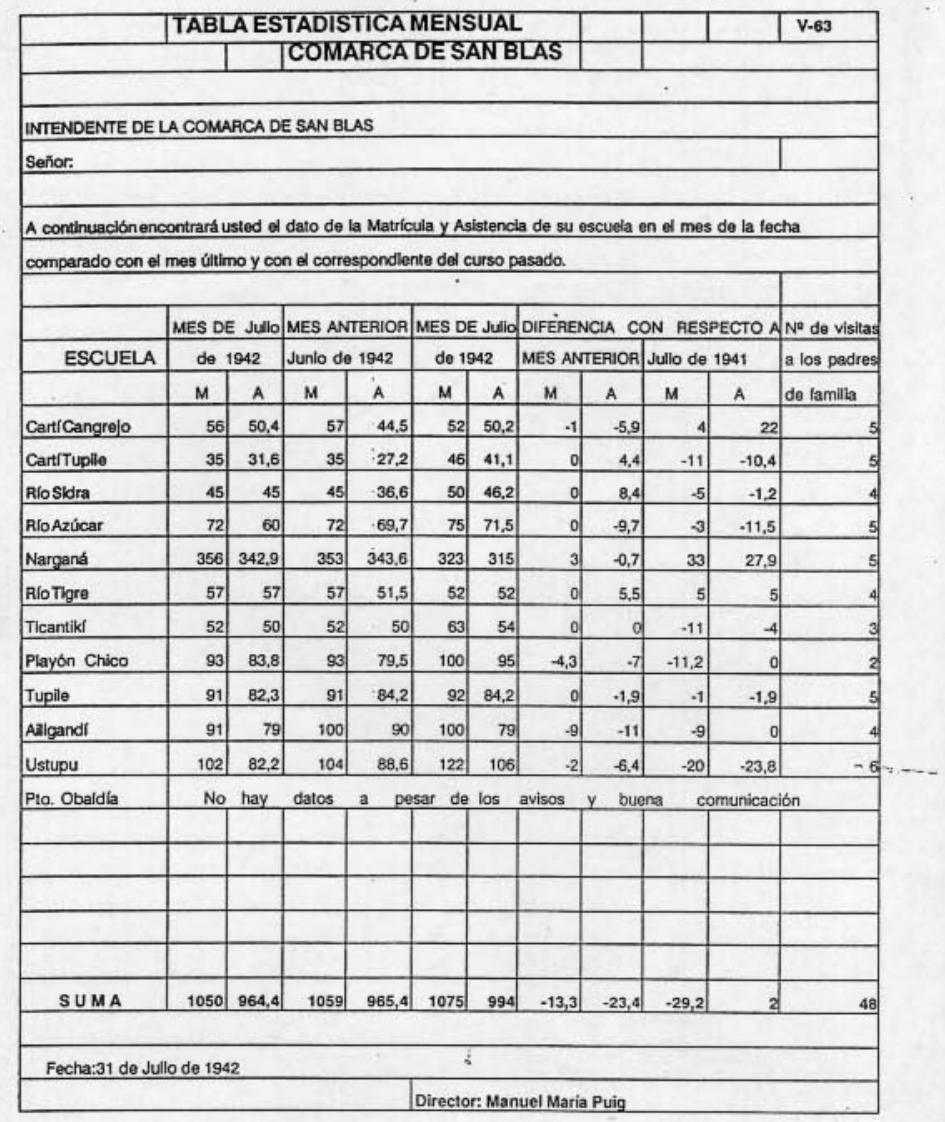




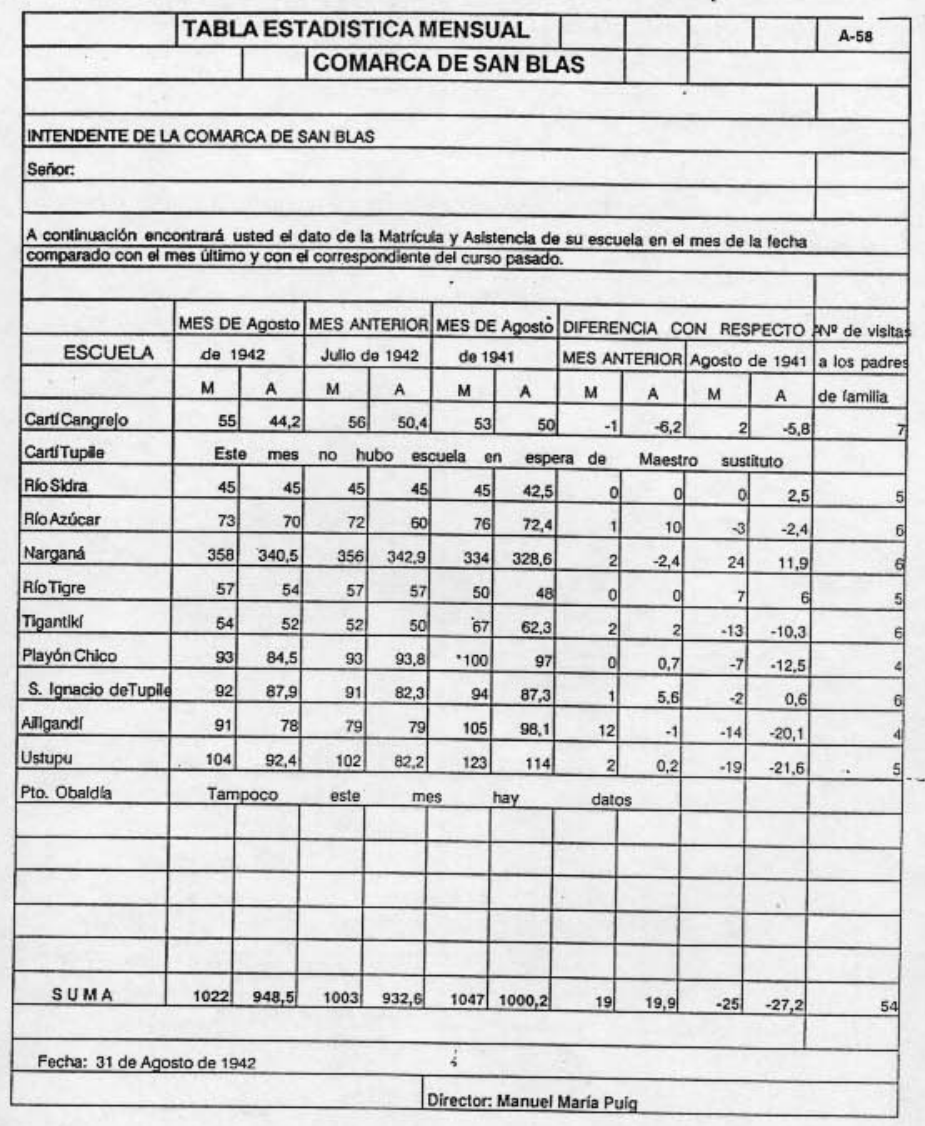




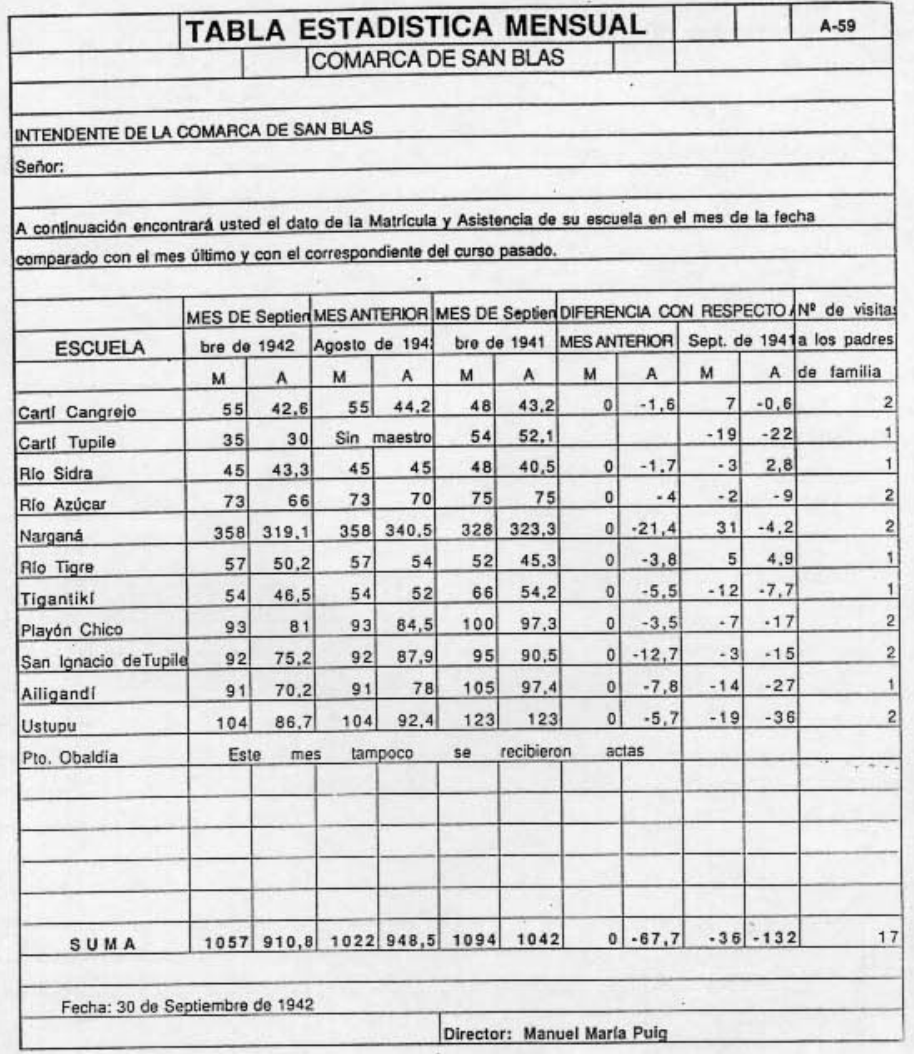




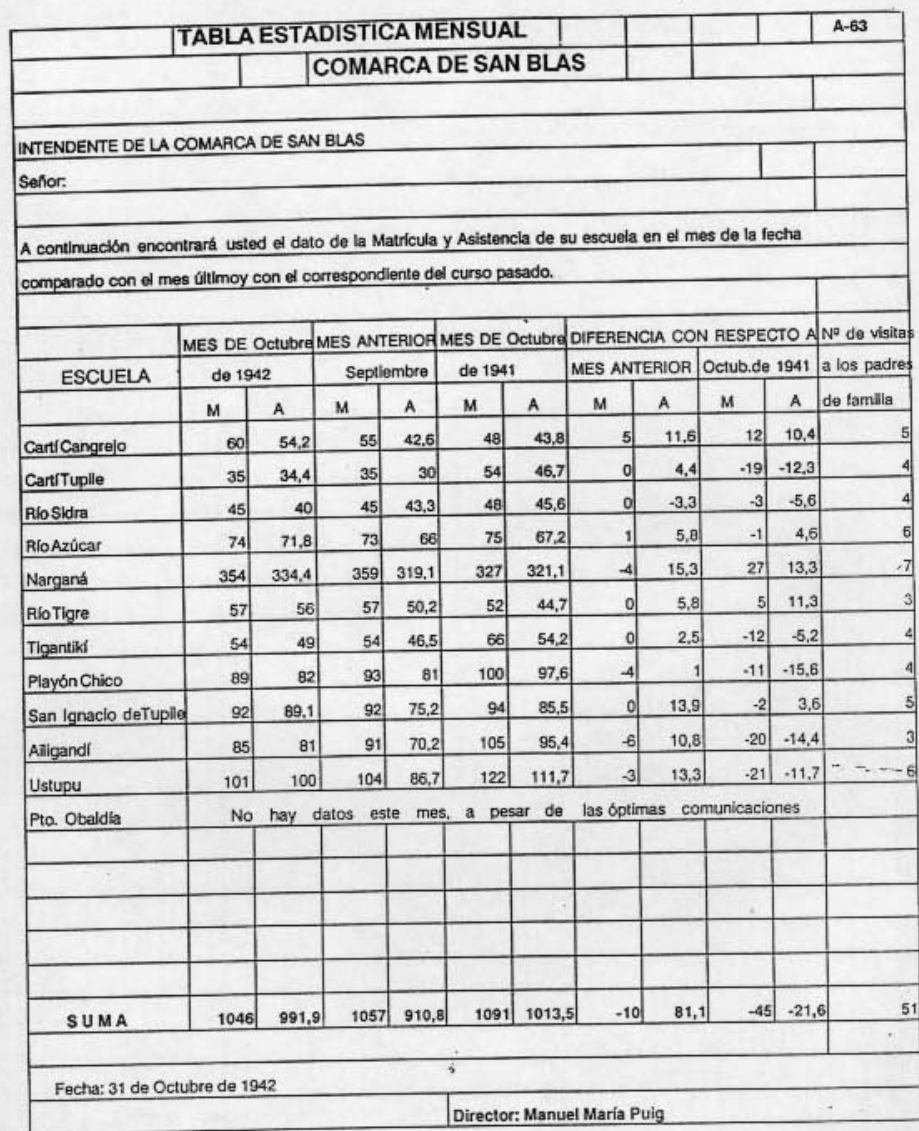




\begin{tabular}{|c|c|c|c|c|c|c|c|c|c|c|c|}
\hline & \multicolumn{7}{|c|}{ TABLAESTADISTICAMENSUAL } & & & & \multirow[t]{2}{*}{ A-19 } \\
\hline & \multicolumn{2}{|c|}{\begin{tabular}{l|l}
$\cdot$ & \\
\end{tabular}} & \multicolumn{5}{|c|}{ COMARCA DE SAN BLAS } & & & & \\
\hline \multicolumn{12}{|c|}{ INTENDENTE DE LA COMARCA DE SAN BLAS } \\
\hline \multicolumn{11}{|l|}{ Seffor: } & \\
\hline \multicolumn{12}{|c|}{ A continuación encontrará usted el dato de la Matricula y Asistencia de su escuela en el mes de la fecha } \\
\hline \multicolumn{12}{|c|}{ comparado con el mes últlmo y con el correspondiente del curso pasado. } \\
\hline & \multicolumn{2}{|c|}{ MES DE JUnio } & \multicolumn{2}{|c|}{ MES ANTERIOA } & \multicolumn{6}{|c|}{ MES DE JUNLDIFERENCIA CON RESPECTO A } & Ne de visitas \\
\hline \multirow[t]{2}{*}{ ESCUELA } & \multicolumn{2}{|c|}{ de 1943} & \multirow{2}{*}{$M$} & \multirow[b]{2}{*}{ A } & \multicolumn{2}{|c|}{ de 1942} & \multicolumn{2}{|c|}{ MES ANTERIOR, } & \multicolumn{2}{|c|}{ Junlo de 1942} & \multirow{2}{*}{\begin{tabular}{|l} 
a los padre: \\
de tamilla \\
\end{tabular}} \\
\hline & \multicolumn{2}{|c|}{\begin{tabular}{l|l} 
M & A \\
\end{tabular}} & & & M & A & $M$ & A & \begin{tabular}{|l|l} 
& \\
\end{tabular} & A & \\
\hline El Porvenir & 17 & 16 & & 15 & \multicolumn{6}{|c|}{ No existla } & \\
\hline Carticangrejo & 50 & 48,7 & 55 & 55 & 57 & 44,5 & -5 & $-6,3$ & -7 & 4,3 & \\
\hline CantrTuplle & 35 & 33,5 & 35 & 35 & 35 & 27,2 & 0 & $-1,5$ & 0 & 6,3 & \\
\hline Riosidra & 55 & 48,1 & 60 & 58 & 45 & 36,6 & -5 & $-9,9$ & 10 & 4,5 & \\
\hline RíoAzúcar & 66 & 62,2 & 62 & 59.4 & 72 & 69,7 & 4 & 2,8 & -6 & 4,5 & \\
\hline Narganá & 360 & 352 & 356 & 348,26 & 353 & 343,6 & 4 & 3,74 & 7 & 8.4 & \\
\hline Rlo Tigre & 61 & 61 & 59 & 59 & 57 & 51,5 & 10 & 2 & 4 & 9.5 & \\
\hline Tigantikl & 57 & 48,6 & 53 & 51,3 & 52 & 50 & 4 & $-2,7$ & 5 & $-1,4$ & \\
\hline PlayónChico & 83 & 80 & 68 & 68 & 93 & 79,5 & 15 & 12 & -10 & 5 & \\
\hline San Ignaclo deTupile & 113 & 107 & 113 & 113 & 91 & 84.2 & 0 & -6 & 22 & 12.8 & \\
\hline Alligandi & 92 & 87.8 & 91 & 91 & 100 & 90 & 1 & $-3,2$ & -8 & $-2,2$ & $\because \quad \therefore \ldots \pi$ \\
\hline Ustupu & 95 & 89,6 & 84 & 82,4 & 104 & 88,6 & 11 & 7,2 & -9 & 1 & \\
\hline Pto. Obaldla & 58 & 52 & 40 & 40 & 80 & 76,8 & 18 & 12 & -22 & $-24,7$ & \\
\hline & & & & & & & & & & & \\
\hline & & & & & & & & & & & \\
\hline & & & & & & & & & & & \\
\hline & & & & & & & & & & & \\
\hline SUMA & 1125 & 1073 & 1076 & 1060,3 & 1139 & 1041 & 49 & 10,14 & .7 & 22,1 & 50 \\
\hline Fecha: 30 de Junio & de 1943 & & & & ; & & & & & & \\
\hline & & & & & Director: & In Jesús & is Erice & & & & . \\
\hline
\end{tabular}


TABLA ESTADISTICA MENSUAL COMARCA DE SAN BLAS

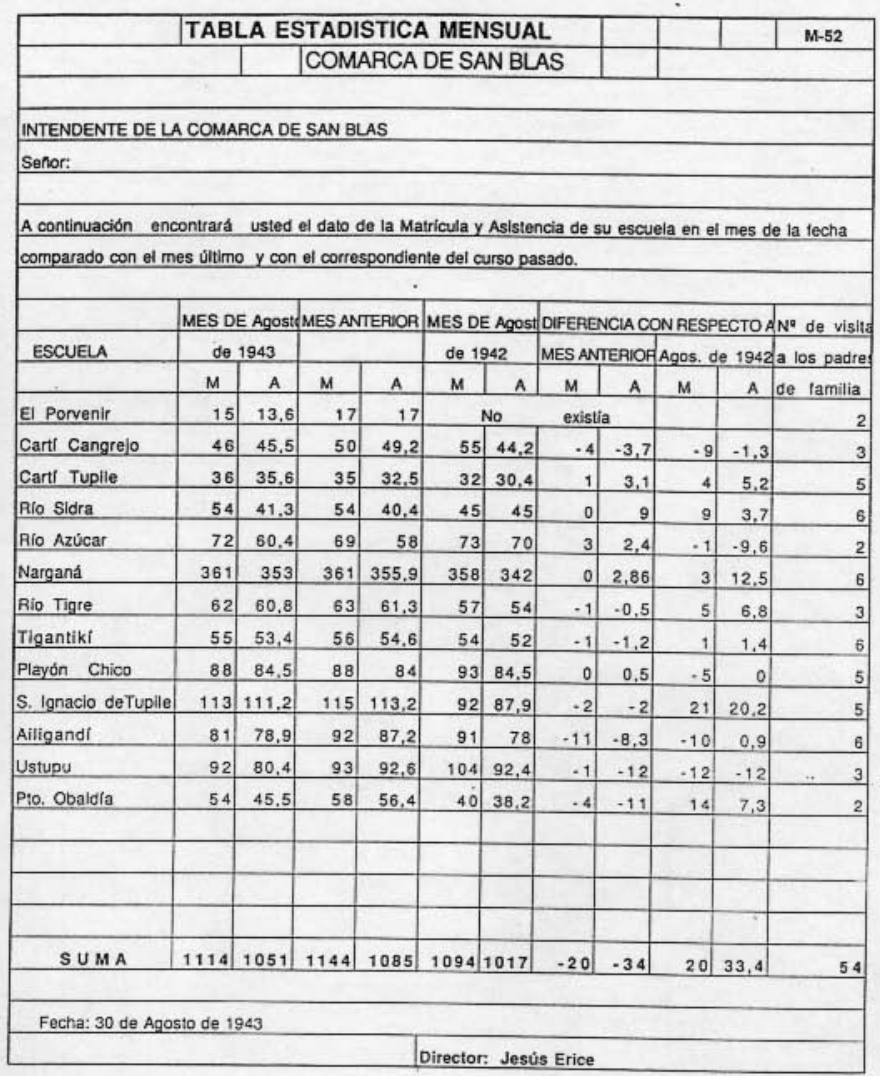




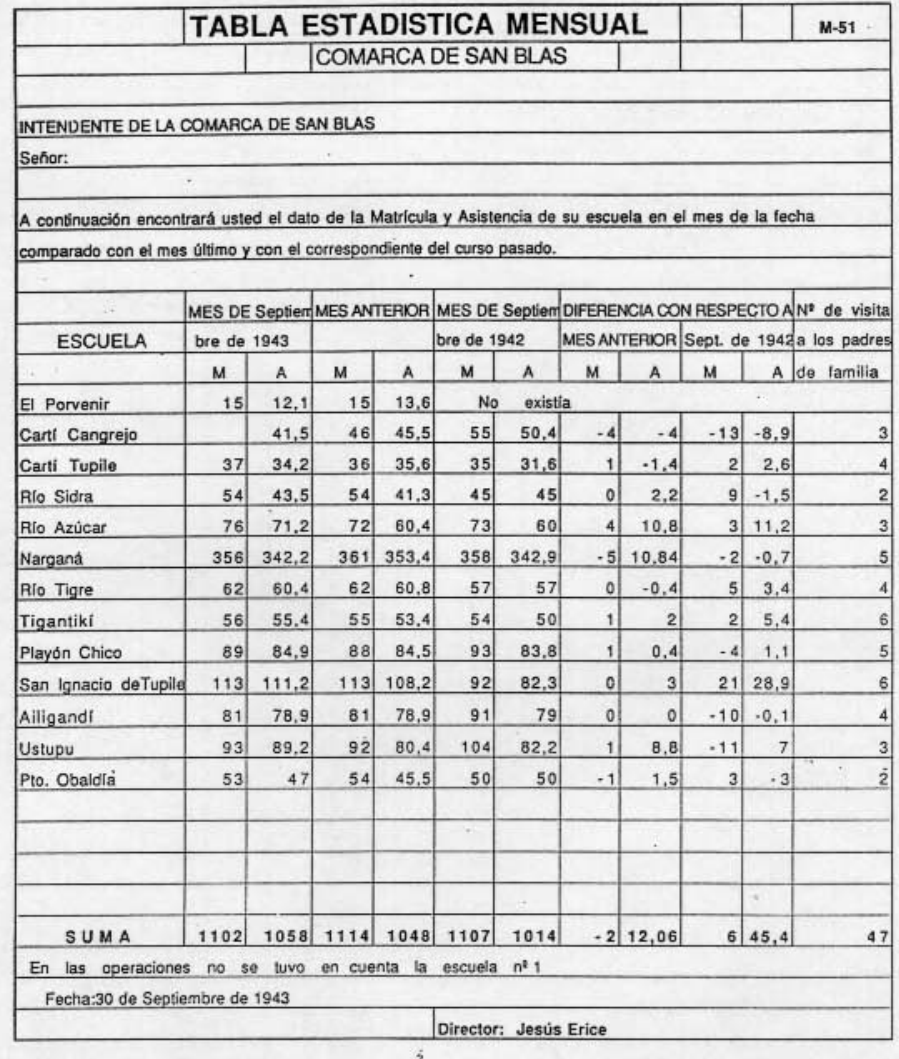




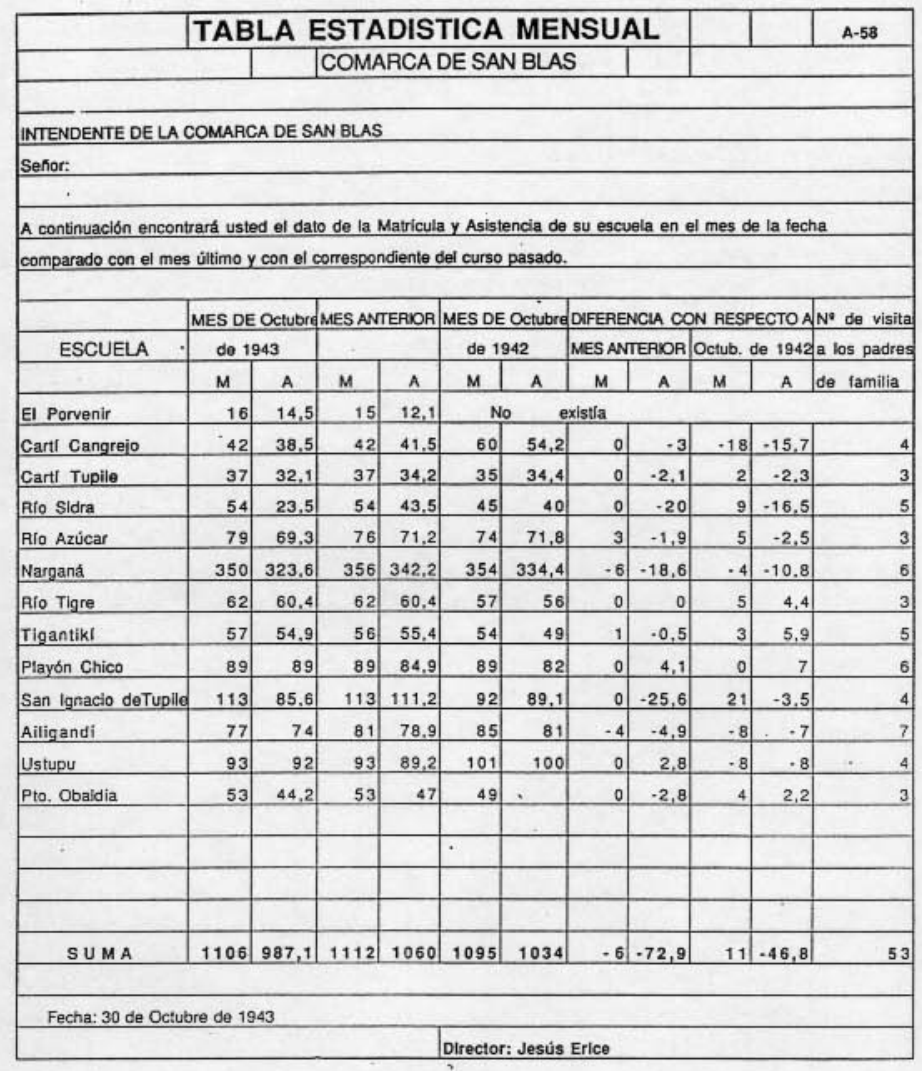




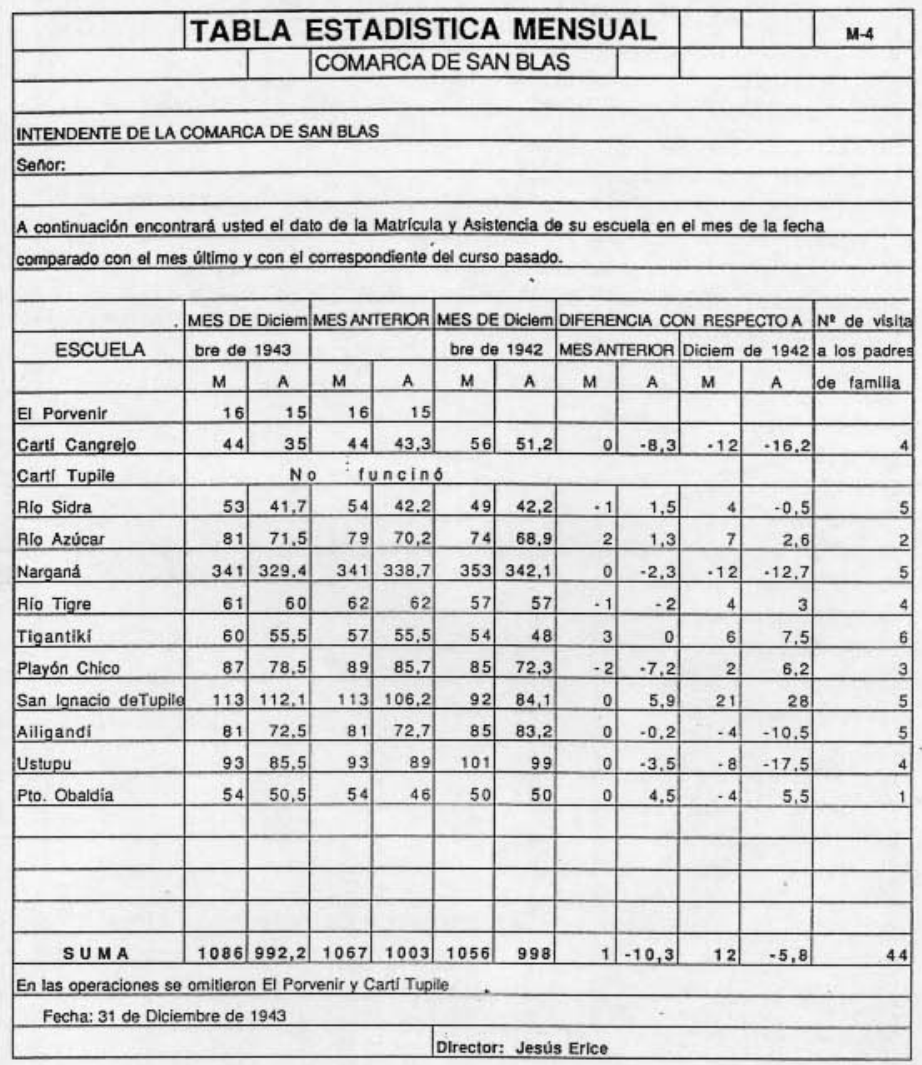


TABLA ESTADISTICA MENSUAL M-3 COMARCA DE SAN BLAS

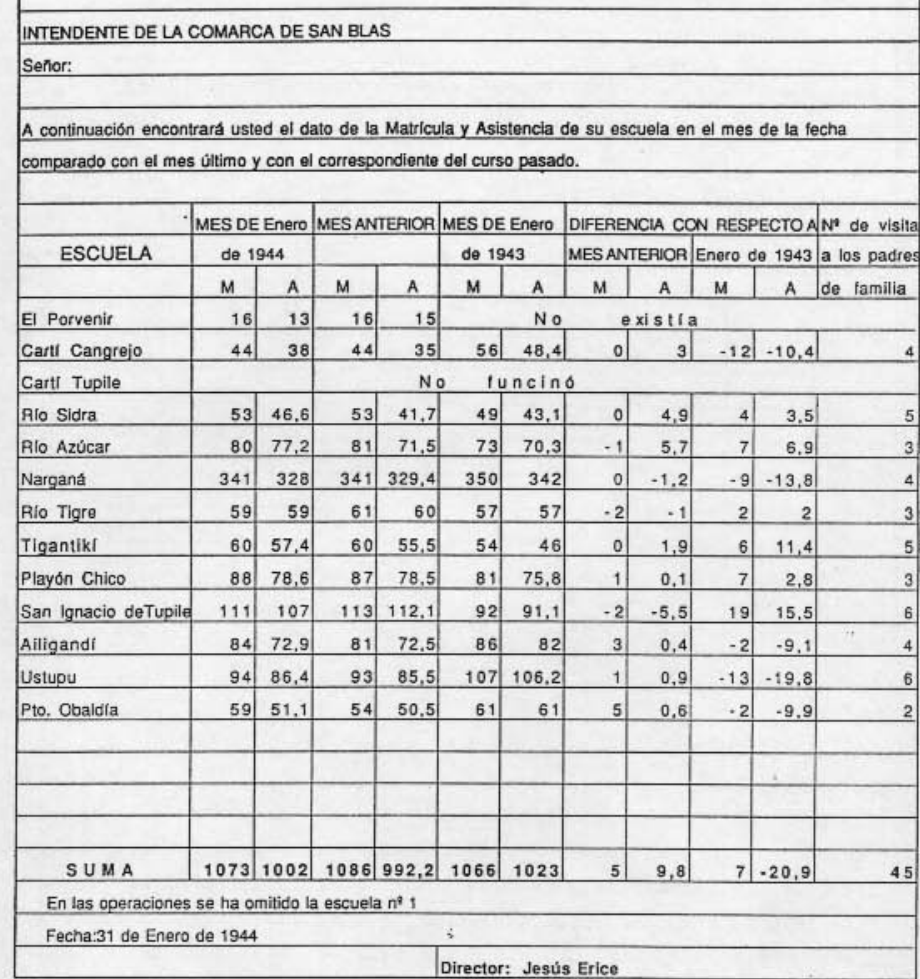




\begin{tabular}{|c|c|c|c|c|c|c|c|c|c|c|c|}
\hline & \multirow{2}{*}{\multicolumn{7}{|c|}{$\begin{array}{l}\text { TABLAESTADISTICA MENSUAL } \\
\text { TCOMARCA DE SANBLAS }\end{array}$}} & & & & $\mathrm{N}-26$ \\
\hline & & & & & & & & & & & \\
\hline \multicolumn{12}{|c|}{ INTENDENTE DE LA COMARCA DE SAN BLAS } \\
\hline \multicolumn{11}{|c|}{$\begin{array}{l}\text { INTENDENIE DELA COMAHCA DE SAT SOAS } \\
\text { SOANOR: }\end{array}$} & \\
\hline \multirow{2}{*}{\multicolumn{12}{|c|}{ A continuación encontrard usted el dato de la Matricula y Asistencia de su escuela en el mes de la fecha }} \\
\hline & & & & & & & & & & & \\
\hline \multicolumn{12}{|c|}{ comparado con el mes último y con el correspondiente del curso pasado. } \\
\hline \multirow{2}{*}{\multicolumn{11}{|c|}{ 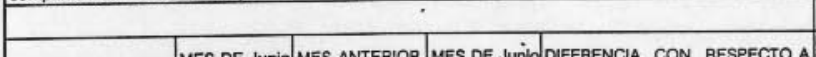 }} & \\
\hline \multirow{3}{*}{ ESCUELA } & \multirow{2}{*}{\multicolumn{2}{|c|}{\begin{tabular}{|c|} 
MES DE Junio \\
de 1944
\end{tabular}}} & & ITERIOR & \multicolumn{6}{|c|}{ MES DE JUNilo DIFERENCIA CON RESPECTO A } & No de visitas \\
\hline & & & \multirow{2}{*}{ M } & \multirow[b]{2}{*}{ A } & \multicolumn{2}{|c|}{ de 1943} & \multicolumn{2}{|c|}{ MES ANTERIOR } & \multicolumn{2}{|c|}{ Junio de 1943} & \multirow{2}{*}{$\begin{array}{l}\text { a los padres } \\
\text { de famila } \\
\end{array}$} \\
\hline & M & 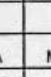 & & & M & A & M & A & \begin{tabular}{|l|l} 
м \\
\end{tabular} & A & \\
\hline El Porvenir & 19 & 17,2 & 13 & 13 & 17 & 16 & 6 & 4.2 & 2 & 1.2 & \\
\hline Carticangre]o & 34 & 34 & 34 & 34 & 50 & 48,7 & 0 & 0 & -16 & $-14,7$ & \\
\hline Cartituple & 30 & 28.6 & 30 & 30 & 35 & 33.5 & 0 & 1.4 & .5 & $-4,9$ & \\
\hline Rlosidra & 51 & 36 & 45 & 42,7 & 55 & 48,1 & 6 & 6,7 & 4 & $.13,5$ & \\
\hline RioAzúcar & 65 & 59.6 & 64 & 62,5 & 66 & 62.2 & & 2,9 & -1 & $-3,6$ & \\
\hline Narganá & 359 & 356 & 353 & 351 & 360 & 352 & 6 & 5 & -1 & 4 & \\
\hline Riotigre & 50 & 49,4 & 50 & 49 & 61 & 61 & 0 & 0.4 & .11 & $.11,6$ & \\
\hline Trgantiki & 40 & 30,6 & 39 & 29.5 & 57) & \begin{tabular}{|l|}
48,6 \\
\end{tabular} & 1 & 1,1 & -17 & $-18,1$ & \\
\hline Playón Chico & 67 & 63,7 & 65 & 63 & 83 & 80 & 2 & 0,7 & -16 & 16.3 & \\
\hline San Ignacio deTuplle & 117 & 114,3 & 117 & 117 & 113 & 107 & 0 & 2,7 & 4. & 7,3 & \\
\hline \begin{tabular}{|l|} 
Allgandl \\
\end{tabular} & 70 & 67 & 66 & 66 & 92 & 87,8 & 4 & 1 & -22 & $.20,8$ & \\
\hline Ustupu & 95 & 94,7 & 85 & 85 & 95 & 89,6 & 10 & 9,7 & 0 & 5,1 & \\
\hline P10. Obaldla & 71 & 63 & 71 & 71 & 58. & 52 & o & 8 & 13 & 9 & \\
\hline & & & & & & & & & & & \\
\hline & & & & & & & & & & & \\
\hline & & & & & & & & & & & \\
\hline & & & & & & & & & & & \\
\hline SUMA & 1068 & 1014 & 1032 & 1013,7 & 1142 & 1086 & 36 & 43,8 & .74 & $.76,9$ & \\
\hline Fecha: 30 de Ju & de 1944 & & & & $i$ & & & & & & \\
\hline & & & & & Director: & or: Jes & & & & & \\
\hline
\end{tabular}


TABLA ESTADISTICA MENSUAL COMARCA DE SAN BLAS

\begin{tabular}{|c|c|c|c|c|c|c|c|c|c|c|c|c|}
\hline & \multicolumn{9}{|c|}{ TABLA ESTADISTICA MENSUAL } & & & \multirow[t]{2}{*}{ A-53 } \\
\hline & & & \multicolumn{7}{|c|}{\begin{tabular}{|l|l|} 
COMARCA DE SAN BLAS & \\
\end{tabular}} & & & \\
\hline \multirow{2}{*}{\multicolumn{13}{|c|}{$\begin{array}{l}\text { INTENDENTE DE LA COMARCA DE SAN BLAS } \\
\text { Señor: }\end{array}$}} \\
\hline & & & & & & & & & & & & \\
\hline \multicolumn{13}{|c|}{ A continuación encontrará usted el dato de la Matricula y Asistencia de su escuela en el mes de la fecha } \\
\hline \multicolumn{13}{|c|}{ comparado con el mes ültimo y con el correspondiente del curso pasado. } \\
\hline & \multicolumn{4}{|c|}{ MES DE Septiem/MES ANTERIOR } & \multirow{2}{*}{\multicolumn{3}{|c|}{$\begin{array}{c}\text { MES DE Septien } \\
\text { bre de } 1943\end{array}$}} & \multicolumn{5}{|c|}{ OIFERENCIA CON RESPECTOA AN` de visita } \\
\hline \multirow[t]{2}{*}{ ESCUELA } & \multicolumn{2}{|c|}{ bre de 1944} & \multicolumn{3}{|c|}{ 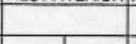 } & & & \multicolumn{2}{|c|}{ MES ANTERIOR } & \multicolumn{2}{|c|}{ Sept. de 1943 a } & a los padres \\
\hline & $M$ & A & M. & A & & M & A & $M$ & A & $\mathrm{M}$ & A. & de familia \\
\hline Carti Cangrejo & 33 & 30 & 33 & 32 & & 42 & 41.5 & 0 & .2 & -9 & -12 & \\
\hline Carti Tupile & 32 & 31 & 36 & 36 & & 37 & 34,2 & -4 & .5 & -5 & $-2,8$ & \\
\hline Rio Sidra & 47 & 39 & 46 & 47 & & 54 & 43,5 & 0 & .8 & .7 & $-4,7$ & \\
\hline Alo Azúcar & 64 & 55,8 & 64 & 47,3 & & 76 & 71,2 & 0 & 8,5 & .12 & -15 & \\
\hline Narganá & 360 & 348,1 & 357 & 349.8 & & 356 & 342,2 & 3 & $-1,7$ & 4 & 5.9 & \\
\hline Rio Tigre & 50 & 49 & 50 & 49 & & 62 & 60.4 & 0 & 0 & .12 & -11 & \\
\hline Tigantiki & 40 & 36,2 & 40 & 31,6 & & 56 & 55,4 & 0 & 4,6 & -16 & .9 .5 & \\
\hline Playón Chico & 71 & 70,7 & 71 & 68,7 & & 89 & 84,9 & 0 & 2 & -18 & \begin{tabular}{|l|}
-14 \\
\end{tabular} & \\
\hline San Ignacio de Tupille & 117 & 114.4 & 117 & 110,1 & & 113 & 111,2 & 0 & 4.3 & 4 & \begin{tabular}{|l|}
3.2 \\
\end{tabular} & \\
\hline Ailigandi & 68 & 65.3 & 68 & 64,3 & & 81 & 78,9 & 0 & 1 & .3 & -14 & \\
\hline Ustupu & 99 & 96.7 & 99 & 98.7 & & 93 & 89.2 & 0 & .2 & 6 & 7,5 &.. \\
\hline Pto. Obaldia & 71 & 66 & 71 & 68 & & 53 & 47 & 0 & 0 & 18 & 19 & \\
\hline & & & & & & & & & & & & \\
\hline & & & & & & & & & & & & \\
\hline & & & & & & & & & & & & \\
\hline & & & & & & & & & & & 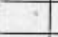 & \\
\hline & & & & & & & & & & & & \\
\hline SUMA & 1052 & 1002 & 1053 & 100 & & 102 & 1058 & -1 & $-4,3$ & .60 & -41 & 24 \\
\hline $\mathrm{Fec}$ & & & & & & & & & & & & \\
\hline & & & & & & ec & Jest & & & & & \\
\hline
\end{tabular}




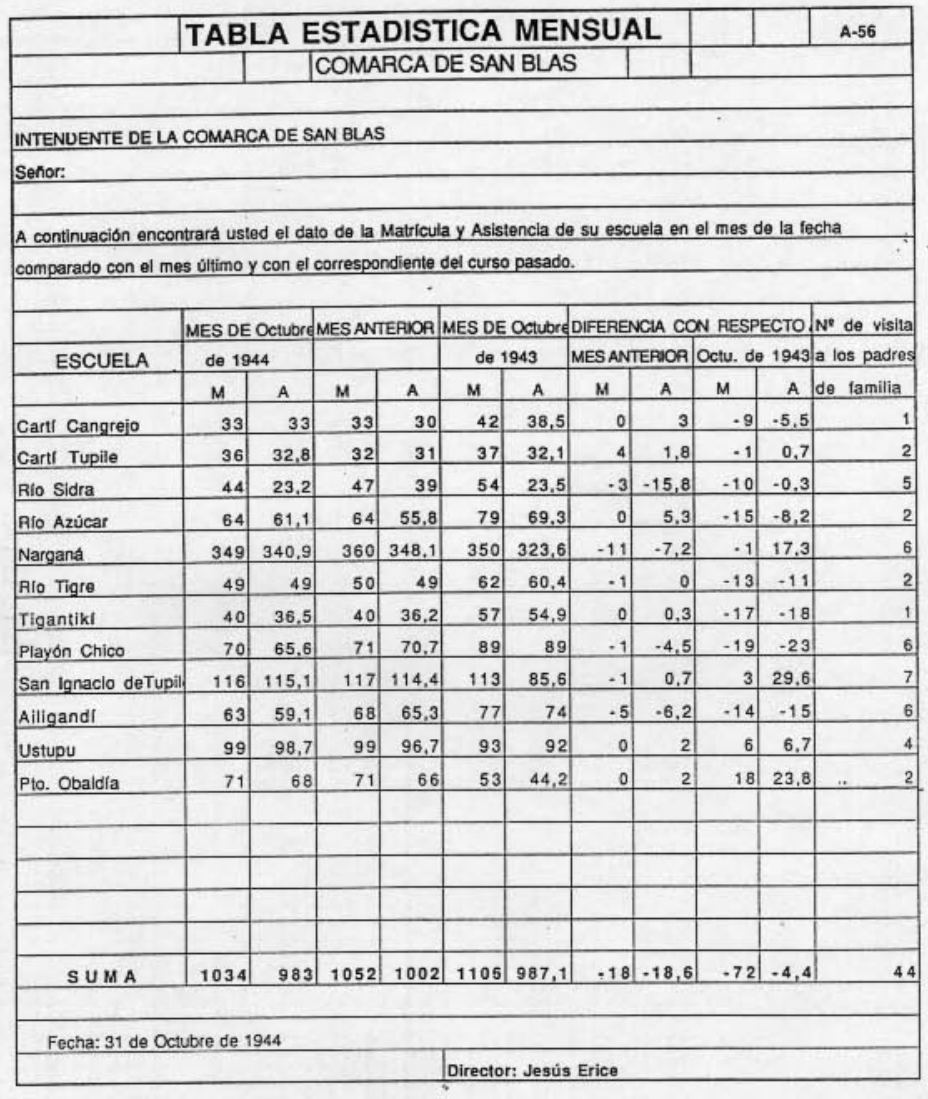




\begin{tabular}{|c|c|c|c|c|c|c|c|c|c|c|c|}
\hline & \multicolumn{6}{|c|}{ TABLAESTADISTICA MENSUAL } & & & & & $M-43$ \\
\hline & & & \multicolumn{5}{|c|}{ COMARCA DESANBLAS } & & & & \\
\hline \multicolumn{12}{|c|}{ INTENDENTE DE LA COMARCA DE SAN BLAS } \\
\hline \multicolumn{11}{|l|}{ Señor: } & \\
\hline \multicolumn{12}{|c|}{ A continuación encontrará usted el dato de la Matricula y Asistencia de su escuela en el mes de la fecha } \\
\hline \multicolumn{12}{|c|}{ comparado con el mes útilimo y con el correspondiente del curso pasado. } \\
\hline & \multicolumn{2}{|c|}{ MES DE Enero } & \multicolumn{2}{|c|}{ MES ANTERIOR } & \multicolumn{2}{|c|}{ MES DE Enero } & \multicolumn{4}{|c|}{ DIFERENCIA CON RESPECTO $A$} & $A N^{N}$ de visitas \\
\hline ESCUELA & \multicolumn{2}{|c|}{ de 1945} & & & \multicolumn{2}{|c|}{ de 1944} & \multicolumn{4}{|c|}{\begin{tabular}{|l|l|} 
MES ANTERIOR & Enero de 1944 \\
\end{tabular}} & a los padres \\
\hline & M & A & $\mathrm{M}$ & A & M & A & $\mathrm{M}$ & \begin{tabular}{l|l} 
A \\
\end{tabular} & $\mathrm{M}$ & A & de familia \\
\hline CartiCangrejo & 41 & 34,2 & 43 & 38 & 44 & 38 & -2 & 3,8 & 3 & $-3,8$ & \\
\hline CarriTuplle & 26 & 21 & 29 & 27,8 & 32 & 28,8 & 3 & $-1,8$ & -6 & $-2,8$ & \\
\hline RloSidra & 42 & 31,5 & 42 & 31 & 53 & 46,6 & 0 & 0.5 & .11 & $-14,7$ & \\
\hline RloAzúcar & 64 & 61,8 & 64 & 59,4 & 80 & 77,2 & 0 & 2,4 & .16 & $-15,4$ & \\
\hline Narganá & 342 & 340,2 & 346 & 340 & 341 & 328,2 & -4 & 0.2 . & 1 & 12 & 5 \\
\hline Rlo Tigre & 49 & 47.7 & 48 & 48 & 59 & 59 & 1 & $-1,7$ & -10 & $-11,3$ & \\
\hline Tigantiki & 38 & 38 & 38 & 38 & 60 & 57.4 & 0 & 0 & -22 & $-19,4$ & \\
\hline Playón Chico & 71 & 69,7 & 71 & 68,8 & 88 & 78,6 & 0 & 0,7 & -17 & $-9,1$ & $\varepsilon$ \\
\hline San Ignacio deTupile & 117 & 115,3 & 117 & 114,5 & 111 & 106,6 & of & 0,8 & 6 & 8,7 & \\
\hline Arigandi & 63 & 56,2 & 59 & 57 & 84 & 72,9 & 4 & $-0,8$ & .21 & $-16,7$ & \\
\hline Ustupu & 95 & 92,9 & 96 & 95,8 & 94 & 86,4 & -1 & $-2,9$ & 1 & 6,5 & . \\
\hline Pto. Obaldáa & 71 & 68 & 71 & 68 & 59 & 51,1 & 0 & 0 & 12 & 16,9 & \\
\hline & & & & & & & & & & & \\
\hline & & & & & & & & & & & \\
\hline & & & & & & & & & & & \\
\hline & & & & & & & & & & & \\
\hline & & & & & & & & & & & \\
\hline SUMA & 1019 & 981,3 & 1024 & 986,3 & 1105 & 1030,4 & -5 & $-6,4$ & .86 & -49 & 44 \\
\hline Fecha: 31 de Ener & ode 194 & & & & 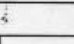 & & & & & & \\
\hline & - & & & & Director: & Jesús E & Erice & & & & \\
\hline
\end{tabular}




\begin{tabular}{|c|c|c|c|c|c|c|c|c|c|c|}
\hline & & \multicolumn{6}{|c|}{ REPUBLICADE PANAMA } & & & M-8 \\
\hline & & \multicolumn{6}{|c|}{ MINISTERIO DE GOBIERNO Y JUSTICIA } & & & \\
\hline & & & & & & & & & & \\
\hline & & \multirow{2}{*}{\multicolumn{6}{|c|}{ DEPARTAMENTO DE ESTADISTICA }} & & & \\
\hline & & & & & & & & & & \\
\hline & \multicolumn{4}{|c|}{ COMARCA DE SAN BLAS } & & \multicolumn{5}{|c|}{ Mes de Diciembre de 1937} \\
\hline & & & & & & & & & & \\
\hline DISTRITO & \multicolumn{6}{|c|}{ 1. Escuelas ...... PRIMARIAS PUBLICAS } & & \multirow{2}{*}{\multicolumn{3}{|c|}{ 2* CENSO ESCOLAR }} \\
\hline & $\mathrm{N}^{0} \mathrm{de}$ & \multicolumn{3}{|c|}{ MATAICULA } & \multicolumn{2}{|c|}{ ASISTENCIA } & MEDIA & & \\
\hline (DivisiórPolltica) & Escuelas & $\mathrm{H}$. & M & Total & $\mathrm{H}$ & $\mathrm{M}$ & Total & $\mathrm{H}$ & M & Total \\
\hline Narganá & \& & 176 & 101 & 277 & 97,39 & 98 & 97,69 & 115 & 85 & 200 \\
\hline RloAzúcar & 2 & 46 & 44 & 90 & 87.8 & 95,95 & 91,87 & 69 & 50 & 119 \\
\hline RioTigre & 1 & 49 & & 49 & 100 & & 100 & 63 & 50 & 113 \\
\hline Ustupu & 1 & 70 & 4 & 74 & 88,64 & 100 & 94,32 & 140 & 130 & 270 \\
\hline Puerto Obaldla & 1 & 11 & 20 & 31 & 90 & 91 & 90,5 & 40 & 40 & 80 \\
\hline Sultupu & 1 & 43 & 7 & 50 & 93,18 & 100 & 96,59 & 120 & 100 & 220 \\
\hline Alligandi & 1 & 46 & & 46. & 97,82 & & 97,82 & 130 & 120 & 250 \\
\hline & & & & & & & & & & \\
\hline & & & & & & & & & & \\
\hline & & & & & & & & & & \\
\hline & & & & & & & & & & \\
\hline & & & & & & & & & & - \\
\hline & & & & & & & & & & \\
\hline & & & & & & & & & & \\
\hline \multicolumn{11}{|c|}{ 1* Especiflquese sl es Escuela Primaria Pública. Primaria Privada. Secundaria o } \\
\hline \multicolumn{11}{|c|}{ Profesional Pública Secundaria o Protesional Privada. } \\
\hline \multicolumn{4}{|c|}{ 2* Se reflere a las Escuelas Primarias Públicas. } & & & & & & & \\
\hline & & & & & \multicolumn{5}{|c|}{ Firma: Simón Bravo, Director } & \\
\hline
\end{tabular}




\begin{tabular}{|c|c|c|c|c|c|c|c|c|c|c|}
\hline & & \multicolumn{5}{|c|}{ REPUBLICA DE PANAMA } & & & \multicolumn{2}{|r|}{ A-65 } \\
\hline & & \multicolumn{6}{|c|}{ MINISTERIO DE GOBIERNO Y JUSTICIA } & & & \\
\hline & & \multicolumn{8}{|c|}{ DEPARTAMENTO DE ESTADISTICA } & \\
\hline & \multicolumn{4}{|c|}{ COMARCA DE SAN BLAS } & \multicolumn{5}{|c|}{ Mes de Septlembre de 1939} & \\
\hline & & & & & & & & & & \\
\hline DISTRITO & \multicolumn{6}{|c|}{ 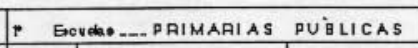 } & & \multirow{2}{*}{\multicolumn{3}{|c|}{2 CENSO ESOOLAA }} \\
\hline & No de & \multicolumn{3}{|c|}{ MATRI CULA } & \multicolumn{3}{|c|}{ ASISTENCIA MEDIA } & & & \\
\hline (DNision Polttica) & Escuelas & $\mathrm{H}$ & M & Total & $\mathrm{H}$ & M & Total & $\mathrm{H}$ & M & Total \\
\hline Carticangrejo & & 34 & & 34 & 97,97 & & 97,97 & 70 & 85 & 155 \\
\hline RloAzúcar & & 35 & 39 & 73 & 97,14 & 99,73 & 98,43 & 35 & 38 & 73 \\
\hline Narganá & & 208 & 111 & 319 & 97,54 & 97,2 & 97,37 & 120 & 135 & 255 \\
\hline Tigre & & 50 & & 50 & 90,98 & & 90,98 & 60 & 75 & 135 \\
\hline Ticantiqui & & 45 & 13 & 58 & \begin{tabular}{|l|}
95,11 \\
\end{tabular} & 45,38 & 70,24 & 58 & 65 & 123 \\
\hline Tupile & & 63 & 18 & 81 & 86, & 75 & 80,25 & 75 & 90 & 165 \\
\hline Alligandr & & 60 & & 60 & 90 & & 90 & 125 & 150 & 275 \\
\hline Ustupu & 2 & 81 & 16 & 97 & 93.45 & 93,12 & 93,28 & 140 & 150 & 290 \\
\hline Permé & 1 & 8 & 11 & 19 & 50 & 63,63 & 56,81 & 10 & 14 & 24 \\
\hline Puerno obaldia & 2 & 36 & 42 & 78 & 97,56 & 95,23 & 96,39 & 50 & 60 & 110 \\
\hline & & & & & & & & & & \\
\hline & & & & & & & & & & \\
\hline & & & & & & & & & & \\
\hline & & & & & & & & & & \\
\hline $1^{\star}$ Especilfquese & icuela Prir & maria Públ & ica. Prin & naria Prive & vada. Secu & & & & & \\
\hline Profesional Pút & Secundarie & a o Protesi & onal Pri & vada & & & & & & \\
\hline $2^{*}$ Se reflere a las & las Prima & rias Públic: & & & & & & & & \\
\hline & & & & Ricardo & lo Velasc & $=0$, Dire & & & & \\
\hline
\end{tabular}




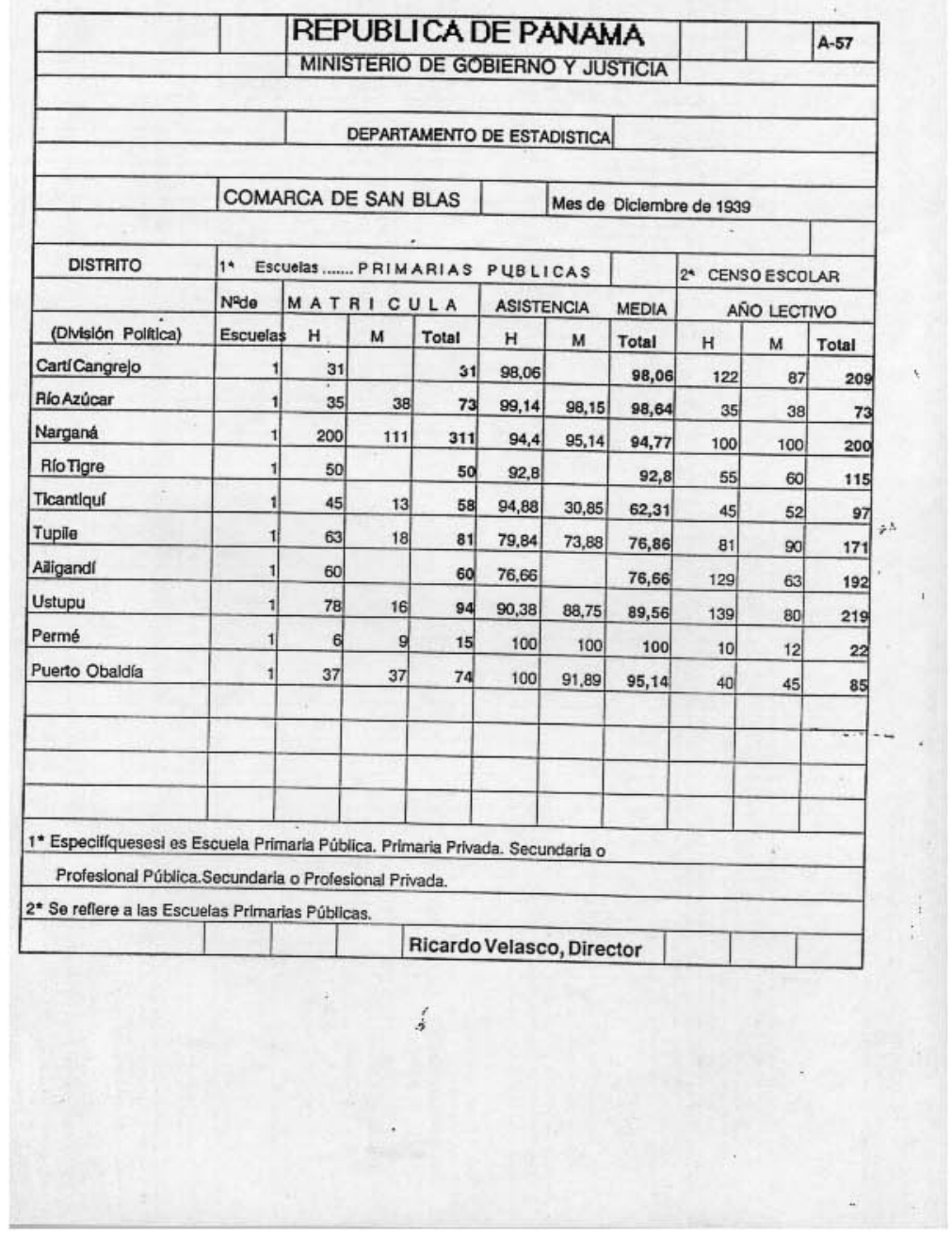




\begin{tabular}{|c|c|c|c|c|c|c|c|c|c|c|}
\hline & \multirow{2}{*}{\multicolumn{7}{|c|}{$\begin{array}{l}\text { REPUBLICA DE PANAMA } \\
\text { MINISTERIO DE GOBIERNO Y JUSTICIA }\end{array}$}} & & \multicolumn{2}{|r|}{ M-26 } \\
\hline & & & & & & & & \multicolumn{3}{|c|}{ MINISTERIO DE GOBIERNO Y JUSTICIA } \\
\hline & & \multicolumn{9}{|c|}{ DEPARTAMENTO DE ESTADISTICA } \\
\hline & \multicolumn{4}{|c|}{ COMARCA DE SAN BLAS } & \multicolumn{5}{|c|}{ Mes de Agosto de 1940} & \\
\hline \multicolumn{11}{|c|}{. } \\
\hline DISTRITO & \multicolumn{6}{|c|}{ 1. Egcuelas.......PRIMARIAS PUBLICAS } & & \multicolumn{3}{|c|}{ 2* CENSOESCOLAR } \\
\hline & No de & \multicolumn{3}{|c|}{ MATAI CULA } & \multicolumn{3}{|c|}{\begin{tabular}{|l|l|} 
ASISTENCIA MEDIA \\
\end{tabular}} & \multicolumn{3}{|c|}{ AÑo LECTIVO } \\
\hline (Dhisión Polltica) & Escuelas & $\mathrm{H}$ & M & Total & $\mathrm{H}$ & M & Totsl & $\mathrm{H}$ & $\mathrm{M}$ & Total \\
\hline Cartisugtupu & & 56 & & 56 & 94,82 & & 94,82 & 120 & 80 & 200 \\
\hline RioAzúcar & & 37 & 38 & 75 & 100 & 100 & 100 & 40 & 40 & 80 \\
\hline Alotigre & & 50 & & 50 & 100 & & 100 & 50 & 50 & 100 \\
\hline Narganá & & 213 & 119 & 332 & 98,57 & 98,31 & $\mathbf{9 8 , 5 9}$ & 100 & 125 & 225 \\
\hline Ticantiqui & & 66 & & 66 & 98,33 & & 98,33 & 50 & 50 & 100 \\
\hline PlayónChico & & 90 & & 90 & 99,66 & & 99,66 & 100 & 85 & 185 \\
\hline Tuplle & & 64 & 21 & 85 & 87,34 & 100 & 98,67 & so & 80 & 170 \\
\hline Alligand & & 85 & & 85 & 85,98 & & 85,98 & 120 & 80 & 200 \\
\hline RloBanano & & 49 & & 49 & 79.59 & & 98,59 & 50 & 40 & 90 \\
\hline Ustupu & & 103 & 27 & 130 & 93,88 & 100 & 96,94 & 120 & 100 & 220 \\
\hline \multirow[t]{4}{*}{ Puerto Obaldla } & & 43 & 39 & 82 & & & & 45 & 50 & 95 \\
\hline & & & & & & & & & & \\
\hline & & & & & & & & & & \\
\hline & & & & & & & & & & \\
\hline \multicolumn{11}{|c|}{$1^{*}$ Especilfquesesi es Escuela Primaria Pública. Primaria Privada. Secundarla o } \\
\hline \multicolumn{11}{|c|}{ Profesional Pública.Secundaria o Profesional Privada. } \\
\hline \multicolumn{11}{|c|}{$2 *$ Se reflere a las Escuelas Primarlas Públicas. } \\
\hline & & & & Ricardo & 10Velas & $c 0$ Dir & & & & \\
\hline
\end{tabular}




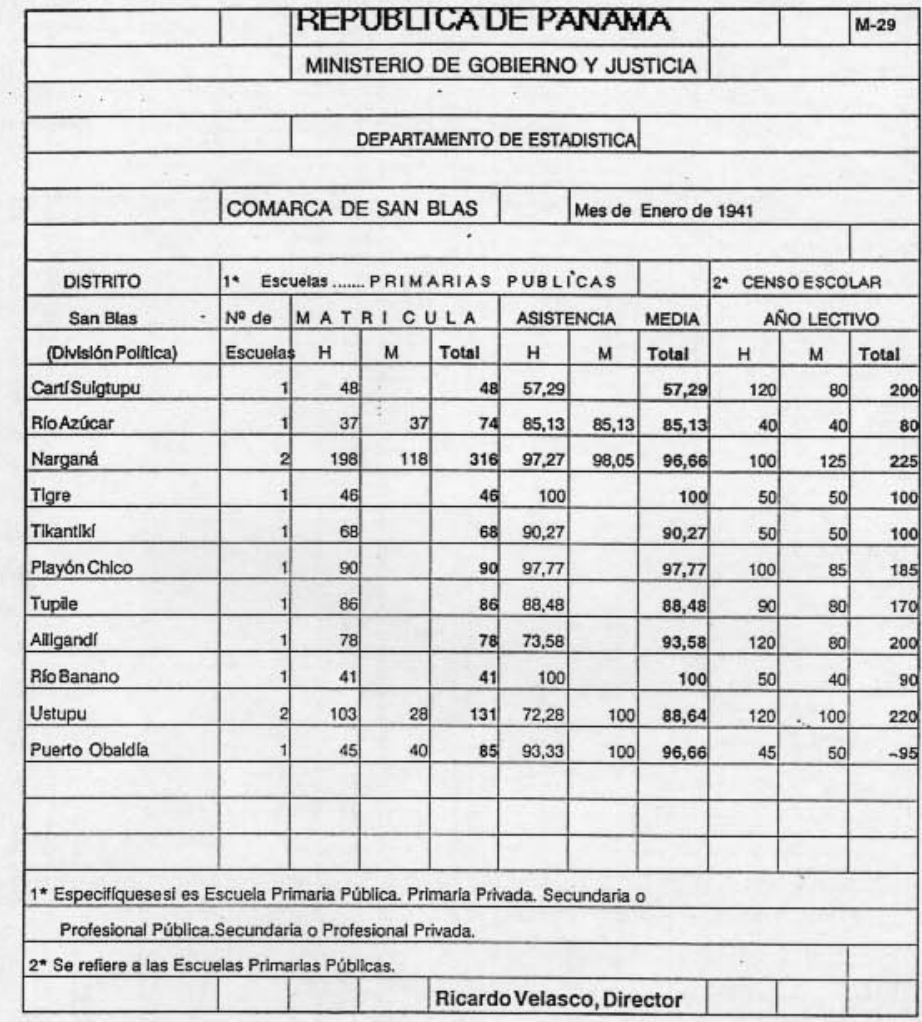




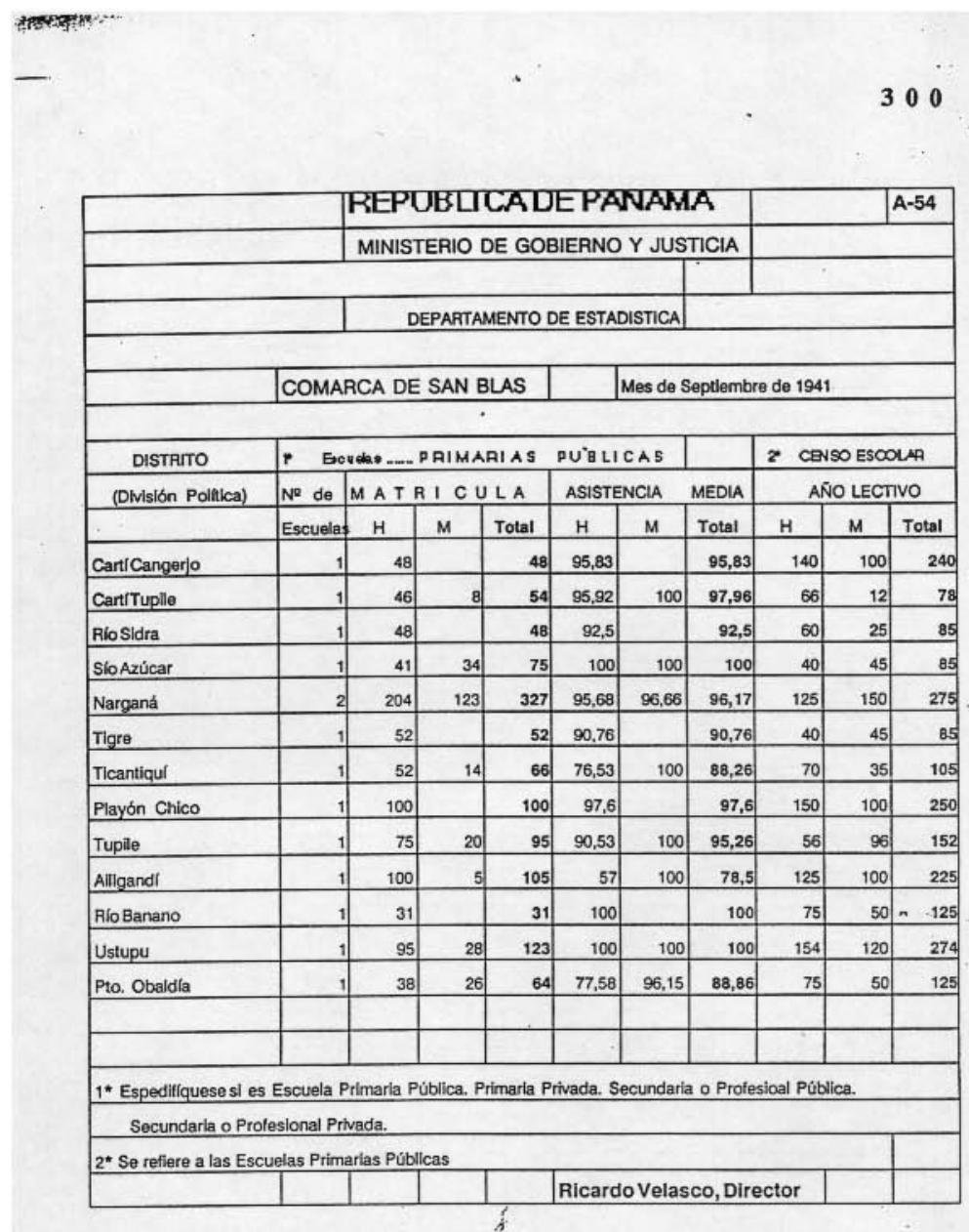




\begin{tabular}{|c|c|c|c|c|c|c|c|c|c|c|}
\hline & & \multicolumn{6}{|c|}{ REPUBLICA DE PANAMA } & & & A-54 \\
\hline & & \multicolumn{6}{|c|}{ MINISTERIO DE GOBIERNO Y JUSTICIA } & & & \\
\hline & & & & & & & & & & \\
\hline & & \multicolumn{6}{|c|}{ DEPARTAMENTO DE ESTADISTICA } & & & \\
\hline & & & & & & & & & & \\
\hline & \multicolumn{4}{|c|}{ COMARCA DE SAN BLAS } & & Mes de & Octubre & & de 1941 & \\
\hline & & & & & & & & & & \\
\hline DISTAITO & \multicolumn{6}{|c|}{ 1. Escuelas ...... PRIMARIAS PU⿴囗BLICAS } & & \multicolumn{3}{|c|}{ 2* CENSO ESCOLAR } \\
\hline \multirow[t]{2}{*}{ (DWisión Pollitica) } & No de & \multicolumn{3}{|c|}{ MATRICULA } & \multicolumn{2}{|c|}{ ASISTENCIA } & MEDIA & \multicolumn{3}{|c|}{ AÑO LECTIVO } \\
\hline & Escuelas & $\mathrm{H}$. & M & Total & $\mathrm{H}$ & $\mathrm{M}$ & Total & $\mathrm{H}$ & \begin{tabular}{l|l} 
\\
\end{tabular} & Total \\
\hline CartiCangrejo & & 48 & & 48 & 95,73 & & 95,73 & 140 & 100 & 240 \\
\hline CarirTuple & 1 & 46 & 8 & 54 & 91,73 & 100 & 95,86 & 66 & 12 & 78 \\
\hline RiloSidra & 1 & 48 & & 48 & 97,68 & & 97,68 & $\infty$ & 25 & 85 \\
\hline RiloAzúcar & 1 & 41 & 34 & 75 & 86,27 & 82,35 & 88,27 & 40 & 45 & 85 \\
\hline Narganá & 2 & 204 & 123 & 327 & 96,17 & 96,66 & 96,17 & 125 & 150 & 275 \\
\hline Rio Tigre & 1 & 52 & & 52 & 90,76 & & 90,76 & 40 & 45 & 75 \\
\hline Ticantikl & 1 & 52 & 14 & 66 & 88,26 & 100 & 88,26 & 70 & 35 & 105 \\
\hline Playón Chico & 1 & 100 & & 100 & 97,6 & & 97,6 & 150 & 100 & 250 \\
\hline Tupile & 1 & 74 & 20 & 94 & 78,64 & 75,5 & 77,5 & 56 & 96 & 152 \\
\hline Ailigandf & 1 & 105 & & 105 & 90,47 & & 90,47 & 125 & 100 & 225 \\
\hline RioBanano & 1 & 31 & & 31 & 100 & & 100 & 75 & 50 & 125 \\
\hline Ustupu & 1 & 96 & 26 & 122 & 98,62 & 70,65 & 85,78 & 154 & $120^{\circ}$ & 274 \\
\hline Pto. Obaldla & 1 & 38 & 26 & 64 & 81,56 & 46,45 & 68,86 & 75 & 50 & 125 \\
\hline \multicolumn{11}{|c|}{$1^{*}$ Espediflquese si es Escuela Primaria Pública. Primaria Privada. Secundaria o Profesioal Pública. } \\
\hline \multicolumn{11}{|c|}{ Secundaria o Profesional Privada. } \\
\hline \multicolumn{11}{|c|}{ 2* Se reflere a las Escuelas Primarlas Públicas } \\
\hline & & & & Ricardo & ovelasc & Co, Dire & ector & & & \\
\hline
\end{tabular}




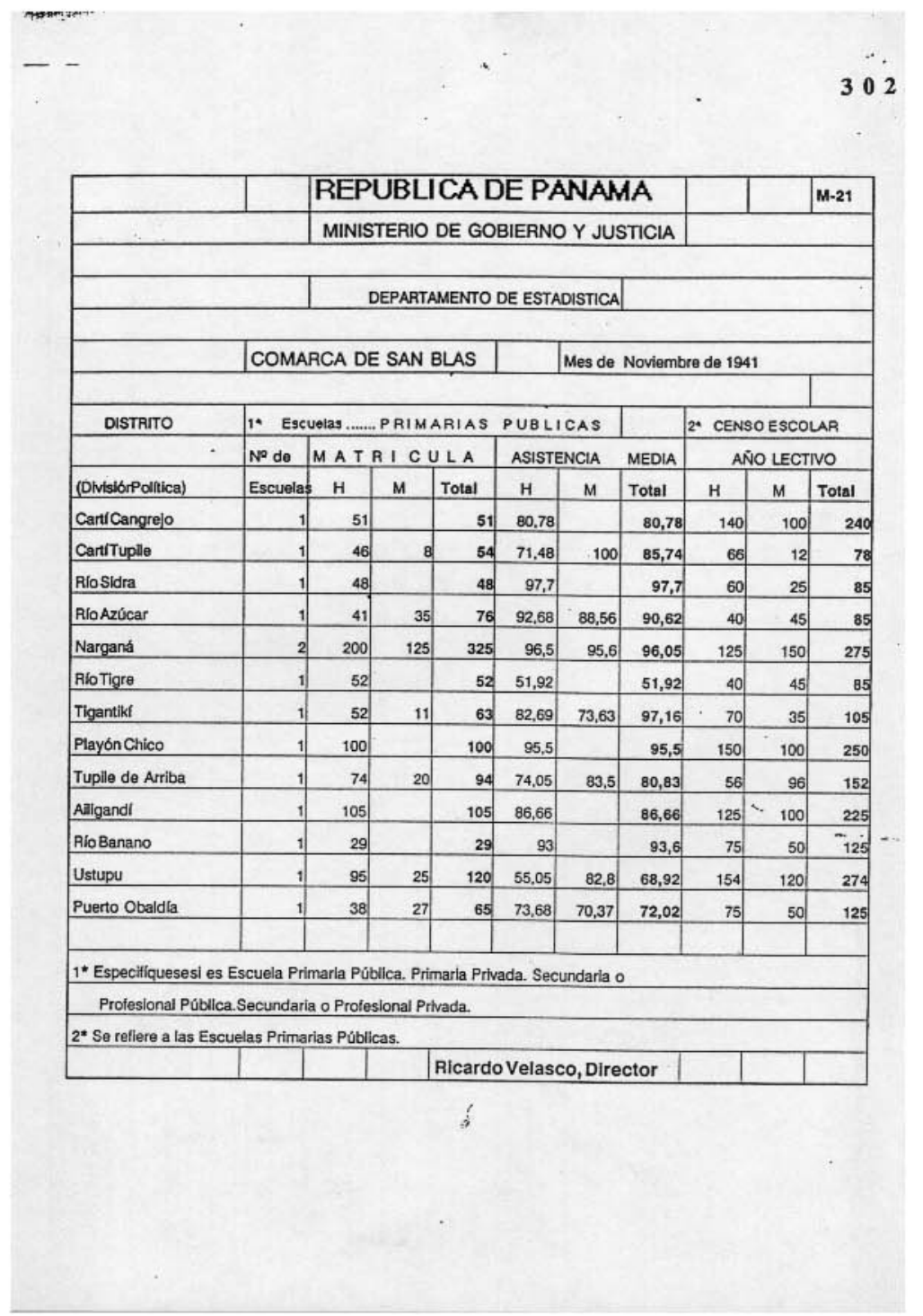




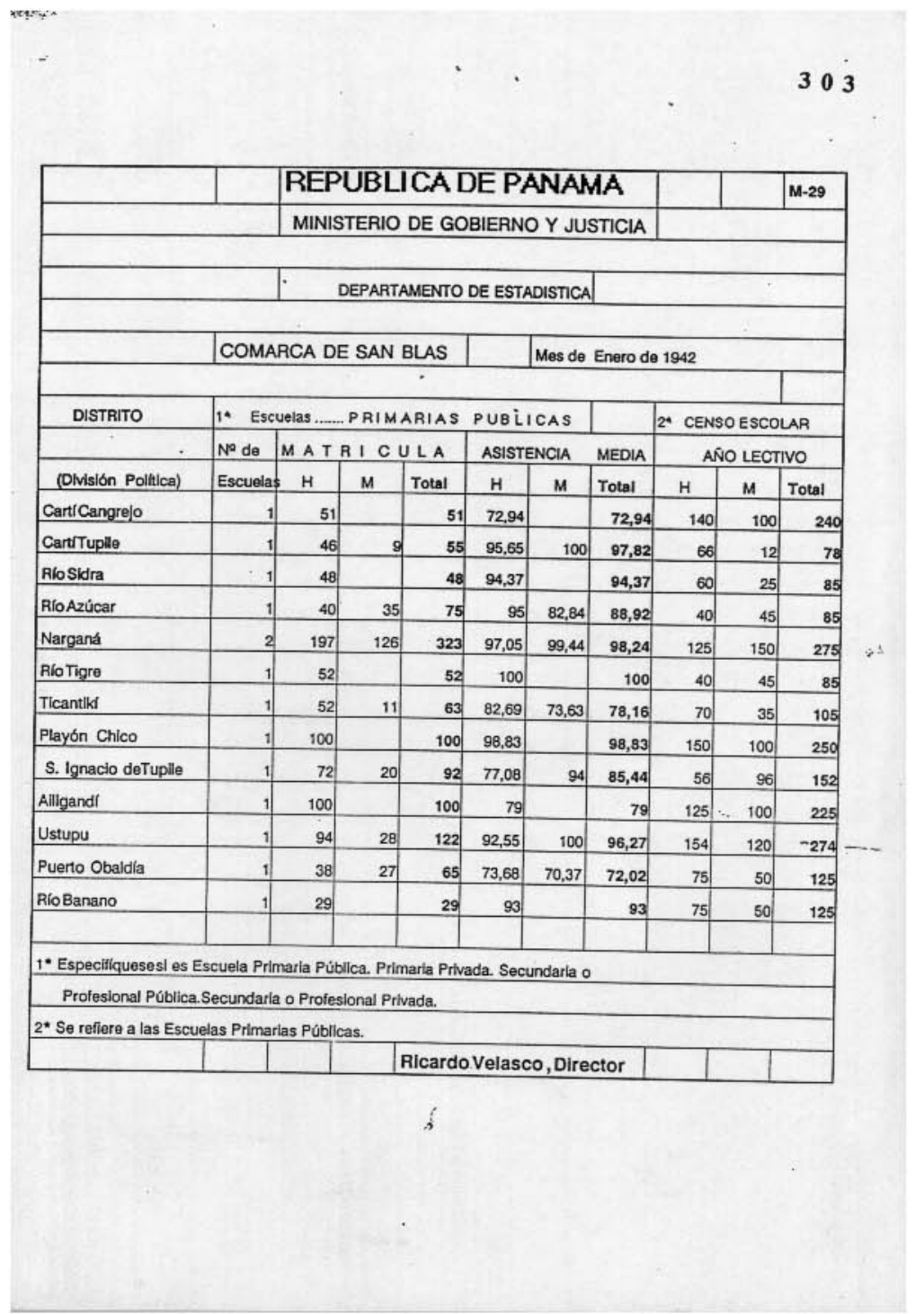




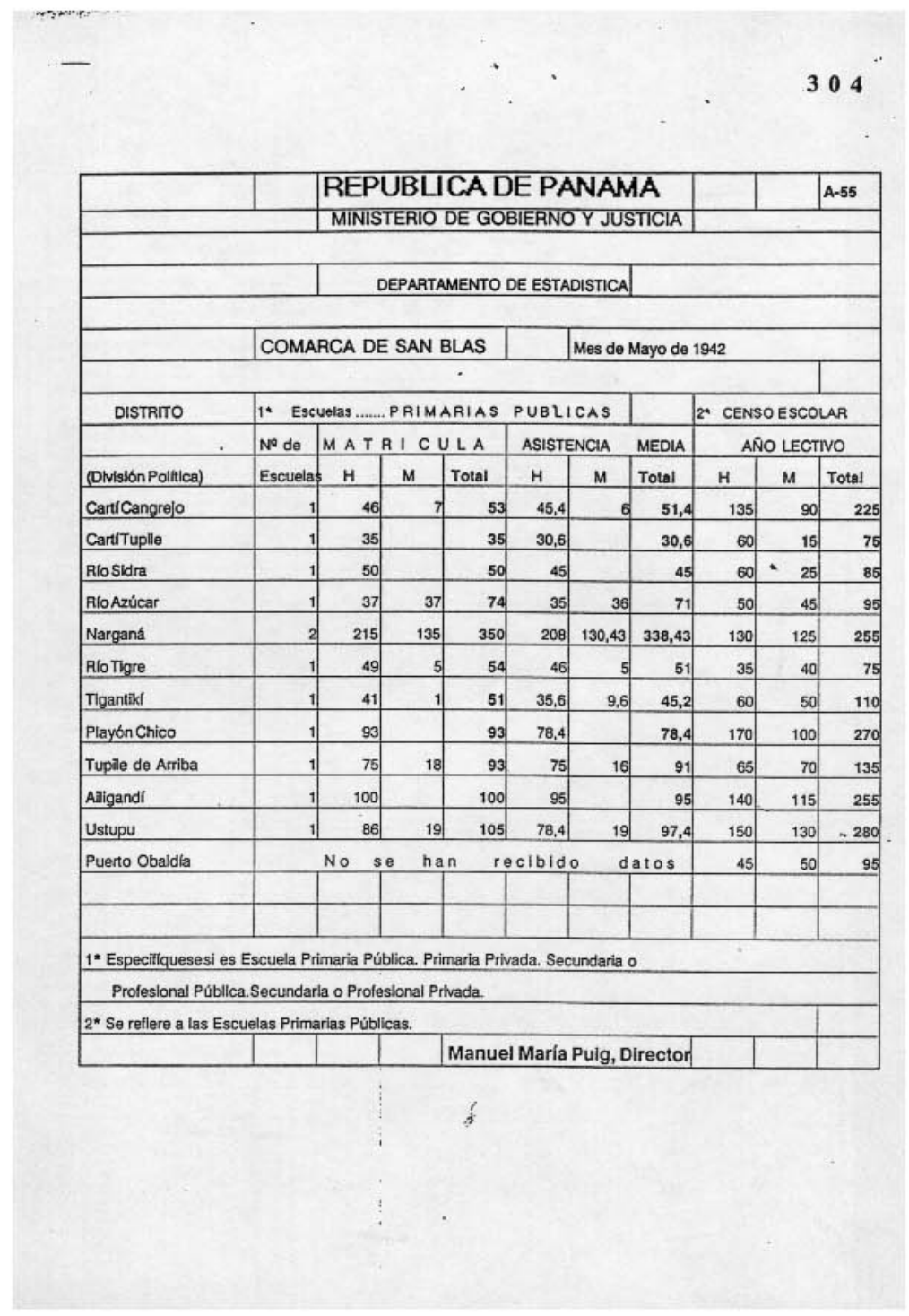




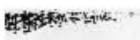

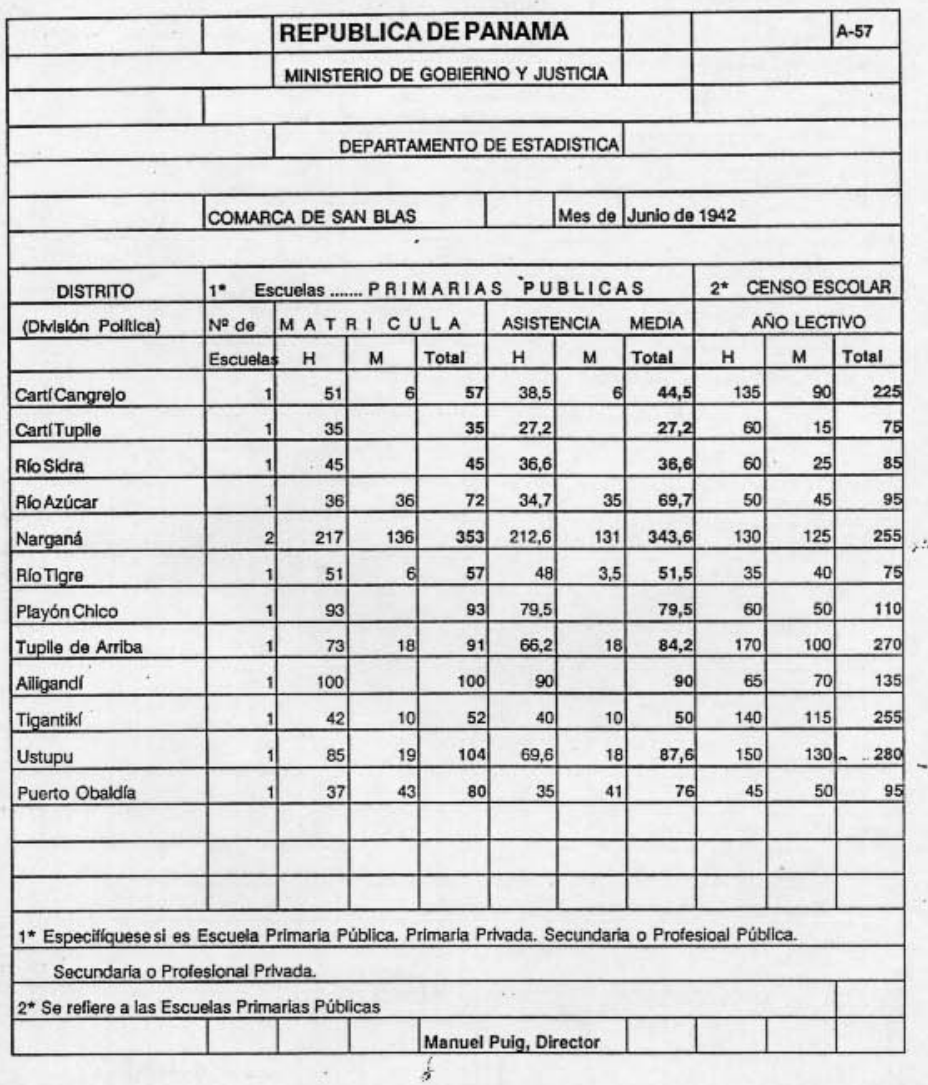




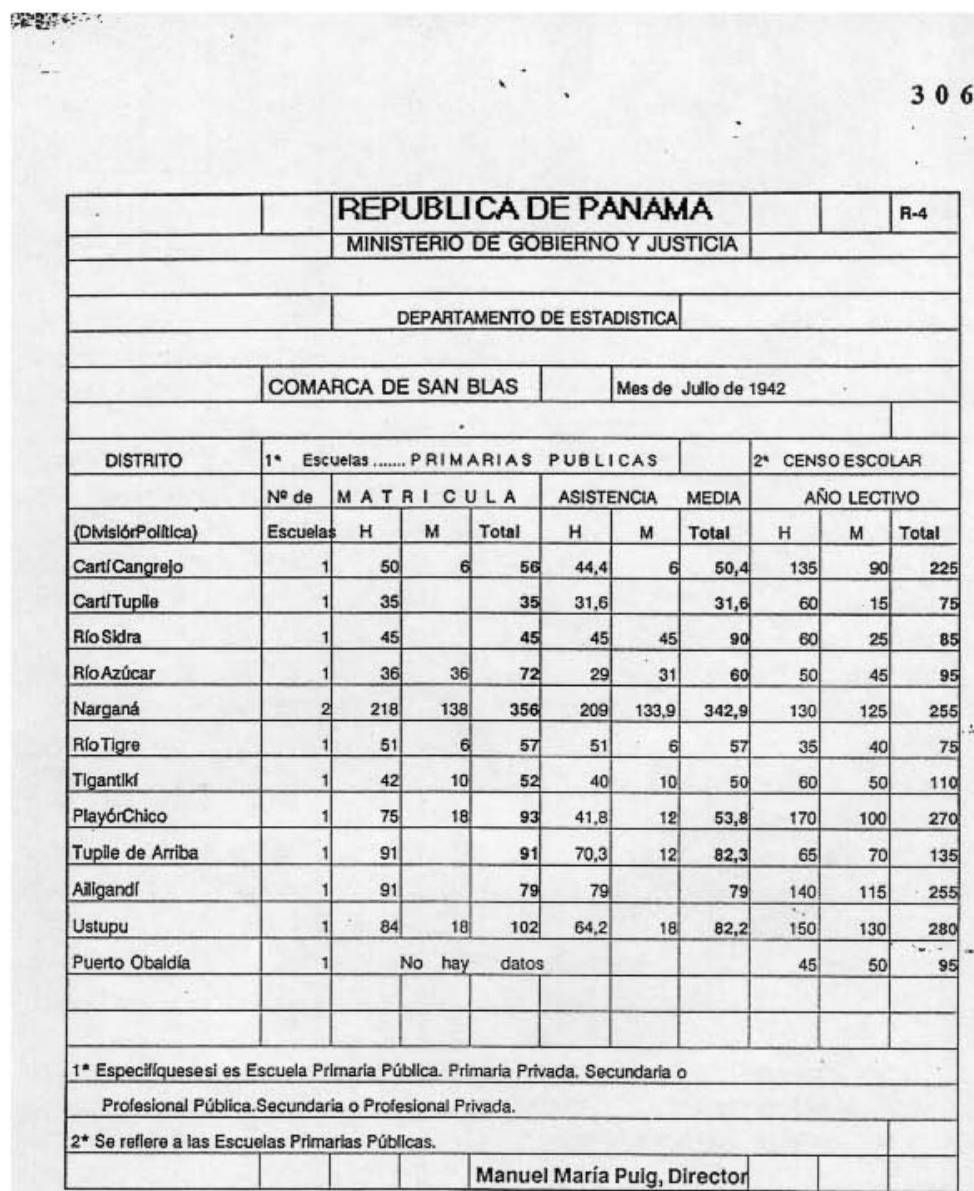




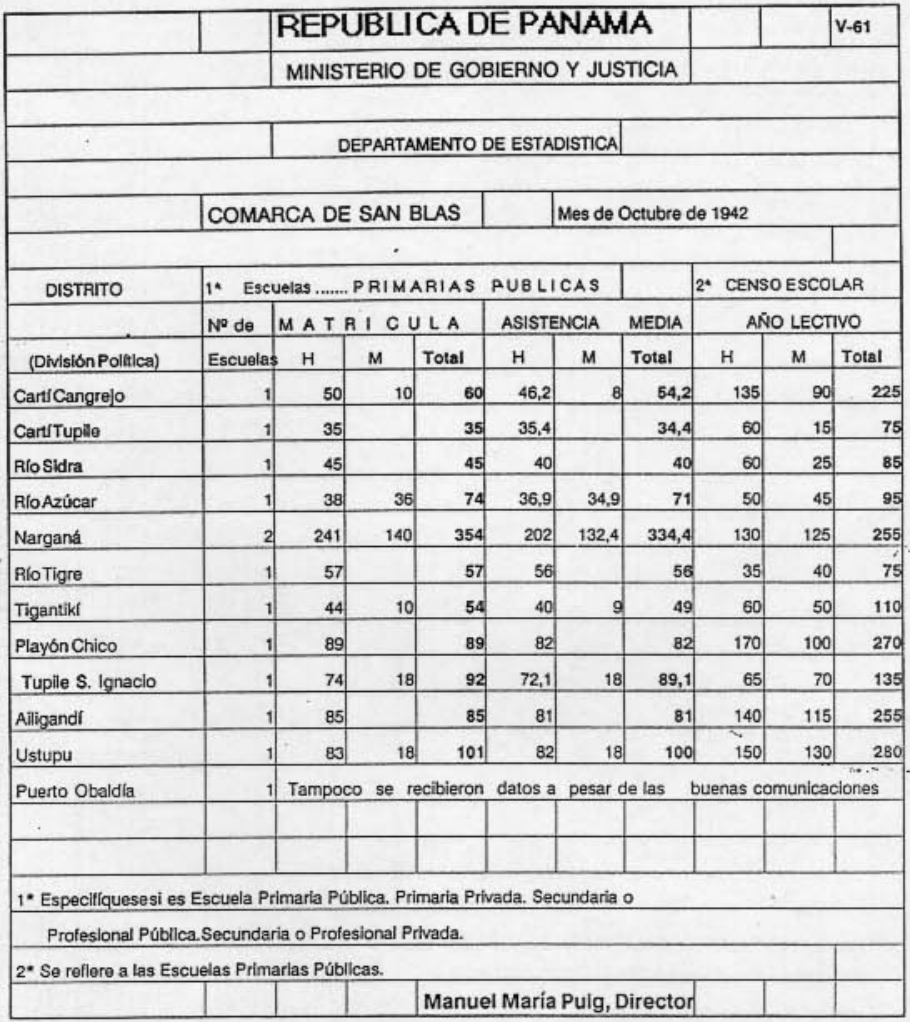




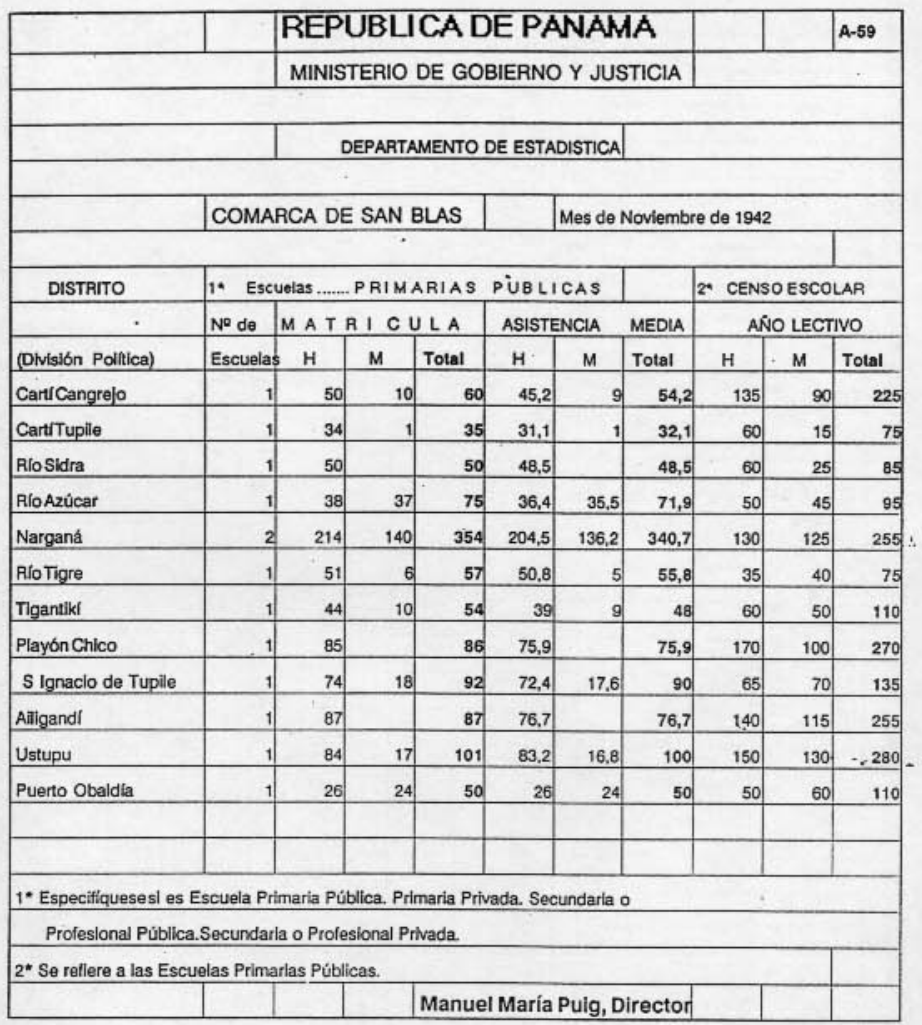




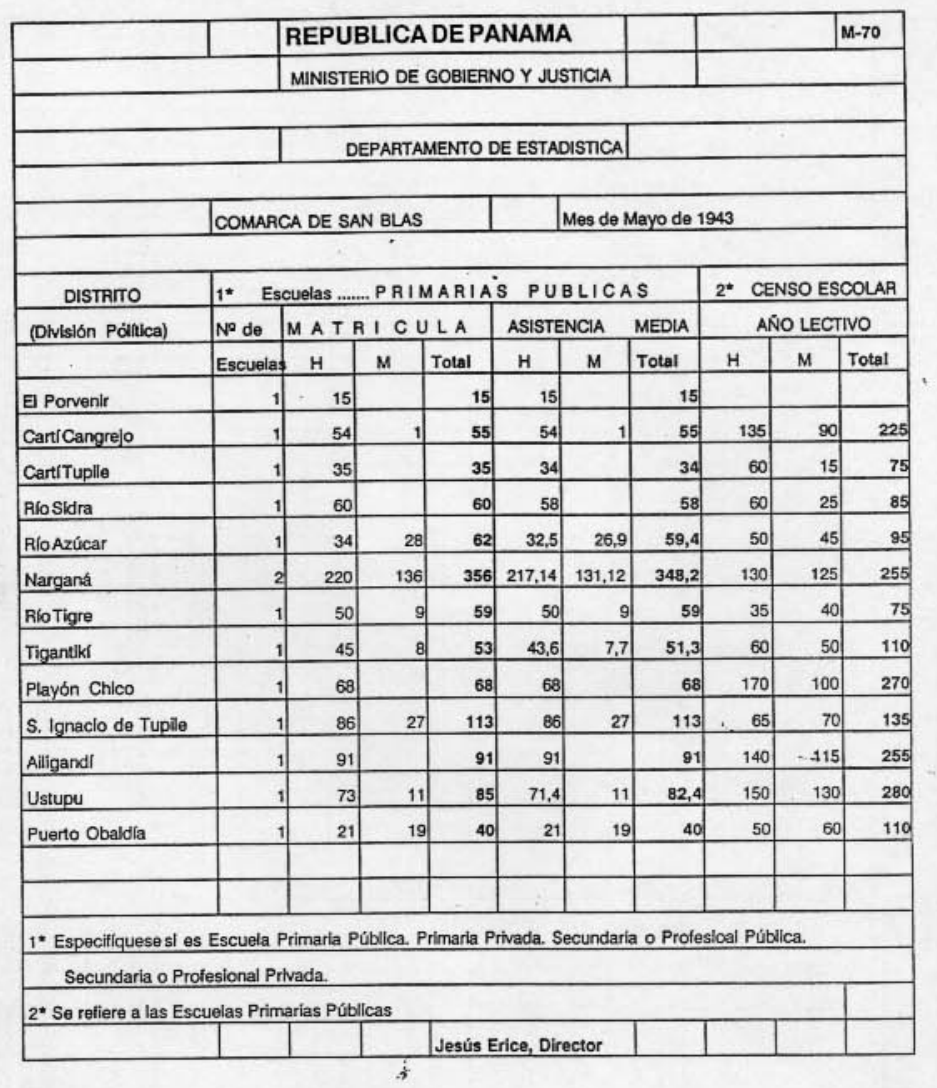




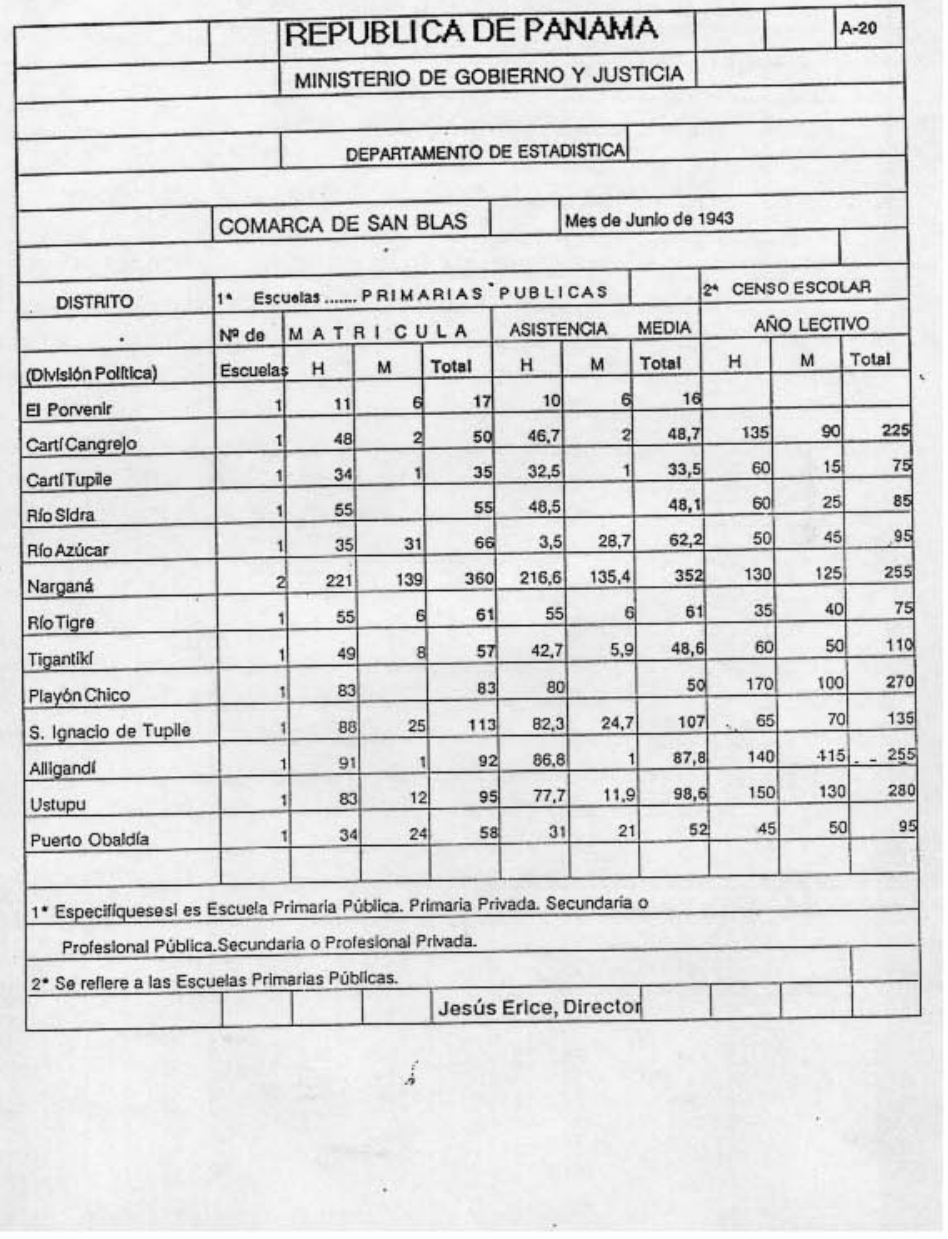




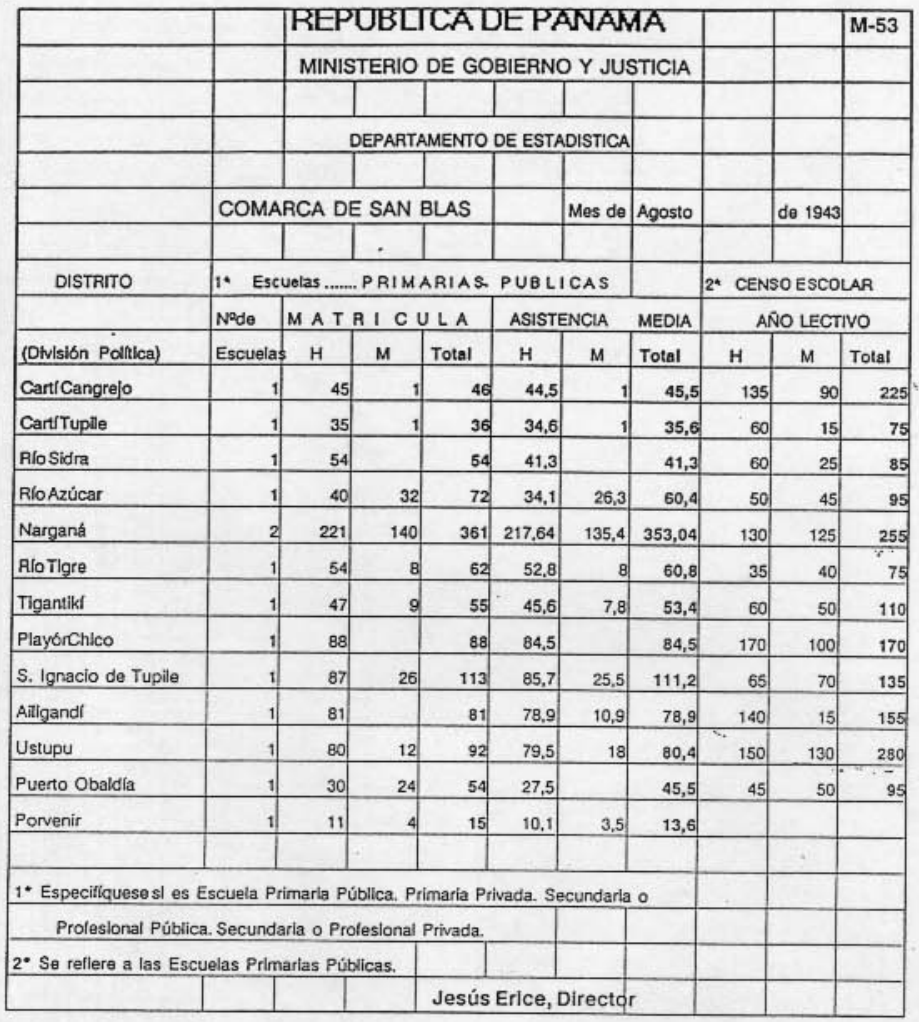


mprexim:?

\begin{tabular}{|c|c|c|c|c|c|c|c|c|c|c|}
\hline & & \multicolumn{6}{|c|}{ REPUBLICA DE PANAIMA } & & & M-53 \\
\hline & & \multicolumn{6}{|c|}{ MINISTERIO DE GOBIERNO Y JUSTICIA } & & & \\
\hline & & & & & & & & & & \\
\hline & & \multicolumn{5}{|c|}{ DEPARTAMENTO DE ESTADISTICA } & & & & \\
\hline & & & & & & & & & & \\
\hline & \multicolumn{4}{|c|}{ COMARCA DE SAN BLAS } & & Mes de & \multicolumn{2}{|c|}{ Septlembre } & de 1943 & \\
\hline & & & . & & & & & & & \\
\hline DISTRITO & \multicolumn{6}{|c|}{ 1. Escuelas ....... PRIMARIAS RUBLICAS } & & \multicolumn{3}{|c|}{ 2* CENSOESCOLAR } \\
\hline & $N^{2} d_{\theta}$ & \multicolumn{3}{|c|}{ MATRICULA } & \multicolumn{2}{|c|}{ ASISTENCIA } & MEDIA & \multicolumn{3}{|c|}{ AÑO LECTIVO } \\
\hline (Dlvisión Pollica) & Escuelas & $\mathrm{H}$ & M & Total & $\mathrm{H}$ & $\mathrm{M}$ & Total & \begin{tabular}{l|l}
$\mathrm{H}$ & \\
\end{tabular} & M & Total \\
\hline Cartl Cangrejo & 1. & 42 & & 42 & 41,5 & & 41,5 & 135 & 90 & 225 \\
\hline CartTuplle & 1 & 36 & 1 & 37 & 33.2 & 1 & 34,2 & 60 & 15 & 75 \\
\hline Rlo Sidra & 1 & 54 & & 54. & 43,5 & & 43,5 & 60 & 25 & 85 \\
\hline Rlo Azúcar & 1 & 42 & 34 & 76 & 40 & 31,2 & 71,2 & 50 & 45 & 95 \\
\hline Narganá & 2 & 218 & 138 & 356 & 211 & 131,4 & 342,4 & 130 & 125 & 255 \\
\hline RloTigre & 1 & 54 & 8 & 62 & 53,4 & 7 & 60,4 & 35 & 40 & 75 \\
\hline TigantikI & 1 & 48 & 8 & 56 & 47,4 & 8 & 55,4 & 60 & 50 & 110 \\
\hline Playón Chlco & 1 & 89 & & 89 & 84,9 & & 84,9 & 170 & 100 & 270 \\
\hline S. Igancio de Tuplle & 1 & 87 & 26 & 113 & 85,7 & 24,5 & 90,2 & 65 & 70 & 135 \\
\hline Ailigandi & 1. & 81 & & 81 & 78,9 & & 78,9 & 140 & 15 & 155 \\
\hline Ustupu & 1. & 81 & 12 & 93 & 78,9 & 12 & 90,9 & 150 & 130 & 280 \\
\hline Puerto Obaldia & 1. & 29 & 24 & 53 & 25 & 24 & 49 & 45 & so. & 95 \\
\hline Porvenir & 1 & 11 & 4 & 15 & 9 & 3,1 & 12,1 & & & \\
\hline \multicolumn{11}{|c|}{$1^{*}$ Especilfquese si es Escuela Primaria Pública. Primarla Privada. Secundaria o } \\
\hline \multicolumn{11}{|c|}{\begin{tabular}{|l|l|l|} 
Profesional Pública. Secundarla o Proleslonal Privada. & & \\
\end{tabular}} \\
\hline \multicolumn{4}{|c|}{ 2* Se reflere a las Escuelas Primarias Públicas. } & & & & & & & \\
\hline & & & & Jesús : & Erice, D & Director & & & & \\
\hline
\end{tabular}


Whe:

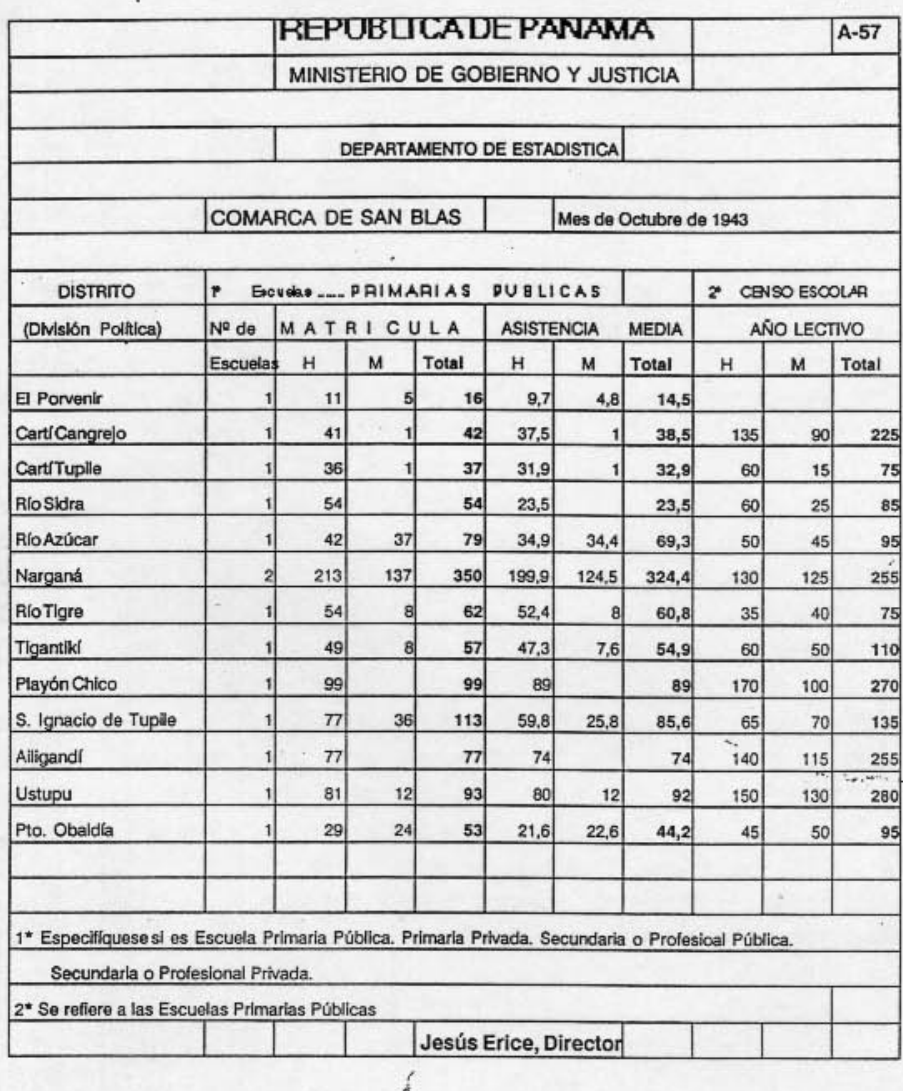




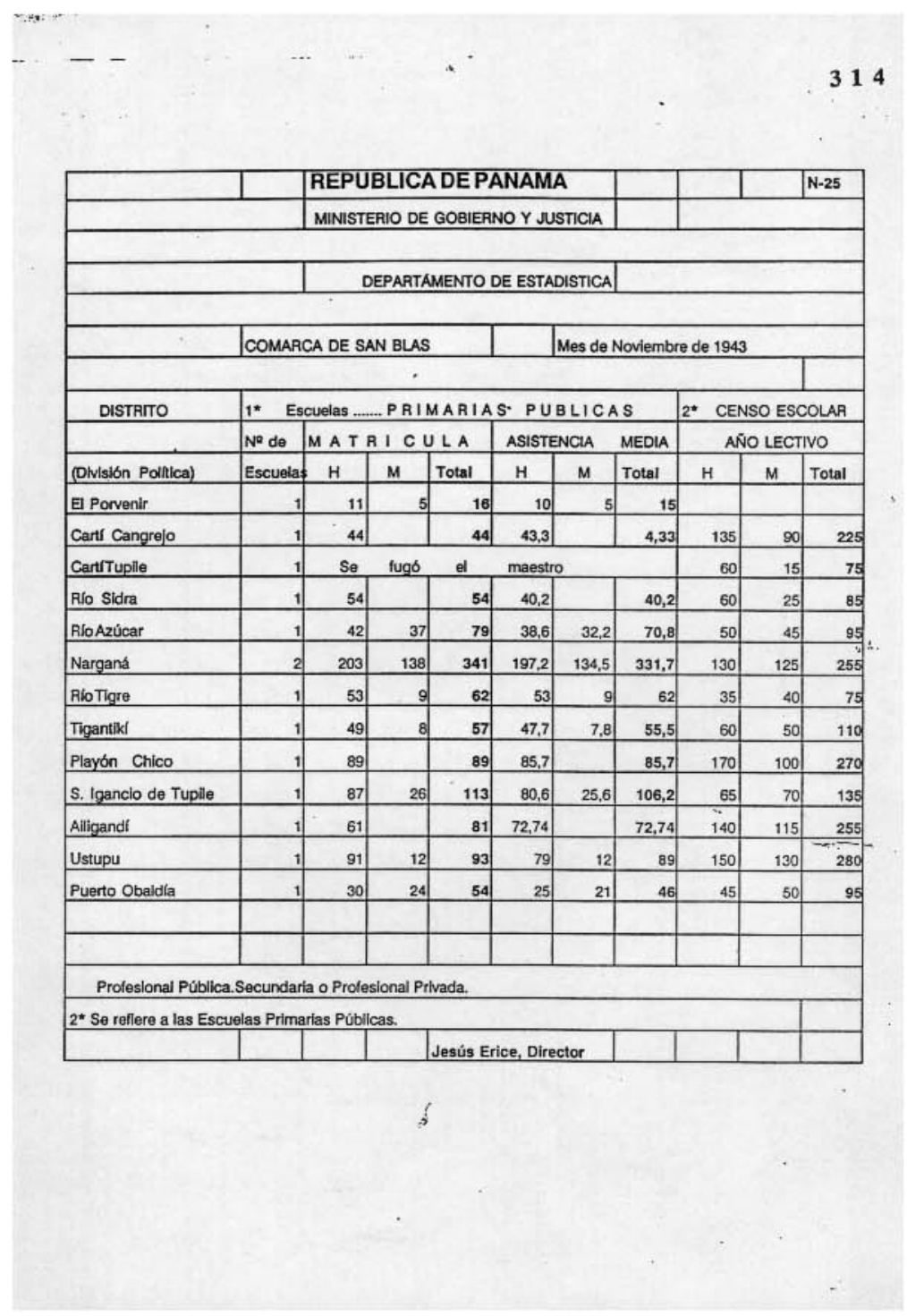




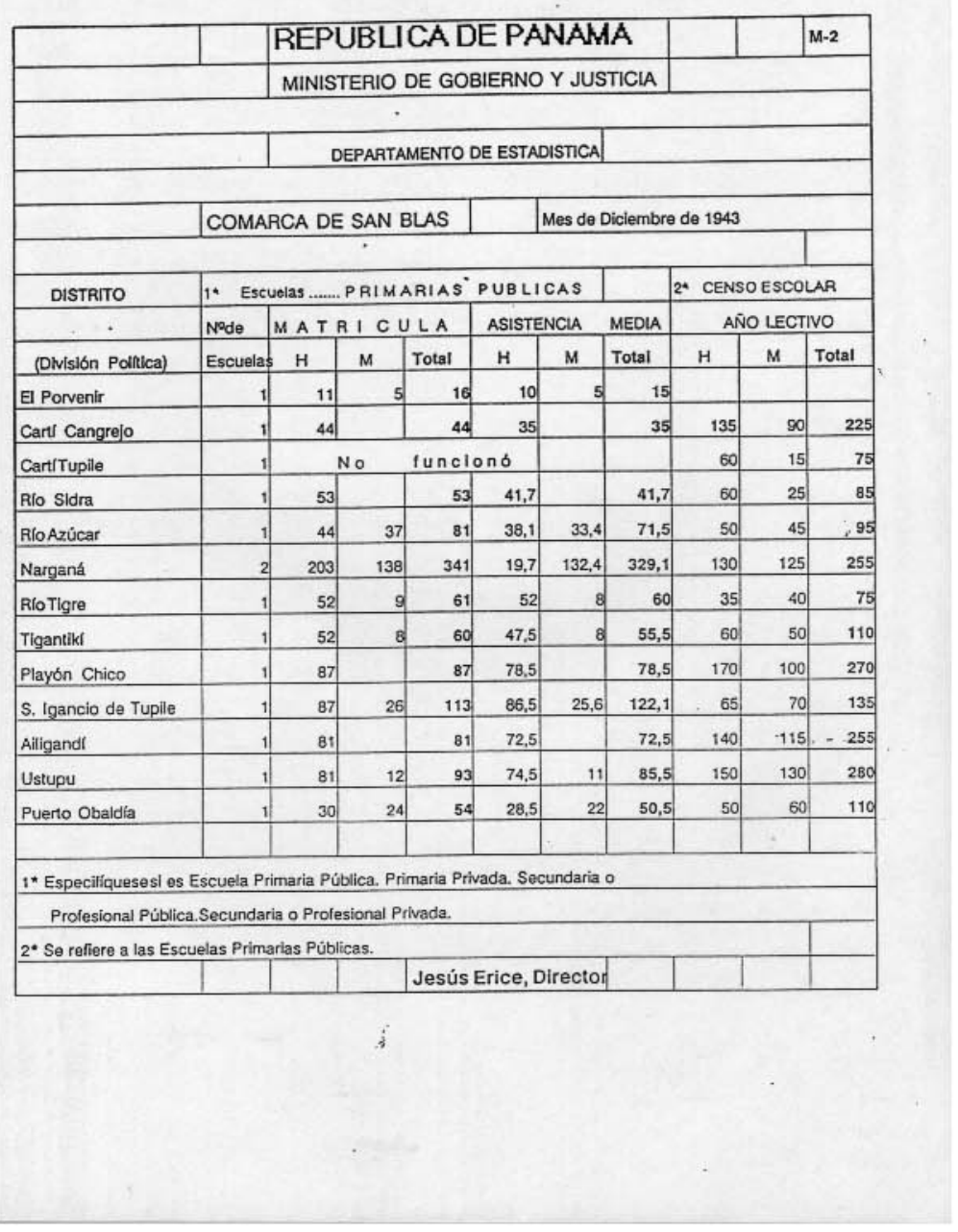




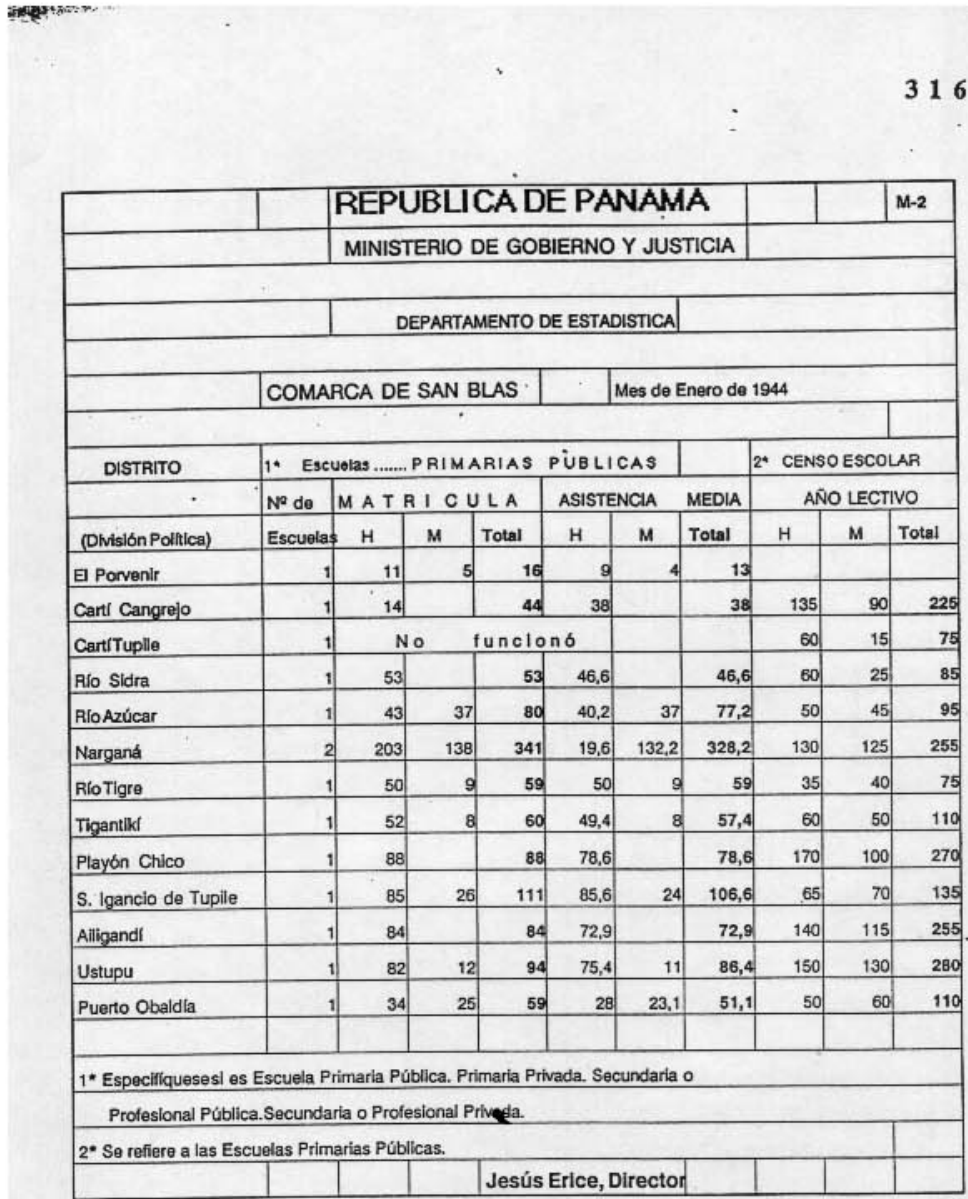

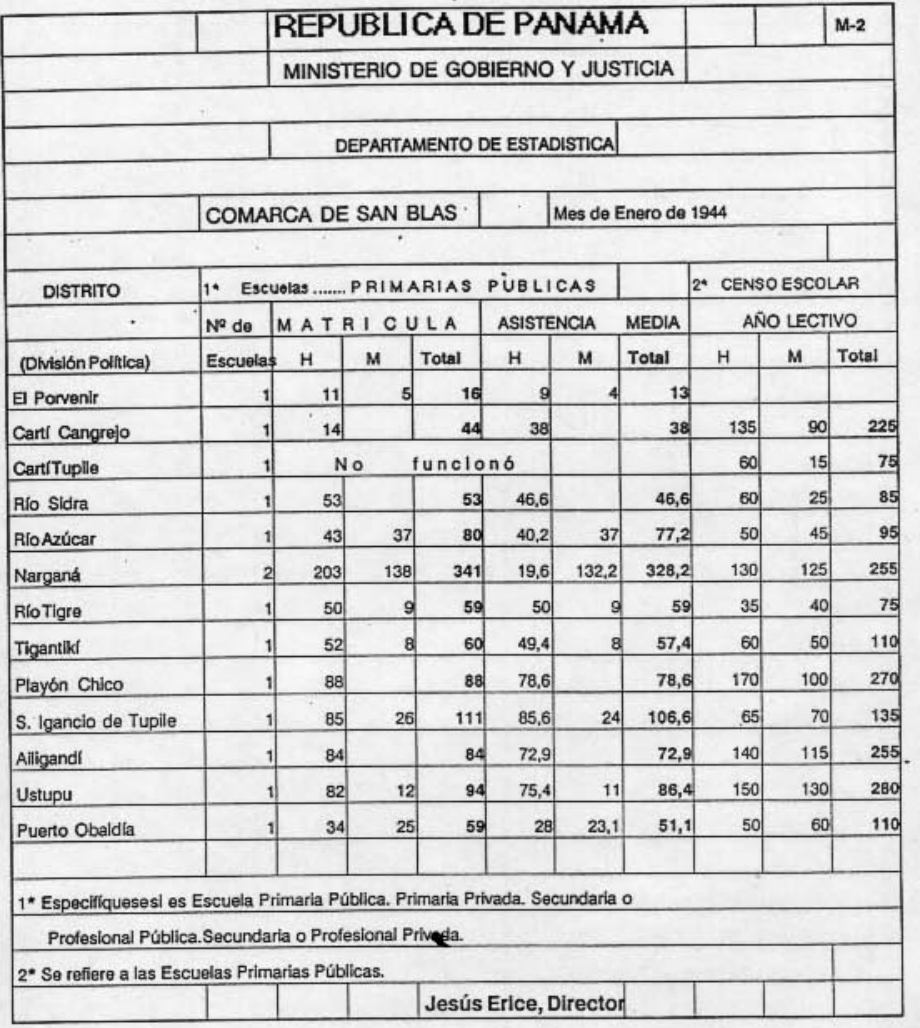




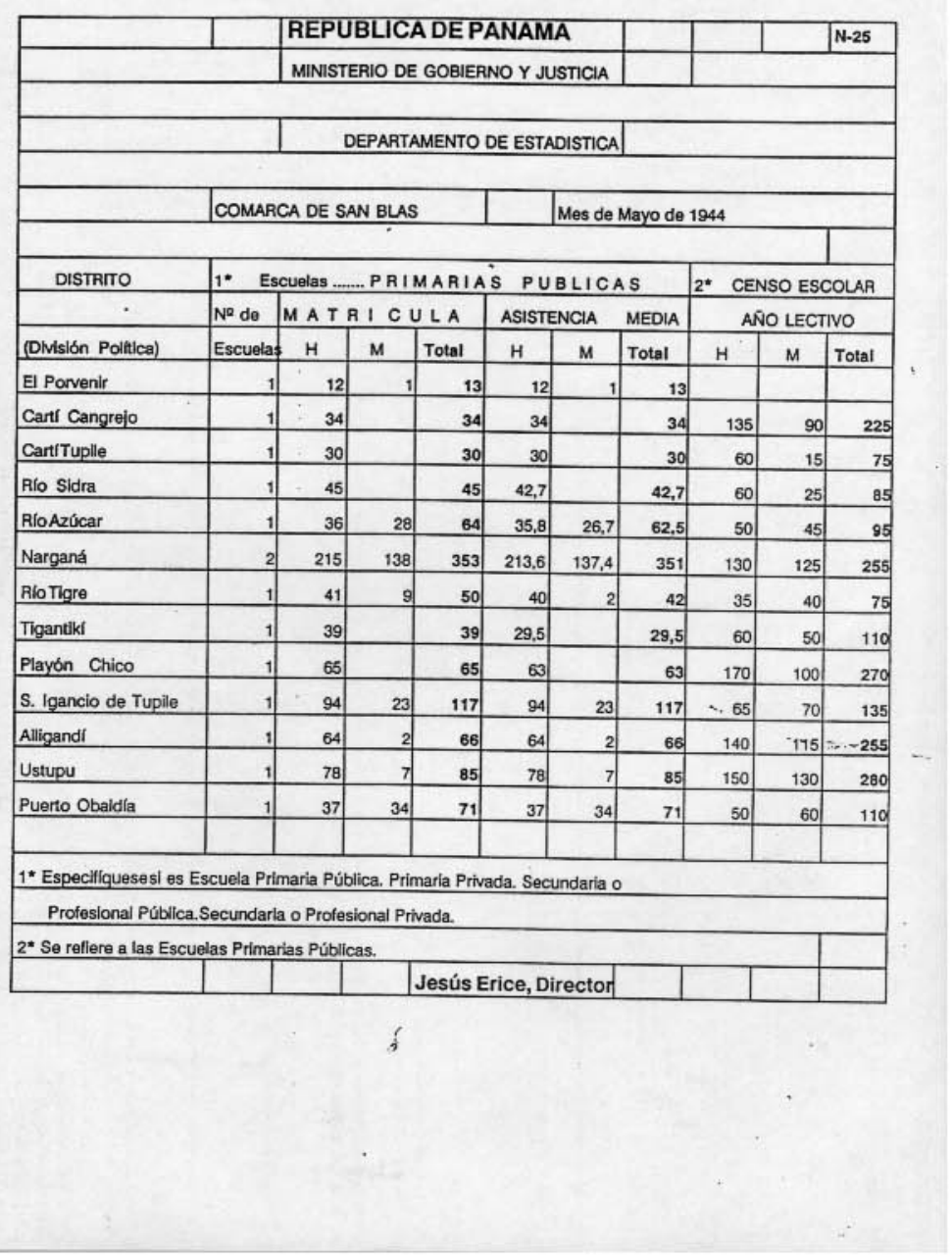




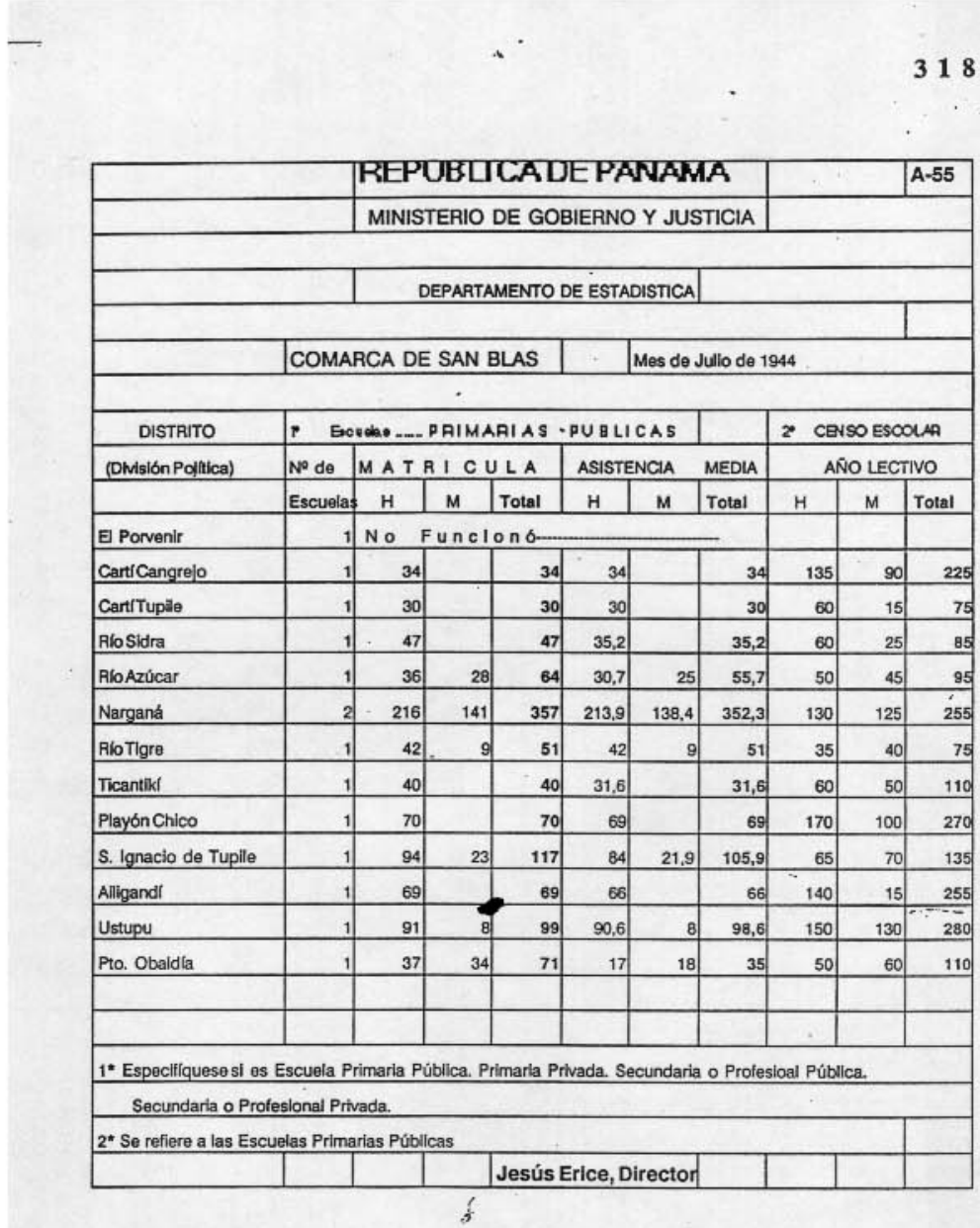




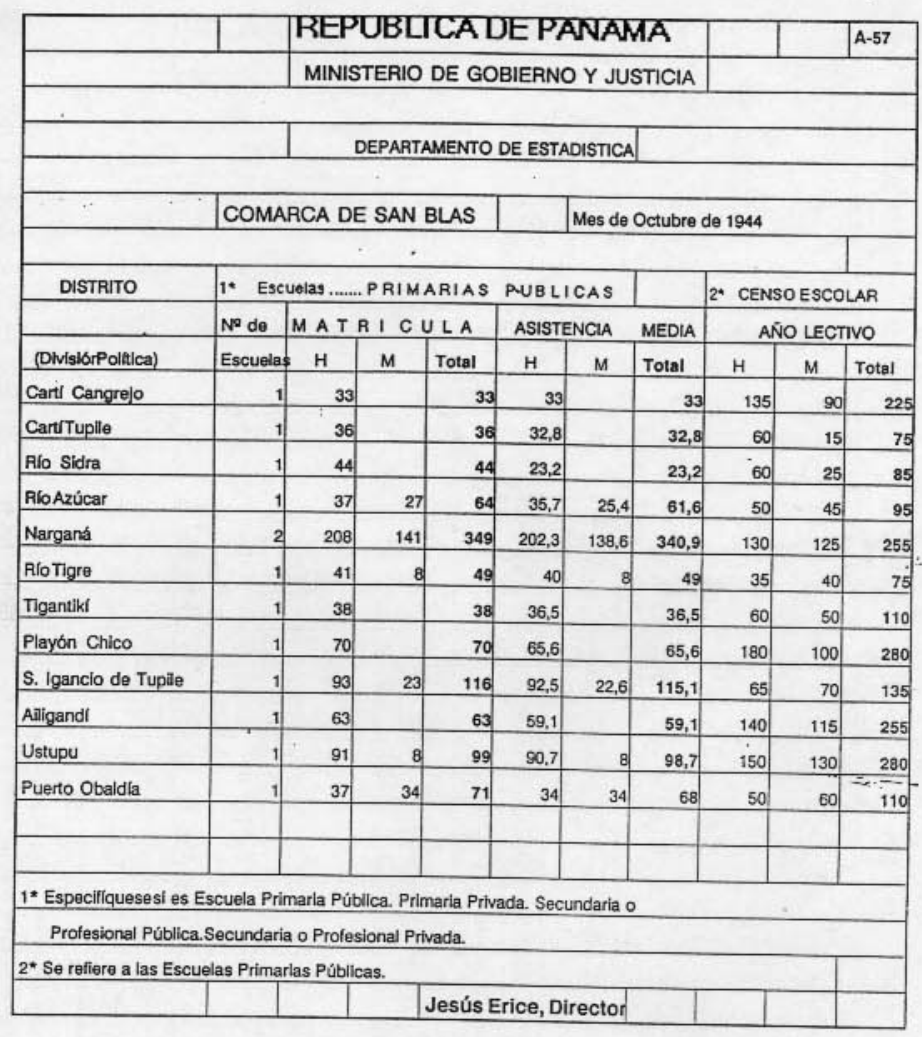




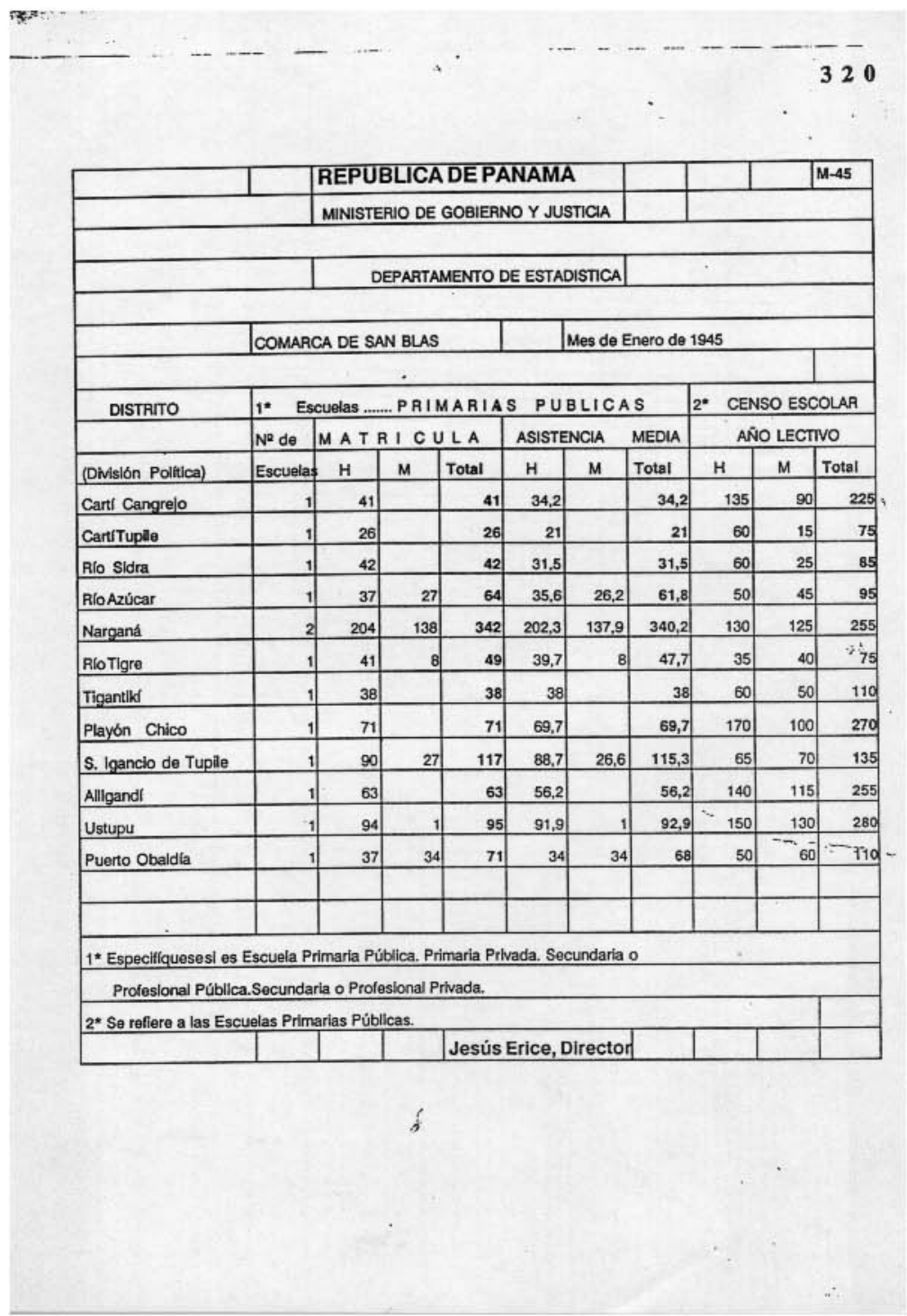




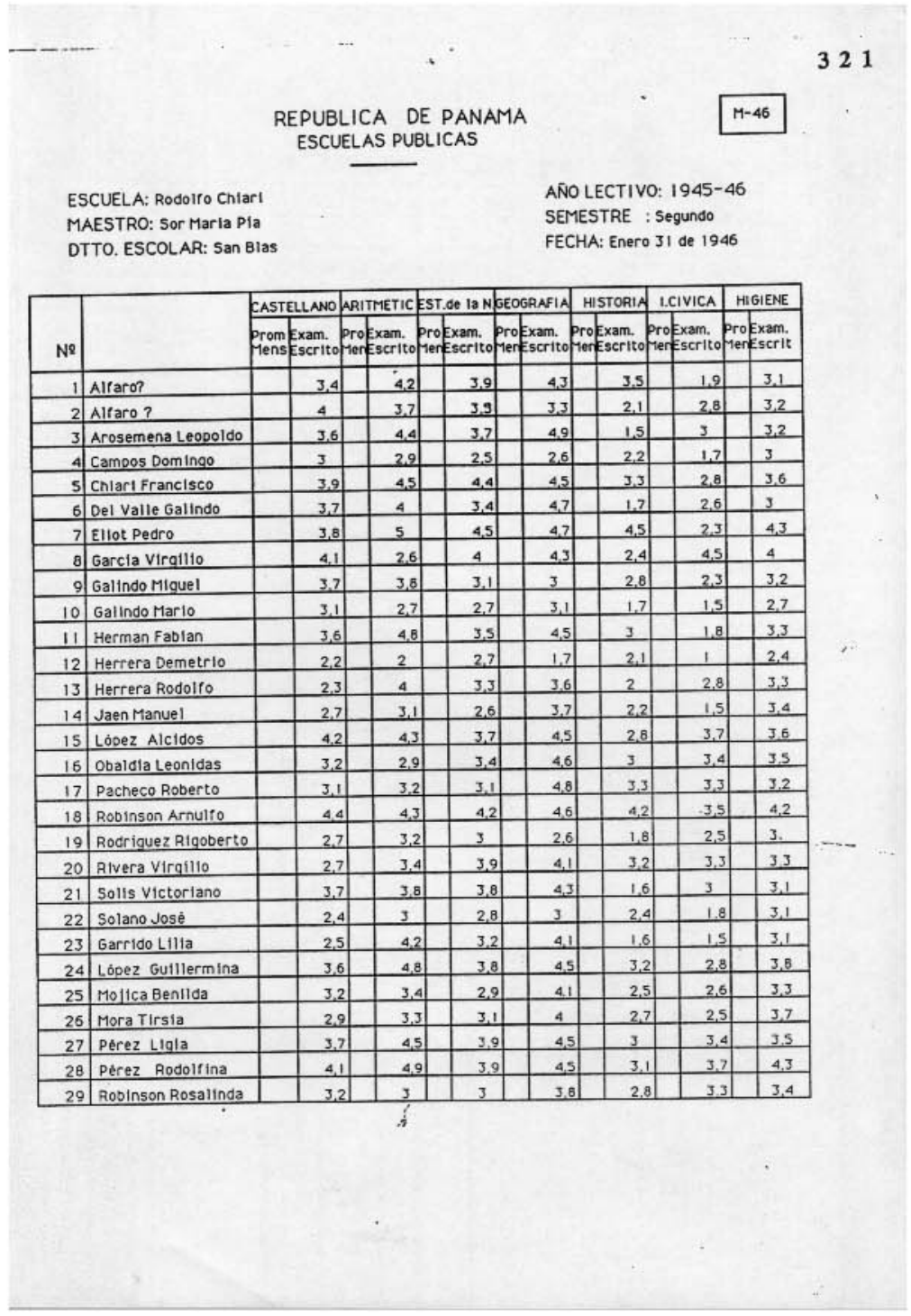


Calificaciones Escolares

Correspondientes al ler grado de la Escuela de Tupile, San Blas, regentada por Guillermina de Sedas, al fin del periodo de 1916-17.

Asignaturas

Promedio

Castellano (Redacción y Dictado)

Lecciones de Cosas

Aritmética

Lectura y Escritura

Dibujo

Labores Femeninas

Canto y Gimnasia

El Calificador $1^{2}$

Fed Gutiérrez

Tupile, Enero 13 de 1917

\begin{tabular}{|c|c|c|c|c|c|}
\hline \multicolumn{6}{|c|}{ Calificaciones } \\
\hline $\mathrm{N}$ & & 2 & $\mathrm{~N}$ & $2^{2}$ & Total \\
\hline $5^{\circ}$ & & 5 & & 10 & 5 \\
\hline 5 & 5 & 5 & 5 & 20 & 5 \\
\hline 5 & 5 & 5 & 5 & 20 & 5 \\
\hline 5 & & 5 & & 10 & 5 \\
\hline 5 & & 5 & & 10 & 5 \\
\hline & 5 & & 5 & 10 & 5 \\
\hline 5 & & 5 & & 10 & 5 \\
\hline
\end{tabular}

A. Linares

Calificaciones Escolares

Otorgadas al ler grado de la Escuela de Narganá, San Blas, regentada por Ana de James, al fin def periodo de 1916-17.

Asignaturas

Castellano

Lecciones de Cosas

Aritmética

Geografía local

Historia

Escritura y Lectura

Dibujo

Agricultura

Labores Femeninas

Composición Dicatado y Copia

Canto

Gimnasia

\begin{tabular}{l}
\multicolumn{5}{c}{ Calificaciones } \\
$\begin{array}{cccc}1^{0} & 2^{2} & \text { Total } & \text { Promedio } \\
4 & 4 & 8 & 4 \\
5 & 5 & 10 & 5 \\
5 & 4 & 9 & 4,5 \\
5 & 5 & 10 & 5 \\
5 & 4 & 9 & 4,5 \\
5-5 & 4-5 & 19 & 4,7 \\
5 & 5 & 10 & 5 \\
4 & 4 & 8 & 4 \\
5 & 5 & 10 & 5 \\
4 & 4 & 8 & 4 \\
5 & 5 & 10 & 5 \\
5 & 5 & 10 & 5\end{array}$
\end{tabular}




$\begin{array}{ll}\text { El Calificador } 1^{\circ} & \text { El Calificador } 2^{\circ} \\ \text { Fed Gutiérrez } & \text { A. Linares }\end{array}$

Narganá, Enero 12 de 1917

Calificaciones Escolares

Otorgadas al ler grado de la Escuela de Corazón de Jesús, San Blas, regentada por Elisa de Salazar, de 1916-17.

Asignaturas

Castellano

Lecciones de Cosas

Aritmética

Geografía local

Historia

Escritura y Lectura

Dibujo

Agricultura

Labores Femeninas

Composición Dicatado y Copia

Canto

Gimnasia

Geometría

El Calificador $1^{\circ}$

Fed Gutiérrez

Calificaciones

$\begin{array}{ccc}1^{\circ} & 2^{2} & \text { Tot } \\ 5 & 4 & 9 \\ 4 & 5 & 9 \\ 5 & 5 & 10 \\ 5 & 5 & 10 \\ 5 & 4 & 9 \\ 5 & 5 & 10 \\ & & \\ 5 & 5 & 10 \\ 5 & 5 & 10 \\ 4 & 4 & 8 \\ 4 & 4 & 8 \\ 5 & 5 & 10\end{array}$

El Calificador $2^{2}$

A. Linares

Corazón de Jesús, enero 12 de 1917 
Cuadro de las Calificaciones otorgadas a la escuela Alternada de Playón Chico, regentada por La Sra Fago en los exámenes finales del curso 1916-17

\section{Asignaturas}

Promedio

Ejercicios de Lengua

Aritmética

Dibujo

Lectura

Escritura

Canto y Gimnasia

Costura
Calificaciones
$\mathrm{N} \quad 1^{\otimes} \mathrm{N}$

$\begin{array}{lllll}5 & 5 & 5 & 5 & 20 \\ 5 & -5 & 4 & 4 & 18\end{array}$

$\begin{array}{lllll}5 & -5 & 4 & 4 & 18 \\ 5 & 5 & 4 & 5 & 19\end{array}$

$\begin{array}{lllll}5 & 5 & 5 & 4 & 19\end{array}$

$\begin{array}{lllll}5 & 5 & 4 & 4 & 18\end{array}$

$\begin{array}{lllll}5 & 5 & 5 & 5 & 20 \\ & 5 & & 5 & 10\end{array}$

El Calificador $1^{\circ}$

Fed Gutiérrez B

El Calificador $2^{\circ}$

Playón Chico, 13 de Enero de 1917

Total

4,5

4,7

4.7

4,5

5 
PRIMEROS ALUMNOS DE LA ESCUELA PUBLICA DE NARGANA

(Curso 1916-17, maestra Ana M. de James)

1.- Alfaro Ricardo

2.- *Arias Ernesto

3.- Andreve Guillermo

4.- Alemán Rita

5.- Arias Elida

6.- Alvarado Luisa

7.- Bernal Melvin

8.- Bernal Elvira

9.- Barcés Matilde

10.- Campos Margarita

11.- Campos Manuel

12.- ${ }^{*}$ Caicedo Dionisio

13.- Calvo Raul

14.- Díaz Temístocles

15.- Díaz Angela

16.- Espinosa Rosa

17.- Flores Mercedes

18.-*Fepillos Edwin

19.-*Garrido Francisco

20.-*Gómez Gregorio

21.- Narciso Gary

22.- Guardia Rosario

23.- García Eloisa

24.- Garrido Martina

25.-*Hernández Carlos

26.- Herrera Tomás

27.-*Iglesias Pablo

28:- Iglesias Marina

29.-- Jiménez Alvarado

30.-*López Andrés

31.- Lionar Elena

32.- *Morris Samuel

33.- Morris Elena

34.- Martínez Simón

35.- Mendoza Pedro

36.- Méndez Josefina
37.- Méndez Juanita

38.-*Núñez José

39.-*Nelson José

40.- Obarrio Catalina

41.- Obaldía Leonidas

42.-*Ossa Franklin

43.- Pérez Félix

44.--Pérez Juan Bautista

45.- Peralta Benito

46. Pinel Pablo

47.- Once Víctor

48.- Porras Belisario

49.- Paredes Miguel A.

50.- Quintero Luis

51.- Robinson Ismael

52.- Robinson Judith

53.- Robinson Raquel

54.- Ribera Carmen

55.- Solano Camilo

56.- Solano David

57.- Solano Berta

58.- Sossa Luzina

59.- Sossa Emilia

60.- Shep Ester

61.- Smith Eva

62.- Smith Evelia

63.-*Tam Enrique

64.-*Torres Abel

65.-*Tejada Calixto

66.- Tejada Eduardo

67.-*Valdés Ramón

68.-*Vallarino Dario

69.- Yam Teresa

70.- Yam Eugenio

71.- Zolandares César

72.- Zúñiga Lucía

* Pasan a $2^{2}$ grado el siguiente curso.

Trans. del orig. mec.

V. RD, n. 976 . 


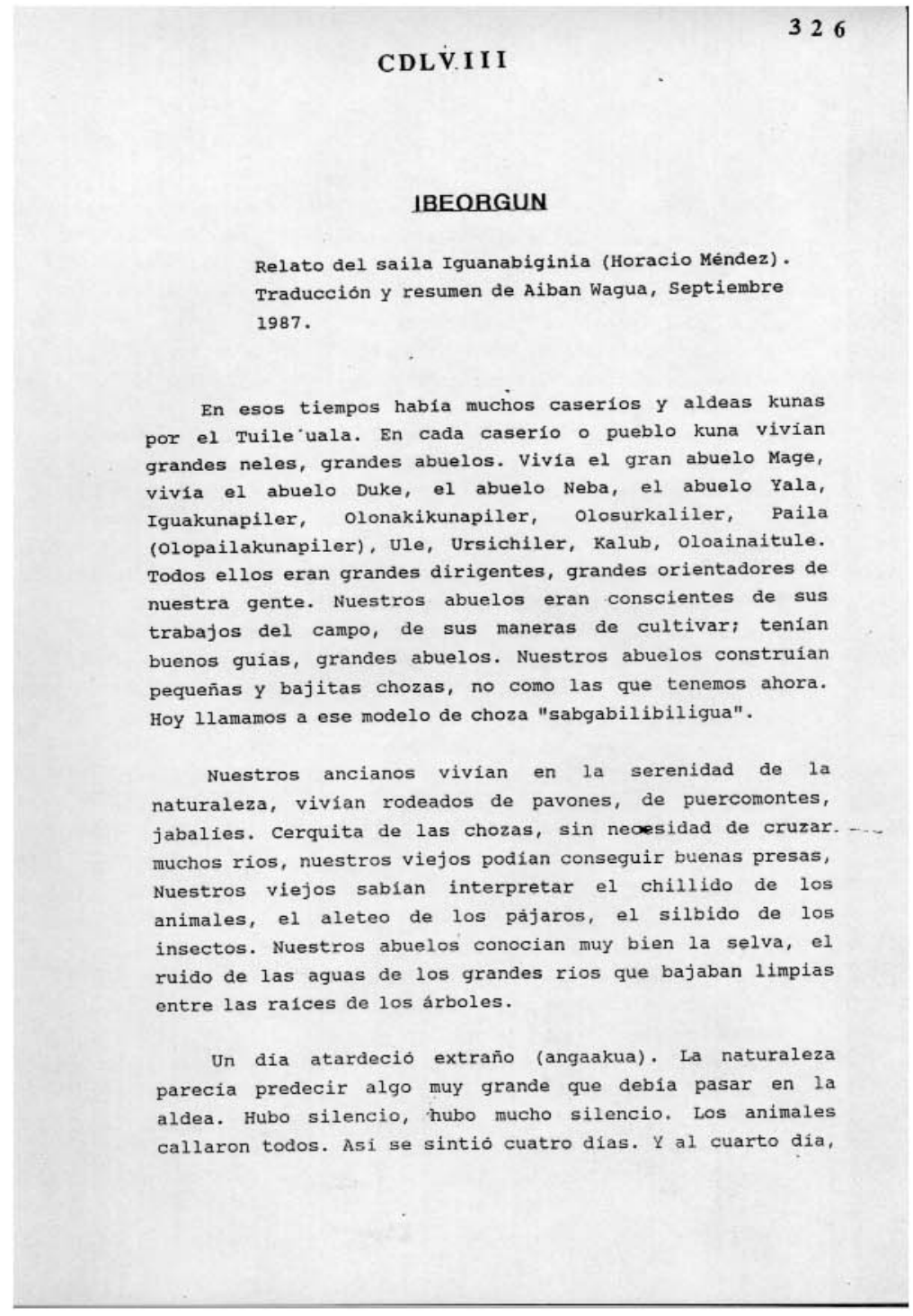


a medianoche, se escuchó un grito muy hondo. Se oyó el grito de alguien que venía subiendo por el rio, por donde nace el rio, por donde las aguas salen claritas de la tierra $y$ de las raices. el grito sonaba cada vez más cerca, más fuerte: Yooh, yooh, yooh!. A la aldea de los kunas llegaron tres jóvenes: Ibeorgun, Uiķudun, Kikadiryai! Ibeorgun empezó a saludar a nuestros abuelos a medianoche:

-Naa, tegite!

$\mathrm{y}$ nadie sabia responder a Ibeorgun. Entonces, él mismo empezó a enseñar a nuestros abuelos las distintas formas de saludar, de desear bienes por las mañanas.

Ibeorgun enseñaba asi a nuestros antepasados. Les decia:

- Contésteme "an nuedye"! - Y alargó la mano a los ancianos, a las mujeres; a los niños los fue abrazando $y$ aupándolos cariñosamente. $\mathrm{Y}$ por eso, los sailas cantan: "Sikui parube agaokuichiye" !. Ibeorgun era un joven kuna: los ancianos lo acogieron, algunos sorprendidos y todos muy felices. Luego Ibeorgun dijo a nuestra gente.

- Ahora, vamos a reposar. Vamos a acostarnos y a tomar una corta muerte. Paba nos quiere regalar una muerte pequeña para reponer las fuerzas. Paba nos quiere amonestar y seguir guiando en los sueños. No olviden los sueños.

Amanecio. Muy de madrugada, antes de que las estrellas fueron apagadas todas por el sol, nuestros abuelos bajaron al rio. Nuestros abuelos bajaron al rio apoyados unos en otros, tomados de la mano para que nadie resbalase en el charco. Ibeorgun bajó con nuestros abuelos. Ibeorgun enseñó también el saludo de la mañana.

- Kilumarye, baninuiganbi sogoye! - decia orgun. Y orientaba responder asi:

- Pernueganbiye!

Luego Orgun se volvia hacia nuestras ancianas, y las 
saludaba también:

- Ammamarye, baninueganbi sogoye!

El gran Ibeorgun aconsejaba a nuestra gente sobre las maneras de bañarse:

- Tomen un baño largo. No se bañen como los pajaritos, que se agitan rápidamente sobre las aguas y salen volando. Ustedes deben tomar un baño largo, porque el rio es como el cayuco lleno de medicinas: fijense dónde tiene sus raices los grandes y fuertes árboles. Con este baño de las mañanas tomamos nuevas fuerzas. Nos llenamos de las ganas de seguir trabajando.

Nuestros abuelos ya conocian, antes de llegar Ibeorgun, los modos de conseguir las fuerzas, las maneras. de organizarse: pero Ibeorgun los completaba, los detallaba más, les abría nuevos caminos, los organizaba mejor.

Nuestros abuelos, después del baño, subian a la aldea. Ibeorgun reanudaba sus enseñanzas. Ibeorgun llamó a uno de nuestros ancianos y le enseñó cómo responder a su canto: "teegi". Nuestros abuelos aprendian a invocar a Paba, nuestros ancianos aprendian nuevas formas de levantar el ... corazón a Paba.

Ibeorgun, como un gran guia del pueblo, instruyó asi a nuestros ancianos, para que ellos a su vez pudieran instruir a otras aldeas, a otras personas que vendrian más tarde. $Y$ hablaba:

- Vamos a mejorar nuestras chozas. Aqui necesitamos una choza grande. Casa de todos. Casa de mujeres, casa de hombres, casa de niños: de todos. Ahí vamos a hablar de Paba, de nuestras enfermedades, de nuestros trabajos, de nuestras grandes y pequeñas cosas. Esta choza, como todas 
de dar forma y consistencia a la choza. Es la choza la que va a dar nombre a las cosas que la van a ayudar a tomar forma. Asi nosotros, asi nuestra comunidad. Ella da, ella nos da su nombre.

Asi Ibeorgun fue enseñando a nuestros abuelos las partes de una choza, parte por parte, etapa por etapa. Sin embargo, las chozas que hacian anteriormente no estaban mal hechas. Eran muy bonitas y muy acomodadas al clima de la región. Con Ibeorgun nació otro estilo de hacer las chozas, el que tenemos ahora, el que conocemos en Kuna Yala.

Ibeorgun no se cansaba de instruir a nuestros abuelos y les seguia diciendo:

- Ustedes no deben hacer una casa sola. La choza macho (el dormitorio) debe tener su pareja: la choza hembra (el soouu: la cocina). Tenemos que construir nuestras chozas. Nosotros no hemos nacido para respirar el aire sucio, aire podrido. Tenemos que trazar ampliar nuestras calles.

Nuestro abuelo orgun tambièn habló de la siembra, del cultivo de la tierra, del cuidado de la Madre- Tierra. Y decia a nuestros grandes abuelos en Yoodi uala:

- Es verdad que paba nos ha dejado buenas tierras. Las plantas crecen solitas! las semillas de otoe, de maiz, de caña... brotan rápidamente, pero nosotros tenemos la obligación, el deber de extenderlo cada vez más por todos los rincones de la Madre-Tierra. Y solamente asi vamos a cuidar a la madre, a la gran Madre-Tierra. Nuestros hijos van naciendo, y para que estos hijos vivan bien, los alimentos también deben ser multiplicados al doble.

Salió el sistema del nainu, la selecclón de semillas diversas para el cultivo, las maneras de cortar y de 
conservar las cepas de plátano, las maneras de dejar al remojo los granos de maiz a sembrar, el uso de hojas podridas para la siembra. Entonces se sembraron toda clase de frutas. Pasaron algunos años, vino la gran cosecha. Todos unidos trabajaron, $y$ todos unidos recogieron los frutos de la tierra. Todos unidos sudaron, $y$ todos unidos se pasaron los frutos de la tierra unos a otros. Entonces la MadreTierra dio mucho aguacate, dio mangos, dio limones, dio mucho maiz, dio platanos de todo tipo. Niños y niñas repartian por las calles las cosas: unos llevaban cestillas de limones, otros de mamey, otros gajos de plátano de cana. Nadie podia pasar hambre; y nadie podia decir que tenia más o menos que su vecino. Al seno de onmaked Nega, a la casa de la reunión que él, junto con todos los de la aldea, habia construido para las reuniones, llegaban cestos de pejivalle, de mangos, de naranjas para que pudieran comer los ancianos y las ancianas que llegaban a escuchar a rbeorgun o a otros ancianos.

Ibeorgun decia a los ancianos:

- Las cosas que nos da Paba, sea de la tierra, del rio - de la selva, no son para que las comamos solos, sino para compartir. Todos tenemos el deber de trabajar, como todos tenemos el derecho de gozar de los frutos de nuestros sudores. El trabajo de todos hace hermosa la tierra, la Madre-Tierra. Si ves venir a un hermano por tu camino y si llevas cañas contigo, no dudes en entregarle una para que éste vaya comiendo la caña a lo largo de su camino.

"Cuando caces un jabali, comparte con los hermanos. Coman los vecinos, con los que menos tienen, con los que no tengan qué comer. Si es un machomonte, distribuyan la carne por las casas de los hermanos enfermos, de los que no pueden salir a conseguir su comida; $y$ que todos vivan bien, coman bien, esten alegres. Pero si la presa es un ñeque 
joven, muy pequeño para repartir, entonces debemos hacer una sopa, para que los hermanos puedan tomar su parte, la parte que les corresponda.

Asi enseñaba Ibeorgun a nuestros abuelos.

orgun también enseño a los ancianos el arte de hacer cestos, de tejer sombreros, abanicos; de labra todos los enseres de la casa.

- Debemos hacerles frente a las enfermedades, porque paba no nos dejó para morir como animales -seguia enseñando Ibeorgun a los ancianos de Yoodiuala-, por esos paba nos puso la selva, nos dejó el rio, nos regó las semillas de todos los árboles. Tenemos que hacerles frente a nuestros enemigos; las serpientes son nuestras enemigas, todas la enfermedades son nuestras enemigas. $Y$ Paba no permite, $Y$ no puede permitir, que bajo cualquier empujón del enemigo caigamos como moscas. Tenemos nuestro aliados $y$ ellos nos van ayudar. Paba nos dejó la intelígencia para eso, para cuidarnos a nosotros mismos, para que sepamos responder a los golpes de los enemigos. Tenemos que aprender el Kabur'igar, el Nusa'igar, el Sia'igar.

Ibeorgun conocia doce tratados de kandur: Ibe kandur, Napas'kandur, Uikudur'kandur, Kalapurba'kandur, Ile'kandur, Bogtule kandur, Sulu kandur...

orgun habló también de la chicha, de las ceremonias de las ninas. De las maneras de celebrar las ceremonias para el pasaje de las niñas de la aldea. Ibeorgun vivió cincuenta años.

orgun no sólo hablaba. Primero se subia al tejado, amarraba los bejucos, trenzaba las pajas; Y luego hablaba. Primero sembraba maiz, sembraba otoe, sembraba name; y luego 
hablaba. Y los ancianos aprendian rápido; los ancianos no se cansaban de trabajar. Nuestros ancianos se unian más y más. Nuestros ancianos veian que solos no podian hacer muchas cosas; unidos $\mathbf{s i}$ podian ser más fuertes y los enemigos no les podian vencer tan fácilmente.

Ibeorgun se dio cuenta de que pronto moriria y empezó a hablar asi:

- Van a venir tiempos diferentes, buenos, llenos de hombres con espiritu de Paba. Pero, todos ustedes deben prepararse antes. Las niñas deben ser bien cuidadas porque van a ser madres de los grandes hombres. Vendrán muchos pajaritos. Vendrá el sikui parube, el sikui kogi. Ustedes deben hacer buenas jaulas para esos pajaritos. Dentro de la jaula pongan plátanos maduros y bastante agua: asi no se escaparán, no saldrản, no pasarán de largo. Cuiden bien a los pajaritos, porque ellos vienen a mejorar esta MadreTierra.

Ibeorgun les hablaba con figuras. Entonces nuestros grandes abuelos que ya mencionamos anteriormente, empezaron a aprender otra lengua, la lengua de los grandes, la lengua de los tiempos que van a venir, la lengua de los acontecimientos que están por suceder. Orgun enseñaba a nuestros grandes ancianos en Yoodiuala.

Pero Ibeorgun no vino solo, no trabajaba solo, no enseñaba solo a los ancianos. Kikadiryai tambien trabajaba, enseñaba a las mujeres. Nuestras ancianas penetraban tambien en el estudio de la naturaleza, de los tejidos, de los colores, de la arcilla, de los pequeños y grandes cestos. orgun decia que todos unidos era mejor, que tenian que hacer una soga muy dura con sus cuerpos, con sus manos, para que todos fueran felices en Yoodiuala. 
orgun decia que después de el iban a venir otros grandes neles. Que él no habia concluido todo. Que todavía nuestros ancianos debian saber mucho más; que él sólo habia podido hacer una parte nada mas, porque Paba era muy grande y lo que El habia creado una sola persona no lo podia acabar. Que iban a venir los neles a la tierra de los kunas para ir perfeccionando poco a poco, para ir enseñando más al pueblo.

orgun pasaba de una enseñanza a otra. Sus instrucciones iban desde cómo hacer la chicha para el paso de las niñas a la edad adulta, como construir la casa, preparar las semillas para el cultivo, hasta cómo poner los pies para cantar en la hamaca central de la gran chicha.

- Tenemos que distinguirnos muy bien de los animales continuaba orgun-, de las bestias que se arrastran, que duermen por el suelo. Para hacer nuestra casa, tenemos que limpiar el terreno muy bien; no dejar ni un hierbajo, porque los ciempies pueden hacer sus nidos, las moscas y las aranas. No debemos tirar en cualquier parte los restos de la comida o la cáscara de las frutas, porque pueden atraer muchas enfermedades.

Ahi nació 2o que conocemos actualmente: el "iset", que significa tener amor, defendernos a nosotros mismos, una red que nos protege.

La gran mujer Kikadiryai tambien enseñaba a nuestras ancianas. Kikadir enseñaba a tejer las hamacas; y las iba 11 amando por sus uso, por sus tamaño, por sus diseños. Kikadir tambien se acercó a la arcilla, a la arcilla roja, a la arcilla negra, a la arcilla amarilla.y es muy largo el relato, si hablamos tambien de Kikadiryai. Una gran nujer 
con una gran historia. Pero aqui tratamos de hablar más de Ibeorgun. Cuando hablamos de Ibeorgun necesariamente tenemos que hablar también de Kikadiryai, porque trabajaron unidos; y por eso hablaron de como debian trabajar en la unidad, los kunas sobre la Madre-Tierra.

Cuando hizo todo 10 posible por enseñar a todos nuestros ancianos, Ibeorgun cambió su modo de hablar y dijo:

- Yo vengo de Sapibe nega: yo no vengo de Paba nega. Nadie puede volver de la casa de Paba. Las grandes ancianas: Nana olotagikiyai, Nan Aleyai, Mu Sobia, Mu Pinuegunsob me prepararon, me adornaron con las mejores dotes, con los grados de inteligencia más altos, con el sabor de la naturaleza. Todo me lo dieron para que yo lo pasara a ustedes, mis hermanos, y no para mi sólo.

"Desde Sapibe'nega, de donde sali, me dirigi a Kaluyorkun". Kaluyorkun se encuentra cerca de Caimán, por Colombia. Y esto ocurris mucho antes que se conociera Colombia, porque no habia llegado Cristóbal Colón. En Abia Yala vivian solamente nuestros abuelos y otros grupos, parecidos o distintos de nosotros, pero que no eran españoles.

Sin enbargo, tenemos que observar que, en la venida de Ibeorgun, el pueblito Kaluyorkun era una de las comunidades más pequeñas y desconocidas de los kunas. Habia muchas y grandes comunidades en Tuile uala. $Y$ ahi no llegó Ibeorgun, porque los grandes nelegan bajan siempre donde hay gente preparada, donde estos grandes no pierdan tiempo, para que sus enseñanzas queden para otras personas; donde hay buenas personas que piensan en Paba y quieren ser mejores.

Desde Kaluyorkun prosiguió Ibeorgun a Kalu Tagarkun (él mismo hablaba de su origen). De ahi pasó a Yoodiuala. 
Luego Ibecrgun pasó el mensaje a Kalu, a Neba, a Mage, a todos los grandes ancianos que le habian seguido. Les dijo que fueran a Kabdi, a Tuile uala, a todos los pueblos para esperar a los grandes neles que iban a bajar para seguir perfeccionando la tierra de los kunas. Los grandes ancianos habian aprendido muchas cosas; sabian cómo interpretar los signos que indicaban la cercania de los grandes neles.

Tbeorgun murio. Ibeorgun murió en Puargana. Paba 10 11 amó. Ibeorgun se enfermó y murió.

V. RD, n. 977 . 


\section{CDLIX}

\section{CANTO A UNA NIÑAEN LA HAMACA}

canta una niña de 10 años

Agosto 19 del 89 c. Sugdup Kuna Yala

Eres una rina y vas a crecer paca lavar la ropa a los tios, vas creciendo para ir a las tiendas a hacer mandados, cuando crezcas 'vas a trabajar para lus visitantes, cargarás agua para tus hermanos, estarás al lado de mamá cosiendo mola.

Mi mamá té está criando iqual que a mi para recibir a los tios te crió para eso, para hacerles trabajos a tus hermanos, estarás lavando ropas a tus hermanos, si hubieras sido un varoncito hubieras crecido para trabajar en el monte, ahora no, ahora eres una niña para atender a los hermanos, lavar sus ropas, eres una niña para hacer en la cocina y recibir a los hermanos, para eso nuestra mamá nos está criando, para hacer mandados a nuestros hermanos, para eso nos está criando, eres una nína para recibir a los tios, eres una niña para hablar con mamá, estar a su lado ayudándola, eres una niña que va creciendo poco a poco para recibir a los $v$ isitantes, nuestra mamá nos está educando, estás creciendo al lado de nuestro hermanito. También el está creciendo igual que tú, nuestra mamá te está criando para lavarle la ropa a nuestro hermanito, para hacerle mandados a nuestros hermanito eres una niña, eres un niña que va crecierdo para hacer los mandados, ir a la tienda igual que 10 hago yo; estamos creciendo para recibir a los tios, vas creciendo como una nina muy bonita, vas creciendo para estar al lado de mamá cosiendo mola, para eso mamá te está criando, ella nos está criando para hacerle sus molas, para cargar aqua para nuestros hermanos, para todo esto 
nuestra mamá ros está criando, eres una niña $\mathrm{y}$ estás creciendo al laclo de nuestro hermanito, eres una niña que en el futuro vas a estar lavando ropa prara los tíos, mamá te está dejando crecer para recibir a los visitantes, estarás lavando ropa pitra toda la familia, vas creciendo igual que yo como una niria para recibir a los visitantes, para ayudar a la gente, para eso estás creciendo, vas creciendo nína, vas creciendo para hacer favores a tus hermanitos.

V. RD, n. 978 . 


\section{B I BLI OGRAFIA}

(Fuentes secundarias)

\section{Obras de metodología}

BARRACLOUGH, G.: "Historia", en FREEDMAN, M., y otros: $\underline{\text { Corrientes de }}$ la investigación en las ciencias sociales. Tecnos-Unesco, Madrid, 1981.

BEST, T.W.: Cómo investigar en educación, Ed. Morata, Madrid, $1982^{9}$.

BRAUDEL, F.: La historia y las ciencias sociales, Alianza Editorial, 19794 .

BROM, J.: Para comprender la historia, Nuestro Tiempo, México, $1981^{3}$.

CARDOSO, C. y BRIGNOLI, H.: Los métodos de la historia, Ed. Crítica, Barcelona, 19814.

CHESNEAUX, J.: ¿Hacemos tabla rasa del pasado?, Siglo XXI, México, 1981.

COHEN, Louis y MANION, Lawrence: Métodos de investigación educativa, Ed. La Muralla, Madrid, 1990 (Aula Abierta).

ESCOLANO BENITO, Agustín: "Introducción", en Diccionario de Ciencias de la Educación. Historia de la Educación I, Anaya, Madrid pp. XI-XLIII. 
FEBVRE, L.: Combates por la historia, Ariel, Barcelona, 19743.

FLOUD, R.: Métodos cuantitativos para historiadores, Alianza, Madrid, 1975.

FONTANA, J.: Historia. Análisis del pasado y proyecto social, Ed. Crítica, Barcelona, 1982.

FORNACA, J.: La investigación histórico pedagógica, Oikos-Tau, Barcelona, 1978.

LE GOFF, J. y MORA, P.: Faire de l'histoire, París, Gallimard, 3 vols. Ed. española: Hacer la historia, Laia, Barcelona, 1978-1980, 3 vols.

HERNANDEZ DIAZ, José María: Iniciación a la historia de la educación de Castilla-León, Universidad de Salamanca, ICE, 1984 (Documentos Didácticos, 31).

LEON, A.: La historia de la educación en la actualidad, UNESCO, París, 1985.

Once ensayos sobre la historia, Fundación Juan March, Madrid, 1976.

RAMA, C.M. : Teoría de la historia. Introducción a los estudios históricos, Tecnos, Madrid, $1974^{3}$ revisada.

: La historiografía como ciencia histórica, Montesinos, Barcelona, 1981.

RUIZ BERRRIO, J.: "El método histórico en la investigación histórica de la educación", Revista Española de Pedagogía, 134 (1976) 449-475.

SADOUL, G. y otros: La historia hoy, Ed. Avance, Barcelona, 1974. 
SCHAFF: Historia y verdad, Ed. Grijalbo, Barcelona, 1976.

SOLA, P.: "Nuevas corrientes en Historia de la Educación", $\underline{\text { Cuadernos de }}$ Pedagogía, 65 (1980) 66-69.

TIANA FERRER, A.: La investigación histórico-educativa actual. Enfoques y métodos, Universidad Nacional de Educación a Distancia, Madrid, 1988.

TOPOLSKY, J.: Metodología de la historia, Ed. Cátedra, Madrid, 1982.

\section{Obras de carácter general (Contextualización)}

ALBA, Manuel M.: Hombres y Dioses Cunas, Panamá, 1947.

ALBA, Manuel M.: Introducción al estudio de las lenguas indígenas de Panamá, Motivos nacionales, Panamá, 1950.

ARCHIBOLD, Guillermo: "La medicina cuna". Actas del IV Simposium Nacional de Antropología, Arqueología y Etnohistoria de Panamá, Universidad de Panamá, INAC, Panamá ,1973.

ARJONA COLOMO, Miguel: Historia de América I, de los pueblos aborígenes a la independencia de los paises americanos, EPESA, Madrid, 1973 (Cuadernos Esquemáticos).

AROSEMENA, Marcia de: "La estrategia española de la colonización del Darién en el siglo XVIII". Actas del III Simposium de Antropología, Arqueología y Etnohistoria de Panamá, Panamá, 1972. 
AROSEMENA, Mariano: Independencia del Istmo, Universidad de Panamá, Instituto de Investigaciones Históricas, Rep. de Panamá, 1959 (Cuadernos de Historia Patria ,1).

AROSEMENA, Pablo: Escritos, Imprenta Nacional, Panamá, 2 tomos, 1930.

BALLESTEROS BERETTA, Antonio: El Cántabro Juan de la Cosa y el descubrimiento de América, Instituto de Cultura de Cantabria, Diputación Regional de Cantabria, 5ํㅡㄴ Centenario del Descubrimiento, 1987.

BALLESTEROS, N. E. y GUERRERO, C.A.: Fenómeno de aculturación de los cunas en la comarca de San Blas, Trabajo de graduación para optar al título de licenciatura en Filosofía y Letras con especialización en Geografía e Historia, Panamá, 1962-63.

BILBAO,I y OTROS: La patria del Indio, Centro de Capacitación Social, Panamá, 1978 (Serie el Indio Panameño ,1).

BILBAO, I.; FALLA, R. y VALDES, E.: Darién: Indios, negros y latinos. Centro de Capacitación Social, Panamá, 1979 (Serie el Indio Panameño, 6).

BLAZQUEZ, Adrián: Pascual de Andagoya. Relación y documentos, Historia 16, Madrid, 1986 (Crónicas de América, 27).

Boletín Indigenista México, XV- 4 (1955).

BORGES, Pedro: Misión y Civilización en América, Alhambra, Madrid, 1987 (Estudios, 36).

CALVO BUEZAS, Tomás: Indios cunas, Libertarias/Prodhufi, Madrid, 1990. 
CAMARGO, Edilia: "Arte y artesanía en el sistema constructivo de los cunas en San Ignacio de Tupile". Actas del Simposium Nacional de Antropología, Arqueología y Etnohistoria de Panamá, Panamá, 1972.

CARRASCO, P. y CESPEDES, G.: Historia de América Latina, Alianza Editorial, Madrid, 1985.

CASTILLERO, Ernesto: "Desvinculación y desmembramiento" Lotería, Panamá, 61 (1946) 23-24 .

: Panamá y los Estados Unidos, Editora Humanidad S. A. Panamá, 1964.

CASTILLERO, Hernesto J.: Historia de la extraña república de Tule. Leyenda e Historia, Biblioteca Selecta, Panamá.

: Historia de Panamá, Ed. Panamá América S.A., Panamá, $1955^{5}$.

CASTILLERO, E. y OBALDIA, E.: Biografía del cacique Nele Kantule.

CATAT, Louis: "Les habitants du Darien Meridional", Revue d'Ethnographie, París, 7 (1889).

CELINA de la DOLOROSA: Las Franciscanas de María Inmaculada, Pasto, $1970^{2}$.

CESPEDES, G. y REGLA, J.: Historia de España y América. Social y económica. Los Austrias. Imperio español en América, III, Vicens, Barcelona, 1982, 4⿳亠丷厂 reed.

"Compendio del actual estado de la provincia de Santa María la Antigua del Darién. Año de 1774", Hombre y Cultura, Tomo 2, Diciembre (1971). 
CONTRALORIA: Panamá en cifras. Años 1980-1984. Dirección de Estadística y Censo, Panamá, 1985.

COOPE, Anne: Sky pilot of the San Blas Indians, American Traet Society, New York, 1931.

CORREA, Grimaldo: "Alfombra de Costumbres y Tradiciones Cunas", Sue, Ustupu, 1972.

COSME,H. y GONDOLA, V.: El fenómeno del albinismo entre los indios kunas, Trabajo de licenciatura en la especialidad de Geografía e Historia, Panamá, 1967-68.

COSTALES, A. y COSTAS, P. de: Cunas y chocoes, Instituto Ecuatoriano de Antropología y Geografía, Quito, 1968.

DARIO CARLES, Rubén: Doscientos años de Periodo Colonial en Panamá, Imprenta Nacional, Panamá, 19592.

DARIO CARLES, Rubén: San Blas. Tierra de los Cunas, Impresora Reproset, Panamá, 1972.

DE SMIDT, León S.: Among the San Blas Indians of Panama, New York, 1948.

DIAZ GRANADOS, Alfonso: "Mitología Kuna: Los kalu", Arreglados y comentados por Leonor Herrera y Marianne C. de Schrimpff, Revista Colombiana de Antropología, Bogotá, XVII (1974).

Documentos fundamentales para la historia de la nación panameña, Imprenta Nacional de Panamá, Edición de la Junta Nacional del Cincuentenario, Panamá, 1953.

Dule Gaya marmaked garda, Dirección Nacional de Curriculum y Tecnología Educativa, 1976. 
ELIADE, Mircea: Mito y Realidad, Guadarrama, Barcelona, 1978³.

ERHMAN LOPEZ, Dialys N.: Régimen jurídico de la Comarca de San Blas, Universidad de Panamá, Facultad de Derecho y Ciencias Políticas, Trabajo de graduación para optar por el título de Licenciada en Derecho y Ciencias Políticas, 1983.

ERICE, Jesús: "Breves apuntes sobre los indios kunas de San Blas", Lotería, Panamá, 61 (1946) 5-23.

: Diccionario de la lengua kuna, Impresora Nacional, Panamá, 1982.

: Gramática de la lengua kuna, Impresora Nacional, Panamá, 1980.

: "El trágico episodio de Río Azúcar", Juventud Sanblaseña, (1951).

: "Historia de la Revolución de los Indios Kunas de San Blas", Juventud Sanblaseña, (1948).

: "Historia de Tikantikí", Juventud Sanblaseña, (1958).

: "Revolución Indígena Kuna", Juventud Sanblaseña, (1950).

EVANS-PRITCHARD, E. E.: La mujer en las sociedades primitivas, Ed. Peninsular, Barcelona, $1975^{2}$.

FALLA, R.: El tesoro de San Blas. Turismo en San Blas, Centro de Capacitación Social, Panamá, 1979 (Serie el indio panameño, 5).

Historia Kuna Historia rebelde. La articulación del archipiélago kuna a la nación panameña, Centro de Capacitación Social, Panamá, (Serie el indio panameño, 4). 
"La conversión religiosa desde la antropología política", Teología y Mundo Contemporáneo. Homenaje a K. Rahner, Ed. Cristiandad, 1975, 393-416.

FARO (EL) Revista mensual ilustrada. Organo oficial del Vicariato Apostólico del Darién, Colón.

FRANCO, Juan: Breves noticias o apuntes de los usos y costumbres de los habitantes del istmo de Panamá y sus producciones 1972, Instituto Nacional de Cultura, Panamá, 1978.

FRIEDMANN, N.S. (de) y AROCHA, J: Herederos del jaguar y la anaconda, Carlos Valencia editores, Bogotá, 1985.

GALVEZ, M. Albertina: Con los indios cunas de Panamá, Ed. del Ministerio de Educación Pública, Guatemala, vol. 31.

GARCIA, Alejandro: El hombre cura con la hierba, Instituto lingüístico de verano, Panamá, 1978.

GASSO, Leonardo: "Carta al R.P. Antonio Iñesta", Lotería, Panamá, (1961) 79-94.

: "La misión de San José de Narganá entre los karibes", Las misiones católicas, Barcelona, vol. XIX-XXII.

"Cartas al P. Alós", Lotería, Panamá, (Abril 1961).

_ : "Catequización de los indios de las costas de San Blas", Lotería, Panamá, 62 (Julio 1946) 5-8.

GIBBON, J.H. y CAMPBELL S.: Relación de viajes al Istmo de Panamá en 1835, Ed. Juan Antonio Susto, Panamá, 1961. 
GIRARD, Raphael: Historia de las Civilizaciones Antiguas de América. Desde sus orígenes, Ed. Istmo, Madrid, 1976, 3 vol.

Gobernantes de la República de Panamá 1903-1968.

GONZALEZ, Raúl: "Ritos de pasajes femeninos entre los indios cunas continentales". Actas del III Simposium Nacional de Antropología, Arqueología y Etnohistoria de Panamá, INCUDE, Universidad de Panamá, 1972.

GORDON, Harris R.: Los indios de Panamá. Los indios tule de San Blas, Imprenta Nacional, Panamá, 1926.

HERRERA, Francisco: Aspectos del desarrollo económico y social de los indios kunas de San Blas, Panamá, 1972 (América Indígena, 32).

HOLMER, Nils M.: Inatoipippiler or the adventures of three cuna boys, Etnografiska Museet, Goteborg, Suecia, 1952.

HOLMER, Nils M. y WASSEN H.: Dos cantos shamanísticos de los indios cunas, Goteborg, 1963 (Estnologiska studer, 27).

: Nia ikala. Canto mágico para curar la locura, Gotenburgo, 1958 (Etnologiska studer, 23).

Hombre y Cultura. Revista del Centro de investigaciones antropológicas de la Universidad de Panamá, Ed. Universitaria, Panamá; I-II (1962-64); 2 (1971); III(1972-73); 2-3 (1977).

HUMPHRIES, Frank T.: The indians of Panama their history and culture, Panama american publishing company, Panamá, 1944. 
IGLESIAS, Margaret G.: Mensajero al pueblo dorado, Versión castellana de Olivia S.D. de Lerín, Ed. the Sunday School Board of the Souther Baptist Convention, 1970.

Iwgia Del grupo internacional de trabajo sobre asuntos indígenas, Dinamarca, 4, 3-4 (1984).

JAEN, Omar: "El problema de la migración insular cuna", Actas del III Simposium Nacional de Antropología, Arqueología y Etnohistoria, Panamá, 1973.

Juventud Sanblaseña. Organo de la juventud de San Blas, Narganá, III (1950).

La Madre Caridad, apuntes para su biografía, Ed. Cervantes, Pasto, 1944.

Las grandes encíclicas sociales, Rerum novarum, Quadragesimo anno, Divini redentoris, Divini illius magistri, Casti connubii. Edición, introducción y notas de G. MARQUEZ, Editorial Apostolado de la Prensa, Madrid, 19616.

LOPEZ DE IGLESIAS, Ildaura: Trabajo sobre la vivienda y la educación en San Blas, copia mimeografiada, Sexto censo de población y vivienda.

Mc CHAPIN: Historias de la tradición cuna, Texto mimeografiado.

_ : "La versión de Nele Pai sobre el reino de los muertos", Lotería, Panamá, 171 (1970) 44-60.

Mc COSKER, Sandra: San Blas Cuna Indian: A means of informal learning. Enculturation in latin america, An anthology, UCLA, Los Angeles, 1976.

MCKIM, Fred: San Blas. An account of the cuna indians of Panama, Goteborg, 1947 (Ethnologiska studier, 15). 
MEAD, Margaret: Adolescencia, sexo y cultura en Samoa, Planeta Agostini, Barcelona, 1984 (Obras Maestras del Pensamiento Contemporáneo, 9).

MEGA, Pedro: Compendio biográfico de los lltmos. y Excmos. monseñores obispos y arzobispos de Panamá, Ed. departamento de bellas artes del ministerio de educación, Panamá,1958.

MISIONEROS HIJOS DEL CORAZON DE MARIA: Memoria del Vicariato Apostólico del Darién, Imprenta acción católica, Panamá,1939.

MONTALVAN, Ana: "Construcciones de paréntesis en la lengua cuna". Actas del III Simposium Nacional de Antropología, Arqueología y Etnohistoria de Panamá, Dirección del patrimonio histórico, Panamá, 1972.

: Proyecto de investigación de las lenguas indígenas de Panamá. Para apoyar los programas de enseñanza bilingüe del Ministerio de Educación, Ministerio de Educación, Panamá,1980.

MUÑOZ: La compañía de Jesús en Colombia.

NORDENSKJOLD, Erland: An historical and ethnological survey of the cuna indians, Goteborgs Museum, Suecia, 1938.

PAEZ, Gumersinda: Los indios de San Blas y la rebelión indígena del año 1925. Tesis de la Facultad de Filosofía e Historia, Universidad de Panamá, 1940.

Panamá y zona del Canal, 1933. 
PEREZ KANTULE, Rubén: "Las molas de los indios cunas", América indígena, México, 8 -1 (1942).

PEREZ, Rafael: La Compañía de Jesús en Centroamérica y Colombia, Heliografía y taller de grabados de Luis N. de Gaviria, Valladolid, 1896, 3 tomos.

PRESTAN, S. Arnulfo: "Cómo el kuna adivina sus sueños," Lotería, Panamá, 290 (1980) 15-27.

: "El rescate del alma en la sociedad cuna", América Indígena, México, 37 (1977).

: El uso de la chicha y la sociedad kuna. I.I.I., México, 1975.

: Ensayo monográfico sobre los caribe-cunas, Universidad de San Buenaventura, Mimeografía, Bogotá.

: "La enfermedad, la curación y la muerte en la sociedad kuna", Revista Nacional de Cultura, Panamá, 2 (1976).

: "Los nuchus cunas". Ponencia presentada en el IV Congreso Nacional de Antropología, Arqueología y etnohistoria, Panamá, 1982 (25-30).

PUIG, Manuel M.: Diccionario de la lengua Caribe-cuna, La Estrella de Panamá, Panamá, 1944.

: Gramática de la lengua Caribe-cuna, Panamá, 1946.

: Jesucristo e Evangeliomal itogedimar gad tegine Dios iba Tummagan gad, Panamá, 1952.

: Katecismo. Jesucristo e igal sunnat S. Blas tulemal gala itigirir narmakal mai, Colón, 1949. 
: Los indios kunas de San Blas. Su origen, tradiciones, costumbres, organización social, cultural y religiosa, Imprenta Nacional, Panamá, 1948.

PUJADAS, Tomás: Misión del Darién, Vicariato apostólico del Darién, Colón, 1976.

PULEIO, Luis Alfonso: Indigenismo en las fuerzas de defensa de Panamá.

REQUEJO SALCEDO, Juan: Relación histórica y geográfica de la provincia de Panamá, Madrid, 1908.

RESTREPO TIRADO, Ernesto: Costumbres de los indios darienitas.

RESTREPO, Vicente: Viajes de Lionel Wafer al Istmo del Darién. Cuatro meses entre los indios, Panamá (Publicaciones de la revista Lotería, 14).

REVERTE, José M.: Literatura oral de los indios cunas. Ensayo literario sobre una cultura aborigen panameña, Ed. del Ministerio de Educación, Dirección Nacional de Cultura, Panamá,1968.

SEVERINO de Sta. TERESA, Fr.: Creencias, ritos, usos y costumbres de los indios catios de la prefectura apostólica de Urabá.

SLATER, Nele Charles y OTROS: Picture-writings and other documents. Comparative ethnografical studies, Part 2, Published by Erland Nordenskiold, Gotenburg, 1930.

SOTO, Rosa María: Estudio de la comunidad de Ustupu, San Blas, Panamá, 1973.

: La estructura de la familia en la tribu kuna, Disertación a licenciatura en misiología, Pontificia Universidad Urbaniana, Roma, 1973. 
STOUT, David B.: San Blas cuna acculturation: An introduction, Viking Fund Publications in Anthropology, New York, 9 (1947).

TORRES DE ARAUZ, Reina: "Consideraciones etnográficas sobre embarazo y parto entre los indios cunas", Actas del III Simposium Nacional de Antropología, Arqueología y Etnohistoria de Panamá. INCUDE, Universidad de Panamá, Panamá, 1972.

: Darién: Etnoecología de una región histórica, INAC, Panamá, 1975.

: $\quad$ "El valor etnográfico de las cartas del misionero jesuita Rev. Padre Leonardo Gassó", Lotería, (1965) 69-74.

: Etnohistoria cuna, Instituto Nacional de Cultura, Panamá, 1974.

: "La mujer cuna", Lotería, Impresora Nacional, (1982) 46-69.

: Panamá Indígena, Instituto Nacional de Cultura, Patrimonio histórico, Panamá,1980.

: "Culturas Prehispánicas del Darién", Hombre y Cultura, Tomo 2, Diciembre (1971).

: "Las culturas indígenas panameñas en el momento de la conquista", Hombre y Cultura, Tomo 3, Abril (1977).

TORRES DE IANNELO, Reina: La mujer cuna, Instituto Indigenista Interamericano, México, 1957.

: "La organización política kuna", Lotería, 3-30 (1958) 81-96. 
: "Posición social de la mujer cuna dentro de la cultura cuna", Lotería, Panamá, 3 -32 (1958).

Ustupu. Estudio de la comunidad de Ustupu, San Blas, 1974.

VALDES R., Maximiliano: "Civilización de Indígenas", Lotería, 61 (1946) 25-27.

VANDERVELDE, M. e IGLESIAS,M.: Nacido primitivo. Traducción de Guillermo Judson, Velde Press, Emmetsburg.

WAFER, Leonel: A new voyage and description of the isthmus of america, Hakluyt society, Oxford, 1934.

WAGUA, Aiban.: Palabras, agujas y molas, Cuaderno de lectura, 1983. : Totoganga, Poemas.

WASSEN, S. H.: $\quad$ Contributions to cuna ethnography, Goteborg, 1949 (Ethnologiska stuider, 16).

: "El Museo etnográfico de Gotemburgo y la cultura cuna". La Estrella de Panamá, Panamá (24,25 y 26 -6- 1955).

: "La misión científica de los indios Tule en Europa", La Prensa, Buenos Aires ( 9- 10-1932).

: Original documents from the cuna indians of San Blas, Goteborg, 1938 (Ethnologiska stuider, 6).

ZAMORA, Antonio de: Historia de la provincia de San Antonio del Nuevo Reino de Granada, Bogotá, 1945, 3 vol. 


\section{Obras de historia de la educación}

BAYLE, Constantino: España y la educación popular en América, Editora Nacional, Madrid, 19412.

BOWEN, James: Historia de la Educación occidental, Herder, Barcelona, 1985, 3 vols.

CANTON, Alfredo: Desenvolvimiento de las ideas pedagógicas en Panamá. 1903-26. Imprenta Nacional, Panamá, 1955.

CAPITAN DIAZ, Alfonso: Historia del pensamiento pedagógico en Europa, Dykinson, Madrid, 1986. 2 vols.

CESPEDES, Francisco: La educación en Panamá. Panorama histórico y antología, Panamá, 1985 (Biblioteca de cultura Panameña, tomo 4).

DELGADO, BUENAVENTURA: "Unidad y diversidad en la enseñanza decimonónica", Perspectivas Pedagógicas, 41,42 (1978) 159-167.

ESTEBAN MEDINA, J.: Educación y sociedad. La lucha por la educación en España 1770-1970, Ayuso.

FURTER, P.: "La utopía, las reformas educativas y la realidad de América Latina", Perspectivas Pedagógicas, 39 (1977) 243-247.

GALE, Lawrence: Educación y desarrollo en América Latina, Paidós, Buenos Aires, 1973.

GOMEZ LLORENTE, L.: "Laicismo y educación en España" Cuadernos de Pedagogía, 87 (1982) 53-60. 
HAVIGHURST, Robert: La sociedad y la educación en América Latina, Eudeba, Buenos Aires, 1970.

HOVRE, F.: Pedagogos y pedagogía del catolicismo, Poblet, Buenos Aires.

LOZANO SEIJAS, Claudio: "La neocolonización educativa de Latinoamérica (1810-1924))", Perspectivas Pedagógicas, $45-46 \quad(1980-81) \quad 69-78$.

LUZURIAGA, Lorenzo: La enseñanza primaria en las Repúblicas Hispanoamericanas, J. Cosano, Madrid, 1921.

MANTOVANI, J.: La educación popular en América, Noya, Buenos Aires, 1958.

MELENDEZ, Silvio: Breve historia de la educación en Panamá, Fergursen Fergursen, Panamá, 1974.

MENDEZ PEREIRA, Octavio: El desarrollo de la instrucción pública en Panamá, Tipografía Moderna, Panamá, 1916.

OSSENBACH SAUTER, Gabriela: "La influencia alemana en la educación preescolar hispanoamericana". Actas del Congreso de Historia de la Educación. Budapest, 1982.

PUELLES BENITEZ, Manuel: Educación e ideología en la España contemporánea (1767-1975), Labor, Barcelona, 1980.

RAMOS, Luz M.: La educación de la economía doméstica en las escuelas públicas de Panamá. Programa de estudios para la escuela profesional, escuelas normales rurales y escuelas primarias urbanas. The times publishing Co. Inc, Panamá, 1929. 
RUIZ RODRIGO, C. y PALACIOS LIS, I.: "Iglesia y educación en la España decimonónica: Política concordataria (1851)", Historia de la Educación, 2 (1983) 287-298.

SIERO DE NORIEGA, F.: Los indios guaymies frente al problema educativo y cultural, Universidad de Panamá, Panamá, 1969.

UZCATEGUI, Emilio: Historia de la educación en Hispanoamérica, Editorial Universitaria, Quito, $1975^{2}$.

WEINBERG, Gregorio: Modelos educativos en la historia de América Latina, Kapelusz, Buenos Aires, 1984.

\section{Obras sobre la educación de los kunas}

WAGUA, Aiban: El indio kuna y su sistema educativo tribal, Análisis de algunos aspectos culturales y su proceso de cambio, Tesis de la Facultad de Ciencias de la Educación, Universidad salesiana, Roma, 1978. 